



\title{
A BIBLIOGRAPHY OF FISHES
}

\author{
BY \\ BASHFORD DEAN
}

ENLARGED AND EDITED BX

CHARLES ROCHESTER EASTMAN

VOLUME I

Authors' Titles A-K

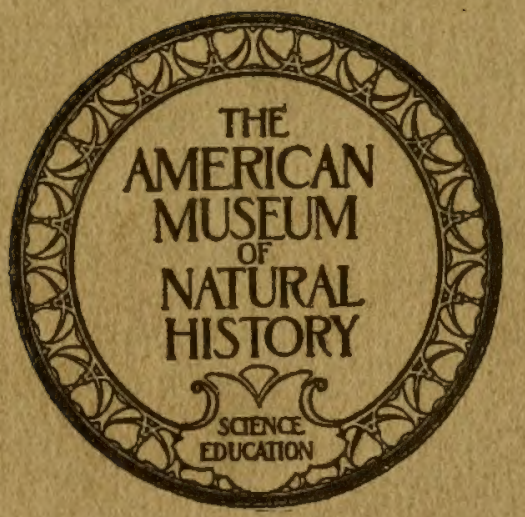

255390

PUBLISHED BY THE MUSEUM 

A BIBLIOGRAPHY OF FISHES 



\section{A BIBLIOGRAPHY OF FISHES}

2
5971
$D 28$

12

BY

V. 1

BASHFORD DEAN

FISHE\&

ENLARGED AND EDITED BY

CHARLES ROCHESTER EASTMAN

\section{VOLUME I}

PUBLICATIONS GROUPED UNDER THE NAMES OF AUTHORS

$\mathbf{A}-\mathbf{K}$

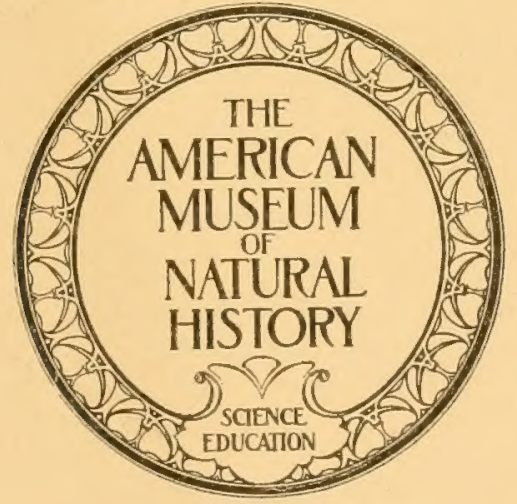

$255=90$

Nalional Museum

NEW YORK

PUBLISHED BY THE MUSEUM

1916

SMITHSONIAN

AUG 181986 

"A king of France, when travelling in Catalonia, discovered an ancient man engaged unremittingly in the planting of date kernels. 'Why,' he asked, 'do you sow the seeds of a tree of such tardy growth, seeing that the dates will not ripen till a hundred years be passed?' 'Am I not then,' replied the other, 'eating the fruit of trees planted by my forefathers who took thought for those who were to come? Why, therefore, should I not do like unto them?" - Travels of the Bohemian Lev, Lord of Rozmilal and Blatna, in Western Europe (1465-1467). 



\section{PREFACE}

IT is clear that Fishes have been of great interest to mankind during a long period, for in all lands they have been the theme of numberless publications. Indeed, at the present time the student who seeks to understand any phase of the knowledge of Fishes may well be confused by the series of references which he must consult. Where he expected a few pages of data he sometimes finds volumes!

This treasury of knowledge is, unfortunately, not easily accessible - its materials are widely scattered, ill digested, sometimes hiding in unexpected places. Then, too, the literature has grown during the last decades by leaps and bounds. The modern investigator is even embarrassed by the task of deciding where to begin his studies. But from any point of view he cannot afford to ignore the results of his predecessors and to repeat work which already has been well done. So in the end, like Cleanthes, he must be willing to work his way to bibliographical knowledge, "hewing wood and drawing water." If he has no special training in hunting references his struggle is apt to be painful and his results imperfect. With the best will in the world he may well remain ignorant of earlier work and in the end make lamentable and inexcusable mistakes. Many instances of these in publications of the past generation make it clear that the time is fully ripe for a general review of ichthyological literature.

The present work is designed to bring together in convenient form all published references to the Science of Fishes and to enable an investigator to find, at a minimal cost of time, what is known of a given theme. These references deal with Fishes broadly (including Cyclostomes and Amphioxus) their hahits, st ructure, development, physiology, pathology, their distribution and kinds - taking into account fossil species as well as recent. All titles are for present purposes grouped under the headings of Authors in Volumes I and II, and Subjects in Volume III, the last volume serving conveniently as the index to the others, for by reason of economy it has seemed expedient not to repeat the separate titles in the index volume, but merely to refer back to them under the captions of their respective authors. Thus, "Jordan, 1891.4" means consult the fourth paper published by David Starr Jordan in 1891. The index, it should further be noted, does not include detailed references to species, genera or even, in many cases, to families of Fishes. 'This would entail many years' additional listing, 
but should unquestionably next be done. Nor does the present bibliography treat exhaustively the vast fields in which Fishes come in touch with markets, table or angling, for these are special domains, less in scientific interest, yet each with its large circle of readers and worthy of a separate bibliography. We note that even without including these themes the lists here considered number over forty thousand titles.

The present work, it may be explained, is an outcome of my study of the literature of Fishes in connection with my investigations in various branches; it began in 1890 in the form of an index to references, and by 1900 included about twenty thousand cards. There was then no distinct plan to publish it. But about this time my students and correspondents came to realize that it contained a mass of material which served them conveniently in their work. And in return for the use of the index they sometimes contributed generous lists of references. And in various other ways the bibliography grew. Thus Geheimrath von Kupffer in Munich allowed me the use of his extensive references to the embryology of Fishes. My preceptor Dr. A. Böhm added many titles, especially in the literature of Cyclostomes, as did also Dr. L. Neumayer of the Anatomical Institute of Munich. In 1910 the Amithsonian Institution gave willing access to the index which had been laboriously prepared by and under the direction of Professor G. Brown Goode, whose lamented death eut short his project of preparing an ichthyological bibliography on somewhat the present lines. I am indebted, also, to Dr. F. J. Cole of Birmingham for valued assistance, for he, again, had planned a work which should serve the needs of students. . . Thus it came about that my bibliography outgrew its original purpose. It had become a storehouse of references which should be made accessible to workers generally.

But evidently it could not be published in the state in which it then stood. It needed additions and revision in large measure before it could safely be sent to press. First of all it would have to be compared title for title with earlier bibliographies, notably with Bosgoed's list of ichthyological writings (1874). Its findings were also to be checked against such standards as the Zoological Record, Carus and Engelmann, Lours Agassiz's bibliography (1848-1854) and the cards of the Concilium Bibliographicum. Then, too, many of its titles needed, for reason of clearness, to be compared with the original publications. By this means errors were to be avoided and new references discovered. Finally, and for the more recent literature, the effort was to be made to induce the many writers in this field to contribute their lists of publications, or to revise their bibliographies when furnished them.

It was in 1910 that my index reached a critical stage in its development. It had become an unwieldy enterprise - too large to be carried on single-handed, yet too valuable to be abandoned. Then it was, at the instance of President Henry Fairfield Osborn, that the Ameriean 
Museum of Natural History happily came to my aid: it allowed me the help of a secretary for transeribing references, and since then it has with great generosity provided the means for editing and enlarging the work. And it now assumes the burden of publishing it. In this it was aided by the Jesup Fund and by certain private subseriptions, notahly by Mrs. Isaac M. Dyckman and Mrs. Bashford Dean.

The labor of completing the Bibliography proved difficult and exacting. About $1910 \mathrm{my}$ former colleague in the Museum, Dr. Iouis Hussakof, was induced to become my collaborator. During 1913-1914 he controlled the results of the eompiler Miss Evelyn Tripp, whose faithful work deserves great credit. But Dr. Hussakof found that the enterprise, added to his other museum duties, was an overtax upon him, so in 1914 he felt obliged, to our mutual regret, to retire as a joint author. He merits, none the less, the sincere thanks of all who use the Bibliography, for the part which he contributed.

In the same year, 1914, Dr. Charles R. Eastman was persuaded to assume the editorship. He was aided during 19151916 by Miss Marguerite Engler, who gave her time devotedly to the Authors' volumes, and from the summer of 1916 onward hy Miss Florence Schwarzwaelder and Mr. Arthur Henn, who made a great number of entries for the indexing. And at this moment; when the work is in press, I need hardly assure the Editor and his assistants of my great gratitude for their help - for no one realizes better than myself that to finish the task fully and accurately demanded sustained and meticulous labor. Dr. Eastman, I should note, was keenly interested in the work from its inception, for from his own studies as a palæichthyologist he appreciated its general importance to investigators and he had already gone widely into the bibliographical field, especially that province of it which has to do with the earlier writers. In this connection he is to be credited with bringing together the principal part of the pre-Limnean literature of Fishes, which appears at the end of the second volume. In fact, while I am writing my acknowledgments, I should make it clear that had not Dr. Eastman come to my literary rescue at the time he did, the bibliography might never have been published, for I myself had become entangled with other matters and could afford neither the time nor the energy to complete it. Dr. Eastman's name would indeed have appeared as co-author of the present work had he himself not modestly declined this "responsibility."

Hence there must be laid to my own score any omissions or defects which may be discovered in the following pages, especially sinee I have followed the steps in the work with great interest, corrected the galley proof and revised the material for the index. But when slips are pointed out I will not hesitate to console myself with the reflection that no bibliography is perfect even for the most special subject. Stevenson knew his theme when he wrote "if you are troubled with a pride of accuracy and would have it completely taken out of you, 
print a catalogue!" . . . Nevertheless I can assure the careful reader that all of us who have labored in the present work have, like Epictetus, "tried incessantly to be accurate - and by this means escaped at least a few errors!"

BASHFORD DEAN.

American Museum of Nalural History,

October 27, 1916. 
Pour bien sçavoir les choses il faut en sçavoir le détail. - La. Rochefoucauld.

\section{CONTEN'TS}

I. AUThORS' Lists OF 'TITLES. VOLUME I, A-K. VOLUME II, L-Z.

II. LIST OF ANONYMOUS PUBLICATIONS.

III. TITLES OF PRE-LINNEAN PUBLICATIONS.

IV. GENERAL BIBLIOGRAPHIES WHICH INCLUDE REFERENCES TO FISHES.

V. VOYAGES AND EXPEDITIONS WHICH RELATE TO FISHES.

VI. PERIODICALS RELATING TO FISH AND FISH-CULTURE, WITH THE ABBREVIATIONS HEREIN USED.

VII. INDFX OF SUBJECTS.

VIII. ADDENDA AND ERRATA. 


\section{EXPLANATORY NOTE}

I. For economy in publication, titles have been simplified; certain words and punctuation marks have been omitted where they appeared unnecessary for a clear understanding of the references.

II. Rules of the American Library Association have been followed ats to (1) alphabetizing, and (2) transliteration of Slavonic names, with rowels as in Italian and consonants as in English. In addition, initial capitals in foreign languages are unaccented, as for instance Abo for Ảbo, Etat for Etat, etc., and Danish and Norwegian nouns are not capitalized.

III. Additions to titles or inserted explanatory phrases are included in inferior brackets [1, parentheses being retained where they occur in titles.

IV. The number of the volume is printed in bold-faced type, immediately succeeding the numerals denoting year of publication.

V. Authors' titles are arranged chronologically as to years and alphabetically as to publications within the same year.

VI. Where titles have been taken from standard works of reference (e. $\%$., British Museum Library Catalogue and the bibliographies of Agansiz, Bosgoed, Carus, and Engelmann, ete.) the numbers for pages and volume have not as a rule been verified. 


\section{BIBLIOGRAPHY OF FISHES}

A. More about sharks. Forest \& Stream, 1874, 3, 85.

1874.1

The salmon fisheries of Oregon. Forest \& Stream, 1874, 2, 290. 1874.2

A., $C n$. De wijze, waarop de zenuwen eindigen in het elektrische orgaan der Mormyri. Album Natuur, 1858, 22-23.

1858.1

Een te Berlijn aangebragte levende Malapterurus [electricus] Album Natuur, 1858, 14-15.

1858.2

A., H. Rare fishes tof New Zealand] N. Zeal. Journ. Sci., 1S83, 1, 465-466.

1883.1

A., J. Perch, at Chester, Pa. American Sportsman, 1874, 4, 293. $\quad 1874.1$

On the protection and spawning times of lake trout and black bass in Lake George. Forest \& Stream, 1876, 5, 362 .

1876.1

A., T. Blind-trout eggs. Forest \& Stream, 1876, 7, 35.

1876.1

Aagaard, $B$. Den kunstige udklækning af inlandsfisk [Künstliche Zucht von Süsswasserfischen] Norsk Fiskerit., Bergen, 1912, 31, 29-35; 221-231. 504-510.

1912.1

Aalderink, $H$. De zoetwatervisschen in Nederland, en de kunst om ze te vangen. 4 vols. Groningen, 1899. 248 p. $8^{\circ}$.

1899.1

Abbott, Charles Conrad [1843-] Description of new species of apodal fishes in the museum of the Academy of Natural Sciences of Philadelphia. Proc. Acad. Nat. Sci. Philad., 1860 (1861), 475-479.

1861.1

- Description of a new species of Astroscopus [A. guttatus] Brev., in the museum of the Academy of Natural Sciences of Philadelphia. Proc. Acad. Nat. Sci. Philad., 1860 (1861), 365. pl. vii. 1861.2
- Description of a new speries of Chatoëssus [C. insociabilis] Cuv. from New Jersey. Proc. Acad. Nat. Sci. Philad., 1860 (1861), 365-366. 1861.3

Description of a new species of Exocetus [E. chiliensis] from Chili. Proc. Acad. Nat. Sci. Philad., 1860 (1861), 472-473. 1861.4

Descriptions of four new species of North American Cyprinidæ. Proc. Acad. Nat. Sci. Philad., 1860 (1861), $473-474$.

1861.5

Descriptions of new species of American freshwater fishes. Proc. Acad. Nat. Sci. Philad., 1860 (1861), 325-328. 1861.6

Descriptions of two new species of Pimelodus from Kansas. Proc. Acad. Nat. Sci. Philad., 1860 (1861), 568569.

1861.7

- Note on Poecilichthys and Percina. Proc. Acad. Nat. Sci. Philad., 1860 (1861), $479 . \quad 1861.8$

Note on Hypognathus nitidus Gir. Proc. Acad. Nat. Sci. Philad., 1861 (1862), 156.

1862.1

Notes on the habits of Aphredoderus sayanus. Proc. Acad. Nat. Sci. Philad., 1861 (1862), 95-96. 1862.2

On Cyprinus corporalis Mitch. [referring it to the genus Semotilus Rafinesque] Proc. Acad. Nat. Sci. Philad., 1861 (1S62), 154-156. 1862.3

On Squalus americanus Mitchill referring it to the genus Odontaspis Agassiz] Proc. Acad. Nat. Sci. Philad., 1861 (1862), 399-401. 1862.4

- Observations on Cottus copei Abbott. Proc. Acad. Nat. Sci. Philad., 1861 (1862), 15-16. 1862.5

On Belone truncata and on the flesh of Lepidosteus. Proc. Acad. Nat. Sci. Philad., 1863 (1861), 282. 1864.1 
Abbott, $C . C$. An ugly customer [Lepidosteus] Riverside Magazine, 1867, 1, 174-176.

1867.1

Catalogue of vertebrate animals of New Jersey. Rept. State Geologist New Jersey, 1868, appendix E, 751-830.

1868.1

Fishes, $p$ 806-830. The list comprises 19 marine and 43 freshwater species, but many of the names are synonyms.

Notes on fresh-water fishes of New Jersey. Amer. Naturalist, 1871, 4, 99-117. fig.

1871.1

-.. Further notes on New Jersey fishes. Amer. Naturalist, 1871, 4, 717720. pl.

1871.2

Mud-loving fishes. Amer. Naturalist, 1871, 4, 385-391. figs. 1871.3

The banded sunfish (Mesogonistius chotodon Gill) Sci. Gossip, 1872, 8, 29-30. fig.

1872.1

- The pirate (Aphredoderus sayanus Cuv.) Sci. Gossip, 1872, 8, 151152. fig.

1872.2

The Stone Age fish and fishing [Lepidosteus osseus] Sci. Gossip, 1872, 8, 268-270. fig.

1872.3

- Notes on the gizzard-shad in New Jersey [Dorosoma (Chatoëssus) cepedianum] Sci. Gossip, 1873, 9, 5556.

1873.1

The silver-fin (Hypsilepis analostanus Cope) Sci. Gossip, 1873, 9, 224-225. fig.

1873.2

The darter (Boleosoma olmstedi Storer) Sci. Gossip, 1874, 10, 57-58. fig.

1874.1

- The golden minnow (Hybognathus osmerinus Cope) Sci. Gossip, 1874, 10, 9-10. fig.

1874.2

Note on the breeding habits of the mud-minnow Melanura (Umbra) limi] Pop. Sci. Monthly, 1874, 4, 744745.

1874.3

- Notes on the Cyprinoids of central New Jersey. Amer. Naturalist, 1874, 8, 326-338. fig.

1874.4

The big-eared sunfish (I chthelis [Pomotis] appendix) Sci. Gossip, 1875, 11, 7-9. fig.

1875.1

Two mud-loving fishes [An aquarial study of their color and certain habits! Sci. Gossip, 1875, 11, 104-107. figs.

1875.2
Notes on the habits of the yellow perch. Field \& Forest, 1876, 1, 3-4.

1876.1

A voracious fish $[\boldsymbol{E}$ sox reticulatus and Melanura limi] Forest \& Stream 1876, 5, 404.

1876.2

Traces of a voice in fishes. Amer. Naturalist, $1877,11,147-156 . \quad 1877.1$

Notes on some fishes of the Delaware River. The larger acanthopterous fishes of the Delaware River. Rept. U. S. Fish Comm. 1875 (1878), 4, 825845

1878.1

-Winter habits of the eel. Sci. News, 1879, 1, 183-184. - Chicago Field, $1879,11,220$.

1879.1

The intelligence of fish. Science, $1883,1,327-328$.

1883.1

- A naturalist's rambles about home. New York, 1884. 485 p. $8^{\circ}$. 1884.1

Chap. xxxiv. Brief notes on fishes. Chap. xxxy. Traces of voices in fishes.

On the habits of certain sunfish [Mesogonistius chatodon and Enneacanthus similans] Amer. Naturalist, 1884, 17, 1254-55.

1884.2

Upland and Meadow. New York, 1886. 397 p. 12。 1886.1

Chap. ix contains some general observations on fishes.

Cyclopedia of natural history ... for popular use. 'Troy, N. Y., 1888. 620 p. $8^{\circ}$.

1888.1

Fishes, p. 561-612.

Abbott, (Miss) Elizabeth Caroline Jane, \& Gadow, Hans Friedrich. Sec Gadow \& Abbott.

Abbott, James Francis. The marine fishes of Peru. Proc. Acad. Nat. Sci. Philad., 1899, 324-364. [Abstract] Amer. Naturalist, 39, 397. 1899.1

Notes on Chilean fishes, with de scription of a new species of Sebastodes. Proc. Acad. Nat. Sci. Philad., 1899 (1900), $475-477$. 1900.1

List of fishes collected in the river Pei-Ho, at Tien-T'sin. China, by Noah Fields Drake, with descriptions of seven new species. Proc. U. S. Nat. Mus., 1901, 23, 483-491. 7 figs. 1901.1

Abbott, W.J.Lewis. The Pleistocene vertebrates of south-east England. South-east. Naturalist, 1908, 96-113.

1908.1 
Abbs, Cooper. Observations on the remarkable failure of haddocks [Gadus aglefinus] on the coasts of Northumberland, Durham and Yorkshire. Phil. Trans. Roy. Soc. London, 1792, 82, 367-373.

1792.1

Abel, Othenio. Die Anpassungsformen der Wirbeltiere an das W asserleben. Schrift. Ver. Verbr. Nat. Kennt., Wien, 1905, 48. Jahrg.

1905.1

Fossile Flugfische. Verh. Deutsch. Zool. Gesell., 1905, 15, 47-48. - Jahrb. Geol. Reichsanst. Wien, 1906, 56, 1-88. 3 pls. \& 13 figs.

1905.2

_- Die Lebensweise der altpaläozoischen Fische. Verh. Zool.-Bot. Ges. Wien, 1907, 57, 158-168.

1907.1

- Die Anwendung der Röntgenstrahlen in der Paläontologie. Verh. Zool.-Bot. Ges. Wien, 1908, 58, 232-233. 1908.1

Bau and Geschichte der Erde. Wien \& Leipzig, 1909. 22 p. 10 figs.

1909.1

Die Bedeutung der fossilen Wirbeltiere für die Abstammungslehre. Jena, 1911. (Die Abstammungslehre; no. 9)

1911.1

- Grundzüge der Palaeobiologie der Wirbeltiere. Stuttgart, 1912. 708 p. 470 figs.

1912.1

- Ueber den Erwerb des Flugvermögens. Schrift. Ver. Verbr. Nat. Kenntn., Wien, 1912, 52, 215-236. 3 figs.

1912.2

Abelsdorff, Georg. Ueber die Erkennbarkeit des Sehpurpurs von Abramis brama mit Hülfe des Augenspiegels. Sitzber. Akad. Wiss. Berlin, 1895, 325329.

1895.1

Ueber Sehpurpur und Augenhintergrund bei den Fischen. Arch. Anat. Physiol. (Physiol. Abth.), 1896, 345-347.

1896.1

Abelsdorff, Georg, \& Kottgen, Else. See Kottgen \& Abelsdorfi.

Abelsdorff, H. Die ophthalmoskopische Erkennbarkeit des Sehpurpurs. Zeitschr. Psych. Phys. Sinn. 1897, 14, 77-90. Abstract in Zool. Centralbl., $1879,5,26-27$.

1897.1

Abendroth, Ernst Robert. Ueber Kowalevsky's Untersuchungen über die Entivicklungsgeschichte des Amphioxus lanceolatus. Sitzber. Ges. Isis, Dresden, 1869 (1870), 25-26.
Abildgaard, Petrus Christian. Kurze anatomische Beschreibung des Säugers (Myxine glutinosa L.) Sitzber. Ges. Naturf. Fr. Berlin, 1792, 193-200. (With discussion by M. E. Bloch, 244 251]

1792.1

Abonyi, Sándov. A halak ezüstös csillogásánok biológiai jelentösége. Math. Termt. Közlem, Budapest, 1908, 40, 530-532.

1908.1

Adatok a tengeri csontos halak bélesatornájának szövettanához [Beiträge zur Histologie des Darmkanals der marinen Knochenfische] Math. Termt. Értes, Budapest, 1910, 28, 315-368. pls. vii-xi.

1910.1

Abraham, (Rev.) Nendick. On the breeding habits of Chromis philander. Ann. Mag. Nat. Hist., 1901, 7. ser. 8, 321-325. - Journ. Mier. Soc. London, 1901. 639 .

1901.1

Abt, $F . N$. Ichthys. Specimen ichthyologicum de muræna et ophichtho. ... Upsalix, $1789.12^{\circ}$. 1789.1

Achelis, Hans. Das Symbol des Fisches und die Fischdenkmäler der römischen Katakomben. Marburg, 1888. 110 p. 2 pl. $8^{\circ}$. 1888.1

Achiardi, Antonio d'. Bibliografia mineralogica, geologica e paleontologica della Toscana. Roma, 1875. 57 p. $8^{\circ}$. 1875.1

Ackerhof, A. D. Die Nutzung der Teiche und Gewaisser durch Fischzucht und Pflanzenbau. Quedlinburg, 1869. 140 p. pl.

1869.1

— Die ärarialische Fischkultur-Anstalt Engelstein. Bayerische FischereiZeitg., 1880, 5, 42-43.

1880.1

Ackermann, Karl. Bibliotheca Hassiaca. Repertorium der landeskundlichen Litteratur für den Kaiserlichen Preussischen Regierungsbezirk Kassel. Abhandl. u. Ber. Ver. Naturk., Kassel, $1884,31,31-175 ; 1889,34 \&$ \& $3,1-130$; 1891,36 \& $37,81-96 ; 1892,38,53-64$; $1894,39,1-18 ; 1895,40,1-39 ; 1896$, $41,1-9 ; 1897,42,1-37 . \quad 1884.1$

(editor) Thierbastarde. Zusammenstellung der bisherigen Beobachtungen über Bastardirung im Thierreiche nebst Litteraturnachweisen. 2. Theil: Die Wirbelthiere [Fische] Abhandl. u. Ber. Ver. Naturk., Kassel, 1898, 43, 4-11. 
Acki, Takeo, \& Seno, Hidemi. See Seno \& Acki.

Acloque, Alexandre. L'anguille. $\mathrm{Na}$ turaliste, 1894, 16, 155-157.

1894.1

Mours de la truite des rivières. Naturaliste, $1894,16,31-32 . \quad 1894.2$

L'anguille. Cosmos, Paris, 1897, 47, 71-73. 3 figs.

1897.1

La question de l'anguille. Cosmos, Paris, 1897, 46, 355-358. 1897.2

- Le poisson-lune. Cosmos, Paris, $1897,46,109-111$. fig.

1897.8

L Le chabot de rivière. Cosmos, Paris, 1899, 40, 73-76. fig. 1899.1

Poissons plats. Cosmos, Paris, 1899, 41, 805-808. figs.

1899.2

Faune de France, contenant Ia description de toutes les espèces indigènes. ... Les poissons, les reptiles, les batraciens, les protochordes. Paris, 1900. 1124 figs. $S^{\circ}$.

1900.1

Poissons, p. 339-545.

Le brochet. Cosmos, Paris, 1900, 43, 266-269. figs. 1900.2

- Nos pêcheurs de haute mer. Tours, 1903. $4^{\circ}$. 1903.1

- Les silurides. Cosmos, Paris, 1908, 59, 35-37.

1908.1

La structure des dents. Cosmos, Paris, 1912, 66, 596-595. 2 figs. 1912.1

Adam, G. Vorkommen von Seefischen in süssen Gewässern. [Abstract Naturw. Wochenschr., 1898, 13, 417 418.

1898.1

Adam, Victor. Voyage d'un chasseur en Afrique; ou revue générale des chasses et pêches dans ce pays. Paris. 1839. figs. $4^{\circ}$.

1839.1

Adams, A.C. \& Kendall, William Converse. Report upon an investigation of the fishing grounds off the west coast of Florida. Bull. U. S. Fish. Comm., 1889 (1891), 9, 289-312. pl. \& fig.

1891.1

Tists of the Brachyura, Mollusea and Fishes collected. By WV. C. Kendall. p. 303-310.

Adams, Andrew Leith [-1882] For biographical notice and list of works see Scottish Naturalist, 1883-84, 7, 41-43.

- On the death of fishes on the coast of the Bay of Fundy. Quart.
Journ. Geol. Soc. London, 1868, 24, 303-305. - Amer. Naturalist, 1868, 2, 337-342. [Abstracts] Geol. Mag., 1868, 5, 240, 241. - Amer. Journ. Sci., 2. ser. 46, 269.

1868.1

Notes of a naturalist in the Nile Valley and Malta. Edinburgh, 1870. 295 p. 11 pls. \& figs.

Fishes of Malta, p. 274-279.

1870.1

- Field and forest rambles, with notes and observations on the natural history of eastern Canada. London, 1873. 333 p. pls. \& figs. $8^{\circ}$. 1873.1 Fishes, part iii, p. 201-257.

The lake trouts. Rept. U.S. Fish Comm., 1872-73 (1874), 2, 357362.

1874.1

Reprinted from the author's "Field \& forest rambles," 1873.

Adams, Arthur [1820-1878] 'The Zoology of the Voyage of H. M. S. "Samarang" under the command of Captain Sir E. Belcher ... during... 1843-46. Edited by A. Adams. London, 1850. fol.

1850.1

Each section has its own title-page and pagination. Fishes, by Sir J. Richardson. 28 p. $10 \mathrm{pls}$.

- Musical fishes. Zoologist, 1861, 19,7517 .

1861.1

A remarkable shark. Zoologist, $1861,19,7516$. 1861.2

Snake-like fishes. Zoologist, 1861, 19, 7406-17. 1861.3

- A viviparous fish. Zoologist, 1863, 21, 8527-28. 1863.1

Adams, Arthur, Baikie, William Balfour, \& Barron, Charles. Manual of natural history for the use of travellers, being a description of the families of the animal and vegetable kingdoms: with remarks on the practical study of geology and meteorology. London, 1854. 749 p. $\mathrm{s}^{\circ}$.

1854.1

Adams, Charles Christopher [1873-] Baseleveling and its faunal significance with illustrations from southeastern United States. Amer. Naturalist, 1901, $35,839-852$.

1901.1

Adams, Leverett Allen. Description of the skull and separate cranial bones of the wolf-eel (Anarrhichthys ocellatus) Sci. Bull. Ḱansas Univ., 1908, 4, 331355. pls. $x x V-x x x v i$.

1908.1

Adams, Lionel Ernest [1854-] The flight of flying-fish. 'Zoologist, 1906, 4. ser. $10,145-148$. 
Additional notes on flying-fish. Zoologist, 1909, 4. ser. 13, 201-207. 1909.1

Adams, W. H. D. [translator ] Mysteries of the ocean. New ed., revised. London, 1870 , figs. $8^{\circ}$.

1870.1

From the 3. ed. of Arthur Mangin's Les mystères de l'océan. Tours, 1865.

Adams, Walter Marsham. Fish supply of Great Britain. 'Trans. Soc. Sci. London, 1883, 562.

1883.1

- A popular history of fisheries and fishermen of all countries, from the earliest times. Internat. Fisheries Exhib. Handb. London, 1883. 84 p. $8^{\circ}$.

1883.2

Adamson, William Agar] Salmonfishing in Canada; by a resident. Edited by Sir J. E. Alexander. London, 1860. sm. $8^{\circ}$. map, pl., \& figs.

1860.1

The appendix includes "Observations on the habits of the salmon family; by W. Henry."

Addario, Carmelo. Sull' apparente membrana limitante della retina ciliare. Monit. Zool. Ital., Firenze, 1902, 13, 16-18.

1902.1

- Sulla istogenesi del vitreo nell' occhio dei selaci. Mon. Zool. Ital., Firenze, 1902, 13 (Suppl.), 18. 1902.2

- Ueber die Matrix des Glaskörpers im menschlichen und tierischen Auge. Anat. Anz., 1902, 21, 9-12.

1902.3

Adderley, (Sir) Augustus John [1835 - ]. The fisheries of the Bahamas. Internat. Fisheries Exhib. Handb. London, 1883. $8^{\circ}$.

1883.1

Adler, Heinrich. Zur Hebung der Seefischerei Oesterreichs. Eine Skizze. Wien, 1903. $16 \mathrm{p}$. $8^{\circ}$.

1903.1

Adloff, $P$. Ueber das Gebiss im Lichte der Entwickelungslehre. Schrift. Phys.-ökon. Ges. Königsberg, 1904, 45, Sitzber., 54-55. 1904.1

Adolphi, $H$. Ueber das Verhalten von Wirbeltierspermatozoen in strömenden Flüssigkeiten. Anat. Anz., 1906, 28, 138-149. 2 figs. 1906.1

Adorno, M., Mercadante, $L ., \&$ Jannaci, $F$. See Mercadante, Jannaci, \& Adorno.

Aequaviva, Andrea. L'Adriatico c la pesca sulle coste dell' Abruzzo e delle Marche. [Terano, 1902] $8^{\circ}$. 1902.1
Afanassjew, $M . J$. Ueber eiförmige Kiörper an den Gefühlsorganen der Fische. [Translated from the Russian] [n. p.] 1874.

1874.1

Aflalo, Frederick George. Sea fishing on the English coast. London, 1891. $190 \mathrm{p}$. figs. $12^{\circ}$.

1891.1

A sketch of the natural history of Australia, with some notes on sport. London, 1896.307 p. pls. \& figs. $12^{\circ}$. 1896.1

Fishes, p. 195-254.

- English neglect of edible fish. Sat. Rev., 1897, 83, 601 .

1897.1

Sea-fish. London, 1898. 256 p. $12 \mathrm{pl} .64$ figs. $8^{\circ}$. (The Angler's Library, vol. ii) 1898.1

A sketch of the natural history (Vertebrates) of the British Islands. Edinburgh \& London, 1898. 498 p. pls. \& figs. $12^{\circ}$.

Fishes, p. $317-\$ 39$.

- Sea and coast fishing. London, 1901. 228 p. 5 pls. \& 47 figs. $12^{\circ}$.

1901.1

Fish notes. Field Natural. Quarterly, 1902, 1, 291-294. $\quad 1902.2$

- Six uncommon British sea-fish. Field Natural. Quarterly, 1902, 1, 7-13. $1 \mathrm{pl}$.

1902.3

Some signs of age and sex in fishes. Field Natural. Quarterly, 1902, 1, 182-185.

1902.4

- Some spring movements of seafish. Field Natural. Quarterly, 1902, 1, 99-102.

1902.5

Colour in fishes. Field Natural. Quarterly, 1903, 2, 212-215. 1903.1

- British salt-water fishes, with a chapter on the artificial culture of sea fish by R. B. Marston. London, 1904. 328 p. 12 col. pls. $5^{\circ}$.

1904.1

- Defensive methods of fish. Cornhill Mag., 1904, 90, 822 .

1904.2

The sea fishing industry of England and Wales. London, 1904. $386 \mathrm{p}$. pl. - [Review] Rev. Scient., 1905, 5. sér. 4, 753-755. 1904.3

[editor] The sportsman's book for India. London, 190t. 567 p. pls. \& map. $8^{\circ}$. 1904.4

Part ii. Fishing, by F, O. Gadsden, Captain Gibson, and others. Contains notes on sea and freshwater fishes. 
Aflalo, $F \cdot G$.

- The nationality of fishes. Chambers's Journ., 1905, 82, 218. 1905.1 'The salt of my life. London, 1905. 277 p. 39 figs. $12^{\circ}$. 1905.2

Aflalo, Frederich George, \& Paske, C. T. Sec Paske \& Aflalo.

Aflalo, ${ }^{\prime}$. G., Bickerdyke, J., Maxwell, (Sir) H., \& Pycraft, W.P. Living animals of the world. London, 1902.

Fishes, vol. ii, p. 609-669. pls.

1902.1

Agar, W.E. The development of the skull and visceral arches in Lepidosiren and Protopterus. Trans. Roy. Soc. Edinb., 1906, 45, 49-64. pls. i-iii.

1906.1

The spiracular gill cleft in Lepidosiren and Protopterus. Anat. Anz. 1906, 28, 298-304. 5 figs. $\quad 1906.2$

- The development of the anterior mesoderm, and paired fins with their nerves, in Lepidosiren and Protopterus. Trans. Roy. Soc. Edinb., 1907, 45, 611639. pl. \& 7 figs.

1907.1

- On the appearance of vascular filaments on the pectoral fin of Lepidosiren paradoxa. Anat. Anz., 1908, 33, 27-30. 5 figs.

1908.1

- The spermatogenesis of Lepidosiren paradoxa. Quart. Journ. Mier. Sci., 1911, 57, 1-44. 5 pls. \& 1 fig.

1911.1

Transverse segmentation and internal differentiation of chromosomes. Quart. Journ. Mier. Sci., 1912, 58, 285298. pls. xii-xiii.

1912.1

Agassiz, Alexander [1835-1910]. For biography, see Letters and recollections of Alexander Agassiz ... edited by G. R. Agassiz. Boston \& New York, 1913. 454 p.

[Notes on the described species of Holconoti found on the western coast of North Americal Proc. Boston Soc. Nat. Hist., 1861, 8, 122-134. 1861.1

Observations sur les métamorphoses des poissons. Ann. Sci. Nat. (Zool.), 1865, 5. sér. 3, 55-58. 1865.1

Sur les métamorphoses subies par certaines poissons avant de prendre la forme propre à l'adulte. C. R. Acad. Sci. Paris, 1865, 60, 152-153. - Ann. Mag. Nat. Hist., 1865, 3. ser. 16, 69-70.

1865.2
- Ueber die Metamorphosen der Fische. Ausland, 1865, 38, 191-192.

1865.3

- [Reproduction of sharks and rays] Proc. Boston Soc. Nat. Hist., 1871 (1872), 14, 339-341.

1872.1

The development of flounders. Amer. Naturalist, 1876, 10, 705-708. Rev. Sci. Natur., 1876, 6, 1-11. . 1876.1

Sur le développement des Pleuronectes. Journ. Zool. (Gervais), 1877, 6, 193-197. - Rev. Sci. Nat. Montpellier, 1877, 6, 129-139. $\quad 1877.2$

_- On the young stages of some osseous fishes. I. Development of the tail. Proc. Amer. Acad. Arts Sci., 1878, 13, 117-127. pls. \& figs. - Ann. Mag. Nat. Hist., 1878, 5. ser. 1, 419-421.

II. Development of the flounders. Proc. Amer. Acad. Arts Sci., 1879, 14, 1-25. pls. - Arch. Zool. Expér. Génér., $1879,8,38-42$.

III. On the young stages of some osseous fishes. Proc. Amer. Acad. Arts Sci., 1882, 17, 271-303. 20 pls. 1878.1

'The development of Lepidosteus. Proc. Amer. Acad. Arts Sci., 1879 , 14, 65-75. pls. - Arch. Zool. Expér. Gén., 1880, 8, 10-12. 1879.1

- Embryology of the gar-pike (Lepidosteus) Science News, 1879, 1, 19-20.

1879.2

Note préliminaire sur le développement des plies. Arch. Zool. Expér. Gén., 1879, 6, 305-310. figs.

1879.3

Sur les premiers états des poissons osseux. Arch. Soc. Phys. Nat. Genève, 1883, 8, 572-574. 1883.1

- Pelagic stages of young fishes. Journ. Roy. Micr. Soc., 1886, 6, $402-$ 403.

1856.1

- Three cruises of the United States coast and geodetic survey steamer "Blake." Bull. Mus. Compar. Zool. 1888, 15.

1888.1

Sketches of the characteristic deep-sea types of fishes, p. 21-36. 11 pls. \& figs.

Preliminary note on some modifications of the chromatophores of fishes and crustaceans. Bull. Mus. Compar. Zool., 1892-93 (1892), 23, 189-193. pl. 1892.1

Three letters to the Hon. Marshall MeDonald, U. S. Comm. of Fish 
and Fisheries, on the dredging operations off the west coast of Central America to the Galapagos, to the west coast of Mexico, and in Gulf of California, in charge of Alex. Agassiz, carried on by the U. S. Fish Comm. steamer "Albatross." Bull. Mus. Comp. Zool., $1892,21,185-200$.

1892.2

Agassiz, Alexander, \& Whitman, Charles Otis. The development of osseous fishes. I. The velagic stages of young fishes. Mem. Mus. Comp. Zool., 1885,14 , no. 1 , pt. $1,1-56$. pls.

II. The pre-embryonic stages of development. Part first. 'The history of the egg from fertilization to cleavage. Ibid., 1889, 14, no. 1, pt. 2, 1-40. pls.

1885.1

On the development of some pelagic fish eggs. Preliminary notice. Proc. Amer. Acad. Arts Sci., 1885, 20, 23-75. pl.

1885.2

Also separate under the title: "A review of the development of the fish based on observations from 1879-1883 upon 22 species of eggs.'

Développement des poissons osseux. Histoire de l'ouf depuis la fécondation jusqu'à la segmentation. Arch. Zool. Expér. Gén., 1891, 8, 17-21.

1891.1

Agassiz, John] Lowis [Rodolphe] [1807-1873] For biography see L. Agassiz, his life and correspondence, by Elizabeth Cabot Cary Agassiz. 2 vols. London, 1885. Also his life by Jules Marcou. 2 vols. New York, 1896.

Beschreibung einer neuen Species aus dem Genus Cyprinus Linn. Isis (Oken), 1828, 21, 1046-1049; 1829 , 22, 414-415. - Bull. Univ. Sci. Ind. (Férussac), 1828, 19, 117-118. 1828.1

In Agassiz's Bibliographia Zoologiæ et Geologim this paper is again cited under the following title: "Agassiz etOken, Cyprinus uranoscopus, nouvelle espèce trouvée par la premier à Munich et presentée à la réunion des savans d'Allemagn à Berlin par ce dernier. Isis, 1828, x, p. 10.46 1829 , iii \& iv, p. 414."

[Prospectus de l'] Histoire naturelle des poissons d'eau douce de l'Europe Centrale, ou description anatomique et historique des poissons qui habitent les lacs et les fleuves de la chaîne des Alpes et les rivières qu'ils reçoivent dans leurs cours. Munich, 1830. pl. small fol. 1830.1

[Review] Bull. Univ. Sci. (Férussac), 1830, 23. 270-272. Livraison 1 of the work to which this prospectus refers was published in 1839 .

Untersuchungen über die fossilen Fische der Lias-Formation. Jahrb. f. Miner., 1832, 139-149.
Untersuchungen ibber die fossilen Süsswasser-Fische der tertiären Formationen. Jahrb. f. Miner., 1832, 129138.

1832.2

- Neue Entdeckungen über fossile Fische. Neues Jahrb. Miner., 1833, 675-677. - Edinb. New Phil. Journ., 1844, 37, 331-347. 1833.1

- Recherches sur les Poissons Fossiles. 5 vols. with atlas. Neuchâtel, 1833-1843.

1833.2

[Reviews] Isis (Oken), 1834, 105; 1835, 135 - Neues Jahrb. Miner., 1834, 242-484; 1835 $595 ; 1844,250$. - Amer. Journ. Sci., 1835, 28, 193; 1836, 30, 34. - Calcutta Journ. Nat. Hist., $1843,3,313-344 ; 4,63-83$.

For collation, with dates of the various parts, see Woodward \& Sherborn, A Catalogue of British Fossil Vertebrata, 1890, p. xxv-xxix.

Synoptische Uebersicht der fossilen Ganoiden. Neues Jahrb. Miner., 1833, 470 481. - Bull. Soc. Imp. Moscotr, 1835, 8, 202-233.

1833.3

Abgerissene Bemerkungen über fossile Fische. Neues Jahrb. Miner. 1834, 379-390. - Bull. Soc. Imp. Nat. Moscou, 1835, 8, 181-201. 1834.1

Description de quelques espèces de cyprins du Lac de Neuchâtel, qui sont encore inconnues aux naturalistes. Mém. Soc. Sci. Nat. Neuchâtel, 1834, 1, 33-48. - L'Institut, 1836, 4, 419-420. - Proc. Zool. Soc. London, 1835, pt. 3, 149-151.

1834.2

- On a new classification of fishes, and on the geological distribution of fossil fishes. Proc. Geol. Soc. London, 1834, 2, 99-102. - Philos. Mag., London, 1834, 5, 459-462. - Edinb. New Philos. Journ., 1835, 18, 175-178; 19, 331-346. - Neue Notizen (Froriep), 31, $225-230 ; 241-245$.

1834.3

- On the fossil fishes of Scotland. Rept. British Assoc. Adv. Sci., 1834, 646-649. - L'Institut, 1835, 3, 65-66.

1834.4

- - Remarks on certain points in the anatomy of Lepidosteus] Proc. Zool. Soc. London, 1834, pt. 2, 119-120.

1834.5

- Remarks on the different species of the genus Salmo which frequent the various rivers and lakes of Europe. Rept. British Assoc. Adv. Sci., 1834, 617-623. - L'Institut, 1835, 3, 72-73. - Edinb. New Philos. Journ., 1834, 17, 380-385.
1834.6 
Agassiz, J.L. R.

Ueber das Alter der Glarner Schiefer-Formation, nach ihren FischResten. Neues Jahrb. Miner., 1834, 301-306.

1834.7

Coup d'ocil synoptique des Ganoides fossiles. Bull. Soc. Natur. Moscou, 1835, 8, 202-318.

1835.1

Notice sur les fossiles du terrain crétacé du Jura Neuchâtelois. Mém. Soc. Sci. Nat. Neuchâtel, 1835, 1, 126145. - L'Institut, 1835, 4, 420-421.

1835.2

- On the arrangement and geology of fishes. Edinb. New Philos. Journ. 1835, 19, 331-346.

1835.3

Remarques sur les poissons fossiles. Bull. Soc. Natur. Moscou, 1835 , 8, 180-201.

1835.4

Revue critique des poissons fossiles figurés dans l'Ittiolitologia Veronese. Neues Jahrb. Miner., 1835, 290316 .

1835.5

Sur les poissons fossiles de la formation houillière. L'Institut, 1835 , 3, 253-254.

1835.6

Ueber die Familie der Karpfen. Mém. Soc. Sci. Nat. Neuchâtel, 1835, 1, 33. - Arch. f. Naturges. (Wiegmann), $1838,1,73-82$.

1835.7

[Views of the affinities and distribution of the Cyprinida] Proc. Zool. Soc. London, 1835, pt. 3, 149-151. Arch. f. Naturges. (Wiegmann), 1836, 2, 240 .

1835.8

Note to a paper by William Buckland in Edinb. Philos. Mag, 1836, 8, 6-7.

[Characters of the four known species of chimaroid dental plates and description of a fifth, Chimara greenowii]

1836.1

Extracts from Recherches sur les Poissons Fossiles] Amer. Journ. Sci. $1836,30,33-53$.

1836.2

_ Les poissons fossiles de l'Angleterre. L'Institut, $1836,4,85-86$.

1836.3

Kiinstliche Steinkerne von Konchylien und Fische. Neues Jahrb. Miner., 1838, 49-51.

1838.1

Description of fishes from the Upper Silurian. (In Murchison's Silurian System, 1839, p. 606-608) $\quad 1839.1$

Describes Onchus murchisoni and $O$. tenuistriatus.
- Fishes of the Old Red Sandstone] (In Murchison's Silurian System, 1839, p. 589-601)

1839.2

Histoire naturelle des poissons d'eau douce de l'Europe centrale. 2 vols. Neuchatel, $1839-42.27$ pls. $8^{\circ}$. 1839.3

Of the 27 plates Salmo comprises 24 and Thymallus 3 . This atlas of plates was published as livraison 1 of a work which was to appear in parts and deal exhaustively with the freshwater fishes of central Europe. No text accompanying these plates was ever published. Livraison 2 was an atlas of plates by C. Vogt dealing with the embryology of Coregonus. This was accompanied by an octavo volume of text. A review of livraison 1 appeared in Amer. Journ. Sci., 1840, 39, 390-391.

- Enumeration des poissons fossiles d'Italie. Nuovi Annali Sci. Nat. Bologna, 1840, 4, 244-245; 325-332.

1840.1

Observations sur la structure des écailles de poissons. Ann. Sci. Nat. (Zool.), 1840, 2. sér. 13, 58-61. 1840.2

Observations sur la structure et le mode d'accroissement des écailles des poissons, et réfutation des objections de M. Mandl. Annales Sci. Nat. (Zool.) 1840, 14, 97-110. pls. iv-vi. 1840.3

Remarques à l'occasion d'une note de M. Mandl, sur la structure des écailles de poissons. C. R. Acad. Sci. Paris, 1840, 10, 191-194. - Edinb. New Philos. Journ., 28, 287-291. - Ann. Sci. Nat. (Zool.), 2. sér. 13, 58-61. - Neue Notizen (Froriep), 1840, 14, 179-182; $1841,18,33-41$.

1840.4

On the fossil fishes found by Mr. Gardner in the province of Ceará, in the north of Brazil. Edinb. New Philos. Journ., 1841, 30, 82-84.

1841.1

Nomenclator Zoologicus, continens nomina systematica generum animalium tam viventium quam fossilium, secundum ordinem alphabeticum disposita, adjectis auctoribus, libris, in quibus reperiuntur, anno editionis, etymologia et familiis, ad quas pertinent, in singulis classibus. Soloduri, 184246. $4^{\circ}$.

1842.1

The part on fishes has the following title, bastard: Nomina systematica generum piscium tam viventium quam fossilium, secundum ordinem alphabeticum disposita, etc. vi, 1-69. The Index Universalis, forming vol. ii of this work, was published in 1846 . Vide infra.

Report on the fossil fishes of the Devonian system or Old Red Sandstone. Rept. British Assoc. Adv. Sci., 1842, 80-88. 1842.2

German translation in Biblioth. Univers. Genève, 1S.13, 43, 353-369. - Neues Jahrb. Miner., 1843, $750-751$. 
Bericht über die fossilen Fische des Old Red Sandstone, im Auftrage der britischen Versammlung, im Jahre 1842, erstattet. Biblioth. Univers. Genève, 1843, 43, 353-369. - Neues Jahrb. Miner., 1843, 750-751. — L'Institut, $1843,11,14-16$.

1843.1

- Notice sur la succession des poissons fossiles dans la série des formations géologiques. Neuchâtel, $1843.16 \mathrm{p}$. $4^{\circ}$. Also in Ann. Sci. Nat. (Zool.), 3. sér. $1844,2,251-271$.

1843.2

" Extrait de la $18^{\mathrm{e}}$ et dernière livsaison des Recherches sur les Poissons Fossiles.'

Synoptical table of British fossil fishes, arranged in the order of the geological formations. Rept. British Assoc. Adv. Sci., 1843, 194-207. - Edinb. New Philos. Journ., 1844, 37, 331-347. Ann. Sci. Nat. (Zool.), 3. sér. 1844, 251-261.

1843.3

Valeur géologique des dents de squales pour la détermination des terrains. Actes Soc. Helvét. Sci. Nat., Lausanne, 1843, 83-84.

1843.4

De la forme des placoïdes et tableau général des espèces de placoïdes rangés par terrains. Neuchâtel, 1844. 18 p. $4^{\circ}$.

1844.1

"Extrait de la $18^{\circ}$ et dernière livraison des Recherches sur les Poissons Fossiles."

Essai sur la classification des poissons. Neuchâtel, 1844. 8 p. 1 pl. Also in Edinb. New Philos. Journ., 1844, 37, $132-143$.

1844.2

- Extrait de la $18^{\mathrm{e}}$ et dernière livraison des Recherches sur les Poissons Fossiles," "Review] Neue Notizen (Froriep), 1844, 31, 225$230 ; 241-245$.

- Monographie des Poissons Fossiles du Vieux Grès Rouge, ou Système Dévonien (Old Red Sandstone), des Iles Britanniques et de Russie. 3 pts. in 2. Neuchâtel, 1844-1845. Text, xxxvi, 171 p., with atlas of 43 pls. $4^{\circ}$.

1844.3

Note sur la succession des poissons fossiles dans la série des formations géologiques. Ann. Sci. Nat. (Zool.), 1844, 3. sér. 2, 251-271.

1844.4

Notice sur les dents et les rayons des Placoïdes. Neuchâtel, 1844. $4^{\circ}$.

1844.5

On fossil fishes. Edinb. New Philos. Journ., 1844, 37, 331-334. Biblioth. Univers. Genève, 44, no. 100 , 334-356.

1844.6

Essentially a résumé of the author's Recherches sur les Poissons Fossiles.
[Sur le cerveau des poissons] Bull. Soc. Sci. Nat. Neuchâtel, 1844, 1, 147-148.

1844.7

- - Sur les progrès de l'étude de l'ichthyologie. [Announces the completion of his Poissons Fossiles] Bull. Soc. Sci. Nat. Neuchâtel, 1844, 1, 49-50. 1844.8

Sur quelques poissons fossiles du Brésil. C. R. Acad. Sci. Paris, 1844, 18, 1007-1015. - L'Institut, 1844, 12, 187188.

1844.9

Tableau général des poissons fossiles rangés par terrains. Neuchâtel, 1844. 17 p. 4\%. Also in Ann. Sci. Nat. (Zool.), 1844, 3. sér. 2, 251-271.

1844.10

"Extrait de $1 \mathrm{l} 18^{\circ}$ et dernière livraison des Recherches sur les Poissons Fossiles."

[Nouvelles observations sur les nageoires des poissons] Actes Soc. Helvétique Sci. Nat., Genève, 1845, p. 49.

1845.1

Fin-rays are very variable in form - not uniform as generally represented by authors. They may be used for determining family position of fragments of fossil fishes.

On fossil fishes, particularly those of the London clay. Edinb. New Philos. Journ., 1845, 39, 321-327; 1846, 40, 121-125; Ann. Sci. Nat. (Zool.), $1845,21-48$.

1845.2

Rapport sur les poissons fossiles de l'argile de Londres. [French and English text, with restoration of Scionurus bowerbankii] Rept. British Assoc. Adv. Sci., 1844 (1845), 279-310. pl. Ann. Sci. Nat. (Zool.), 1845, 21-48. L'Institut, 1845, 219-232. 1845.3

[Résumé de ses travaux sur l'encéphale des poissons] Actes Soc. Helvétique Sci. Nat., Genève, 1845, 91-92.

1845.4

Nomenclatoris Zoologici. Index universalis, continens nomina systematica classium, ordinum, familiarum et generum animalium omnium, tam viventium quam fossilium. Soloduri, 1846. viii, 393 p. $4^{\circ}$. 1846.1

The Nomenclator, of which this volume is the index, was published in 1812. Vide supra. Another edition was published in 1848 .

IOn Huro nigricans Cuvier; regarded as identical with Centrarchus fasciatus and $C$. obscurus of DeKay. - On young Scaphirhynchus from the Ohio River] Proc. Boston Soc. Nat. Hist., $1846,2,184$.

1846.2 
Agassiz, J. L. R.

On the ichthyological fossil fauna of the Old Red Sandstone. Edinb. New Philos. Journ., 1846, 41, $17-49$

1846.3

Translated from Monographie des Poissons Fossiles du Vicux Grès Rouge.

Rapports qui existent entre les faits relatifs a l'apparition successive des êtres organisés a la surface du globe. Bull. Soc. Sci. Nat. Neuchâtel, 1846, 1 , 366-369.

1846.4

Sur les poissons des terrains paléozoiques. Soc. Philom., Proc. Verb., 1846, 61-62. - L'Institut, 1846, 14 , 163.

1846.5 - Sur un nouveau genre de pois-
sons fossiles (Emidichthys) du terrain dévonien de l'Eifel. Bull. Soc. Géol. France, 1846, 2. sér. 3, 488-489。 1846.6

An introduction to the study of natural history in a series of lectures delivered in the hall of the College of Physicians and Surgeons, New York. New York, 1847. $8^{\circ}$.

1847.1

Fishes: Lectures ix \& $\mathrm{x}, \mathrm{p} .38-47$... figs.

On the fishes of the London clay. Rept. Brit. Assoc. Adv. Sci., 1846 (1847), 52.

1847.2

[Plan for an investigation of the embryology, anatomy and effect of light on the blind-fish of the Mammoth Cave, Amblyopsis spelocus] Proc. Amer. Acad. Arts Sci., 1847, 1, 180.

1847.3

Bibliographia Zoologix et Geologix. A general catalogue of all books, tracts, and memoirs on zoology and geology, by Prof. Louis Agassiz ... corrected, enlarged, and edited by H. E. Strickland. 4 vols. London, Ray Society, $1848-54$. $8^{\circ}$.

1848.1

The black-banded Cyprinidx [Abstract] Proc. Amer. Assoc. Adv. Sci. 1848,70 .

1848.2 The black bands are not specific characters.
Cyprinodonts are separated from the Cyprinidæ on ground of differences in brain structure.

- Monograph of garpikes $[\mathrm{Ab}$ stract] Proc. Amer. Assoc. Adv. Sci., $1848,70-71$.

1848.3

Divides garpikes into sharp-nosed and flatnosed; the former group comprises 3 species, the latter 2 or 3.

Nomenclatoris zoologici index universalis, continens nomina systematica classium, ordinum, familiarum et generum animalium omnium, tam viventium quam fossilium, secundum ordinem alphabeticum unicum disposita, adjectis homonymiis plantarum. Soloduri, 1848. $1135 \mathrm{p} .12^{\circ}$. 1848.4

- IOn the fishes of Lake Superior] Proc. Amer. Assoc. Adv. Sci., 1848, 30 32.

1848.5

[Remarks on the existence of numerous minute water tubes in fishes] Proc. Boston Soc. Nat. Hist., 1848, 3, 27-28. - Amer. Journ. Sci., 1848, 6, 431-432.

1848.6

[Remarks on some of the Salmonidæ of Lake Superior Soc. Nat. Hist., $1848,3,61-62.1848 .7$

Remarks on the petrifaction of Mallotus villosus in Iceland. Proc. Boston Soc. Nat. Hist., 1848, 3, 42. 1848.8

ITwo new genera of fishes from Lake Superior, Percopsis and Rhinichthys] Proc. Boston Soc. Nat. Hist., $1848,3,80-81$.

1848.9

- On the differences between progressive, embryonic, and prophetic types in the succession of organized beings through the whole range of geological times. Proc. Amer. Assoc. Adv. Sci., 1849, 2, 432-438. - Edinb. New Philos. Journ., 1850, 49, 160-165.

1849.1

- Classification of mammalia, birds, reptiles, and fishes from embryonic and Palrezoic data. Edinb. New Philos. Journ., 1850, 49, 395-398.

1850.1

Geographical distribution of animals. Edinb. New Philos. Journ., 1850, 49, 1-33. - [Abstract] Tagsber. Fortschr. Nat. Heilk. (Froriep), Zool. Abth., 1850, 1, 247-248. - Christian Exam. \& Religious Misc., March, 1850, no. 258.

1850.2

- Geographische Verbreitung der Fische. Tagsber. Fortsch. Nat. Heilk. (Froriep), Zool. Abth., 1850, 1, 244-247.

1850.3

[Manner of producing sounds in cat-fish and drum-fish] Proc. Amer. Acad. Arts Sci., 1850, 2, 238. 1850.4

On Petromyzontidx and their embryonic development and place in the natural history system. Edinb. New Phil. Journ., 1850, 49, 242-246. 1850.5 
- 1 On the scales of the bonitol Proc. Amer. Acad. Arts Sci., 1850, 2 , 238.

1850.6

Scales shown to be intermediate between ctenoid and cycloid types, the serrations being merely marginal, and not extending over the posterior surface.

Remarks on species belonging to the genus Lepidosteus. Proc. Boston Soc. Nat. Hist., $1850,3,182 . \quad 1850.7$

[Remarks on the development of air-bladders in fish] Proc. Amer. Assoc. Adv. Sci., 1850, 72.

1850.8

Some points in the anatomy of the Silurida] Proc. Amer. Acad. Arts Sci., 1850, 2, 238.

1850.9

- Ueber die Lachssippe (Salmonidæ). Tagsber. Fortschr. Nat. Heilk. (Froriep) Zool. Abth. 1850, 1, 241-244.

1850.10

Observations on the blind fish of the Mammoth Cave. Amer. Journ. Sci., 1851, 2. ser. 11, 127-128. - Edinb. New Philos. Journ., 1851, 51, 254-256. Tagsber. Fortschr. Nat. Heilk. (Froriep) Zool. Abth., 1851, 2, 45-47. 1851.1

Report on the vertebrate fossils exhibited to the Association. [Abstract] Proc. Amer. Assoc. Adv. Sci., 1851, 178180.

1851.2

[Description of a new Cestracion from China (C.zebra) and comparison of its dentition with fossil shark teeth from Indianal Proc. Amer. Acad. Sci., 1853. $3,65-66$.

1853.1

Directions for collecting fishes and other objects of natural history.

1853.2

Cireular signed L. Agassiz, Professor of Zoolony and Geology in the Lawrence Scientific School at Cambridge, MIass.

- Embryology of the heart in fishes] Proc. Amer. Acad. Arts Sci., $1853,3,65$.

1853.3

- Extraordinary fishes from California, constituting a new family Holconoti or Embiotocidæ] Amer. Journ. Sci., 1853, 2. ser. 16, 380-390. - Edinb. New Phil. Journ., 57, 214-217. - Arch. Naturges., Berlin, 1854, 20. Jahrg., 1, 149-163.

1853.4

Observations sur quelques poissons des Etats-Unis. C. R. Acad. Sci. Paris, 1853, 37, 184. - L'Institut, 1853, 21, 287.

1853.5

- Recent researches of Professor Agassiz. [Extract from a letter to J. D.
Dana dated Cambridge, June 9, 1853 , detailing some of the results of a rapid tour from Charleston, S. C., through Alabama, Mississippi, and Louisiana, thence up the Mississippi to St. Louis, Chicago, and along by the Great Lakes to New York and Massachusetts] Amer. Journ. Sci., 1853, 16, 134-136. 1853.6

[Reference to a list of fishes found in the Tennessee River] Proc. Amer. Acad. Arts Sci., 1853, 3, 70.

1853.7

Remarks on new species of sharks discovered by the author on the coast of the United States] Proc. Amer. Acad. Arts Sci., 1853, 3, 63-64. 1853.S

[Remarks on the family of $\mathrm{Cy}$ prinodonts 3 Proc. Amer. Acad. Arts Sci., 1853, 3, 42-43.

1853.9

Remarkable sexual differences shown to exist in mature fish. P’ecilia and Mollienisia Cuv. and Val are really female and male of the same species, Heterandria, Zy'gonectes.

Additional notes on Holconoti. Amer. Journ. Sei., 1854, 17, 365-369. Edinb. New Philos. Journ., 1854, 57, 214-228. - Arch. Naturges. Berlin, $1854,20,149-162 ; 21,30-34 . \quad 1854.1$

Fossil sharks of the Tertiary of South Carolina. Proc. Elliott Soc. Nat. Hist., Charleston, S. C., 1854, 1, 4.

1854.2

Notice of a collection of fishes from the southern bend of the 'Tennessee River, [in the state of] Alabama. Amer. Journ.Sci., 1854, 2. ser. 17, 297-308; 353-369. Also separate. 31 p. $8^{\circ}$.

1854.3

The primitive diversity and number of animals in geological times. Amer. Journ. Sci. Arts, 1854, 2. ser. 17, 309-324. - Edinb. New Philos. Journ., 1854, 57, 271-292. - Ann. Mag. Nat. Hist., 1854, 2. ser. 14, 350-366. - Archiv. Sci. Phys. Natur., 1855, 30, 27-50. 1854.4

Synopsis of the ichthyological fauna of the Pacific slope of North America, chiefly from the collections made by the expedition under the command of Capt. C. Wilkes, with recent additions and comparisons with eastern types. Amer. Journ. Sci., 1855, 2. ser. 19, 71$99 ; 215-231$.

1855.1

- - Development of scales in garpike and sturgeon are similar; one of the points serving to indicate close relationship of the two] Proc. Boston Soc. Nat. Hist., 1856, 6, 63. 1856.1 
Agassiz, J. L. R. [Habits of the Glanis of Aristotle] Proc. Amer. Acad. Arts Sci., 1856, $3, ; 25-333$.

1856.2

Notice of the fossil fishes found in California by William P. Blake, geologist of the United States Pacific Railroad survey under the command of Lieutenant R. S. Williamson, United States topographical engineers. (In explorations and surveys for a railroad route from the Mississippi River to the Pacific Ocean. Appendix I, p. 30-34, Washington, 1856) - Abstract in Amer. Journ. Sci., 1856, 2. ser. 21, 272-275.

1856.3

[On some young gar'pikes from Lake Ontario] Proc. Boston Soc. Nat, Hist., 1856, 6, 47-48. - Amer. Journ. Sci., 1857, 2. ser. 23, 284-285. 1856.4

[Orthagoriscus mola, on grounds of internal anatomy does not belong in same family with Diodon and Tetraodon, but is type of a distinct family] Proc. Amer. Acad. Arts Sci., 1856, 3, 319.

1856.5

Ovarian development in some Gadidx and Chelonia] Proc. Boston Soc. Nat. Hist., 1856, 6, 9-10. 1856.6

[Plagiostomes regarded as a distinct class of animals from fishes, on account of different mode of development] Proc. Boston Soc. Nat. Hist., $1856,6,38$.

1856.7

- [Reference to embryology of a species of shark, Acanthias americanus] Proc. Boston Soc. Nat. Hist., 1856, 6, $37-38$.

1856.8

- Remarks on the classification of fishes, Proc. Boston Soc. Nat. Hist. $1856,6,63$.

1856.9

Discusses the systematic position of ganoids.

- Sur les poissons vivipares. L'Institut, $1856,24,164$.

1856.10

Viviparous reproduction in the common haddock. Proc. Boston Soc. Nat. Hist., $1856,6,9-10$.

1856.11

Nouvelle espèce d'Esoce du Lac Ontario. L'Institut, 1857, 25, 128.

1857.1

[Various existing systems of classification of fishes] Proc. Amer. Acad. Arts Sci., 1857, 4, 8-9.

1857.2

The anthor abandons his own classification based on the character of the scales as too artificial.
-.'The classification of fishes] Proc. Amer. Acad. Sci., 1858, 4, 108.

1858.1

The structure of mouth as related to facial bones furnishes a hint for classification of fishes.

[On some Salmonidx; the Characini; on the so-called migrations of certain fishes] Proc. Boston Soc. Nat. Hist., 1858, 6, 418-419. 1858.2

[Remarks on a catalogue of the fishes of Jamaica, by Richard Hill, of Kingston] Proc. Boston Soc. Nat. Hist., 1858, 6, 414-415.

1858.3

[Remarks on a new species of skate from the Sandwich Islands (Goniobatis meleagris)] Proc. Boston Soc. Nat. Hist., $1858,6,385$.

1858.4

[Remarks on Dr. B. Dowler's paper "Discovery of viviparous fish in Louisiana"] Amer. Journ. Sci., 1858, 2. ser. 19, 136.

1858.5

Concerning Pociiia multilineala Lesueur the author remarks: "MIllienesia of Lesener is founded upon the male of the same species he has described as Pacilia multilineata. There cannot be the slightest doubt about it."

[Remarks on new fishes from Lake Nicaragua, collected by Julius Fröbel] Proc. Boston Soc. Nat. Hist., 1858, 6, 407-408.

1858.6

- [Remarks on the affinities of the genera belonging in family Discoboli] Proc. Boston Soc. Nat. Hist., 1858, 6, 411-412.

1858.7

Remarks on the classification of fishes and the zoological relations of the family of Chromids. Proc. Boston Soc. Nat. Hist., 1858, 6, 407-408. 1858.8

Remarks on the manner and reproduction of selachians. Proc. Boston Soc. Nat. Hist., 1858, 6, 377-378.

1858.9

"Aristotle does not speak of Plagiostomes with fishes, but calls them Selachians, and Prof. A. follows the ancient naturalist, giving them the same name."

[The so-called claspers of skate supposed to be used for prehensile purposes are shown to be organs of copulation] Proc. Boston Soc. Nat. Hist., $1858,6,377$.

1858.10

[Difference in size of anal fin in male and female of Mallotus villosus] Proc. Boston Soc. Nat. Hist., 1860, 7, 399. 
- IReference to geographical distribution of the freshwater fishes of Europe] Proc. Boston Soc. Nat. Hist., $1862,9,178$.

1862.1

The fishes of headwaters of the Rhine, Rhone and Danube are shown to be the same, while those of the lower waters differ from one another as well as from those of the sources.

Metamorphosis of embryo fish at hatching] Proc. Boston Soc. Nat. Hist., 1863, 9, 326.

1863.1

Lettres relatives à la faune ichthyologique de l'Amazone. Ann. Sci. Nat. (Lool)., 1865, 5. ser. 4, 382-383; 1866, 5, 226-228; 309-311. - Ann. Mag. Nat. Hist., 1866, 3. ser. 17, 398.

1865.1

Métamorphoses subies par certains poissons avant de prendre la forme propre à l'adulte. C. R. Acad. Sci. Paris, 1865, 60, 152-153. - Ann. Sci. Nat. (Zool.), 5. ser. 3, 55-58.- Ann. Mag. Nat. Hist., 1865, 3. ser. 16, 69-70.

1865.2

The author states that Argyropelecus hemigymnus is the young of Zeus faber. This statement has not been confirmed; see Kner, $R$.

Remarks on the classification of Siluroids. Proc. Boston Soc. Nat. Hist., 1867 (1868), $11,354$.

1868.1

Siluroids are characterised as "an order of Ganoid fishes which should be placed between the sturgeons and garpikes." Four families are recognized: Gonodonts, Loricaria, Callichthyoids and Doradides. The brain greatly resembles that of a sturgeon.

Mode of copulation among selachians] Proc. Boston Soc. Nat. Hist., $1871,14,341$.

1871.1

- Fish-nest [of Chironectes pictus] in the sea-weed of the Sargasso sea. Amer. Journ. Sci., 1872, 3. ser. 3, 154156. - Ann. Mag. Nat. Hist., 1872, 4. ser. 9, 243-245. - Bull. Soc. Sci. Nat. Neuchâtel, 1873, 9, 165-169. - Canadian Nat., 1871, n. s. 6, 354-356. Month. Micr. Journ., 1872, 7, 129-130. - Sci. Amer., 1872, 26, 40-41. 1872.1

The wonders of the egg. Sci. Amer., 1873, 28, 259; 275-276; 306307.

1873.1

Figures are given of the egg of the skate, a young shark, and of Callorhynchus.

Un voyage d'exploration scientifique dans l'Atlantique et l'Amérique du Sud. Revue Scientif., 1873, 2. sér. 4, 1077-1093. 1873.2

Seven letters to B. M. Peirce, of which the first two only mention fishes. I. But dans lequel sont entrepris les draguages. - Resultats probables, p. 1077-1079.

II. La mer Sargasses, - Le nid du Chironectes pictus, p. 1079-1080.
- Pisces Celebes. Icones Piscium, 4 tabulæ, ineditx. London, 1874. $4^{\circ}$. 1874.1

Fragment of an unfinished work found among the papers of the author after his decease.

Three different modes of teething among selachians. Amer. Naturalist, $1874,8,129-135$. 1874.2

Proof of this paper was uncorrected by the author before his death.

[Professor Agassiz on fish as food] Chicago Field, 1880, 12, 325.

1880.1

Cartas ineditas . . relativas á viagem ... realisada na Amazonia (de 11 de Agosto 1865 até 26 de Marco 1866) [Edited by Emil A. Goeldi] Boll. Mus. Hist. Nat., Pará, 1896, 1, 144-156. 1896.1

Lettres inédites de Louis Agassiz [Traduites par L. Islely] Bull. Soc. Sci. Nat. Neuchâtel, 1896, 24, 111-125. 1896.2

Centenaire de la naissance de Louis Agassiz. Bull. Soc. Vaud. Sci. Nat., 1907, 5. sér. 43, 301-302. - Ses travaux en zoologie et en paléongologie, par Henri Blanc. Ibid., p. 315-340. $2 \mathrm{pls}$.

1907.1

Agassiz, Louis, \& Agassiz, (Mrs.) Elizabeth Cabot Cary. A journey in Brazil. Boston \& London, 1868. figs. $8^{\circ}$.

1868.1

Observations on fishes are found in chapters i, iv, vii, xi.

Agassiz, Louis, \& Baird, Spencer Fullerton. Natural history illustrations prepared under the direction of Louis Agassiz and Spencer F. Baird, 1849. Six species of North American freshwater fishes. Explanation of plates by David Starr Jordan. Washington, 1889. 12 p. 6 pls. $4^{\circ}$.

1889.1

Six plates drawn by A. Sonrel in 1849, under the direction of Agassiz and Baird, for a projected monograph on the fresh-water fishes of jected monograph on The species figured are:

i. Notropis megalops (Raf.)

ii. Hybopsis kentuckiensis (Raf.).

iii. Semotilus bullaris (Raf.).

iv. Semotilus atromaculatus (Mitehill).

v. Lucius reticulatus (Le Sueur).

Agassiz, Louis, Cabot, J. Elliot, \& others. Lake Superior: its physical character, vegetation, and animals, compared with those of other and similar regions, by Louis Agassiz; with a narrative of the tour, by J. Elliot Cabot, and contributions by other scientific 
Agassiz \& Cabot.

gentlemen. Boston, 1850. 428 p. 17 pls. $8^{\circ}$.

1850.1

Reviewed in Amer. Journ. Sci., 1850, 2. ser. 10, 125-127. Account of the Petromyzonidx reprinted in New Philos. Journ. Edinb., 1850, 49, 242-246.

Agassiz, Louis, \& Egerton, (Sir) Philip Grey. A systematic and stratigraphical catalogue of the fossil fish in the cabinets of Lord Cole and Sir Philip Grey Egerton. By Sir Philip Grey Egerton. - With notes of his system of ichthyology, hitherto uncommunicated to the public, by L. Agassiz [The synoptical table of the orders and families is in French, by Agassiz] London, 1837. 23 p. $4^{\circ}$.

1837.1

Agassiz, Louis, Girard, Charles, \& Suckley, George. See Girard, Suckley \& Agassiz.

Agassiz, Louis, \& Gould, Augustus Addison. Principles of zoology, touching the structure, development, distribution, and natural arrangement of the races of animals, living and extinct; with numerous illustrations. Part 1. Comparative physiology. Boston, 1848. 236 p. $8^{\circ}$. 1848.1 2. ed. Boston, 1851. 460 p. $\mathcal{S}^{\circ}$. German version, Stuttgart, $1851.8^{\circ}$.

Agassiz, Louis, \& Muiller, Johannes. See Müller \& Agassiz.

Agassiz, Louis, \& Spix, Johann B. See Spix \& Agassiz.

Agassiz, Louis, \& Vogt, Carl. Anatomie des Salmones. Mém. Soc. Sci. Nat. Neuchâtel, 1845, 3, 1-196. $17 \mathrm{pls.}$ \& 14 figs.

1845.1

Ahl, Jonas Nicolaus. Specimen ichthyologicum de Muræena et Ophichtho. Inaug. Dissert. Upsala, 1789. $8^{\circ}$.

1789.1

Another edition of the same

(In Thunberg, $C . P$. Dissertationes Academicx Upsalix, etc. vol. iii, no. 1. Upsala, 1801. $8^{\circ}$ )

1801.1

Ahlborn, Christian Georg Friedrich. Zur Neurologie der Petromyzonten. Nachr. Gesell. WViss. Göttingen, 1882, no. $20,677-682$.

1882.1

Untersuchungen über das Gehirn der Petromyzonten. Zeitschr. Wiss. Zool., 1883, 39, 191-294. pls. Also separate; Leipzig, 1883.

1883.1

Ueber den Ursprung und Austritt der Hirnnerven von Petromyzon. Zeitschr. Wiss. Zool., 1884, 40, 286-308. pl.

1884.1
Ueber die Segmentation des Wirbelthierkörpers. Zeitschr. Wiss. Lool., 1884, 40, 309-330.

1884.2

Der Flug der Fische. Realgymnasium des Johanneums, 70. Geburtstage Prof. Dr. Karl Möbius. Hamburg, 1895. 56 p. pl. Z Zool. Jahrb. (Syst.), 1897, 9, 329-338.

1895.1

Ueber die Bedeutung der Heterocerkie und ähnlicher unsymmetrischer Schwanzformen schwimmender Wirbelthiere für die Ortsbewegung. - Zeitschr. Wiss. Zool., 1895, 61, 1-15. pl. Zool. Centralbl., 1895, 5, 298-299. [Abstract] Journ. Micr. Soc. London, 1896, pt. 3, 299.

1895.2

Ahlburg, Johannes. Die Trias im südlichen Oberschlesien. Abhandl. Geol. Landesanst, Berlin, 1906, n. s. 50 , 1-163. 6 pls.

1906.1

Ahlers, Charles. Das Absteigen der Forellen aus Quellbächen. Allgem. Fisch. Zeitg., 1900, 25,21-23; 83.

1900.1

Ahmad, A. Interim reports of the marine fishery investigations of the government steam trawler "Golden Crown." Coll. Papers Fish. Surv. Bengal, 1911, 19-41.

1911.1

Aicard, Jean. Sur l'époque du départ pour la pêche en Islande. C. R. Acad.Sci. Paris, 1892, 118, 330. 1892.1

Aichel, Otto. Zur Kenntnis des histologischen Baues der Retina embryonaler Teleostier. Erlangen, 1896. 25 p. 2 pls.

1896.1

Kurze Mitteilung über den histologischen Bau der Riechschleimhaut embryonaler Teleostier. Sitzber. Ges. Morph. Physiol. München, 1897, 11, 73-78. fig.

1897.1

Zur Kenntniss des embryonalen Rückenmarkes der 'Teleostier. Sitzber. Gesell. Morph. Physiol. München, 1897, 11, 25-40. figs.

1897.2

Vörlaufige Mitteilung über die Entwicklung der Nebennieren bei Selachiern und über eine neue Homologie der Nebennieren in der Wirbeltierreihe. Sitzber. Phys. Med. Soc. Erlangen, 1900, 1-86. [Abstract] Anat. Anz. $1900,17,30-31$.

1900.1

Vergleichende Entwicklungsgeschich te und Stammesgeschichte der Nebennieren. Arch. Mikr. Anat., 1900, 56, 1-80. pls. i-iii \& fig. 
Das Tectum loborum opticorum embryonaler Teleostier mit Berücksichtigung vergleichend anatomischer Verhaltnisse. Inaug. Dissert., Erlangen, 1901. 22 p.

1901.1

Aigner, Josef. Salzburg's Fische; mit Vorwort von J. Th. M. Zetter. Jahresber. Vaterl. Mus. Carolino-August. Landeshaupst. Salzburg, 1859 , 72-92.

1859.1

Aiken, James. Notes on the fishes of New Amsterdam market. 'Timehri Journ. Agric. Commerc. Soc. Brit. Guiana, 1913, 3. ser. 3, 49-50. 1913.1

Ainsworth, Stephen H. The grayling in Michigan. Amer. Sportsman $1874,4,283$.

1874.1

Ainsworth, W.F., Tristram, H.B., \& Kingsley, - The Nile fish in Galilee. Athenæum, 1865, 2, 248; 277; $310-311$.

1865.1

Airaghi, Carlo. Di un Pholidophorus del Retico lombardo. Rend. Istit. Lombard., 1908, 2. ser. 41, 768-772 fig.

1908.1

Aitch, $W$. Suspended animation in frozen fish. Forest \& Stream, 1875, 4, 37.

1875.1

Aitchison, (Brigade-Surg.) James Edward Tierney. Zoology of the Afghan delimitation commission. Fishes, by $\mathrm{A}$. Günther. Trans. Linn. Soc., 1888-94 (1889), 2. ser. 5.

1889.1

Fishes, by A. Günther, p. 106-109. pl.

Aitken, John. Discovery of a new species of fish of the genus Acrolepis in the Millstone Grit of Yorkshire. Pop. Sci. Rev., 1874, 13, 213-214. 1874.1

- Fish remains from the Coal Measures. Trans. Manchester Geol. Soc., 1876, 13, 199-202.

1876.1

Notes on the discovery of a new fish, of the genus Acrolepis $\mathbf{A g}$., in the Millstone Grit, near Hebden Bridge, Yorkshire. Trans. Manchester Geol. Soc., $1876,13,36-43$.

1876.2

Ajasson de Grandsagne (Vicomte) J. B. Francois Etienne. Précis d'ichthyologie, ou, d'histoire naturelle des poissons; collection de figures dessincées par Raymond. Paris, 1828. $8^{\circ}$. 1828.1

Résumé d'ichthyologie; ou, d'histoire naturelle des poissons, précédé d'une introduction et suivi d'une biographie et d'un vocabulaire. 2 vols. Paris, 1829. 48 pls. $12^{\circ}$.
Traité élémentaire d'hictoire naturelle des poissons ... avec un appendice sur les poissons fossiles. Paris, 1829. $16^{\circ}$. (Encyclopédie portative)

1829.2

Akamatsu, Kunitaro. The older accounts about Salanx microdon Bleeker [Text in Japanese] Zool. Mag., Tōkyō, 1904, 16, 323-344.

1904.1

Akashi, T. [On poisoning by fish: Tetrodon, etc.] Ijishinshi, Tōkyō, 1880 , no. 27.

1880.1

Akekio, Sekizawa. Memorandum on fish culture in Japan, with a notice of experiments in breeding the California trout. Rept. U. S. Fish Comm., 1879 (1882), 7, 645-648.

1882.1

Akerly, Samuel. Economical history of the fishes sold in the markets of the city of New-York. Amer. Monthly Mag., 1818, 2, 292-296; 370-372; 473475. 1817.1

Notes on the market fishes of New York.

- Supplement to the agriculture of Richmond county, Staten-Island $[N . Y$. Trans. Agric. Soc. N. Y., Assembly no. $100,1843,454-461$.

1843.1

Contains a list of fishes observed on the soutl side of Staten Island.

Akers, George F'. Fish culture in Tennessee. Forest \& Stream, 1877, 8, 49.

1877.1

-_ Concerning striped bass. Forest \& Stream, 1879, 11, 36.

1879.1

Aladyna, $M$. Sur le tissu du squelette des Téléostéens ¡Russian with French résumé] Biol. Zeitschr. Moscow, 1910, 1, 229-240.

1910.1

Ueber den Bau der Knochen bei den Knochenfischen [Text in Russian] Journ. Conf. Nat. Méd. Russes, Moscov, $1910,12,551-552.1910 .2$

Albee, Louise Rankin. The Bartlett collection. A list of books on angling, fishes and fish culture in Harvard College Library. Cambridge, 1891. 180 p. $8^{\circ}$. In Harvard College Library, Bibliographical Contributions no. 51).

1891.1

Albert I, Honoré Charles (Prince de Monaco) Deuxième campagne scientifique de l'Hirondelle dans l'Atlantique de Nord. Bull. Soc. Géogr., 1887, 7. sér. 8, 530-546. - C. R. Acad. Soc. Géogr., 1887, 260. 
Albert I, $H$. C .

La pêche de la sardine sur les côtes d'Espagne. Rev. Scient., 23 avril, 1887.

1887.2

Also published separately under the title "L'industrie de la sardine sur les côtes de la Galice." Paris, 1887. $18^{\circ}$.

- Poissons-lune (Orthagoriscus mola) capturés pendant deux campagnes de 1" Hirondelle." Bull. Soc. Zool. France, 1889, 14, 16-18. 1889.1

- Résultats des campagnes scientifiques accomplies sur son yacht ['Hirondelle] par le Prince de Monaco. Monaco, 1889-1896. 11 fasc. $4^{\circ}$.

\section{1}

Poissons provenant des compagnes du yacht .. par R. Collett. 1896, fasc. 10. 198 p. 6 pls.

- Sur la quatrième campagne de la "Princesse Alice." C. R. Acad. Sci. Paris, 1898, 126, 1-4; 1903, 136, 211215. fig.

1898.1

Sur la distribution bathymétrique de certaines espèces d'animaux marins. Cinquantenaire Soc. Biol. Paris, 1899, 55-56.

1899.1

Deuxième voyage au Spitsberg. Bull. Mus. Hist. Nat., 1900, 7-13. 4 figs.

1900.1

Sur la cinquième campagne scientifique de la "Princesse Alice II." C. R. Acad. Sci. Paris, 1904, 138, 13981400 .

1904.1

Sur la septième campagne scientifique de la "Princesse Alice": La mer des Sargasses. C. R. Acad. Sci. Paris, $1906,142,621-624$.

1906.1

Albert, Federico. La introducción de los salmones. Mem. Soc. Cient. Chile, $1902,12,1-54$. figs.

1902.1

La pesquería comparada en la colonia del Cabo i Chile. Minis. Indus., Soc. Ensayos Zool. Bot., Santiago, 1903, 3-15.

1903.1

Bericht an den bayerischen Landesfischereiverein über den Transport von Lachs- und Forelleneiern und lebenden Schleien und Forellen nach Rio Blanco im Auftrage der chilenischen Regierung. Allgem. Fisch. Zeitg., 1906, 31. Jahrg., 497-499.

1906.1

Zweiter Bericht an den bayerischen Landesfischereiverein über die Aussetzung von Lachsen und Forellen in die Flüsse Chiles. Allgem. Fisch. Zeitg., 1907, 32. Jahrg., 13-14. 1907.1
El agotamiento de los recursos naturales de bosques, pesca i caza. Boletin de Bosques, Pesca i Caza, Santiago, $1912,1,217-288$.

1912.1

La esplotación de la pesca i sus pruductos en Noruega. Boletin de Bosques, Pesca i Caza, Santiago, 1912, 1, 324-327.

1912.2

La lejislación de la pesca maritima del Japon i sus efectos. Boletin de Bosques, Pesca i Caza, Santiago, 1912, 1, 191-196.

1912.3

Mi opinion profesional sobre los bosques, la pesca i la caza. Boletin de Bosques, Pesca i Caza, Santiago, 1912, $1,3-6$.

1912.4

Albin, Eleazar. The history of esculent fish, with plates drawn and engraved by Eleazer Albin; and an essay on the breeding of fish, and the construction of fish-ponds, by Roger North. London, 1794. 80 p. 18 col. pls. $4^{\circ}$.

1794.1

Albrecht, idolf. Zur Entwicklungsgeschichte des Achsenskeletes der Teleostier. Inaug. Dissert. Strasburg, 1902. 45 p. 2 pls.

1902.1

Albrecht, [Karl Martin] Paul. For biographical notice see Leopoldina, 1894, 30. 163-164; Zeitschr. Ethnol., 1894, 26,420 .

Beitrag zur Morphologie des M. omo-hyoides und der ventralen inneren Interbranchialmusculatur in der Reihe der Wirbelthiere. Kiel, 1876. $105 \mathrm{p}$. pls. i-vi.

1876.1

Sur la valeur morphologique de l'articulation mandibulaire, du cartilage de Meckel et des osselets de l'ouie avec essai de prouver que l'écaille du temporal des mammifères est composée primitivement d'un squamosal et d'un quadratum. Bruxelles, 1883. 22 p. fig.

1883.1

- Sur la valeur morphologique de la trompe d'Eustache et les dérivés de l'are palatin, de l'are mandibulaire et de l'are hyoïdien des vertébrés, suivi de la preuve que le "symplectico-hyomandibulaire" est morphologiquement indépendant de l'are hyoïdien. Bruxelles, 1884. 41 p. 13 figs. $\quad 1884.1$

Sur les spondylocentres épipituitaires du crâne, la non-existence de la poche de Rathke, et la présence de la chorde dorsale et de spondylocentres 
dans le cartilage de la cloison du nez des vertébrés. Bruxelles, 1884. 33 p. 4 figs. $8^{\circ}$.

1884.2

Sur la non-homologie des poumons des vertébrés avec la vessie natatoire des poissons. - Quelques mots de critique à propos d'un récent article de M. le Dr. Albrecht par M. le Dr. Renson. Hambourg, 1886. 44 p. 4 figs

1886.1

Ueber die morphologische $\mathrm{Be}$ deutung Penischisis, Epi- und Hypospadie. Centralbl. Chirurgie, 1886, 1-3.

1886.2

- Ueber eine in zwei Zipfel auslaufende, rechtsseitige Vorderflosse bei einem Exemplare von Protopterus annectens Owen. Sitzber. Preuss. Akad. Wiss., Berlin, 1886, 32, 545-546. pl.

1886.3

Vergleichend anatomische Untersuchungen. Erster Band; erstes Heft. Hamburg, 1886. 42 p. 5 figs.

1886.4

Albro, Samuel. Condition of the shore fisheries of Massachusetts and Rhode Island in 1871. Rept. U. S. Fish Comm., 1871-72 (1873), 1, 8.

1873.1

Alcock, (Surg. Maj.) Alfred William. Descriptions of some new and rare species of fishes from the Bay of Bengal, obtained during the season of 1888-89. Journ. Asiatic Soc. Bengal, 1889, 58 , pt. 2, 296-305. pl.

1889.1

List of the Pleuronectidse obtained in the Bay of Bengal in 1888 and 1889 , with descriptions of new and rare species. Journ. Asiat. Soc. Bengal, $1889,57,279-295 ;$ 296-305. pls. xvixviii, xxii.

1889.2

-... On the bathybial fishes of the Bay of Bengal and neighboring waters, obtained during the seasons 1885-1889. Ann. Mag. Nat. Hist., 1889, 6. ser. 4, $376-399 ; 450-461$.

1889.3

- Descriptions of some new and rare species of fishes from the Bay of Bengal, obtained during the season of 1888-89. Journ. Asiat. Soc. Bengal, $1890,58,296-305$. pl.

1890.1

Observations on the gestation of some sharks and rays. Journ. Asiatic Soc. Bengal, 1890, 59, pt. 2, 51-56. pl. 1890.2
On some undescribed shorefishes from the Bay of Bengal. Ann. Mag. Nat. Hist, 1890, 6. ser. 6, 425443. 3 figs.

1890.3

On the bathybial fishes collected in the Bay of Bengal during the season 1889-1890. Ann. Mag. Nat. Hist., 1890 , 6. ser. 6, 197-222; $295-311$. pls. viii-ix.

1890.4

On a viviparous bathybial fish from the Bay of Bengal. Proc. Zool. Soc. London, 1891, pt. 2, 226-227. fig. 1891.1

- On the deep-sea fishes collected by the "Investigator" in 1890-91. Ann. Mag. Nat. Hist., 1891, 6. ser. 8, 16-34; 119-138. pls. vii-viii. 1891.2

A case of commensalism between a gymnoblastic Anthomedusiod (Stylactis minoi) and a scorprenoid fish (Minous inermis). Ann. Mag. Nat. Hist., 1892, 6 ser. 10, 207-214; 345-365. pl. xviii. 1892.1

Illustrations of the zoölogy of H. M. Indian marine surveying steamer "Investigator," under the command of Comm. A. Carpenter and Comm. R. F. Hoskyn. Calcutta, 1892. 4 1892.2 Part i. Fishes. pls. i-vii.

- On the bathybial fishes collected during the season of 1891-92. Ann. Mag. Nat. Hist., 1892, 6. ser. 10, 345365. pl. \& 2 figs. 1892.3

- On utero-gestation in Trygon bleekeri. Ann. Mag. Nat. Hist., 1892, 6. ser. 9, 417-427. pl. 1892.4

Some observations on the embryonic history of Pleroplatea micrura. Ann. Mag. Nat. Hist, 1892, 10, 1-8. pl. - Journ. Roy. Micr. Soc. London, 1892 , pt. 5, 588-589.

1892.5

An account of the deep-sea collection made during the season of 1892 1893. Journ. Asiatic Soc. Bengal, 1893. $62,169-18 t$. pls. viii-ix.

1893.1

New species of Lophius, Physiculus, Neobythites, Odontostomus, and Congromuræena. Journ. Asiatic Soc. Bengal, 1893, 62, pt. 2, 177-184. pl.

1893.2

An account of a recent collection of bathybial fishes from the Bay of Bengal and from the Laccadive Sea. Journ. Asiatic Soc. Bengal, 1894, 63, 115-137. pls.

1894.1 
Alcock, A. W.

On a new species of viviparous fish of the family Ophididie. Ann. Nag. Nat. Hist., 1895, 6. ser. 16, 144146.

1895.1

A supplementary list of the marine fishes of India, with descriptions of 2 new genera and 8 new species. Journ. Asiatic Soc. Bengal, 1896, 65, 301-338.

1896.1

A note on the deep-sea fishes, with descriptions of some new genera and species, including another probably viviparous Ophidioid. Ann. Mag. Nat. Hist., 1898, 7. ser. 2, 136-156. fig.

1898.1

Report on the natural history results of the Pamir boundary commission. Calcutta, 1898. 45 p. 5 pls. $4^{\circ} .1898 .2$

A descriptive catalogue of the Indian deep-sea fishes in the Indian Museum, collected by the royal Indian marine survey ship "Investigator." Calcutta, 1899. 220 p. 1 map. 1899.1

[Review] Nature, 1899, 61, 291.

A guide to the zoological collections exhibited in the fish gallery of the Indian Museum. Calcutta, 1899. 92 p. $8^{\circ}$.

1899.2

Halimochirurgus centriscoides, a new deep-sea fish from the Gulf of Manár] Proc. Asiatic Soc. Bengal, $1899,68,78$.

1899.3

An interesting instance of commensalism between a fish and a zoophyte and some models of some typical deepsea fishes made by native artists] Proc. Asiatic Soc. Bengal, 1899, 68, 37-39.

1899.4

_Loölogical gleanings from the royal Indian marine ship "Investigator." Sci. Mem. by Medical Officers of the Army India, Calcutta, 1901, 12, 3576.

1901.1

A naturalist in Indian seas. Four years with the royal Indian marine survey ship "Investigator." London, 1902. 328 p. figs. $8^{\circ}$.

1902.1

A large Indian sea-perch. $\mathrm{Na}$ ture, $1905,71,415$.

1905.1

Alcock, (Surg.-Maj.) Alfred William, \& McGilchrist, A.C. Illustrations of the zoology of the royal Indian marine surveying steamer "Investigator." 3 pts. Calcutta, 1892-1907. 4\% 1892.1 Part ii. Fishes, plso i-xxxriii.
Alcock, (Surg.-Maj.) Alfred William, \& Wood-Mason, James. See WoodMason \& Alcock.

Alcock, (Miss) Rachel. The digestive process of Ammocoetes. Proc. Cambr. Philos. Soc., 1891, 7, 252-255. - Zool. Centralbl. 7. Jahrg., 169.

1891.1

The peripheral distribution of the cranial nerves of Ammocotes. Journ. Anat. Phys., 1898, 33, 131-153. pl. \& 2 figs.

1898.1

- On proteid digestion in Ammocoetes. Journ. Anat. Phys. London, 1899, 33, 612-637.

1899.1

Abstract of article published in 1891. See also W. A. Nagel, in Zool. Centralbl., 1899, 7, 169.

Aleksandrov, $K . P$. Die Fischerei im Flussgebiet der Wolga oberhalb Saratow. I. Die Fischerei im ersten. Inspektionsrayon. St. Petersburg, 1909. 98 p. 4 maps.

1909.1

Das Laichen des Sterlets in der Wolga bei Simbirsk im Frühjahre 1910 [Text in Russian] Messager Commerce de Poissons, St. Petersb., 1910, 25, 255-258.

1910.1

Alemán, Jesús. Un punto de duda respecto del aparato venenoso del I ctalurus dugesii. Naturaleza, Soc. Mex. Hist. Nat., 1891, 2. ser. 1, 498-499. 2 figs.

1891.1

Alenitsin, Vladimir Dimitrievič. Ueber die Fischfauna der TroitzkoTscheljabinskischen Seen. Trud. St. Petersb., 1873,4,59-60. 1873.1

Schilderung der Troitzko-Tscheljabinskischen Seen und deren FischFauna. Travaux Soc. Imp. Natur. St. Pétersb., 1874, 5, 1-78.

1874.1

- Biologische Mittheilungen über Fische der 'Troitzko-'Tscheljabinski' schen Seen. Ryechi i Protok, 1880, 6, 78-84.

1880.1

Alenitzen, $W . D$. See Alenitsin, T. D.

Alessandri, Guilo de. Contribuzione allo studio dei pesci terziarii del Piemonte e della Liguria. Mem. Accad. Sci. 'Torino, 1895, 2. ser. 45, 262-29t. pl.

1895.1

Ricerche sui pesci fossili di Paranà (Repubblica Argentina) Atti Accad. Sei. Torino, 1895-96, 31, 715730. pl. 
- Anvanzi di Oxyrhina hastalis del Miocene di Alba. Atti Soc. Ital. Sci. Nat., Milano, 1896, 36, 263-269. pl.

1896.1

La pietra da Cantoni de Rosignano e di Vignale (Basso Monferrato). Studi stratigrafici e paleontologici. Mem. Mus. Civ. Stor. Nat., Milano, 1897, 6, fasc. 1, 1-98. pls. i-vi. 1897.1

Appunti di geologia e di paleontologia sui dintorni di Acqui. Atti Soc. Ital. Sci. Nat., Mus. Civ. Milano, 1901, 39, 173-348. pl.

1901.1

Note d' ittiologia fossile. Atti Soc. Ital. Sci. Nat, Mus. Civ. Stor. Nat. Milano, 1902, 41, 443-462. pl. 1902.1

- Sopra alcuni odontoliti pseudomiocenici dell' Istmo di Suez. Atti Soc. Ital. Sci. Nat., Milano, 1902, 41, 287312. pl.

1902.2

Studii sui pesci triasici della Lombardia. Mem. Soc. Ital. Sci. Nat., Mus. Civ. Stor. Nat., Milano, 1910, 7, no. 1, 1-145. 9 pls.

1910.1

Alessandrini, Antonio. Observations sur le pancréas des poissons; extraites d'une lettre adréssée aux rédacteurs. Ann. Sci. Nat., 1833, 29, 193195. - Polygrafo, 1833, 14, 266-267.

1833.1

Descriptio veri pancreatis glandularis et parenchymatosi in Accipensere et in Esoce reperti. Novi Comm. Acad. Sci. Instit. Bonon., Bologna, 1836, 2, 335-349.

1836.1

Observationes super intima branchiarum structurâ piscium cartilagineorum. Novi Comm. Acad. Sci. Instit. Bonon., Bologna, 1840, 4, 329344. pls. i-v.

1840.1

- De piscium apparatu respirationis tum speciatim Orthagorisei: Orthagoriscus alexandriniRanzani. Novi Comm. Acad. Sci. Instit. Bonon., Bologna, 1839, 3, 359-382.

1839.1

- Apparatus branchiarum Heterobranchi anguillaris, Heterobranchus anguillaris Geoff., Silurus anguillaris Linnæi. Novi Comm. Acad. Sci. Instit. Bonon., Bologna, 1837 (1842), 5, 149164. pls. i-ii.

1842.1

- De intima squamarum textura piscium, deque scutulis super corio scatentibus crocodili atque armadili. Novi Comm. Acad. Sci. Instit. Bonon., Bologna, $1849, \quad 9, \quad 371-392 ; \quad 393-410$. 5 pls.
Alessi, C. Sviluppo della colonna vertebrale nei Clupeidi: ricerche, confronti, critica. Inaug. Dissert. Avola, 1898. 13 p. $8^{\circ}$. 1898.1

Alessi, Giuscppe. Introduzione alla zoologica del mare di Sicilia. Atti Soc. Gioenia Catania, 1836, 11, 89. $\quad 1836.1$

Alexander, A.B. Notes on the halibut fishery of the northwest coast in 1896. Bull. U. S. Fish Comm. 1897 (1898), 17, 141-144.

1898.1

Notes on the boats, apparatus, and fishing methods employed by the natives of the South Sea Islands and results of fishing trials by the "Albatross." Rept. U. S. Fish Comm. 1901 (1902), 27, 741-829. pls. \& figs.

1902.1

- Report on statistics and methods of the fisheries. Rept. Bur. Fisheries, Washington, 1904 (1905), 121162.

1905.1

Statistics of the fisheries of the Great Lakes in 1903. Rept. Bur. Fisheries, Washington, 1904 (1905), 643731.

1905.2

- Statistics of the fisheries of the Gulf States, 1902. Rept. U. S. Fish Comm., 1903 (1905), 29, 411-481.

1905.3

Statistics of the fisheries of the Ner England states, 1902. Rept. Bur. Fisheries, Washington, 1904 (1905), 245-325.

1905.4

-. Statistics of the fisheries of the South Atlantic states, 1902. Rept. U.S. Fish Comm., 1903 (1905), 29, 343-410.

1905.5

Preliminary examination of halibut fishing grounds of Pacific coast. Dept. Commerce \& Labor Wash., Fish. Doc. no. $763,1912,1-56$.

1912.1

Alexander, D. Hoore. A review of piscine tubercle, with a description of an acid-fast bacillus found in the cod. 21. Rept. Lancashire Sea-Fish Lab., 1912 (1913), 43-50. fig. - Trans. Liverpool Biol. Soc., 1913, 27, 219-226. fig.

1913.1

Alexander, D. Hoore, \& Riddell, W. See Ridell \& Alexander.

Alexander, Henry. On the remains of fish in flints. Quart. Journ. Geol. Soc. London, 1853, 10, 334.

1853.1

Alexander, (Sir) James Edward. Salmon fishing in Canada. 2 vols. London, 1849. $8^{\circ}$. 1849.1 
Alexander, $J . E$.

1853. $8^{\circ}$

1860. $8^{\circ}$. The same. 3 . ed. London, On the preservation of fishing streams. Dundee, 1867. 12 ${ }^{\circ}$ 1867.1

On the preservation of fish and preventing the pollution of rivers. Rept. British Assoc. Adv. Sci., 1880, 672.

1880.1

Alexander, Thomas. Fish and fishing in fresh waters. Seaside Library, [New York, 1879?] 27, no. 567; 1-28, Lakeside Library [Chicago] 4, no. 90; 541-568. figs.

1879.1

Alferaki, Sergij Nikolaevic. See Alpheraki, S. $N$.

Al Fresco ipseudon, for Kenworthy, C.J.I

Alix, Edmund. Sur l'absence de véritables apophyses articulaires aux vertèbres des poissons osseux. Bull. Soc. Philom. Paris, 1874, 6. ser. 11, 6-7. Journ. Zool. (Gervais), 1874, 3, 20-21.

1874.1

- Sur les connexions de la cage branchiale des lamproies [Cyclostomata] Bull. Soc. Philom. Paris, 187980 (1880), 7. ser. 4, 208.

1880.1

Allamand, Johann Nicolaus Sebastian. Kort verhaal van de uitwerkselen, welke een Americannse Vis veroorzaakt op degeenen, die hem aanraaken [Gymnotus] Verhandl. Holl. Maatsch. Wet. Haarl., 1776, 17, 372-379.

1776.1

Allee, $W . C$., \& Shelford, Victor $E$. See Shelford \& Allee.

Allen, Bennel Mills. Some observations upon the eye of Bdellostoma stouti. Science, 1902, n. s. 15, 467-468. 1902.1

The eye of Bdellostoma stouti Anat. Anz., 1905, 26, 208-211. 11 figs. 1905.1

The origin of the sex-cells of Amia and Lepidosteus. Journ. Morphol., 1911, 22, 1-36. 5 pls. \& fig.

1911.1

Allen, Edward Johnson. On the fauna and bottom-deposits near the thirtyfathom line from the Eddystone grounds to Start Point. Journ. Mar. Biol. Assoc., 1897-99, n. s. 5, 365-542. 8 pls. \& 16 charts.

1897.1

Pages 381-387 are by IR. H. Worth.
'The regulations of the local sea fisheries committees in England and Wales. Journ. Mar. Biol. Assoc., Plymouth, 1897, n. s. 4, 386-395. 1897.2

Report on the present state of knowledge with regard to the habits and migrations of the mackerel (Scomber scomber) Journ. Mar. Biol. Assoc., $1897-99$, n. s. 5, 1-29.

1897.3

'The Stockholm fisheries conference. Nature, $1899,61,54 ; 227$. Remarks by W. A. Herdman, 78, 177; by George Murray, 102; by H. M. Kyle, 151-152. - [Review] Science, 1899, n. s. $10,977-978$.

1899.1

Mackerel and sunshine. Journ.

Mar. Biol. Assoc., Plymouth, 1909, n.s. 8, 394-406. 5 figs.

1909.1

A selected bibliography of marine bionomics and fishery investigation. Plymouth, [priv. print.] 1911. 29 p. $8^{\circ}$.

1911.1

Allen, E. J., \& Todd, $R . A$. The fauna of the Salcombe Estuary. Journ. Mar. Biol. Assoc., Plymouth, 1900, n.s. 6, 151-217. map. 1900.1

The fauna of the Exe Estuary. Journ. Mar. Biol. Assoc., Plymouth, 1902, n. s. 6, 295-335. map. 1902.1

Allen, $G$. From fish to reptile. Cornhill Mag., 1882, 46, 21. - Eclectic Mag., $1882,99,392$.

1882.1

- Fish which can live out of water. Cornhill Mag., 1885, 52, 523.Eclectic Mag., 1886, 106, 81. - Pop. Sci. Monthly, 1886, 28, 334. 1885.1

Allen, George $R$. Notes on the feeding of parent trout with reference to virility of eggs produced. Trans. Amer. Fisheries Soc. 1905 (1906), 122-123. 1906.1

Allen, $H$. On the pectoral filaments in the sea-robin (Prionotus palmipes) Proc. Acad. Nat. Sci. Philad. 1885 (1886), 377.

1886.1

Allen, $R$. N. On some drawings of fishes of the river Quorra. Proc. Zool. Soc. London, 1836, pt. 4, 147. 1836.1

Allen, William $F$. The blood-vascular system of the Loricati, the mailchecked fishes. Proc. Wash. Acad. Sci., 1905, 7, 27-157. 6 pls. \& 42 figs. 1905.1

Distribution of the lymphatics in the head and in the dorsal, pectoral 
and ventral fins of Scorpanichthys marmoratus. Proc. Wash. Acad. Sci., 1906, 8, 41-90. 3 pls. \& 10 figs. $\quad 1906.1$

Distribution of the subcutaneous vessels in the head region of the ganoids, Polyodon and Lepidosteus. Proc. Wash. Acad. Sci., 1907, 9, 79-158. 15 pls. \& 28 figs.

1907.1

Distribution of the subcutaneous vessels in the tail region of Lepidosteus. Amer. Journ. Anat., 1908, 8, 4988. 25 figs. - Anat. Rec., Philad., $1908,2,65-70$.

1908.1

- Distribution of the lymphatics in the tail region of Scorpanichthys marmoratus. Amer. Journ. Anat., 1910, 11, 1-53. 12 figs.

1910.1

Notes on the breeding season and young of Polyodon spathula. Journ. Wash. Acad. Sci., 1911, 1, 280-283.

1911.1

- Studies on the development of the veno-lymphatics in the tail-region of Polistotrema (Bdellostoma) stouti. Quart. Journ. Micr. Sci., 1913, 69, pt. 2, 309360. pls. xix-xxi.

1913.1

Allen, William S. Statement concerning the menhaden fishery. Rept. U. S. Fish Comm., 1877 (1879), 5, 413414.

1879.1

Allent, $B$. Les animaux industrieux. Paris, [n.d.] $16^{\circ}$.

Allêon, Dulac. Mélanges d'histoire naturelle. 2 vols. Lyons, 1765. $16^{\circ}$.

1765.1

Allerton, Walter $S$. Notes of the Catskill range. Forest \& Stream, 1876, 7, 289.

1876.1

Alleyne, $H . G$. \& Macleay, W.M. The ichthyology of the Chevert Expedition. Proc. Linn. Soc. N. S. Wales, $1877,1,261-281$; 321-359. pls. iii-iv; $\mathrm{x}$-xvii.

1877.1

Allis (junior), Edward Phelps. The anatomy and development of the lateral line system in Amia calva. Journ. Morph., 1888-89, 2, 463-540. pls. xxxxlii \& 10 figs.

1888.1

The cranial muscles and cranial and first spinal nerves in Amia calva. Journ. Morph., 1895, 11, 485-491; 1897 , 12, 487-808. pls. \& figs.

1895.1

The morphology of the petrosal bone and of the sphenoidal region of the skull of Amia calva. Zool. Bull., 1897, $1,1-26$. 1897.1
'The homologies of the occipital and first spinal nerves of Amia and teleosts. Zool. Bull., 1898, 2, 83-97.

1898.1

- Les inuscles crâniens, les nerfs crâniens et les premiers nerf́s spinaux chez l'Amia calva. Arch. Zool. Expér. Gén., 1898, 3. sér. 6, 63-90. 4 figs.

1898.2

On the morphology of certain of the bones of the cheek and snout of A mia calva. Journ. Morph., 1898, 14, 425-466. pl.

1898.3

An abnormal musculus obliquus superior in Carcharias. Anat. Anz., 1899, 16, 605-607. fig. $\quad 1899.1$

On certain homologies of the squamosal, intercalar, exoccipital and extrascapular bones of Amia calva. Anat. Anz., 1899, 16, 49-72. 1899.2

A reply to certain of Cole's criticisms of my work on Amia calva. Anat. Anz., 1899, 15, 364-379. 1899.3

The lateral sensory canals of Polypterus bichir. Anat. Anz., 1900, 17, 433-451. 3 figs. - [Abstract] Journ. Roy. Mier. Soc. London, 1900, pt. 5, 572 .

1900.1

The premaxillary and maxillary bones, and the maxillary and mandibular breathing valves of Polypterus bichir. Anat. Anz.,1900, 18, 257-289. 3 figs.-Journ. Roy. Mier. Soc. London, 1901, 24-25.

1900.2

The pseudobranchial circulation in Amia calva. Zool. Jahrb., 1900, 14, 107-134. pl. - [Abstract] Journ. Roy. Micr. Soc. London, 1900, pt. 2, 138.

1900.3

The lateral sensory canals, the eye-muscles, and the peripheral distribution of certain of the cranial nerves of Mustelus laevis. Quart. Journ. Micr. Sci., 1901, n. s. 45, 87-236. pls. $x$-xii \& fig. - [Abstract] Journ. Roy. Micr. Soc. London, 1902, 29.

1901.1

The lateral sensory system in the Muranidæ. Intern. Monats. Anat. Physiol., 1903, 20, 125-170. pls. 1903.1

On certain features of the cranial anatomy of Bdellostoma dombeyi. Anat. Anz., 1903, 23, 259-281; 321-339. fig. 1903.2 
Allis, $E$. $P$.

- On certain features of the lateral canals and cranial bones of Polyodon folium. 'Kool. Jahrb., 1903, 17, 659-678. pl. \& 2 figs.

1903.3

- The sliull, and the eranial and first spinal muscles and nerves in Scomber scomber. Journ. Morph., 1903, 18, 45-328. pls. - [Abstracts] Anat. Anz., 1903, 24, 408-410. - Journ. Comp. Neur. Pysch., 1903, 14, 83-84. 1903.4

'The latero-sensory canals and related bones in fishes. Intern. Monats. Anat. Pliysiol., 1904, 21, 401-502. pls. viii-xx \& fig.

1904.1

- The cranial anatomy of the mail-cheeked fishes. Anat. Anz., 1907, $30,568-573$.

1907.1

The pseudobranchial and carotid arteries in Ameiurus. Anat. Anz., 1908, 33, 256-270. fig.

1908.1

The pscudobranchial and carotid arteries in Polypterus. Anat. Anz., $1908,33,217-227$. fig.

1908.2

'The pseudobranchial and carotid arteries in the gnathostome fishes. Zool. Jahrb. (Abth. Anat.), 1908, 27, 103-134. pl.

1908.3

- The cranial anatomy of the mail-cheeked fishes. Zoologica, 1909 , 22, 1-219. 5 pls.

1909.1

'The pseudobranchial and carotid arteries in Chlamydoselachus anguinews. Anat. Anz., 1911, 39, 511-519. 2 figs.

1911.1

- The pseudobranchial and carotid arteries in Polyodon spathula. Anat. Anz. 1911, 39, 257-262; 282-293. fig.

1911.2

'The branchial, pseudobranchial and carotid arteries in Chimara (Hydrolagus) collici. Anat. Anz., 1912, 42, 10 18. 2 figs.

1912.1

- 'The branchial, pseudobranchial and carotid arteries in lieptanchus (Nolidanus) cinereus. Anat. Anz., 1912, 41, 478-192. 2 figs. 1912.2

'The branchial, pseudobranchial and carotid arteries in Raja radiata. Anat. Anz., 1912, 41, 579-589. 2 figs.

1912.3

'The pscudobrinchial and carotid arteries in Esox, Salmo and Gadus, fogether with a description of the arter- ies in the adult Amia. Anat. Anz., 1912 , 41, 113-142. 6 figs.

1912.4

- The homologies of the ethmoidal region of the Sclachian skull. Anat. Anz., 1913, 44, 322-328. 1913.1

Certain homologies of the palato-quadrate of sclachians. Anat. Anz., 1914, 45, 353-373.

1914.1

'The pituitary fossa and trigemino-facialis chamber in Ceratodus forsteri. Anat. Anz., 1914, 46, 625-637.

1914.2

'The pituitary fossa and trigemino-facialis chamber in selachians. Anat. Anz., 1914, 46, 225-253. fig.

1914.3

The pseudobranchial and carotid arteries in Ceratodus forsteri. Anat. An\%., 1914, 46, 638-648.

1914.4

Allison, Edith $M$, \& Cockerell, $T$. D. A. See Cockerell \& Allison.

Allman, George James. On the stinging property of the lesser weever-fish ('Trachinus vipera) Ann. Mag. Nat. Hist., 1841, 6, 161-165.

$18+1.1$

The basking shark (Selache max. ima) Nature, 1876, 14, 368-369.

1876.1

Allport, Curzon. A report on the fishbreeding ponds of the Zoological and Acclimatisation Society of Victoria. Introduction of fish into the rivers of the Colony. Proc. 'Lool. Acclim. Soc. Victoria, $1874,3,37-46$.

1874.1

Allport, Morton. Account of the recent successful introduction of the salmon ova to Tasmania. Month. Not. Roy. Soc. Tasmania, 1864, 44-47.

1864.1

- The attempt to introduce salmon ova on board the ship "Beautiful Star"] Month. Not. Roy. Soc. Tasmania, 1864, 110-114. 1864.2

On the food of the salmon in Tasmanian rivers and seas. Month. Not. Roy. Soc. 'T'asmania, 1864, 72-74. 1864.3

On the natural enemies of the salmon in Tasmania. Month. Not. Roy. Soc. Tasmania, 1864, 62-65.

1864.4

Report of the late successful experiment for the introduction of salmon ova and sea-trout ova to Tasmania. Month. Not. Roy. Soc. 'Tasmania, 1866 , 39-42. 
Report on the present state of the fry of the salmon trout at the Plenty; and of the taking of the first spawn from the brown trout. Month. Not. Roy. Soc. Tasmania, 1866, 61-64. 1866.2

Reasons for the introduction of the perch [Perca fluviatilis] into 'Tasmania. Month. Not. Roy. Soc. 'Tasmania, 1868, 56-57.

1868.1

[Extract from a letter on the introduction of salmon in 'Tasmania] Proc. Zool. Soc. London, 1869, 473.

1869.1

- Net-fishing in the Derwent. Month. Not. Roy. Soc. Tasmania, 1869, $50-54$.

1869.2

[Note on the artificial fecundation of ova of grayling (Prototrocles murana) ] Month. Not. Roy. Soc. Tasmania, 1869,6 .

1869.3

- Remarks on the rapid growth of fish] Monthl. Not. Roy. Soc. Tasmania, 1869, 2-3.

1869.4

Salmon smelt caught in the Derwent] Month. Not. Roy. Soc. Tasmania, $1869,47-48$.

1869.5

Additional notes on the introduction of Salmonidx into 'T'asmania. Proc. 'Lool. Soc. London, 1870, 750-752.

1870.1

Brief history of the introduction of salmon (Salmo salar) and other Salmonidx into the waters of Tasmania. Proc. Zool. Soc. London, 1870, 14-30; $750-752$. 1870.2

[Remarks on the present state of the salmon question] Month. Not. Roy. Soc. Tasmania, 1870, 8-9.

1870.3

Observations on the progress of the salmon experiment. Month. Not. Roy. Soc. Tasmania, 1871, 14-16.

1871.1

Thesalmon-trout. Month. Not. Roy. Soc. 'Tasmania, 1871, 43-45.

1871.2

Irregularity in the growth of the salmon [Salmo salar] Month. Not. Roy. Soc. Tasmania, 1872, 55-56. $\quad 1872.1$

Further notes on the salmon experiment. Month. Not. Roy. Soc. Tasmania, 1874, 69-71; ibid., 1875 , $51-55$.

1874.1

On the introduction of salmon to the waters of Tasmania. Proc. Zool. Soc. London, 1874, 206-207. $\quad 1874.2$
Some further notes on the introduction of the salmon into Tasmanian waters. Month. Not. Roy. Soc. 'Tasmania, 1874, 12-18.

$187+.3$

Present state of the salmon cxperiment in 'Tasmania. Rept. Comm. Fish \& Fisheries, 1878 (1879), 819-823. - Month. Not. Roy. Soc. Tasmania, 1878, 109-114.

1878.1

Allport, $S$. On the discovery of some fossil remains near Bahia in South America. Quart. Journ. Geol. Soc. London, 1860, 16, 263-266. pls. xiv-xvii \& figs.

1860.1

Alluaud, Charles. Mission scientifique de Ch. Alluaud en Afrique orientale, Juin 1903-Mai 1904. Mém. Soc. Zool. France, 1904, 17, 167-174. 6 figs. 1904.1

Hydrographie et procédés de pêche. - Poissons.

Alluaud, Charles, \& Vlès, $F r$. Electroeution des poissons et stabilite hydrostatique. C. R. Acad. Sci. Paris, 1911 , $152,1627-1629$.

1911.1

Almeida, $F$., \& Chagas Roquete. Mammiferos, peixes, molluscos e crustaceos que saõ colhidos na costa e rios do Algarve. Inquerito Indust. 1889. Lisboa, 1892, 2. 1892.1

Almen, August. Analyse des Flejsches einiger Fische. Nova Acta Reg. Soc. Sci. Upsala, Extra Ord. Ed., 1877. $1-59$.

1877.1

Almera, Jaime. Compte rendu de l'excursion du 28 Septembre à Sans et à Montijuich. Bull. Soc. Géol. France, 1899, 3. sér. 26, 680-689.2 figs. 1899.1

Descripción geológiea de la comaren titulada "Plana de Vich." Mem. Soc. Españ. Hist. Nat., Madrid, 1906, 3, 423-168. - Mem. Real. Acad. Cien., Barcelona, 1906, 5, 349-397. map.

1906.1

Alonso Lopez, José. Consideraciónes generáles sobre varios puntos históricos, políticos y económicos á favor de la libertad y fomento de los pueblos, y noticias particuláres de esta clase relativas al Ferrol y á su comarea. Madrid, 1820.

1820.1

Alpheraki, S. Flüchtige Bemerkungen über einige rische des Azovschen Mceres ['Text in Russian] Psov. Ruzejn. Ochota, Moskva, 1906, 12, 164 $166 ; 259-261$. 
Alsberg, C.L., \& Clark, E. D. On a globulin from the egg yolk of the spiny dog-fish, Squalus acanthias L. Journ. Biol. Chem., 1908, 5, 243-246. 1908.1

Altazin, Emile. Sur le transport du poisson. Mém. \& C. R. Congr. Intern. Aquiculture \& Pêche, 1900 (1901), 383402.

1901.1

Altenburg, — Die anstalt für künstliche Fischzucht im Boitzenburg. Zeitschr. Akklimatisat., 1868, 6, 35-37.

1868.1

Alth, Alojzy [1819-1896]. Die Versteinerungen der Nizniower Kalksteins. Wien, 1882. $4^{\circ}$. 1882.1

Uwagi nad 'Tarczami Ryb rodzaju Pteraspis i Scaphaspis $\mathrm{z}$ warstw paleozoicznych galicyjskiego Podola. Rozpr. Sprawozd. Wydz. III. Akad. Umiej. w. Krakowie., 1884, 11, 1-28. pl.

1884.1

- Quelques remarques sur les écailles des poissons du genre Pteraspis et Scaphaspis des terrains paléozoiques du Podole en Galicie. Mém. \& C. R. Acad. Sci. Cracov, 1886, 11, 180-187. Arch. Slav. Biol., 1, 217.

1886.1

Ueber die Zusammengehörigkeit der Schilder bei den Fischgattungen Pteraspis, Cyathaspis und Scaphaspis. Wien, 1886. $4^{\circ}$.

1886.2

Alton, Eduard d'. Erklärung der Kupfertafel I das Nervensystem der Lamprete betreffend. Arch. Anat. Physiol. (Müller), 1840, 5-14.' 1840.1

Alton, Eduard d', \& Schlemm, Friedrich. Ueber das Nervensystem der Petromyzon. Arch. Anat. Physiol. (Müller), 1838, 262-273. 1838.1

Alvenstod, S.M. Das vollständigste und neueste Fischbuch; eine Beschreibung aller in Deutschland vorkommenden Fische, nebst Anleitung dieselbe auf leichte Art zu fangen und selbst aus beträchtlichen Fernen herbeilocken zu können. Auf eigene Erfahrungen begründet. Nordhausen, 1837. $16^{\circ}$.

1837.1

Alverà, A. Elenco dei pesci che trovansi nelle acque del Vicentino. Saggio di una pantografia vicentina del Lanzani. [n. p., n. d.]

Not seen: title from G. Cavanna, Bibliogr. Italiana, 1880 , p. 30 .

Alzate y Ramyrez, José Antonio. Extract of a letter from Mexico ad- dressed to the Royal Academy of Sciences at Paris, describing Cyprinodonts of California (In d'Auteroche, C. Voyage en Californie, etc. Paris, 1772)

1772.1

- Sur les poissons vivipares et quelques autres objets d'histoire naturelle. Introd. aux Observ. Phys. (Rozier), 1773, 1, 221.

1773.1

Am., Sc. Yeux des reptiles et des poissons. Bull. Soc. Linn. Nord France, Amiens, 1879, 4, 136-138.

1879.1

Amans, Paul C. Généralités sur les organes de locomotion aquatique. C. R. Acad.Sci. Paris, 1887, 105, 1035. 1887.1

Comparaisons des organes de la locomotion aquatique. Ann. Sci. Nat., 1888, 7. sér. 6, 1-164.

1888.1

Amberg, Otto. Beiträge zur Biologie des Katzensees. Vierteljahrsschr. Nat. Ges. Zürich, 1900, 15. Jahrg., 59-136. pls. \& figs.

1900.1

- Biologische Notiz über den Lago di Muzzano. Forsch. Ber. Biol. Stat. Plön., 1903, 10, 74-85. 2 figs. 1903.1

Amblève, Henri d', pseudonym for Gillet, Henri.

Ambrose, John. Some observations on the fishing grounds and fish of St. Margaret's Bay, N. S. Proc. Trans. Nova Scotia Inst. Nat. Sci., Halifax, $1867,1,33-43 ; 2,67-75 . \quad 1867.1$

- On the fishes of St. Margaret's Bay. Proc. Trans. Nova Scotia Instit. Nat. Sci., Halifax, 1868, 2, 87-94.

1868.1

Our fishes and their enemies.

Proc. Trans. Nova Scotia Instit. Nat. Sci., Halifax, 1890, 7, 394-403. 1890.1

Ambrosetti, Juan B. Doctor Florentino Ameghino (1854-1911) Anal. Mus. Nac. Hist. Nat. Buenos Aires, 1912 , 22, p. vii-lxxii.

1912.1

Ameghino, Florentino [1854-1911] For biographical notice and list of publications see Ambrosetti, J. B., in Anal. Mus. Nac. Hist. Nat. Buenos Aires, 1912, 22, vii-Ixxii. Also Mathew, IV. D., in Pop. Sci. Monthly, 1912, 70, $303-307$.

Notas sobre cuestiones de geología y paleontología Argentinas. Boletin Inst. Geogr. Argentino, 1896, 17, 87-108. - [English] Geol. Mag., 1897, 4. dec., 4, 4-20. 1896.1 
—_ Sinópsis geológico-paleontólogica. Suplemento. La Plata, 1899. 13 p. $4^{\circ}$.

1899.1

Les formations sédimentaires du Crétacé supérieur et du Tertiaire de Patagonie avec un parallèle entre leurs faunes mammalogiques et celles de l'ancien continent. Anal. Mus. Nac. Buenos Aires, 1906, 15, 1-568. 2 pls. \& 358 figs.

1906.1

"Poissons de l'étage Salamanquéen," p. 70 73. - List of Patagonian fossil fishes with descriptions of new species, p. 176-188. - Geological range of Patagonian fossil sharks, p. 463-161.

Notes sur les poissons du Patagonien. Anal. Mus. Nac. Buenos Aires, 1908, 16, 477-497. 7 figs.

1908.1

Ameln, Johan. Society for promoting the Norwegian fisheries. Rept. U.S. Fish Comm., 1878 (1880), 6, 241-243.

1880.1

Amengual, Recaredo. Tratado de Pesca. [n. p.] 1912.

1912.1

Ami, Henry $M$. Innoydart formation of Nova Scotia. Bull. Geol. Soc. Amer., 1901, 12, 301-312. fig.

1901.1

Ammon, Ludwig von. Ueber neue Stücke von Ischyodus. Ber. Naturw. Ver. Regensburg, 1894-1895 (1896), 5, 253-263. pls. v-vi \& fig.

1896.1

Ein schönes Exemplar von $I s-$ chyodus avitus. Geogn. Jahresh., München, 1899, 11, 158-160. pl. 1899.1

Ueber eine Tiefbohrung durch den Buntsandstein und die Zechsteinschichten bei Meelrichstadt an der Rhön. Geogn. Jahresh., München, 1901, 13, 149-193. 12 figs. 1901.1

Amoretti, Carlo. Sopra il cangiamento di clima avvenuto in Italia, e specialmente nella Lombardia. Opuscoli Scelti Sci. e Arti, 1796, 19, 407.

1796.1

- Osservazioni sulle anguilla. Mem. Soc. Ital. Modena, 1803, 10, 679-686.

1803.1

Amsden, Frank $J$. Game and fish protection. Trans. Amer. Fisheries Soc. 1895 (1896), 100-105.

1896.1

Amthor, $R$. Ein ausgesprochenes Bonebed im Rhät. Zeitschr. Naturw. Stuttgart, 1907-1908, 79, 299. - Zeitschr. Naturw. Leipzig, 80, 91-96. pl.

1907.1

Anchieta, José de. Jos. de Anchieta epistola, quam plurimarum rerum natu- ralium, qux S. Vincentii (nune $\mathrm{S}$. Pauli) provinciam incolunt, sistens descriptionem à Didaco de Toledo Lara Ordonhez adjectis annotationibus edita, jussuque $r$. scient. Academix Olisiponensis ejus memoriis ad historiam transmarinarum nationum proficientibus adjecta. Olisipoi, 1799. $4^{\circ}$. 1799.1

Contains the earliest observations on the natural history of Brazil, the famous Jesuit José de Anchieta having gone to Saõ Paulo in 1553 and lived there many years.

Andersen, B. Fiskeriberetninger. Tidsskr. Fiskeri, 1866, 1, 71-74; 181189.

1866.1

Skematik Beretning over Limfjordfiskeriet fra 1 April 1864 til 31 Marts 1865. Tidsskr. Fiskeri, 1866, 1, $75-77$

1866.2

Beretning om Fiskeriet i Limfjorden. Tidsskr. Fiskeri, 1870, 4, 230235 .

1870.1

Skematisk Beretning over Fiskeriet i Limfjorden $i$ afvigte Aar, et regne fra 1 April 1867 til 31 Marts 1868. Tidsskr. Fiskeri, 1870, 4, 93-95. 1870.2

Bericht uiber die Fischerei im Limfjord. Vom 1 April 1869 bis 31 März 1870. [Translated from the Danish] Circul. Deutsch. Fischerei Ver., 1871, 33-35.

1871.1

Udbyttet af Fiskeriet i Limfjorden i Aaret 1877/78-1878/79. Tidsskr. Fiskeri, 1879, 5, 300-303. 1879.1

Andersen, $O$. Baahuslens Fiskerier. Korrespondent-Artikler fra Fiskerimødet i Lysekil i September 1868. [Reprint of articles in the "Aftenbladet," Christiania, 1868] Kristiania, 1868. $8^{\circ}$.

1868.1

Om Ordningen af Sommersildfisket i Graendsevandet mod Sverige. Kristiania, 1868. $8^{\circ}$. 1868.2

Christianiafjordens FiskerierForbad mod Grundvad. Morgenbladet, Christiania, 1872, no. $283 . \quad 1872.1$

Anderson, A. Voracious and cannibalistic propensities of some fishes. Zoologist, 1871, 2. ser. 6, 2647.

1871.1

Anderson, $A$. A. The Musconetcong trout. Forest \& Stream, 1879, 12, 412.

1879.1

Anderson, A.G. On the decomposition of fish. 26. Ann. Rept. Fish Board Scotland, 1909, pt. 3, 13-39. pl. 1909.1 
Anderson, A.J. A few remarks concerning a parasitic fish, found in the Holothuria of the Cocos-Islands [Fierasfer] Natuurk. Tijdschr. Nederl. Indie, 1859-60, 20 (4. ser. 6), 253-256; 388.

1859.1

Anderson, George. On pisciculture. Proc. Philos. Soc. Glasgow, 1853 (1864), 5, 233-243.

1864.1

Anderson, $H . K$. The Australian "fresh-water perch" (Percalates fluviatitis) Aquar. Australia, 1911, 21-23. 2 figs.

1911.1

Anderson, $J$. Recreations in agriculture, natural history, arts, and miscellaneous literature. 2 vols. London, 1799-1800. illustr. $8^{\circ}$. 1800.1

Contents: On the migration of fishes, p. 124. Salmon infested by insects, p. 126. Fishes, in what manner their spawn is fecundated, vol. ii, 1. 50. Singular phenomena respecting fishes in India, vol. ii, p. 259

Anderson, $J$. Organic remains in the Old Red Sandstone of Fife. Edinb. New Philos. Journ., 1837, 23, 137. 1837.1

Anderson, James. An account of the present state of the Hebrides and western coast of Scotland. Edinburgh, 1785. clxv, 452 p. map. $S^{\circ}$. 1785.1

Historical introduction concerning the British fisheries, p. i-clxv.

$S$ 'The same. 2.ed. Dublin, 1786. 1786.1

Anderson, (Rev.) John. On the fossil fishes and yellow sandstone. Rept. 28. Meet. Assoc. Adv. Sci. 1858 (1859), pt. 2, 74-75.

1859.1

On the yellow sandstone of Dura Den and its fossil fishes. [Abstract] Quart. Journ. Geol. Soc. London, 1860 , $16,136-137$.

1860.1

Anatomical and zoological researches; comprising an account of the zoological results of the two expeditions to Western Yunnan in 1868 and 1875. 2 vols. London, 1878.

1878.1

Pisces, vol. i, 863-869; vol. ii, pl. Ixxix.

- The salmon disease and the pollution of rivers. Fishing Gazette, 1880 , 4, 527-528.

1880.1

Notes on the biology of the salmon and grilse. Bull. U. S. Fish. Comm., 1883, 3, 429-430.

1883.1

The fishes of the Nile. Nature, $1899,59,399-402$.
Anderson, Richard Johnson. The morphology of the omohyoid muscle. Trans. Ulster Med. Soc., Dublin Journ Med. Sci., 1881, 72, 171-184. 1881.1

- The myomeres in fishes. Abstract of report on occupation of a table at the Zoological Station, Naples. $1889,1-7$.

1889.1

See Brit. Assoc. Reports, 1889, from which a part is taken.

Some considerations respecting the parietal bone. Intern. Monatsschr. Anat. Physiol., 1904, 21, 319-343. 83 figs.

1904.1

Anderson, Thomas. Composition of fish manure and some sorts of animal refuse. Trans. Highl. Soc., 1857, 7; continued in vols. for 1861 and 1863.

1857.1

Anderson, $W$. An account of some poisonous fish in the South Sea. Phil. Trans. Roy. Soc. London, 1776,66 , 554-574.

1776.1

Anderson, $W$. Six-gilled shark ( Notidanus griseus) on the west coast of Scotland. Ann. Scot. Nat. Hist., 1894 , 182-183.

1894.1

Anderssen, Joakim. Beretning om Fiskeriafdelingen ved Verdensudstillingen i Philadelphia i 1876. Nordisk. Tidsskr. Fiskeri, 1878, n. s. 4, 171-204.

1878.1

Report on the department of fisheries in the World's Exposition in Philadelphia, 1876. [Translated by $\mathrm{H}$. Jacobson] Rept. U. S. Fish Comm. 1878 (1880), 5, 47-71.

1880.1

Andersson, Lars Gabriel. Comparison of Cottus poecilopus Heckel with Cottus gobio Linnaus. Bihang Svenska Vet. Akad. Handl., 1898, 24, 1-14. 1898.1

Några anteckningar om Orthagoriscus mola (L). Ofvers. Vetensk. Akad. Förh. Stockholm, 1900, 57, 603-633.

1900.1

Anderton, J.L. Statement concerning the menhaden fishery. Rept. U.S. Fish Comm. 1877 (1879), 5, 460-461.

1879.1

Anderton, $T$. Observations on New Zealand fishes ... made at the Portobello marine fish-hatchery. Trans. Proc. New 'Leal. Inst., 1906 (1907), 39, 477-496. pls. xvii-xx. 1907.1

André, $J$. Sur la préparation du micropyle dans la coque des oufs de truite 
[Salmo fario] Journ. Anat. Phys., 1875, 11. Année, 197-202.

André, William. A description of the teeth of the Anarrhichas lupus Linnxi, and of those of the Chatodon nigricans of the same author; to which is added an attempt to prove that the teeth of cartilaginous fishes are perpetually renewed. Phil. Trans. Roy. Soc. London, 1784, 74, 274-282. pls. xi-xiii.

1784.1

Andrea, Mosè de. Relazione sulle condizioni di pesca nel Lago Maggiore. Acquicolt. Lombarda, Milano, 1901, 3, $167-168$.

1901.1

Andreae, Achilles [1859-] Vorläufige Mittheilung über die Ganoiden (Lepidosteus und Amia) des Mainzer Beckens. Verh. Natur. Medic. Ver. Heidelberg, 1893, 2. ser. 5, 7-15. 2 figs.

1893.1

- Beiträge zur Ḱenntniss der fossilen Fische des Mainzer Beckens. Abh. Senck. Nat. Ges., 1894, 18, 351-364. pl.

1894.1

Kurzer Ueberblick über das Miocän von Oppeln in Schlesien und seine Fauna. Zeitschr. Deutsch. Geol. Ges., 1904, 56, Protok. p. 249-255. fig. 1904.1

Andreasen, Kristoffer. Lidt om Islandsfiskeriet Dansk Fiskeriforen. Medlemsbl. Aarg., 1897, 6, 118-121; 126-127. pl.

1897.1

Andrée, A. Om Gottländska saltsjöfisket. Öfvers. Vetensk. Akad. Förh. Stockholm, 1850, 112-118.

1850.1

Andrée, Karl. Geographic des Welthandels, mit geschichtlichen Erläuterungen. 2 vols. Stuttgart, 1867-1872. $8^{\circ}$.

1867.1

The herring and cod fisheries are described in vol. i.

Andres, Ad. Drei Nilfishe für das Aquarium (Barilius niloticus, Chelothiops bibie, Micralestes acutidens) Blätt. Aquar.-Terrar. Kunde, 1913, 24. Jahrg. $337-339.3$ figs.

1913.1

Ueber das Frei- und Gefangenleben einiger Nilfische. Blätt. Aquar.Terrar. Kunde, 1913, 24. Jahrg., 577578. 2 figs.

1913.2

Andres, Anoelo. Caratteri sessuali secondari della Tinca. Rendiconti $\mathrm{R}$. Ist. Lomb. Sci. Lett. 1897, 2. ser. 30 , 1430-1458. pls. vi-viii.
Le miospine della Tinca. Rendiconti R. Ist. Lomb. Sci. Lett., 1897, 2. ser. 30, 1123-1139. pls. iv-v.

1897.2

- Anatomia della Tinca (Tinca vulgaris Cuv.) con referenza ad altre Ciprinida. Milano, 1899.95 p. 3 pls. $8^{\circ}$.

1899.1

I merite d'Ulisse Aldrovandi. Atti Soc. Ital. Progr. Sci., 1908, 1. Riun. 201-231.

1908.1

Andresen, $P$. Versuchsfischerei im Kaiser Wilhelm-Kanal. Naturw. Wochenschr., 1899, 14, 219-221. 1899.]

Die Resultate der im Jahre 1899 ausgeführten Versuchsfischerei im Kaiser Wilhelm-Kanal. Naturw. Wochenschr., 1900, 15, 210-211. 1900.1

Andrews, Charles William. A descriptive catalogue of the Tertiary vertebrata of the Fayum, Egypt. London, 1906. xxxviii, 324 p. pls. 4 1906.1

Note on some vertebrate remains collected in the Fayûm, Egypt, in 1906. Geol. Mag., 1907, 5. dec., 4, $97-100.2$ figs.

1907.1

Andrews, Ethan Allen. The Bahama Amphioxus, John Hopkins Univ. Circ. $1893,12,104$.

1893.1

An undescribed acraniate, $A$ symmetron lucayanum. Studies Biol. Lab. Johns Hopkins Univ., 1894, 5, 213-247. pls. xiii-xiv.

1894.1

An Amphioxus from Japan. Zool. Anz., 1895, 18, 57-60. 1895.1

Andrews, Thomas [-1895] Propagation of the Salmonidx. London, 1883. $12^{\circ}$. 1883.1

Andrews, William [1802-1880] Observations on the parr (Salmo salmulus) Proc. Nat. Hist. Soc. Dublin, 1849-55, 1, 116-117.

1849.1

Observations on the salmon, parr, and gravelling. Proc. Nat. Hist. Soc. Dublin, 1849-55, 1, 111-116.

1849.2

On the European Hemiramphus and lesser torked-beard. Proc. Nat. Hist. Soc. Dublin, 1849-55, 1, 117-119. 1849.3

On the species of Cottus on the southwest coast. Proc. Nat. Hist. Soc. Dublin, 1849-55, 1, 119-122. 1849.4 
Andrews, $W$.

On the varieties of the Pleuronectida. Proc. Nat. Hist. Soc. Dublin, 1849-55, 1, 134-135.

1849.5

On harbour fish and on the formation of piscinx. Nat. Hist. Rev., 1854, 1, 26-30.

1854.1

The spawning states of the Syngnathidx, or pipe-fish family. Nat. Hist. Review, 1854, 1, 230-235. 1854.2

Remarks on the Percidæe and Serrani, and on an addition to the ichthyology of Ireland. Nat. Hist. Rev., $1855,2,36-38$. pl.

1855.1

Notes on the fishes of the western coasts, and record of the occurrence of the boar-fish (Capros aper) in the Irish seas. Nat. Hist. Review, 1858, 5, 188-191. - Proc. Nat. Hist. Soc. Dublin, 1856-59 (1860), 2, 104-107. 1858.1

On the Syngnathida, or pipefish family. Proc. Nat. Hist. Soc. Dublin, 1859-62 (1863), 3, 43-45. - Nat. Hist. Rev., 1860, 7, 397-399. - Zoologist, $1860,18,7052-7054$.

1860.1

Record of the occurrence of the Bergylt [Sebastes norvegicus] and Greenland bullhead [Cottus gronlandicus] on the Irish coast. Proc. Nat. Hist. Soc. Dublin, 1856-59 (1860), 2, 61-62. 2 pl.

1860.2

Notes on the salmon fisheries of Ireland. Dublin Quart. Journ. Sci., 1863, 3, 152-171. - Journ. Roy. Dublin Soc., 1863-65 (1866), 4, 81-100. 1863.1

On the occurrence of Merlangus albus [Gadus poutassou], new to Irish ichthyology. Dublin Quart. Journ. Sci., 1864, 4, 7-9. - Proc. Nat. Hist. Soc. Dublin, 1862-63 (1865), 4, 9-11. 1864.1

- Remarks on the Salmonidx. Proc. Nat. Hist. Soc. Dublin, 1862-63 (1865), 4, 9-11; 53-57. - Dublin Quart. Journ. Sci., 1864, 4, 49-53.

1864.2

Further notes on Salmonidx. Proc. Nat. Hist. Soc. Dublin, 1862-63 (1865), 4, 85-86. - Dublin Quart. Journ. Sci., 1865, 5, 30-34. 1865.1

Notes on Cottus gronlandicus the Greenland bullhead. Proc. Nat. Hist. Soc. Dublin, 1862-63 (1865), 4, $223-227$.

1865.2

On the sea fisheries of Ireland, and with reference to trawling. Dublin
Quart. Journ. Sci., 1865, 5, 1-30. pls. ii-iv.

1865.3

On the herring fisheries of Ireland. Dublin Quart. Journ. Sci., 1866, 6. 235-249. - Journ. Roy. Dublin Soc., $1870,5,12-26$.

1866.1

On the ichthyology of the southwest coast of Ireland, and a collection of zoological specimens obtained for the society during the summer and autumn of 1868. Journ. Roy. Dublin Soc., 1869 , 5, 379-389.

1869.1

Note on an example of Orthagoriscus oblongus from the Irish coast. Proc. Roy. Dublin Soc., 1871, 6, 56-61. pl.

1871.1

State of the sea-coast fisheries of Ireland. Journ. Roy. Dublin Soc., $1875,6,397-418 ; 459-461$.

1875.1

Angelis d'Ossat, Gioacchino de. Addizioni alla ittiofauna fossile del Monte Titano. Riv. Ital. Paleontol., 1896, 2, $250-257$.

1896.1

Il Trigonodon oweni E. Sism., e l' Umbrina pecchiolii Lawl. nel Miocene di Sardegna. Riv. Ital. Paleontol., 1896, 2, 100-101.

1896.2

Angermann, Theodor. Acara coruleo-punctata var. latifrons Steind. u. Kn. Blätt. Aquar.-Terrar. Kunde, 1908, 19, $157-159$.

1908.1

Angerstein, $W$. Die internationale Fischerei-Austellung. Zeitg. Internat. Fischerei-Austellung, Berlin, 1880.

1880.1

Anikin, V.P. Beiträge zur Kenntnis der Fische von Westsibirien. [Text in Russian] Tomsk, 1903. (Sammlung zur Erinnerung an E. G. Sališčev, p. 119-138.)

1903.1

Beschreibung einiger neuer asiatischer Fischarten. [Text in Russian] 'Tomsk. Rath Univ., Tomsk, 1905, 1-18. $8^{\circ}$.

1905.1

Die Fische der Gattung Diptychus Steind., ihre Systematik und biologische Bedeutung [Text in Russian] Tomsk. Rath Univ., 'Tomsk, 1906, 1-84.

1906.1

Anisits, J. D. Ein neues Vorkommen von Gyrinurus batrachostoma Mir. Ribeiro. Sitz. Ber. Ges. Natf. Freunde Berlin, 1912, 465-468. fig. $\quad 1912.1$ 
Eine seltene Missbildung bei einem Rochen. Sitz. Ber. Ges. Natf. Freunde Berlin, 1912, 223-245. 3 pls. \& 7 figs.

1912.2

Anjubault, P.A. Revue des espèces de poissons qui vivent dans le département de la Sarthe, et observations sur la pisciculture. Mém. Soc. Agric. Sci. Arts Sarthe, 1855, 1.

1855.1

Ankarsvärd, G., \& Hammar, J.A. Zur Kenntnis der Ganoidenthymus (Amia calva, Lepidosteus osseus) Zool. Jahrb. (Anat.), 1913, 36, 291-306. 2 pls. \& 5 figs.

1913.1

Annandale, Nelson. Notes on the freshwater fauna of India. No. VII. A new goby from fresh and brackish water in lower Bengal. Journ. Proc. Asiat. Soc. Bengal, 1906, 2, 201-202. fig.

1906.1

The fauna of brackish ponds at Port Canning, Lower Bengal list of fishes collected 1 Rec. Indian Mus., $1907,1,41-42$. 1907.1

Melanic specimens of the Putia (Barbus ticto) Rec. Indian Mus., 1907, 1,81 . 1907.2

— A new sting ray of the genus Trygon [T. microps] from the Bay of Bengal. Rec. Indian Mus., Calcutta, 1908, 2, 393-394. pl. 1908.1

Report on the fishes taken by the Bengal fisheries steamer "Golden Crown." Part I. Batoidei. Mem. Indian Mus., 1909, 2, no. 1, 1-60. pls. i-v \& 10 figs.

1909.1

- Additional notes on the Batoidei. Report on the fishes taken by the Bengal fisheries steamer "Golden Crown." Part II. Mem. Indian Mus. 1910, 3, no. 1, 1-5. 2 pls. 1910.1

- Some recent advances in our knowledge of the freshwater fauna of India. Journ. Asiat. Soc. Bengal, 1912, 8, 39-53. 3 pls.

1912.1

Notes on the fishes, batrachia and reptiles of the Lake of Tiberias. Journ. Asiatic Soc. Bengal, 1913, 9, 31 41. figs.

1913.1

Ánnandale, Nelson, \& Jenkins, $J$. $T$. Plectognathi and Pediculati. Report on the fishes taken by the Bengal fisheries steamer "Golden Crown." Part 3. Mem. Indian Mus., 1910, 3, no. 1, 7-21. pls.
Annandale, Nelson, \& Robinson, H. [A second species of Periophthalmus] Science, 1901, n. s. 14, 272.

1901.1

Annaniassen, $A b r$. Fiskeriet og tilvirkning af Ilipvish paa Shetlandsöerne. Norsk Fiskeritidende, Bergen, 1885, 4. - English translation] Bull. U. S. Fish Comm. 1885, 5, 316-319.

1885.1

Annerstedt, L., \& others. Föslag till lag om ratt till fiske. Stockholm, 1894. $8^{\circ}$

1894.1

Annin (junior), James. Spawning of California brook trout iS. fontinalis] in New York. Chicago Field, 1878, 9, 182.

1878.1

Food for fishes. Proc. Central

Fishculture Soc., Chicago, 1879, 59-62.

1879.1

- Inflammation of the eye in trout. Chicago Field, 1879, 11, 292.

1879.2

- Trout in hard water. Tom. cit.

291.

1879.3

'Trout in hard water. Trans.

Amer. Fisheries Soc. 1879 (1880), 1517.

1880.1

- Poachers. 'Trans. Amer. Fisheries Soc. 1881 (1882), 76-81. 1882.1

The rainbow trout. Trans. Amer. Fisheries Soc. 1882 (1883), 2022. 1883.1

Notes pertaining to fish culture. Trans. Amer. Fisheries Soc. 1884 (1885), 109-111.

1885.1

Winged enemies of fish. 3. Ann. Rept. Comm. Fish, Game \& Forests N. Y., 1898, 199-204. 2 pls. 1898.1.

Annone, $J . J \cdot d^{\prime}$. De piscibus, in quorum abdomine vermes inclusi erant. Acta Helvet., 1759, 4, 301 . $\quad 1759.1$

Ansell, Alfred W. 'Trawling (In Papers of Conferences Intern. Fisheries Exhib., vol. vii. London, 1883) 1883.1

Anslijn, Nicolaas [1777-1838]. Afbeeldingen van Nederlandsche dieren. 2 vols. Leiden, $1820-30$. 44 pls. $8^{\circ}$.

Vol. ii, l'isces. 1820.1

- Systematische Beschrijving der ... Visschen. Leiden, 1828. 8 1828.1 
Anthony, Harry. On the 'blackfish,' a species of Clarias. Proc. Zool. Soc. London, 1864, p. 18. - Ann. Mag. Nat. Hist., 1864, 3. ser. 14, 224-225.

1864.1

Anthony, R. Pisciculture marine. Science XY' Siècle, 15 décembre, 1907. 1907.1

_La piscifacture du turbot au labora toire maritime du Aluséum (SaintVaast-la-Hougue) Bull. Mus. Hist. Nat. Paris, 1907, 557-559. fig.-C. R. Acad. Sci. Paris, 1907, 145, 513-516. Bull. Soc. Centr. Aquicult., Paris, 1907, 19, 257-259.

1907.2

- The cultivation of the turbot. Proc. 4. Intern. Fish. Congr., Wash. Bull. Bur. Fisheries, 1908, 28, pt. 2, 859-870. pls. \& figs. 1908.1

Le laboratoire maritime du Muséum d'Histoire Naturelle (SaintVaast-la-Hougue) pendant l'année 1907. Ann. Sci. Nat. Paris, 1908, 9. sér. 7, $27-79$.

1908.2

_- Pisciculture marine industrielle. Science XX' Siècle. 1908 , no. 66, 4148.

1908.3

_- Technique de la pisciculture marine. Rev. Scient. Paris, 1908, 5. sér. 20, no. 22.

1908.4

_.. La croisière du "René." Entreprise pour contribuer à l'étude de la biologie de la sardine. 5. Congrès Nat. Pêches Maritimes des Sables-d'Olonne 1909, 1-6. map. -- Résultats des opérations effectuées au cours de la croisièrè. Ibid., 1910, 1-S.

1909.1

Elevage du Zeugopterus punctatus Bl. au laboratoire maritime de SaintVaast-la-Hougue. C. R. Acad. Sci. Paris, 1909, 149, 1156-1158. 1909.2

Recherches sur l'influence de la captivité sur la maturation génitale chez le turbot. 5. Congrès Nat. Pêches Maritimes des Sables-d'Olonne 1909 (1910), 1-11. fig.

1910.1

Anthony $R$., \& Chevroton, $L$. Considérations sur les attitudes et la locomotion de l'hippocampe. Etude chronophotographique. Arch. Zool. Paris, 1913, 51, 11-22. 10 figs. $\quad 1913.1$

Anthony, Raoul, \& Perrier, Edmond. See Perrier \& Anthony.

Anthony, $R$. \& Salmon, $J$. La pygomélie, son interprétation, sa place dans la classification tératologique, ses différents degrés. C. R. Soc. Biol. Paris, 1901, 53, 135-136.

1901.1

Antipa, Gregor. Ueber die Beziehungen der 'Thymus zu den sogenannten Kiemenspaltenorganen bei Selachiern. Anat. Anz., 1892, 7, 690-692. 2 figs. 1892.1

\section{Lacul razine starca actualà a} pescariilor din el si mijlócele de indreptare. Bucuresci, 1894. 15 p. $8^{\circ}$.

1894.1

Studii asupra pescariilor din Romania. Bucuresci, 1895. 80 p. pl. $8^{\circ}$.

1895.1

- Die Fischereiverhältnisse Rumäniens. Allgem. Fischerei-Zeitg., 1901 , no. $15,327-331 ;$ no. $16,338-341$.

1901.1

- Die Clupeinen des westlichen Teiles des schwarzen Meeres und der Donaumündungen. Denkschr. Akad. Wiss. Wien, 1905, 78, 1-56. 3 pls. \& 6 figs. - Anz. Akad. Wiss. Wien, 1904, 41, 299-303.

1905.1

Ueber die Störe und ihre Wanderungen in den europäischen Gewässern mit besonderer Berücksichtigung der Störe der Donau und des schwarzen Meeres. Stenogr. Protok. Verh. Internat. Fish-Kongr. Wien, 1905, 134-152. Abstract in Allgem. Fisch. Zeitg., 1906, $31,246-249$.

1906.1

Clupeidele Mărĕ Negre. Mem. Asoc. Română Inaintarea Rěspând. 1908, pt. 2, 551-555. 1908.1

- - Fauna ichtiologică a României. Public. Fond. Adamachi Acad. Română, 1909, 3, no. 16, 1-294. 31 pls. - Also separate; Bucarest, 1909.

1909.1

Die Biologie des Donaudeltas und des Inundationsgebietes der unteren Donau. Verh. 8. Intern. Zool. Iongress, Graz, 1910 (1911), 163-20s. 18 figs.

1911.1

-.... Fischerei und Flussregulierung. Allgem. Fisch. Zeitg., 1911, nos. 16 \& 17. $8 \mathrm{p}$.

1911.2

Antoni, Nils. "Deltabildungen" (Holmgren), und derartige Strukturen bei den Ganglienzellen von Lophius. Anat. Anz., 1907, 31, 214-219. 6 figs. 1907.1

Antwerp, W. van. Growth, spawning, edible qualities and manner of cook- 
ing German carp received from the United States Fish Commission in 1880. Bull. U. S. Fish Comm. 1882 (1883), 2, 300.

1883.1

Apáthy, Stefan [=Istvain] Ueber das leitende Element des Nervensystems und seine Lagebeziehungen zu den Zellen bei Wirbelthieren und Wirbellosen. C. R. 3. Congr. Internat. Zool., Leyde, 1895, 132-136. - Mitth. 'Lool. Stat. Neapel, 1897, 12, Heft 4.

1895.1

- Die Mikrotechnik der Morphologie. Abth. I. Braunschweig, 1896.

1896.1

Apgar, A. C. Binocular vision of lateral-eyed fishes. Journ. 'Trenton Nat. Hist. Soc., 1886-88, 1, 6-8. 1886.1

Apostolidès, Nikolaos Christo. La pêche en Grèce. Athens, 1883. $\$ 7$ p. $8^{\circ}$.

1883.1

Sur les poissons d'eau douce de la Thessalie. C. R. Acad. Sci. Paris, $1892,114,794$.

1892.1

Appelloof, A. Ueber einige Resultate der Íreuzbefruchtung bei Knochenfischen. Aarbog Bergens Museums, 1894-95, 1, 1-17. pl.

1894.1

Appun, KarlFerdinand. Fische und Fischfang in Britisch-Guyana. Ausland, $1870,43,1110-1116 ; 1135-1140 ; 1156-$ 1161 .

1870.1

Apstein, Carl. Junge Schollen (Pleuronectes platessa $\mathrm{L}$.) kommen nicht in der Ostsee vor. Mitth. Sect. Küsten Hochseefisch., 1894, no. 5, 103-107. 1894.1

Das Vorkommen junger Goldbutt in der Ostsee. Schrift. Nat. Ver. Schleswig-Holstein, 1897, 11, 74. 1897.1

Altersbestimmung bei Fischen. 1900, 12, 34-35.

1000

- Zur Lebensgeschichte des Goldbutts (Scholle, Pleuronectes platessa) Vortrag ... Fischerei-Leit. Neudamm, $1902,5,726-727 ; 744-745 . \quad 1902.1$

Junge Butt (Schollen, Pleuronectes platessa) in der Ostsee. Wiss. Meeresuntersuch., Kiel, 1905, n. s. 8, 1-25. 10 figs.

1905.1

Die Bestimmung des Alters pelagisch lebender Fischeier. Mitth. Deutsch. Seefisch. Ver., Berlin, 1909, 25, 364-373.
Cyclopterus lumpus, der Seehase: seine Fischerei und sein Mageninhalt. Mitth. Deutsch. Seefisch. Ver., 1910, 26, 450-465. 12 figs.

1910.1

- Hat ein Organismus in der 'Tiefe gelebt, in der er gefischt ist? Intern. Rev. Ges. Hydrobiol. \& Hydrogr., 1910, 3, 17-33. fig.

1910.2

- Die Verbreitung der pelagischen Fischeier und Larven in der Beltsee und den angrenzenden Meeresteilen 190809. Wiss. Meeresuntersuch. Abth. Kícl, 1911, 2. s. 13, 225-281. 12 figs.

1911.1

Apstein, C., \& Hensen, $V$. See Hensen \& Apstein.

Apstein, C., \& Hinkelmann, $A$. Der Hering in der Schlei. Schr. Nat. Ver. Schleswig-Holstein, 1898, 11, 222225.

1898.1

Apstein, Carl, Knauthe, Karl, Berthelmann, - , Borcherding, Fr., Cronheim, - ' \& Debschitz, $H$. von. See Knauthe, Apstein, Berthelmann, Borcherding, Cronheim \& Debschitz.

Arányi, Bela. A durbancs [Gasterosteus] Természet., Budapest, 1870, 6, 65-70.

1870.1

Arbenz, $E$. Aufzucht von Forellen. Schweiz. Fisch. Zeitg., 1896, 4, 57-66.

1896.1

Arbuthnot, James. Natural history of those fishes ... that are indigenous to, or occasionally frequent the coast of Buchan. Aberdeen, 1815. 159 p. $8^{\circ}$.

1815.1

Arcangeli, Alceste. I cambiamenti dell' epitelio intestinale del Box salpa I. durante l' assorbimento. Arch. Ital. Anat. Embriol., 1906, 5, 150-176. pl. 4 figs.

1906.1

Istologia e fisiologia dell' epitelio e delle glandole stomacali del Box salpa L. Nota preliminare. Atti Congr. Natural. Ital., 1906, 572-575. 1906.1

Contributo alle conoscenze della struttura minuta dello stomaco del $B o x$ salpa L. secondo lo stato funzionale. Arch. Zool. Napoli, 1909, 3, 261-346. 2 pls.

1909.1

La dentatura del Carassius auratus L., cenni storici ed osservazioni. Riv. Mens. Pesca, Pavia, 1910, n. s. 5, $177-192$.

1910.1 
Arcangeli, $A$.

La muscolatura delle ossa faringee di Carassius auratus L. e la sua funzione. Riv. Mens. Pesca, Pavia, 1911, n. s. $6,237-248$.

1911.1

Arcère, Louis Etienne. La pêche. 1763. $8^{\circ}$. 1763.1

Archer, pseudonym for Stackwell, G. A.

Archer, A. Laxen og dens Formerelse i Norge. Udgivet af Selskabet for Folkeoplysningens Fremme. 2. Tillaegshefte til Tidsskriftet Folkevennen, Christiania, 1877. $8^{\circ}$.

1877.1

The same. 2. ed. Christiania, 1879. $8^{\circ}$.

1879.1

Archer, Walter $E$. How far may the salmon examined be considered typical of their respective classes? Rept. Lab. Roy. Coll. Physic. Edinb., 1900, 18, 9-11.

1900.1

The source from which salmon obtain nourishment and the exchange of material in the body during their sojourn in fresh water. Rept. Lab. Roy. Coll. Phys. Edinb., 1900, 18, 12. 1900.2

Archiac, (Vicomte) Etienne Jules Adolphe Desmier de St. Simon d'. Paléontologie de la France. Paris, 1868. 726 p. $8^{\circ}$.

1868.1

Archibald, Ch. F. Food of the eel. Zoologist, 1899, 3, 558.

1899.1

Arendsen Hein, S. A. Over oogleden in Fornices conjunctivæ bij Teleostomi. Tijdschr. Nederl. Dierk. Vereen, 1913, 2. ser. 12, 238-279. 32 figs.

1913.1

Arendt, Edouard. De capitis ossei Esocis lucii structura regularis. [n. p.] 1822. fig. $4^{\circ}$.

1822.1

Arens, $C$. Bastarde zwischen Forelle und Bachsaibling. Allgem. Fisch. Zeitg. 1893, 18, 148-149.

1893.1

- Ueber den Lachsbastard. Allgem. Fisch. Zeitg., 1894, 19, 346-347.

1894.1

Ueber Behandlung und Besetzung von Teichen. Vortrag gehalten im Landwirtschaftlichen Verein der goldenen Aue. Schweiz. Fisch. Zeitg., 1896 , $4, \quad 70-71 ; \quad 79-80 ; \quad 94-97 ; \quad 108-110$; 115-116.

1896.1

Die Laichzeit der Bach- und der Regenbogenforelle. Allgem. Fisch. Zeitg., 1898, 23, 71-73.
Ueber die Färbung der Forellen und die Farbe ihres Fleisches. Allgem. Fisch. Zeitg., 1904, 29, 288-289. 1904.1

- Erfahrungen über die Laichzeit der Regenbogenforelle. Stenogr. Protok. Verh. Intern. Fisch. Kongress. Wien, 1905 (1906), 154-160. 1906.1

Observations on the spawning season of the rainbow trout. Rept. Sea Inland Fish. Ireland, 1904 (1906), 310314. - Fisheries Ireland Sci. Invest., 1904, 9-13.

1906.2

Arey, Melvin F. Geology of Black Hawk County. Ann. Rept. Iowa Geol. Surv., 1906, 16, 409-452. 1 map. 4 figs. 1906.1

Reports occurrence of Onychodus remains.

Arielson, - Introduction du bass d'Amérique [Grystes nigricans] en Angleterre. Bull. Soc. Acclim., 1872, 2. ser. 9, 400 .

1872.1

Ariola, $V$. Due pesci abissali del Mediterraneo. Ann. Aquicoltura Lombarda, 1904, 6, 125-129. pl. 1904.1

Nuovo pesce abissale del Golfo di Genova (Cubiceps capensis Smith) Riv. Mens. Pesca, Pavia, 1912, 7, 185192. pl.

1912.1

Pesci nuovi o rari per il Golfo di Genova. Ann. Mus. Civ. Stor. Nat. Genova, 1904, 3. ser. 1, 153-168.

1904.2

Cattura di squali nel Golfo di Genova. Atti Soc. Ligust. Sci. Nat., Genova, 1913, 24, 3-19. 4 figs. 1913.1

Aristotle [B.C. 384-322] Aristotle on the parts of animals. Translated, with introduction, and notes, by W. Ogle. London, 1882. xli, 263 p. $8^{\circ}$. 1882.1

There is also a French translation by Jules Barthélemy Saint-Hilaire, 1887.

'The works of Aristotle translated into English . . Volume IV, Historia animalium, by D'Arcy Wentworth Thompson. Oxford, 1910. 486$633 \mathrm{p}$.

1910.1

This work is reviewed by T. N. Gill in Science, 1911, n. 5. 33, 730-738. Earlier English translations have been published bj Thomas Taylor, 1809 , and Richard Creswell, 1862. There is also a French translation by Jules Barthélemy Saint-Hilaire, 1883, and a German version by Aubert \& Wimmer, 1868. Consult also Sundevall's Thierarten des Aristotles, 1863, and the Index Aristotelicus, published by the Berlin Academy. 
Armand, B. La boutarge ¡Préparation des œufs de Mugil cephalus] La Nature, 1897, 25, 106-107.

1897.1

Armistead, A. Wilson. A transfer of leather carp (Cyprinus carpio) from the government ponds at Washington, U. S. A. to Scotland. Bull. U. S. Fish Comm. 1881 (1882), 1, 341-342. 1882.1

Armistead, Joseph $J$. A short history of the art of pisciculture. Leeds, 1870. 71 p. illus. $8^{\circ}$.

1870.1

Les plantes aquatiques et la nourriture du poisson. Bull. Soc. Cent. Aquicult. France, 1889, 1, 50-55.

1889.1

- Atmospheric and other influences on the migration of fishes. Bull. U. S. Fish Comm. 1893 (1894), 13, 93-99.

1894.1

Fish culture. Science, 1896, n. s. 3, 770-771. - Proc. Roy. Inst. Great Britain, 1897, 15, 39-52. 6 pls. \& 2 figs.

1896.1

- A handy guide to fish culture. Scarborough, 1897. figs. $12^{\circ}$. 1897.1

Armour, Andrew Exhibition of Carboniferous fish remains] 'Trans. Geol. Soc. Glasgow, 1867, 2, 69. 1867.1

Armstrong, George. Historia civil y natural de la isla de Menorca [etc.] Traducido par D. José Antonio Lasierra. Madrid, 1781.

1781.1

Arnaud, Emile. Notice sur un Saurocephalus [nov. sp.]. de l'étage Aptien des environs d'Apt. Ann. Soc. Litt. Sci. Apt, 1863-64 (1865), 1, 71-76. fig.

1865.1

Note sur les poissons fossiles du Crétacé inférieur des environs d'Apt (Vaucluse) Bull. Soc. Géol. France, $1882,10,131-134$.

1882.1

Arnault de Nobleville, $L . D ., \&$ Salerne, Francois. See Salerne \& Arnault de Nobleville.

Arnold, A., \& Samuel, Edward A. The living world. Animals, birds, fishes [etc.] 2 vols. Boston, 1868. figs. $4^{\circ}$.

1868.1

Arnold, D.J. Zur Biologie der Kaspischen Finte, Clupea caspia Eichw. Arb. Kaspischen Exped., St. Petersb., 1907, 1, 222-242. 2 pls. [Russian with German résumé] - C. R. Congr. Intern. Zool. Berne, 1904, 283-288, 4 figs. 1907.1
Arnold (junior), Isac. Succèssful propagation of black bass. Bull. U.S. Fish Comm., 1882 (1883), 2, 113-115.

1883.1

Arnold, J.B. Letters on the naturalization of sea fishes in a lake chiefly supplied with fresh water. Proc. Zool. Soc. London, 1830-31, pt. 1, 126. 1830.1

Arnold, $J . N$. Ueber das Absterben der Lachse in der Kura in Folge der Infection der Kiemen durch Schimmelpilze. Nikolsk Fischzuchtanstalt, St. Petersb., 1901, no. 5, 50-52. 1901.1

Beobachtung über die Ernährung der Wildfische in einigen Gewässern der Waldai-Höhen IText in Russian J Nikolsk Fischzuchtanstalt, St. Petersb., 1902, no. 5, 59-70. pl.V̌st. Rybopromyšl., St. Petersb., 1902 , 17, 59-69. pl. 1902.1

Bericht über die Tätigkeit der Kaiserlichen Russischen Gesellschaft für Fischzucht und Fischerei für das Jahr 1904 [Text in Russian] Věst. Rybopromyšl., St. Petersb., 1905, 20, 445-469.

1905.1

Versuche der künstlichen Befruchtung von Clupea kessleri "Text in Russian] Vĕst. Rybopromyšl., St. Petersb., 1906, 21, 478-480. $\quad 1906.1$

Arnold, Johann Paul. Meine Scheibenbarsche. Nerthus, Altona, 1902; p. 801.

1902.1

- Ueber die Fischnahrung in den Binnengewässern. Verh. 5. Internat. Zool. Kongress, Berlin, 1901 (1902), 553-566. pl. 1902.2

Ctenops vittatus, ein neueingeführter Fisch. Natur u. Haus, Dresden, 1904, 12, 337-338. figs.

1904.1

- Meine Beobachtungen über die Haltung und Zucht des Kampffisches. Blätt. Aquar. Terrar. Kunde, 1904, 15. Jahrg., 53-57.

1904.2

Tetrodon cutcutia, ein neueingeführter Fisch. Natur u. Haus, Dresden, 1904, 12, 263-264. 2 figs. 1904.3

Trichogaster latius Day. Tom. cit., 183-185. pl. 1904.4

Die Zucht von Ctenops vittatus im Zimmeraquarium. Wochenschr. Aquar. Terrar. Ḱ unde, 1904, 1. Jahrg. 189. 
Arnold, J. P.

Neueingeführte Fische. Wochenschr. Aquar. Terrar. Kunde, 1906, 3. Jahrg., 307.

1906.1

Pantodon buchholzi Peters. Tom. cit., 475. figs. - Blätt. Aquar. Terrar. Kunde, 1908, 19. Jahrg., 659. 1906.2

- Polycentropsis abbreviata Boul. T'om. cit., 451-453.

1906.3

Ueber den Ursprung der neuen Haplochilus panchax-varietäten. Tom. cit., 653.

1906.4

Die Ausstellung fremdländischer Zierfische des Vereins "Rossmässler." Wochenschr. Aquar. Terrar. Kunde, 1907, 4. Jahrg., 434.

1907.1

- Noch etwas über Pantodon buchholzi Peters. T'om. cit., 661. 1907.2

Nochmals die neuen Panchaxvarietäten. Blätt. Aquar. Terrar. Kunde, 1907, 6. Jahrg., 77. 1907.3

Haplochilus chaperi Sauvage und Haplochilus elegans Blgr. Wochenschr. Aquar. Terrar. Kunde, 1908, 5. Jahrg., 297; 314; 327. figs. 1908.1

Polycentropsis abbreviata Boul. und seine Zucht im Zimmeraquarium. Tom, cit., 93-95; 105-106; 119-120. figs.

1908.2

Der Schlammspringer (Periophthalmus koelreuteri (Pall. Bl.) und seine Haltung im Aquarium. Tom. cit, 1-3; $13-15 ; 25-27.2$ figs.

1908.3

Westafrikanische Fundulus-arten. Blätt. Aquar. Kunde, Stuttgart, 1908, 19. Jahr., 469-470; 489-491; 517$520 ; 536-540$. pl.

1908.4

Girardinus guppyi Gthr. Wochenschr. Aquar. Terrar. Kunde, 1909, 6. Jahrg., 606-608.

1909.1

Heterogramma corumbe Eigenm. \& Ward. Blätt. Aquar. 'Terrar. Kunde, 1909, 20. Jahrg., 305-308; 321-324. 3 fige.

1909.2

Marcusenius longianalis Blgr. Wochenschr. Aquar. 'Terrar. Kunde, 1909, 6. Jahrg, 529-531。 fig. 1909.3

Petersius spilopterus Boul. Blïtt. Aquar. Terrar. Kunde, 1909, 20. Jahrg., 471-473. fig.

1909.4

- Pocilia heteristia Regan. Zur Nomenklatur von Pocilia amazonica.
Wochenschr. Aquar. Terrar. Kunde, 1909, 6. Jahrg., 695-697.

1909.5

Pocilia reticulata Peters, die letzte Neuheit des Jahres 1908. Blätt. Aquar. Terrar. Kunde, 1909, 20. Jahrg., 249-253. fig.

1909.6

Polycentrus schomburghii Müll. u. Trosch. Wochenschr. Aquar. Terrar. Kunde, 1909, 6. Jahrg., 617-619. fig. 1909.7

Pyrrhulina nattereri Steind. Blätt. Aquar. Terrar. Kunde, 1909, 20. Jahrg., 427-430. 2 figs.

1909.8

Xenomystus nigri. Wochenschr. Aquar. Terrar. Kunde, 1909, 6. Jahrg., 661-662. fig

1909.9

Xiphophorus helleri var. guentheri. Tom. cil., 433-435. 2 figs.

1909.10

Belonesox belizanus Kner. IVochenschr. Aquar. Terrar. Kunde, 1910, 7. Jahrg., 45-48. fig.

1910.1

Heterogramma agassizii Regan. Tom. cit., $133-135 ; 149-150$. fig.

1910.2

Ueber die Fortpflanzung von Polycentrus schomburgkii im Zimmeraquarium. Tom. cit., 90-92. 2 figs.

1910.3

Acanthophthalmus kuhlii C.u V. Wochenschr. Aquar. Terrar. Kunde, 1911, 8. Jahrg., 373-374. fig. 1911.1

Acara tetramenus Heck. Tom. cit., 213-214. fig.

1911.2

- Acara thayeri Steindachner. Tom. cit., 245-247. fig. 1911.3

Ein Beitrag zur Kenntnis von Pantodon buchholzi Peters. Tom. cit. 57-59. fig.

1911.4

Die bisher eingeführten westafrikanischen Fundulus-Arten. Tom. cit., 601-604. 3 figs.

1911.5

Die bis jetzt eingeführten westafrikanischen Haplochilus-Arten. Tom. cit., 557-559; 575-577. 6 figs. 1911.6 $\begin{array}{rlr}\text { Cichlasoma } & \text { aureum Günther. } \\ \text { lom. cit., 757-759. } & \text { fig. } & 1911.7\end{array}$

- Danio analipunctatus nov. sp. BIgr., ein neuer Danio. Blätt. Aquar. Terrar. Kunde, 1911, 22. Jahrg., 525527. fig. - Wochenschr. Aquar. Terrar. Kunde, 1911, 8. Jahrg., 473-474. fig. 
Danio malabaricus Jerdon und seine Zucht im Zimmeraquarium. Wochenschr. Aquar. Terrar. Kunde, 1911, 8. Jahrg., 390-392. fig.

1911.9

- Eleotris species. Blätt. Aquar. Terrar. Kunde, 1911, 22. Jahrg., 217219. fig.

1911.10

Eruthrinus salmoneus Gronow. Wochenschr. Aquar. 'Terrar. Kunde, 1911, 8. Jahrg., 573-575. fig. 1911.11

- Der Formen- und Farbenkreis der Haplochilus panchax-Gruppe. Tom. cit., 669-672. 3 figs.

1911.12

- Fundulus sjöstedti Lönnberg. Tom. cit., 137-139. fig.

1911.13

- Geophagus jurupari

Heckel. Tom. cit., 105-107. fig.

1911.14

Haplochilus fasciolatus Gthr. Tom. cit., 273-275. fig.

1911.15

Hautwucherungen bei Fischen. Tom. cit., 322.

1911.16

Heros spurius Heck. Blätt. Aquar. Terrar. Kunde, 1911, 22. Jahrg. 329-331; 368-369. fig.

1911.17

- Macrodon trahira Spix. Wochenschr. Aquar. Terrar. Kunde, 1911, 8. Jahrg., 686-689. 2 figs.

1911.18

Meine Erfahrungen bei der Haltung von Cynolebias bellotii Stdr. Tom. cit., 617-619; 634-635. 3 figs. 1911.19

- Paragoniates microlepis Stdr Tom. cit., 429-431. fig. 1911.20

Petersius spilopterus Blgr. Tom. cil., 737-739. 2 figs.

1911.2

Pacilia heteristia Rgn. Blått. Aquar. Terrar. Kunde, 1911, 22. Jahrg., 124-125; 137-138. 1911.22

Pterophyllum scalare C. und V. Wochenschr. Aquar. Terrar. Kunde, 1911, 8. Jahrg., 165-166. fig. 1911.23

- Trichogaster labiosus Day. Blätt. Aquar. Terrar. Kunde, 1911, 22. Jahrg. 509-511. fig.

1911.24

- Ueber die Geschlechtsunterschiede bei Rasbora heteromorpha Duncker. Wochenschr. Aquar. Terrar. Kunde, 1911, 8. Jahrg., 649-650. fig.

1911.25

Ein weiterer Beitrag zur Geschlechtsentwicklung des Männchens von Pantodon buchholzi Peters. Tom. cit., 586-587. 2 figs.

1911.26
Weiteres über den Schmetterlingsfisch (Pantodon buchholzi Peters) Blätt. Aquar. Terrar. Kunde, 1911, 22. Jahrg., 397-398. fig. - Wochenschr. Aquar. Terrar. Kunde, 1911, 8. Jahrg., 449-451. 2 figs.

1911.27

Zehn Jahre Aquarienliebhaber. Blätt. Aquar. Terrar. Kunde, 1911, 22. Jahrg., 170-172; 182-185. 2 figs.

1911.28

Zur Fundulus gularis-Frage. Wochenschr. Aquar. Terrar. Kunde, 1911, 8. Jahrg., 463. 1911.29

- Zur Haplochilus panchax-varietäten-frage. Tom. cit., 707. 1911.30

- Alestes chaperi Sauvage. Wochenschr. Aquar. Terrar. Kunde, 1912, 9. Jahrg., 441-442. fig. 1912.1

- Anabas fasciolalus Blgr. Tom. cit., 763-764. fig. 1912.2

Barbus pentazona Blgr. Tom. cit., 277-279. fig. 1912.3

Clarias dumeritii Stdr. Tom. cit., 233-234. fig. 1912.4

Corydoras undulatus Rgn. Tom. cit., 777-779. fig.

1912.5

Cyprinodon (Lebias) spec.? aus Persien und seine Zucht im Zimmeraquarium. Tom. cit., 665-668. fig.

1912.6

Danio albolineatus Blyth. ein neuer Danio. Tom. cit., 221-223. fig. 1912.7

Evorthodus breviceps Gill. Tom. cit., 685-688. 4 figs. 1912.8

- Die Familie Nandida. Tom. cit., 133-135. 3 figs. 1912.9

- Girardinus formosus Girard. Tom. cit., 553-554. fig. 1912.10

-Gymnallabes typus Gthr. Tom. cit., 705-706. fig. 1912.11

- Haplochilus senegalensis Stdr. Tom. cit., 61-62. fig. 1912.12

Haplochromis moffati Casteln. T'om. cit., 742. fig. 1912.13

Der Kletterfisch (Anabas scandens Daldorff), seine Pflege und Zucht im Zimmeraquarium. Tom. cit., 105106. fig.

1912.14

17.

Lebias sophia Heckel. Tom. cit., 1912.15 
Arnold, $J . P$.

Nannacara taria Regan; ein neuer Zwergeichlide aus dem Amazonenstrom. Tom. cit., 521-524. fig.

1912.16

Paraglyphidodon oxycephalus Blkr. Tom. cit., 393. fig. 1912.17 Pelmatochromis arnoldi Blgr. Tom. cit., 601-602. fig. 1912.18 Pelmatochromis taniatus Blgr. Tom. cit., 365-367. fig. $\quad 1912.19$

- Phago loricatus Gthr. Tom.cil., 649-650. fig.

1912.20

- P'recilia dominicensis Val. Tom. cit., 505-506. fig.

1912.21

- Polycentropsis abbreviata Blgr. und scine Zucht im Zimmeraquarium. Tom. cit., 797-801. fig.

1912.22

Prochilus percula Blkr. Tom. cil., 305-307; 325-327.

1912.23

- Rasbora maculata Duncker. Tom. cit., 45-46. fig. 1912.24

- Rivulus tenuis Meek, nicht Rivulus flabellicauda Regan. Tom. cit., 617618. fig.

1912.25

- Scatophagus argus L. und seine Haltung im Zimmeraquarium. Tom. cit., 409-411. fig.

1912.26

- Die schwarzgescheckte Poecilia sphenops. Tom.cit., 691-692. fig.

1912.27

- Tilapia lepidura Blgr. Tom. cit., 161-163. fig.

1912.28

Ueber das Laichgeschäft des Trichogaster labiosus. Bliitt. Aquar. Terrar. Kunde, 1912, 23. Jahrg., 597 598. fig.

1912.29

Ueber Melanismus bei den lebendgebärenden Zahnkarpfen. Wochenschr. Aquar. Terrar. Kunde, 1912, 9. Jahrg., 377-379. 2 figs. 1912.30

- Ueber Zuchterfolge bei Fundulus bivittatus Lönnberg. Tom. cit., 77-80. 2 figs.

1912.31

- Xenocara dolichoptera Ḱner. Tom. cit., 193-194. 2 figs. 1912.32

Zur Nomenklatur der bisher eingefühten Xiphophorus-Arten. Tom. cit., 725-726. fig. 1912.33

Anostomus taniatus Kner und eporinus frederici Bloch. Wochenschr.
Aquar. Terrar. Kunde, 1913, 10. Jahrg. 525-526. 2 figs. 1913.1

Chrysichthys species. Tom. cit., 449-450. 2 figs. 1913.2

- Cichlosoma coryphanoides Heck. Tom.cit., 854-855. fig. 1913.3

Cichlosoma fenestratum Gthr. Tom. cit., 621. fig. 1913.4

Cichlosoma salvini Gthr. 'Tom. cit., 373-374. fig.

1913.5

Cichlosoma severum (Heros spurius Heck.) Tom. cit., 833-835. fig.

1913.6

Copeina callolepis und Copeina arnoldi Regan. Tom. cit., 245-247. 2 figs.

1913.7

-Corydoras macropterus Regan. Tom. cit., 337. fig. . 1913.8

Eleotris pisonis Gmelin. Tom. cit., 925-926. fig. 1913.9

- Eleotris species aus dem Amazonenstrom. Tom. cit., 723-724. fig.

1913.10

Das Ende des XiphophorusStreites. Tom. cit., 411-414. 1913.11

Fundulus chrysotus var. nubrifrons Jor, und seine Zucht im Aquarium. Tom. cit., 813-814. fig.

1913.12

Fundulus noltii Agassiz. Wochenschr. Aquar. Terrar. Kunde, 1913, 10. Jahrg., 581. fig.

1913.13

- Heterogramma ef. toniatum pertense var. nov. Haseman. Tom. cit., 910-912.

1913.14

- Pelmatochromis guentheri Sauvage. Tom. cit., 779-780. fig. 1913.15

- Pelmatochromis sp. n. Tom. cit., 661-662.

1913.16

Pocilia amazonica Garman.

Tom. cit., 641-642. fig.

1913.17

869-870. fig

om. cit.,

- Rasborichthys spec.? T'om. cit., 285-286. fig.

1913.19

- Rivulus strigatus sp. n. Regan.

Tom. cit., 353-355. fig.

1913.20

Tilapia tholloni Sauvage. Tom. cit., 301-302. fig. 
Uam amphiacanthoides Heck. Tom. cit., 849-850. fig. 1913.22

Weiteres über Anabas fasciolatus Blgr. Tom. cit., 681-682; 723. 2 figs.

1913.23

Der Zitteraal (Gymnotus electricus) im Zimmeraquarium. 'T'om. cit., 318-320. fig.

1913.24

Arnold, Julius. Ueber die Beziehung der Blut und Lymphgefässe zu den Saftkanälchen. Archiv. Path. Anat. Physiol. (Virchow), 1875, 62 157-194.

1875.1

Arnold, Ralph. The palæontology and stratigraphy of the marine Pliocene and Pleistocene of San Pedro, California. Mem. Californ. Acad. Sci., 1903, 3, 1-420. pls. xvi-xvii.

1903.1

Arras, Lucien d'. Sur les accidents causés par les poissons. Inaug. Dissert., Paris, 1877. $8^{\circ}$.

1877.1

Arrigoni degli Oddi, (Conte) Ettore. Materiali per la fauna Padovana dei vertebrati. I. Mammiferi, rettili, anfibi e pesci. Atti Soc. Veneto-'Trent. Sci. Nat., 1895, 2. ser. 2, 1-81. 1895.1

Arsaky, Apostolus. Commentatio piscium cerebro et medulla spinali. Inaug. Dissert., Halx, 1813. $46 \mathrm{p}$. 3 pls. $4^{\circ}$.

1813.1

The same. 2. ed. Lipsiæ, 1836. Abstract in Arch. (Müller), 1836, 247. Repert. Anat. Phys., 1837, 2, 21. 1836.1

Arsenjev, $V^{\top}$. Observations sur les Salmonoides du pays transussurien [Text in Russian] Ann. Mus. Zool. Acad. Sci. St. Pétersb., 1909, 13, lx-lxiii. 1909.1

Arsonval; A. d'. La production d'électricité par les êtres vivants. Rev. Sci. France Etranger, Paris, 1891, 48, 1-14. figs.

1891.1

- Recherches sur la décharge électrique de la torpille. C. R. Acad. Sci. Paris, 1895, 121, 145-151.-Rev. Scient., 4, 117.

1895.1

Power of electrical fishes. Zoologist, $1896,20,306$.

1896.1

Artaud, J.B.L. Notice pour servir à l'histoire naturelle du Gouramy iOsphromenus] Bull. Hist. Nat. Soc. Linn. Bordeaux, 1821, 2, 188. 1821.1

- Notice sur l'Osphromenus olfax Commerson. Bull. Sci. Nat. (Férussac), $1829,18,116-117$.
- Notice pour servir à l'histoire naturelle du gouramy [Osphromenus] Bull. Soc. Hist. Nat. Bordeaux, 1821, 2, 188.

1821.1

Artedi, Peter [1705-1735] Bibliotheca Ichthyologica . . emendata et aucta a Iohanne Iulio Walbaum. Grypeswaldixe, 1788-1792. 5 pts. See Walbaum, $J . J$. (editor).

For a detailed account of Artedi's ichthyological contributions, edited by Linnæus, see Gill's synopsis in Smithson. Misc. Coll., 1874, $11,27-45$

Arthaber, Gustav von. Die Cephalopodenfauna der Reiflinger Kalke. Beitr. Paläont. Geol. Oesterr.-Ungarn, $1896,10,1-112 ; 192-242.15$ pls. d 12 figs.

1896.1

Arthur, $W$. On the brown trout introduced into Otago. Trans. Proc. New Zeal. Inst., 1878 (1879), 11, 271-290. pl.

1879.1

History of fish culture in New Zealand. Trans. Proc. New Zeal. Inst., 1881, 14, 180-210. pls. xii-xiv. 1881.1

Notes on some specimens of $\mathrm{mi}$ gratory Salmonidx. Trans. Proc. New Zeal. Inst., 1880 (1881), 13, 175-193. pls. iv $-\mathrm{v}$.

1881.2

Notes on the New Zealand sprat [Clupea sprattus] Trans. New Zeal. Inst., 1883, 16, 203-208. pl. \& fig. New Zeal. Journ. Sci., 1883, 1, 234.

1883.1

Notes on the picton herring, Clupea pilchardus (C. sagax, New Zealand form) Trans. Proc. New Zeal. Inst., 1883, 16, 205-213. pl. - New Zeal. Journ. Sci., 8, 391-392. 1883.2

Notes on the salmon disease in the Tweed and other rivers, and its remedy. New Zeal. Journ. Sci., 1882 (1883), 1, 347-353. 1883.3

- On diseased trout in Lake Wakatipu. Trans. Proc. New Zeal. Inst., 1883, 16, 198-203. pl.-New Zeal. Journ. Sci., 1883, 1, 234-235. 1883.4

On the brown trout introduced into Otago. Paper no. 2. Trans. Proc. New Zeal. Inst, $1883,16,467-512$. pls. xliii-xliv.

1883.5

- Notes on New Zealand fishes. Trans. Proc. New Zeal. Inst., 1884, 17, 160-172. pl. 1884.1

-__ Notes on the New Zealand frostfish. New Zeal. Journ. Sci., 1884, 2, 157-158.
1884.2 
Arthur, IV.

On the brown trout (Salmo fario Ausonii) in Otago waters. New Zeal. Journ. Sci., 1884, 2, 36-37.

1884.3

Arundo, pseudonym for Beaver, John.

Arustamoff, M. Ueber die Natur des Fischgiftes. Centralbl. Bakt. Parasit, $1891,10,113-119$.

1891.1

Asai, 'T. Untersuchungen über die Struktur der Riechorgane bei Mustelus lavis. Anat. Hefte, 1913, 49, 1. Abth., $441-521$.

1913.1

Ascanius, $P$. Icones rerum naturalium, ou figures enluminées d'histoire naturelle du Yord. Copenhague, 17721806.

1772.1

Cahier 1 [sécond édition]: p. 1-8, 1806.

$\begin{array}{ll}2 & \text { p. } 1-8,1772 \\ 3 & \vdots \text { p. } 1-6,1806 \\ 4 & \vdots \text { p. } 1-6,1806 \\ 5 & \vdots \text { p. } 1-8,1805\end{array}$

With each there are ten plates. Cahier 3 and 4 were originally issued in 1775 and $1776 \mathrm{re}-$ spectively. Cahier 5 was edited with a preface by J. Rathke.

Beretning um silde-tusten [Regalecus remipes] Dansk. Selsk. Skrift, N. Saml., 1788, 3, 419-422. 1788.1

Ascherson, $P$. [Ueber den Fang der Hutta (Mugil cephalus) mit Hilfe der wilden Delphine] Sitzber. Ges. Naturf. Fr. Berlin, 1892, 145-148. 1892.1

Ascoli, Maurizio. Ematopoesi nei ciclostomi. 'Torino, 1896. 1896.1

_- Sull' ematopoesi nella Lampreda. Atti Accad. Sci. 'Torino, 1898, 33, 916923. pl. - Arch. Ital. Biol., 1898, 30 , 270-277. pl. - Monit. Zool. Ital., 9, 189.

1898.1

Ueber die Blutbildung bei der Pricke. Arch. Mikr. Anat., 1899, 53, 623-631. pl. Abstract in Journ. Roy. Micr. Soc. I London, 1899, 2. ser. 19, 21 ; 269.

1899.1

Ascroft, R.L. Note on the American shad. Rept. Lancashire Sea-Fish. Lab. 1899 (1900), 29-30. - 'Trans. Liverpool Biol. Soc, $1900,14,173-174.1900 .1$

- Notes on the white fluke or flounder. Rept. Lancashire Sea-Fish. Lab. 1899 (1900), 30-34. - 'Trans, Liverpool Biol. Soc., 1900, 14, 17t-177.

1900.2

Ashton, John [18:3t-] Curious creatures in zoology. London, 1890. 348 p. 130 figs. $8^{\circ}$ 1890.1
Ashworth, Edmund. Remarks on the artificial propagation of salmon at Stormontfield, near Perth. Bolton, 1875. $8^{\circ}$.

1875.1

Ashworth, Edmund, \& Ashworth, Thomas. A treatise on the propagation of salmon and other fish. London, 1853. 68 p. pl. \& figs. $8^{\circ}$ 1853.1

Ashworth, Edmund, Jardine, William, \& Fleming,... Report upon the experiments conducted at Stormontfield, near Perth, for the artificial propagation of salmon. Rept. Brit. Assoc. Adv. Sci., 1856, 451-45S.

1856.1

Ashworth, Thomas. On the scientific cultivation of salmon fisheries. Rept. Meet. Brit. Assoc. Adv. Sci., 1862 (1863), notices, 121-122.

1863.1

Essay on the practical cultivation of a salmon fishery ... London, 1866. $12^{\circ}$.

1866.1

The salmon fisheries of England, 1868, from authentic information obtained for the House of Commons, to which is added valuable and exclusive information, extracted from the reports of the commissioners of fisheries in France, America, Norway and Russia. London \& Bath, 1S68: 117 p. $12^{\circ}$.

1868.1

Ashworth, Thomas, \& Ashworth, Edmund. Report upon the fisheries of .. Spain and Portugal. Manchester, 1857. $8^{\circ}$

1857.1

Askanazy, Max. Weitere Mitteilungen über die Quelle der Infektion mit Distomum felineum. Schrift. Oekon.Physik. Ges. Königsberg, 1906, 46, 127131. 1906.1

Asmuss, Hermann. Ueber die Knochen- und Schuppen-Reste im Boden Lieflands. Bull. Acad. Sci. St. Pétersb., 1839, 6, 220. - Neues Jahrb. Miner., 1840,738

1839.1

Das vollkommenste Hautskelet. der bisher bekannten Thierreihe. An fossilen Fischen des Alten Rothen Sandsteins aufgefunden und aus ihren Resten erläutert. Abh. Erlangung der Magisterwürde, Dorpat, 1856.39 p. 1856.1

Asper, Goltlieb. Mitheilungen über die Fischbrutanstalt bei der Wasserkirche. Vierteljahrsschr. Naturf. Ges. Zuirich, 1880, 423-435.

1880.1

-_- Beitråge zur Kenntniss der Tiefseefauna der Schweizerseen. Zool. Anz., $1880,3,130 ; 250$. 
- Die Fischerei im Kanton Tessin. Zürich, 1883.

1883.1

- Die Seeforellen des Zïrichsees. Zürich, 1884.

1884.1

- Fische der Schweiz und der künstlichen Fischzucht. Bern, 1890. fig. $8^{\circ}$.

1890.1

Les poissons de la Suisse et la pisciculture. Lausanne, 1891. 192 p. 78 figs. $8^{\circ}$.

1891.1

Assaky, Georges. Origine des feuillets blastodermiques chez les vertébrés. Paris, 1886. 136 p. figs. $8^{\circ}$. 1886.1

Assheton, Richard. On growth centres in vertebrate embyros. Anat. Anz., 1905, 27, 125-127; 156-170. 9 figs.

1905.1

Certain features characteristic of teleostean development. Guy's Hospital Rept., 1907, 61, 345-388. 18 figs. 1907.1

The development of Gymnarchus niloticus. Budgett Memorial Vol., 1907, 293-421. pls. \& figs.

1907.2

- - Report upon sundry teleostean eggs and larvae from the Gambia River. Budgett Memorial Vol., 1907, 433-442. 6 figs.

1907.3

Assmann, Paul. Ueber Aspidorhynchus. Arch. Biontol., Berlin, 1906, 1 , 49-79. 2 pls. \& 6 figs.

1906.1

Asso y del Rio, Ignacio Jordan de [1742-1814] Introductio in oryetographiam et zoologiam Aragonia. [n. p.] 1784.

1781.1

Introducción á la ichthyología oriental de España. Anales Ciencias Nat., 1801, 4, 28-52. Also separate; Madrid, 1801. 28 p. $4^{\circ}$. 1801.1

Asvadourova, Nina. Recherches sur la formation de quelques cellules pigmentaires et des pigments. Arch. Anat. Mier., 1913, 15, 153-314. 2 pls. \& 5 figs.

1913.1

Athanasiu, Sava. Studii geologice in districtul Suceava. Bull. Soc. Sci. Bucarest, 1898, 7, 61-84. 3 figs. 1898.1

Athias, - Sur la vacuolisation des cellules nerveuses. Anat. Anz., 1906, 28, 492-495.

1906.1

Atkins, Charles $G$. Fish culture. Amer. Naturalist, 1868, 1, 296-30t.
Fecundity of fishes. Sci. American, $1870,22,161$.

1870.1

Fourth report of the commissioner of fisheries of the state of Maine. $1870,1-38$. pls. i-ii.

1870.2

Activity of trout and salmon. Amer. Naturalist, 1872, 6, 369. 1872.1

- Propagation of salmon. Amer. Naturalist, 1872, 6, 170-172. - Forest \& Stream, 1873, 1, 162. 1872.2

Reproduction of sturgeon. Abstract of paper by Kowalewsky, Owsjannikow and Wagner, q.v., in Amer. Naturalist, $1872,6,175$. 1872.3

On the salmon of eastern North America and its artificial culture. Rept. U. S. Fish Comm. 1872-73 (1874), 2 226-337. pls, iv-xiii. 1874.1

Salmon breeding at Bucksport. Proc. Amer. Fish-Culture Assoc., 1874, 3. Ann. Meet., 24-30. - Forest \& Stream, 1874, 2, 20-21. 1874.2

- Salmo [Oncorhynchus] quinnat and Salmo salar. Forest \& Stream. $1874,2,388-389 . \quad 1874.3$

Salmon breeding at Bucksport Trans. Amer. Fisheries Soc. 1874 (1875). $22-30$.

1875.1

Report on the collection and distribution of Penobscot salmon in 187374 and 1874-75. Rept. U. S. Fish Comm. 1873-75 (1876), 3, 48.)-530.

1876.1

- Landlocked salmon. Rod it Gun, 1876, 8, 5 . 1876.2

All about cels. Forest \& Stream, $1878,11,130-131 . \quad 1878.1$

Obaervations on the occurrence of spawn in eels.

On a collection of eggs of Schoodic salmon in 1875 and 1876 . Rept. U.S. Fish Comm. 1875-76 (1878) 4. 910-919. 1878.2

- The enduring power of salmon milt. Chicago Field, 1879, 11, 164.

1879.1

Living eags from dead fish. Chicago Field, 1879, 11, 32. 1879.2

Propagation of landlocked salmon. Forest \& Stream, 1879, 11, $1868.1 \quad 721$. 
Atkins, $C . G$.

Report on the collection and distribution of Schoodic salmon eggs in 1877-78. Rept. U. S. Fish Comm. 1877 (1879), 5, 817-846.

1879.4

Salmo salar and the Schoodic salmon. Nature, $1879,20,29 .-C h i-$ cago Field, 1879, 11, 276.

1879.5

Cheap fixtures for the hatching of salmon. Rept. U. S. Fish Comm. 1878 (1880), 6, 945-966. 15 figs.

1880.1

Report on an attempt to collect eggs of Sebago salmon in 1878. Rept. U.S. Fish Comm. 1878 (1880), 6, 775787.

1880.2

Habitat of Sebago salmon, p. 775. Characteristics of Sebago salmon, p. 776 .

Report on the collection and distribution of Schoodic salmon eggs in 1878-79. Rept. U. S. Fish Comm. 1878 (1850), 6, 789-814.

1880.3

- Report on the propagation of Penobscot salmon in 1879-80. - Report on the propagation of Schoodic salmon in 1879-80. Rept. U. S. Fish Comm. 1879 (1882), 7, 733-766. 1882.1

Sketch of the Penobscot salmonbreeding establishment. - Sketch of the Schoodic salmon-breeding establishment. Bull. U. S. Fish Comm. 1882 (1883), 2, 373-382.

1883.1

Report on the propagation of Penobscot salmon in 1880-81. - Report on the propagation of Schoodic salmon in 1880-81. Rept. U. S. Fish Comm. 1880 (1883), 8, 623-651.

1883.2

Report on the propagation of Penobscot salmon in 1882-83. - Report on the propagation of Schoodic salmon in 1882-83. Rept. U. S. Fish Comm. 1882 (1884), 10, 858-871.

1884.1

- Ten questions concerning the habits and breeding of landlocked salmon, with replies. Bull. U. S. Fish Comm., 1884, 4, 383-384.

1884.2

The biennial spawning of salmon (The Bucksport experiments) 14. Ann. Meet. Amer. Fish. Soc, 1885, 89-94.

1885.1

- Memoranda on landlocked salmon (Salmo salar) Bull. U. S. Fish Comm. 1884 (1885), 4, 341-344. 1885.2
- Notes on landlocked salmon. Trans. Amer. Fisheries Soc. 1884 (1885) $40-54$.

1885.3

- Report on the propagation of Penobscot salmon in 1883-84. - Report upon the propagation of Schoodic salmon in 1883-84. Rept. U. S. Fish Comm. 1883 (1885), 11, 1007-1015.

1885.4

Report on the propagation of Penobscot salmon in 1884-85. - Report on the propagation of Schoodic salmon in 1884-85. Rept. U. S. Fish Comm. 1884 (1886), 12, 177-187.

1886.1

Report upon the propagation of Penobscot salmon in 1885-86. - Report upon the propagation of Schoodic salmon in 1885-86. Rept. U. S. Fish Comm. 1885 (1887), 13, 141-156.

1887.1

'The river fisheries of Maine. Rept. on Fisheries \& Fish. Ind. U. S. 1887, sec. 5, 1, 673-728. pls. clxivclrviii.

1887.2

Report on the artificial propagation of codfish at Woods Hole, Mass. Rept. U. S. Fish Comm. 1886 (1859), 14, 783-791.

1889.1

Report upon the propagation of Penobscot salmon in 1886-87. - Report on the propagation of Schoodic salmon at Grand Lake Stream, Maine 1886-87. Report U. S. Fish Comm. 1886 (1889), 14, 747-759. $\quad 1889.2$

The food problem in fish culture. 'Trans. Amer. Fisheries Soc. 1894 (1895), 58-66.

1895.1

Methods employed at Craig Brook Station in rearing young salmonoid fishes. Bull. U. S. Fish Comm. 1893 (1895), 13, 221-228.

1895.1

- The study of fish diseases. Trans. Amer. Fisheries Soc., 1901 (1902), \$2-89.

1902.1

The live food problem. Trans. Amer. Fisheries Soc. 1903 (1904), 71-78.

1904.1

- The utilization of neglected fishes. Trans. Amer. Fisheries Soc. $190 \pm(1905), 178-182 . \quad 1905.1$

The early feeding of salmonoid fry. Trans. Amer. Fisheries Soc. 1905 (1906), 75-81.

1906.1 
- Experiments in fasting of fry. Trans. Amer. Fisheries Soc, 1906 (1907), 123-129.

1907.1

- Foods for young salmonoid fishes. Proc. 4. Intern. Fish. Congr., Washington, 1908, pt. 2, 839-851.

1908.1

- Manipulation of salmon eggs. Trans. Amer. Fisheries Soc. 1907 (1908), 218-222.

1908.2

- Atlantic salmon in fresh water. Trans. Amer. Fisheries Soc. 1911 (1912), 135-138.

1912.1

Atkins, Charles $G_{\text {., \& }}$ Foster, $N . W$. See Foster \& Atkins.

Atkinson, G.C. Salmon in the 'Tyne in 1866. Nat. Hist. Trans. Northumberland Durham, 1867, 1, pt. 3, 408410.

1867.1

Atkinson, George $T$. Notes on a fishing voyage to the Barents Sea in August, 1907. Journ. Mar. Biol. Assoc., Plymouth, 1908, n. s. 8, 71-98. pl. \& 3 figs. \& map.

1908.1

- Marking and transplantation experiments with plaice and some notes on the natural history of that fish. Proc. Suffolk Instit. Arch. Nat. Hist., 1909, 13, pt. 3, 1-13. 5 pls.

1909.1

- An experiment in the transplantation of plaice from the Barents Sea ("White Sea") to the North Sea. Journ. Mar. Biol. Assoc., Plymouth, 1910 , n. s. 8, 502-511.

1910.1

Report on the English plaice marking experiments, 1906-1908. 4. Rept. North Sea Fish Invest. Comm., 1912, 225-290. 14 pls.

1912.1

Atkinson, George T', \& Lee, Rosa M. See Lee \& Atkinson.

Atkinson, J.C. Notes on fishes, more especially salmon and eels. Zoologist, 1844, 2, 524-532.

1844.1

Atthey, Thomas. Some remarks on the report of Professor Owen's paper on fish remains found in the Northumberland coal-field. Geol. Mag., 1867, 4, 378-381.

1867.1

Notes on various species of Ctenodus obtained from the shales of the Northumberland coal-field. Ann. Mag. Nat. Hist., 1868, 4. ser. 1, 77-87.- Nat. Hist. Trans. Northumberland Durham, 1868, 3, 54-66. pls. i-iii. 1868.1

Here the paper is accredited to Hancock and Atthey.
On the occurrence of palatal teeth belonging to the genus Climaxodus $M ' C o y$ in the Low Main shale of Newsham. Ann. Mag. Nat. Hist., 1868, 4. ser. 2, 321-323. - Nat. Hist. Trans. Northumberland Durham, 1868-70 (1868), 3, pt. 2, 306-309. 1868.2

On the articular bone and supposed vomerine teeth of Ctenodus obliquus, and on Paloconiscus hancocki n. sp., from the Low Main, Newsham, Northumberland. Ann. Mag. Nat. Hist., 1875, 4. ser. 15, 309-312. pl. - Nat. Hist. Trans. Northumberland Durham, 1877, 5, 227-230. 7 pls: $\quad 1875.1$

- Notes on a paper by R. H. 'Iraquair, on the structure of the lower jaw in Rhizodopsis and Rhizodus. Ann. Mag. Nat. Hist., 1877, 4. ser. 20, 129130. - Nat. Hist. Trans. Northumberland Durham, 1880, 7, 175-176. 1877.1

Atthey, Thomas, \& Hancock, Albany. See Hancock \& Atthey.

Atthey, Thomas, Hancock, Albany, \& Howse, $R$. See Hancock, Howse, \& Atthey.

Atthey, $T .$, \& Kirkby, $J . W$. See Kirkby \& Atthey.

Atwater, $W . O$. Menhaden \& other fish, and their products, as related to agriculture. Rept. U. S. Fish Comm. 1877 (1879), 5, 194-267. 1879.1

Fish as food. Forest \& Stream, $1880,14,204-206 . \quad 1880.1$

The nutritive qualities and values of various kinds of fish, comparing them with the composition and value of animal foods. Trans. Amer. Fisheries Soc. 1880 (1881), 44-58.

1881.1

The chemical composition and nutritive value of fish. Trans. Amer. Fisheries Soc. 1881 (1882), 124-130. 1882.1

_- Report of progress of an investigation of the chemical composition and economic values of fish and invertebrates used for food. Rept. U. S. Fish Comm. 1880 (1883), 8, 231-285. 1883.1

Zur Chemic der Fische. Bericht Nat. Ges. Chem. Berlin, 1883, 16, 18391846.

1883.2

On the chemistry of fish. Amer. Chem. Journ., 1887, 9, 421-452; 1888, $10,1-20$. 
Atwater, $W . O$.

Contributions to the knowledge of the chemical composition and nutritive values of American food-fishes and invertebrates. Rept. U. S. Fish Comm. 1883 (1885), 11, 433-499. 2 pls. Abstract in Proc. Amer. Assoc. Adv. Sci., 1881, 71-73. - Canadian Naturalist, 1881, n. s. 9, 407-409.

1885.1

Ueber die Ausnützung des Fischfleisches im Darmkanale im Vergleich mit der des Rindfleisches. Zeitschr. Biolog., 1888, 24, 16-28.

1888.1

Atwater, $W$. O., \& Goode, George Brown. See Goode \& Atwater.

Atwood, NathanielE. Remarks on a specimen of Naucrates and on the natural history of the cod. Proc. Boston Soc. Nat. Hist., 1859-61 (1861), 7, 4. 1859.1

- Remarks on a specimen of Aspidophorus taken on the Newfoundland Grand Bank. Op.cit., 8, 218. 1861.1

- On variable habits of many species of fish. Proc. Boston Soc. Nat. Hist., 1862-63 (1865), 9, 189-190.

1863.1

- On. several species of native fishes. Proc. Essex Inst., 1864-65, 4, 101-103.

1864.1

- - On the habits of some of our salt water fishes. Proc. Boston Soc. Nat. Hist., 1864-66 (1866), 10, 65-68.

1864.2

On the jaws and stomach-contents of certain sharks [Carcharias tigris, sp. nov., and Mustelus canis] T'om. cit., 79-80.

1864.3

On the habits of the halibut, especially in distinction from the cod. I'om. cit., 182-183.

1865.1

Some points in the history of the rod. Tom. cit. 103-104.

1865.2

On the habits and distribution of the haddock. Tom. cit..322-323.

1866.1

On the habits of our native species of Gadidx. Proc. Boston Soc. Nat. Hist., 1866-68 (1868), 11, 100-102.

1866.2

- On 'T'orpedo occidentalis Storer. Proc. Essex Inst., 1866-67 (1868), 5 , $14-15$.

1866.3

- lixhibition of a cod fish which had a number of sand-ecls in the walls of the abdominal cavity with remarks by Jeffries Wyman] Proc. Boston Soe. Nat. Hist., 1866-68 (1868), 11, 364.

1868.1

- Description of a shark, Carcharias tigris Atwood. Proc. Boston Soc. Nat. Hist., 1868-69 (1869), 12, 268-269.

1869.1

Some points in the natural history of a few of our edible sea-fish, and particularly of the halibut and bluefish. Torn. cit., 402-403.

1869.2

Remarks on the habits of several of our marketable fishes, etc. Bull. Essex Inst., 1870, 2, 48.

1870.1

On the capelin (Mallotus villosus) and halibut. Proc. Boston Soc. Nat. Hist., 1870-71 (1872), 14, 134-135.

1871.1

Remarks on the habits of bluefish, etc. Tom. cit., 92. 1871.2

Atwood, Thomas. The history of the Island of Dominica... ete. London, 1791. viii. 285 p. $8^{\circ}$. 1791.1

$\begin{array}{rr}\text { 1795. } 8^{\circ} \text {. } & \text { Gömantingen, } \\ 1795.1\end{array}$

Atwood, William. Statement concerning the menhaden fishery. Rept. U. S. Fish Comm. 1877 (1879), 5, 404.

1879.1

Au, Wilhelm. Monogamie, Polygamie und Polyandrie bei den Fischen. Blätt. Aquar. Terrar. Kunde, 1912, 23. Jahrg, 581-582.

1912.1

Aube, $F$. L'île d'Arguin et les pêcheries de la côté occidentale d'Afrique Rev. Marit. Colon, 1872, 470. 1872.1

Aubert, Hermann. Ueber die künstliche Befruchtung der Fischeier und einige Erscheinungen der ersten Entwickelung derselben. Jahresber. Schles. Ges., Breslau, 1852 (1853), 31, 86-94; 1854, 32, 40-43. - Ann. Landwirths. $1853,22,115-121$.

1853.1

Beiträge zur Entwickelungsgeschichte der Fische Zeitschr. Wiss. Zool., 1854, 5, 94-103; 7, 345-364. pl. 1854.1

lintwicklung des Herzens und des Blutes in Hechteier. Leipzig, 1855. $\mathrm{S}^{\circ}$.

1855.1

Blessure produite par une pastenaque \{'lrygon\} Paris, 1861. $8^{\circ}$.

1561.1 
Aubeux, — Réflexion sur les avantages que présenterait l'acclimatation du colin [Gadus virens] en Maine-etLoire. Bull. Soc. d'Etudes Sci. d'Angers, 1878-79 (1880), S. et 9. années, $207-210$.

1880.1

Auboin, Stéphen. Erpetologie et ichthyologie, ou traité des reptiles et des poissons. Paris, 1831. $8^{\circ}$.

1831.1

Aubry, O. Haplochilus fasciolatus. Wochenschr. Aquar. Terrar. Kunde, 1912, 9. Jahrg., 538-539. fig. 1912.1

Cichlosoma nigrofasciatum Gthr. Wochenschr. Aquar. Terrar. Kunde, 1913, 10. Jahrg., 814-816. fig. 1913.1

Auché, A. Sur le cocco-bacille rouge de la sardine. C. R. Mém. Soc. Biol. Paris, 1894, 10. sér. 1, 1S-21. 1894.1

Audeville, André $d^{\prime}[-1896]$ La truite arc-en-ciel d'Amérique (Salmo inideus) Bull. Soc. Nat. d'Acel., 1888, 1-20. figs.

1888.1

Audiganne, A. La région du bas de la Loire. Les paludières des marais salins et les pêcheurs des côtes. Revue Deux Mondes, 1868, 2. sér. 78, 198-228.

1868.1

Audigê, J. Sur l'exophthalmie infectieuse de certains poissons d'eau douce. C. R. Acad. Sci. Paris, 1903, 137, 936-938.

1903.1

Sur quelques particularités observées dans les tubes rénaux du barbeau (Barbus fluviatilis Agass.) C. R. Acad. Sci. Paris, 1903, 136, 1473-1474.

1903.2

Note sur la structure de la partic antérieure du rein de quelques poissons. Bull. Soc. Hist. Nat. Toulouse, 1904, 37 , 31-33.

1904.1

- Note sur l'étisie des poisson d'eau douce. Bull. Soc. Hist. Nat. Toulouse, 1904, 37, 29-30.

1901.2

_... Sur la structure de la vessic urinaire de Barbus fluviatilis Agassiz. C. R. Assoc. Anat., 1904, 6, 186-188.

1904.3

L'excrétion chez les poissons. Bull. Station Piscicult., Toulouse-Paris, 1905, 2, 13-17.

1905.1

Quelques particularités de la structure du rein chez les poissons. Bull. Station Piscicult. Toulouse-Paris, $1905,2,18-19$.
Contribution à l'étude des reins des poissons téléostéens. Arch. Zool. Expér., 1910, 5. sér. 4, 275-624. pl. \& 104 figs.

1910.1

Audigé, $J_{.,} \&$ Loup, —— De la capacité reproductrice de quelques téléostéens d'eau douce maintenus en milieu restreint. Bull. Soc. Hist. Nat. Toulouse, 1909, 42, 175-179. 1909.1

Audigê, J., \& Roule, Louis. See Roule \& Audigé.

Audouin, Jean Victor, \& Edwards, Henri Milne. Recherches pour servir ì l'histoire naturelle du littoral de la France, etc. 2 vols. Paris, 1832-34. illust.

1832.1

Audubon, John .J. Notes on shad and trout. Forest \& Stream, 1876, 6, $216 ; 285$.

1876.1

Auer, Carl. Das Verhalten meiner Fische vor und nach dem Erdbeben. Natur \& Haus, 1909, 17. Jahrg., 687.

1909.1

Auerbach, Leopold. Ueber die Lobi optici der Knochenfische. Allgem. Zeitschr. Psychiatrie, 1888, 44.1888 .1

Die Lobi optici der Teleostier und die Vierhügel der höher organisirten Gehirne. Morph. Jahrb., 1889, 14, 373-393. pl.

1889.1

Ueber einen sexuellen Gegensatz in der Chromatophilie der Keimsubstanzen, nebst Bemerkungen zum Bau der Eier und Ovarien niederer Wirbelthiere. Sitzber. Preuss. Akad. Wissen., Berlin, 1891, 713-750.

1891.1

Das IVesen der Neurofibrillen. Monatsschr. Psychiatr. Neurol., 1911$12,30,72$. - Arch. Psychiatr., 1911-12, $49,330-331$.

1912.1

Auerbach, Max. Die Dotterumwachsung und Embryonalanlage vom Gangfisch und der Aesche im Vergleich zu denselben Vorgängen bei der Forelle. Verh. Naturwissen. Ver. Karlsruhe, 1904, 17, 57-82. pls. i-iv.

1904.1

August, - Ueber einen Fischreren. Sitzber. Ges. Natf. Freunde Berlin, 1839-59 (1811-1912), 33-34. 1841.1

Aukarsvärd, G., \& Hammar, $J$. Aug. Zur Kenntnis der Ganoidenthymus (Amia calva, Lepidosteus osseus) Zool. Jahrb., 1913, 36 (Abth. Anat.), 293-306. 2 pls. \& 5 figs. 1913.1 
Aulin, Henrik. Tankar om sättet att rät traktera historia naturalis. Inaug. Dissert. Abo, 1760, 23 p. $4^{\circ}$. 1760.1

Aunap, $E$. Ueber die Chondriosomen der Gonocyten bei Knochenfischen. Anat. Anz., 1913, 44, 449-459. 1913.1

Aurivillius, C.W.S. Vergleichende thiergeographische Untersuchungen über die Plankton-Fauna des Skageraks in den Jahren 1893-1897. Kongl. Svensk. Vet. Akad. Handl., 1897-98 (1898), 30, 1-426.

1898.1

- Om hafsevertebraternas utvecklingstider och periodiciteten $\mathrm{i}$ larvformernas uppträdande vid Sveriges vestkust. Bih. Kongl. Svensk. Vet Akad. Handl., 1899, 24, 1-91. 1899.1

Austen, $E . E$. Notes on a recent zoological expedition on the lower Amazon. Proc. Zool. Soc. London, $1896,768-779$. 1896.1

Austin, Amory. A historical sketch of fish-culture. Proc. Newport Nat. Hist. Soc., 1891-99 (1900), 9, 85-107. 1900.1

Austin, C.E. Geological notes on the locality in Siberia where fossil fish and Estheria have been found Quart. Journ. Geol. Soc. London, 1862, $19,71-74$

1862.1

Autenrieth, Hermann Friedrich [1799-1874] Ueber das Gift der Fische. Tübingen, 1833. figs.

1833.1

Autenrieth, $J, H, F$. Bemerkungen über den Bau der Scholle (Pleuronectes platessa) insbesondere, und den Bau der Fische im allgemeinen. Arch. Zool. Zootomie, 1800, 1, pt. 2, 47-103. 1800.1

Avolio, Francesco Paola. Osservazioni pratiche intorno la pesca, corso e cammino de' Tonin. Messina, 1816. 164 p. $8^{\circ}$.

1816.1

Ayers, Hourd [1861-] Untersuchungen über Pori abdominales. Morph. Jahrb. 1884, 10,341-349. pl. 1884.1

Beiträge zur Anatomie und Physiologie des Dipnoër. Jena Zeitschr., 1885, 18, 479-527. pls. xvi-xviii.

1885.1

'The morphology of the carotids, based on a study of the blood-vessels of Chlamydoselachus anguineus Garman. Bull. Mus. Comp. Zool., 1889, 17, 191223. pl.
Contribution to the morphology of the vertebrate head. Zool. Anz. $1890,13,504-507$.

1890.1

- The ear of man, its past and its future [vertebrate cephalogenesis] Lectures Marine Biol. Lab., 1890, 1, no. 9, 188-230. 17 figs.

1890.2

Concerning vertebrate cephalogenesis. Journ. Morph., 1891, 4, 221245. 1891.1

Discusses, inter alia, sense organs and pineal eye of cyclostomes.

Vertebrate cephalogenesis. II. A contribution to the morphology of the vertebrate ear, with a reconsideration of its functions. Journ. Morph., 1892 , 6, 1-360. pls. i-xii \& 26 figs. 1892.1

The Macula neglecta again. Zool. Anz., 1893, 8, 238-240. 1893.1

On the genera of the Dipnoi dipneumones. Amer. Naturalist, 1893. 27, 919-932.

1893.2

Bdellostoma dombeyi Lac. Mar. Biol. Lab., 1893 (1894), 2, 125-161. 14 figs.

1894.1

The origin and growth of brain cells in the adult body. Journ. Comp. Neurol., 1896, 6, 211-214. 1896.1

The unity of the gnathostome type. Amer. Naturalist, 1906, 40, $75-94$. 1906.1

The ventricular fibres of the brain of Myxinoids. Anat. Anz., 1908. 32, 445-448. 5 figs.

1908.1

Ayers, Howard, \& Jackson, C. M. Morphology of the Myxinoidei. 1. Skeleton and musculature. Journ. Morph., 1900, 17, 185-226. pls. xxiixxiii \& figs. - Bull. Univ. Cincinnati, 1900, 2. ser. 1, 1-15. pls. i-ii. 1900.1

Ayers, Howard, \& Worthington, Jutia. The skin end-organs of the trigeminus and lateralis nerves of Bdellostoma dombeyi. Amer. Journ. Anat., 1907, 7, 327-336. 10 figs.

1907.1

The finer anatomy of the brain of Bdellostoma dombeyi. (1) The acustico-lateral system. Amer. Journ. Anat., 1908, 8, 1-16. pls. (2) The fasciculus communis system. Journ. Comp. Neurol., 1911, 21, 593-617. pls. 1908.1 
Ayres, (Dr.) William O. [18171891] For a detailed list of this author's publications on fishes of the Pacific coast, see Gill's bibliography in Bull. U. S. Nat. Museum, 1882, no. 11.

Descriptions of four species of fishes from Brookhaven, L. I., two of which are believed to be new. Proc. Boston Soc. Nat. Hist., 1841-44 (1844), $1,67-68$. 1842.1

- Enumeration of the fishes of Brookhaven, L. I., with remarks upon the species observed. Proc. Boston Soc. Nat. Hist., 1841-44 (1842), 58-59. $1-$ Boston Journ. Nat. Hist., 1842, 4, no. $2,255-264$. Ibid., 1843,4 , no. 3 , 265-292. pls. xii-xiii.

1842.2

Description of a new species of Leuciscus [L. nasutus] Proc. Boston Soc. Nat. Hist., 1841-44 (1843), 1, 130.

1843.1

Descriptions of four species of fish from Brookhaven, I. I., all of which are believed to be new. Boston Journ. Nat. Hist., $1843-44,4$, no. 3 , 293-302. pls. xii-xiii.

1843.2

An attempt to prove that Cottus cognatus of Richardson, Cottus viscosus of Haldeman, and Uranidea quiescens of Dekay, are one species, and are identical with Cottus gobio of Linnæus. Boston Journ. Nat. Hist., 1845-47 (1847), 5, no. 1, 116-136. pl. 1845.1

- On a characteristic black lateral stripe in the young of Leuciscus pulchellus, etc. Proc. Boston Soc. Nat. Hist., 1848-51 (1851), 3, 54. 1848.1

- On a very curious fish, for which the name Malacosteus niger is proposed. Tom. cit., $69-70$.

1848.2

On an obscure point in the anatomy of Leuciscus. Tom. cit., 46.

1848.3

- On the distribution of Aphredoderus sayanus. Tom. cit., 5.

1848.4

On the muscular apparatus of the pharyngeal bones in Catostomus. Tom. cit., 87.

1848.5

On the occurrence of Myliobates acuta at Long Island. Tom. cit., 57.

1848.6

[Description of Percopsis pellucida, a fish from the Winooski river] Tom. cit., 164-165.
A new species of Leuciscus [L. pulchelloides] from Fairfield county, Connecticut, 1848-51 (1851), 3, 157.

1849.2

- Observations on Leuciscus pulchellus Storer. Proc. Amer. Assoc. Adv. Sci., 1819, 2, 402-406. 1849.3

- On curious malformations in the skulls of Labrax. Tom. cit., 121. 1849.4

On the teeth of Carcharias ceruleus Dekay, and on the generic relations of $C$. griseus. Tom. cit., 264.

1849.5

Some remarks upon a species of pike [Esox lucius] Tom.cit., 173.

1849.6

-Description of a new genus of fishes, Malacosteus. Boston Journ. Nat. Hist., 1850-57 (1857), 6, no. 1, $53-63$.

1850.1

- Description of a new species of Polypterus, from west Africa [ $P$. palmas] Boston Journ. Nat. Hist., 185057 (1857), 6, no. 2, 241-246. pl. Abstract in Proc. Boston Soc. Nat. Hist. 1848-51 (1851), 3, 181. 1850.2

Statements showing that Cottus variabilis is distinct from Cottus gronlandicus, Proc. Boston Soc. Nat. Hist., 1848-51 (1851), 3, 312. 1850.3

- A fish from Para, Vandellia cirrhosa. Proc. Boston Soc. Nat. Hist., $1851-54$ (1854), 4, $31 . \quad 1851.1$ cit., 289

Habits of the bluefish. Tom. 1852.1

- Introduction of the muscalonge (Esox nobilior) into the Connecticut river. Tom. cit., $288 . \quad 1852.2$

- Description of four species of fishes, Camarina nigricans, poronotus simillimus Ayres, johnius nobilis, and seriphus politus] Proc. Calif. Acad. Nat. Sci., 1854-57 (1857), 1, 77-86. figs. Reprinted in 2. ed. of the Academy's Proceedings, 1873.

1854.1

[Description of new fishes from California] Proc. Calif. Acad. Nat. Sci., 1854-57 (1857), 1, 3-22. - Reprinted in 2. ed. of the Academy's Proceedings, $1873 . \quad 1854.2$

New species of Californian fishes. Proc. Boston Soc. Nat. Hist., 1854-56 (1856), 5, 94-103. 1854.3 
Ayres, $W . O$.

[Deseription of new species of Californian fishes] Proc. Calif. Acad. Nat. Sci., 1854-57 (1857), 1, 23-77. Reprinted in 2. ed. of the Academy's Proceedings, 1873.

1855.1

- Notice of freshwater fishes taken in the bay of San Franciscol Proc. Calif. Acad. Nat. Sci., 1858-62 (1863), 2, 163.

1860.1

- IOn new fishes of the Californian coast] Proc. Calif. Acad. Sci., 1858-62 (1863), 2, 25-32; 52-64; $73-86 ; 156-158 ; 207-211$. figs. 1860.2

- Remarks in relation to the fishes of California which are included in Cuvier's genus Sebastes. Proc. Calif. Acad. Nat. Sci., 1858-62 (1863), 2, 211-218. figs.

1860.3

Notes on the sebastoid fishes occurring on the coast of California,
U. S. A. Proc. Zool. Soc. London, 1863, 390-402. 9 figs. - Ann. Mag. Nat. Hist., 1864, 3. ser. 13, 330-342.

1863.1

- IRemarks in relation to the genus Notorhynchus] Proc. Calif. Acad. Nat. Sci., 1863, 3, pt. 1, 15.

1863.2

Ayrton, $W$. The adventures of a salmon in the river Dee. London, 1853. $12^{\circ}$.

1853.1

Ayson, L. F. Introduction of American fishes into New Zealand. Proc. 4. Intern. Fish Congr., Washington, 1908, pt. 2, 967-975. 1908.1

Azuni, Alb. Histoire géographique, politique et naturelle de la Sardaigne. 2 vols. Paris, 1802. $8^{\circ}$. 1802.2 German ed. Leipzig \& Hamburg, 1803. $8^{\circ}$. 1803.1 
B. About the perch [Perca fluviatilis] Fish. Gazette, 1880, 4, 446.

1880.1

Under this initial numerous short articles on fish and fishing appeared in Forest \& Stream and Chicago Field during the late '70's and early ' 80 's.

Giftige einheimische Fische. Allgem. Fisch. Zeitg., 1895, 20, 381382.

1895.1

B., zon. Vom Altmuhlhecht. Bayer, Fischerei-Zeitg., 1879, 4. Jahrg., 67-68. 1879.1

B., A. W. Respiration of fishes. Amer. Naturalist, 1872, 6, 235-236.

1872.1

Abstract of dissertation by N. Gréhant, 1869, q.v.

B., B. Les fanons branchiaux du squale pélerin. Journ. Sci. Math. Phys. Nat., 1877, 6, 71. 1877.1

B., B.O. The spawn of eels. Forest \& Stream, 1875, 4, 61.

1875.1

B., D. L. C. D. Dictionnaire raisonné ... des animaux, etc. Paris, 1759. See La Chesnaye-Desbois, $F$. A. A. de.

B., G.A. Causes affecting the migratory movements of mackerel. Fish. Gazette, 1878, n. s. 2, 172 . 1878.1

B., H. See Baars, Herman.

Baader, Friedrich. Beiträge zur Kenntniss der Fische von Marocco. Bericht Senckenberg. Naturf. Ges., 1873-74 (1875), 179-182.

1875.1

Baars, Herman. La pêche dans la mer du Nord. L'autorité de Dunkerque, 1862 , nos. du $6,8,10,13,15$, 17, 20 Mai.

1862.1

- Beretning om den internationale fiskeri-udstilling i Amsterdam i 1861. Christiania, 1862. pl. $8^{\circ}$. 1862.2

- Les pêches de la Norwège. Boulogne-sur-Mer. 1866. 61 p. 6 pls. 1866.1 12 pls.

The same. 2. ed. Paris, 1867. 1867.1
- Beretning om den internationale fiskeri-udstilling i Boulogne-sur-Mer, 1866. Bergen, 1867. $8^{\circ}$ 1867.2

- Die Fischereindustrie Norwegens. Bergen, 1873. $8^{\circ}$. 1873.1

- L'industrie de la pêche en Norwège (traduit de l'allemand) Boulogne, 1876. 81 p. $8^{\circ}$. 1876.1

Die Fischereindustrie Norwegens. 2. ed. Bergen, 1880. 1880.1

Babåk, Edward. Ueber den Einfluss der Nahrung auf die Länge des Darmkanales. Biol. Centralbl., 1903, 23, 477-483. $\quad 1903.1$

Vergleichende Untersuchungen über die Darmatmung der Cobitidinen und Betrachtung über die Phylogenese derselben. Biol. Centralbl., 1907, 27, $697-703$.

1907.1

Ueber die provisorischen Atemmechanismen der Fischembryorten. Zentralbl. Physiol., 1911, 25, 370-374.

1911.1

Zur Atmung der F'ischembryonen und Jungfische. Blätt. Aquar.'Terrar. Kunde, 1912, 23, 134-136. fig. 1912.1

- Ueber die Vernichtung des Atemzentrums durch Erstickung bei Cobitis (Misgurnus) fossilis und über das Leben des Fisches bei alleiniger Hautatmung. Zentralbl. Physiol., 1914, 27, 1111-1114.

1914.1

Babåk, Edward, \& Dedek, B. Untersuchungen ůber den Auslösungsreiz der Atembewegungen bei Süsswasserfischen. Arch. Ges. Physiol., 1907, 119, 183-529. fig.

1907.1

- Zur Frage über das Zustandekommen der Atembewegungen bei Fischen. Zentralbl. Physiol., 1908, 21, 1-6. 1908.1

Babák, E., \& Hepner, J. Die Synchronie des Atem- und Herzrhythmus bei den Fischembryonen und der 
Babák \& Hepner.

Einfluss der Temperatur. Folia Neurobiol. Haarlem, 1912, 6, 367-373. fig. 1912.1

Babcock, John Pease. The game fishes of British Columbia. British Col. Provincial Informat. Bur., Bull. 25. Victoria, 1908. $8^{\circ}$. pl. 1908.1

Babcock, William C. Report of shad operations conducted at Fort Washington, Md. Rept. U. S. Fish Comm. 1883 (1885), 11, 1035-1041.

1885.1

Report of operations at Fort Washington, Md., for the purpose of collecting shad eggs. Rept. U. S. Fish Comm. 1884 (1886), 12, 189-192. 2 pls. 1886.1

Babes, $Y$. \& Riegler, $R$. Ueber eine Fischepidemie bei Bukarest. Zentralbl. Bakter. Parasitenkunde, 1905, 33, no.6. pl.

1905.1

Babson, John $J$. History of the town of Gloucester, Cape Ann, including the town of Rockport. Gloucester, 1860. $8^{\circ}$.

1860.1

Babukhin, Aleksandr 'Ivanovich. Ueber den feineren Bau und Ursprung des Axencylinders. Centralbl. Med. Wiss., 1868, 6, 755-757. 1868.1

Entwickelung der electrischen Organe und Bedeutung der motorischen Endplatten. Centralbl. Med. Wiss., $1870,8,241-244 ; 257-259$. 1870.1

Ueber die Bedeutung und Entwickelung der pseudoelektrischen Organe. Centralbl. Med. Wiss., 1872, 10, 545-548.

1872.1

Ueber den Bau der electrischen Organe beim Zitterwels Malapterurus electricus] Centralbl. Med. Wiss., 1875, $13,129-133$; 145-149; 161-165; 624.

1875.1

Uebersicht der neuen Untersuchungen über Entwickelung, Bau und physiologische Verhältnisse der electrischen und pseudoëlectrischen Organe. Arch. Anat. Physiol., 1876, 501-542.

1876.1

Beobachtungen und Versuche am Zitterwelse und Mormyrus des Nils. Arch. Anat. Physiol., 1877, 250-274.
Die Säulenzahl im electrischen Organ von Torpedo marmorata. Centralbl. Med. Wiss., 1882, 20, 866-869.

1882.1

Ueber die Praeformation der electrischen Elemente im Organ der Zitterfische, und den von Hrn. Weyl dawider gerichteten Angriff. Arch. Anat. Physiol. (Phys. Abth.), 1882, 414-419. 1882.2

- Adaptability of electric fish to their surroundings. Nature, 1883, 28, 216.

1883.1

Zur Begründung des Satzes von der Praeformation der elektrischen Element im Organ der Zitterfische. Arch. Anat. Physiol., 1883, 239-254. figs.

1883.2

Bach, $M$. Die Fische. Natur. $u$. Offenbarung, 1868, 14, 304-322; 349364.

1868.1

Der Rheinlachs oder Salm. Natur. u. Offenbarung, 1868, 14, 404418.

1868.2

Nestbauende Fische und fischausbrïtende Muscheln. Natur. u. Offenbarung, 1871, 17, 38-49. pl.

1871.1

Bachmann, Isidor. Ueber Ganoiden-Fische und ihre Entwicklung in dem ältern geologischen Formationen. Mitth. Natur. Gesell. Bern (Sitzber.), $1877,45-46$.

1877.1

Backer, C. A. Zoetwaterflora en vischteelt. Teysmannia Batavia, 1911, 22, 501-515. 3 pls.

1911.1

Backer, Fr. Fra Lofoten. (Opsynschefens Fiskeriberetning 1877. Opsynet og Lofotloven af 23de Mai 1857) Dagbladet, Christiania, 21 \& 23 Marts, 1878.

1878.1

Backman, Gaston. Die Bauchflosse der Selachier. (1) Die Bauchflosse der Batoidei. Svensk. Vet. Akad. Handl. Stockholm, 1913, 50, no. 7, 1-141. 11 pls. - Zweite Abteilung. Die Bauchflosse der Holocephali. Ibid., 1915, 53, no. 3, 1-63. 4 pls.

1913.1

Backman, K.A. Beskrifning öfver Jalasjärvi kapell. Suomi, 1852, 11, 231 326.

1852.1

Bacounin, - Mémoire sur le Gordius d'eau douce des environs de Turin. Mem. Accad. Torino, 178889, 4, 23-42. - Journ. Phys. (Rozier), $1791,39,204$. 
Bade, Ernst. Die Goldfische. Berlin, 1894. $8^{\circ}$.

1894.1

Das Süsswasseraquarium. Berlin, 1896. $8^{\circ}$.

1896.1

Die eingeführten Gurami-Arten. Blätt. Aquar. Terr. Freun., 1897, 8; 189-191. fig.

1897.1

Fundulus (majalis), Minnow, and Umbra (limi) Blätt. Aquar. Terr. Freun., 1897, 8, 173-174. pl. 1897.2

- Die künstliche Fischzucht. Magdeburg, 1897. 86 p. $8^{\circ} .2$ pls. \& 15 figs.

1897.3

Welse (Siluridæ) Blätt. Aquar. Terr. Freun., 1897, 8, 25-26. pl.

1897.4

Der amerikanische Schlammfisch (Amia calva L.) Blätt. Aquar. Terr. Freun., 1898, 9, 68-69. fig.

1898.1

- Der Diamantbarsch (Euneacanthus simulans Kay) Blätt. Aquar. Terr. Freun., 1898, 9, 273-274. pl.

1898.2

- Der Kampffisch (Betta pugnax) Blätt. Aquar. Terr. Freun., 1898, 9, 53-54. $1 \mathrm{pl}$.

1898.3

-.. Der Karpfe und seine Rassen. Blätt. Aquar. Terr. Freun., 1898, 9, 186-1S9; 202-204; 211-213; 230-231.

1898.4

Der rote Zahnkarpfen Aplochilus latipes Blk. Blätt. Aquar. Terr. Freun., 1898, 9, 240-241. fig. 1898.5

-Die Schleihe (Tinca vulgaris Cuv.) Blätt. Aquar. Terr. Freun., $1898,9,166-168$.

1898.6

- Der schwarzgebändete Sonnenfisch [Mesogonistius chotodon (Baird) Gill] Blätt. Aquar. Terr. Freun., 1898, 9, $80-82$. fig.

1898.7

Der Chanchito (Heros fasciatus) als Zierfisch und seine Zucht im Zimmeraçuarium. Berlin, 1899.' $8^{\circ}$. 29 p. pl. \& 7 figs. 1899.1

Die Ellritze (Phoxinus laxvis Ag.) Blätt. Aquar. Terr. Freun., 1899 , 10, 85-87. fig.

1899.2

Geophagus brasiliensis Heck. Blätt. Aquar. Terr. Freun., 1899, 10, 221-222. fig.
- Die Groppe und ihre Gewöhnung an das Aquarium. Blätt. Aquar. Terr. Freun., 1899, 10, 249-250. fig. 1899.4

- Der Kaimanfisch (Lepidosteus osseus) Blätt. Aquar. Terr. Freun., 1899, 10, 22-24. fig. 1899.5

Der langohrige Sonnenfisch (Lepomis auritus Gill) Blätt. Aquar. Terr. Freun., 1899, 10, 1-2. fig. $\quad 1899.6$

Muschel und Fisch. Blätt. Aquar. Terr. Freun., 1899, 10, 113-115; 131-133. fig.

1899.7

- Das Photographieren lebender Fische im Aquarium. Blätt. Aquar. Terr. Freun., 1899, 10, 204. 1899.8 Die Seenadel. Blätt. Aquar. Terr. Freun., 1899, 10, 277-278. fig. 1899.9 Unsere Stichlinge und ihr Nestbau. Blätt. Aquar. Terr. Freun.,
1899, 10, 59-64. pl. - Der Schleierschwanz und der Teleskopschleierschwanz (Carassius auratus), ihre Zucht und Pflege und die Beurtheilung ihres Wertes. Magdeburg, 1900. 5 pls. \& 19 figs. 1900.1

- Die eingeführten nordamerikanischen Wirthschaftsfische für den Teich und das Aquarium. Berlin, 1901. 48 p. 9 pls. 1901.1 —Die mitteleuropäischen Süsswasserfische; ihre Naturgeschichte, Lebensweise und ihr Fang. 2 vols. in 1. Stuttgart, 1901-02. 176 p. 32 pls. \& 101 figs. $8^{\circ}$.

1901.2

- Das Photographiren lebender Fische im Aquarium. Amat. Photograph, Diisseldorf, 1901, 15, 145-146. 1901.3

- Der Schlạmmfisch. Bläit. Aquar.-Terrar. Kunde, 1902, 13. Jahrg. 16-18. figs. 2-4. 1902.1

Die Kopulationstachel der bisher eingeführten Kärpflinge und die Kreuzungen der Kärpflinge. Blätt. Aquar.-Terrar. Kunde, 1904, 15. Jahrg., 369-382.

1904.1

Neue Fischimporte für den Aquarien-Liebhaber. Blätt. Aquar.Terrar. Kunde, 1904, 15. Jahrg., 81-82. fig.

1904.2

Barbus nov. spec. aus Indien. Blätt. Aquar.-Terrar. Kunde, 1905 , 16, 217-218.

1905.1 
Bade, $E$.

Die Schwanz- und Afterflossen des Schleierschwanzes. Blätt. Aquar.Terrar. Kunde, $1905,16,74-77 ; 86-88$; $96-98 ; 105-106$.

1905.2

Die direkte Ueberführung von Stichlingen in Seeswasser. Blätt. Aquar-Terrar. Kunde, 1906, 17, 374.

1906.1

Das Seewasser-Aquarium. Magdeburg, 1907. 16 pls. \& 104 figs.

1907.1

Das Zimmer-Aquarium. 3. ed. Berlin, 1907. pl. \& 89 figs. 1907.2

Das Süsswasser-Aquarium. 3. ed. Berlin, 1909. 42 pls. \& 610 figs. $8^{\circ}$. 1909.1

- Das Süsswasser-Aquarium. Nachtrag. Berlin, 1911. 2 pls. \& 24 figs. $8^{\circ}$.

1911.1

Praxis der Aquarienkunde. 2. ed. Magdeburg, 1911. vii, 203 p. 13 pls. \& 220 figs.

1911.2

Handbuch für Naturaliensammler. Berlin, 1912. 43 pls. \& 465 figs.

1912.1

Labyrinth fishes. Part 2. Aquarium, Dec. 1912, 56-58. 1912.2

Badeigts de Laborde, — Rapport sur les pêches de la morue et du hareng sur les côtes de la Norvège. Paris, 1815. 16 p. $\mathrm{S}^{\circ}$.

1815.1

- Sur les brais et goudrons de France. Bull. Soc. Encour. Paris, $1815,14,141-148$.

1815.2

Baden, Hans Tikjob. Nogle til Bestemmelse af de fra danske Farvande kendte flyndere (Pleuronectidæ) Flora \& Fauna, Aarborg f. Naturhist. 1903, 5, 13-14.

1903.1

Badenoch, $L . N$. The movements of the mackerel. Knowledge, 1903, 26, 136-138.

1903.1

Badham, (Rev.) Charles David. Last of the Scombers. Fraser's Mag. 1853, 47, 257. 1853.1

Pike, salmon, silurus, herring and company. Fraser's Mag., 1853, $48,467$.

1853.2

Prose halieutics, or ancient and modern fish tattle. London, 1854. 552 p. $12^{\circ}$.

1854.1

Baehr, W. B. von. Ueber das von Fimer beschriebene Brustbein vom
Karpfen (Cyprinus carpio) Zool. Jahrb. (Abth. Anat.), 1906, 22, 629636. pl.

1906.1

Baer, G. A. IOn the capture of a large Manta, $5.25 \mathrm{~m}$., on the coast of Peru, with remarks on the occurrence of this ray in the gulf of Panama. Discussion by Prof. Vaillant! Bull. Mus. Hist. Nat. Paris, 1899, 5, 111-113.

1899.1

Baer, $K . E$. von. Ueber den Seitencanal des Störs. Arch. Anat. Physiol. (Meckel), 1826, 376-377.

1826.1

Ueber Entwickelungsgeschichte der Thiere. Isis, 1829, 2, 206-216. Also separate; Königsberg, 1829, and Leipzig, 1835.

1829.1

- Ueber die Entwickelungsweise der Schwimmblase der Fische. Notizen (Froriep), 1834, 39, 177-180.

1834.1

Beobachtung über die Entstehung der Schwimmblase ohne Ausführungsgang. Bull. Sci. Acad. St. Pétersb., 1836, 1, 15-16. - Arch. Naturg. (Wiegmann), 1837, 1, 248 . 1836.1

Sur la conformation de la vessie natatoire sans issue des poissons. L'Institut, $1836,4,410-411$.

1836.2

Untersuchungen über die Entwickelungsgeschichte der Fische, nebst einem Anhange über die Schwimmblase. Arch. Anat. Physiol. 1835 (1836), p. Ixxvi-clxii. 1836.3

Ueber das Skelet der Nawaga, welches in einem grossen Theil seiner Länge hohle, Luftsäcke aufnehmende Råume enthält. Bull. Acad. Sci. St. Pétersb., 1838, 3, 359-360. - Notizen (Froriep), 6, 170. - Isis, 1839, 648649.

1838.1

Bericht über einige ichthyologische Nebenbeschäftigungen auf einer Reise an den Peipus. Bull. Phys. Math. Acad. St. Pétersb., 1851, 9, 359-362. - Mélanges Biolog., 1851, 1, 309-313.

1851.1

Materialien zu einer Geschichte des Fischfangs in Russland und den angrenzenden Meeren. Mélanges Biolog., 1853, 1, 568-652.

1853.1

- Ein Wort über einen blinden Fisch als Bildungs-Hemmung. Bull. Acad. St. Pétersb., 1862, 4, 215-220.

1862.] 
Etwas über Fische und Fischereien (aus dem Kalender für 1866 besonders abgedruckt) St. Pétersb., 1866. $8^{\circ}$.

1866.1

Ueber zweckmässige Bewirthschaftung privater Fischereien. Sitzber. Nat. Ges. Dorpat, 1871, 3, 263270 .

1871.1

[Ueber das Vorkommen eines Scaphirhynchus in Turkestan] Sitzber. Nat. Ges. Dorpat, 1873 (1874), 3, 5. Heft, 386-387.

1874.1

Baert, J.F.B. De vriji zeevisscherij. (Naar aanleiding van het verslag omtrent den staat der zeevisscherijen in 1857, 1858 en 1859) De Economist, $1860,389-402$.

1860.1

Bätke, $H$. Ueber das Flimmern des Kaltblüterherzens. Arch. Ges. Physiol., Bonn, 1898, 71, 412-420. 1898.1

Baglioni, Silvestro. Die Bedeutung des Harnstoffs bei den Selachiern. Centralbl. Physiol., 1905, 19, 385-388.

1905.1

Ueber das Sauerstoffbedürniss des Zentralnervensystems bei Seetieren. Zeitschr. Allgem. Physiol., 1905, 5, $415-434$.

1905.2

- Die Bedeutung des Harnstoffes als chemische Lebensbedingung für das Selachierherz. Zeitschr. Allgem. Physiol., 1906, 6, 213-216.

1906.1

Beiträge zur allgemeinen Physiologie des Herzens. Der Einfluss der chemischen Lebensbedingungen auf die Tätigkeit des Selachierherzens. Zeitschr. Allgem. Physiol., 1906, 6, 71-98. 2 pls. \& fig.

1906.2

Einige Daten zur Kenntnis der quantitativen Zusammensetzung verschiedener Körperflïssigkeiten von Seetieren. Beitr. Chem. Physiol., 1906, $9,50-66$.

1906.3

Vergleichende chemische Untersuchungen an den Muskeln, den elektrischen Organen und dem Blutserum von Torpedo ocellata. Beitr. Chem. Physiol., 1906, 8, 456-471.

1906.4

Zur Kenntnis des N-Stoffwechsels der Fische. Zentralbl. Physiol., $1906,20,105-108$.

1906.5

Der Atmungsmechanismus der Fische. Ein Beitrag zur vergleichenden Physiologie des Atemrhythmus. Zeitschr. Allgem. Physiol., 1907, 7, 177282. 6 pls. \& 7 figs.
Aeussere Lebensbedingungen und Organe bei Fischen. Umschau, Frankfurt, 1908, 12, 606-609。 1908.1

- Il nesso tra le condizioni esterne e la forma e la funzione di alcuni organi nei pesci. - Note 1a. Meccanicarespiratoria. Monit. Zool. Ital. Ann., 1908, 19, 180-191. - Nota 2a. Vesica natatoria. Ibid., 1908, 19, 200-207. 2 figs.

1908.2

Zur Physiologie der Schwimmblase der Fische. I. Zeitschr. Allgem. Physiol., 1908, 8, 1-80. 10 figs. - II. Ibid., 1910, 11, 145-149. 1908.3

Ein Nervenmuskelpräparat von
Rochen. Zeitschr. Biol. Techn. Method., 1909, 1, 374-376. fig.

1909.1

Zur Physiologie des Geruchsinnes und des Tastsinnes der Seetiere. Zentralbl. Physiol., 1909, 22, 719-793. - Arch. Ital. Biol., 1909, 52, 225-230. 1909.2

- Zur Kenntnis der Leistungen einiger Sinnesorgane (Gesichtsinn, Tastsinn und Geruchsinn) und des Zentralnervensystems der Cephalopoden und Fische. Zeitschr. Biol., 1910, 53, 255286. 2 figs.

1910.1

Zur vergleichenden Physiologie der Atembewegungen der Wirbeltiere. I. Fische, Ergebn. Physiol., Wiesbaden, $1910,9,90-137.2$ figs. 1910.2

Bagnall, George. Piscatorial rambles; or, the fisherman's pocket companion. London, 1865. 8 $8^{\circ} \quad 1865.1$

Baikie, William Balfour, Adams, Arthur, \& Barron, Charles. See Adams, Baikie \& Barron.

Bail, Theodore. Kürzere Mittheilungen. 3. Saprolegnien als Tödter von Fischen im Freien. Schriften Naturf. Ges. Danzig, 1869, n. s. 2, 11. 1869.1

Bailey, Samuel E., \& Ritter, W.E. See Ritter \& Bailey.

Bailey, Washinglon. New facts regarding California salmon. Forest \& Stream, 1880, 14, $206 . \quad 1880.1$

Baillon, Louis François Antoine. Catalogue des mammifères, oiseaux, reptiles, poissons et mollusques testacés marins observés dans l'arrondissement d'Abbeville. Mém. Soc. d'Emul., Abbeville, 1833. 
Bailly, E. M. Description des filets pêcheurs de la baudroie. Ann. Sci. Nat., 1824, 2, 523-533. pl. - Notizen (Froriep), 8, 166; 177-183. - Dublin Phil. Journ., 1, 94.

1824.1

Recherches d'anatomie et de physiologie comparées du système nerveux dans les quatre classes d'animaux vertébrés. Arch. Gén. Méd., 1824, 4, 45-60. - Notizen (Froriep), 7, 133134.

1824.2

Baily, $W_{\text {[illiam }} H_{\text {[ellier }}$ On the occurrence of fish-remains in the Old Red Sandstone of Portishead, near Bristol. Geol. Mag., 1864, 1, 293.Rept. Brit. Assoc. Adv. Sci., 34, 49-50.

1864.1

Baird, G. W. Flight of flying fish. Science, 1886, 8, 10-12.

1886.1

Baird, Spencer Fullerton [1823-1887] For biography, see his life by William Healey Dall, 1915, also sketch by George Brown Goode, prefixed to his Bibliography of S. F. Baird, in Bull. U. S. Nat. Mus., no. 20, 1883.

Outlines of general zoology ... Fishes, by Spencer F. Baird ... Reprinted from the Iconographic Encyclopædia of science, literature and art. New York, 1851. xxii, 502 p. $8^{\circ}$.

1851.1

Iconographic Encyclopædia of science, literature and art ... Translated from the German with additions and edited by Spencer F. Baird. 4 vols. of text. $8^{\circ} .2$ vols. of pls. $4^{\circ}$. New York, 1852.

1852.1

Vol. ii contains the part relating to fishes, entirely rewritten by Baird.

Report on the fishes observed on the coasts of New Jersey and Long Island during the summer of 1854. 9. Ann. Rept. Smithson. Instit., 1854 (1855), 317-325; *337.

1855.1

List of fishes inhabiting the state of New York: sent to the New York State Cabinet of Natural History by the Smithsonian Institution in May, 1855. 9. Ann. Rept. of the Regents of the Univ. State of New York on the condition of the State Cabinet of Natural History, etc., 1856, 22-29.

1856.1

Catalogues of fishes, copied from a "Report on the fishes observed on the coasts of New Jersey and Long Island during the summer of 1854."
From the ninth annual report of the Smithsonian Institution for 1854. Geol. County Cape May, State of New Jersey, 1857, 146-148.

1857.1

- - IA description of the genus Ceratichthys] Proc. Acad. Nat. Sci. Philad., 1856 (1857), 212. 1857.2

-The basking shark - the "great sea monster." Amer. Agricul., 1868, 27, 130 .

1868.1

(editor) Annual Record of Science and Industry. 8 vols. New York, 1871-78. $8^{\circ}$.

1871.1

Artificial ice in packing fish. Ann. Rec. Sci., 1871-72, 355. 1871.2

Black bass in the Potomac. Ann. Rec. Sci., 1871-72, 264. 1871.3

- British Museum fishes. Ann. Rec. Sci., 1871-72, 206. 1871.4 Notice of the lack of facilities for obtaining specinens.

Capture of horse mackerel in Buzzard's bay. Ann. Rec. Sci., 187172,263

1871.5

Catalogue of fishes in the British Museum. Ann. Rec. Sci., 1871-72, 206.

1871.6

Alludes to the collection of fishes in the $\mathrm{Mu}-$ seum of Comparative Zoology, Cambridge, which is compared with that in the British Museum.

Cause of death of fresh-water fish in salt water. Ann. Rec. Sci., 1871-72, 265. 1871.7

Cephalaspis in America. Ann. Rec. Sci., 1871-72, 248. 1871.S

Notice of Cephalaspis dawsoni Lankester, from the Devonian beds of Gaspé, Quebec.

Cod-fisheries of Alaska. Ann. Rec. Sci., 1871-72, 259.

1871.9

Commissioner of Fisheries. Ann. Rec. Sci., 1871-72, 605-606. 1871.10

Confusion of names of fishes. Ann. Rec. Sci., 1871-72, 207. 1871.11

Explanation of error in Land and Water by which "horse-mackerel" and "bluefish" are confounded.

- Development of the lamprey. Ann. Rec. Sci., 1871-72, 213. 1871.12

Did Hendrik Hudson find salmon in the Hudson river? Ann. Rec. Sci., 1871-72, 264. 1871.13

Fishes of Cuba. Ann. Rec. Sci., 1871-72, 211.
1871.14 
Fish-guano flour from Loffoden. Ann. Rec. Sci., 1871-72, 342-343.

1871.15

Fishing steamer. Ann. Rec. Sci., $1871-72,606 . \quad 1871.16$

Food for young trout. Ann. Rec. Sci., 1871-72, 217. 1871.17

The food of the sea-herring. Ann. Rec. Sci., 1871-72, 208-210. 1871.18

Fossil fishes of Wyoming. Ann. Rec. Sci., 1871-72, 248. $\quad 1871.19$ Notice of recent investigations by E. D. Cope.

Fresh-water fishes of Algeria. Ann. Rec. Sci., 1871-72, 211. 1871.20

Fungus growth on fish and their eggs. Ann. Rec. Sci., 1871-72, 267.

1871.21

Gourami fish. Ann. Rec. Sci., $1871-72,214$.

1871.22

Note on the facility with which this fish may be transported.

Importance of killing freshlycaptured fish. Ann. Rec. Sci., 1871-72, 387.

1871.23

Increase of salmon in the British provinces. Ann. Rec. Sci., 1871-72, 260.

1871.24

Killing fish with torpedoes in

Florida. Ann. Rec. Sci., 1871-72, 267.

1871.25

Landlocked salmon. Ann. Rec. Sci., 1871-72, 216.

1871.26

Living eyeless fish. Ann. Rec. Sci., 1871-72, 266.

1871.27

Lütken on ganoid fishes. Ann. Rec. Sci., 1871-72, 214 1871.28

- A new Lophioid fish. Ann. Rec. Sci., 1871-72, $214 . \quad 1871.29$

Nutrition of young fish in hatching establishments. Ann. Rec. Sci., 1871-72, 350 .

1871.30

Occurrence of the pompano (and Spanish mackerel) northward. Ann. Rec. Sci., 1871-72, 260. 1871.31

Peculiarities of salmon kelts. Ann. Rec.Sci., 1871-72, 215. 1871.32

Phosphorescence of dead fish. Ann. Rec. Sci., 1871-72, 211. 1871.33
Preservation of dead salmon for an indefinite time. Ann. Rec. Sci., $1871-72,356$.

1871.34

- Proper fish for stocking rivers. Ann. Rec. Sci., 1871-72, 265. 1871.35

- Relations of ganoids to plagiostomes. Ann. Rec. Sci., 1871-72, 261263.

1871.36

Report of the Connecticut fish commissioners. Review in Ann. Rec. Sci., 1871-72, 348.

1871.37

- Salmon-fishing in Loch Tay.

Ann. Rec. Sci., 1871-72, 215. 1871.38

- Schools of young bluefish. Ann.

Rec. Sci., 1871-72, 278. 1871.39

Spawning of herring. Ann. Rec. Sci., 1871-72, 207. 1871.40

Spawning of the goose fish (Lophius americanus) Amer. Naturalist, $1871,5,785-786 . \quad 1871.41$

Stocking waters of New York with fish. Ann. Rec. Sci., 1871-72, 266.

1871.42

Tailless trout in Scotland. Ann. Rec. Sci., 1871-72, 217. 1871.43

Tame codfish. Ann. Rec. Sci. 1871-72, 212. 1871.44

Teeth of the sturgeon. Ann. Rec. Sci., 1871-72, $213 . \quad 1871.45$

- Theory of the salmon fly. Ann. Rec. Sci., 1871-72, $263 . \quad 1871.46$

Use of the pectoral fins of fish. Ann. Rec. Sci, 1871-72, 261. 1871.47

- Alleged gigantic pike. Ann. Rec. Sci., 1872-73,301. 1872.1

- Another pelagic fish-nest. Ann. Rec. Sci., 1872-73, 260. 1872.2

Bluefish on the southern coast. Ann. Rec. Sci., 1872-73, 265. 1872.3

Breeding salmon and trout in inclosures. Ann. Rec. Sci., 1872-73, 415. 1872.4

- Change of color in fishes. Ann. Rec. Sci., 1872-73, 319. 1872.5

Chinese Cyprinidx. Ann. Rec. Sci., 1872-73, 262. 1872.6

Comparison of American and French fisheries. Ann. Rec. Sci., 1872$73,398$. 
Baird, S. F.

Cope on the fossil fish of the Kiansas Cretaccous. Ann. Rec. Sci., 1872-73, 258. 1872.8

Death of an aged carp. Ann. Rec. Sci., 1872-73, 262.

1872.9

_- Fish-culturists' association at Albany. Ann. Rec. Sci., 1872-73, 400. 1872.10

Fisheries or the gulf of Naples. Ann. Rec. Sci., 1872-73, 399. 1872.11

Fishery exposition at Gothenburg [Sweden] Ann. Rec. Sci., 187273,400 .

1872.12

Fossil fishes and insects from the Nevada shales. Ann. Rec. Sci., $1872-73,308$.

1872.13

—_ French fish-breeding establishment. Ann. Rec. Sci., 1872-73, 399.

1872.14

French fisheries for 1870. Ann. Rec. Sci., 1872-73, 397.

1872.15

Generation of eels. Ann. Rec. Sci., 1872-73, 299.

1872.16

Genesis of Hippocampus. Ann. Rec. Sci., 1872-73, 261.

1872.17

Monster cod. Ann. Rec. Sci., 1872-73, 264.

1872.18

- Nature of the blue coloring matter in fishes. Ann. Rec. Sci., 187273,302 .

1872.19

Sci., 1872-73, 259 .

Ann. Rec. 1872.20

On the decrease of fish on the southern coast of New England. Bull. Phil. Soc. Wash., 1872, 1, 52. - Rept. U. S. Fish Comm. 1871-72 (1873), xvii-xl.

1872.21

- Planting shad in the valley of the Mississippi and the Lakes. Ann. Rec. Sci., 1872-73, 410.

1872.22

Reports of the United States Fish Commissioner for 1872-88. See United States Commission of Fish and Fisheries, under the respective dates of publication of the Reports.

- Respiration in fish. Ann. Rec. Sci., 1872-73, 261 . 1872.23

Stones in the stomachs of codfisb. Ann. Rec. Sei., 1872-73, 264.

1872.24
—- Teeth in young sturgeons. Ann. Rec. Sci., 1872-73, 264. $\quad 1872.25$

- Venomous fish in the Mauritius. Ann. Rec. Sci., 1872-73, 263. 1872.26

Absence of fish above the Yosemite Falls (and in the headwaters of the Hudson) Ann. Rec. Sci., 1873-75, 305.

1873.1

Alleged occurrence of shad in the Mississippi. Ann. Rec. Sci., 187375,448 .

1873.2

- Alleged shower of fish-scales. Ann. Rec. Sci., 1873-75, 350. 1873.3 Arrival of salmon eggs in New Zealand. Ann. Rec. Sci., 1873-75, 462.

1873.4

A bill to regulate the use of stationary apparatus in the capture of fish. Fol., bill form, 1873, 1-6. 1873.5

Blood corpuscles of the Salmonidæ. Ann. Rec. Sci., 1873-75, 299.

1873.6

Cultivation of fish in ditches and ponds. Ann. Rec. Sci., 1873-75, 443.

1873.7

Culture of sea-fish in fresh water. Ann. Rec. Sci., 1873-75, 435.

1873.8

Curious fish. Ann. Rec. Sci., $1873-75,342$.

1873.9

- Description of apparatus used in capturing fish on the sea-coast and lakes of the United States. Rept. U.S. Fish Comm. 1871-72 (1873), 253-274. maps.

1873.10

Fish guano. Ann. Rec. Sci., $1873-75,387$.

1873.11

The fish of the Caspian sea. Ann. Rec. Sci., 1873-75, 459. 1873.12

Food of the basking shark. Ann. Rec. Sci., 1873-75, 328. 1873.13

-... The fresh-water fisheries of India. Ann. Rec. Sci., 1873-75, 465.

1873.14

Geographical distribution of percoid fishes. Ann. Rec. Sci., 1873-75, 291.

1873.15

Gloucester halibut fishery. Ann. Rec. Sci., 1873-75, 460. 1873.16

Habits of the black bass. Ann. Rec. Sci., 1873-75, 322. 
Hybrids of salmon and trout. Ann. Rec. Sci., 1873-75, 442. 1873.18

Increase in the growth of trout Ann. Rec. Sci., 1873-75, 448. 1873.19

Influence of external pressure in the life of fishes. Ann. Rec. Sci., 187375,467 .

1873.20

- A large fish [Promocrops guasa, from Floridal Ann. Rec. Sci., 187375,317 .

1873.21

- List of fishes collected at Wood's Hole. Rept. U. S. Fish Comm. 187172 (1873), 1, 823-827.

1873.22

- List of patents granted by the United States to the end of 1872, for inventions connected with the capture, utilization or cultivation of fishes and marine invertebrates. Rept. U. S. Fish Comm. 1871-72 (1873), 1, 275280.

1873.23

- Marked salmon on the American coast. Ann. Rec. Sci., 1873-75, 444.

1873.24

Memoranda of inquiry relative to the food-fishes of the United States. Rept. U. S. Fish Comm. 1871-72 (1873), 1, 1-3.

1873.25

- Natural history of some of the more important foodfishes of the south shore of New Fingland. I. The scup, Stenotomus argyrops (Linn.) Gill. II. The blue-fish, Pomatomus saltatrix (Linn.) Gill. Rept. U. S. Fish Comm. 1871-72 (1873), 1, 228-252. 1873.26

- Naturalization of trout in New Zealand. Ann. Rec. Sci., 1873-75, 447.

1873.27

The New England fisheries. American Sportsman, 1873, 3, 23.

1873.28

New Scaphirhynchus in Turkestan. Ann. Rec. Sci., 1873-75, 336.

1873.29

Notices in regard to the abundance of fish on the New England coast in former times. Rept. U. S. Fish Comm. 1871-72 (1873), 1, 148-172.

1873.30

Planting California salmon at Fort Edward. Forest \& Stream, 1873 298.

1873.31

Prices of American fish-eggs and fry in England. Ann. Rec. Sci., 187375,459 .
Questions relative to the foodfishes of the United States. Rept. U. S. Fish Comm. 1871-72 (1873), 1, 3-6.

1873.33

- Reproduction of the eel. Ann.

Rec. Sci., 1873-75, 306. 1873.34

Respiration in fishes at different ages. Ann. Rec. Sci., 1873-75, 304.

1873.35

Salmon in the Hudson. Forest \& Stream, 1873, 233. 1873.36

- Shad in California waters. Ann. Rec. Sci., 1873-75, 449. 1873.37

Shad in the Alleghany river. Ann. Rec. Sci., 1873-75, 462. 1873.38

Shad in the Altamaha river. Ann. Rec. Sci., 1873-75, 450. 1873.39

- Shad in the Sacramento river.

Ann. Rec. Sci., 1873-75, 449. 1873.40

- Signal telegraphy and the herring-fishery. Ann. Rec. Sci., 1873-75, 73.

1873.41

- Statistics of fish and fisheries on the south shore of New England. Rept. U. S. Fish Comm. 1871-72 (1873), 1 . $172-181$.

1873.42

Statistics of fish and fisheries on the south shore of New England. Rept. U. S. Fish Comm. 1871-72 (1873), 1, $173-181$

1873.43

- Supplementary testimony and information relative to the condition of the fisheries of the south side of New England, taken in 1872. Rept. U. S. Fish Comm. 1871-72 (1873), 1, 182-195.

1873.44

Taking California salmon with the hook. Ann. Rec. Sci., 1873-75, 464.

1873.45

Testimony in regard to the present condition of the fisheries, taken in 1871. Rept. U. S. Fish Comm. 187172 (1873), 1, 7-72. 1873.46

Transporting salmon eggs to New Zealand. Ann. Rec. Sci., 187375,445 .

1873.47

- Trade in frozen herring. Ann. Rec. Sci., 1873-75, 432. $\quad 1873.48$

Treatment of fish-ponds. Ann. Rec. Sci., 1873-75, 452. 1873.49

United States Commission of Fish and Fisheries. Part I. Report on 
Baird, S. F.

the condition of the sea fisheries of the south coast of New lingland in 1871 and 1572. Washington, 1873. xlvii, \$52 p. pls. \& charts.

1873.50

Report of the commissioner, p. vii-xli.

Mlaska cod-fisheries in 1873.

Ann. Rec. Sci., 1874-75, 424. 1874.1

... The basking shark. Ann. Rec. Sci., 1874-75, 351 .

1874.2

Bibliography. Ann. Rec. Sci., $1874-75,617-632$.

1874.3

- The blue-black trout. Forest \& Stream, 1874, 3, 277.

1874.4

Destruction of fish on the Oregon coast by nitro-glycerine. Ann. Rec. Sci., 1874-75, $428 . \quad 1874.5$

-... Fish-culture in Castalia Springs [Ohio] Ann. Rec. Sci., 1874-75, 425.

1874.6

Food-fishes of the United States. Forest \& Stream, 1874, 1, 330. 1874.7

- lood of the shad. Ann. Rec. Sci., 1874-75, 310 .

1874.8

'The French fisheries. Ann. Rec. Sci., 1874-75, 422 .

1874.9

The garfish. Forest \& Stream, $1874,1,375$.

1874.10

- Introduction of British fish into India. Ann. Rec. Sci., 1874-75, 426.

1874.11

Introduction of California salmon into Australia. Forest \& Stream, $1874,2,229$.

1874.12

'The introduction of young salmon into New York waters. Forest \& Stream, 1874, 1, 347.

1874.13

-Malformation of fish embryos. Ann. Rec. Sci., 1874-75, 294. 1874.14

- Marine fisheries of Maine in 1873. Ann. Rec. Sci., 1874-75, 420.

1874.15

Mr. Balfour on the embryology of sharks. Ann. Rec. Sci., 1874-75, cliv.

1874.16

'The "Nerfling" fish. Ann. Rec. Sci., 1874-75, 311. 1874.17

Opinion as to the probable cause of the rapid diminution of the supply of food-fishes on the coast of New Lingland, and especially of Maine.
Rept. Comm. Inland Fisheries Mass. $1874,42-45$.

1874.18

Pisciculture and the fisheries. Forest \& Stream, 1874, 2, 52. 1874.19

The seal and herring fisheries of Newfoundland. Ann. Rec. Sci., 1874 75,424 .

1874.20

Shad in the gulf of Mexico. Ann. Rec. Sci., 1874-75, 338. 1874.21

- Spinal column of the sturgeon as an article of food. Ann. Rec. Sci., $1874-75,447$.

1874.22

Sterlet from St. Petersburg at the Brighton aquarium. Ann. Rec. Sci., 1874-75, 428.

1874.23

Stocking a pond in Utah with eels. Ann. Rec. Sci., 1874-75, 428.

1874.24

The tarpum. Forest \& Stream, $1874,2,389$.

1874.25

-..- Transporting living trout. Ann. Rec. Sci., 1874-75, 427.

1874.26

United States Commission of Fish and Fisheries. Part II. Report of the Commissioner for 1872 and 1873. A. Inquiry into the decrease of the food-fishes. B. The propagation of food-fishes in the waters of the United States. Washington, 1874. cii, 808 p. pls. \& maps. $8^{\circ}$.

1874.27

Report of the commissioner, p. $\mathrm{i}$-xcii.

Conclusions as to decrease of cod-fisheries on the New England coast. Rept. Comm. Inland Fisheries Mass., 1875, 38-41.

1875.1

Discoveries in the biological history of fishes. Ann. Rec. Sci., 1875-76, cxcviii.

1875.2

- Distribution of trout eggs from Tasmania to the neighboring colonies. Ann. Rec. Sci., 1875-76, 420. 1875.3

Effect of polluted water on fishes. Ann. Rec. Sci., 1875-76, 416.

1875.4

__ Experiments with young Maine salmon. Ann. Rec. Sci., 1875-76, 418. 1875.5

Failure in introducing salmon and trout. Ann. Rec. Sci., 1875-76, 439.

1875.6

Fish at great depths. Ann. Rec. Sei., 1875-76, 425.

1875.7 
-... Fish-culture in China. Ann. Rec. Sci., 1875-76, 427.

1875.8

Fish-culture in Kentucky. Forest \& Stream, 1875, 5, 243.

1875.9

Fisheries of the arctic regions. Ann. Rec. Sci., 1875-76, 439. 1875.10

Food for trout. Ann. Rec. Sci., $1875-76,433$.

1875.11

- Fossil Lepidosteus. Ann. Rec. Sci., 1875-76, 347 .

1875.12

Further contribution to the minute anatomy of the Tænix, which prey on fish. Ann. Rec. Sci., 1875-76, xeii.

1875.13

Further observation on the Cercaria in the intestines of fish. Ann. Rec. Sci., 1875-76, xcvii.

1875.14

Grayling in the Au Sable river, Michigan. Ann. Rec. Sci., 1875-76, 344.

1875.15

Habits of eels. Ann. Rec. Sci., 1875-76, 346 .

1875.16

Hybrid fish. Ann. Rec. Sci., 1875-76, 418 .

1875.17

Illumination for attracting fish. Ann. Rec. Sci., 1875-76,.428. 1875.18

Importation of the gourami into Paris. Ann. Rec. Sci., 1875-76, 420 .

1875.19

- Increase of English fishes in Tasmania. Ann. Rec. Sci., 1875-76, 419 .

1875.20

- Largest pike ever taken in England. Ann. Rec. Sci., 1875-76, 346.

1875.21

Leptocephali are larval forms of congers, etc. Ann. Rec. Sci., 1875-76, 348 .

1875.22

Letter in reference to resolution of the legislature of Oregon as to the protection of salmon in the Columbia river, 1875 . U. S. 43. Congress, 2. Session, Senate misc. docs. 33 and 79. 2 p. $8^{\circ}$.

1875.23

- Married salmon. Ann. Rec. Sci., 1875-76, 432.

1875.24

Mr. C. G. Atkins's experiments on the artificial hatching of the smelt. Ann. Rec. Sci., 1875-76, 421. 1875.25

Physical condition of the herring-fishery. Ann. Rec. Sci., 1875-76, 433.
Pisciculture and the fisheries (A general summary of progress) Ann. Rec. Sci., 1875-76, cx; cxviii; cexxivccxxix.

1875.27

Productive season of the cod on the Faroe Islands. Ann. Rec. Sci., 1875-76, 347 .

1875.28

Prof. Baird's report. Comparative value of anadromus and other fishes. Forest \& Stream, 1875, 3, 356. 1875.29

- Protection of salmon. Forest \& Stream, 1875, 5, 166. 1875:30

Report of the occurrence of large codfish off Mazatlan. Ann. Rec. Sci., $1875-76,344$.

1875.31

- Salmon in the Sacramento river. Ann. Rec. Sci., 1875-76, 432.

1875.32

Salmon in the San Joaquin. Ann. Rec. Sci., 1875-76, 430. 1875.33

- Seth Green's artificial hatching of sturgeon. Ann. Rec. Sci., 1875-76, 422 .

1875.34

Softness of bones in old congers. Ann. Rec. Sci., 1875-76, 347. 1875.35

Stocking the rivers on the west side of Lake Champlain by the United States Fish Commission. Ann. Rec. Sci., 1875-76, 419 .

1875.36

Uebersetzung von dem Bericht von Prof. Baird über Abnahme essbarer Seefische an der Neuenglandküste. Circul. Deutsch. Fischerei-Zeitg., 1874 (1875), 1. Jahrg, 193-198. 1875.37

United States salmon-hatching establishment. Ann. Rec. Sci., 1875-76, 434. 1875.38

Capture of salmon in the Connecticut river. Ann. Rec. Sci., 187677,409 .

1876.1

Capturing eels in Cochin China. Ann. Rec. Sci., 1876-77, 403. 1876.2

Cause of the black spots on the scales of fish. Ann. Rec. Sci., 1876-77, 323.

1876.3

A characteristic type of fishes of the northern Atlantic exemplified in the species variously called" Sea Wolf," etc. Ann. Rec. Sci., 1876-77, clxvii.

1876.4

Connecticut river shad for California. Forest \& Stream, 1876, 7, 66.

1876.5 
Baird, S. $F$.

Connection of meteorology and herring-fisheries. Ann. Rec. Sci., 187677,387 .

1876.6

Cultivation of carp in California. Ann. Rec. Sci., 1876-77, 403.

1876.7

- Curious habits of fishes. Ann. Rec. Sci., 1876-77, 324.

1876.8

Fish afllicted by crustaceous parasites, called Argulus, which adhere to their gills. Ann. Ree. Sei., 1876-77, clx.

1876.9

- Habits of the salmon. Ann. Rec. Sci., 1876-77, 320.

1876.10

Hatching whitefish in the Detroit river. Ann. Rec. Sci., 1876-77, 403.

1876.11

- Incubation of Chromis paterfamilias. Ann. Rec. Sci., 1876-77, 322 1876.12

A new form of fishes discovered by Herr Bucholz in west Africa. Ann. Rec. Sei, 1876-77, clxvii. $\quad 1876.13$

- New work on European freshwater fishes. Ann. Rec. Sci., 1876-77, 319.

1876.14

One cause of the death of fishes. Ann. Rec. Sci., 1876-77, 405. 1876.15

The pilot fish. Ann. Rec. Sci. $1876-77,319$.

1876.16

- Poey's catalogue of Cuban fishes. Ann. Rec. Sci., 1876-77, 320.

1876.17

- Potomac river fisheries. Ann. Rec. Sci., 1876-77, 388 .

1876.18

Rafinesque's fishes of Ohio. Ann. Rec. Sci., 1876-77, 318. 1876.19

The rainbow fish. Ann. Rec. Sici., $1876-77,321$. 1876.20

Rapidity of growth in certain fishes. Ann. Rec. Sci., 1876-77, 405 .

1876.21

-.. Remarkable structure of young fishes. Ann. Rec. Sci., 1876-77, 323.

1876.22

Renerved attempt to send salmon eggs to New Zealand. Ann. Rec. Sci., 1876-77, 407.

1876.23

-. Salmon eggs in South Africa. Ann. IRec. Sci., 1876-77, 408. 1876.24
Salmon in the antipodes. Ann.

Rec. Sci., 1876-77, 408.

1876.25

Shad in the Mississippi. Ann.

Rec. Śi., 1876-77, 406. $\quad 1876.26$

- Some curious Australian fishes.

Ann. Rec. Sci., 1876-77, 319. 1876.27

The U. S. Fish Commission.

Forest \& Stream, 1876, 6, 147. 1876.28

United States Commission of Fish and Fisheries. Part III. Report of the commissioner for 1873-74 and 1874-75. Washington, 1876. liii, 777 p. $8^{\circ}$.

1876.29

Report of the commissioner, p. vii-xlv.

Utilization of warmed waters in fish-culture. Ann. Rec. Sci., 1876-77, 406.

1876.30

Genuine white shad in the Ohio. Forest \& Stream, 1877, 8, 280. 1877.1

A new fish [Chimara plumbea] Forest \& Stream, 1877, 9, 381. 1877.2

- Salmon in the Chesapeake. Forest \& Stream, 1877, 8, 296. 1877.3

- Salmon in the Hudson. Forest \& Stream, 1877, 10, 154.

1877.4

Salmon in the Richelien. Forest \& Stream, 1877, 9, 143. 1877.5

Statistics of coast and river fisheries. U. S. Fish Comm. Circ. no. 19. Washington, 1877. 1877.6

Statisties of the cod fisheries. U. S. Fish Comm. Circ. no. 17. Washington, 1877.

1877.7

- Statistics of the mackerel fisheries, etc. U. S. Fish Comm. Circ. no. 16. Washington, 1877.

1877.8

- Statistics of the mullet fisheries, etc. U. S. Fish Comm. Circ. no. 18. Washington, 1877. 1877.9

- All about eels. Forest \& Stream, 1878, 11, 130-131. $\quad 1878.1$

- The Delaware salmon. Chicago Field, 1878, 9, 165; 10, 243. 1878.2

- The fishery statistics of the United States. Trans. Amer. FishCult. Assoc., 1878, 72-74. 1878.3

The herring fishery of the coast of Sweden. Cape Ann Advertiser, Aug. $9,1878$. 1878.4 
The periodicity of herrings. Chicago Field, 1878, 10, 35. 1878.5

Propagation of eels. Sunbury (Pa.) American, Aug. 30 or Sept. 6, 1878.

1878.6

United States Commission of Fish and Fisheries. Part IV. Report of the commissioner for 1875-76. Washington, 1878. ix, 1029 p. 1878.7 Report of the commissioner, p. $1{ }^{*}-50 *$.

Another new fish on our coast. Chicago Field, 1879, 11, 117. 1879.1

Circular relating to fish trade and consumption of fish. Chicago Field, 1879, 12, 35 .

1879.2

The farmer's fish [carp] Forest \& Stream, 1879, 13, 846.

1879.3

Fishes of the deep sea. Forest \& Stream, 1879, 12, 6.

1879.4

The Hudson salmon. Forest \& Stream, 1879, 12, 444.

1879.5

- Is it herring spawn? Forest \& Stream, 1879, 12, 5 .

1879.6

[A letter concerning California salmon in Europel Chicago Field, $1879,11,131$.

1879.7

The national fish commission. Forest \& Stream, 1879, 13, 725. 1879.8

Transportation of alewife eggs Forest \& Stream, 1879, 12, 225. 1879.9

United States Commission of Fish and Fisheries. Part V. Report of the commissioner for 1877. Washington, 1879. xlviii, 981 p. $8^{\circ}$. 1879.10 Report of the commissioner, p. $1^{*}-18 *$.

- California salmon-eggs. Forest \& Stream, 1880, 15, 107.

1880.1

Destruction of fish. Chicago Field, $1880,14,236$.

1880.2

Eggs for distribution. Forest \& Stream, 1880, 15, 366. 1880.3

- A good fish for barren waters [carp] Chicago Field, 1880, 12, 323, 324.

1880.4

Salmon eggs. Chicago Field, $1880,14,284$. 1880.5

- Striped bass and shad in California. Forest \& Stream, 1880, 14, 410 .
- Ueber Anlegung von Fischpässen. Bayerische Fischerei-Zeitg., $1880,5,4-6 ; 25-26 . \quad 1880.7$

United States Commission of Fish and Fisheries. Part VI. Report of the commissioner for 1878. Washington, 1880. Ixiv, 988 p. 16 pls.

1880.8

Report of the commissioner, p. i-lxiv.

United States Commission of Fish and Fisheries. Part VII. Report of the commissioner for 1879. Washington, 1882. li, 846 p. $8^{\circ}$. pls.

1882.1

Report of the commissioner, p. i-li.

United States Commission of Fish and Fisheries. Report of the commissioner for 1880 . Washington, 1883. xlvi, 1060 p. $8^{\circ}$ 1883.1

Report of the commissioner, p. i-xlvi.

United States Commission of Fish and Fisheries. Part IX. Report of the commissioner for 1881. Washington, 1884. lxxi, 1146 p. $8^{\circ} .1884 .1$

Report of the commissioner, p. i-lxxi.

United States Commission of Fish and Fisheries. Report of the commissioner for 1882. Washington, 1884. xcii, 1101 p. $8^{\circ}$. 1884.2

Report of the commissioner, p. i-xcii.

Baird, Spencer Fullerton, \& Agassiz, Louis. See Agassiz \& Baird.

Baird, Spencer F., \& Girard, Charles. Description of new species of fishes collected by Captains R. B. Marcy and Geo. B. MeClellan in Arkansas. Proc. Acad. Nat. Sci. Philad., 1853 (1854), 390-392.

1853.1

Exploration of the Red river of Louisiana, in the year 1852 by Randolph B. Marcy, assisted by George B. McClellan. Washington, 1853. (In U. S. Congress. Senate. 32. Cong. 2. sess, Ex. [Doc.] no. 54) 1853.2

Fishes, by S. F. Baird and C. Girard. Appendix F, p. 245-252, pls. xii-xiv.

Report of an expedition down the Zuni and Colorado rivers by Captain L. Sitgreaves. Washington, 1853. In U. S. Congress. Senate. 33 Cong. 1. sess. Ex. [Doc.] 1853.3 Fishes, p. 148-152. 3 pls.

Descriptions of new species of fishes collected by Mr. John H. Clark on the U.S. and Mexican Boundary Survey, under Lt.-Col. Jas. D. Graham. 
Baird \& Girard.

Proc. Acad. Nat. Sci. Philad., 1853 (1854), 387-390.

1854.1

_Cyprinidx of Heerman's collection] Proc. Acad. Nat. Sci. Philad., 1854 (1855), 135-138.

1855.1

Descriptions of new species of fishes collected in T'exas, New Mexico and Sonora, by Mr. John H. Clark, on the U. S. and Mexican Boundary Survey, and in 'lexas by Capt. Stewart Van Vliet, U. S. A. Proc. Acad. Nat. Sci. Philad., 1854 (1855), 24-29. 1855.2

- Notice of a new genus of Cyprinidse [Cochlognathus] Proc. Acad. Nat. Sci. Philad., 1854 (1855), 158.

1855.3

Die Süsswasser-Fische Californiens und Oregons. Abstract in Lotos, $1861,11,55-56$. 1861.1

Baird, Spencer $F$. \& Henry, Joseph. See Henry \& Baird.

Baird, Spencer F., \& McDonald, Marshall. Echelle McDonald pour la remonte des poissons migrateurs; lettre adressée ì M. C. Raveret-Wattel. Bull. Soc. Acclim. Paris, 1882, 3. sér. 9, 453 .

1882.1

Baird, $W$. Notes on the food of some fresh-water fishes, more particularly the vendace and trout. Edinb. New Philos. Journ., 1857, 6, 17-24.

1857.1

- Note on the Lernoca cyclopterina occurring in the gills of the Cycloperinus spinosus, a fish from Greenland. Proc. Zool. Soc. London, 1861, 239-240. - Ann. Mag. Nat. Hist., 1861, 3. ser. 8, 496.

1861.1

Bajon, $\left(D r_{0}\right)$ Mémoire sur un poisson à commotion électrique connu à Cayenne sous les nom d'anguille tremblante. Journ. Phys. (Rozier), 1774, 3, $47-58$.

1774.1

Mémoires pour servir d l'histoire de Cayenne et de la Guiane Françoise, dans lesquels on fait connoître la nature du climat... des observations sur l'histoire naturelle du pays, \& sur la culture des terres. 2 vols. Paris, 1777-78. $8^{\circ}$.

1777.1

Poissons, vol. ii, 287-326. - German verion; Erfurt, 1780.

_- Descrizione d' un pesce che da la scossa electricca, conosciuto a Cayenne sotto nome d'Anguilla tremante. Opuse. Scelt. Sci. Arte, 1779, 1, 69-95. 1779.1
Baker, A. $F$. Do fishes hear? Proc. Dublin Univ. Biol. Assoc., 1876. 1, 33-38.

1876.1

Baker, Frank Collins. The ecology of the Skokie Marsh Area, with special reference to the mollusca. Bull. Illinois State Lab. Nat. Hist., 1910, 8, 441-499. 19 pls. 1910.1

Baker, S. White, The Albert N'Yanza, great basin of the Nile, and explorations of the Nile sources. 2 vols. London, 1866. $8^{\circ}$. 1866.1

Fishes, $i$, p. $40 ; 290 ; 361 ; i i$, p. $97 ; 130-132$.

Baker, William. Large sturgeons in the Usk. Zoologist, 1847, 5, 1649.

1847.1

Boar-fish at Bridgewater. Zoologist, $1850,8,2856$.

1850.1

Bakhuizen van den Brink, $R . C$. Piscatio, pêcherie, visscherij: de ware beteekenis dezer woorden gehendhaafd tegen Prof. M. de Vries. 's Gravenhage, 1858. $8^{\circ}$.

1858.1

Bakker, Gerbrandi. Osteographia piscium; Gadi præsertim æglefini, comparati cum Lampride guttato, specie rariori. Groningæ, 1822.246 p. pls. Review in N. Act. Nat. Cur., 2, 67. Isis (Oken), 22, 102-104.

1822.1

Bakker, Nelly C. Analyse des Elektrokardiogramms auf Grund von am Aalherzen ausgeführten Untersuchungen. Keitschr. Biol., 1912, 59, 335-365. 40 figs.

1912.1

Analyse des Elektrokardiogramms des Aales (Anguilla vulgaris) Zentralbl. Physiol., 1912, 26, 784-787. 6 figs.

1912.2

Balaguer y Primo, D. Francesco. Gria de los peces. Madrid, 1878. $8^{\circ}$. (In Libros de Cuesta)

1878.1

Balbiani, Edouard Gerard [1822-99] For biography and list of works, see Bibliogr. Anat., 1899, 7, 151-152.Nature, 60, 399. - Bull. Soc. Ent. Paris, 265-266. - Arch. Anat. Micr., 1900, 3, i-xxxvi.

Sur la cellule embryogène de l'ouf des poissons osseux. C. R. Acad. Sci. Paris, 1873, 77, 1373-1377. 1873.1

Leçons sur la génération des vertébrés. Paris, 1879. 1879.1

L Les poissons vivipares. Rev. Scient., 1886, 37, 732 . 1886.1 
Baldaque da Silva, A. A. Estado actual das pescas em Portugal ... Lisboa, 1891. 515 p. col. pls., figs. \& map. $8^{\circ}$.

1891.1

Baldinger, E. G. Sur l'âge d'un brochet. N. Med. Physik. Journ. Marburg [1802?], 5, pt. 1, 29. 1802.1

Baldner, Leonhard. Das Vogel-, Fisch- und Thierbuch; herausgegeben von Lauterborn. Ludwigshafen, 1903. $8^{\circ}$ - See also Nat. Wochenschr., 1901 , 16, 432-437.

1903.1

Baldwin, Astley $H$. Concerning flat-fish. Once a Week, 1863, 9, 38-41.

1863.1

Flat-fishes. Chambers's Journ., $1879,56,76-78$.

1879.1

Baldwin, Charles $H$. Notes on the fish and fisheries of Japan. Bull. U. S. Fish Comm. 1884, 4, 352.1884.1

Balfour, Francis Maitland. A preliminary account of the development of the elasmobranch fishes. Quart. Journ. Micr. Sci., 1874 , n. s. 14, 323-364. pls. xiii-xiv.

1874.1

- A comparison of the early stages in the development of vertebrates. Quart. Journ. Mier. Sci., 1875 , n. s. $15,207-226 . \quad 1875.1$

- On the development of the spinal nerves in elasmobranch fishes. Abstract in Proc. Roy. Soc. London, 1875, 24, 135-136. - Philos. Trans. Roy. Soc. London, 1876, 166, 175-196. pls. xvi-xviii. Summary in Month. Micr. Journ. London, 15, 235. - Arch. Zool. Expér. Paris, 1877, 6, xxvixxviii.

1875.2

On the development of elasmobranch fishes. Journ. Anat. Physiol., $1876,10,377-411$. pls. xv, xvi; 517570. pls.; 672-688. pl.; 1887, 11, 128-172. pls.; 406-490. pls.; 674706. pls.; 1878, 12, 177-216. pls.

1876.1

On the origin and history of the urino-genital organs of vertebrates. Journ. Anat. Physiol., 1876, 10, 1748. 8 figs.

1876.2

- On the spinal nerves of Amphioxus. Journ. Anat. Physiol., 1876, 10, 689-692. - Collected Pap. Physiol. Lab. Univ. College, London, 1873, no. 3, 38-41. - Quart. Journ. Micr. Sci., 1880, n. s. 20, 90-91. 1876.3
- On the development of the proto-vertebræ in elasmobranchs. Rept. Brit. Assoc. Adv. Sci., 1877, 46, 147.

1877.1

A monograph on the development of elasmobranch fishes. London, 1878. xi, 295 p. 20 pls. $8^{\circ}$. 1878.1

A classical work, reprinted from a series of papers published in Journ. Anat. Physiol., $1876-78$.

-... On the origin and history of the urino-genital organs of vertebrates. Journ. Anat. Physiol., 1878, 10, 17-48. 1878.2

On the structure and development of the vertebrate ovary. Quart. Journ. Micr. Sci., 1878, n. s. 18, 383438. pls. xvii-xix. 1878.3

Observations on the ovary of elasmobranchs, p. $381-415$.

A treatise on comparative embryology. 2 vols. London, 1880-81.

1880.1

Chordata, ii, p. 443-446. Special bibliographies are given at the end of each volume.

On the development of the skeleton of the paired fins of Elasmobranchii, considered in relation to its bearings on the nature of the limbs of the vertebrata. Proc. Zool. Soc. London, 1881, pt. 3, 656-671. pls. lvii-lviii \& figs. - Stud. Morph. Lab. Cambridge, 1, 51-68. 2 pls.

1881.1

On the nature of the organ in adult teleosteans and ganoids, which is usually regarded as the head-kidney or pronephros. Quart. Journ. Micr. Sci., 1882, n. s. 30, 12-16. - Biol. Centralbl., 1881-82, 1, 459-461. Stud. Morph. Lab. Cambridge, 1, 6974 .

1882.1

The author shows that the pronephros is a purely larval organ, and never constitutes an active part in the excretory system of the adult

Works, edited by M. Foster and A. Sedgwick. 4 vols. London, 1885. $8^{\circ}$. [Vol. iv is an atlas of 53 pls. to illustrate vol. i) 1885.1 Embryology of the Cyclostomata, vol, iii, p. 82-101.

Balfour, F. M., \& Parker, $W . K$. On the structure and development of Lepidosteus. Phil. Trans. Roy. Soc. London, 1882, 173, 359-442. pls. xxi-xxix. Abstract in Proc. Roy. Soc. London, 33, 112-119. - Rept. British Assoc. Adv. Sci., 1880, 559. - Stud. Morph. Lab. Cambridge, 1, 89-98.

1882.1 
Balfour, IV. Note on the Rev. G. Gordon's list of Moray fishes. Zoologist, 1852, 10, 3599 .

1852.1

- Some account of the zoological Museum at Haslar Hospital. Zoologist, $1852,10,3613-3615$.

1852.2

Catalogue of the fishes of Orkney and Zetland. Zoologist, 1853, 11, 3845-3847; 3950-3952; 4018-4020.

1853.1

Balkwill, $F, H$. Teeth of shark. Zoologist, 1875, 2. ser. 10, 4344-4345.

1875.1

Ball, H.D. Statement concerning the menhaden fishery. Rept. U. S. Fish Comm. 1877 (1879), 5, 425.

1879.1

Ball, $R$. On a new sturgeon (Acipenser thompsoni) Proc. Roy. Irish Acad. 1904-05, 25, 21.

1904.1

Ball, Robert. On a provision in the fotus of the spined dog-fish. Proc. Irish Acad., 1847, 3, 230-231. 1847.1

On the probable occurrence of the Lepidopus argyreus in Dublin bay. Nat. Hist. Rev., 1855, 2, 45-46. 1855.1

Ball, W. H. Protection of fishes in lake Michigan. Proc. Central FishCulture Soc., Chicago, 1880 (1881), 39-46.

1881.1

Balland, $H$. Sur la composition des poissons, des crustacés et des mollusques. C. R. Acad. Sci. Paris, 1898, 126, no. 14, 1728-1734. 1898.1

Ballau, N.E. Fish culture in the past and future. Proc. Central FishCulture Soc., Chicago, 1880 (1881), 59 61.

1881.1

Ballion, $E$. Table générale et systematique des matières contenues dans les premiers 56 volumes (années 1829-1881) du Bulletin de la Société imperiale des Naturalistes de Moscou. Moscou, 1882. 110 p. $8^{\circ}$

1882.1

Ballon, $I I . A$. Malaria in the West Indies. Girardinus as destroyer of mosquito larva] Science, 1908, n. s. 28, 885 .

1908.1

Ballou, Nahum E. "Ichthyos," pseudon.] Origin, development and progress of fish culture. Forest \& Stream, $1875,4,342 ; 373 ; 385 ; 405$. Ibid., 5 $4 ; 19$.
Fish culture. Forest \& Stream $1875,5,67 ; 99 ; 116$.

1875.2

The natural and economic history of the Salmonidæ. Forest \& Stream, $1876,6,68 ; 100 ; 116 ; 131 ; 147 ; 164$ 179 .

1876.1

Ballowitz, $E$. Untersuchungen über die Struktur der Spermatozoën. A Fische. Arch. Mikr. Anat., 1890, 36, 226-250. pls. xi-xii.

1890.1

- Ueber den Bau des elektrischen Organes von Torpedo mit besonderer Berücksichtigung der Nervenendigungen in demselben. Arch. Mikr. Anat. 1893, 42, 459-568. pls. xxix-xxxi.

1893.1

Ueber die Bewegungserscheinungen der Pigmentzellen. Biol. Centralbl., 1893, 13, 625-630. 1893.2

- Ueber den feineren Bau des elektrischen Organs des gewöhnlichen Rochen (Raja clavata L.) Anat. Hefte, 1897, 7, 283-375. pls. i-xi. 1897.1

Ueber die sogenannten "Dornpapillen" im elektrischen Organ des Zitteraales (Gymnotus electricus L.) Anat. Anz., 1897, 13, 643-648. 2 figs.

1897.2

Ueber die Uebereinstimmung des feineren Baues der elektrischen Organe bei den starkelektrischen und schwachelektrischen Fischen. Vorläufige Mitteilung. Anat. Anz., 1897, 13, $124-126$.

1897.3

Zur Anatomie des Zitteraales (Gymnotus electricus L.), mit besonderer Beriicksichtigung seiner electrischen Organe. Arch. Mikr. Anat., 1897, 50, 686-750. pls.

1897.4

Electric organ of Malapterurus electricus. Journ. Roy. Micros. Soc. London, 1898, pt. 6, 622. 1898.1

- Electric organs (Gymnotus) Journ. Roy, Micros. Soc. London, 1898, pt. 1, 65-66. 1898.2

- Die Nervenendigungen in dem elektrischen Organ des afrikanischen Zitterwelses (Malapterurus electricus Lacép.) Anat. Anz., 1898, 15, 85-92.

1898.3

Ueber Kernformen und Sphären in den Epidermiszellen der Amphioxuslarven. Anat. Anz., 1898, 14, 405-407. 1898.4 
Das elektrische Organ des afrikanischen Zitterwelses. Jena, 1899. $96 \mathrm{p} .4^{\circ}$. pls. \& figs.

1899.1

Ueber polytome Nervenfaserteilung. Anat. Anz., 1899, 16, 541546. figs. Abstract in Journ. Roy. Micros. Soc. London, 1899, pt. 1, 2324.

1899.2

Ueber den Bau des Geruchsorgans der Cyclostomata. Sitzber. Akad. Wiss. Berlin, 1904, 671-676.

1904.1

Die Riechzellen des Flussneunauges (Petromyzon fluviatilis L.) Arch. Mikr. Anat. Bonn, 1905, 65, 78-95. pl.

1905.1

-- Ueber die Spermien des Flussneunauges (Petromyzon fluviatilis L.) und ihre merkwürdige Kopfborste. Arch. Mikr. Anat., 1905, 65, 96-120. pl.

1905.2

- Ueber chromatische Organe in der Haut von Knochenfischen. Anat Anz., 1912, 42, 186-192, 2 pls. \& 15 figs.

1912.1

Die chromatischen Organe in der Haut von Trachinus vipera Cuv. Ein Beitrag zur Kenntnis der Chromatophoren-Vereinigungen bei Knochenfischen. Zeitschr. Wiss. Zool., 1913, 104, 471-529. $5 \mathrm{pls}$.

1913.1

Notiz uiber das Vorkommen alkoholbeständiger karminroter und braunroter Farbstoffe in der Haut von Knochenfischen. Zeitschr. Physiol. Chem., 1913, 86, 215-218.

1913.2

Ueber chromatische Organe, schwarzrote Doppelzellen und andere eigenartige Chromatophorenvereinigungen; über Chromatophorenfragmentation und über den feineren Bau des Protoplasmaus der Farbstoffzellen. Anat. Anz., 1913, 44, 108-116. 4 figs. 1913.3

Ueber die Erythrophoren in der Haut der Seebarbe (Mullus L.), und iiber das Phänomen der momentanen Ballung und Ausbreitung ihres Pigmentes. Nach Beobachtungen an der lebenden Zelle. Arch. Mikr. Anat., 1913, 83, 1. Abth., 290-304. 2 pls.

1913.4

Ueber eine eigenartige zelluläre Struktur des sogenannten Ligamentum annulare im Auge von Knochenfischen. Anat. Anz., 1913, 45, 9193.

1913.5
Ueber Erythrophoren besonderer Art in der Haut von Knochenfischen. Arch. Mikr. Anat., 1913, 82, 1. Abth., 206-219. pl.

1913.6

Ueber schwarzrote Doppelzellen und andere eigenartige Vereinigun gen heterochromer Farbstoffzellen bei Knochenfischen. Anat. Anz., 1913, 44 81-91. 29 figs.

1913.7

Ueber schwarzrote und sternförmige Farbzellenkombination in der Haut von Gobiiden. Ein weiterer Beitrag zur Kenntnis der Chromatophoren und Chromatophoren-Vereinigungen bei Knochenfischen. Zeitschr. Wiss. Zool., 1913, 106, 527-593. 5 pls. \& 25 figs.

1913.8

- Das Verhalten der Kerne bei der Pigmentströmung in den Erythrophoren von Knochenfischen. Nach Beobachtungen an der lebenden Rotzelle von Mullus. Biol. Centralbl., 1913, 33, 490-493. 5 figs. 1913.9

Das Verhalten der Zellkerne bei der Pigmentströmung in den $\mathrm{Me}$ lanophoren der Knochenfische. Biol. Centralbl., 1913, 33, 267-272. 8 figs.

1913.10

Die chromatischen Organe, Melaniridosomen, in der Haut der Barsche (Perca und Acerina) Dritter Beitrag zur Kenntnis der Chromatophoren-Vereinigungen bei Knochenfischen. Zeitschr. Wiss. Zool., 1914, 110, 1-35. 3 pls. \& 8 figs. 1914.1

Balsamo-Crivelli, Giuseppe. De-

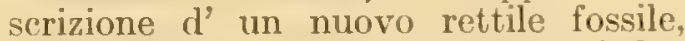
della famiglia dei Plesiosauri, e di due pesci fossili, trovati nel calcareo nero, sopra Varenna sul lago di Como. Polit. di Milano, 1839. fig. 1839.1

Balsamo-Crivelli, Giuseppe Gabriele, \& Maggi, Leopoldo. Sur les organes essentiels de la reproduction des anguilles. Bull. Hebd. Assoc. Sci France, 1872, 11, 9-13. - Journ. Zool. (Gervais), 1872, 1, 388-393. 1872.1

Ueber die Fortpflanzungsorgane der Aale. Leopoldina, 1871-72, 7. Heft, 110-111. - Arch. Naturgesch., 1872, 38. Jahrg. 1, 59-76. - Aus d. Natur, 1872,60 (n. s. 48), 308-311.

1872.2

Intorno agli organi essenziali della riproduzione delle anguille, alle particolarità anatomiche del loro apparecchio escretore genito-orinario, e 
Balsamo-Crivelli \& Maggi.

alla forma delle loro intestina, come carattere specifico. Mem. Istit. Lomb., Milano, 1873, 3. ser. 3, 229-239. pl. Abstracts in Rend. Istit. Lomb., Milano, 2. ser. 5, 20-22. - Tidsskr. Fiskeri, 7, 74-84. Review by Germer Baillière in Journ. Anat. Physiol., 9, 109-112. 1873.1

Baltzer, A. Ueber den Hautschild eines Rochen aus der marinen Molasse. Mitth. Naturforsch. Gesell. Bern (Abh.), 1889, 155-158. pl. 1889.1

Baluchin, - Beobachtungen und Versuche am Zitterwelse und Mormyrus des Niles. Arch. Anat. Physiol. (Physiol. Abth.), Berlin, 1877, 250-273. pl.

1877.1

Bambeke, Charles van. Premiers effets de la fécondation sur les oeufs de poissons: sur l'origine et la signification du feuillet muqueux ou glandulaire chez les poissons osseux. C. R. Acad. Sci. Paris, 1872, 74, pt. 1, 1056-1060.

1872.1

De la présence du noyau de Balbiani dans l'œuf des poissons osseux. Bull. Soc. Méd. Gand, 1873, 39, 352-353. - Monthly Micr. Journ., 12, 61-62. - Journ. Anat. Physiol., 10, $335-336$.

1873.1

The presence of Balbiani's nucleus in the ovum of osseous fishes. Monthly Micr.Journ., 1874, 12, 6162. Abstract in Journ. Anat. Physiol., 1874, 10, 335-336. 一 Ann. Bull. Soc. Méd. Gand, Sept. 1873.

1874.1

Recherches sur l'embryologie des poissons osseux. I. Modification. de l'ouf non fécondé après la ponte. II. Premières phases du développement. Mém. Cour. et Mém. Sav. Etrang. Belgique, 1876, 40, 1-66. $3 \mathrm{pl}$. 1876.1

Review by E, van Beneden in Bull. Roy Acad. Belgique, 1875, 2. sér. 39, 75-84.

Contributions à l'histoire do la constitution de l'œuf. I. Rapport médiat de la vesicule germinative avec la péripherie du vitellus. Bull. Acad. Sci. Bruxelles, 1883, 6, 843-877. Arch. Biol., 4, 803-832. pl. 1883.1

Remarques sur la reproduction de la blennie vivipare (Zoarces viviparus Cuv.) Bull. Acad. Roy. Belgique, 1888, 3. sér. 15, 92-117.

1888.1

Contributions ì l'histoire de la constitution de l'œuf. II. Elimination d'éléments nucléaires dans l'ouf ovarien de Scorpana scrofa L. Bull. Acad. Roy. Belgique, 1893, 3. sér. 25, 323364. pls. i-ii. - Arch. Biol., 13, 89124. pls, v-vi.

1893.1

Liste des travaux publiés par M. le Prof. Ch. van Bambeke. Ijivre jubillaire van Bambeke, 1899, i-vii.

1899.1

Bambridge, $B . R$. Swans and the destruction of fish spawn. Fishing Gazette, $1879,3,87-88$.

1879.1

Bamford, Edith E. Variations in the skeleton of the pectoral fins of Polypterus. Proc. Zool. Soc. London, 1913, 292-300. 5 figs.

1913.1

Bamps, C., \& Geraets, $E$. Faune des poissons de la province de Limbourg avec tableaux dichotomiques pour la détermination des genres et des espèces. Hasselt, 1897. 44 p. $8^{\circ}$.

1897.1

Bancks, G. IV. A world beneath the waters; or, Merman's country. London, 1895. figs. $12^{\circ}$. 1895.1

Bancroft, $E . N$. On the fish known in Jamaica as the sea devil (Cephalopterus manta) Zool. Journ., 1829, 4, 444-457. - Isis, 1831, 1363-1364.

1829.1

- On several fishes of Jamaica. Proc. Zool. Soc. London, 1831, pt. 1. 134-135. - Zool. Journ., 1832-34 (1835), 5, 409-424.

1831.1

- Account of several fishes and other animals of Jamaica. Zool. Journ., 1832-34 (1835), 5, 409-416.

1835.1

Remarks on some animals sent from Jamaica. Zool. Journ., 1832-34 (1835), 5, 80-86. - Isis, 1831, 1363 64.

1835.2

Bancroft, Edward. An essay on the natural history of Guiana, in South America. Containing a description of many curious productions in the animal and vegetable systems of that country. In several letters from a gentleman of the medical faculty [E. Bancroft] during his residence in that country. London, 1769. 402 p. pl. $8^{\circ}$ 1769.1

Fishes of Guiana, 186-202.

German version. Frankfurt of Leipzig, 1769.248 p. $16^{\circ}$. $\quad 1769.2$ 
Bancroft, Frank W. Color inheritance in Fundulus hybrids. Proc. Soc. Exper. Biol. Med. N. Y., 1911, 9, 8-9. 1911.1

Heredity of pigmentation in Fundulus hybrids. Journ. Exper. Zool., 1912, 12, 153-178. 30 figs.

1912.1

Bancroft, Thomas L. On a weak point in the life history of Neoceratodus forsteri Krefft. Proc. Roy. Soc. Queensland, Brisbane, 1912, 23, 251-256. fig. 1912.1

On an easy and certain method of hatching Ceratodus ova. Proc. Roy. Soc. Queensland, 1914, 25, 1-3. 5 figs.

1914.1

Band, $H$. Ueber Fischerei im nordwestlichen Afrika. Isis (Russ), 1879, 198-199.

1879.1

Banditten, Eben. On carp-culture, chiefly in relation to agriculture. Rept. U. S. Fish Comm. 1878 (1880), 6, $667-670$.

1880.1

Recent contributions to pond cultivation. Bull. U. S. Fish Comm. 1881 (1882), 1, 385-387.

1882.1

Bang, Ivan. Studien über Histon. [Report on discovery and preparation of scombron, a histon in mackerel sperm] Zeitschr. Physiol. Chem., 1899, 27, 463.

1899.1

Bangerter, $H$. Nestbau bei Polyacanthus cupanus var. Blätt. Aquar. Terrar. IKunde, 1914, 25. Jahrg., 524 525. fig.

1914.1

Banister, (Rev.) J. D. Voracity and carnivorous propensity of the eel. Zoologist, 1843, 1, 108-109 1843.1

Banks, J. Catalogus Bibliothecæ Historico-Naturalis. 5 vols. London, 1796-1800.

1796.1

Banks, (Sir) Joseph. For biographical memoir, see Sir. William Jardine, in Naturalists' Library, 1835, Ichthyology, vol. i.

- Journal of the Right Hon. Sir Joseph Banks ... during Captain Cook's first voyage in H. M. S. "Endeavour" in 1768-71 to Terra del Fuego, Otahite, New Zealand, Australia [etc.] Edited by Sir Joseph D. Hooker. London, 1896. 457 p. 1896.1

Banks, R.W. On the Tilestones, or Downton sandstones, in the neighbourhood of Kington, and their con- tents. Quart. Journ. Geol. Soc. London, 1856, 12, 93-101. pl. 1856.1

Banmeyer, American lake trout and whitefish in France. Bull. U. S. Fish Comm. 1884, 4, 52. 1884.1

Bannerman, $W . B$. Note on Dr. Bentley's paper "The natural history of malaria." Journ. Nat. Hist. Soc. Bombay, 1910, 20, 525.

1910.1

Banta, A. $M$. The fauna of Mayfield's cave. Carnegie Instit. Washington, 1907, no. 67, 1-114. pls. i-ii.

1907.1

Baraldi, Giovanni. Omologia fra gli organi accessori della respirazione dei pesei, e gli organi accessori dell' udito degli altri vertebrati, e più specialmente fra le ossa branchiosteche ed opercolari e l'ossa timpanico e le cartilagini del padiglione dell' orecchio dei mammiferi. Atti Soc. Tose. Sci. Nat. Pisa, 1877. 3, 1-56. 1 pl. 1877.1

Barbagallo, Pietro, \& Drago, Umberto. Primo contributo allo studio della fauna elmintologica dei pesci della Sicilia orientale. Arch. Parasitol., Paris, 1903, 7, 408-427. - Atti Accad. Gioenia Sci. Nat., Catania, 1904, 4. ser. 17, no. 3, 1-32.

1903.1

Barbaro, G.C. The fishes of Malta and Gozo, with their Maltese, Italian and English names, and season. [n. p.] 1869.

1869.1

Barbarus, Hermolaus. C. Plinii Secundi Naturalis Historix ... cum commentariis et adnotationibus $\mathrm{H}$. Barbari, etc. 10 vols. [n. p.] 1778-91. $8^{\circ}$.

1778.1

Barber, $C$. $H$. Success in raising landlocked salmon. Bull. U. S. Fish Comm. 1884, 4, 87. 1884.1

Barbère, A. G., \& Bicci, $G$. Contribution à la connaissance des modifications que le jeûne apporte dans les éléments anatomiques des différents organes et tissus de l'economie animal. Arch. Ital. Biol., 1903, 39. 1903.1

Barbiche, (l'Abbé) Les poissons de la Nied allemande. Metz, 1887. 19 p. $8^{\circ}$ - Bull. Soc. Hist. Nat. Metz, 1887, 17, 163-180. 1887.1

Barbier (junior), Paul. Noms de poissons. Notes étymologiques et lexicographiques. Revue des Langues Romanes, Montpellier, 1908-13, 51, $385-406 ; \quad 52, \quad 97-129 ; 53,26-57 ; 54$, $149-190 ; 56,172-247$.
1908.1 
Barbieri, Ciro. Note sulla struttura e funzione del cervello nei vertebrati inferiori. Atti Soc. Ital. Sci. Nat., Mus. Civ. Stor. Nat. Milano, 1905, 44, 86-96. 3 figs.

1905.1

Sull importanza degli strati granulari profondi nei lobi olfattori ed ottici dei vertebrati inferiori. Monit. Zool. Ital., 1905, 16, 238-240. 1905.2

Differenziamenti istologici nella regione ottica del cervello di teleostei ed anfibi anuri. Atti Soc. Ital. Sci. Nat, Mus. Civ. Milano, 1906, 44, 165-192. pl. \& 2 figs.

1906.1

Intorno ad una interessante mostruosità embrionale doppia nei salmonidi. Rivista Mens. Pesca, Milano, 1906, 8, 89-91.

1906.2

Sull' origine delle mostruosità embrionali doppi nei Teleostei. Atti Soc. Ital. Sci. Nat. Civ. Milano, 1906, $45,100-106.3$ figs.

1906.3

Le alose del Mediterraneo e gli agoni dei laghi Lombardi. Studio preliminare. Rivista Mens. Pesca, Milano, $1907,9,69-82 ; 125-143$. pl.

1907.1

- Intorno allo sviluppo dei nervi cranici nei teleostei. Atti Congr. Natural. Ital., 1906 (1907), 590-596.

1907.2

Pesca d' acqua dolce e marina. Milano, [1907 J 198 p. 83 figs. $8^{\circ}$. (In Biblioteca Agricola Vallardi) 1907.3

Su di una particolare forma di degenerazione osservata nelle uova di trota arcobaleno (Salmo irideus Gibb.) Rivista Mens. Pesca, Milano, 1907, 9, $152-157$.

1907.4

La alimentazione naturale degli agoni [Alosa finta] Rivista Mens. Pesca, Milano, 1908, 10, 237-242.

1908.1

Le esperienze di W. Hein sulla resistenza delle uova di trota a svariate azioni meccaniche. Rassegna. Rivista Mens. Pesca, Milano, 1908, 10, 21-23.

1908.2

Gli agoni [Alosa finta] dei laghi dell' Italia settentrionale, ed alcune brevi considerazioni intorno alla loro origine. Rivista Fisica, Matem. Sci. Nat., Pavia, 1908, 18, 273-286. 1908.3

Ricerche sullo sviluppo dei nervi cranici nei Teleostei. Morphol. Jahrb. 1908, 37, 161-201. 2 pls.

1908.4
Neuromeri e somiti meta-otici in embrioni di Salmonidi. Atti Soc. Ital. Sei. Nat., Mus. Civ. Milano, 1909, 47, 185-257. 2 pls.

1909.1

Barbieri, $N . A$. Etude anatomique sur la terminaison arétinienne du nerf optique dans la série des vertébrés. C. R. Acad. Sci. Paris, 1912, 154, 15321535. fig.

1912.1

Barbour, Thomas [1884--] Notes on Bermudian fishes. Bull. Mus. Comp. Zool., 1904-06, 46, 109-135. 4 pls.

1904.1

Notes on Rhinomuræna. Proc. Biol. Soc. Washington, 1908, 21, 39-42. 1908.1

The smallest Polyodon. Biol. Bull., Woods Hole, 1911, 21, 207-208. 3 pls.

1911.1

The zoogeography of the East Indian archipelago. [Translated from the Dutch of P. van Kampen] Amer. Naturalist, 1911, 45, 537-560. 1911.2

Two preoccupied names. Proc. Biol. Soc. Washington, 1912; 25, 187.

1912.1

Barbour, Thomas, \& Cole, Leon J. Vertebrata from Yucatan. Reptilia, amphibia and pisces. Bull. Mus. Comp. Zool., 1906, 50, 146-159. pls. i-ii.

1906.1

Rhamdia depressa and $R$. sacrificii, sp. nov., are described.

Barbour, Thomas, \& Townsend, Charles H. See Townsend \& Barbour.

Barboza du Bocage, José Vincente. See Bocage, J.V. Barboza du.

Barceló y Combis, Francisco. Catálogo metódico de los peces que habitan ó frecuentan las costas de las Islas Baleares. Revista Prog. Cienc. 1868, 18, nos. 3 \& 4. Also separate; Madrid, 1868. 46 p. $8^{\circ}$.

1868.1

Addenda al catálogo de los peces de las Baleares, inserto en la Revista de los Progresos de las Ciencias exactas, fisicas y naturales, tomo XVIII, núm. 3 y 4. Anales Soc. Español. Hist. Nat., $1875,4,59$.

1875.1

Gymnetrus [Regalecus] gladius Cuv., y Trygon [Pleroplatea] altavela Bonap., de las costas de Mallorea. Anales Soc. Español. Hist. Nat., 1877. 6, 13. 
Barclay, John. Remarks on some parts of the animal that was cast ashore on the island of Stronsa, September 1808. Edinb. Mem. Wernerian Nat. Hist. Soc., 1808-10, 1, 418-430. - Isis (Oken), 1818, 3, 2096. 1808.1

Bardeen, Charles Russell. The bimeric distribution of the spinal nerves in Elasmobranchii and Urodela. Journ. Comp. Neurol. Psychol., 1904, 14, 67. - Amer. Journ. Anat., 3, v-vi. 1904.1

Bardeleben, Karl von. Die Homologie des Unterkiefers in der Wirbeltierreihe. C. R. Assoc. Anat., 1905, 7, 140. - Verh. Anat. Ges., 19, 16-17. 1905.1

- Ueber den Unterkiefer der Säugetiere. Sitzber. Ges. Nat. Freunde, Berlin, 1905, 156-159.

1905.2

Zur vergleichenden Anatomie, besonders Paläontologie des Unterkiefers der Wirbeltiere. Verh. Anat. Ges., 1907, 21, 34-37.

1907.1

Bardi, Ugo. Trattato... di piscicoltura e ostricoltura. Milano, 1879. $8^{\circ}$ 1879.1

Bardier, $E$. Action cardiaque du sérum d'anguille. C. R. Mém. Soc. Biol. Paris, 1898, 548.

1898.1

Bardin, A. Blankenberghe. Bruges, $1866.12^{\circ}$.

La pêche à Blankenberghe, p. 1-43.

Barfod, $H$. Zwei seltene Gäste unter den Fischen der westlichen Ostsee. Prometheus, 1900, 347-349.

1900.1

-_ Beobachtungen am Zahnkärpfchen (Girardinus decemmaculatus) Natur u. Haus, Dresden, 1902, 10, 57. 1902.1

- Gesunde und kranke Aale in Aquarien und in der freien Natur. Nerthus, Altona, 1902, 4, 688-691.

1902.2

Neue Beobachtungen über das Laichen der Frühjahrsheringe im Kaiser-Wilhelm-Canal für 1902. Naturw. Wochenschr., 1902, 17, 560-562. 1902.3

Einige Notizen zur Unterscheidung männlicher und weiblicher Aale. Natur u. Haus, Dresden, 1902, 10, 121.

1902.4

Die Versuchsfischerei auf dem Kaiser-Wilhelm-Canal für 1901. Naturw. Wochenschr., 1902, 17, 164-166. 1902.5
Das Vordringen der Ostseeorganismen in den Kaiser-Wilhelm-Kanal mit besonderer Berücksichtigung der wichtigsten Nutzfische, Nerthus, Altona, 1904, 6, 101-109; 123-130.

1904.1

Barfurth, Dietrich. Ueber Nahrung und Lebensweise der Salme, Forellen und Maifische. Inaug. Dissert., Bonn, 1874. $8^{\circ}$. Archiv Naturgesch., 1875, 1, 122-15s.

1874.1

The food and mode of living of the salmon, the trout, and the shad. Rept. U. S. Fish. Comm. 1S73-75 (1876), 3, 735-759.

1876.1

Ueber Sterilität der Salmoniden. Protokoll Gen. Versam. Rhein. Fisch. Ver., 1884

1854.1

Biologische Untersuchungen über die Bachforelle. Arch. Mikr. Anat., 1886, 27, 128-172. 2 pls.-Journ. Roy. Mier. Soc., 6, 768. 1886.1

Ueber dic Ursache der Unfruchtbarkeit bei den Salmoniden. Jahresher. Rhein. Fisch. Ver., $1886 . \quad 1886.2$

Die Ausbrütung der Salmoniden mit Quellwasser. Jahresber. Rhein. Fisch. Ver., $1888 . \quad 1888.1$

Eine Larve von Petromyzon planeri mit drei Schwanzspitzen. Archiv. Entwickel.-Mech., 1899, 9, $27-$ 31. 3 figs.

1899.1

Barin, L. T. Salmon in the Clackamas river. Bull. U. S. Fish Comm. $1886,6,111-112$.

1886.1

Barkas, Thomas Pallister [1819-1891] Fossils from the Coal Measures. Geol. Mag., 1868, 5, $486 . \quad 1868.1$

- On Climaxodus, or Poecilodus; a palatal tooth from the Low Main coal-shale, Northumberland. Geol. Mag., 1868, 5, 495-497. figs. 1868.2

On the fauna of the Low Main coal seam, Northumberland [genus Diplodus] Geol. Mag., 1868, 5, 580-5s1.

1868.3

Results of the fossil gathering from the Northumberland Low Main coal-shale. Sept. $1868 . \quad 1868.4$

Climaxodus ovatus and Diplodus. Geol. Mag., 1869, 6, 42 .

1869.1

Notes on various species of Ctenodus found in the Low Main coalshale, Newsham colliery, Northumberland. Geol. Mag., 1869, 6, 314-316. 
Barkas, 'T. I'. pl. - Neues. Jahrb. Mineral., 1870 , $1035-1036$.

1869.2

Teeth of Climaxodus [Janassa], from the Coal Measures. Geol. Mag., $1869,6,381$

1869.3

Unusual forms of Ctenoptychins. Geol. Mag., 1869, 6, 43. figs.

1869.4

Illustrated guide to the fish, amphibian, reptilian, and supposed mammalian remains of the Northumberland Carboniferous strata. London, 1873. 117 p. 10 pls. \& 248 figs. $8^{\circ}$.

1873.1

Ctenoptychius or Kammplatten. Ann. Mag. Nat. Hist., 1881, 5. ser. 8, $350-354$

1881.1

Barkas, William James. Amphicentrum [Cheirodus] in a new horizon. Geol. Mag., 1874, n. s. 1, 431-432.

1874.1

Hybodus, a Coal Measure fish. Geol. Mag., 1874, n. s. 1, 163-168; 239; 287-288. figs. - Neues Jahrb. Mineral., $1875,108$.

1874.2

List of Palrozoic fishes. Geol. Mag., 1874, n. s. 1, 542-553. - Neues Jahrb. Mineral., 1875, 331. 1874.3

- On the microscopical structure of fossil teeth from the Northumberland Coal Measures. In 16 chapters, with 75 figs. Monthly Review of Dental Surgery, 1874-75.

1874.4

On the genus Ctenodus, a fish found in the true Coal Measures of Great Britain. Journ. Proc. Roy. Soc. New South Wales, 1876 (1877), 10, 99123. pls. i-v.

1877.1

- Ctenacanthus, a spine of $\mathrm{Hy}$ bodus. Journ. Proc. Roy. Soc. New South Wales, 1877 (1878), 11, 145-155.

1878.1

On a dental peculiarity of the Lepidosteidx. Journ. Proc. Roy. Soc. New South Wales, 1877 (1878), 11. 203-207.

1878.2

- On the scapula (?), coracoid, ribs, and scales of Ctenodus. Journ. Proc. Roy. Soc. New South Wales, 1877 (1878), 11, 58-64.

1878.3

On the sphenoid, cranial bones, operculum, and supposed ear-bones of Ctenodus. Journ. Proc. Roy. Soc. New South Wales, 1877 (187S), 11, 5157.

1878.4
Barker, W. L. On fish culture. Wiltshire Arch. Nat. Hist. Mag., 1869 11, 252-258.

1869.1

Barnes or Berners, Juliana. A treatyse of fysshynge wyth an angle; being a facsimile reproduction of the first book on the subject of fishing printed in England by Wynkyn de Worde at Westminster in 1496. With an introduction by M. G. Watkins. London, 1880. 23 p. figs. $4^{\circ}$ : 1880.1

Barnes, A. G. Growth and spawning of German carp in Alabama. Bull. U. S. Fish Comm. 1881 (1882), 1, 424. 1882.1

Barnes, A. S., \& Vincent, S. See Vincent \& Barnes.

Barnes, William M. Supposed occurrence of sail-fish (Histiophorus) Bull. U. S. Fish Comm. 1883, 3, 423424. 1883.1

Barnston, George. The whitefish of the Great Lakes-lake Superior. Rept. U. S. Fish Comm. 1872-73 (1874), 2, 79-80.

1874.1

Barnwell (pseudon.) See Roosevelt, $R . B$.

Barrande, Joachim. Indication sommaire des vestiges de poissons connus dans les dépôts siluriens. (In his Crustacés divers et poissons des dépôts siluriens de la Bohême, p. 99-116) Prague \& Paris, 1872. 1872.1 Review in Arch. Zool. Expér. Paris, 2 ii-vii.

Parallèle entre les poissons, les trilobites et les céphalopodes siluriens. (In his Crustacés divers et poissons des dépôts siluriens de la Bohême, p. 119127) Prague \& Paris, 1872. $\quad 1872.2$ Review in Arch. Zool. Expér. Paris, 2, ii-vii.

Barras de Aragón, Francisco de las. Pesces de agua dulce de la parte occidental de la region Cético-extremeña. Anal. Soc. Españ. Hist. Nat., 1894, 2. ser. 2, 129-132.

1894.1

Noticia de algunos monstruos existentes en el gabinete de historia natural de Huelva. Bol. Soc. Españ. Hist. Nat., Madrid, 1905, 5, 322-324.

1905.1

Barrett, $W . H$. Note on the liver of a haddock in which a sand-eel was partly embedded. Rept. Fish. Scotland, 1885, App. F, 70-72. 3 pls.

1885.1 
Barrett, W. W. Fish culture in North Dakota. Trans. Amer. Fisheries Soc., 1899 (1900), 62-64. 1900.1

Barrett-Hamilton, G.E. $H$. Aequoreal pipe-fish (Nerophis aquoreus) at Waterville, Co. Kierry. Zoologist, $1892,16,77-78$.

1892.1

Extraordinary abundance of herrings in the rivers Suir and Barrow. Irish Naturalist, 1S99, 8, 165. 1899.1

A suggestion as to a possible mode of origin of some of the secondary characters in animals as afforded by observations on certain salmonoids. Proc. Philos. Soc. Cambridge, 1900, 10, 279-285.

1900.1

- Investigations upon the lifehistory of salmon, and their bearing on the phenomena of nuptial and sexual ornamentation and development in the animal kingdom generally. Ann. Mag. Nat. Hist., 1902, 7. ser. 10, 106-120.

1902.1

Observations on the flight of flying fish (Exocotus, sp. incertx) Ann. Mag. Nat. Hist., 1903, 7. ser. 11, 389393.

1903.1

Barrington, Charles George. Seventy years' fishing. London, 1906. 308 p. frontisp. $8^{\circ}$. 1906.1

Chap. i. Stray remarks on habits of the salmon. Chap. vi. Sea trout.

Barrington, Daines. On some particular fish found in Wales. Phil. Trans. Roy. Soc. London, 1767, 57, 204-214.

1767.1

Observations on the best way of managing carp, from real experience, and the best methods now in use; in a letter to J. R. Forster. Philos. Trans. Roy. Soc. London, 1772, 61, 311-313.

1772.1

Some account of a fossil [fish] lately found near Christ-church, in Hampshire; in a letter to Dr. Maty, Sec. R. S. . . Philos. Trans. Roy. Soc. London, 1773, 63, 171-172. pl. vii.

1773.1

Of the Gillaroo trout walar ausonii Val.j; in a letter to the Rev. Dr. Horsley. Philos. Trans. Roy. Soc. London, 1774, 64, 116-120. $\quad 1774.1$

Barrois, Charles. Byssacanthus gosseleti, poisson du Dévonien supérieur. Ann. Soc. Géol. Nord., 1874-75, 2. 200-201.
Catalogue des poissons fossiles du terrain Crétacé du Nord de la France. Bull. Sci. Départ. Nord., $1874,6,101-110 ; 130-136$. 1874.2

- Sur le Byssacanthus gosseleti, plagiostome du Dévonien de l'Ardenne. C. R. Assoc. Hranç. Avanc. Sci., 1874 (1875), 3, 381-382. — Neues Jahrb. Mineral., 1875, 978.

1875.1

Note sur la veine poissonnière du terrain Houiller d'Aniche. Ann. Soc. Géol. Nord, 1910, 39, 49-64. 3 figs.

1910.1

Barrois, Th. Sur la faune des eaux douces des Açores. Lille, 1896. 3 maps. $8^{\circ}$.

1896.1

Barron, Charles, Adams, Arthur, \& Baikie, William Barron. See Adams, Baikie \& Barron.

Barron, Charles, \& Macdonald, J. D. See Macdonald \& Barron.

Barry, (Rev.) George. The history of the Orkney islands. Edinburgh, 1805. 509 p. pls. $8^{\circ}$. 1805.1

Fisheries, Book iii, 385-392.

Bart, M. Anton. Zapiski o rybach z Dniestru, polawianych we wsi Pobereże, kolo Jezupola ¿On fish which are caught in the river Dniester at Pobereze, near Jezupol] Kosmos, Lemberg, 1877, 2, 448-451. 1877.1

- Notizen über Fische, welche im Prut von seinen Quellen bis zum Delatyn vorkommen. Kosmos, Zeitschr. Naturf. Ges. Kopern. Lemberg, 1882 (1883).

1883.1

- Materyjaly do Ichthyjologicznej faunj Dniestru i jego dorzeczy. Lwow, 1883. $16 \mathrm{p}$.

1883.2

Bartels, Fritz. Der knurrende Gurami (Ctenops vitaltus vel Osphromenus striatus) Prakt. Zierfischzüchter, 1910, 7-10. fig.

1910.1

Das Wachstum der Fische. Prakt. Zierfischzüchter, 1910, 56-58.

1910.2

Barteniew, L. . Ueber Fischgehirn. Voyenno-Med. Journ. St. Petersb. 1867, 98, 105-118. $\quad 1867.1$

Bartet, \& Raveret-Wattel, $C$. See Raveret-Wattel \& Bartet.

Barthélemy-Lapommeraye,

Nouvelle tentative de l'introduction du gourami de l'île Maurice en France, 
Barthélemy-Lapommeraye, entreprise par M. Liénard. Bull. Soc. Imp. Zool. Acclimat., $1863,10,739$ 740 .

1863.1

Sur l'introduction récente du gourami [Osphromenus olfax] en France, et instructions relatives à ce sujet. Bull. Soc. Imp. 'Zool. Acclimat., 1865, 2 sér. 2, 195-203. fig.

1865.1

Bartlett, 1. D. [Letter respecting the Lepidosiren in the Crystal Palace] Proc. Zool. Soc. London, 1856, 346348. figs.

1856.1

Note on the artificial propagation of salmon. Ann. Mag. Nat. Hist., 1859, 3 ser. 4, 159-160. - Proc. Zool. Soc. London, 125-126.

1859.1

Bartlett, $E$. Fishes of Borneo and adjacent islands, with notes. Sarawak Gazette, 1896, July, Sept., Oct.Note-book Sarawak, 1896 , no. 2, 92$99 ; 128-136 ; 148-154 ; 186-197$.

1896.1

Bartlett, John. Catalogue of books on angling, including ichthyology, pisciculture, fisheries, and fishing laws. [With] Supplement [Anon.] 2 vols. Cambridge, 1882-86. $8^{\circ}$. 1886.1

- The Bartlett collection. A list of books on angling, fishes and fish culture, by Louise Rankin Albee. Library Harvard Univ. Bibl. Contrib. no. 51 . Cambridge, 1896.180 p. $8^{\circ}$. 1896.1

Bartlett, $S . P$. The cultivation of crappies in ponds. Bull. U. S. Fish Comm. 1883, 3, 362 .

1883.1

Value of carp as furnishing food for black bass. Trans. Amer. Fisheries Soc. 1898 (1899), 85-89.

1899.1

'The value of carp as a food product of Illinois waters. Trans. Amer. Fisheries Soc, 1900 (1901), 8087.

1901.1

- Angling for carp and some hints as to best method of cooking. Trans. Amer. Fisheries Soc. 1903 (190) 1 , 47-50. 1904.1

- Carp, as seen by a friend. 'T'rans. Amer. Fisheries Soc. 1905 (1906), $207-$ 211. 1906.1

The future of the carp. Trans. Aner. Fisheries Soc. 1909 (1910), 151 154.
The decrease of coarse fish and some of its causes. Trans. Amer. Fisheries Soc. 1911 (1912), 195-206.

1912.1

Barton, E. L. Balumeen fishing in Bombay harbour. Journ. Bombay Nat. Hist. Soc., 1898, 2, 742-743.

1898.1

Angling holidays, with some notes on the life history of salmon. [London, 1900] 8 p. pl. \& figs.

1900.1

A contribution to the anatomy of the digestive tract in Salmo salar. Journ. Anat. Physiol., 1900, 2. ser. 14, 295-300. pls. lx-Ixiii. 1900.2

The digestive tract in kelts. Journ. Anat. Physiol., 1902, n. s. 16, 142-146. pls. viii-ix.

1902.1

- Notes on the digestive tract of salmon and sea trout kelts from the river Tweed, January to May, 1901. Rept. Fish. Board Scotland, 1902, 20, pt. 2, 101-110. $9 \mathrm{pls}$. 1902.2 - Salmon, their food and feeding. Country Life, 1904, 2. 1904.1

Barty, $T$. The angel fish, or monk fish (Squatina angelus), in loch Ryan. Scott. Natural., 1884, n. s. 1, 106.

1884.1

Basarow, A. Vorlesungsversuch über Torpedos. Ber. Chem. Ges. Berlin, $1877,10,25-26$

1877.1

Basch, Beiträge zur Physiologie und Pathologie der Thymus. Jahrb. f. Kinderheilk., 1906, n. s. 14.

1906.1

Basilewski, Stephanus. Ichthyographia Chinx Borealis. Nouv. Mém. Soc. Nat. Moscou, 1855, 10, 215-264. 9 pls. 1855.1

Bassani, Francesco. Annotazioni sui pesci fossili del calcare eoceno di M. Bolea. Atti Soc. Sci. Padova, 1874, 3 169-191. - Atti Soc. Venet. Trent. Padova, 1876, 3, 1-28.

1874.1

Ittiodontoliti del Veneto. Atti Soc. Sci. Padova, 1876, 5, 275-308. Boll. Comit. Geol. Italia, 8, 456-457. Verh. Geol. Reichsanst., Wien, 162-163.

1876.1

Pesci fossili nuovi del calcare eoceno di M. Bolca: (Hemirhamphus edwardsii; Vomeropsis valenciennesii; Rhamphosus biserratus; Carangopsis 
lanceolatus) Atti Soc. Sci. Padova, 1876, 5, 143-154. pl.

1876.2

Nuovi Squalidi fossili [Carcharodon simus, Oxyrhina zignoi, Otodus lawleyi] Atti Soc. Tosc. Pisa, 1877, 3, 77-82. pl. - Neues Jahrb. Mineral. 1879,723 .

1877.1

Ichthyodontolitha Veneta; pesci fossili del Veneto. Padova, 1878. $8^{\circ}$.

1878.1

Note sur les poissons fossiles du laboratoire de paléontologie au jardin des plantes de Paris. Guide du Géol. Exposition Univ. 1878 et Coll. publiq. privées de Paris. Paris, 1878. 4 p.

1878.2

- Ricerche sui pesci fossili del Mioceno medio di Gahard in Francia. Atti Soc. Sci. Padova, 1879, 6, 43-70. pl.

1879.1

Studio sui pesci fossili eretacei dell' isolar di Lesina. Boll. Soc. Venet. Trent. Sci. Nat., 1879, 1, 6-7. 1879.2

- Ueber einige fossile Fische von Comen. Verh. Geol. Reichsanst. Wien, 1879, 204-205.

1879.3

- Vorläufige Mittheilungen über die (fossile) Fischfauna der Insel Lesina. Verh. Geol. Reichsanst. WVien, 1879, 162-170.

1879.4

Appunti su alcuni pesci fossili d'Austria e di Württemberg. Atti Soc. Sci. Padova, 1880, 8, 74-109. pl.

1880.1

- Note paleontologiche. Atti Soc. Venet. Trent. Sci. Nat., 1880, 7, 16-29. pl.

1880.2

Su due giacimenti ittiolitici nei dintorni di Crespano. Boll. Soc. Venet. Trent. Sci. Nat., 1880, 4, 1-8. - Bull. Soc. Sci. Padova, 1, 147-154. 1880.3

- Vorläufige Mittheilungen über die Fischfauna der Insel Lesina. Ueber einige fossile Fische von Comen. Neues Jahrb. Mineral., 1880, 1, 118120.

1880.4

- Aggiunte alla ittiofauna eocenica dei monti Bolca e Postale. Boll. Soc. Venet. Trent. Sci. Nat., 1881, 2, 14.

1881.1

Contribuzione alla fauna ittiologica del Carso presso Comen in Istria. Atti Soc. Venet. Trent, 1881, 7, 1-15. 2 pls.

1881.2
Nuove note paleontologiche. Boll. Soc. Venet. Trent. Sci. Nat., 1881, 2, 187-189.

1881.3

Osservazioni sulla lista di pesci fossili del calcare di Montegazzo del S. C. Ferretti. Boll. Soc. Sci. Padova, 1881, 2, 1-18.

1881.4

- Descrizione dei pesci fossili di Lesina accompagnata da appunti su alcune altre ittiofaune cretacee (Pietraroia, Voirons, Comen, Grodischtz, Crespano, Tolfa, Hakel, Sahel-Alma e Vestfalia) Denkschr. Akad. Wiss., Wien, 1882, 45, 195-288. 1882.1

Intorno ad un nuovo giacimento ittiolitico nel Monte Moscal. Atti Soc. Venet. Trent. Sci. Nat., 1883, 9, pt. 1, 149-150.

1883.1

Pesci attraverso le ere geologiche. Boll. Soc. Venet. Trent. Sci. Nat., 1883, 2, 116-117. 1883.2

- Zwei Fische aus der Kreide des Monte S. Agata im Görzischen. Jahrb. Geol. Reichsanst., 1884, 33, 403-406. pl.

1884.1

Elementi di zoologia descrittiva. Milano, 1885.246 p. 327 figs. $16^{\circ}$. 1885.1

- Risultati ottenuti dallo studio delle principali ittiofaune cretacee. R. Istit. Lombardo Sci., Rend., 1885, 2. ser. 18.

1885.2

Sull' età degli strati a pesci di Cattellavazzo nel Bellunese. Boll. Soc. Geol. Ital., 1885, 4, 143-148. pl.

1885.3

Avanzi di pesei volitici nel Veronese. Atti Soc. Ital. Sci. Nat., 1886, 28, 142-163. pl. 1886.1

- Sui fossili e sull' età degli scisti bituminosi triasici di Besano in Lombardia. Atti Soc. Ital. Sci. Nat., 1886, 29, 15-72.

1886.2

Sulla probabile esistenza del genere Carcharodon, nel mare titonico. Atti Soc. Ital. Sci. Nat., 1886, 28, 75-s1. figs.

1886.3

Colonna vertebrale di Oxyrhina mantelli, scoperta nel calcare senoniano di Castellavazzo nel Bellunese. Mem. Soc. Ital. Sci, 1888, 3. ser. 7, 1-6. 3 pls.

1888.1

- Ricerche sui pesci fossili di Chiavon (strati di Sotzka, Miocene in- 
Bassani, $F$.

feriore) Atti Accad. Sci. Napoli, 1888, 2. ser. 3, no. 6, 104 p. 18 pls. Abstract in Rend. Accad. Sci. Napoli, 2. ser. 2, 373-382. - Rept. 58. Meet. Brit. Assoc. Adv. Sci., 675-677. 1888.2

- Sopra una nuova specie di Ephippus scoperta nell' Eoceno medio di Val Sordina presso Lonigo (Veronese) Boll. Soc. Geol. Ital., 1888, 7, 1-3. pl. 1888.3

Su alcuni pesci fossili del deposito quaternario di Pianico in Lombardia. Atti Soc. Ital. Sci. Nat. 1886 (1888), 29, 344-351. 1 pl. 1888.4

Sopra un nuovo genere di fisostomi scoperto nell' Eoceno medio del Friuli, in provincia di Udine. Atti Accad. Sci. Napoli, 1889, 2. ser. 3, no. 4, 1-4. pl.

1889.1

Contributo alla paleontologia della Sardegna. Ittioloti Miocenici. Atti Accad. Sci. Napoli, 1891, 2. ser. 4, no. 3, 60 p. 2 pls. Abstract in Rend. Accad. Sci. Napoli, 2. ser. 3, 237. - [Remarks by A. S. Woodward] Geol. Mag., 3. ser. 8, 465. 1891.1

-...- Sull' età del calcare di M. Pettine presso Giffoni Valle Piana, in provincia di Salerno. Boll. Soc. Geol. Ital., 1891. - Rend. Accad. Lincei, Roma, 10, 1005.

1891.2

Avanzi di vertebrati inferiori nel calcare marnoso triasico di Dogna in Friuli. Atti Accad. Lincei, Roma, 1892, 4. ser. 1, 284-287. fig.

1892.1

Gl' ittioliti delle marne di Salcedo e di Novale nel Vicentino. Atti R. Istit. Ven. Sci. Lettere Arti, 1892, 7. ser. 3, 1031-1045.

1892.2

- Sui fossili e sull' età degli scisti bituminosi di Monte Pettine presso Giffoni Valle Piana in provincia di Salerno. Mem. Soc. Ital. Sci., 1892, 40 , no. 3 .

1892.3

Appunti di ittiologia fossile italiana. R. Accad. Sci. Fis. Mat. Napoli, 1895, 2. ser. 7, 1-16. 1 pl.

1895.1

Avanzi di Carcharodon auriculatus scoperti nel calcare eocenico di Valle Gallina presso Avesa. Atti Accad. Verona, 1895, 3. ser. 71, 1-11. Abstract in Riv. Ital. Paleont., 1, 8996.
La ittiofauna della Dolomia principale di Giffoni (provincia di Salerno) Palxontogr. Ital., 1896, 1, 169-210. $7 \mathrm{pls}$.

1896.1

Rivista critica di opere di ittiologia fossile. Riv. Ital. Paleont., 1896. $6 \mathrm{p}$.

1896.2

Aggiunte all' ittiofauna eocenica dei Monti Bolca e Postale. Palæontogr. Ital., 1898, 3, 77-88. 2 pls. Abstract in Zool. Centralbl., 5, 760 .

1898.1

La ittiofauna del calcare eocenico di Gassino in Piemonte. Atti Accad. Sci. Fis. Mat. Napoli, 1599, 2. ser. 9, no. 13,41 p. 3 pls. 1899.1

Sulla "Hirudella laticauda $\mathrm{O}$. G. Costa" degli schisti bituminosi triasici di Giffoni, nel Salernitano. Rend. Acead. Sci. Fis. Mat., Napoli, 1899, 3. ser. 5, 225-227. 1899.2

Avanzi di Clupea (Meletta) crenata nelle marne di Ales in Sardegna. Rend. Accad. Sci. Fis. Mat., Napoli, 1900, 3. ser. 6, 156-158.

1900.1

- Su alcuni avanzi di pesci nelle marne stampiane del bacino di Ales in Sardegna. Rend. Accad. Sci. Fis. Mat., Napoli, 1900, 3. ser. 6, 191-194. 1900.2

Il Notidanus griseus Cuvier nel Plioceno della Basilicata e di altre regioni Italiane e straniere. Rend. Accad. Sci. Fis. Mat. Napoli, 1901, 3. ser. 7, 175-180. $1 \mathrm{fig}$.

1901.1

Nuove osservazioni paleontologiche sul bacino stampiano di Ales in Sardegna. Rend. Accad. Sci. Fis. Mat. Napoli, 1901, 3. ser. 7, 262-264. 1901.2

Rivista critica di lavori d' ittiologia fossile. Riv. Ital. Paleont., 1901, 7, pt. 1, 8 p.; pt. 3, 4 p.; 9, pt. 3, 4 p.

1901.3

- Su alcuni avanzi di pesci del Plioceno toscano. Monit. Zool. Ital., 1901, 12, 189-191. - Riv. Ital. Paleontol., 7,4 .

1901.4

_. Sui pesci fossili della pietra lecesse; lettera al Prof. Conino de Giorgi, in Lecee. Napoli, 1903. 2 p. $4^{\circ}$.

1903.1

La ittiofauna delle argille marnose pleistoceniche di Taranto e di Nardò (T'erra d' Otranto) Atti Accad. Sci. Napoli, 1905, 2. ser. 12, no. 3, 59 p. 3 pls. 
- Sur quelques restes de poissons fossiles recucillis dans les argilles écailleuses ophitifères de l'Apennin septentrional. (In Sacco, F. Les formations ophitifères du Crétacé) Bull. Soc. Belge Géol. Paléont. Hydrol., $1905,19,25 \pm-256$.

1905.2

Su alcuni avanzi di pesci nell' arenaria glauconiosa della isole Tremiti. Rend. Accad. Sci., Napoli, 1907, 3. ser. 13, 156-160. 4 figs.

1907.1

- Sui fossili e sull' età del deposito di Castro dei Volsci, in provincia di Roma (Miocene superiore) Boll. Com. Geol. Italia, 1909, 40, 409-416. pl.

1909.1

Sopra un Beridice del calcare miocenico di Lecce, di Rosignamo Piemonte e di Malta (Myripristis melitensis A. S. Woodward sp.) Atti Accad. Sci. Napoli, 1914, 2. ser. no. 1, 1-14. 2 pls.

1914.1

Bassani, Francesco, \& Erasmo, $G \cdot d^{\prime}$. La ittiofauna del calcare cretacico di Capo d' Orlando presso Castellammare (Napoli) Mem. Soc. Ital. Sci., 1912, $40,1-63.6$ pls. \& 15 figs.

1912.1

Bassett, Henry. Fossiliferous Oldhaven beds at Ipswich. Geol. Mag., 1903,4 . ser. 10, 453-456.

1903.1

Report on hydrographic observations made in the Irish sea during 1912. Rept. Lancashire Seafisheries Lab., 1912 (1913), 151-167. map. 10 tables.

1913.1

Bassett-Smith, Percy William. Notes on the parasitic Copepoda of fish obtained at Plymouth, with descriptions of new species. Ann. Mag. Nat. Hist., 1896, 6. ser. 18, 8-16. pls. iiivi. 1896.1

- Notes on the fish collection in the museum of the Bombay Natural History Society, with a systematic catalogue. Journ. Bombay Nat. Hist. Soc., 1897, 10, 597-608.

1897.1

Some new parasitic copepods found on fish at Bombay. Mnn. Mag. Nat. Hist., 1898, 7. ser. 1, 1-17. 7 pls.

1898.1

A systematic description of parasitic Copepoda found on fishes, with an enumeration of the known species. Proc. Zool. Soc. London, 1899, 438507. pl.

1899.1
Snake-bites and poisonous fishes. Journ. Bombay Nat. Hist. Soc., 1903, 15, 112-130.

1903.1

Bassler, Ray Smith [1878-] Symposium on ten years' progress in vertebrate paleontology. Bull. Amer. Geol. Soc., 1912, 23, 155-156. 1912.1

Paleozoic fishes, by B. Dean, p. 224-228, Mesozoic and Cenozoic fishes, by C. R. Eastman, p. 228-232.

Bassoli, G. G. Otoliti fossili terziari dell' Emilia. Riv. Ital. Paleont., 1906, 12, 36-58. 2 pls. 1906.1

I pesci terziari della regione Emiliana. Riv. Ital. Paleont. 1907. $13,36-13$.

1907.1

Otoliti fossili di pesci. Atti Soc. Natural. Modena, 1909, 4. ser. 11, 39-41. 7 figs.

1909.1

Bastard, _- Observations sur les fécondations qui s'opèrent sous l'eau. Bull. Orléans, 1812, 4, 162-166. 1812.1

Baster, Job. Natuurkundige uitspanningen. Haarlem, 1762. $4^{\circ}$.

1762.1

- Opuscula subseciva, observationes miscellaneas de animalculis et plantis, quibusdam marinis, eorumque ovariis et seminibus continentia. 2 vols. in 1. Haarlem, 1762-65. 29 pls. $4^{\circ}$.

1762.2

Vol. i. Hirudine piscium, piscium auditu, piscium squammis. Vol. ii. Piscium pediculis.

Over de bekleedselen van de huid der dieren in't algemeen, en bijzonder over de schubben der vissen. Verh. Maatsch. Haarlem, 1762, 6, $764-766$.

1762.3

- Beschrijving van den Kiú-yú of goudvis. Verhandi. Holl. Maatschappij Wet., 1763, 7, 215-246. 1763.1

Also separate, Haarlem, 1763. col. pl. $8^{\circ}$.

Bataille, $V$. Note sur certaines espèces de poissons de la Guyane. Bull. Soc. Zool. Acclim., Paris, 1863, 10, 668-669.

1863.1

Bataillon, $E$. Sur une maladie de la truite et des neufs de la truite. C. R. Soc. Biol., Paris, 1893, 5. 1893.1

Contribution à l'étude de la peste des eaux douces. C. R. Acad. Sci. Paris, 1894, 118, 942-944. 1894.1

La courbe respiratoire de l'ouf de poisson et la mécanique de l'extension du blastoderme. C. R. Acad. Sci. Paris, 1896, 123, 264-267. 1896.1 
Bataillon, $E$.

Evolution de la fonction respiratoire chez les embryons d'amphibiens et de téléostéens. C. R. Soc. Biol. Paris, 1896, 48, 730-753.

1896.2

Les premiers stades du développement chez les poissons et les amphibiens. Nouvelles recherches sur les mécanismes de l'évolution. Arch. Zool. Expér. Gén., 1896, 3. sér. 2, 281317. pls.

1896.3

Sur les rapports qui existent entre le premier sillon de segmentation et l'axe embryonnaire chez les amphibiens et les téléostéens. C. R. Acad. Sci. Paris, 1896, 122, 1508-1511.

1896.4

— Sur les mécanismes de l'évolution. Arch. Zool. Expér. Gén. Paris, 1897, 3. sér. 5, 281-317. pls. 1897.1

L Le blastoderme et le parablaste chez les poissons osseux. C. R. Assoc. Franc., 1900, 28, pt. 2, 529-533. 1900.1

Blastotomie spontanée et larves jumelles chez Petromyzon planeri. C. R. Acad. Sci. Paris, $1900,130,1201-$ 1202.

1900.2

- Pression osmotique de l'ouf, et polyembryonic expérimentale. C. R. Acad. Sci. Paris, 1900, 130, 1480-1482. 1900.3

La pression osmotique et l'anhydrobiose. C. R. Soc. Biol. Paris, 1900, 52, 437-438.

1900.4

- Recherches expérimentales sur l'évolution de la lamproie (Petromyzon planeri) C. R. Acad. Sci. Paris, 1900 , $130,1413-1415 ; 1480-1482$. Abstract in Rev. Scient., 13, 724. - Journ. R. Micr. Soc. London, pt. 4, 442. 1900.5

- La segmentation parthénogénétique expérimentale chez les amphibiens et les poissons. C. R. Acad. Sci. Paris, 1900, 130, 115-118. $\quad 1900.6$

- Sur le développement de la pigmentation chez les métis des poissons osseux. C. R. Assoc. Franc., 1900, 23, pt. $2,533-537$.

1900.7

- La pression osmotique et les grands problèmes de la biologie. Arch. Entwickl. Mech., 1901, 11, 149-184. $\mathrm{pl}$.

1901.1

- Sur la valeur comparée des solutions salines où sucrées, en tératogenèse expérimentale. C. R. Acad. Sci. Paris, 1901, 132, 852-854. 1901.2
- La segmentation parthénogénétique expérimentale chez les œufs de Petromyzon planeri. C. R. Acad. Sci. Paris, 1903, 137, 79-80.

1903.1

Nouveaux essais de parthénogénèse expérimentale chez les Vertébrés inférieurs (Rana fusca et Petromyzon planeri) Arch. Entwickl. Mech., 1904, 18, 1-56. 4 pls. \& 12 figs.

1904.1

Bataillon, E., \& Dubard,

Sur une maladie de la truite et des cufs de truite. C. R. Soc. Biol. Paris, 1895, 9. sér. 5, 353-355.

1895.1

Bataillon, E, Dubard, - \& Terre, Un nouveau type de tuberculose. C. R. Soc. Biol. Paris, $1897,49,446-449$.

1897.1

Bataillon, E., \& Köhler, $R$. See Köhler \& Bataillon.

Batarra, G. Litteræ ad C. Toninium de Rajis. Atti Accad. Sci. Siena, 1765, 4,353 .

1765.1

Observationes zootomicæ. Atti Accad. Sci. Siena, 1771, 4, 353. 1771.1

Reproduction des raies. Mem. Accad. Sci. Siena, 1771, 9, 353. 1771.2

Batchelder, J. M. Argyreiosus unimaculatus n. sp. Proc. Boston Soc. Nat. Hist., $1846,2,78-79 . \quad 1846.1$

Batelli, A. Istologia della pelle ne' pesci teleostei. Riv. Sci. Ind. Napoli, $1880,12,372-388$.

1880.1

Bateman, (Rev.) Gregory Climenson. Fresh-water aquaria. London, 1890. figs. $12^{\circ}$.

1890.1

Bateman, $G_{0} C_{.,}$\& Bennett, R. A.R. Book of aquaria. ... 2 vols. in 1. London, 1902 . $12^{\circ}$ ' 1902.1

Bates, George A. The pronephric duct in elasmobranchs. Journ. Morphol., 1914, 25, 345-373. 5 pls. 1914.1

Bates, $H . W$. The naturalist on the river Amazon. 2 vols. London, 1863. pl. $8^{\circ}$.

1863.1

Description and figures of Mesonauta insignis, Carapus, llemaramphus, rol. ii, p. 139.

Bateson, $W^{T}$. The sense organs and perceptions of fishes, with remarks on the supply of bait. Journ. Mar. Biol. Assoc, London, 1859, 1, 225-257. pl. $\mathrm{xx}$. 1889.1 
Contractibility of the iris in fishes and cephalopods. Journ. Mar. Biol. Assoc., London, 1890, 1, 215-216.

1890.1

Modes in which fish are affected by artificial light. Journ. Mar. Biol. Assoc., London, 1890, 1, 216-217.

1890.2

On the perceptions and modes of feeding of fishes. Morph. Labor. Univ. Cambridge, 1892, 5, 100-101. Proc. Phil. Soc. Cambridge, 7, 42-43.

1892.1

Materials for the study of variation, treated with especial regard to discontinuity in the origin of species. London, 1894. $8^{\circ}$. figs.

1894.1

Fishes, p. 466-474.

- On two cases of color-variation in flat-fishes, illustrating principles of symmetry. Proc. Zool. Soc. London, 1894, 246-249. pl.

1894.2

- ISpecimens of Clupea pilchardus showing variation in the number and size of the scales] Tom. cit., 16t. 1894.3

Note in correction of a paper on colour-variation in flat-fishes. T'om. cit., 890-891.

1895.1

Bather, Francis Arthur [1863-] The name Mesites wrongly applied to Cuvier's genus Galaxias] Ann. Mag. Nat. Hist., 1898, 7. ser. 1, 102-103.

1898.1

Batt, $J$ L'industrie de la pêche. Rev. Scient., 1900, 13, 622-628. 1900.1

Battista, $G$. Conclusioni di uno studio sullo sviluppo della colonna vertebrale dei Teleostei. Atti Soc. Ital. Sci. Nat., 1883, 25, 368-387. 1883.1

Baucher, $F$. J.A. Des huiles de foie de morue médioinales aux Iles Sainte-Pierre et Miquelon. Arch. Méd. Navale, 1878, 29, 129-135. 1878.1

Baude, $J . J$. L'empoissonnement des eaux douces; les poissons sédentaires et les poissons voyageurs: production, élève et acclimatation des espéces. Police de la pêche. Revue des Deux Mondes, 1861, 2. sér. 31, 293344.

1861.1

Baudelot, Emile. Recherches expérimentales sur les fonctions de l'encéphale des poissons. C. R. Acad. Sci. Paris, 1863, 57, 949-953.- Journ. Anat. Physiol., 1, 110-112.- Ann. Sci. Nat. 5. sér. 1, 105-112.
- Considérations sur quelques particularités du système musculaire des poissons. C. R. Acad. Sci. Paris, 1867, 64, 1205-1205.

1867.1

D'un phénomène comparable à

la mue chez les poissons. C. R. Acad. Sci. Paris, 1867, 65, 247-450.-Ann. Sci. Nat., 5. sér. 7, 339-344. 1867.2

Etude sur le disque céphalique des rémoras. C. R. Acad. Sci. Paris, 1867, 64, 625-627. - Ann. Sci. Nat., 1867, 5. ser. 7, 153-160. pl.-Ann. Mag. Nat. Hist, 1867, 3. ser. 19, 375376.

1867.3

Considérations relatives à la pièce scapulaire des silures. Bull. Soc. Sci. Nat. Strasb., 1868, 1, 83-84.

1868.1

Considérations sur la structure des nageoires impaires des poissons osseux. Tom. cit., 138-142. 1868.2

Considérations sur le trone latéral du pneumogastrique chez les poissons. Tom. cit., 109-112. 1868.3

Considérations sur les premières vertèbres des cyprins, des loches et des silures. Tom. cit., 87-109.

1868.4

De la détermination des pièces osseuses qui se trouvent en rapport avec les premières vertèbres chez les cyprins, les loches et les silures. C. R. Acad. Sci. Paris, 1868, 66, 330-334.

1868.5

De la détermination homologique d'une branche du nerf pathétique chez le merlan. Bull. Soc. Sci. Nat. Strasb., 1868, 1, 81-83. $\quad 1868.6$

Note sur le disque ventral du Cyclopterus lumpus. Tom. cit., 113.

1868.7

Observation sur l'os coracoïdien et la première côte du Cottus fuviatilis. Tom. cit., 142-144.

1868.8

Observation relative à une branche anastomotique des nerfs trijumeau et pneumogastrique cher le merlan. Tom. cit., 114-116. 1868.9

$\begin{array}{rr}\text { Observations sur le rocher des } \\ \text { poissons. Tom. cit., 84-87. } & 1868.10\end{array}$

Sur une branche des nerfs spinaux observée dans quelques types de poissons. Bull. Soc. Sci. Nat. Strasb., $1868,1,145-147$.

1868.11 
Baudelot, $E$.

Observation sur les origines de la branche operculaire du nerf latéral du pneumogastrique chez quelques poissons. Op. cit., 1869, 2, 22-24.

1869.1

- Observation sur un petit centre nerveux qui se trouve en rapport avec le faisceau postérieur de la commissure de Haller chez l'épinoche IGasterosteus] Tom. cit., 37-40. 1869.2

Observations relatives à la structure du squelette des raies. Tom. cit., $45-48 ; 49-54$.

1869.3

Observations sur la structure intime du cervelet des poissons osseux. 'Tom. cit., 40-45.

1869.4

- Recherches relatives à la strueture intime des centres nerveux chez les poissons osseux. Tom. cil., 111-124.

1869.5

Tissu des lobes antérieurs de l'épinoche étudié dans l'eau ordinaire ou distillée. Tom. cit., 113-124. 1869.6

Etude sur l'anatomie comparée de l'encéphale des poissons. Mém. Soc. Sci. Nat. Strasb., 1870, 6, 51-128. $2 \mathrm{pls}$.

1870.1

- Notes critiques. Arch. Zool. Expér. Gén., 2, 1873, 63-64. 1873.1

Homologies of brain-parts and osseous connection between swim-bladder and labyrinth of cyprinoids.

Note sur un rameau dorsal du nerf pathétique chez les gades. $O p$. cit., 1873, 2, 51-52.

1873.2

Observations sur la structure et le développement des nageoires des poissons osseux. Tom. cit., 18-24.

1873.3

Recherches sur la structure et la développement des écailles des poissons osseux. 'Tom. cit., 87-244; 429-480. pls. v-xi.

1873.4

Note sur un procédé relatif à la dissection du systeme nerveux chez les poissons. Journ. Microgr., 1878, 2. Also separate; Montpellier, 1878. $4 \mathrm{p}$. $8^{\circ}$.

1878.1

Recherches sur le système nerveux des poissons. Paris, 1883. $178 \mathrm{p}$. 10 pls. $4^{\circ}$. Abstract by E. Duboueil in Revue Sci. Nat. Montpellier, 1883-84, 3, 633-638,

1883.1

Baudouin, Marcel. Le congrès international des pêches maritimes des
Sables d'Olonne (1896) Rev. Scient., $1879,7,233-240$.

1879.1

L'industrie de la sardine en Vendée. Rev. Soc. Sci. Paris, 1888, 106, 1461-1463. - Rev. Scient., 41, $651-660 ; 689-692$.

1888.1

La pisciculture marine. Inst. Int. Bibliog. Sci. Paris, 1897, 4, 1-52. 29 figs. $8^{\circ}$ - Rev. Nat. Sci. Paris, 10, 418-419.

1897.1

- La pisciculture marine de Floedevig (Norvège) Rev. Scient., 1897, 8, 108-113. 5 figs.

1897.2

-. Le Lerncenicus spratto $[=$ Lernoconema monillaris M. Edw.], parasite de la sardine en Vendée. C. R. Acad. Sci. Paris, 1904, 139, 998-1000. 1904.1

- Nouvelles observations sur le Lernxenicus, copépode parasite de la sardine. Bull. Mus. Hist. Nat. Paris, 1905, 10, 299-300.

1905.1

Les parasites de la sardine. Rev. Scient., 1905, 3, 715-722. 6 figs.

1905.2

Du mode d'attaque de la sardine (Clupea pilchardus W.) par un copépode parasite, le Lernacnicus sardince M. B. en Vendée: Bull. Soc. Sci. Nat. Nantes, 1907, 2. sér. 7, 97-114.

1907.1

- Mode d'attaque du spratt (Clupea spratta) par le Lemoenicus spratta, copépode parasite de l'oeil du poisson. C. R. Assoc. Franç. Avc. Sci. Paris, 1907, 36, pt. 1, 259; pt. 2, $727-741$

1907.2

- Un nouveau parasite du sprat.t (Clupea spratta) Constatation d'un Lernaenicus sardina nobis sur un spratt présentant en outre trois Lernaenicus spratte. Bull. Mus. Hist. Nat. Paris, 1908, 14, 17-18.

1908.1

Baudran, $G$. De l'influence des eaux résiduelles de sucrerie sur les poissons. Bull. Soc. Centr. Agricult. France, 1893, 5, 50-99.

1893.1

Baudrillart, _ Dictionnaire des pêches, contenant l'histoire naturelle des poissons et des autres animaux aquatiques. Paris, 1827. 638 p. \& atlas of 44 pls. (Traité général des eaux et forets, chasses et pêches. pt. 4)

1827.1

Bauer, $P$. Fischzuchtanstalt im Moskauischen zoologischen Garten. Anz. Fischerei, 1892, 6, 273-275. 1892.1 
Bauer, Victor. Ueber sukzessiven Helligkeitskontrast bei Fischen. Zentralbl. Physiol., 1909, 23, 593-599.

1909.1

Ueber das Farbenunterscheidungsvermögen der Fische. Arch. Ges. Physiol., 1910, 133, 7-26.

1910.1

Ueber die tonische Innervation der Pigmentzellen bei den Plattfischen. Zentralbl. Physiol., 1910, 24, 724-726.

1910.2

Zu meinen Versuchen über das Farbenunterscheidungsvermögen der Fische. Erwiderung an C. Hess. Arch. Ges. Physiol., 1911, 137, 622-626. 1911.1

Baum, $H$. Ueber das Ablaichen von Danio rerio. Wochenschr. Aquar. Terrar. Kunde, 1910, 7. Jahrg., 570. 1910.1

Etwas von Danio rerio. Blätt. Aquar. Terrar. Kunde, 1912, 23. Jahrg., 495-496. 2 figs.

1912.1

Cyprinodon (Lebias) sophia Heck. Blätt. Aquar. Terrar. Kunde, 1913, 24. Jahrg., 290-292. 3 figs.

1913.1

Baumann, Franz. Beiträge zur Biologie der Stockhornseen. Rev. Suisse Zool., 1910, 18, 647-728. fig.

1910.1

Baumann, Moritz. Ueber kiunstliche Fischzucht. Landw. Zeitg. (Fühling), 1874, 23 (n. s. 12), 664-673. 1874.1

Baumbach, $F^{\prime}$, von. Das Fischbruthaus am Feldberg in Taunus.' 'Zeitschr. Ver. Nass. Land. Forstw, 1880, 62 (n. s. 11), 17-22. - Circul. Deutsch. Fisherei. Ver., 1879 (1880), 239-244.

1880.1

Baumberger, Ennst. Fauna der untern Kreide im westschweizerischen Jura. I. Teil. Stratigraphische Einleitung. Abh. Schweiz. Paläont. Ges., 1903, 30, no. 4, 1-60. 3 pls. \& 29 figs.

1903.1

Baumberger, $E$., \& Moulin, $H$ La sćrie néocomienne à Valangin. Bull. Soc. Sci. Nat. Neuchâtel, 1898, 26, 150-210. 2 pls. \& 6 figs. 1898.1

Baume, Robert. Odontologische Forschungen. Leipzig, 1882. 307 p. 152 figs. $8^{\circ}$.

Teeth of fishes, p. 41-52.

Baumeister, $L$. Ueber die Augen von Boleophthalmus und Periophthal- mus. Bull.-annexe Rev. Suisse Zool. $1911,19,26-28$.

1911.1

Ueber die Augen der Schlammspringer (Periophthalmus und Boleophthalmus) Zool. Jahrb. (Anat.), 1913, $35,341-354.6$ figs.

1913.1

Baumert, F. M. Chemische Untersuchungen über die Respiration des Schlammpeizgers (Cobitis fossilis) Breslau, 1853. 73 p. pl. $4^{\circ}$. 1853.1

Ueber die Haut und Kiemenrespiration des Schlammpeizgers und anderer Fische. Annal. Chem. Pharm. (Liebig), 1853, 88, 18-56. 1853.2

Baumgardt, Gustav. Gedächtnisproben bei Fischen. Blätt. Aquar. 'Terrar. Kunde, 1904, 15, 121-122.

1904.1

Die Eingewöhnung heimischer Fischarten für das Aquarium. Blätt. Aquar. Terrar. Kunde, 1913, 24. Jahrg. 388-391. 3 figs.

1913.1

Baumgartner, —_ Fische und Fischfang im Plattensce in Ungarn. Natur, 1879, n. s. 5, 395-396. 1879.1

Baumhauer, Eduard Hendrit van. Over eene stof vorkommende in de Perispermia der zaden die mit hoornachtig Albumen gezegd worden te bastaan. Utrecht, $1846 . \quad 1846.1$

Ueber das lösliche Eiweiss der Fische. Journ. Prakt. Chem., 1848, $45,120-122$.

1848.1

Ueber die Zusammensetzung des Muskelgewebes der Fische. $O p$. cit., 1848, 44, 506-511. 1848.2

Baur, Albert. Mittheilungen über die Metamorphose der Neunaugen [Petromyzon] Verh. Phys.-Nedic. Soc. Erlangen, 1865-67 (1867), 1. Heft, 4145 .

1867.1

Baur, E. Ein Modell des elektrischen Organs der Fische. Zeitschr. Elektroch. Halle, 1913, 19, 590-592.

1913.1

Baur, Georg Hermann Carl Ludwig. For biography and-list of works, see Amer. Naturalist, 1898, 32, 717-718; 1899, 33, 15-30. - Auk, 1898, 15, 286287. - Geol. Mag., 1898, 5, 379-381. Leopoldina, 1898, 34, 126. - Nature, 1898, 58, 350. - Ornith. Monatsber., 1898, 6, 167-168.--Science, 1898, 8, 68-71. - Zoologist, 1899, 3, 95-96. 
Baur, G. H. C.L.

Preliminary note on the origin of limbs. Amer. Naturalist, 1885, 19 , 1112.

1885.1

Ueber das Archipterygium und die Entwicklung des Cheiropterygium aus dem Ichthyopterygium. Zool. Anz., 1885, 8, 663-666.

1885.2

Ueber die Morphogenie der Wirbelsäule der Amnioten. Biol. Centralbl., $1886,6,332-342$; 353-363.

1886.1

Bemerkungen über Sauropterygia und Ichthyopterygia. Zool. Anz., $1887,10,245-252$.

1887.1

On the morphology and origin of the Ichthyopterygia. Amer. Naturalist, 1887, 21, $837-840$.

1887.2

On the morphology of ribs. Amer. Naturalist, 1887, 21, 942-945.

1887.3

Ueber Lepidosiren paradoxa Fitzinger. Zool. Jahrb., 1887, 2, 575583.

1887.4

Ueber den Ursprung der Extremitäten der Ichthyopterygia. Bericht Versam. Geolog. Vereins, 1888. 4 p. pl.

1888.1

On the morphology of ribs and the fate of the actinosts of the median fins in fishes. Journ. Morph., 1889, 3, 463-466. 7 figs.

1889.1

On the morphology of the vertebrate skull. (1) The optic elements. (2) The temporal arches. Journ. Morph., 1889, 3, 467-474. 1889.2

The pelvis of the Testudinata, with notes on the evolution of the pelvis in general. Journ. Morphol., 1891, 4, 345-359. 13 figs. 1891.1

Reference to structure of pelvis in dipnoans and selachians, 358-359.

Ueber Rippen und ahuliche Gebilde und deren Nomenclatur. Anat. Anz., 1893, 9, 116-120.

1893.1

- Mr. Walter E. Collinge's "Remarks on the preopercular zone and sensory canal of Polypterus." Anat. Anz., 1896, 12, 247-248. 1896.1

Bause, $B$. Rybky zapasici ze Siamu (Betla pugnax) Vismir Roc., 1897, 4. ser. 27, 37-38. fig.

1897.1

Bayer, Edwin, \& Fritsch, Anton. See Fritsch \& Bayer.
Bayer, Franz. Ueber einige interessante Skeletbestandtheile von Coregonus murcna. Böhm. Ges. Wiss., mat.-nat. Cl. Prag, 1889, 393-105. pl. 1889.1

- Ueber den heutigen Zustand der Systematik der Fische. Jahresber. Graf Straka Akad., Prag, 1899 (1900), 36-46.

1900.1

Neue Fische der Kreideformation Böhmens. Palæontogr. Bohemiæ, 1902, 7, 1-18. 3 pls. \& 9 figs. - Verh. Geol. Reichsanst., Wien, 1903, 269-274. 4 figs.

1902.1

- Article on fishes] Otto's Encyclopædia, 1904, 22, 400-414. 4 pls. \& fig.

1904.1

- Neue Resteder Gattung Portheus Cope (Xiphactinus I eidy) aus der böhmischen Kreide [Text in Bohemian] Trans. Bohem. Imper. Francis Joseph Acad. Sci. Prague (2. Cl.), 1908, 17, 11 p. pl. \& 6 figs.

1908.1

- Neue Reste von Portheus Cope (Xiphactinus Leidy) aus dem böhmischen Turon. Bull. Intern. Acad. Sci. Prague, math.-nat. Sec., 1909, 14, 98103. pl. \& 4 figs.

1909.1

Bayer, Franz, \& Fritsch, Anton. See Fritsch \& Bayer.

Bayer, $H$. von. Fishways. Proc. 4. Intern. Fish Congr., Washington, 1908, pt. 2, 1041-1057. 21 figs. 1908.1

A method of measuring fish eggs. Proc. 4. Intern. Fish Congr., IVashington, 1908, pt. 2, 1009-1014. 1908.2

Bayer, $J$. Ueber eine neue Art Fischfanges in Serbien. Verh. Zool.Bot. Ges. Wien, 1863, 13 (Sitzb.), 7071.

1863.1

Zur Fischfutter-Frage. Oesterr.Ungar. Fischerei Zeitg., 1880, 261-262.

1880.1

Bayet, $L$. Première note sur quelques dépôts tertiares de l'Entre-Sambro-et-Meuse. Bull. Soc. Belge Geol. Pal. Hydrol., 1896, 10, 133-160. 1 pl. \& 6 figs.

1896.1

Baylis, H. A. Some observations on the tentacles of Blennius gallorugine. Journ. Linn. Soc. London (Zool.), 1914 , 32, 295-306. 2 pls. \& fig.

1914.1

Bayliss, $W . M .$, \& Staring, E. $H$. On the uniformity of the pancreatic 
mechanism in vertebrata. Journ. Physiol., 1903, 29.

1903.1

Baženov, A. Luciotrutta leucichthys in der mittleren Wolga [Text in Russian] Věst. Rybopromyšl., St. Petersb., 1905, 20, 195-199.

1905.1

- Ueber die Salmoniden in der mittleren Wolga [Text in Russian Věst. Rybopromyšl., St. Petersb., 1905, 20, 693-694. 1905.2

- Der Stör und der Hausen in der mittleren Wolga [Text in Russian] Věst. Rybopromyšl., St. Petersb., 1906, 21, 1-6. 3 pls.

1906.1

Ueber die Wanderung von Clupea kessleri bis oberhalb von Samara im Jahre 1905 [Text in Russian] Věst. Rybopromyšl., St. Petersb., 1906, 21, 118-135.

1906.2

Bazin, A. Lettre sur quelques petits museles [de poissons] qui sont restées inconnus jusqu'à ce jour. Rev. Zool., 1839, 151-152.

1839.1

Mémoire sur les muscles internes et sur l'appareil aquifère des branchies des poissons. C. R. Acad. Sci. Paris, 1839, 8, 877-878. - L'Institut, 7, 179 .

1839.2

Note sur les muscles placés entre les lames des branchies des poissons. C. R. Acad. Sci. Paris, 1839, 8, 842.

1839.3

Sur le système nerveux des poissons. Soc. Phil. Extr. Proc. Verb., 1839, 83; 84-85. - L'Institut, 7, 245; 263-264.

1839.4

Observations sur la pisciculture et sur les règlements qui régissent la pêche. Act. Soc. Linn. Bordeaux, 1858, 21 (3. sér. 2), 461-469. 1858.1

Beacall, T. A tooth of Hybodus grossicornis from the Inferior Oolite. Nature, 1898, 58, 390.

1898.1

Beach, Horace. The paddle fish (Polyodon spathula) Bull. Wisconsin Nat. Hist. Soc., 1902, 2, 85-86. 1902.1

Beal, Carl Hugh, \& Jordan, David Starr. See Jordan \& Beal.

Beale, Lionel $S$. On the germinal matter of the ovarian ova of the stickleback. Trans. Micr. Soc. London, 1867, n. s. $15,85-86$.

1867.1

Bean, Barton Appler [1860-] Black bass and crappie for eastern waters. Shooting \& Fishing, 1889, 7, 8. 1889.1
The cutlass fish. Forest \& Stream, 1889, 33, 169. 1889.2

- Double-headed animals. Tom. cit., 164

1889.3

Record of a double-headed Mustelus sp. 6 in. long, from near Lima, Peru, and of doubleheaded specimens of Salmo of two species hatched in the Washington hatchery.

- Fish breeding in Canada. Tom. cit., 149-150. 1889.4

Fish culture in Illinois. Tom. cit., 150 .

1889.5

- 1 land fish. Tom. cit., 186.

1889.6

Habits of a Samoan species of Periophthalmus

- Large-mouth black bass in Texas [Micropterus salmoides] Tom. cit., 167.

1889.7

-.. Large plantings of fish in the west. Shooting \& Fishing, 1889, 7, 7. $\quad 1889.8$

- A rare deep-sea fish [Malacosteus niger(?) Ayres in stomach of a halibut from eastern part of George's bank] Forest \& Stream, 1889, 33, 144.

1889.9

Singularly colored catfish. Shooting \& Fishing, 1889, 7, 7. 1889.10

- Stocking the waters of the $\mathrm{Na}$ tional park. Tom. cit., $6 . \quad 1889.11$

Study of freshwater food fishes. Forest \& Stream, 1889, 33, 181. 1889.12

- Susquehanna bass and perch. Tom. cit., $186 . \quad 1889.13$

Black bass prospects in the Potomac. Shooting \& Fishing, 1890, May 22.

1890.1

'The conger eel. Forest \& Stream, 1890, 34, 377. 1890.2

Delaware river shad hatching. Shooting \& Fishing, 1890, May 22.

1890.3

Perch spawning in confinement. Shooting \& Fishing, 1890, 7, 7. 1890.4

- The rock bass. Tom. cit., 6 .

1890.5

The American Fisheries Society. Forest \& Stream, 1S91, 36, 397. 1891.1

Fishes collected by William P. Seal in Chesapeake bay, at Cape 
Bean, $B . A$.

Charles City, Va., Sept. 16 to Oct. 3, 1890. Proc. U. S. Nat. Mus., 1891, 14, 83-94. 1891.2

-... A cat-fish in armor. Forest $\mathbb{E}$ Stream, 1892, 37, 199. 1892.1

Fisheries of the Pacific states. Tom. cit., 501.

1892.2 cit., 199.

Tom. 1892.3

- New Hampshire fish culture. Tom. cit., 302-303. 1892.4 cit., 422 .

Pacific salmon and trout. Tom.

World's Fair fishes. Tom. cit., 401. 1892.6

- The New Hampshire Fish Commission. Tom. cit., 142.

1893.1

- A new Trinidad flounder ( $C y$ clopsetta chittendeni n. sp.) Trinidad Field Nat. Club, 1895, 2, $176 . \quad 1895.1$

Notes on Williamson's whitefish in breeding colors, from Little Spokane river, and remarks on the distribution of the species. Bull. U.S. Fish Comm. 1894 (1895), 14, 205-206. 1895.2

- Scientific results by the U. S. Fish Commission steamer "Albatross." Descriptions of two new flounders, Gastropsetta frontalis and Cyclopsetta chittendeni. Proc. U. S. Nat. Mus., 1895, 17, 633-636. 3 figs. $\quad 1895.3$

Myoxocephalus mednius, new species. Bull. U. S. Nat. Mus., 1898, no. 47 , pt. 2, 1983-1984. 1898.1

- Notes on capture of rare fishes. Proc. U. S. Nat. Mus., 1898, 21, 639640.

1898.2

- Porocottus quadratus new species. Bull. U. S. Nat. Mus., 1898, no. 47, pt. 2, 1898.

1898.3

- A group of land fishes. Shooting \& Fishing, 1900, 7, $7 . \quad 1900.1$

- The conger ecl. Science, 1902, n. s. 15,715 .

1902.1

A rare whale shark [Rhinodon] Tom. cit., 353.

1902.2

Steclhead salmon in lake Michigan. Forest \& Stream, 1902, 58, 430. fig.
- Notice of a collection of fishes made by $H$. H. Brimley in Cane river and Bollings creek, North Carolina, with a description of a new species of Notropis ( $N$. brimleyi) Proc。 U. S. Nat. Mus., 1903, 26, 913-914. 1903.1

- Notice of a small collection of fishes, including a rare eel, recently received from ... Barbados, West Indies. Tom. cit., 26, 963-964. fig.

1903.2

A new pelican fish [Gastrostomus pacificus] from the Pacific. Smithson. Misc. Coll., 1904, 45, pts. 3, 4, 254255. fig

1904.1

The Bahama islands. Baltimore, 1905. illus.

1905.1

Fishes, p. 293-325.

The history of the whale shark (Rhinodon typicus Smith) Smithson. Misc. Coll., 1905, 48, 139-148. 3 pls. \& 4 figs.

1905.2

Notes on an adult goblin shark (Mitsukurina owstoni) of Japan. Proc. U. S. Nat. Mus., 1905, 28, 815-818. 8 figs.

1905.3

- Notes on a collection of fishes from Mexico, with description of a new species of Platypoecilus. Proc. U. S. Nat. Mus., 1908, 33, 539-542. fig.

1908.1

On Ctenolucius Gill, a neglected genus of characin fishes, with notes on the typical species. Tom. cit., 701-703. 1908.2

- The proper name of the American eel Inquilla rostruta (Le Sueur) Science, 1909, n. s. 29, 871-872. 1909.1

- A remarkable carp. Forest \& Stream, 1909, 73, 1022。 1909.2

Bean, Barton A., \& Eigenmann, Carl H. See Eigenmann \& Bean.

Bean, Barion A., \& Evermann, Barton Warren. See Evermann \& Bean.

Bean, Barton A., Evermann, Barton $W$. \& Wilcox, W. A. Fisheries of Indian river, Florida. Senate Document no. 46, 54. Congress, 2. session, 1897.

1897.1

Bean, Barton A., \& Seale, Alvin. See Seale \& Bean.

Bean, Barton A., \& Smith, Hugh McCormich. See Smith \& Bean. 
Bean, B. A., \& Weed, Alfred $C$. Description of a new skate (Dactylobatus armatus) from deep water off the southern Atlantic coast of the United States. Proc. U. S. Nat. Mus., 1909, 36, 459-461. pl.

1909.1

Descriptions of two new species of electric rays, of the family Narcobatidx, from deep water off the southern Atlantic coast of the United States. Proc. U. S. Nat. Mus., 1909, 36, 677680. fig.

1909.2

- Notes on Anteliochimæra and related genera of chimæroid fishes. Proc. U. S. Nat. Mus., 1910, 37, 661664. 2 pls.

1910.1

Notes on certain features of the life history of the Alaskan freshwater sculpin. Smithson. Misc. Coll., 1910, 52, $457-460$.

1910.2

- A review of the venomous toadfishes. Proc. U. S. Nat. Mus., 1910, 38, 511-526. 4 pls. \& 8 figs. 1910.3

An electric ray and its young from the west coast of Florida. Proc. U. S. Nat. Mus., 1911, 40, 231-232. pls. $\mathrm{x}-\mathrm{xi}$.

1911.1

- Notes on the coloration of fishes. Proc. Biol. Soc. Washington, 1911, 24, 69-76.

1911.2

Notes on the genus Lepomis. Proc. U. S. Nat. Mius., 1911, 40, 369376. pls. xlii-1.

1911.3

Recent additions to the fish fauna of the District of Columbia. Proc. Biol. Soc. Washington, 1911, 24, 171-174.

1911.4

Notes on a collection of fishes from Java, made by Owen Bryant and IVilliam Palmer in 1909, with description of a new species. Proc..U.S. Nat. Mus. 1912, 42, 587-611. pls. Ixxiiilxxv.

1912.1

Bean, Tarleton Hoffman [1846-] The burbot (Lota maculosa) Sci. News, 1878, 1, 42-44. pl.

1878.1

Description of a new sparoid fish, Sargus holbrookii, from Savannah bank. Proc. U. S. Nat. Mus., 1878, 1, 198-200.

1878.2

Description of a species of $L y-$ codes ( $L$. turneri) from Alaska, believed to be undescribed. Proc. U. S. Nat. Mus., 1878, 1, 463-466.
Gameness of the Quinnat salmon. Chicago Field, 1878, 10, 4 .

1878.4

Observations on certain fish in the U. S. National Museum. Fishing Gazette, 1878, n. s. 2, 350-351. 1878.5

On the identity of Euchalarodus putnami Gill, with Pleuronectes glaber (Storer), with notes on the habits of the species. Proc. U. S. Nat. Mus., $1878,1,345-348 . \quad 1878.6$

- On the occurrence of Stichreus punctatus (Fabr.) Kröyer, at St. Michael's, Alaska. Proc. U. S. Nat. Mus., $1878,1,279-281$.

1878.7

Contributions to the natural history of arctic America, made in connection with the Howgate polar cxpedition (1877-78) Fishes collected in Cumberland gulf and Disko bay. Bull. U. S. Nat. Mus., 1879, 15, 101-138.

1879.1

- Description of a new species of Ameiurus (A. ponderosus) from the Mississippi river. Proc. U. S. Nat. Mus., 1879, 2, 286-291. 1879.2

Description of an apparently new species of Gasterosteus (G.alkintsii) from the Schoodic lakes, Maine. Proc. U. S. Nat. Mus., 1879, 2, 67-69. 1879.3

Descriptions of some genera and species of Alaskan fishes. Proc. U. S. Nat. Mus., 1879, 2, 353-359.

1879.4

Descriptions of two species of fishes collected by Prof. A. Dugès in central Mexico. Proc. U.S. Nat. Mus., $1879,2,302-306$.

1879.5

Fishes collected in Cumberland gulf and Disko bay. Bull. U. S. Nat. Mus., 1879, no. 15, 107-140. 1879.6

List of European fishes in the collection of the United States National Museum. Proc. U.S. Nat. Mus., 1879, 2, 10-44.

1879.7

A new fish from Alaska, with notes upon other species of the genus Anarrhichas. Proc. U. S. Nat. Mus., 1879, 2, 212-218. $\quad 1879.8$

-.. Notes on a collection of fishes from eastern Georgia. Proc. U. S. Nat. Mus., 1879, 2, 284-286. $\quad 1879.9$

On the occurrence of Hippoglossus vulgaris Flem. at Unalaska and 
Bean, $T, H$.

Stt. Michael's, Alaskia. Proc. U. S. Nat. Mus., 1879, 2, 63-66. 1879.10

On the species of Astroscopus of the eastern United States. Proc. U.S. Nat. Mus., 1879, 2, 57-63.

1879.11

Putnam's flatfish, a smooth plaice. Sci. News, 1879, 1, 104.

1879.12

Check-list of duplicates of North American fishes distributed by the Smithsonian Institution in behalf of the United States National Museum, 1877-80. Proc. U. S. Nat. Mus., $1880,3,75-116$.

1880.1

Description of a new hake (Phycis earlii) from South Carolina, and a note on the occurrence of Phycis regius in North Carolina. Proc. U. S. Nat. Mus., 1880, 3, 69-70. 1880.2

Descriptions of new fishes from Alaska and Siberia. Proc. U. S. Nat. Mus., 1881, 4, 144-159.

1881.1

- Descriptions of new species of fishes (Uranidea marginata, Potamocottus bendirei) and of Myctophum crenulare J. and G. Proc. U. S. Nat. Mus., 1881, 4, 26-29.

1881.2

Directions for collecting and preserving fish. Proc. U. S. Nat. Mus., 1881, 4, 235-238. - Bull. U. S. Fish Comm. 1883, 3, 197-200.

1881.3

Movements of young alewives (Pomolobus sp.) in Colorado river, Texas. Bull. U. S. Fish Comm. 1881, $1,69-70$.

1881.4

- Notes on a collection of fishes made by Capt. Henry E. Nichols, U. S. N., in British Columbia and southern Alaska, with descriptions of new species and a new genus (Delolepis) Proc. U. S. Nat. Mus., 1881, 4, 463-474.

1881.5

Notes on some fishes from Hudson's bay. Proc. U. S. Nat. Mus., 1881 , 4, $127-129$.

1881.6

- A partial bibliography of the fishes of the Pacific coast of the United States and of Alaska for the year 1880 . Proc. U. S. Nat. Mus., 1881, 4, 312317.

1881.7

A preliminary catalogue of the fishes of Alaskan and adjacent waters. Proc. U. S. Nat. Mus., 1881, 4, $239-$ 272 .
Catalogue of the collection of fishes exhibited by the U. S. National Museum at the international fisheries exhibition, London. Washington, 1883. $8^{\circ}$.

1883.1

Description of a new species of Alepidosaurus (A. asculapius) from Alaska. Proc. U. S. Nat. Mus., 1883, 6, 661-663.

1883.2

- Description of a species of whitefish, Coregonus hoyi (Gill) Jordan, called "smelt" in some parts of New York. Proc. U. S. Nat. Mus., 1883, 6, 658-660.

1883.3

List of fishes known to occur in the Arctic ocean north of Behring strait. Cruise of the revenue steamer "Corwin" 1881 (1883), 118-120.

1883.4

Note on the occurrence of a silver lamprey, Ichthyomyzon castaneus Girard, in Louisiana. Proc. U. S. Nat. Mus., 1883, 6, 117-119. 1883.5

- Notes on a collection of fishes made in 1882 and 1883 by Capt. Henry E. Nichols, U. S. N., in Alaska and British Columbia, with a description of a new genus and species, Prionistius macellus. Proc. U.S. Nat. Mus., $1883,6,353-361 . \quad 1883.6$

- Notes on fishes collected by Capt. Chas. Bendire, U. S. A., in Washington Territory and Oregon, May to October, 1881. Proc. U. S. Nat. Mus., 1883, 6, 89-93. 1883.7

Notes on fishes observed at the head of Chesapeake bay, in the spring of 1852, and upon other species of the same region. Proc. U. S. Nat. Mus., 1883, 6, 365-367.

1883.8

- Notes on some fishes collected by James G. Swan, in Washington Territory, including new species of Macrurus. Proc. U. S. Nat. Mus., $1883,6,362-364$.

1883.9

- Brook trout from Monadnock lake and Cristine lake, New Hampshire. Bull. U. S. Nat. Mus., 1884, 4, 293-294.

1884.1

The burbot. Fisheries \& Fish. Ind. of U. S., 1884, 7. sec., 235-240.

1884.2

Descriptions of a new species of white fish (Coregonus nelsonii) from Alaska. Proc. U. S. Nat. Mus., 1884, 7. 48 . 
- Descriptions of Physiculus fulvus and Lotella maxillaris, new species of fishes collected in 1881 by the U. S. Fish Commission. Proc. U. S. Nat. Mus., 1884, 7, 240-242.

1884.4

The first occurrence of Pscudotriacis microdon Capello, on the coast of the United States. Proc. U. S. Nat. Mus., 1884, 7, 147-150.

1884.5

Lists of fishes collected by the U. S. Fish Commission at ITood's Hole, Mass., during the summer of 1881. Rept. U. S. Fish Comm. 1882 (1884), 10, 339-344.

1884.6

On the oecurrence of branch alewife in certain lakes of New York. Fisheries \& Fish. Ind of U. S., 1884, 1 sec., 588-594.

1884.7

- On the occurrence of the striped bass in the lower Mississippi valley. Proc. U.S. Nat. Mus., 1884, 7, 242-244.

1884.8

- Report upon the department of fishes in the U. S. National Museum for 1884. Rept. U.S. Nat. Mus., 1884, pt. $2,160-169$.

1884.9

The white fishes of North America. Rept. Amer. Fish Culture Assoc., $1884,32-39$.

1884.10

Comments on Zygonectes mannii and $Z$ ygonectes auroguttatus. Proc. U.S. Nat. Mus., 1885, 8, 555.

1885.1

- Description of a new species of Aspidophoroides (A. güntheri) from Alaska. Proc. U. S. Nat. Mus., 1885, $8,74-75$.

1885.2

Description of a new species of Pempheris ( $P$. poeyi) from Cuba. Proc. U. S. Nat. Mus., 1885, 8, 229-230.

1885.3

Description of a new species of Plectromus ( $P$. crassiceps) taken by the U. S. Fish Commission. Proc. U. S. Nat. Mus., 1885, 8, 73-74. 1885.4

The distribution of the Salmonidre in Alaska. Proc. Biol. Soc. Washington, 1885, 2, 1xi-lxiii.

1885.5

- Note on Stoasodon narinari Euphrasen. Proc. U. S. Nat. Mus., 1885, 8, 192-193.

1885.6

- Notes on Epinephelus nigritus, Caulnlatilus microps and Coryphona hippurus. Proc. U. S. Nat. Mus., 1885, 8, 230-233.
- Notes upon an exploration of Long Island sound. Bull. U. S. Fish Comm. 1885, 5, $33 . \quad 1885.8$

On Stathmonotus, a new genus of fishes related to Murmonoides, from Florida. Proc. U. S. Nat. Mus., 1885, 8, 191-192. pl.

1885.9

On the identity of Cottus maculatus Fischer with Coltus bubalis Euphrasen. Proc. U. S. Nat. Mus., 1885, 8, 166-167.

1885.10

On the occurrence of Hadropterus aurantiacus (Cope) in the French Broad river, North Carolina. Proc. U. S. Nat. Mus., 1855, 8, 165-166.

1885.11

Rocky mountain whitefish. Forest \& Stream, 1885, 25, $390 . \quad 1885.12$

(translator) Extract from the report of A. Annaniassen on his voyage to Iceland. Rept. U. S. Fish Comm. 1884 (1886), 12, 309-313. $\quad 1886.1$

- The trout of Sunapee lake. Forest \& Stream, 1886, 26, 129-130.

1886.2

- Catalogue of the collection of fishes. Descript. Catal. Rept. Exhib. U.S., 1887, 387-510. 1887.1

The cod fishery of Alaska. Fisheries \& Fish. Ind. of U. S., 1887, 5. sec., 1, 198-224. pl. 1887.2

- Cruise of the "Grampus" on the southern mackerel grounds. Boston Herald, 1887, May 9, May 26, and June 6.

1887.3

Description of a new genus and species of fish (Acrotus willoughbyi) from Washington Territory. Proc. U.S. Nat. Mus., 1887, 10,631-632. 1887.4

Description of a new species of Thyrsitops ( $T$. vinlaceus) from the fishing banks off the New England coast. Proc. L. S. Nat. MIus., 1887, 10, 513514.

1887.5

Description of a supposed new species of char (Salvelinus aureolus) from Sunapee lake, New Hampshire. Proc. U. S. Nat. MIus., $1887,10,628-630$.

1887.6

Descriptions of five new species of fishes sent by Prof. A. Dugès from the province of Guanajuato (Mexico) Proc. U. S. Nat. Mus., 1887, 10,370375. pl.
1887.7 
Bean, $T . H$.

The fishery resources and fishinggrounds of Alaska. Fisheries \& Fish. Ind of U.S., 1857, 3. sec., 81-115. pls. i-iv.

1857.8

- Notes on a young red snapper (Lutjanus blackfordi). from Great South bay, Long Island. Proc. U. S. Nat. Mus., 1887, 10, 512.

1887.9

Report on examination of clupeoids from carp ponds. Bull. U. S. Fish Comm. 18s7, 6, 441-442. 1887.10

- Description of Coregonus musillus, a new species of whitefish from Alaska. Proc. U. S. Nat. Mus., 1888, 11,526 .

1888.1

Distribution and some characters of the Salmonidx. Amer. Naturalist, $1888,22,306-314$.

Fishes, determined from photographs. (In Dawson, George M. Report on an exploration in the Yukon district, N. W. T. etc. Canada Geol. Surv. Rept., 1887-88, n.s. 3, pt. 1) 1888.3

Key to the genera of Salmonida (In Goode, G. B. American fishes, New York, 1888, p. 440. 2. ed., Boston, 1903)

1888.4

- Report on the fishes observed in Great Egg Harbor bay, N. J., during the summer of 1887. Bull. U.S. Fish Comm. 1887 (1888), 7, 129-151. pls. i-iii.

$18 S 8.5$

Bears, birds and fishes. Forest \& Stream, 1889, 33, 348; 365. 1889.1

Black bass in ponds. Op.cit., $32,9$.

1859.2

Crossing of salmon and trout. Tom. cit., 321.

1889.3

Explorations in gulf of Mexico. Tom. cit., 195. 1889.4

Fish and fishing in Alaska. Tom. cit., $27 ; 48-19$. 1889.5

'The hagfish. Tom. cit., 66.

1889.6

-.- A hybrid between the lake trout and brook trout (Salvelinus namaycush and $S$. fontinalis) Bull. U. S. Fish Comm. 1887 (1889), 7, 216. 1859.7

Introduction of a supposed carp sucker into New South Wrales. Forest \& Stream, 1889, 32, 10.
Lake and brook trout hybrid. Op. cit., 31, 520 .

1889.9

- Lake trout. Op. cit., 32, 9.

1889.10

L_Landlocked and Atlantic salmon. Op.cit., 31, 520 .

1889.11

32,10 .

Op. cit., 1889.12

- Notes on salmon, trout and eels. T'om. cit., 9.

1889.13

- Ozark mountain trout. Tom. cit., 320 .

1889.14

— The pike-perch. Tom. cit., 470. 1889.15

- Rainbow trout in France. Tom. cit., 218. 1889.16

'The red-spotted trout of New England. Shooting \& Fishing, 1889, 5, $6-7$.

1889.17

Report on the department of fishes in the U. S. National Museum, 1856. Rept. Smithson. Inst., 1889, 2 $167-172$.

1889.18

- Rubbish in the Thames. Forest \& Stream, 1889, 31, 520.

1889.19

Saibling and brown trout hybrid. Op. cit., 32, 401 .

1889.20

- Saibling in Sterling lake. Tom. cit., $10 ; 50$.

1889.21

- Salmon and trout of North America. 'Tom. cit., 219-222. 1889.22 - Sawdust in streams. T'om. cit., 91. 1889.23

- 'The silver eel. T'om. cit., 330. 1889.24

- Some recent papers by Charles Crirard. ()p. (il., 31, j1). 1589.25

- Sunapee trout from Dan's Hole pond. $O p$. cit., 32,390 .

1889.26

-. The Alaskan salmon and their allies. Trans. Amer. Fisheries Soc. 1890, 49-66.

1890.1

- The American Fisheries Society. Forest \& Stream, 1890, 35, 378. 1890.2

The basses and their allies. Tom. cit., 2-5. figs.

1890.3

The bluefish in his abundance. Tom. cit., 25. 1890.4 
Bluefish in Long Island waters.

Tom. cit., 205.

1890.5 cil., 152 .

The calico bass in Europe. Tom. cit., 128 .

The Cape Charles tiger. Tom.

- Description of a new cottoid fish collected by the U. S. Fish Commission (Synchirus n. g., gilli n. sp.) Proc. U. S. Nat. Mus, 1890, 12, 641-642.Ann. Mag. Nat. Hist., 1890, 6. ser. 6, 118-120.

1890.8

Destructive fishing. Forest \& Stream, 1890, 35, 125.

1890.9

25.

1890.10

Fish of Florida waters. Tom. cit., $487-494$.

1890.11 cit., 333.

The fresh-water drum. Tom. 1890.12 205.

Game fishes of Idaho. Tom. cit. 1890.13

— The golden trout. Tom. cit., 377. 1890.14

- Ice fishing in aretic Alaska. Tom. cit., 417 . 1890.15

- Mortality among black bass. Tom. cit., 105.

1890.16 cit., 145 .

The mudfish or lawyer. Tom. $34 \overline{102}$.

1890.17

1890.18

- New fishes collected off the coast of Alaska and the arjacent region southward. Proc. U. S. Nat. Mus., 1890, 13, $37-45$.

1890.19

_- New Hampshire fish-culture. Forest \& Stream, 1890, 35, 293. 1890.20

- Notes on fishes collected at Cozumel, Yucatan, by the U. S. Fish Commission, with descriptions of new species. Bull. U. S. Fish Comm. 1888 (1890), 8, 193-206. pl.

1890.21

- Notes on the brook trout. Forest \& Stream, 1890, 35, 292.

1890.22

Observations upon fishes of Great South bay, Long Island, N. Y. 19. Rept. Comm. Fish., Smithson. Inst. 1890, 237-281. 26 pls. 1890.23

Rearing sea fishes. Forest \& Stream, 1890, 35, 416 .
Report on the department of fishes in the U. S. National Museum, 1890. Rept. Smithson. Inst., 1890, 205209.

1890.25

Report on the proposed introduction of the Jamaica mountain mullet (Agonostoma monticola) into the United States. Bull. U. S. Fish Comm. 1888 (1890), 8, 443-451.

1890.26

Report on the salmon and salmon rivers of Alaska. Report to 51. Congress 1. sess. House of Rep. Misc. Doc. no. 211. Washington, 1890. 50 p. 34 pls. \& maps. $8^{\circ}$.

$1890.26 a$

- Return of Schoodic salmon. Forest \& Stream, 1890, 35, 113. 1890.27 cit., 369 1890.28

The salmon of Alaska. Op. cit. 34, 210-211; 231 . $\mathbf{1 8 9 0 . 2 9}$

Scientific results of explorations by the U. S. Fish Commission steamer "Albatross," no. 8. Description of a new cottoid fish from British Columbia. Proc. U.S. Nat. Mus., 1890,-12, 641-642. 1890.30

Scientific results of explorations by the U. S. Fish Commission steamer "Albatross," no. 11. New fishes collected off the coast of Alaska and the adjacent region southward. Proc. U.S. Nat. Mus., 1890, 13, 37-45. 1890.31

A supposed hybrid trout. Forest \& Stream, 1890, 35, 377. 1890.32 - Susquehanna river pollution. Tom.cit., 265.

1890.33

_- The tautog. Op. cil., 34, 271. 1890.34

35,378

The tench in Missouri. $O p$. cit. 1890.35

—_ Transfer of Illinois fishes. Tom. cit., 45 .

1890.36

- Voracity of the wall-eyed pike. Tom. cit., 112. 1890.37

- The weakfish. $0 p$. cit., 34, 312. 1890.38

- Winninish of the Metabetchouan. Op. cit., 35, 145; 171; $190 . \quad 1890.39$

- Work of the Fish Commission. Tom. cit., 252. 1890.40

A yearling landlocked salmon. Tom. cit., 274. 1890.41 
Bean, T. $H$.

Atlantic salmon in winter. Tom. cit., 489 .

1891.1

The bluefish. Op. cit., 36, 147. 1891.2

- The blue-striped trigger fish. Tom. cit., 24. 1891.3 305.

Carp in California. Op. cit., 37 ,

Connecticut fish culture. $O p$. cit., 36, 497 .

1891.5

The death of salmon after spawning. Amer. Naturalist, 1891, 25, 88.

1891.6

- Illinois fish culture. Forest \& Stream, 1891, 37, 502.

1891.7

- Jurisdiction over the lakes. Tom. cit., 445 . 1891.8

Kennerley's salmon. Tom. cit. 36, 498-499. - Trans. Amer. Fisheries Soc., $1891,41-46$.

1891.9

Landlocked salmon in Bisby lakes. Op. cit., 37, 21. $\quad 1891.10$

- Larval conger eel. Tom. cit. 352. 1891.11 - Maine fish culture. Op. cil., 36 498. 1891.12 Michigan fish culture. Tom. cit., 9.

- New Hampshire Fish Commission work. Tom, cit., 30. 1891.14

- New York Fish Commission. Tom. cit., 234.

1891.15

Pennsylvania Fish Commission. Tom. cit., 425.

1891.16

Report on the proposed introduction of the Jamaica mountain mullet into the United States. Bull. U. S. Fish Comm. 1888 (1891), 8, 443-451.

1891.17

- Report on the salmon and salmon rivers of Alaska, with notes on the conditions, methods, and needs of the salmon fisheries. Bull. U. S. Fish Comm. 1889 (1891), 9, 165-208. 42 pls. 1891.18

The status of fish culture. Forest \& Stream, 1891, 35, 469. 1891.19 36,1 .
Trout and salmon in Mexico. 1891.21

Op. cit., 37,353 .

sion ex-

1891.22

hibit. Tom. cit., 312

36,515 .

Whale, walrus and seal. Op. cit., 1891.23

Wisconsin fish culture. Tom. 1891.24

Wyoming fish culture.'Tom. cit. 1891.25

Yellowstone park fishes. $O p$. cit., 37, 392-393.

1891.26

- American Fisheries Society. $O p$. cit., 38, 524.

1892.1

Description of a new species of star-gazer (Cathetostoma albigutta) from the gulf of Mexico. Proc. U. S. Nat. Mus., 1892, 15, 121-122.

1892.2

- Effects of garbage on fish. Forest \& Stream, 1892, 38, 469. $\quad 1892.3$

- Fisheries at the World's Fair. Tom. cit., 493.

1892.4

- Fisheries on the Great Iakes. Tom. cit., 537.

1892.5

- Food for fishes. Tom. cit., 515. 1892.6

Massachusetts fisheries and game. Tom. cit., $200 . \quad 1892.7$

- The menhaden. Tom. cit., 221. 1892.8 cit., 559

A national salmon park. Tom. 1892.9

Notes on fishes collected in Mexico by Prof. Dugès, with descriptions of new species. Proc. U. S. Nat. Mus., $1892,15,283-287 . \mathrm{pl}$.

1892.10

Observation upon fishes and fish culture. Bull. U. S. Fish Comm. 1890 (1892), 10, 49-61.

1892.11

- Pennsylvania fish protective association. Forest \& Stream, 1892, 38, 317. 1892.12

- Piscatorial exhibition in I tondon. Tom. cit., 270.

1892.13 cil., 269

Protect the black bass. Tom. 1892.14

- Rearing fish for distribution. T'om. cit., 585.

1892.15

- Sale of reared trout in close time. Tom. cit., 537. 1892.16 
Salmon spawning without going to sea. Tom. cit., 270.

1892.17

Slaughter of birds and fishes, Tom. cit., 97 .

1892.18

Una nueva especie de lampera. Naturaleza, Mexico, 1892, 2. ser. 2, 171-172. pl.

1892.19

Description of a new blennioid fish from California (Plagiogrammus n. g., hopkinsi n. sp.) Proc. U.S. Nat. Mus., 1893, 16, 699-701. fig. 1893.1

The fishes of Pennsylvania, with descriptions of the species and notes on their common names, distribution, habits, ete. Harrisburg, 1893. $149 \mathrm{p}$. 35 pls. $8^{\circ}$.

1893.2

Bibliography of the salmon of Alaska and adjacent regions. Bull. U. S. Fish Comm. 1892 (1894), 12, 3949 .

1894.1

Description of a new species of fish, Bleekeria gilli. Proc. U. S. Nat. Mus., 1894, 17, 629-630.

1894.2

Description of a new species of rockfish (Sebastichthys brevispinis) from Alaska. Proc. U. S. Nat. Mus., 1894. $17,627-628$.

1894.3

Life history of the salmon. Bull. U. S. Fish Comm. 1892 (1894), 12, 2138. 1894.4

World's Fisheries Congress. Report of the secretary of the general committee. Bull. U. S. Fish Comm. 1893 (1894), 13, 1-14.

1894.5

The Pacific salmon (Oncorhynchus sp.), with notes on the habits of young. Trans. Acad. Sci. New York, $1896,15,182-188$.

1896.1

The rainbow trout. 1. Ann. Rept. Comm. Fish., Game \& Forests of N. Y. 1895 (1896), 135-140. 3 pls.

1896.2

(translator) New method of pond culture. [From the French of Jousset de Bellèsme] Trans. Amer. Fisheries Soc., 1896 (1897), 69-87.

1897.1

Notes upon New York fishes received at the New York Aquarium, 1895-97. Bull. Amer. Mus. Nat. Hist., 1897, 9, 327-375. - 2. Ann. Rept. Comm. Fish., Game \& Forests of N. Y. 1896 (1897), 207-251. 4 pls.

1897.2
Notes on Mexican fishes obtained by Dr. Carl Lumholtz. Bull. Amer. Mus. Nat. Hist., 1898, 10, 165168.

1898.1

Notes upon fishes received at the New York Aquarium, with description of a new species of snapper from Bermuda. Tom. cit., 45-50.

1898.2

Fishes of the south shore of Long Island. Science, 1899 , n. s. 9 , $52-55$.

1899.1

The identity of common and Labrador whitefish (Coregonus clupeiformis and labradoricus) Tom . cit., 416417.

1899.2

Catalogue of the fishes of Long Island, with notes upon their distribution, common names, habits, and rate of growth. 6. Ann. Rept. Forest, Fish \& Game Comm. of N. Y. 1900 (1901), 373-478. col. pls. \& figs. $\quad 1901.1$

'The food and game fishes of New York: notes on their common names, distribution, habits and mode of capture. 7. Ann. Rept. Forest, Fish \& Game Comm. of N. Y. 1901 (1902), 251-460. col. pls.

1902.1

Catalogue of the fishes of New York. Bull. N. Y. State Mus. no. 60. 56. Ann. Rept. N. Y. State Mus., 1903, 3, $784 \mathrm{p}$.

1903.1

- Report on the fishes of Great South bay, Long Island, collected in the summer of 1901. 55. Ann. Rept. N. Y. State Mus., 1903, r109-r128.

1903.2

- Description of fish. 8. \& 9. Ann. Repts. Forest, Fish \& Game Comm. of N. Y. 1902 \& 1903 (1904), 303-318. 8 col. pls.

1904.1

Catalogue of the fishes of New York. Rept. N. Y. State Mus., 19021904 (1905), 3. ser. 56, 3-787. 1905.1

- A catalogue of the fishes of Bermuda, with notes on a collection made in 1905 for the Field Museum. Field Columbian Mus., 1906, Pub. 108, Zool. ser., 2. ser. 7, 21-89. 14 figs.

1906.1

Descriptions of new Bermudian fishes (11 n. sp. in: Iridio 4, Labrisomus, Antennarius, Holocentrus, Cryptotomus, Eupomacentrus, Hippocampus, Monacanthus) Proc. Biol. Soc. Washington, 1906, 19, 29-34. 1906.2 
Bean, $T . H$.

Difficulties in fish culture. Ann.

Repts. Forest, Fish \& Game Comm. of

N. Y. 1901-1905-1906 (1907), 359-370.

1907.1

Report of the state fish culturist for the year 1906. Ibid., 177-231. pls.

1907.2

Some practical difficulties in the way of fish culture. Trans. Amer. Fisheries Soc., 1907, 36. meet., 184-192.

1907.3

Notes eye disease of young trout as a new bacterial disease, not to be confused with popeye, a parasitic disease. Also the gill louse so fatal to trout 2 or 3 years old.

Report of the state fish culturist. 13. Ann. Rept. Forest, Fish \& Game Comm. of N.Y., 1908, 1-63. 1908.1

Parasite (Filaria mibra Leidy) found in intestine of catfish in Hackensack river. Also occurs in eels and sunfish in that region.

- California salmon propagation. Forest \& Stream, 1910, 35, 399. 1910.1

Cooperative protection. Tom. cit., 1910, 35, 489 .

1910.2

- Georgia fish-culture. Tom. cit. $1910,35,354$.

1910.3

—- The golden trout. Tom. cit., 435.

1910.4

Is the golden trout a hybrid? Tom. cit., 429 .

1910.5

- Maine fish and game. Tom. cit., 449.

1910.6

Millions of shad. Tom. cit., 325.

1910.7 353.

A new hybrid trout. Tom. cit.,

Notes on New York fishes. 14. Ann. Rept. Forest, Fish \& Game Comm. of N. Y., 1910, 192-228. 1910.9

Notes on a larval worm (nematode?), in eruptions on the skin of the eel, others in the skin of black bass.

Pennsylvania fish-culture. Tom. cit., 398-399.

1910.10

A plea for the systematic study of fish diseases. Trans. Amer. Fisheries Soc. 1909 (1910), 39. meet., 65-73.

1910.11

Emphasizes the importance of the subject, and scanty knowledge to date. Gives bibliography with reviews of the most important papers.

Salmonidx planted in Yellowstone park. Tom. cit., $325 . \quad 1910.12$
- Small red salmon. Tom. cit. 1910.13

- Tropical fish as a food supply. Tom.cit., $399 . \quad 1910.14$

- An albino brook trout. Forest \& Stream, 1911, 36, 314. 1911.1

- Angling at the World's Fair. Tom. cit., 409.

1911.2

- Annual report of the fish culturist, state of New York, Conservation Commission. Bureau of Fish Culture. 1. Ann. Rept., 1911, 1-57. pls. - 2 . Ann. Rept., 1-56. pls.

1911.3

California fish culture. Forest \& Stream, 1911, 36, 274.

1911.4

Dead alewives in lake Ontario.

Tom. cit., 429.

1911.5

- Eastern fish in California. Tom. cit., 251 .

1911.6

Fish-culture in Alaska. Tom. cit., 41.

1911.7

Fish hatchery for lake Ontario. Tom. cit., 101.

1911.8

353 1911.9

—. The lemon sole. Tom. cit., 351.

1911.10

265.

A marine reservation. Tom. cit., 1911.11 347.

om. cit., - Massachusetts fish culture. Tom cit., 89 .

1911.13 - Nevada fish culture. Tom. cit., 211-212.

1911.14 cit., 153

New York fish culture. Tom. 1911.15

- Notes on black bass. Trans. Amer. Fisheries Soc. 1910 (1911), 40. meet., 123-128.

1911.16

Notes on the occurrence of various parasites in food fishes in New York hatcheries and aquaria. Records the occurrence of both nematode and trematodes in the eyes in cases examined. cit., 460 .

Ohio Fish Commission. Tom. 1911.17 The pike family. Tom. cit., 210 $233 ; 333$.

1911.18

- Salt-water fish wanted. Tom cit., 453.

1911.19 
cit., 271

Shedding teeth in salmon. Tom. - Stocking lake Ontario. Tom. cit., 165.

1911.21 cit., 173

Works of the Commission. T'om. 1911.22

Description of new fishes of Bermuda. Proc. Biol. Soc. Washington, 1912, 25, 121-126.

1912.1

Bean, T. H. \& Bean, Barton A. Description of Gobioides broussoneti, a fish new to North America, from the gulf of Mexico. Proc. U. S. Nat. Mus., 1894, 17, 631-632. fig.

1894.1

Notes on fishes collected in Kamchatka and Japan by Leonhard Stejneger and Nicholai A. Grebnitski, with a description of a new blenny. Proc. U.S. Nat. Mus., 1896, 19, 381-392. pls.

1896.1

Fishes collected at Bering and Copper islands by Nikolai A. Grebnitski and Leonhard Stejneger. Proc. U. S. Nat. Mus., 1897, 19, 237-251. (Contributions to the natural history of the Commander islands, no. 12) $\quad 1897.2$

- Description of a new blenny-like fish of the genus Opisthocentrus, collected in Vulcano bay, Port Mororan, Japan, by Nicholai A. Grebnitski. Proc. U.S. Nat. Mus., 1897, 20, 463-464. pl.

1897.1

Note on Oxycottus acuticeps (Gilbert) from Sitka and Kadiak, Alaska. Proc. U. S. Nat. Mus., 1898, 21, 655656.

1898.1

Bean, Tarleton $I$. \& Dresel, $H . G$. A catalogue of fishes received from the public museum of the Institute of Jamaica, with descriptions of Pristipoma approximans and Tylosurus euryops, two new species. Proc. U. S. Nat. Mus. 1885, 7, 151-170.

1885.1

Diagnoses of three new species of fishes from the gulf of Mexico. Proc. Biol. Soc. Washington, 1895, 2, 99-100.

1895.1

Bean, Tarleton H., \& Goode, G.B. See Goode \& Bean.

Bean, Tarleton H., \& Harris, William C. See Harris \& Bean.

Beard, Daniel $C$. The paddlefish of the Mississippi. Scient. Amer., 1878, 39,391 .
Beard, John. On the segmental sense organs of the lateral line, and on the morphology of the vertebrate auditory organ. Zool. Anz., 1884, 7, 123-126; 140-143.

1884.1

- On the cranial ganglia and segmental sense organs of fishes. Zool. Anz., 1885, 8, 220-223. 1885.1

\section{The system of branchial sense} organs and their associated ganglia in Ichthyopsida; a contribution to the ancestral history of vertebrates. Quart. Journ. Micr. Sci., 1885, 2. ser. 26, 95156. pls. viii-x. - Studies Biol. Lab. Owen's College, 1886, 1, 170-224. pls. vii-ix.

1885.2

- The parietal eyc in fishes. Nature, $1887,36,246-248 ; 340-341$. fig.

1887.1

The ciliary or motor-oculi ganglion and the ganglion of the ophthalmicus profundus in sharks. Anat. Anz. 1888, 2, 565-575. 7 figs. $\quad 1888.1$

- A contribution to the morphology and development of the nervous system of vertebrates. Anat. Anz., 1888, 3 874-884; 899-905. 1888.2

- The development of the peripheral nervous system in vertebrates; Elasmobranchii and Aves. Quart. Journ. Micr. Sci., 1888, 29, 153-227. pls. xvi-xxi. 1888.3

Also published separately with three other papers. Jena, 1889.

The old mouth and the new; a study in vertebrate morphology. Anat. Anz., 1888, 3, 15-24. - Nature, 37, 224-227. fig.

1888.4

The origin of the segmental duct in elasmobranchs. Anat. Anz., 1888, 2 , 646-652. Abstract in Amer. Naturalist, 1888, 21, 1037.

1888.5

The parietal eye of the cyclostome fishes. Quart. Journ. Micr. Sci., 1888, 29, 55-73. pls. vi-vii. - Nature, 36, nos. 924, 928 .

1888.6

The teeth of myxinoid fishes. Anat. Anz., 1888, 3, 169-172. - Nature, 37, 499 . 1888.7

The nature of the teeth of the marsipobranch fishes. Zool. Jahrb. (Morph. Abth.), 1889, 727-752. pls. xxxiv-xxxy.

1889.1

The nose and Jacobson's organ. Zool. Jahrb. (Anat. Abth.), 1889, 3, 753783. pls. xxvi-xxviii.

1889.2

Also published separately with three other papers, under the title of Morphological Studies. Jena, 1889. 
Beard, $J$.

On the early development of Lepidosteus osseus. Proc. Roy. Soc. London, 1859, 46, 108-118. Abstract in Journ. Roy. Micr. Soc. London, 1889, $622-626$.

1889.3

Some annelidan affinities in the ontogeny of the nervous system of vertebrates. Nature, 1889, 39, 259-261. fig.

1889.4

On the inter-relationships of the Ichthyopsida; a contribution to the morphology of vertebrates. Anat. Anz., $1890,5,146-159 ; 179-188$. $\quad 1890.1$

Prof. Rabl and the mode of development of the vertebrate peripheral nervous system. Anat. Anz., 1890, 5, 125-128.

1890.2

The histogenesis of ganglion-cells and nerves. Anat. Anz., 1892, 7, 290302 .

1892.1

The transient ganglion cells and their nerves in Raja batis. Anat. Anz., 1892, 7, 191-206. 8 figs.

1892.2

Hermaphroditism of lampreys. Journ. Roy. Micr. Soc. London, 1893, pt. 2,156 .

1893.1

- Notes on lampreys and hags. Rept. Brit. Assoc. Adv. Sci. 1892 (1893), 789-790. - Anat. Anz., 8, 59-60.

1893.2

The development and probable function of the thymus. Anat. Anz., $1895,9,476-486 ; 10,272$.

1895.1

- The pronephros of Lepidosteus osseus. Anat. Anz., 1895, 10, 198-201.

1895.2

The history of a transient nervous apparatus in certain Ichthyopsida. An account of the development and degeneration of ganglion-cells and nerve fibres. Zool. Jahrb., 1896, 9 (Morph. Abth.), 319-426. 8 pls.

1896.1

On certain problems of vertebrate embryology. Jena, 1896. $78 \mathrm{p.}$ $8^{\circ}$. Abstract in Journ. Roy. Micr. Soc. London, 1897, pt. 2, 109. - Nat. Sci., $1897,10,5-7$.

1896.2

On the disappearance of the transient nervous apparatus in the series: Scyllium, Acanthias, Mustelus and Torpedo. Anat. Anz., 1896, 12, 371-374. 1896.3

- Transient nervous system in skate. Journ. Roy. Micr. Soc. London, 1896, pt. 5, 496-197.
'The yolk-sac, yolk and merocytes, in Scyllium and Lepidosteus. Anat. Anz., 1596, 12, 334-347. Abstract in Journ. Roy. Micr. Soc. London, pt. 6, 603-604.

1896.5

- Alternation of generations in vertebrates] Nat. Sci., 1897, 10, 5-7.

1897.1

Abstract of the author's article: On certain problems of vertebrate embryology, 1896.

Further remarks on the phenomena of reproduction in animals and plants. Anat. Anz., 1897, 11, 634-641. 1897.2

The source of leucocytes and the true function of the thymus. Anat. Anz., 1900, 18, 550-560.

1900.1

The morphological continuity of the germ-cells in Raja batis. Veterinarian, 1901, 74, 300-318. - Anat. Anz., 18, 465-485. - Journ. Roy. Micr. Soc. London, 1901, 504-505.

1901.1

A thymus-element of the spiracle in Raia. Anat. Anz., 1900, 18, 359-363. figs. Abstract in Journ. Roy. Micr. Soc. London, 1901, pt. 1, 17.

1900.2

The determination of sex in animal development. Anat. Anz., 1902, 20, 556-561. - Zool. Jahrb., 16, 703764. 3 figs.

1902.1

The germ-cells of Pristiurus. Anat. Anz., 1902, 21, 50-61. $\quad 1902.2$

The germ cells. (1) Raja batis. Zool. Jahrb., 1902, 16, 615-702. 2 pls. \& 3 figs.

1902.3

Heredity and the epicycle of the germ-cells. Biol. Centralbl., 1902, 22, $321-328$; $353-360 ; 398-408$. 3 figs.

1902.4

The origin and histogenesis of the thymus in Raja batis. Zool. Jahrb., $1902,17,403-480$. 6 pls. \& 8 figs.

1902.5

The germ-cells. Journ. Anat. Phys. London, 1903-04, 38, 82-102; 205-232; 341-359. 2 pls. 1903.1

A morphological continuity of germ-cells as the basis of heredity and variation. Rev. Neurol. Psychiatry Edinburgh, 1904, 2, 1-34; 114-142; 185-217. 2 pls. \& 5 figs.

1904.1

Beardslee, Lester. The game and fish of Alaska. Forest \& Stream, 1879, 13, $723-724$. 1879.1 
Beardsley, A.E. The destruction of trout fry by Hydra. Bull. U. S. Fish Comm. 1902 (1904), 22, 157-160.

1904.1

Beattie, James $M$. On the anatomy of the red cod (Lotella bacchus) Trans. New Zeal. Inst., 1891, 23, 71-83. 4 pls. 1891.1

Beaufort, Lieven Ferdinand de. Over de communicatie tusschen gehoororgaan en zwemblass bij Clupeiden en verwanten. Tijdschr. Nederl. Dierk. Ver., 1908, 2. ser. 11, 3.

1908.1

Die Schwimmblase der Malacopterygier. Morphol Jahrb., 1908 (1909), 39, 526-644. pl \& 10 figs. Also separate; Leiden, 1908.132 p. pl.

1909.1

Over Stiphodon elegans. Tijdschr. Nederl. Dierk. Ver., 1911, 2. ser. 12, p. xxxv.

1911.2

Weitere Bestätigung einer zoogeographischen Prophezeiung. Zool. Anz., Leipzig, 1910, 36, 249-252. 1910.1

Lomargus microcephalus an onze kust gevangen. Tijdschr. Nederl. Dierk. Ver., 1911, 2. ser. 12, p. lxviii.

1911.1

On some new Gobiidx from Ceram and Waigen. Zool. Anz., 1912, 39, 136-143.

1912.1

Over de zoetwatervisschen van Timor en Babber. Versl. Wis-Nat. Afd. Akad. Wet. Amsterdam, 1912, 21, 133138 [English translation] Proc. Sect. Sci. Akad. Wet. Amsterlam, 1912, 15, 235-240.

1912.2

- Fishes of the eastern part of the Indo-Australian archipelago, with remarks on its zoogeography. Bijdr. Nederl. Dierk. Ver. Amsterdam, 1913, 95-163. pl. \& 8 figs.

1913.1

Beaufort, L. F. de, \& Weber, Max. See Weber \& Beaufort.

Beaujon, A. Overzidit der geschiedenis van de Nederlandsche zeevisscherijen. Leiden, $1885 . \mathrm{S}^{\circ}$.

1885.1

Beaumont, (Vicomte) E. H. de. Etudes théoriques et pratiques sur la pisciculture. Paris, 1869.311 p. $12^{\circ}$. 1869.1

Notice sur la carte ichthyologique des principaux cours d'eau et lacs de la France. 1879. $\mathrm{S}^{\circ}$. 1879.1
Beauregard, $H$. Examen ophthalmoscopique de l'oeil des poissons. Bull. Soc. Philom. Paris, 1875, 12, 79-81.

1875.1

- Recherches sur les réseaux vasculaires de la chambre postérieure de l'oeil des vertébrés. Ann. Sci. Nat., 1876, 4, 87-119. pl. 1876.1

Contribution à l'étude de Orthagoriscus truncatus (Flem.) Bull. Soc. Ouest France, 1893, 3, 229-246. pl.

1893.1

Encéphale et nerfs crâniens du Ceratodus [with remarks on the general theory of the vertebrate limb] Journ. Anat. Phys., 1881 (1883), 17, 230-242. pl.

1883.1

Beauregard, H., \& Pouchet, G. See Pouchet \& Beauregard.

Beaurieu, G.G. de. Cours d'histoire naturelle; ou, tableau de la nature considérée dans l'homme, les quadrupèdes, les oiseaux, les poissons et les insectes. 7 vols. Paris, 1770 . 46 pls. $12^{\circ}$.

1770.1

Beaux, O.de. Die Geisbrasse (Sargus vulgaris Geoffr.) Die Seebrasse oder Pagel (Pagellus erythrinus Cuv.) Die Goldbrasse (Chrysophrys aurata L.) Blitt. Aquar-Terrar. Kunde, 1910, 21. Jahrg., 1-4. fig.

1910.1

Beavan, Arthur $H$. Fishes I have known. London, 1905. 279 p. pls. \& figs. $12^{\circ}$. 1905.1 The same. 2. ed. London, 1908. $12^{\circ}$ 。 1908.1

Beavan, (Capt.) Reginald. Descriptions of two imperfectly known species of cyprinoid fishes from the Punjab, India. Proc. Zool. Soc. London, 1872, 150-153. fig.

1872.1

Handbook of the freshwater fishes of India. London, 1877. $247 \mathrm{p}$. 12 pls. $8^{\circ}$. 1877.1

List of the freshwater fishes of the Indian continent, p. 206-218.

Beccari, Nello. Ricerche sulle cellule e fibre del Mauthner e sulle loro connessioni in pesci ed anfibii (Salmo fario, S. irideus e Salamandrina perspicillata) Arch. Ital. Anat. Embr., 1908, 6, 660 705. 7 pls.

1908.1

Le cellule dorsali o posteriori dei Ciclostomi. Ricerche nel Petromyzon marinus. Monit. Zool. Ital., 1909, 20, 308-323. 2 pls. \& fig. 
Beccari, $N$. Sopra alcuni rapporti del fascicolo longitudinale posteriore con i nuclei di origine dei oculomotore e trocleare nei Teleostei. Monit. Zool. Ital., 1909, 20, 242-247. 2 figs.

1909.2

Bechstein, $J$ : $M$. Naturgeschichte der Stubenthiere, Säugethiere, Amphibien, Fische, Insekten und Würmer. Gotha, 1797. $8^{\circ}$. 1797.1

Beck, Goltlieb. Ueber die Haftscheibe der Echeneis remora. Inaug. Dissert. Schaffhausen, 1879. Also separate; Bern, 1879. Review in Verh. Schweiz. Naturf. Ges. Bern, 1878 (1879), 61, 139-141.

1879.1

Becker, E. E. Ceralodus forsteri; seine Verbreitung und Lebensweise [Text in Russian] Dnevn. Otd. Icht. Imp. R. Obšč. Acclimat., Moskva, 1901, $31,66-72$.

1901.1

Becker, Grace. Vom Aal. Natur \& Haus, 1903, 12, 67-69. 1903.1

Becker, H. Zur Iienntnis der ostsibirischen Jurafische. Mitth. Naturw. Ver. Neu-Vorpommern \& Rügen, 1895, 26, 173-180.

1895.1

Die Forellen-Brutanstalt des Herrn. Rud. Linke zu Tharandt (Kgr. Sachsen) Deutsch. Landw. Presse, Berlin, 1901, 28, 475.

1901.1

Becker, $K$. Weitere Beobachtungen bei dem Halten der Groppe (Cottus gobio) im Zimmeraquarium. Wochenschr. Aquar.-Terrar. Kunde, 1909, 6. Jahrg., 111-112. fig.

1909.1

Becker, Ludwig. On a Syngnathus from Hobson's bay. Trans. Philos. Inst. Victoria, 1857, 1, 14. pl. 1857.1

- On a viviparous fish, from Hobson's bay. Trans. Philos. Inst. Victoria, 1857, 1, 11-13. pl. 1857.2

Beckford, Frank $J . B$. On the fish of Dorset: their habits, mode of capture, etc. Proc. Dorset Nat. Hist. Antiq. Field Club, 1897, 18, 1-43. 1897.1

Beckley, (Mrs.) Emma Metcalf. Hawaiian fisheries and methods of fishing. Honolulu, 1883. 21 p. $8^{\circ}$. 1883.1

Beckmann, Joseph. Sur le tic des poissons. Hannov. Mag., 1769. 1769.1

Beckwith, Cora $J$. 'The early history of the lateral line and auditory anlages of
Amia. Science, 1902, 15, 575. Abstract in 3. Rept. Mich. Acad. Sci., 1902, p. 82. 1902.1

The early development of the lateral line system of Amia calva. Biol. Bull. Woods Hole, 1907, 14, 23-28. 12 figs.

1907.1

Becquerel, Antoine César. Rapport sur des expériences faites sur la torpille. C. R. Acad. Sci. Paris, 1837, 5, 788.

1837.1

Rapport sur un mémoire de $\mathbf{M}$. Armand Moreau ayant pour titre: Recherches sur la nature de la source électrique de la torpille. C. R. Acad. Sci. Paris, 1862, 54, 963-966.

1862.1

- Réponse à une note adressée par M. Matteucci à l'académie, dans la séance du 26 mai. C. R. Acad. Sci. Paris, 1862, 54, 1137-1139. 1862.2

Becquerel, Antoine César, \& Breschet, Gilbert. See Breschet \& Becquerel.

Beddard, Frant Evers. Note on the ovarian ovum in the Dipnoi. Zool. Anz., 1886 (1887), 9, 635-637. - Journ. Roy. Micr. Soc. London, 1887, pt. 1, 44.

1887.1

Observations on the development and structure of the ovum in the Dipnoi. Proc. Zool. Soc. London, 1886 (1887), 4, 505-527. 3 pls. 1887.2

\section{- Observations on the ovarian} ovum of Lepidosiren (Protopterus) Proc. Zool. Soc. London, 1886 (1887), pt. 3, 272-292. pls. - Zool. Anz., 1886, 9, 373-375.

1887.3

Bede, Cuthbert, pseudonym for Bradley, (Rev.) Edward, writer on angling.

Bedford, $F$. P. Notes on the occurrence of Amphioxus at Singapore. Nature, 1900, 61, 444-445. fig. 1900.1

Bedot, $M$. Sur la faune de l'Archipel Malais. Résumé in Rev. Suisse Zool., Genève, 1909, 17, 143-169. 1909.1

Bedriago, Jacques van. Der Chinesische Fisch Macropodus venustus $[\mathrm{PO}$ lyacanthus viridi-auratus1 Zool. Garten, $1874,15,93-97$.

1874.1

Beebe, C. W. Fish; how they got their names. Outing, 1905, 46, 618.

1905.1

Beecher, Charles Emerson. 'The origin and significance of spines. Amer. 
Journ. Sci., 1898, 4. ser. 6, 1-20; 125136 ; 249-268; 329-359. pl. \& 73 figs. 1898.1

Beechey, F.W. Zoology of Beechey's voyage to the Pacific and Behring straits. (Mammals, birds, reptiles and fishes by Lay and Bennett, Mollusea, etc.) London, 1839. $47 \mathrm{pls}$.

1839.1

Results of deep dredging off the mull of Galloway. Ann. Mag. Nat. Hist., 1S42, 10, 21-25.

1842.1

Beede, J. W., \& Rogers, Austin $F$. Coal Measures faunal studies, IV. Upper Coal Measures, Neosho river section. Kansas Univ. Sci. Bull., 1906, 3, 377-388

1906.1

Beeman, Henry $W$. On the propagation of black bass. 'T'rans. Amer. Fisheries Soc. 1906 (1907), 182, 1907.1

Beer, Theodor. Die Accomodation des Fischauges. Arch. Physiol., Bonn, 1894, 58, 523-650. pl. \& 35 figs. Deutsch Naturf. Verh., 1894, 369.

1894.1

Der gegenwartige Stand unserer Kenntniss über das Hören der Tiere. Klin. Wochenschr., Wien, 1896, 40.

1896.1

Die Accomodation des Auges in der Thierreihe. Klin. Wochenschr., Wien, 1898, 42. - Journ. Phys., 189899, 23, 29-30. - Nature, 1898, 58, 483.

1898.1

Ueber primitive Sehorgane. Klin. Wochenschr., Wien, 1901, 45, nos. 11-13, 1-73. 30 figs.

1901.1

Beerbohm-Feilenhof, Die

Fischerei des kurischen Haffs und der Nebengewässer desselben sowie der anliegenden Theile der Ostsee. Circul. Deutsch. Fischerei Ver., 1872, 196-208.

1872.1

Beeson, C.H., \& Eigenmann, Carl II. See Eigenmann \& Beeson.

Beguis, J.M.F. Essai sur l'histoire naturelle des vertébrés de la Provence, poissons et batraciens. Marseille, 1882. 430 p. $8^{\circ}$.

1882.1

Behning, A.L. Ueber die Nahrung des Sterlets [Russian with German résumé] Arb. Biol. Wolga-Stat., Saratov, 1912,4 , pt. $1,57-71 ; 73-74 ; 75-$ 93. pls.

1912.1

Bericht über die Tätigkeit der biologischen Wolga-Station während des Sommers 1912 [Russian with German résumé] Arb. Biol. Wolga-Stat., Saratov, 1913, 4, no. 2, 1-82. 1913.1

Behr, A. Ueber das Wandern der Augen bei den Pleuronektiden. Korresp. Naturf. Ver. Riga, 1899, 42, 174175. 1899.1

Behr, S. von. Fischzucht. Deutsch. Landw. Presse, 1875, 2, 552. 1875.1

_- Vortrag im Deutschen FischereiVerein über künstliche Fischzucht. Deutsch. Landw. Presse, 1877, 4, 242.

1877.1

Amerikanische Lesefriichte. Circul. Deutsch. Fischerei Ver., 1878, no. 3, 77

1878.1

Dr. H. A. Meyers Aufbewahrung von Eiern. Circul. Deutsch. Fischerei Ver., 1878 (1879), 69-70. 1879.1

Erbriatung von Maifisch-Eiern betreffend. Circul. Deutsch. Fischerei Ver., 1878 (1879), 68-69.

1879.2

Ueber Fischzuchtbestrebungen in den Vereinigten Staaten von Nordamerika und in Deutschland. Circul. Deutsch. Fischerei Ver., 1877 (1879), $42-54$.

1879.3

Neue Einführung amerikanischer Fische. Circul. Deutsch. Fischerei Ver., 1879 (1880), 24-25. 1880.1

Treatment of fish eggs at seá. Bull. U. S. Fish Comm. 1881 (1882), 1, $346-347$.

1882.1

-..- Five American Salmonidx in Germany, Bull. U. S. Fish. Comm. 1882 (1883), 2, 237-246. 1883.1

Management of spawning carp. Bull. U. S. Fish Comm. 1883, 3, 392.

1883.2

[Fang der Wanderfische, besonders der Lachse in Holland betreffend Berlin [n. d.

Reprint from Deutsch. Landw. FischereiVerein.

Behrens, $G$. Die Hybridisation von Salmoniden. Biol. Centralbl., 1885-86, 5, 639-640.

1885.1

-.-Untersuchungen über die Hornzähne von Myxine glutinosa. Zool. Anz., 1891, 14, 83-87. 1891.1

Die Reifung und Befruchtung des Forelleneies. Anat. Hefte, 1898, 10, 2. Abth., 227-285. 6 pls. Abstract in Zool. Centralbl., 1898, 6, 489-490.

1898.1 
Beigel, Cecylia. Zur Regeneration des Kiemendeckels und der Flossen der Teleostier Text in Russian] Bull. Intern. Acad. Sci. Cracovie, 1910, ser. B math.-nat. Cl., 655-690. 2 pls. \& fig. 1910.1

Zur Regeneration der Haut bei den Teleostiern [Text in Russian] Księga Pamiątkowa Uczezeniu, Lwów, 1911, 235-247. pl.

1911.1

Regeneration der Barteln bei Siluroiden. Arch. Entw. Mech., 1912, 34, 363-370. pl.

1912.1

Bélanger, $C$. Voyage aux IndesOrientales, 1825-29. Zoologie. 'Text and atlas. Paris, 1834. $8^{\circ}$.

1834.1

Atlas with 40 colored plates of mammals, birds, fishes, etc.

Belcher, $E$. The last of the arctic voyages in search of Sir J. Franklin. With natural history by Richardson [Fishes], Owen, Bell, Salter and Reeve. 2 vols. London, 1855. 40 pls. \& maps. $8^{\circ}$

1855.1

Belcher, R. N. Account of a collection of fishes from the Atlantic coast of north Africa. Proc. Zool. Soc. London, $1830-31,145$.

1830.1

Beling, Theodor. Der Fischreiher und die Sternschnuppen. Zool. Garten, Frankfurt, 1872, 13, 141-148. $\quad 1872.1$

Bell, Alwin S. Sun fish at Abbotsbury. 'Loologist, 1870, 2. ser, 5, 2260.

1870.1

- Sun fish [Orthagoriscus mola] on the Dorsetshire coast. '/oologist, 1870, 2. ser. 5, 2260.

1870.2

'Thrasher [Alopecias mulpes] in the West bay, Portland. Zoologist, 1870 , 2 ser. 5, 2348.

1870.3

Bell, Charles. On the fecundation of fish. Trans. Amer. Fisheries Soc. 1873 (1874), 15-17.

1874.1

Bell, $F$. $J$. The eye-like spots in fishes. Pop. Sci. Rev., 1881, 20, 221 234.

1881.1

Note on some parasites of fishes from Madras determined by Dr. Örley. Ann. Mag. Nat. Hist., 1884, 5. ser. 13, 173-175.

1884.1

Bell, Hugh. Observations on the Scotch herring fishery. [n. p.] 1774.

1774.1
- Observations upon the Scoteh fisheries. Edinburgh, 1792. $12^{\circ}$.

1792.1

Bell, J.C. Are sounds made in the air audible in the water? Journ. Comp. Neurol. Psychol., 1904, 14, 80-81.

$190+.1$

Bell, R. Shark's teeth from local Cretaceous formations. Rept. Belfast Club, 1905, 2, pt. 5, 330-331. . 1905.1

Bell, Robert. Merkillinen kala. Suomen Kialastus Lehti, 1899, 8, 92-93. Fiskeritidskr. Finland, 1899, 8, 93-94.

1899.1

Bell, William. Deseription of a species of Chxtodon, called by the Malays "Ecan bonna." Phil. Trans. Roy. Soc London, 1793, 83, 7-9. 2 pls. 1793.1

Bellamy, J.C. Housekeeper's guide to the fish market for each month of the year, and an account of the fishes and fisheries of Devon and Cornwall in respect of commerce, economy, natural history, and statistics. Plymouth \& London, 1843. 144 p. $18^{\circ}$. 1843.1

Description of two greenstreaked wrasses (Labrus lineatus Flem.) Ann. Mag. Nat. Hist., 1845, 13, 77.

1845.1

Belle, - Briefliche Mitteilung. Blätt. Aquar-'Terrar. Kunde, 1910, 21 , $797-798$ 1910.1

- Elternsorge bei den Fischen. Blätt. Aquar-'Terrar. Kunde, 1910, 21 Jahrg., 813-81t.

1910.2

Bellemo, Eugenio. I nostri pescatori dentro e fuori d' Italia. Padova, 1906. $\mathrm{S}^{\circ}$ 1906.1

Bellesme, Jousset de. American catfish in the Trocadéro Aquarium of Paris. Bull. U. S. Fish Comm. 1886, 6, 257.

1886.1

Bellet, 1. La grande pêche de la morne à 'Terre Neuve. Paris, 1902. $8^{\circ}$. 1902.1

Bellin, $N$. Déscription géographique de la Guyane. Contenant... le climat, les productions de la terre et les animaux, leurs habitans, leurs mocurs, leurs coutumes, et le commerce qu'on y peut faire. [Paris] 1762. 294 p. maps, etc.

1762.1

Belling, D.E. Der Bau der vorderen paarigen Extremitaten und des Schulterguirtels der 'I'rigla im Zusammenhang 
mit dem Bau entsprechender Organe bei anderen Teleostei. Bull. Soc. Imp. Nat. Moscou, 1911 (1912), 25, pts. 1-3, 4692. pls. ii-iii.

1911.1

Bellingham, O'Bryen. Description of a specimen of the Orthagoriscus mola (sun fish), caught off the Irish coast in June, 1839. Nag. Nat. Hist., 1840, 4 , 235-241.

1840.1

Bellini, Arturo. Il lavoriedo da pesea nella laguna di Comacchio. Venezia, 1899. pl. $S^{\circ}$.

1899.1

Die natürliche Productivität des Aalfanges in den "Valli di Comacchio." Allgem. Fischerei Zeitg., 1899, 24, 90-95. pl.

1899.2

- Die Wanderungen der Aale. Vortrag ... Deutsch. Fischerei Zeitg., Stettin, 1901, 24, 565-567; 609-610; 621-622.

1901.1

Expériences sur l'élevage de l'anguille en stabulation à Comacchio. Bull. Soc. Centr. Aquicult., Paris, 1907, $19,81-93 ; 141-146 ; 186-196 ; 215-224$.

1907.1

-_Esperienze di anguilli-cultura. Milano, 1907. $8^{\circ}$.

1907.2

Riproduzione e metamorfosi dell' anguilla nell' oceano Atlantico. Rivista Mens. Pesca, Milano, 1908, 10. $5-17$.

1908.1

- Aalzucht-Versuche. Zeitschr. Fischerei, Berlin, 1911, 15, 136-181.

1911.1

Bello y Espinosa, Domingo. Zoologische Notizen aus Puerto Rico. Zool. Garten, 1871, 12, 348-351. 1871.1

L'aquiculture dans le sud-ouest de la France. Revue Travaux Scient., Paris, 1896. Also separate; Paris, 1896. $8^{\circ}$.

1896.1

Belloc, Emile. Noms scientifiques et vulgaires des principaux poissons et crustacés d'eau douce, suivis d'un index bibliographique. Paris, 1899. 199 p.

$$
\text { Index bibliographique, p. 158-180. }
$$

1899.1

Observations sur une variété de Tinca vulgaris. C. R. Assoc. Franç. Avanc. Sci., 1901, 30, pt. 1, 143. 1901.1

Circulation des poissons nigrateurs. La Nature, 1903, 31, 197-199. fig.
Faune et flore des lacs pyrénéens, considérées au point de vue de l'influence du milieu. C. R. Assoc. Franç. Avane. Sci., 1911, 39, pt. 2, 232-235. 1911.1

Bellonci, Giuseppe. Ricerche intorno all' intima tessitura del cervello dei 'Teleostei. Atti Accad. Rom. Mem. Sci. Fis., 1879, 3, 258-270. - Atti Accad. Lincei, $1879, \mathbf{3}, \mathbf{1 8 3 - 1 8 4 .} \quad \mathbf{1 8 7 9 . 1}$

- Sulla struttura del cervello dei pesci. Rend. Accad. Istit. Bologna, 1879, 97-100.

1879.2

- Struttura di centri nervosi dei vertebri. Roma, 1880. $4^{\circ}$. 1880.1

Ueber den Ursprung des Nervus opticus und den feineren Bau der Tectum opticum der Knochenfische. Zeitschr. Wiss. Zool., 1880, 35, 23-29. pls. i-ii.

1880.2

Intorno al tetto ottico dei Teleostei; risposta ad una nota del Prof. Fritsch. Zool. Anz., 1882, 5, 480-483.

1882.1

Intorno alla struttura e alle connessioni dei lobi olfatorii negli artropodi superiori e nei vertebrati. Atti $R$. Accad. Lincei, 1S81-82, 13, 555-564. pls. i-ii. - Arch. Ital. Biol. 1883, 3, 191-196

1882.2

Blastoforo e linea primitiva dei vertebrati. Roma, 1884. 4 ${ }^{\circ}$ 1884.1

Sulla regione ottica dei pesci e degli anfibi. Rend. Accad. Istit. Bologna, 1881-82 (1883), 24-26. 1883.1

Intorno all' apparato olfattoriottico (nuclei rotondi Fritsch) del cervello dei Teleostei. Atti R. Accad. Linn. Mem. Sci. Fis., 1887, 1, 318-323. Also separate; Rome, 1885. pl. $4^{\circ}$.

1887.1

Ueber die centrale Endigung des Nervus opticus bei den Vertebraten. Zeitschr. Wiss. Zool., 1888, 47, 1-46. pls. i-viii \& 4 figs.

1888.1

Teleostei, p. 13-16.

Bellotti, Cristoforo. Sopra due specie di pesci raccolte in Egitto durante l'inverno del 1873-74 [A pogon pharaonis; Haliophis guttatus! Atti Soc. Ital. Sei. Nat., 1874 (fasc. 3), 17, 263-265.

1874.1

Note ittiologiche. Atti Soc. Ital. Sci. Nat., 1878, 20, 53-60. 1878.1

Note ittiologiche. Osservazioni fatte sulla collezione ittiologica del civico 
Bellotti, $C$.

Museo di Storia Naturale in Milano. Atti Soc. Ital. Sci. Nat., 1879, 22, 33-38. 1879.1

Di una notevole varieti di colorazione della tinca comune. Atti Soc. Ital. Sci. Nat., Mus. Civ. Milano, 1906 , 44, 218-220. pl. - Rivista Mens. Pesca, Milano, 1906, 8, 12-13. pl.

1906.1

- Note ittiologiche. Atti Soc. Ital. Sci. Nat., 1890, 31, 213-229. pl. 1890.1

Appunti all' opera del Dottor Emilio Moreau: "Histoire naturelle des poissons de la France," e al relativo supplemento. Atti Soc. Ital. Sci. Nat., 1891, 33, 107-144. pl.

1891.1

Note al manuale d' ittiologia francese del Dott. Emilio Moreau. Atti Soc. Ital. Sci. Nat., 1892, 34, 19-35.

1892.1

Un nuova siluroide giapponese (Neobagrus fuscus, n. g. \& n. sp.) Atti Soc. Ital. Sei. Nat., 1892, 99-101. 2 figs. 1892.2

Di un nuovo Pteraclide giapponese [Pteraclis macropus] Atti Soc. Ital. Sci. Nat., Mus. Civ. Stor. Nat. Milano, 1903, 62, pt. 2, 136-139. pl. 1903.1

Sopra una forma ibrida di ciprinide esistente nei laghi di Varano e Monate. Atti Soc. Ital. Sci. Nat., Mus. Civ. Milano, 1904, 43, 1-6. pl.-Aquicoltura Lombarda, Milano, 1904, 6, 69-75. pl.

1904.1

Bellotti, Cristoforo, \& Panceri, $P$ Rettificazioni alle specie finora note di Ciprinodonti europei. Letta alla Aceademia reale delle Scienze ed inscrita nella Gazzetta Piemontese del 1856. no. 280 .

1856.1

Bellotti, Cristoforo, Ronchetti-Monteviti, $G_{\text {., }}$ \& Mazzarelli, $G$. Relazione intorno alla colonizzazione del persicosole (Pomotis auritus) nei laghi lombardi. Aquicoltura Lombarda, Milano, $1905,7,59-62$.

1905.1

Belogolowy, $G$. Studien zur Morphologic des Nervensystems der IVirbeltiere. I. Die Entwickelung des Nervus terminalis bei Selachiern. II. Die Morphologie des Plexus ophthalmicus des 'l'rigeminus bei Ichthyopsida, besonders bei Amia calca und Lepidosteus osseus. Bull. Soc. Natural. Moscou, 1912, 25, 1-34. pl. \& 3 figs.

1912.1
Belousov, N. Appareil pour contenir les poissons. Trav. Soc. Nat., Charikov, 1906, 41, 47-50. pl. 1906.1

- La structure intime de la membrane operculaire et des terminaisons nerveuses dans les muscles striés des poissons. Trav. Soc. Nat., Charikov, 1909, 42, 96-108. pl.

1909.1

Belt, $A$. On the occurrence of Raia undulata Lacép. on the Sussex coast. Hastings and E. Sussex Naturalist, $1912,8 a-8 b$.

1912.1

Beltrémieux, Edouard. Faune du département de la Charente-Inférieure. Ann. Acad. La Rochelle, 1864. Also separate; La Rochelle, 1864. 2. ed. 1884.

1864.1

Bemmelen, A.A.van. Bijdrage tot de kennis onzer inlandsche diernamen, en lijst van visschen in Nederland waargenomen. Herklots, Bouwstoffen Fauna van Nederland. Leiden, 1866, 2, 137 $141 ; 3,318(418)-413(513)$. $\quad 1866.1$

_ Lijst van visschen in Nederland. Leiden, 1866. $8^{\circ}$.

1866.2

Bemmelen, J.F. van. Ueber vermuthliche rudimentäre Kiemenspalten bei Elasmobranchiern. Mith. Zool. Stat. Neapel, 1886, 6, 165-184. pls.

1886.1

Bẻnardeau, $F$. Pêche et reproduction du saumon en Loire. Paris, 1905. 52 p. $4^{\circ}$.

1905.1

Benda, Carl. Die Dentinbildung in den Hautzähnen der Selachier. Arch. Micr. Anat., 1881, 20, 246-270. pl.Sitzber. Nat. Ges. Halle, 1881, 38-40.

1881.1

Bender, $O$. Nochmals die Homologie der Paukenhöhlen [Erwiderung auf die Arbeiten von H. Fuchs] Anat. Anz., 1910, 37, 120-128.

1910.1

Bendire, (Major) Charles Emil [1836-1897] Red trout, or redfish of Oregon and Idaho. Forest \& Stream, $1878,10,156$.

1878.1

- The redfish [Hypsifario (Salmo) liennerlyi] of Idaho. Forest \& Stream, $1879,13,806$. fig.

1879.1

The redfish [Salmo kennerlyi] of the Northwest. Forest \& Stream, 1879, 13, 744 .

1879.2

Notes on Salmonidse of the upper Columbia. Proc. U. S. Nat. Mus., 1882, 4, 81-87. - Smithson. Misc. Coll. $1882,22,81-87$. fig.

1882.1 
Bendixen, $B . E$. Efterretninger om Nordmor og Kristiansund. Skolens Indydelsesskrift for 1868. Irristiansund. II. Ibid., 1870.

1868.1

Benecke,Berthold. For biography see Humboldt, 1886, 5, 240.- Schrift. Phys.-ökon. Ges. Königsberg, 1887, 27 (Sitzber.) 17-18.

- Beiträge zur Geschichte der Fischere in Ost- und Westpreussen. Altpreuss. Monatsschr., 1880, 17, $300-$ $332 ; 385-416$.

1880.1

Die Fischerei in Ost- und Westpreussen. I. Deutsche Fischerei Zeitg., $1880,93-95 ; 101-103 ; 121-122 ; 131-$ $132 ; 241-242 ; 305-307 ; 329-332 ; 354-$ $355 ; 379-380 ; 395-396 ; 422-424 ; 458-$ $459 ; 476-477$.

1880.2

- Die Metamorphose von Petromyzon. 2. ed. Leipzig, 1880. $8^{\circ}$.

1880.3

Ueber ostpreussische FischereiVerhäItnisse. Deutsch. Fischerei Zeitg., $1880,85-86$.

1880.4

- Von der Fischerei in Ost- und Westpreussen. Berichte des Fischerei Ver. Prov. Ost-u. Westpreuss., 1880-81, no. $1,4-8$; no. $2,14-16$.

1880.5

- Zur "Gewohnheit der Lauffische." Deutsch. Fischerei Zeitg., 1880, 279.

1880.6

Z Zur Metamorphose des Flussneunauges [Petromyzon fluviatilis] Zool. Anz., 1880, 3, 329-330.

1880.7

Fische, Fischerei und Fischzucht in Ost- und Westpreussen, auf Grund eigener Anschauung gemeinfasslich dargestellt. Königsberg, 1881. 514 p. 11 pls. \& 493 figs. $4^{\circ}$.

1881.1

Die Schuppen unserer Fische. Schrift. Phys.ölion. Ges. Íönigsberg, 1881, 22, 112-117. 4 pls. Also separate; Königsberg, 1882. $4^{\circ}$.

1882.1

Ein neuer Cyprinoidenbastard (Scurdinopsis alburniformis) Zool. Anz., 1854, 7, 228-230.

1884.1

- Beobachtungen über den Aufsteig des Lachses in den Flüissen. Circul. Deutsch. Fisch. Ver., 1886. 1886.1 This is translated as follows:

Observations on salmon in German rivers. Bull. U. S. Fish Comm. $1886,6,119-122$.
The enemies of pond culture in central Europe. Bull. U. S. Fish Comm. $1886,6,337-342$.

1886.3

The results of the London Fisheries Exhibition in their practical value for Germany. Rept. U. S. Fish Comm. 1884 (1886), 12, 1185-1186. 1886.4

Die 'Teichwirthschaft; praktische Anleitung zur Anlage von T'eichen und deren Nutzung durch Fisch- und Krebszucht. Berlin, 1886. 126 p. 80 figs. $8^{\circ}$.

1886.5

Die Westpreussischen Fische. (Im Auftrage des Westpreussischen Fischereivereins aus seinem Werke "Fische, Fischerei und Fischzucht in Ost- und Westpreussen" zusammengestellt) Danzig, 1887. 1887.1

— Om vattnets nyttiggörande genom fiskodling. Helsingfors, 1887. 55 p.

1887.2

- Die Teichwirtschaft. 2. ed., Berlin, 1889. 3. ed., Berlin, 1894. 4. ed., Berlin, 1902.

1889.1

Giftige einheimische Fische. Allgem. Fischerei Zeitg., 1895, 20. Jahrg., 381-382.

1895.1

Benecke, Berthold, Borne, Max von dem, \& Dallmer, Eugen. See Borne, Benecke \& Dallmer.

Benecke, Berthold, \& Kupfier, Carl von. See Kupffer \& Benecke.

Beneden, Edouard van. Contribution à l'histoire du développement embryonnaire des téléostéens. Bull. Acad. Sci. Bruxelles, 1877, 2. ser. 44, 742-770. - Quart. Journ. Micr. Sci., 1878, 18, pp. 41-57. pl. 1877.1

- Additions à la faune ichthyologique des côtes de Belgique. Bull. Acad. Sci. Bruxelles, 1883, 5, 404-420. Also separate; Bruxelles, 1883. 1883.1

Les tuniciers sont-ils des poissons dégénérés? quelques mots de réponse à Dohrn. Zool. Anz., 1887, 10, 407-413; $433-436$.

1887.1

[Raia batis] Bull. Acad. Roy. Belgique, 1894, 3. sér. 27, 872. 1894.1

Beneden, Pierre J.van. Sur le siège du goût dans la carpe. L'Institut, 1835, 3, 180-181. - Bull. Acad. Sci. Bruxelles, $1835,2,103-107$.

1835.1

- Sur un crustacé parasite nouveau, avec l'énumération des espèces de 
Beneden, $P . J . v$. cette classe qu'on observe sur les poissons du littoral de Belgique. Bull. Acad. Sci. Bruxelles, 1851, 18, 286-290. - Rev. Mag. Zool., 1851, 415. 1851.1

_- Sur quelques parasites d'un poisson rare sur nos côtes (le maigre d'Europe, Sciana aquila Cuv.) Bull. Acad. Sci. Bruxelles, 1852, 19, 98-109. 1852.1

- Sur Sciona aquila et Scymnus glacialis. Bruxelles, 1852-53. 3 pls. $4^{\circ}$.

1852.2

Développement de la queue des plagiostomes. Bruxelles, 1853-61. 3 pls. $S^{\circ}$.

1853.1

- Espèce nouvelle du genre Onchocotyle, vivant sur les branchies du Scymnus glacialis. Bull. Acad. Sci. Bruxelles, 1853, 20, 58-68. pl. 1853.2

Note sur la symmétrie des poissons Pleuronectes dans leur jeune âge. Bull. Acad. Belgique, 1853, 20, 205-210. - L'Institut, 1853, 22, 86-87.- Ann. Sci. Nat., 3. sér. (Zool.), 1853, 20, 340342.

1853.3

- Sur un poisson rare de nos côtes (Scymnus glacialis) et ses parasites. Bull. Acad. Sci. Bruxelles, 1853, 20, 258263. - Ann. Nat. Hist., 1854, 2. ser. 13 236-237.

1853.4

Sur les vers parasites du poissonlune (Orthagoriscus mola) et le Cecrops latreillii, qui vit sur ses branchies. Bull. Acad. Sci. Bruxelles, 1855, 22, 520-527. pl.

1855.1

Un nouveau poisson du littoral de Belgique (Petromyzon omalii) Bull. Acad. Sci. Bruxelles, 1857, 2. sér. 2, 549-554. - L'Institut, 1857, 25, 309. pl.

1857.1

Sur un Lernanthrope nouveau [Lernanthropus petersi] du Serranus goliath. Bull. Acad. Sci. Bruxelles, 1857, 1, 51-63. pl.

1857.2

- Sur un nouveau Dinémoure $[D$. elongata] provenant du Scymnus glacialis. Bull. Acad. Sci. Bruxelles, 1857, 1, 226-235. pl.

1857.3

Sur le développement de la queue des poissons plagiostomes. Bull. Acad. Roy. Belgique, 1861, 2. sér. 11, 287-293. pl. - Ann. Sci. Nat., 1861, 4. sér. 15 (Zool.), 124-128.

1861.1

_- Sur quelques poissons rares des côtes de Belgique. Bull. Acad. Sci. Bruxelles, 1865, 20, 45-53. 1865.1
Etude scientifique de l'exposition des produits et des engins de pêche de Bergen, rapport officiel. Bruxelles, 1866.

1866.1

Rapport de M. Beneden, chargé d'étudier sous le rapport scientifique, l'exposition des produits et des engins de pêche à Bergen. Bruxelles, 1866. 12 p. 1866.2

Le commensalisme dans le règne animal. Bull. Acad. Belgique, 1869, 28, $621-648$.

1869.1

Un Palrdaphus nouveau du terrain Dévonien $[P$. devoniensis] Bull. Acad. Sci. Bruxelles, 1869, 2. sér. 27, 378-385. pl.

1869.2

Les Echeneis et les Naucrates dans leurs rapports avec les poissons qu'ils hantent. Bull. Acad. Roy. Sci. Belgique, 1870, 2. sér. 30, 181-185.

1870.1

Recherches sur quelques poissons fossiles de Belgique. Bruxelles, 1870. 4 pls. $8^{\circ}$ - Bull. Acad. Roy Belgique, 1871, 2. sér. 31, 153-179

1870.2

Les poissons des côtes de $\mathrm{Bel}$ gique, leurs parasites et leurs commensaux. Mém. Acad. Sci. Bruxelles, 1870 (1871), 38

1871.1

Notice sur un nouveau poisson du terrain Laekenien [Dentex laekeniensis] Bull. Acad. Roy. Sci. Belgique, 1872, 2. sér. 34, 420-423. pl.-Journ. Zool. (Gervais), 1873, 2, 122-125. fig. 1872.1

Poissons de nos côtes. Abstract in Bull. Sci. Départ. Nord, 1873, 5, 220223.

1873.1

Sur un nouveau poisson du terrain Bruxellien [Homorhynchus bruxelliensis] Bull. Acad. Roy. Sci. Belgique, 1873, 2. sér. 35, 207-211. pl. - Journ. Zool. (Gervais), 1873, 2, 250-254. fig. 1873.2

Sur une dent de Notidanus. Ann. Soc. Géol. Belgique, 1874, 1, 64.

1874.1

Un mot sur le Selache (Hannovera) aurata du Crag d'Anvers. Bull. Acad. Sci. Bruxelles, 1876, 2. sér. 42, 294-299. pl.

1876.1

Sur des éperons génitaux de pélerin [Selache aurata] trouvés dans lo Crag d'Anvers. Journ. Zool. (Gervais) $1876,5,357-358$.

1876.2 
Sur un poisson fossile nouveau (Semiophorus schaerbeekii) des environs de Bruxelles et sur certains corps énigmatiques du Crag d'Anvers. Bull. Acad. Sci. Bruxelles, 1Ss1, 1, 116-126. pl. \& 5 figs.

1881.1

Comparaison de Ctenodentex (Dentex) lackeniensis Van Beneden, avec les genres Dentex et Lutjanis. Bull. Soc. Belge Géol., 1896, 10, 202-204.

1896.1

Beneden, P.J.van, Hauzeur, Nicolas, \& Dupont, Eduard. Sur les fouilles de Chaleux. Bull. Acad. Sci. Belgique, 1865, 2. sér. 20, 54-60.

1865.1

Reference to fossil sharks' teeth, p. 55 .

Beneden, P.J.van, \& Koninck, L.G. de. Notice sur le Paladaphus insignis. Bull. Acad. Roy. Belgique, 1864, 2. sér. 17, 143-151. pls. i-ii.

1864.1

Benedict, $I, M$. On the structure of two fish tapeworms from the genus Proteocephalus Weinland. Journ. Morph., 1900, 16, 337-368. pl. 1900.1

Benham, W. Blaxland. Structure of pharyngeal bars of Amphioxus. London, 1893. 2 pls.

1893.1

Heteropleuron hectori, the New Zealand lancelet. Quart. Journ. Micr. Sci., 1901, n. s. 14, 273-280. pl. Abstract in Journ. Roy. Micr. Soc. London, 1901, 263-264.

1901.1

- On the New Zealand lancelet [ Heteropleuron hectori sp. nov.] Trans. Proc. New Zeal. Instit., 1901, 33, 120122. pl.

1901.2

An apparently new species of Regalecus (R. parkeri) Trans. New Zeal. Instit., 1903, 36, 198-200. pl.

1903.1

Benham, W. B., \& Dunbar, W. $J$. On the skull of a young specimen of the ribbon-fish, Regalecus. Proc. Zool. Soc. London, 1906, 544-556. 2 pls. 1906.1

Bennet, J.A., \& Oliver, G. van. Naamlijst van Nederlandsche visschen. Verhandl. Naturk., Haarlem, 1824, 13, 1-122.

1824.1

Bennett, E.F.T. Movements of fish. Art Journ., 1899, 51, 289-293. figs.

1899.1

Bennett, Edward Turner. Description of a new species of Julis Cuv. [J. argus] Zool. Journ., 1827, 3, 577578. figs.
Observations on the fishes contained in the collection of the Zoological Society. Zool. Journ., 1827, 3, 371-378; 1828, 4, 31-43. pl. - Bull. Sci. Nat. (Férussac), 1829, 17, 439-441; 18, 131; 1831, 27, 191-192.

1827.2

Notes on fishes from Jamaica. Zool. Journ., 1829, 86-90. 1829.1

Memoir of the life and public services of Sir Stamford Raffles, edited by Lady Raffles, London, 1830. 1830.1 Fishes, p. 694.

-...- Observations on a collection of fishes, formed during the voyage of H. M.S. "Chanticleer," with characters of two new species. Proc. Zool. Soc. London, 1830, 1, 112.

1830.2

Characters of new genera and species of fishes of the Atlantic coast of northern Africa presented by Capt. Belcher. Proc. Zool. Soc. London, 1831, 146-14S.

1831.1

Observations on a collection of fishes from the Mauritius, with characters of new genera and species. Proc. Zool. Soc. London, 1831, pt. 1, 32; 5961; 126-128; 165-169; pt. 2, 184; pt. $3,206$.

1831.2

Poissons décrits. Bull. Sci. Nat. (Férussac), 1831, 27, 191-192.

1831.3

Pterois russellii nova species. Proc. Zool. Soc. London, 1831, 128.

1831.4

Characters of new species of fishes from Ceylon. Proc. Zool. Soc. London, 1832, 182-184. - Isis (Oken), 1835, 449-451.

1832.1

Characters of some new species of fishes, collected by Mr. Cuming. Proc. Zool. Soc. London, 1832, 4-5. Isis (Oken), 1835, 366-367. 1832.2

Two new fishes from the Mauritius [Atherina punctata and Julis strigiventer] Proc. Zool. Soc. London, 1832, 184.

1832.3

Characters of new species from the Mauritius. Proc. Zool. Soc. London, 1833, 32. - Isis (Oken), 1835, 358-361.

1833.1

Characters of new fishes from western Africa. Proc. Zool. Soc. London, 1834, 45-46.

1834.1

Acanthurus kintii n. sp. Proc. Zool. Soc. London, 1835, 119. - Isis (Oken), 1835, 180. 
Bennett, E. T. Characters of several fishes from the Isle de France. Proc. Zool. Soc. London, 1835, 206-208. 1835.2

Characters of several previously undescribed fishes from Trebizond, collected by Keith Abbott. Proc. Zool. Soc. London, 1835, pt. 3, 91-92. - Isis (Oken), 1837, 137-138.

1835.3

Bennett, E. T., \& Lay, G. T. See Lay \& Bennett.

Bennett, $F$. D. Narrative of a whaling voyage round the globe, etc. 2 vols. London, 1840.

1840.1

Bennett, $F . W$. On a communication between the air bladder and the cloaca in the herring. Journ. Anat. Phys., 1879, 14, 405-406. 1879.1

Bennett, George. Notes on sharks, more particularly on two enormous specimens of Carcharias leucus, captured in Port Jackson, Sydney, New South Wales. Proc. Zool. Soc. London, 1859, 27 ; 223226.

1859.1

On the fish called Glyphisodon biocellatus. Proc. Zool. Soc. London, 1859, 222-223.

1859.2

Gatherings of a naturalist in Australasia, etc. London, 1860. 1860.1

- On the river cod (Gristes peelii) and perch of the colonists. Rept. Acclimat. Soc. N. South Wales, 1864, 3 , \$1-82.

$186 \pm .1$

- [Remarks on Cyprinus auratus] 6. Ann. Rept. Acclimat. Soc. N. South Wales, 1867, 49-50.

1867.1

On the [poisonous] "toadfish" (Tetrodon hamiltoni) of New South Wales. N. South WTales Med. Gaz. Sydney, $1870-71,1,176$; 305. pl. 1870.1

Bennett, John Whitchurch. A selection of rare and curious fishes found upon the coast of Ceylon. London, 1828-30. 6 pts. 30 pls. $4^{\circ}$. 1828.1

Reviews in Bull. Sci. Nat. (Férussac), 1829, 16, 131; 1830, 21, 325. - Lit. Gaz. London, $1830,223$.

The same. 2. ed. rondon,
$\begin{aligned} & \text { 1834. } 30 \mathrm{pls} \text { fol. } \\ & \text { - The same. } 3 .\end{aligned}$
1851. $30 \mathrm{pls}$. fol.

Bennett, R.A. R., \& Bateman, G. C. See Bateman is Bennett.
Bennett, $T$. Salmon-fishing on the Novarro. Overland Monthly, 1874, 12, 119-124. - Forest \& Stream, 1874, 2, 29.

1874.1

Benoist, $E$. Mémoire sur la pisciculturc. Congrès Scient. France, 1862 , 29. sess., 254-262.

1862.1

Bensley, B.A. Report on the sardine industry in relation to the Canadian herring fisheries. Ann. Rept. Marine Fisher. Canada, 1902, no. 22a, 59-62.

1902.1

Bent, Ben, pseudonym for Pinckney, Frank S.

Bentivoglio, Tito. Di un Petromyzon marinus catturato ad Angelo Lomellino. Atti Soc. Nat. Modena, 1895, 13, 198.

1895.1

Bentley, $C$. A. The natural history of Bombay malaria. Journ. Nat. Hist. Soc. Bombay, 1910, 20, 392-422. 1910.1

Bentley, $C . S$. The sense of pain in fishes. London, 1881. $8^{\circ}$ - Gresham Angling Soc. Papers, 1882-83. 1881.1

Bentley, I. Madison, \& Washburn, Margaret F'. See Washburn \& Bentley.

Beraneck, $E$. Organs du sens branchiaux. Bull. Soc. Sci. Neuchâtel, 1889, 6.

1889.1

Béraud, $T . C$. Considérations théoriques et notions pratiques sur la pisciculture. Mém. Soc. Acad. Maine et Loire, 1858, 3, 4-16.

1858.1

Berenstamm, $V . A$. Künstliche Befruchtung des Laiches der Teleskopfische [Text in Russian] Akvarium, Moskva, 1910, 3, 500-502. $\quad 1910.1$

Berent, Waclaw. Zur Kenntnis der Parablastes und des Keimblätterdifferenzirung im Ei der Knochenfische Jena Zeitschr. Naturw., 1896, 2. ser, 30, 291-343; 344-349. 3 pls. \& 4 figs.

1896.1

Beresin, W. I. Ueber den Einfluss der Gifte auf das isolierte Fischherz. Arch. Ges. Physiol., 1913, 150, 549-568. pl. \& 3 figs.

1913.1

Berg, A. Couches crétaciques supérieures sur les bords de la mer d'Aral [Text in Russian] Bull. Soc. Impér. Nat. Moscou, 1903 (1901), 8-12. 1904.1

Berg, Carlos. Ucber Rhodeus amarus. Correspbl. Naturf. Ges. Riga, 1880 , 23. Jahrg, 5S-60.

1850.1 
Geotriamacrostoma (Burm.) Berg, y Thalassophryne montevidensis Berg, dos peces particulares. Anal. Mus. La Plata (Zoológica), 1893, 1, 1-7. pls. 1893.1

Enumeración sistemática y sinonimica de los peces de las costas argentina y uruguaya; contribución al estudio de los peces sudamericanos. Anal. Mus. Nac. Buenos Aires, 1895, 2. ser. 1, 1-120. pl.

1895.1

_._. Sobre peces de agua dulce nuevos ó poco conocidos de la República Argentina. Anal. Mus. Nac. Buenos Aires, 1895, 2. ser. 1, 121-165. 3 pls.

1895.2

- - Contribuciónes al conocimiento de los peces sudamericanos, especialmente de los de la República Argentina. Anal. Mus. Nac. Buenos Aires, 1896-97, 2. ser. 1, 263-302.

1897.1

Contents: I. Peces de agua dulce. II. Peces marinos.

Lista de las publicaciónes cientificas hechas desde 1873 hasta 1897 por il Dr. Carlos Berg. Bol. Inst. Geogr. Argentino, 1897, 18, 71-82.

1897.2

Publicado con il titulo "Apurtaciónes para la bibliografía argentina" por el Dr. Estanislao S. Zeballos.

Comunicaciónes ictiológicas. Com. Mus. Nac. Buenos Aires, 1898, 1, $9-13 ; 1899,1,91-97 ; 1899,1,163-174$; $1901,1,293-311$.

1898.1

- Substitución de nombres genéricos. Com. Mus. Nac. Buenos Aires, 1898, 1, 41-43.

1898.2 fishes.

Beitrag zu Dr. G. Hagmann's "Acanthicus hystrix Spix aus dem unteren Amazonas." Zool. Anz., 1901, 24, 586.

1901.1

Berg, Lew Semenowitch. Ichthyofauna of Asiatic Russia. I. Fishes of the Trans-Caspian region collected by N. A. Warentzow [Text in Russian] Tagebl. Ges. Fr. Natur. Moskau (Zool. Abth.), 1898, 2, 14-20. 2 figs. 1898.1

- Beiträge zur Ichthyofauna des Kaukasus. Mitth. Kaukas. Mus., Tiflis, 1899, 1, 41-80.

1899.1

Ueber Theilung und Bildung des Parablastes bei Esox lucius [Text in Russian] Tagebl. Ges. Fr. Natur. Moskau (Zool. Abth.), 1899, 2, 29-52. 22 figs.

1899.2
-_. Die Fische des Baikalsees IText in Russian] Ann. Mus. Zool. Acad. Sei. St. Pétersb., 1900, 5, 326-372. pl.

1900.1

Fish and fisheries in the delta of the Sir-Darien river and the Aral sea [Text in Russian] Works Soc. Navigation (Fish Div.), St. Petersb., 1900, 2. 1900.2

Condition in 1900 of the Sir-Darien and Aral fisheries [Text in Russian] Works Soc. Navigation (Fish Div.), St. Petersb., 1902, no. 3, p. $16 . \quad 1902.1$

On the taxonomy of the Cottidre of lake Baikal [Text in Russian] Ann. Mus. Zool. Acad. Sci. St. Pétersb., 1903, 8, 99-114. 1903.1

- Zur Systematik der Acipenseriden. Zool. Anz., 1904, 27, 665-667.

1904.1

Einige Worte iiber den "Dick" (Acipenser schypa, glaber, brandti) ['Text in Russian] 'Trd. Obšč. Jest., Saratov, 1905, 4, pt. 2, 281-283. 1905.1

- Die Fische von Turkestan [Text in Russian] Mitth. Turkestan. Abh. K. Russ. Geogr. Gesell., 1905, 4, 1-261. 6 pls. \& 35 figs.

1905.2

Notiz ïber die Fischerei in den Gewässern des Semiretschje-Gebiets [Text in Russian] Russ. Sudochod., St. Pétersb., 1905, 20, 49-56. 1905.3

- Verzeichnis der Fische von Russisch-Turkestan. Ann. Mus. Zool. Acad. Sci. St. Pétersb., 1905, 10, 316332.

1905.4

- Beschreibung einiger kaukasischer Fische [Cobitis caucasica, n. sp.] Bull. Acad. Sci. St. Pétersb., 1906, 5. sér. 24, 35-39. fig.

1906.1

Description of a new species of Leucogobio from Korea. Ann. Mag. Nat. Hist., 1906, 7. sér. 18, 394-395.

1906.2

Fisheries of the basin of the Wolga above Saratow [Text in Russian] St. Petersburg, 1906. 85 p. 1906.3

Fisheries of the 4. Inspection District, 4. ed. Pamphlet issued by Dept. of Agriculture.

- Note on Doliichthys stellatus Sauvage. Ann. Mag. Nat. Hist., 1906, 7. ser. 18, $393 . \quad 1906.4$

-_. On the distribution of Cottus pocilopus Heck. in Siberia IText in Russian] Trav. Sous-Sect. 'Twïtskosawsk- 
Berg, L. S.

Kiakhta Soc. Imp. Russe Géogr., 1906, 7, no. 1, 78-92.

1906.5

_ Notice sur les poissons du lac Kossogol (bassin du Baikal) [Text in Russian] Op. cit., 8, 64-70. 1906.6

Ueber Gyrinocheilus kaznakovi sp. n. (Cyprinidxe subfam. Gyrinocheilini) aus Siam [Text in Russian] C. R. Trav. Soc. Nat. St. Pétersb., 1906, 37, 305-307. German résumé, 364-366.

1906.7

Uebersicht der Cataphracti (fam. Cottidx, Cottocomephoridx und Comephoridx) des Baikalsees. Zool. Anz., 1906, 30, 906-911.

1906.8

Uebersicht der Fischerei im Wolga-Bassin vom Flusse Vetluga bis zur Mündung der Kama [Text in Russian] Russ. Sudochod., St. Petersb., 1906, 21, pt. 6, S4-114; pt. 7, 73-100. 1906.9

Uebersicht der Marsipobranchii Caspiomyzon n. g. pro Petromyzon wagneri] des russischen Reiches. Bull. Acad. Sci. St. Pétersb., 1906, 5. sér. 24, 169-183. fig.

1906.10

Uebersicht der Salmoniden vom Amur-Becken. Zool. Anz., 1906, 30, 395-398.

1906.11

Zur Osteologie der BaikalseeCataphracti. 'Trav. Soc. Nat. St. Pétersb., 1906, 37, 1. livraison, 30-32; $40-41$.

1906.12

- Beschreibungen einiger neuer Fische aus dem Stromgebiete des Amur. Ann. Mus. Zool. Acad. St. Pétersb., 1907, $12,418-423$.

1907.1

Die Cataphracti des Baikal Sees (fam. Cottidie, Cottocomephoridx und Comephoridx) Beiträge zur Osteologie und Systematik. Wiss. Ergebn. Zool. Exped. Baikal See, St. Petersburg \& Berlin, 1907. 3. ed. 75 p. 5 pls. \& 17 figs.

1907.2

Description of a new eyprinoid fish, Acheilognathus signifer, from Korea, with a synopsis of all the known Rhodeinx. Ann. Mag. Nat. Hist., 1907, 7. ser. $19,159-163$

1907.3

Description of a new cyprinoid fish, Paraleucogobio notacanthus, from northern China. Ann. Mag. Nat. Hist., 1907,7 . ser. $19,163-164$.

1907.4

Einige Worte über die Notiz von V. Ciratzianow: "die Neunaugen des russischen Reiches" [Russian with German résumé] Trav. Soc. Nat. St. Pétersb., 1907, 37, 336-341; 367-370.

1907.5

Fishes. (In W. Braznikoff's "Materials relating to the fauna of the eastern seas of Russia ") [Text in Russian] Mém. Acad. Imp. Sci. St. Pétersb. 1907, 8. sér. 20, 179-181.

1907.6

Notes sur quelques espèces paléarctiques du genre Phoxinus [Text in Russian] Ann. Mus. Zool. Acad. Sci. St. Pétersb., 1907, 11, 196-213. 1907.7

- Notice sur le Gobio rivularis Basilewsky ['Text in Russian] Ann. Mus. Zool. Acad. Sci. St. Pétersb., 1907, 11, 2.

1907.8

- Notice sur le groupe des Rhodeinæ (fam. Cyprinidæ) du bassin de l'Amour ['T'ext in Russian] Ann. Mus. Zool. Acad. Sci. St. Pétersb., 1907, 11, $10-14$

1907.9

- Les poissons du bassin de l'Amour. Ichthyologia amurensis. [Text in Russian] Bull. Acad. Sci. St. Pétersb., 1907, 6. sér. 1, 326-327. 1907.10 A review of the cobitoid fishes of the basin of the Amur. Proc. U.S. Nat. Mus., 1907, 32, 435-438. 1907.11

A review of the species of the tenspined sticklebacks or Pygosteus from east Asia. Proc. U.S. Nat. Mus., 1907, $32,451-454$.

1907.12

Révision des poissons d'eau douce de la Corée [Text in Russian] Ann. Mus. Zool. Acad. Sci. St. Pétersb., 1907, 12, 1-12.

1907.13

_- Sur l'Aspro streber Sieb. et Acerina schraetser (L.) trouvés dans la delta du Danibe. Ann. Mus. Zool. Acad. Sci. St. Pétersb. 1907, 11, 3-4. 1907.14

Anweisungen zum sammeln zoologischer Objekte. III. Anleitung zum sammeln und versenden von Fischen, Amphibien und Reptilien. Ann. Mus. Zool. Acad. Sci. St. Pétersb., 1908. 10 p. 1908.1

Collection de poissons recueillis par N. Bailkov dans la Mandchourie [Text in Russian] Ann. Mus. Zool. Acad. Sci. St. Pétersb., 1908, 12, 67-68. 1908.2

Liste des poissons de l'Ob ['Text in Russian] Ann. Mus. Zool. Acad. Sci. St. Pétersb., 1908, 13, 221-228. 1908.3 
Liste des poissons de la Kolyma [Text in Russian] Ann. Mus. Zool. Acad. Sci. St. Pétersb., 1908, 13, 69-107. 1908.4

Sur le saumon de la mer d'Aral (Salmo trutta aralensis subsp. nov.) [Text in Russian] Ann. Mus. Zool. Acad. Sci. St. Pétersb., 1908, 13, 315323.

1908.5

- Sur le saumon de la mer Noire (Salmo salar labrax Pall.) [Text in Russiant Ann. Mus. Zool. Acad. Sci. St. Pétersb., 1908, 13, 255-266. 1908.6

Sur un exemplaire de la truite (Salmo trutta L.) d'une coloration étrange [Text in Russian] Ann. Mus. Zool. Acad. Sci. St. Pétersb., 1908, 13, xxxvxxxvi.

1908.7

- Vorläufige Bemerkungen über die europäisch-asiatischen Salmoninen, insbesondere die Gattung Thymallus. Ann. Mus. Zool. Acad. Sci. St. Pétersb. 1908, 12, 500-514.

1908.8

Bemerkungen über die Gattung Nematabramis Blgr. Ann. Mus. Zool. Acad. Sci. St. Pétersb., 1909, 14, xliii. 1909.1

Beschreibung von Diplophysn labiata herzensteini nov. subsp. Cobitidini) aus Turkestan. Ann. Mus. Zool. Acad. Sci. St. Pétersb., 1909, 14, 10-11. 1909.2

Ichthyologia amurensis rText in Russian] Mém. Acad. Sci. St. Pétersb., 1909, 8. sér. 24, 1-270. 3 pls.

1909.3

Quelques remarques concernant l'ouvrage de M. V. Gratzianow "Un essai de révision des poissons de la Russie" [Text in Russian] Ann. Mus. Zool. Acad. Sci. St. Pétersb., 1909, 13, $437-470$.

1909.4

Ueber die Gattungen Acanthogobio Herzst. und Hemibarbus Blkr. Ann. Mus. Zool. Acad. Sci. St. Pétersb., 1909, 14, 103-106.

1909.5

- Nachtrag zu meiner Arbeit über die europäisch-asiatischen Salmoninen. Ann. Mus. Zool. Acad. Sci. St. Pétersb., 1910,15 , ii-iii.

1910.1

Rapport sur une mission zoologique au Caucase en 1909 [Text in Russian] Ann. Mus. Zool. Acad. Sci. St. Pétersb., 1910, 15, p. 0153-0170. 1910.2

Die von K. A. Satunin in der Göl-Niederung gesammelten Fische
'Text in Russian! Izv. Kavk. Otd. Russ, Geogr. Obšč., Tiflis, 1910, 20, 127-128.

1910.3

- Apparition en masse de Sarda sarda (Bl.) sur la côte orientale de la mer Noire en 1910 [Text in Russian] Ann. Mus. Zool. Acad. Sci. St. Pétersb., $1911,16, \mathrm{p} . \mathrm{xv}-\mathrm{xvi}$.

1911.1

Catalogue of the fishes of the basin of the river Kama [Text in Russian] Illus. Guide to Kama, Perm, 1911, p. $72-74$.

1911.2

- On Morone labrax (L.) trouvé dans la mer Noire [Text in Russian] Ann. Mus. Zool. Acad. Sci. St. Pétersb., 1911,16 , p. xxiv.

1911.3

- Note sur le Percocottus glehni Dyb. [Text in Russian] Ann. Mus. Zool. Acad. Sci. St. Pétersb., 1912, 17, p. i-ii.

1912.1

- Poissons (Marsipobranchii et Pisces) Teleostei. Ostariophysi. Faune de la Russie et des pays limitrophes fondée principalement sur les collections du Musée Zoologique de l'Académie Impériale des Sciences de St. Pétersbourg. St. Pétersbourg, 1912. 336 p. 8 pls. \& 27 figs. $\quad 1912.2$

- Les poissons du bassin du fleuve Kuban, Ciscaucasie [Text in Russian? Ann. Mus. Zool. Acad. Sci. St. Pétersb., $1912,17,116-122$.

1912.3

Sur les poissons des fleuves Sary-su et Noura, province d'Akmolinsk [Text in Russian] Ann. Mus. Zool. Acad. Sci. St. Pétersb., 1912, 17, 53-55.

1912.4

_ Sur un specimen de la Lampetra fluviatilis japonica (Mart.), provenant de la côte occidentale de Kamtchatka [Text in Russian] Ann. Mus, Zool. Acad. Sci. St. Pétersb., 1912, 17, p. iii.

1912.5

Ueber die Zusammensetzung und Herkunft der Fischfauna des AmurFlusses mit Bezug auf die Frage von den zoogeographischen Regionen für die Siisswasserfische. Zool. Jahrb. (Abt. Syst.), 1912, 32, 475-520. pl. 1912.6

Description of an adult specimen of Crystallias matsushima Jord. \& Syn. Ann. Mus. Zool. Acad. Sci. St. Pétersb., 1913, 18, 16-17.

1913.1

Description of a new species of Garra (= Discognathus) from eastern Persia. Ann. Mus. Zool. Acad. Sci. St. Pétersb., 1913, 18, p. Ixi. 1913.2 
Berg, L.S.

Note sur le Percocottus glehni Dyb. (fam. Gobiidse) ['T'ext in Russian] Ann. Mus. Zool. Acad. Sci. St. Pétersb., 1913, 17, p. i-iii.

1913.3

_ Les poissons du bassin du fleuve Kuban, Ciscaucasis ['Text in Russian\} Ann. Mus. Zool. Acad. Sci. St. Pétersb., $1913,17,116-122$.

1913.4

- A review of the clupeoid fishes of the Caspian sea, with remarks on the herring-like fishes of the Russian empire. Ann. Mag. Nat. Hist, 1913, 11, $472-480$.

1913.5

_- Die Siisswasserfische des westlichen Transkaukasiens ['Text in Russian] Trd. Obsc. Izuc. Cernomor. Pob. St. Pétersb., 1913, 2, 179-189。 1913.6

-_..- Sur les poissons des fleuves Sarysu et Noura, prov. d'Akmolinsk ['Text in Russian] Ann. Mus. Zool. Acad. Sci. St. Pétersb., 1913, 17, 53-55. 1913.7

Sur un spécimen de l'Acipenser medirostris Ayres trouvé dans le bas Amour ['lext in Russian] Ann. Mus. Zool. Acad. Sci. St. Pétersb., 1913, 18, 16.

1913.8

- Sur un specimen de la Lampetra fluviatilis japonica (Mart.), provenant de la côte occidentale de Kamtchatka [Text in Russian] Ann. Mus. Zool. Acad. Sci. St. Pétersb., 1913, 17, p. iii.

1913.9

Sur un spécimen du Morone labrax (L.), provenant de Sébastopol [Text in Russian] Ann. Mus. Zool. Acad. Sci. St. Pétersb., 1913, 17, p. xlviii-xlix.

1913.10

Ueber eine von A. I. Czerski in der Umgebung von Wladiwostok und im Becken des Sees Hanka erbeutete Sammlung von Süsswasserfischen [Text in Russian] Mem. Soc. Study of the Amur Country, Vladivostok, 1913, 13 , $11-21$.

1913.11

Die von der Expedition des Jahres 1912 längs dem westlichen Ufer des Meeres erbeuteten kaspischen Heringe ['Text in Russian] Mat. Etude Pêche en Russie, St. Pétersb., 1913, 2 , no. $3,1-50$. 14 pls.

1913.12

Berg, Lew Semenowitch, \& Kouznetzoff, 1. D. Program for collection of fishes. - Programs and instructions for preserving and assembling collections of natural history ['Text in Russian] Mus.
Zool. Acad. Sci. St. Pétersb. [1908?] 19 p. 3 figs.

1908.1

Berg, P.J. [Auszug eines Briefes des Banko-liommissarius Bergius in Stockholm an den Herrn D. und Prof. Kölpin zu Stettin, die Naturgeschichte und Verpflanzung des Sterlets betreffend] Beschäft. Ges. Naturf. Fr. Berlin, 1776 , 2. $534-535$.

1776.1

Bergasse, - Sur la fécondation artificielle du saumon. Trav. Acad. Rouen, 1852-53, 217-231. 1852.1

Bergen, H.B. Die Fischerei-Industrie Norwegens. [n. p.] 1873. $8^{\circ} .84$ p. Review in Zool. Garten, 1873, 14, 480. Extract in ibid., p. 434.

1873.1

Berger, - Unter welchem Verhältnissem empfiehlt sich die Anlage von Karpfenteichen? Circul. Deutsch. Fischerei Ver., 1874 (1875), 27-30.

1875.1

Berger, $E$. Beiträge zur Anatomie des Fischauges. Zool. Anz., 1882, 4, 258-262. 1882.1

Beiträge zur Anatomie des Sehorgans der Fische. Morph. Jahrb., 1883, 8, 97-168. pls. 1883.1

Berger, H.A.C. Die Versteinerungen der Fische und Pflanzen im Sandstein der Coburgischer Gegend. Coburg, 1832. figs. $4^{\circ}$. Review in Isis, 1832, 10, 1114. - Neues Jahrb. Mineral., 1839, 225. - Bull. Soc. Géol. France, 6, 62.

1832.1

Berger de Xivrey, Jules. Traditions tératologiques. Paris, 1838. 8. 1838.1

Berghaus, A. Der Sterlet [Acipenser ruthenus] in Pommern. Natur, 1877, 1. s. $3,673-675$.

1877.1

Der Hering. Natur, 1880, n. s. 6, 275-277; 292-295.

1880.1

Bergman, Arvid M. Finnen, Tetrarhynchus-Larven, im Fleische von Heilbutten, Hippoglossus vulgaris Fleming. Fortschr. Veterin.-Hygiene, Berlin, $1903,1,212-216$.

1903.1

Bergmeister, $O$. Beitrag zur vergleichenden Embryologie des Coloboms. Sitzber. Akad. Wiss. Wien, math.nat. Cl., 1875, 71, 3. Abth., 343-351. pl. Also separate; Wien, 1875. $9 \mathrm{p}$. col. pl.

1875.1

Bergner, Johannes. Das Vorkommen des gemeinen Sonnenfisches (Eupo- 
motis aureus Jord.) im Rhein. Allgem. Fisch. 'Leitg., 1906, 31. Jahrg., 374-375.

1906.1

Bergroth, Ernst Evald. Anmärkningar om fiskfaunen i nedra Irtisch og Ob. Oefvers Finsk. Vet. Soc., 1880, 22, 1-8.

1880.1

-..- Additions and corrections to the "Index Zoologicus" of C. O. Waterhouse. Zoologist, 1904, 4. ser. 9, 63-67. - Ibid., 1908, 4. ser. 12, 252-255.

1904.1

Bergroth, Ivar Ossian. Ett och annat fràn Ryska Karelen. 'Tidskr. Jägare \& Fisk., 1S95, 41-55.

1895.1

Berisch, C. L. Gründliche Anweisung wie sowohl die zahme als wilde Fischerei gehörig zu betreiben ist, um den höchstmöglichen Ertrag hiervon zu erlangen, zum Nutzen für FischereiAufseher und Teichwärter bei ansehnlichen Fischereien. Leipzig, 1794. $12^{\circ}$.

1794.1

Berkeley, Miles Joseph. Nouvelle végétation parasite sur des poissons. Ann. Sci. Nat., 1864, 1.

1864.1

Berkenhout, John. Synopsis of the natural history of Great Britain and Ireland, containing a systematic arrangement and concise description of all the animals, vegetables and fossils, which have hitherto been discovered in these kingdoms. 2 vols. London, 1795. $8^{\circ}$.

1795.1

Berkhouse, Jerry $R$. Some experiments on the artificial expression and fertilization of gold fish. Trans. Amer. Fisheries Soc. 1908 (1909), 142-144.

1909.1

Berkowsky, - Ueber das Fischgift. Archiv. Russ. (Erman), 1859, 18, $501-517$.

1859.1

Berlack, J. Symbola ad anatomiam vesicæ natatoriæ piscium. Ratisbonx, 1834. $8^{\circ}$.

1834.1

Berlepsch, H.A. Schweizerkunde, Land, Volk und Staat, geographischstatistisch, übersichtlich-vergleichend dargestellt. Braunschweig, 1S64. $8^{\circ}$.

Fische, p. 285-289.

1864.1

Berlin, $K$. Om de elektriska fiskarna. Upsala, 1866. $\mathrm{S}^{\circ}$. 1866.1

Berliner, Kurt. Die Entwicklung des Geruchsorgans der Selachier. Arch. Mikr. Anat., 1902, 60, 385-406. pl. \& 7 figs.
Bernard, H. M. An attempt to deduce the vertebrate eyes from the skin. Quart. Journ. Micr. Soc., 1897, n. s. 39 , 343-370. pl.

1897.1

- New reading for the annulate ancestry of vertebrata. Nat. Sci., 1898, 13, $17-30$.

1898.1

Bernard, Pierre, \& others. Le jardin des plantes; description complète, historique et pittoresque du muséum d'histoire naturelle. Par P. Bernard, I. Couailhac, Gervais et Emm. Lemaout. 2 pts. Paris, 1842-43. figs. $8^{\circ} .1842 .1$

Part ii: Oisenux, reptiles, poissons, insectes et crustacés; par Emmanuel Lemaout. 1843. 664 p. pls.

Bernard, (Sir) Thomas. An account of a supply of fish, for the manufacturing poor. [n. p.] $1813.14 \mathrm{p} . \mathrm{s}^{\circ}$.

1813.1

Bernard de Reste, $C$. Histoire des pêches, des découvertes et des établissements des Hollandois dans les mers du Nord; ouvrage traduit du hollandois par les soins du Gouvernement [etc.] 3 vols. Paris, 1791. figs. map. $8^{\circ}$.

1791.1

Bernhard, C. Die Aalquappe, Lota vulgaris. Wochenschr. Aquarienk., Braunschweig, 1904, 1, 118-119. 1904.1

Bernhard, $P$. Meine Erfahrungen bei der Zucht des Diamantbarsches, Enneacanthus gloriosus. Wochenschr. Aquar.-Terrar. Kunde, 1914, 11. Jahrg., 81-82. fig.

1914.1

Bernhardt, E. D. Forellenfang in der Themse. Fischerei Zeitg., Neudamm, 1901, 4, 323-324. 1901.1

Bernoulli, A.L. Zur Frage des Hörvermögens der Fische. Arch. Ges. Physiol., 1910, 134, 633-644.

1910.1

Bernstein, J., \& Tschermak, Armin. Ueber das thermische Verhalten des elektrischen Organs von Torpedo. Erster Teil. Sitzber. Akad. Wiss. Berlin, 1904, 301-313. fig.

1904.1

Untersuchungen zur 'Thermodynamik der bioelektrischen Ströme. Zweiter Teil. Ueber die Natur der Kette des elcktrischen Organs bei Torpedo. Arch. Physiol., 1906, 112, 439 521. 10 figs.

1906.1

Bert, Paul. Reproduction de l'extrémité caudale enlevée chez des poissons osseux. C. R. Mém. Soc. Biol. Paris, 1863, 5, 100-101. 1863.1 
Bert, $P$.

- Note sur la mort des poissons de mer dans l'eau douce. Mém. Soc. Sci., Bordeaux, 1866, 4, cah. 2, 47-49; 5, 185-188. - Ann. Sci. Nat., 1867, 5. sér. 7, 369-371.

1866.1

- Note sur la présence de l'A mphioxus lanceolatus dans le bassin d'Arcachon et sur ses spermatozoïdes. Mém. Soc. Sci. Phys. Nat., Bordeaux, 1866, 4, $55-58$.

1866.2

[Note sur l'Amphioxus lanceola¿us] Mém. Soc. Sci. Phys. Nat., Bordeaux, 1867, 5, 15-17.

1867.1

- Note sur quelques points de la physiologie de la lamproie (Petromyzon marinus Linn.) Ann. Sci. Nat., 1867 , 5. sér. 7, 371-373. - Mém. Soc. Sei. Phys. Nat., Bordeaux, 1866, 4, cah.1, 82-84.

1867.2

[Notes sur les hippocampes et la seiche] Mém. Soc. Sci. Phys. Nat., Bordeaux, 1867, 5, 17-19. 1867.3

_... Sur la mort des animaux à sang froid par l'action de la chaleur. Mém. Soc. Sci. Phys. Nat, Bordeaux, 1867, 5, p. xxii.

1867.4

- Sur l'Amphiosus. C. R. Acad. Sci. Paris, 1867, 65, 364-367. - Ann. Mag. Nat. Hist., 1867, 20, 302-304. C. R. Mém. Soc. Biol. Paris, 17-22.

1867.5

- Sur la raison pour laquelle certains poissons vivent plus longtemps à l'air que certains autres. C. R. Mém. Soc. Biol. Paris, 1868, 49-51. 1868.1

- Première note sur la mort des poissons de mer dans l'eau douce. C. R. Mém. Soc. Biol. Paris, 1867 (1869), 4. sér. 4, 22.

1869.1

- Recherches sur la respiration des poissons. C. R. Mém. Soc. Biol. Paris, $1869,1,330-331$.

1869.2

- Leçons sur la physiologie comparée, profesées au inuséum d'histoire naturelle. Paris, 1870. $8^{\circ}$. 1870.1

De la pisciculture dans le département de l'Yonne. Bull. Soc. Sci. l'Yonne, 1871, 25 (2. sér. 5), 3-8. 1871.1

Sur les phénomènes et les causes de la mort des animaux d'eau douce que l'on plonge dans l'eau de mer. C. R. Acad. Sci. Paris, 1871, 73, 382-464.

1871.2
- Influence des hautes pressions sur les poissons. C. R. Mém. Soc. Biol. Paris, 1873 (1874), 5. sér. 5, 160-161.

1874.1

- [Remarques physiologiques sur l'Amphioxus] C. R. Mém. Soc. Biol. Paris, 1872 (1874), 5. sér. 4, 72-73.

1874.2

- Action de l'acide carbonique dissous sur les poissons. C. R. Mém. Soc. Biol. Paris, 1874 (1875), 6. sér. 1. 214.

1875.1

- Clef analytique des poissons du département de l'Yonne. Guide du Naturaliste, 1879 , no. 5 , p. 67 ; no. 6 , p. 80 .

1879.1

Bertelli, $D$. Pieghe dei reni primitivi. Contributo alla morfologia e allo sviluppo del diaframma. Atti Soc. Toscana, 1898, 16, 72-10s.

1898.1

\section{Berthelmann, ___, Borcherding,} Fr., Cronheim, Debschitz, $H$. v., Knauthe, Karl, \& Apstein, C. See Knauthe \& others.

Berthelot, Sabin. De la pêche sur la côte occidentale d'Afrique. Paris, 1840. 302 p. map. $8^{\circ}$. 1840.1 1860 .

A second edition was published at Paris in - Die Aufbewahrung lebender Seefische in Piscinen und auf Fischbehälterschiffen [Translated from the French by Dr. Carl Bolle] Zeitschr. Akklimat., 1865 , n. s. 3, 187-203.

1865.1

Des movens d'encouragement pour les progrès de la pêche cotière. Bull. Soc. Imp. Zool. Acclimat., 1865. 2. sér. 2, 709-721.

1865.2

Nouveau système de pêche. Réservoirs de dépôt. Bateaux viviers. Conservation du poisson. Paris, 1865. $8^{\circ}$. Extract in Bull. Soc. Acclim. Paris, 1865, 2. sér. 2, 176-194.

1865.3

- De la pêche sur les côtes de l'Algérie. Paris, 1866. $8^{\circ}$. 1866.1

- Des pêches à la traine en mer et du dépeuplement de notre fond de pêche. Bull. Soc. Acclim. Paris, 1867, 2. sér. 4, 480-500.

1867.1

__ Etudes sur les pêches maritimes dans la Méditerranée et l'océan. Paris, 1868. 487 p. $8^{\circ}$.

1868.1

Oiseaux voyageurs et poissons de passage; étude comparée d'organisme, de moeurs et d'instinct. 2 vols. Paris, $1875-76.8^{\circ}$. 
Berthelot, Sabin, \& Detzem, See Detzem \& Berthelot.

Berthelot, Sabin, \& Webb, Philip Barker. See Webb \& Berthelot.

Berthier, $V$. Le poisson-chat [Ameiurus] Bull. Soc. Hist. Nat. Autun, 1905, no. 18, 157-162.

1905.1

Lamproie marine (Petromyzon. marinus Linné) Bull. Soc. Hist. Nat. Autun, no. 21, 1908, 58-61. 1908.1

Bertholdi, - Ueber einen in Tauris fossil gefundenen Hai-Zahn. Bull. Soc. Nat. Moscou, 1833, 6. 1833.1

Berthoule, Amédée. Les écoles de pisciculture. Bull. Soc. Acclimat., 1887, 1, 27.

1887.1

Rapport adressé au ministre de la marine et des colonies, au nom du comité consultatif des pêches maritimes, sur les moeurs du saumon. Paris, 1888. 67 p. $8^{\circ}$.

1888.1

Les pêches en Norvège. Rev. Scient., 1892, 49, 618-627. 1892.1

Berthoule, Amédée, \& BouchonBrandely, Germain Jean Baptiste. See Bouchon-Brandely \& Berthoule.

Berthoule, Amédée, \& Bouffet, See Bouffet \& Berthoule.

Berthoule, Amédée, \& Vaillant, Léon. Le saumon et la loi sur la pêche [Suivi de] Sur la présence du saumon dans les eaux marines de la Norvège. Paris, 1889. 17 p. $8^{\circ}$. - Rev. Sci. Nat. Appliq. Bull. Bimens. Soc. Acclim.), 1889, no. 3 .

1889.1

Berthoumieu, $V$. Essai bibliographique sur l'histoire naturelle du Bourbonnais. Rev. Scient. Bourbonn., 1899, $12,10-22 ; 41-49 ; 104-113 ; 126-136$; $201-211 ; 221-238 ; \quad 1900,13,38-45$; $90-103 ; 155-163$.

3899.1

Bertini, $E$. Le ossa basali del cranio dei pesci in rapporto con la teoria vertebrale del cranio. Genova, 1907. 31 p.

1907.1

Bertram, James $G$. The harvest of the sea; a contribution to the natural and economic history of the British food fishes. London, 1865. 519 p. pl. \& figs. $8^{\circ}$. 1865.1

Thesame [Reprint] New York, 1866. 519 p. pls. $8^{\circ}$. 1866.1

There are also three other English editions, the last published in 1855 .
- Modern fish. Brit. Almanac Companion, 1883.15 p. $\quad 1883.1$

The unappreciated fisher folk. London, 1883. $\$ 3$ p. $8^{\circ}$. (Intern. Fisheries Exhib. Handb.) $\quad 1883.2$

__Ellangowan, pseudon.] Outdoor sports in Scotland. London, 1889. 388 p. $8^{\circ}$. 1889.1

Chap. xvii, Salmonia. Chap. xviii, Troutiana.

The same. 2. ed. London, 1890. 388 p. $5^{\circ}$.

1890.1

Bertrand, $E$. Recueil de divers traités sur l'histoire naturelle de la terre et des fossiles. Avignon, 1766. $4^{\circ}$.

1766.1

Contents: Des poissons fossiles, ou Ictyopètres. - Divers états de ces poissons. - Leurs espèces.

Bertrand, Emile. Sur le poisson mosaïque (Phoxinus umbrosus) Bull. Soc. Centr. Aquicult. France, 1889, 1, 94.

1889.1

Sur quelques poissons récemment acclimatés en France. Bull. Soc. Centr. Aquicult. France, 1890, 2, 140.

1890.1

Observations sur divers modes de reproduction chez les poissons. Bull. Soc. Centr. Aquicult. France, 1893, 5, 115-119.

1893.1

Bertrand, J.E.(editor) Descriptions des arts et métiers. Neuchâtel, 1779. $8^{\circ}$.

1779.1

Vols. $x$ and $x$ i of this work bear the bastard title: Traité des pêches, et histoire des poissons. See Duhamel du Monceau, H. L.

Bertrand, Louis. Poissons et crustacés d'eau douce alimentaires de l'Imérina (Madagascar) Bull. Soc. Nation. Acclimat. France, 1900, 47, 348-349.

1900.1

Bertrand, M. Note sur l'établissement de M. le capitaine Silhouette à Biarritz. Bull. Soc. Nat. Acclimat. France, 1873, 2. sér. 10, 209-214. 1873.1

Bertuch, Fr.J. Tafeln der allgemeinen Naturgeschichte nach ihren drey Reichen; nebst vollständiger synoptischer Enumeration aller bis jetzt bekannten Naturkörper und ihrer Charakteristik: neu umgearbeitete Ausgabe. Weimar, 1806-07. $4^{\circ}$. 1806.1

Besana, Giuseppe. Sulla convenienza di acclimatare nei nostri laghi il coregono azzurro. Giorn. Ital. Pesca Acquicult., $1897,1,326-328$.
1897.1 
Besana, $G$.

Durata dell' incubazione delle uova di Coregoni schinzii. Acquicult. Lombard., 1900, 2, 14-15.

1900.1

Sulla pesea dei coregoni nel lago di Como durante il divieto, a scopo di incubazione. Acquicult. Lombard., 1901, 3, 223-227; 249-251.

1901.1

Die Einführung des gemeinen Sonnenfisches (Pomotis auritus Günth.) im Varano-See. Allgem. Fischerei Zeitg., 1902, 27, 239-241. 1902.1

- American fishes in Italy. Proc. 4. Intern. Fish. Congress, Washington, D. C., 1908, pt. 2, 947-954. 1908.1

La questione della pesca degli agoni [Alosa finta] con la canna nel lago di Como. Rivista Mens. Pesca, Milano, $1908,10,152-15 S$.

1908.2

Besana, Giuseppe, Burguières, $E$., Genazzini, $E$., Gervasoni, $T$., \& Vinciguerra, D. See Vinciguerra \& others.

Besnou, Léon lObservations sur les poissons et la pisciculture dans le département de la Manche] Congrès Scient. France, 27. sess., 1860 (1861), 1, 280-284.

1861.1

Besselich, $N$. Mittheilungen betreffend die Fischerei in Trier. Circul. Deutsch. Fischerei Ver. 1874 (1875), 256-259.

1875.1

Notizen uiber das Fischwesen an der Mosel, Sauer, etc. Circul. Deutsch. Fischerei Ver. 1875 (1876), 359-362.

1876.1

Bessels, Emil. Ueber fossile Selachier-Eier. Jahresber. Vaterl. Naturk. Württemberg, 1869, 25, 152-155. 1869.1 $H$

Beta, H. (pseudon.) See Bettziech,

Bethe, Albrecht. Ueber die Erhaltung des Gleichgewichtes. Biol. Centralbl., 1894, 14, 95-114; 563-582.

1894.1

Ueber die Silbersubstanz in der Haut von Alburnus lucidus. Zeitschr. Physiol. Chem., 1895, 20, 472-177.

1895.1

Die Locomotion des Haifisches (Scyllium) und ihre Bezichungen zu den einzelnen Gehirntheilen und zum Labyrinth. Archiv. Gesell. Physiol., 1899, 76, 471-496. figs.
Ueber die Neurofibrillen in den Ganglienzellen von Wirbelthieren und ihre Beziehungen zu den Golginetzen. Arch. Mikr. Anat., 1900, 55, 373-558.

1900.1

Bethune, (Rev.) George W. A Waltonian library; or a list of such works as relate to fish and fishing. (Appended to Dr. Bethune's edition of Walton \& Cotton's 'The compleat angler. New York, 1847. Vol. ii, p. 151-203) 1847.1

Betta, Francisco Edoardo de [18221896] Sulla piscicoltura in generale e sulla possibilità ed utilitì della sua introduzione nel Veronese, ete. Mem. Accad. Agric. Comm. Arti Verona, 1861, 40,7-51. pl. Also separate; Verona, 1861. $8^{\circ}$.

1861.1

Ittiologia Veronese ad uso populare e per servire alla introduzione della piscicoltura nella provincia, etc. Mem. Acead. Agric. Comm. Arti Verona, 1862, 41, 259-409. Also separate; Verona, 1862. $8^{\circ}$ 1862.1

Materiali per una fauna Veronese, etc. Mem. Accad. Agric. Comm. Arti Verona, 1863, 42, 1-144. Also separate; Verona, 1863. 144 p. $8^{\circ}$. 1863.1

Sul carpione del lago di Garda (Salmo carpio L.) Atti Istit. Ven. Soc. Litt. Arti, 1891, 1, S03--808. 1891.1

Bettany, George Thomas, \& Parker, William Kitchen. See Parker \& Bettany.

Bettoni, Eugenio. Influsso della pressione barometrica sopra alcuni pesci d' acqua dolce. Atti Soc. Ital. Șci. Nat., 1867, 10, 422-432. 1867.1

Note illustrativa sulla mostra di piscicoltura alle esposizioni riunite di Milano nel 1894. Brescia, 1894. $11 \mathrm{p}$. $8^{\circ}$.

1894.1

Piscicoltura d'acqua dolce. Milano, 1894. 85 figs. $8^{\circ}$. $\quad 1894.2$

Bettoni, Eugenio, \& Vinciguerra, Decio. Sulli stabilimenti di piscicoltura all' estero. Roma, 1885. fig. $8^{\circ}$.

1885.1

On the fish-cultural establishments of central Europe. Rept. U.S. Fish Comm. 1886 (1889), 14, 539-601. 7 pls.

1889.1

Bettoni, Giulio. Elementidipiscicoltura d' acqua dolce. Aquicolt. Lombard., 1899, 1, no. 2, 15-19; no. 3, 17- 
19; no. 4, 33-37; no. 5, 31-37; 1900 , 2, $74-77$.

1899.1

Di un nuovo apparato per trasporto degli avannoti. Neptunia, 1901, 16, 92-97.

1901.1

Bettziech, $J$, also styled Beta, $H$. (pseudon.)

[Beta, H., pseudon.] Die Be'wirthschaftung des Wassers und die Ernten daraus, mit einem Vorworte von Dr. Brehm. Leipzig \& Heidelberg, 1868. 318 p. 20 figs. $8^{\circ}$.

1868.1

Fischcultur, p. 40-56. Künstliche Laichung und Befruchtung, p. 196-207. AquariumsCultur, p. 227-272.

[Beta, H. pseudon.] Der Aalstaat in Italien. Annal. Landw. Wochenbl., 1869, 13-15.

1869.1

[Beta, H. pseudon.] Neue Werke und Winke für die Bewirthschaftung des Wassers (Hydronomie) Leipzig \& Heidelberg, 1870 . 44 p. 2 figs. $8^{\circ}$.

1870.1

-_- [Beta, H. pseudon.] Die Aalzucht. Landw. Zeitg., 1871, 20 (n. s. 8), 417-418.

1871.1

Der wirthschaftliche Werth der Wassernutzung durch Fischzucht. Berlin, 1873. 44 p. $8^{\circ}$. (In Samml. Wissensch. Vorträge, 8. ser. Heft 174)

1873.1

Beudant, Francois Sulpice, Edwards, Henri Milne, \& Jussieu, Antoine Laurent de. Cours élémentaire d'histoire naturelle. 10. ed. Paris, 1867. 4 vols. $8^{\circ}$.

1867.1

Zoologie, par H. Milne Edwards. 497 figs. A German translation of this work, in 3 vols. appeared at Stuttgart in 1868, and there are several later French editions.

Beuerle, Gustav. Meine Beobachtungen über Scatophagus argus im Zimmeraquarium. Wochenschr. Aquar.Terrar. Kunde, 1912, 9. Jahrg., 554-555. fig.

1912.1

Beveridge, Arthur. Occurrences of Labrus mixtus $L$. on the west coast of Sutherlandshire. Ann. Scott. Nat. Hist. $1892,1,141$.

1892.1

Bewick, Thomas [1753-1828] A memoir of Thomas Bewick, written by himself, embellished by numerous wood engravings designed and engraved by the author for a work on British fishes, and never before published. Neweastleon-Tyne, 1862. 344 p. figs. $8^{\circ} .1862$.
The same. New ed., prefaced and annotated by Austin Dobron. Newcastle-on-Tyne, 1887. 393 p. $8^{\circ}$.

1887.1

Bewley, B.F. The lump-sucker of Rathlin island. Zoologist, 1864, 22, 9296.

1864.1

Bexar, pseudonym for Johnson, Samuel M.

Beyrich, Heinrich Eirnst [1815-1896] For hiography and works, see Leopoldina, 1S96, 32, 110-113; Zeitschr. Prakt. Geol., 1900, 97-110.

Ueber Xenacanthus decheni und Holacanthodes gracilis, zwei Fische aus der Formation des Rothliegenden in Nord-Deutschland. Archiv. f. Mineral. (Karsten), 1848, 22, 646-654. - Sitzber. Akad. Wiss. Berlin, 1848, 24-33. 1848.1

Ueber einige organische Reste der Lettenkohlenbildung in Thüringen [Ceratodus] Zeitschr. Deutsch. Geol. Gesell., 1850, 2, 153-180. 1850.1

Ueber einen Pterichthys von Gerolstein. Zeitschr. Deutsch. Geol. Ges., 1877, 29, 751-756. — Neues Jahrb. Mineral., 1878, 438. pl. 1877.1

Bézier, Toussaint. Le cycloptère lompe (Cyclopterus lumpus Linn.) Bull. Soc. Sci. Méd. Ouest, Rennes, 1894, 3 , 113-116.

1894.1

Sur quelques cas d'albinisme et de mimétisme. Trav. Scient. Univ. Rennes, 1902, 1, 191-194. - Bull. Soc. Sci. Méd. Ouest, Rennes, 1902, 11, 127131.

1902.1

Sur l'existence de Ctenacanthus cf. bohemicus Barr. dans le calcaire dévonien inférieur de la Roussière, en Saint-Germain-le-Fouilloux (Mayenne) Bull. Soc. Sci. Méd. Ouest, Rennes, 1913, 22, 67-79. pl. 1913.1

Bharatkar, $K$. C., Suzuki, $U$. Mihata, M., Otsuki, R., \& Inouye, $R$. See Suzuki \& others.

Biagi, $G$. La fovea centrale della retina nei Lofobranchi. Spezia, 1899. 12 p. $8^{\circ}$.

1899.1

Bianchi, V. La Belone vulgaris Flem. dans la région orientale du golfe de Finlande. Ann. MIus. Zool. Acad. Sci. St. Pétersb., 1907, 11, iv.

1907.1

Bianconi, Giovanni Giuseppe [18091878] Lettera sul Ostracion fornasini, 
Bianconi, $G . G$.

n. sp. de pesce del Mosambico. Nuov. Ann. Sci. Nat. Bologna, 1846, 2. ser. 5, 113-115. figs. - Rendicont. Accad. Sci. Istit. Bologna, 1848-49, p. 34. 1846.1

Osservazione intorno al volume XX della Ittiologia del Sig. Valenciennes. Nuov. Ann. Sci. Nat. Bologna, 1848, 2. ser. 10, 54-58.

1848.1

Pisces Novi Mozambicani. Rendicont. Accad. Sci. Istit. Bologna, 1853-54, p. 68-69; 1856-57, p. 100.

1853.1

Specimina zoologica Mosambicana quibus vel novx vel minus not animalium species illustrantur. Bononix, 1850-70. 363 p. $48 \mathrm{col}$. pls.

1855.1

Fascicles $x$, xii-xiii deal with fishes, and were published in 1855, 1857 and 1859. Abstracts with diagnoses of new species were published in advance of the fascicles (20 in all) of this work. some in the Nuovi Annali Sci. Nat. Bologna and others in the Rendiconti of the Bologna Academy.

Sulla Trigla lineata. Rendicont. Accad. Sci. Istit. Bologna, 1856-57, p. 101-102.

1856.1

Bianconi, Joannes Josephus. See Bianconi, Giovanni Giuseppe.

Biberhofer, Raôul. Ueber Regeneration bei Amphioxus lanceolatus. Arch. Entw. Mech:, 1906, 22, 15-17. 2 figs.

1906.1

Bibron, Gabriel [1806-1848] Dictionnaire universel d'histoire naturelle . . par MIM. Arago ... Bibron, etc. 16 vols. See Orbigny, A.C.V.D. $d^{\prime}$.

Bibron, Gabriel, \& Bory de SaintVincent, Jean Baptiste George Marie. Reptiles et poissons (In Expédition scientifique de Morée. Paris, 1833. vol. iii, pt. $1,57-80$ )

1833.1

Poissons de Morée, p. 76-80.

Bicci, G., \& Barbère, A. G. See Barbère \& Bicci.

Bickel, Adolf. Beiträge zu der Lehre von den Bewegungen der Wirbelthiere. Arch. Phys. (Pflïger), 1896, 65, 231247.

1896.1

Bickerdyke, John. Successful fishculture in the Highlands. Blackwood's Edinburgh Mag., 1893, 154, 835-842.

1893.1

Sea fishing. With contributions on antipodan and foreign fish by $\mathrm{W}$. Senior, and on tarpon by A. C. Harms- worth. London, 1895. 562 p. pls. \& figs. $S^{\circ}$. (Badminton library) 1895.1

Bickerdyke, John, Aflalo, Frederick George, Maxwell, (Sir) H., \& Pycraft, W. P. See Aflalo \& others.

Bickford, Elizabeth. The hypophysis of the Calamoichthys calabaricus (Smith) Anat. Anz., 1895, 10, 465-470. 1895.1

Bickford, W. M. Notes on the Montana grayling. Trans. Amer. Fisheries Soc. 1913 (1914), 153-156.

1914.1

Bickmore, Albert Smith [1839-1914] A specimen of Amphioxus from Bird shoal off Beaufort, N. C. Proc. Boston Soc. Nat. Hist., 1862-63 (1865), 9, 333334.

1865.1

- Travels in the East Indian archipelago. London, 1868. 555 p. 33 pls. \& maps. $8^{\circ}$.

Fishes, p. 52, 329, 332, 354.

Bicknell, E. P., \& Dresslar, Fletcher B. A review of the species of the genus Semotilus. Proc. Acad. Nat. Sci. Philad., 1885 (1886), 14-18.

1886.1

Bicknell, Edwin. Note on the teeth of Ceratodus and sharks. Proc. Boston Soc. Nat. Hist., 1870-71 (1872), 14, 189. 1872.1

Bidie, William. Catalogue of the fishes in the Government Central Museum. Madras, 1874. $8^{\circ}$ 1874.1

Biedie, G. Char (Salmo alpinus) in loch Lomond. Ann. Scot. Nat. Hist. 1895 (1896), 124; 258

1896.1

Biedl, A. Die funktionelle Bedeutung des Interrenalorganes der Selachier. Verhandl. 8. Intern. Zool. Kong. Graz, 1910 (1912), 505-511.

1912.1

Biehn, H. Rivulus Rabellicauda, seine Pflege und Zucht. Wochenschr. Aquar.-Terrar. Kunde, 1911, 8. Jahrg. 345-346. fig.

1911.1

Bieler, G.A. Ueber Lachsfischerei und Lachszucht im Rhein und seinen Zuflüssen. Deutsch. Fischerei Zeitg., 1880, 411. - Erste Oester.ungar. Fischerei Leitg., 174-175.

1880.1

_- Ueber die Lebensweise des Rheinlachses und dessen natürliche und künstliche Vermehrung. Deutsch. Fischerei /eitg., 1903, 26, 165-166; 241; 145.

1903.1 
Bieler, Willy. Zur Kenntnis des männlichen Geschlechtsapparats einiger Acanthocephalen von Fischen. Zool. Jahrb. (Anat. Abth.), 1913, 36, 525578. pl. \& 15 figs.

1913.1

\section{Bielschowsky,}

Fine Modifikation meines Silberimprägnationsverfahrens zur Darstellung der Neurofibrillen. Journ. Psychol. Neuro., 1908, 12.

1908.1

Bielz, Eduard Albert [1826?-1898] Uebersicht der lebenden Fische Siebenbürgens. Verh. Mitth. Siebenbürg, $1853,4,172-185 . \quad p l . \quad$ Also separate; Hermannstadt, 1853. $8^{\circ}$.

1853.1

— Fauna der Wirbelthiere Siebenbürgens. .. Eine Preisschrift, etc. Hermannstadt, 1856 . vi, 200 p. $8^{\circ} .1856 .1$

- Die Fauna der Wirbelthiere Siebenbürgens nach ihren jetztigen Bestande. Verh. Siebenb. Ver. Naturwiss., $1888,38,113-120$.

1888.1

Bierhance, Ernst. Lebias sophioe Heckel. Wochenschr. Aquar-Terrar. Kunde, 1912, 9. Jahrg. 443. fig. 1912.1

Biermann, A. Neuestes illustrirtes Fischereibuch, oder Anweisung, die wilde und zahme Fischerei zum Vergnügen und Nutzen mit Erfolg betreiben zu können, nebst Belehrung über Teichwirthschaft und Andeutungen über die künstliche Fischzucht. Hamm, 1865. 120 p. 55 figs. $8^{\circ}$.

1865.1

Biesenbach, Robert. Künstliche Fischzucht und Teichwirthschaft. Ein Hand-und Werkbuch für Fischzïchter und Teichwirthe. Leipzig, 1897. 144 p. $8^{\circ}$.

1897.1

Biétrix, Eugène. L'ouf de la sardine. Journ. Anat. Physiol., 1891, 26. 1891.1

-Distribution sanguine dans les lamelles branchiales des poissons (Squales et téléostéens) Soc. Philom. Paris, 1894, no. 6, p. 2.

1894.1

Sur la pression du sang dans le coeur des poissons. C. R. Soc. Philom. Paris, 1894, no. 5, 16-17:

1894.2

Etude de quelques faits relatifs à la morphologie générale du système circulatoire à propos du réseau branchial des poissons. Paris, 1895. 56 p. 9 figs. $4^{\circ}$.

1895.1

Lacunes et endothélium dans les vaisseaux branchiaux des poissons. C.
R. Soc. Philom. Paris, 1895, no. 9, p. 30 .

1895.2

Quelques considérations sur les notions de lacune et d'endothélium en anatomie générale, à propos du réseau vasculaire branchiale des poissons. C. R. Soc. Philom. Paris, 1895, no. 8, 26-27.

1895.3

Biétrix,Eugène, \& Fabre-Domergue, $P$. See Fabre-Domergue \& Biétrix.

Biétrix, Eugène, \& Pouchet, Georges. See Pouchet \& Biétrix.

Bigelow, Henry Bryant. The sense of hearing in the goldfish (Carassius auratus L.) Amer. Naturalist, 1904, 38 , 275-284.

1904.1

Bigelow, $H . R$. The action of the visual purple in the eel. Med. Rec. New York, 1880, 18, 37. 1880.1

Bigelow, Samuel $L$. Observations on some of the habits of Salmo fontinalis. Boston Journ. Nat. Hist., 1848, 6, 49-53. 1848.1

Big Hatchet (pseudon.) Fish in the Wabash. Chicago Field, 1878, 9, 324.

1878.1

Bigland, John. A natural history of birds, fishes, reptiles and insects. Philadelphia, 1828 . 179 p. 12 col. pls. $8^{\circ}$.

1828.1

Fishes, p. 97-120

The same. 2. ed. "Philadelphia, 1832. $8^{\circ}$.

1832.1

The same. 3. ed. Philadelphia, 1865.1

Bigot, $A$. Catalogue des sélaciens jurassiques du Calvados et de l'Orne. Bull. Soc. Linn. Normandie, 1897, 4. sér. 10, 7-13.

1897.1

Bigot, A., \& Brasil, L. Description de la faune des sables jurassiques supérieurs du Calvados. Mém. Soc. Normandie, 1904, 21, 85-108. pls. i-iv.

1904.1

Bigsby, John Jeremiah [1792-1881] Thesaurus Devonico-Carboniferous. The flora and fauna of the Devonian and Carboniferous periods. London, 1878. $\mathrm{x}, 447$ p. pl.

1878.1

Bikélas, $D$. Sur la nomenclature de la faune grecque. Athens, 1878. 1878.1

Bilharz, Theodor [1825-1862] Alestes macrolepidotus, ein neuer Nilfisch. Sitzber. Akad. Wiss. Wien, math.-nat. Cl., 1852, 9, 469-472. pl. 1852.1 
Bilharz, $T$.

- Beobachtungen über den Zitterwels. Nachricht. Georg-Augusts Univ. Gesell. Wiss. Göttingen, 1853, 134-136. - Bericht Verh. Ges. Beförd. Naturw. Freiburg, 1853, 1, 3-8; 22-26; 65-67; 1856, 2, 173-175. - Ook Afzonderlijk, Leipzig, 1857.

1853.1

Das electrische Organ des Kitterwelses anatomisch beschrieben. Leipzig, 1857. vi, 52 p. 4 pls. $4^{\circ}$. 1857.1

Billard, Georges. Allongement inusité des nageoires chez une tanche vulgaire. Bull. Soc. Zool. France, 1912, 37, 276-278. fig.

1912.1

Billard, Georges, \& Bruyant, Charles. Vitalité des alevins de truite dans les cultures d'algues. C. R. Soc. Biol. Paris, 1905, 58, 447-448.

1905.1

Billroth, $T$. \& Meissner, $G$. See Meissner \& Billroth.

Bing, Robert, \& Burckhardt, Carl Rudolf. Das Centralnervensystem von Ceratodus forsteri. (In "Zoologische Forschungsreisen in Australien und dem Malayischen Archipel" von Prof. Dr. Richard Semon. Jena, 1905. I. pt. 5, 513-584. pl. \& 36 figs.) - Anat. Anz., 1905, 25, 588-599. 4 figs.

1905.1

Binnell, Robert. A description of the river Thames, etc.... To which is added, a description of those fish ... that are caught in the Thames, or sold in London, etc. London, 1785. $296 \mathrm{p}$. 8 pls. $8^{\circ}$.

1785.1

Binney, Amos [1803-1847] Report on Storer's Report on the fishes, reptiles and birds of Massachusetts. Amer. Journ. Sci., 1840, 38, 393-396. 1840.1

_ [Results of his observations made during two successive summers at $\mathrm{Na}$ hant, on the habits of the Orthagoriscus mola, or short sunfish! Proc. Boston Soc. Nat. Hist., 1841-44 (1844), 1, 93.

1842.1

Binney, Edward William [1812-1881] Fossil fishes of the Pendleton coal-field. Trans. Geol. Soc. Manchester, 1840, 1, $153-178$.

1840.1

T. On a giant tooth of a fossil shark. Proc. Lit. Philos. Soc. Manchester, 1878-79 (1879), 18, 11S. 1879.1

Binney, Edward Willam, \& Kirkby, Iames Walker. On the upper beds of the Fifeshire Coal Measures. Quart. Journ.
Geol. Soc. London, 1SS2, 38, 245-256. pl.

1882.1

Fishes are included in the list of species.

Binney, William Greene. On the habits of the Orthagoriscus mola or short sunfish. Proc. Boston Soc. Nat. Hist., $1841-44$ (1844), 1, 93.

1842.1

- Remark on the tunny or horse mackerel. Proc. Boston Soc. Nat. Hist.; 1841-44 (1844), 1, S1. 1812.2

Biot, Jean Baptisle [1774-1862] Mémoire sur la nature de l'air contenu dans la vessie natatoire des poissons. Mém. d'Arcueil, 1807, 1, 252-281; 1809, 2, 487-491.

1807.1

Biozzi, Biozzo. Nota sul lago o stagno di Orbetella, pesci e altri animali acquatici. Esposiz. Internaz. Pesca in Berlino, 1880, Sez. Italiano, Catalogo, 215217.

1880.1

Bippen, $N$ : Das Ausbriten von Fischeiern in feuchter Luft. Congr. Intern. Pêche Piscicult. St. Petersb. 1903, pt. 1, 255-256. 1903.1

Birchall, E. Howard. La girelle (Coris julis Guinther) at the Crystal Palace Aquarium. Zoologist, 1876, 2. ser. 11, 5158-5160.

1876.1

Bird, John. Account of an electric fish [from Calabar'] 'Zoologist, 1875, 2 ser. 10, 4625-4626. 1875.1

Bird, M.C. II. A question of coloration (fishes) Zoologist, 1902, 4. ser. 6, 150-151.

1902.1

Birge, Edward A. Vertical distribution of the lower plants and animals in the inland lakes. Trans. Amer. Fisheries Soc. 1897 (1898), 25-30.

1898.1

The respiration of an inland lake. Trans. Amer. Fisheries Soc. 1907 (1908), 223-241.

1908.1

Gases dissolved in the waters of Wisconsin lakes. Bull. Bur. Fish. Washington, 1910, 28, 1273-1294.

1910.1

Birge, Edward A., \& Juday, Chancey 'The effect of a scarcity of oxygen and cxcess of nitrogen on fishes] Bull. TViscon. Geol. Nat. Hist. Surr. (Scien. ser. no. 7), 1911, 22, 129-134. 1911.1

Birkholz, $J$. C. Oekonomische Beschreibung aller Arten Fische welche in den Gewiissern der Churmark gefunden werden. Berlin und Strassburg, 1770. $\mathrm{S}^{\circ}$. 
Bischof, Carl Gustav Christoph [17921870]. Untersuchung der Luft, welche die Fischart Cobitis fossitis von sich giebt. Allgem. Journ. Chem., 1818, 78-92.

\section{1}

Bischoff, Theodor Ludwig Wilhelm von [1807-1882] Lepidosiren paradoxa. Anatomisch untersucht und beschrieben. Leipzig, 1840. vi, 34 p. 7 pls. $4^{\circ}$. Abstracts in Notizen (Froriep), 1840, 16, 145-148. - Arch. Anat. Physiol., 1840, 179. 1840.1

Bischoff, $W$. Anleitung zur AngelFischerei mit Abbildungen und Beschreibung der hierzu sich eignenden Fischarten. München, 1864. 2. ed. München, 1883. 4 pls. $8^{\circ}$. 1864.1

Bishop, Harman $N$. The palpebral and oculo-motor apparatus in fishes: observations on morphology and development. Journ. Anat. Phys., 1899, 34 (n. s. 14), 1-40. Abstract in Zool. Centralbl., 1900, 7, 523-524.

1899.1

Bishop, Watson $L$. Eels in water pipes and their migration. Proc. Trans. Nova Scotian Inst. Nat. Sci. Halifax, 1908, 11, 640-650.

1908.1

Bisselick, J.W. van. Over de innervatie van het rompmyotoom [Note on the innervation of the trunkmyotome] Proc. Sect. Sci. Acad. Wet. Amsterdam, 1905, 7, 708-711. - Versl. Wis. Nat. Afd. Acad. Wet. Amsterdam, 1905, 13, $727-730$.

1905.1

Bissell, John $H$. Fish culture - a practical art. Trans. Amer. Fisheries Soc. 1886 (1887), 37-43.

1887.1

The Canadian and American fisheries of the Great Lakes. Bull. U. S. Fish Comm. 1887 (18s9), 7, 7-10.

1859.1

- Cooperation in fish culture. Trans. Amer. Fisheries Soc. 1888 (1889), 89-99. 1889.2

-Detroit white fish station. Trans. Amer. Fisheries Soc. 1891 (1893), 16-20.

1893.1

Grayling in Michigan. Trans. Amer. Fisheries Soc. 1891 (1893), 27-29. 1893.2

Bist, — Sur la vessie natatoire des poissons. Mém. Soc. Arcueil, 1807. 1807.1

Bitterli, S. Ueber Anlage von Fischpaissen. Schweiz. Fisch. Zeitg., 1910, 18. Jahrg. 49-57. 11 figs.
Bitting, A. W. Preparation of the cod and other salt fish for the market; including a bacteriological study of the causes of reddening. U. S. Dept. Agric. Bur. Chem. Bull., 1911, 133. 63 p. 7 pls. \& 4 figs.

1911.1

Bittner, Alexander [1850-] Fischzähne im norischen Hallstätter Kalke von Mïhlthal bei Piesting. Verh. Geol. Reichsanst. 1898, no. 15, 321-326. 2 figs.

1898.1

Bizzozero, Enzo. Sur la régénération de l'épithélium intestinal chez les poissons. Atti R. Accad. Sci. Torino, 1904, 38, 966-978. pl. - Arch. Ital. Biol. Torino, 41, 233-245. pl. 1904.1

Bjeletzkij, N.F. La physiologie de la vessie aérienne. Arb. Naturf. Ges. Charkow, 1883, 17, 39-266. pl. Abstract in Biol. Centralbl., 1885, 4, 639640.

1883.1

Bjelooussow, $N$. Mouvements respiratoires chez les poissons [Text in Russian] Trav.Sci. Nat.Zool. Charkow, 1901, 35, 1-38. pl. Abstract in Zool. Centralbl., 1902, 9, $383 . \quad 1901.1$

Björklund, Rudolf Bernhard. Ovambolandet. Geogr. Fören. Tidskr., 1891, 3, 248-267. pl.

1891.1

Björkmann, - Zeit, wenn das Eis aufgeht und der Brachsen leichet auf der See und im Kirchspiel Ofwansio in Gestrikland beobachtet [Sparus Neue Abhandl. Schwed. Akad., 1785, 230-234.

1785.1

Blaauw, $F . E$. Notes on the zoological garden of Berlin. Proc. Zool. Soc. London, 1900, 299-306. 1900.1

Blackford, Eugene G. English and American whitebait. Chicago Field, $1878,9,340$.

1878.1

Peculiar features of New York fish market. Chicago Field, 1879, 10, 331 .

1879.1

Peculiar features of the fish market. Trans. Amer. Fisheries Soc. 1878 (1879), 77-82. $\quad 1879.2$

The protection of striped bass. Chicago Field, 1879, 12, 214. 1879.3

Whitebait. Forest \& Stream, $1879,12,104$. 1879.4

Whitebait in American waters. Chicago Field, 1879, 11, 52. 1879.5 
Blackford, E. G.

- Do sharks harbor their young? Scient. American, 1880, 43, 72。1880.1

Whitebait. Trans. Amer. Fisheries Soc. 1879 (1880), 11-14. 1880.2

- - Carp in an installment of shad from James river. Bull. U. S. Fish Comm.1884, 4, 112.

1884.1

A few facts in relation to the food and spawning seasons of fishes on the Atlantic coast. 'Trans. Amer. Fisheries Soc. 1883 (1884), 5-S. 1884.2

Is legislation necessary for the protection of ocean fishes? Trans. Amer. Fisheries Soc. 1884 (1885), 60-65. 1885.1

Catch of shad in the Hudson river for 1885. Bull. U. S. Fish Comm. 1886 (1887), 6, 294.

1887.1

Note on the spawning season of the eel. Science, 1899 , n. s. 9, 740-741.

1899.1

Blackwall, $J$. Notes on the salmon. Ann. Nat. Hist., 1843, 11, 409-414.

1843.1

Notes on the salmon iSalmo salar] and bull-trout [Salmo eriox] Ann. Nat. Hist., 1850, 2. ser. 5, 241-246.

1850.1

Blackwell, Anna. Pisciculture in France. Once a Week, 1861, 4, 427-428.

1861.1

Bladh, Pehr Johan. Om mar-cldar. K. Svenska Vetenskaps-Akad. Handlingar, 1807, 28, 79-103.

1807.1

Bladon, James. Large sturgeon in the Usk. 'Zoologist, 1846, 4, 1555-1556. 1846.1

Blainville, Henri Marie Ducrotay [1777-1850] Note sur plusieurs espèces de squale, confondues sous le nom de Squalus maximus de Linné. Journ. Phys. 1810, 71, 248-259. - Bull. Soc. Philom. Paris, 1810, 2, 169-171. 1810.1

- Mémoire sur le Squale peregrinus. Ann. Mus. Hist. Nat., 1811, 18, 85-135. - Bull. Soc. Philom. Paris, 1811, 2, 365-368. Also separate; Paris, 1811. pl. $4^{\circ}$. 48 p. 1811.1

Prodrome d'une nouvelle distribution systématique du règne animal. Bull. Soc. Philom. Paris, 1816, 8, 105124.
- Mémoire sur l'opercule des poissons. Bull. Soc. Philom. Paris, 1817, 104-112. - Isis (Oken), 1818, 14121419 .

1817.1

-Ueber den Iriemendeckel der Fische. Deutsch. Arch. Physiol., 1817, 4, 262-266. - Isis (Oken), 1808, 14121419 . 1817.2

Note sur le Stylephus (Stylephorus chordatus de Shaw). Journ. Phys., 1818, 87, 68-71. 1818.1

- Poissons fossiles (In Nouveau Dictionnaire d'Histoire Naturelle. Nouvelle édition, etc., 1808, vol. xxvii) Also separate; Paris, 1808.

1808.2

- Sur la structure des branchies dans les foetus de squales: Lettre de Macartney. Journ. Phys., 1818, 86, 157-158. - Deutsch. Arch. Phys., 1818, 4, 295-296.

1818.3

Sur les ichthyolites ou les poissons fossiles. Paris, 1818. $8^{\circ}$. 1818.4

- Poissons (In Faune Française; ou, histoire générale et particulière des animaux qui se trouvent en France . . par L. P. Vieillot, A. G. Desmarest, $\begin{array}{ll}\text { etc. Paris, } 1820-30 . & \mathrm{S}^{\circ} \text { ) } \\ \end{array}$

- Note sur l'analogue du peigne des oiseaux dans l'oil des reptiles et des poissons. Journ. Phys., 1822, 95, 72.

1822.1

_- Sur la structure et l'analogue de la plaque dorso-céphalique des Rémoras ou Echénéis. Bull. Soc. Philom. Paris, 1822, 119-120. - Journ. Phys., 1822, 95, 132-134.

1822.2

Die versteinerten Fische, geologisch geordnet und naturhistorisch beschrieben ... aus dem Französischen übersetzt. Herausgegeben, mit Anmerkungen und mit einer Vorrede versehen von J. F. Krüger. Quedlinburg \& Leipzig, 1823. $232 \mathrm{p}$.

1823.1

This is a translation of the article Poissons Fossiles in Nouv. Diet. d'Hist. Nat., 1818, 27 $q . \imath$. Review in Bulletin (Ferussac), 1824, 2, 94

- Rapport sur les résultats scientifiques du voyage de la "Bonite" autour du monde. Compt. Rend. 1838, 6, 445-460. - Notizen (Froriep), 1838, 7, 225-232; 243-248.

1838.1

- Rapport fait ... sur les collections d'histoire naturelle recueillies pendant le voyage de "La Favorite" (In Voyage autour du monde sur " La Favorite"... pendant 1830-32. Paris, 1839. vol. v, pt. 1) 
Blaizot, L. L'épithélium utérin chez Acanthias vulgaris Risso avant la première gestation. C. R. Soc. Biol. Paris, 1908, 64, 339-341; 453-455. $\quad 1908.1$

_... Note sur l'origine des cellules libres trouvées dans l'épithélium utérin d'Acanthias vulgaris R. avant le debut de l'histolyse épithéliale. C. R. Assoc. Anat. Réun., 1908, 10, 30-31. 1908.2

Observations sur la gestation chez Acanthias vulgaris R. Bull. Soc. Zool. France, 1908, 33, 57-59. 1908.3 _- Recherches sur l'évolution de l'utérus d'Acanthias vulgaris Risso. Mém. Soc Zool. France, 1909, 22, 5-48. 1909.1

Blake, Charles Carter. Sharks' teeth at Panama. Geologist, 1862, 316.

1862.1

- On a new fish jaw from the Gault near Folkestone [Pachyrhizodus glyphodus Blake \& Mackiel Geologist, 1863, 133-134. 1863.1

Blake, James Henry. On the nourishment of the foetus in the embiotocoid fishes. Proc. Cal. Acad. Nat. Sci., 1867, 3, 314-317. 3 figs. Abstract in Journ. Anat. Physiol., 1868, 2, 280-282. 1867.1

- On the organs of copulation in the male of the embiotocoid fishes. Proc. Cal. Acad. Nat. Sci., 1867, 3, 371-372.

1867.2

On the anal-fin appendages of embiotocoid fishes. Journ. Anat. Phys. 1868 (1869), 3, 30-32. pl. 1869.1

The habits and migrations of some of the marine fishes of Massachusetts. Amer. Naturalist, 1870, 4, 513521.

1870.1

The fossil tooth of a species of shark, which was found near Martinez. Proc. Cal. Acad. Sci., 1873, 5, 172.

1873.1

Blake, John A. The Irish salmon fisheries. London, 1863. 28 p. $8^{\circ}$.

1863.1

The history and position of the sea fisheries of Ireland. Waterford, 1868. 133 p. $8^{\circ}$.

1868.1

Blake, J.F. A monograph of the fauna of the Cornbrash. Pisces. Pal. Soc. Mon., London, 1905, 59, 1-100. pls. i-ix.

1905.1

Blake, $R$. De dentium formatione et structura in homine et variis animalibus. Edinburgh, 1798. $8^{\circ}$. 1798.1
Blake, Willixm Phipps. Fossil fish in the Great basin, Nevada. Proc. Cal. Acad. Nat. Sci., 1863, 3, 306-307. 1863.1

Tooth of the extinct elephant, from Placer county; shark teeth and other remains from 'Tulare county. Proc. Cal. Acad. Nat. Sci., 1866, 3, 290.

1866.1

Report to the United States Centennial Commission upon the principal aquariums abroad in 1873. Rept. U. S. Fish Comm. 1882 (1884), 10, 631640. 2 figs.

1884.1

Blake-Knox, $I I$. Voracity of the angler [Lophius piscatorius] Loologist, $1865,23,9470$.

1865.1

Glances into the ichthyology of the county of Dublin. Zoologist, 1866 , 1, 505-510.

1866.1

Blakeslee, M.A. Shad in Alleghany river. Forest \& Stream, 1874, 12, 228.

1874.1

Blakey, Robert. Historical sketches of the angling literature of all nations. London, 1856. 335 p. $12^{\circ}$. 1856.1

Blakiston, 'T'. Notes of a naturalist on his passage towards the far west. Zoologist, 1857, 15, 5840-5843. 1857.1

Blanc, Eduard. Sur les poissons qui habitent les sources et les puits artésiens du Sahara. Mém. Soc. Zool. France, 1895, 8, 164-172. 1895.1

Répertoire des poissons d'eau douce de la Russie. Ann. Sci. Nat. Zool., 1900, 8. ser. 11, 251-275. 1900.1

Blanc, Henri. Mortalité exceptionnelle des brochets du Léman en 1887. Bull. Soc. Vaud. Sci. Nat., 1888, 23, 33-37.

1888.1

- Sur la maturation et la fécondation de l'œuf de la truite des lacs. Arch. Sci. Nat., 1891, 3. période, 26, 575576 - C. R. 74. Sess. Soc. Helvét. Sei. Nat., 1891, 54-56.

1891.1

- Note préliminaire sur la maturation et la fécondation de l'oeuf de la truite. Bull. Soc. Vaud. Sci. Nat., 1892, 3. sér. 27, 272-275. - Journ. Roy. Mier. Soc. London, 1892, 2. ser. 12, 344.

1892.1

Etude sur la fécondation de l'oeuf de la truite. Berichte Naturf. Ges. Freiburg, 1894, 8, 163-189. pl. Abstract in Bibliog. Anat. (Nicholas), 
Blanc, $H$.

1894, 2, 16-17.-Journ. Roy. Micr. Soc. London, 1894, 2. ser. 14, 324. 1894.1

Résultats d'une série de pêches pélagiques faites en 1894 et 1895 dans le lac Léman pour étudier la distribution verticale et horizontale du plankton. C. R. 78. Sess. Soc. Helvét. Sci. Nat., 1895, 40-44.

1895.1

- A propos de la fécondation de l'ouf de la truite. Bibliog. Anat. (Nicholas), 1898, 6, 222-225, 4 figs. Abstract in $/$ ool. Centralbl., 1899, 6, 490.

1898.1

[Fécondation de la truite. Démonstration] Verh. Schweiz. Naturf. Ges., Bern, 1898, 81, 72-73. 1898.2

- Sur la fécondation de l'ocuf de la truite. Bull. Soc. Zool. Suisse, Bern, 189S, 5, 5-6. - Arch. Sci. Nat., 1898, 4. sér. 6, 497-498.

1898.3

- De l'élevage rationnel des œufs et des alevins de la truite. Bull. Suisse Pêche Piscicult., 1899, 1, 1-4. 1899.1

Die rationelle Aufzucht der Forelle. Schweiz. Fisch. Zeitg., 1899, 6. Jahrg., 253-258.

1899.2

- Mélanges ichthyologiques. Arch. Soc. Phys. Nat. Genève, 1901, 12, 553554. - Bull. Soc. Vaud. Sci. Nat., 1901. 37, xxxvii-xxxviii.

1901.1

Les travaux de Louis Agassiz en zoologic et en palćontologie. Bull. Soc. Vaud. Sci. Nat., 1907, 5. sér. 43, 315340. 2 pls.

1907.1

Petromyzon planeri manquent des orifices branchiaux externes Verh. Schweiz. Naturf. Ges. 1912 (1913), 95, 230-231.

1913.1

Blanc, Louis. Les monstres doubles splanchnodynes. Ann. Soc. Linn., Lyon, 1896, 43, 189-224. $\quad 1896.1$

Blanchard, Charles Emile [1820-] Un naturaliste du dix-neuvième siècle. L. Agassiz. Paris, 1865. 64 p. $8^{\circ}$. 1865.1

Extrait de la Revue des Deux Mondes.

- Les poissons des caux douces de la France; anatomie, physiologie, description des especes, mours, instincts, industrie, commerce, ressources alimentaires, pisciculture, législation concernant la pêche. Paris, 1866.656 p. 151 figs. $8^{\circ}$. 1866.1
De l'accroissement de la taille chez les animaux à sang froid. C. R. Acad. Sci. Paris, 1867, 64, 558-560.

1867.1

Oefversigt af piscikulturens historia under innevarande sekel med särskildt afseende på Frankrike. Oefvers. Helsingfors, 1868,27 p. $8^{\circ}$.

1868.1

Historik öfver fiskodlingen intill förra seklets slut. Tidskr. Fiskerinäring Aquikultur (Malmgren), 1869, 1 Jahrg., 26-35.

1869.1

Ofversigt af fiskodhingens historia i Frankrike under innevarande sekel. Tidskr. Fiskerinäring Aquikultur (Malmgren), 1869, 1. Jahrg., 38-63.

1869.2

Om de nödiga vilkoren för fiskarnes trefnad och förökning. Tidskr. Fiskerinäring Aquikultur (Malmgren), 1869, 1. Jahrg., 74-86.

1869.3

Les poissons des eaux douces de la France. 2. ed. Paris, 1880. xvi, 656 p. 32 pls. \& 115 figs. $8^{\circ}$. 1880.1

Remarque relative à la communication précédente ("Sur les variations observées dans la pêche du hareng sur les côtes de Norvège") C. R.Acad Sci. Paris, 1882, 94, 826. 1882.1

Etude de l'anguille de rivière, après son passage de l'eau douce dans les eaux salées. C. R. Acad. Sci. Paris, $1890,109,169-170$.

1890.1

Remarques à l'occasion de la communication précédente [Sur les moeurs du Clinus argentatus Cuv. et Val. par M. Fr. Guitel] C. R. Acad. Sci. Paris, 1893, 115, 297-298. 1893.1

Blanchard, Raphaêl [1858-] Mittheilungen über den Bau und die Entwickelung der sogenannten fingerförmigen Drüse bei den Knorpelfischen. Witth. Embryol. Instit. Univ. Wien, 1878, 1, 179-192. 2 pls. 1878.1

Recherches sur la structure et le développement de la glande superanale (digitiforme) des poissons cartilagineux. Journ. Anat. Phys., 1878, 14, 442-450. Abstract in Rev. Internat. Sci., 1878 , 2, 402 .

1878.2

-.. La fécondation dans la série animale. Paris, 1879.

1879.1

Glycogène chez les embryons de squale. Bull. Soc. Zool. France, 1882, 
7, 405. - Zool. Anz., 18s3, 6, 67.Journ. Micr. Soc. London, 1883, 2. ser. 3, pt. 2, 493.

1882.1

- Sur les fonctions de la glande digitiforme ou superanale des plagiostomes. C. R. Acad. Sci. Paris, 1882, 95, 1005-1007. - Bull. Soc. Zool. France, 1882, 7, 399-401. 1882.2

__ Sur les fonctions des appendices pyloriques. C. R. Acad. Sci. Paris, 1883, 96, 1241, 1244. - Bull. Soc. Zool. France, 1883, 8, 143-146. 1883.1

Anormalie des nageoires chez le protoptère. Bull. Soc. Zool. France, $1894,19,54-57.8$ figs.

1894.1

- Sur le vairon montagnard (Phoxinus lavis var. montanus) Bull. Soc. Zool. France, 1896, 21, 155-156.

1896.1

Observations sur la faune des eaux chaudes. C. R. Soc. Biol. Paris, 1903, 55, 947-950; 1069-1070. 1903.1

Blanchard, Raphaël, \& Regnard, Paul. See Regnard \& Blanchard.

Blanchard, Raphaël, \& Richard, $J$. Sur la faune des lacs élevés des Hautes Alpes. Mém. Soc. Zool. France, 1897, $10,43-61$.

1897.1

Blanchère, Henri de la. See La Blanchère, $H$. de.

Blanchet, $M$. Le Cardium edule dans l'alimentation de la truite. Bull. Soc. Nation. Acclimat. France, 1912, 59, $382-385$.

1912.1

Elevage de muges et de bars, en eau douce, à Saint-Valéry-sur-Somme. Bull. Soc. Nation. Acclimat. France, 1914, 61, 133-137.

1914.1

Blanchet, Rodolphe [1807-] Influence de l'hydrogène sulfuré sur les poissons et application de cette remarque à quelques faits géologiques. C. R Acad. Sci. Paris, 1844, 20, 112 . 1844.1

Wirkung des Schwefelwasserstoffes auf die Fische. Annalen (Liebeg), 1845, 54, 109-112.

1845.1

Goniobates agassizi. Bull. Soc. Vaud. Sci. Nat., 1858-60 (1861), 6, 472-473. - Neues Jahrb. Mineral., 1862, 753. pl. 1861.1

Blanchon, H.L.Alphonse. Manuel pratique du pisciculteur. Paris, 1898. $\mathrm{v}, 320$ p. 65 figs. $12^{\circ}$. (Encyclopédie Roret)
_- L'incubation artificielle des oeufs de salmonides et les appareils cellulaires Cosmos, Paris, 1911, 65, 465-467.

1911.1

La truite domestique. Production rationelle des salmonides en eaux fermées. Paris [1911] 231 p. 43 figs.

1911.2

Le cyprin doré de la Chine et ses variétés. Cosmos, Paris, 1912, 66 , 624-626.

1912.1

Blanchon, Pierre. Les usiniers et la pisciculture. Piscicult. Prat., 1898, 3 , no. $3,37-40$.

1898.1

Blanck, $A$. Die Fische der Seen und Flüsse Mecklenburgs-Schwerin. Arch Ver. Naturgesch. Meckl., 1881, 34, 94154; 241-250. Also separate; Schwerin, 1881. $64 \mathrm{p}$. 1881.1

Blanckenhorn, Max. Neues zur Geologie und Paläontologie Aegyptens. Zeitschr. Deutsch. Geol. Ges., 1901, 53, 52-132. 2 pls. \& 15 figs.

1901.1

Blanding, William. Fecundity of the striped bass. Proc. Acad. Nat. Sci. Philad., 1841 (1842), 39

1841.1

Blanford, William Thomas [1832 - ] Zoology and geology (In Goldsmid, Sir F. J., and others. Eastern Persia, an account of the journeys of the Persian Boundary Commission, 1870-72. 2 vols. London, 1876. 30 pls. \& 4 maps. $8^{\circ}$ ) 1876.1

Vol. ii. The zoology and geology, by W. T. Blanford.

The distribution of vertebrate animals in India, Ceylon and Burma. Philos. Trans. Roy. Soc. London, 1901, 194, 335-436. Abstract in Proc. Roy. Soc. London, 1901, 67, 484-492.

1901.1

Blankenburg, von. FischereiBestrebungen in Pommern. Circul. Deutsch. Fischerei Ver., 1879, no. 1, 29-30.

1879.1

Blatchley, Willis S. On the American species of the genus Umbra. Proc. Acad. Nat. Sci. Philad., 1885 (1886), 12-13.

1886.1

On the genus Aphredoderus. Proc. Acad. Nat. Sci. Philad., 1885 (1886), 136-137. 1886.2

A review of the species of the genus Pimephales. Proc. Acad. Nat. Sci. Philad. 1855 (1886), 63-65. 1885.3 
Blatchley, $W . S$.

Indiana caves and their fauna. Ann. Rept. Indiana Geol. Nat. Resources, 1896, 21, 121-185. pls. 1896.1 Fishes, p. 183-185.

Blathwayt, $F$. L. Fish on the coast of Somerset. Zoologist, 1906, 10, 470.

1906.1

Blaue, Julius. Ueber den Bau der Nasenschleimhaut bei Fischen und Amphibien. Zool. Anz., 1852, 5, 657-660. - Arch. Anat. Phys., 1884 (Anat. Abth.), 231-309.

1882.1

Blaue, Otto. Misserfolge bei der Zucht des Tetragonopterus mbropictus. Wochenschr. Aquar-Terrar. Isunde, 1911, 8. Jahrg., 465-466

1911.1

Blavier, A. 'Théorie explicative du régime climatologique observé en France sur le littoral océanien, depuis 1880 , et de la disparition de la sardine sur ce littoral depuis la même époque. C. R. Acad. Sci. Paris, 1882, 94, 769-772.

1882.1

Bleeker, Pieter [1819-1878] For bibliography, obituary notice, etc., see Nat. Tijdschr. Neder.-Indië, 1881, 40, 1-158. Also Weber, M., and de Beaufort, L. F. Index of the ichthyological papers of P. Bleeker. Leiden, 1911. $410 \mathrm{p}$.

Bijdragen tot de geneeskundige topographie van Batavia. Generisch overzicht der Fauna. Nat. \& Geneesk. Arch. Neder.-Indië, 1844, 1, 551-553; 1845, 2, 505-528

1844.1

- Overzicht der Siluroiden welke te Batavia voorkomen. Nat. \& Geneesk. Arch. Neder.-Indië, 1846, 2. ser. $3,135-184$.

1846.1

Siluroideorum bataviensium species nuperrime detectæ. Nat. \& Geneesk. Arch. Neder-Indië, 1846, 2. ser. 3, 284-293.

1846.2

Labroideorum ctenoideorum bataviensium diagnoses et adumbrationes. Verh. Batav. Genootsch., 1847, 21, 133. Also separate; Batavia, 1847. $8^{\circ}$

1847.1

Nieuwe bijdrage tot de kennis der Siluroïden van Java. Verh. Batav. Genoot.sch., 1847, 21, 1-12.

1847.2

-.. Pharyngognathorum Siluroideorumque species novx javanenses. Nat. \& Geneesk. Arch. Neder.-Indië, 1847,2 . ser. 4, 15.5-169.
- Siluroideorum bataviensium conspectus diagnosticus. Verh. Batav. Genootsch., 1847, 21, 1-60. Also separate; Batavia, 1847. $8^{\circ}$. 1847.4

A contribution to the ichthyolgy of Sumbawa. Journ. Ind. Arch., 1848, 2, no. 9, 632-639.

1848.1

Bijdrage tot de kennis der Blennioïden en Gobioïden van den Soenda-Molukschen Archipel, met beschrijving van 42 nieuwe soorten. Verh. Batav. Genootsch., 1849, 22, 1-40.

1849.1

Bijdrage tot de kennis der ichthyologische fauna van het eiland Bali, met beschrijving van eenige nieuwe species. Verh. Batav. Genootsch., 1849, 22, 1-11.

1849.2

Bijdrage tot de kennis der ichthyologische fauna van het eiland Madura, met beschrijving van eenige nieuwe species. Verh. Batav. Genootsch., 1849, 22, 1-16. Also separate; Batavia, 1849. $4^{\circ}$.

1849.3

Bijdrage tot de kennis der ichthyologische fauna van Midden- en Oost-Java, met beschrijving van eenige nieurve species. Verh. Batav. Genootsch., 1850, 23, 1-23. Also separate; Batavia, $1849.4^{\circ}$.

1849.4

Bijdrage tot de kennis der Percoïden van den Malajo-Molukschen Archipel, mit beschrijving von 22 nieuwe soorten. Verh. Batav. Genootsch., 1849, 22, 1-64. Also separate; Batavia, $1849.4^{\circ}$. 1849.5

- Bijdrage tot de kennis der Scleroparei van den Soenda-Molukschen Archipel. Verh. Batav. Genootsch., $1849,22,1-10$.

1849.6

A contribution to the knowledge of the ichthyological fauna of Celebes. Journ. Ind. Arch., 1849, 3, 65-74.

1849.7

Overzigt der te Batavia voorkomende gladschubbige Labroïden met beschrijving van 11 nieuwe soorten. Verh. Batav. Genootsch., 1849, 22, 1-64. Also separate; Batavia, 1849. $\mathrm{S}^{\circ}$.

1849.8

Bijdrage tot de kennis der Chretodontoïden van den Soenda-Molukschen Archipel. Verh. Batav. Genootsch., 1850, 23, 1-31. Also separate; Batavia, 1850 . $4^{\circ}$.

1850.1 
Bijdrage tot de kennis der ichthyologische fauna van Midden- en Oost-Java, met beschrijving van eenige nieuwe species. Verh. Batav. Genootsch., 1850, 23, 1-23. $\quad 1850.2$

Bijdrage tot de kennis der Maenoïden van den Soenda-Molukschen Archipel. Verh. Batav. Genootsch., $1850,23,1-13$.

1850.3

Bijdrage tot de kennis der Notacanthini van den Soenda-Molukschen Archipel. Verh. Batav. Genootsch., $1850,23,1-6$.

1850.4

Bijdrage tot de kennis der Sciaenoïden van den Soenda-Molukschen Archipel, met beschrijving van 7 nieuwe soorten. Verh. Batav. Genootsch., 1850, 23, 1-31. Also separate; Batavia, 1850 . $4^{\circ}$.

1850.5

Bijdrage tot de kennis der Sparoïden van den Soenda-Molukschen Archipel. Verh. Batav. Genootsch., 1850, 23, 1-16. Also separate; $\mathrm{Ba}-$ tavia, $1850.4^{\circ}$.

1850.6

Bijdrage tot de kennis der Teuthiden van den Soenda-Molukschen Archipel. Verh. Batav. Genootsch. 1850, 23, 1-13.

1850.7

Bijdrage tot de kennis der visschen met doolhofvormige kieuwen von den Soenda-Molukschen Archipel. Verh. Batav. Genootsch., 1850, 23 , 1-15. Also separate; Batavia, 1850. $4^{\circ}$.

1850.8

Bijdrage tot de kennis der ichthyologische fauna van Borneo, met beschrijving van 16 nieuwe soorten van zoetwatervisschen. Nat. Tijdschr. Neder.-Indië, 1851, 1, 1-16. 1851.1

Bijdrage tot de kennis der ichthyologische fauna van de Bandaeilanden. Nat. Tijdschr. Neder.-Indië, 1851, 2, 225-261.

1851.2

Bijdrage tot de kennis der ichthyologische fauna van Riouw. Nat. Tijdschr. Neder.-Indië, 1851, 2, 469497.

1851.3

Cheilinoïdes, een nieuw geslacht van gladschubbige Labroïden van $\mathrm{Ba}$ tavia. Nat. Tijdschr. Neder.-Indië, 1851, 2, 71-72. pl. Also separate; Batavia, 1851. $8^{\circ}$.

1851.4

Derde bijdrage tot de kennis der ichthyologische fauna van Borneo, met beschrijving van eenige nieuwe soorten van zoetwatervisschen. Nat. Tijdschr. Neder.-Indië, 1851, 2, 57-70. 1851.5

- Faunæ ichthyologica Jave insularumque adjacentium genera et species nova. Nat. Tijdschr. Neder.Indië, 1851, 1, 98-10S. 1851.6

Nieuwe bijdrage tot de kennis der ichthyologische fauna van Borneo, met beschrijving van eenige nieuwe soorten van zoetwatervisschen. Nat. Tijdschr. Neder.-Indië, 1851, 1, 259275.

1851.7

Nieuwe bijdrage tot de kennis der ichthyologische fauna van Celebes. Nat. Tijdschr. Neder.-Indië, 1851, 2, 209-224.

1851.8

Nieuwe bijdrage tot de kennis der Percoidei, Scleroparei, Sciaenoidei, Maenoidei, Chaetodontoidei en Scomberoidei van den Soenda-Molukschen Archipel. Nat. Tijdschr. Neder.-Indië, $1851,2,163-179$.

1851.9

Over drie nieuwe soorten van Tetraodon van den Indischen Archipel. Nat. 'Tijdschr'. Neder-Indië, 1851, 1 , 96-97. Also separate; Batavia, 1851. $8^{\circ}$.

1851.10

- Over eenige nieuwe geslachten en soorten van Makreelachtige visschen van den Indischen Archipel. Nat. Tijdschr. Neder.-Indië, 1S51, 1, 341-372.

1851.11

Over eenige nieuwe soorten van Belone en Hemiramphus van Java. Nat. 'Tijdschr. Neder.-Indië, 1851, 1, 93-95. Also separate; Batavia, 1851. $8^{\circ}$.

1851.12

Over eenige nieuwe soorten van Blennioiden en Gobioiden van den Indischen Archipel. Nat. Tijdschr. Neder.-Indië, 1851, 1, 236-258. pl. Also separate; Batavia, 1851. $8^{\circ}$.

1851.13

Over eenige nieuwe soorten van Megalops, Dussumieria, Notopterus en Astronesthes. Nat. Tijdschr. Neder.Indië, 1851, 1, 417-424. Also separate; Batavia, 1851. $8^{\circ}$.

1851.14

Over eenige nieuwe soorten van Pleuronectoïden van den Indischen Archipel. Nat. Tijdschr. Neder.-Indië, $1851,1,401-416$.

1851.15

- Over eenige nieuwe soorten van Scleroparei van den Indischen Archipel. Nat. 'Tijdschr. Neder.-Indië, 1851, 1 , $17-27$. 
Bleeker, $P$.

- Over twee nieuwe soorten van Callionymus van den Indisehen Archipel. Nat. Tijdschr. Neder.-Indië, 1851, 1, 28-32. Also separate; Batavia, 1851. $8^{\circ}$.

1851.17

Oxybeles brandesii Blkr., eene nieuwe soort van Ophidini van Banda Neira. Nat. Tijdschr. Neder.-Indië, 1851, 1, 276-278. figs. Also separate; Batavia, 1851 .

1851.18

Vierde bijdrage tot de kennis der ichthyologische fauna van Borneo, met beschrijving van eenige nieuwe sonorte van zoetwatervisschen. Nat. Tijdschr. Neder.-Indië, 1851, 2, 193-208. 1851.19

Vijfde bijdrage tot de kennis der ichthyologische fauna van Borneo, met beschrijving van eenige nieuwe soorten van zoetwatervisschen. Nat. Tijdschr. Neder.-Indië, 1851, 2, 415442.

1851.20

- Visschen van Banka. Nat. Tijdschr. Neder.-Indië, 1851, 1, 159161 .

1851.21

-... Visschen van Biliton. Nat. Tijdschr. Neder.-Indië, 1851, 1, 478479 .

1851.22

- Visschen van Borneo. Nat. Tijdschr. Neder.-Indië, 1851, 1, 161162.

1851.23

Visschen van Solor. Nat. Tijdschr. Neder.-Indië, 1851, 2, 347-348.

1851.24

Visschen van Straat Malakka, Prince of Wales Island en Singapore. Nat. Tijdschr. Neder.-Indië, 1851, 1, $480-481$.

1851.25

Bijdrage tot de kennis der Balistini en Ostraciones van den Indischen Archipel. Verh. Batav. Genootsch., 1852, 24, 1-38. 7 pls. Also separate; Batavia, 1852. $4^{\circ}$. 1852.1

Bijdrage tot de kennis der Blootkakige visschen van den SoendaMolukschen Archipel [Gymnognathi] Verh. Batav. Genootsch., 1852, 24, 1-26. Also separate; Batavia, 1852. $4^{\circ}$.

1852.2

Bijdrage tot de kennis der Chirocentroidei, Lutodeiri, Butirini, Elopes, Notopteri, Salmones, Echeneoidei en Ophidini van den SoendaMolukschen Archipel. Verh. Batav. Genootsch., 1852, 24, 1-32. 1852.3
Bijdrage tot de kennis der Haringachtige visschen van den SoendaMolukschen en van den Indischen Archipel. Verh. Batav. Genootsch., $1852,24,1-52$.

1852.4

Bijdrage tot de kennis der ichthyologische fauna van Blitong (Billiton), met beschrijving van eenige nieuwe soorten van zoetwatervisschen. Nat. Tijdschr. Neder.-Indië, 1852, 3, 87-100. Also separate; Batavia, 1852. $8^{\circ}$.

1852.5

Bijdrage tot de kennis der ichthyologische fauna van de Moluksche eilanden. Visschen van Amboina en Ceram. Nat. Tijdschr. Neder.-Indië, 1852, 3, 229-309.

1852.6

Bijdrage tot de kennis der ichthyologische fauna van het eiland Banka. Nat. Tijdschr. Neder.-Indië, $1852,3,443-460$.

1852.7

Bijdrage tot de kennis der ichthyologische fauna van Singapore. Nat. Tijdschr. Neder.-Indië, 1852, 3, 51-86.

1852.8

Bijdrage tot de kennis der ichthyologische fauna van Timor. Nat. Tijdschr. Neder.-Indië, 1852, 3, 159-174. 1852.9

Bijdrage tot de kennis der Makreelachtige visschen van den Soenda-Molukschen Archipel. Verh. Batav. Genootsch., 1852, 24, 1-93.

1852.10

Bijdrage tot de kennis der Plagiostomen van den Indischen Archipel. Verh. Batav. Genootsch., 1851 (1852), 24, 1-92. 4 pls. Also separate; Batavia, 1852. $4^{\circ}$.

1852.11

Bijdrage tot de kennis der Pleuronecteoidei van den Soenda-Molukschen Archipel. Verh. Batav. Genootsch., 1852, 24, 1-32. 1852.12

Bijdrage tot de kennis der Snoekachtige visschen van den SoendaMolukschen Archipel. Verh. Batav. Genootsch., 1852, 24, 1-28. Also separate; Batavia, 1852. $4^{\circ}$ 1852.13

- Derde bijdrage tot de kennis der ichthyologische fauna van Celebes. Nat. Tijdschr. Neder.-Indië, 1852, 3, 739-782.

1852.14

_- Diagnostische beschrijvingen van nieuwe of weinig bekende vischsoorten van Sumatra. Tiental I-IV. Nat. Tijdschr. Neder.-Indië, 1852, 3, 569-608.

1852.15 
- Nieuwe bijdrage tot de kennis der ichthyologische fauna van Amboina. Nat. 'Tijdschr. Neder.-Indië, 1852, 3, 545-568.

1852.16

- Nieuwe bijdrage tot de kennis der ichthyologische fauna van Ceram. Nat. Tijdschr. Neder.-Indië, 1852, 3, 689-714. Also separate; Batavia, 1852. $8^{\circ}$.

1852.17

- Nieuwe bijdrage tot de kennis der ichthyologische fauna van het eiland Banka. Nat. Tijdschr. Neder-Indië, 1852, 3, 715-738.

1852.18

- Nieuwe visschen van BandaNeira. Nat. Tijdschr. Neder-Indië, 1852, 3, 643-646.

1852.19

- Visschen van Solor. Nat. Tijdschr. Neder.-Indië, 1852, 3, 490-491.

1852.20

Zesde bijdrage tot de kennis der ichthyologische fauna van Borneo. Visschen van Pamangkat, Bandjermassing, Braboekarta en Sampit. Nat. Tijdschr. Neder.-Indië, 1852, 3, 407442.

1852.21

-_L Antennarius [Chironectes Cuv.] notophthalmus, eene nieuwe soort van de Meeuwenbaai. Nat. Tijdschr. Neder.-Indië, 1853, 5, 543-545. Also separate; Batavia, 1853. $8^{\circ}$. 1853.1

Bijdrage tot de kennis der ichthyologische fauna van Solor. Nat. Tijdschr. Neder.-Indië, 1853, 5, 67-96. Also separate; Batavia, $1853 . \mathrm{S}^{\circ}$.

185.3 .2

Bijdrage tot de kennis der ichthyologische fauna van Ternate. Nat. -Tijdschr. Neder.-Indië, 1853, 4, 131140.

1853.3

Bijdrage tot de kennis der Murænoïden en Symbranchoïden van den Indischen Archipel. Verh. Batav. Genootsch., 1853, 25, 1-76. Also separate; Batavia, 1853. $4^{\circ}$. 1853.4

- Bijdrage tot de kennis der Troskieuwige visschen van den Indischen Archipel. Verh. Batav. Genootsch., 1853, 25, 1-38. Also separate: Batavia, 1853. $4^{\circ}$. 1853.

Derde bijdrage tot de kennis der ichthyologische fauna van Amboina. Nat. Tijdschr. Neder.-Indië, 1853,4 , 91-130.

1853.6

Derde bijdrage tot de kennis der ichthyologische fauna van Ceram. Nat.
Tijdschr. Neder.-Indië, 1853, 5, 233248.

1853.7

Diagnostische beschrijvingen van nieuwe of weinig bekende vischsoorten van Batavia. Tiental I-VI. Nat. Tijdschr." Neder.-Indië, 1853, 4 , $451-516$.

1853.8

__ Diagnostische beschrijvingen van nieuwe of weinig bekende vischsoorten van Sumatra. Tiental $\mathrm{V}-\mathrm{X}$. Nat. Tijdschr. Neder.-Indië, 1853, 4, 243-302.

1853.9

Exocotus hexagona, eene nieume soort van Banka. Nat. Tijdschr. Neder.-Indië, 1853, 4, 206-207. 1853.10

Index specierum piscium $\mathrm{ma}$ layo-molucceusium in volumine 5 diarii Societatis Indo-Batava descriptarum. Nat. Tijdschr. Neder.-Indië, 1853, 5, $547-550$.

1853.11

- Nalezingen op de ichthyologie van Japan. Verh. Batav. Genootsch. 1853, 25, 1-56. 1853.12

- Nalezingen op de ichthyologische fauna van Bengalen en Hindostan. Verh. Batav. Genootsch., 1853, 25, 1-164. 6 pls. Also separate; $\mathrm{Ba}$ tavia, 1853. $4^{\circ}$.

1853.13

Nalezingen op de ichthyologische fauna van het eiland Banka. Nat. Tijdschr. Neder.-Indië, 1853, 5, $175-194$.

1853.14

Nieuwe bijdrage tot de kennis der ichthyologische fauna van Ternate en Halmaheira (Gilolo) Nat. Tijdschr. Neder.-Indië, 1853, 4, 595-610. Also separate; Batavia, 1853. $8^{\circ}$. 1853.15

Nieuwe tientallen diagnostische beschrijvingen van nieuwe of weinig bekende vischsoorten van Sumatra. Nat. Tijdschr. Neder.-Indië, 1853, 5, $495-534$.

1853.16

Over eenige nieuwe soorten van Homaloptera v. Hass. (Balitora Gray) van Java en Sumatra. Nat. Tijdschr. Neder.-Indië, 1853, 4, 155-164. Also separate; Batavia, 1853. $8^{\circ}$. 1853.17

Sicydium parvei, een nieuwe soort van de Preanger-Regentschappen. Nat. Tijdschr. Neder.-Indië, 1853, 4, $426-427$.

1853.18

Vierde bijdrage tot de kennis der ichthyologische fauna van Amboina. Nat. Tijdschr. Neder.-Indië, 1853, 5, 317-352. 
Bleeker, $P$.

Vierde bijdrage tot de kennis der ichthyologische fauna van Celebes. Nat. Tijdschr. Neder.-Indië, 1853, 5, 153-174.

1853.20

Zevende bijdrage tot de kennis der ichthyologische fauna van Borneo. Zoetwatervisschen van Sambas, Pontianak en Pengaron. Nat. 'Tijdschr. Neder.-Indië, 1853, 5, 427-462. 1853.21

Bijdrage tot de kennis der ichthyologische fauna van Batjan. Nat. Tijdschr. Neder.-Indië, 1854, 7, 359378.

1854.1

Bijdrage tot de kennis der ichthyologische fauna van de Kiokoseilanden. Nat. Tijdschr. Neder.-Indië, $1854,7,37-48$. Also separate; Batavia, $1854-58$.

1854.2

Bijdrage tot de kennis der ichthyologische fauna van Halmaheira (Gilolo) Nat. Tijdschr. Neder.-Indië, $1854,6,49-62$.

1854.3

Bijdrage tot de kennis der ichthyologische fauna van het eiland Flores. Nat. Tijdschr. Neder--Indië, $1854,6,311-338$.

1854.4

Bijdrage tot de kennis der ichthyologische fauna van Japan. Verh. Akad. Amsterdam, 1854, 1, 1-16. Also separate; Amsterdam \& Batavia, $1853-$ 59. 12 pls. $4^{\circ}$.

1854.5

Bijdrage tot de kennis der Sphyrænoiden van den Indischen Archipel. Verh. Batav. Genootsch., 1854 57, 26, 1-22. Also separate; Batavia, 1854. $4^{\circ}$.

1854.6

Dactylopterus cheirophthalmus van de Banda-eilanden. Nat. Tijdschr. Neder.-Indië, 1854, 7, 494-495. Also separate; Batavia, 1854. $8^{\circ}$. 1854.7

Derde bijdrage tot de kennis der ichthyologische fauna van de Bandaeilanden. Nat. Tijdschr. Neder.-Indië, 1854, 6, 89-114.

1854.8

- Diagramma hamatochir, eene nieuve soort van Ternate. Nat. Tijdschr. Neder-Indië, 1854, 6, 175176.

1854.9

Diagramma polytonioüles, cene nieuwe soort van Solor. Nat. Tijdschr. Neder-Indië, 1854, 6, 376-378. 1854.10

- Eleotris tolsoni, eene nieuwe soort van Java's Westhock nabij de Meeurvenbai. Nat. Tijdschr. Neder.-
Indië, 1854, 6, 542-543. Also separate; Batavia, 1854. $\mathrm{S}^{\circ}$.

1854.11

-.. Faunæ ichthyologicx japonicx species novx. Nat. Tijdschr. Neder.Indië, 1854, 6, 395-426. $\quad 1854.12$

Ichthyologische waarnemingen gedaan op verschillende reizen in de residentie Bantam. Nat. Tijdschr. Neder-Indië, 1854, 7, 309-326. 1854.13

Index specierum piscium in voluminibus $21-26$ actorum Societatis Artium et Scientiarum Bataviensis descriptarum ... Verh. Batav. Genootsch., 1854, 26, 1-24. Also separate; Batavia, 1854-57. $4^{\circ}$. 1854.14

Index specierum piscium malayo-moluccensium in volumine 6 diarii Soc. Indo-Batava descriptarum. Nat. Tijdschr. Neder.-Indië, 1854, 6, 544 546.

1854.15

Index specierum piscium malayo-moluccensium in volumine 7 diarii Soc. Indo-Batav descriptarum. Nat. Tijdschr. Neder-Indië, 1854, 7, 498500 .

1854.16

-_ Iets over visschen levende in zeesterren en over eene nieuwe soort van Oxybeles. Nat. Tijdschr. Neder.Indië, 1854, 7, 162-163. figs. Also separate; Batavia, 1854. $8^{\circ}$. 1854.17

- Nieuwe bijdrage tot de kennis der ichthyologische fauna van Timor. Nat. Tijdschr. Neder--Indië, 1854, 6, 203-214. Also separate; Batavia, 185460. $8^{\circ}$.

1854.18

Nog iets over visschen levende in echinodermen. Nat. Tijdschr. Neder.-Indië, 1854, 7, 495-496. 1854.19

Over eenige nieuwe soorten van Notopterus van den Indischen Archipel. Nova Acta Acad. Leop. Carol. Nat. Cur., 1854, 24, 49-62. 5 pls. 1854.20

Over eenige nieurve visschen van de Kokos-eilanden. Nat. 'Tijdschr. Neder.-Indië, 1854, 7, 353-358. Also separate; Batavia, 1854. $8^{\circ}$. 1854.21

Overzicht der ichthyologische fauna van Sumatra, met beschrijving van eenige nieuwe soorten. Nat. Tijdschr, Neder.-Indië, 1854, 7, 49-10S. 1854.22

Specierum piscium javanensium novarum vel minus cognitarum diagnoses adumbratx. Nat. Tijdschr. Neder. Indië, 1S54, 7, 415-448. 1854.23 
Species piscium bataviensium novæ vel minus cognitx. Nat. Tijdschr. Neder.-Indië, 1854, 6, 191-202. 1854.24

Vijfde bijdrage tot de kennis der ichthyologische fauna van Amboina. Nat. 'Tijdschr. Neder.-Indië, 1854, 6, $455-508$

1854.25

Vijfde bijdrage tot de kennis der ichthyologische fauna van Celebes. Nat. Tijdschr. Neder.-Indië, 1854, 7, 225-260.

1854.26

- Visschen van de Natoena-eilanden. Nat. Tijdschr. Neder.-Indië, 1854, 7, 163-164.

1854.27

- Achtste bijdrage tot de kennis der ichthyologische fauna van Borneo. Zoetwatervisschen van Bandjermasin. Nat. Tijdschr. Neder.-Indië, 1855, 8, 151-168.

1855.1

Achtste bijdrage tot de kennis der ichthyologische fauna van Celebes. Nat. Tijdschr. Neder.-Indië, 1855, 9, 281-314.

1855.2

- Antennarius lindgreeni, eene nieuwe soort van Banka. Nat. Tijdschr. Neder.-Indië, 1855, 8, 192-193. Also separate; Batavia, 1855. $8^{\circ}$. 1855.3

Bijdrage tot de kennis der ichthyologische fauna van de Batoeeilanden. Nat. Tijdschr. Neder.-Indië, $1855,8,305-328$.

1855.4

Bijdrage tot de kennis der ichthyologische fauna van het eiland Groot-Obi. Nat. Tijdschr. Neder.Indië, 1855, 9, 431-438. Also separate; Batavia, 1855. $S^{\circ}$ 1855.5

Derde bijdrage tot de kennis der ichthyologische fauna van Batjan. Nat. Tijdschr. Neder.-Indië, 1855, 9, 491504.

1855.6

Derde bijdrage tot de kennis der ichthyologische fauna van de Kokoseilanden. Nat. Tijdschr. Neder.-Indië, $1855,8,169-180$.

1855.7

Index specierum piscium malayo-moluccensium in volumine 8 diaril Societatis Indo-Batava descriptarum. Nat. Tijdschr. Neder.-Indië, 1855, 8, $552-554$.

1855.8

Index specierum piscium malayo-moluccensium in volumine 9 diarii Societatis Indo-Batavæ descriptarum. Nat. Tijdschr. Neder.-Indië, 1855, 9, $527-528$.
Nalezingen op de vischfauna van Sumatra. Visschen van Lahat en Sibogha. Nat. Tijdschr. Neder.-Indië, $1855,9,257-280$.

1855.10

Negende bijdrage tot de kennis der ichthyologische fauna van Borneo. Zoetwatervisschen van Pontianak en Bandjermasin. Nat. Tijdschr. Neder.Indië, $1855,9,415-430$. 1855.11

Nieuwe bijdrage tot de kennis der ichthyologische fauna van Sumbawa. Nat. Tijdschr. Neder.-Indië, 1855, 9, 113-115. Also separate; Batavia, 1855. $8^{\circ}$.

1855.12

Over eenige nieuwe visschen van Ternate. Nat. Tijdschr. Neder.Indië, 1855, 9, 155.

1855.13

Over eenige visschen van Van Diemensland. Verh. Akad. Amsterdam, 1855, 2, 1-30.

1855.14

Tweede bijdrage tot de kennis der ichthyologische fauna van Batjan. Nat. Tijdschr. Neder.-Indië, 1855, 9, 191-202.

1855.15

Tweede bijdrage tot de kennis der ichthyologische fauna van de Batoe-eilanden. Nat. Tijdschr. Neder.Indië, $1855,9,65-72$.

1855.16

Tweede bijdrage tot de kennis der ichthyologische fauna van Halmaheira (Gilolo) Nat. Tijdschr. Neder.Indië, 1855, 9, 105-112. $\quad 1855.17$

Verslag van eenige vischverzamelingen van Oost-Java. Nat. Tijdschr. Neder.-Indië, 1855, 9, 391-414.

1855.18

Vierde bijdrage tot de kennis der ichthyologische fauna van de Kokos-eilanden. Nat. Tijdschr. Neder.Indië, 1855, 8, 445-460.

1855.19

Vijfde bijdrage tot de kennis der ichthyologische fauna van Ternate. Nat. Tijdschr. Neder.-Indië, 1855, 8, 295-304. Also separate; Batavia, 1855$56 . \mathrm{S}^{\circ}$.

1855.20

_ Visschen van de Duizend-eilanden. Nat. Tijdschr. Neder-Indië, $1855,8,344$.

1855.21

_ Visschen van Tikoe, Sumatra's Westkust. Nat. Tijdschr. Neder.Indië, 1855, 8, 345 . 1855.22

Zesde bijdrage tot de kennis der ichthyologische fauna van Amboina. Nat. Tijdschr. Neder.-Indië, 1855, 8, 
Bleeker, $P$.

391-434. Also separate; Batavia, 1855. $\mathrm{S}^{\circ}$. 1855.23

Zevende bijdrage tot de kennis der ichthyologische fauna van Celebes. Nat. 'Tijdschr. Neder.-Indië, 1855, 8, $435-444$.

1855.24

- Beschrijvingen van nieure en weinig bekende vischsoorten van Amboina. Act. Soc. Sci. Indo-Neerl., 1856, 1, 1-76. Also separate; Batavia, 1856. $4^{\circ}$.

1856.1

- Beschrijvingen van nieuwe of weinig bekende vischsoorten van Menado en Makassar grootendeels verzameld op eene reis naar den Molukschen Archipel in het gevolg van den Gouverneur-Generaal Duymaer van Twist. Act. Soc. Sci. Indo-Neerl., $1856,1,1-80$.

1856.2

- Bijdrage tot de kennis der ichthyologische fauna van het eiland Boero. Nat. Tijdschr. Neder.-Indië, $1856,11,383-414$.

1856.3

Bijdrage tot de kennis der ichthyologische fauna van het eiland Nias. Nat. Tijdschr. Neder.-Indië, 1856-57, 12. 211-228. Also separate; Batavia, 1856. $8^{\circ}$.

1856.4

Carcharias (Prionodon) amblyrhynchus, eene nieuwe haaisoort gevangen nabij het eiland Solombo. Nat, Tijdschr. Neder.-Indië, 1856, 10, 467468. Also separate; Batavia, 1856.

1856.5

Index specierum piscium malayo-moluccensium in voluminibus $1-10$ diarii Soc. Indo-Batavæe descriptarum. Nat. Tijdschr. Neder.-Indië, 1856, 10, $472-500$.

1856.6

Index specierum piscium malayo-moluccensium in voluminibus 11 \& 12 diarii Soc. Indo-Batavx descriptarum. Nat. Tijdschr. Neder.-Indië, 1856-57, 12, 511-512.

1856.7

Reis door de Minahassa en den Molukschen Archipel gedaan in de maanden September en October 1855 in het gevolg van den GouverneurGeneraal A. J. Duymaer van Twist. 2 vols. Batavia, $18556 . \quad 1856.8$

Tweede bijdrage tot de kennis der ichthyologische fauna van het eiland Bintang. Nat. Tijdschr. Neder.Indië, 1856, 10, 345-356.

1856.9
Verslag omtrent cenige vischsoorten gevangen aan de Zuidkust van Malang in Oost-Java. Nat. Tijdschr. Neder.-Indië, 1856, 11, 81-92. 1856.10

- Verslag van einige verzamelingen van zee- en zoetwatervisschen van het eiland Banka. Nat. Tijdschr. Neder.-Indië, 1856, 11, 415-420. Also separate; Batavia, 1856. $\mathrm{S}^{\circ}$. 1856.11

Vijfde bijdrage tot de kennis der ichthyologische fauna van de Bandaeilanden. Nat. Tijdschr. Neder.-Indië, 1856, 11, 93-110. Also separate; Batavia, 1856. $8^{\circ}$. 1856.12

Visschen van Saparoea. Nat. Tijdschr. Neder.-Indië, 1856, 10, 469.

1856.13

- Visschen waargenomen te Laboeha, eiland Batjan. Nat. Tijdschr. Neder.-Indië, 1856, 11, 253-254.

1856.14

Vischsoorten nieuw voor de kennis der fauna van het eiland Ceram. Nat. Tijdschr. Neder.-Indië, 1856, 11, 486-487. Also separate; Batavia, 1856. $8^{\circ}$.

1856.15

- Zevende bijdrage tot de kennis der ichthyologische fauna van Ternate. Nat. Tijdschr. Neder.-Indië, 1856, 10, $357-386$

1856.16

Achtste bijdrage tot de kennis der ichthyologische fauna van Ternate. Nat. Tijdschr. Neder.-Indië, 1856-57, 12, 191-210.

1857.1

Achtste bijdrage tot de kennis der vischfauna van Amboina. Act. Soc. Sci. Indo-Neerl., 1857, 2, 1-102. 1857.2

Bericht omtrent eenige vischsoorten nieuwe voor de kennis van het eiland Ceram. Nat. Tijdschr. Neder.Indië, 1856-57, 12, 508.

1857.3

Bericht omtrent eenige vischsoorten van Tobali, eiland Banka. Nat. 'Iijdschr. Neder.-Indië, 1856-57, 12, 273-275.

1857.4

Bijdrage tot de kennis der ichthyologische fauna van de Sangi-eilanden. Nat. 'Tijdschr. Neder.-Indië, 1857, 13, 369-380. Also separate; Batavia, 1857. $8^{\circ}$.

1857.5

Bijdrage tot de kennis der Sphyrænoiden van den Indischen Archipel. Verh. Batav. Genootsch., 1854-57, 26, 1-22. 
Conspectus specierum piscium moluccensium hucusque cognitarum. Acta Soc. Sci. Indo-Neerl., 1857, 2, 123. Also separate; Batavia, 1857. $4^{\circ}$.

1857.7

Derde bijdrage tot de kennis der ichthyologische fauna van de Batoeeilanden. Nat. Tijdschr. Neder.-Indië, 1856-57, 12, 229-242.

1857.8

— Descriptiones specierum piscium Javanensium novarum vel minus cognitarum diagnosticx. Nat. Tijdschr. Neder-Indiê,, 1857, 13, 323-368. Also separate; Batavia, 1857. $8^{\circ}$. 1857.9

Index descriptionum specierum piscium Bleekerianarum in voluminibus 1 ad 19 diarii Societatis Scientiarum Indo-Batavx. Nat. Tijdschr. Neder.Indië, 1857, 14, 447-486. $\quad 1857.10$

Index specierum piscium in voluminibus 21-26 actorum Societatis Artium et Scientiarum Indo-Batava descriptarum adjectis citationibus ubi descriptiones Bleekerianse recentiores emendatæque reperiuntur. Verh. Batav. Genootsch., 1854-57, 26, 1-24

1857.11

Nieurve bijdrage tot de kennis der ichthyologische fauna van Bali. Nat. Tijdschr. Neder.-Indië, 1856-57, 12, 291-302. Also separate; Batavia, 1856. $8^{\circ}$

1857.12

- Nieuwe nalezingen op de ichthyologie van Japan. Verh. Batav. Genootsch., 1854-57, 26, 1-132. 1857.13

Over eenige vischsoorten gevangen bij Prigi aan Java's Zuidkust. Nat. 'Tijdschr. Neder.-Indië, 1857, 14, 244-246.

1857.14

Over eenige vischsoorten nieuw voor de kennis der fauna van Biliton. Nat. Tijdschr. Neder.-Indië, 1857, 13, 283-287.

1857.15

Over eenige vischverzamelingen van verschillende gedeelten van Java. Nat. Tijdschr. Neder.-Indië, 1857, 13, 475-480. Also separate; Batavia, 1857.

1857.16

Tiende bijdrage tot de kennis der ichthyologische fauna van Borneo. Visschen van de rivieren Barito, Kahajan en Kapoeas. Act. Soc. Sci. IndoNeerl., 1857, 2, 1-21.

1857.17

Tweede bijdrage tot de kennis der ichthyologische fauna van Boeroe. Nat. 'Tijdschr. Neder.-Indië, 1857, 13, $55-82$.
Verslag omtrent eenige vischsoorten van Timor-Koepang en TimorDelhi. Nat. Tijdschr. Neder.-Indië, $1857,13,387-390$.

1857.19

Verslag van cene nieuwe verzameling visschen van Batjan. Nat. Tijdschr. Neder.-Indië, 1857, 13, 381 386.

1857.20

Zesde bijdrage tot de kennis der vischfauna van Sumatra. Visschen van Padang, Troessan, Priaman, Siboga en Palembang. Act. Soc. Sci. Indo-Neerl., $1858,3,1-50$.

1858.1

Bijdrage tot de kennis der vischfauna van den Goram-Archipel Nat. Tijdschr. Neder.-Indië, 1858, 15, $197-218$.

1858.2

De visschen van den Indischen Archipel. Siluri. Act. Soc. Sci. IndoNeerl., 1858, 4.

1858.3

Elfde bijdrage tot de kennis der ichthyologische fauna van Borneo. Visschen van Sinkawang. Act. Soc. Sci. Indo-Neerl., 1858, 3, 1-4.

1858.4

Elfde bijdrage tot de kennis der vischfauna van Celebes. Visschen van Makassar. Act. Soc. Sci. Indo-Neerl., $1858,3,1-2$.

1858.5

Enumeratio specierum piscium Javanensium hucusque cognitarum. Nat. Tijdschr. Neder.-Indië, 1858, 15, 359-456. Also separate; Batavia, 1858. $8^{\circ}$

1858.6

Holacanthus pseudannularis, eene nieuwe soort van Batavia. Nat. Tijdschr. Neder.-Indië, 1S5S, 15, 169 171.

1858.7

- Ichthyologix Archipelagi Indici Prodromus. Visschen van den Indischen Archipel. I. Siluri. Verh. Natuurk. Ver. Batavia, 1858, 4, 1-370. Also separate, together with "Vol. II, Cyprini"; Batavia, 1858-60. 2 vols. $4^{\circ}$. 1858.8

Index specierum piscium in voluminibus I-III actorum Societatis Scientiarum Indo-Neerlandicæ descriptarum. Act. Soc. Sci. Indo-Neerl., 1858, 3, 1-6. Also separate; Batavia, $1857-$ 58. $4^{\circ}$

1858.9

Negende bijdrage tot de kennis der vischfauna van Amboina. Act. Soc. Sci. Indo-Neerl., 1858, 3, 1-6. 1858.10

Tiende bijdrage tot de kennis der vischfauna van Amboina. Act. Soc. Sci. Indo-Neerl., 1858, 3, 1-4.

1858.11 
Bleeker, $P$.

Tiende bijdrage tot de kennis der vischfauna van Celebes. Act. Soc. Sci. Indo-Neerl., 1858, 3, 1-16. 1858.12

Tweede bijdrage tot de kennis der vischfauna van Singapore. Nat. Tijdschr. Neder.-Indië, 1858, 15, 241254.

1858.13

Ueber das Vorkommen von Fischen in Echinodermen und über eine neue Species von Oxybeles $(O$. brandesii) Arch. Holländ. Beitr. Naturk., 1858, 1 , $255-257$.

1858.14

Vierde bijdrage tot de kennis der ichthyologische fauna van Japan. Act. Soc. Sci. Indo-Neerl., 1858, 3, 1-46.

1858.15

- Vierde bijdrage tot de kennis der vischfauna van Biliton. Nat. Tijdschr. Neder.-Indië, 1858, 15, 219240.

1858.16

Vijfde bijdrage tot de kennis der ichthyologische fauna van de Kokos-eilanden. Nat. Tijdschr. Neder.Indië, 1858, 15, 457-468.

1858.17

Visschen van Java's Zuidkust. Nat. 'Tijdschr. Neder.-Indië, 1858, 15, 159-162.

1858.18

_- Bijdrage tot de kennis der vischfauna van Bawean. Nat. Tijdschr. Neder.-Indië, 1859, 18, 351-358. Also separate; Batavia, 1859. $8^{\circ}$. 1859.1

Bijdrage tot de kennis der vischfauna van Nieuw-Guinea. Act. Soc. Sci. Indo-Neerl., 1859, 6, 1-24. Also separate; Batavia, 1859. $4^{\circ}$. 1859.2

Conspectus specierum Mugilis Archipelagi Indici analyticus. Nat. Tijdschr. Neder.-Indië, 1858-59, 16, 275-280.

1859.3

Derde bijdrage tot de kennis der ichthyologische fauna van Bali. Nat. Tijdschr. Neder.-Indië, 1858-59, 17, 141-175. Also separate; Batavia, 1859. $8^{\circ}$.

1859.4

Eene verzameling zee- en zoetwatervisschen, gevangen bij Priaman, verzameld door $H$. Diepenhorst. Nat. 'Tijdschr. Neder.-Indië, 1858-59, 16 , 336-338.

1859.5

- Eenige vischjes uit de rivier van Priaman en cenige van de Zuidkust van Java, verzameld door G. F. James. Nat. Tijdschr. Neder.-Indië, 1858-59, 16, 211-212.

1859.6
Enumeratio specierum piscium hucusque in Archipelago Indico observatarum. ... Act. Soc. Sci. IndoNeerl., 1859, 6, i-xxxvi; 1-276. Also separate; Batavia, 1859. $4^{\circ}$. 1859.7

Exocotus speculiger van Banda. Nat. Tijdschr. Neder.-Indië, 1858-59, 16, 314 .

1859.8

- Negende bijdrage tot de kennis der vischfauna van Banka. Nat. Tijdschr. Neder.-Indië, 1859, 18, 359378. Also separate; Batavia, 1859. $8^{\circ}$.

1859.9

Nog iets over het geslacht Heterophthalmus. Nat. Tijdschr. Neder.Indië, 1858-59, 16, 253-255. 1859.10

Ophiocephalus micropeltes II. V. $H$. gevangen in de rivieren van westelijk Borneo en aangeboden door den heer C. M. H. Kroesen. Nat. Tijdschr. Neder-Indië, 1858-59, 16, 241. 1859.11

- Over de geslachten der Cobitinen. Nat. Tijdschr. Neder,-Indië, $1858-59,16,302-304 . \quad 1859.12$

Over eene nieuwe verzameling vischsoorten van Benkoelen van A.J. IV. van Ophuysen. Nat. Tijdschr. Neder.-Indië, 1858-59, 16, 273-275.

1859.13

Over eenige vischsoorten van de Zuidkustwateren van Java. Nat. Tijdschr. Neder.-Indië, 1859, 19, 329-352. Also separate; Batavia, 1859. $8^{\circ}$.

Systema Silurorum. Nat. Tijdschr. Neder.-Indië, 1858-59, 16, 38-41.

1859.15

Twaalfde bijdrage tot de kennis der vischfauna van Borneo. Visschen van Sinkawang. Act. Soc. Sci. IndoNeerl., 1858-59, 5, 1-10.

1859.16

Twaalfde bijdrage tot de kennis der vischfauna van Celebes. Visschen van Manado. Act.Soc.Sci. Indo-Neerl., $1858-59,5,1-4$.

1859.17

Verslag van eene verzameling visschen van Westelijk Borneo, aangeboden door J. H. A. Sonneman Rebentisch. Nat. Tijdschr. Neder.-Indië, $1858-59,16,433-436$.

1859.18

Vierde bijdrage tot de kennis der ichthyologische fauna van Timor. Visschen van Atapoepoe. Nat. Tijdschr. Neder.-Indië, 1858-59, 17, 129140. Also separate; Batavia, 1859.

1859.19 
Vijfde bijdrage tot de kennis der ichthyologische fauna van Japan. Act. Soc. Sci. Indo-Neerl., 1858-59, 5, 1-12. 1859.20

Vischsoorten gevangen bij Benkoelen en aangeboden door J. A. IV. van Ophuysen. Nat. Tijdschr. Neder.Indië, 1858-59, 16, 243-244. 1859.21

- Vischsoorten gevangen bij $J_{a-}$ para, verzameld door S. A. Thurkow. Nat. Tijdschr. Neder--Indië, 1858-59, 16, 406-409.

1859.22

- Vischsoorten uit de Moessi, Saleh, Padang en Kommering, verzameld door E. A. Lange en G. A. van Delden. Nat. Tijdschr. Neder.-Indië, 1858-59, 16, 384-388.

1859.23

- Vischsoorten uit de zoete wateren van Benkoelen, verzameld door J. A. W. van Ophuysen. Nat. Tijdschr. Neder.-Indië, 1858-59, 16, 210-211.

1859.24

Vischsoorten van Anjer, verzameld door F. H. Eysinger. Nat. 'Tijdschr. Neder.-Indië, 1858-59, 16, 45.

1859.25

Vischsoorten van Banjoewangi en Buitenzorg, verzameld door $H$. Zollinger, H. von Rosenberg en $O$. J. U. F. Huguenin. Nat. Tijdschr. Neder.Indië, 1858-59, 16, 47-48.

1859.26

Vischsoorten van Batjan, verzameld door J. G. F. Bernelot Moens. Nat. Tijdschr. Neder.-Indië, 1858-59, 16, 208-210.

1859.27

-- Vischsoorten van de Kokoseilanden, verzameld door Dr. Anderson. Nat. Tijdschr. Neder.-Indië, 1858-59, 16, 240.

1859.28

Vischsoorten van Muntok, verzameld door F. IV. Dolge. Nat. Tijdschr. Neder.-Indië, 1858-59, 16, 251252.

1859.29

- Vischsoorten van Palembang, verzameld door $\mathrm{E}$. A. Lange en $\mathrm{F}$. J. P. Storm van's Gravensande. Nat. Tijdschr. Neder.-Indië, 1858-59, 16, 263266.

1859.30

Vischsoorten van Palembang, verzameld door R. V. Heyliger. Nat. Tijdschr. Neder.-Indië, 1858-59, 16. 338-341.

1859.31

- Vischsoorten van Riouw en Lingga, verzameld door E. Netscher, F. F. Meyer en H. Raat. Nat. Tijdschr. Neder.-Indië, $1858-59,16,45-47$.

1859.32
Vischsoorten van Sinkawang, verzameld door J. H. A. B. Sonnemann Rebentisch. Nat. Tijdschr. Neder.Indië, $1858-59,16,195-196 . \quad 1859.33$

- Vischsoorten van Tanara. Nat. lijdschr. Neder.-Indië, 1S58-59, 16, 316-317.

1859.34

Vischsoorten van Tjilatjap, verzameld door H. 'Tievez. Nat. Tijdschr. Neder.-Indië, 1858-59, 16, 37. 1859.35

Visschen uit de omstreken van Montrado verzameld door G. J. Filet. Nat. Tijdschr. Neder.-Indië, 1858-59. 16, 196-197.

1859.36

Visschen uit de Serayoe, verzameld door G. C. Schonck. Nat. Tijdschr. Neder.-Indië, 1858-59, 16, 241 242.

1859.37

Visschen van Amboina verzameld door den heer Schröder. Nat. Tijdschr. Neder.-Indië, 1858-59, 16 , 28-31. $\quad 1859.38$

Visschen van Anjer, verzameld door J. G. F. Bernelot Moens. Nat. Tidjschr. Neder.-Indië, 1858-59, 16 , 424-425.

1859.39

Visschen van Biliton, verzameld door A. Hendriks. Nat. Tijdschr. Neder.-Indië, 1858-59, 16, 261-262.

1859.40

Visschen van de Kokos-eilanden, verzameld door J. G. C. Ross en Dr. A. J. Anderson. Nat. Tijdschr. Neder.Indië, 1858-59, 16, 205-206. 1859.41

Visschen van Kioetei, verzameld door J. Wolff. Nat. Tijdschr. Neder.Indië, 1858-59, 16, 206. $\quad 1859.42$

Visschen van Tikoe verzameld door E. A. Ludeking. Nat. Tijdschr. Neder.-Indiè, 1858-59, 16, 26.

1859.43

Visschen van Wonosobo. Nat. Tijdschr. Neder.-Indië, 1858-59, 16, 302.

1859.44

Zeevisschen gevangen in de nabijheid van Benkoelen, verzameld door J. A. W. van Ophuysen. Nat. Tijdschr. Neder.-Indië, 1858-59, 16 , 239.

1859.45

Zevende bijdrage tot de kennis der vischfauna van Sumatra. Visschen van Palembang. Act. Soc. Sci. IndoNeerl., 1858-59, 5, 1-12. 1859.46 
Bleeker, $P$.

- Zoetwatervissehen uit de omstreken van Ngawi, verzameld door J. T. van Bloemen Waanders. Nat. Tijdschr. Neder.-Indië, 1858-59, 16, $357-358$.

1859.47

Achtste bijdrage tot de kennis der vischfauna van Simatra. Visschen van Benkoelen, Priaman, Tandjong, Palembang en Diambi. Act. Soc. Sci. Indo-Neerl., $1860,8,1-88$.

1860.1

Conspectus systematis Cyprinorum. Nat. Tijdschr. Neder.-Indië, 1859-60, 20, 421-441.

1860.2

Derde bijdrage tot de kennis der vischfauna van Singapore. Nat. Tijdschr. Neder.-Indië, 1859-60, 20, 446-456.

1860.3

Dertiende bijdrage tot de kennis der vischfauna van Borneo. Act. Soc. Sci. Indo.-Neerl., 1860, 8, 1-64. 1860.4

Dertiende bijdrage tot de kennis der vischfauna van Celebes. Visschen van Bonthain, Badjoa, Sindjai, Lagoesi en Pompenoea. Act. Soc. Sci. IndoNeerl., 1860, 8, 1-60.

1860.5

Elfde bijdrage tot de kennis der vischfauna van Amboina. Act. Soc. Sci. Indo-Neerl., 1860, 8, 1-14. 1860.6

Hemiramphus buffonis Val. en Mugil vaigiensis $Q$. et $\mathrm{G}$. van Batjan, verzameld door $O$. J. U. F. Huguenin. Nat. 'Tijdschr. Neder.-Indië, 1859-60, 20,417 .

1860.7

-... Negende bijdrage tot de kennis der vischfauna van Sumatra. Visschen uit de Lematang-Enim en van Benkoelen. Act. Soc. Sci. Indo-Neerl., $1860,8,1-12$.

1860.8

Nieuwe vischsoorten van Singapore, verzameld door Fr. Graaf de Castelnau. Nat. Tijdschr. Neder.Indië, 1859-60, 20, 236-239. 1860.9

Ordo Cynrini, Karpers. Act. Soc. Sci. Indo-Neerl., 1860, 7 (n. s. 2), 1-492.

1860.10

This forms a companion volume to the work entitled "Visschen van den Indischen Archipel. Vol. I. Siluri," published at Batavia in $185 \mathrm{~S}$. See supra.

- Over de plaatsing in het stelsel van de Luciocephaloiden. Nat. Tijdschr. Neder.-Indië, $1859-60,20$, 395397.

1860.11

- Over eenige vischsoorten van de Kaap de Goede Hoop. Nat. Tijdschr. Neder.-Indië, 1860, 21, 49-80. 1860.12
Over het natuurlijk stelsel der visschen. Nat. Tijdschr. Neder.-Indië, $1859-60,20,461-462$.

1860.13

- Soorten van visschen van Badjoa, verzameld door E. Netscher. Nat. Tijdschr. Neder.-Indië, 1859-60, 20, 197-198.

1860.14

Tiende bijdrage tot de kennis der vischfauna van Banka. Nat. Tijdschr. Neder.-Indië, 1860, 21, 135142.

1860.15

Tiental vischsoorten van de Kokos-eilanden, verzameld door A. J. Anderson. Nat. Tijdschr. Neder.Indië, $1859-60,20,142-143 . \quad 1860.16$

Twaalfde bijdrage tot de kennis der vischfauna van Amboina. Act. Soc. Sci. Indo-Neerl., 1860, 8, 1-4. 1860.17

Vijfde bijdrage tot de kennis der vischfauna van 'T'imor. Vischsoorten van Atapoepoe. Nat. Tijdschr. Neder.Indië, 1S59-60, 20, 442-145. $\quad 1860.18$

Vischsoorten van Amboina, verzameld door D. S. Hoedt. Nat. Tijdschr. Neder.-Indië, 1859-60, 20, 204.

1860.19

Vischsoorten van Badjoa, verzameld door B. Schreuders. Nat. 'Tijdschr. Neder.-Indië, 1859-60, 20, 129.

1860.20

Vischsoorten van Badjoa, verzameld door E. Netscher. Nat. Tijdschr. Neder.-Indië, 1859-60, 20, 140142.

1860.21

Vischsoorten van Bali, verzameld door P. L. van Bloemen Waanders. Nat. Tijdschr. Neder.-Indië, 1859-60, 20, 205-207.

1860.22

Vischsoorten van Biliton, verzameld door den heer Kruymel. Nat. Tijdschr. Neder.-Indië, 1859-60, 20, 201-202.

1860.23

Vischsoorten van Bintang, verzameld door E. F. Meyer. Nat. Tijdschr. Neder.-Indië, 1859-60, 20, 87-88. 1860.24

Vischsoorten van Bonthain, verzameld door J. L. de Zeeger. Nat. Tijdschr. Neder.-Indië, 1859-60, 20, 332.

1860.25

- Vischsoorten van de Aroe-eilanden, aangeboden door $\mathrm{O}$. Mohnike. Nat. Tijdschr. Neder.-Indië, 1859-60, 20,332 .

1860.26 
Vischsoorten van Japan, verzameld te Desima, door Jhr. J. L. C. Pompe van Meerdervoort. Nat. 'Tijdschr. Neder.-Indië, 1859-60, 20, 231236.

1860.27

Vischsoorten van Karangbollong, verzameld door $F$. J. Schultze. Nat. Tijdschr. Neder.-Indië, 1859-60, 20, 202-204.

1860.28

Vischsoorten van de Kokoseilanden, verzameld door A. J. Anderson. Nat. Tijdschr. Neder.-Indië, 1859$60,20,202$.

1860.29

- Vischsoorten van Priaman, verzameld door H. Diepenhorst. Nat. Tijdschr. Neder.-Indië, $1859-60,20$, 198-199.

1860.30

- Vischsoorten van Siam, verzameld door Fr. de Castelnau. Nat. Tijdschr. Neder.-Indië, 1859-60, 20 , 101-102.

1860.31

- Vischsoorten van Singapore, verzameld door Fr. Graaf de Castelnau. Nat. Tijdschr. Neder.-Indië, 1859-60, 20, 216-217.

1860.32

Visschen gevangen in de baai van Amboina en aangeboden door $\mathrm{O}$. Mohnike. Nat. Tijdschr. Neder.-Indië, 1859-60, 20, 331-332.

1860.33

- Visschen uit de omstreken van Tandjong aan' de Samangka-baai, verzameld door den heer Hunnius. Nat. Tijdschr. Neder.-Indië, 1859-60, 20, 219-220.

1860.34

Visschen van Anjer en uit het meer Dano, verzameld door J. G. F. Bernelot Moens. Nat. Tijdschr. Neder.Indië, 1859-60, 20, 240-241. 1860.35

- Zesde bijdrage tot de kennis der vischfauna van Japan. Act. Soc. Sci. Indo-Neerl., 1860, 8, 1-104. 1860.36

Zoetwatervisschen van Singapoera, verzameld door F. Graaf de Castelnau. Nat. Tijdschr. Neder.Indië, 1860, 21, 334.

1860.37

Zoetwatervisschen van Sintang, verzameld door A. H. Thepas. Nat. Tijdschr. Neder.-Indië, 1859-60, 20 , $199-200$.

1860.38

Aanteekening ISynonymie und Priorität von Fischnamen] Versl. Akad. Amsterdam, 1861, 12, 81-82.

1861.1

Derde bijdrage tot de kennis der ichthyologische fauna van Boeroe.
Nat. Tijdschr. Neder.-Indië, 1861, 22, 109-114.

1861.2

Elfde bijdrage tot de kennis der vischfauna van Banka. Nat. Tijdschr. Neder.-Indië, 1861, 22, 107-108. 1861.3

Iets over de geslachten der Scaroiden en hunne Indisch-archipelagische soorten. Versl. Akad. Amsterdam, 1861, 12, 228-244. 1861.4

Iets over de vischfauna van het eiland Pinang. Versl. Akad. Amsterdam, 1861, 12, 64-80. 1861.5

-..Mededeeling omtrent vischsoorten, nieuw voor de kennis der fauna van Singapoera. Versl. Akad. Amsterdam, 1861, 12, 28-63. 1861.6

Notice sur le genre Trachinus et ses espèces. Ann. Sci. Nat., 1861, 4. sér. 16 (Zool.) , 375-382. - Versl. Akad. Amsterdam, 1862, 14, 113-122. 1861.7

Over eenige vischsoorten van Benkoelen, verzameld door A. J. W. van Ophuysen. Nat. Tijdschr. Neder.Indië, 1861, 22, 65-66.

1861.8

Tweede bijdrage tot de kennis der vischfauna van Bawean. Nat. Tijdschr. Neder.-Indië, 1861, 22, 243246.

1861.9

Vierde bijdrage tot de kennis der vischfauna van Bali. Nat. Tijdschr. Neder.-Indië, 1861, 22, 239-242.

1861.10

Vischsoorten gevangen bij Prigi, verzameld door C. G. C. Greiner. Nat. Tijdschr. Neder.-Indië, 1861, 22, 88-89.

1861.11

Vischsoorten, nieuw voor de kennis der fauna van Singapoera, verzameld door Fr. Graaf de Castelnau. Nat. Tijdschr. Neder.-Indië, 1861, 22, 101-102.

1861.12

Vischsoorten van Nieuw-Guinea, verzameld door F. G. Beckman. Nat. Tijdschr. Neder.-Indiè, 1861, 22, 98100.

1861.13

Zesde bijdrage tot de kennis der vischfauna van Ceram. Nat. Tijdschr. Neder.-Indië, 1861, 22, 228-238.

1861.14

Zesde bijdrage tot de kennis der vischfauna van Timor. Nat. Tijdschr. Neder.-Indië, 1861, 22, 247-261.

1861.15 
Bleeker, $P$.

-_ Zoetwatervisschen van Gombong in zuidelijk Midden-Java, verzameld door P. Bruyn van Rozenburg. Nat. Tijdschr. Neder.-Indië, 1861, 22 , 100-101.

1861.16

Atlas ichthyologique des Indes Orientales Néerlandaises, publié sous les auspices du Gouvernement colonial néerlandais. Amsterdam, 1862-77. 9 vols. 36 livraisons.

1862.1

i. Scaroides et Labroides. 1862. 48 pls.

ii. Siluroides, Chacoides et Hétérobranchoides. 1862, 53 pls.

iii. Cyprins. 1863. 43 pls.

iv. Murènes, Symbranches, Leptocéphales. 1864. 49 pls.

v. Baudroies, Ostracions, Gymnodontes, Balistes. 1865. 47 pls.

vi. Pleuronectes, Scombrésoces, Clupées, Clupésoces, Chauliodontes, Saurides. 1866-72. 46 pls.

vii. Percoides. I, Priacanthiformes, Serraniformes, Grammisteiformes, Percæformes, Datniæformes. 1873-76. 41 pls.

viii. Percoides. II, Bogodoides, Cirrhitéoides. 876-77. $34 \mathrm{pls}$

ix. Toxotoidei, Pempheridoidei, Chætodontoidei, Nandoidei, etc. $1877.55 \mathrm{pls}$.

-Conspectus generum Labroideorum analyticus. Versl. Akad. Amsterdam, 1862, 13, 94-109. - Proc. Zool. Soc. London, 1861, 408-418. Also separate; Amsterdam, 1862. $\quad 1862.2$

Description de quelques espèces nouvelles de Silures de Suriname conservées aux Musées de Leide et d'Amsterdam. Versl. Akad. Amsterdam, 1862, 14, 371-389. - Natuurk. Verh. Maatsch. Wet. Haarlem, 20, 104. 16 pls. Also separate; Amsterdam, 1862. $\mathrm{S}^{\circ}$.

1862.3

- Neuvième article sur la faune ichthyologique de l'île de Ternate. Versl. Akad. Amsterdam, 1862, 14, 9598.

1862.4

Notices ichthyologiques (I-X) Versl. Akad. Amsterdam, 1862, 14, 123-141. Also separate; Amsterlam, 1863. $8^{\circ}$.

1862.5

- Notice sur les genres Parasilurus, Eutropichthys, Pseudeutropius et Pseudopangasius. Versl. Akad. Amsterdam, 1862, 14, 390-399. Also separate; Amsterdam, 1862. $8^{\circ}$. 1862.6

Notice sur les genres Tracheliopterichthys, Hemicetopsis et Pseudocetopsis. Versl. Akad. Amsterdam, 1862, 14, 400-403. Also separate; Amsterdam, 1862. $8^{\circ}$. 1862.7

Sixième mémoire sur la faune ichthyologique de l'île Batjan. Versl. Akad. Amsterdam, 1862, 14, 99-112.
_- Sur quelques genres de la famille des Pleuronectoïdes. Versl. Akad. Amsterdam, 1862, 13, 422-429. 1862.9

Synonyma Labroideorum Indoarchipelagicorum hucusque observatorum revisa, adjectis specierum novarum descriptionibus. Versl. Akad. Amsterdam, 1862, 13, 274-308. 1862.10

Beschrijving en afbeelding van eene nieuwe soort van Brama (Abramis) uit de omstreken van Leiden. Versl. Akad. Amsterdam, 1863, 15, 235-238. - Neder. Tijdschr. Dierk. $1863,1,371-373$.

1863.1

Description de quelques espèces de Cobitoides et de Cyprinoides de Ceylon. Versl. Akad. Amsterdam, 1863, 15, 239-253. - Neder. Tijdschr. Dierk., 1863, 1, 373-380. Also separate; Amsterdam, 1863. $8^{\circ}$.

1863.2

Description de quelques espèces de poissons nouvelles ou peu connues de Chine envoyées au Musée de Leide par M. G. Schlegel. Neder. Tijdschr. Dierk., $1863,1,135-150$.

1863.3

Description de quelques espèces nouvelles ou peu connues d'Ophisuroides de l'Inde archipélagique. Neder. Tijdschr. Dierk., 1863, 1, 179-186. 1863.4

- Description de trois espèces nouvelles de Siluroïdes de l'Inde archipélagique. Versl. Akad. Amsterdam, 1863, 15, 70-76. - Neder. Tijdschr. Dierk., 1863, 1, 368-371. 1863.5

Description d'une nouvelle espèce du genre Nemacheilus. Versl. Akad. Amsterdam, 1863, 15, 254-256. - Neder. Tijdschr. Dierk., 1863, 1, 380381.

1863.6

Deuxième notice sur la faune ichthyologique de l'île de Flores. Neder. Tijdschr. Dierk., 1863, 1, 248-252. Also separate; La Haye, $1863.4^{\circ}$.

1863.7

Deurième notice sur la faune ichthyologique de l'île d'Obi. Neder. Tijdschr. Dierk., 1863, 1, 239-245. Also separate; Haga Comitis, 1863. $4^{\circ}$. 1863.8

Dixième notice sur la faune ichthyologique de l'ile de Ternate. Versl. Akad. Amsterdam, 1863, 15, 265-266. - Neder. Tijdschr. Dierk., 1865, 2, 67-68. 
Glyphidodon westermani, une nouvelle espèce de Java. Versl. Akad. Amsterdam, 1863, 15, 30-31. - Neder. Tijdschr. Dierk., 1863, 1, 360-361.

1863.10

Mémoire sur les poissons de la côte de Guinée. Nat. Verh. Holl. Maatsch. Wetensch., 1863, 2. ser. 18, $1-136$.

1863.11

- Notice sur deux espèces inédites du genre Aphthalmichthys Kp. Neder. Tijdschr. Dierk., 1863, 1, 163-166.

1863.12

- Notice sur le genre Ichthyophis Less., et sur l'Ichthyophis tigrinus et l'Ichthyophis pantherinus de Lesson. Versl. Akad. Amsterdam, 1863, 15, 460 466. - Neder. Tijdschr. Dierk., 1865 , $2,77-79$.

1863.13

These species are referred to the genus Gymnomuræna Lacépède.

Notice sur les noms de quelques genres de la famille des Cyprinoiddes. Versl. Akad. Amsterdam, 1863, 15, 261-264. - Neder. Tijdschr. Dierk., $1865,2,65-67$.

1863.14

Notice sur quelques poissons de l'île de Morotai. Neder. Tijdschr. Dierk., 1863, 1, 160. Also separate; Leide, $1863.44^{\circ}$.

1863.15

Notices sur une collection de poissons de la Nouvelle Hollande faite à Port Jackson. Versl. Akad. Amsterdam, 1863, 15, 442-451. - Neder. Tijdschr. Dierk., 1865, 2, 68-73. 1863.16

- Onzième notice sur la faune ichthyologique de l'île de Ternate. Neder. Tijdschr. Dierk., 1863, 1, 228238. Also separate; Hagx Comitis, 1863. $4^{\circ}$.

1863.17

Over eenige vischsoorten van het eiland Banka, het Rijks Museum van natuurlijke historie te Leiden aangeboden door J. F. R. S. van den Bossche. Neder. Tijdschr. Dierk., 1863, 1, 72-73.

1863.18

- Septième notice sur la faune ichthyologique de l'île de Batjan. Neder. Tijdschr. Dierk., 1863, 1, 151153. Also separate; Leide, 1863. $4^{\circ}$.

1863.19

Septième notice sur la faune ichthyologique de l'île de Céram. Neder. Tijdschr. Dierk., 1863, 1, 253-261. Also separate; La Haye, 1863. $4^{\circ}$. 1863.20

Septième mémoire sur la faune ichthyologique de l'île de Timor.
Neder. Tijdschr Dierk., 1863, 1, 262276. Also separate; La Haye, 1863. $4^{\circ}$

1863.21

Sur deux nouvelles espèces de Citharichthys de Suriname et de Guatimala. Versl. Akad. Amsterdam, 1863, 15, 452-455. - Neder. Tijdschr. Dierk., $1865,2,73-74$.

1863.22

- Sur les genres de la famille des Cobitioïdes. Versl. Akad. Amsterdam, 1863, 15, 32-44. - Neder. Tijdschr. Dierk., 1863, 1, 361-368. 1863.23

- Sur une nouvelle espèce d'Echidne de l'île de Rotti. Neder. Tijdschr. Dierk., 1863, 1, 246-247. Also separate; La Haye, $1863.4^{\circ}$.

1863.24

- Sur une nouvelle espèce de poisson du Japon appartenant à un nouveau genre. Versl. Akad. Amsterdam, 1863, 15, 257-260. — Neder. Tijdschr. Dierk., 1863, 1, 382-383. 1863.25

Sur quelques espèces nouvelles ou peu connues de Gymnothorax de l'Inde archipélagique. Neder. Tijdschr. Dierk., 1863, 1, 167-171. 1863.26

- Sur quelques genres nouveaux du groupe des Doras. Neder. Tijdschr. Dierk., 1863, 1, 10-18. $\quad 1863.27$

Sur quelques genres nouveaux du groupe des Synodontis. Neder. Tijdschr. Dierk., 1863, 1, 52-55.

1863.28

Sur une nouvelle espèce de Synaptura du Cap de Bonne Espérance. Versl. Akad. Amsterdam, 1863, 15, 456-459. - Neder. Tijdschr. Dierk., 1865, 2, $75-76$

1863.29

- Systema Cyprinoideorum revisum. Neder. Tijdschr. Dierk., 1863, 1 , $187-218$.

1863.30

- Systema Silurorum revisum. Neder. Tijdschr. Dierk., 1863, 1, 77122.

1863.31

- Treizième mémoire sur la faune ichthyologique de l'île d'A mboine. Versl. Akad. Amsterdam, 1863, 15, 19-29. Neder. Tijdschr. Dierk., 1863, 1, 355360.

1863.32

Troisième mémoire sur la faune ichthyologique de l'île de Halmahera. Neder. Tijdschr. Dierk., 1863, 1, 153159. Also separate; Leide, 1863. $4^{\circ}$

1863.33

Description de quelques espèces inédites de poissons de l'archipel des 
Bleeker, $P$.

Moluques. Neder. Tijdschr. Dierk., 1864, 2, 177-180. Also separate; La Haye, 1864. 4․ - Amsterdam, 1865. $8^{\circ}$.

1864.1

Description de quelques espèces de Cobitioïdes et de Cyprinoïdes de Ceylon. Nat. Verh. Holl. Maatsch. Wetensch., 1864, 2. ser. 20, 1-23.

1864.2

- Description des espèces de Silures de Suriname conservées aux Musées de Leide et d'Amsterdam. Nat. Verh. Holl. Maatsch. Wetensch., 1864, 2. ser. 20, 1-104.

1864.3

- Deuxième notice sur la faune ichthyologique de l'île de Harouko. La Haye, 1864. $4^{\circ}$.

1864.4

Deuxième notice sur la faune ichthyologique de l'île de Saparoea. Versl. Akad. Amsterdam, 1864, 16 359-361. - Neder. Tijdschr. Dierk. 1865, 2, 99-100.

1864.5

Notice sur la faune ichthyologique de Siam. Versl. Akad. Amsterdam, 1864, 16. 352-358. pl. - Nat. Tijdschr. Neder.-Indië, 1864, 20. - Neder. Tijdschr. Dierk., 2, 33-37. Also separate; Batavia \& Amsterdam, 1864. $8^{\circ}$

1864.6

Notice sur la faune ichthyologique des îles Arou. Versl. Akad. Amsterdam, 1864, 16, 366-368. - Neder. Tijdschr. Dierk., 1865, 2, 101-102. 1864.7

Notice sur quelques poissons de I'île de Noussalaut. Versl. Akad. Amsterdam, 1864, 16, 364-365. - Neder Tijdschr. Dierk., 1865, 2, 198-199.

1864.8

Notice sur quelques poissons de l'île Grand-Key. Versl. Akad. Amsterdam, 1864, 16, 362-363. - Neder. Tijdschr. Dierk., 1865, 2, 100-101. 1864.9

Systema Murænorum revisum. Neder. Tijdschr. Dierk., 1864, 2, 113 122. Also separate; Amsterdam, 1865. $8^{\circ}$

1864.10

Description de deux espèces inédites de Cobitioïdes. Neder. Tijdschr. Dicrk., 1865, 2, 11-14. 1865.1

Description de deux espèces inédites de Gnathopogon et de Rasbora de l'île de Java. Neder. 'Tijdschr. Dierk., $1865,2,137-140$.

1865.2

Description de deux espèces inćdites des genres Callechelys et Piso- donophis. Neder. 'Tijdschr. Dierk., $1865,2,213-216 . \quad 1865.3$

- Description de quelques espèces de Murènes de Suriname. Neder. Tijdschr. Dierk., 1865, 3, 233-249. Also separate; Amsterdam, 1865. $8^{\circ}$.

1865.4

Description de quelques espèces de poissons du Japon, du Cap de BonneEspérance et de Suriname, conservées au Musée de Leide. Neder. Tijdschr. Dierk. 1865, 2, 250-269. Also separate; Amsterdam, 1865. $8^{\circ}$. 1865.5

Enumération des espèces de poissons actuellement connues de l'île d'Amboine. Neder. Tijdschr. Dierk., 1865, 2, 270-293. Also separate; Amsterdam, 1865. $8^{\circ}$.

1865.6

- Enumération des espèces de poissons actuellement connues de l'île de Céram. Neder. Tijdschr. Dierk., 1865, 2, 182-193. Also separate; La Haye, 1865. $4^{\circ}$.- Amsterdam, 1865. $8^{\circ}$.

1865.7

___ Notice sur le genre Apionichthys IKp. (Soleotalpa Gthr.) Neder. Tijdschr. Dierk., 1865, 2, 306-308. 1865.8

- Notice sur le genre Paraploactis et description de son espèce-type. Neder. Tijdschr. Dierk., 1865, 2, 168 170.

1865.9

- Notice sur les Ostracions confondus sous le nom d'Ostracion quadricornis L. et description des Ostracion notacanthus et guineensis. Neder. Tijdschr. Dierk., 1865, 2, 298-305. pl. Also separate; Amsterdam, 1865. $8^{\circ}$.

1865.10

Notice sur les poissons envoyés de Chine au Musée de Leide par M. G. Schlegel. Neder. Tijdschr. Dierk., 1865, 2, 55-62. Also separate; Amsterdain, 1865. $8^{\circ}$.

1865.11

Notice sur quelques poissons de la baie de Manille. Neder. Tijdschr. Dierk., 1865, 2, 30-32. Also separate; La Haye, 1865. $4^{\circ}$.- Amsterdam, 1865. $\mathrm{S}^{\circ}$.

1865.12

- Notice sur quelques poissons de l'île de Harouko. Neder. Tijdschr. Dierk., 1865, 2, 63-64; 3, 41-42. Also separate; Amsterdam, 1865. $8^{\circ}$.

1865.13

Notices sur quelques genres et espèces de Cyprinoïdes de Chine. Neder. Tijdschr. Dierk., 1865, 2, 28-29. Also separate; Amsterdam, 1865. $8^{\circ}$. 
Notice sur une nouvelle espèce de Xiphasia [trachypareia] Neder. Tijdschr. Dierk., 1865, 2, 194-196. Versl. Akad. Amsterdam, 1865, 17, 193-197. Also separate; Amsterdam, 1865. $8^{\circ}$.

1865.15

- Nouvelle notice sur la faune ichthyologique de Siam. Neder. Tijdschr. Dierk., 1865, 2, 33-37. Also separate; Amsterdam, 1865. $8^{\circ}$. 1865.16

Paralaubuca, un genre nouveau de Cyprinoïdes de Siam. Neder. Tijdschr. Dierk., 1865, 2, 15-17.

1865.17

Poissons inédits indo-archipélagiques de l'ordre des Murènes. Neder. Tijdschr. Dierk., 1865, 2, 38-54. Also separate; Amsterdam, 1865. $8^{\circ}$.

1865.18

Quatrième notice sur la faune ichthyologique de l'île de Bouro. Neder. Tijdschr. Dierk., 1865, 2, 141-151.

1865.19

Rhinobagrus et Pelteobagrus, deux genres nouveaux de Siluroïdes de Chine. Neder. Tijdschr. Dierk., 1865 , 2, 7-10.

1865.20

Sixième notice sur la faune ichthyologique de Siam. Neder. Tijdschr. Dierk., 1865, 2, 171-176.

1865.21

Sur une nouvelle espèce de Puntius à épine anale dentelée. Versl. Akad. Amsterdam, 1865, 17, 198-202. Neder. Tijdschr. Dierk., 1865, 2, 196198.

1865.22

Synonyma Muranorum indoarchipelagicorum hucusque observatorum revisa, adjectis habitationibus citationibusque ubi descriptiones figuræque eorum recentiores reperiuntur. Neder. Tijdschr. Dierk., 1865, 2, 123-136. Also separate; Amsterdam, 1865. $8^{\circ}$

1865.23

Description de quelques espèces inédites des genres Pseudorhombus et Platophrys de l'Inde archipélagique. Neder. Tijdschr. Dierk., 1866, 3, 43-50.

1866.1

Description de quelques espèces inédites ou peu connues de Clupéoïdes de l'Inde archipélagique. Neder. 'Tijdschr. Dierk., 1866, 3, 293-308. Also separate; Amsterdam, 1866. $8^{\circ} .1866 .2$

- Description du Narcacion polleni... des mers de l'île de la Réunion. Neder. Tijdschr. Dierk., 1866, 3, 171173. Also separate; La Haye, 1866. $4^{\circ}$.

1866.3
Description d'une espèce inédite de Cheilinus. Neder. Tijdschr. Dierk., 1866, 3, 134-135.

1866.4

Description d'une espèce inédite de Stolephorus de Suriname. Neder. Tijdschr. Dierk., 1866, 3, 178-180.

1866.5

Description d'une espèce inćdite de Triacanthus de l'Inde archipélagique. Neder. Tijdschr. Dierk., 1866, 3, 51-52.

1866.6

- Description d'une espèce inédite d'Exocet découverte par M. François Pollen. Neder. Tijdschr. Dierk., 1866 , 3, 130-133.

1866.7

- Notice sur le Cirrhites punctatus C. et V. Neder. Tijdschr. Dierk., 1866 , $3,174-177$.

1866.8

Révision des espèces de Mastacembelus (Belone) Cuv., de l'Inde archipélagique. Nederland. Tijdschr. Dierk., 1866, 3, 214-236. Also separate; Amsterdam, 1866. $8^{\circ}$. 1866.9

Révisión des Hémirhamphes de l'Inde archipélagique. Neder. Tijdschr. Dierk., 1866, 3, 136-170. Also separate; Amsterdam, 1866. $8^{\circ}$.

1866.10

Sur la pluralité des espèces Indo-archipélagiques du genere Megalops (Lacép.) Neder. Tijdschr. Dierk., $1866,3,278-292$. Also separate; Amsterdam, $1866.8^{\circ}$.

1866.11

Sur les espèces d'Exocet de l'Inde archipélagique. Neder. Tijdschr. Dierk., 1866, 3, 105-129. Also separate; Amsterdam, 1866. $8^{\circ}$. 1866.12

Synonyma Balistidorum, Ostracionidorum, Gymnodontidorumque Indo-archipelagicorum hucusque observatorum revisa, adjectis habitationibus citationibusque, ubi descriptiones figuræque eorum recentiores reperiuntur. Neder. Tijdschr. Dierk., 1866, 3, 20-40. Also separate; Amsterdam, 1866. $8^{\circ}$.

1866.13

- Systema Balistidorum, Ostracionidorum, Gymnodontidorumque revisum. Neder. Tijdschr. Dierk., 1866 , 3, 8-19. Also separate; Amsterdam, 1866. $8^{\circ}$.

1866.14

Description de quelques espèces nouvelles de Gobius de Madagascar. Arch. Néerl. Sci. Nat., 1867, 2, 403-420. Also separate; Haarlem, 1867. 1867.1 
Bleeker, $P$.

Description et figure d'une espèce inédite de Crossorhinus de l'archipel des Moluques. Arch. Néerl. Sci. Nat., 1867, 2, 400-402.

1867.2

Quatrième notice sur la faune ichthyologique de l'île de Halmahéra. Arch. Néerl. Sci. Nat., 1867, 2, $397-$ 399.

1867.3

Cinquième notice sur la faune ichthyologique de l'île de Solor. Versl. Akad. Amsterdam, 1868, 2. ser. 2, 283288.

1868.1

Description de deux espèces inédites de Choerops. Arch. Néerl. Sci. Nat., 1868, 3, 273-277. 1868.2

- Description de deux espèces inédites d'Epinephelus rapportées de l'île de la Réunion par M. M. Pollen et van Dam. Versl. Akad. Amsterdam, 1868, 2. ser. 2, 336-341. 1868.3

Description de deux espèces nouvelles de Blennioïdes de l'Inde archipélagique. Versl. Akad. Amsterdam, 1868, 2. ser. 2, 278-280.

1868.4

Description de trois espèces inédites de Chromidoïdes de Madagascar: Paratilapia polleni, Tilapia oligacanthus, Paretroplus damii. Versl. Akad. Amsterdam, 1868, 2. ser. 2, $307-314$.

1868.5

Description de trois espèces inédites de poissons des îles d'Amboine et de Waigiou. Versl. Akad. Amsterdam, 1868, 2. ser. 2, 331-335. 1868.6

Description d'une espèce de Rhombodites de l'île de la Réunion. Arch. Néerl. Sci. Nat., 1868, 3, 277-278.

1868.7

- Description et figure d'une nouvelle espèce de Trachypterus de l'ŝle d'Amboine. Arch. Néerl. Sci. Nat., 1865, 3, 279-280.

1868.8

Denxième notice sur la faune ichthyologique des îles Arou. Versl. Akad. Amsterdam, 1868, 2. ser. 2, 305306.

1868.9

- Deuxième notice sur la faune ichthyologique des îles Sangir. Versl. Akad. Amsterdam, 1868, 2. ser. 2, 302304.

1868.10

Douzième notice sur la faune ichthyologique de l'île de 'T'ernate. Versl. Akad. Amsterdam, 1S68, 2. ser. 2, 273-274.

1868.11
- Huitième notice sur la faune ichthyologique de l'île de Batjan. Versl. Akad. Amsterdam, 1868, 2. ser. 2, $276-277$.

1868.12

Notice sur la faune ichthyologique de l'île de Guébé. Versl. Akad. Amsterdam, 1868, 2. ser. 2, 271-272.

1868.13

Notice sur la faune ichthyologique de l'île de Waigiou. Versl. Akad. Amsterdam, 1868, 2. ser. 2, 295-301.

1868.14

- Notice sur le Parupeneus bifasciatus (Mullus bifasciatus Lacèp.) de l'île de la Réunion. Versl. Akad. Amsterdam, 1868, 2. ser. 2, 342-348.

1868.15

Sixième notice sur la faune ichthyologique de l'île de Bintang. Versl. Akad. Amsterdam, 1868, 2. ser. 2, 289-294.

1868.16

Troisième notice sur la faune ichthyologique de la Nouvelle-Guinée. Versl. Akad. Amsterdam, 1868, 2. ser. 2, 281-282.

1868.17

Troisième notice sur la faune ichthyologique de l'île d'Obi. Versl. Akad. Amsterdam, 1868, 2. ser. 2, 275.

1868.18

Description de deux espèces inédites d'Alticus de Madagascar. Yersl. Akad. Amsterdam, 1869, 2. ser. 3, 234236.

1869.1

Description d'une espèce inédite de Cxsio de l'íle de Nossibé. Versl. Akad. Amsterdam, 1869, 2. ser. 3, 7879.

1869.2

Description d'une espèce inédite de Chatopterus de l'île d'Amboine: C. microlepsis. Versl. Akad. Amsterdam, 1869, 2. ser. 3, 80-\$5. $\quad 1869.3$

Description d'une espèce inédite de Glyphidodon de l'île de la Réunion. Versl. Akad. Amsterdam, 1869, 2. ser. 3, 231-233.

1869.4

Description et figure d'une espèce inédite de Platycèphale. Versl. Akad. Amsterdam, 1869, 2. ser. 3, 253254.

1869.5

Neuvième notice sur la faune ichthyologique du Japon. Versl. Akad. Amsterdam, 1869, 2. ser. 3, 237-252.

1869.6

Sur les espèces confondues sous le nom de Genyoroge bengalensis Gunth. 
Versl. Akad. Amsterdam, 1869, 2. ser. 3, 64-77. Also separate; Amsterdam, 1869. $8^{\circ}$.

1869.7

Description d'une espèce inédite de Botia de Chine et figures du Botia elongata et du Botia modesta. Versl. Akad. Amsterdam, 1870, 2. ser. 4, 254-256.

1870.1

- Description et figure d'une espèce inédite de Hemibagrus de Chine. Versl. Akad. Amsterdam, 1870, 2. ser. 4, 257-258.

1870.2

- Description et figure d'une espèce inédite de Rhynchobdella de Chine. Versl. Akad. Amsterdam, 1870, 2. ser. 4, 249-250.

1870.3

-...- Mededeeling omtrent eenige nieuwe vischsoorten van China. Versl. Akad. Amsterdam, 1870, 2. ser. 4, 251253.

1870.4

Description de deux espèces inédites de Labroïdes d'Amboine. Arch. Néerl. Sci. Nat., 1871, 6, 326-328.

- Mémoire sur les Cyprinoïdes de Chine. Verh. Akad. Amsterdam, 1871, 12, 1-91. Also separate; Amsterdam, 1871.

1871.2

Notice sur les peintures chinoises de Cyprinoïdes, déposées au Muséum de l'université de Groningue par M. J. Senn Van Basel. Versl. Akad. Amsterdam, 1872, 2. ser. 6, 117-121. 4 pls.

1572.1

Sur le genre Moronopsis Gill (Paradules Blkr.) et ses espèces indoarchipélagiques. Arch. Néerl. Sci. Nat., $1872,7,373-380$.

1872.2

Addition au mémoire sur la faune ichthyologique de Chine. Neder. Tijdschr. Dierk., 1873, 4, 233-234.

Description de deux espèces nouvelles de Sciénoides de Surinam. Arch. Néerl. Sci. Nat., 1S73, 8, 456-461.

1873.2

Description de quelques espèces de poissons de l'île de la Réunion et de Madagascar. Neder. Tijdschr. Dierk., 1873, 4, 92-105.

1873.3

- Description de quelques espèces inédites de Xenocypris. Neder. Tijdschr. Dierk. 1873, 4, 62-69. 1873.4

- Description de trois espèces inédites du genre Acanthorhodeus. Neder. Tijdschr. Dierk., 1873, 4, 70-76.
Description d'une espèce inédite de Gadus (Boreogadus) des mers d'Islande. Arch. Néerl. Sci. Nat., $1873,8,462-463$. 1873.6

Description d'une espèce inédite de Heliases d'Amboine. Neder. Tijdschr. Dierk., 1873, 4, 111-112. 1873.7

Description et figure du Cichla temensis Humb. Versl. Akad. Amsterdam, 1873, 2. ser. 7, 32-34. 1873.8

Description et figure du Lethrinus güntheri Blkr. Arch. Néerl. Sci. Nat., 1873, 8, 153-154. 1873.9

Description et figure d'une espèce insulindienne d'Orthagoriscus [O. oxyuropterus] Versl. Akad. Amsterdam, 1873, 2. ser. 7, 151-153. pl.

1873.10

Mededeelingen omtrent eene herziening der Indisch-Archipelagische soorten van Epinephelus, Lutjanus, Dentex en verwante geslachten. Versl. Akad. Amsterdam, 1873, 2. ser. 7, 4046.

1873.11

- Mémoire sur la faune ichthyologique de Chine. Neder. Tijdschr. Dierk., 1873, 4, 113-154. 1873.12

- Notice sur les Grammistes punctatus et ocellatus. Neder. Tijdschr. Dierk., 1873, 4, 106-110. 1873.13

- Notice sur le Symodus macrocephalus Lac. (Luciobrama typus Blkr.) Neder. Tijdschr. Dierk., 1873, 4, 89-91. 1873.14

Révision des espèces de Dentex, Synagris, Gymnocranius, Gnathodentex et Pentapus de l'Inde archipélagique et du Japon. Verh. Akad. Amsterdam, $1873,13,1-64$.

1873.15

Révision des espèces indo-archipélagiques des genres Lutjanus et Aprion. Verh. Akad. Amsterdam, 1873, 13, 1-102.

1873.16

Révision des espèces indo-archipélagiques du genre Cæsio et de quelques genres voisins. Arch. Néerl. Sci. Nat., 1873, 8, 155-182.

1873.17

Révision des espèces indo-archipélagiques du genre Holocentrum. Neder. Tijdschr. Dierk., 1873, 4, 198232.

1873.18

Révision des espèces indo-archipélagiques du genre Lethrinus. Neder. 'Tijdschr. Dierk., 1873, 4, 318-344. 
Bleeker, $P$.

Révision des espèces indo-archipélagiques du genre Myripristis. Neder. Tijdschr. Dierk., 1873, 4, 178-197.

1873.20

- Révision des espèces indo-archipélagiques du groupe des Anthianini. Neder. Tijdschr. Dierk., 1873, 4, 155169.

1873.21

- Kévision des espèces indo-archipélagiques du groupe des Priacanthini. Neder. Tijdschr. Dierk., 1873, 4, 170177.

1873.22

-... Révision des espèces insulindiennes des genres Diapterus et Pentaprion. Versl. Akad. Amsterdam, 1873, 2. ser. 7, 233-255.

1873.23

- Révision des espèces insulindiennes du genre Therapon. Neder. Tijdschr. Dierk., 1873, 4, 372-393.

1873.24

- Sur le genre Parapristipoma et sur l'identité spécifique des Perca trilineata Thunb., Pristipoma japonicum Cuv. et Diagramma japonicum Blkr. Arch. Néerl. Sci. Nat., 1873, 8, 19-24.

1873.25

Sur les espèces de Scolopsis Cuv. de l'Inde archipélagique. Neder. Tijdschr. Dierk., 1873, 4, 345-371. 1873.26

.... Sur les espèces du genre Culter Basil. Neder. Tijdschr. Dierk., 1873, 4, 77-88.

1873.27

-_ Sur les espèces indo-archipélagiques d'Odontanthias et de Pseudopriacanthus. Neder. Tijdschr. Dierk., $1873,4,235-240$.

1873.28

Troisième notice sur la faune ichthyologique des îles Arou. Versl. Akad. Amsterdam, 1873, 2. ser. 7, 3539.

1873.29

Esquisse d'un système naturel des Gobioides. Arch. Néerl. Sci. Nat. 1874, 9, 289-331.

1874.1

Mededeeling omtrent den stand der uitgave van den Atlas ichthyologique des Indes orientales. Versl. Akad. Amsterdan, 1874, 2. ser. 8, 123-126.

1874.2

Mémoire sur les Sciénoïdes et les Sillaginoïdes de l'Inde archipélagique. Verh. Akad. Amsterdam, 1874, $14,1-76$.

1874.3

- Notice sur les genres Amblyeleotris, Valenciennesia et Brachyeleotris. Versl. Akad. Amsterdam, 1874, 2. ser. 8, 372-380.

1874.4
Révision des espèces d'Ambassis et de Parambassis de l'Inde archipélagique. Nat. Verh. Holl. Maatsch. Wetensch., 1874, 3. ser. 2, no. 2, 83-106.

1874.5

Révision des espèces indo-archipélagiques du groupe des Apogonini. Nat. Verh. Holl. Maatsch. Wetensch. 1874, 3. ser. 2, no. 1, 1-82. 1874.6

- Révision des espèces indo-archipélagiques du groupe des Epinephelini et de quelques genres voisins. Verh. Akad. Amsterdam, 1874, 14, 1-134.

Révision des espèces insulindiennes de la famille des Synanceoiddes. Nat. Verh. Holl. Maatsch. Wetensch. 1874, 3. ser. 2, no. 3, 1-22. $\quad 1874.8$

Sur les espèces insulindiennes de la famille des Nandoïdes. Arch. Néerl. Sci. Nat., 1874, 9, 455-465.

- Sur les espèces insulindiennes de la famille des Opisthognathoïdes. Arch. Néerl. Sci. Nat., 1874, 9, 466476.

1874.10

- Typi nonnulli generici piscium neglecti. Versl. Akad. Amsterdam, 1874, 2. ser. 8, 367-371. 1874.11

Description du genre Parascorpis et de son espèce-type. Arch. Néerl. Sci. Nat., $1875,10,380-382 . \quad 1875.1$

Gobioideorum species insulindicæ novx. Arch. Néerl. Sci. Nat. $1875,10,113-134$.

1875.2

Notice sur l'Elopichthys dahuricus. Proc. Zool. Soc. London, 1875 , $534-536$.

1875.3

Notice sur les Eleotriformes et description de trois espèces nouvelles. Arch. Néerl. Sci. Nat., 1875, 10, 101 112.

1875.4

Révision des espèces insulindiennes de la famille des Mulloïdes. Verh. Akad. Amsterdam; 1875, 15, 1-40.

1875.5

Sur la famille des Pseudochromidoïdes et révision de ses espèces insulindiennes. Verh. Akad. Amsterdam, $1875,15,1-32$.

1875.6

Sur les espèces insulindiennes de la famille des Cirrhitéoïdes. Verh. Akad. Amsterdam, 1875, 15, 1-20.

1875.7 
Description de quelques espèces inédites de Pomacentroïdes de l'Inde archipélagique. Versl. Akad. Amsterdam, 1876, 2. ser. 10, 384-391. 1876.1

Description de quelques espèces insulindiennes inédites des genres Oxyurichthys, Paroxyurichthys et Cryptocentrus. Verh. Akad. Amsterdam, 1876, 2. ser. 9, 138-148.

1876.2

- Genera familise Scorprenoideorum conspectus analyticus. Versl. Akad. Amsterdam, 1876, 2. ser. 9, 294-300.

1876.3

- Mémoire sur les espèces insulindiennes de la famille des Scorpénoïdes. Versl. Meded. Akad. Afd. Nat., 1876, $16,1-100$. 5 pls.

1876.4

- Notice sur le genre Chætodon Art. (Pomacanthus Lac. Cuv.) et sur la pluralité de ses espèces vivantes. Arch. Néerl. Sci. Yat., 1876, 11, 178185.

1876.5

_ Notice sur les genres et sur les espèces des Chétodontoïdes de la sousfamille des Taurichthyiformes (Chætodon, Heniochus, Chelmo) Versl. Meded. Akad. Afd. Nat. 1876, 2. ser. 10, 308320.

1876.6

- Notice sur les genres Gymnocæsio, Pterocæsio, Paracæesio et Liocæsio. Versl. Meded. Akad. Afd. Nat., 1876, 2. ser. 9, 149-154.

1876.7

- Révision des Sicydiini et Latrunculini de l'Insulinde. Versl. Akad. Amsterdam, 1876, 2. ser. 9, 271-293.

1876.8

Sur la pluralité des espèces insulindiennes de Toxotes. Versl. Akad. Amsterdam, 1876, 2. ser. 9, 155-167.

1876.9

- Systema Percarum revisum. Pars I et II. Arch. Neder. Sci., 1876, 11, $247-340$.

1876.10

Catalogus van ichthyologische verhandelingen en bijdragen. Jaarb. K. Akad. Afd. Nat., 1877, 100-132

1877.1

Description de deux espèces inédites du genre Prochilus Klein (Amphiprion Bl. Schn.) Versl. Akad. Amsterdam, 1877, 2. ser. 11, 135-137.

1877.2

Mémoire sur les Chromides marins ou Pomacentroïdes de l'Inde archipélagique. Nat. Verh. Holl. Maatsch. Haarlem, 1877, 3. ser. 2, 1-166.
Notice sur la sousfamille des Holacanthiformes et description de quelques espèces insuffisamment connues. Arch. Néerl. Sci. Nat., 1877, 6. ser. 12, 17-37. pl.

1877.4

Notice sur les espèces nominales des Pomacentroïdes de l'Inde archipélagique. Arch. Néerl. Sci. Nat., 1877, 6 . ser. $12,38-41$.

1877.5

Notice sur l'identité des genres Gnathanacanthus Blkr. et Holoxenus Gthr. Versl. Akad. Amsterdam, 1877, 2. ser. 11, 132-134.

1877.6

Over slokdarm en maag van Caprodon schlegeli. Versl. Akad. Amsterdam, Proc.-Verb. 24 Nov., 1877.

1877.7

Révision des espèces de Pempheris de l'Inde archipélagique. Arch. Néerl. Sci. Nat., 1877, 12, 42-54.

1877.8

Révision des espèces insulindiennes de la famille des Chétodontoïdes. Versl. Meded. Akad. Afd. Nat., $1877,17,1-174$.

1877.9

Révision des espèces insulindiennes de la sousfamille des Eleotriformes. Versl. Akad. Amsterdam, 1877, 2. ser. 11, $13-110$.

1877.10

- Scriptorum ichthyologicorum huc usque in lucem editorum enumeratio chronologica. Jaarb. Akad. Afd. Nat., 1877, 56-99.

1877.11

Sur les espèces confondues sous les noms de Chrysophrys hasta, berda, calamara et schlegeli. Versl. Akad. Amsterdam, 1877, 2. ser. 11, 1-12.

1877.12

Vischsoorten van Nieuw-Guinea, van Singapore, China, Japan en Mauritius. Versl. Akad. Amsterdam, Proc.Verb. 27 Oct., 1877.

1877.13

Description des espèces insulindiennes du genre Stigmatogobius. Versl. Meded. Akad. Afd. Nat., 1878, 12, 199-208.

1878.1

Notice sur le Sparus cuvieri (Chrysophrys cuvieri Day) Versl. Meded. Akad. Afd. Nat., 1878, 13, 43-46. pl.

1878.2

Quatrième mémoire sur la faune ichthyologique de la Nouvelle-Guinée. Arch. Néerl. Sci. Nat., 1878, 13, 35-66. 2 pls.

1878.3 
Bleeker, $P$.

— Révision des espèces insulindiennes du genre Uranoscopus L. Versl. Meded. Akad. Afd. Nat., 1878, 2. ser. 13, 47-59.

1878.4

- Sur deux espèces inédites de Cichloïdes de Madagascar. Versl. Meded. Akad. Afd. Nat., 1878, 2. ser. 12, 192-19S. 3 figs.

1878.5

Sur les espèces du genre Hypophthalmichthys Blkr. (Cephalus Basil nec Bl. nec Al.) Versl. Meded. Akad. Afd. Nat., 1878, 2. ser. 12, 209-218. 2 pls.

1878.6

Contribution à la faune ichthyologique de l'île Maurice. Verh. Meded. Akad. Afd. Nat., 1879, 18, 123. 3 figs.

1879.1

Enumération des espèces de poissons actuellement connues du Japon et description de trois espèces inédites, Conger japonicus, Pseudosciona acanthodes, Aphoristia orientalis. Versl. Meded. Akad. Afd. Nat., 1879, 18, 1-33. 3 pls.

1879.2

- Mémoire sur les poissons à pharyngiens labyrinthiformes de l'Inde archipélagique. Verh. Meded. Akad. Afd. Nat., $1879,19,1-56$.

1879.3

Révision des espèces insulindiennes de la famille des Callionymides. Versl. Meded. Akad. Afd. Nat., 1879, 2. ser. 14, 79-107.

1879.4

- Révision des espèces insulindiennes du genre Platycephalus. Versl. Meded. Akad. Afd. Nat., 1879, 19, 1-31.

1879.5

Sur quelques espèces inédites ou peu connues de poissons de Chine, appartenant au Museum de Hambourg. Versl. Meded. Akad. Afd. Nat., 1879, 18, 1-17. 2 pls.

1879.6

Musei Hamburgensis species piscium novx minusque cognitas descripsit et depingi curavit. Abh. Naturw. Ver. Hamburg, 1880, 7, 1. Abth., 25-30. pl. 1880.1

Bleeker, Peter, \& Pollen, F. P.L. Poissons de Madagascar et de l'île de la Réunion. Leide, 1874. 104 p. 24 pls. $4^{\circ}$.

1874.1

Blegvad, $H$. Some small leptocephalids from the Atlantic. Vidensk. Meddel. Naturh. Foren. Copenhagen, 1913, 64 (7. ser. 4), 135-140. 1913.1
Bleicher, - Un pêcheur naturaliste au 17. siècle. Léonard Baldner. Rev. Scient., 1888, 41, 626-628. 1888.1

Bles, Edward $J$. The correlated distribution of abdominal pores and nephrostomes in fishes. Journ. Anat. Phys., 1898, 32, 484-513. 6 figs. 1898.1

On the openings in the wall of the body cavity of vertebrates. Proc. Roy. Soc, London, 1898, 62, 232-247. Abstract in Journ. Roy. Micr. Soc. London, 1898, pt. 2, 186. - Zool Centralbl., 5, 816-817.

1898.2

Bliss, (junior) Richard. Appearance of colour in fish kept in alcohol. Abstract in Pop. Sci. Rev., 1872, 11, 335336.

1872.1

On the osteology of the anterior vertebræ in Doras niger, with a comparison of the structure of the dorsal fin in Doras and Balistes. Proc. Boston Soc. Nat. Hist., $1870-71$ (1872), 14 , 3-12.

1872.2

-... Peculiar coloration in fishes. Amer. Naturalist, 1872, 6, 237. 1872.3

Descriptions of some peculiarities in the structure of the fin spines of the siluroids and doradoids. Proc. Boston Soc. Nat. Hist., 1875, 17, 386.

1875.1

Descriptions of new species of Mauritian fishes. Trans. Roy. Soc Mauritius, 1879 (1883), 13, 45-63.

1883.1

Bloch, Adolphe. Des variations de longeur de l'intestin. Bull. Mém. Soc. Anthrop. Paris, 1904, 5. sér. 5, 160-197.

1904.1

Bloch, Léopold. Schwimmblase, Knochenkapsel und Weber'scher Apparat von Nemachilus carbatulus Günther. Zeitschr. Naturw. Jena, 1900, 34 (n. s. 27), 1-64. 2 pls. \& 12 figs. Abstract in Zool. Centralbl., 8, 539-540. 1900.1

Bloch, MarcElieser [1723-1799] For a detailed bibliography of this author's ichthyological works, see Gill, T. N., in Smithson. Misc. Coll., 1872, 11, no. 247.

Naturgeschichte der Maräne [Salmo marcena] Beschäft. Ges. Naturf. Fr. Berlin, 1779, 4, 60-94.

1779.1

Oeconomische Naturgeschichte der Fische in den Preussischen Staaten, besonders der Mark'schen und Pommer'schen Provinzen. Schrift. Ges. Naturf. Fr. Berlin, 1780, 1, 231-296.

1780.1 
Oeconomische Naturgeschichte der Fische Deutschlands. Berlin, 178285. 3 pts. in 1 \& atlas. 108 col. pls. $4^{\circ}$ \& fol.

1782.1

Also issued as pts. 1-3 of his Allgemeine Naturgeschichte der Fische.

Ichthyologie, ou Histoire naturelle, générale et particulière des poissons. Avec des figures enluminées, dessinées d'après nature. 12 vols. 452 col. pls. fol.

1785.1

$1^{e}$ Série. A Berlin, chez l'auteur, et chez François de la Garde libraire, 1785-1788.

$2^{2}$ Série. A Berlin, chez l'auteur. - A Leipzic dans la Musée de Mr. Beytang [ete.] 1797.

This is a translation in 12 volumes, by Laveau, of the German series entitled Allgemeine Naturgeschichte der Fische.

- Naturgeschichte der ausländischen Fische. Berlin, 1785-95. 9 pts. in $2, \&$ atlas ( 3 vols.) 324 col. pls. $4^{\circ}$ \& fol.

1785.2

Also issued as pts. 4-12 of his Allgemeine Naturgeschichte der Fische. The plates are numbered in continuation of those of the Oeconomische Naturgeschichte der Fische Deutschlands. The nine parts of his work are complementary to the author's Natural History of Foreign Fishes, and together they form a uniform series, afterwards entitled Allgemeine Naturgeschichte der Fische, vols. i-xii.

Pleuronectarum duplex species descripta ( $P l$. zebra et dentatus) Nov. Acta Acad. Petropol., Hist., 1785, 3, Suppl., 139-143.

1785.3

- Von den vermeinten doppelten Zeugungsgliedern der Rochen und Haye. Schrift. Ges. Naturf. Fr. Berlin, 1785 , 6, 377-393. pl.

1785.4

Tabula Blochii naturalem historiam Piscium in forma minori representans. Augsburg, 1786. Obl. fol.

1786.1

Kuupfer zu D. Bloch's Fischwerck. Berlin, 1787.

1787.1

Atlas of 10 plates without text.

Uber zwei merkwïrdige Fischarten (Notacanthus chemnitzii und Silurus militaris) Abh. Böhm. Ges. 1787, 3, 278-282. $2 \mathrm{pls}$.

1787.2

Abhandlung von den vermeinten männlichen Gliedern des Dornhayes (Acanthias vulgaris Risso) Schrift. Ges. Naturf. Fr. Berlin, 1788, 8, 9-15. fig.

1788.1

Beskrivning over tvende nve Aborrer (Perca) fra Indien. K. Danske Selsk. Skrift. N. Saml., 1788, 3, 383385.
Charactere und Beschreibung des Geschlechts der Papageyfische Callyodon. Abh. Böhm. Ges., 1788, 4, 242248. 3 pls.

1788.3

Sur le Gastrobranchus, nouveau genre de poisson. Bull. Soc. Philom. Paris, 1791, 1, 1-26.

1791.1

Bemerkungen über den Säuger, Myxine glutinosa L. Sitzber. Ges. Naturf. Fr. Berlin, 1792, 193-200.

1792.1

Beschreibung zwei neuer Fische. Schrift. Ges. Naturf. Fr. Berlin, 1792, 10, 422-424. pl.

1792.2

Sur le Gastrobranchus (Myxine) Mag. Encycl. (Millin), 1797, 3, 154.

1797.1

Histoire naturelle des poissons, avec les figures dessinées d'après nature par Bloch, ouvrage classé par ordres, genres et espèces, d'après le système de Linné; par René-Richard Castel. 2. édition. 10 vols. Paris, Deterville,

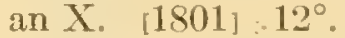

1801.1

This is a cheap edition of Laveau's translation of the author's work above cited. It constitutes vols. xxxii-xli of Suites à Buffon. See Buffon, Count.

Bloch, Marc Elieser, \& Schneider, Johann Gottlob. M. E. Blochii, Systema Ichthyologix iconibus cx illustratum. Post obitum auctoris opus inchoatum absolvit, correxit, interpolavit Jo. Gottlob Schneider, Saxo. Berolini, 1801. Ix, 584 p. 110 col. pl. $8^{\circ}$.

1801.1

"A compilation in which the various species described by authors are collected together, and referred with very little judgment to the gener. admitted. The class is arranged in a new manner, avowedly according to the number of the fins, but very frequently in defiance of their true number and morphology, as notably in the genera $1,2,4,7,21,37,38$, but also in very many others." - T. N. Gill, Smithson. Misc. Coll., no. 247, 1872, 11, 39

Blochmann, $F$. Können die Fische hören? Jahrb. Ver. Vat. Naturk. Württemberg, 1903, 59, xev-xevii.

1903.1

Block, M. Ueber die neueren Versuche zur künstlichen Erzeugung der Fische in Frankreich. Ann. Landwirtsch., 1852 (1853), 21, 274-287.

1853.1

Blocquel, S. Ichthyologie de la jeunesse; beautés de l'histoire naturelle des poissons, cétacés et crustacés. Paris, 1826. 60 figs. $16^{\circ}$.
1826.1 
Blomfield, J.E. The thread-cells and epidermis of Myxine. Quart. Journ. Micr. Sci., 1882, 22, 355-361. pl.

1882.1

Bloomfield, J.C. The fisheries of Ireland. London, 1S83. 33 p. $8^{\circ}$. (Internat. Fisheries Exhib: Lit., 7, Conferences, pt. 4)

1883.1

Blosser, Christian B. Reports on the expedition to British Guiana of the Indiana University and the Carnegie Museum, 1908. Report No. 3. The Marine Fishes. Ann. Carnegie Mus., 1909, 6, no. 1, 295-300. 3 pls. 1909.1

Blot, Marcel. La biologie de l'anguille. La Nature, Paris, 1911, 39, pt. $2,58-61.3$ figs.

1911.1

Bluett, - Méthode facile pour obtenir le squelette des petits poissons. Philos. Mag., 1830, 151. - Bull. (Férussac), $1830,22,157$.

1830.1

Blum, $J$. Ueber die Begattung von Zoarces viviparus L. Zool. Garten, $1882,4,124$.

1882.1

Blume, $W$. Ueber freie Zellen in den Hohlräumen von Selachierembryonen. Inaug. Dissert., München, 1913.

1913.1

Blumenbach, Johann Friedrich [1752-1841] Handbuch der Naturgeschichte. Göttingen, 1779-80. 1779.1

This work passed through twelve editions, the last, published 1830, being a volume of 668 pages. "Von der Fische," p. 214-256.

Abbildungen naturhistorischer Gegenstände, etc. 2. ed. Göttingen, 1810 (1797-1830) [Consists of 100 pls. with descriptive letterpress, in 10 Hefte?

1797.1

Hefte $1,3,4 \& 5$ only are of the second edition. The issue of the first edition began in 1796.

Manuel d'histoire naturelle, traduit de l'Allemand and edited with notes]... par S. Artaud. 2 vols. Metz, 1803. illust. $8^{\circ}$.

1803.1

Blumhof, Johann Georg Ludwig [translator] Herrn Bengt And. Euphrasen's Reise nach der schwedischwestindischen Insel St. Barthelemi und den Inseln St. Eustache und St. Christophe [etc.] Aus dem Schwedischen übersetzt von Joh. Georg Lud. Blumhof. Göttingen, 179S. 1798.1

Bluntschli, $I$. Eisenhämatoxylinund Biondipriparate der Leber von Ceratodus forsteri und Acipenser ruthe- nus. Verh. Anat. Ges., 1903, 17, 198199. fig.

1903.1

Der feinere Bau der Leber von Ceratodus forsteri. Zoologische Forschungsreisen in Australien und dem malayischen Archipel (Jena), 1904, 1, 333-376. pl. \& 24 figs.

1904.1

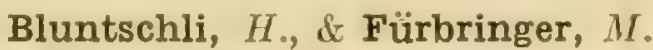
See Fürbringer \& Bluntschli.

Blyth, Edward [1810-1873] For biography and works, see Trans. Norf. Norwich Nat. Soc. 1884, 3, 38-46.

1884.1

- Stegostoma carinatum etc.] Journ. Asiat. Soc. Bengal, 1847, 16, 725. 1847.1

- Report on Ceylon mammals, birds, reptiles and fishes. (In E. F. Kelaert, Prodromus faunæ Zeylanicæ) Ceylon, 1852. $8^{\circ}$. 1852.1

On some fishes from the Sitang river and its tributary streams. Journ. Asiat. Soc. Bengal, 1860, 29, 138-174.

1860.1

The cartilaginous fishes of lower Bengal. Journ. Asiat. Soc. Bengal, 1860 (1861), 29, 35-45. 1861.1

Remarks on the distribution of Salmonidx. Proc. Nat. Hist. Soc. Dublin, 1865, 4, pt. 2, 87. 1865.1

Blytt, H. H. P., \& others. Beretning om Fiskeri-Udstillungen i Amsterdam 1861. Christiania, 1862. 59 p.

1862.1

This report was prepared by H. H. P. Blytt, D. C. Stolk, H. C. Lehmkuhl and Gottlob Thomsen.

Boake, $B$. On the air-breathing fish of Ceylon. Journ. Ceylon Branch Roy. Asiat. Soc., 1866, 12S-142. 1866.1

Boardman, George A. The Winninish of the Saguenay. Its identity with the Salmo gloveri, or landlocked salmon. Forest \& Stream, 1875, 5, 83. 1875.1

Boardman, Samuel L. Some outlines of the agriculture of Maine. Rept. Comm. Agriculture 1862 (1863), 3959 .

Fish and fish-breeding, p. 55-56.

Boas, Johan Erik Vesti. Scaroidemes tandforhold. Vidensk. Meddel. Naturhist. Foren. Kjöbenhavn, 1877-78, 315350. 2 pls. 
- Om conus arteriosus hos Butirinus og hos andre Teleostier. Vidensk. Meddel. Naturhist. Foren., 1879-80, 333-342. pl. - Morph. Jahrb., 1880, 6, 527-534. pl.

1879.1

Die Zähne der Scaroiden. Zeitschr. Wiss. Zool., 1879, 32, 2. Heft, 189215.

1879.2

Ueber Herz und Arterienbogen bei Ceratodus und Protopterus. Morph. Jahrb., 1880, 6, 321-354. 2 pls. \& 3 figs.

1880.1

- Lelırbuch der Zoologie. Jena, 1894. 2. ed. 427 figs. $8^{\circ}$. 1894.1

Ueber Neotenie.

Festschrift, 1896, 2, 1-20.

Gegenbaur 1896.1

Lærebog i zoologien, nærmest ti] brug for studerende og lærere. Kabenhavn, 1888. 570 p. $\mathcal{S}^{\circ}$. 1888.1

2. ed. Kobenhavn, 1894. 608 p. $8^{\circ}$

3. ed. Kobenhavn, 1905, $672 \mathrm{p}, 8^{\circ}$.

Text book of zoology. London, 1896. 576 p. $8^{\circ}$.

1896.1

Boase, $H$. On two species of fishes taken in Mount's bay, Cornwall. Proc. Zool. Soc. London, 1833, pt. 1, 114-115.

1833.1

Bobierre, Adolphe. De la composition de têtes de sardines et de leur emploi en agriculture. Soc. Acad. Ann. Nantes, 1868, 39, 35-39.

1868.1

Bocage, José Vicente Barboza du [1823-1907] For biographical notice, see Ibis, 1908, 9. ser. 2, 611. - Franca, Carlos, in Bull. Soc. Portug. Sci. Nat., 1908, 2, 141-194.

Les fanons branchiaux du "squale pélerin." Jorn. Sci. Math. Phys. Lisboa, 1878, 6, 71 .

1878.1

Prologo ao catalogo dos peises de Portugal por Felix de Brito Capello. Mem. Acad. Sci. Lisboa, 1881, 46 (n. s. 6, pt. 1), 1-3.

1881.1

- José d'Anchieta. Jorn. Sci. Math. Phys. Nat. Lisboa, 1897, 2. ser. 5, 126-132.

1897.1

Publicações scientificas de J. V. Barboza du Bocage (1857-1901) Lisboa, 1901. 39 p. $8^{\circ}$.

1901.1

Bocage, José Vicente Barboza du, \& Capello, Felix de Brito. Diagnoses de algumas especies inéditas da familia Squalidxe que frequentam os nossos mares; trabalho apresentado á Aca- demia real das sciencias de Lisboa. Mem. Acad. Real Sci. Lisboa, 1864 (1865), 3, 1-3. Also separate; Lisboa, 1864.

1864.1

Sur quelques espèces inédites de Squalidæ de la tribue Acanthiana Gray, qui frequentent les côtes du Portugal. Proc. Zool. Soc. London, 1864, 260 263.

1864.2

- Apontamentos para a ichthyologia de Portugal; peixes Plagiostomos; primeira parte, Esqualos. [Text in French and Portuguese] Lisboa, 1866. 40 p. 3 pls. $4^{\circ}$. 1866.1

Boccius, Gottlieb. A treatise on the management of freshwater fish, with a view to making them a source of profit to landed proprietors. London, 1841. 38 p. $5^{\circ}$

1841.1

Fish in rivers and streams; a treatise on the production and management of fish in fresh iaters, by artificial spawning, breeding, and rearing; showing also the cause of the depletion of all rivers and streams. London, 1848. 38 p. $8^{\circ}$.

1848.1

Die Fluss-, Bach- und Teichfischerei; oder, über das künstliche Ausbrïten und Auferziehen der wichtigsten, schmackhaftesten und beliebtesten Fische, und über die Ursachen der Abnahme dieser schwimmenden Bevölkerungen. Aus dem Englischen übersetz und mit einem Anhang, enthaltend: London's Fischeultur in Grossbritannien; $\mathrm{A}$. de Quatrefages, $\mathrm{Ab}$ handlung über künstliche Befruchtungen: Milne Edwards, Anreicherung der Flüsze mit Fische; Chinesisches Verfahren, die Fischbrut zum Auskriechen zu bringen; Bloch's Monographie des Kíarpfen-geschlechtes, von A. Gunderlich. 2. ed. Weimar, 1861. 12 ${ }^{\circ}$ 1861.1

Bock, Friedrich Samuel. Versuch einer vollständige Natur- Handlungsgeschichte der Heringe. Königsberg, 1769. $8^{\circ}$. 1769.1

Versuch einer wirthschaftlichen Naturgeschichte ron dem Königreich Ost- und West-Preussen. 5 vols. Dessau, 1784. $S^{\circ}$. 1784.1

Band iv, Die inländischen Vögel, Säugethiere, Amphibien und Fische.

Bock, Richard. Die Flugbarbe (Nuria danrica Ham. Buch.) Blätt. Aquar-Terrar. Iíunde, 1914, 25. Jahrg., 212-213. fig. 1914.1 
Bocourt, Firmin M. [1819-] Notes sur les reptiles, les batraciens et les poissons recueillis pendant un voyage dans le royaume de Siam. Nouv. Arch. Mus. Hist. Nat. Paris, 1866, 2, 4-19.

1866.1

Descriptions de quelques acanthoptérygiens nouveaux appartenant aux genres Serranus et Mesoprion recueillis dans l'Amérique centrale: Serranus varius, S. courtadei, S. quinquefasciatus, S. acanthophorus, Mesoprion pacificus. Ann. Sci. Nat. (Zool.), 1868, 5. sér. 10, 222-224.

1868.1

Note sur des poissons percoides appartenant au genre Centropomus $(C$. unionensis, $C$. mexicanus, $C$. scaber, $C$. cuvieri), provenant du Mexique et de l'Amérique centrale. Ann. Sci. Nat. (Zool.), 1868, 5. sér.9, 90-91. 1868.2

-... Note sur les poissons du genre Tétragonoptère provenant du Mexique et du Guatemala. Ann. Sci. Nat. (Zool.), 1868, 5. sér. 9, 62. 1868.3

Description de quelques reptiles et poissons nouveaux appartenant à la faune tropicale de l'Amérique. Nouv. Arch. Mus. Hist. Nat. Paris, 1869, 5 (Bull.), 19-2t.

1869.1

Bocourt, Firmin, \& Vaillant, Léon. See Vaillant \& Bocourt.

Bodahl, E.A. Om fiskeopdrat i Danmark. Tidssk. Norsk. Landbrug, Kristiania, 1908, 15, 297-302. 1908.1

Boddaert, Albert, \& Lim-BoonKeng. See Lim-Boon-Keng and Boddaert, Albert.

Boddaert, Peter. Epistola ... de Chatodonte argo descripto, ex Museo J. Alb. Schlosseri. [Text in Dutch and Latin] Amstelodamæ, 1770. $4 \mathrm{col}$. pls. $4^{\circ}$.

1770.1

Over den gevlakten klipvisch. Amsterdam, 1770. col. pl. $t^{\circ} .1770 .2$

- De tweedoornige klipvisch. Amsterdam, 1772. col. pl. $4^{\circ}$. 1772.1

Epistola . . de Chatodonte diacantho descripto. ['Text in Dutch and Latin] Amstelodamx, 1772. col. pl. $4^{\circ}$.

1772.2

Beschreibung zweier merkwürdiger Fische (Sparus palpebratus und Murona colubrina) Neue Nord. Beitr. (Pallas), 1781, 2, 55-57. fig. 1781.1
- Beschreibung einiger seltnen amboinischen Fische und des Sargus palpebratus. Schrift. Ges. Naturf. Fr. Berlin, 1782, 3, 458-460. 1782.1

Boddaert, $P ., \&$ Schlosser, J. A. Miscellanea de amphibiis et piscibus Amboinæ. 5 pts. Amstelodamæ, 176872. 7 col. pl. $4^{\circ}$.

1768.1

Bodenstein, $E$. Der Seitencanal von Cottus gobio. Zeitschr. Wiss. Zool., 1883, 37, 121-145. pl.

1883.1

Bodin, Th. Das Wachsthum des Aales. Natur (Muiller), 1878, n. s. 4 , 615-616.

1878.1

Zur Charakteristik der neuvorpommerschen Fischzuchtanstalten. Natur (Müller), 1879, n. s. 5, 32. 1879.1

Boeck, Axel. Indberetning til Departementet for det Indre om de af ham i Vinteren 1861-62 anstillede videnskabelige Undersøgelser angaaende Vaarsildfiskeriet. MIorgenbladet, Christiania, 1862, no. 300 .

1862.1

Om sildeaat. Tidsskr. Fiskeri, $1866,1,154-162$.

1866.1

Over Haaring-aas. Album $\mathrm{Na}$ tuur, 1868, 371-378. - Tidsskr. Fiskeri, $1867,1,154$. - Arch. Naturg., 1868, 34 , pt. $1,72-81$.

1868.1

Beretning om Sildefisket ved den norske og den bohuslenske kyst. Tidsskr. Fiskeri, 1870, 123-160. 1870.1

Indberetning om de af ham i 1870 anstillede Undersøgelser om Sildefiskerierne ved Norges og Bohuslens kyster. Morgenbladet, Christiania, 1871, nos. 203, 204, 208, 209. - Tidsskr. Fiskeri, 1871, 123-159. 1871.1

Om Silden og Sildefiskerierne, navnlig det norske Vaarsildfiske. (I) Indberetning til den konlige norske Regjerings Department for det Indre om foretagne praktish-videnshabelige Undersogelser. Christiania, 1871. $8^{\circ}$.

1871.2

- Bemaerkninger angaaende Sildefisket ved Hvaloerne i December forrige Aar. Morgenbladet, Christiania, 1871 (1872), no. $266 \mathrm{~A}$.

1872.1

Indberetning fra Stipendiad ... om forskjellige Fiskeriforholde i Graendsevandene mellem Smaalenene og Sverige, ved Hvaløerne m. V. Afgiven dil Departementet for det Indre under 8de Oktober 1871. Christiania, 1872. $8^{\circ}$.

1872.2 
Det norske Sildefiske. Tidsskr. Fiskeri, 1872 (1873), 1-40. 1873.1

- Det bohuslenske Sildefiskeries Historie. Nord. Tidsskr. Fiskeri, 1874, 1-27.

1874.1

- Indberetning til den konlige norske Regjerings Department for det Indre om hans i 1873 foretagne Undersogelser af de norske Sildefiskerier navnlig Storsildfisket i Nordland. Nord. Tidsskr. Fiskeri, 1875, 253-278.

1875.1

Boeck, Axel, \& Feddersen, J.A. The Nortregian herring fisheries. Rept. U. S. Fish Comm. 1873-75 (1876), 3, 97-122.

1876.1

Boeck, G. Zur Naturgeschichte der Diebel, IKarausche oder des Giebels [Carassius vulgaris] Circul. Deutsch. Fischer. Ver., 1875, 1. Jahrg., no. 7, 388-389.

1875.2

Zum Lachsfange. Circul. Deutsch. Fischer. Ver., 1875 (1876), 358-359.

1876.1

Gewässer für Forellen- und Maränen-Arten. Deutsch. Fischer. Zeitg., 1879, 325-326.

1879.1

Zur künstlichen Fischzucht. Deutsch. Fischer. Zeitg., 1879, 95.

1879.2

Boeck, Thorvald. Oversigt over litteratur, love, forordninger, rescripter m.m. vedrorende de norske Fiskerier. Efter foranstaltning af Central-committeen for norges Deltagelse i fiskeriudstillingen i Boulogne-sur-Mer 1866. Christiania, 1566. $8^{\circ}$.

1866.1

Verzeichniss der Schriften und Abhandlungen, die Norwegischen Fischereien betreffend, in chronologischer Ordnung zusammengestellt. Christiania, 1850. $\mathrm{S}^{\circ}$.

1880.1

Boecker, Wolfram. Callichthys fasciatus und sein Laichgeschäft. IVochenschr. Aquar.-Terrar. Kunde, 1909, 6. Jahrg., 18-20.

1909.1

Böckh, $G$. Ueber eine eigenthümliche Verkrüppelung des Kiarpfens ( $C y$ prinus carpio L.) Correspbl. Ver. Naturk. Presburg, 1863, 2. Jahrg. [Verh.7. Jahrg. p. 107. 1863.1

Bögershausen, W. Etwas vom Rivulus ocellatus. Wochenschr. Aquar.Terrar. Kunde, 1910, 7. Jahrg., $317-$ 318. fig.
Böhi, $U$. Beiträge zur Entwicklungsgeschichte der Leibeshöhle und der Genitalanlage bei den Salmoniden. Morph. Jahrb., 1904, 32, 505-586. pl. \& 37 figs.

1904.1

Böhm, A.A. Ueber die Befruchtung des Neunaugeneies [Petromyzon] Sitzber. Bayer. Akad. Wiss., math.-nat. Cl., 1887, 1. Heft, 53-62. - Sitzber. Ges. Morph. Phys., 1887, 3, 9-11.-Abstract in Journ. Roy. Micr. Soc. London, pt. 6, 932-933.

1887.1

Ueber Reifung und Befruchtung des eies von Petromyzon planeri. Arch. Mikr. Anat., 1888, 32, 613-670. pls. Abstract in Journ. Roy. Micr. Soc. London, 1889, pt. 2, 189-190. 1888.1

Ueber die Befruchtung des Forelleneies. Sitzber. Ges. Morph. Phys., 1891, 7, 63-73. 13 figs. 1891.1

Böhme, Richard. Ueber den Intestinaltractus von Clarias melanoderma Bleeker. Bern, 1904. 3 pls. 1904.1

Ueber den Luftatmungsapparat eines sumatranischen WVelses. Mitth. Naturf. Ges. Bern, 1904, p. vi-viii.

1904.2

Boeke, Jan. Die Bedeutung des Infundibulums in der Entwicklung der Knochenfische. Anat. Anz., 1901, 20, 17-20. 2 figs. - Abstract in Journ. Roy. Micr. Soc. London, 1901, 634. Zool. Centralbl., 1902, 9, 383-384.

1901.1

On the development of the entoderm, of Kupffer's vesicle, of the mesoderm of the head and of the infundibulum in Muræenoids. [Text in Dutch and English] Versl. Vergad. WisNatuurk. Afdeel. Konink. Akad. Wetensch., Amsterdam, 1902, 10, 468-474. - Proc. Sect. Sci. Kon. Akad. Wetensch. Amsterdam, 1902, 4, 442-148.

1902.1

On the structure of the light perception cells in the spinal cord, on the neurofibrilla in the ganglion cells, and on the innervation of the striped muscles in Amphioxus lanceolatus. Proc. Sect. Sci. Kon. Akad. IVet. Amsterdam, 1902, 5, 350-358. pl. 1902.2

Ueber das Homologon des Infundibularorganes bei A mphioxus lanceolatus. Anat. Anz., 1902, 21, 411-414. 3 figs. - Abstract in Journ. Roy. Micr. Soc. London, 1902, 546. 1902.3 
Boeke, $J$.

Ueber die ersten Entwicklungsstadien der chorda dorsalis; ein Beitrag zur Centrosomenlehre. Nederl. Bijdr. Anat. (Petrus Camper), 1902, 1, 568586. pl. \& 7 figs.

1902.4

Beitrïge zur Entwicklungsgeschichte der Teleostier. I. Die Gastrulation und Keimblätterbildung bei den Murmoiden. Bijdr. Anat. (Petrus Camper), 1903, 2, 135-210. 2 pls. \& 18 figs. II. Die Segmentierung des Kopfmesoderms, die Genese der Kopfhöhlen, das Mesectoderm der Ganglienleisten und die Entwicklung der Hypophyse bei den Mursenoiden. Ibid., 1904, 2, 439510. 3 pls. \& 25 figs.

1903.1

- Die Entwickling des Kopfmesoderms bei den Teleostiern [Text in Dutch] Handl. Nederl. Nat. Geneesk. Congres, 1903, 9, 234-237. 1903.2

- On the development of the myocard in teleosts [Text in Dutch \& English] Proc. Acad. Sci. Amsterdam, 1903, 6, 218-225. pl. - Versl. Vergad. Wis-Natuurk. Afd. Kon. Akad. Wetensch., Amsterdam, 1903, 12, 374-381. pl.

1903.3

- On the early development of the weever fishes (Trachinus vipera and Trachinus draco) Tijdschr. Nederl. Dierk. Ver., 1903, 2. ser. 8, 148-157. pl.

1903.4

- Unpigmented example of sole, Rhombus maximus [Text in Dutch] Jaarb. Rijksinstit. Onderz. Zee, Helder, 1903 (1904), 40-42.

1904.1

Eier und Jugendformen von Fischen der südlichen Nordsee mit besonderer Beruicksichtigung des holländischen Untersuchungsgebiets. Verh. Rijksinst. Onderz. See, Helder, 1906 1, pt. 4, 1-36.

1906.1

Iets over de visscherij in WestIndie. Maatsch. Natuurk. Onderz. Nederl. Kolonien, 1906, Bull. no. 51, $1-28$.

1906.2

- The later larval development of the Trachinida ('Trachinus vipera and Trachinus draco) 'Tijdschr. Nederl. Dierk. Ver., Helder, 1907, 2. ser. 10, 245-254.

1907.1

- On gastrulation and the covering of the yolk in the teleostean egg. Versl. Vergad. Wis-Nat. Afd. Kon. Akad. Wetensch., Amsterdam, 1907, 15, 607-615. 2 pls. - Proc. Sect. Sci.
Akad. Wet. Amsterdam, 1907, 9, 800s08. 2 pls.

1907.2

Over den bouw van de gangliencellen in het centraal zenuwstetsel van Branchiostoma lanceolatum. I. Versl. Wis-Nat. Afd. Akad. Wet. Amsterdam, 1907, 16, 5-11. pl.-Proc. Sect. Sci. Akad. Wet. Amsterdam, 1907, 10, 86-93. pl. - II. Versl. Vergad. Wis-Nat. Afd. Kon. Akad. Wetensch., Amsterdam, 1908, 17, 32-38:- Proc. Sect. Sei. Akad. Wet. Amsterdam, 1908 , 11, 53-59. pl.

1907.3

Das Infundibularorgan im Gehirn des Amphioxus. Anat. Anz., 1908, 32, 473-488. 12 figs.

1908.1

Die Innervierung der Muskelsegmente des Amphioxus (Branchiostoma) lanceolatum, nebst einigen Bemerkungen über die Endigungsweise der motorischen Nerven bei den Vertebraten. Anat. Anz., 1908, 33, 273-290. 9 figs.

1908.2

Neue Beobachtungen über das Infundibularorgan im Gehirn des Amphioxus und das homologe Organ des Craniotengehirnes. Anat. Anz., 1914, 44, 460-477. 12 figs. 1914.1

Boeke, J., \& Dammerman, $K$. W. De saccus vasculosus der visschen een receptief nerveus orgaan en niet een klier. Versl. Vergad. Wis-Nat. Afd. Kon. Akad. Wetensch., Amsterdam, 1910, 19, 62-67. - Proc. Akad. Wet. Amsterdam, 1910, 13, 1S6-192. 1910.1

Böker, $H$. Der Schädel von Salmo salar. Ein Beitrag zur Entwickelung des Teleostierschädels. Anat. Hefte, Wiesbaden, 1913, 49, 1. Abth., 359-397. Also separate; IViesbaden, 1913. 4 pls. \& 10 figs.

1913.1

Böklen, Hermann. Die Gattung Ceratodus. Jahrb. Ver. Naturk. Wuirttemberg, 1887, 43, 76-\$1.

1887.1

Discusses Triassic dental plates.

Boem, - Der böhmische Lachs auf dem Aussterbestaat. Allgem. Fischerei Zeitg., 1900 , 25, no. 23, 435437. 1900.1

Böök, Albert Theodor. Vähän Hiimeen kalastusoloista. Suomen Kalastus Lehti, 1892, 1, 156-161. - Fiskeritidskr. Finland, 1892, 1, 156-160.

1892.1

Boepple, J.F. Notes on the fish of the Cumberland river. Trans. Amer. Fisheries Soc. 1911 (1912), 181-182. 
Boer, $W . G$. De dominio gentium aquatico. Trajectum ad Rhenum [Utrecht] 1845. $8^{\circ}$.

1845.1

Börgershausen, W. Rivulus flabellicauda. Wochenschr. Aquar-Terrar. Kunde, 1910, 7. Jahrg., 629-630. fig.

1910.1

Boerner, J.C. H. Zoologix Silesiacx prodromus. - Pisces Silesiæ. Neue Oekon. Nachrich. Ges. Schlesien, 1781, 2, 187.

1781.1

- Beschreibung eines Fisches, Gadus fischeri, dipterygius, cirratus, cirris 3, maxilla superiore longiore. Neue Oekon. Nachrich. Ges. Schlesien, $1785,6,75$.

1785.1

Boettger, D. Nutzfische in Unterågypten. Zool. Garten, 1896, 37, 94.

1896.1

Das Maul als Bruttasche bei manchen Fischen. Zool. Garten, 1902, $43,96-110$.

1902.1

Boettger, O. Ueber den Fang von Stören im Main. 12. Bericht Offenbach. Ver. Naturk., 1871, 12-13. 1871.1

Böttger, Wilhelm Carl. Organe zur Luftatmung bei Fischen. Wochenschr. Aquar.-Terrar. Kunde, 1912, 9. Jahrg., 651-653. fig.

1912.1

Zur Frage nach der Giftigkeit des Aalblutes. Wochenschr. Aquar.Terrar. Kunde, 1912, 9. Jahrg., 558-559.

1912.2

Bötticher, Wolfgang. Ein Aquarienfisch vor 260 Jahren [Cobitis fossitis] Nerthus, Altona, 1902, 4, 43-46. 1902.1

Böving Petersen, J. $O$. Sjaldne grester i danske farvande [Scomber scomber in the Danish sea] Dansk Fiskeritidende, København, 1910, 204-205.

1910.1

Bogacev, $V, V$. Ueber die pliocänen Suisswasserfische Sibiriens. Vorl. Mitth. Jurjev. Sitzb. Naturf.-Gesell., 1908, 17, xi-xiv.

1908.1

Bogacki, Kamil. Experimentelle Flossenregeneration bei europäischen Süisswasserfischen. Arch. Entw. Mech., 1906, 22, 18-20. pl.

1906.1

Bogaerde, A. J. L. van den. Het distrikt St. Nikolaas, voorheen land van Waas, provincie Oost-Vlaanderen, beschouwd met betrekking tot deszelfs natuur-, staat- en geschiedkunde. St. Nikolaas, 1825. 3 vols. pls. $8^{\circ}$.

1825.1

Vischvangst en benaming der visschen, $p$. $172-179$.

Bogge, $E . B$. The fishing Indians of Vancouver's island. Mem. Anthropol. Soc. London, 1870, 3, 260-266. 1870.1

Bogle, Polynemus sele or isinglass fish at Arracan. Journ. Nat. Hist. Calcutta, 1842, 2, 615-616. 1842.1

Bogojavlenskij, $N . \quad V .$, Chmělevskij, $\left(., V_{.}\right.$Gracianov, $V . I .$, Zograf, J. $N$. , Hindze, $B . K ., \&$ Voronkov, N.V. See Chmëlevskij, Gracianov \& others.

Bogoljubsky, S. Zur Kenntnis der Dorsalflosse bei Motella tricirrata. Zeitschr. Wiss. Zool., 1908, 90,327-333. pl. 1908.1

Bohadsch, Johannes Baptista. De quibusdam animalibus marinis, eorumque proprietatibus, orbi litterario vel nondum, vel minus notis. Liber cum nonnullis [12] tabulis æri incisis, ab auctore super vivis animalibus delineatis. Dresdæe, 1761. $12 \mathrm{pls} .4^{\circ}$.

1761.1

Beschreibung einiger minderbekannten Seethiere, aus dem Lateinisch übersetzt von Leske. Dresden, 1776. figs. $4^{\circ}$. 1776.1

Bohls, $J$. Mittheilungen über Fang und Lebensweise von Lepidosiren aus Paraguay. Nachr. Ges. Wiss. Göttingen, math.-phys. Cl., 1894, no. 2, 80-83.

1894.1

Bohn, Georges. Conditions normales de la respiration pour les animaux marins. C. R. \& Mém. Soc. Biol. Paris, 1903, 99, 290-291.

1903.1

- Les tropismes, la sensibilité différentielle et les associations chez le branchellion de la torpille. C. R. Mém. Soc. Biol. Paris, 1907, 63, 545-548. fig. 1907.1

Bohnhof, $E$. Die Organisation der See-Fischerei in den Staaten Europas und Nord-Amerikas. Berlin, 1889. $4^{\circ}$.

1889.1

Bohr, Christian. Sur la sécrétion de l'oxygène dans la vessie natatoire des poissons. C. R. Acad. Sci., Paris, 1892, 114, 1560-1562.

1892.1

The influence of section of the vagus nerve on the disengagement of gases in the air bladder of fishes. Journ. Physiol., 1894, 15, 494-500. 1894.1 
Bois, A. diu. Qux apud veteres de piscibus electricis exstant argumenta. Berlin, 1843 . $8^{\circ}$.

1843.1

Boiseau, $R . F$. Goldfish in the Potomac. Forest \& Stream, 1878, 10, 154.

1878.1

Bois-Reymond, E. du. See DuBois-Reymond, $E$.

Boitard, M. P. Manuel d'histoire naturelle, comprenant les trois règnes de la nature, ou genera complet des animaux, des végétaux et des minéraux. Paris, 1827. 2 vols. with atlas. $18^{\circ}$.

1827.1

The atlas includes 155 plates of fishes, some colored.

Boiteux, Louis. La culture de la truite à Langen, près de Münster (Westphalie) La Nature, Paris, 1911, 39, pt. 1, 84-87. 5 figs.

1911.1

Bojanus, L. Observations sur l'opercule branchial des poissons. Mém. Soc. Nat. Moscou, 1817, 5, 264-269.

1817.1

Bemerkungen in Bezug auf die Deutung der Kopfknochen der Fische. Isis, 1818, 12, 2095-2096.

1881.1

- Versuch einer Deutung der Kinochen im Kopfe der Fische. Isis, 1818, 498-510. pl.

1818.2

Bolam, George. On the occurrence of the Vaagmaer (Trachypterus arcticus) at Berwick-on-Tweed. History Berwick Natural. Club, 1891, 8, 509.

1891.1

Ichthyological Notes. History Berwick Natural. Club, 1899, 16, 201201.

1899.1

Lesser fork-beard or tadpole fish, Raniceps trifurcalus Turton. History Berwick Natural. Club, 1901, 17, 112.

1901.1

Bolau, Cornetius Carl Heinrich. Kleine Mitheilungen aus dem Aquarium des Zoologischen Gartens in Hamburg. Verh. Naturw. Ver. Hamburg, 1878 , n. s. 3, 122-130.

1878.1

Entwickelung von Scyllium catulus im Hamburger Aquarium. Zool. Garten, 1879, 92. 1879.1

- Ueber dic Paarung und Fortpflanzung der Scyllium-Arten. Zeitschr. Wiss. Zool., 1881, 35, 321-325. 2 figs.
Ueber eine gelbe Varietät vom Flussaal, Anguilla vulgaris Fl. Arch. Naturgesch. (Wiegmann), 1881, 47. Jahrg., 1, 136-139. - Ann. Nat. Hist., $1882,9,65-67$.

1881.2

Ueber lebende Schuppenmolche (Lepidosiren annectens) und die Familie der Lungenfische. Verh. Naturw. Ver. Hamburg, 1910, 3 ser. 17, liv-lv.

1910.1

Lungenfisch, Stummelschwanzeidechse und Rot-Albinos der Sumpfschnecke. Verh. Naturw. Ver. Hamburg, 1901, 3. ser. 9, xlviii.

1901.1

—- Haifischeier. Blätt. Aquarienk., MIagdeburg, 1904, 15, 360-361. 1904.1

Die deutschen Versuche mit gezeichneten Śchollen. Mitth. Deutsch. Seefischer. Ver. Berlin, 1905, 21, 411421. 6 figs. - Wiss. Meeresuntersuch. Kiel, 1906, n. s. 7, no. 1, 79-131. 5 figs. \& 3 maps.

1905.1

— Einige Beobachtungen an Stichlingen im Seewasseraquarium. Zool. Garten, 1905, 46. Jahrg., 48-50. 1905.2

Bolau, Hermann, \& Heincke, Friedrich. See Heincke \& Bolau.

Boldo, Baltasar Manuel. Producción maritima particular, observada en La Coruna; comisionado por S. M. para la expedición del Señor Conde de Mopox y Jaruco, en la Isla de Cuba. Santiago, 1797. 20 p. pl. $8^{\circ}$. 1797.1

Bolitho, Thomas Simon. Report of the exportation of the pilchards [Clupea pilchardus] Trans. Nat. Hist. Antiq Soc. Penzance, 1851, 1, 253-259. 1851.1

Short note on the pilchard, more especially with reference to its migration during the summer of 1850 . Trans. Nat. Hist. Antiq. Soc. Penzance, 1851 , $441-445$.

1851.2

- Report of the exportation of pilchards, for 1851. Trans. Nat. Hist. Antiq. Soc. Penzance, 1864, 2, 51-54.

1864.1

Bolivar, Ignacio. Sobre la clasificación del.Roseti. Anal. Soc. Españ. Hist. Nat., 1903, 3, 239.

1903.1

_. Indicación de algunos peces notables de La Coruna. Bol. Soc. Espan. Hist. Nat., 1907, 7, 206-209. 2 pls. 
Bolk, L. Mededeeling over melanoblasten bei jungen teleostiern. Tijdschr. Neder. Dierk. Ver., Helder, 1908, 2. ser. 11, vii. 1908.1

Ueber die segmentale Anordnung der Melanoblasten bei jungen Teleostiern. Verh. Anat. Ges., 1908, 22, 135-139.

1908.2

Beobachtungen über Entwicklung und Lagerung von Pigmentzellen bei Knochenfischembryonen. Arch. Mikr. Anat. 1910, 75, 414-434. pl. \& 6 figs. 1910.1

Boll, E. Fischregen in Pommern und Mecklenburg. Arch. Ver. Freunde Naturgesch. Mecklenburg, 1858, 151152.

1858.1

Die Fische Mecklenburgs. Arch. Ver. Freunde Naturgesch. Mecklenburg, 1859, 13, 143.

1859.1

Ein Stör bei Treptow a. d. T' gefangen. Arch. Ver. Freunde Naturgesch. Mecklenburg., 1864, 188-189.

1864.1

Boll, E., \& Clunie, John. Sec Clunie \& Boll.

Boll, Franz. Die Lorenzini'schen Ampullen der Selachier. Arch. Mikr Anat., 1868, 4, 375-391. pl. 1868.1

Beiträge zur Physiologie von Torpedo. Arch. Anat. Phys., 1873, 10, 76-102. Abstract in Naturforscher (Sklarek), 1873, 6, 337-338. 1873.1

- Die Structur der electrischen Platten von Malapterurus. Arch. Mikr. Anat., 1873, 10, 242-254.

1873.2

Ein historischer Beitrag zur Kenntniss von Torpedo. Arch. Anat Phys. 1873 (1874), 152-158. 1874.1

- Die Structur der electrischen Platten von Torpedo. Arch. Mikr. Anat., 1874, 10, 101-121. pl. 1874.2

Ueber elektrische Fische. Berlin, 1874. $8^{\circ}$. (In Virchow, R. Sammlung gemeinverständlicher wissenschaftlicher Vorträge, ser.9, Heft 210) 1874.3

-Le vesicole di savi della torpedine. Atti R. Accad. Lincei Roma 1874-75 (1875), 2. ser. 2, 385-392. Arch. Anat. Phys., 1875, 456-468. Monatsber. Akad. Berlin, 1875, 238241. pl.

1875.1

- Neue Untersuchungen zur Anatomie und Physiologie von Torpedo.
Monatsber. Akad. Wiss. Berlin, 1875 (1876), 710-721. - Arch. Anat. Phys., 1876, 462-479. pl.

1876.1

- Nuove ricerche sulla struttura delle piastrine elettriche della torpedine. Atti R. Accad. Lincei Roma, 1875-76 (1876), 2. ser. 3, pt. 2, 483-492. - Journ. Micrographie, $1877,1,142-147 ; 203-$ 208.

1876.2

Bolles, $E, C$. Rapid change of color in fish. Amer. Naturalist, 1867, 1, 391.

1867.1

Bolling, - - Oplysninger om nogle danske Fisk. Tidsskr. Fiskeri, 1868, Aarg. 2, 291.1868 .1

Bollman, Charles Harvey [18681889] Notes on a collection of fishes from the Escambia river, with description of a new species of Zygonectes (Z. escambix) Proc.U.S. Nat. Mus., $1887,9,462-465$.

1887.1

[Coregonus tullibee bisselli] Bull.

U. S. Fish Comm. 1888, 8, 223. 1888.1

Report upon the fishes of Kalamazoo, Calhoun, and Antrim counties, Michigan. Bull. U. S. Fish. Comm. 1888 (1891), 8, 219-225. 1891.1

A review of the Centrarchida, or fresh-water sunfishes, of North America. Rept. U. S. Fish Comm. 1888 (1892), 16, 557-579. pls. Ixviiilxxii.

1892.1

Bollman, Charles Harvey, \& Evermann, Barton Warren. See Evermann \& Bollman.

Bollman, Charles Harvey, \& Jordan, David Stary. See Jordan \& Bollman.

Bollman, Charles Harvey, \& Meek, Seth Eugene. See Meek \& Bollman.

Bolten, D.G.J. Visschen als Muskietenverdelgers. Bull. Landb. WestIndie, Paramaribo, 1909, 19, 1-7. pl.

1909.1

Bolton, Herbert. Catalogue of the types and figured specimens in the geological department of the Manchester museum, Owens Collegel Rept. Mus. Assoc., 1893. Museum Handbooks, 1893.

1893.1

Fishes, p. 30-34.

Supplementary list of types and figured specimens in the geological department, Manchester museum. Rept. Mus. Assoc., 1894, p. 250-254. Museum Handbooks, 1894. 
Bolton, $H$.

The animal life of the Lancashire Coal Measures. Trans. Manchester Micr. Soc., 1895, 123-135. 2 pls.

1895.1

Fishes, p. 130-131.

- Note on Myriolepis hibernica Traq. Trans. Manchester Geol. Soc. 1895, 22, 628-632. 2 pls.

1895.2

Notes on plant and fish remains from the Jarrow colliery, Co. Kilkenny. Trans. Manchester Geol. Soc., 1895 , 22, 613-628.

Fishes, p. 622-623.

- On the occurrence of the genus Listracanthus in the English Coal Measures. Geol. Mag., 1896, 3, 424426. fig.

1896.1

The palmontology of the Lancashire Coal Measures. Parts I-III. Trans. Manchester Geol. \& Mining Soc., 1905, 28, 378-420; 578-650; 668689.

Fishes, p. 401-105; 601-621; 676-680.

1905.1

- The geology of Lancashire. Victoria County Hist., Lancashire volume, 1907, 1.

1907.1

- On a marine fauna in the Basement-beds of the Bristol coalfield. Quart. Journ. Geol. Soc. London, 1907, 63, 445-469. pl.

Pisces, p. $467-468$.

- Faunal horizons in the Bristol coalfield. Quart. Journ. Geol. Soc. London, 1911, 67, 316-341. pl. 1911.1 Pisces, p. 336.

Boltze, $F$. Ueber die Fischerei in der Grafschaft Mansfeld. Circul. Deutsch. Fischer. Ver., 1874, 5-8. - Zeitschr. Landw. Central-Ver. Prov. Sachsen, 1874, 31, 183-187.

1874.1

Bolze, $H$. Junge Aale. Natur (Müller), 1878, n. s. 4, 555 . 1878.1

Bomare, J. Christian Valmont de. Dictionnaire raisonné universel d'histoire naturelle, contenant l'histoire des animaux, des végétaux, des mineraux ... [etc.] 6 vols. Paris, 1764. $8^{\circ}$.

1764.1

1. ed. 15 vols. Lyon, 1791. $8^{\circ}$. Dutch translation with appendix. 3 vols. Dordrecht, $1767-70.4^{\circ}$

Bompas, George C. Life of Frank Buckland. 6. ed. London, 1885. 433 p. portr.

1885.1

Chap. x. About fish, etc. Chap. xi. Scotch fishries.
Bonafous, $C$. Introduzione delle carpe del Tibet in Piemonte. Torino, 1827. $8^{\circ}$

1827.1

Bonaparte, Charles Lucien Jules Laurent, (Prince de Canino) [1803-1857] Saggio di una distribuzione metodica degli animali vertebrati. Giorn. Arcad. $1831,49,1-77$. - Isis (Oken), 1832 , col. $283-320$.

1831.1

Iconografia della fauna italica per le quattro classi degli animali vertebrati. 3 vols. Roma. 1832-41. pls.

Pesci, vol. iii. 78 pls.

1832.1

Zusätze und Berichtigungen zu den Säugethieren nach der Classification der Fische. Isis (Oken), 1833, col. 12181230 .

1833.1

Nouvelle classification des animaux vertébrés. Revue Zool. 1838, 1 $208-217$.

1838.1

Selachorum tabula analytica. Nuov. Ann. Sci. Nat. 1838, 2, 195-214. -Mém. Soc. Sci. Nat., Neuchâtel, 1839, 2. Also separate; Rome, 1839.

1838.2

Synopsis vertebratorum systematis. Nuov. Ann. Sci. Nat., 1838, 2, 105-133. - Ann. Med. Chir. (Metaxà), 1839, 1, 213-226; 268-279. Isis (Oken), 1839, col. 848-861. - Rev. Zool., 1839, p. 308 . 1838.3

- Systema vertebratorum. C. R. Acad. Sci. Paris, 1838, 7, 656-658.

1838.4

Smisurato pesce del peso di 4000 libre [Squalus carcharodon Smith] Ann. Med. Chir. (Metaxà), 1839, 1, 3538.

1839.1

_- Sur une nouvelle espèce de Squalius. Nuov. Ann. Sci. Nat. Bologna, 1839.

1839.2

Systema ichthyologicum. Mém. Soc. Sci. Nat. Neuchâtel, 1839, 2, 1-2.

1839.3

Monographia Leuciscorum europxorum. Actes du 1. Congrès de Pise, 1840 , p. 150 .

1840.1

Observations sur la torpille. Actes du 1. Congrès de Pise, 1840, p. 18.

1840.2

Observations sur les Orthagorisques et les doubles emplois auxquels ont donné lieu les espèces de ce genre. Actes du 1. Congrès de Pise, 1840, p. 165. 
Prodromus systematis ichthyologix. Nuov. Ann. Sci. Nat. Bologna, $1840,4, \quad 181-196 ; \quad 272-277$. - Isis (Oken) 1841, 626-638. - Ann. Med. Chir. (Metaxà), 1840, 3, 343-363.

1840.4

Sur un Blennius qui vit dans les eaux du Caldana en Toscane. Actes du 1. Congrès de Pise, 1840, p. 175.

1840.5

Manuel d'ich thyologie italienne. Actes du 2. Congrès de Turin, 1841, p. 233 .

1841.6

- A new systematic arrangement of vertebrated animals. 'Trans. Linn. Soc. London, 1841, 18, 247-304. 1841.7

Pisces, p. 287-304.

Comparaison entre les familles des percides et des scombrides. Actes du 3 . Congrès de Florence, 1842, p. 359.

1842.1

Descrizione di un nuovo Leuciscino veduto per la prima volta nella peschiera dello Scoglietto del Durazzo in Genova [Squalius pareti] Nuov. Ann. Sci. Nat., 1842, 7, 148-151. 1842.2

Sur le Dasbotes fullonica. Actes du 3. Congrès de Florence, 1842, p. 363.

1842.3

Sur l'encéphale des lamproies, comparé à celui des raies. Actes du 3. Congrès de Florence, 1842, p. 373.

1842.4

- Sur les Lagocephalus pennant Sw. Actes du 3. Congrès de Florence, 1842 , p. 359.

1842.5

Sur une espèce de Trachyptère présenté par le docteur Vérany. Actes du 3. Congrès de Florence, 1842, p. 461.

1842.6

Rilievi sul volume XVII dell' "Istoria naturale dei pesci" di Valenciennes che contiene i Leuciscini. Atti Sci. Ital., 1844, 431-438. 1844.1

- Specchio generale del sistema ittiologico. Atti Sci. Ital, 1844, 386400.

1844.2

Catalogo metodico dei Ciprinidi d'Europa, e rilievi sul volume XVII della storia naturale dei pesci del Sign. Valenciennes. Milano, 1845.20 p. $4^{\circ}$.

1845.1

Catalogo metodico dei pesci Europci. Atti Sci. Ital., 1845, 1-95. Also separate; Napoli, 1846. 97 p. $4^{\circ}$.
- Catalogue systématique des $\mathrm{Cy}$ prinides européens. Actes du 6. Congrès de Milan, 1845, p. $381 . \quad 1845.3$

- Observations sur les Echénéides. Actes du 6. Congrès de Milan, 1845, p. 372 .

1845.4

Observations sur les Leuciscus de Lombardie, décrits par le docteur de Philippi. Actes du 6. Congrès de Milan, 1845 , p. 180.

1845.5

Specchio generale dei sistemi erpetologico, anfibiologico ed ittiologico. Milan, 1845. 11 p. $4^{\circ}$. 1845.6

- Système ichthyologique. Actes du 6. Congrès du Milan, 1845, p. 379.

1845.7

Sur deux espèces de poissons (Cubiceps bipinnatus et Scaurus siculus) Actes du 7. Congrès de Naples, 1846, p. 715 .

1846.1

- Conspectus systematis ichthyologixe. Editio reformata. Nuov. Ann. Sci. Nat. 1850, 3. ser. 6, 453-456. Also separate; Lugdunum Batavorum, 1850. $8^{\circ}$.

1850.1

Bonarelli, Guido. I fossili senoniani dell' Appennino centrale che si conservano a Perugia nella Collezione Bellucci. Atti Accad. Sci. Tórino, 1899, 34, 1020-1027. pl.

1899.1

Bondouy, Th. Sur les phénomènes digestifs dans les tubes pyloriques chez quelques téléostéens. Bull. Soc. Scient. Méd. Ouest, 1897, 8, 56-60. 1897.1

Bonelli, Francis André. Description d'une nouvelle espèce de poisson de la Méditerranée appartenant au genre Trachyptère [ $T$. cristatus] avec des observations sur les caractères de ce même genre. Mem. Accad. Torino, 1819, 24, 485-494. pl. - Isis (Oken), $1819,4,432$.

1819.1

Bonivento, Adolfo. Description de la pêcherie dans la vallée Figheri .... Chioggia, 1902. $8^{\circ}$.

1902.1

La peschiera di valle Figheri. Descrizione. Riv. Mens. Pesca, Milano, $1907,9,44-48$.

1907.1

Bonizzi, Paolo [1840-89] Prospetto sistematico e catalogo dei pesci del Modenese. Ann. Soc. Nat. Modena, $1869,4,239-269$. 1869.1

- Sulle varietà della specie Gasterosteus aculeatus. Arch. Zool. Anat. Fisiol., Modena, 1869, 2. ser. 1, 156163. pl. Also separate; Torino \& Florence, 1870.8 p. $\quad 1869.2$ 
Bonnard, A. Pêche côtière, et colonisation maritime en Algérie. Paris, 1902. $4^{\circ}$.

1902.1

Bonnaterre, (L'abbé) Joseph P. [c. 1752-1804] Tableau encyclopédique et méthodique des trois règnes de la nature... Ichthyologie: Paris, 1788. vi, 215 p. 102 pls. $4^{\circ}$.

1788.1

This volume forms one of the parts of the zoological portion of Ency"clopédie Méthodique, etc. the whole comprising 196 volumes, 1782 1832. For dates of publication of the various parts, see Sherborn, C. D., and Woodward, B. B. in Proc. Zool. Soc. London, 1893, 582B84; 1899, p. 595. For an estimate of l'Abbe Bonnaterre's compilation, see Gill, T. N., in Smithson. Misc. Coll., 1872, 11, 37.

Bonnet, Charles. Lettre sur les moyens de conserver diverses espèces d'insectes et de poissons dans les cabinets d'histoire naturelle. Observ. Physique \& Hist. Nat., 1774, 3, 296; 5, 12

1774.1

Euvres d'histoire naturelle et de philosophie. $S$ vols. Neuchâtel, 1779-1783. pls. $4^{\circ}$. 1783.1

Les harengs, vol. iv, pt. 2, p. 228-231.

The same. German version. 3 vols. Leipzig, 1783.

1783.2

Mémoire sur le Royaume de l'Algarve. Mem. Acad. Real Sci. Lisboa, 1850, p. 87.

1850.1

Bonnet, $H$. von, \& Merkel, $O$. See Merkle \& Bonnet.

Bonnet, $R$. Studien zur Physiologie und Pathologie der Fische. Allgem. Fisch. Zeitg., 1883, p. 79; 1884, p. 169 $192 ; 206$.

1883.1

Bonnier, Pierre. Sur les fonctions statique et hydrostatique de la vessie natatoire et leurs rapports avec les fonctions labyrinthiques. C. R. Soc. Biol. Paris, 1895, 10. sér. 2, 745-747.

1895.1

_- Sur le sens latéral. C. R. Soc. Biol. Paris, 1896, 3, 917-919. 1896.1

Bonome, A. Sull' istogenesi della nevroglia normale nei vertebrati. Arch. Ital. Anat. Embr., 1907, 6, 157-345. 9 pls.

1907.1

Bonomi, I. Contributo alla conoscenza dell' ittiofauna miocenica di Mondaino. Riv. Ital. Paleontol., 1896, 2, 199-239. pl.

1896.1

Bonorden, Albert. Das Laichgeschäft des Rasbora heteromorpha. Blätt. Aquar.'lerrar. Kunde, 1911, 22. Jahrg., 813.
Das Laichgeschäft der Rasbora heteromorpha. Wochenschr. Aquar.-Terrar. Kunde, 1913, 10. Jahrg., 927-928.

1913.1

Bonpland, Aimé Jacques Alexandre, \& Humboldt, Friedrich Heinrich Alexander von. See Humboldt \& Bonpland.

Bonsdorff, Evert Julius [1810-1898] Speciel jemförande beskrifning af Hufvudskålsbenen hos Laken (Gadus lota, Linn.) Acta Soc. Sci. Fenn., Helsingfors, $1845,2,1177-1181$. pls. xix-xxvii.

1845.1

Beskrifning af ett missbildadt cranium hos en man, jemte några anmårkningar öfvel" uppkomsten och betydelsen af de så kallade "ossicula vormiana." Acta Soc. Sci. Fenn., Helsingfors, 1846, 2, 1283-1299. pls. xxiii-xxvii.

1846.1

Speciel jemförande beskrifning af Hufvudskabsbenen hos Laken (Gadus lota L.) [=Lota vulgaris Cuv.] Acta Soc. Sci. Fenn., Helsingfors, 1847, 2, 1177-1181. 4 pls.

1847.1

Bidrag till blodkärlsystemets jemförande anatomie (III Portvensystemet hos Gadus lota) Acta Soc. Sci. Fenn., Helsingfors, 1852, 3, 571-590. 2 pls.

1852.1

Portven systemet hos Gadus lota. Helsingfors, is51. 2 pls. $4^{\circ}$

Anatomisk undersökning af arteriella kärlsystemet hos Laken. Oefvers. Finsk Vetenskaps Soc. Förh., 1853, 1, 97.

1853.1

Anatomisk undersökning af Vensystemet hos åtskilliga i Finland förekommande Fiskar (1851) Oefvers. Finsk Vetenskaps Soc. Förh., 1853, 1, 166.

Caudalportvensystem hos Laken. Oefvers. Finsk Vetenskaps Soc. Förh., 1853, 1, 155.

1853.3

Om nerverna hos Raja clavata. Oefvers. Finsk Vetenskaps Soc. Förh., 1854, 2, 24-25.

1854.1

Jämförander undersökningar af hjärnan hos fiskarna. Oefvers. Finsk Vetenskaps Soc. Förh., 1855, 2, 53.

1855.1

- Om de lägre vertebraternas med kärna försedda blodkroppar (1851) Oefvers. Finsk Vetenshaps Soc. Förh., $1855,2,53$.

1855.2 
Undersökningar af Nervsystemet hos Rockan (Raja clavata) Ofvers. Finsk Vetenskaps Soc. Förh., 1855, 2, 10-11; 24-25.

1855.3

- Jemförande anatomisk beskrifning af cerebralnerverna hos Raja clavata. Acta Soc. Sci. Fenn., 1857, 5, 185-227. 3 pls.

1857.1

Bont, M.J. de. Een woord over kunstmatige vischfokkerij. Tijdschr. Nederl. Maatsch. Nijverheid, 1863, 26 (3. ser. 4), 416-444.

1863.1

- Verslag. over de Inrigting voor Piscicultuur op de Diergaarde aanwezig. Nederl. Tijdschr. Dierk., 1863, 1. Jahrg., p. xxv-xxxiv. Also separate; Amsterdam, 1863. $8^{\circ}$.

1863.2

— Nog een woord over de kunstmatige vischfokkerij. Tijdschr. Nederl. Maatsch. Nijverheid, 1867, 30 (3. ser. 8), 376-412.

1867.1

La culture pratique du saumon et de ses congénères et la pisciculture au jardin zoologique d'Amsterdam. Nederl. Tijdschr. Dierk., 1873, 4, 241269. 14 figs. Also separate; Amsterdam, 1872. pl. $8^{\circ}$.

1873.1

Bonvalot, $E . T$. Chasse et pêche dans le Rosemont. Strasbourg, 1866. $8^{\circ}$.

1866.1

Bonvoisin, Leo. Concerning eels. Fishing Gaz., 1877, no. 22, p. 3.

Sleeping and feeding habits of fish. Fishing Gaz., 1877, no. 14, p. 7.

1877.2

Books, St. John. The osteology and arthrology of the haddock (Gadus aglefinus) Scient. Proc. Roy. Soc. Dublin, 1893.

1893.1

Boosey, Thomas. Anecdotes of fish and fishing. London, 1887. 251 p. $8^{\circ}$. 1887.1

This is a reprint of his Piscatorial reminiscences, published in 1835 .

Booth, William. Catalogue of [his] valuable library ... comprising about 10,000 volumes ... with works on angling, etc. Manchester, 1884. 193 p. $8^{\circ}$.

1884.1

Borcẻa, Jean. Des différences de structure histologique et de sécretion entre le rein antérieur et le rein postérieur chez les elasmobranches mâles. C. R. Acad. Sci. Paris, 1904, 138, 1342 1343.
- Note complémentaire sur la morphologie du rein des elasmobranches. Bull. Soc. Zool. France, 1904, 29, 209-210.

1904.2

__._Quelques considérations sur l'appareil urinaire des elasmobranches. Bull. Soc. Zool. France, 1904, 29, 143148. 2 figs.

1904.3

Quelques observations sur une épinoche: Gasterosteus aculeatus L. (variété leiurus C. et V.), provenant d'une rivière se déversant au fond de la baie Aber, près du laboratoire de Roscoff. Bull. Soc. Zool. France, 1904, 29, 140-141.

1904.4

Sur la glande nidamentaire de l'oviducte des elasmobranches. C. R. Acad. Sci. Paris, 1904, 138, 99-101.

1904.5

Sur le développement du rein et de la glande de Leydig chez les elasmobranches. C. R. Acad. Sci. Paris, 1904, 139, 747-749.

1904.6

- Sur les entonnoirs segmentaires du Centrina risso Salviani $\pi$ Bull. Soc. Sci. Méd. Ouest Rennes, 1904, 13, 108-110. - Trav. Sci. Univ. Rennes, $1904,3,178$.

1904.7

- Sur un cas de conformation anormale de l'oviducte droit chez une petite roussette, Scyllium canicula. Bull. Soc. Zool. France, 1904, 29, 138-140. 1904.S

Recherches sur le système urogénital des elasmobranches. Arch. Zool. Expér. Paris, 1905, 4. sér. 4, 199484. 2 pls.

1905.1

Sur quelques faits relatifs au développement du rein des elasmobranches. C. R. Acad. Sci. Paris, 1905, 140, 672-674. 4 figs.

1905.2

Observations sur la musculature branchiostégale des téléostéens. Ann. Scient. Univ. Jassy, 1907, 4, 203-225. 17 figs.

1907.1

Observations sur quelques raies de la Baie de Naples. Ann. Scient. Univ. Jassy, 1907, 4, 180-186. 1907.2

Observatiuni asupra câtorva specii de Rajide din golful de Neapol. Public. Fond. Adamachi Acad. Româna, 1907,4 , no. 20, 109-114.

1907.3

Observatiuni asupra diferentierii si desvoltárii musculaturii branchiostegale la teleosteeni. Public. Fond. Adamachi Acad. Româna, 1907, 4, 89-107. 17 figs.
1907.4 
Borcéa, $J$.

- Une observation sur la maturité et la parturition chez le Pristiurus melanostomus Bp. Ann. Scient. Univ. Jassy, 1908, 5, 84-85. [Embryo with 6 gill slits! 1908.1

Quelques observations sur la circulation embryonnaire chez les téléostéens. Bull. Soc. Zool. France, 1909 , 34, 189-191.

1909.1

- Sur les masses mésodermiques intermédiaires et leurs dérivés chez les téléostéens. C. R. Acad. Sci. Paris, $1909,149,637-640$.

1909.2

- Sur l'origine du coeur, des cellules migratrices et des cellules pigmentaires chez les téléostéens. C. R. Acad. Sci. Paris, 1909, 149, 688-689. 1909.3

- Observations sur la circulation embryonnaire che\% les téléostéens. Ann. Scient. Univ. Jassy, 1910, 6, 84 100. 9 figs.

1910.1

- Sur les entonnoirs segmentaires du Notidanus (Heptanchus) cinereus Gml. Ann. Scient. Univ. Jassy, 1910, 6, 101-103. fig.

1910.2

Borchardt, Fritz. Das Laichgeschäft von Cichlasoma severum und die Aufzucht der Jungen. Blätt. Aquar.-Terrar. Kunde, 1913, 24. Jahrg., 244-246. fig.

1913.1

Borcherding, Fr. Beiträge zue Molluskenfauna der nordwestdeutschen Tiefebene, etc. Jahreshefte Naturw. Ver. Lüneburg, 1885-87. 42 p. 1887.1

Angabe der Fische des Bederkesaer Sees und anderer Wässer nach Fischeraussagen.

Die Tierwelt der nordwestdeutschen Tiefebene. (In Die freie Hansestadt Bremen und ihre Umgebungen. Bremen, 1890) 1890.1

Borcherding, Fr., Cronheim, Debschitz, H. von, Knauthe, Karl, Apstein, $C$., \& Berthelmann, See Knauthe, Apstein \& others.

Borchert, Max. Zur Kenntnis des Zentralnervensystems von Torpedo. Erste Mittheilung. Denkschr. Med. Naturwiss. Gesell. Jena, 1903, 10, 1-59. 10 pls. - Neurobiologische Arbeiten (O. Vogt), 2. ser. 1, pt. 1 .

1903.1

- Ueber Markscheidenfärbung bei niederen Wirbelthieren. Arch. Anat. Physicl. (Physiol. Abt.), 1904, 572-575. 1904.1

Ueber eine bisher unbekannte Gesetzmässigkeit im Zentralnervensys- tem von Torpedo. Anat. Anz., 1905, 26, 289-292. 2 pls. \& fig. 1905.1

Zur Kenntnis des Zentralnervensystems von Torpedo. Zweite Mittheilung. Morphol. Jahrb., 1906, 36, 52-81. 3 pls.

1906.1

Borckert, Hans. Anatomisch-physiologische Untersuchung der Haftscheibe von Cyclopterus lumpus L. Inaug. Dissert. Kiel, 1889. 36 p. 2 pls.

1889.1

Bordage, Edmond. Les vertébrés, descendent-ils des arthropodes? Revue Scient., 1892, 49, 333-349. 1892.1

- Adaptation des poissons plats aux couleurs des fonds marins. Biologica, Paris, 1911, 1, 269-273. 15 figs.

1911.1

Bordas, L. L'appareil venimeux de la Murène (Murana helena L.) Naturaliste, Paris, 1907, 29, 227-228. $\quad 1907.1$

Borderer (pseudon.) See Brown, William Sorley.

Borggreve, Bernard. Die Wirbelthiere des Regierungsbezirks Wiesbaden. Jahrb. Nassau. Ver. Naturk., 1897, 50, 145-178.

1897.1

Borgmann, Hugo. Die Fischerei im Walde. Ein Lehrbuch der Binnenfischerei fuir Unterricht und Praxis. Berlin, 1892. 283 p. figs.

1892.1

Ueber die Einwirkung der Seife auf Fische. Förstl. Naturw. Zeitschr. (Tubeuf), 1893, 1, 276-277. 1893.1

- Beiträge zum Fischereischutz. Allgem. Fischerei Zeitg., 1898, 23, 428430. 1898.1

Borja y Goyeneche, Joaquin de. La pesca. Mem. Real Acad. Cien. Artes, Barcelona, 1901-04 (1902), 4, no. 17, 237-262.

1902.1

Borlase, William [1695-1772] The natural history of Cornwall. The air, climate, waters, rivers, lakes, sea ... rare birds, fishes, shells, reptiles, and quadrupeds, . . . etc. Oxford, 1758. xix, $326 \mathrm{p}$.

1758.1

Sect. ii. Sea-fish and first cetaceous, p. 261-2S2.

Borley, J.O. The poison apparatus of the weever. Trans. Norfolk \& Norwich Nat. Soc., 1907, 8, 369-373. fig.

1907.1

On the cod marking experiments in the North sea conducted by the Marine Biological Association of the United Kingdom from the S. S. "Huxley" 
during 1904-07. Cons. Perman. Intern. Explor. Mer Rapp., 1909, 10, no. 7 , 1-10. map.

1909.1

Report on the vitality of trawlcaught plaice. 2. Rept. North Sea Fish Invest. Comm., 1909, pt. 2, 1-50. 3 figs. 1909.2

- A comparison of the condition of the plaice of different regions as to weight. 4. Rept. North Sea Fish Invest. Comm., 1912, 81-105. 11 figs.

1912.1

Report on the experimental transplantation of plaice to the Dogger bank. Carried out by the Marine Biological Association in the years 1904-8. 4. Rept. North Sea Fish Invest. Comm., 1912, 1-79. \& pls. \& 20 figs. $\quad 1912.2$

Bormann, A. F. Die neue Pözilie mit der schwarz-weiss-roten Rückenflosse. Prakt. Zierfischzüchter, 1910, 60-61.

1910.1

Rasbora heteromorpha, eine Seltenheit. Prakt. Zierfischzüchter, 1910, 25-26.

1910.2

Born, G. Bemerkungen über den Zahnbau der Fische. Zeitschr. Organ. Phys. (Heusinger), 1827, 1, 182-206. figs. - Bull. Sci. Nat. (Férussac), 1828, 15,167 .

1827.1

- Ueber den innern Bau der lamprete (Petromyzon marinus) Zeitschr. Organ. Phys. (Heusinger), 1827, 1, 170181. - Bull. Sci. Nat. (Férussac), 1828, 13, 360. - Ann. Sci. Nat., 13, 22-37. fig.

1827.2

Observations sur la grande lamproie (Petromyzon marinus) Ann. Sci. Nat., 1828, 13, 22-37.-Bull. Sci. Nat. (Férussac), 1828, 13, 268-362. 1828.1

Bornaud, Eduard. Etude histologique des nerfs et de la muqueuse buccale chez les poissons. Bull. Soc. Vaud. Sci. Nat., 1887, 23, 6-18.

1887.1

Sur la nature et l'origine de la gaine de sarcolemme chez les poissons. Bull. Soc. Vaud. Sci. Nat., 1887, 23, 1-6. pls.

1887.2

Borne, Max von dem [1826?-1894] Beitrag zu der Frage, in welchem Alter die in Fischbrut-Anstalten ausgebrüteten jungen Fische den freien Gewässern zu übergeben sind. Circul. Deutsch. Fischerei Ver., 1872, 185-187. 1872.1

Jahresbericht der FischzuchtAnstalt zu Berneuchen bei Wusterwitz,
N./M. pro 1872/73. Circul. Deutsch. Fischerei Ver., 1873, 234-236. 1873.1

Mittheilung die Bachforelle betreffend. Circul. Deutsch. Fischerei Ver., 1873, 1. Jahrg., no. 2, 42-46.

1873.2

Die Wanderfische.

Deutsch.

Landw. Presse, 1874, p. 77. 1874.1

- Die Fischzucht. Berlin, 1875. 124 p. 22 figs. $8^{\circ}$ 1875.1

Illustrirtes Handbuch der Angelfischerei. Auf Grund der neuesten Erfahrungen in Deutschland, England und Amerika bearbeitet. Berlin, 1875. 380 p. 195 figs. $8^{\circ}$ 1875.2

- Mittheilungen über die Erfolge seiner Fischzucht-Anstalt im Jahre 1873-74. Circul. Deutsch. Fischerei Ver., 1874 (1875), 163-166. 1875.3

Mittheilungen über die Süsswasserfischereien in den Vereinigten Staaten Amerikas. Circul. Deutsch. Fischerei Ver. 1874 (1875), 66-68. 1875.4

Staats-Fischzucht-Anstalt in Californien. Deutsch. Landw. Presse, 1875, 519-520.

1875.5

- How can our lakes and rivers be again stocked with fish in the shortest possible time? Rept. U. S. Fish Comm. 1873-75 (1876), 3, 681-683. 1876.1

Ueber Beschaffenheit der Gewässer, in denen Forellen und andere Salmoniden gedeihen. Circul. Deutsch. Fischerei Ver. 1876 (1877), 236-237.

1877.1

Uebersicht der Resultate der Fischzucht-Anstalt in Berneuchen bei Wusterwitz N./M. während des Jahres 1875-76. Circul. Deutsch. Fischerei Ver. 1876 (1877), 154-155. 1877.2

Wegweiser für Angler durch Deutschland, Oesterreich und die Schweiz. Berlin, 1877. 302 p. $12^{\circ}$.

1877.3

Wie können unsere See'n und Flüsse in kürzester Frist wieder fischreich gemacht werden? Circul. Deutsch. Fischerei Ver. 1876 (1877), 26-28. Translation in Rept. U. S. Fish Comm. 1873-75 (1876), 3, 681-683. 1877.4

Befruchtung und Ausbrütung anklebender Fischeier. Deutsch. Fischerei Zeitg., 1878, 1. Jahrg., 174-175.

1878.1 
Borne, $M \cdot v \cdot d$. fornischen Troges bei der Fischzucht. Zeitschr. Ver. Nass. Land. \& Forstw., 1878,60 (n. s. 9), 327-330. figs. 1878.2

- Bericht über die Gewinnung von Marïnnen-Eiern am Schal- und Selenter See im Herbste 1877. Circul. Deutsch. Fischerei Ver., 1878, 5-19.

1878.3

Bericht über die Züchtung von Lachsen, Coregonen und Aeschen im Jahre 1877-78. Circul. Deutsch. Fischerei Ver., 1878, 97-114.

1878.4

- Der Californische Bruttrog. Deutsch. Fischerei Zeitg., 1878, 1. Jahrg., 18-19. 1878.5

Dr. J. Knoch's Reise zur Wolga behufs der Sterlettbefruchtung, im Bull. Soc. Imp. Nat. Moscou., 1871, 44. Circul. Deutsch. Fischerei Ver. 1877 (1878), 185-186.

1878.6

Grundsätze bei Errichtung von Laich-Schonrevieren. Circul. Deutsch. Fischerei Ver. 1877 (1878), 3. 1878.7

Jahresbericht über die Resultate der Fischzucht-Anstalt zu Berneuchen bei Wusterwitz während der Brutperiode 1876-77. Circul. Deutsch. Fischerei Ver. 1877 (1878), 138-139. 1878.8

Lachsfischerei in Oregon und Californien. Circul. Deutsch. Fischerei Ver., 1878, 93.

1878.9

Shadfischzucht in Maryland. Circul. Deutsch. Fischerei Ver., 1878, 91-93.

1878.10

- Der tiefe Californische Bruttrog. Deutsch. Fischerei Zeitg., 1878, 41-42; $1879,213-214$.

1878.11

_- Tragbare Brutanstalten. Circul. Deutsch. Fischerei Ver. 1877 (1878), 210-211.

1878.12

Die transportable Brut-Anstalt. Circul. Deutsch. Fischerei Ver., 1878, 134-135.

1878.13

Wie kann man unsere Gewässer nach den in ihnen vorkommenden Fischarten classifiziren und welche Fische sind am besten geeignet, die verschiedenen Arten von Fischwässern ertragreich zu machen? Circul. Deutsch. Fischerei Ver. 1877 (1878), 89-93.

1878.14

_... Bericht über die Züchtung von Fischen aus Eiern, welche der deutsche
Fischerei-Verein im Jahre 1878-79 vertheilt hat. Circul. Deutsch. Fischerei Ver. 1879, 165-172.

1879.1

Erbrütung von 10,000 Eiern der amerikanischen Forelle (Salmo fontinalis) Circul. Deutsch. Fischerei Ver. $1879,134-135$.

1879.2

Ueber die Wichtigkeit der Coregonenzüchtung. Circul. Deutsch. Fischerei Ver. 1878 (1879), 47-53. 1879.3

- Fang der Fischfeinde. Circul. Deutsch. Fischerei Ver. 1879 (1880), 26-29.

1880.1

Eine improvosirte Fischzuchtanstalt am Bader See in den bayerischen Alpen. Circul. Deutsch. Fischerei Ver. 1879 (1880), 108.

1880.2

Die Maräne ¿Coregonus lavaretus] des Leba-Sees und der Ostsee. Circul. Deutsch. Fischerei Ver. 1879 (1880), 1. Jahrg., no. $2,47$.

1880.3

Der selbstauslesende Bruttrog. Circul. Deutsch. Fischerei Ver. 1879 (1880), 22-23; 40-43.

1880.4

Trockene Verpackung frisch befruchteter Fischeier. Deutsch. Fischerei Zeitg., 1880, 479.

1880.5

- Trockene Versendung von Fischeiern. Oester.-Ungar. Fischerei Zeitg., 1880, 375. 1880.6

Ueber die richtige Benutzung des Californischen Troges und des TrichterApparats zum Anbrüten von Fischeiern. Circul. Deutsch. Fischerei Ver. 1879 (1880), 39-40.

1880.7

Ueber die Züchtung von Fischen aus Eiern, welche der deutsche Fischereiverein im Jahre 1879-80 vertheilt hat. Circul. Deutsch. Fischerei Ver. 1879 (1880), 96-119.

1880.8

Ueber Filtrir-Apparate. Circul. Deutsch. Fischerei Ver. 1879 (1880), 44. 1880.9

-_._Ueber Teichwirthschaft. Circul. Deutsch. Fischerei Ver. 1879 (1880), 244-246. 1880.10

—ählen der Fischeier. Erste Oester.-Ungar. Fischerei Zeitg., 1880, 29.

1880.11

Die Fischzucht. 2. ed. Berlin, 1881. 174 p. 64 figs. $12^{\circ}$. 1881.1 
Die Fischerei-Verhältnisse des deutschen Reiches, Oesterreich-Ungarns, der Schweiz und Luxemburgs, bearbeitet im Auftrage des deutschen FischereiVereins. Berlin, 1881 (1882). $4^{\circ}$.

1882.1

On pond-fisheries. Rept. U. S. Fish Comm. 1879 (1882), 7, 649-650.

1882.2

The American black bass. Bull. U. S. Fish Comm. 1883, 3, 221-224.

1883.1

Der amerikanische SchwarzBarsch (Micropterus salmoides) Deutsch. Fischerei Ver., 1883, no. 2. 1883.2

Raise carp. Rept. U. S. Fish Comm. 1880 (1883), 8, 673-680. 1883.3

Ueber die Fischereiverhältnisse der Werra. Verh. Ver. Rheinl. Westph., 1883, 38, 158-161.

1883.4

Fischerei und Fischuucht im Harz mit besonderer Berücksichtigung der Forellen. Berlin, 1883 (1884). $72 \mathrm{p}$. 9 figs. $8^{\circ}$.

1884.1

Report on black bass sent from America to Germany in 1883. Bull. U. S. Fish Comm. 1884, 4, 384. 1884.2

Spawning in Germany of the large-mouthed black bass sent from the United States in 1882. Bull. U. S. Fish Comm. 1884, 4, 219.

1884.3

- Success of fish culture. Bull. U. S. Fish Comm. 1884, 4, 115-123.

1884.4

Wooden tank for the transportation of living fish. Bull. U. S. Fish Comm. 1884, $4,168$.

1884.5

Distribution of American fish and fish eggs by the German Fishery Association. Bull. U. S. Fish Comm. $1885,5,261-263$.

1885.1

Die Fischzucht. 3. ed. Berlin, 1885. 207 p. 111 figs. $8^{\circ}$. 1885.2

How to raise carp and other food fish which spawn in summer. Rept. U. S. Fish. Comm. 1883 (1885), 11, 1133-1142.

1885.3

- Putting bass into carp ponds. Bull. U. S. Fish Comm. 1885, 5, 359.

1885.4

Der Schwarzbarsch und der Forellenbarsch (black bass) Micropterus salmoides und dolomieu Lacépède, ihr wirthschaftlicher Werth und ihre Züchtung. Berlin, 1886. 8 p. $8^{\circ}$. 1886.1

- The same. 2. ed. Wien, 1887. $16 \mathrm{p} .8^{\circ}$.

1887.1

A large catch of carp. Bull.

U. S. Fish Comm. 1886 (1887), 6, 116.

1887.2

- Piscicultura na China [translation] Rev. Agric. Imp. Instit. Flumineuse Agric. Red. Lad. Netto, 1888, 19, $196-200$.

1888.1

- Der amerikanische Zwergwels (small cat-fish) und der Fleckenwels (spotted cat-fish) in Deutschland (Ameiurus nebulosus und $A$. caudafurcatus) Neudamm, 1891. 12 p. figs. $8^{\circ}$.

1891.1

Kurze Anleitung der Fischzucht in Teichen. Berlin, 1891. $8^{\circ}$. 1891.2

- Der amerikanische Hundsfisch (dogfish) in Deutschland. Neudamm, 1892 (1893) 7 p. fig. $8^{\circ}$. 1893.1

Die amerikanischen Sonnenfische (sunfish) (Calicobarsh, Steinbarsh, Sonnenfish, Mondfish, i.e., Pomoxys) in Deutschland. Neudamm, 1893. $15 \mathrm{p}$ 4 figs. $8^{\circ}$.

1893.2

Süsswasserfischerei. Anleitung für praktische Fischer. Berlin, 1894. 157 p. 204 figs. $8^{\circ}$ 1894.1

- Künstliche Fischzucht. Berlin, 1895. 202 p. 88 figs. $8^{\circ}$. 1895.1

- 'Teichwirtschaft. Berlin, 1895. 190 p. 63 figs. $8^{\circ}$. 1895.2

Kurze Anleitung zur Fischzucht in Teichen. 2. ed. Neudamm, 1897. 63 p. $8^{\circ}$.

1897.1

DeramerikanischeCalico-Barsch (Silber-Barsch) in Europa. 2. ed. Neudamm, 1901. $16 \mathrm{p}$.

1901.1

Kurze Anleitung zur Fischzucht in Teichen. 3. ed. Neudamm, 1904. 103 p. 53 figs. \& pl. $8^{\circ}$.

1904.1

Taschenbuch der Angelfischerei. 4. Auflage, neu bearbeitet von Horst Brehm. Berlin, 1904. 377 p. pl.

1904.2

Borne, Max von dem, Benecke, Berthold, \& Dallmer, Eugen. Handbuch der Fischzucht und Fischerei. Berlin, 1886. 701 p. 581 figs. $8^{\circ}$. 1886.1 
Bornemann, Johann Georg [18311896] Ueber Semionotus im oberen Keupersandstein. Zeitschr. Deutsch. Geol. Ges., 1854, 6, 612-620. pl. 1854.1

Borodin, Nikolai Andreevich (i.e., Nikolaus Andreas) An attempt to impregnate artificially the eggs of Acipenser stellatus. Bull. U. S. Fish. Comm. $1885,5,275-276$.

1885.1

The biological stations of western Europe and of the United States of North America [Text in Russian] Mém. Acad. Imp. Sci. St. Pétersb., 1894, S. sér. 1, no. 2.

1894.1

Statistical review of fish culture in Europe and North America. Bull. U. S. Fish Comm. 1893 (1894), 13, 193196. - Trans. Amer. Fisheries Soc. 1893 (1894), 104-110.

1894.2

Note on the Clupea of the Caspian and Black seas ['Text in Russian] Ann. Mag. Mus. Zool. Acad. St. Pétersb., 1896, 1, 81-94. 6 figs.

1896.1

__ Materials for the biology of sturgeons ['Text in Russian] Moscow, 1897. 5 p. pl. $8^{\circ}$.

1897.1

Die künstliche Verbreitung des russischen Stör (Acipenser güldenstädtii) in Uralfluss. Allgem. Fischerei Zeitg., 1899, 24, 337-338.

1899.1

Die Fischerei im Don und AzovMeer; Bericht über eine Abcommandirung in dieses Gebiet [Text in Russian] Novočerkassk, 1901. 153 p. 3 pls. map.

1901.1

- Zur Biologie der Acipenseriden [Text in Russian] Dnevn. XI Sjězda Russ. Jest. Vrač., St. Petersb., 1901, 12, 301-302.

1901.2

Kurze Anleitung zur Befruchtung von Störeiern und zur Erbrütung von Jungen daraus [Text in Russian] St. Petersb., 1902. $3 \mathrm{p}$.

1902.1

-_. Ueber das Studium der jungen Fische [Russian with English résumé] Nikolsk Fischzucht, St. Petersb., 1903, no. $7,82-98$.

1903.1

-_Untersuchungen über die Lebensweise und die Fortpflanzung der Kaspihäringe [Russian with English résumé] Věst. Rybopromyšl., St. Petersb., 1904, 19, 167-198.

1904.1

Bericht über die 'Thätigkeit des ersten Spezialisten für Fischzucht am
Departement der Landwirthschaft, für das Jahr 1904 [Text in Russian] Izv. Minist. Zeml., St. Petersb., 1905, pts. 13-14.

1905.1

L- Les clupéidées de la mer Caspienne. C. R. 6. Congr. Intern. Berne, 1904 (1905), 264-281. pl. \& 10 figs.

1905.2

Eine Relictenform von Clupea cultiventris im System der mittleren Wolga Text in Russian] Věst. Rybopromyšl., St. Petersb., 1905, 20, 282283.

1905.3

-_ Eine neue Art kaspischer Heringe, Clupea engrauliformis n. sp. [Russian with German résumé] Vèst. Rybopromyšl., St. Petersb., 1906, 21, 197-204. pl. \& 2 figs.

1906.1

Ueber den Winterschlaf des Kiarpfens und anderer Fische IText in Russian] Věst. Rybopromšyl., St. Petersb., 1906, 21, 214-216. 1906.2

__ Zur Verteidigung der Ural-Fischerei [Text in Russian] St. Petersb., 1910. 69 p. pl. 1910.1

Borodin, Nikolaus Andreas, \& Suvorov, $E$. Die Heringe des Kaspischen Meeres und deren Fang. Arbeiten der Kaspischen Expedition des Jahres 1904. Pt. 2, 1908. 372 p.

1908.1

Borowski, G.H. Gemeinnützige Naturgeschichte des Thierreichs, darinnen die merkwürdigsten und nützlichsten Thiere in systematischer Ordnung beschrieben und alle Geschlechter in Abbildungen nach der Natur vorgestellt werden. 5 vols. Berlin \& Stralsund, 178084. 228 pls. $8^{\circ}$.

1784.1

Fische, vol. v. 42 pls.

Borsenkow, J., Usow, S., \& Rouillier, $C$. Ueber die FischzüchtungsAnstalt des Herrn Wrassky. Arch. Russ.(Erman), 1859, 18, 65-83. 1859.1

Borsieri, Clementina. La forma giovanile del Centrolophus pompilus (Cuv. Val.) Monit. Zool. Ital. Firenze, 1902 , 13, 35-38.

1902.1

Sulle specie europee del genere Atherina. 'Lool. Anz, 1902, 25, 597600 .

1902.2

Contribuzione alla conoscenza della fauna ittiologica della colonia Eritrea. Ann. Mus. Civ. Stor. Nat. Genova, 1904, 3. ser. 4, 187-220. 1904.1 
Contribuzione alla conoscenza delle specie europee del genere Atherina. Ann. Agricolt., 1904, no. 233, 129-220. 5 pls. \& 3 figs.

1904.2

Materiali per una fauna dell' Arcipelago Toscano. Isola del Giglio. I. Sulla presenza nell' isola del Giglio del Gobius knerii Steind., e sulla sua identità col Gobius steindachnerii Kolomb. Ann. Mus. Civ. Stor. Nat. Genova, 1904, 3. ser. 1, 7-13.

1904.3

I caratteri e la classificasione dei Fisostomi. Riv. Mens. Pesca, Pavia, 1910 , n. . 5 (12), 65-72; 139-147; 210218.

1910.1

Bortolotti, Emma. Contribuzione alla conoscenza dei fossili del Miocene medio nel Bolognese. Riv. Ital. Palseont., 1898, 4, 55-61.

1898.1

Bory de Saint-Vincent, Jean Baptiste George Marie [1780-1846] Voyages dans les quatre principales îles des mers d'Afrique. Paris, 1804. 3 vols. atlas. $4^{\circ} \& 8^{\circ}$.

1804.1

Dictionnaire classique d'histoire naturelle. Paris, 1822-31. 17 vols.

1822.1

Observations microscopiques sur la laite de la lamproie. Journ. Physiol. (Magendie), 1822, 2, 231-233. 1822.2

Expédition scientifique en Morée, entreprise et publiée par ordre du gouvernement français. Travaux de la section des sciences physiques, sous la direction de $\mathbf{M}$. le colonel Bory de SaintVincent. Paris, 1832-35. 3 vols. atlas. $4^{\circ}$.

1832.1

Vol, iii, Poissons.

Bos, Jan Ritzema. Einige Bemerkungen über Pleuronectiden. Biol. Centralbl., 1886, 6, no. 9, 270-273. 1886.1

Bosgoed, D. Mulder. Proeve van eene ichthyologische bibliographie; catalogus van boeken en geschriften over de natuurlijke geschiedenis van de visschen, de kunstmatige vischteelt en de visscherijen; met vermelding van de charters, resolutiën en ordonnantiën betrekkelijk de Nederlandsche visscherijen, uitgegeven van wege de Nederlandsche maatschappij ter bevordering van Nijverheid. Haarlem, 1871. $247 \mathrm{p}$. $8^{\circ}$.

1871.1

Bibliotheca ichthyologica et piscatoria; catalogus van boeken en geschriften over de natuurlijke geschie- denis van de visschen en walvisschen, de kunstmatige vischteelt, de visscherijen, de wetgeving op de visscherijen, enz. Haarlem, 1874. 474 p. $8^{\circ}$. 1874.1 First title-page is in French.

Bośniacki, Zygmunt Grzymala. Flisz europejski. [Ichthyofauna der Menilitschiefer] Kosmos Lwów Roczn., 1911, 36, 871-899.

1911.1

Bosniaski, S. de [Alcuni esemplari di nuove specie di pesci fossili] Atti Soc. Toscana Sci. Nat. Pisa, Proc. Verb. $1878,1, \mathrm{xxx}$-xxxi.

1878.1

[Del carattere della ittiofauna fossile e della stratigrafia dei piani a congerie, formazione gessifera e del Tripoli del Gabbro e suoi dintorni] Atti Soc. Tosc. Sci. Nat. Pisa, Proc. Verb., 187879,1 , lii-lix.

1878.2

Studii sui pesci fossili del Mioceno del Gabbro. Atti Soc. Tosc. Sci. Nat. Pisa, Proc. Verb., 1878-79, 1, xviii-xix.

1878.3

Nuove specie di pesci fossili del Tripoli del Gabbro] Atti Soc. Tosc. Sci. Nat. Pisa, Proc. Verb., 1879, 1, 30-31.

1879.1

- Sui pesci fossili terziari delle marne di Cutrò e Reggio. Atti Soc. Tosc. Sci. Nat. Pisa, Proc. Verb., 1879 , $1,82-83$.

1879.2

Bossche, J.F.R.S. van den. Over eenige vischsoorten van het eiland Bangka. Leiden, 1862. $4^{\circ}$. 1862.1

Bosset, Charles Philip de. Notice sur la présence temporaine de l'Ophidium [Fierasfer] imberbe dans la cavité du corps d'une holothurie orangée, etc. Mém. Soc. Sci. Nat. Neuchâtel, 1839, 2, 1-2.

1839.1

Bossi, - Statistique du département de l'Ain. Paris, 1808. 4 . 1808.1

Bossuat, Emile. Les helminthes dans le foie [Floriceps saccatus dans le foie de l'Orthagoriscus mola] Arch. Parasitol., Paris, 1902, 6, 161-206. 13 figs.

1902.1

Bostock, John [1773-1846] Sur les modifications que la chaleur fait éprouver à l'huile de poisson. Ann. Gén. Sci. Phys., 1820, 7, 354-355.

1820.1

Botelho, C. Deux nouveaux trypanosomes des poissons. C. R. Soc. Biol. Paris, 1907, 63, 2S-29.
1907.1 
Both, E. Girardinus reticulatus, seine Pflege und Zucht. Wochenschr. Aquar. Terrar. II unde, 1910, 7. Jahrg., 262-263.

1910.1

Bothe, A. Die Locomotion des Haifisches (Scyllium) und ihre Bezichungen zu den einzelnen Gehirntheilen und zum Labyrinth. Arch. Ges. Phys. (Pflüger), 1899, 76, 470-493. Abstract in Zool. Centralb1., 7, 566-567.

1899.1

Bottard, [Louis] Alphonse [1854-] L'appareil à venin des poissons. C. R. Acad. Sci. Paris, 1889, 108, 534-537. C. R. Mrém. Soc. Biol. Paris, 9. sér. 1, 131-138.

1889.1

Les poissons venimeux. Contribution à l'hygiène navale. Paris, 1889. 198 p. 34 figs. $8^{\circ}$. 1889.2

Bottazzi, Filippo. Intorno alla corteccia cerebrale, e specialmente intorno alla fibre nervose intracorticali dei vertebrati. Ricerche Labor. Anat. Norm. Roma, 1893, 3, 241-316.

1893.1

Il cervello anteriore e le vie olfattorie centrali dei pesci cartilaginei. Atti Congr. Med. Intern., 1894, 4, 110 112.

1894.1

- Il cervello anteriore dei selacei. Ricerche Labor. Anat. Norm. Roma, 1895, 4, 225-243. pl.

1895.1

Ueber die Innervation des Herzens von Scyllium canicula und Raja squinato. Centralbl. Physiol., 1901, 14, no. 26. 10 figs.

1901.1

- Contribution à la connaissance de la coagulation du sang de quelques animaux marins et des moyens pour l'empêcher. Arch. Ital. Biol., 1902, 37, 49-63.

1902.1

Untersuchungen über das viscerale Nervensystem der Selachier. Zeitschr. Biol., 1902, 43, 372-442. 2 pls.

1902.2

Sulla regolazione della pressione osmotica negli organismi animali. Nota 3a. - Pressione osmotica e conduttività elettrica del saceo muscolare del siero di sangue e dell' orina dei pesci. Arch. Fisiol., 1906, 3, 547-556. 2 figs. 1906.1

_- Grassi e glueogeno nel fegato dei Selacii. Rend. Accad. Lincei, 1907, 5. ser. 16, pt. 2, 514-517.

1907.1

Recherches chimico-physiques sur les liquides animaux. I. Le "temps d'écoulement" du sérum du sang de quelques animaux marins et terrestres. Arch. Ital. Biol., 1908, 50, 97-105. II. Le contenu en azote protéique du sérum du sang des divers animaux. Ibid., 128-135.

1908.1

Ricerche chimico-fisiche sui liquidi animali. I. Il "tempo di deflusso" del siero del sangue di alcuni animali marini e terrestri. II. Vertebrati. Rend. Accad. Lincei, 1908, 5. ser. 17, pt. 1, $792-802$

1908.2

Bottemanne, $C$. J. Bevolking en ontvolking van het vischwater. De Economist, Amsterdam, 1872, 597-620.

1872.1

- The California salmon eggs in Europe. Chicago Field, 1880, 12, 387. 1880.1

- - Shipment of salmon ova to the Netherlands in 1877. Rept. U. S. Fish Comm. 1878 (1880), 6, 914-916. 1880.2

Do grilse spawn? Trans. Amer. Fisheries Soc. 1880 (1881), 30-32. 1881.1

- California salmon in the Netherlands. Rept. U. S. Fish Comm. 1879 (1882), 7, 709-713.

1882.1

-.. Penning of salmon in order to secure their eggs. Bull. U. S. Fish Comm. $1884,4,169$.

1884.1

Ansjovis-eieren uitgekomen. Tijdschr. Nederl. Dierk. Vereen, 1891 , 3, li-lii.

1891.1

Bottemanne, C.J., \& Hock, P.P.C. Bericht über Steerthamen-Fischerei, und über Larven und Junge einiger wichtigen Fischarten. Leiden, 1888. 6 pls. $\mathrm{S}^{\circ}$.

1888.1

Botti, $U$. Sopra una nuova specie di Myliobatis [salentinus], reperita nelle vicinanze di Galugnano sulla via da Lecee a Maglie nel commune di San Donato. Atti Soc. Tosc. Sci. Nat. Pisa, 1879, 1, 12; 1877, 3, 371-282. - Boll. Comit. Geol. Italia, 1878, 9, 332.-Neues Jahrb. Mineral., 1879, 724. 1879.1

Bouchon-Brandely, Germain Jean Baptiste [1847-1893] Report on the state of pisciculture in France and the neighboring countries. Rept. U. S. Fish Comm. 1872-73 (1874), 2, 513-523.

1874.1

Rapport sur l'état de la pisciculture en France et dans les pays voisins. Arch. Miss. Sci. Litt., 1875, 3. sér. 2, 299-313.
1875.1 
Traité de pisciculture pratique et d'aquiculture en France et dans les pays voisins. Paris, $1876.472 \mathrm{p} .8^{\circ} \& 4^{\circ}$.

1876.1

Rapport au Ministre de l'instruction publique sur la pisciculture en France et ostréiculture dans la Méditerranée. Paris, 1878. 113 p. $8^{\circ} \cdot 1878.1$

—_ Rapport présenté à la commission du repeuplement des eaux, sur la situation du littoral français de la Méditerranée, au point de vue de la pêche, de la pisciculture et de la conchylioculture. Paris, 1880.

1880.1

Bouchon-Brandely, Germain Jean Baptiste, \& Berthoule, Amédée. Les pêches maritimes en Algérie et en Tunisie. Rev. Maritime \& Colon., 1890, 107, 161-219; 454-512. - Rev. Scient., 1891, 46, 552-563. Also separate; Paris, 1891. 122 p. $8^{\circ}$.

1891.1

Boudouy, Th. Action de la tyrosinase sur les produits de la digestion trypsique chez Trutta fario. Bull. Soc. Scient. Méd. Ouest Rennes, 1899, 8, 88-90.

1899.1

- Action du suc des tubes pyloriques de la truite sur la fibrine. C. $R$. ¿ Mém. Soc. Biol. Paris, 1899, 51, 453454.

1899.2

- Du rôle des tubes pyloriques dans la digestion chez les téléostéens. Arch. Zool. Expér., 1899, 3. ser. 7, 419-460. 3 pls. Abstract in Journ. Roy. Mier. Soc. London, pt. 1, p. 33.

1899.3

Recherches du zymogène dans la rate des poissons. Bull. Soc. Sci. Méd. Ouest Rennes, 1899, 8, 90-91. $\quad 1899.4$

Recherches sur la valeur physiologique des tubes pyloriques de quelques téléostéens. C. R. Acad. Sei. Paris, $1899,128,745-746$. Abstract in Journ. Roy. Micr. Soc. London, pt. 3, 273. Rev. Scient., 11, 407.

1899.5

Bouffet, —_ Essais de pisciculture dans la rivière d'Aude aux laboratoires de Quillan et de Gesse. Bull. Soc. Acclim. France, 1889, 36, 265-273. 1889.1

Bougainville, Lowis Antoine de [17291811] Voyage autour du monde par . . "La Bondeuse" et "L'Etoile," en 1766-1769. Paris, 1771. vii, 417 p. 3 pls. \& maps.

1771.1

Observations on fishes by $P$. Commerson, who accompanied this navigator, were published at a later date by Lacépède and Cuvier \& Valenciennes from MS. notes now deposited in the Bibliothèque Nationale at Paris.
Bouim, Pol. Etude sur l'évolution normale et l'involution du tube seminifère. Arch. Anat. Micr. Paris, 1897, 1, 225-263; 265-339. pl.

1897.1

Nouvelle technique pour la fixation et le traitement ultérieur des oeufs de salmonides. C. R. Hebd. Mém. Soc. Biol. Paris, 1903, 55, 1691-1692. 1903.1

Recherches sur la figure achromatique de la cytodiérèse; sur la télophase des gros blastomères chez les salmonides. Arch. Zool. Expér. Gén., Paris, 1905, 4. sér. 3, xcii-xcviii. 5 figs. 1905.1

Boulangê, René. Caractères distinctifs des diverses espèces de saumons. Journ. Agricult. Pratique, 1869, 3. année, 1, 348-350. fig.

1869.1

Boulart, Raoul A. [1849-] Du macropode de la Chine [Polycanthus viridiauratus] Journ. Zool. (Gervais), 1872, 1, $243-254$.

1872.1

Boulart, Raoui A., \& Gervais, $H$. See Gervais \& Boulart.

Boulenger, Charles L. On the breeding-habits of a cichlid fish (Tilapia nilotica) Proc. Zool. Soc. London, 1908, $405-407$.

1908.1

Pisces (record for 1907) Zool. Record, 1909, 44. 56 p. 1909.1

Pisces (record for 1908) Zool.

Record, 1910, 45. 51 p. $\quad 1910.1$

Pisces (record for 1909) Zool. Record, 1911, 46. 44 p. $\quad 1911.1$

Pisces (record for 1910) Zool. Record, 1911, 47. 39 p. 1911.2

The luminous organs of Lamprotoxus flagellibarba. Fisheries Ireland Sci. Invest. 1912 (1913), no. 2. 2 p. pl.

Boulenger, Edward $G$. Remarks on two species of fishes of the genus Gobius from observations made at Roscoff. Proc. Zool. Soc. London, 1911, 40-44.

1911.1

Notes on the breeding of the "millions" fish (Girardinus poeciloides) Proc. Zool. Soc. London, 1912, 906-908.

1912.1

The luminous organs of Lamprotoxus flagellibarba. Fisheries Ireland Sci. Invest. 1912 (1913), no. 2, 1-2. pl.

1913.1 
Boulenger, Gcorge Albert [1858-] An account of the fishes collected by Mr. C. Buckley in eastern Ecuador. Proc. Zool. Soc. London, 1887, 2, 274-283. 5 pls.

1887.1

An account of the fishes obtained by Surgeon Major A. S. G. Jayakar at Muscat, east coast of Arabia. Proc. Zool. Soc. London, 1887, 653-667. pl.

1887.2

For second and third accounts, see infra, 1889,1892 .

Descriptions of [three] new South American characinoid fishes. Ann. Mag. Nat. Hist., 1887, 5. ser. 19, 172174.

1887.3

- On [three] new fishes from the lower Congo. Ann. Mag. Nat. Hist., 1887, 5. ser. 19, 148-149.

1887.4

On new siluroid fishes from the Andes of Columbia. Ann. Mag. Nat. Hist., 1887, 5. ser. 19, 348-350. 1887.5

Pisces (record for 1886) Zool. Record, 1887, 23. 24 p. $\quad 1887.6$

- Pisces (record for 1887) Zool. Record, 1888, 24. 34 p. 1888.1

Description of a new snake and two new fishes obtained by Dr. $H$. von Ihering in Brazil Pimelodus (Pseudorhamdia) nigribarbis, Girardinus iheringii] Ann. Mag. Nat. Hist., 1889, 6. ser. 4, 265-267.

1889.1

On the species of Rhacophorus confounded under the name of $R$. maculatus. Proc. Zool. Soc. London, 1889, 27-32.

1889.2

- Second account of the fishes obtained by Surgeon Major A. S. G. Jayakar at Muscat, east coast of Arabia. Proc. Zool. Soc. London, 1889, pt. 2, 236-246.

1889.3

- Description of a new species of Mormyrus, Ann. Mag. Nat. Hist., 1890, 6. ser. 6, 193.

1890.1

Descriptions of two new cyprinodontoid fishes [Cyprinodon danfordii and Haplochilus hartii] Ann. Mag. Nat. Hist., 1890, 6. ser. 6, 169-170. 1890.2

- Descriptions of two new gobioid fishes from the cape of Good Hope. Marine Invest. South Africa, 1890, 1, $1-2$.

1890.3

Descriptions of two new species of the siluroid genus Arges (taczanowstii and whympeii) Proc. Zool. Soc. London, $1890,450-452$. pl.

1890.4

List of the reptiles, batrachians, and freshwater fishes collected by Professor Moesch and $\mathrm{Mr}$. Iversen in the district of Deli, Sumatra. Proc. Zool. Soc. London, 1890, 31-40. $\quad 1890.5$

- Pisces (In Ridley, H. N. Notes on the zoology of Fernando Noronha) Journ. Linn. Soc. London (Zool.), 1890 , 20, 483.

1890.6

- Pisces (record for 1888) Zool. Record, 1890, 25. 30 p. $\quad 1890.7$

- Pisces (record for 1889) Zool. Record, 1890, 26. 30 p. 1890.8

An account of the siluroid fishes obtained by Dr. H. von Ihering and Herr Sebastian Wolff in the Province Rio Grande do Sul, Brazil. Proc. Zool. Soc. London, 1891, 231-235. 2 pls.

1891.1

[Exhibition of and remarks upon, young specimens and eggs of a South African siluroid fish, Galeichthys feliceps] Proc. Zool. Soc. London, 1891, 148.

1891.2

On reptiles, batrachians, and fishes from the Lesser West Indies. Proc. Zool. Soc. London, 1891, 351-357.

1891.3

- Renewed pectoral limb of a Protopterus annectens. Proc. Zool. Soc. London, 1891, 147-148. 1891.4

Description of a new blennioid fish from Kamtschatka (Blenniophidium petropauli n. g. et sp.) Proc. Zool. Soc. London, 1892, 583-585.

1892.1

Description of a new siluroid fish from China. Ann. Mag. Nat. Hist., 1892, 6. ser. 9, 247.

1892.2

Note on Toxoles microlepis Gthr. and Toxotes microlepis Blyth. Ann. Mag. Nat. Hist., 1892, 6. ser. 9, 143-144. 1892.3

On Lucioperca marina C. \& V. Proc. Zool. Soc. London, 1892, 411 413. pl.

1892.4

On some new or little known fishes obtained by Dr. J. W. Evans and Mr. Spencer Moore during their recent expedition to the province of Matto Grosso, Brazil. Ann. Mag. Nat. Hist., 1892, 6. ser. 10, 9-12. 2 pls. 1892.5

Pisces (record for 1890) Zool. Record, 1892, 27, 1-35. 
Pisces (record for 1891) Zool. Record, 1892, 28. 41.p. 1892.7

'Third account of the fishes obtained by Surgeon Major A. S. G. Jayakar at Muscat, east coast of Arabia. Proc. ' Zool. Soc. London, 1892, 134-136.

1892.8

Descriptions of new freshwater fishes from Borneo. Ann. Mag. Nat. Hist., 1893, 6. ser. 13, 245-251. 1893.1

List of the fishes collected by Mr. E. W. Oates in the southern Shan states, and presented by him to the British Museum. Ann. Mag. Nat. Hist., 1893, 6. ser. 12, 198-203.

1893.2

Note on the variations of the lateral shields in the three-spined stickleback (Gasterosteus aculeatus) Ann. Mag. Nat. Hist., 1893, 6. ser. 11, 228-229.

1893.3

Pisces (record for 1892) Zool. Record, 1893, 29, 1-39.

1893.4

- Description of a new siluroid fish from Burma (Macrones peguensis) Ann. Mag. Nat. Hist., 1894, 6. ser. 14, 196.

1894.1

Descriptions of a new lizard and a new fish obtained in Formosa by Mr. Holst. Ann. Mag. Nat. Hist., 1894, 6. ser. 14, 462-463.

1894.2

L-..- Les perches des eaux douces du Chili. Act. Soc. Cient. Chile, 1894, 4, 9-17.

1894.3

-. Pisces (record for 1893) Zool. Record, 1894, 30. $43 \mathrm{p}$.

1894.4

[Abstract of a report on a large collection of fishes formed by Dr. C. Ternetz at various localities in Matto Grosso and Paraguay, with descriptions of new species] Proc. Zool. Soc. London, $1895,523-529$.

1895.1

- Catalogue of the fishes in the British Museum. 2. ed. London, 1895. 394 p. 15 pls. $8^{\circ}$.

1895.2

- Description of a new characinoid fish of the genus Parodon [ $P$. caliensis] Ann. Mag. Nat. Hist., 1895, 6. ser. 16 , 480.

1895.3

Description of a new eagle-ray from Mascat (Rhinoptera jayakarin.sp.) Ann. Mag. Nat. Hist., 1895, 6. ser. 15, 141.

1895.4

Descriptions of two new fishes obtained by Dr. C. Hose in Sarawak.
Ann. Mag. Nat. Hist, 1895, 6. ser. 15, 247.

1895.5

- Descriptions of two new South American characinoid fishes (Leporimus semivittatus and $\mathbf{X}$ iphostoma lateristriga) Ann. Mag. Nat. Hist., 1895, 6. ser. 15, 449.

1895.6

List of freshwater fishes collected by Mr. A. Everett on Palawan and Balabac. Ann. Mag. Nat. Hist., 1895, 6. ser. 15, 185-187.

1895.7

On a collection of fishes from the Rio Paraguay. Proc. Zool. Soc. London, 1895, 523-529; 1898, 25-39. 1895.8

Pisces (record for 1894) Zool. Record, 1895, 31, 1-43. 1895.9

Remarks on some cranial characters of the salmonoids. Proc. Zool. Soc. London, 1895, 299-302. fig.

1895.10

Viaggio del Dr. A. Borelli nella Republica Argentina. Poissons. Boll. Mus. Zool. Anat. Comp. Torino, 1895, $10,1-3$.

1895.11

Description of a new siluroid fish [Trichomycterus goeldii] from the Organ mountains, Brazil. Ann. Mag. Nat. Hist., 1896, 6. ser. 18, 154. 1896.1

- Descriptions of new fishes from the upper Congo. Ann. Mag. Nat. Hist., 1896, 6. ser. 17, 309-311; 1897 . $20,422-427$.

1896.2

Descriptions of new fishes from the upper Shiré river, British Central Africa, collected by Dr. Percy Rendall and presented to the British Museum by Sir Harry H. Johnston, K. C. B. Proc. Zool. Soc. London, 1896, 915-920. pl. \& 4 figs.

1896.3

Liste des poissons recueillis par le R. P. Louis Jalla à Kazungula; haut Zambèse. Bull. Mus. Zool. Anat. Comp. Torino, 1896,11 , no. 260, 1-2. 1896.4

- On a collection of fishes from the Rio Paraguay. Trans. Zool. Soc. London, $1896,14,25-39$. 6 pls. $\quad 1896.5$

On a little-known Australian fish (Threpterius maculosus Richardson), with remarks on the family Cirrhitidx. Ann. Mag. Nat. Hist., 1896, 6. ser. 18, 397-399.

1896.6

On freshwater fishes from Smyrna. Ann. Mag. Nat. Hist., 1896, 6. ser. $18,153-154$.
1896.7 
Boulenger, G. A.

- Pisces (record for 1895) Zool. Record, 1896, 32, 1-43. 1896.8

- An account of the freshwater fishes collected in Celebes by Drs. P. and F. Sarasin. Proc. Zool. Soc. London, 1897, 426-429. pl.

1897.1

- Description of a new ceratopterine eagle-ray from Jamaica (Ceratobatis robertsi n. sp.) Ann. Mag. Nat. Hist. 1897, 6. ser. 20, 227-228.

1897.2

- Description of a new fish from lake Nyassa (Chromis auratus) Ann. Mag. Nat. Hist., 1897, 6. ser. 19, 155.

1897.3

Description of a new gymnotine fish of the genus Sternopygus (S. macrops) Ann. Mag. Nat. Hist., 1897, 6. ser. 20,305 .

1897.4

- Descriptions of new fishes from the Mekran coast, Persia. Ann. Mag. Nat. Hist., 1897, 6. ser. 20, 420-422.

1897.5

- [Exhibition of specimens, and remarks upon the habits, of the siluroid fish Vandellia cirrhosa] Proc. Zool. Soc. London, 1897, 901; 921-922. 1897.6

- A list of the fishes obtained by M. J. Stanley Gardiner at Rotuma, South Pacific ocean. Ann. Mag. Nat. Hist., 1897, 6. ser. 20, 371-374. 1897.7

On a collection of fishes from the island of Marajo, Brazil. Ann. Mag. Nat. Hist., 1897, 6. ser. 20, 294-299.

1897.8

On a gigantic sea perch, Stereolepis gigas. Proc. Zool. Soc. London, 1897, 917-918. pl.

1897.9

On a specimen of Acanthocybium solandri from the Arabian sea. Proc. Zool. Soc. London, 1897, 272-273.

1897.10

On the habitat of the siluroid fish, Anoplopterus platychir Gthr. Ann. Mag. Nat. Hist., 1897, 7. ser. 1, 254-255.

1897.11

Pisces (record for 1896) Zool. Record, 1897, 33. 39 p.

1897.12

Viaggio del Dott. Alfr. Borelli nel Chaco Boliviano e nella Repubblica Argentina. Poissons. Boll. Mus. Zool. Anat. Comp. 'Torino, 1897, 12, no. 279, 1-4.

1897.13

Description of a new genus of cyprinoid fishes (Catlocarpio siamensis n. g. et sp.) from Siam. Ann. Mag. Nat. Hist., 1898, 7. ser. 1, 450-451. 1898.1

- Description of a new siluroid fish (Synodontis obesus) from west Africa. Ann. Mag. Nat. Hist., 1898, 7. ser. 2,415 .

1898.2

Descriptions of two new fishes from the coast of Sind (Epinephelus townsendi and Pseudochromis caudalis) Ann. Mag. Nat. Hist., 1898, 7. ser. 2, 133-134.

1898.3

Descriptions of two new siluroid fishes from Brazil. Ann. Mag. Nat. Hist., 1898, 7. ser. 2, 477-478. 1898.4

Exhibition of and remarks upon specimens of Polypterus lapradii Stdr., with external opercular gills. Proc. Zool. Soc. London, 1898, 493.

1898.5

The flat fishes of Cape Colony. Marine Invest. South Africa, 1898, 1, $1-4$.

1898.6

A list of reptiles, batrachians and fishes collected by Cav. Guido Boggiani in the northern Chaco. Ann. Mus. Civ. Stor. Nat. Genova, 1898, 2. ser. 39, 125-127.

1898.7

Matériaux pour la faune du Congo. Ann. Mus. Congo (Série Zool.), 1898-1900, 1, fasc. 1-6. 164 p. 1898.8

Fasc. 1, Mormyres, 1-20. 9 pls.

2, Elopes, Characins, Cyprins, 21-3s. $10 \mathrm{pls}$.

3. Silures, Acanthoptérygiens, Mastacembles, Plectognathes. 39-58. $10 \mathrm{pls}$.

" 4, Polyptères, Clupées, Mormyres, Cha-

“ 5, Cyprins, 5ilures, 10 pls. Acanthopterygiens. 97-128.8 pls.

"6, Mormyres, Characins, Cyprins, Silures, Acanthoptérygiens, Dipneustes. 129-164. 9 pls.

- On a collection of fishes from the Rio Jurua, Brazil. Trans. Zool. Soc. London, 1898, 14, 421-428. pls. xxxixxlii.

1898.9

On a collection of fishes from the Rio Paraguay. Proc. Zool. Soc. London, $1898,25-39$.

1898.10

On a new genus of salmonoid fishes from the Altai mountains (Phylogephyra altaica) Ann. Mag. Nat. Hist., 1898, 7. ser. 1, 329-331. fig. 1898.11

On the habitat of the siluroid fish Anoplopterus platychir Gthr. Ann. Mag. Nat. Hist., 1898, 7. ser. 1, 254-255. 1898.12 
On the species of Polypterus. Ann. Mag. Nat. Hist., 1898, 7. ser. 2, 416-420.

1898.13

Pisces (record for 1897) Zool. Record, 1898, 34. 33 p. 1898.14

Report on the collection of fishes made by Mr. J. E. S. Moore in lake Tanganyika during his expedition 1895-1896. Trans. Zool. Soc. London, 1898, 15, 1-30. pls. \& figs. Abstract in Proc. Zool. Soc. London, 1898, 494 497.

1898.15

- A revision of the African and Syrian fishes of the family Cichlidæ. Proc. Zool. Soc. London, 1898, 132 152; 1899, 98-143. pls. xi-xii \& fig. 1898.16 - A revision of the genera and species of fishes of the family Mormyridæ. Proc. Zool. Soc. London, 1898, 775-821. pl.

1898.17

- Viaggio del Dr. Enrico Festa nell' Ecuador e regioni vicine. Poissons de l'Equateur. Parts 1 et 2. Boll. Mus. Torino, 1898, 13, no. 329, 1-13; 1899, 14, no. 335, 1-8. $\quad 1898.18$

A contribution to the history of the Carboniferous ganoid, Benedenius deneensis Traquair, with notes on two newly-discovered specimens. Mag Nat. Hist, 1899,7 ser 4,445 451. pls.

1899.1

Description of a new genus of gobioid fishes from the Andes of Ecuador (Oreogabius). Ann. Mag. Nat. Hist., 1899, 7. ser. 4, 125-126. 1899.2

Description of a new genus of perciform fishes from the cape of Good Hope. Ann. South Africa Mus., 1899, 1, 379-380. pl.

1899.3

Description of a new osphromenoid fish from the Congo. Ann. Mag. Nat. Hist., 1899, 7. ser. 3, 242-243.

1899.4

Descriptions of two new gobiiform fishes from the cape of Good Hope. Rept. Marine Biol. Cape Good Hope. 1898 (1899), 196-197. 1899.5

Descriptions of two new homalopteroid fishes from Borneo. Ann. Mag. Nat. Hist., 1899, 7. ser. 4, 228229.

1899.6

-.- Exhibition of, and remarks upon, some living specimens of a siluroid fish (Clarias lazera) from Damietta] Proc. Zool. Soc. London, 1899, 715.

1899.7
Fxhibition of a specimen of a fish (Polypterus congicus) from the river Congo with abnormal opercular gills] Proc. Zool. Soc. London, 1899, $554-555$.

1899.8

On a specimen of Lepidopus atlanticus Goode and Bean, from Madeira. Ann. Mag. Nat. Hist., 1899, 7. ser. 3, 180-181. 1899.9

On the occurrence of Gobius capito on the coast of Brittany. Ann. Mag. Nat. Hist., 1899, 7. ser. 4, 229230. Abstract in Zoologist, 1899, 3, 429.

1899.10

- On the reptiles, batrachians and fishes collected by the late Mr. John Whitehead in the interior of Hainan. Proc. Zool. Soe. London, 1899, 956-962. 1899.11

- On the South Pacific fishes of the genus Callanthias. Ann. Mag. Nat. Hist., 1899, 7. ser. 3, 346-347. 1899.12

Pisces (record for 1898) Zool. Record, 1899, 35. 45 p. 1899.13

Second contribution to the ichthyology of lake Tanganyika. On the fishes obtained by the Congo Free State Expedition under Lieut. Lemaire in 1898. Trans. Zool. Soc. London, 1899, 15, 87-96. pls. 1899.14

Viaggio del Dr. Enrico Festa nel Darien e regioni vicine. Poissons de l'Amérique centrale. Boll. Mus. 'Torino, 1899, 14, no. 346. 4 p.

1899.15

Abundance of the greater sillsmelt (Argentina silus Ascan.) on the market of Boston, Lincolnshire. Ann. Mag. Nat. Hist., 1900, 7. ser. 6, 160.

1900.1

- Additions à la faune ichthyologique. Ann. Mus. Congo, 1900-02, 2, fasc. 2 .

1900.2

- Characters of the genus Xenotilapia (correction) Proc. Zool. Soc. London, 1900, pt. 1, 3-4. $\quad 1900.3$

Description of a new sea-horse, Hippocampus jayakari, from Muscat. Ann. Mag. Nat. Hist., 1900, 7. ser. 6, 51-52. fig.

1900.4

Descriptions of new fishes from the cape of Good Hope. Marine Invest. South Africa, 1900 , no. 8, 10-12. 3 pls.
1900.5 
Boulenger, $G$. A.

Descriptions of three new species of siluroid fishes from southern Brazil. Ann. Mag. Nat. Hist., 1900, 7. ser. 5, 165-166.

1900.6

Descriptions of two new atherinoid fishes from Mexico. Ann. Mag. Nat. Hist., 1900,7 . ser. 5, 5t-55.

1900.7

Diagnoses of [eight] new fishes discovered by J. E. S. Moore in lake Tanganyika. Ann. Mag. Nat. Hist., 1900,7 . ser. 6,478 .

1900.8

[Exhibition of, and remarks upon, a specimen of Polypterus lapradii with large external gills] Proc. Zool. Soc. London, 1900, 267.

1900.9

Fishes (In Victoria history of counties of England: Hampshire and the isle of Wight, 1900, vol. i, p. 197203)

1900.10

List of the fishes collected by Mr. J. S. Budgett in the river Gambia. Proc. Zool. Soc. London, 1900, 511516.

1900.11

A list of the fishes collected by Mr. Rupert Vallentin in the Falkland islands. Ann. Mag. Nat. Hist., 1900, 7. ser. 6, 52-54.

1900.12

On a specimen of Lophotes cepedianus from the cape of Good Hope. Marine Invest. South Africa, 1900, no. 8, 13. pl.

1900.13

On some little-known African siluroid fishes of the subfamily Doradinx. Ann. Mag. Nat. Hist., 1900, 7. ser. 6, 520-529.

1900.14

On the occurrence of Salmo macrostigma in Sardinia. Ann. Mag. Nat. Hist., 1900, 7. ser. 8, 14, 1900.15

- On the reptiles, batrachians and fishes collected by the late Mr. John Whitehead in the interior of Hainan. Proc. Zool. Soc. London, 1899 (1900), 956-962. pls. lxvi-lxix. 1900.16

- Pisces (record for 1899) Z/ool. Record, 1900, 36. $43 \mathrm{p}$. 1900.17

Poissons nouveaux (Matériaux pour la faune du Congo) Ann. Mus. Congo, 1900-02, 1. sér. 164. 1900.18

Viaggio del Dr. A. Borelli nel Matto Grosso e nel Paraguay. III. Liste des poissons recueillis ì Urucum et à Carandasiñho, près de Corumbì. Boll. Mus. Zool. Anat. Comp. Torino, 1900,15 , no. 370.4 p.

1900.19

Description of a new fish of the family Cichlidx from the French Congo (Pelmalochromis batesii) Ann. Mag. Nat. Hist., 1901, 7. ser. 8, 114-116.

1901.1

Description of a new fish of the genus Gobius $[G$. percivali] obtained by Mr. A. Blayney Percival in south Arabia. Proc. Zool. Soc. London, 1901, 2, 152-154. fig.

1901.2

Description of a new silurid fish of the genus Anoplopterus, from Cameroon. Ann. Mag. Nat. Hist. 1901, 7. ser. 8, 447-148.

1901.3

Description of a new silurid fish of the genus Gephyroglanis, from South Africa. Ann. South Africa Mus., 1901, 2, 227-225. pl.

1901.4

Descriptions of four new African freshwater fishes. Ann. Mag. Nat. Hist., 1901, 7. ser. 7, 80-82. 1901.5

Descriptions of [four] new freshwater fishes discovered by Mr. F. IV Styan at Ningpo, China. Proc. Zool. Soc. London, 1901, 268-271. pls. Abstract in Zool. Centralbl., 1901, 8, 682 .

1901.6

Descriptions of three new siluroid fishes of the genus Synodontis discovered by Mr. IV. L. S. Loat in the White Nile. Ann. Mag. Nat. Hist. 1901, 7. ser. 8, 10-12.

1901.7

Descriptions of two new fishes discovered by Dr. IV. J. Ansorge in southern Nigeria. Proc. Zool. Soc., London, 1901, pt. 2, 623-624. pl.

1901.8

Diagnoses of four new fishes discovered by MIr. J. E. S. Moore in the lakes Albert and Albert Edward. Ann. Mag. Nat. Hist., 1901, 7. ser. 8, 12-14. 1901.9

Diagnoses of new fishes discovered by Mr. J: E. S. Moore in lakes Tanganyika and Kivu. Ann. Mag. Nat. Hist., 1901, 7. ser. 7, 1-6.

1901.10

Diagnoses of new fishes discovered by Mr. W. L. S. Loat in the Nile. Ann. Mag. Nat. Hist., 1901 , 7. ser. $8,444-446$.

1901.11

Exhibition of one of the type specimens of a new species of Protop- 
terus from the Congo. Proc. Zool. Soc. London, 1900 (1901), 775. 1901.12

List of the fishes of the characinid genus Alestes Müll. \& 'Trosch., with a key to their identification. Ann. Mag. Nat. Hist., 1901, 7. ser. 8, 486490 .

1901.13

- List of the fishes of the characinid genus Distichodus Muill. \& Trosch., with a key to their identification. Ann. Mag. Nat. Hist., 1901, 7. ser. 8, 510-513.

1901.14

Notes on the classification of teleostean fishes. I. On the Trachinida and their allies. II. On the Berycidx. III. On the systematic position of the genus Lampris, and on the limits and contents of the suborder Catosteomi. IV. On the systematic position of the Pleuronectidx. Ann. Mag. Nat. Hist., 1901, 7. ser. 8, 261-271. figs.; 9, 197$204 ; 1902,10,147-152$. fig.; $295-304$. fig.

1901.15

The first of these articles is reviewed by D.S. Jordan in Amer. Naturalist, 1902, 36, 160-162.

On a small collection of fishes from lake Victoria made by order of Sir H. H. Johnston. Proc. Zool. Soc. London, 1901, pt. 2, 158-162. 1901.16

- On some deep-sea fishes collected by Mr. F. W. Townsend in the sea of Oman. Ann. Mag. Nat. Hist., 1901, 7. ser. 7, 261-263. pl. - Journ. Bombay Nat. Hist. Soc., 14, 372-374. pl.

1901.17

- On the fishes collected by Dr.

W. J. Ansorge in the Niger delta. Proc. Zool. Soc. London, 1901, 4-10. 3 pls. Abstract in Zool. Centralbl., $1901,8,682$.

1901.18

- On the genera of Osteoglossidæ. Ann. Mag. Nat. Hist., 1901, 7. ser. 8, 514-515.

1901.19

- On the presence of a superbranchial organ in the cyprinoid fish Hypophthalmichthys. Ann. Mag. Nat. Hist. 1901, 7. ser. 8, 186-188. Abstracts in Zool. Centralbl., 8, 682. - Journ. Roy. Micr. Soc. London, 1901, 639-640.

1901.20

Pisces (record for 1900) Zool. Record, 1901, 37. 34 p. $\quad 1901.21$

Les poissons du bassin du Congo. Bruxelles, 1901. lxii, 532 p. 25 pls., map \& figs. Review in Nature, 66, $339-340$.

1901.22

Contains special bibliographies of Congo fishes, and of the species of Polypterus and Protopterus.
- Third contribution to the ichthyology of lake Tanganyika. Report on the collection of fishes made by Mr.J. E. S. MIoore in lakes Tanganyika and Kivu during his second expedition, 1899-1900. Trans. Zool. Soc. London, 1901, 16, 137-160.9 pls. 1901.23

Contributions to the ichthyology of the Congo. I. On some new fishes from the French Congo. II. On a collection of fishes from the Lindi river. Proc. Zool. Soc. London, 1902, pt. 1, 234-237. pls. xxii-xxiv; 265-271. pls. xxviii-xxx.

1902.1

Description of a new Barbus from Natal (B. bowkeri) Ann. Mag. Nat. Hist., 1902, 7. ser. 9, 288-289.

1902.2

Description of a new characinid fish (Citharidium ansorgii n. $\mathrm{g}$. et sp.) discovered by Dr. W. J. Ansorge in southern Nigeria. Ann. Mag. Nat. Hist., 1902, 7. ser. 9, 144-145. 1902.3

- Description of a new cyprinodontid fish (Orestias tirapatex) from eastern Peru. Ann. Mag. Nat. Hist., 1902, 7. ser. 10, 153-154. 1902.4

- Description of a new South African galeid selachian [Scylliagaleus quecketti n. g. et sp.] Ann. Mag. Nat. Hist., 1902, 7 . ser. 10, 51-52. pl.

1902.5

Description of new deep-sea gadid fish from South Africa. [Tripterophysis gilchristi n. g. et sp.] Ann. Mag. Nat. Hist, 1902, 7. ser, 9, 335336. fig.

1902.6

Description of two new cyprinoid fishes from Morocco. Ann. Mag. Nat. Hist., 1902, 7. ser. 9, 124-125.

\section{7}

Description of two new fishes of the genus Loricaria from northwestern Ecuador. Ann. Mag. Nat. Hist. 1902, 7. ser. 9, 69-71. 1902.8

Description of two new gobiiform fishes from the cape of Good Hope. Marine Invest. South Africa Dept. Agric. 1902, 1, 8-9. 1902.9

Descriptions of new fishes and reptiles discovered by Dr. F. Silvestri in South America. Ann. Mag. Nat. Hist., 1902, 7. ser. 9, 281-288. 1902.10

- Descriptions of new fishes from the cape of Good Hope. Marine Invest. South Africa Dept. Agric. 1902 , 1, 10-12. 3 pls.

1902.11 
Boulenger, $G$. A.

Descriptions of new fishes from the collection made by Mr. E. Degen in Abyssinia. Ann. Mag. Nat. Hist., 1902, 7. ser. 10, 421-439. 1902.12

Descriptions of two new fishes discovered by Dr. W. J. Ansorge in southern Nigeria (Phractura ansorgii and Fundulus gularis) Proc. Zool. Soc. London, 1902, 623-624. pl. 1902.13

- Diagnoses of new cichlid fishes discovered by Mr. J. E. S. Moore in lake Nyassa. Ann. Mag. Nat. Hist., $1902,7$. ser. $10,69-71$.

1902.14

The explanation of a remarkable case of geographical distribution among fishes. Nature, 1902, 67, 84.

1902.15

Fishes (In Victoria history of the counties of England: Hertfordshire, 1902, vol. i, p. 189-190) 1902.16

Fishes (In Victoria history of the counties of England: Northamptonshire, 1902, vol. i, p. 108-109)

1902.17

Fishes (In Victoria history of the counties of England: Surrey, 1902, vol. i, p. 198-199)

1902.18

The flat fishes of Cape Colony. Marine Invest. South Africa Dept. Agric. 1902, 1, 1-4.

1902.19

Further remarks on the Carboniferous ganoid Benedenius deneensis 'Traquair. Ann. Mag. Nat. Hist., 1902,7 . ser. 10, 52-53. 1902.20

- List of the cold-blooded vertebrates hitherto recorded from the Uganda Protectorate (In Johnston, Sir H., Uganda Protectorate. London, 1902, vol. i, p. 445-449) 1902.21

A list of the fishes, batrachians and reptiles collected by Mr. J. Heliott Darling in Mashonaland, with descriptions of new species. Proc. Zool. Soc. London, 1902, 13-18. pls.

1902.22

List of the fishes, batrachians and reptiles collected by the late Mr. P. O. Simons in the provinces of Mendoza and Cordova, Argentina. Ann. Mag. Nat. Hist., 1902, 7. ser. 9, 336339. 1902.23

List of the fishes collected by Mr. W. L. S. I oat at Gondokoro. Ann. Mag. Nat. Hist., 1902, 7. ser. 10 , $260-264$.
- Matériaux pour la faune du Congo, additions à la faune ichthyologique du bassin du Congo. Ann. Mus. Congo, Zool., 1902, 1. ser. 2, fasc. $2,19-57.10$ pls.

1902.25

- On a specimen of Lopholes cepedianus from the cape of Good Hope. Marine Invest. South Africa Dept. Agric. 1902, 1, 13 . pl.

1902.26

On some characters distinguishing the young of various species of Polypterus. Proc. Zool. Soc. London, 1902, 121-125. 2 pls.

1902.27

On the fishes collected by Mr. S. L. Hinde in the Kenya district, east Africa, with descriptions of four new species. Proc. Zool. Soc. London, 1902, 221-224. pls. 1902.28

On the genus Ateleopus of Schlegel. Ann. Mag. Nat. Hist., 1902 , 7. ser. 10, 402-403. fig. 1902.29

Pisces (In report on the collections of natural history made in the antarctic regions during the voyage of the "Southern Cross," 1902, 5, 174189. 8 pls.)

1902.30

Pisces (record for 1901) Zool. Record, 1902, 38. 39 p. $\quad 1902.31$

- Second account of the fishes collected by Dr. W. J. Ansorge in the Niger delta. Proc. Zool. Soc. London, 1902, 2, 324-330. pls. xxviii-xxix.

1902.32

Description of a new fish of the genus Arges from Venezuela. Ann. Mag. Nat. Hist., 1903, 7. ser. 11, 601602 .

1903.1

- Description of a new fish of the gobiid genus Rhiacichthys from British New Guinea. Proc. Zool. Soc. London, 1903, pt. 2, 124-125. pl.

1903.2

Description of a new silurid fish of the genus Clarias from British Central Africa. Ann. Mag. Nat. Hist., 1903,7 . ser. 12, 362-363. 1903.3

Description of a new west African fish of the genus Alestes. Ann Mag. Nat. Hist., 1903, 7. ser. 12, 594 595.

1903.4

Descriptions of four new species of Barbus discovered by Mr. A. Blayney Percival in east Africa. Ann. Mag. Nat. Hist., 1903, 7. ser. 11, 52-54. pl. 1903.5 
- Descriptions of new freshwater fishes from southern Cameroon. Ann. Mag. Nat. Hist., 1903, 7. ser. 12, 435441 .

1903.6

Descriptions of six new perciform fishes from the coast of Natal. Ann. South Africa Mus., 1903, 3, 6367. 6 pls.

1903.7

Descriptions of two new deepsea fishes from South Africa. Marine Invest. South Africa Dept. Agric. 1903, 2, 167-169. pls.

1903.8

- Descriptions of two new fishes discovered by Major C. Delmé Radcliffe in the Victoria Nyanza. Ann. Mag. Nat. Hist., 1903, 7. ser. 12, 218 219.

1903.9

- Diagnoses of four new species of Barbus from the Nile. Ann. Mag. Nat. Hist., 1903, 7. ser. 12, 532-533.

1903.10

List of freshwater fishes (In Annandale, N., \& Robinson, H., Fase. Malay. Zool., 1903, 2, 303) 1903.11

List of the African species of the cyprinid genus Labeo, with a key to their identification. Ann. Mag. Nat. Hist., 1903, 7. ser. 12, 355-362.

1903.12

- On the fishes collected by $\mathrm{Mr}$.

G. L. Bates in southern Cameroon. Proc. Zool. Soc. London, 1903, pt. 1, 21-29. 5 pls.

1903.13

Pisces (record for 1902) Zool. Record, 1903, 39. 47 p. $\quad 1903.14$

Report on the fishes collected by Mr. Oscar Neumann and Baron Carlo von Erlanger in Gallaland and southern Ethiopia. Proc. Zool. Soc. London, 1903, pt. 2, 328-334. pls.

1903.15

- Sur les affinités du genre Oreosoma. C. R. Acad. Sci. Paris, 1903, 137, 523-525.

1903.16

- Barbus entonia and B. holotania, new names for Barbus lessleri Günther nec Steindachner. Ann. Mag. Nat. Hist., 1904, 7. ser. 14, 218.

1904.1

Description of a new Barbus from Cameroon. Ann. Mag. Nat. Hist., 1904, 7. ser. 13, 237-238. 1904.2

Description of a new fish of the genus Alestes from Natal. Ann. Mag. Nat. Hist., 1904, 7. ser. 14, 155.
Descriptions of new west African freshwater fishes. Ann. Mag. Nat. Hist., 1904, 7. ser. 14, 16-20. 1904.4

- Descriptions of three new fishes discovered by the late Mr. J. S. Budgett in the Niger. Proc. Zool. Soc. London, 1904, pt. 1, 197-199. 2 pls.

1904.5

Diagnoses of three new species of Barbus from lake Victoria. Ann. Mag. Nat. Hist., 1904, 7. ser. 13, 449450 .

1904.6

Fishes, systematic account of Teleostei (In The Cambridge Natural History, vol. vii, p. 541-727. London, 1904)

1904.7

On a new cyprinodontid fish from Egypt. Ann. Mag. Nat. Hist., 1904, 7. ser. 14, 135-136. 1904.8

On the type specimen of a west African fish, Clarias laviceps Gill. Proc. Zool. Soc. London, 1904, pt. 1, 200-201. 1904.9

Pisces (record for 1903) Zool. Record, 1904, 40.43 p.

1904.10

A synopsis of the suborders and families of teleostean fishes. Ann. Mag. Nat. Hist., 1904, 7. ser. 13, 161-190.

1904.11

Uebersicht der Unterordnungen und Familien der Teleostier; übersetzt von Dr. F. Hilgendorf. Arch. Naturgesch. (Wiegmann), 1904, 70 (n. s. 1), 197-228. 1904.12

- Another new Barbus from Morocco. Novit. Zool., 1905, 12, 505. fig.

1905.1

Description of a new fish of the genus Paratilapia, from the upper Zambesi. Ann. South Afric. Mus., 1905, 3, 301-302. pl.

1905.2

Description of a new mormyrid fish from the White Nile [Marcusenius harringtoni n. sp.] Ann. Mag. Nat. Hist., 1905, 7. ser. 15, 457. 1905.3

Descriptions of four new freshwater fishes discovered by Dr. W. J. Ansorge in Angola. Ann. Mag. Nat. Hist., 1905, 7. ser. 15, 457-459. 1905.4

The distribution of African freshwater fishes (In Presidential address to British Association, Section D) Rept. British Assoc. Adv. Sci., 1905, 412-432. - Nature, London, 1905, 72, $413-421$. 
Boulenger, G. A.

A list of freshwater fishes of Africa. Ann. Mag. Nat. Hist., 1905, 7. ser. 16, $36-60$. 1905.6

-... On a British specimen of the great sea-perch Epinephelus cernioides Capello. Ann. Mag. Nat. Hist., 1905, 7. ser. 15, 592-593.

1905.7

On a collection of fishes from lake Bangwelo. Ann. Mag. Nat. Hist., 1905, 7. ser. 16, 642-647. 1905.8

On a second collection of fishes made by Mr. S. L. Hinde in the Kenya district, east Africa. Proc. Zool. Soc. London, 1905, pt. 1, 62-64. 1905.9

- On a small collection of fishes from the Kasai river (Congo) Ann. Mag. Nat. Hist., 1905, 7. ser. 16, 640642 .

1905.10

Pisces (record for 1904) Zool. Record, 1905, 41. 57 p. $\quad 1905.11$

- Poissons de la Guinée espagnole. Mem. Soc. Españ. Hist. Nat., 1905, 1, 187-188.

1905.12

- A series of fishes from lake Chad and the Shari river. Proc. Zool. Soc. London, 1905, pt. 1, 151. 1905.13

Description of a new Barbus from the Uganda Protectorate. Ann. Mag. Nat. Hist., 1906, 7. ser. 18, 36.

1906.1

- Description of a new fish of the genus Clarias from Uganda. Ann. Mag. Nat. Hist., 1906, 7. ser. 17, 569.

1906.2

Description of a new mormyrid fish from south Cameroon. Ann. Mag. Nat. Hist., 1906, 7. ser. 18, 36-37.

1906.3

Description of a new silurid fish of the genus Doumea Sauvage, from Angola [D. angolensis] Ann. Mag. Nat. Hist., 1906, 7. ser. 18, 347-348.

1906.4

Descriptions of new fishes discovered by Mr. E. Degen in lake Victoria. Ann. Mag. Nat. Hist., 1906, 7. ser. 17, 433-452.

1906.5

- Fourth contribution to the ichthyology of lake Tanganyika. Report on the collection of fishes made by Dr. IV. A. Cunnington during the third 'Tanganyika expedition 1904-1905. Trans. Zool. Soc. London, 1906, 17, 537-619. 2 pls.

1906.6
The distribution of African freshwater fishes. Rept. 75. Meet. Brit. Assoc. Adv. Sci., 1905 (1906), 412-432. - Review in Nature, 72, 413421 .

1906.7

On a collection of fishes from Gallaland. Ann. Mag. Nat. Hist., 1906, 7. ser. 17, 557-566. 1906.8

On a second species of the silurid genus Mochocus. Ann. Mag. Nat. Hist., 1906, 7. ser. 18, 147-148. 1906.9

On some fishes from the Kivango river (Congo system) in Angola, collected by Dr. W. J. Ansorge. Ann. Mag. Nat. Hist., 1906, 7. ser. 17, 110-112.

1906.10

On some west African species of Barbus. Ann. Mag. Nat. Hist., 1906, 7. ser. 18, 32-35.

1906.11

On the presence of two species of Anabas in the White Nile and the Bahr-el-Gebel. Ann. Mag. Nat. Hist., 1906, 7. ser. 18, 348. 1906.12

- Description of a new cichlid fish from Portuguese East Africa. Ann. Mag. Nat. Hist., 1907, 7. ser. 20, 50.

1907.1

- Description of a new cyprinid fish of the genus Labeo from the Transvaal. Ann. Mag. Nat. Hist., 1907, 7. ser. 19, 392.

1907.2

Descriptions of three new fishes from Central Africa. Ann. Mag. Nat. Hist., 1907, 7. ser. 20, 487-489. 1907.3

Descriptions of three new freshwater fishes discovered by Mr. G. L. Bates in south Cameroon. Ann. Mag. Nat. Hist., 1907, 7. ser. 20, 50-52 ; 485487.

1907.4

- Descriptions of two new African species of Barbus. Ann. Mag. Nat. Hist., 1907, 7. ser. 20, 336-337. 1907.5

-.. Descriptions of two new freshwater fishes discovered by Dr. W. J. Ansorge in Mossamedes, Angola. Ann. Mag. Nat. Hist., 1907, 7. ser. 20, 108109.

1907.6

Fishes. Nation. Antarct. Exped., 1907, 2, no. 4, 1-5. 2 pls. 1907.7

List of the fishes collected by Mr. J. S. Budgett in the river Gambia, with notes by J. S. Budgett (In The Work of John Samuel Budgett, Cambridge, 1907, p. 95-99)

1907.8 
On a collection of fishes, batrachians and reptiles, made by $\mathrm{Mr}$. S. A. Neave in Rhodesia, north of the Zambesi, with field notes by the collector. Mem. Proc. Manchester Liter. Philos. Soc., 1907, 51, no. 12, 1-12.

1907.9

On an African Barbel hitherto confounded with Barbus trimaculatus Peters. Ann. Mag. Nat. Hist., 1907, 7. ser. 19, 492-493.

1907.10

On a small collection of fishes made in the eastern watershed of the Transvaal by Capt. G. E. Bruce, Proc. Zool. Soc. London, 1907, $307-$ 311. 2 pls. \& 2 figs.

1907.11

- On Barbus aureus Cope, from Natal. Ann. Mag. Nat. Hist,, 1907, 7. ser. 19, 390-391. fig.

1907.12

On the cold-blooded vertebrata of Saghalien. Proc. Zool. Soc. London, 1907,414

1907.13

- On the variations of Stereolemis gigas, a great sea-perch from California and Japan. Ann. Mag. Nat. Hist., 1907,7 . ser. 19, 489-491. 2 figs.

1907.14

Zoology of Egypt; the fishes of the Nile. 2 vols, London, 1907. li, 578 p. pls. A-F, i-xevii. 4. 1907.15

Description of a new silurid fish of the genus Synodontis from south Cameroon. Ann. Mag. Nat. Hist., 1908, 8. ser. 2, 30-31.

1908.1

Descriptions of two new cyprinodontid fishes from west Africa. Ann. Mag. Nat. Hist., 1908, 8. ser. 2 , 29-30.

1908.2

Diagnosis of new fishes discovered by Capt. E. L. Rhoades in lake Nyassa. Ann. Mag. Nat. Hist. 1908, 8. ser. 2, 238-243.

1908.3

Diagnoses of new fishes from the upper Zambesi. Ann. Mag. Nat. Hist., 1908, 8. ser. 2, 492-495. 1908.4

Exhibition of, and remarks upon, a remarkably malformed plaice (Pleuronectes platessa) Proc. Zool. Soc. London, 1908, 161-164.

1908.5

- Note on Clarias capensis C.\& V. Ann. Natal Govt. Mus., 1908, 1, $237-239$

1908.6

- On a collection of freshwater fishes, batrachians and reptiles from
Natal and Zululand, with descriptions of new species. Ann. Natal Govt. Mus., $1908,1,219-235.2$ pls.

1908.7

On a small collection of reptiles, batrachians and fishes made by Dr. E. Bayon in Uganda (Collezioni zoologiche fatte nell' Uganda dal Dott. E. Bayon. I) Ann. Mus. Civ. Storia Nat. Genova, 1908-10, 3. ser. 4, 5-7. 5 figs. 1908.8

On a second collection, etc. Ibid., p. 302307. 3 figs.

A revision of the African fishes of the subfamily Clariinæ. Proc. Zool. Soc. London, 1907 (1908), 1062-1097. 10 figs.

1908.9

Catalogue des poissons du Congo du Musée d'Histoire Naturelle de Luxembourg. Faune du Sarkuru à Kondué (Collection Ed. Luja) Monatsber. Gesell. Luxemburg. Naturf., 1909, n. s. 3. Jahrg., 189-202. Also separate; Luxemburg, 1909. 16 p.

1909.1

Catalogue of the freshwater fishes of Africa in the British Museum (Natural History) London, 1909.

1909.2

Description of a new characinid fish from Mexico. Ann. Mag. Nat. Hist., 1909, 8. ser. 4, 497-498. 1909.3

Description of a new freshwater gobiid fish from the Niger. Ann. Mag. Nat. Hist., 1909, 8. ser. 3, 42. 1909.4

- Descriptions of new freshwater fishes discovered by Mr. G. L. Bates in south Cameroon. Ann. Mag. Nat. Hist., 1909, 8. ser. 4, 186-188. 1909.5

Descriptions of three new fishes from Portuguese Guinea. Ann. Mag. Nat. Hist., 1909, 8. ser. 4, 429-431. 1909.6

The Percy Sladen trust expedition to the Indian ocean in 1905, under the leadership of Mr. J. Stanley Gardiner. A list of the freshwater fishes, batrachians and reptiles obtained by Mr. J. Stanley Gardiner's expedition to the Indian ocean. Trans. Linn. Soc. London, 1909, 2. ser. 12, 291-300. pl: 1909.7

Ruwenzori expedition reports. XV. Pisces, batrachia and reptilia. Trans. Zool. Soc. London, 1909, 19, 237-247. 2 pls. 
Boulenger, $G$. A.

- Descriptions of three new freshwater fishes from west Africa. Ann. Mag. Nat. Hist., 1910 , 8. ser. 6, 424426.

1910.1

Ichthyology; distribution in time and space. Encyel. Britannica, 1910, 11. ed. 14, 267-270.

1910.2

Ichthyology; history and literature from 1850. Encycl. Britannica, 1910, 11. ed. 14, 247-250.

1910.3

On a large collection of fishes made by Dr. W. J. Ansorge in the Quanza and Bengo rivers, Angola. Ann. Mag. Nat. Hist., 1910, 8. ser. 6 , $537-561$.

1910.4

Peces de la Guinea Española (In Catálogo sistemático de la fauna de las posesiónes españolas del golfo de Guinea. Según los datos que se mencionan en este tomo) Mem. Soc. Españ. Hist. Nat., $1910,1,545-596$.

1910.5

Refers to his article at p. 187 of the same rolume.

- Poisson cyprinodonte nouveau du Bas-Congo. Monatsber. Gesell. Luxemburg. Naturf., 1910 , n. s. 4. Jahrg., 285.

1910.6

Catalogue of the fresh-water fishes of Africa in the British Museum (Natural History) London, 1911. $529 \mathrm{p}$.

1911.1

- Collezioni zoologiche fatte nell' Uganda dal Dott. E. Bayon (On a third collection of fishes made by Dr. E. Bayon in Uganda, 1909-1910) Ann. Mus. Stor. Nat. Genova, 1911, 3. ser. 5, 64-78. 3 pls.

1911.2

- Description of a new African fish of the genus Clarias from lake Rukwa [C. hilgendorf] Ann. Mag. Nat. Hist., 1911, 8. ser. 8, 54. 1911.3

- Description of a new cichlid fish from Mashonaland Pelmatochromis darlingi] Ann. Mag. Nat. Hist, 1911, S. ser. 7, 377.

1911.4

- Description of a new fish of the genus Polypterus from Liberia [Polypterus lowei] Ann. Mag. Nat. Hist., 1911, S. ser. 7, 377-378.

1911.5

- Descriptions of four new African fishes of the genus Mastacembelus. Ann. Mag. Nat. Hist., 1911, 8. ser. 8, $637-639$
Descriptions of new African cyprinodont fishes. Ann. Mag. Nat. Hist., 1911, 8. ser. 8, 260-268. 1911.7

Descriptions of new freshwater fishes discovered by Dr. W. J. Ansorge in Portuguese Guinea. Ann. Mag. Nat. Hist., 1911, 8. ser. 7, 373-377. 1911.8

Descriptions of three new characinid fishes from southwestern Colombia ¿Lebiasina, Luciocharax, Curimatus] Ann. Mag. Nat. Hist., 1911, 8. ser. 7, 212-213.

1911.9

Descriptions of three new freshwater fishes discovered by Mr. G. L. Bates in south Cameroon Labeo, Clarias, Pelmatochromis] Ann. Mag. Nat. Hist., 1911, 8. ser. 8, 372-373. 1911.10

Descriptions of two new African barbels. Ann. Mag. Nat. Hist., 1911, 8. ser. 8, 369-370.

1911.11

- Further descriptions of new freshwater fishes discovered by Dr. W. J. Ansorge in Portuguese Guinea. Ann. Mag. Nat. Hist., 1911, 8. ser. 8, $56-57$.

1911.12

Liste des poissons représentés dans une nouvelle collection de la rivière Sankuru (Kasaï) reçue de M. E. Luja. Monatsber. Gesell. Luxemburg. Naturf., 1911, n. s. 5. Jahrg., 218-225. 1911.13

On a collection of fishes from the lake Ngami basin, Bechuanaland. Trans. Zool. Soc. London, 1911, 18, 399-418. 3 pls. \& 3 figs. $\quad 1911.14$

On a third collection of fishes made by Dr. E. Bayon in Uganda, 1909-1910. Annal. Museo Civico, Genova, 1911, 3. ser. 5, 64-78. 3 pls. 1911.15

Description d'un poisson nouveau du genre Haplochilus provenant du Katanga. Rev. Zool. Africaine, Bruxelles, 1912, 2, 47-4S。 1912.1

-Description of a new cichlid fish [Pelmatochromis annoldi] from the lower Niger. Ann. Mag. Nat. Hist., 1912, 8. ser. 10, 263.

1912.2

Description of a new fish from British Central Africa. Ann. Mag. Nat. Hist., 1912, 8. ser. 9, 519-521. 1912.3

_- Description of a new fish [Tilapia grahami n. sp.] from British East Africa. Ann. Mag. Nat. Hist., 1912, 8. ser. 9, 519-521.

1912.4 
Descriptions of three new African cichlid fishes of the genus Tilapia, preserved in the British Museum. Ann. Mag. Nat. Hist., 1912, 8. ser. 10, 138140 .

1912.5

Descriptions of two new fishes [Alestes, Amphilius] from the Nile system. Ann. Mag. Nat. Hist., 1912, 8. ser. 10, 601-602.

1912.6

On a collection of fishes made by Mr. A. Blayney Percival in British East Africa to the east of lake Baringo. Proc. Zool. Soc. London, 1912, 672676. $3 \mathrm{pls}$.

1912.7

- Poissons recueillis dans la région du bas Congo par M. le Dr. W. J. Ansorge. Ann. Mus. Congo (Sér. Zool.), Bruxelles, 1912, 1-25. 6 pls.

1912.8

The small devil-fish. Country Life, 1912, 414-415. 2 figs. 1912.9

- A synopsis of the fishes of the genus Mastacembelus. Journ. Acad. Nat. Sci. Philad., 1912, 2. ser. 15, $197-203$.

1912.10

Description d'un poisson nouveau recueilli à Luluabourg (Congo Belge) Rev. Zool. Afr. Bruxelles, 1913, 2, 394-395.

1913.1

—Descriptions de deux poissons nouveaux provenant des récoltes de M G. Luja à Kondué, Kasai. Monatsber. Gesell. Luxemburg Naturf., 1913, n. s. 7. Jahrg., no. 3, 42-43.

1913.2

Description of a new cyprinodont fish from the Sobat river. Ann. Mag. Nat. Hist., 1913, 8. ser. 12, 566.

1913.3

Descriptions of five new cichlid fishes from Africa. Ann. Mag. Nat. Hist., 1913, 8. ser. 12, 482-485. 1913.4

Descriptions of four new fishes discovered by Mr. G. L. Bates in the Nyong river, south Camercon. Ann. Mag. Nat. Hist., 1913, 8. ser. 12, 67 70.

1913.5

Descriptions of three new fishes discovered in the Gold Coast by Dr. H. G. F. Spurrell. Proc. Zool. Soc. London, 1913, 51-53. pl.

1913.6

Sur une petite collection de poissons recueillis dans l'Uelé par la mission dirigée par M. Hutereau. Rev. Zool. Afr. Bruxelles, 1913, 2, 155-161.
Boulenger, George Alfred, Annandale, Nelson, Wall, E., \& Regan, C. Tate. Reports on a collection of batrachia, reptiles and fish from Nepal and the Western Himalayas. Rec. Indian Mus., 1907, 1, 149-158. pl.

1907.1

Boulton, William B. The Thames salmon experiments. Mag. Sports \& Pastimes (Baily), London, 1904, 82 368-377.

1904.1

Bouney, T.G. Destruction of fish by frost. Nature, 1891, 43, 368, 1891.1

Bounhiol, Jean Paul. Régime respiratoire des poissons marins vivant en captivité. C. R. Assoc. Franç. Avanc. Sci., 1904, 32, pt. 2, 813-815. $\quad 1904.1$

- Mesures respiratoires sur les poissons marins. C. R. Acad. Sci., Paris, 1905, 140, 60-62. 1905.1

Recherches expérimentales sur la respiration aquatique. II. La respiration des poissons marins dans ses rapports avec la captivité et la pisciculture. Bull. Sci. France et Belgique, $1905,39,227-305$. pl. 1905.12

Sur la technique expérimentale des mesures respiratoires chez les poissons. C. R. Soc. Biol. Paris, 1906 , $60,473-474$.

1906.1

Sur les poissons comestibles du lac Mélah (la Calle, Algérie) C. R. Acad. Sci. Paris, 1907, 144, 513-515

1907.1

Quelques faits biologiques relatifs aux poissons comestibles des côtes de l'Algérie. C. R. Assoc. Franç. Avanc. Sci., 1908, 36, pt. 1, 240-241; pt. 2, 591-594.

1908.1

_- Les mœurs ambulatoires du thon commun en Méditerranée. Bull. Soc. Hist. Nat, Afrique, Alger, 1911, 3, 149-151.

1911.1

Les pseudo-migrations du thon méditerranéen (Thynnus vulgaris Cuv. et Val.) C. R. Assoc. Franç. Avanc, Sci., 1911, 40. sess., 119-120. 1911.2

Une théorie hydrodynamique des pseudo-migrations du thon commun (Thynnus vulgaris Cuv. et Val.) dans Ia Méditerranée. C. R. Acad. Sci. Paris., 1911, 152, 733-736. 1911.3

Sur la détermination de l'âge de la sardine algérienne. C. R. Acad. Sci. Paris, 1912, 154, 1721-1723. 1912.1 
Bounhiol, $J . P$.

- Nouvelles observations sur la reproduction de la sardine algérienne. C. R. Acad. Sci. Paris, 1913, 156, 20082010 .

1913.1

- Sur la reproduction de la sardine algérienne. C. R. Acad. Sci. Paris, $1913,156,1565-1567$.

1913.2

Bourdet, P.F. M. Notice sur des fossiles inconnus qui semblent appartenir à des plaques maxillaires de poissons dont les analogues vivants sont perdus, et que j'ai nommés Ichthyosiagônes. Genève \& Paris, 1822. $4^{\circ}$. fig. - Bull. (Férussac), 1824, 2, 100.

1822.1

Histoire naturelle des ichthyodontes, ou dents fossiles qui ont appartenu d̀ la famille des poissons, sous les rapports géologiques et zoologiques. Bull. (Férussac), 1824, 3, 231. 1824.1

Bourée, $H$. L'océanographie vulgarisée. De la surface aux abîmes. Paris [1912] 140 p. illustr. $4^{\circ}$. 1912.1

Bourgeois, — Notice sur les poissons de mer, conservés frais par réfrigération et importés dernièrement à Rouen. Bull. Soc. Libre Démulat. Seine-Inférieure 1878-79 (1879), 362374.

1879.1

Bourienne, - $\quad$ Sur un ichthyodorulite trouvé à Moult] Bull. Soc. Linn. Normandie, 1857-58, 3, 17-18.

1858.1

Bourjot, (Dr.) Alexandre [18011886] Liste des poissons que l'on rencontre le plus souvent au marché d'AIger, ou guide à la pêcherie. Bull. Soc. Climatol. Algérie, 1864-68 (1867), 1, $418-433$; 485-513; 556-582.-Op. cil. 1868, 2, 14-25; 134-138. Also separate; Alger, 1870 . $8^{\circ}$.

1867.1

Bourne, Gilbert $C$. Destruction of immature fish. Journ. Marine Biol. Assoc., 1889-90, n. s. 1, 153-161.

1889.1

Fisheries and fishing industries of the United States. Journ. Marine Biol. Assoc., 1889-90, n. s. 1, 217.

1889.2

Bourne, R. H. The porus genitalis in the Myxinidx. Journ. Linn. Soc. London, 1898, 26, no. 170, 487-495. Abstract in Journ. Roy. Micr. Soc. 1898, pt. 4, 413.

1898.1
Bouros, $G$. Ueber drei Fische der Alten. Isis (Oken), 1841, 645-648. Also separate; Athens, $1840.8^{\circ}$.

1840.1

Boussac, $P$. Hippolyte. Les poissons sur les monuments pharaoniques. Naturaliste, Paris, 1909, 31, 285-287. 3 figs.

1909.1

Les poissons de la Méditerranée et de la Mer Rouge représentés. sur les monuments pharaoniques. Naturaliste, Paris, $1910,32,267-268 ; \quad 287-288$. 2 figs.

1910.1

Les poissons sur les monuments pharaoniques. Naturaliste, Paris, 1910, $32,11-13 ; 25-26 ; 48-49 ; 62-63 ; 86$; $96-97 ; \quad 158-159 ; \quad 229-231 ; \quad 241-242$; $255-256$.

1910.2

Boussingault, Jean Baptiste Joseph Dieudonné [1802-1887] Deux spécimens d'un poisson rare au Pérou, le Pimelodus [Stygogenes] cyclopum. C. R. Acad. Sci. Paris, 1864, 58, 917.1864 .1

Bout, $H$. Notice historique sur la pisciculture. Revue Maritime et Colon. 1879, 63. Also separate; Nancy \& Paris, 1879. 34 p. $8^{\circ}$. 1879.1 - Coup d'oil sur la pisciculture et ses procédés. Revue Maritime et Colon., 1880, 64, 473-487. Also separate; Paris, 1880. 17 p. $8^{\circ} .1880 .1$

Boutan, L., \& Pacovitza, E. P. Sur la pêche pélagique en profondeur. C. R. Acad. Sci. Paris, 1895, 121, 174.

1895.1

Bouvaist, - Rapport sur le congrès de pisciculture. Annales Assemblées Départementales, Paris, 1889, 132 139. 1889.1

Bouvé, Thomas Tracy $[1815-]$ The herring fishery in the town of Pembroke, Mass. Proc. Boston Soc. Nat. Hist., 1851-54 (1854), 4, 288. 1854.1

Bouvet, Georges. Un poisson nouveau pour nos rivières: le Lepomis megalotis Raff. Bull. Soc. Etude Sci. Angers, 1900, n. s. 29, 255-257. 1900.1

Bouvier, Eugène L. Le mimetisme chez les poissons. Naturaliste, 1888, 10, 17-20. figs.

1888.1

Les poissons recueillis dans les expéditions scientifiques du "Travailleur " et du "Talisman." Naturaliste, 1890,12 , no. $77,122-123$; no. 78,34 . 
La torpille. Naturaliste, 1890 , 12, 221-223; 250-251. 7. figs. 1890.2

Emile Blanchard. Notice néerologique. Nouv. Arch. Mus. Hist. Nat. Paris, 1900 , 4. sér. 2, iii-xxviii.

1900.1

Bouville, $R$. Drouin de. See Drouin de Bouville.

Bouyat, A., \& Gruvel, A. See Gruvel \& Bouyat.

Boveri, Theodor [1862-] Ueber die Niere des Amphioxus. Med. Wochenschr., 1890, 8, 1-13. 2 figs. 1890.1

Ueber die Bildungsstätte der Geschlechtsdrüsen und die Entstehung der Genitalkammern beim Amphioxus. Anat. Anz., 1892, 7, 170-181. fig. Abstract in Journ. Roy. Micr. Soc. London, 1892, pt. 3, 344.

1892.1

Die Nierenkanälchen des Amphioxus. Zool. Jahrb. 1892 (1893), 5, 429-510. 4 pls. \& 5 figs.

1893.1

Bemerkungen über den Bau der Nierenkanälchen des Amphioxus. Anat. Anz., 1904, 25, 599-604. fig. 1904.1

Ueber die phylogenetische Bedeutung der Sehorgane des Amphioxus. Zool. Jahrb., 1901 (Suppl.), 7, 409428. 10 figs.

1904.2

Bowden, (Rev.) John. Norway; its people, products and institutions. London, 1867. xii, 250 p. $8^{\circ}$. 1867.1

Chap. xiv. The fisheries of Norway, etc. p. $147-158 ; 246-247$.

The naturalist in Norway. Notes on the wild animals, birds, fishes and plants of that country, with some account of the principal salmon fisheries. London, 1869. 263 p. 8 col. pls. $8^{\circ}$.

1869.1

Chap. xxvii. The fisheries of Norway.

Bowdich, (Mrs.) T. Edward, afterwards Lee, (Mrs.) Sarah [1791-1856] Freshwater fishes of Great Britain. London, 1828-1838. $47 \mathrm{col}$. figs. $4^{\circ}$. Reviews in Liter. Gaz., London, March 15, 1828. - Bull. (Férussac), 1828, 15, 16.5.

1828.1

Bower, Seymour. Instructions for taking whitefish eggs. Bull. U. S. Fish Comm. 1884, 4, 113-114.

1884.1

The artificial hatching of whitefish and brook trout and the relations of planting to results. Trans. Amer. Fisheries Soc. 1895 (1896), 89-99.

1896.1

The propagation of small-mouth black bass. Trans. Amer. Fisheries Soc. 1896 (1897), 127-136. 1897.1

- Fish protection and fish production. Trans. Amer. Fisheries Soc. 1897 (1898), 58-63. 1898.1

- Natural versus assisted reproduction of certain kinds of fishes. Trans. Amer. Fisheries Soc. 1898 (1899), 46-56.

1899.1

The rainbow trout in Michigan. Trans. Amer. Fisheries Soc. 1909 (1910), 130-134.

1910.1

Bower, Ward T. Notes on the taking of quinnat salmon eggs. Trans. Amer. Fisheries Soc. 1905 (1906), 232-238.

1906.1

Notes on the increase in size of fish ova after water hardening. 'Trans. Amer. Fisheries Soc. 1909 (1910), 92100.

1910.1

Fish culture in Alaska. (Alaska fisheries and fur industries in 1911) Bur. Fisheries Doc. no. 766. Rept. Comm. Fisheries, 1911. 1911.1

Bowerbank, James Scolt [1797-1877] On the probable dimensions of Carcharodon megalodon from the Crag. Ann. Mag. Nat. Hist., 1852, 2. ser. 9, $120-123$

1852.1

Muller's top-knot [Rhombus hirtus Yarrell 1 at St. Leonards. Zoologist, 1872,2 . ser. $7,2996 . \quad 1872.1$

Angel-fish at St. Leonard's [Squatina angelus] Zoologist, 1873, 2.

ser. 8, 3653-3654. 1873.1

Beaumaris shark Lamna cornubica] and boar-fish [Capros aper] at Hastings. Zoologist, 1873, 2. ser. 8, 3617 .

1873.2

Callionymus lyra at St. Leonards. Zoologist, 1873, 2. ser. 8, 3495.

1873.3

Beaumaris shark (Lamna cornubica) taken off Hastings. Zoologist, 1874, 2. ser. 9, 4201-4202. 1874.1

Fishing frog [Lophius piscatorius] at St. Leonards. Zoologist, 1874, 2. ser. 9, 4000-4001. 1871.2 
Bowers, George Meade [1863-] Report of the commissioner for the year ending June 30, 189s. Rept. U. S. Fish Comm. 1898 (1899), 24, i-xxix. 1899.1

Reports for succeeding years are to be found in vols. $25-29$ of the same series, and in Repts. Bureau of Fisheries from 1904 onward.

- Dredging and other collecting stations of the U. S. Fish Commission steamer "Albatross." Rept. U.S. Fish Comm. 1903 (1905), 29, 397-432. 1905.2

Bowles, B. F. Landlocked salmon. 'Trans. Amer. Fisheries Soc. 1872 (1873), 39-46. 1873.1

Bowles, E. Augustus. Boar-fish [Capros aper] at 'Teignmouth. Zoologist, $1895,19,194$. 1895.1

Bowles, William [1705-1780] Introducción á la historia natural, y á la geografia física de España redited by J. N. de Azara y Perera] Madrid, 1775. xlviii, $529 \mathrm{p}$. 1775.1

—_ The same. 2. ed. Madrid, 1782. 1782.1

Bowlker, Charles [-1779] The art of angling and compleat fly-fishing, describing the different kinds of fish, etc. 2. ed. Birmingham, 1774. viii, $116 \mathrm{p}$. $16^{\circ}$.

1774.1

This work passed through a number of editions. In the first, published 1758 , the name of Richard Bowlker, father of Charles, appears as author.

Bowlker, Richard. The art of angling... containing a particular account of the several sorts of freshwater fish. Worcester [1758?] iv, 95 p. $12^{\circ} .1758 .1$

Later editions appear under the name of Charles Bowlker as author.

Bowman, Alexander. The distribution of the larva of the eel in Scottish waters. Fisheries Scotland Sci. Invest. 1912 (1913), no. 2, 1-11.

1913.1

The spawning areas of sand-eels in the North sea. From the records of the Scottish Fishery Research steamer "Goldseeker." Fisheries Scotland Sci. Invest. 1913 (1914), no. 3, 1-13. 1914.1

Boyce, $R$., \& Stephens, $J$. $W^{T}$. See Stephens \& Boyce.

Boyd, James $P$. Wonders of the heavens, earth, and ocean, etc. Philadelphia, 1888. 832p. illust. $8^{\circ}$. 1888.1 Contains considerable mention of fish.

Boyer, E. R. Mesoderm in teleosts; especially its share in the formation of the pectoral fin. Bull. Mus. Comp.
Zool., 1892, 23, 92-133. 8 pls. Abstract in Journ. Roy. Micr. Soc., London, 589.

1892.1

Boyer, Jacques. Les aloses et leur pêche. Cosmos, Paris, 1909, n. s. 61, 235-239.

1909.1

Boyer-Tonfrède, $J . F . B$. La pêche de la courtine. [Bordeaux, 1848] $8^{\circ}$. 1848.1

Boys, William [1735-1803] Collections for the history of Sandwich, with notices of the other cinque ports; containing a list of beasts, fishes, etc., that have fallen under the inspection of the author. London, 1786-92. 4 1786.1

Boz (pseudon.) See Kinsey, J.W.

Bozza, Vincento. Catalogo sistematico dei più rari ittiolitj del monte Bolca che si conservano nel gabinetto privato. Trans. Roy. Irish Acad., 1794, 5, 312.

1794.1

Braam Houckgeest, Andreas Everard van. Bericht wegens den Lophius histrio. Verh. Holl. Maatsch. Wet., Haarlem, 1774, 15, 20-28. $\quad 1774.1$

Brabazon, Wallop. The deep sea and coast fisheries of Ireland, with suggestions for the working of a fishing company. Illustrated by William Cooper. Dublin \& London, 1848. 112 p. pls. \& figs. $8^{\circ}$.

1848.1

Brachet, $A$. Recherches sur le développement du pancréas et du foie (sélaciens, reptiles, mammifères) Journ. Anat. Phys., 1896, 32, 620-696. 3 pls. —Zool. Centralbl., 4, 462-463. 1896.1

Sur le développement du foie et sur le pancréas de l'Ammocotes. Anat. Anz., 1897, 13, 621-636. 6 figs. Abstract in Journ. Roy. Micr. Soc. London, 1897, 17, 517.

1897.1

Gastrulation et formation de l'embryon chez les chordés. Anat. Anz., $1905,27,212-221$; 239-246; 384. 8 figs.

1905.1

- Sur la signification morphologique de la région occipitale du crâne. Bull. Mém. Soc. Anthrop. Bruxelles, 1909, 27, lvii-lxxv. 3 figs. 1909.1

Recherches sur la gastrulation et l'origine de l'hypoblaste du tube digestif chez Amia calva. Zool. Jahrb., 1912 (Suppl.no. 15), 2, 425-456. pl. 1912.1

Brachet, A., \& Swaen, A. See Swaen \& Brachet. 
- Brackel, Gregorius von. De cutis organo quorundam animalium ordinis plagiostomorum disquisitiones microscopicæ. Inaug. Dissert. Dorpati, 1858. 54 p. pl. $8^{\circ}$.

1858.1

Brackett, $E$. A. Do all California salmon die after spawning? Forest \& Stream, 1879, 12, 325.

1879.1

Stocking streams with trout; fingerlings versus fry. Rept. Mass. Comm. Inland Fisheries \& Game, 1893. Also separate; Boston, 1899. 1893.1

Brackett, Walter $\boldsymbol{M}$. On the Canadian sea trout. Chicago Field, 1880, 13, 51. 1880.1

Bradford, Charles Barker. The brook trout. New York [1900] figs. $16^{\circ}$.

1900.1

The angler's guide, a handbook of the haunts and habits of the popular game fishes, inland and marine ... and a summary of the fishing resorts. New York, 1908. xxxi, 155 p. pl. $12^{\circ}$.

1908.1

Bradley, C.L. On the occurrence of Gyrodactylus elegans on sticklebacks in the Hampstead ponds, January, 1860. Journ. Linn. Soc. London (Zool.), 1861, 5, 209-210.

1861.1

Bradley, Frant: Howe [1838-1879] Preliminary notice of certain beds of fishremains in the Hamilton group of western New York. Amer. Journ. Sci., 1866, 2. ser. $42,70-72$.

1866.1

Bradley, Thomas. The habits of the electric eel, as observed at the royal gallery of practical science, West Strand. Mag. Nat. Hist., 1838, n. s. 2, 668-670. - Notizen (Froriep), 1838, 9, 97-99.

1838.1

Brady, George Stewardson [1832-] Ray's bream [Brama rayi] taken near Seaham harbor. Nat. Hist. Trans. Northumberland \& Durham, 1872, 4, pt. 2, 511.

1872.1

Brady, Thomas F. Report of the proceedings taken to relieve the distress on the islands of Boffin and Shark, county Galway, chiefly by the promotion of the fisheries. Dublin, 1873. $8^{\circ}$. 1873.1

Braess, Martin. Der Aal und seine Entwicklung. Kosmos, Stuttgart, 1908, 5. Jahrg., 206-210. 7 figs. 1908.1

Die Forelle (Salmo fario L.) Kosmos, Stuttgart, 1910, 6. Jahrg., 107111. 2 figs. 1910.1
Braeunig, Karl. Ueber musculöse Verbindungen zwischen Vorkammer und Kammer bei verschiedenen Wirbelthierherzen. Arch. Anat. Physiol. (Physiol. Abth.), 1904, Suppl., 1-19. pl. 1904.1

Bräunle, Eduard. Die Lurch- oder Molchfische. Wochenschr. Aquar.-Terrar. Kunde, 1911, 8. Jahrg., 546-547. fig.

1911.1

Braganza, (Dom) Carlos de (King of Portugal) See Carlos de Braganza.

Brainerd, (Prof.) J. Fossil fishes. Annals Science (Cleveland, Ohio), 1852, 1, 18-20. 3 figs.

1852.1

The species here made known was afterwards described by J. S. Newberry under the name of Palconiscus brainerdi, and later as Gonatodus brainerdi.

Braithwaite, George F'oster. Fishes and their food; being a paper on the salmon family, with illustrations of their habits, taken principally from the counties of Westmorland and Cumberland. Kendal, 1863. 32 p. $16^{\circ}$ 1863.1

The Salmonidæe of Westmorland, angling reminiscences, and leaves from an angler's note book. London, 1884. $\mathrm{x}, 188 \mathrm{p}$. pls. $8^{\circ}$.

1884.1

Series of papers originally published in the Westmorland Gazette.

Brakeley, John $H$. Plants for carp ponds. Bull. U. S. Fish Comm. 1884, 4, 159-160.

1884.1

Notes on carp and frog culture. Bull. U.S. Fish Comm. 1885, 5, 209-216.

1885.1

Rapid growth of carp due to abundance of food. Bull. U. S. Fish Comm. 1887 (1889), 7, 20. $\quad 1889.1$

Brammer, $C$. Halsnæs-fiskeriernes opkomst og nuræende tilstand. 'Tidsskr. Fiskeri, 1872, 5. Jahrg., 153-202. 1872.1

_- Fiskerierne paa Halsnas $i$ aaret 1872. Tidsskr. Fiskeri, 1873, 175-194.

1873.1

Fiskerierne paa Halsnæs fra 1ste Januar til 1ste Juli 1873. Nord. Tidsskr. Fiskeri, 1874, n. s. 1. Jahrg., 64-84.

1874.1

These reports are continued in the same serial for the years $1874-79$.

Branca, Hermann Wilhelm. Fossile Flugtiere und Erwerb des Flugvermögens. Abh. Akad. Wiss. Berlin, physik.-math. Cl., 1908, 1-49. 8 figs.

1908.1 
Branco, Carl Wilhelm Franz [1844 - ] Ueber eine neue Lepidotusart aus der Wealden. Berlin, 1885. 2 figs. $8^{\circ}$.

1885.1

- Beiträge zur Kenntnis der Gattung Lepidotus. Abh. Geol. Specialkarte Preussen u. Thüring. Staaten, 1887, 7, 323-406. 8 pls. \& 2 figs. 1887.1

- Ueber das Gebiss von Lepidotus koeneni. Berlin, 1890.

1890.1

Brand, $F . N$. Polycentropsis abbreviata. Prakt. Zierfischzüchter, 1910 , 33-35. fig.

1910.1

Brandes, Gustav. Biologisches vom afrikanischen Lungenfisch. Zeitschr. Naturw., Leipzig, 1893, 66, 402. 1893.1

Die Brutpflege der Fische. Zeitschr. Naturw., Leipzig, 1893, 66, 358368.

1893.2

-... Spiraldarm von Lamna cornubica. Zeitschr. Naturw., Leipzig, 1893, 66,404

1893.3

Die Entwickelung der Aale. Zeitschr. Naturw, Leipzig, 1898, 70, $410-412$. 1898.1

Die Lorenzinischen Ampullen. Verh. Deutsch. Zool. Ges., 1898, 8, 179 182. - Zool. Centralbl., 7, 567. 1898.2

- Die Leuchtorgane der Tiefseefische Argyropelecus und Chauliodus. Zeitschr. Naturw, 1899, 71, 447-452. Abstract in Verh. Deutsch. Zool. Ges., 9, 247-248.

1899.1

Ein neuer viviparer Fisch $(G i-$ rardinus decemmaculatus) Zeitschr. Naturw., 1900, 73, 301-302.

1900.1

Brandicourt, Virgile. La montée d'anguille dans la Somme. Bull. Soc. Linn. Nord France, Amiens, 1891, 10, 166-169.

1891.1

La montée d'anguille dans la Somme. La Nature, 1897, 25, pt. 2, 215.

1897.1

L Les moeurs cynégétiques du monde aquatique. La Nature, 1901, 29. 147-150. fig.

1901.1

_- Dissémination des plantes par les poissons. Bull. Soc. Linn. Nord France, Amiens, 1905, 17, 139-143.

1905.1

Les poissonniers de la Somme. Cosmos, Paris, 1912, 66, 243-246. 4 figs.
Brandt, Aleksandr Theodorovich [1844 - ] Ueber borstenartige Gebilde bei einem Hai und eine muthmassliche Homologie der Haare und Zähne. Biol. Centralbl., 1898, 18, 257-270. 9. figs. Abstract in Journ. Roy. Mier. Soc., London, 1898, 18, 409.

1898.2

Grundriss der Zoologie und vergleichende Anatomie. Berlin, 1911. $8^{\circ}$.

1911.1

Fische (Pisces), p. 391-413.

Brandt, Johann Friedrich [1802-1879] Bemerkungen über die Störarten, welche Hausenblase liefern. Jahrb. Pharm. Berlin, 1831, 32, 48-59.

1831.1

Nachträgliche Bemerkungen über die Störarten, welche Hausenblase liefern. Jahrb. Pharm. Berlin, 1831, 32 , $317-320$.

1831.2

Ueber Albinismus und eine abweichende Farbenspielart des Sterläd (Acipenser muthenus) Bull. Acad. Sci. St. Pétersb., 1850, 10, 13-16. 1850.1

Fische (In Middendorf, A. Th. von. Reise in den äussersten Norden und Osten Siberiens während der Jahre 1843 und 1844. Vol. ii, pt.2. St. Pétersbourg \& Leipzig, 1847-59) $\quad 1859.1$

- Bemerkungen über die Classification der kaltblütigen Rückenmarkthiere: zur Beantwortung der Frage: Was ist ein Fisch? Mém. Acad. Imp. Sci. St. Pétersb., 1865, 7. sér. 9, no. 3, 30 p. Also separate; St. Pétersbourg, 1865. $4^{\circ}$. Abstract in Bull. Acad. Sci. St. Pétersb., 8, 535-536. 1865.1

Bericht uiber den ersten Theil meiner Beiträge zur Kenntniss der Entwickelungsstufen der ganoiden Fischformen. Bull. Acad. Sci. St. Pétersb., $1865,8,536-538$. Summary in Zeitschr. Ges. Naturw., Berlin, 1865, 27, 181.

1865.2

- Bericht über den zweiten Theil meiner Beitrüge zur Kenntniss der Entwickelungsstufen der ganoiden Fischformen. Bull. Acad. Sci. St. Pétersb., 1866, 9, 43-48.

1866.1

- Einige Worte über die europäisch-asiatischen Störarten (Sturionides) Mélanges Biol., 1869, 7, 110-116. Bull. Acad. Sci: St. Pétersb., 1870, 14, $171-176$. 1869.1

Brandt, Johann Friedrich, \& Lowe, R. T. Description d'un nouveau genre de poisson de la famille des Murénoides. 
Mém. Sav. Etrang. St. Pétersb., 1854, 7, 169-176.

1854.1

Brandt, Johann Friedrich, \& Ratzeburg, J.T.C. Medizinische Zoologie. 2 vols. Berlin, 1829-33. 63 figs. $4^{\circ}$.

1829.1

Brandt, Karl [1854-] Ueber das Stettiner Haff. Leipzig, 1896. $4^{\circ}$.

1896.1

Die Fauna der Ostsee, insbesondre die der Kieler Bucht. Verh. Deutsch. Zool. Ges., 1897, 7, 10-34. 4 figs. 1897.1

Beiträge zur Kenntnis der chemischen Zusammensetzung des Plankton. Wissensch. Meeresunters., Kiel, 1898, 2. ser. 3, 43-90. 1898.1

Ueber den gegenwärtigen Stand der Aalfrage. Schrift. Naturw. Ver. Schleswig-Holstein, 1898, 11, 235-239.

1898.2

L La vie dans les mers. Rev. Scient.. 1899, 4. sér. 12, 513-526. 1899.1

- Ueber Dr. Petersens neue Beiträge zur Aalfrage und seine neue Methode, den Fangertrag an Wanderaalen erheblich zu vermehren. Mitt. Deutsch. Seefischerei Ver., 1905, 21, 333-338. 2 figs.

1905.1

Branner, John Casper [1850-] Geology of the northeast coast of Brazil. Bull. Geol. Soc. Amer., 1902, 13, 41-98. 19 figs.

1902.1

Branner, John Casper, \& Jordan, David Starr. See Jordan \& Branner.

Bransford, John F. \& Gill, Theodore Nicholas. See Gill \& Bransford.

Branson, Edwin Bayer [1877-] Notes on some Carboniferous cochliodonts with descriptions of seven new species. Journ. Geol., 1905, 13, 20-34. 2 pls.

1905.1

- Fish remains from the Salem limestone of Indiana. 30. Ann. Rept. Dept. Geol. \& Nat. Resourc. Indiana, 1906, 1376-1394. 2 pls.

1906.1

Cladodus compressus, a correction. Science, 1908, n. s. 27, 311-312.

1908.1

Proposes this name for Cladodus striatus of Branson, the specific title having bcen preoccupied.

Dinichthys intermedius Newberry, from the Huron shale [of Ohio] Science, 1908 , n. S. 28, 94 .
Notes on Dinichthys terrelli Newberry, with a restoration. Ohio Naturalist, 1908,8 , no. $8,363-369.2$ pls.

1908.3

Notes on some dinichthyids from northern Ohio. Abstract in Science, 1909, n.s. 29, 197.

1909.1

Notes on the Ohio shales and their faunas. Univ. Missouri Bull.,1911 12 (Sci.ser. 2), 23-32. 3 pls. 1911.1

The Devonian fishes of Missouri. Univ. Missouri Bull., 1914, 15 (Sci. ser. 2), 59-74. 4 pls.

1914.1

Brashnikov, $V$. Beiträge zur Fauna der russischen östlichen Mecre, gesammelt von dem Schoner "Storosh" in den Jahren 1899-1902. Mém. Acad. Sci. St. Pétersb., 1907, 8. sér. 20, 2-185. 2 pls.

1907.1

Brasil, Louis. Observations sur la faune de la région de Luc-sur-Mer (Calvados) Bull. Soc. Géol. Normandie, 1901, 5. sér. 4, 75-83.

1901.2

Brasil, Louis, \& Bigot, A. See Bigot \& Brasil.

Brasil, Louis, \& Gadeau de Kerville, Henri. Note sur un centrisque bécasse (Centriscus scolopax L.) Poisson acanthoptérygien pêché dans le département de Calvados. Bull. Soc. Amis Sci. Nat. Rouen, 1905, 4. sér.40, 199 200. pl.

1905.1

Brass, Arnold. Die Accommodation des Auges der Knochenfische. Zeitschr. Naturw., 1881, 53, 901-903. 1881.1

Brass, Emil. Nutzbare Tiere Ostasiens. Pelz- und Jagdtiere, Haustiere, Seetiere. Neudamm, 1904. viii, 130 p. $8^{\circ}$

1904.1

Brass, John L. Tube for aerating water. Trans. Amer. Fisheries Soc. 1906 (1907), 188.

1907.1

Brassey, (Lady) Annie. In the trades, the tropics, and the roaring forties. New York, 1885. 532 p. illust. $8^{\circ}$. 1885.1

Contains descriptions of some West Indian fishes.

Brattsröm, Julius. Kraniet och Skuldergördeln hos Murana anguilla. Upsala, 1875. $31 \mathrm{p}$.

1875.1

Brauer, August. Diagnosen von neuen Tiefseefischen welche von der Valdivia-Expedition gesammelt sind. Zool. Anz., 1902, 25, 277-298. 1902.1 
Brauer, $A$.

Ueber den Bau der Augen einiger

Ticfseefische. Verh. Deutsch.Zool. Ges., $1902,12,42-57.7$ figs. Abstract in Zool. Centralbl., 1902, 9, 712-714.

1902.2

Ueber einige von der ValdiviaExpedition gesammelte Tiefseefische und ihre Augen. Sitzber. Gesell. Naturw., Marburg 1901 (1902), 115-130. 3 figs. 1902.3

-Die Augen der 'liefseefische. Ber. Senckenberg. Nat. Ges., Frankfurt a. M., 1904 (Protok.), 102-104. 1904.1

Die Gattung Myctophum. Zool. Anz., 1904, 28, 377-404. 9 figs. 1904.2

[Demonstration von Schnitten durch das Auge von Sternoptyx und von Myctophiden] Verh. Deutsch. Zool. Ges., 1904, 14, 241.

1904.3

_.. Ueber die Leuchtorgane der Innochenfische. Verh. Deutsch. Zool. Ges., 1904, 14, 16-35. 15 figs. 1904.4

- Die Leuchtorgane der Tiefseefische. Ber. Senckenberg. Nat. Ges., Frankfurt a. M., 1905, $7 *-9 *$. 1905.1

Die Tiefseefische. I. Systematischer Teil (In Chun, C. Wiss. Ergebnisse Deutsch. Tiefsee-Exped. "Valdivia," 1898-99, vol. $\mathrm{xv}$, p. 1-420. 18 pls. Jena, 1908)

1908.1

Die Tiefseefische. II. Anatomischer Teil (In Chun, C. Wiss. Ergebnisse Deutsch. 'Tiefsee-Exped. "Valdivia," 1898-99, vol. xv, 1-266. 24 pls. Jena, 1908)

1908.2

Braun, J. Oscar. Aus dem Liebesleben des Kiampffisches. Blätt. Aquarienkunde. Stuttgart, 1908, 19, 7-8; 14-16.

1908.1

Braun, Maximilian Gustav Christian Carl [1850 - ] Zur Naturgeschichte des Flunders [Pleuronectes flesusi Zool. Anz., 1880, 3, 594 .

1880.1

Ueber das Wachsthum der Fische in der Unterwarnow. Arch. Ver. Fr. Naturg. Mecklenburg, 1893, 45. 118-125.

1893.1

Priparation von Skeletheilen von Selachiern. Verh. Deutsch. Geol. Ges. Göttingen, 1894, 3, 87-88. 1894.1

-. Zur Entwicklungsgeschichte der Holostomiden. Zool. Anz., 1894, 17, 165-167.

1894.2
Die deutsche Fischerej in isländischen Gewässern. Natur, Halle, 1902, 51, 13-15.

1902.1

Ueber Fische als Lieferanten von Parasiten des Menschen. Ber. Fischerei Ver. Ostpreuss., Königsber@, 1903-04. $47-48$; Ibid., $1904-05,3-4$. $\quad 1903.1$

- Die Verhältniszahl der Geschlechter beim Stichling. Ber. Fischerei Ver. Ostpreuss., Königsberg, 190405, 11-12.

1904.1

Die Fische des frischen Haffs. Ber. Fischerei Ver. Ostpreuss., Königsberg, 1905-06, 6-12.

1905.1

Braun, Paul. Ueber die Zucht von Bitterlingen. Blätt. Aquar-Terrar. Kunde, 1901, 12. Jahrg., 214-216.

1901.1

Brauner, A. Bestimmungstabelle und Verbreitung der Häringe im Schwarzen und Azowschen Meere. Nachtrag zu der Arbeit " Die Häringe (Clupeidæ) des Schwarzen und des Azowschen Meeres." 'Trav. Soc. Nat. Amat. Sci. Nat. Bessarabie, 1912, 2, pt. 2, 217-221.

1912.1

Die Heringe (Clupeidx) des Schwarzen und des Azowschen Meeres. Trav. Soc. Nat. Amat. Sci. Nat. Bessarabie, 1912, 2, pt. 2, 115-134. 1912.2

Braunschweig, Karl. Die Pflege und Zucht des Kampffisches (Betta splendens Regan) Blätt. Aquar.-Terrar. II unde, 1910, 21. Jahrg., 509-511.

$$
1910.1
$$

Braus, Hermann. Ueber die Rami ventrales der vorderen Spinalnerven einiger Selachier. Inaug. Dissert. Jena, 1892. 35 p. $8^{\circ}$.

1892.1

Ueber die Innervation der paarigen Extremitäten bei Selachiern, Holocephalen und Dipnoern. Ein Beitrag zur Gliedmassenfrage. Jena. Zeitschr., 1897,31 (n. s. 24), 239-468. 8 pls. \& 3 figs.

1898.1

Ueber die Extremitäten der Selachier. Verh. Anat. Gesell., 1898, 12, 166-180. 6 figs.

1898.2

Beiträge zur Entwicklung der Muskulatur und des peripheren Nervensystems der Selachier. I. Theil. Die metotischen Urwirbel und spino-occipitalen Nerven. II. Theil. Die paarigen Gliedmassen. Morph. Jahrb., Leipzig, 1899, 27, 415-496; 501-629. 6 pls. \& 12 figs.
1899.1 
Origin of paired fins in Selachians. Abstract in Journ. Roy. Micr. Soc., London, 1899, 571-572.

1899.2

Die Muskeln und Nerven der Ceratodusflosse; ein Beitrag zur vergleichenden Morphologie der freien Gliedmaasse bei niederen Fischen und zur Archipterygiumtheorie. (In Semon, $R$. Zoologische Forschungsreisen in Australien und dem Malayischen Archipel ... in den Jahren 1891-1893. Jena, 1901. Vol. i, 137-300. 9 pls. \& 25 figs. - Also in Jena. Denkschr., 1901, 4)

1900.1

Ueber neuere Funde versteinerer Gliedmassen, Innorpel und Muskeln von Selachiern. Verh. Phys. Med. Ges. Würzburg 1901 (1902), n. s. 34, 177-192. 1902.1

Tatsächliches aus der Entwickelung des Extremitätenskelettes bei den niedersten Formen. Zugleich ein Beitrag zur Entwickelungsgeschichte des Skelettes der Pinna und der Visceralbogen. Festschr. Haeckel, 1904, 377 435. pls. xiii-xiv \& figs. - Jena. Denkschr., 1904, 11, 377-436. 2 pls. \& 13 figs.

1904.2

Autogene Nervenentstehung in transplantierten Gliedmassenanlagen. Arch. Internat. Physiol., 1905, 2, 55-56. 1905.1

Die Entwickelung der Form der Extremitäten und des Extremitätenskelets. (In Hertwig, O. Handbuch der vergleichenden und experimentellen Entwickelungslehre der Wirbeltiere, Bd. iii, Teil 2, p. 167-338. Jena, 1906) 1906.1

Experimentelle Beiträge zur Morphologie. Band i. Leipzig, 1906. illust. 1906.2

Ist die Bildung des Skeletes von den Muskelanlagen abhängig? Eine experimentelle Untersuchung an der Brustflosse von Haiembryonen. Morph. Jahrb., 1906, 35, 240-321. 3 pls. \& 18 figs.

1906.2

Ueber den embryonalen Kiemenapparat von Heptanchus. Anat. Anz. 1906, 29, 545-560. 2 figs. 1906.3

Zur Entwicklungsgeschichte niederer Haie. Notizen über Vorkommen im Mittelmeer, Taxonomie, Eier und Eihüllen dieser Fische. (1) Ueber das Vorkommen niederer Haie im Mittelmeer. Fischereigeräte und -methoden. (2) Taxonomische Beurteilung der Notidaniden und Spinaciden auf Grund embryonaler Merkmale. (3) Eier und Eihüllen bei einigen primitiven Haiarten. Sitzber. Akad. Wiss. Berlin, 1906, 52, 907-932. 8 figs.

1906.4

Experimentelle Untersuchungen über die Segmentalstruktur der motorischen Nervenplexus. Anat. Anz., Jena, 1909, 34, 529-551. 5 figs. 1909.1

-... Imitationen im Knochensystem. auf Grund embryonaler Transplantationen. Verh. Ges. Deutsch. Nat. Aerzte, 1909, 80. Vers., 2. Teil, 516-517. 1909.2

- Präparatorische und experimentelle Untersuchungen über die motorischen Nerven der Selachierflosse. Anat. Hefte, Wiesbaden, 1910, 40, 2. Heft, $423-488$.

1910.1

Ueber Nervengeflechte. Verh. Anat. Ges., 24. Vers., Brüssel, 1910, 1430. - Anat. Anz., 1910, 37, 14. Also separate; Jena, $1910 . \quad 1910.2$

Die Nervengeflechte der Haie und Rochen. Jena. Zeitschr. Naturw., 1911, 47, 569-632. 2 pls. \& 7 figs.

1911.1

Bray, William L., \& Eigenmann, Carl H. See Eigenmann \& Bray.

Brayton, Alembert Winthrop, \& Jordan, David Starr. See Jordan \& Brayton.

Breckwoldt, $J . J$. Die Fischerei auf der Unter-Elbe. Deutsch. Fischerei Zeitg., 1879, 2. Jahrg., 269-270; 277$278 ; 294-295$; 309-311.

1879.1

- Fortschritte in der Elb-Fischerei. Deutsch. Fischerei Zeitg., 1880, 3. Jahrg., 115.

1880.1

Bree, $W . T$. Notice of stones found in the stomachs of pike. Mag. Nat. Hist., 1830, 3, 241-242. $\quad 1830.1$

Breemen, $P . J$. van, \& Redeke, $H . C$. See Redeke \& Breemen.

Brefeld, $F$. Der Stockfisch-Leberthran in naturhistorisch-chemisch-pharmazeutischer Hinsicht. Hamm, 1835. $8^{\circ}$.

1835.1

Brehm, Alfred Edmund [1829-1884] For biographical notice, see Krause, $E$., in Brehm's Tierleben, 3. ed., vol. i. Leipzig \& Wien, 1890.

Illustrirtes Thierleben; allgemeine Kunde des Thierreichs. 6 vols. Hildburghausen, 1863-69. illust. $8^{\circ}$.

Fische, vol. ii, p. 547-812 
Brehm, A.E.

- Das Berliner Aquarium. Monatshefte (Westermann), 1869, p. 46. fig.

1869.1

- (editor) Das süsswasser-aquarium. 2. ed. Leipzig, 1869. 8 1869.2

For first edition, see Roszmäzler, $E$. A.

Beobachtungen ïber Bewegungen verschiedener Fische des Berliner Aquariums. Sitzber. Ges. Naturf. Freunde Berlin, 1871, S5-88. $\quad 1871.1$

Illustriertes Thierleben. 2. ed. 10 vols. Leipzig, $1876-80$. illust. $8^{\circ}$.

1876.1

Die Fische, von Alfred Brehm, vol. ii, p. 1416. 11 pls. \& 145 figs.

_- La vida de los animales, conocimiento general del reino animal. Traducción directa de la segunda edición Alemana por Don Carlos Fernandez de Castroverde; primera edición española. 6 vols. Barcelona, 1882.

1882.1

Peces, vol. v, p. 1-672. 27 pls. \& 251 figs.

The archer-fish.

[Translated from Brehm's 'Thierleben] Knowledge, 18s3, 3, 280-281. fig. 1883.1

Brehm's Tierleben. Allgemeine Kunde des Thierreichs. 3. ed. 10 vols. Leipzig \& Wien, 1890-93. illust. $8^{\circ}$.

1892.1

Die Fische, von Alfred Brehm, unter Mitwirkung von Dr. Wilhelm Hacke, neubearbeitet von Prof. Dr. Pechuel-Loesche, 1892. vol. ii, p. 1-517. 11 pls. \& 146 figs.

Brehm's Tierleben. 4. ed. 14 vols. Leipzig \& Wien, 1914. 1914.1.

Die Fische, von Alfred Brehm, unter Mitwirkung von Viktor Franz, neubearbeitet von Otto Stech. vol. iii, p. 1-590. 63 pls. \& 172 figs.

Brehm, Christian Ludwig ]1787-1864 Ein noch unbekannter gefährlicher Feind der Fische (Sorex fodiens) Isis (Oken), 1830, 23, 1126-1128.

1830.1

Brehm, $H$. Die Fische und die Fischzucht auf der Landes-ProductenAusstellung in Stuhlweissenburg in Ungarn. Deutsch. Fischerei Zeitg., 1879 , 2. Jahrg., 215-216.

1879.1

Brehm, Horst (editor) 'laschenbuch der Angelfischerei. 4. Auflage. Berlin, 1904. See Borne, M. ion dem. 1904.1

Breitenbach, W. Wiederkäuer unter den Fischen. Kosmos, 1855, 1, 136138.

1885.1

Breitfuss, L. L. Statisties of the North Sea fisheries. Supplement: The fisheries of the Murman coast ( $N$. Russia) Rapp. Intern. Explor. Mer., 1905, App. J, p. 122-126. 1905.1 Die wichtigsten Ergebnisse der wissenschaftlichgewerblichen MurmanExpedition in der Barents-See während des Dezenniums 1895-1909 [Text in Russian] Trd. Jub. Akklim. Sjězda, Moskva, 1908, 2, 50-73. 1908.1

Breitfuss, L. L., Soldatov; $V_{\text {. }} K_{\text {., }}$ Göbel, J., and others. W issenschaftlichpraktische Murman-Expedition. Bericht über die Tätigkeit pro 1904. Comité Unterstuitzung Küstenb. Russischen Nordens, St. Pétersb., 1908. Ixxi, 342 p. 3 maps \& 8 pls.

1908.1

Brenchley, Julius Lucius [1817?1873] Jottings during the cruise of $\mathrm{H}$. M. S. "Curaçoa" among the South Sea islands in 1865. London, 1873. $487 \mathrm{p}$. 59 pls. illust. map. $\mathrm{S}^{\circ}$. 1873.1 Reptiles and fishes, by A. Günther.

Brenner, Mirten Magnus Wilhelm. Lumpenus nebulosus. Notiser Sällskap. Fauna Flora Fenn. Förh., 1S71-74, n.s. $10,463$.

1874.1

Iktyologiska notiser. Meddel. Soc. Fauna Flora Fenn., 1896, 22, 59.

1896.1

Breschet, Gilbert [1784-1845] Rapport fait à l'Académie des Sciences, par M. Duméril, sur trois mémoires d'anatomie, relatifs à l'organe de l'ouie dans les poissons. Ann. Sci. Nat., 1832, 27, $309-316$.

1832.1

Recherches anatomiques et physiologiques sur l'organe de l'ouie des poissons. Mém. Acad. Sci. Paris, 1838, 5, 607-729. $17 \mathrm{pls}$. Also separate; Paris, 1838. 4\% 1838.1

Breschet, Gilbert, \& Becquerel, Antoine César. Expériences sur la commotion électrique de la torpille. C. R. Acad. Sci. Paris, 1835, 1, $242 . \quad 1835.1$

Expériences sur la torpille. Ann. Sci. Nat., 1836, n. s. 6, 123 . 1836.1

Recherches expérimentales physico-physiologiques sur la température des tissus et des liquides animaux. C.R. Acall sici. Paris, 1s:36, 3, 771-7s1. Ann. Sci. Nat., 7, 94-101. - Notizen (Froriep), 1, 289-297. 1836.2

Bretagne, C. Pisciculture à domicile, stabulation de l'anguille. Revue Deux Mondes, 1876, 40. 1876.1 
Bretherton, Bernard J. A contribution to our knowledge of the food fishes of the Oregon coast from specimens. (In report of Oregon State Biologist. Salem, Oregon, 1900.9 p. illust.) 1900.1

Breton, William Henry. Scandinavian sketches; or, A tour in Norway . . . London [1835] vii, 354 p. pls. $8^{\circ}$.

1835.1

Fisheries and fishing of Norway receive frequent mention.

Brett, Alfred Thomas. Fish-hatching and fish-culture in Herefordshire, with notes on pisciculture by Peter Hood. Trans. WVatford Nat. Hist. Soc. 1875-77 (1878), 1, 179-186.

1878.1

Breuer, Josef. Ueber die Function der Bogengänge des Ohrlabyrinthes. Med. Jahrbücher, 1874, 72-124. 1874.1

Ueber die Function der Otolithen-Apparate. Arch. Gesammt. Physiol., 1891, 48, 195-306.

1890.1

Ueber den Galvanotropismus (Galvanotaxis) bei Fischen. Sitzber. Akad. Wiss. Wien, 1905, 114, 3. Abth., $27-56$.

1905.1

Ueber den Galvanotropismus (Galvanotaxis) der Fische. Anz. Akad. Wiss. Wien, math.-nat. Cl., 1905, 42. Jahrg., 81 .

1905.2

Brevoort, James Carson [1818-1887] Description of the Sclene argentea of Lacépède, a fish whose existence has been doubted. Ann. Lyc. Nat. Hist. New York, 1852, 5; 68-76. pl. 1852.1

Notes on some figures of Japanese fish. (In Narrative Commodore M. C. Perry's Expedition to Japan, vol. ii, p. 253-256. 9 pls. Washington, 1856)

Contains notice of Ditrema, etc.

1856.1

Note on the Selene argentea of Lacépède, etc. Ann. Lyc. Nat. Hist. New York, 1858, 6, 30-35.

1858.1

Enumeration of the fish described and figured by Parra, scientifically named by Felipe Pocy. Proc. Acad. Nat. Sci. Philad. 1863 (1864), 174-180.

1864.1

- American sardine and anchovy. Forest \& Stream, 1873, 1, 5. 1873.1

Capture and preservation of the anchovy. Forest \& Stream, 1873, 1, 70.

1873.2

The gurnard as an edible fish. Forest \& Stream, 1873, 1, 86. 1873.3
Names of the codfish. Ann. Rec.Sci. Med. 1872 (1873), 424. 1873.4 The sprat and the whitebait Forest \& Stream, 1873, 1, 38. 1873.5

Ichthyological extracts from the note book of a naturalist. Forest \& Stream, 1877, 9, 326 .

1877.1

Brew, C. Salmonidæ of Frazer river, British Columbia. Edinb. New Philos. Journ., 1861, 2, ser. 13, 16t. 1861.1

Brewer, William Henry [1828-1910] Fish culture in the olden time. Amer. Naturalist, $1874,8,557-559$ - - Forest \& Stream, 1874, 3, 100. 1874.1

Brewster, $C . E$. The relation of the fish and game warden in the work of fish propagation. Trans. Amer. Fisheries Soc. 1900 (1901), 69-72.

1901.1

Brewster, (Sir) David [1781-1868] On the structure of the crystalline lens in fishes and quadrupeds, as ascertained by its action on polarized light. Phil. Trans. Roy. Soc. London, 1816, 311317. pl. - Journ. Phys., 1817, 84, 379383.

1816.1

- On the crystalline lens in fishes, birds, reptiles and quadrupeds. Rept. Brit. Assoc. Adv. Sci., 1. \& 2. meet., 1831-32 (1833), 81. 1831.1

On the anatomical and optical structure of the crystalline lenses of animals, particularly of the cod. Phil. Trans. Roy. Soc. London, 1833, 123, 323-332. pl. 1833.1

On the anatomical and optical structure of the crystalline lenses of animals, particularly those of the hare and the salmon. Phil. Trans. Roy. Soc. London, 1836, 126, 35-48. pls. - Mag. Zool. \& Bot., 1, 206. - Edinb. Philos. Mag., 8, 193. fig. 1836.1

On the structure of the fossil teeth of the sauroid fishes. Rept. Brit. Assoc. Adv. Sci., 7. meet., 1838 (1839) Not. \& Abstr., 90.

1838.1

Brewster, Edwin Tenney [1866-] The collapse of evolution. Science, 1905, n. s. $22,796-797 . \quad 1905.1$

Brian, Alessandro. Note su alcuni crostacei parassiti dei pesci del Mediterraneo. Boll. Mus. Zool. Anat. Comp. Genova, 1902, 115, 1-16. pl. - Atti Soc. Ligustica Sei. Nat. Geogr., Genova, 13, 30-45. pl. 1902.1 
Brian, $A$. Sui copepodi parassite di pesci marini dell' isola d'Elba. 4. Nota. Atti Soc. Ligustica Sci. Nat. Geogr., Genova, 1903, 14, 77-84.

1903.1

Una crociera in Norwegia. Atti Soc. Ligustica Sci. Nat. Geogr., Genova, $1905,16,3-31$.

1905.1

- Note préliminaire sur les copépodes parasites des poissons provenant des campagnes scientifiques de S. A. S. le Prince Albert de Monaco ou déposés dans les collections du Musée Océanographique. Bull. Mus. Océan., Monaco, 1908, 110, 1-18.

1908.1

Un établissement de pisciculture aux Etats-Unis. Bull. Soc. Linn. Nord France, Amiens, 1883, 6, 149-156.

1883.1

Brice, John Jones [1842-] The fish and fisheries of the coastal waters of Florida. Rept. U. S. Fish Comm. 1896 (1898), 22, 263-342.

1898.1

The fisheries of Indian river, Florida. Rept. U.S. Fish Comm. 1896 (1898), 22, 223-227. 36 pls. 1898.2

Report of the commissioner for the fiscal year ending June 30, 1896. Rept. U.S. Fish Comm. 1896 (1898), 22, $1-10$.

1898.3

Report of the commissioner, etc. Rept. U. S. Fish Comm. 1897 (1898), 23, i-xvi.

1898.4

Bridel, _ Essai statistique sur le canton de Vaud. Zurich, 1818. 1818.1

Bridge, Thomas William [1848-1909] For obituary notice, see Proc. Roy. Soc. London, 1910, $82 B$, vii-x.

- The cranial osteology of $A \mathrm{mia}$ calva. Journ. Anat. Physiol., London, $1877,11,605-622$. pl.

1877.1

Osteology of Polyodon folium. Proc. Roy. Soc London, 1878, 27, 454456. - Phil. Trans. Roy. Soc. London, 1878, 169, pt. 2, 683-733. 3 pls. Also separate; London, 1879.5 p. $4^{\circ}$.

1878.1

Pori abdominales of vertebrata. Journ. Anat. Phys., 1879, 14, 81-102.

1879.1

The air-bladder in certain siluroid fishes. Proc. Phil. Soc. Birmingham, $1890,6,131-136$.

1890.1

On the structure and function of the air-bladder in certain fishes. Proc.
Phil. Soc. Birmingham, 1890, 7, 144187.

1890.2

Some points in the cranial anatomy of Polypterus. Proc. Phil. Soc. Birmingham, 1890, 6, 118-130. 1890.3

On certain features in the skull of Osteoglossum formosum. Proc. Zool. Soc. London, 1895, 302-310. pl. 1895.1

The mesial fins of ganoids and teleosts. Journ. Iinn. Soc. London (Zool.), 1896, 25, 530-599; 600-602. 3 pls.

1896.1

The morphology of the skull in the Paraguayan Lepidosiren and other Dipnoi. Trans. Zool. Soc. London, $1897-$ 98, 14, 325-376. 2 pls. - Proc. Zool. Soc. London, 1897, pt. 3, 602-603.

1897.1

On the presence of ribs in Polyodon (Spatularia) folium. Proc. Zool. Soc. London, 1897, 722-724. 1897.2

-..- [Polyodon has cartilaginous ribs] Zool. Anz., 1897, 20, 240.

1897.3

The air-bladder and its connection with the auditory organ in Notopterus borneensis. Journ. Linn. Soc. London (Zool.), 1900, 27, 503-540. 2 pls. Abstract in Journ. Roy. Micr. Soc., London, 1900, 20, 452-453. $\quad 1900.1$

Fishes, exclusive of the systematic account of Teleostei. (In the Cambridge Natural History, volume on Fishes, etc., p. 139-537. London, 1904)

1904.1

Bridge, Thomas William, \& Haddon, Alfred C. Contributions to the anatomy of fishes. I. The air-bladder and WVeberian ossicles in the Siluridx. Proc. Roy. Soc. London, 1889, 46, 309-328. 1889.1

Contributions to the anatomy of fishes. II. The air-bladder and Weberian ossicles in the siluroid fishes. Phil. Trans. Roy. Soc. London, 1893, 184 B, 65-333. pls. Abstract in Proc. Roy. Soc. London, 52, 139-157. 1893.1

Note on the production of sounds by the air-bladder of certain siluroid fishes. Proc. Roy. Soc. London, 1894, 55, 439-441.

1894.1

Bridgman, H. H., \& Cayley, J.J. See Cayley \& Bridgman.

Briggs, $J . J$. Capture of large fishes on the Trent. Zoologist, 1843, 1, 323.

1843.1 
Notes on the birds, fishes and insects observed near St. Margaret's bay, Kent. Zoologist, 1852, 10, 36113613.

1852.1

Appearance of a fish supposed to be the fox-shark (Carcharias vulpes) off Scarborough. Zoologist, 1854, 12, 45134514.

1854.1

Remarks on Anacharis alsinastrum as a food for swans and an obstruction to the free migration of salmon. Zoologist, 1856, 14, 5161-5163. 1856.1

Brightman, Benjamin F. Statement concerning the menhaden fishery. Rept. U. S. Fish Comm. 1877 (1879), 5, 379.

1879.1

Brightman, Potter. Condition of the shore fisheries of Massachusetts and Rhode Island in 1871. Rept. U. S. Fish Comm.1871-72 (1873), 1, 70-71. 1873.1

Brigidi, Vincenzo, \& Tafani, Alessandro. Notizie preventive sullo sviluppo del sangue e dei vasi. Atti Soc. Tosc., Pisa, 1878, 3, 228-251. 2 pls. 1878.1

Brimley, C.S. On the mud minnow (Umbra pygmoea) as an air-breather. Amer. Naturalist, 1896, 30, 944. 1896.1

Brindley, $H . H$. On a specimen of the white bream (Abramis blicca Bloch) without pelvic fins. Proc. Zool. Soc. London, 1891, 1, 108-109. pl. 1891.1

Note on some abnormalities of the limbs and tail of dipnoan fishes. Proc. Phil. Soc. Cambridge, 1900, 10, 325-327. pl. Abstract in Journ. Roy. Micr.Soc., London, 1901, 21, 24-25.

1900.1

Brinkmann, Martin Cecilius August. Histologie, Histogenese und Bedeutung der Mucosa uteri einiger viviparer Haie und Rochen. Mitth. Zool. Station Neapel, 1903-04, 16, 365-408. 3 pls. 1903.1

Brinley, Francis. Condition of the shore fisheries of Massachusetts and Rhode Island in 1871. Rept. U. S. Fish Comm. 1871-72 (1873), 1, S. 1873.1

Brinton, William. Experiments and observations on the structure and function of the stomach in the vertebrate class. Proc. Roy. Soc. London, 1862, 11, $357-358$.

1862.1

Contains reference to digestion in fishes.

Brion, Cécile. Pisciculture, mémoire sur l'appareil rotatif Cécile Brion pour l'incubation des oufs fécondés et l'éle- vage de jeunes poissons. Verdun, 1866. $8^{\circ}$. 1866.1

Briot, A. Action hémolytique du venin de vive (Trachinus draco) C. R. Soc. Biol. Paris, 1902, 54, 1197-119s.

1902.1

Immunisation des lapins contre lc venin de la vive, et action préventive du sérum des animaux immunisés. C. R. Soc. Biol. Paris, 1902, 54, 1172-1174. 1902.2

Sur l'action du venin de la vive (Trachinus draco) C. R. Soc. Biol. Paris, 1902, 54, 1169-1171.

1902.3

Différence d'action venimeuse des épines dorsales et des épines operculaires de la vive. C. R. Soc. Biol. Paris, $1903,55,623-624$.

1903.1

- Etudes sur le venin de la vive (Trachinus draco) Journ. Phys. Path., Paris, 1903, 5, 271-282. 1903.2

La rascasse a-t-elle un venin? C. R. Soc. Biol. Paris, 1904, 57, 666-667. 1904.1

Sur l'existence d'une kinase dans le venin de la vive (Trachinus draco) C. R. Soc. Biol. Paris, 1904, 56, 1113-1114. 1904.2

Sur l'action soi-disant venimeuse de la rascasse. C. R. Assoc. Franc. Sci. 33. sess. 1904 (1905), 904.1905 .1

Briot, A., \& Gaver, F. von. Changements survenus dans la faune du vieux port de Marseille. C. R. Soc. Biol. Paris, 1905, 58, 1095-1097.

1905.1

Briquel, $M . P$. Les dents de Ceratodus. Bibliogr. Anat., Nancy, 1898, 6, 11-16. 2 figs. 1898.1

Demonstrates origin of dental plates through concrescence of tubercles.

Brisout de Barneville, Charles $N . F$. [1823-1893] Note sur le groupe des Gobiésoces. Rev. Zool., 1846, 143-146; 209-212. 1846.1

- Note sur les Diodoniens. Rev. Zool., 1846, 136-143. 1846.2

- Note sur les espèces du genre Lepadogaster de Gouän. Rev. Zool., 1846, 278-283.

1846.3

Note sur un nouveau genre de la famille des Discoboles (Trachelochismus) Rev. Zool., 1846, 212-213. $\quad 1846.4$

Note sur le genre Centropristis Cuv. Rev. Zool., 1847, 130-134. 1847.1 
Brisout de Barneville, $C . N . F$.

Note sur un nouveau genre d'anguilliformes (Ichthyapus) Rev. Zool., $1847,219-220$.

1847.2

Bristol, Charles Lawrence [1859-] The New York Aquarium. Pop. Sci. Monthly, 1901, 58, 405-412. $\quad 1901.1$

- Bermuda fishes. How they are brought to the aquarium. Bull. N. Y. Zool. Soc., 1903, no. 9, 77-91. 1903.1

- On the color-patterns of certain Bermuda fishes. Science, 1903, n. s. 17, 492.

1903.2

Bristol, Charles Lawrence, \& Carpenter, $F, W$. On the occurrence of Amphioxus at Bermuda. Science, 1900, n. s. 11,170 .

1900.1

Brito Capello, $F . A$. de, \& Barboza du Bocage, $J . V$. See Bocage \& Capello.

Brittain, Thomas [1806-1884] The sea-horse (Hippocampus brevirostris) Sci. Gossip 1873 (1874), 248-249. fig.

1873.1

Broadhead, $J . M$. Upon the abundance of fish on the New England coast in former times. Rept. U.S.Fish Comm. 1871-72 (1873), 1, 169-170. 1873.1

Broca, Pierre Paul de [1824-1880] Pêches maritimes, etc. Paris, 1865. 266 p. $18^{\circ}$.

1865.1

— The halibut fishery of the United States. Rept. U. S. Fish Comm. 187375 (1876), 3, 169-171.

1876.1

Brocchi, Paul [- 1898] Les pêcheries des côtes de l'Adriatique. Paris, 1880. figs. $4^{\circ}$.

1880.1

Les bordigues de Martigues. Paris, 1881. 35 p. fig. $4^{\circ}$. 1881.1

Rapport sur la pêche en Italie. Paris, 1883. $4^{\circ}$. 1883.1

Traité de zoologie agricole, comprenant des éléments de pisciculture, d'apiculture de sériciculture, d'ostréiculture, etc. Paris, 1886. 984 p. 603 figs. $8^{\circ}$.

1886.1

Note sur l'état actuel de la pisciculture d'eau donce. Bull. Soc. Centr. Aquicult., 1889, 1, 6.

1889.1

Sur les causes qui ont amené la disparition du saumon dans la Meuse française. Bull. Soc. Centr. Aquicult., $1889,1,64$.
Des étangs en général et observations faites dans la Dombes sur leur exploitation. Bull. Soc. Centr. Aquicult., 1890, 2, 183-207. Also separate; Paris, 1891. $8^{\circ}$.

1890.1

-... Le saumon ordinaire (Salmo salar) Bull. Soc. Centr. Aquicult., 1892, 4, 65. Also separate; Lille \& Paris, 1892. $8^{\circ}$.

1892.1

Note sur la pisciculture dans les départements de la Savoie et de la HauteSavoie. Bull. Soc. Centr. Aquicult., 1893, 5, 120-137.

1893.1

_ Note sur la pisciculture dans le département de l'Isère. Bull. Soc. Centr. Aquicult., 1894, 6. 1894.1

—- Note sur l'établissement de pisciculture d'Amiens. Bull. Soc. Centr. Aquicult., 1894, 6.

1894.2

La pisciculture dans les eaux douces. Paris, 1896. 328 p. 126 figs.

1896.1

Review in Bull. Soc. Centr. Aquicult. 1596, 8, 81-82.

Broch, Hjalmar. Undersogelser over sild in aarene 1904-1906. Norsk Fisket. Bergen, 1907, 26, 15-19. 1907.1

Norwegische Heringsuntersuchungen während der Jahre 1904-1906. Unsere Heringsstämme und ihre Wanderungen. Bergens Mus. Aarbog, 1908 no. 1. 69 p. 5 pls.

1908.1

__ Sind die Heringsstämme erbliche

Rassen? Zool. Anz., 1908, 33, 68-69. 2 figs.

1908.2

Broch, O. J. Statistiske Tabeller vedkommende Saltvandsfiskerierne og Saelfangsten i Tillaegget. (In Kongeriget Norge Norske Fold, dets sociale Forhold, Sundhedstilstand, Naeringsveie, Redningsvaesen, Sam faerdselsmidler og Ekonomi. Christiania, 1876. p. $71-75$ )

1876.1

Sur les variations observées dans la pêche du hareng sur les côtes de Norvège. C. R. Acad. Sci. Paris, 1882, $94,823-826$.

1882.1

Brock, J. Ueber den Eierstock de Knochenfische. Sitzber. Phys. Med. Soc. Erlangen, 1877, Heft 9, 118-119.

1877.1

Beitrïge zur Anatomie und - Histologie der Geschlechtsorgane der Knochenfische. Morphol. Jahrb., 1878, 4, 505-572. $2 \mathrm{pl}$.
1878.1 
Untersuchungen über die Geschlectsorgane einiger Murmoiden. Mitth. Zool. Stat. Neapel, 1881, 2, 415494. pls. xviii-xx.

1881.1

Ueber Terminalkörperchen ähnliche Organe in der Haut von Knochenfischen. Intern. Monatschr. Anat. Phys., $1887,4,301-311$. pl.

1887.1

Ueber Anhangsgebilde des Urogenitalapparates von Knochenfischen. Zeitschr. Wiss. Zool. 1887 (18S8), 45, 532-541. pl.

1888.1

Brockmann, Heinrich. De pancreate piscium. Inaug. Dissert. Rostochii, 1846. 24 p. pl.

1846.1

Broderip, William John [1789-1859] [Remarks on drawings of three teleosts from Port Praya, with description of a new species, Acanthurus kingii] Proc. Zool. Soc. London, 1835, 3, 119. 1835.1

—Z Zoological recreations. London, 1847. viii, 380 p. $8^{\circ}$. 1847.1

A second edition was published at London in 1848, and a third in 1849. The work contains some notes on fishes previously printed in the New Monthly Magazine.

Brodgen, $T . J . H$. Fish of the Lincolnshire wash and fenland. Naturalist, $1899,357-361$.

1899.1

Brodie, Peter Bellinger [1815-1897] On the Upper Keuper sandstone (included in the New Red marl) of Warwickshire. Quart. Journ. Geol. Soc. London, 1856, 12, 374-376.

1856.1

- Note on the occurrence of a new species of fish in the Upper Keuper sandstone in Warwickshire. Quart Journ. Geol. Soc. London, 1858, 14 , 165-167. pl.

1858.1

- On the discovery of fossil fish [Semionotus brodiei] in the New Red Sandstone (Upper Keuper) in Warwickshire. Rept. Brit. Assoc. Adv. Sci., 56. meet., 1886, 629 .

1886.1

Notes on the Upper Keuper section at Shrewley, where the fish were found, and on the Trias generally in Warwickshire. Quart. Journ. Geol. Soc. London, 1887, 43, 540-542.

1887.1

On some additional remains of cestraciont and other fishes in the green gritty marls immediately overlying the red marls of the Upper Keuper in $\mathrm{W}$ arwickshire. Quart. Journ. Geol. Soc. London, 1893, 49, 171-174. Abstract in Ann. Mag. Nat. Hist., 11, 259. 1893.1
Brögger, A.W. Vistefundet en ældre stenalders kjøkkenmedding fra Jxderen. Stavanger, 1908. 102 p. 5 pls. \& 20 figs. $8^{\circ}$.

1908.1

Broers, H.J. Hengelen, en wat er bij valt op te merken. Album Natuur, $1876,163-194 ;$ 195-201. figs. 1876.1

Brofeldt, Pelka. Epämuodostuneista hauenpäistä [Ueber missgebildete Köpfe von Esox lucius] Meddel. Soc. Fauna Flora Fennica, Helsingfors, 1912 , $38,13-16 ; 199-200$.

1912.1

Brohl, Engelbert. Die sogenannten Hornfäden und die Flossenstrahlen der Fische. Jena. Zeitschr. Naturw., 1909, 45, 345-380. 2 pls. \& 5 figs. $\quad 1909.1$

Brohmer, Paul. Das Fxkretionssystem eines Embryos von Chlamydoselachus anguineus Garm. Anat. Anz., 1908, 33, 621-627.

1908.1

Die Sinneskanäle und die Lorenzini'schen Ampullen bei Spinax-Embryonen. Anat. Anz., 1908, 32, 25-40. \& figs.

1908.2

- Der Kopf eines Embryos von Chlamydoselachus und die Segmentierung des Selachierkopfes. Jena. Zeitschr. Naturw., 1909, 44, 647-698. 4 pls. \& 15 figs.

1909.1

Broili, Ferdinand. Ueber Diacranodus texensis Cope (=Didymodus? compressus Cope) Neues Jahrb. Mineral., 1904, Beilage Bd. 19, 467-484. 2 pls. 1904.1

Broman, Ivar. Ueber Bau und Entwickelung von physiologisch vorkommenden atypischen Spermien. Anat. Hefte, 1902, 18, 507-547. 11 pl. 1902.1

Ueber die Entwickelung der Mesenterien, der Leberligamente und der Leberform bei den Lungenfischen. (In Semon, R. Zoologische Forschungsreisen in Australien und dem Malayischen Archipel ... in den Jahren 1891-1893. Jena, 1905, vol. i, pt. 5, 585-640. pl. \& 54 figs. - Also in Jena. Denkschr., 1905, 4)

1905.1

Brongniart, Alexander [1770-1847] On the occurrence of a fossil fish (Paloothrissum freieslebenensi Blainville) in the bituminous formation of Westfield, Mass. Amer. Journ. Sci. Arts, 1821, 3, 220-221.

1821.1

Brongniart, Charles Jules Edme. For biography, see Bull. Soc. Linn. Normandie, Caen, 1899, 3, lxi.-Geol. 
Brongniart, $C . J, E$.

Mag., 1900, 7, 430-431. - Quart. Journ. Geol. Soc., 1900, 56, liii.-Ottawa Naturalist, $1900,14,174$.

Notice sur quelques poissons des lignites de Ménat. Bull. Soc. Linn. Normandie, Caen, 1880, 4, 353-358. 1880.1

Faune ichthyologique. Pt. 1. [Contained in "Etudes sur le terrain houiller de Commentry," by H. Fayol, E. Sauvage and others] Bull. Soc. Indus. Miner., 1888, 3. sér. 2, 3-38. Also separate; St. Etienne, 1888. 1888.1

- Sur un nouveau poisson fossile du terrain houiller de Commentry (Allier) [Pleuracanthus gaudryi] C. R. Acad. Sci. Paris, 1888, 106, 1240-1242. - Rev. Scient. Bourbon., 1, 127-132. figs. Abstract in Rev. Scient., 41, 568 . - Bull. Soc. Géol. France, 16, 546-550.

1888.2

Bronn, Heinrich Georg [1800-1862] Ueber die Fisch-Abdrücke in EisensteinNieren des mittel-rheinischen Steinkohlen Gebirges und über Palooniscum macropterum n. sp. insbesondere. Zeitschr. f. Mineral., 1829, 2, 483-494. Bull. Sci. (F'érussac), 20, $410 . \quad 1829.1$

Ueber zwei fossile Fischarten: Cyprinus coryphanoides und T'etragonolepis semicinctus aus dem Gryphitenkalke bei Donau-Eschingen. Neues Jahrb. Mineral., 1830, 14-30. pl.Bull. Sci. (Férussac), 22, 140. 1830.1

Lethra geognostica, oder Abbildungen und Beschreiben der für die Gebirgs-Formation bezeichnendsten Versteinerungen. Stuttgart, 1834-37. Text in $8^{\circ} \&$ atlas in fol.

1834.1

- Index palæontologicus, oder Uebersicht der bis jetzt bekannten fossilen Organismen. 2 vols. in 3 . Stuttgart, $1848-49.8^{\circ}$.

1848.1

Beiträge zur triasischen Fauna und Flora der bituminösen Schiefer von Raibl in Kärnthen. Neues Jahrb. Mineral., 1858, 1-32; 129-144. - Verh. Nat. Med. Ver. Heidelberg, 1857-59, 108-110. - Jahrb. Lit. Heidelberg, 1858, $342-344$.

1858.1

Die Klassen und Ordungen des Thier-Reichs wissensehaftlich dargestellt in Wort und Bild. 6 vols. Leipzig \& Heidelberg, 1859-1907. illustr. $8^{\circ}$. 1859.1

Fische, 13d. vi, 1. Abth., 1876-1903.
Die Filassen und Ordnungen des Thierreichs wissenschaftlich dargestellt ... fortgesetzt von W. Keferstein [and others] 6 vols. Leipzig \& Heidelberg, 1859-74. 1874.1

Pisces, von A. A. W. Hubrecht [und MI. Sagemehi] Vol, vi. For later editions, see $\mathbf{F a}$ varo, $G_{.}$, and Favaro \& Mozajko.

Brons, Bernhard. Die Lofotenfischerei. Naturf. Ges. Emden, 1894, 78. Jahresb., 79-100.

1894.1

Bronson, $E$. D. Parasites on trout. Forest \& Stream, 1876, 6, 401. $\quad 1876.1$

Brook, George [1857-1893] Salmon disease in the Eden. Naturalist, Huddersfield, 1877-78, n. s. 3, 145-147. pl. 1877.1

Notes on the salmon disease in the Esk and Eden. Trans. Bot. Soc. Edinb., 1879, 13, 389-394. 1879.1

Development of pelagic fish-eggs. Nature, 1885, 30, 601. 1885.1

Ichthyological notes. Rept. Fish. Board Scotland, 1885, 222-227. pl. 1885.2

On some points in the development of Motella mustela L. Journ. Linn. Soc. London (Zool.), 1885, 18, 298-307. pls. Abstract in Journ. Roy. Mier. Soc., London, 5, 785-786.

1885.3

On the development of the herring. Rept. Fish. Board Scotland, 1885, App. $F, 32-51$. pl.

1885.4

Preliminary account of the development of the lesser weever fish [Trachinus vipera] Journ. Linn. Soc. London (Zool.), 1885, 18, 274-291. 4 pls. Abstract in Journ. Roy. Mier. Soc., 5, 34-35.

1885.5

Preliminary account of the food of the haddock. Rept. Fish. Board Scotland, 1885, 128-134.

1885.6

The spawning period of the British food fishes. Rept. Fish. Board Scotland, 1885, 242-254.

1885.7

Sur l'origine de l'hypoblaste dans les oufs des téléostéens pélagiques. Arch. Zool. Expér., 1885, 2. sér. 3, xxixxiii. - Quart. Journ. Micr. Sci., n. s. 25, 29-36.

1885.8

Notes on the British species of Zeugopterus, Proc. Roy. Phys. Soc. Edinb., 1886, 9, 362-369. 3 pls. 1886.1 
The formation of the germinal layers in Teleostei. Trans. Roy. Soc. Edinb. 1887, 33, pt. 1, 199-239. Abstract in Proc. Roy. Soc. Edinb., 1887, 13, 590-591.

1887.1

Notes on the larval stages of Motella. Proc. Roy. Phys. Soc. Edinb., 1887, 10, 156-161. pl.

1887.2

On the relation of yolk to blastoderm in teleostean fish ova. Proc. Roy. Phys. Soc. Edinb., 1887, 9, 187-193. Abstract in Journ. Roy. Micr. Soc., London, 1887, pt. 2, 211.

1887.3

Note on the epiblastic origin of the segmental duct in teleostean fishes and in birds. Proc. Roy. Phys. Soc. Edinb. 1886-87 (1888), 14, 368-370.

1888.1

Notes on the British species of Lepadogaster, and on the development of the vertical fins. Proc. Roy. Phys. Soc. Edinb., 1890, 10, 161-168. pl.

1890.1

IOnos cimbrius L. or Gadus cimbrius L.] Proc. Roy. Phys. Soc. Edinb., 1890,10 , pt. $1,157-161$. pl. 1890.2

Brook, George, \& Calderwood, W. $L_{\text {s. }}$. See Calderwood \& Brook.

Brook, George, \& Ewart, J.C. See Ewart \& Brook.

Brook, George, \& Scott, T. List of the marine fauna collected at the Tabert laboratory during 1885. Pt. 1. [Fishes] Rept. Fish. Board Scotland, 1885, 232234.

1885.1

Brookes, Richard. A new and accurate system of natural history. 6 vols. London, 1763. illust. $12^{\circ}$.

1763.1

Vol. iii. The history of fishes and serpents, etc. $\mathrm{xxi}^{4}, 408 \mathrm{p}$. pls.

The same. 2. ed. $\begin{array}{r}\text { London, } \\ 1773.1\end{array}$
$\begin{array}{r}\text { 1773. The same. } 3 . \text { ed. London, } \\ 1790.1\end{array}$

Brookover, Charles. Pinkus's nerve in Amia and Lepidosteus. Science, 1908, n. s. 27, 913-914.

1908.1

The olfactory nerve, the nervus terminalis and the preoptic sympathetic system in Amia calva. Science, $1909, \mathrm{n}$. s. 29, 713-714

1909.1

The olfactory nerve, the nervus terminalis and the preoptic sympathetic system in Amia calva L. Journ. Comp. Neurol., 1910, 20, 49-11s. pl. \& 32 figs.

1910.1

Brookover, Charles, \& Jackson, Theron S. The olfactory nerve and the nervus terminalis of Ameiurus. Journ. Comp. Neurol., 1911, 21, 237-259. 15 figs.

1911.1

Brookover, Charles, \& Sheldon, Ralph Eduard. See Sheldon \& Brookover.

Brooks, H. St.John. The osteology and arthrology of the haddock (Gadus aglefinus) Proc. Dublin Soc. Sci., 1885, 4, 166-196. 5 pls. 1885.1

Brooks, William Keith [1848-1908] For biographical notice, see Andrews, $E$. A., in Science, 1908, n. s. 28, 777-786. Also article by Andrews \& Conklin in Journ. Exper. Zool., 1910, 9, 1-52. portr.

- Development of unfertilized eggs of vertebrates and mollusca. Amer. Naturalist, 1877, 11, 622-623. 1877.1

Alternation of periods of rest with periods of activity in the segmenting eggs of vertebrates. Johns Hopkins Univ. Studies, 1883, 2, 117-118. pl.

1883.1

- Artificial propagation of seafishes. Pop. Sci. Monthly, 1889, 35, $359-367$.

1889.1

The genus Salpa. With a supplementary paper by Maynard $M$. Metcalf. Mem. Johns Hopkins Univ., 1893, 2, 1-396. 57 pls. \& 28 figs. Abstract in Zool. Centralbl., 1895, 1, 900-908.

1893.1

Origin of the chordata in the genus Salpa. Mem. Biol. Lab. Johns Hopkins Univ., 1893, 178-203. 1893.2

-_. 'The origin of the food of marine animals. Bull. U. S. Fish Comm. 1893 (1894), 13, 87-92. 1893.3

- The old naturalist-Conrad Gesner (1516-1565) Pop.Sci. Monthly, $1895,47,49-59$. 1895.1

Broom, Robert. On a species of Colacanthus from the Upper Beaufort beds of Aliwal North. Rec. Albany Mus. Grahamstown, S. Africa, 1905, 1, 338339.

1905.1

On the geological horizons of the vertebrate genera of the Karroo formation. Rec. Albany Mus. Grahamstown, S. Africa, 1907, 2, 156-163.

1907.1 
Broom, $R$.

- An attempt to determine the horizons of the fossil vertebrates of the Karroo. Ann. South Afric. Mus., 1909, 7, 285-289.

1909.1

- The fossil fishes of the Upper Karroo beds of South Africa. Ann. South Afric. MIus., 1909, 7, 251-269. 2 pls.

1909.2

- On some fossil fishes in the collection of the Albany Museum. Rec. Albany Mus. Grahamstown, S. Africa, 1912, 2, 391-393. 1912.1

On some fishes from the Lower and Middle Karroo beds. Ann. South Afric. Mus., 1913, 12, 1-5. pl. \& fig. Trans. Roy. Soc. South Africa, 1913, 3, 399-402. 3 pls.

1913.1

On some fossil fishes from the diamond-bearing pipes of Kimberley. Trans. Roy. Soc. South Africa, Cape Town, 1913, 3, 399-402. 3 pls. 1913.2

On the origin of the cheiropterygium. Bull. Amer. Mus. Nat. Hist., 1913, 32, 459-464. 6 figs.

1913.3

Describes the pectoral arch in Sauripterus taylori Hall. For further discussion, see Gregory, W. K., in Ann. N. Y. Acad. Sci., 1915, 26, 360-364.

On the structure of the mandible in the Stegocephalia. Anat. Anz., 1913, 45, 73-78.

1913.4

Contains some references to fishes.

Brotherson, Andrew. The Greenland shark, Lamargus borealis, and its parasite Lernoa elongata. Nat. Hist. Club, Berwick, 1879, 8.

1879.1

Sea trout or common trout. The Carham pond experiments (1880) Nat. Hist. Club, Berwick, 1882, 9. 1882.1

The salmon disease. (In Herbert, David (editor) . Fish and fisheries, p. 172179. Edinburgh, 1883. $8^{\circ}$ ) 1883.1

Brougham, W. H. Fish culture for the Thames. Fish. Gazette, 1877, n. s. 2,4 .

1877.1

_- The Norfolk and Suffolk broads. Fish. Gazette, 1877, n. s. 2, 3-4. 1877.2

- Fish culture at Chertsey bridge. Fish. Gazette, 1878, n. s. 2, 121. 1878.1

- Salmonidre for the 'Thames. Fish. Gazette, 1878, n. s. 2, 196.1878 .2

- Freshwater fish. 'The bream. Fish. Gazette, 1879, n.s. 3, 14-15. 1879.1
The pike or jack. Fish. Gazette, 1879 , n. s. 3, 86-87; 97-98. $\quad 1879.2$

The Thames trout. Fish. Gazette, 1879 , n. s. 3, 121-122. 1879.3

Broussonet, Pierre Marie Auguste [1761-1807] Mémoire sur les différentes espèces de chiens de mer. Mém. Acad. Sci. Paris, 1780, 641-680. - Journ. Phys., 26, 51-67; 120-131. 1780.1

Account of the Ophidium barbatum Linn. Phil. 'Trans. Roy. Soc. London, 1781, 71, 436-448. - Trans. Linn. Soc. London (Zool.), 5, 279. 1781.1

Ichthyologia, sistens piscium descriptiones et icones. Decas i. London [1782] iv, 41 p. 11 pls. $4^{\circ}$. 1782.1

No more published.

Mémoire sur le trembleur, espèce peu connue de poisson électrique. Mém. Acad. Sci. Paris, 1782, 692-698.-Journ. Phys., 27, 139-143. - Leipzig. Mag., $1786,305-312$.

1782.2

Mémoire pour servir à l'histoire de la respiration des poissons. Mém. Acad. Sci. Paris, 1785, 174-196. Journ. Phys., 31, 289-304.

1785.1

Observations sur le loup marin (Anarrhichas) Mém. Acad. Sci. Paris, 1785, 161-169. pl.

1785.2

Observations sur les vaisseaux spermatiques des poissons épineux. Mém. Acad. Sci. Paris, 1785, 170. 1785.3

Mémoire sur la régéneration de quelques parties du corps des poissons. Mém. Acad. Sci. Paris, 1786, 684-688. - Journ. Phys., 1786, 35, 62. 1786.1

Mémoire sur le voilier [IIstiophorus velifer] Mém. Acad. Sci. Paris, 1786, 450-455. pl.

1786.2

Observations sur les écailles de plusicurs espèces de poissons qu'on croit communément dépourvus de ces parties. Journ. Phys., 1787, 31, 12-19.

1787.1

Brouwer, Emil de. Rapport sur l'exposition internationale d'appareils de pêche, qui a eu lieu à Amsterdam, en 1861. Ostende, 1862. 68 p. 10 figs. $8^{\circ}$.

1862.1

Rapport sur l'exposition internationale d'appareils de pêche, qui a eu lieu à Bergen en Norvège, en 1865. Ostende, 1866.135 p. $8^{\circ}$. 1866.1 
L'exposition internationale de pêche de Boulogne-sur-mer. Ostende, 1868. 282 p. 16 pls. $8^{\circ}$. 1868.1

Brown, Albert $W$. On Tetracotyle petromyzontis, a parasite of the brain of Ammocoetes. Quart. Journ. Micr. Sci., 1899, n. s. 41, 489-498. pl. 1899.1

Brown, Alexander $B$. Do salmon feed in fresh water? The question viewed from the histological characters of the gut. Zool. Anz., 1898, 21, 514-515; $517-523$.

1898.1

Brown, Alfred W. The fishes of loch Lomond and its tributaries. Scott. Natural., 1891, 1, 114-124.

1891.1

Char (Salmo alpinus) in loch Lomond. Ann. Nat. Hist. Scot., 1896, 192.

1896.1

- Some observations on the young scales of the cod, haddock and whiting before shedding. Proc. Roy. Soc. Edinb., 1903, 24, 437-438.

1903.1

Brown, Barnum [1873-] Notes on Cuban fresh-water fishes. Science, 1913 . n. s. 37, 667-66s.

1913.1

Brown, Campbell. Ueber das Genus Hydobus und seine systematische Stellung. Palaontogr., 1900, 44, 149-174. 2 pls. \& 7 figs. Abstract in Zool. Centralbl., 7, 471-478.

1900.1

Brown, Francis $H$. Some observations on the fauna of Madeira. Proc. Boston Soc. Nat. Hist., 1869, 12, 205214.

1869.1

Brown, Guillermo. Servicios de bosques, pesca i caza en Australia i Nueva Zelanda. Boletin de Bosques, Pesca i Caza, Santiago, 1912, 1, 318-323.

1912.1

Brown, J. Alexander. See HarvieBrown, $J$. A.

Brown, John Coggin. Note on $J a-$ nassa bituminosa Schlot, from the Marl Slate, Thickley, Durham. Naturalist, 1905, 220-222. pl.

1905.1

Brown, $J . J$. 'The American angler's guide. New York, 1876. $8^{\circ}$. 1876.1

Brown, Orville $H$. The immunity of Fundulus eggs and embrvos to electrical stimulation. Amer. Journ. Physiol. 1903, 9, 111-115.

1903.1

The permeability of the membrane of the egg of Fundulus heteroclitus.
Amer. Journ. Physiol., 1905, 14, 354358.

1905.1

Brown, Richard. Notes on the northern Atlantic for the use of travellers; compiled from authentic sources. London, 1880 . viii, 142 p. $12^{\circ}$. 1880.1

Contains ehapters on the cod fisheries, herring and mackerel fisheries, etc.

Brown, Robert. Notes of the third capture of Scymnus [Lomargus] borealis Flem off the Scottish coast. Zoologist, $1860,18,6861$.

1860.1

Observations on the medicinal and economical value of the oulachan (Osmerus pacificus Richardson) Pharm. Journ. \& Trans., 1868, 9, 583. 1868.1

- (editor) Danish Greenland, its people and its products. London, 1877. $8^{\circ}$.

1877.1

Synopsis of the Greenland fauna, by Henry Rink, p. 429-463.

Brown, Thomas [1778-1820] A description of the Exocotus volitans. Phil. Trans. Roy. Soc. London, 1778, 68, 791800. figs.

1778.1

Brown, (Captain) Thomas. Description of a new species of British fish (Platessa carnaria) Edinb. Journ. Nat. \& Geogr. Sci., 1830, 2, 99. - Bull. Sci. Nat. (Férussac), 23, 272.

1830.1

Zoologist's text-book, embracing the characters of the classes, orders, and genera, of almost the whole animal kingdom. 2 vols. London, 1832. 107 pls. $12^{\circ}$.

1832.1

Popular natural history; or the characteristics of animals portrayed in a series of illustrative anecdotes. 3 vols. London [1835?] $12^{\circ}$.

1835.1

Fishes in general, vol. iii, p. 99-206. pls.

Brown, William. The natural history of the salmon, as ascertained by the recent experiments in the artificial spawning and hatching of the ova and rearing of the fry, at Stomont field on the Tay. Glasgow, 1862.136 p. 2 pls. $8^{\circ}$.

1862.1

The history of the salmon. Intell. Observ., 1863, 2, 1S8-190. 1863.1

Brown, W. H. Dates of publication of "Recherches sur les poissons fossiles " ... par L. Agassiz. (In Woodward, A. S., \& Sherborn, C. D. A catalogue of British fossil vertebrata, p. xxv-xxxv. London, 1890) 
Browne, Alexander Montagu. Notes on the vertehrate animals of Leicestershire [Fish] Zoologist, 1887, 45, 59-61. 1887.1

On a fossil fish (Chondrosteus) from Barrow-on-Soar hitherto recorded only from Lyme Regis. 'Trans. Soc. Litt. Phil. Leicester, $1889,16-36.2$ pls. \& 3 figs.

1889.1

_._ - The vertebrate animals of Leicestershire and Rutland. London, 1889. 223 p. 4 pls. \& map. $S^{\circ}$. 1889.2

- Revision of a genus of fossil fishes, Dapedius. 'Trans. Soc. Litt. Phil. Leicester, 1890, 196-203. pl. 1890.1

- Notes upon Colobodus, a genus of Mesozoic fossil fishes. Rept. British Assoc. Adv. Sci., 61. meet., 1891, 644 645 .

1891.1

- On some vertebrate remains not hitherto recorded from the Rhxtic beds of Britain. Rept. British Assoc. Adv. Sci., 63. meet., 1893, 748-749. 1893.1

Browne, Frank Balfour. Report on the eggs and larva of teleostean fishes observed at Plymouth in the spring of 1902. Journ. Marine Biol. Assoc., Plymouth, 1903, 2. ser. 6, 598-625. pl.

1903.1

On the early stages in the life histories of certain freshwater fishes. Trans. Norfolk Norwich Natural. Soc., 1907, 8, 478-488. 10 figs.

1907.1

-_. The North Sea fisheries investigations. Nature, 1908, 77, 523-524.

1908.1

Browne, $F$. Balfour, \& Garstang, Walter. See Garstang \& Browne.

Browne, (Rev.) P. W. Where the fishers go: the story of Labrador. New York, 1909. xxiv, 366 p. map \& figs. 1900.1

Browne, Patrich [1720?-1790] Catalogue of the fish of Ireland. Shaw's London Mag., or Gentleman's Month. Intelligencer, 1774.

1774.1

The civil and natural history of Jamaica, etc. 2. ed. London, 1789. viii, 490 p. map. fol. 1789.1 1756 .

The first edition was published at London in

Browne, (Sir) Thomas [1605-1682] An account of fishes found in Norfolk and on the coast. (In his collected works. 4 vols. London \& Norwich, 1835)

1835.1
Notes and letters on the natural history of Norfolk, more especially on the birds and fishes, from manuscript ... in the Sloane Collection in the Library of the British Museum and in the Bodleian Library, Oxford; with notes by Thomas Southwell. London, 1902. xxvi, 104 p. $\mathrm{S}^{\circ}$.

1902.1

Notes on fishes of Norfolk, p. 31-56.

Brown-Sêquard, Charles Edouard. For biography and works, see Arch. Physiol., 1894, 6, 501-516. - Biol. Centralbl., 1894, 14, 785-800. - Rept. Smithsonian Instit., 1898, 677-696.

Recherches expérimentales sur l'influence excitatrice de la lumière, du froid et de la chaleur sur l'iris, dans les cinq classes d'animaux vertébrés. Journ. Physiol., 1859, 2, 281-294; 451-460. 1859.1

- De la poche musculaire orbitaire des poissons pleuronectes (Pleuronectidx) C. R. Soc. Biol. Paris 1869 (1870), 5. sér. 1, 199.

1870.1

Browntree, Walter $S$. On some points in the visceral anatomy of the Characinidx, with an inquiry into the relations of the ductus pneumaticus in the Physostomi generally. Trans. Linn. Soc. London (Zool.), 1903, 9, 47-81. pls. 1903.1

Bru de Ramon, J.B. Colección de laminas que representan los animales $\mathrm{y}$ monstruos del real gabinete de historia natural de Madrid. 2 vols. Madrid, 1786. fol.

1786.1

Bruce, James [1730-1794] Travels to discover the source of the Nile, in the years 1768-1773. 7 vols. Edinburgh \& London, 1790. pls. \& maps. 1790.1

Descriptions of the "binny " and the method of fishing for it, p. 211-215.

A French translation of this work was published at Paris in 1790, and a German version at Leipzig in 1791. There are two later English editions.

Bruce, W.S. The fishes of the coast Arctic Expedition. Rept. Brit. Assoc. Adv. Sci., 71. meet., 1902, 687. 1902.1

Bruch, Carl W.L. [1820?-1884] Ueber die Mikropyle der Fische; aus einem Sendschreiben an C. Th. v. Siebold. Zeitschr. Wiss. Zool., 1856, 7, 172-175. figs.

1856.1

Ueber die Mittelhand der Fische. Zeitschr. Wiss. Zool., 1861, 11, 165-169. pl.

1861.J 
Ueber osteologische Gattungscharactere beim Karpfengeschlecht. Würzburg. Naturw. Zeitschr., 1861, 2, 86-91.

1861.2

Vergleichende Osteologie des Rheinlachses (Salmo salar L.) mit besonderer Berücksichtigung der Myologie nebst einleitenden Bemerkungen über die skelettbildenden Gewebe der Wirbelthiere. Mainz, 1861. 22 p. 7 pls.

1861.3

A second edition was published at Mainz in 1875. 25 p. 7 col. pls.

Vergleichung des Schädels mit der Wirbelsäule des Laches, mit einer Aufzählung sämmtlicher Skelettheile desselben nach der Art ihrer Zusammensetzung. Abh. Senckenb. Naturf. Ges., 1862-63, 4, 73-131. Also separate; Frankfurt-a.-Main, 1862. 1862.1

- Ueber die Bedeutung der Fischflossen. Ber. (Offenbach), 1865, 6, 3852.

1865.1

Bruch, Edmond. Ftudes sur l'appareil de la génération chez les sélaciens. Inaug. Dissert. Strasbourg, 1860. 79 p. $11 \mathrm{pl}$. $4^{\circ}$,

1860.1

Brücher, $K$. Biologisches aus Neapel. Jahrb. Nassau Ver. Nat., Wiesbaden, 1912, 65. Jahrg., 99-124. 17 figs.

1912.1

Brügger, Ch.G. Naturgeschichtliche Beiträge zur Kenntniss der Umgebung von Chur. Pisces. Chur, 1874. 1874.1

Brühl, CarlBernhard. Osteologisches aus dem Pariser Pflanzengarten. Wien, 1856. 76 p. 11 pls.

1856.1

Zootomie aller Thierklassen, nach Autopsien skizzirt. Lief. 1-40. Wien, 1877-88. 160 pls. fol. 1877.1

Zur Osteologie der Knochenfische, nach Materialien aus dem Pariser Pflanzengarten. Berlin, 1887. xliii, 76 p. 11 pls. \& 150 figs. 4․ 1887.1

- Amia- und Hydrocyon-Unterkiefer. Wien, 1891. pl. 4\% 1891.1 pl. $4^{\circ}$

Balistes-Skelet. Wien, 1891. 1891.2

- Dipnoi- und Holocephalikopf. Wien, 1891. 7 pls. $4^{\circ}$.

1891.3

Karpfen-Skelet. Wien, 1891. 2 pls. $4^{\circ}$. 1891.4

Labrax- und PleuronectidenKopf. Wien, 1891. 6 pls.
Brühl, Ludwig. Photographien lebender Fische. Sitzber. Ges. Naturf. Freunde Berlin, 1900, no. 4, 142-144.

1900.1

Bericht über die in fischereilicher Beziehung wichtigen Vorträge auf dem 5. Internationalen Zoologen Kongress zu Berlin vom 12.-16. August 1901. Fischerei Zeitung, Neudamm, 1901, 4, $753-759 ; 770-773 ; 786-789 ; 802-803$.

1901.1

Der Lachs in Europa, Asien und Amerika. Helios, Frankfurt a. Oder, 1910, 26, 25-26.

1910.1

Brüning, Christian. Eleotris maculata. Natur u. Haus, Dresden, 1902, 10 , 305-307. 2 figs.

1902.1

Brutpflege bei den Fischen. Nerthus, 1903, 5. Jahrg., 399-402.

1903.1

Fischwaffen. Natur u. Haus, Dresden, 1903, 12, 23-25. 6 figs. 1903.2

Die Gattung Poccilia. Natur u. Haus, Dresden, 1903, 11, 364-366.

1903.3

Pastellen eines Fisches. Natur u. Haus, Dresden, 1903, 11, 188-189.

1903.4

Zur Fischfauna der Süssgewässer Deutsch-Ost-Afrikas. Blätt. Aquarienkunde, Magdeburg, 1903, 14, 301-305. 1903.5

- Polyacanthus cupanus. Blätt. Aquarienkunde, Magdeburg, 1904, 15, $104-105$.

1904.1

Rhinichthys atronasus. Natur u. Haus, Dresden, 1904, 12, 164-166. fig. 1904.2

- Amerikanische Volksnamen der Süsswasserfische. Blätt. Aquarienkunde, Magdeburg, 1905, 16, 61-64. 1905.1

Die Familie der Kletterfische. Natur u. Haus, Dresden, 1905, 13. Jahrg., 344-346. 2 figs. 1905.2 _ Die Familie der Osphromenidæ. Natur u. Haus, Dresden, 1905, 14. Jahrg., 52-54. fig.

1905.3

- Z Haus, Dresden, 1905, 13. Jahrg., 129130. 2 figs. 1905.4

- Versuche uiber das Hören der Fische. Natur u. Haus, Dresden, 1906, 14 Jahrg., 312-313. 1906.1 
Brüning, $C$.

Eigentümliche Flossenbildungen bei Suisswasserfischen. Natur u. Haus, Dresden, 1907, 15. Jahrg., 260-263. 15 figs.

1907.1

Malapterurus electricus Lac. Blätt. Aquarienkunde, Stuttgart, 1908. 19, 667-671.

1908.1

Amerikanische Characiniden. Nochenschr. Aquar.-Terrar. Kunde, 1910, 7. Jahrg., 541-543. 3 figs. 1910.1

Amerikanische Zahnkarpfen. I. Allgemeine Uebersicht. Wochenschr. Aquar.-Terrar. Kunde, 1910, 7. Jahrg., 3-6. 4 figs. II. Die Poecilinx. Ibid., 57-59. 19 figs. Anableps tetrophthalmus von Klingelhöffer. Ibid. 62. III. Characodontina. Ibid., 117-118. 5 figs. IV. Cyprinodontinx. Ibid., 161-162.2 figs.

1910.2

- Die Gattung Enneacanthus (Gill) IVochenschr. Aquar.-Terrar. Kunde, 1910, 7. Jahrg., 642-643.

1910.3

"Neuheiten" im geheizten Seewasser. Wochenschr. Aquar-Terrar. Kunde, 1910, 7. Jahrg., 457-459. 3 figs 1910.4

Panzerwelse.

Wochenschr. Aquar-Terrar. II unde, 1910, 7. Jahrg. 685-687. 3 figs.

1910.5

Afrikanische Anabantidx. Wochenschr. Aquar--Terrar. Kunde, 1911, 8. Jahrg., 305-307. fig.

1911.1

Dorichthys. Bekannte Fremdlinge. Wochenschr. Aquar.-Terrar. Kunde, 1911, 8. Jahrg., 461-463. fig. 1911.2

Fische der Vorzeit. Wochenschr Aquar-Terrar. Kunde, 1911, 8. Jahrg. 8-10. 3 figs.

1911.3

- Ichthyologisches Handlexikon. Braunschweig, 1911. 287 p. figs. $8^{\circ}$

1911.4

_ Rasbora heteromorpha, ein Rätsel. Wochenschr. Aquar-'Terrar. Kunde, 1911, 8. Jahrg., 718-719.

1911.5

Ein Rhamphichthys. Wochenschr. Aquar-Terrar. Kunde, 1911, 8. Jahrg., 585-586. fig.

1911.6

Zwei Varietaiten von Pantodon buchholzi Pet. Wochenschr. Aquar.Terrar. Kunde, 1911, 8. Jahrg., 346-347. 3 figs.

1911.7
- Beobachtungen an exotischen IVelsen. Wochenschr. Aquar.-Terrar. Kunde, 1912, 9. Jahrg., 569-571. 4 figs.

1912.1

Import im Bild. Zusammenstellung der in jüngster 'Leit neu importierten Characiniden oder Salmler. Wochenschr. Aquar.-Terrar. Kunde, 1912, 9. Jahrg., 730. 10 figs.

1912.2

- Phractolomusansorgii. Wochenschr. Aquar-'Terrar. Kunde, 1912, 9. Jahrg., 801-802, \& figs.

1912.3

_- Zwei ostasiatische Barben. Wochenschr. Aquar.'Terrar. Kunde, 1912, 9. Jahrg., 249-250. 2 figs.

1912.4

Zwei Wochen aus meinem Tagebuche. Wochenschr. Aquar-Terrar. Kunde, 1912, 9. Jahrg., 350-352. 5 figs. 1912.5

- Einige Fische aus dem Nigerdelta. Wochenschr. Aquar.-Terrar. Kunde, 1913, 10. Jahrg., 485-486. 5 figs.

1913.1

Die Phractolæmidx. Wochenschr. Aquar.-Terrar. IS unde, 1913, 10. Jahrg., 153-154. 3 figs.

1913.2

- Psellus sebe. Wochenschr. Aquar.-Terrar. Kunde, 1913, 10. Jahrg. 740-741. 3 figs.

1913.3

Ein tonerzeugender Wels aus dem Amazonenstrom. Wochenschr. Aquar.-Terrar. Kunde, 1913, 10. Jahrg., $889-890.3$ figs.

1913.4

Bruinings, $W$. Zur Phvsiologie des Kreislaufs der Fische. Arch. Ges. Phys. 1899, 75, 599-641. Abstract in Zool. Centralbl., 6, 680-682.

1899.1

Brünnich, Morten Thrane [17371827] Ichthyologia Massiliensis, sistens piscium descriptiones eorumque apud incolas nomina. Accedunt Spolia Maris Adriatici. Hafnia et Lipsia, 1768. xvi, 110 p. $\mathrm{S}^{\circ}$.

1768.1

Velsens Beskrivelse (Gadus raninus) [= Raniceps fuscus Kr.] K. Dansk. Selsk. Shrift., 1779, 12, 291-29S. pls.

1779.1

Den barbugede pampelfisk (Coruphana apus) en nye art; og dens giaest skrukketrolden (Oniscus cremita), en opdagelse af Dr. König paa Madras. K. Dansk. Selsk. Skrift.. N. Saml., 1782, 2 , $319-325 ; 1783,3,406$.
178:. 1 
Om den islandske fisk vaagmaeren [Gymnogaster arcticus] K. Dansk. Selsk. Skrift., N. Saml., 1788, 3, 408-413.

1788.1

- Om en ny fiskart, den draabeplettede pladefisk [Lampris gutlatus] fanget ved Helsingör i Nordsöen 1786 [Zeus guttatus] K. Dansk. Selsk. Skrift., N. Saml., 1788, 3, 398-407. $\quad 1788.2$

- Om silde-tusten: Regalecus remipes. K. Dansk. Selsk. Skrift., N. Saml., 1788, 3, 414-418.

1788.3

Brüssow, — Mittheilungen über die Resultate seiner Fischzucht-Anstalt in Schwerin, sowie über Aalbrut und Krebszucht. Circul. Deutsch. Fischerei Ver. 1876 (1877), 162-164. 1877.1

Ein Beitrag zur Kunde der Lebensweise der Goldbutte [Pleuronectes platessa] an der Ostküste SchleswigHolsteins. Deutsch. Fischerei Zeitg., 1879, 2. Jahrg., 253-254. 1879.1

Brugmans, Sebald Justinus [17631819] Aanmerkingen over de middelen door welke de visschen zich bewegen in het algemeen en over het vermogen der Uitademing tot dat einde in het bijzonder. Verh. 1. Kl. Nederl. Instit., 1812, 1, 185-217. pl.

1812.1

Brugnatelli, Luigi Gasparo [17611818] Nota sopra una combinazione naturale di olio di pesce e ossiprussica (acido prussico st. fr.) Giorn. Fisica Stor. Nat. (Brugnatelli), 1815, 8, 137 138. - Annal. Chimie, 96, 96-98.

1815.1

Bruhin, P. Thomas A. Die Wirbelthiere Vorarlbergs: eine Aufzählung der bis jetzt bekannten Säugethiere. Vögel, Amphibien und Fische Vorarlbergs, einschliesslich des Rheinthales und des Bodensees. Verh. Zool. Bot. Ges. Wien, 1868, 18, 223-262. - Zool. Garten, Frankfurt, 8, 434-437.

1868.1

Zoologisches aus den Frankfurter Mess-Relationen. Zool. Garten, Frankfurt, 1872, 13, 309-314; 341-343; 372-375; 14, 261-265; 301-305. 1872.1

Bruhn, Johannes. Typische Formen ostasiatischer Labyrinthfische. Wochenschr. Aquar--Terrar. Kunde, 1911, 8. Jahrg., 517-518; 532-533. 13 figs.

1911.1

Bruhns, $E$. Mittheilung über die Brut-Resultate der Grossherzoglichen Fischzucht-Anstalt Gremsmühlen bei
Eutin während des Jahres 1875-76. Circul. Deutsch. Fischerei Ver. 1876 (1877), 156-157. 1877.1

Ueber Karpfenwiesen. Circul. Deutsch. Fischerei Ver. 1876 (1877), 2830.

1877.2

Erfreuliches Resultat der Fischzuchtanstalt Gremsmühlen. Circul. Deutsch. Fischerei Ver. 1877 (1878), 119.

1878.1

Brumpt, $E$. Mode de transmission et évolution des trypanosomes des poissons. Description de quelques espèces de trypanoplasmes des poissons d'eau douce. Trypanosome d'un crapaud africain. C. R. Soc. Biol. Paris, 1906, 1 , $162-164$.

1906.1

- Sur quelques espèces nouvelles de trypanosomes parasites des poissons d'eau douce; leur mode d'évolution. C. R. Soc. Biol. Paris, 1906, 1, 160-162.

1906.2

Brumpt, E., \& Lebailly, C. Description de quelques nouvelles espèces de trypanosomes et d'hémogregarines parasites des téléostéens marins. C. R. Acad. Sci. Paris, 1904, 139, 613-615.

1904.1

Brunati, Roberto. Sopra alcune ossa faringee fossili spettanti al genere Labrus e considerazioni sopra le ossa faringee di alcuni Labridi viventi nel Mediterraneo. Atti Soc. Ital. Sci. Nat. Mus. Civ. Milano, 1909, 48, 103-114. 1909.1

Brunchorst, Jórgen [1862-] Om sop paa Klipfisk. Bergen, 1889. $8^{\circ}$.

1889.1

_- Die biologische Meeresstation in Bergen. Bergens Museums Aarsberetnung 1890 (1891), no. 5, 1-31. 4 pls.

1891.1

_- Norges fiske deres udbredelse og levevis. Bergen, 1898. 68 p. illust. $12^{\circ}$.

1898.1

Brunn, Albert Wilhelm von [18491895] Ueber die neueren die Entwicklung des Pancreas betreffenden Arbeiten. Arch. Ver. Freunde Naturg. Mecklenburg, 1896, 49. Jahrb., 2. Abth., xxixxxxi.

1896.1

Brunn, Max von. Ein Gold-Stuhr. Nerthus, 1901, 3. Jahrg., 260-261.

1901.1

Brunt, C. van. Wind-fish or winfish [Argyrosomus artedi (Gill) of the Hudson river] Forest \& Stream, 1878, 10,219 . 
Brusina, Spiridion [1845-] Manoscritto descrizione dei crostacei, dei testacei e dei pesci che abitano le lagune ed il golfo Veneto, dall' Abate Stefano Chiereghini [edited by S. Brusina] Pisa, 1870. 280 p. $8^{\circ}$.

1870.1 Lettera sulla piscicoltura. Boll. Agar. Dalmaz., 1888, 17, 273-279.

1888.1

Morski psi sredozemmoga i crljenoga mora. Glasnik Soc. Hist. Nat. Croatica, Agram, 1888, 3, 1-64. 1888.2

Due elenchi dei pesci della Dalmazia di M. Botteri, coll' aggiunta di Heckel, Bellotti, Stalio, ecc. Glasnik Soc. Hist. Nat. Croatica, 1891, 6, 111151. Also separate; Agram, 1891. $8^{\circ}$

1891.1

Nachlese zur kroatischen Ichthyologie und Fischerei. Agram, 1892. $8^{\circ}$.

1892.1

Pabirci za hrvatsku ihtiologiju i za ribarstvo. Glasnik Soc. Hist. Nat. Croatica, Agram, 1892, 7, 1-68. 1892.2

Divije noveribice i akvarij [Zwei neue Aquarienfische] Glasnik Soc. Hist. Nat. Croatica, Agram, 1898, 10, 217222.

1898.1

Gregorci (Gasterosteus) iz Srbile. Glasnik Soc. Hist. Nat. Croatica, Agram, 1898, 10, 209-212.

1898.2

Naše jesetre [Acipenser] Rad Jugoslavenske Akad., 1902, no. 149, 1-69. pl.

1902.1

Brussel, Theodor van. Natuurkundige beschryving van eenige byzondere dieren, visschen en gekorvene diertjes. Amsterdam, 1798. 170 p. $10 \mathrm{col}$. pls. $8^{\circ}$.

1798.1

Bruttan, Das Vorkommen der Forellen in Livland. Sitzber. Nat. Ges. Dorpat, 1885, 8, 237-243.

1888.1

Brutzer,GregoriusGuilielmus [-1883] De Scaphirhyncho rafinescii disquisitiones anatomicæ. Inaug. Dissert. Dorpat, 1859. 40 p. 2 pls. $8^{\circ}$. 1859.1

Bruyant, Charles. Note sur la faune supéricure des lacs d'Auvergne. Assoc. Franc. Avanc. Sci., 22. sess., 1893, pt. 1 , p. $255-256$.

1893.1

- Note relative à la biologie du saumon. Bull. Soc. Hist. Nat. Auvergne, Clermont, 1896. [Inachevé] 1896.1

Reference from Emile Belloc's Index bibliographique, 1896.
- Note sur les moeurs de la Trutta fario et du Phoxinus lavis. Bull. Soc. Centr. Aquicult., 1898, 10, 102-103.

1898.1

Hybrides de truite et d'omblechevalier. Ann. Stat. Limnol. Besse, $1910,2,125-133$.

1910.1

- Rectifications à la faune ichthyologique de l'Auvergne. Féras et ombleschevaliers. Ann. Stat. Limnol. Besse, $1910,1,380-381$.

1910.2

Bruyant, Charles, \& Billard, G. See Billard \& Bruyant.

Bruyant, Charles, \& Dieulafé, Léon. See Dieulafé \& Bruyant.

Bruyant, Charles, \& Eusebio, J.B.A. Matériaux pour l'étude des rivières et lacs d'Auvergne. Introduction à l'aquiculture générale. Clermont-Ferrand, 1904. 162 p. 5 pls. \& 5 figs. $\quad 1904.1$

Bruyère, Henri. Le Ceratodus. La Nature, 1901, 29, pt. 2, 89-91. fig.

1901.1

Le sandre commun ou fogoseh. Bull. Soc. Nat. Agricult. Paris, 1909, 21, $45-47$.

1909.1

Excursion à l'établissement de pisciculture du Val-Saint-Germain. Bull. Soc. Nation. Acclimat. France, 1910, 57. année, 552-558.

1910.1

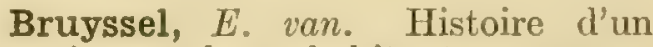
aquarium et de ses habitants, avec gravures colorées. Paris, 1865. $8^{\circ}$. 1865.1

Bryan, William Alanson. A monograph of Marcus island. Occas. Papers Bernice Pauahi Bishop Mus. Polyn. Ethn. Nat. Hist. Honolulu, 1903, 2, no. $1,77-128.8$ figs. map. 1903.1

Appendix, p. 125-139. Annotated list of the Marcus Island fishes by W. A. Bryan and Albert C. Herre.

- Three new Hawaiian fishes. Occas. Papers Bernice Pauahi Bishop Mus. Nat. Hist., Honolulu, 1906, 2, 22-37.

1906.1

Bryant, Edwin E. For biographical notice, see Peabody, G. F., in 'Trans, Amer. Fisheries Soc. 1904 (1905), 45-52.

The power of the state to regulate fisheries and the taking of fish. Trans. Amer. Fisheries Soc. 1901 (1902), 33-41. 1902.1

Bryant, Harold $C$. 'Teeth of a cestraciont shark from the Upper Triassic of 
northern California. Univ. Cal. Pub., Bull. Dept. Geol., 1914, 8, 27-30. 3 figs. 1914.1

Bryant, William. Account of an electrical eel, or the torpedo of Surinam. Trans. Amer. Phil. Soc., Philad., 1786, 2, 166-169.

1786.1

Bryce, James [1806-1877] Geology of Clydesdale and Arran; embracing also the marine zoology and the flora of Arran, with complete list of species, and notes on the rarer insects of Arran. London \& Glasgow, 1859. 199 p. pl. $8^{\circ}$.

1859.1

Bryce, Thomas $H$. The dividing cells of the embryo of Lepidosiren. Journ. Anat. Physiol., London, 1903, 38, Ixx. 1903.1

Histogenesis of the blood in larval forms of Lepidosiren. Lancet, 1904, $167,406$.

1904.1

The histology of the blood of the larva of Lepidosiren paradoxa. I. Structure of the resting and dividing corpuscles. Trans. Roy. Soc. Edinb., 1905, 41, 291-310. 5 pls. \& 2 figs. - II. Hæmatogenesis. Ibid., 435-467. 4 pls. \& 5 figs.

1905.1

Note on the development of the thymus gland in Lepidosiren paradoxa. Journ. Anat. Physiol., London, 1906, 40, 91-99. 6 figs.

1906.1

Brydone, $R$. M. Further notes on the stratigraphy and fauna of the Trimingham Chalk. Geol. Mag., 1906, 5. dec. $3,13-22 ; 72-78 ; 124-131$. 6 pls. \& fig.

1906.1

Bucek, Léon. Die Ellritze, Phoxinus lœvis [Leuciscus phoxinus] und ihre Verwerthung bei dem Krebsfange. Erste Oester-ungar. Fischerei Zeitg., 1880, 3.

1880.1

Buch, Christian Leopold von [17741853] Lettre sur le gisement des couches calcaires à empreintes de poissons et sur les Dolomies de la Franconie. Journ. Phys., 1822, 95, 258-267. - Taschenb. (Leonhard), 2, 239-260. - Bull. Soc. Géol. France, 6, 97.- Bull. Sci. Nat. (Férussac), 2, 47.

1822.1

Buch, S.A. Indberetning til departmentet for det Indre om de i 1885 udförte praktisk-videnskabelige undersögelser over vaarsildfisket. Christiania, 1886. $8^{\circ}$.

1886.1

Buchan, $P$. Annals of Peterhead, from its foundation to the present time, including an account of the rise, progress, improvements, etc., of the town. Peterhead, 1819 . xii, 144 p. 6 pls. $8^{\circ}$.

1819.1 109.

Fishing towns, p. 108. Fish on the coast, p.

Buchanan, afterwards Hamilton, (Dr.) Francis [1762-1829] An account of the fishes found in the river Ganges and its branches. Edinburgh \& London, 1822. 405 p. 39 pls. $8^{\circ}$ 1822.1

Review in Bull. Gén. Universel (Férussac), $1823,3,253$.

Buchanan, John Young [1844-] Fish and drought. Nature, 1911, 88, $107-110 ; 144$. fig.

1911.1

Buchanan, $T$. Sketches of the comparative anatomy of the organ of hearing, founded chiefly on the ear of the Squalus. Mem. Werner. Nat. Hist. Soc., 1828-29, 6, 144-170. 2 pls. 1828.1

Buchanan-Wollaston, $H . J$. Report on the results of the fish-egg cruise made by the S. S. "Huxley" in June, 1909. 3. Rept. North Sea Fish. Invest. Comm., 1911, 207-231. 2 pls. \& 13 figs.

1911.1

Buchenau, Franz [1831-] Ein Fischregen. Abhandl. Naturw. Ver. Bremen, 1873, 3, 440. 1873.1

- Naturwissenschaftlich-geographische Litteratur uiber das nordwestliche Deutschland. Abhandl. Naturw. Ver. Bremen, 1897, 14, 2. Heft, 335-340.

1897.1

Buchenberger, A. Fischereirecht und Fischereipflege im Grossherzogthum Baden. Tauberbischof sheim, 1888. 159 p. 8 figs. $8^{\circ}$.

1888.1

The same. 2. ed. Karlsruhe,
1903. xvi, 280 p.

Buchet, Gaston. Contribution à l'étude des pêches canariennes. C. R. Assoc. Franç. Avanc. Sci., 28. sess. 1900 , pt. 1, 264-265. 1900.1

Buchholz, Reinhold Wilhelm [-1876] Ueber die Mikropyle von Osmerus eperlanus. Arch. Anat., 1863, 71-81; 367372. fig.

1863.1

Buc'Hoz, Pierre Joseph [1731-1807] Lettres périodiques sur les avantages que la société peut retirer de la connoissance des animaux. Paris, 1769-70. $8^{\circ}$.

1769.1

- Aldrovandus lotharingix; ou, Catalogue des animaux, quadrupedes, 
Buc'Hoz, $P . J$.

reptiles, oiseaux, poissons, insects, vermisseaux et coquillages, qui habitent la Lorraine et les Trois-Evêchés. Paris, 1771. $8^{\circ}$.

1771.1

(editor) La nature considérée sous ses differents aspects; ou, Lettres sur les animaux, les végétaux et les minéraux. Paris, 1771-\$3. 47 vols. $12^{\circ}$.

1771.2

Ouvrage périodique.

Les dons merveilleux et diversement coloriés de la nature dans le regne animal; ou, Collection d'animaux précicusement coloriés pour servir à l'intelligence de l'histoire générale et économique des trois regnes. Paris, 1782. 84 pls. fol.

1782.1

Traité de la pêche; ou, L'art de soumettre les poissons à l'empire de l'homme, précédé de l'histoire naturelle de ces animaux. Paris, 1786. $12^{\circ}$.

1786.1

Bucht, Johan Fredrich. Om Hollola socken uti Tavastland. Inaug. Dissert. (Pelir Adrian Gadd, proeses) Abo, 1792. 31 p. $4^{\circ}$.

$1792: 1$

Buchtala, Hans. Elementaranalyse der Eihäute von Scyllium stellare, Pristiurus melanostomis und Scyllium canicula und Verteilung des Stickstoffes in Denselben. Zeitschr. Physiol. Chem., Strassburg, 1908, 56, 11-17. 1908.1

Buck, Emil. Die Zucht junger Stichlinge im Süsswasser-Aquarium. Zool. Garten, 1875, 16. Jahrg., 251-252.

1875.1

Das Zimmer-Bassin-Aquarium und seine Apparate. 'Lool. Garten, 1879, 20, 135-144. 4 figs.

1879.1

Buck, H.H. Report upon hatching one million whitefish egrs from the Great lakes, at Orland, Me., etc. Bull. U.S. Fish Comm. 18833, 3, 454-455.

1883.1

Buck, W. J., \& Chapman, Abel. See Chapman \& Buck.

Buck, IT. O. 'The fishing at Grand Lake stream. Trans. Amer. Fisheries Soc. 1906 (1907), 233-236. 1907.1

- Some details of salmon culture. 'Trans. Amer. Fisheries Soc. 1909 (1910), 120-123.

1910.1

Controlling the movements of fish. 'Trans. Amer. Fisheries Soc. 1911 (1912), 139-146.
Fishways for the rank and file. Trans. Amer. Fisheries Soc. 1912 (1913), 101-114.

1913.1

Buckenferde-Stempel, Richard Heinrich. Zum Transport der Coregonen-Brut. Deutsch. Fischerei Zeitg. 1878, 1. Jahrg., 50.

1878.1

Zum 'Transport von Fischbrut. Deutsch. Fischerei Zeitg., 1878, 1. Jahrg., 122-123.

187S.2

- Maikäfer als Fischfutter. Deutsch. Fischerei Zeitg., 1879, 2. Jahrg., 154.

1879.1

Buckingham, James Silk [17861855] Canada, Nova Scotia, New Brunswick, and the other British provinces in North America, with a plan of national colonization. Paris \& London, 1843. 540 p. $8^{\circ}$.

1843.1

Fish industries of the Provinces in $1839, \mathrm{p}$. $312 ; 346 ; 362 ; 366 ; 371-384 ; 406-7$.

Buckland, C. T. Some Indian fish. Longman's Mag., 1889, 13, 366-376.

1859.1

Buckland, Francis Trevelyan [18261880] For biography, see Bompas, $G$. C., Life of Frank Buckland. London, 1885. $S^{\circ}$

Curiosities of natural history. London, 1857. $8^{\circ}$.

1857.1

The same, second series, 1860. A new series, 2 vols., 1866 . Third and fourth series, 1872 There have been several editions of each series, the first American in 1859.

- A familiar history of the British fishes [n. p.] [1859] $16^{\circ}$. 1859.1

-_ Fish hatching. London, 1863. $12^{\circ}$.- Canad. Naturalist, 1864, n. s. 1 . $124-136$

1863.1

On the culture of fish. Proc. Roy. Instit. Great Britain, 1863, 4, 7586.

1863.2

Manual of salmon and trout hatching; or an explanation of the fish hatching apparatus at the Royal Horticultural Gardens, etc. London, 1864. 36 p. $12^{\circ}$.

1864.1

On salmon-hatching and salmonladders. Rept. Brit. Assoc. Adv. Sci., 34. meet. 1864 (1865), Not. \& Abstr. 90-91.

1865.1

- On the scientific cultivation of a salmon river. Rept. Brit. Assoc. Adv. Sci. 36. meet. 1866 (1867), Not. \& Abstr. $71-72$. 
Zalmladders [with English text] Nederl. Mag., 1867, 39-40. 2 pls.

1867.2

Chimara monstrosa [Haringkoning I Land and water, London, 1868, p. 377.

1868.1

On the progress of oyster and salmon cultivation in England. Rept. Brit. Assoc. Adv. Sci., 38. mect. 1868 (1869), Not. \& Abstr., 90-91. 1869.1

Bemerkungen über Lachzucht in der Zeitschrift "Land and Water." Circul. Deutsch. Fischerei Ver., 1872, 264-265.

1872.1

En Indsamling af Orredæg. Tidsskr. Fiskeri, 1872, 207-214. 1872.2

- Familiar history of British fishes. London, 1873. 396 p. $8^{\circ}$. (Society for Promoting Christian Knowledge, no. 11)

1873.1

- Log-book of a fisherman and zoologist. I_ondon, 1875.407 p. 4 pls. $8^{\circ}$.

1875.1

Report on the fisheries of Norfolk, especially crabs, lobsters, herrings, and the broads. London, 1875. $84 \mathrm{p}$. 4 pls. $8^{\circ}$.

1875.2

Log-book of a fisherman and zoologist. 3. ed. London, 1876. 339 p. pls. \& figs. $8^{\circ}$.

1876.1

Most of the articles are reprinted from Land and Water.

The ribbon fish. Forest \& Stream, 1877, 9, 24. 1877.1

- Snub-nosed salmon. Forest it Stream, 1877, 8, 96.

1877.2

The capelin, Mallotus villosus, of Cuvier. Forest \& Stream, 1878, 11, 280.

1878.1

Earbones, or brain ivory of fishes. Fish. Gazette, 1878, n. s. 2, 517-518. Forest \& Stream, 1878, 11, 320. 1878.2

The pollution of rivers and its effects upon the fisheries and supply of water to towns and villages. London, 1878. $8^{\circ}$.

1878.3

Sexes of soles. The solenette [Solea minuta] Fish. Gazette, 1878, n. s. 2, no. S0, 519. - Chicago Field, 1878, $10,244$.

1878.4

What do salmon feed on in fresh water? Fish. Gazette, 1879, 3, 452.

1879.1
Angel, fiddle-fish, or monk-fish (Squatina angelus) from the North sea. Chicago Field, 1880, 14, 69. $\quad 1880.1$

The salmon disease. Chicago Field, 1880, 12, 339-340. $\quad 1880.2$

Natural history of British fishes; their structure, economic uses, and capture by net and rod. Cultivation of fishponds, fish suited for acclimatisation, artificial breeding of salmon. London, 1881. figs. $16^{\circ}$. 1881.1

The author, in the preface, refers to his " $\mathrm{Fa}$ miliar history of the British fishes "as the first edition. The work, however, has been entirely rewritten.

Notes and jottings from animal life [Edited by G.C. Bompas] London, 1882. pl. \& figs. $8^{\circ}$.

1882.1

The substance of these papers originally appeared in "Land and Water." Several of them contain references to fishing.

Natural history of British fishes. 2. ed. London, 1891. $12^{\circ}$. (Society for Promoting Christian Iínowledge)

1891.1

Buckland, Francis Trevelyan, \& Walpole, Spencer. Report on the sea fisheries of England and Wales. London, 1879. $8^{\circ}$.

1879.1

On the salmon disease. London,
1880.1

Buckland, F.T., Walpole, Spencer, \& Young, Archibald. Report on the herring fisheries of Scotland, 1878. $8^{\circ}$. Great Britain Sessional Papers, 1878, 5, 21.

1878.1

Treats of the natural history of the herring, and effects of temperature on the herring fishery, etc.

Report on the disease which has recently prevailed among the salmon in the Treed ... and other rivers in England and Scotland. Great Britain Sessional Papers, 1880, 5, 14. - Also separate; London, 1880. $8^{\circ} .1880 .1$

Buckland, Francis Trevelyan, \& Young, Archibald. Report of special commissioners to enquire into the effect of recent legislation on salmon fisheries in Scotland. Edinburgh, 1871. 139 p. fol. Great Britain Sessional Papers, $1871,5,25 . \quad 1871.1$

Buckland, Frant: See Buckland, Francis Trevelyan.

Buckland, William [178t-1856] On the fossil beaks of four extinct species of fishes, referable to the genus Chimæra, 


\section{Buckland, $W$.}

that occur in the Oolitic and Cretaceous formations of England; with note by L. Agassiz. Phil. Mag. \& Journ. Sci., 1836, 3. ser. 8, 4-7. - Proc. Geol. Soc. London, 2, 205-206. - Neues Jahrb. Min. 1836,625 .

1836.1

Geology and mineralogy considered with reference to natural theology, 2 vols. Philadelphia, 1837. 1837.1

Fossil fishes, vol, i, p. 202-204. Plates of fish, vol. ii. pls. $27 \mathrm{a}-27 \mathrm{~b}$.

On the discovery of fossil fishes in the Bagshot sands at Goldworth hill, 4 miles north of Guildford. Proc. Geol. Soc. London, 1838, 2, 687-688. - Phil. Mag. \& Journ. Sci. 1838, 3. ser. 13, $387-$ 388. - Rev. Zool., 1839, 25. 1838.1

-Notices relative to palæontology. Ann. Mag. Nat. Hist., 1812, 9, 158-161.

1842.1

Contains notes on ichthyolites.

On ichthyopatolites or petrified track-wings of ambulatory fishes upon sandstone of the Coal formation. Proc. Geol. Soc. London, 1843, 4, 204. - Ann. Mag. Nat. Hist., 1844, 13, 152.- Neues Jahrb. Mineral., 1844, 511. 1843.1

- On modes of locomotion in fishes. Proc. Ashmol. Soc., 1844-52, 2, 21-22.

1844.1

Buckley, Thomas Edward, \& HarvieBrown, J. A. See Harvie-Brown \& Buckley.

Buddén, Emil Johannes. Ueber den Aal in den Saimagewässern i'Text in Finnish] Luonnon Ystävä, 1901, 5, 3233.

1901.1

Budden, $R . H$. La piscicultura in Montagna. Torino, $1883.8^{\circ}$. 1883.1

Budge, Julius. Ichthyologische Bemerkungen. Arch. Anat. Physiol. (Müller), 1848, 383-387. fig. 1848.1

Ueber die Lautäusserungen des Schlammpitzgers [Misgurnus fossilis] Mitth. Naturwiss. Ver. Neu-Vorpommern, Rügen, 1873-74, 5. \& 6. Jahrg., 18.

1873.1

Ueber die Fischgattung Tetrodon. Mitth. Naturwiss. Ver. Neu-Vorpommern, Rügen, 1875, 7. Jahrg., 10-11.

1875.1

Budgett, J.Herbert. Note on habits of Polypterus. Budgett memorial volume, 1907, 291-292.

lieprinted from The Field, Dec. 3, 1902.
Budgett, John Samuel [1872-1906] For biographical notice, see article by Arthur E. Shipley in Budgett memorial volume. Cambridge, 1907. p. 1-55. $4^{\circ}$. Abstract concerning Polypterus. Science, $1900, \mathrm{n}$. s. 12, 735. $\quad 1900.1$

- The breeding-habits of Protopterus, Gymnarchus, and some other west African fishes. Science, 1900, n. s. 11,1015 .

1900.2

Observations on Polypterus and Protopterus. Proc. Philos. Soc. Cambridge 1899 (1900), 10, 236-240. 1900.3

On some points in the anatomy of Polypterus. Proc. Zool. Soc. London, 1900, 430-433. - Science, 1900, n. s. 11, 879-888. - Trans. Zool. Soc. London, 1901, 15, 323-338. pls.

1900.4

On the breeding-habits of some west African fishes, with an account of the external features in development of Protopterus annectens and a description of the larva of Polypterus lapradei. Proc. Zool. Soc. London, 1900, 835-836. Trans. Zool. Soc. London, 1901, 16, 115-136. 2 pls. \& 5 figs.

1900.5

The habits and development of some west African fishes. Proc. Cambridge Soc., 1901, 11, 102-104. 1901.1

- On the anatomy of the larval Polypterus. Rept. Brit. Assoc. Adv. Sei., 71. meet., 1901, 693.

1902.1

On the structure of the larval Polypterus. 'Trans. Zool. Soc. London, 1902, 16, 315-340. 3 pls. \& 5 figs.

1902.2

Note on the spiracles of Polypterus. Proc. Zool. Soc. London, 1903, 1, 10-11.

1903.1

The work of John Samuel Budgett . . being a collection of his zoological papers... edited by J. Graham Kerr, with articles by Richard Asheton and Arthur Shipley... Cambridge, 1907. 494 p. $4^{\circ}$. 1907.1

i. Observations on Polypterus and Protopterus, p. 91-95.

ii. List of the fishes collected by Mr. J. S Budgett in the River Gambia, p. 95-100.

ii. On some points in the anatomy of l'olypterus, p. 100-119. 7 pls. \& 7 figs.

iv. On the breeding habits of some West African fishes, with an account of the external features in the development of Protopterus an nectens and a description of the larva of Polyp. terus lapradei, p. 119-141. 2 pls. \& 4 figs.

v. The habits and development of some West African fishes, p. 141-143.

vi. On the structure of the larval Polypterus, p. 15t-185. 2 pls. \& 4 figs.

vii. Note on the spiracles of Polypterus, p. 193-195. 
Ueber die Larven von Hyperopsus bebe Lac. [Translated from English] Blätt. Aquar.-Terrar. Kunde, 1910, 21 Jahrg., 163-164. 2 figs.

1910.1

Büchele, J. Die Wirbelthiere der Memminger Gegend; ein Beitrag zur bayerischen Fauna. Memmingen, 1860. $8^{\circ}$.

1860.1

Fische der Iller, p. 28.

Büchler, G. F. Die Haltung des Fischlaiches. Oester.ungar. Fischerei Zeitg., 1880, 201. 1880.1

Büchner, $G$. Mémoire sur le système nerveux du barbeau, Cyprinus barbus L. Mém. Soc. Hist. Nat. Strasbourg, 1835 , 2, 1-52. pl. Also separate; Strasbourg, 1836.

1835.1

- Sur les nierfs des poissons. L'Institut, 1836, 4, 296-298.

1836.1

Ueber die Nerven der Fische.

Notizen (Froriep), 1836, 50, 212-215.

1836.2

Bücker, Friedrich. Der Brachsenfang [Abramis brama] in den deutschrussischen Ostseeprovinzen. Mitth. Geogr. Ges. Wien, 1869, 12 (n. s. 2) $272-278$

1869.1

Bühler, Anton. Rückbildung der Eifollikel bei Wirbelthieren. I. Fische. Morph.Jahrb., 1902, 30, 377-452. 2 pls. \& 2 figs.

1902.1

Bühler, A., \& Felix, W. See Felix \& Bühler.

Buen y del Cos, Odón de. La région méditerranée des Baléares. Bull. Soc. Zool. France, 1905, 30, 98-106. 1905.1

- Peces de la costa mediterranea de Marruecos (notas preliminares) Bol. Soc. Españ. Hist. Nat., 1912, 12, 153166.

1912.1

Buen y del Cos, Odón de, \& Fage, Louis. Un nouveau Gobiidé méditerranéen du genre Aphya: A phya ferreri, $\mathbf{n}$. sp. Arch. Zool. Expér., 1908, 4. sér. 8. $\mathrm{cv}-\mathrm{cx} .5$ figs.

1908.1

Büren, A. von. Zur Hechtfrage. Schweiz. Fischerei Zeitg., 1897, 5. Jahrg., по. 21, 200-201 1897.1

Bütschli, $O$. Beiträge zur Kenntnis der Fischsporospermien. Zeitschr. Wiss. Zool., 1881, 35, 629-651. pl. 1881.1

Büttikofer, $J$. Reisebilder aus Liberia. 2 vols. Leiden, 1890. figs.

1890.1

Fische, vol, ii, 447-453
Buffa, $E$. Recherches expérimentales sur la toxicité du sang de la lamproie. Arch. Ital. Biol., 1900, 33, 177-185.

1900.1

Buffa, $E$.. \& Scofone, L. See Scofone \& Buffa.

Buffon, (Comte) Georges Lowis Leclerc de [1707-1788] For an account of scientific writings, see Flourens, M.P.J. Buffon: histoire de ses travaux et de ses idées. Paris, $1844.12^{\circ}$.

Histoire naturelle ... avec la description du cabinet du roi. 44 vols. Paris, 1749-1804.

1798.1

Under this series are included 5 volumes, by Lacépède, 1798-1803, entitled "Histoire naturelle des poissons."

Histoire naturelle .. nouvelle édition ... ouvrage rédigé par C. S. Sonnini. 64 vols. Paris, 1799-1805, 1799.1

This edition includes 13 volumes by Sonnini, 1802-04, entitled "Histoire naturelle des poissons."

Histoire naturelle par Buffon, dediée au citoyen Lacépède [par lequel cette édition fut rédigé 76 vols. Paris, 1799-1809.

1799.2

This series includes 14 volumes by Lacépède, 1799-1804, entitled "Histoire naturelle de poissons.

Histoire naturelle de Buffon, classée... d'après le systême de Linné ... par R. R. Castel ... nouvelle édition (Suites) 80 vols. Paris, 1801-03.

1801.1

The first 26 volumes only are of the "nouvelle Edition, 1802." The original issue began to appear in 1799. The "Suites aे Buffon" include 10 volumes by Bloch, 1801, entitled "Histoire naturelle des poissons.

Histoire naturelle, générale et particulière des poissons. . . faisant suite à l'histoire naturelle, générale et particulière, composée par Leclerc de Buffon et mise dans un nouvel ordre par C.S. Sonnini, avec des notes et des additions, par C.S. Sonnini. 13 vols. Paris, 180304. 77 pls.

1803.1

Cuvres complètes de Buffon ... mises en ordre par M. le Comte de Lacépède. Nouvelle édition. 31 vols. Paris, 1825-28. 1825.1

This edition first appeared in 1820-22. It was reissued in 1825 , and again in 1828 and 1829 The "Suite ì Buffon" comprises 5 volumes by Lacépède, 1825, entitled "Histoire naturelle des quadrupèdes .... poissons et cetaces.

A natural history of the globe, and of man; beasts, birds, fishes, reptiles, and insects. From the writings of Buffon, Cuvier, Lacépède, and other 
Buffon, G. L. L.

eminent naturalists. 4 vols. London, 1831. $12^{\circ}$.

1831.1

Suites à Buffon, formant avec les œuvres de cet auteur un cours complet d'histoire naturelle. 74 vols. Paris, 1834-74.

1834.1

This series includes 2 volumes with atlas, entitled "Ichthyologie, par A. H. A. Duméril," 1865-70.

A natural history, general and particular... translated from the French of Count Buffon by William Smellie, etc. 2 vols. London, 1860. figs. $4^{\circ}$.

1860.1

"A new edition, corrected and enlarged. To which is added a history of birds, fishes, reptiles and insects ... by Henry Augustus Chambers.

Buglia, G., \& Constantino, A. Gibt es ein desamidierendes Ferment in der Leber von Scyllium catulus? [Kein glykokollspaltendes Ferment vorhanden] Zentralbl. Physiol., 1913, 26, 1178-1179.

1913.1

Bugnion, Edouard. Descriptions de quelques alevins de truite monstreux. Bull. Soc. Vaud. Sci. Nat. 1879 (1880), 16, 463-466. - Arch. Sci. Phys. Nat. Genève, 1880, 3. sér. 3, 190-192. 1880.1

Développement des sélaciens. Bull. Soc. Vaud., 1894, 30, xxxi-xxiv. C. R. Soc. Helvét. Sci. Nat, 77. sess., $1894,76-81$.

1894.1

_- Le poisson-ballon de Ceylon blow-fish, globe-fish - Tétraodon ou Tetrodon. Bull. Soc. Vaud. Sci. Nat., 1911, 5. sér. 47, xxvii-xxviii. - Arch. Sci. Phys. Nat. Genève, 1911, 4. sér. 32, $72-73$.

1911.1

Buhle, Christian Adolph. Das Fischbuch. Beschreibung und Abbildung mehrerer in- und ausländischen Fische. Halle, 1812. pls. $8^{\circ}$.

1812.1

Buhse, Friedrich Alexander. Die künstliche Fischzucht in Finnland. Correspbl. Naturf. Ver. Riga, 1862, 12. Jahrg., 74-76.

1862.1

Z Zwei einheimische Lachsbritanstalten. Correspbl. Naturf. Ver. Riga, 1862, 12. Jahrg., 145-157.

1862.2

Buijtendijk, $F, J . J$. Over de samenstelling der urine van haaien bij normale en versterlite diurese. Versl. Wis. Nat. Afd. Akad. Wet. Amsterdam, 1909, 18, 264-267. - Proc. Akad. Wet. Amsterdam, 1909, 12, 380-383.
Over de veranderingen in het bloedserum van haaien na verbloeding. Versl. Wis. Nat. Afd. Akad. Wet. Amsterdam, 1909, 18, 261-264. - On the changes in the blood serum of sharks after bleeding. Proc. Akad. Wet. Amsterdam, 1909, 12, 377-380.

1909.2

Over het zuurstof-verbruik van het zenuwstelsel. VersI. Wis. Nat. Afd. Akad. Wet. Amsterdam, 1910, 19, 615621. 2 figs. - Proc. Akad. Wet. Amsterdam, 1910, 13, 577-582. 2 figs. 1910.1

Ueber die Farbe der Tarbutten nach Exstirpation der Augen. Biol. Centralbl., 1911, 31, 593-596. 2 figs. 1911.1

Buist, $G$. On shark fishing at Kurrachee. Proc. Zool. Soc. London, 1850, 18, 100-102.

1850.1

Buist, Robert. The Stormontfield piscicultural experiments, 1853-66. Edinburgh, 1866 . 32 p. figs. $12^{\circ}$. 1866.1

Observations on the salmon. Field, June, 1867.

1867.1

Buist, T.P. On the development of the pectoral girdle in the pipefish (Syngnathus acus) Ann. Mag. Nat. Hist., 1912, 8. ser. 10, 613-621. pl. 1912.1

Buist, $W$. Further results of the artificial breeding of salmon at the Stormontfield pond. Zoologist, 1856, 14, 5163-5164.

1856.1

Bujack, Johann Gottlieb. Naturgeschichte der höheren Thiere mit besonderer Berücksichtigung der Fauna Prussica. Köningsberg, 1837. 2 pls. $8^{\circ}$.

1837.1 $300^{4}$

Naturgeschichte der preussischen Fische, p.

Bujor, $P$. Contribution à l'étude de la métamorphose de l'Ammocotes branchialis et Petromyzon planeri. Rev. Biol. France, 1891, 3, 301-315; 325339 ; $365-390 ; 417-426$; 474-486. pls.; 4, 41-64. 2 pls.

1891.1

- Note préliminaire sur la métamorphose de l'Ammocates branchialis et Petromyzon planeri. Rev. Biol. France, 1891, 3, 201-212.

1891.2

Bulach, Irugues de. Sur la pisciculture en Alsace-Lorraine. Bull. Soc. Sci. Agricul. Arts Basse-Alsace, 1878, 12, 138-144.

1878.1

Bull, $E$. Einige Bemerkungen über Fischpulver. Med. Wochenschr., St. Pétersbourg, 1888. 1888.1 
Bullen, Al. Blue-back trout. Forest \& Stream, 1879, 12, 395-396. 1879.1

Bullen, Frank Thomas. 'The cruise of the "Cachalot" round the world after sperm whales. 2. ed. London, 1899. $\mathrm{xx}, 379$ p. pls. $8^{\circ}$.

1899.1

Various kinds of fishes are mentioned.

Deep-sea plunderings, a collection of stories of the sea. London, 1901. 350 p. pls. $12^{\circ}$. 1901.1

Deep-sea fish, p. 309-318.

York, 1902

The same. American ed. New 1902.1

- Creatures of the sea, being the life-stories of some sea-birds, beasts, and fishes. London, 1904. 141 p. $8^{\circ}$.

1904.1

Denizens of the deep. New York [1904] 430 p. figs. $8^{\circ}$. 1904.2 Fishes, p. 146-310.

Bullen, G.E. Plankton studies in relation to the western mackerel fishery. Journ. Mar. Biol. Assoc., Plymouth, 1908, n. s. 8, 269-302. 6 pls. \& 2 figs. 1908.1

Notes on the post-larval development of the German or Crucian carp (Carassius vulgaris) Trans. Hertfordsh. Nat. Hist. Soc., 1909, 14, 15-18. 1909.1

Some notes upon the feeding habits of mackerel and certain clupeoids in the English channel. Journ. Mar. Biol. Assoc., Plymouth, 1912, n. s. 9, 394-403.

1912.1

Mackerel and Calanus. Nature, London, 1913, 91, 531 .

1913.1

On some cases of blindness in marine fishes [Corneal opacitis and cataract] Proc. Zool. Soc. London, 1913. 634-638.

1913.2

Buller, Nathan R. Propagation and care of yellow perch. Trans. Amer. Fisheries Soc. 1905 (1906), 223-224.

1906.1

Bullmore, $W . K$. Capture of a rare fish (Ausonia cuvieri) at Falmouth. Ann. Mag. Nat. Hist., 1863, 3. ser. 18 , 424-425.

1863.1

Notes on Ausonia cooksii. Journ. Roy. Instit. Cornwall, 1866-67, 2, 163166. - Rept. Polytech. Soc. Cornwall, 1866, 34, 61-64. figs.

1866.1

Bullo, $G$. S. Piscicultura marina. Verona, 1891. 11 pls. $8^{\circ}$.
Revisione sulla laguna di $\mathrm{Co}$ macchio. Proveddimenti. Padova, 1894. 2 pls. $8^{\circ}$.

1894.1

Bullock, $W . J$. The grayling Thymallus vulgaris] their habits, homes, food, and the various methods of capturing them. Fish. Gazette, 1879, 3, 465-466 $478-479 ; \quad 490-491$; 503-504; 515-516.

1879.1

Bumpus, Hermon Carey [1862-] The breeding of animals at Woods Holl during the month of March, 1898. Science, 1898, n. s. 7, 485-487. 1898.1

The breeding of animals at Woods Holl during the month of May, 1898. Science, 1898 , n. s. 8, 58-61.

1898.2

The breeding of animals at Woods Holl during the months of June, July and August. Science, 1898, n. s. 8, 850-858.

1898.3

On the identification of fish artificially hatched. Amer. Naturalist, $1898,32,407-412$. 2 figs. $\quad 1898.4$

On the reappearance of the tile-fish (Lopholatilus chamceleonticeps) Science, 1898, 8, 576-578.

1898.5

A recent variety of the flatfish, and its bearing upon the question of discontinuous variation. Science, 1898, 7, 197-198.

$1898.6^{6}$

The work of the biological laboratory of the U. S. Fish Commission at Woods Holl. Science, 1898, n. s. 8, 96. 1898.7

The breeding of animals at Woods Holl during the month of September, 1899. Science, 1899, n. S. 9, $581-583$.

1899.1

- The identification of adult fish that have been artificially hatched. Trans. Amer. Fisheries Soc. 1898 (1899), 70-73. 2 pls.

1899.2

The reappearance of the tilefish. Bull. U. S. Fish Comm. 1898 (1899), 18, 321-333.

1899.3

Methods and results of scientific work at Woods Holl. Trans. Amer. Fisheries Soc. 1899 (1900), 12-17. 1900.1

Buncombe (pseudon.) Trout regions of North Carolina. Forest \& Stream, 1874, 2, 241.

1874.1

Bund, John William Willis. See Willis-Bund, $J$. 
Bungartz, Jean. Aquarienfische und ihre Pflege. Lechenich, Rheinland, 1897. 16 p. $8^{\circ}$.

1897.1

- The same. 2. ed. Leipzig, 1901. 16 p. $8^{\circ}$ 1901.1

Bunge, Alexander von [1803-1890] Ueber die Nachweisbarkeit eines biserialen Archipterygium bei Selachiern und Dipnoërn. Jena. Zeitschr., 1873 (1874), 8, 293-307; 579. 2 pls. 1874.1

- Naturhistorische Nachrichten aus der Polarstation an der LenaMündung; aus einem Briefe an den Akademiker Is. V. Schrenck. Bull. Acad. Imp. Sci. St. Pétersb., 1883, 28, $517-546$.

1883.1

Fische, p. 533-531.

Bunge, G. von. Ueber die Zusammensetzung des Knorpels vom Haifisch. Zeitschr. Phys. Chem., 1899, 28. 1899.1

Bunge, $R$. \& Eberth, $C . J$. See Eberth \& Bunge.

Buniva, M. F. Mémoire sur la physiologie et la pathologie des poissons, suivi d'un tableau indiquant l'ichthyographie subalpine. Mém. Acad. Sci. Turin, 1802-03, 10, 78-121. 1802.1

Bunker, Frederic S. On the structure of the sensory organs of the lateral line of Ameinus nebulosus Le Sueur. Anat. Anz., 1897, 13, 256-260. 1897.1

Burch, G.J., \& Gotch, Francis. See Gotch \& Burch.

Burchardt, Eugen. Beiträge zur Kenntnis des Amphioxus lanceolatus, nebst einem ausführlichen Verzeichnis der bisher über Amphioxus veröffentlichten Arbeiten. Jena. Zeitschr. Naturw., 1900, 34, 719-832. 9 pls.

1900.1

Burchell, William $J$. Travels in the interior of southern Africa. 2 vols. London, 1822-24.

1822.1

Freshwater fishes described, vol. i, p. 425

Burckhardt, Carl Friedrich [1830 - ] Verzeichniss der bis jetzt in der Umgebung von Gera beobachteten Fische Jahresber. Ges. Freunde Naturwiss. Gera, 1860, 62-63.

1860.1

Burckhardt, Carl Rudolf [18661908] For biographical sketch and list of publications, see Imhof, $G_{0}$, in Verh. Naturf. Ges. Basel, 1910, 20, 1-37.
Ueber Protopterus annectens. Sitzber. Ges. Naturf. Freunde Berlin, $1890,158$.

1890.1

Kurze Mitteilungen über Protopterus annectens und über einen in seiner chorda dorsalis vorkommenden Parasiten (Amphistomur chordale) Sitzber. Ges. Naturf. Freunde Berlin, 1891, $23-25 ; 62-64$.

1891.1

Die Zirbel von Ichthyophis glutinosus und Protopterus annectens. Anat. Anz., 1891, 6, 348-349.

1891.2

Das Centralnervensystem von Protopterus annectens; eine vergleichendanatomische Studie (In Festschrift zum 70. Geburtstage Leuckarts. Berlin, 1892. 164 p. 5 pls. $4^{\circ}$ ) Abstracts in Biol. Centralbl., 1893, 13, 427-439. Journ. Comp. Neurol., 1892, 2, 89-91. 1892.1

Ueber das Centralnervensystem der Dipnoër. Verh. Deutsch. Zool. Ges., 1892, 2, 92-95. 1892.2

Die Homologien des Zwischenhirndaches und ihre Bedeutung für die Morphologie des Hirns bei niederen Vertebraten. Anat. Anz., 1893, 9, 152155. fig.

1893.1

Bemerkungen zu K. F. Studnička's Mitteilung über das Fischgehirn. Anat. Anz., 1894, 9, 468-469. 1894.1

Die Homologien des Zwischenhirndachs und ihre Bedeutung für die Morphologie des Hirns bei niederen Vertebraten. Anat. Anz., 1894, 9, 152. 1894.2

Schlussbemerkung zu K. F Studnička's Mitteilungen über das Fischgehirn. Anat. Anz., 1895, 10, 207-208.

1894.3

Zur vergleichenden Anatomic des Vorderhirnes bei Fischen. Anat. Anz., 1894, 9, 375-382. 5 figs. 1894.4

Beitrag zur Morphologie des Kleinhirns der Fische. Arch. Anat. Physiol. (Anat. Abth.), 1897, Suppl.-Bd., 111-136. pl.

1897.1

Hirnbau und Stammesgeschichte der Wirbeltiere. C. R. Soc. Helvét. Sci. Nat., 80. sess., 1897, 51. - Arch. Sci. Phys. Nat., 1897, 4. sér. 4, 483-485. 1897.2

Das Selachierhirn und seine zoologisch-systematische Bedeutung. C. 1R. Soc. Helvét. Sci. Nat., 80. sess., 1897, 
62-63. - Arch. Sci. Phys. Nat., 1897, 4. sér. 4, 480-483.

1897.3

Sur la forme extérieure du cerveau des sélaciens. Arch. Sci. Nat., 1898, 4. sér. 6, 621-622.-C. R. Soc. Helvét. Sci. Nat., 81. sess., 115-132.

1898.1

Beiträge zur Anatomie und Systematik der Læmargiden. Anat. Anz., 1900, 18, 488-492. 4 figs. 1900.1 Berichtigung, p. 560 .

On the luminous organs of selachian fishes. Ann. Mag. Nat. Hist., 1900, 7. ser. 6, 558-568. figs. 1900.2

Ueber die Selachier. Ber. Senckenberg. Naturf. Ges., Frankfurt-a.-M., 1900 , cxxvi.

1900.3

Ueber das Gehirn von Isistius brasiliensis. Arch. Sci. Phys. Nat. Genève, 1902, 4. ser. 14, 534-535. C. R. Soc. Helvét. Sci. Nat., 85. sess., $1902,77$.

1902.1

Das koische Tiersystem. Verh. Naturf. Ges. Basel, 1904, 15, 377-414.

1904.1

Das Centralnervensystem von Ceratodus forsteri. C. R. 6. Cong. Intern. Zool., Berne 1904 (1905), 314-315. 1905.1

Das erste Buch der aristotelischen Tiergeschichte. Zool. Annalen $1905,1,1-28$.

1905.2

- Geologische Untersuchungen im Gebiet zwischen Glan und Lauter (Bayer. Rheinpfalz) Geogn. Jahresh., 1906, 17. Jahrg., 1-92. 28 figs. 1906.1

Hirnbau und Stammesgeschichte der Wirbeltiere. Ber. Senckenberg. Naturf. Ges., Frankfurt-a.-M., 1906 , $71 *-75 *$

1906.2

Ueber den nervus terminalis. Verh. Deutsch. Zool. Ges. 16. Vers., 1906, 203-204. 1906.3

Das Central-nervensystem der Selachier als Grundlage für eine Phylogenie des Vertebratengehirnes. I. Teil. Einleitung und Scymnus lichia. Nova Acta Acad. Leop. Carol., Halle, 1907. 73, 241-450, 5 pls. \& 64 figs. 1907.1

- Das Central-nervensystem der Selachier, etc. II. Teil. Die übrigen Paläoselachier. Op. cit., 1911, 94, 1112. pl. \& 85 figs.

1911.1

Notizen iber die Fauna der Adria bei Rovigno. III. Zur Kenntnis der Fische von Rovigno. Zool. Anz., $1911,37,282-288$.

1911.2

Burckhardt, Carl Rudolf, \& Bing, Robert. See Bing \& Burckhardt.

Burda, Victor. L'élevage de la carpe. Etangs \& Rivières, 1898, 11, 1-3; 17$19 ; 33-36$.

1898.1

1898 .

Berlin, 1898.2

Burdick, $C . H$. Testimony in regard to the present condition of the fisheries, taken in 1871. Rept. U. S. Fish Comm. 1871 (1873), 1, 30 .

1873.1

Bureau, Louis. Sur une monstruosité de la raie estellée (Raja asterias Rond.) Bull. Soc. Zool. France, 1890 , 14, 313-316. figs.

1890.1

Le saumon de la Loire dans ses rapports avec réglementation de la pêche. Bull. Soc. Sci. Nat. Ouest France, Nantes, 1891, 1, pt. 1, 8-19.

1891.1

Note sur la capture d'un espadon épée, Xiphias gladius, à l'embouchure de la Loire. Bull. Soc. Ouest France, Nantes, 1895, 5, 53-57. pl. 1895.1

-Coup d'œil sur la faune du département de la Loire-Inférieure. Nantes, 1898. 1898.1

—_- Poissons capturés sur les côtes bretonnes [Centrina vulpecula] et dans l'Erdre [Lepomis megalotis] Bull. Soc. Sci. Nat. Ouest France, Nantes, 1901, 2. sér. 1, pt. 1, xxxv.

1901.1

- Note sur la présence du Béryx décadactyle, Beryx decadactylus Cuv. et Val. (poisson acanthoptérygien) sur les côtes océaniques de France. Bull. Soc. Sci. Nat. Ouest France, Nantes, 1905, 15, 207-209. pl. 1905.1

Burger, $H$. Thatsächliche Mittheilung über Teichfischerei-Erträge im Jahre 1861. Schles, Landw. Zeitg., $1862,10-11 ; 13-14$. 1862.1

Burgersdijk, Leendert Alexander Johannes. De dieren afgebeeld, beschreven en in hunne levenswijze geschetst. 3 vols. Leiden, 1862-71. col. pls. $8^{\circ}$.

1862.1

Fishes, rol. i, p. 463-500; vol. iii, p. 99-264. 10 pls.

Burgerstein, Alfred. Die zoologischen und botanischen Abhandlungen in den im Jahre 1896 erschienenen 
Burgerstein, A.

Jahresberichten österreichischer Mittelschulen mit dentscher Unterrichtssprache. Verh. Zool. Bot. Ges., Wien, 1897, 47, 197-200.

1897.1

Burguières, $E$., Genazzini, $E$., Gervasoni, $T$., Vinciguerra, $D ., \&$ Besana, G. See Vinciguerra, Besana \& others.

Burke, Charles Victor. The relation between the coloration and the bathymetrical distribution of the Cyclogasteridx. Science, 1911, n. s. 34, 447458.

1911.1

- A new genus and six new species of fishes of the family Cyclogasteridx. Proc. U. S. Nat. Mus., 1912, 43, 567574.

1912.1

Note on the Cyclogasteridx [Careproctus longipinnis, n. sp.] Ann. Mag. Nat. Hist., 1912, 8. ser. 9, 507-513.

1912.2

Burke, C. V., \& Gilbert, C. H. See Gilbert \& Burke.

Burlend, T. H. The urogenital organs of Chimoera monstrosa. Proc. Zool. Soc. London, 1910, 510-534. 14 figs.

1910.1

Burlend, T. H., \& Parker, W. $N$. Sce Parker \& Burlend.

Burmeister, Hermann [Carl Conrad] [1807-1892] For biography and list of works, see Anales Soc. Cienc. Argentina, 1892, 33, 145-150; Ibid., 1896, 41, 97-107. - Anales Mus. Nac. Buenos Aires, 1895, 4, 315-357.

Zoologischer Hand-Atlas。 2. ed. Berlin, 1860. 42 pls. $4^{\circ}$. 1860.1 Fishes, pt. 4 .

Petromyzon macrostomus, descripción de una nueva especie de pez. Anales Mus. Pub. Buenos Aires, 1868, 1, 35-37.

1868.1

Burn, $J . H$. A catalogue (part ii) of ancient and modern books ... and the most extensive collection of books relative to angling and field sports ever offered for sale. London, 1820. $85 \mathrm{p}$. $12^{\circ}$.

1820.1

Burnaby, Andrew [c. 1734-1812] Travels through the middle settlements in North America in the years 1759 and 1790. London, 1798. $4^{\circ}$. 1798.1

Gives a list of the fishes of Virginia.
Burne, $R . H$. On the presence of a branchial basket in Myxine glutinosa. Proc. Zool. Soc. London, 1892, 706-708. pl.

1892.1

- On the aortic arch of Saccobranchus fossilis. Journ. Linn. Soc. London (Zool.), 1894, 25, 48-55. pl.

1894.1

"Porus genitalis" in the Myxinidæ. Journ. Linn. Soc. London (Zool.), 1898, 26, 487-495. pl.

1898.1

- Note on the innervation of the supraorbital canal in the cat-fish (Chimara monstrosa) Proc. Zool. Soc. London, 1901, 1, 184-187. fig. 1901.1

[Remarks on a preparation of the head of a sea-lamprey (Petromyzon marinus), designed to show the mechanism by which water is drawn into, and expelled from, the olfactory chamber Proc. Zool. Soc. London, 1908, pt. 1, 65.

1908.1

The anatomy of the olfactory organ of teleostean fishes. Proc. Zool. Soc. London, 1909, 610-663. 6 figs.

1909.1

Exhibition of, and remarks upon, certain elastic mechanisms in fishes and reptiles. Proc. Zool. Soc. London, 1909, 201-204. 2 figs. 1909.2

Exhibition of specimens of adaptive structures for the respiration of air in some aquatic invertebrates and tropical freshwater fishes. Proc. Zool. Soc. London, 1909, 545.

1909.3

Note on the membranous labyrinth of Neoceratodus forsteri. Anat. Anz., 1913, 43, 396-400. 4 figs. 1913.1

Burnell, A. $H$. The pilot fish. Amer. Naturalist, 1876, 10, 687. 1876.1

Burnett, (Sir) W. On the effects produced by poisonous fish on the human frame. Proc. Roy. Soc. London, 1846, 5, 609 .

1846.1

Burnham, Charles W. Notes on the yellow bass. 'Trans. Amer. Fisheries Soc. 1909 (1910), 103-106.

1910.1

Burr, Higford [Remarks on sex of goldfish and perch $1874,2,325$.

1874.1

Burrow, G. M. Account on two cases of death from eating mussels; with some general observations on fish poison. London, 1815. $8^{\circ}$. - Trans. Linn. Soc. London, 12, 590 .

1815.1 
Burrows, C. Acton. Propagating black bass. Forest \& Stream, 1875, 4, 342.

1875.1

Burrows, $U$. A. A probable origin of the perforation in shark's teeth from the Crag. Proc. Geol. Assoc. London, 1874-76, 4, 165-166.

1876.1

Burton, Edward. Description of a species of Agriopus Cuv. (A. unicolor) Proc Zool. Soc. London, 1835, 3, 116118. - Isis, 1837, 179.

1835.1

Monacanthus hystrix n. sp. Proc. Zool. Soc. London, 1835, 2, 121-122. L'Institut, 3, 214-215.

1835.2

Burton, (Sir) Richard Francis [18211890] The lake regions of Central Africa, a picture of exploration. 2 vols. London, 1860. pls. $8^{\circ}$. 1860.1

Fishes, vol. i, p. 56; vol. ii, p. 59, 67, 108, 280.

Burtt, $J . L$. On fish destroyed by sulphuretted hydrogen in the bay of Callao. Amer. Jour. Sei., 1852, 2. ser. 13, 433-434. - Proc. Acad. Nat. Sci. Philad., 1852, 1-2.

1852.1

Busch, Wilhelm [1826-1881] De selachiorum et ganoideorum encephalo. Inaug. Dissert. Berlin, 1848. 48 p. 3 pls. $4^{\circ}$.

1848.1

Buschkiel, Alfred. Zur Frage nach dem Ursprung anormaler Flossenbildungen bei Fischen. Wochenschr. Aquar.-Terrar. Kunde, 1907, 4. Jahrg., 66-68.

1907.1

Wissenschaftliche Ergebnisse der Aquarienkunde. II. Parasitäre Fischkrankheiten. Intern. Rev. Hydrobiol., Leipzig, 1908, 1, 833-839.

1908.1

Zur Biologie der Groppe (Cottus gobio L.) Blätt. Aquarienkunde, Stuttgart, 1908, 19, 342-348.

1908.2

Busenitz, - Bericht über die wissenschaftliche Tätigleit des westpreussischen Fischereivereins im Jahre 1902. Schrift. Naturf. Ges., Danzig, 1904, 11, xxxvii-xxxviii.

1904.1

Bush, Richard J. Reindeer, dogs and snowshoes; a journal of Siberian travel and explorations made in the years 1865-67. New York, 1871. 529 p. illust. $8^{\circ}$.

1871.1

Mentions the varieties of fish and modes of catching them in Russia.

Bushnan, John Stevenson [1808?1884] Fishes, particularly their structure and economical uses. Edinburgh,
1840. 219 p. 31 pls. $12^{\circ}$. Naturalist's library, edited by Sir William Jardine, vol. xxvii)

1840.1

Also appears as vol. xxxv of 2. edition of the Naturalist's library, Edinburgh, 1845-46.

Bussell, — Bass fishing in Sullivan county, N. Y. Forest \& Stream, $1880,15,29$.

1880.1

Butler, Arthur Gardiner [1844-] Trout culture at Reading. Fish. Gazette, $1879, \mathbf{3}, 245 ; 306$.

1879.1

Butler, G.W. Report on the spawning of the common sole (Solea vulgaris) in the aquarium of the Marine Biological Association laboratory at Plymouth during April and May, 1895. Journ. Mar. Biol. Assoc. 1895-97, n. s. 4, 3-9.

1895.1

Butler, $H . D$. The family aquarium. New York, 1858. 121 p. 12 . 1858.1

Butler, James $D$. Codfish. Its place in American history. Trans. Wisc. Acad., 1897, 11, 261-273.

1897.1

Butler, Myron. Fish for New York waters. Forest \& Stream, 1880, 15, 428 .

1880.1

Butler, $N . R$. Work of the Pennsylvania fisheries department. Trans. Amer. Fisheries Soc. 1913 (1914), 111120.

1914.1

Butler (junior), William. Notes on trout work in Michigan. Trans. Amer. Fisheries Soc. 1889 (1900), 25-31.

1900.1

Butscher, Arthur. Der Makropode und seine Zucht. Blätt. Aquar-Terrar. Freunde, 1900, 11. Jahrg., 149-151.

Etwas uiber den Kampffisch. Nerthus, 1901, 3. Jahrg., 625-626.

1901.1

Unser Freund, der Girardinus decemmaculatus. Blätt. Aquar-Terrar. Kunde, Magdeburg, 1901, 12, 281-282.

1901.2

Butt, Isaac. The Trish deep sea fisheries. Dublin, 1874. 27 p. $8^{\circ}$.

1874.1

Buxbaum, L. Der Wanderzug der Mainfische im Frühling 1892. Zool. Garten, 1892, 33, 184-188. 1892.1

Ein Zug Aale auf der Wanderschaft im Main. Zool. Garten, 1892 , 33, 20-21. 
Buxbaum, $L$.

_ Die Mainfische und ihre Namen. Zool. Garten, 1893, 34, 233-235. 1893.1

Der Wanderzug der Mainfische im Sommer 1892. Zool. Garten, 1893, $34,11-13$.

1893.2

Der Wanderzug der Mainfische im Frühjahre 1894. Allgem. Fischerei Zeitg., 1894, 19, 277-279. 1894.1

Unsere Mainfische. Zool. Garten, $1895,36,294-297$. 1895.1

Der Wanderzug der Mainfische im Frühjahre 1895. Allgem. Fischerei Zeitg., 1895, 20, 312-314. 1895.2

Der Zug der Mainfische im Frühjahre 1896. Allgem. Fischerei Zeitg., 1896-97, 21. Jahrg., 320. Zool. Garten, 1899, 40. Jahrg., 90-91. Ibid., 41. Jahrg., 55-56. Ibid., 1900, 42. Jahrg., 390-392. - Die Natur, 1899 , 48. Jahrg., 466. 1899.1

Die Wanderung der Mainfische im Frühiahre 1901. Allgem. Fischerei Zeitg., 1901, 26, 352. 1901.1

Der Wanderzug der Mainfische im Frühling 1902. Allgem. Fischerei Zeitg., 1902, 27, 283-284. 1902.1

-Die Mainfische und ihr Wanderzug. Aus d. Heimath, Stuttgart, $1903,16,12-15 ; 48-52$. 1903.1

Die Wanderung der Mainfische im Frühjahre 1904. Allgem. Fischerei Zeitg., 1904, 29. Jahrg., 223-224. 1904.1

Buxtorf, August. Geologie der Umgebung von Gelterkinden im Basler Tafeljura. Beiträge Geol. Karte Schweiz, 1901, 2. ser. 6, 1-106. 2 pls. \& 2 figs.

1901.1

Buys, J.T. Eeen nieuw leven. Overzigt van de visscherijen in de laatste tien jaren, naar aanleiding van het niet toekennen van premiën. De Gids, 1867 , 94-123.

1867.1
Buytendijk, $F . J . J$. See Buijtendijk, $F . J . J$.

Byerley, Isaac. On the Trachinus draco, or otter-pike, sting fish, or weever. Mem. Lit. Phil. Soc. Liverpool, 1849, 5, 156-168.

1849.1

Byers, William $N$. The abundant game of Colorado. Forest \& Stream, $1878,11,310$.

1878.1

- Grayling of Colorado. Forest \& Stream, 1878, 11, 300.

1878.2

Traits of Rocky mountain trout. Forest \& Stream, 1879, 12, 174. 1879.1

Bykowski, L., \& Nusbaum, Józef. See Nusbaum \& Bykowski.

Byrne, $L . W$. Notes on the young of Blennius galerita L. Journ. Mar. Biol. Assoc., 1900-03, 2. ser. 6, 383-386.

1902.1

On Lepadogaster stictopteryx. Proc.

Zool. Soc. London, 1902, 102. $\quad 1902.2$

- On the number and arrangement of the bony plates of the young John Dory. Biometrika, 1902, 2, 115-120. pl.

1902.3

A new species of Pteridium (Scopoli) from the north-east Atlantic. Ann. Mag. Nat. Hist., 1906, 7. ser. 18, 448-450. fig.

1906.1

The fishes collected by the "Huxley" from the north side of the bay of Biscay in August, 1906. Journ. Mar. Biol. Assoc., 1907-10, n. s. 8, 1-5. fig. 1907.1

Byrne, $L . W ., \&$ Garstang, W. See Garstang \& Byrne.

Byrne, L.W., \& Holt, Ernest W. L. See Holt \& Byrne.

Byström, C. Om fiskodlingen i atskilliga fremmande länder. Oefvers. K. Svenska Vetensk. Akad. Forh., 1863 (1864), 305-342.

1864.1

Report on various piscicultural establishments visited by the author in Germany. Switzerland and France. 
C. Migratory Coregoni. Field, Farm, Garden, 1878, 51, 39. 1878.1

C., A.B. A school of fish that may be clupeoids from lake Ontario. Chicago Field, 1879, 11, 308.

1879.1

C., A. G. Grubs in bass. Forest \& Stream, 1880, 15, 247. 1880.1

C., A. P. Curious fishes of the New York Aquarium, etc. Forest \& Stream, $1877,8,47$.

1877.1

C., ('. C. Fish culture. Fish. Gazette, 1879, 3, 66. 1879.1

C., C. H. Snakes in trout. Amer. Sportsman, 1874, 4, 253.

1874.1

C., $E$. Etude comparée sur le développement de la colonne vertébrale chez la Lépidostée [A criticism of Gegenbaur, Carl: "Ueber die Entwickelung der Wirbelsâule des Lepidosteus, mit vergleichend anatomischen Bemerkungen] Arch. Sci. Phys. Nat., Genève, 1868 , n. s. 32, 237-249.

1868.1

- Fish swallowing fish. Forest \& Stream, 1880, 13, 985.

1880.1

C., $F$. Canadian fish culture. Forest \& Stream, 1875, 4, 261.

1875.1

C. G.H. Salmon in the Connecticut. Forest \& Stream, 1878, 10, 265. 1878.1

C., H. E. Eastern Long Island. Menhaden oil and the fisheries. Scient. American, 1871, 24, 21.

1871.1

C., R. F. Salmon in the Elkhorn river. Forest \& Stream, 1876, 6, 165.

1876.1

C., $R . G$. Fish culture in Nebraska. Forest \& Stream, 1877, 8, 340. 1877.1

C., S.W. Migrations of the crappie [of the Ohio river and tributaries] Forest \& Stream, 1878, 10, 339. 1878.1

C., W. [Protective color adaptation in fishes and reptiles] Mag. Nat. Hist., $1835,8,230$.

1835.1

Black bass in the Delaware. Rod \& Gun, 1875, 7, 51 .
C., W. $H$. New England fisheries. Chicago Field, 1878, 9, 404. 1878.1

Cabibbe, Giacomo. Contributo alla conoscenza della struttura della cistifellea e del coledoco in alcuni vertebrati inferiori e nell' uomo. Atti Accad. Fisiocritici, Siena, 1903, 4. ser. 14, 361396.

1903.1

Cabot, J. Elliot, \& Agassiz, Louis. See Agassiz, Cabot \& others.

Cabot (junior:), Samuel. The abundance of horse mackerel (Temnodon saltator) this season in Beverly harbor. Proc. Boston Soc. Nat. Hist., 1845-48 (1848), 2, 179 .

1848.1

A specimen of the shovel fish from the Ohio river. Proc. Boston Soc. Nat. Hist., 1845-48 (1848), 2, 184.

1848.2

Cabrera Latorre, Angel. Ictiología ibérica. Memoria de los peces del mar de Andalucia: autógrafo inédito. Rev. Ciencias, Madrid, 1887, 32, 141-189.

1887.1

Cacheux, Emile. Etude sur les poissons et la pêche dans les colonies francaises. Congr. Intern. Pêche Piscicult. St. Pétersb., 1903, pt. 1, 227-236.

1903.1

Cadiat, L. O. Sur l'influence du pneumogastrique et l'action de la digitaline sur les mouvements du coeur chez les squales. C. R. Acad. Sci. Paris, 1879, 88, 1136-1138. - Journ. Anat. Physiol., Paris, 1879, 19, 38.-Rev. Intern. Sci., 1879, 3, 556. 1879.1

Cafauek, $F$. Das Skelet der Knochenganoiden. [n, p.] 1883. $8^{\circ}$.

1883.1

Cahall, W. C. The teeth as evidence of evolution. Amer. Naturalist, 1890 , 24, 224-236.

1890.1

The evolution of the circulatory organs. Amer. Naturalist, 1891, 24 237-247. 6 figs.

1891.1

Caillaud, René. Sur la pisciculture fluviatile et marine. Bull. Soc. Acclim. Paris, 1858, 5, 395-400. 
Caillaud, $R$.

La pisciculture en Vendée. Annuaire Soc. Emulation Vendée, 1860, 6. 16 p. Also separate; Napoléon-Vendée, $1860,16 \mathrm{p}$.

1860.1

- Expériences d'élevage de certains poissons de mer dans les eaux douces. Bull. Soc. Acclim., Paris, 1863, 10, 189-190.

1863.1

Aquiculture. Aperçu de l'état actuel de la pisciculture fluviatile dans diverses localités de la France. Bull. Soc. Acclim., Paris, 1864, 2. sér. 1, 580591; 735-755.

1864.1

Caillo, _ Recherches sur la pêche de la sardine en Bretagne, et sur les industries qui s'y rattachent. Nantes, 1855. $96 \mathrm{p}$. $8^{\circ}$.

1855.1

Caird, James, Huxley, Thomas Henry, \& Lefevre, George Shaw. Extracts from the report of the commissioners appointed to inquire into the sea fisheries of the United Kingdom, etc. London, 1861. Reprinted in Rept. U. S. Fish Comm. 1871-72 (1873), 1, 145-148.

1873.1

Cairncross, David. The origin of the silver eel, with remarks on bait and fly-fishing. London, 1862 . viii, $96 \mathrm{p}$. $8^{\circ}$.

1862.1

Cajal, S. Ramón. See Ramón y Cajal, $S$.

Cajetan, J. Ein Beitrag zur Lehre der Anatomie und Physiologie des Tractus intestinalis der Fische. Inaug. Dissert. Bonn, 1883. $8^{\circ}$. 1883.1

Calamai, Luigi. Sull' anatomia della torpedine e sopra un gabinetto di anatomia comparata. Firenze, $1845.8^{\circ}$.

1845.1

Calamink, pseudonym for Wilson, John L.

Calandruccio, Salvatore. Sul ramo laterale del trigemino nei Murenoidi. Bull. Accad. Gioenia Sci. Nat. Catania, 1896, n. s. 14-15. - Atti Accad. Gioenia Sci. Nat. Catania, 1897, 4. ser. no. 2, 1-8. pl.

1896.1

Calandruccio, S., \& Grassi, G. B. See Grassi \& Calandruccio.

Calberla, E. Der Befruchtungsvorgang beim Ei von Petromyzon planeri: ein Beitrag zur Kenntniss des Baues und der ersten Entwicklung des be- fruchteten Wirbelthiereies. Zeitschr. Wiss. Zool., 1877, 30, 437-486. 3 pls.

1877.1

Zur Entwicklung des Medullarrohres und der Chorda dorsalis der Teleostier und der Petromyzonten. Morph. Jahrb., 1877, 3, 226-270. 2 pls.

1877.2

-Z Zur Entwickelungsgeschichte des Petromyzon. Amt. Bericht Vers. Deutsch. Naturf. München, 1877, 50, 188-189.

1877.3

Calderwood, W. L. Notes on the Greenland shark (Lomargus microcephalus) 4. Rept. Fish. Board Scotland, 1885 (Append. $F$ ), 228.

1885.1

Description of work on the Scottish Fishery Board's steamer "Garland," with statement of results. 5 . Ann. Rept. Fish. Board Scotland 1885 (1886) (Append. $F$ ), 45.

1886.1

- Notes on an intra-uterine specimen of the porbeagle (Lamna cornubica) 6. Rept. Fish. Board Scotland, 1887, 263.

1887.1

- On the swimming bladder and flying powers of Dactylopterus volitans. Proc. Roy. Soc. Edinb., 1890, 17, $132-$ 138. pl.

1890.1

- The Plymouth mackerel fishery of 1889-90. From data collected by Mr. Wm. Roach. Journ. Mar. Biol. Assoc., 1891-92, n. s. 2, 4-14. 1891.1

A contribution to the knowledge of the ovary and intra-ovarian egg in teleosteans. Journ. Mar. Biol. Assoc., 1891-92, n. s. 2, 298-313. 2 pls. 1892.1

Experiments on the relative abundance of anchovies off the south coast of England. Journ. Mar. Biol. Assoc., 1891-92, n. s. 2, 268-271. 1892.2

The head kidney of teleostean fishes. Journ. Mar. Biol. Assoc., 189192 , n. s. 2, 43-46. pl.

1892.3

Monthly reports on the fishing in the neighbourhood of Plymouth. Journ. Mar. Biol. Assoc., 1891-92, n. s. 2, 277-279; 394-395. 8 charts. 1892.4

- Notes on Centrina salviani. Journ. Mar. Biol. Assoc., 1891-92, 2, 322-324. pl.

1892.5

- On the destruction of immature fish, and a discussion on remedial measures. By the staff of the Marine Biologi- 
cal Association. Part 1. Introductory statement. Rept. Brit. Assoc. Adv. Sci., 62. meet., 1892, 763-765. - Part 2. On the relation of size to sexual maturity. Ibid., 767.

1892.6

Monthly reports on the fishing in the neighbourhood of Plymouth. Journ. Mar. Biol. Assoc., 1893-95, n. s. 3, 107-110. 4 charts.

1893.1

Note on the capture of a freshwater eel in a ripe condition. Ann. Mag. Nat. Hist., 1893, 6. ser. 12, 35.

1893.2

Observations on the migratory movements of Salmonidre during the spawning season, Proc. Roy. Soc. Edinb., 1898, 22, 47-55.

1898.1

Report on the Cruive dykes and Cruive fishings of Scotland. 7. Rept. Fish. Board Scotland, 1899, pt. 2, 51 .

1899.1

The coast salmon fisheries of Scotland. 8. Rept. Fish. Board Scotland, 1900, pt. 2, 15.

1900.1

Note on the range of the salmon spawning season in Scotland. 9. Rept. Fish. Board Scotland, 1901, pt. 2, 53.

1901.1

Salmon hatcheries in Scotland. 19. Ann. Rept. Fish. Board Scotland, 1901, pt. 2, 88 .

1901.2

Water temperature in relation to the early annual migration of salmon from the sea to rivers in Scotland [3 papers] 19. Ann. Rept. Fish. Board Scotland, 1901, pt. 2, p. 57. - 20 . Rept., 1902, pt. 2, p. 111.-21. Rept. 1903, pt. 2, p. 71 .

1901.3

A contribution to the life history of the salmon, as observed by means of marking adult fish. 20. Ann. Rept. Fish. Board Scotland, 1902, pt.2, 55-100.

1902.1

Continued as a series of articles appended to annual reports for the years 1904-10.

A comparison of the relative results of certain net fisheries, season 1902. 21. Ann. Rept. Fish. Board Scotland, 1903, pt. 2 (Append. 2), 55. 1903.1

The observance of the weekly close time. 21. Ann. Rept. Fish. Board Scotland, 1903, pt. 2, 59.

1903.2

The temperature of the river Tay and its tributaries in relation to the ascent of salmon. 21. Ann. Rept. Fish. Board Scotland, 1903, pt. 2, 77. 1903.3
An estimate of the proportion of the sexes of salmon in certain Scottish rivers, during the winter and spring months. 22. Ann. Rept. Fish. Board Scotland, 1904, pt. 2 (Append. 5), 102.

1904.1

The feeding habits of salmon fry reared in the freshwater ponds at Tugnet. 23. Ann. Rept. Fish. Board Scotland, 1904, pt. 2 (Append. 4), 86.

1904.2

Notes on the relative numbers of grilse and salmon in the lower waters of the river Tay during the spawning season. 22. Ann. Rept. Fish. Board Scotland, 1904, 6, pt. 2, 107 . 1904.3

- Notes on the 'Tay bull-trout, with an analysis of its flesh. 22. Ann. Rept. Fish. Board Scotland, 1904, 8, pt. 2, 111 .

1904.4

Observations on the seaward migration of smolts in the estuary of the river Tay. 23. Ann. Rept. Fish. Board Scotland, 1904, pt. 2 (Append. 3), 80 .

1904.5

Table showing river and estuarine salmon net fisheries, for fish season 1904. 22. Ann. Rept. Fish. Board Scotiand, 1904, pt. 2, $13 . \quad 1904.6$

Autumn migration of salmon smolts in Scotland. 24. Ann. Rept. Fish. Board Scotland, 1905, pt. 2 (Append. 3), 70.

1905.1

Natural history notes. 1. Smolts reared in fresh water. 2. Spawning of smolts. 3. Salmon caught out at sea. 24. Ann. Rept. Fish. Board Scotland, 1905 (Append. 4), 75. 1905.2

"The white spot" affecting salmon in the island of Lewis. 24. Ann. Rept. Fish. Boárd Scotland, 1905, pt. 2 (Append. 5), 78.

1905.3

The bull trout of the Tay and of Tweed. Proc. Roy. Soc. Edinb., 1906, 25, pt. 1, 27-38. pl.\& 2 figs. 1906.1

Experiment to test the length of time sea-lice remain attached to salmon in fresh water. 25. Ann. Rept. Fish. Board Scotland, 1906 (Append. 5), 75.

1906.2

Note on the smolt to grilse stage of the salmon, with exhibition of a marked fish recaptured. Proc. Roy. Soc. Edinb., 1906, 26, 321-324. fig.

1906.3 
Calderwood, W.L.

… I specimen of the salmon in transition from the smolt to the grilse stage. Proc. Roy. Soc. Edinb., 1906, 25, pt. 1, 395-400. 2 pls. \& fig. 1906.4

- The life of the salmon. London, 1907. 157 p. $8^{\circ}$.

1907.1

Report on a male kelt, kept for a year in fresh water, and found to be again ripe for spawning; with a statement by Dr. D. Noel Paton. 27. Ann. Rept. Fish. Board Scotland, 1908, pt. 2, 43.

1908.1

Note on crossing salmon by transporting ripe milt. 28. Ann. Rept. Fish. Board Scotland, 1909, pt. 2, 61.

1909.1

The salmon rivers and lochs of Scotland. London, 1909. 442 p. figs. $4^{\circ}$.

1909.2

Infrequency of spawning in the salmon, as shown by the study of the scales of fish caught in fresh water. 29. Ann. Rept. Fish. Board Scotland, $1910,1$.

1910.1

- Salmon fisheries. 30. Ann. Rept. Fish. Board Scotland, 1912, pt. 3, $240-244$

1912.1

- Salmon fisheries. 31. Ann. Rept. Fish. Board Scotland, 1913, 240249. pl.

1913.1

Calderwood, W. L., \& Brook, George. Report on the food of the herring. 4. Rept. Fish. Board Scotland, 1885,102 .

1885.1

Calderwood, W.L., \& Holt, Ernest $W^{\top}$. L. See Holt \& Calderwood.

Caldwell, $E . E$. The gar problem. Trans. Amer. Fisheries Soc. 1912 (1913), 61-64.

1913.1

Caldwell, W. $H$. On the development of the monotremes and Ceratodus. Journ. Proc, Roy. Soc. New South WVales, 1885, 18, 117-122; 138. 1885.1

Calkins, Gary Nathan [1869-] Lymphosporidium trutte, nov. gen. \& nov. sp. The cause of a recent epidemic among brook trout, Salvelinus fontinalis. Zool. Anz., 1900, 23, 513-520. 6 figs. - Science, n. s. 12, 64-65. - Proc. Amer. Assoc. Adv. Sci., 49. meet., 1900, $238-239$

1900.1

Report upon the recent epidemic among brook trout (Salvelinus fontinalis) on Long Island. 4. Ann. Rept.
Comm. Fish., Game \& Forests N. Y. 1899 (1900), 175-190. 8 pls. 1900.2

Calkins, Gary Nathan, Dean, Bashford, Harrington, $N . R$., \& Griffin, $B . B$. See Dean, Harrington, \& others.

Call, Richard Ellsworth [1856-] Memoranda on a collection of fishes from the Ozark region of Missouri. Proc. Davenport Acad. Nat. Sci., 1887, 5,73 .

1887.1

- The fishes of the Des Moines basin. Proc. Iowa Acad. Sci., 1892, 1, $43-56$.

1892.1

- The life and writings of Rafinesque. Publications Filson Club, Louisville, Ky., 1895, 10, $227 . \quad 1895.1$

(editor) Ichthyologia Ohiensis [by C. S. Rafinesque] and the ich thyologic bibliography of Rafinesque. Cleveland, 1899. 175 p. $8^{\circ}$. 1899.1

Callaway, Otis, \& Cockerell, Theodore Dru Alison. See Cockerell \& Callaway.

Calloni, S. Il ripopolamente dei nostri laghi ticinesi. Agricolt. Ticinese, Lugano, 1886. Also separate; Lugano, 1886. 33 p. $8^{\circ}$.

1886.1

Calmette, $A$. Les venins, les animaux venimeux et la sérothérapie antivenimeuse. Paris, 1907.

Poissons, p. 302-327.

1907.1

Venomous fishes. Poison as a means of defense. Scient. Amer. Suppl., $1907,64,12$. 8 figs.

1907.2

Calugareanu, D. Die Darmatmung von Cobitis fossilis. I. Mitteilung. Ueber den Bau des Mitteldarms. Arch. Ges. Physiol., Bonn, 1907, 118, 42-51. pl. - II. Mitteilung. Ueber den Gaswechsel. Ibid., 120, 425-450. 1907.1

- Chlorschwankungen im Organismus des Wetterfisches (Cobitis fossilis) je nach dem Chlorgehalt des Mediums. Archiv Physiol. (Pflüger), 1910, 133, 260-266.

1910.1

Variations du chlore dans l'organisme de la loche (Cobitis fossilis), suivant la teneur en chlore du milieu. C. R. Mém. Soc. Biol. Paris, 1910, 68, $895-896$.

1910.2

Calvet, Louis. La station zoologique de Cette. Son origine, son évolution, son organisation actuelle avec une esquisse de la faune et de la flore ma- 
rines de la région et un compte rendu des fêtes jubilaires de la station. Trav. Inst. Zool. Univ. Montpellier Stat. Zool. Cette, 1905, 2. sér. 15, 1-91. 16 pls.

1905.1

Cambridge, $F$. P. The giant goby (Gobius capito) Zoologist, 1903, 4. ser. 7, 429. pl.

1903.1

Camerano, Lorenzo. Ricerche intorno alla distribuzione dei colori nel regno animale. Mem. R. Accad. Sci. Torino, 1885, 36, 329-360. pls. 1885.1 Pisces, p. 349. pl. \& figs.

- L'Exocotus furcatus. [n. p.] 1891. $8^{\circ}$.

1891.1

Relazione intorno alla memoria di E. Giglio-Tos intitolata: "Sulle cellule del sangue delle Lamprida." Atti Accad. Sci. Torino, 1896, 31, 731.

1896.1

Lo studio quantitativo degli organismi ed il coefficiente somatico. Atti Accad. Sci. Torino, 1900, 35, 327346. - Arch. Ital. Biol., 'T'urin, 33, $157-176$.

1900.1

Notice of the somatic coefficient of fishes. Science, 1901, n. s. 13, 276.

1901.1

Osservazioni intorno al Gadus saida Lepechin, della Baia di Teplitz (In Osservazioni scientifiche eseguite durante la spedizione polare di S. A. R. Luigi Amedeo di Savoia, 1899-1900, p. 609-620. Milan, 1903) 1903.1

Camerano, Lortnzo, \& Salvadori, Tomaso. Relazione intorno alla memoria del Dott. Ermanno Giglio-Tos intitolata: "La struttura e l' evoluzione dei corpuscoli rossi del sangue nei vertebrati." Atti Accad. Sci. Torino, 1897. 32, 237-239.

1897.1

Caméré, ___ Notice sur les divers types d'échelles à poissons installées sur la Seine entre Paris et Rouen. Congr. Internat. Aquicult. Pêche 1900 (1901), Mem.\& C. R., 134-144. pl. 1901.1

Cameron, Alexander $T$. Note on the iodine content of fish-thyroids [Scyllium thyroids contain more iodine than any thyroid previously reported on] Biochem. Journ., 1913, 7, 466470 .

1913.1

Cameron, John. On the presence and significance of the superior commissure throughout the vertebrata
Journ. Anat. Physiol., London, 1904, 38, 275-292. 2 pls.

1904.1

The superior commissure in teleosteans, $p$. 279.

Cameron, John, \& Milligan, Witliam. The development of the auditory nerve in vertebrates. Journ. Anat. Physiol., London, 1910, 44, 111-132. 30 figs.

1910.1

Camichel, __ \& Mandoul,

Des colorations blene et verte de la peau des vertébrés. C. R. Acad. Sci. Paris, $1901,133,826-828$.

1901.1

Campagna, D. del. Faunula del Giura superiore di Collalto di Solagna (Bassano) Boll. Soc. Geol. Ital., 1904, 23, 239-269. pl.

1904.1

Campanyo, $L$. Histoire naturelle du département des Pyrénées-Orientales. 3 vols. Perpignan, 1S61-64. $8^{\circ}$.

1861.1

Campaux, A. De ecloga piscatoria qualem a veteribus adumbratam absolvere sibi proposuerat Sannazarius, thesim proponebat. Paris, 1859. 106 p. 2 pls. $8^{\circ}$.

1859.1

Campbell, J.B. Notes on McCloud river, California, and some of its fishes. Bull. U. S. Fish Comm. 1881 (1882), 1, 44-46.

1882.1

Campbell, James Duncan. The fisheries of China. Intern. Fisheries Exhib. Lit., London, 1883. Conferences, 5, pt. 4 .

1883.1

Campbell, James MacNaught. Porbeagle Lamna cornubica, taken in the firth of Clyde] Sci. Gossip, 1880, 16, 277.

1880.1

Notes on a short sun-fish, Orthagoriscus mola Linn., caught in the firth of Clyde. Proc. Nat. Hist. Soc. Glasgow, 1881, 5, 176-178. $\quad 1881.1$

$$
\text { Capture of a marked skate. }
$$
Ann. Scott. Nat. Hist., 1905, 56. 1905.1

Campbell, W. D. On a new fish (Discus aureus) Trans. Proc. New Zeal. Instit., 1579, 11, 297-298.

1879.1

Camper, Peter [1722-1789] Verhandeling over het gehoor der geschubde visschen. Eerste Afdeeling: Over het hersengestel, zenuwen en gehoorgang der geschubde visschen. Verhandel. Holland. Maatsch. Wetensch. Haarlem, $1763,7,1$ slot. 1763 
Camper, $P$.

Mémoire sur l'organe de l'ouie des poissons. Mém. Acad. Roy. Sci. Paris, $1774,6$.

1774.1

Bemerkungen über die Classe derer Fische, die von Linné schwimmenden Amphibien genannt werden. Schrift. Ges. Naturf. Freunde Berlin, $1786,7,197-218$.

1786.1

Campiche, G., Pictet, $F . J .$, \& Tribolet, $G$. de See Pictet, Campiche \& Tribolet.

Camps y de Olzinellas, Carlos de. Observaciónes ictiológicas. Mem. Acad. Cien. Barcelona, 1906, 5, 473-478.

1906.1

Camus, Lucien, \& Gley, E. De l'action destructive d'un sérum sanguin sur les globules rouges d'une autre espèce animale. Immunisation contre cette action. C. R. Acad. Sci. Paris, $1898,126,428-431$.

1898.1

- De la toxicité du sérum d'anguille pour des animaux d'espèce différente (lapin, cobaye, hérisson) C. R. Soc. Biol. Paris, 1898, 129-130. 1898.2

Sur le mécanisme de l'immunisation contre l'action globulicide du sérum d'anguille. C. R. Acad. Sci. Paris, $1898,127,330-332$.

1898.3

Expériences concernant l'état réfractaire du sérum d'anguille. Immunité cytologique. C. R. Acad. Sci. Paris, 1899, 129, 231-233. 1899.1

Action hématolytique et toxicité générale du sérum d'anguille pour la marmotte. C. R. Acad. Sci. Paris, 1905, 140, 1717-1718.

1905.1

Camus, Lucien, \& Nicloux, Maurice. Sur la dissociation de l'hémoglobine oxycarbonée au niveau des branchies. C. R. Soc. Biol. Paris, 1903, 55, $792-$ 794.

1903.1

Camuset, $G$. Sur le développement pathologique de l'œil chez le cyprin dit poisson-télescope. C. R. Acad. Sci. Paris, 1874, 78, 198-200.

1874.1

Canavan, E. O'H. On ecls. Trans. New Zeal. Instit., 1893, 25, 191-193. pl.

1893.1

Cancrin, Franz Ludwig von. Abhandlung von dem Anlegen, dem Bau und der Ausbesserung der Teiche, und besonders der Fischteiche. Frankfurta.-M., 1791. 2 pls. $8^{\circ}$.
Canestrelli, G. Denti di Ptychodus Agass. nel terziario dell' Appennino toscano e milano. Atti Soc. Toscana Sci. Nat., Pisa, 1910, 26, 102-120. pl.

1910.1

Canestrini, Alessandro. Le condizioni ittiologiche del Trentino e la nuova legge sulla pesea. Atti Accad. Agiati Rovereto, 1913, 4. ser. 1, 113-151.

1913.1

Canestrini, Giovanni $[1835$ - $]$ Ueber die Stellung von Ophiocephalus Bl. im Systeme. Verh. Zool. Bot. Ver. Wien, $1858,8,437-440$.

1858.1

Ueber die Stellung der Helmichthyiden im Systeme. Verh. Zool. Bot. Ver. Wien, 1859, 9, 27-30. 1859.1

Zoologische Mittheilungen. I. Ueber die Stellung der Aulostomen im Systeme. Verh. Zool. Bot. Ver. Wien, $1859,9,75-78$.

1859.2

Zur Kritik des Müller'schen Systems der Knochenfische. Verh. Zool. Bot. Ver. Wien, 1859, 9, 119-129. 1859.3

Zur Systematik der Percoiden. Verh. Zool. Bot. Ver. Wien, 1860, 10 , 291-314.

1860.1

- Catalogo dei pesci del golfo di Genova. Arch. Zool. Anat. Fisiol., $1861,1,262-267$.

1861.1

I gobii del golfo di Genova. Arch. Zool. Anat. Fisiol., 1861, 1, 121157. 4 pls

1861.2

- Intorno allo svíluppo del Dactylopterus volitans C. V., ed al genere Cephalacanthus. Arch. Zool. Anat. Fisiol., 1861, 1, 45-51. 1861.3

— Pleuronettidi del golfo di Genova. Arch. Zool. Anat. Fisiol., 1861, $1,1-44.4$ pls.

1861.4

- Sopra una nuova specie di Ophiocephalus senza ventrali, Ophiocephalus apus. Arch. Zool. Anat. Fisiol., $1861,1,77-79$. pl. 1861.5

- Sopra una nuova specie di Tetrapturus. Arch. Zool. Anat. Fisiol., 1861, 1, 239-261. pl.

1861.6

I Blennini, Anarrhichadini e Callionimini del golfo di Genova. Arch. Zool. Anat. Fisiol., 1862, 2, 83118. 4 pls.

1862.1

Intorno alla Solea oculata Risso.

Arch. Zool. Anat. Fisiol., 1862, 2, 117 -

118. pl. 
I Gadidi e Macrouridi del golfo di Genova. Arch. Zool. Anat. Fisiol., $1863,2,343-376$.

1863.1

Note ittiologiche. Arch. Zool. Anat. Fisiol., 1864, 3, 100-112. pl. iv. 1864.1

i. Sopra una nuova specie di Mesites, ii Sopra una nuova specie di Gobius d'acqua dolce. iii. Sopra una varieta dell' Alburnus alborella De-Fil. iv. Nota sul genere Scardinus. v. Nota sul genere Telestes. vi. Nota sul genere Barbus.

Sopra alcuni pesci poco noti o nuovi del Mediterraneo nota. Mem. Accad. Sci. Torino, 1864, 2. ser. 21, 359-367. 2 pls.

1864.2

Studi sui Lepadogaster del Mediterraneo. Arch. Zool. Anat. Fisiol., 1864, 3, 177-196. pl.

1864.3

Note ittiologiche. Arch. Zool. Anat. Fisiol., 1865, 3, 301-316. 1865.1

i. Sul Gobius punctatissimus m. ii. Sul genere Leuciscus Rond. iii. Sulla Cobitis larrata DeFil. iv. Sullo Squalius albus Bp. v. Sul Phoxinus lavis $\mathrm{Ag}$. vi. Sulle specie nostrali del genere Gasterosteus L. vii. Enumerazione dei Ciprini del Modenese.

Catalogo dei pesci d' acqua dolce d' Italia. Ann. Soc. Nat. Modena, 1866. 1, 73-90. pl.

1866.1

Prospetto critico dei pesci d' acqua dolce d' Italia. Arch. Zool. Anat. Fisiol., 1866, 4, 47-187. pl. 1866.2

Riflessione sul vivajo di pesci marini del lago dolce di Arquà. Movimento scientifico, redatto dal conte Leonardo Salimbeni. 1866, 1-9. 1866.3

Due note ittiologiche. I. Sopra alcuni pesci dell' Arno. II. Effetti di dimagramento osservati nel Gobius fluviatilis Bon. Ann. Soc. Nat. Modena, $1867,2,7-12 ; 12-13$.

1867.1

Intorno ai Labroidi nel Mediterraneo. Ann. Soc. Nat. Modena, 1868 , 3, 104-144. pls. Abstract in Comment. Fauna Flora Venezia \& 'Trent. $1868,1,105-119$.

1868.1

- Nuove specie italiane di animali. I. Sopra una nuova specie di Gobius [G. avernensis] Comment. Fauna Flora Venezia \& Trent., 1868, 1, 169-173.

1868.2

Compendio di zoologia ed andtomia comparata. I, Vertebrati. Milano, $1869.8^{\circ}$.

1869.1

Sopra alcuni pesci dell' Australia: Histiopterus recurvirostris, Scorpis oblongus n. sp., Chrysophrys gibbiceps,
Chilodactylus nigricans. Arch. Zool. Anat. Fisiol., 1869, 2. ser. 1, 151-155. pl.

1869.2

Pesci d' Italia (In Cornalia, E. Fauna d' Italia. Milano, 1870-74. $4^{\circ}$. pt. 3, p. 1-208)

1870.1

Intorno alla riproduzione e lo sviluppo dei Lofobranchi. Rivista Sci. Indust. Prin. Scop. Inven., Firenze, $1871,3,53$.

1871.1

Note zoologiche. I. Sul proboscistoma del Saccardo. II. Intorno ai Lofobranchi adriatici. Atti Istit. Venezia, 1871, 16, 1045-1067. - Arch. Sci. Phys. Nat., 41, 355-358. - Ann. Mag. Nat. Hist., 4. ser. 8, 215-217.

1871.2

Sul maschio della Cobitis tenia L. Rivista Pred., Firenze, 1871, 3. anno, 71.

1871.3

Ueber das Männchen von Cobitis tania Linn. Arch. Naturgesch., 1871, 37, 222-224. - Zeitschr. Wiss. Zool., $1871,21,538-539$.

1871.4

Caratteri sessuali secondarii della tinca. Atti Soc. Veneto-Trent. Sci. Nat. Padova, 1872, 1, 127-129. pl. 1872.1.

Studii recenti intorno alla generazione delle anguille. Atti Soc. Veneto-Trent. Sci. Nat., Padova, 1872, 1, 70-74.

1872.2

La pesca nelle acque dolci. Articolo inserito nella Rassegna di agricoltura, industria e commercio, pubblicata dalla Società d' Incoraggiamento in Padova. Anno 1, novembre, 1873.

1873.1

Sopra una nuova specie di Leiognathus. Atti Soc. Veneto-Trent. Sci. Nat., 1889,11 , pt. 2. $\quad 1889.1$

La malattia dominante delle anguille. Atti R. Istit. Veneto Sci. 1892 (1893), 7. ser. 4. 1893.1

II disegno di legge per la conservazione della laguna di Venezia e gli interressi pescherecci e vallicoli. Atti R. Istit. Sci. Veneto, 1898, 7. ser. 9, 760-768.

1898.1

Canestrini, Ricardo [1858?-1892] I pesci del Trentino. Ann. Soc. Alpinisti Tridentini, 1885, 11, 1-63. Also separate; Roveredo, 1885. 63 p. $8^{\circ}$. 
Canestrini, $R$.

Nota sui pesci mostruosi. Atti Soc. Sci. Padova, 1886, 9, 117-125.

1886.1

Osservazioni sull' apparato uditivo di alcuni pesci. Atti Soc. Padova, 1886, 9, 256-282. pl.

1886.2

Canestrini, R., \& Parmigiani, L. Gli otoliti dei pesci. Atti Soc. VenetoTrent. Sci. Nat., 1883, 8, 280-339. 2 pls.

1883.1

Cannarella, $P$. Contribuzione alla formazione dello scheletro cefalico dei pesci Murenoidi. Catania, 1898. 4 pls. $4^{\circ}$.

1898.1

Cannieu, A. Sur l'évolution sexuelle des truites des Pyrénées. C. R. Acad. Sci. Paris, 1891, 112, 957-959. 1891.1

Cano, $U$., \& Martínez, $G$. Einfluss der Wasserfauna auf Choleravibrionen. Vorläufige Mitteilung [Ohne Einfluss Centralbl. Bakt. Parasit., 1912, 67, 1. Abth., 431-133. 1912.1

Cantor, Theodore Edward [1809-] Description of new species of Zygæna. Quart. Med. Journ. Calcutta, 1837, 315-320. - Trans. Med. Phys. Soc. 1837,8 , cexi-ccxv.

1837.1

_- Notes respecting some Indian fishes, collected, figured and described, etc. Journ. Roy. Asiat. Soc. Bengal, 1839, 5, 165-172.

1839.1

On the production of isinglass from certain Indian fishes. Proc. Zool. Soc. London, 1839, 7, 115-117. - Ann. Mag. Nat. Hist., 1810, 4, 399-401.

1839.2

General features of Chusan, with remarks on the flora and fauna of that island. Ann. Mag. Nat. Hist., $1842,9,265-278 ; 361-370 ; 481-493$.

Pisces, p. 48. -493.

1842.1

Notice of the foetus of Zygona laticeps Cantor. Ann. Mag. Nat. Hist., $1845,16,372-374$

1845.1

Catalogue of Malayan fishes. Journ. Roy. Asiat. Soc. Bengal, 1849, 18, 983-1042.

1849.1

Descriptions of two species of Indian eels. Nat. Tijdschr. Neder.Indië, 1853, 4, 227-242. 2 pls. 1853.1

Cantraine, Francois Joseph [18011863] Mémoire sur le Serranus tinca. Bull. Acard. Sci. Bruxelles, 1835, 2, 207-
208. - Mém. Acad. Sci. Bruxelles, 1838, 11, 1-9. pl. $4^{\circ}$. 1835.1

—_ Mémoire sur un poisson nouveau [Acanthoderma temminckii] trouvé dans le canal de Messine, etc. Brussels, 1837. 19 p. 2 pls. $4^{\circ}$. 1837.1

Canu, Eugène. Notes de biologie marine, fauniques ou éthnologiques. Ann. Stat. Aquic. Boulogne-sur-M., $1893,1,99-116$.

1893.1

Ponte, oufs et larves des poissons osseux, utiles ou comestibles, observés dans la Manche. Ann. Stat. Aquic. Boulogne-s.-M., 1893, 1, $117-$ 132. pls. viii-Xv. 1893.2

_- Notes sur la pisciculture marine. Boulogne-sur-Mer, 1894. $4^{\circ} . \quad 1894.1$

- Note sur la distribution du hareng, comparée aux caractères physiques et biologiques des eaux dans la Manche. Bull. Soc. Centr. Aquicult. Pêche, 1897, 9, 179-188.

1897.1

Capel, Charles C. Trout culture. A practical treatise on the art of spawning, hatching and rearing trout. London, 1877. 93 p. $\mathrm{S}^{\circ}$.

1877.1

- Do fish sleep? Fish. Gazette, 1878, n. s. $2,172$.

1878.1

- [Notes on the colour of trout] Fish. Gazette, 1878, n. s. 2, 401. 1878.2

Fish-culture, private and public. Fish. Gazette, 1879, 3, 102. 1879.1

Capellini, Giovanni [1S33-] Di $\mathrm{N}$. Stenone e dei suoi studii geologici in Italia. Bologna, 1870.35 p. $4^{\circ}$.

1870.1

Capello, Felix de Brilo. Catalogo dos peixes de Portugal que existem no Museu de Lisboa. Jorn. Sci. Math. Phys. Nat. Lisboa, 1868, 1, 233-264; 307-313.

1868.1

- Descripção de dois peixes novos provenientes dos mares de Portugal [Chimara affinis, Pseudotriakis microdon Jorn. Sci. Math. Phys. Nat. Lisboa, 1868, 1, 31t-317. pls. 1868.2

Description de trois nouveaux poissons des mers du Portugal: Trachurue fallax, Chimara affinis, Pseudotriakis microdon. Jorn. Sci. Math. Phys. Nat. Lisbon, 1868, 1, 318-322. pl.

1868.3 
- Peixes novos de Portugal e da Africa occidental, e caractéres distinctivos d' outras especies já conhecidas. Jorn. Sci. Math. Phys. Nat. Lisboa, 186S, 1, 151-169. pl.

1868.4

- Appendice ao catalogo dos peixes de Portugal que existem no Museu de Lisboa. Jorn. Sci. Math. Phys. Nat. Lisboa, 1870, 2, 223-228.

1870.1

Catalogo dos peixes de Portugal que existem no Museu de Lisboa. Jorn. Sci. Math. Phys. Nat. Lisboa, 1870, 2, 51-63;131-153. pl.

1870.2

Lista de algumas especies de peixes colligidos ou observados na bahia de Lagos (Algarve) Jorn. Sci. Math. Phys. Nat. Lisboa, 1870, 2, 229-232

1870.3 de "Squalus maximus" Linn. "Cetorhinus blainvillei] pescado nas costas de Portugal. Jorn. Sci. Math. Phys. Nat. Lisboa, 1870, 2, 233-238. pl. 1870.4

Noticia ácerca de um peixe pouco conhecido proveniente do Brasil [Chatostomus hystrix C.\& V.] Jorn. Sci. Math. Phys. Nat. Lisboa, 1870, 2, 6469. pl.

1870.5

_- Sur l'identité du Prometteus paradoxus Cap. et du Nesiarchus nasutus J. Y. Johnson. Jorn. Sci. Math. Phys. Nat. Lisboa, 1870, 2, 154. 1870.6

Primeira lista dos peixes da ilha da Madeira, Açores, e das possessões portuguezas d' Africa, que existem no Museu de Lisboa. Jorn. Sci. Math. Phys. Nat. Lisboa, 1871, 3, 194-202; 280-282; 1873, 4, 83-8s.

1871.1

Segundo appendice ao catalogo dos peixes de Portugal. Jorn. Sci. Math. Phys. Nat. Lisboa, 1873, 4, 307-311.

1873.1

Algumas considerações ácerca da industria piscicola em Portugal. Jorn. Sci. Math. Phys. Nat. Lisboa, 1876, 5, 159-164.

1876.1

Terceiro appendice ao catalogo dos peixes de Portugal. Jorn. Sci. Math. Phys. Nat. Lisboa, 1876, 5, 165-167.

1876.2

Catalogo dos peixes de Portugal. Mem. Acad. Sci. Lisboa, 1881, 46 (n. s. 6, pt. 1), 1-73.

1881.1

Obra postuma, com prologo por J. V. Barboza du Bocage.

Capello, Fetix de Brito, \& Bocage, José Vincente Barboza du. See Bocage \& Capello.
Cappelle, $I I$. van. Die Forelle, ihre Zucht und ihr Fang. Nat. Ges. Hannover, 1908, 55-57. Jahresber., 62-64.

1908.1

Cappello, $O$. Teleologia del sistema urinifero vascolare scoperto da Jacobson nei pesci e nei rettili. Giorn. Accad. Sci. Lett. Arti, Roma, 1845, 102, 42-47.

1845.1

Capsoni, Giovanni. Sul olio di merluzzo e sulle sue mediche proprietà. Giorn. Farm. Chim. Sci. Acc. Cattaneo), Milano, 1831, 14, 9.

1831.1

Car, Lazar. Biologijska klasifikacija i fauna naših sladkih voda. Glasnik Hrvatsk. Narosl. Društva, 1911, 23, 24-85. 37 figs.

1911.1

Caradaillac de Saint-Paul, G. de, \& Roule, L. See Roule \& Caradaillac de Saint-Paul.

Caraffa, Tito de. Essai sur les poissons des côtes de la Corse .. Bull. Soc. Sci. Hist. Nat. Corse, 1902, 22. année, 253-259. Also separate; Bastia, 1902.

1902.1

Caraven-Cachin, Alfred. Catalogue des poissons des eaux douces du Département du Tarn. C. R. Assoc. Franç. Avanc. Sci., 23. sess., 1895, 2, 656659 .

1895.1

- Quelques notes sur la faune ichthyologique du Département du Tarn. Rev. Hist. Sci. Département Tarn, Albi, 1903, 28, 1-22. 1903.1

Carazzi, Davide. Effetti dello scoppio delle torpedini sopra gli animali marini. Monit. Zool. Ital., 1897, 8, $254-256$.

1897.1

Sulle funzioni dei canali semicircolari del vestibolo e del nervo vestibolare. Riv. Patologia Nerv. Mentale, 1898, 3, 300-306. 1898.1

- Ricerche sul plancton del lago Fusaro [etc.] Boll. Notizie Agrarie, Roma, 1900, 22, 1270-1287. $\quad 1900.1$

Sulla circolazione arteriosa cardiaca ed esofagea delle Scyllium catulus (nota preliminare) Monit. Zool. Ital., 1904, 15, 147-148.

1904.1

- Sulla circolazione arteriosa cardiaca ed esofagea dello Scyllium catulus. Internat. Monatschr. Anat. Hist., Leipzig, 1904, 21, pt. 1, 1-20. pl. 1904.2 Sulla Selache maxima Gunn. Zool. Anz., 1904, 28, 161-165. fig. 
Carazzi, $D$.

- Sul sistema arterioso di Selache maxima e di altri squalidi (Acanthias vulgaris, Mustelus vulgaris, Scyllium catulus, S. canicula, Squatina vulgaris) Anat. Anz., 1905, 26, 63-96; 124-134. 24 figs.

1905.1

Noterelle biologiche sui muggini. Natura, 1913, 4, 153-156. 1913.1

Ueber die Schlafstellung der Fische [Beobachtung im Meere schlafender Mugil-Arten! Biol. Centralbl., 1913, 33, 425-427.

1913.2

Carbonell, E.T. Fisheries of Prince Edward island. Canada Comm. Conserv. Lands, Fish. Game, etc. Ottawa, 1911, 158-163. $4^{\circ}$.

1911.1

Carbonnier, Pierre. Guide pratique du pisciculture. Paris, 1864. $12^{\circ}$.

1864.1

Etude sur les causes de la mortalité des poissons d'eau douce. Bull. Soc. Acclim., Paris, 1866, 2. sér. 3, 603-608. Abstract in Ann. Sci. Nat., 5. sér. 9, 92.

1866.1

Observations sur le brochet [Esox lucius] Bull. Soc. Acclim., Paris, 1867, 2. sér. 4, 574-577.

1867.1

Rapport et observations sur l'accouplement d'une espèce de poisson de Chine. Bull. Soc. Acclim., Paris, 1869, 2. sér. 6, 408-414.

1869.1

Sur le mode de reproduction d'une espèce de poisson de la Chine. C. R. Acad. Sci. Paris, 1869, 69, 489-491. 1869.2

- Nouvelle note sur un poisson de Chine appartenant au genre Macropode. Bull. Soc. Acclim., Paris, 1870, 2. sér. 7, 26-32. figs.

1870.1

- Sur l'élevage d'un poisson de Chine du genre Macropode. Cosmos, $1870,6,354-356$.

1870.2

- Du transport des poissons. Bull. Soc. Acclim., Paris, 1871, 2. sér. 8, 606609. fig.

1871.1

- Le Macropode de Chine. Bull. Soc. Acclim., Pàris, 1872, 2. sér. 9, 7-14. 1872.1

Sur la reproduction et le développement du poisson télescope ( $C y$ prinus macrophthalmus), originaire de la Chine. C. R. Acad. Sci. Paris, 1872, 75, 1127-1129. - Bull. Hebd. Assoc. Sci. France, $1872,11,180-182$. Bull. Soc. Acclim., Paris, 1872, 2. sér. 9, 789-790.
Trois mémoires pour servir à l'histoire zoologique du poisson de Chine, le Macropode. Paris, 1872. 24 p. figs.

1872.3

- De l'influence de la pression extérieure sur la vie des poissons et de la lumière lunaire sur la végétation aquatique. Bull. Soc. Acclim., Paris, $1873,10,16-23$.

1873.1

- Instructions aux chepteliers; troisième section. Poissons; instructions sur les pratiques de l'incubation artificielle, le transport des oufs et de l'alevin. Bull. Soc. Acclim., Paris, 1873, 2. sér. 10, 11-15.

1873.2

On the reproduction and development of the telescope-fish of China. Ann. Mag. Nat. Hist., 1873, 4. ser. 11, 76-77.

1873.3

Le fondule (Fundula cyprinodonta Cuv.) Bull. Soc. Acclim., Paris, 1874, 3. sér. 1, 665-671.

1874.1

Importation de poissons exotiques: Anabas, poissons combattants, gouramis. Bull. Soc. Acclim., Paris, 1874, 4. sér. 1, 526-529.

1874.2

Om det ydre tryks inflydelse paa fiskens. Liv. Nord. Tidsskr. Fiskeri, 1874, 1, 85-89.

1874.3

- Sur le mode de respiration de diverses espèces de poissons à pharyngiens labyrinthiformes. C. R. Acad. Sci. Paris, 1874, 78, 501-502. - Bull. Hebd. Assoc. Sci. France, 1873-74 (1874), 13, 387-388.

1874.4

- Le gourami et son nid. Bull. Soc. Acclim., Paris, 1876, 3. sér. 3, 835-846. Abstract in C. R. Acad. Sci. Paris, 1876 , 83, 1114-1116. - Ann. Mag. Nat. Hist., 1877, 4. ser. 19, 274-276. - Bull. Soc. Zool. France, 1876, 1, 213-215. Journ. Zool. (Gervais), 1876, 5, 442445. - Pop. Sci. Rev., 1877, n. s. 1 , 211-212. - Arch. Vétérin. Alfort, 1877, 2, 192-194.

1876.1

Nidification du poisson arc-enciel [Colisa vulgaris] de l'Inde. Bull. Soc. Acclim., Paris, 1876, 3. sér. 3, 11-22. - C. R. Acad. Sci. Paris, 1875, 81, 11361139. - Ann. Mag. Nat. Hist., 1876, 4. ser. 17, 172-174. - Bull. Hebd. Assoc. Sci. France, 1875-76 (1876), 17, 198201. - Journ. Zool. (Gervais), 1876, 4. sér. 17, 170-174.

1876.2

- Rapport et observations sur l'aquarium d'eau douce du Trocadéro. Bull. Soc. Acclim., Paris, 1879, 6, 281304. 
M. Carbonnier and the paradise fish. Chicago Field, 1880, 13, 398-399. 1880.1

Mours d'un poisson de la famille des silures, le Callichthys fasciatus Cuvier. C. R. Acad. Sci. Paris, 1880, 91, 940-942. - Ann. Mag. Nat. Hist. 1881, 5. ser. 7, 73-74.

1880.2

Sur le Callichthys fasciatus Cuvier. Bull. Soc. Zool. France, 1880, 5 , 288-290.

1880.3

- Reproduction des poissons-soleil Bull. Soc. Acclim., Paris, 1881, 4. ser. 9, 55-56.

1881.1

Reproductions de poissons exotiques. Bull. Soc. Acclim., Paris, 1881, 4. sér. 8, 103-112.

1881.2

Cardoso (junior), João. Notas africanas. I. Pescadores et pescarias no archipelago de Cabo-Verdo. Ann. Sci. Nat. Porto, 1895, 2, 171-174; 3, 93-96; 211-216.

1895.1

- Notas africanas. II. Plantas empregadas na pesca. Ann. Sci. Nat. Porto, 1897, 4, 69-76.

1897.1

Notas africanas. III. Ichthyologia Cabo-Verdiana. Ann. Sci. Nat. Porto, 1900, 6, 33-49.

1900.1

Carenius, Ephraim. Physico-oeconomisk beskrifning öfver Hvittis socken i Björneborgs län. Inaug. Dissert., Petr Adrian Godd, proses. Abo, 1759. 72p. $4^{\circ}$.

1759.1

Cargiulo, A. Contributo all' istologia del tessuto di sostegno nelle glandole. Riv. Ital. Sci. Nat., Siena, 1904, 24, 5-12.

1904.1

Cariboo, pseudonym for Rowen, John $J$.

Carlet, Gaston [1845-1892] Sur le rôle du bulbe artériel chez les poissons. C. R. Acad. Sci. Paris, 1876, 82, 569570.

1876.1

- Mémoire sur les écailles des poissons téléostéens. Ann. Sci. Nat., 1878, 6. sér. 8, 1-19. 9 figs. 1878.1

- Sur les écailles des poissons osscux. C. R. Acad. Sci. Paris, 1879 , 88, 396-397.

1879.1

Sur une truite mopse. Journ. Anat. Phys., 1879, 15. année, 154-160.

1879.2
Carlier, - Liste des reptiles et des poissons. Dict. Géograph. Prov. Liége, 1831.

1831.1

Carlini, A. de. Vertebrati della Valtellina. Atti Soc. Ital., 1888, 31, 17-90.

1888.1

Pisces, p. 85-90.

Carlisle, Anthony. The Croonian lecture on the arrangement and mechanical action of the muscles of fishes. Phil. Trans. Roy. Soc. London, 1805, 96, 112. $\mathrm{pl}$.

1805.1

- On the breeding of eels. Phil. Mag. (Tilloch), 1822, 59, 109-110.

1822.1

Carll, W.E. Salmon fishing in the Willamette and Clackamas rivers, Oregon. Amer. Fish Culturist, 1904, 1. 8-10.

1904.1

Carlos de Braganca, Dom (King of Portugal) Investigaçoes scientificas feitas a bordo do yacht "Amelia." Pescas maritimas. Lisboa, 1899. 3 pls. fol.

1899.1

Resultados das investigações scientificas feitas a bordo do yacht "Amelia." Ichthyologia, II. Lisboa, 1904. 107 p. 2 pls. $4^{\circ}$. 1904.1

Carlson, A.J. Contributions to the physiology of the heart of the California hagfish (Bdellostoma dombeyi) Zeitschr. Allgem. Physiol., Jena, 1904, 4, 259288. pl.

1904.1

- The rate of the nervous impulse in the spinal cord and in the vagus and the hypoglossal nerves of the Californian hagfish (Bdellostoma dombeyi) Amer. Journ. Physiol., 1904, 10, 401418. fig.

1904.2

The presence of cardio-regulative nerves in the lampreys. Amer. Journ. Physiol., 1906, 16, 230-232.

1906.1

Carlsson, (Miss) Albertina. Ueber die Zahnentwicklung bei einigen Knochenfischen. Zool. Jahrb. (Anat. Abth.), 1894, 8, 217-244. 2 pls. \& figs. 1894.1

Carlsson, Wilhelm. Historiallinen ja maantieteellinen kertomus Pirkkalan pitäjäästä. - Pitäjään kertomuksia I. Suom. Krij. Seur. Toim., Helsingfors, 1869, 47, 204. pl.

1869.1

-_ Entinen Ikalinen. Historiallinen kertomus Ikalisten. Parkanon ja Kankaanpään pitäjistä. — Pitảjään kertomuksia IV. Suom. Kirj. Seur. Toim. XLVII, Helsingfors, 1871, 47, 232. 
Carlton, Frank C. The color changes of some fishes. Science, 1904, 2. ser. 19, 245.

1904.1

Carmichael, Dugald [1772-1827] Description of four species of fish found on the coast of Tristan da Cunha. Trans. Linn. Soc. London, 1817, 12, 500-513. pls. xxiv-xxvii.

1817.1

Caron, Charles. Expériences et observations sur la pisciculture. Mém. Soc. Acad. Arch. Sci. Oise, 1852-54, 2, 450-459. Also separate; Beauvais, 1855. $22 \mathrm{p}$.

1852.1

Pisciculture. Expériences à l'établissement départemental de pisciculture de l'Aisne. Beauvais, 1865. pls. $8^{\circ}$.

1865.1

Carpenter, A. Flying fish. Zoologist, 1886, 43, 265-266. - Nature, 32, 147-148.

1886.1

Carpenter, Charles. The sexes of whitefish. Forest \& Stream, 1878, 9, 430. 1878.1

Carpenter, $F$. W. \& Bristol, $C . L$. See Bristol \& Carpenter.

Carpenter, George Herbert, \& others. Zoology [of Dublin district] Handbook Brit. Assoc. Adv. Sci., 1908, 108-222. 6 pls. \& 12 figs.

1908.1

Carpenter, P. Herbert, \& Jeffreys, J.Gwyn. See Jeffreys \& Carpenter.

Carpenter, William Benjamin [18131885] Description of some peculiar fish's ova. Monthly Micr. Journ., $1870,3,177-179$.

1870.1

Report on scientific researches carried on during the months of August, September and October, 1871, in the H. M. surveying-ship "Shearwater." Proc. Roy. Soc. London, 1872, 20, 535644.

1872.1 510 .

Biological research in Mediterranean, p. 537-

- The fisheries of British North America. Nature, $1878,18,170-172$; 232-234. Abstract in Chicago Field, $1878 ; 9,387$.

1878.1

Carpenter, W. Lant. The deep sea: its biological condition. [n. p.] 1870 . 2 pls. $8^{\circ}$.

1870.1

- The salmon sickness. Forest \& Stream, 1850, 14, 7 .

1880.1

Carpentier, E. Visite à l'établissement de pisciculture de M. Alphonse
Lefebvre. Bull. Soc. Linn. Nord France, Amiens, 1911, 20, 388-390.

1911.1

Carpentier, F. W., \& Kappers, Cornelius Ubbo Ariêns. See Kappers \& Carpentier.

Carpentier, Jules. La pêche raisonnée et perfectionnée du pêcheur fabricateur. Paris, 1879. 92 figs. $8^{\circ}$.

1879.1

Carr, (Miss) A.M. Food of fishes. Rept. Northumberland Sea Fish. Comm 1907 (1908), 68-71.

1908.1

Age determinations in the common dab, long rough dab and whiting Rept. Northumberland Sea Fish. Comm. 1908 (1909), 51-54.

1909.1

- 'The food and condition of fish obtained from the northeast coast. Rept. Northumberland Sea Fish. Comm. 1908 (1909), 41-50.

1909.2

Carr, John. On the ascent of salmon over the elevations in the course of rivers, called salmon-leaps. Philos. Mag., London, 1809, 34, 321-324.

1809.1

On the generation and other obscure facts in the natural history of the common eel. Philos. Mag., London, $1809,34,272-277$.

1809.2

On salmon fry. Philos. Mag., London, 1810, 35, 251-256. 1810.1

Carr, John Wesley. Fishes of the Nottinghamshire Trent in 1822, recorded by Michael Drayton in the "Polyolbion"; with notes on their present occurrence. Naturalist, 1898, 33-36. 1898.1

- Trent fishes not mentioned in Drayton's "Polyolbion." Naturalist, 1898,80 .

1898.2

Carr, T.F. Robertson. Notes on the Scotch fisheries. Bull. U. S. Fish Comm. 1884, 4, 64 .

1884.1

Notes on the Scotch herring fisheries. Bull. U. S. Fish Comm. 1884, 4,$60 ; 431$

1884.2

Carradori, Gioachino [1758-1818] Osservazioni dalla quale parche si rilevi, che i pesci soffrono nel inverno un grado d' intorpidimento. Opuscoli Scelti Sci., Milano [1797?], 18, 165.

1797.1

Versuche und Beobachtungen über das Athmen der Fische. Journ. Chemie (Scherer), 1799, 2. 
Carraroli, A. Avanzi di pesci fossili pliocenici del Parmense e del Piacentino. Riv. Ital. Paleon., Bologna, 1897, 3, 23-27. pl. \& 7 figs.

1897.1

Carrière, $J$. Die Sehorgane der Thiere vergleichend-anatomisch dargestellt. München \& Leipzig, 1885.

1885.1

Carrigan, — On some structural peculiarities in the pipe fishes. Zoologist, $1860,18,6813-6814$.

1860.1

Carrington, John Thomas [1846-] Fish culture for the Thames. Zoologist, 1876,2 . ser. $11,5110-5113$.

1876.1

-Murcna helena Linnæus (the Murry of Yarrell, the Muræena of Couch) Zoologist, 1876,2 . ser. 11, 5053-5061. fig.

1876.2

- Occurrence of the boar-fish [Capros aper] on the various parts of the south and south-east coasts of England. Zoologist, 1879, 3 ser. 3, 342.

1879.1

Greenland bullhead 1 Cottus grœnlandicus] at Brighton and Southend. Zoologist, 1880, 3. ser. 4, 147-148.

1880.1

Jersey fishes. Record of Labrus donovani and Lepadogaster condollii from isle of Jersey. Zoologist, 1881, 3. ser. 5,28 .

1881.1

Carroll, Michael. The seal and herring fisheries of Newfoundland together with a condensed history of the island. Montreal, 1873. 61 p. $8^{\circ}$. 1873.1

Carruccio, Antonio [1839-] Lijst van 135 visschen verzameld an de kusten van Sardinië en Sicilië. Atti Soc. Ital. Sci. Nat., 1870, 12, 567-586.

1870.1

- Note anatomo-zoologiche sulle mascelle dentifere di un Hexanchus griseus adulto preso a Porto d'Anzio. Boll. Soc. Rom. Stud. Zool., 1896, 5, fase. 5-6, 165-176. pl. 1896.1

- Indications principales sur les vertébrés de la nouvelle collection régionale du Musée Zoologique de la $\mathrm{R}$. Université de Rome. Boll. Soc. Rom. Stud. Zool. 1899, 8, 72-82. 1899.1

Sui caratteri morfologici che distinguono un Siluro proteropodo del genere Rhinelepis, e cenno sulle forme principali della famiglia Siluridæ di recente introdotte nel Museo. Boll. Soc
Zool. Ital., 1903, 2. ser. 4, 12; 77-84; 159-168.

1903.1

- Sulla Selache maxima Gunner testè avuta dal Museo Zoologico della R. Università di Roma. Boll. Soc. Zool. Ital., 1906, 2. ser. 7, 191-202. 1906.1

Sulla Selache maxima Gunn. Boll. Soc. Zool. Ital., 1907, 2. ser. 8, 307314.

1907.1

- Sopra un Rhinobatus halavi Rüpp. testè avuto dal Museo Zoologico della $R$. Università di Roma, preso forse per la prima volta nel mare Toscano. Boll. Soc. Zool. Ital., 1908, 2. ser. 10, 97-105.

1908.1

- Sopra un raro Odontaspis taurus Müll. catturato presso il golfo di Cagliari. Boll. Soc. Zool. Ital., 1910, 2. ser. 11, $267-272$.

1910.1

_._. "Plectognathi" del Museo Zoologico Universitario e specialmente di due recenti "Orthagoriscus," uno di Viesti e l' altro di Civita-Vecchia. Boll. Soc. Zool. Ital., 1912, 3. ser. 1, 401-416.

1912.1

Su diversi esemplari di "Prionodon" di recente introdotti nel Museo Zoologico della R. Università di Roma. Boll. Soc. Zool. Ital., 1912, 3. ser. 1, $451-466$.

1912.2

Carswell, James. Report on the artificial propagation of the codfish at Woods Hole, Mass., for the season of 1885-86. Rept. U. S. Fish Comm. 1886 (1889), 14, 779-782. 1889.1

Carte, Alexander. On the Balistes capriscus. Nat. Hist. Rev. 1854, 1. 161-163. 1854.1

Notes on the genus Chiasmodon. Proc. Zool. Soc. London, 1866, 35-39. pl.

1866.1

Notes on the voracity of Chiasmodus niger. Rept. Brit. Assoc. Adv. Sci., 35. meet. 1865 (1866), 84. 1866.2

Carter, $E . N$. Notes on sturgeon culture in Vermont. Trans. Amer. Fisheries Soc. 1904 (1905), 60-63. 2 pls.

1905.1

Carter, Henry John [1813-1895] Notes on Myriosteon [Pristis] Ann. Mag. Nat. Hist., 1870, 4. ser. 5, 449450 .

1870.1

Carter, J. T'. 'The evolution of the vertebrate skull, with special reference to the development and suspensorium of the jaws. Trans. Odont. Soc., 1905, $42,125-150$. figs.

1905.1 
Carter, Robert. A summer cruise on the coast of New England. Boston, 1884. $261 \mathrm{p}$.

1884.1

Contains various notes upon the habits of the marine fishes of Mrssachusetts and Maine.

Cartier, 0 . Beschreibungen neuer Pharyngognathen; ein Beitrag zur Kenntniss der Fische des philippinischen Archipels. Verh. Phys. Med. Würzburg, 1874, n. s. 5, 96-106.Arbeit. Zool. Instit. Würzburg, 1874, 1 , 168-178.

1874.1

Cartolari, $E$. Di una pneumopatia dei Loricati. Nota zoo-patologica. Riv. Ital. Sci. Nat., Siena, 1905, 25, $97-$ 99.

1905.1

Cartwright, George. A journal of transactions and events during a residence of nearly sixteen years on the coast of Labrador, etc. 3 vols. Newark, 1792. $4^{\circ}$.

1792.1

Cod and salmon fisheries, vol. iii, p. 220-239.

Cartwright, (Rev.) William. Rambles and recollections of a fly-fisher. London, 1854. illust. $12^{\circ}$. 1854.1

- Facts and fancies of salmon fishing. With original illustrations By Clericus. London, 1874. pls. \& figs. $8^{\circ}$.

1874.1

Carus, Carl Gustav [1789-1869] Ueber einige Eigenthümlichkeiten im Bau der Lamprete (Petromyzon marinus) Arch. Physiol. (Meckel), 1816, 2, 600-614.

1816.1

Lehrbuch der Zootomie. Leip-
zig, 1818.
A second edition in 2 volumes was published A second edition
Leipzig in 1834 .

Carus gegen Desmoulins: dass das Rückenmark der Lamprete allerdings Nerven habe. Isis (Oken), 1827, 1005-1007. - Bull. (Férussac), 1828, 14, 268-269.

1828.1

Carus, Julius Victor [1823-] On the Leptocephalidx. Rept. Brit. Assoc. Adv. Sci. 30. meet. 1860 (1861), 2, pt. 2,125 .

1861.1

Ueber die Leptocephaliden. Leipzig, 1861. 19 p. $4^{\circ}$. 1861.2

Geschichte der Zoologie bis auf J. Müller und C. Darwin. München, 1872. xii, 739 p. TGeschichte der Wissenschaften in Deutschland, Bd. xii)

1872.1

Histoire de la zoologic depuis l'antiquité jusqu'au XIXe siècle. 'Tra- duction française par P. O. Hagenmüller, et notes par A. Schneider. Paris, 1880. 623 p. $8^{\circ}$.

1880.1

Vertebrata. 1. Class. Pisces (In his Prodromus faunæ Mediterranex; sive, Descriptio animalium maris Mediterranei incolarum quam comparata silva rerum quatenus innotuit adiectis locis et nominibus vulgaribus eorumque auctoribus in commodum zoologorum. vol. ii, p. 489-711. Stuttgart, 1889-93)

1893.1

Carus, J. Victor, \& Engelmann, Wilhelm. Bibliotheca zoologica. Verzeichniss der Schriften über Zoologie, welche in den periodischen Werken enthalten und vom Jahre 1846-1860 selbständig erschienen sind. Leipzig, 1861. vol. ii. 2144 p. $8^{\circ}$. 1861.1

Carus, Julius Victor, \& Gerstaecker, C.E.A. Handbuch der Zoologie. 2 vols. Leipzig, 1863-75. $8^{\circ}$. 1863.1

Bd. i, Wirbelthiere [bearbeitet von W. C. H. Peters] etc.

Carus, Paul. The fish as a mystic symbol in China and Japan. Open Court, Chicago, 1911, 25, 385-411. fig. 1911.1

The fish in Brahmanism and Buddhism. Open Court, Chicago, 1911, 25, 343-357.

1911.2

Carvalho, Coltz de. A pesca em Buarcos. Ann. Sci. Nat., Porto, 1894, 1, 193.

1894.1

Carver, Jonathan [1732-1780] Travels through the interior parts of North America, in the years 1766, 1767 and 1768. 3. ed. London, 1781. xxii, 543 p. 5 pls. $8^{\circ}$.

1781.1

Chapter on fish, etc., p. 411-49.4. The first edition appeared in 1778 .

Cary, H.H. Period of incubation of eggs of German carp. Bull. U. S. Fish Comm., 1883, 3, 447.

1883.1

- The St. Johns river as a shad stream. Bull. U. S. Fish Comm., 1885, 5, 422 .

1885.1

Case, Ermine Cowles. The development and geological relations of the vertebrates. Part I. The fishes. Journ. Geol., Chicago, 1898, 6, 393416. 3 figs.

1898.1

The vertebrates from the Permian bone bed of Vermilion county, Illinois. Journ. Geol., Chicago, 1900, 8, 698-729. $5 \mathrm{pls}$. 
On the value of the evidence furnished vertebrate fossils of the age of certain so-called Permian beds in America. Journ. Geol., Chicago, 1908, 16, 572-580.

1908.1

Evidence furnished by the fishes, p. 579 .

Revision of the Amphibia and Pisces of the Permian of North America ... with a discussion of the fossil fishes by Louis Hussakof. Carnegie Instit. Washington, 1911, Pub. no. 146. 179 p. 32 pls. $4^{\circ}$.

1911.1

The Permian fishes of North America, by Louis Hussakof, p. 153-175. 7 pls.

Case, L., Greeley, H., \& others. See Greeley, Case \& others.

Casselmann, A. Ueber einen Versuch hinsichtlich der Wirkung angeblich giftiger Fische auf eine Katze. Pharm. Zeitschr. Russland, 1871, 10, 193-196.

1871.1

Castel, René Louis Richard [17581832] Histoire naturelle des poissons avec les figures dessinées d'après nature par Bloch. 10 vols. Paris, 1801.

1801.1

This work is included in Suites a $\mathrm{Buffon}$ par R. R. Castel. A second edition was published in $\mathrm{An} \times[1802$ ? and a third in 1837 .

Castellaneta, Vincenzo. Sulla questione del timo in Ammocoetes. Monit. Zool. Ital., 1913, 24. anno, 161-174. 2 pls.

1913.1

Castelnau, (Comte) François L. de Laporte de [1812-1880] Expédition dans les parties centrales de l'Amérique du Sud, de Rio de Janeiro à Lima, et de Lima au Para; exécutée ... pendant les années 1843 à 1847. 14 vols. in 13 Paris, 1850-59. $8^{\circ} .4^{\circ} \&$ fol. 1855.1

Part vii, Zoologie [The second title reads:] Animaux nouveaux ou rares recueillis, etc. 3 vols. $1855-59$.

Tom. iii, Poissons, par le Comte F. de Castelnau. 1855. xii, 112 p. $50 \mathrm{col}$. pls.

Note sur les poissons de l'Afrique australe. C. R. Acad. Sci. Paris, 1860 , 50, 788-789.

1860.1

Vischsoorten, nieuw voor de kennis der fauna van Singapore. Nat. Tijdschr. Neder. Indië, $1860,20,236-$ 239. Also separate; Batavia, 1860. $8^{\circ}$.

1860.2

Mémoire sur les poissons de l'Afrique australe. Paris, 1861. vii, $78 \mathrm{p} . \mathrm{s}^{\circ}$.

1861.1

Pluie de poissons; tremblement de terre à Singapore. C. R. Acad. Sci. Paris, 1861, 52, 880-\$82.
A shower of fish. Zoologist, $1861,19,7649 . \quad 1861.3$

Contribution to the ichthyology of Australia. Proc. Zool. Acclim. Soc. Victoria, 1872, 1, 29-247; Ibid., 1873, 2, 37-158. pl. Also separate; Melbourne, 1872 . $8^{\circ}$.

1872.1

- Notes on the edible fishes of Victoria. Exhibition Essays, Victorian Exhib. 1872-73, no. 5, 1-17 [Melbourne, 1872] 1872.2

Contributions ì l'ichthyologie de l'Australie. Abstract in Journ. Zool. (Gervais), 1873, 2, 47-48; Ibid., 1874, 3, $85-88$.

1873.1

Des poissons comestibles de Victoria. Journ. Zool. (Gervais), 1874, $3,144-151$.

1874.1

Researches on the fishes of Australia. - Intercol. Exhib. Essays, Victorian Dept., 1875, no. 2. $8^{\circ} .1875 .1$

Mémoire sur les poissons appelés barramundi par les aborigènes du nord-est de l'Australie. Journ. Zool. (Gervais), 1876, 5, 129-136. 1876.1

- Remarques au sujet du genre Neoceratodus. Journ. Zool. (Gervais), $1876,5,342-343$.

1876.2

Australian fishes, new or little known species. Proc. Linn. Soc. New S. Wales, 1877, 2, 225-248. 2 pls.

1877.1

Essay on the ichthyology of Port Jackson. Proc. Linn. Soc. New S. W ales, 1878, 3, 347-402. 1878.1

Notes on the fishes of the Norman river. Proc. Linn. Soc. New S. Wales, 1878, 3, 41-51. 1878.2

- Ompax, a new Australian ganoid (?) Proc. Linn. Soc. New S. Wales, 1879, 3, 347-401. pl. 1879.1

- On a ganoid fish from Queensland [Ompax spatuloides] Proc. Linn. Soc. New S. IVales, 1879, 3, 164-165. fig.

1879.2

On several new Australian (chiefly) freshwater fishes. Proc. Linn. Soc. New S. Wales, 1879, 3, 140-144.

1879.3

Castiglioni, $A$. Il pesce persico (Perca) e l' arborella. Milano, 1902.

1902.1 
Castillo, Luis. Conducción del pescado fresco i su trasporte por ferrocarril. Boletin Bosques, Pesca i Caza, Santiago, 1912, 1, 484-489.

1912.1

Contribución al estudio biolójico de los peces marítimos comestibles de Chile. Boletin Bosques, Pesca i Caza, Santiago, 1912, 1, 90-102.

1912.2

La enseñanza profesional de la pesca. Boletin Bosques, Pesca i Caza, Santiago, 1912, 1, 490-494.

1912.3

Las estaciónes de zoolojía marítima i reconocimiento hidrográfico de los fondos de pesca. Boletin Bosques, Pesca i Caza, Santiago, 1912, 1, 466-470.

1912.4

- Fabricación de la sardina en aceite. Boletin Bosques, Pesca i Caza, Santiago, 1912, 1, 338-346.

1912.5

Importación del pescado seco, deducciónes que se desprenden de ella. Boletin Bosques, Pesca i Caza, Santiago, $1912,1,419-424$

1912.6

El medio mas económico de secar el pescado. Boletin Bosques, Pesca i Caza, Santiago, 1912, 1, 196-199.

1912.7

- L_Los puertos de pesca; necesidad de buscar nuevos mercados para el espendio de la producción pesquera de Chile. Boletin Bosques, Pesca i Caza, Santiago, 1912, 1, 470-475.

1912.8

Radicación de los pescadores nacionales i colonización de nuestros puertos de pesea. Boletin Bosques, Pesca i Caza, Santiago, 1912, 1, 494498.

1912.9

- Refrijeración i conjelación del pescado. Boletin Bosques, Pesca i Caza, Santiago, 1912, 1, 327-334.

1912.10

- La rémora, pez piloto del tiburon. Boletin Bosques, Pesca i Caza, Santiago, 1912, 1, 208-209.

1912.11

La venta i el valor alimenticio del pescado fresco. Boletin Bosques, Pesca i Caza, Santiago, 1912, 1, 346350.

1912.12

- Viaje de estudios de pesca en Chile. Boletin Bosques, Pesca i Caza, Santiago, 1912, 1, 815-835.

1912.13

Castle, William Ernest, \& Davenport, Charles Benedict. See Davenport i Castle.
Casto de Elera, Francisco. Catálogo sistemático de toda la fauna de Filipinas conocida hasta el presente, y á la vez el de la colección zoológica del Museo de PP. Dominicos del colegio-universidad de Santo 'Tomás de Manila. 3 vols. Manila, 1895. $8^{\circ}$. 1895.1 Vol. i, Vertebrados. $701 \mathrm{p}$.

Castrên, Erik. Kort beskrifning öfver Pudasjärvi socken i Oesterbotten. Tidn. utg. af et Sällsk. ̊̉bo, 1776, no. $10,79-81$; no. $12,81-96$; no. $13,97-104$.

1776.1

Castrén, Samuel. Observationer giorde i Utsjoki Lappmark åren 1795 och 1797. Finsk Hushållningssällskapet, 1803, Handl. 1, 344-355. 1803.1

Pisces, p. $346 ; 350$.

Castro, Manuel Fernandez de. Aëtobatis poeyii, nueva especie fósil procedente de la isla de Cuba. Anal. Soc. Español. Hist. Nat. Madrid, 1873, 3, 193-212. 4 pls.

1873.1

Catesby, Mark [1679?-1749] The natural history of Carolina, Florida and the Bahama islands; containing the figures of birds, beasts, fishes, serpents - with their descriptions in English and French, etc. 3. ed. 2 vols. London, 1771. illus. fol. 1771.1

The editio princeps was published at London 1731-43, 2 volumes, in folio. The second edition was revised by G. Edwards.

- Piscium, serpentum, insectorum aliorumque nonnullorum animalium nec non plantarum quarumdam imagines quas M. Catesby in posteriore parte ... illius operis quo Carolinxe Floridxe et Bahamensium insularum tradidit historiam naturalem, ejusque appendice descripsit . . edere coperunt N.F. Eisenberger et $\mathrm{G}$. Lichtensteger, et. .Die Abbildungen verschiedener Fische. Norimbergx, 1777. iv, 100 p. $109 \mathrm{col}$. pls.

1777.1

Latin and German in parallel columns.

Catois, E. H. Note sur l'histogénèse du bulbe olfactif chez les sélaciens. Bull. Soc. Linn. Normandie, 1897, 5. sér. 1, 79-84. fig.

1897.1

- Sur l'anatomie microscopique de l'encéphale chez les poissons. Bull. Soc. Linn. Normandie, 1897, 5. sér. 1 , fasc. 1 (Proc.Verb.), xxxviii-xl. 1897.2

Sur l'histologie et l'anatomie microscopique de l'encéphale chez les poissons. C. R. Acad. Sci. Paris, 1897, 124, 204-206. - Bull. Sci. France Belgique, $36,1-166.10$ pls.

1897.3 
La névroglie de l'encéphale chez les poissons. C. R. Acad. Sci. Paris, 1898, 126, 433-435.

1898.1

Note sur l'anatomic microscopique de l'encéphale chez les poissons (téléostéens et sélaciens). Structure des cellules nerveuses. Bull. Soc. Linn. Normandie, 1899, 5. sér. 2, 94-118.

1899.1

Recherches sur l'anatomie microscopique de l'encéphale chez les poissons [Comm. Verb.] Bull. Soc. Zool. France, 1899, 24, 31-32. 1899.2

- Recherches histologiques sur les voies olfactives et sur les voies cérébelleuses chez les téléostéens et les sélaciens. C. R. Assoc. Franç. Avanc. Sci. 28. sess. 1900 (1901), 2, 515-519.

1901.1

Recherches sur l'histologie et l'anatomie microscopique de l'encéphale chez les poissons. Bull. Scient. France Belg., 1902, 36, 1-166.

1902.1

Caton, John Dean [1812-] 'Trout fishing in the Yosemite valley. Amer. Naturalist, $1870,3,519-522 . \quad 1870.1$

Capture of a saw-fish [Pristis antiquorum] on the beach at Galveston, Texas. Amer. Naturalist, 1879, 13, 654.

1879.1

Cattaneo, Giacomo [1857-] Note d' istologia comparata. I. Ulteriori ricerche sulla struttura delle glandule peptiche dei selaci, ganoidi e teleostei. II. Sul significato fisiologico delle glandule da me trovate nello stomaco dello storione et sul valore morfologico delle loro cellule. Bolletino Scient. Pavia, 1886, 8, nos. 3 \& 4.

1886.1

Struttura e sviluppo dell' intestino dei pesci. Boll. Scient., Pavia, 1886, 8, 4-11.

1886.2

Sull' esistenza delle glandule gastriche nell' Acipenser sturio e nella Tinca vulgaris. Rend. Istit. Lombardo Sci., Milan, 1886, 2. ser. 19, 676-682. pl.

1886.3

Sulle papille esofagee e gastriche del Luvarus imperialis. Atti Soc. Ligustica Sci. Nat., Genova, 1892, 3, 298-303.

1892.1

- Sul tempo e sul modo di formazione delle appendici piloriche nei Salmonidi. Monit. Zool. Ital., 1900, 11 (Suppl.), 10-11.

1900.1
Cattie, J. Th. Ueber die Genitalien der männlichen Aale und ihre Sexualunterschiede. Zool. Anz., 1880, 3, 275-279. fig. - Smithson. Misc. Coll. 22, art. 1.

1880.1

Die Epiphyse der Plagiostomi, Ganoidei und Teleostei. Zool. Anz., 1881, 23, 604 .

1881.1

- Verglijkend-anatomische en histologische onderzoekingen van de epiphysis cerebri der Plagiostomi, Ganoidei en Teleostei. Academisch proefschrift. Leiden, 1881. 104 p. 3 pls. $8^{\circ}$.

1881.2

Recherches sur la glande pinéale (epiphysis cerebri) des Plagiostomes, des Ganoïdes et des Téléostéens. Arch. Biol., 1882, 3, 101-194. 3 pls. 1882.1

Ueber das Gewebe der Epiphyse von Plagiostomen, Ganoiden und Teleostier. Zeitschr. Wiss. Zool., 1883, 39 , $720-722$.

1883.1

Caullery, Maurice. Les yeux et l'adaptation au milieu chez les animaux abyssaux. Rev. Gén. Sci., Paris, 1905, 16, 324-340. 14 figs.

1905.1

Caullery, Maurice, \& Mesnil, $F$. Sur des haplosporidies parasites de poissons marins. C. R. Mém. Soc. Biol., Paris, 1905, 58, 640-642.

1905.1

Caumont, Arcisse de [1802-1873] Lettre relatif à l'époque du frai des truites. C. R. Acad. Sci. Paris, 1850, 31, 862-863. - L'Institut, 18, 410.

1850.1

Communication sur les moeurs des poissons [Anguilla] Bull. Soc. Linn. Normandie, $1857-58,3,127-128$.

1858.1

Causans, Maxime de. Application de nouvelles méthodes de pisciculture à la production de la truite dans le département de la Haute-Loire. Bull. Soc. Acclim., Paris, 1859, 6, 118-122.

1859.1

Caustier, E. Appareil pour l'éclosion et l'élevage des Salmonides. Bull. Soc. Centr. Aquicult., Paris, 1907, 19, 137-140. fig.

1907.1

Caux, John William de. The herring and the herring fishery. London, 1881. 159 p. $8^{\circ}$.

1881.1

Cavalié, $M$. Sur les terminaisons nerveuses motrices et sensitives dans les muscles striés, chez la torpille (Torpedo marmorata) C. R. Mém. Soc. Biol. Paris, 1902, 54, 1279-1280. 1902.1 
Cavaliê, $M$

_- La vésicule biliaire et sa circulation artérielle chez Torpedo galvani, chez Galeus canis et chez Scyllium. Soc. Sci. Stat. Zool. Arcachon. Trav. Lab. Paris, 1903, 7, 23-28. fig. - C. R. Mém. Soc. Biol., Paris, 55, 1386-1388.

1903.1

Les chromoblastes du tégument externe dorsal de Torpedo galvani. C. R. Mém. Soc. Biol., Paris, 1904, 56, $46-47$.

1904.1

- Etat des terminaisons nerveuses dans les muscles striés sous l'influence du curare [Recherches microscopiques sur la localisation de l'empoisonnement par le curare C. R. 14. Congr. Intern. Méd. Anat., 1904, 110-113, 1904.2

_ Note sur les rapports des terminaisons nerveuses motrices avec les fibres musculaires striées chez le lapin et chez la torpille. C. R. 14. Congr. Intern. Méd. Anat., 1904, 122. 190ł.3

Recherches sur les ramifications nerveuses dans les lames de l'organe électrique de Torpedo galvani. C. $\mathbf{R}$. Mém. Soc. Biol., Paris, 1904, 56, 653654. - Bibliog. Anat., Nancy, 13, 214 220. figs.

1904.4

- Sur quelques points de la structure de l'organe électrique (Torpedo galvani) C. R. Soc. Biol., Paris, 1905, 58, 158-160.

1905.1

Cavanna, Guelfo [1850-] Elementi per una bibliografia italiana intorno all' idrofauna agli allevamenti degli animali acquatici e alla pesca. Firenze, 1880 . viii, 170 p. $8^{\circ}$. 1880.1

Cavazzani, $E$. L'ichthyotoxique chez les Petromyzon marinus. Arch. Ital. Biol., Turin, 1892, 18, 182-186. 1892.1

Cavendish, Henry. An account of some attempts to imitate the effects of the torpedo by electricity. Phil. Trans. Roy. Soc. London, 1776, 66, 196-225. pl.

1776.1

Cavenne, - Rapport sur un mémoire de M. Artaud; notice pour servir à l'histoire naturelle du gouramy [Osphromenus olfax Lacép.] Bull. Soc. Linn. Bordeaux, 1827, 2, 188-191.

1827.1

Cavolini, Filippo [1756-1810] Memoria sulla generazione dei pesci e dei granchi. Napoli, 1787. $4^{\circ}$.

1787.1

Abhandlung über die Erzeugung der Fische und der Krebse; aus dem
Italienischen übersetzt mit Anmerkungen; herausgegeben von E.A. W. Zimmermann. Berlin, 1792. viii, 192 p. 3 pls.

1792.1

Dissertatio de piscium et cancrorum generatione. Neapolis, 1808. fig. $4^{\circ}$. 1808.1

- Frammento inedito sotto titolo di: Appendice sulla generazione de' pesei cartilaginosi ossiano amfibii respiranti per mezzo delle branchie al modo de' pesci spinosi. Mem. Accad. Sci. Napoli, 1819, 1, 291-341. fig. Abstract in Bull. Sci. (Férussac), 1827, $306 . \quad 1819.1$

Cayley, J. J., \& Bridgman, $H . H$. A central wholesale fish market for London. Internat. Fisheries Exhib. Lit., London, 1883. Conferences, 10, pt. 4 .

1883.1

Cecca, Raffaele. Sugli effetti tossici delle punture di alcuni pesci. Clin. Med. Ital. Milano, 1902, 41, 82-87.

Cecconi, Giacomo. Vertebrati della foresta die Vallombrosa. Arch. Zool., Napoli, 1903, 1, 339-344. $\quad 1903.1$

- Alcune osservazioni intorno ad un allevamento di Salmo irideus Gibb. Acquicoltura Lombarda, Milano, 1904, 6, 281-287.

1904.1

Cecil, William Alleyne $3 d$ Marquis of Exeter [1825-1895] The rearing of black bass, and piscicultural experiments at Burghley (In CholmondeleyPennell, H. Fishing, . . pike and other coarse fish. London, 1885. $8^{\circ}$ )

1885.1

Cederhielm, Johann. Faunx ingricx prodromus exhibens methodicam descriptionem insectorum agri petropolensis, præmissa mammalium, avium, amphibiorum, et piscium enumeratione. Leipzig, 1798. xviii, 348 p. 3 pls. $8^{\circ}$. 1798.1

Cederström, G. Carl. Fiskodling och sveriges fiskerier, etc. Stockholm, 1857. 269 p. 7 pls.

1857.1

— Om Linålen (Ammocotes branchialis) Oefvers. K. Vet. Akad. Förh., Stockholm, 1861, 18, 91-92. 1861.1

Ueber den gemeinen Querder. Zeitschr. Gesammt. Naturw., 1862, 19, $71-72$.

1862.1

Jakttagelser om fiskarten Cobitis tania Lin. Oefvers. II. Vet. Akad. Förh., Stockholm, 1874, 31, no. 9, 4753. 
Anteckningar om norra Bohusläns vertebrat-fauna. Oefvers. K. Vet. Akad. Förh., Stockholm, 1877, 33, no.4, 57-68. Ibid., 36, no. 2, 53-62. 1877.1

- Opastus kalastuksen hoidossa pienempien kalavesien omistajille ja kalastajille. Wiipurissa, 1894. 68 p. $8^{\circ}$.

1894.1

- Svenska kommentarier till Finska Tidskriften för Jägare och Fiskare. Tidskr. Jägare \& Fisk., 1894, 2.

1894.2

- Neuvoja kalastuksen hoidossa. Suomen oloihin sovittanut ja tekijän luvalla julkaissut suomen kalastusyhdistys. Helsingissä, 1895. 89 p. $8^{\circ}$.

1895.1

Toutaimen kasvattaminen. Suomen Kalastus Lehti, 1895, 4, 83. Fiskeritidskr. Finland, 1895, 4, 85.

1895.2

$\mathrm{Om}$ inflytelsen af fiskevattnens höjd öfver hafvet på fiskarternas förekomst och utbredning. Tidskr. Jägare \& Fisk., 1899, 7, 127-129.

1899.1

Cépède, Casimir. Myxosporidies des poissons des Alpes françaises. C. R. Assoc. Franc. Avanc. Sci., 33. sess. 1904, 905-914.

1904.1

Le blageon et la suiffe bouchesse (Squalius agassizii Heck.) dans les lacs et les cours d'eau de la région Delphinosavoisienne. Ann. Univ. Grenoble, 1905, 17, 301-306. - Bull. Mensuel. Assoc. Avanç. Sci., Congrès Grenoble, no. 9, 260.

1905.1

Myxidium giardi Cépède et la prétendue immunité des anguilles à l'égard des infections myxosporidiennes. C. R. Mém. Soc. Biol. Paris, 1906, 60, 170-173. fig.

1906.1

Sur la prétendue immunité des Cobitis à l'égard des infections myxosporidiennes. C. R. Mém. Soc. Biol. Paris, 1906, 60, 15-16.

1906.2

Sur une microsporidie nouvelle, Pleistophora macrospora, parasite des loches franches du Dauphiné. C. R. Mém. Sac. Biol., 1906, 1, 13-15. 1906.3

- A propos de la déhiscence des spores des myxosporidies. C. R. Mém. Soc. Biol. Paris, 1907, 1, 135-137.

Contribution à l'étude de la biologie de la sardine (Alosa sardina Risso) Feuille Jeun. Natural., 1907, 4. sér. 38. année, 54-56. 2 figs. 1907.2
Contribution à l'étude de la nourriture de la sardine. C. R. Acad. Sci. Paris, 1907, 144, 770-772. 1907.3

Quelques remarques sur la nourriture de la sardine. C. R. Acad. Sci. Paris, 1907, 144, 865-867.

1907.4

Remarques à propos de la communication de M. Bounhiol relative aux variations du plancton marin, "Quelques faits biologiques relatifs aux poissons comestibles des côtes de l'Algérie." C. R. Assoc. Franç. Avanc. Sci., 37. sess., $1907,241$.

1907.5

La myxosporidiose des anguilles dans les eaux douces, saumâtres et salées du Boulonnais. Bull. Soc. Acad. Boulogne-sur-Mer, 1908, 8, 17-24.

1908.1

\section{Observations et remarques sur} la nourriture de la sardine. C. R. Assoc. Franç. Avanc. Sci. 36. sess., 1908, pt. 1, 263-267; Ibid., pt. 2, 774-778. 1908.2

- La nourriture des sardines adultes de Saint-Sébastien. C. R. Congr. Nat. Pêches Marit. Sables-d'Olonne, 1909-10, 154-160.

1910.1

La nourriture des sardines adultes de Star-Point. C. R. Congr. Nat. Pêches Marit. Sables-d'Olonne, 1909-10, 150-152.

1910.2

Le problème de la nourriture de la sardine. Bull. Soc. Acad. Boulognesur-Mer, 1910, 10, 1-24. 1910.3

Sur la pêche à la rogue et l'industrie de la rogue de hareng. C. R. Congr. Nat. Pêches Marit. Sablesd'Olonne, 1909-10, 22-23. 1910.4

Cépède, Casimir, \& Giard, Alfred. See Giard \& Cépède.

Cerda, Juan de la $C$. Proposed transmission of salmon eggs to Chile and importation of Chilean species of fishes. Bull. U. S. Fish Comm. 1885, 5, 247-248.

1885.1

Ceresole, Julius. Ein neuer Bacillus als Epidemieerreger beim Goldfische (Carassius auratus) Allgem. Fischerei Zeitg., 1900, 25. Jahrg., no. 20, 368.Zentralbl. Bakter. Parasitenkunde, 1900 , 28,305 .

1900.1

Cerfontaine, Paul. Mémoire couronné sur le développement de l'Amphioxus. Rapport de Edouard van Beneden. Bull. Acad. Sci. Belgique, 1905, 643-660. 


\section{Cerfontaine, $P$.}

Recherches sur le développement de l'Amphioxus. Arch. Biol., 1905, 22, 229-418. 10 pls. \& 9 figs.

1905.2

Čerkasov, (Baron) $P . G$. Der Wechsel der Schlundzähne bei Karpfen [Text in Russian] Priroda i ochota, Moskva, 1903, 2, 5-8. 2 pls.; 3, 110 111.

1903.1

Cerrigan, Dominik. On some structural peculiarities of the mouth in the pipefishes (Syngathidæ) Proc. Dublin Nat. Hist. Soc., 1859-62, 3.

1859.1

Cerruti, Attilio. Sulle "risoluzioni nucleolari" nella vescicola germinativa degli oociti di alcuni vertebrati. Anat. Anz., 1905, 26, 613-622. 16 figs.

1905.1

Sull' evoluzione dell' uovo ovarico nei selaci. Atti Accad. Sci., Napoli, 1908, 2. ser. 13, 1-90. 7 pls̀. 1908.1

Cetti, Francesco [1726-1778] Amfibi e pesci di Sardegna. Sassari, 1777. x, 208 p. 5 pls.

Pesci, p. 71-208.

1777.1

Cetti, Giovanni. Il pescatore de Lario. Descrizione delle reti e dei vari generi di pesca in uso sul lago di Como. Como, 1862. pl. $8^{\circ}$.

1862.1

Chabot, - Réflexions sur la pisciculture. Ver sailles, 1854. $8^{\circ}$.

Chabry, L. Sur le mécanisme de la natation des poissons. Journ. Anat. Physiol., Paris, 1883, 19. année, 582585. 2 figs.

1883.1

Chadwick, B. P. The destruction of young fish by unsuitable fishing implements. Bull. U. S. Fish. Comm. 1881 (1882), 1, 339-340.

1882.1

Chadwick, John. Marblehead. Harper's New Monthly Mag., 1874, 49, 181-202.

1874.1

Cod fisheries with figures of "unloading fish" and "drying fish," p. 195-197.

Chaignon, $H$. de. Contributions à l'histoire naturelle de la Tunisie. Bull. Soc. Hist. Nat. Autun, 1904, no. 17, 1-166.

1904.1

Chailland, - Dictionnaire raisonné des eaux et des forêts, etc. Paris, 1769. $4^{\circ}$.

1769.1

Chaine, Joseph. Les poissons d'Orient (poisson rouge, etc.) et leur culture. Bordeaux, 1899. 48 p. $4^{\circ}$. 1899.1
Compte-rendu du Congrès international d'agriculture et de pêche de 1900. Rev. Intern. Pêche Pisciculture, St. Pétersb., 1900, 2, pt. 3, 2. 1900.1

Disposition particulière du génio-hyoïdien chez deux téléostéens (Mullus surmuletus Linn. et Callyonymus lyra Linn.) Proc. Verb. Soc. Sci. Phys. Nat. Bordeaux, 1899-1900 (1900), 64-66.

1900.2

Anatomie comparée de certains muscles sus-hyoïdiens. Bull. Sci. France Belgique, 1901, 35, 1-210. pls. i-viii.

Poissons, p. 140-170.

1901.1

Revue de la pisciculture et des pêches en France pendant l'année 1900. Rev. Intern. Pêche Pisciculture, St. Pétersb., 1901, 3, pts. 1, 7-11. 1901.2

Contribution à la myologie des chondroptérygiens. Proc. Verb. Soc. Sci. Phys. Nat. Bordeaux, 1901-02 (1902), 18-19.

1902.1

Sur la constitution de la région sushyoïdienne chez les vertébrés en général. C. R. Mém. Soc. Biol. Paris, $1902,428-430$.

1902.2

Revue de la pisciculture et des pêches en France pendant l'année 1902. Rev. Intern. Pêche Pisciculture, St. Pétersb., 1903, 4, pts. 1 \& 2. 1903.1

Sur le "ligament mandibulooperculaire" des Téléostéens. Proc. Verb. Soc. Sci. Phys. Nat. Bordeaux, 1904, 29-30.

1904.1

Conséquences de la variation de la direction des axes de la tête et du corps chez les vertébrés. Proc. Verb. Soc. Sci. Phys. Bordeaux, 1904-05 (1905), 49-50.

1905.1

- Le dépresseur de la mâchoire inférieure, son étude comparative chez le vertébrés, sa signification morphologique. Bull. Sci. France Belgique, 1905, $39,1-56$. 2 pls.

1905.2

Recherches sur la langue des téléostéens. C. R. Mém. Soc. Biol. Paris, 1907, 62, 924.- Réun. Biol. Bordeaux, 1907, 63.

1907.1

Observations sur l'appareil urinaire de la vive (Trachinus draco L.) Proc. Verb. Soc. Sci. Phys. Nat., Bordeaux, 1908-09 (1909), 5-6. 1909.1

Chaine, Joseph, \& Künstler, $J$. See Kuinstler \& Chaine. 
Chalker, Robert B. Catch of shad in Connecticut for 1885. Bull. U. S. Fish Comm. 1886 (1887), 6, 439-441. 1887.1

Catch of shad in Connecticut for 1886. Bull. U. S. Fish Comm. 1886 (1887), 6, 297-298.

1887.2

Catch of shad in Connecticut for 1887. Bull. U. S. Fish Comm. 1887 (1889), 7, 112.

1889.1

Chalmers, Thomas. More about eels. Forest \& Stream, 1877, 8, 360. 1877.1

Eels, tadpoles and turtles. Forest \& Stream, 1878, 11, $46 . \quad 1878.1$

Generation of eels. Chicago Field, 1878, 9, 291.

1878.2

Movements of eels. Forest \& Stream, 1878, 11, 259.

1878.3

Salmon in the Connecticut. Chicago Field, 1878, 9, 307. 1878.4

- Turtles and eels. Forest \& Stream, 1878, 11, 86 . 1878.5

Eels, bass and shad. Chicago Field, $1879,12,229$. 1879.1

The generation of eels. Chicago Field, 1879, 11, 169.

1879.2

- Mr. Chalmers on eel breeding. Chicago Field, 1879, 11, 115-116.

1879.3

Pickerel fishing through the ice. Chicago Field, 1879, 11, 52 . 1879.4

Chamberlain, $F$. $M$. Some observations on salmon and trout in Alaska. Rept. U. S. Comm. Fisheries 1906 (1907), 1-112. Bureau Fish. Doc. no. 627. pl. \& fig.

1907.1

Chamberlain, $F . M ., \&$ Cobb, John $N$. See Cobb \& Chamberlain.

Chamberlain, $W . B$. Change of color in fish. Amer. Naturalist, 1867, 1, 497.

1867.1

Chamberlayne, C. $F$. Nationalism in state fisheries. Trans. Amer. Fisheries Soc. 1892 (1893), 187-196. 1893.1

The pressing need. Trans. Amer. Fisheries Soc. 1894 (1895), 10-18.

1895.1

Chamberlin, Thomas Crowder [1843 - ] On the habitat of the early vertebrates. Journ. Geol., 1900, 8, 400-412.
Chambers, E.T.D. The ouananiche and its Canadian environment. 1. Ann. Rept. Comm. Fish. Game \& Forests New York, 1895 (1896), 145148. figs.

1896.1

Game fisheries of Quebec. Canada Comm. Conserv. Lands, Fish. Game etc. Ottawa, 1911. p. 198-212. $4^{\circ}$.

1911.1

Chambers, Robert [1802-1871] Vestiges of the natural history of creation [By R. Chambers] Edinburgh, 1844.

1844.1

Six editions of this work had been published by 1847 , and a twelfth appeared in 1881 .

[Chambers, $W_{\text {.] }}$ Fish and oysters. Chambers's Journ., 1874, 51, 43-46.

1874.1

Chambers, IW. Oldham. The introduction and acclimatisation of foreign fish. Intern. Fisheries Exhib. Lit., London, 1883. Conferences, 11, pt. 18. 1883.1

- The propagation of freshwater fish excluding Salmonidæ. Intern. Fisheries Exhib. Lit., London, 1883. Conferences, 11, pt. 7 . 1883.2

'The propagation of the Salmonidx. Intern. Fisheries Exhib. Lit., London, 1883. Conferences, 11, pt. 3.

1883.3

American fish cultivated by the National Fish Culture Association of England. Bull. U. S. Fish Comm. 1887 (1889), 7, 17-19.

1889.1

On a thorough hatching vase. Trans. Amer. Fisheries Soc. 1888 (1889), 25-27. 2 figs.

1889.2

Champeaux, - de. Rapport sur l'exposition internationale de produits de pêche ouverte à Bergen, fait par M. de Champeaux, au nom d'une commission spéciale. Paris, 1866. $8^{\circ}$. 1866.1

Champion, $P$. Note sur trois espèces de poissons chinois, et sur leur emploi dans l'industrie et l'alimentation. Bull. Soc. Acclim., Paris, 1865, 474-477. 1865.1

The three species are determined as Collichthys lucidus. Otolithus maculatus and Murcena pekinensis (Basilewsky)

Champneys, A.C. On fish. Rept. Marlborough College Nat. Hist. Soc. $1870,10-16$.

1870.1

Champy, Christian. Recherches sur l'absorption intestinale et le rôle des 
Champy, $C$.

mitochondries dans l'absorption et la sécrétion. Arch. Anat. Micr., 1912, 13, 55-170. 3 pls. \& 40 figs.

1912.1

_- Granules et substances réduisant l'iodure d'osmium. Journ. Anat. Physiol., Paris, 1913, 49, 323-343. 15 figs.

1913.1

Chandler, A.C. On a lymphoid structure lying over the rnyelencephalon of Lepisosteus. Univ. Cal. Pub. Zool., Berkeley, 1911, 9, 85-104. pls. $\mathrm{x}-\mathrm{xii}$.

1911.1

Chanvalon, Jean Baptiste Thibault de [c. 1725-1785] Voyage ì la Martinique, contenant diverses observations sur la physique, l'histoire naturelle, l'agriculture, les mœurs, \& les usages de cette isle, faites en 1751 \& dans les années suivantes. Paris, 1763. viii, 235 p. $4^{\circ}$.

1763.1

Chao, Ed. Los tres reinos de la naturaleza. Museo pintoresco de historia natural. 9 vols. Madrid, 185258. illust. $4^{\circ}$.

1852.1

Chapellier, J.Ch. Quelques considérations sur le dépeuplement progressif de nos rivières, les moyens d'empêcher le poisson de périr en masse dans les rigoles d'irrigation, et le repeuplement des petits cours d'eau. Annal. Soc. Emulat. Départ. Vosges 1864 (1865), 12, 1. cah., 288-293.

1865.1

Chaper, Maurice [1834-1896] Observation d'un cas d'adaptation de certains poissons à des eaux de salure très différentes. Bull. Soc. Zool. France, 1883, 8, 445-449.

1883.1

Chapman, Abel, \& Buck, W. J. Wild Spain (Espana agreste) records of sport with rifle, rod and gun, natural history and exploration. London, 1893. $\mathrm{xx}, 472$ p. 51 pls. \& map. $8^{\circ}$. 1893.1

Chapman, Frederick Revans. New or little-known Victorian fossils in the National Museum. Part vii. On a new cephalaspid from the Silurian of Wombat creek. Proc. Roy. Soc. Victoria, Melbourne, 1906, n. s. 18, pt. 2, 93-100. 2 pls.

1906.1

- On the occurrence of the selachian genus Corax in the Lower Cretaceous of Queensland. Proc. Roy. Soc. Victoria, Melbourne, 1909, n. s. 21, pt. 2, 452-453. fig.

1909.1

- A study of the Batesford Limestone. Proc. Roy. Soc. Victoria, Melbourne, 1910, n.s.22, pt. 2, 307. 1910.1
Report on Jurassic and Carboniferous remains. Rec. Geol. Surv. Victoria, 1912, 3, pt. 2, 234-236. pl.

1912.1

- Note on the occurrence of the Cainozoic shark, Carcharoides, in Victoria. Vict. Naturalist, $1913,30,142-$ 143. fig.

1913.1

Chapman, Frederick Revans, \& Pritchard, George B. Fossil fish remains from the Tertiaries of Australasia, Part i. Proc. Roy. Soc. Victoria, Melbourne, 1904, n. s. 17, pt. 1, 267-297. 2 pls. - Part ii. Ibid., 1907, n. s. 20, pt. 1, 59-76. 4 pls.

1904.1

Chapman, Henry Cadwalader [1845 -] Homologies of the alisphenoid and petromastoid bones in vertebrates. Proc. Acad. Nat. Sci. Philad. 1894 (1895), 32-52.

1895.1

Chapman, (senior) Pearson. Habits of the shad and herring, as they appear in the Potomac river to one who has watched them for fifty years. Bull. U.S. Fish Comm. 1884, 4, 61-64.

1875.1

Chappe d'Auteroche, Jean [17281769] Voyage en Sibérie... contenant ... Ia description géographique ... de la route de Paris à Tobolsk; l'historie naturelle de la même route (La description du Kamtchatka ... par M. Kracheninnikow . . . traduit du Russe) 3 vols. in 4. Paris, 1768. illust. $4^{\circ}$.

1768.1

Remarques sur le sterlet, vol. i, p. 200-201. Poissons, vol. ii, p. $455-485$.

Voyage en Californie...etc., en 1769. Paris, 1772. 170 p. plan \& 2 pls. $4^{\circ}$.

This is translated as follows:

A voyage to California, to observe the transit of Venus. By Mons. Chappe d'Auteroche. With an historical description of the author's route through Mexico, and the natural history of that province. . . London, 1778. 315 p. plan. $8^{\circ}$. 1778.1

Cyprinodonts of California are described in an extract from a letter by Don José Antonio de Alzate y Ramyrez, p. 77-105.

Chappellier, A. Note sur un essai d'élevage d'Ameiurus nebulosus dans le Loiret. Bull. Soc. Centr. Aquicult., Paris, 1907, 19, 25t-256. 1907.1

Charbonnel-Salle, Louis. Recherches expérimentales sur les fonctions hydrostatiques de la vessie natatoire. 
Ann. Sci. Nat. (Zool.), 18s7, 7. sér. 2, 305-331. 6 figs. - C. R. Acad. Sci. Paris, 104, 1330-1333.

1887.1

Charbonnier, Henry J. Notes on the reptiles, amphibia, and fish of the Bristol district. Proc. Bristol Soc., 1888, 2. ser. 5, 133-142.

1888.1

Charbonnier, Henry J., \& Morgan, C. Lioyd. The reptiles, amphibians and fishes of the Bristol district. Handbook Brit. Assoc. Adv. Sci., 1898, 197-199.

1898.1

Charcot, (Commandeur) Jean. Expédition antartique française 1903-05. Paris [1907]

1907.1

Poissons, par Léon Vaillant, p. 1-51.

Charlesworth, Edward [1813-1893] For biography and works see Geol. Mag., 1893, 10, 526-528; Quart. Journ. Geol. Soc., 1894, 50 (Proc.), 47-50.

- Notice of the teeth of Carcharias megalodon occurring in the Red Crag of Suffolk. Mag. Nat. Hist., 1837, n. s. 1, 225-227.

1837.1

- A notice of the remains of vertebrated animals occurring in the Tertiary beds of Norfolk and Suffolk. Mag. Nat. Hist., 1838, n. s. 2, 40-43. 1838.1

Illustrated zoological notices. On the fossil remains of a species of Hybodus from Lyme Regis. Mag. Nat. Hist., 1839, n. s. 3, 242-248. 1839.1

On a tooth of the genus Otodus Ag. from the London Clay. Mag. Nat. Hist., 1839, n. s. 3, 351-352. pl. 1839.2

On some fossil teeth of the genus Lamna from the London Clay. Mag. Nat. Hist., 1839, n. s. 3, 451-452. pl. 1839.3

On the fossil bodies regarded by M. Agassiz as the teeth of a fish, and upon which he has founded his supposed genus Sphenonchus. Rept. Brit. Assoc. Adv. Sci., 15. meet., 1845, pt. 2, 56.

1845.1

Charrin, A. L'infection chez les poissons. C. R. Mém. Soc. Biol., Paris, 1893, 331-333.

1893.1

Charvet, Pierre Alexandre. Explication d'une monstruosité observée sur le cyprin doré de la Chine. Nouv. Bull. Soc. Philom. Paris, 1826, 1, 140-141. Bull. Sci. Nat. (Férussac), 1828, 13, 139-140.
Catalogue des animaux qui se trouvent dans le département de l'Isère. Bull. Statist. Sci. Nat. Département Isère, Grenoble, 1846.

1846.1

De la destruction et de la reproduction du poisson dans les eaux douces dans l'arrondissement de Grenoble. Bull. Soc. Statist. Sci. Nat. Département Isère, Grenoble, 1869, 1, 63-98.

1869.1

Chase, A. W. Note on subterranean fishes in California. Amer. Journ. Sci., 1874, 3. ser. 7, 74. - Forest \& Stream, 1874, 2, 70 .

1874.1

On the use of giant powder (dynamite) for obtaining specimens of fish at sea. Proc. Cal. Acad. Sci., 1874, 5, 334-337. - Scient. American, 31, 118. - Amer. Sportsman, 4, 35-38. 1874.2

Chatelanat, $H$. Notes sur les migrations des poissons du. lac Léman. Bull. Soc. Vaud. Sci. Nat., Lausanne, 1874, 13, 36-38.

1874.1

Notice sur la pisciculture dans le canton de Vaud. Bull. Soc. Vaud. Sci. Nat., 1880, 16, 521-532. Also separate; Lausanne, 1880.12 p. $8^{\circ}$.

1880.1

Chater, F.J.T. The relations of the state with fishermen and fisheries, including all matters dealing with their protection and regulation. Intern. Fisheries Exhib. Lit., London, 1883. Conferences, 9, pt. 4 . 1883.1

Chatin, Joannes [1847-] Les organes des sens dans la série animale. Leçons d'anatomie et de physiologie comparées faites à la Sorbonne. Paris, 1880. viii, 726 p. illust. $8^{\circ}$. 1880.1

Sur les homologies des lobes inférieurs du cerveau des poissons. C. R. Acad. Sci. Paris, 1889, 108, 628-630. 1889.1

Sur les myélocytes des poissons. C. R. Acad. Sci. Paris, 1889, 109, 745747.

1889.2

Chatto, William Andrew. Also styled Oliver, Stephen (pseudon.), and Fisher, Paul (pseudon.)

Chatton, Edouard. Un amibe, Amoba mucicola n. sp., parasite des branchies des Labres, associé à une Trichodine. C. R. Mém. Soc. Biol., Paris, 1909, 67, 690-692. 1909.1 
Chaudejambon, ___ Concerning eels. Fish. Gazette, 1877 , no. 29, 5.

1877.1

Chaudhuri, Banawari Lal. Description of a new species of Danio [ $D$. annandalei] from Lower Burma. Rec. Indian Mus., Calcutta, 1908, 2, pt.2, 125-126.

1908.1

Description of a new species of saw-fish [Pristis annandalei] captured off the Burma coast by the government of Bengal's steam trawler "Golden Crown." Rec. Indian Mus., Calcutta, 1908, 2, 391-392. fig.

1908.2

-Description of two new species of $\operatorname{Caran} x[C$. gupto, C. auricoronœ] from the bay of Bengal. Rec. Indian Mus., Calcutta, 1909, 3, 141-143. 2 figs.

1909.1

-Descriptions of new species of Botia $[B$. birdi] and Nemachilus [ $N$. macmahoni] Rec. Indian Mus., Calcutta, 1909, 3, 339-342. 1909.2

Mosquito-larvæ eating propensity of the genus Haplochilus. Journ. Proc. Asiat. Soc., Bengal, 1909, 5, xxxvixxxvii.

1909.3

Description of a new species of Nemachilus [ N. mackenziei] from northern India. Rec. Indian Mus., Calcutta, 1910, 5, 183-185.

1910.1

- Triacanthus weberi, sp. nov. Journ. Proc. Asiat. Soc., Bengal, 1910, 6, 497-501. pl.

1910.2

Fish and mosquito larvæ. Calcutta Med. Journ., 1911, 6, 1-14.

1911.1

Contributions to the fauna of Yunnan based on collections made by J. Coggin Brown, B. Sc. Part II. Fishes. Rec. Indian Mus., Calcutta, 1912, 6, 13-24. pl.

1912.1

Descriptions of some new species of freshwater fishes from north India. Rec. Indian Mus., Calcutta, 1912, 7, 437-444. 4 pls.

1912.2

- Freshwater sting rays of the Ganges. Journ. Proc. Asiat. Soc., Bengal, 1912, 7, 625-629. 1912.3

Macrones menoda var. trachacanthus (Cuv, et Val.) Rec. Indian Mus. Calcutta, 1912, 7, 210-212. 1912.4

Zoological results of the Abor expedition, 1911-12. Fish. Rec. Indian Mus., Calcutta, 1913, 8, 243-257. 3 pls. 1913.1
Chaudhuri, Banawari Lal, \& Sewell, R.B.S. See Sewell \& Chaudhuri.

Chauvassaignes, François. Le peuplement des eaux, etc. ClermontFerrand, 1880. 42 p. $8^{\circ}$. 1880.1

Chauvin, $F . M$. A. La culture de la mer appliquée aux baies du littoral de la France; exposé et moyens pratiques, suivis d'un rapport sur le mémoir présenté par l'auteur à la Société Impériale Zoologique d'Acclimatation, présidée par M. Isidore Geoffroy Saint-Hilaire. Lannion, 1858. 48 p. $8^{\circ}$. 1858.1

Chavannes, Auguste. Observations sur quelques points de la fécondation et de l'éclosion artificelle des poissons. Bull. Soc. Vaud. Sci. Nat., Lausanne, 1854, 24-25. 1854.1

Réempoissonnement des eaux vaudoises. Rev. Mag. Zool., 1865, 2. sér. 17, 219-223.

1865.1

Note sur la naturalisation du saumon du Rhin dans le lac Léman. Bull. Soc. Acclim., Paris, 1869, 2. sér. 6, 364-368.

1869.1

Sur l'introduction des saumons dans le lac Léman. Verh. Schweiz. Naturf. Ges., 1869, 53, 67. Also separate; Soleure, 1869.

1869.2

- Naturalisatie van zalmen in het meer van Genève en in het WennerMeer. Tijdschr. Ned. Maatsch. Bevord. Nijverheid., 1870. 14 p. 1870.1

Chavannes de la Giraudière, $H$.de. Souvenirs d'un vieux pêcheur. 'Tours, 1853. $8^{\circ}$.

1853.1

Cházari, Estéban. Piscicultura en agua dulce. Mexico, 1884. 828 p. 150 figs. $8^{\circ}$. 1884.1

Chearney, $R$. Large roach [Leuciscus rutilus! in the Lea. Zoologist, 1875 , 2. ser. 10, 4726-4727.

1875.1

Checcia-Rispoli, $G$. Un nuovo rinvenimento di Lepidocyclina nell' eocene della Sicilia. Natural. Sicil. Palermo, 1905, 17, 253-254. 1905.1

Cheeseman, Thomas $F$. Notes on the sword fish (Xiphias gladius) Trans. New Zeal. Instit. 1875 (1876), 8, 219 220.

1876.1

- American salmon in New Zealand waters. Forest \& Stream, 1877, 7, 340. 
- Exportation of salmon ova to New Zealand in 1876. Rept. U. S. Fish Comm. 1875-76 (1878), 4, 965-967.

1878.1

Shipment of salmon ova to New Zealand in 1877. Rept. U. S. Fish Comm. 1878 (1880), 6, 837. 1880.1

Notice of the occurrence of the basking shark (Selache maxima L.) in New Zealand. Trans. New Zeal. Instit. 1891, 23, 126-127.

1891.1

Chelussi, Italo. Note di geologia marchigiana. Atti Soc. Ital. Sci. Nat Mus. Civ. Milano, 1906, 44, 269-300. 1906.1

Cheney, A. Nelson. Smelts. Forest \& Stream, 1876, 6, 55. 1876.1

Ice fishing for smelts in Lake Champlain.

Food fish and fish food. Trans. Amer. Fisheries Soc. 1883 (1884), 27 32.

1884.1

Does transplanting affect the food or game qualities of certain fishes? Trans. Amer. Fisheries Soc., 1885, 5559.

1885.1

The monster black bass. Forest \& Stream, 1885, 23, $126 . \quad 1885.2$

Salmon in the Hudson river. Bull. U. S. Fish Comm. 1886 (1887), 6, 351-352. 1887.1

Relation of the American Fisheries Society to protective fish laws. Trans. Amer. Fisheries Soc. 1891 (1892), $47-51$.

1892.1

Food for fishes. Trans. Amer. Fisheries Soc. 1892 (1893), 22-29. 1893.1

Food for fishes. 1. Ann. Rept. Comm. Fish. Game \& Forests New York 1895 (1896), 99-117. 2 pls. \& 13 figs.

1896.1

Information for all who apply for state fish. 1. Ann. Rept. Comm. Fish. Game \& Forests New York 1895 (1896), 150.

1896.2

- Instructions for transporting and planting young fish. 1. Ann. Rept. Comm. Fish. Game \& Forests New York 1895 (1896), 149.

1896.3

- Mascalonge, pike, pickerel and pike-perch. 1. Ann. Rept. Comm. Fish. Game \& Forests New York 1895 (1896), 121-124. 3 pls. \& 3 figs.

1896.4

Shad of the Hudson river. 1. Ann Rept Comm Fish Game \&
Forests New York 1895 (1896), 125134. pl.

1896.8

- Black bass, and their distribution in the waters of the state of New York. 2. Ann. Rept. Comm. Fish. Game \& Forests New York 1896 (1897), 176-184. illust.

1897.1

Concerning the work of the Fisheries, Game and Forest Commission of the State of New York. Trans. Amer. Fisheries Soc. 1896 (1897), 112120.

1897.2

- The pike-perch (Stizostedium vitreum) 2. Ann. Rept. Comm. Fish. Game \& Forests New York 1896 (1897). 203-206. pl. 1897.3

- Fish represented in colored plates. 3. Ann. Rept. Comm. Fish. Game \& Forests New York, 1898, 239-248. 5 pls. 1898.1

- Fishways, their construction and use. 3. Ann. Rept. Comm. Fish. Game \& Forests New York, 1898, 222-233. 7 pls.

1898.2

A natural hatchery for trout. 3. Ann. Rept. Comm. Fish. Game \& Forests New York, 1898, 234-238. 2 pls.

1898.3

- A synopsis of the history of fish culture. 3. Ann. Rept. Comm. Fish. Game \& Forests New York, 1898, 191198. 3 pls.

1898.4

The common eel. 4. Ann. Rept. Comm. Fish. Game \& Forests New York, 1899, 279-288. 2 pls. 1899.1

Figures of fishes in colors. 4. Ann. Rept. Comm. Fish. Game \& Forests New York, 1899, 289-296. 4 pls.

1899.2

Shad culture in the Hudson river. 5. Ann. Rept. Comm. Fish. Game \& Forests New York 1899 (1900), 241247.

1900.1

Trout fry and trout fingerlings.

5. Ann. Rept. Comm. Fish. Game \& Forests New York 1899 (1900), 249257.

1900.2

- Report of the state fish culturist. 6. Ann. Rept. Forest, Fish \& Game Comm. New York 1900 (1901), 47-55.

1901.1

Cheney, Simeon F. Correspondence on the subject of sea fisheries. Rept. U. S. Fish Comm. 1871-72 (1873), 1, 135. 
Chenu, Jean Charles [1808-1879] Encyclopédie d'histoire naturelle; ou, Traité complet de cette science d'après les travaux des naturalistes les plus éminents de toutes les époques, etc., .. par le Dr. Chenu. 31 vols. Paris, 1850-80. $4^{\circ}$.

1874.1

Comprises 22 volumes of text, 9 volumes of registers and 2 volumes of plates. Originally published in 1850-61; but frequently reissued with title-pages bearing later dates.

Vol. xix. Reptiles et poissons, avec la collaboration de M. E. Desmarest. 1874. ii, 360 p. 48 pls.

Chesnaye-Desbois, Francois Alexandre Aubert de la. See La ChesnayeDubois, $F$. A. A. de.

Chester, John. Essay on the pilchard [Clupea pilchardus] Ann. Rept. R. Cornwall Polytechn. Soc., 1835, 3, $102-$ 107.

1835.1

Chevalier, $P$. Die Fischbrutanstalt Hülsberg bei Lüttringhausen. Deutsch. Fischerei Zeitg., 1879, 2. Jahrg., 376.

1879.1

Chevrel, René. Sur le système nerveux grand sympathique des poissons osseux. C. R. Acad. Sci. Paris, $1888,107,530-531$.

1888.1

- Sur l'anatomie du système nerveux grand sympathique des elasmobranches et des poissons osseux. Arch. Zool. Expér., Paris, 1890, 2. sér. 5, no. 5, 196 p. 3 pls. Abstract in Rev. Sci. France, Paris, 47, 596-597. 1890.1

- Recherches anatomiques sur le système nerveux grand sympathique de l'esturgeon. C. R. Acad. Sci. Paris, 1891, 117, 441-443. - Arch. Zool. Expér., Paris, 3. sér. 2, 401-444. pl.

1893.1

Sur la reproduction de l'anguille commune (Anguilla vulgaris Flem.) Bull. Soc. Linn. Normandie, 1898, 5. sér. 1, 201-256.

1898.1

Essai sur la morphologie et la physiologie du muscle latéral chez les poissons osseux. Arch. Zool. Expér., Paris, 1913, 52, 473-607. 19 figs. 1913.1

Valeur fonctionnelle des myomères irrégulièrement plissées. Contraction des fibres profondes d'arriere en avant et des fibres superficielles d'avant en arric̀re.

Chevroul, Michel Eugène [17861889] Expériences chimiques sur le cartilage du Squalus peregrinus. Ann. Mus. Hist. Nat. Paris, 1811, 18, 136153.
Sur le cartilage et la liqueur contenue dans les cavités intervertébrales du Squalus peregrinus. Ann. Mus. Hist. Nat. Paris, 1811, 18, 154-155. 1811.2

Dictionnaire des sciences naturelles. 60 vols. Paris, 1816-30. $8^{\circ}$.

1816.1

Chevreuse, Auguste. Lettres sur les effets de pisciculture. Ann. Soc. Emulat. Vosges 1866 (1867), 12, 450460.

1867.1

Cherreuse, $E$. Essais de pisciculture dans les Vosges. Bull. Soc. Acclimat., Paris, 1868, 2. sér. 5, 824-828.

1868.1

Cherrolat, L. A. A. Dictionnaire universel d'histoire naturelle ... par MM. Arago ... Chevrolat, etc. 16 vols. Paris, 1839-45. $8^{\circ}$. 1839.1

There are two later editions, one published in 1849, the other in 1861. See Orbignj, A. C. V.D. $d^{\prime}$.

Chevroton, L., \& Anthony, $R$. See Anthony \& Chevroton.

Chiaje, Stefano delle [1794-1860] Lettera anatomico-fisiologica sulla esistenza delle glandule renali ne' batraci $e$ ne' pesci, con riflessioni intorno al loro ufficio nel feto umano. Il Progresso, 1839, 24, 181-190.

1839.1

- Anatomiche disamine sulle Torpedini. Atti Istit. Incorr. Napoli, 1840 , 6, 291-308.

1840.1

Sulla esistenza delle glandule renali ne' batraci e ne' pesci. Atti Istit. Incorr. Napoli, 1840, 6, 207-222. 1840.2

- Notizia su due Gimnoti elettrici dall' America recati vivi in Napoli. Nuov. Annal. Sci. Nat., Bologna, 1847, 2, 7-8, 268-273.

1847.1

Discrizione, anatomia, e potere elettrico del Gymnoto della Real Casa. Rendic. R. Accad. Sci. Napoli, 1848, 7, 208-232.

1848.1

Chiappi, $T$. Sopra una forma ibrida di Ciprinide esistente nei laghi di Varano e Monate. Monit. Zool. Ital., 1902, 13 (Suppl.), 28-30.

1902.1

Il Leuciscus fucini Bp. Monit. Zool. Ital., 1903, 14, 352-354. 1903.1

Le specie italiane di Leuciscus comprese nel sottogenere Leucos Bp. Boll. Soc. Zool. Ital., Roma, 1906, 2. ser. 7, 21-47, pl. \& fig.

1906.1 
Chiarini, Pietro. Ricerche sulla struttura degli organi fosforescenti dei pesci (In Ricerche Fisiol. Sci. Affini dedicado à Luigi Luciani, p. 381-402. pl. Milano, 1900)

1900.1

Changements morphologiques que l'on observe dans la rétine des vertébrés par l'action de la lumière et de l'obscurité. La rétine des poissons et des amphibies. Arch. Ital. Biol., 1905, 42, 303-322. 4 figs.

1905.1

Chiarini, Pietro, \& Gatti, $M$. Ricerche sugli organi biofotogenetici dei pesci. Atti Roy. Accad. Lincei, 1899, 5. ser. 8, pt. 1 (Rendic.), 551-556; Ibid., pt. 2, $81-87$.

1899.1

Chiarugi, Giulio. Di un organo epiteliale situato al dinanzi della ipofisi e di altri punti relativi allo sviluppo della regione ipofisaria in embrioni di T'orpedo ocellata. Monit. Zool. Itai., 1898, 9, 37-56. figs.

1898.1

Della regione parafisaria del telencefalo e di alcuni ispessimenti del corrispondente ectoderma tegumentale in embrioni di Torpedo ocellata. Monit. Zool. Ital., 1905, 16, 182-186. - Arch. Ital. Anat. Embriol., 1906, 5, 359-375. 3 pls.

1905.1

Chichoff, $G$. Contribution à l'étude de la faune de la mer Noire. Animaux récoltés sur les côtes bulgaires. Arch. Zool. Expér., 1912, 5. sér. 10 (Notes \& Rev.), xxix-xxxix. 1912.1

Chiereghini, Stefano [1745-1820] Ipsa Chiereghinii conchylia, ovvero contribuzione pella malacologia Adriatica desunta dal manoscritto descrizione de' crostacei, de' testacei, e de' pesci che abitano le lagune e golfo Veneto, rappresentati in figure, a chiaroscuro ed a colori dall' Abate S. Chiereghini ... illustrata da S. Brusina.' Pisa, 1870. 280 p. $8^{\circ}$.

1870.1

Chievitz, J. H. Notice on Prof. W. Newton Parker's communication on the poisonous organs of Trachinus. Anat. Anz., 1888, 3. Jahrg., 787. 1888.1

Untersuchungen über die Area centralis retina. Arch. Anat. Physiol. (Anat. Abth., Suppl.), 1889, 139-194. pl. vi.

1889.1

Untersuchungen über die Entwicklung der Area und Fovea centralis retinæ. Arch. Anat. Physiol. (Anat. Abth.), 1890, 332-365. pls. xviii-xx.

Syngnathus typhle, p. 350-354.
Ueber das Vorkommen der Area centralis retinæ in den vier höheren Wirbeltierklassen. Arch. Anat. Physiol. (Anat. Abth.), 1891, 311-333. 1891.1 Fische, p. 318.

Chifflot, - Conte, A., \& Vaney, $C$. Iryste de l'ovaire chez le Cyminus auratus. C. R. Assoc. Franc. Avanc. Sci., 35. sess., 1907, pt. 2, 533-535.

1907.1

Chion, Rapport sur une notice de M. Ballot relative à deux carpes monstrueuses pêchées dans des étangs. Mém. Soc. Roy. Sci. Orléans, $1838,1.23$ p. pl.

1838.1

Chisholm, $C$. On the poison of fish. Med. Surg. Journ., Edinb., 1808, 4, 393-422. - Giorn. Soc. Incorr., Milano, 8, 154-161.

1808.1

Chittenden, Russell Henry [1856-] On the chemical composition of the llesh of Hippoglossus americanus. Amer. Journ. Sci., 1877, 3. ser. 13, $123-124$.

1877.1

Chlopin, G. W., \& Nikitin, A. F. Der Einfluss der Naphtha und ihrer Producte auf die Fische. Soc. Imp. Russe Pêche Pisciculture, 1899, no. 3. $9 \mathrm{p}$.

1899.1

Chmělevskij, $\check{C} . V$., Gracianov, $V$. $I .$, Zograf, $J$. $N$., Hindze, $B . K$., Voronkov, $N . V .$, \& Bogojavlenskij, $N . V$. Die Fischerei und die Fischzucht im Nordwest-Gebiete [Text in Russian] Trd. Otd. Ichtiol. Obšč. Akklimat., Moskva, 1907, 5, 1-315. 6 pls. \& 15 figs.

1907.1

Chodnew, S. Skizzen des Fischfanges auf dem Moskwa-Flusse und einige Worte über Teichfischerei [Text in Russian] Moscou, 1872.

1872.1

Choffat, Paul. Recueil de monographies stratigraphiques sur le système crétacique du Portugal. II. Le crétacique supérieur au nord du Tage. Direct. Serv. Géol. Portugal, 1900. 287 p. 11 pls.

1900.1

-__ Le crétacique dans l'Arrabida et dans la contrée d'Ericeira, accompagné d'une description de Colodus anomalus, n. sp., par F. Priem. Supplément paléontologique. Comm. Serv. Geol., Lisboa, 1904-05, 6, 1-55.

1904.1

Cholmondeley-Pennell, Henry [1837 - ] . The angler-naturalist; a popular history of British fresh-water 
Cholmondeley-Pennell, $H$.

fish, with a plain explanation of the rudiments of ichthyology. London, 1863. 425 p. figs. $12^{\circ}$. 1863.1

Most of the illustrations are borrowed from Yarrell's "History of British fishes." There is also a later edition of this work [1875?]

\section{Proved facts in the history of the} salmon. Canadian Naturalist, 1864, 1, 144-166.

1864.1

The book of the pike,... the history of the fish, etc. London, 1865. $\mathrm{xV}, 254$ p. 8 pls. $12^{\circ}$.

1865.1

The second part of the work, which treats of pike fishing, was originally published in the Fisherman's magazine and review, 1864-65, and most of the illustrations are taken from that journal.

- (editor) Fishing gossip; or, stray leaves from the note-books of several anglers. Edinburgh, 1866. 329 p. illust. $8^{\circ}$.

1866.1

Many of these articles were originally published in the Fisherman's magazine, and the frontispiece is taken from that journal. One of the articles, by John G. Fennell, is on Curiosities of angling literature.

Can fish feel pain? The question considered analogically and physiologically. With a few words on the ethics of angling. London, 1870. $14 \mathrm{p}$. $12^{\circ}$.

1870.1

- Fishing. With contributions from other authors [William Senior, G. C. Davies, H. R. Francis and others? 2 vols. London, 1885 . illust. $8^{\circ}$. (The Badminton library of sports and pastimes, no. 58)

1885.1

Vol. i, Salmon and trout.

Vol. ii, Pike and other coarse fish.

The same. 2. ed. 2 vols. London, 1886. illust. $8^{\circ}$ (The Badminton library of sports and pastimes) 1886.1

Vol. i, Salmon and trout culture, by T. Andrews. p. 472 .

Vol. ii, The cultivation of coarse fish, by R. B. Marston. - The rearing of black bass, and piscicultural experiments at Burghley, by the Marquis of Exeter. p. 412 .

The sporting fish of Great Britain with notes on ichthyology. London, 1886. 185 p. 18 pls. 4\% 1886.2

Chop, $K$. Neue Mittheilungen über die Zähne und Fischreste aus dem Schlotheimer Keuper. Zeitschr. Gesammt. Naturw., Halle, 1857, 9, 127132. pl.

1857.1

Choronshitsky, Boris. Die Entstehung der Milz, Leber, Gallenblase, Bauchspeicheldrüse und des Pfortadersystems bei den verschiedenen Abthei- lungen der Wirbelthiere. Anat. Hefte, 1900, 13, 363-623. 85 figs. 1900.1

Chorošchin, I. P. Ueber den gegenwärtigen Stand der Fischerei im UralKosaken-Heere [Text in Russian] Congrès Intern. Pêche Pisciculture St. Pétersb., 1902, pt. 2, 77-117. 1902.1

Christison, (Sir) Robert. On the composition of the flesh of the salmon in the "clean" and "foul " condition. Proc. Roy. Soc. Edinb. 1869-72 (1872), 7, 694-697.

1872.1

The salmon disease. Lancet, $1879,1,636$.

1879.1

Christison, Sanderson. Curious fishes of the deep sea. Scient. American, 1905, 92, 188. 6 figs.

1905.1

Christopher, $H$. Schmarotzerfische. Natur \& Haus, Dresden, 1905, 14. Jahrg., 55-57. 4 figs.

1905.1

Christy, Robert Miller. A catalogue of local lists of British mammals, reptiles, and fishes, arranged under counties. Zoologist, 1893, 3. ser. 17, 252264.

1893.1

- Note on the occurrence of the white-tailed eagle (Haliotus albicilla) and the salmon (Salmo salar) at Harwich in 1666. Essex Naturalist, 1899, 11, 76-78.

1899.1

Chudeau, $R$. Les conditions qui déterminent la taille des animaux. C. R. Mém. Soc. Biol., Paris, 1898, 10. sér. 5, 951-952.

1898.1

- Pêche et biologie. Bordeaux, 1900. $8^{\circ}$. 1900.1

Les conditions de la pêche en Algérie. C. R. Cong. Soc. Sav. Alger, Paris, 1905, 105-113.

1905.1

Chudeau, R., \& Gruvel, A. See Gruvel \& Chudeau.

Chun, Carl [1852-] Ueber die geographische Verbreitung der pelagisch lebenden Seethiere. Zool. Anz., 1886, 9, 55-59; 71-75.

1886.1

Die pelagische Thierwelt in grösseren Meerestiefen und ihre Beziehungen zu der Oberfächenfauna. Bibl. Zool., 1887, 1, 1-66. 5 pls. $\quad 1887.1$

Ueber die Existenz einer pelagischen Tiefsecfauna. Schriften Phys.aekon. Ges. Königsb., 1888, 28 (Sitzber.), 9-11. 
- Die pelagische Thierwelt in grossen Meerestiefen. Verh. Ges. Deutsch. Natf., 1890, 1. 'Teil, 69-85. Jahresb. Schles. Ges., Breslau, 1892, $20-27$.

1890.1

- Ueber die biologischen Untersuchungen der Hensenschen PlanktonExpedition. Schriften Phys.-oekon. Ges. Königsb., 1891, 31 (Sitzber.), 14-15.

1891.1

- Leuchtorgan und Facettenauge. Ein Beitrag zur Theorie des Sehens in grossen Meerestiefen. Biol. Centrabl. $1893,13,544-571$. 8 figs.

1893.1

Atlantis. Biologische Studien ïber pelagischen Organismen (In Leuckart, R. Bibliotheca Zoologica, Bd. vii, 19. Heft, p. 1-260. Leipzig, 1894) 1894.1

- Zur Biologie der pelagischen Sïsswasserfauna. Jahresb. Schles. Gescll., Breslau, 1895, 2. Abth., 80-83.

1895.1

Die Beziehungen zwischen dem arktischen und antarktischen Plankton. Stuttgart, 1897.

1897.1

- Die Resultate der Tiefseeforschung und die Aufgaben einer deutschen Tiefsee-Expedition. Verh. Gesell. Deutsch. Natf., 1897, 1. Teil, 122-134.

1897.2

-Die deutsche Tiefsee-Expedition. Berichte. Zeitschr. Gesell. Erdk., Berlin, 1899, 34, 75-134.

1899.1

—_Erläuterungen zu seiner Ausstellung der Ergebnisse der deutschen Tiefsee-Expedition. Verh. Gesell. Deutsch. Natf., 1899, 1. Teil, 141-143.

1899.2

-.. Von der deutschen TiefseeExpedition. Ann. Hydrogr., 1899, 27, 100-102.

1899.3

Aus den Tiefen des Weltmeeres. Schilderung von der deutschen TiefseeExpedition. Jena, 1900. 549 p. figs. $8^{\circ}$.

1900.1

- The same. 2. ed. Jena, 1903. 1903.1

- (editor) Wissenschaftliche Ergebnisse der deutschen Tiefsee-Expedition auf dem Dampfer "Valdivia" 1898-99. 15. Band. Jena, 1908. 42 pls. \& 187 figs.

1908.1

Inhalt: Die Tiefsee-Fische, von Prof, Dr. August Brauer. I. Systematischer Teil. II. Anatomischer Teil.
Church, Daniel T. Condition of the shore fisheries of Massachusetts and Rhode Island in 1871. Rept. U. S. Fish Comm. 1871-72 (1873), 1, 31. 1873.1

Statement concerning the menhaden fishery. Rept. U. S. Fish Comm. 1878 (1880), 5, 418 .

1880.1

The sea and coast fisheries. Bull. U. S. Fish Comm. 1893 (1894), 13, 37-38.

1894.1

Churchill, (Consul) - Persian fisheries. Forest \& Stream, 1877, 9, 249.

1877.1

Churchill, Sylvanus. Notice of a double fish. Amer. Journ. Sci., 1834, 26, 116-117. fig.

1834.1

Chydenius, Johan Jacob, \& Furuhjelm, J.E. Berättelse öfver en naturhistorisk resa i Karelen, företagen på Sällskapets pro Fauna et Flora Fennica bekostnad. Notiser Sällskapets Fauna \& Flora Fenn. Förh., 1858 (1859), n. s. 1, 81-118.

1859.1

Pisces, p. 85-90

Chyzer, Kornél [1836-] Reliquia Petényianæe, nehany szó Petényröl mint ichthyologrol. Termr. Füzetek, Budapest, $1881, \mathbf{5}, 23-26 ; 88 ; 91-146 ; 273$.

1881.1

Beiträge zur naturwissenschaftliche Kenntniss des Lempliner Komitates. Die Fische des Lempliner Komitates. Jahrb. Ungar. Karpath. Ver., $1882,9,12-25$.

1882.1

Ciaccio, Carmelo. Sull' esistenza di un tessuto mieloide differenziato negli animali inferiori. Anat. Anz., 1905, 26, 222-224.

1905.1

Sur la fine structure et sur les fonctions des capsules surrénales des vertébrés. Arch. Ital. Biol., 1905, 43, $17-34$.

1905.2

Sur l'existence de tissu myéloide dans le rein des plagiostomes. C. R. Soc. Biol. Paris, 1906, 60, 77. 1906.1

Contributo alla morfologia ed istogenesi del tessuto mieloide ['T'essuto linfo-renale dei pesci] Monit. Zool. Ital. $1907,18,127-132$.

1907.1

Sur la physio-pathologie des tissus hémopoiétiques. I. La moëlle osseuse et les tissus myéloïdes. II. Les tissus lymphoïdes. Folia Hämatologica, $1909,8$.
1909.1 
Ciaccio, Giuscppe Vincenzo. Intorno al finale distribuimento de' nervi nell' organo elettrico della torpedine (Torpedo narke Risso) Arch. Zool. Anat. Fis., 1870, 2. ser. 2, 5-9.

1870.1

- Structure intime de l'organe électrique de la torpille. Journ. Zool. (Gervais), 1874, 3, 481-485. 1874.1

Intorno all' intima tessitura dell' organo elettrico della torpedine (Torpedo narke Risso, Torpedo galvani Bonap.) Nuovo Cimento, 1874, 2. ser. 12, 5-9. Ibid., 1876, 2. ser. 15, 34-41. Rendic. Accad. Sci. Bologna, 1874, 105109. - Lo Spallanzani, 1875, 4, 433.

1874.2

Della somiglianza tra la piastra elettrica e I' eccito-motoria della torpedine, e di alcune differenze che mostrano nella struttura loro i segmenti interanulari della fibre nervee che vanno all' organo elettrico della stressa. Rendic. Accad. Sci. Bologna, 1875-76, 16-21.

1876.1

Ueber den feineren Bau des elektrischen Organs des Rochens (Torpedo narke) Untersuch. Naturlehre (Moleschott), 1576, 11, 416-419. pl.

1876.2

Intorno alle piastre motrici delle torpedini e delle razze. Rendic. Accad. Sci. Bologna, 1876-77 (1877), 12-13.

1877.1

Nuove osservazioni intorno alla terminazione dei nervi motori nei muscoli striati delle torpedini e razze, e intorno alla somiglianza tra la piastra elettrica delle torpedini e la motrice. Lo Spallanzani, 1877, 6, 501. - Journ. Micrograph., 1878, 2. année, 27-31; 65-68; $108-113 ; \quad 160-164 ; \quad 205-210$ $256-260 ; 301-306 ; 350-353 . \quad 1877.2$

Osservazioni intorno al modo come terminano i nervi motori ne' muscoli striati delle torpedini e delle razze, e intorno alla somiglianza tra la piastra elettrica delle torpedini e la motrice. Mem. Accad. Sci. Bologna, 1877, 3. ser. 8, 361-415. - Rendic. Accad. Sci. Bologna 1876-77 (1877), 135-139.

1877.3

Nota sopra la punteggiatura della piastra elettrica del gimnoto o anguilla del Surinam. Rendic. Accad. Sci. Bologna 1878-79 (1879), 163-164.

1879.1

- Osservazioni istologiche intorno alla terminazione delle fibre nervose motive ne' muscoli striati delle torpedini, del topo casalingo e del ratto albino, condizionati col doppio cloruro d' oro e cadmio. Mem. Accad. Sci. Bologna, 1882, 4 . ser. 4, 821-830. 2 pls. - Journ. Microgr., 7, 38-41. 1882.1

Nota sopra la terminazione delle fibre nervose motrici ne' muscoli striati delle torpedini condizionati col doppio cloruro d' oro e cadmio. Rendic. Accad. Sci. Bologna 1882-83 (1883), 18-22.

1883.1

Osservazioni microscopiche intorno agli organi elettrici delle torpedini. Mem. Accad. Sci. Bologna, 1897, 5. ser. 7, 213-245. pls. i-iv. - Arch. Ital: Biol., 33, 51-72. 2 pls.

1897.1

Cialona, Marco. Osservazioni pratiche sull' epoca della comparsa e della variabilità quantitativa delle specie animali più comuni nel plankton del porto di Messina. Ric. Lab. Anat. Norm. Roma, 1901, 8, 149-155. 2 figs. 1901.1

Ciamician, $J$. Ueber die Wirbelsäule des Meeraals (Murana conger) Bericht Naturwiss. Ver. Technisch. Hochschule Wien, 1878, 3, 48-49.

1878.1

Cicile-Brion, ___ Pisciculture; mémoire sur l'appareil rotatif CicileBrion, pour l'éclosion des œufs fécondés et l'élevage des jeunes poissons. Verdun, 1866. $\&$ p.

1866.1

Cignetti, Fr. Toxicität des Blutserums und des Muskelsaftes der Schleie. Arch. Intern. Pharmacodyn. Thérapie, $1900,7$.

1900.1

Cirincione, $G$. Zur Entwicklung der Wirbelthierauges. Ueber die Entwicklung der capsula perilenticularis. Leipzig, 1898. 24 p. 9 pls. fol. 1898.1

Cisi-Halem, Elektrische Fische; eine gemeinverståndliche Darstellung. Nerthus, 1901. 3. Jahrg., 491-493; 515-516; 429-530. 12 figs. $\quad 1901.1$

Cisow, Alexander. Ueber das Gehörorgan der Ganoiden. Arch. Mikrosk. Anat., 1880, 18, 486-519. 2 pls.

1880.1

Cisternas, Rafael. Catálogo de los peces comestibles que se crian en las costas españolas del Mediterráneo y en los rios y lagos de la provincia de $\mathrm{Va}$ lencia. Valencia, 1867. $8^{\circ}$. 1867.1 
- Descripción del Ammodyles terebrans, nueva especie de pece del Mediterráneo. Anal. Soc. Hist. Nat. Madrid, $1875,4,163-168$.

1875.1

- Ensayo descriptivo de los peces de agua dulce que habitan en la provincia de Valencia. Anal. Soc. Hist. Nat. Madrid, 1877; 6, 69-138.

1877.1

Claparède, A. de. Zur Frage der Verfolgung der den schweizerschen Fischereien schädlichen Thiere. Bern, 1885. 55 p. $8^{\circ}$.

1885.1

Clapham, Thomas. Do fish hear? Forest \& Stream, 1878, 11, $111 . \quad 1878.1$

More about the movement of eels. Forest \& Stream, 1878, 10, 462.

1878.2

Grayling on Long Island. Chicago Field, 1879, 11, 196.

1879.1

- How do trout leap a fall? Chicago Field, 1879, 11, 244.

1879.2

Little eels once more. Forest \& Stream, 1879, 12, 346.

1879.3

Food for brook trout. Trans. Amer. Fisheries Soc. 1879 (1880), 4-6.

1880.1

Clapp, A.F. The Susquehanna; its past, present and future. Trans. Amer. Fisheries Soc. 1892 (1893), 135-137.

1893.1

Clapp, (Miss) Cornelia Maria [1849 -] Some points in the development of the toadfish (Batrachus tau) Journ. Morph., 1891, 5, 494-501. figs. 1891.1

- Relation of the axis of the embryo to the first cleavage plane. Mar. Biol. Labor. IVoods Holl, 1898, 139151. 6 figs.

1898.1

The lateral line system of Batrachus tau. Journ. Morph., 1899, 15, 223-264. 4 pls. \& 8 figs. 1899.1

Clapp, W. F. Collecting from haddock on the George's banks. Nautilus, 1912, 25, 104-106.

1912.1

Clark, A. Howard. Notes on the fisheries of Gloucester, Mass. Bull. U.S. Fish Comm. 1884, 4, 401-410. 1884.1

Notes on the New England fishery for swordfish during the season of 1884. Rept. U. S. Fish Comm. 1884 (1886), 12, 233-239.

1886.1

The coast of Connecticut and its fisheries (In The fisheries and fishery industries of the United States, edited by George Brown Goode, sect. 2, p. 311340. Washington, 1887)

1887.1

The fisheries of Massachusetts (In The fisheries and fishery industries of the United States, edited by George Brown Goode, sect. 2, p. 113-280. Washington, 1887) $\quad 1887.2$

The fisheries of Rhode Island (In The fisheries and fishery industries of the United States, edited by George Brown Goode, sect. 2, p. 281-310. Washington, 1887) 1887.3

Historical references to the fisheries of New England (In The fisheries and fishery industries of the United States, edited by George Brown Goode, sect. 2, p. 675-737: Washington, 1887)

1887.4

History of the iced fish and frozen fish trade of the United States. Trans. Amer. Fisheries Soc. 1886 (1887), 68-81.

1887.5

Fish preservation by the use of acetic, boracic, salicylic and other acids and compounds. Trans. Amer. Fisheries Soc. 1887 (1888), 28-34. 1888.1

Clark, A. Howard, \& Goode, George Brown. See Goode \& Clark.

Clark, A. Howard, Goode, George Brown, \& others. See Goode, Collins, \& others.

Clark, Andrew. Observations on the anatomy of the skin of a species of Muræna. Trans. Roy. Micr. Soc. London, 1849, 2, 141-150. pl. 1849.1

Clark, Austin Hobart [1880-] On the name of the common American eel [Anguilla chrisypa Rafinesque] Proc. Biol. Soc. Washington, 1903, 16, 52.

1903.1

Habits of West Indian whitebait [Sicydium plumieri] Amer. Naturalist, 1905, 39, 335-337. 1905.1

Clark, E. D., \& Alsberg, C. L. See Alsberg \& Clark.

Clark, Frank $N$. Raising the grayling in confinement. Chicago Field, $1880,12,356$.

1880.1

- The red-banded trout of California. Chicago Field, 1880, 13, 26.

1880.2

On the rearing of whitefish in spring water, and its relation to their 
Clark, $F . N$. subsequent distribution. Bull. U.S. Fish Comm. 1881, 1, 301-306. 1881.1

Account of operations at the Northville fish-hatching station of the United States fish commission, from 1874 to 1882 , inclusive. Bull. U. S. Fish Comm. 1883, 3, 355-372. 1883.1

- Description of the United States fish hatchery at Alpena, Michigan. Bull. U. S. Fish Comm. 1882 (1883), 2, 388.

1883.2

- Report of operations connected with the propagation of whitefish (Coregonus albus) at the Northville station, Northville, Michigan, for the season of 1880-81. Rept. U. S. Fish Comm. 1880 (1883), 8, 553-596. fig.

1883.3

Spawning of California mountain trout reared in confinement from eggs brought from McCloud river. Bull. U.S. Fish Comm., 1883, 3, 256. 1883.4

- Report of operations at the Northville and Alpena (Mich.) stations for the season of 1882-1883. Rept. IJ. S. Fish Comm. 1882 (1884), 10, 813838.

1884.1

- Report of work at the United States hatchery, Northville, Mich. 1881-82. Rept. U. S. Fish Comm. 1881 (1884), 9, 1037-1062.

1884.2

- Natural as compared with artificial hatching of whitefish. Bull. U. S. Fish Comm., 1885, 5, 321-323. 1885.1

- Notes on experiments in penning shad and taking eggs at Battery Station, Havre de Grace, Md., in 1883. Rept. U.S. Fish Comm. 1883 (1885), 11, 10451050 .

1885.2

- Report of operations at the Northville and Alpena stations for the season of 1883-84. Rept. U. S. Fish Comm. 1883 (1885), 11, 975-988. 1885.3

- Results of planting young whitefish in lake Erie. What the fishermen think of the whitefish propagation. Bull. U. S. Fish Comm., 1885, 5, 113120.

1885.4

Report of operations at the Northville and Alpena (Mich.) stations during the season of 1884-85. Rept. U.S. Fish Comm. 1884 (1886), 12 , 151-167.

1886.1
Results of planting white fish in lake Erie. Trans. Amer. Fisheries Soc. 1885 (1886), 40-50.

1886.2

- Disadvantage of planting small fish. Bull. U. S. Fish Comm. 1886 (1887), 6, 421-422

1887.1

- Report of operations at the Northville and Alpena stations during the season of 1885-86. Rept. U. S. Fish Comm. 1885 (1887), 13, 121-129. 1887.2

Report on distribution of fish and eggs from Northville and Alpena stations for the season of $1885-86$. Bull. U. S. Fish Comm. 1886 (1889), 6, 395-399.

1889.1

Report of operations at the Michigan stations of the United States Fish Commission for the year 1886-87. Rept. U. S. Fish Comm. 1886 (1889), 14, 729-736.

1889.2

- Whitefish distributed from Northville and Alpena stations. Bull. U. S. Fish Comm. 1887 (1889), 7, 64.

1889.3

- Rearing and distributing trout at the Northville Station, U. S. Fish Commission. Trans. Amer. Fisheries Soc. 1891 (1892), 30-33.

1892.1

Rearing fish for distribution. Trans. Amer. Fisheries Soc. 1892 (1893), 78-81.

1893.1

History and methods of whitefish culture. Bull. U. S. Fish Comm. 1893 (1894), 13, 213-220.

1894.1

Notes in connection with the United States fish hatcheries in Michigan. Trans. Amer. Fisheries Soc. 1898 (1899), 27-32.

1899.1

What is protection to food fishes? Trans. Amer. Fisheries Soc. 1899 (1900), 21-29. 1900.1

Methods and results in connection with the propagation of commercial fishes for the Great lakes. Trans. Amer. Fisheries Soc. 1900 (1901), 88-95.

1901.1

- A successful year in the artificial propagation of the whitefish. Trans. Amer. Fisheries Soc. 1902 (1903), 97-99. 1903.1

Commercial fish and fisheries. Rept. Michigan Acad. Sci., 1904, 6, 6568. 1904.1 
- Notes on small-mouth bass culture at the Northville, Mich., station. Trans. Amer. Fisheries Soc. 1905 (1906), 174-180. fig.

1906.1

- Notes on a new hatching jar. Trans. Amer. Fisheries Soc. 1907 (1908), 159-162. fig.

1908.1

A plan for promoting the whitefish production of the Great lakes. Proc. 4. Intern. Fish. Congr., Washington, 1908, 635-642. - Bull. U. S. Bureau Fish., 1910, 28, 637-642.

1908.2

Clark, George. The game laws from King Henry III. to the present period. London, $1786.12^{\circ}$.

1786.1

Includes some mention of fish and fishing.

Clark, G. A., \& Jordan, David Starr. See Jordan \& Clark.

Clark, G.C. On the grayling and fish in general. 4. Ann. Book Michigan Sportsman's Assoc, 1881, p. 77. 1881.1

Clark, Henry James [1826-1873] Mind in nature; or the origin of life and the mode of development of animals. New York, 1865. 315 p. 200 figs. $8^{\circ}$. 1865.1

Description of form and structure of Amphioxus, p. 227-230.

Clark, Henry W. Statement concerning the menhaden fishery, Rept. U. S. Fish Comm. 1877 (1879), 5, 425.

1879.1

Clark, Howard IWalion, \& Evermann, Barton Warren. See Evermann \& Clark.

Clark, Howard Walton, \& Goldsborough, Edmund Lee. See Goldsborough \& Clark.

Clark, Howard Walton, \& Meek, Seth Eugene. See Meek \& Clark.

Clark, James. An annotated list of Cornish fishes. Zoologist, 1907, 4. ser. 11, 415-427; 453-459; Ibid., 1908, 12, $13-29$

1907.1

Clark, John. The salmon disease. Intern. Fisheries Exhib. Lit., London, 1883. Conferences, 11, pt. 4. 1883.1

Clark, Nelson W. Propagation of fish: an address to the legislature. Detroit, 1871. 23 p. $8^{\circ}$.

1871.1

Hatching white fish. Forest \& Stream, 1874, 2, 340.

1874.1

Fish hatching. Forest \& Stream, $1875,5,179$.
Clark, $R$. S. Notes on some freshwater fishes from Buenos Aires. Sci. Res. Scottish Nat. Antarctic Exped., Edinburgh, 1912, 4, 107-110. pl. 1912.1

- Scottish national Antarctic expedition. "Scotia" collection of fishes from St. Helena. Proc. Roy. Phys. Soc. Edinb., 1913, 19, 47-53.

1913.1

Clark, William. Catalogue of Dr. Clark's casts of placoderm fishes. Berea, Ohio, 1896. 2 p.

1896.1

- Some new points on fin attachment of Dinichthys and Cladodus. Proc. Ohio Acad. Sci., 1898, 6, 46-48. figs.

1898.1

Clark, $W . B$. The cerebellum of Petromyzon fluviatilis. Journ. Anat. Physiol., London, 1906, 40, 318-325. pl.

1906.1

Clarke, $F . E$. On two new fishes [Argyropelecus intermedius and Egoronichthys appelii] Trans. Proc. New Zeal. Instit. 1877 (1878), 10, 243-246. pl.

1878.1

On a new fish found at Hokitika Argentina decagon] Trans. Proc. New Zeal. Instit. 1878 (1879), 11, 295-297.

1879.1

On some new fishes. Trans. Proc. New Zeal. Instit. 1878 (1879), 11, 291-295. 2 pls.

1879.2

Description of a new species of Trachypterus [T. tarawato] Trans. New Zeal. Instit. 1880 (1881), 13, 195-199. fig.

1881.1

Notes on the occurrence of a species of Lophotes on the coast of Taranaki. 'Trans. New Zeal. Instit., 1897, 29, 251-252. pl. 1897.1

On two new globe-fish. Trans. New Zeal. Instit., 1897, 29, 243-250. 2 pls.

1897.2

Discussion of same article, by James Hector. Ibid., p. 604 .

- Notes on occurrence of Regalecus argenteus on the Taranaki coast. Trans. New Zeal. Instit., 1898, 30, 254266. 3 pls.

1898.1

Notes on New Zealand Galaxidæ, more especially those of the western slopes; with descriptions of new species. Trans. New Zeal. Instit., 1899, 31, 78-91. 2 pls.

1899.1

Notes on Parore (the Mangrove fish) Trans. New Zeal. Instit., 1899, 31, 96-101. pl.
1899.2 
Clarke, $F . E$. On Exocatus ilma: a new species of flying fish. Trans. New Zeal. Instit., $1899,31,92-96$. pl.

1899.3

Clarke, Frank Wigglesworth [1847 Reproduction of a fish's tail. Amer. Naturalist, $1874,8,363-364$. 1874.1

Electric fishes. Penn Monthly, $1875,6,808-817$.

1875.1

Clarke, George. Menobranchus destructive to the spawn of the whitefish. Ann. Rec. Sci. \& Med. (Baird) 1872 (1873), 421.

1873.1

Clarke, $H . R$. Propagation of trout by the Southside Club. Bull. U. S. Fish Comm., 1885, 5, 436.

1885.1

Clarke, J.B. The opah in Shetland. Ann. Scott. Nat. Hist., 1905, 246-247.

1905.1

Clarke, John Mason [1857-] On the higher Devonian faunas of Ontario county, New York. Bull. U. S. Geol. Surv., 1885, no. 16, 1-80. pls. i-iii.

1885.1

Four new species of fossil fishes are described, one of Dinichthys, one of Palmoniscus and two of sharks.

New or rare species of fossils from the horizons of the Livonia salt shaft. Rept. State Geol. N. Y., 1893, 2, 162-168. pl.

1893.1

Describes a new Arthrodiran species under the name of Coccosteus (?) halmodeus, sp. nov.

The fossil fishes of Cañon City, Colorado. Amer. Geologist, 1895, 15, 121.

1895.1

Catalogue of the type specimens of Palrozoic fossils in the New York State Museum. Bull. New York State Mus., Albany, 1903, 65 (Palæont. 8), $1-847$.

1903.1

A number of type specimens of fossil fishes are included.

Clarke, John Mason, \& Luther, D. Dana. Stratigraphic and palæontologic map of Canandaigua and Naples Quadrangles. Bull. New York State Mus., Albany, 1904, no. 63. 76 p. - 56. Ann. Rept. New York State Mus., Albany, 1904, 2. $76 \mathrm{p}$.

1904.1

Clarke, Robert. Fishes of northern New York - frozen fish. Amer. Journ. Sci., 1854, 17, 291-292.

1854.1

Clarke, S. C. Notes on some of the coast fishes of Florida. Amer. Naturalist, 1871, 4, 693-694.
The fishes of east Florida... from notes of a naturalist. Forest \& Stream, 1873, 1, 257-258. 1873.1 Notes on the habits of 18 marine fishes.

The jew-fish and the tarpum. Forest \& Stream, 1874, 2, 252. 1874.1

Traits of southern fish. Forest \& Stream, 1874, 2, 324. 1874.2 The Canadian sea trout Salmo canadensis (Hamilton Smith) Forest \& Stream, 1875, 3, 357. 1875.1

Comparative size of trout in Europe and America. Forest \& Stream, $1875,5,230$.

1875.2

The pompano (Bothrolomus pompanus Holbrook) and the cavalli, or crevalle (Caranx defensor De Kay) Forest \& Stream, 1875, 3, 388. 1875.3

The pompano question. Forest \& Stream, 1875, 4, 85. 1875.4

The fishes of Scandinavia and our Northwest compared. Forest \& Stream, 1876, 7, 132.

1876.1

- Game fish of Florida (In Hallock, C. Camp life in Florida, p. 50-66. 1876)

1876.2

Large eels. Forest \& Stream, $1876,7,253$. 1876.3

- The crevalle and the ladyfish. Forest \& Stream, 1877, 8, 303. 1877.1

Notes on Caranx defensor Cuv. and Albula conorhynchus Gill taken at Halifax Inlet, Florida.

- More about sharks. Forest \& Stream, 1877, 9, 85.

1877.2

_- Some Florida fishes. Forest \& Stream, 1877, 8, 96.

1877.3

Notes on Promicrops guasa, Epinephelus nigritus, Scyllium cirratum and other species.

The lampern. Forest \& Stream, $1878,11,259$.

1878.1

On a river-lamprey found attached to a Polyolon folium in Lake Pepin, Minn.

- About sharks. Forest \& Stream, $1880,14,349$.

1880.1

- Intelligence of fishes. Chicago Field, 1880, 14, 163.

1880.2

68-69.

Rays. Chicago Field, 18s0, 14, 1880.3

Salt iwater trout (Cynoscion carolinensis) Chicago Field, 1880, 13, 253. 
The fishes of the east Florida coast (In Van Doren, L. O. The fishes of the east Atlantic coast, p. 99-159. New York, 1884) $8^{\circ}$.

$188 \pm .1$

Article on fishes in American Game Fishes, edited by G. O. Shields. Chicago \& New York, 1892. 1892.1

Clarke, W. Branwhite [1798-1878] Notice of the fourth occurrence of the argentine [Scopelus humboldtii Yarr.] upon the British shores, with note by W. Yarrell. Mag. Nat. Hist., 1838, n. s. 2, 22-26. figs.

1838.1

Clarke, W. Bruce, \& Jackson, W. Hatchett. See Jackson \& Clarke.

Clarke, William Barnard. Letter ... to William Yarrell,... noticing the recent occurrence of the fry of a species of Hemiramphus on the coast of Suffolk; with some additional observations by Mr. Yarrell. Mag. Nat. Hist., 1837, 1, 505-507. fig. 1837.1

Notice of the fourth occurrence of the argentine (Scopelus humboldtiv Yarr.) upon the British shores; with additional remarks, by W. Yarrell, Esq. Mag. Nat. Hist., 1838, n. s. 2 , 22-26. fig.

1838.1

Clarke, William Barnard, \& Yarrell, William. See Yarrell \& Clarke.

Clarke, William Eagle. The torpedo on the Yorkshire coast. Zoologist, 1882, 3. ser. 6, 193.

1882.1

- Notes on the vertebrate fauna of Yorkshire. Zoologist, 1884, 3. ser. 8, 171-184.

Fishes, p. 180-184.

1884.1

- Scorpona dactyloptera Delaroche, and its accurrence in the British North sea area. Proc. Phys. Sac. Edinb., 1893, 12, 94-101. pl. ii. 1893.1

Some fishes new to or rare in the fifth of Forth. Ann. Scott. Nat. Hist., $1895,23-28$.

1895.1

The fishes of the firth of Forth and its tributaries: species added since Dr. Parnell's "Essay" of 1837. Ann. Scott. Nat. Hist., 1900, 8-17; 202-215. 1900.1

Occurrence of the long-finned tunny off the Orkney islands. Ann. Scott. Nat. Hist., Edinb., 1900, 248.

1900.2

Clarke, William Eagle, \& Nelson, T. H. See Nelson \& Clarke.
Clarke, William Eagle, \& Roebuck, W. Denison. A handbook of the vertebrate fauna of Yorkshire. London, 1881. $8^{\circ}$. 1881.1

Clarke, $W . G$. A list of the vertebrate animals found in the neighborhood of Thetford. Trans. Norfolk Norwich Nat. Soc., 1897, 6, 300-327. $\quad 1897.1$

Short sunfish near Scarborough. Zoologist, 1898, 56, 439 . 1898.1

- Yarrell's blenny (Carelophus ascanii) and the two-spotted goby (Gobius ruthensparri) at Scarborough. Zoologist, 1898, 4. ser. 2, 191. 1898.2

Notes on the natural history of Thetford district. Trans. Norfolk Norwich Nat. Soc., 1907, 8, 387-392. 1907.1

Clarke, W. H., \& Mortimer, John. Mémoire sur une espèce de poisson de la côte de Surinam, qui a quatre yeux. Rev.Zool., 1839, 121. 1839.1

On a fish with four eyes. Rept. Brit. Assoc. Adv. Sci., 8. meet., 1838 (1839), $110 . \quad 1839.2$

Clarke, William $J$. Short sun-fish (Orthagoriscus mola) at Filey. Zoologist, 1896,3 . ser. 20, 307; 390. 1896.1

- Notes from Scarborough. Zoologist, 1897, 4. ser. 2, $28 . \quad 1897.1$

- Short sunfish (Orthagoriscus mola) near Scarborough. Zoologist, 1898, 4. ser. 2, 439 . 1898.1

Zoological notes from Scarborough during 1904. Zoologist, 1905, 4. ser. 9, 72-75. 2 figs. 1905.1

Cottus bubalis at Scarborough. Naturalist, London, 1912, 191. 1912.1

- Plauer's lamprey near Scarborough. Naturalist, London, 1912, 185.1912 .2

Clark-Kennedy, Alexander. Food of the cod [Gadus morrhua] Zoologist, 1866, 2. ser. 3, 1223 . 1866.1

Lampreys in the Thames near Windsor. Zoologist, 1867, 2. ser. 2, 836. 1867.1

- A large pike. Zoologist, 1867, 2. ser. 2, 638 . 1867.2 Variety of the perch [Perca fluviatilis] Zoologist, 1867, 2. ser.2, 954. 1867.3 
Clark-Kennedy, $A$.

Large pike in Buckinghamshire. Zoologist, 1868, 2. ser. 3, 1061. 1868.1

Bloch's gurnard [Trigla cuculus] in Galloway. Zoologist, 1875, 2. ser.10, 4724-4725.

1875.1

Sun fish in Fleet bay, Galloway. Zoologist, 1875, 2. ser. 10, 4725. 1875.2

- Large pike in Galloway. Zoologist, 1879, 3. ser. 3, 307.

1879.1

Clausmann, P., \& Gautier, $A r$ mand. See Gautier \& Clausmann.

Clavẻ, J. La pêche et la pisciculture à l'exposition universelle. Rev. Deux Mondes, 1868, 2. sér. 73 (38. année), 122-149.

1868.1

La pêche et les poissons. Rev. Deux Mondes, 1868, 2. sér. 74 (38. année), 783-784.

1868.2

Clavigero, (Abate) Francisco Xavier [1731-1787] Storia antica del Messico cavata da' migliori storici spagnuoli, e da' manoscritti, e dalle pitture antiche degl' Indiani . . e dissertazioni sulla terra, sugli animali, e sugli abitatori del Messico. 4 vols. Cesana, 1780. $4^{\circ}$.

1780.1

The history of Mexico, collected from Spanish and Mexican historians, from manuscripts, and ancient paintings of the Indians. To which are added, critical dissertations on the land, the animals, and inhabitants of Mexico. Translated by Charles Cullen, Esq. 2 vols. London, 1787. $4^{\circ}$.

1787.1

Storia della California. Opera postuma. Venice, 1789. 2 vols. 1789.1

- Breve noticia de las plantas y animales de México. La Naturaleza, 1882, 6 (Apéndice)

1882.1

Claypole, (Miss) Agnes Mary. The enteron of the Cayuga lake lamprey. Proc. Amer. Micr. Soc., 1895, 16, 101105; 125-164. pls. iii-x.

1895.1

Claypole, Edward WTaller [1835-1901] For biographical notices and list of writings, see articles in Amer. Geol., $1902,29,1-17$.

- Note on a large fish-plate from the Upper Chemung (?) beds of northern Pennsylvania [Holonema rugosum, sp. nov.] Proc. Amer. Phil. Soc., 1883, 20, 664-666. fig.

1883.1
- On the occurrence of fossiliferous strata in the lower Ponent (Catskill) group of middle Pennsylvania. Amer. Naturalist, 1883, 17, 274-282.

1883.2

Fish-remains in the NorthAmerican Silurian rocks. Science, $1884,4,34 ; 270$. 1884.1

On Ctenacanthus and Gyracanthus from the Chemung of Pennsylvania. Proc. Amer. Assoc: Adv. Sci., 33. meet., 1884 (1885), 489-490. 1884.2

On some fish remains recently discovered in the Silurian rocks of Pennsylvania. Proc. Amer. Assoc. Adv. Sci., 33. meet. 1884 (1885), 424428.

1884.3

- On some remains of fish from the Upper Silurian rocks of Pennsylvania. Rept. Brit. Assoc. Adv. Sci., 54. meet., 1884, 733-734.

1884.4

Preliminary note on some fossil fishes recently discovered in the Silurian rocks of North America. Amer. Naturalist, $1884,18,1222-1226$. 1884.5

- On the recent discovery of Pteraspidian fish in the Upper Silurian rocks of North America. Quart. Journ. Geol. Soc., 1885, 41, 48-64.-Geol. Mag., 1885, dec. 3, 2, 89-90. 1885.1

- A letter concerning the collection of fossil fishes made at Berea, Ohio, by Dr. Wm. Clark] Amer. Geologist, $1888,2,62-64$.

1888.1

-. The American Devonian placoderms. Bull. Geol. Soc. Amer., 1890, 616.

1890.1

- Palxontological notes from Indianapolis (A. A. A. S.) Pterichthys, Castoroides, etc. Amer. Geologist, $1890,6,255-260 . \quad 1890.2$

-...- Mémoire préliminaire sur la découverte de poissons fossiles dans les terrains siluriens supérieurs $d^{\prime}$ Amérique. Intern. Geol. Congress, Washington, D. C., 1891. 1891.1

- Dentition of Titanichthys and its allies. Amer. Geologist, 1892, 10, 193.

1892.1

The head of Dinichthys. Amer. Geologist, $1892,10,199-207$. pls. viviii. 1892.2

- A new gigantic placoderm from Ohio. Amer. Geologist, 1892, 10, 1-4. fig. 
On the structure of the American pteraspidian, Palæaspis (Claypole); with remarks on the family. Quart. Journ. Geol. Soc., London, 1892, 48, 542-561. 8 figs.

1892.4

The cladodont sharks of the Cleveland shale. Amer. Geologist, 1893, 11, 325-331. pls. vii-viii. 1893.1

The fossil fishes of Ohio. Rept. Geol. Surv. Ohio, 1893, 7, pt. 2, 602619. 6 pls.

1893.2

- A new coccostean; Coccosteus cuyahoge. Amer. Geologist, 1893, 11, 167-171. 2 figs.

1893.3

On three new species of Dinichthys. Amer. Geologist, 1893, 12, 275279. pl.

1893.4

Structure of the bone of Dinichthys. Proc. Amer. Micr. Soc., 1893, 15, 189-191. 5 figs.

1893.5

The three great fossil placoderms of Ohio. Amer. Geologist, 1893, 12, 89- 99 .

1893.6

- The Upper Devonian fishes of Ohio. Geol. Mag., 1893, n. s. dec. 3, 10, 443-148. 2 figs.

1893.7

Cladodus? magnificus, a new selachian. Amer. Geologist, 1894, 14, 137-140. pl.

1894.1

On a new placoderm, Brontichthys clarki, from the Cleveland shale. Amer. Geologist, 1894, 14, 379-380. pl. - 3. Ann. Rept. Ohio Acad. Sci., $1895,8-9$.

1894.2

- Actinophorus clarki Newberry. Amer. Geologist, 1895, 16, 20-25. pl. 1895.1

The cladodonts of the Upper Devonian of Ohio. Rept. Brit. Assoc. Adv. Sci., 65. meet., 1895, 694.-Geol. Mag., 1895, 4. ser. 2, 473 .

1895.2

The great Devonian placoderms of Ohio. Geol. Mag., 1895, 4. dec. 2, 473-474. - Rept. Brit. Assoc. Adv. Sci., 65. meet., 1895, 695 .

1895.3

- The oldest vertebrate fossil. Nature, 1895, 52, 55. 1895.4

This distinction is awarded to Onchus clintoni.

On a new specimen of Cladodus clarki. Amer. Geologist, 1895, 15, 1-7. 2 pls.

1895.5

On the structure of the teeth of the Devonian cladodont sharks. Proc. Amer. Micr. Soc., 1895, 16, 191-195. 4 pls.

1895.6
Recent contributions to our knowledge of the cladodont sharks. Amer. Geologist, 1895, 15, 363-368.

1895.7

The ancestry of the Upper Devonian placoderms of Ohio. Amer. Geologist, 1896, 17, 349-360. 1896.1

Dinichthys prentis-clarki. Amer. Geologist, 1896, 18, 199-201. pl. vii.

1896.2

A new Titanichthys. Amer. Geologist, 1896, 17, 166-169. pl.

1896.3

On the structure of some Paleozoic spines from Ohio. Trans. Amer. Micr. Soc., 1896, 18, 151-154. pl.

1896.4

On the teeth of Mazodus. Trans. Amer. Mier. Soc., 1896, 18, 146-150. pl.

1896.5

- Microscopical light in geological darkness. Trans. Amer. Micr. Soc., 1897, 19, 3-27. $\quad 1897.1$

- On the structure of some Paleozoic spines from Ohio. Trans. Amer. Micr. Soc., 1897, 18, 151-154. pl.

1897.2

A new Dinichthys, Dinichthys kepleri. Amer. Geologist, 1897, 19, 322-324. pl.

1898.1

Traquair on Silurian fish. Amer. Geologist, 1900, 25, 244-248. 1900.1

- The Devonian era in the Ohio basin. Amer. Geologist, 1903, 32, 312322; 335-352.

1903.1

Cleef, J.S. van. How to restore our trout streams. Trans. Amer. Fisheries Soc., 1885, 50-55.

1885.1

Cleland, Herdman Fitzgerald [1869-] The fossils and stratigraphy of the Middle Devonic of Wisconsin. Wisconsin Geol. Nat. Hist. Surv., 1911, Bull. no. 21. 222 p. 1 map. 5 figs. 1911.1

Some Devonian fishes are described.

Cleland, J. Burton. Injuries and diseases of man in Australia attributable to animals (except insects) Journ. Trop. Med., 1912, 16, 25-31; 43-47.

1912.1

Cleland, J.Burton, \& Johnston, T. Harvey. Relative dimensions of the red blood cells of vertebrates, especially of birds. Emu, 1912, 11, 188-197.

Includes some mention of fishes.
1912.1 
Cleland, John. On the skeleton, muscles, and viscera of Malapterurus beninensis. Proc. Phys. Soc. Edinb., 1854-58 (1858), 1, 381-396. - Edinb. New Phil. Journ., 1858, 2, ser. 8, 177192. pls.

1858.1

- Description of several fishes from Old Calabar. Proc. Phys. Soc. Edinb., 1859, 2, 359-361. - Edinb. New Phil. Journ., 2. ser. 15, 303-305.

1859.1

On the anatomy of Orthagoriscus mola, the short sunfish. Rept. Brit. Assoc. Adv. Sci., 31. meet. 1861 (1862), pt. 2, 138. - Nat. Hist. Rev., 1862, 170-185. figs.

1862.1

- On ribs and transverse processes, with special relation to the theory of the vertebrate skeleton; terminal forms of life; the classification of the vertebrata. 3 parts. [n. pl.] 1863. $8^{\circ}$.

1863.1

On the structure of the tail in Myxine. 4. Rept. Fishery Board Scotland, 1885. - Rept. Brit. Assoc. Adv. Sci., 55. meet. 1885 (1886), 1069. 1886.1

- On the spiracle of fishes in its relation to the head, as developed in the higher vertebrates. Rept. Brit. Assoc. Adv. Sci., 55. meet. 1885 (1886), 1069.

1886.2

- On the viscera of Gymnotus electricus. Rept. Brit. Assoc. Adv. Sci., 55. meet. 1885 (1886), 1068-1069.

1886.3

Clemens, James W. Notice of the spoonbill sturgeon, or paddle fish, of the Ohio [Polyodon spathula] Amer. Journ. Sci., 1827, 12, 201-205. 1827.1

Clemens, James W., Mitchill, Samuel L. \& Hildreth, S. P. See Mitchill, Hildreth \& Clemens.

Clemens, Paul. Die äusseren Kiemen der Wirbeltiere. Anat. Hefte, 1895, 5, 1. Abth., 51-156. 4 pls. 1895.1

Clément, A.L., \& Troncet, $L . J$. Les animaux de France utiles ou nuisibles. Vertébrés, mammifères, oiseaux, reptiles, batraciens, poissons. Paris, 1897. 171 p. $16^{\circ}$.

1897.1

Clément, $C$. Le barbeau méridional (Barbus meridionalis Risso) Bull. Soc. Etud. Sci. Nat. Nîmes, 1875, 3. année, 137-139.

1875.1

Clene, $P . T$. Plankton researches in 1901 and 1902. Svensk. Vet. Akad. Handl., 1903, 36, 1-53.
Clerc, A., \& Lœper, $M$. Formule hémoleucocytaire de l'intoxication par le sérum d'anguille. C. R. Mém. Soc. Biol. Paris, 1902, 54, 1062-1064. 1902.1

Influence des injections intraveineuses de peptone sur l'intoxication par le sérum d'anguille. C. R. Mém. Soc. Biol. Paris, 1902, 54, 1061-1062.

1902.2

Clerc, Vladimir. Courte notice sur mes excursions zoologiques en 1903 et 1904. Bull. Soc. Oural. Sci. Nat., Ekaterinburg, 1905, 25, 18 . 1905.1

Notice sur quelques collections helminthologiques inédites [Russian with French résumé Bull. Soc. Oural. Sci. Nat., Ekaterinburg, 1905, 25, 29-34.

1905.2

Contains some notice of fishes.

Clericus, pseudonym for Cartwright, (Rev.) William.

Clift, $M$. Report on shad-hatching operations in 1872. Rept. U. S. Fish Comm. 1872-73 (1874), 2, 403-405.

1874.1

Clift, William [1775-1849] Expériences pour déterminer l'influence de la moëlle épinière sur l'action du cœur dans les poissons. Bull. Sci. Soc. Philom., 1815, 197-198.

1815.1

Experiments to ascertain the influence of the spinal marrow on the action of the heart in fishes. Phil. Trans. Roy. Soc. London, 1515, 105, 91-96. 2 pls.

1815.2

Versuche, den Einfluss des Rüchenmarks auf die Thätigkeit des Herzens in den Fischen auszumitteln. Deutsch. Arch. (Meckel), 1816, 2, 140-145.

1816.1

Clift, (Rev.) William. The salmon and its culture. Phrenological Journ., $1872,6,19-27$.

1872.1

-... Shad culture. Trans. Amer. Fisheries Soc. 1872 (1873), 21-28.

1873.1

Important events in fish culture during the year 1872. Trans. Amer. Fisheries Soc. 1873 (1874), 4-10. 1874.1

Organization of the American Fish Culturists Association. Amer. Sportsman, 1S74, 3, 348.

1874.2

Report on shad hatching operations in 1872 . Rept. U. S. Fish Comm. 1872-73 (1874), 2, 403-405. 1874.3 
Cligny, Adolphe. Multiplication des anguilles. Rev. Encyclop. Larousse, 1897 , 7. année, no. $189,318-319$. 3 figs.

1897.1

Sur l'éthologie du hareng. C. R. Mém. Soc. Biol. Paris, 1904, 56, pt. 2, 347-348.

1904.1

Poissons des côtes d'Espagne et de Portugal (Océan Atlantique) Boulogne, 1905. $4^{\circ}$.

1905.1

Les prétendues migrations du maquereau. Boulogne, 1905. $4^{\circ}$.

1905.2

Sur un Lernæenicus parasite du sprat. C. R. Mém. Soc. Biol. Paris, 1905, 59, 165-166.

1905.3

Variations géographiques des Pleuronectides. C. R. Acad. Sci. Paris, $1905,140,526-529$.

1905.4

- Aphya minuta (Risso), espèce nouvelle pour le Pas-de-Calais. C. R. Assoc. Franç. Avanc. Sci., 34. sess., 1906, $585-586$.

1906.1

- La biologie du maquereau. La Science au XX. Siècle, Paris, 1906, 4 , 330-335. fig.

1906.2

- Elevage des Salmonides en Allemagne. Bull. Soc. Cent. Aquicult. Pêche, Paris, 1906, 18, 265-283. Also separate; Paris, $1906.8^{\circ} . \quad 1906.3$

- Transplantation des poissons marins. Bull. Soc. Cent. Aquicult. Pêche, Paris, 1906, 18, 105-108. 1906.4

Migrations marines de la truite commune. C. R. Acad. Sci. Paris, 1907, 145, 1302-1304. Also separate; Paris, 1908.

1907.1

- Sur un nouveau genre de Zeides [Parazenopsis argenteus, n. g. et n. sp.] C. R. Acad. Sci. Paris, 1909, 148, 873874 .

1909.1

Titres et travaux scientifiques Ipubliés par A. Cligny] (1896-1910) Boulogne-sur-Mer, 1910 . 65 p. $8^{\circ}$.

1910.1

Captures d'anguilles en pleine mer. Ann. Stat. Aquic., Boulogne-surMer, 1912, 2, 142-148.

1912.1

Contribution à l'étude de nos Scorpenides: Helicolenus dactylopterus Delaroche 1809 , et les espèces dites maderensis. Ann. Stat. Aquic., Boulogne-sur-Mer, 1912, 2, 73-81. 1912.2
- La dégénérescence de la truite arc-en-ciel. Bull. Soc. Acclim., Paris, $1912,59,588-595$.

1912.3

Deux Clupéides à supprimer de la nomenclature: Harengula latulus C. et V., et Meletta phalerica Risso. Ann. Stat. Aquic., Boulogne-sur-Mer, 1912, $2,65-72$.

1912.4

Le Liparis liparis Linné dans le Pas-de-Calais. Ann. Stat. Aquic., Boulogne-sur-Mer, 1912, 2, 115-120. 1912.5

Migration marine de l'anguille commune. C. R. Acad. Sci. Paris, 1912, 154, 727-729. - Bull. Soc. Acclim., Paris, 59, 524-526. $\quad 1912.6$

— Note sur quelques Zeidæe rares ou peu connus. Ann. Stat. Aquic., Boulogne-sur-Mer, 1912, 2, 97-106.

1912.7

Un nouveau Zeide du Maroc,

Parazenopsis argenteus, n. g., n.sp. Ann. Stat. Aquic., Boulogne-sur-Mer, 1912, $2,82-88$.

1912.8

Le prétendues migrations du hareng. Ann. Stat. Aquic., Boulognesur-Mer, 1912, 2, 49-54. 1912.9

— Pseltodes enumci des côtes mauritaniennes. Ann. Stat. Aquic., Boulognesur-Mer, 1912, 2, 107-110. 1912.10

Le stationnement du hareng et du maquereau sur le fond avant la ponte, et son importance pour la pêche au chalut. Ann. Stat. Aquic., Boulogne-surMer, 1912, 2, 121-141.

1912.11

La truite de mer. Ann. Stat. Aquic., Boulogne-sur-Mer, 1912, 2, 1347.

1912.12

Climax (pseudon.) German carp in Tennessee. Chicago Field, 1880, 14, 263.

1880.1

Interesting facts about fish in Harpeth river and the tributaries. Chicago Field, 1880, 13, 304-305. 1880.2

Some interesting facts about fish in Tennessee waters. Chicago Field, 1880, 13, 252.

1880.3

Fine sport at Guaymas, Mexico. Fish. Gazette, 1881, 5, 72. 1881.1 Refers to sharks, Spanish mackerel, devil fish, tc.

Clinton, De Witt [1769-1828] An introductory discourse delivered on the 4th of May, 1814. Trans. Liter. Philos. Soc. New York, 1815, 1, 19-184. 1815.1

Fishes, p. 63-65. 
Clinton, De W.

- Some remarks on the fishes of the western waters of the state of NewYork, in a letter to S. L. Mitchell, M.D. Trans. Liter. Philos. Soc. New York, $1815,1,493-501$.

1815.2

Account of the Salmo otsego or the Otsego basse. Amer. Med. Philos. Reg., 1822, 3, 188.

1822.1

- Description of a new species of fish from the Hudson river IClupea hudsonia] Ann. Lyceum Nat. Hist. New York, 1824, 1, 49-50. fig. - Bull. Sci. Nat. (Férussac), 2, 92-93.

1824.1

Clinton, G.P. Observations and experiments on Saprolegnia infesting fish. Bull. U. S. Fish Comm. 1893 (1894), 13, 163-172. pl.

1894.1

Clodi, $E$. Ueber Massenfänge von Renken im Traunsee. Oesterr. Fischerei-Zeit., 1911.

1911.1

Clogg, Stephen. Ray's bream [Brama rayi] near Liskeard. Zoologist, 1866, 2 ser. 1, 349 .

1866.1

Silvery hairtail iTrichiums lepturus] at Looe, Polperro, etc. Zoologist, 1871, 2. ser.6, 2444-2445. 1871.1

- Greater forkbeard [Phycis furcatus] of Love, Cornwall. Zoologist, 1874, 2. ser. 9, 3839 . 1874.1

Salmon peal [Salmo cambricus] attacked by a garfish. Zoologist, 1874, 2 . ser. 9,4160 .

1874.2

Thresher shark on the Cornish coast [measurements of a specimen 9 feet 3 inches] Zoologist, 1881, 3. ser. 5, $386-387$.

1881.1

Cloquet, Hippolyle [1787-1840] Ichthyologie (In Dictionnaire des sciences naturelles, vol. xxii, p. 443-548. Paris, 1821)

1821.1

Also published separately under the title of Considerations générales sur l'ichthyologie. Paris, 1822. 109 p. 2 pls. $5^{\circ}$.

Cloquet, Jules Germain [1790-1883] Notice sur la pisciculture en France pendant l'année 1857. Bull. Soc. Acclim., Paris, 1858, 5, 49-54. 1858.1

- Note sur la reproduction du saumon dans un étang. Bull. Soc. Acclim., Paris, 1859, 6, 255-256. 1859.1

Clunie, John, \& Boll, E. Fischsterben zur Wrangelsburg in Vorpommern im August 1863. Arch. Ver.
Freunde Naturgesch. Mecklenburg, 1863, 17. Jahrg., 313-317. 1863.1

Cn., A. Over de elektrische visschen. Album Natuur (Wetensch. bijblad), $1857,45-46$.

1857.1

Coaz, J. Die Fischerei in der Schweiz. Ausstellungszeitung. Offizielles Organ der schweizerischen Landesausstellung, 1883, p. 229; 236. Zürich, 1883. fol.

1883.1

Geschichtlicher Ueberblick ïber die Verhandlungen und Massnahmen mit Bezug auf die Regulirung der Fischerei im Bodensee und Hebung seines Fischstandes. Bern, 1892. 12 p. $8^{\circ}$.

1892.1

(editor) Forêts, chasse et pêche. [Bibliographie de la] Pêche (In Bibliographie Nationale Suisse; Répertoire méthodique de ce qui a été publié sur la Suisse et ses habitants. Fascicule V 9 c. Berne, 1898. 57 p. $8^{\circ} .1898 .1$

Cobb, John N. The fisheries of lake Ontario in 1897. 3. Ann. Rept. Comm. Fish. Game \& Forests New York 1897 (1898), 205-221.

1898.1

- Possibilities for an increased development of Florida's fishery resources. Bull. U. S. Fish. Comm. 1898, 17, 349-351.

1898.2

- The commercial fisheries of lake Erie, lake Ontario, and the Niagara and St. Lawrence rivers. 5 Ann. Rept. Comm. Fish. Game \& Forests New York 1899 (1900), 189-239. 4 pls. 1900.1

The sturgeon fishery of Delaware river and bay. Rept. U. S. Fish Comm. 1899 (1900), 25, 369-380. 4 pls. 1900.2

Commercial fisheries of the Hawaiian islands. Rept. U. S. Fish Comm. 1901 (1902), 27, 381-499. 6 pls. \& 9 figs. - Bull. U.S. Fish Comm. 1903 (1905), 23, pt. 2, 717-765. 5 pls. \& figs. - Rept. U. S. Fish Comm. 1904, 28, 433-512.

1902.1

The commercial fisheries of the interior lakes and rivers of New York and Vermont. Rept. U. S. Fish Comm. 1903 (1905), 29, 225-246.

1905.1

Report on the salmon fisheries of Alaska, 1905. U.S. Dept. Commerce Labor, 1905, 43-49.

1905.2

'The commercial fisheries of Alaska in 1905. Rept. U. S. Comm. 
Fisheries 1905 (1906), Bur. Fish. Doc. no. $603,1-46$. 1906.1

The fish ponds of the Hawaiian islands. Overland Monthly, San Francisco, 1906, 47, 197-203. 8 figs. 1906.2

Investigations relative to the shad fisheries of North Carolina. North Carolina Geol. Surv., 1906, Economic Paper no. 12. 42 p. 11 charts. 1906.3

Peculiar marine mimics. Washington (D. C.) Star, Sunday Magazine, July 7, 1907 .

1907.1

Report on the fisheries of Alaska. Rept. U. S. Comm. Fisheries 1906 (1907), Bur. Fish. Doc. no. 618, $1-70$.

1907.2

- Superstitions about fishes. Washington (D. C.) Star, Sunday Magazine, April 7, 1907.

1907.3

Fishes fond of going ashore. Washington (D. C.) Star, Sunday Magazine, Oct. 25, 1908.

1908.1

- Odd things about fishes. Washington (D. C.) Star, Sunday Magazine, June 14, 1908. 1908.2 Parental care among fishes. Washington (D. C.) Star, Sunday Magazine, May 17, 1908.

The voices of fishes. Washington (D. C.) Star, Sunday Magazine, Oct. 4, 1908. 1908.4

- Eel in ald lore. New York Tribune, Dec. 12, 1909, p. 8. 1909.1

- Hawaiian "fishery rights." Trans. Amer. Fisheries Soc. 1908 (1909), 160-163.

1909.2

An odd lot of fishes. Wrashington (D. C.) Star, Sunday Magazine, March 14, 1909.

1909.3

The king salmon of Alaska. Trans. Amer. Fisheries Soc. 1909 (1910), 124-128.

1910.1

The salmon fisheries of the Pacific coast. Rept. Comm. Fisheries 1910 (1911), Bur. Fish. Doc. no. 751. 179 p.

1911.1

Fish-canning plant on shipboard. Technical World Magazine, Chicago, $1912,17,174-175.4$ figs. 1912.1

Our wonderful fisheries in the Hawaiian islands. Overland Monthly, San Francisco, 1912, 59, 493-499. 9 figs.

1912.2
Cobb, John N., \& Chamberlain, F. M. Statisties of fisheries of Alaska for 1911 (Alaska fisheries and fur industries in 1911) Rept. U. S. Comm. Fisheries, 1911, Bur. Fisheries Doc. no. 766.

1911.1

Cobb, John N., \& Marsh, Millard C. See Marsh \& Cobb.

Cobbold, Thomas Spencer [18281886] Description of a malformed trout. Edinb. New Phil. Journ., 1855, 2, 238-242. - Rept. Brit. Assoc. Adv. Sci., 25. meet., 1855, pt. 2, 109-110.

1855.1

Notice of a variety of cod, termed the "Lord Fish." Proc. Roy. Phys. Soc. Edinb. 1854-58 (1858), 1, 51-52.

1858.1

- The eye of the cod-fish. Intell. Observ., 1862, 1, 199-209. fig. 1862.1

-_- Histological observations on the eye of the cod-fish (Morrhua vulgaris), with especial reference to the choroid gland and the cones of the retina. Journ. Linn. Soc. London (Zool.), 1862, 6, 145152.

1862.2

- - On the cranial bones of Lepidosiren [Protoplems] annectens. Proc. Zool. Soc. London, 1862, 129-132. pl. 1862.3

The sunfish as a host. Intell. Observ., 1863, 2, 82-89. pl. 1863.1

Remarks on Distoma clavatum from a swordfish. Journ. Linn. Soc. London (Zool.), 1867, 9, 200-205. 1867.1

The destruction of fish and other aquatic animals by internal parasites. Intern. Fisheries Exhib. Lit., London, 1883. Conferences, 6, pt. 7.

1883.1

Cobres, Joseph Paul von. Delicix Cobresianx. Büchersammlung zur Naturgeschichte. 2 vols. Augsburg, 1781-82. $8^{\circ}$. 1781.1

Cocaud, Maurice. Les marais à poissons de la Vendée. Rev. Sci. Nat. Ouest, 1896, 6, 153-155. $\quad 1896.1$

Cocchi, Igino [1828-] Monografia dei Pharyngodopilidæ, nuova famiglia di pesci Labroidi. Ann. Mus. Fis. Stor. Nat., Firenze, 1864, 1, 65-153. Also separate; Firenze, 1864.88 p. $4^{\circ}$. Abstract in Neues Jahrb. Mineral., $1865,381-383$.

1864.1 
Cocchi, $I$.

On a new family of labroid fishes. Florence, 1864.88 p. $4^{\circ}$.Abstract in Geol. Mag., 1865, 2, 411412.

1865.1

Cocco, Anastasio [1799-1854] Ueber einige neue Fische des Meeres von Messina. Isis (Oken), 1831, 1340-1342.

1831.1

Su di alcuni pesci de' mari di Messina. Giorn. Sci. Lett. Arti Sicilia, 1833, 42, 9-21. pl. - Maurolico, 2, 236244.

1833.1

- Su di una nuova razza Raja jojenia] Atti Accad. Gioenia Catania, 1834, 11, 85-88. pl.

1834.1

Osservazioni intorno taluni pesci del mare di Messina, lettera di Anastasio Cocco al Prof. Oronzio Gabriele Costa di Napoli. Giorn. Il Faro, 1838, 4. Also separate; Messina, 1838. pl. $8^{\circ}$.

1838.1

Su di alcuni Salmonidi del mare di Messina; lettera al Ch. D. Carlo Luciano Bonaparte. Nuovi Ann. Sci. Nat., 1838, 2, 161-194. 4 pls. 1838.2

- Sopra un nuovo specie di Trachurus. Giorn. Inominato, Messina, 1839.

1839.1

Sul Paralepis hyalinus. Atti Accad. Gioenia Catania, $1839,13,49$ 55. pl.

1839.2

- Intorno ad alcuni nuavi pesci del mare di Messina. Lettera del Prof. Anastasio Cocco al Signor Augusto Krohn. Messina, 1844. pl. 1844.1

Qualche pensieri sulla ittiologia. Atti Sci. Ital., 1845, 747-749. ' 1845.1

Indice ittiologico del mare di Messina. Nat. Sicil., 1884, 3, 145-148; 176-179; 269-272; 328-332; Ibid., 25$29 ; 68-72 ; 85-88 ; 113-116 ; 177-180$; $191-194 ; 228-232 ; 238-240 ; 291-294$; Ibid., 5, 11-16; 35-40; 62-67; 109-112; 143-149.

1884.1

- Intorno alla famiglia dei Corifenidi e ad una nuova Corifena del mare di Messina; lettera inedita al Camillo Ranzani. Nat. Sicil., 1886, 5, $161-166$; 189-192.

1886.1

- Intorno ad alcuni nuovi pesci del mare di Messina: lettera al Sig. Augusto Krohn di Livonia, ristampata per cura del Dr. Luigi Facciolà. Nat. Sicil.. 1888, 7, 101-104; 125-128. 1888.1
Cocco, Anastasio, \& Scuderi, Luca. Su di un nuove pesce del mare di Messina [Diana valenciennesi] Giorn. Sci. Lett. Arti Sicilia, 1835, 51, 264-270. pl. Also separate; Palermo, 1835. 1835.1

Cocco, Luigi. Studi sui denti dei Plagiostomi con note paleontologiche. Atti Rendic. Accad. Sci. Lett. Arti, Acireale, 1896, n. s. 7, 3-25. 1896.1

Cocheris, Hippolyte (editor) La vieille. 1861. $8^{\circ}$. See Fournival, Richard de.

1861.1

Cochran, Fitz. Salmon culture in Nova Scotia. Forest \& Stream, 1876, 6, 369 .

1876.1

Cochy-y-Bonddhu (pseudon.) Notes on trout and trout fishing. Fish. Gazette, 1878, n. s. 2, no. 79, 505. 1878.1

Cockerell, Theodore Dru Alison [1866-] A provisional list of the fishes of Jamaica. Bull. Inst. Jamaica, $1892,1,97$.

1892.1

Aulostoma maculatum $\mathrm{Val}$. and Rhinobatus undulatus Olfers. Journ. Instit. Jamaica, 1893, 1, 178. $\quad 1893.1$

- A point in nomenclature. Science, 1902 , n. s. 16, 745-746. 1902.1

Three fishes new to the fauna of New Mexico. Proc. Biol. Soc. Washington, 1904, 16, 49.

1904.1

The species are named as follows: Etheostoma lepidum, Notropis macrostomus and Tetragonopterus argentatus.

The fossil fauna and flora of the Florissant (Colorado) shales. Univ. Colorado Stud., 1906, 3, 157-176. pl.

Fishes, p. 160.

1906.1

The fishes of the Rocky Mountain region. Univ. Colorado Stud., 1908, 5, 159-178. 9 figs. 1908.1

Some results of the Florissant expedition of 1908. Amer. Naturalist, 1908, 42, 569-581. 12 figs. 1908.2

Fishes, p. 570-574.

A fossil garpike from Utah. Science, 1909, n. s. 29, 796. 1909.1

The nomenclature of the American fishes usually called Leuciscus and Rutilus. Proc. Biol. Soc. Washington, 1909, 22, 215-218.

1909.2

On the validity of the North American cyprinid genus Notemigonus. Proc. Biol. Soc. Washington, 1909, 22, 211-214. 
The scales of the cobitid and homalopterid fishes. Proc. Biol. Soc. Washington, 1909, 22, 205-208. 1909.4 - The cyprinid subfamily Chondrostominæ. Proc. Biol. Soc. Washington, 1910, 22, 209-210. fig. 1910.1

- [On scales of Ellipes branneri] (In Jordan, D. S. Description of a collection of fossil fishes, etc. Ann. Carnegie Museum, 1910, 7, 27) 1910.2 - On the scales of some malacopterygian fishes. Proc. Biol. Soc. Washington, 1910, 23, 111-113.

1910.3

The scales of the African characinid fishes. Smithson. Misc. Collect., 1910, 56, по. 1. 10 p. 2 pls. 1910.4

The scales of the African cyprinid fishes, with a discussion of related Asiatic and European species. Proc. Biol. Soc. Washington, 1910, 23, 141-152. pl.

1910.5

The scales of the atherinid fishes. Proc. Biol. Soc. Washington, $1910,23,47-48$.

1910.6

The scales of the clupeid fishes. Proc. Biol. Soc. Washington, 1910, 23, 61-63.

1910.7

The scales of the European cyprinoid fishes. Zool. Anz., 1910, 36, 475-480. 3 figs.

1910.8

- The scales of the mormyrid fishes, with remarks on Albula and Elops. Smithson. Misc. Collect., 1910, 56, no. 3.4 p. 3 figs.

1910.9

- Additional note on reticulated fish-scales. Science, 1911 , n. S. 34, 126127.

1911.1

A new minnow [ Notropis horatii] from Colorado. Science, 1911, n. s. 34, 614-615.

1911.2

- Note on the scales of the osteoglossid fishes. Proc. Biol. Soc. Washington, 1911, 24, 39.

1911.3

The scales of the albulid fishes. Science, 1911, n. s. 33, S65-S66. 1911.4

The scales of freshwater fishes. Biol. Bull., 1911, 20, 367-386. 5 pls.

1911..)

The scales of some Asiatic cyprinid fishes. Zool. Anz., 1911, 38, 84 87. 5 figs.

1911.6

- The scales of the dipnoan fishes. Science, 1911, n. s. 33, 831-832. 1911.7
- Some notes on fish scales. Proc. Biol. Soc. Washington, 1911, 24, 209214.

1911.8

Animals and plants described as new from Colorado in 1911. Univ. Colorado Stud., 1912, 9, 75-89. 1912.1

- [Remarks on distribution of fishes, with proposal of a new family name Distichodontidx] Science, 1912 n. S. $35,545-546$.

1912.2

These notes are appended to a review of $\mathrm{H}$. A. Pilsbry's "Non-marine mollusea of Patagonia," in Princeton Univ. Exped. to Patagonia, vol. iii.

Observations on fish scales. Bull. Bureau Fisheries 1912 (1913), 32 119-174. 9 pls. \& figs. 1913.1

- Ordovician (?) fish remains in Colorado. Amer. Naturalist, 1913, 47, 216-247.

1913.2

A peculiar dermal element in chimæroid fishes. Science, 1913, n. s. 38,363 .

1913.3

The scales of some Queensland fishes. Mem. Queensland Mus., Brisbane, 1913, 2, 51-59.

1913.4

The scales of the blennoid fishes. Proc. Biol. Soc. Washington, 1913, 26, 89-92.

1913.5

The scales of the simenchelyid, ophidiid, brotulid and bregmacerotid fishes. Proc. Biol. Soc. Washington, $1913,26,75-77$.

1913.6

Some fossil fish scales. Zool. Anz., 1914, 45, 189-192. fig. 1914.1

Cockerell, Theodore Dru Alison, \& Allison, Edith $M$. The scales of some American Cyprinidæ. Proc. Biol. Soc. W ashington, 1909, 22, 157-164. pl.

1909.1

Cockerell, Theodore Dru Alison, \& Callaway, Otis. Notes on the scales of fishes. The herbivorous Cyprinidæ. Proc. Biol. Soc. Washington, 1909, 22, 121-124.

1909.1

Observations on the fishes of the genus Notropis. Proc. Biol. Soc. Washington, 1909, 22, 189-196. 1909.2

Cockerell, Theodore Dru Alison; \& Evermann, Barton Warren. See Evermann \& Cockerell.

Cockerell, Theodore Dru Alison, \& Moore, Evelyn V. On the modifications of the circuli in the scales of Asiatic 
Cockerell \& Moore

cyprinid fishes. Zool. Anz., 1910, 36, 252-253. $5 \mathrm{figs.}$

1910.1

On the nature of the teeth in ctenoid scales. Proc. Biol. Soc. Washington, 1910, 23, 91-93. 3 figs. 1910.2

Cocks, Alfred Heneage. An autumn visit to Spitzbergen; supplementary remarks. Zoologist, 1884, 3. ser. 8, 13-20.

Fishes, p. 18-20

1884.1

- On the yawning of fishes and of other vertebrates. Zoologist, 1910, 4 ser. 14, 384-385.

1910.1

Cocks, W.P. Echinorhinus spinosus. Ann. Mag. Nat. Hist., 1850, 2. ser. 5, 71.

1850.1

Coco-Zanghy, Giuseppe. Un erratacorrige proposta in zoologia ovvero il mio viaggio in Tiberiade ed il vero pesce di S. Pietro. Atti Accad. Gioenia Sci. Nat. Catania, 1877, 3. ser. 11, 237-265.

1877.1

Coester, Oskar. Zur Fütterung der Salmonidenbrut. Allgem. Fisch. Zeitg. 1903 , no. 23

1903.1

Zur Einbürgerung der Regenbogenforelle. Allgem. Fisch. Zeitg., 1907 , 32. Jahrg., 377-382.

1907.1

Coffin, C.E. Garfish and black bass. Forest \& Stream, 1874, 2, 330. 1874.1

Coggi, Alessandro. Intorno ai corpi rossi della vessica natatoria di alcune Teleostei. Mitth. Zool. Stat. Neapel, 1886-87, 7, 381-400. pl. 1886.1

Ueber den epithelialen Theil der sogenannten Blutdrüsen in der Schwimmblase des Hechtes (Esox lucius) Morphol. Jahrb., 1889, 15, 555-559. $\mathrm{pl}$.

1889.1

Un' anomalia in un embrione di selacio. Mem. Accad. Sci. Istit. Bologna, 1891, 5. ser. 1, 353-362. pl. Ibid., 1892, 2, 763-772.

1891.1

- Sullo sviluppo delle ampolle di Lorenzini. Atti Accad. Lincei, Roma, 1891, 4. ser. 7, pt. 2, 222-229. 2 figs. - Arch. Ital. Biol., 1891, 16, 253-261. 2 figs.

1891.2

_L Le vescicole di savi e gli organi della linea laterale nelle torpedini. Atti Accad. Lincei, Roma, 1891, 4. ser. 7, pt. 2, 197-205. 5 figs. - Arch. Ital. Biol., 16, 216-224. pl. 1891.3
Zur Abwehr. Zool. Anz., 1894, $16,120-122$.

1894.1

Alcuni fatti che riguardano la cresta neurale cefalica dei selaci. Atti Accad. Lincei, Roma, 1895, 5. ser. 4, pt. 1, 265-269. - Arch. Ital. Biol. Turin, 23, 355-359. 1895.1

Ricerche su taluni derivati dell' ectoderma nel capo dei selaci. Il cordone gangliare anteriore in Torpedo $\mathrm{e}$ Pristiurus. Ricerche Labor. Anat. R. Univ. Roma, 1895, $5 . \quad 1895.2$

- Nuove ricerche sullo sviluppo delle ampolle di Lorenzini. Atti Accad. Lincei, Roma, 1902, 5. ser. 2, pt. 1, 289297; 338-340. - Arch. Ital. Biol., Turin, 38, 321-333.

1902.1

Sviluppo degli organi di senso laterale, delle ampolle di Lorenzini a i loro nervi rispettivi in Torpedo. Arch. Zool., Napoli, 1902, 1, 59-107. 2 pls.

1902.2

Sullo sviluppo e la morfologia delle ampolle di Lorenzini e loro nervi. Arch. Zool. Napoli, 1905, 2, 309-383. 3 pls. \& 4 figs.

1905.1

Coghitt, G. E., \& Herrick, C. L. See Herrick \& Coghitt.

Cohen, Nat $H$. Concerning fish laws in Illinois. Trans. Amer. Fisheries Soc. 1901 (1902), 133-136.

1902.1

Cohn, Franz. Bemerkungen zur Histologie und Drüsenfunktion des Corpus Luteum; eine Erwiderung an Dr. W. Lubosch. Anat. Anz., 1904, 25, 6972.

1904.1

Cohn, Fritz. Tetrodon cf. T. cutcutia, seine Pflege und Zucht. Blätt. Aquar.Terrar. Kunde, 1912, 23. Jahrg., 582585. fig.

1912.1

Cohn, Hermann. Ueber Sehstörungen nach Vergiftungen durch Wildpasten und Hecht. Schles. Ges. Vaterl. Cultur, Breslau, 1879, 57. Jahresber. 82-85. - Arch. Augenheilk., 1879, 9. 148-163.

1879.1

Cohn, Ludwig. Ueber die Myxosporidien von Esox lucius und Perca fuviatilis. Zool. Jahrb., 1896, 9 (Anat. Abth.), 227-272. 2 pls. $\quad 1896.1$

Die Fischereiverhältnisse in den Masurischen Seen. Ber. Fischerei-Ver. Ostpreussen, Königsberg 1901-02 (1902), 53-56. 
Ueber die Bruttasche von Syngnathus typhle. Anat. Anz., 1903, 24, 192-199. fig.

1903.1

- Ueber I costeus enigmaticus Lock. Zool. Anz., 1905, 29, 522-526. 1905.1

Die Seitenlinie von Icosters enigmaticus. Zool. Anz., 1906, 30, 178183. 5 figs.

1906.1

Die Schwimmblase einiger Scianiden. Zool. Anz., 1907, 32, 433-440. 4 figs.

1907.1

Ueber die Schuppen der Seitenlinie einiger Scopeliden. Zool. Anz., 1907, 32, 366-370. 4 figs.

1907.2

Cohnheim, Otto. Zur Frage der Eiweissresorption. 3. Mitteilung. Sitzber. Heidelberg. Akad. W iss., 1911, 30. Abth., 7 p. - Zeitschr. Physiol. Chem. 1912, 76, 293-297.

1911.1

Coker, Robert $E$. The fisheries and the guano industry of Peru. Proc. 4. Intern. Fish Congr., Washington, 1908, pt. 1, 333-365. 6 pls.

1908.1

A study of the guano industry and fisheries of Peru. Trans. Amer. Fisheries Soc. 1907 (1908), 248-251. 3 cuts.

1908.2

Colb, - Ueber die Vorzüge des "Fränkischen und Aischgrunder" Karpfens, sowie über die Karpfen Vermittlungseinrichtungen in Bayern. Allgem. Fischerei Zeitg., 1904, 29. Jahrg., 88-92.

1904.1

Cole, Frank J. On the cranial nerves of Chimora monstrosa, with a discussion of the lateral line system and of the morphology of the chorda tympani. Trans. Roy. Soc. Edinb., 1896, 38, 631680. 2 pls. \& fig.

1896.1

On the sensory and ampullary canals of Chimæra. Anat. Anz., 1896, 12, 172-182. fig.

1896.2

- The cranial nerves of Chimara monstrosa. Proc. Roy. Soc. Edinb., 1897, 21, 49-56. fig.

1897.1

Observations on the structure and morphology of the cranial nerves and lateral sense organs of fishes; with special reference to the genus Gadus. Trans. Linn. Soc. London (Zool.), 1898, 7, 115-221. 3 pls. \& fig.

1898.1

The peripheral distribution of the cranial nerves of Ammocoetes. Anat. Anz., 1898, 15, 195-200. 1898.2
- - Reflections on the cranial nerves and sense organs of fishes. Trans. Liverpool Biol. Soc., 1898, 12, 228-247. - Anat. Anz., 16, 40-48. 1898.3

On the cranial nerves and sense organs of fishes: a reply [to Mr. Allis] Anat. Anz., 1899, 16, 40-48. 1899.1

- Notes on Professor Judson Herrick's paper on the cranial nerves of the codfish. Journ. Comp. Neurol., 1900, 10, 317-322.

1900.1

A proposed neurological bibliography of the Ichthyopsida. Journ. Comp. Neurol., 1900, 10, 214-217.

1900.2

The morphology of the Pleuronectidx. Nature, 1902, 65, 585. 1902.1

- A monograph on the general morphology of the myxinoid fishes, based on a study of Myxine. Parts $\mathrm{i}-\mathrm{v}$. Trans. Roy. Soc. Edinb., 1905-1913. pls.

1905.1

This monograph was published in parts as follows:

i. The anatomy of the skeleton. Trans. Roy. Soc. Edinb., 1905, 41, 749-788. 3 pls.

ii. The anatomy of the muscles. Ibid., 1907 . 45, 683-757, 4 pls.

iii. Further observation on the skeleton. Ibid., 1909, 46, 669-681.

iv. On some peculiarities of the afferent and efferent arteries of Myxine. Ibid., 1912, 48, 215-230. pl.

v. The anatomy of the gut and its appendages. Ibid., 1913, 49, 293-344. 4 pls.

Notes on Myxine. Anat. Anz., $1905,27,323-326$.

1905.2

The ribbon-fish. Nature, 1913, $91,607$.

1913.1

Cole, Frank $J .$, \& Dakin, W. J Further observations on the cranial nerves of Chimæra. Anat. Anz., 1906, 28, 595-599.

1906.1

Cole, Frant: J., \& Ewart, J. C. See Ewart \& Cole.

Cole, Frank J., \& Johnstone, James. Pleuronectes. London, 1901. viii, 252 p. 11 pls. (In Liverpool Marine Biology Committee, Memoirs, no. 8)

1901.1

Reprint in Rept. Lancashire Sea-Fisheries Laboratory at University College, Iiverpool, and the Sea-Fish Hatchery at Piel, 1901, 10.-Review in Trans. Liverpool Biol. Soc. 16, 145-396. - Nature, 65, 459-460. pls, i-xi, Science, n. s. 15, 465-466.

Cole, Frank J., Scott, Andrew, Johnstone, James, \& Herdman, W. A. See Herdman, Scott \& others. 
Cole, George Arthur James, Newton, $E . T$. Dixon, A. $F$. Westropp, $T . J$, Scharff, R. F., \& Ussher, R.J. Sce Scharff, Ussher \& others.

Cole, George Watson. Bermuda in periodical literature, with accasional references to other works. A bibliography [Brookline, Mass.] 1907. $275 \mathrm{p}$. 1907.1

Cole, Leon Jacob. The German carp in the United States. Rept. U. S. Bur. Fisheries 1904 (1905), 523-641. 3 pls. \& 4 figs.

Bibliography, p. 637-641.

1905.1

The status of the carp in America. Trans. Amer. Fisheries Soc. 1905 (1906), 201-206.

1906.1

The occurrence of Heros in Yucatan. Science, 1907, n. s. 26, 637638.

1907.1

Cole, Leon Jacob, \& Barbour, Thomas. See Barbour \& Cole.

Cole, Leon Jacob, Sumner, Francis B., \& Osburn, Raymond C. See Sumner, Osburn \& Cole.

Cole, Leon Jacob, \& Young, Robert $T$. See Young \& Cole.

Cole, William Willoughby (sd Earl of Enniskillen) [1807-1886] Alphabetical catalogue of the type specimens of fossil fishes in the collection of the Earl of Enniskillen, at Florence court. Geol. Mag., 1869, 6, 556-561.

1869.1

Cole, William Willoughby, \& Egerton, Philip Grey. . See Egerton \& Cole.

Coleman, $N$. Change of temperature in water containing recently fertilized shad [Clupea menhaden] eggs. Another note on the same. Amer. Naturalist, $1872,6,493$.

1872.1.

Coleman, Robert IV. A bibliographical catalogue of the Waltonian library belonging to the estate of $R$. W. Coleman. By Joseph Sabin. New York, 1866. 3-149 p. 2 pls. $8^{\circ}$.

1866.1

- Catalogue of the library of books on angling of the late $R$. W. Coleman... which will be sold at auction by Sotheby, Wilkinson and Hodge... July 8, 1897. London, 1897. 36 p. $4^{\circ}$

1897.1

Colenso, William [1811-1899] Notes on the genus Callorhynchus, with a description of an undescribed New Zealand species [C.dasycaudatus] Trans. New Zeal. Instit., 1878, 11, 298-300. pls.

1878.1

Colenutt, G. W. Discovery of fossil fish in the Eocene strata of Ryde, isle of Wight. Sci. Gossip, 1880, 16, 141.

1880.1

Coles, Russell J. Observations on the habits and distribution of certain fishes taken on the coast of North Carolina. Bull. Amer. Mus. Nat. Hist., 1910, 28, 337-348.

1910.1

Notes on the embryos of several species of rays, with remarks on the northward summer migration of certain tropical forms observed on the coast of North Carolina. Bull. Amer. Mus. Nat. Hist., 1913, 32, 29-35. pl. \& 2 figs.

1913.1

Colgan, Nathaniel [1851-] An Irish naturalist in Spain in the eighteenth century. Irish Naturalist, 1911, $20,1-5$.

1911.1

Colladon, Louis Théodore Frédéric [1792-1862] Expériences sur la torpille. C. R. Acad. Sci. Paris, 1836, 3, 490-492. - L'Institut, 1836, 4, 350-351.-Ann. Sci. Nat., 1836, 2. sér. 6, 255-256.Notizen (Froriep), 2, 229-231. 1836.1

Collenette, A. Note on Luvarus imperialis, a very rare fish. Rept. Trans. Guernsey Soc. Nat. Sci., 1904, 4, 235-237.

1904.1

Collett, Robert [1842-] Oversigt Norges vigtigste Hvirveldyr. Stat. Aarbog Konger. Norge, af Dr. O. J. Broch. Kristiania, 1871, 590-659.

1871.1

L_Lycodes sarsii, n. sp., ex ordine Anacanthinorum gadoideorum. Forh. Vidensk. Selsk. Christiania 1871 (1872), 62-66. pl. Also separate; Christiania, 1872. $8^{\circ}$.

1872.1

Slægten Latrunculus Günth., og dens nordiske arter. Forh. Vidensk. Selsk. Christiania 1872 (1873), 1-12.

1873.1

Norges fiske, med bemarkninger om deres Udbredelse. Forh. Vidensk. Selsk. Christiania, 1874, 1-240. 2 pls. \& map.

1874.1

On two apparently new species of Gobius from Norway $[G$. orca, $G$. scorpioides] Ann. Mag. Nat. Hist., 1874, 4. ser. 13, 446-447. 1874.2 
Bidrag til kundskaben om Norges Gobier. Forh. Vidensk. Selsk. Christiania, 1874 (1875), 151-179. pl. 1875.1

Carte zoogéographique, contenant une liste complète de tous les animaux vertébrés de Norvège. Christiania, 1875. 2. ed. Christiania, 1876.

1875.2

- Norges fiske, med bemærkninger om deres Udbredelse. Christiania, 1875. 240 p. 2 pls. \& map. $8^{\circ}$

1875.3

On a new Motella (septentrionalis) from Norway. Ann. Mag. Nat. Hist., 1875, 4. ser. 15, 82-83. 1875.4

Carte zoogéographique, contenant une liste complète de tous les animaux vertébrés de Norvège. 2. ed. Christiania, 1876.

1876.1

De i Norge hidtil fundne fiske fra de glaciale og postglaciale Afleiringer. Nyt Mag. Naturvid., 1877, 23, pls. 3-4, $11-40$.

1877.1

Om slægterne Latrunculus og Crystallogobius. Forh. Vidensk. Selsk. Christiania, 1876 (1877), no. 6. 43 p. 2 pls.

1877.2

Fiske, indsamlede under den norske Nordhavs-expeditions 2 forste togter, 1876 og 1877. Forh. Vidensk. Selsk. Christiania, 1878, no. 4. 24 p.

1878.1

Fiske fra Nordhavs-expeditionens sidste togt, sommeren 1878. Forh. Vidensk. Selsk. Christiania, 1878, no. 14. $106 \mathrm{p}$.

1878.2

On Latrunculus and Crystallogobius, two remarkable forms of gobioid fishes. Proc. Zool. Soc. London, 1878, 318-339. figs.

1878.3

Om den saakaldte Thynnus peregrinus Coll. Forh. Vidensk. Selsk. Christiania, 1879 , no. 15. 3 p. 1879.1

On a new fish of the genus Lycodes [L. pacificus] from the Pacific. Proc. Zool. Soc. London, 1879, 381-382. fig.

1879.2

Den norske Nordhavs-expedition 1876-1878. Zoologi. Fiske. Christiania, 1880. 164 p. 3 figs. \& 5 pls.

1880.1

Titlepage and text in Norwegian and English.

Glaciale mergelboller med indesluttede fiskelevninger fra Bejeren i
Salten. Aarsh. Tromso Mus, 1880, 3 96-104. - Zeitschr. Gesammt. Naturwiss., 5, $839-843$.

1880.2

- Meddelelser om Norges fiske i aarene 1875-78. Forh. Vidensk. Selsk. Christiania 1879 (1880), no. 1. 107 p. $2 \mathrm{pl}$.

1880.3

The Norwegian North Atlantic expedition 1876-78. Zoology. Fishes. Christiania, 1880. 164 p. 1880.4

English \& Norwegian text in parallel columns.

Om to for Norges fauna nye dybvandsfiske. Forh. Vidensk. Selsk. Christiania, 1880 , no. 8. 10 p. pl.

1880.5

Raja nidrosiensis, en ny rokke fra Throndhjemsfjorden. Forh. Vidensk. Selsk. Christiania, 1881, no. 7. 8 p. pl.

1881.1

Thynnus thunnina Cuv., og Fierasfer dentalus, Cuv., nye for Norges fauma. Forh. Vidensk. Selsk. Christiania, 1882 , no. 19.9 p. pl. 1882.1

Myliobatis aquila (Linn.), ny for Norges fauna. Forh. Vidensk. Selsk. Christiania 1882 (1883), no. 29. 4 p.

1883.1

Om de $\mathrm{i}$ vort anrhundrede ved de norske kyster strandede exemplarer af slaegten Regalecus. Forh. Vidensk. Selsk. Christiania, 1883, no. 16.36 p. 3 pls.

1883.2

_Lidt om "So-Ormen" eller "So-slangen." Naturen, 1884, 8. Jahrg., no. 2.

1884.1

A discussion of sea serpents with special reference to Eurypharynx or Gasterostomus, Regalecus and Selachus.

Meddelelser om Norges fiske i aarene 1879-83 (2 det hoved supplement til "Norges fiske") Nyt Mag. Naturv., 1884, 29, 47-123. pl. 1884.2

Om Beryx borealis Düb. \& Iİor. 1884. Forh. Vidensk. Selsk. Christiania, 1884 (1885), no. 1.7 p. pl.

1885.1

On a new pediculate fish from the sea off Madeira [Linophryne lucifer] Proc. Zool. Soc. London, 1886, 138-143. pl.

1886.1

- Aphanopus minor, en ny dybvandsfisk af Trichiuridernes familie fra Gronland. Forh. Vidensk. Selsk. Christiania 1886 (1887), no. 19.7 p.

1887.1 
Collett, $R$.

- Diagnoses de poissons nouveaux provenant des campagnes de " $\mathrm{L}$ 'Hirondelle." Bull. Soc. Zool. France, 1889-90.

1889.1

i. Sur un genre nouveau de la famille des Murmidæen, Bull. Soc. Zool. France, 1889, 14, $122-132$.

ii. Sur un genre nouveau de la famille des Stomiatidx. Ibid., 291-293.

iii. Description d'une espèce nouvelle du genre Hoplostethus. Ibid., 306.

iv. Description d'une espèce nouvelle du genre Notacanthus. Ibid., 307-30s.

v. Descriptions de deux espèces nouvelles du genre Onus Risso. Op. cit., 1890, 15, 105109

_- Sur quelques poissons rapportés de Madère par le Prince de Monaco. Bull. Soc. Zool. France, 1890, 15, 218 224.

1890.1

- Oversigt over de tri-cirrate arter af slagten Onus. Forh. Vidensk. Selsk. Christiania, 1891 (1892), no. 11. $17 \mathrm{p}$.

1892.1

-. On a new agonoid fish (Agonus gilberti) from Kamtschatka. Proc. Zool. Soc. London, 1894, 670-675. pl.

1894.1

Le genre Cyclothone Goode et Bean. I. Considérations historiques. II. Description d'une espèce nouvelle [C. grandis] recueillie par S. A. le Prince de Monaco. Bull. Soc. Zool. France, 1896, 21, 94-97; 99-102.

1896.1

- Poissons provenant des campagnes du yacht "L'Hirondelle" (18851888) Monaco, 1896. viii, 198 p. 6 pls. Review in Nat. Science, 11, 301302.

1896.2

Résultats des campagnes scientifiques accomplies sur son yacht par Albert I, Prince souverain de Monaco, vol. $x$.

Om en del for Norges fauna nyl fiske fundne i 1880-1896. Arch. Math. Naturv., Christiania, 1897, 19, no. 8. $25 \mathrm{p}$.

1897.1

- Om ensamling fiske fra Azorerne, tilhørende Museet i Ponta Delgada. Arch. Math. Naturv., Christiania, 1897, 19, no. 7. $17 \mathrm{p}$.

1897.2

- Om Pterycombus brama Fries. Bergens Museums Aarbog 1896 (1897), no.6. 13 p. 2 pls. \& fig. $\quad 1897.3$

On Chlamydoselachus anguineus Garm., a remarkable shark found in Norway 1896 (In Festsk. H. M. Kong Oscar II ved Regjeringsjubilaet 1897 , K. Fredriks Univ., vol. ii, p. 1-17. 2 pls. Christiania, 1897) 1897.4
- Contributions to the knowledge of the genus Lycodes Reinh. I. Lycodes sarsii Coll. Skrifter Vidensk. Selsk. Christiania, 1898 (1899), no. 1. 19 p. 2 pls. - II. Lycodes gracilis M. Sars. Ibid., 1899 (1900), no.6. 22 p. 3 pls. \& fig.

1899.1

- Norge i det nittende aarhundrede. Christiania, 1900. illust. fol.

1900.1

Norges vigtigste Hvirveldyr, p. 83-113,

Om fem for Norges fauna nye fiske (1897-1900) Arch. Math. Naturv., Christiania, 1901, 23, no. 7. 25 p.

1901.1

Om tre for Norges fauna nye fiske fra "Michael Sars" to forste togter i 1900 og 1901. Arch. Math. Naturv., Christiania, 1903, 25, no.2. 26 p.

1903.1

Meddelelser om Norges fiske i aarene 1884-1901. I. Forh. Vidensk. Selsk. Christiania, 1902 (1903), no. 1. $121 \mathrm{p}$.

1903.2

Diagnoses of four hitherto undescribed fishes from the depths south of the Faroe islands. Forh. Vidensk. Selsk. Christiania, 1904, no. 9. 7 p.

1904.1

Meddelelser om Norges fiske i aarene 1884-1901. II. Forh. Vidensk. Selsk. Christiania, 1903 (1904), no. 9. $175 \mathrm{p}$.

1904.2

_ Meddelelser om Norges fiske i aarene 1884-1901. III. Forh. Vidensk. Selsk. Christiania, 1905, no. 7. 173 p. 1905.1

On some fishes from the sea off the Azores [Lampadena chavesi, n. sp.] Zool. Anz., 1905, 28, 723-730. 1905.2

Fiske, indsamlede under "Michael Sars's" T'ogter i Nordhavet, 1900 1902. Rept. Norw. Fish. Marine Invest., Bergen, 1909, 2, no. 3. 152 p. 2 pls. 1909.1

Lepidopus atlanticus (Goode \& Bean) en pelagisk Trichiuride, fundet ved Finmarken. Forh. Vidensk. Selsk. Christiania, 1912 (1913), no.4. 5 pl.

Collin, Host \& Collin.

Collin, Alb. En sterlett (Acipenser muthenus L.) tagen i Pythis viken (Ein Stör in der Bucht von Pythis gefangen] Tidskr. Jäg. Fisk., Helsingfors, 1904, $12,15$.

1904.1 
Collin, Jonas [1St0-] Bidrag til kundskab om Danmarks fiskerier. Copenhagen, 1873-75. $8^{\circ}$.

1873.1

Meddelelse om Brama paschtii Esmark. Forh. Skand. Naturforsk. Kjobenhavn 1873 (1874), 11, 418-423.

1874.1

Om "Ringflyndere." Nordisk Tidsskr. Fiskeri, $1876, n$. s. 3. Jahrg. 51-53.

1876.1

Bidrag til Kundskab om Danmarks fiskerier. Nordisk Tidsskr. Fiskeri, 1878, n.s. 4. Jahrg., 1-11; 205-219.

1878.1

Collinge, Walter Edward [1867-] On the preservation of teleostean ova. Ann. Mag. Nat. Hist., 1892, 6. ser. 10, $228-230$.

1892.1

The lateral canal system of Lepidosteus osseus. Proc. Birmingham Philos. Soc., 1893, 8, 263-272. 6 pls.

1893.1

The morphology of the sensory canal system in some fossil fishes. Proc. Birmingham Philos. Soc., 1893, 9, 114. 2 pls.

1893.2

Note on the lateral canal system of Polypterus. Proc. Birmingham Philos. Soc., 1893, 8, 255-262. 3 pls.

1893.3

- The sensory canal system of fishes. I. Ganoidei. Quart. Journ. Micr. Sci., 1894, n. s. 36, 499-537. 2 pls. Abstract in Rept. Brit. Assoc. Adv. Sci., 63. meet., 1893, 810-811. 1894.1

- On the presence of scales in the integument of Polyodon folium. Journ. Anat. Physiol., London, 1895, 29, 485487. 2 figs.

1895.1

- On the sensory and ampullary canals of Chimæra. Proc. Zool. Soc. London, $1895,878-890.3$ pls. Abstract in Zool. Anz., 19, 31. 1895.2

- On the unsymmetrical distribution of the cranial nerves of fishes. Journ. Anat. Physiol., London, 1895, 29 , $352-354$.

1895.3

- The sensory canal system of fishes. II. Teleostei. Suborder A, Physostomi. Proc. Zool. Soc. London, 1895, 274-299. 4 pls.

1895.4

Some researches upon the sensory canal system of ganoids. Proc. Birmingham Philos. Soc., 1895, 77-81. 1895.5
The preopercular zone and sensory canal of Polypterus. Anat. Anz. $1896,12,87$.

1896.1

Collinge, Walter $E$., \& Vincent, Swale. On the so-called suprarenal bodies in Cyclostoma. Anat. Anz, 1896, 12, 232-241. 2 figs. Abstract in Journ. Roy. Mier. Soc. London, 1896, 6, 605606 .

1896.1

The suprarenal bodies of fishes. Nat. Science, 1897, 10, 318-322. 1897.1

Collingwood, Cuthbert [1826-] Note on the existence of gigantic seaanemones in the China sea, containing within them quasi-parasitic fish. Ann. Mag. Nat. Hist., 1868, 4. ser. 1, 31-33.

1868.1

Observations on the habits of flyingfish (Exocotus) Rept. Brit. Assoc. Adv. Sci., 37. meet. 1867 (1868), 80-81.

1868.2

Collins, A.S. The impregnation of eggs in trout breeding. Amer. Naturalist, 1870, 4, 601-610.

1870.1

Spawning races for brook trout. Trans. Amer. Fisheries Soc. 1872 (1873), 28-32.

1873.1

Hatching the grayling. Forest \& Stream, 1874, 3, $164 . \quad 1874.1$

- Numerous articles on trout culture] American Sportsman, 1874, 3.

1874.2

Decrease of brook trout in the Unites States. Rod \& Gun, 1875, 6, 280.

1875.1

Fish culture in America. Forest \& Stream, 1875, 5, 227. 1875.2

Fish culture in the United States. Rod \& Gun, 1875, 6, 362.

1875.3

Raising brook trout. Forest \& Stream, 1876, 6, 165. 1876.1

Collins, D.E., \& Collins, J.W. See Collins, J. W., \& Collins, D.E.

Collins, John D. Propagation of salmon in Salmon river, Oswego county, New York. Bull. U. S. Fish Comm. 1885, 5, 287-288.

1885.1

Collins, Joseph W. Gill-nets in the cod fishery; a description of the Norwegian cod-nets, with directions for their use, and a history of their introduction into the United States. Bull. U. S. Fish Comm. 1880, 1, 1-17. pl. 1880.1 
Collins, $J . W$.

- Hatching the "angler" or "fishing frog." Forest \& Stream, 1880, 15, 8.

1880.2

Hatching the Lophius. Forest \& Stream, 1880, 15, 28.

1880.3

A new species of mackerel. Forest \& Stream, 1880, 15, 28. 1880.4

Fisherman's aid to science. Forest \& Stream, 1881, 17, 512. 1881.1

- Improvement in mackerel fishing. Forest \& Stream, 1881, 17, 50.

1881.2

First arrival of mackerel in New York in the spring of 1882. Bull. U. S. Fish Comm. 1881 (1882), 1, 402.

1882.1

- An inquiry into the capture of young cod-fish in Chesapeake bay. Bull. U. S. Fish Comm. 1881 (1882), 1, 401-402.

1882.2

Appearance of dogfish (Squalus acanthias) on the New England coast in winter; letter to Prof. S. F. Baird. Bull. U. S. Fish Comm. 1882 (1883), 2,8 .

1883.1

Correspondence relative to the procurement of certain fishery implements for the government of New South Wales; letter to Prof. S. F. Baird. Bull. U. S. Fish Comm. 1882 (1883), 2, 291-299. 1883.2

Notes on the halibut fisheries of 1881-82. Bull. U. S. Fish Comm. 1882 (1883), 2, 311-316.

1883.3

- Notes on the herring fishery of Massachusetts bay in the autumn of 1882. Bull. U. S. Fish Comm. 1882 (1883), 2, 287-290.

1883.4

- Notes on the movements, habits, and captures of mackerel for the season of 1882. Bull. U. S. Fish Comm. 1882 (1883), 2, 273-285.

1883.5

Report upon a cruise made to the tile-fish ground in the smack " Josie Reeves," September, 1882. Bull. U. S. Fish Comm. 1882 (1883), 2, 301-310.

1883.6

Shad taken in mackerel gillnets; from a letter to Prof. S. F. Baird. Bull. U. S. Fish Comm. 1882 (1883), 2 , 95.

1883.7

Success of the gill-net cod fishery on the New England coast, winter of
1882-83. Bull. U. S. Fish Comm. 1883,

3, $441-443$.

1883.8

History of the tilefish. Rept. U. S. Fish Comm. 1882 (1884), 10, 237-294. 2 pls.

1884.1

- Movements of mackerel in winter. Bull. U. S. Fish Comm. 1884, 4, 15. 1884.2

Note on the destruction of mackerel by dogfish. Bull. U. S. Fish Comm. 1884, 4, 248.

1884.3

On the abundance of halibut near Iceland. Bull. U. S. Fish Comm. 1884, 4, 463-464.

1884.4

On the scarcity of mackerel in the gulf of St. Lawrence. Bull. U. S. Fish Comm. 1884, 4, 427-430; 435-438.

1884.5

Report of a trip of exploration in Chesapeake bay. Rept. U. S. Fish Comm. 1882 (1884), 10, 1035-1038.

1884.6

A search for mackerel off Block island, Montauk, and Sandy Hook in November, 1883. Bull. U. S. Fish Comm. 1884, 4, 49-51.

1884.7

What codfish sometimes swallow. Bull. U. S. Fish Comm. 1884, 4, 175.

1884.8

Notes on the English herring and mackerel fisheries, and the methods of curing. Bull. U. S. Fish Comm. 1885, 5,40 .

1885.1

The red-snapper grounds in the gulf of Mexico. Bull. U. S. Fish Comm. $1885,5,145-146$.

1885.2

Result of the introduction of gill-nets into the American cod fisheries. Trans. Amer. Fisheries Soc. 1884 (1885), 212-228.

1885.3

Unusual abundance of cod on Brown's bank. Bull. U. S. Fish Comm. 1885, 5, 234.

1885.4

The Icelandic halibut fishery. An account of the voyages of the Gloucester schooners to the fishery grounds near the north coast of Iceland. Rept. U. S. Fish Comm. 1884 (1886), 12, 289-300.

1886.1

Delaware and its fisheries (In The fisheries and fishery industries of the United States, edited by George Brown Goode, pt. 9, p. 407-119. Washington, 1887) 
Notes on an investigation of the great fishing banks of the western Atlantic. Bull. U. S. Fish Comm. 1886 (1887), 6, 369-381.

1887.2

Notes on the red-snapper fishery. Bull. U. S. Fish Comm. 1886 (1887), 6, 299-300.

1887.3

Report of the discovery and investigation of the fishing grounds made by the Fish Commission steamer "Albatross" during the cruise along the Atlantic coast and in the gulf of Mexico. with notes on the Gulf fisheries. Rept. U. S. Fish Comm. 1885 (1887), 13, $217-$ 311. 9 pls.

1887.4

- The shore fisheries of southern Delaware (In The fisheries and fishery industries of the United States, edited by George Brown Goode, sect. 5, vol. i, p. 527-541. Washington, 1887) 1887.5

Notes on the occurrence of mackerel off the coast of Florida. Bull. U. S. Fish Comm. 1887 (1889), 7, 128.

1889.1

Report upon the operations of the United States Fish Commission schooner "Grampus" from June 5, 1886 , to March 15, 1887. Rept. U. S. Fish Comm. 1886 (1889), 14, 701-720. pl.

1889.2

Report upon the division of fisheries. Rept. U. S. Fish Comm. 1887 (1891), 15, 335-362.

1891.1

The fisheries at the World's Fair. Trans. Amer. Fisheries Soc. 1891 (1892), 33-41. 2 pls.

1892.1

Report upon the fisheries of the Pacific coast of the United States. Rept. U.S. Fish Comm. 1888 (1892), 16 3-269. 4 figs. \& 49 pls.

1892.2

The fisheries exhibit at the World's Fair. Trans. Amer. Fisheries Soc. 1893 (1894), 122-129. 1894.1

The Norwegian fisheries. Trans. Amer. Fisheries Soc. 1893 (1894), 6070.

1894.2

Collins, Joseph W., \& Collins, D.E. Report of the operations of the United States Fish Commission schooner "Grampus" from March 15, 1887, to June 30, 1888. Rept. U.S. Fish Comm. 1887 (1891), 15, 491-598. $16 \mathrm{pls}$.

1891.1

Collins, Joseph $W$, Earll, R. E., Clark, A. H., \& Goode, G. B. See Goode, Collins \& others.
Collins, Joseph $W$. \& Goode, G. B. See Goode \& Collins.

Collins, Joseph W., Goode, George Brown, \& Scudder, N.P. See Goode, Collins \& Scudder.

Collins, Joseph W., \& Rathbun, Richard. 'The sea fishing grounds of the east.ern coast of North America from Greenland to Mexico (In The fisheries and fishery industries of the United States, edited by George Brown Goode, sect. 3, p. 5-78. 17 charts. Washington, 1887)

1887.1

Collins, Joseph W., \& Smith, H.M. Report on the fisheries of the New England states. Bull. U.S. Fish Comm. 1890 (1892), 10, 73-176. 1892.1

A statistical report on the fisheries of the Gulf states. Bull. U. S. Fish Comm. 1891 (1893), 11, 93-184.

1893.1

Colmeiro y Penido, Miguel. Noticia sucinta de los animales y plantas que mencionó Cervantes en el Quijote, etc. Madrid, 1895.15 p. $8^{\circ}$. 1895.1

Cololian, $P$. L'action physiologique des différents sels de soude sur les poissons d'eau douce. Journ. Phys. Path. Gén. Paris, 1901, 3, 681-688. - C. R. Mém. Soc. Biol. Paris, 53, 693-695.

1901.1

La toxicité des alcools chez les poissons. Journ. Phys. Path. Gén. Paris, 1901, 3, 535-546. 1901.2

Colson, (Miss) Julia. Boar-fish, Capros aper [on the British coast] Sci. Gossip, 1879, 15, 112.

1879.1

Colton-Salter, G. H. See Salter, G. H. Colton.

Comber, $E$. Protective legislation for Indian fisheries. Journ. Bombay Nat. Hist. Soc., 1907, 17, 637-644.

1907.1

Comendador, Antoni Sanchez. See Sanchez-Comendador, Antoni.

Comère, Joseph. De l'utilité des algues dans l'élevage et l'alimentation des poissons, à propos de la florule de l'étang de la Pujade. Bull. Soc. Hist. Nat., Toulouse, 1904, 37, 61-68. Bull. Stat. Piscicul., Toulouse-Paris, 2 46-50.

1904.1

Comes, Salvatore. Sulla funzione glandulare del follicolo e sulla differenziazione degl' involucri nell' uovo di 
Comes, $S$.

Belone acus Rond. Anat. Anz., 1905, 26, 9-17. 10 figs.

- Sulla zona plasmatica perinucleare nell' oocite di alcuni Teleostei. Boll. Accad. Gioenia Sci. Nat. Catania, 1905, fasc. $86,22-26$.

1905.2

Sulle relazioni tra vescicola germinativa ed ooplasma nell' oocite di Serranus scriba (Cuv.) Nota preliminare. Anat. Anz., 1906, 28, 17-24; 83-96. 23 figs.

1906.1

Comettant, 0 . Une visite à l'exposition internationale de pêche et d'aquiculture à Arcachon. [n. p.] 1869.

1869.1

Commerson, Philibert [1727-1773] Manuscript notes and drawings of over 160 species of fish observed by this naturalist were published in part by Lacépède, and still more extensively by Cuvier and Valenciennes. See vol. i, p. 122-124, of "Histoire Naturelle des Poissons, "1828, by the two last-named authors.

Comolli, Antonio. Ricerche istologiche sul tessuto interrenale dei Teleostei. Arch. Ital. Anat. Embriol., Firenze, 1912-13, 11, fasc. 3, 377-408. 2 pls.

1912.1

Comolli, $G$. Delle varie maniere di pescagione nel lago di Como. Almanacco provinziale di Como, 1848. 12 p.

1848.1

Companyo, Louis [1781-1871] Histoire naturelle du département des Pyrénées-Orientales. Perpignan, 1863.

1863.1

Comparetti, André. Observationes anatomicæ de aure interna comparata. Padua, 1789. $4^{\circ}$.

1789.1

Comstock, Anna Botsford. Handbook of nature study for teachers and parents. Ithaca, 1914. 938 p. illust.

Fish study, p. 149-177.

1914.1

Comstock, J. C. Fish breeding. Rept. Comm. Patents'1S59 (1860), 217238.

1860.1

Comte, Joseph Achille [1802-1866] Règne animal de Cuvier, disposé en tableaux méthodiques; ouvrage adopté par le conseil royal de l'instruction publique, pour l'enseignement de l'histoire naturelle dans les etablissements de l'université, avec 91 tableaux, re- présentant environ 5000 figs. Paris, 1832-40. fol.

1832.1

Fishes, pt. 13. 10 pls.

Concha, pseudonym for Thomson, John H., of New Bedford.

Condon, J.C. Statement concerning the menhaden fishery. Rept. U. S. Fish Comm. 1877 (1879), 5, 478. 1879.1

Condorelli-Francaviglia, Mario. Animali marini abbandonati sulla spiaggia di Catania dalle acque di maremoto del 28 dicembre 1908. Boll. Soc. Zool. Ital., 1909, 2. ser. 10, 328-333. 1909.1

Condorelli-Francaviglia, Mario, \& Perrando, G. G. Notizie sul Carcharodon carcharias L., catturato nelle acque di Augusta e considerazioni medicolegali su resti umani trovati nel suo tubo digerente. Boll. Soc. Zool. Ital., 1909, 2. ser. 10, 164-183. pl.

1909.1

Confevron, - de. De quelques bassins artificiels français propres à la pisciculture. Bull. Soc. Centr. Aquicult. France, 1894, 6, 49-53; 128-134. 1894.1

Configliachi, Pietro [1779-1844] Sull' analise dell' aria contenuta nella vescica natatoria dei pesci. Pavia, 1809. 81 p. $4^{\circ}$.

1809.1

Conger, A. C., \& Landacre, $F . L$. See Landacre \& Conger.

Conklin, E. G. The early development of chordates in the light of embryology of ascidians. Science, 1905, n. s. $21,264-265$.

1905.1

Conn, Carl. Etwas über Cichliden. Blätt. Aquar-Terrar. Kunde, 1913, 24. Jahrg., 666-670. fig.

1913.1

Ein neuer blauer Cichlide [Acara sp.l Blätt. Aquar.-Terrar. Kunde, 1913, 24. Jahrg., 500-502.

1913.2

Conn, Herbert William, \& Kingsley, John Slerling. See Kingsley \& Conn.

Conner, Charles $H$. Glochidia of Unio on fishes. Nautilus, 1905, 18, 142143.

1905.1

Conrad, - Brutpllege bei Paratilapia multicolor. Wochenschr. Aquar.Terrar. Kunde, 1908, 5. Jahrg., 374.

1908.1

Constable, G. C. A hardy goldfish. Nature, 1910, 82, 308.

1910.1 
Constable, W.J. Luvarus imperiatis on the coast of Donegal. Irish Naturalist, $1911,20,78$.

1911.1

Constantino, A., \& Buglia, G. See Buglia \& Constantino.

Conte, A., \& Vaney, C. See Vaney \& Conte.

Conte, A., Vaney, $C$., \& Chifflot, See Chifflot, Conte \& Vaney.

Conway, $J$. Forays among salmon and deer. London, 1861. 12 ${ }^{\circ}$. 1861.1

Conybeare, William Daniel [17871857] On the discovery of fossil fish, the tooth of a saurian reptile, and other remains, in the limestone of Burdiehouse, near Edinburgh. Philos. Mag., 1834, 3. ser. 4, 77-79.

1834.1

Cooke, (Miss) Elizabeth, \& Loeb, Leo. The comparative toxicity of sodium chloride and of staining solutions upon the embryo of Fundulus. Proc. Soc. Exper. Biol. Med., 1909, 6, 113-115. 1909.1

Cooke, John H. Notes on the Globigerina limestones of the Maltese islands. Geol. Mag., 1896, dec. 4, 3, 502-511.

1896.1

List of fossil fishes, p. 509 .

Coolidge, A. Monstrosities among trout. Amer. Naturalist, 1869, 3, 288290. figs.

1869.1

Coomáraswámy, A. K. List of fishteeth from the Bagshot sands (London basin) Proc. Geol. Assoc. London, 1904, 18, 83-84.

1904.1

Cooper, C.F. Cephalochorda. Systematic and anatomical account (In Gardiner, J. S. Fauna and geography of the Maldive and Laccadive archipelagoes, etc., vol. i, p. 347-360. pl. \& figs. Cambridge, 1903)

1903.1

Cooper, G.S. Exportation of salmon ova to New Zealand in 1876. Rept. U. S. Fish Comm. 1875-76 (1878), 4, 978.

1878.1

Shipment of salmon and whitefish ova to New Zealand in 1877 and 1878. Rept. U. S. Fish Comm. 1878 (1880), 6, 855 .

1880.1

Cooper, James Graham [1830 - ] On new genera and species of Californiand fishes. I. Dekaya anomala, Chromis [Ayresia] punctipinnis, Orcynus pacificus. II. Exocotus californicus, Urolophus halleri. III. Myxodes elegans, Gillichthys mirabilis, Pleroplatea marmorata. Proc. Calif. Acad. Sci., 1863, 3, 70-77; 93-97; 108-114; 160 . pls. 1863.1 - The fauna of California and its geographical distribution. Proc. Calif: Acad. Sci., 1868, 4, 61-81. 1868.1

Allusions to fishes of California fauna, p. 63(it.

-.. Fishes (In Cronise, Titus Fey. The natural wealth of California, p. 487-498. San Francisco, 1868) 1868.2

Some recent additions to the fauna of California. Proc. Calif. Acad. Sci., 1868, 4, 3-13. 1868.3

The fauna of Montana territory. IV. Fishes. Amer. Naturalist, 1870, 3, 125-127.

1870.1

Cooper, Mark A. Letter referring to experiments of IV. C. Daniell, M.D., in introducing shad into the Alabama river. Rept. U. S. Fish Comm. 187273 (1874), 2, 389.

1874.1

Cope, Edward Drinker [1840-1897] For biography and list of works, see Amer. Geol., 1896, 23, 1-41. - Ibid., 1900, 26, 67-128. - Amer. Naturalist, $1897,31,410-419 ; 831-863$ - Proc. Amer. Phil. Soc., 1900 (Memorial vol. i), 275-314. - Science, 1897, n. s. 5, 707-717. - Ibid., 6, 225-243. Mem. Soc. Cienc. "Antonio Alzate," Mexico, 1899, 14, 39-48. - Ann. Soc. Géol. Belgique, 1902, 29, 3-77.

[Observations upon certain cyprinoid fish in Pennsylvania] Proc. Acad. Nat. Sci. Philad., 1861 (1862), $522-524$

1862.1

On a blind silurid [Gromias nigrilabris from Pennsylvania. Proc. Acad. Nat. Sci. Philad. 1864, 231-233. 1864.1

Partial catalogue of the coldblooded vertebrata of Michigan. Part I. Proc. Acad. Nat. Sci. Philad., 1864, 276-285.

1864.2

33 species of fishes from Michigan are enumerated, 5 of which are described as new. In addition, 9 new freshwater teleost species are described from other parts of the United States besides Michigan.

Description of a new Ceratichthys taken in the Conestogo] Proc. Acad. Nat. Sci. Philad., 1865, 277.

1865.1

Contained in foot-note to his Partial catalogue of the cold-blooded vertebrata of Michigan.

Description of a new Platygobio from Bridger's pass. Proc. Acad. Nat. Sci. Philad., 1865, 277. 1865.2

Contained in foot-note to his Partial catalogue of the cold-blooded vertebrata of Michigan. 
Cope, E. D.

- Note on the fishes brought from the Platte river, near Fort Riley, by Dr. WVm. A. Hammond. Proc. Acad. Nat Sci. Philad., 1865, 85-87.

1865.3

Treats of Lepidosteus, Cylindrosteus and Alburnus.

- On the geographical distribution of certain fishes. Proc. Acad. Nat Sci. Philad., 1865, 274.

1865.4

Partial catalogue of the coldblooded vertebrata of Michigan. Part II. Proc. Acad. Nat. Sci. Philad., 1865, 78-88. 1865.5

Contains much important matter in the form of foot-notes.

Supplementary note on a peculiar genus of Cyprinidx. Proc. Acad. Nat. Ści. Philad., 1865, 87-88. 1865.6 Éricymba.

- An addition to the vertebrate fauna of the Miocene period, with a synopsis of the extinct Cetacea of the United States. Proc. Acad. Nat. Sci. Philad., 1867, 138-156.

1867.1

New species are referred to the genera Aëtobatis, Notidanus and Galeocerdo.

Description of a new genus (Phenacobius terelulus) of cyprinoid fishes from Virginia. Proc. Acad. Nat. Sci. Philad., 1867, 95-97. 1867.2

-- On the genera of freshwater fishes Hypsilepis Baird, and Photogenis Cope, their species and distribution. Proc. Acart. Nat. Sei. Philad., 1867, $156-166$

1867.3

- On the distribution of freshwater fishes in the Allegheny region of southwestern Virginia. Journ. Acad. Nat. Sci. Philad., 1S68, 6, 207-247. 3 pls.

1868.1

- On the origin of genera. Proc. Acad. Nat. Sci. Philad., 1868, 242-300.

1868.2

- Description' of some extinct fishes previously unknown. Proc. Boston Nat. Hist. Soc., 1869, 12, 310-317.

1869.1

Deseriptions of new species of American and African fishes. Trans. Amer. Phil. Soc., 1869, 13, pt. 2, $400-$ 407.

1869.2

- Supplementary synopsis of the Esoces of middle North America. 'Trans. Amer. Phil. Soc., 1S69, 13, pt. 2 , $407-410$.

1869.3

-..- Synopsis of the Cyprinida of Pennsylvania. 'Trans. Amer. Phil. Soc., 1869,13, pt. 2, 351-399. 4 pls. \& figs.
- Fourth contribution to the

history of the fauna of the Miocene and Eocene periods of the United States. Proc. Amer. Phil. Soc., 1870, 11, 285294.

1870.1

Among fossil fishes, Muliobatis olottoides, IT. rectidens and Calorhynchus acus are described as new species.

-... Note on fishes from Atlantic City, N. J. Priacanthus altus and Hemirhamphus macrorhynchus. Proc. Acad. Nat. Sci. Philad., 1870, 121.

1870.2

Observations on some fishes new to the American fauna, found at Newport, R. I.: Vomer curtus, Balistes powellii, T'etraodon trichocephalus, Gobiesox strumosus. Proc. Acad. Nat. Sci. Philad., 1870, 118-121.

1870.3

- Observations on the fauna of the southern Alleghanies. Amer. Naturalist, $1870,4,392-402$.

1870.4

The distribution of Lepidosteus and other genera is discussed.

Observations on the fishes of the Tertiary shales of Green river. Wyoming territory. Proc. Amer. Phil. Soc., $1870,11,380-384$

1870.5

Partial synopsis of the freshwater fishes of North Carolina. Proc. Amer. Phil. Soc., 1870, 11, 448-495. fig.

1870.6

- Supplementary note on two new fishes from the southern coast. Proc. Acad. Nat. Sci. Philad., 1870, 120-121. 1870.7

The species are referred to Centropristis and Gobiesox.

Contribution to the ichthyology of the Lesser Antilles. Trans. Amer. Phil. Soc., 1871, 14, 445-483. 1871.1

Contribution to the ichthyology of the Marañon. Proc. Amer. Phil. Soc., 1871, 11, 559-570. 8 figs. 1871.2

[Exhibition of Green river fishes of Wyoming named Lithichthys pusillus and Cyprinodon levatus] Proc. Amer. Philos. Soc., 1871, 11, $316 . \quad 1871.3$

Fishes from the Amazon river. Proc. Acad. Nat. Sci. Philad., 1871, 55. 1871.4

-..- Life in Wyandotte cave. Ann. Mag. Nat. Hist., 1871, 8, 368-370. Proc. Acad. Nat. Sei. Philad., 1872, 297-298. - 3. \& 4. Ann. Rept. Geol. Surv. Indiana 1871-72 (1872), 160-164. - Amer. Naturalist, $1872,6,406-422$.

1871.5 
Ninth contribution to the herpetology of tropical America. Proc. Acad. Nat. Sci. Philad., 1871, 200-224.

1871.6

Refers to two species of Hydrops and Tetragonopterus among teleosts.

Note on Saurocephalus Harlan. Proc. Amer. Phil. Soc., 1871, 11, 608. Abstract in Amer. Journ. Sci., 1871, 3. ser. 1, 386 .

1871.7

- Observations on the systematic relations of the fishes. Proc. Amer. Assoc. Adv. Sci., 20. meet., 1871, $317-$ 343. - Amer. Naturalist, 1871, 5, $579-$ 593. - Ann. Mag. Nat. Hist., 1872, 4. ser. 9, 155-168.

1871.8

- On Plectognathi and Lophobranchii. Proc. Acad. Nat. Sci. Philad., 1871, 157-158.

1871.9

On some etheostomine perch from Tennessee and North Carolina. Proc. Amer. Phil. Soc., 1871, 11, $261-$ 270.

1871.10

On some of the siluroids of the Amazon. Proc. Acad. Nat. Sci. Philad., 1871, 112.

1871.11

On the fishes of a freshwater Tertiary in Idaho, discovered by Capt. Clarence King. Proc. Amer. Phil. Soc., $1871,11,538-547$.

1871.12

- On the fishes of the Ambyiacu river. Proc. Acad. Nat. Sci. Philad., 1871, 250-292.

1871.13

On the fishes of the 'Tertiary shales, Green river, Wyoming. 2. [4] Ann. Rept. U. S. Geol. Surv. IVyoming \& Territ. 1870 (1871), 425-431. 1871.14

On the Saurodontidre. Proc. Amer. Phil. Soc., 1871, 11, 529-538.

1871.15

A partial synopsis of the fishes of the fresh waters of North Carolina. Proc. Amer. Phil. Soc., 1871, 11, 448495.

1871.16

- Remaiks on Asteracanthus Ag., from New Jersey, and Labidesthes Cope, from Tennesseel Proc. Amer. Philos. Soc., 1871, 11, 439-440. 1871.17

- Report on recent reptiles and fishes, obtained by the naturalists of the Hayden expedition for the survey of Wyoming and contiguous territories in 1870. 2. [4] Ann. Rept. U. S. Geol. Surv. Wyoming \& Territ. 1870 (1871), $432-442$.
On the fossil reptiles and fishes of the Cretaceous rocks of Iiansas. 2. [4] Ann. Rept. U. S. Geol. Surv. Wyoming \& Territ. 1870 (1871), 385-424.

1871.19

Second addition to the history of the fishes of the Cretaceous of the United States. Proc. Amer. Phil. Soc. $1871,11,240-244$.

1871.20

Species are described of the following genera: Beryx, Sphagepoea, Enchodus, Pneumatosteus, Crommyodus, Ischyodus and Pristis.

- Supplementary notice of a new chimarid [Leptomylus cooki] from New Jersey. Proc. Amer. Phil. Soc., 11 , 384.

1871.21

Cold-blooded vertebrates collected by the Telmantepec canal survey (In Report of Captain R. W. Shufeldt, U.S. N., on the Telmantepec canal survey, Appendix D, 99-139. Washington, 1872)

1872.1

Evolution and its consequences Penn. Monthly Mag., 1872, 222-236.

1872.2

The fish-beds of Osino, Nevada. Amer. Naturalist, $1872,6,775-776$.

1872.3

Amyzon mentale and Trichophanes hians are mentioned.

The method of creation of organic forms. Proc. Amer. Phil. Soc., 1872, 12, 229-263.

1872.4

A new genus of saurodont fishes, Erisichthe, from the Kansas Niobrara. Proc. Acad. Nat. Sci. Philad., 1872, $280-281$.

1872.5

Note of some Cretaceous vertebrata [Anogmius contractus] in the State Agricultural College of Kansas, U. S. A. Proc. Amer. Phil. Soc., 1872, 12, 168170.

1872.6

Notices of new vertebrata from the upper waters of Bitter creek, $\mathrm{Wy}$ oming territory. Proc. Amer. Phil. Soc., $1872,12,483-486$.

1872.7

This first appeared as Paleontological Bulletin no. 6, published Aug. 20, 1872.

- Observations on the distribution of certain extinct vertebrata in North Carolina. Proc. Amer. Phil. Soc., 1872, 12, 210-216.

1872.8

Reference is made to Diodon antiquus.

On the families of fishes of the

Cretaceous formation of Kansas. Proc. Amer. Phil. Soc., 1872, 12, 327-357.

1872.9 
Cope, $E . D$.

On the occurrence of fossil Cobitidx in Idaho. Proc. Amer. Phil. Soc., $1872,12,55$.

1872.10

- On the geology and paleontology of the Cretaceous strata of Kansas. 5. Ann. Rept. U. S. Geol. Surv. Montana \& 'Territ., 1872, 318-349.

1872.11

Pisces, p. 337-348.

- On the Tertiary coal and fossils of Osino, Nevada. Proc. Amer. Phil. Soc., 1872, 12, 478-481.

1872.12

On two extinct forms of Physostomi of the neotropical region. Proc. Amer. Phil. Soc., 1872, 12, 52-55.

1872.13

Prymnetes longiventer and Ancdopogon tenuidens are described.

Reference to fishes from the Cretaceous of Iiansas, in a letter to Prof. Lesley. Proc. Amer. Phil. Soc., 1872, 12, 174-176.

1872.14

Remarks on Hyrtl's collection of fish skeletons! Proc. Amer. Phil. Soc., 1872, 12, 191.

1872.15

Remarks on the evolution theory in reply to Mr. Eli K. Price. Proc. Amer. Phil. Soc., 1872, 12, 317-320.

1872.16

Report on the recent reptiles and fishes of the Survey, collected by Campbell Carrington and C. M. Dawes. 5. Ann. Rept. U.S. Surv. Territ. (Hayden), 1872, pt. 4, 467-476.

1872.17

The peculiar coloration of fishes. Amer. Naturalist, 1872, 6, 637. 1872.18 Has reference to article by Richard Bliss, $\mathrm{Jr}$.

A contribution to the ichthyology of Alaska. Proc. Amer. Phil. Soc., $1873,13,24-32$.

1873.1

On some new batrachia and fishes from the Coal Measures of Linton, Ohio. Proc. Acad. Nat. Sci. Philad., $1873,340-343 ; 417-419 . \quad 1873.2$

On the extinct vertebrata of the Eocene of Wyoming, observed by the expedition of 1872 , with notes on the geology. 6. Ann. Rept. U. S. Geol. Surv. Territ., 1873, pt. 2, 545-649. 6 pls.

Pisces, p. 633-649.

1873.3

On two new species of Saurodontidx. Proc. Acad. Nat. Sci. Philad. 1873, 337-339.

1873.4

The species are referred to Portheus and Daptinus.
Sketch of the zoology of Maryland (In Walling \& Gray, New topographical atlas of Maryland, p. 16-18. 1873)

1873.5

Pisces, p. 17.

- Sketch of the zoology of Ohio (In Walling \& Gray, New topographical atlas of Ohio, p. 25-27. 1873) 1873.6 I'isces, p. 25-26.

Description of a Ctenodus from the Coal Measures of Ohio. Proc. Acad. Nat. Sci. Philad., 1874, 91-92. 1874.1

On some batrachia and Nematognathi brought from the upper Amazon by Prof. Orton. Proc. Acad. Nat. Sci. Philad., 1874, 120-137. 1874.2

Report on the stratigraphy and Pliocene vertebrate paleontology of northern Colorado. Bull. U. S. Geol. Geogr. Surv. Territ., 1874, 1, no. 1, 9-28.

1874.3

Includes also: "Supplement. Additions to the synopsis of new vertebrata from the Territory of Colorado, 1873 ," p. 22-28.

Report on the vertebrate paleontology of Colorado. Ann. Rept. U.S. Geol. Geogr. Surv. Territ. 1873 (1874), pt. 2, 427-533. 8 pls.

1874.4

An abstract of this paper appeared in Journ. Zool. 1875, 4, 351-359, with a list of the species described.

Report upon the vertebrate fossils discovered in New Mexico, with descriptions of new species. Ann. Rept. Geogr. Surv. West 100. Meridian, Appendix $\mathrm{FF}_{3}$, 591-609. Washington, 1874) 1874.5

- Review of the vertebrata of the Cretaceous period found west of the Mississippi river. Bull. U. S. Geol. Geogr. Surv. 'Territ., 1874, 1, no. 2, 3-48.

1874.6

Section ii, List of species of vertebrata from the Cretaceous formations of the west.

The succession of life in North America. Penn. Monthly, 1874, 5, 138145. - Ann. Mag. Nat. Hist., 1874, 4. ser. 13, 326-331.

1874.7

Supplementary notices of fishes from the freshwater Tertiaries of the Rocky mountains. Bull. U. S. Geol. Geogr. Surv. Territ., 1874, 1, no. 2, 4951.

1874.8

Sur les Plagopterhinés [Plagopterhinidx. et l'ichthyologie de l'Utah. Journ. Zool. (Gervais), 1874, 3, 507-508.

1874.9 
Check list of North American batrachia and reptilia. Washington, 1875. 104 p. $8^{\circ}$. 1875.1 Refers to distribution of Nearctic fishes, $p$. 54-95.

Note on the ichthyology of lake Titicaca. Journ. Acad. Nat. Sci. Philad., 1874-81, n. s. 8, 185-187.

1875.2

- On a new genus iOsphyolax pelluciduss of Lophobranchiate fishes. Proc. Acad. Nat. Sci. Philad., 1875, 450. pl.

1875.3

On fossil remains of reptilia and fishes from Illinois. Proc. Acad. Nat. Sci. Philad., 1875, 401-411. - Ann. Mag. Nat. Hist., 1876, 4. ser. 17, 178184.

1875.4

- On the fishes of the Tertiary shales of the South park. Bull. U. S. Geol. Geogr. Surv. Territ., 1875, 2. ser. no. 1, 3-5.

1875.5

Report on the vertebrate fossils from the Fort Union group of Milk river (In Dawson, George M. Report geology and resources of the region in the vicinity of the forty-ninth parallel, from the Lake of the Woods to the Rocky mountains, with lists of plants and animals collected, and notes on the fossils. Appendix B, p. 333-337. Ottawa, 1875)

1875.6

Synopsis of the vertebrata of the Miocene of Cumberland county, New Jersey. Proc. Amer. Phil. Soc., $1875,14,361-364$.

1875.7

- Systematic catalogue of vertebrata of the Eocene of New Mexico, collected in 1874. Rept. Engineer Dept. U. S. Army, in charge of Lieut. Geo. M. Wheeler, p. 5-37. Washington, 1875.

1875.8

- The Twin lake trout. Forest \& Stream, 1875, 3, 373 .

1875.9

The vertebrata of the Cretaceous formations of the West. Rept. U. S. Geol. Surv. Territ., 1875, 2, 1-303. 57 pls.

1875.10

Pisces, p. 179-244. pls. xxxix-lv.

On a new genus of fossil fishes [Cyclotomodon vagrans] Proc. Acad. Nat. Sci. Philad., 1876, 113.- Journ. Zool. (Gervais), 1876, 5, 356-357.

1876.1

On the geologic age of the vertebrate fauna of the Eocene of New
Mexico. Proc. Acad. Nat. Sci. Philad., 1876, 63-66. - Amer. Journ. Sci., 1876, 3. ser. 12, 297-298.

1876.2

On the Plagopterinæ and the ichthyology of Utah. Proc. Amer. Phil. Soc., $1876,14,129-139$.

1876.3

A contribution to the knowledge of the ichthyological fauna of the Green river shales. Bull. U. S. Geol. Geogr Surv. Territ., 1877, 3, no. 4, 807-819.

1877.1

Descriptions of extinct vertebrata from the Permian and Triassic formations of the United States. Proc. Amer. Phil. Soc., 1877, 17, 182-196.

\section{2}

The following species of fossil fishes are described: Strigilina gurleiana, Ctenodus pusillus and Orthacanthus quadriseriatus. p. 191-192.

New fossil fishes from Wyoming. Amer. Naturalist, 1877, 11, 570. 1877.3

A list of species is given without descriptions.

On the classification of the extinct fishes of the lower types. Proc. Amer. Assoc. Adv. Sci., 26. meet., 1877, 26, 292-300.

1877.4

On the genus Erisichthe. Bull. U. S. Geol. Geogr. Surv., 1877, 3, no. 4, 821-823.

1877.5

On some new and little known reptiles and fishes from the Austroriparian region. Proc. Amer. Phil. Soc., $1877,17,63-68$.

1877.6

On some new or little known reptiles and fishes of the Cretaceous No. 3, of Kansas. Proc. Amer. Phil. Soc, $1877,17,176-181 . \quad 1877.7$

On the vertebrata of the bone bed in eastern Illinois. Proc. Amer. Phil. Soc., 1877, 17, 52-63. 1877.S

- Report on the geology of the region of the Judith river, Montana, and on vertebrate fossils obtained on or near the Missouri river. Bull. U. S. Geol. Geogr. Surv., 1877, 3, no. 3, 565597. 4 pls.

1877.9

- Report upon the extinct vertebrata obtained in New Mexico by parties of the expedition of 1874 (In Geogr. Surv. West 100. Meridian, vol. iv, Palæontology, 26-41; 269. 13 pls. Washington, 1877) 1877.10

The Suessonian fauna in North America. Amer. Naturalist, 1877, 11, 95-99. 
Cope, $E . D$

Synopsis of the cold-blooded vertebrata procured by Prof. James Orton during his exploration of Peru in 1876-77. Proc. Amer. Phil. Soc., 1877 17, $33-49$.

1877.12

- Notice of a new locality of the Green river shales containing fishes, insects and plants in a good state of preservation] Paleont. Bull., 1877, no. 25. p. 1 .

1877.13

- Descriptions of fishes from the Cretaceous and 'Tertiary deposits west of the Mississippi river. Bull. U.S. Geol. Geogr. Surv., 1878, 4, no. 1, 67-77. 1878.1

Cretaceous vertebrates of the upper Missouri. Proc. Acad. Nat. Sci. Philad. 1877 (1878), $266 . \quad 1878.2$

Descriptions of new vertebrata from the Upper Tertiary formations of the West. Proc. Amer. Phil. Soc., 1878, 17, 219-231. 1878.3

This is contained also in Paleont. Bull. no. 28

The fauna of the lowest Tertiary of France. Amer. Naturalist, 1878, 12 , $761-762$.

1878.4

- Mount Lebanon fishes in Dakota. Amer. Naturalist, 1878, 12, 57.

1878.5

- The snout fishes of the Kansas Chalk. Amer. Naturalist, 1878, 12 , 128-129.

1878.6

Synopsis of the fishes of the Peruvian Amazon, obtained by Professor Orton during his expeditions of 1873 and 1877. Proc. Amer. Phil. Soc., $1878,17,673-701$.

1878.7

The Amyzon Tertiary beds. Amer. Naturalist, 1879, 13, 332. 1879.1

- A contribution to the zoology of Montana. Amer. Naturalist, 1879,13 , $432-441$.

1879.2

The fishes of Klamath lake, Oregon. Amer. Naturalist, 1879, 13, $784-785$.

1879.3

- Lota maculosa in the Susquehanna river. Amer. Naturalist, 1879 13,457 .

1879.4

The relations of the horizons of extinct vertebrata of Europe and North America. Bull. U. S. Geol. Geogr. Surv. 'Territ., 1879, 5, no. 1, 33-54.

1879.5
A sting ray [Xiphotrygon acutidens] from the Green river shales of Wyoming. Amer. Naturalist, 1879 , 13, 333 .

1879.6

- The Manti beds of Utah. Amer. Naturalist, 1880, 14, 303-304. 1880.1

On the zoological position of Texas. Bull. U.S. Nat. Mus., 1880, 17 , $1-51$.

1880.2

Second contribution to the history of the vertebrata of the Permian formation of Texas. Proc. Amer. Phil. Soc., $1880,19,38-58$.

1880.3

Issued also as P'aleont. Bull. no, 32. $22 \mathrm{p}$ Description of Ectosteorhachis nitidus, p. 56-58.

- Traquair on Platysomidx. Amer. Naturalist, $1880,14,439-440$.

1880.4

Catalogue of the vertebrata of the Permian formation of the United States. Amer. Naturalist, 1881, 15, $162-164$.

1881.1

- Extinct Palæozoic fishes from Canada. Amer. Naturalist, 1881, 15, 252-253. 1881.2

Notice of a paper by J. F. Whiteaves.

A new genus of Catostomidx [Lipomyzon] Amer. Naturalist, 1881, 15,59 .

1881.3

- - On the vertebrata of the Wind river Eocene beds of $\mathbf{W y o m i n g}$. Bull. U. S. Geol. Geogr. Surv., 1881, 6, no. 1, 183-202. Notice in Amer. Naturalist. 15,74 .

1881.4

Permian vertebrata. Amer. Naturalist, 1882, 16,925. $\quad 1882.1$

- Contributions to the history of the vertebrata of the Lower Eocene of Wyoming and New Mexico, made during 1881. Proc. Amer. Phil. Soc., 1883, $20,139-197$.

1883.1

Species of Clastes and Pappichthys are described at p. 142.

Fourth contribution to the history of the Permian formation of T'exas. Proc. Amer. Phil. Soc., 1883, 20,628-629. 1883.2

Issued also as part of P'aleont. Bull., no. 36

- A new chondrostean [Crassopholis magnicaudatus] from the Eocene. Amer. Naturalist, 1883, 17, 1152-1153. 1883.3

A new Pliocene formation in the Snake river valley. Amer. Naturalist, $1883,17,867-868$. 
- On a new extinct genus and species of Percidx from Dakota territory. Amer. Journ. Sci., 1883, 3. ser. $25,414-416$.

1883.5

On the fishes of the recent and Pliocene lakes of the western part of the Great basin, and of the Idaho Pliocene lake. Proc. Acad. Nat. Sci. Philad. 1883, 134-166. map.

1883.6

A Carboniferous genus of sharks still living. Science, $1884,3,275-276$. - Amer. Naturalist, 1885, 19, 878879.

1884.1

The reference is to Chlamydoselachus anguineus Garman.

The genus Pleuracanthus. Amer. Naturalist, $1884,18,818$. pl. xxiii.

1884.2

The fishes of the Batsto river, New Jersey. Proc. Acad. Nat. Sci. Philad. 1883 (1884), 132-133. 1884.3

- Note on the phylogeny of the vertebrata. Amer. Naturalist, 1884, $18,1255-1257$

1884.4

On some vertebrata from the Permian of Illinois. Proc. Acad. Nat. Sci. Philad. 1883 (1884), 108-110.

$188+.5$

On the structure of the skull in the elasmobranch genus Didymodus. Proc. Amer. Phil. Soc., 1884, 21, 572590. pl. - Paleont. Bull., no. 38.

1884.6

- Permian fishes and reptiles. Proc. Acad. Nat. Sci. Philad. 1883 (1884), 69.

1884.7

- Pleuracanthus and Didymodus. Science, 1884, n. s. 3, 645-646. 1884.8

The skull of a still living shark of the Coal Measures. Amer. Naturalist, $1884,18,412-413$.

1884.9

The vertebrata of the 'Tertiary formations of the West. Book I. Rept. U. S. Geol. Surv. Territ., 1884, 3, 1-1009. $76 \mathrm{pls}$.

1884.10

Pisces, p. 49-100. pls. i-xiv.

Eocene paddle-fish and Gonorhynchidx. Amer. Naturalist, 1885, 19, 1090-1091.

1885.1

- On the evolution of the vertebrata, progressive and retrogressive. Amer. Naturalist, $1885,19,140-148$; 234-247; 341-353.
The position of Pterichthys in the system. Amer. Naturalist, 1885, 19, 289-291. 2 figs.

1885.3

An interesting connecting genus of chordata [Myclerops ordinatus] Amer. Naturalist, 1886, 20, 1027-1031. fig.

1886.1

On two new forms of Polyodont and Gonorhynchid fishes [Crossopholis magnicaudatus, Notogoneus osculus, Priscacara hypsacanthus] from the Eocene of the Rocky mountains. Mem. Nat. Acad. Sci. Washington, 1886, 3, pt. 2, 161-165. pl.

1886.2

The Mesozoic and Canozoic realms of the interior of North America. Amer. Naturalist, 1887, 21, 445-462.

1887.1

Goode's American fishes. Amer. Naturalist, 1888, 22, 714-716. pl.

1888.1

- The pineal eye in extinct vertebrates. Amer. Naturalist, 1888, 22, 914-917. 4 pls. 1888.2

- Brongniart and Döderlein on Xenacanthus. Amer. Naturalist, 1889, 23, 149-150.

1889.1

On a species of Plioplarchus [P. septemspinosus] from Oregon. Amer. Naturalist, 1889, 23, 625-626. 1889.2

The Silver lake of Oregon and its region. Amer. Naturalist, 1889, 23, 970-982. pl. \& fig.

1859.3

Storms on the adhesive disk of Echeneis. Amer. Naturalist, 1889, 23, $254-255$.

1889.4

Synopsis of the families of vertebrata. Amer. Naturalist, 1889, 23, 849-877.

Pisces, p. 853-860.

The vertebrata of the Swift Current river, II. Amer. Naturalist, $1889,23,151-155$. 1889.6

Notice of the occurrence of remains of Amia p. 151 .

- The homologies of the fins of fishes. Amer. Naturalist, 1890, 24, 401-423. 9 figs. \& 5 pls. 1890.1

— Newberry's Paleozoic fishes of North America. Amer. Naturalist, $1890,24,844-847 . \quad 1890.2$

Systematic catalogue of the species of vertebrata found in the beds of the Permian epoch in North America 
Cope, E. D.

with notes and descriptions. Trans. Amer. Phil. Soc., 1890, n. s. 16, 285-286. 1890.3

A. S. Woodward's fossil fishes. Amer. Naturalist, 1891, 25, 646-647.

1891.1

On some new fishes from South Dakota. Amer. Naturalist, 1891, 25, 654-658. Abstract in Proc. Amer. Assoc. Adv. Sci., 40. meet., 1891, 40, 285.

1891.2

On the characters of some Paleozoic fishes. Proc. U. S. Nat. Mus., 1891, 14, 447-463. 6 pls.

1891.3

On the non-actinopterygian Teleostomi. Amer. Naturalist, 1891, 25, 479-481. 1891.4

On vertebrata from the Tertiary and Cretaceous rocks of the North West territory. I. The species from the Oligocene or Lower Miocene beds of the Cypress hills. Contrib. Canadian Palæont., 1891, 3, 1-25. 14 pls. 1891.5 Pisces, p. 1-4. pl. i.

American Devonian fishes found in Belgium. Amer. Naturalist, 1892, 26, 1025.

1892.1

A contribution to the vertebrate paleontology of Texas. Proc. Amer. Phil. Soc., 1892, 30, 123-131. pl. \& fig. 1892.2

On a Mesozoic Pycnodont, Microdon dumbelii, sp. nov., p. 12S-129.

- Crook on Saurodontidx from Kansas. Amer. Naturalist, 1892, 26, 941-942. 1892.3

- New fishes from western Canada [Coregonus coulterii $\mathrm{E}$. and $\mathrm{G}$. from Kicking Horse river, Field, B. C.j Amer. Naturalist, 1892, 26, 961-964.

1892.4

On some new and little known Paleozoic vertebrates. Proc. Amer. Phil. Soc., 1892, 30, 221-229. 2 pls. 1892.5

- On some points in the kinetogenesis of the limbs of vertebrates. Proc. Amer. Phil. Soc., 1892, 30, $282-$ 285.

1892.6

- On the phylogeny of the vertebrata. Proc. Amer. Phil. Soc., 1892, 30, 278-281. 2 figs.

1892.7

Fritsch's fauna of the Gaskohle of Bohemia [Xenacanthus dechenii
Goldf., Trissolepis kounoviensis Fritsch Amer. Naturalist, 1893, 27, 1079-1081.

2 pls. \& figs.

1893.1

On Symmorium, and the position of the cladodont sharks. Amer. Naturalist, 1893, 27, 999-1001. 1893.2

- Tossil fishes from British Columbia. Proc. Acad. Nat. Sci. Philad. 1893 (1894), 401-402.

1894.1

A new extinct species of $\mathrm{Cy}$ prinidx. Proc. Acad. Nat. Sci. Philad. 1893 (1894), 19-20.

1894.2

- On the fishes obtained by the Naturalist expedition in Rio Grande do Sul. Proc. Amer. Phil. Soc., 1894, 33, 84-108. $6 \mathrm{pls}$.

1894.3

- On three new genera of Characinidæ. Amer. Naturalist, 1894, 48, 67. 1894.4

Von Thering on the fishes and mammals of Rio Grande do Sul. Amer. Naturalist, 1894, 28, 791-792. $\quad 1894.5$

- New and little known Paleozoic and Mesozoic fishes. Journ. Acad. Nat. Sci. Philad. 1894 (1895), 2. ser. 9, 427-448. 3 pls. \& 5 figs. $\quad 1895.1$

- Fishes in isolated pools. Amer. Naturalist, 1896, 30, 943-944. 1896.1

Fishes of north and middle America. Amer. Naturalist, 1897, 31, 214-216.

1897.1

A review of Jordan and Evermann's "Fishes of North and Middle America."

On new Paleozoic vertebrata from Illinois, Ohio and Pennsylvania. Proc. Amer. Phil. Soc., 1897, 36, 71-82. 2 pls.

1897.2

Alphabetical cross reference catalogue of all the publications of Edward Drinker Cope, from 1859 till his death in 1897. See Frazer, $P_{\text {, }}$ in Mem. Soc. Ciene. "Antonio Alzate," Mexico, 1899, $14,39-48$.

1899.1

Catalogue chronologique des publications de Edward Drinker Cope de 1859 ì 1897 inclusivement. See Frazer, $P$., in Ann. Soc. Géol. Belgique, $1902,29,3-77$.

1902.1

Bibliography of the published writings of Edward Drinker Cope This is a manuscript list comprising upwards of 1300 titles, compiled by Anna M. Brown, and now preserved 
in the American Museum of Natural History]

It was not possible to make use of this list while the present Bibliography of Fishes was in preparation, but it is not believed that any important ichthyological contributions have been overlooked.

Cope, E.D., \& Yarrow, H.C. Report upon the collections of fishes made in portions of Nevada, Utah, California, Colorado, New Mexico, and Arizona, during the years $1871,1872,1873$, and 1874. U. S. Geogr. Surv. West 100. Meridian, vol. v. Washington, 1875.

1875.1

Copeland, HerbertEdson, \& Jordan, David Starr. See Jordan \& Copeland.

Copeland, Manton. The olfactory reactions of the puffer or swellfish, Spheroides maculatus (Bloch and Schneider) Journ. Exper. Zool., 1912, 12, 363368.

1912.1

Coquidé, $M$. La pêche à la morue. Bull. Instit. Océanogr., Monaco, 1909 , no. 153. $24 \mathrm{p}$.

1909.1 r. $O$.

Coquina, pseudonym for Shields,

Corbin, G. B. Voracity of pike. Zoologist, 1873, 2. ser. 8, 3617. 1873.1

Food of the salmon. Zoologist, 1874, 2. ser. 9, 3839 .

1874.1

- Large chub (Leuciscus cephalus) in the Hampshire Avon. Zoologist, 1906, 4. ser. 10, 435-436.

1906.1

- Large eel in the Hampshire Avon. Zoologist, 1907, 4. ser. 11, 357358.

1907.1

Corbin, $P . F . J ., \&$ Herdman, $W . A$. See Herdman \& Corbin.

Corblin, Henri. Recherches sur la locomotion du poisson et sur la fonction hydrostatique de la vessie natatoire. C. R. Mém. Soc. Biol. Paris, 1887, 8. ser. 4, 652-658.

1887.1

Corchus, Bela. Hauki talvisäilioissä. Suomen Kalastus Lehti, 1898, 7, 177178. - Fiskeritidskr. Finland, 1898, 7, 178-179.

1898.1

Cordeaux, John [1830?-1899] Greenland shark [Squalus borealis] on the Dogger bank. Zoologist, 1866, 2. ser. 1, 230 .

1866.1

- Boar-fish [Capros aper] at the mouth of the Humber. Zoologist, 1879 , 3. ser. 3, 342 .
Cordes, $C$. La pêche du requin [Selachoidei] Bull. Soc. Acclim., Paris, 1876, 3. ser. 3, 853-890.

1876.1

Cordes, Fr. Praktische Erfahrungen über Teichfischerei für Karpfen. Journ. Landw., 1871, 19. Jahrg., 226-234.

1871.1

Coregonus (pseudon.) Curious features of fish ova. Forest \& Stream, 1877, 7, 404 . 1877.1

Experiments and observations on the artificial impregnation of fish ova.

Corfield, Henri. Electric fishes. Nature, 1888, 38, 515. 1888.1

Cori, Carl J. Ueber paarige Afterund Schwanzflossen bei Fischen. Sitzber. Deutsch. Nat. Med. Ver. Lotos, Prag, 1896, n. s. 16, 43-46. 1896.1

- Zur Frage der Schleppnetzfischerei in den oesterreichischen Meeresrebieten. Oesterr. Fischerei Zeitg., 1904, 1. Jahrg., 163-164. 1904.1

- Das Blutgefässsystem des jungen Ammocoetes. Arb. Zool. Inst. Wien, 1906, 16, 217-312. 2 figs. 1906.1

- Hermaphroditismus bei Fischen. Verh. Intern. Fisch. Kongr. Wien, 1905 (1906), Stenogr. Protok., 109-111.

1906.2

Zucht der Meeresfische. Verh.

Intern. Fisch. Kongr. Wien, 1905 (1906), Stenogr. Protok., 343-347. 1906.3

Der Naturfreund am Strand der Adria. Leipzig, $1910 . \quad 1910.1$

Corinaldi, $E$. Cause de la rarété du poisson dans la baie de Nice. Congrès Scient. France, 44. sess., 1878, 1, 271276.

1878.1

Cormack, W. E. On the natural history and economical uses of the cod, capelin, cuttle-fish and seal. Edinb. New Phil. Journ., 1826, 1, 32-41. 1826.1

Ueber die Naturgeschichte verschiedener Fische in Newfoundland und Labrador. Isis (Oken), 1832, 677-679.

1832.1

Cornalia, Emilio [1824-1882] Sulle branchie transitorie dei feti plagiostomi. Giorn. Istit. Lomb., Milano, 1856, 9, 256-278. 3 pls.

1856.1

Fauna d' Italia. 4 pts. Milano, $1870-74.4^{\circ}$ 1871.1 72. Pesci, per G. Canestrini, pt. iii, 1-208. 1871- 
Cornalia, $E$.

Sulla Taphrobia pilchardi, nuovo genere di crostacei parassiti. Atti Soc. Ital. Milano, 1875, 18, 197-200. 1875.1

Cornet, $J$. Les poissons du Congo. Congo Illustré, $1893,2,56-80$. 1893.1

Sur la faune du terrain houiller inférieur de Baudour (Hainaut) C. R. Acad. Sci. Paris, 1906, 142, 734-736.

1906.1

Ancistrodon et autres poissons de la craie de Nouvelles. Ann. Soc. Géol. Belgique, 1910, 36, B 224-B 226.

1910.1

Cornide, José. Memorie sobre la pesca de la sardinia en las costas de Galicia. Madrid, 1774.

1774.1

- Papel escrito sobre pesca y su estado en el reino de Galicia, con la historia de su creación, fomento y decadencia, dirigida al rey desde Santiago en enero de 1786 .

1786.1 Manuscript work cited by De la Paz Graells.
1864.

Ensayo de una historia de los peces y otras producciónes marinas de la costa de Galicia, arreglado al sistema del Caballero Cárlos Linneo; con un tratado de las diversas pescas, y de las redes y aparejos con que se practican. [Coruña] 1785. 263 p. $\quad 8^{\circ} . \quad 1788.1$

Corning, Hanson Kelly. Beiträge zur Kenntniss der Wundernetzbildungen in den Schwimmblasen der Teleostier. Morphol. Jahrb. 1888, 14, 1-53. 2 pls. 1888.1 Ueber die ventralen Urwirbel-
knospen in der Brustflosse der Teleostier. Morphol. Jahrb. 1894, 22, 79-98. 2 pls.

1894.1

Merocyten und Umwachsungsrand bei Teleostiern (In Festschrift zum siebenzigsten Geburtstag von Carl Gegenbaur, vol. ii, 103-132. 2 pls. Leipzig, 1896)

1896.1

Cornish, G. A. Notes on the fishes of Canso. Rept. Dept. Mar. \& Fish. Canada, Ottawa, 1902-1905 (1907), 39, 81-80. 1907.1

Cornish, I. Present state of the salmon and Chamnel fisheries, and of the statute laws by which they are regulated, with the natural history of the salmon. London, 1824. $8^{\circ}$. 1824.1

Cornish, Thomas [1830-] Occurrence of the lesser forked beard [Rani- ceps trifurcus] in Mount's bay, Cornwall. Zoologist, 1863, 21, 8642. 1863.1

Additional note by E. Newman, p. 8642-8643.

Angel-fish [Lophius piscatorius] and pilot-fish [Naucrates ductor] at Penzance. Zoologist, 1864, 22, 9145.

1864.1

Maigre [Sciona aquila] off Lands End [and in Mount's bay! Zoologist, 1864, 22, 9295-9296; 9366. 1864.2

- Pilot-fish and large mackerel at Penzance. Zoologist, 1864, 22, 9145.

1864.3

- Kingfish [Lampris guttatus] in St. Austell bay. Zoologist, 1865, 23, 9698. 1865.1

- Lump sucker at Lands End. Zoologist, 1865, 23, 9558. 1865.2

Swordfish and tunny off Penzance. Zoologist, 1865, 23, 9814. 1865.3

Ausonia cuvieri captured off Falmouth. Zoologist, 1866, 2. ser. 1, $501-504$.

1866.1

- Fresh-water cels in salt water. Zoologist, 1866, 1, 348.

1866.2

-_. Muller's topknot ¿Rhombus punctatus] and streaked gurnard [Trigla lineata] at Penzance. Zoologist, 1866, $1,311$.

1866.3

On the occurrence of the spinous shark in Mount's bay, Cornwall. Zoologist, 1866, 1, 102-105. $\quad 1866.4$ Additional notes, p. 113.

Pisa gibbsii and sun-fish at Penzance. Zoologist, 1866, 1, 390.

1866.5

- Surmullet, etc., taken at Penzince. Zoologist, 1866, 1, 349. 1866.6

- Tadpole fish [Raniceps trifurcus] in Mount's bay. Zoologist, 1866, 1, 272.

1866.7

- Trifurcated hake [Raniceps trifurcus] and smooth Serranus at Penzance. Loologist, 1866, 1, 348. 1866.8

Whiting taken in mackerel driftnets. '/oologist, 1866, 1, 272. 1866.9

Allice shad [Clupea alosa] in Mount's bay. 'Loologist, 1S67, 2, 916. 1867.1

Notes of a stay at Prussia cove [Mount's bay, Cornwall] 'Zoologist, 1867, 2, 961-965. 1867.2 
Scyllarus arctus near Penzance [a note on the food of the cod] Zoologist, 1867, 2, 563; Ibid., 3, 1223. 1867.3

The silvery hair-tail (Trichiurus lepturus) in Mount's bay. Zoologist, 1867, 2, 793-794.

1867.4

Allice shad [Clupea alosa] at St. Ives. Zoologist, 1868, 3, 1463. 1868.1

Boar-fish near Penzance, [and] at Whitsand bay, Lands End. Zoologist, $1868,3,1222$.

1868.2

Globe fish [Tetrodon stellatus] at Penzance. Zoologist, 1868, 3, 1484.

1868.3

Homelyn ray [Raja maculata] and gemmeous dragonet [Callionymus lyra] off Plymouth. Zoologist, 1868, 2. ser. 3, 1295.

1868.4

- Picked dog-fish with coralline attached. Zoologist, 1868, 3, 1222.

1868.5

- Salmon peel at Penzance. Zoologist, $1868,3,1222$. 1868.6

- Saury pilie or skipper [Scomberesox saurus Yarrell] at Penzance. Zoologist, 1868, 3, 1463.

1568.7

- Short-finned tunny Thynnus brachypterus] at Penzance. Zoologist, $1868,3,1463$.

1868.8

Gilthead at Penzance Chrysophrys aurata] Zoologist, 1870, 5, 21082109.

1870.1

Greater forked-beard [Phycis blennioides] at the Lands End. Zoologist, $1870,5,2144$.

1870.2

Habits of the sucking-fish [Echeneis remora] Zoologist, 1870, 5, 22252226.

1870.3

- On a shark captured in Mount's bay, supposed to be identical with the basking shark of Pennant and the broadheaded gazer of Couch. Zoologist, $1870, \mathbf{5}, 2253-2260$. 1870.4

- Pilchards in Mount's bay on Christmas day. Zoologist, 1870, 5, 2027.

1870.5

- Small-eyed rays [Raja maculata] in Mount's bay. Zoologist, 1870, 5, 2348.

1870.6

- Spinous shark taken off Penzance. Zoologist, 1870, 5, 2347. 1870.7
Sting ray [Trygon pastinaca] near Penzance. Zoologist, 1870,5 , 2347-2348. $\quad 1870.8$

- Large surmullet [Mullus surmuletus] Zoologist, 1871, 6, 2812.

1871.1

- More specimens of the silvery hairtail [Trichiurus lepturus] at Penzance. Zoologist, 1871, 6, 2529. 1871.2

_ - Great abundance of pilchards [Clupea pilchardus] on the Cornish coast. Zoologist, 1872, 7, 2908. 1872.1

- Large whiting [Gadus merlangus] near Penzance. Zoologist, 1872, 7, 2996.

1872.2

- Occurrence off Penzance of a Syngnathus hitherto unobserved as British. Zoologist, 1872, 7, 3274-3276.

1872.3

Silver eel [Anguilla acutirostris] of extraordinary size. Zoologist, 1872 , 7. 2996 . 1872.4

The silvery hairtail in Whitsand bay. Zoologist, 1872, 7, 3027.

1872.5

- Spotted gunnel [Centronotus gunellus] and lesser forked-beard near Penzance. Zoologist, 1872, 7, 2947. 1872.6

Pilot-fish off Penzance. Zoologist, $1873,8,3653$.

1873.1

- Rare fishes at Penzance. Zoologist, $1873,8,3697$. 1873.2

- Fox shark [Alopecias vulpes] off Scilly. Zoologist, 1874, 9, 4080. 1874.1

- Lumpsucker and whiff [Rhombus megastoma Yarrell] off the Cornish coast. Zoologist, 1874, 9, 4037. 1874.2

Pimelepterus cornubiensis, a supposed new fish, at Penzance. Zoologist, $1874,9,4255-4258 . \quad 1874.3$

- Ray's bream [Brama rayi] near Penzance. Zoologist, 1874, 9, 4266; Ibid., 1875, 10, 4542. 1874.4

- Small lumpsucker three inches long] Zoologist, 1874, 9, 3839. 1874.5 - The species of mackerel. Zoologist, $1874,9,4037$. 1874.6

Large surmullet off Penzance. Zoologist, 1875, 10, 4668; 4704. 1875.1

Spinous shark in Mount's bay. Zoologist, 1875, 10, 4501. 1875.2 
Cornish, $T$.

Torpedo, electrical ray or numbfish, on the Cornish coast. Zoologist, $1875,10,4500-4501$.

1875.3

- Abundance of mackerel in Mount's bay. Zoologist, 1876, 11, 4767. 1876.1

Giant grey mullet [Mugil capito] Zoologist, 1876, 11, 4806-4807. 1876.2

On the occurrence of the centrine shark [Squalis centrina] off the coast of Cornwall. Zoologist, 1877, 3. ser. 1, 221-222. - Sci. Gossip, 1877, 13, 139.

1877.1

Notes on some fish and crustacea recently obtained in Cornwall. Zoologist, $1878,2,423-426$.

1878.1

Red mullet [Mullus surmuletus] off the Cornish coast-in December. Zoologist, $1878, \mathbf{2}, 61$.

1878.2

-... Swordfish [Xiphias gladius] in Mount's bay. Zoologist, 1878, 2, 351.

1878.3

Vertebrata. Pisces, corrected and revised from the work of Jonathan Couch, A Cornish fauna, 18381 Journ. Roy. Inst. Cornwall, 1878, no. 19, pt. 2 , 428-450.

1878.4

3, 62 .

1879.1

- On some little-known fishes and crustacea. Zoologist, $1879, \mathbf{3}, 473-477$.

1879.2

Pilot-fish and short sun-fish [Orthagoriscus mola] in Mount's bay, Cornwall. Zoologist, 1879, 3, 306.

1879.3

Swordfish [Xiphias gladius] on the Cornish coast. Zoologist, 1879, 3, 307.

1879.4

Eckstrom's topknot [Rhombus cardina] and Couch's Erythrinus [Pagellus erythrinus] on the Cornwall coast. Zoologist, 1880, 4, 449-450. 1880.1

L Late stay of pilchards and early arrival of mackerel on the Cornish coast. Zoologist, $1880,4,112-113$. $\quad 1880.2$

Lesser grey mullet [M Iugil chelo of Yarrell and Couch] on the Northumberland coast. Zoologist, 1880, 4, 448449.

1880.3

Short-finned tunny [Thynnus brachypterus] at Penzance. Zoologist, $1880,4,366-367$.
The Cuckoo ray. Zoologist, 1881.1

_ The mackerel season in Cornwall. Zoologist, 1881, 5, 27-28. 1881.2

Pilchards on the Cornish coast. Zoologist, 1881, 5, 387.

1881.3

- Rare fishes on the Cornish coast. Zoologist, 1881, 5, 385. $\quad 1881.4$

_ Red mullet [Mullus surmuletus] off the Cornish coast in December. Zoologist, 1881, 5, $69 . \quad 1881.5$

Salmon at sea. Zoologist, 1881,

5, 213.

1881.6

Capture of a 27 pound salmon, 14 miles off the Scilly islands; about 100 miles from mouth of any river.

- The dorse, or golden cod, in Cornwall. Zoologist, 1882, 6, 75. 1882.1

- Rare fishes on the Cornish coast. Zoologist, 1882, 6, 192-193. $\quad 1882.2$

-.... Spinous shark at Penzance. Zoologist, 1882, 6, 22-23. 1882.3

Habits of the pilchard. Zoologist, $1883,7,505-506$.

1883.1

- Mackerel and pilchard fisheries. Intern. Fisheries Exhib. Lit., London, 1883. Conferences, 6, pt. 4. 1883.2

- Migrations of the pilchard. Zoologist, 1883, 7, 431. $\quad 1883.3$

The "white trout" of Pennant. Zoologist, 1883, 7, $228 . \quad 1883.4$

Basking shark in Mount's bay. Zoologist, 1885, 9, 351-352. 1885.1

Dentex vulgaris in Mount's bay. Zoologist, 1885, 9, 312-313. $\quad 1885.2$

Food of the common cod Zoologist, 1885, 9, 34; 71; 114. 1885.3

The young of the garfish. Zoologist, $1885,9,439$.

1885.4

Large catches of mullet and mackerel on the Cornish coast. 'Loologist, 1891, 15, 195.

1891.1

- Ray's bream [Brama rayi] near Penzance. Zoologist, 1891, 15, 35.

1891.2

Cornuel, $J$. Description de débris de poissons fossiles provenant principalement du calcaire néocomien du département de la Haute-Marne. Bull. Soc. Géol. France, 1877, 3. ser. 5, 604-626. pl. 
Note sur de nouveaux débris de Pycnodontes portlandiens et néocomiens de l'est du bassin de Paris. Bull. Soc. Géol. Paris 1879 (1880), 3. sér. 8, 150162.

1880.1

- Nouvelle note sur des Pycnodontes portlandiens et néocomiens de l'est du bassin de Paris, et sur des dents binaires de plusieurs d'entre eux. Bull. Soc. Géol. France, 1883, 3. ser. 11, 1828. pl.

1883.1

Corré, A. Note pour servir à l'histoire des poissons vénéneux. Arch. Méd. Navale, 1865, 3, 136-147. 1865.1

Corrigan, Dominick $\int$. On some structural peculiarities in the pipefishes. Zoologist, 1860, 18, 6813-6814. 1860.1

On some structural peculiarities of the mouth in the pipefishes. Proc. Nat. Hist. Soc. Dublin 1859-62 (1863), 3, 4-6. figs. - Proc. Nat. Hist. Rev., $1862,7,33-36$.

1863.1

Corrigeen, pseudonym for Adams, (Rev.) $I$.

Cortese, $F$. Alcune illustrazioni all' anatomia del sistema nervoso de' pesci. Atti R. Istit. Veneto Sci., 1846, 5, 354355.

1846.1

- Sopra una anomalia riscontrata nei nervi ottici di un pesce. Mem. Istit. Sci. Venezia 1867 (1868), 14, 55-72.

1868.1

Cortier, (Captain) — Sur l'habitat du Barbus deserti Pellegrin. Bull. Mus. Hist. Nat. 1909 (1912), 412. 1912.1

Cory, Charles Barney. Hunting and fishing in Florida, ... Boston, 1896. 304 p. 2 pls. illustr. $8^{\circ}$. 1896.1

Cosmopolitan, pseudonym for Yarrow, Henry Crécy.

Cosmovici, $L$. Les poissons fossiles en Roumanie. Rev. Sci. France Etranger, Paris, 1886, 3. sér. 11, 115. 1886.1

- Les couches à poissons des monts Petricica et Cozla (Roumanie) Jassy, 1887. fig. $4^{\circ}$.

1887.1

Cosson, Ernest Saint-Charles [18191889] Sur l'acclimatation de la carpe et de la tanche dans les eaux douces de l'Algérie. Bull. Soc. Acclim., Paris, $1862,9,15-20$.

1862.1

Costa (pseudon.) Fish and fishing in California. Amer. Angler, 1884, 6, 152.
Costa, Achille [1823-] Fauna del regno di Napoli... continuata da A. Costa. Napoli, 1850-86. $4^{\circ}$. See Costa, O. G.

- Storia critica de' lavori di zoologia e paleontologia pubblicati da' Napolitani dal 1851 al 1856. Il Giamb. Vico, 1857, 2, 438-460.

1857.1

Di un novello genere di pesci Esocetidei. Ann. Mus. Zool. Napoli, $1862,1,54-57 . \quad 1862.1$

Di un piccolo Trachiptero. Ann. Mus. Zool. Napoli, 1862, 1, 50-54. fig. 1862.2

Osservazioni su talune specie di Pleuronettidei; Rhombus candidissimus, Monochirus hispidus, Plagusia picta, $\mathbf{n}$. sp. Ann. Mus. Zool. Napoli, 1862, 1, 44-50.

1862.3

Della pescicoltura nel golfo di Napoli. Atti R. Istit. Incorag. Napoli, 1864, 1, 193-206. Also separate; Napoli, 1865. 16 p. $4^{\circ}$. 1864.1

- Sulla Mustela boccamela e $M$. vulgaris. Rendic. R. Accad. Sci. Napoli, 1865, 4, 32-33. $\quad 1865.1$

Sulla cagione dell' abbondanza del Lepidopo, o pesce bandiera [Lepidopus caudatus] nel mercato di Napoli. Rendic. R. Accad. Sci. Napoli, 1868, 7, 16-17.

1868.1

- Osservazioni sul Krohnius filamentosus, e sullo sviluppo della pinna codale ne' Trachypterus. Ann. Mus. Zool. Napoli 1865 (1869), 5, 41-43. fig. 1869.1

Dell' uso della mela-terragna, nella pesca marina, e dell' azione della medesima sui pesci. Rendic. R. Accad. Sci. Napoli, 1870, 9, 122-127. 1870.1

Illustrazione di un Centrolofo pescato nel golfo di Napoli. Ann. Mus. Zool. Napoli 1866 (1871), 6, 84-87.

1871.1

- Nota sul Vexillifer de Filippi Gasco. [Fierasfer] Ann. Mus. Zool. Napoli 1866 (1871), 6, 88. fig. 1871.2

- La pesca nel golfo di Napoli. Atti R. Istit. Incorag. Napoli, 1871, 2. ser. 7. $96 \mathrm{p}$.

1871.3

- On the fisheries of the gulf of Naples. Rept. U. S. Fish Comm. 187172 (1873), 1, 139-141.

1873.1 
Costa, Oronzio Gabriele [1787-1867] Sopra un frammento ittiolitico di genere sconosciuto nota. [n. p.] [n. d.] 8 p.

- Fauna del regno di Napoli, ossia enumerazione di tutti gli animali che abitano le diverse regioni di questo regno e le acque che le bagnano; contenente la descrizione di nuovi o poco esattamente conosciuti; con figure ricavata da originali viventi e depinte al naturale di O.G. Costa (continuata da A. Costa) 19 sections in 11 vols. Napoli [1829-] 1832-70 [-86] illust. $4^{\circ}$.

1829.1

Fishes, vol, iii, $30 \mathrm{pls}$. Review in Isis (Oken), $1846,39,706-718$, with extract from discussion of Branchiostoma.

-Cénni zoologici, ossia descrizione sommaria delle specie nuove di animali discoperti in diverse contrade del regno nell' anno 1834. Napoli, 1834.

1834.1

Pesci della fauna napolitana con illustrazione di specie nuove. Napoli, 1840-54. 3 vols. \& suppl. 106 pls. $4^{\circ}$

1840.1

Notice sur le Branchiostoma [Amphioxus] C. R. Acad. Sci. Paris, 1841, 13, 873. - L'Institut, 1841, 9, no. 407,345

1841.1

Esame comparativo delle osservazioni fatti dal Cavolini e dal Quatrefages sugli embrioni del Syngnathus ophidion L. Rendic. R. Accad. Sci. Napoli, 1843, 2, 97-104.

1843.1

- Storia e anatomia del Branchiostoma lubricum. Frammenti Anat. Comp. (Costa), 1843, fasc. 1. 13 p. pl.

1843.2

Osservazioni intorno alle Echeneide in generale ed in particolare su l'Echeneis musignani. Ann. Accad. Aspir. Nat., 1844, 2, 234. - Atti Sci. Ital., 1844, 369-371.

1844.1

- Storia naturale di qui pesciolini volgarmente tra noi conosciuti col nome di Cicinelli o Cicinielli [Atherina hepsetus, Clupea sprattus e Gobius aphya] Ann. Accad. Aspir. Nat., 1844, 2, 88.

1844.2

Descrizione di un nuovo pesce della famiglia de' Gadini. Napoli, 1845. 3 pls. $4^{\circ}$.

1845.1

Di un nuovo pesce [Merlucius uruleptus, n. sp.] della famiglia de' Gadini pescato nel golfo di Napoli ai 3 febbraio 1846. Atti Accad. Pontan., Vapoli, 1846, 5, 171-182.
Entozoon trovato entro le ovaie dell' Uranoscopus scaber. Ann. Accad. Aspir. Napoli, 1846, 3, 76-80. 1846.2

[Extract from discussion of Branchiostoma, from Costa's Fauna del regno di Napoli. Isis (Oken), 1846, 39, $708-713$.

1846.3

Nota sulla vescica natatoria dell' Uranoscopo. Ann. Accad. Aspir. Napoli, 1846, 3, 236-237. 1846.4

Ricerche osteologiche sull' apparecchio pterigo-timpanico del capo de' pesci. Atti Sci. Ital., 1846, 470-473. - Il Giamb. Vico, 1, 393-412. 1846.5

- Nota sul pancreas della Chimera. Ann. Accad. Aspir. Napoli, 1847, 3, 233235.

1847.1

Di un nuovo pesce della famiglia de' Gadini [Merluccius uraleptus] Atti Accad. Pontan., Napoli, 1849, 5, 171182. 3 pls.

1849.1

- Storia ed anatomia dell' anguilla e monografia delle nostrali specie di questo genere. Napoli, 1850. 9 pls. $4^{\circ}$.

1850.2

- Depositi di ittioliti nel regno de Napoli. Nuov. Ann. Sci. Nat. Bologna, 1851, 3. ser. 4, 469-478.

1851.1

Note sur l'anatomie des anguilles. Ann. Sci. Nat. (Zool.), 1851, 3. ser. 15, $291-294$.

1851.2

Spechio comparativo degli Squalidei fossili, discoperta finora negli Stati Uniti di America e nel regno di Napoli. Rendic. R. Accad. Sci. Napoli, 1852, n. s. 1, 12s-133.

1852.1

- Descrizione di alcuni pesci fossili del Libano. Atti R. Accad. Sci. Napoli, 1855, 2, 97-112.

1855.1

Ittiologia fossile Italiana; opera da servire di supplemento alle ricerche sui pesci fossili di L. Agassiz. Disp. i-iv. Napoli, $1855-56.48$ p. 4 pls. $4^{\circ}$.

1855.2

Su di un nuovo genere di pesce fossile [Cacus] Atti R. Accad. Sci. Napoli, 1855, 2, 234-238. 1855.3

- Sui pesci fossili di Bra, seconda memoria. [n. p.] 1855 [?] 9 p. pl. 1855.4

Descrizione di alcuni pesci fossili del Libano. Mem .R. Accad. Sci. Napoli, 1857, 2, 97-112 2 pls. 1857.1 
Ittiologia fossile Italiana. Edizione simile all' opera dell' Agassiz sui pesci fossili alla quale è destinata a sopplimento. Disp. v. Napoli, 185759. 4 pls. $4^{\circ}$

1857.2

- Sopra talune specialità anatomiche o fisiologiche de' pesci Selacini o Plagiostomi. Il Giamb. Vico, 1857, 1; 409-437; Ibid., 2, 113-115. 1857.3

Proposta di studi sugli organi sessuali maschili dei Selacini [Selachoidei] Bull. Accad. Aspir. Nat. Napoli, $1861,21$.

1861.1

Descrizione di alcuni fossili dell' isola Pianosa presso quella dell' Eilba, con illustrazioni e comenti sulla Fistulana echinata Brocchi; sopra i denti fossili del genere Sargus e Chrysophrys Valenciennes; sul genere Sphrrodus Agassiz; e sopra le specie a tal genere attribuite. Atti R. Istit. Incorag. Napoli, 1863, 11, 1-46.

1863.1

- Notizie intorno agli scavi recentemente eseguiti nella roccia ad ittioliti di Pietraroja. Rendic. R. Accad. Sci. Napoli, 1864, 3, 230-233.

1864.1

- Nuove osservazioni e scoperte intorno ai fossili della calcarea ad ittioliti di Pietraroja. Atti R. Accad. Sci. Napoli, 1865, 2, no. 22. 4 pls.Rendic. R. Accad. Sci. Napoli, 4, 395398.

1865.1

- Studi sopra $\mathrm{i}$ terreni ad ittioliti delle provincie Napolitane; diretti a stabilire l' età geologica de' medesimi. Parte seconda. Atti R. Accad. Sci. Napoli, 1865, 2, no. 16.3 pls. Also separate; Napoli, 1865. 33 p. 3 pls.

1865.2

-... Degli otoliti in generale, e iconografia di quelli propri de' pesci viventi nel Mediterraneo che bagna le provincie Napolitane e la Sicilia, seguita da quella de fossili dei terreni terziari delle medesime regioni. Atti $R$. Accad. Sci. Napoli, 1866-68, 3, no. 15. 29 p. - Rendic. R. Accad. Sci. Napoli, $1867,6,66-69$.

1866.1

Illustrazione di due ittioliti, del genere Lepidotus, recentemente ottenuti dagli scisti bituminosi del pettine presso Giffoni, seguita da talune critiche osservazioni su questo genere. Atti $R$. Accad. Sci. Napoli, $1866-68,3$, no. 12 , 1-10. 2 pls.

1866.2

Studi sopra i terreni ad ittioliti delle provincie Napolitane. Parte iv.
Atti R. Accad. Sci. Napoli, 1868, 3 no. 18.

1868.1

Coste, Jean Jacques Marie Cyprien Vicior [1807-1873] Notice historique sur l'établissement de pisciculture de Huningue. Paris, $1850 . \quad 1850.1$

Instructions pratiques sur la pisciculture; suivies de mémoires et de rapports sur le même sujet. Paris, 1853. pls. $12^{\circ}$.

1853.1

A German version was published at Quedlinburg in 1853, and a second French edition at Paris in 1856.

Rapport au ministre sur les industries de Commacchio, etc. Paris, 1855. fol.

1855.1

Voyage d'exploration sur le littoral de la France et de l'Italie. Paris, 1855. $4^{\circ}$.

1855.2

Report on the means of stocking all the streams of France with fish (In Garlick, Theodatus. A treatise on the artificial propagation of certain kinds of fish, p. 55-67. Cleveland, 1857. $8^{\circ}$ ) 1857.1

Instructions pratiques sur la pisciculture. 2. ed. Paris, 1858. 144 p. fig. $12^{\circ}$.

1858.1

Voyage d'exploration sur le littoral de la France et de l'Italie. Deuxième édition, suivi de nouveaux documents sur les pêches fluviales et marines. Paris, 1861. $4^{\circ}$. 1861.1

Practical instructions in fishraising (In Fry, W. H., editor. A complete treatise on artificial fishbreeding, p. 29-80. New York, 1866. $\left.12^{\circ}\right)$

1866.1

Voyage d'exploration sur le littoral de la France et de l'Italie; rapport sur les industries de Comacchio, du lac Fusaro, de Marennes et de l'anse de l'Aiguillon. Paris, 1866. $8^{\circ}$. 1866.2

The introduction contains the report dated Jan. 1st, 1855, concerning the "Etablissement de Huninge."

Durée de l'incubation des oeufs de roussette. C. R. Acad. Sci. Paris, 1867, 64, 99-100.-Ann. Mag. Nat. Hist., 1867, 3. ser. 19, $227 . \quad 1867.1$

Epoque du frai des principales espèces de poissons qui se reproduisent dans les eaux douces. Journ. des Fermes, 1869, 1. année, no. 12, 204-205.

1869.1 
Coste, J. J. M. ('. V. Instructions pratiques sur la pisciculture. Journ. des Fermes, 1869 , 1. année, no. 6, 91-93; no. 7, 109-110; no. $9,144-146$; no. $11,182-185$; no. 12 , 203-204; no. 13, 223-224; no. 16, 285287 ; no. $17,305-306$; no. $20,363-364$; no. $21,385-386$; no. $22,404-406.1869 .2$

Acclimatation des poissons. Paris, 1874. $8^{\circ}$. 1874.1

Coste, Jean J. M.C.V., \& MilneEdwards, Alphonse. See Milne-Edwards \& Coste.

Coste, $P$. Nidification des épinoches et des épinochettes. Mém. Savants Etrang., Paris, 1846, 10, 574-588. pl. Also separate; Paris, 1848. 4 1846.1

Sur la manière dont les épinoches construisent leurs nids et soignent leurs aufs. C. R. Acad. Sci. Paris, 1846, 22, 814-818. - Edinb. New Philos. Journ., 42, 322-327.

1846.2

Ueber den Nestbau des Gasterosteus aculeatus. Neue Notizen (Froriep), $1846,38,177-179$.

1846.3

- Segmentation d'une portion (la cicatricule) du vitellus pendant le passage de l'oeuf à travers l'oviducte, chez les oiseaux, les reptiles écailleux, et les poissons cartilagineux. C. R. Acad. Sci. Paris, 1847, 24, 623-624.

1847.1

Recherches sur la domestication des poissons et sur l'organisation des piscines. C. R. Acad. Sci. Paris, 1849, 29, 797-801.

1849.1

Origine de la cicatricule ou du germe chez les poissons osseux. C. R. Acad. Sci. Paris, 1850, 30, 692-693.

1850.1

Recherches sur la segmentation de la cicatricule chez les oiseaux, les reptiles écailleux, et les poissons cartilagineux. C. R. Acad. Sci. Paris, 1850 , 30, 638-642.

1850.2

Mémoire sur les moyens de repeupler les eaux de la France. C. R. Acad. Sci. Paris, 1853, 36, 237-245.

1853.1

Note sur l'acclimatation des poissons. Bull. Soc. Acclim., Paris, $1854,1,11-13 ; 75-79$.

1854.1

Observations sur une note insérée par M. Millet ... Bull. Soc. Acclim., Paris, 1854, 1, 75-79. 1854.2
Origine de la monstruosité double chez les poissons osseux. C. R. Acad. Sci. Paris, 1855, 40, 868-873; 931-933. 1855.1

Etudes sur les mours et sur la génération d'un certain nombre d'animaux marins. C. R. Acad. Sci. Paris, 1858, 47, 45-50. - Ann. Nat. Hist., 1858, 3. sér. 2, 197-202.

1858.1

Domestication des poissons de la famille des Pleuronectes. C. R. Acad. Sci. Paris, 1861, 52, 1058-1059.

1861.1 de vue de l'industrie des pêches. C. R. Acad. Sci. Paris, 1862, 44, 805-809.

1862.1

Instruction pour le transport des gouramis. Bull. Soc. Acclim., Paris, 1865, 2. ser. 2, 76-80.

1865.1

- Durée de l'incubation des œufs de roussette [Squalus catulus Linn.] C. R. Acad. Sci. Paris, 1867, 64, 99-100. - Ann. Mag. Nat. Hist., 1867, 3. ser. $19,227$.

1867.1

Cotta, Bernhard von [1808-1879] [Fischabdruck aus der Braunkohlenformation von Seifhennersdorf] Berg - \& Hüttenm. Zeitg., 1868, 27. Jahrg. (n.f. 22. Jahrg.), 174.

1868.1

Geologisches Repertorium mit einem vollständigen Index. Leipzig, 1877. 400 p. $8^{\circ}$. 1877.1

The half-title of this work reads: "Beiträge zur Geschichte der Geologie."

Cotteau, Gustave Honoré [1818-1894] Note sur le Ptycholepis bollensis des calcaires bitumineux de Vassy (Yonne) Bull. Soc. Sci. Yonne, 1865, 19, pt. 2, 337-340.

1865.1

Cotton, Charles, \& Walton, Izaak. See Walton \& Cotton.

Couch, Jonathan [1789-1870] Some particulars of the natural history of fishes found in Cornwall. Trans. Linn. Soc. London, 1822, 14, 69-92. - Mag. Nat. Hist., 5, 311-316. - Isis (Oken), 22, 1078-1089.

1822.1

On the use of the electrical faculty of the torpedo. Ann. Philos. (Thomson), 1823, n. s. 6, 156-157.

1823.1

Fishes new to the British fauna. Mag. Nat. Hist., $1832, \mathbf{5}, \mathbf{1 5 - 2 4 ;} 741$.

1832.1 
Treatise on the pilchard (Clupea pilchardus) Trans. Polytechn.Soc. Cornwall, 1835, 65-101.

1835.1

A description of the characteristics of a kind of Trigla hitherto confounded with the Trigla blochii. Mag. Nat. Hist., 1836, 9, 463-466. 1836.1

- A Cornish fauna, etc. Truro, 1838-44. 3 pts.

1838.1

Revised \& edited in 1878 by Thos. Cornish $\left(q . v_{*}\right)$

- Description of a species of ray fish [Raja asterias] not hitherto included in the British fauna. Mag. Nat. Hist., 1838, 2. ser. 2, 71-73.

1838.2

Observations on the lancelet (Amphioxus lanceolatus Yarr.) Mag. Nat. Hist., 1838, 2. ser. 2, 381-384. figs.

1838.3

Cyclopterus coronatus, coronated lump fish, Couch. Mag. Nat. Hist., 1839, 2. ser. 2, 382.

1839.1

Observations in further illustration of the history and statistics of the pilchard fishery. Trans. Polytechn. Soc. Cornwall, 1840, 11-26. 1840.1

- Account of a specimen of the oblong sun-fish (Orthagoriscus oblongus), taken at Par, in Cornwall, and preserved in the museum of the Royal Institution of Cornwall at Truro. Ann. Mag. Nat. Hist., 1841, 6, 144-145.

1841.1

- An account of fish nearly allied to Hemiramphus, taken in Cornwall. Proc. Linn. Soc. London (Zool.), 1842 1 , no. $15,151-152$.

1842.1

Note on the occurrence near Polperro, in Cornwall, of a fish new to the British catalogue, and supposed to be the Orphe of Rondelet. Zoologist, $1843,1,81-84$.

1843.1

- Account of a species of seabream, new to the British fauna, and perhaps hitherto undescribed. Zoologist, 1844, 2, 393-395.

1844.1

The natural history of the mackerel and its fishery, with a reference to others of the scomberoid family that have been taken in Cornwall. Rept. Roy. Polytechn. Soc. Cornwall, $1844,47-61$.

1844.2

On the ova of the large spotted dog-fish. Ann. Mag. Nat. Hist., 1844, 14, 25-26.
Account of the capture, in Cornwall, of the six-branchial or gray shark (Notidanus griseus Couch), but lately recognized in the British fauna. Zoologist, 1846, 4, 1337-1340. 1846.1

-... Description of a new ray. Zoologist, $1847,5,1880-1881 . \quad 1847.1$

- On the egg-purse and embryo of a species of Myliobatis. Rept. Brit. Assoc. Adv. Sci., 17. meet., 1847, 80.Trans. Nat. Hist. Soc. Penzance, 1851, 1, 151-154. fig.

1847.2

An account of a fish, nearly allied to the genus Hemiramphus, taken in Cornwall. Proc. Linn. Soc. London (Zool.), 1849, 1, 151-152.

1849.1

Description of Brama pinnasquamata, a supposed unrecognized British fish. Zoologist, 1849, 7, xxvixxviii.

1849.2

- Description of Scomber punctatus, a species of mackerel not hitherto recognized by naturalists. Zoologist, $1849,7,29-31$. - Trans. Nat. Hist. Soc. Penzance, 1851, 1, 352-355. fig.

1849.3

Account of the capture in Cornwall of the six-branchial or gray shark [Notidanus griseus] but lately recognized in the British fauna. Trans. Nat. Hist. Soc. Penzance, 1851, 1, 98-101.

1851.1

Addition of a new fish to the Cornish fauna. Trans. Nat. Hist. Soc. Penzance, 1851, 1, 284-285. $\quad 1851.2$

Capture of a species of Atherine (Atherina boyeri), new to the British fauna. Zoologist, 1S51, 9, 2992-2993.

1851.3

The recent capture, in Cornwall, of Hemiramphus europaus. Trans. Nat. Hist. Soc. Penzance, 1851, 1, 145148.

1851.4

On a supposed unrecognized fish of the genus Brama. Trans. Nat. Hist. Soc. Penzance, 1857, 1, 191-194. fig.

1857.1

Memoir of the natural history of the salmon tribe; from materials chiefly collected in Cornwall and the west of England. Trans. Polytechn. Soc. Cornwall, 1859, 1-29. $\quad 1859.1$

Remarks on the natural history of the Parr. Trans. Polytechn. Soc. Cornwall, 1860, 50-57. $\quad 1860.1$ 
Couch, $J$.

- The angler or toadfish. Intell. Observ., 1862, 1,353-362. fig. 1862.1

The history of the fishes of the British islands. London, 1862-65. 4 vols, illust. $8^{\circ}$. 1862.2

Vol. i. Chondropterygians, Percoids and Sparoids. 1862,245 p. $57 \mathrm{pls}$.

Vol. ii. Trigloids, Trachinoids, Sciænoids, Scombroids, Gobioids, Blennioids and Trachypteroids. $1863.265 \mathrm{p} .63 \mathrm{pls}$.

Vol. iii. Acanthopterygians, Pharyngognaths and Anacanthines. 1864. $208 \mathrm{p} .48 \mathrm{pls}$.

Vol. iv. Malacopterygians, Lophobranchians and Plectognaths. 1865.439 p. 73 pls.

There are two later editions; the second appeared in 1867-69 and the third in 1877.

- The skipper, skopster, or saury. Intell. Observ., 1862, 1, 46-49. 1862.3

- Ribband fishes of the genus Gymnetrus. Intell. Observ., 1863, 2 1-8. pl. \& figs.

1863.1

The sea lamprey [Petromyzon marinus! Intell. Observ., 1863, 2, 411417. pls. \& fig.

1863.2

The four-horned trunk fish (Ostracion quadricornis), a native of England. Intell. Observ., 1864, 5, $407-$ 409 .

1864.1

On two species of sharks believed to have been confounded together under the name of "basking shark." Trans. Nat. Hist. Soc. Penzance, 1864, 2, 234-237.

1864.2

Essay on the natural history of the pilchard [Clupea pilchardus] Ann. Rept. Roy. Cornwall Polytechn. Soc., 1865, no. $33,65-101$.

1865.1

- Additions to the fauna of Cornwall: Rhodophyton couchii, Ausonia curieri. Journ. Roy. Instit. Cornwall, $1866,2,154-160$.

1866.1

- A filefish of the Mediterranean, as distinguished from a species of the family (Balistes), that has been taken in Cornwall. Ann. Rept. Roy. Cornwall Polytechn. Soc., 1866, no. 34, 65-67.

1866.2

The fish Echeneis remora] obtained in Cornwall. Journ. Roy. Instit. Cornwall, 1866-67, 2, 361. 1866.3

On the occurrence on the coast of Cornwall of an example of the fish called Ausonia cuiveri or Luvaru. Proc. \%ool. Soc. London, 1866, 332-335. fig. - Journ. Roy. Instit. Cornwall, 1866$67,2,160-162$.

1866.4
Remarks on the structure and actions of the iris of the eye in some species of fishes. Intell. Observ., 1866, 8, 180-183.

1866.5

A history of the fishes of the British islands. 4 vols. 2. ed. London, 1867-69. illust.

1867.1

- Report of the proceedings in several dredging excursions on the south-east coast of Cornwall, in the summer of 1866. Ann. Rept. Cornwall Polytechn. Soc., 1867, no. 35, 64-70.

1867.2

Irregularities of structure in fishes. Student \& Intell. Observ., 1868, 1, 328-336.

1868.1

On the structure and manner of growth of the scales of fishes. Intell. Observ., 1868, 12, 246-253.

1868.2

Some account of newly discovered British fish of the family Gadidre and the genus Couchia. Journ. \& Proc. Linn. Soc. London Zool., 1868, 9, 38-41. fig.

1868.3

Mullus surmuletus: habits of the surmullet in ancient as compared with modern times. Student \& Intell. Observ., 1869, 2, 368-372.

1869.1

Couch, Richard Quiller [1816-1863] A natural history of the mackerel. Ann. Rept. Cornwall Polytechn. Soc., 1844, no. 14, 47-61.

1844.1

Notes on the nidification of fishes. Zoologist, 1844, 2, 795-799.

1844.2

- Notes on the fishes of the district of the Land's End. Zoologist, $1846,4,1400-1419$; $1847,5,1608-1614$; $1644-1648 ; 1705-1714 ; 1822-1831 ; 1848$, $6,1972-1980$.

1846.1

Notice of the capture of two rare British fishes in Mount's bay. Trans. Nat. Hist. Soc. Penzance, 1851, $1,95-97$.

1851.1

On a new muscle discovered in the eye of fishes. Trans. Nat. Hist. Soc. Penzance, 1851, 1, 97. 1851.2

On the mackerel. 'Trans. Nat. Hist. Soc. Penzance, 1S51, 1, 223-228.

1851.3

On the migrations of the pilchard [Clupea pilchardus] Trans. Nat. Hist. Soc. Penzance, 1851, 1, 126-144. 1851.4 
Occurrence of the black fish (Centrolophus pompilus Cuv.) in Mount's bay. Zoologist, 1859, 17, 6335. 1859.1

On the occurrence of the derbio (Lichia glaucus Cuv.) in Mount's bay. Zoologist, 1859, 17, 6333-6335. 1859.2

Notice of the capture, in Mount's bay, of Pennant's globe-fish ['Tetrodon pennantii] Trans. Nat. Hist. Soc. Penzance, 1864, 2, 34-36. 1864.1

Notice of the capture of a sturgeon differing from those recognised as British. Trans. Nat. Hist. Soc. Penzance, 1864, 2, 17-18.

1864.2

On the nest of the fifteen-spined stickleback. Trans. Nat. Hist. Soc. Penzance, 1864, 2, 79-83. 1864.3

- Remarks on the capture of the fox or thrasher shark [Alopecias vulpes] in Mount's bay. Trans. Nat. Hist. Soc. Penzance, 1864, 2, 223-224. 1864.4

Couchman, J. W. Transporting carp from the United States Fish Commission to Brazil. Bull. U. S. Fish Comm. 1882 (1883), 2, 382. 1883.1

Coues, Elliott [1842-1899] Note on Hemirhamphus [richardi?] Amer. Naturalist, $1872,6,49$.

1872.1

Couffon, Olivier. Etude critique sur les faluns du Haguineau. Bull. Soc. Etud. Sci. Angers, 1904, n. s. 33, 35-85. 2 figs.

1904.1

Contains references to fish.

Les faluns de l'Anjou et de la Touraine dans le Saumurois. Bull. Soc. Etud. Sci. Angers, 1904, n. s. 33, 216223.

1904.2

Contains references to fish.

Etude critique sur les faluns de Chalonnes (Gisement des PierresBlanches) Bull. Soc. Etud. Sci. Angers, 1905, n. s. 34, 155-222. pl. \& fig. 1905.1 Pisces, p. 212-213; 220.

Coulon, Louis [1605-1664] Les poissons fossiles du Musée d'Histoire Naturelle d'Elbeuf, avec notes spéciales sur les espèces de la Seine-Inférieure. Bull. Soc. Etud. Sci. Nat. Elbeuf, 1903. 21, 99-162. 2 pls.

1903.1

Un séjour à Dieppe au point de vue de l'histoire naturelle. 2. Les vertébrés marins. Bull. Soc. Etud. Sci. Nat. Elbeuf, 1905, 23, 109-137. 1905.1
Coumes, - Notice historique sur l'établissement de pisciculture de Huningen. Strassbourg, 1862. 143 p. illust. $8^{\circ}$.

1862.1

Rapport sur la pisciculture et la pêche fluviatiles en Angleterre, en Ecosse et en Islande, considérées au double point de vue des procédés de production, tant naturelle qu'artificielle, et de la législation qui protège le peuplement des cours d'eau. Strassbourg, 1863. 104 p. $8^{\circ}$. 1863.1

- Note sur l'organisation et la surveillance de la pêche fluviale dans la Grande-Bretagne. Paris, 1881. 1881.1

Couper, William. Salmo wilmoti. Forest \& Stream, 1880, 15, 9; 277.

1880.1

Silver bass. Forest \& Stream $1880,15,247 . \quad 1880.2$

Coupin, Henri. L'aquarium d'eau douce et ses habitants. Paris, 1893. 348 p. 228 figs. $12^{\circ}$ 1893.1

- Les poissons commensaux. Rev. Scient., Paris, 1899, 4. ser. 11, 433-436. 1899.1

_- Soins donnés aux jeunes par les poissons. Ia Nature, 1901, 29, pt. 2, 244-247. 3 figs. 1901.1

-.. Les poissons qui parlent. La Nature, 1904, 32, pt. 1, 379. 1904.1

L L'élevage de la sole. La Nature, 1905, 33, pt. 2, 204-206. 3 figs. 1905.1

Les moyens de défense des poissons. La Nature, 1913, 41, pt. 2, 104-106. 10 figs.

1913.1

Courcy, (Le Marquis) _ de. L'empire du milieu (la Chine); description géographique, précis historique institutions sociales, religieuses, politiques; notes sur les sciences, les arts, l'industrie et le commerce. Paris, 1866. $S^{\circ}$.

1866.1

Poissons d'eau salée et poissons d'eau donce, p. 161-162. Industrie des pêcheurs; engins de pêche; ruses des pêcheurs, pisciculture, etc. p. $462-465$

Courtenay, J.S. Statistics of the pilchard fishery for the years 1838 and 1839. Trans. Cornwall Polytechn. Soc., $1840,27-34$.

1840.1

A guide to Penzance and its neighborhood, including the islands of Scilly, with an appendix containing the natural history of western Cornwall ... Penzance, 1845. vi, 223 p. 7 pls. \& map. $\mathrm{S}^{\circ}$. 
Coutaud, $H$. Observations sur sept cas d'empoisonnement par le foie de requin à l'île des Pins (NouvelleCalédonie) en 1873. Inaug. Dissert., Montpellier, 1879. 47 p. $4^{\circ}$. 1879.1

Coutière, $H$. Poissons venimeux et poissons vénéneux. Paris, 1899. 1899.1

Les poissons nuisibles. Causeries Sci. Soc. Zool. France, 1900, 25-36.

1900.1

- Sur la non-existence d'un appareil à venin chez la murène hélène. C. R. Mém. Soc. Biol. Paris, 1902, 54, $787-788$.

1902.1

_. Sur le prétendu appareil venimeux de la murène hélène. Bull. Soc. Philom. Paris, 1907, 9. ser. 9, 229-234. 3 figs.

1907.1

Couvreur, $E$. Etude sur la respiration des poissons. Mécanisme respiratoire chez les cyclostomes. Ann. Soc. Linn. Lyon, 1895, 44, 105-109. figs. Abstract in Journ. Roy. Micr. Soc., 1898, 24.

1898.1

- Sur le mécanisme respiratoire de la torpille. C. R. Mém. Soc. Biol. Paris, 1902, 54, 1252-1253.

1902.1

Sur la respiration de la torpille. Ann. Soc. Linn. Lyon, 1903, 49, 78-79. 1903.1

Coward, T.A. (editor) The vertebrate fauna of Cheshire and Liverpool bay. 2 vols. London, 1910. 1910.1.

Pisces, by James Johnstone, vol. ii, p. 59-168.

The smelt in Rostherne mere. Mem. Proc. Manchester Liter. Philos. Soc., 1912, 56, no. 15, 1-2. 2 figs.

1912.1

Cowdry, C. C. Fish preying upon mosquito larva in Uganda. Bull. Entom. Research, 1911, 2, 182. 1911.1

Cowe, Robert. The white-fishery on the coast of Berwichshire. Hist. Berwick. Nat. Club, 1834, 1, 219-228.

1834.1

Cox, Irwin Edward Bainbridge [1838 -] 'The Angler's Diary, or, forms for registering the fish taken during the year; to which is prefixed a list of fishing stations in England. London, 1866-67. $4^{\circ}$.

1866.1

Facts and useful hints relating to fishing and shooting ... edited by I. E. B. C. [i.e., I. E. B. Cox ] London, 1866. 115 p. illust. $S^{\circ}$. 1866.2
The Angler's Diary and fisherman's guide to the rivers and lakes of the world, to which is added forms for registering the fish taken during the year. London, 1868. $4^{\circ}$. 1868.1

The Angler's Diary and fisherman's guide to the rivers and lakes of the world; to which are added a list of rivers of Great Britain, with their stations; also forms for registering the fish taken during the year. London, 1877. $8^{\circ}$.

1877.1

Cox, $P$. Observations on the distribution and habits of some New Brunswick fishes. Bull. New Brunswick Nat. Hist. Soc., 1893, 11, 33-42.

1893.1

- Fresh-water fishes and batrachia of the peninsula of Gaspé, P.Q., and their distribution in the maritime provinces of Canada. Trans. Roy. Soc. Canada, 1900, 2. ser. 5, 141-154. 1900.1

Cox, Ross. Adventures on the Columbia river, including the narrative of a resident of six years on the western side of the Rocky mountains. 2 vols. London, 1831. 768 p. $8^{\circ}$. 1831.1 Fisheries, vol. ii, p. 129, 249, 304, 366 .

Cox, S. S. Address on various aspects of fishing and the fisheries. Trans. Amer. Fisheries Soc. 1884 (1885), 91109.

1885.1

Cox, Ulysses 0 . A report upon the fishes of southwestern Minnesota. Rept. U.S. Fish Comm. 1894 (1896), 20, 605616.

1896.1

A revision of the cave fishes of North America. Rept. U. S. Bur. Fisheries, 1905, 377-393. 6 pls. \& figs.

1905.1

Cox, Ulysses O., \& Eigenmann, Carl $H$. See Eigenmann \& Cox.

Cox; Ulysses O., \& Evermann, Barton Warren. See Evermann \& Cox.

Cox, William van Zant. A glance at Billingsgate. Trans. Amer. Fisheries Soc. 1885 (1886), 76-85. 1886.1

- Transporting fish in the British Isles. Trans. Amer. Fisheries Soc. 1886 (1887), 56-58.

1887.1

Coxe, Frank. Opening the Broad and other rivers of North Carolina to shad, bass, etc. Bull. U.S. Fish Comm. $1884,4,232$.

1884.1 
Coxe, William [1747-1828] Catalogue des poissons du lac de Neuchâtel. Paris, 1790.

1790.1

There is also an edition of this work in German.

Cozette, $P$. Les parasites des poissons, parasites végétaux [Saprolégniacées, Monoblépharidées] C. R. Cong. Soc. Sav., Paris, 1906 (Sect. Sci.), 138168

1906.1

Cragin, Francis Whittemore. Note on the chestnut lamprey [Petromyzon castanerus] Bull. Washburn. Coll. Lab. Nat. Hist., 1885, 1, no. 3, 99-100.

1885.1

Preliminary list of Kansas fishes.

Bull. Washburn Coll. Lab. Nat. Hist., 1885, 1, 105-111.

1885.2

- Vertebrata from the Neocomian of Kransas. Colorado College Stud., Sci. Sect., 1894, 5, 64-73. 2 pls. 1894.1

- A study of some teleosts from the Russell substage of the Platte Cretaceous series. Colorado College Stud., Sci. Sect., 1901, 9, 25-37. 3 pls. 1901.1

Craigie, D. On the anatomical peculiarities of the sturgeon [Acipenser sturio] Mem. Wern. Soc. Edinb., 1826 (1830), 6, 334-364.

1830.1

Cramer, Frank. Description of a little-known Agonoid fish, Hippocephalus japonicus. Proc. Cal. Acad. Sci., 1894, 2. ser. 4, 147-153. pl. 1894.1

On the cranial characters of the genus Sebastodes (rockfish) Proc. Cal. Acad. Sci., 2. ser. 1895, 5, 573-610. 2 pls.

1895.1

Cramer, Frank, \& Gilbert, Charles Henry. See Gilbert \& Cramer.

Cramer, Rudolf. Ueber Mene rhombeus (Volta sp.) Zeitschr. Deutsch. Geol. Ges., 1906, 58, 181-212. pl.\& 8 figs.

1906.1

Crandall, J.S. Statement concerning the menhaden fishery. Rept. U. S. Fish Comm. 1877 (1879), 5, 427. 1879.1

Crandall, Lee $S$. On Alfaro cultratum. Copeia, New York, 1914, no. 13 4.

1914.1

Crane, (Miss) Agnes. On certain genera of living fishes and their fossil affinities. Geol. Mag., 1877, 4, 209219. - Proc. Brighton Nat. Hist. Soc., 24, 44-58. - Proc. Geol. Assoc., 5, no. 3. 1877.1
Boar-fishes [Capros aper] at the Brighton aquarium. Sci. Gossip, 1879 , 15,161 . 1879.1

Cranston, $C . K$. The fish and game laws of Oregon. Trans. Amer. Fisheries Soc. 1912 (1913), 75-88.

1913.1

Cranz, David [1723-1777] Historie van Groenland, behelzende eene naauwkeurige beschryvinge van's lands ligging, gesteldheid, en natuurlijke zeldzaamheden, den aart, zeden en gewoonten der inwooneren, etc. 3 vols. Haarlem, 1767. $8^{\circ}$

1767.1

A second Dutch edition of this work was published in 1786. An English version by J. Gambold appeared in 1767, and there are German translations of 1765 and 1771 .

Crawford, George $W$. Fish in Nebraska - Products of the "Elkhorn Wreck." Forest \& Stream, 1876, 6, 266.

1876.1

Crawford, $J$. On the rectal glands of the elasmobranchs. Proc. Roy. Soc. Edinb. 1900 (1901), 23, 55-60. pl.

1901.1

Crawshay, L. R. On an experiment in the keeping of salmon (Salmo salar) at the Plymouth laboratory. Journ. Mar. Biol. Assoc., 1908, n. s. 8, 303312. pl.

1908.1

Credner, Carl Hermann [1841-] Die Kreide von New Jersey [Coprotithus (Macropoma) mantelli] Zeitschr. Deutsch. Geol. Ges., 1870, 22, 191-251. 1870.1

Creighton, Robert $J$. Exportation of salmon and whitefish ova to New Zealand in 1876. Rept. U. S. Fish Comm. 1875-76 (1878), 4, 970-979.

1878.1

- Shipment of salmon and whitefish ova to New Zealand and Australia in 1877 and 1878. Rept. U. S. Fish Comm. 1878 (1880), 6, 839-842. 1880.1

Fish-culture in New Zealand. Bull. U. S. Fish Comm. 18s1, 1, 51-52. 1881.1

Cremer, $J$. Die Matte'sche Zierfischzuchtanstalt in Iakwitz bei Berlin. Nat. Wochenschr., 1897, 12, 547-549. fig.

1897.1

Cremer, Max. Ueber die Einwirkung von Forellensamenpressaft auf Forelleneier. Sitzber. Ges. Morph. Physiol. München, 1900, 17, 111.

1900.1 
Cremer, $M$.

- Ueber den Reflexschlag von Torpedo, aufgenommen mit dem Saitenelektrometer. Verh. Ges. Deutsch. Naturf. Aerzte, 80. Versamm., 1909, 523.

1909.1

Ueber den Verlauf des Schlages von Malapterurus electricus. Zentralbl. Physiol., 1912, 26, 981-984.- Med. Klinik, 8. Jahrg., 1727-1728. 1912.1

Cremony, John C. Mackerel catching. Overland Monthly, 1870, 4, 161168 .

1870.1

Creon, - Some disorders of freshwater fishes. Fish. Gazette, 1878, n. s. $2,73-74$.

1878.1

Creplin, $F . C . H$. Die Fische in den Scheeren von Mörkö, . . aus dem Schwedischen [von C. U. Ekström] übersetzt und mit einigen Anmerkungen versehen von ... F. C. H. Creplin. 1835. $8^{\circ}$.

1835.1

Ueber die Fortpflanzungsweise des Aals. Arch. Naturgesch., 1841, 7, pt. 1, 230-233.

1841.1

Beschreibung der Psorospermien des Kaulbarsches nebst einigen Bemerkungen über die der Plötze und andere. Arch. Naturgesch., 1842, 8, 61-66. pl. $\&$ figs.

1842.1

Crespigny, $C . C . d \epsilon$. Notes on the friendship existing between the malacopterygian fish Premnas biaculeatus and the Actinia crassicornis. Proc. Zool. Soc. London, 1869, 248-249. 1869.1

Crespon, $J$ : Faune méridionale, ou description de tous les animaux vertébrés vivants et fossiles... sauvages ou domestiques qui se rencontrent toute l'année ou qui ne sont que de passage dans la plus grande partie du midi de la France. Nîmes, 1844.

1844.1

Cresswell, Richard (editor) Aristotle's History of animals. 10 books. London, 1887.

1887.1

Cretté de Palluel, Albert. Ennemis peu connus des oiseaux d'eau. Ornis, Paris, 1902-03, 12, 118.

1902.1

Crettiez, Jean. Sur la culture de l'ombre-chevalier [Salvelinus umbla I..] du Léman ì l'établissement de pisciculture de 'Thonon. Métis et hybrides de ce salmonide. C. R. Assoc. Franc. Avanc. Sci., 35. sess., 1906, 119; 498506. - Bull. Suisse Pêche, 8, 4-7; 2629.

1906.1
- Sur la reproduction artificielle des corégones. C. R. Assoc. Franc. Avanc. Sci., 35. sess., 1906, 118-119; 494-498. - Bull. Soc. Centr. Aquicult. Paris, 19, 97-101.

1906.2

Crevatin, Francesco. Ueber das sogenannte Stäbchennetz im elektrischen Organ der Zitterrochen. Anat. Anz., 1898, 14; 243-250. 2 figs. 1898.1

- Contributo alla conoscenza del rene de' pesci. Della diversa maniera di cellule dei canalicoli renali. Rendic. $R$ Accad. Sci. Istit. Bologna, 1904, n. s. 8 , 54-55.

1904.1

Crèvecœur, $F$. F. A new species of fish [Etheostoma arcus-celestis, n. sp.] Trans. Iransas Acad. Sei., 1903, 18, $177-178$.

1903.1

A new species of 'Campostoma? Trans. Kansas Acad. Sci., 1908, 21, 155157. 1908.1

Crichton-Browne, James. Dexterity and the bend sinister. Proc. Roy. Instit. Great Brit., 1907, 18, 623-652. 10 pls. \& 6 figs.

1907.1

Discussion of asymmetry of flat-fishes, $p$. 648-649

Crisafulli, $E$. Il telencefalo degli Scyllii. Riv. Patol. Nerv. Firenze, 1901, 6, 481-490. fig.

1901.1

Ricerche comparative di elettrofisiologia e fine anatomia sui nervi elettrici. Giorn. Assoc. Med. Nat. Napoli, $1901,11$.

1901.2

Crisp, Edwards. On some points relating to the structure and mechanism of the wolf-fish [Anarrhichas lupus] Ann. Mag. Nat. Hist., 1853, 2. ser. 11, 463466.

1853.1

On the situation, form and capacity of the gall-bladder in the vertebrata, on its absence in certain cases, and on the colour of the bile. Proc. Zool. Soc. London, 1862, 132-139.

1862.1

On the change of colour in the common trout [Salmo fario] Proc. Zool. Soc. London, 1864, 166.

1864.1

Crispo-Barbaro, George. The fishes of Malta, with their Maltese, Italian, and English names and season. 2. ed. Malta, 1877. 13 p. $8^{\circ}$. 1877.1

Crivelli, Giuseppe Gabriel Balsamo. Sec Balsamo-Crivelli, $G$. 
Crivelli-Serbelloni, $G$. La memoria nei pesci. Acquicolt. Lombard., 1900, 2. anno, 317-321.

1900.1

Crocker, Timothy. Condition of the shore fisheries of Massachusetts and Rhode Island in 1871. Rept. U. S. Fish Comm. 1871-72 (1873), 1, 50-53. 1873.1

Cronheim, Waller. Die Bedeutung der Mineralstoffe für das Wachstum des Ḱarpfens. Allgem. Fischereizeitg., 1908, $33,114-120$.

1908.1

Gesamtstoffwechsel der Nichtsäuger. I. Die kaltblütigen Wirbeltiere (In Oppenheimer, C. Handbuch der - chemic, etc. Jena, 1910. Bd. iv, ieil ii, p. 405-445)

1910.1

_- Beiträge zur Kenntnis der Nahrungsaufnahme der Karpfen. Zeitschr. Fischerei, 1911, 15, 111-119. 1911.1

Gesamtstoffwechsel der Kaltblütigen Wirbeltiere, im besonderen der Fische. Zeitschr. Fischerei, 1911, 15, 319-370.

1911.2

Cronheim, Walter, \& Schiemenz, Paul. Die Schädigung der Fischerei in der Obra durch die Stärkefabrik in Bentschen. Zeitschr. Fischerei, 1901 9, 81-109.

1901.1

Cronheim, _.., Debschitz, H.von, Knauthe, Karl, Apstein, $C$., Berthelmann, \& Borcherding, Fr. See Knauthe, Apstein, \& others.

Crook, Alja Robinson [1864-] Ueber einige fossile Knochenfische aus der Mittleren Kreide von Kansas. Palæontogr., 1892, 39, 107-124. 4 pls. 1892.1

Crooks, Sl.John. Occurrence of the sun-fish [Orthagoriscus mola] at Sunderland. Trans. Tyneside Nat. Field Club, 1860, 4, 187-188.

1860.1

Crosby, John Schuyler. Stocking the streams of Montana with fish. Bull. U. S. Fish Comm., 1883, 3, 301-302.

1883.1

Crossland, Cyril. The flight of Exocotus. Nature, 1911, 86, 279-280.

1911.1

Crowe, - Notes on Iceland and its fisheries. Nautical Mag., 1869, 669682.

1869.1

Crowell, Alexander. Condition of the shore fisheries of Massachusetts and Rhode Island in 1871. Rept. U. S. Fish Comm. 1871-72 (1873), 1, 49.
Crumplen, $T$. A paper on the causes of the apparent diminution of fish in the river Thames; with remedial suggestions. Gresham Angling Soc. Papers, sess. 188283. Also separate; London, 1881. $8^{\circ}$.

1881.1

Cuénot,Lucien. Anatomie comparée de l'appareil pulmonaire des poissons. Vessie natatoire. [n. p. 1887?] 1887.1

- Les poissons commensaux et parasites. Le Naturaliste, Paris, 1892 , 14, 53-57. figs.

1892.1

De l'adaptation au manque d'eau ct à la vie terrestre. Poissons. Le Naturaliste, 1895, 2. ser. 9, 11-14; 20-22. figs.

1895.1

Les moyens de défense chez les animaux. Bull. Soc. Zool. France, 1898, 23, 37-58. figs. 1898.1

___ Présentation d'une sole à deux faces colorées. C. R. Mém. Soc. Biol. Paris, 1905, 58, 914-916. - Réunion Biol. Nancy, 1905, 63-65. 1905.1

Sur une sole à deux faces colorées. Trav. Labor. Soc. Sci. Stat. Biol. Arcachon 1905 (1906), 8, 82-89. fig.

1906.1

Néphrophagocytes dans le cour et le rein des poissons osseux. C. R. Mém. Soc. Biol. Paris, 1907, 1, 750-752. - Réunion Biol. Nancy, 1907, 30-32.

1907.1

Les néphrophagocytes du cœur des poissons osseux. Zool. Jahrb., 1912 15. Suppl., 3, 241-252. pl. 1912.1

Culbertson, Glenn. A note on the breeding habits of the common or white sucker [Catostomus teres] Proc. Indiana Acad. Sci. 1903 (1904), 65-66. 1904.1

Cummings, Bruce $F_{\text {. Some fish }}$ notes from the north Devon coast. Zoologist, 1907, 4. ser. 11, 140-142.

1907.1

Cummings, $H$. Some practical observations on trout culture. Gresham Angling Soc. Papers, sess. 1882-83. Also separate; London, 1882. 1882.1

Cundall, Frank. Bibliotheca Jamaicensis. Some account of the works on Jamaica in the library of the Institute. Kingston, Jamaica, 1895.38 p. $8^{\circ}$.

1895. 1

Another edition was published at Kingston in $1902.83 \mathrm{p} .8^{\circ}$. 
Cundall, $F$ :

- Bibliography of the West Indies . . Kingston, 1909. 1909.1

Cunisset-Carnot, _ L La vie des poissons pendant l'hiver. Bull. Suisse Pêche Piscicult., Neuchâtel, 1909, 10, 2-7.

1909.1

Cunningham, Joseph Thomas. Critical note on !the latest theory in vertebrate morphology. Proc. Roy. Soc. Edinb., 1884, 12, 758-765. 3 pls. 1884.1

- On the nature and significance of the structure known as Kupffer's vesicle in teleostean embryos. Proc. Roy. Soc. Edinb., 1885, 13, 4-14. 2 pls.

1885.1

On the relations of the yolk to the gastrula in teleosteans, and in other vertebrate types. Quart. Journ. Micr. Sci., 1885, 26, 1-35. 4 pls. - Proc. Roy. Soc. Edinb., 1885, 167-171. 1885.2

_- Significance of Kupffer's vesicle and remarks on other questions of vertebrate morphology. Quart. Journ. Micr. Sci., 1885, 25, 1-15. pl. 1885.3

On the mode of attachment of the ovum of Osmerus eperlanus. Proc. Zool. Soc. London, 1886, 292-295. pl.

1886.1

The reproductive organs of Bdellostoma, and a teleostean ovum from the west coast of Africa. Trans. Roy. Soc. Edinb., 1886, 33, pt. 1, 247250. Abstract in Journ. Roy. Micr. Soc., 1888, pt. 2, 192-193.

1886.2

Salmonidæ. Encyclopædia Britannica, 9. ed., 1886, 20, 221-227.

1886.3

Dr. Dohrn's inquiries into the evolution of organs in the Chordata. Quart. Journ. Micr. Sci., 1887, n. s. 27, 265-284.

1887.1

- Herr Max Weber and the generative organs of Myxine. Zool. Anz., 1887, 10, 241-244.

1887.2

On the development of the oviduct in teleosteans. Proc. Roy. Phys. Soc. Edinb., 1887, 116, 342-345.

1887.3

On the structure and development of the reproductive elements in Myxine glutinosa L. Quart. Journ. Micr. Sci., 1887, n. s. 27, 49-76. 2 pls. Review in Tijdschr. Neder. Dierk. Ver., 2. ser. 1 , ccxiil-ccxvi.
- Ova of Myxine. Zool. Anz., 1887, 10, 390-392. - Quart. Journ. Micr. Sci., 27, 49-76.

1887.5

Preliminary inquiries at Plymouth into the marine fauna and the ova of fishes. Journ. Mar. Biol. Assoc., $1887-88,1,194-201$.

1887.6

- The eggs and larvæ of teleosteans. Trans. Roy. Soc. Edinb., 1888, 33, pt. 1, 97-136. 7 pls.

1888.1

- Remarks on some teleostean ova, and their development. Rept. Brit. Assoc. Adv. Sci., 58. meet., 1888, 703-704.

1888.2

- Anchovies in the English channel. Journ. Mar. Biol. Assoc., 1889-90, n. s. 1, 328-339. fig. 1889.1

Colour-changes in Cottus bubalis. Journ. Mar. Biol. Assoc., 1889-90, n. s. 1, 458-459.

1889.2

- The rearing of larval fish. Journ. Mar. Biol. Assoc., 1889-90, n. s. 1, 370-375. 1889.3

- Studies of the reproduction and development of teleostean fishes occurring in the neighbourbood of Plymouth. Journ. Mar. Biol. Assoc., 188990, n. s. $1,10-54$. 6 pls. $\quad 1889.4$

The vernacular names of common fishes. Journ. Mar. Biol. Assoc., $1889-90$, n. s. $1,92-94$. 1889.5

On the secondary sexual characters in the genus Arnoglossus. Proc. Zool. Soc. London, 1890, 540-546.

1890.1

A treatise on the common sole (Solea vulgaris), considered both as an organism and as a commodity. Prepared for the Marine Biological Association of the United Kingdom. Plymouth, 1890.147 p. 18 pls. $4^{\circ}$. Abstract in Ann. Mag. Nat. Hist., 1890,6 . ser. 6,497 .

1890.2

The distribution of Crystallogobius nilssonii. Journ. Mar. Biol. Assoc., 1891-92, n. s. 2, 158. Rept. Brit. Assoc. Adv. Sci., 61. meet. 1891 (1892), 687.

1891.1

The egg and larva of Callionymus lyra. Journ. Mar. Biol. Assoc., 1891-92, n. s. 2, 89-90. pl. 1891.2

An experiment concerning the absence of color from the lower sides of flat-fishes. Zool. Anz., 1891, 14, 27-32. fig. 
Ichthyological contributions. Journ. Mar. Biol. Assoc., 1891-92, n. s. 2, 325-332. pl.

1891.4

i. Zeugopterus norvegicus (Günther) ii. On a stage in the metamorphosis of Solea. iii. 1 larval stage of the mackerel. iv. Growth of young herring in the Thames estuary.

On some disputed points in teleostean embryology. Ann. Mag. Nat. Hist., 1891, 6. ser. 7, 203-221. 1891.5

On some larval stages of fishes. Journ. Mar. Biol. Assoc., 1891-92, n. s. 2, 68-74, 2 pls.

1891.6

On the rate of growth of some sea fishes, and the age and size at which they kegin to breed. Journ. Mar. Biol. Assoc., 1891-92, n. s. 2, 222-264.

1891.7

On the reproduction and development of the conger. Journ. Mar. Biol. Assoc., 1891-92, n. s. 2, 16-42.

1891.8

The rate of growth of some sea fishes and their distribution at different ages. Journ. Mar. Biol. Assoc., 1891-92, n. s. 2, 95-118. $\quad 1891.9$

Report on the probable ages of young fish collected by $\mathrm{Mr}$. Holt in the North sea. Journ. Mar. Biol. Assoc., 1891-92, n. s. 2, 344-362.

1891.10

The reproduction and growth of the pilchard. Journ. Mar. Biol. Assoc. 1891-92, n. s. 2, 151-157. pl. 1891.11

The evolution of flat-fishes. Natural Sci., 1892, 1, 191-199; 635638.

1892.1

The growth of the pilchard or sardine. Nature, $1892,45,255-256$.

1892.2

On the growth of food-fishes and their distribution at different ages. Rept. Brit. Assoc. Adv. Sci., 61. meet. 1891 (1892), 685-686.

1892.3 558.

Pilchards. Nature, 1892, 45,

- Recent additions to our knowledge of the natural history of some Devonshire sea fish. Rept. Devonshire Assoc. Adv. Sci., 1892, 24, 470-475.

1892.5

- Spermatogenesis in Myxine glutinosa. Quart. Journ. Micr. Sci., 1892,
33, 169-186. pl. - Zool. Anz., 1892, $14,22-27$.

1892.6

- Experiments and observations made at the Plymouth laboratory. Journ. Mar. Biol. Assoc., 1893-95, n. s. 3, 247-277. 3 figs.

1893.1

i. Diagnostic characters in flat fishes. ii. The development of the egg in flat fishes and pipefishes. iii. A piebald plaice. iv. Growth and distribution of young food-fishes. V. Notes on rare or interesting specimens.

Experiments on the rearing of fish larvæ in the season of 1894. Journ. Mar. Biol. Assoc., 1893-95, n. s. 3, 206207.

1893.2

Fishery publications of the United States. Journ. Mar. Biol. Assoc., 1893-95, n. s. 3, 236-245.

1893.3

The immature fish question. Journ. Mar. Biol. Assoc., 1893-95, n. s. $3,54-77$.

1893.4

The larva of the eel. Journ. Mar. Biol. Assoc., 1893-95, n. s. 3, 278-287. fig. - Bull. Soc. Centr. Aquicult. France, 1895, 7, 37-4S. 1893.5

The life-history of the pilchard. Journ. Mar. Biol. Assoc., 1893-95, n. s. 3, 148-153. 3 figs. 1893.6

The migration of the anchovy; summary of a report to the council of the association. Journ. Mar. Biol. Assoc., 1893-95, n. s. 3, 300-303. 1893.7

- On the destruction of immature fish, and a discussion on remedial measures. By the staff of the Marine Biological Association. Part 3. The protection of immature fish. Rept. Brit. Assoc. Adv. Sci., 62. meet. 1892 (1893), 767-768. 1893.8

The ovaries of fishes. Journ. Mar. Biol. Assoc., 1893-95, n. s. 3, 154165. 6 figs.

1893.9

Researches on the coloration of the skins of flat-fishes. Journ. Mar. Biol. Assoc., 1893-95, n. s. 3, 111-118.

1893.10

Young stages of Zeugopterus punctatus. Journ. Mar. Biol. Assoc., $1893-95$, n. s. 3, 202-205. 1893.11

Flat-fishes. Ann. Rept. Plymouth Instit., 1894, 11, 30-42. 2 pls.

1894.1 
Cunningham, $J . T$.

Additional evidence on the influence of light in producing pigments on the lower sides of flat fishes. Journ. Mar. Biol. Assoc., 1895-97, n. s. 4,5359.

1895.1

North sea investigations. Journ. Mar. Biol. Assoc., 1895-97, n. s. 4, 10 47.

1895.2

i. Statistics of small fish landed at Grimsby ii. Notes on the general course of the fishing. iii. Observations on the natural history of plaice. iv. On the relations of the generative organs, and of the sexes, in some fishes. $V$. Two trips to the Eastern grounds.

North sea investigations. Journ. Mar. Biol. Assoc., 1895-97, n. s. 4, 97 143.

1895.3

i. The size of mature plaice, turbot and brill on different fishing grounds. ii. Observations at sea and in the markets. iii. Causes of the observed distribution of fish in the North sea. iv. Proposed restrictions on the landing of undersized plaice in the light of the new evidence.

- On a specimen of Leptocephalus morrisii. Journ. Mar. Biol. Assoc., $1895-97$, n. s. $4,73-74$. 1895.4

- On the peculiarities of plaice from different fishing grounds. Journ. Mar. Biol. Assoc., 1895-97, n. s. 4, 315359. fig.

1895.5

The origin of species among flatfishes. Natural Sci., 1895, 6, 169-177; $233-239$

1895.6

Physical and biological conditions in the North sea. Journ. Mar. Biol. Assoc., $1895-97$, n. s. 4, 233-263.

1895.7

- Recent reports of fishery authorities. The Scottish, Newfoundland, and United States reports. Journ. Mar. Biol. Assoc., 1895-97, n. s. 4, 203213.

1895.8

The reproductive maturity of the common eel. Journ. Mar Biol. Assoc., 1895-97, n. s. 4, 87-88. fig

1895.9

The size of mature plaice, turbot and brill on different fishing grounds. Journ. Mar. Biol. Assoc., 1895-97, n. s. 4, $97-107$.

1895.10

The natural history of the marketable marine fishes of the British islands. London \& New York, 1896. xvi, 375 p. figs. $8^{\circ}$. 1896.1

Reviews in Nature, 1896, 55, 361-362. Natural Sci., $1896,10,340-343$
- Note on the eggs of Myxinoids. Quart. Journ. Micr. Sci., 1897, n. s. 40, $277-278$.

1897.1

- The discovery of the larva of the common eel. Nature, 1897, 55, $467-468$. 3 figs.

1897.2

- On the histology of the ovary and ovarian ovum in teleostean fishes. Abstract in Journ. Roy. Micr. Soc. London, 1897, 353-35̃.

1897.3

Recapitulation. Science-Progress, $1897,6,483-510$. 1897.4

On the histology of the ovary and of the ovarian ova in certain marine fishes. Quart. Journ. Micr. Sci., 1898 , n. s. $40,101-163.3$ pls.

1898.1

Comparisons are made with the fishes of the West Indian fauna. "List of papers and books cited, in chronological order," p. 159-160.

On young stages of teleosteans.

Proc. Roy. Irish Acad., Dublin, 1900 3. ser. 5, 752-753.

1900.1

In article entitled "The fauna and flora of Valencia harbour on the west coast of Ireland."

Sexual dimorphism in the animal kingdom. A theory of the evolution of secondary sexual characters. London, 1900. 317 p. figs. $8^{\circ}$. 1900.2

Eel. Encyclopædia Britannica, 9. ed. Suppl., 1902, 27, 685-686. 1902.1

- Habits of the gar-fish and mackerel. Nature, 1902, 65, 586. 1902.2

The morphology of Pleuronectidæ. Nature, 1902, 65, 511. 1902.3

Zones of growth in the skeletal structures of Gadidre and Pleuronectidx. 23. Ann. Rept. Fish. Board Scotland, 1905, pt. 3, 125-140. 3 pls. 1905.1

A peculiarly abnormal specimen of the turbot. Journ. Mar. Biol. Assoc., 1907-10, n. s. 8, 44-46. pl. - Proc. Zool. Soc. London, 1907, 174-181. pl.

1907.1

The errant eel. The transformations and migrations of a strange fish. Scient. Amer. Suppl., 1910, 69, 92-93. fig.

1910.1

On the marine fishes and invertebrates of St. Helena. Proc. Zool. Soc. London, 1910, 86-131. 4 pls. \& 4 figs. 1910.2

Cunningham, Joseph Thomas, \& MacMunn, C.A. On the coloration of the shins of fishes, especially of 
Pleuronectida. Philos. Trans. Roy. Soc. London, $1893,184 B, 765-812.2$ pls. Abstract in Proc. Roy. Soc. London, 1893, 53, 384-385. 1893.1

Cunningham, Robert Oliver. Notes on the natural history of the strait of Magellan and west coast of Patagonia, made during the voyage of $H$. M. S. "Nassau " in the years 1866-69. Edinburgh, 1871. 1870. xvi, 517 p. 21 pls. $8^{\circ}$.

1870.1

Reptiles, amphibia, fishes, crustacea and mollusca are described.

- Notes on the reptiles, amphibia, fishes, mollusca, and crustacea obtained during the voyage of H. M. S. "Nassau" in the years 1866-69. Trans. Linn. Soc. London (Zool.), 1871. 27, 465-502. 12 pls.

1871.1

Causes of the observed distribution of fish in the North sea. Journ. Mar. Biol. Assoc., 1895-97, n. s. 4, no. 2 , 233.

1895.1

On a few points in the structure of Laborde's shark (Euprolomicrus labordii) Proc. Zool. Soc. London, 1899, 732-734.

1899.1

Cunnington, $W . A .$, \& Boulenger, Charles L. A biological expedition to the Birket el Qurun, Fayum Province of Egypt. Rept. Brit. Assoc. Adv. Sci., 78. meet. 1908 (1909), 732. 1909.1

Curcič, Tejsil. Die volkstümliche Fischerei in Bosnien und der Herzegowina mit besonderer Berücksichtigung der Savefischerei bei Donja Dôlina. Wiss. Mitt. Bosnien-Herzegowina, 1912, 12, 490-589. 96 figs.

1912.1

Curle, T. J. On an apparatus for transporting live fish. Forest \& Stream, $1875,3,310$.

1875.1

Curry, $J . J$. Condition of the shore fisheries in Massachusetts and Rhode Island in 1871. Rept. U. S. Fish Comm. 1871-72 (1873), 1, S.

1873.1

Cursiter, James IV. The deal-fish (Trachypterus arcticus Brünn.) in Orkney Ann. Scott. Nat. Hist., 1896, 160 . 161.

1896.1

Curtis, George. [On the habits of Esox fasciatus] Proc. Boston Soc. Nat. Hist. 1859-61 (1861), 7, 159-160.

1861.1

Curtis, George Carroll. The preservation of our fish supply. The banks on our east coast and their origin. Scient. Amer. Suppl., 1912, 74, 106-107. 2 figs.
Curtis, George $I I$. Diatoms, the food of fish in Kansas. Amer. Micr. Journ., 1901, 22, 275-280.

1901.1

The food of fish in central Kansas. Trans. Kansas Acad. Sci. $1901,17,75-78$.

1901.2

Curtis, $J . E$. Fish in the National park and tributaries of Snake river. Propagation of whitefish. Bull. U. S. Fish Comm., 1884, 4, 335-336. 1884.1

Curtis, W. C., \& Leferre, G. See Leferre \& Curtis.

Custance, (Colonel) F. H. Trout breeding. (In The Marquis of Granby. The trout, p. 141-244. London, 1898. pls. \& figs. $8^{\circ}$ )

1898.1

Cutler, Manassch. Selections from a note-book of Manasseh Cutler, entitled "A description of the animals in North America taken from actual observation" [in 1786] Bull. Essex Instit. 1897 (1898), 29, 120-127. 1898.1

Cutts, Richard D. 'The fisheries and fishermen of the North Pacific (In Senate 42. Congress, 2. Session, 1872, Ex. Doc. no. 34. S5 p.) 1872.1

Cuvier, Georges Frédéric [1773-1838] (editor) Dictionnaire des sciences naturelles, dans lequel on traite méthodiquement des differens êtres de la nature . . 60 vols. Paris, 180t-30. $8^{\circ}$.

1804.1

Cuvier, (Baron) Georges Léopold Chrétien Frédéric Dagobert [1769-1832] For biography and list of works, see Duvernoy, G. L. Notice historique sur les ouvrages et sur la vie de MI. le Baron Cuvier. Paris, 1833. - Flourens, M. J. P. Cuvier. Histoire de ses travaux, etc. 2. ed. Paris, 1845.

Tableau élémentaire de l'histoire naturelle des animaux. Paris, 1798. 710 p. 14 pls. $8^{\circ}$. 1798.1

_L Leçons d'anatomie comparée . recueillies et publiées sous ses yeux par C. Duméril ... [and afterwards C. L. Duvernoy] 5 vols. Paris, 1800-05. illust. $S^{\circ}$ 1800.1

Sur les dents des poissons. Bull. Soc. Philom. Paris, 1801, 3, 25-26.

1801.1

- Lectures on comparative anatomy. Translated from the French ... by IV. Ross. 2 vols. London, 1802. $8^{\circ}$. 1802.1 
Cuvier, G. L. C. F. D.

Recherches d'anatomie comparée sur les dents. Bull. Soc. Philom. Paris, 1803, 3, 165-168.

1803.1

Rapport sur le mémoire de M. Delaroche, rélatif à la vessie aérienne des poissons. Ann. Mus. Hist. Nat. Paris, 1809, 14, 165-183. - Philos. Mag., 35, 291-302.

1809.1

Vorlesungen über vergleichende Anatomie, von G. Cuvier ... übersetzt und mit Anmerkungen und Zusätzen vermehrt von I. H. Froriep ... und von I. F. Meckel. 4 pts. Leipzig, 1809-10. illust. $8^{\circ}$.

1809.2

- Mémoire sur les os de reptiles et de poissons des carrières ì plâtre des environs de Paris. Ann. Mus. Hist. Nat. Paris, $1810,16,115-134 . \quad 1810.1$

- Note sur un poisson peu connu, pêché récemment dans le golfe de Gênes (le Lophote cépedien Giorna) Ann. Mus. Hist. Nat. Paris, 1813, 20, 393-400.

1813.1

Mémaire de la composition de la mâchoire supérieure des poissons, et sur le parti qu'on peut en tirer pour la distribution méthodique de ces animaux. Bull. Soc. Philom. Paris, 1814, 73-78.Isis (Oken), 1818, 2, 285-289; 10591072. - Mém. Mus. Hist. Nat. Paris, $1815,1,102-132$.

1814.1

Observations et recherches critiques sur différents poissons de la Méditerranće, et à leur occasion sur des poissons d'autres mers, plus ou moins liés avec eux. Bull. Soc. Philom. Paris, 1814, 80-92. - Mém. Mus. Hist. Nat. Paris, $1814,1,226-241 ; 312-330$; $353-363 ; 451-466$. - Isis (Oken), 1818 , 1182-1191; 1636-1646; 1656-1658; $1658-1665$; $1665-1670$. pls. xi, xvi, xxiii.

1814.2

- Sur un poisson célèbre et cependant presque inconnu des auteurs systématiques, appelé sur nos côtes de l'ocćan, aigle ou maigre, et sur celles de la Méditerranée, umbra, fegaro, et poisson royale; avec une description abrégée de sa vessie natatoire (Sciana umbra) Mém. Mus. Hist. Nat. Paris, 1815, 1 , 1-21.

1815.1

Abstracts in Bull. Soc. Philom. Paris, 1814, 182-184. - Isis (Oken), 1818, 1170-1180.

- Le règne animal distribué d'après son organisation, pour servir de base à l'histoire naturelle des animaux et d'introduction à l'anatomie comparée. 4 vols. Paris, 1817. illust. 1817.1 Poissons, vol. ii. $532 \mathrm{p}$.

- Sur le genre Chironectes Cuv. (Antennarius Commerson) Mém. Mus. Hist. Nat. Paris, 1817, 3, 418-435. 3 pls.

1817.2

Sur les Diodons, vulgairement orbes épineux. Mém. Mus. Hist. Nat. Paris, 1818, 4, 121-138.

1818.1

- Sur les poissons du sous-genre Mylètes. Mém. Mus. Hist. Nat. Paris, 1818, 4, 444-456. 1818.2

- Ueber Argentina sphyrona und Mullus imberbis. Isis (Oken), 1818, 2 , 1181-1192. figs.

1818.3

Sur les poissons du sous-genre Hydrocyon, sur deux nouvelles espèces de Chalceus, sur trois nouvelles espèces de Serrasalmes, et sur l'Argentina glossodonta de Forskahl, qui est l'Albula gonorhynchus de Bloch. Mém. Mus. Hist. Nat. Paris, 1819, 5, 351-379. 3 pls.

1819.1

-_. Alphabetisches und systematisches Register...von F. O. Lietzau. Leipzig, 1824. 141 p. 9 pls. $8^{\circ} \cdot 1824.1$

C. Plinii Secundi Historiæe naturalis libri xxxvii ... Pars tertia continens zoologiam. G. Cuvier notis... illustrata etc. vols. iii \& iv. 1827-28. $8^{\circ}$.

1827.1

- Sur le Scarus, Bull. Sci. Nat. (Férussac), 1827, 11, 444-445. 1827.2

Le règne animal distribué d'après son organisation, pour servir de base à l'histoire naturelle des animaux et d'introduction à l'anatomie comparée. 2. ed. 5 vols. Paris, 1829. illust. $8^{\circ}$.

Poissons, vol. ii.

1829.1

- On the mullets of Europe. Edinb. Journ. Sci., 1830, n. s. 2, 61-66. 1830.1

- Das Thierreich ... Nach der zweiten . A A Asgabe übersetzt und durch Zusätze erweitert von F. S. Voigt. 6 vols. Leipzig, 1831-43. $8^{\circ}$.

1831.1

Rapport verbal sur la monographie des esturgeons de MIM. Brandt et Ratzeburg, fait à l'Académie des Sciences. Ann. Sci. Nat., 1831, 22, 222-224.

1831.2

Sur le poisson appelé Machæra. 
Nouv. Ann. Mus. Hist. Nat., 1832, 1, 43-49. pl.

1832.1

The animal kingdom, arranged according to its organization, serving as a foundation for the natural history of animals. Translated from the last [i.e., second] French edition with additional notes, etc. London, 1834-37. 4 vols. text \& 4 vols. pls. $8^{\circ}$

Reptiles and fishes, vol. ii.

The animal kingdom ... by the Baron Cuvier ... with additional descriptions of species . . . by E. Griffith and others. 16 vols. London, 1827-35. $8^{\circ}$.

1834.2

Vol. $x$. Pisces, with supplementary additions by Edward Griffith, Charles Hamilton Smith [and P. B. Lord] 680 p. 62 pls. 1834.

- Leçons d'anatomie comparée - recueillies et publiées sous ses yeux par C. Duméril [and afterwards by C. L. Duvernoy] 2. ed. 8 vols. in 9. Paris, $1835-46.8^{\circ}$.

1835.1

Le règne animal distribué d'après son organisation, pour servir de base à l'histoire naturelle des animaux et d'introduction à l'anatomie comparée. 3. ed. 17 vols, in 20. Paris, 1836-49. $4^{\circ}$.

1836.1

This edition, known as the "Disciples' edition," was issued in 262 livraisons. Those comprising "Les poissons, par A. Valenciennes" form volumes iv and $\mathrm{v}$ of the series, and were published in 1836 .

Cuvier's animal kingdom, etc. London, 1840 . vii, 670 p. illust. $8^{\circ}$.

1840.1

Fisbes and Radiata, by R. Mudie. Another edition of this mork was published at London in 1819 , and it was subsequently reissued at various dates by different publishers.

Histoire des sciences naturelles, depuis leur origine jusqu'à nos jours chez tous les peuples connus, professée au collége de France . . complétée, rédigée, annotée et publiée par $M$. Magdeleine de Saint-Agy. 3 pts. in 5 vols. Paris, $1841-45$. $8^{\circ}$.

1841.1

A classified index and synopsis of the animal kingdom, arranged in conformity with its organization. With supplementary additions by E. Griffith. London, 1844. 328 p. $8^{\circ}$. 1844.1

Das Thierreich ... Nach der zweiten ... Ausgabe frei ins Deutsche übersetzt und durch Zusätze eingerichtet von A. V. Streubel. Berlin, 1846. 972 p. pl. $8^{\circ}$.
Cuvier, (Baron) Georges, \& Duméril, A. M. C. Rapport fait à l'Académie Royale des Sciences, sur un mémoire de M. Breschet, sur les organes de l'audition des poissons. Ann. Sci. Nat., 1830, 21, 105-112. - Isis (Oken), 1834, 27, 1150 .

1830.1

Cuvier, (Baron) Georges, Lacépède, (Comte) B. G.E., \& Vauquelin, L. N. See Lacépède, Vauquelin \& Cuvier.

Cuvier, (Baron) Georges, \& Valenciennes, Achille. Histoire naturelle des poissons, considérations préliminaires. Ann. Sci. Nat., 1827, 12, 396414. - Notizen (Froriep), 1828, 20, 241-250; 23, 464-469. - Bull. Sci. Nat. (Férussac); 16, 287; 19, 369; 20, 333. Isis (Oken), 1829, 22, 75-77. - Arch. Anat. Physiol. (Müller), 1835, 248. Mag. Zool. Bot. (Jardine), 1837, 1, 283. 1827.1

Histoire naturelle des poissons. 22 vols. Paris, 1828-49. 650 pls.

1828.1

The two issues of this work differ only in the setting of the text.

Account of the Scomber scomber L. and the Garum of the ancients. Edinb. Journ. Sci. 1832 , n. s. 6, 286294.

1832.1

Histoire naturelle du hareng et de quelques espèces voisines, telles que l'alose, la sardine, le white-bait. Biblioth. Univers. Arch.: Genève, 1848, 7, 22-23.

1848.1

Cyon, Elie de. Recherches expérimentales sur les fonctions des canaux semi-circulaires et sur leur rôle dans la formation de la notion et de l'éspace. Ann. Sci. Nat. (Zool.), 1878, 6. sér. 7, no. 8. $96 \mathrm{p}$.

1878.1

— Les organes périphériques de sens de l'espace. C. R. Acad. Sci. Paris, 1900, 130, 267-269. 1900.1

Cypress (junior), $J$., pseudonym for Hawes, William $P$.

Czenpinski, Paulus. Dissertatio inauguralis zoologico-medica, sistens totius regni animalis genera, in classes et ordines Linnæana methodo digesta, præfixa cuilibet classi terminorum explicatione, etc. Viennæ, 1778. 122 p. $8^{\circ}$.

1778.1

Czermâk, Johann Nepomuk [18281873] Vorläufige Mittheilungen über die Schwimmblase von Esox lucius. Zeitschr. Wiss. Zool., 1850, 2, 121-123.

1850. 
Czermâk, Nicolai. Die Mitochondrien des Forelleneies. Anat. Anz., $1901,20,158-160$. fig.

Das Centrosoma im Befruchtungsmomente bei den Salmoniden. Vorläufige Mittheilung. Anat. Anz. 1903,22 , 393-400. 5 figs. 1903.1
Czernáy, A. Notice sur Cobitis merga Krynickii. Bull. Soc. Impér. Nat. Moscou, 1852, 25, 548-549. pl. \& fig. 1852.1

Beobachtungen über das Variiren der Artkennzeichen der Süsswasserfische in der Umgegend von Charkow. Bull. Soc. Impér. Nat. Moscou, 1857, 30 , pt. 1, 227-249. 1857.1 


\section{D}

D. The carp of Virginia. Forest \& Stream, 1877, 8, 113.

1877.1

- The fish culturists' convention at Chicago. Forest \& Stream, 1879, 12, 704 .

1879.1

- Fish items from Norfolk, Va. Forest \& Stream, 1877, 8, 269. 1877.2

Trouting in Nova Scotia. Forest \& Stream, 1874, 2, 274. 1874.1

D., A. Bass and maskalonge fishing. Forest \& Stream, 1880, 14, 429. 1880.1

D., A.B. Fishing items from Crystal river, Florida. Forest \& Stream, 1877, 9, 269.

1877.1

D., C. U. Cod fishing at Gaspé. Forest \& Stream, 1874, 2, 81-82. 1874.1

D., H.D. The natural law of distribution. Forest \& Stream, 1879, 13, 790.

1879.1

Remarks on introduction of fish into foreign countries.

D., H.V. Remarks on the natural history of the parish of Slapton near Dartmouth, Devonshire. Mag. Nat. Hist., 1830, 3, 393-397. 1830.1

D., L. Genuine and prolific carp. Chicago Field, 1880, 13, $20 . \quad 1880.1$

D., R. G. The size and growth of Penobscot salmon. Chicago Field, 1879, 11, 341. Ibid., 12, 21 . 1879.1

D., T.E. White perch for stock fish. Forest \& Stream, 1875, 4, $166 . \quad 1875.1$

Dabry de Thiersant, Pierre [1826 - ] Note sur la pisciculture en Chine. Bull. Soc. Acclim., Paris, 1863, 10, 556566. - Rev. Marit., 1864, 10, 243-252.

1863.1

- Note sur le transport des gouramis. Bull. Soc. Acclim., Paris, 1868, 2. sér. 5, 591-592. 1868.1

- Note sur la culture du gourami à Java. Bull. Soc. Acclim., Paris, 1869, 2. sér. 6, 732-734.

1869.1
- Histoire naturelle du gourami [Osphromenus olfax Commerson] Bull. Soc. Acclim., Paris, 1870, 2. sér. 7, 671 688.

1870.1

- La pisciculture et la pêche en Chine, précédé d'une introduction sur la pisciculture chez les divers peuples par J. L. Soubeiran. Paris, 1872. 173 p. 51 pls. $8^{\circ}$.

1872.1

Dabry de Thiersant, $P$., \& Sauvage, Henri Emile. See Sauvage \& Dabry de Thiersant.

Daday, Jenö [=Eugene] Neue Thierarten aus der Süsswasserfauna von Budapest [Text in Hungarian] Termr. Füzatek, Budapest, 1855, 9, 127-135; 208-215.

1885.1

Fische, auf Grund der literarischen Daten zusammengestellt. Result. Wiss. Erforsch. Balatonsees (Fauna), 1896, 2, no. 12, 217-231.

\section{1}

Die natürliche Nahrung der Fische der Teiche Ungarns. Budapest, 1897. xiii, $4 \$ 1$ p. 62 figs. $S^{\circ}$. 1897.1

Review by R. Franée in Rovart. Lap. Köt., p. 194-197. 4 figs.

Nyctotherus piscicola, n. sp., ein neuer Fischendoparasit aus Südamerika. Zool. Anz., 1905, 29, 233-238. 4 figs.

1905.1

In südamerikanischen Fischen lebende Trematodenarten. Zool. Jahrb. (Syst. Abth.), 1907, 24, 469-590. 6 pls. 1907.1

Da Fano, C. See Fano, C. da.

Dagincourt, Emmanuel [1856-] Couche à poissons à la base du Lias supérieur aux environs de Saint-Amand (Cher) Bull. Soc. Géol. France, 1880, 3. sér. 8, 355-357. 1880.1

Dagincourt, Emmanuel, Carez,Léon, \& Douvillé, Henri. Annuaire géologique universel. Revue de géologie et de paléontologie. 14 vols. Paris, 1885$98.8^{\circ}$. 
Dagry, A. Dispositions à prendre pour l'acclimatation et le transport des poissons exotiques provenant des régions lointaines. Bull. Soc. Acclim., Paris, 1911, 58, 417-426. fig. 1911.1

Daguin, - Acclimatation en France de nouveaux salmonides. C. R. Acad. Sci. Paris, 1893, 116, 907-910.

1893.1

Répertoire alphabétique des noms vulgaires et locaux des poissons d'eau douce de France. Naturaliste, Paris, 1904, 26, 185-187; 206; 217-218; $230-231 ; 242-243$; 254-255; 267-268; 280. - Ibid., 1905, 27, 27-2S; 40; 52.

1904.1

Dahl, Friedrich Theodor [1856-] Ueber die Verbreitung der Seethiere in der Elbe. Schrift. Schlesw.-Holst. Nat. Ver., 1S89, 7, pt. 2, 74-75.

1889.1

- Die Berregung der fliegenden Fische durch die Luft. Zool. Jahrb. (Syst. Abth.), 1891, 5, 679-688. 1891.1

Zur Frage der Bewegung fliegender Fische. Zool. Anz., 1892, 15, 106108. 1892.1

Untersuchungen über die Thierwelt der Unterelbe. Deutsch. Meere Ber., 1893, pt. 3, 149-186.

1893.1

Die Verbreitung freischwimmender Thiere im Ocean. Schrift. Schlesw.Holst. Nat. Ver., 1895, 10, 281-290; 319. 1895.1

Karl August Möbius. Ein kurzes Lebensbild, nach authentischen Quellen entworfen. Zool. Jahrb. Suppl., 1905, 8, Festschr. Möbius, 1-22. 1905.1

Dahl, Knut. Dyr ag Vildmænd. Reiser i Sydafrika ag Nordvest Australien. 2 vols. Kristiania, 1897. illust. $\&$ maps.

1897.1

Beretning om fiskeriundersogelser $\mathrm{i}$ og om Trondhjemsfjorden 1898. Norske Selsk. Skrift., 1898, no. 10. 62 p. pls. \& maps.

1898.1

__ Om fiskeriet med Strxedriot i Beetstadfjorden. Aarsberetn. Norges Fiskerier, Bergen, 1900. 32 p. 1900.1

Orret og unglaks samt lovgivningens forhold til dem. Christiania, 1902. 52 p. 3 pls. $8^{\circ}$.

1902.1

Trout and young salmon. Report on researches on the wanderings of the salmon-peel [Text in Norwegian] Irristiania, 1902. 51 p. pls. $8^{\circ} .1902 .2$

English translation in Nyt Mag. Naturv., 1904, 42, 221-338. 3 pls. \& 7 figs.

\section{Skolpens fiskeforsök i Finmar-} kens Oesttear og ved Bären Eiland sommeren 1902. Aarsberetn. Norges Fiskerier, 1903. $41 \mathrm{p}$.

1903.1

Undersökelser av Skreibanker for Strakingen Tranen-Kristiansund med S. S. "Tri" Aarsberetn. medk Norge Fiskerier. [Kristiania?] 1903. 1903.2

- Artificial fish hatehing in Norway. Rept. Lancashire Sea Fish. Invest., 1906, 109-125. $\quad 1906.1$ 1906. Fiskeri og Utklækning. $\begin{array}{r}\text { Bergen, } \\ 1906.2\end{array}$

- Nyere oplysninger om unglaks og dens opholdssteder Neuere Beobachtungen über den jungen Lachs und seine Wanderung] Norsk Fisket, Bergen, 1906, 25, 522-529.

1906.3

Undersökelser over Nytten av Torskeutklæekning i Ostlændske fiorde. Aarsberetn. Norges Fiskerier, 1906. $97 \mathrm{p}$.

1906.4

- Artificial fish-hatching in Ncrway. II. Investigations concerning the effects of liberating artificially hatched cod larva in the fiords of southern Norway. Proc. Trans. Liverpool Biol. Soc., 1907, 21, 209-269. 4 charts. 1907.1

Sildens skjal som middel til studium af sildens alder, vekst og vandringer [Die Heringsschuppen als Hilfsmittel für das Studium des Alters, des Wachsthums und der Wanderungen des Herings] Naturen, Bergen, 1907 , 31, 352-359.

1907.2

- Fiskeforsk i Skagerak 19061907 [Fischerei-versuche an der norwegischen Kuiste von Skagerak] Aarsberetn. Norges Fiskerier, 1908, 75-106.

1908.1

Vægttab hos notstaaet vaarsild [Gewichtsverlust in Netzen stehender Frühjahrsheringe] Norsk Fisket, Bergen, 1908, 27, 127-129.

1908.2

The assessment of age and growth in fish. A short account of the development of present methods and main literature on the subject (Sammelbericht) Internat. Rev. Hydrobiol. Stuttgart, 1909, 2, 758-769. $\quad 1909.1$ 
The problem of sea fish hatching. Rapp. Cons. Perman. Intern. Explor. Mer, $1909,10 \mathrm{~B}$, no. 5, 1-40. 13 figs. 1909.2

The scales of the herring as a means of determining age, growth and migration. Rept. Norw. Fish. Mar. Invest., Bergen, 1909, 2, no, 6, 1-36. $3 \mathrm{pls}$.

1909.3

Sild og laks [Herring and salmon] Rept. Norw. Fish. Mar. Invest., 1909, 2, pt. 1, 134-147.

1909.4

Vor kundskab om aalens forplantning og vandringer [Unsere Kenntnis von der Fortpflanzung und den Wanderungen des Aals] Naturen, Bergen, 1909, 33, 20-29.

1909.5

- Alder og vekst hos laks og orret belyst ved studiet av deres skjael. Kristiania, 1910.115 p. 10 pls. $8^{\circ}$.

At head of title: Landbruksdepartementet.

Age and growth of salmon and trout in Norway. London, 1911. 141 p. 10 pls.

1911.1

- Opgover for studiet of fiskens tilvetest, von ferskvand. Norsk Fiskerit., Bergen, 1911.

1911.2

Nogle opgaver for studiet af fiskens tilvakst i vore ferskvand [Aufgaben des Studium des Wachstums unserer Süsswasserfische] Norsk Fiskerit., Bergen, 1912, 31, 135-151.

1912.1

Dahl, Knut, Damas, D., \& Sund, Oscar. Fiskenes alder og vekst [Age and growth of fishes] Rept. Norw. Fish. Mar. Invest., 1909 , 2, pt. 1, 132133.

1909.1

Dahl, Knut, \& Dannevig, Gunder Mathiesen. Undersogelser over nytten af torskeudklækning i ostlandets fjorde Investigations upon the utility of hatching cod-fish in the eastern fjords of Norway] Aarsberetn. Norges Fiskerier, Bergen, 1906, 1-121.

1906.1

Dahl, Knut, \& Hjort, Johan. See Hjort \& Dahl.

Dahl, Svend. Bibliotheca zoologica Danica, 1876-1906. Kobenhavn, 1910. 262 p. $8^{\circ}$

1910.1

Dahlberg, August. Kyrkstadin kalankasvatuslaitoksesta. Suomen Kalastus Lehti, 1897, 6, 17. - Fiskeritidskr. Finland, 1897, 6, 17.
Dahlgren, Ulric $[1870-]$ 'The giant ganglion cells in the spinal cord of the order Heterosomata Cope (Anacanthini pleuronectoidei Güther) Anat. Anz., 1897, 13, 281-293. 4 figs. 1897.1

The giant ganglion cell apparatus. Journ. Comp. Neurol, 189s, 8, no. 3, 177-179.

1898.1

- The maxillary and mandibular breathing valves of teleost fishes. Journ. Morphol., 1898, 14, 117-124. Zool. Bull., 1898, 2, no. 3, 117-124. 3 figs. - Science, 1899, n. s. 9, 313.

1898.2

A new type of electric organ in an American teleost fish, Astroscopus. Science, 1906, n. s. 23, 469-470. 1906.1

The luminous organ of a new species of Anomalops. Science, 1908 , n. s. 27, 454-455. 1908.1

The oral opening of the nasal cavity in Astroscopus. Science, 1908, n. s. 27, 993-994.

1908.2

The origin of the electricity tissues in fishes. Amer. Naturalist, 1910, 44, 193-202.

1910.1

Origin of the electric tissues of Gymnarchus nilolicus. Carnegie Instit. Washington, 1914, Pub. no. 183, 159194. 9 pls. \& 9 figs.

1914.1

Literature, p. 191.

Dahlgren, Ulric, \& Silvester, $C . F$. The electric organ of the stargazer Astroscopus Brevoort. A new form of electric apparatus in an American teleost. Anat. Anz., 1906, 29, 387-403. 13 figs.

1906.1

Daimeries, A. Notes ichthyologiques (Système Landenien et Heersien) Ann. Soc. Roy. Malac. Belgique (Bull. des Séances), 1888-89, 23, xlii-xliii; xlvxlix; ci-civ. Ibid., 24, v-x; xxxix-xliv. Ibid., 26, lxxii-lxxviii. Ibid., 27, xiixvi.

1888.1

Dainelli, $G$. Appunti geologici sulla parte meridionale del capo di Leuca. Boll. Soc. Geol. Ital., 1901, 20, 616690. 3 pls.

1901.1

Dakin, $W . J$. The osmotic concentration of the blood of fishes taken from sea water of naturally varying concentration. Bio-Chemical Journ., 1907, 3. 1907.1

Note on the biology of teleost and elasmobranch eggs. Rept. Brit. 
Dakin, W. J.

Assoc. Adv. Sci., 80. meet., 1911, 631632.

1911.1

Notes on the biology of fish eggs and larva. Internat. Rev. Hydrobiol., Leipzig, 1911, 3, 487-495.

1911.2

Dakin, W. J., \& Cole, F.J. See Cole \& Dakin.

Dal, $G$. Sui vertebrati delle arenarie mioceniche di Belluno. Atti Accad. Sci. Veneto-Trent.-Istriana, 1908, n. s. 5. anno, 106-120. 7 figs.

1908.1

Daldorff, D.C. de. Natural history of Perca [Anabas] scandens, nov. sp. Trans. Linn. Soc. London (Zool.), 1797, 3, 62-63. - Voigt's Magazine, 2, pt. 2, $348-350$

1797.1

Daleau, François. La pêche à la crevette et les alevins dans le département de la Gironde. Actes Soc. Linn. Bordeaux, 1898, 53, lxxxv-lxxxvi.

189S.1

- Anguilles et canards. Proc. Verb. Soc. Linn. Bordeaux, 1909, 63, Ixxii.

1909.1

Dall, William Healey [1845 - ] Alas$\mathrm{ka}$ and its resources. Boston, 1870. 628 p. 15 pls. $8^{\circ}$.

1870.1

- The food fishes of Alaska. Rept. Comm. Agric. 1870 (1871), 375-392

1871.1

On the marine faunal region of the north Pacific, etc. Proc. Acad. Nat. Sci. Philad. 1876 (1877), 205-208.

1877.1

Recognizes an Oregonian, Aleutian and an Arctic faunal province for marine invertebrates in the north Pacific.

Notes on the Pacific coast trade in shells, shrimps, cod, and salmon. Bull. U. S. Fish Comm. 1883, 3, 425.

1883.1

Notes on the fishing products exported from San Francisco, Cal., during the year 1883. Bull. U. S. Fish Comm. 1884, 4, 125-12S.

1884.1

Reports of the Belgian Antaretic expedition [Review of Résultats du voyage du S. Y. "Belgica" en 1877-8-9, sous le commandement de A. de Gerlache de Gomery'] Science, 1905, n. s. 21, 624-625.

1905.1

Dalla. For names, other than English, with this prefix (except when written as one word), see under part following the prefix.
Dallas, James. On rapid change of colour in Gasterosteus. Ann. Mag. Nat. Hist., 1S95, 6. ser. 16, 489-490.

1895.1

Dallas, William Sweetland [18241890] (translator) On Oneirorles eschrichtii Lütken, a new Lophiid fish from Greenland. Ann. Mag. Nat. Hist., 1872, 4. ser. 9, 329-344. See Luitken, Christian, 1871.

1872.1

- Spolia Atlantica, by C. F. Lütken. Ann. Mag. Nat. Hist., 1881, 5. ser. 7, $1-14 ; 107-123$.

1881.1

Dalla-Torre, Karl Wilhelm von $[1850$ -] Die naturhistorischen Programmaufsätze der österreichischen Unterrichtsanstalten. Bot. Zool. Oesterreich 1850-1900. Festschr. k. k. Zool.-Bot. Ges. Wien, 1901, 535-600.

1901.1

Dallmann, Georg. Meine Erfahrungen bei der Zucht des Danio rerio. Blätt. Aquar-Terrar. Iunde, 1911, 22. Jahrg., 149-151; 221-222; 236-237. fig.

1911.1

Dallmer, Eugen. Fische und Fischerei im süssen Wasser mit besonderer Berücksichtigung der Provinz Schleswig-Holstein. Segeberg, 1877. 116 p. $\mathrm{S}^{\circ}$. 1877.1

- Der Hecht. Circul. Deutsch. Fischerei-Ver., 1877, 1. Jahrg., no. 2, $35-39$. 1877.2

—.. Ein Besuch bei einem Störfischer. Deutsch. Fischerei Zeitg., 1878, 1. Jahrg., 89-90.

1878.1

Künstliche Fischzucht in Schleswig-Holstein. Deutsch. Fischerei-Zeitg., 1878, 1. Jahrg., 44.

1878.2

Die Maräne ¿Coregonus lavaretus! im Selenter See. Circul. Deutsch. Fischerei-Ver。1S77 (1878), 1. Jahrg. 208.

1878.3

Nutzbarmachung der Mergelkuhlen. Deutsch. Fischerei-Zeitg., 1878, 1. Jahrg., 147-148.

1878.4

-Ueber die Fortpflanzung der Aale, Deutsch. Fischerei-Zeitg., 1878 , 1. Jahrg., $1-3 ; 9-10 ; 17-18 . \quad 1878.5$

Ueber Lachzucht. Landw. Zeitschr., Cassel, 187S, 259-262. 1878.6

Forellen-Teiche. Deutsch. Fischerei-Zeitg., 1879, 2. Jahrg., 57-58; 146-148. - Circul. Deutsch. Fischerei Ver. 1879 (1880), no. 2, 44-46. 1879.1 
The propagation of eels. Chicago Field, 1879, 11, 83.

1879.2

Ueberführung von Zandern nach England. Circul. Deutsch. Fischerei Ver. 1878 (1879), no. 2, 53-59. 1879.3

Dallmer, Eugen, Borne, Max von dem, \& Benecke, Berthold. See Borne, Benecke \& Dallmer.

Dalrymple, John. Some account of a peculiar structure in the eyes of fishes. Mag. Nat. Hist., 1838, 2, 136$141 ; 624$.

1838.1

Dalton, Henry $G$. The history of British Guiana; comprising a general description of the colony, together with an account of its climate, geology, staple products, and natural history. 2 vols. London, 1855. 3 pls. \& map. $8^{\circ}$.

Fishes, vol. ii, p. 336-359.

1855.1

Daly, Reginald Aldworth [1871-] First calcarenus fossils and the evolution of the limestones. Bull. Geol. Soc. Amer., 1910, 20, 153-170.

1910.1

Damas, D. Contribution à la biologie des Gadides. Rapp. Cons. Perman. Intern. Explor. Mer, 1909, 10 B, no. 3, 1-277: 21 pls. \& 25 figs. 1909.1

Fiskenes gytning, egg og yngel. Oversigt [The spawning, eggs and fry of fishes. General outlines] Rept. Norw. Fish. Mar. Invest., 1909, 2, pt. 1 , 106-117.

1909.2

Torskefiskene (Gadidæ) The cod family (Gadidæ) Rept. Norw. Fish. Mar. Invest., 1909, 2, pt. 1, 116$129 ; 146-153$.

1909.3

Damas, D., Sund, Oscar, \& Dahl, Knut. See Dahl, Damas \& Sund.

Dambeck, Karl. Die geographische Verbreitung der Fische. Gaea, 1871, 7, 275-282.

1871.1

Die geographische Verbreitung der Meerfische. Petermann's Mittheil., $1873,19,241-246$.

1873.1

Die Verbreitung der Süsswasserund Vanderfische. Ausland, 1873, 46. Jahrg., 550-553.

1873.2

Die geographische Verbreitung der Fische in Beziehung auf Physiologie. Natur, 1874, 23, 189-192; 198-200; 203-205; 220-221. pl.

1874.1

Die horizontale und vertikale Verbreitung der Fische. Natur, 1875, n. S. $1,145-147 ; 153-155 ; 161-163$; 171-174; 186-188; 193-196. maps.

1875.1

Zur Geschichte des Kabeljaufanges bei Neufundland. Ausland, 1876, 49. Jahrg., 332-334. 1876.1

Die geographische Verbreitung der Schellfische (Gadidæ) mit Beziehung auf Grossfischerei und Handel. Gaea, $1877,13,158-163 ; 224-231 ; 345-352$; $422-429$.

1877.1

Der Katzenhai, Scyllium catulus L. [S. stellare Flem.] mit Eiern und Jungen im Aquarium zu Berlin. Natur, 1877 , n. s. 3, 507-509. fig. 1877.2

- Seenadeln und Seepferdchen [Lophobranchii] im Aquarium zu Berlin. Natur, 1877, n. s. 3, 424-427. figs.

1877.3

Die Verbreitung der Süsswasserund TVanderfische in Afrika. Amtl. Bericht 50. Versamm. Deutsch. Naturf., 1877, 179-180. 1877.4

Sinnen- und Seelen-Vermögen der Fische. Natur, n. s. 1878, 4, 349$352 ; 365-366$.

1878.1

Geographical distribution of the Gadidx or the cod family, in its relation to fisheries and commerce. Rept. U. S. Fish Comm. 1877 (1879), 5, 531-557.

1879.1

Die Verbreitung der Süss- und Brackwasser-Fische in Afrika. Jena. Zeitschr., 1879, 13, 404-456. $\quad 1879.2$

Zur Geschichte der Heringsfischerei und des Heringshandels. Ausland, 1881, 54. Jahrg., 273-275. 1881.1

Dames, Withelm Barnim [1843-1898] For biography and list of works, see Leopoldina, 1898, 34, 170. - Geol. Verh. Wien, 1898, 408-410. - Geol. Mag., 1899, 6, 191-192.

IUeber Fischzähne aus der obersenonen Tuffkreide von Maestricht, Rhombodus, n. sp.I Sitzber. Naturf. Freunde Berlin, 1881, 1-3. 4 figs.

1881.1

Ueber eine tertiäre Wirbelthierfauna von der westlichen Insel des Birket-el-Qurun im Fajum (Aegypten) Sitzber. Akad. Wiss. Berlin, 1883, 6, 129-153. pl. 1883.1 Pisces, p. 135-153.

- Ueber die Gattung Saurodon Hays. Sitzber. Ges. Naturf. Freunde Berlin, 1887, 72-78. 1887.1 
Dames, $W . B$.

- Ueber Titanichthys pharao, nov. gen., nov. sp., aus der Íreideformation Aegyptens. Sitzber. Ges. Naturf. Freunde Berlin, 1887, 69-72. 4 figs.

1887.2

Discusses the systematic position of Enchodus.

Amblypristis cheops, $\mathrm{n}$. g. et $\mathrm{n}$. sp., aus dem Eocän Aegyptens. Sitzber. Ges. Naturf. Freunde Berlin, 1888, 106109.

1888.1

Die Ganoiden des deutschen Muschelkalks. Palæont. Abhandl., 1888-89, 4, pt. 2, 131-180. 7 pls. \& 2 figs.

1888.2

- Ueber Gigantichthys und Onchosaurus. Neues Jahrb. Mineral., 1889, 1, 201-202.

1889.1

[Ueber eine Mittheilung des Herrn Dr. Reis in München, betreffend die Zurechnung der Acanthodier zu den Selachiern] Sitzber. Ges. Naturf. Freunde Berlin, 1892, 153-155. 1892.1

Damiani, Giacomo. Contribuzione all' ittiofauna del mare dell' Elba. I-III. Riv. Ital. Sci. Nat., Siena, 1892, 4; 1893,$4 ; 1895,5$.

1892.1

- Ancora sui Gobius italici. Riv. Ital. Sci. Nat., Siena, 1896, 16,.77.

1896.1

- Appunti ittiologici sul mercato di Genova. Riv. Ital. Sci. Nat., Siena, $1896,16,117-120 ; 129-135$. 1896.2

I Gobius italici, e specialmente del Gobius colonidnus Risso a Genova. Riv. Ital. Sci. Nat., Siena, 1896, 16, 55$62 ; 77$.

1896.3

- Nota ittiologica (Pomatomus telescopium) Riv. Ital. Sci. Nat., Siena, 1896, 16, 58-59.

1896.4

—-Sul "Mauroticus amethystinopunctatus" nuovo pel golfo di Genova, con note sugli "Sternoptychidx" mediterranei. Atti Soc. Ligust. Sci. Nat. Geogr. Genova, 1896, 7, 98-103. Boll. Mus. Zool. Anat. Comp. Genova, no. 42. 6 p. - Boll. Natural. Coleott. Siena, 16. ann., 38.

1896.5

Di una Selache maxima a Portoferraio. Mon. Zool. Ital., Firenze, $1903,14,351$.

1903.1

- Su alcuni rari Scombridi dell' isola d' Elba (189S-1908) Boll. Soc. Zool. Ital., 1909, 2. ser. 10, 10t-116.

1909.1
- Di un "Regalecus gladius" Walb. all' isola d' Elba, con note sui "Regalecus" mediterranei. Boll. Soc. Zool. Ital., 1913, 3. ser. 1, 329-339.

1913.1

Dammerman, $K$. W W. Der Saccus vasculosus der Fische ein Tiefeorgan. Zeitschr. Wiss. Zool., 1910, 96, 654-726. 4 pls. \& fig.

1910.1

Dammerman, $K$. W., \& Boeke, $J$. See Boeke \& Dammerman.

Damon, William $E$. Ocean wonders; a companion for the seaside. New York, 1877. $8^{\circ}$.

1877.1

The same.

1888. 229 p. $8^{\circ}$.

2. ed. New York, 1888.1

Dampf, — Die Plattfische IPleuronectidx] der Ostsee. Schrift. Phys.ökon. Ges. Königsberg, 1908, 48. Jahrg., 236. 1908.1

Dampier, William [1652-1715] Dampier's voyages; consisting of a new voyage round the world, a supplement to the voyage to Campeachy, a discourse of winds, a voyage to New Holland, and a vindication, in answer to the chimerical relation of William Funnell. Edited by John Masefield. 2 vols. London, 1906. illust. \& maps. $8^{\circ}$.

1906.1

Dana, James Dwight [1813-1895] For biography and list of works, see Amer. Journ. Sci., 1895, 49, 329-356. - Journ. Geol., Chicago, 1895, 3, 335340 ; 341-342; 601-621. - Trans. N. Y. Acad. Sci., 1S95, 14, 260-262. - Amer. Geologist, 1896, 17, 1-16. - Bull. Amer. Geol. Soc., 1896, 7, 461-479.

Fossil vertebra of shark. Amer. Journ. Sci., 1St6, 1, $286 . \quad 1846.1$

- Fossils of the exploring expedition under the command of Charles Wilkes, U. S. N.; a fossil fish from Australia, and a Belemnite from Tierra del Fuego. Amer. Journ. Sci., 1848, 5, 433-435.

1848.1

The classification of animals based on the principle of cephalization [Fishes] Amer. Journ. Sci., 1863, 36, 321-352; 440-442. - Edinb. New Phil. Journ., 1863, 19, 81-102; 260-273. 1863.1

Manual of geology. With special reference to American geological history, etc. Philadelphia \& London, 1863. xvi, $795 \mathrm{p}$. illust.

1863.2 
On certain parallel relations between the classes of vertebrates, and on the bearing of these relations on the question of the distinctive features of the reptilian birds [Fishes] Amer. Journ. Sci., 1863, 36, 315-321. Edinb. New Phil. Journ., 1863, 19, $75-81$.

1863.3

- Manual of geology, with special reference to American geological history, etc. Revised American ed. New York, 1866. xvi, 798 p. illust. 1866.1

- The same. 2. ed. New York \& London, 1875. xvi, 828 p. illust.

1875.1

The same. 3. ed. New York \& London, 1880. xiv, 911 p. illust. 1880.1

The same, 4. ed. New York \& London, 1895. 1087 p. illust. 1895.1

- Notice of the vertebrata of the Cretaceous formations of the West, by E. D. Cope. Amer. Journ. Sci., 1876, 3. ser. 11, 65-66.

1876.1

[Notice of] Dr. J. S. Newberry's descriptions of new fossil fishes, etc. Amer. Journ. Sci., 18s8, 3. ser. 35, 498.

1888.1

Danckelmann, E. von. Beitrag zur Kenntniss der Verbreitungsgrenzen der fliegenden Fische im südindischen Ocean. Arch. Naturgesch., 1880, 46 , pt. 1, 280-284.

1880.1

Danforth, C. H. A $74 \mathrm{~mm}$. Polyodon. Biol. Bull. Woods Hole, 1911, 20, 201-204. 3 figs.

1911.1

- The heart and arteries of Polyodon. Journ. Morphol., 1912, 23, 409454. 19 figs.

1912.1

The myology of Polyodon. Journ. Morphol., 1913, 24, 107-146. 10 figs.

1913.1

Daniel, J.W. The Salmonidx of Texas. Forest \& Stream, 1878, 10, 339.

1878.1

Daniell, William [1769-1837] Interesting selections from animated nature, quadrupeds, birds, fishes, plants, etc., with illustrative scenery, drawn, engraved and published by IV. D. London, 1809. 60 pls. $4^{\circ}$. 1809.1

Daniell, $W . C$. Letters referring to his experiments in introducing shad into the Alabama river. Rept. U. S. Fish Comm. 1872-73 (1874), 2, 387-389.
Danilewsky, C. Coup d'oil sur les pêcheries en Russie. Exposé statistique et technique, annexé à la collection de produits et outils de la pêche. Paris, 1S67. $8^{\circ}$.

1867.1

Ein Fall von Vergiftung mit Fischgift. Wratsch, 1885 , no. 50 .

1885.1

Dankler, $M$. Der Rheinlachs oder Salm. Natur, 1899, 48. Jahrg., 353356.

1899.1

Vetterpropheten aus dem Tierreich. Natur, 1899, 48, 426-428. 1899.2

- Aus dem Leben und Treiben unserer Fische. Blätt. Aquar-Terrar. Kunde, 1900, 11. Jahrg, 132-141.

1900.1

- Das Gedächtnis der Fische. Blätt. Aquar.-Terrar. Kunde, 1902, 13 Jahrg., 117-118.

1902.1

- Neue Aquarienfische. Natur, $1902,51,114-115$.

1902.2

Dannemann, Johann Friedrich [1859 -] Grundriss einer Geschichte der Naturwissenschaften zugleich eine Einführung in das Studium der naturwissenschaftlichen Litteratur. I. Erläuterte Abschnitte aus den Werken hervorragender Naturforscher aller Völker und Zeiten. Leipzig, 1896. 375 p. 44 figs. $8^{\circ}$. 1896.1

Danner, Hermann. Der Aal geht aufs Land! Deutsch. Fischerei-Zeitg., 1880, 3. Jahrg., 422. - Erste Oesterr.ungar. Fischereizeit.g., 1880, 174. 1880.1

Dannevig, Gunder Mathisen. Artificial hatching of salt-water fish and lobsters in Norway. Bull. U. S. Fish Comm. 1885, 5, 437-440. 1885.1

Report of operations at the hatching establishment for marine fishes, Arendal, 1884. Bull. U. S. Fish Comm. $1885,5,154-160$.

1885.2

Salmonidæ in Australia. Bull. U. S. Fish Comm. 1885, 5, 440-442.

1885.3

Hatching lobsters and cod in Norway. Bull. U. S. Fish Comm. 1886 (1887), 6, 13-14.

1887.1

The hatchery for marine fishes at Flodevigen, Norway. Rept. Brit. Assoc. Adv. Sci., 66. meet., 1897, 831. 
Dannevig, G. $M$.

Fiskeri og videnskab. 4 vols. in 2. Arendal, 1899-1906. $\delta^{\circ}$. 1899.1 Vol. iii has subtitle: Udklækningens resultater.

On the necessity of marine fish hatching, its results and its present position in Norway. Congr. Intern. Pêche Piscicult. St. Pétersb., 1903, pt. 1, 249-252.

1903.1

Artificial fish-hatching in Norway. I. Letter from Captain G. M. Dannevig. Rept. Lancashire Sea-Fish. Lab., 1906, 104-108. - Proc. Trans. Liverpool Biol. Soc., 1907, 21, 204-208. 1906.1

Beretning om de i aarne 19031905 forebogne fiskeriundersogelser i Sondenfjildske fjorde. Norges Fiskerier, 1906,1 .

1906.2

Apparatus and methods employed at the marine fish hatchery at Flödevig, Norway. Paper presented before the fourth international fishery congress held at Washington, September, 1908. Bull. U. S. Bur. Fisheries, 1910, 28, 799-809. pl. \& 8 figs.

1910.1

- The utility of sea-fish hatching. Paper presented before the fourth international fishery congress held at Washington, September, 1908. Bull. U. S. Bur. Fisheries, 1910, 27, 811-816. 1910.2

- En redredning af udklakningssagen. [n. p.] 1911. 87 p. 1911.1

_- Et sidste ord i udklakningssagen. [n. p.] 1911.

1911.2

Dannevig, Gunder Iathiesen, \& Dahl, Knut. See Dahl \& Dannevig.

Dannevig, Harold Christian [1860?1914] For biographical notice, see $\mathrm{N}$. Lockyer in Biol. Results of Fishing Experiments carried on by the F. I. S. "Endeavour." Austral. Fisheries, 1915.

The influence of temperature on the development of the eggs of fishes. 13. Ann. Rept. Fish. Board Scotland, 1893 (1894), 147-152. pl. 1894.1

- On the hatching operations at Dunbar marine hatchery. 14. Ann. Rept. Fish. Board Scotland, 1895 (1896), 150-157.

1896.1

The results for subsequent years are published in the same series of Reports for the years 18951901 inclusive.

- On the rearing of larval and post-larval plaice and other flat-fishes.
15. Ann. Rept. Fish. Board Scotland 1897, pt. 3, 175-193. pl. 1897.1

On the rate of growth of plaice. 17. Ann. Rept. Fish. Board Scotland, 1899, 232-247. pl.

1899.1

Report on the hatching work at the marine hatchery, bay of Nigg, Aberdeen, during the spring season 1900. 19. Ann. Rept. Fish. Board Scotland, 1901, 229-234. $\quad 1901.1$

Report on the operations at the bay of Nigg hatchery during the spring season of 1901. 20. Ann. Rept. Fish. Board Scotland, 1902, pt. 3, 440-446.

1902.1

On the first successful experiment with importation of European sea fishes to Australian waters. Rept. Fish. New South Wales, 1902, pt.2, 5-17.

1902.2

- On the reproduction of sea fishes. The result of preliminary investigations in New South Wales waters. Rept. Fish. New South Wales, 1902, p.. 2, 21-25.

1902.3

The sea mullet, Mugil dobula Günther. Rept. Fish. New South Wales, 1902, pt. 2, 26-33. pl. 1902.4

Dannevig, Harold Christian, \& Fulton, $T$. Influence of temperature on the development of the eggs of fishes; on hatching operations at Dunbar. Edinburgh, 1895. 28 p. 2 pls.

1895.1 $E$.

Danois, Edouard le. See Le Danois,

Dantan, $L$. La mémoire chez les poissons lObservations de MM. Ménégaux, Rabaud, Lafargue, et Bohn] Bull. Instit. Psychol. Internat., Paris, 1904, 4, 373-381.

1904.1

Notes ichthyologiques. Arch. Zool. Expér. Gén., 1905, 4. sér. 3, lxilxxviii. 3 figs.

1905.1

Observations sur les organes de la ligne latérale chez les larves des téléostéens. C. R. Assoc. Franç. Avanc. Sci., 34. sess., 1906, pt. 2, 582-583.

1906.1

Dantziger, Carl. Bericht über die diesjährigen Erfolge des Heringsfanges. Circul. Deutsch. Fischerei Ver., 1873, no. $1,4-5$.

1873.1

- Die fünf ersten Betriebsjahre der Emden Heringsfischerei-Actien-Gesellschaft. Circul. Deutsch. Fischerei Ver. 1877 (1878), no. 4, 103-113. $\quad 1878.1$ 
Bericht ïber Versuche mit der Grundnetzfischerei durch Emden $\mathrm{He}$ ringslogger. Emden, 1879. 48 p. $\mathrm{S}^{\circ}$. 1879.1

The first five years of the Emden Jointstock Herring-Fishery Association. Rept. U. S. Fish Comm. 1877 (1879), 5, 751-776.

1879.2

Die holländische und deutsche Häringsfischerei im Jahre 1878. Deutsch. Fischerei Zeitg., 1879, 2. Jahrg., 34-35; 50-52.

1879.3

Darbishire, A. D. On the direction of the aqueous current in the spiracle of the dogfish; together with some observations on the respiratory mechanism in other elasmobranch fishes. Journ Linn Soc. London (Zool.), 1907, 30, 86-94. 3 figs.

1907.1

D'Arenberg, Pierre. Acclimatation du black-bass en France (Micropterus salmoides) Bull. Soc. Acclim., Paris, 1911, 58, 533-535.

1911.1

Dareste, Camille [1822-] Observations sur l'ostéologie du poisson appelé Triodon macroptère. Ann. Sci. Nat. (Zool. ) 1819, 3. sér. 12, 68-83. pl.

1849.1

Examen de la place que doit occuper dans la classification le poisson fossile décrit par S. Volta, sous le nom Blochius longirostris. Ann. Sci. Nat. (Zool.), 1850, 3. sér. 14, 133-142.1850.1

- Recherches sur la classification des poissons de l'ordre des Plectognathes. Ann. Sci. Nat. (Zool.), 1850, 3. sér. 14 105-133.

1850.2

Etudes sur les types ostéologiques des poissons osseux. C. R. Acad. Sci. Paris, 1872, 75, 942-946; 10181021 ; 1086-1089; $1172-1175 ; 1253-$ 1256.

1872.1

On the natural affinities of the Balistidx. Ann. Mag. Nat. Hist., 1872, 4. ser. 10, 68-70.

1872.2

Sur les affinités naturelles des poissons de la famille des Balistes. C. R. Acad. Sci. Paris, 1872, 74, 1527-1530. - Journ. Zool. (Gervais), 1872, 1, 268272.

1872.3

Monographie des poissons de la famille des Symbranchides. C. R. Acad. Sci. Paris, 1873, 77, 815-819; 878-879.

1873.1

Note additionelle à la monographie des poissons de la famille des Sym- branchides, C. R. Acad. Sci. Paris, $1873,77,878-879$.

1873.2

- Note sur. le Leptocéphale de Spallanzani. C. R. Acad. Sci. Paris, 1873, 76, 1304-1307. - Journ. Zool. (Gervais), 1873, 2, 295-299. 1873.3

Monographie des poissons anguilliformes. C. R. Acad. Sci. Paris, 1874, 79, 988-990.

1874.1

Résumé d'une monographie des poissons anguilliformes. Arch. Zool. Expér. Gén., 1875, 4, 215-232. 1875.1

Sur la reproduction des anguilles. C. R. Acad. Sei. Paris, 1875, 81, 159161.

1875.2

Darraca, Ulysse. Poissons des environs de Bayonne, des eaux douces et eaux salées. [n. p. 1860?]

1860.1

Darton, Nelson Horatio [1865-] Catalogue and index of contributions to North American gealogy 1732-1891. Bull. U. S. Geol. Surv., 1896, no. 127, 1-1045.

1896.1

Fish remains in Ordovician rocks in Bighorn mountains, Wyoming, with a résumé of Ordovician geology of the Northwest. Bull. Geol. Soc. Amer., 1906, 17, 511-566. pls., figs. \& map.

1906.1

Darwin, Charles Robert [1809-1872] The descent of man, and selection in relation to sex. 2 vols. London, 1871. $16^{\circ}$.

1871.1

Part of chapter xii contains an account of the best authenticated cases of sexual differentiation in fishes.

The same. 2. ed. London, 1883. xvi, 693 p. $8^{\circ}$. illust. 1883.1

Das-Gupta, II em Chandra. Paleontological notes on the Gangamopteris beds of Khunmu (in Kashmir) Journ. Proc. Asiat. Soc. Bengal, 1910, 6, 179180.

1910.1

Daubenton, Louis Jean Marie [17161799] Histoire naturelle ... contenant les poissons (In Encyclopédie méthodique, vols. i-iii. Paris, $1782-87.4^{\circ}$ )

1782.1

Fishes are treated in vol. iii of this work which is edited from Buffon's Histoire naturelle des animaux. The illustrations of the fishes were separately compiled by M. l'Abbé Bonnatere, and published in 1788. They include more the of clanged according to the Linnxan system of classification. For an estimate of the work, see Gill, $T$. $N$., in Smithson. Misc. Coll., 1872, 11, 37. 
Davenport, Charles Benedict [1866 -] The fauna and flora about Cold Spring harbor, L. I. Science, 1908, n. s. 8, 685-689.

1908.1

Davenport, Charles Benedict, \& Castle, William Emest. On the acclimatization of organisms to high temperatures. Arch.Entwick.-Mech., 1895, 2, 227-249.

1895.1

David, La pêche du saumon dans le quartier de Bayonne. Bull. Soc. Centr. Aquicult. France, 1896, 8. 1896.1

David, $J$. On the histological structure of the medulla of Petromyzon. Journ. Comp. Neurol., 1892, 2, 92-94.

1892.1

David, J.J. Fragmentary notes on the generative organs of some cartilaginous fishes. [n. p.] 1861. pl. $4^{\circ}$.

1861.1

David, J.J. Die Lobi inferiores des Teleostier- und Ganoidengehirnes. Inaug. Diss., Basle, 1892. 48 p. 2 pls. $8^{\circ}$.

1892.1

David, T. W. Edgeworth. Stratigraphical note on the fish-bed at the railway ballast quarry, near Gosford. Mem. Geol. Surv. New South IVales, Palæont., 1890, no. 4, vii-ix. $\quad 1890.1$

Davidoff, $M$. von. Beiträge zur vergleichenden Anatomie der hinteren Gliedmassen der Fische. Morphol. Jahrb., 1879-84.

1879.1

i. Haie, Chimæra und Ganoidei chondrostei MIorphol. Jahrb., 1879, 5, 450-520. 4 pls.

i $a$. Ueber das Skelet der hinteren Gliedmassen der Ganoidei holostei und der physostomischen Knochenfische. Vorläufige Mittheilung. Ibid., 1880, 6, 125-128.

ii. Ganoidei holostei. Ibid., 1850, 6, 433-468. iii. Ceratodus, Ibid., 1S81, 9, 117-162.

Ueber das Epithel des Darmes und seine Beziehungen des Darmepithels zum lymphoiden Gewebe. Sitzber. Ges. Morph. Physiol. München, 1886, 2.

1886.1

Davidoff, M. von, Emery, Carlo, \& Schoebel, $E$. Vertebrata [containing bibliography and review of fish literature] Zool. Jahresber., Berlin, 1897, $1-37 ; 68-74$.

1897.1

Davidson, George. [Note on a habit of the thresher shark] Proc. Cal. Acad. Sci., 1871, 4, 127.

1871.1

Davidson, H.E. Davidson's ichthytaxidermy; an improved method of preserving fishes. Invented and patented by H. E. Davidson, M.D. New York, 1885. 11 p. fig.
Davidson, .William. Observations on the properties of some fish oils, and on the utility of chloride of lime in destroying their putrid adour. Edinb. Journ. Sci., 1827, 7, 97.

1827.1

On the removal of the fetid odours of fish oils. Edinb. New Phil. Journ., 1840, 28, 258-260. — Journ. Prak. Chem. (Erdmann), 1840, 20, 188190.

1840.1

Davies, Arthur Morley. The base of the Gault in eastern England. Geol. Mag., 1899, 4. dec. 6, 159-163; 234.

1899.1

Davies, Arthur Morley, \& Wells, $H$. $G$. See Wells \& Davies.

Davies, George Christopher. Fishing: a comprehensive handbook of the art, including sea-fishing. London [1873?] 64 p. figs. $16^{\circ}$.

1873.1

This edition was published by Dean and son. An edition ras published by the "graphotypin company" in 1873, as one of the series called "Champion handbooks."

Davies, Hugh, \& Latham, J. See Latham \& Davies.

Davies, $J . H$. Farther observations on the influence of fresh water on marine animals. Communicated by James $L$. Drummond. Mag. Nat. Hist., 1829, 2, 217-218.

1829.1

Davies, William [1814-1891] For biography, see Amer. Naturalist, 1S91, 25, 410-412. - Geol. Mag., 1891, 3. dec. 8, 144; 190-192.-Quart. Journ. Geol. Soc., 1891, 47, 56.

Holoptychius and Glyptolepis. Geologist, 1863, 135-136. 1863.1

Alphabetical catalogue of type specimens of fossil fishes in the British Museum. Geol. Mag., 1871, 8, 208-216; 334-335.

1871.1

On the rostral prolongations of Squaloraia polyspondyla Ag. Geol. Mag., 1872, 9, 145-150. pl. Notice in Neues Jahrb. Mineral., 1874, 216.

1872.1

On the nomenclature of Saurocephalus lanciformis of the British Cretaceous deposits, with description and figures of a new species ( $S$. woodwardii) Geol. Mag., 1878, 2. dec. 5, 254262. pl. - Neues Jahrb. Mineral., 1878, 983-986.

1878.1

On some fish exuvix from the Chalk, generally referred to Dercetis 
[Leptotrachelus] elongatus Ag. Geol. Mag., 1879, 2. dec. 6, 145-148. Neues Jahrb. Mineral., 1880, 1, 120.

1879.1

- A note on Professor Cope's "Edestus and Pelecopterus," etc. Geol. Mag., 1886, 3. dec. 3, 141-142. 1886.1

On new species of Pholidophorus from the Purbeck beds of Dorsetshire. Geol. Mag., 1887, 3. dec. 4, 337-339.

1887.1

Davis, A.C. Statement concerning the menhaden fishery. Rept. U. S. Fish Comm. 1877 (1879), 5, 475.

1879.1

Davis, Bradley Moore [Abstract] On the origin of the epiphysis cerebri in Amia, and summary of the literature on the epiphysis cerebri. Proc. Indiana Acad. Sci., 1896, 259-271. 1896.1

.Contains an extensive bibliography.

Davis, Bradley Moore, \& Eycleshymer, A.C. See Eycleshymer \& Davis.

Davis, Bradley Moore, \& Jordan, David Starr. Sce Jordan \& Davis.

Davis, Charles H.S. The Catopterus gracilis. Trans. Sei. Assoc. Meriden, Conn., 1887, 2, 21-22. fig. 1887.1

Davis, Frederica $K$. \& Parker, George Howard. See Parker \& Davis.

Davis, $H . B$. Gratifying results of propagating German carp. Bream and carp in ponds together. Table qualities of carp. Bull. U. S. Fish Comm. 1882 (1883), 2, 317-318.

1883.1

Davis, $J . F$. Zoological observations made in the neighbourhood of Tenby. Ann. Mag. Nat. Hist., 1841, 7, 234-236.

Refers to a Zygœna malleus, ten feet long.

Davis, John. Parasites on fish. Science Gossip, 1878, 14, 33-34. pl.

1878.1

Davis, James William [1846-1893] For biography and list of works, see Geol. Mag., 1893, 3. dec. 10, 427-432. - Trans. Leeds Geol. Assoc., 189293, 8, 79-82. - Quart. Journ. Geol. Soc., 1894, 50, 44-47. - Proc. Yorkshire Geol. Soc., 1894, n. s. 12, pt. 4, 319-334.

On the occurrence of certain fish-remains in the Coal Measures, and the evidence they afford of their freshwater origin. Proc. Yorkshire Geol.
Soc., 1871-72, n. s. 6, pt. 1, 40-52. Rept. Brit. Assoc. Adv. Sci., 48. meet., 1878, 539.

1871.1

On a bone-bed in the Lower Coal Measures, with an enumeration of the fish-remains of which it is principally composed. Quart. Journ. Geol. Soc., $1876,32,332-340$.

1876.1

- Ichthyography of the northern part of the IVest Riding coal-field. Barnsley, 1878. 19 p. $8^{\circ}$. 1878.1

Description of a new species of fossil fish-spine, Ctenacanthus minor, from the Lower Coal Measures of Yorkshire. Geol. Mag., 1879, 2. dec. 6, 531532. fig.

1879.1

- Notes on Pleurodus affinis, sp. ined. Agassiz [Pleuroplax rankini] and description of three spines of Cestracionts from the Lower Coal Measures. Quart. Journ. Geol. Soc., 1879, 35, 181187. pl. - Ann. Mag. Nat. Hist., 1879, 5. ser. 3, 93. — Neues Jahrb. Mineral., $1880,2,103$.

1879.2

__. On Ostracocanthus dilatatus, gen. et sp. nov. A fossil fish from the Coal Measures south-east of Halifax, in Yorkshire. Rept. Brit. Assoc. Adv. Sci., 49. meet., 1879, 343. - Proc. Yorkshire Geol. Soc., 1879, n. s. 7, pt. 2, 191-195.

1879.3

- On a new species of Gyracanthus, a fossil fish from the Coal Measures (Gyracanthus denticulatus) Ann. Mag. Nat. Hist., 1880, 5. ser. 6, 372373. figs.

1880.1

- On the fish-remains found in the cannel coal in the middle Coal Measures of the West Riding of Yorkshire, with the descriptions of some new species. Quart. Journ. Geol. Soc., 1880, 36, 56-67.

1880.2

On the distribution of fossil fishes in the Yorkshire coal-fields. Proc. Yorkshire Geol. Soc., 1880, n. s. 7, pt. 3, 228-241. - Proc. Geol. Assoc., 1881, 6, 359-370.

1880.3

- On the genus Pleuracanthus Agass, including the genera Orthacanthus Agass. and Goldf., Diplodus Agass., and Xenacanthus Beyr. Quart. Journ. Geol. Soc., 1880, 36, 321-336. - Ann. Mag. Nat. Hist., 1880, 5. ser. 5, 259 260. pl. \& figs.

1880.4

On the teleostean affinities of the genus Pleuracanthus. Ann. Mag. Nat. Hist., 1880, 5. ser. 5, 349-357.

1880.5 
Davis, $J . W$.

Notes on the fish-remains of the bone-bed of Aust, near Bristol; with the description of some new genera and species. Quart. Journ. Geol. Soc., 1881, 37, 414-425. pl.

1881.1

On Anodontacanthus, a new genus of fossil fishes from the Coal Measures; with descriptions of three new species [A. acutus, obtusus, fastigia[us] Quart. Journ. Geol. Soc., 1881, 37, $+27-429$.

1881.2

- On Palocospinax priscus Egerton. Ann. Mag. Nat. Hist., 1881, 5. ser. 7, 429-432. pl.

1881.3

- On the genera Ctenoptychius Agassiz; Ctenopetalus Agassiz; and Harpacodus Agassiz. Ann. Mag. Nat. Hist., 1881, 5. ser. 8, 424-427. 1881.4

On the zoological position of the genus Petalorhynchus Ag., a fossil fish from the Mountain Limestone. Rept. Brit. Assoc. Adv. Sci., 51. meet., 1881, 646.

1881.5

- Notes on the occurrence of fossil fish-remains in the Carboniferous Limestone series of Yorkshire. Proc. Yorkshire Geol. Soc., 1882, n. s. 8, pt. 1, 3963.

1882.1

- On the fossil fish-remains from the Armagh limestone in the collection of the Earl of Enniskillen. Proc. Geol. Soc., 1882, 38, 12-13.

1882.2

- On the fossil fishes of the Carboniferous Limestone series of Great Britain. Scient. Trans. Roy. Dublin Soc., 1883, 2. ser. 1, 327-600. 14 pls.

1883.1

Description of a new genus of fossil fishes from the Lias. Ann. Mag. Nat. Hist., 1884, 5. ser. 13, 448-453. pl.

1884.1

Description of a new species of Ptycholepis from the Lias of Lyme Regis. Ann. Mag. Nat. Hist., 1884, 5. ser. 13, 335-337. pl.

1884.2

On a new species of Colacanthus (C. tingleyensis) from the Yorkshire cannel coal. Trans. Linn. Soc. London (Zool.), 18S4, 2. ser. 2, pt. 13, 427-433. pls. xlvi-xlix.

1884.3

On a new species of Heterolepidolus $[H$. minor] from the Lias. Proc. Yorkshire Geol. Soc., 188t, n. s. 8, pt. 3, 403-107. pl.

1884.4
- On some remains of fossil fishes from the Yoredale series at Leyburn in Wensleydale. Quart. Journ. Geol. Soc., 1884, 40,614-634. pls. xxvi-xxvii. Geol. Mag., 1884, 3. dec. 1, 91-92.

1884.5

The fossil fishes of the Chalk of Mount Lebanon, in Syria. Scient. Trans. Roy. Dublin Soc., 1885, 2. ser. 3 , 457-636. pls. xiv-xxxviii. 1855.1

- Note on Chlamydoselachus anguineus Garman. Proc. Yorkshire Geol. Soc., 1885, n. s. 9, pt. 1, 98-113. pl.

1885.2

On Heterolepidotus grandis, a fossil fish from the Lias. Journ. Linn. Soc. London (Zool.), 1885, 18, 293-298. pl.

1885.3

- Notes on a collection of fossil fish-remains from the Mountain Limestone of Derbyshire. Geol. Mag., 1886 , 3. dec. 3, 149-157. figs.

1886.1

On some fish-remains from the Tertiary strata of New Zealand. Geol. Mag., 1886, 3. dec. 3, 93-94.

1886.2

Note on a fossil species of Chlamydoselachus. Geol. Mag., 1887, 3. dec. 4, 392-393.-Proc. Zool. Soc. London, 1887, 542-544.

1887.1

On Chondrosteus acipenseroides Ag. Quart. Journ. Geol. Soc., 1887, 43, 605-616. pl.

1887.2

Note on a species of Scymnus from the Upper Tertiary formation of New Zealand. Geol. Mag., 1888, 3. dec. 5, 315-316.

1888.1

- On fossil fish-remains from the Tertiary and Cretaceo-Tertiary formations of New Zealand. Scient. Trans. Roy. Dublin Soc., 1889, 2. ser. 4, 1-62. 7 pls.

1889.1

Summary of geological literature relating to Yorkshire. Proc. Yorkshire Geol. Soc., 1889, n. S. 11, pt. 1, 128-129.

1889.2

Fossil fish-remains from Carboniferous shales at Cultra, county Down, Ireland. Proc. Yorkshire Geol. Soc., 1890 , n. s. 11, pt. 2, 332-334.

1890.1

On a new species of Coccodus ( $C$. lindstrœmi Davis) Quart. Journ. Geol. Soc., 1890, 46, 565-568. pl. 1890.2 
On Colacanthus phillipsii Agassiz. Geol. Mag., 1890, 3. dec. 7, 159-161.

1890.3

On the dentition of Pleuroplax (Pleurodus) A. S. Woodward. Ann. Mag. Nat. Hist., 1890, 6. ser. 5, 291294. pl.

1890.4

On the fossil fish of the Cretaceous formations of Scandinavia. Scient. Trans. Roy. Dublin Soc., 1890, 2. ser. 4, 363-434. pls. xxxviii-xlvi. - Notice in Amer. Naturalist, 1891, 25, 569-570.

1890.5

Summary of geological literature relating to Yorkshire. Proc. Yorkshire Geol. Soc., 1890, n. s. 11, pt. 2, 344.

1890.6

On the discovery of a new species of fossil fish (Strepsodus brockbanki) in the Upper Coal Measures limestone of Levenshulme, near Manchester. Mem. Proc. Manchester Lit. Phil. Soc., 1891, 4. ser. 4, 1-3. - Geol. Mag., 1891, 3. dec. 8, 465.

1891.1

On the fossil fish-remains of the Coal Measures of the British islands. Part I. Pleuracanthida. Scient. Trans. Roy. Dublin Soc., 1893, 2. ser. 4, 703748. pls. Ixv-lxxiii. - Review in Geol. Mag., 3. dec. 10, 72-75.

1893.1

On the fossil fish-remains of the Coal Measures of the British islands. Part II. Acanthodidæ. Scient. Trans. Roy. Dublin Soc., 1894, 2. ser. 5, 249258. pls. xxvii-xxix.

1894.1

Davis, Peter. Condition of the shore fisheries of Massachusetts and Rhode Island in 1871. Rept. U.S. Fish Comm. 1871-72 (1873), 32-33.

1873.1

Davis, William T. The brook lamprey in New Jersey. Copeia, 1915, no. 1 s, $1-2$.

Davy, (Sir) Humphry [1778-1829] Salmonia... with some account of the habits of fishes belonging to the genus Salmo. London, 1828. 273 p. $8^{\circ}$.

1828.1

A second edition of this work was published at London in 1829 , a third in 1832, and a fourth in 1851. The work was reviewed by Sir Walter Scott in Quarterly Review, 1828, p. 503.

An account of some experiments on the torpedo. Phil. Trans. Roy. Soc. London, 1829, 15-18. - Annal. Chimie, 41, 438-444. - Phil. Mag., 6, 81-84.Annalen (Poggendorff), 16, 311-315. Journ. (Schweigger), 2. ser. 55 (Jahrb.
25), 454-455.-Ibid., n. S. 57 (Jahrb. 27), 17-23. 1829.1

Davy, John [1790-1868] An account of some experiments and observations on the torpedo (Raja torpedo Linn.) Phil. Trans. Roy. Soc. London, 1832. 259-278. - Ann. Sci. Nat., 1832, 30, 192-204. - Annalen(Poggendorff, 1832), 27, 542-551. - Phil. Mag., 1832, 3. ser. 1, 67. - Notizen (Froriep), 1834, 43, 229-230. - L'Institut, 1835, 3, 153154. - Phil. Trans., 1834, 531-550.

1832.1

Observations on the torpedo, with an account of some additional experiments on its electricity. Phil. Trans. Roy. Soc. London, 1834, 531550. Abstract in Notizen (Froriep), 43 229-230. Also separate; London, 1834. 20 p. pl.

1834.1

On the temperature of some fishes of the genus Thynnus. Proc. Roy. Soc. London, 1835, 3, 327-328. Edinb. New Phil. Journ., 19, 325-331. - Notizen (Froriep), 46, 321-326. Ann. Sci. Nat. (Zool.), 1835, 2. sér. 3, 380. - Arch. (Wiegmann), 2, 243.

1835.1

On the male organs of some of the cartilaginous fishes. Phil. Trans. Roy. Soc. London, 1839, pt. 1, 139-150. 1839.1

- Researches, physiological and anatomical. 2 vols. London, 1839.

1839.2

Miscellaneous observations on the torpedo. Proc. Roy. Soc. London, $1841,4,590$.

1841.1

On the torpedo. Proc. Roy. Soc. London, 1841, 4, 291.

1841.2

Note from MIr. Gulliver, on the size of the blood-corpuscles of birds, with measurements by Dr. Davy of the blood-corpuscles of some fishes and of a humming bird. Proc. Zool. Soc. London, 1846, 26-36. 1846.1

- Some observations on the charr (Salmo umbla), relating chiefly to its generation and early life. Trans. Roy. Soc. Edinb., 1852, 20, 321-334. 1852.1

Ueber die Eier der Salmoniden Abstract in Frorieps Tagsber. (Zool. Abth.), 1852, 3, no. 694, 255-256. 1852.2

- Some observations on fish in relation to diet. Trans. Roy. Soc. Edinb., 1853, 20, 599-606.—-Edinb. New Phil. Journ., 55, 225-234. 1853.1 
Davy, $J$.

On the impregnation of the ova of the Salmonida. Trans. Roy. Soc. Edinb., 1854, 21, pt. 1, 1-5.

1854.1

Some observations on the ova of the salmon in relation to the distribution of species. Proc. Roy. Soc. London, $1854,6,149-150 ; 7,363-368$. Phil. 'Trans. Roy. Soc. London, 1854, 21-30. - Ann. Mag. Nat. Hist., 1855, 2. ser. 16, 205-206. Abstract in L'Institut, $1855,23,446$.

1854.2

- Some miscellaneous remarks on the Salmonidx. Trans. Roy. Soc. Edinb., 1855, 21, pt. 2, 245-254. Ann. Mag. Nat. Hist., 1856, 2. ser. 17, 420-124. - Proc. Roy. Soc. London, $1856,8,27-33$.

1855.1

On the vitality of the ova of the Salmonidæe of different ages. Proc. Roy. Soc. London, 1856, 8, 27-33. 1856.1

- The angler in the Lake district; or, piscatory colloquies and fishing excursions in Westmoreland and Cumberland. London, 1857. 360 p. $12^{\circ}$.

1857.1

- On the urinary secretion of fishes, with some remarks on this secretion in other classes of animals. Trans. Roy. Soc. Edinb., 1857, 21, 543-548.

1857.2

Some observations on the fishes of the Lake district. Edinb. New Phil. Journ., 1859, n. s. 9, 1-11. Abstract in Rept. Brit. Assoc. Adv. Sci., 28. meet., 1858, 122.

1859.1

Some miscellaneous observations on the tadpole; on the albumen of the newly-laid egg; on the growth of birds; their specific gravity; and on the stomach of fishes in relation to digestion. Edinb. New Phil. Journ., 1860, n. s. 11, 252-271. - Proc. Roy. Soc. Edinb., 4, 253-254.

1860.1

Fragmentary notes on the generative organs of some cartilaginous fishes. Trans. Roy. Soc. Edinb., 1861, 22, 491506. pl. Also separate; Edinburgh, 1861. 16 p. $4^{\circ}$.

1861.1

Some observations on the vitality of fishes as tested by increase of temperature. Rept. Brit. Assoc. Adv. Sci., 32. meet., 1862, $125 . \quad 1862.1$

Physiological researches. London \& Edinburgh, 1863. 1863.1
On the colour of the salmon. Edinb. New Phil. Journ., 1863, n. s. 18, 247-249. - Rept. Brit. Assoc. Adv. Sci., 33. meet., 1863, 102.

1863.2

- Some observations on the Salmonida, chiefly relating to their generative power. Rept. Brit. Assoc. Adv. Ści., 34. meet., 1864, 93.

1864.1

Dawson, G. H. The salmon. Rept. Marlborough College Nat. Hist. Soc., $1868,10-17$.

1868.1

Dawson, George. The grayling [Thymallus vulgaris] A true angler's experience with this interesting fish. Fish. Gazette, 1878, n. s. 2, no. 85, 577.

1878.1

Fish swallowing fish. Forest \& Stream, 1879, 13, 926.

1879.1

Dawson, George Mercer [1849-] British North American boundary commission report on the geology and resources of the region in the vicinity of the forty-ninth parallel ... Montreal \& London, 1875. 397 p. 18 pls. $8^{\circ}$.

1875.1

- Salmon in rivers of the Pacific slope. Nature, 1879, 19, 528. 1879.1

Report on an exploration in the Yukon district, Northwest Territory, etc. Rept. Canada Geol. Surv., 188788, n. s. 3, pt. 1.

1887.1

Fishes, determined from photographs by $T$. H. Bean,

Dawson, Jean. The mechanism of feeding and breathing in the lamprey. Science, 1904, n. s. 19, 218-219. 1904.1

The breathing and feeding mechanism of the lampreys. Bull. Mar. Biol. Lab., Woods Holl, 1905, 9, 1-21; 91-111.

1905.1

Dawson, John. On the vitality of the heart of a shark. Journ. Med. Surg., Boston, 1852, 46, 82-84. 1852.1

Dawson, (Sir) John William [18201899] On a new species of stickleback (Gasterosteus gymnetes) Canadian Naturalist, $1859,4,321$.

1859.1

On the Lower Coal Measures, as developed in British America. Quart. Journ. Geol. Soc. London, 1859, 15, 6276.

1859.2 I'isces, p. 72-73.

On the conditions of the deposition of coal, more especially as illus- 
trated by the coal-formation of Nova Scotia and New Brunswick. Quart. Journ. Geol. Soc. London, 1866, 22, 95169. 7 pls.

1866.1 Fishes, p. 133, 144 .

Notes on the post-Pliocene geology of Canada; with especial reference to the conditions of accumulation of the deposits and the marine life of the period. Canadian Naturalist, $1872,6,112$.

1872.1

Lower Carboniferous fishes of New Brunswick. Canadian Naturalist, 1877, 2. ser. 8, 337-340. figs. 1877.1

- Acadian geology. The geological structure, organic remains and mineral resources of Nova Scotia, New Brunswick and Prince Edward island. 3. ed. London, Edinburgh, Montreal, Halifax, \& New York, 1878. xxvi, 694 p. illust. $8^{\circ}$.

1878.1

Note on a fossil fish and marine worm found in the Pleistocene nodules of Greens creek, on the Ottawa. Canadian Rec. Sci., 1890, 4, 86-88. 1890.1

Some salient points in the science of the earth. New York, 1894. 499 p. illust.

1894.1

Dawson, R. A., \& Herdman, W. A. See Herdman \& Dawson.

Dax, (Vicomte) Louis de. Note sur les hippocampes. Bull. Soc. Polymath. Morbihan, 1863, 40-14. 1863.1

Day, E. C. H. On Acrodus anningio Agass., with remarks upon the affinities of the genera Acrodus and Hybodus. Geol. Mag., 1864, 1, 57-65. 2 pls.

1864.1

- On a head of Hybodus delabechei. Geol. Mag., 1865, 2, 565. 1865.1

Day, Francis [1829-1889] For biography and list of works, see Nature, $1889,40,282$. - Zoologist, 1889, 3. ser. 13, 306-305. - Proc. Cotteswold Nat. Field Club, 1892, 10, 2-3. - Trans. Norfolk Norwich Nat. Soc., 1894, 5, 7-8.

The fishes of Malabar. London, 1865. 293 p. $20 \mathrm{col}$. pls. $4^{\circ}$. 1865.1

On the fishes of Cochin, on the Malabar coast of India. Part 1. Acanthopterygii. Part 2. Anacanthini. Proc. Zool. Soc. London, 1865, 2-40; 286-318.
On some fishes from the $\mathrm{Wy}$ naad: Nemacheilus striatus, Garra alta, Homaloptera brucei. Proc. Zool. Soc. London, 1867, 347-350. 1867.1

- On some new or imperfectly known fishes of India. Proc. Zool. Soc. London, 1867, 699-707; 935-942.

1867.2

Later contributions under the same title are found in the Proceedings for the years 1868 and 1873.

- On some new or imperfectly known fishes of Madras. Proc. Zool. Soc. London, 1867, 558-565; 935-942.

1867.3

On the fishes of the Neilgherry hills and rivers around their bases. Proc. Zool. Soc. London, 1867, 281-302. 1867.4

-_ Catalogue of Indian freshwater fishes (Acanthopterygii and Cyprinodontidæ) Madras Quart. Journ., 1868 , 1-73. Ibid., 1869, 328-333. 1868.1

- Observations on some Indian fishes: Barbus neilli, $B$. guentheri, $B$. ambassis, B. nashii. Proc. Zool. Soc. London, 1868, 580-585. 1868.2

- Observations on some of the freshwater fishes of India [Respiration of fishes] Proc. Zool. Soc. London, 1868, 274-288.

1868.3

-... On a new gobioid fish from Madras [Euctenogobius striatus] Proc. Zool. Soc. London, 1868, 272-273.

1868.4

- On some new fishes from Madras. Proc. Zool. Soc. London, 1868, 192-199. 1868.5

On some new or imperfectly known fishes of India. Proc. Zool. Soc. London, 1868, 149-156. 1868.6

- Pisciculture on the Neilgherry hills. Madras Quart. Journ., 1868 , 37-99. 1868.7

On the fishes of Orissa. Proc. Zool. Soc. London, 1869, 296-310; 369387.

1869.1

Remarks on some of the fishes in the Calcutta museum. On the freshwater fishes of Burma, part 1. Proc. Zool. Soc. London, 1869, 511-527; $548-560 ; 611-623 . \quad 1869.2$

Description of five new species of fishes from Burmah. Proc. Zool. Soc. London, 1870, 99-101.

1870.1 
Day, $F$.

- Notes on some fishes from the western coast of India. Proc. Zool. Soc. London, 1870, 369-374.

1870.2

Notes on the fishes of Nancowry harbour, Nicobar islands. Journ. Roy. Asiat. Soc. Bengal, 1870, 39, pt. 2, $31-35$.

1870.3

Notes on the genus Hara Blyth. Journ. Roy. Asiat. Soc. Bengal, 1870 , 39, pt. 2, 37-40. pl.

1870.4

Observations on the Andamanese. Proc. Roy. Asiat. Soc. Bengal, $1870,153-177$.

1870.5

- On the fishes of the Anadaman islands. Proc. Zool. Soc. London, 1870, $677-705$.

1870.6

- On turtle and fish oils. Madras Quart.Journ., 1870, 294-301. 1870.7

- Monograph of Indian Cyprinidx. Journ. Roy. Asiat. Soc. Bengal, 1871, 40, pt. 2, 95-143; 277-336; 337367. - Ibid., 1872, 41, 1-85; 171-176; 318-326.

1871.1

- Notes on Indian siluroid fishes. Proc. Zool. Soc. London, 1871, 286-289.

1871.2

On fish as food, or the reputed origin of disease. Indian Med. Gazette, $1871,6,5-8 ; 26-29$.

1871.3

On Hamilton Buchanan's original drawings of fish in the library of the Asiatic Society of Bengal. Proc. Roy. Asiat. Soc. Bengal, 1871, 195-209.

1871.4

On the freshwater siluroids of India and Burmah. Proc. Zool. Soc. London, 1871, 703-721.

1871.5

- Remarks on Indian fishes. Proc. Zool. Soc. London, 1871, 631-638.

1871.6

Report on the fish and fisheries of the fresh waters of India. Simla, 1871. 49 p. $8^{\circ}$. 1871.7

- Notes on fish collected by Dr. Stoliczka in Kachh. Journ. Roy. Asiat. Soc. Bengal, 1872, 41, pt. 2, $258-260$.

1872.1

- On the identity of the siluroid genera Erethistes and Hara. Proc. Roy. Asiat. Soc. Bengal, 1872, 122-123.

1872.2

Extracts from the late Dr. Buchanan's "Fishes of Bengal," with remarks. Proc. Zool. Soc. London, 1873, 743-748.

1873.1

- On some new fishes of India. Journ. Linn. Soc. London (Zool.), 1873, $11,524-530$.

1873.2

- On some new or imperfectly known fishes of India and Burmah. Proc. Zool. Soc. London, 1873, 107-112; 236-240.

1873.3

On some new or little-known fishes of India: Cirrhitichthys bleckeri, Barbus thomasii, B. lithopidos, Chela boopis, Hemiramphus cirrhatus. Proc. Zool. Soc. London, 1873, 704-710.

1873.4

Report on the freshwater fish and fisheries of India and Burmah. Calcutta, 1873.307 p. $8^{\circ}$. 1873.5

- Report on the sea fish and fisheries. Calcutta, 1873. $8^{\circ}$. 1873.6

- Remarks on some Indian fishes: Sicydium fasciatum, n. S., Semiplotus macclellandi, Labeo dyocheilus. Journ. Roy. Asiat. Soc. Bengal, 1874, 43, pt. $2,31-32$.

1874.1

The fishes of India; being a natural history of the fishes known to inhabit the seas and fresh waters of India, Burma, and Ceylon. Text and atlas in 4 parts. London, 1875-78. $\mathrm{xx}, 778$ p. 198 pls. $4^{\circ}$.

1875.1

Geographical distribution of Indian freshwater fishes. Part 1. The Acanthopterygii, spiny-rayed teleostean fishes. Part 2. The Siluridx. Part 3. Conclusion. Journ. Linn. Soc. London (Zool.), 1876, 13, 138-155; 338-353. Ibid., 1879, 14, 534-579. $\quad 1876.1$

- On some of the fishes of the Deccan. Journ. Linn. Soc. London (Zool.), 1876, 12, 565-578. 1876.2

- On the fishes of Yarkand. Proc. Zool. Soc. London, 1876, 781-807.

1876.3

On the introduction of trout and tench into India. Journ. Linn. Soc. London (Zool.), 1876, 12, 562-565.

Fish and fisheries of Bengal (In Hunter, IV. W. Statistical account of Bengal, vol. xx. London, 1877. $8^{\circ}$ ) 1877.1

Notice of the capture of Coregonus oxyrhynchus in Lincolnshixe. Proc. Zool. Soc. London, 1877, 419-420. fig. 
On amphibious and migratory fishes of Asia. Journ. Linn. Soc. London (Zool.), 1877, 13, 198-215. 1877.3

Devil fishes. Chicago Field,
$1878,10,83$.

Exhibition of, and remarks upon, three jaws of Indian sharks] Proc. Zool. Soc. London, 1878, $976 . \quad 1878.2$

On some Irish Gasterostei. Journ. Linn. Soc. London (Zool.), 1878. 13, 110-114. 3 figs.

1878.3

[Remarks on Mr. Whitmee's paper on the manifestation of fear and anger in fishes] Proc. Zool. Soc. London, 1878, 214-221.

1878.4

For reply to this, see whitmee, $S_{\text {. }} J_{\text {, }}$, in Proc. Zool. Soc. Londion, 1878, 221-222.

Scientific results of the second Yarkand mission. Ichthyology. Calcutta $[1878] 25$ p. 5 pls. $4^{\circ}$. 1878.5

Clupea pilchardus and $C$. sprattus figured; with air-bladder, stomach, and crecal appendages. Proc. Zool. Soc. London, 1879, 759. pl.

1879.1

$C$ sagax Jenn. not regarded as a climatal variety of $C$ spraitus.

- On the fishes of Weston-superMare. Proc. Zool. Soc. London, 1879, 742-763. 2 pls.

1879.2

On the identity of Trigla pociloptera and T. hirundo. Proc.Zool. Soc. London, 1879, 179-181. pl. 1879.3

On the occurrence of Morrhua macrocephala at the mouth of the Thames. Journ. Linn. Soc. London (Zool.), 1879, 14, 689-692.

1879.4

What are whitebait? Forest \& Stream, 1879, 12, 497.

1879.5

The burbot (Lota vulgaris) and air-bladders of fishes. Proc. Cotteswold Nat. Field Club, 1880, 7, 221-242.

1880.1

The fishes of Great Britain and Ireland. Text and atlas. London \& Edinburgh, $1880-84.179$ pls. $8^{\circ}$.

1880.2

The vernacular names of many species of fish are given in English, French and Dutch.

Functions of the air bladder in fish. Scient. Amer., 1880, 43, 104. 1880.3

Greenland bullhead at Brighton. Zoologist, 1880, 3. ser. 4, 14\$. 1880.4
Instincts and emotions in fish. London, $1880.8^{\circ}$.

1880.5

-C Large-headed cod [Gadus morrhual at the mouth of the Thames. Zoologist, 1880, 3. ser. 4, 26-27. $\quad 1880.6$

Notes on the fresh-water fishes of India. Zoologist, 1880, 3. ser. 4, 431$437 ; 461-471$.

1880.7

On the air-bladders of fish. Zoologist, 1880, 3. ser. 4, 97-104. Abstract in Science Gossip, 1880, 16, 88.

1880.8

On the change of colour in the boar-fish, and the growth of the turbot. Zoologist, 1880, 3. ser. 4, 383-388.

1880.9

On the fishes of Afghanistan.

Proc. Zool. Soc. London, 1880, 224-232. 1880.10

On the specific identity of Scomber punctatus Couch, with Scomber scomber Linn. Journ. Linn. Soc. London (Zool.), 1880, 15, 146-149. pl.

1880.11

_. The origin of varieties in Salmonidæ. Zoologist, 1880, 3. ser. 4, 133-137. $\quad 1880.12$

Scomber punctatus [scomber] on the Cornish coast. Zoologist, 1880, 3. ser. 4, 303-304. 1880.13

Sea fishes in fresh water. Chicago Field, 1880, 13, 327-328. 1880.14

- Additions to the British fish fauna. Zoologist, 1881, 3. ser. 5, 424425.

1881.1

- Instincts and emotions in fish. Journ. Linn. Soc. London (Zool.), 1881, $15,31-58$.

1881.2

Observations on some British fishes. Journ. Linn. Soc. London (Zool.), 1881, 15, 310-318. $\quad 1881.3$

On Asiatic blowpipe fishes. Zoologist, 1881, 3. ser. 5, 91-96. 1881.4

- On the Hebridal argentine [Argentina sphyrana] Journ. Linn. Soc. London (Zool.), 1881, 15, 78-84. pl. Abstract in Zoologist, 1880, 4, 112.

1881.5

- On the range of $A$ pogon ellioti. Proc. Zool. Soc. London, 1881, 650-651. 1881.6

- On the specific identity of Scomber punctatus Couch with S. scom- 
Day, $F$.

ber Linn. Journ. Linn. Soc. London (Zool.), 1881, 15, 146-149. pl. 1881.7

Rare fishes on the Cornish coast. Zoologist, 1881, 3. ser. 5, 338-340; 385$386 ; 424$.

1881.8

Remora or sucking-fish, off the Cornish coast. Zoologist, 1881, 3. ser. $\mathbf{5}, 338$.

1881.9

- Blindness in codfish. Zoologist, 1882, 3. ser. 6, 191-192. 1882.1

The digestive organs of the 1882.2

Do salmon spawn in the sea? Zoologist, 1882, 3. ser. 6, 153. 1882.3

- On hybrids between salmon and trout. Proc. Zool. Soc. London, 1882, 751-753.

1882.4

On the food of sea fishes. Zoologist, 18s2, 3. ser. 6, 235-236. 1882.5

- On the food of the herring. Zoologist, 1882, 3. ser. 6, 268-269.

1882.6

On the identity of Anguilla kieneri Günther, with a gadoid Lycodes. Proc. Zool. Soc. London, 1882, 536-537.

1882.7

On the identity of the Arnoglossus lophotes Günther, with $A$. grohmanni. Proc. Zool. Soc. London, 1882, 748750. pl.

1882.8

On variations in form and hybridism in Salmo fontinalis. Journ. Linn. Soc. London (Zool.), 1882, 17, 13-19.

1882.9

—_ The Severn salmon - whence it comes and where it goes. Zoologist, 1882 , 3. ser. 6, 221-228.

1882.10

Catalogue of the exhibits in the Indian section (Internat. Fisheries Exhib.) London, 1883. 198 p. $8^{\circ}$.

1883.1

- Fish culture. Intern. Fisheries Exhib. Lit., London, 1883. Handbooks, 2, pt. 1. 105 p. 4 pls.

1883.2

The food of fishes. Intern. Fisheries Exhib. Lit., London, 1883. Conferences, 6, pt. 8.36 p. 1883.3

Indian fish and fishing. Intern. Fisheries Exhib. Lit., London, 1883. Handbooks, 2, pt. 6. 59 p. 1883.4
- Natural history at the International Fisheries Exhibition. Zoologist, 1883, 3. ser. 7, 233-239. 1883.5

- Observations on British Salmones. I. Trout. Journ. Linn. Soc. London (Zool.), 1883, 16, 396-417.

1883.6

On the occurrence of Paralepis coregonoides in Cornwall. Zoologist, 1883, 3. ser. 7, 381-382; 506. 1883.7

The commercial sea fishes of Great Britain. Intern. Fisheries Exhib. Lit., London, 1883 (1884). Conferences, 8, pt. 1. 328 p.

1884.1

- Conilera cylindracea, a parasite of Acanthias vulgaris] Proc. Zool. Soc. London, 1884, 44.

1884.2

Exhibition of, and remarks upon, a specimen of a dog-fish (Acanthias vulgaris) internally devoured by parasites. Proc. Zool. Soc. London, 1884 , 44-45.

1884.3

- Note on a new blenny (Lumpenus lampretoformis) Rept. Edinb. Fish Board, 1884, 2, 78 .

1884.4

Observations on the marine fauna off the east coast of Scotland. Journ. Linn. Soc. London (Zool.), $1884,17,81-102$.

1884.5

On races and hybrids among the Salmonidx. Proc. Zool. Soc. London, 1884, 17-40; 376-380; 581-593. 2 pls. Ibid., 1885, 241-243. Extract in Amer. Naturalist, 1884, 18, 1158-1160. 1884.6

On the occurrence of Lumpenus lampetriformis off the east coast of Scotland. Proc. Zool. Soc. London, 1884, 445-447. pl. 1884.7

- Salmon breeding. Nature, 1884 , 30,488 .

1884.8

- The basking shark. Zoologist, 1885, 3. ser. 9, 235-236.

1885.1

The effects of an elevated temperature on fishes. Bull. U. S. Fish Comm., 18s5, 5, 142-144.

1885.2

Exhibition of, and remarks upon, a specimen of the vendace (Coregonus vandesius), the diseased intestine of a sea-trout, and a portion of the siftingapparatus of the basking shark (Selache maxima) Proc. Zool. Soc. London, $1885,483-484$. fig. 
The fisheries of India. Rept. U. S. Fish Comm. 1883 (1885), 11, 383413.

1885.4

Hybridization among Salmonidæ. Nature, 1885, 31, 599-600. 1885.5

Occurrence of "Torpedo marmorata" off the coast of Cornwall. Nature, 1885, 32, 197.

1885.6

On a supposed hybrid between the dab (Pleuronectes limanda) and the flounder ( $P$. flesus) Proc. Zool. Soc. London, 1885, 929-930. pl. ' 1885.7

- On the hybridisation of Salmonidæ at Howietoun. Rept. Brit. Assoc. Adv. Sci., 55. meet., 1885, 1059-1063.

1885.8

On the occurrence of Lumpenus lampetriformis lampretoformis] and $G a$ diculus argenteus off Aberdeen. Nature, $1885,32,223$.

1885.9

On the rearing, growth, and breeding of salmon in fresh water in Great Britain. Abstract in Bull. U. S. Fish Comm. 1885, 5, 307-308. 1885.10

_ Rare fishes off Aberdeen. Zoologist, 1885,3 . ser. 9, 312.

1885.11

Relationship of the Indian and African freshwater fish-faunas. Journ. Linn. Soc. London (Zool.), 1885, 18, 308-317.

1885.12

The young of the garfish. Zoologist, 1885 , 3. ser. 9, 482-483. 1885.13

- Migration of the Salmonidæ. I. Notes on "early" and "late" salmon rivers. II. Periods of migration. Naturalist, 1886, 19-29; 115-128.

1886.1

Note on Orcynus thynnus (L.) Ann. Mag. Nat. Hist., 1886, 5. ser. 17 400-402.

1886.2

- Notes on the breeding of fishes.

Proc. Cotteswold Nat. Field Club, 1886, 8, 188-212.

1886.3

Notes on the breeding of Salmonidre. Proc. Cotteswold Nat. Field Club, 1886, 8, 301-340. Ibid. 1890, 9, 136-158.

1886.4

On the British weevers, the bib (Gadus luscus), and the poor-cod (G. minutus) Ann. Mag. Nat. Hist., 1886, 5. ser. 17, 526-530.

1886.5

"Scopelus mülleri." Nature $1886,34,571-572$.
British and Irish Salmonidx. London, 1887. 298 p. 12 pls. $8^{\circ}$

1887.1

The British Salmonidx. Journ. Nat. Fish. Cult. Assoc., 1887, 1, 3-25. 1887.2

Experiments with salmon in Scotland. Bull. U. S. Fish Comm. 1886 (1887), 6, 56 .

1887.3

- Notes on creal appendages of fresh-water trout. Journ. Nat. Fish. Cult. Assoc., 1887, 1, 243-255. 1887.4

Notes on the creal appendages of Cardiganshire trout. Journ. Nat. Fish. Cult. Assoc., 1887, 1, 369-374.

1887.5

On a supposed hybrid between the pilchard (Clupea pilchardus) and the herring $(C$. harengus), and on a specimen of Salmo purpuratus. Proc. Zool. Soc. London, 1887, 129-130. pl. 1887.6

On the occurrence of Scorpana scrofa off the south coast of England. Proc. Zool. Soc. London, 1887, 342.

1887.7

Zygana dissimilis Murray. Ann. Mag. Nat. Hist., 1887, 5. ser. 20, 389.

1887.8

- Exhibition of, and remarks upon, a specimen of the Spanish loach (Cobitis tania) and of some hybrid Salmonidæ] Proc. Zool. Soc. London, 1888, 3.

1888.1

-.. Observations on the fishes of India. Part I. Proc. Zool. Soc. London, 1888, 258-265.

1888.2

On the bib (Gadus luscus) and poor-cod (G. minutus) Ann. Mag. Nat. Hist., 1888, 6. ser. 1, 151-154. Ibid., 2, $387-389$. 1888.3

- On the breeding of salmon from parents which have never descended to the sea [Read 1885] Trans. Linn. Soc. London (Zool.), 1888, 2. ser. 2, 447-468. 2 pls.

1888.4

- On Trachinus draco and $T$. vipera. Ann. Mag. Nat. Hist., 1888, 6. ser. 1, 351-353.

1888.5

- Supplement to the fishes of India. London, 1888. $4^{\circ}$. 1888.6

- Fishes (In The fauna of British India, including Ceylon and Burma, edited by W. T. Blanford. 2 vols. London, Calcutta, etc., 1889. 341 figs.)

1889.1

Notice in Ann. Mag. Nat. Hist., 1889, 6 ser. 5, 115-117. 
Day, $F$.

- Remarks on some Norfolk eels. Trans. Norfolk Norwich Nat. Soc., 1889 , 4, 333-337.

1889.2

Notes on hybridization. Fish. Proc. Cotteswold Nat. Field Club, 1890 , 9, 334-373. 1890.1

Notes on the fish and fisheries of the Severn. Proc. Cotteswold Nat. Field Club, 1890, 9, 202-219. 1890.2

- On the loch Leven trout (Salmo levenensis) Journ. Linn. Soc. London (Zool.) 1890, 20, 71-90. 1890.3

- On the mode of propagation of the common eel. Proc. Cotteswold Nat. Field Club, 1890, 9, 44-51. 1890.4

- iDescription of Cyclopium cyclopum Humboldt) (In Whymper, E. Travels amongst the Great Andes of the Equator. Supplementary appendix p. 137-139. London, 1891)

1891.1

Day, Thomas. Statement concerning the menhaden fishery. Rept. U. S. Fish Comm. 1877 (1879), 5, 390.

1879.1

Deakin, Richard [-1873] Fishes observed at Nice, 1865 . The Chimæra and the Alepocephalus. Intellect. Obsnrv., 1866, 8, 241-245. fig. 1866.1

De Alessandri, Giulio. See Alessandri, G. de.

Dean, Bashford [1867-] Bibliography of Bashford Dean, 1887-1909. Edited by Louis Hussakof. Washington, 1910. 12 p. $8^{\circ}$.

1910.1

- Report on the supposed fisheating plant, Utricularia. 18. Rept. N. Y. State Comm. Fisheries, 1889, 183 198. 4 pls.

1889.1

- Notes on the common catfish. 19. Rept. N. Y. State Comm. Fisheries, 1891, 299-305. pl.

1891.1

Pineal fontanelle of placoderm and catfish. 19. Rept. N. Y. State Comm. Fisheries, 1891, 307-363. 14 pls.

1891.2

Note on the mode of origin of the paired fins. Trans. N. Y. Acad. Sci., 1892-93, 12, 121-125. 1892.1

Contributions to the anatomy of Dinichthys. Trans. N. Y. Acad. Sci., 1893, 12, 187-185.
- A new cladodont from the Ohio Waverly, Cladoselache newberryi, n. sp. Trans. N. Y. Acad. Sci., 189394, 13, 115-119. pl.

1893.2

Note on the spawning conditions of the sturgeon. Zool. Anz., 1893, 16 , 473-475. - Forest \& Stream, 41, 525. - Allgem. Fischerei Zeit., 1893, 388390.

1893.3

On the fin-structures of Diplurus. Trans. N. Y. Acad. Sci., 1893-94, 13, 22 .

1893.4

— On 'Trachosteus and Mylostoma, notes on their structural characters. Abstract in Bull. U. S. Fish Comm 1891 (1893), 11, 70-71. $\quad 1893.5$

Recent experiments in sturgeon hatching on the Delaware. [Read before World's Fisheries Congress, Chicagol 'Trans. N. Y. Acad. Sci., 1893, 13, 69-74. Reprint in Bull. U. S. Fish Comm. 1893 (1894), 13, 335-339. fig.

1893.6

Contributions to the morphology of Cladoselache (Cladodus) Journ. Morph., 1894, 9, 85-115. pl. 1894.1

Dr. Ryder's work with the United States Fish Commission (In The Ryder memorial volume, p. 10-12. Philadelphia, 1895)

1895.1

The early development of Amia. Quart. Journ. Micr. Sci., London, 1895, n. s. $38,413-444.2$ pls. \& 13 figs. Abstract in Journ. Roy. Micr. Soc., 2. ser. 16, 173-174. pl.

1895.2

The early development of garpike and sturgeon. Journ. Morph., $1895,11,1-62$. 4 pls. \& 4 figs. 1895.3

Fishes, living and fossil; an outline of their forms and probable relationships. New York \& London, 1895. xiv, 300 p. 344 figs: Review by A.S. Woodward. Geol. Mag., 1896, 135. - Nat. Sci., London, 1896, 8, 267 270. 1895.4

Columbia University biological series. III.

Notes of the ancestral sharks Read before New York Academy of Sciences, Nov. 11, 1895] Anat. Anz., 1895, 11, 424. - Science, n. s. 2, 742. 1895.5

Notes on the early development of the Ganoids, Lepidosteus, Acipenser, and Amia. Rept. Brit. Assoc. Adv. Sei., 65. meet., $1895,734$. 
On the gastrulation of teleosts. Science, 1895, n. s. 3, 60.

1895.7

- The fin-fold origin of the paired limbs, in the light of the ptychopterygia of Palæozoic sharks. Anat. Anz., 1896, 11, 673-679. S figs. Abstract in Zool. Centralbl., 1896, 3. Jahrg., 850-852.

1896.1

- Is Palæospondylus a Cyclostome? Trans. N. Y. Acad. Sci., 1896, 15, 100-104. pl. Abstracts in Science, n. s. 3, 214. - Amer. Naturalist, 30, no. 357,745 .

1896.2

IObservations on the instinct in some of the lower vertebrates] Trans. N. Y. Acad. Sci., 1896, 15, 126-127. Abstract in Anat. Anz., 11, 696. 1896.3

Behavior and food-taking of Amia when newly hatched.

- On the early development of ganoids. C. R. 3. Congrès Intern. Zool. (Leyde) 1895 (1896), 336-346. Abstract in Journ. Roy. Micr. Soc., 1896, 2. ser. 16, 497-498. - Science, n. s. 2,575 .

1896.4

- On the larval development of Amia calva. Zool. Jahrb. (Syst. Abth.), 1896, 9, 639-672. pls。 \& 17 figs. Abstract in Journ. Roy. Micr. Soc. 2. ser. 17, 20-21.

1896.5

On the supposed kinship of Palæospondylus. Zool. Anz., 1896, 19, 96. - Anat. Anz., 1896, 11, 656. 1896.6

- On the vertebral column, fins and ventral armoring of Dinichthys. Trans. N. Y. Acad. Sci., 1896, 15, 157163. 2 pls. Review by C. R. Eastman, in Amer. Geologist, 18, 316-317. 1896.7

Public aquariums in Europe. Pop. Sci. Monthly, 1896, 50, 13-27. 7 figs.

1896.8

Review of A. S. Woodward's "Catalogue of fossil fishes in the British Museum. Part III." Science, 1896, n. S. $4,1-2$.

1896.9

Review of S. Garman's "The Cyprinodonts." Science, 1896, n. s.4, $25-26$.

1896.10

- Sharks as ancestral fishes. Nat. Sci. London, 1896, 8, 245-253. 6 figs. 1896.11

A Californian marine biological station. Nat. Sci. London, 1897, 11, 28-35. 4 figs.
Note on the ventral armoring of Dinichthys. Trans. N. Y. Acad. Sci., 1897, 16, 57-61. 2 pls. 1897.2

On a new species of Edestus, E. lecontei, from Nevada. Trans. N. Y. Acad. Sci., 1897, 16, 61-69. 2 pls.

1897.3

On a plan of development of a myxinoid. Science, 1897, n. s. 5, 435.

1897.4

(editor) New species and a new genus of American Palæozoic fishes, together with notes on the genera Oracanthus, Dactylodus, Polyrhizodus, Sandalodus, Deltodus. From a nearly completed MS. (1890-1891) by John Strong Newberry. Edited with an introduction and notes by Bashford Dean. Trans. N. Y. Acad. Sci. 189697 (1898), 16, 282-304. 2 pls. 1898.1

In this paper 16 new species are described, and the new genus Stenognathus is proposed. See Newberry, $J_{.} S_{*}, 1892$.

- On the development of the California hag-fish, Bdellostoma stouti Lockington. Quart. Journ. Micr. Sci. London, 1898, n. s. 40, 269-279. pl. 1898.2

- Remarks on the affinities of Palcospondylus gunni. In reply to Dr. R. H. Traquair. Proc. Zool. Soc. London, 1898, 343-347. 1898.3

- Devonian fishes for the American Museum. Science, 1899, n. s. 10, 978.

1899.1

Memorial notice of Nathan Russell Harrington. Columbia Univer. Quart., 1899, 44-46. 1899.2

Contains reference to studies of Polypterus.

Notes on the development of a myxinoid. Science, 1899 , n. s. 9, 311.

1899.3

- On the dogfish (Amia calva), its habits and breeding. 4. Ann. Rept. Comm. Fish. Game \& Forests New York, 1899, 246-256. 3 pls. 1899.4

On the embryology and phylogeny of Chimara [Abstract of paper read before the American Morphological Society] Science, 1899, n. s. 11, 169170.

1899.5

On the embryology of $B$ dellostoma stouti. A general account of myxinoid development from the egg and segmentation to hatching (In Festschrift zum siebenzigsten Geburtstag von Carl von Kupffer, p. 221-276. pls. xv-xxvi \& 25 figs. Jena, 1899)

1899.6 
Dean, $B$.

On the new genus of lamprey, Macrophthalmia chilensis. Science, 1899, n. s. 9, 740. 1899.7

Review of a paper by Plate in Sitzber. Ges. Naturf. Freunde Berlin, 1897, 137-141.

- Review of J. N. Baskett's "Story of the fishes." Science, 1899, n. s. 10, 968-969.

1899.8

The Devonian "lamprey," Palaospondylus gunni Traquair, with notes on the systematic arrangement of the fish-like vertebrates. Mem. N. Y. Acad. Sci., 1900, 2, 1-32. pl.\& fig. 1900.1

The egg of the hag-fish, Myxine glutinosa Linnæus. Mem. N. Y. Acad. Sci., 1900, 2, 33-46. pl. 1900.2

'The Jay 'Terrell collection of fossil fishes. Amer. Mus. Journ., 1900, 1, 10-12. 2 figs.

1900.3

Carl von Kupffer, his life and work, with bibliography. Science, $\mathbf{1 9 0 0 ,}$ n. s. $11,361-369$.

1900.4

Memorial notice of the fishculturist, Major Fred. Mather. Science, 1900 , n. S. 11, 556-557.

1900.5

The early development of sharks from a comparative standpoint [Read before New York Academy of Sciences] Science, 1901, n. S. 15, 626. 1901.1

Instruction offered in the Fishery Commission laboratory at Bergen. Science, 1901, n. s. 16, 676. 1901.2

[Letter to the Quarterly regarding field work in Japan] Columbia Univers. Quarterly, 1901, 4, 84-87.

1901.3

Palaeontological notes. Mem. N. Y. Acad. Sci., 1901, 2, 85-134. pls. iii-viii \& 18 figs. Review by C. R. Eastman in Amer. Naturalist, 35, 417420.

1901.4

I. On two new Arthrodires from the Cleveland shale of Ohio.

II. On the characters of Mylostoma Newberry.

III. Further notes on the relationships of the Arthrognathi.

Reminiscence of holoblastic cleavage in the egg of the shark, Heterodontus (Cestracion) japonicus Macleay. Annot. 'Lool. Japonenses, 1901, 4, pt. 1, 1-7. pl.

1901.5

Biometric evidence in the problem of the paired limbs of the vertebrates. Amer. Naturalist, 1902, 36, 837-847. fig.
Historical evidence as to the origin of the paired limbs of vertebrates. Amer. Naturalist, $1902,36,767-776$. fig.

1902.2

The preservation of musclefibres in sharks of the Cleveland shale. Amer. Geologist, 1902, 30, 273-279. 2 pls.

1902.3

- Review of O. P. Hay's "Bibliography and catalogue of the fossil vertebrata of North America." Science, 1902 , n. s. 16, 701-703.

1902.4

Additional specimens of the Japanese shark Mitsukurina. Science, 1903, n. s. 17, 630-631. 1903.1

Albinism, partial albinism, and polychromism in hag-fishes. Amer. Naturalist, 1903, 37, 295-298. 3 figs. 1903.2

The eggs of the eastern Atlantic hag-fish, Myxine limosa Gir. Science, 1903, n. s. $17,433$.

1903.3

Obituary notice of a lung-fish. Pop. Sci. Monthly, 1903, 63, 33-39. 7 figs.

1903.4

An outline of the development of a chimeroid. Bull. Mar. Biol. Labor. Wood's Holl, 1903, 4, 270-286. 19 figs. 1903.5

A preliminary account of studies on the Japanese frilled shark, Chlamydoselachus [Read before the central \& western branch of the American Society of Zoologists] Science, 1903, n. s. 17 , 487.

1903.6

The egg-cases of chimæroid fishes [Abstract of paper presented at first meeting of the eastern branch of the American Society of Zoologists] Amer. Naturalist, 1904, 38, 482-487.

1904.1

Evolution in a determinate line as illustrated by the egg-cases of chimaroid fishes. Bull. Mar. Biol. Labor. Wood's Holl, 1904, 7, 105-112.

1904.2

Fossil fishes in the American Museum of Natural History. Science, 1904, n. s. $19,437$. 1904.3

- In the matter of Menaspis [Abstract of paper read before the Society of American Palæontologists] Science, 1904, n. s. 19, 253; 798-800. 
In the matter of the Permian fish Menaspis. Amer. Geologist, 1904, 34, 49-53. pl.

1904.5

- Notes on Chimæra. Two Japanese species, C. phantasma Jordan and Snyder, and C. mitsukuri, n. sp., and their egg-cases. Journ. Sei. College, Imperial Univ. Tokyo, 1904, 19, no. 3. 9 p. pl. 1904.6

- Notes on Japanese myxinoids. A new genus Paramyxine, and a new species Homea okinoseana. Reference also to their eggs. Journ. Sci. College, Imperial Univ. Tokyo, 1904, 19, no. 2. 25 p. pl. \& 4 figs.

1904.7

Notes on the long-snouted chimæroid of Japan, Rhinochimara (Harriotta) pacifica (Garman) Mitsukuri. Journ. Sci. College, Imperial Univ. Tokyo, 1904, 19, no. 4. 24 p. 2 pls. \& fig.

1904.8

L'œuf de Chimara colliei et l'adaptation de sa capsule. C. R. Mém. Soc. Biol. Paris, 1904, 56, 14-15. 1904.9

Peculiarities in the development of Chimera colliei. Abstract in Bull. 6. Congrès Intern. Zool. Berne, 1904, no. $3,5-6$.

1904.10

Review of R. H. 'Traquair's "The Lower Devonian fishes of Gemünden." Science, 1904, n. s. 19, 6465.

1904.11

Still another memoir on Palæospondylus. Review of IV. J. Sollas and I. B. J. Sollas's paper "An account of the Devonian fish, Palcospondylus gunni Traquair." Science, 1904, n. s. 19, 425-426.

1904.12

- A visit to the Japanese zoological station at Misaki. Pop. Sci. Monthly, 1904, 65, 195-204. 1904.13

- History of the study of fossil fishes (In Jordan, D. S. Guide to the study of fishes, 1, 422-428. New York, 1905. 2 vols. 427 illus.) 1905.1

Memorial notice of Eugene $\mathrm{G}$. Blackford [with bibliography] Seience, 1905 , n. s. 21, 232-233.

1905.2

Some embryological evidence as to the position of Chimra. C. R. 6. Congrès Intern. Zool. (Berne) 1904 (1905), 294-297.

1905.3

Chimæroid fishes and their development. Public. Carnegie Instit., Washington, 1906, no.32. 195 p. pl: \& 144 figs.
Notes on the living specimens of the Australian lungfish, Ceratodus forsteri, in the Zoological Society's collection. Proc. Zool. Soc. London, 1906, 168-17s. pl.

1906.2

Dr. Eastman's recent papers on the kinship of the Arthrodires. Science, 1907, n. s. 26, 46-50.

1907.1

- Notes on Acanthodian sharks. Amer. Journ. Anat., 1907, 7, 209-226. 36 figs.

1907.2

Dentition, skull, vertebral column, etc. Relationship to Cladoselachians.

Preface to "Catalogue of the type and figured specimens of fossil vertebrata in the American Museum of Natural History, Part I. Fishes, by L. Hussakof." Bull. Amer. Mus. Nat. Hist., 1908, 25, 1-2. 1908.1

Studies on fossil fishes during the year 1907 [Portion of the address of the retiring president of the Society of Vertebrate Paleontologists, New Haven, December 27, 1907] Science, 1908, n. s. 27, 201-205. 1908.2

The giant of ancient sharks. Amer. Mus. Journ., 1909, 9, 233-234. pl.

1909.1

- Memorial natice of T. Nishikawa, 1874-1909. Science, 1909, n. s. 30,750 .

1909.2

- [Review of] Gaskell's "The origin of the Vertebrata." Science, 1909 , n. s. 29, 816-818. 1909.3

The post-anal gut and its relation to the doctrine of recapitulation. Science, 1909, n. s. 29, 427-42S. 1909.4 Studies on fossil fishes (sharks,
chimæroids and arthrodires) Mem. Amer. Mus. Nat. Hist., 1909, 9, 211287. 16 pls. \& 65 figs.

1909.5

Contents:

1. Cladoselachian sharks [5 n. sp.]

2. Ctenacanth shark from the Devonian of hio.

3. Well-preserved specimen of the Liassic shark, Paloespinax priscus.

4. Note on Archoobatis gigas.

5. Jurassic chimæroid Ischyodus.

6. Chimaroid egg-capsule from the North

American Cretaceous.

7. Mounted specimen of Dinichthys terrelli.

8. Notes on a newly mounted Titanichthys.

9. The arthrodire Trachosteus clarki.

10. Development of certain plates in Dinichthys.

11. "Pelvic fins" of the arthrodires. Anton Dohrn. Pop. Sci.
Monthly, 1910, 75, 98-101. 
Dean, $B$.

[Review of] Gaskell's "Cyclostomes and fishes." Science, 1910, n. s. $31,26 \pm-265$.

1910.2

Collecting fossil fishes in Ohio. Amer. MIus. Journ., 1911, 11, 302-303.

1911.1

- The new fossil aquarium. Amer. Mus. Journ., 1911, 11, 160-161. 1911.2

Note on the Ohio placoderm Dinichthys terrelli. Science, 1911, n. s. 34,801 .

1911.3

Additional notes on the living specimens of the Australian lungfish (Ceratodus forsteri) in the collection of the Zoological Society of London. Proc. Zool. Soc. London, 1912, 607-612. 2 figs.

1912.1

Coloration, size, age, breathing, feeding, regeneration.

Changes in the behavior of the eel during transformation. Ann. N. Y. Acad. Sci., 1912, 22, 321-326. 1912.2

- The exhibition of fishes. Amer. Mus. Journ., 1912, 12, 171-177. 7 figs. 1912.3

Existing reptiles, batrachians, recent and extinct fishes. 43. Ann. Rept. Amer. Mus. Nat. Hist., 1912, 46-51.

1912.4

A fish [Protopterus annectens] out of water. Amer. Mus. Journ., 1912, 12, 251-253. pl. \& 4 figs.

1912.5

Orthogenesis in the egg capsules of Chimæra. Bull. Amer. Mus. Nat. Hist., 1912, 31, 35-40. 2 figs. 1912.6

Paleozoic fishes. Bull. Geol. Soc. Amer., 1912, 23, 224-228. $\quad 1912.7$

The plan of development in series of forms of known descent and its bearing upon the doctrine of preformation. Proc. 7. Intern. Zool. Congress (Boston) 1907 (1912), 396399.

1912.8

Fish exhibits in the American Museum of Natural History. Amer. Mus. Journ., 1914, 14, 36-38. 1914.1

A bibliography of fishes to be published. Science, 1915, n. s. 42, 32.

1915.1

Dean, Bashford, Harrington, $N . R$., Calkins, Gary Nathan, \& Griffin, $B . B$. The Columbia University zoological expedition of 1896 ; with a brief account of the work of collecting in Puget sound and on the Pacific coast. Trans. N. Y. Acad. Sci., 1896, 16, 33-42. pl. 1896.1

Dean, Bashford, \& Sumner, F. B. Notes on the spawning habits of the brook lamprey (Petromyzon wilderi) Trans. N. Y. Acad. Sci., 1897, 16, 321324. pl.

1897.1

Dean, Herbert $D$. Discouragements in bass culture. Trans. Amer. Fisheries Soc. 1902 (1903), 153-155. 1903.1

Grayling. Trans. Amer. Fisheries Soc. 1912 (1913), 139-144. 1913.1

Dean, Samuel. Use of fish as fertilizer (In IVorcester, Thomas. The New England farmer. 2.ed., 1797) 1797.1

Deane, Samuel. Upon the abundance of fish on the New England coast in former times. Rept. U. S. Fish Comm.1871-72 (1873), 1, 161. 1873.1

Debeyre, A. Sur la présence des cellules dans les ébauches des racines antérieures. Bibliogr. Anat. Nancy, 1907, 16, 280-289. 6 figs. 1907.1

Debierre, Charles. Note sur un merlan hermaphrodite. C. R. Mém. Soc. Biol. Paris, 1887, 8. sér. 4, 31-32. 1887.1

De Blois, E.T. Statement concerning the menhaden fishery. Rept. U.S. Fish Comm. 1877 (1879), 5, 425. 1879.1

The origin of the menhaden in: dustry. Bull. U. S. Fish Comm. 1881 (1882), 1, 46-51.

1882.1

Debschitz, $H$. von. Der Kalikobarsch. Blätt. Aquar.-Terrar. Freunde, 1898, 9. Jahrg., 261-262.

1898.1

(editor) Der amerikanische Calico-barsch (Silber-barsch) Centrarchus hexanthus in Europa. Von Max von dem Borne-Berneuchen. 2. Auflage. Neudamm, 1901. 16 p. pl. $8^{\circ}$. 1901.1

This was published the same year as the original edition, by Max von dem Borne. See supra.

Einiges vom Amia calva. Prometheus, Berlin, 1901, 12, 715-716.

1901.2

Das Jahr des Teichwirthes und Fischzüchter; ein Wegweiser für den Arbeitsgang bei der Bewirtschaftung ablassbarer Gewässer, etc. Neudamm, 1901. 96 p. $8^{\circ}$. 1901.3

- Piratenbarsch. Blätt. Aquar.Terrar. Freunde, 1901, 12, 79. 1901.4 
Vom amerikanischen Hundsfisch, Amia calva. Natur, 1901, 50, 368-369. - Fischereizeitg., Neudamm, $1901,4,411-442$.

1901.5

Debschitz, $H$, von, Knauthe, Karl, Apstein, C., Berthelmann, Borcherding, Fr. \& Cronheim, See Knauthe, Apstein \& others.

De Causans, Maxime. See Causans, Maxime de.

De Causans, (Viscount) — The fish-cultural establishment of lake Saint-Front, Haute Loire, France. Bull. U. S. Fish Comm., 1885, 5, 201-202.

1885.1

Decken, (Baron) Carl Claus von der [1833-1865] Baron C. C. von der Decken's Reisen in Ost-Afrika in 1859-61 ... Bearbeitet von O. Kersten. Mit einem Vorworte von ... A. Petermann. 4 vols. in 6. Leipzig \& Heidelberg, 1869-79. illust.

1869.1

Bd.iii, pt. 1. Uebersicht der Ostafrikanischen Süsswasser-Fische, etc., von $E$. von Martens. 1869 .

Bd. iii, pt. 2. Neue Süsswasserfische der v. d. Decken'schen Sammlung, von W. C. H. Peters. 1869.

Decker, Friedrich. Zur Physiologie des Fischdarmes (In Kölliker, A. von. Zur Feier seines siebenzigsten Geburtstage... von C. Gegenbaur und Andere herausgegeben, no. 23, 387-411. Leipzig, 1887. 444 p. 17 pls. $8^{\circ}$ ) 1887.1

Decker, W. Der Steinbutt (Rhombus maximus) verschluckt grosse Steine. Mitth. Deutsch. Seefischerei-Ver., Berlin, $1896,12,219$.

1896.1

Decker, $W$., Heincke, $F$., \& Henking, $H$. Die Seefischerei Norwegens. Abh. Deutsch. Seefischerei-Ver., Berlin, 1901, 6, 1-182. 20 pls.

1901.1

Décocq, - Mâchoire d'un Halocyon (poisson) dans la craie de Lezennes. Ann. Soc. Géol. Nord, 1870-74 (1875), 69.

1875.1

Dedek, B., \& Babák, Eduard. See Babák \& Dedek.

Deecke, Johannes Ernest Wilhelm [1862 - ] Ueber Fische aus verschiedenen Horizonten der Trias. Palæontographica, 1888-89 (1889), 35, 97-138.

1889.1

- Die mineralogische, geologische und paläontologische Litteratur über die Provinz Pommern. Mitth. NeuVorpommern, 1894, 25, 54-92. 1894.1

Paläontologische Betrachtungen. IV. Ueber Fische. Neues Jahrb. Mineral., 1913, 2, 69-92.

1913.1

Defay, — Bemerkung über eine Bastard-Art von Barben und Karpfen. Schrift. Berlin. Ges. Naturf. Freunde, 1785-86, 7, 490 .

1785.1

- Sur des anguilles vénimeuses. Journ. Pharm., 1819, 5, 509-513.

1819.1

De Forest, John W. History of the Indians of Connecticut from the earliest period to 1850 . Hartford, 1851. $509 \mathrm{p}$. $8^{\circ}$

1851.1

Fishing, p. 8.

Deganello, Umberto. Gli ordegni nervosi periferici del ritmo respiratorio nei pesci teleostei. Ricerche anatomiche e sperimentali. Rend. Accad. Lincei Roma, 1907, 5. ser. 16, pt. 2, 279-291. 13 figs.

1907.1

Les appareils nerveux périphériques du rythme respiratoire chez les poissons téléostéens. Arch. Ital. Biol., $1908,49,113-127$.

1908.1

_- Die peripherischen, nervösen Apparate des Atmungsrhythmus bei Knochenfischen. Eine anatomische und experimentelle Untersuchung. Arch. Gesammt. Physiol., Bonn, 1908, 123, 40-94. 48 figs.

1908.2

Degoutin, N., Villada, Manuel $M$., Gandara, Guillermo, \& Urbina, Manuel. See Villada, Gandara \& others.

Dei, A. La vessica idrostatica dei pesci e l' apparato aereostatico e pulmonare degli ucelli. Riv. Ital. Sci. Nat., $1895,15,97-99 ; 133-136 . \quad 1895.1$

Organi di locomozione degli ucelli e dei pesci. Riv. Ital. Sci. Nat., 1896, 16, 145-146.

1896.1

Deichsel, Gerhard. Beiträge zur Kenntnis des Knochenfischauges mit besonderer Berücksichtigung der Frage nach der Accomodation. Inaug. Dissert. Breslau, 1908. 63 p. 8. 1908.1

Deinek, D.I. Sur la structure de la vessie natatoire des poissons ['Text in Russian with French résumé] Trav. Soc. Nat., St. Pétersb., 1901, 32, pt. 1, 253260.

1901.1 
Deinek, D. $I$. Zur Frage über den Bau der Schwimmblase. Zeitschr. Wiss. Zool., 1904, 78, 149-164. pls. viii-ix \& figs.

1904.1

Deister, Georg. Fischbrut-Aufzucht im Aquarium] Deutsch. FischereiZeitg., 1850, 3. Jahrg., 339. - Erste Oesterr.-ungar. Fischerei-Zeitg., 1880, 135.

1880.1

De Kay, C. 'Trout farms in Bohemia. U. S. Consular Repts., 1895, 49, 41-47. 1895.1

Dekay, James Ellsworth [1792-1851] The probable identity of the genera Ophiognathus Harwood and Saccopharynx Mitchill. Amer. Journ. Sci., 1829, 15, 358 .

1829.1

- Fishes of New York. 2 vols. Albany, 1842.79 pls. \& 250 figs. $4^{\circ}$.

1842.1

Zoology of New York; or, The New York fauna. Comprising detailed descriptions of all the animals hitherto observed within the state, with brief notices of those occasionally found near its borders (In Natural history of New York [State] Geological Survey. Albany, 1842. Vol. i, pts. 3 and 4. 102 pls. $4^{\circ}$ )

1842.2

Pt. iv, Eishes, with a chapter on fossil fishes. In this is given a list of fossil fishes found in the United States and known to the author. "List of works referred to," p. xi-xii.

- Zoology of the state of New York. 6 pts. in 5 vols. New York, 1842-44. 329 pls. $4^{\circ}$.

P'isces, vol. iii, pt. 4. 1842.

Catalogue of the fishes inhabiting the state of New York, as classified and described in part IV of the New York fauna, with an appendix containing a list of the fishes inhabiting the state, discovered since the publication of the zoology. New York, 1855.

1855.1

Dekhuyzen, Marinus Cornelis. Bekervormige roode bloedlichaampjes (chromokrateeren) Versl. K. Acad. Wet. Amsterdam (Wis. Nat. Afd.), 1898-99 (1899), 7, 193-196. - Proc. K. Acad. Wet. Amsterdam (Sect. Sci.), 1, 151-157. - Anat. Anz., 15. Jahrg., 206-212. 6 figs. Abstract in Journ. Roy. Micr. Soc., 1899, 152. 1899.1

- Ergebnisse von osmatischen.Studien, namentlich bei K̈nochenfischen, an der biologischen Station des Bergenser
Museums während eines Aufenthalts vom 23 Juli bis 27 Aug. 1904. Bergens Mus. Aarbog, 1904, no. 8. 5 p. 1904.1 Over den osmotischen druk in bloed en urine van visschen. Versl. K. Acad. Wet. Amsterdam (Wis. Nat. Afd.), 1904, 13, 418-430. - Proc. II. Acad. Wet. Amsterdam (Sect. Sci.), 1905, 7, pt. 2, 537-549. - Arch. Néerl. Sci., 1905, 2. ser. 10, 121-136. 1904.2

Delachanel, $B$., \& Mermet, $A$. Sur un calcul intestinal d'esturgeon, C. R. Acad. Sci. Paris, 1874, 78, 1859. - Ann. Chimic Phys., 1874, 5. sér. 3, 193-195.Bull. Soc. Chim. Paris, 187t, 22, 62-64.

1874.1

Delachaux, Theodor. Fischfressende Pflanzen. Schweiz. Fischereizeitg., 1894, 2, 45. Also separate; Pfäffikon-Zürich, 1894. 1 p. $8^{\circ}$.

1894.1

- Der amerikanische Lachs oder Namaycush in der Schweiz. Schweiz. Fischereizeitg., 1895, 3, 238. Also separate; Pfäffikon-Zürich, $1895.1 \mathrm{p} .8^{\circ}$. 1895.1

- Der Iltis, ein Fischfeind. Schweiz. Fischereizeitg., 1895, 3, S5. Also separate; Pfäffikon-Zürich, 1895. $1 \mathrm{p} . \mathrm{S}^{\circ}$.

1895.2

Z Zur Geschichte des Rötel [Salvelinus] (Seesaibling, Omble-chevalier. Als Antwort auf die Frage der" "Schweiz. Fischereizeitg." Nr. 25 vom 7. Dez. 1895) Schweiz. Fischereizeitg., 1896, 4, 5-6. Also separate; Pfäffilion-Zürich, 1896. 1 p. $S^{\circ}$.

1896.1

Delafontaine, _ Le Dinichthys, genre nouveau de poissons dévoniens. Bull. Hebd. Assoc. Scient. France, 1877, 20, 266-268.

1877.1

Delage, Marie Yves [1854-] Sur les relations de parenté du congre et du leptocéphale. C. R. Acad. Sci. Paris, $1886,103,698-699$.

1S\$6. 1

Sur une fonction nouvelle des otocystes. C. R. Acad. Sci. Paris, 1887, 103, 795. - Arch. Zool. Expér., 1887, 2. sér. 5, 1-26.

1887.1

Delage, Marie Yves, \& Hẻrouard, Edgard. Traité de zoologic concrète. Tome viii. Les procordés. Paris, 1898. $8^{\circ}$.

1898.1

Delahaye, $N . B$. Quelques réflexions au sujet d'une lettre de M. l'abbé Landriot isur les poissons fossiles des schistes 
de Museł Bull. Soc. Géol. France, 1849 , 2. sér. 6, 374-377.

1849.1

De la Pylaie, Recherches, en France, sur les poissons de l'océan, pendant les années 1832 et 1833. Mém. Congrès Scient. de France, 2. sess., Poitiers. Rouen, 1834 (1835), 524-534.

183.5 .1

Delarbre, Antoine [1724-1811] Essai zoologique, ou histoire naturelle des animaux sauvages, quadrupèdes et oiseaux indigènes; de ceux qui ne sont que passagers, ou qui paraissent rarement, et des poissons et amphibies observés dans cette province. Paris, 1798. $8^{\circ}$. 1798.1

Delarive, $A$. Observations relatives aux communications récentes de M. Marey, sur la décharge électrique de la torpille. C. R. Acad. Sci. Paris, 1871. 73, 1256-1258.

1871.1

Sur l'origine de l'électricité qui se manifeste dans les poissons électriques. Arch. Sci. Phys. Nat., 1871, 42, 315-318. 1871.2

Delaroche, François Etienne [-1813] Expériences sur la température propre de quelques animaux à sang froid. Nouv. Bull. Soc. Philom. Paris, 1807, 1, 169170 .

1807.1

Sur les ouvertures du peritoine dans les raies; et sur la communication entre le pericarde et le peritoine dans les raies et les squales. Nouv. Bull. Soc. Philom. Paris, 1808, 1, 197-198. 1808.1

Observations sur des poissons recucillis dans un voyage aux îles Baléares et Pythiuses. Ann. Mus. Hist. Nat. Paris, 1809, 13, 98-122; 313-361. fig. Also separate; Paris, 1809. 75 p. 6 pls. $4^{\circ}$. Abstract in Nouv. Bull. Soc. Philom. Paris, 1809, 1, 377-378. 1809.1

Observations sur la vessie aérienne des poissons. Ann. MIus. Hist. Nat. Paris, 1809, 14, 184-217; 245-289. Nouv. Bull. Soc. Philom. Paris, 1809, 1, 409-412. - Journ. (Schweigger), 1, 161172.

1809.2

Observations sur l'habitation des poissons dans les eaux profondes. Nouv. Bull. Soc. Philom. Paris, 1809, 1, 349351 .

1809.3

Suite du mémoire sur les espèces de poissons observées à Iviça. Ann. Mus. Hist. Nat. Paris, 1809, 13, 313-361. 5 pls.

1809.4
Sur deux animaux vivant sur les branchies des poissons [Chondracanthus zei et Polystoma thynni] Nouv. Bull. Soc. Philom. Paris, 1810, 2, 270-271.

1810.1

De la Roche, John Francis. The voyage of John Francis de la Roche, Knight, Lord of Roberval, to the countries of Canada, Saguenay and Hochelaga, with three tall ships, and two hundred persons both men, women and children, begun in April, 1542, in which parts he remained the same summer and all the next winter (In Pinkerton, John A general collection of ... voyages and travels in all parts of the world, 1812,12 , 675-678. London, 1808-14. illust. $8^{\circ}$.

1812.1

Fishes, p. 677 .

Delattre, $A d$. Composition de quelques huiles de poisson. Répert. Chim. Pure \& Appliquée, 1859, $1 . \quad 1859.1$

Delaval, Albert. Elevage de poissons télescopes de la Chine et du Japon à Saint-Max-Lez-Nancy. Bull. Soc. Acclim. Paris, 1899, 46. année, 345-358.

1899.1

- Ueber dreischwänzige Teleskopfische [Text in Russian] Dnevn. Otd. Icht. Imp. R. Obsc. Acclim., Moskva, 1903, 2, pt. 2, 44-46. 1903.1

De la Vallêe Poussin, Charles [Observations sur l'extension de Lamna [Odontaspis] elegans Ag. i travers les terrains crétacés et tertiaires] Bull. Soc. Belge Géol., 1875, 2, 56.

Del Campagna, D. See Campagna, D. del.

Delchef, $J$. Sur la pulsation des sinus veineux chez l'anguille (Anguilla fluviatilis) Arch. Intern. Physiol., 1905, 2, 123-126. fig.

1905.1

Delesse, Achille, Laugel, M. A. \& Lapparent, Albert de. Revue de géologie. 18 vols. Paris, 1860-78. 1860.1

Delessert, Adolphe. Souvenirs d'un voyage dans l'Inde 1834-39. Paris, 1843. $35 \mathrm{pls}$. $8^{\circ}$. 1843.1

Histoire naturelle par F. E. Guérin-Méneville et d'autres.

Delezenne, $C$. Sur la coagulation du sang chez les batraciens et les poissons. C. R. Mém. Soc. Biol. Paris, 1897, 10. sér. 4, 489-490.

1897.1

Delfin, Federico T'eobaldo. Catálogo de los peces de Chile. Rev. Chil. Hist. 
Delfin, $F \cdot T$.

Nat., 1898, 2, 92-93; 144-150; 161-163. Ibid., 1899, 3, 15-24; 57-62; 79-85; 95-99; $110-113 ; \quad 121-124 ; \quad 131-134$; 151-161. Ibid., 1900, 4, 4-6; 21-25; $29-31 ; 55-58 ; 69-71 ; 82-84 ; 110-111$; $129-131 ; 166-167 ; 185-186.1898 .1$

Descripción de un nuevo Traquinido chileno (Notothenia porteri) Rev. Chil. Hist. Nat., 1899, 3, 117-120.

1899.1

Lista metódica de los peces de la Bahia de Concepción i sus alrededores. Rev. Chil. Hist. Nat., 1899, 3, 176-178.

1899.2

Nuevo jénero de Acantopterijios abdominales. [n. p.] 1899 . 4 p. fig. 1899.3

- Nuevo pez para la fauna de Chile [Centriscus fernandezianus, n. sp.] Rev. Chil. Hist. Nat, 1899, 3, 75-78. 1899.4

- Alcunas observaciónes sobre la colección, conservación i remisión de peces para los museos. Rev. Chil. Hist. Nat., 1900, 4, 148-152.

1900.1

- Nota de ictiolojía. El nuevo jénero Cilus. Act. Soc. Sci. Chili, 1900, 10, 53-60. figs.

1900.2

Voracidad de la Bdellostoma polytrema de Girard. Act. Soc. Sci. Chili, $1900,10,419-434 .-$ Rev. Chil. Hist. Nat., 1902, 6, 218-226.

1900.3

The corvina of Chile. Ex. Chilean corvina of Buffalo exposition. Revist. Marina, 1901, nos. 169-173, 37-50.

1901.1

Concordancia de nombres vulgares $\mathrm{i}$ cientificos de los peces de Chile. Rev. Chil. Hist. Nat., 1902, 6, 71-76.

1902.1

Nuevas especies de la familia Rajida. Rev. Chil. Hist. Nat., 1902, 6, 262-270. 7 figs.

1902.2

Adición al catálogo de los peces de Chile, con descripción de una nueva especie. Rev. Chil. Hist. Nat., 1903, 7, 220-225. figs.

1903.1

- Contribución a la ictiolojía Chilena. Rev. Chil. Hist. Nat., 1903, 7, 268-273. fig. - Ibid., 1904, 8, 11-13. fig.

1903.2

Los congrios de Chile. Rev. Chil. Hist. Nat., 1903, 7, 15t-192. pl. 1903.3
Delfortrie, Eugène. Les broyeurs [Cestraciontes] du Tertiaire Aquitanien. Act. Soc. Linn. Bordeaux, 1871, 28 (3. sér. 8), 213-236. 4 pls.

1871.1

- Eclaircissements sur une mâchoire fossile provenant du Pliocène toscan de Volterrano, attribuée par M. Roberto Lawley au genre Sphærodus. Act. Soc. Linn. Bordeaux, 1876, 31 (4. ser. 1), 33-35.

1876.1

Sur quelques dents de forme singulière provenant des faluns de Saucats (Gironde) Act. Soc. Linn. Bordeaux, 1876,31 (4. sér. 1), 31-32.-Journ. Zool. (Gervais), 1876, 8, 330-331. figs. 1876.2

Etude sur le genre Notidanus, Notidanus thevenardi, n. sp. Act. Soc. Linn. Bordeaux, 1878, 32 (4. sér. 2), 253-256. figs.

1878.1

Delheid, $E d$. Découverte d'une gigantesque défense de Colorhynchus rectus Ag. Ann. Soc. Roy. Malacol. Belgique (Bull.), 1896, 29, lxxxv. 1896.1

_ L'ossuaire de Saint-Gilles (Bruxelles) Ann. Soc. Roy. Malacol. Belgique (Bull.), 1896, 30, xliv-l. 1896.2

Découverte de Myliobates dixoni.

Nouvelles découvertes dans l'argile de Boom (Oligocène moyen) Ann. Soc. Roy. Malacol. Belgique (Proc.Verb.), 1898, 27, Ixi-lxiv.

1898.1

Découverte d'un squale bruxellien. Ann. Soc. Roy. Malacol. Belgique (Bull.), 1899, 34, lxxiii-lxxv. $1 \$ 99.1$

Quelques découvertes dans l'argile de Boom. Ann. Soc. Roy. Malacol. Belgique (Bull.), 1899, 34, lxxv-lxxx. 1899.2

Quelques mots sur un sirénien de l'argile de Boom et un Scombéride du même terrain. Ann. Soc. Roy. Malacol. Belgique (Bull.), 1903, 37, xxv-xxviii.

1903.1

Quelques poissons éocènes et oligocènes de la Belgique. Une chélonée rupelienne atteinte d'exostoses. Ann. Soc. Roy. Malacol. Belgique (Bull.), $1906,41,104-112$.

1906.1

Quelques fossiles bruxelliens de la région de Waterloo. Ann. Soc. Roy. Malacol. Belgique (Bull.), 1908, 43, 184186.

1908.1

Delidon, E.S. La pêche de la sardine. Ann. Soc. Linn. Maine-et-Loire, Angers, 1866, 8. année, 79-82.

1866.1 
Expérimentation d'un nouvel apparat pour la pêche de la sardine $[C l u-$ pea pilchardus] Ann. Soc. Linn. Maineet-Loire, Angers, 1869, 11. année, 177180 .

1869.1

Delisle de Sales, —_ Dictionnaire théorique et pratique de chasse et de pêche. 2 vols. Paris, 1769. 12 1769.1

“An anonymous work, attributed to Delisle de Sales, and derived for the most part from the ancient authors, with an improved system of ichthrology borrowed from Buffon." - Westwood \& Satchell.

Delius, A. Die Teichwirthschaft. Leipzig, 1874. 104 p. 5 figs. $8^{\circ}$.

1874.1

Die Zwecke, Erfahrungen und Aussichten bezüglich der Bestrebungen zur Förderung der Fischereien. Circul. Deutsch. Fischerei-Ver. 1874 (1875), no. $1,9-21$.

1875.1

Della. For names, other than English, with this prefix (except when written as one word), see under part following the prefix.

Delle-Chiaje, Stefano. See Chiaje, Stefano delle.

Del Lupo, Michele. See Lupo, Michele del.

Delouche, Pisciculture à SaintMartin d'Ablois (Marne); lettre addressée à M. P. Carbonnier. Bull. Soc. Acclim. Paris, 1870, 2. sér. 7, 142-145.

1870.1

\section{Delpéré de Cardaillac de Saint-} Paul, G. See Saint-Paul, G. Delpéré de Cardaillac.

Delsman, $H . C$. Ist das Hirnbläschen des Amphioxus dem Gehirn der Kranioten homolog? [n. p.] 1913, 10 figs.

1913.1

Over haring en haringschubben. Med. Vissch., Helder, 1913, 20, 174-183. 1913.2

Delvaux, $E$. Documents stratigraphiques et paléontologiques pour l'étude monographique de l'étage yprésien. Ann. Soc. Géol. Belgique, 1887, 14, 57-74. pl. \& fig.

1887.1

Delvaux, E., \& Ortlieb, $J$. Les poissons fossiles de l'argile yprésienne de Belgique. Description paléontologique accompagnée de documents stratigraphiques pour servir à l'étude monographique de cet étage. Ann. Soc. Géol. Belgique, 1888, 15, 50-66. 2 pls. 1888.1
Demahis, $J$. Un nouveau poisson [Macropodus] Journ. Fermes, 1869, 1. année, no. 18, 327-328. 1869.1

Demelle, A., \& Grynfeltt, $E$. See Grynfeltt \& Demelle.

Demenge, Emile. Un nouveau Cybium découvert dans le terrain bruxellien. La Nature, 1897, 25. année, pt. 2, $331-332$. 3 figs.

1897.1

Démidoff, Anatole Nikolaevich (Prince of San Donato) [1812-1870] Voyage dans la Russie méridionale et la Crimée exécuté en 1837 sous la direction de M. A. de Démidoff. 4 vols. \& atlas in 2 vols. Paris [1839-] 1840-42. $8^{\circ}$ $\&$ fol.

1840.1

Vol, ii. Observations sur la faune pontique [Poissons, par A. von Nordmann] 1840. $32 \mathrm{col}$ pls.

Demme, $R$. Das arterielle Gefässsystem von Acipenser ruthenus. Wien, 1860. 31 p. 4 pls. $4^{\circ}$. 1860.1

Demontmerot, Charles, \& Roche, $A$. See Roche, A., \& Demontmerot, Charles.

Dempsey, W. Shad in the St. John's river, Florida. Bull. U. S. Fish Comm. 1886 (1887), 6, 96.

1887.1

Dempster, Henry. The deckedwelled fishing boat, and fisheries and fish market reform; being dialogues on these important subjects. Glasgow, 1868. pls. $16^{\circ}$.

1868.1

Dendy, Arthur [1865-] Parietal eye and adjacent organs [fishes] Journ. Roy. Micr. Soc., 1899, 376-377. 1899.1

On a pair of ciliated grooves in the brain of the Ammocote, apparently serving to promote the circulation of the fluid in the brain-cavity. Proc. Roy. Soc. London, $1902,69,485-494$. figs. Zool. Anz., 1902, 25, 511-519. figs.

1902.1

On the parietal sense-organs and associated structures in the New Zealand lamprey (Geotria australis) Quart. Journ. Micr. Sci., London, 1907, 51, 129. 2 pls. 1907.1

The pineal gland. Sci. Progress, 1907, no. 6. 23 p. 1907.2

The pineal sense organs and associated structures in Geotria and Sphenodon. Rept. Brit. Assoc. Adv. Sci., 76. meet., 1907, 604-605. 1907.3 
Dendy, $A$

Reissner's fibre and the subcommissural organ in the vertebrate brain. Rept. Brit. Assoc. Adv, Sci., 82. meet., 1912 (1913), 507.

1913.1

Dendy, A., \& Olliver, M.F. On the New Zealand lamprey. Trans. New Zealand Instit., 1902, 34, 147-149.

1902.1

Denil, G. Les échelles à poissons et leur application aux barrages de Meuse et d'Ourthe. Bull. Acad. Sci. Belgique 1908 (1909), 1221-1224.

1909.1

Denis, W. Metabolism studies on cold-blooded animals. I. The urine of the fish. Journ. Biol. Chem., Baltimore, 1912, 13, 225-232.

1912.1

Denison, Alfred (editor) A literal translation into English of the earliest known book on fowling and fishing, written originally in Flemish and printed at Antwerp in the year 1492. [London] 1872. 24 p. pls. \& figs. $8^{\circ}$. 1872.1

Denison, (Sir) $W$. On the death of fishes during the monsoon off the coast of India. Proc. Geol. Soc., London, 1862, 18, 453. - Ann. Mag. Nat. Hist. 1863, 3. ser. 11, 320 .

1862.1

Denissenko, Gabriel. Mittheilung über die Gefässe der Netzhaut der Fische. Arch. Mikrosk. Anat., 1880, 18, 480-485. pl. \& fig.

1880.1

- Ueber den Bau der äusseren Körnerschicht der Netzhaut bei den Wirbeltieren. Arch. Mikrosk. Anatomie, 1881, 19, 395-440. pl. 1881.1

_ Einiges über den Bau der Netzhaut des Aales. Arch. Mikrosk. Anat. $1882,21,1-20$.

1882.1

Zur Frage vom Baue der Augen der Knorpelganoiden. Klin. Monatsbibl. Augenheilk., 1889, 27. 1889.1

Dennis, Oregon Milton. Fish protection. Trans. Amer. Fisheries Soc. 1905 (1906), 133-138.

1906.1

- The necessity of the state making laws for the protection of food fishes after stocking waters by the state or United States. Trans. Amer. Fisheries Soc. 1907 (1908), 103-104.

1908.1

Some reasons for failure of fish protective legislation and some suggestive remedies. Trans. Amer. Fisheries Soc. 1908 (1909), 152-156.
Dennis, William. Condition of the shore fisheries of Massachusetts and Rhode Island in 1871. Rept. U. S. Fish Comm. 1871-72 (1873), 1, 13.

1873.1

Denny, Alfred: Zoology [of Sheffield] Handbook Brit. Assoc. Adv. Sci., 1910, 448-502.

1910.1

Denny, W. A., \& Eigenmann, Carl $H$. See Eigenmann \& Denny.

Denso, Johann Daniel (editor) [17081795] Physikalische Bibliothek, herausgegeben von J. D. Denso. 8 vols. Rostack, 1754-61. $8^{\circ}$.

1754.1

Some articles on fish are contained in vol. ii

Denton, Sherman $F$. Fish represented in the colored plates. 5. Ann. Rept. Comm. Fish. Game \& Forests New York, 1899 (1900), 259-264. pls.

1900.1

Figures of fishes in colors. 6. Ann. Rept. Comm. Fish. Game \& Forests New York, 1900 (1901), 367-372. pl. \& fig.

1901.1

Denys, $R$. Observation relative à l'emploi comme reproducteurs de truites conservées en captivité. Bull. Soc. Centr. Aquicult. France, 1894, 6, 90.

1894.1

Denys, $R ., \&$ Hausser, - Quelques mots sur la pisciculture en Suisse. Bull. Soc. Centr. Aquicult. France, 1894, 6, 202-205.

1894.1

Depéret, Charles. Note sur la présence d'une espèce d'Athérine (Atherina boieri Risso) dans les eaux douces du canal du Midi, à Castelnaudary. Bull. Soc. Hist. Nat. Toulouse, 1885, 17, 82 84 .

1885.1

Recherches sur la succession des faunes de vertébrés miocènes de la vallée du Rhone (In his Etudes paléontologiques dans le bassin du Rhone, période Miocène, Arch. Mus. Hist. Nat, Lyon, 1887, 4, 45-313. 24 pls.) $\quad 1887.1$

Poissons, p. 85-88.

Depéret, Charles, \& Fabre, G. See Fabre \& Depéret.

Depéret, Charles, \& Vidal, L. M. See Vidal \& Depéret.

Depp, Nicolas de. Note sur les poissons télescopes. Bull. Soc. Centr. Aquicult. France, 1894, 6, 243. pl. 1894.1

G. $d^{\prime}$. 
Derbès, Alphonse. Des ressources que présente le département des Bouches-du-Rhone sous le rapport de la pisciculture. Bull. Soc. Acclim. Paris, 1856, 3, 22-29.

1856.1

D'Erchia, $F$. See Erchia, $F$. $d^{\prime}$.

Dercum, $F$. The lateral sensory apparatus of fishes. Proc. Acad. Nat. Sci. Philad., 1879 (1880), 152-154. 1880.1

Derjugin, K. M. Excursion de M. K. M. Derjuguine dans le Transcaucase sud-ouest [Text in Russian] Ann. Mus. Zool. Acad. Sci. St. Pétersb., 1898, 3, xii-xiv.

1898.1

- Puteshestvie $\mathrm{v}$ dolinu srednjavo i nizhnjavo techenie reki Obi i fauna etoi oblasti. Trav. Soc. Nat. St. Pétersb., 1898, 29, pt. 2, 47-140. pl. 1898.2 French résumé, p. 139-140.

Materials for the ichthyological fauna of southwestern Transcaucasia [Text in Russian] Ann. Mus. Zool. Acad. Impér. St. Pétersb., 1899, 148171. pl.

1899.1

On the ichthyofauna of southeastern Trans-Caucasia [Text in Russian] Ann. Rept. Zool. Mus. Impér. Acad. Sci., 1899.

1899.2

Beobachtungen über die ersten Stadien der Entwicklung bei den Eiern von Perca fluviatilis unter normalen und künstlichen Bedingungen. Trav. Soc. Nat. St. Pétersb., 1901, 32, pt. 1, 125131.

1901.1

Corrigendum ad descriptionem Chondrostoma colchicum Kessl [Text in Russian] Ann. Mus. Zool. Acad. Impér. St. Pétersb., 1901, 6, xxv-xxvi. 1901.2

- Einige Entwicklungs-Stadien von Lophius piscatorius Text in Russian] Dnevn, St. Petersb., XI Sjezda russ. Jest Vrac., 1901, 12, 338. 1901.3

Ueber einige Stadien in der Entwickelung von Lophius piscatorius [Text in Russian] Trav. Soc. Nat. St. Pétersb., 1902, 32, pt. 4, 1-45. pl. \& 8 figs. 1902.1

Murmansche biologische Station 1899-1905. Trav.Soc. Nat.St. Pétersb., $1906,37,1-179$.

1906.1

Die Entwicklung der Brustflossen und des Schultergürtels bei Exocœtus volitans. Zeitschr. Wiss. Zool., 1908, 91, 559-598. 2 pls. $\quad 1908.1$
Die Entwicklung der Extremitäten bei Exocoetes [Text in Russian] Trav. Soc. Nat. St. Pétersb., 1908, 39, pt. 1, 101-103.

1908.2

Der Bau und die Entwickelung des Schultergürtels und der Brustflossen bei Teleostiern [Text in Russian] Trav. Soc. Nat. St. Pétersb., 1909, 39, pt. 4, 1-148. 7 pls. \& 13 figs. - Zeitschr. Wiss. Zool., 1909, 96, 572-653. 3 pls. \& 8 figs.

1909.1

The question of the origin of the paired extremities [Text in Russian] Biol. Journ., Moscow, 1910, 1, no. 3.

1910.1

- Bemerkungen über den Bau und die Entwicklung der paarigen Extremitäten der IKnochenfische. I. Ueber das Auftreten von äusseren Brustflossen während der Entwicklung von Symbranchus (Subord. Symbranchii) II. Ein seltener Fall von Anomalie bei den Knochenfischen. Anat. Anz., 1912, 41. Jahrg., 457-460. 3 figs. 1912.1

Derjugin, $K$., \& Drzhevetzkic, $V$ Account of an excursion in the valley of the upper and middle streams of the river Obi, undertaken in the summer of the year 1897 by students of the St. Petersburg University. Bull. Lab. Biol. St. Pétersb., 1898, 2, 37-47. 1898.1

Derjugin, $K$., \& Rozhdestvensky, $E$. Ueber den Bau und die Entwicklung der Bauchflossen bei den Teleostiern. Vorläufige Mittheilungen. Anat. Anz., 1912, 41. Jahrg., 643-647. 2 figs. 1912.1

Derschau, $\boldsymbol{W}$, von. Zur Frage der Maifisch-Erbrütung. Allgem. FischereiZeitg., 1894, 19, 34-36.

1894.1

Dervieux, L. Il fegato dell' Ammocotes branchialis e del Petromyzon planeri. Boll. Mus. Zool. Univ. Torino, 1898,13 , no. 320.7 p. $\quad 1898.1$

Derẑavin, A. Beiträge zur Kenntnis der Fischwanderungen im Wolga-Delta im Jahre 1910 [Russian with German résumé\} Arb. Ichth. Laboratoriums Astrachan, 1913, 2. ser. 3, 1-60. 1913.1

De Sanctis, L. See Sanctis, $L$. de.

Desco, Bela von. Ueber die künstlichen und natürlichen Ursachen der Veränderungen der Fischfang und der Verminderung der Fische im Hernádflusse Ober-Ungarns. Verh. 5. Internat. Zool. Kongres Berlin, 1902, 567-578. 1902.1 
Descourtilz, Michel Etienne [1775c.1835] Voyages d'un naturaliste, et ses observations. 3 vols. Paris, 1809. col. pls.

1809.1

Deseille, Ernest [1835 - ] Histoire de Ia pêche à Boulogne depuis ses origines. Mém. Soc. Acad. Boulogne-sur-Mer, 186S-70 (1873), 4, 85-305. 1873.1

Etude sur les origines de la pêche à Boulogne-sur-Mer d'après les chartes, les comptes de deniers et autres documents officiels. Mém. Soc. Acad. Boulogne-sur-Mer, $1873-76$ (1S76), 5, 74114.

1876.1

Desjardins, Julien Francois [17991840] Description d'une nouvelle espèce de poisson de l'ile Maurice, appartenant à la famille des Pectorales pediculées et au genre Chironecte. Rev. Mag. Zool., 1840. pl.

1840.1

Deslongchamps, Jacques Amand Eudes [1794-1867] Mémoire sur une fossile du calcaire de Caen, présumé être une défense caudale d'une espèce inconnue de mourine, ou raie-aigle. Mém. Soc. Linn. Calvados, 1825, 270-282. Bull. (Férussac), 8, 279. - Ibid., 9, 241.

1825.1

- Mémoire sur le genre Plagiostome. Bull. Soc. Géol. France, 1831, 1, 221.

1831.1

- Note sur une anguille monstrueuse retirée d'un puits. Mém. Soc. Linn. Normandie, 1835, 5, 47-51.L'Institut, 1836, 4, 87-88. - Notizen (Froriep), 1836, 48, 129-131. figs.

1835.1

- Note concernant des pêches phosphorescentes. Mém. Soc. Linn. Normandie, 1838, 6, 307-308. 1838.1

Sur le mode de propagation des anguilles. L'Institut, 1838, 6, 133-134.

1838.2

- Observations pour servir à l'histoire anatomique et physiologique des Trigles. Mém. Soc. Linn. Normandie, $1843,7$.

1843.1

- Mémoire sur une raie bouclée monstrueuse. Mém. Soc. Linn. Normandie, 1853, 9, 138-144. 1853.1

Note concernant les effets de la gelée sur l'oeil du Gadus barbatus L., avec quelques remarques anatomiques sur les yeux des Gades. Mém. Soc. Linn. Normandie, 1853, 9, 151-162.

1853.2
Note sur trois cas de tumeurs souscutancees développées dans l'espèce de la raie bouclée. Mém. Soc. Linn. Normandie, 1853, 9, 145-150. 1853.3

Note sur une nouvelle espèce de poisson du genre Aspidophore. Mém. Soc. Linn. Normandie, 1853, 9, 167-173.

1853.4

Remarques sur quelques anomalies dans la configuration de plusieurs vertèbres de la plie commune, Pleuronectes platessa L. Bull. Soc. Linn. Yormandie, 1860-61 (1861), 6, 44-50. pl.

1861.1

-... Note sur de petits poissons monstrueux produits par des oufs de la truite du lac de Genève, Salmo lemanus Cuv., fécondés artificiellement. Bull. Soc. Linn. Normandie, 1861-62 (1862), 7, 191-194. figs.

1862.1

- Note sur des céphalopodes et des crustacés renfermés dans la cavité abdominale de poissons et de reptiles des argiles Infra-Oolithiques de Caen. Bull. Soc. Linn. Normandie, 1S66, 10, 156169. 1866.1

Desmarest, Anselme Gaêtan [17811838] Première décade ichthyologique, ou description complète de dix espèces de poissons nouvelles ou imparfaitement connues, habitant la mer qui baigne les côtes de l'île de Cuba. Mém. Soc. Linn. Paris, 1823, 2. Also separate; Paris, 1823. 50 p. 6 pls. $8^{\circ}$. 1823.1

Desmarest, Eugène [1816-1889] Observations sur les mours des anguilles. Rev. Mag. Zool., 1866, 18, 161-165.

1866.1

Desmarest, $E$, \& Chenu, J.C. Reptiles et poissons. See Chenu, J.G. Encyclopédie d'histoire naturelle, etc. Paris, 1874.

Desmoulins, Louis Antoine [17941828] Anatomische und physiologische Untersuchungen über das Nervensystem der Fische. Deutsch. Arch. Physiol. (Meckel), 1822, 7, 566-571. Ibid., 1823 . 8, 185-190.

1822.1

- Mémoire pour servir de complément à.ses recherches sur le système nerveux des poissons. Journ. Physiol. (Magendie), 1822, 2, 348-354. 1822.2

Recherches anatomiques et physiologiques sur le système nerveux des poissons. Journ. Physiol. (Magendie), 1822, 2, 127-135; 348-353. 1522.3 
Note sur la détermination du rapport qui existe entre le développement sphérique donné par le plissement des rétines des oiseaux et des poissons, ct la sphère de l'œil circonscrite à ces rétines. Arch. Génér. de Méd., 1823, 3, 418-424. - Notizen (Froriep), 4, 305306.

1823.1

Mémoire sur les différences qui existent entre le système nerveux de la lamproie et celui des animaux vertébrés, sous le rapport des propriétés physiques, du nombre et du mécanisme de réunion des parties. Journ. Physiol. (Magendie), 1824, 4, 239-257. - Bull. Sci. Nat. (Férussac), 4, 435-438. - Notizen (Froriep), 9, 257-261.

1824.1

Ueber das Gehirn-Rückenmarksystem des Petromyzon fuviatilis und $P$.branchialis. Notizen (Froriep), 1825, 10, 149-150.

1825.1

Ueber die Verschiedenheiten, welche hinsichtlich des Nervensystems der Lamprete und desjenigen der rückgratigen Thiere stattfinden. Notizen (Froriep), 1825, 9, 257-261

1825.2

Desmoulins, L.A., \& Magendie, François. Note sur l'anatomie de la lamproie. Journ. Physiol. (Magendie), 1822, 2, 224-231. - Deutsch. Arch. Physiol. (Meckel), 1823, 8, 236-242.

1822.1

Desnickij, V.M. Versuche mit der Aufzucht und Fütterung von Sterletsbrut in den Jahren 1910 und 1911 auf der Fischzuchtanstalt in Saratov [Text in Russian] Věst. Rybopromyšl., St. Petersb., 1912, 26, 91-94.

1912.1

Desor, Pierre Jean Edouard [18111882] Experiments with chloroform on animals, Proc. Boston Soc. Nat. Hist. 1848, 3, 15.

1848.1

Experiments on minnows and sticklebacks.

- Fish of the artesian wells [in the Sahara desert] Geol. Mag., 1864, 1, 3233.

1864.1

Desormes, Clément. Note sur une épidémie de poissons, communiquée à M. le docteur Rayer. Ann. Sci. Nat., 1832, 27, 205-208. Extract in Gazette Médicale, Mai 29, 1832. — Isis (Oken), 1832, 7, 632 .

1832.1

Despax, R., \& Roule, $L$. See Roule \& Despax.

Despinoy, —_ \& Garreau, Des eaux et des extraits de foie de morue et de leurs propriétés médicinales. Paris, 1870. 32 p. $12^{\circ}$ 。

1870.1
Desrochers, $J . E$. Un maskinonge [Esox estor Gill] remarquable. Natural. Canad., 1895, 22, 191-192. 1895.1

- Poisson-castor (Amia ocellicaudata Lacép.) Natural. Canad., 1904, 31. 38-39.

1904.1

Dessaix, $J$. Le lac Léman. Poissons; la pêche; réglementation de la pêche. Rev. Moderne, 1868, 48, 498-510.

1868.1

Destinex, $P$. Sur deux Diplodus et un Chomatodus de l'ampélite alunifère de Chokier, et deux Cladodus de Visé. Ann. Soc. Géol. Belgique, 1s97, 24, 219-223.

1897.1

Ctenacanthus tenuistriatus Ag. dans le calcaire carbonifère de Visé. Bull. Soc. Géol. Belgique, 1902, 29, B108-B110.

1902.1

Faune et flore des psammites du Condroz (Famennien) Ann. Soc. Géol. Belgique, 1904, 31, M247-M257. 1904.1

Desvaux, Auguste Nicaise [17841856] Sur les poissons de la Loire-Inférieure. Paris, 1843. 1843.1

_- Essai d'ichthyologie des côtes océaniques et de l'intérieur de la France. Angers, 1851. 3 pls. $8^{\circ}$.

1851.1

Desvignes, —_ Rapport sur l'odorat des poissons. L'Institut, 1835, 3, no. $111,207$.

1835.1

Desvignes, — Erklärung des Geruchs der Fische. Arch. Anat. Physiol. (Müller), 1836, 5, cliv.-Bull. Acad. Sci. Bruxelles, 2, 169.

1836.1

Detzem, — \& Berthelot, Sabin. Fécondation artificielle des poissons. Mém. Soc. Emulation du Doubs, 1851. 1851.1

Deutsch, [pseudon.] Der Schutz der offenen Gewässer in Bayern mit einem historischen Rückblick auf die Niederbayerischen Fischerei-Verhältnisse. Bayer. Fischerei Zeitg., 1879, 4. Jahrg. no. 5 ; no. 6 .

1879.1

Deutsch David Henrit. Oeconomiska Anteckningar rörande Norra delen af Uleåborgs län, under resor derstädes, på Hans Erlaucht, Riks-Cancelleren m. m. Grefve N. P. Rumanzoffs omkostnad och Kejs. Finska Hushållnings-Sällskapets försorg gjorde åren 1814 och 1815. Finska Hushallningssällskapet, 1819, handl. 3, 263-408. $\quad 1819.1$

Pisces, p. 296-300; 387-388. 
Deutsch, Georg. Zur Geschichte der Fischerei in Oesterreich und Ungarn. Oesterr-ungar. Fischerei Zeitg., 1880, 22-23.

1880.1

D'Evant, Teodoro. See Evant, Teodoro d'.

Deville, Charles Joseph Sainte-Claire. See Sainte-Claire Deville, C. J.

De Vis, Charles W. Note on the wolf fish [Anarhichas lupus] Zoologist, 1865, 23, 9558 .

1865.1

Description of three new fishes of Queensland [Oligorus goliath, Synaptura fitzroiensis, Engraulis carpentarla] Proc. Linn. Soc. New S. Wales, 1883, 7 , 318-320.

1883.1

Description of two new Queensland fishes [Callionymus achates, Mugil nasutus] Proc. Linn. Soc. New S. Wales, 1883, 7, 620-621. 1883.2

Descriptions of some new Queensland fishes ¿Cleidopus gloriamaris, Homalogrystes lucluosus, Scolopsis specularis, Porichthys queenslanda, Pleuronectes mortoniensis] Proc. Linn. Soc. New S. WVales, 1883, 7, 367-371. 1883.3

Descriptions of new genera and species of Australian fishes. Proc. Linn. Soc. New S. Wales, 1884, 8, 283-289.

1884.1

Fishes from South Sea islands. Proc. Linn. Soc. New S. WVales, 1884, 8, $445-457$.

1884.2

New Australian fishes in the Queensland museum. Proc. Linn. Soc. New S. Wales, 1885, 9, 389-400; 453$462 ; 537-547 ; 685-698 ; 869-887.1885 .1$

The ribbon fish (a Regalecus in Queensland waters) Proc. Roy. Soc. Queensland, 1892, 8, 109-113. 1892.1

Cestraciontidx. Ann. Queensland Mus., Brisbane, 1911, 10, 18. pl.

1911.1

A second species of Enoplosus ("old wife" fish) " $E$. serotinus n. sp.] Ann. Queensland Mus., Brisbane, 1911, no. 10,29 .

1911.2

Devyver, Johannes. Definiatur nutritio corporum organicorum in genere, compareturque nutritionis processus vegetabilium cum processu animalium; exponatur deinde progrediens ejus in variis animalium classibus evolutio. Ann. Acad. Louvain, 1823, 5. 1823.1
Dewalque, Georges Jean Gustave [1826-] Une nouvelle dent de Carcharodon dans le gravier de la Meuse. Bull. Acad. Roy. Belgique, 1864, 2. sér. 18, 400-401.

1864.1

Note sur les dents de poisson du dépôt de transport de la Meuse et de ses affluents. Bull. Acad. Roy. Belgique, 1871, 2. sér. 32, 50-51. 1871.1

—_ [Débris de Céphalaspides dans l'étage taunusien de l'Ardenne] Ann. Soc. Géol. Belgique, 1875, 2, 44. 1875.1

Antacanthus insignis, du calcaire carbonifère de Belgique. Journ. Zool. (Gervais), 1877, 6, 415-416. 1877.1

Note sur un poisson du calcaire carbonifère inférieur [Antacanthus insignis] Ann. Soc. Géol. Belgique, 1878, 5, 59-60.

1878.1

Dewhurst, Henry William. The natural history of the order Cetacea, and the oceanic inhabitants of the Arctic regions. London, 1834. 294 p. 23 pls. $8^{\circ}$.

1834.1

Dewitz, $J$. Bemerkungen zu Herrn E. P. Allis' Arbeit "The skull and the cranial and first spinal muscles and nerves in Scomber scomber." Anat. Anz., $1904,24,408-410$.

1904.1 C.

Dexter, pseudonym for Kirk, Henry

Dexter, $E$. A fish farm. Amer. Naturalist, 1870, 3, 202-207. 2 figs. 1870.1

Deyl, Jan. Ueber die Sehnerven bei Siluroiden und Acanthopsiden. Anat. Anz., 1896, 11. Jahrg., 8-16. 5 figs. 1896.1

Zur vergleichenden Anatomie des Sehnerven. I. Teil. Bull. Intern. Acad. Sci. Imp. Franc--Jos. I, Prag, 1895 (1896), $1-80$.

1896.2

Deynoot, IV. T. G. Specimen oeconomico-politico-juridicum inaugurale, de magno sive halecum piscatu Belgico (haringvisscherij) Lugduni Batavorum, 1829. $8^{\circ}$.

1829.1

Deyrolle, Théophile. Notice sur une espèce remarquable de poisson qui vit dans les eaux du lac de Van [Alburnus tarichi Pall.] Rev. Mag. Zool., 1871-72, 2. sér. 23, 401-405. pl.

1871.1

Dezani, $S$. Le basi proteiche contenute nello sperma e nelle ovaie del tonno ed i loro prodotti idrolitici. 
Giorn. Accad. Meà., Torino, 1908, 71, 11.1-122. 1908.1

Dezsö, Bela von. Ueber die künstlichen und natürlichen Ursachen der Veränderungen der Fischfauna und der Verminderung der Fische im Hernadflusse Ober-Ungarns. 'Tagebl. 5. Intern. Zool. Kongres Berlin, 1901, no. 8, 8-9.

1901.1

D'Halloy, Léon. Fish-culture at Gouville, France. Bull. U. S. Fish Comm. 1885, 5, 255-256. 1885.1

Diamare, Vincenzo. I corpuscoli surrenali di Stannius ed i corpi del cavo addominale dei teleostei. Notizie anatomiche e morfologiche. Boll. Soc. Nat. Napoli, 1895, 9, 10-24.

1895.1

- Ricerche intorno all' organo interrenale degli elasmobranchi ed i corpuscoli di Stannius de' teleostei. Contributo alla morfologia delle capsule surrenali. Mem. Soc. Ital. Sci., Roma, 1899, 3. ser. 10. 3 pls. 1899.1

Studii comparativi sulle isole di Langerhans del pancreas. Intern. Monatschr. Anat., Leipzig, $1899,16,155-$ 208. 5 pls. - Ibid., 1905, 22, 129-187. 2 pls.

1899.2

Sulla morfologia delle capsule surrenali. Nota critica. Anat. Anz., $1899,15,357-360$.

1899.3

Cisti epiteliali nel cosidetto pancreas dei Petromizonti. Monit. Zool. Ital., 1901, 12, 194-195. 1901.1

Sulla costituzione dei gangli simpatici negli elasmobranchi e sulla morfologia dei nidi cellulari del simpatico in generale. Anat. Anz., 1902, 20, 418-429.

1902.1

Sullo sviluppo e morfologia delle capsule soprarenali. Boll. Soc. Nat. Napoli, 1903, 17, 55-62.

1903.1

- Varietà anatomiche dell' interrenale. Arch. Ital. Anat. Embriol., 1905, 4, 366-369. 4 pls.

1905.1

- Su i rapporti della vena porta e delle arterie splancnice in Scyllium catulus e Torpedo marmorata. Contributo all' anatomia splanenica negli elasmobranchi. Nota riassuntiva. Anat. Anz., 1909, 34, 522-559.

1909.1

I vasi splancnici e le loro relazioni topografiche in Scyllium catulus e Torpedo marmorata. Contributo all' anatomia splancnica negli elasmobranchi. Arch. Zool., Napoli, 1910, 4, pt. 4, 437-488. pl.

1910.1

Contributo all' anatomia comparata del sistema linfatico. I linfatici splanici in Torpedo marmorata. Intern. Monatschr. Anat., Leipzig, 1913, 30, Heft 1, 21-15. pl.

1913.1

Diamare, $V$. \& Kuliabko, A. Zur Frage nach der physiologischen Bedeutung der Langerhans'schen Inseln im Pancreas. Vorläufige Mittheilung. Centralbl. Physiol., 1904, 18, 432-435. 1904.1

Diamare, $V ., \&$ Montuori, A. Ricerca del glucosio nel sangue dei selaci. Rend. Accad. Ści., Napoli, 1907, 3. ser. 13, 348-355.

1907.1

- Se esista glucosio nel sangue dei selaci. Comunicazione preliminare. Riv. Mensile di Pesca, Milano, 1907, 9, 30-32.

1907.2

Diaz y Martinez, Eduardo. Canabota (Hexanchus griseus Gml.) Anal. Acad. Cienc. Habana, 1910, 46, 82-86. 2 pls.

1910.1

Pez velero americano (Histiophorus nigricans Lac.) Anal. Acad. Cienc. Habana, 1910, 46, 86-88. pl.

1910.2

Dibley, $G$. On the teeth of Ptychodus and their distribution in the English Chalk. Quart. Journ. Geol. Soc., 1911, 67, pt. 2, 263-277. 6 pls. 1911.1

Dickerson, $F . B$. The protection of fish and a closed season. 'Trans. Amer. Fisheries Soc. 1898 (1899), 32-46.

1899.1

The benefits of the propagation of game fish to the state of Michigan. 6. Rept. Michigan Acad. Sci., 1904, 69 71. 1904.1

Dickerson, Mary Cynthia, \& Jordan, David Starr. See Jordan \& Dickerson.

Dickson, $H . N$. Physical investigations. Preliminary paper. Journ. Mar. Biol. Assoc., 1892, n. s. 2, 159-170; $272-275$.

1892.1

The distribution of food-fishes in relation to their physical surroundings. Nat.Sci., 1895, 6, 30-37. fig. 1895.1

Dickson, $J . H$. Ueber Fischgift. Isis (Oken), 1818, 1615-1616. 1818.1 
Dickson, (Baron) Oscar [1823-1897] Appendix to catalogue of Mr. Oscar Dickson's Swedish collection. Gothenburg, 1882. $4^{\circ}$.

1882.1

[Catalogue of] Mr. Oscar Dickson's Swedish collection. International Fisheries Exhibition, Edinburgh, 1882. Gothenburg, 1882. $4^{\circ}$. 1882.2

Didélot, Léon. Notesur un Pycnodus nouveau du Néocomien moyen (Pycnodus heterodon) Bull. Soc. Géol. France, 1874-75 (1875), 3. sér. 3, 237-256. pl. 1875.1

Pycnodus heterodon n. sp. aus dem mittleren Neokom. Neues Jahrb. Mineral., 1875, 778.

1875.2

Dieckmann, $P$. Beiträge zur Anatomie des Hemirhamphus pogonognathus. [n. p.] 1904. 3 pls.

1904.1

Diesing, Karl Moritz [1800-1867] Beschreibung eines neuen Kratzers aus dem Lootsenfische (Naucrates ductor) Sitzber. Akad. IViss. Wien, math.-nat. Cl., 1854, 12, 681-682. pl.

1854.1

Diessner, Bruno. Emploi des produits Spratt pour la nourriture de la truite. Allgem. Fischerei Zeitg., 1893, 18, no. 26, 404-406. - Bull. Soc. Centr. Aquicult. France, 1894, 4, 121-124.

1893.1

Die Salmo iridea. FischereiZeitg., Neudamm, 1901, 4, 835-837.

1901.1

Die künstliche Zucht der Forelle. 2. Auflage. Neudamm, 1902. xi, $209 \mathrm{p}$. 108 figs.

1902.1

Ein Apparat zur Aufzucht von

Fischbrut in Verbindung mit einem Bassin für die Fische [Text in Russian] Věst. Rybopromyšl., St. Petersb., 1910 , 25, 258-261.

1910.1

Dietz, $P . A$. Over de grootte der ansjoviseieren in de Zuiderzee. Meded. Vissch. Helder, 1908, 15, 66-73. 1908.1

Over den vorm der myotomen bij de Teleostei. Tijdschr. Nederl. Dierk. Vereen., 1909, 2. ser. 11, xxvxxvii.

1909.1

- Mededeeling over de plaats der Gadiden in het systeem. T'ijdschr. Nederl. Dierk. Vereen., 1912, 2. ser. 12, lxxxvi-lxxavii.

1912.1

Vergelijkende anatomie van de kaak- en kicuw-boogspieren der Teleostei. Leiden, 1912. 196 p. 1912.2
Ueber die Form der Myotome der Teleostier und ihre Beziehung zur äusseren Leibesgestalt. Anat. Anz., 1913, 44. Jahrg., 56-64. 6 figs. 1913.1

Dietzell, B.E., \& Kressner, $M . G$. Ueber die Bestimmung der Phosphorsäure im Fisch-Guano. Zeitschr. Anal. Chem., 1879, 18, 225-230.

1879.1

Dieulafé, Léon. Les fosses nasales des vertébrés (Morphologie et embryologie) Journ. Anat. Physiol. Paris, 1904, 40, 268; 414-444. 19 figs. - Ibid., $1905,41,102-112 ; 300-318 ; 478-560$; 658-678. 33 figs.

1904.1

Dieulafé, Léon, \& Bruyant, $C$. Une carpe adulte. C. R. Assoc. Anat., 1904, sess. 6,207

1904.1

Diguet, Léon. Sur le Céphaloptère du golfe de Californie [Extraits d'une lettre à L. Vaillant! Bull. Mus. Hist. Nat., Paris, 1898, 4, 127-129. $\quad 1898.1$

Diguet, L., \& Vaillant, L. See Vaillant \& Diguet.

Dikson, $B$. Ergebnisse der Beobachtungen über die Biologie von Clupea kessleri Gr. im Jahre 1905 [Text in Russian] Věst. Rybopromyšl., St. Petersb., 1905, 20, 503-532. 1905.1

Ueber das Auffinden von jungen Clupea liessleri im Ueberschwemmungsgebiet der Wolga oberhalb Saratov [Text in Russian] Věst. Rybopromyšl., St. Petersb., 1905, 20, 117-119. 1905.2

Ueber die Ernährung des Ziehenden-herings (Clupea kessleri Gr.) in der mittleren Wolga [Text in Russian] Věst. Rybopromyšl., St. Petersb., 1905, 20, 276-282.

1905.3

Zur Entwicklung der Rückenplättchen und der Rückenflosse bei dem Sterlet [Text in Russian] Vèst. Rybopromyšl., St. Petersb., 1912, 27, 363371.

1912.1

Dill, Heman S. Statement concerning the menhaden fishery. Rept. U. S. Fish Comm. 1877 (1879), 5, 405. 1879.1

Dimick, $F . F$. The fish trade organizations. Trans. Amer. Fisheries Soc. 1913 (1914), 157-160.

1914.1

Dimmock, George [1852-] Belostomidx and other fish-destroying bugs. Bull. U.S. Fish Comm. 1856, 6, 353-359. - Zoologist, 1857, 3. ser. 11, 101-105.

1886.1 
Dinks, pseudonym for Peel, Jonathan.

Dinsmore, A. $H$. Maine and the sportsman. Trans. Amer. Fisheries Soc. 1901 (1902), 159-162.

1902.1

Yellowstone park as a national fishing resort. Trans. Amer. Fisheries Soc. 1905 (1906), 195-198.

1906.1

Diorio, Vinc. Sui di un pesce molto raro per i mercati di Roma [Labrus luvarus Rafin.] Atti Accad. Pontif. Nuov. Lincei, 1869, 22, 121-123. fig. 1869.1

Dissard, A. Nouvel appareil destiné ì mesurer les échanges respiratoires dans l'habitat aquatique. C. R. Mém. Soc. Biol. Paris, 1894, 10. sér. 1, 316-317. fig.

1894.1

- L'asphyxie chez les poissons. Naturaliste, 1898, 20, 186-189. 1898.1

Dissard, A., \& Noê, J. See Noé \& Dissard.

Disselhorst, Rudolf. Die acessorischen Geschlechtsdrüsen der Wirbelthiere. Arch. Wiss. Prakt. Tierheilk, 1897, 23, 245-280.

1897.1

- Ausführapparat und Anhangsdriisen der männlichen Geschlechtsorgane [Fische] (In Oppel, Albert. Lehrbuch der vergleichenden mikroskopischen Anatomie der Wirbeltiere, pt. 4, 9-31. figs. 10-38. Jena, 1904) 1904.1

Distant, William Lucas [1845-] Abundance of sharks in tropical seas. Zoologist, 1897, 4. ser. 1, $36 . \quad 1897.1$

[Record of a wolf-fish at Brighton] Zoologist, 1904, 4. ser. 8, 392.

1904.1

To what height can a carp spring from the water? Zoologist, 1904, 4. ser. 8, 353 .

1904.2

Ditten, $H$. $S$. Beretning om de trufne foranstaltninger sigtende tilfiskeriernes forbedring i Christianiafjorden inden for Drobak i aaret 1871. Chris. tiania, $1872.7 \mathrm{p} .4^{\circ}$.

1872.1

Dittmer, $R$. Die deutsche Hochsee-, See- und Iïusten-Fischerei im 19. Jahrhundert und bis zum Jahre 1902. Hannover \& Leipzig, 1902. iii, 70 p. 1902.1

Dittrich, Rudolf. Ueber das Leuchten der Tiere. Wissensch. Beilage $z$. zool. Progr. Realgymn. am Zwinger in Breslau, 1888.
Dixon, A.Francis, Westropp, T.J. Scharff, $R . F$. Ussher, $R$. J., Cole, $G$. A.J., \& Newton, E. T. See Scharff, Ussher \& others.

Dixon, $B . I$. [Ueber morphologische Merkmale der ersten Stadien der Jungfische von Clupea kessleri Gr. [Russian with German résumé] Arb. Biol. WolgaStation Saratov, 1913, 4. ser. 3, 1-17

1913.1

Dobelmann-Degerloch, $H$. Die Zucht und Aufzucht von Betla pugnax. Blätt. Aquar.-Terrar. Freunde, 1899, 10, 157-159; 173-175. fig. 1899.1

Dobrée, $N . F$. Immense take of flounders [Pleuronectes flesus] on the Danish coast. Zoologist, 1863, 21, 8331. 1863.1

Dobrizhoffer, Martin. Geschichte der Abiponer, einer berittenen und kriegerischen Nation in Paraguay. Bereichert mit eine Menge Beobachtungen über die ... vierfüssigen Thiere, Amphibien, Fische, Vögel, etc. 3 vols. Wien, 1783. $8^{\circ}$. 1783.1

First published in Latin. There are also later Latin and English editions. One was published at London in 1822.

Dobson, George Edward [1848-1895] Notes on the respiration of some species of Indian fresh-water fishes. Proc. Zool. Soc. London, 1874, 312-321. Abstract in Naturforscher (Sklarek), 1875, 8. Jahrg., 295-296.

1874.1

The climbing perch [Anabas scandens] Nature, 1879, 20, 169. 1879.1

Dodds, Gideon S. Segregation of the germ-cells of the teleost. Lophius. Journ. Morphol., 1910, 21, 563-611. 34 figs.

1910.1

Doderlein, Pietro [-1895] I pesci del mare di Sicilia. Modena \& Palermo, 1872. 28 p. $S^{\circ}$.

1872.1

-Descrizione di una specie di pesce del genere esotico Lobotes presa nelle acque dei contorni di Palermo. Atti Accad. Sci. Palermo, 1875, n. s. 5, 12 p.

1875.1

Prodromo della fauna ittiologica della Sicilia ossia prospetto metodico delle varie specie di pesci che vennero sin' ora riscontrate nei mari di Sicilia. Atti Accad. Sci. Palermo, 1878, n. s. 6.

1878.1

Prospetto metodico delle varie specie di pesci riscontrate nelle acque 


\section{Doderlein, $P$.}

marine e fluviale della Sicilia annesso al prodromo della fauna ittiologica. Atti Accad. Sci. Palermo, 1878-79, n. s. $6,25-63$.

1878.2

Sulla comparsa del Pagrus ehrenbergii Cuv. Val., e del Chrysophrys ceruleosticta Cuv. Val., nel mare di Sicilia. Giorn. Sci. Nat. Palermo, 1879, 14 112-124.

1879.1

- Manuale ittiologico del Mediterraneo. Palermo, 1881-91. $8^{\circ}$. 1881.1 iii. Elasmobranchi Bp., Batoides. 1855, p. $121-256$

iv. Acantopterigi perciformi. 1859, p. 1-188.

v. Teleostei, Acantopterigi perciformi (Seguito e fine) 1891, p. 193-320.

Rivista delle specie del genere Epinephelus Bloch, o Cerna Bonap., riscontrate sin' ora nei mari della Sicilia. Giorn. Sci. Nat. Palermo, 1882, 15, 168-259. 1882.1

Una nota sopra lo Scopelus doderleini Facciolà; lettera al Dot. Facciolà. Natur. Sicil., 1881-82 (1882), 1, 258263.

1882.2

- Ricorrenza del Rhinobatus halavi Rüpp. nelle acque marine della Sicilia. Natur. Sicil., 1884, 3, 169-175. $\quad 1884.1$

Rinvenimento di una specie di pesce dell' esotico genere Pimelepterus Lac. nelle acque del golfo di Palermo. Natur. Sicil., 1884, 3, 81-86. - Giorn. Sci. Nat. Palermo, 1S84, 16, 238-245.

1884.2

Rinvenimento della Raia chagrinea Pennant, nelle acque del golfo di Palermo. Natur. Sicil., 1885, 4, 97-99. 1885.1

- Descrizione zoologico-zootomica di una novella specie di pesee del mar di Sicilia, Pteridium armatum Dod. Natur. Sicil., 1886, 5, 73-80; 105-108. pl.

1886.1

Comparsa del Cybium commersonii Lac. nelle acque del circondario marittimo di Palermo. Natur. Sicil., 1888, 7, 105-109; 129-133. 1885.1

Doderlein, P., \& Riggio, G. Rinvenimento del Callionymus phacton Günther nelle acque del golfo di Palermo. Natur. Sicil., 1890, 9, 133-139. pl. 1890.1

Dodero, G., \& Léger, L. See Léger \& Dodero.
Dodge, Charles Wright. Fish fungus at Caledonia. Trans. Amer. Fisheries Soc. 1895 (1896), 109-112.

1896.1

Dodge, Simeon. Statement concerning the menhaden fishery. Rept. U. S. Fish Comm. 1877 (1879), 5, 399. 1879.1

Döderlein, Ludwig. Faunistische Studien in Japan. Enoshima und die Sagami-Bai. Arch. Naturgesch., 1882$83,49,102-123$.

1882.1

- Ein Stomiatide aus Japan. Arch. Naturgesch., 1882, 48, pt. 1, 26-31. pl. 1882.2

Das Skelet von Pleuracanthus. Zool. Anz., 1889, 12, 123-127. fig.

1889.1

Pisces (In Steinmann, G., \& Döderlein, L. Elemente der Paläontologie, p. 529-587. Leipzig, 1890 . illust. $8^{\circ}$ )

1890.1

Forelle und Ringelnatter. Mitth. Philomath. Gesell., Strassburg, 1911, 4, pt. 3, 333-336. pl.

1911.1

Döderlein, Ludwig, \& Steindachner, Franz. See Steindachner \& Döderlein.

Döllinger, $I$. Ueber den Luftsack der Fische. Arch. Zool. Zootomie, 1804, 4, 2. Heft, 160-171.

1804.1

Ueber den eigentlichen Bau des Fisch-Herzens. Annal. Wetterau. Gesell., 1811, 2, 311-313.

1811.1

Ueber die Vertheilung des Blutes in den Kiemen der Fische. Abh. Bayer. Akad. Wiss. Minchen, math.-phys. Cl., $1837,2,783-794$.

1837.1

Dönhoff, — Ueber das Verhalten kaltblutiger Thiere gegen Frosttemperatur. Arch. Anat. Physiol., 1872, 724 727.

1872.1

Dönitz, $F . K$. W. Ueber eine besondere Vorrichtung bei der Fischgattung Teuthyes ['Teuthis], die Flossenstacheln aufrecht zu erhalten. Sitzber. Ges. Naturf. Freunde Berlin, 1866, 25. 1866.1

- Ueber Antennarius urophthalmus Bleeker, einen Fisch von Singapore. Sitzber. Ges. Naturf. Freunde Berlin, $1867,6-7$.

1867.1

Ueber die Gelenke an der Rücken-und Afterflosse des Teuthies Cuv. Val. Arch. Anat. Physiol., 1867, 210 220. pl. 
[Mittheilungen über Giftfische] Mitth. Deutsch. Gesell. Ostasien, 1873, 1, 10. Heft, 6. Ibid., 1876, 2, 151 .

1873.1

Doering, $C$. A. Die Fischerei in Württemberg. Württemb. Wochenbl. Landw., 1880, 3. Jahrg., 123-124. Oesterr-ungar. Fischerei-Zeitg., 1880, 214-215.

1880.1

Doerr, R., \& Raubitschek, $H$. Toxin und anaphylaktisierende Substanz des Aalserums. Berlin. Klin. Wochenschr., 1908, 45. Jahrg., 1525-1528.

1908.1

Doflein, Franz J.Th. Beiträge zur Kenntniss der Karpfenkrankheiten. Allgem. Fischerei Zeitg., 1898, 23, 6061. 2 figs.

1898.1

- Bericht über eine wissenschaftliche Reise nach Californien. Sitzber. Gesell. Morph. Physiol., 1899, 14, pt. 2, 105-118. 9 figs.

1899.1

Bericht über meine Reise nach Westindien und Nordamerika. Sitzber. Bayer. Akad. Wiss. München, math.phys. Cl., 1899, 28, 539-573. 1899.2

Ueber die Eibildung und Eiablage von Billostoma stouti Lock. Festschrift zum siebenzigsten Geburtstag von Carl von Kupffer, 1899, 339-352. 2 pls. \& figs.

1899.3

Zur Entwicklungsgeschichte von Bdellostoma stouti Lock. Verh. Deutsch. Zool. Gesell., 1899, 21-30.

1899.4

Fauna und Ozeanographie der japanischen Küiste. Verh. Deutsch. Zool. Gesell., 1906, 62-72. 1906.1

Ostasienfahrt: Ergebnisse und Beobachtungen eines Naturforschers in China, Japan und Ceylon. Leipzig, 1906. $511 \mathrm{p}$. 1906.2 Review in Nature, London, 1906, 74, 510.

Ueber Leuchtorgane bei Meerestieren. Sitzber. Gesell. Morph. Physiol. 1906.

1906.3

Ueber den Geruchsinn bei Wassertieren. Biol. Zentralbl., 1911, 31 . $706-707$

1911.1

Doflein, Franz J. Th., \& Hesse, R. Sce Hesse \& Doflein.

Doflein, Franz J. Th., \& Hofer, Bruno. See Hofer \& Doflein.
Dogiel, Alexander Stanislaus [1852-] Bau der Retina der Ganoiden [Text in Russian] Trudui Kasan Univ., 1883. 11, 6. Heft. 124 p. 3 pls. 1883.1

- Die Retina der Ganoiden. Arch. Mikros. Anat., 1883, 22, 419-472. 2 pls. Extract in Journ. Roy. Micr. Soc., 1883. 2. ser. 3, 632 .

1883.2

Ueber den Bau des Geruchsorgans bei Ganoiden, Knochenfischen und Amphibien [Text in Russian] Trudui Kasan Univ., 1886, 16, no. 1. 82 p. pl. - Arch. Mikros. Anat., 29, 74-139; 593-594. 2 pls. - Biol. Centralbl. 6, 428-431.

1886.1

Ueber das Verhalten der nervösen Elemente in der Retina der Ganoiden, Reptilien, Vögel und Säugetiere. Vorläufige Mittheilung. Anat. Anz., 1888, 3, 133-144. 7 figs. 1888.1

Ueber die Nervenendigungen in den Geschmacks-Endknospen der Ganoideen. Arch. Mikros. Anat., 1897, 49, 769-790. 2 pls.

1897.1

Das periphere Nervensystem des Amphioxus (Branchiostoma lanceolatum) Anat. Hefte, 1903, 21, 145-213. 18 pls. 1903.1

Dogiel, Johann. Die Bedingungen der automatisch-rhythmischen Herzkontraktionen. Arch. Gesell. Physiol., 1910 135, 1-103. 3 pls. \& 79 figs. $\quad 1910.1$

Dogiel, Johann, \& Kasem-Beck, See Kasem-Beck \& Dogiel.

Dohrn, [Felix] Anton [1840-] The missing link between the vertebrates and invertebrates. Amer. Naturalist, 1876. 10, 598-602.

1876.1

Der Ursprung der Wirbelthiere und das Princip des Functionwechsels: genealogische Skizzen. Leipzig, 1876.

1876.2

—_ Die Entstehung der Hypophysis bei Petromyzon planeri. Zool. Anz. 1882, 5, 587-588. - Nature, London, $1852,27,91$.

1882.1

- Studien zur Urgeschichte des Wirbelthierkörpers. Mittheil. Zool. Stat. Neapel, 1882-1906. 1882.2

Einleitung, 1882, 3, 252.

i. Der Mund der Knochenfische. 1852, 3 253-263. pls.

ii. Die Entstehung und Bedeutung der Hypophysis bei den Teleostiern. 1882, 3, 261-279. pls. 


\section{Dohrn, A}

iii. Die Entstehung und Bedeutung der Hypophysis bei Petromyzon planeri. IS83, 4, 172-189. pl.

iv. Die Entwicklung und Differenzirung der Kiemenbogen der Selachier. 1S81, 5, 102-151. pls.

v. Zur Entstehung und Differenzirung der Visceralbogen bei Pelromyzon planeri. $18 \mathrm{~S} 4, \mathbf{5}$ $152-161$. pl.

vi. Die parigen und unparen Flossen der Selachier. $188 \pm, 5,161-195$. pl.

vii. Entstehung und Differenzirung des Zungenbein- und Ǩiefer-apparates der Selachier.

$1856,6,1-48$. 5 pls.

viii. Die Thyreoidea bei Petromyzon, Amphioxus und den Tunicaten. $1886,6,49-92$. pls. ix. Die Bedeutung der unparren Flosse für die Beurtheilung der genealogischen Stellung der Tunicaten und des Amphioxus, und die Reste der Beckenflosse bei Petromyzon. $1886,6,399-132$. pl.

x. Zur Phylogenese des Wirbelthierauges. $1856,6,432-480$. pl

xi. Thyreoidea und Hypobranchialrinne, Spritzlochsack und Pseudobranchialrinne bei Fischen, Ammocoetes und Tunicaten. 1886-87, 7, 128-176. pls.

xii. Thyreoidea und Hypobranchialrinne, Spritzlochsack und Pseudobranchialrinne bei Fischen, Ammocoetes und Tunicaten, 1886-87,

7, 301-337. pls.

xiii. Ueber Nerven und Gefässe bei Ammocoetes und Petromyzon planeri. $1888,8,233-306$. pls.

xiv. Ueber die erste Anlage und Entwicklung der motorischen Rückenmarksnerven bei den Selachiern. 1S88, 8, 441-461. pl.

xv. Neue Grundlagen zur Beurtheilung der Metamerie des Liopfes. $18 \$ 9-91, \mathbf{9}, 330-131$ pls.

xvi. Ueber die erste Anlage und Entwicklung der Augenmuskelnerven bei Selachiern und das Einwandern von Medullarzellen in die motorischen Nerven. 1891-93, 10,1-40. pls. xvii. Nervenfaser und Ganglienzelle. Histogenetische Untersuchungen. 1891-93, 10, 255311. pls.

xviii. Die Occipitalsomite bei verschiedenen

Selachierembryonen. Thatsächliches, 1902, 15,

1-82. pls.

xix. Vagus und Lateralis bei Selachierembryonen. $1902, \mathbf{1 5}, 82-138$. pls.

xx. Die Schwann'schen Kerne, ihre Herkunft und Bedeutung. Erwiderung an A. von Tölliker. $1902,15,138-186$, pls.

xxi. Theoretisches über Occipitalsomite und

Vagus. Competenzconflict zwischen Ontogenie und vergleichender Anatomie. 1902, 15, 186279.

xxii. Weitere Beiträge zur Beurtheilung der Occipitalregion und der Ganglienleiste der Selachier. 1902, 15, 555-65t. pls.

xxiii. Die Mandibularhöhle der Selachier.

1906, 17, 1-116. pls.

xxiv, Die Prämandibularhöhle, 1906, 17 116-294. pls. pls

xxv. Der Trochlearis. $1906-08,18,143-436$

Bemerkungen über den neuesten

Versuch einer Lösung des Wirbeltierkopf-problems. Anat. Anz., 1890, 5, $53-64 ; 78-85$.

1890.1

Die Schwann'schen Ferne der Selachier-Embryonen. Anat. Anz. $1892,7,348-351$.

1892.1

Doleschall, C.Ludwig [-1559] Over Oxybeles gracilis Blkr. Nat. Tijdschr.
Nederl.-Indie, 1858, 15 (4. ser. 1), 163168. - Arch. Naturgesch., 26, pt. 1, 319-323.

1858.1

- On Oxybeles [Fierasfer] gracilis Blecker. Ann. Mag. Nat. Hist., 1861, 3. ser. 7, 340-342.

1861.1

Ueber das Vorkommen von Fischen in der Magenhöhle von Seesternen. Abstract in Notiz. (Froriep), 1861, 3, 191.

1861.2

Dollfus, Ernest. [1852-1872] Le nid de l'épinoche. Feuill. Jeunes Natural., $1871-72,2,8-9$.

1871.1

Dollo, Louis [1857-] La vie au sein des mers et les poissons abyssaux. Rev. Quest. Sci., 1885, 19, 476.-Ibid., 20. 168. Ibid., 21, 33-64. figs. 1885.1

Première note sur les téléostéens du Bruxellien (Eocène moyen) de la Belgique. Bull. Soc. Belge Géol. (Proc.Verb.), 1889, 3, 218-226.

1889.1

Le vol chez les vertébrés. Rev. Quest. Sci., 1889, 26, 146-173. 1889.2 Les poissons volants, p. 150-161.

Première note sur les téléostéens du Crétacé supérieur de la Belgique. Bull. Soc. Belge Géol. (Proc.-Verb.), 1892, 6, 180-189. 4 figs.

1892.1

- Sur la morphologie des côtes. Bull. Scient. France Belgique, 1892, 24, 113-129.

1892.2

Les lois de l'évolution. Bull. Soc. Belge Géol., 1893, 7, 165-170. 1893.1

Sur la morphologie de la colonne vertébrale. Bull. Scient. France Belgique, 1893, 25, 1-17.

1893.2

Sur le Lepidosteus suessoniensis. Bull. Scient. France Belgique, 1893, 25, 193-197.

1893.3

Mours et coutumes des poissons du Congo. Bull. Soc. Belge Géogr. $1895,19,38-10$.

1895.1

- Cours de zoologie rpoissons de la Belgique et poissons du Congol Bruxelles, 1896. 14 p. $8^{\circ}$.

1896.1

- Sur la phylogénie des Dipneustes. Bull. Soc. Belge Géol. (Mém.), 1896, 9, 79-128. 10 pls.

1896.2 Review in Amer. Naturalist, 1896, 30, 479.

Cyrodraco antarcticus, poisson abyssal nouveau, recueilli par l'Expédi- 
tion Antarctique Belge (communication préliminaire) Bull. Scient. Acad. Roy. Belgique, 1900, 128-137.

1900.1

Gerlachea australis, poisson abyssal nouveau, recueilli par l'Expédition Antarctique Belge (communication préliminaire) Bull. Scient. Acad. Roy. Belgique, 1900, 194-206.

1900.2

Macrurus lecointei, poisson abyssal nouveau, recueilli par l'Expédition Antarctique Belge (communication préliminaire) Bull. Scient. Acad. Roy. Belgique, $1900,383-401$.

1900.3

- Racovitzia glacialis, poisson abyssal nouveau, recueilli par l'Expédition Antaretique Belge (communication préliminaire) Bull. Scient. Acad. Roy. Belgique, $1900,316-327$.

1900.4

Cours de géologie lles grandes époques de l'histoire de la terrel Bruxelles, 1903. 28 p. figs.

1903.1

Fishes, p. 10-14.

Le Pteraspis dans l'Ardenne. C. R. Acad. Sci. Paris, 1903, 136, 699701.

1903.2

Poissons (In Expédition Antarctique Belge. Résultats du voyage du S. Y. "Belgica." Zoologie. Anvers, 1904. 240 p. 12 pls. \& 6 figs. $4^{\circ}$.

1904.1

Sur quelques points d'éthologie paléontologique relatifs aux poissons. Bull. Soc. Belge Géol. (Proc.-Verb.), 1906, 20, 135-139.

1906.1

Bathydraco scotice, poisson abyssal nouveau recueilli par l'Expédition Antarctique Nationale Ecossaise. Note préliminaire. Proc. Roy. Soc. Edinb., $1906,26,65-75$.

1906.2

Neobythites brucei, poisson abyssal nouveau recueilli par l'Expédition Antarctique Nationale Ecossaise. Note préliminaire. Proc. Roy. Soc. Edinb., 1906, 26, 172-181.

1906.3

Prymnothonus hookeri, poisson pélagique de l' "Erebus" et de la "Terror" retrouvé par l'Expédition Antarctique Nationale Ecossaise. Note préliminaire. Proc. Roy. Soc. Edinb., $1907,27,35-45$.

1907.1

Les ptyctodontes sont des arthrodères. Bull. Soc. Belge Géol., 1907, 21 , 97-108. pl.
Notolepis coatsi, poisson pélagique nouveau recueilli par l'Expédition Antarctique Nationale Ecossaise. Note préliminaire. Proc. Roy. Soc. Edinb., 1908, 28, 58-6t.

1908.1

Cynomacrurus pirici, poisson abyssal nouveau recueilli par l'Expédition Antarctique Nationale Ecossaise. Proc. Roy. Soc. Edinb., 1909, 29, 316326.

1909.1

The fossil vertebrates of Belgium.

Ann. N. Y. Acad. Sci., 1909, 19, 99-119. 5 pls.

1909.2

- Nematonurus lecointei, poisson abyssal de la "Belgica" retrouvé par l'Expédition Antarctique Nationale Ecossaise. Note préliminaire. Proc. Roy. Soc. Edinb., 1909, 29, 488-498. $\quad 1909.3$

- La paléontologie éthologique. Bull. Soc. Belge Géol., 1909, 23, 377-421. pls.

1909.4

-... Les poissons voiliers. Zool. Jahrb. (Syst. Abth.), 1909, 27, 419-138. 2 figs. 1909.5

Les teléostéens à ventrales abdominales secondaires. Verh.Zool.-Bot. Gesell. Wien, 1909, 59, (135)-(140)

1909.6

Sur un Dipneuste nouveau, de grandes dimensions, découvert dans le Dévonien supérieur de la Belgique. Bull. Acad. Belgique (Cl. Scient.), 1913, 15-17.

1913.1

Palcedaphus abeli n. sp.

Dollo, Louis, \& Storms, Raymond. Sur les téléostéens du Rupélien. Zool. Anz., 1S88, 11, 265-267. 1888.1

Domander, Adolf Fredrit. Röd abborre. Tidskr. Jägare \& Fisk., 1893, 1, 236-237.

1893.1

Domen, $M$. S. Sopra una specie di Orthagoriscus nuova per Catania, catturata presso l' isola dei Ciclopi (Orthagoriscus truncatus Flem.) Boll. Accad. Gioenia Sci. Nat. Catania, 1905, 85, 16-19. fig.

1905.1

Donaldson, R.J. Raising carp in rice fields. Bull. U. S. Fish Comm. $1885, \mathbf{5}, 284$.

1885.1

Doncieux, L. Catalogue descriptif des fossiles nummulitiques de l'Aude et de l'Hérault. Poissons. Ann. Univ. Lyon, 1905, 17, 29-30.

1905.1 
Donnadieu, A.L. Sur une hémiptérie de volume observée chez une carpe. C. R. Acad. Sci. Paris, 1870, 70, 200-201.

1870.1

Donndorf, Johann August [17541837] Zoologische Beiträge zur 13ten Ausgabe des Linné'schen Natursystems. 3 vols. Leipzig, 1792-9S. $8^{\circ}$. 1798.1

Bd. iii, Ichthyologische Beiträge.

Donovan, Edward [1768-1837] The natural history of British fishes. 5 vols. London, 1802-0S. 120 pls. $8^{\circ}$. 1802.1

The naturalist's repository; or, Monthly miscellany of exotic natural history, exhibiting rare and beautiful specimens of foreign birds, insects, shells, quadrupeds, fishes, and marine productions, especially such new subjects as have not hitherto been figured. 5 vols. London, 1823-27. 180 pls. $8^{\circ}$. 1823.1

Doolittle, A. A. The plankton environment in the Connecticut lakes. Rept. U. S. Comm. Fish. 1907 (1908), Bur. Fisheries Doc. no. 633, 65-77. map \& chart.

1908.1

Dop, Paul. Influence de quelques substances sur le développement des Saprolégniées parasites des poissons. Bull. Soc. Bot. Paris, 1905, 52, 156-158.

1905.1

Doppelmair, G.G. Ueber die biologische Station der Fischzuchtanstalt Nikolisk [Text in Russian] Trav. Soc. Nat. St. Pétersb., 1906, 37, pt. 1, 226-230. 1906.1

Doria, Giacomo, Ferrari, S. M., \& Lessona, M. Archivio per la zoologia, l'anatomia e la fisiologia. Genova, 1861.

1861.1

1866. The same. 2. ed. Modena,
1866.1

The same. 3. ed. Torino \&
Firenze, 1869.

Dorin, S. Fish swallowing fish. Forest \& Stream, 1850, 13, 967. 1850.1

Dorlodot, $H$. de. Réplique ì M. Leriche sur la signification géologique des Pteraspis. Bull. Soc. Belge Géol., 1912, 36, 64-65.

1912.1

Sur la signification des Pteraspis du Gedinnien de l'Ardenne et du Condroz. Bull. Soc. Belge Géol. (Proc.Verb.), 1912, 26, 21-40.
Dormal, $V$. Sur des poissons dévoniens dans le bassin de Namur (rivage septentrional) Ann. Soc. Roy. Malacol. Belgique (Bull.), 1887, 22, cxi-cxii.

1887.1

Dormitzer, Max. Die Wirbelsäule der Fische. Lotos, 1852, 2, 60-63.

1852.1

Dorner, $H$. Künstliche Haifischbrut in Hamburg. Gartenlaube, 1873, no. 37 , 601-603. fig.

1873.1

Doss, Carl Bruno [1861-] Ueber neue Funde mitteldevonischer Fischreste bei Segewold in Livland und im Untergrund von Riga. İorrespbl. Naturf. Ver. Riga, 1898, 40, 107-109.

1898.1

Dossie, Robert. On the edulcoration of fish-oil; explanation of the principles on which the purification of fish-oil may be performed, and of the uses to which it is applicable. Phil. Mag., 1S03, 15, 105-115. - Journ. Nat. Philos. (Nicholson), 5, 5-16.

1803.1

Dougall, $J$. Instance of gelatinous deposit on a salmon. Proc. Philos. Soc. Glasgow, 1880-82 (1S82), 13, 584.

1882.1

Dougherty, W.E. Suspended animation. Forest \& Stream, 1875, 4, 118.

1875.1

Resuscitation of two frozen Salmo fontanalis after five months' suspended animation.

Douglas-Ogilby, $J$. See Ogilby, $J$. Douglas.

Douglass, William. A summary, historical and political, of the first planting, progressive improvements, and present state of the British settlements in North America. 2 vols. London, 1760. $8^{\circ}$.

1760.1

There appears to have been an earlier [1755] edition, from which this seems to be not textually different. New England fisheries are described in rol. i, p. 29t-304.

Doumet-Adanson, $P$. Napoléon. Catalogue des poissons recueillis ou observés à Cette, accompagné de notes explicatives et de quelques idées sur la pisciculture marine. Rev. \& Mag. Zool., $1860,12,299-301 ; 355-370 ; 405-409$; $444-447 ; 494-509 ; 521-524$. 1860.1

Description d'un nouveau genre de poissons de la Méditerranée, Trachelocirrhus mediterraneus (Navarchus sulcatus) Rev. \& Mag. Zool., 1863, 15, 
212-223; 425-432. - Presse Scient., $1863,1,537-538$.

1863.1

- Ichthyologie de la côte languedocienne. Montpellier, 1869. 1869.1

Comparaison de la faune ichthyologique des étangs salés avec celle de la mer sur les côtes du Languedoc. Congrès Scient. France, 1872, 35, 118134.

1872.1

Douseman, $H . F$. Report relative to hatching and planting of the Penobscot salmon. Rept. U. S. Fish Comm. 1872-73 (1874), 2, 383-384.

1874.1

- Raising trout. Proc. 1. Ann Meet. Central Fishculture Soc. Chicago, $1879,31-33$

1879.1

-_. Forellen-Aufzucht für den Markt. Oesterr.-ungar. Fischerei-Zeitg., 1850, 61. - Deutsch. Landw. Presse, 1880, 7. Jahrg., 73-74

1880.1

Douvillé, Henri, Dagincourt, Emmanuel, \& Carez, Léon. See Dagincourt, Carez \& Douvillé.

Dove, Karl [1863-] Deutsch-Sudwest-Afrika. Ergebnisse einer wissenschaftlichen Reise im südlichen Damaralande. Mitt. Ergänz.-Heft (Petermann), 1896, 120. 93 p. pl. 1896.1

Verbreitung der Fische.

Dow, John M. Extract from a letter respecting Anableps dowii. Proc. Zool. Soc. London, 1861, 30-31.

1861.1

Letter to Dr. Günther regarding Thalassophryne and its poisonouspower] Proc. Zool. Soc. London, 1865 , 677.

1865.1

Dowell, $B . F$. Cultivating trout in Oregon. Bull. U. S. Fish Comm. 1884. $4,217$.

1884.1

Efforts in trout-culture. Bull. U. S. Fish Comm. 1884, 4, 64. 1884.2

Dowler, $B$. Discovery of viviparous fish in Louisiana. Journ. New Orleans Med. Surv., 1854. - Amer. Journ. Sei. 1855, 2. ser. 19, 133-136. - Ann. Mag. Nat. Hist., 1855, 15, 206-210. 1854.1

Downey, Hal. The lymphatic tissue of the kidney of Polyodon spathula. Folia Haematol., Leipzig, 1909, 8, 415466. pl.

1909.1

Phagocytosis of Erythrocytes in the lymphorenal tissue of Polyodon spa- thula. Folia Haematol., Leipzig, 1910 , 9.

1910.1

- The origin and structure of the plasma cells of normal vertebrates, especially of the cold-blooded vertebrates, and the Eosinophils of the lung of Amblystoma (plasma cells in Polyodon spathula) Folia Haematol., Leipzig, 1911. 11.

1911.1

Downing, S.W. Propagation of the Pacific salmon. Trans. Amer. Fisheries Soc. 1900 (1901), 154-158.

1901.1

-... The whitefish; some thoughts on its propagation and protection. Trans. Amer. Fisheries Soc. 1904 (1905). 104110.

1905.1

Collecting, hatching and distribution of pike perch; why the great loss of eggs. Trans. Amer. Fisheries Soc. 1905 (1906), 239-246.

1906.1

A plan for promoting the whitefish production of the Great lakes. Proc. 4. Intern. Fish. Congr., Washington, D. C., 1908, 627-633. 1908.1

Are the hatcheries on the Great lakes of benefit to the commercial fishermen? Trans. Amer. Fisheries Soc. 1911 (1912), 127-134.

1912.1

Downman, $R . H$. Shad, herring, ete., excluded from the Rappahannock river by dams. Bull. U. S. Fish Comm. $1883,3,392$.

1883.1

Doyère, $M . P . L . M$. Sur un micropyle dans des aeufs du Loligo media et Syngnathus ophidion. Bull. Soc. Philom. Paris, 1849.

1849.1

Drago, Umberto, \& Barbagallo, Pietro. See Barbagallo \& Drago.

Dralet, — Considérations sur l'histoire naturelle des poissons, sur la pêche et les lois qui la régissent. Toulouse, $1821.8^{\circ}$.

1821.1

Drayton, Michael. Fishes of the Nottinghamshire Trent in 1822, recorded by Michael Drayton. See Carr, J.W. in The Naturalist, 1898, no.493, p. 33-36. 1898.1

Drechsel, $C . F$. Oversigt over vore Saltvands-Fiskerier i Nordsöen og Farvandene indenfor Skagen. Kjöbenhaven, 1890. 39 pls. \& 15 charts. $4^{\circ}$. 1890.1

Drechsel, Edmund. Beiträge zur Chemie einiger Seetiere. [n. p. circa 1885 ?] 
Dreger, $J$. Die geologische Aufnahme der NW-Section des Kartenblattes Marburg und die Schichten von Eibiswald in Steiermark. Verhl. k. k. Geol. Reichsanst., Wien, 1902, 85-104.

1902.1

Fossil fishes mentioned.

Dresel, H.G. (translator) A hybrid plaice - Platessa vulgaris with Rhombus maximus, by K. E. H. Krause. Bull. U. S. Fish Comm. 1882 (1883), 2, 341342 .

1883.1

Description of a new species of flounder, Citharichthys macrops, from Pensacola, Florida. Proc. U. S. Nat. Mus., 1885, 7, 539-541.

1885.1

Notes on some Greenland fishes. Proc. U. S. Nat. Mus., 1885, 7, 244-256. 1885.2

Dresel, H.G., \& Bean, T. $H$. See Bean \& Dresel.

Dresslar, Fletcher B., \& Bicknell, E. P. See Bicknell \& Dresslar.

Dresslar, Fletcher B., \& Fesler, Bert. A review of the mackerels (Scombrinx) of America and Europe. Bull. U. S. Fish Comm. 1887 (1889), 7, 429-446. 11 pls.

1889.1

Drevermann, $F$. Ueber Pteraspis dunensis F. Roemer sp. Zeitschr. Deutsch. Geol. Ges., 1904, 56, 275-289. 3 pls.

1904.1

- Ein fossiler Hai. 41. Ber. Senckenberg. Nat. Ges. Frankfurt-a.-M. 1910, 191-193. fig.

1910.1

Ein Riesenfisch aus dem weissen Jura [Lepidotus palliatus] 43. Ber. Senckenberg. Naturf. Gesell. Frankfurta.-M., 1912, 4-6. pl.

1912.1

Drew, G. Harold. Some notes on parasitic and other diseases of fish. Parasitology, Cambridge, 1910, 3.

1910.1

- Some cases of new growths in fish. Journ. Mar. Biol. Assoc. 1912, n. s. 9, 281-287. pl.

1912.1

Drew, Joseph. Cornish sucker [Lepidogaster cormubiensis! Sci. Gossip, 1871 (1872), 206.

1872.1

Drew, S.H. Notes on Regalecus sp. Trans. New Zealand Instit., 1898, 30 , 253-25.
Drewsen, Christian. Om de unge Aals vandringer. Kroyer, Nat. Tidsskr. 1837, 1, 21-24. Ibid., 4, 412. - Archiv. f. Naturges.(Wiegmann), 6, 241. 1837.1

Dreyer, A. Nordseefische. Jahrb. St. Gall. Nat. Ges., 1904 (1905), 52-54. 1905.1

Dreyzehner, Zwei Beobachtungen über Brutpflege der Cichliden. Wochenschr. Aquar.-Terrar. Kunde, 1909, 6. Jahrg., 503-504. 1909.1

Zuchterfolge bei Pelmatochromis subocellatus (?) . Blätt. Aquar.-Terrar. Kunde, 1911, 22. Jahrg., 448-450. 2 figs.

1911.1

- Der kleinste neue Zwergcichlide (Heterogramma?) Blätt. Aquar.-'Terrar. Kunde, 1912, 23. Jahrg., 22-23. 1912.1

Weitere Beobachtungen über Pelmatochromis subocellatus. Blätt. Aquar.-Terrar. Kunde, 1912, 23. Jahrg., $70-71.2$ figs.

1912.2

Drieberg, $C$. Singing fish of Batticaloa. Spolia Zeylanica, 1908, 5, 67-68.

1908.1

Dröscher, Wilhelm. Beiträge zur Kenntniss der histologischen Struktur der Kiemen der Plagiostomen. Leipzig, 1881. 55 p. $8^{\circ}$. Reprint in Arch. Naturgesch., 1882, 48, pt. 1, 120-177. 4 pls.

1881.1

Beitrag zur Kenntniss der Nahrung unserer Fische. Allgem. Fischere Zeitg., 1897, 22, 361-366.

1897.1

Kuhan ravinto. Suomen Kalastus Lehti, 1898, 7, 6-8; 26-29. 1898.1

Zur Verbreitung der grossen Maräne. Fischerei-Zeitg., Neudamm, 1901, $4,35-39$

1901.1

Fischerei und Wissenschaft. Fischerei-Zeitg., Neudamm, 1902, 5, 818822.

1902.1

Nachtrag zum obigen Artikel, von Wilhelm Halbfass. Op. cit., 6, 49-51.

Ein Beitrag zur Lebensgeschichte der grossen Maräne. Fischerei-Zeitg. Neudamm, 1907, 10, 725-729; 741-747.

1907.1

- Die Nahrung unserer wirtschaftlich wichtigsten Wildfische. FischereiZeitg., Neudamm, 1907, 10, 757-761, 778-781; 810-813; 821-827. Ibid., 11, 6-11. 
Der Schaalsee und seine fischereiwirtschaftliche Nutzung. Ein Fischereiwirtschaftliches Gutachten. Zeitschrift Fischerei, Berlin, 1908, 13, 173283. 2 pls.

1908.1

Droogleever Fortuyn, A.B. Over de motorische facialis- en abducenskern van Lophius piscatorius. Versl. K. Akad. Wet. Amsterdam (Wis. Nat. Afd.), 1909, 17, 905-90S. pl. - Proc. K. Akad. Wet Amsterdam (Sect. Sci.), 12, 44-47. pl.

1909.1

Intrede der motorische hersenzenuwen in de medulla oblongata [Amia] Tijdschr. Nederl. Dierk. Vereen., 1913, 2. ser. 12, xlviii-xlix. 1913.1

Drossaart, $P . K$. Eenige bijzonderheden betrekkelijk de Haringsvaart. Jaarboekje Vlaardingen, 1868, 1. Jahrg., $36-37$.

1868.1

Drouet, Henri. Faune açorréene tet histoire naturelle de l'archipel] Mém. Soc. Agric. Sci. Lettres Dept. Aube, 1861. Also separate; Troyes, 1861. $4^{\circ}$ 1861.1

Drouin de Bouville, Raoul de. Le repeuplement des rivières en Meurthe et Moselle. Systèmes adoptés. Résultats obtenus. Bull. Soc. Sci., Naney, 1901, 3. sér. 2, 84-95; C. R. Congr. Soc. Sav., Paris, 1901, 148-157. 1901.1

Batraciens et poissons du bassin de la Moselle supérieure. Bull. Soc. Sci., Nancy, 1902, 3. sér. 3, 136-156. map.

1902.1

L'alimentation des Salmonides. Bull. Piscicult., Toulouse, 1908, 6-12.

1908.1

Influence des variations thermiques brusques sur les œufs, alevins et jeunes sujets de Salmonides. C. R. Mém. Soc. Biol. Paris, 1908, 65, 259261.

1908.2

L'omble à collerette [Salvelinus] Bull. Piscicult., Toulouse, 1908, 3-8. - C. R. Mém. Soc. Biol., Paris, 1908, 64, 229-231.

1908.3

Maladie des abcès du barbeau (Myxoboliasis tuberosa) Bull. Soc. Sci., Nancy, 1909, 3. sér. 9, 525-548. 1909.1

Apparition de la furonculose en France. C. R. Acad. Sci. Paris, 1910 , $151,337-340$.

1910.1

Le choix des races d'élevage en salmoniculture. Communic. 9. Congrès
Intern. Zool., Monaco, 1913, 3. sect. 43-44.

1913.1

Droz, S., \& Perrot, L. See Perrot \& Droz.

Drüner, $L$. Ueber die Wirbeltheorie des Schädels. Ber. Senckenberg Nat. Ges., Frankfurt-a.-11., 1905, 152*-156*.

1905.1

- Die Kiemenbogen der Wirbel. tiere und ihre Abkömmlinge. Ber. Senckenberg Nat. Ges., Frankfurt-a.-M., $1906,6^{*}-10^{*}$. 1906.1

Drummond, James $L$. On certain appearances observed in the dissection of the eyes of fishes. Trans. Roy. Soc. Edinb., 1814, 7, 377-386. 1814.1

On a goldfish having vegetable fibres issuing from an ulcer on its back. Zoologist, 1843, 1, 84. fig. $\quad 1843.1$

Drygalski, E. von. Zum Kontinent des eisigen Südens. Berlin, 1901.

1904.1

Some mention of Antaretic fishes.

Drzewina, Anna. O thance limfatycznej w nerce niekórych ryb [Sur le tissu lymphoïde du rein de certains poissons] Kíosmos Polski., 1904, 29, 504-520.

1904.1

Sur la non-spécificité des cellules granuleuses du rein de l'Acipenser sturio L. (note préliminaire) C. R. Mém. Soc. Biol. Paris, 1904, 56, pt. 1, $957-959$.

1904.2

- Sur l'organe lymphoïde de l'osophage des sélaciens (note préliminaire) C. R. Mém. Soc. Biol. Paris, 1904, 56 $637-639$

1904.3

Contribution à l'étude du tissu lymphoide des Ichthyopsidés. Arch. Zool. Expér. Gén., 1905, 4. sér. 3, 145338. pl. \& figs.

1905.1

Modifications des leucocytes acidophiles chez certains téléostéens marins soumis à des variations de salure. C. R. Mém. Soc. Biol. Paris, 1906, 9, 167-16s. 1906.1

Influence de la dessalure sur les leucocytes granuleux des sélaciens. C. R. Mém. Soc. Biol. Paris, 1908, 64, 10391041 .

1908.1

L La préhension des aliments par les poissons. Bull. Instit. Psychol. Internat., Paris, 1908, 8, 328-330. 
Drzewina, $A$.

—- Sur l'épithélium séreux de l'Acipenser güldenstädtii Brandt. Arch. Anat. Micr., Paris, 1908, 10, 269-277. 5 figs. 1908.3

Epithélium et glandes de l'œesophage de la torpille (note préliminaire) C. R. Mém. Soc. Biol., Paris, 1909, 66, $570-571$.

1909.1

Leucocytes à granulations acidophiles dans le sang des poissons téléostéens. C. R. Mém. Soc. Biol. Paris, 1909, 66, 514-516.

1909.2

Sur les éosinophiles de l'intestin de certains téléostéens. C. R. Mém. Soc. Biol., Paris, 1910, 68, 1012-1013. 1910.1

Sur l'organe lymphoïde et la muqueuse de l'oesophage de la torpille (Torpedo marmorata Risso) Arch. Anat. Micr., Paris, $1910,12,1-18.9$ figs.

1910.2

—_ Contribution à l'étude des leucocytes granuleux du sang des poissons. Arch. Anat. Micr., Paris, 1911, 13, 319 376. pl.

1911.1

Cellules géantes dans l'épithélium intestinal des téléostéens à jeun. C. R. Mém. Soc. Biol., Paris, 1912, 72 , 18-19.

1912.1

Drzewina, Anna, \& Pettit, Auguste. Sur des hyperplasies tissulaires consécutives à l'ablation de la rate chez les Ichthyopsidés. C. R. Mém. Soc. Biol. Paris, 1904, 56, pt. 2, 628-630. - Bull. Mus. Hist. Nat., Paris, 1905, 57-59. Bull. Intern. Acad. Sci., Cracovie, 1905, 66-67.

1904.1

Drzhevetzkič, $V$., \& Derzughin, $K$. See Derzughin \& Drzhevetzkič.

D'Souza, $V$. On fishes indigenous to Sind. Journ. Bombay Branch Roy. Asiat. Soc., 1872, 8, 18-21.

1872.1

Dubalen, - Note sur un poisson inal connu du bassin de l'Adour. Bull. Soc. Borda, Dax, 1878, 2. trimestre Also separate; Dax, 1878.

1878.1

Du Bocage, José Vincente Barboza. See Barboza du Bocage, José Vincente.

Dubois, Auguste. Les macropodes. Journ. Agricult. Pratique, 1874, 38. année, 2, 390-391. fig. 1874.1

Dubois, Auguste, \& Schardt, $H$. See Schardt \& Dubois.
Dubois, Emil. Quxe apud veteres de piscibus electricis extant argumenta. Berolini, 1843. $8^{\circ}$.

1843.1

- Vorläufiger Abriss einer Untersuchung über den sogenannten Froschstrom und über die elektromotorischen Fische. [n. p.] 1843. $8^{\circ}$.

1843.2

Dubois, Louis. Cours d'agriculture et d'économie rurale et domestique. Paris, 1824.

1824.1

Dubois, Michel. De l'embryogénie de l'anguille. Bull. Soc. Linn. Nord France, Amiens, 1875, 2, 94-97; 119.

1875.1

Du dépeuplement des eaux. Bull. Soc. Linn. Nord France, Amiens, 1875, 2, 189-193.

1875.2

_ Les poissons des environs d'Amiens. Bull. Soc. Linn. Nord France, Amiens, 1879, 4, 292-295. Ibid., 1892$93,11,37-38 ; 168-169 ; 246-248 ; 276-$ 279. Ibid., 1894-95, 12, 38-39; 250252.

1879.1

Du repeuplement des eaux dans le département de la Somme. Bull. Soc. Linn. Nord France, Amiens, 1891, 10, $54-56$.

1891.1

Du rempoissonnement des cours d'eau dans le département de la Somme. Bull. Soc. Linn. Nord France, Amiens, 1894-95, 12, 370-375.

1895.1

Dubois, Raphaël. Sur le mécanisme de la respiration et du cri chez le Protopterus annectens. C. R. Assoc. Franç. Avanc. Sci., 20. sess., 1891, pt. 1, 244.

1891.1

Contribution à l'étude du mécanisme respiratoire des dipnoïques et de leur passage de la torpeur estivale à la vie active. Ann. Soc. Linn. Lyon, 1892, 2. sér. 39, 65-72. figs. 1892.1

Sur l'empoisonnement des animaux d'eau douce par l'hypochlorite de chaux. Ann. Soc. Linn. Lyon, 1895, 42, 49-52.

1895.1

Leçons de physiologie généralc et comparée. Paris, 1898. 1898.1

Absence de sucre et de glycogène dans les organes électriques de la torpille. Ann. Soc. Linn. Lyon, 1899, n. s. 45, 96-98. $\quad 1899.1$

- Observations sur la torpille. Ann. Soc. Linn. Lyon, 1899, n. s. 45, 80-81. 
Sur la production de la chaleur par les animaux à sang froid immergés dans l'eau. Ann. Soc. Linn. Lyon, 1899 , n. s. $45,77-78$.

1899.3

Sur le cuivre normal dans la série animale [Clupea harengus, $C$. sardina, Tinca vulgaris, Cyprinus carpio] C. R. Mém. Soc. Biol., Paris, 1900, 52, 392-394. - Ann. Soc. Linn. Lyon, 1901, 47, 93-97.

1900.1

Du Bois-Reymond, Emil Heinrich [1818-1896] For biography and works, see Chem. Zeitg., 1896, 20, 1035.Amer. Naturalist, 1897, 31, 268-269.Arch. Anat. Physiol. (Physiol. Abth.), 1897, vii-xxvi. - Science, 1897, n. s. 5, 217-219.

Vorläufiger Abriss einer Untersuchung über den sogenannten Froschstrom und über die elektromotorischen Fische. Annal. Phys. Chem. (Poggendorff), 1843, 58, 1-30.

1843.1

- Untersuchungen über thierische Elektricität. Annal. Phys. Chem. (Poggendorff), 1848, 75, 463-464。 1848.1

Recherches sur l'électricité animale. Arch. Bibl. Univ., 1850, 14, 105122. - Ber. Verh. K. Preuss. Akad. Wiss, Berlin, 1851, 380-398. - Ibid., 1852, 111-140. - Ibid., 1853, 76-122. - Untersuch. (Moleschott), 1857, 2, 137-157; 247-277. - Ibid., 3, 125-172. - Ibid., 1858, 4, 1-15.

1850.1

- Nouvelles recherches sur l'électricité animale. Ann. Chimie, 1853, 39, 114-127. - Arch. Bibl. Univ., 1853, 23, 121.

1853.1

- Mittheilungen über einen lebendigen Zitterwels] Monatsber. Akad. Wiss. Berlin, 1857, 424-430. 1857.1

- Nachricht von einem nach Berlin gelangten lebenden Zitterwels. Monatsber. Akad. Wiss. Berlin, 1857, 424429. - L'Institut, 25, 435-436. 1857.2

- Note sur le malaptérure électrique. Annal. Chimie Phys, 1858, 3. sér. 52, 124-125. - Phil. Mag. 1858, $15,45-48$.

1858.1

Ueber lebend nach Berlin gelangte Zitterwelse aus Westafrika. Monatsber. Akad. Wiss. Berlin, 1858, 81111. - Untersuch. (Moleschott), 5, 109136.

1858.2

Bemerkungen über die Reaction der elektrischen Organe und der Mus- keln. Archiv Anat. Physiol. (Reichert), $1859,846-853$.

1859.1

Zur Geschichte der Entdeckungen am Zitterwelse (Malapterums electricus) Archiv Anat. Physiol. (Reichert), 1859, 210-212.

1859.2

Ueber Jodkalium-Elektrolyse und Polarisation durch den Schlag des Zitterwelses. Monatsber. Akad. Wiss. Berlin, 1861 (1862), 1105-1128. fig. Untersuch. (Moleschott), 1862, 8, 549571.

1862.1

Ueber die räumliche Ausbreitung des Schlages der Zitterfische. Monatsber. Akad. Wiss. Berlin, 1864 (1865), 317-354. pl.-Untersuch. (Moleschott), 1865, 9, 437-473. 1865.1

Dr. Carl Sachs' Untersuchungen am Zitteraal, Gymnotus electricus, nach seinem Tode bearbeitet von E. du BoisReymond. Mit zwei Abhandlungen von G. Fritsch. Leipzig, 1881. xxviii, 446 p. illust. $8^{\circ}$.

1881.1

Contains copious bibliographical references. Abstract in Journ. R. Micr. Soc. London, 1881, 2. 602 .

Vorläufiger Bericht über die von Prof. Gustav Fritsch in Aegypten und am Mittelmeer angestellten bisherigen Untersuchungen an elektrischen Fischen] Erste Hälfte. Monatsber. Akad. Wiss. Berlin, 1881, 1149-1164. Arch. Anat. Physiol. (Physiol. Abth.), $1882,61-75$

1881.2

Vorläufiger Bericht über die von Prof. Gustav Fritsch in Aegypten und am Mittelmeer angestellten neuen Untersuchungen an elektrischen Fischen. Zweite Hälfte, Sitzber. Akad. Wiss. Berlin, 1882, pt. 1, 477-503. - Arch. Anat. Physiol. (Physiol. Abth.), 1882, $387-413$.

1882.1

Ueber die Fortpflanzung des Zitteraales (Gymnotus electricus) Arch. Anat. Physiol. (Physiol. Abth.), 1882, 76-80.

1882.2

On a new principle affecting the systematic distribution of the Torpedinidx, and on the probable occurrence of T. occidentalis (Storer) on the British coast. Rept. Brit. Assoc. Adv. Sci., 53. meet., London, 1883, 592-595.

1883.1

Ueber secundär-elektromotorische Erscheinungen an Muskeln, Nerven und elektrischen Organen. Sitzber. 
Du Bois-Reymond, E. $H$.

Akad. Wiss. Berlin, 1883, pt. 1, 343-404. 3 figs. Abstract in Biol. Centralbl., 3 , $537-540$.

1883.2

Lebende Zitterrochen in Berlin. Sitzber. Akad. Wiss. Berlin, 1884, pt. 1, 181-242. 8 figs. Ibid., 1885, pt. 2, 691-750. 5 figs. - Arch. Anat. Physiol. (Phys. Abth.), 1885, 86-145. \& figs. Ibid., 1887, 51-110. 5 figs. $\quad 1884.1$

Bemerkungen über einige neuere Versuche an Torpedo. Sitzber. Akad. IViss. Berlin, 1888, 5, 353; 531-554.

1888.1

Vorläufiger Bericht über die von Prof. Gustav Fritsch angestellten neuen Untersuchungen an elektrischen Fischen. Sitzber. Akad. Wiss. Berlin, 1891, pt. 1, 223-226. - Arch. Anat. Physiol. (Physiol. Abth.), 1892, 217-220.

1891.1

Ueber einige Versuche an ganz jungen Zitterrochen. Arch. Anat. Physiol. (Physiol. Abth.), 1893, 190-192.

1893.1

Du Bois-Reymond, Emil Heinrich, \& Sachs, C. See Sachs \& Du BoisReymond.

Du Bois-Reymond, René. Ueber die gestreiften Muskeln im Darm der Schleie. Arch. Anat. Physiol. (Physiol. Abth.), 1890, 176-177.

1890.1

Ueber die Bewegung der fliegenden Fische. Zool. Jahrb. (System. Abth.), 1891, 5, 922-924.

1891.1

Die fliegenden Fische im Lichte der Versuche von O. Lilienthal über Luftwiderstände. Arch. Anat. Physiol. (Physiol. Abth.), 1894, 371-374. 1894.1

Duboscq, Octave, \& Léger, Louis. See Léger \& Duboscq.

Dubourdieu, (Rev.) John. A statistical survey of the county Antrim. 2 pts. Dublin, 1812. $8^{\circ}$.

1812.1

The first part contains a section (p. 113-126) on the fishes of lough Neagh, including the first definite notice of a charrlike fish in Ireland. This fish, there called the whiting, is identified as Salmo alpinus.

Dubreuil, E. Note sur le brochet. Ann. Soc. Horticult. Hist. Nat. Hérault, 1870, 2. sér. 2, 29-30.

1870.1

Recherches sur le système nerveux des poissons. Abstract in Rev. Sci. Nat. Montpellier, 1885, 3, 633-638. 1885.1
Dubreuil, G., \& Renaut, J. See Renaut \& Dubreuil.

Dubuisson, $H$. Contribution à l'étude du vitellus [poissons] Arch. Zool. Expér. Gén., 1906; 4. sér. 5, 272-281; 379-391.

1906.1

Ducastel, $M$. Saltvandsparker. Nordisk Tidsskr. Fiskeri, 1879, n. s. 5. Jahrg., 240-249.

1879.1

— Transformation des marais salants en réservoirs à poissons. Bull. Soc. Acclim. Paris, 1879, 3. sér. 6, 73-93. 2 figs. - Rept. U. S. Fish Comm. 1880 (1883), 8, 517-531.

1879.2

Ducceschi, $V$. Gli animali aquatici possiedono il senso dell' udito? Riv. Ital., 1903, 6.

1903.1

Duchamp, G., \& Renault, J. See Renault \& Duchamp.

Duchasseint,Louis. Matériaux pour la faune d'Auvergne. Notes ichthyologiques. Rev. Sci. Bourbonn., 1897, 10. année, 205-216.

1897.1

Duchaussoy, $H$. Notes recueillies dans les archives. II. "Ung gros esturgeon pesché à Amyens." Bull. Soc. Linn. Nord France, Amiens, 1891. 10, 118-119.

1891.1

Duchemin, Emile. Besondere Todesart der Karpfen Idurch Kröten] Lotos, 1870, 20. Jahrg, 151.

1870.1

Die Krröte als Karpfentödter. Ausland, 1870, no. 20.

1870.2

Singulière cause de la mortalité des carpes d'un vivier. C. R. Acad. Sci. Paris, 1870, 70, 823, 1009.

1870.3

Duclos, Gilbert. American silver perch or calico bass. Bull. U. S. Fish Comm. 1887 (1889), 7, 215-216. 1889.1

Ducret, $E$. Sur le développement des membres pairs et impairs de la truite. Arch. Sci. Phys. Nat., Genève, 1893, 3. sér. 30, 271-273.

1893.1

Contributions à l'étude du développement des membres pairs et impairs des poissons téléostéens, type Truttr lacustris. Thèse. Lausanne, 1894. 29 p. 2 pls. $8^{\circ}$ 1894.1

Ducrotay de Blainville, Henri Marie. See Blainville, $H$. M. de.

Dudgeon, R. E. On subaqueous vision. Phil. Mag., 1871, 41, 350-353. 1871.1 
Düben, M. W. von. Beretning angaaende nogle for Skandinaviens fauna nye fiske. Skand. Naturf. Förhandl. 1844, 4, 222-227. $\quad 1844.1$

Mittheilungen über die Meerfische Norwegens] Arch. Skand. Beitr. Naturgesch., 1845, 1, 164-169. 1845.1

- UUeber die Meeresfauna Norwegens] Arch. Skand. Beitr. Naturgesch., 1845, 1, 136-138.

1845.2

Düben, $M$. W. von, \& Koren, $J$. Ichthyologiska bidrag. I. Vet. Akad. Handl., Stockholm, 1844, 27-120. Isis (Oken), 1848, 142-143.

1844.1

[Beschreibung von zwölf für die skandinavische Fauna neuen Fischen] Arch. Skand. Beitr. Naturgesch., 1845, 1, 450-452.

1845.1

Om nya Skandinaviska Fiskar. Oefvers K. Vet. Akad. Förh., Stockholm, $1845,2,9-12$.

1845.2

Duerden, James Edward [1869-] The operations in Jamaica of the Caribbean sea fisheries development syndicate, Ltd. (Jamaica fisheries) Daily Gleaner, Kingston, Jamaica, April 16, 1898. 6 p.

1898.1

The fisheries of Barbados. West Ind. Bull. Journ. Imp. Agric. Dept., 1901, Extra Number, 20-32.

1901.1

Duerigen, Bruno. Das Terrarium und ... die Pflege und Züchtung der Makropoden. See Martin, $P . L$. Die Praxis der Naturgeschichte, etc. Theil iii, Heft 2. 1882. $8^{\circ}$. 1882.1

- Fremdländische Zierfische. Ein Handbuch für die Naturgeschichte, Pflege und Zucht der bisher eingeführten Aquarien-fische. 2. Aufl. Magdeburg, 1897. ix, 352 p. 22 pls. \& 21 figs. $8^{\circ}$.

1897.1

Ueber das Leben und Treiben der Makropoden (Polyacanthus viridiauratus) Nat. Wochenschr., 1897, 12, $545-547$

1897.2

Duff, $R . P . R$. Exportation of salmon ova to New Zealand in 1876 . Rept. U. S. Fish Comm. 1875-76 (1878), 4 , 963-964; 970 .

1878.1

Duff, $R . W$. The herring fisheries of Scotland. Intern. Fisheries Exhib. Lit., London, 1883. Conferences, 6, pt. 3 .
On the fisheries of Great Britain and the fisheries exhibition of 1883 . Rept. U. S. Fish Comm. 1883 (1885), $11,317-324$.

1885.1

Dufossê, $A$. De l'hermaphrodisme chez certains vertébrés [Serranus] Ann. Sci. Nat. (Zool.), 1854, 5, 295-332.L'Institut, 1854, 394-395. Ibid., 1855, 428. - C. R. Acad. Sci. Paris, 1854, 39 , 890-893. Ibid., 1855, 41, 890-893; 1006-100s. Ibid., 1856, 43, 23-26.

1854.1

Des différents phénomènes physiologiques nommés voix des poissons. C. R. Acad. Sci. Paris, 1858, 46, 352356. Ibid., 1858, 47, 916. Ibid., 1862, $54,393-395$.

1858.1

- De l'ichthyopsophie ou des différents phénomènes physiologiques nommés "voix des poissons." C. R. Acad. Sci. Paris, 1866, 62, 978-980.

1866.1

Töne bei Fischen. Abstract in Lotos, 1868, 18. Jahrg., 62-63. 1868.1

Sur les bruits et les sons expressifs que font entendre les poissons. C. R. Acad. Sci. Paris, 1872, 74, 14541455. - Bull. Hebd. Assoc. Sci. Trance, $1872,11,25-26$.

1872.1

- Recherches sur les bruits et les sons expressifs que font entendre les poissons d'Europe et sur les organes producteurs de ces phénomènes acoustiques ainsi que sur les appareils de l'audition de plusieurs de ces animaux. Ann. Sci. Nat. (Zool.), 1874, 5. sér. 19, no. 5, 3-53. Ibid., 1874, 5. sér. 20, no. 3, 1-134. Extract in C. R. Acad. Sci. Paris, 74, 1454-1455. Ibid., 75, 1074-1078.

1874.1

Sur un organe de préhension chez un poisson et autres fragments pour servir à la monographie du genre Hippocampe. Journ. Anat. Phys., $1874,10,368-375 . \quad 1874.2$

Duge, $F$. Heringseier im Magen der Schellfische. Mitt. Deutsch. Seefischerei Ver., Berlin, 1903, 19, 460. 1903.1

Beobachtungen über den $\mathrm{Be}-$ stand der Plattfische auf den Fischgründen der Nordsee. Mitt. Deutsch. Seefischerei Ver., Berlin, 1905, 21, 3136.

1905.1

Dugès, Alfredo. Aparato venenoso del bagre (Ictalurus dugesi Bean) Naturaleza, Mexico, 1891, 1, 405-40s.

1891.1 
Dugès, $A$.

- Gambusia infans Woolman.

Mem. Soc. Cient. "Alzate," Mexico, 1902, 17, 121-123. pl. 1902.1

Note on the functions of the fins of fishes. Science, 1905, n. s. 22, $798-800$.

1905.1

Rôle des nageoires chez les poissons. Bull. Soc. Zool. France, 1905, 30, 107-110. - Mem. Soc. Cient. "Alzate," Mexico, 1905, 22, 217-220. - Arch. Intern. Physiol., 3, 127-129. 1905.2

Duguid, - Letter on the deal fish (Trachypterus vogmarus) Proc. Zool. Soc. London, 1851, 19, 116-117.Ann. Mag. Nat. Hist., 1853, 2. ser. 11, $468-469$.

1851.1

Duhamel du Monceau, Henry Louis [1700-1782] Traité général des pêsches, et histoire des poissons qu'elles fournissent, .. 4 vols. in 3 . Paris, 1769-82. illust. fol.

1769.1

"Traite général des pêches et histoire des poissons ou des animaux qui vivent dans l'eau. Suite de la seconde partie. Tome iv."

The fourth volume bears the above title, the three preceding, which appeared at intervals between 1769 and 1782 , are entitled "Traité général des pêsches maritimes et fluviatiles." This work, written in collaboration with $\mathrm{L}$. $\mathrm{H}$. de La Marre, was incorporated in the "Collection des arts et métiers," and has been much pirated. The plates number 250; not all of them, however, are of strict fidelity to nature

Allgemeine Abhandlung von der Fischereyen und Geschichte der Fische; übersetzt mit Anmerkungen von D. G. Schreber. 3 vols. Leipzig \& İönigsberg, 1773. illust. 4 ${ }^{\circ} 1773.1$

- Dictionnaire de toutes les espèces de pêches ... d'après Ovide, Jove, Aldrovande, Jonston, Buc'hoz, etc., suivi d'un vocabulaire de pêche, par Duhamel Du Monceau. Paris, 1775. $4^{\circ}$.

1775.1

This is adapted from the "Traité général," and alleged to be (under this title) a book of extraordinary rarity.

Encyclopédie méthodique. Dictionnaire de toutes les espèces de pêches. Paris, L'an quatrième [1796] $4^{\circ}$. 1796.1

This is an adaptation of the "Traité général " under a new title.

Duhamel du Monceau, H. L., \& others. Of the herring fishery, translated from the French of M. Duhamel and others. Phil. Mag., 1803, 17, 218225. Ibid., 18, 12-25.

1803.1

Duigan, James. Is access to the sea a necessity to cels? Trans. New Zealand Instit., 1876, 8, 221-222. 1876.1
Dujardin, Félix. Sur les zoospermes de la carpe. Ann. Sci. Nat., 1837, 2. sér. 8, 297-302.

1837.1

Duke, $F . W$. Extract of the speech made in the Bengal legislative council at the budget debate on the 15 th April, 1909. Coll. Papers Fish. Surv. Bengal, 1911,88 .

1911.1

Duke of Edinburgh. See Edinburgh, Duke of.

Dulac, Alléon. Mélanges d'histoire naturelle. 2 vols. Lyon, $1765.12^{\circ}$.

176.5. 1

Histoire naturelle du hareng, vol. ii., 368-393.

Du Mênil, August Peter Julius [1777-1852] Chemische Zergliederung der Fischknochen (Hechtsknochen) Neues Journ. Pharm. (Trommsdorff), $1820,4,273-279$.

1820.1

Duméril, André Marie Constant [1774-1860] For biographical notice and list of works, see Abeille, 1889, 26, 252-259.

Zoologie analytique, ou méthode naturelle de classification des animaux. Paris, 1806. xxxiii, 344 p. $8^{\circ}$. 1806.1

Mémoires de zoologie et d'anatomie comparée. Paris, 1807. $146 \mathrm{p}$. $8^{\circ}$.

1807.1

Contains the following, articles, reprinted from Millen's Magazin Encyclopédique for 1807 and from other sources.

Mémoire sur l'odorat des poissons.

Mémoire sur le mécanisme de la respiration des poissons.

Dissertation sur la famille des poissons cyclostomes, pour démontrer leur rapports avec les animaux sans vertèbres.

Iémoire sur l'anatomie des lamproies.

- Mémoire sur le mécanisme de la respiration dans les poissons. Nouv. Bull. Soc. Philom. Paris, 1807, 1, 26-28. - Journ. Nat. Phil. (Nicholson), 28, 350-359.

1807.2

Mémoire sur l'odorat des poissons. Nouv. Bull. Soc. Philom. Paris, 1807, 1, 14-15. - Journ. Nat. Phil. (Nicholson), 29, 344-351. 1807.3

_. Sur deux espèces de poissons du genre Pétromyzon décrites par M.J.J. Omalius-de-Hallois. Résumé in Nouv. Bull. Soc. Philom. Paris, 1808, 1, 165166.

1808.1

Dissertation sur la famille des poissons cyclostomes, pour démontrer leurs rapports avec les animaux sans vertèbres. Paris, 1812. $8^{\circ}$. 1812.1 
Dissertation sur les poissons qui se rapprochent le plus des animaux sans vertèbres. Thèse. Paris, 1812. $40 \mathrm{p}$. $4^{\circ}$.

1812.2

Rapport fait à l'Académie des Sciences sur trois mémoires d'anatomie relatifs à l'organe de l'ouìe dans les poissons, par M. Breschet. Ann. Sci. Nat. (Zool.), 1832, 27, 309.

1832.1

Bericht über Breschet's Gehörorgane der Fische. Isis (Oken), 1835 11,972 .

1835.1

Considérations générales sur le sous-ordre des poissons osseux dits jugulaires ou protéropodes, formant la tribu unique des Sténopes. C. R. Acad. Sci. Paris, 1855, 41, 229-246. - L'Institut, 23, 285-286.

1855.1

Prodrome d'une classification des poissons après la méthode naturelle. C. R. Acad. Sci. Paris, 1855, 41, 133137.

1855.2

Considérations générales sur les classifications en histoire naturelle, et exposé sommaire du plan de l'ichthyologie analytique à l'aide de tableaux synoptiques. C. R. Acad. Sci. Paris, $1856,42,1029-1034$.

1856.1

Ichthyologie analytique ou classification des poissons, suivant la méthode naturelle, à l'aide de tableaus synoptiques. Mém. Acad. Sci. Paris, 1856, 27, pt. 1, 1-511. - Also separate; Paris, 1856. 511 p. $4^{\circ}$.

1856.2

Rapport sur un mémoire de $M$. Hollard, sur les Ostracionides. C. R Acad. Sci. Paris, 1857, 44, 1194-1197. — L'Institut, 25, 197-198.

1857.1

Sur les organes des sens et en particulier sur ceux de l'odorat, du goût, et de l'oule dans les poissons. C. R. Acad. Sci. Paris, 1858, 46, 867879

1858.1

Duméril, André Marie Constant, \& Cuvier, Georges Léopold Chrétien Frédéric Dagobert. See Cuvier \& Duméril.

Duméril, André Marie Constant, Flourens, Marie Jean Pierre, \& Duvernoy, Georges Louis. Structure de l'encéphale des raies et des squales et origine des nerfs crâniens chez ces poissons. Paris, 1854. 28 p. $4^{\circ}$.

1854.1
Duméril, Auguste Henri André [1812-1870] For biography and list of works, see Arch. Mus. Hist. Nat. Paris, 1871, 7 (Bull.), 15-24. Also Gervais, F. L. P. Discours ... etc., suivi de la liste de ses travaux scientifiques. Paris, 1871. $4^{\circ}$.

Monographie de la famille des torpédiniens, ou poissons plagiostomes électriques. Rev. Mag. Zool., 1852, 4, $176-189 ; 227-244 ; 270-285$. Also separate; Paris, 1852.

1852.1

Sur les torpédinienes. Abstract in Extraits Procès-Verb. Soc. Philom. Paris, 1852, 16, 63-64. 1852.2

Monographie de la tribu des Scylliens ou Roussettes (poissons plagiostomes) comprenant deux espèces nouvelles. Rev. Mag. Zool., 1853, 2. sér. 5, 8-25; 73-87;119-130. pl. 1853.1

Sur la tribu des Scylliens. C. R. Acad. Sci. Paris, 1853, 36, 288-289.

1853.2

Note sur un travail inédit de Bibron relatif aux poissons plectognathes gymnodontes (Diodons et Tetrodons) Rev. Mag. Zool., 1854, 2. sér. 7, 274 282 .

1854.1

Résumé de quelques leçons d'ichthyologie. Procès-Verb. Soc. Philom. Paris, 1855, 78-80. - L'Institut, 23, 356-357.

1855.1

Essai de classification des poissons qui forment le groupe des Echénéides. C. R. Acad. Sci. Paris, 1858, 47, 374-378. L'Institut, 26, 297. 1858.1

Lettres relatives au catalogue des poissons de la collection du Muséum d'Histoire Naturelle de Paris, et au catalogue de la ménagerie des reptiles; suivies de notes sur la ménagerie des reptiles. Arch. Mus. Hist. Nat. Paris, $1858-61,10,429-460 . \quad 1858.2$

Note sur des truites d'une espèce nouvelle (Salar macrostigma A. Dum.) récemment envoyées d'Algérie à la société. Bull. Soc. Acclim. Paris, 1858, 5, 444-446. - C. R. Acad. Sci. Paris, 47, 160-162.- Rev. Mag. Zool., 10, 396-399. - L'Institut, 26, 256. pl.

1858.3

Reptiles et poissons de l'Afrique occidentale. Etude précédée de considérations générales sur leur distribu- 
Duméril, A. H.A.

tion géographique. C. R. Acad. Sci. Paris, 1858, 51, 878-850. - Archiv. Mus. Hist. Nat. Paris, 10, 137-268. 4 pls.

1858.4

Geruchsorgane der Fische. Abstract in neue Notizen (Froriep), 1860, 1. Jahrg., 373.

1860.1

De la nécessité et de la possibilité d'accrôitre les ressources alimentaires fournies par les poissons fluviatiles, et note sur une truite propre à l'Algérie. Bull. Soc. Acclim. Paris, 1863, 1. année, 252-265.

1863.1

Des bruits que les poissons font entendre. Annuaire Sci. (Déhérain), Paris, 1863, 2, 238-251.

1863.2

Des animaux utiles à l'homme; programme d'un cours de zootechnie ou zoologie appliquée. Mém. Soc. Imp. Sci. Nat. Cherbourg, 1865, 11, 229-252.

Poissons, p. 239-240; 246; 250-251.

1865.1

Des produits que les squales et les raies fournissent à l'homme pour son alimentation et pour diverses industries. Ann. Soc. Linn. Départ. Maineet-Loire, Angers, 1865, 7, 129-137.

1865.2

Histoire naturelle des poissons ou ichthyologie générale. 2 vols. and atlas. Paris, 1865-70. illust. $8^{\circ}$.

1865.3

Vol. i. Elasmobranches, Plagiostomes et Holocéphales. 1865. $720 \mathrm{p}$.

Vol. ii. Ganoìdes, Dipnés, Lophobranches. 1si(1). $6: 21$ (?).

These two volumes form part of Roret's "Collection des suites à Buffon."

Note sur les habitudes de voracité des squales et sur les moyens d'attaque et de défense des squales et des raies. Ann. Soc. Linn. Départ. Maineet-Loire, Angers, 1865, 7, 138-144.

1865.4

De l'empoissonnement des eaux destinées à rendre les pêches plus abondantes. Bull. Soc. Acclim. Paris, 1866, 2. sér. 3, 369-370.

1866.1

Des poissons vénéneux. Ann. Soc. Linn. Départ. Maine-et-Loire, Angers, 1866, 8, 1-17.

1866.2

- Des poissons voyageurs qui, à l'époque de la réproduction, abandonnent la mer pour remonter les fleuves. Annuaire Sci.(Déhérain), 1S66, 5, $217-$ 247.

1866.3
- Montée de l'éperlan iOsmerus eperlanus] de la mer dans les fleuves. Bull. Soc. Acclim. Paris, 1866, 2. sér. 3, 459-460.

1866.4

- Observations sur les lépidosiréniens (Prolopterus annectens Owen) qui ont vécu à la ménagerie des reptiles du Muséum d'Histoire Naturelle et y ont formé leur cocon. C. R. Acad. Sci. Paris, 1866, 62, 97-100. - Ann. Mag. Nat. Hist., 1866, 3. ser. 17, 160. 1866.5

On venomous fishes. Ann. Mag. Nat. Hist., 1867, 3. ser. 20, 153-167.

1867.1

Prodrome d'une monographie des esturgeons et description des espèces de l'Amérique du Nord qui appartiennent au sous-genre Antaceus. Nouv. Arch. Mus. Hist. Nat. Paris, 1867, 3, 131-188. 6 pls. Also separate; Paris, 1867. 61 p. $4^{\circ}$.

1867.2

- Note sur trois poissons: Acipenser dabryanus, Polyodon gladius et Peristethidion prionocephalum, accompagnée de quelques considérations générales sur les groupes auxquels ces espèces appartiennent. Nouv. Arch. Mus. Hist. Nat. Paris, 1868, 4, 93-116. 1868.1

Préface (In La Blanchère, H. La pêche et les poissons. Nouveau dictionnaire général des pêches. Paris, 1868. xv, 859 p. illust.) 1868.2

- Note sur Polypterus lapradei, n. sp., et Polypterus senegalus 1 C. R. Acad. Sci. Paris, 1869, 69, 898-899. 1869.1

Les Lophobranches. Mém. Soc. Sci. Nat. Cherbourg, 1869-70, 15 (2. sér. 5), 137-168.

1869.2

De la vessie natatoire des ganoides et des dipnés. Ann. Soc. Linn. Départ. Maine-et-Loire, Angers, 1870 , 12. année, 150-169.

1870.1

- Des animaux utiles à l'homme. Paris, 1870. 18 p. $8^{\circ}$ 1870.2

L_ Le Lépidosiren et le Protoptère appartenant à la classe des poissons, ou ils sont les types de la sous-classe des dipnés. Ann. Soc. Linn. Maine-etLoire, Angers, 1870, 12. année, 139-149. 1870.3

On the presence of peculiar organs belonging to the branchial apparatus in the rays of the genus Cephaloptera [Dicerobatis] Ann. Mag. Nat. Hist., 1870, 4. ser. 5, 385-386. 1870.4 
Sur la présence, chez les raies du genre Céphaloptère [Dicerobatis], d'organes particuliers de l'appareil branchial. C. R. Acad. Sci. Paris, 1870, 70, $491-492$.

1870.5

Vessie natatoire des ganoides et des dipnés. Ann. Soc. Linn., Maine-etLoire, Angers, 1870, 12, 1-20. 1870.6

Dumesnil, André. Les poissons sauteurs. La Nature, 1906, 34, pt. 2 , 161-162. fig.

1906.1

Dumont d'Urville, Jules Sebastien César [1790-1842] Voyage sur la corvette "L'Astrolabe," exécuté par ordre du roi, pendant les années 1826-1829, sous le commandement de M. Dumont d'Urville. 19 vols. Paris, 1830. 500 pls.

1830.1

- Voyage au pole sud et dans 1'Océanie sur les corvettes "L'Astrolabe" et "La Zélée" ... pendant 1837-40, sous le commandement de $M$. J. Dumont d'Urville. Paris, [1841] 1842-54. $8^{\circ} \&$ fol.

1842.1

Vol. iii, pt. 2. Reptiles et poissons, par $\mathrm{H}$. Jacquinot et A. Guichenot.

Dumortier, Vincent Eugène, \& Falsan, A. See Falsan \& Dumortier.

Dumreicher, Armand von. Gesammtiberblick über die Wasserwirthschaft des nordwestlichen Oberharzes. Clausthal, 1868. 88 p. $8^{\circ}$. 1868.1

Dunbar, George Powers [1812-1850] Ichthyological papers by George Powers Dunbar, with a sketch of his life by J. L. Wortman. Amer. Naturalist, 1882, 16, 381-388. 1882.1

Contains notes on Lepidosteus and Megalops.

Dunbar, W. J., \& Benham, W. Blaxland. See Benham \& Dunbar.

Duncan, $C$., \& Hoppe-Seyler, $F$. Beiträge zur Kenntniss der Respiration der Fische. Zeitschr. Physiol. Chem., $1892,17,165-181$.

1892.1

Duncan, F. Martin. Cassell's natural history. London, 1913. 423 p. illust.

1913.1

1913. 78 p. $12^{\circ}$.

London,

Wonders of the sea. London, 1913. $12^{\circ}$. 1913.3

Duncan, F. Martin, \& Duncan, L.T. Rambles by the shore. London, 1913. 72 p. $12^{\circ}$.
Duncan, J. Barker. Salmon and trout hatcheries in Scotland. Bull. U.S. Fish Comm. 1885, 5, 451-456. 1885.1

Duncan, J. W. Exportation of salmon ova to New Zealand in 1875. Rept. U.S. Fish Comm. 1875-76 (1878), 4, 963 .

1878.1

Duncker, Georg. Der Kaulkopf (Cottus gobio) im Aquarium. Blätt. Aquar-Terrar. Freunde, 1891, 2. Jahrg. $183-185$.

1891.1

- Syngnathus acus L. in der westlichen Ostsee (Neustädter Bucht) Zool. Anz., 1891, 14, 78.

1891.2

Der Elbbutt, eine Varietät der Flunder (Pleuronectes flesus L. var. leiurus) Schrift. Naturwiss. Ver. Schleswig-Holstein, 1892, 9, 275-291. 3 figs.

1892.1

Ein muthmasslicher Bastard zwischen Pleuronectes platessa L. und Pl. limanda L. Zool. Anz., 1892, 15, 451-453.

1892.2

Bericht über die Verpflanzung einer Anzahl sogennant Elbbutt (Pleuronectes flesus L. var. leiurus) in den grossen Plöner See. Zeitschr. Fischerei, $1894,2,82-85$.

1894.1

Variation und Verwandtschaft von Pleuronectes flesus L. und $\mathrm{Pl}$. platessa L. Vorläufige Mittheilung. Zool. Anz., 1895, 18, 53-56. 1895.1

Variation und Verwandtschaft von Pleuronectes flesus L. und $P l$. platessa L., untersucht mittelst der Heincke'schen Methode. Inaug. Dissert. Kiel, 1895. 55 p. 8 pls. \& 20 figs.

1895.2

The same. Wiss. Meeresuntersuch. Kiel (Abt. Helgoland), 1896, n. s. 1, Heft 2, 47-104. 4 pls. \& 20 figs.

1896.1

Neue und seltene Fische der Neustädter Bucht. Mitteil. Geogr. Gesell. Naturh. Mus. Lübeck, 1896, 2. ser. $77-80$.

1896.2

Korrelationsstudien an den Strahlenzahlen einiger Flossen von $A$ cerina cernua L. Biol. Centralbl., 1897, 17, 785-794; 815-831. 1897.1

Noch einmal die Ostseescholle. Mitth. Deutsch. Seefischerei Ver., 1897, 13, 452 .

1897.2 
Duncker, $G$.

Preliminary report on the results of statistical and ichthyological investigations made at the Plymouth laboratory. Journ. Mar. Biol. Assoc., 1897-99, n. s. 5, 172-175.

1897.3

Zur Frage nach einem indigenen Schollenbestand der Ostsee. Mith. Deutsch. Seefischerei Ver., 1897, 13, 8-12.

1897.4

- Naturgeschichte des Herings, von Friedrich Heincke. Kritisches Referat. Biol. Centralbl., 1899, 19, 363-383.

1899.1

Biologische Beobachtungen an Lophobranchiern. Abh. Naturwiss. Ver. Hamburg, 1900, 16, no. 3, 1-12. 1900.1

- Variation und Asymmetrie bei Pleuronectes flesus L. statistisch untersucht. Wiss. Meeresuntersuch. Kiel (Abt. Helgoland), 1900, n. s. 3, 333-406. 5 pls. \& 3 figs. Summary in Zool. Anz., 23, 141-148.

1900.2

Bemerkungen zu G. Surbeck's Aufsatz: das "Copulationsorgan" von Cottus gobio L. Zool. Anz., 1901, 24, 153-154.

1901.1

- Die Fische der malayischen Halbinsel. Mitth. Naturhist. Mus. Hamburg, 1904, 21, 133-207. 2 pls。 \& fig.

1904.1

Junge Goldbutt (Pleuronectes platessa L.) in der Neustädter Bucht. Mitth. Deutsch. Seefischerei Ver., 1904, 20, 40t-407. fig.

1904.2

Ueber Regeneration des Schwanzendes bei Syngnathiden. Arch. Entw.Mech., Leipzig, 1905, 20, 30-37. pl. Ibid., 1907, 24, 656-662. pl. \& 2 figs

1905.1

- Syngnathiden-Studien. I. Variation und Modifikation bei Siphonostoma typhle L. Mitth. Naturhist. Mus. Hamburg, 1908, 25, 1-115. 3 pls. \& 4 figs.

190S.1

- Pisces. Teil I. Syngnathidx (In Die Fauna Südwest-Australiens, herausgegeben von IV. Michaelsen und R. Hartmeyer, Bd. ii, p. 233-250. Jena, 1909)

1909.1

- On some syngnathids (pipefish) from Ceylon. Spolia Zeylanica, $1910,7,25-34$. pl. $\quad 1910.1$

Two new species of Doryichthys and Urocampus are described.
Ueber Jugendstadien von Amphisile. Verh. Naturhist. Ver. Hamburg, 1911, 3. ser. 18, lxxvii. 1911.1

- Die Gattungen der Syngnathidae. Mitth. Naturhist. Mus. Hamburg, 1912,29 , pt. 2, 219-240.

1912.1

Die Süsswasserfische Ceylons. Mitth. Naturhist. Mus. Hamburg, 1912, 29, pt. 2, 241-272. 2 pls. [Awaous, Barbus] 1912.2

Two new species of Awaous and Barbus are described.

- Ueber einige Lokalformen von Pleuronectes platessa L. Jahrb. Wiss. Anstalt Hamburg, 1913, 30, 197-252. pls.

1913.1

Dunin-Gorkavič, A.A. Der Norden des Gouvernement Tobolsk. Beschreibung des Landes, seiner natürlichen Reichthümer und der gewerblichen Thäigkeit seiner Bewohner [Text in Russian] St. Petersburg, 1904. x, 359 p. 43 figs. \& map.

1904.1

Dunker, Withelm Bernhard Rudolph Hadrian [1809-1855] Ueber die in der Tertiär-Formation des Wiener Beckens vorkommenden Fisch-Ueberreste, mit Beschreibung einiger neuen merkwürdigen Arten. Beitr. 3. PetrefactenKunde (Münster), 1846, 7. Heft, 1-31. figs. 1846.1

Ueber einen neuen Asteracanthus aus dem Korallen-Kalke des Lindener Berges bei Hannover. Palxontogr., 1848, 1, 188-189. pl. 1848.1

Asteracanthus ornatissimus Ag. aus dem Korallen-Iialke von Hohenggelsen bei Hildesheim. Palæontogr. 1851, 1, 316-318. pl.

1851.1

Fischerei-Iílender für Deutschland, Oesterreich und die Schweiz auf das Jahr 1880. Stettin, 1880. 264 p. $12^{\circ}$.

1880.1

Dunlop, James $C$. On the changes in the value of salmon as a food stuff. 18. Ann. Rept. Fish. Board Scotland, 1900, pt. 2, 165-168.

1900.1

Dunn, Horace D. Do the spawning salmon [Oncorhynchus quinnat] ascending the Sacramento river all die without returning to sea? Rept. U. S. Fish Comm. 1878 (1880), 6, 815-818. 1880.1

- Fish-culture on the Pacific coast. Bull. U. S. Fish Comm. 1887 (1889), 7, 49-50.

1859.1 
Salmon not injured by catfish. Bull. U. S. Fish Comm. 1887 (1889), 7, 56.

1889.2

Dunn, Mathias. Remarks on some Cornish fishes. Journ. Roy. Instit, Cornwall, 1880, 6, no. 22, 354-359.

1880.1

Ichthyological notes from Mevagissey, Cornwall. Zoologist, 1884, 3. ser. 8, 348-349.

1884.1

Number of eggs in the Gadidx. Bull. U. S. Fish Comm. 1884, 4, 76.

1884.2

- Spawning of fish. Zoologist, 1884, 3. ser. 8, 116.

1884.3

Food of mackerel, pilchards and herrings. Bull. U. S. Fish Comm. 1885 5, 308 .

1885.1

Facts in the life history of the pollack, Gadus pollachius. Zoologist, 1887, 3. ser. 11, 241-248.

1887.1 511-512.

Pilchards. Nature, 1892, 45 1892.1

On the food, migrations, growth, and other habits of the mackerel. 61. Ann. Rept. Roy. Cornwall Polyt. Soc., 1893, 98-112.

1893.1

- Remarks on some senses in fishes, including a sixth faculty. 63 . Ann. Rept. Cornwall Polyt. Soc., 1895, 95-108.

1895.1

- Mimicry in fishes. 64. Ann. Rept. Cornwall Polyt. Soc., 1896, 5659.

1896.1

On the occurrence of large numbers of larval herring at the surface. Journ. Mar. Biol. Assoc., 1897-99, n. s. 5, 184-185.

1897.1

Die sieben Sinne der Fische Deutsch. Fischerei Zeitg., 1901, 24 $205-206$; 225-226; 229-230; 253-255; $264-266 ; 286-287 ; 289-290$.

1901.1

Dunn, Matthias, \& Holt, Ernest W. L. Gadus esmarkii Nilsson, the Norway pout, an addition to the fish fauna of the English south-western district. Journ. Mar. Biol. Assoc., 1897-99, n. s: 5, 7981.

1897.1

Dunning, Philo. Two hundred tons of dead fish, mostly perch, at lake Mendota, Wisconsin. Bull. U. S. Fish Comm. 1884, 4, 439-443.
Duparc, $H . M$. De kunstmatige vischteelt en vischfokkerij, behelzende de geschiedenis, de onderscheidene verrigtingen, benevens de toepassingen van de kunstmatige bevruchting en vermenigvuldiging der visschen. Amsterdam, 1854. $8^{\circ}$.

1854.1

Kunstmatige vischteelt. Algemeen Handelsblad. Amsterdam, 4 Jan., 1871.

1871.1

Duperrey, Louis Isidore [1786-1865] Voyage autour du monde exécuté sur la corvette "La Coquille," pendant les années 1822-25; publié sous les auspices de S. E. MI. le comte de Charrol. 6 vols. \& atlas. Paris, 1826-30. $4^{\circ} \&$ fol.

1826.1

Du Plessis, George. Maladies des perches de l'Orbe. Bull. Soc. Vaud. Sci. Nat., 1868, 9, 696.1868 .1

_ Essai sur la faune profonde des lacs suisses. Nouv. Mém. Soc. Helvet. Sci. Nat., 1885, 29. Also separate; Genève, $1885.4^{\circ}$. 1885.1

Du Plessis, George, \& Forel, $F, A$. See Forel \& Du Plessis.

Dupont, Edouard Francois [1841-] Sur les ossements de la faune maestrichtienne placés récemment dans les galeries du musée royal à Bruxelles. Bull. Acad. Sci. Belgique, 1887, 13, 706-710.

1887.1

Dupont, Edouard, Beneden, $P . J$. van, \& Hauzeur, Nicolas. See Beneden, Hauzeur \& Dupont.

Dupony, — Kalojen arkuus lämpömäärän vaihdoksille. Fiskeritidskr. Finland, 1894, 3, 15.

1894.1

D'Urban, W. S. M. Catalogue of animals and plants, collected and observed in the valley of the river Rouge and the neighboring townships, in the countries of Argenteuil and Ottawa. Rept. Geol. Surv. Canada, 1858, 226243.

1858.1

Fishes, p. 232-233.

Capture of a torpedo, or cramp ray [Torpedo habetans Lowe] at-Beer, Devon. Zoologist, 1879, 3. ser. 3, 491.

1879.1

Occurrence of the red band-fish Cepola rubescens (Linn.) at Exmouth. Zoologist, 1879, 3. ser. 3, 183-184.

1879.2 
D'Urban, W. S. M.

The maigre, or shade-fish [Sciana aquila] off the Devonshire coast. Zoologist, 1850, 3. ser. 4, 449. 1880.1

Occurrence of the lump-sucker in Devonshire. Zoologist, 1883, 3. ser. 7, 228 .

1883.1

Occurrence of the wolf-fish [Anarrhichas lupus L.] in Devonshire. Zoologist, 1883, 3. ser. 7, 227-228.

1882.3

Durbin, (Miss) Marian Lee (afterwards Ellis) A new genus and twelve new species of tetragonopterid characins (Reports on the expedition to British Guiana of the Indiana University and the Carnegie MIuseum, 1908, no. 2) Ann. Carnegie Mus., 1909, 6, $55-72$. 1909.1

For later papers by this author, see Ellis, (Mrs.) Marian Lee Durbin.

Durchman, Josef Oskar. Wiitasaarelta. Fiskeritidskr. Finland, 1899 , 8, 218.

1899.1

Dureau, Alexis. Etudes sur les poissons électriques, la torpille, le gymnote, la raie, le silure trembleur. Paris, 1868. $8^{\circ}$. Abstract in Bull. Hebd. Assoc. Scient. France, 1S69, 5, 18t-191. 1868.1

- Des poissons électriques. Exposé anatomique et physiologique. Paris, 1868. 19 p. $8^{\circ}$. 1868.2

Durègne, $E$. Sur les dragages en eau profonde au large d'Arcachon. Act. Soc. Linn. Bordeaux, 1887, 41, xxxiii.

1887.1

Animaux nouveaux pour la région, recueillis à Arcachon. Act. Soc. Linn. Bordeaux, 1889, 43, x; lxxv. Ibid., 1890,44 , xix.

1889.1

Durnford, $C . D$. Flying-fish flight and an unfixed law of nature. Ann. Mag. Nat. Hist., 1906, 7. ser. 17, 15s167. - Amer. Naturalist, 40, 1-11.

1906.1

The flying-fish problem. Ann. Mag. Nat. Hist., 1906, 7. ser. 18, 327338. - Amer. Naturalist, 1907, 41, 65$76 ; 347-348$. 5 figs.

1906.2

Du Rondeau, François [1732-1803] Mémoire sur la loche campinoise. Mém. Acad. Sci. Bruxelles, 1783, 4, 247-255.

1783.1

D'Urville, Jules Sébastien César Dumont. See Dumont d'Urville, J.S.C.
Duthie, Robert. The fisheries of Shetland. 10. Ann. Rept. Fish. Board Scotland, 1891, pt. 3, 202-210. 1891.1

Dutrochet, René Joachim Henri [1776-1847] Recherches sur la chaleur propre des êtres vivans à basse température. Ann. Sci. Nat. (Zool.), 1840, 2. sér. 13, 5-58.

Poissons, p. 22-24.

1840.1

\section{Recherches sur la chaleur vitale} des animaux à basse température. C. R. Acad. Sei. Paris, 1840, 10, 383390. - Edinb. New Phil. Journ., 29, 152-160.

Poissons, p. 385.

Duval, Mathias [1844-] Sur l'existence chez les poissons d'un noyeau antérieur de l'hypoglosse. C. R. Mém. Soc. Biol. Paris, 1876 (1877), 6. sér. 3, 12-13.

1877.1

Duvernoy, Georges Louis [1777-1855] Sur quelques dispositions du système sanguin abdominal dans certains poissons. Nouv. Bull. Soc. Philom. Paris, 1833, 168-169.

1833.1

- Sur quelques particularités du système sanguin abdominal et du canal alimentaire de plusieurs poissons cartilagineux. Ann. Sci. Nat. (Zool.), 1835, 2. sér. 3, 275-281. Ibid., 1836, 2. sér. 5, 312.

1835.1

- Note sur deux bulbes artériels faisant les fonctions de coeurs accessoires, qui se voient dans les artères innominées de la chimère arctique. Ann. Sci. Nat. (Zool.), 1837, 2. sér. 8, 35-41. pl. - C. R. Acad. Sci. Paris, 5, 463466.

1837.1

- Note sur quelques dents fossiles d'Oran. C. R. Acad. Sci. Paris, 1837 5, 491-496.

1837.2

- Du mécanisme de la respiration dans les poissons. C. R. Acad. Sci. Paris, 1839, 9, 75-80. - Ann. Sci. Nat. (Zool.), 1839, 2. sér. 12, 65-91. - L'Institut, 1839, 7, 232.- Rev. Mag. Zool., 1839, 216.

1839.1

Note sur le diaphragme branchial qui fait partie du mécanisme de la respiration des poissons. C. R. Acad. Sci. Paris, 1839, 8, 867-871. - Rev. Mag. Zool., 1839, 189.

1839.2

Note sur un nouveau genre de ver intestinal, de la famille des Ténioïdes, le Bothrimone de l'esturgeon 
(Bothrimonus sturionis nob.) Ann. Sci. Nat. (Zool.), 1842, 2. sér. 18, 123-126. - Proc.-Verb. Soc. Philom. Paris, 1842, $41-42$.

1842.1

Observations pour servir à la comnaissance du développement de la Pocilie de Surinam (Pocilia surinamensis Val.), précédées d'une esquisse historique des principaux travaux sur le développement des poissons aux deux prémières époques de la vie. C. R. Acad. Sci. Paris, 18t4, 18, 667-679; 720-723. - Ann. Sci. Nat. (Zool.), 18t4, 3. sér. 1, 313-360. - Notizen (Froriep), 32, 1-8; 17-25; 33-40; 48$56 ; 65-71 ; 81-86$.

1844.1

Note sur le sinus veineux génital des lamproies. C. R. Acad. Sci. Paris, $18 \pm 6,22,662-666$.

1846.1

Rapport sur un mémoire ayant pour titre: "Détermination des parties qui constituent l'encéphale des poissons," par MMI. Philipeaux et Vulpian. C. R. Acad. Sci. Paris, $1852,35,169-$ 176.

1852.1

- Note additionnelle à la lettre de M. le professeur Förg, "Remarques sur l'appareil pulmonaire du Gymnarchus niloticus." Ann. Sci. Nat. (Zool.), 1853, 3. sér. 20, 15t-162. pl.

1853.1

Rapport sur un mémoire de MM. Philipeaux et Vulpian, qui a pour sujet la structure de l'encéphale des raies et des squales, et l'origine des nerfs craniens chez ces poissons. C. R. Acad. Sci. Paris, $1854,38,336-344 ; 366-370$; $421-424$.

1854.1

Duvernoy, Georges Louis, Duméril, André Marie Constant, \& Flourens, Marie Jean Pierre. See Duméril, Flourens \& Duvernoy.

D'yakonov, $K$. S. Ueber die phosphorhaltigen Körper der Hühner- und Störeier. Med. Chem. Untersuch., 1866, 1, 221-227. - Zeitschr. Chemie, 4, 154 .

1866.1

Dybowski, Benedikt Ivan [1834-] Versuch einer Monographie der Cyprinoiden Livlands, nebst einer synoptischen Aufzählung der europäischen Arten dieser Familie. Arch. Naturk. Biol. Dorpat, 1864, 2. ser. 6, 133-362. Also separate; Dorpat, $1862.8^{\circ} .1864 .1$

Vorläufige Mittheilungen über die Fischfauna des Ononflusses und des Ingoda in Transbaikalien. Verh. Zool.
Bot. Ver., Wien, 1869, 19, 945-958. 5 pls.

1869.1

- Zur Kenntniss der Fischfauna des Amurgebietes. Verh. Zool. Bot. Ver., Wien, 1872, 22, 209-222. 1872.1

Ueber Comephorus baicalensis Pall. Verh. Zool. Bot. Ver., IVien, 1873, 23, 475-484. pl. - Lotos, 1874, 24. Jahrg., 122-124.

1873.1

Die Fische des Baikal-IVassersystemes. Verh. Zool. Bot. Ver., Wien, 1874, 24, 383-394.

1874.1

_- Ueber den Baikalischen "Fettsfisch" Comephorus baicalensis Lac., und den Jungfisch derselben [Text in Polish ] Kosmos, Lwów, 1901, 26, 112141. Abstract in Zool. Centralbl., 8, 683-686. fig. - Journ. Roy. Micr. Soc., $1902,167$.

1901.1

Sur les résultats de certaines recherches, tant récentes qu'antérieures, concernant la faune de lac Baikal, ainsi que la question de son ancienneté ['Text in Polish] Kosmos, Lwów, 1907, 32, 1-50.-Ibid., 1908, 33, $536-574$.

1907.1

Dybowski, Wladislav. Die mit Lungen versehenen Fische. Sitzber. Naturf. Ges. Dorpat, 1878, 4, 225-228. 1878.1

Dyce, Robert. On the identity of Morrhua punctata and Morrhua vulgaris. Ann. Mag. Nat. Hist., 1860, 3. ser. 5, 366-369. 3 pls. $\quad 1860.1$

Notes on some peculiarities in the eye of the mackerel Scomber scomber! Ann. Mag. Nat. Hist., 1866, 3. ser. 17, 307-309. pl. 1866.1

Dyce, Robert, \& Sim, George. Catalogue of fish found in the vicinity of Aberdeen; with English, scientific, and local names. Trans. Nat. Hist. Soc. Aberdeen, 1878, 89-93.

1878.1

Dyche, L. L. A new and enlarged fish hatchery for the state of Kansas. Trans. Amer. Fisheries Soc. 1911 (1912), 155-180.

1912.1

- Regarding fishways and dams. Trans. Amer. Fisheries Soc. 1911 (1912), 301-306.

1912.2

The Kansas fish law. Trans. Amer. Fisheries Soc. 1912 (1913), $137-$ 138. 
Dyche, L. L.

Report on progress in the construction of new pond-fish hatchery in Kansas. Trans. Amer. Fisheries Soc 1912 (1913), 145-146.

1913.2

One year's work at the Kansas state fish hatchery. Trans. Amer. Fisheries Soc. 1913 (1914), 77-86.

1914.1

Possibilities of an acre fish pond. Trans. Amer. Fisheries Soc. 1913 (1914), $67-76$.
Dyer, Reuben. Condition of the shore fisheries in Massachusetts and Rhode Island in 1871. Rept. U. S. Fish Comm. 1871-72 (1873), 1, 33. 1873.1

Dyhrn, (Graf) Ernst. Kurze Anweisung zur Teichwirthschaft. Breslau, 1782. 3 pls. $8^{\circ}$. 1782.1

Dykeman, $J . R$. On the impregnation of trout eggs. Trans. Amer. Fisheries Soc. 1873 (1874), 13-15.

1874.1 
E., J.F. Elävien kalojen kuljettaminen. Suomennos Saksasta. Helsingfors, 1887.7 p. $8^{\circ}$. 1887.1

\section{E. E. M. See Millard, E.E.}

E., $W . W$. Pickerel versus trout. Forest \& Stream, 1874, 3, 155. 1874.1

Observation on pickerel causing the decrease of trout in Adirondack waters.

Eagle Clarke, $W$., \& Young, $M$. See Young \& Eagle Clarke.

Earl of Enniskillen. See Cole, William Willoughby.

Earle, Edward $M$. 'The fish pot of the Caribbean sea. Journ. Mar. Biol. Assoc., 1890, n. s. 1, 199-204. 1890.1

Earle, $H . G ., \&$ Strickland, $J$. Goodall. See Strickland \& Earle.

Earll, R. Edward. A report on the history and present condition of the shore cod-fisheries of cape Ann, Mass., together with notes on the natural history and artificial propagation of the species. Rept. U. S. Fish Comm. 1878 (1850), 6, 685-740.

1880.1

- Statisties of the fisheries of Maine. Census Bull., 1881, no. 278, 47.

1881.1

The present condition of fish culture. Nature, 1883, 28, 542-544.

1883.1

The Spanish mackerel, Cybium maculatum (Mitch.) Ag.; its natural history and artificial propagation, with an account of the origin and development of the fishery. Rept. U. S. Fish Comm. 1880 (1883), 8, 395-426. 3 figs.

1883.2

Hatching blackfish and Spanish mackerel. Bull. U. S. Fish Comm. $1884,4,415-416$.

1884.1

- The coast of Maine and its fisheries (In The fisheries and fishery industries of the United States, edited by George Brown Goode, pt. 1, p. 5-102. Washington, 1887)

1887.1
Eastern Florida and its fisheries (In The fisheries and fishery industries of the United States, edited by George Brown Goode, p.519-531. Washington, 1887)

1887.2

The fisheries of South Carolina and Georgia (In The fisheries and fishery industries of the United States, edited by George Brown Goode, pt. 13, p. 499-518. Washington, 1887)

1887.3

The herring fishery and the sardine industry (In The fisheries and fishery industries of the United States, edited by George Brown Goode, sect. 5, 1, 419-524. 30 pls. Washington, 1887) 1887.4

Maryland and its fisheries (In The fisheries and fishery industries of the United States, edited by George Brown Goode, p. 421-448. Washington, 1887)

1887.5

- New Jersey and its fisheries (In The fisheries and fishery industries of the United States, edited by George Brown Goode, p. 379-400. Washington, 1857)

1887.6

- North Carolina and its fisheries (In The fisheries and fishery industries of the United States, edited by George Brown Goode, p. 475-497. Washington, 1887)

1887.7

Pennsylvania and its fisheries (In The fisheries and fishery industries of the United States, edited by George Brown Goode, p.400-405. Washington, 1887)

1887.8

The Spanish mackerel fishery (In The fisheries and fishery industries of the United States, edited by George Brown Goode, sect. 5, 1, 543-552. pl. Washington, 1887) $\quad 1887.9$

State fish commissioners. Trans. Amer. Fisheries Soc. 1887 (1888), 23-28.

1888.1

Earll, R. Edward, Goode, George Brown, Collins, J. W., \& Clark, A. H. See Goode, Collins \& others. 
Earll, R. Eduard, \& Smith, Hugh McComich. The American sardine industry in 1856. Bull. U. S. Fish Comm. 1887 (18S9), 7, 161-192. 1889.1

Eastman, Charles Rochester [1S68-] For list of writings, see Ann. Rept. Mus. Comp. Zool. Harv. Coll., 1895-1909; Johns Hopkins Univ. Circular, 1913, no. 10, 36-38.

- Beitråge zur Íenntniss der Gattung Oxyrhina, mit besonderer Berücksichtigung von Oxyrhina mantelli Agassiz. Palæontogr., 1894, 41, 149191. 2 pls.

1894.1

- (iranslator) History of instruction in geology and palæontology in German universities, by Karl A. von Zittel. Amer. Geologist, 1894, 14, 179 185.

1894.2

- Observations on the dorsal shields in the dinichthyids. Amer. Geologist, 1896, 18, 222-223. $\quad 1896.1$

- Preliminary note on the relations of certain body-plates in the dinichthyids. Amer. Journ. Sci., 1896, 4. ser. $2,46-50$.

1896.2

Remarks on Petalodus alleghaniensis Leidy. Journ. Geol., 1896, 4, 174 176.

1896.3

[Review of] On the vertebral column, fins and central armoring of Dinichthys, by Bashford Dean. Amer. Geologist, 1896, 18, 316-317. 1896.4

[Review of] Unter-Tertiäre Selachier aus Südrussland, von Dr. Otto Jaekel. Amer. Geologist, 1896, 17, $245-247$.

1896.5

Daniel Denison Slade [Memorial notice with list of writings] New Eng. Hist. Gen. Register, 1897, 51, 1-14.

1897.1

On Ctenacanthus spines from the Keokuk limestone of Iowa. Amer. Journ. Sci. 1897, 4. ser. 3, 10-12. 2 figs.

1897.2

On the characters of Macropetalichthys. Amer. Naturalist, 1897, 31, 193-499. pl. \& fig.

1897.3

On the occurrence of fossil fishes in the Devonian of Iowa. 7. Ann. Rept. Iowa Geol. Surv., 1897, 108-116. pl.

1897.4

Review by C. R. lieyes in Amer. Geologist, 22, $237-239$.
- On the relations of certain plates in the dinichthyids, with descriptions of new species. Bull. Mus. Comp. Zool. Harv. Coll., 1897, 31, 19-41. 5 pls.

1897.5

Tamiobatis vetustus, a new form of fossil skate. Amer. Journ. Sci., 1897, 4. ser. 4, 85-90. pl. \& fig. 1897.6

Agassiz's work on fossil fishes. Amer. Naturalist, 1898, 32, 170-185. 1898.1

- Dentition of Devonian Ptyctodontidæ. Amer. Naturalist, 1898, 32, 473-48s; $545-560$. 50 figs. $\quad 1898.2$

- Some new points in dinichthyid osteology. Proc. Amer. Assoc. Adv. Sci., 1898, 47, 371-372. - Amer. Naturalist, $1898,32,747-768.6$ figs. Science, n. s. 8, 400-401. 1898.3

- Descriptions of new species of Diplodus teeth from the Devonian of north-eastern Illinois. Journ. Geol., $1899,7,489-493$. pl.

1899.1

- Notes on fossil fishes found in the Devonian at Milwaukee, Wisconsin. Journ. Geol., 1899, 7, 278, 283. 1899.2

Report on the department of vertebrate palxontology [Records the discovery of Dinichthys pustulosus] Ann. Rept. Mus. Comp. Zool. Harv. Coll., 1898-99 (1899), 15-16. 1899.3

Some new American fossil fishes. Science, 1899, n. s. 9, 624-644. 1899.4

- Upper Devonian fish-fauna of Delaware county, New York. 17. Ann. Rept. N. Y. State Geol., 1899, 318-327. - 51. Ann. Rept. N. Y. State Mus., 1899, 2, 318-327.

1899.5

Dentition of some Devonian fishes. Journ. Geol., 1900, 8, 32-41: 7 figs. 1900.1

The dental organs of Dinichthys, Dipterus, and Cladodus are described.

Fossil lepidosteids from the Green river shales of Wyoming. Bull. Mus. Comp. Zool. Harv. Coll., 1900, 36, 67-75. 2 pls.

1900.2

- Jurassic fishes from Black hills of South Dakota. Bull. Geol. Soc. America, 1899 (1900), 10, 397-408. 4 pls. \& 2 figs.

1900.3

Karpinsky's genus Helicoprion. Amer. Naturalist, 1900, 34, 579-582. fig. 1900.4 
New fossil bird and fish remains from the Middle Eocene of Wyoming. Geol. Mag., 1900, 4. dec. 7, 54-58. pl. 1900.5

Devonian fish-remains from the Eifel district [Comment on article by Baron F. von Huenel Amer. Geologist, 1900, 25, 391-392.

1900.6

[Review of] The Devonian" "lamprey," Paloospondylus gunni Traquair, by Bashford Dean. Journ. Geol., 1900 , 8, 286-289.

1900.7

Einige neue Notizen über devonische Fischreste aus der Eifel. Centralbl. Mineral., 1900 (1901), 177178.

1901.1

Systematic palæontology of the Eocene deposits of Maryland [Pisces] Maryland Geol. Surv., 1901, 98-115. 4 pls.

1901.2

- On Campodus, Edestus, Helicoprion. Acanthodes, and other PermoCarboniferous sharks. Abstract in Science, 1901, n. s. 14, 795. - Scient. Amer. Suppl., 62, 21505.

1901.3

- [Review of] Palæontological notes, by Bashford Dean. Amer. Naturalist, 1901, 35, 417-420. 1901.4

[Review of] 'Traquair's Bradford presidential address, 1900. Amer. Naturalist, 1901, 35, 327-330. 1901.5

The Carboniferous fish-fauna of Mazon creek, Illinois. Journ. Geol., 1902, 10, 535-541. 4 figs. 1902.1

- Notice of interesting new forms of Carboniferous fish-remains. Amer. Naturalist, 1902, 36, 849-854. 2 figs.

1902.2

On Campyloprion. a new form of Edestus-like dentition. Geol. Mag., 1902, 4, dec. 9, 148-152. pl. \& 3 figs.

1902.3

On the genus Peripristis St. John. Geol. Mag., 1902, 4. dec. 9, 388391. 2 figs.

1902.4

—_ [Review of] The structure and classification of the Tremataspidæe by William Patten. Amer. Naturalist, $1902,36,505-507$.

1902.5

Phylogeny of the cestraciont group of sharks. Abstract in Science, 1902 , n. s. 16, 267.

1902.6

- Some Carboniferous cestraciont and acanthodian sharks. Bull. Mus.
Comp. Zool. Harv. Coll., 1902, 39, 5599. 7 pls. \& 14 figs.

1902.7

- Some hitherto unpublished observations of Orestes St. John on Palaeozoic fishes. Amer. Naturalist, 1902. 36, 653-659. 4 figs.

1902.8

Synopsis of the Missourian and Permo-Carboniferous fish-fauna of Kansas and Nebraska. Abstract in Science, 1902, n. s. $16,266-267$.

1902.9

- (editor) Textbook of palæontology, by Karl A. von Zittel. Vol. II [Vertebrates exclusive of mammals] London, 1902. viii, 283 p. illust.

1902.10

Pisces, revised by A. S. Woodward, p. 2-114.

- Carboniferous fishes from the central western states. Bull. Mus. Comp. Zool. Harv. Coll., 1903, 39, 163-226. 5 pls. \& 17 figs.

1903.1

[Discussion of views concerning alleged appendages of Tremataspis Amer. Naturalist, 1903, 37, 573-577. 2 figs.

1903.2

- Devonian fish-fauna of Iowa. Abstract in Bull. Geol. Soc. Amer., 1903, 13, 537.

1903.3

On the nature of Edestus and related forms [with bibliography] (In Mark anniversary volume, New York, 1903, p. 279-289. pl.) 1903.4

- A peculiar modification amongst Permian dipnoans [Sagenodus] Amer Naturalist, 1903, 37, 493-495. 2 figs.

1903.5

Sharks' teeth and cetacean bones from the Red Clay of the tropical Pacific (In Reports on the scientific results of the expedition to the tropical Pacific, in charge of Alexander Agassiz, in the $\mathrm{U} . \mathrm{S}$. Fish Commission steamer "Albatross," from August, 1899, to March, 1900. No. 5) Mem. Mus. Comp. Zool. Harv. Coll., 1903, 26, 179-191. 3 pls. \& 5 figs. 1903.6

Asterolepid appendages. Amer. Journ. Sci., 1904, 4. ser. 18, 141-144.

1904.1

Descriptions of Bolca fishes Bull. Mus. Comp. Zool. Harv. Coll., 1904, 46, 1-36. 2 pls. \& 4 figs. 1904.2

- The earliest mention of fossil fishes. Science, 1904, n. s. 20, 648-649. 1904.3 
Eastman, C.R

Further light on the Tremataspida [Discussion of views of William Patten] Science, 1904, n. s. 19, 397.

1904.4

Jordan on fossil labroid and chretodont fishes. Science, 1904, n. s. $20,245-246$.

1904.5

- Jurassic fishes from Spanish lithographic limestone. Review of contribution by H. E. Sauvage, entitled "Noticia sobre los peces de la Caliza litográfica de la Provincia de Lérida." Science, 1904, n. s. 19, 397.

1904.6

Marginal and ridge-scales in Cephalaspis and Drepanaspis. Science, 1904, n. s. 19, 703-704. 1904.7

On the dentition of Rhynchodus and other fossil fishes. Amer. Naturalist, 1904, 38, 295-299. 2 figs. 1904.8

On Upper Devonian fish-remains from Colorado. Amer. Journ. Sci., 1904, 4. ser. 18, 253-260. 6 figs.

1904.9

Palreontology. - Walther's Solenhofen fauna. - Karl Alfred von Zittel: ein Nachruf [von J. F. Pompecky] Amer. Naturalist, 1904, 38, 677-678.

1904.10

Tertiary elasmobranchs from southern Italy [Review of paper by Maria Pasquale] Science, 1904, n. s. 19 396.

1904.11

- Systematic palæontology of the Miocene deposits of Maryland [Pisces] Maryland Geol. Surv., 1904, 71-93. 27 pls.

1904.12

- Varixe auctoritatis.

Science, 1904 , n. s. 20, 215-217.

1904.13

Note on Joinville's mention of Cretaceous fishes from Lebanon, and reference to Albert Fortis on Eocene fishes of monte Bolca, Italy.

- Archxological notes; ichthyological names. Science, 1905, n. s. 22, 23.

1905.1

- A brief general account of fossil fishes. Rept. Geol. Surv. New Jersey, $190 \pm$ (1905), 27-66.

1905.2

The literature of Edestus. Amer. Naturalist, 1905, 39, 405-409. 1905.3

Notes on the history of natural science; Oppian on fishing. Subterranean fishes. Roman ichthyology. Science, 1905, n. S. 21, 516-517. 1905.4

Peter Artedi. Science, 1905. n. s. $22,378-379$.

1905.5
The Triassic fishes of New Jersey. Rept. Geol. Surv. New Jersey, 1904 (1905), 67-102. pls. 1905.6

L- Les types de poissons fossiles du Monte Bolca au Muséum d'Histoire Naturelle de Paris. Mém. Soc. Géol., Paris, 1905, 13, no. 34, 1-33. 5 pls. \& fig.

1905.7

- Dipnoan affinities of arthrodires. Amer. Journ. Sci., 1906, 4. ser. 21, 131143. 4 figs.

1906.1

- Notes on the history of natural science. Hippocratean fishes. Science, 1906, n. s. 23, 194-195. 1906.2

- Sharks' teeth and cetacean bones (In Reports on the scientific results of the expedition to the eastern tropical Pacific, in charge of Alexander Agassiz, by the U. S. Fish Commission steamer "Albatross," from October, 1904, to March, 1905) Bull. Mus. Comp. Zool. Harv. Coll., 1906, 50, 73 98. 4 pls.

1906.3

- Structure and relations of $\mathrm{My}$ lostoma. Bull. Mus. Comp. Zool. Harv. Coll., 1906, 50, 1-30. 5 pls. \& 8 figs.

1906.4

Devonic fishes of the New York formations. Mem. N. Y. State Mus., 1907, 10, 1-235. 15 pls. \& 35 figs. 1907.1

Review by L. Hussakof in Science, 1908, n. s. 28, 311-313.

Mylostomid dentition. Bull. Mus. Comp. Zool. Harv. Coll., 1907, 50, 209-228. pl. \& 4 figs. 1907.2

Palatal dentition of Dinomylostoma described as consisting of three paired elements.

Devonian fishes of Iowa. 18. Ann. Rept. Iowa Geol. Surv. 1907 (1908), 29-386. 16 pls. \& 41 figs. 1908.1

Description of the auditory organ and other soft parts of Rhadinichthys deani, by G. H. P'arker, p. 272.

The discovery of similar fossilized remains from the Caney shale of Oklahoma is reported in Bull. Geol. Soc. Amer, 1913, 24, 119-120.

- Notice of a new colacanth fish from the Iowa Kinderhook. Journ. Geol., 1908, 357-362.

1908.2

Jean Albert Gaudry. Science, 1909 , n. s. 29, 138-140.

1909.1

- Mylostomid dental plates. Science, 1909 , n. s. 29, 997-998. $\quad 1909.2$

- Mylostomid palatal dental plates. Bull. Mus. Comp. Zool. Harv. Coll., 1909, 52, 261-269. 3 figs. 1909.3

Dinognathus interpreted as a compound crushing element homologous with the anterior pair in Mylostoma. 
A new species of Helodus. Ann. Carnegie Mus., 1909, 5, 488-489. 1909.4

- Catalog of fossil fishes in the Carnegie Museum. Part I. Fishes from the Upper Eocene of monte Bolca. Mem. Camegie Mus., 1911, 4, 349-441. 11 pls. \& 5 figs.

1911.1

Part ii. Supplement to the catalog of fishes from the Upper Eocene of Monte Bolca. Mem. Carnegie Mlus., 1914, 6, no. 5. 6 pls.

Part iii. Catalog of fossil fishes from the lithographic stone of Cerin, France. Tom. cit., no. 6. 9 pls.

Part iv. Descriptive catalog of fossil fishes from the lithographic stone of Solenhofen, Bavaria. Tom, cit, no. 7. 16 pls.

Jurassic saurian remains ingested within fish. Ann. Carnegie Mus., 1911, 8, 182-187. 2 pls.

1911.2

New elasmobranchs from Solenhofen in the Carnegie Museum. Amer. Journ. Sci., 1911, 4. ser. 31, 399-404. 3 pls.

1911.3

- Paleontology. - Fishes [Record of progress during the year] Amer. Year Book 1910 (1911)

1911.4

Similar reviews for the years 1911-1915 are found in subsequent volumes of the same annual.

Triassic fishes of Connecticut. Connecticut State Geol. Nat. Hist. Surv., 1911, Bull. no. 18, 1-77. 11 pls. \& 8 figs.

1911.5

Mesozoic and Cenozoic fishes [Summary of recent literature] Bull. Geol. Soc. America, 1912, 23, 228-232.

1912.1

Tertiary fish-remains from Spanish Guinea in west Africa. Ann. Carnegie Mus., $1912,8,370-378.2$ pls.

1912.2

Notes on Triassic fishes belonging to the families Catopteridæ and Semionotidx. Ann. Carnegie Mus., 1914, 9, 139-148. 2 pls.

1914.1

Columbus on the Remora. Copeia, 1915, no. 19, 11-12.

1915.1

Dipterus remains from the Upper Devonian of Colorado. Ann. Carnegie Mus., 1915, 9, 279-284. figs. 1915.2

- Early figures of the Remora. Nature, 1915, 95, 344-345. figs. 1915.3 See also articles on the Reversus and Hippocampus in Sci. Monthly, 3, 31-46, and Rept. Smithson. Inst. 1915 (1916), 349-357.

Eastway, R. E. Where I keep my fish. Aquar. Australia, 1911, 6-8. figs.

1911.1

Eaton, George Francis [1872 - ] Notes on the collection of Triassic fishes at Yale. Amer. Journ. Sci., 1903, 4. ser. 15, 259-268. 2 pls.

1903.1

Eayrs, Winslow. Correspondence on the subject of the sea fisheries. Rept. U. S. Fish Comm. 1871-72 (1873), 1, 136.

1873.1

Ebel, J. Gottlieb. Observationes nevrologica ex anatome comparata. Frankfurt-a.-O, 1788. $8^{\circ}$. Reprinted in Scriptores nevrologici minores (Ludwig), 3, 148 .

1788.1

Ebeling, Christian W. Ueber die Fischfauna der Magdeburger Gegend. Blätt. Handel, Gewerbe u. Soc. Leben, Magdeburg, 1871, no. 27, 213-214.

1871.1

Vergleich der Fischfauna von Magdeburg mit der böhmischen. 1. \& 2. Jahresber. Naturwiss. Ver. Magdeburg, 6. Sitz., Juni, 1871.

1871.2

Eben, Ueber Karpfenzucht, hauptsächlich mit Bezug auf unsere Landwirthschaft. Ber. Fischerei Ver. Prov. Ost u. IVest Preussen, 1877, no. 3, 2-4. - Deutsch. Fischerei Zeitg., 1879, 2. Jahrg., 110-112. - Rept. U. S. Fish Comm. 1878 (1880), 6, 667-670. 1877.1

- Ueber Anlage von Karpfenteichen. Ber. Fischerei Ver. Prov. Ost u. West Preussen, 1878, no. 5, 4-5. 1878.1

Eberhard, $K$. Die Fortpflanzung des Aales. Gartenlaube, Leipzig, 1874, 120. figs.

1874.1

Eberth, C.J. Ueber das Darmepithel des Cobitis [Misgurnus] fossilis. Naturwiss. Zeitschr., Würzburg, 1862 , 3, 44-45.

1862.1

Zur Kenntniss der Blutplättchen bei den niederen Wirbelthieren (In Kölliker, A. von. Festschrift zur Feier seines siebenzigsten Geburtstages ... no. 2, p. 37-48. pl. Leipzig, 1887. 4․) 1887.1

Eberth, $C . J ., \&$ Bunge, $R$. Die Nerven der Chromatophoren bei Fischen. Arch. Mikrosk. Anat., 1895, 46, 370-378. 2 pls.

1895.1

Eberts, - Die internationale Fischerei-Ausstellung in Wien im September 1902. Allgem. Forstzeitg. Frankfurt-a.-M., 1903, 79, 60-64.

1903.1

Die Fischerei in den Talsperren. Allgem. Forstzeitg. Frankfurt-a.-M. 1911, 87, 334-338.

1911.1 
Ebner, Victor von. Ueber die Schleimabsonderung an der Oberhaut der Forellenembryonen. Anz. Akad. Wiss. Wien, 1886, 23, 57-58. 1886.1

Die Chorda dorsalis der niederen Fische und die Entwicklung des fibrillären Bindegewebes. Zeitschr. Wiss. Zool., 1896, 62, 469-526. 2 pls. 1896.1

- Ueber den Bau des Chorda dorsalis des Amphioxus lanceolatus. Sitzber. Akad. Wiss. Wien, math.-nat. Cl., 1896, 104, 199-22S. 4 pls. 1896.2

Ueber den feineren Bau der Chorda dorsalis der Cyclostomen. Sitzber. Akad. Wiss. Wien, math.-nat. Cl., 1896, 104, pt. 3, 7-16. fig. 1896.3

Ueber den feineren Bat der Chorda dorsalis von Acipenser. Sitzber. Akad. Wiss. Wien, math.-nat. Cl., 1896, 104, pt. 3, 149-159.

1896.4

- Ueber den feineren Bau der Chorda dorsalis von Myxine, nebst weiteren Bemerkungen über die Chorda von Ammocoetes. Sitzber. Akad. Wiss. Wien, math.-nat. Cl., 1896, 104, pt. 3 , 124-139. fig. 1896.5

Ueber die Chordascheiden der Fische. Verh. Anat. Gesell., 1896, 10, 128-130.

1896.6

- Ueber die Wirbel der Knochenfische und die Chorda dorsalis der Fische und Amphibien. Sitzber. Akad. IViss. Wien, math.-nat. Cl., 1896, 105, pt. 3, 123-161. 4 pls. \& fig. 1896.7

Eckardt, George. Carp propagation and blue carp. Bull. U. S. Fish Comm. 1882 (1883), 2, 168.

1883.1

Eckardt, $R$. Bericht über die weiteren Erfolge meiner Maränenzucht, im Anschluss an den vorigjährigen Bericht. Circul. Deutsch. Fischerei Ver. 1874 (1875), no. 6, 237241.

1875.1

Bericht über weitere Versuche der Zucht der grossen Maräne des Madü-Sees mittels kïnstlich befruchteten Laiches. Circul. Deutsch. Fischere Ver. 1876 (1877), no.6, 235-239. 1877.1

Bericht über die im Auftrage des deutschen Fischerei-Vereins in Jahre 1876 angestellten Versuche zur Vermehrung der Maifische, sowie über die Fortsetzung und glückliche Ausführung dieser Versuche im Jahre 1877. Circul. Deutsch. Fischerei Ver. 1877 (1878), no. $5,139-149$.
- Bericht über die weiteren Erfolge der Madue-Maränenzucht. Circul. Deutsch. Fischerei Ver. 1877 (1878), no. 7, 204-206.

1878.2

Madü-See-MIaräne, Coregonus maraena [C. lavaretus] Deutsch. Fischerei Zeitg., 1878, 1. Jahrg., 10-12.

1878.3

Ankunft Californischer Lachseier. Deutsch. Fischerei Zeitg., 1879 , 2. Jahrg., 366.

1879.1

- Bericht über die mit Versendung von angebrüteten Karpfen-Eiern wie Karpfenbrut erzielten Erfolge. Circul. Deutsch. Fischerei Ver., 1879, no. 4 111-115.

1879.2

- Bericht über Transport von hoch embryonirten Edelfischeiern mit Schneeverpackung. Circul. Deutsch. Fischerei Ver., 1879, no. 3, 106-107. 1879.3

The experiments in propagating the maifische (Alosa vulgaris) in 1876 and 1877. Rept. U. S. Fish Comm. 1877 (1879), 5, 853-S66.

1879.4

Ein neues bewährtes Verfahren fuir den sicheren Versandt der Edelfischbrut, ohne Transportführer mit Luftpumpe. Circul. Deutsch. Fischerei Ver. 1879, no. 4, 131-132. 1879.5

Bericht über Karpfenvermehrung. Circul. Deutsch. Fischerei Ver. 1880, no. 1, 21-23.

1880.1

The peculiarities of blue carp. Bull. U. S. Fish Comm. 1881 (1882), 1, 389-390.

1852.1

Report on the propagation and growth of carp. Rept. U.S. Fish Comm. 1879 (1882), 8, 671-673. 1S52.2

Ecker, Alexander [1816-1857] Flimmerbewegung im Gehörorgan von Petromyzon marinus. Arch. Anat: (Müller), 1844, 520-521. figs.

1844.1

Einige Beobachtungen über die Entwicklung der Nerven des elektrischen Organs von Torpedo galvanii. Zeitschr. Wiss. Zool., 1849, 1, 38-17.

1849.1

Ueber Bewegungserscheinungen an den Furchungskugeln des Fischeies. Froriep's Tagsber. (Zool.), 1852, no. 568, 3, $78-80$.

1852.1

- Anatomische Beschreibung des Gehirns vom karpfenähnlichen NilHecht [Mormyrus cyprinus] Leipzig, 1854. figs. $4^{\circ}$. 1854.1 
Ueber die Flimmerzellen im Gehörorgan der Cyclostomen. Berichte Verh. Naturw. Ges. Freiburg, 1854, 1, 29-32.

1854.2

Ueber das elektrische Organ von Mormyrus dorsalis. Berichte Verh. Naturw. Ges. Freiburg, 1855, 1, 176178.

1855.1

Ueber den elektrischen Nerven des Zitterwelses. Zeitschr. Wiss. Zool. $1855,6,140-142$.

1855.2

- Untersuchungen zur Ichthyologie. Freiburg-in-Breisgau, 1857. pls. $4^{\circ}$.

1857.1

Ueber das elektrische Organ der Mormyri. Berichte Verh. Naturw. Ges. Freiburg, 1858, 1, 472-477.

1858.1

Eikhard, Conrad [1822-] Ein Beitrag zur Physiologie des elektrischen Organes beim Zitterrochen. Beitr. Anat. Physiol. (Eckhard), 1858, 1, 157179. pl.

1858.1

—-Ueber die Endigungsweise der Nerven in den Schleimkanälen des Zitterrochen. Beitr. Anat. Physiol. (Eckhard), 1858, 1, 85-94.

1858.2

- Notiz über die Ursachen der Bewegung des Caudalherzens des Aales. Beitr. Anat. Physiol. (Eckhard), 1863, 3, 167-169.

1863.1

Eckstein, D. The fisheries of Amsterdam in 1882. Rept. U. S. Fish Comm. 1883 (1885), 13, 1192-1194.

1885.1

Eckstein, Karl. Kaulquappen als Forellenfutter. Fischerei-Zeitg., Neudamm, 1901, 4, 595-596.

1901.1

Fischerei und Fischzucht. Leipzig, 1902. 143 p. $16^{\circ}$ (Sammlung Göschen, no. 156)

1902.1

Die geographische Verbreitung der Fische Mitteleuropas. Deutsch. Fischerei-Zeitg., 1905, 28, 375-376. Stenogr. Protok. Verh. Intern. Fisch.Kongr. Wien, 1905, 112-115. 1905.1

- Die Fischerei-Verhältnisse der Provinz Brandenburg zu Anfang des 20. Jahrhunderts nebst Fischereikarte in 8 Blättern im Auftrage des FischereiVereins bearbeitet. II. Die Gewässer der Provinz Brandenburg in alphabetischer Reihe und deren Fischereilichen Verhältnisse. Berlin, 1908, vii, 275 p.
Edgell, E. Wyatt. See WyattEdgell, $E$.

Edgeworth, $F . H$. The development of the head muscles in Scyllium canicula. Journ. Anat. Physiol. London, 1902, 37 (2. ser. 17), 73-86. 7 pls. 1902.1

On the morphology of the cranial muscles in some vertebrates [including fishes] Quart. Journ. Micr. Sci., London, 1911, 56, pt. 2, 167-316. 99 figs.

1911.1

Edinburgh, Duke of. Notes on the sea fisheries and fishing population of the United Kingdom (In Intern. Fisheries Exhib. Lit., London, 1883. Conferences, 4) 1883.1

Edinger, Ludwig. Ueber die Schleimhaut des Fischdarmes. Bonn, 1876. 2 pls. $8^{\circ}$.

1876.1

- Ueber die Bedeutung des Corpus striatum. Deutsch. Med. Vochenschr. 1887 , no. 26.

1887.1

Untersuchungen über die vergleichende Anatomie des Gehirns. I. Das Vorderhirn des Ammocotes, Teleostier, Selachier, etc. Abh. Senckenberg. Naturf. Ges., Frankfurt-a.-M., 1888, 15, pt. 3, 91-122. 4 pls. Abstract in Anat. Anz., 1892, 7. Jahrg., $472-476$

1888.1

- Vorlesungen über den Bau der nervösen Centralorgane. 4. ed. Leipzig, 1893. 145 figs. $8^{\circ}$. 1893.1

Vergleichend-anatomische und entwickelungsgeschichtliche Studien im Bereiche der Hirnanatomie. IV. Die Faserung aus dem Stammganglion Corpus striatum; vergleichend-anatomisch und experimentell untersucht Anat. Anz., 1894, 9. Jahrg., 53-60. 4 figs. 1894.1

-_- Untersuchungen uber die vergleichende Anatomie des Gehirns. II. Das Zwischenhirn der Selachier und der Amphibien. Abh. Senckenberg. Naturf. Ges., Frankfurt-a.-M., 1895, 18, 1-55. 5 pls.

1895.1

- Die Entwicklung der Gehirnbahnen in der Tierreihe. Deutsche Med. Wochenschr., 1896, no. 39. 1896.1

Haben die Fische ein Gedächtnis? Das Ergebnis einer Enquete Allgem. Fischerei Zeitg., München (Suppl.), 1899, 241-242. - Rept. Smithson. Instit., 1899, 275-394. - Ber. 
Edinger, $L$.

Senckenberg. Naturf. Ges., Frankfurta.-M., 1900, cvii-cxvi.

1899.1

Das Cerebellum von Scyllium canicula. Arch. Mikros. Anat., 1901. 58, 661-678. 2 pls.

1901.1

Vorlesungen über den Bau der nervösen Centralorgane. 7. ed. Leipzig, 190 .

1904.1

Die Deutung des Vorderhirnes bei Petromyzon. Anat. Anz., 1905, 26. Jahrg., 633-635.

1905.1

- Einiges vom Gehirn des Amphioxus. Anat. Anz., 1906, 28. Jahrg., 417-428. 15 figs.

1906.1

Ueber das Gehirn von Myxine glutinosa. Abh. Akad. Wiss. Berlin, 1906, no. 1, 1-36. 3 pls.

1906.2

Kurze Demonstration von Hirnmodellen. Zentralbl. Physiol., 1907, 21, 498.

1907.1

- The relation of comparative anatomy to comparative psychology. Journ. Comp. Neurol., 1908, 18, 437457. 5 figs.

1908.1

_- Ueber das Hören der Fische und anderer niederer Verbraten. Physiol. Centralbl., 1908, 21, 498-499. 1908.2

- Vorlesungen über den Bau den nervösen Centralorgane des Menschen und der Tiere. Bd. II. Vergleichende Anatomie des Gehirns. Leipzig, 1908.

1908.3

Ueber das Kileinhirn. Monatsschr. Psych. Neurol., 1910, 28, 86-87. Arch. Psych., 47, 961-963.

1910.1

Warum wir die Fische angeln können. Das Ergebnis einer Umfrage. Kosmos, Stuttgart, 1911, S. Jahrg., 135-137. - Schweiz. Fischerei Zeitg., 19. Jahrg., 173-175.

1911.1

Edlund, Gustaf Withelm. Fiskar och Fiskodling. Helsingfors, 1884. $104 \mathrm{p}$.

1884.1

Kaloista ja Kalanviljelyksestä Helsingissä, 1886。 $64 \mathrm{p}$. 1886.1

Edmunds, M.C. The introduction of salmon into American waters. Trans. Amer. Fisheries Soc. 1872 (1873), 32-39.

1873.1

Obstructions to the ascent of fish in the tributaries of lake Champlain. Rept. U.S. Fish Comm. 1872-73 (1874), 2, 622-629. pl.

1874.1
Edwards, Alexander McKenzie. On inflammation in fishes. Proc. Roy. Phys. Soc. Edinburgh, 1861 (1863), 2, 228-233.

1863.1

Edwards, Alphonse Milne. See Milne-Edwards, $A$.

Edwards, Arthur Mead. Life beneath the waters; or the aquarium in America. New York, 1858. $12^{\circ}$.

1858.1

Edwards, B. J. Condition of the shore fisheries of Massachusetts and Rhode Island in 1871. Rept. U. S. Fish Comm. 1871-72 (1873), 1, 53-59.

1873.1

Edwards, Charles Lincoln. A preliminary plan for the Los Angeles zoological park and aquarium. Proc. Los Angeles Zool. Soc., 1912, 1, 1-20. 7 figs.

1912.1

Edwards, Charles L., \& Jordan, David Starr. See Jordan \& Edwards.

Edwards, George [1694-1773] Gleanings of natural history, exhibiting figures of quadrupeds, birds, insects, plants, etc.; most of which have not, till now, been either figured or described. 3 vols. London, 1758-64. 150 pls. $4^{\circ}$. 1758.1

Fishes, vol ii, p. 153-160. pls 282-284. Second title-page in French, and English and French text in parallel columns.

A catalogue of the birds, beasts, fishes, insects, plants, etc., contained in Edwards' Natural history ... with their Latin names, etc. London, 1776. See Linnæus, $C$.

1776.1

Edwards, Henri Milne [1800-1885] Eléments de zoologie. Oiseaux, reptiles, poissons. Paris, 1835. $8^{\circ} .1835 .1$

Remarques sur les affinités naturelles du Lepidosiren. Ann. Sci. Nat. (Zool.), 1840, 2. sér. 14, 159-162.Ann. Mag. Nat. Hist., 1841, 5, 466-468.

1840.1

Rapport sur la pisciculture Ann. Sci. Nat. (Zool.), 1850, 2. sér. 14, 53-67.

1850.1

Leçons sur la physiologie et l'anatomie comparée de l'homme et des animaux. 14 vols. Paris, 1857-80. $8^{\circ}$

1857.1

Report on artificial fish-culture, and on stocking barren and impoverished rivers with fish artificially hatched. (In Garlick, Theodatus. A treatise on 
the artificial propagation of certain kinds of fish, $1857,35-54,8^{\circ}$ ) 1857.2

- Rapport sur un mémoire de $\mathrm{M}$. Jobert, relatif à la réspiration aérienne de quelques poissons du Brésil. C. R. Acad. Sci. Paris, 1878, 86, 935-938. Ann. Mag. Nat. Hist., 1878, 5. ser. 2, 105-108.

1878.1

Edwards, Henri Milne, \& Coste, Travaux et rapports de la commission de pisciculture, adressés au Ministre du commerce. Paris, 1850.

1850.1

Edwards, Henri Milne, Jussieu, A. de, \& Beudant, $F$. S. See Beudant, Edwards \& Jussieu.

Edwards, Thomas. Another supposed new flounder. Zoologist, 1856 , 14, $5065-5066$.

1856.1

Contributions and additions to the fishes of Banffshire. Mag. Nat. Hist. \& Naturalist, 1860, no. 2, 36-39.

1860.1

The tench [Tinca vulgaris] found in the Moray firth. Zoologist, 1862, 20, 8138 .

1862.1

- Note on the argentine [Scopelus humboldti] 'Zoologist, 1863, 21, 84638464.

1863.1

- Occurrence of Drummond's echiodon (Echiodon drummondii Fierasfer dentatus]) at Banff. Zoologist, 1863, 21, 8495 .

1863.2

- Occurrence of the dory (Zeus faber) at Banff. Zoologist, 1863, 21, 8727 .

1863.3

New British fishes. Zoologist. 1864, 22, 9366-9371.

1864.1

Bloch's gurnard (Trigla blochi) in the Moray firth at Banff. Zoologist, 1866,2 . ser. 1, 312 .

1866.1

- Occurrence of the allice shad (Alosa communis $[=$ Clupea alosa $]$ ) on the Aberdeenshire coast. Zoologist, 1866, 2. ser. 1,349 .

1866.2

A few additional particulars regarding Couchia edwardii. Proc. Linn. Soc. London (Zool.), 1870, 10, 1-4.

The silvery hairtail (Trichiurus lepturus) found in the Moray firth at Banff. Sci. Gossip, 1876, 137. 1876.1

- Nilsson's goby [Gobius nilssonii in the Moray firth] Sci. Gossip, 1876 (1877), p. 88 .
Morris's tape-fish [Leptocephalus morrisii] at Pennan, Aberdeenshire. Zoologist, 1878, 3. ser. 2, 60-61.

1878.1

Occurrence of the dealfish iTrachypterus arcticus 1 on the Banffshire coast. Zoologist, 1879, 3. ser. 3, 220221.

1879.1

On the occurrence of the Norwegian Argentina silus on the shore of the Moray firth, Banffshire. Journ. Linn. Soc. London (Zool.), 1881, 15, 334-336.

1881.1

The dorse [Gadus callarius] or golden cod, on the Banffshire coast. Zoologist, 1882, 3. ser. 6, $23 . \quad 1882.1$

Edwards, Vinal $N$. Report on the fisheries of Nantucket, Edgartown, Hyannis, Martha's Vineyard, etc., in 1871-72. Rept. U. S. Fish Comm. 1871-72 (1873), 1, 187-192. 1873.1

On the occurrence of the oceanic bonito, Orcynus pelamys (Linné) Poey, in Vineyard sound, Mass. Smithsonian Miscell. Collections, 1880, 19, 263.

1880.1

Edwards, Vinal N., \& Sherwood, George H. See Sherwood \& Edwards.

Edwards, William $H$. A voyage up the river Amazon, including a residence at Pará. London, 1847. 210 p. $12^{\circ}$.

1847.1

Eeden, Frederik William van. De internationale tentoonstelling van visscherij in 1867, te 's Gravenhage. Tijdschr. Nederl. Maatsch., 1870, 11, 116118.

1870.1

De Nederlandsche zeevischerijen in 1873. Tijdschr. Nederl. Maatsch. 1875, 38 (3. ser. 16), 96-104. 1875.1

Egerton, (Sir) Philip de Malpas Grey [1806-1881] On the discovery of ichthyolites in the southwestern portion of the North Staffordshire coal-field. Proc. Geol. Soc., 1835, 2, 202-203. - Phil. Mag., 1835, 3. ser. 7, 517. 1835.1

Catalogue of fossil fish in the collections of Lord Cole and Sir Philip Grey Egerton, arranged alphabetically; with references to the localities, geological positions, and published descriptions of the species. Phil. Mag., 1836, 8, 366373. - Ann. Mag. Nat. Hist., 1, 487.Edinb. New Phil. Journ., 1841, 31, 144. 1836.1 
Egerton, $P . M . G$.

A catalogue of fossil fish in the collections of the Earl of Enniskillen and Sir P. Grey Egerton. Ann. Mag. Nat. Hist., 1841, 7, 487-498. Also separate; Chester, 1841. 3 p. $4^{\circ}$.

1841.1

Notice on the occurrence of Triassic fishes in British strata. Proc. Geol.Soc., 1841, 3, 409-410.-Phil. Mag., 3. ser. 19, 522. - Ann. Mag. Nat. Hist., 8, 391. - Neues Jahrb. Mineral., 1843, p. 118.

1841.2

On some new ganoid fishes. Proc. Geol. Soc., 1843, 4, 183-184. Ann. Mag. Nat. Hist., 13, 151-152.

1843.1

On some new species of fossil chimaroid fishes, with remarks on their general affinities. Proc. Geol. Soc., 1843, 4. 153-157; 211. - Ann. Mag. Nat. Hist., 12, 467-471. Ibid., 14, 73. Phil. Mag., 3. ser. 24, 51.

1843.2

-_ On some new species of fossil fish, from the Oxford clay at Christian Malford. Ann. Mag. Nat. Hist., 1844, 14, 513. - Quart. Journ. Geol. Soc., $1845,1,229-232$.

1844.1

Description of a fossil ray from Mount Lebanon (Cyclobatis oligodactylus) Quart. Journ. Geol. Soc., 1S45, 1, 225229.

1845.1

Description of the mouth of a Hybodus found by W. B. Ibbetson in the Isle of Wight. Quart. Journ. Geol. Soc., 1845, 1, 197-198. pl.

1845.2

On the remains of fishes found by Mr. Kaye and $\mathrm{Mr}$. Cunliffe in the Pondicherry beds. Quart. Journ. Geol. Soc., 1845, 1, 164-171. 1845.3

Supplement to a memoir on the fossil species of Chimara (Ischyodus gigas) Proc. Geol. Soc. London, 1846, 4, 211-212.

1846.1

Description of some new American fishes (In Lyell, C. On the coalmines of eastern Virginia) Quart. Journ. Geol. Soc., 1847, 3, 275-278.

1847.1

On the nomenclature of the fossil chimaroid fishes. Quart. Journ. Geol. Soc., 1847, 3, 350-353.

1847.2

Observations on Mr. M'Coy's paper on some fossil fishes of the Carboniferous period. Ann. Mag. Nat. Hist., 1848, 2. ser. 2, 189-190.

1848.1

On Pterichthys. Quart. Journ. Geol. Soc., 1848, 4, 302-304. pl. 1848.2
- Palichthyologic notes. Supplemental to the works of Prof. Agassiz. Quart. Journ. Geol. Soc., 1848-60.

1848.3

1. Family Cephalaspides, genus Pterichthys. $1848,4,302-314$. pl.

2. On the affinities of the genus Platysomus. $1849,5,329-332$. fig.

3. On the Ganoidei heterocerci. $1850,6,1-10$. 2 pls.

4 . On the affinities of the genera Tetragonolepis and Dapedius. 1853, 9, 274-279; 367. pl. 5. On two new species of placoid fishes [Ctenacanthus hybodoides and $C t$. nodosus] from the Coal measures. 1853, 9, 280-282. pl.

6. On a fossil fish [Dipteronotus cyphus] from the upper beds of the New Red Sandstone at Bromsgrove. 1854, 10, 367-371. pl.

7. On two new species of Lepidotus $[L$. longiceps and breviceps] from the Deccan. 1854, 10, 371-374. pl.

8. On some ichthyolites from the Nummulitic limestone of the Mokattam hills, near Cairo. 1854, 10, 374-378. pl.

9. On some fish-remains from the neighbourhood of Ludlow: $1857,13,282-289.2$ pls. Ann. Mag. Nat. Hist, 2. ser. 19, 427-428.

10. On Paloeniscus superstes, 1858, 14, 164165. $\mathrm{pl}$.

i1. Remarks on the nomenclature of the Devonian fishes. $1860,16,119-136$. 9 figs.

Observations on Mr. M'Coy's description of the tail of Diplopterus. Ann. Mag. Nat. Hist., 1849, 3, 53-54.

1849.1

Description of the specimens of a fossil fish from the tableland of the Deccan, in the peninsula of India. Quart. Journ. Geol. Soc., 1851, 7, 273.

1851.1

Fish: Elasmodus, Palæoniscus, Lepidotus, Pholidophorus, Ophiopsis, Ptycholepis, Leptolepis, Lophiostomus (In Figures and descriptions of British organic remains) Mem. Geol. Surv. United Kringdom, 1852, 6. dec. 10 pls. $8^{\circ}$.

1852.1

- Notes on the fossil fish from Albert mine. Quart. Journ. Geol. Soc., $1853,9,115$.

1853.1

Identification of the Lower Carboniferous fishes collected at Albert mine, New Brunswick. by Charles Isyell.

On some new genera and species of fossil fishes. Ann. Mag. Nat. Hist., $1854,13,433-436$.

1854.1

Fish: Asteracanthus, Pholidophorus, Histionotus, Aspidorhynchus, Ptycholepis, Oxygnathus, Pycnodus (In Figures and descriptions of British organic remains) Mem. Geol. Surv. United Kingdom, 1855, S. dec. 10 pls. $8^{\circ}$.

1855.1

On the unity of the genera Pleuracanthus, Diplodus, and Xenacanthus, and on the specific distinction of the 
Permian fossil Xenacanthus decheni Beyrich. Ann. Mag. Nat. Hist., 1857, 2. ser. 20, 423-124.

1857.1

Fish: Cosmolepis, Thrissonotus, Pachycormus, Endactis, Centrolepis, Nothosomus, Pleuropholis, Megalurus, Macropoma (In Figures and descriptions of British organic remains) Mem. Geol. Surv. United Kingdom, 1858, 9. dec. 10 pls. $8^{\circ}$.

1858.1

On Chondrosteus, an extinet genus of the Sturionidx, found in the Lias formation at Lyme Regis. Phil. Trans. Roy. Soc. London, 1858, 871-886. 3 pls. Abstract in Proc. Roy. Soc. London, 9, 233.

1858.2

Description of Tristichopterus, Acanthodes, Climatius, Diplacanthus and Cheiracanthus (In Figures and descriptions of British organic remains) Mem. Geol. Surv. United Kingdom, 1861, 10. dec. 3 pls. $8^{\circ}$. 1861.1

Remarks on the ichthyolites of Farnell road. Description of Acanthodes mitchelli. Rept. Brit. Assoc. Adv. Sci., 13. meet., 1860 (1861) (Notices \& Abstract), 77-78.

1861.2

On a new species of Pterichthys ( $P$. macrocephalus Egerton) from the yellow sandstone of Farlow, county Salop. Quart. Journ. Geol. Soc., 1862, 18, 103-106. pl. \& 3 figs.

1862.1

On some ichthyolites (Myriolepis clarkei, Cleithrolepis granulatus, Palooniscus antipodeus) from New South Wales. Quart. Journ. Geol. Soc., 1864, $20,1-5$.

1864.1

On a new species of Acanthodes (A. wardi) from the coal-shales of Longton. Quart. Journ. Geol. Soc., 1866, 22, 468-470. - Phil. Mag., 31, 546-547.

1866.1

On the characters of some new fossil fish from the Lias of Lyme Regis. Quart. Journ. Geol. Soc., 1868, 24, 499505. - Ann. Mag. Nat. Hist., 3. ser. 2, 459. - Phil. Mag., 37, 152-153. - Geol. Mag., 5, 389-390.

1868.1

Alphabetical catalogue of type specimens of fossil fishes in the collection of Sir Philip de Malpas Grey Egerton, Bart., at Oulton Park. Geol. Mag., 1869, 6, 408-413.

1869.1

On two new species of Gyrodus: $G$. goweri and $G$. coccoderma. Quart. Journ.Geol. Soc., 1869, 25, 379-386. 5 figs. - Phil. Mag., 39, 387.
On a new chimæroid fish (Ischyodus orthorhinus $\sigma^{7}$ ) from the Lias of Lyme Regis. Quart. Journ. Geol. Soc., 1871, 27, 275-278. pl. - Phil. Mag., 42, 315.

1871.1

Fish: Heterolepidotus, Isocolum, Osteorachis, Platysiagum, Palæospinax, Semionotus and Drepanephorus (In Figures and descriptions of British organic remains) Mem. Geol. Surv. United Kingdom, 1872, 13. dec. 9 pls. $8^{\circ}$.

1872.1

- On Prognathodus guentheri Egerton, a new genus of fossil fish from the Lias of Lyme Regis. Quart. Journ. Geol. Soc., 1872, 28, 233-237. - Ann. Mag. Nat. Hist., 4. ser. 9, 325.1872 .2

On Platysiagum sclerocephalum Egerton and Palocospinax priscus Egerton. Quart. Journ. Geol. Soc., 1873, 29, 419-421.

1873.1

Notice of Harpactes velox, a predaceous ganoid fish of a new genus, from the Lias of Lyme Regis. Geol. Mag., 1876, 2. dec. 3, 441-442. 1876.1

On some new pycnodonts: Calodus ellipticus Egerton, C. gyrodoides Egerton, Pycnodus bowerbanki Egerton. Geol. Mag., 1877, 2. dec. 4, 49-55. 1877.1

On some remains of ganoid fishes from the Deccan. Palseont. Indica (PreTert. Vert.), 1878, 1, pt. 2, 1-8. 3 pls.

1878.1

Correspondence with Sir Charles Lyell on fossil fishes] (In Eastman, C. R. Notes on Triassic fishes, etc. Ann. Carnegie Mus., 1914, 9, 139-148) 1914.1

Egerton, (Sir) Philip de Malpas Grey, \& Agassiz, Louis. See Agassiz \& Egerton.

Egerton, (Sir) Philip de Malpas Grey, \& Huxley, Thomas Henry. Illustrations of new or rare British fossil fishes. 6 parts. London, $1852-72.62$ pls. $8^{\circ}$. 1852.1

Egerton, (Sir) P. de M.G., \& Kaye, C. $T$. Observations on certain fossiliferous beds in southern India. With an appendix on the remains of fishes found by Kaye and Cunliffe in the Pondicherry beds. Trans. Geol. Soc., 1842, 7, 85-96.

1842.1

Egerton, (Sir) Philip de Malpas Grey, \& Miall, Louis Compton. On remains of ganoid fishes from the Deccan. On the ganoid Ceratodus, etc. Calcutta, 1877. 4 pls. $4^{\circ}$.

1877.1 
Eggeling, $H_{\circ}$ Dündarmrelief und Ernährung bei Knochenfischen. Jena. Zeitschr. Naturw., 1907, 43, 417-529. 3 pls.

1907.1

Eggeling, Otto, \& Ehrenberg, Frederick. The freshwater aquarium and its inhabitants. New York, 1908. 352 p. 128 figs. $8^{\circ}$.

1908.1

Eggers, Henrik Franz Alexander [1844 - ] Flyvefiskens Flugt. Tidsskr. Popul. Fremstilling. Naturvidensk., 1878, 5. ser. 5, 160 . 1878.1

Eglit, $P . I .$, \& Lebedincev, $A . A$. See Lebedincev \& Eglit.

Egounoff, Sophie. Développement histologique du tube digestif de la truite: Rev. Suisse Zool., 1907, 15, 19-74. 2 pls. 1907.1

Egounoff, Sophie, \& Yung, E. Recherches sur l'histogénèse de l'intestin de la truite. Arch. Sci. Phys. Nat. Genève, 1907, 4. sér. 23, 89-90.

1907.1

Ehlers, Ernst Heinrich [1835 - ] Amphioxus von Helgoland. Zool. Anz., $1878,1,247-248$.

1878.1

Die Epiphyse am Gehirn der Plagiostomen. Zeitschr. Wiss. Zool. (Suppl.), 1878, 30, 3. Heft, 607-634. 2 pls. Also separate; Leipzig, 1878. 2 pls. $8^{\circ}$.

1878.2

- Lamna cornubica an der ostfriesischen Küste. Nachr. König. Ges. Wiss. Göttingen, 1886, no. 18, 547-550. 1886.1

\section{Ueber Lepidosiren.}

Verh. Deutsch. Zool. Ges., Leipzig, 1894, 4 , 32-34. 1894.1

Ueber Lepidosiren paradoxa Fitz., und $L$. articulata, n. sp. aus Paraguay. Nachr. König. Ges. Wiss. Göttingen, 1894, no. 1, 84-91. - Ann. Mag. Nat. Hist., 1894, 6. ser. 14, 1-8. 1894.2

Zur Kenntniss der Eingeweide von Lepidosiren. Vorläufige Mittheilung. Nachr. König. Ges. Wiss. Göttingen, 1895, no. 2, 34-50. 1895.1

Ehnle, H. Fundulus pallidus, Fundulus heteroclitus und Fundulus chrysotus. Blätt. Aquar-Terrar. Kunde, 1910, 21. Jahrg., 685-686. 2 figs.

1910.1

Haplochilus chaperi Sauvage. Blätt. Aquar-Terrar. Kunde, 1910, 21. Jahrg., 809-810. fig. 1910.2

Mollienisia latipinna. Blätt. Aquar.-'Terrar. Kunde, 1910, 21. Jahrg., 605-607. 2 figs.
Neuere Beobachtungen über Haplochilus sp. und Haplochilus rubrostigma. Blätt. Aquir-Terrar. Kunde, $1910,21$. Jahrg., 453-456. 3 figs. 1910.4

- Neuere Beobachtungen von $\mathrm{Xi-}$ phophorus helleri var. guentheri. Blätt. Aquar.-Terrar. Kunde, 1910, 21. Jahrg., 230-232.

1910.5

- Paratilapia multicolor. Blätt. Aquar.-Terrar. Kunde, 1910, 21. Jahrg., 845-846. fig.

1910.6

- Pocilia pacitioides. Wochenschr. Aquar.-Terrar. Kunde, 1910, 7. Jahrg., 345-346. fig.

1910.7

Pseudocorynopoma doria. Wochenschr. Aquar.-Terrar. Kunde, 1910, 7. Jahrg., 697-698. fig. 1910.8

- Pseudoxiphophorus bimaculatus. Blätt. Aquar-Terrar. Kunde, 1910, 21. Jahrg, 737-738. fig.

1910.9

- Rivulus flabellicauda Regan. Blätt. Aquar-Terrar. Kunde, 1910, 21. Jahrg., 341-343. 2 figs.

1910.10

Trichogaster lalius. Blätt. Aquar.-Terrar. Kunde, 1910, 21. Jahrg., 557-559. 2 figs.

1910.11

Ehrenbaum, Ernst [1861 - ] Bericht über die Fischerei mit steert- und feststehenden Hamen auf dem holländisch Diep und Haringvliet. Mitth. Deutsch. Seefischerei Ver., 1889, 21-25; 80-84.

1889.1

Zoologische Wanderstation an der Nordsee. Mitth. Deutsch. Seefischerei Ver., 1889, 4-10. 1889.2

Aufenthaltsorte und Fang von untermässigen Seefischen. Review of paper by T. W. Fulton. Mitth. Deutsch. Seefischerei Ver., 1892, 97-108. 1892.1

Bericht über die Seefischerei von Neuvorpommern und Rügen. Mith. Deutsch. Seefischerei Ver., 1892, 3-40.

1892.2

Bericht über die von der Sektion für Küisten- und Hochseefischerei im Mai und Juni 1892 veranstaltete Versuchsfischerei auf der Unter-Ems. Mitth. Deutsch. Seefischerei Ver., 1892, 162-187. 2 pls.

1892.3

Die Sardelle (Engraulis encrasicholus L.) Aussichten einer deutschen Sardellenfischerei und Kritik der holländischen Arbeiten über die Sardelle. Mitth. Deutsch. Seefischerei Ver., 1892 (Suppl.) $21 \mathrm{p}$.

1892.4 
Ueber Fischerei und Fische der Zuidersee. Review of paper by P.P.C. Hoek. Mitth. Deutsch. Seefischerei Ver., 1892, 126-131.

1892.5

Bericht über eine Reise nach den wichtigsten Fischereiplätzen der Vereinigten Staaten und über die Fischereiabteilung auf der Ausstellung in Chicago im Jahre 1893. Mitth. Deutsch. Seefischerei Ver., 1894-95 (Suppl.) 124 p.

1894.1

Hollands Stellung zur Frage der Ueberfischung der Nordsee von P. P. C. Hoek. Mitth. Deutsch. Seefischerei Ver., 1895, 6-11.

1895.1

Statistische und biologische Untersuchungen über den Rheinlachs von Dr. P. P. C. Hoek. Mitth. Deutsch. Seefischerei Ver., 1895, 12-24. 1895.2

Beiträge zur Naturgeschichte einiger Elbfische [Osmerus eperlanus L., Clupea finta Cuv., Acerina cernua L., Acipenser sturio L.] Wiss. Meeresuntersuch. Kiel (Abt. Helgoland), 1896, n. s. 1, Heft 1, 35-79. 3 pls.

1896.1

- Die Köderfrage bei der Seefischerei. Mitth. Deutsch. Seefischerei Ver., 1896, 291-299.

1896.2

Ueber Küstenfischerei an der Nordsee. Mitth. Deutsch. Seefischerei Ver., 1896, 330-341.

1896.3

Eier und Larven von Fischen der deutschen Bucht. Wiss. Meeresuntersuch. Kiel (Abt. Helgoland), 1897-1904. 1897.1

i. [Eggs and larvæ of flat-fishes and sprat] 1897, n. s. 2, 253-324. $3 \mathrm{pls}$.

ii. Die Bestimmung der schwimmenden Fischeier und die Methodik der Eimessungen, ron Fr. Heincke und E. Ehrenbaum. 1900, n. S, 3, 127-332. 2 pls. \& 17 figs.

iii. Fische mit festsitzenden Eiern. 1904. n. s. 6, $127-200$. 13 pls. fig.

Dr. Hoek's Untersuchungen über die Steerthamenfischerei im Jahre 1896. Mitth. Deutsch. Seefischerei Ver. 1896 (1898), 262-270.

1898.1

Versuch einer Berechnung des Fischereiertrages der Nordsee. Mitth. Deutsch. Seefischerei Ver., 1899, 29-39.

1899.1

Entvölkerung des Meeres durch übermässige Befischung. Review of paper by W. Garstang. Mitth. Deutsch. Seefischerei Ver., 1901, 24-25.

1901.1

Die Fische der Arctis. Fauna Arctica, 1901, 2, 65-168.
Internationale Pläne zur Erforschung der nordischen Meere. Fischerei Zeitg., 1902, 5, 6-7. fig.

1902.1

Ueber die Schnelligkeit des Wachstums bei einigen Gadiden. Review of paper by T. IV. Fulton. Fischerei Zeitg., 1902, 629-633; 641-644.

1902.2

Das Arbeitsfeld der deutschen Hochseefischerei. Die Woche, Berlin, 1904, 247-249.

1904.1

Die grossen Seefischereien im Nordatlantischen Ozean, Neufundland, Island, Lofoten. Die Flotte, Berlin, 1904.

1904.2

Die Fische der Olga-Expedition (In Zoologische Ergebnisse einer Untersuchungsfahrt ... nach der Bäreninsel und Westspitzbergen, VI) Wiss. Meeresuntersuch. Kiel (Abt. Helgoland), 1905, n. s. $7,45-70$.

1905.1

- Die Fischerei auf der Weltausstellung in St. Louis, 1904. Mitth. Deutsch. Seefischerei Ver., 1905, 259294. 15 figs.

1905.2

Makrelen in der deutschen Nordsee. Mitth. Deutsch. Seefischerei Ver. $1905,148-154$

1905.3

Die Aalfrage. Die Woche, Berlin, 1907, pt. 2, 348-351. 1907.1

Joh. Schmidts Untersuchungen über den Aal. Nat. Rundsch., 1907, 22. Jahrg., 339-342; 353-355.

1907.2

Versuche mit gezeichneten Flundern oder Elbbutt (Pleuronectes flesus) Mitth. Deutsch. Seefischerei Ver., 1907, 23, 473-479. - Wiss. Meeresuntersuch. Kiel (Abt. Helgoland), 1908, n. s. 8, 191199. fig.

1907.3

Die Fortpflanzungsverhältnisse der Seefische. Ber. Senckenberg. Naturf. Ges., Frankfurt-a.-M., 1908, 106*-108*.

1908.1

Ueber Eier und Jugendformen der Seezunge und anderer im Frühjahr laichender Fische der Nordsee. WViss. Meeresuntersuch. Kiel (Abt. Helgoland), 1908 , n. s. 8, 203-269. 6 pls. \& 17 figs. 1908.2

Eier und Larven von Fischen. 1. Teil. Nordisches Plankton, 1909, 4, 1-216. 81 figs. 2. Teil. Ibid., 1909, 10, 217-413. 148 figs. 1909.1

- Ueber die Lebensverhältnisse unserer Fische (Köhler, Pollack, Witt- 
Ehrenbaum, $E$.

ling, Seehecht, Schellfisch, Rotzung, Kliesche, Kabeljau, Flunder, Hering) Der Fischerbote, 1909-12. $\quad 1909.2$

- Eier und Larven der im Winter laichenden Fische der Nordsee. II. Die Laichverhältnisse von Scholle und Flunder, nebst Fangtabellen von E. Ehrenbaum und W. Mielck. Wiss. Meeresuntersuch. Kiel (Abt. Helgoland), 1910, n. s. 9, Heft 2, 143-176. 7 pls. \& fig. 6 tables.

1910.1

- Eier und Larven von Pleuronectiden der Nordsee und benachbarter Gewässer; neuere Untersuchungen aus den Jahren 1904 bis 1909. Rapp. \& Proc. Verb. Conseil Perman. Intern. Explor. Mer, $1910,12 c$, no. 3. 32 p. 1910.2

- Ein Fischereibiologie für Hamburg und die Unterelbe. Der Fischerbote, 1910, 83-84.

1910.3

- Sprottenschwärme in der deutschen Bucht. Der Fischerbote, 1910, 265-267.

1910.4

- Ueber künstliche Zucht im Bereich Seefischerei. Der Fischerbote, 1910, 169-175.

1910.5

- Der angebliche Rückgang der Nordseefischerei. Der Fischerbote, 1911, 213.

1911.1

- Der Flussaal. Review of Emil Walter's Monographie. Der Fischerbote, $1911,4-11 ; 41-44 ; 77-83.1911 .2$

- Die Plattfischlarven der Nordsee und benachbarter Gewässer nach Zeit und Ort ihres Vorkommens. Rapp.\& Proc. Verb: Conseil Perman. Intern. Explor. Mer, 1911, 13, pt. 3. 22 p. 1911.3

- Tabellen zur Bestimmung planktonischer Eier der Nordsee und benachbarter Gewässer (mit Ausschluss der Ostsee) Rapp. \& Proc. Verb. Conseil Perman. Intern. Explor. Mer, 1911, 13. 19 p. 2 pls.

1911.4

- Ueber den Elbhering. Der Fischerbote, 1911, 70-74.

1911.5

Ueber die Flunder (Pleuronectes flesus L.) (In Aus deutscher Fischerei. Festschrift für E. Uhles. Neudamm, 1911)

1911.6

Zur Frage der Wanderungen unserer Seefische. Der Fischerbote, 1911 . $12-14$.

1911.7

- Report on the mackerel. Preliminary account. Rapp. \& Proc. Verb.
Conseil Perman. Intern. Explor. Mer, 1912,14 , p. 10.

1912.1

- Ueber Fische von Westafrica besonders Kamerun. Der Fischerbote, 1913, 5, 308; 358; 398; 506. 1913.1

Ehrenbaum, Ernst, \& Marukawa, H. Altersbestimmung und Wachstum beim Aal. Zeitschr. Fischerei, Berlin, 1913, 14, 89-127. 2 pls.

1913.1

Ehrenbaum, Ernst, \& Strodtmann, $S$. Eier und Jugendformen der Ostseefische. Wiss. Meeresuntersuch. Kiel (Abt. Helgoland), 1904, n. s. 6, 51-126. Ibid., 1905, n. s. 7, 133-216. 17 figs.

1904.1

Ehrenberg, Christian Gottried [17951876] Ueber den Fisch Holocentrum christianum. Isis (Oken), 1829, 22, 1310-1314.

1829.1

Beobachtungen über neue Lager fossiler Infusorien und das Vorkommen von Fichten-Blüthenstaub neben deutlichem Fichtenholz, Hayfischzähnen, Echiniten und Infusorien in volhynischen Feuersteinen der Kreide. Ber. Akad. Wiss. Berlin, 1838, 102-104.

1838.1

Ueber in dem Magen eines peruanischen Flussfisches als Speise gefundene mikroskopische Organísmen. Ber. Akad. Wiss. Berlin, 1848, 3-5.-Ann. Mag. Nat. Hist., 1848, 2. ser. 1, 465-466.

1848.1

Ehrenberg, Christian Gottried, \& Hemprich, F. G. Sce Hemprich \& Ehrenberg.

Ehrenberg, Frederick, \& Eggeling, Otto. See Eggeling \& Ehrenberg.

Ehrenkreutz, (Baron) von. Das Ganze der Angelfischerei. 8. ed. Quedlinburg, 1864. fig. $8^{\circ}$. 1864.1

The same. 16. ed., neubearbeitet von Johannes Borchard. Leipzig, 1904. 316 p.

Ehrström, $C . R$. Bidrag til Laxens Naturalhistora. Notiser Sällsk. Faun. Flor. Förh., 1861, 6. heft, 184-188.

1861.1

Ehrström, Robert. Ueber ein neues Histon aus Fischsperma. Zeitschr. Physiol. Chem., 1901, 32, 350-354.

Prepared from sperm of Lota.

1901.1

Eichelbaum, $E$. Ueber das Auftreten von Sprotten und Heringen vor und in der Elbenmündung im Winter 1910-1911. Mitth. Deutsch. Seefischerei Ver., 1911, 27, 238-254. 2 maps.

1911.1 
Eichholtz, Ioannes Henricus. De piscium atque amphibiorum nudorum lobis opticis atque olfactoriis. Berolini, 1811. $8^{\circ}$.

1841.1

Eichwald, Carl Eduard von [17951876] De selachis Aristotelis zoologiæ geographica specimen inaugurale, etc. Vilnæ, 1819. $\mathrm{S}^{\circ}$.

1819.1

- Neue Deutung des Kiemendeckels der Fische, nebst vergleichend anatomischen Beobachtungen über das Zungenbein der Tirbelthiere. Isis (Oken), 1833, 858-897. fig. 1833.1

__ Einige Bemerkungen uber das kaspische Meer. Arch. Naturgesch., 1838, 4, 97-112.

1838.1

- Fauna Caspio-Caucasica non nullis observationibus novis illustrata. St. Petersburg, 1841. 74 pls. fol.

1841.1

_- Faunæ Caspio-Caucasiæ illustrationes universe. Nouv. Mém. Soc. Nat. Moscou, 1842, 7, 163-220.

1842.1

- Ueber die Fische des devonischen Systems in der Gegend von Pawlowsk. Bull. Soc. Nat. Moscou, 1844, 17, 824843. - Arch. Russ. (Erman), 4, 461-474. - Arch. Mineral. (Karsten \& Dechen), $1845,19,667-690$.

1844.1

Nachtrag zu der Beschreibung der Fische des devonischen Systems aus der Gegend von Pawlowsk. Bull. Soc. Nat. Moscou, 1846, 19, 277-318. 1846.1

Lethra Rossica, ou Paléontologie de la Russie décrite et figurée. 3 vols. Stuttgart, 1853-61.

1853.1

Pisces, vol. 1, p. 1493-1607. 4 pls. Vol. 2, p. $1196-1256.12 \mathrm{pls}$.

- Beitrag zur geographischen Verbreitung der fossilen Thiere Russlands. Alte Periode. Bull. Soc. Nat. Moscou, $1857,30,305-354$.

1857.1

— Sur un terrain jurassique à poissons et insectes d'eau douce de la Sibérie orientale. Bull. Soc. Géol. Paris, 1863, $21,19-25$.

1863.1

— Spicilèges de paléontologie et de zoologie de la Russie. 1. Palooteuthis marginalis. 2. Acerina fischeri. 3. $\mathrm{Ha}$ licharus grypus. Arch. Zool. Expér., 1873,2 , p. xiii-xvi.

1873.1

Eidsvaag, Edvard. Havtemperatur og fiskeri [Meerestemperatur und Fischereien] Bergen Norsk Fisk., 1909, 28, 396-401; 428.

1909.1
Eifert, Edwin. Der gelbe Haplochilus (Hapl. spec.?) Prakt. Zierfischzüchter. $1910,39-40$.

1910.1

Eigenmann, Carl H. [1863-] For list of writings, see bibliography in Indiana Univ. Bull., 1905, 2, no. 6, 10-16.

- A review of the genera and species of Diodontidxe found in American waters. Ann. N. Y. Acad. Sci., 1885, 3, 297-311.

1885.1

- Notes on the specific names of certain North American fishes. Proc. Acad. Nat. Sci. Philad., 1887, 295-296.

1887.1

A review of the American Gasterosteidæe. Proc. Acad. Nat. Sci. Philad. 1886 (1887), 233-252.

1887.2

- Description of a new species of Ophichthys (Ophichthys retropinnis) from Pensacola, Fla. Proc. U. S. Nat. Mus. 1887 (1888), 10, $116 . \quad 1888.1$

On the development of California food fishes. Amer. Naturalist, 1889, 23, $107-110$.

1889.1

- On the genus Clevelandia. Amer. Naturalist, 1889, 23, 916-918. 1889.2

- The barracuda. Zoe, 1890,1 ,
1890.1

The coloration of fishes. IV. Amer. Sci., 1890, 7, 35. 1890.2

— The development of Micrometrus aggregatus, one of the viviparous surfperches. Amer. Naturalist, 1890, 23, 923-927.

1890.3

- The evolution of the cat-fishes. Zoe, 1890, 1, 10-15.

1890.4

The food fishes of California fresh waters. Rept. State Board Fish Comm. Calif., 1890, 53-65.

1890.5

- The Point Loma blind fish and its relatives. Zoe, $1890,1,65-72.2$ pls. 1890.6

The continuity of the germ plasm in vertebrates. Proc. Indiana Acad. Sci., 1891, 168-172.

1891.1

Cymatogaster aggregatus.

A new diodont [Chilomycterus californiensis, sp. nov.] Amer. Naturalist, $1891,25,1133$.

1891.2

On the genesis of the chromatophores in fishes. Amer. Naturalist, 1891, 25, 112-118. 3 pls.
1891.3 
Eigenmann, $C . H$.

- On the precocious segregation of the sex-cells in Micrometrus aggregatus Gibbons. Journ. Morph., 1891, 5, 481492. pl.

1891.4

The spawning seasons of San Diego fishes. Amer. Naturalist, 1891, 25, 578-579.

1891.5

- Biological stations. Proc. Indiana Acad. Sci. 1891 (1892), 172-175.

1892.1

- Branchiostoma elongatum Sundevall, at San Diego, California. Amer. Naturalist, 1892, 26, 70.

1892.2

Early stages in the development of Cymatogaster. Proc. Indiana Acad. Sci., 1892, 58-62.

1892.3

Explorations in western Canada. Proc. Indiana Acad. Sci., 1892, 56.

1892.4

The eyes of blind fishes. Abstract in Proc. Indiana Acad. Sci. 1891 (1892), 175.

1892.5

- The fishes of San Diego, California. Proc. U. S. Nat. Mus., 1892, 15, 123-178. 9 pls.

1892.6

Local variations. Proc. Indiana Acad. Sci., 1892, 81.

1892.7

On the presence of an operculum in the Aspredinidæ. Amer. Naturalist, 1892, 26, 71 . Abstract in Proc. Indiana Acad. Sci. 1891 (1892), $175 . \quad 1892.8$

- The Percopsidx of the Pacific slope. Science, 1892, n. s. 20, 233-234. 1892.9

Catalogue of the freshwater fishes of Central America and southern Mexico. Proc. U. S. Nat. Mus., 1893, 16, 53-60.

1893.1

Early stages in the development of Cymatogaster. Proc. Indiana Acad. Sci. 1892 (1893), 58-62.

1893.2

- The fishes of San Diego, California. Proc. U. S. Nat. Mus. 1892 (1893), 15, 123-178. 9 pls. 1893.3

On the occurrence of the spiny boxfish (genus Chilomycterus) on the coast of California. Proc. U. S. Nat. Mus., 1893, 15, 485.

1893.4

- Biological survey of Indiana] Zoology. Proc. Indiana Acad. Sci. 1893 (1894), 67-76.

1894.1

Bibliography of Indiana fishes, p. 71-76.
'The effect of environment on the mass of local species. Proc. Indiana Acad. Sci. 1893 (1894), 226-229. 1894.2

- Notes on some South American fishes. Ann. N. Y. Acad. Sci., 1894, 7, 625-637.

1894.3

On the viviparous fishes of the Pacific coast of North America. Bull. U. S. Fish. Comm. 1892 (1894), 12, 381478. $26 \mathrm{pls}$.

1894.4

- Results of explorations in western Canada and the northwestern United States. Bull. U. S. Fish Comm. 1892 (1894), 12, 101-132. pl.

1894.5

- Development of sexual organs in Cymatogaster. Abstract in Proc. Indiana Acad. Sci. 1894 (1895), 138.

1895.1

Leuciscus balteatus (Richardson), a study in variation. Amer. Naturalist, 1895, 29, 10-25. 4 pls. - Proc. Indiana Acad. Sci. 1894 (1895), 87-99. 1895.2

The bearing of the origin and differentiation of the sex cells in Cymatogaster on the idea of the continuity of the germ plasm. Amer. Naturalist, $1896,30,265-271 . \quad 1896.1$

- Director's first report of the Indiana University biological station. Proc. Indiana Acad. Sci. 1895 (1896), 203-296. 1896.2

Part i. Turkey lake as a unit of environment, p. 209-239.

Part ii. The inhabitants of Turkey lake, p. 239-264.

Part iii. Variation, p. 265-296.

- - The history of the sex-cells from the time of segregation to sexual differentiation in Cymatogaster. Abstract in Trans. Amer. Micr. Soc., 1896, 17, 172 17. 1896.3

_- Sex-differentiation in the viviparous teleost Cymatogaster. Arch. Entwick-Mech. Organ., 1896, 4, 125-179. 6 pls. - Trans. Amer. Micr. Soc., 1896, 17, 172-173.

1896.4

The Amblyopsidx and eyes of blind fishes. Proc. Indiana Acad. Sci., $1897,230-231$.

1897.1

- The Amblyopsidx, the blind fish of America. Rept. Brit. Assoc. Adv. Sci., 67. meet., 1897, 685-686. 1897.2

A new blind fish. Proc. Indiana Acad. Sci., 1897, 231.

1897.3

Steindachneria. Amer. Naturalist, $1897,31,158-159$. 
The origin of cave faunas. Abstract in Proc. Indiana Acad. Sci. 1897 (1898), 229-230. 1898.1

The blind fishes of North America. Pop. Sci. Monthly, 1899, 56, 473486.

1899.1

A case of convergence. Proc. Indiana Acad. Sci. 1898 (1899), $247-$ 257. figs. - Science, 1899 , n. s. 9, 217 ; $280-282$.

1899.2

Chologaster agassizii and its eyes. Proc. Indiana Acad. Sci., 1899, 251.

1899.3

Degeneration in the eyes of the Amblyopsidx, its plan, process and causes (Summary) Proc. Indiana Acad. Sci., 1899, 239-241.

1899.4

Degeneration in the eyes of the cold-blooded vertebrates of the North American caves. Proc. Indiana Acad. Sci., 1899, 31-46. figs. - Science, 1899, n. s. 11, 492-503. figs.

1899.5

Explorations in the caves of Missouri and Kentucky. Proc. Indiana Acad. Sci. 1898 (1899), 58-61. 1899.6

The eyes of the blind vertebrates of North America. 1899-1903.

1899.7

i. The eyes of the Amblyopsidæ. Arch. Entw.-Mech. Organ., 1899, 8, 545-617. 5 pls. \& figs.

$v$. The history of the eye of the blind fish Amblyopsis from its appearance to its disintegration in old age [with bibliography] (In Mark anniversary volume, p. 167-204. 4 pls. New York, 1903) - Proc. Indiana Acad. Sci., 1901, 101-105.

Notes on the blind fishes. Science, 1899 , n. s. 9,370 .

1899.8

- Viviparous fishes.

Overland Monthly, 1899, 217-224.

1899.9

The blind fishes. Biol. Lect. Marine Biol. Lab. Woods Hole, 1899 (1900), 113-126.

1900.1

- Causes of degeneration in blind fishes. Pop. Sci. Monthly, 1900, 57, 399-405. figs.

1900.2

The development of the conger eel. Science, 1900, n. s. 12, 401-402.

1900.3

The development of the eyes in the blind fish, Amblyopsis. Proc. Amer. Assoc. Adv. Sci., 1900, 230. - Science, 1900 , n. s. $12,302$.

1900.4

The structure of blind fishes. Pop. Sci. Monthly, 1900, 57, 49-58.
The eel question and development of the conger eel. Proc. Indiana Acad. Sci. 1900 (1901), 165-166. 1901.1

- The history of the eye of Amblyopsis. Proc. Indiana Acad. Sci., 1901, 101-105. - Science, 1901, n. s. 14, 631. Ibid., 15, 523-524. 1901.2

The blind fish of Cuba. Abstract in Science, 1902, n. S. 16, 347

1902.1

The blind fishes of Cuba. Grant no. 68. Preliminary report. Science, 1902, n. s. 16, 792-793. - Carnegie Instit. Year Book, Washington, D. C., 1904, no. 2, p. xlii.

1902.2

Description of a new oceanic fish [Psenes edwardsii, n. sp.] found off southern New England [with notes on the characters of Nomeidal Bull. U.S. Fish Comm. 1901 (1902), 21, 35-36. fig. - Proc. Indiana Acad. Sci. 1900 (1901), 166.

1902.3

The egg and development of the conger eel [Leptocephalus conger] Bull. U. S. Fish. Comm. 1901 (1902), 21, 3744. 15 figs. - Proc. Indiana Acad. Sci., 1900, 165-166. 1902.4

- The freshwater fishes of western Cuba. Bull. U. S. Fish Comm. 1901 (1902), 21, 211-236. 2 pls. 1902.5

Investigations into the history of the young squeteague [Cynoscion regalis! Bull. U. S. Fish Comm. 1901 (1902), 21, 45-51. 9 figs. - Proc. Indiana Acad. Sci. 1900 (1901), 166.

1902.6

The solution of the eel question.

Trans. Amer. Micr. Soc., 1902, 24, 5-18. 4 pls. - Science, 1902, n. s. 15, 636. World Today, 1903, 4, 478-482.

1902.7

- Zoological miscellany. Proc. Indiana Acad. Sci. 1901 (1902), 107 113. 1902.8

_- Auf der Suche nach blinden Fischen in Cuba. Umschau, Frankfurt-a.-M., 1903, 7, 365-367. - World Today, 5, 1129-1136. figs. - Science, 1903 , n. s. 15, 636 . 1903.1

- New genera of South American freshwater fishes, and new names for old genera. Sinithson. Miscell. Collect. 1903, 45, 144-148.

1903.2

Report on the freshwater fishes of western Cuba. Bull. U. S. Fish Comm. 1902 (1903), 211-236. 4 pls.

1903.3 
Eigenmann, C. H.

- The freshwater fishes of western Cuba. Bull. U. S. Fish Comm. 1902 (1904), 22, 211-236. 2 pls. \& figs.

1904.1

- On a Leptocephalus of the conger eel (Contrib. Zool. Lab. Indiana Univ, no. 54) Science, 1904, n. s. 19, 629-630. fig.

1904.2

- Divergence and convergence in fishes (Contrib. Zool. Lab. Indiana Univ. no. 64) Biol. Bull. Woods Hole, $1905,8,59-66.4$ figs.

1905.1

The fishes of Panama. Science, 1905 , n. s. 22, 18-20. 1905.2

The mailed cat-fishes of South America [Loricariidæ] Science, 1905, n. s. 21, 792-795.

1905.3

The freshwater fishes of South and Middle America. Pop. Sci. Monthly, 1906, 68, 515-530. . 1906.1

_ Fowler's "Heterognathous fishes "with a note on the Stethaprioninæ (Contrib. Zool. Lab. Indiana Univ. no. 90) Amer. Naturalist, 1907, 41, $767-772$.

1907.1

- On a collection of fishes from Buenos Aires (Contrib. Zool. Lab. Indiana Univ. no. 80) Proc. Washington Acad. Sci., 1907, 8, 449-458. 3 pls.

1907.2

On further collections of fishes from Paraguay. Ann. Carnegie Mus., $1907,4,110-157.15$ pls. 1907.3

The pociliid fishes of Rio Grande do Sul and La Plata basin. Proc. U. S. Nat. Mus., 1907, 32, 425-433. 11 figs.

1907.4

- Preliminary descriptions of new genera and species of tetragonopterid characins (Zoological results of the Thayer Brazilian expedition) Bull. Mus. Comp. Zool. Harvard College, 1908, 52, 91-106.

1908.1

Adaptation (In Fifty years of Darwinism; modern aspects of evolution: centennial addresses in honor of Charles Darwin, before the American Association for the Advancement of Science, Baltimore, Friday, January 1, 1909 , p. 182-208. 2 pls. New York, 1909)

1909.1

Cave vertebrates of America, a study in degenerative evolution. Washington, D. C., 1909. 241 p. 29 pls. \&
72 figs. (Carnegie Institution of Washington Pub. no. 104) 1909.2

The freshwater fishes of Patagonia and an examination of the Archiplata-Archhelenis theory (In Reports of the Princeton University expeditions to Patagonia 1896-1899, vol. iii, pt. 1, Zoology, p. 227-374. 7 pls. \& fig. Princeton, 1905-11) 1909.3

\section{Some new genera and species of} fishes from British Guiana (Reports on the Expedition to British Guiana of the Indiana University and the Carnegie Museum 1908, no. 1) Ann. Carnegie Mus., 1909, 6, 4-54.

1909.4

Catalogue [and bibliography of the freshwater fishes of tropical and south temperate America (In Reports of the Princeton University expeditions to Patagonia 1896-1899, vol. iii, pt. 2, Zoology, p. 375-511. Princeton, 190511)

1910.1

Description of a new species of Pygidium. Ann. Carnegie Mus., 1911, 7, 214. pl.

1911.1

Description of two new tetragonopterid fishes in the British Museum. Ann. Mag. Nat. Hist., 1911, 8. ser. 7, 215-217.

1911.2

New characins in the collection of the Carnegie Museum. Ann. Carnegie Mus., $1911,8,164-181$. 6 pls. \& 2 figs.

1911.3

The Cuban blind fishes. Proc. 7. Intern. Zool. Congr., Boston, 1907 (1912), 697-698.

1912.1

— The freshwater fishes of British Guiana, including a study of the ecological grouping of species, and the relation of the fauna of the plateau to that of the lowlands. Mem. Carnegie Mus., 1912, 5, 1-578. 103 pls.

1912.2

The origin of the fish-fauna of the fresh waters of South America. Proc. 7. Intern. Zool. Congr., Boston, 1907 (1912), 958-959.

1912.3

For full account, see "Reports of the Princeton University Expeditions to Patagonia," vol. iii, 1905-11.

_- Some results from an ichthyological reconnaissance of Colombia, South America. Part I. Indiana Univ. Studies, 1912 , no. $16,1-27$.

1912.4

This publication constitutes no. 8 of the Indiana University Bulletin, vol. 10. The "University Studies " form a subseries of the Bulletin, the separate numbers of which are published at irregular intervals. 
The fishes of South America. Bull. Pan-American Union, 1913, 37, no. 6, 781-800. 18 figs.

1913.1

On two new species of fishes collected by Miss Lola Vance in Peru. Ann. Carnegie Mus., 1913, 8, 421-422. pl.

1913.2

Some results from an ichthyological reconnaissance of Colombia, South America. Part II. Indiana Univ. Studies, 1913, no. 18, 7-32.

1913.3

L Los peces de Sud América. Bol. Unión Panamericana, 1914, 38, 1-21.

1914.1

- On new species of fishes from the Rio Meta basin of eastern Colombia and on albino or blind fishes from near Bogota. Indiana Univ. Studies, 1914, no. $23,229-230$.

1914.2

Some results from studies of South American fishes. Indiana Univ. Studies, 1914, no. 20, 20-48. $\quad 1914.3$

This paper is a continuation of Indiana University Studies nos, 16, 18 and 19, all of which embody results of investigation of extensive series of South American fishes.

The Cheirodontinæ, a subfamily of minute characid fishes of South America. Mem. Carnegie Mus., 1915, 7, 1-99. 17 pls. \& 36 figs.

1915.1

The Serrasalmininx and Mylinæ. Ann. Carnegie Mus., 1915, 9, 226-272. $15 \mathrm{pls}$.

1915.2

- Description of a new Sphagebranchus from the Bahamas. Ann. Carnegie Mus., 1916, 10, 55-56.

1916.1

New and rare fishes from South American rivers. Ann. Carnegie Mus., $1916,10,77-86$. $\quad 1916.2$

On Apareiodon, a new genus of characid fishes. Ann. Carnegie Mus., $1916,10,71-76$.

1916.3

On the species of Salminus. Ann. Carnegie Mus., 1916, 10, 91-92.

1916.4

Eigenmann, Carl H., \& Bean, Barton $A$. An account of Amazon river fishes collected by J. B. Steere; with a note on Pimelodus clarias. Proc. U.S. Nat. Mus., 1907, 31, 659-668. 5 figs.

1907.1

Eigenmann, Carl H., \& Beeson, Charles $H$. Preliminary note on the relationship of the species usually united under the generic name Sebastodes. Amer. Naturalist, 1893, 27, 668-671.

1893.1

The fishes of Indiana. Proc. Indiana Acad. Sci. 1893 (1894), 76-108. - Rept. Indiana State Fish Comm. $1894,40-64$.

1894.1

Pteropodus dallii, n. sp. Amer. Naturalist, 1894, 28, 66. 1894.2

A revision of the fishes of the subfamily Sebastina of the Pacific coast of America. Proc. U. S. Nat. Mus., 1894, 17, 375-407.

1894.3

Eigenmann, Carl H., \& Bray, W.L. A revision of the American Cichlidx. Ann. N. Y. Acad. Sci., 1894, 7, 607-624.

1894.1

Eigenmann, Carl H., \& Cox, Ulysses $O$. Some cases of saltatory variation. Science, 1900, n. s. 12, 300.Amer. Naturalist, 1901, 35, 33-38. Proc. Amer. Assoc. Adv. Sci., 49. meet. $1900,207$.

1900.1

Eigenmann, Carl $H .$, \& Denny, IT. A. The eyes of Typhlotriton spelceus. Abstract in Proc. Indiana Acad. Sci. 1898 (1899), 252-253. 1899.1

Contains some references, to the eyes of blind fishes.

Eigenmann, Carl H., \& Eigenmann, (Mrs.) Rosa Smith. Cyprinodon californiensis Girard. IV. Amer. Sci. $1888,5,3-4$.

1888.1

- A list of the American species of Gobiidæ and Callionymidre, with notes on the specimens contained in the Museum of Comparative Zoology, at Cambridge, Massachusetts. Proc. Cal. Acad. Sci., 1888, 2. ser. 1, 51-78. 1888.2 Notes on some Californian fishes, with descriptions of two new species. Proc. U. S. Nat. Mus., 1888, 11, 463466.

1888.3

- Preliminary notes on South American Nematognathi. Proc. Cal. Acad. Sci., 1888, 2. ser. 1, 119-172. Ibid., 2, 28-56.

1888.4

South American Nematognathi. Amer. Naturalist, 1888, 23, 647-649. 1888.5

- Contributions from the San Diego biological laboratory. I. W. Amer. Sci., 1889, 6, 44-47. 1889.1

Description of a new species of Cyprinodon. Proc. Cal. Acad. Sci., 1889, 2. ser. 1, 270 . 1889.2 


\section{Eigenmann \& Eigenmann.}

Description of new nematognathoid fishes from Brazil. W. Amer. Sci., 1889, 6, 8-10. 1889.3

Notes from the San Diego biological laboratory. The fishes of Cortez banks; additions to the fauna of San Diego; fishes of Etna springs, Napa county, California; fishes of Allen springs, Lake county, California. W. Amer. Sci., 1889, 6, 123-132; 147-150.

1889.4

On the development of California food fishes. Amer. Naturalist, 1889, 23, 107-110. 1889.5

On the genesis of the color-cells of fishes. W. Amer. Sci., 1889, 6, 61-62. 1889.6

On the phosphorescent spots of Porichthys margaritatus. IV. Amer. Sei., $1889,6,32-34$.

1889.7

Preliminary descriptions of new species and genera of Characinidæ. W. Amer. Sci., 1889, 6, 7-S.

1889.8

A review of the Erythrininx. Proc. Cal. Acad. Sci., 1889, 2. ser. 2, 100-116. pl.

1889.9

- A revision of the edentulous genera of Curimatinse. Ann. N. X. Acad. Sci., 1889, 4, 409-440. 1889.10

- The young stages of some selachians. IV. Amer. Sci., 1889, 6, 150151. - Amer. Naturalist, 25, 150-151.

1889.11

Additions to the fauna of San Diego. Proc. Cal. Acad. Sci., 1890, 2. ser. 3, 1-24.

1890.1

Descriptions of new species of Sebastodes. Proc. Cal. Acad. Sci., 1890, 2. ser. 3, 36-38.

1890.2

- A revision of the South American Nematognathi, or cat-fishes. Occasional papers Cal. Acad. Sci., 1890, 1, 1-50s. figs. \& map.

1890.3

Collus beldingi, sp. nov. Amer. Naturalist, 1891, 25, 1132-1133. 1891.1

Recent additions to the ichthyological fauna of California. Proc. Indiana Acad. Sci., 1891, 159-161. 1S91.2

A catalogue of the fishes of the Pacific coast of America, north of Cerros island. Ann. N. Y. Acad. Sci., 1892, 6, 349-358.

1892.1
A catalogue of the fresh-water fishes of South America. Proc. U.S. Nat. Mus., 1892, 14, 1-81.

1892.2

- New fishes from western Canada. Amer. Naturalist, 1892, 26, 961-964.

1892.3

Preliminary descriptions of new fishes from the Northwest. Amer. Naturalist, 1893, 27, 151-154. 1893.1

Eigenmann, Carl H., \& Fisher, Homer $G$. The Gymnotida of transAndean Colombia and Ecuador. Indiana Univ. Studies, 1914, no. 25, 235-237.

1914.1

Eigenmann, Carl H., \& Fordice, Morton $W$. Catalogue of the fishes of Bean Blossom creek, Monroe county, Indiana. Proc. Acad. Nat. Sci. Philad. 1885 (1886), 410-411.

1886.1

- A review of the American Eleotridinx. Proc. Acad. Nat. Sci. Philad. 1885 (1886), 66-80.

1886.2

Eigenmann, Carl H., \& Hansell, George. Preliminary notes upon the arrangement of rods and cones in the retina of fishes. Proc. Indiana Acad. Sci. 1898 (1899), 239.

1899.1

Eigenmann, Carl H., \& Henn, Arthur. On new species of fishes from Colombia, Ecuador and Brazil. Indiana Univ. Studies, 1914, no. 24, 231-234.

1914.1

Description of three new species of characid fishes. Ann. Carnegie Mus, 1916, 10, 87-90. pl. 1916.1

These species are referred to the genera $\mathrm{He}$ miodus, Leporinus and Astyanax.

Eigenmann, Carl H., Henn, Arthur, \& Wilson, Charles. New fishes from western Colombia, Ecuador and Peru. Indiana Univ. Studies, 1914, no. 19, $1-15$.

1914.1

Eigenmann, Carl H., \& Horning, $J . E$. A review of the Chetodontidx of North America. Ann. N. Y. Acad. Sci., 1857, 4, 1-18.

1887.1

Eigenmann, Carl $H_{.}$\& Hughes, $E$. $G$. A review of the North American species of the genera Lagodon, Archosargus and Diplodus. Proc. U. S. Nat. Mus., 1887, 10, 65-74.

1887.1

Eigenmann, Carl H., \& Jordan, David Starr. See Jordan \& Eigenmann. 
Eigenmann, Carl $H .$, \& Kennedy, Clarence $H$. Unilateral coloration with a bilateral effect in case of specimens of Leptocephali] Science, 1901, n. s. 13, 828-830.

1901.1

The Leptocephalus of the American eel, and other American Leptocephali. Bull. U. S. Fish Comm. 1901 (1902), 21, 81-92. 45 figs. - Science, n. s. 14,631 .

1902.1

- On a collection of fishes from Paraguay, with a synopsis of the American genera of cichlids. Proc. Acad. Nat. Sci. Philad., 1903, 497-537.

1903.1

Variation notes. Biol. Bull. Woods Hole, 1903, 4, 227-229. figs.

1903.2

Eigenmann, Carl H., McAtee, W. $L$. \& Ward, D.P. On further collections of fishes from Paraguay. Ann. Carnegie Mus., 1907, 4, 110-157. pl. 1907.1

Eigenmann, Carl H., \& Norris, Allen $A$. Sobre alguns peixes de São Paulo, Brazil. Revist. Mus, Paulista, 1900, 4, 349-362.

1900.1

Aires, 1901, 1, 272

1901.1

Eigenmann, Carl $H .$, \& Ogle, Fletcher. An annotated list of characin fishes in the United States National Museum and the Museum of Indiana University, with descriptions of new species. Proc. U. S. Nat. Mus., 1907, $33,1-36.8$ figs.

1907.1

Eigenmann, Carl $H$., \& Shafer, $G$. $D$. The mosaic of single and twin cones in the retina of fishes. Amer. Naturalist, 1900, 34, 109-118. figs.

1900.1

Eigenmann, Carl H., \& Ulrey, A.B. A review of the Embiotocidx. Bull. U.S. Fish Comm. 1892 (1894), 12, 382-399. pl.

1894.1

Eigenmann, Carl H., \& Ward, D.P. The Gymnotidxe. Proc. Washington Acad. Sci., 1905, 7, 159-188. 4 pls.

1905.1

Eigenmann, Carl H., \& Yoder, $A$. $C$. The ear and hearing of the blind fishes. Proc. Indiana Acad. Sci., 1899, 242-247. figs.

1899.1

Eigenmann, (Mrs.) Rosa Smith, formerly Smith [1858 - ] New California fishes. Amer. Naturalist, 1891, 25, 153156.

1891.1

For earlier writings by this author, see Smith, (Miss) Rosa.
Eigenmann, Rosa Smith, \& Eigenmann, Carl $H$. See Eigenmann, Carl H., \& Eigenmann, (Mrs.) Rosa Smith.

Eijk, J.A. van. Jets over vischteelt. Volksvlijt, 1872, 319-325.

1872.1

De vischteelt op Java. Volksvlijt, 1873, 321-328.

1873.1

Eimecke, Wilhelm. Pterophyllum scalare C. U. V. Wochenschr. Aquar.Terrar. Kunde, 1912, 9. Jahrg., 587-589. 2 figs.

1912.1

Einstmann, $J$. W. Ueber das Venensystem der einheimischen Teleostier. Arch. Naturgesch. Berlin, 1913, 79, Abth. A, 1-31. 2 pls.

1913.1

Eisfeld, Hermann. Die Pommersche Sage von der Herkunft der Maräne [Coregonus lavaretus] Zeitg. Intern. Fischerei-Ausstell. Berlin, 1880, no. 10 (Mai 23-26)

1880.1

Eisig, Hugo. Einfluss der Wassertemperatur auf Fische und Schildkröten. Kosmos, 1883, 12, 442-443. 1883.1

- Ueber das Ruhen der Fische. Ḱosmos, 1883, 12, 438-442. 1883.2

Eisler, Paul [1862-] Die Homologie der Extremitäten. Morphologische Studien. Abh. Naturf. Ges. Halle, 1895, 19, $87-344$.

1895.1

Eismond, Joseph. Ueber das Verhalten des Periblastes beim Wachstum der abgefurchten Scylliumkeime. Anat. Anz. (Verh. Anat. Gesell.), 1903, 23, 106-112; 199. 4 figs. 1903.1

- Ueber Regulationserscheinungen in der Entwicklung der in Teilstücke zerlegten Rochenkeimscheiben. Arch. Entw.-Mech., Leipzig, 1910, 30, pt.2, 411-436. 14 figs. $\quad 1910.1$

Wyniki badán eksperymentalnych nad rozwojem jaj ryb spodoustych [Experimentelle Forschungen über die Entwickelung der Rochenkeime] Warszawa Spraw. Tow. Nauk., 1910, 3, 25$62 ; 112-113$.

1910.2

Eismond, Osip Petrovich. Sur l'origine du périblaste chez les sélaciens. Mém. Soc. Nat. Varsovie (C. R. Sect. Biol. Ann.), 1898, 9. 4 p. $\quad 1898.1$

Bericht über eine Reise in's Ausland während der Sommerferien 1902 [Text in Russian] Prot. Séances Soc. Nat. Univ. Varsovie, 1905, 14, 1-22. 1905.1 
Eismond, O.P.

Ergebnisse experimenteller Untersuchungen an Rochen [Text in Russian Prot. Séances Soc. Nat. Univ. Varsovie, 1910, 22, 51-53.

1910.1

Ein Fall regenerativer Prozesse bei dem Embryo eines Rochens im frühen Entwicklungsstadium [Text in Russian] Prot. Séances Soc. Nat. Varsovie, 1912, 24, 1-3.

1912.1

Ekama, C. Dissertatio de sceleto piscium. Lugduni Batavorum, 1822. $8^{\circ}$.

1822.1

Ekhoff, Emil. Beskrifning öfvers benbyggnaden hos Lampris guttatus. Stockholm, 1875. $8^{\circ}$.

1875.1

Ekman, Frederic Joachim. Beskrifning om Runöi Liffland. Tavastehus, 1847. 325 p. $8^{\circ}$.

1847.1

Ekman, Gunnar. Ueber einen Fall von Rückbildung der letzten Kiemenspalte bei Squalus acanthias L. Oefvers. Finska Vet. Soc. Förh., 1910, 52A, no. 9. 6 p. 4 figs.

1910.1

Ekman, Gunnar, Pettersson, O., \& Trybom, $F$. Resultaten af den internationella hafsforskningens arbete under åren 1907-1909 och sveriges andel däruti under medverkan af G. Schneider och W. Bjorck. Sammanfattade af svenska hydrografisk-biologiska kommissionens verkställande utskott. K. Jordbruksdept., Stockholm, 1910, no. 22. 142 p. 21 figs. \& 4 maps.

1910.1

Ekman, Sven. Die Wirbeltiere der arktischen und subarktischen Hochgebirgszone im nördlichsten Schweden. Naturw. Untersuch. Sarekgebirg. (Zool.), 1907, 4, 1-124.pl. \& 14 figs. 1907.1

Norrlands jakt och fiske. Upsala \& Stockholm, 1910。 481 p. 11 pls. \& 211 figs.

Fisket, p. 299-467. pl. viii-xi

1910.1

- Om Torneträsks röding, sjöns naturförhüllanden och dess fiske iThe char (Salmo alpinus) of Torneträsk Stockholm, 1912. 54 p. map. 1912.1

Ekman, Thorsten. On vernacular fish-names from lake Vettern [Text in Swedish I Svensk Fisk. Tidskr., 1902, $11,172-173$.

1902.1

- Account of the lakes examined in the district of Gothenburg and Bohus during the summer of 1903 [Text in Swedish 1 Göteborg o Bohusläns Hush.Sällsk. Qvartalsskr., 1904, 97-108.
Ekman, $V$. Walfred. On dead water, being a description of the so-called phenomenon often hindering the headway and navigation of ships in the Norwegian fjords and elsewhere, and an experimental investigation of its causes, etc. With a preface by Professor Vilhelm Bjorknes. Sci. Results Norweg. North Polar Exped. 1893-96, 1906, 5, no, 15, 1-152. 17 pls. [Printed June, 1904] 1906.1

This paper furnishes the first scientific explanation of the alleged "ship-staying" power of the Remora, attributed to it by ancient tradition.

Ekstrand, $C . H$. De fauna Brasiliens. Upsalæ, 1823. $14 \mathrm{p} .4^{\circ}$. 1823.1

Ekström, C.Ulrich [1781-1859] Fiskarne i Mörkö Skärgård. Handl. Akad. Stockholm, 1830, 143-204; 1831, 70$107 ; 270-321 ; 1834,1-74$.

1830.1

- En för Skandinaviens fauna ny fisk, hörande till Artedi slägte Liparis [L. barbatus], funnen i Mörkö Skärgård. Handl. Akad. Stockholm, 1832, 168-171. 1832.1

- Die Fische in dem Scheeren von Mörkö; aus dena Schwedischen übersetzt und mit einigen Anmerkungen versehen von Dr. F. C. H. Creplin. Berlin, 1835. 269 p. 6 pls. 1835.1

__ Iakttagelser öfver formförändringen hos rudan (Cyprinodon carassius Linn.) Handl. Akad. Stockholm, 1838, 213-225.

1838.1

— Om fisket i Bohuslän. Oefvers. K. Vet. Akad. Förh. Stockholm, 1844, 1 , $26-27$; $1846,3,18-20 ; 180-182$; 248$250 ; 1848, \mathbf{5}, 82-85$.

1844.1

Om sillen. Oefvers. K. Vet. Akad. Förh. Stockholm, 1844, 1, 82-83, 119-121; 1845, 2, 191-192.

1844.2

- Beiträge zur Naturgeschichte des Härings im Kattegat] Arch. Skandin. Beitr. Naturgesch., 1845, 1, 141-142. 1845.1

Bidrag till fiskets historia i Skandinavien särdeles vid Sveriges vestra kust. Nya Handl. Götheborg, 1850, 1. 3-16.

1850.1

Förteckning öfver Däggdjur, amphibier och af foglarne några sällaynta, som blifvit funne på Tjörn, under de sistförflutna 10 åren; jemte de fiskarter som finnas i Kattegatt. Nya Handl. Götheborg, 1850, 1, 25-41. $\quad 1850.2$

Kritiska anmärkningar öfver Assessor Hollbergs beskrifning öf ver Bohuslänska fiskarne. Nya Handl. Götheborg, $1850,1,17-24$. 
Ekström, C.Ulrich, Fries, Bengt Fredrik, \& Sundevall, Carl Jakob. See Fries, Ekström \& others.

Elgh, $K$. Einige neue Beobachtungen über den Aal und seinen Aufenthalt im Winter [Text in Swedish] Fisker. Tidskr. Finl., Helsingfors, 1901, 10, 129131. — Tidskr. Jäg. Fisk., Helsingfors, 9, 163-165.

1901.1

Elk (pseudon.) Salmon culture in Norway. Mag. of Sports \& Pastimes (Baily), 1901, 76, 121-123.

1901.1

Ellangowan, pseudonym for Bertram, James $G$.

Elles, Gertrude L., \& Slater, I.L. The highest Silurian rocks of the Ludlow district. Quart. Journ. Geol. Soc., 1906, 62, 195-222. pl. \& map.

1906.1

Elliott, Henry Wood [1846-] The seal-islands of Alaska. (In The history and present condition of the fishery industries, edited by George Brown Goode. Washington, 1881. $4^{\circ}$ ) 1881.1 Catalogue of the fishes of the Pribylov group, p. 136-137.

Elliott, Henry Wood, Goode, George Brown, \& True, Frederick IV. See Goode, Elliott \& True.

Elliott, J. Steele. The vertebrate fauna of Sutton Coldfield park. Journ. Birmingham Nat. Hist. \& Philos. Soc., $1896-97,2,5-10 ; 17-27 ; 34-41 ; 48-54$; $58-63 ; 69-73$.

1896.1

Elliott, Sizar. On the Cestracion philippi (Port Jackson shark), Trigonia and Terebratula of the Australian seas. Trans. Phil. Instit. Victoria, 1858, 2, 1517.

1858.1

Elliott, William [1788-1863] Carolina sports by land and water; including incidents of devil-fishing, etc. Charleston, 1846.292 p. 6 pls. $12^{\circ}$. 1846.1 pls. $12^{\circ}$.

The same. New York, 1859. 5 p. $12^{\circ}$.

1859.1

Ellis, Daniel. Sketch of the natural history of the Salmo salar, or common salmon. Edinb. New Phil. Journ., 1828, 4, 250-273.

1828.1

Ellis, (Sir) Henry [1777-1869] A catalogue of books on angling, with some brief notices of several of their authors. London, 1811. 21 p. $8^{\circ}$.

1811.1

Earliest attempt at a list of books on angling. Registers 75 distinct works in chronological order.
Ellis, (Mrs.) Marian Lee (formerly Durbin) On the species of Hasemania, Hyphessobrycon, and Hemigrammus collected by J. D. Haseman for the Carnegie Museum. Ann. Carnegie Mus., 1911, 8, 148-163. 3 pls. 1911.1

- The plated nematognaths. Ann. Carnegie Mus., 1913, 8, 384-413. 6 pls. 1913.1

Ellis, Max Mapes. The influence of the amount of injury upon the rate and amount of regeneration in Mancasellus macroums (Garman) Biol. Bull. Woods Hole, 1907, 13, 107-113. 3 tables.

1907.1

The gymnotid eels of tropical America. Mem. Carnegie Mus., 1913, 6, no. 3, 109-195. 8 pls. \& 33 figs.

1913.1

Elmassian, M. Une nouvelle Coccidie et un nouveau parasite de la tanche. Arch. Zool. Expér., Paris, 1909, 5. sér. 2, 229-270.

1909.1

Elmgren, Sven Gabriel. Skandinavisk fauna af S. Nilsson. Fjerde delen, Fiskarna, första häftet. Litteraturbl. Allmän Medborg. Bild., 1852, 6, 206207.

1852.1

- Beskrifning öfver St. Mårtens socken. Suomi, 1858, 17, 165-259.

1858.1

Elmhirst, Richard. The whelk (Buccinum undatum) as food of the cod (Gadus callarius). Feeding habits of the conger-eel and some other fish in captivity (In his Notes from Millport marine biological station) Zoologist, 1909, 4. ser. 13, 201-203. 1909.1

On the yawning of fishes (In his Notes from the Millport marine biological station) Zoologist, 1910, 4. ser. 14, 321-323.

1910.1

On some ambicoloured flat-fish from the Clyde. Ann. Scott. Nat. Hist., 1911, 77-79. - Zoologist, 1911, 4. ser. 15, $30-33$.

1911.1

- Observations on the behavior of fish (In his Notes from the Millport marine biological station) Zoologist, 1912, 4. ser. 16, 15-20.

1912.1

Basking shark, Cetorhinus maximus (Gunn.) stranded on the Little Cumbrxa. Glasgow Naturalist, 1913, 5, 66-67.

1913.1

The naturalist at the sea shore. London, 1913. illust. $8^{\circ}$. 1913.2 
Elridge, $S$. On poisoning by fish. Med. Times Gaz., 1879, 2, 377. 1879.1

Elrod, Morton $J$. A biological reconnaissance in the vicinity of Flathead lake. Bull. Univ. Montana, 1902, no. 10 (Biol. ser. no. 3), 91-182. 30 pls. \& 3 figs.

1902.1

Elwes, $E . V$. The sunfish and its parasites. Journ. Torquay Nat. Hist. Soc., 1909, 1, 17-20.

1909.1

Embleton, Dennis. On the short sunfish (Orthagoriscus mola) Trans. Tyneside Nat. Field Club, 1854, 2, 110 119. pl.

1854.1

On the vendace, Coregonus willoughbii (Yarrell); C. marcnula (Jardine \& Jenyns) Nat. Hist. Trans. Northumberland \& Durham, 1877, 5, 146-154.

1877.1

Note on the capture of tunnies and of a fine specimen of the "Bergylt," or Norwegian haddock, off the Tyne, June, 1884. Nat. Hist. Trans. Northumb. \& Durham, 1884-89, 8. 1889.1

Embleton, Dennis, \& Hancock, A. See Hancock \& Embleton.

Embleton, Robert. Notice of the Trigla lavis or smooth gurnard. Hist. Berwick. Nat. Club, 1834, 1, 22-23.

1834.1

Emeljanenko, P.E. Der scheibenförmige Barsch (Mesogonistius chotodon) [Text in Russian] Naturfreund, St. Petersb., 1906, 1, 35-38.

1906.1

- Beobachtungen über die Entwicklung viviparer Fische aus den Eiern [Text in Russian] Žurn. Obšě. Liub. Komm. Rast., St. Petersb., 1907, 14, 215-217.

1907.1

Der Chamäleonfisch (Badis badis) und sein Verhalten im Aquarium [Text in Russian] Naturfreund, St. Petersb., 1907, 2, 275-278. $\quad 1907.2$

Die Krankheiten der Fische und ihre Heilung [Text in Russian] Žurn. Obšč. Liub. Komm. Rast., St. Petersb., $1907,14,22-36 ; 103-117 . \quad 1907.3$

Zwillinge von Girardinus caudimaculatus, eine bemerkenswerthe Erscheinung [Text in Russian] Naturfreund, St. Petersb., 1907, 2, 239-242.

1907.4

Die Bedingungen des Laichens der Fische im Aquarium und die Pflege der Fischbrut [Text in Russian] Zuurn.
Obšč. Liub. Iomm. Rast., St. Petersb., 1908, 15, 172-181.

1908.1

- Die lebendiggebärenden Fische, ihre Pflege und Fortpflanzung im Aquarium [Text in Russian] Naturfreund, St. Petersb., 1908, 3, 73-80; 344-350.

1908.2

- Die Bestimmung des Alters bei Fischen [Text in Russian] Naturfreund, St. Petersb., 1909, 4, 149-153.

1909.1

Fischnester aus Schaum und deren Bedeutung [Text in Russian] Akvarium Moskva, 1909, 2, 351-359. 1909.2

Die Schleimfische (Blenniidæ) des Schwarzen Meeres in ihrem natürlichen Medium und im Aquarium [Text in Russian] Akvarium Moskva, 1909, 2, 458-461.

1909.3

Die Chromiden oder Cichliden, ihre Pflege und Fortpflanzung [Text in "Russian! Naturfreund, St. Petersb., $1910,5,81-86 ; 101-108 ; 134-138 ; 214-$ $226 ; 237-241$.

1910.1 $P$.

Emeljanov, P. See Emeljanenko,

Emerson, $P . H$. Birds, beasts and fishes of the Norfolk broadlands. 2. ed. London, 1896. 412 p. $8^{\circ}$. 1896.1

Emerton, James Henry [1847-] Life on the seashore. Salem, Mass., 1880. 143 p. $12^{\circ}$. 1880.1

Emery, Carlo. Sui riflessi iridescenti della cornea di alcuni pesci ossei. Rendiconto, Napoli, 1876, 15, 166-169. 1876.1

La cornea dei pesci ossei, contribuzione alla morfologia dell' occhio dei vertebrati. Giorn. Sci. Nat., Palermo, 1878, 13, 9-47. 1878.1 C. Contribuzioni all' ittiologia.
$1879-86$.

I. Le metamorfosi del Trachypterus tonia.

II. Intorno al genere Krohnius Cocco. Mitth. Zool. Stat. Neapel, 1879, 1, 581-592. pl. Mem. R. Accad. Lincei, Roma, 3, 390-397.

III. Aggiunte alla sinonimia e alla storia naturale dei Fierasfer.

IV. Sulle condizioni di vita di giovani individui del Tetragonurus cuvieri. Mitth. Zool. Stat. Neapel, 1882, 3, 281-283.

V. Peloria rueppeli Cocco. L.

VII. Forme larvali di Scopelidi

VIII. Le forme larvali dei Blennius del Golfo di Napoli.

IX. Ancora poche parole sulle forme giovanili dei Macruridi. Mitth. Zool. Stat. Neapel, $1883,4,403-419.2$ pls. \& fig. - Mem. R. Accad. Lincei, Roma, 14, 187-419. 
X. Peristethus cataphractus e Trigla hirundo. XI. Polyprion cernium.

III. Trachinus sp.?

XIII. Bellottia apoda Gigl.

XIV. Pteridium atrum Risso.

IV. Phycis mediterranea.

XVI. Rhomboidichthys podas e mancus.

IVII. Larva di genere ignoto. Mitth. Zool. Stat. Neapel, 1886, 6, 149-164. 2 pls. \& fig. Note ittiologiche. Atti Soc.
Ital. Sci. Nat., Milano, 1879, 21, 37-46. pl.

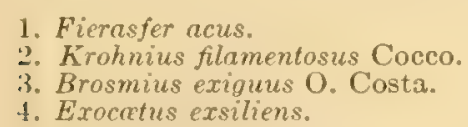

Fierasfer: studî intorno alla sistematica, l' anatomia e la biologia delle specie Mediterranee di questo genere. R. Accad. Lincei, Roma, (1879-80) 1880, 3. ser. (Mem.) 7, 167-254. pls. i-ix. Relazione. Ibid., 1880, 3. ser. (Transunti) 4, 101-105.

1880.1

Le specie del genere Fierasfer nel golfo di Napoli e regioni limitrofe (In Fauna und Flora des Golfes von Neapel, no. $2,1-76.9$ pls. \& 10 figs. Leipzig, 1850. $4^{\circ}$ )

1880.2

- Intorno all' architettura dei fascetti muscolari striati di alcuni vertebrati. Nem. Accad. Sci. Istít., Bologna, 1881, 4. ser. 3, 613-618. pl.Arch. Ital. Biol., 2, 133-134. 1881.1

Zur Morphologie der Kopfniere der Teleostier. Biol. Centralbl., 1881, 1, 527-529.

1881.2

Studi intorno allo sviluppo ed alla morfologia del rene dei Teleostei. Mem. R. Accad. Lincei, Roma, 1882, 13, 43-50. - Arch. Ital. Biol., Turin, 1882, 2, 135-144. pl. Also separate; Rome, 1883. $4^{\circ}$.

1882.1

Sulla esistenza del cosidetto tessuto di secrezione nei vertebrati. Atti $R$. Accad. Sci. Torino, 1882, 18, 338-343. illust.

1882.2

- Intorno alle macchie splendenti della pelle nei pesci del genere Scopelus. Mitth. Zool. Stat. Neapel, 1884, 5, 471482. pl. - Arch. Ital. Biol., 5, 316-325. 3 figs.

1884.1

Z Zur Morphologie der Kopfniere der Teleostier. Erwiederung an Herrn S. Grosglik. Zool. Anz., 1855, 8, 742744.

1885.1

[Phycis blennoides Brünn]

Mitth. Zool. Stat. Neapel, 18s6, 6, 159161. pls. \& figs.
Jose Madrid-Moreno, über die morphologische Bedeutung der Endknospen in der Riechschleimhaut der Ińnochenfische. Biol. Centralbl., 1887, 6, 589-592.

1887.1

-- Ueber die Beziehungen des Cheiropterygiums zum Ichthyopterygium. Zool. Anz., 1887, 10, 185-189. figs.

1887.2

Das Leuchtorgan am Schwanze von Scopelus benoiti. Erwiderung an Herrn Dr. R. von Lendenfeld. Biol. Centralbl., 1888, 8, 228-230. 1888.1

- Nochmals über die Leuchtorgane der Fische. Biol. Centralbl., 1890, 10, $285-286$.

1890.1

- Accesorische und echte Skeletstïcke. Erwiderung an Herrn Dr. G. Thilenius. Anat. Anz., 1897, 13. Jahrg., 600-602.

1897.1

-_. Sulla morfologia degli Acanthodidæ. Riv. Ital. Paleont., Bologna, 1897, 3, 30-33. 3 figs. $\quad 1897.2$

Ueber die Beziehungen des Crossopterygiums zu anderen Formen der Gliedmassen der Wirbeltiere. Eine kritische Erwiderung an Herrn Professor H. K'laatsch. Anat. Anz., 1897, 13. Jahrg., 137-149.6 figs. 1897.3

Quelques mots de réplique à Mr. A. Perrin, au sujet du carpe des Anoures. Anat. Anz., 1898, 14. Jahrg., 381-382.

1898.1

Emery, Carlo, Davidoff, M. von, \& Schoebel, E. See Davidoff, Emery \& Schoebel.

Emery, Carlo, \& Simoni, L. Recherches sur la ceinture scapulaire des Cyprinoïdes. Arch. Ital. Biol., 1886, 7, 390-394.

1886.1

Emmerich, Rudolf, \& Weibel, Emil. Ueber eine durch Bakterien erzeugte Seuche unter den Forellen. Arch. Hygiene, 1894, 21, 1-21.

1894.1

Emmert, $J$. Beiträge zur Entwicklungsgeschichte der Selachier, insbesondere nach Untersuchungen an jüngeren Embryonen von Torpedo marmorata. Arch. Mikrosk. Anat., 1900, 56, 459490. pl. \& figs.

1900.1

Emmons, Ebenezer [1799-1863] A catalogue of the animals and plants of Massachusetts (In Hitcheock's Report Geol. Min. Bot. and Zool. Mass., p. 545551. Amherst, 1833) 
Emory, William Helmsley [1811-] Notes of a military reconnaissance from Fort Leavenworth, in Missouri, to San Diego in California, including parts of Arkansas, Del Norte, and Gila rivers. Washington, 1848. 614 p. $8^{\circ} .1848 .1$ Fish of the Rio Gila without scales. p. 62.

Enckell, Nils. Observationer gjorda i Sodankylä Lappmark år 1789. Handl. K. Vetensk. Akad., 1790, 11, 78-79.

1790.1

Ende, Willem Pieters van den. Iets over de vereeniging ter bevordering der inlandsche ichthyologie. Arnhem, 1851. $8^{\circ}$.

1851.1

- Over, [en: nog iets over] de rangschikking van de klasse der visschen. 2 vols. Aruhem, 1851. $8^{\circ}$. 1851.2

Endicott, Charles. A good fishingground in the South Indian ocean. Bull. U. S. Fish Comm. 1886 (1887), 6, 80.

1887.1

Endler, $F . G .$, \& Scholz, $F . P$. Der schlesische Naturfreund; oder, Beiträge zur schlesischen Naturgeschichte. Breslau, 1809-24. col. pls. 4 ${ }^{\circ} \quad 1809.1$

Endlich, Frederic Miller [1851-] An analysis of water destructive to fish in the gulf of Mexico. Proc. U. S. Nat. Mus. 1881 (1882), 4, 124. 1882.1

Engel, Heinrich. Die Zähne am Rostrum der Pristiden. Zool. Jahrb. (Abt. Anat.), 1909, 29, 51-100. 4 pls. \& 2 figs.

1909.1

Engelen, - Die elektrische Narkose bei Fischen. Deutsch. Med. Wochenschr., 1912, 38. Jahrg., 1558. 1912.1

Engelhardt, Robert. Ueber einige neue Selachier-Formen. Zool. Anz., $1912,39,643-648$.

1912.1

Seven new species are described of the following genera: Scapanorhynchus, Pristiurus, Spinax, Centrophorus, Carcharias, Torpedo.

Monographie der Selachier der Münchener zoologischen Staatssammlung (mit besonderer Berücksichtigung der Haifauna Japans) I. Tiergeographie der Selachier. Abh. Bayer. Akad. Wiss, 1913, 4, Abth. 3, 1-110. pl. \& map.

1913.1

Engelmann, Hermann. Zur Zucht des Moderlieschens (Leucaspius delineatus Sieb.) im Aquarium. Wochenschr. Aquar-Terrar. Isunde, 1910, 7. Jahrg., 5ั43. 4 figs.
Engelmann, Theodor Wilhelm [1843 -] Ueber die Function der Otolithen. Zool. Anz., 1887, 10. Jahrg., 439-444.

1887.1

- Blätterschicht der elektrischen Organe von Raja in ihre genetische Beziehungen zur quergestreiften Muskelsubstanz. [n. pl.] 1894. pl. 1894.1

Engelmann, Wilhelm [1808-1878] Verzeichniss der Bücher über Naturgeschichte welche in Deutschland, Scandinavien, Holland, England, Frankreich, Italien und Spanien, in den Jahren 1700-1846 erschienen sind. Leipzig, 1846.

1846.1

Engelmann, Withelm, \& Carus, $J$. Victor. See Carus \& Engelmann.

Engelmann, Wilhelm, \& Enslin, $T h$. Chr. Fr. See Enslin \& Engelmann.

Engmann, P. Dresdner Neujahrsgrüsse [Aquarienfische] Blätt. Aquar.T'errar. Freunde, 1901, 12. Jahrg., 4143. fig.

1901.1

Einiges über die Guramis. Blätt. Aquar.-Terrar. Freunde, 1901, 12. Jahrg., 99-101; 113-115.

1901.2

Zur Fortpflanzung von Geophagus brasiliensis im Aquarium. Blätt. Aquar.-Terrar. Freunde, 1901, 12. Jahrg., $147-149 ; 155-157$.

1901.3

Haplochilus panchax, seine pflege und Zucht. Natur u. Haus, Dresden, 1902, 10. Jahrg., 10t-107.

1902.1

- Sind Geophagus gymnogenys und Geophagus brasiliensis eine Art? Natur u. Haus, Dresden, 1903, 11. Jahrg., 5763.

1903.1

Chromis multicolor, ein neuer Chanchito. Natur u. Haus, Dresden, 1903, 11. Jahrg., 321-323.

1903.2

Ueber Acara caruleopunciata var. latifrons. Wochenschr. Aquar-Terrar. Íunde, 1907, 4. Jahrg., 377-378; 389$390 ; 401-102 ; 413-115$.

1907.1

Centrarchus macropterus (Lacépède), Pfauenaugenbarsch. Wochenschr. Aquar.-Terrar. Kunde, 1908, 5. Jahrg. $577-578 ; 595-596$. fig.

1908.1

Betrachtungen zu W. Köhlers "Untersuchungen über das Schaumnest und den Schaumnestbau der Osphromeniden." Blätt. Aquar--Terrar. Kunde, 1909, 20. Jahrg., 87-91. 1909.1 
Hemichromis bimaculatus Gill. Wochenschr. Aquar-Terrar. Kunde, 1909, 6. Jahrg., 709-711; 721-723. 2 figs.

1909.2

Nordamerikanische Sonnenfische (Centrarchidæ) Biblioth. Aquar.Terrar. Kunde, 1909, 17. Heft. 52 p.

1909.3

Polyacanthus cupanus var. Blätt. Aquar-Terrar. Í unde, 1909, 20. Jahrg. 473-476. 3 figs.

1909.4

Zum. Iiapitel Zwergcichliden. Wochenschr. Aquar.-Terrar. Kunde, 1909, 6. Jahrg., 675-678. fig. 1909.5

Ein neuer Aquarienfisch, Polycentrus schomburgkii Müll. \& Trosch. Blätt. Aquar-Terrar. Kunde, 1910, 21. Jahrg., 409-410; 423-424.

1910.1

Die Cichliden. II. Cichliden der Alten Welt. III. Cichliden der Neuen Velt (In Bibliothek für Aquarien- und Terrarienkunde, 22. Heft. 34 p. pl. \& 4 figs. Braunschweig, 1911) 1911.1

- Nordamerikanische Sonnenfische (Centrarchidæ) (In Bibliothek für Aquarien- und Terrarienkunde, 25. Heft. 39 p. pl. \& 7 figs. Braunschweig, 1911)

1911.2

Streifzüge in der Umgebung von Buenos Aires. II. Einiges über das Freileben des Chanchitos. Wochenschr. Aquar-Terrar. Funde, 1912, 9. Jahrg., $4-7$; 473-475; 492-493. 3 figs. 1912.1

Enniskillen, (Earl of) See Cole, William Willoughby.

Enoch, Carl, \& Fischel, Friedrich. See Fischel \& Enoch.

Enslin, Th. Chr.Fr., \& Engelmann, Wilhelm. Bibliothek der Forst- und Jagd-Wissenschaft; oder, Verzeichniss der in älterer und neuer Zeit, besonders aber vom Jahre 1750 bis gegen Ende des Jahres 1842 in Deutschland erschienenen Bücher uiber alle Theile des Forst- und Jagdwesens, über die Fischerei und den Vogelfang, zuerst herausgegeben von Th. Chr. Fr. Enslin, von neuen gänzlich umgearbeitet von W. Engelmann, nebst einem vollständigen Materienregister. 2. ed. Leipzig, 1843. $8^{\circ}$.

1843.1

Enwald, Reinh. Skulle ej vår allmoge af rudan (Cyprinopsis carassius Linné) kunna draga större nytta än hvad nu är fallet? Fiskeritidskr. Finl., Helsingfors, 1892, 1, 37-40.
Eoff, John. On the habits of the black bass of the Ohio (Grystes fasciatus) Smithson. Rept. 1854 (1855), 289-290.

1855.1

Ephemera, pseudonym for Fitzgibbon, Edward.

Epton, $J$. The migrations and spawning of sea-fish suitable for food. Intern. Fisheries Exhib. Lit., Edinburgh \& London, 1883, 246-252. 1883.1

Erasmo, Geremia d'. Risultati ottenuti dallo studio di alcuni Actinopterigi del calcare cretacico di Pietraroia in provincia di Benevento. Atti Soc. Ital. Progr. Sci., 4. Riunione (Napoli, Dicembre 1910), 1911.

1911.1

Sopra alcuni avanzi di pesci cretacei della provincia di Lecce. Atti R. Accad. Sci. Fis. Mat. Napoli, 1911, 2. ser. 15 , no. $5 . \mathrm{pl}$.

1911.2

-... Appunti sui fossili del monte Libano illustrati da Oronzio Gabriele Costa. Rivișta Ital. Paleontol., 1912, 18, 91-101. pl.

1912.1

- Su alcuni avanzi di pesci triassici nella provincia di Salerno. Atti R. Accad. Sci. Fis. Mat. Napoli, 1914, 2. ser. 16, 1-12. figs.

1914.1

Il Saurorhamphus freyeri Heckel degli scisti bituminosi cretacei del Carso triestino (Comen, Malidol e Vucigrad) Boll. Soc. Adriat. Sci. Nat. Trieste, 1912, 26, pt. 1, 45-88. 2 pls. \& 15 figs. 1912.1

___ La fauna e l' età dei calcari à ittioliti di Pietraroia. Palæontogr. Italica, 1914, 20, 29-86. Ibid., 1915, 21, 1-53. 13 pls. \& 36 figs. $\quad 1914.1$

The Cretaceous fish-fauna of the province of Benevento is described.

Erasmo, Geremia d', \& Bassani, Francesco. Sec Bassani \& Erasmo.

Erchia, Florenzo d'. Contributo allo studio della volta del cervello intermedio e della regione parafisaria in embrioni di pesci e di mammiferi. Monit. Zool. Ital., Firenze, 1896, 7, 75-80; 118-122; 201213. 2 pls.

1896.1

Ercolani, Giovanni Battista [18191883] Sull' ermafroditismo perfetto delle anguille. Mem. Accad. Sci. Bologna, 1871，1，529-552. - Rendiconto, Bologna, 1872, 36-40. Review in Journ. Anat. Physiol., Paris, 9, 111-112. Abstract in Journ. Zool. (Gervais), 1872, 1, 388-393. - Arch. Phys. Nat. Genève, 1872 , n. s. 49, 183. - Ann. Soc. Nat. Modena, 1872, 6, 234-235. $\quad 1871.1$ 
Ercolani, $G . B$.

Intorno all' opuscolo di Holınbaum-Hornschuch, "De anguillarum sexu ac generatione," con alcune ulteriori considerazioni sull' ermafroditismo delle anguille. Ann. Soc. Nat. Modena, 1872, 7, 59-72. Abstract in Journ. Zool. (Gervais), $1872,1,371-373$.

1872.1

- Perfetto ermaphrodisma delle anguille. Bologna, 1872. $\quad 1872.2$

Nuove ricerche sulla placenta nei pesci cartilaginosi e nei mammiferi e delle sur applicazioni alla tassonomia zoologica e all' antropogenia. Mem. Accad. Sci. Bologna, 1879, 10, 601-982. 11 pls. - Rendiconto, Bologna, 1880 , $20-30$.

1879.1

- Della polidactylia e della polimelia nell' uomo e nei vertebrati. Mem. Accad. Sci. Istit., Bologna, 1881, 4. ser. 3, 727-82S. 4 pls. 1881.1

Della polidactvlia, della melomelia e della polimelia nei rettili e di alcune forme di mostruosità con queste correspondenti, asservate negl organi della locomozione nei pesci, p. \$10-82t. pl. \& fig.

Erdl, Michael Pius [1815-1848] Disquisitiones de piscium glandula choroidali. Inaug. Dissert., Munich, 1839. $4^{\circ}$. Abstract in Arch. Anat. (Müller), 1840, clvi.

1839.1

Ueber das Gehirn der Fischgattung Mormyrus. Gelehrte Anz. München, 1846, 23, 403-407. 1846.1

Ueber eine von Herrn Dr. Prunner gemachte Sendung aus egyptischen Amphibien und Fischen bestehend, nebst Bemerkungen über den Bau des Gymmarchus niloticus. Gelehrte Anz. München, 18t6, 23, 590-598. - Notizen (Froriep), $1,38-40$.

1846.2

Ueber Gymnarchus niloticus. Bull. Akad. Wiss. München, 1846, 534542.

1846.3

—-Beschreibung des Skeletes von Gymnarchus niloticus, nebst Vergleichung mit Skeleten formverwandter Fische. Abh. k. Bayer. Akad. Wiss, math.phys. Kl., 1847, 5, 209-252. pl. Also separate; Munich, 1847. 4 1847.1

Observations sur l'appareil pulmonaire des Gymnarchus nilolicus. Ann. Sci. Nat. (Zool.), 1847, 3. sér. 7, 381.

1847.2

Ueber eine neue Form elektrischen Apparates bei Gymmarchus niloticus. Gelehrte Anz. München, 1817, 24, $585-589$.

1847.3
Ergomysev, $N$. Die Stinte des Herbst- und Frühiahrs-Fanges ['Text in Russian] Věst. Rybopromyšl. St. Petersb., 1910, 25, 378-383.

1910.1

Erhard, $(D r.) \longrightarrow$ Fauna der Cycladen. Leipzig, 1858.

1858.1

Erhard, Hubert. Diplosomen und Mitosen im cilientragenden Ependym eines Haifischembryo. Anat. Anz., 1911, 38. Jahrg., 188-190. 3 figs.

1911.1

Erichsen, John. Melemata de piscaturâ et præparatione salmonum, harengorum et aliorum piscium. Scripta Soc. Sci. Islandicæ, Copenhagen, 1781, 3.

1781.1

Ericsson, Bernhard. Bref från Bayern. Fiskeritidskr. Finl., Helsingfors, $1895,4,26-29 ; 36-40$.

1895.1

Utdrag ur "Berittelse öfver Evois fiskeriförsöksstations verksamhet under år 1899." Fiskeritidskr. Finl., Helsingfors, 1900, 9, 17-19. $\quad 1900.1$

- Bericht über die Thätigkeit der Fischereiversuchsstation und der Fischereischule zu Evois im Jahre 1902 ['Text in Swedish] Fiskeritidskr. Finl., Helsingfors, $1903,12,37-47$.

1903.1

- Berättelse öfver Evois fiskeriförsöksstation och fiskeriskolas verksamhet år 1903-06 Bericht über die 'Tätigkeit der Fischereiversuchsstation und der Fischereischule zu Evois in den Jahren 1903-06] Fiskeritidskr. Finl., Helsingfors, 1904, 13, 105-116. Ibid., $1905,14,54-67$. Ibid., 1906, 15, 77-93 Ibid., 1907, 16, 162-178.

1904.1

_._. Sikens och gösens tillvïxt [Der Zuwachs des Coregonus lavarctus und der Lucioperca sandra] Fiskeritidskr. Finl., Helsingfors, 1905, 14, $103 . \quad 1905.1$

Erman, Adolph Georg [1806-1877] Reise um die Erde, durch Nord-Asien und die beiden Oceane in den Jahren 1828,1829 und 1830 ausgeführt; in einer historischen und einer physikalischen Abtheilung dargestellt. 4 vols. Berlin, 1833. $8^{\circ}$ and atlas in fol.

1833.1

Verzeichniss von Thieren und Pflanzen, welche auf einer Reise um die Erde gesemmelt wurden. Berlin, 1835. 1835.1

Erman, Adolph Georg, \& Müller, Johannes. Neue Fische und ichthyologische Bemerkungen. Zeitschr. Zool. (Gistl), 1837, 1, 40-43. 1837.1 
Erman, Paul. Untersuchungen über das Gas in der Schwimmblase der Fische, und über die Mitwirkung des Darmkanals zum Respirationsgeschäfte bei der Fischart Cobitis fossilis (Schlammpitzger) Ann. Physik. (Gilbert), 1808, 30, 113160. - Abh. Akad. Wiss. Berlin, 1808. 1808.1

Ernst, Adolf [-1900] Sobre el embarbascar ó la pesca por medio de plantas venenosas. Carácas, 1881. $8^{\circ}$. 1881.1

Erxleben, Johannus Christianus Polycarpus [1744-1777] Systema regni animalis per classes, ordines, genera, species, varietates cvm synonymia et historia animalivm. Lipsixe, 1777. xlviii, 636 p. 1777.1

-_-Ueber den Nutzen der Schwimmblase bei den Fischen. Abh. Physik. Chem. Naturh., Copenhagen, 1798, 1, 343.

1798.1

Esch, Ernst, Solger, $F$., Oppenheim, M., \& Jaekel, Otto. Beiträge zur Geologie von Kamerun. Herausgegeben im Auftrage und aus Mitteln der Kolonialabteilung des auswärtigen Amts in Berlin von Dr. Ernst Esch. Stuttgart, 1904. 298 p. 9 pls. \& 83 figs. $8^{\circ}$. 1904.1

Fishes by Otto Jaekel.

Eschricht, Daniel Friedrik [17981863] Bemærkninger om fiskenes Ribbeen. Oversigt. Kjobenhavn, 1850, 132-133.

1850.1

Vergleichende Bemerkungen über die Rippen der Fische. Froriep's Tagsber.(Zool.), 1851, 2, no. 319, 110111.

1851.1

Eschricht,DanielFriedrich, \& Müller, Johannes. Ueber die arteriösen und venösen Wundernetze an der Leber, und einen merkwürdigen Bau dieses Organes beim Thunfische (Thynnus vulgaris) Abh. Akad. Wiss. Berlin, 1835, 1-32. Also separate; Berlin, 1836. fol. 1835.1

Ueber die Wundernetze am Darmkanal des Squalus vulpes L., Alopecias vulpes Nob. Abh. Akad. Wiss. Berlin, 1835, 325-339.

1835.2

Eschscholtz, Johann Friedrich von [1793-1831] Zoologischer Atlas, enthaltend Abbildungen und Beschreibungen neuer Thierarten, während des Flottcapitains von Kotzebue . . 1823-1826, p. 11-15. Berlin, 1829. 18 p. pls. fol.

1829.1

Escribano, Cavetano. Sobre el hallazgo del Cetorhinus (Selache) maximus
Gun., cerca de Melilla. Bol. Soc. Españ. Hist. Nat., 1909, 9, 340-342. pl.

Esdaile, (Rev.) D. Contributions to natural history, chiefly in relation to the food of the people. 2.ed. London \& Edinburgh, 1865. 378 p. 8० 1865.1

Esdaile, Philippa $C$. Intensive study of the scales of three specimens of Salmo salar. Mem. Proc. Manchester Liter. Phil. Soc., 1912, 56, pt. 1, no. 3, 1-22. 4 pls. \& 4 figs.

1912.1

- The scientific results of the salmon scale research at Manchester University. Mem. Proc. Manchester Liter. Phil. Soc., 1913, 57, no. 3. 32 p. 10 figs.

1913.1

Esmark, Lauritz. Nogle for Skandinaviens Fauna nye Fiske. Forh. Skand. Naturf., 1844, 4, 230-231. 1844.1

-_- Beskrivelse over en ny Fisheart, Brama raschii Esmark. Forh. Vidensk. Selsk. Christiania, 1861 (1862), 238-247. fig.

1862.1

Bidrag til Finmarkens fiskefauna. Forh. Skand. Naturf., 1S68, 10, 516-529. - Forh. Vidensk. Selsk. Christiania, 1874, 308-310. $\quad 1868.1$

Om den sorte rotte, Mus rattus. Om en for Skandinavien ny dagsommerfugle (Satyrus alcyone) samt om nogle sjeldent forekommende Tusmorkesværmere. Om tvende nye fiske-arter: Argyropelecus elongatus, Maurolicus tripunctulatus. Forh. Vidensk. Selsk. Christiania, 1870 (1871), 13, 486-490.

1871.1

Tillæg til de bidrag til Finmarkens fiskefauna. Forh. Vidensk. Selsk. Christiania, 1874 (1875), 308-310.

1875.1

Espinas, Alfred Victor [1844-] Die thierischen Gesellschaften, übersetzt von IV. Schloesser. Braunschweig, 1879. 561 p. $8^{\circ}$. 1879.1

Essen, Carl Jonathan von. Fisket i Lappo elf. Fiskeritidskr. Finl., 1897, 6, 37-38.

1897.1

Om fiskeriförhållandena i Jeppo. Fiskeritidskr. Finl., 1898, 7, 16. 1898.1

Essing, Lor. Dreissigjähriger Goldfisch. 26. Jahresber. Westphäl. Prov. Ver., 1898, 41.

1898.1

Estcourt, Charles. The bibliography of angling (In Abel Haywood's Anglers' evenings. Manchester $\left[\mathrm{n}, \mathrm{d}_{.}\right]$) 
Estermann, W. Die Wälder [der Gemeinde Neudorf] Jagd und Fischerei. Luzern, 1875. 29 p. $8^{\circ}$.

1875.1

Eter, Paul. Trichogastarlabiosus Day. IVochenschr. Aquar.-Terrar. Kunde, 1913, 10. Jahrg., 697-698. fig. 1913.1

Etheridge (junior), Robert [1820-] On some undescribed Carboniferous fossils (Petalorhynchus) Geol. Mag., 1875, 2. dec. 2, 241-245. pl.

1875.1

Further contributions to Carboniferous palæontology (Fissodus, Oracanthus and Psammodus) Geol. Mag., 1876, 2. dec. 4, 306-309. pl. 1876.1

- Palæontological notes. Geol. Mag., 1878, 2. dec. 5, 269-270. 1878.1 Remarks on a fish species, Megalichthys hibberti.

- [List of fishes in the Palæozoic strata] Quart. Journ. Geol. Soc., 1881, 37, 51-235.

1881.1

On the analysis and distribution of the British Jurassic fossils. Quart. Journ. Geol. Soc., 1882, 38, 46-236.

Includes notice of fossil fishes.

1882.1

Description of fish remains from the Rolling Downs formation of northern Queensland. Proc. Linn. Soc. N. S. Wales, 1888, 2. ser. 3, pt. 1, 156-161. pl. Also separate; Sydney, 1888. $4^{\circ}$.

1888.1

Note on the occurrence of fish remains in the rocks of the Drummond range, central Queensland. Rec. Geol. Surv. N. S. Wales, 1890, 2, pt. 2, 71-72. pl.

1890.1

- Description of the mutilated cranium of a large fish, from the Lower Cretaceous of Queensland. Rec. Austral. Mus., 1905, 6, 5-8. 2 pls.

1905.1

Ichthyodectes marathonensis, $\mathbf{n}$. sp.

The cranial buckler of a dipnoan fish, probably Ganorhynchus, from the Devonian beds of the Murrumbidgee river, New South Wales. Rec. Austral. Mus., 1906, 6, pt. 3, 129-132. pl. 1906.1

Etheridge (iunior), Robert, \& Woodward, Arthur Smith. On the occurrence of the genus Belonostomus in the Rolling Downs formation (Cretaceous) of central Queensland. Trans. Roy. Soc. Victoria, 1892, 2, 1-7. pl.

1892.1

Etzel, Anton von. Die Ostsee und ihre Küstenländer, geographisch, naturwis- senschaftlich und historisch geschildert.

Leipzig, 1859. $8^{\circ}$.

Fishes, p. 265-275.

1859.1

Grönland geographisch und statistisch beschrieben. Stuttgart, 1860. 665 p. $8^{\circ}$.

1860.1

Fish and fisheries, p. 234-259.

Eudes Deslongchamps, Jacques Amand. See Deslongchamps, Jacques Amand Eudes.

Eulefeld, - Ueber den Schlaf von Fischen. Fischerei Zeitg., Neudamm, $1911,14,447-448$.

1911.1

Euphrasen, Bengt Anders. Beskrifning pà trenne svenska fiskar; Gobius muthensparri et Cottus bubalis. Handl. K. Vetensk. Akad., 1786, p.64.-Abh. Neue Schwed. Akad., 1787, p. 62. 1786.1

- Beskrifning på trenne fiskar. Handl. I. Vetensk. Alkad., 1788, p. 51. - Abh. Neue Schwed. Akad., 1789, p. 47.
1. Trichiurus caudatus.
2. Stromateus argenteus.
3. Stromateus chinensis.

- Raja [Etobatis narinari] beskrifven. Handl. K. Vetensk. Akad., 1790, 11, 217-219.

1790.1

Euphrasen's figure of the spotted eagle ray is reproduced by $\mathbf{E}$. W. Gudger, in Pub. no. 183 of the Carnegie Instit. of Washington, 1914.

Scomber atun och Echeneis tropica beskrisne. Handl. K. Vetensk. Akad., 1791, 12, 315.

1791.1

En ny svensk fisk, Gadus lubb, beskrifven. Handl. K. Vetensk. Akad., 1794, 15, 223-226. pl.

1794.1

Beskrifning öfver Svenska vestindiska Ön St. Barthelemi, samt Öarne St. Eustache och St. Christopher. Stockholm, 1795.

1795.1

Reise nach der schwedisch-westindischen Insel St. Bartholemi, und den Inseln-St. Eustache und St. Christoph; oder Beschreibung der ... natürlichen Produkte dieser Inseln. Aus dem Schwedischen von Joh. Georg Lud. Blumhof ... Göttingen, 1798. 308 p. $8^{\circ}$.

1798.1

Descriptions are given of various species of fish.

Eurén, Gustaf Erik. Luonnon oppia. iii. [Pisces] Lukemisia Kansalle, 1859, no. $109.16 \mathrm{p} .12$ figs.

1859.1

Eusebio, J.B.A., \& Bruyant, $C h$. See Bruyant \& Eusebio. 
Euzière, $J_{.,}$\& Grynfellt, $E$. See Grynfellt \& Euzière.

Evans, A. Kelly. The influence of politics upon the work of the fish culturist, and how fish and game protective associations may assist the latter. Also the international problem of the proper regulation of the fisheries of the Great lakes. Trans. Amer. Fisheries Soc. 1907 (1908), $207-217$.

1908.1

Evans, Herbert McLean [1882-] A new cestraciont spine from the Lower Triassic of Idaho. Bull. Geol. Univ. California, 1904, 3, 397-402. pl. 1904.1

Evans, H.Muir. Observations on the poisoned spines of the weever fish (Trachinus draco) Brit. Med. Journ., 1907, 1, 7376. 3 figs. - Trans. Norfolk \& Norwich Nat. Soc., 1907, 8, 355-368. fig. 1907.1

- Further studies in hæmolysis by weever venom. Brit. Med. Journ., 1910, $1,982-984$

1910.1

Evans, Percy Norton [1869-] Air in the depths of the ocean. Science, 1911 , n. s. $34,562-563$.

1911.1

Evans, William. The porbeagle (Lamna cornubica) in the firth of Forth. Ann. Scottish Nat. Hist. 'Soc., 1905, p. 56.

1905.1

The black sea-bream ¡Cantharus cantharus (L.) - Cantharus lineatus (Mont.) $]$ in the firth of Forth. Ann. Scottish Nat. Hist. Soc., 1907, 148-150. fig. 1907.1

The oar-fish, or king of the herrings, Regalecus glesne (Ascan.) $-R$. banksii (Cuv. and Val.), on the coast of east Lothian. Ann. Scottish Nat. Hist. Soc., 1908, 150-154. fig.

1908.1

The deal-fish or vaagmær, Trachypterus arcticus (Brünn.), on the coast of east Lothian. Ann. Scottish Nat. Hist. Soc., 1909, 20-22.

1909.1

Evant, Teodoro d'. Appendici dactiloidi delle Tryglæ. Osservazioni anatomiche e morfologiche. Atti Accad. Med. Chir. Napoli, 1903, 57, no. 2. 50 p. 3 pls.

1903.1

L' epitelio sensitivo dei raggi digitali delle Trygle. Morfologia ed istologia. Giorn. Assoc. Napol. Med. Nat., 1903, 14, 3-29. pl. - Review in Arch. Ital. Biol., 40, 331-332.

1903.2

La formazione amniotica rudimentale di alcuni pesci (selaci) Acqui- coltura Lombarda, Milano, 1904, 6, 239$2 \pm 1$.

1904.1

- Rudimentäre Amnionbildungen der Selachier. Beiträge zur Phylogenie und Entwickelungs-Mechanik des Amnion. Anat. Anz., 1904, 24. Jahrg., 490492.

1904.2

Everard, H.S. C. "Very like a whale." New Illustr. Mag., July, 1898, 263-271.

1898.1

An account of J. von Cube's Ortus Sanitatis, the first edition of which appeared at Metz in 1475. Two illustrations of fishes are reproduced. The original is said to be the first printed book with illustrations of fish and fishing scenes. The next oldest work containing figures of fish is "Dialogues of Creatures Moralysed" " of which an English reprint, edited by Joseph Haslewood, was published in 1816 .

Everett, Warren $H$. Anatomy of the ear of the dog-fish (Galeus canis) Preliminary paper. Trans. N. Y. Acad. Sci., 1896, 15, 176-182. 2 pls. 1896.1

Evermann, Barton Warren [1853-] A list of the fishes observed in the vicinity of Brookville, Franklin county, Indiana. Bull. Brookville Soc. Nat. Hist., 1886, 2, 1-11. 1886.1

A list of the fishes found in Deer creek near Camden, Indiana. Camden, Ind. "Expositor," Dec. 22, 1887. 1887.1

Little fishes in our brooks. Fountain city "Enterprise" (Flora, Carroll co., Indiana), Jan. 7, 1888.

The ichthyologic features of the Black hills region. Proc. Indiana Acad. Sci., 1892, 73-78.

1892.1

-_- Tro-Ocean pass. Proc. Indiana Acad. Sci., 1892, 29-34. pl. - Pop. Sci. Monthly, 47, 175-186. pls. Inland Educator, 2, 299-306. 5 pls.

1892.2

The work of the U.S. fish commission steamer "Albatross" in the north Pacific and Bering sea in 1892. Proc. Indiana Acad. Sci., 1892, 56-57.

1892.3

A reconnaissance of the streams and lakes of western Montana and northwestern Wyoming. Bull. U. S. Fish Comm. 1891 (1893), 11, 3-60. 27 pls.

1893.1

- A report upon investigations made in Texas in 1891. Bull. U. S. Fish Comm. 1891 (1893), 11, 61-90. pls. xxviii-xxxvi. 
Evermann, $B$. W Description of a new sucker, Pantosters jordani. Bull. U. S. Fish Comm. 1892 (1894), 12, 51-56. fig.

1894.1

The investigation of rivers and lakes with reference to the fish environment. Bull. U. S. Fish Comm. 1893 (1894), 13, 69-73.

1894.2

Report upon the advisability of establishing a fish-hatching station in the state of Tennessee. Senate Miscell. Doc. no. 52, 1894, 53. Cong., 2. Sess., $1-3$.

1894.3

Report upon the advisability of establishing fish-hatchery stations at suitable points in Wyoming and the states of South Dakota, Iowa and Nebraska. Senate Miscell. Doc. no. 53, 1894, 53. Cong., 2. Sess., 1-5. 1894.4

-... The work of the United States fish commission and its relation to the farmer. Rept. Indiana Fish Comm. 1893-94 (1S94), 15-25.

1894.5

In the Sawtooth mountains. Amer. Angler, 1895, 25, 285. - Recreation, 5, 135-137; 196-197; 252-253.

1895.1

Description of a new species of shad (Alosa alabama) from Alabama. Rept. U. S. Fish Comm. 1895 (1896), 21, 203-205.

1896.1

- The opah (Lampris Luna) in Monterey bay. Recreation, 1896, 4, 41.

1896.2

A preliminary report upon salmon investigations in Idaho in 1894. Bull. U. S. Fish Comm. 1895 (1896), 15, 253-284.

1896.3

Review of E. T. D. Chambers' "The ouananiche and its Canadian environment." Amer. Angler, 1896, 26, 359-360.

1896.4

- Trouting in Klamath lakes. Recreation, $1896,5,336 . \quad 1896.5$

- Catfish in Louisiana. Recreation, 1897, 7, 56.

1897.1

The fish fauma of Florida. Bull. U. S. Fish Comm. 1896 (1897), 16, 201-208. - Recreation, 12, 292-295. Southern Sportsman, 1899, 2, 9-14.

1897.2

Lake trout from Montana. Recreation, $1897,7,54-55$.

1897.3
Reclaiming the bass from the Potomac river. Recreation, 1897, 6, 283.

1897.4

- A report upon salmon investigations in the headwaters of the Columbia river, in the state of Idaho, in 1895; together with notes upon the fishes observed in that state in 1894 and 1895. Bull. U. S. Fish Comm. 1896 (1897), 16, 149-202. pls. lxvii-lxxii. 1897.5

-... Review of Wr. Furneaux's "Life in pond and stream." Recreation, 1897, 6. 291.

1897.6

- State fish commissioners. Recreation, $1897,6,468$.

1897.7

—U. S. fish commission investigations at Cater lake. Mazama, 1897, 1, 230-238.

1897.8

White and yellow perch. Recreation, $1897,7,178 ; 494$.

1897.9

Crater lake. Recreation, 1S98, 8, 18-20. 2 figs. 1898.1

Crater lake to be a national park. Recreation, 1898, 8, 396. 1598.2

Key to the species of Lucius. Recreation, 1898, 9, 207. 1898.3

Note on the Columbia sturgeon. Recreation, $1898,8,301$. 1898.4

- Note on the loch Leven trout. Recreation, 1898, 8, 465. 1898.5

- Notes on fishes collected by E. IV. Nelson on the Tres Marias islands and in Sinaloa and Jalisco, Mexico. Proc. Biol. Soc. Wash., 1898, 12, 1-3. 1898.6

Streams of eastern Ohio suitable for trout. Recreation, 1S98, 9, 209. 1598.7

Studying western fishes. Recreation, $1898,9,60$. 1898.8

The ling and other fishes of lake Chelan, Washington. Recreation, 1899, $11,371-372$.

1899.1

A note on Roccus lineatus, Roccus chrysops, and Morone intermipta. Recreation, 1899, 11, 287-288. 1899.2

- Note on a specimen of the molffish, Alepisaurus asculapias. Recreation, $1899,11,373$.

1899.3

Report on investigations by the U. S. fish commission in Mississippi, 
Louisiana and Texas in 1897. Rept. U. S. Fish Comm. 1898 (1899), 24, 285310. 29 pls.

1899.4

Review of David Starr Jordan's "Manual of vertebrates." Recreation, $1899,11,397$.

1899.5

Review of Sir Edward Grey's "Fly fishing." Recreation, 1899, 11, 322.

1899.6

Best bait for bass, - answer to question. Recreation, 1900, 12, 210.

1900.1

Catfish in dry weather, - answer to question. Recreation, 1900, 12, 209-210.

1900.2

Description of two new species of darters from lake Maxinkuckee, Indiana. Rept. U. S. Fish Comm. 1899 (1900), 25, 363-367. pl. 1900.3

- Fish parasites, an answer to queries. Recreation, 1900, 12, 375-376.

1900.4

- A good fishing ground. Recreation, $1900,12,209$.

1900.5

Parasites in fishes, - answer to question. Recreation, 1900, 12, 207-208.

1900.6

- Peculiar trout, - answer to question. Recreation, 1900, 12, 210. 1900.7

Some observations concerning species and subspecies. Science, 1900, n. S. $11,451-455$.

1900.8

- Bait minnows. 6. Ann. Rept. Forest, Fish, Game Comm. New York, 1900 (1901), 307-352. 3 pls. \& figs.

1901.1

- Investigations of the United States fish commission steamer "Albatross." Current Encyclopedia, 1901, 1, 689-693. 3 figs.

1901.2

- The United States fish commission. Current Encyclopedia, 1901, 1, 457-461. 6 figs.

1901.3

- The American species of shad. Abstract in Science, 1902, n. s. 15, 1032. 1902.1

- Answer to query as to fish living in warm water. Recreation, 1902, 17, 457.

1902.2

Answer to query as to food for shiners when kept in confinement for winter fishing. Recreation, 1902, 17, 458.
Bait for large-mouthed black bass. Recreation, 1902, 17, 210. 1902.4

Description of a new species of shad (Alosa ohiensis) with notes on other food-fishes of the Ohio river. Rept. U. S. Fish Comm. 1901 (1902), 27, 273-288. 6 pls.

1902.5

- Facts about the eel. Recreation, 1902, 16, 222 . 1902.6

The fishes of Samoa. Sports Afield, 1902, 29, 70. $\quad 1902.7$

Fishes of the Great lakes. Sports Afield, 1902, 29, 70. 1902.S

General report on the investigations in Porto Rico of the U. S. fish commission steamer "Fish Hawk" in 1899. Bull. U. S. Fish Comm. 1900 (1902), 20, pt. 1, 1-26. 1902.9

Hawailan island fisheries. Sports Afield, 1902, 29, 273. 1902.10

Lake Mashipacong. Recreation, 1902, 16, 291-293. 1902.11

- The large-mouth black bass, answer to a query. Recreation, 1902, $17,457$.

1902.12

- List of species of fishes known to occur in the Great lakes or their connecting waters. Bull. U. S. Fish Comm. 1901 (1902), 21, 95-96. 1902.13

The mystery of the salmon. Outing, $1902,43,562-568$. 1902.14

The native fishermen of Hawaii. Outing, 1902, 43, 660-667. 7 figs.

1902.15

Nerka, the blueback salmon. World Today, 1902, 3, 2221-2228. 9 pls.

1902.16

A new species of shad. Sports Afield, 1902, 29, 63-66. 3 pls. 1902.17

- A new species of shad from the Ohio river. Forest \& Stream, 1902, 58, 408-409. 6 pls. 1902.18 Note on the bonefish. Forest \& Stream, 1902, 58, 347. 1902.19 Note on the carp. Amer. Agricult., Sept., 1902. 1902.20

Pike, pickerel, muscalonge. Forest \& Stream, 1902, 59, 193. $\quad 1902.21$

- Probably parasites, - answer to query. Recreation, 1902, 16, 375.

1902.22 
Evermann, $B . W$.

A salmon mystery. Sports Afield, 1902, 29, 158.

1902.23

Strange fishes of the deep sea. World Today, 1902, 2, 1398-1406. 18 pls.

1902.24

Summary of the scientific results of the fish commission expedition to Porto Rico. Bull. U. S. Fish Comm. 1900 (1902), 20, pt. 1.

1902.25

Where to get small-mouthed black bass, - answer to a query. Recreation, 1902, 17, 210.

1902.26

The cutthroat trout iSalmo clarkii] and its relatives. Country Life in America, 1903, 4, 130. fig. 1903.1

- Statistics of the fisheries of the Middle Atlantic states. Rept. U. S. Fish Comm. 1902 (190t), 28, 433-540.

1904.1

- The bureau of fisheries. San Francisco Trade Journ., 1904, 14, 76SS. 11 figs. - Nation. Geog. Mag., $1904,15,191-212.14$ figs. $\quad 1904.2$

The golden trout of Mt. Whitney. Science, 1904, n. s. 20,61. 1904.3

- The golden trout of Volcano creek. Amer. Fish Culturist, 1904, 1, 5-6. - Trans. Amer. Fish. Soc. 1904 (1905), 148-154.

1904.4

- How to study a lake. Sports Afield, 1904, 126-128.

1904.5

- [Review of ] fish [legislation for 1903] Univ. State N. Y., N. Y. State Library, Review Legislation, 1903 (1904), $18-20$.

$190 \pm .6$

The Salmonidx and Thymallidx of Alaska. Abstract in Science, 1904, n. s. $19,216-217$.

1904.7

.... The United States bureau of fisheries. Pacific Fisherman, 1904, 2, 16-18. 3 pls.

1904.8

The bluegill as a game fish. Shields' MIag., 1905, 1, 335-336. 1905.1

The eggs of the eel. Shields' Mag., 1905, 1, 337. 1905.2

- Review of The freshwater fishes of Mexico, north of the isthmus of Tehuantepec, by Seth Eugene Meek! Shields' Mag., 1905, 1, 352. 1905.3

Introduction of Coho salmon into rivers of Maine. Shields' Mag., $1905,1,337$.
- The most beautiful of all the trouts. Shields' Mag., 1905, 1. 1905.5

- A note calling attention to a mistake by C. F. Holder regarding the fallfish. Shields' Mag., 1905, 1, 411 .

1905.6

- Notice of Prof. Reighard's paper on the breeding habits of the smallmouth black bass. Shields' Mag., 1905, 1, 427. Ibid., 1906, 2, 70. 1905.7

Report of inquiry respecting food-fishes and the fishing grounds. Rept. Bur. Fisheries, 1904 (1905), 81120.

1905.8

- Report of the division of statistics and methods of the fisheries. Rept. U. S. Fish Comm. 1903 (1905), 29, 101-122.

1905.9

- A review of Jordan's "A guide to the study of fishes." Shields' Mag., 1905, 1, 180. - Sports Afield, 1905, 226. 1905.10

- Salmon hatcheries in Alaska. Shields' Mag., 1905, 1, 337. 1905.11

- The spawning time of trout, -answer to a query by S. McDowall, entitled "An interesting trout query." Sports Afield, 1905, 34, 546. 1905.12

Stocking a home stream or pond with trout. Country Life in America, $1905,7,659-663$. 7 figs.

1905.13

Trying to save the grayling. Shields' Mag., 1905, 1, $335 . \quad 1905.14$

- The Argentinidæ. Shields' Mag., $1906,3,46$. 1906.1

The Chautauqua muskallunge. Forest \& Stream, 1906, 67, 828. 1906.2

- Distribution of bluefish. Shields' Mag., 1906, 3, 119.

1906.3

Explorations in Japanese waters. Shields' Mag., 1906, 2, 191. 1906.4

Fish culture in Guatemala. Shields' Mag., 1906, 2, 253-254. 1906.5

Florida a great fish state. Shields' Mag., 1906, 2, 112-113. 1906.6

The golden trout of the southern high Sierras. Bull. Bur. Fisheries, 1906, 25, 1-51. 14 pls. \& map. 1906.7

The graylings. Shields' Mag., $1906,2,191$. 1906.8 
How to stock a pond. Shields' Mag., 1906, 3, 117. 1906.9 - A native of the tropics. Shields' Mag., 1906, 2, 77.

1906.10

- Note on collecting fishes on the east coast of Florida. Shields' Mag., $1906,2,70$.

1906.11

Notice of capture of Chinook salmon in Sunapee lake] Science, 1906, n. s. 24,850 .

1906.12

Shad decreasing rapidly. Shields' Mag., 1906, 3, 184.

1906.13

- The story of the golden trout. Country Life in America, 1906, 10, 212.

1906.14

Surf-fishing on the east coast of Florida. Shields' Mag., 1906, 2, 113.

1906.15

Angling notes from Washington,

D.C. Shields' Mag., 1907, 4, 45. 1907.1

Buffalo fish in lake Maxinkuckee. Shields' Mag., 1907, 4, 332. 1907.2

Chinook salmon in Sunapee lake. Shields' Mag., 1907, 4, 122-123. 1907.3

Fishes of the Philippine islands. Shields' Mag., 1907, 4, 262. 1907.4

The large-mouth black bass. Shields' Mag., 1907, 4, $196 . \quad 1907.5$

Steelhead trout in Michigan. Shields' Mag., 1907, 4, $44 . \quad 1907.0$

United States bureau of fisheries investigations in Kamchatkan and Japanese waters. Shields' Mag., 1907, 4, 125.

1907.7

Descriptions of a new species of trout (Salmo nelsoni) and a new cyprinodont (Fundulus meeki) with notes on other fishes from lower California. Proc. Biol. Soc. Washington, 1908, 21 , 19-30. pl. \& fig.

1908.1

The singing fishes. Shields' Mag., 1909, 8, no. 6, 261.

1909.1

The international fisheries commission. Trans. Amer. Fisheries Soc. 1909 (1910), 53-57.

1910.1

Alaska fisheries and fur industries in 1911. Rept. U. S. Comm. Fisheries, 1911 , no. $766,1-78$.

1911.1

F. M. Chamberlain also assisted in the General Administrative Report.

Alaska fisheries and fur industries in 1911. U. S. Bureau Fisheries, 1912, Doc. no. 766, 1-99.
Fishery and fur industries of Alaska in 1912. U. S. Bureau Fisheries, 1913, Doc. no. 780, 1-123. 1913.1

- How long will fish live out of water? Forest \& Stream, 1913, 80, 79.

1913.2

Alaska fisheries and fur industries in 1913. U. S. Bureau Fisheries, 1914, Doc. no. 797, 1-172.

1914.1

Evermann, Barton Warren, \& Bean, Barton $A$. Indian river and its fishes. Senate Miscell. Doc. no. 46, 1896, 54. Congr., 2. Sess., 5-26. 37 pls. - Rept. U. S. Fish Comm. 1896 (1898), 22, $227-$ 262. $36 \mathrm{pls}$.

1896.1

Evermann, Barton W., \& Bollman, Charles Harvey. Notes on a collection of fishes from the Monongahela river. Proc. N. Y. Acad. Sci., 1886, 335-340.

1886.1

Evermann, Barton $W^{\gamma}$, \& Clark, $H$. IValton. New fishes from Santo Domingo. Proc. U. S. Nat. Mus., 1906, $30,851-855$. 3 figs.

1906.1

Lake Cicott, Indiana, and notes on its flora and fauna. Proc. Biol. Soc. Washington, 1908, 21, 213-218. pl.

1908.1

Fletcher lake, Indiana, and its flora and fauna. Proc. Biol. Soc. Washington, 1910, 23, 81-88. fig. 1910.1

Evermann, Barton Warren, \& Cockerell, Theoidore $D . A$. Descriptions of three new species of cyprinoid fishes. Proc. Biol. Soc. Washington, 1909, 22, 185-188. fig.

1909.1

Evermann, Barton Warren, \& Cox, Ulysses 0 . The fishes of the Neuse river basin. Bull. U. S. Fish Comm. 1895 (1896), 15, 303-310. 1896.1

Report upon the fishes of the Missouri river basin. Rept. U. S. Fish Comm. 1894 (1896), 20, 325-429. 1896.2

Evermann, Barton W. \& Fordice, Morton $W$. List of fishes collected in Harvey and Cowley counties, Kansas. Proc. Acad. Nat. Sci. Philad. 1885 (1886), 412. - Bull. Washburn College Lab. Nat. Hist., 1886, 1, 184-186.

1886.1

Evermann, Barton Warren, \& Gilbert, Charles H. See Gilbert \& Evermann.

Evermann, Barton Warren, \& Goldsborough, Edmund Lee. Notes on some 
Evermann \& Goldsborough.

Mexican fishes. Science, 1902 , n. s. 15, $746-747$.

1902.1

Notes on the fishes and mollusks of lake Chautauqua, New York. Rept. U. S. Fish Comm. 1901 (1902), 27, 169175. - Rept. N. Y. Forest, Fish \& Game Comm., 1900, 357-366. pl.

1902.2

Report on fishes collected in Mexico and Central America, with notes and descriptions of five new species. Bull. U. S. Fish Comm. 1901 (1902), 21, 137-159. 8 figs.

1902.3

Description of a new rock-fish of the genus Sebastodes from California. Proc. U. S. Nat. Mus., 1906, 31, 651-652. fig.

1906.1

The fishes of Alaska. Bull. Bur. Fisheries, 1906, 26, 219-360. 28 pls. \& 114 figs.

1906.2

A check-list of the freshwater fishes of Canada. Proc. Biol. Soc. Washington, 1907, 20, 89-120.

1907.1

Notes on some fishes from the Canal zone. Proc. Biol. Soc. Washington, 1909, 22, 95-104. 3 figs. 1909.1

Further notes on fishes from the Canal zone. Proc. Biol. Soc. Washington, $1910,23,3-6$.

1910.1

Evermann, Barton Warren, \& Hildebrand, Samuel Frederick. On a collection of fishes from the lower Potomac, the entrance of Chesapeake bay, and from streams flowing into these waters. Proc. Biol. Soc. Washington, 1910, 23, $157-161$

1910.1

Evermann, Barton Warren, \& Jenkins, $0 . P$. Description of eighteen new species of fishes from the gulf of California. Proc. U. S. Nat, Mus. 1888, 137-158.

1888.1

Notes on Indiana fishes. Proc. U. S. Nat. Mus., 1888, 43-57. 1888.2

Report upon a collection of fishes made at Guaymas, Sonora, Mexico, with descriptions of new species. Proc. U. S. Nat. Mus., 1891, 121-165. 2 pls.

1891.1

Evermann, Barton Warren, \& Jordan, David Starr. See Jordan \& Evermann.

Evermann, Barton $W_{\text {. \& \& Kendall, }}$ William Converse. The fishes of
Texas and the Rio Grande basin, considered chiefly with reference to their geographic distribution. Bull. U. S. Fish Comm. 1892 (1894), 12, 57-126. 31. pls.

1894.1

A list of the fishes known from the vicinity of Neosho, Missouri. Bull. U. S. Fish Comm. 1894 (1895), 14, 469472 .

1895.1

- An annotated list of the fishes known from the state of Vermont. Rept. U. S. Fish Comm. 1894 (1896), 20, 579604 .

1896.1

Description of a new species of pipefish, Siphostoma scovelli, from Texas, Proc. U. S. Nat. Mus. 1895 (1896), 113-115.

1896.2

- Descriptions of new or little known genera and species of fishes from the United States. Bull. U. S. Fish Comm. 1897 (1898), 17, 125-133. 4 pls. 1898.1

Check list of the fishes of Florida. Rept. U. S. Fish Comm. 1899 (1900), 25, 35-103.

1900.1

- Notes on the fishes of lake Ontario. 6. Ann. Rept. N. Y. Forest, Fish \& Game Comm. 1900 (1901), 479-488. - Rept. U. S. Fish Comm. 1901 (1902), 27, 209-216.

1901.1

An annotated list of the fishes known to occur in lake Champlain and its tributary waters. Rept. U. S. Fish Comm. 1901 (1902), 27, 217-226. 1902.1

- An annotated list of the fishes known to occur in the St. Lawrence river. Rept. U. S. Fish Comm. 1901 (1902), 27, 227-240.

1902.2

An interesting species of fish from the high Andes of central Ecuador. Proc. Biol. Soc. Washington, 1905, 18, 91-105. 2 figs.

1905.1

- Notes on a collection of fishes from Argentina, South America, with descriptions of three new species. Proc. U. S. Nat. Mus., 1906, 31, 67-108. 4 figs.

1906.1

Notes on a pipefish from the mid-North Atlantic. Proc. Biol. Soc. Washington, 1908, 21, 207-210. pl. i908.1

A comparison of the chub-mackerels of the Atlantic and Pacific oceans. Proc. U. S. Nat. Mus., 1910, 38, 327328. 
Evermann, Barton Warren, \& Latimer, Homer Barker. The fishes of the lake of the IVoods and connecting waters. Proc. U.S. Nat. Mus., 1910, 39, 121-136.

1910.1

On a collection of fishes from the Olympic peninsula, together with notes on other west coast species. Proc. Biol. Soc. Washington, 1910, 23, 131-140.

1910.2

Evermann, Barton Warren, \& Marsh, Millard Caleb. Descriptions of new genera and species of fishes from Puerto Rico. Rept. U. S. Fish Comm. 1898 (1899), 24, 351-362.

1899.1

The fishes of Porto Rico. Bull. U. S. Fish Comm. 1900 (1902), 20, pt. 1 , 51-350. pls. i-xlix.

1902.1

- Porto Rico, its fishes and fisheries. Current Encyclopedia, 1902, 2, 1274-1279. 8 figs.

1902.2

- Some strange ocean fishes. World Today, 1902, 3, 1800-1805. 10 pls.

1902.3

Evermann, Barton W., \& Meek, Seth $E$. A review of the species of Gerres found in American waters. Proc. Acad. Nat. Sci. Philad., 1883, 116-124. 1883.1

- A revision of the American species of the genus Gerres. Proc. Acad. Nat. Sci. Philad., 1886, 256-272. 1886.1

A report upon salmon investigations in the Columbia river basin and elsewhere on the Pacific const in 1896. Bull. U. S. Fish Comm. 1897 (1898). 17, 15-84. 8 pls. Also separate; Washington, 1897. $4^{\circ}$.

1898.1

Evermann, Barton Warren, \& Nichols, John Treadwell. Notes on the fishes of Crab creek, Washington, with description of a new species of trout. Proc. Biol. Soc. Washington, 1909, 22, 91-94. 2 pls.

1909.1

Evermann, Barton Warren, \& Radcliffe, Lewis. Notes on a cyprinodont (Orestias agassizii) from central Peru. Proc. Biol. Soc. W Washington, 1909, 22, $165-170$.

1909.1

Evermann, Barton Warren, \& Rutter, Cloudsley. The fishes of the Colorado basin. Bull. U. S. Fish Comm. 1894 (1895), 14, 473-486.

1895.1

Evermann, Barton Warren, \& Scovell, Josiah Thomas. The fishes of the Missouri basin. Proc. Indiana Acad. Sci., $1895,126-138$.

1895.1
Recent investigations concerning the redfish, Oncorhynchus nerka, at its spawning grounds in Idaho. Proc. Indiana Acad. Sci., 1895, 131-134.

1895.2

Evermann, Barton Warren, \& Seale, Alvin. Fishes collected in the Philippine islands by Major Edgar A. Mearns, Surgeon, U. S. Army. Proc. U. S. Nat. Mus., 1906, 31, 505-512. 4 figs. 1906.1

Fishes of the Philippine islands. Bull. Bur. Fisheries, 1906 (1907), 26, 49-110. 22 figs.

1907.1

Evermann, Barton W., \& Smith, Hugh $M$. The whitefishes of North America. Rept. U. S. Fish Comm. 1894 (1896), 20, 283-324. 18 pls. 1896.1

Evermann, Barton Warren, Wilcox, W. A., \& Bean, Barton A. See Bean, Evermann \& Wilcox.

Evers, $M$. Zur Charakteristik des Stichlings (Gasterosteus aculeatus) Jahresber. Naturw. Ver. Elberfeld, 1878, 5. Heft, 26-46. - Isis (Russ), 1879, 4. Jahrg., 225-226; 233-234; 241-242; $249-250 ; 257-259$. Also separate; Elberfeld, 1878 . $8^{\circ}$.

1878.1

Nesterbau und Brutpflege der Stichlinge. Isis (Russ), 1879, 4. Jahrg., $125-126 ; 133-134 ; 141-142 ; 149-150$; $157-158$. 1879.1

Beobachtungen am Stichling. Abstract in Corresbl. Naturf. Ver. Riga, 1850, 23. Jahrg., 129-134.

1880.1

Eversmann, Eduard Friedrich [17941860] Addenda ad Pallasii zoographiam Rosso-Asiatiam in tres partes. Casani, $1835-12$.

1835.1

A facsimile reprint of this work, which was destroyed by fire, was published at London in 1875 by H. E. von Dresser.

Ewald, August. Ueber den Modus der Nervenverbreitung im elektrischen Organ und die Bedeutung desselben für die Physiologie der Entladung des Organs. Heidelberg, 1881.15 p. 1881.1

Ewald, August, \& Krukenberg, $C$. $F$. W. Ueber die Verbreitung des Guanin, bis über sein Vorkommen in der Haut von Amphibien, Reptilien und Petromyzon fuviatilis. Untersuch. Physiol. Instit., Heidelberg, 1882, 4, 3. Heft 353-365.

1882.1

Ueber Besonderheiten der Guaninablagerung bei Fischen. Zeitschr. Biol., 1883, 19, 154-158. 1883.1 
Ewald, $J$. Ueber Menaspis, eine neue fossile Fischgattung. Ber. Akad. Wiss. Berlin, 1848, 33-35. - Arch. Mineral. (Karsten), 1848, 22, 655-657.

1848.1

Ewald, Wolfgang $F$. Die Fortnahme des häutigen Labyrints und ihre Folgen beim Flussaal (Anguilla vulgaris) Arch. Ges. Physiol., 1907, 116, 186-192.

1907.1

Ewart, James Cossar [1851 - ] Note on the abdominal pores and urogenital sinus of the lamprey. Journ. Anat. Physiol., London, 1876, 10, 488-493.

1876.1

On vascular peribranchial spaces in the lamprey. Journ. Anat. Physiol., London, 1878, 12, 232-236.

1878.1

The early history of the herring. Nature, 1883, 29, 105-107. 1883.1

Natural history of the herring. Rept. Scottish Fisheries, 1884, 2, Append. F, no. 4, 61-72. 5 pls. $\quad 1884.1$

Note on deserted spamning grounds of the herring. Proc. Roy. Soc. Edinb., 1854, 270-273.

1884.2

On the natural and artificial fertilisation of herring ova. Proc. Roy. Soc. London, 1884, 36, 450-461. - Bull. U. S. Fish Comm. 1884, 4, 193-197. Nature, 29, 538-540. Extract in Journ. Roy. Micr. Soc., 2. ser.4, 862. 1884.3

On the rigor mortis in fish and its relation to putrefaction. Proc. Roy. Soc. London, 1857, 42, 438-459. 1887.1

The preservation of fresh fish. Bull. U. S. Fish Comm. 1886 (1887), 6, 65-75.

1887.2

The electric organ of the skate. The electric organ of Raia radiata. Phil. Trans. Roy. Soc. London, 1888, 179B, 539-552. 2 pls. Abstract in Proc. Roy. Soc. London, 1888, 44, 308310 .

1888.1

The electric organ of the skate. On the development of the electric organ of Raia batis. Phil. Trans. Roy. Soc. London, 1888, 179B, 399-416. 2 pls. Abstract in Proc. Roy. Soc. London, 1888, 44, 120-121.

1888.2

On the hatching of herring ova in deep water. Proc. Roy. Soc. Edinb., 1888, 9, 47-54.

1888.3

On the presence of bacteria in the lymph, etc., of living fish and other vertebrates. Proc. Roy. Soc. Edinb. 1888, 9, 262-270.

1888.4

- On the structure of the electric organ of Raia circularis. Phil. Trans. Roy. Soc. London, 1888, 179B, 410-116. pl. Abstract in Proc. Roy. Soc. London, 1888, 44, 213-214.

1888.5

- On whitebait. Proc. Roy. Soc. Edinb., 1888, 9, 78-81.

1888.6

On the cranial nerves of elasmobranch fishes. Preliminary communication. Proc. Roy. Soc. London, 1889, 45, 524-537.

1889.1

- The cranial nerves of the torpedo. Preliminary note. Proc. Roy. Soc. London, 1890, 47, 290-291, 1890.1

On the development of the ciliary or motor oculi ganglion. Proc. Roy. Soc. London, 1890, 47, 287-290. 1890.2

On the spiracles of the porbeagle shark (Lamna cornubica) Journ. Anat. Physiol., London, 1890, 24, 227-229. is90.3

On the occurrence of the anchovy (Engraulis encrasicholus) in Scottish waters. Proc. Roy. Soc. Edinb., 1891, 10, 333.

1891.1

The electric organ of the shate. Observations on the structure, relations, progressive development, and growth of the electric organ of the skate. Phil. Trans. Roy. Soc. London, 1892, 183B, 389-420. 5 pls. Abstract in Proc. Roy. Soc. London, 50, 474-476.

1892.1

Collected papers on electrical and lateral sense organs. Edinburgh, 1893. $3 \mathrm{p}$. 1893.1

- The electric organ of the skate. Note on an electric centre in the spinal cord. Proc. Roy. Soc. London, 1893, 53, 388-391. 4 figs.

1893.2

The electric organ of the skate. Observations on the structure, relations, progressive development, and growth of the electric organ of the skate. Phil 'Trans. Roy. Soc. London, 1S93, 183B, $389-420.5$ pls.

1893.3

Ewart, James Cossar, \& Brook, George. Observations on the spanning of the cod. Rept. Fish. Board Scotland, 1855, Append. F, 52-55. - Journ. Roy. Micr. Soc., 5, 786.

1885.1

Ewart, James Cossar, \& Cole, $i$. $J$. On the dorsal branches of the cranial 
and spinal nerves of elasmobranchs. Proc. Roy. Soc. Edinb., 1895, 20, 475480. 2 figs.

1895.1

Ewart, James Cossar, Gibson-Maitland, James Ramsay, \& others. The early history of the herring. Preliminary report of the investigation committee of the fishery board of Scotland. Nature, 1884, 29, 105-107.

1884.1

Ewart, James Cossar, \& Matthews, $J . D$. The dissection of the skate. Edinburgh, 1885. $4^{\circ}$. 1885.1

Ewart, James Cossar, \& Mitchell, $J . C$. The lateral sense organs of elasmobranchs. I. The sensory canals of Lxmargus. II. The sensory canals of the common skate (Raia batis), by J. C. Ewart and J. C. Mitchell. Trans. Roy. Soc. Edinb., 1895, 37, 59-105. 3 pls. Abstract in Zool. Anz., 15, 116-120.

1895.1

Ewbank, Thomas [1792-1870] A visit to the land of the cocoa and the palm. Harper's New Monthly Mag., $1853,7,721-745$. fig.

1853.1

Flying-fish, p. 724.

Exner, Sigmund [1846-] Ueber das Sehen von Bewegungen und die Theorie des zusammengesetzten Auges. Sitzber. k. Akad. Wiss., Wien, 1875 (1876), 72, 3. Abth., 156-190. pl.

1876.1

Exner, Sigmund, \& Januschke, Hans. Ueber Verschiebung der Tapetummasse im Choreoidealepithel unter dem Einflusse des Lichtes in Abramis brama] Zentralbl. Physiol., 1905, 19, $327-328$.

1905.1

Das Verhalten des Guanintapetums von Abramis brama gegen Licht und Dunkelheit. Anz. Akad. Wiss. Wien (math.-nat. Cl.), 1905, 42. Jahrg., 248-268. - Sitzber. Akad. Wiss. Wien, 114, 3. Abth., 693-714. pl. 1905.2 See also under Januschke \& Exnev.

- Die Stäbchenwanderung im Auge von Abramis brama bei Lichtveränderungen. Anz. Akad. Wiss. Wien (math.-nat. Cl.), 1906, 43. Jahrg., 243-244. - Sitzber. Akad. Wiss. Wien, 115, 3. Abth., 269-286. 4 figs. 1906.1

Eycleshymer, Albert Chauncey $[1867$ -] The early development of Amblystoma, with observations on some other vertebrates. Journ. Morph., 1895, 10, 343-418. 5 pls.

1895.1

- The cleavage of the egg of Lepidosteus osseus. Anat. Anz., 1899, 16. Jahrg., 529-536. 5 figs.
Observations on the breeding habits of Ameiurus nebulosus. Amer. Naturalist, 1901, 35, 911-918. 1901.1

The formation of the embryo of Necturus, with remarks on the theory of concrescence. Anat. Anz., 1902, 21. Jahrg., 341-353.

Some references to teleostean embryos.

The early development of Lepidosteus osseus [with bibliography] Publications Univ. Chicago, 1903, 10, 259275. 2 pls.

1903.1

Eycleshymer, Albert Chauncey, \& Davis, Bradley Moore. The early development of the epiphysis and paraphysis in Amia. Journ. Comp. Neurol., 1897, 7, 45-70. pl. 1897.1

Eycleshymer, Albert Chauncey, \& Whitman, C. O. See Whitman \& Eycleshymer.

Eycleshymer, Albert Chauncey, \& Wilson, James Meredith. The gastrulation and embryo formation in Amia calva. Amer. Journ. Anat., 1906, 5, 132162. 4 pls.

1906.1

The adhesive organs of Amia. Biol. Bull. Woods Hole, 1908, 14, 134 148. 2 pls.

1908.1

Eydoux, Joseph Fortuné Théodore, \& Gervais, $F$. L. $P$. Voyage autour du monde de la corvette de S. M. "La Favorite," exécuté pendant les années 1830 , 1831,1832 sous le commandement de M. Laplace. Paris, 1836-39. 1836.1

—_ Voyage de "La Favorite." Poissons. Echeneis sexdecim-lamellata et Syngnathus blainvilleanus. Mag. Zool., 1837, 7. année, Cl. iv, 1-4. 2 pls. 1837.1

Eydoux, Joseph Fortuné Théodore, \& Souleyet, F.L.A. Voyage autour du monde exécuté pendant les années 1836 et 1837 sur la corvette "La Bonito." Paris, 1841.

1841.1

Poissons, vol. i, p. 157-215. $10 \mathrm{pls}$.

Eynard, L. Première contribution à la faune des Cladocères des étangs de Nantoin (Isère) Ann. Univ. Grenoble, 1912, 24, 171-178.

1912.1

Eyrich, George C. "Grindle" fishing in Mississippi. Forest \& Stream, $1877,7,365$.

On Amia calva.

1877.1

Eyrich, Louis. Ueber die Fortpflanzungsweise eines Fisches aus China. Zool. Garten, 1870, 11, 66-67. 1870.1 
F., A. Oar-fish Regalecus banksii in St. Andrews bay. Sci. Gossip, 1880, 16, 160.

1880.1

F., B.E. A good idea for fish transportation. Amer. Sportsman, 1873, 3, 123.

1873.1

F., C.A. California trout [caught in the Genesee river, N. Y.]. Forest \& Stream, 1880, 14, 491.

1880.1

F., D. Curiosity or jealousy of black bass. Forest \& Stream, 1878, 10, 466.

1878.1

F., E. H. Baits for bass. Forest \& Stream, 1878, 9, 491.

1878.1

F., G. What do we know of the fish we catch? Fishing Gazette, 1879, 3, 85-86.

1879.1

F., G.A. Fish in the hot springs of Nevada. Scient. Amer., 1875, 30, 148 149.

1875.1

F., H. Der Hecht im Rhein. Schweiz. Fischerei-Zeitg., 1897,5. Jahrg., no. 21,210 . 1897.1

F., W.W. Habitat of smelts. Forest \& Stream, 1878, 11, 361.

1878.1

Fabani, $C$. Un bel caso di monstruosita riscontrato in una trota. Boll. Natur. Siena, 1897, 17, 42 . 1897.1

Faber, Friedrich [1795-1828] Kort efterretning om en zoologisk reise til del nordligste Jylland i sommeren 1827. Tidskr. Naturvid. Kjobenhavn, 1828, $\mathbf{5}$.

1828.1

- Naturgeschichte der dänischen Schollen. Isis (Oken), 1828, 861-899. - Bull. Sci. Nat. (Férussac), 19, 369373.

1828.2

- Om ejebyeg jedden ‘Cyprinus jeses] 'Tidsskrift (Oerstedt), 1828, 5, $51-57$.

1828.3

Om to lidet bekjendte danske torske-arter [Gadus lycostomus et luscus] Tidsskrift (Oerstedt), 182S, 5, 215-222. - Bull. Sci. Nat. (Férussac), 15, 308309.

1828.4
- Naturgeschichte der Fische Is-

lands. Frankfurt-a.-M., 1829. $4^{\circ}$.

- Ichthyologische Beiträge. Die Gattung Pleuronectes. Arch. Naturg., $1840,1,18-34$. - Isis (Oken), 1841, $449-451$

1840.1

Faber, George Louis. The fisheries of the Adriatic and the fish thereof. A report of the Austro-Hungarian sea fisheries, with a detailed description of the marine fauna of the Adriatic gulf. London, 1883. 292 p. 42 pls. $4^{\circ} .1883 .1$

Fabre, G., \& Depëret, Charles. Liste des vertébrés fossiles de l'Eocène supérieur (étage Ludien) du gisement des Baruques d'Enzet (Gard) Bull. Soc. Etude Sci. Nat. Nimes, 1900, 27, p. xxiv. 1900.1

Fabre-Domergue, $P .[1861-]$ Le régime de la sardine. Programme pour le déterminer. Rev. Gén. Sci., Paris, $1897,7,429-432$.

1897.1

Comment on pêche la sardine. La Nature, 1913,41 , pt. 1, 65-67. 4 figs.

Fabre-Domergue, $P$. \& Biétrix, Eugène. Sur les oufs et les alevins de la sardine dans les eaux de Concarneau. C. R. Mém. Soc. Biol. Paris, 1896, 10. sér. 3, 551-552.

1896.1

Sur l'existence et le développement des oufs de la sardine dans les eaux de Concarneau. C. R. Acad. Sci. Paris, 1896, 122, 1347-1349. Abstract in Rev. Sci., 4. sér. 5, no. 25, 789. 1896.2

La période critique post-larvaire des poissons marins. Bull. Mus. Hist. Nat. Paris, 1897, 3, 57-58. 1897.1

Recherches biologiques applicables à la pisciculture maritime. Sur les oufs et les larves des poissons de mer et sur le turbot. Ann. Sci. Nat. (Zool.), 1897, 8. sér. 3, 151-220. figs. 1897.2

Rôle de la vésicule vitelline dans la nutrition larvaire des poissons marins. C. R. Mém. Soc. Biol. Paris, 1898, 10. 
sér. 5, 466-468. - Bull. Soc. Centr. Aquicult. Pêche, 10, 125-127. 1898.1

Sur le développement de la sole au laboratoire de Concarneau. C. R. Acad. Sci. Paris, 1901, 132, 1136-1138. 1901.1

Appareil à rotation pour l'élevage des oufs et des larves des poissons marins. C. R. Assoc. Franç. Avanc. Sci., Paris, 30. sess., 1902, pt. 1, 144-145. Ibid., pt. 2, 577-582.

1902.1

Développement de la sole (Solea vulgaris) Introduction à l'étude de la pisciculture marine. Paris, 1905. 247 p. 8 pls. $8^{\circ}$.

1905.1

Fabricius, Johann Christian [17451808] Reise nach Norwegen, mit Bemerkungen aus der Naturgeschichte und Oekonomie. Hamburg, 1779. $8^{\circ}$.

1779.1

The same. 2. ed. Nürnberg, 1785. 2 pls. \& map. 1785.1

Voyage en Norvège, [etc.] Traduit d'allemand par Millin et IVinkler. Paris, 1802. $8^{\circ}$.

1802.1

Fabricius, Otto [1744-1822] Fauna Groenlandica, systematice sistens, animalia Gronlandiæ occidentalis. Copenhagen \& Leipzig, 1780. 452 p. pl. $8^{\circ}$.

1780.1

Pisces [new species of Ophidium, Blennius Cottus, Pleuronectes and Salmo], p. 137-183.

Beskrivelse over den punkterte tangsprel [Blennius punctatus] Skrivt. Naturhist. Selsk. Kjöbenh., 1793, 2, 81-96.

1793.1

- Beskrivelse over 2de sieldne Gronlandske fiske: bugte-tanden (campylodon), og den tornefulde rognkald (Cyclopterus spinosus) Skrivt. Naturhist. Selsk. Kjöbenh., 1797, 4, pt. 2, 2133.

1797.1

Nöjagtig beskrivelse over Gronlændernes landdyr- fugle- og fiskefangst, med dertil horende redskaber. Dansk. Vid. Selsk. Skrivt. Kjöbenh., 1809, 6, 2. heft, 231.

1809.1

Om een ny, og 2. lidet bekjendte, flynder-arten nemlig: (1) steen-sueren (Pleuronectes quadridens) (2) den lille hellefisk (Pleuronectes pingius) og (3) den grœnlandske flynder (Pleuronectes platessoides) Abh. K. Dansk. Vid. Selsk. Natur. Kjöbenh., 1824, 1, 39-55. 3 figs.
Fabritius, W. Villebrådstillgången i Muonio och Enontekis jakt-säsongen 1909-10 [Die Menge jagdbaren Wildes in Muonio und Enontekis während der Jagdsaison 1909-10] Finisk Jakttidning, Helsingfors, 1909-10, 5, 146-149.

1910.1

Facciolà, Luigi. Descrizione di due specie di Blennius del mare di Messina: [B. trigloides Cuv. Val., B. canestrinii, n. sp.1 Ann. Soc. Nat. Modena, 1S81, 14, 209-214.

1881.1

Descrizione di due specie di pesci del genere Oxystomus viventi nelle acque di Messina. Nat. Sicil., 1882, 1, 184-189. pl. 1882.1

Descrizione di una nuova specie di Scopelus del mar di Messina. Nat. Sicil., 1882, 1, 193-198. pl. 1882.2

Note sui pesci dello stretto di Messina. Nat. Sicil., 1882, 1, 166-168; 184-189; 193-198. Ibid., 1883, 2, 145148; 186-189; 205-208; 252-256. Ibid. $1884,3,51-54 ; 111-114 ; 163-169 ; 291-$ 296.

1882.3

Sulla forma giovanile del Macrourus colorhynchus. Boll. Scient. Pavia, 1882, 4, 9-13. 2 figs. 1882.4

Di alcune disposizioni organiche dell' Uranoscopus scaber Linn., in rapporto al suo istinto insidiatore. Atti Soc. Nat. Modena, 1883, 1, 17-28. 1883.1

L La forma giovanile del Phycis blennioides. Nota. Nat. Sicil., 1883, 2, 25-29. fig. 1883.2

Caratteri di pesci giovani del mar di Messina. Nat. Sicil., 1884, 3, 231236.

1884.1

- Caratteri giovanili del Chlorophthalmus agassizii. Nat. Sicil., 1884, 3, 71-75.

1884.2

- I giovani del Gonostoma denudatum. Nat. Sicil., 1884, 3, 22-26. 1884.3

I blennii del mar di Messina. Atti Soc. Toscana Sci. Nat., 1885, 6, 273-342. pl.

1885.1

- Su di alcuni rari Pleuronettidi del mar di Messina. Nota preliminare. Nat. Sicil., 1885, 4, 261-266. $\quad 1885.2$

Sul dimorfismo sessuale del Rhomboidichthys mancus. Nat. Sicil., 1886, 5, 213-220; 231-235. 1886.1

_- Intorno a due Lepadogastrini ed un nuovo Nettastoma del mare di Sicilia. Lettera al Cristoforo Bellotti. Nat. Sicil., 1887, 6, 163-167. $\quad 1887.1$ 
Facciolà, $L$.

Sull' esistenza di due forme diverse di Microstoma nel mar di Messina. Nat. Sicil., 1887, 6, 193-197. 1887.2

- Sullo stato giovanile del Rhomboidichthys mancus. Nat. Sicil., 1887, 6 , $39-43 ; 50-53 ; 74-76$.

1887.3

Annunzio ittiologico. Nat. Sicil. 18s8, 7, 167-169.

1888.1

Su di un nuovo Crenilabro del mar di Messina. Nat. Sicil., 1889, 8, 2224.

1889.1

Un' altra parola sul 'Crenilabrus aurantiacus." Nat. Sicil., 1859, 8, 208 210.

1889.2

Sul Trachurus melanosaurus Cocco. Nat. Sicil., 1890, 9, 234-241. 1890.1

Di un autografo dell' abbate Francesco Maurolico intorno ai pesci di Sicilia. Nat. Sicil., 1891, 10, 16-19.

1891.1

_- Le metamorfosi del Conger, vulgaris e del Conger mistax. Nat. Sicil., $1893,12,194-200 ; 223-226 ; \quad 254-259$; 287-288; 309-312. Ibid., 1894, 13, 25$35 ; 56-60$.

1893.1

Sull' esistenza di forme di passaggio da alcune specie di Leptocefalidi agli adulti corrispondenti. Nat. Sicil., $1893,12,99-103 ; 123-127 ; 144-148$.

1893.2

Cattura di un Carcharodon rondeletii M. \& H. nel mare di Messina. Nat. Sicil., 1894, 13, 182-184.

1894.1

- Le metamorfosi del Conger balearicus. Nat. Sicil., 1894, 13, 125-130. 173-177; 219-228. Ibid., 1895, 14, 3950 .

1894.2

La prima forma larvata dell' Anquilla vulgaris. Nat. Sicil., 1894, 13, 133-135; 161-166; 212-221. Ibid., $1895,14,161-166 ; 212-221 . \quad 1894.3$

_- L'Helmichthys dell' Anguilla vulgaris. Riv. Ital. Sci. Nat., Siena, 1897, 17, 116-118.

1897.1

- Il maschio del congro comune non si conosce. Nat. Sicil., 1897, n. s. 2, $174-176$

1897.2

- Sulle uova del Conger vulgaris. Riv. Ital. Sci. Nat., Siena, 1897, 17, 9294.

1897.3

- Sunto di alcune ricerche su l' organizzazione e lo sviluppo dei Leptoce- falidi. Atti Soc. Nat. Modena, 1897, 3. ser. 14, 122-145. 1897.4 — Il maschio della Smaris vulgaris Linn. Annunzio ittiologico. Boll. Scient., Pavia, 1899, 19, 46-47. 1899.1 Smaris chryselis e S. gagarella. Boll. Scient., Pavia, 1S99, 19, 73-75.

1899.2

Sull' esistenza di due specie di Nettastoma nel mare di Messina. Riv. Ital., 1899, 19, 29-32.

1899.3

- Sul Microichthys coccoi Rüpp. Monit. Zool. Ital., 1900, 11, 185-194. pl. 1900.1

- Contributo all' interpretazione del passagio dell' occhio del lato cieco sul lato oculata. Boll. Soc. Zool. Ital., Roma, 1901, 2. ser. 1, 169-1S9. pl.

1901.1

Esame degli studii su lo sviluppo dei Murenoidi e l'organizzazione dei Leptocefali. Atti Soc. Nat. Modena, 1901, 4. ser. 2, 41-82. 2 pls. 1901.2

- Un po' di cronologia relativa agli studii su lo sviluppo dei Murenoidei. Boll. Soc. Zool. Ital., Roma, 1901, 2. ser. 1, 247-262. 1901.3

- Idea succinta dell' organizzazione dei Leptocefali. Monit. Zool. Ital. $1903,14,185-198$. 1903.1

Generi dei vertebrati ittioidi del mare di Messina. Boll. Soc. Zool. Ital., Roma, 1911, 2. ser. 12, 268-287. 1911.1

Scoperta di un individuo maschio del Conger vulgaris Linn. Boll. Soc. Zool. Ital., Roma, 1912, 3. ser. 1, 161-187.

1912.1

Una nuova specie de grosso Conger (C. simulatus) scoperta nel mare di Messina. Boll. Soc. Zool. Ital., Roma, 1913, 3. ser. 2, 101-109.

1913.1

Facciolà, Luigi, \& Cocco, Anastasio. See Cocco \& Facciolà.

Fack, - C Cyprinoiden und deren Zahngestell. Schrift. Naturn. Ver. Schleswig-Holstein, 1897, 11, 84-85.

1897.1

Fage, Louis. Aperçu sur l'exploitation des fonds maritimes du quartier du Port-Vendres. Bull. Soc. Cent. Aquicult. Pêche, 1907, 19, 9-31. 1907.1

_. Essai sur la faune des poissons des îles Baléares et description de quelques espèces nouvelles. Arch. Zool. Expér. Gén., Paris, 1907, 4. sér. 7, 69-93. pl. 1907.2 
- Etude de la variation chez le rouget (Mullus barbatus L. M., surmuletus L.) Arch. Zool. Expér. Gén., 1909, 5. sér. 1, 389-445. pl.

1909.1

- Recherches sur les stades pélagiques de quelques téléostéens de la mer de Nice (parages de Monaco) et du golfe du Lion. Ann. Instit. Océanog. Monaco, 1910,1 , fasc. 7,53 .

1910.1

- Le capelan de la Méditerranée, Gadus capelanus (Risso) et ses rapports avec les espèces voisines, $G$. luscus Linné et $G$. minutus O. Fr. Müller. Arch. Zool. Expér. Gén., 1911, 5. sér. 6, 257-282. 2 pls. \& 3 figs.

1911.1

- Recherches sur la biologie de l'anchois (Engraulis encrassicholus L.) Ann. Instit. Océanog. Monaco, 1911, 24 , $1-37$.

1911.2

- Sur les races locales de l'anchois (Engraulis encrassicholus Linné) Réponse à M. Pietro Lo Giudice. Arch. Zool. Expér. Gén., 1911, 5. sér. 8, lxxii$\operatorname{lxxx}$.

1911.3

- Sur une collection de poissons provenant de la côte méditerranéene du Iaroc. C. R. Assoc. Franc. Avane. Sci., 1911, 40, 578-582. - Bull. Soc. Zool. France, 1912, 36, 215-220. $\quad 1911.4$

L'acclimatation du saumon dans le bassin de la Méditerranée. C. R. Mém. Soc. Biol. Paris, 1912, 72, 851-852.

1912.1

Essais d'acclimatation du saumon dans le bassin de la Méditerranée. Bull. Instit. Océanog. Monaco, 1912 , no. $225.13 \mathrm{p}$

1912.2

Recherches sur la croissance de la sardine (Clupea pilchardus WValb.) C. R. Assoc. Franc. Avanc. Sci., 41. sess., $1912,415-418$.

1912.3

Recherches sur la biologie de la sardine (Clupea pilchardus Walb.) Premières remarques sur la croissance et l'âge des individus, principalement en Méditerranée. Arch. Zool. Expér. Gén. 1913, 52, 305-341. 22 figs. 1913.1

Fage, Louis, \& Buen y del Cos, Odón de. See Buen y del Cos \& Fage.

Fage, Louis, \& Pellegrin, Jacques. See Pellegrin \& Fage.

Fagerlund, Lars Wilhelm. Anteckningar om korpo och houtskärs socknar. Sommarstudier. Bidrag kännedom. Finl. Natur, 1878, 28, 1-334. 6 figs. \& map.
Fahlberg, Samuel. Beskrifning öfver elektriska ålen (Gymnotus electricus) Handl. I. Vetensk. Akad., 1801, 22 , 122-156. - Annal. (Gilbert), 14, 416422.

1801.1

Fairbank, N.K. Delivery of young native fish. Chicago Field, 1880, 14, 27.

1880.1

The power of fish commissioners. Chicago Field, 1880, 13, 412. 1880.2

Quinnat salmon land-locked. Forest \& Stream, 1880, 15, $186 . \quad 1880.3$

Breeding California salmon in fresh water. Proc. 2. Ann. Meet. Central Fishculture Soc. Chicago, 1880 (1881), $47-50$.

1881.1

Fairbanks, John E. Letter on the deep sea fisheries. Rept. Fish. Bay of Fundy, 1851, 167-172. - Rept. Fish. N. Bruns., 1852, 246-249.

1851.1

Fairchild (junior), G. M. Stray notes from Canada. Forest \& Stream, 1875, 5, 162.

1875.1

Remarks on trout and black bass in several Canadian lakes.

Faist, Anton Joseph. Die Fische der bayerischen Gewässer. München, 1871. 32 p. $8^{\circ}$.

1871.1

Faivre, Ernest [1827-1879] Considérations anatomiques sur l'appareil pneumatique de certains poissons. C. R. Mém. Soc. Biol. Paris, 185t, 1, 1-4.

1854.1

Observations anatomiques sur le Cyclopterus lumpus. C. R. Mém. Soc. Biol. Paris, 1856, 3, 70-74.

1856.1

Falcone, Cesar. La cortevvia del cervelletto. Napoli, 1893.

1893.1

Falconer, Hugh [1808-1865] Miscellaneous notes on Indian zoology. II. Note on an Indian species of Esox (In Palæontological memoirs and notes of the late Hugh Falconer, compiled and edited by Charles Murchison, vol. i, p. $589-590$. 1868)

1868.1

Falke, W. Longevity of the carp. Amer. Sportsman, 1874, 4, 359. 1874.1

Falkner, Thomas, A description of Patagonia, and the adjoining parts of South America, containing an account of the soil, produce, animals, etc., of these countries. ... London, 1774. 144 p. 2 maps. $4^{\circ}$. 1774.1 
Falsan, Albert, \& Dumortier, Vincent Eugène. Note sur les terrains subordonnés aux gisements de poissons et de végétaux fossiles du Bas-Bugey. Ann. Soc. Agric. Lyon, 1872, 4. sér. 5, 143-218.

1872.1

Fankhauser, $F$. Statistik der Anstalten zur künstlichen Ausbrütung von Fischereien in der Schweiz. Bern, 1889. 73 p. $4^{\circ}$.

1889.1

- Einiges über künstliche Fischzucht. Schweiz. Zeitschr. Forstwesen, 1896, 287. Also separate: Bern, 1896. 8 p. $8^{\circ}$.

1896.1

- Statistik des Lachsfanges. Stenogr. Protok. Verh. Intern. Fisch.Kongr. Wien, 1905 (1906), 403-407.

1906.1

Fano, $C . d a$. Osservazioni sulla fine struttura della nevrologie. Ricerche Labor. Anat. Umana Univ. Roma, 1906. 12.

1906.1

Fanzago, Filippo. Sul modo col quale le femmine degli Ippocampi introducono le uova nella borsa ovigera dei maschi. Atti Soc. Veneto-Trent. Sci. Nat., 1874 3, 161-162.

1874.1

Faraday, Michael[1791-1867] Notice of the character and direction of the electric force of Gymnotus. Phil. Trans. Roy. Soc. London, $1839,129,1-12$.

1839.1

Faravelli, $E$. Cenno preventivo su di un muscolo a fibre liscie osservato nella zona ciliare dell' occhio del Thynnus vulgaris. Atti Soc. Tosc. Sci. Nat. (Proc. Verb.), 1890, 7, 133-139. - Atti Accad. Sci. Torino, 26, 268-274. - Arch. Ital. Biol., 16, 65-71. pl.

1890.1

Fargioni Tozzetti, $A d$. La pesca nei mari d'Italia e la pesca all' estero esercitata da Italiani. Esposiz. Internaz. Pesca Berlino, 1880 (Sez. Ital. Cata$\log 0), x v-c x x x v i$.

1880.1

Farkas, Koloman, \& Tangl, Franz. See Tangl \& Farkas.

Farlow, William Gilson [1844-] On the nature of the peculiar reddening of salted codfish during the summer season. Rept. U. S. Fish Comm. 1878 (1880), 6, 969-974.

1880.1

- Vegetable parasites of codfish. Bull. U. S. Fish Comm. 1886, 6, 1-6. figs.

1886.1

Farnell, Frank, \& Neilsen, Carl August. 'Trawling operations off the coast of New South Wales, between the Manning river and Jervis bay, carried on by H. M. C. S. "Thetis" under the direction of Frank Farnell, Esq., M. P. Rept. N. S. Wales Sea Fish., 1898, 1-22.

1898.1

Farnell, Frank, \& Waite, Edgar R. Sea fisheries. Report upon trawling operations off the coast of New South Wales between the Manning river and Jervis bay. ... Sydney, 1898. 45 p. 12 pls. $4^{\circ}$. 1898.1

Farnum, Clarence A. California trout in New York state. Forest \& Stream. $1879,13,765$

1879.1

Farr, C. Coleridge. Some effects of the gases dissolved in artesian water on trout, their eggs and fry. Rept. Austral. Assoc. Adv. Sci., 1912, 13. meet., 354362.

1912.1

Farr, C. Coleridge, \& Macleod, D. B. Further experiments on the influence of artesian water on the hatching of trout. Trans. Proc. New Zealand Instit., 1911 23, 55-57.

1911.1

Farr, S.C. Exportation of salmon and whitefish ova to New Zealand in 1876 Rept. U. S. Fish Comm. 1875-76 (1878) 4, 996-997; 999.

1878.1

Farran, George P. Plaice marking experiments on the east coast of Ireland in 1905 and 1906. Fisheries Ireland Scient. Invest. 1907 (1909), no. 3. 86 p. 33 pls. Ibid., 1910 (1911), no. 5. 37 p. 4 pls. 1909.1

Clare island survey. Pisces. Proc. Roy. Irish Acad., 1912, 31, no. 19 $6 \mathrm{p}$. 1912.1

Farwell, J. D., Throckmorton, $S$. $R$., \& Redding, $B$. B. See Throckmorton, Redding \& Farwell.

Fasciolo, Alba. Due casi di deformazione nel Labrax lupus. Atti Soc. Ligustica Sci. Nat. Geog., Genova, 1904, 15, 92-99. pl. - Boll. Mus. Zool. Anat. Comp., Genova, 127, 1-8. pl. 1904.1

Fasten, Nathan. The brook trout disease at Wild Rose and other hatcheries. Biennial Rept. Comm. Fish. IV isconsin, 1911-12 (1912), 12-22. 4 pls. 1912.1

The brook trout disease in Wisconsin waters. Rept. Wisconsin Comm. Fish. 1911-12 (1912), 11-21. 5 figs. 1912.2 
Fastenau, — Ueber die Anlegung von Fischwegen mit besonderer Rücksicht auf Lachse. Circul. Deutsch. Fischerei Ver., 1872, no. 5, 123-153.

1872.1

_- Einige Mittheilungen über Lachsleitern. Circul. Deutsch. Fischerei Ver., 1873, no. 2, 39-41.

1873.1

Fatio, Victor. Faune des vertébrés de la Suisse. Genève \& Bâle, 1865. 1868.1

Sur le développement différent des nageoires pectorales dans les deux sexes et sur un cas particulier de mélanisme chez le véron (Phoxinus lovis Agass.) et quelques autres Cyprinides. Arch. Sci. Phys. Nat. Genève, 1875, n. s. 52, 29-44. - Journ. Zool. (Gervais), $1875,4,215-222$.

1875.1

- Sur un cas particulier de mélanisme chez le véron [Phoxinus lavis Journ. Zool. (Gervais), 1875, 4, 222-229.

1875.2 1876.

Bâle

- Sur les cyprinidés. Arch. Sci. Nat. Genève \& Lausanne, 1876. 1876.2

De la variabilité de l'espèce, à propos de quelques poissons. Arch. Sci. Phys. Nat., 1877, 58, 185-217; 328. Also separate; Genève, 1878. 33 p. $8^{\circ}$. Abstract in Ann. Mag. Nat. Hist., 4. ser. $19,437-458$.

1877.1

Sur la détermination des $\mathrm{Cy}$ prinoïdes. Verh. Naturf. Gesell. Basel, 1876 (1877), 297-302.

1877.2

Histoire naturelle des poissons (In his Faune des vertébrés de la Suisse, vol. 4. 9 pls. Genève \& Bâle, 185290. 786 p. 5 pls. $8^{\circ}$ ) Reviem in Nature, 1883, 27, 220-221.

1882.1

Pt. 1, Anarthropterygiens

Pt. 2, Physostomes-Cyprinidés.

Les corégones de la Suisse. Arch. Sci. Phys. Nat., Genève, 188t, 3. sér. 12 433-437. Ibid., 14, 252-254. - C. R. 67. Sess. Soc. Helvét., Genève, 93-97. Ibid., 68. Sess. 40-42. - Recueil Zool. Suisse, 2, 649-665. 2 pls. $\quad 1884.1$

Ueber die schweizerischen Coregonen. Verh. Schweiz. Naturf. Gesell., 1884, 54-59. Also separate; Luzern, 1884. 5 p. $8^{\circ}$. 1884.2

- Les corégones de la Suisse. Genève, 1885. 6 p. $8^{\circ}$. 1885.1
Corégones divers de la Suisse. Verh. Schweiz. Naturf. Gesell., 1885, 32-35. Also separate; Neuchâtel, 1885. 5 p. $8^{\circ}$.

1885.2

Une maladie du brochet. Genève, 1857. $2 \mathrm{p} . \mathrm{S}^{\circ}$.

1887.1

L'éclairage des échelles à poissons. Diana, 1888, 11, no. 19, 127. Also separate; Berne, 1888. $4^{\circ}$. 1888.1

Les poissons d'Amérique en Suisse. Arch. Sci. Phys. Nat. Genève, 1888, 19, 369-375. Also separate; Berne, 1888. 8 p. $8^{\circ}$. 1888.2

Sur un nouveau corégone francais (Coregonus bezola) du lac du Bourget. C. R. Acad. Sci. Paris, 1888, 106 , $1541-1544$.

1888.3

Question de pisciculture. Arch. Sci. Phys. Nat. Genève, $1889,21,470$ 472. Also separate; Genève, 1889. 3 p. $8^{\circ}$.

1859.1

- Les poissons de la Suisse. Arch. Sci. Phys. Nat. Genève, 1890, 24, 515520. Also separate; Genève, $1890.5 \mathrm{p}$. $8^{\circ}$

1890.1

Les corégones en Suisse. Troubles résultant de l'importation. Les habitants des lacs de Sarnen et de Lungern. Cat. Expos. Nation. Suisse, Géograph. Chasse \& Pêche, 1896, 4 sér. 1, 125-132; 275-277.

1896.1

Quelques nouveautés relatives au genre Corégone en Suisse. Arch. Sci. Phys. Nat. Genève, 1896, 4. sér. 1, 275277.

1896.2

Corégones du type dispersus dans les lacs de Lungern et de Sarnen. Arch. Sci. Phys. Nat. Genève, 1897, 4. sér. 4, 496-497. C. R. 80. Sess. Soc. Helvèt., 1897, 63-64.

1897.1

De la présence d'un corégone du type dispersus dans le lac de Sarnen. Arch. Sci. Phys. Nat. Genève, 1897, 4. sér. 4, 84-85.

1897.2

- Noch ein Wort über die Coregonen des Sarnersee in der Schweiz. Schweiz. Fischerei Zeitg., 1897, 5, 147.

1897.3

Distribution, adaptation et variabilité des poissons en Suisse. Bull. Soc. Zool. France, 1899, 24, 35-44. 1899.1

Quelques effets du rechauffement artificiel de l'eau sur certains poissons. Bull. Soc. Centr. Aquicult. Pêche, 1S99, 11, 137-138. 1899.2 
Fatio, V.

I propos du Coregonus macrophthalmus de Nuisslin. Arch. Sci. Phys. Nat. Genève, 1902, 4. sér. 14, 433-411.

1902.1

- Das Schweizersbild, eine Niederlassung aus palaeolithischer und neolithischer Zeit IQuelques vertèbres de poissons, provenant des fouilles du Schweizersbild] Neue Denkschr. Allg. Schweiz. Gesell. Nat., 1902, 35, 199-203. - C. R. 82. Sess. Soc. Helvét. Sci. Nat., 1902, 60-61. - Arch. Sci. Phys. Nat. Genève, 4. sér. 10, 566-567. 1902.2

- Vererbung und Anpassung bei unsern Fischen. Schweiz. FischereiZeitg., 1904, 12. Jahrg., 238-243. 1904.1

Adaptation chez les poissons. Arch. Sci. Phys. Nat. Genève, 1905, 4. sér. 20, 590-592. - Verh. Schweiz. Naturf. Ges., 88. Vers. 74-76. - C. R. 88. Sess. Soc. Helvét. Sci. Nat., 80-82.

1905.1

- La bouvière, Rhodeus amarus Ag., ì Genève. Arch. Sci. Phys. Nat. Genève, 1905, 4. sér. 20, 680-686.

1905.2

Le haidli du láe de Hallwyl. Arch. Sci. Phys. Nat. Genève, 1905, 4. ser. 20, 599-590.

1905.3

- Hybride de Squalius cavedanus et Alburnus alborella du lac de Lugano. Boll. Soc. Licinese Sci. Nat., 1905, 2, 9-14. pl.

1905.4

Fauché, —, \& Issel, A. See Issel \&̀ Fauché.

Faujas de Saint-Fond, Barthélemy [1741-1819] Mémoire sur un poisson fossile trouve dans une des carrières de Nanterre près de Paris. Ann. Mus. Hist. Nat. Paris, 1802, 1, 353-356. pl. 1802.1

Sur une grosse dent de requin et sur un ćcusson fossile de tortue trouvés dans les carrières des environs de Paris. Ann. Mus. Hist. Nat. Paris, 1803, 2,103109. pl.

1803.1

- Lettre adressée ¿̀ M. de Lacépède, sur les poissons du golfe de la Spezzia et de la mer de Gênes. Ann. Mus. Hist. Nat. Paris, 1806, 8, 365-371.

1806.1

- Notice sur le gisement des poissons fossiles et sur les empreintes de plantes d'une des carrières à plâtre des environs d'Aix, département des Bouches-du-Rhône. Inn. Mus. Hist. Nat. Paris, 1806, 8, 220-226. 1506.2
- Sur le piquant ou l'aiguilion pétrifié d'un poisson du genre des raies, et sur l'os maxillaire d'un quadrupède trouvé dans une carrière des environs de Montpellier, précédée de quelques observations sur les corps organisés, fossiles ou pétrifiés qu'on trouvé dans les environs de cette ville. Ann. Mus. Hist. Nat. Paris, 1809, 14, 376-383. pl.

Faulds, H. Remarks on the dojô [Cobitis barbatula] Trans. Asiat. Soc. Japan, 1878, 6, pt. 1, 183-185. 1878.1

Fauré-Fremiet, $E$. \& Mironesco, Théodore. Sur le chondriome des lames électriques de la torpille. C. R. Mém. Soc. Biol. Paris, 1911, 71, 517-518.

1911.1

Faussek, $V . A$. Beitrïge zur Histologie der Kiemen bei Fischen und Amphibien. Arch. Mikrosk. Anat., 1902, $60,157-174$. pl.

1902.1

- Parasitismus der Anodonta-larven ['Text in Russian] Mém. Acad. Imp. Sci. St. Pétersb., 1903, 8. sér. 13, no. $6,1-141$. 8 pls.

1903.1

- Beiträge zur Frage der Drohbewegungen. Dic Drohbewegungen der Tarantel und der Scolopender. Drohbewegungen bei Wassertieren [Text in Russian! Trav. Soc. Nat., St. Pétersb. (Sect.Zool.), 1908, 37, pt. 2, 53-98. pl. 1908.1

Fauvel, A. [Communication relative à la reproduction de l'anguilles Bull. Soc. Linn. Normandie, 1872-73 (1873), 2. ser. 7, 227-228.

1873.1

Favaro, Giuseppe. Cenni anatomoembriologici intorno al musculus retractor arcuum branchialium dorsalis nei teleostei. Monit. Zool. Ital., 1902, 13, 119-124.

1902.1

- Ricerche sulla morfologia e sullo sviluppo dei muscoli gracili del dorso (musculi supra-carinales) dei teleostei. Arch. Ital. Anat. Embriol., 1902, 1, 448490. 3 pls.

1902.2

- Sopra l' origine filogenetica della tela subcutanea. Atti Accad. Bologna, $1904,20,131-138$.

1904.1

Contributi all' angiologia dei petromizonti. Atti. Accad. Sci. Veneto'l'rent., Padova, 1905, n. s. 2, 9-30. 4 figs.

1905.1

- Il cuore ed i seni caudali dei teleostei. Anat. Anz., 1905, 27. Jahrg., $379-380$. 1905.2 
Note fisiologiche intorno al cuore caudale dei murenoidi (tipo Anguilla vulgaris Turt.) Arch. Fisiol., 1905, 2, 569-580. 2 figs.

1905.3

Ricerche intorno alla morfologia ed allo sviluppo dei vasi, semi e cuori caudali nei ciclostomi e nei pesci. Atti R. Istit. Veneto Sci., 1905, 65 (8. ser. 8), 1-279. 158 figs.

1905.4

Sopra la circolazione caudale nei missinoidi, nei selaci, negli olocefali e nei ganoidi. Nota preventiva. Atti Accad. Sci. Padova, 1905, 21, 135-137.

1905.5

Ueber die Arbeit von S. M. Jossifov (Charkow): "Sur les voies principales et les organes de propulsion de la lymphe chez certains poissons." Anat. Ânz., 1906, 28. Jahrg., 628.

1906.1

Pisces (In Bronn, H. G. Klassen und Ordnungen des Tier-Reichs, Bd. vi, Abt. 1, Lief. 23-28, p. 337-518. 7 pls. \& 78 figs. Leipzig, 1908) 1908.1

Ueber den Ursprung des Lymphgefässsystems. Anat. Anz., 1908, 33. Jahrg., $75-77$.

1908.2

- Cono e bulbo arterioso negli anamni. Monit. Zool. Ital., 1911, 22, no. 4, 121-125. 2 figs.

1911.1

Sviluppo e struttura delle valvole senoatriali degli anamni. Monit. Zool. Ital., 1911, 22, no. 1, 1-3. fig.

1911.2

Ueber angebliche Schwanzsinus bei Petromyzon. Anat. Anz., 1911, 38. Jahrg., 560.

1911.3

Favaro, Giuseppe, \& Mozejko, $B$. Pisces (In Bronn, H. G. K'lassen und Ordnungen des Tier-Reichs, Bd. vi, Lief. 34-38, 519-582. 5 pls. Leipzig, 1913)

1913.1

Favrau, G. P. Plaice-marking experiments on the east coast of Ireland in 1905 and 1906. Dublin, 1909. 33 pls.

1909.1

Favre, J.W. Sur les fossiles crétacés dans le district de Slavianosserbsk du gouvernement d'Ekatherinoslaw. Trud. Kharkov. Univ., 1904, 38, 89-172. 4 pls.

1904.1

Fayol, Henri, \& others. Etudes sur le terrain Houiller de Commentry, etc. 3 vols. \& atlases. St. Etienne, 1887-93. $8^{\circ} \&$ fol

1888.1

Issued in the Bull. Soc. Industrie Minérale as Livres i-iii. Livre iii, published in 1888 , is entitled as follows: Faunes ichthyologique et entomologique, par C. Brongniart et H. E. Sauvage. The subtitle reads:

Pt. 1. [a] Faune ichthyologique. Par C. Brongniart. p. 1-38. figs. 1888.

Pt. 1 [b] Poissons du terrain Houiller de Commentry. I'ar H. E. Sauvage. p. 39-120. $16 \mathrm{pls}$. \& figs. 1888.

These two parts constitute livraison 4 of vol. ii, 3d series, of the above-named Bulletin.

Fea, James. An account of the new method of fishing on the coasts of Shetland. 1884. $8^{\circ}$.

1884.1

Fea, Leonardo. Riassunto generale dei risultati zoologici. Pesci (Viaggio di Leonardo Fea in Birmania e regioni vicine) Ann. Mus. Civ. Storia Nat. Genova, 1897, 2. ser. 17, 477-497. . 2 figs.

1897.1

Fearing, Daniel Butler [1859-] Some early notes on striped bass. 'l'rans. Amer. Fisheries Soc., 32. meet., 1903, 90-98.

1903.1

Grolier Club, New York. A catalogue of angling books, together with a number of manuscripts, angling bookplates, prints, medals, etc., from the collection of a member of the Grolier Club. New York, 1911. 59 p. 8 ${ }^{\circ}$ 1911.1 The preface is signed D. B. F.

Fechner, C.A. Ueber die Fortpflanzungsgeschichte der Aale. Neues Lausitz. Mag., 1864, 41, 249-251. 1864.1

Fechner, Hans, \& Paeske, Carl. Die Deutsche Natur. Fischkalender. 1. Teil. Fische unserer Flïsse und Seen. Zur Einführung in unser Süswasserfischreich. Mit Zeichnungen von Berthold Clauss. Leipzig, 1909. figs. $8^{\circ}$.

1909.1

Fedchenko, A. P. See Fedtschenko, 1.P.

Feddersen, Arthur Fredrik [1835-] Den kunstige fiskeavl. Tidsskr. Fiskeri, 1866, 1. Jahrg., 47-68. 1866.1

Multen [Mugil] som Damfisk i Frankrig. Tidsskr. Fiskeri, 1869, 3. Jahrg., 276-284.

1869.1

Det frisenvolske laxefiskeri og udklrknings-anstalterne. 'Tidsskr. Fiskeri, 1870, 4.Jahrg., 363-364. 1870.1

Oplysninger om danske fisk. Tidsskr. Fiskeri, 1870, 4. Jahrg., 337339.

1870.2

Smalten (Osmerus eperlanus L.) Tidsskr. Fiskeri, 1870, 4. Jahrg., 100105.
1870.3 
Feddersen, A. F.

Ferskvandsfiskeriet. Kjøbenhavn, 1873. 114 p. 44 figs. $8^{\circ}$. 1873.1

Lidt om den kunstige fiskeavl. Kjobenhavn, 1875.16 p. 8 figs. $8^{\circ}$.

1875.1

Die Fischerei im Limfjord vom 1. April 1873 bis 31. März 1874. Circul. Deutsch. Fischerei Ver. 1875 (1876), no. 2,270 .

1876.1

- Fiskeriet fra kastrup og kastrupfiskerne. Nordisk Tidsskr. Fiskeri, 1878, n. s. 4. Jahrg., 145-161. 1878.1

- Fortsatte bidrag til Limfjordsfiskeriets historie. Nordisk Tidssk. Fiskeri, 1878, n. s. 4. Jahrg., 224-271; 318-361. Ibid., 1879, 5. Jahrg., 120-132; 159-179.

1878.2

- Guramien [Osphromenus olfax] Tidsskr. Pop. Fremstilling Naturvidensk., 1878, 5. ser. 5, 50-63. fig.

1878.3

Om anlreg von fiskedamme. Viborg, 1878, 24 p. $8^{\circ}$. 1878.4

Fortegnelse over de Danske ferskvandsfiske. Naturhist. Tidsskr., $1879,12,69-96$.

1879.1

Fra Bakkebolle strand. Nordisk Tidsskr. Fiskeri, 1879, n. s. 5. Jahrg., 133-135.

1879.2

- Ferskvandsfiskenes udbredelse i Danmark. Tidsskr., 1880, $4.11 \mathrm{p}$.

geografiske

Geografisk

1880.1

Gadus morrhua in fresh water Amer. Naturalist, $1880,14,525-526$.

1880.2

Aalmännchen im Süswasser. Allgem. Fischerei Zeitg., 1893, 18, 258-259. - Suomen Kalatus Lehti, 1893, 2, 129 130 .

1893.1

Les anguilles mâles en eau douce Rev. Sci. Nat. Appliq., Paris, 1894, 41, 297-307.

1894.1

En markelig aal. Dansk Fiskeriforen Medlemsbl., 1896, 5. Jahrg., $461-462 ; 493$.

1896.1

Mallen. Dansk Fiskeriforen Medlemsbl., 1896, 5. Jahrg., 442-444. 2 figs.

1896.2

- Regnbueorreden. Dansk Fiskeriforen Medlemsbl., 1897, 6. Jahrg., 458460. fig.

1897.1
Karper. Dansk Fiskeriforen Medlemsbl., 1898, 7. Jahrg., 102-104. 3 figs.

1895.1

Kileorreden. Dansk Fiskeriforen Medlemsbl., 1898, 7. Jahrg., 2627. fig.

1898.2

En regnbueorred. Dansk Fiskeriforen Medlemsbl., 1899, 8. Jahrg., 386-387.

1899.1

Lidt mere om regnbueorreden. Dansk Fiskeriforen Medlemsbl., 1899, \& Jahrg., 403; 464-465; 470-471; 516.

1899.2

Hvidlaksen. Dansk Fiskeriforen Medlemsbl., 1900, 9. Jahrg., 110-112. 1900.1

Lidt om strandkarpen. Dansk Fiskeriforen Medlemsbl., 1900, 9. Jahrg. 478-479. 1900.2

Feddersen, J.A., \& Boek, Axel. See Boeck \& Feddersen.

Federley, Harry. Monströsa torskar [Monströse Dorsche] Meddel. Soc. Fauna Flora Fenn., 1908, 34. Heft, 6874. pl.

1908.1

Federow, $V$. Ueber die Wanderung der Genitalzellen bei Salmo fario. Anat Anz., 1907, 31, 219-223. 2 figs. 1907.1

Fedtschenko, Alelisyei Pavlovich [1844-1873] Reise in Turkestan [Text in Russian] 3 vols. Moscou, 1874-88. $55 \mathrm{pls} .4^{\circ}$

1874.1

Fish are described in vol. ii.

Fêe, Félix. Recherches sur le système latéral du nerf pneumogastrique des poissons. Mém. Soc. Sci. Nat. Strasb. 1866, 6, 2. livr., 129-202. 1866.1

De l'existence d'éléments de canal latéral dans toutes les écailles du muge capiton [Mugil capito] et sur les modifications du système nerveux qui en résultent. Bull. Soc. Sci. Nat. Strasb., 1869, 2, 24-25.

1869.1

De l'existence de nombreux corpuscules tactiles dans des écailles spéciales répandues dans tous les points de la surface du corps chez le brochet. Bull. Soc. Sci. Nat. Strasb., 1869, 2, 3-5.

1869.2

Feel, John. Fish cultivation. Ann. Rept. \& Proc. Barrow Nat. Field Club, 1879, 3, 71-76.

1879.1

Fehling, Hermann von, \& Kurr, von. Untersuchung fossiler Fischzähne 
von unbekannter Abstammung. Naturwiss. Jahresh., Württemberg, 1856, 12. Jahrg., 118-119.

1856.1

Fehlmann, $J . W$. Ein mundloser Karpfen. Intern. Rev. Gesam. Hydrobiol. (Biol. Suppl.), 1912, 4. ser. 2, pt. 2, 1-6. pl.

1912.1

Tubifex tubifex (Müll.) als Futter für Salmonidenbrut. Schweiz. FischereiZeitg., 1912, 20. Jahrg., 76-78. 1912.2

Feilden, Henry Wemyss [1838-] Notes from an Arctic journal. 'Zoologist, 1878, 3. ser. 2, 313-320. 1878.1

4 list of fishes dredged at 30 fathoms in Smith sound.

Feldt, - Ueber die Eimenge der im Winter laichenden Fische. Jahrber. Ver. Nat. Unterweser, 1898 (1899), 6972 .

1899.1

Felix, - Ueber die Entwicklung des Excretions-systemes der Forelle (Vorniere, Urniere, Nachniere) Verh. Anat. Gesell., 1895, 9, 147-152. 1895.1

Felix, Johannes Paul [1859-] Beitrage zur Kenntniss der Gattung Protosphyræna Leidy. Zeitschr. Deutsch. Geol. Gesell., 1890, 42, 278-302. 3 pls.

1890.1

Felix, Walther. Beiträge zur Entwickelungsgeschichte der Salmoniden. Anat. Hefte, Wiesbaden, 1897, 8, 249466. 8 pls. \& 39 figs.

1897.1

Die Price'sche Arbeit, "Development of the excretory organs of a Myxinoid (Bdellostoma stouti Lockington) " und ihre Bedeutung für die Lehre von der Entwickelung des Harnsystems. Anat. Anz., 1897, 13. Jahrg., 570-599. 11 figs.

1897.2

Felix, $W$. \& Bühler, $A$. Die Entwickelung der Harn- und Geschlechtsorgane (In Hertwig, O. Handbuch der vergleichenden und experimentellen Entwicklungslehre der Wirbelthiere, Bd. iii, Teil 1, 81-169; 209-254; 427-432. figs. Jena, 1906)

1906.1

Die Entwickelung des Harnapparates [Myxinoiden, Teleostier, Ganoiden, Selachier, Petromyzonten, Dipnoer]

- Die Entwickelung der Keimdrüsen und ihrer Ausführungsgänge (In Hertwig, O. Handbuch der vergleichenden und experimentellen Entwicklungslehre der Wirbelthiere, Bd. iii, Teil 1, 619-690; 742-750;815-821. figs. Jena, 1906)

1906.2

i. Allgemeine Entwicklung der Geschlechtsorgane. ii. Nomenklatur.

iii. Geschlechtsdrüse der Myxinoiden.

iv. Teleostier.

$v$. Selachier.

vi. Ganoiden.

vii. Petromyzonten.

vii. Dipnoer.

Fellman, Jacob. Anteckningar under min vistelse i Lappmarken, första och andra året. Borga, 1844. 156 p. $8^{\circ}$.

1844.1

Fellmer, $T$. Ueber die Giftigkeit des Aalserums. Jahresber. Rhein. Fischerei-Ver. 1903-04 (1904), 62-65. 1904.1

Fennell, Henry. Hatching American fish at South Kensington, and their introduction into English waters. Bull. U. S. Fish Comm. 1885, 5, 273-275.

1885.1

Fennell, $J$. On the artificial propagation of the ova of the salmon, etc. Proc. Dublin Nat. Hist. Soc., 1849 $55,1$.

1849.1

Fennell, John Greville [1807-1885] Curiosities of angling literature (In Pennell, H. C. Fishing gossip. Edinburgh, 1866.329 p. $8^{\circ}$ ) 1866.1

The book of the roach [Leuciscus rutilus] London, 1870. 118 p. $12^{\circ}$.

1870.1

Fish culture in Great Britain. Fish. Gazette, 1880, 4, 450-452. 1880.1

Fenner, C.W.H. De anatome comparata et philosophia naturali commentatio, sistens descriptionem et significationem cranii, encephali et nervorum in piscibus. Jenæ, 1820. fig. Arch. Anat. Phys. (Müller), 1835, 247. 1835.1

Fenzl, Eduard, Heckel, John Jakob, \& Redtenbacher, _ Abbildungen und Beschreibungen neuer oder seltener Thiere und Pflanzen, gesammelt von Th. Kotschy. Stuttgart, 1868. atlas. $8^{\circ}$.

Fishes, p. 993.

1868.1

Ferguson, \& Hughlett, Report on the fisheries of Maryland, ... Annapolis, 1880. 15 pls. $8^{\circ}$.

1880.1

Ferguson, James. An account of a remarkable fish [Lophius] taken in KingRoad, near Bristol. Phil. Trans. Roy. Soc. London, 1763, 53, 170-173. pl.

1763.1

Ferguson, Jeremiah $S$. The anatomy of the thyroid gland of elasmobranchs, with remarks upon the hypobranchial 
Ferguson, J.S.

circulation in these fishes. Amer. Journ. Anat., 1911, 11, 151-210. 20 figs.

- The behavior and relations of living connective tissue cells in the fins of fish embryos, with special reference to the histogenesis of the collaginous or white fibers. Amer. Journ. Anat., 1912, 13, 129-149. 4 pls.

1912.1

Ferguson, Thomas Barker. Pisciculture. Paris Universal Exposition, 1878 (1880), 5, 419-535. 24 pls. \& 6 figs.

1880.1

Extracts from a report of investigations of the shad fisheries and rivers south of Charleston, S. C., with a view to establishing stations for artificial propagation. Bull. U. S. Fish Comm. $1884,4,244-248$.

1884.1

Ferguson, $W$. On the poisonous fishes of the Carribee islands. Trans. Roy. Soc. Edinb., 1823, 9, 65-80.Bull. Sci. Nat. (Férussac), 9, 105-107. Notizen (Froriep), 8, 326-328. 1823.1

Fermin, Philippe [1730? - ] Histoire naturelle de la Hollande équinoxiale; ou, Description des animaux, plantes, fruits, ... qui se trouvent dans la colonie de Surinam; avec leurs noms différents. Amsterdam, 1765. $8^{\circ}$.

1765.1

Part ii. Des oiseaux, poissons et testacées.

Description générale, historique, géographique et physique de la colonie de Suriname, ce qu'il y a de plus curieux et de plus remarquable, touchant... toutes les diverses espèces d'animaux qu'on y trouve. 2 vols. Amsterdam, 1769. 3 pls. $8^{\circ}$.

1769.1

Fishes, vol. ii, p. 218-281.

Fermor, $X$. Wissenschaftliche Ergebnisse einer Reise von S. Awerinzew in die Tropen Africas I. Einige Befunde zur Kenntnis von Ariodes polystaphylodon. Zool. Anz., 1913, 42, 196-199. 3 figs.

1913.1

Fernandez, Cesareo. Verslag over de zelfde tentoonstelling IText in Spanish Madrid, 1866. $8^{\circ}$.

1866.1

Not seen; title from Bosgoed.

Fernandez de los Senderos, Francisco. Memoria sobre las pescas que se cultivan en las costas meridionales de España, desde el cabo de San Vicente hasta el estrecho de Gibraltar. Huelva, 1850 .

1850.1
Ferrant, $V$. Der Schnäpel, Coregonus oxyrhynchus, in der Sauer. Fauna Luxemburg, 1896, 6, 43-45. fig. 1896.1

Ferrari, S. M., Lessona, $M$. \& Doria, G. See Doria, Ferrari \& Lessona.

Ferreira, Alexandre Rodrigues [17561815] Memoria sobre o peire Piráurucú. 'Arch. Mus. Rio Janeiro, 1903, $12,155-158$.

1903.1

Ferrer y Hernảndez, Jaime. Materiales para la fauna ictiológica de las Baleares. Bol. Soc. Española Hist. Nat., Madrid, 1903, 3, 89-98.

1903.1

- _. Nota acerca del Serranus papilionaceus Cuv. et Val., "Serrá mascle." Bol. Soc. Española Hist. Nat., Madrid, $1906,6,460-462$.

1906.1

Ferretti, A. Pesci fossili di Montegazzo. Boll. Comit. Geol. Italia, 1879, 10, 668-669. - Neues Jahrb. Mineral. $1880,2,390$.

1879.1

Prima lista di resti di pesci fossili. Bull. Soc. Venet.-Trent. Sci. Nat. 1879 , 1, no. 2, 34-35.

1879.2

Ferretti, $U$. L' industria della pesca nella marina di Fano. Riv. Mens. Pesca, Pavia, 1911, 6. ser. 13, no. 1-3, $1-32 ; 88-121 ; 145-184$.

1911.1

Ferris, - Sur la génération du saumon. Journ. Physiol., 1782, 20, 321.

1782.1

Ferry, L. Sur la lamproie marine. C. R. Acad. Sci. Paris, 1883, 96, 721 723. Ibid., 1884, 97, 757-759. Abstract in Ann. Mag. Nat. Hist., 5. ser. $11,388$.

1883.1

Feser, - Milzbrand-Uebertragungs-Versuche auf Fische. Oesterr. Ungar. Fischerei-Zeitg., 1880, 138-139. 1880.1

Fesler, Bertram, \& Dresslar, Fletcher B. See Dressler \& Fesler.

Fesler, Bertram, \& Jordan, David Starr. See Jordan \& Fesler.

Festa, $E$. I pesci del Piemonte. Boll. Mus. Zool. Anat. Comp. Torino, 1892, 7, no. 129 . 6 p.

1892.1

Di un caso di jeterismo nel $\mathrm{Pe}$ tromyzon planeri Bloch. Boll. Mus. Zool. Anat. Comp. 'Torino, 1900, 15, no. 367. 2 p. 
Fibich, $H$. Ueber die Temperatur bei Fischen. Zeitschr. Fischerei Berlin, 1905.

1905.1

Fibich, Stanislaw. Observations sur la température des poissons [Text in Polish] Przegl. Weteryn., Lwów, 1904, 19 , 388-395; 465-468; 509-515. - Allgem. Fischerei Zeitg., 30, 82-86. - Zeitschr. Fisch. Hilfswiss., Berlin, 12, 2953.

1904.1

- Choroby ryb [Les maladies des poissons] Okóln. Krajow. Towarz. Ryback. Krakow., 1905, 265-272. Ibid., 1907, 166-184. Ibid., 1908, 98-104; 274-285. Ibid., $1909,62-75 ; 132-142$; 178-185; 231-239.

1905.1

Choroby infekeyine ryb rLes maladies contagieuses des poissons] Przegl. Weteryn., Lwów, 1909, 24, 85$88 ; 117-121$.

1909.1

Ficalbi, Eugenio. Sulla conformazione dello scheletro cefalico dei pesci murenoidi italiani. Atti. Soc. Tosc. Sci. Nat., Pisa, 1886, 8, 101-158. pl. 1886.1

Fick, AdolfEugen. Ueber das Magenferment kaltblütiger Thiere. Verh. Physiol. Med. Ges., Würzburg, 1873, n. s. 2.

1873.1

Fiebiger, Josef. Ueber Dotterblasenwasserzucht der Salmoniden. Zeitschr. Fisch., 1903, 11, 2. Heft, 124. 1903.1

- Ueber die Bauchflossen der Gobii. Anat. Anz., 1905, 27. Jahrg., 140-155. 9 figs.

1905.1

- Ein Karpfen mit fehlender Schwanzflosse. Oesterr. Fischerei Zeitg., 1907, 5, 83-85. 1907.1

Ueber Coccidien in der Schwimmblase von Gadus-Arten. Vorläufige Mitteilung. Ann. Naturhist. Hofmus., Wien, 1907-08, 22, 124-128. 1907.2

Jahresbericht über die Tätigkeit der Untersuchungsstelle für Fischkrankheiten an der Wiener tierärztlichen Hochschule. Oesterr. Fischerei Zeitg., 1908, 5, 151-153.

1908.1

- Die Beurteilung unserer Marktfische. Zeitschr. Tiermed., 1909, 13, 269-312. pl.

1909.1

Jahresbericht des Institutes für Fischkrankheiten an der IViener tierärztlichen Hochschule. Oesterr. Fischerei Zeitg., 1909, 6, 6-8.

1909.2

Ueber Protozoen als Parasiten der Fische. Verh. Zool. Bot. Gesell. Wien, 1909, 59, 32-48.
Sechste Jahresbericht der Untersuchungsstelle für kranke Fische an der Wiener tierärztlichen Hochschule. Oesterr. Fischerei Zeitg., 1910, 7, 87-88.

1910.1

Fiedler, $H . V$. Haakalsfiskeriet [Scymnus borealis] Tidsskr. Fiskeri, 1866, 1. Jahrg., 26-32. 1866.1

- Fremmede fiskere ved de danske kyster. Tidsskr. Fiskeri, 1870, 4. Jahrg. 211-229.

1870.1

Om fremmedes "trawlfiske" under den jydske Vestkyst i 1871 og 72 , samt beretning om kystbœrnes vaarfiske s. A. Tidsskr. Fiskeri, 1873, 2. Jahrg., 209-214.

1873.1

Fiedler, $J$. The migration of salmon, Salmo salar, in the Baltic. Bull. U. S. Fish Comm. 1885, 5, 185-188. 1885.1

Field; A. R., \& Lyman, Theodore. See Lyman \& Field.

Field, George Wilton [1863-] Utilization of the dogfish. Trans. Amer. Fisheries Soc, 1911 (1912), 283-288.

1912.1

Vater pollution. Trans. Amer. Fisheries Soc. 1912 (1913), 179-182.

1913.1

Alewife fishery of Massachusetts. Trans. Amer. Fisheries Soc. 1913 (1914) 143-152.

1914.1

Field, Irving $A$. Unutilized fishes and their relation to the fishing industries. Bull. Bureau Fisheries, 1907, no. 622, 1-50. pl.

1907.1

Sea mussels and dogfish as food. With discussion. Proc. 4. Intern. Fish. Congr., Washington, D. C., 1908, pt. 1, 241-257.

1908.1

Figgins, $J . D$. New methods of preparing fishes for museum exhibit. Bull. Bureau Fisheries, 1910, 28, 1357-1363.

1910.1

Figuier, Guillaume Louis [1819-1894] L'année scientifique et industrielle, 1856-1867. 14 vols. Paris. $8^{\circ}$. [n. d.]

1858.1

Vol. iii, pt. 2. La pisciculture en France en 1858; la pisciculture maritime.

Vol. v. Essais de pisciculture fluviale dans le départment de l'Hérault; les nids de poissons rapportés de Terre-neuve.

Vol. vi. La pisciculture et l'empoissonnement des eaux douces; acclimatation en France des poissons importés de la Chine. Etat de la pisciculture en Chine. Naturalisation du saumon du Rhin dans le lac de Genève, p. 390. Du transport de poissons vivants, p. 392. 
Figuier, G. L.

Les poissons, les reptiles et oiseaux. Ouvrage illustré de 400 figures et de 24 grandes compositions par A. Mesnel, A. de Neuville et E. Riou. Paris, 1868. 400 figs. $8^{\circ}$. 1868.1

Les animaux articulés, les poissons et les reptiles. 3. ed. Paris, 1876. $8^{\circ} \quad$ (Tableau de la nature) $\quad 1876.1$

Filatoff, D. 'Zur Frage iiber dei Anlage des Knorpelschädels bei einigen Wirbeltieren. Anat. Anz., 1906, 29, 623-633. 8 figs.

1906.1

Filhol, Henri [1843-] Explorations sous-marines: voyage du "Talisman." La Nature, 1884, 161-164; 182186; 198-202. 3 figs. - Nature, 1884, 29, 483-485. 2 figs.

1884.1

L La vie au fond des mers. Les explorations sous-marines et les voyages du "Travailleur" et du "Talisman." Paris, 1855. 301 p. 8 pls. $8^{\circ}$. 1885.1

Description d'un cas de monstruosité observé sur un Rhombus vulgaris. Bull. Soc. Philom. Paris, 188990 , 8. sér. 2, 54-55.

1889.1

Filippi, Filippo de [1814-1867] Développement des poissons. Ann. Univ. Med. Milano, 1841. - Rev. Zool., 1842, p. 45.

1841.1

- Sullo sviluppo del Gobius fluviatilis. Milano, 1841. pls. $8^{\circ}$. 1841.2

Osservazioni intorno all' embriogenia dei Salmonidi del Sig. C. Vogt. Giorn. Istit. Lomb. e Bibl. Ital., 1842, 5, $390-401$.

1842.1

Cenni sui pesci d' acqua dolce della Lombardia. Notiz. Nat. Civ. Lombardia, Milano, 1814, 1, 389. - Nuov. Ann. Sci. Nat. Bologna, 1845, 2. ser. 3, 81-103. Also separate; Milano, 1844. $8^{\circ}$.

1844.1

- (translator) Sul Branchiostoma lubricum restratto dalla memoria di Giovanni Müller] Giorn. Istit. Lomb. e Bibl. Ital., 1845, 10, 277-289. 1845.1

- Sunto di alcune osservazioni sulla embriologia dei pesci. Giorn. Istit. Lomb, e Bibl. Ital, 1845, 10, 405426. - Notizen (Froriep), 38, 1-8; $17-$ 25. Ibid., 41, 177-182.-Ann. Sci. Nat. 7, 65-72, - Giorn. Istit. Lomb. e Bibl. Ital., 12, 153-174.

1845.2

- Beobachtungen über die Embryologie der Fische. Neue Notizen
(Froriep), 1846, 38, no. 815, 1-8. Ibid., no. $816,17-25$. figs.

1846.1

Osservazioni sugli embrioni di Gobius fluviatilis. Atti Sci. Ital. 1846 , $487-489$.

1846.2

- Neue Untersuchungen über die Embryobildung der Fische. Notizen (Froriep), 1847, 3. ser. 3, no. 56, 177-182.

1847.1

Nouvelles recherches sur l'embryogénie des poissons. Lettre adressée à M. Albert Kölliker. Ann. Sci. Nat., 1847, 3. sér. 7, 65-72. 1847.2

Nota sopra una singolare monstruosità di una razza [Trygon pastinaca Bonap.] Nuov. Ann. Sci. Nat. Bologna, 1852, 3. ser. 5, 65-68. pl.

1852.1

- Importanza economica dei pesci e del loro allevamento artificiale. Torino, 1853. $8^{\circ}$.

1853.1

- Nouvelles espèces de poissons. Rev. Mag. Zool., 1853, 5, 164-171.

Labrax osculati, sp. nov. 1853.2

Nouvelle espèce de poisson d'eau douce du Piémont (Cobitis larvata) Rev. Mag. Zool., 1859, 11, 50-51. 1859.1

Zur näheren Kenntniss der Dotterkörperchen der Fische. Zeitschr. Wiss. Zool., 1860, 10, 15-19. 1860.1

Note zoologiche. Arch. Zool. Anat. Fisiol., 1861, 1, 52-76. 1861.1 Lebistes, nuovo genere di pesce della famiglia dei Ciprinodonti, p. 69-70.

Note sopra il genere Leptopterygius di Troschel, p. $73-76$.

Rapporto al Sig. Commendatore Cordova sull' introduzione in Italia del Coregonus wartmanni e del Salmo umbla. Arch. Zool. Anat. Fisiol., 1861, 1, fasc. 2, 228-233.

1861.2

[Sur la faune ichthyologique des lacs d'Italie comparée à celle des laes versant septentrional des Alpes] Bull. Soc. Sci. Nat. Neuchâtel, 1861, 5, 401402. 3 pls.

1861.3

Nuove o poco note specie di animali vertebrati raccolte in un viaggio in Persia nell' estate dell' anno 1862. Arch. Zool. Anat. Fisiol., 1862, 2, $377-$ 394.

1862.1

I'esci, p. 390-394.

Note d' un viaggio in Persia nel 1862. Milano, 1865. $8^{\circ}$. 1865.1 Description of 22 species of fishes, p. 357-360. 
Lettera contenente le ultime sue osservazioni fatte durante una parte del suo viaggio da Singapore a Saigon al Giappone ed alla China. Atti Reale Accad. Sci. Torino, 1867, 2, 227-238.

1867.1

Filippi, Filippo de, \& Verany, J.B. Sopra alcuni pesci nuovi o poco noti del Mediterraneo. Mem. Accad. Sci. Torino, 1859,2 . ser. 18, 187-199. pl.Rev. Mag. Zool., 15, 272-274. 1859.1

Filippo, Silvestri. I pesci dell' Umbria. Perugia, 1892. $11 \mathrm{p}$. 1892.1

Filius Terræ (pseudon.) Destruction of fish by polluted waters. Forest \& Stream, 1877, 8, 240.

1877.1

- Fishing near Alleghany city. Forest \& Stream, 1877, 8, 243. 1877.2

Filleau, A. Mémoire sur la colonie de Saint Pierre et Miquelon et sur les vrais moyens de consolider cet établissement. Paris, 1850. 80 p. $8^{\circ}$.

1850.1

Finck, Max C. Haplochilus rubrostigma. Wochenschr. Aquar-Terrar. Kunde, 1909, 6. Jahrg., 605-606. pl.

1909.1

Ein Beitrag zur Girardinus quppyi-Frage. Wochenschr. Aquar.-Terrar. Kunde, 1910, 7. Jahrg., 329-331. fig.

1910.1

Ctenops vittatus Cuv. et $\mathrm{Val}$. Blätt. Aquar-Terrar. Kunde, 1910, 21. Jahrg., 827-828. fig.

1910.2

- Das Gesellschaftsleben der Zahnkarpfen. Blätt. Aquar.-Terrar. Kunde, 1910, 21. Jahrg., 793-795. fig. 1910.3

- Das Labyrinthfisch-Aquarium. Wochenschr. Aquar-Terrar. Kunde, 1910, 7. Jahrg., 498-500.

1910.4

Die Pflege und Zucht des Trichogaster fasciatus. Blätt. Aquar.-Terrar. Kunde, 1910, 21. Jahrg., 757-758. fig.

1910.5

- Haplochilus panchax. Blätt. Aquar.-Terrar. Kunde, 1911, 22. Jahrg., 691-694. 7 figs.

1911.1

- Heros facetus Jenyus, der Chanchito. Blätt. Aquar-Terrar. Kunde, 1911, 22. Jahrg., 607-609. fig. 1911.2

Macropodus cupanus Cuv. \& Val. Blätt. Aquar.-Terrar. Kunde, 1911, 22. Jahrg., 791-792. 2 figs.

1911.3

- Der Pfauenaugenbarsch (Centrarchus macropterus) Blätt. Aquar.-
Terrar. Kunde, 1911, 22. Jahrg., 429430. fig.

1911.4

- Pacilia dominicensis. Wochenschr. Aquar--Terrar. Kunde, 1911, 8. Jahrg., 184.

1911.5

Pocilia sp.? mit schwarz gelbschwarzer Rückenflosse. Blätt. Aquar.Terrar. Kunde, 1911, 22. Jahrg., 235236. fig.

1911.6

Rivulus ocellatus (Hensel) Blätt. Aquar.-Terrar. Kunde, 1911, 22. Jahrg. 557-558. fig.

1911.7

- Seltene Farbenabänderungen von Platypocilus maculatus var. pulchra (Boul. in litt.) Blätt. Aquar-T'errar. Kunde, 1911, 22. Jahrg., 85-87. 3 figs.

1911.8

Gambusia affinis Grd. (G. holbrooki) Blätt. Aquar-Terrar. Kunde, 1912, 23. Jahrg., 106-107. fig. 1912.1

Die Prachtbarbe, Barbus conchonius Ham. u. Buch. Blätt. Aquar.Terrar. Kunde, 1912, 23. Jahrg., 271272. fig.

1912.2

Praktische Zierfischzucht. Blätt. Aquar.-Terrar. Kunde, 1912, 23. Jahrg., 693-696;711-713. 8 figs. 1912.3

\section{Der Diamantbarsch (Enneacan-} thus gloriosus Holbr.) und seine Zucht. Blätt. Aquar-Terrar. Kunde, 1913, 24. Jahrg., 273-274. fig.

1913.1

Findeis (junior), Guido. IJann man Seewasser-Kärpflinge (Cyprinodon fasciatus) an Süsswasser gewöhnen? Blätt. Aquar.-Terrar. Kunde, 1909, 20. Jahrg., 65-67.

1909.1

Finely, Charles I. Shad in Oregon waters. A new salmon hatchery. Bull. U. S. Fish Comm. 1884, 4, 88. 1884.1

Finn, $W$. Einige Reflexionen über den praktischen Nutzen, welcher sich von der Anfertigung von Fischereikarten erwarten lässt. Ann. Landw., Berlin, 1871, 29. Jahrg., 57, 226-230. 1871.1

Die Fischereien an der Küste von Canada. Deutsch. Fischerei Zeitg., 1878, 1. Jahrg., 124. 1878.1

- Die Häringsfischerei an der Westkïste Schwedens. Deutsch. Fischerei Zeitg., 1878, 1. Jahrg., 66. 1878.2

Zur Aalfrage. Deutsch. Fischerei Zeitg., 1878, 1. Jahrg., 264. 1878.3

- Die Fischerei von Grimsby. Deutsch. Fischerei Zeitg., 1879, 2. Jahrg., 317-318.
1879.1 
Finn, IV.

Ein Fischzüchter. Deutsch. Fischerei Zeitg.; 1879, 2. Jahrg., 365-366.

1879.2

- Die französische Fischereien bei Newfoundland. Deutsch. Fischerei Zeitg., 1879, 2. Jahrg., 206-207. 1879.3

Die Häringsfischerei bei Island. Deutsch. Fischerei Zeitg., 1880, 3. Jahrg., 494-495.

1880.1

- Norwegens Fischereien in 1879 Deutsch. Fischerei Zeitg., 1880, 3. Jahrg., 66-67.

1880.2

Der Schutz der französischen Fischereien. Deutsch. Fischerei Zeitg., 1880, 3. Jahrg., 22-23.

1880.3

Zur deutsch-dänischen Fischereifrage. Deutsch. Fischerei Zeitg., 1880, 3. Jahrg., 377-379; 393-395; 410$411 ; 429-431$.

1880.4

The Iceland herring fisheries. Rept. U. S. Fish Comm. 1879 (1882), 7 , 493-496.

1882.1

Can herring live and increase in inclosed waters? Bull. U. S. Fish Comm. 1884, 4, 333-335.

1884.1

Finsch, Friedrich Hermann Otto [1839 - ] Der amerikanische Shad [Alosa prostabilis] und der erste Versuch seiner Einführung nach Deutschland. Eine naturgeschichtlich-ökonomische Darstellung dieses wichtigen Nutzfisches, mit Beziehung auf unseren Maifisch. Circul. Deutsch. Fischerei Ver. 1875 (1876), 1. Jahrg., no.6, 327-344. 1876.1

Wissenschaftliche Ergebnisse. Wirbelthiere [Fische] (In Reise nach West-Sibirien im Jahre 1876; auf Veranstaltung des Vereins für die Deutsche Nordpolarfahrt zu Bremen unternommen von Dr. O. Finsch, Dr. A. Brehm und Karl Graf von Waldburg-ZeilTrauchburg, Verh. Zool.-Bot. Gesell. Wien, 1880, 29, 282-290) 1880.1

Report on a trip in Germany to secure carp for the United States fish commission. Bull. U. S. Fish Comm. 1881 (1882), 1, 220-225.

1882.1

Report on the transportation of a collection of living carp from Germany. Rept. U. S. Fish Comm. 1879 (1882), 7, $667-670$

1882.2

- Systematische Uebersicht seiner Reisen. Berlin, 1899.

1899.1
Fiore, $G$. Influenza dei centri visivi (lobi ottici e retina) sul pigmento dei pesci colorati. Ann. Ottalmol. Pavia, $1906,35,145-146$.

1906.1

Firens, Pierre. Piscium vivæ icones, in as incisæ $[n, p l ., n . d$.]

These plates, 19 in number, are mentioned by Walbaum in his revised edition of "Artedi" " and by Jonas Dryander in his Catalogue of the library of Joseph Banks.

Firket, Adolphe. Fossiles du poudingue de Burnot proprement dit. Age de cette assise [Scale of Holoplychius? Ann. Soc. Géol. Belgique, 1874, 2 cxxiv-cxxviii.

1874.1

Firth, $J . C$. American salmon in New Zealand waters. Forest \& Stream, $1877,7,340$.

1877.1

Exportation of salmon ova to New Zealand in 1877 and 1878. Rept. U. S. Fish Comm. 1875-76 (1878), 4, 959-962.

1878.1

- Shipment of salmon and whitefish ova to New Zealand in 1877 and 1878. Rept. U. S. Fish. Comm. 1878 (1880), 6, 829-\$31; \$33-834; $836 ; 837$ 839; 866-867;872;875;902. 1880.1

Fischel, Friedrich, \& Enoch, Carl. Ein Beitrag zu der Lehre von den Fischgiften. Fortschr. Medicin, 1892, 10.

1892.1

Fischer, C.E. Die Fischreste aus den Planerschichten von Plauen, Strehlen, Weinböhla, und Grossedlitz. Allgem. Deutsch. Nat. Hist. Zeitg., 1856, 2, 134 145.

1856.1

Ueber das Gehörorgan der Süsswasserfische. Sitzber. Naturw. Ges. Isis, Dresden, 1862, 70-82. $\quad 1862.1$

Fischer, E.G. Zur Frage der, Schonzeit. Deutsch. Fischerei Zeitg., 1879, 2. Jahrg., 214-215.

1879.1

Schädigung der. Fischerei durch die Abwässer einer Stärkefabrik. Fischerei Zeit., Neudamm, 1901, 4, 241244.

1901.1

Fischer, Friedrich. Zur KarpfenBastard-Zïchtung. Deutsch. Landw. Presse, 1880, 7. Jahrg., 235. - Isis (Russ), 1S50, 5. Jahrg., 267-268. Deutsch. Fischerei Zeitg., 1880, 3. Jahrg., 240-241. — Oesterr.-ungar. Fischerei Zeitg., 1850, 110-111. 1880.1

Fischer, Friedrich Christoph Jonathan. Geschichte des teutschen Handels. . Der Schiffarth, Fischerei, Erfindungen, Iün- 
ste, Gewerbe, Manufakturen, der Landwirthschaft. . . 4 vols. Hannover, 1785-92. $8^{\circ}$.

1785.1

Vols. i \& ii, 1785. Vol. iii, 1791. Vol. iv, 1792.

Fischer, Fritz. Der Wels. Nerthus, 1901, 3. Jahrg., 561-562.

1901.1

Fischer, $G$. Sur des dents de requins et des coprolithes renfermés dans des pyromaques arrondies. Bull. Soc. Imp. Nat. Moscou, 1835, 8, 234-244. 1835.1

Fischer, Hans. Wie zủchtet man mit Erfolg Fundulus gularis Variation blau? Wochenschr. Aquar.-Terrar. Kiunde, 1910, 7. Jahrg., 261-262. fig.

1910.1

Fischer, Jacob Benjamin [1730-1793] Versuch einer Naturgeschichte von Livland. Königsberg, 1791. 4 pls. $8^{\circ}$.

Descriptions of 40 species of fishes.

Fischer, Johann Gustav [1819-1889?] Ueber einige afrikanische Reptilien, Amphibien, und Fische des naturhistorischen Museums. Jahrb. Hamburg. Wiss. Anstalten, 1884, 1. Jahrg., 1-39.

1884.1

- Ichthyologische und herpetologische Bemerkungen. Jahrb. Hamburg. Wiss. Anstalten, 1885, 2, 49-119. 4 pls. \& figs.

1885.1

Fischer, Johann von. Flavismus bei einer Schmerle, Gobitis [Nemachilus] barbatula. Zool. Garten, 1874, 15, 471.

1874.1

- Die Fische des St. Petersburger Gouvernements und ihre Bedeutung für das Volk. Zool. Garten, 1875, 16, 281-291.

1875.1

Fischer, Leopold Heinrich [18171886] Ueber das Gehörorgan der Fischgattung Mormyrus. Inaug. Dissert. Freiburg i. Br., 1854. 36 p. pl. $4^{\circ}$.

1854.1

Fischer, $M$. Kreuzung zwischen Fundulus gularis blau und gelb Varietäten. Wochenschr. Aquar-Terrar. Kunde, 1911, 8. Jahrg., 501-502. fig. 1911.1

Fischer von Waldheim, Gotthelf [1771-1853] Versuche über Schwimmblase der Fische; im Namen der Linneischen Societät zu Leipzig entworfen von Gotthelf Fischer. Leipzig, 1795. 80 p. pl.

1795.1

Anatomisch-physiologische Beobachtungen über eine Hauptverschie- denheit der Säugethier- und Fischzähne. Arch. Zool. Zootom. (Wiedemann), 1801, 2, 151-160.

1801.1

_- Sur les poissons. Bull. Soc. Imp. Nat. Moscou, 1831, 3, 116. 1831.1

- Bibliographia palæontologica animalium systematica. Mosquæ, 1834. $414 \mathrm{p}$.

1834.1

Pisces, p. 175-180.

Sur deux poissons fossiles de la Sibérie et de la Grèce. Moscou, 1838. 2 pls. $4^{\circ}$.

1838.1

_ Notice sur le Beryx dinolepidotus, poisson fossile de la craie blanche du gouvernement du Voronèje. Bull. Soc. Imp. Nat. Moscou, 1841, 3, 465-466. pl. - Neues Jahrb. Mineral., 1843, 126.

1841.1

Sur un poisson fossile de !a Grèce (Plabacanthus) Bull. Soc. Imp. Nat. Moscou, 1850, 23, 285-288. 1850.1

- Ommatolampes et Trachelacanthus, genera piscium fossilium nova, in literis Eduardo ab Eichwald datis, descripta. Mosqux, 1851. 8 p. 2 pls. $4^{\circ}$.

1851.1

- Sur quelques poissons fossiles de la Russie. Bull. Soc. Imp. Nat. Moscou, $1852,25,170-176$.

1852.1

Fischer-Sigwart, $H$. Fauna Helvetica (In Bibliographie nationale suisse. Répertoire méthodique de ce qui a été publié sur la Suisse et ses habitants, fasc. 6. xiv, 85 p. Berne, 1900) 1900.1 Poissons, cahier 5.

-. Aus der Schutzzone von Sempach. Arch. Sei. Phys. Nat., Genève, 1904, 4. sér. 18, 370-372. - Arch. Sci. Phys. Nat., Genève, 1904, C. R. 87. sess., 67-69. - Verh. Schweiz. Naturf. Gesell.s Aarau, 87, 57-59. 1904.1

- Der Haldenweiher. Zofingen, 1908. 14 p. pl. $8^{\circ}$ 1908.1

- Der Bitterling (Rhodeus amarus Ag.) im Wauwylermoos. Schweiz. Fischerei Zeitg., 1910, 18. Jahrg., 226228; 276-279.

1910.1

Fisher, A. $K$. Notes on the occurrence of a young crab-eater (Elacate canada), from the lower Hudson valley, New York. Proc. U. S. Nat. Mus. 1890 (1891), 13, 195.

1891.1

Fisher, $F . B$. Fishing and fishculture in Florida. Bull. U. S. Fish Comm. 1881 (1882), 1, 251. 
Fisher, Homer G., \& Eigenmann, Carl H. See Eigenmann \& Fisher.

Fisher, Paul, pseudonym for Chatto, William Andrew. Also styled Oliver, Stephen (pseudon.)

Fisk, Mary. A review of the fishes of the genus Osmerus of the California coast. Bull. Smithson. Instit., 1913, 46, 291-297. fig.

1913.1

Fiske, $\left(R e v_{0}\right)$ A d description of the town of Brookfield, in the county of Worcester. Coll. Mass. Hist. Soc., 1792,

1. ser. 1, 273.

1792.1

Fishes of the ponds and rivers.

Fiskel, Johannes. Die Litteratur iiber die Tierwelt des Königreichs Sachsen. Jahresber. Ver. Nat. Zwickau, 1901 (1902), 1-71.

1902.1

Fitch, Edward A. Large tunny [Orcynus thynnus] on the Essex coast. Zoologist, 1897, 4. ser. 1, 579-580.

1897.1

Fitzgerald, $C$. Viviparous minnows. Amer. Naturalist, 1872, 6, 561-562.

Breeding habits of Pœcilia sp.

Fitzgerald, G. G. On the mudfish (Neochanna apoda), an extract from a letter. Trans. New Zealand Instit., $1873,5,456$.

1873.1

Fitzgibbon, Edward, also styled Ephemera (pseudon.)

A handbook of angling: teaching fly-fishing, trolling, bottom-fishing, and salmon fishing. With the natural history of river fish, and the best modes of catching them. London, 1847. xii, $363 \mathrm{p} . \mathrm{s}^{\circ}$.

1847.1

The same. 2. ed. London, 1818. xil, $361 \mathrm{p}$.

3. ed. London, 1853. viii, 312 p. $8^{\circ}$.

t. ed. London, 1865. $8^{\circ}$.

Fitzgibbon, Edward, \& Young, Andrew. Book of salmon in two parts. Part I. The theory and principles of fly-fishing for salmon, with lists of salmon flies. Part II. The natural history of the salmon, all its known habits described and the best way of artificially breeding it explained. Usefully illustrated with numerous coloured engravings of salmon flies and salmon fry. London, 1850. xvi, 242 p. 9 pls. $16^{\circ}$. 1850.1

Fitzinger, Leopold Joseph Franz Johann [1802-1881] Ueber die Ausar- beitung einer Fauna des Erzherzogthums Oesterreich, nebst einer systematischen Aufzählung der in diesem Lande vorkommenden Säugethiere, Reptilien und Fische, Beitr. Landeskunde Oesterr. Ens, Wien, 1832, 1, 280.

1832.1

Vorläufiger Bericht über eine höchst interessante Entdeckung Dr Natterer's in Brasil. Isis (Oken), 1837, 379-380.

1837.2

Entdeckung von Lepidosiren paradoxa im Amazonflusse.

Bilder-Atlas zur wissenschaftlich-populären Naturgeschichte der Fische in ihren sämmtlichen Hauptformen. Wien, 1864. $77 \mathrm{col}$. pls. $4^{\circ}$.

1864.1

Versuch einer natürlichen Classification der Fische. Sitzber. Akad. Wiss. Wien, math.-nat. Cl., 1873, 67, 5-58.

1873.1

Die Gattungen der europäischen Cyprinen nach ihren äusseren Merkmalen. Sitzber. Akad. Wiss. Wien, math.nat. Cl., 1874, 68, 1. Abth., 145-170. Also separate; Wien, 1874. $8^{\circ}$. 1874.1

Les genres européens de la famille des cyprinides, d'après leurs différents caractères. Journ. Zool (Gervais), $1874,3,335-336$.

1874.2

Bericht über die an den oberösterreichischen Seen und in den dortigen Anstalten für künstliche Fischzucht gewonnenen Erfahrungen bezüglich der Bastardformen der Salmonen. Sitzber. Akad. Wiss. Wien, math.-nat. Cl., 1875, 70, 1. Abth., 394-400. Also separate; Wien, 1875.7 p. $8^{\circ}$.

1875.1

Sind Fischbastarde fruchtbar? Abstract in Zool. Garten, 1875, 16, 156157.

1875.2

Bericht über die an den Seen des Salzkammergutes, Salzburgs und Berchtesgadens gepflogenen Nachforschungen über die Natur des Silberlachses (Salmo schiffermülleri Bloch) Sitzber. Akad. Wiss. Wien, math.-nat. Cl., 1876, 72, 1. Abth., 235-240.

1876.1

Bericht über die gepflogenen Erhebungen bezüglich der in den beiden Seen Nieder-Oesterreichs, dem Erlaphund dem Lunzer-See vorkommenden Fischarten. Sitzber. Akad. Wiss. Wien, math.-nat. Cl., 1878, 78, 1. Abth., 596602.

1878.1

Fitzinger, Leopold Joseph, \& Heckel, Johann Jakob. See Heckel \& Fitzinger. 
Flack, Martin, \& Keith, Arthur. See Keith \& Flack.

Flagg, Henry Collins. Observations on the numb fish, or torporific eel. Trans. Amer. Phil. Soc., 1786, 2, 170-173.

1786.1

Flamel, — L'alcoolisme des poissons. La Nature, 1897, 25, pt. 2, 38-39.

1897.1

Fleischer, Esaias. Forsog til en naturhistorie over fiskene og amphibierne. Kjobenhavn, 1795. $8^{\circ} .1795 .1$

Fleming, $\left(D r_{.}\right) \longrightarrow$, Jardine, $W_{.}, \&$ Ashworth, E. See Áshworth, Jardine \& Fleming.

Fleming, John [1785-1857] A history of British animals, exhibiting the descriptive characters and systematical arrangement of the genera and species of quadrupeds, birds, reptiles, fishes, mollusca, and radiata of the United Kingdom; including the indigenous, extirpated and extinct kinds, together with periodical and occasional visitants. Edinburgh \& London, 1828. $8^{\circ}$. 1828.1

Observations tending to establish the identity of the deal fish of Orkney with the vaagmær of Iceland. Mag. Nat. Hist., 1831, 4, 215-220. 1831.1

- Notice of the remains of a fish found connected with a bed of coal at Clackmannan. Edinb. New Phil. Journ., 1835, 19, 314-317. fig.

1835.1

Description of a species of skate [ Hieroptera abredonensis] new to the British fauna. Edinb. New Phil. Journ., 1841, 31, 236-238.

1841.1

Report upon the experiments conducted at Stormontfield, near Perth, for the artificial propagation of salmon. Rept. Brit. Assoc. Adv. Sci., 26. meet., 1856, 451-458.

1856.1

Flemming, Walther [1843-] Ueber die Structur centraler Nervenzellen bei Wirbelthieren. Anat. Hefte, 1896, 6, 1. Abth., 561-570. pl.

1896.1

Fletcher, Hugh. Report on the geology of part of the counties of Victoria, Cape Breton and Richmond, Nova Scotia. Geol. Surv. Canada, Rept. Progress for 1876-77 (1878), 407-456. 1878.1

Fishes of the Bras d'Or lakes, Cape Breton, p. 403.

Fletcher, John. On the Tay sprat fishery, 1901-1905. 23. Ann. Rept. Fish. Board Scotland, 1905, pt. 3, 156-165.

1905.1
- On the Tay sprat fishery, 19051906. 24. Ann. Rept. Fish. Board Scotland, 1906, pt. 3, 159-168. 1906.1

Fletcher, William W. Report relative to the hatching and planting of the Penobscot salmon. Rept. U. S. Fish Comm. 1872-73 (1874), 2, 380. 1874.1

Flett, John S. The Old Red Sandstone of the Orkneys. Trans. Roy. Soc. Edinb., 1898, 39, 383-424. 4 figs.

Contains references to fossil fishes.

1898.1

Flieszbach, Otto. Meine Girardini, oder wie aus einem Weibchen ein Männchen wurde. Blätt. Aquar.Terrar. Kunde, 1901, 12. Jahrg., $130-$ 131.

1901.1

— Das Laichgeschäft des Chromis multicolor. Natur u. Haus, Dresden, 1903, 11. Jahrg., 323-324. 1903.1

Flint, (Rev.) W., \& Gilchrist, J.D.F. (editors) Science in South Africa. Cape Town, 1905. 505 p. illust. 1905.1

The South African marine fauna and its environment, by J. D. F. Gilchrist, p. 183-198.

Flintoff, $R . J$. A peculiarity in perch. Nature, 1896, 54, 492 .

1896.1

Floericke, Kurt Ehrenreich [1869-] Einheimische Fische. Die Süisswasserfische unsrer Heimat. Stuttgart, 1913. 104 p. illust. $8^{\circ}$. 1913.1

Flourens, Marie Jean Pierre [17941867] Nouvelles expériences sur le système nerveux. Arch. Gén. Méd., 1825, 8, 422-426. - Ann. Sci. Nat., 13, 86-105. - Mém. Acad. Sci. Paris, 1825, 9, 478-497.

1825.1

—_- Expériences sur le mécanisme de la respiration des poissons. Ann. Sci. Nat., 1830, 20, 5-25. - Notizen (Froriep), 27, 165-168. - Mém. Acad. Sci. Paris, 10, 53-72. Also separate; Paris, $1832 . \quad 1830.1$

Sur la respiration des poissons (In his Mémoires de physiologie comparée, no. 1. Paris \& London, 1844. 101 p. 8 pls. $4^{\circ}$ ) 1844.1

- Détermination du noeud vital ou point premier monteur du mécanisme respiratoire dans les vertébrés à sang froid. Ann. Sci. Nat. (Zool.), 1862, 4. sér. 17, 158-161. C. R. Acad. Sci. Paris, 54, 314-317. - Rev. Mag. Zool., 14, 69. 1862.1

Flourens, Marie Jean Pierre, Duvernoy, Georges Louis, \& Duméril, André Marie Constant. See Duméril, Flourens \& Duvernoy. 
Flower, Stanley $S$. Notes on the fauna of the White Nile and its tributaries. Proc. Zool. Soc. London, 1900 950-973.

1900.1

- Zoological gardens, Giza, near Cairo. Report for the year 1903. Cairo, 1904. 48 p. $8^{\circ}$.

1904.1

List of fishes in the zoological gardens at Giza, near Cairo (In his List of animals in the zoological gardens at Giza, 2. ed. Special Rept. Cairo Nat. Print. Dept., 1910, 347-363) 1910.1

Fluegel, C.G. Der Kabeljau, nebst den damit verwandten und für den Handel wichtigen Fischarten. Leipzig, 1842. $32 \mathrm{p}$.

1842.1

Fobes, Peres. A topographical description of the town of Raynham, in the county of Bristol. Coll. Mass. Hist. Soc., 1794, 1. ser. 3, 167-168. 1794.1

Freshwater fisheries of Raynham, Bridgewater and Middleborough, Massachusetts.

Focillon, Adolphe Jean [1823-1890] Rapport sur l'application des bateaux plongeurs de MM. Payerne et Lamiral à l'exploitation, à la culture et à l'acclimatation des animaux aquatiques. Bull. Soc. Acclim. Paris, 1857, 4, 207-214.

1857.1

Förg, — Remarques sur l'appareil pulmonaire du Gymnarchus niloticus (extraites d'une lettre adressée à M. Duvernoy) Ann. Sci. Nat. (Zool.), 1853, 3. sér. 20, 151-162. pl.

1853.1

Förster, $C$. Goldfische von Kröten getödtet. Zool. Garten, 1873, 14. Jahrg, 196-197.

1873.1

Fottinger, Alexandre. Recherches sur la structure de l'épiderme des cyclostomes, et quelques mots sur les cellules olfactives de ces animaux. Bull. Acad. Roy. Belgique, 1876, 2. sér. 41, 599-679. 3 pls.

1876.1

Discussion by Charles van Bambeke and Théodore Schwann on this work, Ibid., p. 6-12.

Fohmann, Vincent [1791-1837] Histoire naturelle du système lymphatique dans les animaux vertébrés. Leipzig \& Heidelberg, 1827. fol. Reviews in Isis (Oken), 1827, 7, 628. - Bull. (Férussac), $1830,22,94$.

1827.1

Fishes, pt. 1.

Das Saugadersystem der Fische. Heidelberg, 1827. 18 figs. fol. 1827.2

- Rapport sur le mémoire de $\mathbf{M}$, Desvignes, "Sur l'odorat des poissons."
Bull. Acad. Roy. Belgique, 1835, 2, 169 174.

1835.1

Rapport sur le mémoire de P. J. van Beneden, "Remarques sur le siège du goût dans la carpe." Bull. Acad. Roy. Belgique, 1835, 2, 103-107.

1835.2

Folger, Walter. A topographical description of Nantucket. Coll. Mass. Hist. Soc., 1794, 1. ser. 3, 153. 1794.1 Contains remarks on New England fisheries.

Folin, (Marquis) Alexandre Guillaume Léopold de [1818-] Pêches et chasses zoologiques. Paris, 1893. 12 $2^{\circ} 1893.1$

Fomin, L. S. Ueber die raubfängische Vernichtung der Häringe im Schwarzen und Azovschen Meere [Text in Russian] Dnevn. Otd. Icht. Imp. R. Obšč. Acclimat., Moskva, 1901, 3, 8384.

1901.1

Fontannes, Charles Francisque [18391886] Nouvelle contribution à la faune et à la flore des marnes pliocènes à Brissopsis d'Eurre (Drôme) [Poissons. Type nouveau de la famille des Clupéidées! Ann. Soc. Agric. Hist. Nat. Lyon, 1885, 5. sér. 7, 423-425. fig. 1885.1

Foote, $E$. The extrabranchial cartilages of the elasmobranchs. Anat. Anz., 1895, 13. Jahrg., 305-308. 4 figs. 1895.1

Forbes, Alexander. California. London, 1839. 352 p. $8^{\circ}$, 1839.1 Fishes, p. 64-75; 179.

Forbes, Edward [1815-1854] Communication on Blennius ocellatus. Mag. Nat. Hist., 1836, 9, $203 . \quad 1836.1$

Forbes, Henry Ogg [1851 - ] Shark's teeth. Nature, $1879,20,456-457$.

1879.1

On a species of Regalecus or great oarfish, caught in Okain's bay. Trans. New Zealand Instit., 1892, 24, 192-198.

1892.1

The first feeding of young trout. Bull. Liverpool Mus., 1897, 1, 24-25.

1897.1

- Habitat of Gastrosteus pungitius Linn. Bull. Liverpool Mus., 1897, 1, 24.

1897.2

- Malapterurus electricus. Bull. Liverpool Mus., 1897, 1, 25. 1897.3

Forbes, James Grant. Sketches historical and topographical of the Floridas; more particularly of east Florida. New York, 1821. 226 p. $8^{\circ}$.

Fishes, p. 93; 107; 117 . 
Forbes, Stephen Alfred. Alburnops nubilus Forbes, n. s. Bull. Ill. State Lab. Nat. Hist., 1878, 1, 56-57.

1878.1

Boleosoma camurum Forbes, n. s. Bull. Ill. State Lab. Nat. Hist., 1878, 1, $40-41$.

1878.2

- Episema jejuna Forbes, n. s. Bull. Ill. State Lab. Nat. Hist., 1878, 1, 60-61.

1878.3

- Esox ravenelli (?) Holbr. Bull. Ill. State Lab. Nat. Hist., 1878, 1, 53.

1878.4

The food of Illinois fishes. Bull. Ill. State Lab. Nat. Hist., 1878, 1, 71-89. - Chicago Field, 1879, 11, 19; 35-36.

1878.5

- Notes on the development of Amia. Proc. Amer. Assoc. Adv. Sci. 27. meet., 1878, 296-298. 1878.6

- On the crustacea eaten by fishes. Bull. Ill. State Lab. Nat. Hist., 1878, 1, $87-89$.

1878.7

- Pocilichthys asprigensis Forbes, n. s. Bull. Ill. State Lab. Nat. Hist., $1878,1,41-12$.

1878.8

- On some sensory structures of young dogfishes. Amer. Quart. Micr. Journ., 1879, 1, 257-260. pl. 1879.1

The food of fishes. Bull. Ill. State Lab. Nat. Hist., 1880,1 , no. 1, 19-70. - Rept. Ill. State Fish Comm. 1884, $90-127$.

1880.1

The food of the darters. Amer. Naturalist, 1880, 14, 697-703. Abstract in Forest \& Stream, 1880, 15, 205.

1880.2

On the food of young fishes. Bull. Ill. State Lab. Nat. Hist., 1880, 1 , no. 3, 19-85. - Fish. Gaz., 1881, 5, 64-189. Abstract in Proc. 2. Ann. Meet. Centr. Fishcult. Soc., 10-19. 1880.3 $1880,15,247$.
Silver

Forest \& Stream, 1880.4

- A rare fish in Illinois. Amer. Naturalist, 1881, 15, 232-233. $\quad 1881.1$

The blind cave fishes and their allies. Amer. Naturalist, 1882, 16, 1-5. 1882.1

The food of young whitefish (Coregonus clupeiformis) Bull. U. S. Fish Comm. 1881 (1882), 1, 19-20; 269270.

1882.2

An inquiry into the first food of young lake whitefish (Coregonus clupei- formis) Bull. U. S. Fish Comm. 1881 (1882), 1, 402-403.

1882.3

- On the first food of the whitefish.

Amer. Field, March 11, 1882. $\quad 1882.4$

Rhizopods as food for young fishes. Proc. Acad. Nat. Sci. Philad. 1881 (1882), 9-10. Abstract in Journ. Roy. Mier. Soc., 1882, 2. ser. 1, 618.

1882.5

The first food of the common whitefish (Coregonus clupeiformis Mitch.) Bull. Ill. State Lab. Nat. Hist., 1883, 1, 95-109. - Rept. U. S. Fish Comm. 1881 (1884), 9, 771-782. Extracts in Trans. Amer. Fish. Soc., 1888, 59-66. 1883.1

The food of the smaller freshwater fishes. Bull. Ill. State Lab. Nat. Hist., 1883, 6, 65-94.

1883.2

A catalogue of the native fishes of Illinois. Rept. Ill. State Fish Comm., 1884, 60-89. pls. Ibid., 1900, 59-80.

1884.1

Destruction of fish food by bladderwort (Utricularia) Forest \& Stream, 1884, 23, 109. - Bull. U. S. Fish Comm.1884, 4, $443 . \quad 1884.2$

- Aberration in the perch. Amer. Naturalist, 1885, 19, 192. 1885.1

Description of new Illinois fishes. Bull. Ill. State Lab. Nat. Hist., 1885, 2 135-139.

1885.2

On the food relations of freshwater fishes: a summary and discussion. Bull. Ill. State Lab. Nat. Hist., 1888, 2, $475-538$.

1888.1

- Studies of the food of freshwater fishes. Bull. Ill. State Lab. Nat. Hist., 1888, 2, 433-473.

1888.2

Notes on the food of the fishes of the Mississippi valley. Trans. Amer. Fisheries Soc. 1888 (1889), 37-59.

1889.1

Preliminary report upon the invertebrate animals inhabiting lakes Geneva and Mendota, Wisconsin, with an account of the fish epidemic in lake Mendota in 1884. Bull. U. S. Fish Comm. 1888 (1890), 8, 473-487. 3 pls. 1890.1

The aquarium of the United States Fish Commission at the World's Columbian exposition. Report of the director. Bull. U. S. Fish Comm. 1893 (1894), 13, 143-158.

1894.1 
Forbes, S. A.

The food of fishes. Bull. Ill. State Lab. Nat. Hist., 1903, 1, no. 3 , 19-70.

1903.1

On the food of young fishes. Bull. Ill. State Lab. Nat. Hist., 1903, 1, no. 3, 71-85.

1903.2

On the local distribution of certain Illinois fishes. An essay in statistical ecology. Bull. Ill. State Lab. Nat. Hist., 1907, 7, 273-303. 9 pls. \& 15 maps.

1907.1

On the general and interior distribution of Illinois fishes. Bull. Ill. State Lab. Nat. Hist., 1909, 8, 381-437. 102 maps.

1909.1

The investigation of a river system in the interest of its fisheries. Trans. Amer. Fisheries Soc. 1910 (1911), 179194.

1911.1

Definite results of survey work on the Illinois river. Trans. Amer. Fisheries Soc. 1911 (1912), 75-84. Also separate under the title: Chemical and biological investigations on the Illinois river, midsummer of 1911. A preliminary statement made to the American Fisheries Society, St. Louis, Mo., October 3,1911

1912.1

Forbes, Stephen Alfred, \& Richardson, Robert Earl. On a new shovel-nose sturgeon [Parascaphirhynchus albus from the Mississippi river. Bull. Ill. State Lab. Nat. Hist., 1905, 7, 37-44. 3 pls.

1905.1

- The fishes of Illinois. Ichthyology (In Natural History Survey of Illinois, 1908, vol. iii. exxxi, 358 p. 55 pls. \& 76 figs. 103 maps)

1908.1

Maps showing distribution of Illinois fishes, to accompany a report on the fishes of Illinois. Urbana, Ill., 1908. 103 maps.

1908.2

Forcade la Roquette, - Note sur les produits de la pêche dans les cours d'eau, les lacs et les étangs d'eau douce de la France. Bull. Soc. Acclim. Paris, 1860, 7, 136-138.

1860.1

Forchhammer, Thomas [-1827] De Blennii vivipari formatione et evolutione observationes, Kilix, 1819. 2 pls. $4^{\circ}$.

1819.1

Fordice, Morton William. Review of the American species of Stromateidæ. Proc. Acad. Nat. Sci. Philad. 1884 (1885), 311-317.
Fordice, Morton W., \& Eigenmann, Carl $H$. See Eigenmann \& Fordice.

Fordice, Morton W., \& Evermann, Barton Warren. See Evermann \& Fordice.

Fordice, Morton W., \& Jordan, David Starr. See Jordan \& Fordice.

Fordice, Morton W., \& Kirsch, Philip H. See Kirsch \& Fordice.

Forel, Francois Alphonse Christian [1811 - ] Notes sur une maladie épizootique qui a sévi chez les perches du lac Léman en 1867. Bull. Soc. Vaud. Sci. Nat., 1866-68, 9, 599-608. 1866.1

La faune profonde du Léman. Bull. Soc. Vaud. Sci. Nat., 1872-73, 12. 1872.1

Enquête sur l'épizootie de typhus qui a sévi sur les perches du lac Léman en 1873. Bull. Soc. Vaud. Sci. Nat. $1874-75,13,400-411$.

1874.1

- Matériaux pour servir à l'étude de la faune profonde du lac Léman. Bull. Soc. Vaud. Sci. Nat, 1874-75, 13, 1-159. Ibid., 1876-77, 14, 97-166; 201-364. Ibid., 1878, 16, 497-535. Ibid., 1879$80,16,149-169 ; 313-394.12$ pls.

1874.2

Faunistische Studien in den Siisswasserseen der Schweiz. Zeitschr. Wiss. Zool., 1878, 30, 383-392. 1878.1

La faune profonde des lacs suisses. Neue Denkschr. Schweiz. Gesell. Naturw., 1885, 29, 2. Abth., 75-78; 106107.

1885.1

- Faune e flore del lago di Ginevra. Boll. Sci., Pavia, 1887, 9, 87. 1887.1

Allgemeine Biologie eines Süsswassersees (In Zacharias, Otto. Die Tierwelt und Pfianzenwelt des Süisswassers. 1891, Bd. i) 1891.1

Cyprinus carpio n'existait pas à l'âge néolithique] Bull. Soc. Vaud. Sci. Nat., 1899 , 35, xiv.

1899.1

Mélanges ichthyologiques. Arch. Sci. Phys. Nat., Genève, 1900, 4. sér. 10 76-77. 1900.1

Quand la lotte a-t-elle été introduite dans le Léman? Bull. Soc. Vaud. Sci. Nat., 1900, 36, xviii-xix. 1900.2

Le Léman. Monographie limnologique. Lausanne, 1901. Tome iii, Livre 1. viii, 411 p. $8^{\circ}$.

1901.1 
L'origine de la faune des poissons du Léman. Bull. Soc. Vaud. Sci. Nat., 1901, 37, 221-225. - C. R. 84. Sess. Soc. Helvét. Sci. Nat., 1901, 5557. - Arch. Sci. Phys. Nat., Genève, 4. sér. 12, 507-508.

1901.2

- La pêche de la féra dans le Léman. Bull. Soc. Vaud. Sci. Nat., 1901, 37, 127-131. Ibid., 1903, 39, xl-xlii.Arch. Sci. Phys. Nat., Genève, 4. sér. 16, $740-741$.

1901.3

Un nouveau procédé de 'pêche dans la région profonde des lacs. Arch. Sci. Phys. Nat., Genève, 1904, C. R., 67.

1904.1

Pêche sur les fauberts. Verh. Schweiz. Naturf. Gesell., Aarau, 1904, 87, 59. - Arch. Sci. Phys. Nat., Genève, 4. sér. 18, 370. Ibid., C. R., 67. 1904.2

La présence dans l'Orbe de Vallorbe de brochets et de perches. Bull. Soc. Vaud. Sci. Nat., 1904, 40, lv-lvi. Arch. Sci. Phys. Nat., Genève, 4. sér. 18,510 .

1904.3

Barbus fluviatilis, Arch. Sci. Phys. Nat., Genève, 1906, 4. sér. 22, 399. 1906.1

La pêche du Léman. Arch. Sci. Phys. Nat., Genève, 1906, 4. sér. 22, 188-189.

1906.2

Statistique de la pêche dans le Léman en 1908. Bull. Suisse Pêche Neuchâtel, 1909, 10, 69-72.

1909.1

Die Fischfauna der schweizerischen Gewässer. Schweiz. Fischerei Zeitg., 1910, 18. Jahrg., 208-210. 1910.1

L'origine des poissons dans les eaux suisses. Arch. Sci. Phys. Nat., Genève, 1911, 4. sér. 31, 567-568. 1911.1

Forel, François Alphonse Christian, \& Du Plessis, $G$. Etude sur le typhus des perches; épizooties de 1867 et 1868. Bull. Soc. Méd. Suisse Rom. Lausanne, 1868, 2,$211 ; 229$.

1868.1

Forest, Jules. Terres-neuves d'Afrique. Naturaliste, Paris, 1902, 2. sér. 24. 133-135. 1902.1

Describes fish \& fishing on the west const of Africa.

Forester, Frank [pseudon. i. e. Herbert, $H$. W.] Frank Forester's fish and fishing of the United States and British provinces of North America, edited by W. H. Herbert. London \& New York, 1849. See Herbert, $H . W$.
- The complete manual for young sportsmen. New York, 1856. $480 \mathrm{p}$. $12^{\circ}$.

1856.1

Game fish, p. 363-379. Sea fishing, p. 468475. For later editions, see Herbert, $H$. $\Pi$.

Forir, H. Contributions à l'étude du système Crétacé de la Belgique. Ann. Mém. Soc. Géol. Belgique, 1887, 14, 25-56. 2 pls. Ibid., 1889, 16, 445-460. pl.

1887.1

Sur quelques poissons et crustacés nouveaux ou peu connus.

Fornario, $G$. Le degenerazioni dell' encefalo e dei muscoli negli Scillium. Ricerche sperimentali. Atti Accad. Med. Chir. Napoli, 1S94, 48. 1894.1

Forrest, H. Edward. The fauna of Shropshire, being an account of all the mammals, birds, reptiles, and fishes found in the county of Salop. Shrews. bury \& London, 1899. vi, 248 p. 24 pls. $8^{\circ}$.

1899.1

Fishes [record of species caught Rec. Caradoc \& Severn Valley Field Club, 1904, 14, 38.

1904.1

Records of fishes observed. Rec. Caradoc \& Severn Valley Field Club, $1906,16,29$.

1906.1

Vertebrates of Wales and Ireland. Zoologist, 1908, 4. ser. 12, 321325; 454 455. - Trans. Caradoc \& Severn Valley Field Club, 4, 245-24S.

1908.1

Forsberg, Anders. Bref från Brändö. Fiskeritidskr. Finl., 1893, 2, 60-62; 126128. Ibid., 1894, 3, 12-14; 138-141. Ibid., 1895, 4, 44-46.

1893.1

Gäddexporten från Alands- och sydvestra Finlands skärgard förr och nu. Fiskeritidskr. Finl., 1893, 2, 20-25.

1893.2

Gäddfisket i Alands och en del af sydvestra Finlands shärgård. Fiskeritidskr. Finl., 1893, 2, 4-8. 1893.3

Alands strömmingsfiske. Fiskeritidskr. Finl., 1894, 3, 40-14; 118-125. Ibid., 1895, 4, 40-44; 75-81. 1894.1

Bref från Aland. Fiskeritidskr. Finl., 1896, 5, 9-11. 1896.1

Några ord om hornsimpan (Cottus quadricornis) och dess vandringar. Fiskeritidskr. Finl., 1898, 7, 30-31.

1898.1

Sydvestra Finlands hafsfiske under 1897. Fiskeritidskr. Finl., 1898, 7, 9-12.
1898.2 
Forsberg, $A$.

Hafsfisket i sydvestra Finland under år 189s. Fiskeritidskr. Finl. $1899,8,18-22$.

1899.1

Forskål, Pehr [1736-1763] Descriptiones animalium avium, amphibiorum, piscium, insectorum, vermium; qux in itinere orientali observavit. Post mortem auctoris edidit Carsten Niebuhr. Havnix, 1775. 164 p. 43 pls. map. $4^{\circ}$.

1775.1

Catalogus piscium melitensium, p. 18.

This work, published posthumously, "is one of the most accurate of faunal lists, and one which shows a fine feeling for taxonomic distinctions scarcely traceable in any previous author." - Jordan, D. S. Guide to the Study of Fishes, vol. $i$, p. 395 .

Icones rerum naturalium quas in itinere orientali depingi curavit; edidit Carsten Niebuhr. Havniz, 1776. $15 \mathrm{p}$. $43 \mathrm{pl} .4^{\circ}$.

1776.1

Forssell, A. L. Bidrag till kännnedom on Echinorhyncherna i Finlands fiskar. Act. Soc. Faun. Flor. Fenn., 1905, 27, no. 3.30 p. 8 figs. $\quad 1905.1$

Forssell, Gösta. Beiträge zur Kenntnis der Anatomie der Lorenzian'schen Ampullen bei Acanthias vulgaris. Zeitschr. Wiss. Zool., 1894, 65, 725-744. pl.

1894.1

Forssner, Hjalmar. Die angeborenen Darm- und Oesophagusatresien. Eine entwickelungsgeschichtliche und patologisch-anatomische Studie. Anat. Hefte, 1907, 34, 1-163. 9 pls. \& 16 figs.

1907.1

Forsström, Karl. Om strömmingsfisket och fiskens behandling vid Träskö i Kimito. Fiskeritidskr. Finl,, 1893, 2, $9-10$.

1893.1

- Strömmingsfisket å den s. k. Träskö-fjärden. Fiskeritidskr. Finl., $1897,6,80-81$.

1897.1

Forsström, Oskar Adolf. Kúvia raja-karjalasta. Kansanvalistus-seuran Toimituksia, 1895, 91, 172. 13 figs.

1895.1

Forster, Johann Reinhold [17291798] A catalogue of the animals of North America. Containing an enumeration of the known quadrupeds, ... fish, insects, etc. London, 1771. $43 \mathrm{p}$. pl. $8^{\circ}$.

1771.1

— A letter ... to the Hon. Daines Barrington, vice-pres. $R$. $S$. on the management of carp in Polish Prussia. Phil. Trans. Roy. Soc. London, 1772 , 61, 310-325.

1772.1
- An account of some curious fishes, sent from Hudson's bay; in a letter to Thomas Pennant, Esq., Phil. Trans. Roy. Soc. London, 1773, 63, 149 160. pl.

1773.1

Zoologia Indica, sistens descriptiones animalium selectorum. Observationes de finibus et indole aëris, soli, marisque Indici; denique faunam indicam. Halæ, 1781. fol.

1781.1

2. ed., Latin and German text. Halæ, 1795. col. pl. fol.

- Enchiridion historize naturali inserviens, quo, termini et delineationes ad avium, piscium, insectorum et plantarum adumbrationes intelligendas et concinnandas, secundum methodum systematis Linnæani continentur. Halæ, 1788. $8^{\circ}$

1788.1

A French translation by Leveillé was published at Paris in 1799.

Descriptiones animalium qux in itinere ad maris Australis terras per annos 1772 , 1773 et 1774 suscepto collegit observavit et delineavit ... nunc demum editæ .... Henrico Lichtenstein. Berlin, 1844. xiii, 424 p. 1844.1

References to fishes and the localities where observed are:

Madeira insula, p. 2

Oceanus Atlanticus, p. 3.

Insula Sti. Jacobi (St. Jago), p. 5-9.

Nova Hollandia, p. 112-148; 152-153.

Insulæ intra tropicos maris Pacifici situx, p. 181-201.

Insulæ tropicæ Orientales, p. 212-237.

Mare Pacificum inter novam Caledoniam et Norfolcise insulam, p. 282-310.

Mare Pacificum et terræ Magellanica et mare Atlanticum, p. 358-362

Promontorium Bonx Spei, p. 407-416.

Forsyth, $J . B$. On the habits of Salmo fontinalis: from a letter addressed to Dr. Storer. Journ. Boston Soc. Nat. Hist., 1847, 5, 412-416.

1847.1

Fortin, Pierre. List of the cetacea, fishes, crustacea, and mollusca, which now inhabit and have inhabited the Canadian shores of the gulf of St. Lawrence, and are the object of fishing operations. ... (In Annual reports of Pierre Fortin, Esq., magistrate in command of the expedition for the protection of the fisheries in the gulf of St Lawrence, during the seasons of 18611862. Quebec, 1863. 109-124) 1863.1

Fortin, $R$. Notes de géologie normande. VI. Sur une carrière de Gaillon. Bull. Soc. Amis Sci. Nat. Rouen, 1900 , 4. sér. 35, 261-263. fig.

1900.1

Fortis, Alberto [1741-1803] Illustrazione storico-fisica d'una collezione di 
pesci fossili estratti dalla montagna di Bolca e posseduti dal Sig. Bozza, e dei quali un libraio d' Augusta avea intrapreso di pubblicare i disegni nel 1785. Saggi Scient. Letterari Accad. Padova, $1789,2,55$.

1789.1

- Due lettere sui pesci fossili di Bolca. Venezia, 1793. 47 p. $8^{\circ}$.

1793.1

These letters are reprinted from Opuscoli Scelti sulle Scieaze e Arti, 1793, 16, 196-216; 356-360.

- Lettera al Sig. Abate Testa sopra i pesci ischeletriti de' monti di Bolca. Opuscoli Scelti Scienze e Arti, 1793, 16, 196-216.

1793.2

- Transunto della replica al Sig. Abate Testa sugli izzioliti de' monti Veronesi. Opuscoli Scelti Scienze e Arti, 1793, 16, 356-360.

1793.3

"La replica fu stampata in Venezia l'anno 1793, nelle Lettere (tre) sui pesci fossili etc." -Vittorio dal Nero, Bibliografia, 1911.

Riflessioni sull' operetta dell' Ab. Domenico Testa intitolata, Lettera sopra i pesci fossili del monte Bolca sul Veronese (1793) Saggi Scient. Lett. Accad. Padova, 1794, 3, 2.

1794.1

Fortis, Alberto, \& Testa, Domenico. Tre lettere sui pesci fossili di Bolca. Venezia, 1793.

1793.1

Fortuyn, A.B. Droogleever. On the motor facialis- and abducens-nucleus of Lophius piscatorius. Proc. Akad. Wet. Amsterdam, 1909, 12, (44)-(47). pl.

1909.1

Over de motorische fascialis- en abducenskern van Lophius piscatorius. Versl. Akad. Wet. Amsterdam, 1909 , 17, 905-908. pl.

1909.2

- Notiz über den Eintritt der motorischen Nervenwurzeln in die Medulla oblongata und über die Läge der motorischen Kerne bei Amia calva L. Folia Neurobiol., Haarlem, 1912, 6, 2730.

1912.1

Foster, D.E. Statement concerning the menhaden fishery. Rept. U. S. Fish Comm. 1877 (1879), 5, 453. 1879.1

Foster, $H . M$. Pond herrings. Trans. Hull Scient. Field Natural. Club, $1898,1,9$.

1898.1

The fishes of the river Hull.

Trans. Hull Scient. Field Natural. Club, 1899, 1, 10-21.

1899.1

Foster, John Wells [1815-1873] On fossil fish in the coal rocks of Ohio. Amer. Journ. Sci., 1851, 12, 282-283.
Foster, (Sir) Michael, \& Balfour, $F$. $M$. The elements of embryology. New York, 1874. illus. $8^{\circ}$. 1874.1

1883. The same. 2. ed. London,

Foster, N.W., \& Atkins, Charles G. Second report of the commissioners of fisheries of the state of Maine. [Augusta] 1868, 1-39. 1868.1

Fougeroux de Bondaroy, - Description d'un poisson du genre des silures, appelé shaid ou shaïden par les Allemands, Silurus glanis. Mém. Hist. Acad. Sci. Paris, 1784, 216-228. pls.

1784.1

Foulis, Robert. Descriptive details of a large shark [Squalus maximus L.] Proc. Boston Soc. Nat. Hist., 1852, 4 , 202-206.

1852.1

Fouquet, $D$. Note sur une espèce d'infusoires parasites des poissons d'eau douce. Arch. Zool. Expér. Gén., Paris, $1876,5,159-165$. pl.

1876.1

Fourcroy, Antoine François de [17551809] Observations sur le gaz azote contenu dans la vessie natatoire de la carpe. Ann. de Chimie, 1789, 1, 47-51. 1789.1

Fourcroy, Antoine Francois de, \& Vauquelin, L. N. Analyse de f'ichthyophthalmite. Ann. Mus. Hist. Nat. Paris, 1804, 5, 317-324. - Journ. de Phys., 61, 106-107.

1804.1

Description et analyse d'une concrétion calculeuse tirée d'un poisson. Ann. Mus. Hist. Nat. Paris, 1807, 10, 179-181.

1807.1

Expériences chimiques pour servir à l'histoire de la laite des poissons. Ann. Mus. Hist. Nat. Paris, 1807, 10, 169-178. - Ann. Chimie, 64, 5-18. Journ. Chem. Phys. (Gehlen), 4, 603611. - Journ. Phil. (Nicholson), 25, 273279. - Mém. de l'Instit., Paris, 1807 , 42-67. - Nouv. Bull. Soc. Philom. Paris, 1, 35-36.

1807.2

Fourmarier, $P$. Découverte de Dipterus à Bilstain. Ann. Soc. Géol. Belgique, 1899,26 , cxiii.

1899.1

Fournel, D. H.L. [-1848] Faune de la Moselle; ou, Manuel de zoologie, contenant la description des animaux libres ou domestiques observés dans le département de la Moselle. Ouvrage rédigé d'après la méthode Cuvier. 2 vols. Metz \& Paris, 1827-40. 12。.

1827.1 
Fournet, Joseph Jean Baptiste Xavier [1801-1869] Recherches sur la distribution et sur les modifications du caractère de quelques animaux aquatiques du bassin du Rhône. Ann. Soc. Agricult. Hist. Nat., 1853.

1853.1

Fournier, — Poissons des rivières de la Haute-Vienne. 26. sess. Congrès Scient. France, 1860, 1, 511-514. 1860.1

Fourny, $M$. Histoire naturelle. Poissons. Catalogue des poissons qui se rencontrent dans le département de la Loire (In Statistique du département de la Loire, 1864, 8, 49-53) 1864.1

Fourny-Dulys, —_ Catalogue des poissons qui habitent les cours d'eau de la région. 29 sess. Congrès Scient. France, 1862, 278-279.

1862.1

Fourtau, $R$. Sur un nouveau gisement de poissons fossiles aux environs des pyramides de Ghizeh. Bull. Soc. Géol. France, 1899, 3. sér. 27, 237-240. 3 figs.

1899.1

Foussagrieves, J.B., \& Mericourt, Leroy de. Recherches sur les poissons toxicographes exotiques des pays chauds. Ann. Hygiène, 1861, Publ. no. 16.

1861.1

Fowler, George Herbert. Probable relation between temperature and the annual catch of anchovies in the Schelde district. Journ. Mar. Biol. Assoc., 1889-90, n. s. 1, 340. pl.

1889.1

Fowler, Henry W[eed] [1878-] Description of Ameiurus lacustris okeechobeensis (Heilprin) Proc. Acad. Nat. Sci. Philad. 1899 (1900), 480-481.

1900.1

A list of fishes collected at Port Antonio, Jamaica. Proc. Acad. Nat. Sci. Philad. 1899 (1900), 118-119.

1900.2

- Notes on a small collection of Chinese fishes. Proc. Acad. Nat. Sci. Philad. 1899 (1900), 179-182. 1900.3

Observations on fishes from the Caroline islands. Proc. Acad. Nat. Sci. Philad. 1899 (1900), 482-496. 2 pls.

1900.4

Contributions to the ichthyology of the tropical Pacific. Proc. Acad. Nat. Sci. Philad. 1900 (1901), 493-528. 4 pls.

1901.1

- Note on Ameiurus prosthistius. Proc. Acad. Nat. Sci. Philad. 1900 (1901), 352-355.

1901.2
Description of a new hemirhamphid. Proc. Acad. Nat. Sci. Philad. 1901 (1902), 293-294. fig. 1902.1

- Fishes from Caroline island. Proc. Acad. Nat. Sci. Philad. 1901 (1902), 324-326.

1902.2

Myctophum phengodes in the north Atlantic. Proc. Acad. Nat. Sci. Philad. 1901 (1902), 620-621. 1902.3

Note on the Odontostomidx [renamed Evermannellidæe] Proc. Acad. Nat. Sci. Philad. 1901 (1902), 211-212.

1902.4

Types of fishes ipreserved in the Philadelphia Academy of Natural Sciences] Proc. Acad. Nat. Sci. Philad. 1901 (1902), 327-341. 4 pls. 1902.5

Description of a new gurnard from Florida, with notes on the colors of some other Florida fishes. Proc. Acad. Nat. Sci. Philad., 1903-04, 55, 328-336. 1903.1

- Description of a new lantern fish. Proc. Acad. Nat. Sci. Philad., 1903-04, 55, 754-755.

1903.2

Centrobranchus chorocephalus.

Descriptions of new, little known and typical Atherinidx. Proc. Acad. Nat. Sci. Philad., 1903-04, 55, 727-742. 3 pls.

1903.3

- Descriptions of several fishes from Zanzibar island, two of which are new. Proc. Acad. Nat. Sci. Philad., 1903-04, 55, 161-176. 3 pls. 1903.4

Life colors of Pocilia limantouri, and description of a new Heros from Mexico. Proc. Acad. Nat. Sci. Philad., 1903-04, 55, 320-323.

1903.5

- New and little known Mugilidx and Sphyrænidæ. Proc. Acad. Nat. Sci. Philad., 1903-04, 55, 743-752. 2 pls. \& 2 figs.

1903.6

- Notes on a few fishes from the Mosquito coast of Nicaragua. Proc. Acad. Nat. Sci. Philad., 1903-04, 55, 346-351. 1903.7

The occurrence of three interesting fishes [Manta manatia, Thunnus thynnus and Cephalacanthus volitans] on the New Jersey coast. Science, 1903, n. S. $17,594-595$.

1903.8

A collection of fishes from Sumatra [With bibliography] Journ. Acad. 
Nat. Sci. Philad., 1904, 2. ser. 12, 495560. 21 pls. 1904.1

Description and figure of Coregonus nelsonii Bean. Proc. Amer. Phil. Soc. Philad., 1904, 43, 451-453. 2 pls. - Science, n. s. 21, 315.

1904.2

- Description of a new race of Notropis chalybous from New Jersey. Proc. Acad. Nat. Sci. Philad. 1904-05, 56, 239-240. pl.

1904.3

New, little known and typical berycoid fishes [Holocentridæ] Proc. Acad. Nat. Sci. Philad., 1904-05, 56 , 222-238. 6 figs.

1904.4

New, rare or little known scombroids. Proc. Acad. Nat. Sci. Philad., 1904-05, 56, 757-771. 2 figs. Ibid., 1905-06, 57, 56-88. 5 figs. Ibid., 1906$07,58,114-122.3$ figs.

1904.5

- Note on the Characinidæ. Proc. Acad. Nat. Sci. Philad., 1904-05, 56, 119 1904.6

Eucynopotamus, new name proposed for Evermannella Eigenmann, not Fowler.

Notes on fishes from Arkansas, Indian Territory and Texas. Proc. Acad. Nat. Sci. Philad., 1904-05, 56, 242-249. fig. 1904.7

Exoglossum in the Delaware. Science, 1905, n. s. 21, 994. 1905.1

Note on the broad white fish ‘Coregonus kennicotti Jordan and Gilbert] Science, 1905, n. s. 21, 315. 1905.2

___ Notes on some Arctic fishes, with a description of a new Oncocottus. Proc. Acad. Nat. Sci. Philad., 1905-06, 57, 362-370. 5 figs.

1905.3

Some fishes from Borneo. Proc Acad. Nat. Sci. Philad., 1905-06, 57, $455-523$. 1905.4

Thirteen new species are described.

Descriptions of two new species of Centropomus $[C$. gabbi, $C$. heringi Fowler] Proc. Acad. Nat. Sci. Philad. 1906-07, 58, 423-428. 2 figs. $\quad 1906.1$

- Fishes in winter. Forest \& Stream, 1906, 69, $1022 . \quad 1906.2$

The fishes of New Jersey. Ann. Rept. New Jersey State Mus. Trenton, 1905 (1906), 35-477. pl. 1906.3

Further knowledge of some heterognathous fishes. Parts I-II. Proc.
Acad. Nat. Sci. Philad., 1906-07, 58 , 293-351; 431-483. 60 figs. $\quad 1906.4$

- Notes on Pennsylvania fishes. Amer. Naturalist, 1906, 40, 595-596.

1906.5

- Pimephales notatus in the lower Susquehanna. Amer. Naturalist, 1906, 40,743 .

1906.6

Some cold-blooded vertebrates of the Florida Keys [fishes] Proc. Acad. Nat. Sci. Philad., 1906-07, 58, 79-113. pl. \& 13 figs.

1906.7

- Some new and little known percoid fishes. Proc. Acad. Nat. Sci. Philad., 1906-07, 58, 510-52s. 10 figs. 1906.8

- Some unusual New Jersey fishes. Science, 1906, n. s. 24, 596-597. 1906.9

- A collection of fishes from Victoria, Australia. Proc. Acad. Nat. Sci. Philad., 1907-08, 59, 419-444. 10 figs. 1907.1

Gambusia in New Jersey. Science, 1907, n. s. 26, 639. 1907.2

- Notes on lancelets and lampreys. Proc. Acad. Nat. Sci. Philad., 1907-08, 59, 461-166. 2 figs.

1907.3

- Notes on Serranida. Proc. Acad. Nat. Sci. Philad., 1907-08, 59, 249-269. 5 figs.

1907.4

Records of Pennsylvania fishes. Amer. Naturalist, 1907, 41, 5-21. fig.

1907.5

- A supplementary account of the fishes of New Jersey. Ann. Rept. New Jersey State Mus., Trenton, 1906 (1907), 251-350. pl.

1907.6

- Further notes on New Jersey fishes. Ann. Rept. New Jersey State Mus., Trenton, 1907 (1908), 120-189. 3 pls.

1908.1

- Notes on sharks. Proc. Acad. Nat. Sci. Philad., 1908-09, 60, 52-70.

Eulamia odontaspis, n. sp.

1908.2

A synopsis of the Cyprinidx of Pennsylvania. Proc. Acad. Nat. Sci. Philad., 1908-09, 60, 517-553. pl.

Notropis keimi, n. sp.

1908.3

Fundulus lucio again in New Jersey. Science, 1909, n. s. 30, 526.

1909.1 
Fowler, $H . W$.

A new species of fish of the genus Atopichthys, with notes on New Jersey fishes. Proc. Acad. Nat. Sci. Philad., 1909-10, 61, 406-408.

Atopichthys phillipsi, n. sp.

1909.2

- Note on some New Jersey fishes [Also first record in southern New Jersey of Hemidactylium scutatum ? Science, 1909, n. s. 29, 79.

1909.3

Notes on fishes at Corson's inlet, New Jersey. Science, 1909, n. s. 29, 544. 1909.4

Notes on New Jersey fishes, amplibians and reptiles. Ann. Rept. New Jersey State Museum, Trenton, 1908 (1909), 349-40s.

Fishes, p. 351-392.

1909.5

The smooth hound Mustelus mustelus] and some other fishes in New Jersey. Science, 1909 , n. s. 30, 815.

1909.6

Description of four new cyprinoids (Rhodeinæ) Proc. Acad. Nat. Sci. Philad., 1910-11, 62, 476-486.

1910.1

Little known New Jersey fishes. Proc. Acad. Nat. Sci. Philad., 1910-11, 62, 599-602.

1910.2

_- A new albuloid fish from Santo Domingo. Proc. Acad. Nat. Sci. Philad., 1910-11, 62, 651-654. fig.

1910.3

- Note on some Pennsylvania fishes. Science, $1910, \mathrm{n}, \mathrm{s}, 31,345-346$.

1910.4

Note on the distribution of some Pennsylvania fishes. Science, 1910, n. s. 32, 926-927.

1910.5

- Notes on batoid fishes. Proc. Acad. Nat. Sci. Philad., 1910-11, 62, 468-475. 2 figs.

1910.6

- Notes on chimæroid and ganoid fishes. Proc. Acad. Nat. Sci. Philad., 1910-11, 62, 603-612. pl. 1910.7

- Notes on the variation of some species of the genus Notropis. Proc. Acad. Nat. Sci. Philad., 1910-11, 62 , 273-293. 7 pls.

1910.8

The proper restriction of Eucynopotamus. Science, 1910, n. s. 31, 790.

1910.9

Galeocharax, n. g., founded on Cynopotamus gulo.

Carcharias borneensis and Barbus elongatus, as preoccupied names. Science, 1911, n. s. 33, 748 .

1911.1
A description of the fossil fish remains of the Cretaceous, Eocene and Miocene formations of New Jersey; with a chapter on the geology by Henry B. Kiimmel. Bull. Geol. Surv. New Jersey, 1911, no. 4, 1-192. 10 pls. \& 108 figs.

1911.2

The fishes of Delaware. Proc. Acad. Nat. Sci. Philad., 1911-12, 63, $3-16$.

1911.3

-. A new flat fish from New Jersey. Proc. Acad. Nat. Sci. Philad., 1911-12, 63, 200-203. 2 figs.

1911.4 Citharichthys micros, n. sp.

New freshwater fishes from western Ecuador. Proc. Acad. Nat. Sci. Philad., 1911-12, 63, 493-520. 7 figs.

1911.5

Notes on clupeoid fishes. Proc. Acad. Nat. Sci. Philad., 1911-12, 63, 204-221. 4 figs.

1911.6

Notes on salmonoid and related fishes [Stomias, Synodus] Proc. Acad. Nat. Sci. Philad., 1911-12, 63, 551-571. 3 figs.

1911.7

- Some fishes from Venezuela. Proc. Acad. Nat. Sci. Philad., 1911-12, $63,419-437.5$ figs.

1911.8

- Description of nine new eels, with notes on other species. Proc. Acad. Nat. Sci. Philad., 1912-13, 64, 8-33. 9 figs.

1912.1

- Hermaphrodite shad in the Delaware. Science, 1912, n. S. 36, 18-19

1912.2

Records of fishes for the middle Atlantic states and Virginia. Proc. Acad. Nat. Sci. Philad., 1912-13, 64, 34-59. 2 figs.

1912.3

Some features of ornamentation in freshwater fishes. Amer. Naturalist, $1912,46,470-476$. pl. 1912.4

Fowlerina Eigenmann, a preoccupied generic name. Science, 1913, n. s. 38,51 .

1913.1

Description of a new blenny from New Jersey, with notes on other fishes from the middle Atlantic states. Proc. Acad. Nat. Sci. Philad., 1914, 65, 342358. fig.

1914.1

- Fishes and reptiles from Assuan, Egypt. Copeia, 1914, no.8, 1-2. 1914.2

- Fishes in polluted waters. $\mathrm{Co}$ peia, 1914 , no. 5,4 .
1914.3 
- Hadropterus peltatus in the Delaware. Science, 1914, n. s. 40, 939-940.

1914.4

The long-nosed dace in the Hackensack, New York. Copeia, 1914, no. $11,3$.

1914.5

Notes on catostomoid fishes. Proc. Acad. Nat. Sci. Philad. 1913 (1914), 65, 45-60. fig.

1914.6

- Notes on New Jersey fishes. Copeia, 1914, no. 13, 1-2.

1914.7

- Notes on the fishes at Ocean city, Maryland. Copeia, 1914, no. 2, 2-3.

1914.8

Notes on the fishes of the Chincoteague region of Virginia. Proc. Acad. Nat. Sci. Philad. 1913 (1914), 65, 61-65.

1914.9

Some type specimens of the American cyprinoid fishes of the genus Rutilus. Proc. Acad. Nat. Sci. Philad. 1913 (1914), 65, 66-71. 7 figs. 1914.10

- A list of Santo Domingo fishes. Copeia, 1915, no. 24, 49-50.

1915.1

Note on some gymnotid fishes. Copeia, 1915, no. 15, 1-2.

1915.2

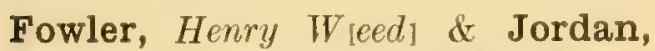
David Starr. See Jordan \& Fowler.

Fowler, Henry [Weed] \& Phillips, Richard $J$. A new fish of the genus Paralepis from New Jersey. Proc. Acad. Nat. Sci. Philad. 1910 (1911), 62, 403406. fig.

1910.1

Paralepis barracudina, $\mathbf{n}$. sp.

Fishes in the water-supply of Wilmington, Delaware. Copeia, 1913, no. $1,3-4$.

1913.1

Fowler, Henry [Weed] \& Sharp, Benjamin. See Sharp \& Fowler.

Fox, C. Squalus (Echinorhinus) spinosus. Nature, $1873,9,42$.

1873.1

Fox, Charles. Notice of a new mode of preparing fish-skins for museums. Amer. Journ. Sci., 1839, 36, 196-197.

1839.1

Fox, E. Exportation of salmon ova to New Zealand in 1876 . Rept. U.S. Fish Comm. 1875-76 (1878), 4, 968 .

1878.1

Fox, $H$. Notes on the geology and fossils of some Devonian rocks on the north coast of Cornwall. Geol. Mag., 1900, 4. dec. 7, 145-152. pl. 1900.1
Fox, Howard. The pilchard fisheries of Falmouth, England, 1882. Rept. U. S. Fish Comm. 1883 (1885), 13, 1183-1184.

1885.1

Fox, William $J$. Names of animals published by Osbeck in 1765. Science, 1900, n. s. $12,716-718 . \quad 1900.1$

Fox-Strangways, $C$. Carboniferous limestone fossils from south Derbyshire. Mem. Geol. Surv. England, 1905, 141, 13-21.

1905.1

Foyn, Sven. Torskefiskeriet og hvalfangsten i Finmarken. Morgenbl., Christiania, 1879, no. 67 A. 1879.1

Fr., L. von. Vom Bodensee-Zander. Schweiz. Fischereizeitg., 1893, 1, 135. Also separate; Pfäffikon-Zürich, 1893. 1 p. $8^{\circ}$. 1893.1

Fraas, Carl Nicol [1810-1875] Die künstliche Fischerzeugung nach den Erfahrungen der künstliche FischzuchtAnstalt der General-Comité des Landwirthschaftlichen-Vereins von Bayern. 2. ed. München, 1854. $2 \mathrm{pls} .8^{\circ}$.

1854.1

Fraas, Eberhard [1862-1915] Kopfstacheln von Hybodus und Acrodus, sogenannte Ceratodus heteromorphus Ag. Jahresh. Ver. Vaterl. Naturk. Württemberg, $1889,45,233-240$. pl. \& 4 figs.

1889.1

- Neue Selachier-Reste aus dem oberen Lias von Holzmaden in Württemberg. Jahresh. Ver. Vaterl. Naturk. Württemberg, 1896, 52, 1-25. 2 pls.

1896.1

i. Hybodus hauffianus E. Fraas (= Hybodus reticulatus Quenstedt, non Agassiz)

$$
\text { ii. Paloospinax smith-woodwardii E. Fraas. }
$$

Ceratodus priscus E. Fraas aus dem Hauptbuntsandstein. Ber. Oberrhein. Geol. Ver., 1904, 37, 30-32. fig.

1904.1

Die geognostische Sammlung Württembergs im Parterre-Saal, zugleich ein Leitfaden für die geologischen Verhältnisse und die vorweltlichen Bewohner unseres Landes. 2. ed. Stutgart, 1906. 84 p. 51 figs. $\quad 1906.1$

Säge von Propristis schweinfurthi Dames aus dem oberen Eocän von Aegypten. Neues Jahrb. Mineral., Geol. Pal., 1907, 1, 1-6. pl. 1907.1

Chimäridenreste aus dem oberen Lias von Holzmaden. Jahresh. Ver. Vaterl. Naturk. Württemberg, 1910, 66, 55-63. pl. 
Fraas, Oscar Friedrich [1824-1897] Squatina acanthoderma von Nusplingen. Berlin, 1854. 3 pls. $8^{\circ}$. 1854.1

A few notes upon the more recent discoveries and improvements in pisciculture [Translated and condensed from second edition of his "Künstliche Erzeugung," etc.] Rept. U.S. Patent Comm., 1861 , p. 301-304.

1861.1

- Ueber Semionotus und einige Iieuperconchylien. Jahresh. Ver. Vaterl. Naturk. Württemberg, 1861, 17, 81101. pl.

1861.2

Fraenkẻl, A. Ueber die Wirkung des Rizins auf Fischblut. Ein Beitrag zur Frage der natürlichen Immunität. Beitr. Chem. Phys. Path., 1903, 4. 1903.1

Fraenkel, Fritz. Die Zucht des Fadensackwelses (Saccobranchus fossilis) Blätt. Aquar.-Terrar. Kunde, 1912, 23. Jahrg., 567-568. 2 figs.

1912.1

- Haltung und Zucht der Groppe (Cottus gobio) Blätt. Aquar-Terrar. Kunde, 1913, 24. Jahrg., 401-403. fig. 1913.1

- Meine Seefische, Blätt. Aquar.Terrar. Kunde, 1913, 24. Jahrg., 681684. 2 figs.

1913.2

Fraiche, Félix. Traité des procédés de multiplication naturelle et artificielle des poissons. Paris, 1863. figs. $12^{\circ}$.

1863.1

Fraipont, Charles. Description d'un nouveau Pteraspis [ $P$. dewalquei, n. sp.] du Gedinnien belge, et sur un remarquable bouclier ventral de Pteraspis crouchi (Lank.) des schistes taunusiens. Ann. Soc. Géol. Belgique, 1908, 35, M. 3-M. 5.2 pls.

1908.1

- Sur les ostracophores belges. Bull. Soc. Géol. Belgique, 1912, 26, 6669.

1912.1

Fraipont, Julien Jean Joseph [1857 - Un nouveau ganoilde du calcaire carbonifère de Belgique (Benedenius soreili, n. sp.) Ann. Soc. Géol. Belgique, 1889-90, 17, 211-220. pl. 1889.1

Fraisse, Paul Hermann [1851-] Die Fische des Maingebeites von Unterfranken und Aschaffenburg. WVürzburg, 1880. 19 p. $8^{\circ}$. 1880.1

France, Raoul Heinrich. A rovarok mint haltáplálék Insekten als Fischnahrung] Rovart. Lapok, 1897, 4, 194197. 4 figs.
Franchère, Gabriel. Relation d'un voyage à la côte du nord-ouest de l'Amérique septentrionale dans les années 1810-1814. Montreal, 1820. 284 p. $8^{\circ}$.

1820.1

Fisheries in the Columbia river, p. 236-238.

The same. 2. ed. New York, 1854. 376 p. 3 pls. $12^{\circ}$. 1854.1

Francis, Francis [1822-1886] Fishculture; a practical guide to the modern system of breeding and rearing fish. London, 1862.267 p. illust. $12^{\circ}$.

1862.1

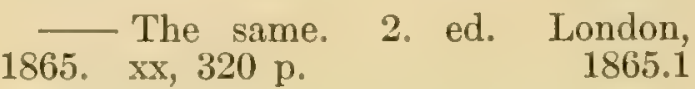
Reports on salmon ladders, with original drawings, plans and sections. London, 1870. 32 p. pl. $4^{\circ}$. 1870.1

Herrings and mackerel Scomber scomber in Brighton aquarium. Zoologist, 1872, 2. ser. 7, 3339-3340. 1872.1

Grund der Abnahme der Lachse. Circul. Deutsch. Fischerei Ver., 1873, no. $2,47-50$.

1873.1

The colour of trout. Fish. Gazette, 1878 , n. S. 2, no. 64, 327-328. Chicago Field, 1878, 10, 164. 1878.1

A migratory Coregonus. Field, Farm and Garden, 1878, 51, 10-17.

1878.2

White trout and salmon in Galway. Fish. Gazette, 1878, n. s. 2, no. $56,231-232$.

1878.3

The practical management of fisheries. A book for proprietors and keepers. London, 1883. 114 p. illust. $8^{\circ}$.

1883.1

Franciscus, Erasmus [1627-1694] Ostund West-Indischer wie auch Sinesischer Lust- und Stats-garten. . . Nürnberg, 1762. xxxvi p. $66 \mathrm{pls}$. fol. 1762.1 Fishes, p. $20-35 ; 150-153 ; 449 ; 452 ; 681$; $926 ; 960 ; 986 ; 1027 ; 1392$.

Franck, François. See FrançoisFranck, Charles $A$.

Franco, $G$. Elenco dei nomi dialettali dei principali pesci del distretto peschereccio e del mercato di Gallipoli (Puglie) Riv. Mens. Pesca, Pavia, 1911, 6. sér. 13, 193-197.

1911.1

Francois-Franck, Charles $A$. The electricity of the torpedo. Nature, 1879 , 19, 295-297; 320-322. figs. 1879.1 
Etudes expérimentales de mécanique respiratoire. C. R. Mém. Soc. Biol. Paris, 1906, 1, 799-802.

1906.1

i. Analyse graphique des mouvements respiratoires des poissons téléosteens.

ii. Fonctionnement de la membrane limitante operculaire; son rôle dans la respiration régulière et dans mouvements respiratoires redoublés chez les poissons téléostéens.

- Mécanique respiratoire des poissons téléostéens. C. R. Mém. Soc. Biol. Paris, 1906, 1, 962-967. 2 figs. 1906.2

i. Technique des explorations graphiques.

ii. Technique des prises de vues photo- et chrono-photographiques dans l'étude de la mécanique respiratoire des poissons téléostéens.

Note complémentaire sur les mouvements actifs de la membrane limitante operculaire des poissons téléostéens. C. R. Mém. Soc. Biol. Paris, $1906,1,838-839$.

1906.3

- Recherches anatomo-physiologiques sur le cour et l'appareil circulatoire des poissons et des mollusques céphalopodes. I. Cour et circulation coronaire des sélaciens. C. R. Mém. Soc. Biol. Paris, 1913, 2, 617-620. fig. 1913.1

Frank, Felix. Beitrag zur Zucht der Teleskopfische. Isis (Russ), 1880, 5. Jahrg., 179-180.

1880.1

Frank, $P$. Berichte aus Argentinien. II. Ueber drei lebendgebärende Zahnkarpfen aus Argentinien. Blätt. Aquar.Terrar. Kunde, 1913, 24. Jahrg., 370373. 3 figs.

1913.1

Franke, Johann. Die Ernährung der Fische und die Bedeutung des Planktons. Stenogr. Protok. Verh. Internat. Fisch.Kongr., Wien, 1905 (1906), 115-123; $124-127$.

1906.1

Causes of degeneration of American trout in Austria. Proc. 4. Intern. Fish. Congr., Washington, D. C., 1908, pt. 2, 983-989.

1908.1

- Radical prevention of Costia necatrix in salmonoid fry. Proc. 4. Intern. Fish. Congr., Washington, D. C. 1908, pt. 2, 917-928.

1908.2

Franklin, C. L. Phosphorescence in deep-sea animals. Science, $1900, \mathrm{n}$. s. 11, 954 .

1900.1

Franklin, Dwight. A method of preparing fishes for museum and exhibition purposes. Proc. 4. Intern. Fish. Congr., Wrashington, D. C., 1908, pt. 2, 13531363. pl.
A method of preparing fishes for museum and exhibition purposes. Bull. Bureau Fisheries, 1910, 28, 1353-1355. pl.

1910.1

Note on a nesting sunfish. Copeia, 1914, no. 11, 1.

1914.1

Some fish of the middle west. Amer. Mus. Journ., 1914, 14, 37.

1914.2

Franque, Heinrich. De Amia calvo anatomia. Inaug. Dissert. Berolini, 1847. 12 p. pl. 1847.1

Frantzius, Alexander von [18211877] Ueber den glatten Hay des Aristoteles. Arb. Ver. Schles. Gesell., 1849, $37-39$

1849.1

Franz, $K$. Ueber die Entwicklung von Hypochorda und Ligamentum longitudinale ventrale bei Teleostiern. Morphol. Jahrb., 1897, 25, 143-169. pl.

1897.1

Franz, Viktor. Zur Anatomie, Histologie und funktionellen Gestaltung des Selachierauges. Jena. Zeitschr. Naturw., $1905,40,697-840$. pl. \& 32 figs. 1905.1

Beobachtungen am lebenden Selachierauge. Jena. Zeitschr. Naturw. $1906,41,429-471$. 1906.1

- Ueber die Sinnesfähigkeiten der Haifische. Natur. Zeitsch. Naturfr., Leipzig, 1906, 2, 566-570. 1906.2

_ Bau des Eulenauges und Theorie des Teleskopauges. Biol. Centralbl., $1907,27,271-278 ; 341-351$. $\quad 1907.1$

Die biologische Bedeutung des Silberglanzes in der Fischhaut. Biol. Centralbl., 1907, 27, 278-285. 1907.2

- Der Lumpfisch (Cyclopterus lumpus L.) Natur u. Haus, Dresden, 1907, 15. Jahrg., 323-327. 15 figs.

1907.3

Ueber das Auge und das Sehen der Wirbeltiere. Zeitschr. Naturw. Stuttgart, 1907, 78, 383-385. 1907.4

Ueber die Bedeutung des sogenannten "Dotterkerns" im Schollenei. Verh. Deutsch. Zool. Ges., 1907, 17, 99-105. 14 figs.

1907.5

- Neuere Ergebnisse über Fischwanderungen in der Nord- und Ostsee. Intern. Rev. Hydrobiol. \& Hydrogr., 1908, 1, 243-256.

1908.1

- Die Struktur der Pigmentzelle.

Biol. Centralbl., 1908, 28, 536-543; 545-548. 11 figs. 1908.2 
Franz, $V$.

Unsere gegenwärtigen Kenntnisse vom Lebenslauf des Aales ( $A n$ guilla vulgaris Flem.) und ihre ökonomische Bedeutung. Intern. Rev. Hydrobiol. \& Hydrogr., 1908, 1, 488-498.

1908.3

Einige Versuche zur Biologie der Fischlarven. Intern. Rev. Hydrobiol. \& Hydrogr., 1909, 2, 557-579. 1909.1

Die Scholle, ein Nutzfisch der deutschen Meere. Meereskunde, Berlin, 1909, 3, pt. 12, 1-37.

1909.2

Die Eiproduktion der Scholle (Pleuronectes platessa L.) IViss. Meeresuntersuch. Kiel (Abt. Helgoland), 1910, n. S. 9, Heft. 1, 59-141. 8 pls. \& 18 figs. Abstract in Mitt. Deutsch. Seefischerei Ver., 26, 522-526. fig.

1910.1

- Farbenanpassung bei Fischen. Kosmos, Stuttgart, 1910, 7. Jahrg., 215217. fig.

1910.2

Der feinere Bau des Processus falciformis im Auge der Knochenfische. Arch. Vergl. Ophthalm., Leipzig, 1910, 1, 427-443. 3 pls.

1910.3

Die japanischen Knochenfische der Sammlungen Haberer und Doflein. Abh. Bayer. Akad. Wiss., 2. Cl., 1910, Suppl. 4, no. 1, 1-135. pls. \& 7 figs.

1910.4

- Die Laichwanderungen der Fische. Ein Beitrag zur Gesellschaftsbiologie der Tiere. Arch. Rassen Ges. Biol., 1910, 7. Jahrg., 159-168. 1910.5

Photographien mit ultraviolettem Lichte. Teil 1. Vom Ovarialei der Ínochenfische. Zeitschr. Wiss. Mikr., $1910,27,41-43$. pl.

1910.6

Phototaxis und Wanderung. Nach Versuchen mit Jungfischen und Fischlarven. Intern. Rev. Hydrobiol. \& Hydrogr., 1910, 3, 306-334. 1910.7

Ueber die Bedingungen der Phototaxis bei freibeweglichen 'Tieren. Zentralbl. Physiol., 1910, 24, 833-837. fig.

1910.8

Ueber die Ernährungsweise einiger Nordseefische, besonders der Scholle. IViss. Meeresuntersuch. Kiel (Abt. Helgoland), 1910, 9, 197-215.

1910.9

Ueber die Wanderungen der Fische, insbesondere des Aals. Natur. 'Leitschr., Leipzig, 1910, 6, 111-117, 149-154.
Untersuchungen über das spezifische Gewicht der planktonischen Fischeier. Wiss. Meeresuntersuch. Kiel (Abt. Helgoland), 1910, 9, 177-196. 3 figs.

1910.11

- Zur Eiproduktion der Scholle (Pleuronectes platessa L.) Nachträge. Wiss. Meeresuntersuch. Kiel (Abt. Helgoland), 1910, n. s. 9, Heft 2, 217-224. 2 figs.

1910.12

Zur Physiologie und Pathologie der Chromatophoren. Biol. Centralbl. $1910,30,150-158$.

1910.13

— Beiträge zur Kenntnis der Phototaxis; nach Versuchen an Süsswassertieren. Intern. Hydrobiol. \& Hydrogr. 1911, Biol. Suppl., 2. ser. 4, 1-11. fig.

1911.1

Fischwanderungen. Himmel . u. Erde, 1911, 23. Jahrg., 546-559. 7 figs.

1911.2

Das intracraniale und intracerebrale Verhalten des Nervus trochlearis bei den Knochenfischen. Anat. Anz., 1911, 38, 592-598. 11 figs. $\quad 1911.3$

- Das Kleinhirn der Ǩnochenfische. Zool. Jahrb. (Anat. Abt.), 1911, 32, 401-464. 3 pls. \& 32 figs. - Verh. 20.-21. Vers. Deutsch. Zool. Gesell. 1911, 200-205.

1911.4

Das Mormyridenhirn. Zool. Jahrb. (Anat. Abt.), 1911, 32, 465-492. 3 pls. \& 9 figs.

1911.5

- Ueber die Bedingungen der Phototaxis bei freibeweglichen Tieren. Centralbl. Physiol., 1911, 24, 833-837.

1911.6

Ueber Ortgedächtnis bei Fischen und seine Bedeutung für die Wanderungen. Kurzer Bericht über das Resultat einer Umfrage. Intern. Hydrobiol. \& Hydrogr , 1911, 4, 327-330. - Schweiz. Fischerei Zeitg., 19, 107-108. - Allgem. Fischerei Zeitg., 1911, no. 10. Verh. Deutsch. Nat. Aerzte Vers., 83, pt. 2, 411-418. - Arch. Hydrobiol., Stuttgart, 7, 637-674.

1911.7

W- Weitere Phototaxisstudien. I. Zur Phototaxis bei Fischen. Intern. Hydrobiol. \& Hydrogr., 1911, Biol. Suppl., 3. ser. 3, 1-23.

1911.8

Beitrag zur Kenntnis des Ependyms im Fischgehirn. Biol. Centralbl. $1912,32,375-383$.

1912.1

— Beiträge zur Kenntnis des Mittelhirns und Zivischenhirns der Knochenfische. Folia Neurobiol., Haarlem, 1912, 6, 402-441. 
Ueber das Kleinhirn und die statische Funktion bei den planktonischen Fischlarven. Verh. 8. Intern. Zool. Kong., Graz, 1910 (1912), 516-520. 6 figs.

1912.3

- Ueber das Lernvermögen der Fische. Allgem. Fischerei Zeitg., 1912, 37, 361-364.

1912.4

- Vom Gehirn der Fische. Blätt. Aquar.-Terrar. Kunde, 1912, 22. Jahrg., $431-433 ; 447-449 ; 468-469.2$ figs.

1912.5

Faseranatomie des Mormyridengehirns. Anat. Anz., 1913, 45, 271279. fig.

1913.1

Franz, Viktor, Brehm, Alfred, \& Steche, Otto. Die Fische, in Brehm's Tierleben. 4. ed. See Brehm, A.E.

Franz, Viktor, \& Stechow, E. Symbiose zwischen einem Fisch und einem Hydroidpolypen. Zool. Anz., 1908, 32, $752-754$.

1908.1

Fraser, Alexander. Natural history of the salmon, herring, cod, etc., with a short account of Greenland. ... Inverness, $1830.8^{\circ}$.

1830.1

- The same. 2. ed. 1833. $12^{\circ}$.

1833.1

Fraser, J.E. Notes on the spawning of the Anguillæ. Rept. Brit. Assoc. Adv. Sci., 60. meet., 1890 (1891), 866.

1891.1

Fraser, Robert. A review of the domestic fisheries of Great Britain and Ireland. Edinburgh, 1818. 4\% 1818.1

Frater, pseudonym for George, William. Articles signed "member of the Worcester Angling Society " are by the same author.

Frauen, $M$. Störzucht in Holstein. Circul. Deutsch. Fischerei Ver, 1877 (1878), no. 6, 166-170.

1878.1

_- Zucht der Neunaugen. Circul. Deutsch. Fischerei Ver., 1879, no. 4, 135136.

1879.1

Frauenfeld, (Ritter) Georg von [18071873] Ueber den Fischaufstand. Abstracts in Lotos, 1873, 23, 81-83. Verh. Zool. Bot. Ges., 1872, p. 389. Zool. Miscellen, 16, 2. Hälfte. 1873.1

Frazer, Persifor [1844-] [Memorial notice of E. D. Cope and portrait] Amer. Naturalist, 1897, 31, 410-413.
- Alphabetical cross-reference catalogue of all the publications of Edward Drinker Cope from 1859 till his death in 1897. Mem. Soc. Cient." Antonio Alzate "Mexico, 1899, 14, 39-48. 1899.1

Catalogue chronologique des publications de Edward Drinker Cope de 1859 à 1897 inclusivement. Ann. Soc. Géol. Belgique, 1902, 29, 3-77.

1902.1

Frazer, $W . M$. On the disease in gold fish in connection with the development of Saprolegnia ferox. Proc. Dublin Nat. Hist. Soc., 1849, 1. 1849.1

Some observations on the disease in fish called fungus, which is so fatal in aquaria, fish ponds, etc. Zoologist, $1856,14,5126-5133$.

1856.1

Frech, Fritz, Philippi, E., Jaekel, Otto, \& Volz, Wilhelm. Sce Philippi, Jaekel \& others.

Frédéricq, Léon [1851-] Sur ]a physiologie de la branchie. Arch. Zool. Expér., Paris, 1891, 2. sér. 9, 120-122.

1891.1

— Sur la concentration moléculaire du sang et des tissus chez les animaux aquatiques. Bull. Acad. Sci. Belgique, $1901,428-434$.

1901.1

Sur la perméabilite de la membrane branchiale. Bull. Acad. Sci. Belgique, 1901, 68-70.

1901.2

Note sur la concentration moléculaire des tissus solides de quelques animaux d'eau douce [Pisces] Arch. Intern. Physiol., 1905, 2, 129-130.

1905.1

Frêdol, Alfred (pseudon.) Set Moguin-Tandon, C. H.B.A.

Freeburg, $B$. White trout. Ludlow trout ponds. Forest \& Stream, 1878, 10, 134.

1878.1

Freeden, von. Untersuchung der in den Logbüchern unserer Logger enthaltenen Angaben über ihre [Härings-] Fänge und die begleitenden meteorologischen und geographischen Umstände. Circul. Deutsch. Fischerei Ver. 1874 (1875), no. 5, 200-214. pl. 1875.1

Freeman, Frederick. The history of Cape Cod. 2 vols. Boston, 1860-62. $8^{\circ}$. 1860.1

Contains numerous notes on fish and fisheries.

Fréminville, (Chevalier) Christophe Paulin de la Poix de [1787-1848] De- 
Fréminville, $C . P . P$.

scription de quelques nouvelles espèces de poissons de l'ordre des Branchiostèges. Nouv, Bull. Soc. Philom. Paris, 1813, 2, 249-253.

1813.1

- Six nouvelles espèces des genres Balistes et Tetrodon. Nouv. Bull. Soc. Philom. Paris, 1813, 3, 249-253.

1813.2

Notice sur une nouvelle espèce de poisson, appartenant au genre Cestracion $[C$. quoyi] de Cuvier. Mag. Zool. 1840, 2. sér. 2. 4 p. pl.

1840.1

Frémy, Edmond [1814-1894] Recherches chimiques sur les os. C. R Acad. Sci. Paris, 1854, 39, 1052-1060.

1854.1

Frémy, Edmond, \& Valenciennes, Achille. See Valenciennes \& Frémy.

Frenzel, $F$. Verfahren zur Einbalsamirung von Fischen. Berlin, 1892. $4^{\circ}$

1892.1

Frenzel, Johannes. Temperaturmaxima für Seetiere. Arch. Ges. Physiol., $1885,36,458-466$.

1885.1

- Zu viel Lust. Allgem. Fischerei Zeitg., 1894, 19, 89-91.

1894.1

- Fiskarnes motståndskraft mot värme. Fiskeritidskr. Finl., 1896, 5, 101. - Deutsch. Fischerei Zeitg., 1896. 1896.1

-Transport frisch befruchteter Salmonideneier. Allgem. Fischerei Zeitg., $1896,21,4-6$.

1896.2

__ (editor) Handwörterbuch der Zoologie, Anthropologie, und Ethnologie. Breslau, 1897. $8^{\circ}$.

1897.1

Zähes Leben der Aale. Blätt. Aquar.-Terrar. Freunde, 1897, 8. Jahrg. $42-43$.

1897.2

Frere, H.T. Disease in fish. Abundance of fish in Norfolk. Zoologist, 1848 , 6, 2030 .

1848.1

Freud, Sigmund. Beobachtungen über Gestaltung und feineren Bau der als Hoden beschriebenen Lappenorgane des Aals. Sitzber. Akad. Wiss. Wien, 1877, 75, 1. Abth., 419-431.

1877.1

Ueber den Ursprung der hinteren Nerventwurzeln im Rückenmark von Ammocoetes (Petromyzon planeri) Sitzber. Akad. Wiss. Wien, 1877, 75, 3. Abth., 15-27. Also separate; Wien, 1877. $13 \mathrm{p}$.

1877.2
Ueber Spinalganglien und Rückenmark der Petromyzon. Sitzber. Akad. Wiss. Wien, 1878 (1879), 78, 3. Abth., 81-167. Also separate; Wien, 1878. 87 p. $8^{\circ}$.

1879.1

Freund, Ludwig. Die Verwertung der Fische, Krusten und Weichtiere. Sitzber. Deutsch. Nat.-Med. Ver. Böhmen, 1905, 53, 282-338.

1905.1

- Anomalien des Fischskeletts. Ergebnisse Allgem. Pathol. Anat., Wiesbaden, 1907, 11, 2. Abth., 709-729.

1907.1

- Hermaphroditismus bei Clupea harengus. Lotos, Prag, 1909, 57, 97-98. 1909.1

- Kieferverbildung bei Cyprinus carpio. Lotos, Prag, 1909, 57, 97: 1909.2

Krankheiten der Fische. Jahresber. Leistung. Gebiete Vet.-Med. (Ellenberger-Schütz), 1911-12, 30-31. 1911.1

- Bauchauftreibung bei Corydoras paleatus Jenyns (Callichthys punctatus) Blätt. Aquar-Terrar. Kunde, 1912, 23. Jahrg., 485-486. 3 figs.

1912.1

- Notizen über Piscicola geometra. Blätt. Aquar-Terrar. Kunde, 1912, 23. Jahrg., 496-498.

1912.2

- Indische Fische als Moskitovertilger. Blätt. Aquar-Terrar. Kunde, 1913, 24. Jahrg., 469-471.

1913.1

Frey, E. Disposition of whitefish eggs sent to Switzerland. Bull. U. S Fish Comm. 1885, 5, 358.

1885.1

Freyer, Heinrich [1802-1867] Fauna der in Krain bekannten Säugethiere, Vögel, Reptilien und Fische; nach $\mathrm{Cu}$ viers System geordnet, mit AbbildungsCitaten und Angabe des Vorkommens, nebst einem vollständigen Register der lateinischen, deutschen und krainischen oder slavischen Namen. Laibach, 1842. $8^{\circ}$.

1842.1

Friant, A. Recherches anatomiques sur les nerfs trijumeau et facial des poissons osseux. Nancy, 1879. 6 pls. $8^{\circ}$. 1879.1

Friant, A., \& Jourdain, S. See Jourdain \& Friant.

Frič, Anton. See Fritsch, $A$.

Fricke, Karl. Die fossile Fische aus der oberen. Juraschichten von Hannover Palxontographica, 1875, 22, 347-398. 5 pls. 
Friedel, Ernst. Seltene Fische aus der Havel. Zool. Garten, 1869. 10. Jahrg., 93-94. 1869.1

Fischwesen in Holland, Belgien und England. Circul. Deutsch. Fischerei Ver., 1871 , no. $7,21-32 ; 48-71$.

1871.1

Der kleine Stichling, Gasterosteus pungitius L., bei Berlin. Zool. Garten, 1871, 12. Jahrg., 28-31.

1871.2

Ungewöhnliches Verhalten des Flussaals. Zool. Garten, 1871, 12. Jahrg., 312-313.

1871.3

- Fischwesen in Skandinavien und Schleswig-Holstein. Circul. Deutsch. Fischerei Ver. 1874 (1875), no. 2, 83-90; no. 4, 135-155.

1875.1

Führer durch die Fischerei-Abtheilung des märkischen ProvinzialMuseums der Stadtgemeinde Berlin, nebst Verzeichniss; Zusammenstellung von Fischereiausdrücken und Verzeichniss der in der Mark vorkommenden Fischarten, etc. Berlin, 1880. 36 p. $8^{\circ}$. 1880.1

Die lebenden Wasserthiere auf der Internationalen Fischerei-Ausstellung $\mathrm{zu}$ Berlin im Jahre 1880. Zool. Garten, 1880, 21. Jahrg., 289-298; 323335.

1880.2

- Ein wiithender Schwertfisch. Zool. Garten, 1880, 21. Jahrg., 319. 1880.3

Aus der Vorzeit der Fischerei. Berlin, 1884. $8^{\circ}$ (Virchow, R. Sammlung gemeinverständlicher wissenschaftlicher Vorträge. Serie 19, Heft 441, 442)

1884.1

Friedländer, $E$. La pesca nelle lagune di Commacchio. Firenze, 1872. 100 p. pl. $8^{\circ}$.

1872.1

Friedländer, Oscar Oswald [1832Notes on the menhaden fishery. Bull. U. S. Fish Comm. 1882 (1883), 2, 252. 1883.1

Notes on the menhaden fishing in 1883. Bull. U. S. Fish. Comm. 1884, $4,47-48$.

1884.1

Friedmann, $E$. Beiträge zux Zahnentwicklung der Knochenfische. Morphol. Arbeiten, 1897, 7, 546-582. 16 figs.

1897.1

Friedrich, Eduard. Lachs- und Aalfang bei Dievenow (Pommern) Circul. Deutsch. Fischerei Ver., 1871, no. 7, 4142.
Mittheilungen vom 26. Juni über die Seefischerei bei Berg-Diewenow Circul. Deutsch. Fischerei Ver., 1871, no. $2,38-39$.

1871.2

Friedrich, Josef. Transportgefäss für Fische und andere Wassertiere. D. R. Patente Kl., 1905,45 h, no. 173497. 2 p. pl.

1905.1

Transportgefäss für im Wasser lebende Organismen. Schweiz. Patente Kl., 1907, 109, no. 34428. 2 p. pl.

1907.1

Friedrich, Max Julius [1862-] Mollienisia latipinna Lesueur. Blätt. Aquar.-Terrar. Kunde, 1909, 20. Jahrg., 409-413. 1909.1

Rivulus flabellicauda Regan. Blätt. Aquar.-Terrar. Kunde, 1910, 21. Jahrg., 637-638. fig. 1910.1

Cyprinodon variegatus. Blätt. Aquar-Terrar. Íunde, 1911, 22. Jahrg. 103-104. fig.

1911.1

Friele, Hermann [1838-] An account of the fisheries of Norway in 1877. Rept. U. S. Fish Comm. 1877 (1879), 5, $707-739$.

1879.1

Friend, $R . A$. Statement concerning the menhaden fishery. Rept. U. S. Fish Comm. 1877 (1879), 5, 377. 1879.1

Fries, Bengt Fredrit [1799-1839] Ichthyologiska bidrag till Skandinaviens fauna. Handl. K. Vetensk. Akad., 1837, 23-58. Ibid., 1838, 165-185. - Isis (Oken), 1839, 745-749. - Arch. Naturgesch., 4. Jahrg., pt. 1, 236-250. pl. Ibid., 5, pt. 1, 9-40. Ibid., 6, pt. 1, 1835. - Ann. Mag. Nat. Hist., 1838, 2, 96-105.

1837.1

-_- Metamorphos anmärkt hos lilla hafsnålen (Syngnathus lumbriciformis) Handl. K. Vetensk. Akad., 1837, 59-65. - Arch. Naturgesch., 1838, 4. Jahrg., 251-256. - Ann. Mag. Nat. Hist., 1838, 2, 451-455. Ibid., 1839, 3, 69-70.- Rev. Zool., 1839, 212. 1837.2

Om Stirren, Salmo salmulus Ray. Handl. K. Vetensk. Akad., 1837, 1-13. - Arch. Naturgesch., 5. Jahrg., pt. 1, 9-19.

1837.3

Pterycombus, ett nytt fiskslägte från Ishafvet. Handl. K. Vetensk. Akad., 1837, 14-22.-Arch. Naturgesch. 5. Jahrg., pt. 1, 19-26. 1837.4

- Granskning af de vid Svenska kuster na förekommande arter af fisk- 
Fries, B. $F$.

slägtet raja. Handl. I. Vetensk. Akad., 1838, 126-164. - Isis (Oken), 1841, 441448.

1838.1

Granskning af de vid Sveriges kuster förekommande arter af slägtet Gobius L. Handl. K. Vetensk. Akad., 1838, 238-247. - Arch. Naturgesch., 6. Jahrg., 233-240. - Isis (Oken), 1841, $453-455$.

1838.2

Ichthyologische Beiträge zur scandinavischen Fauna. Arch. Naturgesch., 1838, 1. Jahrg., 236-250. pl.

1838.3

Om Cyclopterus minutus. Handl. K. Vetensk. Akad., 1838, 226-227. fig.

1838.4

Die Gattung Callionymus $L$. Arch. Naturgesch., 1839, 5. Jahrg., 2634.

1839.1

- Die Gattung Clinus Cuv. Arch. Naturgesch., 1839, 5. Jahrg., 34-40.

Ichthyologische Beiträge zur Fauna von Skandinavien. Isis (Oken), $1839,740-754$.

1839.3

On the genus Syngnathus. Ann. Mag. Nat. Hist., 1839, 2, 96-105.

1839.4

Fries, Bengt Fredrik, Ekstrom, $C$. Ulrich, \& Sundevall, C. J. Skandinaviens fiskar målade efter lefvande exemplar och ritade på sten af $\mathrm{W}$. von Wright, med text af B. F. Fries, C. U. Ekström och C. J. Sundevall (Pisces Scandinavire . . Versio Latina. - Bihang innefattande beskrifningar öfver de i Skandinavien bruklige fiskeredskap) Stockholm, 1836-48. iv, 222 p. 63 pls. $4^{\circ}$. 1836.1

A second edition was published in 1893, revised by $F$. A. Smitt, and this was translated into English by D. L. Morgan. See infra.

For reviews of the original edition, see Arch. Naturgesch., 1837, pt. 2, 234. - Rev. Zool., 1839, 212. - Ann. Mag. Nat. Hist., 1841, 6, 378.

A history of Scandinavian fishes, with coloured plates by IV. von Wright; second edition revised and completed by F. A. Smitt [Translated by D. L. Morgan! 2 parts. Stockholm \& London, 1893-95. vi, 1240 p. 54 pls. \& 134 figs. $4^{\circ}$.

1893.1

Printed in double column.

Friis, Gabriel Michael. Fiskeoiet. Et bidrag til den sammenlignende anatomi. Inaug. Dissert. Kjobnhavn, 1879. $92 \mathrm{p}$. 2 pls. $8^{\circ}$.

1879.1
Friis, Jens Andreas. Tilfjelds i ferierne, elber jager-og fiskerliv i hoifjeldene. Christiania, 1876. $8^{\circ}$. 1876.1

Friis, Niclas Christian. Berättelse om sill-fiskeriet uti Nordlanden i Norrige. Handl. K. Vetensk. Akad., 1770, 158.

1770.1

- Berättelse om torsk-fiskeriet i Norrige. Handl. K. Vetensk. Akad., $1770,296$.

1770.2

Berättelse om gråsiks-fiskeriet uti Nordlanden i Norrige. Handl. K. Vetensk. Akad., 1771, 42; 247. Ibid., $1772,157$.

1771.1

Fripp, H.E. On the function of sight in fishes, and on certain structural peculiarities of the fishes' eye. Proc. Nat. Hist. Soc., Bristol, 1866, 1, 1-4. 1866.1

Frisch, Karl von. Leuchtorgane und Augen der Tiefseefische. [n. p.] 1909. 1909.1

Ueber die Beziehungen der Pigmentzellen in der Fischhaut zum sympathischen Nervensystem. Vorläufige Mitteilung (In Festschrift für Carl Wilhelm Theodor Richard Hertwig, 1910, vol. iii, p. 15-28. 2 pls. \& 3 figs.)

1910.1

Zur Physiologie der Pigmentzellen. Zentralbl. Physiol., 1910, 24, 248249.

1910.2

Zur Physiologie des Farbwechsels der Fische. Verh. Zool. Bot. Gesell. Wien, 1910, 60, (198)-(200) 1910.3

Beiträge zur Physiologie der Pigmentzellen in der Fischhaut. Arch. Ges. Physiol., 1911, 138, 319-387. 2 pls. \& 8 figs.

1911.1

- Die Pigmentzellen der Fischhaut. Biol. Centralbl., 1911, 31, 412-415. 1911.2

Ueber den Einfluss der Temperatur auf die schwarzen Pigmentzellen der Fischhaut. Biol. Centralbl., 1911, 31, 236-248. 3 figs.

1911.3

Ueber den Farbensinn der Fische. Verh. 20,-21. Vers. Deutsch. Zool. Ges., $1911,220-225$.

1911.4

Sind die Fische farbenblind? Zool. Jahrb., 1912 (Allg. Zool. Physiol. Abth.), 33, 107-126. 2 figs. $\quad 1912.1$

Ueber das Parietalorgan der Fische als funktionierendes Organ. Sitzber. Ges. Morphol. Physiol. München, $1912,27,16-18$. 1912.2 
- Ueber Farbenanpassung des Crenilabrus. Zool. Jahrb., 1912 (Allg. Zool. Physiol. Abth.), 33, 151-164. 1912.3

- Ueber farbige Anpassung bei Fischen. Zool. Jahrb., 1912 (Allg. Zool. Physiol. Abth.), 32, 171-230. 2 pls. \& 4 figs.

1912.4

Weitere Untersuchungen über den Farbensinn der Fische. Zool. Jahrb., 1913 (Allg. Zool. Physiol. Abth.), 34, 43-68.

1913.1

Fritel, $P, H$. Poissons fossiles des environs de Paris. 'Le Naturaliste, 1904, 26, 41-44. 7 figs.

1904.1

L Les poissons fossiles des environs de Paris. Le Naturaliste, 1906, 28, 197199. 6 figs.

1906.1

_ Sur les poissons fossiles du bassin de Paris. Le Naturaliste, 1908, 30, 257-258; 270-271. 5 figs. $\quad 1908.1$

Fritsch, Anton Jan [1832-1914] České ryby [Bohemian fishes] Živa, 1859 , 36- 19 ; 108-118; 178-194; 224-242. 1859.1

Kritisches Verzeichnis der Fische Böhmens. Lotos, 1859, 199-205. 1859.2

Nový druh českých ryb [A new species of Bohemian fish Ziva, 1863, 18s-189.

1863.1

- Diagramm der Fische Böhmens. Zusammengestellt nach Heckel und Iner. Süsswasserfische der österreichischen Monarchie. Prag, 1868. pl. fol.

1868.1

- Die Fauna der BöhmerwaldSeen. Sitzber. K. Böhm. Ges. Wiss., Prag, 1871, 3-11.

1871.1

Ueber den Lachs in Böhmen. Zool. Garten, 1871, 12. Jahrg., 225-229.

1871.2 1872. $8^{\circ}$

Prag, 1872.1

- Die Fluss-Fischereien in Böhmen und ihre Beziehung zur künstlichen Fischzucht. Prag, 1873. pls. $8^{\circ}$.

1873.1

- Slunka (Leucaspius delineatus Sieb.), nová pro Čechy ryba. Vesmír, $1873,2,133$.

1873.2

Ueber die Crustaceenfauna der Wittingauer Teiche, und über eine für Böhmen neue Fischart Leucaspius delineatus Siebold. Sitzber. K. Böhm. Ges. Wiss., Prag, 1873, 33-49.
Bericht über die Fortschritte der Lachs- und Forellenzucht in den Jahren 1871-74, nebst kurzer Anleitung zur künstlichen Fischzucht. Prag, 1874. 40 p. $8^{\circ}$.

1874.1

Ueber die Entdeckung eines

Lurchfisches, Ceratodus barrandei, in der Gaskohle des Rakonitzer Beckens. Sitzber. K. Böhm. Ges. Wiss., Prag, 1874, 193-195. - Verh. Geol. Reichsanst. Wien, 1875, 59-60. - Neues Jahrb. Mineral., 1875, 669-670. $\quad 1874.2$

—_ Ueber die Fauna der Gaskohle des Pilsner und Rakonitzer Beckens. Sitzber. IK. Böhm. Ges. Wiss., Prag, 1875, 70-79.

1875.1

Die Resultate der künstlichen Fischzucht in Böhmen. Zool. Garten, 1876, 17. Jahrg., 303.11876 .1

Bericht über die Iachs- und Forellenzucht in Böhmen während des Jahres 1874-75. Circul. Deutsch. Fischerei Ver. 1876 (1877), no. 2, 61-66.

1877.1

O ještěru Broumovském (Chelidosaurus vranyi Fr.) [Ueber den Braunauer Selachier Vesmír, 1877, 6, 241. fig.

1877.2

Zur Fauna der Gaskohle von Zaboř bei Schlan, Kroučová bei Renč und Třemošná bei Pilsen, sowie über die Sphærosideritkugeln von Zilov. Sitzber. K. Böhm. Ges. IV iss., Prag, 1877, 1-8.

1877.3

- Die Reptilien und Fische der böhmischen Kreideformation. Prag, 1878. 46 p. 10 pls. \& 66 figs. 1878.1

Ueber die Stellung der Gymnotini im System. Sitzber. Ges. Naturf. Freunde Berlin, 1878, 5-7. $\quad 1878.2$

Bericht über die Laichzucht in Böhmen in den Jahren 1876 bis 1879 . Prag, 1879. 20 p. $8^{\circ}$.

1879.1

O vývoji lipenů ‘Ueber die Entwicklung der Aesche] Vesmir, 1879, 8, 76 .

1879.2

Ueber einen neuen Fisch [Istieus spottii\} aus dem Pläner des Weissen Berges bei Prag. Sitzber. K. Böhm. Ges. Wiss., Prag, 1879, 3-4. 1879.3

Ueber Pterichthys. Zeitschr. Ges. Naturw., 1881, 54, 1. Heft, 1-8.

1881.1

Fauna der Gaskohle und der Kalksteine der Permformation Böhmens. 
Fritsch, A.J.

3 vols. Prag, 1883-95. 132 pls. \& 310 figs. 4\%. Reviews in Geol. Mag., 1893, 3. dec. 10, 175-178. - Quart. Journ. Geol. Soc. London, 1893, 49-80. 10 pls. - Nat. Sci., 1893, 2, 435-438, 3 figs. 1883.1

Vol. ii, Dipnoi, Selachii, Stegocephali.

Vol. iii, Pleuracanthus, Acanthodidæ, Megalichthys, Palæoniscidæ.

- Fischerei-Karte des Königreichs Böhmen. Prag, 18s8. fol. 1888.1

Ueber die Brustflosse von Xenacanthus decheni Goldf. Zool. Anz., 1888, 11, 113-114. fig.

1888.2

- Notiz über Xenacanthus. Zool. Anz., 1889, 12, 386-387. 1889.1

- Preliminary notes on the Palæozoic elasmobranchs, Pleuracanthus and Xenacanthus, from the Lower Permian of Bohemia. Geol. Mag., 1890, 3. dec. 7, 566 .

1890.1

- Restorations of the Palreozoic elasmobranch genera Pleuracanthus and Xenacanthus. Rept. Brit. Assoc. Adv. Sci., 60. meet., 1890, 822.

1890.2

Ueber Pterygopodien permischer Haifische der Gattungen Pleuracanthus und Xenacanthus. Zool. Anz., 1890, 13, 318-320. fig.

1890.3

Ueber die Xenacanthiden. Zool. Anz., 1891, 14, 21-22. fig. 1891.1

With restoration of an adult of $\mathrm{X}$. decheni \&.

Der Elbelachs. Eine biologischanatomische Studie. Prag, 1894. 116 p. pl. \& 85 figs. $8^{\circ}$.

1894.1

Ueber neue Wirbelthiere aus der Permformation Böhmens, nebst einer Uebersicht der aus derselben bekannt gewordenen Arten. Sitzber. K. Böhm. Ges. Wiss., Prag, 1895, no. 52.17 p. fig.

1895.1

- Studien über ein Gebiete der böhmischen IKreideformation. Paläontologische Untersuchungen der einzelnen Schichten. IV. Die Chlomeker Schichten. Arch. Nat. Landesdurchf. Böhmen, 1897, 10, no. 4. 84 p. 125 figs. 1897.1

—Ueber Fischpässe bei Nadelwehren. Allgem. Fischerei Zeitg., 1897, 22, 408. - Oester. Monatsber. fo öffentl. Baudienst, 1897, 10.

1897.2

Vorläufige Notiz über Miscellanea palxontologica aus Böhmen und America. Sitzber. II. Böhm. Ges. Wiss., Prag, 1905, no. 21. 3 p.

1905.1
České ryby a jich cizopasnici [Die Fische Böhmens und ihre Parasiten] Prag, 1908. 75 p. 111 figs. 8 1908.1

Fritsch, Anton, \& Bayer, Edwin. Studien im Gebiete der böhmischen Kreideformation. Paläontologische Untersuchungen der einzelnen Schichten. Perucer Schichten. Arch. Nat. Landesdurchf. Böhmen, 1900, 11, no. 2. 184 p. 31 figs.

1900.1

- Nové ryby českého útvarn Křédového. Ceska Akad. Praze, 1902. 18 p. 3 pls. $4^{\circ}$.

1902.1

- Neue Fische und Reptilien aus der böhmischen Kreideformation. Prag, 1905. 34 p. 7 pls. \& 30 figs. Review by $\mathrm{O}$. Abel in Verh. Geol. Reichsanst., 1905, p. 225.

1905.1

Fritsch, Anton, \& Kaıka, I. Kurze Anleitung zur rationellen Karpfenzucht [Text in Russian] Uebersetzt aus dem Deutschen von E. Grimm unter der Redaction und mit Anmerkungen von $O$. A. Grimm. St. Petersburg, 1909. 32 p. 1909.1

Fritsch, Anton, \& Vávra, V. Ueber Nahrung des Karpfens. Arch. Nat. Landesdurchf. Böhmen, 1894, 9, 120123. fig.

1894.1

Fritsch, Gustav Theodor [1838-] Brain of fishes. Monatsber. Akad. Wiss. Berlin, 1875, 508-521.

1875.1

[Ueber den feineren Bau der Centralorgane bei den Fischen] Sitzber. Ges. Naturf. Freunde Berlin, 1875, 133137.

1875.2

- Ueber den feineren Bau des Fischgehirnes. Monatsber. Akad. Wiss. Berlin, 1876, 26-29.

1876.1

Ueber Homologien im Bau des Centralnervensystems bei verschiedenen Thierklassen. Zeitschr. Anat. Entwick., $1877,578-580$.

1877.1

[Ueber die Stellung der Gymnotini im Systeme] Sitzber.Ges. Naturf. Freunde Berlin, 1878, 5-7. $\quad 1878.1$

Further comment on the same subject by E. V. Martens, Ibid., p. 10.

- Untersuchungen über den feineren Bau des Fischgehirns, mit besonderer Berủcksichtigung der Homologien bei andern Wirbelthierklassen. Berlin, 1878. xv, 94 p. 13 pls. \& 16 woodcuts. fol.

1878.2

Vorlegung eines Präparates des Nervensystemes von Eledone. Sitzber. Ges. Naturf. Freunde Berlin, 1878, 7-9. 1878.3 
The Gymnotus. Abstract in Pop. Sci. Rev., 1879, n. s. 3, 221-222.

1879.1

Zur Anatomie des Fischgehirns. Arch. Anat. Physiol., 1880 (Physiol. Abth.), 272-277.

1880.1

Z Zwei Abhandlungen (In DuBois-Reymond, E. Dr. Carl Sach's Untersuchungen am Zitteraal, Gymnotus electricus, etc.) Leipzig, 1881. xxviii, 446 p. 8 pls. $8^{\circ}$ )

1881.1

Bericht uiber eine Reise zur Untersuchung der in den Museen Englands und Hollands vorhandenen Torpedineen. Sitzber. Akad. Wiss. Berlin, 1882, 27, 1007-1010. - Ann. Mag. Nat. Hist., 5. ser. 11, 58-61. - Arch. Anat. Physiol. 1884 (Physiol. Abth.), 70-73. 1882.1

-__ Bericht über die Fortsetzung der Untersuchungen an elektrischen Fischen. Beiträge zur Embryologie von Torpedo. Sitzber. Akad. Wiss. Berlin, 1883, pt. 1, 205-209. pl. - Arch. Anat. Physiol., 1884 (Physiol. Abth.), 74-78. pl.

1883.1

Die elektrischen Fische im Lichte der Descendenzlehre. Berlin, 1883. $8^{\circ}$ (Virchow, R. Sammlung gemeinverständlicher wissenschaftlicher Vorträge, Serie 18, Heft 430) $\quad 1883.2$

Offener Brief an meine Opponenten in Sachen "Fischgehirn." 'Zeitschr. Wiss. Zool., 1883, 38, 165-166.

1883.3

Ergebnisse der Vergleichungen an den elektrischen Organen der Torpedineen. Sitzber. Akad. Wiss. Berlin, 1884, pt. 1, 445-456. figs. - Arch. Anat. Physiol., $1886^{\circ}$ (Physiol. Abth.), $358-370$

1884.1

- Ueber den Angelapparat des Lophius piscatorius. Sitzber. Akad. Wiss. Berlin, 1884, pt. 2, 1145-1151. illus.

1884.2

Ueber die vergleichende Anatomie der elektrischen Organe und Nerven. Amtl. Ber. 56. Vers, Deutsch. Naturf. Aertzte, Freiburg i. Br., 1883 (1884), 138-140.

1884.3

Zur Organisation des Gymnarchus niloticus. Sitzber. Akad. Wiss. Berlin, 1885, pt. 1, 119-129. 2 figs. 1885.1

Die äussere Haut und die Seitenorgane des Zitterwelses (Malopterurus electricus) Sitzber. Akad. Wiss, Berlin 1886, 415-436.
Ergebnisse der Vergleichungen an den elektrischen Organen der Torpedinen. Arch. Anat. Physiol., 1896 (Physiol. Abth.), 358-370. 1886.2

— Die Parasiten des Zitterwelses. Sitzber. Akad. Wiss. Berlin, 1886, 99108. pl. Also separate; Berlin, 1886. $8^{\circ}$.

1886.3

Ueber einige bemerkenswerthe Elemente des Centralnervensystems von Lophius piscatorius L. Arch. Mikr. Anat., 1886, 27, 13-31. 2 pls. - Tageb. 59. Vers. Deutsch. Naturf. Aertzte, p. 376.

1886.4

Uebersicht der Ergebnisse einer anatomischen Untersuchung über den Zitterwels (Malopterurus electricus) Sitzber. Akad. Wiss. Berlin, 1886, $1137-$ 1140.

1886.5

- Die elektrischen Fische. Erste Abtheilung. Malopterurus electricus. Leipzig, 1887-90. 146 p. 2 pls.

1887.1

Ueber Bau und Bedeutung der Kanalsysteme unter der Haut der Selachier. Sitzber. Akad. Wiss. Berlin, 1888, 273-306. 4 figs. 1888.1

— Das numerische Verhältniss der Elemente des elektrischen Organs der Torpedineen zu den Elementen des Nervensystems. Sitzber. Akad. Wiss. Berlin, 1889, 1101-1111. illus. 1889.1

Die elektrischen Fische. Zweite Abtheilung: die Torpedineen. Leipzig, 1890. 146 p. 20 pls. fol. 1890.1

Ueber das numerische Verhältniss der Ganglienzellen im Lobus electricus der Torpedineen zu ihren peripherischen Endorganen. Arch. Anat. Physiol., 1890 (Physiol. Abth.), 183-186.

1890.2

Weitere Beiträge zur Kenntniss der schwach elektrischen Fische. Sitzber. Akad. Wiss. Berlin, 1891, 941-962. 4 figs. - Arch. Anat. Physiol., 1892 (Physiol. Abth.), 221-242. 4 figs. 1891.1

Zweiter Bericht uber neuere Unteirsuchungen an elektrischen Fischen. Sitzber. Akad. Wiss. Berlin, 1891, pt. 1, 601-602.

1891.2

On the origin of the electric nerves in the Torpedo, Gymnotus, Mormyrus and Malapterurus. Rept. Brit. Assoc. Adv. Sci., 1892, 757-758. - Nature, $1893,47,271-274$. 6 figs. 1892.1 
Fritsch, G.T. Zur Innervation der elektrischen Organe [in 'Torpedo, Gymnotus, etc.] Arch. Anat. Physiol., 1893 (Physiol. Abth.), 55t-555. 1893.1

Antwort an Herrn Ballowitz in Betreff der elektrischen Platte von Torpedo. Arch. Anat. Physiol., 1894 (Physiol. Abth.), 369-371.

1894.1

Einige erläuternde Bemerkungen zu A. Coggi's Aufsatz: Les vésicules de Savi et les organes de la ligne latérale chez les torpilles (Arch. Ital. Biol., 1891, 16), Zool. Anz., 1894, 16, 37-39. 1894.2

Ewart's investigations on electric fishes. Nature, 1894, 49, 222-223.

1894.3

Ueber Discopyge tschudii Heck. Sitzber. Akad. Wiss. Berlin, 1895, 10511054. 2 figs.

1895.1

Ueber Hypnos subniger. Sitzber. Akad. Wiss. Berlin, 1895, pt. 1, 423-424.

1895.2

Ueber Färbung und Zeichnung bei den elektrischen Fischen. Tagebl. Intern. Zool. Congress., Berlin, 1901, no. 8, p. 11. - Verh. 5. Intern. Zool. Congress, Jena, 1902, 643-647. 1901.1

-Die Retinaelemente und die Dreifarbentheorie. Abh. Akad. Wiss. Berlin, 1904, phys.-math. Cl., Abh. 2, 1-19. pl. 1904.1

Fritsch, Karl Wilhelm Georg von [1838 - ] Beitrag zur Kenntnis der Tierwelt der deutschen Trias. Abh. Naturf. Ges. Halle, 1901-06, 24, 217-285. 9 pls.

1901.1

Fritsche, Ernst. Die Entwicklung der Thymus bei Spinax niger. Zool. Anz., 1909 , 35, 85-93. 6 figs.

1909.1

- Die Entwicklung der Thymus bei Selachiern. Jena. Zeitschr. Naturw., $1910,46,77-112.18$ figs.

1910.1

Fritze, Adolf. Die Fauna von Yezo im Vergleich zur Fauna des übrigen Japan. Mitth. Deutsch. Ges. Natur- \& Völkerk. Ostasiens, Yokohama, 1891, 5, pt. 46, 235-249. - Stettiner Entomol. Zeitg., 1891, 288-303.

1891.1

Fröhlich, Alfred. Ueber den Einfluss der Zerstörung des Labyrinthes beim Seepferdchen nebst einigen Bemerkungen über das Schwimmen dieser Tiere. Arch. Ges. Physiol., 1904, 106, 84-90. pl. \& fig.

1904.1
Froriep, August. Ueber das Homologon der Chorda tympani bei niederen Wirbeltieren. Anat. Anz., 1887, 2. Jahrg., 486-493. fig.

1887.1

- Zur Entwickelungsgeschichte der Kopfnerven. I. Ueber die Entwickelung des Trochlearis bei Torpedo. II. Ueber die Kiemenspaltenorgane der Selachierembryonen. Verh. Anat. Ges., Jena, 1891, 55-65. figs.

1891.1

Ueber die Ganglienleisten des Kopfs und des Rumpfes und ihre Kreuzung in der Occipitalregion. Beitrag zur Entwickelungsgeschichte des Selachierkopfes. Arch. Anat. Physiol., 1901 (Anat. Abth.), 371-394. pl. \& 3 figs. 1901.1

- Einige Bemerkungen zur Kopffrage. Anat. Anz., 1902, 21. Jahrg., 545553.

1902.1

- Zur Entwickelungsgeschichte des Wirbeltierkopfes. Anat. Anz., 1902, 21. Jahrg., 34-46.

1902.2

Die occipitalen Urwirbel der Amnioten im Vergleich mit denen der Selachier. Verh. Anat. Ges., 1905, 19. Vers. 111-120. 4 figs.

1905.1

Offene Linsensäckchen bei Selachierembryonen. Verh. Anat. Ges., 1905, 19. Vers. 228.

1905.2

Sur la genèse de la partie occipitale de crâne. C. R. Assoc. Anat., 1905, 7, 156-157.

1905.3

Ueber die Einstülpung der Augenblase. Arch. Mikr. Anat., 1905, 66 1-11. pl.

1905.4

Die Entwickelung des Auges der Wirbeltiere (In Hertwig, O. Handbuch der vergleichenden und experimentellen Entwickelungslehre der Wirbeltiere . . . , pt. $2, \quad 152-154 ; \quad 164-176 ; \quad 198-206$; 237-259. Jena, 1906. figs. $8^{\circ}$ ) 1906.1

Selachier, Cyclostomen, Teleostier und Ganoiden.

Ueber den Ursprung des Wirbeltierauges. München. Med. Wochenschr., 1906, 53. Jahrg., 1739-1742.

1906.2

Ueber Entwicklung und Bau des autonomen Nervensystems. Med.-Nat. Arch., 1908, 1, 301-321.

1908.1

Frossard de Saugny, $E$. Etude de la pêche dans le lac Léman et ses affluents. Lausanne, 1884. 28 p. $8^{\circ}$. 
Frost, Charles C. The compressed burbot or eel pout [Lota compressa] Amer. Naturalist, $1870,4,251-252$.

1870.1

Frost, George Allan. The internal cranial elements and foramina of Dapedius granulatus, from a specimen recently found in the Lias at Charmouth. Quart. Journ. Geol. Soc., 1913, 69, 219-222. 2 figs.

1913.1

Frosterus, Erik Johan. Anteckningar, utdragne i från wasa (numera wasa cefra och nedra). Prosteris tabeller. Finsk Hushallningssällsk., 1826, 2. ser. 7, 64-78.

1826.1 Pisces, p. 75-78.

Frothingham, H.P. Fish and game protection in New Jersey. Trans. Amer. Fisheries Soc. 1896 (1897), 137-145.

1897.1

Frouin, Albert. Filtration de l'hémolysine du sérum d'anguille au travers des membranes de collodion. C. R. Mém. Soc. Biol. Paris, 1908, 65, 355-356.

1908.1

Fry, Edward. Remarks on the morphology of the vertebrate skeleton. Proc. Zool. Soc. London, $1850,18,15-22$.

1850.1

Fry, W. H. (editor) A complete treatise on artificial fish-breeding, including the reports on the subject made to the French academy, and particulars of the discovery as pursued in England; translated and edited by W. H. Fry. New York, 1854. 188 p. illus. $8^{\circ}$.

1854.1

The same. 2. ed. New York,
1866. $12^{\circ}$.

Fryd, Carlos. Die Otolithen der Fische in Bezug auf ihre Bedeutung für Systematik und Altersbestimmung. Inaug. Dissert. Altona \& Kiel, 1901. 54 p. 14 figs. $8^{\circ}$.

1901.1

Frye, Wakefield $G$. The fisheries of Nova Scotia in 1882. Rept. U. S. Fish Comm. 1883 (1885), 11, 1184.

1885.1

Fryer, C.W. Queer fish. Fish. Gaz., 1877 , no. 3 , p. 6.

1877.1

Fryer, Charles $E$. The growth of salmon. Nature, 1873, 8, 285-286. figs. Pop. Sci. Monthly, 1874, 4, 27-30. figs.

1873.1

A national fisheries society for Great Britain. Intern. Fisheries Exhib. Lit., London, 1883. Conferences, 4, pt. 6.

1883.1
The relations of the state with fishermen and fisheries, including all matters dealing with their protection and regulation. Intern. Fisheries Exhib. Lit., London, 1883. Conferences, 9, pt. 3.

1883.2

The salmon fisheries. Intern. Fisheries Exhib. Lit., London, 1883 , Handbooks, 2, pt. 4.77 p. fig. 1883.3

Fryer, Charles E., \& Masterman, $A$. $T$. Report to the secretary of the board of agriculture and fisheries. Ann. Rept. Proz. Sea Fish. 1903 (1905), 109 p. $8^{\circ}$. 1905.1

Report to the secretary of the board of agriculture and fisheries on sea fisheries. Ann. Rept. Proc. Sea Fish. 1903 (1906). 98 p. $8^{\circ}$. 1906.1

Fuchs, Fanny. Ueber die Entwicklung des Vorderhirns bei niederen Vertebraten. Zool. Jahrb. (Anat. Abth.), 1908, 25, 547-610. 8 pls.\& fig. 1908.1

Fuchs, Hugo. Ueber die Homologie der Paukenhöhlen und das Verhältnis zwischen Nervenverlauf und Skelett. Anat. Anz., 1910, 37. Jahrg., 473-496.

1910.1

Erwiderung auf die Arbeiten von $\mathrm{O}$. Bender.

Fuchs, R. F. [Review of ] Beiträge zur Physiologie des elektrischen Organes der Zitterrochen, by S. Garten. Biol. Centralbl., 1900, 21, 159-160. 1900.1

Fuchs, Sigmund. Einige Beobachtungen an den elektrischen Nerven von Torpedo ocellata. Centralbl. Physiol., $1894,8,529-530$. 1894.1

Ueber die Functionen der Organe der Seitenlinie bei den Selachiern. Centralbl. Physiol., 1895, 9, 692-693.

1895.1

Ueber die Function der unter der Haut liegenden Canalsysteme bei den Selachiern. Arch. Ges. Physiol., 1895, 59, 454-178. pl. 1895.2

Fuchs, Theodor [1842-] Ueber die Fischfauna der Congerien-Schichten. Verh. Geol. Reichsanst. Wien, 1871, 227-228.

1871.1

Ueber die Natur der Edestiden, mit besonderer Rücksicht auf die Gattung Helicoprion. Sitzber. Akad. Wiss. Wien, 1900, 109, 5-9. pl. \& 3 figs.

1900.1

Fülleborn, $F$. Bericht über eine zur Untersuchung der Entwickelung von 
Fülleborn, $F$.

Amia, Lepidosteus und Necturus unternommene Reise nach Nord-America. Sitzber. Akad. Wiss. Berlin, 1894, 465478 .

1894.1

Fürbringer, Karl. Beiträge zur Kenntniss des Visceralskelets der Selachier. Morphol. Jahrb., 1903, 31, 360-445. 3 pls. Ibid., 620-622. 1903.1

Beiträge zur Morphologie des Skelettes der Dipnoer, nebst Bemerkungen über Pleuracanthiden, Holocephalen und Squaliden (In Semon, R. Zoologische Forschungsreisen in Australien und dem Malayischen Archipel, 1, 423-510. 5 pls. \& 38 figs. Jena, 1904)

1904.1

Notiz über einige Beobachtungen am Dipnoerkopf. Anat. Anz., 1904, 24. Jahrg., 405-408.

1904.2

Fürbringer, $\operatorname{Max}[1846-]$ Untersuchungen zur vergleichenden Anatomie der Muskulatur des Kopfskelets der Cyclostomen. Jena. Zeitschr. Naturw., $1875,9,1-129$. figs.

1875.1

- On the excretory system of ganoids. Morphol. Jahrb., 1878, 4, 5660.

1878.1

Zur vergleichenden Anatomie und Entwickelungsgeschichte der Excretionsorgane der Vertebraten. Morphol. Jahrb., 1878, 4, 1-111. 3 pls.

1878.2

- Zur Lehre von den Umbildungen der Nervenplexus. Morphol. Jahrb. 1879, 5, 324-394. 2 pls.

1879.1

Ueber die mit dem Visceralskelet verbundenen spinalen Muskeln bei Selachiern. Jena. Zeitschr. Naturw., 1895, 2. ser. 23, 127-135.

1895.1

Ueber die spino-occipitalen Nerven der Selachier und Holocephalen und ihre vergleichende Morphologie (In Festschrift zum siebenzigsten Geburtstage von C. Gegenbaur .... iii, p. 349-788. 8 pls. \& fig. Leipzig, 189697. 3 vols. $4^{\circ}$ )

1896.1

Zur systematischen Stellung der Myxinoiden und zur Frage des alten und neuen Mundes. Morphol. Jahrb. 1900 $28,478-482$.

1900.1

Morphologische Streitfragen. I. Nervus trochlearis. II. Rabl's Methode und Behandlung der Extremitatenfrage. Morphol. Jahrb., 1902, 30, 85-274.

1902.1
- Erwiderung ito Rabl's criticism of his paired fin doctrine] Anat. Anz., 1903, 23. Jahrg., 190-197. 1903.1

- Notiz über oberflächliche Knorpelelemente im Kiemenskelet der Rochen (extraseptalia), zugleich nach von J. Ed. Stumpff gemachten Beobachtungen. Morphol. Jahrb., 1903, 31, 623627. figs.

1903.2

- Schlussübersicht über den gesamten Inhalt von Professor Semon's zoologischen Forschungreisen (In Semon, R. Zoologische Forschungreisen in Australian und dem Malayischen Archipel., Bd. i, 1495-1554. Jena, 1913)

Fuirbringer, Max, \& Bluntschli, $H$. (editors) Gesammelte Abhandlungen von Carl Gegenbaur. 3 vols. Leipzig, 1912. 1822 p. 65 pls. 73 figs. $8^{\circ}$.

1912.1

Fürbringer, Paul. Die Muskeln des Kopfskelets der Myxine glutinosa unter specieller Würdigung der Kaufunktion. Jena, 1874. 22 p. $8^{\circ}$.

1874.1

Untersuchungen zur vergleichenden Anatomie der Muskulatur des Kopfskelets der Cyclostomen. Jena. Zeitschr. Naturw., 1875, 9, 1-93. 4 pls

1875.1

Fürnrohr, August Emil. Die Fische in den Gewässern um Regensburg. Stadt am Hof, 1847.

1847.1

Fürst, Carl M. Haarzellen und Flimmerzellen. Anat. Anz., 1900, 18, 190-203.

1900.1

- Ringförmige Bildungen im Kopf- und Spinalganglienzellen bei Lachsembryonen. Anat. Anz., 1900, 18, 253-255. figs.

1900.2

Ringe, Ringreihen, Fäden und Kinäuel in den Kopf- und Spinalganglienzellen bei Lachse [Text in Danish] Biol. Selsk. Forhandl., Kjöbenhavn, 1901-02, 13-15. - Anat. Hefte, Wiesbaden, 19, pt. 1, 387-420. 2 pls. 1901.1

\section{Zur Kenntnis der Histogenese} und des Wachstums der Retina. Lunds Univ. Arsskr., 1904, 40, pt. 2, no. 1. 45 p. 3 pls.

1904.1

Fugger, Eberhard. Die Gaisberggruppe. Jahrb. Geol. Reichsanst. Wien, 1906, 56, 213-258. 7 figs. 1906.1

Contains mention of fossil fishes.

Fuhrmann, Otto. Myxosporidies des corégones du lac de Neuchâtel. 
Arch. Sci. Phys. Nat., Genève, 1902, 4. sér. 16, 331-332.

1902.1

L'evolution des 'Ténias et en particulier de la larve des Ichtyoténias. Arch. Sci. Phys. Nat., Genève, 1903, 4. sér. 16, 335-337.

1903.1

Introduction en Europe d'un silure d'Amérique (Amiurus nebulosus, catfish) Arch. Sci. Phys. Nat., Genève, 1903, 4. sér. 16, 331-332.

1903.2

L'omble chevalier des zones profondes. Arch. Sci. Phys. Nat., Genève, 1903, 4. sér. 16, 332-333. - Bull. Suisse Pêche et Pisciculture, 1903, no. 2, 17-19. fig.

1903.3

La pisciculture dans le canton de Neuchâtel. Arch. Sci. Phys. Nat. Genève, 1903,4. sér. 16, 733-734. 1903.4

- Salvelinus salvelinus var. profundus. Bull. Soc. Sci. Nat. Neuchâtel. 1903, 31, 382-384.

1903.5

_ Einiges über den Star bei Forellen. Allgem. Fischerei Zeitg., 1904, 29. Jahrg., 451-452.

1904.1

La pêche et la pisciculture en Suisse. Bull. Suisse Pêche et Piscicult., 1904, 144-153.

1904.2

- Ueber die Entstehung des Neuenburger-, Murtner- und Bieler-Sees nebst Bemerkungen über die Fischereiverhältnisse derselben. Schweiz. Fischerei Zeitg., 1904, 12, 192-199.

1904.3

- Ueber eine Krankheit der weiblichen Geschlechtsorgane des Hechtes. Allgem. Fischerei Zeit.g., 1904, 29. Jahrg., 469-471.

1904.4

Cas intéressants de soins paternels chez les poissons. Bull. Suisse Pêche Piscicult., 1905, no. 6, 81-87. fig. Abstract in Arch. Sci. Phys., Genève, 1906, 21, 219.

1905.1

- Encore le catfish. Bull. Suisse Pêche et Piscicult., 1905, 90-92. 1905.2

- Exhibit of Scleropages osteoglossum, showing buccal incubation] Arch. Sci. Phys. Nat., Genève, 1905, 20, 578 579.

1905.3

- Les maladies de nos poissons Arch. Sci. Phys. Nat., Genève, 1905, 19 , 205.

1905.4

- On affinities of Phreatobius cisternarum. Arch. Sci. Phys. Nat., Genève, 1905, 4. sér. 20, 579. 1905.5
_- Scleropages formosum und über Phreatobius cisternarum. Verh. Schweiz. Naturf. Ges. Aarau, 1905, 88, 50-51. Arch. Sci. Phys. Nat., Genève, 4. sér. 20, 578-579.

1905.6

Sur l'origine des lacs de Neuchâtel, de Morat et de Bienne, avec des observations sur la pêche relatives au premier. Bull. Suisse Pêche et Piscicult., 1905, 17-26. fig.

1905.7

- Untersuchungen über die Nahrung einiger Salmoniden. Allgem. Fischerei Zeitg., 1905, 30. Jahrg., 2-4.Bull. Suisse Pêche et Piscicult., 1905, no. 6, 119-123. 15 figs.

1905.8

_ Les établissements de pisciculture de la Suisse. Bull. Suisse Pêche et Piscicult., 1906, 41-46; 60-63; 80-82; 113-118; 136-140. 8 figs. 1906.1

- La pêche et la pisciculture à l'exposition de Milan. Bull. Suisse Pêche et Piscicult., 1906, 97-101; 119$120 ; 165-168 ; 197-198$.

1906.2

- Soins paternels chez les poissons. Arch. Sci. Phys. Nat., Genève, 1906, 4. sér. 21, 219.

1906.3

- Bericht über die Fischereiverhältnisse der Vereinigten Staaten. Schweiz. Fischerei Zeitg., 1908, 18. Jahrg. 15 p. 6 figs. - Bull. Suisse Pêche Piscicult., 1908, 122-125; 156162; 184-188. 7 figs. 1908.1

_- La piscicultura negli Stati Uniti. Relazione. Riv. Mens. Pesca Napoli, $1909,11,51-64 ; 160-164$. 1909.1

Poisson hermaphrodite du lac de Neuchâtel. Arch. Sci. Phys. Nat., Genève, 1909, 27, 316. 1909.2

Un cas d'hermaphrodisme chez un vengeron (Leuciscus rutilus) du lac de Neuchâtel. Bull. Soc. Sci. Nat. Neuchâtel, 1910, 36, 82-85. 5 figs. 1910.1

Fuhrmann, Otto, \& Yung, Emile. De l'influence d'un jeûne prolongé sur les éléments histologiques de l'intestin chez les poissons. Arch. Sci. Phys. Nat., Genève, 1899, 4. sér. 8, 483-485. 1899.1

- Recherches sur la digestion des poissons. Arch. Zool. Expér. Gén., 1900, 3. sér. 8, 333-351. 2 pls. 1900.1

Histologie de la muqueuse intestinal de Lota vulgaris.

Fujita, Masakatsu. Kwanden-Denki no gyorui ni oyobosu hanwo jikken [Experiments on the reaction of fishes both living and dead, towards induction currents of electricity] Zool. Mag., Tokyo, $1906,18,153-155$. 1906.1 
Fujita, Tsunenobu. Artificial incubation of flat fish ['Text in Japanese] Zool. Mag., Tokyo, 1903, 15, 316-321.

1903.1

Tansui san no kaisen-byō [Disease of freshwater fishes] Zool. Mag., Tokyo, 1904, 16, 439-142. $190 \pm .1$

On a new species of Chloromyxum from the gall-bladder of the carp. Annotat. Zool. Japonenses, 1913, 8, 257-259. fig.

1913.1

Fujita, T'sunenobu, \& Otaki, Keinosuke. Nippon gyorui satei ho [Direction for the strdy of Japanese fishes] Tokyo, 1904. 44 p.

1904.1

Fujita, Tsunenobu, Otaki, Keinosuke, \& Higurashi, Tadashi. See Otaki, Fujita \& Higurashi.

Fullarton, $J . H$. On the development of the plaice (Pleuronectes platessa) 9. Ann. Rept. Fish. Board Scotland, 1891, pt. 3, 311-316. 3 pls. Ibid., 1893, 11, 274-283. 2 pls. Also separate; London, 1893. $8^{\circ}$.

1891.1

On the oviposition and growth of the lesser sand-eel (Ammodytes tobianus L.) 12. Ann. Rept. Fish. Board Scotland, 1894, pt. 3, 313-321. 1894.1

On the generating organs and products of T'omopteris onisciformis Esch. Zool. Jahrb., 1895, 8, 4. Heft, 425-446. 3 pls.

1895.1

- On the larval and post-larval development of the brain of the lesser sand-eel (Ammodytes tobianus L.) 13 Ann. Rept. Fish. Board Scotland, 1895, 276-288. 3 pls.

1895.2

Fullarton, $J, H .$, \& Fulton, $T$. Wemyss. See Fulton \& Fullarton.

Fuller, $A . R$. The breeding of eels. Chicago Field, 1879, 11, 148. 1879.1

Fuller, Alfred $E$. New and improved devices for fish culturists. Proc. 4. Intern. Fish. Congr., Washington, D. C. 1908, pt. 2, 991-1000. 3 pls. 1908.1

New and improved devices for fish culturists. Scient. Amer. Suppl., $1910,70,17-19.7$ figs.

1910.1

Fuller, Thomas. Carp in England in the seventeenth century. Bull. U. S. kish Comm. 1884, 4, 14.

1884.1

Fullerton, Samuel $F$. Protection as an aid to propagation. Trans. Amer. Fisheries Soc. 1906 (1907), 59-64.

1907.1
- The modern hatching house. Trans. Amer. Fisheries Soc. 1908 (1909), 132-137. 2 figs.

1909.1

The future of our brook trout. Trans. Amer. Fisheries Soc. 1911 (1912), 99-102.

1912.1

Fulliquet, $G$. Recherches sur le cerveau du Protopterus annectens. Recueil Zool. Suisse, 1886, 3, 1-130. 5 pls.Arch. Sci. Phys. Nat., Genève, 3. sér. 15 , 94-96.

1886.1

Fulton, T. Wemyss. An account of the contemporary work relating to fisheries, including abstracts of the more important papers. 6. Ann. Rept. Fish. Board Scotland, 1888, 276-308. 1888.1

Inquiries into the nature of the food, the spawning, habits, etc., of marine food-fishes. 7. Ann. Rept. Fish. Board Scotland, 1889, 182-185. 1889.1

The scientific work of the fishery board for Scotland. Journ. Mar. Biol. Assoc., 1889, 1-17.

1889.2

The distribution of immature sea-fish, and their capture by various modes of fishing. 8. Ann. Rept. Fish. Board Scotland, 1890, 157-210. 1890.1

Notes and memoranda. 1. The anchovy in Scottish waters. 2. Experiments on the migratory movements of sea fish. 3. The migrations and reproduction of the common eel (Anguilla vulgaris) 4. Rare and uncommon fishes. 5. Experiments in the cross-fertilisations of different species of fish. 8. Ann. Rept. Fish. Board Scotland, 1890, 351-35S.

1890.2

Notes on contemporary work relating to fisheries in this and other countries. 8. Ann. Rept. Fish. Board Scotland, 1890, 359-375. 1890.3

The proportional numbers and sizes of the sexes among sea-fishes. 8 . Ann. Rept. Fish. Board Scotland, 1890, 348-350.

1890.4

- Report on the trawling experiments of the "Garland" and on the statistics of east coast fisheries. 8. Ann. Rept. Fish. Board Scotland, 1890, 22156. 3 pls.

1890.5

The scientific work of the fishery board for Scotland. Journ. Mar. Biol. Assoc., 1890, n. s. 1, 75-91. 1890.6

- The spawning and spawning places of marine food-fishes. 8. Ann. Rept. Fish. Board Scotland, 1890, 257269. 
An account of contemporary scientific fishery work and fisheries in this and other countries. 9. Ann. Rept. Fish. Board Scotland, 1891, 388-423.

1891.1

The capture and destruction of immature sea-fish. 9. Ann. Rept. Fish. Board Scotland, 1891, 201-211. fig.

1891.2

Review by E. Ehrenbaum in Mitth. Deutsch. Seefischerei Ver., 1892, 97-108.

The chief fishing ground on the east coast of Scotland, with charts showing their position and extent. 9. Ann. Rept. Fish. Board Scotland, 1891, 177183. 2 pls.

1891.3

The comparative fecundity of sea-fishes. 9. Ann. Rept. Fish. Board Scotland, 1891, pt. 3, 243-268. 1891.4

- On over-fishing of the sea and the culture of sea-fish. 10. Ann. Rept. Fish. Board Scotland, 1891, pt. 3, 171-193. 2 pls.

1891.5

- Report on the trawling experiments of the "Garland" and on the statistics of east coast fisheries. 9. Ann. Rept. Fish. Board Scotland, 1891, 21176. 2 pls.

1891.6

An account of contemporary scientific fishery work and fisheries in this and other countries. 10. Ann. Rept. Fish. Board Scotland, 1892, 326-353.

1892.1

- Observations on the reproduction, maturity and sexual relations of the food-fishes. 10. Ann. Rept. Fish. Board Scotland, 1892, 232-243. pl. 1892.2

- On over-fishing of the sea and the culture of sea-fish. 10. Ann. Rept. Fish. Board Scotland, 1892, 171-193. 2 pls.

1892.3

- Report on the trawling experiments of the "Garland" and on the statistics of east coast fisheries. 10 . Ann. Rept. Fish. Board Scotland, 1892, 23-159. 2 pls.

1892.4

- An account of contemporary scientific fishery work and fisheries in this and other countries. 11. Ann. Rept. Fish. Board Scotland, 1893, 486-502.

1893.1

- An experimental investigation on the migrations and rate of growth of the food-fishes. 11. Ann. Rept. Fish. Board Scotland, 1893, 176-196. fig.

1893.2
Report on the trawling experiments of the "Garland" and on the statisties of east coast fisheries. 11 Ann. Rept. Fish. Board Scotland, 1893, 23-166. pl.

1893.3

An account of contemporary scientific fishery work and fisheries in this and other countries. 12. Ann. Rept. Fish. Board Scotland, 1894, 383404.

1894.1

An account of the sea-fish hatchery at Dunbar. 12. Ann. Rept. Fish. Board Scotland, 1894, 196-209. pl. \& fig.

1894.2

- The capture and destruction of immature sea-fish. The relation between the size of the mesh of trawl-nets and the fish captured. 12. Ann. Rept. Fish. Board Scotland, 1894, 302-312.

1894.3

Description of the marine hatchery at Dunbar, Scotland. Bull. U. S Fish Comm. 1893 (1894), 13, 257-262. 1894.4

Report on the trawling experiments of the "Garland" and on the statistics of east coast fisheries. 12. Ann. Rept. Fish. Board Scotland, 1894, 23-164.

1894.5

An account of contemporary scientific fishery work and fisheries in this and other countries. 13. Ann. Rept. Fish. Board Scotland, 1895, 332348.

1895.1

The capture and destruction of immature fish. The relation between the size of hooks and the size of fish captured. 13. Ann. Rept. Fish. Board Scotland, 1895, 133-136. 1895.2

The relation of marine currents to offshore spawning areas and inshore nurseries. 13. Ann. Rept. Fish. Board Scotland, 1895, 153-164. pl. $\quad 1895.3$

Report on the trawling experiments of the "Garland" and on the statisties of east coast fisheries. 13. Ann. Rept. Fish. Board Scotland, 1895, $17-122$.

1895.4

L'état actuel de la pisciculture marine. Rev. Gén. Sci. Appliq., 1896, 7. année, no. 5, 237-248. 7 figs. 1896.1

Künstliche Fortpflanzung der Seefische. Allgem. Fischerei Zeitg., $1896,21,6-7$.

1896.2

Record of observations made on board the "Garland " during 1895. 14. Ann. Rept. Fish. Board Scotland, 1896, pt. 3, 35-62.
1896.3 
Fulton, T. W.

- Report on the trawling experiments of the "Garland" and on the statistics of east coast fisheries. 14. Ann. Rept. Fish. Board Scotland, 1896, $17-127$.

1896.4

Review of the trawling experiments of the "Garland" in the firth of Forth and St. Andrews bay in the years 1S86-1895. 14. Ann. Rept. Fish. Board Scotland, 1896, 128-149. 2 pls. 1896.5

The currents of the North sea and their relation to fisheries. 15. Ann, Rept. Fish. Board Scotland, 1897, 334395. 2 pls. \& 3 figs.

1897.1

- Report on the trawling experiments of the "Garland" and on the statistics of east coast fisheries. 15. Ann. Rept. Fish. Board Scotland, 1897, $17-106$.

1897.2

- On the growth and maturation of the ovarian eggs of teleostean fishes. 16. Ann. Rept. Fish. Board Scotland, 1898, pt. 3, 88-124. pl. \& fig.

1898.1

On the maturation of the pelagic eggs of teleostean fishes. Zool. Anz. 1898, 21, 245-252. figs.

1898.2

The ovaries and ovarian eggs of the angler or frog-fish (Lophius piscatorius) and of the John Dory (Zeus faber) 16. Ann. Rept. Fish. Board Scotland, 1898, pt. 3, 125-134. 2 pls. 1898.3

Report on the trawling experiments of the "Garland" and on the statistics of east coast fisheries. 16 . Ann. Rept. Fish. Board Scotland, 1898 , $17-87$.

1898.4

On the migratory movements and rate of growth of the grey or common gurnard. 17. Ann. Rept. Fish. Board Scotland, 1899, 210-231. 2 figs.

1899.1

Report on the trawling experiments of the "Garland " and on the statistics of east coast fisheries. 17. Ann. Rept. Fish. Board Scotland, 1899, 17-78.

1899.2

Additional note on the surface currents of the North sea. 18. Ann. Rept. Fish. Board Scotland, 1900, 370381 .

1900.1

Report of an inquiry on the action of the herring seine-net. 18. Ann. Rept. Fish. Board Seotland, 1900, 242271.

1900.2
Report on the trawling experinents of the "Garland" and on the statistics of east coast fisheries. 18. Ann. Rept. Fish. Board Scotland, 1900, 1976.

1900.3

Ichthyological notes. 19. Ann. Rept. Fish. Board Scotland, 1901, 282291.

1901.1

i. The Norway pout (Gadus esmarkii)

ii. Silvery pout (Gadus (Gadiculus) argenteus) iii. Couch's whiting (Gadus poutassou)

iv. The Hebridean smelt or argentine (Argentina sphyræna)

v. The greater argentine (Argentina silus)

vi. The sharp-tailed Lumpenus (Lumpenus lampetraeformis

vii. The Norway haddock (Sebastes marinus)

viii. Toung fishes on the deep-water grounds.

ix. Opah or king-fish (Lampris luna)

x. The torpedo (Torpedo nobiliana)

- Investigations made on board steam trawlers. 19. Ann. Rept. Fish. Board Scotland, 1901, pt. 3, 58-91.

1901.2

On the rate of growth of the cod, haddock, whiting and Norway pout. 19. Ann. Rept. Fish. Board Scotland, 1901, pt. 3, 154-228. 8 pls.

1901.3

Report on the trawling experiments of the "Garland" and on the statistics of east coast fisheries. 19. Ann. Rept. Fish. Board Scotland, 1901, $17-57$.

1901.4

Ichthyological notes. 20. Ann. Rept. Fish. Board Scotland, 1902, 539541 .

i. The anchovy (Engraulis encrasicholus)

ii. The silvery pout (Gadus (Gadiculus) argenteus)

iii. The red mullet (Mullus surmuletus)

iv. The great silver smelt (Argentina silus)

$\checkmark$. The opah or king-fish (Lampris luna)

vi. Macrurus loevis.

vii. The white-beaked dolphin (Delphinus (Lagenorhynchus) albirostris)

North sea investigations. 20. Ann. Rept. Fish. Board Scotland, 1902, pt. $3,73-237.3$ pls. \& 2 figs. 1902.2

Rate of growth of sea-fishes. 20 . Ann. Rept. Fish. Board Scotland, 1902, pt. 3, 326-439. 8 pls. \& 5 figs. $\quad 1902.3$

Report on the trawling experiments of the "Garland" and on the statistics of east coast fisheries. 20. Ann. Rept. Fish. Board Scotland, 1902, pt. $3,17-72$.

1902.4

The distribution, growth and food of the angler. 21. Ann. Rept. Fish. Board Scotland, 1903, 186-217. 1903.1 
Ichthyological notes. 21. Ann. Rept. Fish. Board Scotland,
228-231.

i. Sturgeons.

ii. King-fish (Lampris luna)

iii. The relative numbers of the sexes among skates and rays.

- Investigations on the abundance, distribution and migration of the foodfishes. 21. Ann. Rept. Fish. Board Scotland, 1903, pt. 3, 15-108. pl.

1903.3

Report on the operations at the marine hatchery, bay of Nigg, Aberdeen. 21. Ann. Rept. Fish. Board Scotland, 1903, pt. 3, 180-185. Ibid., 1905, 23. Ann. Rept., pt. 3, 120-124. Ibid., 1906, 24. Ann. Rept, pt. 3, 108-115. 2 pls. Ibid., 1907, 25. Ann. Rept., pt. 3, 256259. Ibid., 1908, 26. Ann. Rept., pt. 3, 93-96. Ibid., 1909, 27. Ann. Rept., pt. 3, 68-73. Ibid., 1910, 28. Ann. Rept., pt. 3, 11-15.

1903.4

- Ichthyological notes. 22. Ann. Rept. Fish. Board Scotland, 1904 281-287. pl.

1904.1

i. The young of the conger (Leptocephalus)

ii. A post-larval Fierasfer.

iii. The sting-ray (Trygon pastinaca)

iv. The pilchard (Clupea pilchardus)

v. The fecundity of the sprat

vi. Reversed action of the gill-cover in plaice.

A new mark for fish. Conseil

Perm. Intern. Explor. Mer, Public. de Circonstance, 1904, no. 9, 11-14. 1904.2

On the rate of growth of fishes, 22. Ann. Rept. Fish. Board Scotland, 1904, 141-241. 7 pls.

1904.3

On the spawning of the cod (Gadus morrhua L.) in autumn in the North sea. Conseil Perm. Intern. Explor. Mer, Public. de Circonstance, 1904, no. 8, 1-10. pl.

1904.4

The rate of growth of fishes. 22. Ann. Rept. Fish. Board Scotland, 1904, pt. 3, 141-241. 7 pls. Ibid., 1906, 24. Ann. Rept., pt. 3, 179-274. 2 pls.

1904.5

Report on the operations at the marine hatchery, bay of Nigg, Aberdeen. 22. Ann. Rept. Fish. Board Scotland, 1904, 262-269.

1904.6

Spawning of the plaice. Nature, $1904,69,535$.

1904.7

Trawling investigations. 22. Ann. Rept. Fish. Board Scotland, 1904, pt. 3, 13-99.
General index to the scientific reports of the fishery board for Scotland, 1883-1904, with a list of the papers contained in them. 23. Ann. Rept. Fish Board Scotland, 1905, 166-250. 1905.1

Ichthyological notes. 23. Ann. Rept. Fish. Board Scotland, 1905, 251254.

1905.2

i. The young of the conger (Leptocephalus) ii. The anchovy (Engraulis encrasicholus)

iii. The catfish (Anarrhichas lupus)

iv. The spawning of the cod in autumn in the North sea.

On the distribution and seasonal abundance of flatfishes (Pleuronectidse) in the North sea. Rept. North Sea Fish. Invest. Comm. 1902-03 (1905), no. 1, 473-618. 30 figs.

1905.3

Report on the operations at the marine hatchery, bay of Nigg, Aberdeen. 23. Ann. Rept. Fish. Board Scotland, 1905, 120-124.

1905.4

Trawling investigations.

23.

Ann. Rept. Fish. Board Scotland, 1905 , 13-64.

1905.5

On the growth and age of the herring (Clupea harengus) 24. Ann. Rept. Fish. Board Scotland, 1906, pt. 3, 293-342. 3 pls.

1906.1

On the spawning and fecundity of the plaice (Pleuronectes platessa) 24. Ann. Rept. Fish. Board Scotland, 1906. pt. 3, 281-289. 3 tables. 1906.2

- On the spawning of the lumpsucker (Cyclopterus lumpus) and the paternal guardianship of the eggs. 24. Ann. Rept. Fish. Board Scotland, 1906. pt. 3, 169-178. pl. 1906.3

Report on the operations at the marine fish hatchery, bay of Nigg, Aberdeen, in 1905. 24. Ann. Rept. Fish. Board Scotland, 1906, pt. 3, 108-115. 2 pls.

1906.4

Trawling investigations. 24. Ann. Rept. Fish. Board Scotland, 1906. $17-47$.

1906.5

Report of an enquiry into the herring fisheries of the firth of Clyde. Part 1. The statistics of the fisheries. 25. Ann. Rept. Fish. Board Scotland, 1907, pt. 3, 13-196. 12 pls. 1907.1

Report on the operations at the marine fish hatchery, bay of Nigg, Aberdeen, in 1906. 25. Ann. Rept. Fish. Board Scotland, 1907, 256-259. 1907.2

The Lochfyne experiments with plaice. 26. Ann. Rept. Fish. Board Scotland, 1909, pt. 3, 40-72. pl. 1909.1 
Fulton, T. W Report on the operations at the marine fish hatchery, bay of Nigg, Aberdeen, in 1907. 26. Ann. Rept. Fish. Board Scotland, 1909, 93-96. 1909.2

Report on the operations at the marine fish hatchery, bay of Nigg, Aberdeen, in 1908. 27. Ann. Rept. Fish. Board Scotland, 1910, 68-73. 1910.1

A review of the fishery statistics for Scotland. 27. Ann. Rept. Fish. Board Scotland, 1910, 129-191. 1910.2

Report on the operations at the marine fish hatchery, bay of Nigg, Aberdeen, in 1909. 28. Ann. Rept. Fish. Board Scotland, 1911, 11-15. 1911.1

The sovereignty of the sea. An historical account of the claims of England to the dominion of the British seas, and of the evolution of the territorial waters; with special reference to the rights of fishing and the naval salute. Edinburgh, 1911。 xxvi, 799 p. pl. \& 30 figs.

1911.2

On the distribution and seasonal abundance of flatfishes (Pleuronectidx) in the North sea, and the fluctuations in their abundance during the years 1901-1910. 5. Rept. North Sea Invest. Comm., 1913, 67-134. 15 pls. 1913.1

On the marking of plaice and other fish by the S.S. "Goldseeker" during the years 1904-1909. 5. Rept. North Sea Invest. Comm., 1913, 135189. 3 pls.

1913.2

Fulton, T. Wemyss, \& Dannevig, $H$. See Dannevig \& Fulton.

Fulton, T. Wemyss, \& Fullarton, $J . H$. Notes on contemporary work relating to fisheries in this and other countries. 7. Ann. Rept. Fish. Board Scotland, 1889, 384-408.

1889.1

Funk, Ernst. Meine Pseudoxiphophorus bimaculata. Wochenschr. Aquar.Terrar. Kunde, 1910, 7. Jahrg., 485-486. fig.

1910.1

Funke, Otto [1828-1879] Neue Beobachtungen über die Krystalle des Milzvenen- und Fischblutes. Zeitschr. f. Rat. Medicin (Henle \& Pfeuffer), 1852, 2, 198-217.

1852.1

Furneaux, $W$. Life in ponds and streams. London, $1896.8 \mathrm{col}$. pls. $8^{\circ}$.

1896.1

Furtado, Francisco d'Arruda. Nomes vulgares de peixes. Lista dos nomes vulgares das especies de peixes obser- vadas no mercado de Lisboa com os seus equivalentes scientificos (In his Psychologia e ethnologia ... Jorn. Sci. Acad. Sci. Lisboa, 1886, no. 42, 49-64) 1886.1

Furuhjelm, J.E., \& Chydenius, - Johan Jacob. See Chydenius \& Furuhjelm.

Fusari, Romeo. Ricerche intorno alla fina anatomia dell' encefalo dei teleostei. Atti Accad. Sci. Roma, 1857, 4. ser. 3, 148-150.

1887.1

La segmentation des œufs des téléostéens. Arch. Ital. Biol., Turin, 1887, 9, 22-24. - Ital. Boll. Sci., 1887, 9, 82-84. - Ball. Atti Congresso Medico, Paris, 1887.

1887.2

Untersuchungen über die feinere Anatomie des Gehirnes der Teleostier. Month. Intern. Journ. Anat. Histol., $1887,4,275-300$. 3 pls.

1887.3

Beitrag zum. Studium des periferischen Nervensystem vom Amphioxus lanceolatus. Int. Monat. f. Anat. u. Phys., 1889, 4.

1889.1

_- Sur les premières phases de développement des téléostéens. Arch. Ital. Biol., Turin, 1892, 18, 204-239.

1892.1

Sulle prime fasi di sviluppo dei teleostei. Atti Accad. Lincei, 1895, 4. ser. 7, 149-198. 3 pls.

1895.1

- Sulla terminazione centrale del nervo ottico nei teleostei. Revist. Patol. Nerv., 1896, 1. 1896.1

- Présentation de préparations microscopiques démontrant les terminaisons nerveuses dans les muscles striés, dans l'épiderme et dans l'épithélium de la cavité buccale de l'Ammoccetes branchialis. C. R. Assoc. Anat., 3. sess., 1901, 238-239.

1901.1

Contributo allo studio delle terminazioni nervose nei muscoli striati di Ammocotes branchialis. Atti Accad. Sci., Torino, 1905, 40, 1078-1088. pl.Arch. Sci. Med. Torino, 29, 413-424. pl. 1905.1

Contributo allo studio dei nervi cutanei e delle terminazioni nervose nella cute e nella muccosa orale dell' Ammocœtes branchialis. Atti Accad. Sci., Torino, 1907, 42, 192-200. pl.Arch. Sci. Med. Torino, 30.

1907.1

__ Sulla terminazione dei nervi nell' apparecchio branchiale e nel velo boccale dell'Ammocotes branchialis. Atti Accad. Sci., Torino, 1907, 42, 493-503. pl.Arch. Sci. Med. Torino, 31, 190-201. pl. 1907.2 
G. Der Fisch im Thierreiche. Mitth. Fischereiwesen. München, 1876, 1. Jahrg., 9-11.

1876.1

G, - von. Connecticut river salmon. Forest \& Stream, 1876, 6, 354.

1876.1

Destruction of pickerel by black bass. Forest \& Stream, 1876, 6, 232

1876.2

- Fish culture on the Connecticut river. Forest \& Stream, 1876, 6, 401 .

1876.3

Large striped bass caught in the Connecticut. Forest \& Stream, 1876, 6, 357 .

1876.4

Phenomenal run of herring in the Taunton and Nemasket rivers. Forest \& Stream, 1876, 6, 234. 1876.5

Pickerel or bass. Forest d Stream, 1876, 6, 302. $\quad 1876.6$

- A new foe of the shad. Forest \& Stream, 1877, 8, 223.

1877.1

Destruction of shad and striped bass in Connecticut river, resulting from introduction by Fish Commission of black bass.

G., $A . F$. Smelt fishing. Forest \& Stream, 1876, 6, p. 6 .

1876.1

G., A.W. Stocking the Nashua river, N. H., with fish. Forest \& Stream, 1877 , 9, 44 .

1877.1

G., $C . J$. Trout fishing in Oregon. Forest \& Stream, 1880, 14, 451. 1880.1

G., G.S. Trout as vegetarians. Forest \& Stream, $1875,5,275 . \quad 1875.1$

G., J.W. Some results of the "Belgica" expedition. Nature, London, 1906, 74, 298-299. 1906.1

G., L. Die Bastarde des Karpfengeschlechts. Deutsch. Landw. Presse, 1875, 2. Jahrg., 638 .

1875.1

Ein Beitrag zur Naturgeschichte des Hechtes [Esox lucius] Deutsch. Landw. Presse, 1875, 2. Jahrg., 244. Ibid., 1877, 4. Jahrg., 325-326. 1875.2

G., M. Stream protection in Europe. Bull. Zool. Soc., 1910, 707-709. 1910.1
G., $N$. A monster halibut. Forest $\&$ Stream, 1877, 9, 145.

1877.1

G., S.G. IF. Salmon put in the big reservoir, Lancaster, Ohio. Forest \& Stream, 1878, 10, 19 . 1878.1

G., $T$. Fishes feed and discern in sunny weather. Mag. Nat. Hist., 1832 , 5, 289-290.

1832.1

- Lampreys (Petromyzon fluviatilis) Mag. Nat. Hist., 1832, 5, 290.

1832.2

Facts and considerations on the natural history and political impropriation of the salmon fish. Mag. Nat. Hist., 1834, 7, 202-217.

1834.1

The salmon enters and ascends rivers for other purposes besides propagation. Mag. Nat. Hist., 1834, 7, 520521.

1834.2

The salmon parr is neither a hybrid, nor a distinct species, of the genus Salmo, but a state of the common salmon. Mag. Nat. Hist., 1834, 7, 521-522. 1834.3

G., T.R. Fish culture in Virginia. Forest \& Stream, 1877, 9, $23 . \quad 1877.1$

G., W. Removal of fishes. Amer. Journ. Sci., 1841, 40, 405-406. 1841.1

G., W.A. Striped bass in the Piscataqua. Forest \& Stream, 1880, 15, 130.

1880.1

Gaál, Stephan. Adatok az osztrososki - Vepor andesit - tufáinak mediterrán faunájához [Beiträge zur mediterränen Fauna des Osztroski - Vepor Gebirges ] Földt. Közlöny Köt., Budapest, 1905, 35, 2S8-313; 338-365. 7 pls. 1905.1

Gabelentz, H.G.C.von der. Catalog einer Sammlung japanischer Bücher. Zeitschr. Deutsch. Morgenländ. Gesell., 1862,16 (n. s. 6), 532-537. 1862.1

Gachet, H. Note sur l'Orthagoriscus spinosus Bl. Schn. Actes Soc. Linn. Bordeaus, 1832, 5, 253-262. 1832.1

Gad, __ Entrickelungsgeschichtliche Beziehungen zwischen elektrischen 
Gad,

Organen, pseudoelektrischen Organen und Muskeln. Abstract in Naturforsche (Sklarek), 1877, 10. Jahrg., 141-143.

1877.1

Gadd, Pehr Adrian (proses) Physicooekonomisk beskrifning öfver hvittis socken i Bförneborgs län. Inaug. Dissert., Abo, 1759.72 p. $4^{\circ}$. 1759.1 Ephraim Carenius, respond.

Tal om finska climatet och dess fölgder $\mathrm{i}$ landets hushillning. K. Svenska Vetensk. Akad., 1761.52 p. 1761.1 Pisces, p. 31.

- (proses) Oekonomisk beskrifning öfver kulsiala församling i Tavastehus län [Tyrväntö kapell] Inaug. Dissert., Abo, 1767. 20 p. $4^{\circ} .1767 .1$ Lars Palander, respond.

(proses) Dissertatio sistens insecta piscatoribus in maritimis Finlandixe oris noxia. Inaug. Dissert., Aboæ, 1769. 8 p. $4^{\circ}$. - Gött. Gel. Anz., 1770, 360.

Carolus Nicolas Hellinius, respond.

1769.1

- Försök till ichthyologia fennica. Tidningar Sällsk. Abo, 1771 , no. 20 , 153-157. Ibid., no. 21, 161-163. Ibid., 1772, no. 46, 364-368. Ibid., no. 47, $372-374$.

1771.1

(proses) Undersökning om Nyland och Tavastehus län, $i$ anseende till dess läge, vidd, climat, våhrfloder, sjöar och vattuleder, naturs förmåner och brister, näringar, forkrikhet, politie- och cameral-författningar. Inaug. Dissert., Abo, 1789. 84 p. $4^{\circ}$.

1789.1

Pt. 1. Hans Henr. John, respond.

Pt. 2. Sam. Gabr. Mellenius, respond.

Pt. 3. Car. Bergman, respond.

- (proses) Om Sysmä socken i Kymmene-gårds län, och savolax öfredels härad. Inaug. Dissert., Abo, 1792. 34 p. $4^{\circ}$.

Mich. Ticcander, respond.

1792.1

Gadd, Pehr. Lerncopoda alpina från Finland Lernacopoda alpina aus Finland) Meddel. Soc. Fauna Flora Fenn., $1910,36,28 ; 217$.

1910.1

Gadeau de Kerville, Henri [1859-] La faune de l'estuaire de la Seine. Caen, 1856. $8^{\circ}$.

1886.1

- Les animaux et les végétaux lumineux. Bibl. Sci. Contemp. Paris, 1889 (1890)

1890.1

Description d'un poisson et d'un oiseau monstrueux, aiguillat dérodyme et goéland mélomèle. Journ. Anat. Physiol., Paris, 1892, 18, 563-566. pl. 1892.1

- Die leuchtenden Tiere und Pflanzen. Leipzig, $1893 . \quad 1893.1$

Jeunes poissons se protégeant par des méduses. Le Naturaliste, 1894, 2. sér. 8, 267-268.

1894.1

Recherches sur les faunes marine et maritime de la Normandie. 1. voyage. Région de Granville et îles Chausey. Bull. Soc. Sci. Nat. Rouen, 1894, 55-126. 7 pls. \& figs. $\quad 1894.2$

Note sur une plie franche et un flet vulgaire atteints d'albinisme. Bull. Soc. Zool. France, 1895, 20, 155-156.

1895.1

Faune de la Normandie. Fascicule IV. Reptiles, batraciens et poissons. Bull. Soc. Sci. Nat. Rouen, 1896, 147-676. Also separate; Paris, 1897. 532 p. 4 pis. $8^{\circ}$.

1896.1

Recherches sur les faunes marine et maritime de la Normandie. 2. voyage. Région de Grandcamp-lesbains (Calvados) et îles Saint-Marcouf (Manche), Juillet-Septembre, 1894. Bull. Soc. Sci. Nat. Rouen, 1898, 33, 309-422. - Bull. Amis Sci. Nat. Rouen, 4. 33 p.

1898.1

\section{Gadeau de Kerville, Henri, \& Brasil,} Louis. See Brasil \& Gadeau de Kerville.

Gadeceau, Emile. Les poissons et les plantes. I. Lacs et rivières. La Nature, 1909, 37, pt. 1, 370-375. 5 figs. 1909.1

Gadow, Hans [1855-] On the modifications of the first and second visceral arches, with especial reference to the homologies of the auditory ossicles. Phil. Trans. Roy. Soc. London, 1888, 179, 451-485. 4 pls.

1888.1

A classification of vertebrata, recent and extinct. London, $1898 . x$, 82 p. $8^{\circ}$.

1898.1

On the nature of intercalated vertebrx of sharks. Journ. Anat. Physiol., London, 1900, p. xlv-xlvi. $\quad 1900.1$

Gadow, Hans, \& Abbott, E. C. On the evolution of the vertebral column of fishes. Phil. Trans. Roy. Soc. London, 1894, 186, 163-221. figs. Abstract in Proc. Roy. Soc. London, 56, 296-299.

1894.1 
Gael, J. Dissertatio historico-juridica inauguralis, quxdam de piscationis jure continens ... Inaug. Dissert. Lugduni Batavorum, 1765. $8^{\circ}$.

1765.1

Gaertner, $F$. von. Zur Rassenfrage der IKarpfen. Allgem. Fischerei Zeitg., 1S98, 23, 95-96.

1898.1

Gage, George. Statement concerning the menhaden fishery. Rept. U. S. Fish Comm. 1877 (1879), 5, 479.

1879.1

Gage, Simon Henry [1851 - ] Notes on the Cayuga lake star-gazer. Cornell Rev., 1878, 91-94. - Geol. Survey of Ohio, 1882, 4, pt. 1 (Zool.), 990-993.

1878.1

The form and size of the red blood corpuscles of the adult and larval lamprey eels of Cayuga lake. Proc. Amer. Soc. Micr., 1888, 10, 77-83. figs. - The Nicroscope, 8, 322-327. Abstract in Journ. Roy. Micr. Soc. London, no. 4 , $49 \pm$.

1888.1

The red blood corpuscles of lamprey eels in relation to jurisprudence. N. Y. Med. Journ., 1888, 48, 149-150. figs.

1888.2

Notes on the physiology and structural changes in Cayuga lake lampreys. Proc. Amer. Assoc. Adv. Sci., 40. meet., 1891, 322 .

1891.1

The comparative physiology of respiration. Amer. Naturalist, 1892, 26, S17-832.

1892.1

The brain of Diemyctylus viridescens, from larval to adult life, and comparisons with the brain of Amia and Petromyzon (In Wilder Quart.-Cent. Book, p. 259-313. 7 pls. Ithaca, 1893)

1893.1

The lake and brook lampreys of New York, especially those of Cayuga and Seneca lakes (In Wilder Quart. Cent. Book, p. 421-493. 7 pls. Ithaca, 1893)

1893.2

Transformation of the lake and of the sea lamprey. Proc. Amer. Assoc. Adv. Sci., 43. meet., 1894, 254-255.

1894.1

Transformation of the brook lamprey (Lampetra wilderi), and parasitism among lampreys. Proc. Amer. Assoc. Adv. Sci., 47. meet., 1898, 372-373. - Science, n. s. 8, 401.

1898.1

Further notes on the brook lamprey (Lampetra wilderi) Proc. Amer. Assoc. Adv. Sci., 48. meet., 1899, 256257.
Comparison of the habits and mode of life of Amphioxus and Ammocotes. Science, 1905, n. s. 21, 265-266. 1905.1

Glycogen in animal tissue. Amer. Journ. Anat., 1905, 4, xii-xiii. 1905.2 Amphioxus and Ammocoetes.

The lampreys of the Cayuga lake basin: fate of lampreys after spawning: non-parasitism of the brook lamprey. Science, 1911, n. s. 33, 389.

1911.1

Gage, Simon Henry, \& Meek, Seth Eugene. The lampreys of Cayuga lake. Proc. Amer. Assoc. Adv. Sci., 35. meet., 1886,269 .

1886.1

Gaglio, G. Esperienze sull' anestesia del labirinto dell' orecchio nei pesci cani (Scyllium catulus) Atti Accad. Lincei, Roma (Rendic.), 1902, 5. ser. 11, pt. 2, 277-285. fig. - Areh. Ital. Biol., Turin, 38, 383-392. fig.

1902.1

Gail, de. L'établissement de pisciculture de Retournemer. Bull. Soc. Centrale Aquiculture et Pêche, 1907, 19, 49-59. Also separate; Paris, 1907.

1907.1

Notes de pisciculture. Sur le fonctionnement de l'étang à reproducteurs des huttes. Ann. Forestières, 1908, $47,417-420$.

1908.1

Sur le fonctionnement d'un bassin à reproducteurs crée à Retournemer. Ann. Forestières, 1908, 47, 420-421.

1908.2

Gaillard, Claude. Notes sur quelques espèces de Cyprinodons de l'Asie Mineure et de la Syrie. Arch. Mus. Hist. Nat. Lyon, 1895,6 , no. 2.15 p. figs.

1895.1

Gaillard, Claude, \& Lortet, Louis. See Lortet \& Gaillard.

Gailois, $N$. Les curiosités de l'exposition maritime internationale du Hâvre. Paris, 1868. $18^{\circ}$. 1868.1

Gaimard, Joseph Paul [1790-1858] Description de 21 espèces de poissons, rapportées par MM. Quoy et Gaimard. Bull. Sci. Nat. (Férussac), 1823, 3, 255. Ibid., 4, 41 .

1823.1

Voyages de la commission scientifique du Nord. Voyage en Skandinavie, en Laponie, au Spitzberg et aux Feröe. Paris, 1842-56.

1842.1

Sect. vii, Zoologie. 
Gaimard, Joseph Paul, \& Quoy, Jean René Constantin. See Quoy \& Gaimard.

Gaines, Kemp. Growth, spawning, and distribution of German carp reared from 20 fish furnished by the United States Fish Commission, November 29, 1880. Bull. U. S. Fish Comm. 1882 (1883), 2, 392 .

1883.1

Gairaud, Clément. La pêche au Vénézuela. Bull. Soc. Centr. Aquicult. Pêche, 1899, 11, 19-20.

1899.1

Gal, $F . G$. Les poissons mommifiés de l'Egypte [surtout le Lates niloticus] La Nature, 1902, 30, pt. 1, 235. 1902.1

Galasso, $F$. Anatomia macro- e microscopica della mucosa palatina di Murona helena L., con speciale riguardo alla questione dell' apparecchio velenifero. Catanzaro, 1901. 34 p. 3 pls.

1901.1

Galbert, (Comte) Alphonse de. Documents de pisciculture applicables à toutes les masses d'eaux. 2. ed. Grenoble, 1865.60 p. pl. $8^{\circ}$ 1865.1

Renseignements sur l'établissement de pisciculture de la Buisse (Isère) Bull. Soc. Centr. Aquicult. France, 1893, 5.

1893.1

L La pisciculture dans l'Isère. Rev. Sci. Nat. Appliq., Paris, 1896. $69 \mathrm{p}$.

1896.1

- L'aquiculture et l'université de Grenoble. Bull. Mém. Acad. Delphin., Grenoble, 1902, 4. sér. 15, 285-298.

1902.1

Repeuplement des cours d'eau. Protection des poissons et crustacés. C. R. Assoc. Franc. Avanc. Sci., Paris, 1904 (1905), 33, pt. 2, 755-760. 1905.1

Gale, Albert. The culture of freshwater fishes. Agric. Gaz., N. S. Wales, 1904, 15, 72-78; 535-537. pl. 1904.1

- Notes on the breeding-habits of the purple-striped gudgeon, Kreffitus adspersus Castelnau. Austr. Zool., 1914, 1 , pt. 1, 25-26.

1914.1

Gallardo, Angel. Carlos Berg. Reseña biográfica. Anal. Mus. Nac. Buenos Aires, 1902, 7, ix-xl. 1902.1

Gallichan, Walter $M$. Fishing and travel in Spain. A guide to the angler. London, 1904. 22. \% . i pls. 12.

1904.1
The trout waters of England. A practical guide to the fisherman for sea trout, brown trout and grayling. Edinburgh, 1908. xi, 160 p. 2 pls. 1908.1

Galli-Valerio, B. Note sulla fauna dei vertebrati Valtellinesi. Riv. Ital. Sci. Nat., 1910, 30, 125-128. $\quad 1910.1$

Gallo, Agostino. Le vente giornate dell' agricoltura e di piaceri della villa di A. G. Nuova edizione. Brescia, 1775. $4^{\circ}$.

1775.1

Gallup, B. Frank. Catching dogfish for oil and guano. Bull. U. S. Fish Comm. 1882 (1883), 2, $246 . \quad 1883.1$

Galton, John C. How fishes breathe: Pop. Sci. Rev., 1871, 10, 341-355.

1871.1

The song of fishes. Pop. Sci. Rev., 1874, 13, 337-349. pl. 1874.1

Galvani, L. Taccuino delle esperienze sulla torpedine fatte nel 1795 a Sinigaglia ed a Rimini. Annales Mus. d' Hist. Nat., 1797. See also Nuovo Cimento, 1869, 2. ser. 2.

1869.1

Gambel, William. On a new species of Mergulus, ray, from the coast of California. Journ. Acad. Nat. Sci. Philad., 1850-54, n. s. 2, 55 .

1850.1

Gamgee, John. On artificial refrigeration. Rept. U. S. Fish Comm. 1877 (1879), 5, 901-972. 3 pls. 1879.1

The Pensacola fisheries. Pensacola Gaz., 1880, Feb. $10 . \quad 1880.1$

Gampe, - Saat in's Wasser [Fischzuchtanstalt zu Einsiedel im Erzgebirge] Gartenlaube, Leipzig, 1874 , no. $8,124-128$. pls.

1874.1

Gampert, O. Ueber die Niere der Cyprinoiden. Zeitschr. Wiss. Zool., $1866,16,372$.

1866.1

- Untersuchungen über die Niere der Cyprinoiden und der Amphibien. Inaug. Dissert. Zürich, 1866. 8\% 1866.2

Gandara, Guillermo, Urbina, Manuel, Degoutin, $N$. Villada, Manuel $M$. See Villada, Gandara \& others.

Gandolfi-Horygold, A. de. L'anguille (Anguilla vulgaris Cuv.) Bull. Soc. Fribourg Sci. Nat., 1911, 19, 47-48.

1911.1

Ganfini, Carlo. Sui nervi spinooccipitali di Amia calva (Bonap.) Monit. Zool. Ital., 1912, 23, 15-22, 3 figs.

1912.1 
Lo sviluppo del sistema nervoso simpatico in alcuni pesei. Arch. Ital. Anat. Embriol., Firenze, 1912, 10, 574 645. 5 pls.

1912.2

\section{Ganivet, Guérin. See Guerin-Gani-} vet,

Garbe, Richard [1857 - ] The Physiologus and the Christian fish symbol. Open Court, Chicago, 1914, 28, 405-411.

1914.1

Garbiglietti, Antonio [1807-1887] Sulla riproduzione delle anguille. Giorn. R. Accad. Med. Torino, 1872, 3. ser. 11, $106 ; 168$.

1872.1

Garbini, A. Osservazione e dati statisti-economoci sui pesci e sulla pesca di Benaco. Verona, 1897. 2 maps. $8^{\circ}$.

1897.1

Garbowski, $T$. Amphioxus als Grundlage der Mesodermtheorie. Anat. Anz., 1898, 14. Jahrg., 473-497. 4 figs. 1898.1

Garces, Modesto. Un viaje á Venezuela. Bogota, 1890. 1890.1

García Canizares, Felipe. Informes sobre la pesca de lo biajaiba. Acad. Ciencias Habana, 1911, 47, 1076-1086.

1911.1

Garcia Solá, Francisco. The fisheries of Spain. Intern. Fisheries Exhib. Lit., London, 1883. Conferences, 5, pt. 9, 353-363.

1883.1

Garde, August. The fisheries of Iceland. Rept. U. S. Fish Comm. 1884 (1886), 12, 301-308.

1886.1

Garden, Alexander. An account of the Gymnotus electricus or electric eel. Phil. Trans. Roy. Soc. London, 1775, 65, pt. 1, 102-110.

1775.1

Gardiner, $E, J . L$. Note on the fish remains from the Old Red Sandstone of Portishead. Proc. Bristol Nat. Hist. Soc., 1892, 2. ser. 7, 34-35.

1892.1

Gardiner, J. Stanley. Notes on the distribution of the land and marine animals, with a list of the land plants and some remarks on the coral reefs. Fauna \& Geogr. Maldive Laccadive Archip., 1906, 2 (Suppl. 2), 1046-1079.

1906.1

Gardner, Testimony in regard to the condition of the fisheries taken in 1871. Rept. U. S. Fish Comm.187172 (1873), 1, 47.

1873.1
Gardner, A. P. Experiments in the pond culture of trout, suckers and catfish. Bull. U. S. Fish Comm., 1883, 3, $417-420$.

1883.1

Gardner, George [1812-1849] Geological notes made during a journey from the coast into the interior of the province of Cearí in the north of Brazil, embracing an account of a deposit of fossil fishes. Edinb. New Phil. Journ., $1841,30,75-82$.

1841.1

On the geology and fossil fishes of north Brazil. Rept. Brit. Assoc. Adv. Sci., 11 meet., 1840 (1841), pt. 2, 118-120.

1841.2

Gareis, Anton. Die Bewirthschaftung des Meeres mit Rücksicht auf den Adriatischen Golf. 2. ed. Wien, 1875. 103 p. $8^{\circ}$.

1875.1

Garganico, $P$. Statuto della società anonima italiana di piscicultura. Como, 1865. $4^{\circ}$.

1865.1

Gargiulo, Antonio. Contributo all' istologia nelle glandole. Riv. Ital. Sci. Nat., 1903, 23, 99-106; 117-122; 148150. Ibid., 1904, 24, 5-12. 1903.1

Garlick, Theodatus. A treatise on the artificial propagation of fish, with the description and habits of such kinds as are the most suitable for pisciculture; also, directions for the most successful modes of angling for such kind of fish as are herein described. New York \& Cleveland, 1857. 142 p. $8^{\circ}$. 1857.1

Hybridization of fish. Papers read before the Kirtland Soc. Nat. Sci. Cleveland, 1874, 45-48. $\quad 1874.1$

The birth of fishculture. Proc. 1. Ann. Meet. Central Fishculture Soc Chicago, 1879, 22-25.

1879.1

A treatise on the artificial propagation and habits of such kinds as are suitable for domestic fish-culture. 2. ed. Cleveland, 1880.128 p. 4 pls $8^{\circ}$ 1880.1

The beginning of fish-culture in America. Trans. Amer. Fisheries Soc. 1883 (1884), 47-48.

1884.1

Garman, Harison. [1858-] A preliminary report on the animals of the Mississippi bottoms near Quincy, Illinois, in August, 1888. Bull. Ill. Lab. Nat. Hist., 1891, 3, 123-184. 1891.1 Fishes, p. 134-148. 
Garman, $H$.

- The origin of the cave fauna of Kentucky, with a description of a new blind beetle. Science, 1892, 20, 240-241. 1892.1

Contrins some notes on blind fishes.

A preliminary list of the vertebrate animals of Kentucky. Bull. Essex Instit., Salem, 1894, 26, 1-63. 1894.1

- Some notes on the brain and pineal structures of Polyodon folium. Bull. Ill. Lab. Nat. Hist., 1896, 4, 299310. 6 pls. Also separate; Springfield, 1896. $8^{\circ}$.

1896.1

Garman, Samuel [?1846-] On the shates (Rajæ) of the eastern coast of the United States. Proc. Boston Soc. Nat. Hist. $1874-75$ (1875), 17, 170-181. fig. 1875.1

Fishes and reptiles from lake Titicaca] Bull. Mus. Comp. Zool. Harv. Coll., 1871-76, 3, no. 11, 273-278.

1876.1

Notes on some fishes from the western coast of South America. Proc. Boston Soc. Nat. Hist. 1875-76 (1877). 18, 202-205.

1877.1

On the pelvis and external sexual organs of selachians, with especial reference to the new genera Potamotrygon and Disceus. Proc. Boston Soc. Nat. Hist., 1877, 19, 197-215.

1877.2

Variation in the colors of animals. Proc. Amer. Assoc. Adv. Sci., 25. meet., 1876 (1877), 187-204.

1877.3

Fishes, p. 192-194.

New species of selachians in the museum collection. Bull. Mus. Comp. Zool. Harv. Coll., 1879-80, 6, 167-172.

1879.1

Synopsis and descriptions of the American Rhinobatidx. Proc. U. S Nat. Mus., 1880, 516-523.

1880.1

New and little-known reptiles and fishes in the museum collections. Bull. Mus. Comp. Zool. Harv. Coll., 1881, 8, no. 3, 85-93.

1881.1

- North American freshwater fishes. Sci. Observ., 1851, 3, no. 8, 5763.

1881.2

- Report on the selachians (In Reports on the results of dredging, under the supervision of Alexander Agassiz, along the Atlantic const of the United States during the summer of
1880, by the U. S. coast survey steamer "Blake") Bull. Mus. Comp. Zool. Harv. Coll., 1881, 8, 231-237. 1881.3 - The American species of the genus Dasybatis. Bull. U. S. Nat. Mus., $1882,16,65-72$.

1882.1

- An extraordinary shark. Bull. Essex Instit., 1884, 16, 47-55. figs.

1884.1

New sharks: Chlamydoselachus anguineus and Heptranchias pectorosus. Bull. Essex Instit., 1884, 16, 3-15. pl.

1884.2

- The oldest living type of vertebrata, Chlamydoselachus. Science, $1884 ; 3,345$.

1884.3

- The oldest living type of vertebrates. Science, 1884, 4, 484. 1884.4

- A peculiar selachian. Sciedce, $1884,3,116-117$.

A species of Heptranchias süpposed to be new. Bull. Essex Instit. Salem, 1884, 16, 56-57.

1884.6

The American salmon and trout, including introduced species. 19. Ann. Rept. Comm. Inland Fisheries Mass., 1855, 1-23. 19 pls. Also separate; Boston, 1885. 23 p. $8^{\circ}$. 1885.1

Chlamydoselachus anguineus Garm., a living species of cladodont shark. Bull. Mus. Comp. Zool. Harv. Coll., 1885, 12, 1-35. 20 pls. 1885.2

The generic name of the pastinacas, or sting rays. Proc. U. S. Nat. Nius., 1885, 8, 221-224. 1885.3

Notes and descriptions taken from selachians in the U. S. National Museum. Proc. U. S. Nat. Mus., 1885, 8, 39-44.

1885.4

On the frilled shark IChlamydoselachus anguineus! Proc. Amer. Assoc. Adv. Sci., 33. meet., 1885, 537-538. 158 Е.5

The tail of Chlamydoselachus. Science, 1887, 9, 267.

1887.1

On the lateral canal system of the Selachia and Holocephala. Bull. Mus. Comp. Zool. Harv. Coll., 18s8, 17, no. 2, 57-119. 53 pls. 1888.1

Cave animals from southwestern Missouri. Bull. Mus Comp. Zool. Harv. Coll., 1S\$9, 17, no. 6, 225-240. 2 pls. 
A large carp and its history. Proc. Boston Soc. Nat. Hist., 1859, 24, 168-170.

1889.2

On a genus and species of the Characines (Henochilus wheatlandii, gen. et sp. nov.) Bull. Essex Instit., 1890 , 22, 49-52. pl.

1890.1

- On species of Cynopotamus. Bull. Essex Instit., 1890, 22, 11-14 1890.2

On species of Gasteropelecus. Bull. Essex Instit, 1890, 22, 8-10.

1890.3

- On the species of the genus Anostomus. Bull. Essex Instit., 1890, $22,15-23$.

1890.4

On the species of the genus Chalcinus in the Museum of Comparative Zoology at Cambridge, Mass. Bull. Essex Instit., 1890, 22, 1-7. 1890.5

- The Discoboli, Cyclopteridæ, Liparopsidx and Liparididx. Mem. Mus. Comp. Zool. Harv. Coll., 1892, 14, no. 2. 96 p. 13 pls.

With copious bibliography.

1892.1

- The distribution of fishes. Science, 1892, 19, 187.

1892.2

- Dr. D. H. Storer's work on the fishes. Science, 1892, 19, 295-296.

1892.3

- The resicles of Savi. Science, $1892,19,128$.

1892.4

- The lac de Marbre trout, a new species. Science, 1893, 22, 23. 1893.1

- The cyprinodonts. Mem. Mus. Comp. Zool, Harv. Coll., 1895, 19, no. 1, $1-179.12$ pls.

1895.1

- Sexual rights and lefts. Amer. Naturalist, 1895, 29, 1012-1014. 1895.2

- Cross fertilization and sexual rights and lefts among vertebrates. Amer. Naturalist, 1896, 30, 232. 1896.1

Report on the fishes collected by the Bahama expedition, of the State University of Iowa, under Prof. C. C. Nutting, in 1893. Bull. Lab. Nat. Hist. Univ. Iowa, 1896, 4, 76-93. 4 pls.

1896.2

Reports on an exploration of the west coast of Mexico, Central and South America, and off the Galapagos islands, in charge of Alexander Agassiz, by the U. S. fish commission steamer "Alba- tross," during 1891. The fishes. Mem. Mus. Comp. Zool. Harv. Coll., 1899, 24, 1-431. $97 \mathrm{pls}$.

1899.1

A species of goby from the shores of Clipperton island. Proc. New England Zool. Club, 1899, 1, 63-64. 1899.2

Additions to the ichthyological fauna of the Bermudas, from the collections of the Yale expedition of 1898. Trans. Connecticut Acad. Sci., 1900, 10, pt. 2, 510-512.

1900.1

- Genera and families of the chimæroids. Proc. New England Zool. Club, $1901,2,75-77$.

1901.1

Some fishes from Australasia. Bull. Mus. Comp. Zool. Harv. Coll., 1903, 39, 229-241. 5 pls. 1903.1

The chimæroids (Chismopnea Raf., 1815; Holocephala Müll., 1834), especially Rhinochimara and its allies. Bull. Mus. Comp. Zool. Harv. Coll. 1904, 41, 243-272. 15 pls. 1904.1

New Plagiostomia. Bull. Mus. Comp. Zool. Harv. Coll., 1906, 46, 203208.

1906.1

- Pisces (In Vertebrata from the Savanna of Panama. No. 12) Bull. Mus. Comp. Zool. Harv. Coll., 1906, 46. 229-230. 1906.2

Paper from the John E. Thayer expedition of 1904. No. 3.

- New Plagiostomia and Chismopnea. Bull. Mus. Comp. Zool. Harv. Coll., 1908, 51, 251-256. 1908.1

The Chismopnea (chimæroids) Mem. Mus. Comp. Zool. Harv. Coll., $1911,40,79-101$.

1911.1

- Pisces (In Some Chinese vertebrates) Mem. Mus. Comp. Zool. Harv. Coll., 1912, 40, 111-123. 1912.1

The Plagiostomia (sharks, skates and rays) Mem. Mus. Comp. Zool. Harv. Coll., 1913, 36, 1-528. 77 pls. 1913.1

The text and atlas are in separate volumes.

Garman, Samuel, \& Denton, Sherman $F$. Abnormal embryos of trout and salmon. Soc. Scient. Observ., Boston, $1886,5,1-7$.

1886.1

Garman, Samuel, \& Putnam, Frederich Ward. See Putnam \& Garman.

Garnault, Paul. Rectification [Cyclostoma elegans] Zool. Anz., 1885, 11, 623-624. 
Garnett, Thomas [1799-1878] Facts on the natural history and habits of the salmon, and some opinions on the laws affecting them, with suggestions for their improvement. Clitheroe [1867] $59 \mathrm{p}$. $8^{\circ}$.

1867.1

Consists of letters written at different times from 1834 to 1866 , some of which were published in Loudon's Magazine of natural history, and in various newspapers.

Garnier, Jules [1839-] Anguille géante à la Nouvelle-Calédonie. Rev. Scient., 1903, 4. sér. 19, 700. 1903.1

\section{Garreau, —, \& Despinoy, - See Despinoy \& Garreau.}

Garrett, A.J. Descriptions of new species of fishes. Julis ornatissimus, Chironectes rubrofuscus, Ophisurus californiensis, Choctodon multicinctus. Proc. Calif. Acad. Sci., 1863, 3, 63-66; 103107.

1863.1

Garrey, Walter $E$. A slight reflex shown by sticklebacks. Biol. Bull. Woods Hole, 1905, 8, 79-84. fig. 1905.1

Garrigou, Joseph Louis Félix [1835 -) Les poissons fossiles. La Nature, 1874, 2, 115-118. figs.

1874.1

Garstang, Walter. The chromatophores of animals [Fishes] Sci. Progress, $1895-96,4,123-125$.

1895.1

- Hjort's hydrographic-biological studies of the Norwegian fisheries: a review. Journ. Mar. Biol. Assoc., 1897-99, n. s. 5, 56-71. Also separate; Plymouth, 1897. $8^{\circ}$.

1897.1

Malformation of the mouth in the common seabream. Journ. Mar. Biol. Assoc., 1897-99, n. s. 5, 345-347.

1897.2

On the variation, races and migrations of the mackerel (Scomber scomber) Journ. Mar. Biol. Assoc., 189799 , n. s. 5, 235-295.

1897.3

Preliminary note on the races and migrations of the mackerel (Scomber scomber) Rept. Brit. Assoc. Adv. Sci., 68. meet., 1898, 902-904. 1898.1

- Albinism and natural selection. Nature, 1900, 62, 620-621. 1900.1

Observations on Merluccius merluccius.

An albino hake (Merluccius merluccius) Journ. Mar. Biol. Assoc., 190003 , n. s. 6, 275-276.

1900.2

- Experiments on the artificial rearing of sea-fish. Rept. Brit. Assoc. Adv. Sci., 69. meet., 1899 (1900), 784.

1900.3
Gadus esmarkii (Nilss.) in shallow water. Journ. Mar. Biol. Assoc., 1900-03, n. s. 6, 274-275.

1900.4

The impoverishment of the sea. Journ. Mar. Biol. Assoc., 1900-03, n. s. 6, 1-69.

1900.5

Reviewed by E. Ehrenbaum in Mitth. Deutsch. Seefischerei Ver., 1901, 24-25.

Preliminary experiments on the rearing of sea-fish larva. Journ. Mar. Biol. Assoc., 1900-03, n. s. 6, 70-93. Also separate; Plymouth, 1900 . $8^{\circ}$.

1900.6

Report on trawling and other investigations carried out in the bays of the southeast coast of Devon during 1901 and 1902. Journ. Mar. Biol. Assoc., $1900-03$, n. s. 6, 435-527. 1900.7

Experiments in the transplantation of small plaice to the Dogger bank. Rept. North Sea Fish. Invest. Comm. 1902-03 (1905), no. 2, 45-65. 2 figs. \& map.

1905.1

General report on the fishery investigations. Rept. North Sea Fish. Invest. Comm. 1902-03 (1905), no. 2, $1-11$.

1905.2

The natural history of the North Sea [President's address] 'Trans. Norfolk \& Norwich Nat. Soc., 1905, 8, 5-14.

1905.3

Provisional report on the natural history of the plaice based on the work of Committee $B$ in the period ending June 30, 1904. Rapp. \& Proc. Verb. Perman. Intern. Explor. Mer, 1905, 3 (App. H), 3-53. figs. charts \& tables. 1905.4

- Report on- experiments with marked fish during 1902-03. Rept. North Sea Fish. Invest. Comm. 1902-03 (1905), no. 2, 13-42. 6 maps. 1905.5

- Report on the trawling investigations, 1902-03, with especial reference to the distribution of the plaice. Rept. North Sea Fish. Invest. Comm. 190203 (1905), no. 2, 67-197. 6 figs. 2 maps.

1905.6

The fisheries of the North sea and the bearings of recent investigations upon the problems of supply. Journ. Soc. Arts London, 1906, 54, 401409.

1906.1

The disappearance of the plaice. Naturalist, London, 1909, 34, 403-407. 1909.1 
The distribution of the plaice in the North sea, Skagerak and Kattegat, according to size, age and frequency. Report on the trawling investigations of the research steamers from October 1902 to July 1907. Proc. Verb. Conseil Perman. Intern. Explor. Mer, 1909, 11, 65133. 6 pls. \& 6 figs.

1909.2

Report on experiments with marked plaice during 1904 and 1905. Rept. North Sea Fish. Invest. Comm. 1909 (1912), no. 4, 153-224. 5 figs. \& 29 pls.

- 1912.1

Garstang, Walter, \& Browne, $F$. Balfour. Motella tusca. A nev British record. Journ. Mar. Biol. Assoc., 1900$03, \mathrm{n} . \mathrm{s} .6,626-627$.

1900.1

Garstang, Walter, \& Byrne, L. W. The fauna of the Salcombe estuary. Pisces. Journ. Mar. Biol. Assoc., 190003, n. s. 6, 214-215.

1900.1

Garstang, Walter, Petersen, C.G.J., \& Kyle, H. N. See Petersen, Garstang \& Kyle.

Garten, S. Beiträge zur Physiologie des elektrischen Organes der Zitterrochen. Abh. Sächs. Gesell. Wiss., Leipzig, 1900, 25, 253-366. 4 pls.

1900.1

Reviewed by R. F. Fuchs in Biol. Centrabl. 21. 159-160.

Die Veränderungen in den Ganglienzellen des elektrischen Lappens der Zitterrochen nach Durchschneidung der aus ihm entspringenden Nerven. Arch. Anat., 1900, 133-154. 2 pls. $\quad 1900.2$

Die Produktion der Elektrizitat (In Winterstein, H. von. Handbuch der vergleichenden Physiologie, Bd. iii, Teil 2, 105-224. Jena, 1910) 1910.1

- Ueber einen Fall von periodischer Tätigkeit der Ganglienzelle. Nach Versuchen an Malapterurus electricus. Zeitschr. Biol., 1910, 54, 399430. 5 pls. \& 4 figs.

1910.2

Ueber Bau und Funktion der elektrischen Organe. Verh. Gesell. Naturf. Aertze, 83. Vers. Leipzig, 1911, Teil 1, 151-183. Also separate; Leipzig, 1911. 34 p. 26 figs. $8^{\circ}$ (Witting, A. Sammlung wissenschaftlicher Vorträge)

1911.1

Gasch, Adolf. Die Reichwirthschaft auf dem Sr. kaiserl. Hoheit dem Herrn Erzherzog Albrecht von Oesterreich gehörigen Gute Kaniów, Bezirk Biala, Galizien. Bielitz, 1880.12 p. $4^{\circ}$.

1880.1
- Pond cultivation on the Kaniów estate (district of Biala, Galicia) the property of his Imperial Highness, Archduke Albrecht of Austria. Rept. U.S. Fish Comm. 1880 (1883), 8, 535-543.

1883.1

- Pond culture; the food and spawning of carp. Rept. U. S. Fish Comm. 1883 (1885), 11, 1143-1150.

1885.1

Zucht der Suisswasserfische 1885 bis 1905. Stenogr. Protok. Verh. Intern. Fisch.-Kongr. Wien, 1905 (1906), 256259.

1906.1

Gaskell, J.F. The distribution and physiological action of the suprarenal medullary tissue in Petromyzon fluviatilis. Journ. Anat. Physiol., London, 1912, 44, 59-67. 3 figs. 1912.1

Gaskell, Walter Holbrook. Spinal and cranial nerves. Journ. Anat. Physiol., London, 1888, 23, p. v. 1888.1

On the origin of the central nervous system of vertebrates. Brain, 1889,12 , p. 1 .

1889.1

On the relation between the structure, function, distribution and origin of the cranial nerves; together with a theory of the origin of the nervous system of vertebrata. Journ. Physiol. Cambridge, $1889,10,153-211.5$ pls. \& 3 figs.

1889.2

On the origin of vertebrates from a crustacean-like ancestor. Quart. Journ. Micr. Sci., 1890, 31, 379-444. 4 pls.

1890.1

The origin of the vertebrates. Proc. Cambridge Phil. Soc., 1895, 9, 19-47. - Nature, 1896, 54, 551-565.

1895.1

'The origin of vertebrates; presidential address. Rept. Brit. Assoc. Adv. Sci., 66. meet., 1896, 942-972. 9 figs. 1896.1

On the origin of vertebrates, deduced from the study of Ammocotes. Journ. Anat. Physiol., London, 18981906. 1898.1

i. The origin of the brain. Journ. Anat. Physiol., London, 1898, 32, 513-553. \& figs.

ii. The origin of the vertebrate cranio-facial skeleton. Ibid., 553-581. pl. \& 3 figs.

iii. On the origin of the branchial segmentation. Ibid., 1899, 33, 15t-188. pl. \& 6 figs.

iv. The thyroid or opercular segment; the meaning of the facial nerve. Ibid. 638-671. pl. \& 15 figs.

$\mathrm{v}$. On the origin of the pro-otic segmentation: the meaning of the trigeminal and eye-muscle nerves. Ibid., 1900, 34, 465-513. 11 figs. 
Gaskell, W. H.

vi. The old mouth and the olfactory organ; the meaning of the first nerve. Ibid., 514-537. 9 figs

vii. On the evidence of prosomatic appendages in Ammocotes, as given by the course and distribution of the trigeminal nerve. Ibid., 537561.5 figs.

viii. The palreontological evidence: Ammocoetes a cephalaspid. Ibid., 562-587. 3 pls. \& $S$ figs.

ix. On the origin of the optic apparatus; the meaning of the optic nerves. Ibid., 1901, $\mathbf{3 5}$, 221-267. 12 figs.

$x$. On the origin of the auditory organ; the meaning of the eighth cranial nerve; together with a consideration of the origin of the cranial nerves as a whole, in accordance with the principles laid down in part I. Ibid., 1902, 36, 16420S. 13 figs.

xi. The origin of the vertebrate body cavity and excretory organs; the meaning of the somites of the trunk and of the ductless glands. Ibid., 1903, 37, 168-219. 6 figs.

xii. The principles of embryology. Ibid. $1905,39,371-101$

xiii. The origin of the notochord and alimentary canal. Ibid., 1906, 40, 305-317. 5 figs.

The origin of the cartilaginous skeleton of vertebrates. Journ. Anat. Physiol., London, 1898, 32, 45-46.

1898.2

On the meaning of the cranial nerves. Presidential address to the Neurological Society for the year 1899. Brain, 1899, 22, 329-372. 18 figs.

1899.1

The origin of vertebrates. London \& New York, 1908. ix, 537 p. 168 figs.

1908.1

Gaspard, $B$. Organisation du poisson connu sous le nom de carpeau. Trav. Soc. Emul. Jura, 1828, 44-49. Journ. Physique, 1829, 9, 225-229.

1828.1

Recherches anatomiques sur les carpeaux. Bull. Sci. Nat. (Férussac), $1830,22,138-140$.

1830.1

Gast, Reinhard. Die Entwickelung des Oculomotorius und seiner Ganglien bei Selachier-Embryonen. Mitt. Zool. Stat. Neapel, 1909, 19, 269-444. 5 pls. 1909.1

Gatcombe, John. Silvery hairtail [Trichiurus lepturus] on the coast of Devon. Zoologist, 1871, 2. ser. 6, 2529 Ibid., 1876, 11, 4806.

1871.1

Blackfish [Centrolophus] on the coast of Cornwall. Zoologist, 1872, 2. ser. 7, 3236 .

1872.1

Occurrence of the bogue off Plymouth (Sparus boops $=$ Boops vulgaris) Zoologist, 1872, 2. ser. 7, 3189.
Occurrence of the tunny [Thynnus thynnus] at Plymouth. Zoologist, 1872, 2. ser. 7,3276 .

1872.3

- Fox shark off the coast of Cornwall. Zoologist, 1873, 2. ser. 8, 3697 .

1873.1

Pilot-fish [Naucrates ductor] at Plymouth. Zoologist, 1874, 2. ser. 9, 4266.

1874.1

Red band-fish [Cepola rubescens] at Plymouth. Zoologist, 1876, 2. ser 11,4767

1876.1

- Large mackerel [Scomber scomber] at Plymouth. Zoologist, 1878, 3. ser. 2, 107.

1878.1

- Srrordfish [Xiphias gladius] and sunfish [Tetraodon mola] on the coast of Devon. Zoologist, 1878, 3. ser. 2, 351352.

1878.2

Boar-fish [Capros aper] on the Devonshire coast. Zoologist, $1879,3$. ser. 3, 429 .

1879.1

- Boar-fish off Plymouth. Zoologist, 1879, 3. ser. 3, 461-462. 1879.2

Porbeagle shark [Squalus cornubicus] off Plymouth. Zoologist, 1881, 3. ser. 5, 425 .

1881.1

Thresher shark 14 feet in length] off the coast of Devon. Zoologist, 1882, 3. ser. 6, 434 .

1882.1

Gatti, Michele A. Il Chrondostoma genei Bp., nella provineia di Teramo. Boll. Soc. Romana Zool., 1896, 5, $211-$ 217.

1896.1

-.... Contribuzione alla conoscenza del genere Alburnus in Italia. Bull. Soc. Romana Zool., 1897, 6; 161-176. 1897.1

Ricerche sugli organi biofotogenetici dei pesci. Parte II. Organi di tipo elettrico. Parte III. Sviluppo degli organi dei due tipi. Atti Accad. Lincei, Roma (Rendic.), 1899, 5. ser. 8, 81-87.

1899.1

- Ricerche sugli organi luminosi dei pesci. Ann. Agricolt., Roma, 1904, no. 233, 7-126. pl.

1904.1

Gatti, Michele A., \& Chiarini, Pietro. See Chiarini \& Gatti.

Gauckler, Philippe [1826-] La pisciculture et le repeuplement des cours d'eau. Epinal, 1879. 18 p. 8 $^{\circ} 1879.1$

Les poissons d'eau douce et la pisciculture. Paris, 1850. 299 p. 37 figs. $8^{\circ}$. 
Gaudry, Jean Albert [1827-1908] For biographical notice, see Science, 1909 , n. s. $29,138-140$; also sketch with portrait in Boule, M. La paléontologie zoologique [with bibliography] Paris, 1915. $3: 3$ p. $\mathrm{S}^{\circ}$.

Les enchainements du monde animal dans les temps géologiques. Fossiles primaires. Paris, 1883. figs. $8^{\circ}$.

Fishes, p. 218-250.

1883.1

Les vertébrés fossiles des environs d'Autun. Bull. Soc. Autun, 1888, $1,1-78$. 3 pls. \& figs.

1888.1

Extracts from the author's previously published papers on the batrachians and fishes of the Permian of Autun.

Les enchaînements du monde animal dans les temps géologiques. Fossiles secondaires. Paris, 1890. 322 p. figs. $8^{\circ}$.

Fishes, p. 146-168.

Gaupp, Ernst. Die Entwickelung der Wirbelsäule. Zool. Centralbl., 1897, 4, $533-550$.

1897.1

Zur Entwickelung der Schädelknochen bei den Teleostiern. Verh. Anat. Ges., Jena, 1903, 17, 113-123. figs.

1903.1

Gauss-Garády, Viktor von. Unsere Makrele in neuer biologischer Beleuchtung. Oesterreich. Fischerei Zeitg., $1909,6,169-170$.

1909.1

Gautier, Armand. Empoisonnement par un poisson toxicophore en rade de $R$ io Janeiro. Arch. Méd. Nav. Paris, 1861, 2, 266 .

1864.1

L_ichthyotoxine, poison du sang de l'anguille. Etangs \& Rivières, 1896, 9. année, 267-269.

1896.1

Gautier, Armand, \& Clausmann, $P$. Le fluor dans l'organisme animal. Bull. Soc. Chim. France, 1913, 4. sér. 13, $909-$ 924.

1913.1

Gautier, Armand, \& Mourgues, L. Sur les alcaloides de l'huile de foie de morue [Gadus morrhua, G. callarias, $G$. carbonarius, etc.] C. R. Acad. Sci. Paris, $1888,107,110-112 ; 626-630$. 1888.1

- Sur un corps, à la fois acide et base, contenu dans les huiles de foie de morue; l'acide morrhuique. C. R. Acad. Sci. Paris, 1888, 107, 740-743. 1888.2

Gauthier, $C . W$. Whitefish in the Great lakes. Comm. Conservation Canada, 1911, 146-153.
Gauthier, Henri. Du transport des poissons frais par les chemins de fer. Mém. \& C. R. Congr. Intern. d'Aquicult. et Pêche, 1900 (1901), 242-248.

1901.1

Gautrelet, Jean. Communication osmotique chez les poissons entre le milieu intérieur et le milieu extérieur (à propos de deux notes de M. Quinton) C. R. Acad. Sci. Paris, $1905,140,108-$ 109.

1905.1

Gavini, _ _ Sur les progrès de la pisciculture dans le département de l'Hérault [extrait du rapport] Bull. Soc. Acclim. Paris, 1860, 7, 30-32. 1860.1

Gavinus, Tentamen ichthyologiæ Melitenis. Melistæ, 1859. 1859.1

Gawrilenko, A. Die Entwickelung des Geruchsorgans bei Salmo salar (Zur Stammesentwickelung des Jacobsonschen Organs) Anat. Anz., 1910, 36. Jahrg., 411-427. 23 figs. 1910.1

Gay, Claudio [1800-1873] Historia fisica $y$ politica de Chile. 8 vols. Paris, 1848. 1848.1

Vol. ii. Zoologia, p. ii, 137-370. pls.

Gay, John, \& Seal, William P. The past and present of fish culture with an inquiry as to what may be done to further promote and develop the science. 'Trans. Amer. Fisheries Soc. 1890 (1891), 66-79.

1891.1

Gay-Lussac, Louis Joseph, \& Humboldt, Alexander. Expériences sur la torpille. Ann. de Chimie, 1805, 56, 1523. - Journ. (Nicholson), 13, 180-184. - Phil. Mag. (Tilloch), 23, 356-360.

1805.1

Gazola, (Count) Giovambattista. Lettere recentemente pubblicate sui pesci fossili Veronesi con annotazioni inedite agli estratti delle medesime. Verona, 1794. 6 pls. $8^{\circ}$. 1794.1

— Lettera al Sig. Francesco Orazio Scorticagna di Lonigo sopra la descrizione di un pesce petrificato da esso publicato in Vicenza (pesce del Bolca) Verona, 1805.

1805.1

Notice by G. B. Brocchi in his Conchiologia fossile subapenina, p. 75. Milano, 1811.

Geare, Randolph $I$. The lake whitefish (In The fisheries and fishery industries of the United States, edited by George Brown Goode. Sect. 1, p. 507540. 2 pls. Washington, 1884) 1884.1 The progress of our fisheries. Leslie's Popular Sci. Monthly, 1S84, 18, $503-510$.

1884.2 
Geare, $R . I$.

The remora or sucking-fishes. Scient. Amer., 1902, 87, 73. 2 figs.

1902.1

The allmouth Lophius piscatorius] Amer. Inventor, 1903, 10, 143.

1903.1

A nest-building fish [Pterophryne histriol Scient. Amer., 1903, 89, 218.

1903.2

A list of the publications of the United States National Museum, 19011906. With an index to titles. Bull. U. S. Nat. Mus., 1906, no. 51, suppl. 1. 40 p.

1906.1

Ichthyological papers are enumerated.

Geay, $F$. Pêches dans les affluents de l'Orinoque. Etangs \& Rivières, 1896, 9. année, 324-326;361-365. Ibid., 1897, 10. année, $37-41 ; 85-90 ; 147-151 ; 344-$ $3+6$.

1896.1

Geay, F., \& Pettit, Auguste. See Pettit \& Geay.

Gebhard, John. Catalogue of the quadrupeds, birds, reptiles, amphibians, fishes, etc., added to the state cabinet of natural history from Jan. 1, 1849, to Jan. 1, 1850. 3. Ann. Rept. State Cab. Nat. Hist. N. Y., 1850, 17-26. 1850.1

Gebhardt, Walther. Ueber das älteste geologisch bekannte Vorkommen von Knochengewebe (Placodermen) Anat. Anz., 1907, 30, 72-90. 1907.1

Geddes, James. Catfish take the fly. Forest \& Stream, 1880, 15, 267. 1880.1

Geer, Carl de, \& Fahlberg, Algot. See Fahlberg \& Geer.

Geering, Traugott. Fischer und Schiffer. Basel, 1886. 1886.1

Gegenbaur, Carl [1826-1903] Grundzüge der vergleichende Anatomie. Leipzig, 1859. xiv, 606 p. illust. 1859.1

Ueber den Bau und die Entwickelung der Wirbelthiereier mit partieller Dottertheilung. Arch. Anat. Physiol., Leipzig, 1861, 491-529. pl.-Gesam. Abh., Leipzig, 1912, 2, 21-18. pl.

1861.1

Ossifikation und Skelettgewebe. Jena. Zeitschr. Naturw., 186t, 1, 343369. pl. Ibid., 1866, 3, 206-246. 2 pls.

1864.1

Half-title reads: Ucher die Bildung des Knochengewebes.
- Untersuchungen zur vergleichenden Anatomie der Wirbelthiere. 3 Hefte in 1. Leipzig, 1864-72. 37 pls. $4^{\circ}$.

1864.2

Heft i. Carpus und Tarsus, 1864. vii, $127 \mathrm{p}$. 6 pls.

Heft ii. Schultergürtel der Wirbelthiere. Brustflosse der Fische. 1865 . vi, 176 p. 9 pls. Heft iii. Das Kopfskelet der Selachier; ein Beitrag zur Erkenntniss des Kopfskeletes der Wirbelthiere. 1872 . $\mathrm{x}, 316 \mathrm{p}, 22 \mathrm{pls}$.

- Vergleichende Anatomie und entwicklungsgeschichtliche Untersuchungen, besonders an Fischen. 4 vols. Leipzig, 1864-65. pls. $8^{\circ}$.

1864.3

- Sur la métamorphose des poissons. Arch. Sci. Phys. Nat., Genève, 1865 , n. s. 24, 161.

1865.1

Zur vergleichenden Anatomie des Herzens, Jena. Zeitschr. Naturw., 1865, 2, 365-383. - Gesam. Abh., Leipzig, 1912, 2, 168-176. 1865.2

i. Ueber den Bulbus arteriosus der Fische, p. 365-375.

- Ueber den Brustguirtel und die Brustflosse der Fische. Jena. Zeitschr. Naturwiss., 1866, 2, 121-125. - Gesam. Abh., Leipzig, 1912, 2, 160-165. 1866.1

- Ueber den Bulbus arteriosus der Fische (In his Zur vergleichenden Anatomie des Herzens. Jena. Zeitschr. Naturwiss., 1866, 2, 365-374. - Gesam. Abh., Leipzig, 1912, 2, 168-176) 1866.2

Ueber die Entwickelung der Wirbelsäule des Lepidosteus, mit vergleichend-anatomischen Bemerkungen. Jena. Zeitschr. Naturw., 1867, 3, 359-419. 3 pls. \& 2 figs. - Gesam. Abh., Leipzig, 1912, 2, 251-304. 3 pls. \& 2 figs. Criticism by E. C. In Arch. Sci. Phys. Nat., Genève, 1868, n. s. 32, 237-249. 1867.1

_- Ueber primäre und secundäre Knochenbildung mit besonderer Beziehung auf die Lehre vom Primordialcranium. Jena. Zeitschr. Naturwiss., 1867, 3, 54-73. - Gesam. Abh., Leipzig, $1912,2,185-202 . \quad 1867.2$

- Ueber Skelettgewebe der Cyclostomen. Jena. Zeitschr. Naturw., 1869, 5, 43-53. pl.

1869.1

Grundzüge der vergleichenden Anatomie. 2. ed. Leipzig, 1870. 892 p. 319 figs. $8^{\circ}$.

1870.1

Ueber das Gliedmassenskelett der Enaliosaurier. Jena. Zeitschr. Naturwiss., 1870, 5, 332-349. pl. 1870.2

Comparison of the skeletal parts of ichthyosaurs with selachians, etc. 
Ueber das Skeletgewebe der Cyclostomen. Jena. Zeitschr. Naturw., 1870, 5, 43-53. - Gesam. Abh., Leipzig, 1912, 2, 318-327. pl.

1870.3

- Ueber das Skelett der Gliedmassen der Wirbelthiere im Allgemeinen und der Hintergliedmassen der Selachier insbesondere. Jena. Zeitschr. Naturw. 1870, 5, 397-447. 2 pls. \& figs. - Gesam. Abh., Leipzig, 1912, 2, 345-389. 3 pls. \& 7 figs.

1870.4

Ueber die Modificationen des Skelets der Hintergliedmassen bei den Männchen der Selachier und Chimxeren. Jena. Zeitschr. Naturw., 1870, 5, 448458. pl. \& 9 figs, - Gesam. Abh., Leipzig, 1912, 2, 390-398. pl. \& 9 figs.

1870.5

Ueber die Kopfnerven von Hexanchus und ihr Verhältniss zur "Wirbeltheorie" des Schädels. Jena. Zeitschr. Naturw., 1871, 6, 497-559. fig.-Gesam. Abh., Leipzig, 1912, 2, 455-509. pl.

1871.1

Ueber das Archipterygium. Jena. Zeitschr. Naturw., 1873, 7, 131141. pl. - Gesam. Abh., Leipzig, 1912 , 2, 529-538. pl.

1873.1

- Grundriss der vergleichenden Anatomie. Leipzig, 1874. 406 p. 320 figs. $8^{\circ}$.

1874.1

Zur Morphologie der Gliedmassen der Wirbelthiere. Morphol. Jahrb., 1876, 2, 396-420. 4 figs. - Gesam. Abh., Leipzig, 1912, 3, 97-116. 4 figs.

1876.1

Bemerkungen über den Vorderdarm niederer Wirbelthiere. Morphol. Jahrb., 1878, 4, 314-319. - Gesam. Abh., Leipzig, 1912, 3, 123-127. 1878.1

Elements of comparative anatomy, etc., translated ffrom the second German edition] by F. L. Bell .... the translation revised and a preface written by E. R. Lankester. London, 1878. xxiv, 645 p. illust. $8^{\circ}$.

1878.2

- Grundriss der vergleichende Anatomie. 2. Auflage. Leipzig, 1878. viii, 655 p. illust.

1878.3

Ueber das Kopfskelet von Alepocephalus rostratus Risso. Morphol. Jahrb., 1878, 4 (Suppl.), 1-42. 3 pls. \& fig. - Gesan. Abh., Leipzig, 1912, 3, 131-164. 3 pls. \& fig.

1878.4

[Besprechung von] A. Schneider: Beiträge zur vergleichenden Anatomie und Entwicklungsgeschichte der Wirbelthiere. Morphol. Jahrb., 1879, 5, 526-528. - Gesam. Abh., Leipzig, 1912 , $3,182-185$.

1879.1

Zur Gliedmassenfrage. An die Untersuchungen von Davidoff's angeknüpfte Bemerkungen. Morph. Jahrb., 1879, 5, 521-525. - Gesam. Abh., Leipzig, 1912, 3, 176-181.

1879.2

- [Besprechung von] G. Swirski: Untersuchungen über die Entwicklung des Schultergürtels und des Skeletes der Brustflosse des Hechtes. Morphol. Jahrb., 1883, 8, 484.

1883.1

[Besprechung von] E. von Rautenfeld: Morphologische Untersuchungen über das Skelet der hinteren Gliedmassen von Ganoiden und Teleostiern. Morphol. Jahrb., 1884, 9, 325-326. Gesam. Abh., Leipzig, 1912, 3, 218-219.

1884.1

Bemerkungen über die Abdominalporen der Fische. Morphol. Jahrb. 1885, 10, 462-464. - Gesam. Abh., Leipzig, 1912, 3, 255-257. 1885.1

Gustaf Retzius. Das Gehörorgan der Wirbelthiere. Morphol. Jahrb., 1886, 11, 126-128. - Gesam. Abh. Leipzig, 1912, 3, 271-273. 1886.1

Ueber die Occipitalregion und die ihr benachbarten Wirbel der Fische (In Festschrift zum siebenzigsten Geburtstag von Albert von Kölliker, p. 1-33. pl. \& 2 figs. Leipzig, 1887) - Gesam. Abh., Leipzig, $1912,3,310-339$. pl. \& 2 figs.

1887.1

Die Metamerie des Kopfes und die Wirbeltheorie des Kopfskeletes im Lichte der neueren Untersuchungen betrachtet und geprüt. Morphol. Jahrb., 1888, 13, 1-114. - Gesam. Abh., Leipzig, 1912, 3, 340-432.

1888.1

Ueber den Conus arteriosus der Fische. Morphol. Jahrb., 1891, 17, 596-610. 7 figs. - Gesam. Abh., Leipzig, 1912, 3, 466-477. 7 figs. 1891.1

Ueber Cöcalanhänge am Mitteldarm der Selachier. Morphol. Jahrb. 1892, 18, 180-184. fig. - Gesam. Abh. Leipzig, 1912, 3, 478-481. fig. 1892.1

Zur Phylogenese der 'Zunge. Morphol. Jahrb., 1894, 21, 1-18. 5 figs. - Gesam. Abh., Leprig, 1912, 3, 482 496. 5 figs,

1894.1

Clavicula und Cleithrum. Morphol. Jahrb., 1895, 23, 1-20. 5 figs.- 
Gegenbaur, $C$.

Gesam. Abh., Leipzig, 1912, 3, 532-548. 5 figs.

1895.1

Das Flossenskelet der Crossopterygier und das Archipterygium der Fische. Morphol. Jahrb., 1895, 22, 119160. 5 figs. - Gesam. Abh., Leipzig, $1912,3,497-531$. 5 figs。 1895.2

- Festschrift zum siebenzigsten Geburtstage von C. Gegenbaur, etc. 3 vols. Leipzig, 1896-97. See Haeckel, Ernst, \& others.

1896.1

Vergleichende Anatomie der Wirbelthiere mit Berïcksichtigung der Wirbellosen. 2 vols. Leipzig, 1898-1901. 974 illust. $8^{\circ}$.

1898.1

Gesammelte Abhandlungen, herausgegeben von M. Fürbringer und $H$. Bluntschli; mit einem Vorwort von $M$. Fürbringer. 3 vols, Leipzig, 1912. 68 pls. 73 figs.

1912.1

- Kritische Bemerkungen über die Metamerie des Schädels. Gesam. Abh., Leipzig, 1912, 3, 562-574.

1912.2

Gegenbaur, Carl, \& Miklucho-Maclay, $N$. de. See Miklucho-Maclay \& Gegenbaur.

Gegenbaur, Carl, \& others. Festschrift. A von Kölliker zur Feier seines siebenzigsten Geburtstages gewidmet von seinen Schülern. Leipzig, 1887. vi, 444 p. 17 pls.

1887.1

i. Ueber die Occipitalregion und die ihr benachbarten Wirbel der Fische. Von C. Gegenbaur.

v. Das Geruchsorgan der Tetrodonten, nebst Bemerkungen über die Hautmuskulatur deselben. Von R. Wiedersheim.

xxiii. Zur Physiologie des Fischdarmes. Von F. Decker.

Gẻhin, Joseph Jean Baptiste [18161859] Sur l'identité de la truite et du rené. Bull. Soc. Hist. Nat. Départ. Moselle, 1866,10, p. 5 .

1866.1

Révision des poissons qui vivent dans les cours d'eau et dans les étangs du département de la Moselle, avec quelques considérations sur le Darwinisme. Bull. Soc. Hist. Nat. Départ. Moselle, 1868, 11, 139-242. Also separate; Metz, 1868. 106 p. $8^{\circ}$.

1868.1

- Note sur une variété du chevenne commun [Leuciscus cephalus] et sur un cas pathologique observé sur un barbeau de la Moselle. Bull. Soc. Hist. Nat. Départ. Moselle, $1870,12,31-37 . \quad 1870.1$

Géhin, Joseph Jean Baptiste, \& Rémy, Anweisung zur künstlichen Fort- pflanzung der Fische; oder, die Kunst Fische zu säen wie man Getreide säet, nebst den beglaubigen Berichten der dafür niedergesetzten Ausschüsse der Gesellschaft für Ackerbau und Gartenkunde zu Paris. Grimma, 1851. $16^{\circ}$.

1851.1

- Fécondation artificielle des poissons. Paris, 1851. $8^{\circ}$ 1851.2

Gehuchten, A. van. Contribution à l'étude du système nerveux des téléostéens. La Cellule, 1894, 10, 255-295. 3 pls.

1894.1

- La moelle épinière de la truite (Trutta fario) La Cellule, 1895, 11, 111-173. 7 pls.

1895.1

L- Les cellules de Rohon dans la moelle épinière et la moelle allongée de la truite (Trutta fario) Bull. Acad. Roy, Belgique, 1896, 3. sér. 30, 495-519. 7 figs.

1896.1

Contribution à l'étude des cellules dorsales (Hinterzellen) de la moelle épinière des vertébrés inférieurs. Bull. Acad. Roy. Belgique, 1897, 3. sér. 34, 24-38.

1897.1

- Les corps restiformes et les connexions bulb-cerebelleuses. Le Nevraxe, 1904, 6, 123-154.

1904.1

Gehuchten, A.van, \& Nelis, Charles. Quelques points concernant la structure des cellules des ganglions spinaux. La Cellule, 1898, 14, 373-384. pl. 1898.1

Geidies, $H$. Zum Laichakt des Maulbrïters (Haplochromis strigigena Pfeff. = Paratilapia multicolor) Blätt. Aquar.Terrar. Kunde, 1912, 28. Jahrg., 679680. fig.

1912.1

- Acara caruleo-punctata Kner \& Steind. Blätt. Aquar.-Terrar. Kunde, 1913, 24. Jahrg., 729-731. 2 figs.

1913.1

Geinitz, Hans Bruno [1814-1900] Characteristik der Schichten und Petrefacten der sächsischen Kreidegebirges. 3 Hefte [Leipzig] 1839-42. 1840.1

Heft 2. B, Fische, Crustaceen, Mollusken. 1840. 63 p. 8 pls.

- Zur Fauna des Rothliegenden und Zechsteins. Zeitschr. Deutsch. Geol. Gesell., 1860, 12, 467-470. 1860.1

Refers to the dorsal spine of Xenacanthus decheni.

- Die fossilen Fischschuppen aus dem Pläner-Kalke von Strehlen. Denkschr. Ges. Natur- u. Heilk. Dresden, 1868, 31-56. 4 pls. - Verh. Geol. Reichsanst, 1869, 14-15. 1868.1 
Das Elbthalgebirge in Sachsen. Zweiter Theil. Der mittlere und obere Quader. VI. Würmer, Krebse, Fische und Pflanzen. Palæontographica, 1875, 20, 199-245. 9 pls.

1875.1

Die sogennanten ISoprolithenlager von Helmstedt, Büddenstedt und Schleweke bei Harzburg. Abh. Naturw. Gesell. Isis, Dresden, 1883, 3-9. pl.

1883.1

Ueber neue Funde in den Phosphatlagern von Helmstedt, Büddenstedt und Schleweke. Abh. Naturw. Gesell. Isis, Dresden, 1883, 37-45. pl.

1883.2

Contains frequent mention of fossil fish remains.

Ueber ein Graptolithen-führenden Geschiebe mit Cyathaspis von Rostock. Zeitschr. Deutsch. Geol. Gesell., 1884, 36, 854-857. pl.

1884.1

Geinitz, Hans Bruno, \& Marck, W. von der. Zur Geologie von Sumatra. Cassel, 1876.2 pls. $4^{\circ}$.

1876.1

some fossil fishes are described.

Geisenheyner, L. IVirbelthierfauna von Kreuznach. I. Fische, Amphibien, Reptilien. Wiss. Beilage Progr. 30. K. Gymn. Kreuznach, 1888. — Zool. Garten, 24, p. 95.

1888.1

- Ueber die Physica der heiligen Hildegard von Bingen und die in ihr enthaltene älteste Naturgeschichte des Neunauges. Sitzber. Naturf. Ver. Preuss. Rheinl. Westfalen, 1911, E, 49-72.

1911.1

Gejtel, Nikolai. En stor Päijänne gädda. Tidskr. Jägare \& Fisk., 1898, 6, $71-72$

1898.1

Gelin, Henri. Poissons des DeuxSèvres et des eaux douces de la Vendée. Mém. Soc. Vulgarisation Sci. Nat. DeuxSèvres, 1911, 2, 35-64.

1911.1

Gellner, F. Der rote Fundulus (Fundulus sjöstedti?) Wochenschr. Aquar.Terrar. Kunde, 1911, 8. Jahrg., 73-74. fig.

1911.1

Characidium (Jobertina) rachovii (Regan) oder Leporinus melanopleura? Wochenschr. Aquar.-Terrar. Kunde, 1913, 10. Jahrg., 193-194. 2 figs. 1913.1

Gemelli, Fr. A. Sur la structure de la région infundibulaire des poissons. Journ. Anat. Physiol., Paris, 1906, 42 77-86. pl.
Gemelli, Giovanni. Notizie sulla pesca nel lago d'Orta. Acquicult. Lombarda, Milano, 1905, 3, 141-144.

1905.1

Gemmellaro, Gaetano Giorgio [1832 - Ricerche sui pesci fossili della Sicilia. Atti Accad. Gioen. Sci. Nat., Catania, 1857, 13, 279-328. 6 pls. 1857.1

Saggio d'ittiologia del golfo di Catania. Atti Accad. Gioen. Sci. Nat., Catania, 1868, 19, 113-158. $\quad 1868.1$

Gemmellaro, Mariano. Ittiodontoliti del Miocene medio di alcune regioni delle provincie di Palermo e di Girgenti. Giorn. Soc. Sci. Nat. Econ., Palermo, 1912, 29, 117-156. 4 pls.

1912.1

Ittiodontoliti eocenici di Patàra (fra Trabia e Termini Imerese) Giorn. Soc. Sci. Nat. Econ., Palermo, 1912, 29, 287-312. pl.

1912.2

Two new species: Acrodus \& Ginglymostoma.

Gemmill, James $F$. The pseudobranch and intestinal canal of teleosteans. Rept. Brit. Assoc. Adv. Sci., 68. meet., 1899, 588-589.

1899.1

Cyclopia in osseous fishes. Rept. Brit. Assoc. Adv. Sci., 70. meet., 1900 784-785.

1900.1

The anatomy of symmetrical double monstrosities in the trout. Proc. Roy. Soc. London, 1901, 68, no. 444, 129-134.

1901.1

- A contribution to the study of double monstrosities in fishes. Proc. Zool. Soc. London, 1903, 2, 4-23. pl.

1903.1

Notes on supernumerary eyes, and local deficiency and reduplication of the notochord in trout embryos. Proc. Zool. Soc. London, 1906, pt. 1, 449-452. pl.

1906.1

On Cyclopia in osseous fishes. Proc. Zool. Soc. London, 1906, 443-449.

1906.2

'The teratology of fishes. Glasgow, 1912. 74 p. 26 pls. \& 114 figs.

1912.1

Gemzöe, K.J. Om aalens alder og vrekst IOn the age and growth of the eel] Beret. Danske Biol. Stat., Kjobenhavn, 1907, 14, 10-38.

1907.1

Genazzini, $E$., Gervasoni, $T$., Vinciguerra, $D$., Besana, $G$., \& Burguières, $E$. See Vinciguerra, Besana \& others. 
Gendersen Stort, A.G.H.van. Over de teleneuronen in het netvlies van Lenciscus rutilus. Versl. Akad. Wet. Amsterdam, 1897, 425-428.

1897.1

Genetz, Arvid Thorsten Birger. Några tankar i anledning af fiskeriföreningens årsberättelse. Fiskeritidskr. Finl., 1897, 6, 199-202.

1897.1

Lax i norra delen af Ladoga. Fiskeritidskr. Finl., 1899, 8, 218.

1899.1

Gengou, $O$. De l'action empêchante du citrate de soude sur l'hémolyse par le sérum d'anguille. C. R. Mém. Soc. Biol. Paris, 1907, 1, 736-738.

1907.1

De l'influence des électrolytes sur l'hémolyse par le sérum d'anguille. C. R. Mém. Soc. Biol. Paris, 1907, 63 . 93-95.

1907.2

Gens, Emile. De la protection des poissons d'eau douce. Verviers, 1879.

1879.1

Rapport sur l'exposition de pêche de Berlin. Moniteur Belge, 1880 , septembre 19.

1880.1

- Notions sur les poissons d'eau douce de Belgique. Bruxelles, 1885.

1885.1

- La pisciculture et l'aquiculture appliquée à la Belgique. Bruxelles, 1891.

1891.1

_- La pêche dans le lac de la Gileppe (Belgique) Bull. Soc. Centr. Aquicult. France, 1893, 5, 196-198.

1893.1

Gensch, H. Die Blutbildung auf dem Dottersack bei IInochenfischen. Vorlåufige Mittheilung. Arch. Mikrosc. Anat., 1881, 19, 144-146.

1881.1

Gensoul, Joseph. Monographie des poissons du département de Saône-etLoire. Bull. Soc. Hist. Nat. Autun, 1908, no. 20, 153-250. Ibid., 1909, no. 22. 201-206.

1908.1

- Note sur deux poissons hybrides, gardon et brême bordelière (Leuciscus rutilus et Blicca bjorkna. Gardon et rotengle, Leuciscus mutilus et Scardinius erythrophthalmus) Bull. Soc. Hist. Nat. Autun, 1908, no. 21 (Proc. Verb.), $107-$ 109.

1908.2

- Le rock-bass. Bull. Soc. Nat. Acclimat. France, 1910, 57, 112-116. fig.

1910.1

La reproduction du calico-bass on Europe (Pomoxys anmularis Raf.)
Bull. Soc. Nat. Acclim. France, 1913, 60, 284-287.

1913.1

Gent, John $J$. Upon the abundance of fish on the New England coast in former times. Rept. U. S. Fish Comm. 1871-72 (1873), 1, 149-154. 1873.1

Gent, John J., Trumbull, J. Hammond, \& others. See Trumbull, Gent \& others.

Gentes, $L$. Structure du lobe glandulaire de l'hypophyse chez les poissons. Bull. Soc. Anat. Physiol. Bordeaux, 1903, 24

1903.1

- Signification choroidienne du sac vasculaire. C. R. Mém. Soc. Biol. Paris, 1906, 60, 101-103. 1906.1

- Développement comparé de la glande infundibulaire et des plexus choroïdes dorsaux chez la torpille. C. R. Mém. Soc. Biol. Paris, 1908, 64, 687689.

1908.1

Développement et évolution de l'hypencéphale et de l'hypophyse de Torpedo marmorata Risso. Trav. Soc. Sci. Stat. Zool. Arcachon, 1908, 11, 1-64. Abstract in C. R. Mém. Soc. Biol. Paris, 64, 1073-1075.

1908.2

Développement et évolution du sac inférieur de l'hypophyse de Torpedo marmorata Risso. C. R. Mém. Soc. Biol. Paris, 1908, 64, 1073-1075. 1908.3

Les lobes latéraux de l'hypophyse de Torpedo marmorata Risso. C. R. Mém. Soc. Biol. Paris, 1908, 64, $1072-$ 1073.

1908.4

- Sur le développement des lobes inférieurs chez les sélaciens. C. R. Mém. Soc, Biol. Paris, 1908, 64, 836-838.

1908.5

Gentil, Ambroise [1842-] Ichthyologie de la Sarthe. Le Mans, 1884. 24 p. $8^{\circ}$.

1884.1

Gentil, W. Voyage dans les mers de l'Inde. 2 vols. Paris, 1781. 27 pls. \& maps. $4^{\circ}$.

1781.1

Poissons de la baie de Manille, vol. ii, p. 105106. Phénomène d'une quantité de poissons échoué proche de Manille en 1767, p. 107, 356. Poissons du Fort-Dauphin, p. 402. P'oisson volant; banes de poissons, p. 735.

Geoffroy-Saint-Hilaire, Albert. Note sur les mocurs du Lepidosiren annectens. C. R. Acad. Sci. Paris, 1863, 57,511 .

1863.1

Geoffroy-Saint-Hilaire, Etienne François [1772-1844] Dissertation sur 
l'organe de l'ouie de l'homme, des reptiles et des poissons. Amsterdam \& Paris, 1778. $8^{\circ}$.

1778.1

Another edition, Leipzig, 1780, $8^{\circ}$.

- Premier mémoire sur l'organe d'ouie des reptiles, et de quelques poissons, que l'on doit rapporter aux reptiles. Mém. Acad. Roy. Sci. Paris, 1786, 11, 164.

1786.1

- Memoir on the comparative anatomy of the electric organs of the torpedo, the Gymnolus electricus and the Silurus electricus. Phil. Mag. London, $1801,15,126-136$.

1801.1

- Description de l'Achire barbu, espèce de Pleuronecte indiquee par Gronow. Ann. Mus. Hist. Nat. Paris, $1802,1,152-155 . \mathrm{pl}$.

1802.1

Description d'un nouveau genre de poisson [Polypterus bichir] de l'ordre des abdominaux. Bull. Soc. Philom. Paris, 1802, 3, 97-98. - Magas. Encycl. (Millin), 8, 92-96. - Phil. Mag., 18, 36-43. - Mag. Physik Naturgesch (Voigt), 5, 438-446.

1802.2

- Histoire naturelle et description anatomique d'un nouveau genre de poisson du Nil, nommé Polyptère. Ann. Mus. Hist. Nat. Paris, 1802, 1, 57-68. Phil. Mag., 18, 36-43. - Mag. Physik Naturgesch.(Voigt), 5, 438. $\quad 1802.3$

- Mémoire où l'on compare les organes électriques de certains poissons. Bull. Soc. Philom. Paris, 1802, 3, 169170. - Annal. (Gilbert), 14, 397-415.

1802.4

Mémoire sur l'anatomie comparée des organes électriques de la raie torpille, du gymnote engourdissant, et du silure trembleur. Ann. Mus. Hist. Nat. Paris, 1802, 1, 392-407. pl.Phil. Mag., 15, 126-136. — Mag. Physik Naturgesch.(Voigt), 7, 1. fig. 1802.5

Sur les branchies du Silurus anquillaris. Bull. Soc. Philom. Paris, 1802, 3, 105.

1802.6

- Sur quelques habitudes communes au requin et au pilote. Bull. Soc. Philom. Paris, 1802, 10, pt. 3, 113-114. - Mag. Encycl. (Millin), 8, pt. 1, 531534.

1802.7

Considérations sur les pièces de la tête osseuse des animaux vertébrés, et particulièrement sur celles du crâne des oiseaux. Ann. Mus. Hist. Nat. Paris, $1807,10,342-365$. pl.

Poissons, p. 342-346.
Observations sur l'affection mutuelle de quelques animaux, et particulièrement sur les services rendus au requin par le pilote. Ann. Mus. Hist. Nat. Paris, 1807, 9, 469-476. 1807.2

Premier mémoire sur les poissons, où l'on compare les pièces osseuses de leurs nageoires pectorales avec les os de l'extrémité antérieure des autres animaux à vertèbres. Ann. Mus. Hist. Nat. Paris, 1807, 9, 357-372. pl.

1807.3

Second mémoire sur les poissons. Considérations sur l'os furculaire, une des pièces de la nageoire pectorale. Ann. Mus. Hist. Nat. Paris, 1807, 9, 413-427.

1807.4

- Le sternum des poissons. Paris, 1807. 18 p. pl. $4^{\circ}$.

1807.5

- Sur le sac branchial de la baudroie, et l'usage qu'elle en fait pour pêcher. Ann. Mus. Hist. Nat. Paris, $1807,10,480-481$.

1807.6

Sur les nageoires pectorales des poissons osseux. Paris, 1807. pl. $4^{\circ}$.

1807.7

Troisième mémoire sur les poissons, où l'on traite de leur sternum sous le point de vue de sa détermination et de ses formes générales. Ann. Mus. Hist. Nat. Paris, 1807, 10, 87-104. pl. 1807.8

- Note sur quelques habitudes de la roussette. Ann. Mus. Hist. Nat. Paris, 1808, 7, 227-230. 1808.1

—-De la synonymie des espèces du genre Salmo qui existent dans le Nil. Ann. Mus. Hist. Nat. Paris, 1809, 14, 460-466. Abstract in Bull. Soc. Philom. Paris, 1810, 73-74.

1809.1

Extrait de "La description de l'Egypte." Paris, 1809. 27 pls.

Poissons du Nil, de la mer Rouge et de la Méditerranée (In Description de l'Egypte . . . Histoire naturelle, 1809 , vol. i, pt. 1, p. 1-52. 27 pls. Paris, 1809-30. $4^{\circ}$ ) 1809.2

Des usages de la vessie aérienne des poissons. Ann. Mus. Hist. Nat. Paris, 1809, 13, 460-464. 1809.3

Note sur deux espèces d'emissole [Mustelus] Ann. Mus. Hist. Nat. Paris, $1811,17,160-163$.

1811.1

De la charpente osseuse des organes de la respiration dans les poissons, ramence aux mêmes parties des autres 
Geoffroy-Saint-Elaire, E. F. animaux vertébrés. Bull. Soc. Philom. Paris, 1817, 185-189. - Deutsch. Arch. (Meckel), 4, 271-274. - Isis (Oken), $1818,8,1419-1421$.

1817.1

Du squelette des poissons ramené dans toutes ses parties à la charpente osseuse des autres animaux vertébrés, et premièrement de l'opercule des poissons. Bull. Soc. Philom. Paris, 1817, 125-127. - Deutsch. Arch. (Meckel), 4, 269-271. - Isis (Oken), 1818, 14221425.

1817.2

Ueber das Zungenbein in verschiedenen Thieren, besonders den Fischen. Isis (Oken), 1817, 8, 1281.

1817.3

Ueber die Knochen an welche die Athemorgane bei den Fischen angeheftet sind. Mém. Acad. Sci., Paris, 1817; Isis (Oken), 1817, 8, 1282. 1817.4

- Sur le sternum des poissons. Ann. Mus. Nat. Hist. Paris, 1818, 10, 77. - Isis (Oken), 5, 781. Ibid., 6, 10551059 .

1818.1

— Trois mémoires sur les poissons, où l'on compare les pièces osseuses de leurs nageoires pectorales avec les os de l'extrémité antérieure des autres animaux à vertèbres. Ann. Mus. Hist. Nat. Paris, 1818, 9, 357; 413. Ibid., 10, 87. fig. - Isis (Oken), 6, 1049. 1818.2

- Ueber den Gabelknochen der Fische. Isis (Oken), 1818, 1052-1055. 1818.3

Ueber die Knnochenstïcke der Brustflosse. Isis (Oken), 1818, 10191052.

1818.4

Du mode de formation de la vertèbre de ses elémens, de leur arrangement respectif dans les diverses classes des animaux, et premièrement de la vertèbre chez la lamproie. Isis (Oken), $1821,7,171$.

1821.1

Considérations générales sur la vertèbre. Mém. Mus. Hist. Nat. Paris, 1822, 9, 89-119. 2 pls. - Isis (Oken), $1823,1392-1409$

1822.1

Ein in Paris lebend angekommen Gymnotus electricus. Ann. Physik (Gilbert), 1822, 70 .

1822.2

Sur les tiges montantes des vertèbres dorsales, pieces restreintes dans les mammifères ¿̀ un état rudimentaire et portées chez les poissons au maximum du développement; pour servir à l'intel- ligence de la notice sur la gaour. Mém. Mus. Hist. Nat. Paris, 1822, 9, 76-88.Isis (Oken), 1823, 1386-1392. 1822.3

De l'aile operculaire ou auriculaire des poissons, considérée comme un principal pivot, sur lequel doit rouler toute recherche de détermination des pièces composant le crâne des animaux; suivi de tableaux synoptiques donnant le nombre et expliquant la composition de ces pièces. Mém. Mus. Hist. "Nat. Paris, 1824, 11, 420-444. pl. 1824.1

Dissertatio philosophica inauguralis: De sceleto piscium, auctore Jano Van der Hoeven. Bull. Sci. Nat. (Férussac), 1824, 2, 86-89.

1824.2

Lettre aux rédacteurs des Annales des Sciences Naturelles [sur l'audition des poissons] Ann. Sci. Nat., 1824, 2, 255-256.

1824.3

__ Note complémentaire de l'article sur les prétendus osselets de l'ouie des poissons. Mém. Mus. Hist. Nat. Paris, $1824,11,258-260$.

1824.4

Note sur 1'Achirus barbatus, $\mathrm{n}$. sp. Bull. Soc. Philom. Paris, 1824, 11, pt. 3, 146-147. figs.

1824.5

- Observations sur les prétendus osselets de l'ouie trouvés par E. H. Weber [chez les poissons] Ann. Sci. Nat., 1824, 1, 436-440.

1824.6

Rapport sur le mémoire de M. le docteur Bailly, intitulé: Description des filets pêcheurs de la baudroie. Ann. Sci. Nat., 1524, 2, 311-323. - Bull. Sci. Nat. (Férussac), 9, $210 . \quad 1824.7$

Sur l'analogie des filets-pêcheurs de la baudroie avec une partie des apophyses montantes des vertèbres, et spécialement avec les premiers rayons de la nageoire dorsale des silures. Mém. Mus. Hist. Nat. Paris, 1824, 11, 132-142. Abstract in Bull. Sci. Nat. (Férussac), 9, 240-241.

1824.8

- Sur la nature et la formation de calculs produits soit normalement dans les cellules auditives des poissons, soit pathologiquement dans d'autres canaux intérieurs, quand ceux-ci sont privés d'issues naturelles et sécrétoires. Bull. Soc. Philom. Paris, 1824, 124-125.

1824.9

Sur la nature, la formation et les usages des pierres qu'on trouve dans les cellules auditives des poissons. Mém. Mus. Hist. Nat. Paris, 1824, 11, 241-257. 1824.10 
Sur les parties de son organisation que la baudroie emploie comme instruments de pêche. Mém. Mus. Hist. Nat. Paris, 1824, 11, 117-131. 1824.11

Sur une chaîne d'osselets découverte chez quelques poissons osseux, et annoncés comme les analogues des osselets de l'oreille. Bull. Soc. Philom. Paris, 1824, 100-102.

1824.12

Sur une nouvelle détermination de quelques pièces mobiles chez la carpe, ayant été considérées comme les parties analogues des osselets de l'oreille; et sur la nécessité de conserver le nom de ces osselets aux pièces de l'opercule. Mém. Mus. Hist. Nat. Paris, 1824, 11 , 113-160.

1824.13

- Némoire sur la structure et les usages de l'appareil olfactif dans les poissons, suivi de considérations sur l'olfaction des animaux qui odorent dans l'air. Ann. Sci. Nat, 1825, 7, 322-354. 2 pls. - Abstracts in Bull. Sci. Nat. (Férussac), 10, 406. - Isis (Oken), 2, 173. Also separate; Paris, 1825.34 p. 2 pls. $8^{\circ}$.

1825.1

Sur quelques objections et remarques concernant l'aile operculaire ou auriculaire des poissons. Mém. Mus. Hist. Nat. Paris, 1825, 12, 13-17. 1825.2

Observations sur les usages accessoires des sacs branchiaux chez la baudroie, à l'occasion de la discussion rappelée dans le Bulletin, tome 9, no 208. Bull. Sci. Nat. (Férussac), 1827, 10, 165-166.

1827.1

Des applications de la théorie des analogues à l'organisation des poissons. Ann. Sci. Nat., 1830, 19.

1830.1

Observations sur la concordance des parties de l'hyoïde dans les quatre classes des animaux vertébrés, accompagnant, à titre de commentaire, le tableau synoptique, ou cette concordance est exprimée figurativement. Nouv. Ann. Mus. Hist. Nat. Paris, 1832, 1 321-356. pl.

1832.1

Geoffroy Saint-Hilaire, Isidore [1805-1861] Histoire naturelle des poissons de la mer Rouge et de la Méditerranée (In Description de l'Egypte . . Histoire naturelle, 1827, vol. i, pt. 1. Paris, $1809-30.4^{\circ}$ )

1827.1

- Suite de l'histoire naturelle des poissons du Nil (In Description de l'Egypte .. . Histoire naturelle, 1827, vol. i, pt. 1. Paris, 1809-30. $4^{\circ}$ )

1827.2
De la culture et de l'éducation des animaux chez les Romains. Bull. Soc. Zool. Acclim., 1854, 241-244.

1854.1

Les poissons, p. 244.

Observations relatives aux vues de M. Coste sur la formation des monstres doubles. C. R. Acad. Sci. Paris, $1855,40,873-878$.

1855.1

George, $A . F$. The fish and fisheries of Maryland. Trans. Amer. Fisheries Soc. 1899 (1900), 49-54.

1900.1

George, Seymour. Notice of the capture of a large stingaree [Trygon thalassia] Trans. Proc. New Zealand Inst. 1880 (1881), 13, 426.

1881.1

Georgi, Johann Gottlieb [1729-1802] Geographisch-physikalische und naturhistorische Beschreibung des Russischen Reichs. 3 vols. Königsberg, 1797-1802.

1797.1

Nachtrag in 13 Abtheilungen. Beschreibung einiger Arten von Fische.

Geraets, E., \& Bamps, C. See Bamps \& Geraets.

Gerbe, Z. Observations sur la nidification des Crénilabres, Rev. Mag. Zool., 1864, 2. sér. 16, 255-258; 273$279 ; 337-340$.

1864.1

Formation des produits adventifs de l'œuf des plagiostomes. C. R. Acad. Sci. Paris, 1872, 75, 366-369. 1872.1

Recherches sur la segmentation de la cicatricule et la formation des produits adventifs de l'œuf des plagiostomes et particulièrement des rajes. Journ. Anat. Physiol., 1872, 8, 609-616. 3 pls.

1872.2

- Segmentation de la cicatricule dans l'cuf des poissons plagiostomes. C. R. Acad. Sci. Paris, 1872, 74, 1339 1341. - Journ. Zool. (Gervais), 1872, 1, 366-369.

1872.3

Du lieu où se forme la cicatricule chez les poissons osseux. Journ. Anat. Physiol., 1875, 11, 329-333. 1875.1

Gerber, Ed. Beiträge zur Geologie der östlichen Kientaleralpen. Neue Denkschr. Allg. Schweiz. Gesell. Nat., $1905,40,19-88.3$ pls. \& 28 figs. 1905.1 Fossil fishes mentioned.

Gerbing, Luise. Aus der Geschichte des Schwansees. Mitt. Sächs.-Thüring. Ver. Erdkunde, 1910, 34. Jahrg., 73-81. 1910.1 
Gergens, - Ein über Land wandernder Fisch [Gasterosteus aculeatus] Natur, 1862, 11, 80 .

1862.1

Gerhardt, $K$. Elonichthys scheidi, n. sp. aus dem Culm von Lenzkirch im Schwarzwald. Ber. Oberrhein. Geol. Ver., 1899, 32, 16-22. 2 figs. 1899.1

Gerhardt, Paul. Fischwege und Fischteiche. Die Arbeiten des Ingenieurs zum Nutzen der Fischerei. Leipzig, 1904. 147 p. illust. $4^{\circ}$. 1904.1

Gerhardt, Ulrich. Der gegenwärtige Stand der Kenntnisse von den Copulationsorganen der Wirbeltiere, insbesondere der Amnioten. Erg. Fortschr. Zool., 1908, 1, 367-402. 16 figs. 1908.1

Gerl, $G$. von. Fischereiwirtschaftslehre. Wien, 1898.

1898.1

Gerlach, Georg. Neuere lebendgebärende Zahnkarpfen. Wochenschr. Aquar.-Terrar. Kunde, 1908, 5. Jahrg., $120-121 ; 129-130 ; 187-188 ; 269-270$. fig.

1908.1

- Ambassis lala. Blätt. Aquar.Terrar. Kunde, 1909, 20. Jahrg., 469471. 1909.1

- Rivulus spec. Blätt. Aquar.Terrar. Kunde, 1909, 20. Jahrg., 797799. fig.

1909.2

Pseudoxiphophorus bimaculatus. Blätt. Aquar-Terrar. Kunde, 1910, 21. Jahrg., 33-35. fig.

1910.1

Weitere Mitteilungen über $P o$ cilia heteristia Regan. Blätt. Aquar.Terrar. Kunde, 1910, 21. Jahrg., 707$708 ; 723-725$.

1910.2

- Barbus fasciolatus Günther. Blätt. Aquar.-Terrar. Kunde, 1911, 22. Jahrg., 33-34; 51. fig.

1911.1

Cyprinodon (Lebias) iberus Val. Blätt. Aquar.-'Terrar. Kunde, 1911, 22. Jahrg., 621-623; 639-641. fig. 1911.2

- Fundulus rubrifrons Jordan, ein neuer Fundulus von Florida. Blätt. Aquar.-Terrar. I unde, 1911, 22. Jahrg. 655-657. fig.

1911.3

Haplachilus melastigma Blätt. Aquar-T'errar. Kunde, 1911, 22. Jahrg., 493-495; 512-514. fig.

1911.4

- Haplochilus spilauchen A. Dum. Blätt. Aquar.-Terrar. I unde, 1911, 22. Jahrg., 722-723. fig.
Betrachtungen über die Farbenvariationen der Haplochilus panchaxGruppe. Blätt. Aquar-Terrar. Kunde, 1912, 23. Jahrg., 239-243. 7 figs. 1912.1

Einiges über Gambusia holbrooki (affinis Grd.) (Antwort an A. Th. Kiel) Blätt. Aquar.-Terrar. Kunde, 1912, 23 Jahrg., 403-404.

1912.2

- Haplochilus lineatus Day. Blätt. Aquar.-'Terrar. Kunde, 1912, 23. Jahrg., 65-67. 2 figs.

1912.3

- Haplochilus sexfasciatus var.? Blätt. Aquar-Terrar. Kunde, 1912, 23. Jahrg., 741-742. fig.

1912.4

-... Nochmals Xiphophorus rachovii Regan. Blätt. Aquar--Terrar. Kunde, 1912, 23. Jahrg, 756-757.

1912.5

- Weitere Mitteilungen über $C y$ prinodon (Lebias) iberus Val. Blätt. Aquar.-Terrar. Kunde, 1912, 23. Jahrg., 691-693. fig.

1912.6

Zur Pflege und Aufzucht des Xiphophorus strigatus Regan $(=X i$ phophorus helleri var. güntheri) Blätt. Aquar.-Terrar. Kunde, 1912, 23. Jahrg., 787-789. fig. 1912.7

Zwei weitere Varietäten von Platipocilus maculatus. Blätt. Aquar.Terrar. Kunde, 1912, 23. Jahrg., 677679. 2 figs.

1912.8

Nochmals Xiphophorus rachovi. Blätt. Aquar-Terrar. Kunde, 1913, 24. Jahrg., 322-325. 2 figs.

1913.1

Germano, Eduardo. La tuberculosi sperimentale nei pesci. Giorn. Arte Med., 1900, 22.

1900.1

Germar, Ernst Friedrich [1786-1853] Ueber die Fisch-Abdrucke im bituminösen Mergelschiefer der Grafschaft Mannsfeld. Taschenb. Gesam. Mineral., 1824, 18, 61-74. fig. 1824.1

Gerrard, - \& Gray, John Edward. See Gray \& Gerrard.

Gerstaecker, Carl Eduard Adolph, \& Carus, Julius Vihtor. See Carus \& Gerstaecker.

Gertz, Hans. Gibt elektrische Reizung phototrope Netzhautreaktion bei Abramis brama? Arch. Ophthalm. (Graefe), 1911, 78, 224-226. 1911.1

Gervais, François Louis Paul [18161879] Sur les animaux vertébrés de l'Algérie, envisagés sous le double rap- 
port de la géographie zoologique et de la domestication. Ann. Sci. Nat. (Zool.), 1848, 3. sér. 10, 202-208. 1848.1 Poissons, p. 203.

_- Zoologie et paléontologie françaises (Animaux vertébrés), ou nouvelles recherches sur les animaux vivants et fossiles de la France. 2 vols. Paris, 1848-52.

1848.2

A second edition of this work was published in 1859 .

- Remarques sur les poissons fluviatiles de l'Algérie, et description de deux genres nouveaux sous les noms de Coptodon et Tellia. Ann. Sci. Nat. (Zool.), 1853, 3. sér. 19, 5-17. - L'Institut, 1853, no. 1001. - Extraits Proc. Verb. Soc. Philom., 1853, p. 24.

1853.1

Description d'un poisson fossile du terrain crétacé de la Drome, suivie d'une liste des poissons fossiles que l'on a recueillis en France. Ann. Sci. Nat. (Zool.), 1855, 4. sér. 3, 321-329. 1855.1

Sur un poisson labroide fossile dans les sables marins de Montpellier (Labrodon pavimentatum) Mém. Acad. Sci. Nontpellier, 1855, 3, 513-515. pl.

1855.2

Sur la gagnette, Blennius varus ou gagnotte. Rev. Mag. Zool., 1859, 2. sér. 2, 133-143.

1859.1

Zoologie et paléontologie françaises. Text and atlas. 2. ed. Paris, 1859. viii, 544 p. \& atlas of 84 pls. $4^{\circ}$.

1859.2

Acclimatation du saumon dans le bassin de l'Hérault. Mém. Acad. Sci. Montpellier, 1861-62, 438.

1861.1

Note sur différentes espèces de vertébrés fossiles observés pour la plupart dans le midi de la France. Ann. Sci. Nat.(Zool.), 1861, 4. sér. 16, 286302.

1861.2

Poissons, p. 301-302.

Essais d'acclimatation du saumon dans le bassin de l'Hérault. C. R. Acad. Sci. Paris, 1862, 54, 147. 1862.1

Essais de pisciculture dans le département de l'Hérault, pendant l'année 1861. Montpellier, 1862. viii, $7 \mathrm{p}$.

1862.2

- Sur un nouveau genre d'ichthyodorulithe propre au grès miocène de Léognan, Gironde. Rev. Mag. Zool., 1863, 15, 449. - C. R. Acad. Sci. Paris, 1863, 57, 1007-1008.
Cas de polymélie (membres surnuméraires) observés sur un batracien du genre Pelobates et sur une espèce du genre raie. C. R. Acad. Sci. Paris, $1861,59,800-803$.

1864.1

- Essais de pisciculture dans le département de l'Hérault, pendant l’année 1863. Montpellier, 1864. 7 p.

1864.2

- Essais de pisciculture dans le département de l'Hérault, pendant l'année 1864. Montpellier, 1865. 4 p.

1865.1

Essais de pisciculture dans le département de l'Hérault, pendant l'année 1865. Paris, 1866. 7 p. 1866.1

Nouvelles remarques sur les poissons fluviatiles de l'Algérie. C. R. Acad. Sci. Paris, 1S66, 63, 1051-1058. Ann. Mag. Nat. Hist., 1867, 3. ser. 19, 131-138.

1866.2

Note sur le Calamoichthys calabaricus] C. R. Acad. Sci. Paris, 1867, 64, 1003-1004.

1867.1

- Sur les poissons de l'Algérie. Bull. Soc. Imp. Zool. Acclimat., 1867, 2. sér. 4, 8-12.

1867.2

(Rectification d'une erreur typographique commise à la p. 530 de la Zoologie et Paléontologie françaises, à propos du Pachystetes gregatus Aymard] Bull. Soc. Géol. France, 1870-71 (1871), 2. sér. 28, 75 .

1871.1

Sur les poissons fossiles observés par M. V. Thiollière dans les gisements coralliens du Bugey. Bull. Soc. Géol. Paris, 1871, 28, 10-14.

1871.2

Description des poissons fossiles provenant des gisements coralliens du Jura dans le Bugey. Deuxième partie. Ann. Soc. Agric. Lyon, 1872, 4. sér. 5, 9-85.

1872.1

Sur les Hemirhynchus deshayes [Palocorhynchus] trouvés dans le Calcaire Grossier de Puteaux. Bull. Soc. Géol. France, 1871-72 (1872), 2. sér. 29,307 .

1872.2

Observations relatives à une communication de M. de Candolle, sur les recherches scientifiques relatives au lac Léman. C. R. Acad. Sci. Paris, 1874, 79, 1036.

1874.1

Présence du genre Lépidostée parmi les fossiles du bassin de Paris. C. R. Acad. Sci. Paris, 1874, 79, 844846. - Journ. Zool. (Gervais), 1874, 3. $457-461$. 
Gervais, $F . L . P$.

- Remarques au sujet des poissons du Sahara algérien. C. R. Acad. Sci. Paris, 1874, 79, 557-558. - Journ. Zool. (Gervais), 1874, 3, 455-457.Ann. Mag. Nat. Hist., 1874, 4. ser. 14, $462-463$.

1874.3

[Addition aux observations sur ne mâchoire fossile provenant du genre Sphrerodus trouvée en Toscane dans le Pliocène de Volterranol Journ. Zool. (Gervais), 1875, 4, 516-517. 1875.1

- Poissons du groupe des Ceratodus, existant dans la rivière Fitzroy (Australie) C. R. Acad. Sci. Paris, 1876, 82, 1034. - Ann. Mag. Nat. Hist., 1876,4 . ser. 17,486 .

1876.1

Gervais, François Louis Paul, \& Eydoux, $F$. See Eydoux \& Gervais.

Gervais, François Louis Paul, \& Gervais, Henri Frédéric Paul. Observations relatives à un squale pélerin [Selache maxima] récemment pêché à Concarneau. C. R. Acad. Sci. Paris, 1876, 82, 1237-1241.-Journ. Zool. (Gervais), 1876, 5, 319-329. 3 pls.

1876.1

Addition au mémoire sur le squale pélerin. Journ. Zool. (Gervais), $1877,6,40$.

1877.1

Gervais, Henri Frédéric Paul, \& Boulart, $R$. Les poissons. Synonymie, description, mours, frai, pêche. Iconographie des espèces composant plus particulièrement la faune française. 3 vols. Paris, 1876 . $60 \mathrm{pls}$. \& 56 figs. $8^{\circ}$.

Vol. i. Poissons d'ean douce.

Vols. ii \& iii. Poissons de mer.

Gervais, Henri Frédéric Paul, \& Gervais, François Louis Paul. See Gervais, $F . L$. $P$., \& Gervais, H.F.P.

Gervasoni, Tullio. Acquicoltura ed ictio-fauna della provincia di Bergamo. Acquicolt. Lombard., 1899,1 , no. 6, 1017.

1899.1

Gervasoni, Tullio, Vinciguerra, $D$., Besana, $G$., Burguières, $E$, \& Genazzini, E. See Vinciguerra, Besana \& others.

Gether, A. Uebersicht über die von der Weser aus betriebene Grönländische und Siidsee-Fischerei. Petermann's Mitth., 1863, 311.

1863.1

Geusch, II. Das secundare Entoderm und die Blutbildung beim Ei der
Knochenfische. Inaug. Dissert., Königsberg, 1882. $8^{\circ}$.

1882.1

Gevers Deynoot, W. T. De magno sive halecum piscatu belgico (haringvisscherij) Lugdunum Batavorum, 1829. $4^{\circ} \& 8^{\circ}$.

1829.1

Geyer, Georg. Zur Stratigraphie der Gailthaler Alpen in Kärnten. Verh. Geol. Reichsant., IVien, 1897, 114-127.

1897.1

Geyer, Hans. Acerina schratseri, ein deutscher Aquarienfisch. Natur u. Haus, Dresden, 1902, 10. Jahrg., 144146.

1902.1

Die Spindelbarsche. Natur u. Haus, Dresden, 1902, 10. Jahrg., 193194.

1902.2

Der Makropode. Blätt. Aquar.-

Terrar. Kunde, 1910, 21. Jahrg., 97-99; 115-117. fig.

1910.1

— Etwas über den Rivulus ocellatus Hensel. Wochenschr. Aquar.-Terrar. Kunde, 1912, 9. Jahrg., 650-651. fig.

1912.1

Gherardi, Silvestro [1802-1879] Di due preziosi MSS. del Galvani sulla torpedine. Mem. Accad. Sci. Bologna, 1869, 9, 147-198.

1869.1

Ghidini, A. L' ittiofauna del cantone Ticino nel 1910. Boll. Soc. Ticinese Sci. Nat., 1910, 6, 65-74. 1910.1

Ghigi, Alessandro. Dimonstrazione di preparati sullo sviluppo dei denti del Balistes capriscus. C. R. 6. Congr. Intern. Zool. Berne, 1905, 327. 1905.1

- Ricerche sulla dentatura dei teleostei. Arch. Zool., Napoli, 1905, 2, 439-462. pl.\& 5 figs. 1905.2

Giacobini, Enrico. La pesca in Italia. Provvedimenti governativi negli anni 1904 e 1905. Riv. Mens. Pesca, Milano, 1906, 8, 228-243. $\quad 1906.1$

Giacomini, Ercole. Alcune ricerche intorno alla struttura istologica dell' ovidutto dei selaci. Proc. Verb. Accad. Fis., Siena, 1894, 203, no. 6, 113. 1894.1 Sulla regressione del sacco vitellino nei selaci. Proc. Verb. Accad. Fis., Siena, 1894, 203, no. 6. Abstract in Monit. Zool. Ital. Firenze, 6, 24-25.

1894.2

Contributo all' istologia dell' ovario dei selaci con speciale riguardo sopra ad alcune particolarità di strut- 
tura riscontrate nell' ovario di Myliobatis bovina Geoffr. Ric. Lab. Anat. Norm. Roma, 1896, 5, 221-274. 2 pls. \& 2 figs.

1896.1

Brevi osservazioni intorno alla minuta struttura del corpo interrenale e dei corpi soprarenali dei selaci. Atti Accad. Fis., Siena, 1898, 4. ser. 10, 835 843.

1898.1

Sulla maniera onde i nervi si terminano nei miocommi e nelle estremitì delle fibre muscolari dei miomeri nei selaci. Atti Accad. Fis., Siena, 1898, 4. ser. $10,560-562$.

1898.2

- Sulla maniera onde i nervi si terminano nei miocommi e nelle estremitì delle fibre muscolari dei miomeri nei teleostei. Atti Accad. Fis., Siena, 1898, 4. ser. 10, 371-372.

1898.3

Sulla struttura delle branchie dei petromizonti. Nota. Ann. Facol. Med. e Mem. Accad. Med.-Chir. Univ. Perugia, 1900,12 , pts. 3 \& 4, 221233. - Monit. Zool. Ital., Firenze, 11 (Suppl.), 9-10.

1900.1

- Sulle cosi dette glandole salivari dei petromizonti. Monit. Zool. Ital., 1900, 11 (Suppl.), 7-8. - Ann. Facoltà Med. Univ. Perugia, 12, pts. 3-4, 234-238.

1900.2

Sul pancreas dei petromizonti con particolare riguardo al pancreas di Petromyzon marinus. Anat. Anz., 1900, 18 (Verh. Anat. Gesell.), 44-52; 215.

1900.3

Contributo alla conoscenza delle capsule surrenali nei ciclostomi. Sulle capsule surrenali dei petromizonti. Monit. Zool. Ital., 1902, 13, 143-162. 2 pls.

1902.1

Relazione tra il pancreas dell' Ammocoetes e del Petromyzon. Brevissima nota. Monit. Zool. Ital., 1902, 13 (Suppl.), 49.

1902.2

- Sulla esistenza della sostanza midollare nelle capsule surrenali dei teleostei. Monit. Zool. Ital., 1902, 13, 183-189.

1902.3

Contributo alla conoscenza delle capsule surrenali dei ganoidi e particolarmente sull' esistenza della loro sostanza midollare. Monit. Zool. Ital., 1904, 15 , 19-32.

1904.1

Contributo alla conoscenza delle capsule surrenali di ciclostomi. Sulle capsule dei missinoidi. Rendic. Sess.
Accad. Sci. Istit. Bologna, 1904, n. s. 8, $135-140$.

1904.2

Contributo alla conoscenza del sistema delle capsule surrenali dei teleostei. Sulla sostanza midollare (organi soprarenali o tessuto cromaffine) di Amiurus catus L. Rendic. Sess. Accad. Sci. Istit. Bologna, 1905, n. s. 9, 183-189. pl. 1905.1

Sulle capsule surrenali e sul simpatico dei Dipnoi. Ricerche in Protopterus annectens. Rendic. Accad. Lincei, Roma, 1906, 5. ser. 15, pt. 1, 394398.

1906.1

Altre osservazioni intorno all' epoca del differenziamento sessuale nelle anguille. Rendic. Sess. Accad. Sci. Istit. Bologna, 1908, n. s. 12, 170-171. 1908.1

- Il sistema interrenale e il sistema cromaffine (sistema feocromo) nelle anguille adulte, nelle cieche e nei Leptocefali. Mem. Accad. Sci., Bologna, 1908, 6. ser, 5, 113-147. 2 pls. Abstract in Monit. Zool. Ital., 20, 92-93. 1908.2

Intorno alla gonogenesi delle anguille e all' epoca del differenziamento sessuale in questi Murenoidi. Rivist. Mens. Pesca, Milano, 1908, 10, 59-67.

1908.3

Sulla disposizione del sistema interrenale e del sistema feocromo nelle anguille adulte, nelle cieche e nei Leptocefali. Rendic. Sess. Accad. Sci. Istit. Bologna, 1908, n. s. 12, 172-175. 1908.4

Sulla gonogenesi nelle anguille. Intorno all' epoca del differenziamento sessuale in questi Murenoidi. Rendic. Sess. Accad. Sci. Istit. Bologna, 1908, n. s. 12, 25-36. - Neptunia, Riv. Ital. Pesca Acquic. Mar., Venezia, n. s. 23, 49-51.

1908.5

- I corpi postbranchiali nelle cieche e nelle anguille adulte. Monit. Zool. Ital., 1909, 20, 88-92. 3 figs. 1909.1

- Il sistema interrenale e il sistema cromaffine (sistema feocromo) in altre specie di Murenoidi. Rendic. Sess. Accad. Sci. Istit. Bologna, 1909, n. s. 13, 87-98. - Mem. Accad. Sci. Bologna, 1910, 6. ser. 6, 175-216. 2 pls. Ibid., 1911,6 . ser. 7, 113-150. 5 pls. \& figs. Arch. Ital. Anat. Embriol., Firenze, $1912,8,237-245$.

1909.2

- Il sistema interrenale e il sistema cromaffine (sistema feocromo) nelle anguille adulte, nelle cieche e nei Leptocefali. Monit. Zool. Ital., 1909, 20, 92-93. 
Giacomini, $E$.

Il sistema interrenale e il sistema cromaffine (sistema feocromo) in alcune specie di teleostei con rene cefalico (pronephros) persistente. Caratteri differenziali fra interrenale anteriore e corpuscoli di Stannius. Cenno sullo sviluppo di questi organi nei Salmonidi. Rendic. Accad. Sci. Istit. Bologna, 1910, n. s. 14, 86-103.

1910.1

Anatomia microscopica e sviluppo del sistema interrenale e del sistema cromaffine dei Salmonidi. Rendic. Accad. Sci. Bologna, 1911, n. s. 15, $107-$ 108. - Mem. Accad. Sci. Bologna, 1912 , 6. ser. 8, 67-87. 2 pls. \& 6 figs. 1911.1

Il sistema interrenale e il sistema cromaffine (sistema feocromo) dei Ciprinidi. Rendic. Accad. Sci. Istit. Bologna, 1911, n. s. 15, 109-110. 1911.2

- Il sistema interrenale e il sistema cromaffine (sistema feocromo) dei lofobranchi. Rendic. Accad. Sci. Istit. Bologna, 1911, n. s. 15, 108-109. 1911.3

I corpi postbranchiali dei teleostei. Rendic. Accad. Sci. Istit. Bologna, 1912 , n. s. $16,77-87$.

1912.1

Giaja, Jean. Sur l'ablation de la vessie natatoire des poissons. C. R. Mém. Soc. Biol. Paris, 1908, 65, 125-126.

1908.1

Giard, Alfred [1846-1908] For partial bibliography, see his Exposé des titres et travaux scientifiques (1869-1896) Paris, 1896. 300 p. $4^{\circ}$.

Discussion de l'article de M. G. Pouchet: Sur les conséquences de l'ablation d'un oil chez les poissons] Assoc. Franç. Avanc. Sci., 6. sess., 1877, 621

1877.1

Observations sur le catalogue des poissons du Boulonnais. Bull. Sci. Nord, 1888, 1, 441-460.

1888.1

Sur le Peroderma cylindricum Heller, copépode parasite de la sardine. C. R. Acad. Sci. Paris, 1888, 107, 929931.

1888.2

- The evolution of flat-fish. Natural Science, 1892, 1, 356-359; 635-638.

1892.1

Quelques remarques sur la truite de mer. C. R. Mém. Soc. Biol. Paris, 1892, 9. sér. 4, 872-876.

1892.2

__ Sur la persistance partielle de la symétrie bilatérale chez un turbot
(Rhombus maximus L.), et sur l'hérédité des caractères acquis chez les pleuronectes. C. R. Mém. Soc. Biol. Paris, 1892, 9. sér. 4, 31-34.

1892.3

Exposé dés titres et travaux scientifiques (1869-1896) Paris, 1896. 300 p. $4^{\circ}$.

1896.1

L- Les épinoches et l'eau de mer. Rev, des Rev. Hist. Nat., 1900, 1, 81-82.

1900.1

Sur l'adaptation brusque de l'épinoche (Gasterosteus trachurus Cuv. et $\mathrm{Val}$.) aux eaux alternativement douces et marines. C. R. Mém. Soc. Biol. Paris, 1900, 52, 46-48.

1900.2

Sur un cas de palistrophie chez la loche d'étang (Cobitis fossilis L.) C. R. Mém. Soc. Biol. Paris, 1900, 52, 93-94.

1900.3

A propos des observations de $\mathrm{M}$. R. Blanchard sur la faune des eaux chaudes. C. R. Mém. Soc. Biol. Paris, 1903, 55, 1003-1004.

1903.1

- A propos du Barbus callensis Guichenot (Mollus barbatus R. Blanch. nec J.) C. R. Mém. Soc. Biol. Paris, 1903, 55, 1144-1147; 1187-1188. 1903.2

Réponse par R. Blanchard, p. 1185-1187; $1261-1262$

- Exuviations métamorphiques chez les Ascarides des poissons (groupe de l'Ascaris adunca Rud.) C. R. Mém. Soc. Biol. Paris, 1903, 55, 627-630.

1903.3

Notes éthologiques sur le hareng des côtes du Boulonnais. C. R. Mém. Soc. Biol. Paris, 1903, 55, 573-575.

1903.4

Sur l'éthologie du hareng des côtes du Boulonnais. C. R. Mém. Soc. Biol. Paris, 1904, 56, 1058-1061. 1904.1

Euvres diverses réunies et rééditées par les soins d'un groupe d'élèves et d'amis. 2 vols. Paris, 1913. 1913.1

Tome I. Biologie générale.

Tome II. Faune et flore de Wimereux; Notes diverses de zoologie.

Giard, Alfred, \& Cépède, Casimir. Sur la ponte de la morue dans le sud de la mer du Nord. C. R. Acad. Sci. Paris, $1907,145,659-662$.

1907.1

Giard, Alfred, \& Roché, Georges. Sur la réforme du service central des pêches maritimes. Bull. Scient. France Belgique, 1899, 32, 536-550. 1899.1 
Gibbes, Lewis R. [1810-1894] Catalogue of the fauna of South Carolina (In Tuomey, M. Report on the geology of South Carolina. Columbia, S. C., 1848. 293 p. 56 maps. $4^{\circ}$ ) 1848.1

Gibbes, Robert Wilson [1809-1866] Monograph of the fossil Squalidx of the United States. Journ. Acad. Nat. Sci. Philad., 1847-50, 2. ser. 1, 139-147. 4 pls. Ibid., 191-206. 3 pls. Also separate; Philadelphia, 1848. $4^{\circ}$.

1847.1

New species of Myliobates from the Eocene of South Carolina, with other genera not heretofore observed in the United States. Journ. Acad. Nat. Sci. Philad., 1847-50, 2. ser. 1, 299-300. pl. Also separate; Philadelphia, 1849. $4^{\circ}$.

1847.2

Description of new species of Squalides from the Tertiary beds of South Carolina. Proc. Acad. Nat. Sci. Philad., 1848, 3, 266-268.

1848.1

On the fossil Squalidx of the United States. Notices in Proc. Acad. Nat. Sci. Philad., 1848, 3, 41-43.Amer. Journ. Sei., 1849, 2. ser. 7, 441.Froriep Tagsber. (Zool. 1), 1850, no. 67, 97-104. Ibid., no. 70, 105-108. 1848.2

- New species of fossil Myliobates, from the Eocene of South Carolina, and new fossils from the Cretaceous, Eocene and Pliocene of South Carolina, Alabama and Mississippi. Proc. Amer. Assoc. Adv. Sci., 2. meet., 1849, 193-194.

1849.1

Fossils common to several formations [fish teeth] Proc. Amer. Assoc. Adv. Sci., 3. meet., 1850, 70-71. 1850.1

Gibbons, W. P. Description of new species of viviparous marine and freshwater fishes, from the bay of San Francisco, and from the river and lagoons of the Sacramento. Proc. Acad. Nat. Sci. Philad. 1854 (1856), 7, 122-126. Arch. Naturgesch., 21, pt. 1, 331-341.

1854.1

Description of a new trout! Salmo iridia. Proc. Calif. Acad. Nat. Sci., 1855, 2, 35-36.

1855.1

[Remarks on the acclimatization of food fishes! Proc. Calif. Acad. Nat. Sci., 1869, 4, 52 .

1869.1

Description of a new species of trout from Mendocino county [Salmo mendocinensis Gibbons] Proc. Calif. Acad. Nat. Sci. 1875 (1876), 6, 142-144. 1876.1
Gibian, Annie. Beiträge zur Kenntnis des Hyobranchialskeletes der Haie: eine vergleichend-embryologische Untersuchung. Morphol. Jahrb., 1912, 45, 57-95. pl. \& 13 figs.

1912.1

Gibson, $E$. Notes on the New Zealand whitebait. Trans. Proc. New Zealand Instit., 1903, 35, $311 . \quad 1903.1$

Gibson, $H . O . S$. The cephalochorda "Amphioxides." Trans. Linn. Soc. London (Zool.), 1910, 13, 213-256. pl. \& 4 figs.

1910.1

Gibson, W.T. The development of the hypochord in Raia batis: with a note upon the occurrence of the epibranchial groove in amniote embryos. Anat. Anz., 1909, 35, 407-428. 13 figs. $\quad 1909.1$

Gibson-Maitland, (Sir) James Ramsay. Essay on the salmon disease, its nature, causes and possible remedies. Fish. Gazette, 1881, 5, 612-615. 1881.1

Gibson-Maitland, James Ramsay, Ewart, James Cossar, \& others. See Ewart, Gibson-Maitland \& others.

Gidley, John Williams [1866-] Some new American pycnodont fishes. Proc. U. S. Nat. Mus., 1913, 46, 445449. 6 figs.

1913.1

Giebel, Christoph Gottried Andreas [1820-1881] Fauna der Vorwelt monographisch dargestellt. 3 vols. in 6. Leipzig, 1847-52. 1847.1

Bd. i, 3. Abth., Die Fische der Vorwelt. Leipzig, 18.18. $467 \mathrm{p}$.

- Vier neue Fische aus dem dunkeln Kreide-Schiefer von Glarus [Anenchelum breviceps, Palimphyes crassus, $P$. gracilis, Pachygaster spinosus] Neues Jahrb. Mineral., 1847, 665-668. 1847.2

Die Fische der Vorwelt in seiner Berücksichtigung der lebenden Fische. Leipzig, 1848. $8^{\circ}$.

1848.1

Ueber die Fische im Muschelkalk von Esperstädt. Neues Jahrb. Mineral., 1848, 149-157. $\quad 1848.2$

Ueber die im bunten Sandstein Bernburgs vorkommenden Fischreste. Zeitschr. Gesammt. Naturw., 1853, 1, 30-32.

1853.1

Odontographie. Vergleichende Darstellung des Zahnsystems der Wirbelthiere. Leipzig, 1855. 52 pls. $4^{\circ}$.

1855.1

Räthselhafter Fisch aus dem Mansfelder Kupferschiefer. Zeitschr. Gesammt. Naturw., 1856, 7, 367-372. 2 pls. 
Giebel, $C . G . A$.

Ueber Saurier- und Fischreste aus dem Thüringer Keuper. Zeitschr. Gesammt. Naturw., 1856, 8. pl. 1856.2

- Dichelodus, ein neuer Fisch im Mansfelder Ku upferschiefer. Zeitschr. Gesammt. Naturw., 1857, 9, 121-126. pl.

1857.1

Aechte Kinochenfische im Steinkohlengebirge. Zeitschr. Gesammt. Naturw., 1860, 16, 324-331. - Neues Jahrb. Mineral., 1861, 623-626. 1860.1

Ichthyologische Mittheilungen. Zeitschr. Gesammt. Naturw., 1862, 20, 321-324.

1862.1

- Diplodus Agassiz und Xenacanthus Beyrich [Pleuracanthus] im Wettiner Kohlengebirge. Zeitschr. Gesammt. Naturw., 1868, 31, 23-25.Verh. Geol. Reichsanst. Wien, 1868, 155.

1868.1

- Notous [Amia] megacephalus, n. sp. aus den Tertiärschichten Frankreichs. Zeitschr. Gesammt. Naturw., $1869,33,511$. 1869.1

Trachypoma marmorata, ein neuer Wels aus dem Amazonenstrome. Zeitschr. Gesammt. Naturw., 1871, 37 (n. f. 3), 97.

1871.1

Ueber einen neuen Zitterwels aus Gabun] Zeitschr. Gesammt. Naturwiss., 1878, 51 (n. f. 3), 142-143.

1878.1

Gieche, Ernst. Neunaugen-Fang bei Schwedt-a.-O. Deutsch. Fischerei Zeitg., 1878, 1. Jahrg., 374-375. 1878.1

Gienke, $I$. Die Schwarzgrundel (Gobius niger) und ihre Zucht im Seewasseraquarium. Wochenschr. Aquar.Terrar. Kunde, 1912, 9. Jahrg., 489-490. fig.

1912.1

Etwas über die Seenadel [Syngnathus] Wochenschr. Aquar--Terrar. IKunde, 1913, 10. Jahrg., 325-327; 398399. 2 figs.

1913.1

Lebias calaritanus und seine Zucht im Seewasseraquarium. Wochenschr. Aquar.-Terrar. Kunde, 1913, 10. Jahrg., 494-495; 572-573. 1913.2

- Secfische, welche sich zu Zuchtversuchen im Aquarium cignen. Blätt. Aquar.-'lerrar. Kunde, 1913, 24. Jahrg., 701-705. 3 figs.

1913.3

Giers, Carl Robert (prases) Orsaken til Cuma Kronolax- och sikfiskets förm- inskning, som ock de hjelpemedel, som deremot kunna vidtagas. Inaug. Dissert., Abo, 1771. 15 p. $4^{\circ}$. Reprint in Tidskr. Fiskerinår. Aquikult. (Malmgren), 1869, 36-37.

1771.1

Isaac M. Arenander, respond.

Gierse, August. Untersuchungen über das Gehirn und die Kopfnerven von Cyclothone acclinidens. Morph. Jahrb., 1904, 32, 602-688. 3 pls. 1904.1

Giesecke, $E$. Die Lachseigewinnung und Erbrütung im Gebiete der IVeser und Ems. Allgem. Fischerei Zeitg. 1901, 26, 199-201. 1901.1

Ueber Karpfenfütterung. Allgem. Fischerei Zeitg., 1901, 26, 50-54.

1901.2

Gifford, George. The disappearance of sardines from the Vendean coast, and its causes. Bull. U. S. Fish Comm. 1882 (1883), 2, 13-14.

1883.1

Giglioli, Enrico Hillyer [1845-] La fosforescenza del mare. Bollet. Soc. Geogr. Italiana, Firenze, 1870. 1870.1

- Basking shark [Selache maxima] Nature, 1877, 15, 273.

1877.1

Beiträge zur Kenntniss der Wirbelthiere Italiens. Arch. Naturgesch., 1879, 45. Jahrg., pt. 1, 93-99.

Pisces, p. 98-99.

1879.1

Elenco dei mammiferi, degli uccelli e dei rettili ittiofagi ... appartenenti alla fauna italiana, e catalogo degli anfibi e dei pesci italiani. Firenze, 1880 . $8^{\circ}$.

1880.1

Pisces, p. 18-55.

- On Haloporphyrus lepidion

Risso. Nature, 1880, 21, 202. 1880.2

New and very rare fish from the Mediterranean. Nature, 1882, 25, 535. Ibid., 1883, 27, 198-199.

1882.1

- Intorno a due nuovi pesci dal golfo di Napoli. Zool. Anz., 1883, 6, $397-400$.

1883.1

L La scoperta di una fauna abissale nel Mediterraneo. 3. Congr. Geograf. Internaz., Roma, 1884, 2.

1884.1

[On deep-sea fishes killed by the] earthquake in the western Riviera. Nature, $1887,36,4$.

1887.1

Rediscovery of Lepidosiren paradoxa. Nature, 1887, 35, $343 . \quad 1887.2$ 
Note intorno agli animali vertebrati raccolti dal Conte Augusto Boutourline e dal D. Leopoldo Traversi ad Assab e nello Scioa negli anni 1884-87. Ann. Mus. Civ. Storia Nat. Genova, 1888, 2. ser. 6, 5-73.

1888.1

Pesci, p. 67-73.

Record of the discovery of another specimen of Lepidosiren paradoxa Fitz. Nature, 1888, 38, 102.

1888.2

On a supposed new genus and species of pelagic gadoid fishes from the Mediterranean Eretmophorus kleinenbergi] Proc. Zool. Soc. London, 1889, 328-332. pl.

1889.1

Di una nuova specie di Macruride appartenente alla fauna abissale del Mediterraneo. Zool. Anz., 1893, 16, 343-345.

1893.1

- Sulle granulaziani degli eritrociti nei girini di taluni anfibi. Anat. Anz., 1896, 12, 321-334.

1896.1

Observations also on the lamprey, p. 331-334.

- I pesci del Trentino. Vol. ii. Storia naturale dei pesci del Trentino $e$ di due specie straniere che interessano la piscicoltura trentina. Trento, 1902. 122 p. 33 figs. $8^{\circ}$.

1902.1

Giglioli, Enrico Hillyer, \& Issel, Raffacle. Pelagos, saggi sulla vita et sui prodotti del mare. Genova, 1884.

1884.1

Giglioli, Henry Hillyer. See Giglioli, Enrico Hillyer.

Giglio-Tos, Ermanno. Sulle cellule del sangue della lampreda. Mem. R Accad. Sci. Torino, 1896, 2. ser. 46, 219 252. pl. - Boll. Musei Zool. Anat. Comp. Torino, 11, no. 247.4 p. 1896.1

- Sur les cellules du sang de la lamproie. Arch. Ital. Biol., Turin, 1896, 26, no. 1, 93-96.-Journ. Roy. Micr. Soc., 1897, pt. 2, 112.

1896.2

L' ematopoesi nella lampreda. Atti R. Accad. Sci. Torino, 1897, 32, 362-376. pl. - Arch. Ital. Biol., Turin, 27, 459-473. pl. Abstract in Journ. Roy. Micr. Soc., 1897, p. 355. 1897.1

La struttura e l'evoluzione dei corpuscoli rossi del sangue nei vertebrati. Mem. R. Accad. Sci. Torino, 1897, 47, 39-101. 2 pls.

1897.2

I trombociti degli ittiopsidi e dei sauropsidi. Mem. R. Accad. Sci. Torino, 1898, 2. ser. 48, 143-208. 2 pls.
French résumé in Arch. Ital. Biol., Turin, 29, 287-293.

1898.1

— A proposito dei "cromocrateri" nel sangue della lampreda. Anat. Anz., 1899, 15, 298-300.

1899.1

Gilbert, Charles Henry [1859-] List of fishes observed at Punta Arenas, on the Pacific coast of Central America. Bull. U. S. Fish Comm. 1882 (1883), 2, 112.

1883.1

Notes on the fishes of Kansas. Bull. Washburn Coll. Lab. Nat. Hist., $1884,1,10-16$.

1884.1

Description of three new fishes from Kansas. Proc. U. S. Nat. Mus., 1885, 7, 512-514. 1885.1

A list of fishes collected in the east fork of White river, Indiana, with descriptions of two new species. Proc. U. S. Nat. Mus., 1885, 7, 199-205.

1885.2

- Notes on the fishes of Switz City swamp, Greene county, Indiana. Proc. U. S. Nat. Mus., 1885, 7, 206-210.

1885.3

Second series of notes on the fishes of Kansas. Bull. Washburn Coll. Lab. Nat. Hist., 1885, 1, 97-99. 1885.4

Third series of notes on Iiansas fishes. Bull. Washburn Coll. Lab. Nat. Hist., 1886, 1, 207-211. 1886.1

Descriptions of new and little known etheostomoids. Proc. U. S. Nat. Mus., 1888, 10, 47-64. 1888.1

Description of a new species of Bathymaster from Puget sound and Alaska. Proc. U. S. Nat. Mus. 1888 (1889), 11, 554

1889.1

- Fourth series of notes on the fishes of Kansas. Bull. Washburn Coll. Lab. Nat. Hist., 1889, 2, 38-43. 1889.2

A list of fishes from a small tributary of the Poteau river, Scott county, Arkansas. Proc. U. S. Nat. Mus. 1888 (1889), 11, 609-610. $\quad 1889.3$

- Notes on fishes from the lowlands of Georgia, with a description of a new species (Opsopoodus bollmani) Bull. U. S. Fish. Comm. 1888 (1890), 8, 225-229.

1890.1

- Notes on the occurrence of Gillichthys y-cauda at San Diego, California. Proc. U. S. Nat. Mus. 1889 (1890), 12. 363. 
Gilbert, $C . H$.

A preliminary report on the fishes collected by the steamer "Albatross" on the Pacific coast of North America during the year 1889 , with descriptions of twelve new genera and ninety-two new species, Proc. U.S. Nat. Mus., 1890, 13, 49-126. 1890.3

Description of a new species of eel (Sphagebranchus kendalli) Bull. U. S. Fish Comm. 1889 (1891), 9, 310.

1891.1

Description of a new species of Etheostoma (E. micropterus) from Chihuahua, Mexico. Proc. U.S. Nat. Mus. 1890 (1891), 13, 289-290.

1891.2

Report of explorations made in Alabama during 1889 , with notes on the fishes of the Tennessee, Alabama, and Escambia rivers. Bull. U. S. Fish Comm. 1889 (1891), 9, 143-159. pl.

1891.3

A supplementary list of fishes collected at the Galapagos islands and Panama, with descriptions of one new genus and three new species. Proc. U. s.' Nat. Mus, 1890 (1891), 13, 449-455 (Scientific results of explorations by the U. S. Fish Commission steamer " Albatross," No. 19)

1891.4

Descriptions of apodal fishes from the tropical Pacific. Proc. U. S. Nat. Mus., 1892, 14, 347-352 (Scientific results of explorations by the U.S. Fish Commission steamer "Albatross," No. 21)

1892.1

Descriptions of thirty-four new species of fishes collected in 1888 and 1889, principally among the Santa Barbara islands and in the gulf of California. Proc. U. S. Nat. Mus., 1892, 14, 539-566 (Scientific results of explorations by the U. S. Fish Commission steamer "Albatross," No. 22)

1892.2

- Report on the fishes of the Death valley expedition, collected in southern California and Nevada in 1891 , with descriptions of new species. North Amer. Fauna, 1893, no. 7, pt. 2, 229-234. 2 pls.

1893.1

- The breeding of the gourami Journ. Bombay Nat. Hist. Soc., 1894, $8,435-438$

1894.1

The ichthyological collections of the steamer "Albatross" during the years 1890 and 1891. Rept. U. S. Fish Comm. 1893 (1895), 19, 393-476. 15 pls.

1895.1
Notes on fishes from the basin of the Mackenzie river, in British America. Bull. U. S. Fish. Comm 1894 (1895), 14, 23-25. 1895.2

Descriptions of twenty-two new species of fishes collected by the steamer "Albatross," of the United States Fish Commission. Proc. U. S. Nat. Mus. 1897, 19, 437-457. 6 pls. 1897.1

The fishes of the Klamath basin. Bull. U. S. Fish Comm. 1897 (1898), 17 1-13. figs.

1898.1

On the occurrence of Caulolepis longidens Gill on the coast of California. Proc. U. S. Nat. Mus., 1899, 21, 565566. 1899.1

- Report on fishes obtained by the steamer "Albatross" in the vicinity of Santa Catalina island and Monterey bay. Rept. U. S. Fish Comm. 1898 (1899), 24, 25-29. 2 pls. $\quad 1899.2$

Results of the Branner-Agassiz expedition to Brazil. III. The fishes. Proc. Washington Acad. Sci., 1900, 2, 161-184. pl.

1900.1

Notes on fishes from the Pacific coast of North America. Proc. Calif. Acad. Sci. (Zool.), 1904, 3. ser. 3, 255271. 5 pls.

1904.1

The deep-sea fishes of the Hawaiian islands (In Jordan, D. S., \& Evermann, B. IV. The aquatic resources of the Hawaiian islands. II. Bull. U. S Fish Comm. 1903 (1905), 23, pt. 2, 575-713. 45 pls. \& 44 figs.

1905.1

Certain scopelids in the collection of the Museum of Comparative Zoology. Bull. Mus. Comp. Zool., Cambridge, 1906, 46, 255-263. 4 pls.

1906.1

The lantern fishes (In Reports on the scientific results of the expedition to the tropical Pacific, in charge of Alexander Agassiz, by the U. S. Fish Commission steamer " Albatross," from August, 1899, to March, 1900, Commander Jefferson F. Moser, U. S. N., commanding. No. 10. Mem. Mus. Comp. Zool., Cambridge, 1908, 26, 216238. $7 \mathrm{pls}$

1908.1

- Notes on lantern fishes from southern seas, collected by J. T. Nichols in 1906. Bull. Amer. Mus. Nat. Hist., 1911, 30, 13-19. fig.

1911.1

Lampanyctus nicholsi $\mathrm{n}$. sp.

Age at maturity of the Pacific coast salmon of the genus Oncorhyn- 
chus. Rept. British Columbia Comm. Fish., 1912, I 57-70. 17 pls. - Bull. Bureau Fisheries, 1912 (1913), 32, 3-22. 1912.1

The salmon of Swiftsure bank and the Fraser river sockeye run of 1912. Rept. British Columbia Comm. Fish., 1912, I 13-24. pl.

1912.2

Descriptions of two new fishes of the genus Triglops from the Atlantic coast of North America. Proc. U. S. Nat. Mus., 1913, 44, 465-468. pl.

1913.1

The lantern fishes of Japan. Mem. Carnegie Mus., Pittsburg, 1913 6, 67-107. pls.

1913.2

Contributions to the life-history of the sockeye salmon (no. I) Rept British Columbia Comm. Fish. 1913 (1914), R 53-57. 13 figs.

1914.1

Gilbert, Charles Henry, \& Burke, Charles $V$. Fishes from Bering sea and Kamchatka. Bull. Bureau Fisheries, 1910 (1912), 30, 33-96. 38 figs. 1912.1

- New cyclogasterid fishes from Japan. Proc. U. S. Nat. Mus., 1912, 42, 351-380. 7 pls. \& 18 figs. 1912.2

Gilbert, Charles Henry, \& Cramer, Frank. Report on the fishes dredged in deep water near the Hawaiian islands, with descriptions and figures of twentythree new species. Proc. U. S. Nat. Mus., 1897, 19, 403-435. 12 pls. 1897.1

Gilbert, Charles Henry, \& Evermann, Barton Warren. The salmon fisheries of the Columbia river basin. U. S. Congress, Senate Miscell. Doc. no. $200,1894,1-55.13$ pls.

1894.1

A report upon investigations in the Columbia river basin, with descriptions of four new species of fishes. Bull. U. S. Fish Comm. 1894 (1895), 14, 169-204. 6 pls.

1895.1

Gilbert, Charles Henry, \& Jordan, David Starr. See Jordan \& Gilbert.

Gilbert, Charles Henry, \& Scofield, Norman Bishop. Notes on a collection of fishes from the Colorado basin in Arizona. Proc. U. S. Nat. Mus., 1898, 20, 487-499. 4 pls.

1898.1

Gilbert, Charles Henry, \& Starks, Edwin C. The fishes of Panama bay. Mem. Calif. Acad. Sci., 1904, 4, 1-304. 33 pls. - Biol. Contrib. Hopkins Seaside Lab. Leland Stanford Univ., 1904, no. 32, 1-304. - Also separate; Stanford University, Cal., 1904. 4.1904.1

Gilbert, Charles Henry, \& Thompson, Joseph $C$. Notes on the fishes of Puget sound. Proc. U. S. Nat. Mus. 1905, 28, 973-988. 3 figs. $\quad 1905.1$

Gilbert, James Zacchaus. On the skull of Xerobates (?) undata Cope. Kansas Univ. Quarterly, 1898, ser. A, 7, 143148. 3 figs.

1898.1

Evesthes jordani, a primitive flounder from the Miocene of California. Univ. California Publ. Geol., 1910, 5, 405-411. 2 pls. $\quad 1910.1$

Gilbert, N.C., \& Marshall, William Stanley. See Marshall \& Gilbert.

Gilbert, W.L. Growth of the saibling (Salmo salvetinus) in the Old Colony trout-ponds at Plymouth, Mass. Bull. U. S. Fish Comm. 1881 (1882), 1, 427.

1882.1

- Sale of artificially reared trout. Trans. Amer. Fisheries Soc. 1892 (1893), $113-118$. 1893.1

The past, present and future of trout culture. Bull. U. S. Fish Comm. 1893 (1894), 13, 47-48.

1894.1

Gilchrist, J. D. F. The flat-fishes of the Cape Colony. Trans. South Afric. Phil. Soc., 1899, 10, viii.

1899.1

Catalogue of fishes recorded from South Africa. Marine Invest. South Africa, Cape Town, 1901 (1902) 1, no. 6, 97-179.

1902.1

For a later catalogue of fishes of the Cape Province, see Thompson, W. W. in Marine Biol. Rept. Prov. Cape Good Hope, 1914, no. 2, 132 167.

- History of the local names of Cape fish. Trans. South Afric. Phil. Soc., 1902, 11, 207-232. 1902.2

- South African fishes. Marine Invest. South Africa, Cape Town, 1902 , 2, 101-113. 6 pls. 1902.3

Descriptions of new South African fishes. Marine Invest. South Africa, Cape Town, 1903, 2, 203-211. $10 \mathrm{pls}$. Ibid., 3, 1-16. 18 pls. - Rept. Govt. Biol. Cape Good Hope, 1903, 108-123.

1903.1

The development of some South African fishes. Rept. South Afric. Assoc. Adv. Sci., Cape Town, 1903, 310 311. 
Gilchrist, $J, D . F$.

The development of South African fishes. Part 1. Rept. Govt. Biol. Cape Good Hope, 1902 (1903), 54-80. 4 pls. - Marine Invest. South Africa, Cape Town, 1903, 2, 181-201. 4 pls. Ibid., 1904, 3, 131-152. 7 pls. 1903.3

- South African fishes. Rept. Govt. Biol. Cape Good Hope, 1902 (1903), 196-210. 6 pls.

1903.4

Additional notes on the development of South African fishes. Rept. South Afric. Assoc. Adv. Sci., Cape Town, 1904, 318-321.

1904.1

Descriptions of new South African fishes. Marine Invest. South Africa, Cape Town, 1904, 3, 1-16. 18 pls. Rept. Govt. Biol. Cape Good Hope, 1903 (1905), 108-123.

1904.2

Cases of extensive mortality among marine animals on the South African coast, with suggestions as to their cause or causes. Rept. British Assoc. Adv. Sci., 1905, 434-435. 1905.1

- Recent discoveries in the South African deep sea. Rept. British Assoc. Adv. Sci., 1905, 435.

1905.2

The South African marine fauna and its environment (In Flint, W. \& Gilchrist, J. D. F., editors. Science in South Africa, p. 183-198. Cape Town, 1905. 505 p. illust.)

1905.3

- Description of fifteen new South African fishes with notes on other species. Marine Invest. South Africa, Cape Town, 1908, 4, 143-171. 14 pls. 1908.1

Description of a new species of sting-ray (Trygon) from South Africa. Trans. Roy. Soc. South Africa, 1913, 3, 33-35. fig.

1913.1

Introduction of "millions," Marine Biol. Rept. Union South Africa, 1913, no. 1, 67-70. pl.

1913.2

Review of the South African Clupeidx (herrings) and allied families of fishes. Marine Biol. Rept. Union South Africa, 1913, no. 1, 46-66. 1913.3

Gilchrist, $J . D . F$. \& Thompson, IV. Wardlaw. The Blenniidre of South Africa. Ann. South Afric. Mus., 1908, 6, $97-143$.

1908.1

Descriptions of fishes from the coast of Natal. Ann. South African Mus., London, 1908, 6, 145-206; 213279. Ibid., 1911, 11, 29-58. 1908.2
The Cape klip fishes. South African Journ. Sci., Cape Town, 1911, 7, 214-224.

1911.1

Descriptions of three new species of freshwater fishes from South Africa. Ann. Mag. Nat. Hist., 1911, 8. ser. 7, $477-478$.

1911.2

- The freshwater fishes of South Africa. Ann. South African Mus. London, 1913, 11, 321-463. figs. 1913.1

Giles, A.E. Concerning fat bodies in ganoids] Studies Biol. Lab., Owen's College, 1890, 2, 125-131.

1890.1

Gill, E. Leonard. A catfish new to British seas. Trans. Nat. Hist. Soc. Northumberland, $1904-07$, n. s. 1, 499500 .

1904.1

- A catfish new to British seas [A. latifrons] Rept. Dove Marine Laboratory, Cullercoats, 1906, p.47. 1906.1

Gill, Theodore Nicholas [1837-1914] Description of a new generic form of Gobiinæe from the Amazon river. Ann. Lyceum Nat. Hist., N. Y., 1853-58, 6. $4 \mathrm{p}$.

1853.1

Description of a new genus of Pimelodina from Canada. Ann. Lyceum Nat. Hist., N. Y., 1853-58, 6. $3 \mathrm{p}$.

1853.2

Prodromus descriptionis familia Gobioidarum duorum generum novorum. Ann. Lyceum Nat. Hist., N. Y., 1853$58,6.3 \mathrm{p}$.

1853.3

Prodromus descriptionis subfamilix Gobinarum squamis cycloideis piscium, a cl. IV. Stimpsono in mare Pacifico acquisitorum. Ann. Lyceum Nat. Hist., N. Y., 1853-58, 6, 1-4.

1853.4

Synopsis of the freshwater fishes of the western portion of the island of Trinidad, West Indies. Ann. Lyceum Nat. Hist, N. Y., 1853-58, 6, 363-430.

1853.5

On the fishes of New York. Rept. Smithson. Inst., 1857, 253-269. 1857.1

Analytical synopsis of the order Squali, and revision of the nomenclature of the genera. Ann. Lyceum Nat. Hist., N. Y., 1858-62, 7, 45-48. 1858.1

Description of a new generic form of Gobiina from the Amazon river. Ann. Lyceum Nat. Hist., N. Y., 1858$62 ; 7,45-48$.

1858.2 
Description of a new genus of Pimelodinx from Canada. Ann. Lyceum Nat. Hist., N. Y., 1858-62, 7, 3942.

1858.3

- Prodromus descriptionis familixe Gobioidarum duorum generum novorum. Ann. Lyceum Nat. Hist., N. Y., 1858-62, 7, 16-19.

1858.4

- Prodromus descriptionis subfamilix Gobinarum squamis cycloideis piscium, a cl. IV. Stimpsono in mare Pacifico acquisitorum. Ann. Lyceum Nat. Hist., N. Y, 1858-62, 7, 12-16.

1858.5

- Description of a new genus of Salarianx from the West Indies. Proc. Acad. Nat. Sci. Philad. 1859 (1860), 168-169.

1860.1

Description of a new South American type of siluroids, allied to Callophysus. Proc. Acad. Nat. Sci. Philad. 1859 (1860), 196-197. 1860.2

Description of a third genus of Hemirhamphinæ. Proc. Acad. Nat. Sci. Philad. 1859 (1860), 155-157. 1860.3

Description of a type of gobioids intermediate between Solinx and 'Tridentigerina. Proc. Acad. Nat. Sci. Philad. 1859 (1860), 195-196. $\quad 1860.4$

- Description of Hyporhamphus, a new genus of fishes allied to Hemirhamphus Cuv. Proc. Acad. Nat. Sci. Philad. 1859 (1860), 131-132. 1860.5

Description of new generic types of cottoids, from the collection of the North Pacific Exploring Expedition under Com. John Rodgers. Proc. Acad. Nat. Sci. Philad. 1859 (1860), 165-166.

1860.6

- Descriptions of a new species of Callianidre. Proc. Acad. Nat. Sci. Philad. 1859 (1860), $167 . \quad 1860.7$

- Notes on a collection of Japanese fishes, made by Dr. J. Morrow. Proc. Acad. Nat. Sci. Philad. 1859 (1860), 144-150.

1860.8

-. On Dactyloscopus and Leptoscopus, two new genera of the family of Uranoscopidæ. Proc. Acad. Nat. Sci. Philad. 1859 (1860), 132-133. 1860.9

- On the genus Callionymus of authors. Proc. Acad. Nat. Sci. Philad. $1859(1860), 128-130$.

1860.10

Conspectus piscium in expeditione ad oceanum Pacificum septentrio- nalem, C. Ringoldio et J. Rodgersio ducibus, a Gulielmo Stimpsono collectorum. Sicydianr. Proc. Acad. Nat. Sci. Philad. 1860 (1861), 100-102. 1861.1

- Genus Shyrænops Gill (In Poey, Felipe. Memorias sobre la historia natural de Cuba, p. 349-350. Habana, 1861) 1861.2

A Latin diagnosis of the genus and comments on the relationships.

\section{Ichthyology (In Phelp,}

Washington described, p. 30-32. Washington, 1861)

1861.3

- Monograph of the genus Labrax of Cuvier. Proc. Acad. Nat. Sci. Philad. 1860 (1861), 108-119.

1861.4

Monograph of the genus Labrosomus Sw. Proc. Acad. Nat. Sci. Philad. 1860 (1861), 102-108. 1861.5

Monograph of the Philypni. Proc. Acad. Nat. Sci. Philad. 1860 (1861), 120.

1861.6

Notes on the nomenclature of North American fishes. Proc. Acad. Nat. Sci. Philad. 1860 (1861), 19-21.

1861.7

On the pertinence of the Alosa teres Dekay, to the genus Dussumiera Val. Proc. Acad. Nat. Sci. Philad. 1860 (1861), 21-22. 1861.8

Appendix to the "Monograph of the Philypni," and description of the genus Lembus of Günther. Proc. Acad. Nat. Sci. Philad. 1861 (1862), 16-17.

1862.1

Catalogue of the fishes of the eastern coast of North America, from Greenland to Georgia. Proc. Acad. Nat. Sci. Philad. 1861 (1862) (Suppl.), $1-63$.

1862.2

Description of a new generic type of blennoids. Proc. Acad. Nat Sci. Philad. 1861 (1862), 261-263.

1862.3

Description of a new species of the genus Anableps of Gronovius. Proc. Acad. Nat. Sci. Philad. 1861 (1862), 3-6.

1862.4

Description of a new species of the genus Tigoma of Girard. Proc. Boston Soc. Nat. Hist. 1861 (1862), 8, $42-46$.

1862.5

Descriptions of new species of Pimelodina. Proc. Boston Soc. Nat Hist. 1861 (1862), 8, 42-46. 1862.6 
Gill, $T \cdot N$.

Descriptions of a new species of Sillago. Proc. Acad. Nat. Sci. Philad. 1861 (1862), 505. 1862.7

Descriptions of two species of marine fishes, Proc. Acad. Nat. Sci. Philad. 1861 (1862), 98. 1862.8

- Monograph of the tridigitate uranoscopoids. Proc. Acad. Nat. Sci. Philad. 1861 (1862), 263-271. 1862.9

Notes on some genera of fishes of the western coast of North America. Proc. Acad. Nat. Sci. Philad. 1861 (1862), 164-168.

1862.10

Observations on the genus Cottus, and descriptions of two new species. Proc. Boston Soc. Nat. Hist. 1861 (1862), 8, 40-42.

1862.11

On a new type of aulostomatoids,

found in Washington territory. Proc. Acad. Nat. Sci. Philad. 1861 (1862), $164-170$.

1862.12

- On new generic types of fishes. Proc. Acad. Nat. Sci. Philad. 1861 (1862), 77.

1862.13

- On the classification of the

Eventognathi or Cyprini, a suborder of Teleocephali. Proc. Acad. Nat. Sci. Philad. 1861 (1862), 6-9. 1862.14

On the genus Anisotremus Gill. Proc. Acad. Nat. Sci. Philad. 1861 (1862), 105-10s.

1862.15

- On the genus Podothecus. Proc. Acad. Nat. Sci. Philad. 1861 (1862), 258-261.

1862.16

- On the Haploidonotinæ. Proc. Acad. Nat. Sci. Philad. 1861 (1862), 100-105.

1862.17

- On the identity of the genera

Neommenis of Girard, and Lutjanus of Bloch. Proc. Acad. Nat. Sci. Philad. 1861 (1862), 93-95.

1862.18

- On the Liostomina. Proc. Acad. Nat. Sci. Philad. 1861 (1862), 89-93.

1862.19

Revision of the genera of North American Scimine. Proc. Acad. Nat. Sci. Philad. 1861 (1862), 79-89. 1862.20

- Synopsis generum Rhyptici et affinium. Proc. Acad. Nat. Sci. Philad. 1861 (1862), 52-54.

1862.21

Synopsis of the chanichthyoids. Proc. Acad. Nat. Sci. Philad. 1861 (1S62), 507-510.
- Synopsis of the genera of the subfamily of Pimelodinx. Proc. Boston Soc. Nat. Hist. 1861 (1862), 8, 46-55.

1862.23

- Synopsis of the harpagiferoids Proc. Acad. Nat. Sci. Philad. 1861 (1862), 510-512.

1862.24

- Synopsis of the notothenoids Proc. Acad. Nat. Sci. Philad. 1861 (1862), 512-522.

1862.25

- Synopsis of the polynematoids Proc. Acad. Nat. Sci. Philad. 1861 (1862), 271-282.

1862.26

- Synopsis of the sillaginoids Proc. Acad. Nat. Sci. Philad. 1861 (1862), 501-505.

1862.27

- Synopsis of the subfamily of Clupeinx, with descriptions of a new genera. Proc. Acad. Nat. Sci. Philad. 1861 (1862), 33-38.

1862.28

- Synopsis of the subfamily of Percinx. Proc. Acad. Nat. Sci. Philad. 1861 (1862), 44-52.

1862.29

- Synopsis of the uranoscopoids Proc. Acad. Nat. Sci. Philad. 1861 (1862), 108-117.

1862.30

Appendix to the synopsis of the subfamily of Percina. Proc. Acad. Nat Sci. Philad. 1862 (1863), 15-16. 1863.1

Description of a new generic type of mormyroids and note on the arrangement of the genus. Proc. Acad. Nat. Sci. Philad. 1862 (1863), 443-445.

1863.2

Description of a new species of Cirrhitus. Proc. Acad. Nat. Sci. Philad. 1862 (1863), 122-124.

1863.3

Description of new species of Alepidosauroida. Proc. Acad. Nat. Sci. Philad. 1862 (1863), 127-132. 1863.4

Note on some genera of fishes of western North America. Proc. Acad. Nat. Sci. Philad. 1862 (1863), 329-333. 1863.5

Note on the family of myliobatoids, and on a new species of Etobatis [E. laticeps] Ann. Lyceum Nat. Hist. N. Y., 1863-67, 8, 138-141. 1863.6

- Note on the scimnoids of California. Proc. Acad. Nat. Sci. Philad. 1862 (1863), 16-18.

1863.7

- Notes on the family of scombroids. Proc. Acad. Nat. Sci. Philad. 1862 (1863), 328-329.

1863.8 
Notice of a collection of the fishes of California, presented to the Smithsonian Institution by Mr. Samuel Hubbard. Proc. Acad. Nat. Sci. Philad. 1862 (1863), 274-282.

1863.9

Notice of a new species of Hemilepidotus, and remarks on the same group (Temnistix) of which it is a member. Proc. Acad. Nat. Sci. Philad. 1862 (1863), 13-14.

1863.10

On a new family type [Chrnopsis] of fishes related to the blennioids. Ann. Lyceum Nat. Hist., N. Y., 1863$67,8,141-144$.

1863.11

- On a new genus of fishes allied to Aulorhynchus and on the affinities of the family Auloryhynchoidx, to which it belongs. Proc. Acad. Nat. Sci. Philad. 1862 (1863), 233-235.

1863.12

On a new species of Priacanthus discovered in Narragansett bay, R. I. Proc. Acad. Nat. Sci. Philad. 1862 (1863), 132-133.

1863.13

On a remarkable new type of fishes allied to Nemophis [Plagiotremus spilistius] Ann. Lyceum Nat. Hist., N. Y., 1863-67, 8, 138-141. pl.

1863.14

On the classification of the families and genera of the Squali of California. Proc. Acad. Nat. Sci. Philad. 1862 (1863), 483-501. 1863.15

On the limits and affinity of the family of leptoscopoids. Proc. Acad. Nat. Sci. Philad. 1862 (1863), 501-506.

1863.16

On the limits and arrangement of the family of scombroids. Proc. Acad Nat. Sci. Philad. 1862 (1863), 124-127.

1863.17

On the subfamily of Argentininge Proc. Acad. Nat. Sci. Philad. 1862 (1863), 14-15.

1863.18

On the synonymy and systematic position of the genus Etelis of Cuvier and Valeniciennes. Proc. Acad. Nat. Sci. Philad. 1862 (1863), 445-449.

1803.19

On the west African genus Hemichromis and descriptions of new species in the museums of the Academy and Smithsonian Institution. Proc. Acad. Nat. Sci. Philad. 1862 (1863), 134-139.

1863.20

Remarks on the relations of the genera and other groups of Cuban fishes.
Proc. Acad. Nat. Sci. Philad. 1862 (1863), 235-242.

1863.21

- Synopsis of the carangoids of the eastern coast of North America. Proc. Acad. Nat. Sci. Philad. 1862 (1863) $430-443$.

1863.22

- Synopsis of the family of cirrhitoids. Proc. Acad. Nat. Sci. Philad 1862 (1863), 102-124. 1863.23

Synopsis of the species of lophobranchiate fishes of western North America. Proc. Acad. Nat. Sci. Philad 1862 (1863), 282-284. 1863.24

Catalogue of the fishes of lower California in the Smithsonian Institution, collected by Mr. J. Xantus. Proc. Acad. Nat. Sci. Philad. 1862 (1863), 140-151; 242-246; 249-262. Ibid. 1863 (1864), $80-88$.

1864.1

Catalogue of the North American scirnoid fishes. Proc. Acad. Nat. Sci. Philad. 1863 (1864), 28-32. 1864.2

Description of a new generic type of ophidioids. Proc. Acad. Nat. Sci. Philad. 1863 (1864), 209-211.

1864.3

Description of a new species of Choerojulis from North Carolina. Proc. Acad. Nat. Sci. Philad. 1863 (1864), 205-207.

1864.4

Description of the genus Oxyjulis Gill. Proc. Acad. Nat. Sci. Philad. 1863 (1864), 330-331.

1864.5

Description of the genus Stereolepis Ayres. Proc. Acad. Nat. Sci. Philad. 1863 (1864), 329-330. 1864.6

Descriptions of some new species of Pediculati, and on the classification of the group. Proc. Acad. Nat. Sci. Philad. 1863 (1864), 88-92. 1864.7

Descriptions of the genera of gadoid and brotuloid fishes of western North America. Proc. Acad. Nat. Sci. Philad. 1863 (1864), 242-254. 1864.8

Descriptions of the gobioid genera of the western coast of temperate North America. Proc. Acad. Nat. Sci. Philad. 1863 (1864), 262-267. 1864.9

Descriptive enumeration of a collection of fishes from the western coast of Central America, presented to the Smithsonian Institution by Capt. John M. Dow. Proc. Acad Nat. Sci. Philad. 1863 (1864), 162-180. 1864.10 
Gill, $T . N$.

[Review of] Holbrook's Ichthyology of South Carolina. Amer. Journ Sci., 1864, 2. ser. 37, 89-94. 1864.11

Note on some recent additions to the ichthyological fauna of Massachusetts. Proc. Acad. Nat. Sci. Philad. 1863 (1864), 332-333.

1864.12

Note on the genera of Hemirhamphinx. Proc. Acad. Nat. Sci. Philad. 1863 (1864), 272-273. 1864.13

Note on the species of Sebastes of the enstern coast of North America. Proc. Acad. Nat. Sci. Philad. 1863 (1864), 333-335.

1864.14

Notes on the labroids of the western coast of North America. Proc. Acad. Nat. Sci. Philad. 1863 (1864), 221-224.

1864.15

- On an unnamed generic type allied to Sebastes. Proc. Acad. Nat. Sci. Philad. 1863 (1864), 207-209.

1864.16

On the genus Periophthalmus of Schreider. Proc. Acad. Nat. Sci. Philad. 1863 (1864), 271-272. 1864.17

On the gobioids of the eastern corst of the United States. Proc. Acad. Nat. Sci. Philad. 1863 (1864), 267-271.

1864.18

Synopsis of the family of lepturoids, and description of a remarkable new generic type. Proc. Acad. Nat. Sci. Philad. 1863 (1864), 224-229. 1864.19

- Synopsis of the family of Lycodoidæe. Proc. Acad. Nat. Sci. Philad. 1863 (1864), 254-262.

1864.20

Synopsis of the North American gadoid fishes. Proc. Acad. Nat. Sci. Philad. 1863 (1864), 229-242. 1864.21

Synopsis of the pomacentroids of the western coast of North and Central America. Proc. Acad. Nat. Sci. Philad. 1863 (1864), 213-221. 1864.22

Critical remarks on the genera Sebastes and Sebastodes of Ayres. Proc. Acad. Nat. Sci. Philad. 1864 (1865), 145-147.

1865.1

Description of a new generic type of pleuronectoids [Metoponops cooperi Gill in the collection of the Geological Survey of California. Proc. Acad. Nat. Sci. Philad. 1864 (1865), 198-199.
- Description of a new labroid genus [Pimelometopon Gill] allied to Trochocopus Gthr. Proc. Acad. Nat. Sci. Philad. 1864 (1865), 57-59. 1865.3

- Descriptions of new genera and species of eastern American pleuronectoids. Proc. Acad. Nat. Sci. Philad. 1864 (1865), 220-224.

1865.4

Note on the family of stichæoids. Proc. Acad. Nat. Sci. Philad. 1864 (1865), 208-211.

1865.5

Note on the nomenclature of genera and species of the family Echeneidoida. Proc. Acad. Nat. Sci. Philad. 1864 (1865), 59-61.

1865.6

Note on the paralepidoids and microstomatoids, and on some peculiarities of Arctic ichthyology. Proc. Acad. Nat. Sci. Philad. 1864 (1865), 187-189.

1865.7

On several points in ichthyology and conchology. Proc. Acad. Nat. Sci. Philad. 1864 (1865), 151-152. 1865.8

On the affinities of several doubtful British fishes. Proc. Acad. Nat. Sci. Philad. 1864 (1865), 199-208. - Ann. Mag. Nat. Hist., 3. ser. 15, 40-48.

1865.9

Second contribution to the selachology of California. Proc. Acad. Nat. Sci. Philad. $186+$ (1865), 147-151.

1865.10

Synopsis of the cyclopteroids of eastern North America. Proc. Acad. Nat. Sci. Philad. 1864 (1865), 189-194.

1865.11

Synopsis of the eastern American sharks. Proc. Acad. Nat. Sci. Philad. 1864 (1865), 258-265. 1865.12

Synopsis of the fishes of the gulf of St. Lawrence and bay of Fundy. Canadian Naturalist, 1865, 2, 244-266.

1865.13

Synopsis of the pleuronectoids of California and northwestern America. Proc. Acad. Nat. Sci. Philad. 1864 (1865), 194-198.

1865.14

Synopsis of the pleuronectoids of the eastern coast of North America. Proc. Acad. Nat. Sci. Philad. 1864 (1865), 214-220.

1865.15

- Note on several genera of cyprinoids. Proc. Acad. Nat. Sci. Philad. 1865 (1866), 69-70. 1866.1 
Observations on fishes (In Narratives of the career of Hernando de Soto in the conquest of Florida, etc., translated by Buckingham Smith, p. 223-226. New York, 1866. xxviii, 324 p. map. $4^{\circ}$.

1866.2

On a new generic type of sharks. Proc. Acad. Nat. Sci. Philad. 1865 (1866), 177.

1866.3

- On a new genus of Serraninx. Proc. Acad. Nat. Sci. Philad. 1865 (1866), 10t-106.

1866.4

- On the cranial characteristics of Gadus proximus Grd. Proc. Acad. Nat. Sci. Philad. 1865 (1866), 69. 1866.5

On the genus Caulolatilus. Proc. Acad. Nat. Sci. Philad. 1865 (1866) 66-68.

1866.6

- Synopsis of the genus Pomoxys Raf. Proc. Acad. Nat. Sci. Philad. 1865 (1866), 64-66.

1866.7

On some new species of fishes obtained by Prof. Orton from the Maranon, or upper Amazon, and Napo rivers. Proc. Acad. Nat. Sci. Philad. 1870 (1871), 92-96.

1871.1

Note on Cottus groenlandicus Fabr. Proc. Acad. Nat. Sci. Philad., $1872,213-214$.

1872.1

Catalogue and bibliography of the fishes of the east coast of North America. Rept. U. S. Fish Comm.187172 (1873), 1, 779-822.

1873.1

- Note on the Scombrocottus salmoneus Peters, and its identity with Anoplopoma fimbria. Proc. Acad. Nat. Sci. Calif., 1873, 5, 56-57. - Ann. Mag. Nat. Hist., 4. ser. 12, 74-75. 1873.2

- The number of classes of vertebrates and their mutual relations. Amer. Journ. Sci., 1873, 6, 432-435. - Ann. Mag. Nat. Hist., 4. ser. 13, 71-73.

1873.3

- On a new American species of pleuronectoid (Glyptocephalus acadianus) Proc. Acad. Nat. Sci. Philad., 1873, 360362.

1873.4

On recent additions to the fish fauna of Massachusetts. Proc. Amer. Assoc. Adv. Sci., 22. meet., 1873, pt. 2 , 31-36.

1873.5

On the homologies of the shoulder-girdle of the dipnoans and other fishes. Ann. Mag. Nat. Hist., 1873, 4. ser. 11, 173-178.

1873.6

- On the limits of the class of fishes. Amer. Naturalist, 1873, 7, 71-79.

1873.7

On the species of the genus Micropterus Lac., or Grystes auct. Proc. Amer. Assoc. Adv. Sci., 22. meet., 1873, pt. 2, 55-72.

1873.8

- Arrangement of the families of fishes, or classes Pisces, Marsipobranchii and Leptocardii. Smithson. Misc. Coll. 1872 (1874), 11, no. 247 . xlv, 49 p.

1874.1

Bibliography of reports of fishery commissions. Rept. U. S. Fish Comm. 1872-73 (1874), 2, 774-784.

1874.2

Natural and economical history of the gourami. Rept. U.S. Fish Comm. 1872-73 (1874), 2, 710-728. pl. 1874.3

On the identity of Esox lewini with the Dinolestes mülleri of Klunzinger. Ann. Mag. Nat. Hist., 1874, 4. ser. 14, 159-160.

1874.4

On the geographical distribution of fishes. Ann. Mag. Nat. Hist., 1875, 4. ser. 15, 251-255.

1875.1

— Fishes (In Kidder, J. H. Contributions to the natural history of Kerguelen island, made in connection with the United States transit of Venus expedition, $1874-75$, p. 41-42. Washington, 1876.122 p. $8^{\circ}$ ) 1876.1

- Genus Pareques Gill [Pareques acuminatus (Schneider) Gill] (In Goode, G. B. Catalogue of the fishes of the Bermudas, ete.) Bull. U.S. Nat. Mus., 1876 , no. 5 , p. 50 .

1876.2

Notes on fishes from the isthmus of Panama, collected by Dr. J. F. Bransford, U. S. N. Proc. Acad. Nat. Sci. Philad., 1876, 335-339. 1876.3

- Report on ichthyology (In Simpson, J. H. Report of the explorations across the great basin of the territory of Utah in 1859, p. 383-431. 9 pls. Washington, 1876) 1876.4

- Analysis of the four subgenera of Stizostethium] (In Jordan, D. S., \& Gilbert, C. H. Contributions to North American ichthyology, based primarily on the collections of the United States National Museum. II. A. Bull. U. S. Nat. Mus., 1877, no. 10, p.45) 1877.1 Genera of Centrarchidx (In Jordan, D. S. Contributions to North 
Gill, T.N.

American ichthyology, based primarily on the collections of the United States National Museum. II. A. Bull. U.S. Nat. Mus, 1877 , no. 10, 31-32) 1877.2

The genus Sebastapistes, based on S. strongia, etc. (In Streets, Thomas H. Contribution to the natural history of the Hawaiian and Fanning islands. Bull. U.S. Nat. Mus., 1877, no. 7, p. 62)

1877.3

- Notes on the genus Enneacanthus and table of the species] (In Jordan, D. S. Contributions to North American ichthyology, based primarily on the collections of the United States National Museum. II. A. Bull. U.S. Nat. Mus., 1877 , no. 10, 27-30) 1877.4

On the kinds of fish which are found associated with medusæ. Nature, London, 1877, 16, 362.

1877.5

The scientific names of our common sunfishes. Field \& Forest, 1877, 2, 188-190.

1877.6

Catalogue of the fishes of the east coast of North America. Smithson. Miscell. Collect., 1878, 14, art. 2. $25 \mathrm{p}$.

1878.1

Genus Myxocyprinus Gill (In Jordan, D. S. Contributions to North American ichthyology, based primarily on the collections of the United States National Museum. III. B. Bull. U. S. Nat. Mus., 1878, no. 12, p. 217)

1878.2

- A new species of Chimæra found in American waters. Bull. Phil. Soc. Washington, 1878, 2, 182.- Ann. Mag. Nat. Hist., 5. ser. 1, 183-184. 1878.3

On a remarkable generic type of characins [Elopomorphus jordanii] Ann. Mag. Nat. Hist., 1878, 5. ser. 2, 112 . Field \& Forest, 3, 167-169.

1878.4

[Review of] Wallace's geographical distribution of animals. Field \& Forest, 1878, 3, 69-74; 78-80; 98-101; $167-168$.

1878.5

- Note on Antennariidæ. Proc U. S. Nat. Mus. 1878 (1879), 1, 221222.

1879.1

Note on the Ceratiidre. Proc.

U. S. Nat. Mus. 1878 (1879), 1, 227-231. 1879.2

Note on the Maltheida. Proc. U. S. Nat. Mus. 1878 (1879), 1, 231-232. 1879.3
IOn the homology of the dentition of Dinichthys with that of recent lungfishes] (In Newberry, J. S. Rept. Geol. Surv. Ohio, 1875, vol. ii, p. 7-8) Also separate; Columbus, 1879. 1879.4

On the proper specific name of the common pelagic antennariid, Pterophryne. Proc. U. S. Nat. Mus. 1878 (1879), 1, 223-226.

1879.5

On the identity of the genus Leurynnis Lockington, with Lycodopsis. Proc. U.S. Nat. Mus., 1880, 3, 247248.

1880.1

- Synopsis of the pediculate fishes of the eastern coast of extra-tropical North America. Smithson. Misc. Collect., 1880, 19, 215-221. 1880.2

Giunther's literature and morphography of fishes $\mathrm{A}$ review of Dr. A. Günther's Introduction to the study of fishes] Forest \& Stream, 1881, 17, 8688.

1881.1

- Note on the latiloid genera.

Proc. U. S. Nat. Mus., 1881, 4, 162-164.

1881.2

Record of recent scientific prog ress in zoology. Fishes, etc. Ann. Rept. Smithson. Instit. 1880 (1881), 365-375.

1881.3

Origin of sounds produced by fishes, p. 366 .

Temperature of fishes, p. $367-369$.

The flight of flying-fishes, p. 369-370.

Affinities of Pleuracanthus, p. 370-371.

The Platysomids and Palæoniscids, p. 371.

On the sexes of the eels, $p .371-372$.

Pleuronectids without pectorals, p. $372-373$.

A new economical fish, p. 373-374.

The rock-fishes of California, p. $374-375$.

A deep-sea rock-fish, p. 375.

Bibliography of the fishes of the Pacific coast of the United States to the end of 1879. Smithson. Misc. Coll., 1882, 23. $78 \mathrm{p}$.

1882.1

Note on the affinities of the ephippiids. Proc. U. S. Nat. Mus., $1882,5,557-560$. 1882.2

Note on the genus Sparus. Proc. U. S. Nat. Mus., 1882, 5, 566-567.

1882.3

Note on the Pomatomidre. Proc. U. S. Nat. Mus., 1882, 5, 557. 1882.4

Note on the relationships of the echeneiids. Proc. U.S. Nat. Mus., 1882, 5, 561-566.

1882.5

On the family Centropomidx. Proc. U. S. Nat. Mus., 1882, 5, 484-485. 1882.6 
On the relations of the family Lobotidx. Proc. U. S. Nat. Mus., 1882, 5, 560-561.

1882.7

[Diagnosis of cranial characteristics of the sparoid genus] Calamus (In Jordan, D. S., \& Gilbert, C. H. Contributions to North American ichthyology, based primarily on the collections of the United States National Museum. IV. Bull. U. S. Nat. Mus., 1883 , no. 16, p. 926) 1883.1

Relationships and diagnosis of the family Chiasmodontidæ (In Jordan, D. S., \& Gilbert, C. H. Contributions to North American ichthyology, based primarily on the collections of the United States National Museum. IV. Bull. U. S. Nat. Mus., 1883, no. 16, p. 964)

1883.2

- Comparative cranial characteristics of sparoid genera Diplodus, Archosargus and Stenotomus (In Jordan, D. S., \& Gilbert, C. H. Contributions to North American ichthyology, based primarily on the collections of the United States National Museum. IV. Bull. U. S. Nat. Mus., 1883, no. 16, p. 929)

1883.3

- Nomenclature of the xiphiids. Proc. U. S. Nat. Mus., 1883, 5, 485-486.

1883.4

- Note on the Bdellostomidæe and Myxinidae. Proc. U. S. Nat. Mus. $1882(1883), 5,517-520$. $\quad 1883.5$

- Note on the leptocardians. Proc. U. S. Nat. Mus. 1882 (1883), 5, 515516.

$1883: 6$

- Note on the myzonts or marsipobranchiates. Proc. U. S. Nat. Mus. $1882(1883), 5,516-517$.

1883.7

Note on the petromyzontids. Proc. U. S. Nat. Mus. 1882 (1883), 5, 521-525.

1883.8

On the family and subfamilies of Carangidx. Proc. U. S. Nat. Mus. 1882 (1883), 5, 487-493.

1883.9

On the proper name of the blue fish. Proc. U.S. Nat. Mus. 1882 (1883), 5, $567-570$.

1883.10

Outline of a proposed subdivision of the Squali (In Jordan, D. S., \& Gilbert, C. H. Contributions to North American ichthyology, based primarily on the collections of the United States National Museum. IV. Bull. U.S. Nat. Mus., 1883, no. 16, p. 967) 1883.11
Supplementary note on the Pediculati. Proc. U. S. Nat. Mus. 1882 (1883), 5, 551-556. $\quad 1883.12$

Diagnosis of new genera and species of deep-sea fish-like vertebrates. Proc. U. S. Nat. Mus. 1883 (1884), 6, 253-260. Also separate; Washington, 1884.

1854.1

Notes on the Stromateidie. Proc. Amer. Phil. Soc., 1884, 21, 664 672.

1884.2

- On the anacanthine fishes. Proc. Acad. Nat. Sci. Philad. 1883 (1884), $167-183$

1884.3

A contribution to the terminology of ichthyography. Proc. U. S. Nat. Mus. 1884 (1885), 7, 356-357. 1885.1

Note on the Sternoptychidx. Próc. U. S. Nat. Mus. 1884 (1885), 7, 349-351.

1885.2

On the mutual relations of the hemibranchiate fishes. Proc. Acad. Nat. Sci. Philad. 1884 (1885), 154-166.

1885.3

The osteological characteristics of the Lutjaninæ. Proc. U. S. Nat. Mus. 1884 (1885), 7, 351-355. 1885.4

Synopsis of the genera of the superfamily Teuthidoidea (families Teuthididxe and Siganidæ) Proc. U. S. Nat. Mus. 1884 (1885), 7, 275-281.

1885.5

- Synopsis of the plectognath fishes. Proc. U. S. Nat. Mus. 1884 (1885), 7, 411-427. 1885.6

Teleostei (In Kingsley, J. S. The standard natural history. Lower vertebrates, vol. iii, 98-298. 94 figs. Boston, 1885)

1885.7

The characteristics of the elacatids. Proc. U. S. Nat. Mus. 1887 (1888), 10, 612-614. pl.

1888.1

-... Note on the Gramma loreto of Poey. Proc. U. S. Nat. Mus. 1887 (1888), 10, 615-616. 1888.2

The extinct seleroderms. Amer. Naturalist, 1888, 22, 828-830. 1888.3

The primary groups of mailcheeked fishes. Amer. Naturalist, 1888, 22, 356-358.

1888.4

- Some extinct scleroderms. Amer. Naturalist, 1888, 22, 446-448. 1888.5 
Gill, T. N.

Gleanings among the Pleuronectidx, with observations on the name Pleuronectidix. Proc. U. S. Nat. Mus. 1885 (1889), 11, 593-606. 1889.1

The halosauroid fishes typical of a special order. Amer. Naturalist, 1889 , 23, 1015-1016.

1889.2

Nesting of the black bass. Forest \& Stream, 1S89, 33, 163-164.

1889.3

The notacanthid fishes as representatives of a peculiar order. Amer. Naturalist, 1859, 23, 1016-1017.

1889.4

On the classification of the mailcheeked fishes. Proc. U. S. Nat. Mus. 1888 (1889), 11, 567-592. 1889.5 - The families of ribbon-fishes. Amer. Naturalist, 1890, 24, 481-482. 1890.1

The characteristics of the Dactylopteroidea. Proc. U. S. Nat. Mus. 1890 (1891), 13, 243-248. pl. 1891.1

The characteristics of the family of scatophagoid fishes. Proc. U. S. Nat. Mus. 1890 (1891), 13, 355-360. fig.

1891.2

Note on the Aspredinidæ. Proc. U. S. Nat. Mus. 1890 (1891), 13, 347352 .

1891.3

- Note on the genus Felichthys of Swainson. Proc. U.S. Nat. Mus. 1890 (1891), 13, 353-354.

1891.4

On the family Ranicipitidx. Proc. U. S. Nat. Mus. 1890 (1891), 13, 235-238. pl.

1891.5

- On the relations of Cyclopteroidea. Proc. U. S. Nat. Mus, 1890 (1891), 13, 361-376. 3 pls. $\quad 1891.6$

- Osteological characteristics of the family Amphipnoidx. Proc. U. S. Nat. Mus. 1890 (1891), 13, 299-302.

1891.7

The osteological characteristics of the family Anguillidx. Proc. U. S. Nat. Mus. 1890 (1891), 13, 157-160.

1891.8

_. The osteological characteristics of the family Hemitripteridx. Proc. U. S. Nat. Mus. 1890 (1891), 13, 377380. pl.

1891.9

- Osteological characteristics of the family Murrenesocidx. Proc. U.S. Nat. Mus. 1890 (1891), 13, 231-234.
The osteological characteristics of the family Murænidæ. Proc. U.S. Nat. Mus. 1890 (1891), 13, 165-170.

1891.11

The osteological characteristics of the family Simenchelyidw. Proc. U. S. Nat. Mus. 1890 (1891), 13, 239242 .

1891.12

The osteological characteristics of the family Synaphobranchidx. Proc. U. S. Nat. Mus. 1890 (1891), 13, $161-$ 164 .

1891.13

Notes on the Tetraodontoidea. Proc. U. S. Nat. Mus. 1891 (1892), 14, 705-720. pl.

1892.1

- A comparison of antipodal faunas. Mem. Nation. Acad. Sci. $1893,6,91-124$. $\quad 1893.1$

- Families and subfamilies of fishes. Mem. Nation. Acad. Sci., 1893, 6, 127-138.

1893.2

-. A segregation of freshwater fishes. Science, 1893, 22, $345 . \quad 1893.3$

Sharks in fresh water. Science, 1893, 22, 165. 1893.4

- A South American lamprey. Science, 1893, 23, 30. 1893.5

Lepidosirenids and bdellostomids. Amer. Naturalist, 1894, 28, 581584.

1894.1

- Manuscript notes on Hyperprosopon, Ditrema smitti, etc. (In Eigenmann, C. H. On the viviparous fishes of the Pacific coast of North America. Bull. U. S. Fish Comm. 1892 (1894), 12, 381-391)

1894.2

The proper generic name of the tunnies. Proc. U. S. Nat. Mus, 1893 (1894), 16, 693-694.

1894.3

The differential characters of the Salmonidx and Thymallidre. Proc. U. S. Nat. Mus. 1894 (1895), 17, $117-$ 122.

1895.1

The genera of Branchiostomidx. Amer. Naturalist, 1895, 29, 457-459. 1895.2

The genus Leptophidium. Amer. Naturalist, 1895, 29, 167-168. 1895.3

The nomenclature of the family Pociliidxe or Cyprinodontidx. Proc. U. S. Nat. Mus. $189 \pm$ (1895), 17, 115116.

1895.4

The nomenclature of the Myliobatidx, or Etobatidx. Proc. U. S. Nat. Mus. 1894 (1895), 17, 111-114. 1895.5 
On the nomenclature and characteristics of the lampreys. Proc. U.S. Nat. Mus. 1894 (1895), 17, 107-110.

1895.6

On the relations and nomenclature of Stizostedion or Lucioperca. Proc. U. S. Nat. Mus. 1894 (1895), 17, 123128.

1895.7

The differential characters of characinoid and erythrinoid fishes. Proc. U. S. Nat. Mus. 1895 (1896), 18, 205209.

1896.1

The differential characters of the syngnathid and hippocampid fishes. Proc. U. S. Nat. Mus. 1895 (1896), 18, $153-159$.

1896.2

The families of synentognathous fishes and their nomenclature. Proc. U. S. Nat. Mus, 1895 (1896), 18, 167178.

1896.3

Lipophrys a substitute for Pholis. Amer. Naturalist, 1896, 30, 498. 1896.4

The nomenclature of Rachicentron or Elacate, a genus of acanthopterygian fishes. Proc. U. S. Nat. Mus. 1895 (1896), 18, 217-219.

1896.5

The nomenclature of the fishes of the characinoid genus Tetragonopterus. Proc. U. S. Nat. Mus. 1895 (1896), 18, 225-227.

1896.6

Note on Plectroplites and Hypoplectrodes, genera of serranoid fishes. Ann. Mag. Nat. Hist., 1896, 6. ser. 18, 197-198. - Proc. U. S. Nat. Mus. 1895 (1896), 18, 567-568.

1896.7

Note on the Devonian Palaeospondylus. Science, 1896,2 . ser. 4, 1011.

1896.8

- Note on the fishes of the genus Characinus. Proc. U. S. Nat. Mus. 1895 (1896), 18, 213-215. 1896.9

Note on the nomenclature of the poeciloid fishes. Proc. U. S. Nat. Mus. 1895 (1896), 18, 221-224.

1896.10

Notes on characinoid fishes with ctenoid scales, with a description of a new Psectrogaster. Proc. U. S. Nat. Mus. 1895 (1896), 18, 199-203. 1896.11

- Notes on Orectolobus or Crossorhinus, a genus of sharks. Proc. U.S. Nat. Mus. 1895 (1896), 18, 211-212.

1896.12

- Notes on the genus Cephaleutherus of Rafinesque, and other rays with aberrant pectoral fins (Propterygia and Hieroptera) Proc. U. S. Nat. Mus. 1895 (1896), 18, 195-198. $\quad 1896.13$

- Notes on the nomenclature of Scymnus or Scymnorhinus, a genus of sharks. Proc. U. S. Nat. Mus. 1895 (1896), 18, 191-193.

1896.14

- Notes on the synonymy of the Torpedinidxe or Narcobatidx. Proc. U. S. Nat. Mus. 1895 (1896), 18, 161165.

1896.15

On the application of the name Teuthis to a genus of fishes. Proc. U.S Nat. Mus. 1895 (1896), 18, 179-189.

1896.16

On the proper name of the gunnels, or butter-fishes. Proc. U. S. Nat, Mus. 1895 (1896), 18, 147-151. 1896.17

[Review of] Fishes, living and fossil, by Bashford Dean. Science, 1896 , n. s. 3, 909-917.

1896.18

- Vertebrata of the sea. Science, 1896, n. s. 3, 319 .

1896.19

- The agonoid genus Percis of Scopoli. Science, 1897, 2. ser. 6, 958.

1897.1

- Some questions of nomenclature. Proc. Amer. Assoc. Adv. Sci., 45. meet., 1896 (1897), 135-165. - Ann. Rept. Smithson. Instit. 1896 (1898), $457-483$.

1897.2

The determinants for the major classification of fish-like vertebrates. Rept. Brit. Assoc. Adv. Sci., 67, meet. 1897 (1898), 696-697. 1898.1

On the derivation of the pectoral member in terrestrial vertebrates. Rept. Brit. Assoc. Adv. Sci., 67. meet., 1897 (1898), $697 . \quad 1898.2$

- Larval stage of the eel. Science, 1899, 2. ser. 9, 820 . 1899.1

The proper names of Bdellostoma or Heptatrema. Proc. U. S. Nat. Mus., 1901, 23, 735-738. 1901.1

The whale-shark (Rhinodon typicus) as an American fish. Science, 1902, 2. ser. 15, 824-826. 1902.1

The fishes of the African family Kneridæ. Science, 1903, 2. ser. 18, 338339.

1903.1

The hosts of argulids and their nomenclature. Science, 1903, 2. ser. 17 , 33. 1903.2

Notice of C. B. Wilson's "North American parasitic copepods of the family Argulidæ." 
Gill, $T, N$.

- A little-known devil-fish. Science, 1903, 2. ser. 18, 473.

1903.3

A new name (Hoplias) for the genus Macrodon of Müller. Proc. Biol. Soc. W ashington, $1903,16,50 . \quad 1903.4$

Note on the fish genera named Macrodon. Proc. U. S. Nat. Mus., 1903, 26, 1015-1016.

1903.5

- On some fish genera of the first edition of Cuvier's "Règne animal" and Oken's names. Proc. U. S. Nat. Mus., 1903, 26, 965-967.

1903.6

- On some neglected genera of fishes. Proc. U. S. Nat. Mus., 1903, 26, 959-962.

1903.7

On the relations of the fishes of the family Lamprididx or opahs. Proc. U. S. Nat. Mus., 1903, 26, 915-924. fig. 1903.8

The use of the name torpedo for the electric catfish. Proc. U. S. Nat. Mus., 1903, 26, 697-698.

1903.9

Walbaum and binomialism. Science, 1903, 2. ser. 17, 744-746. 1903.10

- The Encyclopedia Americana on ichthyology. Science, 1904, 2. ser. 19 , $675-676 ; 767$.

1904.1

Extinct pediculate and other fishes. Science, 1904, 2. ser. 20, 845-846.

1904.2

Labracinus the proper name for the fish genus Cichlops. Proc. U. S. Nat. Mus., 1904, 28, 119.

1904.3

The morays at the [New York] aquarium. New York Zool. Soc. Bull., 1904, no. 15 , 180-181.

1904.4

Note on the genus Prionurus or Acanthocaulos. Proc. U. S. Nat. Mus., 1904, 28, 121.

1904.5

On the systematic relations of the ammodytoid fishes. Proc. U. S. Nat. MIus., 1904, 28, 159-163. fig. 1904.6

A remarkable genus of fishes, the umbras. Smithson. Mise. Collect., $1904,46,295-305$. fig.

1904.7

State ichthyology of Massachusetts. Science, 1904, 2. ser. 20, 321338. Rept. U. S. Bureau Fisheries, $190 t$ (1905), 163-188.

1904.8

- Ancient Greek fish and other names. Science, 1905, 2. ser. 22, 140 141.
- Flying fishes and their habits. Ann. Rept. Smithson. Instit. 1904 (1905), 495-515. 4 pls. \& fig. 1905.2

- An interesting Cretaceous chimaroid egg-case. Science, 1905, 22 601-602.

1905.3

The life-history of the angler. Smithson. Misc. Collect., 1905, 47, pt. 2, 500-516. 3 pls. \& figs.

1905.4

The life-history of the sea-horses (hippocampids) Proc. U. S. Nat. Mus., 1905, 28, 805-814.

1905.5

- A new anarrhichadoid fish [Lycichthys paucidens, n. sp.] Proc. Biol. Soc. Washington, 1905, 18, 251. 1905.6

A new introduction to the study of fishes [Review of the Cambridge Natural History, vol. vii] Science, 1905, 2. ser. 21, 653-661.

1905.7

Note on the genera of synanceine and pelorine fishes. Proc. U. S. Nat. Mus., 1905, 28, 221-225. fig. 1905.8

- Note on the habits of an ophidiid (cusk-eel) Science, 1905, 2. ser. 22, 342. 1905.9

On the generic characteristics of Prionotus stearnsii. Proc. U. S. Nat. Mus., 1905, 28, 339-342. 1905.10

On the habits of the great whale shark (Rhineodon typus) Science, 1905, 2. ser. 21, 790-791.

1905.11

- Origin of freshwater faunas. Abstract in Rept. \& Intern. Geogr. Cong. 1904 (1905), 617.

1905.12

The Sargasso fish not a nestmaker. Science, 1905, 2. ser. 22, 841.

1905.13

- The scorprenoid fish, Neosebastes entaxis, as the type of a distinct genus. Proc. U.S. Nat. Mus., 1905, 28, 219-220. 2 figs.

1905.14

The sculpin and its habits. Smithson. Misc. Collect., 1905, 47, pt. 2, 348-359. fig.

1905.15

- The fish genus Alabes or Cheilobranchus. Science, 1906, 2. ser. 23, 584585 . 1906.1

Le fondule (Fundula cyprinodonta) of Carbonnier an Umbra. Science, 1906, 2. ser. 24, 818-819. 1906.2

Parental care among freshwater fishes. Ann. Rept. Smithson. Instit. 1905 (1906), 403-531. pl.

1906.3 
The remarkable story of a Greek fish, the glanis. Bull. George Washington Univ., 1906, 5, 5-13. 1906.4

The family of cyprinids and the carp as its type. Smithson. Misc. Collect., 1907, 48, pt. 3, 195-217. 13 pls.

1907.1

Life histories of toadfishes (batrachoidids), compared with those of weevers (trachinids) and stargazers (uranoscopids) Smithson. Misc. Collect., $1907,48,388-127.20$ figs. 1907.2

The lumpsucker: its relationship and habits. Smithson. Misc. Collect., $1907,50,175-191$.

1907.3

- Some noteworthy extra-European cyprinids. Smithson. Misc. Collect., 1907, 48, 297-340. 66 figs. 1907.4

-- Stone-gathering fishes. Amer. Naturalist, 1907, 41, 468-469. $\quad 1907.5$

The tarpon and lady-fish and their relatives. Smithson. Misc. Collect., 1907, 48, pt. 3, 31-46. 4 pls.

1907.6

The work of Pterophryne and the flying-fishes. Abstract in Science, 1907 , 2. ser. 25, 63-64.

1907.7

Choerodon in place of Chorops for a labroid genus of fishes. Proc. U. S. Nat. Mus., 1908, 35, 155-156. 1908.1

The millers-thumb and its habits. Smithson. Misc. Collect., 1908, 52, 101116.

1908.2

- Note on the genus Kuhlia. Proc. Acad. Nat. Sci. Philad. 1907 (1908), 59, 150.

1908.3

- Recent discoveries in the history of the common eel. Science, 1908, 2. ser. $28,845-846$.

1908.4

The story of the devil-fish. Smithson. Misc. Collect. 1908, 52, 155180.

1908.5

- Angler fishes: their kinds and ways. Ann. Rept. Smithson. Instit. 1908 (1909), 565-615.

1909.1

The archer-fish and its feats. Smithson. Misc. Collect., 1909, 52, 277 286.

1909.2

Notes on oral gestation in cichlid fishes] Science, 1909, 2. ser. 29, 676.

1909.3

The selachians admitted as a distinct class. Science, 1909, 2. ser. 29, 193-194.
The structural characteristics and relations of the apodal fishes. Science, 1910, 2. ser. 31, 789-790. 1910.1

- A new translation of Aristotle's "History of animals." Science, 1911, 2. ser. 33, 730-738.

1911.1

Notes on the structure and habits of the wolf-fishes. Proc. U. S. Nat. Mus., 1911, 39, 157-187. 11 pls. 1911.2

Systematic zoölogy: its progress and purpose. Proc. 7. Intern. Zool. Congr., Boston, 1907 (1912), 786-806.

See also Mitchill, S. L., 1814.

1912.1

Gill, Theodore Nicholas, \& Bransford, John $F$. Synopsis of the fishes of lake Nicaragua. Proc. Acad. Nat. Sci. Philad., 1877, 175-191.

1877.1

Gill, Theodore Nicholas, \& Ryder, John A. Diagnoses of new genera of nemichthyoid eels [Serrivomer, Spinivomer, Labichthys] Proc. U. S. Nat Mus., 1884, 6, 260-262. 1884.1

- Note on Eurypharynx and an allied new genus. Phil. Anz., 1884, 7, 119-123.

1884.2

On the anatomy and relations of the Eurypharyngida. Proc. U. S. Nat. Mus., 1884, 6, 262-273. 1884.3

On the literature and systematic relation of the saccopharyngoid fishes. Proc. U. S. Nat. Mus., 1885, 7, 4865.

1885.1

Gill, Theodore Nicholas, \& Smith, Hugh $M$. The moringuid eels and their geographical distribution. Proc. Amer. Assoc. Adv. Sci., 49. meet., 1900, 245246.

1900.1

— The moringuid eels in American waters. Science, 1900, 2. ser. 11, 973974.

1900.2

- A new family of jugular acanthopterygians [Caristiidæ] Proc. Biol. Soc. Washington, 1905, 18, 249-250.

1905.1

Gill, Theodore Nicholas, \& Townsend, Charles Haskins. Diagnoses of new species of fishes found in Bering sea. Proc. Biol. Soc. W ashington, 1897, 11, 231-234.

1897.1

- The largest deep-sea fish. Science, 1901, 2. ser. 14, 937-938. 1901.1

Gilleron-Fuhrer,

Die Balchen-Fischerei im Thunersee. Schweiz. Fischereizeitg., 1894, 2, 61. $\quad 1894.1$ 
Gillespie, A. Lochhart. Changes in the digestive activity of the secretions of the alimentary canal of the salmon in different conditions. 18. Ann. Rept. Fish. Board Scotland, 1898, pt. 2, 23-35. pl.

1898.1

Gillespie, Samuel. Growth and food of carp. Bull. U. S. Fish Comm. 1882 (1883), 2, 300 .

1883.1

Gillet de Grandmont, Anatole. Première note sur la pêche de la morue. Brest, 1845.18 p. $8^{\circ}$.

1845.1

Sur l'histoire de la pisciculture Bull. Soc. Acclim. Paris, 1862, 9, 978988. Also separate; Paris, 1862. $8^{\circ}$.

1862.1

Education du saumon dans les lacs. Bull. Soc. Acclim. Paris, 1863, 10, 332-334.

1863.1

La féra, incubation, éclosion, éducation. Bull. Soc. Acclim. Paris, $1863,10,16-20$.

1863.2

- Pisciculture du lac Pavin. Education des saumons. Bull. Soc. Acclim. Paris, 1863, 10, 261-263. 1863.3

Rapport sur les pontes des poissons de mer présenté au nom de la commission des fécondations artificielles. Bull. Soc. Acclim. Paris, 1863, 10, 385395. - Rev. Marit., 1863, 9, 433-443.

1863.4

Rapport sur des études relatives à la pratique des fécondations artificielles. Bull. Soc. Acclim. Paris, 1864, 2. ser. 1, 12-26.

1864.1

Viviers-laboratoires de Concarneau, leur description, leur utilité, leur avenir. Bull. Soc. Acclim. Paris, 1864, 2. sér. 1, 261-269.

1864.2

Gilliams, $J$. Description of a new species of fish of the Linnæan genus Perca [Scolopsis sayanus] Journ. Acad. Nat. Sci. Philad., 1824, n. s. 4, 80-82. pl. Extract in Bull. Sci. Nat. (Férussac), 5, 277-278.

1824.1

Gilliss, James Melvin [1811-1865] Reports upon the fishes and reptiles of Chili. Philadelphia, 1854. $8^{\circ}$, 1854.1

Gilpin, J. Bernard. On the food fishes of Nova Scotia. Proc. Trans. Nova Scotian Instit. Nat. Sci., 1863-70.

1863.1

No. 1. On the common herring [Clupea elongata] 'Trans. Nova Scotian Instit. Nat.Sci., 1862 (1863), 1, pt. 1, 4-11.
No. 2. On the gaspereaux [Alosa tyrannus] Ibid., 1861 (1865), 1, pt. 3, 107-114.

No. 3. The mackerel. Ibid., 1865 (1866), 1, pt. $4,11-17$

No. 1. The trouts and salmons. Ibid., 1865 (1866), 1, pt. 4, 76-91.

No. 5. The cod family. Ibid., 1867 (1868), 2, pt. 2, 101-111.

- Winter quarters of Nova Scotian salmon. Ann. Rec. Sci. (Baird), 1872 (1873), 446.

1873.1

Orthagoriscus mola Couch, taken in Halifax harbor, Oct. 1873. Proc. Trans. Nova Scotian Instit. Nat. Sci. 1873 (1874), 3, pt. 4, 343-344. 1874.1

- Mackerel on the Nova Scotia coast. Forest \& Stream, 1878, 10, 420.

1878.1

Gilpin, John. On the annual passage of herrings. Trans. Amer. Phil. Soc., 1786, 2, 236-239. map. - Leipziger Magazin, 1785, 90-95. $\quad 1786.1$

Gilson, Gustave. L'anguille, sa reproduction, ses migrations et son intérêt économique en Belgique. Ann. Soc. Roy. Malacol. Belgique, 1908, 43, 7-58. 3 figs.

1908.1

Capture d'un Leptocephalus morrisii au cap Grisnez. Ann. Soc. Roy. Malacol. Belgique, 1908, 43, 132-138.

1908.2

Giltay, Carel Marinus, Commentatio de Esoce lucio, neurologice descripto et cum reliquis vertebratis animalibus comparata. Lugduni Batavorum, 1832. 5 pls. $4^{\circ}$.

1832.1

Gindce, $B . K$. Die Fischerei in den Donaumuindungen [Text in Russian] Trd. Jub. Akklim. Sjězda, Moskva, 1909, 2 (Sekc. Ichtiol.), 95-111. 1909.1

Gintel, Frederic. Fecundation of the eggs of Clinus argentatus. Rev. Scient., août, 1892 .

1892.1

Giordano, D. Ittiologia del golfo di Gaeta. Napoli, 1890. 65 p. $4^{\circ} .1890 .1$

Giorna, Michel Esprit. Eclaircissement sur un poisson accidentellement épineux [Cyprimus idus L.] qu'on trouve dans les rivières de la $27 i e ̀ m e$ division militaire [Piémont] Mém. Acad. Sci. Turin, 180t-05, 12 \& 13, 229-234.

1804.1

Mémoire sur cinq poissons, dont deux sont d'espèces nouvelles, savoir une grande raie, et un baliste, qui ont été nommés et insérés par le célèbre Lacépède dans la seconde partie du vol. 
5 de son "Histoire des poissons," et les trois autres sont de nouveaux genres. Mém. Acad. Sci. Turin, 1804, 8. 1804.2 Grande raie. Mém. Acad. Sci. Turin, 1805, 2, 4. 1805.1

Mémoire sur des poissons d'espèces nouvelles et de genres nouveaux. Mém. Accad. Sci. Turin, 1805, 2, 1-19; $177-180$.

1805.2

Giovene, $G$. M. Di alcuni pesci del mare di Puglia. Mem. Soc. Italiana, 1829, 20, 21-42. Supplemento. Ibid., 336-346.

1829.1

Girard, Albert Alexandre. Catalogo dos mammiferos, peixes, molluseas e crustaccos colhidos na costa e rios do Algarve. Lisbon, 1892. fol. 1892.1

Description d'un Echeneis nouveau des côtes du Portugal. Boll. Soc. Geogr. Lisbon, 1893, 11, 611-615. pl.

1893.1

Etude sur un poisson des grandes profondeurs, du genre Himantolophus, dragué sur les côtes du Portugal. Boll. Soc. Geogr. Lisbon, 1893, 11, 603-610. pl.

1893.2

- Note sur un poisson-lune (Orthagoriscus mola L.), de grandes dimensions, capturé sur les côtes du Portugal. Ann. Sci. Nat. Porto, 1894, 1, 31-33.

1894.1

Sur Saccopharynx ampullaceus des grandes profondeurs de l'Atlantique, et Halargyreus johnsoni. Lisbon, 1895. 4 pls. $4^{\circ}$.

1895.1

Girard, Charles Frédéric [1822-1895] For biography and bibliography, see Goode, G. B., in Bull. U. S. Nat. Mus., 1891, no. 41.141 p.

A monograph of the freshwater Cotti. Proc. Amer. Assoc. Adv. Sci., 2. meet., 1849 (1850), 409.

1850.1

-... On the genus Cottus auct. Proc. Boston Soc. Nat. Hist. 1848 (1851), 3, 183-190.

1851.1

- Some additional observations on the nomenclature and classification of the genus Cottus. Proc. Boston Soc. Nat. Hist. 1848 (1851), 3, 302-305.

1851.2

Bibliography of fishes, 1851 (In his American zoological, botanical and geological bibliography for 1851. Amer. Journ. Sci., 1852, 2. ser. 13, app.)

1852.1
Contributions to the natural history of the freshwater fishes of North America. I. A monograph of the cottoids. Smithson. Contrib. Knowl., 1852,3 , art. 3.80 p. 3 pls. 1852.2

— Révision du genre Cottus des auteurs. Nouv. Mém. Soc. Helvet. Sci. Nat., 1852, 12, 28. Also separate; Zurich, 1852. $4^{\circ}$. 1852.3

- Fishes (In Marcy and McClellan's exploration of the Red river of Louisiana in the year 1852 . Washington, 1853. $8^{\circ}$ ) 1853.1

_... Fishes (In Sitgreaves' Report of an expedition down the Zuñi and Colorado rivers. Washington, 1853. $\mathrm{S}^{\circ}$ )

1853.2

-.-Description of new species of fishes collected by Capts. R. B. Marcy and Geo. B. MeClellan in Arkansas. Proc. Acad. Nat. Sci. Philad. 1853 (1854), 6, 390 .

1854.1

- Descriptions of new species of fishes collected by Mr. John H. Clark, on the United States and Mexican Boundary survey, under Col. J. D. Graham. Proc. Acad. Nat. Sci. Philad. 1852 (1854), 6, 387.

$185 \pm .2$

Deseriptions of some new fishes from the river Zuñi. Proc. Acad. Nat. Sci. Philad. 1853 (1854), 6, 368-369.

$$
1854.3
$$

- Note upon a nest constructed by catfish. Proc. Acad. Nat. Sci. Philad. 1853 (1854), 6, 387.

1854.4

Observations upon the American species of the genus Esox. Proc. Acad. Nat. Sci. Philad. 1853 (1854), 6, 386.

1854.5

On a new genus of American cottoids. Proc. Boston Soc. Nat. Hist. 1851 (1854), 4, 18-19. 1854.6

- On a new species of the genus Salmo. Proc. Acad. Nat. Sci. Philad. 1853 (1854), 6, 380 .

1854.7

- On the Salmo oquassa, nova species. Proc. Boston Soc. Nat. Hist. 1851-54 (1854), 4, 262-263. 1854.8

Report to Lieut. James M. Gilliss, U. S. N., upon the fishes collected by the U. S. Naval Astronomical Expedition to the southern hemisphere during the years 1849-50-51-52. 2 vols. Washington, 1855. 42 pls. 9 maps. $4^{\circ}$.

1855.1 
Girard, $C . F$. Abstract of a report to Lieut. James M. Gilliss, U. S. N., upon the fishes collected during the U. S. Naval Astronomical Expedition to Chili. Proc. Acad. Nat. Sci. Philad. 185 $1-55$ (1856), 7, 197-199.

1856.1

Characteristics of some cartilaginous fishes of the Pacific coast of North America. Proc. Acad. Nat. Sci. Philad. 1854-55 (1856), 7, 196-197.

1856.2

Description of new species of fishes from the state of Massachusetts. Proc. Boston Soc. Nat. Hist. 1854-56 (1856), 5, 40 .

1856.3

Descriptions of new fishes collected by A. L. Heermann, naturalist attached to the survey of the Pacific railroad, under Lieut. R. S. Williamson, U. S. A. Proc. Acad. Nat. Sci. Philad. 1854-55 (1856), 7, 129-140. 1856.4

Enumeration of the species of marine fishes collected at San Francisco, California, by Dr. C. B. R. Kennerly, naturalist attached to the survey of the Pacific railroad route under Lieut. A. IV. Whipple. Proc. Acad. Nat. Sci. Philad. 1851-55 (1856), 7, 141-142.

1856.5

Notice of a new species of Salmonidx [Salmo gloverii] from the northeastern part of the United States. Proc. Acad. Nat. Sci. Philad. 1854-55 (1856), 7, 85-86.

1856.6

Notice upon the viviparous fishes inhabiting the Pacific coast of North America, with an enumeration of the species observed. Proc. Acad. Nat. Sci. Philad. 1854-55 (1856), 7, 318323. - Arch. Naturgesch., 21, 342-354.

1856.7

Observations upon a collection of fishes made on the Prcific coast of the United States by Lieut. W. P. Trowbridge, U.S. A., for the Museum of the Smithsonian Institution. Proc. Acad. Nat. Sci. Philad. 1854-55 (1856), 7, 142156.

1856.8

[On the Embiotocidæ] Proc. Boston Soc. Nat. Hist. 1854 (1856), 5, 81-82.

1856.9

Contributions to the ichthyology of the western const of the United States, from specimens in the museum of the Smithsonian Institution. Proc. Acad. Nat. Sci. Philad. 1856 (1857), 8, 131-137.
A list of the fishes collected in California by Mr. E. Samuels, with descriptions of the new species. Boston Journ. Nat. Hist. $1850-57$ (1857), 6 , 533-541. 4 pls.

1857.2

- Notice upon the species of the genus Salmo of authors, observed chiefly in Oregon and California. Proc. Acad. Nat. Sci. Philad. 1856 (1857), 8, $217-220$.

1857.3

- On "Acanthocotti" in Storer's Fishes of Nova Scotia. Boston Journ. Nat. Hist. 1850-57 (1857), 6, 247-250.

1857.4

On "Gasterostei" in Storer"s Fishes of Nova Scotia. Boston Journ. Nat. Hist. 1850-57 (1857), 6, 254-260.

1857.5

Report upon fishes collected on the survey (In Report of Lieut. Henry L. Abbot, upon explorations for a railroad route from the Sacramento valley to the Columbia river, made by Lieut. R. S. Williamson assisted by Lieut Henry L. Abbot. U. S. Senate Miscell Doc. no. 78, 1857, 33. Congr., 2. Sess. no. 1, 11-31. 11 pls.)

1857.6

Researches upon the cyprinoid fishes inhabiting the fresh waters of the United States west of the Mississippi valley, from specimens in the museum of the Smithsonian Institution. Proc. Acad. Nat. Sci. Philad. 1856 (1857), 8, 165-213. 1857.7

Pages 209-213 of this paper are occupied with an appendix in which descriptions are given of several new cyprinoid species from the eastern United States.

Ichthyology (In United States and Mexican boundary survey, under the order of Lieut. Col. IV. H. Emory, Major first cavalry and United States commissioner, vol. ii, pt. 2, 1-85. 41 pls. Washington, 1858-59. 2 vols. $\left.4^{\circ}\right)$

1858.1

Notice upon new genera and new species of marine and freshwater fishes from western North America. Proc. Acad. Nat. Sci. Philad. 1857 (1858), 9, 200-202. 1858.2

Fishes (In General report upon the zoology of the several Pacific railroad routes, 1857. U. S. Senate Miscell. Doc. no. 78, 1859, 33. Congr., 2. Sess. xiv, 400 p. 27 pls.) 1859.1

Also published separately under the title of Fishes of North America, observed on a survey for a railroad route from the Mississippi river to the Pacific ocean. Washington, 1858. 2] pls. $4^{\circ}$. 
Ichthyological notices. Proc. Acad. Nat. Sci. Philad. 1858 (1859), 223-225. Ibid., 1859 (1860), 56-68; 100$104 ; 113-122 ; 157-161$.

1859.2

Notes upon various new genera and new species of fishes, in the museum of the Smithsonian Institution, and collected in connection with the United States and Mexican Boundary Survey, Major William Emory, Commissioner. Proc. Acad. Nat. Sci. Philad. 1858 (1859), 167-171

1859.3

- Report on fishes collected on the survey (In Report of explorations for a railroad route near the $32 \mathrm{nd}$ parallel of north latitude, lying between Doña Ana, on the Rio Grande, and Pimas villages, on the Gila, by Lieut. John G. Parke, 1855. U. S. Senate Miscell. Doc. no. 78, 1859, 33. Congr., 2. Sess., no. 4, 83-91. 10 pls.) 1859.4

Report on fishes collected on the survey (In Report of Lieut. E. G. Beckwith, upon explorations for a railroad route, near the 38 th and 39 th parallels of north latitude, by Captain J. W. Gunnison, and near the 41 st parallel of north latitude, by Lieut. E. G. Beckwith. U. S. Senate Miscell. Doc. no 78, 1859, 33. Congr., 2. Sess., no. 4, 2127. $6 \mathrm{pls}$.)

1859.5

Report upon fishes collected on the survey (In Report of explorations for a railway route (near the 35 th parallel of north latitude) from the Mississippi river to the Pacific ocean, by Lieutenant A. W. Whipple assisted by Lieut. J. C. Ives, 1853-54. U. S. Senate Miscell. Doc. no. 78, 1859, 33. Congr., 2. Sess., no. 5, 47-59. 13 pls.) 1859.6

- Les poissons aveugles des cavernes américains. Le Naturaliste, 1888 , 10, 107-108. fig。

1888.1

__ Les poissons souterrains du nouveau-monde. Le Naturaliste, 1888, $10,222$.

1888.2

L La faune souterraine des Andes et de la Cordillère. C. R. Congrès Intern. Zool., Paris, 1889, 110-113.

1889.1 Les poissons musiciens. Le
Naturaliste, $1889,11,57-58$. fig. 1889.2 Les poissons musiciens. Le
Naturaliste, $1889,11,57-58$. fig. 1889.2

Les poissons souterrains du nord de l'Afrique. Le Naturaliste, 1889, 11, 103-106. 5 figs.

1889.3

__ La maladie du barbeau (Barbus vulgaris L.) Le Naturaliste, 1890, 12, 254.

1890.1
Les poissons vivipares de la côte américaine de l'océan Pacifique. Le Naturaliste, $1590,12,24-25 ; 39 ; 61-$ 62. figs.

1890.2

Girard, Charles, \& Baird, Spencer Fullerton. See Baird \& Girard.

Girard, Charles, Suckley, George, \& Agassiz, Louis. Fishes of North America. 6 pts. Washington, 1857-59. 84 pls. $4^{\circ}$.

1857.1

Girard, Joseph, \& Pettit, Auguste. See Pettit \& Girard.

Girard, O. France et Chine, vie publique et privée des Chinois anciens et modernes, passé et avenir de la France dans l'extrème Orient. 2 vols. Paris. 1869. $8^{\circ}$.

1869.1

Contains an account of methods of fishing among the Chinese.

Girardet, - - \& Girardet, Lac de Neuchâtel; énumération des poissons qui s'y trouvent. Neuchâtel, 1797. 3 p. $24^{\circ}$

1797.1

Girardi, Michele. Saggio di osservazioni anatomiche intorno agli organi elettrici della torpedine. Mem. Soc. Ital. Sci., Verona, 1786, 3, 553-570.

1786.1

Girardin, J., \& Marchand, Ernest. Analyse des saumures de hareng et de leur emploi en agriculture. Journ Pharm. 1860, 37, 89-10t. - Journ Agric. Prat., 1, 186-192.-C. R. Acad. Sci. Paris, 50, 273-279, - Mém. Soc. Imp. Sci. Agricult. Arts, Lille, 1859 (1860), 2. sér. 6, 235-250. 1860.1

Girardin, $J . \&$ Preisser, $F$. Observations sur l'épuration et la désinfection des huiles de poisson. Trav. Acad. Rouen, 1841, 100-113.

1841.1

Examen chimique de l'huile de foie de raie [Raia clavata et $R$. batis] Trav. Acad. Rouen, 1842, 102-106. Journ. Prak. Chem., 26, 399-103.Journ. Pharm., 1, 503-507. - Annal. (Liebig), 44, 320-321. - C. R. Acad. Sci. Paris, 14, 618-621.

1842.1

Giraud-Teulon, Marc Antoine Louis Félix [1816-1887] Du principe qui préside au mécanisme de la natation chez les poissons et du vol chez les oiseaux. C. R. Acad. Sci. Paris, 1856, 43, 10341035.

1856.1

Girdwoyn, Michal. Nieco o przyrodzie lososia pospolitego (Trutta salar L.) i sposobach jego cechowania w Anglii 
Girdwoyń, $M$.

[Einige Worte über die Natur des Lachses (T'rutta salar) und die Bezeichnungsweiso desselben in England] Warsaw, 1878, $3 \mathrm{p}, 4^{\circ}$. 1878.1

- Pathologie des poissons. Maladies, monstruosités et anomalies des oufs et des embryons. Paris, 1880. $19 \mathrm{p} .11 \mathrm{pls}$. $4^{\circ}$. 1880.1

Girgensohn, Otto Gottlieb Leonhard [1784-1853] Anatomie und Physiologie des Fisch-Nervensystems. Mém. Acad. Imp. Sci. St. Pétersb., 1846, 5, 278-589. $15 \mathrm{pls}$.

1846.1

Girod, Paul. Les poissons d'après Aristote; leurs applications à l'hygiène et à la thérapeutique d'après les médecins grecs, d'Hippocrate à Actuarius. Inaug. Dissert. Paris, 1880. 88 p. 1880.1

Gissler, Nils. Blennius capite dorsoque fulvo-flavescente, lituris nigris, pinna ani flava, descriptus. Anat. Transalp., [n. d.] 1, 485.

Not seen; title from L. Agassiz.

Giussani, C.A. A list of works, essays, ete. relating to Japan. Trans. Asiat. Soc. Japan, 1886, 14, pt. 2, 87118.

1886.1

Contains references to Japanese publications on fishes.

Gjers, Carl Robert. Fiskodlingen förordad i Finland för ett sekel sedan. Tidskr. Fiskerin. \& Aquikultur (Malmgren), 1869, 1. Jahrg., 36-37. 1869.1

Gladwin, Charles O. Black bass in the Connecticut. Forest \& Stream, $1876,6,300$.

1876.1

- Salmon in the Connecticut. Forest \& Stream, 1876, 6, 300. $\quad 1876.2$

Shad netting in the Connecticut near Higganum. Forest \& Stream, $1876,6,234$.

1876.3

- Size of the black bass of Florida. Forest \& Stream, 1879, 12, 15. 1879.1

Glaesner, Leopold. Die Gastrulation von Petromyzon und die "Concresscenz"-Frage. Zool. Anz., 1910, 35, 728-733. 2 figs.

1910.1

- Studien zur Entwicklungsgeschichte von Petromyzon fluviatilis. Furchung und Gastrulation. Zool. Jahrb., 1910, 29, 139-190. 2 pls. \& 31 figs.

1910.2

Glässel, Wilhelm. Ueber die Goldfischzucht im Aquarium. Blätt. Aquar.-
Terrar. Kunde, 1911, 22. Jahrg., $300-$ 301.

1911.1

Glage, Friedrich. Ueber die Bedeutung der Haifische für die Fischbeschau Zeitschr. Fleisch.-Milchhyg., 1902, 13. Jahrg., 37-41.

1902.1

Glaize, E. P., \& Pellegrin, $J$. See Pellegrin \& Glaize.

Glangeaud, $P h$. Les poissons et les reptiles du Jurassique des environs de Poitiers, d'Angoulême et de la Rochelle. Bull. Soc. Géol. France, 1896, 3. sér. 24 , 155-171. 2 pls. \& fig. Abstract in C. R Soc. Géol., no. 6, lx-1xii.

1896.1

Glaser, Friedrich . Fischerei-Verhältnisse im Ober-Rhein zwischen Basel und Schaffhausen. Deutsch. Fischerei Zeitg., 1878, 1. Jahrg., 90. 1878.1

Glaser, Ludwig [1818-1898] [Nest des Stichlings im Aquarium] Zool. Garten, 1865, 6. Jahrg., 189-192. 1865.1

- Account of teleosts in his aquarium] ['Text in German] Zool. Garten, 1866, 7. Jahrg., 113-115; 272-274.

1866.1

Glaser, Otto C. Movement and problem solving in Ophiura brevispina. Journ. Exper. Zool., 1907, 4, 203-219. 5 figs. \& 6 tables.

1907.1

- Changes in chemical energy during the development of Fundulus heteroclitus. Science, 1912, n. s.35, 189 191.

1912.1

- Die Entwicklungsarbeit des Fundulus heteroclitus] Math. Naturw. Anz. Budapest, 1912, 30, 927-928. $\quad 1912.2$

_- Die Entwicklungsarbeit im Fundulusei. VIII. Beitrag zur Energetik der Ontogenese. Biochem. Zeitschr., Berlin, 1912, 44, 180-184. 1912.3

Glazier, $W . C . W$. On the destruction of fish by polluted waters in the gulf of Mexico. Smithson. Miscell. Coll. 1882, 22, art. 2, 126-127. 1882.1

Gleason, Henry Allan, \& Hart, Charles A. See Hart \& Gleason.

Gleditsch, Johann Gottlieb [17141786] Exposition abrégée d'une fécondation artificielle des truites et des saumons, qui est appuyée sur des expériences certaines, faites par un habile naturaliste, traduite de l'allemand. Mém. Acad. Sci. Berlin, 1764, 20, 47.

1764.1 
Glennan, A. $H$. Fish killed by poisonous water. Bull. U. S. Fish Comm. 1886 (1887), 6, 10-11.

1887.1

Gley, $E$. Recherches sur le sang des sélaciens. Action toxique du sérum de torpille (Torpedo marmorata) Bull. Mus. Hist. Nat. Paris, 1904, 10, 282-284. C. R. Acad. Sci. Paris, 138, 1547-1549.

1904.1 \& Gley.

Gley, E., \& Camus, L. See Camus

\section{Glinsky,}

Zur Kenntniss des Baues der Magenschleimhaut der Wirbelthiere. Centralbl. Medic. Wissens., 1883.

1883.1

Gloede, Herman. Der Neunaugenfang bei Fiddichow. Deutsch. Fischerei Zeitg., 1880, 3.Jahrg., 485-486. 1880.1

Gloenkler, $K$. Vom Untersee. Schweiz. Fischerei Zeitg., 1895, 3, 218. Also separate; Pfäffikon-Zürich, 1895. 3 p. $8^{\circ}$.

1895.1

Glogau, Henrik. Ueber den Fang eines Störs in Schweden. Zool. Garten, $1863,4,20$.

1863.1

Gloger, Constantin W. Lambert. Schlesiens Wirbelthier-Fauna; ein systematischer Ueberblick der in dieser Provinz vorkommenden Säugethiere, Vögel, Amphibien und Fische, mit Rücksicht auf den allgemeinen Charakter des Landes, sowie auf das locale und quantitative Vorkommen seiner Thiere, namentlich mit Angabe ihres Ansteigens auf Berghöhen und ihrer wichtigsten Abänderungen. Breslau, 1833. $8^{\circ}$.

1833.1

Glover, Thomas, An account of Virginia. Phil. Trans. Roy. Soc. London [1836] no. 126, 623 .

1836.1

Contains a list of the fishes of Virginia and describes the Indian mode of fishing by firelighting.

Glowacki, Julius. Die Fische der Save und des Isonzo. 1. Jahresber. Staats-Untergymnasium Cilli, 1895-96 (1896), 1-37. Abstract in Verh. Zool. Bot.Ges. Wien, 47, 197-198. 1896.1

Gluge, $G$. Sur quelques points d'anatomie pathologique comparée, suivie de quelques observations sur la structure des branchies dans les épinoches. Bull. Acad. Roy. Belgique, 1838, 5, 771-782.

1838.1

Beobachtung zahlreicher Balggeschwülste als epidemische Krankheit bei Fischen. Anat. Mikr. Untersuch. Allgem. Path., 1841, 2.
Gmelin, Carl Christian [1762-1837] Gemeinnützige systematische Naturgeschichte der Fische. 2. Auflage. Mannheim, 1829. 28 pts. 164 figs. $8^{\circ}$.

1829.1

The first edition of this work was published in 1818 , and a third was published in $1839.406 \mathrm{p}$.

Gmelin, Johann Frederick [17481801] Caroli a Linné ... Systema Naturæ per regna tria naturæ, secundum classes, ordines, genera, species, cum characteribus, differentiis, synonymis, locis. Tomus I [-] III. Editio decimo tertia, aucta, reformata. Cura Jo[annis] Fred[erico] Gmelin. 3 vols. in 9 parts. Lipsix, 1788-93. 1788.1

The three volumes of this alleged edition of Linnæus, being very much amplified, were divided into parts, with half titles, for binding, of which the first is devoted to the Regnum Animale, and contains the part (p. 1126-1516) which treats of fishes. Tomus ii deals with the Regnum Vegetabile, and Tomus iii with the Regnum Lapideum

Dr. T. N. Gill's comments on this work are as follows:

This edition is noticed under the date of 1788 and the name of Gmelin, as that naturalist is alone responsible for the incorporation of the many species described since the last edition of the Systema Naturæ revised by Linne. The compilation displays very little acquaintance with any branch of zoology, and species are incorporated into the system in defiance of the characters of the groups to which they are recharacters of the groups to which they are re-
ferred. This is evidently the result of blind confidence in the accuracy and powers of discrimination of those whose species were incorporated by him into the System, as he did not hesitate to adopt their views as to generic relations, however much the inherent evidences of their own descriptions might oppose their views." - Smithson. Miscell. Collect., 1872, 11, 37.

Gmelin, Samuel Gottlieb [1743-1774] Reise durch Russland, zur Untersuchung der drey Naturreiche in den Jahren 1769 und 1770 , mit einer Vorrede, herausgegeben von P.G. Pallas, 4 vols. St. Petersburg \& Leipzig, 1770-74. 147 pls. $8^{\circ}$.

1770.1

Gobin, Alphonse [1828-] Note sur les resources que présente actuellement le Haut-Rhône au point de vue de la pêche. Lyon, 1869. $8^{\circ}$ 1869.1

La pisciculture d'eau douce et salée à l'exposition universelle de 1878 . Paris, 1879. 90 p. 34 figs. $8^{\circ} .1879 .1$

La pisciculture en eaux douces. Paris, 1889. 93 figs. $12^{\circ}$. 1889.1

La pisciculture en eaux salées. Paris, 1891. figs. $12^{\circ}$. 1891.1

Gobin, Alphonse, \& Guénaux, G. La pisciculture en eaux douces. Paris, 1907. 348 p. illust. $12^{\circ}$. 1907.1 
Gobley, _ Recherches chimiques sur les cufs de carpe. Journ. Pharm. 1850, 17, 401-417. Ibid., 18, 107-119.

1850.1

Recherches chimiques sur la laitance de carpe. Journ. Pharm., 1851, $19,406-421$

1851.1

God, Arthur. L'amiure ou poissonchat. La Nature, 1902, 30, pt. 2, 2S3284. fig.

1902.1

Goddard, Malcolm. Fish remains from the marine Lower Triassic of Aspen ridge, Idaho. Univ. California Publ. Bull. Geol., 1907, 5, 145-148. 5 figs.

1907.1

Goddschild, — Om den nye sildeform ved hvaloerne. Morgenbladet, Christiania, 1872, no. 251 B. $\quad 1872.1$

Godenier, $C . E . P$. De la fécondation et de l'éclosion artificielles des œufs de poissons et de l'éducation du frai, suivant le procédé de MM. Géhin et Rémy. Grenoble \& Paris, 1852. 22 p. $8^{\circ}$.

1852.1

Treatise on the artificial fecundation and incubation of the eggs of fish, and the rearing of the young fish, according to the processes of Messrs. Gehin and Remy (In Fry, W. H. editor. A complete treatise on artificial fish-breeding, p. 7-28. Paris, 1866. $\left.12^{\circ}\right)$

1866.1

Godet, Philippe. Sur le Ceratodus forsteri. Bull. Soc. Sci. Nat. Neuchâtel, $1880,12,334-335$.

1880.1

L’anguille (Anguilla vulgaris L.) et son développement. Bull. Soc. Sci Nat. Neuchâtel, 1899, 26, 78-88. pl.

1899.1

Godlewsk, Emil. Bemerkungen zu der Arbeit von H. H. Newman: "Further studies of the process of heredity in Fundulus hybrids." Arch. Entw.Mech. Organ., Leipzig, 1910, 31, 335338.

1910.1

Godman, Frederick Ducane [1834-] Natural history of the Azores. London, 1870. 358 p. 2 maps. $8^{\circ}$. 1870.1

Godon, $J$ Contributions à la faune du nord; amphibiens et poissons. Feuille Jeunes Natural., Paris, 1905, 4. sér. 36, p. 47.

1905.1

Contributions à la faune des vertébrés de la région du nord. Feuille Jeunes Natural., Paris, 1908, 4. sér. 38, 83-84; 142.

1908.
Godron, Dominique Alexandre [18071880] Zoologie de la Lorraine [poissons] Mém. Acad. Stanislas Nancy, 1862, 355628.

1862.1

Goebel, $F$. Ueber den Silbergehalt der Fischschuppen. Bull. Soc. Nat. Moscou, 1836, 9, 326-328. 1836.1

Goebel, $H$. Stor sillen, Ammodytes lanceolatus, ved Murmankysten [Ammodytes lanceolatus on the Murman coast] Norsk Tidskr. Fiskeri, 1906, 25, 172.

1906.1

Goebel, $J$., Breitfuss, L. L., Soldatov, V.K., \& others. See Breitfuss, Soldatov \& others.

Goeldi, Emil August. Kopfskelett und Schultergürtel von Loricaria cataphracta, Balistes capriscus und Acipenser ruthenus. Vergleichend-anatomische und entwicklungs-geschichtliche Studien zur Deckknochenfrage. Jena. Zeitschr. Naturw., 1884, 17 (n. s. 10), 401-447. 3 pls. Abstract in Zool. Anz., 6, 420 422.

1854.1

- Piscicultura na China. Versao portugueza do original allemão do Sñr. M. von dem Borne (Thaer-bibliothek), 1885. Rev. Agric. Instit. Flumin. Agric. Rio de Janeiro, 1888, 19, 196-200.

1888.1

(editor) Cartas ineditas de Louis de Agassiz relativas á viagem por elle realisada na Amazonia de 2 dt Agosto de 1865 até 26 de Março 1866. Bol. Mus. Paraense Hist. Nat. Pará, 1894, 1, 144-156.

1894.1

A Lepidosiren paradoxa descoberta na ilha de Marajo. Bol. Mus Paraense Hist. Nat. Pará, 1896, 1, 438442. map. Abstract in Nature, 54, 270. - Naturw. Wochenschr., 1897, 12, no. $27,319$.

1896.1

Peixes (In his Instruccões praticas sobre o modo de colligir productos da natureza para o Museu Paraense de historia natural e ethnographia. Bol. Mus. Paraense Hist. Nat. Pará, 1896, 1. 239-243. pl.)

1896.2

- Further notes on the Amazonian Lepidosiren. Proc. Zool. Soc. London, 1895, 852-857. 3 figs.

1898.1

Lepidosiren paradoxa. Bol. Mus. Paraense Hist. Nat. Pará, 1897 (1898), 2, 247-250.

1898.2

On the Lepidosiren of the Amazons; being notes on five specimens ob- 
tained between 1895-97, and remarks upon an example living in the Pará Museum. Trans. Zool. Soc. London, 1898, 14, pt. 7, 413-420. 2 pls. Abstract in Proc. Zool. Soc. London, 1897, 921.

1898.3

Primeira contribuição para o conhecimento dos peixes do valle do Amazonas e das Guyanas; estudos ichthyologicos dos annos 1894-1898. Bol. Mus. Paraense Hist. Nat. Pará, 1897 (1898), 2, 443-488. pl.

1898.4

Die Fischwelt des AmazonasGebietes; Doppel-Vortrag gehalten vor der naturforschenden Gesellschaft in Bern (Schweiz) Prometheus, Berlin, $1900,11,275-280 ; 473-474 ; 487-491$; 505-509. 27 figs.

1900.1

Naturwunder der Insel Marajo am Amazonenstrom; Vortrag gehalten am 29 Juni 1899 vor der Geographischen Gesellschaft in Bern. Die Schweiz, Zürich, 1900, 546-551; 589-593. illust.

1900.2

A piraiba gigantesco siluroideo do Amazonas (Piratinga pirá-ä̈ba Goeldi, adulto $=$ Piratinga filamentosa Lichtenstein juv.) Bol. Mus. Paraense Hist. Nat. Pará, 1901 (1902), 3, 181-194. 2 pls. 1902.1

Nova zoologica aus der Amazonas-Region. Neue Wirbeltiere. C.R. 6. Congr. Internat. Zool. Berne, 1905, $542-549$.

1905.1

Goenry, — Les wagons spéciaux affectés au transport des poissons vivants. Rev. Gén. Chemins de Fer, Paris, 1902, 2. sér. 25, 292-298.

1902.1

Goeppert, Ernst. Die Entwicklung des Pankreas der Teleostier. Morphol. Jahrb., 1893, 20, 90-111. figs. 1893.1

Untersuchungen zur Morphologie der Fischrippen. Morphol. Jahrb. 1895, 23, 145-217. 3 pls. \& figs. 1895.1

Bemerkungen zur Auffassung der Morphologie der Rippen in Rabl's "Theorie des Mesoderms." Morphol. Jahrb., 1897, 25, 244-249. 1897.1

Der Kehlkopf von Protopterus annectens (Owen) Anatomische Untersuchung (In Festschrift zum siebzigsten Geburtstage von Ernst Haeckel, p. 115-132. pl. \& 5 figs. Jena, 1904) Denkschr. Jena. Med. Gesell., 1904, 2. 465-522. 7 pls.
Goeppert, Heinrich Robert, \& Meyer, Hermann von. Index Palaontologicus (In Bronn, H. G. Handbuch einer Geschichte der Natur, 1848-49, vol. iii, 2 pts. Stuttgart, 1841-49. $8^{\circ}$ ) 1848.1

Goertz, $A$. Ueber in Japan vorkommende Fisch- und Lack-Vergiftungen. Med. Wochenschr. St. Petersb., 1878, 3, 94-96; 101-102.

1878.1

Go̊schke, Franz. Goldfischzucht. Deutsch. Fischerei Zeitg., 1879, 2. Jahrg., 172-173.

1879.1

Goette, Alexander [1840-] Zur Entwicklungsgeschichte der Wirbeltiere. Vorläufige Mitteilung. Centralb. Med. Wiss., 1869, no. $26 . \quad 1869.1$

Beiträge zur Entwickelungsgeschichte der Wirbelthiere. Arch. Mikr. Anat., 1873-78.

1873.1

I. Der Keim des Forelleneies. Ibid., 1873, 9, 679-708. pl.

III. Ueber die Entwickelung des Centralnervensystems der Teleostier. Ibid., 1878, 15, 139-157.

IV. Ueber die Sinnesplatte der Teleostier. Ibid., $157-180$.

V. Ueber die Entwickelung der Wirbelsaite bei Teleostiern und Amphibien. Ibid., 180-200. $+\mathrm{pls}$.

Zur Entwicklung der Kopfniere der Teleostier (In his Die Entwicklungsgeschichte der Unke. Leipzig, 1875. 964 p. 22 pls. $8^{\circ}$ ) 1875.1

Beiträge zur vergleichenden Morphologie des Skeletsystems der Wirbelthiere. Arch. Milkr. Anat., 187879.

1878.1

I. Die Cyklostomen. Ibid., 1878, 15, 316340: 428, pl.

II. Die Ganoiden. Ibid., 442-461. pl. pls

IV. Chimæra. Ibid., 531-541.

V. Die Teleostier, Ibid, $1879,16,117-152$ 2 pls.

Entwicklung des Centralnervensystems der Teleostier. Bonn, 1878. 4 pls. $8^{\circ}$.

1878.2

Zur Entwickelungsgeschichte der Teleostierkieme. Zool. Anz., 1878, 1 , 52.

1878.3

Zur Morphologie des Wirbelsystems. I-II. [Neunaugen und Teleostier] Zool. Anz., 1878, 1, 11;29. 1878.4

Ueber die Entstehung und die Homologien des Hirnanhangs. Zool. Anz., 1883, 6, 344-347. 1883.1

Ueber die Entwicklung von Petromyzon fluviatilis. Vorläufige Mitteilung. Zool. Anz., 1888, 11, 160-163.

1888.1 
Goette, $A$.

Entwicklungsgeschichte

des

Flussneunauges (Petromyzon fluviatilis) (In his Abhandlungen zur Entwicklungsgeschichte der Tiere, 1890, 5. Heft. 95 p. 9 pls. Hamburg \& Leipzig, 1882-90. 5 Hefte. $\left.4^{\circ}\right)$

1890.1

Ueber den Ursprung der Wirbelthiere. Verh. Deutsch. Zool. Gesell., 1895, 5, 12-30.

1895.1

Ueber die Kiemen der Fische. Zeitschr. Wiss. Zool., 1901, 69, 533-577. 4 pls. \& fig.

1901.1

Lehrbuch der Zoologie. Leipzig, 1902. 512 figs.

1902.1

Fische, p. 312-418.

Ueber den Ursprung der Lungen. Zool. Jahrb. (Abth. Anat.), 1904, 21, 141160. figs.

1904.1

Review by $R$. von Hanstein in Naturw. Rundsch., 20. Jahrg., 159-160.

Ueber den Einfluss gesteigerter IVärme auf die Fische. Arch. Hygiene, München, 1909, 70, 293-298.

1909.1

Mittheilung über die Entstehung der Kopfnerven bei Fischen und Amphibien] Zool. Anz., 1913, 42, 58-60.

1913.1

Die Entwicklung der Kopfnerven bei Fischen und Amphibien. Arch. Mikr. Anat., 1914, 85, pt. 1, 1-165. 10 pls. \& 6 figs.

1914.1

Goettig, L. Der Fang des Herings und die Ursachen seiner Abnahme an Schleswigs Ostküste. Deutsch. Landw. Presse, 1875, 2. Jahrg., 646.

1875.1

Goeze, Johann August Ephraim [1731 -1793] Von den Fisch-Lernäen. Leipziger Mag. Naturk., 1784, 1, 39. 1784.1

Europäische Fauna oder Naturgeschichte der Europe; Thiere in angenehmen Geschichten. 9 vols. Leipzig, 1791-1803. $8^{\circ}$.

1794.1

Bd. vii, Fische.

Goffin, A. Les pêcheries et les poissons du Congo belge. Bruxelles, 1909

1909.1

Gogorza y Gonzalez, José. Peces de las islas Filipinas. Anal. Soc. Española Hist. Nat., Madrid, 1885, 14, 72 74.

1885.1

Peces (In Quiroga y Rodriquez, F. Apuntas de un viaje por el Sáhara occidental. Anal. Soc. Española Hist. Nat., Madrid, 1886, 15, 521) 1886.1
Datos para la fauna Filipiana. Anal. Soc. Española Hist. Nat., Madrid, $1888,17,247-303$.

1888.1

Fishes, p. 281-303.

Influencia del agua dulce en los animales marinos. Anal. Soc. Española Hist. Nat., Madrid, 1891, 20, 221-270. pl.

1891.1

Golcher, William. Trip to the fish hatcheries of Illinois and Michigan. Forest \& Stream, 1877, 9, 226. 1877.1

The Minnesota state hatchery. Forest \& Stream, 1878, 9, 469. 1878.1

Goldberger, Joseph. Some known and three new endoparasitic trematodes from American freshwater fish. Bull. Hygienic Lab., U. S. Public Heálth and Marine-Hospital Service, 1911, no. 71. 35 p. 5 pls.

1911.1

Goldfuss, Georg August [1782-1848] Handbuch der Zoologie. 2 vols. Nürnberg, 1820 . $8^{\circ}$.

1820.1

- Petrefacta Germanix. Abbildungen und Beschreibungen der Petrefacten Deutschlands und der angrenzenden Länder. 3 Theile. Düsseldorf, 1826-44. illust. fol. 1826.1

The same. 2. Auflage. 3. Theile. Leipzig, 1862-63. illust. $4^{\circ} \&$ fol

An index to this work, by C. Giebel, was published at Leipzic in $\mathbf{1 8 6 6}$.

Description of the Orthacanthus dechenii. Quart. Journ. Geol. Soc., 18t9, 5. 21-23.

1849.1

Goldsborough, Edmund Lee, \& Clark, H. Walton. Fishes of West Virginia. Bull. Bureau Fisheries, 190s, 27, 29-39. fig.

1908.1

Goldsborough, Edmund Lee, \& Evermann, Barton Warren. See Evermann \& Goldsborough.

Goldsborough, Edmund Lee, \& Kendall, William Converse. See Kendall \& Goldsborough.

Goldschmidt, Richard. Amphioxides. Vertreter einer neuen AcranierFamilie. Biol. Centralbl., 1905, 25, 235240. fig.

1905.1

- Notiz über Branchiostoma elongatum Sundevall. Zool. Anz., 1905, 29, 132-133. fig.

1905.2

Amphioxides und Amphioxus. Zool. Anz., 1906, 30, 443-448. 3 figs. 1906.1 
Das Bindgewebe des Amphioxus. Sitzber. Ges. Morphol. Physiol. München, 1908, 24, 53-78. 27 figs. 1908.1

Die Amphioxides-Formen. Deutsch. Südpol.-Exped., 1909, 11, 3; 231-241. pl. \& fig.

1909.1

Einführung in die Vererbungswissenschaft. Leipzig, 1911. 1911.1

\section{Goldsmith, —_ Johnson, _.. \& Smart, — See Smart, Goldsmith \& Johnson.}

Goldsmith, $M$. Contribution ì l'étude de la mémoire chez les poissons. Bull. Instit. Psychol. Intern., Paris, 1912, 12, 161-176.

1912.1

Goldsmith, Middleton. An address on fish-culture. Rutland, 1872. $16 \mathrm{p}$. $S^{\circ}$.

1872.1

- The Brighton aquarium. Amer. Sportsman, 187 $\$$, 5, 55 .

1874.1

Protection of fish and game. Rod \& Gun, 1875, 7, 106; 123. 1875.1

Trout as vegetarians. Forest \& Stream, 1875, 5, 35.

1875.2

Landlocked salmon. Gun, 1876, 8, 5 .

Rod \& 1876.1

Goldsmith (Mlle.) — Recherches sur la psychologie de quelques poissons littoraux. Bull. Instit. Psychol. Intern., Paris, 1905, 5, 51-68.

1905.1

Discussion: Observations de MM. Giard, Delage et Yourievitch.

Goldstaub, Max. Der Physiologus und seine Weiterbildung. Philologus, 1899 (1901), Suppl. Bd. 8, 339-404.

1901.1

Goldstein, Kurt. Untersuchungen über das Vorderhirn und Zwischenhirn einiger Knochenfische (nebst einigen Beitragen über Mittelhirn und Kleinhirn derselben) Arch. Mikr. Anat., 1905, 66 135-219. 5 pls. \& 23 figs.

1905.1

Goldthwait, $J . W ., \&$ Atwood, $W$. IV. See Atwood \& Goldthwait.

Goll, Hermann. Le saumon commun (Salmo salar Val.) Bull. Soc. Vaud. Sci. Nat., 1878, 15, 483-496.

1878.1

lObservations morphologiques et biologiques sur quelques corégones du lac Léman et du lac de Neuchâtel] Arch. Sci. Phys. Nat., Genève, 1882, 3. sér. 9, 50-54. Also separate; Genève, 1882. 3 p. $8^{\circ}$.

1882.1
Contribution à l'histoire naturelle des corégones du lac de Neuchâtel. Arch. Sci. Phys. Nat., Genève, 1883, 3. sér. 10, 341-343. - C. R. Soc. Helvét. Sci. Nat., 66. sess., 49-51. 1883.1

The American brook trout recommended for Swiss waters. Bull. U. S. Fish Comm. 1886 (1887), 6, 206-208.

1887.1

_- Du repeuplement de nos lacs et de ses dangers. Bull. Soc. Centr. Aquicult. France, 1892, 4, 186-190. Also separate; Paris, 1892. 4 p. $8^{\circ}$.

1892.1

Nouveau corégone trouvé dans le lac Léman. Genève, 1892. 3 p. $12^{\circ}$.

1892.2

Der Platton(Brachsmen)-Fang im Murten-See. Schweiz. Fischere Zeitg., 1893, 1, 203-206. Also separate; Pfäffikon-Zürich, 1893.3 p. $8^{\circ}$.

1893.1

Ueber Walliser Fische. Schweiz. Fischerei Zeitg., 1893, 1, 277; 285. Ibid., 1894, 2, 18. Also separate; PfäffikonZürich, 1893-94. 5 p. $8^{\circ}$. 1893.2

Lac de Morat et quelques spécimens typiques de poissons. Arch. Sci. Phys. Nat., Genève, 1907, 24, 505-507. - C. R. Soc. Helvét. Sci. Nat., 90. sess., 92-94. - Actes Soc. Helvét. Sci. Nat. 90. sess., 71-72.

1907.1

Golovin, $E$. Beobachtungen über die Pigmentzellen der Wirbelthiere [Text in Russian] Mém. Sci. Univ. Imp. Kazan, 1907, 74, pt. 1, 1-29. 1907.1

Golowatschow, $A$. Notice sur quelques espèces de poissons du genre Acipenser. Bull. Soc. Nat. Moscou, 1857 30 , pt. 3, 530-543.

1857.1

Golubcov, $N$. A. Die Fischereien im Gouvernment Archangelsk [Text in Russian] Věst. Rybopromyšl. St. Peterb., 1910, 25, 361-377.

1910.1

Golusda, Pedro. Conservación i fomento de la pesca fluvial. Boletin de Bosques, Pesca i Caza, Santiago, 1912, 1, 21-27.

1912.1

- Crianza de peces de agua dulce; algunas instrucciónes sobre su trasporte, mantención i cultivo. Boletin de Bosques, Pesca i Caza, Santiago, 1912, 1 , 409-413.

1912.2

- Descripción de las especies piscicolas que debemos elejir para el cultivo artificial. Boletin de Bosques, Pesca i Caza, Santiago, 1912, 1, 199-205. 1912.3 
Golusda, $P$.

Mi opinión sobre la piscicultura en Chile. Boletin de Bosques, Pesca i Caza, Santiago, 1912, 1, 475-480. 1912.4

La piscicultura en jeneral. Boletin de Bosques, Pesca i Caza, Santiago, $1912,1,102-106$.

1912.5

Piscicultura "La Dehesa." Boletin de Bosques, Pesca i Caza, Santiago, $1912,1,480-483$. 1912.6

Trasporte de peces vivos en Alemania. Boletin de Bosques, Pesca i Caza, Santiago, 1912, 1, 407-409. 1912.7

Golyneč, V. See Golynetz, W.

Golynetz, W. On the fish-fauna of the government of Perm ['Text in Russian] Journ. Fisher. Industr. St. Petersb., 1894, 9, 515-526.

1894.1

Ergebnisse der Beobachtungen über den Zug der Heringe im östlichen Theile des Wolga-Deltas im Frühjahre 1904 [Text in Russian] Arbeit. Kaspischen Exped., St. Petersb., 1907, 1, 215221.

1907.1

Gómez Ocaña, José. Contribución al estudio de las funciónes de los lóbulos ópticos de los peces. Bol. Soc. Española Hist. Nat., 1908, 8, 247-249. fig. 1908.1

Gondermann, K. Heimische fische im Aquarium. Wochenschr. Aquar.Terrar. Kunde, 1911, 8. Jahrg., 347-350. 8 figs.

1911.1

Etwas von den Cichliden. Blätt. Aquar-Terrar. Ki unde, 1912, 23. Jahrg., $274-275.3$ figs.

1912.1

Gonovinius, Sven (respondent) Enfaldiga tankar om nyttan som England kan hofva of sina nybyggen i Norra America. Inaug. Dissert. Abo, 1763. 22 p. $4^{\circ}$.

1763.1

Kalm, Pehr, prases.

Good, Arthur. L'amiure ou poissonchat. La Nature, 1902, 30, pt. 2, 283284. fig.

1902.1

Goodchild, John George [1844-] The Black hill of Earlston. [Devonian fishes] Hist. Berwick. Natural. Club, 1905, 19, 51-59. 4 figs.

1905.1

Goode, George Brown [1851-1896] The billfish in fresh water. Amer. Naturalist, 1871, 5, 439.

1871.1

- Descriptions of two new species of fishes from the Bermuda islands
[Diapterus lefroyi; Engraulis chœrostomus] Amer. Journ. Sci., 1874, 8, 123125. - Ann. Mag. Nat. Hist., 3. ser. 14, 379-381. - Amer. Sportsman, \&, 307308.

1874.1

The orange filefish (Ceratacanthus aurantiacus Mitchill) Gill. Amer. Sportsman, 1874, 4, 353. 1874.2

- The Plagopterinx and the ichthyology of Utah. Amer. Sportsman, $1874,4,333$.

1874.3

The shad and shad fishery of the St. John's river, Florida] Rept. U. S. Fish Comm. 1872-73 (1874), 2 , p. xlviii-xlix.

1874.4

Tarpum. Forest \& Stream, 1874, 2, 292 . 1874.5

The United States Fish Commission. Amer. Sportsman, 1874, 4, 266.

1874.6

The United States Fish Commission. Dredging on the coast of Connecticut. Amer. Sportsman, 1874, 4, 313 .

1874.7

- United States Fish Commission. The experiments with young shad. Amer. Sportsman, 1874, 4, 376. 1874.8

United States Fish Commission. The fish laboratory. Amer. Sportsman, $1874,4,392-393$.

1874.9

The United States Fish Commission. Fish tales from Noank. Amer. Sportsman, 1874, 4, 291. 1874.10

The United States Fish Commission. Noank: the laboratory. Amer Sportsman, 1874, 4, $273 . \quad 1874.11$

Albino fishes. Amer. Naturalist, 1875, 9, 517. — Rod \& Gun, 1875, 7, 43. 1875.1

Albinoism in fishes. Forest \& Stream, 1875, 4, 231. 1875.2

Parasitism in fishes, notably in the case of Brevoortia (menhaden) Field \& Forest, 1875, 1, 53 .

1875.3

Bermuda and its fish markets. Forest \& Stream, 1876, 6, 83-84. 1876.1

Catalogue of the fishes of the Bermudas, based chiefly upon the collections of the United States National Museum. Bull. U.S. Nat. Mus., 1876, 1, no. 5. 82 p. - Smithson. Miscell. Collect., 13, art. 5 .

1876.2 
Collection to illustrate the animal resources of the United States. Washington, 1876. $10 \mathrm{p}$.

1876.3

- The short pompano ('Trachynotus ovatus) and the amber fish (Seriola sp.) Forest \& Stream, 1876, 6, 20.

1876.4

Fifth and sixth annual reports of the curators of the museum of the Wesleyan University. Middletown, Conn., 1877. 30 p. $8^{\circ}$.

1877.1

Contains an account of the ichthyological collections of this museum and of the ich thyological discoveries in the Beraun [Bohemia]

A preliminary catalogue of the reptiles, fishes, and leptocardians of the Bermudas, with descriptions of four species of fishes believed to be new [Julis nitidissima, Belone jonesii, Atherina harringtonensis, Fundulus rhizphoral Amer. Journ. Sci., 1877, 14, 289-298. Also separate; New Haven, 1877. 12 p. $8^{\circ}$.

1877.2

-. Provisional catalogue of the fishes of Bermuda. Hamilton, Bermuda, May, 1877, 1-8. $8^{\circ}$.- Bermuda Almanac, 1878-81, 116-122. 1877.3

Statistics of American fisheries prepared by Mr. Goode. Doc. \& Proc. Halifax Commission, 1877, Appendix O. - Trans. Amer. Fish-cult. Assoc. 1878, 99-108.

1877.4 A.

B. Product of weirs and traps.

C. Products of marine fisheries of southern Massachusetts and Rhode Island.

D. Products of marine fisheries of northern Atlantic states.

The Clupea tyrannus of Latrobe. Proc. U. S. Nat. Mus., 1878, 1, 5-6. Chicago Field, 9, 323.

1878.1

Coast sketches. Provincetown in summer. Forest \& Stream, 1878, 10, 74.

1878.2

Confusion in the names of some of the American fishes of the herring family. Forest \& Stream, 1878, 10, 82.

1878.3

- Migration of fishes. Trans. Amer. Fish-cult. Assoc., 1878, 27-64. 2 pls. - Forest \& Stream, 10, 94; 116; $194 ; 254$.

1878.4

- A new " silver gar " on the coast. Chicago Field, 1878, 9, 307. 1878.5

(translator) Notes on the American species of the genus Cybium, by Felipe Poey. Proc. U. S. Nat. Mus., $1878,1,3-5$.
The occurrence of Belone latimanus in Buzzard's bay, Massachusetts Proc. U. S. Nat. Mus., 1878, 1, 6-7.

1878.7

The occurrence of Hippocampus antiquorum, or an allied form, on St. Georges banks. Proc. U. S. Nat. Mus. $1878,1,45-46$.

1878.8

Questions relative to the cod and the cod fisheries. Washington, 1878. $4 \mathrm{p}$.

1878.9

Questions relative to the mackerel and mackerel fisheries. Washington, 1878. $32 \mathrm{p}$.

1878.10

A revision of the American species of the genus Brevoortia, with a description of a new species from the gulf of Mexico. Proc. U. S. Nat. Mus., $1878,1,30-42$.

1878.11

Seventh annual report of the curators of the museum of the Wesleyan University. Middletown, Conn., 1878. 24 p. $8^{\circ}$. 1878.12

Contains various allusions to the collection of fishes.

A study of the popular names of the menhaden. Amer. Naturalist, 1878 , 12, 735-739.

1878.13

-..-American ichthyology in 1878. Science News, 1879, 1, 97-100. 1879.1

Biography of the menhaden. Proc. Central Fish-cult. Soc. Chicago, 1879, 48-59.

1879.2

Catalogue of the collection to illustrate the animal resources and the fisheries of the United States, exhibited at Philadelphia in 1876 by the Smithsonian Institution, etc. Washington, 1879. 351 p. $8^{\circ}$ 1879.3

- Eighth annual report of the curators of the museum of the Wesleyan University. Middletown, Conn., 1879. 17 p. $8^{\circ}$.

1879.4

Game fishes of the United States. New York, 1879-81. 46 p. 20 pls. \& map. fol.

1879.5

The gulf threadfish. Forest \& Stream, 1879, 12, 785 .

1879.6

- History of the American menhaden. Rept. U. S. Fish Comm. 1877 (1879), 5, Append. A, 1-529. 31 pls. Abstract in Amer. Naturalist, 12, 735739. - Proc. U. S. Nat. Mus., 1, 30-42. 1879.7 
Goode, G. B.

- A letter on the influence of the moon on fish. Forest \& Stream, 1879, 11,485 .

1879.8

The menhaden. Science News, $1879,1,360-363 ; 373-377 . \quad 1879.9$

The North American fisheries. Arrangements with Great Britain. Memoranda in relation to statistics of the fisheries of North America, prepared for Senator Edmunds in response to his request of December 31, 1878. Congressional Record, 1879, 9, no. 89, 2-4.

1879.10

On the occurrence of Lycodes vahlii Reinhardt, on La Have and Grand banks. Proc. U.S. Nat. Mus., 1879, 2, 209-210. - Smithson. Miscell. Collect., 19 , art. 5 .

1879.11

On two fishes from the Bermudas, mistakenly described as new by Doctor Günther. Proc. U. S. Nat. Mus., 1879, 1, 462-463. - Amer. Journ. Sci., 17,340 .

1879.12

- Plan of inquiry into the history and present condition of the fisheries of the United States. Washington, 1879. 54 p. $8^{\circ}$. Reprint in Rept. U. S. Fish Comm. 1880 (1881), 7, 1-54. 1879.13

A preliminary catalogue of the fishes of the St. John's river and the east coast of Florida, with descriptions of a new genus [Jordanella] and three new species [J. florido, Fundulus confluentus, Gambusia arlingtonia] Proc. U. S. Nat. Mus., 1879, 2, 108-121. - Smithson. Miscell. Collect., 19, art. 2. $\quad 1879.14$

A study of the trunk-fishes (Ostraciontidx), with notes upon the American species of the family. Proc. U. S. Nat. Mus., 1879, 2, 261-283.Smithson. Miscell. Collect, 19, art. 2.

1879.15

- The two kinds of river herring. Rept. Comm. Fisheries of Virginia, Richmond, 1879 , p. 14.

1879.16

Another new fish on the Atlantic coast (Auxis rochei) Forest \& Stream, 1880, 15, 28.

1880.1

The Berlin exhibition; some new particulars in regard to it. New York Times, Aug. 1, 1880.

1880.2

Catalogue of the American fish exhibit at Berlin. Chicago Field, 1880 , 13,220 .

1880.3

- The census of the fisheries. Newport Mercury, August 14, 1880.

1880.4
Contributions to the GedenkBlätter zur Eröffnung der Internationalen Fischerei-Ausstellung zu Berlin, 1880. Berliner Tageblatt, April 20, 1880 , p. 3-4.

1880.5

- Descriptions of seven new species of fishes from deep soundings on the southern New England coast, with diagnoses of two undescribed genera [Monolene and Thyris] of flounders, and a genus [Hypsicometes] related to Merlucius. Proc. U. S. Nat. Mus., 1880, 3, 337-350. - Smithson. Miscell. Collect., 1880,22 , art. 1.

1880.6

- A distinguished immigrant. Professor Baird's European carp. Amer. Agriculturist, $1880,39,13-14 . \quad 1880.7$

- Das erste Jahrzehnt der Wirksamkeit der Fisch-Kommission der Vereinigten Staaten, ihre Geschichte, ihr System und ihre Arbeiten für die Wissenschaft und die öffentliche Wohlfahrt. Vollständige Uebersicht über eine Musterverwaltung. Circular Deutschen Fischerei-Verein, Berlin, 1880, 190-197. - Oesterr.-ungar. Fischerei Zeitg., 4, $7 ; 15 ; 20$.

1880.8

Exhibit of the fisheries and fish culture of the United States of America at the Internationale Fischerei-Ausstellung, held at Berlin, April 20, 1880, and forming a part of the collections of the National Museum, made by the United States Fish Commission. Bull. U. S. Nat. Mus., 1880, no. 18, 1-263. 1850.9

— The first decade of the United States Fish Commission; its plan of work and accomplished results, scientific and economical. Forest \& Stream, 1880, 15, 85-87; 166. - Chicago Field, 18s0, 14, 58. - Nature, 22, 597-599. - Proc. Amer. Assoc. Adv. Sci., 28. meet., 563574. - Bull. U. S. Fish Comm. 1882 (18S3), 2, 169-178. - Rept. U. S. Fish Comm. 1880 (1883), 8, 53-62. 1880.10

Frigate mackerel again heard

1880.11

The frigate mackerel, Auxis rochei, on the New England coast. Proc. U. S. Nat. Mus., 1880, 3, 532.Amer. Naturalist, 14, 805-810. - Smithson. Miscell. Collect., 22, art. 1. 1880.12

How to distinguish the two species of herring. Chicago Field, 1880, 22, 341 . 1880.13

- Internationale Fischerei-Ausstellung, Berlin, 1880. Amerikanische Abtheilung. Verzeichniss der Aussteller, 
nach dem von dem Deutschen FischereiVerein festgestellten Programme geordnet. Berlin, April 20, 1880.7 p. fol.

1880.14

Materials for a history of the $X$ iphias gladius L. Washington, 1880 . 24 pls. $8^{\circ}$.

1880.15

New fish [Helorus voraginorm] Forest \& Stream, 1880, 16, 109. 1880.16

- A short biography of the menhaden; an abstract of "A history of the menhaden." Proc. Amer. Assoc. Adv. Sci., 28. meet., 1880, 425-437. 1880.17

- Statistics of the fisheries of the United States in 1880] Compendium Tenth Census, 1880, pt. 2, Table cvi, 1402-1403. - Bull. U. S. Fish Comm. $1883,3,270-271$.

1880.18

The turbot and sole in America. Forest \& Stream, 1880, 15, 103-104.

1880.19

The use of agricultural fertilizers by the American Indians and the early English colonists. Amer. Naturalist, $1880,14,473-479$.

1880.20

Use of fish, especially menhaden, as fertilizer along the Atlantic coast.

The eel question. Forest \& Stream, 1881, 18, 91-93; 111-113; 132; 133.

1881.1

Epochs in the history of fish culture. Trans. Amer. Fish-cult. Assoc., 1881, 34-57. - Forest \& Stream, 16, $311 ; 332 ; 353$.

1881.2

The first decade of the United States Fish Commission, its plan of work and accomplished results, scientific and economical. Proc. Amer. Assoc. Adv. Sci., 29. meet., 1881, 563-574. - Nature, London, 22, 579-599. - Smithson. Rept., 1880, 140-149. - Rept. U. S. Fish Comm. 1880 (1883), 8, 53-62. Bull. U. S. Fish Comm. 1882 (1883), 2, 169-178.

1881.3

Fishermen of America. New York Daily 'Tribune, June 23, 1881.

1881.4

- The fishermen of the United States. Abstract in Trans. Anthropol. Soc. Washington, 1881, 1, 62-66. 1881.5

- Fishes from the deep water of the south coast of New England obtained by the U.S. Fish Commission in the summer of 1880. Proc. U.S. Nat. Mus., 1881， 3, 337-350; 467-486. Smithson. Miscell. Collect., 22, art. 1.
- Notacanthus phasganorus, a new species of Notacanthidx from the Grand banks of Newfoundland. Proc. U.S. Nat. Mus., 1881, 3, 535-537. Smithson. Miscell. Collect., 22, art. $1 . \quad 1881.7$

Preliminary statistical report on the fisheries of California, Oregon, Washington, and Alaska. Census Bull., 1881 , no. 176, p. 6. 1881.8

The saibling or Bavarian char. Forest \& Stream, 1881, 16, 50-51.

1881.9

- The carangoid fishes of the United States, pompanoes, crevalles, amber-fishes, etc. Bull. U. S. Fish Comm. 1881 (1882), 1, 30-43. 1852.1

-Catalogue of the collection to illustrate the animal resources and the fisheries of the United States lexhibited at Philadelphia in 1876 $\mathrm{j}$ Bull. U. S. Nat. Mus., 1882, 2, no. 14. - Smithson. Miscell. Collect., 23, art. 4. 1882.2

Note on article by Captain E. T. Deblois on the origin of the menhaden industry. Bull. U. S. Fish Comm. 1881 (1882), 1, 46. 1882.3

Notes on the life-history of the eel, chiefly derived from a study of recent European authorities. Bull. U.S. Fish Comm. 1881 (1882), 1, 71-124. Trans. Amer. Fish-cult. Assoc., 1882, 81-123.

1882.4

The taxonomic relations and geographical distribution of the members of the sword fish family, Xiphiida. Proc. U. S. Nat. Mus., 1882, 4, 415-433. - Smithson. Miscell. Collect., 22, art. 2. 1882.5

American investigations upon the food of fishes. Intern. Fisheries Exhib. Lit., London, 1883. Conferences, p. 29-33.

1883.1

The development of the American mackerel fisheries. Intern. Fisheries Exhib. Lit., London, 1883. Conferences, p. 30-32. 1883.2

- The fisheries of the United States. Intern. Fisheries Exhib. Lit., London, 1883. Official Catalogue, 1. ed. p. 283-285. 2. ed. p. 189-191. 1883.3

The generic names Amitra and Thyris replaced. Proc. U. S. Nat. Mus., $1883,6,109$. 1883.4

Great International Fisheries Exhibition, London, 1883. United 
Goode, $G$. B.

States of America. A preliminary catalogue and synopsis of the collections exhibited by the U.S. Fish Commission and by special exhibitors, with a concordance to the official classification of the exhibition. Washington, 1883. 107 p. Abstract in Science, 1, 447-450. Ibid., 2, 139-141; 612-615.

1883.5

Importance of forest protection to fishculture in the United States. Intern. Fisheries Exhib. Lit., London, 1883. Conferences, p. 13-14. 1883.6

Materials for a history of the sword fishes, Rept. U. S. Fish Comm. 1880 (1883), 8, 287-394. 24 pls. Trans. Amer. Fish-cult. Assoc., 1882 , 84-150. - Forest \& Stream, 18, p. 410. Ibid., 19, 52; 70; 91-92; 111-112; 132 $133 ; 149-150 ; 193 ; 231-232$.

1883.7

Notes on the lampreys (Petromyzontidx) Bull. U. S. Fish Comm. 1882 (1883), 2, 349-354.

1883.8

On the fisheries of the world (In Lalor, J. L. Cyclopædia of political economy, vol. ii, 211-231. Chicago, 1883)

1883.9

- On the landlocked salmon. Intern. Fisheries Exhib. Lit., London, 1883. Conferences, 29-31. $\quad 1883.10$

On the methods of protection of fisheries. Intern. Fisheries Exhib. Lit., London, 1883. Conferences, p. 3638.

1883.11

Recent progress of the Canadian fisheries. Intern. Fisheries Exhib. Lit., London, 1883. Conferences, p. 46-47.

1883.12

- A review of the fishery industries of the United States and the work of the United States Fish Commission. Intern. Fisheries Exhib. Lit., London, 1883. Conferences, 5, pt. 1, 3-82. 1883.13

Salmon culture in the United States. Intern. Fisheries Exhib. Lit., London, 1883. Conferences, p. 28-29.

1883.14

The scientific results of the Fisheries Exhibition. Intern. Fisheries Exhib. Lit., London, 1883. Conferences, p. 31-32.

1883.15

The successes of fish culture in the United States and Canada. Intern. Fisheries Exhib. Lit., London, 1883. Conferences, p. 27-29.
The suitability of the black bass for introduction into England. Letter to R. B. Marston, Esq. Intern. Fisheries Exhib. Lit., London, 1883. Conferences, p. 18-19.

1883.17

- The aims and limitations of modern fish-culture. Science, 1884, 3, no. 54,208 .

1884.1

Beginning of natural history in America. Proc. Biol. Soc. Wash., 1884 $86,3,35-105$.

1884.2

Fishery treaties (In Lalor, J. L. Cyclopsdia political economy, vol. iii, 941-944. Chicago, 1884) 1884.3

- The food fishes of the United States (In The fisheries and fishery industries of the United States, edited by George Brown Goode, sect. 1, pt. 3, 163-682. 218 pls. Washington, 1884)

1884.4

Natural history of the mackerel. Rept. U. S. Fish Comm. 1881 (1884), 9, 93-138. Abstract in Proc. Biol. Soc. Washington, $1882, \mathbf{1}$, p. $32 . \quad 1884.5$

An ocean monarch. The Chautauquan, $1884,4,582-584$. $\quad 1884.6$

- The art of fish-culture. The Chautauquan, 1885, 5, 401-407; 470472 .

1885.1

A brief biography of the halibut. Amer. Naturalist, 1885, 19, 953-969.

1885.2

De Forenede Nord Amerikanske staters fiskeritilsyn. Fiskertid., Copenhagen, 1885, no. 15, 133-135. Ibid., no. $17,149-150$.

1885.3

Pisciculture (In Encyclopædia Britannica, 9. ed., 1885, vol. xix, 126129)

1885.4

The status of the United States Fish Commission in 1884. A review of what has been accomplished in fish culture and the investigation of the American Fisheries. Rept. U. S. Fish Comm. 1884 (1886), 12, 1139-1180. 1886.1

Provisional regulations of the United States Commission of Fish and Fisheries. Circular U. S. Comm. Fish and Fisheries, 1887, no. 2, 1-12. 1887.1

The swordfish fishery (In The fish and fishery industries of the United States, edited by George Brown Goode, sect. 5, pt. 4, 315-326. Washington, 1887) 1887.2 
American fishes; a popular treatise upon the game and food fishes of North America, with especial reference to habits and methods of capture. New York, 1888. xv, 496 p. illust.

1888.1

- The beginnings of American science. The third century. Proc. Biol. Soc. Wash., 1888, 4, 1-94. 1888.2

The depths of the ocean. Atlantic Monthly, 1889, 63, 124-128.

1889.1

The color of fishes. Science, 1890, 15, 211-213. 3 figs. $\quad 1890.1$

Published writings of Charles F. Girard. Bull. U. S. Nat. Mus., 1891, no. 41. 141 p. Also separate; Washington, 1891. $8^{\circ}$.

1891.1

The relation of scientific research to economic problems. An address delivered before the World's Fisheries Congress, Chicago, 1893. Bull. U. S. Fish Comm. 1893 (1894), 13, art. $8,49-58$

1894.1

Bibliography of the published writings of Philip Lutley Sclater, F. R. S., secretary of the Zoological Society of London. Bull. U. S. Nat. Mus., 1896, no. 49. xix, 135 p. Abstract in Nat. Science, 1897,10 , no. $63,350 . \quad 1896.1$

American fishes; a popular treatise upon the game and food fishes of North America, with especial reference to habits and methods of capture. 2. ed. completely revised and largely extended by Theodore Gill. Boston, 1903. viii, 562 p. illust.

1903.1

Goode, George Brown, \& Atwater, W.O. American fisheries. A history of the menhaden, by G. Brown Goode, with an account of the agricultural uses of fish, by W. O. Atwater, and an introduction bringing the subject down to date. New York, 1880. x, 529 p. 31 pls. $8^{\circ}$. Reviewed in Nature, London, 22, 335 .

1880.1

Goode, George Brown, \& Bean, Tarleton Hoffman. Descriptions of two new species of fishes [Macrurus bairdii and Lycodes verrillii] recently discovered by the U.S. Fish Commission, with notes upon the occurrence of several new forms. Amer. Journ. Sci., 1877, 3. ser. 14, 470-478. Notice in Nature, 17, 213.

1877.1

The craig flounder of Europe, Glyptocephalus cynoglossus, on the coast of North America. Proc. U. S. Nat. Mus., 1878, 1, 19-23. - Smithson. Miscell. Collect., 19, art. 1.

1878.1

- Description of Argentina syrtensium, a new deep-sea fish from Sable island bank. Proc. U. S. Nat. Mus., 1878, 1, 261-263. - Smithson. Miscell. Collect., 19, art. $1 . \quad 1878.2$

Description of Caulolatilus microps, a new species of fish from the Gulf coast of Florida. Proc. U. S. Nat. Mus., 1878, 1, 42-45. - Smithson. Miscell. Collect., 19, art. 1. 1878.3

Descriptions of two gadoid fishes Phycis chesteri and Haloporphyrus viola, from the deep-sea fauna of the northwestern Atlantic. Proc. U.S. Nat. Mus., 1S78, 1, 256-260. - Smithson. Miscell. Collect., 19, art. $1 . \quad 1878.4$

Descriptions of two new species of fishes, Lutjanus blackfordi and Lutjanus stearnsii, from the coast of Florida. Proc. U. S. Nat. Mus., 1878, 1, 176-181. - Smithson. Miscell. Collect., 19, art. 1.

1878.5

The identity of Rhinonemus caudacuta (Storer) Gill with Gadus cimbrius Linn. Proc. U. S. Nat. Mus., 1878, 1, 348-349. - Smithson. Miscell. Collect., 19, art. 1 .

1878.6

A note on the black grouper (Epinephelus nigritus (Holbrook) Gill) of the southern coast. Proc. U. S. Nat. Mus., 1878, 1, 182-184. - Smithson. Miscell. Collect., 19, art. 1. 1878.7

The oceanic bonito on the coast of the United States. Proc. U. S. Nat. Mus., 1878, 1, 24-26. - Smithson. Miscell. Collect., 19, art. $1 . \quad 1878.8$

On a new serranoid fish, Epinephelus drummondhayi, from the Bermudas and Florida. Proc. U. S. Nat. Mus., 1878, 1, 173-175. - Smithson. Miscell. Collect., 19, art. 1.

1878.9

Catalogue of a collection of fishes obtained in the gulf of Mexico, by Doctor J. W. Velie, with descriptions of seven new species. Proc. U. S. Nat. Mus., $1879,2,333-345$. - Smithson. Miscell. Collect., 19, art.2. 1879.1

Catalogue of a collection of fishes sent from Pensacola, Florida, and vicinity, by Mr. Silas Stearns, with descriptions of six new species. Proc. U. S. Nat. Mus., 1879, 2, 121-156. Smithson. Miscell. Collect., 19, art. 2.

1879.2 


\section{Goode \& Bean.}

- A catalogue of the fishes of Essex county, Massachusetts, including the fauna of Massachusetts bay and the contiguous deep waters. Bull. Essex Instit., 1879, 11, 1-38. Also separate; Salem, 1879 . 38 p. $8^{\circ}$.

1879.3

Description of Alepocephalus bairdii, a new species of fish from the deep-sea fauna of the western Atlantic. Proc. U.S. Nat. Mus., 1879, 2, 55-57. Smithson. Miscell. Collect., 19, art. 2.

1879.4

Description of a new genus and species of fish, Lopholatilus chamoleonticeps, from the south coast of New England. Proc. U. S. Nat. Mus., 1879, 2, 205-209. - Smithson. Miscell. Collect., 19 , art. 2 .

1879.5

Description of a new species of amber-fish (Seriola stearnsii) obtained near Pensacola, Florida, by Mr. Silas Stearns. Proc. U. S. Nat. Mus., 1879, 2, 48-51. - Smithson. Miscell. Collect., 19 , art. 2.

1879.6

- Description of a new species of Liparis (L. ranula) obtained by the United States Fish Commission off Halifax, Nova Scotia. Proc.U.S. Nat. Mus., 1879, 2, 46-48. - Smithson. Miscell. Collect., 19, art. 2.

1879.7

Description of a species of Lycodes (L. paxillus) obtained by the United States Fish Commission. Proc. U. S. Nat. Mus, $1879,2,44-46$. Smithson. Miscell. Collect., 19, art. 2.

1879.8

Discoveries of the U. S. Fish Commission. Notices of fifty species of east-coast fishes, many of which are new to the fauna. Amer. Journ. Sci., 1879 , 3. ser. 17, 39-48.

1879.9

- Note of Platessa ferruginea D. H. Storer, and Platessa rostrata H. R. Storer. Proc. U. S. Nat. Mus, 1879, 2, 361-362. - Smithson. Miscell. Collect., 19 , art. 2.

1879.10

On the identity of Brosmius americanus Gill with Brosmius brosme (Müller) White. Proc. U. S. Nat. Mus. 1879, 2, 362-363.

1879.11

On the occurrence of Lycodes vahlii Reinhardt on La Have and Grand banks. Proc. U. S. Nat. Mus., 1879, 2 , 209-210. - Smithson. Miscell. Collect., 19, art. 2.

1879.12

Range of the grayling. Chicago Field, $1879,11,4$.
Benthodesmus, a new genus of deep-sea fishes, allied to Lepidopus. Proc. U. S. Nat. Mus., 1881, 4, 379383. - Smithson. Miscell. Collect. 22 art. 2.

1881.1

- Description of a new species of fish (Apogon pandionis) from the deep waters off the mouth of the Chesapeake bay. Proc. U. S. Nat. Mus., 1881, 4, 160-161. - Smithson. Miscell. Collect. 22, art. 2.

1881.2

Descriptions of twenty-five new species of fish from the southern United States, and three new genera, Letharcus, Ioglossus and Chriodorus. Proc. U. S. Nat. Mus., 1882, 5, 412-137. 1882.1

- A list of the (296) species of fishes recorded as occurring in the gulf of Merico. Proc. U. S. Nat. Mus., 1882, 5, 234-240.

1852.2

Reports on the results of dredging under the supervision of Alexander Agassiz, on the east coast of the United States, during the summer of 1880 , by the U.S. coast survey steamer "Blake," Commander J. R. Bartlett, U. S. N., commanding. Report on the fishes Bull. Mus. Comp. Zool., Harv. Coll., $1882,10,183-226$.

1882.3

Notes on some Florida fishes. Proc. U. S. Nat. Mus., 1Ss4, 7, 42-47.

1884.1

Description of a new genus and species of pediculate fishes (Halieutella lappa) Proc. Biol. Soc. Wash., 1855, 2 , 88.

1885.1

Description of Leptophidium cervinum and $L$. marmoratum, new fishes from deep water off the Atlantic and Gulf coasts. Proc. U. S. Nat. Mus., $1885,8,422-124$.

1885.2

Descriptions of new fishes obtained by the U. S. Fish Commission, mainly from deep water off the Atlantic and Gulf coasts. Proc. U. S. Nat. Mus., 1855, 8, 589. Also separate; Washington, 1886.

1885.3

- On the American fishes in the Linnaran collection. Proc. U. S. Nat. Ius., 1885, 8, 193-208.

1885.4

Reports on the results of dredging, under the supervision of Alexander Agassiz, in the gulf of Mexico $(1877-78)$ and in the Caribbean sea (1879-80), by the U.S. Coast Survey steaner "Blake" Lieut. Commander C. D. Sigsbee, U. S. 
N., and Commander J. R. Bartlett, U. S. N., commanding. Bull. Mus. Comp. Zool., Harv. Coll., 1886, 12, no. 5, $153-170$.

1886.1

The subtitle reads: "XXVIII. Description of thirteen species and two genera of fishes from the "Blake 'collection."

The present condition of the study of deep-sea fishes. Proc. Amer. Assoc. Adv. Sci., 40. meet., 1891, 324.

1891.1

On Cetominidx and Rondeletiida, two new families of bathybial fishes from the northwestern Atlantic (In Scientific results of explorations by the U. S. Fish Commission steamer "Albatross," no. 28. Proc. U. S. Nat. Mus., 1894, 17, 451-454. pl.)

1894.1

On Harriotta, a new type of chimaroid fish from the deeper waters of the northwestern Atlantic (In Scientific results of explorations by the U.S. Fish Commission steamer "Albatross," no. 30. Proc. U. S. Nat. Mus., 1894, $17,471-473)$

1894.2

- A revision of the order Heteromi, deep-sea fishes, with a description of the generic types Macdonaldia and Lipogenys (In Scientific results of explorations by the U. S. Fish Commission steamer "Albatross," no. 29. Proc. U. S. Nat. Mus., 1894, 17, 455-470)

1894.3

Oceanic ichthyology. A treatise on the deep-sea and pelagic fishes of the world, based chiefly upon the collections made by the steamers "Blake" "Albatross" and "Fishhawk" in the northwestern Atlantic. Mem. Mus. Comp. Zool., Harvard Coll., 1896, 22, 1-553. 124 pls. \& 27 figs. - Special Bull. U.S. Nat. Mus., 1895. xxxv, 529 p. 123 pls.

1896.1

Review in Nat. Science, 10, no. 63, 338-390. Ibid., 11, no. 65, 71 .

Goode, George Brown, \& Clark, A. Howard. The menhaden fishery (In The fisheries and fishery industries of the United States, edited by George Brown Goode, sect. 1, 327-415. 32 pls. Washington, 1887)

1887.1

Goode, George Brown, \& Collins, Joseph W. The winter haddock fishery of New England. Amer. Fish-cult. Assoc., 1882, 43-56. - Bull. U. S. Fish Comm. 1881 (1882), 1, 226-235. 1882.1

The bank traw-line cod fishery (In The fisheries and fishery industries of the United States, edited by George Brown Goode, sect. 1, 148-187. 5 pls. Washington, 1887)

1887.1

The bank hand-line cod fishery (In The fisheries and fishery industries of the United States, edited by George Brown Goode, sect. 1, 123-133. 2 pls. Washington, 1887)

1887.2

- The fishermen of the United States (In The fisheries and fishery industries of the United States, edited by George Brown Goode, sect. 4, 1-129. 13 pls. Washington, 1857) 1857.3

The Georges bank cod fishery (In The fisheries and fishery industries of the United States, edited by George Brown Goode, sect. 1, 187-198. 6 pls. Washington, 1887)

1887.4

The haddock fishery of New England (In The fisheries and fishery industry of the United States, edited by George Brown Goode, sect. 1, 234-241. 3 pls. Washington, 1887) - Bull. U. S. Fish Comm. 1881 (1882), 1, 226-235. Trans. Amer. Fish-cult. Assoc., 11. meet. 1882, 43-56. Abstract in Forest \& Stream, 18, 311-312.

1887.5

The hake fishery (In The fisheries and fishery industries of the United States, edited by George Brown Goode, sect. 1, 241-243. 3 pls. Washington, 1887)

1887.6

The Labrador and gulf of Saint Lawrence cod fisheries (In The fisheries and fishery industries of the United States, edited by George Brown Goode, sect. 5, pt. 1, 133-147. 6 pls. Washington, 1887)

1887.7

The mackerel fishery (In 'The fisheries and fishery industry of the United States, edited by George Brown Goode, sect. 1, 245-313. 28 pls. Washington, 1887)

1887.8

Goode, George Brown, Collins, Jo-

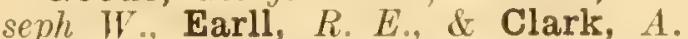
Howard. Materials for a history of the American mackerel fishery. Rept. U. S. Fish Comm. 1881 (1884), 9, 91-531.

1884.1

Goode, George Brown, Collins, Joseph W., \& Scudder, N.P. The halibut fisheries (In The fisheries and fishery industries of the United States, edited by George Brown Goode, sect. 1, 3-119. 22 pls. Washington, 1857) 1887.1 
Goode, George Brown, \& others. 'The fisheries and fishery industries of the United States. Prepared through the co-operation of the commissioner of fisheries and the superintendent of the 10 th census. Sect. $1-v .2$ vols. Washington, $1884-87.547$ pls. $4^{\circ}$. 1887.1

i. Natural history of useful aquatic animals. 1884. 292 pls.

ii. A geographicai zeview of the fisheries industries and fishing communities for $1880,1887$.

iii. The fishing grounds of North America, edited by Richard Rathbun. 1887.

iv. The fishermen of the United States, by G. B. Goode \& J. IV. Collins 1887.

v. History and methods of the fisheries. 2 vols. 1887. $255 \mathrm{pls}$.

Goodenough, Samuel. A description of the porbeagle shark, the Squalus cornubicus of Gmelin, var. A. Trans. Linn. Soc. London, 1797, 3, 80-83. pl.

1797.1

Goodey, T. A contribution to the skeletal anatomy of the frilled shark. Chlamydoselachus anguineus Gar. Proc. Zool. Soc. London, 1910, 540-571. 5 pls.

1910.1

Vestiges of the thyroid in Chlamydoselachus anguineus, Scyllium catulus and Scyllium canicula. Anat. Anz., 1910, 36. Jahrg., 104-108. 4 figs. 1910.2

Goodrich, Edwin Stephen. Vertebrata, craniata (cyclostomes and fishes) (In Lankester, E. R. Treatise on zoology, vol. ix. London, 1900-09. 7 pts. in $8 . x v i, 518$ p. 514 figs. $8^{\circ}$ ) 1900.1

- On the pelvic girdle and fin of Eusthenopteron. Quart. Journ. Micr. Sci., London, 1901, 2. ser. 45, 311-324. pl. \& 12 figs.

1901.1

On the excretory organs of Amphioxus. Proc. Roy. Soc. London, 1902, $69,350-351$.

1902.1

- On the structure of the excretory organs of Amphioxus. Quart. Journ. Micr. Sci., London, 1902, 45, 493-591. pl. \& fig.

1902.2

Occupation of a table at the Zoological Station at Naples. Report of the committee. Appendix A. On the structure and development of the excretory apparatus of Amphioxus. Rept. Brit. Assoc. Adv. Sci., 72. meet., 1903, 260.

1903.1

On the dermal fin-rays of fishes, living and extinct. Quart. Journ. Mier. Sci., London, 1904, 47, 465-522. 7 pls. \& 6 figs.
- Notes on the development, structure and origin of the median and paired fins of fish. Quart. Journ. Micr. Sci., London, 1906, 60, 333-376. 5 pls. \& 3 figs.

1906.1

On the scales of fish, living and extinct, and their importance in classification. Proc. Zool. Soc. London, 1907 (1908), 751-774. 4 pls. \& 9 figs. 1908.1

- On the systematic position of Polypterus. Rept. Brit. Assoc. Adv. Sci., 77. meet., 1907 (1908), 545-546.

1908.2

On the structure of the excretory organs of Amphioxus. Part 2. The nephridium in the adult. Part 3. Hat schek's nephridium. Part 4. The nephridium in the larva. Quart. Journ. Mier. Sei., London, 1909, 54, 185-205. 6 pls. \& fig.

1909.1

On the segmental structure of the motor nerve-plexus. Anat. Anz. 1910, 36, 109-112. fig. 1910.1

A case of hermaphroditism in Amphioxus. Anat. Anz., 1912, 42, 318-320. 2 figs. 1912.1

- Note on an hermaphrodite Amphioxus. Rept. Brit. Assoc. Adv. Sci., 82. meet., 1913, 489.

1913.1

On the structure of bone in fishes; a contribution to palæohistology. Proc. Zool. Soc. London, 1913, 80-85. 4 figs.

1913.2

Goodsir, John [1814-1867] On certain peculiarities in the structure of the short sun-fish (Orthagoriscus mola) Edinb. New Phil. Journ., 1841, 30, 188-194.

1841.1

- Ueber die Anatomie des Amphioxus lanceolatus Yar. Neue Notiz. (Froriep), 1841, 19, no. 401, 69-72.

1841.2

On the conferva which vegetates on the skin of the gold-fish. Ann. Mag. Nat. Hist., 1842, 9, 333-337. 1842.1

- On the anatomy of the Amphioxus lanceolatus, lancelet of Yarrell. Trans. Roy. Soc. Edinb., 1844, 15, $247-$ 263. 2 pls.

1844.1

- On the electrical apparatus in Torpedo, Gymnotus, Malapterurus, and Raja. Edinb. Med. Journ., 1855-56, 1, $139-142 ; 277-282 ; 563-565 . \quad 1855.1$

On the morphological constitution of limbs. Edinb. New Phil. Journ. 1857, n. s. 5, 178-181. 1857.1 
On the morphological constitution of the skeleton of the vertebrate head. Edinb. New Phil. Journ., 1857, n. S. 5, 123-178.

1857.2

- Anatomical details of the new species of Malapterurus. Proc. Roy. Phys. Soc. Edinb. 1854-58 (1858), 21 22.

1858.1

- On certain peculiarities in the structure of the short sun-fish (Orthagoriscus mola) Anat. Mem. Edinb. (Goodsir), 1868, 1, 394-400. 1868.1

- On the electrical apparatus in Torpedo, Gymnotus, Malapterurus and Raja. Anat. Mem. Edinb. (Goodsir), 1868, 2, 289-305.

1868.2

Gordon, Galgliesh. A preliminary list of the fishes of Tirhoot, Bengal. Journ. Nat. Hist. Soc. Bombay, 1910, $20,428-434$.

1910.1

Gordon, W.J. Our country's fishes and how to know them. London, 1902. 152 p. 32 pls. figs. $8^{\circ}$.

1902.1

Gorham, F.P. Some physiological effects of reduced pressure on fish. Journ. Boston Med. Soc., 1899, 3, 250-256. pl.

1899.1

The gas-bubble disease of fish and its cause. Bull. U. S. Fish Comm. 1899 (1901), 19, 33-37. pls. 1901.1

Gorham, $F . P ., \&$ Marsh, M.C. See Marsh \& Gorham.

Gorham, W.B. Some observations on the culture of yellow perch in ponds. Trans. Amer. Fisheries Soc. 1911 (1912), 153-154.

1912.1

Gorjanovič-Kramberger, Dragutin [ $=K a r l] \quad$ Beiträge zur Kenntnis der fossilen Fische der Karpathen. Palæontographica, 1879, 26, 51-68. 3 pls.

1879.1

Die fossilen Fische von Wurzenegg bei Prassberg in Steiermark. Jahrb. Geol. Reichsanst., Wien, 1880, 30, 565572 .

1880.1

- Studien über die Gattung Saurocephalus Harlan; ein Beitrag zur Neocom-Fischfauna der Insel Lesina. Jahrb. Geol. Reichsanst., Wien, 1881, 31, 371-379.

1881.1

Saurocephalus and related genera are placed in family Scopeloidei and subfamily Saurodontidæ, and a new genus Solenodon is described.

-. Bemerkungen zur fossilen Fischfauna der Karpathen. Verh. Geol. Reichsanst., Wien, 1882, 111-114.

1882.1

Notice in Neues Jahrb. Mineral., 1882, 2, 109.
— Die jungtertiäre Fischfauna Croatiens. Parts I-II. Beitr. Palæeont. Oesterr.-Ungarn, 1882, 2, 86-135. 8 pls. Ibid., 1883, 3, 65-85. 2 pls. $\quad 1882.2$ Review in Neues Jahrb. Mineral., 1883, 2 (Ref.), 109-111.

Ueber fossile Fische der südbaierischen Tertiärbildungen. Verh. Geol. Reichsanst., Wien, 1882, 231-235.

1882.3

- Vorlüufige Mittheilungen über die aquitanische Fischfauna der Steiermark. Verh. Geol. Reichsanst., Wien, $1882,27-29$.

1882.4

\section{Palæichthyologische Beiträge.} Glasnik Narav. Družt., Zagreb, 1886, 1, 123-137.

1886.1

Palæichthyoložki prilozi (Collectæ palæoichthyologicæ) Dis II. Rad Jugoslav. Akad., 1891, 106, 58-129. 8 pls.

1891.1

De piscibus fossilibus Comeni, Mrzleci, Lesinæ et M. Libanonis, et appendix de piscibus oligocrenicis ad Tüffer, Sagor et Trifail. Opera Acad. Sci. Art. Slav. Merid., Agram, 1895, 16, 1-67. $12 \mathrm{pls}$.

1895.1

Hungarian and Latin text in parallel columns.

- Palæichthyologische Bemerkungen. Verh. Geol. Reichsanst., Wien, $1898,105-106$.

1898.1

- Ueber fossile Fische von Tüffer in Steiermark und Jurjevčani in Kroatien. Glasnik Narav. Družt., Zagreb, 1898, 10, 12-34. 2 pls. $\quad 1898.2$

— Palæichthyologische Beiträge. Mitth. Ungar. Geol. Anstalt, Budapest, 1902 (1903), 14, 1-21. 4 pls. \& 5 figs.

1903.1

Die obertriadische Fischfauna von Hallein in Salzburg. Beitr. Palæont. Geol. Oesterr.-Ungarn, 1905, 18, 193224. 5 pls. \& 19 figs. 1905.1

Gorka, Sandór. A halak hallásáról [Ueber das Gehör der Fische] Termész. Közl., Budapest, 1906, 38, 579-581.

1906.1

—A halak úszóhólyagjának élettani szerepe [Die physiologische Rolle der Schwimmblase der Fische] 'Termész. Közl., Budapest, 1908, 40, 73-74.

1908.1

Gorkom, Karel Wessel van. De vischteelt op Sawah's in de Preangerregentschappen. Tijdschr. Nijverheid. Nederl. Indie, 1868, 13 (n. s. 8), 142-146. 1868.1 
Goronowitsch, $N$. Studien über die Entricklung des Medullarstranges bei Knochenfischen, nebst Beobachtungen über die erste Anlage der Keimblätter und der Chorda bei Salmoniden. Morphol. Jahrb., 1885, 10, 376-445. 4 pls.

1885.1

- Das Gehirn und die Cranialnerven von Acipenser ruthenus. Ein Beitrag zur Morphologie des Wirbelthierkopfes. MIorphol. Jahrb., 1888, 13, 427-514. $12 \mathrm{pls}$.

1888.1

Développement des nerfs craniens chez les embryons de la forelle [Text in Russian] Bull. Soc. Impér. Nat. Moscou, 1897, n. s. 10, 30-32. 1897.1

- Der Trigemino-fascialis-Komplex von Lota vulgaris (In Festschrift zum siebenzigsten Geburtstage von C. Gegenbaur, 1897, vol. iii, 1-42. 2 pls. \& 15 figs. Leipzig, 1896-97. $4^{\circ}$ ) 1897.2

- Untersuchungen über die erste Anlage der Kranialnerven bei Salmo fario. Nouv. Mem. Soc. Nat. Moscou, 1898, 21, 1-55. 3 pls. \& 37 figs. 1898.1

Gorrick, C.H. My largest trout. Aquar. Australia, 1911, 24-26. illust.

1911.1

Gortani, Michele. Pholidophorus faccii, n. s., nel Raibliano di Cazzaso in Carnia. Riv. Ital. Paleont., 1907, 13, 117-122. pl.

1907.1

Gosch, Christian Carl August [1832 -] Udsigt over Danmarks zoologiske literatur med en indledende fremstilling af de videnskabelige grundsætninger for naturvidenskabens især zoologiens studium. Kjobenhavn, 1870。 $360 \mathrm{p}$. $\mathrm{S}^{\circ}$.

1870.1

- The same. 2. ed. 2 vols. Kjobenhavn, $1873 . \quad 1873.1$

The same. 3. exl. 2 rols. Kjobenhavn, 1875-78. $\quad 1875.1$

Gosden, Frank. Food of sea fishes; whiting [1/Rerlangus vulgaris] and whiting pout [Morrhua lusca] Zoologist, 1880, 3. ser. 4, 304-305.

1880.1

Gosnell, $R$. $E$. The fisheries tof British Columbial Compend. to Yearbook Brit. Columbia, 1897, 62-77. 2 pls. 1897.1

Goss, David Kopp, \& Jordan, David Starr. See Jordan \& Goss.

Goss, David Kopp, \& Meek, Seth E. See Meek \& Goss.
Gosse, Philip Henry [1810-1888] The Canadian naturalist. London, 1840. 372 p. 44 figs. $12^{\circ}$. 1840.1

- The ocean. London, 1849. 360 p. 52 illust. $8^{\circ}$. 1849.1

Natural history. Fishes. London, 1851.

1851.1

- A naturalist's sojourn in Jamaica. London, 1851 . $508 \mathrm{p} .12^{\circ}$.

1851.2

- Natural history of fishes. London, 1854. $8^{\circ}$.

1854.1

- Manual of marine zoology. British isles. 2 vols. London, 1855-56. $12^{\circ}$.

1885.1

The aquarium; or, Unveiling of the wonders of the deep. London, 1856. $12^{\circ}$.

1856.1

Gosselet, Jules Auguste Alexandre [1832 - ] Mâchoire de Ptychodus latissimus découverte à Condé. Ann. Soc. Géol. Nord. 1870-74 (1875), p. 12.

1875.1

- Constant Prévost. Coup d'œil rétrospectif sur la géologie en France pendant la première moitié du xixe siècle. Lille, $1896.8^{\circ}$. 1896.1

Découverte de poissons [Pteraspis dans le terrain dévonique du Pas-deCalais. C. R. Acad. Sci. Paris, 1903, 136,540 .

1903.1

Gotch, Francis. The electromotive properties of the electrical organ of Torpedo marmorata. Phil. Trans. Roy. Soc. London, 1888, 178, 487-537. 4 figs.

1888.1

—_ Experiments on some curarised torpedoes. Proc. Phys. Soc., 1888, 2, p. 5.

1888.2

- Further observations on the electromotive properties of the electrical organ of Torpedo marmorata. Phil. Trans. Roy. Soc. London, 1889, 179, 329-363. 2 pls. \& 3 figs.

1889.1

The electric organs of fishes. Proc. Biol. Soc. Liverpool, 1892, 6, 148154.

1892.1

The electric fish of the Nile. Science, 1899, 2. ser. 10, 963-964.Proc. Roy. Instit. Gt. Britain, 1900, 16 114-115.

1899.1

Gotch, Francis, \& Burch, G.J. The electromotive properties of the electri- 
cal organ of Malapterurus electricus. Abstract in Proc. Roy. Soc. London, 1896, 60, no. 369, 37-39. - Nature, 54, no. $1387,92-93$.

1896.1

- The electromotive properties of Malapterurus electricus. Phil. Trans. Roy. Soc. London, 1896 (1897), $187 \mathrm{~B}$, 347-407. 3 pls. \& 8 figs.

1897.1

- Note on the electromotive force of the shock and the electrical resistance of the organ in Malapterurus electricus. Proc. Roy. Soc. London, 1900, 65, 434445. 2 figs,

1900.1

Gotch, Francis, \& Sanderson, $J$. Burdon. See Sanderson \& Gotch.

Gotrian, - Uebersicht über die Fischerei-Verhältnisse der Provinz Posen. Allgem. Fischerei Zeitg., 1896, 21. Jahrg., 265-269; 288-291; 307-308.

1896.1

Gottberg, Gunnar. Ammodytes-arterna vid Finlands kuster [Die Ammodytes-Arten an den Küsten Finlands] Acta Soc. Fauna \& Flor. Fenn. Helsingfors, 1910,33 , no. 5, 1-41. pl. 1910.1

Iakttagelser offver lakens tillväxt, lek och födoämnen hos oss [Beobachtungen über den Zuwachs, das Laichen und die Nahrung von Lota vulgaris in Finland] Fiskeritidskr. Finl., 1910, 19, 114-121.

1910.2

Lumpenus lampetriformis i de till Finland gränsande hafven. Meddel. Soc. Fauna Flora Fenn., 1910, 36. Heft, $38-48 ; 215-216.2$ figs.

1910.3

- Mateen kasvusta Suomessa ¿Ueber den Zuwachs der Lota vulgaris in Finland] Luonnon Ystävä, Helsingfors, $1910,14,100-102$.

1910.4

Pholis gunnellus vid Finlands kuster. Meddel. Soc. Fauna Flora Fenn., 1910, 36. Heft, 36-38; 217. 1910.5

Gottsche, Carl Moritz [1808-1892] Ueber das Balkensystem im Fischgehirne. Notizen (Froriep), 1833, 36, 3638.

1833.1

Ueber die Vierhügel, Thalamus opticus und Stabkranz des Reil im Grïtenfischgehirne. Notizen (Froriep), $1833,37,36-40$.

1833.2

Fortsetzung der Untersuchung des Grätenfischgehirns. Notizen (Froriep), 1834, 40, 52-57.

1834.1

Ueber die Retina im Auge der Grätenfische. Arch. Anat. Physiol. (Müller), 1834, 457-466. pl. 1834.2
Die seeländischen PleuronectesArten. Arch. Naturgesch. (Wiegmann), 1835, 2, 133-186.

1835.1

- Vergleichende Anatomie des Gehirns der Grätenfische. Arch. Anat. Physiol. (Müller), 1835, 244-294; 433486. 3 pls.

1835.2

Goủan, Antoine [1733-1821] Historia piscium, sistens ipsorum anatomen externam, internam, atque genera in classes et ordines redacta.-Or, Histoire des poissons, contenant la déscription anatomique de leurs parties externes et internes, et le caractère des divers genres rangés par classes et par ordres. Avec un vocabulaire complet, des tables raisonnées en latin et en françois. Strasbourg, 1770 . xviii, 252 p. 4 pls. $4^{\circ}$.

1770.1

"The text is in both Latin and French, corresponding on opposite pages. The modifications introduced into the class by Linné in the tenth edition of the Systema Naturæ are adopted. The genera were quite well described, and three new ones still retained in the system (Lepadogaster, Lepidopus, and Trachypterus) were established." - T. N. Gill, Smithson. Miscell. Collect., $1872,11,35$.

- Geschichte der Fische, welche derselben åussere und innere Beschaffenheit und in Klassen und Ordnungen abgetheilte Gattungen enthält. Nebst vollständiger Terminologie und nöthigen Registern. Aus dem Lateinischen übersetzt von K. v. Meidinger. Wien, 1781. $8^{\circ}$.

1781.1

Goudy, John. The heaviest American salmon. Forest \& Stream, 1878, 10, 265.

1878.1

Gough, William B. Testimony in regard to the present condition of the fisheries taken in 1871. Rept. U. S. Fish Comm. 1871 (1873), 1, 31. 1873.1

Gould, Augustus Addison [18051866] The questions of the identity of the fishes of North America and Europe. Proc. Boston Soc. Nat. Hist. 1844 (1848), 2, 107.

1848.1

Gould, N.E. Time of approach of fish to the New England coast. Bull. U.S. Fish Comm. 1885, 5, 216. 1885.1

Gouriet, $E$. Remarques sur la locomotion des poissons. C. R. Acad. Sci. Paris, 1861, 58, 200-202.

1864.1

Du rôle de la vessie natatoire. Ann. Sci. Nat. (Zool.), 1866, 5. sér. 6, 369-382.

1866.1

Recherches expérimentales sur la locomotion des poissons. Niort, 1866. 88 p. $4^{\circ}$. 
Gouriet, $E$.

Remarques sur les variations des nageoires dans la classe des poissons. C. R. Acad. Sci. Paris, 1868, 66, 13451348.

1868.1

Gourret, Paul. Les pêcheries et les poissons de l'étang de Thau. Paris, 1886. 67 p. figs. $8^{\circ}$.

1886.1

Nouvelle contribution à la faune pélagique du golfe de Marseille. I. Classe des poissons. Arch. Biol., 1890, $10,312-321$.

1890.1

Ichthyologie Marseillaise. Famille des labroïdes. Ann. Mus. Hist. Nat. Marseille (Zool.), 1893, 4, no. 3. 86 p. 7 pls.

1893.1

L La consommation et le commerce du poisson, des coquillages, etc., à Marseille. Ann. Mus. Hist. Nat. Marseille (Zool.), 1894, 4, 20-29.

1894.1

___ Examen de la pâture de quelques puissons comestibles du golfe de Marseille. Ann. Mus. Hist. Nat. Marseille (Zool.), 1894, 4, 29-36; 96-100. 1894.2

Examen de l'état de maturité sexuelle de quelques poissons comestibles du golfe de Marseille. Ann. Mus. Hist. Nat. Marseille (Zool.), 1894, 4, $34-43 ; 100-110$.

1894.3

Les madragues de Marseille. Ann. Mus. Hist. Nat. Marseille (Zool.), 1894, 4, 59-75. 3 figs.

1894.4

L La pêche des battudes à Marseille. Ann. Mus. Hist. Nat. Marseille (Zool.), 1894, 4, 75-83.

1894.5

- La pêche des issaugues à Marseille. Ann. Mus. Hist. Nat. Marseille (Zool.), 1894, 4, 44-60.

1894.6

La pêche des mugelières. Ann. Mus. Hist. Nat. Marseille (Zool.), 1894 $4,54-82$. 1894.7

- La pêche des palangres à Marseille. Ann. Mus. Hist. Nat. Marseille (Zool.), 1894, 4, 44-58.

1894.8

La pêche des thys à Marseille, en 1891. Ann. Mus. Hist. Nat. Marseille (Zool.), 1894, 4, 83-96. $\quad 1894.9$

La pêche du brégin à Marseille. Ann. Mus. Hist. Nat. Marseille (Zool.), $1894,4,72-74 ; 82-93$.

1894.10

Les pêcheries et les poissons de Ia Méditerranée. Paris, 1894. fig. $8^{\circ}$. 1894.11
- Statistique de la pêche des poissons taxés, des thons, des sardines, des langoustes, des homards et des squinades, en 1891; consommation et commerce du poisson, des coquillages, etc., à Marseille. Ann. Mus. Hist. Nat. Marseille (Zool.), 1894, 4, 20-31; 40-54.

1894.12

Statistique de la pêche des poissons taxés, des thons, des sardines et des langoustes pendant les années 1889 et 1890. Ann. Mus. Hist. Nat. Marseille (Zool.), 1894, 4, 5-20. 1894.13

Les anguilles de l'étang de Thau et leur pêche. Etangs \& Rivières, 1896, 9, 329 .

1896.1

Documents zoologiques sur l'étang de Thau. Trav. Inst. Zool. Univ. Montpellier Stat. Marit., 1896, n. s. 5. $55 \mathrm{p}$.

1896.2

Les pêcheries et les poissons de l'étang de Thau. Paris, 1896. $67 \mathrm{p}$. fig. $8^{\circ}$.

1896.3

Examen de l'état de maturité sexuelle chez quelques poissons comestibles de Marseille. Ann. Mus. Hist. Nat. Marseille, 1897, 2. sér. 5, 20-23. 1897.1

Statistique des poissons pêchés dans le golfe de Marseille en 1893, 1894 et 1895. Ann. Mus. Hist. Nat. Marseille, 1897, 2. sér. 5, 8-19. 1897.2

Gowrie, pseudonym for Smith, W. Anderson.

Graah, Wilhelm August [1794-1863 Narrative of an expedition to the east coast of Greenland ... in search of the lost colonies. ... London, 1837. 199 p. map. $8^{\circ}$.

1837.1

Grabau, H. Mesonauta insignis Gthr. Wochenschr. Aquar--Terrar. Kunde, 1912, 9. Jahrg., 457-458. fig.

1912.1

Grabill, L. R. Report of operations at the shad-hatching station at Battery island, near Havre de Grace, Md., during the season of 1886. Bull. U. S. Fish Comm. 1886 (1887), 6, 361-368.Rept. U.S. Fish Comm. 1886 (1889), 14, 807-814. 1887.1

Gracianov, Valerian $I$. Ueber die sogenannte "Kauplatte" der Cyprinoiden. Zool. Anz., 1900, 23, 66-73. 5 figs.

1900.1

Ueber die Arten der Familie Cottida im Baikalsee [Text in Rus- 
sian! Dnevn. 11. Sjěsda Russ. Jest. Vrac.., St. Petersb., 1901, 12, pts. 23-30, $410-411$.

1901.1

Hornige Gebilde bei Fischen [Text in Russian] Dnevn. Otd. Icht. Imp. R. Obšč. Acclim., Moskva, 1902, 7, 213-217.

1902.1

- Die Ichthyofauna des Baikalsees [Text in Russian] Dnevn. Zool. Otd. Obšč. Liub. Jest., Moskva, 1902, 3, no. $3,18-61$.

1902.2

Beitrag zur Ichthyofauna des russischen Nordens [Text in Russian] Zap. Russ. Georg. Obšč., St. Petersb., 1904, 41, pt. 1, 171-249. 2 pls. \& 12 figs.

1904.1

Die Emanzipation der Thiere von der Macht des umgebenden Mediums [Text in Russian] Jest. Geogr., Moskva, 1904, 9, no. 7, 46-69. 1904.2

Zamyetka o Asperina improvisa Ostroum [Text in Russian] Bull. Acad. Sci. St. Pétersb., 1905, 5. sér. 23, 35-39. 1905.1

Ueber eine besondere Gruppe der Rochen. Zool. Anz., 1906, 30, 399-406. 2 figs. 1906.1

Bemerkungen über die während der Studienreise nach Minsk gesammelten Fische [Text in Russian] Trd. Iruž. Izsl. Russ. Prir., Moskva, 1907. 3, 145-151.

1907.1

Malacobatis, gen. nov. for Raia mucosa Pallas; synoptische Tabelle der Plagiostomi] Trd. Otd. Icht. Imp. R. Obšč. Acclim., Moskva, 1907, 4. 1907.2

Die Neunaugen des russischen Reiches ['Text in Russian] Dnevn. Zool. Otd. Obšč. Liub. Jest., Moskva, 1907,3 , no. $7-8,18$.

1907.3

Uebersicht der Süsswassercottiden des russischen Reiches. Zool. Anz., 1907, 31, 654-660.

1907.4

- Versuch einer Uebersicht der Fische des russischen Reiches in systematischer und geographischer Hinsicht [Text in Russian] Trd. Otd. Icht. Imp. R. Obšč. Acclim., Moskva, 1907, 4. $\mathrm{xxx}, 567 \mathrm{p}$.

1907.5

- Zur Kenntnis der Neunaugen des russischen Reiches [Text in Russian] Trd. Otd. Icht. Imp. R. Obšě. Acclim., Moskva, 1907, 6, 353-384.

- $\quad 1907.6$

Die Wanderungen der Fische [Text in Russian] Ochotn. Věstn.,
Moskva, 1908, Beil., Ochotničkoe Enciklopedija, 1908, 1, 37-71. 3 pls.

1908.1

Gracianov, Valerian $I$., Zograf, $J$. $N$., Hindze, $B . K$., Voronkov, $N$. V., Bogojavlenskij, $N$. V., \& Chmèlevskij, C.V. See Chmělevskij, Gracianov \& others.

Graefe, M. Ueber Fütterung der Fische. Circul. Thüring. Fischerei Ver., 1880, 3. Jahrg., 11-12.

1880.1

Graeffe, Eduard. Das SüsswasserAquarium. Kurze Anleitung zur besten Construction der Aquarien und Instandhaltung derselben, sowie Schilderung der Süsswasser-Thiere. Hamburg, 1861. 50 figs. $8^{\circ}$. 1861.1

Uebiersicht der Seethierfauna des Golfes von Triest nebst Notizen über Vorkommen, Lebensweise, Erscheinungs- und Fortpflanzungszeit der einzelnen Arten. Arb. Zool. Instit. Univ. Wien \& Zool. Stat. Triest, 1886, 7. Also separate; Wien, 1888. $8^{\circ}$. 1886.1

Graeger, Johann Nicolaus. Ueber die Auffindung und Bestimmung des Jods im Leberthran. Arch. Pharm., $1841,76,60-61 ; 187 . \quad \cdot 1841.1$

Graells, Mariano de la Paz. Manual prático de piscicultura, etc., escrito y publicado por orden de S. M. el Rey. Madrid, 1864. cxxiii, 264 p. pls. $8^{\circ}$.

1864.1

Aquicultura. Estudios y observaciónes sobre los establecimientos piscicolas, ostricolas, etc. Madrid, 1867. 218 p. 12 pls. $4^{\circ}$. 1867.1

Catálogo de los peces de las costas de Cataluña y Valencia. Ann. Comisión Permanente de Pesca, Madrid, 1869, 2.

1869.1

Recursos que ofrecen à los pobres de nuestras playas. Ann. Comisión Permanente de Pesca, Madrid, 1869, 2.

1869.2

Exploración cientifica de las costas del departamento marítimo del Ferrol. Madrid, 1870. 16 pls. $8^{\circ}$.

1870.1

Graff, Ludwig von [1851 - ] Fauna der Alpenseen. Graz, 1887. 8 1887.1

- Bibliothek des Professors der Zoologie und vergleichlichen Anatomie, Dr. Ludwig von Graff. Graz, 1891. $337 \mathrm{p}$. 1891.1

Piscés und Dipnoi, p. 287-301. 
Graham, W. M. A fish that preys on mosquito larvx in southern Nigeria. Bull. Entomol. Research, London, 1911, 2, 137-139.

1911.1

Graichen, Hans, Einiges über Pocilia reticulata Peters. Wochenschr. Aquar.-Terrar. Íunde, 1909, 6. Jahrg., 338-339.

1909.1

Haplochilus elegans Boulenger. Wochenschr. Aquar-Terrar. Kunde, 1909, 6. Jahrg., 349-351. fig. 1909.2

Haplochilus species aus Cochin (Vorderindien) Wochenschr. Aquar.Terrar. Kunde, 1909, 6. Jahrg., 517-518. fig.

1909.3

Graino, $C$. Datos para la fauna de la provincia de Oviedo. Bol. Soc. Españ. Hist. Nat., Madrid, 1905, 5, 269-272.

1905.1

Gramberg, J.S. G. Troebokvisscherij. Tijdschr. Ind. Taal-, Land, ete. Kunde, 1877, 24, no. 4-5, 298-317.

1877.1

Gramsch, $E$. Die Zucht der Rotfeder im Aquarium. Wochenschr. Aquar-Terrar. Kunde, 1909, 6. Jahrg., 615-616. fig.

1909.1

Ein Beitrag zur Pflege unserer einheimischen Fische im Aquarium. Wochenschr. Aquar.-Terrar. Kunde, 1911, 8. Jahrg., 436-437. fig. 1911.1

Granby, Marquis of. The trout. London, 1898. pls. \& figs. $8^{\circ}$. 1898.1

Grandauer, $A$. Die Fische in den Gewässern um Augsburg. Ber. Naturhist. Ver. Augsburg, 1853, 6, 21. 1853.1

Grandey, —_, \& Jobert, Clément. See Jobert \& Grandey.

Grandidier, Alfred [1836-] Histoire physique, naturelle et politique de Madagascar. Paris, 1875-99. $4^{\circ}$.

1875.1

Poissons, par II. Sauvage, 1887-91, vol. xvi. 543 p. 61 pls.

Grandmont, Anatole Gillet de. See Gillet de Grandmont, Anatole.

Grandsagne, Jo. B. Francois Etienne Ajasson de. Précis d'ichthyologie ou $d^{\prime}$ histoire naturelle des poissons. Paris, 1829. 80 p. 46 pls.

1829.1

Grant, Issac $H$. Movements of menhaden. Cateh of herring. Bull. U. S. Fish Comm. 1883, 3, 470. 1853.1
Grant, John. Statement concerning the menhaden fishery. Rept. U. S. Fish Comm. 1877 (1879), 5, 378. 1879.1

Grant, J. Lewis. Yellow perch of Owasco lake. Forest \& Stream, 1877, 8, 99.

1877.1

Grant, Madison. Ouananiche stocking. Forest \& Stream, 1898, 51, 292

1898.1

Grant, Robert Edmond [1793-1874] On the structure of the eye of the swordfish (Xiphias gladius Linn.) Mem. Wern. Soc. Edinb., 1826-31, 6, 113-122. 1826.1

On the viscera of the common swordfish (Xiphias gladius Linn.) Trans. Med.-Chir. Soc. Edinb., 1828, 3, 79-93.

1828.1

Grant, William Robert Ogilvie [1863 - ] A revision of the fishes of the genera Sicydium and Lentipes, with descriptions of five new species. Proc. Zool. Soc. London, 1884, 153-172. pls.

1884.1

Grassi, Giovanni Battista. Beiträge zur näheren Kenntnis der Entwicklung der Wirbelsäule der Teleostier. Morphol. Jahrb., 1883, 8, 457-473. 1883.1

Développement de la colonne vertébrale chez les poissons osseux. Arch. Ital. Biol., 1853, 4, 236-268.

1883.2

- Lo sviluppo della colonna vertebrale ne' pesci ossei. Atti Accad. Lincei, Roma (Mem.), 1885, 15, 311-372. \& pls.

1885.1

- Reproduzione e metamorfosi della anguillea. Giorn. Ital. Pesca e Acqui., 1887, no. 7-8. Abstract in Monit. Zool. Ital., 8, 233-234. 1887.1

The reproduction and metamorphosis of the common eel (Anquilla vulgaris) Proc. Roy. Soc. London, 1896, 60, 260-271. - Quart. Journ. Micr. Sci. London, n. s. 39, 371-385. figs. - Bull. Soc. Centr. Aquicult. Pêche, 1897, 9, no, 3-1, 97-108. Abstract in Journ. R. Micr. Soc., 1897, pt. 2, 111. Also separate; Halle, 1898. $4^{\circ}$ 1896.1

Contribuzione allo studio dello sviluppo dei murenoidi. I. Murana helena. II. Di alcune uova e prelarve, che si potrebbe supporre appartenenti ad Anguilla anguilla. Mem. R. Comitat. Talassogr. Ital., Roma, 1910, 1, 1-16. pl. 
- Nuova contribuzione alla storia dello sviluppo dei murenoidi. Atti Accad. Lincei, Roma (Rendic.), 1912, 5. ser. 21, pt. 2, 15-20.

1912.1

Ricerche sulle anguille argentine allevate forzatamente in vasche di acqua dolce. Atti Accad. Lincei, Roma (Rendic.), 1912, 5. ser. 21, pt. 2, 675-677.

1912.2

Metamorfosi dei murenoidi. Ricerche sistematiche ed ecologiche. Jena, 1913. 15 pls.

1913.1

La talassobiologia e la pesca. Mem. R. Comit. Talassografico Ital. Venezia, 1913, 19, 1-42. - Atti Soc. Ital. Prog. Sci., Roma, 1913, 6, 59-95. 1913.2

Grassi, Giovanni Battista, \& Calandruccio, Salvatore. Le leptocefalide e la loro transformazione in murenide. Atti Accad. Lincei, Roma (Rendic.), 1892, 5. ser. 1, 375-379.

1892.1

Ancora sullo sviluppo dei murenoidi. Terza nota preliminare. Bull. Accad. Gioenia Sci. Nat. Catania, 1893, n. s., pt. 34-35, 2-5. - Atti Accad. Lincei, Roma (Rendic.), 1893, 5. ser. 5, 348-349.

1893.1

Ulteriori ricerche sui leptocefali. Atti Accad. Lincei, Roma (Rendic.), 1893, 5. ser. 5, 450-452.

1893.2

Soluzione di un enigma antichissimo, ossia scoperta della metamorfosi de l'anguilla. Venezia, 1894. 1894.1

- Sullo sviluppo dei murenoidi. Atti Accad. Lincei, Roma (Rendic.), 1896, 5. ser. 5, pt. 1, 348-349. $\quad 1896.1$

Ulteriori studi sullo sviluppo dell' anguilla e sul congro. Atti Accad. Lincei, Roma (Rendic.), 1896, 5. ser. 5. 241.

1896.2

Descrizione d'un Leptocephalus brevirostris in via di trasformarsi in Anguilla vulgaris. Atti Accad. Lincei, Roma (Rendic.), 1897, 5. ser. 6, pt. 1, 239-240. 2 figs. Abstract in Nature, 56, 85. 2 figs. - Amer. Naturalist, 31, no. 368,726 .

1897.1

- Fortpflanzung und Metamorphose des Aales. Allgem. Fischerei Zeitg., 1897, 22, 402-408; 423-428. 8 figs.

1897.2

- Riproduzione e metamorfosi delle anguille. Giorn. Ital. Pesca e Acquic., 1897, no. 7-8. Abstract in Monit. Zool. Ital., Firenze, 8, 233-234.

1897.3
Ulteriori ricerche sulle metamorfosi dei murenoidi. Atti Accad. Lincei, Roma (Rendic.), 1897, 5. ser. 6 , 43.

1897.4

- Aalens forvandling og forplantning. Dansk Fiskeriforen. Medlemsbl., 1898, 7. Jahrg., 306-307; 322-325; 339343 ; 354-355; 362-364. 7 figs. 1898.1

Ueber Fortpflanzung und Metamorphose der Aale. Natur, 1898, 47, $97-99 ; 111-114 ; 124-126.3$ figs.

1898.2

- Riproduzione e metamorfosi delle anguille. Acquicolt. Lombarda, Milano, 1903, 5, 57-58; 72-75; 110-111; 160-168. 1903.1

Gratacap, Louis Pope [1851 - ] Fishremains and tracks in the Triassic rocks at Weehawken, N. J. Amer. Naturalist, $1886,20,243-246.2$ pls. \& 2 figs.

1886.1

Fossils and fossilization. Amer. Naturalist, 1896, 30, 902-912; 993-1003. 1896.1

Biographical memoir of Robert Parr Whitfield; with a bibliography by L. Hussak of. Ann. N. Y. Acad. Sci., 1911, 20, pt. 3, 385-398. pl. 1911.1

Gratzianow, Valerian. See Gracianov, Valerian $I$.

Grave, Caswell. The fisheries laboratory at Beaufort, sixth session. Science, 1905, n. s. 21, 732-737. 1905.1

Work on Beaufort fishes by Dr. E. W. Gudger, p. 735 .

Gravenhorst, Johann Ludwig Christian [1777-1857] Vergleichende Uebersicht des Linneischen und einiger neuern zoologischen Systeme. Göttingen, 1807.

1807.1

Gravier, Charles. La station biologique marine de San Diego (Californie) Rev. Gén. Sci., 1912, 23, 440-443. 4 figs.

1912.1

Gray, A.F. The Boston aquarium. Forest \& Stream, 1875, 5, 68. $\quad 1875.1$

Gray, Albert A. On the labyrinth of animals. Proc. Zool. Soc. London, 1905, $1,143-145$.

1905.1

Gray, George Robert [1808-1872] Narrative of an expedition to the shores of the Arctic sea in 1846 and 1847. London, 1850. 247 p. maps. $8^{\circ} .1850 .1$

Gray, Henry $R$. The river Sorel. Forest \& Stream, 1874, 3, 283. 1874.1 
Gray, John Edwaird [1800-1875] On the genus Plagiostoma. Ann. Phil. (Thomson), 1825, 10, $153 . \quad 1825.1$

List of fish of Australia (In King's Survey of coast of Australia, 1827, p. $\left.435.8^{\circ}\right)$

1827.1

-... Illustrations of Indian zoology of new and hitherto unfigured Indian animals from the collection of General Hardwicke. 2 vols. London, 1830-34. 202 pls. fol.

1830.1

-Description of a new genus (Micropus) of percoid fish, discovered by Samuel Stutchbury in the Pacific sea, and now in the British Museum. Zool. Miscell., 1831, 20.

1831.1

Description of three new species of fish from the Sandwich islands, in the British Museum. Zool. Miscell., 1831, 33.

1831.2

Description of three new species of fish, including two undescribed genera [Leucosoma and Samaris] discovered by John Reeves, Esq., in China. Zool. Miscell., 1831, 4-5.

1831.3

Description of twelve new genera of fish, discovered by Gen. Hardwicke in India, the greater part in the British Museum. Zool. Miscell., 1831, 7-10.

1831.4

- Descriptions of three species of Notopterus, found by Gen. Hardwicke in the Indian seas. Zool. Miscell., 1831, 16.

1831.5

- The zoological miscellany, pts. i-vi. London, 1831-44. $4^{\circ}$. 1831.6

Characters of two new species of sturgeon (Acipenser, Linn.) Proc. Zool. Soc. London, 1834, 2, 122-123. Arch. Naturgesch. (Wiegmann), p. 272. Isis (Oken), 1835, 1050-1051. 1834.1

Description of a new species of Tetrapturus from the cape of Good Hope. Ann. Mag. Nat. Hist., 1838, 1, 313. pl.

1838.1

- Systematic arrangement of fishes, with list of the genera. Syn. Brit. Mus., 1838. $12^{\circ}$

Revised 1840 and 1842.

1838.2

- Fishes (In Beechey's "Zoology of Beechey voyage to the Pacific and Behring straits." London, 1839. 47 pls.)

1839.1

- The exhibition of fisher in museums. Ann. Mag. Nat. Hist., 1841, 6, 157.
Three hitherto unrecorded species of freshwater fishes [Galaxias fasciatus, Anguilla dieffenbachii, Eleotris basalisı, brought from New Zealand and presented to the British Museum by Dr. Dieffenbach. Zool. Miscell., 1842, p. 73.

1842.1

Description of two freshwater fish from New Zealand (In Dieffenbach, Ernst. Travels in New Zealand ... vol. ii, p. 221-225. London, 1843. 2 vols. illust: $8^{\circ}$ )

1843.1

Description of a new species of Amphioxus [A. belcheri] from Borneo. Proc. '/sool. Soc. London, 1847, 15, 3536. - Ann. Mag. Nat. Hist., 1847, 19, $463-464$.

1847.1

Mammalia and fish of the Arctic regions. See Rae, J. Narrative of an expedition to the shores of the Arctic sea in 1846 and 1847. London, 1850. $8^{\circ}$.

1850.1

- On the British specimens of Regalecus. Proc. Zool. Soc. London, 1849, pt. 17, 78-84. - Ann. Mag. Nat. Hist., 1850, 2. ser. 5, 501-507. 1850.2

List of the specimens of fish in the collection of the British Museum. Part I. Chondropterygii. London, 1851. 160 p. 2 pls. $8^{\circ}$. 1851.1

Description of a new form of lamprey from Australia [Geotria australis n. g. et sp.] with a synopsis of the family. Proc. Zool. Soc. London, 1851, pt. 19, 235-241. - Ann. Mag. Nat. Hist., 1854, 2. ser. 13, 58-65. pls. 1851.2

(editor) Catalogue of fish collected and described by L. 'T. Gronow, now in the British Museum. London, 1854. $8^{\circ}$

1854.1

Observations on a living African Lepidosiren in the Crystal palace. Proc. Zool. Soc. London, 1856, pt. 24, 342-346. - Arch. Naturgesch. (IViegmann), 1857, pt. 1, 330-339. 1856.1

Description of a new genus of lophobranchiate fishes from western Australia. Proc. Zool. Soc. London, 1859, pt. 27, 38-39. - Ann. Mag. Nat. Hist., 3. ser. 4, 309-311. pl. 1859.1

On Pelamys sarda, a British fish. Ann. Mag. Nat. Hist., 1859, 3. ser. 4, 399.

1859.2

On the mud-fish of the Nile (Protopterus annectens?) Ann. Mag. Nat. Hist., 1860, 3. ser. 5, 70-71. 1860.1 
On the habits of the pipe-fish and other fishes. Ann. Mag. Nat. Hist., 1861, 3. ser. 6, 494-496. - Proc. Zool. Soc. London, 1861, pt. 19, 238-239.

1861.1

On the occurrence of the opah (Lampris lauta) on the British coast. Ann. Mag. Nat. Hist., 1861, 3. ser. 8, 192.

1861.2

Capture of Diodon pennatum. Ann. Mag. Nat. Hist., 1862, 3. ser. 9, 260.

1862.1

- New British fishes [Sebastes viviparus, Spinax niger] Ann. Mag. Nat. Hist., 1868, 4. ser. 1, 312.

1868.1

-_ Rare British sharks [Echinorhinus spinosus, Hexanchus griseus] Ann. Mag. Nat. Hist., 1868, 4. ser. 1, 76.

1868.2

- Transporting fish alive. Ann. Mag. Nat. Hist., 1868, 4. ser. 2, 319.

1868.3

Transportation of live fish from America and south of the equator to England.

On the injury inflicted on ships by the broad-finned swordfish of the Indian ocean. Ann. Mag. Nat. Hist., 1871, 4. ser. 8, 338-339.

1871.1

List of the books, memoirs and miscellaneous papers by ... J. E. Gray. With a few historical notes [By J. Saunders] London, 1872-[75] 58 p. $8^{\circ}$.

1872.1

File-fish (Balistes capriscus) at Weymouth. Ann. Mag. Nat. Hist., 1873, 4. ser. 12, 267-268.

1873.1

Gray, John Edward, \& Gunn, Ronald. Notices accompanying a collection of quadrupeds and fish from Van Diemen's land; with notes and descriptions of the new species. Ann. Mag. Nat. Hist., 1838, 1, 101-111. 1838.1

Gray, John Edward, \& White, Adam. Fish [Synonymy by A. White] (In List of the British animals in the museum, pt. 8. London, 1851. $12^{\circ}$ )

1851.1

Gray, Robert [1825-1887] Notes on the marine zoology of Dunbar; fishes, crustacea, etc. Zoologist, 1849, 6, 2518-2522.

1849.1

Gray, William. Certain habits of salmon. Forest \& Stream, 1874, 2, 244.

1874.1

Graydon, George. On the fish enclosed in stone of monte Bolca. Trans. Roy. Irish Acad., 1794, 5, 281-318.

1794.1
Grazianow, W. See Gracianov, Valerian I.

Greaves, John. A fossilised fish and Ichthyosaurus found in a stone quarry near Stratford upon Avon. Mag. Nat. Hist., 1832, 5, 549 . 1832.1

Greaves; Richard. On the discovery of bones of birds, fishes and mammalia, in the limestone cliff at Eel point in Caldy island. Proc. Geol. Soc. London, 1838 (1842), 3, 322.

1842.1

Grebnitski, N. Liste des poissons recueillis aux îles Commandeur et à Kamtchatka [Text in Russian] Messager Pêche, 1897, 12, 323-339. 1897.1

Greeff, Richard [1829-1892] Die Fauna der Guinea-Inseln. Sitzber. Ges. Gesam. Naturw., Marburg, 1884, no. 2, 41-79.

1884.1

Greeley, Arthur White. Notes on the tide-pool fishes of California, with a description of two new species. Bull. U. S. Fish Comm. 1899 (1901), 19, 7-20.

1901.1

Greeley, Horace. Die Fischzucht in den Vereinigten Staaten von Nordamerika. Ann. Landw. Wochenbl., 1873, 107-108.

1873.1

Greeley, Horace, Case, L., \& others. The great industries of the United States. Hartford, 1872. illust. $8^{\circ}$. 1872.1

Fish-culture and artificial breeding, p. 11981206.

Green, A. The economic fishes of British Columbia. Proc. Nat. Hist. Soc. Brit. Columbia, 1891, 1, 20-33.

1891.1

The Salmonidx of British Columbia. Proc. Nat. Hist. Soc. Brit. Columbia. 1891, 1, 7-19. 1891.2

- Preliminary note on the size of salmon eggs in relation to estimating their number. Rept. Sea Inland Fish, Ireland, 1902-03 (1905), pt. 2, 351-352.

1905.1

Green, Chester $K$. The increase of whitefish and lake trout in lake Ontario. Trans. Amer. Fisheries Soc. 1898 (1899), 82-84.

1899.1

- Value of aquatic plants in pond culture. Trans. Amer. Fisheries Soc. 1904 (1905), 173-176.

1905.1

Green, Erik $H$. The chemical composition of the subdermal connective tissue of the ocean sun-fish. Bull. U. S. Fish Comm. 1899 (1901), 19, 321-324. 
Green, E. $H$.

Notes by the way. Spolia Zeylan., Colombo, 1907, 4, 183-184.

1907.1

Green, Erik H., \& Tower, Ralph Winfred. Ichthylepidin in den Schuppen amerikanischer Fische. Zeitschr. Physiol. Chem., Strassburg, 1902, 35, 196-200.

1902.1

The organic constituents of the scales of fish. Bull. U. S. Fish Comm. 1901 (1902), 21, 97-102.

1902.2

Green, H.A. On the homologies of the chorda tympani in selachians. Journ. Compar. Neurol., 1900, 10, 411 421.

1900.1

Green, $H . J$. The herring fisheries. Intern. Fisheries Exhib. Lit., London, 1853. Conferences, 11, pt. 10. 1883.1

Green, John. An analysis of the scales of the striped bass (Labroax lineatus) Proc. Brit. Soc. Nat. Hist., 1858, 6, 374. - Amer. Journ. Sci., 1858, 26,447 .

1858.1

Fish scales have the chemical constitution of bone, as shown from observations made upon the scales of Megalops, from the gulf of Mexico Proc. Boston Soc. Nat. Hist. 1856 (1859), 6, 362-363.

1859.1

Structure of teeth and scales in Pristis sagittata. Proc. Boston Soc. Nat. Hist. 1856 (1S59), 6, 67. 1859.2

- Structure of the scales of Amia. Proc. Boston Soc. Nat. Hist. 1861 (1862), 8, 218

1862.1

Green, Loren IV. Condition of the United States trout ponds. Bull. U.S. Fish Comm. 1885, 5, 309. 1885.1

On a disease affecting the rainbow trout at McCloud river station. Bull. U. S. Fish. Comm. 1885, 5, 472.

1885.2

Report on the packing of salmon on the Pacific coast from 1883 to 1886. Bull. U. S. Fish Comm. 1856 (1887), 6 286-288.

1887.1

Salmon in the McCloud river during the season of 1856 . Bull. U. S. Fish Comm. 1886 (1887), 6, 334-336.

1887.2

Green, Monroe A. A Kennebec salmon caught in the Hudson river. Bull. U. S. Fish Comm. 1881 (1882), 1, 271.
Green, R.Y. Notice of salmon trout in Ouseburn, Newcastle-on-Tyne, in the spawning season. Trans. Nat. Hist. Soc. Northumb. 1884 (1889), 8, $184-185$.

1889.1

Green, Seth. [Fish raising] Proc. Boston Nat. Hist. Soc. 1866 (1868), 11. $360-361$.

1868.1

- Shad and shad spawn destroyed by warmth of water in Connecticut river. Rept. Conn. Comm. Fisheries, $1869,7$. 1869.1

Trout-culture. Rochester, 1870. 92 p. figs. $16^{\circ}$. 1870.1

- Fish-culture in New York. Scient. Amer., 1872, 23, 66. 1872.1

Fish-culture. Rept. Comm. Agricult., Washington, 1872 (1873), 248-274. 1873.1

Catching shad with fly. Amer. Sportsman, 1874, 4, 89. 1874.1

- Device for hatching the spawn of fishes. Rept. U. S. Fish. Comm. 1872 (1874), 2, 579

1874.2

_- Does fish raising pay? Amer. Sportsman, 1874, 5, 54. 1874.3

- Fish distributed in New York waters. Amer. Sportsman, 1874, 4, 13.

1874.4

The growth of shad. Forest \& Stream, 1874, 2, 276. 1874.5

- Michigan grayling. Forest \& Stream, 1874, 2, 165;212. 1874.6

- Need of fish protection. Amer. Sportsman, 1874, 4, 342 .

1874.7

- Report on shad-hatching operations. Operations in 1872. Rept. U.S. Fish Comm. 1872 (1874), 2, 405-406.

1874.8

- Report on shad-hatching operations. Operations in 1873. Rept. U. S. Fish Comm. 1872 (1874), 2, 406-40s.

1874.9

- Salmon spawn. Forest d Stream, 1874, 3, 261. $\quad 1874.10$

Seth Green on shad and black bass, and on hybrid fish. Amer. Sportsman, 1874, 3, 378 .

1874.11

Shad in lake Ontario. Forest \& Stream, 1874, 2, 292. 1874.12

Can depleted streams be restocked? Forest \& Stream, 1875, 5, 211.

1875.1 
Distribution of fry. Forest \& Stream, 1875, 4, $117 . \quad 1875.2$

- Experiences of a practical fishculturist. Trans. Amer. Fisheries Soc. 1874 (1875), 22-24.

1875.3

- Fish-culture. Amer. Sports$\operatorname{man}, \mathbf{1 8 7 5}, \mathbf{5}, 323$.

1875.4

Instinct of salmon. Forest \& Stream, 1875, 4, 37.

1875.5

New method for hatching and transporting fish eggs. Amer. Sportsman, $1875,4,265$.

1875.6

On stocking the Great lakes with whitefish. Forest \& Stream, 1875, 5, 307 .

1875.7

- Spawning seasons. Forest \& Stream, 1875, 4, 166. 1875.8

- Stocking depleted waters. Forest \& Stream, 1875, 4, 84. - Trans Amer. Fisheries Soc. 1875 (1876), 19-22

1875.9

Suitable temperature of the water. Amer. Sportsman, 1875, 5, 361.

1875.10

Crowding trout ponds. Forest \& Stream, 1876, 7, 3.

1876.1

Enemies of trout. Forest \& Stream, 1876, 7, 115

1876.2

Fish distribution for state waters. Forest \& Stream, 1876, 7, 385. 1876.3

- Food for young trout. Forest \& Stream, 1876, 7, 179.

1876.4

- Impregnating spawn. Forest \& Stream, 1876, 7, 244.

1876.5

- Parasites on trout. Forest \& Stream, 1876, 6, 401. $\quad 1876.6$

- Stocking trout ponds. Forest \& Stream, 1876, 6, 85 .

1876.7

Artificial culture of black bass. Forest \& Stream, 1877, 8, 359. 1877.1

- Propagation of fish. Trans. Amer. Fisheries Soc. 1876 (1877), S-13. 1877.2

California trout in New York. Forest \& Stream, 1878, 11, 203. 1878.1

California trout in the east. Forest \& Stream, 1878, 10, 134. 1878.2

The goldfish question. Chicago Field, 1878, 9, 277.
- More about eels. Fish. Gazette, 1878, n. s. 2, no. 78, 496 . $\quad 1878.4$

On eels. Forest \& Stream, 1878.

11,110 .

1878.5

- Striped bass in the Genessee river. Forest \& Stream, 1878, 10, 419.

1878.6

Why fish in ponds may become

blind. Forest \& Stream, 1878, 9, 488 .

1878.7

Young trout eaten by goldfish. Chicago Field, 1878, 9, 102. 1878.8

- California mountain trout in eastern waters. Forest \& Stream, 1879, $12,264$.

1879.1

- Hybrid trout. Forest \& Stream, $1879,13,885$.

1879.2

Mortality of young trout. Forest \& Stream, 1879, 12, 45. 1879.3

- On fish-culture. Fish. Gazette, 1879 , n. s. 3, 219. 1879.4

-. Small mackerel. Forest \& Stream, 1879, 12, 145. 1879.5

Stocking waters with various kinds of fish. Chicago Field, 1879, 11, 276.

1879.6

- Successful cultivation of hybrids. Forest \& Stream, 1879, 13, 865. 1879.7

The alewife in fresh water. Forest \& Stream, 1880, 15, 167. 1880.1

Fertile hybrids. Forest \& Stream, $1850,15,366$.

1880.2

How the first shad were hatched. Forest \& Stream, 1880, 15, 128. 1880.3

Hybrid trout. Chicago Field, $1880,14,284$. 1880.4

Restocking trout streams. Chicago Field, 1880, 13, $237 . \quad 1880.5$

Stocking waters with various kinds of fish. Trans. Amer. Fisheries Soc. $1879(1880), 22-26 . \quad 1880.6$

Ueber den Einfluss der WVasserwärme auf das Gedeihen der Fische. Circul. Deutsch. Fischerei Ver. 1879 (1880), no. 6, p. 248.

Wie bald die Eierbefruchtung stattgefunden hat. Circul. Deutsch. Fischerei Ver. 1879 (1880), 249. 1880.8

Fish-culture, Journ. Amer. Agric. Assoc., 1881, 1, 141-142. 1881.1 
Green, S.

- General notes on fish-culture. Trans. Amer. Fisheries Soc. 1880 (1881), 13-19. 1881.2

Hybridizing fishes. 'Trans. Amer. Fisheries Soc. 1881 (1882), 5-9.

1882.1

The introduction of landlocked salmon into Woodhull lake, New York, and the subsequent capture of some of them. Bull. U. S. Fish Comm. 1881 (18S2), 1, 421 .

1882.2

Rearing of California mountain trout (Salmo irideus) Bull. U. S. Fish Comm. 1881 (1882), 1, 23.

1882.3

Salmon caught in Genessee river, New York. Bull. U. S. Fish Comm. 1881 (1882), 1, 23.

1882.4

Hatching striped bass, sturgeon and trout. 'Trans. Amer. Fisheries Soc. 1882 (1883), $37-40$.

1883.1

On the spawning of black bass. Amer. Angler, 1884, 6, $133 . \quad 1884.1$

Home fishing and home waters; a practical treatise on fish culture, the utilization of farm streams, the management of fish in the artificial pond, the transportation of eggs and fry; with observations on common fish and the methods of capturing them. New York, 1888. 81 p. $8^{\circ}$.

1888.1

Green, Seth, \& Collins, A.S. Troutculture. Caledonia \& Rochester, N. Y., 1870. 92 p. $\mathrm{S}^{\circ}$.

1870.1

Green, Seth, \& Roosevelt, Robert Barmwell. See Roosevelt it Green.

Green, William Spotswood. Notes on the Irish mackerel fisheries. Bull. U. S. Fish Comm. 1893 (1894), 13, 357360 .

1894.1

Green, Wyman R. A description of the specimens of the teleostean genus Enchodus in the university of Kansas. Kansas Univ. Sci. Bull., 1913, 7, 71-107. $17 \mathrm{pls}$.

1913.1

Greene, Charles Witson. The phosphorescent organs in the toadfish, Porichthys notatus Girard. Journ. Morphol., 1899, 15, 667-696. 3 pls. 1899.1

Contributions to the physiology of the California hagfish, Polistotrema stouti. I. The anatomy and physiology of the caudal heart. II. The absence of regulative nerves for the systemic heart.
Amer. Journ. Physiol., 1900, 3, 366382. 6 figs. Ibid., 1902, 6, 318-324.

Abstract of pt. $\mathrm{i}$ in Amer. Naturalist, 1900, 34, 666-667.

Notes on the physiology of the circulatory system of the California hagfish, Polistotrema stouti. Amer. Journ. Physiol. (Proc.), 1902, 6, xii-xiii. - Science, n. s. 15, 342.

1902.1

Physiological studies of the Chinook salmon. I. Relation of the blood pressure to the functional activity. II. A study of the blood and serous liquids by the freezing-point method. Bull. Bureau Fisheries, 1904 (1905), 24, 429-456. 15 pls. \& 7 figs.

1905.1

An experimental determination of the speed of migration of salmon in the Columbia river. Journ. Exper. Zool., 1910, 9, no. 3, 579-591. pl.

1910.1

The speed of migrating salmon in the Columbia river. Proc. Indiana Acad. Sci. 1909 (1910), 125-126. 1910.2

The migration of the salmon in the Columbia river. Bull. Bureau Fisheries, 1909 (1911), 29, 129-148. 2 pls.

1911.1

The absorption of fat in the salmon muscular tissue and its resorption during the migration fast. Amer. Journ. Physiol., 1912, 29, xxxix-xl.

1912.1

The absorption of fats by the alimentary tract, with special reference to the formation of the pyloric coeca in the king salmon, Oncorhynchus tschawytscha. 'Irans. Amer. Fisheries Soc. 1911 (1912), 261-270.

1912.2

Anatomy and histology of the alimentary tract of the king salmon. Bull. Bureau Fisheries, 1912, 32, 73100. 4 pls.

1912.3

A new type of fat-storing muscle in the salmon, Oncorhynchus tschawytscha. Amer. Journ. Anat., 1912, 13. 175-181. pl.

1912.4

On the absorption of fat by the salmon stomach. Amer. Journ. Physiol., 1912, 30, 278-282. 2 figs.

1912.5

The storage of fat in the salmon muscular tissue and its resorption during the migration fast. Proc. Amer. Soc. Biol. Chemists, 1912, 2, 52-54. - Journ. Biol. Chem., 11, xviii-xx. 
An undescribed longitudinal differentiation of the great lateral muscle of the king salmon. Anat. Record, 1913, 7, 99-101.

1913.1

Greene, J., \& Reay, - - On the mutual relations of the cold-blooded vertebrata. Journ. Linn. Soc. London (Zool.), 1861, 5, 218-228. $\quad 1861.1$ Pisces, p. 227-228.

Greenfield, Alfred. Report upon the receipt and hatching of American whitefish ova and planting of the fry in Australia. Bull. U. S. Fish Comm. 1884, 4, 190-191.

1884.1

Greenwood, $B$. Minnows and sticklebacks. Chicago Field, 1878, 9, 339

1878.1

Gregg, (Dr.) Amos. Memoranda of the natural history ... of the island of Hayti. Philad. Med. Phys. Journ., 1806, $18-26$.

1806.1

Gregg, W. H. Breeding habits of the dace [Rhinichthys atronasus] Amer. Naturalist, 1879, 13, 321.

1879.1

Gregory, $E$. H. Die Kupffer'sche Blase bei der Forelle (Trutta fario) (In Festschrift zum siebenzigsten Geburtstag von C. von Kupffer, 711-716. 2 pls. Jena, 1899)

1899.1

Beiträge zur Entwickelungsgeschichte der Knochenfische. Anat. Hefte, Wiesbaden, 1902 (1903), 20, 151230. 9 pls. \& 11 figs.

1903.1

Die Entwickelung der Kopfhöhlen und des Kopfmesoderms bei Ceratodus forsteri (In Semon, R. Zoologische Forschungsreisen in Australien und dem Malayischen Archipel in den Jahren 1891-1893. vol. i, pt. 5, 641-660. 23 figs. Jena, 1905)

1905.1

Gregory, Emity Ray [1863-] Origin of the pronephric duct in selachians. Zool. Bull., Boston, 1897, 1, no. 3, 123129. 8 figs. Abstract in Science, n. S. 5, 1000 .

1897.1

Gregory, George Elliott. Japanese fisheries. Trans. Asiat. Soc. Japan, 1877, 5, pt. 1, 102-113. Also separate; Yokohama, 1877. Reprinted in 1888.

1877.1

Gregory, J. $U$. Wiminish fishing on the Saguenay. Forest \& Stream, $1873,1,53$. 1873.1

Gregory, John Walter [1864-] The geography of Victoria. Melbourne, 1903. 290 p. figs.
Gregory, William King [1876-] Anent gizzards. Science, 1904, n. s. 20, 888. 1904.1

Reference to gizzard-like structures in fishes.

The relations of the anterior visceral arches to the chondrocranium. Biol. Bull., Woods Hole, 1904, 7, 55-66. fig.

1904.2

The orders of teleostomous fishes. A preliminary review of the broader features of their evolution and taxonomy. Ann. N. Y. Acad. Sci., 1907, 17, pt. 2, 437-508. 2 pls. $\quad 1907.1$

Further notes on the evolution of paired fins. Science, 1911, n. S. 34, 892. Ibid., 1912, n. s. 35, 595. 1911.1

The limbs of Eryops and the origin of paired limbs from fins. Science, 1911, n. s. 33, 508-509.

1911.2

Critique of recent work on the morphology of the vertebrate skull, especially in relation to the origin of mammals. Journ. Morphol., 1913, 24, 1-42. 25 figs.

1913.1

Bibliography, p. 41-42.

- Crossopterygian ancestry of the Amphibia. Science, 1913, n. s. 37, 806808.

1913.2

- Present status of the problem of the origin of the Tetrapoda, with special reference to the skull and paired limbs. Ann. N. Y. Acad. Sci., 1915, 36, $317-$ 383. pl. \& 15 figs.

1915.1

Bibliography, p. 376-383.

The temporal fossa of vertebrates in relation to the jaw muscles. Science, 1915, 41, 763-765.

1915.2

Reference to jaw-muscles of Dinichthys.

Gregory, William King, \& Adams, $L$. A. Locomotive adaptations in fishes illustrating "habitus" and "heritage." Ann. N. Y. Acad. Sci., 1914, 23, 267-268. 1914.1

Origin of myomeres and of fins in fishes

Gregory, William K., \& Nichols, John Treadwell. Long Island fishes noted by Mr. J. G. Raynor. Copeia, 1915 , no. 25, 59-60.

1915.1

Grêhant, Louis François Nestor [1838 - ] Recherches physiologiques sur la respiration des poissons. Ann. Sei. Nat. (Zool.), 1869, 5. sér. 12, 371382. - Laboratoire de Physiologie, 1869 , 299-310. Abstract in C. R. Mém. Soc. Biol. Paris, 1, 152-153. - Journ. 
Gréhant, $L . F . N$

Anat. (Robin), 7, 213-221. - C. R. Acad Sci. Paris, 1872, 74, 621-624. Naturforscher (Sklarek), 5. Jahrg., 128132.

1869.1

Recherches sur l'excrétion de l'urée et sur la respiration des poissons. Inaug. Dissert. Abstract by F. Terrier in Rev. Scient. France Etranger, 1870 , 7. année, 223-224.

1870.1

Renouvellement de l'air dans les poumons. - Respiration des poissons. Rev. Scient. France Etranger, 1871, 2. sér. 1. année, 206-212; 276-286; 416426.

1871.1

Recherches et dosage de l'urée dans les tissus et dans le sang des animaux vertebres. C. R. Acad. Sci. Paris, 1903, 137, 558-560.

1903.1

Gréhant, Louis François Nestor, \& Jolyet, Félix. Formation de l'urée par la décharge électrique de la torpille. C. R. Mém. Soc. Biol. Paris, 1891, 43, $687-689$.

1891.1

Grêhant, Louis François Nestor, \& Picard, — De l'asphyxie, et de la cause des mouvements respiratoires chez les poissons. C. R. Acad. Sci. Paris, $1873,74,646-648$.

1873.1

Greil, Alfred. Ueber die Entwickelung des Truncus arteriosus der Anamnier. Anat. Anz., 1903, 23, 91-105. figs.

1903.1

- Bemerkungen zur Frage nach dem Ursprunge der Lungen. Vorläufige Mitteilung. Anat. Anz., 1905, 26, 625632. 5 figs.

1905.1

Ueber die Entstehung der Kiemendarmderivate von Ceratodus forsteri. Anat. Anz., 1906, 29 (Suppl.), 115-131. 21 figs.

1906.1

Ueber die Homologie der Anamnierkiemen. Anat. Anz., 1906, 28, $257-$ 272. 6 figs.

1906.2

_- Ueber die Bildung des Kopfmesoderms bei Ceratodus forsteri. Anat. Anz. (Verh. Anat. Ges.), 1907, 30 (Suppl.), 59-72.

1907.1

Entwickelungsgeschichte des Kopfes und des Blutgefäisssystems von Ceratodus forsteri. Erster 'Theil: Gesammtentwickelung bis zum Beginn der Blutzirkulation (In Semon, R. Zoologische Forschungsreisen in Australien und dem Malayischen Archipel in den
Jahren 1891-1893, vol. i, pt. 6, 661-934. 22 pls. \& 264 figs. Jena, 1908) 1908.1

Ueber die erste Anlage der Gefässe und des Blutes bei Holo- und Meroblastiern (speziell bei Ceratodus forsteri) Anat. Anz., 1908, 32. Jahrg. 7-64. 3 pls.

1908.2

Entwicklungsgeschichte des Kopfes und des Blutgefässsystems von Ceratodus forsteri. Zweiter Theil: Die epigenetischen Erwerbungen während der Stadien 39-48. Jena. Denkschr. 1913, 4, 935-1492. 19 pls.

1913.1

Grein, Helène. Einige Untersuchungen über den Einfluss verschieden gefärbten Lichts auf die Entwicklung von Gadus virens. Intern. Rev. Ges. Hydrobiol. Hydrogr., Leipzig, 1914, 6 , 423-428. pl.

1914.1

Gremaud, A. Notice sur l'établissement de pisciculture crée par M. Devevey à Chenaleyres près Belfaux. Bull. Soc. Fribourg. Sci. Nat., 1881-1883, 3. \& 4. année, 1, 55-60. Also separate; Fribourg, 188t. 4 p. $8^{\circ}$.

1881.1

Grenacher, Hermann [1843-] Beiträge zur näheren Kenntniss der Musculatur der Cyclostomen und Leptocardier. Inaug. Dissert., Leipzig, 1867. $8^{\circ}$. Reprint in Zeitschr. Wiss. Zool., 1867, 17, Heft 4, 577-597.

1867.1

Gressin, L. Contributions à l'étude de l'appareil à venin chez les poissons du genre "vive" [Trachinus draco, $T$. vipera, $T$. radiatus et $T$. araneus] Inaug. Dissert., Paris, 1884. 51 p. pl. $\mathrm{S}^{\circ}$. 1884.1

Gressner, - Account of mortality of carp in a pond caused by parasitic worms [Text in German] Sitzber. Naturw. Ges. Isis, Dresden, 1867, p. 46. 1867.1

Grette, $A$. Ueber Centralnervensystem der Teleostier. Bonn, 1879. 4 pls.

1879.1

Greve, - Die Fortpflanzung des Aales. Zool. Garten, 1874, 15. Jahrg., 354-355.

1874.1

Grevê, Carl Heinrich. Ueber die Lebensweise der central-asiatischen Arten der Gattung Scaphirhynchus. Sitzber. Naturf. Ges. Univ. Dorpat, $1896,11,137-144$.

1896.1

An old record of the occurrence of the sturgeon (Acipenser sturio L.) in the Clyde. Trans. Nat. Hist. Soc. Glasgow, 1897, n. s. 4, 385. 
Grewingk, Constantin Caspar Andreas [1819-1887] Ueber die paläolithische Schichtenfolge Livland's und Pander's Saurodipterinen. Neues Jahrb. Mineral., 1861, 60-63. fig. 1861.1

Grieg, James A. En notis om Regalecus glesne Ascanius. Nyt Mag. Naturviden., Kristiania, 1886, 33, 232-234. - Ann. Mag. Nat. Hist., 5. ser. 19, 246-247.

1886.1

- Aalens forplantning og udvikling. Naturen, 1895, 228-242. 3 figs.

1895.1

Arktiske udliggere. Naturen, 1896, 376-380. fig.

1896.1

Hvor leger laksen? Jager og

Fisker Forenings Tidskr., 1896, 226-232.

1896.2

14-19. fig.

_- Ichthyologiske notiser. Bergens Mus. Aarb. 1894-95 (1896), no. 5. 20 p. fig. Ibid. 1898 (1899), no.3. 23 p. 5 figs. Ibid. 1911 (1912), no. 6, 3-38. 2 pls.

1896.4

- Brygdefangsten. Naturen, 1897, 85-90. 2 figs.

1897.1

Mere om aalens udvikling. $\mathrm{Na-}$ turen, 1897, 37-42. fig.

1897.2

- Nogle nye norske pattedyr og fiske. Naturen, 1897, 283-285. fig.

1897.3

Om en ved Golten strandet Regalecus glesne. Asc. Bergens Mus. Aarb. 1899 (1900), no. 3. 14 p. 2 figs. 1900.1

Orrittvillinger. Jager og Fisker Forenings Tidskr., 1900, 24-25. 1900.2

- Nogle for Norges fauna nye fiske. Naturen, 1901, 332-334. 1901.1

The fox shark (Alopecias vulpes) [Text in Norwegian] Norsk Tidskr. Fiskeri, 1902, 21, 469-472. 1902.1

The sea-serpent from the Hauglandsvand ['Text in Norwegian] $\mathrm{Na}$ turen, 1902, 26, 213-216.

1902.2

Wogle laksenstiser. Jager og Fisker Forenings Tidskr., 1902, 246-248.

1902.3 145-149

Klumpfisken. Naturen, 1903, 1903.1

Tre nye norske fiske. Naturen, 1903, 218-219.
$317-318$

Digeraalen. Naturen, 1904, 1904.1

94.

Svartfisken. Naturen, 1904, 931904.2

Karusformet orret. Jager og Fisker Forenings Tidskr., 1906, 67.

1906.1

Aalens alder og væxt Alter und Wachstum des Aals] Norsk Tidskr. Fiskeri, 1908, 27, 441-446. 1908.1

- Naar indvandrede roien $i$ indsjoerne i det sydlige Norge? [Die Zeit der Einwanderung von Salmo alpinus in die Seen des südlichen Norwegens] Naturen, 1908, 32, 77-84. 1908.2

Legemstemperaturen hos fiske og andre sjodyr [Die Körpertemperatur bei Fischen und anderen Meertieren] Naturen, 1909, 33, 286-287. 1909.1

En sjelden fisk [Macrurus coelorhynchus in Norge] Naturen, 1910, 34, 62-63.

1910.1

- Larver av aal og havaal ¡Larven von Anguilla und Conger vulgaris an der norwegischen Küste] Naturen, 1910, 34, 349-350.

1910.2

Dyrelevninger fra de gamle bopladser paa hardangervidden [Salmo eriox Linn] Bergens Mus. Aarb., 1911, no. $5,8-11$.

1911.1

Syk og monstros orret [Kranke und monströse Forellen] Naturen, $1911,35,27-31 . \quad 1911.2$

En for Norges fauna nij fisk [Lepidopus atlanticus] Naturen, 1913, 37, 61-64.

1913.1

Griese, $A d$. Das Laichen der Karauschen und die künstliche Ausbrütung des Laichs im Zimmer. Nerthus, 1901, 3. Jahrg., 406-40s.

1901.1

Griffin, B. B., Dean, Bashford, Harrington, $N . R$. . \& Calkins, $G . N$. See Dean, Harrington \& others.

Griffini, Achille. Lavori, pubblicati fino al gennaio 1897. Torino, 1897. S p. $8^{\circ}$. 1897.1

Studio quantitativo di alcune giovani Squalus secondo i loro coefficienti somatici. Rend. Accad. Acireale, $1900,10,1-16$.

1900.1

Ittiologia italiana. Descrizione dei pesci di mare e d' acqua dolce. Milano, 1903. x, 475 p. figs. $12^{\circ}$. 1903.1 
Griffith, Edward [1790-1858] The class Pisces, arranged by the Baron Cuvier, with supplementary additions by Edward Griffith . . . and Lieut.Col. Charles Hamilton Smith rand P. B. Lord] London, 1834. 680 p. 62 pls. $8^{\circ}$. 1834.1

Published as vol. $x$ of Cuvier's Animal kingdom. London, $1827-35$

Griffith, Hiram E. Bass fishing in the Niagara river. Forest \& Stream, $1874,2,60$. 1874.1

Griffith, William. Result of planting shad in the Ohio river. Bull. U. S. Fish Comm. 1882 (1883), 2, 12. 1883.1

Griggs, J. W. Wind-fish. Forest \& Stream, 1878, 10, 219. 1878.1

Grigorian, Constantin. Beitrag zur Kenntnis der Luftathmungsorgane der Labyrinthici und der Ophiocephaliden (Vorläufige Mittheilung) Zool. Anz., 1900, 23, 161-170. 6 figs. $\quad 1900.1$

- Die Luftathmung der Fische ['T'ext in Russian] Izv. Obšč. Lìub. Jest., Dnevn. Zool., Moskva, 1901, 3, pt. 3, 14-24. 6 figs.

1901.1

Grigorjanc, Konstantin. See Grigorian, Constantin.

Grimble, $A$. The salmon and seatrout rivers of England and Wales. 2 vols. London, 1904. 47 pls. $\quad 1904.1$

Grimm, $E$. Die Süsswasserfische Deutschlands (In Die Süsswasserfische des Europäischen Russlands. Ihre Merkmale, Vermehrung, Verbreitung und ökonomische Bedeutung [Text in Russian] St. Petersburg, 1906. 65 p.)

1906.1

See also Nitsche, $H$. Die Süsswasserfische Deutschlands. 1898.

Grimm, $G$. Fischerei und Jagd in den russischen Gewüssern. Uebersetzt von G. Josephy. Arch. Naturgesch., 1892, 58, 191-208. 1892.1

Grimm, Oscar von. Ueber das Geruchsorgan der Störe. Vorläufige Mittheilung. Götting. Nachricht, 1872, $537-539$.

1872.1

Fischzucht, Fischfang und Thrangewinnung in Russland. Russische Rev., 1882, 21, 268-280. 1882.1

Ueber der Sterlet. Allgem. Fischerei Zeitg., 1895, 20, no. 8, 145-146.

1895.1

Der Fischfang im Kaspi-See und in der Wolga ['Text in Russian] St. Petersburg, 1896.154 p. $8^{\circ}$. 1896.1
Die Kaspi-Wolga-Fischerei. Mitth. Deutsch. Seefischereiver., 1897, 13, 387-420. fig.

1897.1

Die Häringe des Azov'schen Meeres ['Text in Russian] Nikolsk Fischzucht, St. Petersb., 1901, pt. 4, 17-31. - Věst. Rybopromyšl., St. Petersb., 16, 57-70.

1901.1

Versuch der Bestimmung des Wachstums der Jungfische und ihrer Ernährung durch ihr Gewicht ['Text in Russian] Nikolsk Fischzucht, St. Petersb., 1901, pt. 5, 41-49. 1901.2

Versuchte Anwendung der Methode, durch Wägung das Wachstum von Fischen in seiner Abhängigkeit vom Futter zu bestimmen [Text in Russian] Věst. Rybopromyšl., St. Petersb., 1901, 16, 379-387.

1901.3

Die Fische in den Seen des Waldai und ihr Fang. Fischerei Zeitg., 1902, 5, 657-662; 681-685; 689-692.

1902.1

- Warum giebt es in den Teichen keine guten Karauschen mehr? Ausgabe der Kaiserlichen Russischen Gesellschaft für Fischerei und Fischzucht [Text in Russian] St. Petersb., 1902. 18 p. 3 figs.

1902.2

Welche Fische soll man in Teichen züchten? Ausgabe der Kaiserlichen Russischen Gesellschaft für Fischerei und Fischzucht [Text in Russian] St. Petersb., 1902. 20 p. 10 figs.

1902.3

Wie befruchtet und ziichtet man künstliche Fische? Ausgabe der Kaiserlichen Russischen Gesellschaft für Fischerei und Fischzucht Text in Russian] 2. ed. St. Petersb., 1902. 40 p. 9 figs.

1902.4

Ueber das Vorkommen der Forelle im Gouv. Saratov ['Text in Russian] Věst. Rybopromyšl., St. Petersb., $1904,19,341$.

1904.1

Ueber die Einwirkung der Temperatur auf das Wachstum der Fische [Text in Russian] Nikolsk Fischzucht, St. Petersb., 1904, no. 9, 136-140. fig. 1904.2

Ueber die wahre Natur des Wolga-Sigs [Text in Russian] Věst. Rybopromyšl., St. Petersb., 1904, 19 , 150-153.

1904.3

Die 50-jährige Tätigkeit der Fischzuchtanstalt Nikolsk IText in 
Russian] Nikolsk Fischzucht, St. Petersb., 1905, no. 10, 1-34. 10 figs.

1905.1

Eine der Ursachen für die Periodicität der Ausbeute an Brachsen in Seen [Text in Russian] Věst. Rybopromyšl., St. Petersb., 1905, 20, pt. 5, 266-271.

1905.2

Welchen Einfluss hatte der Sommer des Jahres 1904 auf die Fische der Novgorod'schen Seen und auf deren Fang? [Text in Russian] V'cst. Rybopromyšl., St. Petersb., 1905, 20, 187-195.

1905.3

-. Der Goktscha-See und seine Fische [Text in Russian] Vést. Rybopromyšl., St. Petersb., 1906, 21, 513-520.

1906.1

Ein Stör mit drei Rogensäcken [Text in Russian] Věst. Rybopromyšl., St. Petersb., 1906, 21, 287.

1906.2

Zur Fortpflanzung des Sterlets [Text in Russian] Vèst. Rybopromyšl., St. Petersb., 1910, 25, 315-324. 1910.1

Grimm, Oscar von, Henking, $H$., Levinsen, Chr., \& Trybom, Fil. Bericht über die Anstalten zur Vermehrung des Lachses und der Meerforellen in den Flüssen der Ostsee. Conseil Perman. Intern. Explor. de la Mer, Public. de Circonstance, 1905, no. 28, 1-34. 1905.1

Grinnell, Joseph, \& Jordan, David Starr. See Jordan \& Grinnell.

Grisellini, $F$. Sopra la torpedine. Giorn. Ital., 1764, 1, 47.

1764.1

Sopra un pesce Tenia [Trachypterus] pescato nella laguna di Venezia. Giorn. Italia, 1766, 3, 182.

1766.1

Lettera al Sig. Ab. Spallanzani, contenente il saggio di alcune osservazioni sullo sviluppo delle uova di una specie di gobio comune nella laguna di Venezia. Giorn. Italia, 1768, 4, 321 .

1768.1

Osservazioni sullo sviluppo delle celerino comune nella laguna di Venezia. Giorn. Italia, 1768, 4, 321. $\quad 1768.2$

Griswold, Charles D. Experiments with a view to transplanting shad a few months old. Rept. U. S. Fish Comm. 1873-75 (1876), 3, 370-372.

1876.1

Grobben, Carl [1854-] Ueber die Schwimmblase und die ersten Wirbel der Cobitiden. Wissensch. Mitth. Akad.
Ver. Naturhist. Wien, 1875, 3. Heft, 1-15. figs.

1875.1

Grochmalicki, Jan. Badania nad regeneracya soczewki ocznej u ryb [Etude sur la régénération de la lentille chez les poissons] Arch. Nauk., Lwów, 1908, 1, 24.

1908.1

Ueber die Linsenregeneration bei den Knochenfischen. Zeitschr. Wiss. Zool., 1908, 89, 164-172. 6 figs. 1908.2

- Untersuchungen über die Linsenregeneration bei den IKnochenfischen. Bull. Soc. Polon. Av. Sci. Léopol, 1908, fasc. 8, 128-131.

1908.3

Review by O. Rabes in Nat. Wochenschr., 24, 13-14. figs.

- Beiträge sur Entwicklungcgê schichte des Gefässsystems bei den Knochenfischen [Text in Hungarian] Bull. Intern. Acad. Sci. Cracovie, 1910, math.-nat. cl., ser. B, 646-654.-Rozpr. IVydz. Matemat. Przyrod. Akad. 1910. 10 B, 559-603. - Verh. 8. Intern. Zool. Kongr. Graz, 1910 (1912), 929-932.

1910.1

Grochowski, Mieczystaw. O faunie jaskiniowej [Die Fauna der Höhlen] Kosmos Lwów Roczn., 1901, 26, 448462. 1901.1

Contains some mention of fishes.

- O rybach rajskich [Sur le Macropodus viriauratus] Kosmos Lwów Roczn., 1902, 27, 296-301. 1902.1

Gröndal, B. Skyrsla um hid islenzka natturufrædisfelag felagsarid 1890-1891 asamt Islenzka fiskitali. Reykjavik, 1891.

1891.1

Groenewold, B. E. Die Emder Häringsfischerei, ihr Ursprung, ihre Betriebseinrichtungen, ihre Schiffe, deren Ausrüstung und Bemannung, ihr Häringsfang und Häringshandel, kurz dargestellt zur Erläuterung der auf der internationalen Fischerei-Austellung aufgestellten Gegenstände. Emden, 1880. 9 p. $4^{\circ}$. 1880.1

Grönfeldt, $G$. Fisknotiser från Kumo-elfs vattensystem. Notis. Sällsk. Fauna Flora Fenn. Förh., 1871-74, 10. ser. 13, 451-454.

1871.1

Grönvall, Alfred Julian. Berättelse öfver forellkläckningsanstalten vid Harjus jordbruksskola. Fiskeritidskr. Finl., 1892, 1, 137-139. fig.

1892.1

Grognot, — Poissons du département de Saone-et-Loire. Mém. Hist: Nat. Soc. Eduenne, 1866, 1, 205-232.

1866.1 
Grohmann, A., \& Steffen, Theodor. Ueber die Frage nach dem Salzsäuregehalt des Magensafts der Haifische. Zeitschr. Biol., 1910, 55, 58-69. 1910.1

Grohmann, J. Haplochilus rubrostigma. Blätt. Aquar-Terrar. Kunde, 1909, 20. Jahrg., 652-653. 2 figs. 1909.1

Hemichromis bimaculata. Wochenschr. Aquar.-Terrar. Kunde, 1909, 6. Jahrg., 405-407. 2 figs.

1909.2

Gronovius, Laurentius Theodorus [1730-1777] Gymnoti tremuli descriptio, atque experimenta cum eo instituta. Act. Helvet., 1760, 4, 26.

1760.1

Observationes de animalibus aliquot marinæ aquæ innatantibus, atque in littoribus Belgicis obviis. Act. Helvet., $1760,4,35$. fig.

1760.2

__ Zoophylacii Gronoviani fasciculus primus exhibens animalia quadrupeda, amphibia atque pisces, qux in museo suo adservat, rite examinavit, systematice disposuit, descripsit atque iconibus illustravit Laur. Theod. Gronovius, J. U. D. . . . Lugduni Batavorum, 1763. pls. fol.

1763.1

- (editor) C. Plinii Secundi Historia naturalis liber nonus de aquatilium naturâ; recensuit amplissimisque commentariis instruxit I. T. Gronovius. Lugduni Batavorum, 1778. $8^{\circ}$. 1778.1

Catalogue of fish collected and described by Laurence Theodore Gronow, now in the British Museum. Edited from the manuscript by Albert Günther. London, 1854. 12 ${ }^{\circ}$. 1854.1

Gronow, Lorenz Theodor. See Gronovius, Laurentius Theodorus.

Groos, $R$. Les jeux des animaux. Traduit de l'allemand par A. Drir et Van Gennep. Paris, 1902. viii, 360 p. $8^{\circ}$. Notice in Rev. Scient., 4. sér. 17, $467-168$.

1902.1

Groot, G.J.de. De Lichtorganen van Maurolicus pennanti. Tijdschr. Nederl. Dierk. Ver., Helder, 1908, 2. ser. 10, li.

1908.1

Grosglik, S. Zur Morphologie der Kopfniere der Fische. Zool. Anz., $1885,8,605-611$.

1885.1

Zur Frage über die Persistenz der Kopfniere der 'Teleostier. Zool. Anz., 1886, 9, 196-198.

1856.1

Groshans, Georgius Philippus Fredericus. Quxdam naturalia antiqua
(The zoology of Homer and Hesiod [translated by W. B. Macdonald]) Rammerscales, 1846.14 p. $8^{\circ}$. 1846.1

Gross, Otto. Transplantations-Versuche an Hartgebilden des Integuments und der Mundschleimhaut bei Teleostiern und Amphibien. Inaug. Dissert., Basel, 1905-06. 88 p. $8^{\circ}$. 1905.1

Grossart, William [Exhibition of a new Palaoniscus from Shotts] Trans. Geol. Soc. Glasgow, 1864-67 (1867), 2, 56.

1867.1

Grosser, Otto. Metamere Bildungen der Haut der Wirbeltiere [Scyllium und Pristiurus] Zeitschr. Wiss. Zool., 1905, $80,56-79$. 8 figs. 1905.1

- Die Elemente des Kopfvenensystems der Wirbelthiere. Anat. Anz. (Verh. Anat. Gesell.), 1907, 30 (Suppl.), 179-192. 8 figs. 1907.1

Grosser, Otto, \& Przibram, Hans Einige Misbildungen beim Dornhai (Acanthias vulgaris Risso) Arch. Entw.Mech., Leipzig, 1906, 22, 21-37. pl. \& 3 figs.

1906.1

Grotrian, - Om ålens (Anguilla vulgaris) fortplantning och utveckling. Fiskeritidskr. Finl., 1898, 7, 92-95.

1898.1

Der Lachs im Warthegebiete. Fischerei Zeitg., 1901, 4, 227-233. 1901.1

Ueber Fischregionen in Fliessenden Gewässern. Fischerei Zeitg., 1904, 7, 421-423.

1904.1

- Fischereikarte der provinz Posen Herausgegeben vom Fischereiverein für die Provinz Posen. Posen, 1907. 108 p. 1907.1

Grover, $G$. The salmon fisheries of Oregon. Forest \& Stream, 1874, 3, 172. - Amer. Sportsman, 1874, 5, 55. 1874.1

Grube, Adolph Eduard [1812-1880] Die Insel Lussin (Dalmatien) und ihre Meeresfauna. Breslau, 1864. pl. \& map. $8^{\circ}$.

1864.1

Ueber ein auffallend grosses Exemplar des Karpfens (Cyprinus carpio L.) 43. Jahresber. Schles. Ges. Breslau 1865 (1866), 58-59.

1866.1

- Ueber Cyprinus striatus und Abramis leuckarti, zwei schlesische Fische. 44. Jahresber. Schles. Ges. Breslau 1866 (1867), 68-69. 1867.1

Ueber eine in der Oder gefangene Alse, Clupea alosa L. (Alosa vulgaris 
Cuv.) als neu für die schlesische Fauna. 47. Jahresber. Schles. Ges. Breslau 1869 (1870), 43-44.

1870.1

Ueber ein grosses Exemplar des australischen Cestracion philippi Cuv., im zoologischen Museum zu Breslau. 47. Jahresber. Schles. Ges. Breslau $1869(1870), 4 t-45$.

1870.2

[Ueber Lernoocera cyprinacea, ein fischparasit] 51. Jahresber. Schles. Ges. Breslau, 1873, 51-52.

1873.1

Ueber den Fettfisch des Baikalsees (Comephorus baicalensis Pall.) und die Madui-Maräne (Coregonus marana Bloch) 52. Jahresber. Schles. Ges. Breslau 1874 (1875), 50-52. 1875.1

Ueber die Lebensweise und Fortpflanzung unseres Aals (Anguilla Aluviatilis) 52. Jahresber. Schles. Ges. Breslau 1874 (1875), 52-54. 1875.2

Ueber Coregonus albula. 55. Jahresber. Schles. Ges. Breslau 1877 (1878), 75-76.

1878.1

Ueber das Gebiss eines Haifisches (Galeocerdo?) 55. Jahresber. Schles. Ges. Breslau 1877 (1878), 78-79

1875.2

[Ueber den Fisch Sicyases sanguineus, aus Valparaiso] 57. Jahresber. Schles. Ges. Breslau, 1879, 231-232. Ber. Naturw. Sect. Schles. Ges. Vaterl. Cult., 1879-80, 69-70.

1879.1

Gruber, August. Wovon ernährt sich der Zander im Bodensee? Allgem. Fischerei Zeitg., 1893, 18, 339-340.

1893.1

- Haplochilus chaperi. Laichgeschäft und Aufzucht der Jungen. Blätt. Aquar.-Terrar. Kunde, 1911, 22. Jahrg., 612-613. fig.

1911.1

- Maulbrüter, Paratilapia (Chromis) multicolor, Brutpflege und Aufzucht der Jungen. Blätt. Aquar.Terrar. Kunde, 1911, 22. Jahrg., 533534.

1911.2

Grubiczy, Géza. A esuka [Esox lucius 1 Földmível. Erdekeink. Budapest, $1876,4,30-31$.

1876.1

Grünberg, $V$. Notizen über das Leben des Aral-Störs im Syr-Darja [Text in Russian] Russ. Sudochod., St. Petersb., 1905, 20, pt. 7, 86-91. 1905.1

Gruetzner, Paul Friedrich Ferdinand [1847 - ] Ueber den Blutkreislauf der
Fische. Verh. Ges. Deutsch. Nat. Aerzte, 1897, 68. Vers., 2. Teil, 2. Heft, 498-499.

1897.1

- Demonstration [Kreislauf der Fische] Verh. Anat. Ges., 1899, 13. Vers., 133.

1899.1

Der Kreislauf der Fische. 57.

Jahresber. Vaterl. Naturk. Württemberg, 1901, cxxiii-cxxiv.

1901.1

Ueber den Kreislauf bei Fischen. Verh. Deutsch. Zool. Ges., 1904, 14 201.

$190 \pm .1$

Grunelius, A. von. Ueber die Entwicklung der Haut des Karpfens. Jena. Zeitschr. Naturw. 1912 (1913), 49, 119148. 3 pls. \& 16 figs.

1913.1

Gruvel, A. Mission des pêcheries de la côte occidentale d'Afrique, dirigée par Gruvel. Avant-propos. Actes Soc. Linn. Bordeaux, 1905, 60, 5-6. 1905.1

Les pêcheries des côtes du Sénégal. La Nature, 1908, 36, pt. 1, 129131.

1908.1

- Les pêcheries de l'Afrique occidentale française. Rev. Gén. Sci., 1911, 22, 150-159. 10 figs.

1911.1

- L'anchois (Engraulis eucrassicholus L.) sur la côte occidentale d'Afrique. C. R. Acad. Sci. Paris, 1913, 157, $1468-1470$.

1913.1

Gruvel, A., \& Bouyat, A. Les pêcheries de la côte occidentale d'Afrique. Paris, 1906. 280 p. 1906.1

Gruvel, A., \& Chudeau, R. Mission en Mauritanie occidentale. Act. Soc. Linn. Bordeaux, 1911, 65, 5-10.

1911.1

Preparation et analyse de guanos de poissons.

Gruvel, A., \& Künstler, $J$ See Künstler \& Gruvel.

Grynfeltt, Eduard. Les corps suprarénaux chez quelques squales et leurs rapports avec le système artériel. C. R. Assoc. Anat., 4. sess., Montpellier, 1902. 31-34.

1902.1

_- Distribution des corps suprarénaux des plagiostomes. C. R. Acad. Sci. Paris, 1902, 135, 330-332. 1902.2

- Structure des corps suprarénaux des plagiostomes. C. R. Acad. Sci. Paris, 1902, 135, 373-374.

1902.3

Sur le corps interrénal des plagiostomes. C. R. Acad. Sci. Paris, 1902 , 135, 439-140. 
Grynfeltt, $E$.

Vascularisation des corps surrénaux chez le Scyllium. C. R. Mém. Soc. Biol. Paris, 1902, 54, 144-146. C. R. Acad. Sci. Paris, 134, 362-364.

1902.5

Recherches anatomiques et histologiques sur les organes surrénaux des plagiostomes. Bull. Scient. France et Belgique, $1903,38,1-137.7$ pls. \& 13 figs.

1903.1

- Sur les corps suprarénaux des plagiostomes. C. R. Assoc. Franç. Adv. Sci., 1903, 31, pt. 1, p. $236 . \quad 1903.2$

- Sur le sphincter de l'iris chez quelques téléostéens. Note préliminaire. C. R. Assoc. Anat. Paris, 1908, 10, 102-104.

1908.1

Sur la rétine ciliaire des pois. sons. Soc. Sci. Méd. Montpellier, July, 1909.

1909.1

L. La membrane de Descemet du poissons osseux. Soc. Sci. Méd. Montpellier, May 13, 1910.

1910.1

Les muscles de l'iris chez les téléostéens. Bibliogr. Anat. Nancy, 1910, 20, 265-332. 26 figs. $\quad 1910.2$

- Le muscle tenseur de la choroïde chez les poissons. Arch. Anat. Micr., Paris, 1910, 12, 475-510. 11 figs. - C. R. Acad. Sci. Paris, 1910, 150, 420-421.

1910.3

- Sur l'anatomie comparée de l'appareil de l'accommodation dans l'œil des vertébrés. C. R. Assoc. Anat. Paris, 1910, 12, 76-88. 6 figs. 1910.4

- Etudes anatomiques et histologiques sur l'oil du Protopterus annectens. Bull. Acad. Sci. Lettr. Montpellier, 1911, 210-232. fig.

1911.1

Grynfeltt, Eduard, \& Demelle, $A$. Recherches anatomiques et histologiques sur l'opercule pupillaire des poissons. Bibliogr. Anat. Nancy, 1908, 18, 119 135. 9 figs.

1908.1

Grynfellt, Eduard, \& Euzière, $J$. Les vaisseaux de la rétine chez le congre. Nouveau cas de rétine vasculaire chez les vertébrés inférieurs. Soc. Sci. Méd. Montpellier, June, 1908.

1908.1

Note sur la structure de l'épithélium des toiles choroïdiennes et l'excrétion du liquide cephalo-rachidien chez le Scyllium. C. R. Assoc. Anat. Paris, 1913, 15, 101-111. 4 figs. 1913.1
Guber, Josef. Das Auffüttern junger Salmoniden. Oesterr.-Ungar. Fischerei Zeitg., 1880, 269-271.

1880.1

Das Ausseczen junger Saiblinge in Teiche. Oesterr.-Ungar. Tischerei Zeitg., 1880, 21. 1880.2

Guberleth-Plegher, $T$. Dissertatio de pristina libertate Belgarum sub principibus quam maxime Hollands et Zeelandis commercandi et piscandi per mare Septentrionale et ad oras Magna Britannix, pactis etiam sanctita. Lugduni Batavorum, 1791. $4^{\circ}$. 1791.1

Gubernatis, Angelo de [1840-] Zoological mythology, or the legends of animals. 2 vols. London, 1872. $8^{\circ}$.

1872.1

Guccini, L. Sul contenuto gastroenterico dei pesci del Ticino. Rendic. Istit. Lombardo Sci., 1904, 2. ser. 37, 194-201.

1904.1

Gudernatsch, J.F. The relationship between the normal and pathological thyroid gland of fish. Bull. Johns Hopkins Hosp., 1911, 22, no. 242, 1-8. pl. \& 3 figs.

1911.1

- The thyroid gland of the teleosts. Journ. Morphol., 1911, 21, 709-782. 5 pls. \& 21 figs.

1911.2

Gudger, Eugene Willis [1866-] 'The breeding habits and the segmentation of the egg of the pipefish (Siphostoma floridœ) Proc. U.S. Nat. Mus., 1905, 29, 447-500. 7 pls. \& figs. Also separate; Washington, 1905. $57 \mathrm{p}$.

1905.1

A note on the eggs and egg-laying of Pterophryne histrio, the gulfweed fish. Science, 1905, n. s. 22, 841-843.

1905.2

A note on the habits of Rissola marginata. Science, 1905 , n. s. 22, 342343.

1905.3

Notice of his investigations of Beaufort fishes (In Grave, Caswell. The fisheries laboratories at Beaufort, sixth session. Science, 1905, n. S. 21, 735)

1905.4

A note on the hammerhead shark (Sphyrna zygorna) and its food. Science, 1907, n. s. 25, 1005-1006.

1907.1

The oral gestation of the gafftopsail catfish, Felichthys marinus. Science, 1908 , n. s. 27, 991 . 1908.1 
Oral gestation among teleostean fishes. Journ. Elisha Mitchell Sci. Soc., $1909,25,50$. - Science, n. s. 30, 191.

1909.1

Habits and life history of the toadfish (Opsanus tau) Proc. 4. Intern. Fish. Congr., Washington. Bull. U.S. Fish Comm. 1908 (1910), 28, pt. 2, 1071-1109. 7 pls.

1910.1

The jaws of the spotted stingray, Etobatus narinari. Journ. Elisha Mitchell Sci. Soc., 1910, 26, 58-59.Science, 1910, n. s. 31, 917.

1910.2

- Notes on some Beaufort fishes, 1909. Amer. Naturalist, 1910, 44, 395403.

1910.3

The finned-tailed larva of the butterfly ray, Pteroplatea maclura. Journ. Elisha Mitchell Sci. Soc., 1911, 27, 84. - Science, n. s. 33, 943. 1911.1.

The intra-uterine embryo of the bonnet-head shark, Sphyrna tiburo. Science, 1912, 35, 466.

1912.1

Natural history notes on some Beaufort, N. C., fishes, 1910-11. I. Elasmobranchii, with special reference to utero-gestation. II. Teleostomi. Proc. Biol. Soc. Washington, 1912, 25, $141-156 ; 165-176$.

1912.2

Oral gestation in the gaff-topsail cat-fish, Felichthys felis. Science, 1912 , n. s. 35, 192.

1912.3

Fishing for sharks in Key West harbor. Journ. Elisha Mitchell Sci. Soc. 1913, 29, 9 .

1913.1

Natural history notes on some Beaufort, N. C., fishes, 1910-11. III. Fishes new or little known on the coast of North Carolina, collected by Mr. Russell J. Coles. Journ. Elisha Mitchell Sci. Soc., 1913, 28, 157-172. 1913.2

- Natural history notes on some Beaufort, N. C., fishes, 1912. 'Proc. Biol. Soc. Washington, 1913, 26, 97-109.

1913.3

- A second capture of the whale shark, Rhineodon typus, in Florida waters. Science, 1913, n. s. $38,270$.

1913.4

Summary of work done on the fishes of Tortugas. 12. Yearbook Carnegie Instit. Washington, 1913, 176-177.

1913.5

- History of the spotted eagle-ray, Etobatus narinari, together with a study of its external structures. Carnegie Instit. Washington, 1914, public. no. $183,243-323.10$ pls.

1914.1

The nurse sharks of Boca Grande bay, Florida. Science, 1914, n. s. 40 , 386.

1914.2

Natural history of the whale shark (Rhineodon typus) Zoologica, Sci. Contrib. N. Y. Zool. Soc., 1915, 1, no. 19, 349-389.

1915.1

On the occurrence in the southern hemisphere of the basking or bone shark, Cetorhinus maximus. Science, 1915, n. s. 42, no. 1088, 653-656.

1915.2

Utero-gestation in the sharpnosed shark, Scoliodon terranovo. Science, 1915, n. s. 41, no. 1055, 439.

1915.3

Guildenstadt, Anton Johann von [1745-1781] Salmo leucichthys et $C y$ prinus chalcoüdes descripti. Nov. Comment. Acad. Petropol., 1771, 16, Hist., 46. - Mém., 531.

1771.1

Cyprinus capota et $C$. mursa. Nov. Comment. Acad. Petropol., 1772, 17, 507-521. 2 pls.

1772.1

Acerina; piscis ad perce genus pertinens. Nov. Comment. Acad. Petropol., 1774, 19, 455-462. pl. 1774.1

Cyprinus barbus et $C$. capito descriptus. Acta Acad. Petropol., 1778, 2, 239-253. figs.

1778.1

Reisen durch Russland und im Kaukasischen Gebirge; herausgegeben von P. S. Pallas. 2 vols. St. Petersburg, 1787-91. $4^{\circ}$.

1787.1

Contains some mention of fishes.

Gümbel, Carl Wilhelm von [18231898] Fische (In Verzeichniss der in der Sammlung des zoologisch-mineralischen Vereins in Regensburg vorfindlichen Versteinerungen aus den Schichten der Procän- oder Kreideformation aus der Umgegend von Regensburg. Correspbl. Zool.-Mineral. Ver. Regensburg, 1866, 20, 57-58) 1866.1

Guênaux, G., \& Gobin, A. See Gobin \& Guẻnaux.

Günderlich, $A$. Die Fischvermehrung bis ins Unendliche durch die künstliche Befruchtung des Rogens mittelst der Milch; nach dem eigenthümlichen, selbsterfundenen Verfahren des französischen Fischers Rémy, aus dem 
Günderlich, $A$.

Französischen und mit Benützigung einiger andern einschlägigen Materialien zusammengestellt. Weimar, 1861. 20 figs. $12^{\circ}$. 2. ed.

1861.1

Günther, Albert [Carl Ludwig Gotthilf] [1830-1914] Die Fische des Neckars, untersucht und beschrieben. Jahresh. Ver. Vaterl. Naturk. IÜ̈rttemberg, $1853,9,225-360$. pl. Also separate; Stuttgart, 1853.136 p. $8^{\circ}$.

1853.1

Beiträge zur Kenntniss unserer Süsswasserfische. Arch. Naturgesch., 1855, 21. Jahrg., 197-212. pl. \& 2 figs.

1855.1

Ueber einen neuen Fisch, Abramis dobuloides, des Neckars] Jahresh. Ver. Vaterl. Naturk. Württemberg, $1857,13,50-55$. pl.

1857.1

- Catalogue of the fishes of the British Museum. \& vols. London, $1859-70.4^{\circ}$. 1859.1

Vol. i. Acanthopterygii, 1859. xxxi, $521 \mathrm{p}$.

Vol, ii. Acanthopterygii, $1860 . \mathrm{xxi}, 548 \mathrm{p}$.

Vol. iii. Acanthopterygii, 1861. xxv; $556 \mathrm{p}$.

Tol, iv. Acanthopterygii, Pharyngognathi and Anacanthini, 1862. xxi, $534 \mathrm{p}$.

Tol. v. Physostomi, 1864. xxil, 455 p. illust. Vol. vi. Physostomi, 1866. $\mathrm{xv}, 36 \mathrm{~s}$. illust. Vol, vii. I'hysostomi, 1868. xx, $512 \mathrm{p}$.

Vol viii Phrsostomi, Lophohranchii, Plectognathi, Dipnoi, Ganoidei, Chondropterygi, 1870 xxv, 519 p.

-... List of the cold-blooded vertebrata collected by Mr. Fraser in the Andes of western Ecuador. Proc. Zool. Soc. London, 1859, 89-93.

1859.2

On sexual differences found in bones of some recent and fossil species of frogs and fishes. Ann. Mag. Nat. Hist., 1859, 3. ser. 3, 377-387. 2 pls

1859.3

On the reptiles and fishes collected by the Rev. H. B. Tristram in northern Africa. Proc. Zool. Soc. London, 1859, 469-474. pl. $\quad 1859.4$

Second list of cold-blooded vertebrata collected by Mr. Fraser in the Andes of western Ecuador. Proc. Zool. Soc. London, 1859, 402-420. pl. 1859.5

Pisces, p. 418-420.

Alepidosaurus, ein Meerwels Arch. Naturgesch., 1860, 26. Jahrg., pt. 1, 121-123. - Ann. Mag. Nat. Hist., 3. ser. 6, 150-151.

1860.1

Exhibition of a dried specimen of a fish of the genus Centrolophus, obtained by Mr. J. Couch at Polperro,
Cornwall] Proc. Zool. Soc. London, 1860,302 .

1860.2

- On a new species of black-fish found on the coast of Cornwall. Ann. Mag. Nat. Hist., 1860, 3. ser. 6, 46-48.

1860.3

- On a new species of fish belonging to the genus Pagrus $[P$. bocagiz Lowe] Proc. Zool. Soc. London, 1860, 391-392. pl. - Ann. Mag. Nat. Hist., 1861,3 . ser. 8,80 .

1860.4

- On new reptiles and fishes from Mexico. Proc. Zool. Soc. London, 1860 316-319. - Ann. Mag. Nat. Hist., 3. ser. 6, 442-445.

1860.5

On the history of Echeneis. Ann. Mag. Nat. Hist., 1860, 3. ser. 5 386-402. pl. \& fig.

1860.6

Third list of cold-blooded vertebrata collected by Mr. Fraser in Ecuador. Proc. Zool. Soc. London, 1860, 233-240. pl.

1860.7

- Exhibition of a singular fish called Saccolarynx flagellum by Dr. Mitchill, and Ophiognathus ampullaceus by Dr. Harwood. Proc. 'Lool. Soc. London, 1861, 235.

1861.1

- [ Exhibition of some charrs from different localities in England, Wales and Ireland] Proc. Zool. Soc. London, 1861,391

1861.2

- I ist of the cold-blooded vertebrata collected by B. H. Hodgson, Esq., in Nepal. Proc. Zool. Soc. London, 1861, 213-227.

1861.3

Fishes, p. 220-227.

Note on Nannoperca australis. Proc. Zool. Soc. London, 1861, 116-117. pl. \& fig. Ibid., 1862, p. 208.-Ann. Mag. Nat. Hist., 3. ser. 7, 490-491. 1861.4

On a collection of fishes sent by Capt. Dow from the Pacific coast of Central America. Proc. Zool. Soc. London, 1861, 370-376. illust. - Ann. Mag. Nat. Hist., 1862, 3. ser. 9, 326331 .

1861.5

On a new genus of Australian freshwater fishes [Nannoperca australisj Ann. Mag. Nat. Hist., 1861, 3. ser. 7, 490-491. - Proc. Zool. Soc. London, 1861, 116-117. pl. \& fig. Ibid., $1862,208$.

1861.6

- On a new species of fish of the genus Gerres [G. longirostris Rapp.] 
Ann. Mag. Nat. Hist., 1861, 3. ser. 8, 189. - Proc. Zool. Soc. London, 1861 142-143. pl.

1861.7

On a new species of Plectropoma [P. richardsonii] from Australia. Proc. Zool. Soc. London, 1861, 391-392. pl.

1861.8

On the British species of Mugil, or grey mullets. Ann. Mag. Nat. Hist., 1861, 3. ser. 7, 345-352. illust. 1861.9

On the immature state of the sca-devil (Lophius piscatorius) Ann. Mag. Nat. Hist., 1861, 3. ser. 7, 190195. pl. \& 3 figs.

1861.10

On three new trachinoid fishes Crapatalus novo-zelandice, Aphritis gobio, Chanichthys esox] Ann. Mag Nat. Hist., 1861, 3. ser. 7, 85-90. pl.

1861.11

A preliminary synopsis of the labroid genera. Ann. Mag. Nat. Hist., 1861, 3. ser. 8, 382-389.

1861.12

Contribution to the knowledgo of the British charrs. Proc. Zool. Soc. London, 1862, 37-54. 3 pls. Ibid., 1863, 6-16. 2 pls. Ibid., 1865, 698699. pl. - Ann. Mag. Nat. Hist., 1862, 3. ser. 10, 228-239. Ibid., 1863, 3. ser. 12, 229-239.

1862.1

Descriptions of new species of reptiles and fishes in the collection of the British Museum. Proc. Zool. Soc. London, 1862, 188-194. 3 pls. - Ann. Mag. Nat. Hist., 1863, 3. ser. 11, 134140 .

1862.2

Eine neue art von Mormyrus [M. petersii] Arch. Naturgesch., 1862, 28. Jahrg., p. 64.-Proc. Zool. Soc. London, 1864, p. 22. pl.

1862.3

- Note on Pleuronectes sinensis Lacép. Ann. Mag. Nat. Hist., 1862, 3. ser. 10, 475 .

1862.4

Generic name Tephritis replaced by that of Tephrinectes.

- Some remarks on the genus Trachinus. Ann. Mag. Nat. Hist., 1862, 3. ser. 10, 301-304. pl. \& figs. 1862.5

Systematische Uebersicht der Familien der Stachelflosser. Arch. Naturgesch., 1862, 28. Jahrg., pt. 1, 5363.

1862.6

On new species of fishes from the Essequibo. Ann. Mag. Nat. Hist., 1863, 3. ser. 12, 441-443.
On new species of fishes from Victoria, South Australia. Ann. Mag. Nat. Hist., 1863, 3. ser. 11, 114-117.

1863.2

Description of a labyrinthibranchiate fish from the Nile [Ctenopoma petherici] Ann. Mag. Nat. Hist., 1864, 3. ser. 13, 211.

1864.1

Description of a new fossil fish from the Lower Chalk rat Folkestone] [Plinthophorus robustus] Geol. Mag., 1864, 1, 114-118. pl. 1864.2

Description of a new species of Callionymus $[C$. papilio] from Australia. Ann. Mag. Nat. Hist., 1861, 3. ser. 14, 197-198.

1864.3

- Description of a new species of Mormyrus [M. lamandua] Ann. Mag. Nat. Hist., 1864, 3. ser. 14, 226-227. Proc. Zool. Soc. London, 1864, p. 22. pl.

1864.4

Descriptions of three new species of fishes [Diagramma citrinellum, Therapon percoides, Catopra malabarica] in the collection of the British Museum. Ann. Mag. Nat. Hist., 1864, 3. ser. 14, $374-376$

1864.5

List of the new species of mammals... and freshwater fishes discovered ... in Cambodia and Siam (In Mouhot, A. H. Travels in the central parts of Indo-China, etc., vol. ii, Appendix. London, 1864. 2 vols. $8^{\circ}$ ) 1864.6

On a new generic type of fishes discovered by the late Dr. Leichardt in Queensland. Ann. Mag. Nat. Hist., 1864, 3. ser. 14, 195-197. pl. 1864.7

On a new genus of pediculate fish [Melanocetus johnsonii] from the sea of Madeira. Ann. Mag. Nat. Hist., 1864, 3. ser. 15, 332-334. - Proc. Zool. Soc. London, 1864, 301-303. 1864.8

On a poison-organ in a genus of batrachoid fishes. Ann. Mag. Nat. Hist., 1864, 3. ser. 14, 458-461. 2 figs. - Proc. Zool. Soc. London, 1864, 155158.

1864.9

On.some new species of Central American fishes. Ann. Mag. Nat. Hist., 1s61, 3. ser. 14, 2.2, 32. Proc. Zool. Soc. London, 1S64, 23-27. 2 pls.

1864.10

On the reptiles and fishes obtained by Capt. Speke during the east African expedition. Proc. Zool. Soc. London, 1864, 115.
1864.11 


\section{Günther, $A$.}

Report of a collection of fishes made by Messrs. Dow, Godman and Salvin in Guatemala. Proc. Zool. Soc. London, 1864, 144-154.

1864.12

Report on a collection of reptiles and fishes from Palestine. Proc. Zool. Soc. London, 1864, 488-493.

1864.13

Report on a collection of reptiles and fishes made by Dr. Kirk in the Zambesi and Nyassa regions. Proc. Zool. Soc. London, 1864, 303-314. 2 pls.

1864.14

- An account of the present state of his researches into the British species of salmonoid fishes] Ann. Mag. Nat. Hist., 1865, 3. ser. 16, 59-60.-Proc. Zool. Soc. London, 1865, 197-198.

1865.1

A contribution to the ichthyolugy of west Africa [Synodontis guttatus, S. laben] Ann. Mag. Nat. Hist., 1865, 3. ser. 15, 452-453.

1865.2

Description of a new characinoid genus of fish [Phago loricatus] from west Africa. Ann. Mag. Nat. Hist., 1865, 3. ser. 15, 209-210. pl.

1865.3

Description of a new species of Corvina $[C$. moorii $]$ from the Gambia. Ann. Mag. Nat. Hist., 1865, 3. ser. 16, 48-49.

1865.4

[Note on the change of the name Salmo cambricus to Salmo perisii] Ann. Mag. Nat. Hist., 1865, 3. ser. 15, 75.

1865.5

On the pipe-fishes belonging to the genus Phyllopteryx. Ann. Mag. Nat. Hist., 1865, 3. ser. 16, 141-142. Proc. Zool. Soc. London, 1865, 327328. 2 pls.

1865.6

(editor) The record of zoological literature. Edited by A. C. L. G. Günther, 1864-69. 6 vols. Zool. Soc. London Public., 1865-70.

1865.7

From 1870 on this publication is continued under the title of the Zoological Record. Since 1903 it has been edited by David Sharp, q.v. The annual record for the subject of Pisces, 1886-1905, was contributed by G. A. Boulenger.

Vols. i-v were never indexed. The index for vol. vi will be found in vol. $x$. The Index Zoologicus, in separate volumes nos, i and ii, was compiled by $\mathrm{C}$. O. Waterhouse and edited by David Sharp.

-... Some remarks on Labrus pulcher (Ayres) Proc. Acad. Nat. Sci. Philad., $1865,17,77$.

1865.8

- Description of a new siluroid fish from Ceylon [Arius layardi] Ann.
Mag. Nat. Hist., 1866, 3. ser. 18, 473474. pl.

1866.1

- Descriptions of fish from Vancouver (In Lord, J. K. 'The naturalist of Vancouver island and British Columbia, vol. ii. London, 1866. 2 vols. $8^{\circ}$ )

1866.2

Note on west African species of Hemirhamphus. Ann. Mag. Nat. Hist., 1866, 3. ser. 18, 427.

1866.3

IOn the fishes of the states of Central America, founded upon specimens collected in the fresh and marine waters of various parts of that country by Messrs. Salvin, Godman and Capt. J. M. Dowl Proc.Zool. Soc. London, 1866 , 600-604. 25 pls.

1866.4

This article is preliminary to the report published in Trans. Zool. Soc. London, 1869, 6, $377-$ 394. See infra.

Pharyngognathi, etc. (In Playfair, Sir R. L., \& Günther, Albert C. L. G. The fishes of Zanzibar, p. 80-146. London, $1866.4^{\circ}$ )

1866.5

Remarks on some fishes from the river Amazons in the British Museum Tetragonopterus bartlettii, Cynodon pectoralis] Ann. Mag. Nat. Hist., 1866, 3. ser. 18, 30-31.

1866.6

- Remarks on the skeleton of Ausonia cuvieri. Proc. Zool. Soc. London, 1866, 336-338. fig. - Journ. Roy. Instit. Cornwall, 2, 160-162. $\quad 1866.7$

[Remarks supplementary to $\mathbf{M r}$. Alexander Carte's "Notes on the genus Chiasmodon"] Proc. Zool. Soc. London, 1866, 38-39. 1866.8

Notes on the habits of deep-sea fishes, and on the manner of deglutition, with special reference to Chiasmodus niger Johnson.

Additions to the British fauna. Ann. Mag. Nat. Hist., 1867, 3. ser. 20, 288-291. pl.

1867.1

Additions to the knowledge of Australian reptiles and fishes. Ann. Mag. Nat. Hist., 1867, 3. ser. 20, 45-68. 1867.2

Description of a new species of Apocryptes [A. polyophthalmus] Ann. Mag. Nat. Hist., 1867, 3. ser. 20, 117.

1867.3

Description of a new species of Mesoprion [M. mitchelli] Ann. Mag. Nat. Hist., 1867, 3. ser. 19, 257. pl.

1867.4

Descriptions of some new or little known species of fishes in the col- 
lection of the British Museum. Proc. Zool. Soc. London, 1867, 99-104. pl. 1867.5

New fishes from the Gaboon and Gold coast. Ann. Mag. Nat. Hist., 1867, 3. ser. 20, 110-117. 1867.6

On a new form of mudfish from New Zealand. Ann. Mag. Nat. Hist., 1867, 3. ser. 20, 305-309. pl. 1867.7

— On the identity of Alepisaurus (Lowe) with Plagyodus (Steller) Ann. Mag. Nat. Hist., 1867, 3. ser. 19, 185187.

1867.8

Additions to the ichthyological fauna of Zanzibar [Tholichthys osseus, Salarias kirkii, Exocotus melanopus] Ann. Mag. Nat. Hist., 1868, 4. ser. 1 457-459. illust.

1868.1

Description of two new gobiod fishes [Gobius doria, Eleotris dasyrhynchus] from Sarawak. Ann. Mag. Nat. Hist., 1868, 4. ser. 1, 264-266. pl.

1868.2

Descriptions of freshwater fishes from Surinam and Brazil. Proc. Zool. Soc. London, 1868, 229-247. 3 pls. \& 8 figs.

1868.3

Diagnoses of some new freshwater fishes from Surinam and Brazil, in the collection of the British Museum. Ann. Mag. Nat. Hist., 1868, 4. ser. 1, 475-481.

1868.4

Is whitebait the young of the herring? Zoologist, 1868, 3, 1321-1323.

1868.5

IObservations on the various species of Clupea found on the British coasts] Proc. Zool. Soc. London, 1868, 377.

1868.6

[Remarks on salmonoids exhibited by Dr. Murie and Mr. Buckland! Proc. Zool. Soc. London, 1868, 213-214.

1868.7

Report on a collection of fishes made at St. Helena by J. C. Melliss, Esq. Proc. Zool. Soc. London, 1868, 225-228. 2 pls.

1868.8

An account of the fishes of the states of Central America, based on collections made by Capt. J. M. Dow, F. Godman, Esq., and O. Salvin, Esq. Trans. Zool. Soc. London, 1869, 6, $377-$ 494. 24 pls.

1869.1

Addendum ito R. L. Playfair's

"Further contributions to the ichthy" ology of Zanzibar"] Proc. Zool. Soc. London, 1869, 241.

1869.2

Contribution to the ichthyology of Tasmania [Anthias richardsonii, Neptomenus dobula] Proc. Zool. Soc. London, 1869, 429.

1869.3

- Descriptions of some species of fishes from the Peruvian Amazons. Proc. Zool. Soc. London, 1869, 423-429. 6 figs.

1869.4

_ Descriptions of two new species of fishes discovered by the Marquis $J$. Doria [Upeneoides doria, Eleotris heterolepis] Ann. Mag. Nat. Hist., 1869, 4. ser. 3, 444-445.

1869.5

'The fishes of the Holy Land. Student, 1869, 3, 409-417. illust.

1869.6

The fishes of the Nile (In Petherick, J., \& (Mrs.) B. H. Travels in central Africa, etc. vol. ii, Append. C. London, 1869. $8^{\circ}$ )

1869.7

Note on three cyprinodontes (Strableps tetrophthalmus, Rivulus micropus, Girardinus guppii), small freshwater fishes of the island of Trinidad. Proc. Scient. Assoc. 'Trinidad, 1869, 1, 224-227.

1869.8

- Notice of a gigantic species of Batrachus from the Seychelle islands. Ann. Mag. Nat. Hist., 1869, 4. ser. 3, 131-132.

1869.9

- Report of a second collection of fishes made at St. Helena by J. C. Melliss, Esq. Proc. Zool. Soc. London, 1869, 238-239. pl.

1869.10

Notes on Prototroctes, a fish from fresh waters of the Australian regions. Proc. Zool. Soc. London, 1870 , 150-152.

1870.1

- On the occurrence of Lates calcarifer in Australia. Proc. Zool. Soc. London, 1870, 824.

1870.2

Black variety of Platyglossus notopsis. Proc. Zool. Soc. London, 1871, 667.

1871.1

- Ceratodus, and its place in the system. Ann. Mag. Nat. Hist., 1871, 4. ser. 7, 222-227. illust. 1871.2

Description of a new percoid fish from the Macquarie river [Ctenolates macquariensis] Proc. Zool. Soc. London, 1871, 320, pl. 1871.3

Description of Ceratodus, a genus of ganoid fishes, recently discovered in rivers of Queensland, Australia. 
Günther, $A$.

Phil. 'Trans. Roy. Soc. London, 1871, 161, 511-571. 13 pls. - Proc. Roy. Soc. London, 19, 377-379. - Ann. Mag. Nat. Hist., 4. ser. 7, 222-227. - Arch. Naturgesch., 37. Jahrg., 325-344. Nature, 4, 406-408; 428-429; 447.Popular Sci. Rev., 11, 257-266. 1871.4

- Examination of certain "Remarks on Indian fishes" made by Mr. Francis Day in the P'roceedings of the Zoological Society. Proc. Zool. Soc. London, 1871, 761-766. illust. 1871.5

- Note on Comephorus baicalensis. Ann. Mag. Nat. Hist., 1871, 4. ser. 8, 292.

1871.6

- On the young state of fishes belonging to the family of Squamipinnes. Ann. Mag. Nat. Hist., 1871, 4. ser. 8, 318-320. illust.

1871.7

Report on several collections of fishes recently obtained for the British Museum. Proc. Zool. Soc. London, 1871, 652-675. 18 pls.

1871.8

Description of Ceratodus, a genus of ganoids from Quecnsland, Australia. London, $1872.13 \mathrm{pls} .4^{\circ}$.

1872.1

Description of Thrissopater salmones, n. sp). (In Great Britain and Ireland. Geological Survey. Figures and descriptions illustrative of British organic remains, decade xiii. London. 1872. $\left.8^{\circ}\right)$

1872.2

- Description of two new fishes [Lanioperca mordax, Chilodactylus allporli] from Tasmania. Ann. Mag. Nat. Hist., 1872, 4. ser. 10, 183-184. 1872.3

Note on a hitherto unpublished drawing in the Buchanan-Hamilton collection, representing Barbus beavani. Proc. Zool. Soc. London, 1872, 875-878. 2 figs.

1872.4

- Notice of a large siluroid [Platystoma gigas! from the upper Amazons. Ann. Mag. Nat. Hist, 1872,4 . ser, 10 , $449-150$.

1872.5

Notice of some species of fishes from the Philippine islands [Platycephalus fasciatus, Otolithus leuciscus, Atherina lineata, Salarias holomelass Ann. Mag. Nat. Hist., 1872 , 4. ser. 10, 397-399.

1872.6

- - Notice of two new fishes [Symphorus taniolatus, Mugil meyeri] from Celebes. Ann. Mag. Nat. Hist., 1872, 4. ser. $9,438-140$.
- On a new genus of characinoid

fishes [Nannostomus beckfordi] from Demerara. Proc. Zool. Soc. London, 1872,146 .

1872.8

On Psammoperea and Cnidon. Ann. Mag. Nat. Hist., 1872, 4. ser. 10, $426-427$.

1872.9

On some new species of reptiles and fishes collected by J. Brenchley, Esq. Ann. Mag. Nat. Hist., 1872, 4. ser. $10,418-426$.

1872.10

Ueber die Acclimatisation des Lachses in Australien. Circul. Deutsch. Fischerei Ver., 1872, no. 4, 100-102.

1872.11

- Andrew Garrett's Fische der Südsec, beschrieben und redigirt von A. C. L. G. Günther. Band I, II, VIII. Journ. Mus. Godeffroy, 1873, Heft 2, 1-128. 83 pls. Ibid., 1875, Heft 4, 129-260. 67 pls. Ibid., 1909, Heft 16, 261-505. 40 pls. Ibid., 1910, Heft 17, 389-514. $20 \mathrm{pls}$.

1873.1

Notice in Ann. Mag. Nat. Hist., 1873, 4. ser. $12,491-194$.

Erster [und zweiter] ichthyologischer Beitrag nach Exemplaren aus dem Museum Godeffroy. Journ. MIus. Godeffroy, 1873, 2. Heft, 97-103. Ibid., 4. Heft, 89-92. 1873.2

- Further additions to the ich thyological fauna of Zanzibar. Ann. Mag. Nat. Hist., 1873, 4. ser. 12, 182. 1873.3

New fishes from Angola. Ann. Mag. Nat. Hist., 1873, 4. ser. 12, 142144 .

1873.4

Note on Scaphirhynchus fedlschenkoi. Ann. Mag. Nat. Hist., 1873, 4. ser. $12,277$.

1873.5

On a collection of fishes from Chefoo, north China. Ann. Mag. Nat. Hist., 1873, 4. ser. 12, 377-380. 1873.6

Report on a collection of fishes from China. Ann. Mág. Nat. Hist., 1873, 4. ser. 12, 239-250.

1873.7

Reptiles and fishes of the South Sea islands (In Brenchley, J. L. Jottings during the cruise of H. M. S. "Curaçon". . . in 1865, ete. London, 1873. 487 p. 59 pls. $8^{\circ}$ ) 1873.8

A contribution to the fauna of the river Tigris wwith two new species of fishes; Macrones colvillii, Barbus sharpeyi] Ann. Mag. Nat. Hist., 1874, 4. ser. 14, 36-3s. 2 pls. 
Description of a remarkable kind of air-bladder of a fish, probably of the family Scianidx] Ann. Mag. Nat. Hist., 1874, 4. ser. 14, 349-350. pl.

1874.2

Descriptions of new species of fishes in the British Museum. Ann. Mag. Nat. Hist., 1874, 4. ser. 14, 368$371 ; 453-455$.

1874.3

Notes on some fishes obtained at considerable depths in the North Atlantic. Ann. Mag. Nat. Hist., 1874, 4. ser. 13, 138-139.

1874.4

Notice of some new species of fishes from Morocco. Ann. Mag. Nat. Hist., 1874, 4. ser. 13, 230-232. 2 pls.

1874.5

Third notice of a collection of fishes made by Mr. Swinhoe in China Ann. Mag. Nat. Hist., 1874, 4. ser. 13, $154-159$.

1874.6

- Instructions for making observations on and collecting specimens of the fishes of Greenland (In Jones, T. Rupert. Manual of the natural history, geology ... of Greenland and the neighboring regions prepared for the use of the Arctic expedition of 1875 , p. 46-48. London \& Dublin, 1875. $\quad 8^{\circ}$ ) $\quad 1875.1$

Das Sammeln von Reptilien und Fischen (In Neumayer, G. B. Anleitung zu wissenschaftlichen Beobachtungen auf Reisen. Berlin, 1875. $8^{\circ}$ )

The same, 2, ed, Berlin, 1875, $8^{\circ}$. - 3. ed. Hannover, $1906.8^{\circ}$

Contributions to our knowledge of the fish-fauna of the Tertiary deposits of the highlands of Padang, Sumatra. Geol. Mag., 1876, 2. dec. 3, 433-440. 5 pls.

1876.1

Note on a second species $[S$. bainsii] of Spirobranchus (C. \& V.) Ann. Mag. Nat. Hist., 1876, 4. ser. 18, 67.

1876.2

On the urogenital apparatus of a blennioid fish from Tasmania [Clinus despicillatus] Ann. Mag. Nat. Hist., 1876, 4. ser. 17, 403-404.

1876.3

- Remarkable structure of young fishes. Amer. Naturalist, 1876, 10, 239.

1876.4

Investigations upon the young of the swordfish and chrtodonts.

Remarks on fishes, with descriptions of new species in the British Museum, chiefly from southern seas.
Ann. Mag. Nat. Hist., 1876, 4. ser. 17, 389-402. - Trans. New Zealand Instit., 9, 469-472.

1876.5

Account of the fishes collected by Capt. Feilden between $78^{\circ}$ and $83^{\circ}$ north latitude, during the Arctic expedition 1875-76. Proc. Zool. Soc. London, 1877, 293-295. pl. \& figs. 1877.1

Account of the zoological collection made during the visit of $H . M$. S. "Petrel" to the Galapagos islands. Proc. Zool. Soc. London, 1877, 64-93. 3 pls.

1877.2

Fishes, p. 67-69.

- Ichthyology (In Nares, (Sir)

G. S. Narrative of a voyage to the Polar sea during $1875-76$ in H. M. S. "Alert" and "Discovery," vol. ii, 218-222. London, 1877. figs. $8^{\circ}$ )

1877.3

Abstract in Proc. Zool. Soc. London, 1877. $293-295 ; 475-476$.

- Notice of a barbel [Barbus trevelyanis from the Buffalo river, British Caffraria. Ann. Mag. Nat. Hist., 1877, 4. ser. 19, 312-313.

1877.4

On a collection of reptiles and fishes from Duke-of-York, New Ireland, and New Britain. Proc. Zool. Soc. London, 1877, 127-132. 2 pls. 1877.5

- Preliminary notes on new fishes collected in Japan during the expedition of H. M. S. "Challenger." Ann. Mag. Nat. Hist., 1877,4 . ser. 20, 433446.

1877.6

-...- Remarks on New Zealand fishes. Trans. New Zealand Instit., 1877, 9, 469-472.

1877.7

Report on a collection of fishes made by Mr. C. Hart during the late Arctic expedition. Proc. Zool. Soc. London, 1877, 475-477. pl. 1877.8

Notes on a collection of Japanese sea-fishes. Ann. Mag. Nat. Hist., 1878, 5. ser. 1, 485-487. 1878.1

[Pisces] (In Nares, (Sir) G. S. Narrative of a voyage to the Polar sea during $1875-76$ in H. M. S. "Alert" and "Discovery." 2 ed. vol. ii, Append. no. 4. London, 1878. $8^{\circ}$ ) 1878.2

Preliminary notices of deep-sea fishes collected during the voyage of H. M. S. "Challenger." Ann. Mag. Nat. Hist., 1878, 5. ser. 2, 17-28; 179$187 ; 248-251$. 


\section{Günther, $A$.}

- Note on two Bermuda fishes recently described as new [Gerres jonesii, Belone jonesii] Ann. Mag. Nat. Hist., 1879, 5. ser. 3, 389-390. 1879.1

Notice of two new species of fishes from the South seas [Diagramma giganteum, Spharondon euanus] Ann. Mag. Nat. Hist., 1S79, 5. ser. 4, 136-137.

1879.2

IObservations on the collection of fishes of Kerguelen land made during the transit of Venus expeditions in the years 1874-75] Phil. Trans. Roy. Soc. London, 1879, 168 (extra vol.), p. 166.

1879.3

- IObservations on the marine fish fauna of Rodriguez made during the transit of Venus expeditions in the years 1874-75] Phil. Trans. Roy. Soc. London, 1879, 168 (extra vol.), 470-472.

1879.4

- On two new species of fishes from the Bermudas [Gerres jonesii, Belone jonesii] Ann. Mag. Nat. Hist., 1879, 5. ser. 3, 150-151.

1879.5

A contribution to the knowledge of the fish-fauna of the Rio de la Plata. Ann. Mag. Nat. Hist., 1880, 5. ser. 6, 7-15. pl.

1880.1

[Exhibition of a drawing of a fish, Holacanthus tricolor, obtained on the coast of the island of Lewes] Proc. Zool. Soc. London, 1880, 23, 356. 1880.2

Instructions on the collecting and preserving of fishes (In Neumayer, G. Anleitung zu wissenschaftlichen Beobachtungen auf Reisen, p. 418-427. Berlin, 1880)

1880.3

- An introduction to the study of fishes. Edinburgh, 1880. 720 p. figs. $8^{\circ}$.

1880.4

Review in Ann. Mag. Nat. Hist., 1881, 5. ser. 7. 63-64.

- Report on the shore fishes (In 'Zoology of the voyage of H. M. S. "Challenger," vol. i, pt. 6, 1-82. 32 pls. London, 1880. $4^{\circ}$ ) 1880.5

- Account of the zoological collection made during the survey of II. M. S. "Alert" in the straits of Magellan and on the coast of Patagonia. Proc. Zool. Soc. London, 1881, 2-141. 11 pls.

Fishes, p. 10-22. 2 pls. 1881.1

Fish from the Aretic regions In Markham, A. II. A polar recon- naissance, etc., Append. I. London, 1881. 361 p. illust. $8^{\circ}$ ) 1881.2

Note on a fish-palate from the Siwaliks. Rec. Geol. Surv. India, 1881, 14, 240. illust.

1881.3

Report on a collection [of fishes] made by Mr. T. Conry in Ascension island. Ann. Mag. Nat. Hist., 1881, 5. ser. 8, 430-440.

1881.4

- Exhibition on behalf of Sir J. W. P. Campbell Orde, Bart., F. Z. S., of a specimen of a charr (Salmo alpinus) obtained in a loch on North Uist, Hebrides. Proc. Zool. Soc. London, $1882,722$.

1882.1

Report on the fishes (In Tizard, T. H., \& Murray, J. Exploration of the Faröe channel during the summer of 1880 in H. M. S. "Knight Errant." Proc. Roy. Soc. Edinb., 1882, 11, 677 680)

1882.2

Notes on some Indian fishes in the collection of the British Museum Carcharias murrayi, Akysis pictus, Olyra elongata] Ann. Mag. Nat. Hist., 1883, 5. ser. 11, 137-140. fig. 1883.1

- On a new species of Cynolebias from the Argentine republic. Ann. Mag. Nat. Hist., 1883, 5. ser. 11, 140 141. 1883.2

- Fishes (In Report on the zoological collections made in the Indo-Pacific ocean during the voyage of H.M. S. "Alert," 1881-82, 29-33. pl. London, 1884. $\left.8^{\circ}\right)$

1884.1

Description of a specimen of Schedophilus medusophagus, a fish new to the British fauna. Trans. Zool. Soc London, 1885, 11, 223-224. pl. 1885.1

Remarks by 'T'. N. Gill in Science, 1885, n. s. 1. 117 .

- Exhibition of a specimen of a small fish of the genus Fierasfer imbedded in a pearl-oyster. Proc. Zool. Soc. London, 1886, 318-320. illust. 1886.1

Handbuch der Ichthyologie. Uebersetzt von Dr. Gustav von Hayek. Wien, 1886.527 p. 363 figs. $8^{\circ}$.

1886.2

Note on Pachymetopon and the Australian species of Pimelepterus. Ann. Mag. Nat. Hist., 1886, 5. ser. 18, $367-368$.

1886.3

Descriptions of two new species of fishes from Mauritius [Latilus fronticinctus, Platycephalus subfasciatus] Proc. Lool. Soc. London, 1887, 550-551. 2 pls. 
Guide to the galleries of reptiles and fishes in the department of zoology of the British Museum (Natural History) London, 1887.119 p. figs. $8^{\circ}$

Fishes, 47-119. 65 figs.

1887.2

Note on the hapuku of New Zealand (Polyprion prognathus) Ann. Mag. Nat. Hist., 1887, 5. ser. 20, 236-237.

1887.3

- On Australian fishes of the genus Beryx. Ann. Mag. Nat. Hist., 1887, 5. ser. 20, 237-239. illust. 1887.4

Report on the deep-sea fishes collected by H. M. S. "Challenger" during the years 1873-76 (In Report on the scientific results of the voyage of H. M. S. "Challenger" during the years 1873-76, vol. xxii, pt. 57, 1-268. 66 pls. London, 1887. $4^{\circ}$ ) 1887.5

Siluridæ (In Encyclopedia Britannica, 1887, 9. ed., vol. xxii, 67-69. figs.)

1887.6

- Contribution to our knowledge of the fishes of the Yangtsze-Kiang. Ann. Mag. Nat. Hist., 1888, 6. ser. 1, 429-435. Ibid., 1889, 6. ser. 4, 218-229.

1888.1

Report on the fishes obtained by Mr. J. Murray in deep water on the northwest coast of Scotland, between April, 1887, and March, 1888. Proc. Roy. Soc. Edinb., 1888, 15, 205-220. 2 pls.

1888.2

A contribution to our knowledge of the deep-sea fauna of the British islands. Ann. Mag. Nat. Hist., 1889, 6. ser. 4, 249-250; 415-420.

1889.1

[Exhibition of and remarks upon, some fishes not previously known to occur in British waters] Proc. Zool. Soc. London, 1889, 27.

1889.2

Fishes (In Green, W. S. Report of a deep-sea trawling cruise off the southwest coast of Ireland) Ann. Mag. Nat. Hist., 1889, 6. ser. 4, 415-420.

1889.3

Notice of a new fish [Diptychus lansdelli from the Issik Kul. Ann. Mag. Nat. Hist., 1889, 6. ser. 3, 361-362.

1889.4

Notice of two fishes new to the British fauna. Proc. Zool. Soc. London, 1889, 50-51. pl. - Ann. Mag. Nat. Hist., 6. ser. 3, 107.
On some fishes from the KilimaNjaro district. Proc. Zool. Soc. London, $1889,70-72$. pl. $\quad 1889.6$

Report of a deep-sea trawling cruise off the southwest coast of Ireland, under the direction of Rev. W. Spotswood Green. Fishes. Ann. Mag. Nat. Hist., 1889, 6. ser. 4, 415-420. illust.

1889.7

Report on the pelagic fishes (In Report on the scientific results of the voyage of H. M. S. "Challenger" during the years 1873-76, vol. xxxi, pt. 78, 1-47. 6 pls. London, 1889. $4^{\circ}$ )

1889.8

Third contribution to our knowledge of reptiles and fishes from the upper Yangtsze-Kiang. Ann. Mag. Nat. Hist., 1889, 6. ser. 4, 218-229. 1889.9

Contribution to our knowledge of British Pleuronectidx. Proc. Zool. Soc. London, 1890, 40-44. pl. 1890.1

Description of a new species of deep-sea fish from the cape (Lophotes fiski) Proc. Zool. Soc. London, 1890, 244-247. 2 pls.

1890.2

Description of a remarkable fish from Mauritius, belonging to the genus Scorpæna. Proc. Zool. Soc. London, 1891, 482-483. pl. 1891.1

Additional note on the occurrence of Lichia vadigo on the Cornish coast. Ann. Mag. Nat. Hist., 1892, 6. ser. 10, 335-336.

1892.1

Descriptions of the reptiles and fishes collected by Mr. E. Coode-Hore on lake Tanganyika. Proc. Zool. Soc. London, 1893, 628-632. pl. 1893.1

Second report on the reptiles, batrachians, and fishes transmitted by Mr. H. H. Johnston, C. B., from British Central Africa. Proc. Zool. Soc. London, 1893, 616-628. 5 pls.

1893.2

[Exhibition of, and remarks upon, specimens of Lepidosiren paradoxa, collected by Dr. Bohls on the upper Paraguay] Proc. Zool. Soc. London, $1894,316$.

1894.1

An introduction to the study of fishes. 2. ed. Edinburgh, 1894. p. 720 320 figs. $8^{\circ}$.

1894.2

Report on the collection of reptiles and fishes made by Dr. J. W. Gregory during his expedition to mount 
Guinther, $A$.

Kenia. Proc. Zool. Soc. London, 1894, 84-91. 4 pls.

1894.3

- Capture of a specimen of Lepidosiren in the river Amazon; a letter from Dr. Emil Goeldi. Nature, 1896. $54,270$.

1896.1

- Description of two new species of fishes (Mastacembelus and Barbus) Ann. Mag. Nat. Hist., 1896, 6. ser. 17, 397.

1896.2

- Numbers of zoological species linown in the years 1830 and 1831. Ann. Mag. Nat. Hist., 1896, 6. ser. 17, 180.

1896.3

Report on a collection of fishes made by Dr. A. Donaldson Smith during his expedition to lake Rudolf. Proc. Zool. Soc. London, 1896, 217-224. pl. 1896.4

Report on a collection of reptiles and fishes made by Miss M. H. Kingsley during her travels on the Ogowe river and in Old Calabar. Ann. Mag. Nat. Hist., 1896, 6. ser. 17, 261285. 3 pls.

1896.5

Report on the collections of reptiles, batrachians, and fishes made by Messrs. Potanin \& Berezorrski in the Chinese provinces Kansu and SzeChuen. Ann. Acad. Sci. Nat. St. Pétersb., 1896, 199-219. 2 pls. 1896.6

- Deep-sea fishes of the northern Atlantic. Nature, 1897, 55, 559-561.

1897.1

Report on a collection of fishes from Newchwang, north China. Ann. Mag. Nat. Hist., 1898, 7. ser. 1, 257263. pl.

1898.1

- An account of a collection of fishes made by Mr. R. B. N. Walker, C. M. 'L. S., on the Gold coast. Proc. Zool. Soc. London, 1899, 716-732. 5 pls.

1899.1

Complete catalogue of Linné's private collection of fishes, now in possession of the Linnxan society (In his President's anniversary address) Proc. Linn. Soc. London (Zool.), 1899, 15-38.

1899.2

Fishes rof lake Urmi and its neighbourhood] Journ. Linn. Soc. London (Zool.), 1899, 27, 351-391. 2 pls.

1899.3

-A contribution to the history of Plagyodus (Steller) Ann. Mag. Nat. Hist., 1901, 7. ser. 7, 35-36.
On the breeding-habits of Chromis philander; a letter from Nendick Abraham. Ann. Mag. Nat. Hist., 1901, 7. ser. $8,321-325$.

1901.2

Second notice of new species of fishes from Morocco. Novitat. Zool., Tring, 1901, 8, 367-368. 2 pls. 1901.3

- Ichthyology (In Encyclopredia Britannica, 10. ed., 1902, vol. xxix, 394400. figs.)

1902.1

Third notice of new species of fishes from Morocco. Novitat. Zool., Thring, 1902, 9, 446-448. 2 pls. 1902.2

Iast account of fishes collected by Mr. R. B. N. Walker, C.M.Z.S., on the Gold coast. Proc. Zool. Soc. London, 1902 (1903), pt. 2, 330-339. 4 pls. 1903.1

The type of Exococtus exitiens (L. Gmel.) Ann. Mag. Nat. Hist., 1909, S. ser. 3, 147-149.

1909.1

Ichthyology; history and literature down to 1880 (In Encyclopedia Britannica, 11. ed., 1910, vol. xiv, 250267)

1910.1

Shark [Selachians] (In Encyclopadia Britannica, 11. ed., 1911, vol. xxiv, 805-809. 16 figs.)

1911.1

Günther, Albert [Carl Ludwig Gotthilf] \& Hector, James. New mud-fish from New Zealand. Intell. Observ., 1867,12 , no. 5, 399-400.

1867.1

Guinther, Albert [Carl Ludwig Gotthilf] \& Playfair, (Sir) Robert Lambert. Sce Playfair \& Günther.

Gürich, Georg [1859-] Ueber Placodermen und andere devonische Fischreste im Breslauer mineralogischen Museum. Zeitschr. Dentsch. Geol. Gesell.; 1891, 43, 902-911. 5 figs.

1891.1

Guerin-Ganivet,

La faune ichthyologique de la côte Sud-Armoricaine. Trav. Scient. Labor. Zool. Phys. Concarneau, 1912, 4. sér. 6.

1912.1

Guérin-Méneville, Félix Edouard [1799-1874] Iconographic du règne animal de G. Cuvier; etc. Paris \& London, 1830-44. 70 pls. $\quad 1830.1$ Vol. iv. Poissons.

Guerne, Jules de. Les yeux accessoires des poissons osseux (d'après le Dr. Kissow) Bull. Scient., 1850, 2. sér. 3, no. $12,459-470$. pl. Also separate; Paris, 1881. 12 p. pl. $8^{\circ}$ 1880.1 
Conférence du Dr. O. Zacharias sur "Les organismes microscopiques d'eau douce et leur rôle dans la nourriture des poissons." Bull. Soc. Centr. Aquicult. France, 1896, 6, 121-127.

1896.1

Abris flottants pour les salmoides, emploi du cresson. Etangs \& Rivières, 1897, 10. année, 145. 1897.1

La pisciculture dans les catacombes de Paris. Etangs \& Rivières, 1897, 10. année, no. 222, 73-75. 1897.2

Guerne, Jules de, \& Pouchet, Georgcs. See Pouchet \& Guerne.

Guettard, Jean Etienne [1715-1786] Sur la défense du poisson-scie (In his Mémoires sur différentes parties des sciences et arts, vol. i, p. 86. Paris, 1768-83. $4^{\circ}$.

1768.1

Not seen; title and reference from $\mathrm{H}$. Cloquet, 1826

Guiard, J. Sur la glande thyroïde dans la série des vertébrés et en particulier chez les sélaciens. Paris, 1896 $118 \mathrm{p}$.

1896.1

Guibaud, … Les pêcheries allemandes. Rev. Marit. Colon. Paris, 1872.

1872.1

Guichenot, Alphonse. Monographie de deux genres de poissons, les lépisostées et les polyptères, de la famille des clupéoïdes de Cuvier, et de celle des siagonotes de Duméril, précédée de quelques considérations sur ces genres. Mag. de Zool., 1839 (Poissons) pl.

1839.1

Peces de Cuba (In Sagra, Ramon de la. Historia fisica, politica y natural de la isla de Cuba. Vol.' iv. Pari,s 1843)

1843.1

Aperçu géographique sur les poissons du Chile. Rev. Zool., 1847, $10,333-336$.

1847.1

Notice sur un nouveau genre de percoïdes [Pomanotis] Rev. Zool., $1847,10,390-394$.

1847.2

Notice sur l'établissement d'un nouveau genre de Chétodons [Mégaprotodon] Rev. Zool., 1848, 11, 12-14.

1848.1

- Peces de Chile (In Gay, Claudio. Historia fisica y politica de Chile. Paris \& Santiago, 1848) 1848.2 Zoologia, tomo segundo. Peces [par A. Guichenot] p. 137-370.
Sur une nouvelle espèce de malacanthe [Malacanthus brevirostris] Rev. Zool., 1848, 11, 14-15. 1848.3

- Cenno geografico sui pesci del Chili. Nuov. Ann. Sci. Nat. Bologna, 1850, 3. ser. 2, 151-154. 1850.1

_- Exploration scientifique de l'Algérie. Paris, 1850. pls. 1850.2

Vol, iii, Zoologie. Histoire naturelle des reptiles et des poissons.

Poissons (In Sagra, Ramon de la. Histoire physique, politique et naturelle de l'île de Cuba. vol. ii, 206 p. Paris, 1853. $8^{\circ}$ )

1853.1

- Notice sur deux espèces nouvelles de poissons du genre Cyprinodon [C. cyanogaster, C. doliatus] Rev. Mag. Zool., 1859, 2. sér. 11, 377-380. 1859.1

Notice sur un nouveau poisson du genre des Trichomyctères [Astemomycterus pusillus] Rev. Mag. Zool., 1860, 2. sér. 12, 525-527. 1860.1

Notice sur un nouveau poisson du groupe des cténolabres [Labrastre] Rev. Mag. Zool., 1860, 2. sér. 12, 152154 .

1860.2

Faune ichthyologique (In Maillard, L. Notes sur l'île de la Réunion. Paris, 1863. 32 p.) 1863.1

Catalogue des scaridés de la collection du Musée de Paris. Mém. Soc. Sci. Nat. Cherbourg, 1865, 11, 1-75.

1865.1

Catalogue des vomers de la collection du Muscée de Paris. Ann. Soc. Linn. Départ. Maine et Loire, 1865, 8, 32-44.

1865.2

Catalogue des poissons de Madagascar de la collection du Musée de Paris, avec la description de plusieurs espèces nouvelles. Mém. Soe. Sci. Nat. Cherbourg, 1866, 12, 129-148. 1866.1

- Notice sur une nouvelle espèce de poissons appartenant au genre des rhombes [Rhombus orbicularis Guich.] du Muséum de Paris. Mém. Soc. Sci. Nat. Cherbourg, 1866, 12, 243-247.

1866.2

Notice sur un nouveau genre de poissons de la famille des cottoildes, du Musćum de Paris. Mém. Soc. Sci. Nat. Cherbourg, 1866, 12, 253-256. pl.

1866.3

Notice sur le lophiopside, nouveau genre de poisson de la famille des 
Guichenot, $A$.

lophioides, et description de l'espèce type [Lophiopsis vomerinus Guich.] Mém. Soc. Sci. Nat. Cherbourg, 1867, 13, 101106.

1867.1

Notice sur le néosébaste, nouveau genre de poissons de la famille des scorpènoides, et description d'une nouvelle espèce [Neosebastes scorpanoides Guich.1 Mém. Soc. Sci. Nat. Cherbourg, 1867, 13, 83-89.

1867.2

- Notice sur le Salarichthys, nouveau genre de poissons de la famille des blennoïdes, et description de l'espèce type [S. vomerinus Guich.] Mém. Soc. Sci. Nat. Cherbourg, 1867, 13, 96-100.

1867.3

Notice sur le sériolophe, nouveau genre de poissons de la famille des scombéroides et description d'une nouvelle espèce Weriolophus carangoides Guich.] Mém. Soc. Sci. Nat. Cherbourg, 1867, $13,90-95$.

1867.4

Index generum ac specierum Anthiadidorum hucusque in Museo Parisiensi observatorum. Ann. Soc. Linn. Départ. Maine et Loire, 1868, 10, 80-87.

1868.1

- Révision du genre des pagels (Pagellus, Lithognathus, Calamus) Mém. Soc. Sci. Nat. Cherbourg, 1868, 14, 97-123.

1868.2

Notice sur quelques poissons inédits de Madagascar et de la Chine. Nouv. Arch. Mus. Hist. Nat. Paris, 1869, 5, 193-206.

1869.1

- Remarques sur les poissons de la famille des Squamipinnes, avec la description de deux nouvelles espèces de Scorpis. Ann. Soc. Linn. Départ. Maine et Loire, $1879,17,80-86 . \quad 1879.1$

Guichenot, Alphonse, \& Jacquinot, $H$. See Jacquinot \& Guichenot.

Guieysse-Pellissier, A. Etude sur la structure du noyau des cellules épithéliales de l'intestin de Scyllium catulus. C. R. Mém. Soc. Biol. Paris, 1911 , pt. 1, 553-555.

1911.1

Double coloration du mucus des cellules caliciformes par le vert lumière et le mucicarmin. C. R. Mém. Soc. Biol. Paris, 1912, 72, 910-912.

1912.1

Etude de l'épithélium intestinal de la roussette (Scyllium catulus Cuv.) Arch. Anat. Micr. Paris, 1913, 14, 469514. pl. \& 9 figs.

1913.1
Guignon, Nourriture des poissons. Feuille Jeunes Natural., 1903, 4. sér. 33, 171.

1903.1

Guillaume, Charles Eduard. Les époques de la ponte des poissons de rivières. La Nature, 1905,34 , pt. 1, 119-2:22.

1905.1

Guillemain, Constantin [1873-] Beiträge zur Geologie von Kamerun. Abh. K. Preuss. Geol. Landesanst., Berlin, 1910, n. s. 62, 392-398. pl.

Fischreste aus den Mamfe-Schiefern, von Otto Jaekel.

Guillemot, $H$. Pisciculture. Journ. Fermes, 1868, 1. année, no. 1, 12-13. figs. 1868.1

Guillot, $N$. Sur un réservoir particulier que présente l'appareil de la circulation des raies. C. R. Acad. Sci. Paris, $1845,21,1179-1180$.

1845.1

— Mémoire sur la structure du foie des animaux vertébrés. C. R. Acad. Sci. Paris, 1846, 23, 503-509. 1846.1

Mémoire sur la structure du foie des animaux vertébrés. Ann. Sci. Nat. (Zool.), 1848, 3. sér. 9, 113-171. 4 pls.

1848.1

Guimarães, Antonio Roberto Pereira. Description d'un nouveau poisson du Portugal. Jorn. Acad. Sci. Lisboa 1881 (1882), 8, 222-224.

1882.1

Pseudohelotes güntheri, sp. nov.

Liste de quelques espèces de poissons d'eau douce de l'intérieur d'Angola. Jorn. Acad. Sci. Lisboa 1881 (1882), 8, 133.

1882.2

- Description d'un nouveau poisson de l'intérieur d'Angola. Jorn. Acad. Sci. Lisboa, 1884, 9, 85. pl. 1884.1

Lista dos peixes da ilha da Madeira, Açores e das possessões portuguezas d'Africa, que existem no Museu de Lisboa (Supplemento) Jorn. Acad. Sci. Lisboa, 1884, 9, 30 . 1884.2

-Diagnose de trois nouveaux poissons d'Angola. Jorn. Acad. Sci. Lisboa, 1885, 10, 1. 2 pls. 1885.1

Lista dos peixes de ilha da Madeira, Açores e das possessões portuguezas d'Africa, que existem no Museu de Lisboa (Segundo supplemento) Jorn. Acad. Sci. Lisboa, 1885, 10, 1128. 
Guisan, Fr. Ludwig. Mémoire sur le Gymnotus electricus. Bull. Soc. Philom. Paris, 1797, 32-33.

1797.1

—- De Gymnoto electrico, etc. Tübingen, 1819. $35 \mathrm{p}$.

1819.1

Guitel, Frédéric. Sur la coque de l'ouf des Lepadogasters. C. R. Acad. Sci. Paris, 1887, 105, 876.

1887.1

Sur le système de la ligne latérale des Lepadogasters. C. R. Acad. Sci. Paris, $1887,105,687$.

1887.2

_- Sur quelques points de l'embryogénie et du système nerveux des Lepadogasters. C. R. Acad. Sci. Paris, 1887, 105,1270 .

1887.3

- Recherches sur les Lepadogasters. Arch. Zool. Expér. Gén., 1888, 2. sér. 6, 423-647. 14 pls. \& 7 figs. 1888.1

Sur les canaux muqueux des Cycloptéridés. C. R. Acad. Sci. Paris, $1889,109,648-651$.

1889.1

Sur la ligne latérale de la baudroie (Lophius piscatorius) C. R. Acad. Sci. Paris, 1890, 110, 50-52. - Assoc. Franç. Avanc. Sci., 19. sess., p. 511.

1890.1

Sur la structure de la peau de la baudroie (Lophius piscatorius) et des terminaisons nerveuses de sa ligne latérale. Arch. Zool. Expér. Gén., 1890, 2. sér. 8 (Notes et Revue), p. xxxiii. 1890.2

- Sur le cycloptère lumpe. Bull. Soc. Centr. Aquicult. France, 1890, 2, $33-34$.

1890.3

—- Sur les différences sexuelles du Lepadogaster bimaculatus Flem. C. R. Acad. Sci. Paris, 1890, 111, 759. 1890.4

- Sur le nerf latéral des Cycloptéridés. C. R. Acad. Sci. Paris, 1890, 111, $536-539$.

1890.5

- Sur les mœurs et la reproduction des poissons du genre Lepadogaster. Bull. Soc. Centr. Aquicult. France, 1890 , 2, 30-32.

1890.6

- Recherches sur la ligne latérale de la baudroie (Lophius piscatorius) Arch. Zool. Expér. Gén., 1891, 2. sér. 9, 125-190. 3 pls.

1891.1

Recherches sur les boutons nerveux bucco-pharyngiens de la baudroie (Lophius piscatorius) Arch.Zool. Expér. Gén., 1891, 2. sér. 9, 671-697. pl.

1891.2
- Sur le développement des nageoires paires du Cyclopterus lumpus. C. R. Acad. Sci. Paris, 1891, 112, 353-356. fig.

1891.3

- Sur les møurs du Gobius minutus.

C. R. Acad. Sci. Paris, 1891, 113, 292.

1891.4

Sur les organes gustatifs de la baudroie (Lophius piscatorius) C. R. Acad. Sci. Paris, 1891, 112, 879. 1891.5

Observations sur les mœurs du Gobius minutus. Arch. Zool. Expér. Gén., 1892, 2. sér. 10, 499-555. pl.\& 4 figs.

1892.1

- Sur les mours du Clinus argentatus Cuv. et Val. C. R. Acad. Sci. Paris, 1892, 115, 295-298. - Bull. Soc. Centr. Aquicult. France, 1892, 4, 165-167.

1892.2

Sur l'ovaire et l'ouf du Gobius minutus. C. R. Acad. Sci. Paris, 1892 , 114, 612-616. 4 figs. 1892.3

- Description des orifices genitourinaires de quelques Blennius. Arch. Zool. Expér. Gén., 1893, 3. sér. 1, 611658. 2 pls.

1893.1

Observations sur les moeurs de trois blenniidés, Clinus argentatus, Blennius montagui et Blennius sphynx. Arch. Zool. Expér. Gén., 1893, 3. sér. 1, 325384.

1893.2

- Sur les moeurs du Blennius sphynx Cuv. et Val., et du Blennius montagui Fleming. C. R. Acad. Sci. Paris, 1893, 117, 289-291. - Bull. Soc. Centr. Aquicult. France, 1893, 5, 13-16.

1893.3

Observations sur leś mours du Gobius ruthensparri. Arch. Zool. Expér. Gén., 1895, 3. sér. 3, 263-288. 1895.1

Recherches sur le développement des nageoires paires du Cyclopterus lumpus L. Arch. Zool. Expér. Gén., 1896 , 3. sér. $4,345-470$. 5 pls \& 9 figs. 1896.1

Sur un procédé facilitant la recherche des entonnoirs segmentaires du rein des selaciens. Arch. Zool. Expér. Gén., 1897, 3. sér. 5, 385-400. pl.

_. Sur le rein du Lepadogaster gouanii. C. R. Acad. Sci. Paris, 1900, 130, 1773-1777. 2 figs. 1900.1

- Sur les néphrostomes et les canaux segmentaires de quelques séla- 
Guitel, $F$.

ciens (Squatina, Scyllium, Centrina, ete.) Arch. Zool. Expér. Gén., 1900, 3. sér. 8 (Notes et Revue), i-viii. $\quad 1900.2$

Sur le rein des Lepadogaster gouanii Lacépède et $L$. candollii Risso. Bull. Soc. Sci. Méd., Rennes, 1901, 10, 249-253.

1901.1

- Sur le rein des Lepadogaster bimaculatus Fleming et $L$. microcephalus Brook. Bull. Soc. Sei. Méd., Rennes, 1902, 11, 164-178. 5 figs. Trav. Scient. Univ. Rennes, 1, $203-216$. 5 figs.

1902.1

_. Sur la variation du rein dans le genre Lepadogaster. Arch. Zool. Expér. Gén., 1903, 4. sér. 1 (Notes et Revue), i-vi. - Assoc. Franc. Avanc. Sci., 32. sess., 1903, 228.

1903.1

Descriptions comparatives des - Lepadogaster bimaculatus Pennant et $L$. microcephalus Brook. Arch. Zool. Expér. Gén., 1904, 4. sér. 2, 357-495. pl. d 11 figs.

1904.1

- Diagnoses des Lepadogaster bimaculatus Pennant et $L$. microcephalus Brook. C. R. Assoc. Franc. Avanc. Sci., 33. sess., 1904, pt. 2, 774-779. Bull. Assoc. Franç. Avane. Sci., 1904, p. 260 .

1904.2

- Sur les reins du Caularchus mocandricus Girard, gobiésocidé de la côte américaine du Pacifique. Arch. Zool. Expér. Gén., 1905, 4. sér. 4, i-vi. - C. R. Assoc. Franc. Avanc. Sci., 34. sess., $1906,597-601$.

1905.1

Recherches sur l'anatomic des reins de quelques gobiésocidés (Lepadogaster, Caularchus, Gobiesox, Syciases et Choris ochismus) Arch. Zool. Expér. Gén. 1906, 4. sér. 5, 505-700. 5 pls. \& 37 figs.

1906.1

_- Sur la persistance du pronéphros chez les téléostéens. C. R. Acad. Sci. P'aris, 1908, 147, 392-394. fig. 1908.1

-.-Sur l'expulsion des oufs chez l'Entelurus aquoreus Linné. Arch. Zool. Expér. Gén. 1908, 4. sér. 9, xxiv-xxix. fig. - Trav. Scient. Univ. Rennes, 1908, 7, pt. 1, 205-211. fig.

1908.2

Sur les reins des Aphya, Tripterygion et Clinus. Arch. Zool. Expér. Gén., 1910, 5. sér. 5 (Notes et Revue), $\mathrm{i}-\mathrm{x}$. fig.

1910.1

- Sur les reins du Crystallogobius nilssonii (Düben et Koren) Bull. Soc.
Sci. Méd. Ouest, Rennes, 1910, 19, 255267. fig.

1910.2

Sur les reins des Cottus gobio et C. bubalis. Note préliminaire. C. R. Assoc. Anat, 1912, 11, 92-94. - Bull. Soc. Sci. Méd. Ouest, Rennes, 21, 7578.

1912.1

L'appareil fixateur de l'ouf du Kurtus gulliveri. Arch. Zool. Expér. Gén., 1913, 52, 1-11. pl.\&3 figs. 1913.1

Recherches sur l'anatomie des reins du Cottus gobio. Arch. Zool. Expér. Gén., 1913, 52, 447-471. pl.

1913.2

Guitel, F'rédéric, \& Marion, $A . F$. See Marion \& Guitel.

Gulia, Gavino [-1889] Synopsis of the Maltese 'Triglide, by Gallina (In his Repertorio di storia naturale, 147 150. Malta, 1858-63)

1858.1

Catalogu tal hut ta Malta [Catalogue of the Maltese fishes] (In Castagna, P. P. Storia ta Malta bil Gzejjer tahha u li ghadda minn ghaliha, Malta, 1860)

1860.1

Tentamen ichthyologix Melitensis sistens methodo naturali stirpium objectis nonnullis observationibus genera ac species, a recentioribus de re zoologica scriptoribus admissas piscium insularum Melitæ. Melitx, 1861. 71 p. $4^{\circ}$. 1861.1

-.. Index methodicus Melitensium piscium. Melitx, 1862. 1862.1

- L'Aguglia imperiale. Il Barth, Malta, 1871-77. 1571.1

Malta, 1871-77.

Il Barth, 1871.2

- Sul pesce Lovaro. Il Barth, Malta, 1874. 1874.1

L'A ulopus filamentosus in Malta. Il Barth, Malta, 1877. 1877.1

Gulia, Giovanni. Il calendario del pescatore Maltese, guida pei dilettanti di pesea. Guida Generale di Malta e Gozo, 1905.

1905.1

Addition à la faune ichthyologique maltaise. Bull. Soc. Zool. France, $1909,34,191-192$.

1909.1

Cenni bibliografici sulla fauna vertebrata maltese. Boll. Soc. Zool. Ital., 1909, 2. ser. 10, 300-318. 1909.2 
- Sur la découverte du Cephaloptera giorna Risso dans les eaux maltaises. Bull. Soc. Zool. France, 1909, 34, p. 7.

1909.3

Sulla comparsa accidentale del Luvarus imperialis Raf. nel mare dell' isola di Gozo. Boll. Soc. Zool. Ital., 1910,2 . ser. 11, 46-48.

1910.1

Gulland, G. Lovell. The minute structure of the digestive tract of the salmon, and the changes which occur in it in fresh water. Anat. Anz., 1898, 14, 441-455. 12 figs.

1898.1

Report of investigations on the ife history of salmon in fresh water. The minute structure of the digestive tract of the salmon, and the changes which occur in it in fresh water. 18. Ann. Rept. Fish. Board Scotland, 1898, pt. 2, 13-22. 6 pls.

1898.2

The anatomy of the digestive tract in the salmon. Journ. Anat. Physiol., London, 1900, 2. ser. 15, 114116.

1900.1

Gulliver, George [1804-1882] Observations on the muscular fibres of the nsophagus and heart in some of the vertebrate animals. Proc. Zool. Soc. London, 1842, 124-129. Ibid., 1843, 6372.

1842.1

On the size of the red corpuscles of the blood in the vertebrata, with copious tables of measurements. Proc. Zool. Soc. London, 1845, 93-102. 1845.1

Note on the size of the bloodcorpuscles of birds, with measurements by Dr. Davy of the blood-corpuscles of some fishes and of a humming bird. Proc. Zool. Soc. London, 1846, 26-36. Ann. Mag. Nat. Hist., 18, 56. 1846.1

- Additional measurements of the red corpuscles of the blood of vertebrata. Ann. Mag. Nat. Hist., 1848, 2. ser. 2, $449-453$.

1848.1

On the red corpuscles of the blood of vertebrata, and on the zoological import of the nucleus, with plans of their structure, form, and size (on a uniform scale), in many of the different orders. Proc. Zool. Soc. London, 1862, 91-103. 18 figs.

1862.1

Fishes, p. 99.

Fovea centralis in the eye of the fish. Journ. Anat. Physiol., London, $1868,2,12$.
On certain nondescript bones in the skull of osseous fishes. Ann. Mag. Nat. Hist., 1869, 4. ser. 4, 397-398.

1869.1

On the fibres of the crystalline lens of Petromyzonini. Monthly Micr. Journ., London, 1869, 1, 209-211. 4 figs.

1869.2

On certain points in the anatomy and economy of the lampreys. Proc. Zool. Soc. London, $1870,844-850$. \& figs.

1870.1

On the taxonomic characters afforded by the muscular sheath of the oesophagus as regards Sauropsida and other vertebrata. Proc. Zool. Soc. London, 1870, 283-285. $\quad 1870.2$

Anatomy of Planer's lamprey, and a new entozoon (Neuronaia lampe$\operatorname{tra}$ ) living within the skull of the lampreys. Quart. Journ. Micr. Sci., London, 1872, n. s. 12, 102-103. 1872.1

- Fin-rays in the "adipose fin" of the smelt (Osmerus eperlanus) Quart. Journ. Micr. Sci., London, 1872 , n. s. $12,203-204$.

1872.2

On the size of the red corpuscles of the blood of the Salmonidre and some other vertebrates. Proc. Zool. Soc. London, $1872,833-836$.

1872.3

Size of the red corpuscles of the blood of the porbeagle or beaumaris shark (Lamna cornubica) Quart. Journ. Micr. Sci., London, 1872 , n. s. 12, 4041.

1872.4

Observations on the sizes and shapes of the red corpuscles of the blood of vertebrates, with drawings of them to a uniform scale, and extended and revised tables of measurements. Proc. Zool. Soc. London, 1875, 474-495. pl.

Fishes, p. $479-480$.

1875.1

Sketches of the spermatozoa of Petromyzon. Proc. Zool. Soc. London, 1875, 336. figs. - Quart. Journ. Mier. Sci., London, 1875, n. s. 15, 394-395.

1875.2

Gulliver, George, \& Smith, A. See Smith \& Gulliver:

Gummerus, A. En utvandring af mujkor. Fiskeritidskr. Finl., 1898, 7, 196.

1898.1

Gunckel, John $E$. Fish and fishing in Ohio. Trans. Amer. Fisheries Soc. 1892 (1893), 15-21.
1893.1 
Gunckel, J.E. The fish-culturist. Trans. Amer. Fisheries Soc. 1898 (1899), 93-99. 1899.1

Gundel, Emil Valdemar Peter. Aquariums-studier med indledning, angaaende faunaen i Frederiksberg Have og Sondermarken tilligemed en kort anvisning til at indrette et Ferskvandsakvarium. Kjobenhavn, 18s8. 20 p. $8^{\circ}$.

1888.1

Gunderlich, A. Die Fischvermehrung bis in's Unendliche durch die künstliche Befruchtung des Rogens mittelst der Milch. 2. ed. Weimar, 1861. 110 p. 8 pls. $12^{\circ}$. 1861.1

Gunn, James Alexander, \& Jordan, David Starr. See Jordan \& Gunn.

Gunn, $R$. C. Notices accompanying a collection of quadrupeds and fish from Van Diemen's Land, with notes and descriptions of the new species by J.E. Gray. Ann. Mag. Nat. Hist., 1838, 1, 101-111. - Notizen (Froriep), 7, 113118; Arch. Naturgesch., 2, p. 8. Isis (Oken), 1844, 572-576.

1838.1

Gunn, R. Marcus. On the embryology of the retina of teleosteans (Researches at St. Andrews marine laboratory under the Fishery board for Scotland) Ann. Mag. Nat. Hist., 1888, 6. ser. 2, 263-268.

1888.1

Gunn, Ronald, \& Gray, J.E. See Gray \& Gunn.

Gunn, T. $E$. The sturgeon off Yarmouth. Zoologist, 1865, 23, 9470.

1865.1

- A large specimen of the broadnosed eel [Anguilla latirostris] Zoologist, 1866,2 . ser. 1,510 .

1866.1

Smooth-tailed stickleback [Gasterosteus aculeatus] in Norfolk. Zoologist, 1866,2 . ser. 1, 348-349. 1866.2

Sturgeons off the coast of Norfolk and Suffolk. Zoologist, 1866, 2. ser. 1, $311-312 ; 510$.

1866.3

Tariety of the perch. Zoologist, 1866, 2. ser. 1, 510.

1866.4

- Notice of rare fishes occurring in Norfolk and Lothingland. Rept. British Assoc. Adv. Sci., 38. meet., 1868 (1869), 97-98.

1869.1

- Boar-fish [Capros aper] at Eastbourne. Zoologist, 1879, 3. ser. 3, 307.
Monster bream [Abramis brama] in Norfolk. Zoologist, 1879, 3. ser. 3, 342-343.

1879.2

Gunn, W., \& McLeod, M. G. Report of ... Gunn and ... McLeod .... appointed to enquire into the herring fishing industry of Great Britain and Holland. Ottawa, 1889. 4\% 1889.1

Gunner, Johan Ernst [1718-1773] Nachricht vom Berglachs, welcher Coryphonoides rupestris genannt. Werden kann. Drontheim. Gesell. Schrift. 1761, 3, 43-50.

1761.1

Om Hav-katten. Det Trondhiemske Selskabs Skrifter [Drontheim. Gesell. Schrift.] 1763, 1, 270. 1763.1

Efterretning om berglaxen, en rar norsk fisk, som kunde kaldes Coryphanoides rupestris. Drontheim. Gesell. Schrift., $1765,3$.

1765.1

Vom gelben Hayfisch [Scyllium catulus] Drontheim. Gesell. Schrift., 1766,2 , 216-219. pls.

1766.1

Vom Haa-skierding [Carcharias] Drontheim. Gesell. Schrift., 1766, 2, 299 -307.2 pls.

1766.2

Vom Haa-skierding [Somniosus brevipinna] Drontheim. Gesell. Schrift., $1766,2,299$.

1766.3

Vom Pristiurus melastomus. Drontheim. Gesell. Schrift., 1766, 2, 249.

1766.4

- Vom schwarzen Hayfish, sorthaae [Spinax niger] Drontheim. Gesell. Schrift., 1766, 2, 284-290. 2 pls.

1766.5

- Vom sleep-marken [Myxine glutinosal Drontheim. Gesell. Schrift., 1766, 2, 230-236. pl.

1766.6

Von der Seekatze [Chimæra sp.] Drontheim. Gesell. Schrift., 1766, 2, 248.

1766.7

- Beschreibung des Brugden [Selache maxima] Drontheim. Gesell. Schrift., 1767, 3, 28-43. - Ibid., 1770, 4, 13-33.

1767.1

- Vom Lachsstör, Scomber pelagicus L. Drontheim. Gesell. Schrift., 1770,4 , 80-81. figs.

1770.1

Von einem jungen Haybrand [Squalus sp. L.] Drontheim. Gesell. Schrift., 1770, 4, 1-12. figs. 1770.2

Guppy, H.B. Note on the pearly organs of Scopelus. Ann. Mag. Nat. Hist., 1882, 5. ser. 9, 202-204. 1882.1 
Gupta, K. G. Extract from the final report of the 27th January, 1908, regarding fishery matters. Coll. Papers Fish. Surv. Bengal, 1911, 10-18. 1911.1

Extract from the letter No. 2506 , dated 25th August, 1910, from the government of Bengal to the government of India, reporting on fishery investigations in Bengal. Coll. Papers Fish. Surv. Bengal, 1911, 89-90.

1911.2

Extract from the preliminary report of the 20th February, 1907, on the fisheries of Bengal. Coll. Papers Fish Surv. Bengal, 1911, 1-9. 1911.3

Gurewitsch, M.J. Ueber die Form der Nervenelemente der Kleinhirnrinde verschiedener Vertebraten. Neurol. Centralbl., 1905, 24. Jahrg., 54-64. \& figs.

1905.1

Gurley, Revere Randolph. On the classification of the Myxosporidia, a group of protozoan parasites infesting fishes. Bull. U. S. Fish Comm. 1891 (1893), 11, 407-420.

1893.1

The Myxosporidia, or psorosperms of fishes, and the epidemics produoed by them. Rept. U. S. Fish Comm. 1892 (1894), 18, 65-304. 47 pls. 1894.1

The habits of fishes. Amer. Journ. Psychol., 1902, 13, 408-425. 1902.1

Gurney, John Henry. Note on the piscivorous propensities of the common carp. Zoologist, $1860,18,7052$. 1860.1

Occurrence of the swordfish on the Norfolk coast. Zoologist, 1861, 19, 7819 .

1861.1

Salmon in the river Coquet in the last century. Zoologist, 1874, 2. ser. 9, 4160 .

1874.1

- Large pike [46 inches long] Zoologist, 1875, 2. ser. 10, 4574. 1875.1

- Sun-fish at Overstrand in Norfolk. Zoologist, 1875, 2. ser. 10, 4725.

1875.2

Swordfish on the Norfolk coast. Zoologist, 1879, 3. ser. 3, 342. 1879.1

Gurney, Joseph John. Description of fish market at Santa Cruz. Ann. Mag. Nat. Hist., 1840, 6, 328. 1840.1

Gustafsson, Hugo. Smärre meddelanden om fiskeriförhållandena i skilda delar i vårt land. Utdrag ur årsberättelse afgifven af fiskeriföreningens ombudsman i Salo för 1896. Fiskeritidskr. Finl., 1897, 6, 35-36.

1897.1

Guthke, Ernst. Embryologische Studien über die Ganglien und Nerven des Kopfes von T'orpedo ocellata. Jena. Zeitschr. Naturw., 1906, 42, 1-60. 3 pls. \& 7 figs.

1906.1

Guthrie, - A new geographical, historical and commercial grammar, etc. Philadelphia, 1815.

1815.1

Fishes of the United States, p. 360.

Gutmann, _- Ergebnisse der fürstlichen fürstenbergischen Hoffischerei, Donaueschingen. Landw. Correspbl. Carlsruhe, 1861.

1861.1

Gutmann, C.A.B. Wetterfische, Laubfrösche, Blutegel und Spinnen, die sichersten Wetterverkündiger. Beschreibung dieser Thiere und Anweisung zu der Behandlung der Goldfische. Leipzig, 1842. pl. $16^{\circ}$. 1842.1

Gutzén, H. I. Om fiskeriförhållandena e Kuusamo. Fiskeritidskr. Finl., 1895, 4, 47 .

1895.1

Guyénot, Emile. Contribution à l'étude anatomique et physiologique de la vessie natatoire des cyprinidés. Inaug. Dissert., Jena, 1906. 61 p. Abstract in C. R. Mém. Soc. Biol. Paris, 58, 794795. - Mém. Soc. Hist. Nat., Besançon, p. 39 .

1906.1

- Les fonctions de la vessie natatoire des poissons téléostéens. Bull. Scient. France Belgique, 1909, 43, 203296. pl. \& 4 figs.

1909.1

Le rôle hydrostatique de la vessie natatoire des poissons. La Nature, 1912, 40, pt. 2, 22-25. 4 figs. $\quad 1912.1$

Guyon, George [1825?-1878] The thresher or fox shark [Alopecias vulpes] at Ventnor. Zoologist, 1865, 23, 9630. 1865.1

Curative powers of the tench. Zoologist, 1867, 2. ser. 2, 563. 1867.1

Guyon, Joseph, \& Perrier, Léon. See Perrier \& Guyon.

Gysi, $E$., \& Luchsinger, $B$. Ueber das Verhalten der Aal-Iris gegen verschiedenfarbiges Licht. Centrbl. Med. Wissensch., 1879, 7, 691-692. 1879.1 
H. Norfolk fish market. Forest \& Strcam, 1876, 7, 252. 1876.1

- Salmon in Cayuga lake. Forest \& Stream, 1877, 9, 345 .

1877.1

- Salmon in New Jersey. Forest \& Stream, 1877, 8, 207.

1877.2

- Aalmännchen im Süsstrasser. Allgem. Fischerei Zeitg., 1893, 18, no. 21, 321-324.

1893.1

H., A. Forellen als Vegetarianer. Mitth. Fischereiwesen München, 1876 , 1. Jahrg., 6-7.

1876.1

H., A. Rare fishes iTorpedo fairchildi, Carcharodon?] New Zealand Journ. Sci., 1883, 1, 465-466. Ibid., 2, 127-128.

1883.1

H., A. R. The fisheries and other resources of Alaska. Chicago Field, 1879, 10,395 .

1879.1

H., $C . F$. Courtship in lower life. Amer.Sportsman, 1874, 4, 151. 1874.1

The devil fish. Amer. Sportsman, $1874,3,374$.

1874.2

Marine monsters of tradition and fact. Forest \& Stream, 1878, 11, 154-155.

1878.1

H., D.L. Fossil fishes. Amer. Journ. Sci., 1838, 34, 198-200. 1838.1

H., $F$. The New York aquarium. Forest \& Stream, 1876, 7, 83. 1876.1

H., $I I . T$. Yellow perch as black bass food. Amer. Angler, 1884, 6, 182.

1884.1

H., J. Giftige Fische. Deutsch. Fischerei Zeitg., 1879, 2, 374-375.

1879.1

H., $J . D$. Fish protection in Tennessec. Forest \& Stream, 1879, 12, 131.

1879.1

- Success in 'T'ennessee in fish protection. Forest \& Stream, 1S79, 13, 826.

1879.2

- 'T'ennessec shad and salmon. Forest \& Stream, 1879, 12, 185. 1879.3
- Wish culture and protection in Tennessee. Forest \& Stream, 1880, 13, 1005 .

1880.1

- German carp in Tennessee. Forest \& Stream, 1880, 15, 366. 1880.2

H., L. Hajfiskefangst paa Sydhavsoerne. Fra alle Lande, $1876,1,418-$ 423.

1876.1

H., S. L. A big sturgeon and its parasites. Forest \& Stream, 1879, 12, 15.

1879.1

H., T. W. Changes of color in fish. Forest \& Stream, 1876, 7, 2.

1876.1

H., (Dr.) IT. Der gefleckte Fadenwels (Pinoleus maculatus Cuv.) Blätt. Aquar-Terrar. Freunde, 1899, 10. Jahrg., 217.

1899.1

H., W. M. Artificial hatching of egels. Chicago Field, 1879, 12, 21.

1879.1

Haack, Hermann. Die Kaiserliche Fischzucht-Anstalt bei St. Louis. Landw. \& Forstw. Zeitg. Prov. Preussen, 1871, no. 28, 29-31.

1871.1

Küunstliche Zucht der Forellen. Landw. \& Forstw. Zeitg. Prov. Preussen, 1871 , no. 41 .

1871.2

Mittheilungen über die Fischzucht-Anstalt zu Hüningen. Circul. Deutsch. Fischerei Ver., 1871, 1. Jahrg., no. $5,41-48$.

1871.3

Bericht über die 'Thätigkeit der Kaiserlichen Fischzucht-Anstalt zu Hiinigen im Elsass während des Betriebsjahres 1871-72. Circul. Deutsch. Fischerei Ver., 1872, 1. Jahrg., no. 10, 245-25s.

1872.1

Eine Fischzuchtanstalt in der Normandie. Landw. Zeitg. (Fühling), 1872, 21 (n. s. 9), 382-385. 1872.2

- Die rationelle Fischzucht; einekurzgefasste Anleitung für den praktischen Fischzüchter. Leipzig, 1872. 86 p. $8^{\circ}$.

1872.3

Mittheilungen über dic Wirksamkeit der Fischzucht-Anstalt in Hün- 
ingen im Elsass in den Jahren 1872-73 und 1873-74. Circul. Dentsch. Fischerei Ver. 1874 (1875), 1. Jahrg., no. 6, $235-237$.

1875.1

Die Einführung von Aalen in das Donaugebiet nebst Bemerkungen über Acclimatisirung anderer Fischarten. Mitth. Fischereiwesen, München, 1877, 2. Jahrg., 33-35.

1877.1

Ueber Fischzucht und Fischerei. Ber. Fischerei Ver. Prov. Preussen, 1877 , no. 2, 12-14.

1877.2

Aussetzen von Felchen [Coregonus] im Tegernsee. Circul. Deutsch. Fischerei Ver. 1877 (1878), 1. Jahrg., no. 2, 23-25.

1878.1

Bericht uiber das Resultat des An- und Ausbrutungsgeschäftes von Coregonen- und Aescheneiern während des Betriebsfahres 1877-78 in der Kaiserlichen Fischzuchtanstalt zu Hüningen. Circul. Deutsch. Fischerei Ver., 1878, 1. Jahrg., no. 5, 115-119. 1878.2

Bericht über den Transport angebriteter Eier des californischen Lachses Salmo quinnat von Californien nach Europa. . . Circul. Deutsch. Fischerei Ver. 1877 (1878), 1. Jahrg., no. 7, 200-204

1878.3

Bericht über Empfangnahme und Vertheilung der californische Lachseier. Circul. Deutsch. Fischerei Ver., 1878, 1. Jahrg., no. 7, 149-151. 1878.4

Betriebresultate zu Hüningen. Circul. Deutsch. Fischerei Ver. 1877 (1878), 1. Jahrg., no. 6, 162-164. 1878.5

Richtige Forellen-Namen [Salmo] Circul. Deutsch. Fischerei Ver. 1877 (1878), 1. Jahrg., no. 4, 121-123.

1878.6

Die transportable Brutanstalt. Circul. Deutsch. Fischerei Ver. 1877 (1878), 1. Jahrg., no. 5, 120-121. 1878.7

- Ueber den 'Transport von Edelfischeiern auf sehr weite Entfernungen. Circul. Deutsch. Fischerei Ver, 1877 (1878), 2. Jahrg., no. 1, 5-7. 1878.8

Ueber die An- und Ausbrütung von Coregonen. Circul. Deutsch. Fischerei Ver. 1877 (1878), 2. Jahrg., no. 1, 9-10.

1878.9

Ueber die Befruchtung von Salmoniden-Eiern. Circul. Deutsch. Fischerei Ver. 1877 (1878), 2. Jahrg., no. $1,8-9$.
- Die Acclimatisirung des Aales im Donargebiete. Bayer. Fischerei Zeitg., 1879, 4. Jahrg., 24-25.-Oesterr.ungar. Fischerei Zeitg., 1880, 65. 1879.1

Die Aufgabe der Fischzüchter im Donaugebiete. Circul. Deutsch. Fischerei Zeitg., 1879, 2. Jahrg., no. 2, 214; 221-222; 232-233. 1879.2

Aus einem Vortrage über die Aufgabe der Fischzüchter im DonauGebiet. Circul. Deutsch. Fischerei Ver., 1879, 2. Jahrg., no. 4, 118-120. 1879.3

Aussetzung junger Rhein- und Californischer-Lachse in das Quellgebict der Mosel. Circul. Deutsch. Fischerei Ver., 1879, 2. Jahrg., no. 4, 115-118. 1879.4

Die Einführung von Aalbrut in deutsche Gewässer. Circul. Deutsch. Fischerei Zeitg., 1879, 2. Jahrg., no. 1, $65-66$.

1879.5

Die feuchte Anbrütung von Salmoniden und von Coregonen-Eiern. Circul. Deutsch. Fischerei Ver., 1879, 2. Jahrg., no. 1, 17-20.

1879.6

Ueberführung von Blaufelchen und Madue-Maränen an den Bodensee und an den Schliersee. Circul. Deutsch. Fischerei Ver. 1878 (1879), 2. Jahrg., no. $2,59-62$.

1879.7

Vorzüge und Mängel des EisBrutapparates. Circul. Deutsch. Fischerei Ver., 1879, 2. Jahrg., no. 4, 118120.

1879.8

Ausbrütung u. s.w. von MadueMaränen-Eiern. Circul. Deutsch. Fischerei Ver. 1879 (1880), 2. Jahrg., no. 6, 247-248. - Oesterr.-ungar. Fischerei Zeitg., 1880, 52.

1880.1

—. Behandlung der ausgeschlüpften jungen Salmoniden und Coregonen bis $\mathrm{zu}$ ihrer völligen Entwicklung und das Aussetzen derselben. Circul. Deutsch. Fischerei Ver., 1880, 2. Jahrg., no. 1, 1520. 1880.2

Bericht über das im Jahre 1880 erfolgte Aussetzen von 50,000 jungen Rheinlachsen in das Gebiet der Mosel. Circul. Deutsch. Fischerei Ver., 1880, 2. Jahrg., no. 4, 86. 1880.3

_- Einführung der amerikanischen Forelle, Salmo fontinalis, in Deutschland. Cireul. Deutsch. Fischerei Ver., 1880, 2. Jahrg., no. 6, 187-189. Oesterr.-ungar. Fischerei Zeitg., 1880, $375-376$. 
Haack, $H$.

- Einiges über die Zucht der Salmoniden in geschlossenen Räumen. Circul. Deutsch. Fischerei Ver, 1880, 2. Jahrg., no. 1, 5-15. 1880.5

- Die Fortpflanzungsähigkeit der Bastarde. Oesterr.-ungar. Fischerei Zeitg., 1850, p. 59. $\quad 1880.6$

-Quellwasser oder Bachwasser? Oesterr-ungar. Fischerei Zeitg., 1880, 35-37. 1880.7

Rationelle Wasserwirthschaft. Oesterr,-ungar. Fischerei Zeitg., 1880, $2-3 ; 11-12$.

1880.8

- Der Saibling, auch Salbling, Ritter, Rötheli,Rothforelle und Schwanzreuterl, am Starnbergersee Lachs genannt, Salmo salvelinus oder Salmo umbla. Circul. Deutsch. Fischerei Ver. 1879 (1880), 1. Jahrg., no. 6, 258-260. Oesterr.-ungar. Fischerei Zeitg., 1880 , $51-52$.

1880.9

A German view of the American section in the Berlin fishery exhibition. Bull. U. S. Fish Comm. 1881 (1882), $1,57-58$.

1882.1

_ Raising salmonoids in inclosed waters. Rept. U. S. Fish Comm. 1879 (1882), 7, 675-685.

1882.2

-. Treatment of young salmonoids and Coregoni from the time they leave the egg till they are fully developed and can be placed in open waters. Rept. U. S. Fish Comm. 1879 (1882), 7, 687693.

1882.3

- Lachsbastarde auf der Schweizerischen Fischerei-Ausstellung in Zürich. Allgem. Fischerei Zeitg., 1894, 19, 280-281.

1894.1

- Die Kaiserliche Fischzuchtanstalt bei Hüningen im Elsass. Allgem. Fischerei Zeitg., 1904, 29. Jahrg., 401$405 ; 422-426 ; 442-446$.

1904.1

Haacke, Johann Wilhelm. Diagnosen zweier bemerkenswerther südaustralischer Fische. Zool. Anz., 1885, 8, 508-509.

1885.1

Ueber eine neue Art uterinaler Brutpflege bei Wirbelthieren. Zool. Anz., 1885, 8, 488-490.

1885.2

Ueber IIelotis scolus und Eimer's Theorie der Thierzeichnungen. Zool. Anz., 1885, 8, 507-508.

1885.3

Bastardirung der Forelle durch den Bachsaibling. Allgem. Fischerei Leitg., 1893, 18, no. 14, $210 . \quad 1893.1$
Die Schöpfung der Tierwelt. Leipzig \& Vienna, 1893.557 p. 20 pls. $8^{\circ}$.

1893.2

Die Entwickelung der Fischerei und Fischzucht während des letzten Vierteljahrhunderts. Allgem. Fischerei Keitg., 1901, 26, 135-141. 1901.1

-_ Ueber Mundhöhlendrusen bei Petromyzonten. Zeitschr. Wiss. Zool., 1903, 75, 112-146. 2 pls. 1903.1

Haas, Hippolyt Julius [1855-] Eine Beobachtung beziehungsweise des Urinierens bei Fischen (Forellenbarsch, Grystes [Micropterus] salmoides) Freie Hefte Naturwiss. Mitth., Leipzig, 1908, no. $3,1-2$.

1908.1

Einiges über Gasterosteidæ. Wochenschr. Aquar.-Terrar. Kunde, 1908, 5. Jahrg., 206-207. 1908.2

Mitteilungen über Acara caruleopunctata. Wochenschr. Aquar.-Terrar. Kunde, 1908, 5. Jahrg., 245-246.

1908.3

Haase, Carl. Allgemeine Bemerkungen über die Entwickelung und die Stammgeschichteder Wirbelsäule. Anat. Anz., 1892, 8, 288-289. Abstract in Journ. Roy. Micr. Soc., 1893, 304.

1892.1

Haase, Erich [1857-1894] Beobachtungen über fliegende Fische. Zool. Anz., 1892, 15, 26.

1892.1

Haast, (Sir) Johann Franz Julius von [1822-1887] Notes on some undescribed fishes of New Zealand. Trans. New Zealand Instit., 1873, 5, 272-278. $\mathrm{pl}$.

1873.1

On Cheimarrichthys forsteri, a new genus belonging to the New Zealand freshwater fishes. Trans. New Zealand Instit., 1874, 6, 103-104. pl. 1874.1

On the occurrence of Lamna cornubica, porbeagle shark Flem., the Mako of the Maoris, in New Zealand. Trans. New Zealand Instit., 1875, 7, 237-238.

1875.1

On the occurrence of Leptocephalus longirostris Kaup, on the coast of New Zealand. Trans. New Zealand Instit., 1875, 7, 238. $\quad 1875.2$

Sur le Cheimarrichthys forsteri, nouveau genre de poissons propre aux eaux de la Nouvelle-Zélande. Journ. Zool. (Gervais), 1875, 4, 428. 1875.3 
- Notes on Regalecus pacificus, a new species of ribbon-fish from the New Zealand sea. Trans. New Zealand Instit. 1877 (1878), 10, 246-250. pl.

1878.1

Habbard, $W . F$. Report of the salmon-hatching operations in 1878, at the Clackamar hatchery. Rept. U. S. Fish Comm. 1878 (1880), 6, 771-772. 1880.1

Habberton, John. First families of the Atlantic. Harper's Monthly Mag., $1880,60,284-289$.

1880.1

On the cod, mackerel and the herring.

Habersham, William Ney A. Note on the use of the male salmon hook and the run of 1883. Bull. U. S. Fish Comm. $1884,4,52$.

1884.1

Haddon, Alfred Cort [1855-] Suggestion respecting the epiblastic origin of segmental duct. Proc. Roy. Dublin Soc., 1886-87, n. s. 5, 463-471. 1886.1

Survey of fishing grounds, west coast of Ireland, 1890-1891. Introductory note. Proc. Roy. Dublin Soc., 1892, n.s. 7, 221-224.

1892.1

Haddon, Alfred Cort, \& Bridge, $T$. W. See Bridge \& Haddon.

Hadfield, Henry. Basking shark [Selache maxima] off Shanklin Chine, isle of Wight. Zoologist, 1875, 2. ser. 10, 4415-4418.

1875.1

On the flight of the flying-fish. Zoologist, 1881, 3. ser. 5, 68-69. 1881.1

Haeckel, Ernst Heinrich Philipp August [1834-] Zur Phylogenie der australischen Fauna. Systematische Einleitung (In Semon, R. Zoologische Forschungsreisen in Australien und dem Malayischen Archipel ... ausgeführt in den Jahren 1891-1893 von Dr. Richard Semon, vol. i, pt. 1, i-xxiv. Jena, 1893)

1893.1

Systematische Phylogenie der Wirbelthiere (Vertebrata) Dritter Theil des Entwurfs einer systematischen Stammesgeschichte. Berlin, 1895. xx, 660 p. $8^{\circ}$.

1895.1

- Festschrift zum siebzigsten Geburtstage von Ernst Haeckel. ... Jena, 1904. 16 pls. \& 109 figs. 1904.1 See Goeppert, E. - 1904.1

Alte und neue Naturgeschichte. Festrede ... an die Universität Jena am 30. Juli 1908. Jena, 1908. 32 p. $8^{\circ}$. 1908.1

Verzeichnis der Druckschriften von Ernst Haeckel, p. 27-32.
Haeckel, Ernst Heinrich Philipp August, \& others. Festschrift zum siebenzigsten Geburtstage von Carl Gegenbaur am 21. August 1896. 3 vols. Leipzig, 1896-97. illust. 4 1896.1

Vol. i. Die Brustflosse der Crossopterygier, von H. Klaatsch. 133 p. 4 pls.

Vol. iii. Der Ursprung der Vagusgruppe bei den Teleostiern, von B. Haller. 57 p. 4 pls.

Vol. iii. [Das Exkretionssystem der Myxinoiden in seiner Bedeutung für die morphologische Auffassung des Urogenitalsystems der Wirbelthiere, von $R$. Semon. 26 p. 2 pls.

Vol. iii. [Ueber die spino-occipitalen Nerven der Selachier und Holocephalen und ihre vergleichende Morphologie, von M. Fürbringer. 440 p. 8 pls.

Häfeli, - Archivarische Nachricht von einem monströsen Karpfen. Mag. Physik Naturk. (Voigt), 1802, 4 463-464.

1802.1

Hållström, Robert. Die FischereiVerhältnisse im Jahre 1901 in dem Skären von Ingå und Degerby in Nyland [Text in Swedish] Fiskeritidskr. Finl., $1902,11,89-90$.

1902.1

Hämmerle, Ludwig. Anatomie der Brustflosse von Periophthalmus kroelreuteri. Ber. Naturw. Gesell. Freiburg i. B., 1897, 10, 20-32. fig. 1897.1

Haemmerle, Otto. Beschreibung zu dem von ihm construirten selbstwirkenden Fisch-Transportwagen und Tragbütte. Circul. Deutsch. Fischerei Ver. 1874 (1875), 1. Jahrg., no. 2, 91-97.

\section{1}

Selbstthätige Vorrichtung zum Füttern der Forellen in künstlichen Fischzuchts-Anstalten. Osterr. Landw. Wochen. Wien, 1876, 2. Jahrg., no. 12, 134.

1876.1

Haempel, Oskar. Die häufigsten Parasiten unserer Fische aus der Gruppe der Würmer und niederen Krebse. Wien, 1907. 12 figs. 1907.1

Ueber die sogenannte Kauplatte der Cyprinoiden. Inaug. Dissert. Stuttgart, 1907. 22 p. pl. $\quad 1907.2$

- Mitteilungen der Teichwirtschaftlichen Versuchsstation in Frauenberg. Osterr. Fisch. Gesell. Wien, 1908. 35 p. 2 figs.

1908.1

- Die Schlundknochenmuskulatur der Cyprinoiden und ihre Funktion. Zool. Jahrb. (Abth. Anat.), 1908, 27, 95-102. pl. 1908.2

Ueber die sogenannte Kauplatte der Cyprinoiden. Ber. Kgl. Biol. Versuchsstat. München, 1908, 1, 1-21. pl. \& 7 figs. 
Haempel, $O$.

Einiges zur Anatomie und Pliysiologie der Schwimmblase beim Aal und den Renken. Oesterr-ungar. Fischerei Zeitg., 1909, 6, 219-220. Zool. Anz., 34, 381-384.

1909.1

Ueber das Wachstum des Huchens (Salmo hucho L.) Ein Beitrag zur Altersbestimmung der Teleostier. Intern. Rev. Hydrobiol. \& Hydrogr., $1910,3,136-155$. 3 pls.

1910.1

- Zur Frage des Hörvermögens der Fische. Intern. Rev. Hydrobiol. \& Hydrogr., 1911, 4, 315-326. - Natur, 8, $169-176$.

1911.1

- Leitfaden der Biologie der Fische. Stuttgart, 1912. 180 p. 55 figs. 1912.1

- Teichwirtschaftliche Streitfragen. Oesterr-ungar. Fischerei Zeitg., $1912,9$.

1912.2

Haempel, Oskar, \& Hilzheimer, $M$. See Hilzheimer \& Haempel.

Hänig, Kurt. Pflege und Zucht von Danio rerio. Wochenschr. Aquar.Terrar. Kunde, 1912, 9. Jahrg., 224225. pl.

1912.1

Håpke, L. Ichthyologische Beiträge. Bremen, 1876. $8^{\circ}$. 1876.1

- Ichthyologische Beitråge.

Zur Entdeckungsgeschichte der künstlichen Fischzucht. II. Zur Kenntniss der Fischfauna des Wesergebiets. Circ. Deutsch. Fischerei-Ver., 1877, 102-107.

157.1

Fische und Fischerei im IVesergebcite (Zweiter Beitrag) Abh. Naturw. Ver. Bremen, 187S, 5, 157-192. 1878.1

Ichthyologische Beiträge. Fische und Fischerei im Wesergebiete. Abh. Naturw. Ver. Bremen, 1880, 6, 577-616. 1880.1

- Gezeichnete Lachse. Beitr. Naturw. Ver. Bremen, 1895, 1, 39-42.

1895.1

Die Lachsfischerei in der Weser. Abh. Naturw. Ver. Bremen, 1896, 13, 3. Heft, 477-482.

1896.1

Ueber das Weserwehr und seine Fischpässe. Verh. Deutsch. Zool. Ges., 1913, 23. Vers., 195-197.

1913.1

Häyrén, Errnst. Längszonerna i ekenäs skärgård. Geogr. Fören. 'Tidskr., $1900,222-234$.
Haffiner, Carl. Junge Aale. Wochenschr. Aquar-Terrar. Kunde, 1911, 8. Jahrg., 619-620. fig. 1911.1

- Der Panzerwels. Bliatt. Aquar.Terrar. Kunde, 1911, 22. Jahrg., 825S28. fig.

1911.2

- Der Schlammbeisser. Wochenschr. Aquar-Terrar. Kunde, 1911, 8. Jahrg., 776-778. fig.

1911.3

Einiges vom Zwergwels. Wochenschr. Aquar-Terrar. Kunde, 1912 9. Jahrg., 123-124. fig. 1912.1

- Der Hecht im Aquarium. Blätt. Aquar.'Terrar. Kúunde, 1912, 23. Jahrg. 206-208. fig.

1912.2

Die Hundsfische. Wochenschr. Aquar.-Terrar. Kunde, 1912, 9. Jahrg., 349-350. fig. 1912.3

- Eine lireuzung zwischen Xiphophorus helleri var. giintheri und Platypoccilus maculatus var. pulchra. Blätt. Aquar.-'Terrar. Kunde, 1912, 23. Jahrg., 595-596. 2 figs.

1912.4

- Lebensweise und Fang des Herings. Wochenschr. Aquar--Terrar. Kunde, 1912, 9. Jahrg., 443-445; 458459.

1912.5

Nochmals die Kíreuzung zwischen Xiphophorus strigatus Regan (Xiph. helleri var. güntheri) oग mit Platypocilus maculatus var. pulchra o. Blätt. Aquar.-Terrar. Kunde, 1913, 24. Jahrg., 533-535. 5 figs.

1913.1

Hagelberg, Johan. Omituisesta loismadosta Keiteleen Salakoissa. Luonnon Ystävä, 1898, 2, 56-57. 1898.1

\section{Hagemann, _, \& Nölke, See Nölke \& Hagemann.}

Hagenow, Karl Friedrich von [17971865] Fisch und Vogel. Arch. Ver Freunde Naturgesch. Mecklenburg, 1860, 14. Jahrg., 453-454. 1860.1 Goldammer im Magen eines Hechtes.

Hagmann, Goltfried. Acanthicus hystrix Spix, aus dem unteren Amazonas. Zool. Anz., 1901, 24, 173-175. 1901.1

_ Weiterer Beitrag zu Acanthicus hystrix aus dem unteren Amazonas. Zool. Anz., 1902, 25, 414-421. figs.

1902.1

Hagström, Carl $P$. Utdrag utaf esbo sockns beskrifning i Nyland (In Leinberg, - Bidrag till kannedomen af vart land. Jyviiskylii, 1S85, 75-82. $\left.8^{\circ}\right)$

1885.1 
- Utdrag utaf hellsing sockns beskrifning uti Nyland och Borgà Härad (In Leinberg, - Bidrag till kännedomen af vårt land. Jyväskyläi, 1885, $\left.59-74 . \quad 8^{\circ}\right)$

1885.2

Hahn, Walter $L$. Notes on the mammals and cold-blooded vertebrates of the Indiana University farm, Mitchell, Indiana. Proc. U. S. Nat. Mus., 190S, 35, 5t5-581.

1908.1

Haight, Max. Fish in the Chemung. Forest \& Stream, 1877, 9, 23. $\quad 1877.1$

Hailstone, Edwin. Fish-discase in the bream, at Walton hall. Naturalist, Hudersfield, 1877-78, n. s. 3, 170. 1877.1

Haime, Jules [1824-1856] La pisciculture. Revue des Deux Mondes, 1854, 2, 306-333.

1854.1

Pisciculture. Freie Uebersetzung und Bearbeitung des Aufsatzes von Jules Haime "La Pisciculture in der Revue des Deux Mondes vom Juni, 1854. Uebersetzt von Friedrich Kirchmeister. Allgem. Deutsch. Naturhist. Zeitg., 1855, 1.

1855.1

- Pisciculture translated by Gamaliel Bradford] (Appended to Marsh, G.P. Report on the artificial propagation of fish, p. 10-40. Burlington, 1857. $\left.8^{\circ}\right)$

1857.1

Reprinted in 1874 with the title, "The history of fish-culture in Europe from its earlier records to 1854 ."

The history of fish-culture in Europe from its earlier records to 1854. Rept. U. S. Fish Comm. 1872-73 (1874), 2, 465-492.

1874.1

Originally published in 1857 under the title "Pisciculture."

Haime, Jules, Milner, James Wood, Hessel, Rudolf, \& others. See Milner, Haime, Hessel \& others.

Halbertsma, Hidde Justuszoon, [1820-1865] Normaal en abnormaal hermaphroditismus bij de visschen. Versl. Akad. Wet. Amsterdam, Wis. Nat. Afd., 1864, 16, 165-178. pl. 1864.1

Halbfass, Withelm. Nochmals die Madüemaräne. Fischerei Zeitg., 1901, 4, 72-73.

1901.1

Die wissenschaftliche und wirtschaftliche Bedeutung limnologischer Iandesanstalten. Verh. Deutsch. Geographentag., Berlin, 1901, 13, 248-261.

1901.2

Fischerei und Wissenschaft. Fischerei Zeitg., 1902, 6, 49-51. 1902.1
Halcyon (pseudon.) Eels constructing dams. Forest \& Stream, 1877, 8, 145

1877.1

Haldeman, Samuel Stehman [18121850] Description of two new species of the genera Perca, from the Susquehannah river. Journ. Acad. Nat. Sci. Philad., 1839-42, p. 330. 1839.1

Percina bimaculata, n. sp. from Susquehanna. Proc. Boston Soc. Nat. Hist. 1841-44 (1844), 1, 157. 1844.1

Haldenwang, A. Förderung der Fischzucht. Wochenbl. Landw. Ver. Baden, 1878, 170-171. 1878.1

Die Fischculturanstalt Gaesbach bei Baden. Circul. Deutsch. Fischerei Zeitg., 1S79, 2. Jahrg., 196-197.Wochenbl. Landw. Ver. Baden, 1880, $75-76$.

1879.1

Jahresbericht der Fischeulturanstalt Gaesbach bei Baden. Oesterr.ungar. Fischerei Zeitg., 1850, 52-53.

1880.1

Zur Fütterung von Edelfischen in Teichen. Circul. Deutsch. Fischerei Zeitg., 1880, 3. Jahrg., 354. - Erste Oesterr.-ungar. Fischerei 'Zeitg., 1880, $141-142$.

1880.2

Hale, Thomas. The complete body of husbandry. 1758.

1758.1

Haleutica (pseudon.) Curiosities of carp history. Fish. Gazette, 1878, n. s. 2, no. 58, $257-258$.

1878.1

Halford, Frederic M. Floating flies and how to dress them; a treatise on the most modern methods of dressing artificial flies for trout and grayling, with full illustrated directions, and containing ninety hand-coloured engravings of the most killing patterns. Together with a few hints to dry-fly fishermen. London, 1886. 10 pls. $8^{\circ}$. 1886.1 $\begin{array}{lr}\text { Making a fishery. } & \text { London, } \\ 1895 . & 8^{\circ} \text {. }\end{array}$ - The salmon question. Mag. Sports \& Pastimes (Baily), 1900, 74, 8286.

1900.1

The dry-fly man's handbook. A complete manual, including the fisherman's entomology and the making and management of a fishery. London, 1913. 416 p. $8^{\circ}$. 1913.1

Haliburton, Thomas Chandler [17971865] An historical and statistical 
Haliburton, $T$. C.

account of Nova Scotia. 2 vols. Halifax, 1829.

1829.1 255.

Fisheries, vol. i, $185 ; 194 ; 197 ; 206 ; 221 ; 253$

Halkett, Andrew. List of fishes collected in Hudson bay and straits during the season of 1897, S. S. "Diana" Expedition, 30. Ann. Rept. Dept. Marine \& Fish., Ottawa, 1897.

1897.1

An African dipnoid fish (Protopterus annectens) Ottawa Naturalist, $1901,15,184-187$.

1901.1

Obscrvations of animals native in the Algonquin national park. Ottawa Naturalist, 1902, 16, 155-161. 1902.1

Fishes, p. 158-160.

Preliminary report upon the animal life observed during the S.S. "Neptune" Expedition to the Hudson bay and Arctic regions, 1903-04. 37. Ann. Rept. Dept. Marine \& Fish., Ottawa, 1904, xlvii-xlix.

1904.1

A naturalist in the frozen north. Ottawa Naturalist, 1905, 19, 107.

Contains mention of fishes.

1905.1

Report of the Canadian fisheries museum. 38. Ann. Rept. Dept. Marine \& Fish., Ottawa, 1905, 362-370. 1905.3

- Natural history report. 41. Ann. Rept. Dept. Marine \& Fish., Ottawa, 1907-08, 306-310. 42. Ann. Rept., 1909-10, 386-394. 43. Ann. Rept., 1910-11, 368-397. 44. Ann. Rept. $1911-12,417-420$.

1907.1

Note on the European carp. Ottawa Naturalist, 1907, 21, 71. 1907.2

Some curious facts about fishes. Ottawa Naturalist, 1907, 20, 229-235.

1907.3

Investigations as to the destruction wrought among lobsters in the areas of water lying between Cape Sable island and Seal island, Nova Scotia, by the barn-door skate (In his Natural history report, 44. Ann. Rept. Dept. Marine \& Fish., Ottawa, 1910-11,417420)

1910.1

The readjustment of the Canadian fisheries museum. (In his Natural history report. 44. Ann. Rept. Dept. Marine \& Fish., Ottawa, 1910-11, 417420)

1910.2
Check-list of the fishes of the

Dominion of Canada and Newfoundland. Ottawa, 1913. 138 p. 14 pls. $4^{\circ}$.

1913.1

Halkett, Andrew, \& Prince, E. E. See Prince \& Halkett.

Hall, - The fisheries in the olden times. Chicago Field, 1878, 10, 148.

1878.1

Hall, Allen A. Exhibit of the quantity and value of foreign caught fish, imported into the United States, during the years $1829,1832,1838,1843$ and 1848 and the amount of duty which accrued on the same, at the rates levied at each period. Rept. Fish. N. B., 1850, 101. Ibid., 1852, 238.

1850.1

Hall, Ansley. The herring industry of the Passamaquoddy region, Maine. Rept. U. S. Fish Comm. 1896 (1898) $22,443-487$.

189S.1

Hall, E. A., \& McCaughan, J.Z.A. A review of the American genera and species of Mullidx. Proc. Acad. Nat. Sci. Philad. 1885 (1886), 149-155.

1886.1

Hall, E. A., \& Meek, Seth Eugene. See Meek \& Hall.

Hall, E. Swarbreck. On a probably new species of lamprey [Petromyzon] found in Tasmania. Monthly Notices Roy. Soc. Tasmania, 1865, 77-78.

1865.1

Hall, Hermann Christian [-1874] Visscherijen in Friesland en Groningen in 1867. Tijdschr. Nederl. Maatsch. 1868, 31 (3. ser. 9), 204-210. 1868.1

Tochten der alen. Album Natuur, 1873 (Wetensch. bijblad.), 245246.

1873.1

Hall, $J \cdot F$. Statement concerning the menhaden fishery. Rept. U.S. Fish Comm. 1877 (1879), 5, 481. 1879.1

Hall, John James. Phosphorescence in fish. Nature, $1872,6,456.1872 .1$

Hall, J.J. H. van. Rapporten over vischliultuur. 'Tijdschr. Nijverheid. Nederl. Indie, 1873, 18, 393-396. 1873.1

Hall, Marshall [1831-1896] A critical and experimental essay on the circulation of the blood, especially observed in the minute and capillary vessels of the batrachia and of fishes. London, 1831. $8^{\circ}$. 
Das Caudalherz des Aales. Notizen (Froriep), 1832, 34, no. 727, 1-3. figs. 1832.1

Hall, N.E. Clupea and Coregonus. Forest \& Stream, 1877, 8, 4. 1877.1

Hall, Robert. Note on Trachinops taniatus. Proc. Roy. Soc. 'lasmania, 1911, p. 32 .

1911.1

- Notes on Derwent estuary fishes. Proc. Roy. Soc. Tasmania, 1912 (1913), 79-84.

1913.1

Hall, Thomas Sergeant. The tupong or marble fish. Geelong Naturalist, 1896, 5, no. 4, 5-6. 1896.1

- A new genus and a new species of fish from the Mesozoic rocks of Victoria. Proc. Roy. Soc. Victoria, 1900, n. s. 12, 147-151. pl.

1900.1

- A burrowing fish [Galaxias sp from Tasmanial Victorian Naturalist, 1901, 18, 65-66.

1901.1

_. The tupong in salt water [Pseudaphritis bassi Castlenaul Victorian Naturalist, 1901, 17, 31-32. $\quad 1901.2$

The distribution of the freshwater eel in Australia and its means of dispersal. Victorian Naturalist, 1905, 22, 8083.

1905.1

Hall, Townshend Monckton [18451899] Fossil fish in north Devon. Geol. Mag., 1876, 2. dec. 3, 410-412. 1876.1

Haller, Albert von [1708-1777] Sur les yeux de quelques poissons. Mém. Acad. Sci. Paris, 1762, p. $76 . \quad 1762.1$

-Operum anatomici argumenti minorum. Lausannæ, $1768 . \quad 1768.1$

Tom. iii, cap. 37. De cerebro avium et piscium observationes anatomica.

Haller, Bela. Ueber das Centralnervensystem, insbesondere über das Rickenmark von Orthagoriscus mola. Morphol. Jahrb., 1891, 17, 198-270. 3 pls. \& figs.

1891.1

Ueber den Ursprung des Nervus vagus bei den Knochenfischen. Verh. Deutsch. Zool. Gesell., 1895, 5, 55-61.

1895.1

Untersuchungen ïber das Rückenmark derTeleostier. Morphol. Jahrb., 1895, 23, 21-122. 7 pls. \& figs. $\quad 1895.2$

Der Ursprung der Vagusgruppe bei den Teleostiern (In Festschrift zum siebenzigsten Geburtstage von C. Gegenbaur am 21. August 1896, vol. iii, 45100. 4 pls. \& fig. Leipzig, 1896-97. 3 vols. $4^{\circ}$ )
Untersuchungen über die $\mathrm{Hy}$ pophyse und die Infundibularorgane. Morphol. Jahrb., 1898, 25, 31-114. 6 pls. \& 4 figs.

1898.1

- Vom Bau des Wirbelthiergehirns. Theil I. Salmo und Scyllium. Morphol. Jahrb., 1898, 26, 345-641. 11 pls. \& figs.

1898.2

-. Ueber die Urniere von Acanthias vulgaris, ein Beitrag zur Kenntniss sekundärer Metamerie. Morphol. Jahrb., 1901, 29, 283-316. 2 pls. \& 5 figs.

Lehrbuch der vergleichenden Anatomie. Jena, 1904. 914 p. illust. $8^{\circ}$.

1904.1

Ueber den Ovarialsack der Knochenfische. Anat. Anz., 1905, 27, 225-238. 9 figs.

1905.1

- Ueber den Schultergürtel der Teleostier. Arch. Mikrosk. Anat., 1905, 67, 231-266. 2 pls. \& 6 figs. $\quad 1905.2$

Die phyletische Entfaltung der Grosshirnrinde. Arch. Mikrosk. Anat. 1908, 71, 350-466. 10 pls. $\quad 1908.1$

Zur Phylogenese des Nierenorganes (Holonephros) der Knochenfische. Jena. Zeitschr. Naturw., 1908, 43, 729801. 6 pls. \& 8 figs. 1908.2

Weitere Beiträge zur Lehre von der Kontinuität des Nervensystemes. Arch. Mikrosk. Anat., 1910-11, 76, 210252. 2 pls. \& 7 figs.

1910.1

Die Lateralstränge der Knochenfische

Spinalganglien des Trigeminus und Facialis und das Unterhaut-Nervengeflecht der Forelle.

Hallet, Almoran. Condition of the shore fisheries of Massachusetts and Rhode Island in 1871. Rept. U. S. Fish Comm. 1871-72 (1873), 1, 47-49.

1873.1

Hallez, Paul [1848-] Notes fauniques. Arch. Zool. Expér. Gén., 1905, 4. sér. 3, xlvii-lii.

1905.1

Hal1-Hüning en, (Director).

Lachsbastarde auf der Schweizerischen Fischerei-Ausstellung in Zürich. Allgem. Fischerei Zeitg., 1894, 19. Jahrg., no. 16, 280-281.

1894.1

Halliburton, W. D. On the blood proteids of certain lower vertebrata. Journ. Physiol., 1886, 7, 319-323. 1886.1

Metabolism of the salmon. Science Progress, 1898, n. s. 1, 371-377.

1898.1 
Hallmann, Eduard [1813-1855] Ueber den Bau des Hodens und die Entwicklung der Samentiere der Rochen. Arch. Anat. Physiol., 1840, 467-474. pl. 1840.1

Hallock, Charles. Three months in Labrador. Harper's New Monthly Mag., 1861, 22, 577-599; 743-765.

1861.1

Cod fisheries on the Labrador coast and Capelin, p. $59 \pm-595$.

Has the salmon ever frequented the Hudson river? Forest \& Stream, $1873,1,40$.

1873.1

- Mackerel in aquariums. Forest \& Stream, 1873, 1, p. 6 .

1873.2

The Michigan grayling. Forest \& Stream, 1873, 1, 280. Ibid., 1874, 2 168 . 1873.3

- Palæozoic fishes from Ohio. Forest \& Stream, 1873, 1, 54. $\quad 1873.4$

The introduction of hybrid fish. Forest \& Stream, 1873, 1, 22. $\quad 1873.5$

- The Sacramento salmon. Forest \& Stream, 1873, 1, 248. 1873.6

Three peculiar fish in $\mathrm{N}$. $\mathrm{Y}$. market. Forest \& Stream, 1873, 1, 6.

1873.7

Vomer brownei, Lactophrys camelinus and Corvina argyrolanea, caught near New York City.

Fish farming in Westmoreland. Forest \& Stream, 1874, 3, 164. 1874.1

- The grayling once more. Forest \& Stream, 1874, 3, 100.

1874.2

The history of a salmon. Forest \& Stream, 1874, 3, 21.

1874.3

The species of black bass. Forest \& Stream, 1874, 2, 40. $\quad 1874.4$

- Strange incident in fish life. Forest \& Stream, 1874, 3, 116. 1874.5

-... Varieties of bass. Forest \& Stream, 1874, 3, 37. I 1874.6

-...- Early fish culture. Forest \& Stream, 1875, 4, 68.

1875.1

The grayling of Montana. Forest \& Stream, 1875, 4, 182. 1875.2

- The habits of black bass. Forest \& Stream, 1875, 4, 342. 1875.3

Laws for the preservation of fish. 'Trans. Amer. Fisheries Soc. 1874 (1875), $45-46$.

1875.4

- Propagation of black bass. Forest \& Stream, 1875, 4, 357.

1875.5
-_- Subterranean fishes. Forest \& Stream, 1875, 4, 183.

1875.6

- Camp life in Florida. in. p.

Game fish of Florida, by S. C. Clarke, p. 5066.

- The sportsman's gazetteer and general guide. The game animals, birds and fishes of North America; their habits and various methods of capture. New York, 1877. 688 p. 3 maps. $12^{\circ}$. 1877.1

Fishes, p. 339-407; 572-611.

- A new salmonoid. Forest \& Stream, 1878, 11, 88 .

1878.1

_... Viviparous perch [Embiotocidæ] Forest \& Stream, 1879, 11, 512. 1879.1

ㄷ... The shore fisheries of Labrador. Trans. Amer. Fisheries Soc 1880 (1881), $34-40$.

1881.1

$1884,6,216$

1884.1

- Fish of the west. The crappies.

Amer. Angler, 1884, 6, $113 . \quad 1884.2$

- Sea-trout, a distinct variety. Amer. Angler, 1884, 6, $234 . \quad 1884.3$

-..- Transmutation of trout. Amer. Angler, 1884, 6, 7 . 1884.4

- When shad were a penny apiece. Trans. Amer. Fisheries Soc. 1894 (1895), 18-20.

1895.1

Halpérine, $E$. Piscivorous plants. Bull. U. S. Fish Comm., 1885, 5, 353356. 2 pls.

1885.1

Haly, Amyrald. Descriptions of new species of fish in the collection of the British Museum. Ann. Mag. Nat. Hist., 1875, 4. ser. 15, 268-270. 1875.1

- Occurrence of Rhinodon typicus Smith, on the west coast of Ceylon. Ann. Mag. Nat. Hist., 1883, 5. ser. 12, 48-49.

1883.1

- Notes on the collection of fish in the Colombo Museum. Taprobanian, $1886,1,165-167$.

1886.1

Ham, W. A. Statement concerning the menhaden fishery. Rept. U. S. Fish Comm. 1877 (1879), 5, 478. 1879.1

Hambach, Gustav. A preliminary catalogue of the fossils occurring in Missouri [Pisces] Bull. Geol. Surv. Missouri, $1890,1,80-81$.

1890.1

Hamburger, Richard. Ueber die paarigen Extremititen von Squalius, Trigla, Periophthalmus und Lophius. 
Rev. Suisse Zool., 1904, 12, 71-148. 2 pls. Also separate; Geneva, 1904. $8^{\circ}$. 1904.1

Hameau, -, \& Lacoin, $H$. Formulaire de questions. Arcachon, 1866. $8^{\circ}$.

1866.1

Hamel, Egbert de. Large salmon in the Tame. Zoologist, 1870, 2. ser. 5, 2144.

1870.1

Hamilton, Augustus. Note on a large sun-fish (Orthagoriscus mola L.), recently captured at Napier, Hawke's bay. Trans. Proc. New Zealand Instit. $1886,18,135-136$.

1886.1

Bibliography of New Zealand fishes. Trans. New Zealand Instit., $1902,34,539-548$.

1902.1

- Electric ray, Astrape. Trans. New Zealand Instit., 1902, 34, 224-226.

1902.2

-_. Notice of an electric ray new to the fauna of New Zealand, belonging to the genus Astrape [A. aysoni] Trans. Proc. New '/sealand Instit., 1902, 34, 224 -226.3 pls.

1902.3

Hamilton, $E$. Report as to stocking loch Ard with loch Leven trout. Glasgow, 1887.

1887.1

The Riverside naturalist. London, 1890 . figs. $8^{\circ}$.

1890.1

Hamilton, (Dr.) Francis, formerly Buchanan. Fishes of the Ganges, 1822. See Buchanan, $F$.

Hamilton, $R . B$. On the refuse of the codfishery of Newfoundland as convertible into a portable manure. Journ. Agric. Soc., 1853, 14.

1853.1

Hamilton, Robert. British fishes. Edinburgh, 1843.2 vols. $12^{\circ}$. (Jardine's Naturalists' Library, vols. xxxviixxxviii)

1843.1

The same. 2. ed. Edinburgh, 1852-54. 2 vols. 68 col. pls, $8^{\circ}$ (Jardine's Naturalists' Library, vols. xxxvi-xxxvii)

1852.1

Ichthyology of British fishes. 2 vols. Edinburgh, 1860 . pls. $16^{\circ}$.

1860.1

A history of British fishes. 2 vols. London, 1876. $68 \mathrm{col}$. pls. $12^{\circ}$.

1876.1

Hamilton, William. Queries respecting the poisonous properties of fish. Pharmaceut. Journ. 1852 (1853), 12.

1853.1
Hamilton, William John [1805-1867] Review of A. 'Th. von Middendorff's Sibirische Reise (Fossile Fische, bearbeitet von Johannes Müller) St. Petersburg, 1847. Quart. Journ. Geol. Soc. London, 1850, 6, 45-18. $\quad 1850.1$

Hamilton, $W, R$. Croaking of the perch. Bull. U. S. Fish Comm. 1887 (1889), 7, 63.

1889.1

Hamlen, William. Reconnaissance of Florida with a view to shad-hatching. Bull. U. S. Fish Comm. 1884, 4, 206208.

1884.1

Report of shad-hatching operations at Battery station, Havre de Grace, Md., season of 1885. Bull. U. S. Fish Comm. 1885, 5, 401-410. 1885.1

- Report of operations at the Battery shad-hatching station, Havre de Grace, Md., during the season of 1884 . Rept. U. S. Fish Comm. 1884 (1886), 12, 199-20S. 1886.1

- Report on the shad work of the steamer "Halcyon" during the season of 1887. Bull. U. S. Fish Comm. 1887 (1889), 7, 111.

1889.1

Hamlin, Augustus Choate [1828-] On the salmon of Maine. Rept. U. S. Fish Comm. 1874, 2, 338-356. 1874.1

Hamling, J.G. Recently-discovered fossils from the Lower and Upper Devonian beds of north Devon. Trans. Devon. Assoc., 1908, 40, 276-280.

1908.1

Hamm, Wilhelm von [1820-1880] Die künstliche Fischzucht. Ein sicheres Mittel zur Wiederbevölkerung der Gewässer, zur Erzeugung gesunder, wohlschmeckender, kräftiger Nahrungstoffe für Jedermann. . . Leipzig. 1861. 308 p. pls. $8^{\circ}$. 1861.1

Die deutsche Seefischerei. Unsere Zeit, 1867, n. s., 452-471. 1867.1

Hammar, J. Aug. Einige Plattenmodelle zưr Beleuchtung der früheren embryonalen Leberentwickelung [IV. Selachier] Nova Acta Reg. Soc. Scient. Upsaliensis, 1893, 3. ser. 16, no. 5, 2833. pls. - Arch. Anat. Physiol., 1893 (Anat. Abth.), 147-152. pls. 1893.1

- Ueber einige Hauptzüge der ersten embryonalen Leberentwickelung [Selachier] Anat. Anz., 1897, 13, 233247. 14 figs. 1897.1

- Zur Kenntnis der Leberentwickelung bei Amphioxus. Anat. Anz., 1898, 14, 602-607. 5 figs. 1898.1 
Hammar, $J . A$.

Zur Kenntnis der Teleostierthymus. Arch. Mikrosk. Anat., 1908, 73, 1-68. 3 pls. \& 10 figs.

1908.1

Fünfzig Jahre Thymusforschung. Kritische Uebersicht der normalen Morphologie. Ergebnisse Anat. Entwick., Wiesbaden, 1910, 19, 1-274. 1910.1 Fische, p. 132-147; 231-234.

Zur Kenntnis der Elasmobranchier-Thymus. Zool. Jahrb. (Anat. Abth.), 1911, 32, 135-180. 3 pls. \& 6 figs. 1911.1

Hammar, J.Aug., \& Ankarsvärd, G. Sce Ankarsvärd \& Hammar.

Hammarsten, Olof D. Ueber den Nervus collector bei den Teleostiern. Zool. Anz., 1909, 34, 677-679. fig.

1909.1

Ueber die Innervation der Bauchflossen bei den Teleostiern. Morphol. Jahrb., 1911, 42, 665-697. pl. \& 14 figs.

1911.1

Hammarström, Conrad. Salmo irideus and $S$. fontinalis in Jämtland, $N$. Sweden [Text in Swedish] Svensk Fisk. Tidskr., Stockholm, 1901, 10, 159163.

1901.1

Hammond, $J . P$. Fish in Puget sound. Bull. U. S. Fish Comm. 1886 (1887), 6, 195-196.

1887.1

Hammond, $W . H$. Observations on the structure of the red blood-corpuscles of a young trout. Monthly Micr. Journ., 1877, 17, 282-283. 1877.1

- Observations on the structure of the red blood-corpuscles of living pyrenæmatous vertebrates. Monthly Micr. Journ., 1877, 18, 147-149. 2 figs.

1877.2

Hamy, Ernest Théodore Jules [1842 - Note sur une nouvelle espèce d'Ischyodus de l'argile kimméridgienne de Chatillon, près de Boulogne-sur-Mer. Bull. Soc. Géol. France, 1865-66 (1866), 2. sér. 23, 654-657. 2 figs. 1866.1

Hancock, Albany [1806-1873] Notice of the occurrence of fossil fish in the rocks (marl-slate) near the great slipdyke, at Cullercoats Haven. Trans. Tyneside Nat. Field Club, 1848, 1, 275.

1848.1

Observations on the nidification of Girsterosteus aculentus and Gasterosteus spinachia. 'Trans. 'Tyneside Nat Field
Club, 1852, 2, 311-321. 2 pls.-Ann. Mag. Nat. Hist., 1852 , 2. ser. 10, 241248. - Zoologist, 12, 4409-4417. - Froriep's Tagsber.(Zool.), 1852, 3, no. 668, 217-222.

1852.1

Hancock, Albany, \& Atthey, $T$. Notes on the remains of some reptiles and fishes from the shales of the Northumberland coal-fields. Ann. Mag. Nat. Hist., 1868, 4. ser. 1, 266-278; 346-378. 3 pls. - Trans. Nat. Hist. Soc. Northumb., 3, 66-120. 3 pls.

1868.1

On the generic identity of Climaxodus and Janassa, two fossil fishes related to the rays. Ann. Mag. Nat. Hist., 1869, 4. ser. 4, 322-329. pl. Trans. Nat. Hist. Soc. Northumb., 3, 330-339.

1869.1

Note on an undescribed fossil fish from the Newsham coal-shale near Newcastle-upon-Tyne [Archichthys sulcidens] Ann. Mag. Nat. Hist., 1870, 4. ser. 5, 266-268. - Trans. Nat. Hist. Soc. Northumb., 4, 199-201. $\quad 1870.1$

- Notes on various species of Ctenodus obtained from the shales of the Northumberland coal-fields. Trans. Nat. Hist. Soc. Northumb., 1870, 3, 5466.

1870.2

- A few remarks on Dipterus and Ctenodus, on their relationship to Ceratodus forsteri Krefft. Ann. Mag. Nat. Hist., 1871, 4. ser. 7, 190-198. Trans. Nat. Hist. Soc. Northumb., 1872, 4, pt. 2, 397-407. 2 pls. 1871.1

Descriptive notes on a nearly entire specimen of Pleurodus rankinii, on two new species of Platysomus [P. rotundus, $P$. forsteri], and a new $A m p h i-$ centrum [A. striatum] with remarks on a few other fish-remains found in the coal-measures at Newsham. Ann. Mag. Nat. Hist., 1872, 4. ser. 9, 249-262. pls. Trans. Nat. Hist. Soc. Northumb., $1872,4,408-423$.

1872.1

Hancock, Albany, \& Embleton, Dennis. Account of a ribbon-fish (Gymnetrus) taken off the coast of Northumberland. Trans. Tyneside Nat. Field Club, 1846, 1, 288-310. fig.Ann. Mag. Nat. Hist., 2. ser. 4, 1-1s. 2 pls. — Loologist, 7, 2460-2462. 1846.1

Hancock, Albany, \& Howse, Richard. On Doryptems hoffmanni Germar, from the Marl-slate of Midderidge, Durham. Quart. Journ. Geol. Soc., 1870, 26, 623-641. - Phil. Mag., 1871, 4. ser. 41, 76-77. - Trans. Nat. Hist. 
Soc. Northumb., 1872, 4, 243-268. 2 pls.

1870.1

On Janassa bituminosa Schlotheim, from the Marl-slate of Midderidge, Durham. Ann. Mag. Nat. Hist., 1870,4 . ser. 5, 47-62. pls. - Trans. Nat. Hist. Soc. Northumb., 1870, 3, pt. $2,339-357$. pls.

1870.2

Hancock, John. Fishes that travel on the land [Doras costata] Edinb. New Phil. Journ., 1828, 6, 396-397. - Notizen (Froriep), 1829, 150-151. - Isis (Oken), 8, 805.

1828.1

Notes on some species of fishes and reptiles, from Demerara, presented to the Zoological Society by John Hancock, Esq. Zool. Journ., 1828, 4, 240247. - Isis (Oken), 1830, 1259-1261.

1828.2

Observations on the mullets of the coast of Guiana, and the greymullet of the British coast: with incidental remarks on the air-bladder and stomach in fishes. Quart. Journ. Sci. $1830,1,125-139$.

1830.1

- Remarks on the composition of the fin-rays and certain other parts in the anatomy of fishes. Quart. Journ. Sci., $1830,1,287-299$.

1830.2

Handrick, Kurt. Zur Kenntniss des Nervensystems und der Leuchtorgane von Argyropelecus hemigymnus. Zoologica, Stuttgart, 1901, 13, 1-68. 6 pls.

1901.1

Handy, Hetsel. Condition of the shore fisheries of Massachusetts and Rhode Island in 1871. Rept. U. S. Fish Comm. 1871-72 (1873), 1, 52-53. 1873.1

Handyside, $P . D$. History of the Sternoptixing, a family of the osseous fishes, and their anatomical peculiarities; with a description of the S. celebes, a species not hitherto noticed. Edinb. New Phil. Journ., 1839, 27, 324-331. — Rev. Zool., 1839, 154.

1839.1

On the anatomy of a new species of Polyodon, the Polyodon gladius of Martens, taken from the river Yangtsze-Kiang, 450 miles above IVoosung. Part I. Its external characters and structure. Part II. Its nervous and muscular systems. Proc. Roy. Soc. Edinb. 1872-75 (1875), 8, 50-51; 136137.

1875.1

Hanitsch, Richard. An expedition to mount Kina Balu, British North
Borneo. Journ. Straits Branch R. Asiat. Soc., 1900 , no. 34, 49-88. 4 pls.

Contains some references to fishes.

Annual report on the Raffles library and museum for the year 1903. Singapore, 1904. 16 p. $4^{\circ}$. 1904.1

Contains some references to fishes.

Hankinson, T. L. Notes on the fish of Hillsdale county, Michigan. 8. Ann. Rept. Michigan Acad. Sci., 1906, 175-178.

1906.1

Data on stomach contents of fish taken in Walnut lake (In his Biological survey of Walnut lake, Michigan, p. 244-251. Lansing, Mich., 1908)

1908.1

- Fish of Walnut lake (In his Biological survey of Walnut lake, Michigan, p. 198-216. Lansing, Mich., 1908)

1908.2

An ecological study of the fishes of a small stream. Trans. Ill. State Acad. Sci., 1910, 3, 23-31.

1910.1

Ecological notes on the fishes of Walnut lake, Michigan. Trans. Amer. Fisheries Soc. 1910 (1911), 195-206.

1911.1

Hanna, S. W. Description of an eellike creature [Regalecus?] taken in a net at New Harbor, Maine. Bull. U. S. Fish Comm. 1883, 3, 407-410. fig.

1883.1

Hannik, $P$. Zur Girardinus guppyireticulatus-pœcilioides-Frage. Blätt. Aquar.-Terrar. Kunde, 1911, 22. Jahrg., 301-302.

1911.1

Hannover, Adolph [1814-1894] Recherches microscopiques sur le système nerveux. Copenhague \& Paris, 1844.

1844.1

Om bygningen og udviklingen af skjxl og pigge hos bruskfisk, tilligemed udforligere beskrivelse af tvende herhen horende former. Dansk Vid. Selsk. Skrift., Kjöbenhavn, 1868, 7, 483-529. 4 pls. \& 3 figs. Abstract in Oversigt Dansk. Vid. Selsk., Kjöbenhavn, 1867, 31-37; 46-52. - Ann. Sci. Nat. (Zool.), 5. sér. 9, 373-378.

1868.1

Hansell, George, \& Eigenmann, Carl $H$. See Eigenmann \& Hansell.

Hansemann, D. von. Demonstration eines Carcharodon-Zahnes aus Spitzbergen. Sitzber. Gesell. Nat. Freunde Berlin, 1910, 387-389.

1910.1 
Hansen, Andreas $M$. Beretning om den kunstige fiskeavl ved randers. Fiskeritidskr. Finl., 1866, 1. Jahrg., 6970 . 1866.1

Lidt af soli-elvens laxehistories. Medd. Corsk Jaeger- \& Fisker-Forening. Christiania, 1873, 2. Jahrg., 143-145.

1873.1

Hansen, $C$. Nogle oplysninger om vestindisk fiskeri. Dansk Fiskeriforen. Medlemsbl., 1896, 5. Jahrg., 506-508.

1896.1

Hansen, C. P. Zur Geschichte der Fischerei von den Nordfriesischen Inseln. Circul. Deutsch. Fischerei Ver., 1871, no. 3, 39-42.

1871.1

Hansen, Carolus Petrus Matthias [1803-] Thymi in homine ac per seriem animalium descriptionis anatomico-physiologicæ. Particula posterior, disquisitiones de thymo in avibus, reptilibus et piscibus. . . Inaug. Dissert. F. C. Haugsted, proses, Kiobenhavn, 1832. 286 p. 3 pls.

1832.1

Hansen, Hans Jacob [1855-] Fiske Zool. Danica, 1883-90, 2, 27-126. 9 pls.

1883.1

Hansen, $V$. Ueber das Vorkommen und die Menge der Eier einiger Ostseefische. Ber. Komm. Wiss. Untersuch. Deutsch. Meere Kiel, 1883, no. 4. 1883.1

Hansen-Larsen, Christen. Aalens vandring. En biologisk iagttagelse. Dansk. Fiskeritid., 1906, n. s. 4. Jahrg. 363.

1906.1

Hansson, Carl August. Till kännedomen om norra Bohusläns vertebratfauna. Oefvers. K. Vet. Akad. Förh. Stockholm, 1881, 37, no. 4, 19-22.

Fiskar, p. 20-22.

1881.1

Hardaker, Walter Henry. On the discovery of a fossil-bearing horizon in the "Permian" rocks of Hamstend quarries, near Birmingham. Quart: Journ. Geol. Soc., 1913, 68, 639-683. 30 figs.

1913.1

Hardesty, Irving. On the nature of the tectorial membrane and its probable rôle in the anatomy of hearing. Amer. Journ. Anat., 1908, 8, 109-179. 12 figs.

1908.1

Hardin, Sveno. Om venerns laxarter. Oefvers. K. Vet. Akad. Förh., Stockholm, 1861 (1862), 18, 381-384. 1862.1

Harding, Charles WT. Essay on the artificial propagation of anadromous fish other than the salmon and the restocking the tidal waters of our large rivers artificially with smelts, etc. King's Lynn, 1881. 11 p. $4^{\circ}$. 1881.1

- Inquiries concerning the propagation of American smelt and shad, and notes on the fisheries of the IVash in England. Bull. U. S. Fish Comm. 1881 (1882), 1, 428-429.

1882.1

Harding, Garrick M. Suggestions to fish-culturists. Bull. U.S. Fish Comm. 1881 (1882), 1, 55-56.

1882.1

Hardwicke, Thomas [- 1835] Observations on the goramy of India $\left[\mathrm{Os}_{\mathrm{s}-}\right.$ phromenus olfax Commerson], in a letter to N. A. Vigors. Zool. Journ., 1829, 4, 309-314. - Isis (Oken), 1831, 107-108.

1829.1

Hardy, Alfred Erskine Gathorne. The salmon. London, 1898. 276 p. figs. $8^{\circ}$

1898.1

Hardy, Campbell [1831-] On the caplin (Mallotus villosus) Proc. Trans. Nova Scotian Instit. Nat. Sci., 1863-66 (1867), 1, pt. 2, 4-13.

1867.1

Forest life in Acadie. Sketches of sport and natural history in the lower provinces of the Canadian Dominion. London, 1869. 371 p. $8^{\circ}$.

Acadian fish and fishing, p. 211-260.

1869.1

Hardy, $J$. On the nidification of fishes. Zoologist, 1845, 3, 885-886. 1845.1

On Motella tricirrata, a fish new to the Berwickshire coast. Hist. Berwick. Nat. Club, 1873-75 (1876), 7, 470. 1876.1

Hardy, Josiah. Statement concerning the menhaden fishery. Rept. U. S. Fish Comm. 1877 (1879), 5, 410. 1879.1

Harke, W. Einiges über Chirodon arnoldi Boulenger. Wochenschr. Aquar.-Terrar. Kunde, 1913, 10. Jahrg., 265-267. fig.

1913.1

Harlan, Richard [1796-1843] Critical notices of various organic remains hitherto discovered in North America (In his Medical and physical researches. .. Philadelphia, 1835. xxxix, $653 \mathrm{p}$. 38 pls. $8^{\circ}$ ) 1835.1

Fishes, p. 286-290; 291-296.

Notice of plesiosaurian and other fossil reliquix, from the state of New Jersey (In his Medical and physical 
researches..., p. 382-385. pl. Philadelphia, 1835. xxxix, 653 p. 38 pls. $\left.8^{2}\right)$ 1835.2

Contains earliest American figure of an Edaphodon mandibular - which is, however, interpreted as belonging to a fossil reptile, and is not named.

Harlé, Edouard. Faune de la grotte à hyènes rayées de Furninha et d'autres grottes du Portugal. Bull. Soc. Géol. France, 1909, 4. sér. 9, 85-99. 1909.1

Contains mention of fish remains.

Harless, Emil. Briefliche Mittheilung über die Ganglienkugeln der Lobi electrici von Torpedo galvanii. Arch. Anat. (Müller), 1816, 283-291.

1846.1

Ueber den Zahnbau von Myliobates und den verwandten Rochen Trikeras. Abh. K. Bayer. Akad. Wiss., 1847, 5, 841-876. 3 pls. 1847.1

Harley, John. On the Ludlow bonebed and its crustacean remains. Quart. Journ. Geol. Soc., 1861, 17, 542-552. pl.

Fossil fishes, p. 544-546.

1861.1

Harman, $N . B$. The palpebral and oculomotor apparatus of fishes. Observations on morphology and development. Rept. British Assoc. Adv. Sci., 1899, 780-781.-Journ. Anat. Physiol. London, 34, 1-40. 6 pls. 1899.1

Harmer, Sidney Frederic (editor) 'The Cambridge natural history. 10 vols. London, 1895-1902.

1904.1

Vol. vii. Fishes, Ascidians, etc., 1904. xvii, $760 \mathrm{p}$. Fishes, exclusive of the systematic ac count of the Teleostei. By T. W. Bridge. Systematic account of the Teleostei. By G. A Boulenger. Ascidians and Amphioxus. Cephalochordata. By W.A. Herdman.

Harmer, Thomas. Remarks on the very different accounts that have been given of the fecundity of fishes; with fresh observations on that subject. Phil. Trans. Roy. Soc. London, 1768, 57, 280-292. - Neues Hamburg. Mag., 41,457 .

1768.1

Harmsworth, Alfred C. Tarpon fishing in the gulf of Mexico (In Bickerdyke, J. Sea fishing, p. 487-512. London, 1895)

1895.1

\section{Harper, Francis, \& Murphy, Robert} C. See Murphy \& Harper.

Harper, $J$. The sea-side and aquarium; or, Anecdote and gossip on marine zoology. Edinburgh, 1858. figs. $8^{\circ}$.

1858.1
Harrington, Nathan Russell. For memorial notice, see Dean, Bashford, in Columbia Univer. Quart., 1899, 2, 44-46.

The life habits of Polypterus. Amer. Naturalist, 1899, 33, 721-728.

1899.1

Respiratory and breeding habits of Polypterus bichir. Science, 1899, n. s. 9, 314-315.

1899.2

Harrington, Nathan Russell, Dean, Bashford, Calkins, G.N., \& Griffin, $B . B$. See Dean, Harrington \& others.

Harris, D. Fraser. On the hrmoglobinometry and hrmocytometry of the blood of the skate. Journ. Physiol., 1903, 30, 319-321. 1903.1

Harris, Edward. [Letter on Salmo gloverii Girard] Proc. Acad. Nat. Sci. Philad. 1858 (1859), 135-137. 1859.1

Harris, Gwynn. Report upon the shad and herring fisheries of the Potomac river for 1883. Bull. U. S. Fish Comm., $1884,4,13$.

1884.1

Total amount of shad and herring caught on the Potomac river during the spring of 1884. Bull. U. S. Fish Comm., 1884, 4, 221. 1884.2

- Report upon the shad and herring fisheries of the Potomac river for 1885. Bull. U. S. Fish Comm. 1885, 5, 192.

1885.1

Report upon the shad and herring fisheries of the Potomac river for 1886. Bull. U. S. Fish Comm. 1886 (1887), 6, 202.

1887.1

Harris, William $C$. The fishes of North America. New York, 1888. 80 pls. $8^{\circ}$.

1888.1

The fishes of North America that are captured on hook and line. New York, 1908. 138 p. 80 pls. \& figs. fol.

1908.1

Harris, William C., \& Bean, Tarleton $H$. The basses, fresh-water and marine. New York, 1905. 238 p. figs. $8^{\circ}$

1905.1

Harris, William C., Sage, Dean, Townsend, Charles H., \& Smith, $H$. M. See Sage, Townsend \& others.

Harrison, Ross Granville. Ueber die Entwicklung der nicht knorpelig vorgebildeten Skelettheile in den Flossen der Teleostier. Arch. Mikrosk. Anat., 1893, 42, 248-278. 3 pls. 
Harrison, R. G.

- On the development of the fins of teleosts. Johns Hopkins Univ. Circ. no. 111, 1894, 59-61. - Ann. Mag. Nat. Hist., 6. ser. 14, 34-42.

1894.1

Ectodermal or mesodermal origin of the bones of teleosts? Anat. Anz. 1895, 10, 138-143. 3 figs 1895.1

Die Entwicklung der unpaaren und paarigen Flossen der Teleostier. Arch. Mikrosk. Anat., 1895, 46, 500 578. 4 pls.

1895.2

Ueber die Histogenese des peripheren Nervensystems bei Salmo salar. Arch. Mikrosk. Anat., 1901, 57, 354 444. 3 pls. \& figs. - Biol. Bull. Woods Hole, 2, 352-353.

1901.1

- The development of the nerve elements in vertebrates. Brit. Med. Journ., 1906, 2, 1702. 1906.1

Harron, L.G., \& Smith, Hugh M. See Smith \& Harron.

Hart, Charles A., \& Gleason, Henry Allan. On the biology of the sand areas of Illinois. Bull. Illinois Lab. Nat. Hist., 1907, 7, 137-272. 16 pls. \& map.

1907.1

Hart, $W . O$. The oyster and fish industry of Louisiana. Trans. Amer. Fisheries Soc. 1912 (1913), 151-156.

1913.1

Hartemann, Robert. Der Häring und sein Fang. Oesterr.-ungar. Fischerei Zeitg., 1880, 231-233.

1880.1

Hartig, Georg Ludwig (editor) Journal für das Forst, Jagd- und Fischereiwesen zur nützlichen und angenehmen Unterhaltung. Stuttgart, 1806-08. $4^{\circ}$.

1806.1

Harting, James Edmund [1841-] Fishing notes in Holland. Fish. Gazette, 1878, n. s. 2, no. 79, 509.

1878.1

_- Banks' oar-fish [Regalecus banksii] near Whitby. Zoologist, 1880, 3. ser. 4, 145-146.

1880.1

'Trout in the Thames. Zoologist, 1880, 3. ser. 4, 146-147. 1880.2

Essays on sport and natural history. London, 1883. 485 p. figs. $8^{\circ}$.

1883.1

The annals of Irish zoology, p. 295-328. Fishing with cormorants, p. 423-440.

Harting, Pieter [1812-1885] Iets over de vischfokkerij. Album Natuur, $185^{\circ}$ (Wetensch. bijblad.), 374-385. 1852.1
Over de kunstmatige uitbroeijing van vischeijeren. Aanteek. Prov. Utr. Genootsch., 1854-55, 35-36. 1854.1

- Eene zalmkweekerij aan de rivier de Tay. Album Natuur, 1856 (Wetensch. bijblad.), 260-261. 1856.1

Bloedomloopstelsel bij de visschen. Album Natuur, 1857 (Wetensch. bijblad.), 79 .

1857.1

INotice of an article by Hyrtl, in Denkschr. Akad. Wiss. Wien, on MIonopterus und Amphipnous]

- Notiz von] Dr. Theodor Bilharz über "Das elektrische Organ des Zitterwelses, anatomisch beschrieben." Leipzig, 1857. Album Natuur, 1857 (Wetensch. bijblad.), 76-79. 1857.2

L Levende Lepidosiren [Protopterus] annectens in het kristallen paleis. Album Natuur, 1858 (Wetensch. bijblad.), 63-64.

1858.1

Elektrische visschen. Album. Natuur, 1860 (Wetensch. bijblad.), 4142 . 1860.1

[Notice of an article by Armand Moreau, in L'Institut, 1860, 82]

- Overblijfselen van een beenigen visch [Teleosteus primovus] in het overgangsgebergte van den Rijn? Album Natuur, 1860 (Wetensch. bijblad.), 30. 1860.2

- Ureum in de organen van plagiostomen. Album Natuur, 1860 (Wetensch. bijblad.), 27-28.

1860.3

De Javaansche Anabas scandens. Album Natuur, 1861 (Wetensch. bijblad.), 9 . 1861.1

[Notice of an article by Kaup, in Arch. Naturgesch., 1860, 124]

- Visch-regen [Clarias batrachus] Album Natuur, 1861 (Wetensch. bijblad.), 61-62.

1861.2

[See also de Castelnau, in C. R. Acad. Sci. Paris, 52, 880]

- Een monstreuse forel. Album Natuur, 1862 (Wetensch. bijblad.), 10-11.

1862.1

Geluid door visschen voortgebragt. Album Natuur, 1862 (IVetensch. bijblad.), 43.

1862.2

From A. Dufosse, in Ann. Sci. Nat. (Zool.), 1874, 5. sér. 20.

Leerboek van de grondbeginselen der dierkunde in haren geheelen omvang. 3 vols. Tiel, 1862-71. figs. $8^{\circ}$.

1862.3

Fishes, vol. ii, pt. 1. 
Oost-indische visschen. Album Natuur, 1862 (Wetensch. bijblad.), 285287.

1862.4

Overblijfselen van beenige visschen uit het palaeozoische tijdperk. Album Natuur, 1862 (Wetensch. bijblad.), 25.

1862.5

Notice of an article by Giebel, in Neues Jahrb. Mineral., 1861, 623 .

Verschil tusschen de schubben van beenige en kraakbeenige visschen. Album Natuur, 1862 (Wetensch. bijblad.), 11.

1862.6

- Lucht, bevat in de zwemblaas der visschen. Album Natuur, 1863 (Wetensch. bijblad.), 82.

1863.1

Notice of an article by A. Moreau, in C. R. Acad. Sci. Paris, 1863, 57, 37.

- Scheikundige zamenstelling van het vleeschvocht van vischen. Album Natuur, 1863 (Wetensch. bijblad.), 82.

1863.2

Notice of an article by Limpricht, in Ann. Chem. Pharm,, 127, 185.

Giftorganen bij een visch. Album Natuur, 1864 (Wetensch. bijblad.), 43.

1864.1

Notice of an article by Günther, in Nat. Hist. Rev., 1864, p. 309, on Thallassophryne reticulata

Heresnen van Lepidosiren [Protopterus annectens] Album Natuur, 1864 (Wetensch. bijblad.), $3 . \quad 1864.2$

- Lucht in de zwemblaas der visschen. Album Natuur, 1864 (Wetensch. bijblad.), 19-20.

1864.3

Notice of an article by A. Moreau, in L'Institut, 1863, 366

Naschrift ophet vorige. Album Natuur, 1864 (Wetensch. bijblad.), 314316.

1864.4

Physiologische functien van de deelen van de hersenen der visschen. Album Natuur, 1864 (Wetensch. bijblad.), 20-21. 1864.5

Notice of an article by Baudelot, in C. R. Acad. Sci. Paris, 1863, 57, 949.

Invloed van den nervus sympathicus op de zamenstelling der lucht in de zwemblass. Album Natuur, 1865 (Wetensch. bijblad.), 37. 1865.1

Metamorphosen van visschen. Album Natuur, 1865 (Wetensch. bijblad.), 441.

1865.2

See also Agassiz, in Ann. Sci. Nat. (Zool.), 5. sér. 3, 55 .

Notices zoologiques, anatomiques et histiologiques, sur l'Orthragoris- cus ozodura; suivies de considérations sur l'osteogénèse des téléostéens en général. 4\%. Versl. Akad. Wet. Amsterdam, 1868, 11, no. 2. 48 p. pls. Also separate; Amsterdam, 1865. 48 p. 8 pls.

1865.3

Over de voortteling der alen. Versl. Akad. IVet. Amsterdam, Wis. Nat. Afd., 1865-66, 5-7. 1865.4

Vergiftige visch Synanceia brachio] Album Natuur, 1865 (Wetensch. bijblad.), 75 . 1865.5

See also Nadaud, in Les Mondes, 1865, 8, 102

Alen met kuit. Album Natuur, 1866 (Wetensch. bijblad.), 89. 1866.1

Asymmetrie der pleuronecten. Album Natuur, 1866 (Wetensch. bijblad.), 43.

1866.2

Eijeren in den mond van een visch [Geophagus pedicinus] als broedplaats. Album Natuur, 1866 (IVetensch. bijblad.), 319 .

1866.3

From Agassiz, in Ann. Sci. Nat.(Zool.), 5. sér. 4, 382 .

- Vischrijkdom van het Amazonegebied. Album Natuur, 1866 (Wetensch. bijblad.), 78-79. 1866.4

From Agassiz, in Ann. Sci. Nat. (Zool.), 5. sér. 4, $226 ; 309$.

IVaarschijnlijke bij-oogen bij eenen visch. Album Natuur, 1866 (Wetensch. bijblad.), 10 .

1866.5

-Echeneis remora. Album Natuur, 1867 (Wetensch. bijblad.), 36. 1867.1

- Oorzaken van den dood van zeevisschen in zoet water. Album Natuur, 1867 (Wetensch. bijblad.), 42.

1867.2

From P. Bert, in L'Institut, 1867, 116.

Xenacanthus [Pleuracanthus] dechenii, een vischvorm, die selachiers en teleostiers aaneenschakelt. Album $\mathrm{Na}$ tuur, 1867 (Vetensch. bijblad.), 92-93.

1867.3

Zee-zijde [Raja batis] Album

Natuur, $1867^{\circ}$ (Wetensch. bijblad.), 59. 1867.4

___ Zwemblaas der visschen. Album Natuur, 1867 (Wetensch. bijblad.), 30. 1867.5

From E. Couriet, in Ann. Sci. Nat. (Zool.), 1866, 5. sér. 6, 369 .

Allantois der visschen. Album Natuur, 1868 (Wetensch. bijblad.), 19.

1868.1 488. 


\section{Harting, $P$.}

Eijeren van zeevisschen. Album Natuur, 1868 (Wetensch. bijblad.), 8990.

1868.2

Van kleuren veranderende visschen. Album Natuur, 1868 (Wetensch. bijblad.), 59.

1868.3

See also Jonan, in Revue des Cours Scientifique, 1868 , no. 28,448 .

Ademhaling der visschen. Album Natuur, 1870 (Wetensch. bijblad.) 18. Ibid., 1872, 53-54. 1870.1

From N. Gréhant, in Ann. Sci. Nat. (Zool.), 1869 , 5. sér. 12, 380. - C. R. Acad. Sci. P'aris, $1872,74,621-624$.

- De zalm in zoetwater-meren. Album Natuur, 1870 (Wetensch. bijblad.), 348-349.

1870.2

Het voedsel von Echeneis. Album Natuur, 1871 (Wetensch. bijblad.), 94.

1871.1

- Nicuwe ganoide in Nieuw-Holland. Album Natuur, 1871 (Wetensch. bijblad.), 54.

1871.2

_ Snelle kleursverandering bij visschen. Album Natuur, 1871 (Wetensch. bijblad.), 87.

1871.3

… Blauwe kleur bij de visschen. Album Natuur, 1872 (Wetensch. bijblad.), 63. 1872.1

From Pouchet, in Les Mondes, 1872, 228.

De physometer. Een nieuw werktuig tot bepaling van veranderlijke volumina van lucht en van andere lichamen. Versl. Akad. Wet. Amsterdam, 1872, 2. ser. 6, 288-324. pl. Ann. Phys. Chem., 148, 126-143; 244270. - Rev. Cours Scient., 4, 801-803. - Arch. Néerland., 7, 289-327. 1872.2

_- Een merkwardige visch [Ceratodus forsteri] Album Natuur, 1872 (Wetensch. bijblad.), 14-15. 1872.3

- En visch met vier handen. Album Natuur, 1872 (Wetensch. bijblad.), 78-79.

1872.4

Lophobranchii. Album Natuur, 1872 (Wetensch. bijblad.), 23-24.

1872.5

- Voortteling van de alen. Album Natuur, 1872 (Wetensch. bijblad.), 8687.

1872.6

Ademhaling der visschen. Album Natuur, 1873 (Wetensch. bijblad.), $76-77$.

1873.1

From Quinquand, in C. R. Acad. Sci. Faris, 76, 1141
Chemische samenstellung van het kraakbeen van een haai. Album Natuur, 1873 (Wetensch. bijblad.), 8384.

1873.2

Eigendommelijke wijze van voortbeweging van sommige visschen. Album Natuur, 1873 (Wetensch. bijblad.), 348.

1873.3

Het pancreas der visschen. Album Natuur, 1873 (Wetensch. bijblad.) 77.

1873.4

Geluiden door visschen voortgebracht. Album Natuur, 1874 (We tensch. bijblad.), 88 .

1874.1

Observations à propos d'une note de M. Moreau, sur l'application du physomètre à l'étude du rôle de la vessie natatoire. C. R. Acad. Sci. Paris, 1874, 78, 1064-1066.

1874.2

Serranus phaëton. Album Natuur, 1873 (IVetensch. bijblad.), 56.

1874.3

Een nest van jonge visschen. Album Natuur, 1875 (Wetensch. bijblad.), 110-111.

1875.1

See also R. W. Mitchell, in Nature, 1875, 11, 48.

Ingewanden-steen van een steur. Album Natuur, 1875 (Wetensch. bijblad.), 78 .

1875.2

- Jets over de zeelt [Tinca vulgaris] Album Natuur, 1875 (Wetensch. bijblad.), 64 .

1875.3

-_. Mannelijke alen. Album Natuur, 1875 (Wetensch. bijblad.), 28-29.

1875.4

Mannelijke generatieorganen der alen. Album Natuur, 1875 (Wetensch. bijblad.), 53.

1875.5

- Overblijfselen van Lepidosteus in het tertiaire bekken van Parijs. Album Natuur, 1875 (Wetensch. bijblad.), 22-23.

1875.6

- Segmentaalorganen bij haaien. Album Natuur, 1875 (Wetensch. bijblad.), 55 .

1875.7

- Imphioxus. Album Natuur, 1876 (Wetensch. bijblad.), 46-47.

1876.1

From T, H. Huxley, in Ann. Mag. Nat. Hist., 1875,4 . ser. $15,225$.

Ceratodus. Album Natuur, 1876 (Wetensch. bijblad.), 79-80.

1876.2 
De nestbouw van den regenboogvisch. Album Natuur, 1876 (Wetensch. bijblad.), 383-386. 1876.3

Eene eigene inrichting der zwemblaas bij Caranx trachurus. Album Natuur, 1876 (Wetensch. bijblad.), 1415.

1876.4

Een merkwardige visch [Chromis paterfamilias] Album Natuur, 1876 (Wetensch. bijblad.), $290 . \quad 1876.5$

Haaien in zoet water. Album Natuur, 1876 (Wetensch. bijblad.), 6263.

1876.6

Een tweede leptocardier [Epigonichthys cultellus] Album Natuur, 1877 (Wetensch. bijblad.), 40. 1877.1

- Luchtademing van sommige Indische zoetwatervisschen. Album Natuur, 1877 (Wetensch. bijblad.), 8.

1877.2

From G. E. Dobson, in Proc. Zool. Soc. London, 1874,312 .

Nestbouw van den goerami. Album Natuur, 1877 (Wetensch. bijblad.), 321-322.

1877.3

- Veranderingen in zoetwatervisschen ten gevolge van uitwendige omstandigheden. Album Natuur, 1877 (Wetensch. bijblad.), 60-61. 1877.4

See also Fatio, in Arch. Sci. Phys. Nat., 1876, n. S. 59, 35. Ibid., 1877, 58, 185.

Vergelijking der elektrissche organen bij spieren. Album Natuur, 1877 (Wetensch. bijblad.), 76-77. 1877.5

De minhocao. Album Natuur, 1878 (Wetensch. bijblad.), 320-324.

1878.1

Dubbele leiding der zenuwen [Malapterurus electricus] Album Natuur, 1878 (Wetensch. bijblad.), 35.

1878.2

Luchtademende visschen. Album Natuur, 1878 (Wetensch. bijblad.), 15.

1878.3

Variabiliteit der stekelbaarzen. Album Natuur, 1878 (Wetensch. bijblad.), 15-16.

1878.4

- Wijze van verplaatsing der oogen gedurende de ontwikkeling der pleuronecten. Album Natuur, 1878 (Wetensch. bijblad.), 78 .

1878.5

Ademhaling van Amia. Album Natuur, 1879 (IVetensch. bijblad.), 72.
Chorda dorsalis van Amphioxus. Album Natuur, 1879 (Wetensch. bijblad.), 71-72.

1879.2

See J. Renault \& G. Duchamp, in C. R. Acad. Sci. Paris, $1878,86,898$.

De groei van den haring. Album Natuur, 1879 (Wetensch. bijblad.), 6263. 1879.3

Maagsap der visschen. Album Natuur, 1879 (Wetensch. bijblad.), 7879.

1879.4

___ Pseudo-elektrische organen [Mormyrusi Album Natuur, 1879 (Wetensch. bijblad.), 7 .

1879.5

- Zwemblaas. Album Natuur, 1879 (Wetensch. bijblad.), 30. 1879.6

Bloedwarmte van visschen. Album Natuur, 1880 (Wetensch. bijblad.), 39. 1880.1

Notice of article by J. H. Kidder, in Nature, $1879,156$.

- Een Surinaamsche sidderaal.Album Natuur, 1880 (Wetensch. bijblad.), 380 .

1880.2

Geluids-organen bij vischen. Album Natuur, 1880 (Wetensch. bijblad.), 22-23.

1880.3

From W. Sörensen, in C. R. Acad. Sci. Paris, $1879,88,1042-1043$

Homocercie en heterocercie. Album Natuur, 1880 (Wetensch. bijblad.), 14.

1880.4

- In het land der temnladores [Gymnotus electricus] Album Natuur, 1880 (Wetensch. bijblad.), 323-350. fig.

1880.5

- Zichtbaarheid van den lymphaomloop bij visschen. Album Natuur, 1880 (Wetensch. bijblad.), 95. 1880.6

Hartley, $F$. Notes on a specimen of Alepisaurus asculapius Bean, from the coast of San Luis Obispo county, California. Proc. Calif. Acad. Sci., 1895, 5, 49-50. pl.

1895.1

Hartmann, Carl. Goldfisch, Wasserkäfer, Larven von Alytes obstetricans welche 6 Tage lang vollständig eingefroren. 24. Jahresber. Nat. Ver. Preuss. Rheinl. Westfalen, 1896, 50. 1896.1

Hartmann, G.L. Beschreibung der Bernerseen. St. Gallen, 1780. 1780.1 Contains mention of fishes.

Ueber den Bodensee. Ein Versuch. St. Gallen, 1795. 93 p. $8^{\circ}$. 1795.1 
Hartmann, G.L.

Der angebliche Salmo alpinus, oder auseinandergesetzte Naturgeschichte der Rothforelle und der Bachforelle. Alpina, 1806, 1, 87-105. Also separate; Winterthur, 1806.19 p. $8^{\circ}$. 1806.1

Versuch einer Beschreibung des Bodensees. 2. ed. St. Gallen, 1808. 172 p. $8^{\circ}$.

1808.1

Helvetische Ichthyologie; oder, Ausführliche Naturgeschichte der in der Schweiz sich vorfindenden Fische. Zurich, 1827. xii, 240 p. $8^{\circ}$. Abstract in Isis (Oken), 1828, 9, 934-Bull. Sci. Nat. (Férussac), 1828, 13, 250.

1827.1

Hartmann, Robert. Bemerkungen über die elektrischen Organe der Fische. R. Arch. Anat. Physiol. (Reichert), 1861, 646-670. Ibid., 1862, 762-772

1861.1

—- Die Endigungsweise der Gehörnerven im Labyrinthe der Knochenfische. Arch. Anat. Physiol. (Reichert), $1862,508-525$.

1862.1

Ueber den äusseren Habitus und den inneren Bau der Chimara monstrosa. Sitzber. Ges. Naturf. Freunde Berlin, $1876,83-84$.

1876.1

- Der Dorsch und seine Verwandten. Oesterr.-ungar. Fischerei Zeitg., $1880,263-265$.

1880.1

Ueber die Brustflossenmuskeln einiger Fische. Sitzber. Ges. Naturf. Freunde Berlin, 1881, 150-154. 1881.1

Hartmann, Vincenz. Das Kärntner Faukerseethal der Gegenwart und der Vorzeit. 39. Jahresber. Staats-Oberrealschule Klagenfurt, 1886, 1-47. map.

1886.1

Die Fischfauna des Faukersees und seines Zuund Abflusses, p. $41-45$

Fische Kärntens. Jahrb. Naturhist. Mus. Kärnten, 1899, 25, 1-48.

1899.1

Hartmann, Wilhelm. Ueber Fischzucht. Wochenbl. Landw. Ver. Baden, 1869, 177-180. - Neue Freie Presse, Wien, 1871, no. 2569.

1869.1

Der Bodensee, seine Fische und seine Bewirthschaftung. Wochenbl. Landw. Ver. Baden, 1870, 209-211; 217-219; 225-227.

1870.1

- In welchem Alter sollen die künstlich gebrüteten Fische ausgesetzt werden und wo? Wochenbl. Landw.
Ver. Baden, 1870, 325-327; 333-335; 341-343. - Circul. Deutsch. Fischerei Ver., 1871, 1. Jahrg., no. 2, 24-33. 1870.2

Hartshorne, $H$. Change of temperature in water containing recently fertilized shad [Clupea menhaden] eggs Amer. Naturalist, 1872, 6, 492-493.

1872.1

"Another note on the same," by N. Coleman. Ibid., 6, 493 .

Hartsinck, $J . J$. Beschrijving van Guiana of de wilde kust van Amerika, betreffende de aardrijkskunde en historie des landes ... de dieren, vogels, visschen, boomen en gewassen, enz. 2 vols. Amsterdam, 1770. map \& figs. $4^{\circ}$.

1770.1

Description of the fishes, vol. i, 115-124

Hartt, Charles Frederick [1840-1878] A vacation trip to Brazil. Amer. Naturalist, $1867,1,642-651$.

1867.1

Flying fish, p. 643-645.

Hartwig, Georg Ludwig [-1880] Das Leben des Meeres; eine Darstellung für gebildete Allerstände. Frankfurt a. M., 1857. $8^{\circ}$. 1857.1

Die Bewohner des Meeres, p. 87-342.

Hartwig, $P$. Notizen über die Bedeutung der Armknochen bei den Fischen. Nunquam Otiosus, Dresden, $1870,27-28$.

1870.1

Hartwig, $W$. Altes und Neues vom Danio rerio. Wochenschr. Aquar.-Terrar. Kunde, 1908, 5. Jahrg., 213-215. fig.

1908.1

Noch einiges über Acara caruleopunctata var. latifrons Steind. $\mathrm{u}$. $\mathrm{Kn}$. Wochenschr. Aquar.-Terrar. Kunde, 1908, 5. Jahrg., 117-119. fig. 1908.2

Xiphophorus var. rachovii Regan. Wochenschr. Aquar-Terrar. Kunde, 1912, 9. Jahrg., 442-443. fig. 1912.1

Harvey, $M$. Tape-worms in fishes. Forest \& Stream, 1876, 7, 36. 1876.1

- The basking shark in Newfoundland waters. Forest \& Stream, 1877, 7, 356.

1877.1

The basking shark. Forest \& Stream, 1880, 15, 426 .

1880.1

Fishing and consumption of fish in Newfoundland; from letter to Prof. S. F. Baird. Bull. U. S. Fish Comm. 1882 (1883), 2, 102 .
1883.1 
Harvie-Brown, John Alexander [1844 - - Bibliography of the writings of J. A. Harvie-Brown. Arranged for the most part in chronological order. 30 copies privately printed. Stirling, 1897. 32 p. $8^{\circ}$

1897.1

Unusual abundance of dog-fish (Scyllium catulus) on the coasts of Scotland. Zoologist, 1883, 3. ser. 6, 354.

1883.1

The wonderful trout. Edinburgh, 1898.172 p. illus. $16^{\circ} .1898 .1$

Notes on some Scottish Salmonidx. Ann. Scottish Nat. Hist. Soc, $1899,75-84$.

1899.1

Further notes on Salmonidx. Ann. Scottish Nat. Hist. Soc., 1901, 202-207.

1901.1

- Notes on British Salmonidæ. Ann. Scottish Nat. Hist. Soc., 1901, 18 $24 ; 82-92$.

1901.2

Notes on fishes from the county Down coast. Irish Naturalist, 1901, 10, 173.

1901.3

Bass (Labrax lupus) on the west coast of Invernesshire. Ann. Scottish Nat. Hist. Soc., 1902, no. 43, 185. 1902.1

Fish and fishing off the Down coast. Irish Naturalist, 1902, 11, 21-22.

1902.2

Notes on Salmonidx. Ann. Scottish Nat. Hist. Soc., 1902, 14-21.

1902.3

Harvie-Brown, John Alexander, \& Buckley, Thomas Edward. A vertebrate fauna of Sutherland, Caithness and west Cromarty. Edinburgh, 1887. 344 p. pls. $8^{\circ}$. 1887.1

Fishes, p. 252-299. Contains a list of all the fishes of the Moray firth.

A vertebrate fauna of the Outer Hebrides. Edinburgh, 1888. 279 p. illust. \& pls. $8^{\circ}$.

1888.1

Fishes, by W. Anderson Smith, p. 172-225.

A vertebrate fauna of Argyll and the Inner Hebrides. Edinburgh, 1892. 262 p. pls. $8^{\circ}$. 1892.1

Pisces; fresh-water fishes of Argyllshire, by W. A. Smith, p. 219-234.

A fauna of the Moray basin. 2 vols. Edinburgh, 1895. illust. $8^{\circ}$.

1895.1

The extinct vertebrate animals of the Moray firth area, by Dr. [R. H.] Traquair. Vol. ii, p. 235-286. pls, i-ix.
Harwood, $J$. On a newly discovered genus of serpentiform fishes (Ophiognathus) Phil. Trans. Roy. Soc. London, 1827, 49-57. - Bull. Sci. Nat. (Férussac), 12, 277-279. - Notizen (Froriep), 21, 177-179. - Journ. Sci. (Brewster), 8, 300. - Isis (Oken), 1836, 586-588.

Hase, Albrecht. Ueber das Schuppenkleid der Teleostier. Jena. Zeitschr. Naturw., 1907, 42, 607-668. 3 pls.

1907.1

Die morphologische Entwickelung der Ctenoidschuppe. Anat. Anz., $1911,40,337-356.28$ figs. $\quad 1911.1$

Studien über das Integument von Cyclopterus lumpus L. Beiträge zur Kenntnis der Entwickelung der Haut und des Hautskelettes von Knochenfischen. Jena. Zeitschr. Naturw., 1911, 47, 217-342. 8 pls. \& 37 figs. $\quad 1911.2$

Haselhoff, $E$., \& Huinnemeier, $B$. Ueber die Schädlichkeit industrieller Abgänge für die Fischzucht. Landwirthschaft. Jahrb., Berlin, 1901, 30, 583-617.

1901.1

Haseman, John D. Campostoma brevis. Proc. Indiana Acad. Sci. 1905 (1906), 161-163. 1906.1

An annotated catalog of the cichlid fishes collected by the expedition of the Carnegie Museum to central South America, 1907-1910. Ann. Carnegie Mus., 1911, 7, 329-372. 20 pls.

1911.1

Descriptions of some new species of fishes and miscellaneous notes on others obtained during the expedition of the Carnegie Museum to central South America. Ann. Carnegie Mus., 1911, 7, 315-328. 7 pls. \& fig. 1911.2

Some new species of fishes from the rio Iguasú. Ann. Carnegie Mus., 1911, 7, 374-387. 13 pls. \& fig. 1911.3

The relationship of the genus Priscacara. Bull. Amer. Mus. Nat. Hist., 1912, 31, 97-101. 1912.1

Some factors of geographical distribution in South America. Ann. N. Y. Acad. Sci., 1912, 22, 9-112. 15 pls.

1912.2

Haseman, John D. \& Eigenmann, Carl $H$. A brief report upon the expedition of the Carnegie Museum to central South America, together with a list of localities at which Mr. Haseman collected. Ann. Carnegie Mus., 1911, 7, $287-314$. 
Haskell, $E$. $H$. Second annual appearance of young cod hatched by the United States Fish Commission in Gloucester harbor in the winter of 187980. Bull. U.S. Fish Comm. 1882 (1883), 2. 1883.1

Haslewood, Joseph. Literary researches into the history of the book of Saint Albans. London, 1810. $4^{\circ}$.

Deals with early fishing literature.

1810.1

(editor) The dialogues of creatures moralysed. London, 1816. $276 \mathrm{p}$. 1816.1

But one previous edition of the "Dialogues of Creatures" has appeared in English. Haslewood's reprint was limited to 100 copies, of which 56 were destroyed by fire. There is a Dutch edition as early as 1480, and a French of 1482. The illustrations of fish and fishing scenes are among the earliest to appear in printed books.

Hassall, Albert, \& Stiles, Charles Wardell. See Stiles \& Hassall.

Hasse, Johann Carl Franz [1841-] Bemerkungen über das Gehörorgan der Fische. Verh. Phys. Med. Gesell. Würzburg, 1869, 1, 92-104. - Anat. Studien, 1872, 1, 3. Heft, 417-488. 4 pls.

1869.1

Die Cupula terminalis der $\mathrm{Cy}$ prinoiden. Anat. Studien, 1870, 1, 1-8.

1870.1

Beobachtungen über die Sch mimmblase der Fische. Anat. Studien, 1873, $1,583-610.2$ pls.

1873.1

Die Lymphbahnen des inneren Ohres der Wirbelthiere. Anat. Studien, $1873,1,766-816.2$ pls.

1873.2

Die fossilen Wirbel. Morphologische Studien. Morphol. Jahrb., 1876 , 2, 449-477. 2 pls. Ibid., 1877, 3, 328351. 2 pls. Ibid., 1878, 4, 214-268. 4 pls.

1876.1

Zur Anatomie des Amphioxus lanceolatus. Morphol. Jahrb., 1876, 1 , 2. Heft, 282-298. pl.

1876.2

- Die fossilen Squatinx. Neues Jahrb. Mineral., 1877, 981-982. 1877.1

Ueber den verwandtschaftlichen Zusammenhang zwischen Haien und Rochen. Amt1. Ber. 50. Vers. Deutsch. Naturf., 1877, 173-174.

1877.2

Ueber die Verwandtschaftsverhïltnisse der Gattung Selache. Morphol. Jahrb. (Suppl.), 1S78, 43-58. 2 pls.
- Das natürliche System der Elasmobranchier auf Grundlage des Baues und der Entwicklung ihrer Wirbelsåule. Eine morphologische und paläontologische Studic. Jena, 1879-85. 1879.1

Allgemeiner Theil. Jena, 1879. 76 p. 6 figs. Review in Zool. Anz., 1878, 1, 144-148; 167-172 Besonderer Theil. Jena, 1882. 285 p. 40 pls. Ergänzungsheft. Jena, 1855。27 p. pl.

- Ueber den Bau und über die Entwickelung des Knorpels bei den Elasmobranchiern. Zool. Anz., 1879 , 2, 325-329; 351-355; 371-374. 1879.2

-. Einige seltene paläontologische Funde. Palæontogr., 1884, 3. ser. 7, 310. 2 pls.

1884.1

Die Entwicklung der Wirbelsäule der Dipnoi. Vierte Abhandlung über die Entwicklung der Wirbelsäule. Zeitschr. Wiss. Zool., 1892, 55, 533542. pl.

1892.1

Die Entwicklung der Wirbelsäule der Elasmobranchier. Dritte Abhandlung über die Entwicklung der Wirbelsaiule. Zeitschr. Wiss. Zool., 1892, 55, 519-531. pl. 1892.2

Allgemeine Bemerkungen über die Entwicklung und die Stammesgeschichte der Wirbelsäule. Anat. Anz. $1893,8,288-289$.

1893.1

Die Entwicklung der Wirbelsäule der Cyclostomen. Sechste Abhandlung über die Entwicklung der Wirbelsäule. Zeitschr. Wiss. Zool., 1894, 57, 290-305. pl. Abstract in Journ. Roy. Micr. Soc., 1894, pt. 2, 176

1894.1

Die Entwicklung und der Bau der Wirbelsäule der Ganoiden. Fünfte Abhandlung über die Entwicklung der Wirbelsäule. Zeitschr. Wiss. Zool. 1894, 57, 76-96. 2 pls. $\quad 1894.2$

Hasselt, Alexander Wilhelm Michael van [1814?-1902] Natuurhistorische schets der visschen, en van hunne beteekenis voor den mensch. Album Natuur, 1855 (Wetensch. bijblad.), 97-122; 161188. figs.

1855.1

Hasselt, Jan Coenraad van [-1821] Extrait d'une seconde lettre sur les poissons de Java. Bull. Sci. Nat. (Férussac), 1824, 2, 374-377. 1824.1

Sur les poissons de Java [Extrait des lettres ... à M. C. J. Temminck] Bull. Sci. Nat. (Férussac), 1824, 2, 8992; 374-377. 
Haswell, William Aitcheson. Note on the brain of the tiger shark. (Galeocerdo rayneri) Proc. Linn. Soc. New South Wales, 1883, 7, 210-212. 1883.1

On the structure of the paired fins of Ceratodus, with remarks on the general theory of the vertebrate limb. Proc. Linn. Soc. New South IVales, 1883 , 7, 2-11. pl.

1883.2

Note on the young of the sawfish shark (Pristiophorus cirratus) Proc. Linn. Soc. New South IVales, 1885, 9, $680-681$.

1885.1

Studies on the elasmobranch skeleton. Proc. Linn. Soc. New South Wales, 1885, 9, 71-117. 2 pls. 1885.2

- On the development of Heterodontus (Cestracion) philippi. Part I. Proc. Linn. Soc. New South Wales, 1897, 22, 96-103. 2 pls.

1897.1

On a cestode from Cestracion. Quart. Journ. Micr. Sci., London, 1902, 46, 399-415. 3 pls.

1902.1

- On a Gyrocotyle from Chimara ogilvyi and on Gyrocotyle in general. Proc. Linn. Soc. New South Wales, 1902, 27, 48-54. pl.

1902.2

Note on the cephalochorda in the Australian Museum. Rec. Austral. Mus., 1908, 7, 33-35. fig. 1908.1

Haswell, William Aitcheson, \& Parker, Thomas Jeffery. See Parker \& Haswell.

Hatai, Shinkishi. Observations on the efferent neurones in the electric lobes of Torpedo occidentalis. Journ. Cincinnati Soc. Nat. Hist., 1901, 20, 112. pl. - Bull. Univ. Cincinnati, no. 4, 1-12. pl.

1901.1

- On the nature of the pericellular network of nerve cells. Journ. Comp. Neurol., 1903, 13, no. 2, 139-147. pl.

1903.1

Hatch, Frederick Henry [1864-] The discovery of fish-remains in the Ecca shales, near Ladysmith. Ann. Natal Mus., 1910, 2, pt. 2, 227-228.

1910.1

Hatch, Thomas $E$. On the silver trout of Monadnock lake, New Hampshire. Rept. U. S. Fish Comm. 1872-73 (1874), 2, 372 .

1874.1

Hatcher, John Bell [1861-1904] For memorial notice, see Ann. Carnegie Museum, 1904, 2, 597-604.
Some new and little known fossil vertebrates. Ann. Carnegie Mus., 1901, 1, 128-144. 4 pls. 1901.1

- Relative age of the Lance creek (Ceratops) beds of Converse county, Wyoming, the Judith River beds of Montana and the Belly River beds of Canada. Amer. Geol., 1903, 31, 369375.

1903.1

Contains some mention of fossil fish-remains.

Vertebrate fauna of the Judith River beds. Bull. U. S. Geol. Survey, 1905, no. 257, 67-103.

1905.1

Hathaway, Walter $E$. Effects of menhaden fishing upon the supply of menhaden and of the fishes that prey upon them. Proc. 4. Intern. Fish. Congr., 1908, 1, 269-278. 1908.1

Hatschek, Berthold [1854 - ] Studien über Entwicklung des Amphioxus. Wien, 1881. 8 pls.

1881.1

Die paarigen Extremitäten der Wirbeltiere Anat. Anz. (Verh. Anat. Ges.), 1889, 4, 82-90. figs. $\quad 1889.1$

Die Rippen der Wirbeltiere. Anat. Anz. (Verh. Anat. Ges.), 1889, 4, 113-120. figs. 1889.2

Die Metamerie des Amphioxus und des Ammocoetes. Anat. Anz. (Verh. Anat. Ges.), 1892, 7, 136-161. figs.

1892.1

_ Zur Metamerie der Wirbeltiere. Nachtrag und Berichtigung. Anat. Anz., 1892, 7, 89-91. 1892.2

Studien zur Segmenttheorie des Wirbeltierkopfes. 1. Mitteilung. Das Acromerit des Amphioxus. Morphol. Jahrb., 1906, 35, 1-14. pl. 1906.1

Studien zur Segmenttheorie des Wirbeltierkopfes. 2. Mitteilung. Morphol. Jahrb., 1909, 39, 497-525. 2 pls. \& fig.

1909.1

Das primitive Vorderende des Wirbeltierembryos.

Studien zur Segmenttheorie des Wirbeltierkopfes. 3. Mittheilung. Morphol. Jahrb., $1910,40,480-489.2$ pls. \& fig.

1910.1

Ueber das Akromerit und über echte Ursegmente bei Petromyzon.

Hatsel, W.T. Statement concerning the menhaden fishery. Rept. U. S. Fish Comm. 1877 (1879), 5, 477. 1879.1 
Hatta, $S$. On the formation of the germinal layers in Petromyzon. Journ. Coll. Sci., Imp. Univ. Japan, 1892, 5, 129-147.

1892.1

Contributions to the morphology of Cyclostomata. I. On the formation of the heart in Petromyzon. Journ. Coll. Sci., Imp. Univ. Japan, 1897, 10, pt. 2, 224-237. pl.

1897.1

Preliminary note on the development of the pronephros in Petromyzon. Annot. Zool. Japon., Tokyo, 1897, 1, 137-140. - Proc. Roy. Micr. Soc., 1898, pt. 2, 182.

1897.2

Contributions to the morphology of Cyclostomata. 'The development of pronephros and segmental duct in Petromyzon. Journ. Coll. Sci., Imp. Univ. Tokyo, 1900, 13, 311-425. 5 pls. 1900.1

On the lampreys of Japan together with notes on a specimen from Siberia. Annot. Zool. Japon., Tokyo, 1901, 4, 21-29.

1901.1

On the relation of the metameric segmentation of mesoblast in Petromyzon to that in Amphioxus and the higher Craniota. Annot. Zool. Japon., Tokyo, 1901, 4, 43-47.

1901.2

On the gastrulation in Petromyzon. Journ. Coll.Sci., Imp. Univ. Japan, 1907,21 , art. 11, 1-44. 3 pls. 1907.1

Bemerkungen über die früheren Entwicklungsstadien des Gefässsystems des Ammocoetes. Journ. Sapporo Agric. Coll., 1908, 3, 81-107. 3 figs. 1908.1

Ueber die Variabilität und den Dimorphismus des japanischen Neunauges. Annot. Zool. Japon., Tokyo, 1911, 7, 263-270. pl.

1911.1

- Zur Tiergeographie von Hokkaido. Zool. Anz., 1913, 43, no. 1, $27-36$.

1913.1

Hauck, $J$. Etwas über die Beschaffung von tierischem Futter zur Aufzucht von Jungfischen. Natur u. Haus, Dresden, 1904, 12. Jahrg., 277-278. fig.

1904.1

Hauer, Franz von [1822-1899] Ueber einen newen fundort tertiärer Fischreste bei Porcsesd in Siebenbürgen. Ber. Mitth. Freund. Naturw. Haidinger), 1846, 1, 206-209.

1846.1

[Reference to fossil fishes from Krakowika bei Inwald] Naturw. Abh. (Haidinger), 1817; 3, 118.
Haug, Emile. Sur la faune des couches à Ceratodus crétacées du Djoua, près Timassânine (Sahara) C. R. Acad. Sci. Paris, 1904, 138, 1529-1531. 1904.1

Paléontologie (In Documents scientifiques de la mission saharienne. Mission Foureau Lamy, pt. 3, 751-832. pls. Paris, 1905)

1905.1

Traité de géologie. 4 vols. Paris, 1908-11. illust. $8^{\circ}$. 1908.1

Tome ii. Les périodes géologiques, 2025 p. 64 pls. \& 290 figs. Contains references to fossil fishes.

Haupt, $H$. Leuchtende Organismen. Naturw. Wochenschr., 1903, 19, 65-71. 6 figs.

1903.1

- Am Ufer des Schwarzen Meeres. Natur u. Haus, Dresden, 1904, 12. Jahrg., 193-196. 6 figs.

1904.1

Haus, G. A. Beiträge zur Anatomie und Histologie des Darmkanales bei Anarrhichas lupus. Intern. Journ. Anat. Physiol., 1897, 14, 42-52. pl. 1897.1

Hautefeuille, L.B. Les pêches maritimes en France. Leur état actuel. Moyens de les rétablir et de les développer. Paris, $1868.8^{\circ}$.

1868.1

Observation d'un cas de tuberculose rénale chez une carpe. Mém. Soc. Linn. Nord France, 1904, 11, 223-230. 3 pls.

1904.1

Hauwaert, $P$. van. De reuzen van de zee. Naar de natuur geschetst en met platen versierd [Die Seeriesen. Nach der Natur gezeichnet und mit Tafeln verziert] Gand, 1901.64 p. 8 1901.1

Eenige merkwaardige zeedieren afgebeeld en in hunne levenswijze geschetst [Einige merkwürdige Seetiere abgebildet und in ihrer Lebensweise skizziert] Gand, 1901. 64 p. $8^{\circ}$.

1901.2

Haüy, René Just [1743-1822] Encyclopédie méthodique. Histoire naturelle. Tome troisième. Contenant les poissons. Paris \& Liège, 1787. ix, 435 p. $4^{\circ}$.

1787.1

'This is a dictionary, in which the Linnæan orders (miscalled classes of orders), genera, and species are described under their French names in alphabetical order. Tabular synopses (each on a special page) are also given of the classes, genéra, and species under their French names in connection with the descriptions. The work is a very poor and imperfect compilation, by an author practically unacquainted with fishes as well as with the then recent literature of the subject." T. N. Gill, Smithson. Misc. Coll., 1872, 11, 37 . 
Hauzeur, Nicolas, Dupont, Eduard, \& Beneden, P.J.van. See Beneden, Hauzeur \& Dupont.

Havens, $\boldsymbol{W} . S$. Statement concerning the menhaden fishery. Rept. U.S. Fish Comm. 1877 (1879), 5, 441. 1879.1

Hawkes, Arthur J. Eye migration in flat-fishes and Lamarckianism. Nature, $1907,75,79$.

1907.1

Hawkes, (Mrs.) Onera A., formerly Merritt. The presence of a vestigial sixth branchial arch in the Heterodontidx. Journ. Anat. Physiol., London, 1905, 3. ser. 40, 81-84. 2 figs. 1905.1

The theory of nerve components, especially with regard to its relation to the segmentation of the vertebrate head. Journ. Anat. Physiol., London, 1905, 39, 199-241. 2 figs.

1905.2

The cranial and spinal nerves of Chlamydoselachus anguineus Gar. Proc. Zool. Soc. London, 1906, pt. 2, 959-990. 2 pls.

1906.1

On the abdominal viscera and a vestigial seventh branchial arch in Chlamydoselachus. Proc. Zool. Soc. London, 1907, 471-478. 2 figs. 1907.1

Hawkins, $J . W$. An opinion regarding the influence upon the coast fisheries of the steamers used in the menhaden fishery. Bull. U.S. Fish Comm. 1881 (1882), 1, 266-269.

1882.1

Hawser, Martingale, pseudonym for Sleeper, $J . S$.

Haxo, $J$. Multiplication de la truite au moyen de la fécondation artificielle des truites et des saumons. Proc. Verb. Soc. Philom. Paris, 1849, 23-24. L'Institut, 1849, 17, no. 792, 77. 1849.1

—_ Réflexions sur l'ich thyogénie; ou, Eclosion artificielle des œufs de poissons. Epinal, 1851. $12^{\circ}$.

1851.1

A German version of this work was published at Leipzig in 1855.

De la fécondation artificielle des œufs de poissons et de leur éclosion, ... suivi de réflexions sur l'ichthyogénie. Ann. Soc. Emul. Vosges, 1853, 8, 49-131. Also separate; Epinal, 1853. $8^{\circ}$.

Guide du pisciculteur. Paris, 1854. $12^{\circ}$.

1854.1

Guide du pisciculteur d'après des notes et des documents fournis par J.
Remy, recueillis, rédigés et publiés par le Dr. Haxo. Paris, 1860. 12 1860.1

Hay, Oliver Perry [1846-] For list of writings, see his privately published bibliography, dated May 22, 1911.

-... On a collection of fishes from eastern Mississippi. Proc. U. S. Nat. Mus., 1881, 3, 488-515. 1881.1

On a collection of fishes from the lower Mississippi valley. Bull. U. S. Fish Comm. 1882 (1883), 2, 57-75.

1883.1

Note on a collection of fishes from Florida, with descriptions of new or little known species. Proc. U. S. Nat. Mus., 1885, 8, 552-559. 1885.1

A contribution to the knowledge of the fishes of Kansas. Proc. U.S. Nat. Mus., 1887, 10, 242-253. 1887.1

Description of a new species of Petalodus ( $P$. securiger) from the Carboniferous of Illinois. Journ. Geol., 1895, 3, 561-564. figs. 1895.1

For further remarks on the same species, see Eastman, C.R. Ibid., 1895, 4, 174-176.

The lampreys and fishes of Indiana. 19. Ann. Rept. Dept. Geol. Nat. Resources Indiana, 1894 (1895), 146296.

1895.2

On the structure and development of the vertebral column of Amia. Publ. Field Columb. Mus., Zool. ser., 1895, 1, 5-54. 3 pls. 1895.3

- On some collections of fishes made in the Kankakee and Illinois rivers. Publ. Field Columb. Mus., Zool. ser., 1896, 1, 85-97. $\quad 1896.1$

The structure and mode of development of the vertebral column. Science, 1896, n. s. 4, 959-961. 1896.2

Dr. Alexander Goette on the development of the vertebral column. Amer. Naturalist, 1897, 31, 397-406.

1897.1

Dr. Gadow and Miss Abbott on the vertebral column of fishes. Zool. Bull., Boston, 1897, 1, 131-141. 1897.2

Classification of the amioid and lepisosteoid fishes. Amer. Naturalist, 1898, 32, 341-349. 8 figs. $\quad 1898.1$

George Baur. Science, 1898, n. s. 8, 68-71. 1898.2 
Hay, O. P.

- Notes on species of Ichthyodectes, including the new species $I$. cruentus, and on the related and herein established genus Gillicus. Amer. Journ. Sci., 1898, 4. ser. 6, 225-232. figs.

1898.3

Observations on the genus of Cretaceous fishes called by Prof. Cope Portheus. Science, 1898, n. s. 7, 646.

1898.4

Observations on the genus of fossil fishes called by Professor Cope Portheus, by Dr. Leidy Xiphactinus. Zool. Bull., Boston, 1898, 2, 25-54. figs.

1898.5

Protospondyli and Atheospondyli of A. S. Woodward. Science, 1898 , n. s. $\mathbf{7}, 358$.

1898.6

A census of the fossil vertebrata of North America. Science, 1899, n. s. 10, 681-684.

1899.1

On one little known and one hitherto unknown species of Saurocephalus. Amer. Journ. Sci., 1899, 4. ser. 7, 299-304. 5 figs. - Ann. Mag. Nat. Hist., 7. ser. 3, 480-487. 5 figs. 1899.2

- On some changes in the names, generic and specific, of certain fossil fishes. Amer. Naturalist, 1899, 33, $783-792$.

1899.3

- On the names of certain North American fossil vertebrates. Science, 1899, n. s. 9, 593-594. 1899.4

On the nomenclature of certain fossil vertebrates. Amer. Geologist, $1899,24,345-349$.

1899.5

Descriptions of some vertebrates of the Carboniferous age. Proc. Amer. Philos. Soc., 1900, 39, 96-123. pl. \& 3 figs. 1900.1

The chronological distribution of the elasmobranchs. Trans. Amer. Philos. Soc., 1901, 2. ser. 20, 63-75. fig. Reviewed in Amer. Geol., 1901, 29, 255256.

1901.1

Bibliography and catalogue of the fossil vertebrata of North America. Bull. U. S. Geol. Surv., 1902, no. 179, 1-868.

1902.1

Contains a carefully prepared author's and subject catalogue of the literature pertaining to American fossil fishes.

Description of a new species of Cladodus ( $C$. formosus) from the Devonian of Colorado. Amer. Geologist, $1902,30,373-374$. fig.

1902.2
The snout-fishes of Kansas. Abstract in Ann. N. Y. Acad. Sci., 1902, 15, 15. - Amer. Geologist, 29, 192-193. 1902.3

On a collection of Upper Cretaceous fishes from mount Lebanon, Syria, with descriptions of four new genera and nineteen new species. Bull. Amer. Mus. Nat. Hist., 1903, 19, 395-152. 14 pls. \& figs.

1903.1

On certain genera and species of North American Cretaceous actinopterous fishes. Bull. Amer. Mus. Nat. Hist., 1903, 19, 1-95. 5 pls. \& 72 figs. 1903.2

Some remarks on the fossil fishes of mount Lebanon, Syria. Amer. Naturalist, 1903, 37, 685-695. 1903.3

On an important but not wellknown locality furnishing Cretaceous fishes. Abstract in Science, 1904, n. s. 17, 219. - Bull. Geol. Soc. Amer., 14, 542 .

1904.1

The progress of vertebrate palxontology at the American Museum of Natural History, New York. Amer. Geologist, 1905, 35, 31-34.

1905.1

A new fossil stickleback fish [Gasterosteus williamsoni leptosomus] from Nevada. Proc. U. S. Nat. Mus,, 1907, 32, $271-274.3$ figs.

1907.1

- 1 new genus and species of fossil shark related to Edestus Leidy. Science, 1907 , n. s. 26, 22-24. fig.

1907.2

- On the nature of Edestus and related genera, with descriptions of one new genus and three new species. Proc. U. S. Nat. Mus., 1909, 37, 43-61. 4 pls. \& 7 figs.

1909.1

Notice in Science Progress, 1909, 4, 675-676.

- On an important specimen of Edestus; with description of a new species, Edestus mirus. Proc. U. S. Nat, Mus., 1912, 42, 31-38. 2 pls. 1912.1

Edestus and related fossil remains recognized as dental organs of Cestracion-like sharks.

Hayden, $H . H$. The geology of Spiti, with parts of Bashahr and Rupshu. Mem. Geol. Surv. India, 1904, 36, 1-129. 16 pls. \& map.

1904.1

Hayward, Joseph S. Catch of fish in Newfoundland and Labrador in 1881; from letter to Prof. S. F. Baird. Bull. U. S. Fish Comm. 1882 (1883), 2, 286.

1883.1 
Hazen, Anna Putnam, \& Morgan, T. H. See Morgan \& Hazen.

Head, $J . F$. Some remarks on the natural history of the country about Fort Ripley, Minnesota. 9. Ann. Rept. Smithson. Instit. 1854 (1856), 291. 1856.1

Contains a partial list of the fishes of the upper Mississippi.

Grayling in Montana. Forest \& Stream, 1874, 2, 212.

1874.1

Healy, $R$. Striped bass in Piankatank river, Virginia; from a letter to Prof. S. F. Baird. Bull. U. S. Fish Comm. 1882 (1883), 2, 75-76. 1883.1

Heape, Walter. On the fishing in dustry of Plymouth and description of the Marine Biological Association. London, 1887. 4 pls. $8^{\circ}$.

1887.1

Preliminary report upon the faunse and flora of Plymouth sound. Journ. Mar. Biol. Assoc., 1887, 1, 153193.

1887.2

Hearder, $J . N$. The degeneration of our sea fisheries. Rept. Trans. Devonshire Assoc. Adv. Sci., 1871, 4, 213-237.

1871.1

Degeneration of our deep-sea fisheries. Trans. Plymouth Instit. 1869 73 (1873), 4, 42-48.

1873.1

Hearder, William. Capture of a burbot in Cattewater. Zoologist, 1904, 4. ser. 8, 353 .

1904.1

Hearn, Walter Risley. France. Report on the French fisheries on the Great bank of Newfoundland and off Iceland. London, 1899.11 p. $8^{\circ}$. 1899.1

Great Britain Foreign Office Diplomatic and Consular reports. Miscell. Ser. no, 492

Heath, A.J., \& Morgan, C. Lloyd. On the fish-remains of the Lower Carboniferous rocks of the Bristol district. Proc. Nat. Soc. Bristol, 1893, 2. ser. 7, 80-92.

1893.1

Heath, Harold. The association of a fish with a hydroid. Biol. Bull. Woods Hole, 1910, 19, 73-78. 2 figs. 1910.1

Heath, Neil. Effect of cold on fishes. Trans. New Zealand Instit. 1883, 16, 275-278. - Bull. U. S. Fish Comm. 1884, 4, 369-371.

1883.1

Hébert, Edmond [1812-1890] Sur la couche à dents de squales découverte à Bruxelles par M. Rutot. Ann. Soc. Géol. Belgique, 1874, 1, 73-75. 1874.1
Hecht, Selig. The relation of weight to length in the smooth dog-fish, Mustelus canis. Anat. Record, 1913, 7, 39-42. fig.

1913.1

Heckel, Johann Jakob [1790-1857] Ichthyologische Beiträge zu den Familien der Cottoiden, Scorpænoiden, Gobioiden, und Cyprinoiden. Ann. Wien. Mus., 1836, 1, 47. Ibid., 1840, 2, 143164.

1836.1

- Scaphirhynchus, eine neue Fischgattung aus der Ordnung der Chondropterygier mit freien Kiemen. Ann. Wien. Mus., 1836, 1, 68-78. Arch. Naturgesch., 2. Jahrg., 241. 1836.2 - Ueber einige neue, oder nicht gehörig unterschiedene Cyprinen, nebst einer systematischen Darstellung der europäischen Gattungen dieser Gruppe. Ann. Wien. Mus., 1836, 1, 219-234.

1836.3

Fische aus Caschmir gesammelt und herausgegeben von Carl Freiherrn von Hügel, beschrieben von J. J. Heckel. Wien, 1838. 112 p. 13 pls. $4^{\circ}$. 1838.1

Johann Natterer's neue Flussfische Brasilien's nach den Beobachtungen und Mittheilungen des Entdeckers beschrieben. Abth. 1. Die Labroiden. Ann. Wien. Mus., 1840, 2, 325-470. fig. 1840.1

- - Ichthyologie [von Syrien] (In Russegger, Joseph von. Reisen in Europa, Asien und Africa, mit besonderer Rücksicht auf die naturwissenschaftichen Verhältnisse der betreffenden Länder unternommen in den Jahren 1835 bis 1841 , etc. vol. i, pt. 2. Stuttgart, 1841-48, $8^{\circ}$ ) 1841.1

Fishes from the Lebanon Cretaceous are noticed.

On a new European genus of freshwater fish [Aulopyge] Translated by W. Francis. Ann. Mag. Nat. Hist., $1841,7,522-523$.

1841.2

Ueber eine neue Gattung [Aulopyge hugelii] von Süsswasserfischen in Europa; aus einem Schreiben an den Akademiker 'Dr. Brandt. Bull. Sci. Acad. St. Pétersb., 1841, 8, 384.- Ann. Mag. Nat. Hist., 1841, 7, 522-523.

1841.3

Abbildungen und Beschreibungen der Fische Syriens, nebst einer neuen Classification und Characteristik sämmtlicher Gattungen der Cyprinen. Stuttgart, 1843. 258 p. 22 pls 1843.1

Fossil fishes of the Lebanon, p. 234-244. Two new genera, Pyenosternix and Isodus, are described. 
Heckel, $J . J$.

Sopra varie specie italiane di pesci d'acqua dolce. Atti Sci. Ital., 1844, 380-385.

1844.1

Bemerkung über Lepidosiren paradoxa. Arch. Anat. Physiol. (Müller), 1845, 534-535.

1845.1

Ueber die fossilen Fische des Oesterreichischen Kaiserstaates. Ber. Mitth. Freund. Naturw. (Haidinger), $1847,3,327-330$.

1847.1

Eine neue Gattung von Poecilien mit rochenartigem Anklammerungs-Organe $[P$. xiphophorus] Sitzber. Akad. Wiss. Wien, 1848, 289-303. 2 pls.

1848.1

- Pycnodus murattii in lichtem Kalkstein aus der Umgegend von Pola in Istrien. Ber. Mitth. Freund. Naturw. (Haidinger), 1848, 4, 184-189. 1848.2

Vorlegung von Abbildungen fossiler Fische. Sitzber. Akad. Wiss. Wien, 1848, 127-130.

1848.3

Abhandlung über eine neue fossile Fischgattung, Chirocentrites, und die ersten Ueberreste eines Siluroiden aus der Vorwelt. Sitzber. Akad. Wiss. Wien, 1849, 2, 16-19.

1849.1

Ueber eine neue Gattung von Trenioiden (Lapidopides) und eine neue Species aus der Ganoiden Gattung, Lepidotus (L. sulcatus) Sitzber. Akad. Wiss. Wien, 1849, 2, 176-177. 1849.2

Ueber einige bisher unbekannte Arten fossiler Fische aus der Gegend von Görz. Sitzber. Akad. Wiss. Wien, $1849,2,163-165$.

1849.3

- Beiträge zur Kenntniss der fossilen Fische Oesterreichs. Denkschr. Akad. Wiss. Wien, 1850, 1, 201-242. $13 \mathrm{pls}$.

1850.1

Bericht über das Vorkommen fossiler Fische zu Seefeld in Tirol und Monte Bolca im Venetianischen. Jahrb. Geol. Reichsanst., Wien, 1850, 1, 696701.

1850.2

Ueber das Virbelsäulen-Ende bei Ganoiden und Teleostiern. Sitzber. Akad. Wiss. Wien, 1850, 5, 2. Abth., 143-148.

1850.3

Ueber die Wirbelsäule fossiler Ganoiden. Sitzber. Akad. WViss. Wien, 1850, 5, 2. Abth., 358-368. 4 figs. 1850.4

- Bericht einer ichthyologischen Reise. Sitzber. Akad. Wiss. Wien,
1851, 7, 2. Abth., 281-333. Ibid., 8, 347-

390. Ibid., 9, 49-123. 1851.1

Gebiss eines fossilen Haies von Gairach in Untersteiermark. Jahrb. Geol. Reichsanst., Wien, 1851, 2, 149.

1851.2

Stör-Arten der Lagunen bei Venedig. Sitzber. Akad. Wiss. Wien, 1851, 6, 2. Abth., 547-563. 1851.3

Ueber die in den Seen Oberösterreichs vorkommenden Fische. Sitzber. Akad. Wiss. Wien, 1851, 6, 145-149.

1851.4

Ueber die Ordnung der Chondrostei und die Gattungen Amia, Cyclurus, Notxeus. Sitzber. Akad. Wiss. Wien, 1851, 6, 219-224. 1851.5

Ueber eine neue Fisch-Species aus dem Weissen Nil, Protopterus athiopicus. Sitzber. Akad. Wiss. Wien, 1851, 6, 2 Abth., 685-689. 1851.6

Die Fische der Save. Verh. Zool.-Bot. Ver. IVien, 1852, 2, 130-131. 1852.1

Ueber aussergewöhnliche Individuen der Bachforelle (Salar ausonii) Verh. Zool.-Bot. Ver. Wien, 1852, 1, 71-72.

1852.2

Ueberreste eines fossilen Fisches aus der Familie der Lippenfische (Labroiden) Jahrb. Geol. Reichsanst., Wien, 1852, 3, 176-177. 1852.3

Verzeichniss der Fische des Donau-Gebiets. Verh. Zool.-Bot. Ver. Wien, 1852, 2, 28-33.

1852.4

Verzeichniss einiger Fische und Amphibien aus der Gegend von Bozen, und über den Carpione des Garda Sees. Verh. Zool.-Bot. Ver. Wien, 1852, 1, 8182.

1852.5

Addizioni alla conoscenza de' pesci fossili Austriaci. Rendic. R. Accad. Sci., Napoli, 1853, n. s. 2, 42-46. 1853.1

Ueber einen fossilen Fischüberrest aus Sicilien. Verh. Zool-Bot. Ver. Wien, 1853, 3, 70-71.

1853.2

Bericht ïber die vom Herrn Cavaliere Achille de Zigno hier angelangte Sammlung fossiler Fische. Sitzber. Akad. Wiss. Wien, 1854, 11, 122138.

1854.1

Beschreibung des Gymnarchus niloticus Cuvier nach zwei aus dem 
Weissen Nil vorliegenden Exemplaren. Denkschr. Akad. Wiss. Wien, 1854, 6, 11-20. 2 pls. Abstract in Sitzber. Akad. Wiss. Wien, 1852, 9, 680-681.

1854.2 sucht und systematisch verzeichnet Verh. Zool.-Bot. Ver. Wien, 1854, 4, 189-196.

1854.3

Ueber den Bau und die Eintheilung der Pycnodonten, nebst kurzer Beschreibung einiger neuen Arten derselben. Sitzber. Akad. Wiss. Wien, 1854, 8, 433-464.

1854.4

Ueber fossile Fische aus Chiavon und das geologische Alter der sie enthaltenden Schichten. Sitzber. Akad. Wiss. Wien, 1854, 9, 322-334.

1854.5

Neue Beiträge zur Kenntniss der fossilen Fische Oesterreichs. Sitzber. Akad. Wiss. Wien, 1855, 17, 166-168. Denkschr. Akad. WViss. Wien, 11, 187274. 15 pls.

1855.1

Heckel, Johann Jakob, \& Fitzinger, $L . J$. Monographische Darstellung der Gattung Acipenser. Ann. Wien. Mus., 1836, 1, 261-326. Notice in Arch. Naturgesch. (Wiegmann), 1837, 2. Jahrg., 239.

1836.1

Heckel, Johann Jakob, \& Kner, Rudolf. Die Süsswasserfische der Oesterreichischen Monarchie mit Rücksicht auf die angrenzenden Länder. Leipzig, 1858. 388 p. 204 figs. $8^{\circ}$. 1858.1

Neue Beiträge zur Kenntniss der fossilen Fische Oesterreichs. Denkschr. Akad. Wiss. Wien, 1861, 19, 49-76. 10 pls.

1861.1

Heckel, Johann Jakob, Redtenbacher, \& Fenzl, Eduard. See Fenzl, Heckel \& Redtenbacher.

Heckenstaller, — Anstalten für Coregonen- und Salmoniden-Zucht in Bayern. Bayer. Fischerei Zeitg., 1879, 4. Jahrg., 25-27; 37-38; 57-58. 1879.1

Ueber Gewinnung von geeignetem Futter für die Aufzucht von Forellen-, Lachs- und Saibling-Brut. Bayer. Fischerei Zeitg., 1879, 4. Jahrg., 100103.

1879.2

Die Fischzucht-Anstalten an den "Sieben Quellen" bei Starnberg und am Schliersee. Circul. Deutsch. Fischerei Ver. $1879(1880)$, no. 2, 37-39.

1880.1
Hector, A. Remarks on the salmon fishing of Scotland. Edinburgh, 1861. $8^{\circ}$.

1861.1

Hector, (Sir) James. Notice of a swordfish [Histiophorus] stranded on the west coast, in June, 1867. Trans. Proc. New Zealand Instit. 1868 (1869), 1, 44. 1869.1

On a species of Ophisurus $[O$. nove-zelandice found on the coast of New Zealand. With anatomical observations by F. J. Knox. Trans. Proc. New Zealand Instit. 1869 (1870), 2, 3440. pl.

1870.1

On a new species of fish, Coryphonoides nova-zelandia, the okarari of natives. Trans. Proc. New Zealand Instit. 1870 (1871), 3, 136. pl. \& fig.

1871.1

On the Salmonidxe of New Zealand. Trans. Proc. New Zealand Instit. 1870 (1871), 3, 133-136. 2 pls. 1871.2

Notice of Motella nova-zelandia, sp. nov. Trans. Proc. New Zealand Instit. 1873 (1874), 6, 107-108. fig.

1874.1

Descriptions of five new species of fishes obtained in the New Zealand seas by H. M. S. "Challenger" Expedition, July 1874. Ann. Mag. Nat. Hist., 1875, 4. ser. 15, 78-82. 1875.1

Notes on New Zealand ichthyology. Trans. Proe. New Zealand Instit. $1874(1875), 7,239-250 \quad$ Ibid., 1876 (1877), 9, 465-469. 3 pls. Ibid., 1883 (1884), 16, 322-323. - Ann. Mag. Nat. Hist., 1877, 4. ser. 19, 339-342. pl.

1875.2

Notice of Ceratodus forsteri Krefft or barramunda of the Queensland rivers. Trans. Proc. New Zealand Instit. 1874 (1875), 7, 490-492. 1875.3

Exportation of salmon and white fish ova to New Zealand in 1876. Rept. U. S. Fish Comm. 1875-76 (1878), 4, 971-973; $982 ; 989-993 ; 995 ; 998-999$; 1003.

1878.1

The Pacific salmon SSalmo quinnat] Nature, 1879, 20, 338. 1879.1

Shipment of salmon ova to New Zealand in 1877 and whitefish in 1878. Rept. U. S. Fish Comm. 1878 (1880), 6, $835-836 ; 851-852 ; 856 ; 876-878.1880 .1$

Notice of a new fish [Hypolycodes haastii] Trans. Proc. New Zealand Instit. 1880 (1881), 13, 194-195.

1881.1 
Hector, $J$. On the occurrence of the salmon trout in Nelson harbour. Trans. Proc. New Zealand Instit. 1881 (1882), 211213. fig.

1882.1

- The fisheries of New Zealand. Bull. U.S. Fish Comm. 1884, 4, 53-55. 1884.1

Notes on New Zealand fishes. Trans. Proc. New Zealand Instit., 1902, 34, 239-241. 2 pls.

1902.1

Remarks on New Zealand fishes, and on a collection of drawings of native fish by the late F. E. Clarke. Trans. Proc. New Zealand Instit., 1902, 34, $563-564$.

1902.2

Notes on the New Zealand whitebait. Trans. Proc. New Zealand Instit., 1903, 35, 312-319. 1903.1

Hector, (Sir) James, \& Günther, Albert Carl Ludwig Gothilf. See Guinther \& Hector.

Hector, (Sir) James, \& Knox, Frederick John. On a species of Ophisurus, found on the coast of New Zealand; with anatomical observations. Trans. Proc. New Zealand Instit., 1870, 2, 34 40. pl.

1870.1

Hector, Thomas. American salmon in New Zealand. Forest \& Stream $1877,7,403$.

1877.1

Hederström, Hans. Rön om fiskars älder. Svensk Vet. Akad. Handl., 1759, 222.

1759.1

Hédon, E. Toxicité des glycosides hémolytiques pour les poissons et actions antitoxiques. C. R. Mém. Soc. Biol. Paris, 1901, 53, 391-393.

1901.1

Heeckeren Tot Waliën, $L, A, F, H$. van. De oor-pijlstaartrog van den Indischen Archipel, Cephaloptera kuhtii Val. Nat. Tijdschr. Nederl. Indië, 1897, 56 (9. ser. 5), 36-43. pl. 1897.1

Heede, C.J. Gambusia "affinis" and $G$. "holbrooki," two live-bearing fishes. Bull. Brooklyn Aquar. Soc., 1912,1 , no. 6,1 . fig.

1912.1

Hefford, A. E. Note on a conger with abnormal gonad. Journ. Mar. Biol. Assoc., 1907-10, n. s. 8, 318-319. fig.

1907.1

- Note on a hermaphrodite cod (Gadus morrhua) Journ. Mar. Biol. Assoc., 1907-10, n. s. 8, 315-317. fig.

1907.2
The proportionate distribution of the sexes of plaice in the North sea. Conseil Perm. Intern. Explor. de la Mer, Proc.-Verb., 1909, 11, 135-176. 7 figs.

1909.1

Notes on teleostean ova and larva observed at Plymouth in spring and summer, 1909. Journ. Mar. Biol. Assoc., 1910-13, n. s. 9, 1-58. 2 pls.

1910.1

Heger, Paul. Action de la lumière sur les éléments nerveux de la rétine. Bull. Acad. Méd. Belgique, 1896, 4. sér. 10, 167-173. 2 figs. Ibid., 781-784.

1896.1

Hegt, J. Noordhoch. Shipment of salmon ova to the Netherlands in 1877. Rept. U. S. Fish Comm. 1878 (1880), 6 , 916-918. - Bull. U. S. Fish Comm. 1882 (1883), 2, 102.

1880.1

Heide, E. J. Einige Worte über Luciotrutta leucichthys [Text in Russian] Pêch. Chass., Viatka, 1911, 3, 124-126.

1911.1

Bestimmung des Alters der Maräne (Coregonus albula) und deren Bedeutung für die Teichwirtschaft i'Text in Russian! Arbeit. 3. Allruss. Fisch.Congress, St. Petersb. 1910 (1912), pt $3,105-116$.

1912.1

Zur Frage über das Laichen und den Schutz von Luciotrutta leucichthys Güld [Text in Russian] Věst. Rybopromyšl., St. Petersb., 1912, 26, 441447.

1912.2

Heidenhain, $M$. Ueber die Entstehung der quergestreiften Muskelsubstanz bei der Forelle. Arch. Mikrosk. Anat., 1913, 83, 1. Abth., 427-447. 3 pls.

1913.1

Ueber die Teilkörpernatur der Fibrillen und Säulchen in der Muskulatur des Forellenembryos. Anat. Anz. 1913, 44, 251-255. 6 figs.

1913.2

Heidrich, - Ausführlicher Bericht über Verlauf und Ergebnisse der [Ostsee-] Expedition [1901 des Deutschen Seefischereivereins] Abh.Deutsch. Seefischerei Ver., 1902, 7, 1-84. 1902.1

Heilig, K. Zur Kenntnis der Seitenorgane von Fischen und Amphibien. Arch. Anat. Physiol. (Anat. Abth.), 1912, 117-150. 2 pls.

1912.1

Heilprin, Angelo [1853-] Explorations on the west coast of Florida and in the Okeechobee wilderness; with 
special reference to the geology and zoology of the Floridian peninsula. A narrative of researches undertaken under the auspices of the Wagner free institute of science of Philadelphia. Trans. Wagner Free Instit. Sci. Philad., 1887, 1, 1-134. 19 pls. $8^{\circ}$. 1887.1

Additions to the Floridian fauna. Ictalurus okeechobeensis, sp. nov., p. 129-130.

Heimburger, $H . V$. 'The factors that determine the distribution of Boleosoma nigrum in Douglas lake, Cheboygan county, Michigan. 15. Rept. Michigan Acad. Sci., 1913, 120.

1913.1

Hein, S. A. A. Over oogleden en fornices conjunctivae bij teleostomi. Tijds. Ned. Dierk. Ver., Leiden, 1913 , 12, 238-280.

1913.2

Hein, Walter. Zur Biologie der Forellenbrut. Allgem. Fischerei Zeitg., 1906-07.

1906.1

i. Versuche über das Nahrungsbedürfnis der Bachforellenbrut im Bruttrag und im künstlichen Brutbett. Ibid., 1906, 31, 217-221; 239243. 5 figs.

ii. Ueber die absolute Druckfestigkeit der Bachforelleneier. Ibid., 1907, 32, 331-339. 2 pls.

iii. Ueber die Wirkungen von Druck, Stoss und Fall auf die Entwicklung der Bachforelleneier. Ibid., 383-387; 398-102. fig.

iv. Zur Kieserbrütung. Ibid., 441-447.

v. Zwei neue Erbrütungsversuche. Ibid., $463-166$.

vi. Zur weiteren Entwicklung der Kiesbettbrut. Ibid., 487-490. fig.

A contribution to the biology of trout fry. Investigations into the food requirements of brown trout fry in the hatching trough and in the artificial redd. Rept. Sea Inland Fish. Ireland, 1905 (1907), pt. 2, 165-211. 2 pls. Fisheries Ireland Scient. Invest. 1905 (1907), no. 8, 1-16. 2 pls.

1907.1

- Einige Versuche mit neueren Bebrütungsmethoden von Bachforelleneiern. Ber. Kgl. Biol. Versuchsstat. München, 1908, 1, 70-92. 1908.1

Einige Versuche über den Einfluss mechanischer Störungen auf die Entwicklung der Backforelleneier. Ber. Kgl. Biol. Versuchsstat. München, 1908, 1, 22-69. pl.

1908.2

Erbrütungsversuche in der Fischzuchtanstalt Nïhlthal im Winter 190708. Allgem. Fischerei Zeitg., 1908, 33, no. 22-23.

1908.3

Ueber die Wirkungen des Steinkohlenteers auf Fische und einige wirbellose Thiere. Ber. Kgl. Biol. Versuchsstat. München, 1908, 1, 93-114. 2 pls.
Gitterkiesbett und Drehstromapparat. Allgem. Fischerei Zeitg., 1909, 34, no. 5 .

1909.1

Bellini's Sexualdimorphismus der mediterränen Steigaale. Allgem. Fischerei Zeitg., 1910.

1910.1

-Die Forelle und ihre Verwandten. 42. Ber Senckenberg. Nat. Gesell. Frankfurt-a.-M., 1911, 42, 118-119

1911.1

Ueber den Einfluss plötzlicher Temperaturschwankungen auf die Entwickelung der Bachforelleneier und Brut (In Aus deutscher Fischerei, Festschrift für E. Uhles, p. 18-28.

Neudamm, 1911) ， 1911.2

Hein, Walter, \& Winter, $F, W$. Süsswasswerfische Mittel-Europas, herausgegeben im Auftrag des Deutschen Fischerei Vereins, Berlin. Leipzig, 1912. 2 pls.

1912.1

Heincke, Friedrich. Ueber Fischzähne. Zeitschr. Gesammt. Naturw. Halle, 1872, n. s. 6, $318 . \quad 1872.1$

Untersuchungen über die Zähne niederer Wirbelthiere. Zeitschr. Wiss. Zool., 1873, 23, 495-591. 3 pls. 1873.1

Bemerkungen über den Farbenwechsel einiger Fische. Schrift. Naturw. Ver. Schlesw.-Holst., 1875, 1, 255-267. Ibid., 1876, 2, 1. Heft, 214.

1875.1

Ichthyologische Vorträge. Schrift. Naturw. Ver. Schlesw.-Holst., $1875,1,281-283$; 286-287; 288-289; 296-299. Ibid., 1876, 2, 1. Heft, 210; 220 .

1875.2

Die Varietäten des Härings. Zugleich ein Beitrag zur Descendenztheorie. Berlin, $1877 \& 1881.3$ pls. $4^{\circ}$. - Ber. Komm. Wiss. Untersuch. Deutsch. Meere, Kiel, 1881, 7. 85 p. 3 pls.

1877.1

EEinige bisher nicht oder selten in der Ostsee gefundene Fische] Schrift. Naturw. Ver. Schlesw.-Holst., 1878, 3, 1. Heft, 135-136.

1878.1

- Die Gobiidæ und Syngnathidæ der Ostsee nebst biologischen Bemerkungen. Arch. Naturgesch., 1880, 46. Jahrg., pt. 1, 301-354. pl. \& fig. 1880.1

Die Wanderungen der Fische. Natur (Müller), 1880, n. s. 6, 325-327; $345-346 ; 370-372 ; 383-384 ; 407-408$.

1880.2 
Heincke, $F$.

- Die neuesten Forschungen über den Hering. Ausland, 1881, 54, 29-32. 1881.1

'The sea fisheries of Norway. Bull. U. S. Fish Comm. 1886 (1887), 6, $265-272$.

1887.1

Variabilität und Bastardbildung bei Cyprinoiden (In Festschrift zum siebenzigsten Geburtstage R. Leuckarts, p. 64-73. pl. \& figs. Berlin, 1892)

1892.1

Die Fische Helgolands. Leipzig, 1894. 4\%. Wiss. Meeresuntersuch. Kiel (Abt. Helgoland), 1896, n. s. 1, 99120 .

1894.1

-Nachträge zur Fisch- und Mollusken-Fauna Helgolands (In Beiträge zur Meeresfauna von Helgoland. Wiss. Meeresuntersuch. Kiel (Abt. Kiel), 1897, n. s. 2, 233-252. 4 figs. 1897.1

Fish, p. 233-241.

Naturgeschichte des Herings. I. Die Lokalformen und die Wanderingen des Heringes in den europäischen Meeren. Abh. Deutsch. Seefischerei Ver., Berlin, 1898, 2, pt. 1. cxxxvi, 128 p. 26 pls.

1898.1

- The natural history of the herring. 17. Rept. Fish. Board Scotland 1898 (1899), pt. 3, 274-287.

1899.1

Der internationale FischereiKongress in Bergen vom 18. bis 21. Juli 1898. Abh. Deutsch. Seefischerei Ver., 1901, 6, 1-14.

1901.1

The occurrence and distribution of the eggs, larvæ, and various agegroups of the food-fishes in the North sea. Conseil Perm. Intern. Explor. Mer. Rapp. \& Proc. Verb., 1905, 3 (Append. E), 3-39.

1905.1

Die Arbeiten der kgl. Biologischen Anstalt auf Helgoland im Interesse der internationalen Meeresforschung in der Zeit vom 1. IV. 1904 bis 31. III. 1905 (In Die Beteiligung Deutschlands an der internationalen Meeresforschung, 3. Jahresber., p. 5193. pl. Berlin, 1906)

1906.1

- Bericht über die Untersuchungen der Biologischen Anstalt auf Helgoland zur Naturgeschichte der Nutzfische (1. April 1905 bis 1. Oktober 1907) (In Die Beteiligung Deutschlands an der internationalen Meeresforschung, 4.\& 5. Jahresber., p. 66-155. 6 pls. Berlin, 1908)

1908.1
Untersuchungen über die Scholle Generalbericht. I. Schollenfischerei und Schonmassregeln. Vorläufige kurze Uebersicht über die wichtigsten Ergebnisse des Berichts [German \& English text] Conseil Perman. Intern. Explor. de la Mer, 1913.

1913.1

Heincke, Friedrich, \& Bolau, $H$. Die in Deutschland gebräuchlichen Marken zum Zeichnen von Schollen. Wiss. Meeresuntersuch. Kiel (Abt. Helgoland), 1906, n. s. 7, 71-78. 5 figs. 1906.1

Heincke, Friedrich, Decker, W., \& Henking, Hermann. See Decker, Heincke \& Henking.

Heincke, Friedrich, \& Ehrenbaum, Ernst. Die Bestimmung der schwimmenden Fischeier und die Methodik der Eimessungen (In Ehrenbaum, E. Eier und Larven von Fischen der deutschen Bucht. Wiss. Meersuntersuch. Kiel (Abt. Helgoland), 1900, n. s. 3, 127-332. 2 pls. \& 17 figs.)

1900.1

i. Die Bestimmung der schwimmenden Fischeier

ii. Die Methodik der Eimessungen und die Bestimmung der Eier nach der Grösse.

iii. Systematik der schwimmenden Fischeier. iv. Die Eibestimmungen anderer Autoren nach dem Durchmesser.

v. Methodisches Verfahren bei der Bestimmung planktonischer Eier.

vi. Tabelle zur bestimmung schwimmender Fischeier in der deutschen Nordsee.

Table for the determination of pelagic fish eggs. Rept. Lancashire SeaFish. Labor. Liverpool, 1902 (1903), 95-100. - Trans. Liverpool Biol. Soc., 1903, 17, 181-186.

1903.1

Heincke, Iriedrich, \& Henking, Hermann. Die Heringsfischereien Norwegens. Abh. Deutsch. Seefischerei Ver., 1900, 6, 75-118. figs. 1900.1

Ueber Schollen und Schollenfischerei in der südöstlichen Nordsee. Nach deutschen Untersuchungen [Plaice and plaice-fishing. German investigations in the southeastern part of the North seaI (In Die Beteiligung Deutschlands an der internationalen Meeresforschung, 4. \& 5. Jahresb., p. 1-90. Berlin, 1908) 1908.1

Heincke, Friedrich, \& Möbius, Karl. See Möbius \& Heincke.

Heincken, Philip. Die freie hanse Stadt Bremen und ihr Gebiet in topographischer, medizinischer und naturhistorischer, Hinsicht geschildert. 2 vols. Bremen, 1837, $8^{\circ}$.

1837.1

List of 34 freshwater fishes, vol. i, p. 148. 
Heineke, Erich. Die Ganoiden und Teleostier des lithographischen Schiefers von Nusplingen. Geol. Paläontol. Abh., Jena, 1906, n. s. 8, pt. 3, 159-214. 8 pls.

1906.1

Heinemann, $C$. Beitri̊ge zur Anatomie der Retina. Arch. Mikr. Anat., 1878, 14, 409-441. pl.

1878.1

Heinen, A. Die planktonischen Fischeier und Larven der Ostsee. Wiss. Meeresuntersuch. Kiel (Abt. Kiel), 1912, n. s. 14, 129-189.

1912.1

Heinrich, Albin. Mährens und K. K. Schlesiens Fische, Reptilien, und Vögel. Ein Beitrag zur Fauna beider Kronländer. Brünn, 1856. 200 p. $8^{\circ}$. 1856.1

Heinrich, Auqust. Die Bewegungen der fliegenden Fische durch die Luft. Jahresber. Akad. Naturw. Ver. Graz, 1879, 5. Jahrg., 19-21.

1879.1

Heinricius, Johan. Beskrifning öfver stor lojo sockn i Nyland, 1766. Utgifven af Robert Boldt. Geogr. Fören. Tidskr., 1895, 7, 4-5; 161-201. 1895.1

Heinroth, $O$. Untersuchungen über den Fischharn. Kiel, 1895. 16 p. $8^{\circ}$.

1895.2

Heintz, Karl. Die Salmoniden Bosniens und der Herzegorvina. Oesterreich. Fisch. Zeitg., 1910, 7, 287-290.

1910.1

Der Angelsport im Süsswasser. 2. ed. München \& Berlin, 1911. 404 p. 4 pls. \& 319 figs. $8^{\circ}$.

1911.1

Helbing, Hermann. Beiträge zur Anatomie und Systematik der Læmargiden. Anat. Anz., 1902, 21, 658-668. Nova Acta Acad. Leop., Halle, 1902, $82,335-524.2 \mathrm{pls}$.

1902.1

- Ueber den Darm einiger Selachier. Anat. Anz., 1903, 22, 400-407. 3 figs.

1903.1

— Beiträge zur Anatomie und Systematik der Læmargiden. Nova Acta Acad. Leop., Halle, 1904, 82, 335-528. pls, \& figs. - C. R. 6. Congr. Intern. Zool. Berne, 1905, 329. 1904.1

Held, Hans. Beiträge zur Structur der Nervenzellen und ihrer Fortsätze. Arch. Anat. Physiol. (Anat. Abth.) 1895 (1896), 396-416. 2 pls.

1896.1

- Zur Kenntniss einer neurofibrillären Continuität im Centralnerven- system der Wirbeltiere. Arch. Anat. Physiol. (Anat. Abth.), 1905, 55-78. pl.

$190 \div .1$

Die Entwicklung des Nervengewebes bei den Wirbeltieren. Leipzig, 1909. 378 p. 53 pls. \& 275 figs. 1909.1

Helder, $W$. Drei deutsche Raubfische. Blätt. Aquar.-Terrar. Freunde, 1898, 9. Jahrg., 197-199. pl. 1898.1

Die Panzerwelse (Callichthys) Blätt. Aquar.-Terrar. Freunde, 1899, 10. Jahrg., 141-142. fig.

1899.1

_- Die Streifenfarbe (Mullus barbatus L.) Blätt. Aquar.-Terrar. Freunde, 1899, 10. Jahrg., 172-173. fig. 1899.2

Heldreich, Theodor von [1822-1902] La faune de Grèce. Part 1. Athènes, 1878. $8^{\circ}$. 1878.1

Poissons, p. 77-103.

Helland, Amund Theodor [1846-] Ferskvandsfiskenes indvandring i Norge IDie Einwanderung der Süsswasserfische in Norwegen] Naturen, Bergen, 1908, 32, 172-179. - Norsk Tidskr. Fiskeri, 37, 161-167. 1908.1

Hellander, Anders. Kort underrättelse om Utsjoki by i Torneå lappmark samt dess Inbyggares lefnadssätt, tillstånd, vilkor, m.m. Abo Tidn., 1772, 2, 93-109.

1772.1

Helland-Hansen, Björn. Statistical research into the biology of the haddock and cod in the North sea. Conseil Perman. Intern. Explor. Mer, Rapp., $1909,10 \mathrm{~B}$, no. 1, 62 p. 35 figs. 1909.1

Helland-Hansen, Björn, \& Nansen, Fridtjof. Die jährlichen Schwankungen der Wassermassen im norwegischen Nordmeer in ihrer Beziehung zu den Schwankungen der meteorologischen Verhältnisse, der Ernterträge und der Fischereiergebnisse in Norwegen. Intern. Rev. Hydrobiol. \& Hydrogr., 1909, 2, 337-361.

1909.2

Hellenius, Carl Nicolas (resp.) Dissertatio sistens insecta piscatoribus in maritimes Finlandix oris noxia. Aboæ, 1769. See Gadd, P.A. (proses) 1769.1

Anmärkningar öfver laklefvermasken. K. Svensk. Vetensk. Akad. Handl., 1785, 6, 180-191. pl. 1785.1

(proses) Specimen calendari floræ et faunæ Aboensis. Inaug. Dissert. Abo, 1786.20 p. $4^{\circ}$. 1786.1

Johan Gustaf Justander, respond. 
Heller, Camil [1823-] Die Scen Tirols und ihre Fischfauna. Innsbruck, 1869. $4^{\circ}$.

1869.1

- Die Fische Tirols und Vorarlbergs. Zeitschr. Ferdinandeums, 1871, 3. ser. 16. Heft, 295-369. Also separate; Innsbruck, 1872.77 p. $8^{\circ} .1871 .1$

Heller, E., \& Snodgrass, R.E. See Snodgrass \& Heller.

Hellmann, Entwickelung des Labyrinths bei Torpedo. Verh. Deutsch. Otol. Ges. Wurzburg, 1898. 1898.1

Helly, Konrad. Acidophil gekörnte Becherzellen bei Torpedo marmorata. Arch. Mikr. Anat., 1905, 66, 434-439. pl.

1905.1

\section{Helm, F., \& Meyer, A.B. See Meyer \& Helm.}

Helmersen, Gregor von [1803-1885] Sur les ichthyodorulites des terrains russes. L'Institut, 1842,10 , no. 452 , 304

1842.1

Helmholtz, $W$. Ueber einige Gesetze der Verteilung elektrischer Ströme in körperlichen Leitern mit Anwendung auf die thierischen elektrischen Versuche. Annalen Physik (Poggendorf), 1853,89 .

1853.1

Hélot, Paul. Note sur les mœurs et sur la reproduction du poisson de paradis (Macropode de Chine, Polyacanthus viridi-auratus) Bull. Soc. Amis Sci. Nat. Rouen, 1876, 2. sér. 12, 125-133.

1876.1

Hemmen, Nachricht von der trocknen Zubereitung der Fische für ein Naturalien-Cabinet. 1777,11 , no. $3,26-29$.

Naturforscher, 1777.1

Hemprich, F.G., \& Ehrenberg, C.G. Symbolæ physicx, seu icones adhuc ineditæ corporum naturalium novorum aut minus cognitorum qua ex itineribus per Libyam, Egyptiam, Nubiam, Dongolam, Syriam, Arabiam et Habessiniam publico institutis sumptu . . studio annis MDCCCXX-MDCCCXXV redierunt. Zoologica. Berlin, 1899.

1899.1

A posthumous series of plates, the fishes published under the editorship of $F$. Hilgendorf.

Hencke, Hermann. Girardinus decemmaculatus Jen., und G. caudimaculatus Heus. Nerthus, Altona, 1902, 4, 33-34.

1902.1
Henderson, Yandell. Contributions to biology from investigations on the breeding salmon. Pop. Sci. Monthly, $1902,60,503-512$.

1902.1

Hendricks, Karl. Zur Kenntnis des gröberen und feineren Baues des Reusenapparates an den Kiemenbögen von Selache maxima Cuvier. Zeitschr. IViss. Zool., 1908, 91, 427-509. 2 pls. \& 5 figs.

1908.1

Ueber den Reusenapparat an den Kiemenbögen des Riesenhaies (Selache maxima Cuvier) Sitzber. Nat. Ver. Preuss. Rheinl. Westfalen, 1908 (1909), C, 31-37.

1909.1

Hendschel, _ Salz als Heilmittel gegen Parasiten an Forellen. Mitth. Fischereiwesen, München, 1878, 3. Jahrg., 55-56. 1878.1

Henking, Hermann [1858-] Die Fische der Oceane und der Tiefsee und die Ausbreitung unserer Seefischerei. Mitth. Deutsch. Seefischerei Ver., 1899 14, 39-44. 1899.1

Vernacular names in various languages are given of the principal species of marine fish used for food.

Die Befischung der Nordsee durch deutsche Fischdampfer. Mitth. Deutsch. Seefischerei Ver., 1901, 17, 320. map.

1901.1

Die Expedition nach der BärenInsel im Jahre 1900. [n. p.] 1901. 4 pls. map.

1901.2

- Norwegens Seefischerei (mit Ausnahme des Herrings-, Austern und Walfanges) und die damit in Verbindung stehenden Industrie und staatlichen Förderungsmittel. Mit einem Anhang von Franz Lehmann. Abh. Deutsch. Seefischerei Ver., 1901, 6, 2574. 9.pls. 1901.3

Ueber das periodische Auftreten der wichtigsten Nutzfische im Nordseegebiet und Skagerak nach den Fangergebnissen deutscher Fischdampfer. Conseil Perm. Intern. Explor. Mer, Rapp \& Proc. Verb., 1905, 3 (Append. F), édition allemande, 1-29. 2 maps. 1905.1

Die Tätigkeit des Deutschen Seefischerei-Vereins auf statistischem Gebiete bis zum Schluss des Statsjahres 1904 (In Die Beteiligung Deutschlands an der internationalen Mecresforschung, 3. Jahresber., p. 95-191. pl. Berlin, 1906)

1906.1

_ Eine Fahrt des "Poseidon" in das Fanggebiet der grossen Herings- 
fischerei, Sept. 1905. Mitth. Deutsch. Seefischerei Ver., 1907, 23, 243-305. map. 1907.1

Der Aalfang in den Lagunen von Comacchio und Venedig. Ergebnisse einer Studienreise. No. 1. Mitth. Deutsch. Seefischerei Ver., 1908, 24, 366-393. 17 figs.

1908.1

Article no. 2, under the same title, Ibid., p. $394-404$, is by H. O. Lübbert, $q$. v.

Bericht über die statistischen Arbeiten und sonstigen Untersuchungen des Deutschen Seefischerei-Vereins nach internationalen Vereinbarungen (In Die Beteiligung Deutschlands an der internationalen Meeresforschung, 4.-5. Jahresber., 157-257. Berlin, 1908)

1908.2

Die Statistik der deutschen Schollenfischerei im Nordseegebiet. Berlin, 1911. map.

1911.1

Das Meer als Nahrungsquelle. Meereskunde, 1913, 7. Jahrg., 1-30.

1913.1

Henking, Hermann, Decker, W., \& Heincke, Friedrich. See Decker, Heincke \& Henking.

Henking, Hermann, \& Heincke, Friedrich. See Heincke \& Henking.

Henking, Hermann, Trybom, $F$., \& Grimm, O. von. See Grimm, Henking \& Trybom.

Henle, Friedrich Gustav Jacob [18071885] Sur le Narcine, nouveau genre de raies électriques, suivi d'un synopsis des raies électriques en géneral. Ann. Sci. Nat. (Zool.), 1834, 2, 311-315. Also separate; Berlin, 1834. fig. $4^{\circ}$. Reviews in Arch. Naturgesch., 1834, 2. Jahrg., 269. — Isis (Oken), 1834, 1, 66. 1834.1

Henle, Friedrich Gustav Jacob, \& Müller, Johannes. See Müller \& Henle.

Henn, Arthur Wilbur [1890-] On various South American poecilid fishes. Ann. Carnegie Mus., 1916, 10, no. 1-2, 93-142. 4 pls. \& 17 figs.

1916.1

Henn, Arthur W., \& Eigenmann, Carl $H$. See Eigenmann \& Henn.

Henn, Arthur W., Eigenmann, Carl H., \& Wilson, Charles. See Eigenmann, Henn \& Wilson.

Hennah, Thomas Henry. On the scales of fish. Proc. Brighton Sussex Nat. Hist. Soc., 1873, 20, 55-57. 1873.1
Henneguy, Louis Félix. Recherches sur la vitalité des spermatozoïdes chez la truite. C. R. Acad. Sci. Paris, 1877, 84, 1333-1335. - C. R. Mém. Soc. Biol. Paris, 1877 (1879), 6. sér. 4, 274-275.

1877.1

- Procédé technique pour l'étude des embryons de poissons. Bull. Soc. Philom. Paris, 1879, 3, 75-77.-Ann. Mag. Nat. Hist., 5. ser. 3, 240-241. Pop. Sci. Rev., 1879, n. s. 3, 209-210.

1879.1

- Note sur quelques faits relatifs aux premiers phénomènes du développement des poissons osseux. Bull. Soc. Philom. Paris, 1880, 4, 132-135. - Ann. Mag. Nat. Hist., 5. ser. 6, 402-404.

1880.1

Formation du germe dans l'œuf des poissons osseux. C. R. Mém. Soc. Biol. Paris, 1880 (1881), 7. sér. 2, 215217.

1881.1

Sur la formation des feuillets embryonnaires chez la truite. C. R. Acad. Sci. Paris, 1882, 95, 1297-1299.

1882.1

Sur un infusoire flagellé ectoparasite des poissons. C. R. Acad. Sci. Paris, 1883, 76, 658-660. - Ann. Mag. Nat. Hist., 5. ser. 11, 293-294. 1883.1

Sur la ligne primitive des poissons osseux. Zool. Anz., 1885, 8, 103108. - Journ. Roy. Micr. Soc, 5, 425.

1885.1

- Sur une nouvelle maladie des alevins de salmonides. Bull. Soc. Acclim. Paris, 1886. 2 p. $\quad 1886.1$

- Sur le mode d'accroissement de l'embryon des poissons osseux. C. R. Acad. Sci. Paris, 1887, 104, 85-87.

1887.1

Recherches sur le développement des poissons osseux: embryogonie de la truite. Journ. Anat. Physiol., Paris, 1888, 24, 1-183. Also separate; Paris, 1889. $8^{\circ}$. 1888.1

_L Le corps vitellin de Balbiani dans l'ouf des vertébrés. Journ. Anat. Physiol. Paris, 1893, 29, 1-39. pl.

1893.1

Sur la structure de la glande nidamenteuse de l'oviducte des sélaciens. C. R. Soc. Philom., 1893, no. 16, 2-3.

1893.2

Histogenèse de la corde dorsale. C. R. Mém. Soc. Biol. Paris, 1907, 63, 510-512.
1907.1 
Hennequin, $A l$. Note sur la pêche au chalut et autres filets trainants, suivie de quelques considérations générales sur l'industrie de la pêche côtière. Bull. Soc. Acclim. Paris, 1867, 2. sér. 4, $57-76$.

1867.1

Hennig, A., \& Törnebohm, A. E. See Törnebohm \& Hennig.

Hennig, Edwin. Ueber Schleierschwanzzucht. Blätt. Aquar-'Terrar. Kunde, 1904, 15. Jahrg., 82-84. 1904.1

Gyrodus und die Organisation der Pyknodonten. Palæontographica, 1906, 53, 137-206. 4 pls. \& 16 figs.

1906.1

Macropetalichthys pelmensis, $\mathrm{n}$. sp. Centralbl. Min. Geol. Pal., Stuttgart, 1907, 584-591. 5 figs.

1907.1

Ueber einige Pyknodonten $\mathrm{M} e$ sodon spinosum, n. sp.] vom Libanon. Centralbl. Min. Geol. Pal., Stuttgart, 1907, 360-371. 5 figs.

1907.2

- Saurichthys-Funde von Rüdersdorf. Centralbl. Min. Geol. Pal., Stuttgart, 1909, 54-60. 3 figs.

1909.1

_- Die Fischreste. A. Selachia. B. Teleostomata (In Die PithecanthropusSchichten auf Java; geologische und paläontologische Ergebnisse der TrinilExpedition, 1907 und 1908, herausgegeben von L. Selenka und M. Blanckenhorn. p. 54-60. pl. Leipzig, 1911)

1911.1

—- Die Fischfauna der Kreidezeit. Sitzber. Ges. Naturf. Freunde Berlin, 1912, 483-493. Review in Neues Jahrb. Mineral., 1913, 165-166.

1913.1

Ueber neuere Funde fossiler Fische aus Aequatorial- und Südafrika und ihre paläogeographische Bedeutung. Sitzber. Ges. Naturf. Freunde Berlin, 1913, 305-318.

1913.2

Henninger, Gustav. Die Labyrinthorgane bei Labyrinthfischen. Zool. Jahrb. (Abt. Anat.), 1908, 25, 251-304. 4 pls. \& 3 figs. Review in Nat. Rundschau, 1908, 23. Jahrg., 198-200. 1908.1

Henriksen, Hans Peter. Bestemmolsestabeller over de i Danske farvande forekommende fiskearter. Act. Soc. Flor. \& Faun. Fenn., 1904, 4, 73-114; 125-126.

1904.1

Henriques, $J$. Principes généraux de jurisprudence sur les droits de chasse et de pêche suivant le droit commun de la France. Paris, 1775. $4^{\circ} . \quad 1775.1$
Henry, George M. Fishes of Batticaloa, Trincomalee, and Jaffna. Spolia Zeylanica, 1912, 8, 62-64. $\quad 1912.1$

Henry, Joseph, \& Baird, Spencer $F^{\prime}$. Collection to illustrate the fishery resources of the United States. Rod \& Gun, 1875, 7, 105.

1875.1

Henschel, $G$. Anleitung zur Bestimmung unserer Süsswasserfische. Wien, 1890. illust. $12^{\circ}$.

1890.1

Hensel, Reinhold Friedrich [18261881] Beiträge zur Kenntniss der Wirbelthiere Südbrasiliens. Arch. Naturgesch. (Wiegmann), 1868, 356-375.

1868.1

The freshwater fishes of southern Brazil. Arch. Naturgesch. (Wiegmann), 1870, 50-91.

1870.1

Hensen, Victor Andreas Christian [1835 - ] Befischung der deutschen Küsten. Berlin, 1874. 9 maps. fol.

1874.1

- Bemerkungen gegen die Cupula terminalis (Lang.) Arch. Anat. Entwickl., 1878, 486-490. figs. 1878.1

Ueber das Verhalten der Fische des Meeres beim Laichen und die Wichtigkeit dieses Vorganges für die Fischer. Kiel, 1880. 15 p.

1880.1

_- The spawning process of saltwater fish, and its importance to fishermen. Rept. U. S. Fish Comm. 1879 (1882), 7, 548-557. 2 figs. $\quad 1882.1$

- Ueber das Vorkommen und die Menge der Eier einiger Ostseefische, insbesondere derjenigen der Scholle (Platessa platessa), der Flunder (Platessa vulgaris), und des Dorsches (Gadus morrhua L.) 7.-9. Jahresber. Komm. Wiss. Untersuch. Deutsch. Meere Kiel, 1883, 2. Abth., 299-313.

1883.1

On the occurrence and quantity of the eggs of some of the fish of the Baltic, especially those of the plaice ( $P l a-$ tessa platessa), the flounder (Platessa vulgaris), and the cod (Gadus morrhua) Rept. U. S. Fish Comm. 1882 (1884), $10,427-454$.

1884.1

Bemerkung zu vorstehender Arbeit [von J. Reibisch] Wiss. Meeresuntersuch. Deutsch. Meere Kiel (Abt. Kiel), 1899, 2. ser. 4, 249-253. 1899.1

Bericht über die dreissigjährige Thätigkeit der kgl. preussischen Kommission zur wissenschaftlichen Unter- 
suchung der deutschen Meere im Interesse der Fischerei. Mitth. Deutsch. Seefischerei Ver., 1901, 17, 173-179.

1901.1

Ergänzungen und Berichtigung zu den Befunden über die im Anfang des Jahres 1895 in der Nordsee treibend gefundenen Fischeier. Wiss. Meeresuntersuch. Deutsch. Meere Kiel (Abt. Kiel), 1901, 2. ser 5, 152-170. 2 figs.

1901.2

Ueber die Bestimmung des Fischbestandes im Meer. Vortrag, gehalten am 18. Juni $1911 \mathrm{im}$ Schleswig-holsteinischen Naturwissenschaftlichen Verein. Ergänzt zum Zweck dieser Veröffentlichung. Wiss. Meeresuntersuch. Deutsch. Meere Kiel (Abt. Kiel), 1911, 2. ser. 14, 1-32. map.

1911.1

Hensen, Victor A. C. \& Apstein, $C$. Ueber die Eimenge der im Winter laichenden Fische (In Die NordseeExpedition 1895 des Deutschen Seerischereivereins. Wiss. Meeresuntersuch. Deutsch. Meere (Abt. Kiel), 1897, 2. ser. 2, pt. 2, 1-97. 20 pls.) 1897.1

Henshall, James Alexander. Are fish nearsighted? Forest \& Stream, $1878,11,405$. 1878.1

The black bass and his place among fishes. Forest \& Stream, 1878, 11, 180-181.

1878.2

The black bass. Chicago Field, 1880, 13, 279; 413-414. Ibid., 1880, 14, 25-26.

1880.1

- Grubs in fish. Forest \& Stream, $1880,15,241$.

1880.2

Book of the black bass . . Cincinnati. 1881. viii, 463 p. pls. \& figs. $8^{\circ}$.

1881.1

- On the distribution of the black bass. Trans. Amer. Fish-cult. Assoc., 12. ann. meet., 1883, 21-26.

1883.1

Camping and cruising in Florida. Cincinnati, 1884. xvi, 248 p. pls. figs. map.

1884.1

A list of fishes observed in Florida, p. 235-248.

Comparative excellence of food fishes. Trans. Amer. Fish-cult. Assoc., 13. ann. meet., 1884, 115-122. 1884.2

On stocking waters with black bass, 8. Ann. Rept. Ohio Fish Comm. 1883 (1884), 36-39.
On the black bass [collated from "The black bass, its culture, etc." ] 8. Ann. Rept. Ohio Fish Comm. 1883 (1884), 29-36.

1884.4

- Hibernation of the black bass.

Trans. Amer. Fisheries Soc., 14. ann. meet., 1885, 12-17.

1885.1

Contributions to the ichthyology of Ohio. No. 1-2. Journ. Cincinnati Soc. Nat. Hist., $1888,11,76-80 ; 122$ 126.

1888.1

On some peculiarities of the ova of fishes. Journ. Cincinnati Soc. Nat. Hist., 1888, 11, 81-85. 1888.2 - More about the black bass. Cincinnati, 1889. 204 p. figs. $4^{\circ}$. 1889.1

A supplement to the "Book of the black bass." On a collection of fishes from east Tennessee. Journ. Cincinnati Soc. Nat. Hist., 1889, 12, 31-33. 1889.2

- Some observations on Ohio fishes. Journ. Cincinnati Soc. Nat. Hist., 1890, 12, 114-125. 1890.1

Report upon a collection of fishes made in southern Florida during 1889. Bull. U. S. Fish Comm. 1889 (1891), 9, 371--389. Also separate; Washington, 1891. 1891.1

- On fish protection. Trans. Amer. Fisheries Soc. 1890 (1891), 79-84. 1891.2

Teeth of fishes as guide to food habits. Trans. Amer. Fisheries Soc. 1891 (1892), 24-30.

1892.1

Notes on fishes collected in Florida in 1892. Bull. U. S. Fish Comm. 1894 (1895), 14, 209-221. 1895.1

Some preliminary observations concerning the artificial culture of the grayling. Minutes Amer. Fisheries Soc., 27. ann. meet., 1898, 105-108. 1898.1

Some notes on the Montana grayling. Proc. Amer. Fisheries Soc., 28. ann. meet., 1899, 80-85. $\quad 1899.1$

-Hints on grayling culture. Trans. Amer. Fisheries Soc., 29. ann. meet. 1900, 109-117. $\quad 1900.1$

Practical hints on fish culture. Trans. Amer. Fisheries Soc., 30. ann. meet., 1901, 101-104.

1901.1

Food and game fishes of the Rocky mountain region. Trans. Amer. Fisheries Soc., 31. ann. meet., 1902, 74-88.
1902.1 
Henshall, $J . A$.

Bass, pike, perch and others. London \& New York, 1903. xix, $410 \mathrm{p}$. 20 pls. \& figs. $8^{\circ}$. 1903.1

Blood as fish food. Trans. Amer. Fisheries Soc., 32. ann. meet., 1903, 6370 .

1903.2

Angling talks. Amer. Fish Culturist, 1904, 12-14. 1904.1

Book of the black bass, Mieropterus, 2. ed. Cincinnati, 1904. v, $452 \mathrm{p}$. pls. illust.

1904.2

- Experiments in feeding fry. Trans. Amer. Fisheries Soc., 33. ann. meet., 1904, 76-81. figs.

1904:3

On the protection of fish in inland waters. Trans. Amer. Fisheries Soc., 34. ann. meet., 1905, 139-147.

1905.1

A list of the fishes of Montana; with notes on the game fishes. Bull. Univ. Montana, 1906, no. 34. 12 p. 1906.1

Culture of the Montana grayling. Rept. Comm. Fisheries 1906 (1907), Bur. Fish. Doc. no. 628, 1-7. 1907.1

Favorite fish and fishing. New York, 1908. xii, 192 p. illust. 1908.1

Henshaw, Henry Wetherbee, \& Jordan, David Starr. See Jordan \& Henshaw.

Henshaw, Henry Wetherbee, \& Yarrow, Harry Crécy. See Yarrow \& Henshaw.

Hensman, John T. American black bass placed in the river Nene, England. Bull. U. S. Fish Comm. 1884, 4, 166.

1884.1

Hentschel, Ernst. Das Leben des Süsswassers; eine gemeinverständliche Biologie. München, 1909. 336 p. 16 pls. \& 229 figs. $8^{\circ}$.

1909.1

Hepner, $J$., \& Babák, E. See Babảk \& Hepner.

Heppe, J. C. Abbildung und Beschreibung der Fische. 2. ed. Nürnberg, (1782) 1787. 19 pls. $8^{\circ}$. 1782.1

The same: 3. ed. Nürnberg, 1800. 306 p. 69 pls. $8^{\circ}$. 1800.1

Herbert, David (editor) Fish and fisheries; a selection from the prize essays of the International Fisheries
Exhibition, Edinburgh, 1882. Edinburgh \& London, 1883. xlviii, 352 p. maps \& illust.

Herbert, Henry William [rank Forester, pseudon.] [1807-1858] Frank Forester's fishermens' [sic] guide; a manual for professional and amateuer [sic] anglers. Containing descriptions of popular fishes and their habits, preparation of baits, \&c., with a list of tools used in fishing; making it the most complete work on the subject yet published. New York [18-] 64 p. pls. $8^{\circ}$.

Frank Forester's fish and fishing of the United States and British provinces of North America, edited by $\mathrm{H}$ W. Herbert. London, 1849. xvi, 455 p.

1849.1

The same. 2. ed. New York, 1850. xvi, 359 p. $8^{\circ}$ $359 \mathrm{p}$.

he same. 3. ed. New York, 1851. xviii, Supplement to Forester's "Fish and fishing." New York, 1850. $4^{\circ}$.

1850.1

American game in its seasons. New York, 1853. 343 p. figs. $8^{\circ}$.

1853.1

Contains notes on the salmon and perch. A revised edition was published in 1873 .

Frank Forester's fish and fishing of the United States and British provinces of North America. New ed., revised and corrected, with an ample supplement by the author. ... New York, 1864. 12 pls. $8^{\circ}$.

18641

Life and writings of Frank Forester (H. W. Herbert) Edited by D. W. Judd. 2 vols. New York, 1882. pls. $12^{\circ}$ 1882.1

"Life," by Thomas Picton, vol, i, p. 11-104.

"Sketches which were scattered through various periodicals, or were never published. The illustrations are by Charles Hinkle." Preface.

"Trouting along the Catasauqua," vol. i, p. 270-300.

"The smelt of the Passaic," vol. ii, p. 97-107.

"The smelt of the Raritan and Passaic," vol. ii, p. 231-235.

Herdman, William Abbolt [1858-] (edilor) The first [1. to 5.] report upon the fauna of Liverpool bay and the neighbouring seas. Liverpool, 1886. 372 p. 10 pls. \& 2 maps. $8^{\circ}$. 1886.1 Second to fifth reports, 1589-1900.

The foundation and first season's work of the Liverpool Marine Biological Station on Puffin island. Liverpool, 1888. 29 p. $8^{\circ}$. 1888.1 Second to twenty-eighth annual reports, edited by Herdman, 1888-1914. 
Report on the investigations carried on in 1892 in comnection with the Lancashire Sea-Fisheries Laboratory at. University College, Liverpool. Rept. Lancashire Sea-Fish. Labor. Liverpool, 1892 (1893), 1-48. 5 pls.

1893.1

Food of fishes. First list of the fishes of the district from the Solway to the north coast of Wales, and including the Isle of Man.

Catalogue of the "Fisheries collection" in the zoological department, University College, Liverpool. Proc. Liverpool Biol. Soc., 1897, 11, 94-126.

1897.1

- The sea-fish hatching experiments. Rept. Lancashire Sea-Fish. Labor. Liverpool, 1896 (1897), 11-15. Trans. Liverpool Biol. Soc., 11, 67-71. 3 pls.

1897.2

The biological station at Port Erin, being the 16th annual report of the Liverpool Marine Biology Committee. Proc. Trans. Liverpool Biol. Soc., 1903, 17, 15-67.

1903.1

The future of British fisheries investigation. Rept. Lancashire SeaFish. Labor. Liverpool, 1902 (1903), 3954. fig.

1903.2

Scheme for the investigation of the Irish sea. Rept. Lancashire SeaFish. Labor. Liverpool, 1902 (1903), 55-67.

1903.3

Spawning of the plaice. Nature, $1903,69,465 ; 488$

1903.4

Technical instruction in seafisheries science. Rept. Lancashire SeaFish. Labor, Liverpool, 1902 (1903), 101-106. - Trans. Liverpool Biol. Soc., $1903,17,125-140 ; 141-153 ; 187-192$. fig.

1903.5

Ascidians and Amphioxus (In the Cambridge Natural History, vol. vii, p. 33-138. 76 figs. London, 1904) Review in Science, 1904, n. S. 21, 653661.

1904.1

- Sea-fish hatching and rearing. Proc. Trans. Liverpool Biol. Soc., 1905, $19,26-37$.

1905.1

Sea-fish hatching at Port Erin in 1905. Rept. Lancashire Sea-Fish. Labor. Liverpool, 1905 (1906), 203208. - Trans. Liverpool, Biol. Soc., 20, $347-352$.

1906.1

- Sea-fisheries research in England. Proc. Trans. Liverpool Biol. Soc., 1907, 21, 109-128.
Calanus, a further record. Nature, London, 1913, 91, 636.

- Mackerel and Calanus. Nature, London, 1913, 91, 504-505. 1913.2

(cditor) Report for 1912 on the Lancashire Sea-Fisheries Laboratory at the University of Liverpool, and the Sea-Fish Hatchery at Piel. Introduction, p. 1-13. Liverpool, 1913. 1913.3

Herdman, William Abbott, \& Corbin, $P . F . J$. The food of young fishes (In Report on the investigations carried on in 1893 in connection with the Lancashire Sea-Fisheries Laboratory at University College, Liverpool. Proc. Trans. Liverpool Biol. Soc., 1894, 8, 57-92). Rept. Lancashire Sea-Fish. Labor. Liverpool, 1893 (1894), 1-36.

1894.1

Herdman, William Abbott, \& Dawson, $R . A$. Fishes and fisheries of the Irish sea and especially of the Lancashire and western sea-fisheries district. London, 1902. 98 p. 14 figs. $4^{\circ}$. Review in Science, 1902 , n. s. 16, 305306.

1902.1

Herdman, William Abbott, \& Riddell, William. The plankton on the west coast of Scotland in relation to that of the Irish sea. Part III. Rept. Lancashire Sea-Fisheries Labor. Liverpool, 1912 (1913), 168-195. fig. \& 7 tables.

1913.1

Herdman, William Abbott, \& Scott, Andrew. Report on the investigations carried on in 1894-1896 in connection with the Lancashire Sea-Fisheries Laboratory at University College, Liverpool. Rept. Lancashire Sea-Fish. Labor. Liverpool, 1894, 1-59. Ibid., 1895, 1-74. 5 pls. Ibid., 1896, 1-73. 4 pls. - Proc. Biol. Soc. Liverpool, 9, 104-162. 1894.1

Examination of food in stomachs. Distribution of immature and other fish. Faunistio investigations.

Report for 1896 on the Lancashire Sea-Fisheries Laboratory at University College, Liverpool, with a catalogue of the "Fisheries Collection" in the zoological department, University College, Liverpool. Trans. Liverpool Biol. Soc., 1897, 11, 57-126. Also separate; Liverpool, 1897. 73 p. 4 pls. $8^{\circ}$. 1897.1

Herdman, William Abbott, Scott, Andrew, \& Johnstone, James. Report on the investigations carried on in 1899 in connection with the Lancashire SeaFisheries Laboratory at University Col- 
Herdman, $W . A$

lege, Liverpool, and the Sea-Fish Hatchery at Piel, near Barrow. Rept. Lancashire Sea-Fish. Labor. Liverpool, 1889 (1890), 1-117. 6 pls. \& map.

1890.1

Sea-fisheries conferences and the need of a "census." Hatchery work at Piel. Note on the American shad. Notes on the white fluke or flounder.

Report on the investigations carried on in 1897 in connection with the Lancashire Sea-Fisheries Laboratory at University College, Liverpool, and the Sea-Fish Hatchery at Piel, near Barrow. Rept. Lancashire Sea-Fish. Labor. Liverpool, 1897 (1898), 1-52. - Trans. Liverpool Biol. Soc., 12, 176-227. 1898.1

Sea-fisheries exhibition at Liverpool. Experimental sea-fish hatching and rearing. Note upon the shad.

Report on the investigations carried on in 1898 in connection with the Lancashire Sea-Fisheries Laboratory at University College, Liverpool, and the Sea-Fish Hatchery at Piel, near Barrow. Proc. Trans. Liverpool Biol. Soc., 1899, 13, 69-155. - Rept. Lancashire SeaFish. Labor. Liverpool, 1898 (1899), 1-87. 2 pls.

1899.1

Fish hatching work at Piel. Observations on Leptocephalus. Observations on habits and food of young fishes. On sea-fish hatching.

Report on the investigations carried on during 1900 in connection with the Lancashire Sea-Fisheries Laboratory at University College, Liverpool, and the Sea-Fish Hatchery at Piel, near Barrow. Rept. Lancashire Sea-Fish. Labor. Liverpool, 1900 (1901), 1-115. 9 pls.

1901.1

Required survey of fishing grounds. Fish hatching at Piel. Note on a sporozoon parasite of the plaice. On the fish parasites Lepeophtheirus and Lernæa.

Report on the investigations carried on during $190 t$ in connection with the Lancashire Sea-Fisheries Laboratory at the University of Liverpool, and the Sea-Fish Hatchery at Piel, near Barrow. Rept. Lancashire Sea-Fish. Labor. Liverpool, 1904 (1905), 1-128. pls. \& figs. - Proc. Trans. Liverpool Biol. Soc., 19, 181-304.

1905.1

Sea-fish hatching at Piel. Experiments on marking living fishes. Internal parasites and diseased conditions of fishes. Abnormally scaled flounders.

Report on the investigations carried on during 1905 in connection with the Lancashire Sea-Fisheries Laboratory at the University of Liverpool, and the Sea-Fish Hatchery at Piel, near Barrow. Rept. Lancashire Sea-Fish.
Labor. Liverpool, 1905 (1906), 1-208. pls. \& figs.

1906.1

Sea-fish hatching at Piel. Marked fish experiments. Parasites of fishes. Ichthyological notes. Sea-fish hatching at port Erin.

Report on the investigations carried on during 1906 in connection with the Lancashire Sea-Fisheries Laboratory at the University of Liverpool, and the Sea-Fish Hatchery at Piel, near Barrow. Rept. Lancashire Sea-Fish. Labor. Liverpool, 1906 (1907), 1-269. pls. \& figs.

1907.1

Sea-fishery research. Sea-fish hatching at Piel. Notes on food of young fishes.

Report on the investigations carried on during 1907 in connection with the Lancashire Sea-Fisheries Laboratory at the University of Liverpool, and the Sea-Fish Hatchery at Piel, near Barrow. Rept. Lancashire Sea-Fish. Labor. Liverpool, 1907 (1908), 1-406. pls. \& figs. 1908.1

Sea-fish hatching at Piel. Marked fish experiments. Parasites of fishes.

Report on the investigations carried on during 1908 in connection with the Lancashire Sea-Fisheries Laboratory at the University of Liverpool, and the Sea-Fish Hatchery at Piel, near Barrow. Rept. Lancashire Sea-Fish. Labor. Liverpool, 1908 (1909), 1-366. 4 pls. \& 34 figs. - Trans. Liverpool Biol. Soc., 23, 103-334. 4 pls. \& 34 figs. 1909.1

Sea-fish hatching at Piel. Marked fish experiments. Plaice measurements made during 1908. Parasites of fishes.

Report on the investigations carried on during 1909 in connection with the Lancashire Sea-Fisheries Laboratory at the University of Liverpool, and the Sea-Fish Hatchery at Piel, near Barrow. Rept. Lancashire Sea-Fish. Labor. Liverpool, 1909 (1910), 1-297. pls. \& figs. - Trans. Liverpool Biol. Soc., 24, 63-359. 8 pls. \& 53 figs. 1910.1

Sea-fish hatching at Piel. Internal parasites of Irish sea fishes. Report on plaice measurements.

Herdman, William Abbott, Scott, Andrew, Johnstone, James, \& Cole, $F . J$. Report on the investigations carried on during 1901 in connection with the Lancashire Sea-Fisheries Laboratory at University College, Liverpool, and the Sea-Fish Hatchery at Piel, near Barrow. Rept. Lancashire Sea-Fish. Labor. Liverpool, 1901 (1902), 1-240. 11 pls.

1902.1

Sea-fish hatching at Piel. Memoir on the common plaice. 
Herdman, William Abbott, Scott, Andrew, \& Lewis, H. Mabel. An intensive study of the marine plankton around the south end of the Isle of Man. Part VI. Rept. Lancashire Sea-Fish. Labor. Liverpool, 1912 (1913), 196-232. pl. \& 5 figs.

1913.1

Herfort, Karl V. Der Reifungsprocess im Ei von Petromyzon fluviatilis. Anat. Anz., 1893, 8, 721-725. figs.Zeitschr. Böhmischer Arzte, 1898. 18 p. 6 figs. Abstract in Journ. Roy. Micr. Soc., 1893, pt. 1, 43 .

1893.1

Die Conjugation der Vorkerne und die erste Furchungsspindel im Ei von Petromyzon fluviatilis. Anat. Anz. 1899, 16, 369-376. 5 figs. Abstract in Journ. Roy. Micr. Soc., 1899, 574-575.

1899.1

Dic Reifung und Befruchtung des Eies von Petromyzon fuviatilis. Arch. Mikr. Anat., 1900, 57, 54-95. 3 pls.

1900.1

Hêricourt, $J ., \&$ Richet, $C h$. Effets lointains des injections de sérum d'anguille. C. R. Mém. Soc. Biol. Paris, $1898,137$.

1898.1

Hering, - von. Beiträge zu der Frage über die Fütterung junger Fische im geschlossenen Raum. Circul. Deutsch. Fischerei Ver., 1871, no. 7, 47.

1871.1

Herissant, S. Ant. Pr. Bibliothèque physique de la France, ou Liste de tous les ouvrages ... qui traitent de l'histoire naturelle de ce royaume. Paris, 1771. $8^{\circ}$.

1771.1

Herklots, Janus Adrian [1820-1872] Deux nouveaux genres de crustacés vivant en parasites sur des poissons: Epichthys et Ichthyoxenos. Arch. Néerl. Indie, 1870, 5, 120-137.Versl. Akad. Wet. Amsterdam, 4, 156171.

1870.1

Herklotz, E. O. Ueber den Geruchund Geschmacksinn der Karpfen. Verh. Zool.-Bot. Gesell. Wien, 1864, 14, 45-47.

1864.1

Hermann, $C . G$. Unterricht für den Landmann Fischteiche anzulegen. Zittau, 1795. $8^{\circ}$.

1795.1

Hermann, Friedrich. Beiträge zur IKenntnis der Spermatogenese. Arch. Mikr. Anat., 1897, 1, 2. Heft, 276-315. pl. 1897.1
In eigener Sache. Eine Erwiderung an Herrn Dr. Rawitz. Anat. Anz., $1898,15,177-179$.

18981

On spermatogenesis among selachians.

—_ Fossilführende Schichten in der oberen Anhydritgruppe bei Künzelsau. Jahresh. Ver. Vaterl. Naturk. Württemberg, 1901, 57. Jahrg., 351-355. 1901.1

Hermann, $G$. Sur la spermatogénèse chez les selaciens. C. R. Acad. Sci. Paris, 1881, 93, 858-860. - Journ. Anat. Physiol., Paris, 23, 373-432. 3 pls. \& 30 figs.

1881.1

Hermann, Johann. Ueber ein neues amerikanisches Fischgeschlecht, Sternoptyx diaphana, der durchsichtige Brustfalten-Fisch. Naturforscher, 1781, 16. Stück, 8-36. Ibid., 1782, 17. Stück, 249-251. pl. \& figs. 1781.1

- Observationes zoologicæ, quibus novx complures, aliæque animalium species describuntur et illustrantur: opus posthumum edidit Fr. L. Hammer. Argentorati [1804] $4^{\circ}$. 1804.1

Hermann, L. Beiträge zur Lehre von den Haut- und Sekretions-Stromen. Arch. Ges. Physiol., 1894, 58, 242-254.

1894.1

Ueber aktive Veränderungen der Hautfarbe bei gewissen Thierarten. Sitzber. Schrift. Physik-ökon. Gesell. Königsberg, 1896, 37. Jahrg., 35-36.

1896.1

Hermann, O. Die ungarische Fischerei. 2 vols. Budapest, 1887. 2 pls. $8^{\circ}$.

1887.1

Hermann, Rudolf. Ueber das Vorkommen hohler Zähne bei fossilen und lebenden Tieren. Sitzber. Ges. Naturf. Freunde Berlin, 1907, 195-201. 5 figs.

1907.1

Figures are given of Jurassic Pycnodont teeth.

Hermes, Otto. Ueber Aalbrut und Aufzucht junger Aale. Circul. Deutsch. Fischerei Ver., 1880, no. 1, 23-25. Oesterr.-ungar. Fischerei Zeitg., 1880, 83-84.

1880.1

Ueber Aalmännchen und Aalweibchen. Circul. Deutsch. Fischerei Ver., 1880, no. 2, 55-57. fig. 1880.2

Ueber die verschiedenen Formen der Reproductionsorgane der Aale. Sitzber. Ges. Naturf. Freunde Berlin, 1880, 27-28.

1880.3

Zur Fortpflanzung des Aales. Circul. Deutsch. Fischerei Ver., 1880, 
Hermes, $O$.

no. 6, 197-201. - Deutsch. Fischerei Zeitg., 1880, 3. Jahrg., 244-245. fig.

1880.4

Ueber reife männliche $\mathrm{Ge}$ schlechtstheile des Seeals (Conger vulgaris) und einige Notizen über den männlichen Flussaal (Anguilla vulgaris Fleming) Zool. Anz., 1881, 4, 39-44. 2 figs. Bull. U. S. Fish Comm. 1881 (1882), 1, 126-130. Abstract in Ausland, 54, 480 .

1881.1

The propagation of the eel. Rept. U. S. Fish Comm. 1879 (1882), 7, 457-462. pl.

1882.1

Ueber die Naturgeschichte des Aales. Sitzber. Ges. Naturf. Freunde Berlin, 1882, 37-38.

1882.2

The migrations of eels. Rept. U. S. Fish Comm. 1884 (1886), 12, 11231126. 1886.1

Translation of "Zur Wanderung der Aale" by Herman Jacobson. From circular no. 2, 1884, of the German Fishery Association, Berlin, February 27,1884

- Aalmännchen im Süsswasser. Allgem. Fischerei Zeitg., 1893, 18. Jahrg., no. $17,258-259$. 1893.1

Herms, Ernst. Ueber die Bildungsweise der Ganglienzellen im Ursprungsgebiete des Nervus acustico-facialis bei Ammocoetes. Sitzber. Bayer. Akad. Wiss., 1885, 14, 333-354. 2 pls. 1885.1

Heron, (Sir) R. On the breeding of goldfishes in the author's menagerie. Ann. Mag. Nat. Hist., 1842, 8, 533.

1842.1

Heronimus, Ch. Die Entwickelung des Brustflossenskelettes bei Amia calva. Anat. Anz., 1911, 39, 193-203. 8 figs.

1911.1

Hêrouard, Edgard [1858 - ] Théorie de la pentasomxa. Bull. Soc. Zool. France, 1904, 29, 70-81. 9 figs. 1904.1

Sur l'embryon d'Amphioxus, p. 72-73.

Hérouard, Edgard, \& Delage, Marie Yves. Sce Delage \& Hérouard.

Herre, Albert Christian, \& Herre, W. A.B. Annotated list of the Marcus island fishes (In Bryan, W. A. A monograph of Marcus island, 1903. Appendix, p. 125-139)

1903.1

Herre, Albert Christian, \& Jordan, David Starr. See Jordan \& Herre.

Herrera, Alfonso L. [1838-1901] Catálogo de la colección de peces del
Museo Nacional. Mexico, 1896. No.6. $88 \mathrm{p}$.

1896.1

Herrick, Charles Judson [1868-] Contributions to the morphology of the brain of bony fishes. Journ. Comp. Neurol., 1891, 1, 211-245. 4 pls. 1891.1

i. Siluridæ, p. 211-228.

ii. Studies on the brains of some American freshwater fishes, p. 228-245.

Topography and histology of the brain of certain ganoid fishes. Journ. Compar. Neurol., 1891, 1, 149-182. 4 pls.

1891.2

The cranial nerve components of teleosts. Anat. Anz., 1897, 13, 425-431.

1897.1

The cranial nerves of bony fishes. Journ. Comp. Neurol., 1898, 8, 162-170. fig.

1898.1

The cranial and first spinal nerves of Menidia; a contribution upon the nerve components of the bony fishes. Journ. Comp. Neurol., 1899, 9, 153-455. Arch. Neurol. Psychopath., 2, 21-319. 7 pls. \& 5 figs.

1899.1

The metameric value of the sensory components of the cranjal nerves. Science, 1899, n. s. 9, 312-313.

1899.2

The peripheral nervous system of the bony fishes Bull. U. S. Fish Comm. 1898 (1899), 18, 315-320. fig.

1899.3

A contribution upon the cranial nerves of the codfish. Journ. Comp. Neurol., 1900, 10, 265-316. 2 pls.

1900.1

The trigemino-facial ganglionic complex of Gadus and Amiurus. Abstract in Science, 1900, n. s. 11, 168-169. 1900.2

The cranial nerves and cutaneous sense organs of the North American siluroid fishes. Journ. Comp. Neurol., $1901,11,177-249$. 4 pls. 1901.1

The feeding habits of fishes. School Science, December, 1902. 3 p. 1902.1

A note on the significance of the size of nerve fibers in fishes. Journ. Comp. Neurol., 1902, 12, 329-334. Reprint in Bull. Scient. Labor. Denison University, 12, 33-38.

1902.2

[Review of] Johnston on the brain of Acipenser, etc. Science, 1902, n. s. 14, 930-931.

1902.3 
- On the morphological and physiological classification of the cutaneous sense organs of fishes. Amer. Naturalist, 1903, 37, 313-318. Abstract in Science, n. s. 17, 251-252. 1903.1

On the phylogeny and morphological position of the terminal buds of fishes. Journ. Comp. Neurol., 1903, 13, 121-138.

1903.2

- The organ and sense of taste in fishes. Bull. U. S. Fish Comm. 1902 (1904), 22, 237-272. figs. Reprint in Bull. Scient. Labor. Denison University, 12, 39-96. 3 figs.

1904.1

The central gustatory paths in the brains of bony fishes. Journ. Comp. Neurol., 1905, 15, 375-456. - Bull. Scient. Labor. Denison University, 13. 35-116. 40 figs.

1905.1

On the centers for taste and touch in the medulla oblongata of fishes. Jourı. Comp. Neurol., 1906, 16, 403439.

1906.1

- On the connections of the funicular nuclei of the brains of fishes. Science, 1906, n. s. 24, 297.

The relation between the nerves of taste and touch in fishes. Proc. Amer. Assoc. Adv. Sci., 55. meet., 1906, 412.

1906.3

The central reflex connections of cutaneous taste buds in the codfish and the catfish. An illustration of functional adaptation in the nervous system. Science, 1907, n. s. 25, 736-737.

1907.1

A study of the vagal lobes and funicular nuclei of the brain of the codfish. Journ. Comp. Neurol., 1907, 17, 67-89. 8 figs.

1907.2

- The tactile centres in the spinal cord and brain of the sea robin, Prionotus carolinus L. Journ. Comp. Neurol., 1907, 17, 307-327. 15 figs.

1907.3

On the commissura infima and its nuclei in the brains of fishes. Journ. Comp. Neurol., 1908, 18, 409-431. 12 figs.

1908.1

The relations of the central and peripheral nervous system in phylogeny. Anat. Record, 1910, 4, no. 2, 59-70.

1910.1

Herrick, Charles Judson, \& Obenchain, Jeannette B. Notes on the anatomy of a cyclostome brain: Ichthyomy- zon concolor. Journ. Comp. Neurol. 1913, 23, 635-675. 12 figs. $\quad 1913.1$

Herrick, Clarence L. [1858-] The commissures and histology of the teleostean brain. Anat, Anz., 1891, 6, 676681.

1891.1

- Additional notes on the teleost brain. Anat Anz., 1892, 7, 422-431. 10 figs.

1892.1

- Notes upon the anatomy and histology of the prosencephalon of teleosts. Amer. Naturalist, 1892, 26. 112-120. 2 pls.

1892.2

Herrick, Clarence L., \& Coghitt, G. E. See Coghitt \& Herrick.

Herring, $P . T$. A contribution to the comparative physiology of the pituitary body. Quart. Journ. Exper. Physiol. London, 1908, 1, 261-280. pl. \& 8 figs.

1908.1

The physiological action of extracts of the pituitary body and saccus vasculosus of certain fishes. Quart. Journ. Exper. Physiol. London, 1908. 1, 187-188.

1908.2

The development of the elasmobranch pituitary. Quart. Journ. Exper. Physiol. London, 1911, 4, 183-191. 5 figs.

1911.1

Herrlein, - Fischereiwesen im Regierungsbezirk Kassel. Circul. Deutsch. Fischerei Ver. 1878 (1879), no. 2, 64-66. 1879.1

Herrmann, G., \& Verdun, P. Les corps post-branchiaux et la thyroide; vestiges kystiques. C. R. Mém. Soc. Biol. Paris, 1900, 52, 936-938. 1900.1

Herrmann, $W$. Die Barbe. Allgem. Fischerei Zeitg., 1904, 29. Jahrg., 133135.

1904.1

Zur Einbürgerung der Regenbogenforelle. Allgem. Fischerei Zeitg., 1907, 32. Jahrg., 140-142. 1907.1

\section{Hersche, —, \& Heuscher, Johan-} nes. See Heuscher \& Hersche.

Herter, $E$. Zur Kenntnis des Stoffwechsels der Fische, speciell der Selachier. Mitth. Zool. Stat., Neapel, 1891, 10, 342-354. $\quad 1891.1$

Hertwig, ‘Carl Wilhelm Theodor] Richard [1850-] Die lymphoiden Drüsen auf der Oberfläche des Störherzens. Arch. Mikr. Anat., 1873, 9, 62-79. pl.
1873.1 
Hertwig, $R$. Lehrbuch der Zoologie. 2 vols. Jena, 1891-92. illust. $8^{\circ}$. 1891.1

Eireife und Befruchtung. Der Furchungsprozess (In Hertwig, O. Handbuch der Entwickelungslehre der Wirbelthiere Jena, 1903) 1903.1

-.-Lehrbuch der Zoologie. 9. Auflage. Jena, 1910.670 p. illust. $8^{\circ}$. 1910.1 A manual of zoology. Third American from the ninth German edition. 'Translated and edited by J. S. Kingsley. New York, 1913. 606 p. $8^{\circ}$. 1913.1

Hertwig, [Wilhelm August] Oscar [1849 - - Ueber Bau und Entwickelung der Placoidschuppen und der Zähne der Selachier. Jena. Zeitschr. Naturw., 1874, 8, 331-404. 2 pls. 1874.1

Ueber das Hautskelet der Fische. Morphol. Jahrb., 1876, 2, 328-395. 6 pls. Ibid., 1879, 5, 1-21. 3 pls. Ibid., 1881, 7, 1-42. 4 pls.

1876.1

Ueber das Hautskelet von Lepidosteus und Polypterus. Jena. Zeitschr. Naturw., 1879, 12, 80-82.

1879.1

Die Entwicklung des mittleren Keimblattes der Wirbelthiere [Elasmobranchii] Jena. Zeitschr. Naturw., 1883 , 16, 287-290 1883.1

Lehrbuch der Entwicklungsgeschichte des Menschen und der WVirbelthiere. 2. ed. Jena. 1888. viii, 507 p. illust. $8^{\circ}$. 1888.1

The same. 4. ed. Jena, 1893. xiv, $590 \mathrm{p}$ 2 pls. illust. $\mathcal{S}^{\circ}$. illust. $8^{\circ}$.

Strittige Punkte aus der Keimblattlehre der Wirbelthiere. Sitzber. K. Preuss. Akad. Wiss. Berlin, 1901, pt. 1, 528-533.

1901.1

- Allgemeine Biologie. Zweite Auflage des Lehrbuchs "Die Zelle und die Gewebe." Jena, 1906. xvi, 649 p. illus. $8^{\circ}$.

1906.1

(editor) Handbuch der vergleichenden und experimentellen Entwicklungslehre der Wirbeltiere. 3 vols. in 7 pts. Jena, 1906.

1906.2

Die Elemente der Entwicklungslehre des Menschen und der Wirbeltiere. Anleitung und Repertorium für Studierende und Aerzte. 4. ed. Jena, 1910. viii, 458 p. 399 figs. 1910.1
Hertz, G. Die künstliche Fischzucht. Mitth. Mährisch-Schles. Ges. Ackerbau, Natur- \& Landesk., 1861, 389-390; 393-398.

1861.1

Hérubel, Marcel $A$. Pêches maritimes, d'autrefois et d'aujourd'hui. Paris [1911?] 343 p. $8^{\circ}$ (Bibliothèque des Amis de la Marine)

1911.1

Index bibliographique, p. 338-342.

- Sea-fisheries, their treasures and toilers. Translated by Bernard Miall. London, 1912. 366 p. $8^{\circ}$. 1912.1 Bibliography, p. 353-358.

Herwerden, M. A. van. Zur Magenverdauung der Fische. Zeitschr. Physiol. Chem., 1908, 56, 453-494.

1908.1

Zuurafscheiding en enzymwerking in de maag van visschen [Säuresekretion und Enzymwirkung im Magen von Fischen] Onderz. Physiol. Labor. Utrecht, 1908, 5. ser 9, 15-58. 1908.2

Herwerden, M.A. van, \& Ringer, W. E. Die Acidität des Magensaftes von Scyllium stellare. Zeitschr. Physiol. Chem., 1911, 75, 290-307. fig. 1911.1

- Over den aard von het zuur van het maagsap van Scyllium stellare [Ueber die Natur der Säure des Magensaftes von Scyllium stellares Onderz. Physiol. Labor. Utrecht, 1911, 5. ser. 12 , $37-58$.

1911.2

Herwig, - Fischereiverhältnisse in der Lippe. Circul. Deutsch. Fischerei Ver. 1878 (1879), no. 1, 20-31. 1879.1

- Die grosse Heringfischerei Deutschlands und die Mittel zu ihrer Hebung. Mitth. Deutsch. Seefischer Ver., 1897, 13, 109-149.

1897.1

Herzenstein, Salomon Markovich [1854?-1894] Fische (In his Wissenschaftliche Resultate der von N. M. Przewalski nach Central-Asien unternommenen Reisen. Zoologischer 'Theil, Band iii, 2. Abth., 1. Lief. 91 p. 8 pls. 2. Lief, 91-180. 5 pls. 3. Lief, 181-262. 12 pls. St. Petersburg, 1888) 1888.1

Ueber cinen neuen russischen Wels (Exostoma oschanini Herz.) Bull. Acad. Sci. St. Pétersb., 1889, n. s. 33, 119-123.

1889.1

Ichthyologische Bemerkungen aus dem zoologischen Museum der Kaiserlichen Akademie Wissenschaften. Mélanges Biol. Bull. Acad. Sci. St. Pétersb., 1892, 13, 219-235. fig. — Bull. 
Acad. Sci. St. Pétersb., 2. sér. 3, 49-65. fig.

1892.1

Ueber einige neue und seltene Fische des Zoologischen Museums der Kaiserlichen Akademie der IVissenschaften. Ann. Acad. St. Pétersb., 1896. $1,1-14$.

1896.1

Zur Ichthyologie des Issyk-kulBeckens. Ann. Acad. St. Pétersb., 1896. 1, 224-228.

1896.2

Herzenstein, Salomon Markovich, \& Varpakhovskil, $N$. Notizen über die Fischfauna des Amur-Beckens und der angrenzenden Gebiete [Russian text, Latin diagnoses, German résumé] Trudui St. Petersb. Nat., 1887, 18, 1-58. pl.

1887.1

Herzog, $H$. Zur Tuberkulose im Kaltblüterorganismus. Zentralbl. Bakter. \& Parasitenk., 1902, 31, no. 3, 78-84.

1902.1

Hesdörffer, Max. Der amerikanische Hundsfisch (Amia calva), ein neuer Aquarienfisch. Natur u. Haus, 1901, 10, $35-37$.

1901.1

- Neetroplus (neue Art), ein neuer Aquarienfisch aus Mittelamerika. Natur u. Haus, 1902, 11, 3-4.

1902.1

Vom Piratenbarsch. Natur $u$. Haus, 1902, 10, 210-212.

1902.2

Hess, $C$. Untersuchungen über den Lichtsinn bei Fischen. Arch. Augenheilkde. Wiesbaden, 1909, 64 (Suppl.), 1-38. 12 figs.

1909.1

Ueber den angeblichen Nachweis von Farbensinn bei Fischen. Arch. Ges. Physiol., 1910, 134, 1-14. 1910.1

- Experimentelle Untersuchungen zur vergleichenden Physiologie des Gesichtssinnes. Arch. Ges. Physiol., 1911, 142, 405-446. 5 figs. 1911.1

Untersuchungen zur Frage nach dem Vorkommen von Farbensinn bei Fischen. Zool. Jahrb. (Allg. Zool. Physiol. Abth.), 1912, 31, 629-646. fig. 1912.1

Untersuchungen zur vergleichenden Physiologie und Morphologie des Ciliarringes (In Festschrift zum sechzigsten Geburtstage des Prof. Dr. Johann Wilhelm Spengel in Giessen. Zool. Jahrb. 1912, 15 (Suppl.), pt. 3, 155-176. 2 pls. \& fig.)

1912.2

Der Ciliarring der Selachier.
- Neue Untersuchungen zur vergleichenden Physiologie des Gesichtssinnes. Zool. Jahrb. (Abth. Anat.), 1913, 33, 387-440. 2 pls. \& 9 figs. 1913.1

i. Ueber das sogenannte Hochzeitskleid bei Süsswasserfischen.

ii. Ueber einen angeblichen Nachweis von Farbensinn bei der Ellritze.

iii. Beobachtungen an jungen Aalen.

Hesse, Edmond. Sur le minimum d'eau nécessaire pour un petit élévage de salmonides à une température constante de $12^{\circ}$. Ann. Univ. Grenoble, 1908, 20, $325-330$.

1908.1

Protozoaires nouveaux parasites des animaux d'eau douce. Ann. Univ. Grenoble, 1911, 23, no. 2, 393-399. 7 figs.

1911.1

Hesse, Edmond, \& Léger, Louis. See Léger \& Hesse.

Hesse, R., \& Doflein, $F$. Tierbau und Tierleben in ihrem Zusammenhang betrachtet. 2 vols. Leipzig, 1910-13. 35 pls. 900 illust. $8^{\circ}$.

1910.1

Hessel, Johann Friedrich Christian [1796-1872] Ueber Fisch-Abdrücke im Polier-Schiefer. Zeitschrift Mineral (Leonhard), 1825, 2, 489-490.

1825.1

Hesse1, Rudolph. Method of treating adhesive eggs of certain fishes, especially of the Cyprinidx, in artificial propagation. Rept. U. S. Fish Comm. 1872-73 (1874), 2, 567-570. pl.

1874.1

The salmon of the Danube, or the hucho (Salmo hucho), and its introduction into American waters. Rept. U S. Fish Comm. 1872-73 (1874), 2, $161-165$.

1874.2

The carp and its culture in rivers and lakes, and its introduction into America. Rept. U. S. Fish Comm. 1875-76 (1878), 4, 865-900. 6 figs.

1878.1

The culture of carp and construction of ponds. Fish. Gazette, 1880, 4, 618-620; 629-631. Ibid., 1881, 5, $3-4 ; 19-20 ; 26-27 ; 40-41$. Chicago Field, 1880, 13, 382; 414-415. Ibid., 14, 10 . 1880.1

Growth and size of carp. Fish. Gazette, 1880, 4, 409-410. - Chicago Field, 1880, 13, 399-400. 1880.2

Arrival of blue carp from Germany. Bull. U. S. Fish Comm. 1883, 3, 443.
1883.1 
Hessel, $R$.

The carp (In The fisheries and fishery industries of the United States, edited by George Brown Goode, sect. 1, 618-627. Washington, 1884) 1884.1

- Snakes destructive to carp. Bull. U. S. Fish Comm. 1884, 4, 294295.

1884.2

Notes from the carp ponds. Bull. U. S. Fish Comm. 1885, 5, 435.

1885.1

Hessel, Rudolph, Milner, James Wood, Haime, Jules, \& others. See Milner, Haime, Hessel \& others.

Hetting, $M . G$. Die Fisch-Cultur Norwegens. Christiania [n. d.] $20 \mathrm{p}$. $8^{\circ}$.

_- Uddrag af hans indberetning om hans virksomhed til den kunstige fiskeudklaeknings Udbredelse $m$. $m$. Aftenbl. Christiania, 1856 , nos. $236 \&$ 237.

1856.1

Kortfattet veiledning for dem, der ville indrette udklaeknings-apparatei for de vinterlegende ferskvandsfiske. 3. ed. Christiania, 1863. $8^{\circ}$. 1863.1

- Om fredning af vore ferskvandsfiskeries. Aftenbl. Christiania, 1863, nos. $291 \& 295$.

1863.2

Noget om Mjøsene fiskerier. Aftenbl. Christiania, 1866, no. 31.

1866.1

- Nogle ord om fiskerierne i Mjosen. Aftenbl. Christiania, 1866, no. 80 .

1866.2

Observations sur la pêche du saumon dans Trysil-Elv et Klara-Elv; lettre addressée à M. le Docteur J. L. Soubeiran. Bull. Soc. Acclim. Paris, 1866, 2. sér. 3, 137-139.

1866.3

Veiledning til at bygge laxetrapper. Christiania, 1866. $8^{\circ}$. 1866.4

Noget om ordning af fiskeriet i Kristianiafjorden. Aftenbl. Christiania, 1867, no. 22 .

1867.1

Beretning om de Norske ferskvandsfiskerier 1864-1873. Aftenbl. Christiania, 1868, nos. 267, 273 \& 302. - Meddel. Norsk. Jaeger \& FiskerForening, 1873, 2. Jahrg., 1-32. Also separate; Christiania, 1868-74. $8^{\circ}$.

1868.1

Lidt om den lovsmaessige ordning af vore laxe- og orretfiskerier.
Norsk Landmandsbog, Christiania, 1868 , 78-94.

1868.2

Lidt om laxefiskeriet i Namsen. Aftenbl. Christiania, 1869, no. 96.

1869.1

Anleiting für die künstliche Zucht der Winterlaichfische [Aus dem Norwegischen übersetzt] Berlin, 1871. 38 p. 11 illust. $4^{\circ}$.

1871.1

Om fisket indenfor Drobak. Aftenbl. Christiania, 1872, no. 151.

1872.1

Hundebunds saltvandspark i smaalenene. Meddel. Norske Jaeger \& Fisker-Forening, 1873, 2. Jahrg., 72-75. 1873.1

Hunnerorret i glommen. Aftenbl. Christiania, 1874, no. 160. 1874.1

_ Rapport sur les pêcheries maritimes et fluviales de la Norvège, pour les années 1869, 1871, 1873, 1880. Christiania, 1880.

1880.1

Heuglin, Martin Theodor von [18241876] Ueber afrikanische Fische. Sitzber. Akad. Wiss. Wién, 1851, 7, 452.

1851.1

- Reise nach dem Nord Polar Meer (1870-1871) 3 pts. Braunschweig, 1872-74. illust. $8^{\circ}$. 1872.1

Theil i. Reise in Norwegen und Spitzbergen.

Theil ii. Reise nach Novaja Semlja und Waigatsch.

Theil iii. Beiträge zur Fauna, Flora und Geologie von Spitzbergen und Novaja Semlja.

— Beiträge zur Fauna, Flora und Geologie von Spitzbergen und Novaja Semlja. Braunschweig, 1874. 352 p. $8^{\circ}$.

Fische, p. 202-228.

1874.1

Heureuse, $R$. de. The Kern river region and the new speckled trout of Kern river. Scient. Amer. Suppl., 1876, 1, no. $16,256$.

1876.1

Heurtier, - Sur les moyens de repeupler toutes les eaux de la France par l'éclosion artificielle des oufs de poisson. Moniteur Univers., 1852, 1-4.

1852.1

Heuscher, Johannes. "Ballenzünden " im Zugersee. Schweiz. Fischerei Zeitg., 1893, 1. Jahrg., 40-43. Also separate; Pfäffikon-Zürich, 1893. $3 \mathrm{p}$. $8^{\circ}$.

1893.1

Vorlüufiger Bericht über die Resultate ciner Untersuchung des $\mathrm{Wa}$ lensees. Schweiz. Fischerei Zeitg., 1893, 
1. Jahrg., 29. Also separate; PfäffikonZürich, 1893. 15 p. $\mathrm{S}^{\circ}$. 1893.2

- - Der Albelifang im obern Zürichsee. Schweiz. Fischerei Zeitg., 1894, 2. Jahrg., 94-96. Also separate; Pfäffikon-Zürich, 1894.3 p. $8^{\circ}$. 1894.1

Bericht über eine Untersuchung von Teichen im Gebiete des Kantons St. Gallen. Schweiz. Fischerei Zeitg., 1894, 2. Jahrg., 53. Also separate; Pfäffikon-Zürich, 1894.20 p. $8^{\circ}$.

1894.2

Ueber die Fischereiverhältnisse des Kantons Appenzell. Schweiz. Fischerei Zeitg., 1894, 2. Jahrg., 131. Also separate; Pfäffikon-Zürich, 1894. 12 p. $8^{\circ}$.

1894.3

Der Sempacher-See und seine Fischereiverhältnisse Schweiz. Fischerei Zeitg., 1895, 3. Jahrg., 163. Also separate; Pfäffikon-Zürich, 1895. 50 p. $8^{\circ}$.

1895.1

Ueber die Berner-Oberländerseen. Schweiz. Fischerei Zeitg., 1895, 3. Jahrg., 287; 299; 315. Also separate; Pfäffikon-Zürich, 1895.11 p. $8^{\circ}$.

1895.2 $1897,5.696$. $151-154$

1897.1

Coregonen in Aquarium. Schweiz. Fischerei Zeitg., 1898, 6. Jahrg., 109-112.

1898.1

Fischereiverhältnisse in der Aare. Schweiz. Fischerei Zeitg., 1899, 7. Jahrg., 49-53; 57-60; 65-67. 1899.1

Thuner- und Brienzer-See, ihre biologischen und Fischerei-Verhältnisse. Pfäffikon, 1901. 104 p. 10 figs. $4^{\circ}$.

1901.1

Untersuchungen über die Fischereiverhältnisse des Sarnersees. Schweiz. Fischerei Zeitg., 1901, 9. Jahrg. 31 p.

1901.2

Untersuchungen über die Fischereiverhältnisse des Thuner- und Brienzer-Sees. Schweiz. Fischerei Zeitg., $1901,9,132$.

1901.3

- Die Fischerei im Bodensee. Schweiz. Fischerei Zeitg., 1903, 11 Jahrg., 198-205; 218-220; 223-225.

1903.1

- Untersuchungen über die biologischen und Fischereiverhältnisse des
IXlöntalersees. Pfäffikon-Zurich, 1903. 50 p. pl. \& 4 figs. $8^{\circ}$. 1903.2

Anleitung zur Aufzucht von Forellen-Sömmerlingen als Besatz-Material für die Gewässer der Schweiz. Zürich, 1904. 31 p. figs. $8^{\circ} \quad 1904.1$

Das Massensterben der Agoni (Alosa finta var. lacustris Fatio) im Luganersee im Jahre 1904. Allgem. Fischerei Zeitg., 1905, 30. Jahrg., 169173.

1905.1

Ueber Fischereiverhältnisse im Zürichsee, Linth- und IValensee. Schweiz. Fischerei Zeitg., 1905, 13. Jahrg., 217-227.

1905.2

- Beiträge zu einer Monographie des Aegerisees mit besonderer Berücksichtigung seiner Fischereiverhältnisse. Schweiz. Fischerei Zeitg., 1906, 14. Jahrg. 59 p. pl. \& 7 figs. $\quad 1906.1$

- Zucht der Coregonen (Felchen) für die freien Gewässer. Schweiz. Fischerei Zeitg., 1906, 14. Jahrg., 4952. - Stenogr. Protok. Verh. Intern. Fisch-Kongr. Wilm, 1905, 253-256. Allgem. Fischerei Zeitg., 31, 118-121.

19062

Ein Karpfenmopskopf. Schweiz. Fischerei Zeitg., 1911, 19. Jahrg., 262265. 2 figs.

1911.1

Heuscher, Johannes, \& Hersche, - Bericht über den Besuch bayerischer Fischzuchtanstalten. Schweiz. Fischerei Zeitg., 1902, 10 (Append. 1), p. 16.

1902.1

Heusinger, Carl Friedrich von [17921883] Bemerkungen über das Gehörwerkzeug des Mormyrus cyprinoides, Gastroblecus compressus, und Pimelodus synodontis. Arch. Anat. Physiol. (Meckel), 1826, 1, 324-327. - Bull. Sci. Nat. (Férussac), 13, 139.

1826.1

Heusner, - Descriptio monstruorum avium, amphibiorum, piscium quæe extant in museo Berolini. [n. p.] 1824. 1824.1

Heusner, L. Die physiologische Bedeutung des grossen Netzes. München. Med. Wochenschr., 1905, 52. Jahrg., 1130-1132.

1905.1

Hewitson, John. Pike lore. Fish. Gazette, 1877, no. 29, p. 5. 1877.1

Hewson, William. On the lymphatic system in amphibious animals and in fishes. Phil. Trans. Roy. Soc. London, 1770, 59, 204-215. - Journ. Phys. Hist. Nat., 1, 401. 1770.1 
Hextor, J. van, \& Nylant, $P$. See Nylant \& Hextor.

Hey, Felix. Beobachtungen an Girardinus januarius var.? Blätt. Aquar.Terrar. Kunde, 1909, 20. Jahrg., 751753. fig.

1909.1

Ein Gambusenbastard? Blätt. Aquar.-Terrar. I unde, 1910, 21. Jahrg., 23. fig.

1910.1

Heyke, Detlof. Om fiskar funna i ostronskal. Svensk. Vet. Akad. Handl., 1744, 6, 116-117. - Analect. Transalp., $1,297$.

1744.1

Heymanns, Jean François, \& Stricht, $O$. van der. Sur le système nerveux de l'Amphioxus et en particulier sur la constitution et la genèse des racines sensibles. Mém. Cour. Acad. Sci. Belgique, 1898, 56. 74 p. 13 pls.

1898.1

Heynacher, — De digestione piscium. [n. p.] 1837.

1837.1

Heynemann, B. A. Die Nahrung einiger Fischarten in verschiedenem Alter [Text in Russian] Vèst. Rybopromyšl., St. Petersb., 1902, 17, 3949. - Fischzucht. Nikolsk, St. Petersb., 1902, no. 6, 39-59.

1902.1

Heynhold, Paul. Der Perlmutterfisch (Geophagus brasiliensis) Ueber Pflege und Zucht im Zimmeraquarium. Wochenschr. Aquar.-Terrar. Kunde, 1910, 7. Jahrg., 385-387. 2 figs. 1910.1

Chirodon species? Ein unbekannter Fisch aus Süd-Amerika. Ueber seine Zucht und die Entwicklung der Embryonen. Wochenschr. Aquar-Terrar. Kunde, 1911, 8. Jahrg., 317-318; 404-406. 2 figs.

1911.1

Girardinus reticulatus. Ueber Pflege, Zucht und Scheckung. Wochenschr. Aquar.-Terrar. Kunde, 1911, 8. Jahrg., 89-90. 2 figs.

1911.2

Geophagus brasitiensis (der Perlmutterfisch) Wochenschr. Aquar.-Terrar. Kunde, 1912, 9. Jahrg., 321-323. fig.

1912.1

Girardinus januarius Hens. Ein Nachtrag zur gescheckten Spielart. Wochenschr. Aquar.-Terrar. IKunde, 1912, 9. Jahrg., 150-153. 2 figs. 1912.2

Macropodus viridi-auratus, der Makropode oder Grossflosser. Ein Beitrag zur Blutauffischung desselben. Wochenschr. Aquar-Terrar. Kunde, 1912, 9. Jahrg., 50-52. 5 figs. $\quad 1912.3$
Heyser, E. Growth of mirror carp sent to Georgia by the United States Fish Commission; letter to Prof. S. F. Baird. Bull. U. S. Fish Comm. 1882 (1883), 2, 18.

1883.1

Hibbert, Samuel [1782-1848] On the fresh water limestone of Burdiehouse in the neighbourhood of Edinburgh, belonging to the Carboniferous group of rocks; with supplementary notes on other fresh water limestones. Trans. Roy. Soc. Edinb., 1834, 13, 169282. 8 pls.

1834.1

Fossil fishes, p. 182-230; 260-273.

On the fossil fishes of the [Lower Carboniferous] limestone of Burdiehouse. Proc. Roy. Soc. Edinb., 1845, 1, $72-74$.

1845.1

Hibberd, James Shirley [1825-1890] The marine aquarium. London, 1856. figs. $8^{\circ}$.

1856.1

The book of the marine aquarium. London, $1860.16^{\circ} . \quad 1860.1$

Hicks, John. Wanderings by the lochs and streams of Assynt and the north Highlands of Scotland. London, 1855. illust. $16^{\circ}$.

1855.1

Describes fishing in these regions. The illustrations are from sketches by the author.

Hickson, Sidney John [1859-] The fauna of the deep sea, a simple and concise summary of present-day knowledge of the more important facts concerning physical conditions and forms of animal life existing in deep seas, dealing with the two great problems. 1. The modifications of the fauna in correlation with the physical conditions of their habitat. 2. The sources from which the fauna of the deep is derived; and containing a short account of submarine discovery. London, 1893. xvi, 169 p. 23 figs. $8^{\circ}$.

1893.1

Hiester, Charles $E$. Fish-culture for profit. Bull. U. S. Fish Comm. 1881 (1882), 1, 382-383.

1882.1

- Answers to questions relative to catfish. Bull. U. S. Fish Comm. 1882 (1883), 2, 76-79.

1883.1

Higgins, Edward T. Rare fishes occurring at Weston-super-Mare. Zoologist, 1861, 19, 7317-7318. 1861.1

- On otolites or ear-bones of fishes. Abstract in Quart. Journ. Mier. Sci., 1867, n. s. 7, 226-227. 1867.1 
On the otolites of fish, and their value as a test in verifying recent and fossil species. Journ. Linn. Soc. London, 1868, 9, 157-166. Abstract in Geol. Mag., 4, 161-162.

1868.1

Higgins, Henry Hugh [1814-1893] Notes by a field naturalist in the western tropics. Liverpool, 1877. $205 \mathrm{p}$. $S^{\circ}$.

Fishes, p. 10-40; 94; 166-169.

1877.1

Higginson, Francis. Upon the abundance of fish on the New England coast in former times. Rept. U. S. Fish Comm. 1871-72 (1873), 1, 161. 1873.1

Highley, Samuel. A clue to the great sea serpent [Regalecus banksii] Fish. Gazette, 1877, n. s. 1, no. 16, 9-10. figs. 1877.1

Sensitiveness of fish. Fish. Gazette, 1877, n.s. 1, no. 8, 8-9. 1877.2

Where to fish round London. London [1882] vi, 56 p. $8^{\circ}$. 1882.1

Higurashi, Tadashi, Otaki, Keinosuke, \& Fujita, Tsunenobu. See Otaki, Fujita \& Higurashi.

Hikida, T. Homposan Argentinidx no ichi shinshu ni tsuite [On a new species of Argentinidae occurring in Japan] Zool. Mag. Tokyo, 1913, 25, 127-129. pl.

1913.1

Hildebrand, S. F., \& Evermann, Barton Warren. See Evermann \& Hildebrand.

Hildebrand, S. F., \& Meek, Seth Eugene. See Meek \& Hildebrand.

Hildebrand, Wolfgang. Råd och anvisningar angående fiskförökning och fiskfångst från 1600-talet. Fiskeritidskr. Finland, 1897, 6, 82-89.

1897.1

Hildreth, S. P. On the spoonbill sturgeon. Amer. Journ. Sci., 1827, 12 , 202-203.

1827.1

Hildreth, S. P., Clemens, James $W$., \& Mitchill, Samuel Latham. See Mitchill, Hildreth \& Clemens.

Hilgard, Theodore Charles [18281875] On the structure of the head in vertebrata, and its relations to the phyllotactic laws. Proc. Amer. Assoc. Adv. Sci., 11. meet., 1857, 81-95.-Bonplandia, 6, 22-26.

1857.1

Fishes, p. 89-91.

- Numeric relations of the vertebrate system. Amer. Naturalist, 1871,
5, 559-561. - Proc. Amer. Assoc. Adv. Sci, 20. meet., 1871, 307-317. 1871.1

Hilgendorf, Franz Martin [1839-] Ueber den Bau der Oberkinnlade beim Hecht (Esox lucius) Sitzber. Ges. Isis, Dresden, 1871 (1872), 230-231. 1872.1

Japanische lachsartige Fische. Mitth. Deutsch. Ges. Ostasiens, $1876-$ so, 2, 25-31.

1876.1

Der Tara [Gadus brandtii] Mitth. Deutsch. Ges. Ostasiens, 1876, 1, 7. Heft, 39-40.

1876.2

-C Ueber die Artbestimmung des giftigen Fugu (Tetrodon muripes) Mitth. Deutsch. Ges. Ostasiens, 1876 , 1, 10. Heft, p. 6.

1876.3

Ueber den Jugendcharakter der Fischgattung Fistularia. Sitzber. Ges. Naturf. Freunde Berlin, 1877, 236-237.

1877.1

Ueber das Kopfskelet von $C y-$ clopterus lumpus und Liparis. Sitzber. Ges.. Naturf. Freunde Berlin, 1878, 186187.

1878.1

Ueber das Vorkommen einer Brama-Art und einer neuen Fisehgattung Centropholis aus der Nachbarschaft des Genus Brama in den japanischen Meeren. Sitzber. Ges. Naturf. Freunde Berlin, 1878, 1-2. $\quad 1878.2$

Ueber einige neue japanische Fischgattungen. Sitzber. Ges. Naturf. Freunde Berlin, 1878, 155-157. 1878.3

Blaugefärbte Schuppen von Duymaeria. Sitzber. Ges. Naturf. Freunde Berlin, 1879, 121-122.

1879.1

Einige Beiträge zur Ichthyologic Japan's. Sitzber. Ges. Naturf. Freunde Berlin, 1879, 78-81; 105-111. 1879.2

Die Vorrichtungen zur Fixirung der Stacheln bei Monocentris japonicus Houttuyn. Sitzber. Ges. Naturf. Freunde Berlin, 1879, 22-25. $\quad 1879.3$

- Hornbekleidung der Kicfer bei Teuthis. Sitzber. Ges. Naturf. Freunde Berlin, 1880, 121.

1880.1

Japans Fische. Oesterr.-ungar. Fischerei Zeitg., 1880, 271-272; 281282.

1880.2

Ueber eine neue bemerkenswerthe Fischgattung Leucopsarion aus Japan. Monatsber. Akad., Berlin, 1880, 339-341.

1880.3 
Hilgendorf, $F, M$.

- Uebersicht über die japanischen Sebastes-Arten. Sitzber. Ges. Naturf. Freunde Berlin, 1880, 166-172. 1880.4

Einige Larvenformen von Knochenfische [Dactylopterus] Cephalacanthus, Acronurus] Sitzber. Ges. Naturf. Freunde Berlin, 1883, 43-45. 1883.1

- Die Unterschiede von Maifisch und Finte. Sitzber. Ges. Naturf. Freunde Berlin, 1883, 90-91. $\quad 1883.2$

Ueber die Fischgattung Amphisile. Sitzber. Ges. Naturf. Freunde Berlin, 1884, 52-55.

1884.1

Die Vereinigung der Haifischgattung Leptocarcharias mit Triacis. Sitzber. Ges. Naturf. Freunde Berlin, 1884, 138-139.

1884.2

- Ueber Schliffen sogenannter zusammengesetzter Fischzähne. Sitzber. Ges. Naturf. Freunde Berlin, 1886, 8794.

1886.1

- Einige Bemerkungen über die Histologie der Pristis-Zähne. Sitzber. Ges. Naturf. Freunde Berlin, 1888, 109110. 1888.1

- Fische aus dem Victoria-Nyanza (Ukerewe-See), gesammelt von dem verstorbenen Dr. G. A. Fischer. Sitzber. Ges. Naturf. Freunde Berlin, 1888, 7579.

1888.2

- Die Fische der Azoren. Arch. Naturgesch., 1888, 54, 205-213. 1888.3

- [Eine neue Salarias-Art, welche von Herrn Dr. Simroth bei den Açoren entdeckt wurde] Sitzber. Ges. Naturf. Freunde Berlin, 1888, 79.

1888.4

Ueber eine Fischkrankheit an Karpfen aus der Niederlausitz. Sitzber. Ges. Naturf. Freunde Berlin, 1889, 123125.

1889.1

Ueber eine Fischsammlung von Haiti, welche zwei neue Arten, Pocilia tridens und Eleotris maltzani, enthält. Sitzber. Ges. Naturf. Freunde Berlin, $1889,51-55$.

1889.2

The new subgenus Acropœcilia is proposed.

__ Einige ichthyologische Mittheilungen, betreffend Petromyzon, Cepola, Salarias, Leucopsarion und Silurus. Sitzber. Ges. Naturf. Freunde Berlin, 1890, 12-18.

1890.1

Eine Aufzählung der von Emin Pascha und Dr. Stuhlmann gesammelten Fische und Krebse. Sitzber. Ges. Naturf. Freunde Berlin, 1891, 18-20.
- Ein krankhaft verändertes Gebiss eines Haifisches (Galeus galeus L.) Sitzber. Ges. Naturf. Freunde Berlin, 1891, 64-67.

1891.2

Verschiedenheiten zwischen den Saiblingen Mitteleuropas. Sitzber. Ges. Naturf. Freunde Berlin, 1891, 28-29.

1891.3

- Eine neue Stör-Art von NordJapan, Acipenser mikadoi. Sitzber. Ges. Naturf. Freunde Berlin, 1892, 98100.

1892.1

Ueber die Bezahnung der Gattung Mola (Orthagoriscus) Sitzber. Ges. Naturf. Freunde Berlin, 1893, 3-4. 1893.1

Eine neue Characinidengattung, Petersius, aus dem Kinganiflusse in Deutsch Ostafrika, und über die sonstigen von Dr. Stuhlmann dort gesammelten Fische. Sitzber. Ges. Naturf. Freunde Berlin, 1894, 172-173. 1894.1

Bericht über die Leistungen in der Ichthyologie während des Jahres 1892. Arch. Naturgesch., 1895, 61. Jahrg., 2, 259-308.

1895.1

Bemerkungen über den Cyprinus aphya Bloch. Sitzber. Ges. Naturf. Freunde Berlin, 1897, 35-37. $\quad 1897.1$

Neue Chromiden-Art aus Deutsch Südwestafrika. Sitzber. Ges. Naturf. Freunde Berlin, 1902, 141-143. 1902.1

Pseudocheilinus hexatonia Blkr. mit monströser Verdoppelung der Linse. Sitzber. Ges. Naturf. Freunde Berlin, 1903, 3-5.

1903.1

_- Ein Siisswasserfisch aus der Nähe von Alexandria, Paratilapia multicolor. Sitzber. Ges. Naturf. Freunde Berlin, 1903, 429-432.

1903.2

Ein neuer Scyllium-artiger Haifisch, Proscyllium habereri, nov. subgen., n. spec. von Formosa. Sitzber. Ges. Naturf. Freunde Berlin, 1904, 39-41.

1904.1

Fische von Deutsch und Englisch Ost-Afrika, gesammelt von Oscar Neumann 1893-1895. Zool. Jahrb. (Abth. Syst.), 1905, 22, 405-418. 1905.1

Hilgendorf, Franz Martin, \& Kopsch, Friedrich. Bericht über die Leistungen in der Ichthyologie während des Jahres 1890. Arch. Naturgesch., 1898, 59. Jahrg., 2, 173-266. 1898.1 
Hilgendorf, Franz Martin, \& Pappenheim, $P$. Ueber die Fischfauna des Rukwa-Sees. Sitzber. Ges. Naturf. Freunde Berlin, 1903, 259-271. 1903.1

Hilgendorf, Franz Martin, \& Paulicki, A. Infusionstiere als Hautparasiten bei Süsswasserfischen. Centralbl. Med. Wiss., 1869, 7, 33-35. 1869.1

Hill, Charles. Development of the epiphysis in Coregonus albus. Journ. Morphol., 1891, 5, 503-510. figs.

1891.1

The epiphysis of teleosts and Amia. Journ. Morphol., 1894, 9, no. 2. 237-266. 2 pls.

1894.1

- Primary segments of the vertebrate head. Anat. Anz., 1899, 16, 353369. 22 figs.

1899.1

Hill, Edward Smith [1819?-1880] On fishes [Murray river cod, etc.] 3. Ann. Rept. Acclim. Soc. New S. Wales, 1864 , p. 51 .

1864.1

Hill, James $P$. On a fiddler (Trygonorhina fasciatia) with abnormal pectoral fins. Proc. Linn. Soc. New S. Wales, 1895, 2. ser. 10, 206-208. pl.

1895.1

Hill, John [1716-1775] A general natural history; or, new and accurate descriptions of the animals, vegetables and minerals of the different parts of the world. 2. ed. enlarged with 2 additional plates. 3 vols. London, 1771. 57 pls.

1771.1

Hill, Richard. Contributions to the natural history of the shark. Ann. Mag. Nat. Hist., 1851, 2. ser. 7, 353-370.

1851.1

- A naturalist's sojourn in Jamaica. London, 1851. 12 ${ }^{\circ}$. See Gosse, Philip Henry.

1851.2 bay, 1855 . 109 p. $12^{\circ}$.

Montego bay, 1855. 109 p. $12^{\circ}$. 1855.1 Contains mention of several species of $\mathrm{Ja}$ maica fishes.

The devil-fish of Jamaica (Dicerobatis giorna) Intell. Observ., 1863, 2, 167-205. figs.

1863.1

- On poisonous fishes; on fishpoisons. Proc. Sci. Assoc. 'Trinidad, $1868,1,210-223 ; 227-237 . \quad 1868.1$

The fishes of Jamaica. Handbook of Jamaica, 1881, 121-126. 1881.1

Hill, W. W. The black bass. Forest \& Stream, 1874, 2, 163.
Hillas, A.B.E. Record of salmon marking experiments in Ireland 19021905. Fisheries Ireland Scient. Invest. 1904, no. 7, 14-52. - Rept. Sea Inland Fish Ireland, 1904 (1906), pt. 2, 315357.

1904.1

- Report on Roclimills hatchery, 1907-8. Fish. Ireland Scient. Invest. 1907 (1909), no. 9, 8-11.

1909.1

Summary of reports relative to eel fry, 1908-1910. Fisheries Ireland Scient. Invest. 1908 (1910), no. 6. 9 p. Ibid. 1909 (1911), no. 2. 5 p. 1910.1

Hillhouse, William. C. Linnæus, 1707-1778; a biography, with notes on interesting exhibits made before the Birmingham Natural History and Philosophical Society. Birmingham, 1907. 20 p. illust. $8^{\circ}$. 1907.1

Hilton, William $A$. On the intestine of Amia calva. Amer. Naturalist, 1900 , 34, 717-728. 4 pls. 1900.1

Hilzheimer, M., \& Haempel, $O$. Handbuch der Biologie der Wirbeltiere. Stuttgart, 1913. Bibliography of fishes by O. Haempel, p. 170-

Himes, C. F. Carp ponds. Rept. U. S. Fish Comm. 1873-75 (1876), 3, $555-558$.

1876.1

Hinckly (junior), Thomas. Condition of the shore fisheries of Massachusetts and Rhode Island in 1871. Rept. U. S. Fish Comm. 1871-72 (1873), 1, 59-67.

1873.1

Hind, Henry Youle [1823-] Does the Atlantic salmon spawn in the spring as well as in the fall? Forest \& Stream, $1880,13,1025$.

1880.1

- Habits of salmon. Forest \& Stream, 1880, 15, 130-131. 1880.2

- The movements of salmon in the sea. Forest \& Stream, 1880, 14, 491.

1880.3

Spring spawning salmon. The rrilse. Forest \& Stream, 1880, 15, 186187.

1880.4

Hind, Wheelton. Life-zones in the British Carboniferous rocks; report of the committee. Rept. British Assoc. Adv. Sci., 71. meet., 1902, 210-224. Ibid., 73. meet., 1904, 185-192. 5 figs. Ibid., 74. meet., 1905, 226-237. 4 figs.

1902.1 
Hind, Wheelton, \& Howe, John Allen. The geological succession and palæontology of the beds between the Millstone grit and the Limestone massif at Pendle hill and their equivalents in certain other parts of Britain. Quart. Journ. Geol. Soc., 1901, 57, 347-404. 3 pls. \& 3 figs.

1901.1

Hind, Wheelton, \& Stobbs, John T. The Carboniferous succession below the Coal measures in North Shropshire, Denbighshire and Flintshire. Geol. Mag., 1906, 5. ser. 3, 385-400; 445-459; 496-507. 2 pls. \& 5 figs.

1906.1

Hinde, George Jennings [1839-] Pelagic fish-nest. Nature, $1872,6,142$. 1872.1

Conodonts. Pop. Sci. Rev. 1879, n. s. 3, 208-209. 1879.1

Conodonts from Cambro-Silurian, etc. Sci. Gossip, 1879, 15, 115.

1879.2

On conodonts from the Chazy and Cincinnati group of the CambroSilurian, and from the Hamilton and Genesee shale divisions of the Devonian, in Canada and the United States. Quart. Journ. Geol. Soc., 1879, 35, 351369. - Ann. Mag. Nat. Hist., 1879, 5. ser. 4, 166. - Amer. Journ. Sci., 1880, 3. ser. 19, 327. 3 pls.

1879.3

Notes and descriptions of new species of Scotch Carboniferous conodonts. Trans. Nat. Hist. Soc. Glasgow, 1900, n. s. 5, 338-346. 2 pls. $\quad 1900.1$

The bone-bed in the Upper Ludlow formation. Proc. Geol. Assoc. London, 1904, 18, 443-446. $\quad 1904.1$

Hindersson, $H$. A. Ueber die Schwanzflossenmuskulatur der Teleostier. Anat. Anz., 1910, 36, 465-471. 5 figs.

1910.1

Hinds, A. $J$. Trout-culture for market. Forest \& Stream, 1875, 5, 116.

1875.1

Lifting trout spawn. Forest \& Stream, 1876, 5, 339.

1876.1

Hindze, B. K. Das Fischerei-Institut Suisan Ioschushio in Tokio [Text in Russian\} Dnevn. Otd. Icht. Imp. R. Obšč. Acclimat., Moskva, 1903, 2, pt. 2, 33-4t.

1903.1

Hindze, $B . K$., Voronkov, $N . V$. Bogojavlenskij, $N . V .$, Chmĕlevskij, C. V. Gracianov, V. I., \& Zograf, $J . N$ See Chmĕlevskij, Gracianov \& others.
Hinkelmann, - The mode of life of cels. Bull. U. S. Fish Comm. $1884,4,390$.

1884.1

Hinkelmann, Andreas. Die Verbreitung grösserer Thiere im ḰaiserWilhelm-Kanal. Schrift. Naturw. Ver Schlesw.-Holst., 1897, 11, 55-57. 1897.1

Der Abstieg der jungen Heringe aus dem Kaiser Wilhelm-Kanal in die Ostsee im August 1902. Mitth. Deutsch. Seefischerei Ver., 1902, 18, 606-608. 1902.1

Ueber den Aufstieg und die Laichplätze des Herings im Kaiser Wilhelm-Kanal im Frühjahr 1902. Mitth. Deutsch. Seefischerei Ver., 1902, $18,362-367$. 1902.2

Ueber die im Jahre 1901 ausgefühte Versuchsfischerei im Kaiser Wilhelm-Kanal. Mitth. Deutsch. Seefischerei Ver., 1902, 18, 15-18. 1902.3

Ueber die neuesten Ergebnisse der Versuchsfischerei auf dem Kaiser IVilhelm-Kanal. Vortrag, etc. Heimat, Kiel, 1903, 13, 153-164.

1903.1

Versuchsfischerei im Kaiser Wilhelm-Kanal im Jahr 1902. Mitth. Deutsch. Seefischerei Ver., 1903, 19, 88-91.

1903.2

Ueber die im Jahre 1903 ausgeführte Versuchsfischerei auf dem Kaiser Wilhelm-Kanal. Mitth. Deutsch. Seefischerei Ver., 1904, 20, 3-5.

1904.1

Ueber die im Jahre 1905-06 ausgeführte Versuchsfischerei auf dem Kaiser Wilhelm-Kanal. Mitth. Deutsch. Seefischerei Ver., 1906, 22, 14-18. Ibid., 23, 5-7. fig.

1906.1

Die Treibnetzfischerei in der Ostsee mit besonderer Berücksichtigung des Laichplatzes für Heringe bei Fehmarn. Mitth. Deutsch. Seefischerei Ver., 1908, 24, 358-361. 2 figs. 1908.1

Hinkelmann, Andreas, \& Apstein, C. See Apstein \& Hinkelmann.

Hinrichs (junior), Henry. Federal control over fish in boundary waters Trans. Amer. Fisheries Soc. 1912 (1913), 129-133.

1913.1

Hinton, Martin A.C. The Pleistocene deposits of the Oxford and Wanstead district. Proc. Geol. Assoc. London, 1900, 16, 271-281. 2 figs.

1900.1 
Hinton, Martin A. C., \& Kennard, A. S. Contributions to the Pleistocene geology of the Thames valley. I. The Grays Thurrock area. With a subsection on the fossil fishes by E. 'T. Newton. Essex Naturalist, 1901, 11, $336-370.5$ figs.

1901.1

Hintze, Alexander. Svart gädda. Sporten, 1884, 4, 85. $\quad 1884.1$

- Tonfiskfångst. Sporten, 1884, 4, 27 . 1884.2

6, 82-83. 1886.1

— En värdefull och för våra stora insjövatten lämplig fisk (Solea vulgaris) Sporten, 1887, 7, 6.

1887.1 $5-6$.

Black bass. Sporten, 1888, 8,

Forellmete i april. Sporten 1889, 3. ser. $1,41-43$.

1889.1

Blanklax i olika stadier af utveckling. Tidskr. Jägare \& Fisk., 1893 , 1, 45-46. 2 figs.

1893.1

Ovanligt stor harr (Thymallus vulgaris Nilss.) Tidskr. Jägare \& Fisk. $1893,1,140$.

1893.2

- Svartbassen (Micropterus salmoides) Tidskr. Jägare \& Fisk., 1893. 1, 177-179. 2 figs.

1893.3

Anton Stuxberg, sveriges och norges fiskar Tidskr. Jägare \& Fisk. 1894, 2, 236.

1894.1

Gäddan såsom forellfiskare. Tidskr. Jägare \& Fisk., 1894, 2, 110.

1894.2

- Insjöforell (Salmo eriox L.) Tidskr. Jägare \& Fisk., 1894, 2, 75.

1894.3

- Regnbågsforellen (Salmo irideus Gibbons) Tidskr. Jägare \& Fisk., 1895, 3, 76-78. pl.

1895.1

- Huru förhålla sig vikt, längd och kroppsomfang till hvarandra hos abborre i olika vatten. Tidskr. Jägare \& Fisk., 1896, 4, 196-197.

1896.1

— En stor gädda. Tidskx. Jägare \& Fisk., 1897, 5, 207-208; 228-229.

1897.1

Leker Puruvesi- "laxen" pa grunden i sjön? Tidskr. Jägare \& Fisk., $1898,6,77-78$.
- Puruvesi-forellen skall leka i sjön. Tidskr. Jägare \& Fisk., 1898, 6, 105-108. 1898.2

- Utplantering af flundra i vesijärvi. Tidskr. Jägare \& Fisk., 1898, 6, 199-200.

1898.3

Alen som laxätare. Tidskr.

Jägare \& Fisk., 1899, 7, 155-156. 1899.1

Den frïmsta bland forellens fiender. Tidskr. Jägare \& Fisk., 1900, 8, 133-134.

1900.1

Spanakïringen (Idothea entomon) och torsken [Idothea entomon und Gadus morrhua] 'Tidskr. Jägare \& Fisk., 1905, $13,44-47$.

1905.1

Hintze, Harry. Ur min fiskedagbok. Tidskr. Jägare \& Fisk., 1893, 1, 122-132. map.

1893.1

Hipler, J. Belta pugnax, ein maulbrütender Kampffisch. Blätt. Aquar.Terrar. Kunde, 1913, 24. Jahrg., 34-36. fig.

1913.1

- Nochmals maulbrütender Kampffisch (Betta pugnax) Blätt. Aquar.-Terrar. Kunde, 1913, 24. Jahrg., 196-197. 1913.2

Hippius, K. Acara bimaculata L. und A. coeruleo-punctata Steind. I'Text in Russian] Akvarium, Moskva, 1908, $1,106-110$. 1908.1

Girardinus januarius var. reticulata Peters und Precilia reticulata Peters ['Text in Russian] Akvarium, Moskva, $1909,2,392-396 . \quad 1909.1$

- Hemichromis bimaculata ['Text in Russian! Akvarium, Moskva, 1909 , 2, 382-386. 1909.2

Hippolyte-Boussac, $P$. La faune de l'Egypte antique. Rev. Encyclop. Larousse, 1897,7 . année, no. $214,859-863$; no. $215,876-878$. 33 figs.

1897.1

Hi-Regan, pseudonym for Dunne, (Captain) $J$. How and where to fish in Ireland; a hand-guide for anglers. 3. ed. London, 1887. $8^{\circ}$.

1887.1

Hirn, R. Die Hochseefischerei im Bodensee. Schweiz. Fischerei Zeitg., 1896, 4, 11. Also separate; PfäffikonZürich, 1896. 1 p. $8^{\circ}$ 1896.1

Hirota, $S$. On the dendritic appendage of the urogenital papilla of a siluroid. Journ. Coll. Sci. Japan, 1895, 8, 367-380. pl. 
Hirsch, Julius. Ueber das Gehirn, Rückenmark und Augen der Varietiten des Goldfisches (Carassius auratus) Arch. Lntw.-Mech., Leipzig, 1912, 35, 56-63. 11 figs.

1912.1

Hirschberg, J. Fischerei-Bestrebungen im lürstenthum Schwarzburg Sondershausen. Cireul. Deutsch, Fischerei Ver. 1878 (1879), no. 2, 67.

1879.1

Zur Dioptrik und Ophthalmoskopic der Fiseh- und Amphibienaugen. Arch. Anat. Physiol. (Phys. Abth.), 1852, 493-526. 9 figs.

1882.1

Hirschler, $J$. Studien über die interstitiellen Gebilde der quergestreiften Muskelfaser. Bull. Intern. Acad. Sci. Cracovie, math.-nat. Cl., 1910, ser. B, 448-476. pl. \& fig.

1910.1

Hirt, $F r$. Fischerordnung für den Nidauersee. Schweiz. Nischerei Zeitg., 1896, 4, 153. Also separate; PfäffikonZürich, 1896. 2 p. $8^{\circ}$.

1896.1

Seeordnung über den Bielersee von 1570. Schwciz. Fischerei Zeitg., $1897,4,367$. Also separate; PfüffikonZürich, 1897. 4 p. $8^{\circ}$.

1897.1

His, Wilhelm [1831 - ] Untersuchungen über das Ei und die Entwickelung bei Knochenfischen. Leipzig, 1873. 4 pls.

1873.1

- Ueber den Bau des Eies einiger Salmoniden. Verh. Schweiz. Naturf. Ges. Basel, 1873 (1874), 5, 3. Heft, 457461.

1874.1

Ueber die Bildung des LachsEmbryo. Sitzber. Naturf. Ges. Leipzig, 1874, 1. Jahrg., 30.

1874.2

Untersuchungen über die Entwickelung von Knochenfischen besonders über diejenige des Salmens. Zeitschr. Anat. Entwickgesch., 1876, 1, 1-40. 14 figs.

1876.1

Notiz über die Fmbryonalanlage bei Plagiostomen. Verh. Sehweiz. Naturf. Ges. Basel, 1876 (1877), 59, 6869.

1877.1

Ueber die Bildung der Haifischcmbryonen. 'Leitschr. Mnat. Lntwickgesch., 1877, 2, 10S-124. pl. 1877.2

Untersuchungen über dic Bildung des İnochenfischembryo (Salmen) Arch. Anat. Physiol. (Anat. 1blh.), 187S, 180-221. pl.

1878.1
Ueber die Anfänge des peripherischen Nervensystemes. Arch. Anat. Physiol. (Anat. Abth.), 1879, 455-482. 2 pls.

1879.1

Ganglienanlagen bei Embryonen von P'lagiostomen, Batrachiern, Knochenfischen und Säugethieren, $473-480$.

Ueber Untersuchungen zur Entwicklung des Salmes. Verh. Schweiz. Naturf. Ges. Bern, 1878 (1879), 61, 120. 1879.2

Notizen über das Ei und über die Entwickelung von Salmoniden. Internat. Fischerei-Ausstellung. Berlin, 1880, Schweiz. Katalog, 141-153. fig.

1880.1

- Die Entwickelung der menschlichen und thierischer Physiognomien. Arch. Anat. Physiol. (Anat. Abth.), 1892, 384-424. 51 figs. 1892.1

Deals with the embryos of various fishes.

- Zur allgemeinen Morphologie des Gehirns. Arch. Anat. Physiol. (Anat. Abth.), 1892, 346-383. 36 figs.

1892.2

Ueber das frontale Ende des Gehirnrohres. Arch. Anat. Physiol. (Anat. Ablh.), 1893, 157-171. 8 figs. 1893.1

Sonderung und Charakteristik der Entwickelungsstufen junger Selachierembryonen. Arch. Anat. Physiol. (Anat. Abth.), 1894, 337-354. pl.

$189+.1$

Ueber die Vorstufen der Gehirnund der Kopfbildung bei Wirbelthieren. Arch. Anat. Physiol. (Anat. 1bih.) 1894, 313-336. pl.\& 14 figs. 1894.2

Ueber mechanische Grundvorgünge thierischer Formenbildung. Arch. Anat. Physiol. (Anat. Abth.), 1894, 1-80. 50 figs.

1894.3

Ueber den Keimhof oder I'eriblast der Selachier; eine histogenetische Studie. Arch. Anat. Physiol. (Anat. Abth.), 1897, 1-64. 32 figs. $\quad 1897.1$

- Ueber Zellen- und Syncytienbildung: Studien am Salmonidenkeim. Abh. Sïchs. Ges. Wiss., math.-phys, Cl., 1898, 24, no. 5, 401-168. 41 figs. Also separate; Leipzig, 1S9S. pls.

189S.1

- Protoplasmastudien am Salmonidenkeim. Abh. Säichs. Ges. Wiss., math.-phys. Cl., 1899, 25, 110. 3, 159218. 3 pls. \& 21 figs. Also separate; Leipzig, 1899. pls. \& figs. $8^{\circ}$. 1899.1 
Hisinger, Edvard Victor Eugen. Om namnet strömstrykare [Squalius grislagine Linné) Sporten, 1881, 1, 80.

1881.1

Hitchcock, Charles Henry [1836-] New American fossil fish from the Devonian. Geol. Mag., 1868, 5, 184-185.

1868.1

A résumé of Newberry's description of Dinichthys herzeri.

Ueber Dinichthys herzeri Hitch., eine neue amerikanische Form fossiler Fische aus der Devonformation. Neues Jahrb. Mineral., 1868, 874.

1868.2

Hitchcock, Edward II. [1793-1864] Ichthyolites at Westfield, Ct., and at Sunderland, Mass. Amer. Journ. Sci., $1823,6,71-78$.

1823.1

Report on the geology, botany and zoology of Massachusetts. Amherst, 1835. $8^{\circ}$.

Includes a list of fishes.

1835.1

Final report on the geology of Massachusetts. . . Northampton, 1841. illust. 55 pls. map. xii, 831 p.

Fossil fishes, p. 458-525. 23 pls. \& figs.

1841.1

Account of the discovery of the fossil jaw of an extinct family of sharks, from the Coal formation. Proc. Amer. Assoc. Adv. Sci., 9. meet., 1855, 229 230.

1855.1

Description and figure, without name, of the species later described as Edestus minor by Newberry.

[Shark remains from the Coal formation of Illinois, and bones and tracks from the Connecticut river sandstone; in a letter to Prof. Silliman dated Amherst, 12th Oct. 185.51 Amer. Journ. Sci., 1855, 2. ser. 20, 416-417. 185̄5.2

On a new fossil fish, and new fossil footmarks. Amer. Journ. Sci., 1856, 2. ser. 21, 96-100. fig. 1856.1

Hitchcock, $F$. B. New fishes in new places. Forest \& Stream, 1881, 17, 10.

1881.1

Hitchcock, (Miss) Fannie R. M. On the homologies of Edestus. Amer. Naturalist, 1887, 21, 847-848. - Proc. Amer. Assoc. Adv. Sci., 36. meet., 1887, $260-261$.

1887.1

- Preliminary notes on the osteology of Alosa sapidissima. Amer. Naturalist, 1887, 21, 1032-1033. Proc. Amer. Assoc. Adv. Ści., 36. meet., 1887, $259-260$.

1887.2
Further notes on the ostcology of the shad (Alosa sapulissima) Ann. N. Y. Acad. Sci., 1888, 4, 225-228. fig. 1888.1

Hittel, John S. The resources of California, comprising agriculture, mining, geography, etc. San Francisco \& New York, 1863. 464 p. $12^{\circ}$. 1863.1 Fishes, p. 313-317.

Hitz, - Ueber die Barbe. Schweiz. Fischerei Zeitg., 1894, 2, 258. Also separate; Pfäffikon-Zürich, 1894. 2 p. $8^{\circ}$.

1894.1

Hitzel, $E$. Sur les fossiles de l'etage albien, recueillis par M. A. Guébhard dans la région d'Escragnolles (A-M.) Bull. Soc. Géol. France, 1905, 4. sér. 2, $874-880$.

1905.1

Hjelt, Ollo Edvard August [1823-] In systema nervorum sympathicum Gadi lote Linn. observationes. Inaug. Dissert. Helsingfors, 1847. 40 p. pl. $8^{\circ}$.

1847.1

Hjort, Johan. Hydrographic-biological studies of the Norwegian fisheries. Skrifter Vidensk. Selsk. Christiania, math.-nat. Kl., 1895, 1-75. 15 pls.\& charts.

1895.1

- Zur Anatomie und Entwickelungsgeschichte einer in Fleisch von Fischen schmarotzenden Crustacee. Skrifter Vidensk. Selks. Christiania, math.-nat. Kl., 1895, 1-14. 2 pls.

1895.2

Undersakelser over organismerne og strømforholdene i det norske Nordhav "Naturen" ipublished by Bergens Museuml Bergen, 1897. 31 p. 15 figs.

1897.1

Les pêches. Reprinted from "La Norvège" (official work published at the time of the World's Fair in 1900) Bergen, 1900, p. 364-390. 5 pls.

1900.1

- (editor) Report on Norwegian fishery and marine investigations. 2 vols. Christiania \& Bergen, 1900$09.4^{\circ}$. 1900.2

Vol. i. Christiania, 1900. 8 articles.

Vol. ii. Bergen, 1909. Parts 1 \& 2.

Die erste Nordmeerfahrt des norwegischen Fischereidampfers "Michael Siars" im Jahre 1900. Petermann's Mitteilungen, 1901, 47, 73-83; 97-106. 2 pls.

1901.1

_ Fischfang in Norwegen. Deutsch von Dr. Ludwig Brühl. Fischerei Zeitg., 1901, 4, 55-58; 68-70. 1901.2 
Hjort, $J$.

Fishing experiments [Text in Nornvegian] Aarb. Vedk. Norges Fisk., Bergen, 1900 (1901), 251-268. 1901.3

"Michacl Sars," forste togt i Yordhavet aar 1900. Aarsberetning vedkommende Norges fiskerier for 1900 . Bergen, 1901. p. 231-268.9 figs. \& 6 pls.

1901.4

Verslag omtrent waamemingen en onderzoekingen, op de levenswijze van de zalm in het Boven-Moeselgebied betrekking hebbende, ingesteld Augustus-November 1900. Nederlandsche Staats-Courant, 1901. Zeitschr. Fischerei Helfswissenschaften, 1901, 9, 111117.

1901.5

- Fiskeri og hvalfangst i det nordlige Norge. Aarsberetning vedkmomende Norges fiskerier for 190-2. Bergen, 1902. p. 1-251. 74 figs. 1902.1

Forschungsfahrten auf nordischen Meeren. Zeitschr. Gesell. für Erdkunde Berlin, 1904, 484-497. fig.

1904.1

Nogle resultater af den internationale havforskning. Foredrag [Einige Resultate der internationalen Meersforschung. Vortrag] Aarsb. Norges Fiskerier, 1907, 351-387. - Norsk Tidskr. Fiskeri, 26, 413-450.

1907.1

Report regarding the herring. Conseil Perm. Intern. Explor. Mer, Rapp. \& Proc. Verb., 1908-09, 12, no. 5. 17 p. 9 figs.

1908.1

Some results of the international ocean researches. Scottish Oceanogr. Labor., Edinb., 1908, 1-40. 18 figs.

1908.2

Rapport sur les travaux de la commission "A " dans la période 19021907. Conseil Perm. Intern. Explor. Mer, Rapp. \& Proc. Verb., 1909, 10, 1-159. 53 figs.

1909.1

Report regarding the herring. Conseil Perm. Intern. Explor. Mer, Rapp. \& Proc. Verb., 1909, 12, no. 5, 1-17. 1909.2

Eel larvx (Leptocephalus brevirosiris) from the central north Atlantic. Nature, London, 1910, 85, 104-106. figs.

1910.1

Report on herring-investigations until January, 1910. Conseil Perm. Intern. Explor. Mer, Public. de Circonstance, 1910 , no. 53, 1-6.
The "Michael Sars" NorthAtlantic deep-sea expedition, 1910. Geograph. Journ. London, 1911, 349377; 500-523. 3 pls. \& figs. - Nature, 1910,85 , no. $2141,52-55$. 5 figs. 1911.1

_- Die 'Tiefsee-Expedition des "Michael Sars" nach dem Nordatlantik im Sommer 1910. Intern. Rev. Hydrobiol. \& Hydrogr., 1911, 4, 152-173; 335-361. 4 pls.

1911.2

- Der Kampf der französischen Industrie gegen die norwegischen Sardinen. Aarsberetning vedkommende Norges fiskerier, 1913, p. 1-132. 41 figs. 1913.1

Fluctuations in the great fisheries of northern Europe. Conseil Perm. Intern. Explor. Mer, Rapp. \& Proc. Verb., 1914, 10, 1-228. 3 pls. \& 137 figs.

1914.1

Hjort, Johan, \& Dahl, Knut. Fishing experiments in Norwegian fjords (In Report on Norwegian fishery, etc., vol. i, no. 1.215 p. 3 pls. \& 32 figs. Copenhagen, 1900) $\quad 1900.1$

Hjort, Johan, \& Gran, H. H. Hydrographic-biological investigations of the Skaggerrak and the Christiania fjord (In Report on Norwegian fishery, etc., vol. 1 , no. 2.56 p. 41 tables. Copenhagen, 1900)

1900.1

Hjort, Johan, \& Isea, Einar. Some results of the international herringinvestigations 1907-1911. Conseil Perm. Intern. Explor. Mer, Public. de Circonstance, 1911, no. 61, 8-34. 9 figs. Mitt. Deutsch. Seefischerei Ver., 28, 9-22. 7 figs.

1911.1

- Einige Resultate der internationalen Herringsuntersuchungen. Mitt. Deutsch: Seefischerei Ver., 1912, 28, 9-22. 7 figs.

1912.1

Hjort, Johan, \& Murray, (Sir) John. See Murray, (Sir) J., \& Hjort, $J$.

Hjort, Johan, Nordgaard, O., \& Gran, H. H. Report on Norwegian marine investigations 1895-97. Bergens Muscum, 1899. p. 1-50. 8 pls. 1899.1

Hjort, Johan, \& Petersen, C. G. Johanner. Short review of the results of the international fisheries investigations (mostly Norwegian and Danish) Conseil Perm. Intern. Explor. Mer, Rapp. \& Proc. Verb., 1905, 3, 1-43. 10 pls. \& 7 figs. Also separate; Bergen, 1905.

1905.1 
Hjortberg, Gustaf Frederic. Beskrifning på en guaperva Lophius histrio, fångad uti Sjögraset Sargazo. Svenska Vet. Akad. Handl., 1768, 30, 350-355. figs.

1768.1

Hoare, John. The resources of the sea fisheries of Ireland. Journ. Roy. Dublin Soc., 1870, 5, 1-12. 1870.1

- A treatise on fishponds; addressed to the nobility and gentry of Sussex. London, 1870. 49 p. $8^{\circ}$.

1870.2

Hobbs, 0. A list of Ohio river fishes sold in the markets. Bull. U. S. Fish Comm. 1881 (1882), 1, 124-125. 1882.1

Hobbs, William Herbert. The Newark system of the Pomerang valley, Conn. 21. Ann. Rept. U. S. Geol. Surv., 1901, pt. 3, 1-162. 17 pls. \& 59 figs.

References to Triassic fishes.

1901.1

Hochstetter, Ferdinand. Beiträge zur vergleichenden Anatomie und Entwicklungsgeschichte des Venensystems der Amphibien und Fische. Morphol. Jahrb., 1887, 13, 119-172. 3 pls. 1887.1

Entwicklung des Venensystems der Wirbeltiere. Ergebnisse Anat. Entwickl., 1893, 3, 460-489.

1893.1

Cyclostomen, p. 461-462. Selachier, p. 462466. Knochenfische, p. 466-467.

Ueber die Entstehung der Schejdewand zwischen Perikardial- und Peritonealhöhle und über die Bildung des Canalis pericardiaco-peritonealis bei Embryonen von Acanthias vulgaris. Morphol. Jahrb., 1900, 29, 141-168. pl. \& 12 figs.

1900.1

Ueber die Entwicklung der Dottersackzirkulation bei Scyllium stellare. Arch. Mikr. Anat., 1905, 66, 549-560. pl.

1905.1

Hodge, $E . B$. Result of propagating salmon. Rept. U. S. Fish Comm. 1878 (1880), 6, 930 .

1880.1

- Culture of landlocked and Penobscot salmon in New Hampshire. Bull. U. S. Fish Comm. 1885, 5, 423424.

1885.1

Hodgson, Bryan Houghton [1800 1894] Catalogue of the specimens and drawings of mammals, birds, reptiles and fishes of Nepal and Tibet, presented by B. H. Hodgson to the British Museum; with a preface by J. E. Gray. 2. ed. London, 1863. $12^{\circ}$. 1863.1
Hodgson, John. The culture of the eel. Fish. Gazette, 1878, n. s. 2, no. 71, 410.

1878.1

Hoefer, P., \& Tschermak, Armin. See Tschermak \& Hoefer.

Hoek, Paulus Peronius Cato. Ueber den encystirten Scolex von 'Tetrarhynchus ('Tetrarhynchus spec. parasite of the cod) Niederländ. Arch. Zool., 1879, 5, 1-18. pl.

1879.1

Aanteekeningen omtrent larven en jongen der voornaamste in het verslag besproken vischsoorten [Bemerkungen über Larven und Junge einiger wichtigeren in dem Berichte behandelten Fischarten] Tijdschr. Nederl. Dierk. Ver., 1888, 2 (Suppl.), 274-319. 4 pls.

Text in Dutch and German. 1888.1

De invloed der afsluiting en droogmaking op de visscherij in de Zuiderzee [The influence of the closing and "draining" on the fisheries in the Zuiderzee] Onderzoek omtrent de afsluiting en droogmaking van de Zuiderzee, de Wadden en de Lauwerzee, 1890, Nota no. 5, Append. I, i-x. 1890.1

The fishes of the Zuiderzee. Tijdschr. Nerderl. Dierk. Ver., 1890, 2. ser. 3, 38-80. 5 pls. Review by $\mathrm{E}$. Ehrenbaum in Mitt. Deutsch. Seefischerei Ver., 1892, 126-131. 1890.2

De haring van de Zuiderzee. Tijdschr. Nederl. Dierk. Ver., 1890, 2. ser. 3, xvi-xvii.

1890.3

Over hermaphrodiete kabeljauwen. Tijdschr. Nederl. Dierk. Ver. 1890, 2. ser. 3, cxviii-cxix. $\quad 1890.4$

Over het hermaphroditisme van de visschen uit de familien der Percida en Sparidxe. Tijdschr. Nederl. Dierk. Ver., 1890, 2. ser. 3, xxxvii-xxxviii.

1890.5

Rapport over de visscherij in de Zuiderzee [Report on the fisheries in the Zuiderzee] Verslag van den Staat der Nederl. Zeevisscherijen over 1889. 's-Gravenhage, 1890, Append. 3, 189390. 5 pls.

1890.6

Verslag van de onderzoekingen, verricht aan de Nederlandsche tafel van het zoölogisch station van Dr. A. Dohrn te Napels, van 1 Januari tot 1 April 1890. Nederlandsche Staats-Courant, June 1890. 1890.7 
Hoek, $P . P . C$.

- Hermaphroditisme bij visschen 1On hermaphroditism in fishes] Handel. 3. Natuur- en Geneesk. Congres, April 1891. Utrecht, 1891. $2 \mathrm{p}$

1891.1

Omt de levenswijze en de voortplanting van de ansjovis [Leiden] 1891. 3 pls. $4^{\circ}$.

1891.2

Verslag der verrichtingen van der ondergteekende aan de Nederlandsche werktafel in het zoölogisch station van Prof. Dohrn, te Napels, 10 Maart26 Juli 1887. Handel.3. Natuur- en Geneesk. Congres, April 1891. Utrecht, 1891.

1891.3

-_ De zalm op onze rivieren [The salmon of our rivers] Voordracht gehouden te Rotterdam op 1 December 1891 [Rotterdam, 1891] 36 p. pl.

1891.4

Translated into French by M. Bourguin: Le saumon dans les rivières de Hollande. Mémoires et Documents. Annales des Ponts et Chaussées, Juillet, 1893, no. 22, 172-200.

- Mededeelingen omtrent de levenswijze en de voortplanting van de ansjovis en omtrent de ansjovis-visscherij in de Zuiderzee Contributions regarding the life-history and the propagation of the anchovy and the anchovy fisheries in the Zuiderzee] Verslag van den Staat dor Nederl. Zeevisscherijen over 1891. 's-Gravenhage, 1892. p. 326-339. 3 pls. 1892.1

- Sur la truite de mer du Rhin. Tijdschr. Nederl. Dierk. Ver., 1892, 2. ser. 3, 243-266. 2 pls. - Zeitschr. Fischerei Hilfswissenschaften, 1893, 1 , 3-20.

1892.2

De binnen- op zoctwatervisscherij in Zuid-Holland The freshwater fisheries of the province of ZuidHolland Rapport aan Gedeputeerde Staten van Zuid-Holland uitgebracht, 1893. $94 \mathrm{p}$.

1893.1

-...- Wetenschappelijk onderzock in dienst van de visscherij [Scientific research in the service of the fisheries] I.ecture delivered before the 4. Nederlandsch Natuur-en Geneeskundig Congres, Groningen, 1893. 16 p. $\quad 1893.2$

Dic op een hermaphrodiet exemplaar van de rog (Raja clavala) betrekking hebben. 'Tijdschr. Nederl. Dierk. Ver., 1894, 2. ser. 4, xlv-xlvi. 1894.1

Over den toestand, waarin de zalm verkeert, als hij de rivier begint op te stijgen The condition in which the salmon enters the river] Versl. Akad. Wet. Amsterdam, Wis. Nat. Afd., 1894$95,3,48-50$.

1894.2

Rapport over het visschen met den stoomblazer "HD 318" [Report on fishing with steamlaunch "HD 318 "] Verslag van den Staat der Nederl. Zeevisscherijen over 1893. 's-Graven. hage, 1894. p. 319-341. 5 pls. 1894.3

Rapport over statistische en biologische onderzockingen, ingesteld met behulp van in Nederland gevangen zalmen. Verslag van den Staat der Nederl. Zeevisscherijen over 1893. 's-Gravenhage, 1894. p. 349-396. 7 pls. - Zeitschr. Fischerei Helfswissenschaften, $\mathbf{1 8 9 5}, \mathbf{3}, \mathbf{1 - 5 7}$.

1894.4

La pêche en Hollande (In Communications diverses sur les Pays-Bas publices à l'occasion du sixième Congrès International de Navigation Intérieure, p. 87-96. La Haye, 1894) Guide Zoologique, Helder, 1895, 140152. - Les Pays-Bas, Manuel en deux parties, 1898, 289-303.

1895.1

Zur Hebung der Maifischzucht im Rhein. Allgem. Fischerei Zeitg., 1895, 20. Jahrg., 216-218. 1895.2

Karperteelt en karpervijvers [Carp-culture and carp ponds] Maanblad Mededeelingen over Visscherij. 1896. $32 \mathrm{p}$.

1896.1

Recherches statistiques et biologiques sur le saumon des Pays-Bas. Bull. Soc. Centr. Aquicult. Pêche, 1896 , 8, nos. 1-2, 3-63. 5 figs. 1896.2

Welke inrichtingen zijn er voor de exploitatie van de nieuwe door de Regecring te Ijmuiden gebouwde visschershaven noodig en nuttig. Nederlandsche Staats-Courant, $1896.26 \mathrm{p}$.

1896.3

Over de levenswijze van de zalm. Versl. Akad. IVet. Amsterdam, Wis. Nat. Afd., 1897, 6, 176-177.

1897.1

Rapport over het visschen met ankerkuilen, zoowel in den gesloten tijd als daarna. Verslag van den Staat der Nederl. Zeevisscherijen over 1896. 'sGravenhage, 1897. Append. 5, 267-416. $S$ pls.

1897.2

De statistische methode en de "elfties en fintjes" [The statistical method and the little shads and Alice shads] Lecture delivered before the 6 . Nederlandsch Natuur-en Geneeskundig 
Congres. Delft, Verh. 6. Natuur- en Geneesk. Congres [Utrecht], 1897. 4 p. 1897.3

- Neuere Lachs- und MaifischStudien. Tijdschr. Nederl. Dierk. Ver., 1899, 2. ser. 6, 156-242. 5 pls. 1899.1

- Rapport over de Internationale Conferentie voor het onderzoek der zee, gehouden te Stockholm in Juni 1899, uitgebracht aan den Minister van Waterstaat, Handel en Nijverheid. Nederlandsche Staats-Courant, 1899. $12 \mathrm{p}$.

1899.2

- De vischtuigen, volgens de bestaande reglementen in ons vaderland geoorleoofd, gerangschikt naar de provincien. Helder, 1899. 11 tables.

1899.3

- Bericht über Beobachtungen und Untersuchungen der Lebensweise des Lachses im Gebiete der oberen Mosel in der Zeit vom August bis November 1901 [Translated by L. J. Brühl] Fischerei Zeitg., 1901, 4, 625-630.

1901.1

The literature of the ten principal food fishes of the North sea in the form of compendious monographs. Conseil Perm. Intern. Explor. Mer, Public. de Circonstance, 1903, no. 3, 1-107. 10 pls.

1903.1

- Over het internationale onderzoek der zee. Versl. Vergaderingen Wisen Natuurkundige Afdeeling I. Akad. Wet. Amsterdam, Wis. Nat. Afd., 1903, 11, 400-104.

1903.2

Catalogue des poissons du nord de l'Europe avec les noms vulgaires dont on se sert dans les langues de cette région. Conseil Perm. Intern. Explor. Mer, Public. de Circonstance, 190t, no. $12,1-76$.

1904.1

375 species are enumerated, their distribution indicated, and their vernacular names are given in ten European languages.

Ziele und Vege der internationalen Meeresforschung. C. R. 6. Congrès Intern. Zool. Berne, 1904. 17 p.

1904.2

Fischerei- und biologische Untersuchungen, einleitende Uebersicht. Conseil Perm. Intern. Explor. Mer, Rapp. \& Proc. Verb., 1905, 3, vi-xxi. 1905.1

Introductory review of the appendixes: Fisheries and biological investigations. Conseil Perm. Intern. Explor. Mer, Rapp. \& Proc. Verb., 1905, 3. $20 \mathrm{p}$.
Ueber die Lachsarten und deren IVanderungen. Stenogr. Protok. Verh. Intern. Fisch.-Kongr. Wien, 1905 (1906), $165-179$

1906.1

- Die internationale Meeresforschung und die Seefischerei-Statistik. Institut Intern. Statistique, 21. sess., Copenhague, 1907. 7 p. $\quad 1907.1$

Aallarven, glasaaltjes en montées Aallarven in verschiedenen Stadien und Montée] Meded. Vissch., Helder, 1908, 15, 77-82. 1908.1

Het internationaal onderzoek der zee en de vangst van schol in de Noordzee [Die internationale Meeresuntersuchung und der Schollenfang in der Nordsee] Meded. Vissch., Helder, $1908,15,168-175$. 1908.2

Over het visschersonderwijs in ons vaderland [On the education of fishermen in our country] Meded. Vissch., Helder, 1908, 15. 22 p. 1908.3

Bericht iiber Eier und Larven von Gadiden mit besonderer Berücksichtigung der seit Juli 1908 veröffentlichten Arbeiten über diesen Gegenstand dem Central Ausschuss für die internationale Meeresforschung erstattet. Conseil Perm. Intern. Explor. Mer, Rapp. \& Proc. Verb., 1909, 12, no.1. 29 p.

1909.1

Over den leeftijd van den zalm af te leiden uit de structuur der schubben. Versl. Akad. Wet. Amsterdam, Wis. Nat. Afd., 1909, 18, 432-450. 2 pls. - Proc. Acad. Wet. Amsterdam, 12, 485502. 2 pls.

1909.2

Wat het internationale onderzoek der zee ons reeds geleerd heeft [What the international investigation of the sea has already taught us] Werken Genootsch. Natuur-, g. Heelk., Amsterdam, 1909, 2. ser. 6, pt. 2, 118-135.

1909.3

Nog eene over het visschersonderwijs in ons vaderland [Further regarding the education of fishermen in our country] Meded. Vissch., Helder, 1910. 9 p.

1910.1

Propagation and protection of the Rhine salmon. Proc. 4. Intern. Fish. Congr. Washington, D. C. Bull. Bureau Fisheries, 1908 (1910), 28, pt. 2, 817-829. 2 figs,

1910.2

Laichgeschäft und Fang-Verhaltnisse der Gadiden-Arten in der Nordsee. Conseil Perm. Intern. Explor. 
Hoek, P.P. ('.

Ner, Public. de Circonstance, 1911, no. 57. $72 \mathrm{p}$.

1911.1

Ueber die quantitative Verbreitung der Eier und Larven von Gadiden in der Nordsee. Conseil Perm. Intern. Explor. Mer, Rapp.\& Proc. Verb., 1911, 13. $20 \mathrm{p}$.

1911.2

__ Les clupéides (le hareng excepté) et leurs migrations. Conseil Perm. Intern. Explor. Mer, Rapp. \& Proc. Verb., 1912, 14. 40 p.

1912.1

Duitsche en Fransche namen van te Ijmuiden aangevoerde zeevisschen [Deutsche und französische Namen zu Ijmuiden angeführter Seefische\} Meded. Vissch., Helder, 1912, 19, 114-117.

1912.2

- Over leeftijdsbepaling en groei bij de visschen [Ueber Altersbestimmung und Wachstum bei den Fischen] Meded. Vissch., Helder, 1912, 19, 194 201. Ibid., 1913, 20, 8-13.

1912.3

Naar aanleiding van het $K$. B. tot vaststelling van een Reglement voor het. Rijksinstituut voor Visscherijonderzoek [Apropos the royal warrant instituting a regulation concerning the government institution of fishery research! Meded. Vissch., Helder, 1912. 7 p.

1912.4

Das neue Fischereigesetz für das Königreich der Niederlande vom 6 . October 1908 und die See- und Küstenfischerei. Mitt. Deutsch. Seefischerei Ver., 1912. $16 \mathrm{p}$.

1912.5

Die fischereilichen und statistischen Arbeiten der Internationalen Meeresforschung während der Jahre 1902-1912. Conseil Perm. Internat. Explor. Mer, Mém. 1902-12 (1913), $12-41$.

1913.1

L La sardine (Clupea pilchardus) [Leide] 1913. $4^{\circ}$.

1913.2

Hoek, Paulus Peronius Cato, \& Bottemanne, $C . J$. Rapport over ankerkuil-en staalboomenvisscherij [Bericht über die Fischerei mit Steert- und feststehenden Hamen auf dem Hollandsch Diep und Haringvliet. 'Tijdschr. Nederl. Dierk. Ver., 1888, 2 (Suppl.), 1-331. 6 pls.

1888.1

Text in Dutch and German.

Hoek, Paulus Peronius Cato, \& Kyle, Harry $M$. Statistics of the North sea fisheries. I. The fisheries of the various countries. Conseil Perm. Intern. Explor. Mer, Rapp. \& Proc. Verb., 1905, 3 (Append. J), 3-121.

1905.1

Hoek, Paulus Peronius Cato, \& Ostenfeld, C. H. Catalogue des espèces de plantes et d'animaux observées dans le plankton receuilli pendant les expéditions périodiques depuis le mois d'aôt 1902 jusqu'au mois de mai 1905. Conseil Perm. Intern. Explor. Mer, Public, de Circonstance, 1906, no. 33. $122 \mathrm{p}$.

1906.1

Hoek, Paulus Peronius Cato, \& others. Bijdragen tot de kennis der levenswijze en der voortplanting van de ansjovis, enz. [Contributions to the life history and propagation of the anchovy, etc.] Vers. Staat Nederl. Zeevisscherijen, 's-Gravenhage, 1886, 178-201. 2 pls. 1886.1

Hoek, Paulus Peronius Cato, \& Trybom, Fil. Draft-answer to the questions regarding the salmon fisheries of the Baltic, presented by the governments of Denmark, Finland, Russia and Sweden. Conseil Perm. Intern. Explor. Mer, Rapp.\& Proc. Verb., 1907, 7, 152183.

1907.1

Hömberg, $W$. Der Fischteich des Land- und Forstwirts. Anleitung zum Betriebe der Teich-Fischerei. 2. ed. Arnsberg, 1902. 111 p. 1902.1

Ausgabe A: Für den Sohulgebrauch. Ausgabe B: Für Fischerei-Vereine als Vereinsgabe.

Hoepfel, $F$. Meine Erfahrungen bei der Zucht von Hemichromis bimaculatus. Vochenschr. Aquar-Terrar. Kunde, 1913, 10. Jahrg., 117-118. fig. 1913.1

Höptner, Fr. Acara coruleum-punctata. Wochenschr. Aquar.-Terrar. Kunde, 1913, 10. Jahrg., 526-527. fig. 1913.2

Hoernes, $H$. Ueber Flügelformen und Körper fliegender Fische. Zeitschr. Flugtechnik, München, 1913, 4, 299$304 ; 325-333$.

1913.3

Hoernes, Rudolf $[1850-]$ Zur Geologie von Untersteiermark. Die Fischfauna der Cementmergel von Tüffer. Verh. Geol. Reichsanstalt, Wien, 1893, no. $2,41-14$.

1893.1

- Ueber Koprolithen und Enterolithen. Biol. Centralbl., 1904, 24, 566576.

1904.1

Hörschelmann, —_- Ein Beitrag zur Anatomic der Zunge der Fische. Inaug. Dissert. Dorpat, $1866.8^{\circ}$.

1866.1 
Hoeven, Janus van der [1802-1868] De sceleto piscium. Inaug. Dissert. Lugduni Batavorum, 1822. Abstract in Bull. Sci. Nat. (Férussac), 1823, pt. 2, 116. Ibid., 1824, pt. 2, 86-89. 1822.1

Kleine ichthyologische aanteckeningen. Bijdr. Natuur. IVet., 1831, 6, $338-340$.

1831.1

- Ueber die Durchkreuzung der Sehnerven beim Kiabeljau. Arch. Anat. Physiol., 1832, 412-413. figs. 1832.1

- Over Lepidosiren paradoxa, een nieuw geslacht van reptilia. Tijdschr. Natuur. Gesch. Physiol., 1837-38, 4, $407-408$

1837.1

- Nader berigt over Lepidosiren. Tijdschr. Natuur. Gesch. Physiol., 1839, 6, 61-62.

1839.1

Ueber die zellige Schwimmblase des Lepidosteus. Arch. Anat. (Müller), 1841, 221-223. pl.

1841.1

Verzameling van berigten over Amphioxus lanceolatus. Tijdschr. Natuur. Gesch. Physiol., 1841, 8, 73-93. 2 pls.

1841.2

Mededeeling over kleine vischjes waarschijnlijk jongen van $E$ sox belone L., door Prof. Behn, bij Kiel in de Oostzee ontdekt. Tijdschr. Natuur. Gesch. Physiol., 1843, 10, 1-11.

1843.1

Handboek der dierkunde; tweede verbeterde uitgave; met bijvoegsels en aanmerkingen door Leuckart. 3 vols. Amsterdam, 1849-56. pls. $8^{\circ} .1849 .1$ Fishes, vol. ii, p. 18s-419.

De haring en de haringvisscherij. Album Natuur, 1852 (Wetensch. bijblad.), 161-175. figs.

1852.1

Handbook of zoology, translated by the Rev. W. Clark. 2 vols. Cambridge, $1856-58$. $8^{\circ}$.

1856.1

Eene bijdrage tot de vraag naar de veranderlijkheid of onveranderlijkheid der soorten. Album Natuur, 1868 (Wetensch. bijblad.), 44-45. 1868.1

Hofer, A. Ueber Thier- und Pflanzen-Namen. Wien, 1880, 122 p. $8^{\circ}$.

$$
\text { Fishes, p. } 67 .
$$

1880.1

Hofer, Bruno [1861--] Ueber den Bau und die Entwicklung der Cycloidund Ctenoidschuppen. Sitzber. Ges. Morph. Phys. München, 1889, 6, 103 118.

1889.1
__ Eine Salmoniden-Erkrankung. Allgem Fischerei Zeitg., 1893, 18. Jahrg., no. 11, 168-171.

1893.1

- Die Bedeutung der Planktonstudien für die Fischerei in Seen. Allgem. Fischerei Zeitg., 1896, 21. Jahrg., $355-359$

1896.1

- Eine Krankheit des Bachsaiblings. Allgem. Fischerei Zeitg., 1896, 21. Jahrg., no. 24, 431. Ibid., 1897, 22. Jahrg., 6-7.

1896.2

Die sogenannte Pockenkrankheit der Karpfen. Allgem. Fischerei Zeitg., 1896, 21. Jahrg., no. 1, 2-3.

1896.3

Eine angebliche Epidemie unter den Aalen. Allgem. Fischerei Zeitg., 1897, 22. Jahrg., 25-26. 1897.1

Die Rassen der Karpfen. Allgem. Fischerei Zeitg., 1898, 23. Jahrg., $37-40 ; 95-97 ; 153-156 ; 175-176 ; 187-$ $188 ; 205-206 ; 257-259 ; 274-275$. 1898.1

Zur Entstehung der Furunkulose bei Salmoniden. Allgem. Fischerei Zeitg., 1898, 23. Jahrg., no. 2. 1898.2

Die Krankheiten unserer Fische. Allgem. Fischerei Zeitg., 1901, 26. Jahrg., $157-160 ; 180-183 ; 242-245 ; 454-457$; $474-478 ; 493-495$.

1901.1

- Ueber die Mittel und Wege zum Nachweis von Fischwasserverunreinigungen durch Industric- und Städteabwässer. Allgem. Fischerei Zeitg., 1901, 26. Jahrg., 419-424.

1901.2

_- Ueber Missbildungen beim Hecht. Allgem. Fischerei Zeitg., 1901, 26. Jahrg., no. 1, 14-15. 1901.3

Zur Entstehung der Furunkulose. Allgem. Fischerei Zeitg., 1901, 26. Jahrg., no. 13, 291.

1901.4

Die Krankheiten unserer Fische. Fortsetzung. Allgem. Fischerei Zeitg., 1902, 27. Jahrg., 6-9; 21-26; 61-64; $87-88 ; 220-222 ; 262-263 ; 354-356 ; 449-$ 452 .

1902.1

Ueber Lehm als Heilmittel bei Fischkrankheiten. Allgem. Fischerei Zeitg., 1902, 27. Jahrg., 433-435. 1902.2

Die Drehkrankheit der Regenbogenforelle. Allgem. Fischerei Zeitg., 1903, 28. Jahrg., no. 1, 7-8. 1903.1

Ein Fall von perniziöser Anämie durch Octobothrium sagittatum bei der Regenbogenforelle. Allgem. Fischerei Zeitg., 1903, 28. Jahrg., 38-39. 1903.2 
Hofer, $B$.

- Ein neuer Krankheitserreger bei Fischen. Allgem. Fischerei Zeitg., 1903, 28. Jahrg., $24-26$.

1903.3

Ueber die Wirkung der Abwässer von Stärkefabriken in Fischwässern. Allgem. Fischerei Zeitg., 1903, 28. Jahrg., $3-6$.

1903.4

Die biologische Untersuchungsmethode bei Fischwasserverunreinigungen. Allgem. Fischerei Zeitg., 1904, 29. Jahrg., 205-206.

1904.1

Handbuch der Fischkrankheiten. München, 1904. xv, 359 p. 18 pls. \& 222 figs.

1904.2

Review by Einar Lönnberg in Svensk Fisk. Tidskr. Stockholm, 1904, 13, 39-44. Translated in part by T. H. Bean in 12. Ann. Rept. N. Y. Forest, Fish \& Game Comm., 1907.

- Karpfen mit verschlossener Mundspalte. Allgem. Fischerei Zeitg., 1904, 29. Jahrg., 31. fig. 1904.3

Ueber die Einführung der Peipusseemoräne in Deutschland $[$ Coregonus murænal Allgem. Fischerei Zeitg., 1905, 30. Jahrg., 203-204. 1905.1

- Vom Wels. Schweiz. Fischerei Zeitg., 1906, 14. Jahrg., 53-59. fig.

1906.1

- Degenerationserscheinungen bei der Regenbogenforelle [Salmo iridea] Allgem. Fischerei Zeitg., 1907, 32. Jahrg. $510-511$.

1907.1

Studien über die Hautsinnesorgane der Fische. Ber. Kgl. Biol. Versuchsstat. München, 1908, 1, 115-164.

1908.1

Zur Naturgeschichte des Ammerseekilchs, Allgem. Fischerei Zeitg., 1908, 33. Jahrg., 434-436. 1908.2

— Die Süsswasserfische von Mitteleuropa. Leipzig, 1909.

1909.1

- Die Ergebnisse der neueren exakten Vererbungslehre in ihrer Bedeutung für die Fischzucht. Allgem. Fischerei Zeitg., 1912, 37. Jahrg., 2-6; 30-34; 9296; 334-338. Also separate; München, 1912.

1912.1

Hofer, Bruno, \& Doflein, Franz J. Th. Die Rotscuche des Aals. Allgem. Fischerei Zeitg., 1898, 23. Jahrg., no. 1.

1898.1

Hofer, J. Die Trüsche. Schweiz. Fischerei Zeitg., 1894, 2. Jahrg,, 101. Also separate; Pfäffikon-Zürich, 1894. 28 p. $8^{\circ}$.
Die Aesche. Schweiz. Fischerei Zeitg., 1895, 3. Jahrg., 239. Also separate; Pfäffikon-Zürich, 1895. 24 p. $8^{\circ}$.

1895.1

Die Barbe. Schweiz. Fischerei Zeitg., 1895, 3. Jahrg., 215. Also separate; Pfäffikon-Zürich, 1895. 22 p. $8^{\circ}$. 1895.2

- Notizen über die Fischfauna des Kantons Tessin. Schweiz. Fischerei Zeitg., 1895, 3. Jahrg., 267. Also separate; Pfäffikon-Zürich, $1895.16 \mathrm{p}$. $8^{\circ}$.

1895.3

- Der Barsch. Schweiz. Fischerei Zeitg., 1896, 4. Jahrg., 283-314. Also separate; Pfäffikon-Zürich, 1896. $31 \mathrm{p}$. $8^{\circ}$

1896.1

- Der Wels. Schweiz. Fischerei Zeitg., 1896, 4. Jahrg., 1-2. Also separate; Pfäffikon-Zürich, 1896. 2 p. $8^{\circ}$. 1896.2

Rötel-Fischerei. Schweiz. Fischerei Zeitg., 1897, 5. Jahrg., no. 23, 236242 ; no. $24,247-250$; no. 25, 255-258.

1897.1

Nachtrag zu den Notizen über die Fischfauna des Kantons 'Tessin. Schweiz. Fischerei Zeitg., 1898, 6. Jahrg., no. 29, 371-382.

1898.1

- Der Apron, Aspro vulgaris Cuv. \& Val. (Aspro apron Sieb.) Schweiz. Fischerei Zeitg., 1908, 16. Jahrg., 2-7.

1908.1

Die Fischfauna des europäischen Russlands. Schweiz. Fischerei Zeitg., 1909, 17. Jahrg., 71-75; 91-95; 166171.

1909.1

- Glarnerische Gewässer und ihre Fische. Schweiz. Fischerei Zeitg., 1909, 17. Jahrg., 261-264.

1909.2

- Der Bitterling, la bouvière. Schweiz. Fischerei Zeitg., 1910, 18. Jahrg., 270-273. fig. 1910.1

- Die Fischfauna des Kantons Aargau. Mitt. Aargau Nat. Ges., 1911, 12. Heft, 61-74.

1911.1

- Die Fischfauna des Kantons Tessin. Schweiz. Fischerei Zeitg, 1911, 19. Jahrg., 54-58.

1911.2

- Neunaugen (Lampreten), lamproies. Schweiz. Fischerei Zeitg., 1911, 19. Jahrg, 145-147.

1911.3

- Notizen über die Fischfauna des Kantons Aargau. Schweiz. Fischerei Zeitg., 1911, 19. Jahrg., 167-171. Ibid., 1912, 20. Jahrg., 12-18; 74-76. 1911.4 
Wenig beachtete Fische unserer Gewässer I. Telestes agassizi (Val.) (Squalius agassizi) II. Alburnus bipunctatus (Bl.), (Spirlinus bipunctatus Fatio), Bliecke, Breiteli, Bambeli. Schweiz. Fischerei Zeitg., 1911, 19. Jahrg., 1-3; 30-33. fig.

1911.5

Hoffbauer, $C$. Die Altersbestimmung des Karpfen an seiner Schuppe. Allgem. Fischerei Zeitg., 1898, 23. Jahrg., 341-343. 2 figs. Ibid., 1900, 25 Jahrg., $135 ; 150 ; 297$. Abstract in Jahresber. Schles. Fischerei Ver., 1899, 68. 3 pls. \& 2 figs.

1898.1

- Jahresbericht der teichwirtschaftlichen Versuchsstation zu Trachenberg pro 1899-1900. Jahresber. Schles. Fischerei Ver., Breslau, 1899, 55.

1899.1

Die Bedeutung der Körpermesung als Bestimmungsmittel. Allgem. Fischerei Zeitg., 1901, 26. Jahrg., 183184.

1901.1

Jahresbericht der teichwirtschaftlichen Versuchsstation zu Trachenberg pro 1900-01. Breslau, 1901. 63 p. 3 pls.

1901.2

Weitere Beiträge zur Bestimmung des Alters und Wachstumsverlaufes an der Struktur der Fischschuppe (In his Jahresbericht der Teichwirtschaftlichen Versuchsstation Trachenberg, p. 50. Breslau, 1901. 3 pls.)

1901.3

Wie steht es mit der Nachhaltigkeit des Betriebes in der Karpfenteichwirtschaft? Eine fischereiliche Betrachtung nach den Ergebnissen des letzten Wirtschaftsjahres. Zeitschr. Fischerei, Berlin, 1901-02, 9, 118-123.

1901.4

Zur Beurteilung der Beweisführung Dr. Walters ibetreff Altersbestimmung des Karpfens nach der Schuppe] Fischerei Zeitg., 1901, 4, 404406.

1901.5

Ueber den Einfluss des Wasservolumens auf das Wachstum der Fische. Vorläufige Mitteilung. Allgem. Fischerei Zeitg., 1902, 27. Jahrg., 103-104; 119-122

1902.1

Bericht über die Tätigkeit der teichwirtschaftlichen Versuchsstation zu Trachenberg pro 1902. Allgem. Fischerei Zeitg., 1903, 28. Jahrg., no. 8

1903.1

- Ueber das Massensterben der Karpfen im Wirtschaftsjahre 1902. Zeitschr. Landwirtschaftskammer Prov. Schlesien, 1903.

1903.2
Zur Alters- und Wachstumserkennung der Fische nach der Schuppe. Allgem. Fischerei Zeitg., 1904, 29. Jahrg., $242-244$.

1904.1

Weitere Beiträge zur Alters- und Wachstumsbestimmung der Fische, speziel des Karpfens. Zeitschr. Fischerei, Berlin, 1905, 12, 111-142. 4 pls.

1905.1

Untersuchungsergebnisse über Alters- und Wachstumserkennung nach der Schuppe. Stenogr. Prot. Verh. Intern. Fisch.-Kongr. Wien, 1905 (1906), $131-134$.

1906.1

Grundregeln für die fischereiliche Verwertung einselner zur Karpfensucht geeigneter Guts- oder Wirtschaftsteiche. "Unter spezieller Berücksichtigung der schlesischen Verhältnisse. Zeitschr. Landwirtschaftskammer Prov. Schlesien, Breslau, 1907. 9 p. 1907.1

Jahresberichte der teichwirtschaftlichen Versuchsstation zu Trachenberg von 1905 bis 1910-11. Jahresber. Landwirtschaftskammer Prov. Schlesien, Breslau, 1912.

1912.1

Unsere einheimischen Süsswasserfische und die Fischzucht. Leipzig, 1912. 14 pls. \& figs.

1912.2

Hoffman, Horace Addison, \& Jordan, David Starr. A catalogue of the fishes of Greece, with notes on the names now in use, and those employed by classical authors. Proc. Acad. Nat. Sci. Philad. 1892 (1893), 230-285.

1893.1

Hoffiman, $R . E$. Artificial sea-water for aquaria. Bull. U. S. Fish Comm., $1884,4,465-467$.

1884.1

Hoffmann, Carl Ernest Emil. Beiträge zur Anatomie und Physiologie des Nervus vagus bei Fischen. Pro venia legendi Med. Facult. Giessen. Giessen, 1860. 31 p. pl.

1860.1

Hoffmann, Christian Karl. Een hoogst merkwaardige visch [Ceralodus forsteri] Isis (Huizinga), 1872, 1, 217218.

1872.1

- Vorläufige Mittheilung zur Ontogenie der Knochenfische. Zool. Anz. 1880, 3, 607-610; 629-634. 1880.1

Zur Ontogenie der Knochenfische. Versl. Akad. Wet. Amsterdam, 1881, 21, 1-168. 7 pls. $\quad 1881.1$

- Sur l'origine du feuillet blastodermique moyen chez les poissons cartilagineux. Arch. Néerl. Sci. Nat., 1883, 18, 241-258. 2 pls. 1883.1 
Hoffmann, $C . K$.

Z Zur Ontogenie der Knochenfische. Versl. Akad. Wet. Amsterdam, 1883, 23, 1-60. 4 pls. - Arch. Mikr. Anat., 23, 45-108. 3 pls. $\quad 1883.2$

Zur Entwicklungsgeschichte der Urogenitalorgane bei den Anamnia. Zeitschr. Wiss. Zool., 1886, 44, 570-643. 3 pls. \& 4 figs.

1886.1

Kinornelfische, p. 614-621. Knochenfische, p. 621-635.

Ueber den Ursprung und die Bedeutung der sogenannten "freien" Kerne in dem Nahrungsdotter bei den Knochenfische. Zeitschr. Wiss. Zool., 18s8, 46, 518-548. pls.

1888.1

Ueber die Entstehung der endothelialen Anlage des Herzens und der Gefässe bei Haiembryonen (Acanthias vulgaris) Anat. Anz., 1892, 7. Jahrg., 270-273. 3 figs.

1892.1

- Untersuchungen über den Ursprung des Blutes. Verh. Akad. Wet. Amsterdam, 2. Sectie, 1893, p. 3. 1893.1

Zur Entwicklungsgeschichte des Herzens und der Blutgefässe bei den Selachiern. Ein Beitrag zur Kenntniss des unteren Keimblattes. Morphol. Jahrb. 1893, 19, 592-648. 4 pls. \& figs. 1893.2

Zur Entwicklungsgeschichte des Venensystems bei den Selachiern. Morphol. Jahrb., 1893, 20, 289-304. pl.

1893.3

Zur Entwickelungsgeschichte des Selachierkopfes. Vorläufige Mitteilung. Anat. Anz., 1894, 9, 638-653. 5 figs.

1894.1

Beiträge zur Entwicklungsgeschichte der Selachii. Morphol. Jahrb., 1896, 24, 209-286. 4 pls. Ibid., 1897. 25, 250-304. 2 pls. \& 9 figs. Ibid. $1899,27,325-414$. 5 pls. \& 5 figs.

1896.1

Over de teleneuronen in het netvlies van Leuciscus turilus. Verh Akad. Wet. Amsterdam, Wis. Nat. Afd., $1897,5,425-428$.

1897.1

Zur Entwicklungsgeschichte des Sympathicus. I. Die Entwicklungsgeschichte des Sympathicus bei den Selachiern (Acanthias vulgaris) Verh. Akad. Wet. Amsterdam, 2. Sectie, 1901, $7,1-80$. 3 pls.

1901.1

Hoffmann, Ernst. Die Zucht von Bella bellica von Sumatra im Aquarium. Bliitt. Aquar.-'Terrar. Kunde, 1913, 24. Jahrg., 52-53. fig.
Hofimann, Friedrich [1797-1836] Ueber das Thier von Stronsa. Isis (Oken), 1818, 2096-2100. figs. 1818.1

Einige Bemerkungen über die Vegetation und die Fauna von Helgoland. Verh. Ges. Naturf. Freunde Berlin, 1829, 1, 228-260. pl. - Isis (Oken), $1834,443$.

1829.1

Fische, p. 237-238.

Hoffmann, Guido. Asterolepis rhenanus (Pterichthys rhenanus Beyrich) Centralbl. Mineral. Geol. Pal., 1909, 491-495. 3 figs.

1909.1

Ueber das Ruderorgan der Asterolepiden. Palæontographica, 1911, 57, 285-316. 3 pls. \& 26 figs. $\quad 1911.1$

Hoffmann, Ludwig. Zur Kenntnis des Neurocraniums der Pristiden und Pristiophoriden. Zool. Jahrb. (Anat. Abth. $), 1912,33,239-360.12$ pls. \& 8 figs.

1912.1

Hoffimann, M. L., \& Meek, Seth Eugene. See Meek \& Hoffmann.

Hofimeyer, $C . W$. Untersuchungen iiber normales und abnormales Fischblut. Allgem. Fischerei Zeitg., 1907, 32 . Jahrg., 50-53.

1907.1

Hofmann, Ernst [1837-1892] Der Fischzucht schädliche und nützliche Thiere. 40. Jahresh. Ver. Vaterl. Naturk. Württemberg, 1884, 36-46. 4 figs.

1884.1

Hofmann, $E$. Ueber eine Ursache des Sterbens der Fische. Allgem. Fischerei Zeitg., 1903, 28. Jahrg., no. 21. 1903.1

Hofmann, $F . B$. Histologische Untersuchungen über die Innervation der glatten und der ihr verwandten Muskulatur der Wirbeltiere und Mollusken. Arch. Mikr. Anat., 1907, 70, 361-413. pl.

1907.1

Hogarth, Ronald. 'The herring fishery. Intern. Fisheries Exhib. Lit., London, 1883. Conferences, 11, pt. 8.

1883.1

Hogg, John [1800-1869] On the artificial breeding of salmon and trout, with remarks on the modes of fecundating their ova. Proc. Linn. Soc. London, 1838, 33-34. Ibid., 1855, 2, 246-247. 1838.1

On the distribution of certain species of freshwater fish and. on the mode of fecundating the ova of the Salmonidx. Trans. Tyneside Nat. Field Club, 1854-58, 3, 73-87. 
Letter recording the capture of two species of pipe-fish, Syngnathus typhle L. and S. acquoreus L.I Proc. Linn. Soc. London, 1855, 2, 157. 1855.1

- On the external membrane of the unimpregnated and impregnated ova of the common salmon. Proc. Linn. Soc. London, 1855, 2, 330-332.

1855.2

On the occurrence of a large specimen of Thynnus vulgaris in the river Tees. Proc. Linn. Soc. London, 1855, 2, no. 59, 348-349. Ibid., 3, no. $60,360-361$.

1855.3

On the distribution of certain species of freshwater fish; and on the modes of fecundating the ova of the Salmonidx. Trans. Tyneside Nat. Field Club, 1858, 3, 73-87. 1858.1

Occurrence of the dory, Zeus faber, near Hartlepool. Trans. Tyneside Nat. Field Club, 1860, 4, pt. 4, 336. Zoologist, 1861, 19, 7401.

1860.1

- Preservation of salmon ova in ice. Athenæum, 1861, no. 2104, 289. Ibid., 1868, 899 .

1861.1

On the capture of a ribbon fish (Regalecus banksii) [Gymnetrus] near Seaton Snook in the county of Durham. Ann. Mag. Nat. Hist., 1866, 3. ser. 17, 390-391.

1866.1

On the finding of a second ribbon fish. Ann. Mag. Nat. Hist., 1866, 3. ser. 18,136 .

1866.2

- Notes on local fishes [Lophius piscatorius, Clupea finta of Cuvier] Trans. Nat. Hist. Soc. Northumb., 1870 , 3, 175-176.

1870.1

Hohmann, Karl. Die bis jetzt eingeführten Rivulus-Arten. Wochenschr. Aquar.-Terrar. Kunde, 1911, 8. Jahrg., 701-703. 3 figs.

1911.1

Eine hübsche Varietät von $P \propto$ cilia sphenops Cuv. \& Val. Wochenschr. Aquar.-Terrar. IKunde, 1911, 8. Jahrg., 545-546. fig.

1911.2

- Trichogaster lalius Ham. Buch. Etwas über seine Zucht und Pflege. Wochenschr. Aquar.-Terrar. Iunde, 1911, 8. Jahrg., 502-503. fig. 1911.3

Acara thayeri Steindachner (Thayers Buntbarsch) und seine Zucht. Wochenschr. Aquar.-Terrar. Kunde, 1912, 9. Jahrg., 633-634. fig. 1912.1
Osphromenus striatus Gthr. Wochenschr. Aquar.-Terrar. Kunde, 1912, 9. Jahrg., 93-94. fig.

1912.2

Platypœcilus maculatus, schwarzgescheckte Varietät (var. pulchra) Blätt. Aquar--Terrar. Kunde, 1912, 23. Jahrg., 272-273. 2 figs.

1912.3

Tetragonopterus rubropictus Berg. Wochenschr. Aquar.-Terrar. Kunde, 1912, 9. Jahrg., 29-30 fig. 1912.4

Weitere Zuchterfolge und Beobachtungen bei der roten Abart von Rivulus poeyi. Wochenschr. Aquar.Terrar. Kunde, 1912, 9. Jahrg., 422-426. 2 figs.

1912.5

Zwei reizende lebendgebärende Zahnkärpflinge. Wochenschr. Aquar.Terrar. Kunde, 1912, 9. Jahrg., 163165. 2 figs.

1912.6

Etroplus maculatus Bloch.

Wochenschr. Aquar.-Terrar. Kunde, 1913, 10. Jahrg., 429-430. fig. 1913.1

Hohnbaum-Hornschuch, Reinholdus Fridericus Mauritius [1816-] De anguillarum sexu ac generatione. Gryphix, 1842. pls. $4^{\circ}$. 1842.1

Nadere mededeeling over de jongen van Esox belone [Belone vulgaris] Tijdsch. Natuur Gesch. Physiol., 1843, 10, 295-300.

1843.1

Hohner, G. M. On the comparative anatomy of the nervus acusticus. Trans. Roy. Irish Acad., 1903, 32, Sect. B, pt. 1.

1903.1

Holberg, L. Beskrifning öfver Bohuslänske fiskarne, utgifven af Kongl. Vettenskaps och Vitterhs. Samhället i Götheborg. Götheborg [n. d.] $8^{\circ}$.

Holberton, Wakeman. Black bass. Rod \& Gun, 1876, 8, 199. 1876.1

The successful stocking of streams with trout. Bull. U. S. Fish Comm.1883, 3, 192. 1883.1

Holbrook, A. T. The origin of the endocardium in bony fishes. Bull. Mus. Comp. Zool., Harv. Coll., 1894, 25, 79-97. 5 pls. 1894.1

Holbrook, John Edwards [1796-1871] Southern ichthyology; or a description of the fishes inhabiting the waters of South Carolina, Georgia and Florida. New York \& London, 1847. 32 p. 4 pls. $4^{\circ}$. 
Holbrook, $J . E$.

An account of several species of fish observed in Florida, Georgia, etc. Journ. Acad. Nat. Sci. Philad., 1855, 2 , ser. 3, pt. 1, 47-5s.

1855.1

Ichthyology of South Carolina. Charleston, 1855. 182 p. 27 pls. $4^{\circ}$.

1855.2

Nearly the whole of this edition was destroyed by fire. It was issued in numbers, the last terminating in the middle of the description of "Saurus fatens." Descriptions of 52 species and illustrations of 54 are given.

Ichthyology of South Carolina. 2. ed. Charleston, 1860. 205 p. pls. $4^{\circ}$.

1860.1

Vol. i; no more published. This is described as a second edition, the first being cancelled. Like the first, it was issued in numbers (10), and was printed in Cambridge. A collation of both editions of Holbrook's work is given by T. N. Gill in Amer. Journ. Sci.., 1864, 37, 89-9!.

Holden, E. C. The Columbia river salmon. A hatchery needed. Bull. U. S. Fish Comm. 1884, 4, 304. 1884.1

Holder, Charles Frederict [1851-1915] Among the sword-fish. Forest \& Stream, $1876,6,17$.

1876.1

-..- A strange parasitic fish. Scient. Amer., 1881, 44, 23.

1881.1

(editor) Angling. By L. M. Yale and others. New York, 1897. 305 p. illust. $12^{\circ}$. (Out of doors library)

1897.1

The devil-fish. Amer. Sports$\operatorname{man}, 1899,3,374$.

1899.1

Mimicry of the kelp fish. Scient. Amer., 1899, 54, 425-426. 2 figs. 1899.2

Photographing living fishes at Santa Catalina zoological station. Scient. Amer., 1899, 54, 362-363. 2 figs.

1899.3

Some curious sculpins iScorpana guttata] Scient. Amer., 1900, 83, 411-412. fig.

1900.1

Some Pacific sharks and accompanying fishes. Scient. Amer., 1900, 82, 331. 2 figs. $\quad 1900.2$

A rare fish [Luvarus imperialis] Seient. Amer., 1901, 85, 415. 1901.1

Vocal sounds of fishes. Scient. Amer., 1902, 87, 323. 1902.1

The big game fishes of the United States. New York \& London, 1903. xiv, 435 p. pl. Review in Nature, 68, 363-364.
The ribbon fish and the seaserpent. Scient. Amer, 1903, 89, 101102. fig.

1903.2

- Why and how fishes leap. Scient. Amer., 1903, 88, 151-152. 1903.3

-The boy anglers. New York, 1904. 1904.1

Deals with fishes of the United States.

D.Dep-sea sunfish. Scient. Amer. $1904,90,30-31$. fig.

1904.2

- An interesting shark. Scient. Amer., 1905, 93, 243. 3 figs. $\quad 1905.1$

The remoras. Scient. Amer. $1905,33,162-163$. fig. 1905.2

The log of a sea angler. Boston 1906. $385 \mathrm{p}$.

1906.1

- The nest of the kelp fish. Amer. Naturalist, $1907,41,587-588 . \quad 1907.1$

A new fish [Germo macropterus] for America. Scient. Amer., 1907, 96, 196. 2 figs.

1907.2

- Big game at sea. New York, 1908. 352 p. 32 pls. $8^{\circ}$ 1908.1

- A method of studying the life history of fishes. Proc. 4. Intern. Fish. Congr., Washington, 1908, pt. 2, 1137-1141.

1908.2

- A method of transporting live fishes. Proc. 4. Intern. Fish. Congr., Washington, 1908, pt. 2, 1005-1007. 1908.3

Methods of combating fungus discase on fishes in captivity. Proc. 4. Intern. Fish. Congr., Washington, 1908, pt. 2, 933-936.

1908.4

A plan for an educational exhibit of fishes. Proc. 4. Intern. Fish. Congr., IVashington, 1908, pt. 2, 13091314.

1908.5

Sport fishing in California and Florida. Proc. 4. Intern. Fish. Congr., Washington, 1908, pt. 1, 199-207.6 pls.

1908.6

The flying gurnards [Trigla] Scient. Amer., 1909, 100, 395. fig. 1909.1

The Channel islands of California. Chicago, 1910. xvi, 397 p. 12 maps. 32 pls. $8^{\circ}$.

1910.1

A plan for an educational exhibit of fishes. Bull. Bureau Fisheries, 1908 (1910), 28, pt. 2, 1309-1314. 1910.2 
The recreations of a sportsman. New York \& London, 1910. 1910.3

Observation in angling; fishing for the long-finned tuna with a trout rod; how the tuna club has stopped waste and created a noble sport. Amer. Conservation, 1911, 1, 157-162. illust. 1911.1

The game fishes of the world. London [1913] 1913.1

Holder, Charles Frederick, \& Jordan, David Starr. Fish stories. New York, 1909.

1909.1

- Das Rätsel der See-Schlange. Kosmos, Stuttgart, 1913, 10. Jahrg., 287-290. fig.

1913.1

Holder, J. B. [1824-1888] Along the Florida reef. Harper's Monthly Mag., $1871,42,515-526 ; 820-830$. Ibid., 43, $26-36 ; 187-195$.

1871.1

Figure and account of Cephaloptera vampirus and Rhinoptera quadriloba, p. 524-525. Nurse shark, p. 821. Fish parasites in holothurians, p. 829-830. Fishes of the Tortugas reefs, p. 30$32 ; 191$.

Holdsworth, Edmund William II unt, Deep-sea fishing and fishing boats. An account of the practical working of the various fisheries around the British islands, with descriptions of the boats, nets, and other gear in use. London, 1874. pls. $8^{\circ}$.

1874.1

Sea fisheries. London, 1877. 300 p. pls. $16^{\circ}$.

1877.1

- Sea fisheries. Nature, 1877, 15, $135-137 ; 198$.

$1977: 2$

Sea fisheries of the British Associations. Nature, 1877, 15, 23-24.

1877.3

Apparatus for fishing. Intern. Fisheries Exhib. Lit., London, 1883. Handbooks, 1, pt. 4 .

1883.1

Holfert, $H$. Ferdinand. Ueber $A m$ mocotes branchialis [Petromyzon planeri] Sitzber. Ges. Isis, Dresden, 1869 (1870), $147-148$.

1870.1

Holland, (Major) Lampreys and lamperns Petromyzon marinus and $P$. fluviatilis] Sci. Gossip, 1869 (1870), 145151. figs.

1870.1

Holland, $F$. $H$. Fish farming in western New York. Harper's Monthly Mag., 1868, 34, 47.

1868.1

Holland, Theodor. Die Speitzken [i.e. junge Lachsweibchen] an der hinter- pommerschen Kïste. Circul. Deutsch. Fischerei Zeitg., 1878, 1. Jahrg., 318319 .

1878.1

Noch ein Wort über die Coregonen des Garda- und Lebasees. Circul. Deutsch. Fischerei Zeit.g., 1879, 2. Jahrg., no. 1, 123.

1879.1

Holland, William Jacob [1848-] [Note on Diplomystus dentalus] Ann. Carnegie Mus., 1910, 7, 24. pl.

1910.1

'The Carnegie Museum expedition to central South America, 19071910. Ann. Carnegie Mus., 1911, 7, 283286.

1911.1

Contains some notes on fishes.

Hollande, $A$. $C h$. Valeur nutritive de la chair de quelques poissons exotiques acclimatés en France. Ann. Univ. Grenoble, 1913, 25, 537-540. 1913.1

Hollandre, J. J. J. Faune du département de la Moselle et principalement des environs de Metz. Metz, 1826. $12^{\circ}$.

1826.1

Faune du département de la Moselle. Metz, 1838. 12\% 1838.1

Hollard, Henri Louis Gabriel Marc [1801-1866] Coup d'oil sur l'ordre des ganoïdes, et recherches sur les caractères des lophobranches, pour déterminer leurs véritables affinités zoologiques. C. R. Acad. Sci. Paris, 1850, 31, 564 566. - L'Institut, 18, no. 880, 364.

1850.1

Monographie de la famille des balistides. Ann. Sci. Nat. (Zool.), 1853, 3. sér. 20, 71-114. 3 pls. Ibid., 1854, 4. sér. 1, 39-72, 303-339. 3 pls. Ibid., 1854, 4. sér. 2, 321-366. 3 pls. Ibid., 1855,4 . sér. 4, 5-27. pl. Extract in C. R. Acad. Sci. Paris, 1851, 33, 117118.

1853.1

Etudes sur les gymnodontes et en particulier sur leur ostéologie et sur les indications qu'elle peut fournir pour leur classification. Ann. Sci. Nat. (Zool.), 1857, 4. sér. 8, 275-328. pl. Extract in C. R. Acad. Sci. Paris, 45, 796-797.

1857.1

Monographie de la famille des ostracionides. Ann. Sci. Nat. (Zool.), 1857, 4. sér. 7, 121-170. pl. Abstract in C. R. Acad. Sci. Paris, 43, 805-807. L'Institut, 24, no. 1192, 388. 1857.2

Mémoire sur le squelette des poissons plectognathes, étudié au point 
Hollard, H. L. G. M.

de vue des caractères qu'il peut fournir pour la classification. Ann. Sci. Nat. (Zool.) 1860, 4. sér. 13, 5-46. Abstract in C. R. Acad. Sci. Paris, 50, 719-720. - Rev \& Mag. Zool. 2. sér. 12, 171-172. 1860.1

- Etudes relatives au squelette des poissons. Presse Scient., 1861, 3, $778-780$.

1861.1

- De la signification anatomique de l'appareil operculaire des poissons et de quelques autres parties de leur système osseux. Ann. Sci. Nat. (Zool.), 1864, 5. sér. 1, 241-256. Extract in C. R. Acad. Sci. Paris, 1863, 56, 38-39; 633-634. Ibid., 57, 670. - Presse Scient., 1, 38-39; 539-549. - Rev. \& Mag. Zool., 2. sér. 15, 27-28; 167-168; 384385.

1863.1

- Recherches sur la signification homologique de quelques pièces faciales des poissons osseux. Ann. Sci. Nat. (Zool.), 1864, 5 sér. 1, 5-19. Extract in C. R. Acad. Sci. Paris, 57, 670. Rev. \& Mag. Zool., 15, 384-385. Presse Scient. 1, 538-540. 1864.1

Du temporal et des pièces qui en représentent les éléments dans la série des animaux vertébrés. Ann. Sci. Nat. (Zool.), 1864, 5. sér. 1, 359-376. pl. Abstract in C. R. Acad. Sci. Paris, 58, 528-529.

1864.2

Développement de l'encéphale des poissons. C. R. Acad. Sci. Paris, $1866,67,747-748$.

1866.1

Recherches sur la structure de l'encéphale des poissons et sur la signification homologique de ses différentes parties. Journ. Anat. Physiol., Paris, 1866, 3. année, 286-335. 4 pls. Extract in C. R. Acad. Sci. Paris, 60, 768770. - Ann. Mag. Nat. Hist., 3. ser. 16, $70-72$.

1866.2

- Recherches sur l'encéphale des poissons. Mém. Proc. Verb. Acad. Sect. Sci. Montpellier, $1866,6,50-51$.

1866.3

Hollberg, L. Beskrifning öfver Bohuslanske fiskarne. Nya Handl. Vet. Wit. Samh. Götheborg, 1819, 3, 1. Ibid., 1821, 4, 1-64 Ibid., 1822, 5, 1. Abstract in Bull Sci. Nat. (Férussac), 1, 232 .

1819.1

Holle, $K . F$. Handleiding voor de teclt van zoctwatervisch. Tijdschr. Nijverheid Nederl. Indie, 1S61, 7 (n. s. 2), 278-290.
Vischteelt op Sawahs en bemesting van idem. Tijdschr. Nijverheid Nederl. Indie, 1871,15 (n. s. 10), 162170.

1871.1

Handleiding voor de teelt van zoetwatervisch op Java. Tijdschr. Nijverheid Nederl. Indie, 1873, 18, 235-262.

1873.1

Holloway, W., \& Branch, J. The history of animated nature, viz. birds, beasts, fishes and insects; written in association with J. Branch. 4 vols. London, 1804.

1804.1

Holm, John $F$. The development of the olfactory organ in the Teleostei. Morphol. Jahrb., 1894, 21, 620-624. pl. \& fig.

1894.1

Some notes on the early development of the olfactory organ of Torpedo. Anat. Anz , 1894, 10, 201-207. 6 figs.

1894.2

Ueber den feinern Bau der Leber bei den niedern Wirbelthieren. Zool. Jahrb., 1897, 10, 277-286. 2 pls. 1897.1

The finer anatomy of the nervous system of Myxine glutinosa. Morphol. Jahrb., 1901, 29, 365-401. 4 pls. 1901.1

Holm, Theodore for Holmskiold, $T$. de Beskrivning over den fisk mallen [Silurus glanis L.] Dansk. Selsk. Skrift., $1779,12,133-146$.

1779.1

Holmberg, Eduardo Ladislao. Viaje al Tandil y á la Tinta: Act. Acad. Córdoba, 1884, 5, 99-108.

1884.1

Sobre algunos peces nuevos 6 poco conocidos de la República Argentina. Rev. Argentina Hist. Nat., 1891, 1, 180-193.

1891.1

Holmberg, Henrit Johan [18181864] Praktiska reglor för fiskodlare. Helsingfors, 1858.44 p. $8^{\circ}$. 1858.1

Berättelse om resultatet af en utaf Bergskonduktören $\mathrm{H}$. J. Holmberg verställd resa, i ändamål att lemna råd betrïffande artificiel fiskodling och inhemta närmare upplysningar angående strömmingsfisket på Ảland; afgifven i September, 1859. Helsingfors, 1859. 14 p. $8^{\circ}$.

1859.1

Underdånig berättelse om resultatet af anställda undersökningar beträffande fiskens aftagande i Finland och medlen att förekomma detsamma, jemte förslag till fiskodling. Helsingfors, 1859.33 p. $8^{\circ}$. 
Ytterligare om fiskodling. Helsingfors, 1859.53 p. pl. $\mathcal{S}^{\circ} . \quad 1859.3$

Handledning för odling ag sommarfisk i Finland. Helsingfors, 1860. 36 p. pl. $8^{\circ}$.

1860.1

- Künstliche Kultur von Sommerfischen. Notizen (Froriep), 1860, 4, 321$326 ; 337-340 ; 353-356$.

1860.2

Ueber Fischcultur in Finnland. Bull. Soc. Nat. Moscou, 1860, 33, 321449. Ibid., 1861, 34, 201-283. Ibid., $1862,35,148-213$. Ibid., 1863, 36, $127-$ 200. Ibid., 1864, 37, 494-572. 1860.3

Inspektören för fiskerierna i Finland H. J. Holmbergs underdåniga berät,telse om sin verksamhet under år 1860. Helsingfors, 1861 . 55 p. $8^{\circ}$.

1861.1

Inspektören för fiskerierna i Finland H. J. Holmbergs underdåniga berättelse om sin verksamhet under år 1861. Helsingfors, 1862. 66 p. $8^{\circ}$.

1862.1

Inspektören för fiskerierna i Finland H. J. Holmbergs underdåniga berättelse om sin verksamhet under år 1862. Helsingfors, 1863. 117 p. $8^{\circ}$.

1863.1

Inspektören för fiskerierna i Finland H. J. Holmbergs underdåniga berättelse om sin verksamhet under år 1863. Helsingfors, 1863. 89 p. pl. $8^{\circ}$. 1863.2

Till fragån om laxens vandringar. Oefvers. Finsk Vetensk. Soc. Förh., $1864,6,1$.

1864.1

Holmes, E. S. [Oikoi, pseudon.] Range of the catfish. Forest \& Stream, $1880,15,387$.

1880.1

Holmes, Ezekiel. Report on the fishes of Maine, including some of the elementary principles of ichthyology. 2. Ann. Rept. Nat. Hist. Geol. Maine, 1862, 11-117. 2 figs. 1862.1

The "second annual report upon the natural history and geology of the state of Maine, 1862," although paged separately (p. 1-447) had only this - a bastard-title, and formed an appendix to (although not so specified), and was boind with the "Seventh annual report of the secretary of the Maine board of agriculture. 1862. tary of the Maine

The list of fishes embraces 76 species, and was principally based on a manuscript; of this number 57 were marine and 19 freshwater.

Holmes, Francis S. Notes on the geology of Charleston, S. C. Charles- ton Med. Journ., 1849, 3, 655-671. Amer. Journ. Sci., 2. ser. 7, 187-201.

1849.1

List of the post-Pliocene fossils of South Carolina, p. 193-194.

Observations on the geology of Ashley river, South Carolina. Amer. Assoc. Adv. Sci., 1850, 201-204. 1850.1 Remarks on fossil fish.

Contributions to the natural history of the American devil-fish, with descriptions of a new genus from the harbor of Charleston, South Carolina. Proc. Elliott Soc. Nat. Hist., 1856, 1, 39-46. 1856.1

Holmes, $G$. $M$. On the comparative anatomy of the nervus acusticus. Trans. Roy. Irish Acad., Dublin, 1903, $132,101-144$.

1903.1

Holmes, Matthew. Shipment of salmon and whitefish ova to New Zealand in 1877 and 1878. Rept. U. S. Fish Comm. 1878 (1880), 6, 860 .

1880.1

Holmgren, August Emil [1829-1888] Om insamling af " myrägg." Fiskeritidskr. Finl., 1894, 3, 107-109. 1894.1

Kurze vorläufige Mitteilungen über die Spinalganglien der Selachier und Teleostier. Anat. Anz., 1899, 15, 117-125. 11 figs. 1899.1

Zur Kenntniss der Spinalganglien Zellen vom Lophius piscatorius Linn. Anat. Hefte, Wiesbaden, 1899, 12, 71-154. 10 pls.

1899.2

Noch weitere Mitteilungen über den Bau der Nervenzellen verschiedener Tiere. Anat. Anz., 1900, 17, 113-129. 17 figs.

1900.1

Ueber die sogenannten " intracellulären Fäden " der Nervenzellen von Lophius piscatorius. Anat. Anz., 1903, 23, 37-49. figs. 1903.1

Holmquist, Otto. List of fishes col. lected during the Peary auxiliary expedition, 1894. Ann. Mag. Nat. Hist., 1899, 7. ser. 3, 214-223.

1899.1

Der Musculus protractor hyoidei (geniohyoideus auct.) und der Senkungsmechanismus des Unterkiefers bei den Knochenfischen. Zugleich ein Beitrag zur Kenntnis der Atembewegungen. Lunds Univ. Arsskr., 1910, n. s. 6, pt. 2, no. 6. 24 p. pl. \& 4 figs. 1910.1

Studien in der von den $\mathrm{Nn}$. trigeminus und facialis innervierten 
Holmquist, $O$.

Muskulatur der Kinochenfische. 1. Die Trigemino-facialis-Muskulatur beiGadus callarias Linné. 2. Zur vergleichenden Morphologie der $\mathrm{Mm}$. intermandibularis protractor hyoidei und hyoihyoideus. Lunds Univ. Arsskr., 1911, n. s. 7, pt. 2, no 7.79 p. 3 pls.

1911.1

Ueber die Zwischensehnen oder Myocommata in dem Musculus protractor hyoidei der Knochenfische. Lunds Univ. Arsskr., 1913, n. s. 10, pt. 2, no. 7. 5 p. 3 figs.

1913.1

Variationen der NN. manidbularis trigemini und mandibularis externus facialis bei Gadus callarias sowie ihre wahrscheinliche Bedeutung. Lunds Univ. Arsskr., 1913, n. s. 10, pt. 2, no. 3. 10 p. 4 pls.

1913.2

Holmskiold, Theodore de. See Holm, Theodore.

Holmwood, Frederic. On the employment of the Remora by native fishermen on the east coast of Africa. Proc. Zool. Soc. London, 1884, 411-413. figs.

1884.1

See also article on the Remora by C. R. Eastman in Sci. Monthly, 1916, 3, 31-46.

Holst, Nils Olof [1846-] De.senglaciala lagren vid toppeladugård med beskrifning af ett nytt växtfossil, Holstia splendens af O. Hagström. Sver. Geol. Unders., 1906, ser. C, no. 200. 42 p. pl. \& 3 figs. 1906.1

Holt, C. F. Some observations on the black bass. 'Trans. Amer. Fisheries Soc. 1888 (1889), 33-36. 1889.1

Holt, Ernest W. L. Notes on the early life-history of the herring. Ann. Mag. Nat. Hist., 1889, 6. ser. 4, 368372. figs.

1889.1

- Note on a young specimen of Zoarces viviparus. Ann. Mag. Nat. Hist., 1890, 6. ser. 5, 256-257. 1890.1

Notes on some striking forms from the haddock lines, St. Andrews. Scott. Journ. Nat. Hist., 1890, 26-28.

1890.2

On the ova of Gobius. Ann. Mag. Nat. Hist., 1890, 6. ser. 6, 34-40. pl.

1890.3

Additions to the invertebrate fauna of St. Andrews bay. Ann. Mag. Nat. Hist., 1891, 6. ser. 8, 182-184. pl. 18011
North sea investigations. Journ. Mar. Biol. Assoc., 1891-92, n. s. 2, 216219; 363-393. Ibid., 1893-95, n. s. 3 , 78-106; 123-142; 169-201. 3 figs.

1891.2

Observations upon the development of the teleostean brain, with especial reference to that of Clupea harengus, Zool. Jahrb. (Anat. Abth.), 1891, 4, 478-500. 3 pls.

1891.3

On some young specimens of Centrolophus pompilus (Art.) from the coast of Cornivall. Journ. Mar. Biol. Assoc., 1891-92, n. s. 2, 265-267. 1891.4

- On the eggs and larva of teleosteans (In Survey of fishing grounds, west coast of Ireland, 1890 . Scient. Trans. Roy. Dublin Soc., 1891, 2. ser. 4, 435-474. 6 pls.)

1891.5

- Notes on teleostean development. Rept. Brit. Assoc. Adv. Sci., 62. meet., 1892, 772 .

1892.1

On the destruction of immature fish in the North sea. On remedial measures. Rept. Brit. Assoc. Adv. Sci., 62. meet., 1892, 768-772.

1892.2

On the relation of size to sexual maturity (On the destruction of immature fish, and a discussion on remedial measures. Part II) Rept. Brit. Assoc. Adv. Sci., 32. meet., 1892, 765-766.

1892.3

Preliminary note on the fish obtained during the cruise of the SS. "Fingal," 1890 (In Survey of fishing grounds, west coast of Ireland, 1890. Scient. Proc. Roy. Dublin Soc., 1892, n. S. 7, 121-123)

1892.4

Preliminary note on the fish obtained during the cruise of the SS. "Harlequin," 1891 (In Survey of fishing grounds, west coast of Ireland. Scient. Proc. Roy. Dublin Soc., 1892, n. s. 7, pt. 3, 218-220) 1892.5

Reports on the results of the fishing operations (In Survey of fishing grounds, west coast of Ireland, 18901891. Scient. Proc. Roy. Dublin Soc., 1892 , n. s. 7, 225-483)

1892.6

Reports on the scientific evidence bearing on the economic aspects of the fishes collected during the Survey (In Survey of fishing grounds, west coast of Ireland, 1890-1891. Scient. Proc. Roy. Dublin Soc., 1892, n. s. 7, 388-483) 
An examination of the present state of the Grimsby trawl fishery, with especial reference to the destruction of immature fish; revision of tables. Journ. Mar. Biol. Assoc., 1893-95, n. s. 3, 339-448. Ibid., 1895-97, n. s. 4, 410 414.

1893.1

North sea investigations. Journ.

Mar. Biol. Assoc., 1893-95, n. s. 3, 78201.

1893.2

On the relation of size to sexual maturity in round-fish, p. 78-81.

On the destruction of immature fish in the North sea, p. 78-106; 123-128; 169-176.

On the Iceland trawl fishery, with some remarks on the history of the North sea trawling grounds, p. 129-164.

On the territorial fishing grounds of Scarborough and its neighborhood, p. 176-181.

The blonde (Raia blanda, Holt and Calderwoor MS.), a species hitherto confounded with $R$. maculata Montagu, p. 181-181.

The "recessus orbitalis," an accessory visual organ in Pleuronectid fishes, p. 185-188.

On an adult specimen of the common sole with symmetrical eyes, etc., p. 188-190.

The reproduction of Caranx trachurus Linn. p. $190-193$.

On a dwarf variety of the plaice, with some remarks on the occasional ciliation of the scales in that species, p. 194-200.

On some specimens of Molva abyssorum Nilss. from Iceland and Faroe, p. 200-201.

Note on some supposed hybrids between the turbot and the brill. Journ. Mar. Biol. Assoc., 1893-95, n. s. 3, 292299. figs.

1893.3

On the eggs and larval and postlarval stages of teleosteans (In Survey of fishing grounds, west coast of Ireland, 1890-1891. Scient. Trans. Roy. Dublin Soc., 1893, 2. ser. 5, 5-121. 15 pls.)

1893.4

Studies in teleostean morphology from the Marine Laboratory at Cleethorpes. Proc. Zool. Soc. London, 1894 413-446. 3 pls.

1894.1

The "bottle-nose ray" (Raja? alba Lacép.) and its egg-purse. Journ. Mar. Biol. Assoc., 1897-99, n. s. 5, 181183.

1897.1

The great silver smelt, Argentina silus Nilsson, an addition to the list of British fishes. Journ. Mar. Biol. Assoc., 1897-99, n. s. 5, 341-342.

1897.2

Note on Motella cimbria. Journ. Mar. Biol. Assoc., 1897-99, n. s. 5, 343. 1897.3

Notes and memoranda. Journ. Mar. Biol. Assoc, 1897-99, n. s. 5, 8991.

1897.4

Notes on the reproduction of teleostean fishes in the south-western district. Journ. Mar. Biol. Assoc. 1897-99, n. s. 5, 41-50; 107-155. 1897.5

- Observations sur les cufs flottants de téléostéens faites dans le golfe de Marseille, à la station zoologique d'Endoume, durant l'année 1895. Ann. Mus. Hist. Nat. Marseille, 1897, 2. sér. $5,24-34$.

1897.6

_-_ Remarks on Dr. Petersen's report of the Danish biological station for 1895 . Journ. Mar. Biol. Assoc., 1897-99, n. s. 5, $82-88$.

1897.7

- Report on trawling in bays on the south coast of Devon; submitted for the information of the Devon sea fisheries committee. Journ. Mar. Biol. Assoc., 1897-99, n. s. 5, 296-329. 1897.8

[Exhibition of and remarks upon some advanced larvæ of the luminous fish Scopelus glacialis] Proc. Zool. Soc. London, 1898, 279-280; 554-557.

1898.1

La girelle royale et la girelle de Giofredi, doivent-elles toutes deux être rapportées à l'espèce dimorphique Coris julis (Linn.)? Bull. Mus. Hist. Nat. Marseille, 1898, 1, 151-162. figs.

1898.2

On the breeding of the dragonet (Callionymus lyra) in the Marine Biological Association's aquarium at Plymouth; with a preliminary account of the elements, and some remarks on the significance of the sexual dimorphism. Proc. Zool. Soc. London, 1898, 281-315. pl. \& 2 figs.

1898.3

Recent additions to the list of Irish fishes. Irish Naturalist, 1898, 7, $257-258$.

1898.4

Report on a collection of very young fishes obtained by Dr. G. H. Fowler in the Faeroe channel (In Fowler, G. H. Contributions to our knowledge of the plankton of the Faeroe channel. No. v) Proc. Zool. Soc. London, 1898, 550-585. 3 pls. $\quad 1898.5$

Recherches sur la reproduction des poissons osseux, principalement dans le golfe de Marseille. Ann. Mus. Hist. Nat. Marseille (Zool.), 1899, 5, no. 2. 128 p. 9 pls. \& fig. 1899.1

Salmon fisheries. Ann. Rept. Sea Inland Fish Ireland, 1901 (1902), pt. 2, 142-204.

1902.1

Report on the artificial propagation of Salmonidæe for the seasons of 
Holt, $E . W . L$.

1902-1903, 1903-1904, 1904-1905, 19051906, 1906-1907, 1907-1908. Rept. Sea Inland Fish. Ireland, 1902-03 (1905), pt. 2, 346-350. Ibid., 1904, pt. 2, 304309. Ibid., 1906, no. 7. 35 p. - Fish. Ireland Scient. Invest., 1904, no. 7, 3-8. Ibid., 1905, no. 8, 17-23. Ibid., 1906 (1907), no. 7. 35 p. Ibid., 1907 (1909), no. 9.8 .

1905.1

Statistical information relating to the salmon fisheries, Ann. Rept. Sea Inland Fish. Ireland, 1902-03 (1905), pt. 2, Append. 1, 359-362.

1905.2

Substance of reports received from clerks of conservators relative to salmon fisheries. Ann. Rept. Sea Inland Fish. Ireland, 1902-03 (1905), pt. 2, Append. 1, 363-385.

1905.3

Summary of reports relative to cel fry, 1905 to 1907. Fish. Ireland Scient. Invest. 1906 (1908), no. 8.11 p.Rept. Sea Inland Fish. Ireland, 1906 (1908), 262-270.

1908.1

The freshwater eel. A review of recent contributions to knowledge of its life-history. Fish. Ireland Scient. Invest. 1907 (1909), no. 8. 27 p. 8 figs.

1909.1

Summary of reports relative to eel fry, 1907-08. Fish. Ireland Scient. Invest. 1907 (1909), no. 9, 34-39.

1909.2

Report of a survey of trawling grounds on the coasts of counties Down, Louth, Meath and Dublin. Part I. Record of fishing operations. Fish. Ireland Scient. Invest. 1909 (1910), no. 1. 538 p. 2 pls.

1910.1

- Dace in Ireland. Irish Naturalist, $1911,20,116$.

1911.1

Holt, Ernest W. L., \& Byrne, L. W. Notes on the reproduction of teleostean fishes in the south-western district. Journ. Mar. Biol. Assoc., 1897-99, n. s. 5, 333-340.

1897.1

An observation of the colourchanges of a wrasse, Labrus maculatus Donovan. Journ. Mar. Biol. Assoc., 1897-99, n. s. 5, 193-195. 1897.2

- Exhibition of specimens and drawings of a small sucker-fish of the genus Lepadogaster. Proc. Zool. Soc. London, 1898, 589-590.

1898.1

- The British and Irish gobies. Ann. Rept. Sea Inland Fish. Ireland,
1901 (1903), pt. 2, 37-66. 2 pls. \& figs. Ibid., 1902-03 (1905), pt. 2, Append. 5, 162-163. pl.

1903.1

On a young stage of the white sole, Pleuronectes (Glyptocephalus) cynoglossus. Ann. Rept. Sea Inland Fish. Ireland, 1901 (1903), pt. 2, 67-69. pl.

1903.2

On the British and Irish species of the family Stromateidæ. Ann. Rept. Sea Inland Fish. Ireland, 1901 (1903), pt. 2, 70-76. 2 pls.

1903.3

- On the fishes taken by the "Oceana." Ann. Mag. Nat. Hist., 1904, 7. ser. 14, 37-40. fig. 1904.1

Figures and descriptions of the British and Irish species of Solea. Ann. Rept. Sea Inland Fish. Ireland, 1902-03 (1905), pt. 2, Append. 5, 164-175. 6 pls. 1905.1

Note on a specimen of Dentex vulgaris from Dingle bay. Ann. Rept. Sea Inland Fish. Ireland, 1902-03 (1905), pt. 2, Append. 5, 156-161. pl. 1905.2

The marine fauna of the coast of Ireland. Part viii. First report on the fishes of the Irish Atlantic slope. Ann. Rept. Sea Inland Fish. Ireland, 1905, 29-54. pl. \& 2 figs. - Fish. Ireland Scient. Invest. 1905 (1906), no. 2. 28 p. pl. \& 2 figs.

1905.3

On a new species of Lyconus from the northeast Atlantic. Ann. Mag. Nat. Hist., 1906, 7. ser. 18, 423-426. 1906.1

- Biscayan plankton. Part $\mathrm{x}$. The fishes. Trans. Linn. Soc. London, 1907, 2. ser. 10, 189-201. 5 figs. 1907.1

- New deep-sea fishes from the southwest coast of Ireland. Ann. Mag. Nat. Hist., 1908, 8. ser. 1, 86-95. pl. \& fig. 1908.1

Second report on the fishes of the Irish Atlantic slope. Fish. Ireland Scient. Invest. 1906 (1908), no. 5. 63 p. 5 pls. \& 2 figs. - Ann. Rept. Sea Inland Fish. Ireland, 1906 (1909), pt. 2, 141202. 5 pls. \& 2 figs.

1908.2

\section{Preliminary note on some fishes} from the Irish Atlantic slope. Ann. Mag. Nat. Hist., 1909, 8. ser. 3, 279-280. 1909.1

Fourth report on the fishes of the Irish Atlantic slope. List of recorded species with references. Fish. Ireland Scient. Invest. 1908 (1910), no. 5. 7 p. 1910.1 
Preliminary diagnosis of a new stomiatid fish from the southwest of Ireland. Ann. Mag. Nat. Hist, 1910 , 8. ser. 6, 294-297.

1910.2

Third report on the fishes of the Irish Atlantic slope. The Holocephali or Chimæras. Fish. Ireland Scient. Invest. 1908 (1910), no. 4. 26 p. 4 pls. \& 3 figs. Also separate; Dublin, 1910.

1910.3

-.. Fifth report on the fishes of the Irish Atlantic slope. Fishes of the genus Scopelus. Fish. Ireland Scient. Invest. 1910 (1911), 6, 1-33. pl. \& 8 figs.

1911.1

- Sixth report on the fishes of the Irish Atlantic slope. The families Stomiatidx, Sternoptychidx and Salmonidx. Fish. Ireland Scient. Invest. 1912 (1913), no. 1. 28 p. 2 pls. \& 11 figs.

1913.1

Holt, Ernest W. L., \& Calderwood, W. L. Report on the rarer fishes (In Survey of fishing-grounds, west coast of Ireland, 1890-91. Sci. Trans. Roy. Soc. Dublin, 1895, 2. ser. 5, 361-512. 6 pls.)

1895.1

Holt, Ernest W. L., \& Dunn, Matthias. See Dunn \& Holt.

Holt, Ernest W. L. \& Scott, S. D. A record of the teleostean eggs and larvæ observed at Plymouth in 1897. Journ. Mar. Biol. Assoc., 1897-99, n. S. 5. 156171.

1897.1

Holt, George H. The fisheries of Gaspé basin, Quebec, for 1883. Rept. U. S. Fish Comm. 1883 (1885), 11 1185-1186.

1885.1

Holt, $H . H$. Eastern trout on the Pacific slope. Forest \& Stream, 1879, $12,105$.

1879.1

Holten, H.S. von. Anmaerkninger til beskrivelser af Zeus [Lampris] guitatus. Skrivter Naturh. Selsk. Kjøbenhavn, 1802, 5, pt. 2, 129-135. 1802.1

Trichiurus gladius, en ny fisk fra Portugal. Skrivter Naturh. Selsk. Kjøbenhavn, 1802, 5, 19-26. figs. 1802.2

Holton, Marcellus G. Description of improved apparatus in fish-hatching. Rept. U.S. Fish Comm. 1872-73 (1874), 2, 580-582.

1874.1

Holtzsche, Paul. Der Pfauenaugenbarsch (Centrarchus macropterus) und seine Zucht. Wochenschr. Aquar.Terrar. Kunde, 1910, 7. Jahrg., 17-18. fig.

1910.1

Holzbach, Ernst. Die Hemmungsbildungen der Müllerschen Gänge im Lichte der vergleichenden Anatomie und Entwicklungsgeschichte. Beitr. Geburtsh. Gynäkol., 1909, 14, 167-221. 6 figs.

1909.1

Holzmann, August. Modelle des Mechanismus der Kieferzange des Wirbelthiertypus. Verh. Naturh. Ver. Karlsruhe, 1896, 2, 291-292. $\quad 1896.1$

Homann, Karl. Haplochilus chaperi u. H.rubrostigma. Wochenschr. Aquar.Terrar. Kunde, 1911, 8. Jahrg., 420-421. pl.

1911.1

Homburger, L. Zur Verdauung der Fische. Centralbl. Med. Wiss., 1877, 15, 561-562.

1877.1

Homburger, Richard. Ueber die paarigen Extremitäten von Squalius, Trigla, Periophthalmus und Lophius. Rev. Suisse Zool., 1904, 12, 71-148. 2 pls.

1904.1

Home, David Milne. The salmon fisheries of Scotland. Edinburgh, 1882. 20 p. $8^{\circ}$.

1882.1

Salmon and salmon fisheries. Intern. Fisheries Exhib. Lit., London, 1884. Conferences, 6, no. 5. 1884.1

Home, (Sir) Everard [1756-1832] An anatomical account of the Squalus maximus (of Linnæus), which in the structure of its stomach forms an intermediate link in the gradation of animals between the whale tribe and cartilaginous fishes. Phil. Trans. Roy. Soc. London, 1809, pt. 1, 206-220. 3 pls. Ibid., 1813, 227-241. - Journ. de Physique, $71,241-247$.

1809.1

- On the nature of the intervertebral substance in fish and quadrupeds. Phil. Trans. Roy. Soc. London, 1809 , pt. 1, 177-187. pl.

1809.2

On the mode of breeding of the oviviviparous shark, and on the aeration of the fotal blood in different classes of animals. Phil. Trans. Roy. Soc. London, 1810, pt. 1, 205-222. 5 pls. 1810.1

Additions to an account of the anatomy of the Squalus maximus, contained in a former paper; with observations on the structure of the branchial artery. Phil. Trans. Roy. Soc. London, 1813, pt. 1, 227-241. 7 pls. $\quad 1813.1$ 
Home, E.

Lectures on comparative anatomy, in which are explained the preparations in the Hunterian Collection. . etc. 4 vols. London, 1814-23. $4^{\circ}$.

1814.1

Supplement, etc., vols. v \& vi. illust. Vol. vi contains the plates with their descriptions. London, $1828.4^{\circ}$.

On the mode of generation of the lamprey and myxine. Phil. T'rans. Roy. Soc. London, 1815, 105, 265-269. pl. - Deutsch. Arch. Physiol. (Meckel), 1816, 2, 539-542. - Isis (Oken), 1, 3540.

1815.2

On the structure of the organs of respiration in animals which appear to hold an intermediate place between those of the class Pisces and the class Vermes [Cyclostomi] and in two genera of the last mentioned class. Phil. Trans. Roy. Soc. London, 1815, 105, 256-264. 3 pls. - Deutsch. Arch. Physiol. (Meckel), 2, 594-600. — Isis (Oken), 1, 2535.

1815.3

Includes account of structure of gills in Petromyzon and Myxine.

Some account of the feet of those animals whose progressive motion can be carried on in opposition to gravity. Phil. Trans. Roy. Soc. London, 1816, 106, pt. 1, 149-155. 2 pls.

1816.1

Contains account of the sucking dise of Echeneis remora.

Some observations and experiments made on the torpedo of the cape of Good Hope. Phil. Mag., 1816, 48, 14-18.

1816.2

Ueber die Entwicklung des Fötus der eierlegend-lebendiggebärenden Haifische, etc. Deutsch. Arch. Physiol. (Meckel), 1816, 2, 531-539. 1816.3

On the double organs of generation of the lamprey, the conger eel, the common eel, the barnacle and earthworm, which impregnate themselves; though the last from copulating appear mutually to impregnate one another. Phil. Trans. Roy. Soc. London, 1823, 113, 140-151. 6 pls.

1823.1

The Croonian lecture. On the internal structure of the human brain, when examined in the microscope, as compared with that of fishes, insects and worms. Phil. Trans. Roy. Soc. London, 1824, 114, 1-10. 2 pls.

1824.1

Homer. The zoology of Homer, translated by W. B. Macdonald (In Groshans, G. P. F. Quxdam naturalia antiqua. Rammerscales, 1846. 14 p. $\left.8^{\circ}\right)$

1846.1

Homeyer, Eugen Ferdinand von [18091889] Die Wanderungen der Vögel mit Rücksicht auf die Züge der Säugethiere, Fische, und Insecten. Leipzig, 1881. x, 415 p. $8^{\circ}$.

1881.1

Hommel, — Some further intelligence relating to the jaculator fish, mentioned in the Philosophical Transactions for 1764, art. xiv, together with the description of another species, by Dr. Pallas, F. R. S., in a letter to Mr. Peter Collinson. Phil. Trans. Roy. Soc. London, 1777, 56, 186-188. pl. 1777.1

Homo (pseudon.) Eggs of Spanish mackerel, porgee, anchovy and oyster. Forest \& Stream, 1880, 15, 281. 1880.1

Homolle,

Dei caratteri distintivi dell' olio di fegato di merluzzo dagli altri olii vegetali o animali. Ann. di Chim. (Polli), 1854, 18, 261-264.

1854.1

Honeyman, D. Nova Scotian ichthyology. Addition to Jones' Catalogue of 1879. Proc. Trans. Nova Scotian Instit. Nat. Sci. 1885 (1886), 6, pt. 4, 228-232; 328-330.

1886.1

A supposed deep-sea fish [Lophius piscatorius] Proc. Trans. Nova Scotian Instit. Nat. Sci. 1885 (1886), 6, $85-87$.

1886.2

Hood, Peter. Notes on pisciculture. Trans. Watford Nat. Hist. Soc. 1876-77 (1878), 1, 179-186.

1878.1

Hoogendijk, Jan. Rapport aan Z. Exc. den Heere Minister van binnenlandsche zaken over de internationale tentoonstelling te Hâvre in 1868, betreffende het zeewezen, de visscherijen, enz. 'sGravenhage, 1870. iv, $132 \mathrm{p}$. 3 figs. $8^{\circ}$.

1870.1

Hooper, D. Analysis of the oils produced by certain Indian rays and other aquatic vertebrates. Mem. Indian Mus. Calcutta, 1909, 2, Append.

1909.1

Hooper, E.J. Brief notice of some fishes of California in ocean, bay and rivers. Forest \& Stream, 1875, 5, 100.

1875.1

Refers to Sebastes nebulosus, Centrarchus maculosus, Morrhua californica and a few other species.

California fish planting. Forest \& Stream, 1875, 5, 19. 
- Carp in California. Forest \& Stream, 1875, 5, 115 .

1875.3

Edible fish of the Pacific. Forest \& Stream, 1875, 5, 36.

1875.4

Fish and seals in California and notes on salmon. Forest \& Stream, $1875,5,275$.

1875.5

Land-locked salmon and salmon trout in California. Forest \& Stream, $1875,4,166$.

1875.6

- On what do salmon feed? Forest \& Stream, 1875, 5, 280. $\quad 1875.7$

- Progress of fish-culture in California. Forest \& Stream, 1875, 5, 19; 227.

1875.8

- Salmon in the bay of San Fran. cisco. Forest \& Stream, 1875, 4, 217

1875.9

Angling for smelts [Osmerus] in California. Forest \& Stream, 1876, 6, 166.

1876.1

The fisheries and sea-lions of California. Forest \& Stream, 1876, 6, 38.

1876.2

Hopdiquaks,

Eine merkwürdige Platypocilus maculatus Ehe. Wochenschr. Aquar.-Terrar. Kunde, 1913, 10. Jahrg., 626.

1913.1

Hopewell-Smith, A. Two specimens of the head and jaws of the adult Hemirhamphus. A specimen showing developmental defects occurring in the upper jaw of a pike (Esox lucius) Proc. Roy. Soc. Med. London, 1908, 1 (Odont. Sect.), 61-62.

1908.1

Hopkins, Grant Sherman. Structure of the stomach of Amia calva. Proc. Amer. Micr. Soc., 1891, 12, 165-169 figs. Abstract in Proc. Amer. Assoc. Adv. Sci., 39. meet., 339.

1891.1

On the digestive tract of some North American ganoids. Abstract in Proc. Amer. Assoc. Adv. Sci., 1892, 41, 197.

1892.1

The lymphatics and enteric epithelium of Amia calva (In Wilder Quart.-cent. Volume, p. 367-382. 2 pls. Ithaca, 1893)

1893.1

- On the enteron of American ganoids. Journ. Morphol., 1895, 11 411-439. 2 pls.

1895.1

Hopkins, $P$. Fishing experiments of half a century. London, 1873 , fig. $8^{\circ}$.
Hopkins, William. Brief outline or general description of a remarkable fossil, not known to be described, and by some supposed to be an ichthyodorulite. Proc. Amer. Assoc. Adv. Sci., 8. meet., 1854, 287-290. 2 figs. $\quad 1854.1$

Notes on eels. Victorian Naturalist, $1903,20,46-47 ; 49-52 . \quad 1903.1$

Hopkinson, John. Dates of publication of the separate parts of Gmelin's edition (13th) of the "Systema Naturre" of Linnaus, Proc. Zool. Soc. London, 1907 (1908), 1035-1037. 1908.1

- A bibliography of the 'Tunicata. London, 1913. 288 p. $8^{\circ}$ (Ray Society volume for 1912) 1913.1

Contains some references to the literature of fishes.

Hopley, Catherine C. Observations on a remarkable development in the mud-fish. Amer. Naturalist, 1891, 25, 487-489. 5 figs. 1891.1

On renewed pectoral limbs in Protopterus annectens.

Hoppe, $R$. Untersuchungen über den Kauapparat des Cyprinoiden [Leuciscus rutilus] Leipzig, 1894. pls. $8^{\circ}$. 1894.1

Hoppe-Seyler, $F$. \& Duncan, $C$. See Duncan \& Hoppe-Seyler.

Hoppichler, $H$. Die Fischerei in Ober-Oesterreich. Deutsch. Fischerei Zeitg., 1880, 3. Jahrg., 122-124. Oesterr.-ungar. Fischerei Zeitg., 1880, 1. Jahrg., 49-50.

1880.1

Hopyner, F'r. Acara coruleum-punctata. Wochenschr. Aquar-Terrar. Kunde, 1913, 10. Jahrg., 526-527. fig.

1913.1

Horak, Wenzel. Die Teichwirthschaft mit besonderer Rïcksicht auf das südliche Böhmen. Prag, 1869. 215 p. $8^{\circ}$

1869.1

Die Nahrung der Fische. Circul. Deutsch. Fischerei Ver. 1875 (1876), no. $6,355-358$.

1876.1

—Zuchtung des Zander in Teichen. Circul. Deutsch. Fischerei Ver. 1875 (1876), no. 2, 268-269.

1876.2

Die Abfischung des Teiches Rosenberg in der fürstlich Schwarzenber'schen Domaine IVittingau, in Südböhmen, 1876. Circul. Deutsch. Fischerei Ver. 1876 (1877), no. 6, 221-225.

1877.1

- Eine Flussfischerei in Böhmen. Circul. Deutsch. Fischerei Zeitg., 1878 , 1. Jahrg., 97-99. 1878.1 
Hormann, —, \& Morgenroth, Ueber Fütterung von Fischen mit tuberkelbacillenhaltiger Nahrung. Hygien. Rundschau, 1899, 857. 1899.1

Horn, William Austin [1803-1871] Report of the work of the Horn scientific expedition to central Australia. Edited by Baldwin Spencer. 4 parts. London \& Melbourne, 1896. 1896.1

Pt. ii, Zoology。 iv, 431 p. 29 pls. Pisces, by A. Zietz.

Appendix: Description of an additional new species of fish from the Finke and Barcov rivers, by $A$. Zietz.

Horne, John, \& Peach, B. N. See Peach \& Horne.

Hornegg, Clodwig von. Die Fischerei in Bengalen. Oesterr.-ungar. Fischerei Zeitg., 1880, 1. Jahrg., 311-312. 1880.1

— Die Fischwässer Ungarns. Oesterr-ungar. Fischerei Zeitg., 1880, 1. Jahrg., 60-61; 68-69; 74-75; 89; 109; $116 ; 125 ; 139 ; 154 ; 159 ; 167 ; 176-177$; $201 ; 208 ; 216 ; 225 ; 233 ; 242$.

1880.2

Hornell, James. The possibilities of fishery improvement in Jersey; with notes an the present state of marine pisciculture and fishery regulation. Journ. Mar. Zool. Jersey, 1897, 2, 7394.

1897.1

Horner, Leon. On the occurrence of Megalichthys hibberti in a bed of cannel coal in the west of Fifeshire. Proc. Roy. Soc. Edinburgh, 1845, 1, 112. - Edinb. New Phil. Journ., 1836, 20, 307-320.

1845.1

Horning, Jennie E., \& Eigenmann, Carl H. See Eigenmann \& Horning.

Hornschuch, Reinholdus Fridericus Mauritius Hohnbaum. See HohnbaumHornschuh, Reinholdus Fridericus Mauritius.

Hornstedt, Claudius Fredrik [1758 -] Triglia mubicunda, en ökand och besynnerling fisk från Amboina. Handl. IK. Vetensk. Akad., Stockholm, 1788, 9, 49-51.

1788.1

Hornstein, Ferdinand Friedrich. Neues vom Kasseler Tertiär. Zeitschr. Deutsch. Geol. Ges., 1906, 58, 114-118. 2 figs.

1906.1

Horrebov, Niels [1712-1760] The natural history of Iceland; containing a particular ... account of the different soils, burning mountains, minerals, ... and fishes. London, 1758. xx, $207 \mathrm{p}$. fol.
Horrocks, - Kunst der Fliegenfischerei auf Forellen und Aschen. Weimar, $1874 . \quad x, 180$ p. 5 pls. 1874.1 2. ed. Wemar, 1879.

Horsfall, J. H. Salmon ova not the food of the water-ouzel. Zoologist, 1863, 21, 8462-8463.

1863.1

- Observations on the three-spined stickleback, its ova and fry (Gasterosteus aculeatus Linn. and $G$. spinulosus Yarrell) Intell. Observ., 1864, 5, 4-7. fig.

1864.1

Letters on salmon ladders, reprinted by request from "Field" with an introduction. Leeds, $1867.8^{\circ}$.

1867.1

Horsfield, Thomas [1773-1859] Zoological researches in Java and the neighbouring islands. London, 1821-24. 8 pls. $4^{\circ}$.

1821.1

Horst, Rutger. Eene nieuwe Pleuronectoide, Apionichthys bleekeri. Tijdschr. Nederl. Dierk. Ver., 1879, 4, 30-32.

1879.1

- On a case of commensalism of a fish (Amphiprion intermedius Schleg.) and a large sea-anemone (Discosoma sp.) Notes from the Leyden Museum, 190103, 23, 180-182.

1901.1

Horvath, J. Baja környékének halfaunája. Baja, 1896. $8^{\circ}$. 1896.1

Horwood, A.R. The flora and fauna of the Trias (Keuper only) in Leicestershire, with some notes on that of the surrounding counties. Rept. Brit. Assoc. Adv. Sci., 77. meet., 1907, 306-311.

1907.1

Hosch, - Das Sehorgan von Protoplerus annectens. Arch. Mikr. Anat., 1904, 64, 99-110. pl. 1904.1

Høst, H.E. Nogle oplysninger om fiskeriet paa Fareøerne. Norsk Tidskr. Fiskeri, 1873, 7. Jahrg., 97-125. 1873.1

- Fiskereiet paa faerøerne i aarene 1871-73. Norsk 'Tidskr. Fiskeri, 1875, 7. Jahrg., 31-33.

1875.1

Host, H.E., \& Collin, On the Danish fisheries. Norsk Tidskr. Fiskeri, 1874, 7. Jahrg., 126.

1874.1

Hotchkiss, Truman. A strange fish. Amer. Sportsman, 1874, 4, $203 . \quad 1874.1$

Observations on a fish called the "sucker" seen in the gulf of Mexico and on Bahama banks.

Hougberg, Emil. Om fiskfaunan i torneå skärgård. Meddel. Soc. Fauna \& Flora Fenn., 1886, 13, 169. 1886.1 
Hough, Franklin B. Fifth annual report of the regents of the university of the State of New York on the condition of the state cabinet of natural history, and the historical and antiquarian collection annexed thereto. Albany, 1852.

1852.1

Description of Pimelodus gracilis, sp. nov.

Houghton, Robert. Shipment of salmon ova to New Zealand in 1877 and whitefish in 1878. Rept. U. S. Fish Comm. 1878 (1880), 6, 834. 1880.1

Houghton, William [1829?-1897] Note on the existence of a pair of subcutaneous orifices in the head of the eel and conger. Quart. Journ. Micr. Sci., $1864,4,1-2$.

1864.1

- Sticklebacks (Gasterosteus aculeatus) and other nest-making fish. Intel. Observ., 1865, 7, 259-263. 1865.1

- Rumination in fish; the Scarus of the ancients. Intell. Observ., 1867, 11, 190-195.

1867.1

The food of the salmon. Intell. Observ., 1868, 12, 104-110. 1868.1

- On the air or swimming bladder of fishes. Pop. Sci. Rev., 1868, 7, 378385 .

1868.2

On the Silurus and Glanis of the ancient Greeks and Romans. Ann. Mag. Nat. Hist, 1873, 4. ser. 11, 199 206.

1873.1

British freshwater fishes. Illustrated with a coloured figure of each species, drawn from nature by $\mathrm{A}$. $\mathrm{F}$. Lydon. 2 vols. London, 1879. 204 p. 39 pls. fol.

1879.1

The natural history and cultivation of the sole. Intern. Fisheries Exhib. Lit., London, 1883. Conferences, 11, pt. 12.

1883.1

The natural history of commercial sea-fishes of Great Britain and Ireland. Intern. Fisheries Exhib. Lit. London, 1883. Conferences, 10, pt. 1.

1883.2

Houser, Gilbert L. The nerve cells of the shark's brain. Proc. Iowa Acad. Sci., 1897, 4, 151-153.

1897.1

The neurones and supporting elements of the brain of a selachian. Journ. Comp. Neurol., 1901, 11, 65-175. $8 \mathrm{pls}$.

1901.1

Houssay, Frédéric. La metamérie de l'entoderme et du système circulatoire primitif dans la region post-branchiale du corps des vertébrés. C. R. Acad. Sci. Paris, 1891, 120, 959-961. 1891.1

— Etudes d'embryologie sur les vertébrés. Arch. Zool. Expér. Gén., 1893, 3. sér. 1, 1-95. 5 pls. 1893.1

- La forme et la vie. Paris, 1900. 924 p. illust. $8^{\circ}$. 1900.1

- La légende du Lepas anatifera, la Vallisneria spiralis et le poulpe. C. R. Acad. Sci. Paris, 1901, 132, 263-265. 2 figs. 1901.1

Note on supposed mediæval ideas of fish metamorphosis.

Les formes animales et le mouvement. Univ. Paris, 1905, n. s. 6, 1-13. 7 figs.

1905.1

- Notes préliminaires sur la forme des poissons. Arch. Zool. Expér. Gén., 1908, 4. sér. 8, xv-xxxi. 8 figs. 1908.1

—Carènes et poissons. Stabilisation par les nageoires. Rev. Gén. Sci. Paris, 1909, 20, 617-624. 6 figs. 1909.1

- Nouvelle expérience sur la forme et la stabilité des poissons. Rev. Gén. Sci., Paris, 1909, 20, 943-948. 6 figs.

1909.2

-. Sur les conditions hydrodynamiques de la forme chez les poissons. C. R. Acad. Sci. Paris, 1909, 148, 10761078.

1909.3

Poissons et aéronats. Cours Lithogr. Ecole Supér. Aéronautique, 1911. 15 p. 9 figs. 1911.1

Die Entstehung des Fischkörpers infolge des Wasserwiderstandes. Kosmos, Stuttgart, 1912, 9. Jahrg., 161164. 5 figs.

1912.1

Forme, puissance et stabilité des poissons. Paris, 1912. 372 p. 117 figs.

1912.2

Houttuyn, Martin. Natuurlyke historie of uitvoerige beschryving der dieren, planten en mineraalen, volgens het samenstel van den Heer Linnæus. Met naauwkeurige afbeeldingen. 3 vols. in 37 pts. Amsterdam, 1761-85. 296 figs. $8^{\circ}$.

1761.1

Fishes, pts. $7 \& 8$. "Houttuyn, naturaliste laborieux, mais peu instruit; il a traduit et paraphrasé en hollandais le Systema Natura." Cuvier et Valenciennes.

Aanmerkingen omtrent eenige vreemde visschen. Uitgez. Verh. Soc. Wet. Amsterdam, 1765, 10, 506. 1765.1 
Houttuyn, $M$.

_- Beschrijving van eenige Japansche visschen en andere zeeschepselen Verh. Holl. Maatsch. Wet. Haarlem, 1782, 20, pt. 2, 311-350.

1782.1

See also Radermacher, J. C. M.

Houy, Reinhard. Beitrïge zur Kenntnis der Haftscheibe von Echeneis. Zool. Jahrb. (Anat. Abth.), 1909, 29, 101138. 4 pls. \& fig. 1909.1

Hovey, Edmund Otis [1862-] The geological and palæontological collections in the American Museum of Natural History. Science, 1900, 2. ser. 12, $757-760$.

1900.1

Hovey, Edmund Otis, \& Whitfield, R. P. See Whitfield, \& Hovey.

Hovey, Horace Carter. The fisheries of the United States. Scient. Amer., $1879,41,289$.

1879.1

- A transparent fish. Scient. Amer., 1879, 41, $291 . \quad 1879.2$

- The sturgeon fishery. Bull. U.S. Fish Comm. 1884, 4, 346-348. 1884.1

Howard, A. D. 'The catfish as a host for freshwater mussels. Trans. Amer. Fisheries Soc. 1912 (1913), 65-70.

Howard, Henry. Salmon eggs hatched out in New Zealand. Forest \& Stream, 1876, 7, 3.

1876.1

Exportation of whitefish ova to New Zealand in 1876. Rept. U. S. Fish Comm. 1875-76 (1878), 4, 999. 1878.1

Howden, $J . C$. Report on the fishes of the north-east of Scotland. Scot. Naturalist, 1887, 2. ser. 3,4-18. 1887.1

Howe, $F$. Report of a dredging expedition off the southern coast of New England, September, 1899. Bull. U. S. Fish Comm. 1899 (1901), 19, 237-240.

1901.1

Howe, John Allen, \& Hind, Wheelton. See Hind, \& Howe.

Howell, Samuel. Notice of the shad and shad fisheries of the river Delaware. Amer. Journ. Sci., 1837, 32, 134-140.

1837.1

Howes, George Bond [1853-1905] Zoology and food fishes. Intern. Fisheries Exhib. Lit., London, 1883. Handbooks, 2 , pt. 2 .

1883.1

Atlas of practical elementary biology; with a preface by Prof. Huxley. London, 1885.116 p. 24 pls. $4^{\circ}$.

1885.1
- On the skeleton and affinities of the paired fins of Ceratodus with observations upon those of Elasmobranchii. Proc. Lool. Soc. London, 1887, 3-26. pls.

1887.1

Observations on the pectoral finskeleton of the living batoid fishes, and of the extinct genus Squaloraja, with especial reference to the affinities of the same. Proc. Zool. Soc. London, 1890, 675-688. figs.

1890.1

- On the intestinal canal of the Ichthyopsida, with especial reference to its arterial supply, and the appendix digitiformis. Journ. Linn. Soc. London, 1890, 23, 381-410. 2 pls. 1890.2

On the visceral anatomy of the Australian torpedo (Hypnos subnigrum), with especial reference to the suspension of the vertebrate alimentary canal. Proc. Zool. Soc. London, 1890, 669-675. pl.

1890.3

Variation in the kidney of the common thornback (Raia clavata): its nature, range, and probable significance. Journ. Anat. Physiol., London, 1890, 24, 407-422. pl.

1890.4

On some hermaphrodite genitalia of the codfish (Gadus morrhua), with remarks upon the morphology and phylogeny of the vertebrate reproductive system. Journ. Linn. Soc. London, 1891, 23, 539-558. pl. 1891.1

- On the arrangement of the living fishes, as based upon the study of their reproductive system. Rept. Brit. Assoc. Adv. Sci., 61. meet., 1891, 694-695. fig.

1891.2

- On the customary methods of describing the gills of fishes. Rept. Brit. Assoc. Adv. Sci., 61. meet., 1891, 702. 1891.3

On the affinities, inter-relationships, and systematic position of Marsipobranchii. Proc. Trans. Liverpool Biol. Soc., 1892, 6, 122-147. 3 pls.

1892.1

On some remarkable variations of the respiratory organs of Petromyzon and Myxine. Proc. Zool. Soc. London, $1893,730-733$.

1893.1

On synostosis and curvature of the spine in fishes, with especial reference to the sole. Proc. Zool. Soc. London, 1894, 95-101. pl.

1894.1

The morphological method and progress. Rept. Brit. Assoc. Adv. Sci., 
72. meet., 1902, 618-638. - Nature, $1902,66,522-530$. 1902.1

Howse, Richard [1821-1901] A catalogue of the fossils of the Permian system of the counties of Northumberland and Durham, drawn up at the request of the Tyneside Naturalists' Field Club. Trans. Tyneside Nat. Field Club, 1850, 1, 219-264.

Pisces, $\cdot 231-237$.

Discovery of new and rare fossils in the marl-slate of Midderidge. Ann. Mag. Nat. Hist., 1869, 4. ser. 4, 368.

1869.1

Note on the discovery in 183637 of a fossil fish (Acrolepis kirkbyi, n. s.) in the upper division of the Magnesian limestone at Marsden. Trans. Nat. Hist. Soc. Northumb., 1880, 7, 171-173.

1880.1

Note on the capture of a very large tumny in the salmon nets, off Frenchman's bay, near the mouth of the Tyne in August, 1885. 'Trans. Nat. Hist. Soc. Northumb., 1884-89, 8, 223224.

1884.1

Note on the visit of a shoal of tunny to the Northumberland coast in June, 1884. Trans. Nat. Hist. Soc. Northumb., 1884-89, 8, 221-222. 1884.2

Catalogue of the fishes of the rivers and coast of Northumberland and Durham and the adjacent sea. Trans. Nat. Hist. Soc. Northumb., 1890, 10 , $327-384$.

1890.1

Catalogue of the local fossils in the museum of the Natural History Society. Trans. Nat. Hist. Soc. Northumb., 1890, 10, 227-288.

1890.2

Pisces, p. 249-251.

Conl-measures fishes, p. 268-272. 286

Fishes of the Carboniferous Limestone, p. 285-

Additions to the catalogue of the fishes of the rivers and coast of Northumberland and Durham and the adjacent sea. Trans. Nat. Hist. Soc. Northumb., 1894, 11, 350-356. 1894.1

Scorpana dactyloptera and Sebastes viviparus off the coast of Northumberland. Naturalist, London, 1894, 174.

1894.2

Torpedo hebetans Lowe, or $T$. nobiliana of some authors leaptured in a trawl net off the Durham coast near Sunderland] Trans. Nat. Hist. Soc. Northumb., 1900, 13, 107.

1900.1
Howse, Richard, Atthey, Thomas, \& Hancock, Albany. See Hancock, Howse \& Atthey.

Howse, Richard, \& Hancock, Albany. See Hancock \& Howse.

Hoy, James. Some account of the Trichiums lepturus, of Linnsus, found on the shore of the Moray-firth. Trans. Linn. Soc. London, 1815, 11, 210-212. Isis (Oken), 1818, 1917-1918. 1815.1

Hoy, Philo Romayne [1816-1892] Deep-Twater fauna of lake Michigan. Trans. Wisconsin Acad. Sci., 1870-72, 98-101. - Ann. Mag. Nat. Hist., 4. ser. 11,319 . 1870.1

- Mortality of fish in Racine river. Proc. Amer. Assoc. Adv. Sci., 21. meet., 1872, 198-199. 1872.1

Fish-culture. 'Trans. Wisconsin Acad. Sci. 1875-76 (1876), 3, 37-39.

1876.1

On the extent of the Wisconsin fisheries. Trans. Wisconsin Acad. Sci. $1875-76$ (1876), 3, 65-67. 1876.2

Hoye, $K r$. Undersogelser over klipfiskesoppen. Bergen, 1902. 39 p. 5 pls.

1902.1

Hoyer, Heinrich. Ueber den feineren Bau der Milz von Fischen, Amphibien und Vögeln. Inaug. Dissert. Strassburg, 1892.

1892.1

Zur Morphologie des Fischherzens. Bull. Intern. Acad. Sci. Cracovie, 1900, 263-279. figs.

1900.1

Ueber den Bau des Integuments von Hippocampus. Bull. Intern. Acad., Cracovie, 1901, 143-146.

1901.1

Die geologischen Verhältnisse der Umgegend von Sehnde. Zeitschr. Deutsch. Geol. Ges., 1902, 5, 84-143. 2 pls. \& 6 figs.

1902.1

Hoyle, William Evans [1855-] On the deep-water fauna of the Clyde seaarea. Journ. Linn. Soc. London, 1889, $20,442-472$.

1889.1

Exhibit of and remarks on a coloured sketch of a specimen of Beryx splendens. Mem. Proc. Manchester Lit. Phil. Soc., 1907, 51, xx.

1907.1

Huard, Victor A. La question du saumon au lac Saint-Jean. Naturaliste Canadien, 1900, 27, 145-149. Ibid., 1903, 30, 19-21. 
Huard, $V . A$.

Le saumon au lac Saint-Jean. Naturaliste Canadien, 1900, 27, 140142.

1900.2

Du nouveau concernant la "question de l'anguille." Naturaliste Canadien, 1901, 28, 5-9.

1901.1

Comment certains poissons survivent au desséchement des pièces d'eau ou ils habitent. Naturaliste Canadien, 1903, 30, 100-103.

1903.1

Hubault, Paul. Le repeuplement des rivières et l'aquarium du Trocadéro. Rev. Scient., Paris, 1907, 5. sér. 7, 7375 .

1907.1

Hubbard, Jesse W. The yolk nucleus in Cymatogaster aggregatus Gibbons. Proc. Amer. Phil. Soc., 1903, 33, 74-83. 3 pls.

1903.1

Hubbard, Oliver $P$. Letter relating to a singular diseased affection of the perch, Perca flavescens (in Cold pond, Ackworth, N. H.) Proc. Boston Soc. Nat. Hist. 1845-48 (1848), 2, 157.

1848.1

On the resuscitation of frozen fish. Amer. Journ. Sci., 1850, 2. ser. 10, 132-133. Ibid., 12, 291-292.-Ann. Mag. Nat. Hist., 2. ser. 6, 397-398.

1850.1

[Letter giving an account of a fish which was seen to fall to the earth, during a sudden squall of wind and rain, in a town in Vermont Proc. Boston Soc. Nat. Hist. 1856-59 (1859), 6, 283.

1859.1

Hubbard, Waldo $F$. Report of salmon hatching operations in 1878 at the Clakamas hatchery. Rept. U. S. Fish Comm. 1878 (1880), 6, 771-772. 1880.1

Transportation of green brook trout and salmon eggs. Trans. Amer. Fisheries Soc. 1903 (1904), 79-81.

1904.1

Hubbard, (Rev.) William. A general history of New England. Boston, 1815. 676 p. $8^{\circ}$.

1815.1

Contains incidental mention of fisheries, also account of death of fish in a pond at Watertown, Mass., caused by mineral vapor.

\section{Hubbe,}

Mittheilungen über die Seefischerei in Keitum auf Sylt. Circul. Deutsch. Fischerei Ver. 1874 (1875), no. 3,129 .

1875.1

Huber, G. Carl. A brief account of some observations on the sympathetic ganglia of vertebrates. Brit. Med. Journ., 1897, 2, 881; 1398-1401. 1897.1

Huber, G. Carl, \& De Witt, Lydia. A contribution on the motor nerve endings and on the nerve endings in the muscle spindles. Journ. Comp. Neurol., 1898, 7, 169-230. 5 pls.

1898.1

Huber, Gottried. Monographische Studien im Gebiete der Montigglersec (Südtirol) mit besonderer Berücksichtigung ihrer Biologie. Inaug. Dissert. Zürich, 1905. Arch. Hydrobiol. Plankton., Stuttgart, 1, 1-81. figs. 1905.1

Huber, O. Die Kopulationsglieder der Selachier. Zeitschr. Wiss. Zool., Leipzig, 1901, 70, 592-674. 2 pls. \& figs. 1901.1

Mitteilungen zur Kenntniss der Copulationsglieder bei den Selachiern. Anat. Anz., 1901, 19, 299-307. 1901.2

_- Die Copulationsglieder von $L a-$ viraja oxyrhynchus. Zool. Anz., 1908, 32, $717-720$. 4 figs.

1908.1

Huber, Robert $O$. Interessante Formen und Funktionen der Schwimmblase von Fischen. Mitt. Nat. Ver. Univ. Wien, 1908, 6. Jahrg., 128-129. 1908.1

Huberty, $J$. La pisciculture dans le lac de la Gileppe (Belgique) Etangs \& Rivières, 1896, 9. année, 34-40; 51-54.

1896.1

Hubrecht, Ambrosius Arnold Willem. Beiträge zur Kenntniss des Kopfskeletes der Holocephalen. Niederl. Arch. Zool., 1876, 3, 255-276. pl. Morphol. Jahrb., 3, 280-282. . 1876.1

- On a new species of Coris $[C$. bleekeri] from the Molucca archipelago. Ann. Mag. Nat. Hist., 1876, 4. ser. 17, 214-215.

1876.2

- Pisces (In Bronn, H. G. Klassen und Ordnungen des Thier-Reichs, vol. vi. Leipzig \& Heidelberg, 1876. 6 vols. pls.)

1876.3

- Over eene nieuwe Gobius-sort uit de Noordzee. 2. Jaarversl. Zool. Stat. Nederl. Dierk. Ver., 1878, 15-20.

1878.1

List of fishes collected during the two cruises of the "Willem Barents," 1878-79. Niederl. Arch. Zool. (Suppl.), 1881-82, 1.5 p.

1881.1

- On a collection of fishes from the St. Paul's river, Liberia, with description of three new species. Notes Leyden Mus., 1881, 3, 66-71. 1881.2 
Fish-culture as seen at the London exhibition, with special reference to its history, apparatus and the methods used in the United States. Bull. U. S. Fish. Comm., 1883, 3, 337-348. 1883.1

- Early ontogenetic phenomena in mammals and their bearing on our interpretation of the phylogeny of the vertebrates. Quart. Journ. Micr. Sci., London, 1909, 53, 63-68. 1909.1 Contains references to fishes.

Hucke, $K$. Gault in Bartin bei Degord (Hinterpommern) Zeitschr. Deutsch. Geol. Gesell., 1905, 56, 165173.

1905.1

Huckfeldt, G. P. Paratilapia (Chromis) multicolor. Blätt. Aquar-Terrar. Kunde, 1904, 15. Jahrg., 261-262

1904.1

Huddlestone, Frederich. Shipment of salmon ova to New Zealand in 1877. Rept. U. S. Fish Comm. 1878 (1880), 6, 863 .

1880.1

Hudson, George A. Carp caught in Ogeechee river. Bull. U. S. Fish Comm. $1884,4,123$.

1884.1

Hudson, William Henry. Culture of landlocked salmon. Forest \& Stream, $1879,12,504$.

1879.1

Hudson, William M., Pike, Robert $G ., \&$ Bill, James A. Sixth report of the commissioners of fisheries of the state of Connecticut, 1872. Hartford, 1872. 36 p. $8^{\circ}$.

1872.1

- Seventh report of the commissioners of fisheries of the state of Connecticut, 1873. Hartford, 1873. $48 \mathrm{p}$. $8^{\circ}$

1873.1

Huebner, Adolph. Notes upon the increase and decrease of fish. Bull. U.S. Fish Comm. 1886 (1887), 6, 187-190.

1887.1

- Om gösodling. Fiskeritidskr. Finland, 1893, 7, 74-77. 1898.1

- Fischwirtschaft. Gesammelte Arbeiten aus 25-jähriger öffentlicher Tätigkeit und 40-jähriger Praxis. Bautzen, 1905. xi, 363 p. pls.

1905.1

Huefner, Carl Gustav. Zur vergleichenden Anatomie und Physiologie der Harncanälchen. Inaug. Dissert. Leipzig [1866] 28 p. pl.

1866.1

Zur physikalischen Chemie der Schwimmblasengase. Arch. Anat. Physiol. (Abth. Physiol.), 1892, 54-80. 2 pls.
Huegel, A. de. Angler in Torbay. Zoologist, 1870, 2. ser. 5, 1984. 1870.1

Huegel, Carl Alexander Anselm von [1796-1870] Kaschmir und das Reiche der Liek. 4 vols. Stuttgart, 1840-48.

1844.1

Bd. iv, Abth. 2. Fische Kaschmir's nebst einem Anhang von drei neuen Arten aus Indien, von J. J. Heckel.

Huene, (Baron) Friedrich von. Devonische Fischreste aus der Eifel. Neues Jahrb. Mineral. Geol., 1900, 6466. 2 figs. 1900.1

Describes remains of Dinichthys and Rhynchodus. $[R$. emigratus Huene $=R$. major Eastman]

- Rhynchodus emigratus von Huene. Centralbl. Mineral. Geol., 1900, 178. 1900.2

- Die jungtriassische Wirbeltierfauna von Niederschönthal bei Basel. Centralbl. Mineral. Geol., 1911, 422424.

1911.1

Hünnemeier, B., \& Köniø, Joseph. See König \& Hünnemeier.

Huet, Paul. De l'influence du milieu sur les mours de quelques poissons de rivière. Bull. Soc. Acclimat. Paris, 1904, 51. année, 47-54; 83-89. 1904.1

- Les époques de ponte des poissons en rivière et en eau dormante. Rev. Gén. Sci., Paris, 1906, 17, 817-820. La Nature, 1906, pt. 1, $119 . \quad 1906.1$

Huet, $W . G$. [Notes on the trochlear and oculomotor nuclei and the trochlear root in the lower vertebrates] Versl. Akad. Wet. Amsterdam, Wis. Nat. Afd., 1911, 19, 981-987. - Proc. Akad. Wet. Amsterdam, 13, 897-903. pl. \& 5 figs.

1911.1

Hỉtter, Johann. Ueber die Fische in dem Lunzer See und in der Ybbs. Schulprogramm Niederösterr. Landescentral- und Gerverbesch. Waidhofen a. d. Ybbs, 1874. 22 p. $8^{\circ}$. 1874.1

Hufeland, - Grundlage zu einer künftigen Zoonomie. Jena, 1798. 232 p. $8^{\circ}$. 1798.1

Hughes, Elizabeth G., \& Eigenmann, Carl H. See Eigenmann \& Hughes.

Hughes, Elizabeth G., \& Jordan, David Starr. See Jordan \& Hughes.

Hughes, Frank. Experiments on the production of artificial baits. Journ. Mar. Biol. Assoc., 1891-92, n. s. 2, 91$94 ; 220-221$.

1891.1 
Hughes, Smith $E$. Live ponds for fish in New Jersey. Bull. U. S. Fish Comm. 1881 (1882), 1, 349-351. 1882.1

Experiments in penning sea-fish. Bull. U. S. Fish Comm. 1884, 4, 377380.

1884.1

Hughes, William R. Lepidogaster bimaculatus in an aquarium. Zoologist, 1864, 22, 9131-9137.

1864.1

The sleep of fishes. Zoologist, 1874, 2. ser. 9, 3895-3897. 1874.1

Large salmon. Zoologist, 1875 , 2. ser. 10,4460 .

1875.1

\section{Hughlett, See Ferguson \& Hughlett.}

Hugounenq, L. Sur une albumine extraite des œufs de poissons, et sur la chimie comparée des productions sexuelles dans la même espèce. C. R. Acad. Sci. Paris, 1904, 138, 1062-1064. Journ. Pharm. Chim., 6. sér. 19, 521-524.

1904.1

Hugounenq, L., \& Liortet. See Lortet \& Hugounenq.

Huitsfeldt-Kaas, Hartvig. Does the quality of the trout depend upon its food? [Text in Norwegian] Naturen, 1901, 25, 177-185. 8 figs. 1901.1

Young salmon and trout in a river on Jæderen, Norway [Text in Norwegian] Norsk Tidskr. Fiskeri, 1903, 22, 233-249.

1903.1

Size of young salmon in two rivers in Smaalenene, Norway [Text in Norwegian] Norsk Tidskr. Fiskeri, 1904, 23, 444-446.

1904.1

Hvorledes adskilles lakse-, orretog røieyngel fra hinanden. [How to distinguish between young salmons, trouts and red chars] Norsk Jxgerf. Tidskr., Kristiania, 1905, 34, 89-96. fig.

1905.1

Forsog med indforelse af gjors (Lucioperca sandra) i norske vande Versuche mit Aussetzung von 'Zander in norwegische Seen] Norsk Tidskr. Fiskeri, 1906, 25, 187-192.

1906.1

Hoorfor udvandre fiskene fra Ostensjovandet? [Eine Massenauswanderung von Süsswasserfischen aus dem Ostensjösee bei Christiania)] Norsk Tidskr. Fiskeri, 1909, 28, 257-263.

1909.1
Fiskeribiologiske undersokelser i vande i Trondhjemsamterne. Norske Selsk. Skrift. 1912 (1913), no. 14. 75 p. 59 figs.

1913.1

Hulftegger, $H$. Bericht über Versuche mit dem Röthelfang im Zürichsee, 11. November bis 21. Dezember 1890 . Zentralbl. Jagd-, Hundeliebhaber \& Fischereiwesen, 1891, 7, 114. 1891.1

- Der Trüschenfang im obern Zürichsee. Schweiz. Fischerei Zeitg., 1893, 1, 9-13. Also separate; PfäffikonZürich, 1893. 4 p. $8^{\circ}$. 1893.1

Fischerei im Konkordatsgebiet Zürich-Wallensee, Winter 1895. Schweiz. Fischerei Zeitg., 1896, 4, 243246. Also separate; Pfäffikon-Zürich, 1896. 3 p. $8^{\circ}$.

1896.1

Ueber Fang und Fortpflanzung des Hechtes im Zuirichsee IVährend der Laichzeit im Frühjahr 1904. Schweiz. Fischerei Zeitg., 1904, 12, 101-105.

1904.1

Hull, Edward [1829-] On the origin of the fishes of the sea of Galilee. Rept. Brit. Assoc. Adv. Sci., 55. meet., 1885, 1066-1068.

1885.1

On the physical conditions of the Mediterranean basin which have resulted in a community of some species of freshwater fishes in the Nile and the Jordan waters. Quart. Journ. Geol. Soc., 1895, 51, 93-94.

1895.1

Hulme, F. Edward. Natural history lore and legend. London, 1895. 350 p. illust. $8^{\circ}$.

1895.1

Chapter v. Forms reptilian and piscine, p. 264-339.

Hulsiner, $P$. Some trout questions. Forest \& Stream, 1879, 13, 584. 1879.1

Hult, Ragnar [1857-1899] Faunan i de artesiska brunnarna i Algeriet Georg. Fören. Tidskr., 1895, 7, no. 3, 158-159.

1895.1

Hulth, J.M., \& others. Zoologiska studier. Festskrift W. Lilljeborg tillegnad på hans åttiode födelsedag af svenska zoologer. Upsala, 1896. xii, 360 p. 17 pls. \& illust. $4^{\circ}$. 1896.1 i. Bibliographia Lilljeborgiana, by J. M. Hulth.

iii. Zur Kenntniss der Retina der Selachier. von $\mathrm{G}$. Retzius.

Humbert, Alois, \& Pictet, F.J. See Pictet \& Humbert.

Humbert-Claude, $E$. Une gloire vosgienne, Remy, inventeur des procédés pratiques de pisciculture. Nancy, 1897. 
Humboldt, (Baron) Friedrich Heinrich Alexander von [1769-1859], \& Bonpland, A.J.A. Voyage aux régions equinoxiales du nouveau continent, fait en 1799-1804, etc. 24 vols. Paris, 1805-37. pls. \& atlases. $4^{\circ} \&$ fol.

1805.1

Pt. ii. [Zoologie] Recueil d'observations de zoologie et d'anatomie conparée, faites dans l'Océan Atlantique, dans l'intérieur de nouveau continent et dans la Mer du sud pendant les années 1799-1803. [This is the original text, afterwards cancelled, and corresponds to p. 1afterwards cancelled, and corresponds to p. 1-
309 of vol. i of the following, published at Paris in 1812]

Vol, i, no. 3. Mémoire sur l'Eremophilus et l'Astroblepus, deux nouveaux genres de l'ordre des Apodes, p. 17-20. pls. vi-vii.

No. 4. Mémoire sur une nouvelle espèce de Pimelode, jetée par les volcans du royaume de Quito, p. 21-25. pl. Abstract in Phil. Mag., $1806, \mathbf{2 4}, 333-339$. fig.

No. 6. Mémoire sur une nouvelle espèce de Gumnote (G. aequilabiatus) de la rivière de la Madeleine, p. 46-48. pl.

No.7. Observations sur l'anguille électrique (Gymnotus clectricus Linn.) du nouveau continent, p. 49-92.

Vol. ii, no. 4. Recherches sur les poissons fluviatiles... Par MIM. de Humboldt et Valeneiennes, p. 145-216. 4 pls. 1811.

- Beobachtungen aus der Zoologie und vergleichenden Anatomie gesammelt auf einer Reise nach den TropenLändern des neuen Kontinents in ... 1799-1804. Tübingen \& Paris, 1806. $\mathrm{x}, 212$ p. 14 pls. $4^{\circ}$.

1806.1

- Versuche ïber die electrischen Fische. Ann. Physik (Gilbert), 1806, 22, 1-13. - Nova Acta Erfurt, 1809, 4. - Notizen (Froriep), 1836, 49, 55-57.Phil. Mag., 1805, 23, 356-360: 1806.2

Personal narrative of travels to the equinoctial regions of the new continent, during 1799-1804 . . translated by H. M. Williams. 4 vols. London, 1818-19. $8^{\circ}$.

1818.1

Account of the electrical eel and of the means of catching them, etc. Edinb. Phil. Journ., 1820, 2, 242-249.

1820.1

- Personal narrative of travels to the equinoctial regions of America, during the years 1799-1804. Translated and edited by Thomasina Ross. 3 vols. London, 1852.

1852.1 455

Fishes, vol. ii, p. 113-130; 166-167; 437; 454-

Humboldt, (Baron) Friedrich Heinrich Alexander von, \& Gay-Lussac, Louis Joseph. See Gay-Lussac \& Humboldt.

Humboldt, Friedrich Heinrich Alexander von, \& Provençal, __ See Provençal \& Humboldt.
Humboldt, Friedrich Heinrich Alexander von, \& Valenciennes, Achille. Recherches sur les poissons fluviatiles (In Humboldt, F. H. A. von, \& Bonpland, A. J. A. Voyage aux régions equinoxiales du nouveau continent, fait en 1799-1804, etc., vol. ii, no. 4. Paris, 1811)

1811.1

Humphreys, (Mrs.) B. Statement concerning the menhaden fishery. Rept. U. S. Fish Comm. 1877 (1879), 5, 387.

1879.1

Humphreys, Henry Noel [18101879] River gardens; being an account of the best methods of cultivating freshwater plants in aquaria, etc. London, 1857. $12^{\circ}$.

1857.1

Humphreys, John. The suppression and specialization of teeth. Proc. Birmingham Phil. Soc., 1889, 6, 137-161.

1889.1

Humphry, George Murray [18201896] On the homologies of the lower jaw and the bones connecting it with the skull, in birds, reptiles and fishes. Rept. Brit. Assoc. Adv. Sci., 35. meet., 1865, 87-89. - Brit. Journ. Dental Sci., 8, $460-462$.

1865.1

On the homological relations to one another of the fins of fishes. Rept. Brit. Assoc. Adv. Sci., 40. meet., 1870 , 141.

1870.1

On the homological relations to one another of the mesial and lateral fins of osseous fishes. Journ. Anat. Physiol. London, 1871, 5, 59-66.

1871.1

The muscles of Ceratodus. Journ. Anat. Physiol., London, $1872,6,279$ 287. fig.

1872.1

— The muscles of Lepidosiren [Protopterus] annectens, with the cranial nerves. Journ. Anat. Physiol., London, $1872,6,253-270$. fig. 1872.2

The muscles of the smooth dogfish (Mustelus lacvis) Journ. Anat. Physiol., London, 1872, 6, 271-278.

1872.3

Hunger, Oscar. Varieties of carp in Saxony. Bull. U. S. Fish Comm. 1883, 3, 406 .

1883.1

Hunt, Arthur Roope. On the influence of wave-currents on the fauna inhabiting shallow seas. Journ. Linn. Soc. London (Zool.), 1885, 18, 262-274.

Fishes, p. 270-271.

1885.1 
Hunt, Thomas Sterry [1826-1892] Fish manures. Canadian Naturalist, 1859, 4, 13-23.

1859.1

Hunt, IY.T. As to the carp. Trans. Amer. Fisheries Soc. 1911 (1912), 189194.

1912.1

Hunter, John [1728-1793] Anatomical observations on the torpedo. Phil. Trans. Roy. Soc. London, 1774, 63, 481-489. pl.

1774.1

Observations on the gillaroe trout, commonly called in Ireland the gizzard trout. Phil. Trans. Roy. Soc. London, 1774, 64, 310-317.

1774.2

An account of the Gymnotus electricus. Phil. Trans. Rov. Soc. London, $1775,65,395-407.4$ pls. $\quad 1775.1$

On the organ of hearing in fish. Phil. Trans. Roy. Soc. London, 1782 , 72, 379-383.

1782.1

Huntington, L. D. Waste of food fishes. Trans. Amer. Fisheries Soc. 1896 (1897), 121-126.

1897.1

Huntley, R. Hodgson. Return of fish caught in Carham lower water. Hist. Berwickshire Nat. Club, 1873-75 (1876), 115-116.

1876.1

Huot, André. Sur les capsules surrénales, les reins, le tissu lymphoïde des poissons lophobranches. C. R. Acad. Sci. Paris, 1897, 124, 1462-1464. 1897.1

Préliminaire sur l'origine des capsules surrénales des poissons lophobranches. C. R. Acad. Sci. Paris, 1898, 126, 49-50.

1898.1

Recherches sur les poissons lophobranches. Ann. Sci. Nat. (Zool.), 1902, 8. sér. 14, 197-288. 6 pls. Also separate; Paris, 1902. 91 p. 6 pls.

1902.1

Hurdis, J.L., Wedderburn, J. W., \& Jones, John Mathew. See Jones, Wedderburn \& Hurdis.

Hurmalainen, Juho. Alen och Saima-kanal [Der Aal in dem SaimaKanal] Fiskeritidskr. Finland, 1908, 17, 177. - Luonnon Ystävä, Helsingfors, $12,63-64$.

1908.1

Hurst, Charles Herbert, \& Marshall, Arthur Milnes. See Marshall \& Hurst.

Huschke, Emil [1796?-1883] De organorum respiratoriorum in animalium serie metamorphosi generatim scripta, et de vesicâ natatoriâ piscium quxstio. Inaug. Dissert., Jenæ, 1818. $8^{\circ}$.

1818.1

Review in Isis (Oken), 1819, 10, 1636.

Ueber Weber's Gehörknöchelchen der Fische. Isis (Oken), 1822, 889893.

1822.1

Husen, Ebba von, Winkler, $H$. von, Schneider, G., \& Levander, $K$. M. See Schneider, Levander \& others.

Huske, C. J. Shad work in South Carolina. Bull. U.S. Fish Comm. 1883, 3,446 .

1883.1

Report on California trout distribution in South Carolina in 1883 Bull. U. S. Fish Comm. 1884, 4, 164.

1884.1

- Report on the shad work in South Carolina in 1883. Transportation of shad eggs on trays. Bull. U. S. Fish Comm. 1884, 4, 161-164. 1884.2

Shad fishing on the Edisto river. Bull. U. S. Fish Comm. 1884, 4, 165.

1884.3

Hussakof, Louis [1881 - ] Notes on the Devonian "Placoderm," Dinichthys intermedius Newb. Bull. Amer. Mus. Nat. Hist., 1905, 21, 27-36. pl. \& 2 figs. 1905.1

On the structure of two imperfectly known dinichthyids. Bull. Amer. Mus. Nat. Hist., 1905, 21, 409414. 3 pls. \& 2 figs. $\quad 1905.2$

Studies on the Arthrodira. Mem. Amer. Mus. Nat. Hist., 1906, 9, 10515t. 2 pls. \& 25 figs.

1906.1

Z Zebrasoma deani, a fossil surgeonfish from the West Indies. Bull. Amer. Mus. Nat. Hist., 1907, 23, 125-126. pl. 1907.1

Catalogue of the type and figured specimens of fossil vertebrates in the American Museum of Natural History. Part I. Fishes. Bull. Amer. Mus. Nat. Hist., 1908, 25, 1-103. 6 pls. \& 49 figs.

Preface by Bashford Dean, p. i-ii. 1908.1

[Review of] The Devonic fishes of the New York formations, by Charles R. Eastman. Science, 1908, n. s. 28, 311-313

1908.2

A new goblin shark, Scapanorhynchus jordani, from Japan. Bull. Amer. Mus. Nat. Hist., 1909, 26, 257 262. pl. and 3 figs. Abstract in Science, n. s. 29,437 . 1909.1 
The systematic relationships of certain American arthrodires. Bull. Amer. Mus. Nat. Hist., 1909, 26, 263272. pl. \& 8 figs.

1909.2

Bibliography of Bashford Dean, 1857-1909 [Privately printed] Washington, D. C., 1910. 12 p. $8^{\circ}$. 1910.1

Louis Agassiz's later views on the classification of fishes. Science, 1910 , n. s. 32, 925-926.

1910.2

See also Eastman, C. R. Agassiz's work on fossil fishes. Amer. Naturalist, 1898, 32, 170-185.

The newly discovered goblin shark of Japan. Scient. Amer., 1910 102, 186. 3 figs. - Current Literature, 1910, 48, 402-403. 4 figs. $\quad 1910.3$

- Notes on the behavior and reactions of Amphioxus. Science, 1910 , n. s. 31,475 .

1910.4

'The spoonbill fishery of the lower Mississippi. Trans. Amer. Fisheries Soc., 1910, 245-247.

1910.5

Vertebrate paleontology and the evidences for recapitulation. Pop. Sci. Monthly, 1910, 77, 304-307. $\quad 1910.6$

Notes on some upper Devonian Arthrodira from Ohio, U. S. A. in the British Museum (Natural History) Geol. Mag., 1911, 5. dec. 8, 123-128. pl. \& 3 figs.

1911.1

The Permian fishes of North America (In Case, E. C. Review of the Amphibia and Pisces of the Permian of North America. Carnegie Inst. Washington, 1911, Publ. no. 146, 153-178. 7 pls. \& 4 figs.)

1911.2

The spoonbill fishery of the lower Mississippi. Amer. Mus. Journ., 1911, 11, 121-125. 8 figs. - Fishing Gazette, 1911，28，993-995. 6 figs. Abstract in Ann. N. Y. Acad. Sci., 1911, $21,207$.

1911.3

The Cretaceous chimæroids of North America. Bull. Amer. Mus. Nat. Hist., 1912, 31, 195-228. 2 pls. 1912.1 - An extinct giant-shark. 'The race probably died out through its own rapacity. Scient. Amer. Suppl., 1912, 73, 225. 2 figs.

1912.2

- Note on an embryo of Pristis cuspidatus. Bull. Amer. Mus. Nat. Hist., 1912, 31, 327-330. 2 figs. 1912.3

- Notes on Devonic fishes from Scaumenac bay, Quebec. Bull. N. Y. State Mus., 1912, no. 158, 127-139. 3 pls. \& 6 figs.
[Review of] Les poissons wealdiens de Bernissart by R. H. 'Traquair. Science, 1912, n. s. 35, $306 . \quad 1912.5$

'The spawning habits of the sealamprey, Petromyzon marinus. Amer. Naturalist, 1912, 46, 729-740. 5 figs. Abstract in Science, 1912, n. s. 35, 460 461. - Ann. N. Y. Acad. Sci., 1912, 22, 358.

1912.6

Description of four new Palxozoic fishes from North Anerica. Bull. Amer. Mus. Nat. Hist., 1913, 32, 245250. pl. \& 2 figs.

1913.1

-_ Ramsay Heatley Traquair. Science, 1913, n. s. 37, 509-511. 1913.2

Sea-lampreys and their nests. Amer. Mus. Journ., 1913, 13, 323-325. 3 figs.

1913.3

Fishes swallowed by gar-pike. Copeia, 1914, no. 11, $2 . \quad 1914.1$

Notes on a small collection of fishes from Patagonia and Tierra del Fuego. Bull. Amer. Mus. Nat. Hist., 1914, 33, 85-94. 2 figs. $\quad 1914.2$

- On two ambicolorate specimens of the summer flounder, Paralichthys dentatus, with an explanation of ambicoloration. Bull. Amer. Mus. Nat. Hist., 1914, 33, 95-100. 2 figs. 1914.3

[Review of] A catalogue of the fishes of Japan by David Starr Jordan, Shigeho Tanaka and John Otterbein Snyder. Science, 1914, n. s. 39, 178-179. 1914.4

The capture of a basking shark on Long Island. Copeia, 1915, no. 21, $1-3$.

1915.1

- Fishes of the deep sea. Amer. Mus. Journ., 1915, 15, 249-253. 4 figs. 1915.2

Toad-stones a myth. N. Y. Evening Post, Nov. 27, 1915, sect. 3, p. 3.

1915.3

Refers to detached teeth of the fossil ganoid Lepidotus.

The lung-fish remains of the Coal Measures of Ohio, with special reference to the supposed amphibian Eurythorax of Cope. Bull. Amer. Mus. Nat. Hist., 1916, 35, 127-133. 1916.1

-_ A new pycnodont fish, Colodus syriacus, from the Cretaceous of Syria. Bull. Amer. Mus. Nat. Hist., 1916, 35, $135-137$.

1916.2 
Hussakof, Louis, \& Welker, William $H$. Notes on the chemical nature of egg-cases of two species of sharks. Proc. Amer. Soc. Biol. Chemists, 1908, 1, 138139. - Journ. Biol. Chem., 1908, 4, xliv-xlv.

1908.1

Chemical notes on the eggcapsules of two species of sharks. Biochem. Bull., 1911, 1, 216-221. pl.

1911.1

Hutchins, D. E. Nore about carp. Agric. Journ. Cape Good Hope, 1906, $29,197-222$. 3 figs.

1906.1

Hutchinson, Horace G. The decrease of the salmon. Fortnightly Rev., 1900,74 (n. s. 68), 285-294.

1900.1

(editor) Fishing. 2 vols. London \& New York, 1904. pls. \& figs. $8^{\circ}$ 1904.1

Vol. i, pt. 1, Salmon. Pt. 2, Trout. Pt. 3 , Charr and grayling.

Vol. ii, pt. 1, Tarpons and gar-fish. Pt. 2, Pike. Pt. 3, British sea fish.

Hutchinson, $H . N$. Creatures of other days. London, 1894. illust. xxiv, 265 p. $8^{\circ}$.

1894.1

Fishes of bygone days, p. 23-48.

Hutchinson, J. Natural history of the frog-fish of Surinam. York, 1797. $4^{\circ}$. Review in Trans. Linn. Soc. London, 6, 392 .

1797.1

Hutchinson, R. D. Fluefiskeriet anvendelse i Norge. Drammen, 1871. $8^{\circ}$.

1871.1

Hutchinson, $R . F$. Strange incubation in fishes. Nature, 1880, 21, 226.

1880.1

Hutchinson, $T . N$. On the Hippocampus brevirostris [H. antiquorum] Rept. Rugby School Nat. Hist. Soc., 1872 (1873), 44-47.

1873.1

Hutton, Frederick Wollaston [18361905] Contributions to the ich thyology of New Zealand. Trans. Proc. New Zealand Instit., 1872. 5, 259-272. 4 pls. Ibid., 1876, 8, 209-218. Ibid., 1877, 9, 353-354.

1872.1

Notes on some New Zealand fishes. Ann. Mag. Nat. Hist., 1873, 4. ser. 12, 400-401.

1873.1

- Notes on some New Zealand fishes. 'Trans. Proc. New Zealand Instit., 1874, 6, 104-107. 2 pls. 1874.1

- Descriptions of new species of New Zealand fish. Ann. Mag. Nat. Hist., 1875, 4. ser. 16, 313-317. 1875.1
Descriptions of two new fishes from New Zealand [Percis gilliesii, Argentina elongatas Ann. Mag. Nat. Hist., 1879, 5. ser. 3, $53 . \quad 1879.1$

- List of New Zealand fishes. 'Trans. Proc. New Zealand Instit. 1889 (1890), 22, p. 275-285. 1890.1

- Notes on some New Zealand fishes, with description of a new species. 'Trans. Proc. New Zealand Instit., 1896, 28, 314-318.

1896.1

_._On a marine Galaxias [G.bollansi] from the Auckland islands. Trans. Proc. New Zealand Instit., 1902, 34, 19S-199.

1902.1

- On the occurrence of Alepisaurus ferox on the coast of New Zealand. Trans. Proc. New Zealand Instit., 1902 , 34, 197.

1902.2

- Description of a new fish $[\mathrm{BO}$ vichthys roseopictus] Trans. Proc. New Zealand Instit., 1904, 36, 148-149.

1904.1

Index faunæ Novæ Zealandiæ.

London, 1904.372 p. $8^{\circ}$. 1904.2

On the occurrence of Centrolophus in New Zealand. Trans. Proc. New Zealand Instit., 1904, 36, 149-150.

1904.3

Hutton, Frederick Wollaston, \& Hector, James. Fishes of New Zealand. Catalogue with diagnoses of the species; with notes on the edible fishes by James Hector. Wellington, 1872. 133 p. $8^{\circ}$. 1872.1

Hutton, $J . A$. Wye salmon; results of scale reading, 1908 to 1912 . Salmon \& Trout Mag., 1913, 5, 14-39. 1913.1

Hutton, William [1797-1860] Notes on the New Red Sandstone of the county of Durham, below the Magnesian limestone. Trans. Nat. Hist. Soc. Northumb., 1831, 1, pt. 1, 60-71. 1831.1 Contains observations on fossil fishes.

Huxley, Thomas Henry [1825-1895] For biography and list of scientific writings, see Life and letters of ' $\mathrm{T}$. $\mathrm{H}$. Huxley, by his son L. Huxley. 2 vols. London, 1900. $8^{\circ}$. Also The scientific memoirs of T. H. Huxley. 4 vols. London, 1898-1903. $8^{\circ}$.

Observations on the genus Pteraspis, Rept. Brit. Assoc. Adv. Sci., 28. meet., 185S, 82-83.

1858.1

- On Cephalaspis and Pteraspis. Quart. Journ. Geol. Soc., 1858, 14, $267-$ 2S0. pls. 
- Observations on the development of some parts of the skeleton of fishes. Quart. Journ. Micr. Sci., 1859, 7, 33-46.

1859.1

i. On the development of the tail in teleostean fishes. ii. On the development of the palatopterygoid arc and hyomandibular suspensorium in fishes.

Ceylon fishes, a memorandum (In Tennent, J. E. Sketches of the natural history of Ceylon, p. 364-366. London, 1861)

$1 S 61.1$

On Pteraspis dunensis (Archaoteuthis dunensis Roemer) Quart. Journ. Geol. Soc., 1861, 17, 163-166. 2 figs.

1861.2

- Preliminary essay upon the systematic arrangement of the fishes of the Devonian epoch. Mem. Geol. Surv. United Kingdom, 1861, 10. dec., 1-46. 2 pls. \& 21 figs.

1861.3

- Archootcuthis dunensis Roem. ist ein Pteraspis. Neues Jahrb. Mineral., $1862,227$. 1862.1

_- British fossils. Illustrations of the structure of the crossopterygian ganoids. Mem. Geol. Surv. United Kingdom, 1866, 12, 1-48. 10 pls. 1866.1

A manual of the anatomy of vertebrated animals. London, 1871. 510 p. 110 figs. $8^{\circ}$.

1871.1

British fossils [Holophagus gulo] Mem. Geol. Surv. United Kingdom, 1872,13 . dec, 1 p. pl.

1872.1

Preliminary note upon the brain and skull of Amphioxus lanceolatus. Proc. Roy. Soc. London, 1874-75 (1875), 23, 127-132, - Ann. Mag. Nat. Hist., 1875, 4. ser. 15, 225-230. figs. Abstract in Journ. Zool. (Gervais), 4, 237-239. Amer. Journ. Sci., 1875, 3. ser. 9, 404405.

1875.1

On Ceratodus forsteri, with nbservations on the classification of fishes. Proc. Zool. Soc. London, 1876, 24-59. 11 figs. Abstract in Journ. Zool. (Gervais), $1876,5,446-449$.

1876.1

On the nature of the craniofacial apparatus of Petromyzon. Journ. Anat. Physiol., London, 1876, 10, 412-429. 2 pls.

1876.2

Howes (1891) says of this paper: "All recent inquiry into the morphology of the cranio-facial apparatus of the marsipobranchs finds its focus in Huxley's monograph, in which the presence of true jaws was first demonstrated and the complex apparates of the Petromyzontidæe was brought into harmony with that of the higher Gnathostomati."
On the position of the anterior nasal apertures in Lepidosiren. Proc. Zool. Soc. London, 1876, 180-181. fig.

1876.3

$607-613$

The herring. Nature, 1881, 23, 1881.1

A contribution to the pathology of the epidemic known as the "salmon disease." Proc. Roy. Soc. London, 1882, 33, 381-389.

1882.1

Fish diseases. Intern. Fisheries Exhib. Lit., London, 1883. Conferences, 6, pt. 1. $31 \mathrm{p}$.

1883.1

On the oviducts of Osmerus; with remarks on the relations of the teleostean with the ganoid fishes. Proc. Zool. Soc. London, 1883, 132-139. 2 figs.

1883.2

Huxley, Thomas Henry, \& Egerton, (Sir) Philip de Malpas Grey. See Egerton \& Huxley.

Huxley, Thomas Henry, Lefevre, George Shaw, \& Caird, James. See Caird, Huxley \& Lefevre.

Huxley, Thomas Henry, \& Walpole, Spencer. On Saprolegnia in relation to the salmon disease. Extracted from the twenty-first Annual Report of H. M.'s Inspectors of Salmon Fisheries. Quart. Journ. Micr. Sci., 1882, n. s. 22, 311333. 5 figs. Abstract in Nature, 1882 , 25, 437.

1882.1

Huyler, A.J. Shad as shrimp eaters. Forest \& Stream, 1876, 6, 233. 1876.1

Huyssen van Kattendijke, $J, L$. Kunstmatige bevruchting van visschen. Jaarb. Zool. Genootsch. Natura Artis Magistra, Amsterdam, 1853, 113-117.

1853.1

Hyde, Ida $H$. Localization of the respiratory centre in the skate. Amer. Journ. Physiol., 1904, 10, 236-258. figs. 1904.1

Differences in electrical potential in developing eggs. Amer. Journ. Physiol., 1905, 12, 241-275.

Relates to eggs of Fundulus.

1905.1

- The effect of salt solutions on the respiration, heart-beat and blood pressure in the skate. Amer. Journ. Physiol., 1908-09, 23, 201-213.

1908.1

- A study of the respiratory and cardiac activities and blood pressure in the skate following intravenous injections of salt solutions. Kansas Univ. Sci. Bull., 1909, 15, 29-63. pl. \& 49 figs. 1909.1 
Hyde, James F.C. Information concerning experiment with black bass in Baptist or Weswall's pond, Newton Centre, Mass. Rept. Comm. Inland Fisheries, Mass., 1874, p. 35. Ibid., 1875, 30-31.

1874.1

Hyerson, $P . P . B$. Experiment in trout hatching and rearing in Arkansas. Trans. Amer. Fisheries Soc. 1890 (1891), 16-48.

1891.1

Hymans, - Rapport fait ì la chambre des représentants le 17 mai 1866, au nom de la commission chargée de faire une enquête sur la situation de la pêche maritime en Belgique. Moniteur Belge, 1866, 591-637. Also separate; Bruxelles, $1866 . \quad 8^{\circ}$. 1866.1

Hyrtl, Carl Joseph [1811-1894] Antiquitates anatomicre rariores, quibus origo, incrementa et status anatomes, apud antiquissimx memorix gentes, historica fide illustrantur. Vindobonæ, 1835. 109 p. 3 pls. $8^{\circ}$ 1835.1

-... Ueber die Caudal- und KopfSinuse der Fische, und das damit zusammenhängende Seitengefäss-System. Arch. Anat. Physiol. (Müller), 1843, 224-240. - Ann. Sci. Nat. (Zool.), 2. sér. 20, 215-229. 1843.1

Sur le système vasculaire des poissons. L'Institut, 1844, 12, 239-240.

1844.1

Lepidosiren paradoxa: Monographie. Abh. Böhm. Ges. Wiss. 184344 (1845), 5. ser. 3, 605-668. 5 pls. Also separate; Prag, 1845. 5 pls. 1845.1

Ueber das angebliche Fehlen der Harnblase bei einigen Fischgattungen. Sitzber. Akad. Wiss. Wien, 1849, 3, pt. 2, $9-10$.

1849.1

Ueber die Uebergänge der doppelten Ovarien in die einfachen bei den Fischen. Sitzber. Akad. Wiss. Wien, $1849,2,249$.

1849.2

Ueber einige Eigenthümlichkeiten der Schwimmblase bei der Gattung Caranx] Sitzber. Akad. Wiss. IVien, 1849, 2, 331-334.

1849.3

Vortrag über einige interessante Abweichungen der unteren Wirbelbogen der Fische. Sitzber. Akad. Wiss. Wien, $1849,2,79-85$.

1849.4

Beitrige zur Morphologie der Urogenital-Organe der Fische. Denkschr. Akad. Wiss. Wien, $1850,1,391-$ 411. 2 pls.
Ueber das Arterien-System des Lepidosteus. Sitzber. Akad. Wiss. Wien, 1851, 8, 234-241. 1851.1

Das uropoëtische System der Knochenfische. Denkschr. Akad. Wiss. IVien, 1851, 2, 27-100.

1851.2

Ueber die Pori abdominales, die Kiemenarterien und die Glandula thyroiden der Ganoiden. Sitzber. Akad. Wiss. Wien, 1852, 8, 179-185. 1852.1

Ueber die Schwimmblase des Lepidosteus osseus. Sitzber. Akad. Wiss. Wien, 1852, 8, 71. 1852.2

Ueber das Labyrinth und die Aortenbogen der Gattung Ophiocephalus. Sitzber. Akad. Wiss. Wien, math.nat. Cl., 1853, 10, 148-152. Also separate; Wien, 1853 . $8^{\circ}$.

1853.1

- Beitrag zur Anatomie von Heterotis ehrenbergii C. et V. Denkschr. Akad. Wiss. Wien, 1854, 8, 73-88. 3 pls. Abstract in Sitzber. Akad. Wiss. IVien, 12, 396-399.

1854.1

Ueber den Zusammenhang der Geschlechts- und Harnwerkzeuge bei den Ganoiden. Denkschr. Akad. Wiss. Wien, 1854, 8, 65-72. 3 pls. Abstract in Sitzber. Akad. Wiss. Wien, 12, 179180.

1854.2

Ueber weibliche Oviducte bei männlichen Chimaeren, und eine männliche Vesicula seminalis bei Weibchen. Sitzber. Akad. Wiss. Wien, 1854, 11, 1078-1087. pl.

1854.3

Zur Anatomie von Saccobranchus singio C. et V. Sitzber. Akad. Wiss. Wien, 1854, 11, 302-307. pl. 1854.4

Ueber die accessorischen Kiemenorgane und den Darmcanal der Clupeaceen. Sitzber. Akad. Wiss. Wien, math.-nat. Cl., 1855, 17, 163-166.Denkschr. Akad. Wiss. Wien, math.-nat. Cl., 1856, 10, 1. Abth., 47-58. 3 pls.

1855.1

Anatomische Mittheilungen über Mormyrus und Gymnarchus. Denkschr. Akad. Wiss. Wien, 1856, 12, 1-22. 6 pls. Abstract in Sitzber. Akad. Wiss. Wien, 19, 94-97.

1856.1

Système vasculaire des raies. L'Institut, 1857, 25.

1857.1

Das arterielle Gefässsystem der Rochen. Denkschr. Akad. Wiss. Wien, $1858,15,1-36.5 \mathrm{pls}$. Abstract in Sitzber. Akad. Wiss. Wien, 1857, 25, 236-239. 
- Sur l'anatomie du Clarotes heuglini. L'Institut, 1858, 26, 22. 1858.2

Ueber den Amphibienkreislauf von Amphipnous und Monopterus. Denkschr. Akad. Wiss. Wien, math.nat. Cl., 1858, 14, 1. Abth., 38-49. pl.

Contains incidental references to fishes. 1858.3

-..- Anatomische Untersuchung des Clarotes (Gonocephalus) heuglini Ĺner, mit einer Abbildung und einer osteologischen Tabelle der Siluroiden. Denkschr. Akad. Wiss. Wien, 1859, 16, 1-18. pl. Abstract in Sitzber. Akad. Wiss. Wien, 26, 371-372.

1859.1

- Vorläufige Anzeige über gefässlose Herzen. Sitzber. Akad. Wiss. Wien, 1859, 33, 572-577.

Das Fischherz, p. 576-577.

Ueber anangische (gefässlose) Netzhäute. Sitzber. Akad. Wiss. Wien, 1861, 43, 1. Abth., 207-212. 1861.1

Ueber das epigonale Kijemenorgan der Lutodeira, mit einer Tafel und einer osteologischen Tabelle der Clupeiden Cuvier's. Sitzber. Akad. Wiss. Wien, math.-nat. Cl., 1861, 43, 1. Abth., 155-156.

1861.2

Ueber die Nierenknäuel der Haifische. Verh. Zool.-Bot. Ver. Wien, 1861, 11, 125-132.

1861.3

Ueber Wirbelsynostosen und Wirbelsuturen bei Fischen. Denkschr. Akad. Wiss. Wien, 1862, 20, 95-110. 3 pls. Abstract in Sitzber. Akad. Wiss. Wien, 40, 273-275.

1862.1

On nerves without ends. Quart. Rev. Nat. Hist., London, 1863, 95.

1863.1

Ueber besondere Eigenthümlichkeiten der Kiemen und des Skeletes, und über das epigonale Kiemenorgan von Lutodeira chanos. Denkschr. Akad. Wiss. Wien, 1863, 21, 1. Abth., 1-10. pl. Abstract in Sitzber. Akad. Wiss. Wien, 43, 1. Abth., 155-156. 1863.2

Ueber die Injectionen der Wirbelthiernieren und deren Ergebnisse.
Sitzber. Akad. Wiss. Wien, 1863, 47, 1. Abth., 146-204.

1863.3

- Ueber eine neue Rippenart und über das Labyrinth von Polyacanthus hasselti. Denkschr. Akad. Wiss. Wien, 1863, 21, 11-16. 2 pls. Abstract in Sitzber. Akad. Wiss. Wien, math.-nat. Cl., 1862, 44, 1. Abth., 191-192. Also separate; Wien, 1862. $4^{\circ}$. 1863.4

Ueber das Verhalten der Leberarterie zur Pfortader bei Amphibien und Fischen. Sitzber. Akad. Wiss. Wien, 1864, 49, 1. Abth., 167-175. pl. 1864.1

Ueber eine Eigenthümlichkeit des Schlundes von Catla buchanani. Sitzber. Akad. Wiss. Wien, 1864, 49, 1. Abth., 161-166. pl. 1864.2

Ueber die Einmündung des Ductus choledochus in eine Appendix pylorica. Sitzber. Akad. Wiss. Wien, 1865 , 50, 1. Abth., 39-41. pl. Also separate; Wien, 1864.3 p. $8^{\circ} .1865 .1$

Ueber den Seitencanal von Lota. Sitzber. Akad. Wiss. Wien, 1866, 53, 1. Abth., 551-556. Abstract in Ann. Mag. Nat. Hist., 1866, 3. ser. 18, 264. Arch. Sci. Phys. Nat. Genève, 1866, n. s. 27, 279-280. Also separate; Wien, 1866. $8^{\circ}$.

1866.1

Ueber Ampullen am Ductus cysticus der Fische. Denkschr. Akad. Wiss. Wien, 1868, 28, 185-190. 3 pls.

1868.1

Ueber die Blutgefässe der äussern Kiemendeckelkieme von Polypterus lapradei Steindachner. Sitzber. Akad. Wiss. Wien, 1869, 60, 1. Abth., 109-113. pl. Also separate; Wien, $1870.5 \mathrm{p}$. $8^{\circ}$.

1869.1

Die Kopfarterien der Haifische. Denkschr. Akad. Wiss. Wien, 1872, 32, 1. Abth., 263-275. 3 pls. Also separate; Wien, 1872.15 p. $4^{\circ}$.

1872.1

Das Arabische und Hebräische in der Anatomie. Wien, 1879. xlvii, 311 p. $8^{\circ}$.

1879.1

Die alten deutschen Kunstwerke der Anatomic. WVien, 1884. xxi, 230 p. $8^{\circ}$.

1884.1 
Ibbetson, $G . A$. On fossil teeth of fishes in the Palrozoic and lower members of the Mesozoic rocks. London, 1867. 6 pls. $8^{\circ}$.

1867.1

Iches, Lucien. Un ichthyomètre nouveau. Bull. Soc. Acclim. Paris, 1908, 55, 184-186. 2 figs.

1908.1

L Le pejerrey et son introduction en France. Bull. Soc. Acclim. Paris, $1910,67,245-250$.

1910.1

Principaux poissons comestibles de l'Argentine. Bull. Soc. Acclim. Paris, 1911, 58, 321-329.

1911.1

Ihering, Hermann von [1850-] For list of published writings, see Bibliographia dos trabalhos scientificos do Dr. Herm. ann von Ihering. Notas preliminares. Revist. Mus. Paulista, 1911, n. s. 8, no. 2. 39 p.

Das peripherische Nervensystem der Wirbelthiere als Grundlage für die Kenntniss der Regionenbildung der Wirbelsäule. Leipzig, 1878. 1878.1

- Ueber Wirbelverdoppelung bei Fischen. Zool. Anz., 1878, 1, 72-74.

1878.2

- Zur Kenntniss der Gattung Girardinus. Zeitschr. Wiss. Zool., 1883, 38, 468-490. pl.

1883.1

Ueber Brutpflege und Entwick-

lung des Bagre (Arius commersonii Lac.) Biol. Centralbl., 1888, 8, 268-271.

1888.1

Bemerkungen über die zoologisch-systematische Bedeutung der Fisch-Otolithen. Sitzber. Ges. Naturf. Freunde Berlin, 1891, 23-26. 1891.1

Ueber die zoologisch-systematische Bedeutung der Gehörorgane der Teleostier. Zeitschr. Wiss. Zool., 1891, 52, 477-514. pl.

1891.2

Die Küstenfische von Rio Grande do Sul. Deutsch. Volkskal. Brasilien, 1893, 89-119.

1893.1

- Die Süsswasser-Fische von Rio Grande do Sul. Deutsch. Volkskal. Brasilien, 1893, 1-88.
- Os peixes da costa do mar no estado do Rio Grande do Sul nara o anno 1897. Ann. Graciano A. do Azambuja, 1897, 98-123. - Revist. Mus. Paulista, 1896, 2, 25-63. $\quad 1897.1$

Contributions to the herpetology of São Paulo, Brazil. Proc. Acad. Nat. Sci. Philad., 1898, 101-109. 1898.1

Includes the description of a new species of fish, Panlicea jahu, p. 108-109.

Os peixes d'agua doce do estado do Rio Grande do Sul. Ann. Estado Rio Grande, 1898, 161-190.

1898.2

Observações sobre os peixes fosseis do Taubaté. Revist. Mus. Paulista $1899,3,71-75$.

1899.1

Bibliographia 1900-01. Historia natural e anthropologia do Brazil. Revist. Mus. Paulista, 1902, 5, 683-739.

1902.1

Ihering, Rudolf von. Descriptions of four new loricariid fishes of the genus Plecostomus from Brazil. Ann. Mag. Nat. Hist., 1905, 7. ser. 15, 558-561.

1905.1

- Diversas especies novas de peixes nematognathas do Brazil. Notas preliminares. Revist. Mus. Paulista, 1907. n. s. 1, 13-39.

1907.1

Notas preliminares, fasciculo 1. Revist. Mus. Paulista, 1907, n. s. 1, 1-11. 1907.2

Os peixes da agua dóce do Brazil. Revist. Mus. Paulista, 1907, 7, 258-335. pl. \& 7 figs.

1907.3

- Algumas especies novas de peires d'agua doce (Nematognatha) Revist. Mus. Paulista, 1911, n. s. 8, 380-404.

1911.1

New species are described of the genera Corydoras, Plecostomus, and Hempsylichthys.

Bibliographia 1908-1910. Anthropologia e zoologia do Brazil. Revist. Mus. Paulista, 1911, n. s. 8, 501-560.

Piscicultura no Brazil. Rev. Agricola "Chacaras e Quintaes," São Paulo, 1912, 5, nos. 3-5.

1912.1 
Duas especies novas de peixas da familia Cichlidæ. Revist. Mus. Paulista, 1914, n. s. 9, 333-337.

1914.1

Illidge, Thomas. On Ceratodus forsteri. Proc. Roy. Soc. Queensland, 1893. $4 \mathrm{p}$.

1893.1

Imbert, $A$. Sur l'origine du cocur, des cellules vasculaires migratrices et des cellules pigmentaires chez les téléostéens. C. R. Acad. Sci. Paris, 1909, 149, 688689.

1909.1

Imhof, Gottlieb. Prof. Dr. Rudolf Burckhardt, 1866-1908. Verh. Naturf. Ges. Basel, 1910, 20, 1-37.

1910.1

List of publications, p. 32-37.

Imhof, Othmar Emil. Studien zur Kenntniss der pelagischen Fauna der Schweizerseen. Zool. Anz., 1883, 6, $466-471$. 1883.1

Studien über die Fauna hochalpiner Seen, insbesondere des Kantons Graubünden. Chur, 1886. 118 p. $8^{\circ}$.

1886.1

- Notizen über die pelagische Fauna der Süsswasserbecken. Zool. Anz., 1887, 10, 577-582; 604-606.

1887.1

- Fauna der Süsswasserbecken. Zool. Anz., 1888, 11, 166-172; 185-189. 1888.1

- Renseignements sur l'existence des êtres vivants sous la glace dans les lacs des hautes Alpes. Genève, 1892. 2 p. $12^{\circ}$.

1892.1

Ueber das Vorkommen von Fischen in den Alpenseen der Schweizerschen Seen von 473-2460 Meter über Meer. Biol. Centralbl., 1894, 14, 294298.

1894.1

Fortpflanzung des Aales. Biol. Centralbl., 1896, 16, 431-433. 1896.1

Imkeller, Hans. Die Kreidebildungen und ihre Fauna am Stallauer Eck und Enzenauer Kopf bei Tölz. Fin Beitrag zur Geologie der bayerischen Alpen. Palæontogr., 1901, 48, 1-64. 3 pls. \& 7 figs.

1901.1

Includes some mention of Cretaceous fishes.

Immermann, Ferdinand. Die innere Struktur der Schollen-Otolithen. Beiträge zur Altersbestimmung der Fische. II. Wiss. Meeresuntersuch. Kiel (Abt. Helgoland), 1908, n. s. 8, 129176. 5 pls. \& 10 figs.
Imms, A. D. Notes on the gillrakers of the spoonbill sturgeon, Polyodon spathula. Proc. Zool. Soc. London, 1904, pt. 2. pl.

1904.1

- On the oral and pharyngeal denticles of elasmobranch fishes. Proc. Zool. Soc. London, 1905, 41-49. pl.

1905.1

Indrenius, M. Anders. Anmärkningar om Ruovesi socken. Tidn. \& Sällsk. Abo, 1785, 123-126; 137-141; 145-148.

1785.1

Inge, Marc. Recherches sur les nerfs cérébraux et la musculature céphalique de Silurus glanis. Rev. Suisse Zool., 1899, 6.

1899.1

Ingenhousz, John [1730-1799] Extract of a letter from Dr. John Ingenhousz, containing some experiments on the torpedo, made at Leghorn, January 1, 1773. Phil. Trans. Roy. Soc. London, $1775,65,1-4$.

1775.1

Ingersoll, Ernest [1852-] A short lecture on fishes. Forest \& Stream, $1877,8,176$.

1877.1

- On the fish mortality in the gulf of Mexico. Proc. U. S. Nat. Mus. 1881 (1882), 4, 74-80.

1882.1

Ingersoll, John $M$. The morphology of the turbinals. Med. Rec. New York, 1908, 74, 509 . 1908.1

Contains incidental references to fishes.

Ingham, $R . E$. Statement concerning the menhaden fishery. Rept. U. S. Fish Comm. 1877 (1879), 5, 433. 1879.1

Inghilleri, $F$. Sur l'étiologie et la pathogenèse de la peste rouge des anguilles. Note préventive. Arch. Ital. Biol. Torino, 1903, 39, 309-318. $\quad 1903.1$

- Sulla etiologia e patogenesi della peste rossa della anguille. Acquicolt. Lombarda, Milano, 1904, 6, 1-8; 61-69; 93-100.

1904.1

Innes (junior), William T. Preserving fish specimens. Aquarium, Dec. 1912,59 .

1912.1

Inoko, $Y ., \&$ Takahashi, D. See Takahashi \& Inoko.

Inostranzev, A. Dactylodus rossicus sp. nov. Trav. Soc. Naturalistes, St. Pétersb., 1888, 19, 1-18. pl. 1888.1

Inouye, $R$., Bharatkar, $K$. $C$., Suzuki, U., Mihata, M., \& Otsuki, S. See Suzuki, Mihata \& others. 
Ionescu, $C . N$. Les pores abdominaux des Acipenserides. Ann. Sci. Univ. Jassy, 1905, 3, 167-168.

1905.1

Iperen, I.van. Waarneming van een zeldzamen zeevisch, omtrent den keerkring van den kreeft. Natuurk Verh. Holl. Maatsch. Wet. Haarlem, 1867, 2. ser. 12, 3 .

1867.1

Irarrázaval, Alfredo. La pesca en el Japon. Boletin de Bosques, Pesca i Caza, Santiago, 1912, 1, 385-390. 1912.1

Irgens, $A$. Om Kilenotfiskeriet. Medd. Norsk Jaeger \& Fisker-Forening, Christiania, 1873, 2. Jahrg., 97-111. Also separate; Christiania, $1873.16 \mathrm{p}$. $8^{\circ}$.

1873.1

Irving, Washington [1783-1859] Astoria, or anecdotes of an enterprise beyond the Rocky mountains. 2 vols. Philadelphia, 1836. $8^{\circ}$. 1836.1

The fishes and fisheries, especially salmon, are noticed in vol. ii, chaps. $9 \& 14$.

Isaac, - Pound fishing in Long Island sound. Amer. Sportsman, 1874, 4,379 .

1874.1

Notes on the Spanish mackerel, weak-fish, blue-fish, bonito, black fish, sharks, etc.

Ishihava, $M$. Ueber die Flossenbewegung des Seepferdchens. Arch. Ges. Physiol., 1905, 109, 300-306. fig.

1905.1

Ishikawa, Chiyomatsu. A preliminary note on the fishes of lake Biwa. Zool. Mag. Tokyo, 1895, 7, 120 . figs.

1895.1

On the variations of the proportional lengths of the head, etc., as to the total length in our common eel. Annot. Zool. Japon., Tokyo, 1898, 2, 125-126.

1898.1

- Notes on two new species of fishes from the lake Biwa. Annot. Zool. Japon., Tokyo, 1901, 3, 161-164. $\mathrm{pl}$.

1901.1

Notes on some new or little known fishes of Japan. Proc. Nat. Hist. Tokyo Mus., 1904, 1, 1-17. 7 pls. 1904.1

Description of a new species of squaloid shark [Squalus japonicus] from Japan. Proc. Acad. Nat. Sci. Philad., $1908,60,71-73$.

1908.1

Ishikawa, Chiyomatsu, \& Matsuura, $K$. Preliminary catalogue of fishes, including Dipnoi, Cyclostomi and Cephalochorda, in the collection of the natural history department, Imperial Museum. Tokyo, 1897. 64 p. $8^{\circ}$.

1897.1

Issel, Arturo [1842-] Di un rarissimo squalo pescato nel golfo della Spezia. Roma, 1876. pl.

1876.1

- Bibliografia scienifica della Liguria. I. Geologia, paleontologia, mineralogia, etc. Genova, 1887. 113 p. $8^{\circ}$.

1887.1

Issel, Arturo, \& Fauchê, pesca nel compartimento di Genova Genova, 1871.

1871.1

Issel, Raffaele. Studi sulla fauna termale euganea (Nota preventiva) Atti Soc. Ligust. Sci. Nat. Geogr. Genova, 1901, 12, 146-150.

1901.1

Issel, Raffaele, \& Giglioli, Enrico Hillyer. See Giglioli \& Issel.

Isys, Colswold, pseudonym for Glover (Rev.) Richard.

Ito, Keisuke. The fishery industries of the island of Hokkaido, Japan. Bull. U. S. Fish Comm. 1886 (1887), 6, 342345 .

1887.1

The fisheries of Japan. Trans. Amer. Fisheries Soc. 1887 (1888), 17-23. 1888.1

Ivanzov; $N$. Der Scaphirhynchus. Vergleichend-anatomische Beschreibung. Bull. Soc. Sci. Moscou, 1887, 1-41. 2 pls.

1887.1

Ein Fall von scheinbarem Hermaphroditismus bei dem Barsch (Perca fluviatilis) Bull. Soc. Sci. Moscou, 1893, 199-205. pl. 1893.1

Der mikroskopische Bau des elektrischen Organs von Torpedo. Bull. Soc. Sci. Moscou, 1894, 358-399; 407489. 3 pls.

1894.1

Das Schwanzorgan von Raja. Bull. Soc. Sci. Moscou, 1895, 53-118. $3 \mathrm{pls}$.

1895.1

Iversen, Thor. Fiskeforsog i Finmarken sommeren 1906 [Fischereiversuche an der Kiiste Finmarkens im Sommer 1906] Aarsb. Norges Fiskerier, Bergen, 1907, 309-350. 2 maps. 1907.1

Undersøkelser og Fiskeforsøk i det nordlige Norge og Østhavet 1907 [Untersuchungen und Fischerei-Versuche an der Küste des nördlichen Norwegens und im Ostmeere 1907 J Aarsb. Norges Fiskerier, Bergen, 1907, 1-74. 2 maps. 
Fiskeforsok og praktiske Undersøkelser med s/s "Michael Sars" [Fishing experiments and practical researches made by SS. "Michael Sars"] Rept. Norwegian Fish. \& Mar. Invest. 1909, 2, pt. 1, 164-199.

1909.1

Iverus, Ivar $E$. Har tron på fiskarnas hörsel någon grund för sig? Förh. 15. Skand. Naturf. Mötet Stockholm, 1898 (1899), 281-283.
Iverus, $J$. Sur un cestode du Rhombus maximus. C. R. 6. Congr. Intern. Zool. Berne, 1904 (1905), 702-703.

1905.1

Ives, Joseph C., \& Newberry, John Strong. Report on the Colorado river of the west explored in 1857-1858. Washington, 1861. pls. \& figs. $4^{\circ}$. 1861.1

Iwanzoff, $N$. See Ivanzov, $N$. 
J., $A, D . D$. On the breeding of fish and the natural history of their generation. Phil. Mag., 1809, 34, 268-272; 324-333.

1809.1

J., C. T. All about eels. Forest \& Stream, 1878, 11, 130.

1878.1

Movements of eels. Forest \& Stream, 1878, 10, 502.

1878.2

J., I. Q. Trout culture on Long Island. Forest \& Stream, 1874, 2, 181.

1874.1

Jablonovskiǐ, $J$. Ueber einige Vorgänge in der Entwickelung des Salmonidenembryos nebst Bemerkungen über ihre Bedeutung für die Beurteilung der Bildung des Wirbeltierkörpers. Anat. Anz., 1898, 14, 532-551. 19 figs. 1898.1

- Ueber die Bildung des Medullarstranges beim Hecht. Abh. Ber. Zool. Mus. Dresden, 1899, 8, no. 8, 1-18. pl. \& 5 figs.

1899.1

Jablonskiǐ, N.I. Der Marka-KulSee [Text in Russian] Prir. Ochota, Moskva, 1907, pt. 10, 1-14. Ibid., pt. 11, 1-8. Ibid., pt. 12, 1-10. 1907.1

Jaccard, Samuel Auguste [1833-1895] Sur quelques espèces nouvelles de pycnodontes du Jura neuchâtelois. Bull. Soc. Sci. Nat. Neuchatel, 1888, 16, 41-44.

1888.1

Jaccard, Samuel Auguste, \& Pictet, François Jules. See Pictet \& Jaccard.

Jacentkovskiil, $A, V$. Die Fische des Meerbusens von Odessa l'Text in Russian] Mém. Soc. Nat., Odessa, 1909, 33, 89-125.

1909.1

Jachontov, G. Communication de l'excursion sur le lac Baical, faite en été de l'année 1902 [Text in Russian] Prot. Obšč. Jest., Kazani, 1902-03 (1904), no. $212,1-11$.

1904.1

Jacino, Antonino. Uovo e larva di Trachypterus. Nota preliminare. Riv. Mens. Pesca, Milano, 1908, 10, 262.

1908.1

Uovo e larva di Trachypterus. Arch. Zool. Napoli, 1909, 3, fasc. 4, 479482. pl.
Jackson, A. C. [Letter to Prof. Agassiz announcing the discovery of viviparous fishes in Californial (In Agassiz, L. Extraordinary fishes from California. Amer. Journ. Sci., 1853, 16, 381-382)

1853.1

Jackson, Charles L. The Lancashire sea-fisheries. Manchester, 1899. $85 \mathrm{p}$. Reviews in Nature, 60, 311. - Zoologist, 1899, 4. ser. 3, 426.

1899.1

Jackson, C. M. An investigation of the vascular system of $B$ dellostoma dombeyi. Journ. Cincinnati Soc. Nat. Hist., 1901, 20, 13-48. pl.

1901.1

Jackson, C. M., \& Ayers, Howard. See Ayers \& Jackson.

Jackson, Charles Thomas [18051880] Discovery of fossil fish in the coal formation of New Brunswick. Amer. Journ. Sci., 1851, 2. ser. 12, 281-282

1851.1

Report on the Albert coal mine of New Brunswick, etc. Boston, 1851.

1851.2

Descriptions of the fossil fishes of the Albert coal mine, p. 22-25. Two plates, prepared to illustrate this report, but never published, were discovered by C. R. Eastman in 1908, and reproduced by L. M. Lambe in 1910.

An analysis of the body and scales of a species of Palæoniscus from the Albert coal mine, in Hillsborough, New Brunswick. Proc. Boston Soc. Nat. Hist. 1851-54 (1854), 4. 239. 1854.1

Descriptions of five new species of fossil fish, of the genus Palroniscus. From the shales of the coal formation at Hillsboro' New Brunswick. Proc. Boston Soc. Nat. Hist. 1851-54 (1854), 4 , $138-142$

1854.2

The new species described are now known as Rhadinichthys alberti, $R$. brownii and $R$. cairnsii.

IAccount of the method now employed by the Narragansett fish guano company in the extraction of oil from menhaden and of converting the residual matter into a substitute for guano Proc. Boston Soc. Nat. Hist. 1854-56 (1856), 5, 355-356.
1856.1 
On the composition of the scales of the garpike. Proc. Boston Soc. Nat. Hist. 1854-56 (1856), 5, 92. Ibid. 1856-59 (1859), 6, 366 .

1856.2

An account of the sand-sharks which are caught near Nantucket. Proc. Boston Soc. Nat. Hist. 1856-59 (1859), 6, 259 .

1859.1

Jackson, Humphrey. An account of the discovery of the manner of making isinglass in Russia; with a particular description of its manufacture in England, from the produce of British fisheries. In a letter to William Watson, M. D. Phil. Trans. Roy. Soc. London, 1773, 63, 1-15. pl. i.

1773.1

Jackson, J.B. S. Remark on the tunny or horse mackerel] Proc. Boston Soc. Nat. Hist. 1841-44 (1844), 1, 81.

1844.1

IObservation on mode of inflation in Tetraodon turgidus ] Proc. Boston Soc. Nat. Hist. 1844-48 (1848), 2, 52.

1848.1

The occurrence of bluefish at Nahant. Proc. Boston Soc. Nat. Hist. 1844-48 (1848), 2, 248.

1848.2

Jackson, J. W. Carboniferous fishremains in north Derbyshire. Geol. Mag., 1908, 5. dec. 5, 309-310. 1908.1

Jackson, $P$. Earbones, or brain ivory, of fishes. Fishing Gazette, 1879 , 3, 225-226.

1879.1

Jackson, $T$. S., \& Brookover, $C$. See Brookover \& Jackson.

Jackson, William Hatchett, \& Clarke, W. Bruce. The brain and cranial nerves of Echinorhinus spinosus, with notes on the other viscera. Journ. Anat. Physiol., London, 1876, 10, 75-107.

1876.1

Jacob, Arthur. On the Diodon, or Tetraodon mola, or short sunfish of Pennant. Dublin Phil. Journ., 1826, 2, 443.

1826.1

Jacob, Charles. Etudes paléontologiques et stratigraphiques sur la partie moyenne des terrains crétacés dans les Alpes françaises et les régions voisines. Ann. Univ. Grenoble, 1907, 19, 221534. 6 pls. \& 14 figs.

1907.1

[Jacob, $J_{.]}$'An account of the rare fish, Regalecus glesne, caught off Cullercoats, on the 26th of March, 1849. London, 1849. 16 p. pl. \& figs. $8^{\circ}$. 1849.1
Jacobi, A. Ueber die neueren Arbeiten über die Fortpflanzung der Büschelkiemerfische. Sitzber. Nat. Ges. Isis, Dresden, 1906, p. $17 . \quad 1906.1$

Jacobi, Hermann Sieghard Rudolph [1816-] Vesica aërea piscium cum appendice de vesica aërea cellulosa Erythrini. Inaug. Dissert. Berolini, 1840. 25 p. $8^{\circ}$.

1840.1

Jacobi, Stephen Ludwig. Method of breeding fish to advantage. Hannöver. Mag., 1763, no. 23. 1763.1

Also printed in book form; London, 1778. This is said to be the first notice in English of fish-culture.

On the breeding of trout by impregnation of the ova. Hannöver. Mag., 1765, no. 62.

1765.1

- Lettre sur la fécondation artificielle des oufs de saumon et de truite (In Coste, J. J. M. C. V. Instructions pratiques sur la pisciculture, p. 130-139. Paris, 1853)

1853.1

Translated from article in the Hannöverisches Magazin for 1763 .

Abhandlung iiber das Ausbrüten der Forellen. Allgem. Fischerei Zeitg. 1896, 21. Jahrg., 243-250. 2 figs. 1896.1

Jacobs, Christian. Ueber die Schwimmblase der Fische. Zool. Arb., 1898, 3, 387-411. pl. Also separate; Leipzig, 1898. 29 p. pl. $8^{\circ}$. Inaug. Dissert. 1898.1

Jacobs, Edward. Karpfenzucht in Wernigerode 1494. Zeitschr. Harz Ver. Ges. Alterthumskunde, 1879, 12, 371 .

1879.1

Jacobsen, J. P., \& Johansen, A.C. Remarks on the changes in specific gravity of pelagic fish eggs and the transportation of same in Danish waters. Medd. Komm. Havundersøg Ser. Fiskeri, 1908, 3, no. 2. 24 p. 2 figs. 1908.1

Jacobshagen, $E$. Untersuchungen über das Darmsystem der Fische und Dipnoer. Pt. 1. Jena. Zeitschr. Naturw., 1911, 47, 529-568. - Pt. 2. Ibid., 1913, 49, 373-810. pl. \& figs.

1911.1

Jacobsohn, L. Struktur und Funktion der Nervenzellen. Neurol. Centralbl., 1910, 29. Jahrg., 1074-1083. 12 figs.

1910.1

Ueber die Gruppierung der Nervenzellen im Fischrückenmark, erläutert an Querschnitten des Rückenmarks von Tinca vulgaris. Arch. Mikr. Anat., 1911, 78, 1. Abth., 506-528. 9 figs. 
Jacobson, Louis Leven [1783-1843] Extrait d'un mémoire sur un organe particulier de sens dans les raies et les squales. N. Bull. Soc. Philom. Paris, 1812 (1813), 3, 332-337.

1813.1

Om vene systemet hos fiskene. Overs. K. Dansk. Vidensk. Selsk. Forh., Kjobenhavn, 1822-23.

1822.1

Om det lymphatiske system hos krybdyr og fiske. Overs. K. Dansk. Vidensk. Selsk. Forh., Kjobenhavn, 1825-26.

1825.1

- Ueber die Nebennieren der Fische. Abh. K. Dansk. Selsk. Naturvid., Kjøbenhavn, 1828, 3, 39-60. Abstract in Isis, 1848, p. 96.

1828.1

— Sur les branchies temporaires des requins. L'Institut, 1834, 2, 175.

1834.1

Jacoby, Leopold [-1896] Ueber den Knochenbau der Oberkinnlade bei den Aalen (Murænoidei Müll.) Zeitschr. Ges. Naturw., 1867, 30, 258-297. Also separate; Halle, 1867.42 p. 8 pls. $8^{\circ}$. Inaug. Dissert.

1867.1

Der Fischfang in der Lagune von Comacchio. Berlin, 1880. 93 p. 2 pls. 1880.1

Zur Naturgeschichte des Aales. Oesterr.-ungar. Fischerei Zeitg., 1880 , 289-290; 297; 304-305. 1880.2

The cel question. Rept. U.S. Fish Comm. 1879 (1882), 7, 463-483.

1882.1

Jacoby, Martin. Die Hornzähne der Cyclostomen nach Untersuchungen an Myxine glutinosa, Petromyzon fluviatilis und $P$. marinus. Arch. Mikr. Anat, 1894, 43, 117-148. pl.

1894.1

Jacquemont, Tictor [1801-1832] Voyage dans l'Inde pendant les années 1828 à 1832, publié sous les auspices de M. Guizot, Ministre de l'instruction publique. Journal. 4 vols. with atlas. Paris, 1841.

1841.1

No description of the fishes in the volume devoted to systematic zoology; only a reference to plates showing fishes.

Jacquet, Maurice. See Jacquet, Naurice,

Jacquinot, Honoré, \& Guichenot, A. Reptiles et poissons (In Dumont d'Urville, J. Voyage au Pôle Sud et dans l'Océanie sur les corvettes "L'Astrolabe" et "La Zélée," vol. iii, pt. 2. Paris, 1853-54)
Jääskeläinen, Viljo. Kalaloiset Laatokalta [Fischparasiten aus dem Ladoga-See 1 Meddel. Soc. Fauna Flora Fenn., 1910, 36, 55-56; 222-223. 1910.1

Jåckel, Andreas Johannes. Die Fische Bayerns. Abh. Zool. Mineral. Ver. Regensburg, 1864, 101.

1864.1

Ichthyologisches aus meinem Tagebuche von 1864. Corresbl. Zool. Mineral. Ver. Regensburg, 1865, 33-51. Ibid., 1866, 35-48; 65-96.

1865.1

- Alburnus rosenhaueri, ein neuer Fischbastard. Zool. Garten, 1866, 7. Jahrg., 20-25.

1866.1

- An hermaphrodite carp. Abh. Naturhist. Ges. Nürnberg, 1867, 3, 245. 1867.1

- Zwei Abramiden-Bastarden mit verkürzter Afterflosse. Corresbl. Zool. Mineral. Ver. Regensburg, 1869, 23. Jahrg., 98-114.

1869.1

Jaeger, — Der Wanderungstrieb der Tiere, insbesonders der Fische. Jaegers Monatsbl., Stuttgart, 1911.

1911.1

Jaeger, Alfred. Die Physiologie und Morphologie der Schwimmblase der Fische. Arch. Ges. Physiol., 1903, 94, 65-138. pl. \& figs.

1903.1

Die Physiologie der Schwimmblase der Fische. Biol. Centralbl., 1904, 24, 129-142.

1904.1

-Die Schwimmblase der Fischc. Ber. Senckenberg. Naturf. Ges. Frankfurt a.-M., 1904, 63-72. 1904.2

Zur Physiologie der Schwimmblase der Fische. Entgegnung auf den von Frau Reis und Herrn Nusbaum (Lemberg) in $\mathrm{Bd} .27$ dieser Zeitschrift veröffentlichten Aufsatz: "Zur Histologie der Gasdrüse in der Schwimmblase der Knochenfische." Anat. Anz., 1906, 29, 683-686. Ibid, 1907, 30, 588-591.

1906.1

Jäger, $G$. Ueber die Uebereinstimmung des Pygopterus lucius Ag. mit dem Archegosaurus dechenii Goldf. Abh. Bayer. Akad. Wiss. math.-phys. Kl., 1850, 3, 3. Abth., 877-886. pl. 1850.1

Jäger, Gustav [1832-] Die Farbe der Fische. Ausland, 1868, 41, 813-814. 1868.1

Ueber die Funktion der Kiemenspalten. Jahresh. Ver. Vaterl. Naturk. Württemberg, 1876, 32, 95-99. 1876.1 
Erkrankung der Goldfische in Berlin und Stuttgart. Isis (Russ), 1879. 4. Jahrg., 281-282.

1879.1

Bemerkung zu dem Aufsatz von M. Popoff, "Fischfärbung und Selektion." Biol. Centralbl., 1908, 26, 272. Ibid., 28, 448 .

1908.1

Die Farbe der Fische. Arch. Hydrobiol. Planktonk., 1908, 4, 83-85.

1908.2

Jäger, Karl. Die Fische der Wetterau. Wetterau Ges. Festgabe, 1858, 232-242.

1858.1

Jaeger, $O$. Grundzüge der Geschichte der Naturwissenschaften. Stuttgart, 1897. 120 p. $8^{\circ}$. 1897.1

Jaekel, Otto [Max Johannes] [1863 - ] Die Selachier aus dem oberen Muschelkalk Lothrigens. Abh. Geol. Specialk. Elsaas-Lothr., 1889, 3, 275-332. 4 pls.

1889.1

Ueber die Kiemenstellung und die Systematik der Selachier. Sitzber. Ges. Naturf. Freunde Berlin, 1890, 4757.

1890.1

- Ueber fossile Ichthyodorulithen. Sitzber. Ges. Naturf. Freunde Berlin, 1890, 117-131. 4 figs.

1890.2

Ueber Phaneropleuron und $\mathrm{He}-$ mictenodus n. g. Sitzber. Ges. Naturf. Freunde Berlin, 1890, 1-8. fig. 1890.3

- Referate über die in den letzten Jahren erschienenen Arbeiten über Pleuracanthiden. Neues Jahrb. Mineral., 1891, 2, pt. 3, 161-170.

1891.1

Herein are included reviews of a number of writers on the genera Pleuracanthus, Xenacan-
thus and Orthacanthus. These are C. Brongthus and Orthacanthus. These are C. Brong-

-.. Ueber die Gattung Pristiophorus. Arch. Naturgesch., 1891, 57, 15-48. pl. \& figs.

1891.2

Ueber Menaspis, nebst allgemeinen Bemerkungen über die systematische Stellung der Elasmobranchii. Sitzber. Ges. Naturf. Freunde Berlin, 1891, 115131. pl.

1891.3

Remarks on Trenton fish-remains from Canyon City, Colorado, discovered by C. D. Walcott. Bull. Geol. Soc. America, 1892, 3, 173-174. 1892.1

Ueber Chalcodus permianus. Sitzber. Ges. Naturf. Freunde Berlin, 1892, 156-158.
Ueber Cladodus und seine Bedeutung für die Phylogenie der Extremitäten. Sitzber. Ges. Naturf. Freunde Berlin, 1892, 80-92. fig. $\quad 1892.3$

Ueber Dichelodus Gieb., und einige Ichthyodoruliten; eine Entgegnung an Herrn A. Smith Woodward. Neues Jahrb. Mineral., 1892, 1, 145-151. figs.

1892.4

_ [Review of] The Palreozoic fishes of North America by J. S. Newberry. Neues Jahrb. Mineral., 1893, 1, 174-177. 1893.1

- Ueber die Ruderorgane der Placodermen. Sitzber. Naturf. Freunde Berlin, 1893, 178-181.

1893.2

— Die eocänen Selachier von Monte Bolea. Ein Beitrag zur Morphogenie der Wirbelthiere. Berlin, 1894. 176 p. 8 pls. \& 39 figs. $8^{\circ}$.

1894.1

[Revierv of] E. W. Claypole. On the structure of the American Pteraspidian, Palæaspis (Claypole), with remarks on the family. Neues Jahrb. Mineral. 1894, 2. 2 p.

1894.2

Ueber sogenannte Faltenzähne und complicirtere Zahnbildungen überhaupt. Sitzber. Ges. Naturf. Freunde Berlin, 1894, 146-153. 1894.3

[Review of] Notes on the discovery of a vertebrate fauna in Silurian (Ordovician) strata, by C. D. Walcott. Neues Jahrb. Mineral., 1895, 162. 1895.1

Ueber die Organisation der Pleuracanthiden. Sitzber. Ges. Naturf. Freunde Berlin, 1895, 69-85. 2 figs.

1895.2

- Ueber eine neue Gebissform fossiler Selachier. Sitzber. Ges. Naturf. Freunde Berlin, 1895, 200-202. 1895.3

Treats of the dentition of Janassa and Petalodus.

Chimariden-Eier aus dem unteren Dogger von Heiningen in Württemberg. Zeitschr. Deutsch. Geol. Ges., 1896, 48, 691 .

1896.1

Ueber die Stammform der Wirbelthiere. Sitzber. Ges. Naturf. Freunde Berlin, 1896, 107-129. 1896.2

- - Ueber die verschiedenen Rochentypen. Sitzber. Ges. Naturf. Freunde Berlin, 1898, 44-53. 1898.1

[Ueber Hybodus Ag.] Sitzber. Ges. Naturf. Freunde Berlin, 1898, 135146. 3 figs.

1898.2 
Jaekel, $O . M . J$.

- Die verschicdenen Rochentypen. Sitzber. Ges. Naturf. Freunde Berlin, 1898, 44-53.

1898.3

Verzeichniss der Selachier des Mainzer Oligocäns. Sitzber. Ges. Naturf. Ireunde Berlin, 1898, 161-169.

1898.4

Dipterus aus dem rheinischen Devon. Zeitschr. Deutsch. Geol. Ges., 1899, 51 (Protok.), 37-38.

1899.1

Ueber die Organisation der Petalodonten. Zeitschr. Deutsch. Geol. Ges., 1899, 51, 258-298. 2 pls. \& 7 figs.

1899.2

Ueber die primäre Zusammensetzung des Kieferbogens und Schultergürtels. Verh. Deutsch. Zool. Ges. 1899, 249-258. 2 figs.

1899.3

Ueber die Zusammensetzung des Kiefers und Schultergürtels von Acanthodes. Zeitschr. Deutsch. Geol. Ges., 1899, 51 (Protok.), 56-60. 2 figs. 1899.4

Ueber die Reste von Edestiden und die neue Gattung Helicoprion. Neues Jahrb. Mineral., 1900, 2, 144-148. 1900.1

A review of memoir on Helicoprion by A. Karpiusky.

Ueber jurassische Zähne und Eier von Chimäriden. Neues Jahrb. Mineral., 1901, 14, Beilage-Bd., 540564. 4 pls.

1901.1

- Ueber Coccosteus und die Beurtheilung der Placodermen. Sitzber. Ges. Naturf. Freunde Berlin, 1902, 103115. pl.

1902.1

Die Zusammenstellung des Schultergürtels. Verh. Intern. Zool. Congr. Berlin, 1902,610-612. figs. 1902.2

[Review of memoir by] Bashford Dean: Palseontological notes. I. On two new arthrodires from the Cleveland shale of Ohio. II. On the characters of Mylostoma Newberry. III. Further notes on the relationships of the Arthrognathi. Neues Jahrb. Mineral., 1903, 1, 339-342.

1903.1

'Tremataspis und Patten's Ableitung der Wirbeltiere von Arthropoden. Zeitschr. Deutseh. Geol. Ges., 1903, 55 (Protok.), 84-93. 5 figs.

1903.2

-... Ueber die Epiphyse und Hypophyse. Sitzber. Ges. Naturf. Freunde Berlin, 1903, 27-58. figs.
Ueber die Organisation und systematische Stellung der Asterolepiden. Zeitschr. Deutsch. Geol. Ges., 1903, 55, 41-60. 8 figs. 1903.4

- Ueber Ramphodus, nov. gen., einen neuen devonischen Holocephalen von IVildungen. Sitzber. Ges. Naturf. Freunde Berlin, 1903, 383-393. 3 figs.

1903.5

This supposed new genus, afterwards renamer "Rhamphodus," a title which is preoccupied, is founded upon dental plates indistinguishable from the type of Rhynchodus mijor Eastman, described from the Eifel Devonian.

Neue Wirbeltierfunde im Oberdevon von Wildungen. Zeitschr. Deutsch. Geol. Ges., 1904, 56 (Protok.), 159-167. 2 figs.

1904.1

Ueber die Bildung der ersten Halswirbel und die Wirbelbildung im allgemeinen. Zeitschr. Deutsch. Geol. Ges., 1904, 66 (Protok.), 109-119. 7 figs.

1904.2

Ueber einen Torpediniden und andere Fischreste aus dem Tertiär vom Kamerun (In Esch, E. Beitråge zur Geologie von Kamerun, p. 287-291. Stuttgart, 1901)

1904.3

Ueber die primäre Gliederung des Unterkiefers. Sitzber. Ges. Naturf. Freunde Berlin, 1905, 134-147. 14 figs. 1905.1

Einige Beiträge zur Morphologie der ältesten Wirbeltiere. Sitzber. Ges. Naturf. Freunde Berlin, 1906, 180-189. 7 figs.

1906.1

Neue Rekonstruktionen von Pleuracanthus sessilis und von Polyacrodus (Hybodus) hauffianus. Sitzber. Ges. Naturf. Freunde Berlin, 1906, 155159. pl. \& fig.

1906.2

Neue Wirbeltierfunde aus dem Devon von Wildungen. Sitzber. Ges. Naturf. Freunde Berlin, 1906, 73-85. 10 figs.

1906.3

- Ueber die Mundbildung der Wirbeltiere; eingehende Schilderung von L. Mehely [Text in Hungarian] Allatt. Közlem., Budapest, 1906, 5, 8-94. - Sitzber. Ges. Naturf. Freunde Berlin, 1906, 7-32. 20 figs.

1906.4

Ueber Pholidosteus, nov. gen., und die Mundbildung und die Körperform der Placodermen. Sitzber. Ges. Naturf. Freunde Berlin, 1907, 170-186. 6 figs.

1907.1

Description of Pholidosteus frierlelii, $\mathbf{n}$. $\mathrm{g}$. et n. sp.. from the Devonian of Wildungen. 
Beiträge zur Geologie von Kamerun. X. Fischreste aus den MamfeSchiefern. Abh. Kön. Preuss. Geol. Iandesanst., 1909, n. s. 62, 392-398. pl.

1909.1

Ueber die Beurteilung der paarigen Extremitäten. Sitzber. Akad. Wiss. Berlin, 1909, 26, 707-724. 16 figs.

1909.2

Ableitung der Wirbeltierextremitäten von der Grundform der Arthropoden.

Ueber die Ílassen der Tetrapoden. Zool. Anz., 1909, 34, 193-212. 15 figs. 1909.3

Incidental reference to primitive fishes, p. 200. $8^{\circ}$

Die Wirbeltiere. Berlin, 1911. 1911.1

Pisces, Fische als Nebenstamm der zweiten Wirbeltierstufe, p. 25-99. 105 figs.

Wirbelthierreste aus der Trias des Bakonyerwaldes. Pisces. Res. Wissensch. Frforsch. Balatonsees, 1912 , 3, no. 7 (Paläontol.), 17-22. 1912.1

Wege und Ziele der Palæontologie. Palæontol. Zeitschr., 1913, 1, 1-58.

1913.1

Ueber die Wirbeltierfunde in der oberen Trias von Halberstadt. Palnontol. Zeitschr., 1913, 1, 155.

1913.2

Jaekel, Otto [Max Johannes], Esch, Ernest, Solger, $F$., \& Oppenheim, $M$. See Esch, Jaekel \& others

Jaekel, [Otto Max Johannes], Volz, Wilhelm, Frech, Fritz, \& Philippi, Emil. See Philippi, Jaekel \& others.

Järvi, T. H. Die kleine Maräne, Coregonus albula L., als der Zwischenwirt des Dibotricephalus latus L. in den Seen Nord-Tawastlands (Finland). Fiskeritidskr. Finland, 1908, 17, 250-257. 2 figs. - Meddel. Soc. Fauna Flora Fenn., $1909,35,62-67.2$ figs.

1908.1

Ankeriaittemme elämä uusimpain tutkimusten valossa [Das Leben der finländischen Aale im Lichte der nenesten Forschungen] Luonnon Ystävä, Helsingfors, 1909, 13, 89-101. 1909.1

Beobachtungen über die Grösse und das Alter der Aale in Binnengewässern Finlands. Meddel. Soc. Fauna Flora Fenn., 1909, 35, 218-222. 2 figs.

1909.2

Ein Fall von Hermaphroditismus bei Lota vulgaris Cuv. Meddel. Soc. Fauna Flora Fenn., 1909, 35, 226227. fig.

1909.3
Maiti-ja mätipitoisia mateita [Hermaphroditische Exemplare von Lota vulgaris] Luonnon Ystävä, Helsingfors, $1909,13,61-62$.

1909.4

Ueber das Vorkommen des Aales im Wassersysteme des Kymi-Flusses (Finland) Meddel. Soc. Fauna Flora Fenn., 1909, 35, 222-226. fig. 1909.5

Jaffé, Sieafried. Die Aufzucht von Jährlingen in Sandfort. Allgem. Fischerei Zeitg., 1895, no. 9, 158. 1895.1

Bericht iiber einen Versuch zur Wiedereinführung des kalifornischen Silberlachses, Salmo quinnat. Allgem. Fischerei Zeitg., 1896, 21. Jahrg., no. 10, $174-176$.

1896.1

Notes on intensive pond-culture at Sandfort. Bull. U. S. Fish. Comm. 1895 (1896), 15, 311-316. 1896.2

Notes on the rearing of yearling trout [Trutta fario] at Sandford. Bull. U. S. Fish Comm. 1895 (1896), 15, 317. 1896.3

Sur quelques plantes aquatiques importantes pour l'élevage de truites Bull. Soc. Centr. Aquicult. Pêche, 1897, 9, 14-119. - Allgem. Fischerei Zeitg. 1896 , no. $21,377$.

1897.1

L'élevage des salmonides. Rev. Eaux \& Forêts, 1900, 39, 329-331.

1900.1

Regnbågsforellen i saltvatten Fiskeritidskr. Finland, 1900, 9, 6-7.

1900.2

Sur l'introduction et la multiplication en Europe de la truite à nageoires jaunes (Salmo mykiss macdonaldi Jordan et Evermann) du Colorado. Bull. Soc. Acclim. Paris, 1902, 49, 422-424. 1902.1

Trockenfuttermittel in der Fischzucht. Allgem. Fischerei Zeitg., 1902, $86 ; 106 ; 124$.

1902.2

Jaffier, J. Eléments de pisciculture pratique. Paris, 1897. xii, 122 p. 50 figs. $12^{\circ}$.

1897.1

Jagodowski, $I . P$. Zur Frage nach der Endigung der Geruchsnerven bei den Knochenfischen. Anat. Anz., 1901, 19, 257-267. figs. 1901.1

Compte-rendu des travaux exécutés près des côtes sud-ouest de la mer Noire durant les mois de juin et de juillet 1908. Ann. Mus. Zool. Acad. Sci. St. Pétersb., 1909, 14, 0246-0278. 1909.1 
Jagor, A. Fedor [1816-1900] Erfolge der künstlichen Fischzucht im botanischen Garten zu Brïssel. Zeitschr. Acclim., 1865, n. s. 3, 65-66. $\quad 1865.1$

Fischerei in Canada. Circul. Deutsch. Fischerei Ver., 1873, no. 2, 1131.

1873.1

Jakimov, Vasimir D. Zur Lehre von den Blutparasiten der Meeres-Fische. Eine vorläufige Mitteilung [Text in Russian] Arch. Veterin. Nauk, St. Petersb., 1910, 40, 1656-1664. 1910.1

Jakimov, Vasimir D., \& KohlJakimova, Nina. Ueber die Grösse der Erythrocyten der Seefische [Text in Russian Zeitschr. Wiss. Prakt. Veterin. Med., Jurjev, 1912, 6, 73-75.

1912.1

Jalkanen, $J$. Om siklöjfisket i trakten af Nyslott samt en beaktansvärd detalj i dess bedrifvande. Fiskeritidskr. Finland, 1893, 2, 73-76.

1893.1

James, Bushrod W. American salmon and other food fishes. Trans. Amer. Fisheries Soc. 1892 (1893), 139 148.

1893.1

- Alaska's food fishes and the interest of its fisheries. Trans. Amer. Fisheries Soc. 1894 (1895), 67-75.

1895.1

Impoverishment of the food fish industries. Trans. Amer. Fisheries Soc. 1895 (1896), 36-44.

1896.1

- Inter-state protection of food fishes. Trans. Amer. Fisheries Soc. 1896 (1897), 95-101.

1897.1

- State laws for the uniform protection and propagation of food fish. Trans. Amer. Fisheries Soc. 1897 (1898), 113-116.

1898.1

Protection of the food fish supply on the Pacific coast and in Alaska. Trans. Amer. Fisheries Soc. 1898 (1899), 112-120.

1899.1

- The close season for fish. 'Trans. Amer. Fisheries Soc. 1900 (1901), 99 104.

1901.1

New Pennsylvania laws for the protection of food-fish. Trans. Amer. Fisheries Soc. 1901 (1902), 144-151.

1902.1

James, Edwin [1797-1861] Account of an expedition from Pittsburgh to the Rocky mountains, performed in the years 1819 and 1820.2 vols. Philadelphia, 1823. $8^{\circ}$.

1823.1

Contains some mention of fishes.

James, Joseph Francis [-1897] Catalogue of the mammals, birds, reptiles, batrachians and fishes in the collection of the Cincinnati society of natural history. Journ. Cincinnati Soc. Nat. Hist., 1887, 10, 36-48.

1887.1

James, William Powell. From source to sea; or, Gleanings about rivers in many fields. London, 1884. $8^{\circ} .1884 .1$ Contains some mention of fishes.

Jameson, Alexander $C$. Quelques détails sur le pêche et la pisciculture en France. Rev. Britannique, 1867, 2, 319339.

1867.1

- Varieties of bass. Forest \& Stream, 1874, 3, 37.

1874.1

Jameson, Robert [1774-1854] Observations and experiments on various saponaceous compounds, particularly the fish soap of Sir John Dalrymple. Journ. Nat. Phil. (Nicholson), 1800, 3, 108-118.

1800.1

Notice of fossil fishes found in the neighbourhood of Edinburgh. Mem. Werner. Soc. Edinb., 1837, 7, 488-489. - L'Institut, 4, 193-194.

1837.1

Jammes, Léon. Note sur la réproduction du Petromyzon planeri. Bull. Soc. Centr. Aquicult. Pêche, 1899, 11, 101-102. 1899.1

- Recherches expérimentales sur l'acclimatation des organismes aux milieux salins. C. R. Assoc. Franç. Avanc. Sci., 31. sess., 1902, pt. 1, 232233.

1902.1

Janes, Thomas $P$. Fish-culture. 3. Ann. Rept. Comm. Agric. Georgia, 1876 (1877), 5-7.

1877.1

Fisheries. 4. Ann. Rept. Comm. Agric. Georgia, 1877 (1878), 29. 1878.1

Janin de Saint Just, __ Ueber den Gymnotus electricus. Notizen (Froricp), 1821, 1, 209-212.

1821.1

Janke, Heinrich. Der Besuch einer Teichwirthschaft. Circul. Deutsch. Fischerei Zeitg., 1878, 1. Jahrg., 25-28.

1878.1

Jankó, János [1868?-1902] A Magyar halíszat eredete [Herkunft der Magyarischen Fischerei] (In Dritte asiatische Forschungsreise des Grafen 
Eugen Zichy. Budapest \& Leipzig. 1900. 634 p. illust. $\mathrm{S}^{\circ}$ ) 1900.1

Jann, $P . F$. Catch of shad in the Delaware river for 1885 . Bull. U. S. Fish Comm. 1886 (1887), 6, 301. 1887.1

Catch of shad in the Delaware river for 1886. Bull. U. S. Fish Comm. 1886 (1887), 6, 301-302.

1887.2

Jannaci, $F$., Adorno, M., \& Mercadante, $L$. See Mercadante, Jannaci \& Adorno.

Jannettaz, Pierre Michel Edouard [1832-1899] Histoire naturelle. Les poissons. Paris, 1869. $16^{\circ}$. 1869.1

Janosik, Jan. O partialnim tyhovani vajicek u ryb kostnatych [Partial cleavage in the eggs of teleosts] Sitzber. K. Böhm. Gelehrten Ges., 1883, 1-7. pl.

1883.1

Zur Embryologie der Fische ['Text in Bohemian] Prag, 1883. $8^{\circ}$.

1883.2

Histologisch-embryologische Untersuchungen über die Urogenitalsystem. Wien, 1885. 4 pls. $8^{\circ}$. 1885.1

Partielle Furchung bei den Knochenfischen. Arch. Mikrosk. Anat., $1885,24,472-474$.

1885.2

Janson, Otto. Die Schwimmblase der Fische. Natur u. Haus, 1905, 13. Jahrg., 113-114.

1905.1

- Das Meer; seine Erforschung und sein Leben. Leipzig, 1914. 113 p. $8^{\circ}$.

1914.1

Januschke, H., \& Exner, Sigmund. Ueber das Guanintapetum von Abramis brama im Licht und Dunkelauge. Zentralbl. Physiol., 1905, 19, 638-639.

1905.1

See also article by Exner \& Januschke in Zentralbl. Physiol., 1905, 19, 327-328.

Jaquet, Maurice. Anatomie des poissons (In Vogt, C., \& Yung, E. Traité d'anatomie comparée et pratique. Paris, 1894)

1894.1

Recherches sur la vessie natatoire des loches d'Europe. Rev. Suisse Zool., 1894, 2, 431-442. pl. 1894.2

- Anomalie du museau chez un Acipenser ruthenus. Arch. Sci. Méd. Bucarest, 1897, 2, 358-359. fig.Bull. Soc. Sci. Bucarest, 1898, 7, $504-$ 506. fig.

1897.1
Contributions à l'anatomie comparée des systèmes squelettaire et musculaire de Chimoera collei, Callorhynchus antarcticus, Spinax niger, Protoplerus annectans, Ceratodus forsteri et Axolot1. Arch. Sci. Méd. Bucarest, 1897, 2 , 174-206. 4 pls. Ibid., 1898, 3, 300340. 6 pls. Ibid., 1899, 4, 241-273. 6 pls. Ibid., 1900, 5, 60-89. 6 pls.

1897.2

Description d'une nageoire pectorale atrophiée chez le Silurus glanis. Arch. Sci. Méd. Bucarest, 1897, 2, 349351. 6 figs. - Bull. Soc. Sci. Bucarest, 1898, 7, 496-498. 6 figs. 1897.3

L'anatomie et l'histologie du Silurus glanis L. Arch. Sci. Méd. Bucarest, 1898, 3, 101-152. 13 pls.

1898.1

- Recherches sur l'anatomie et l'histologie du Silurus glanis L. Bull. Soc. Sci. Bucarest, 1898, 8, 129-179; 378-392. 15 pls. Ibid., 1902, 10, 404482; 558-568. 27 pls. 1898.2

Anomalie de la région postérieure du corps chez un Silurus glanis. Bull. Soc. Sci. Bucarest, 1899, 8, 786-791. 4 figs.

1899.1

Ligne latérale supplémentaire chez un Acipenser ruthenus. Bull. Soc. Sci. Bucarest, 1899, 8, 791-792. fig.

1899.2

Anatomie comparée du système nerveux sympathique cervical dans la série des vertébrés. Bull. Soc. Sci. Bucarest, $1900,10,240-302$. figs. $\quad 1900.1$

- Etude du squelette céphalique d'une "carpe dauphin." Bull. Soc. Sci. Bucarest, 1902, 10, 544-557. 2 pls. 1902.1

- Description de quelques parties du squelette du Pseudolriacis microdon Capello. Bull. Instit. Océanogr. Monaco, 1905 , no. $36,1-28$. 8 pls. 1905.1

\section{Anomalie de la nageoire anale} chez les Sebastes dactyloptera. Bull. Instit. Océanogr. Monaco, 1906, no. 79 , 1-6. pl.

1906.1

Considérations sur les scorpénides de la mer de Nice. Bull. Instit. Océanogr. Monaco, 1907, no. 109, 1-48. 33 figs.

1907.1

Comprises a discussion of the Mediterranean species of Scorpæna and Sebastodes, with investigations of scale structure. 
Jaquet, $M$.

Description de l'extrémité postérieure du corps anormale chez deux Motella fusca Risso. Bull. Instit. Océanogr. Monaco, 1907, no. 90, 1-9. pl.

1907.2

- Note sur une forme jeune de Trigla. Bull. Instit. Océanogr. Monaco, 1907 , no. $102,1-5$. pl.

1907.3

— Sur deux cas de déformation du museau chez Sargus rondeletti. Bull. Soc. Sci. Bucarest, 1911, 20, 290-309. 17 figs.

1911.1

_ Sur le mode d'occlusion de l'œil d'Orthagoriscus mola Schn. Bull. Soc. Sci. Bucarest, 1911, 20, 25-32. 5 figs.

1911.2

Jardine, A. Johnstone. Observations on the sea-fishery of the colony lof cape of Good Hopel and some of the physiological peculiarities of seals. South African Quart. Journ., 1830, 1, 286-292.

1830.1

Jardine, (Sir) William [1800-1874] Fishes of Guiana. 2 vols. Edinburgh [n. d.] $12^{\circ}$.

Not seen; title from L. Agassiz.

Queries respecting the natural history of the salmon, sea-trout, bulltrout, herling, etc. Journ. Nat. Geogr. Sci. Edinb., 1830, 2, 59-61. - Edinb. New Phil. Journ., 8, 358-359. 1830.1

Observations upon rare or little known British fishes. No. 1. The vendace or vendis of the Lochmaben lochs. Journ. Nat. Geogr. Sci. Edinb., $1831,3,1-4$.

1831.1

Notice of the herling of the Solway being found in the Tweed, with some observations on its habits and distribution. Hist. Berwick. Nat. Club, $1834,1,50-52$.

1834.1

Notice of the parr. Hist. Berwick. Nat. Club, 1834, 1, 82-84. Records (Thomson), 3, 269-272. 1834.2

Observations on the Salmonidx which were met with during an excursion to the northwest of Sutherlandshire in June 1834. Rept. Brit. Assoc. Adv. Sci., 4. meet, 1834, 613-615. Edinb. New Phil. Journ., 18, 46-59.Notizen (Froriep), 43, 289-296; 305309. - Isis (Oken), 1836, 54-59. 1834.3

The natural history of fishes of the perch family (In Naturalist's library, edited by Sir William Jardine, vol. xxxviii. Edinburgh, 1835. $34 \mathrm{pls}$. \& figs. $16^{\circ}$ )

1835.1

2. ed. Edinburgh, 1852. Contains an appendix which consists of extracts from Walton's "Compleat angler" containing observations on the perch, etc.

3. ed. London, 1861.

British Salmonidx. Parts 1 \& 2.

Edinburgh, 1839-41. 12 col. pls. with descriptive letterpress. fol. 1839.1

- Natural history and illustrations of the Scottish Salmonidx. Ann. Mag. Nat. Hist., 1839, 2, 138-139. 1839.2

History of the British Salmonidæ. Notice in Ann. Mag. Nat. Hist., $1840,4,333-334$.

1840.1

- Horx zoologicx. No. IV. Remarks on the structure and habits of Lepidosiren annectens. Ann. Mag. Nat. Hist., 1841, 7, 21-26. illust. 1841.1

Report upon the experiments conducted at Stormontfield, near Perth, for the artificial propagation of salmon. Rept. Brit. Assoc. Adv. Sci., 26. meet., 1856, 451-458. New Edinb. Phil. Journ., n. s. 1856.

1856.1

- Fishes of the perch family (In Naturalist's library, edited by Sir William Jardine, vol. xxxviii. 3. ed. London, 1861. xiii, 207 p. 35 pls.)

1861.1

On the condition of the salmon fisheries of England and Wales in 1861; with a notice of some of the modes of fishing, especially those practised in the Severn and Wye; and remarks on the natural history of the salmon. Edinb. New Phil. Journ., 1862, n. s. 15, 203231. - Proc. Roy. Soc. Edinb. 1857-62 (1862), 4, 539-542.

1862.1

Jardine, (Sir) William, Fleming, (Dr.) — A Ashworth, E. See Ashworth, Jardine \& Fleming.

Jaschschenko, A. P. Katalog der Sammlung des zoologischen Kabinets der Universität. St. Petersburg, 1896. $8^{\circ}$.

1896.1

Jatzow, $R ., \&$ Lenz, $H$. Fische von Ost-Afrika, Madagascar und Aldabra. Abh. Senckenberg. Naturf. Ges., Trankfurt a.-M., 1898, 21, 497-531. 3 pls.

1898.1

Jefferson, $J . P$. On the mortality of fishes in the gulf of Mexico in 1878. Proc. U. S. Nat. Mus., 1878, 1, 363364. - Smithson. Misc. Coll., 1880, 19, art. 1. 
Jefferson, J. P., Porter, J. Y., \& Moore, T. On the destruction of fish in the vicinity of the Tortugas during the months of September and October, 1878. Proc. U. S. Nat. Mus., 1878, 1, 244 246. - Smithson. Misc. Coll., 1880, 19, art. 1.

1878.1

Jefferson, (President) Thomas [17431826] Report on fisheries, communicated to the House of Representatives, February 4, 1791. Amer. State Papers, 1832, 7, 8-21.

1832.1

Report on the cod and whale fisheries, with recommendations for their encouragement.

Jeffery, $W$. Angler or fishing frog (Lophius piscatorius) [captured at the entrance of Pegham harbor] Zoologist, 1868, 2. ser. 3, 1256-1257. 1868.1

Blue shark (Carcharias glaucus) [captured in Chichester harbor] Zoologist, 1868,2 . ser. 3, 1256.

1868.2

Jefireys, John Gwyn [1809-1885] On some species of Japanese marine shells and fishes which inhabit also the north Atlantic. Journ. Linn. Soc. London (Zool.), 1876, 12, 100-109.

1876.1

Jeffreys, John Gwyn, \& Carpenter, P. Herbert. Reports of the "Valorous" expedition. London, 1876. 61 p. 2 pls. map. $8^{\circ}$.

1876.1

Jeffreys, Thomas. The natural and civil history of the French dominions in North and South America, giving a particular account of the climate, soil, animals, etc. 2 pts. London, 1760. $8^{\circ}$.

1760.1

Jeffries, B. Joy [Remarks on the vision of fishes and amphibians] Proc. Boston Soc. Nat. Hist. 1868-69 (1869), 12, 225-227.

1869.1

Jeitteles, Ludwig Heinrich [18301883] Ueber die Süsswasser-Arten der Fisch-Gattung Cottus. Beitrag zu einer wiederholten Revision dieses Genus. Arch. Zool. Anat., 1861, 1, fasc. 2, 158-177. Also separate; Genoa, 1862. $S^{\circ}$

1861.1

Zoologische Mittheilungen, 1861. 1861.2

i. Ueber zwei für die Fauna Ungarns neue Fisehe: Lucioperca volgensis Cuv. Val. und $A l$ burnus maculatus Kessler. Verh. Zool.-Bot. Ges. Wien, 1861, 11, 323-326.

iii. Cobitis merga Irynicki, eine für MittelEuropa neue Art aus der Fisch-Familie der Acanthopsides Heckel und Kner. Ibid., 329. v. Verzeichniss der Fische des Hernad und einiger seiner Zuflüsse. Ibid., 373-374.
- Ueber das Vorkommen von Lucioperca volgensis C. V. bei Wien, nebst Beiträgen zur näheren Kenntniss der beiden mittel-europäischen Lucioperca-Arten. Verh. Zool.-Bot. Ges. Wien, 1862, 12, 113-114. 1862.1

— Vorläufige Mittheilung über einen wahrscheinlich lebendig gebärenden europäischen Süsswasserfisch. Verh. Zool.-Bot. Ges. Wien, 1862, 12 (Sitzber.), 67-69.

1862.2

Note upon this article by $R$. Inner, ibid. $69-71$.

Die Fische der Mark bei Olmütz. Jahresb. Olmützer Gymmas., 1863, pt. 1. Ibid., 1864, pt. 2. Also separate; Olmüitz, 1863. 33 p. $8^{\circ}$. 1863.1

Jeleneff, A. Histologische Untersuchungen des kleinen Gehirnes der Neunauge (Petromyzon fluviatitis) Bull. Acad. Sci. St. Pétersb., 1879, 25, 334345. pl. - Mélanges Biol. Acad. Imp. St. Pétersb., 1877-80, 10, 307-325.

1879.1

Jelgersma, $G$. Der Ursprung des Wirbeltierauges. Morphol. Jahrb., 1906, 35, 377-394. pl.

1906.1

Jenkins, Christopher. Destruction of fish by toads. Scient. Amer., 1870, 23, 85.

1870.1

Jenkins, J. Travis. The distribution of fish in and around Port Erin bay during August and September 1899. Proc. Liverpool Biol. Soc., 1900, 14, 99-102.

1900.1

-_. The fish of Port Erin. Rept. Fauna Liverpool Bay, 1900, 5, 291-294.

1900.2

- The methods and results of the German plankton investigations, with special reference to the Hensen nets. Proc. Liverpool Biol. Soc., 1901, 15, 279-341. 11 figs.

1901.1

Altersbestimmung durch Otolithen bei den Clupeiden. Wiss. Mueresuntersuch. Kiel (Abt. Kiel), 1902, n. s. 6, 81-122. pl. \& 2 figs.

1902.1

The difference between spring and autumn herring. Rept. Lancashire Sea-Fish. Labor. Liverpool, 1902 (1903), no. 11, 28-38. 1903.1

Discussion of official fishery statistics (Lancashire and Western sea fisheries district) Proc. Liverpool Biol. Soc., 1905, 19, 1-50.

1905.1 
Jenkins, $J . T$.

The migration of flat-fish. Ḱnowledge, 1905, 151. fig. 1905.2

Notes on Indian freshwater fish. Rec. Indian Mus., Calcutta, 1909, 3, 286-293.

1909.1

- Sea fishing. A lecture delivered before the Asiatic Society of Bengal on February 17th, 1909. Calcutta, 1909. 9 p. $8^{\circ}$.

1909.2

- Notes on fish from India and Persia, with descriptions of new species. Rec. Indian Mus., Calcutta, 1910, 5, 123-140. pl.

1910.1

On a collection of Indian Pleuronectidx (In Report on the fishes taken by the Bengal fisheries steamer "Golden Crown." Part iv. Mem. Indian Mus., Calcutta, 1910, 3, no. 1, 23-31. pl.)

1910.2

- The fisheries of Bengal. Journ. Roy. Soc. Arts, London, 1911, 60, 146166.

1911.1

Report dated the 24th December 1909 on the marine fishery investigations of the Bengal government steam trawler "Golden Crown," 1908-09. Coll. Papers Fish. Surv. Bengal, 1911, 46-70.

1911.2

Report on the working of the steam trawler "Golden Crown" for the quarter ending September 30, 1909. Coll. Papers Fish. Surv. Bengal, 1911, $42-45$.

1911.3

- Sea fishing. Coll. Papers Fish. Surv. Bengal, 1911, 91-100. 1911.4

Observations on the shallowwater fauna of the bay of Bengal made on the Bengal fisheries steam trawler "Golden Crown," 1908-09. Rec. Indian Mus., Calcutta, 1912, 7, 51-64. pl.

Jenkins, J. Travis, \& Annandale, Nelson. See Annandale \& Jenkins.

Jenkins, J. Travis, \& Johnstone, James. See Johnstone \& Jenkins.

Jenkins, Oliver Peebles $[1850-]$ Note of the fishes of Beaufort harbor, N. C. Johns Hopkins Univ. Circ., 1885, 5,11 .

1885.1

-... List of fishes collected in Vigo county, Indiana, in 1885 and 1888. Hoosier Naturalist, 1887, 2, 93-96.

1887.1
- A list of the fishes of Beaufort harbor, North Carolina. Stud. Biol. Labor. Johns Hopkins Univ., 1887, 4, 83-94.

1887.2

The Hopkins seaside laboratory. Zoe, 1893, 4, no. 1. 23 pls. 1893.1

Description of a new species of Ranzania from the Hawaiian islands. Proc. California Acad. Sci., 1895, 5, 779-784. fig.

1895.1

-Descriptions of fifteen new species of fishes from the Hawaiian islands. Bull. U. S. Fish Comm. 1899 (1901), 19, 387-404. 16 figs. $\quad 1901.1$

Descriptions of new species of fishes from the Hawaiian islands belonging to the families of Labridx and Scaridae. Bull. U. S. Fish Comm. 1899 (1901), 19, 45-65. 22 figs.

1901.2

Report on collections of fishes made in the Hawaiian islands, with descriptions of new species. Bull. U.S. Fish Comm. 1902 (1904), 22, 417-511. 4 pls. \& 56 figs.

1904.1

Temperature conditions in the Kern river region (In Evermann, B. IV The golden trout of the southern high Sierras. Bull. Bureau Fisheries 1905 (1906), 25, 39-43)

1906.1

Jenkins, Oliver Peebles, \& Evermann, Barton Warren. See Evermann \& Jenkins.

Jenkins, Stuart. Origin of the vertebrates. Middle Age, 1897, 15, 193-200; $225-230$.

1897.1

Jenkins, Thomas. Observations on the young of the salmon, more particularly on the samlet or small fish found in the Wye and other rivers in the autumn months, called in Herefordshire "lasprings" or "gravel-lasprings." Ann. Mag. Nat. Hist., 1840, 4, 161-169. - Notizen (Froriep), 14, 209-216.

1840.1

Jenkinson, $J . W$. Growth, variability and correlation in young trout. Biometrika, 1912, 8, 444-455. 1912.1

Jennett, Wallace $R$. Statement concerning the menhaden fishery. Rept. U. S. lish Comm. 1877 (1879), 5, 474.

1879.1

Jennings, Francis $M .{ }_{[0 n}$ eels killed by frost, in a letter to $\mathrm{WV}$. Thompson] Ann. Mag. Nat. Hist., 1841, 7, 236-237. 
Jenny, Fr. Fossilreiche Oligocänablagerungen am Südhang des Blauen (Juragebirge) Verh. Nat. Ges. Basel, 1905, 18, 119-130. pl. 1905.1

Jensen, Adolf Severin [1866-] En karpefisk, der bevogter sine $x g$ [Leucaspius delineatus] Dansk Fiskeriforen. Medlemsbl., 1894, 3. Jahrg., 401-402.

1894.1

\section{$1897-1907$}

Zoologia Danica. Kjøbenhavn,

Fishes, 1897, pt. 10, 127-179. 4 pls. Ibid. 1900, pt. 11, 179-250. 6 pls. Ibid., 1907, pt. 12, 251-360. $18 \mathrm{pls}$.

Om Centrophorus squamosus. Vidensk. Meddel. Naturh. Foren., Kjøbenhavn, 1899, 411-119. pl. 1899.1

Om slimaalens $x g . \quad$ Vidensk. Meddel. Naturh. Foren., Kjøbenhavn, 1900, 1-13. pl.

1900.1

- Whence do the otoliths of the "Ingolf" expedition originate? [Text in Danish I Vidensk. Meddel. Naturh. Foren., Kjøbenhavn, 1900, 251-254.

1900.2

Ichthyologiske studier. Vidensk. Meddel. Naturh. Foren., Kjobenhavn, 1901, 191-215.

1901.1

i. Har den dybe "kolde Area" en egen fiskefauna?

ii. Om en mærkelig variationsrække af $L y c o d e s$ vahlii Reinh.

iii. Om nogle nye arter af slægten Lycodes [Lycodes similis\}

iv. $\mathrm{Om}$ en ny art af slregten Cottunculus [C. subspinosus]

- On some fishes not hitherto observed in the Danish seas IText in Danish] Dansk Fiskeriforen Medlemsbl., Kiobenhavn, 1901, 10. Jahrg., $489-492$. 1901.2

The fishes of east Greenland [Lycenchelys kolthoffi] Meddel. Gronland, 1904, 29, 211-276. 3 pls. 1904.1

- The North-European and Greenland Lycodinx (In Danish Ingolf-Expedition, vol. ii, no. 4, 1-124. 10 pls. \& 33 figs. Copenhagen, 1904) 1904.2

- List of the fish-fauna of the polar deep. Meddel. Komm. Havundersøgelser Fiskeri, 1905, 1, no. 7. 1905.1

On fish-otoliths in the bottomdeposits of the sea. 1. Otoliths of the Gadus-species deposited in the polar deep. Meddel. Komm. Havundersøgelser Fiskeri, 1905,1 , no. 7.14 p. 4 figs.

1905.2

Raja fylla i Skagerak. Vidensk. Meddel. Naturh. Foren., Kjøbenhavn, $1905,227-238$.
Om de for aarene 1908-09 planlagte fiskeriundersögelser ved Gronland. Det Gronlandske Selsk. Aarsskr., Kijobenhavn, 1907, 79-99.

1907.1

—- Beretning om fiskeriundersögelserne ved Gronland i 1909. Beret. Kundgör. Ved. Kolonierne i Gronland, Kjobenhavn, 1909, no. 5, 1-46. 1909.1

- Indberetning om fiskeriundersögelserne ved Gronland i 1908. Beret. Kundgör. Ved. Kolonierne i Gronland, Kjobenhavn, 1909, no. 2, 11-32. 1909.2

Fiskeriundersøgelser i Grønland 1908 \& 1909 [Fishery investigations in Greenland in the years 1908 and 1909] Atlanten, Kjobenhavn, 1910, no. 82, 607-629. 9 figs.

1910.1

Fishes (In Report of the second Norwegian arctic expedition in the "Fram," 1898-1902, no. 25, p. 15. Kristiania, 1910)

1910.2

Jensen, Olaf S, [-1887] Indberetning til departementet for det Indre om de i 1880 udforte praktisk-videnskabelige undersögelser over vaarsildfisket. Christiania, $1880 . \quad 39$ p. $8^{\circ} . \quad 1880.1$

Report on the practical and scientific investigations of the spring herring fisheries during the year 1880 , submitted to the Department of the Interior. Rept. U. S. Fish Comm. 1880 (1883), 8, 127-161.

1883.1

Jentsch, Bernhard. Ueber die fossilen Fischreste des Provinzialmuseums. Sitzber. Physik.-Oekonom. Ges. Preussen, Königsberg, 1883. 3 p. 1883.1

- Beitrag zur Entwicklung und Struktur der Selachierzähne. Leipzig, 1897. Inaug. Dissert. 38 p. 2 pls. $8^{\circ}$.

1897.1

Jenyns, afterwards Blomefield, (Rev.) Leonard [1800-1893] A manual of British vertebrate animals. Cambridge \& London, 1835. xxxii, 559 p. $8^{\circ}$. 1835.1

Fish (In The zoology of the voyage of H. M. S. "Beagle," during the years 1832-1836; edited by Charles Darwin, 1842, pt. 4.172 p. 29 pls. London, 1839-43. 5 pts. $4^{\circ}$ ) 1842.1

Observations in natural history: with an introduction on habits of observing as connected with the study of that science, also a calendar of periodic phenomena in natural history, etc. London, 1846. xvi, 440 p. $12^{\circ}$. 1846.1 
Jerdon, Thomas Claverhill [18111872] On the freshwater fishes of southern India. Madras Journ. Lit. Sci., 1848, 15, pt. 1, 139-149. Ibid., 1849, pt. $2,302-346$.

1848.1

- Ichthyological gleanings in Madras. Madras Journ. Lit. Sci., 1S51, 17, $128-151$.

1851.1

On Pristolemis [Catopra] marginatus Jerd. Ann. Mag. Nat. Hist., 1865, 3. ser. 16, 298.

1865.1

On the extension of certain marine fishes to the freshwater rivers of India. Ann. Mag. Nat. Hist., 1866, 3. ser. $17,153$.

1866.1

Jernström, $L . A$. Om fiskodling och fiskerinäring. Helsingfors, 1871. $19 \mathrm{p}$. $8^{\circ}$.

1871.1

Jerome, George H. The grayling. Amer. Sportsman, 1874, 4, 203. 1874.1

- Whitefish. Amer. Sportsman, $1874,5,168$.

1874.2

First report of the superintendent of the state of Michigan fisheries for 1873-74. Lansing, 1875. $46 \mathrm{p}$.

1875.1

Second report of the superintendent of the Michigan state fisheries for 1875-76. Lansing, 1876 . $45 \mathrm{p}$.

1876.1

A historic salmon. Forest \& Stream, 1878, 11, $360 . \quad 1878.1$

Jesse, Edward [1780-1868] Gleanings in natural history, with local recollections ... to which are added maxims and hints for an angler. London, 1832. xi, $313 \mathrm{p} . \mathrm{S}^{\circ}$.

1832.1

Jesse, Richard. Die Fische Mecklenburgs. 3t. Jahresbericht über das stïdtische Gymnasium zu Waren. Waren, 1903. 34 p. $S^{\circ}$. 1903.1

Jeude, Theodor Willem van Lidth de. See Lidth de Jeude, T. W. van.

Jewett, $E$. Occurrence of shad and salmon in Connecticut river. Rept. U. S. Fish Comm. 1871-72 (1873), 6, 137.

1873.1

Jhering, II crmann von. See Ihering, II. von.

Jiménez de Cisneros, Daniel. Noticia acerca de algunos animales marinos existentes en el gabinete de historia natural del Instituto de Jovellanos.
Bol. Soc. Españ. Hist. Nat,, 1904, 4 291-293.

1904.1

Pescas, p. 293.

Joannis, $L$. de. Observations sur les poissons du Nil, et descriptions de plusieurs espèces nouvelles suivies d'un tableau de toutes les espèces qui vivent dans ce fleuve. Mag. Zool., 1835, 5. année, nos. 1-14. 15 pls. $\quad 1835.1$

- Notice sur la génération des anguilles. C. R. Acad. Sci. Paris, 1839 8, 301-302. 1839.1

Notice sur la parturition et la génération des anguilles. Rev. Zool. $1839,2,48-53$. 1839.2

Jobert, Clément. Recherches pour servir à l'histoire des organes du toucher chez les poissons. Bull. Soc. Philom Paris, 1871, 7, 194-206.

1871.1

— Etudes d'anatomie comparée sur les organes du toucher chez divers mammifères, oiseaux, poissons et insectes. Ann. Sci. Nat. (Zool.), 1872, 5. sér. 16, art. 5. 162 p. 8 figs. Abstract in Rev. Cours Scient., 4, 636-637.

1872.1

Organs du toucher des poissons. C. R. Assoc. Franc. Avanc. Sci., 1. sess 1872 (1873), 613.

1873.1

Ein neuer luftathmender Fisch [Callichthys asper] Kosmos, 1877, 1, 443

1877.1

Recherches pour servir à l'histoire de la respiration chez les poissons. Ann. Sci. Nat. (Zool.), 1877, 6. sér. 5, art. 8. 4 p. - C. R. Acad. Sci. Paris, 84, 309-310. Abstract in Naturforscher (Sklarek), 1877, 10. Jahrg., 156. 1877.2

On the aerial respiration of some Brazilian fishes, Ann. Mag. Nat. Hist., 1878, 5. ser. 2, 105-10s. - Pop. Sci. Rev., 1878, n. s. 2, 334-335. 1878.1

Recherches anatomiques et physiologiques pour servir à l'histoire de la respiration chez les poissons. Ann. Sci. Nat. (Zool.), 1878, 6. sér. 7, art. 5. 7 p. Abstract in C. R. Acad. Sci. Paris, 86, 935-938.

1578.2

- Sur la prétendue voix de certains poissons siluroïdes. C. R. Assoc. Franç. Avanc. Sci., 8. sess. 1879 (1880), 743.

1850.1

- Sur la prétendue pénétration de poissons dans l'urèthre. Arch. Parasitologie, Paris, 1898, 1, 493-502. 1898.1 
Jobert, Clément, \& Grandey, Terminaisons nerveuses chez les poissons. C. R. Mém. Soc. Biol. Paris, 1870, 5. sér. 2, 141-144.

1870.1

Jobert, Clément, \& Jolyet, Félix. Expérience montrant que la torpille recoit partiellement la décharge qu'elle lance. 'Trav. Labor. Soc. Sci. Arcachon, 1895, 57-59. 3 figs. 'Translation in Nat. Wochenschr., 1896, 11, 567-568. 1895.1

Jobert de Lamballe, Antoine Joseph [1799-1867] Recherches anatomiques sur l'organe électrique de la torpille. C. R. Acad. Sci. Paris, 1844, 18, 810. - Notizen (Froriep), 30, 225-228.

1844.1

Considérations sur les appareils électriques de la torpille, du gymnote, etc. C. R. Acad. Sci. Paris, 1851, 33, 41-42.

1851.1

- Des appareils électriques des poissons électriques. Paris, 1858. xiii, 104 p. \& atlas of 11 pls. $8^{\circ}$. 1858.1

Recherches anatomiques sur l'appareil électrique du malaptérure électrique. C. R. Acad. Sci. Paris, 1858, 47, 8-16. - L'Institut, 1858, 26, 221; 230-231. Abstract in Rev. Mag. Zool., 1858, 2. sér. 10, 320-321. 1858.2

Jörgensen, — Lidt om fiskerict i Kina. Dansk. Fiskeriforen. Medlemsbl., 1896, 5. Jahrg., 490-491; 498-500.

1896.1

Johann, L. Ueber eigenthümliche epitheliale Gebilde (Leuchtorgane) bei Spinax niger. Zeitschr. Wiss. Zool., 1899, 66, 136-160. 2 pls. \& fig. 1899.1

Johannsen, Wilhelm. Gasterosteus spinachia L. Wochenschr. Aquar.Terrar. Kunde, 1912, 9. Jahrg., 2-3. fig.

1912.1

Johan-Olsen, Olav. Om sop pa klipfisk den sakaldte mid. Christiania, 1887. $25 \mathrm{p}$. $8^{\circ}$.

1887.1

Johansen, Anders Cornetius Jacob. Zoologien. Dansk Kultur i det 19de aarhundrede, Kjobenhavn, 1901, 174182.

1901.1

Beretning om undersøgelserne vedrorende fiskeriforholdene under skonnerten "Dianas 'Togt" til islands sydog østkyst i aarene 1898-1900. FiskeriBeret. Finan. 1901-1902. Kjobenhavn, 1903. 46 p. $8^{\circ}$.
Contributions to the biology of the plaice with special regard to the Danish plaice-fishery, 1905-12. 1905.1

i. Growth and distribution of the Pleuronectes platessa L. Meddel. Komm. Havundersogelser Fiskeri, Kjobenhavn, 1905, 1, no. 2. 69 p. 12 pls. \& fig.

ii. The marking and transplantation experiments with plaice in the Danish waters in the years 1903-06. Ibid., 1907, 5. 122 p. 6 pls. \& 10 figs.

iii. On the variation in frequency of young plaice in Danish waters in 1902-1907. Ibid. 1908 , 3, no. 4. 48 p. 12 figs.

iv. Is the plaice indigenous to the true Baltic? Ibid., 1909, 3, 22 p. 2 figs.

$\mathrm{v}$. The supposed migrations of plaice from the Kattegat and the Belt sea to the true Baltic. Ibid., 1912, 4, no. 1. 34 p. 5 figs.

Remarks on the life history of the young postlarval eel (Anguilla vulgaris 'Turt.) Meddel. Komm. Havundersogelser Fiskeri, Kjøbenhavn, 1905, 1, no. 6. 9 p. 1905.2

Bericht über die 'Tätigkeit der Kommission C in der Periode Februar 1903-März 1906. 3. Ueber die Schollenfischerei im Kattegat und die Mittel, sie su haben. Conseil Perman. Intern. Explor. Mer, Rapp., 1906, 5, 45-136. 2 pls. \& 3 figs.

1906.1

Bericht über die Eier, Larven und älteren Stadien der Pleuronectiden in der Ostsee nach Zahl, Grösse, Alter und Geschlecht. Conseil Perman. Intern. Explor. Mer, Rapp. et Proc. Verb., 1909, 12. 49 p. 2 figs. Ibid., 1910, 13. 23p. 16 pls. Ibid., 1911, 14. 57 p. 9 figs.

1909.1

- Elemente der exakten Erblichkeitslehre. Jena, 1909.

1909.2

Bericht über die dänischen Untersuchungen über die Schollenfischerei und den Schollenbestand in der östlichen Nordsee, dem Skagerak und dem nördlichen Kattegat. Meddel. Komm. Havundersøgelser Fiskeri, Kjøbenhavn, 1910,3 , no. 8, 1-142.

1910.1

Om rodspxtten og rodspattefiskeriet i Beltfarvandet med nogle bemarkninger om de ovrige flynderarter og flynderfiskeriet i samme farvand IOn the plaice and the other flounders in the Belt sea] Skrift. Udgivn. I Havundersøgelser, Kjobenhavn, 1912, 7. 1-158. 23 pls.

1912.1

Om Gudenaa-laksens vækst. Bemrerkninger paa grundlag af Skxlundersagelser [The growth of Salmo salar in the Gudenaa (Jutland)] Dansk Fiskeritidene Kjobenhavn, 1913, 421424.

1913.1 
Johansen, Anders Cornelius Jacob, \& Jacobsen, J. P. See Jacobsen \& Johansen.

Johansen, Anders Cornelius Jacob, \& Neergaard-Møller, E. Biologisl statiske oplysninger om det Danske saltvandsfiskeri i 1909 [Biological statistics of the Danish salt-water fishery for the year 1909] Meddel. Komm. Havundersogelser, Kjobenhavn, 1912, 1, 1-99. 2 maps.

1912.1

Biological statistical report on the produce of the Danish sea-fishery in 1909 and 1910. Copenhagen, 1912-13. $4^{\circ}$.

1912.2

- Biological statistical report on the produce of the Danish sea-fishery in 1910. Meddel. Komm. Havundersogelser, Kjobenhavn, 1913, 2, 1-179. 21 figs.

1913.1

Johansen, Anders Cornelius Jacob, Petersen, C.G.J., \& Kyle, Harry M. See Petersen, Kyle \& Johansen.

Johansen, $F r$. The fishes of the Denmark expedition. Meddel. Gronl., 1912, 45, 633-675. 3 pls. - DanmarkEkspeditionen til Gronlands Nordostkyst, 1906-08, 5, no. 12.

1906.1

Johanson, Edwin. Zur Frage der dem Fischleben schädlichen Flachsweichen. Russische Zeitschr. Pharmac., $1882,21$.

1882.1

John, Charles, \& Paget, James. Sketch of the natural history of great Yarmouth [Yarmouth] 1834. $8^{\circ}$.

1834.1

John, Hans Henrik. Undersökning om Nyland och Tavastehus län, i anseende till dess läge, vidd, climat, våhrfloder, sjöar och vattuleder, naturs förmåner och brister, näringar, folkrikhet, politie- och Cameral-författningar, pt. 1. Inaug. Dissert., Abo, 1789. 84 p. $4^{\circ}$.

Pehr Adrian Gadd, proses.

John, Johann Friedrich [1782-1847] Beschreibung und Abbildung des Uranoscopus lebecliii. Neue Schrift. Ges. Naturf. Freunde Berlin, 1801, 3, 283287. pl.

1801.1

Johnes, $I I$. Owen. Kelts and smelts. Forest \& Stream, 1875, 5, 306. 1875.1

Johnson, Smart, —, \& Goldsmith, — See Smart, Goldsmith \& Johnson.
Johnson, $A . M$. Shipment of whitefish ova to New Zealand in 1878. Rept. U. S. Fish Comm. 1878 (1880), 6, 879.

1880.1

Johnson, $E$. The fisheries of Pictou, Nova Scotia. Rept. U. S. Fish Comm. 1883 (1885), 11, 1184-1185.

1885.1

Johnson, Frank $M$. Forest, lake and river. The fishes of New England and eastern Canada. 2 vols. Boston, 1902. pls. $4^{\circ}$.

1902.1

Résumé of work done during the past year in the raising of western charr in eastern waters. Trans. Amer. Fisheries Soc. 1901 (1905), 193-209. 9 pls.

1905.1

The care and feeding of fry in pond life. Trans. Amer. Fisheries Soc. 1906 (1907), 230-232. 1907.1

Johnson, J. $P$. Additions to the palxolithic fauna of the Uphall brickyard, Ilford, Essex. Essex Natural., 1901, 11, 209-212. fig.

1901.1

Contains mention of fish-remains.

The Eocene flora and fauna of Walton-Naze, Essex. Essex Natural., $1901,11,284-287$.

1801.2

Some sections in the Cretaceous rocks around Glynde and their fossil contents. Geol. Mag., 1901, 4. dec. 8, $249-251$.

1901.3

Contains some mention of fossil fish-remains.

Johnson, $J . S$. [Hints upon how to make fish-skeletons] Field \& Forest, $1877,2,204$.

1877.1

Johnson, James Yate. Notes on rare and little-known fishes taken at Madeira. Ann. Mag: Nat. Hist., 1862, 3. ser. 10, 161-172; 274-287. Ibid., 11, $237-248$

1862.1

- Remarks on the specimen of Alepisaurus ferox recently obtained at Madeira. Proc. Zool. Soc. London, 1862, 126-128.

1862.2

Descriptions of five new species of fishes obtained at Madeira. Proc. Zool. Soc. London, 1863, 36-46. pl.Ann. Mag. Nat. Hist., 3. ser. 12, 313323.

1863.1

- Descriptions of some new genera and species of fishes obtained at Madeira. Ann. Mag. Nat. Hist., 1863, 3. ser. 11, 58-71. figs.

1863.2

Descriptions of three new genera of marine fishes obtained at Madeira. 
Ann. Mag. Nat. Hist., 1864, 3. ser. 14, 70-78. - Proc. Zool. Soc. London, 1863, 403-410. pl.

1864.1

Descriptions are given of Diretmus argenteus, Halosaurus owenii and Chiasmodon niger.

Description of a new genus of trichiuroid fishes obtained at Madeira [Nealotus tripes] with remarks on the genus Dicrotus Günther, and on some allied genera of Trichiuridx. Proc. Zool. Soc. London, 1865, 434-437. Ann. Mag. Nat. Hist., 1865, 3. ser. 16, $283-286$.

1865.1

Description of Trachichthys darwinii, a new species of berycoid fish from Madeira. Proc. Zool. Soc. London, 1866, 311-315. pl.

1866.1

Description of a new genus of Spinacidx, founded upon a shark obtained at Madeira [Machephilus dumerili on 1 Proc. Zool. Soc. London, 1867, $713-715$

1867.1

Madeira, its climate and scenery. A handbook ... with chapters on the fauna, flora, geology, etc. 3. ed. London, 1885. $\quad \operatorname{xxx}, 310 \mathrm{p} . \quad$ pl. $8^{\circ} .1885 .1$

On some new species of fishes from Madeira. Proc. Zool. Soc. London, $1890,452-459$

1890.1

Johnson, R. D. O. Notes on the habits of a climbing catfish (Arges marmoratus) from the republic of Colombia. Ann. N. Y. Acad. Sci., 1912, 22, 327333: 4 figs.

1912.1

Johnson, Roswell Hill. 'The individuality and variation of the pyloric cxca of the Centrarchidx. 'Trans. Wisconsin Acad. Sci., 1907, 15, 713732. 5 pls. \& 2 figs.

1907.1

Johnson, Samuel M. [Bexar, pseudon.] The gulf thread-fish. Forest \& Stream, 1879, 13, 785 .

1879.1

- A Texas fish [Sphyrona picuda] Forest \& Stream, 1879, 13, 925-926. 1879.2

- Texas trout. Forest \& Stream, $1880,15,49$. 1880.1

Notes on the mortality antong fishes of the gulf of Mexico. Proc. U.S. Nat. Mus., 1881, 4, 205. - Smithson. Misc. Coll., 1882, 22, art. 2. 1881.1

Growth of German carp sent to Savoy, Texas, by the United States Fish Commission; letter to Prof. S. F. Baird. Bull. U. S. Fish Comm. 1882 (1883), 2, 14.

1883.1
Johnson, Samuel William [1830-] Analysis of fish guano. Rept. Comm. Board Agric. 1859 (1860), 35-36. 1860.1

Johnson, $T$. An account of the attempts to transport salmon to Australia. Rept. Brit. Assoc. Adv. Sci., 33. meet. 1863 (1864), 105.1864 .1

An account of the successful accomplishment of the plan to transport salmon ova to Australia. Rept. Brit. Assoc. Adv. Sci., 34. meet. 1864 (1865), 99-100.

1865.1

Johnston, George [1797-1855] Address to the members of the Berwickshire Naturalists' Club. Proc. Hist. Berwick. Nat. Club, 1834, 1, 4-12.

Fishes, p. 6-7.

1834.1

- A list of the fishes of Berwickshire, exclusive of the salmones. Proc. Hist. Berwick. Nat. Club, 1834, 1, 170 176.

1834.2

- Notice of the Myliobatis aquila of Cuvier, or eagle ray of Yarrell. Proc. Hist. Berwick. Nat. Club, 1834, 1, 205.

1834.3

On the nests of the fifteen-spined stickleback, or Gasterosteus spinachia of Linnæus. Proc. Hist. Berwick. Nat. Club, 1834, 1, 200-201.

1834.4

A description of the long-tailed shark. Proc. Hist. Berwick. Nat. Club, 1849, 2, 215-220.

1849.1

Johnston, (Sir) Henry Hamilton [1858 - ] British Central Africa; an attempt to give some account of a portion of the territories under British influence north of the Zambesi. London, 1897. 544 p. figs. $8^{\circ}$.

1897.1

Contains some notice of fishes.

Johnston, (Sir) Henry, Lydekker, Richard, \& others. Harmsworth natural history. London, 1910. See Lydekker, $R$. \& others.

Johnston, H.W. The scales of salmon. Ann. Rept. Fish. Board Scotland, 1907, 25, 54-66. 5 pls.

1907.1

- The scales of salmon. Ann. Rept. Fish. Board Scotland, 1911, 28, pt. 2, 21-24.

1911.1

Johnston, J., \& Smith, W. A. Report of their proceedings as a deputation from the Fishery Board for Scotland to the continent to inquire into the working of the new branding regulations ifor herring] (In Great Britain Sessional Papers, 1890-91, 63. \& p. fol.) 1890.1 
Johnston, John Black [1868 - ] Hind brain and cranial nerves of Acipenser. Anat. Anz., 1898, 28, 580-602. 13 figs.

1898.1

'The olfactory lobes, fore-brain and habenular tracts of Acipenser; a summary of work on their minute structure. Zool. Bull., Boston, 1898, 1, 221241. 5 figs.

1898.2

- The giant ganglion cells of Catostomus and Coregonus. Journ. Comp. Neurol., $1900,10,375-381.2$ pls.

1900.1

Some points in the brain of lower vertebrates. Biol. Bull. Woods Hole, 1901, 2, 356-357.

1901.1

Discusses brain-structure in Petromyzon and Acipenser.

- An attempt to define the primitive functional divisions of the central nervous system. Journ. Comp. Neurol., 1902, 12, 87-106. 2 figs. 1902.1

The brain of Acipenser. A contribution to the morphology of the vertebrate brain. Zool. Jahrb. (Abth. Anat.), 1902, 15, 59-260. 11 pls. \& 33 figs.

1902.2

Review by C. Judson Herrick in Seience, 1902, n. s. 14, 930-931.

The brain of Petromyzon. Journ. Comp. Neurol., 1902, 12, 1-86. 8 pls.

1902.3

Das Gehirn und die Cranialnerven der Anamnier. Ergebnisse Anat. Entwick., Wiesbaden, 1902, 11, 9731112. 8 figs.

1902.4

Deutsche Uebersetzung von Dr. Karl W. Genthe.

The homology of the selachian ampulla. A note on Allis' recent paper on Mustelus lavis. Anat. Anz., 1902, 21, 308-313.

1902.5

The cranial and spinal ganglia and the viscero-motor roots in Amphioxus. Biol. Bull. Woods Hole, 1905, 9, 112-127. 7 figs.

1905.1

The cranial nerve components of Petromyzon. Morph. Jahrb., 1905, 34, 149-203. pl. \& 18 figs.

1905.2

The morphology of the vertebrate head from the viewpoint of the functional divisions of the nervous system. Journ. Comp. Neurol., 1905, 15, 175-275. 4 pls.

1905.3

The radix mesencephalica trigemini. 'The ganglion isthmi. Anat.
Anz., 1905, 27, 364-379. figs. - Journ. Comp. Neurol., 19, 593-644. 40 figs. 1905.4

- The nervous system of vertebrates. Philadelphia. 1906. $\mathrm{xx}, 370 \mathrm{p}$. 180 figs. $8^{\circ}$.

1906.1

- The same. English ed. London, 1907. 1907.1

Additional notes on the cranial nerves of Petromyzonts. Journ. Comp. Neurol., 1908, 18, 569-608. 31 figs.

1908.1

A note on the presence or absence of the glossopharyngeal nerve in myxinoids. Anat. Rec., Philadelphia, 1908, 2, 233-239.

1908.2

On the significance of the caliber of the parts of the neurone in vertebrates. Journ. Comp. Neurol., 1908, 18, 609-618.

1908.3

The central nervous system of vertebrates. Ergebnisse Fortschr. Zool., Jena, 1909, 2, 1-170. 103 figs. 1909.1

- The limit between ectoderm and entoderm in the mouth and the origin of taste buds. Anat. Rec., Philadelphia, 1909, 3, 261-262. - Amer. Journ. Anat., $1910,10,41-67$.

1909.2

- The morphology of the forebrain vesicle in vertebrates. Journ. Comp. Neurol., 1909, 19, 457-539. 45 figs. Abstract in Anat. Rec., Philadelphia, 3, $260-261$.

1909.3

A comment upon recent contributions on the brain of Petromyzonts. Anat. Anz., 1910, 37, 153-158; 182-194. 9 figs.

1910.1

- The evolution of the cerebral cortex. Anat. Rec., Philadelphia, 1910, 4, 143-166. 20 figs.

1910.2

- A note on the forebrain of Chimxra. Anat. Anz., 1910, 36, 233-242. 27 figs.

1910.3

The telencephalon of ganoids and teleosts. Journ. Comp. Neurol., 1911, 21, 489-591. 99 figs.

1911.1

The telencephalon of selachians. Journ. Comp. Neurol., 1911, 21, 1-113. 85 figs.

1911.2

The telencephalon in cyclostomes. Journ. Comp. Neurol., 1912, 22, 341-404. 41 figs. 1912.1

On the telcostean forebrain. Anat. Rec., Philadelphia, 1912, 6, 423438. 3 figs. 
Upon the morphology of the forebrain in fishes. Anat. Anz., 1912, 40, 531-540.

1912.3

-.- Nervous system of vertebrates. Philadelphia, 1913. illust. $S^{\circ}$. 1913.1

Johnston, Lary S. On a specimen of the Jurassic ganoid fish, Pleuropholis lavissima Egerton. Geol. Mag., 1909 , 5. dec. 6, 309-311. pl.

1909.1

Johnston, Robert $M$. General and critical observations on the fishes of Tasmania, etc. Proc. Roy. Soc. Tasmania 1882 (1883), 51-141. 1883.1

-Description of a new species of Odax. Proc. Roy. Soc. Tasmania, 1884, 231-232.

1884.1

Fishes of Tasmania. Proc. Roy. Soc. Tasmania, 1884, lxv-lxvi. $\quad 1881.2$

Notice of recent additions to the list of Tasmanian fishes. Proc. Roy. Soc. Tasmania, 1884, 193-195. 1884.3

_- Observations on six rare fishes recently captured in Tasmanian waters. Proc. Roy. Soc. Tasmania, 1884, 252256.

1884.4

- Description of two rare Tasmanian fishes. Proc. Roy. Soc. Tasmania, $1887,45-46$.

1887.1

Results of the various attempts to acclimatise Salmo salar in Tasmanian waters. Proc. Roy. Soc. Tasmania, $1888,27-46$.

1888.1

Further observations upon the fishes and fishing industries of 'Tasmania, together with a revised list of indigenous species. Proc. Roy. Soc. Tasmania, $1890,22-46$.

1890.1

Reference list of various books and memoirs, on scientific and ... economic subjects, written and published since 1873. Hobart, 1893. 10 p. $8^{\circ}$.

1893.1

Johnston, S.J. Contributions to a knowledge of Australian entozoa. No. II. On a new species of Distomum from the sawfish shark; Pristiophorus cirratus Lath. Proc. Linn. Soc. N. South Wales, 1902, 27, 326-330. pl.

1902.1

Johnston, T. Harvey, \& Cleland, J.Burton. See Cleland \& Johnston.

Johnstone, James. Note on a sporozoon parasite of the plaice (Pleuronectes platessa) Proc. Trans. Liverpool Biol. Soc., 1901, 15, 184-187. pl.
- On some experiments with "drift bottles." Proc. Trans. Liverpool Biol. Soc., 1903, 17, 154-164. 3 figs. 1903.1

Tests to determine the extent of migration of fish eggs.

-- Report on the marine fishes [collected by Messrs. Annandale and Robinson on the coast of Patani and Jhering) (In Fasciculi Malayenses. Zoology, pt. 2, 293-302. pl. London d New York, 1903)

1903.2

\section{Report on the trawling statistics} by the "John Fell" and sea-fisheries bailiffs. Proc. Trans. Liverpool Biol. Soc., 1903, 17, 165-180. 2 figs. 1903.3

Flounders with spinulated scales. Rept. Lancashire Sea-Fish. Labor., 1904, 121-123. fig. - Proc. Trans. Liverpool Biol. Soc., 1905, 19, 301-303. fig. 1904.1

- A malformed plaice. Proc. Trans. Liverpool Biol. Soc., 1904, 18, 111-112.

1904.2

Report on the marine fishes collected by Professor Herdman, at Ceylon, in 1902. Rept. Gov't. Ceylon Pearl Oyster Fish. Gulf of Manaar, 1904, 2, 201-222. 2 pls. \& 2 figs. 1904.3

Some results of the international fishery investigations. Journ. Mar. Biol. Assoc., $1904-06$, n. s. 7, 437-486. 6 figs.

1904.4

Trawling observations and results. Proc. Trans, Liverpool Biol. Soc., 1904, 18, 100-112. pl. Ibid., 1905, 19, 216-241. Ibid., 1906, 20, 232-251. Rept. Lancashire Sea-Fish. Labor., 1903, 20-32. pl. Ibid., 1904, 36-61. fig. Ibid., 1905, 88-108. 2 figs. 1904.5

Abnormally scaled flounders. Proc. Trans. Liverpool Biol. Soc., 1905, 19, 301-303. figs. 1905.1

- British fisheries, their administration and their problems. London, 1905. 350 p. $8^{\circ}$. 1905.2

Review by H. de Varigny in Rev. Scient., 5 . sér. 4, 753-755.

Experiments in marking plaice. Proc. Trans. Liverpool Biol. Soc., 1905, 19, 271-277. illust. - Rept. Lancashire Sea-Fish Labor., 1901, 91-97. pl.

1905.3

Internal parasites and diseased conditions of fishes. Proc. Trans. Liverpool Biol. Soc., 1905, 19, 278-300. 2 pls. \& figs. Ibid., 1906, 20, 295-329. 
Johnstone, $J$.

pl. Ibid., 1907, 21, 270-303. pl. Ibid., 1909, 23, 189-202. 2 pls. Ibid., 1910, 24, 78-99. Ibid., 1911, 25, 88-122. 5 pls.

1905.4

Report on experiments with marked fish during the years 1904 08. Rept. Lancashire Sea-Fish. Labor., 1905, 108-150. fig. \& 2 maps. Ibid., 1906, 126-169. fig. \& 4 maps. Ibid., 1907, 22-43. 2 pls. Ibid., 1908, 15-24. - 'Trans. Liverpool Biol. Soc., 1906, 20, 252-294. fig. \& 2 maps. Ibid., 1907, 21, 226-269. fig. \& 4 maps. Ibid., 1908, 22, 114-135. 2 pls. Ibid., 1909, 23, $117-126$.

1905.5

The food of fishes. Rept. Lancashire Sea-Fish. Labor., 1906, 216227. 2 pls. - Trans. Liverpool Biol. Soc., 1907, 21, 316-327. 2 pls. 1906.1

-Ichthyological notes. Rept. Lancashire Sea-Fish. Labor., 1905, 186191. 2 figs. Ibid., 1906, 209-215. 3 figs. - Trans. Liverpool Biol. Soc., 1906, 20, 330-335. 2 figs. Ibid., 1907, 21, 309-315. 3 figs.

1906.2

On a myxosporidian infection of Gadus esmarkii, with a note on the identification of the parasite by $H . M$. Woodcock. Rept. Lancashire Sea-Fish. Labor., 1906, 204-208. pl. 1906.3

Re-description of a trematode parasite, Allocreadium labracis (Dujardin), from the bass. Rept. Lancashire Sea-Fish. Labor., 1907, 44-53. pl. \& 4 figs.

1907.1

Conditions of life in the sea. A short account of quantitative marine biological research. Cambridge, 1908. 332 p. 29 illust. 3 maps. $8^{\circ}$. 1908.1

Plaice measurements made during 1908-1911. Rept. Lancashire SeaFish. Labor., 1908, 25-34. Ibid., 1910, 114-152. 5 figs. Ibid., 1911, 15-32. Proc. Trans. Biol. Soc. Liverpool, 1909, 23, 127-136. Ibid., 1911, 25, 186-224. Ibid., 1912, 26, 85-102.

1908.2

- An abnormal specimen of the brill. 'Trans. Liverpool Biol. Soc., 1909, 23, 200-202.

1909.1

Internal parasites and diseased conditions of fishes. Rept. Lancashire Sea-Fish. Labor., 1909, 87-100. 2 pls. \& 5 figs. Ibid., 1912, 20-42. 3 pls. \& fig. - T'rans. Liverpool Biol. Soc., 23, 189202. 2 pls. \& 5 figs.

1909.2

- Report on temperature observations in the Iris h sea during 1907-09.
Proc. Trans. Liverpool Biol. Soc., 1909, 23, 167-188. 9 figs. Ibid., 1910, 24, 220-247. 9 figs.

1909.3

The fishes of Cheshire and Liverpool bay (In Coward, T. A. The vertebrate fauna of Cheshire and Liverpool bay, vol. ii, p. 59-168. London, 1910)

1910.1

Internal parasites of fishes from the Irish sea. Proc. Trans. Liverpool Biol. Soc., 1910, 24, 78-99. - 18. Rept. Lancashire Sea-Fish. Labor., 1910, 1637. 11 figs.

1910.2

Recent hydrobiological investigations. The gulf stream and sea-fisheries of northern Europe. Sci. Progress Twentieth Century, London, 1910, 4, 612-622.

1910.3

Report on measurements of Irish sea plaice during the year 1909. Proc. 'Trans. Liverpool Biol. Soc., 1910, 24, 100-184.

1910.4

General summary of the results of the plaice marking experiments carried out during the years 190t-1910. 19. Rept. Lancashire Sea-Fish. Labor., 1911, 153-190. 7 figs. - Trans. Liverpool Biol. Soc., 1911, 25, 225-262. 7 figs. 1911.1

Life in the sea. Cambridge, 1911. $12^{\circ}$. 1911.2

- Diseased conditions of fishes. Rept. Lancashire Sea-Fish. Labor., 1912, 20-42. 3 pls.

1912.1

- Experiments with marked plaice during 1912. Rept. Lancashire SeaFish. Labor,, 1912, 94-98. - Trans. Liverpool Biol. Soc., 1913, 27, 270-274.

1912.2

Hydrographic investigations and the fisheries of the Irish sea. Rept. Lancashire Sea-Fish. Labor., 1912, 99150. 2 figs. - Trans. Liverpool Biol. Soc., 27, 275-326.

1912.3

Report on plaice measurements made during the year 1912. Rept. Lancashire Sea-Fish. Labor., 1912, 6993. 3 tables. - Proc. Trans. Liverpool Biol. Soc., 27, 245-269.

1912.4

Johnstone, James, \& Cole, Frank $J$. See Cole \& Johnstone.

Johnstone, James, Herdman, WV. A., \& Scott, Andrew. See Herdman, IV.A., Scott, Andrew, \& Johnstone, James. 
Johnstone, James, \& Jenkins, J. Travis. Report on the deposits from the Liverpool "hoppers" in relation to shrimps and young fish. Proc. Trans. Liverpool Biol. Soc., 1901, 15, 181-184. 2 pls.

1901.1

Johnstone, James, \& Wignall, $A$. See Wignall \& Johnstone.

Johnstone, James, \& Woodcock, $H . M$. On a myxosporidian infection of Gadus esmarkii; with a note on the identification of the parasite. Proc. Trans. Liverpool Biol. Soc., 1907, 21, 304-308. pl.

1907.1

Joigneaux, $P$. Pisciculture et culture des eaux. Bruxelles \& Paris, 1864. $12^{\circ}$.

1864.1

Joleaud, $A$. Faune de poissons miocènes de la basse vallée du Rhône: mise en śvidence, par la fossilisation, des caractères histologiques de certains dents d'elasmobranches. C. R. Mém. Soc. Biol. Paris, 1910, 69, 481-482.

1910.1

Joleaud, Léonce. Description des terrains néogènes de la plaine du Comtat et de ses abords. Mém. Acad. Vaucluse, Avignon, 1905, pt. 1, 5, 29-82; 197-246. Ibid., 1906, pt. 2, 6, 103-163; 329-355. Also separate; Avignon, 1907.249 p. $8^{\circ}$.

1905.1

Numerous Tertiary fish-remains are described. Poissons elasmobranches. Mém. Acad. Vaucluse, 1905, 2. sér. 5, 392-420.

1905.2

Note sur quelques dents de poissons fossiles du Rio de Oro (Sahara occidental) Bull. Soc. Géol. France, 1907, 4. sér. 7, 514-516.

1907.1

Jolly, J. Sur la cicatrisation épidermique chez les poissons. Bull. Soc. Anat. Paris, 1898, 73, 784-785. 1898.1

Joly, Nicolas [1812-1885] Coup d'œil sur les origines de la pisciculture fluviale et sur l'état actuel de cette industrie en France. Journ. Agric. Pratique Midi France, 1866. Also separate; Toulouse, 1866. $8^{\circ}$. 1866.1

- Etudes sur les mours, le développement et les métamorphoses d'un petit poisson chinois du genre Macropode (Macropodus paradisi) Rev. Sci. Nat., 1872, 1, 447-473. - Mém. Acad. Sci. Toulouse, 1873, 7. sér. 5, 312-340. - Journ. Zool. (Gervais), 1873, 2, 545548.

1872.1
Observations sur les métamorphoses des poissons osseux en général, et particulièrement sur celles d'un petit poisson chinois du genre Macropode, récemment introduit en France. C. R. Acad. Sci. Paris, 1872, 75, 766-768.Ann. Mag. Nat. Hist., 1872, 4. ser. 10, $463-465$.

1872.2

- Le macropode de la Chine, ou poisson de paradis; son embryogénie et ses métamorphoses. La Nature, 1874, 2. année, pt. 1, 83-88.

1874.1

Joly de Sailly, —_ La disparition du saumon des cours d'eau du haut bassin de la Vienne intimement liée à la question des barrages. Année Forestière, 1901, 40, 609-624. 2 figs. - Rev. Eaux Forêts, 1901, 40, 609-624. Also separate; Limoges, $1901 . \quad 1901.1$

De l'emploi de la porcelaine pour augettes destincés à la mise en évolution des œufs embryonnés dans les laboratoires de ville. Congr. Intern. d'Aquicult. Pêche, Mém. \& C. R., 1900 (1901), 33-37.

1901.2

L'établissement de pisciculture de Limoges. Rev. Eaux Forêts, 1901, 40, 737-746.

1901.3

Repeuplement des eaux douces en salmonides. Bull. Soc. Centr. Aquicult. Pêche, 1905, 17, 119-125. Ibid. $1906,18,113-120 ; 145-148 . \quad 1905.1$

Détermination du sexe des anguilles. Bull. Soc. Centr. Aquicult. Pêche, 1907, 19, 275-276. 1907.1

Les échelles à poissons dans les eaux de Belgique. Bull. Soc. Centr. Aquicult. Pêche, 1909, 21, 173-182; $205-215$.

1909.1

Jolyet, F'élix. De la pression du sang dans l'artère branchiale chez les poissons. C. R. Mém. Soc. Biol. Paris, 1872 , 5. sér. 4, 254-255.

1872.1

- Recherches sur la respiration des poissons. Abstract in Rev. Intern. Sci., 1879, 3, 472-473. $\quad 1879.1$

Résultats de ses recherches sur la respiration des poissons. Bourdeaux, 1880.

1880.1

Sur la torpille électrique. Mém. Soc. Sci. Phys. Nat. Bordeaux, 1883, 2. sér. 5, 371-374.

1883.1

Jolyet, Félix, \& Grêhant, Nestor. See Gréhant \& Jolyet. 
Jolyet, Félix, \& Jobert, Clément. See Jobert \& Jolyet.

Jolyet, F'élix, \& Regnard, Paul. Sur une nouvelle méthode pour l'étude de la respiration des animaux aquatiques. C. R. Acad. Sci. Paris, 1876, 82, 1060 1062. fig.

1876.1

Recherches physiologiques sur la respiration des animaux aquatiques. Arch. Phys., 1877, 2. sér. 9, 584-633.

1877.1

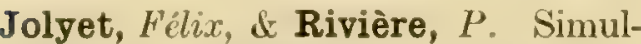
tanéité des décharges des divers départments de l'organe électrique de la torpille. Trav. Labor. Soc. Sci. Areachon, 1895, 55-56. fig. Abstract in Nat. Wochenschr, 1896, 11, 567-568.

1895.1

Joncas, $L . Z$. The fisheries of Canada. Intern. Fisheries Exhib. Lit. London, 1883. Conferences, 5, pt. 3. 1883.1

The fisheries of Canada. The world's fisheries congress, Chicago, 1893. Bull. U. S. Fish Comm. 1893 (1894), 13, 341-348.

1894.1

Jones, A. $I$. The goose fish. Forest \& Stream, 1878, 11, 341. 1878.1

Jones, Edgar $S$. A year with a catfish. Atlantic Slope Naturalist, 1903 1 , no. 3, 31-32.

1903.1

Jones, $F$. Wood. The fauna of CocosKeeling atoll, collected by F. Wood Jones. Proc. Zool. Soc. London, 1909. 132-160.

1909.1

Jones, Handfield. On the structure of the liver in fishes] Proc. Roy. Soc. London, 1854, 6, 145-147.

1854.1

Jones, John $E$. Nid d'épinochette. Feuill. Jeunes Naturalistes, 1871-72, 2, 100.

1871.1

Jones, $J, F$. The speckled catfish. Bull. U.S. Fish Comm. 1884, 4, 321-322

1884.1

Jones, John Matthew. An account of the Bermudian riband fish. Zoologist, 1860, 18, 6986-6989. - Ann. Mag. Nat. Hist., 1860, 3. ser. 6, 132-134. 1860.1

Capture of a large species of Gymnetrus in the Bermudas. Ann. Mag. Nat. Hist., 1860, 3. ser. 6, 132 134.

1860.2

Extracts from the Bermuda Royal Gazette relating to the recent capture of a large species of Gymnetrus in the Bermudas 1 Proc. Zool. Soc. London, 1860, pt. 28, 185-187.

1860.3

- Notes on certain species of Nova Scotian fishes. Canad. Natural. \& Geol., 1865, n. s. 2, 128-135. 1865.1 Notes on the haddock; mackerel, tunny; swordfish, wolf-fish, etc.

Contributions to the ichthyology of Nova Scotia. Proc. Trans. Nova Scotian Instit. Nat. Sci. 1863-66 (1867), $1,45-54$

1867.1

Three genera of fishes from St. Margaret's bay are mentioned.

- A pelagic floating fish-nest Natiure, $1872, \mathbf{5}, 462$. 1872.1

A new fish [Lefroyia bermudensis! Zoologist, 1874, 2. ser. 9, 3837-3838. 1874.1

Note on a small and remarkable lophioid recently taken off Halifax harbour [Lophius americanus juv.] Proc. Trans. Nova Scotian Instit. Nat. Sci. 1871-74 (1874), 3, 103-105. 1874.2

'The visitor's guide to Bermuda, with a sketch of its natural history. London, New York, Montreal \& Halifax, 1876. xii, 156 p. $12^{\circ}$. 1876.1

List of fishes, p. 131-136. A nominal list, with popular names, of 121 species.

The capelin moving south. Forest \& Stream, 1878, 10, $502 . \quad 1878.1$

- Rare fish. Forest \& Stream 1878, 11, 204.

1878.2

Aspidophoroides at Halifax, N.S.

List of the fishes of Nova Scotia. Halifax, 1879.

1879.1

- List of the fishes of Nova Scotia. Proc. Trans. Nova Scotian Instit. Nat. Sci., 1882, 5, 87-97. 1882.1

Jones, John Matthew, Wedderburn, $J$. W. \& Herdis, J.L. The naturalist in Bermuda; a sketch of the geology, zoology, and botany, etc. London, 1859. xii, 200 p. illust. $12^{\circ}$.

1859.1

Jones, Joseph [1833 - ] Investigations, chemical and physiological, relative to certain American vertebrata. Smithson. Contrib. Knowl., 1856, 8, art. 5. Abstract in Bibl. Univ. Arch., 3, 4252. 1856.1

Blood of fishes, p. 6-10. Urine of the bassfish (Corvina ocellata), p. 128.

The grayling again. Forest \& Stream, 1874, 2, 389. 
Jones, Thomas Rupert [1819-1911] Hybodus and other fossils. Geologist, $1863,312-313$

1863.1

- Manual of the natural history, geology and physics of Greenland and the neighboring regions, prepared for the use of the Arctic expedition of 1875. London, 1875. $\mathrm{S}^{\circ}$.

1875.1

Instructions for making observations on and collecting specimens of the fishes of Greenland. by Albert Günther, p. 16-18.

A revised catalogue of the fishes of Greenland, by Chr. Lütken, p. 115-122.

On the straining appendages or branchial fringes of the basking shark (Selachus maximus Gunn.) by Japetus Steenstrup, p. 123-121.

Jones; Thomas Rymer [1810-1880] Pisces (In Todd's Cyclopxdia of anatomy, vol. iii, p. 955-1011. London, 1847)

1847.1

- Aquarium naturalist. London, 1858. xviii, 524 p. 8 pls. $12^{\circ}$. 1858.1

General outline of the organization of the animal kingdom, and manual of comparative anatomy. 3 . ed. London, 1861. 841 p. illust. $8^{\circ}$. 1861.1

The aquarian naturalist. A manual for the sea-side. 2. ed. London, 1868. 524 p. 8 pls. $8^{\circ}$. 1868.1 Chapter Iv, fishes.

Jones, Thomas Wharton [1808-1891] The blood-corpuscle considered in its different phases of development in the animal series. Memoir I. Vertebrata. II. Invertebrata. III. Comparison between the blood-corpuscle of the vertebrat a and that of the invertebrata. Phil. Trans. Roy. Soc. London, 1846, 63-88; 89-101; 103-106. 2 pls. Abstracts in Amer. Journ. Sci., 1846, 2. ser. 1, 128129. - Notizen (Froriep), 37, 38-40.

1846.1

Microscopical characters of the rhythmically contractile muscular coat of the caudal heart of the eel. Proc. Roy. Soc. London, 1868, 343. 1868.1

The caudal heart of the eel a lymphatic heart. Effect of the force with which the lymph-stream is propelled therefrom on the flow of the blood in the vein into which the heart opens. Explanation of the appearance of blood propelled in successive drops, as if from the heart, along the caudal vein. Influence which the force of the lymphstream from the heart exerts in accelerating and promoting the flow of blood in the caudal vein. Phil. Trans. Roy. Soc. London' 1869, 158, 675-683. pl. \& fig. Abstract in Proc. Roy. Soc. London, 16, 230-231.

1869.1
Jones, W. Large salmon. Zoologist, 1873,2 . ser. 8,3618 .

1873.1

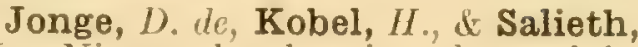
II. Nieuwe beschryving der walvisvangst en haringsvisschery. 4 vols. in 2 Amsterdam [circa] 1792.

1792.1

Groote visschery. 17 copper engraving (including title) of herring-fishing, curing, etc. by A. Van der Laan after S. Van der Meulen. Amsterdam [circa 1792] Oblong 4to. - [Kleine visschery] 17 copper engravings of whaling operations, by A. Van der Laan after S. Van der operations, by A, Van der Laan after S. Van der
Ieulen, Amsterdam [circa] 1792. Oblong 4 to. Not seen; title from Quaritch.

Jonge, J.C.de (editor) Geschiedenes van het Nederlandsche zeewezen. 2. ed. 5 vols. Haarlem, 1862.1862 .1

The first edition of this work, in 6 vols., was published at Amsterdam 1833-48. It contain an account of Dutch and Greenland fisheries.

Jongh, L. J. de. Scheikundige onderzoekingen omtrent de zamenstelling van Levertraan. Onderzoek Phys. Lab. Utrecht, 1842, 1, 336-349. - Annal. (Liebig), 48, 362-366. - Journ. de Pharm., 5, 381-385.

1842.1

Jonquière, Georg. Versuche über den Einfluss cinzelner Teile des centralen Nervensystems des Zitterrochens auf die willkiuliche und reflektorische elektrische 'Tätigkeit derselben. Inaug. Dissert., Bern, 1879. 41 p. $8^{\circ}$. 1879.1

Jopp, Alexander. Results of an inquiry into the causes of the decline in the produce of salmon fisheries in the rivers Dee and Don, in Aberdeenshire, and on the sea coast connected with these rivers. Aberdeen, $1860.40 \mathrm{p}$. $8^{\circ}$.

1860.1

Jordan, Alden $H$. Statement concerning the menhaden fishery. Rept U. S. Fish Comm. 1877 (1879), 5, 391.

1879.1

Jordan, August. Die Fauna der mioeänen Thone von Hassendorf. Abh. Nat. Ver. Bremen, 1901, 15, 224-230.

1901.1

Die organischen Reste in den Bohrproben von der 'Tiefbohrung auf dem Schlachthofe. Abh. Nat. Ver. Bremen, 1909, 17, 523-541. 1909.1

Jordan, David Starr [1851-] A partial synopsis of the fishes of upper Georgia. Ann. Lyceum Nat. Hist. N. Y., 1874-77, 11, 307-377. 1874.1

The cisco of lake Tippecanoe and its relatives. Ann. Rept. Geol. surv. Indiana 1874 (1875), 187-196. Abstract in Amer. Naturalist, 1875, 9, 135-138. Ibid, 1876, 10, 373. 1875.1 
Jordan, D.S.

Synopsis of the genera of fishes to be looked for in Indiana. Ann. Rept. Geol. Surv. Indiana 1874 (1875), 197228.

1875.2

Concerning the fishes of the Ichthyologia Ohiensis. Bull. Buffalo Soc. Nat. Hist., 1876, 91-97. 1876.1

Manual of the vertebrates of the northern United States, including the district east of the Mississippi river and north of North Carolina and Tennessee, exclusive of marine species. Chicago, 1876. $342 \mathrm{p} .12^{\circ}$. 1876.2

2. ed. Chicago, 1878. 407 p. 12 0 8. ed. Chicago, 1899.397 p. $8^{\circ}$.

Contributions to North American ichthyology; based primarily on the collections of the United States National Museum. Bull. U. S. Nat. Mus., 187778.

1877.1

i. Review of Rafinesque's memoirs on North American fishes. Bull. U. S. Nat. Mus., 1877, no. 9, 1-53.

ii. A. Notes on Cottidæ. Etheostomatidæ, Percidæ, Centrarchidæ, Aphododeridæ, Dorysomatidx and Cyprinide, with revisions of the genera and descriptions of new or little known species. Ibid., 1877, no. 10, 1-68.

ii. B. Synopsis of the Siluridx of the fresh waters of North America. Ibid., 1877, no. 10,69110. 45 pls.

iii. A On the distribution of the fishes of the Alleghany region of South Carolina, Georgia and Tennessee, with descriptions of new or little known species by D. S. Jordan and A. W. Brayton $(q . v$.$) . Ibid., no. 12, 1-95.$

iii. B. A synopsis of the family Catostomidæ. Ibid., 1878, no. 12, 97-230.

On the distribution of freshwater fishes. Amer. Naturalist, 1877, 11, $607-613$.

1877.2

On the fishes of northern Indiana. Proc. Acad. Nat. Sci. Philad., $1877,42-82$.

1877.3

- Synopsis of freshwater Siluridx of United States; analyses of genera and species. Bull. U. S. Nat. Mus., 1877, no. 10,69-110. 44 pls. 1877.4

- A catalogue of the fishes of Illinois. Bull. Illinois Labor. Nat. Hist., 1878,1 , no. $2,37-70$.

1878.1

- Catalogue of the fishes of Indiana. 27. Ann. Rept. State Board Agric., 1878,19 .

1878.2

A catalogue of the fishes of the fresh waters of North America. Bull. U. S. Geol. Surv. Territ., 1878, 4.407442.

1878.3

Landlocked salmon and smelts. Forest \& Stream. 1878, 11, 400. 1878.4
Manual of the vertebrates of the northern United States, including the district east of the Mississippi river and north of North Carolina and Tennessee, exclusive of marine species. 2. ed. Chicago, 1878. 407 p. $12^{\circ}$. 1878.5

Notes on a collection of fishes from Clackamas river, Oregon. Proc. U. S. Nat. Mus., 1878, 1, 69-119. 1878.6

Notes on a collection of fishes from the Rio Grande at Brownsville, Texas. Bull. U. S. Geol. Surv. Territ., $1878,4,397-406 ; 663-667 . \quad 1878.7$

On the distribution of freshwater fishes of the United States. Ann. N. Y. Acad. Sci., 1878, 1, 92-120. 1878.8

On the characteristics of trout. Forest \& Stream, 1878, 10, 196. 1878.9

Report on the collection of fishes made by Dr. Elliott Coues, U. S. A., in Dakota and Montana, during the seasons of 1873 and 1874. Bull. U. S. Geol. Surv. Territ., 1878, 4, 777-779.

1878.10

Scientific names of the black bass. Forest \& Stream, 1878, 11, 340.

1878.11

Contributions to North American ichthyology, based primarily on the collections of the United States National Museum. III. B. A synopsis of the family Catostomidx. Bull. U. S. Nat. Mus., 1878, no. 12, 97-237.

1878.12

Another wonderful transformation. Chicago Field, 1879, 11, 20.

1879.1

Concerning striped bass. Forest \& Stream, 1879, 11, 473. $\quad 1879.2$

The Monadnock and lake Winnepisogee trout. Forest \& Stream, 1879, $12,115$.

1879.3

— The original range of the " smallmouth" black bass. Chicago Field, $1879,11,20$.

1879.4

Description of new species of North American fishes. Proc. U. S. Nat. Mus., 1880, 2, 235-241.

1880.1

Does the flying-fish fly? Forest \& Stream, 1880, 15, 265.

1880.2

Notes on a collection of fishes obtained in the streams of Guanajuato and in Chapala lake, Mexico, by Prof. A. Dugès. Proc. U. S. Nat. Mus., 1880, 2, 29S-301.

1880.3 
Notes on certain typical specimens of American fishes in the British Museum and in the Muséum d'Histoire Naturelle at Paris. Proc. U. S. Nat. Mus. 1879 (1880), 2, 218-226. 1880.4 Relates to the following genera: Micropterus, Grystes, Bryttus, Pomotis, Esox, Leuciscus, Gobio, Caratichthys, Graodus.

The redfish identified. Forest \& Stream, 1880, 14, 286.

1880.5

The revision of the Salmonidx.

Forest \& Stream, 1880, 15, 130. 1880.6

Description of a new species of Caranx (Caranx beani) from Beaufort, North Carolina. Proc. U. S. Nat. Mus. 1880 (1881) 3, 486-488.

1881.1

Notes on a collection of fishes from east Florida, obtained by Dr. J. A. Henshall. Proc. U. S. Nat. Mus. 1880 (1881), 3, 17-21.

1881.2

Notes on a collection of fishes from St. John's river, Florida, obtained by Mr. A. H. Curtiss. Proc. U. S. Nat. Ius. 1880 (1881), 3, 22.

1881.3

- Notes on a forgotten paper of Dr. Ayres, and its bearing on the nomenclature of the cyprinoid fishes of the San Francisco markets. Proc. U. S. Nat. Mus. 1880 (1881), 3, 325-327. 1881.4

Four species of Leuciscus and one of Catostomus are noticed.

Notes on Sema and Dacentrus. Proc. U. S. Nat. Mus. 1880 (1881), 3, 327.

1881.5

Story of a salmon. Pop. Sci. Monthly, 1881, 19, 1-6.

1881.6

- Dr. Henshall's scientific nomenclature again. Amer. Angler, 1882, 391.

1882.1

Report on the fishes of Ohio. Rept. Geol. Surv. Ohio, 1882, 4, 7351002.

1882.2

Description of a new species of blenny (Isesthes gilberti) from Santa Barbara, California. Proc. U. S. Nat. Mus. 1882 (1883), 5, 349-351. 1883.1

The Canadian sea-trout (Salve linus fontinalis immaculatus) Amer. Field, July, 1884.

1884.1

Discussions of the Pacific species [of fishes] (In The fisheries and fishery industries of the United States, edited by George Brown Goode and associates. Section i, Natural history of useful aquatic animals. Washington, 1884. 893 p. $4^{\circ}$ )

1884.2

A number of freshwater species and also various marine fishes of the Pacific coast are treated in this work.

The fishes of the Florida keys. Bull. U. S. Fish Comm. 1884, 4, 77-80.

1884.3

Notes on American fishes, preerved in the museums of London, Paris, Berlin and Copenhagen. Proc. Acad. Nat. Sci. Philad. 1883 (1884), 281-293. 1884.4

- Proposed propagation of catfish as a food-fish. Bull. U. S. Fish. Comm. 1884, 4, 292. 1881.5

Description of a new species of Hybognathus (Hybognathus hayi) from Mississippi. Proc. U. S. Nat. Mus. 1884 (1885), 7, 548-550.

1885.1

Description of four new species of Poecilichthys in the United States National Museum. Proc. U. S. Nat. Mus. 1884 (1885), 7, 477-480。 1885.2

- The habits and the value for food of the American channel catfish (Ictalurus punctatus Rafinesque) Bull. U. S. Fish Comm. 1885, 5, 34. 1885.3

An identification of the figures of fishes in Catesby's "Natural History of Carolina, Florida, and the Bahama islands." Proc. U. S. Nat. Mus. 1884 (1885), 7, 190-199.

1885.4

List of fishes at Key West, Florida, with notes and descriptions. Proc. U. S. Nat. Mus. 1884 (1885), 7, $103-150$.

1885.5

List of fishes collected in lake Jessup and Indian river, Florida, by Mr. R. E. Earll, with descriptions of two new species. Proc. U. S. Nat. Mus. 1884 (1885), 7, 322-324.

1885.6

- List of fishes collected in the vicinity of New Orleans by Dr. R. W. Shufeldt, U.S.A. Proc. U.S. Nat. Mus. 1884 (1885), 7, 318-322.

1885.7

List of fishes from Egmont key, Florida, in the museum of Yale College, with description of two new species. Proc. Acad. Nat. Sci. Philad. 1884 (1885), 42-46.

1855.8

Manual of the vertebrates of the northern United States, including the district east of the Mississippi river and north of North Carolina and Tennessee, exclusive of marine species. 3. ed. Chicago, 1885. 406 p. $8^{\circ} .1885 .9$ 
Jordan, D. SS.

The mountain or salmon trout of Oregon. Bull. U. S. Fish Comm. $1885,5,310$.

1885.10

Nematognathi, Scyphophori, 'Teleocephali, Gymnoti and IIaplomi (In 'The standard natural history, edited by' J. S. Kingsley, vol. iii. Boston, 1885)

188.5 .11

- Notes on a collection of fisher from Pensacola, Florida, obtained by Silas stearns, with descriptions of two new species (Exocwetus volador and Grathypops mystacinus) Proc. U. S. Nat. Mus. 1884 (1885), 7, 33:3-40. 1885.12

Notes on Elurichthys eydouxiz and Porichthys porosissimus. Proc. U.S. Nat. Mus. 1884 (1885), 7, 40-41.

1885.13

Votes on fishes collecterl at Guaymas, Mexico, by Mr. H. V. Emeric, with a description of Cobiosoma histrio, a new species. Proc. U. S. Nat. Mus. 1884 (1885), 7, 260-261. 1885.14

- Votes on fishes improperly included in the fauna of the United states. Proe. Acad. Nat. Sei. Philad. 1884 (1885), 99-103.

188.5 .15

Notes on fishes observed in lake Superior. Bull. U. S. I ish Comm. 1885, 5, 191-192.

1885.16

- Soft-rayed fishes (In The standard natural history, edited by J. S. Kingsley, vol. iii, p. 110-17\%. 3 figs Boston, 1885)

1885.17

Supplementary notes on North American fishes. Proe. U. S. Nat. Mus. $1884(1885), 7,545-545$

1885.18

Identification of the species of Cyprinidas and Catostomidae, deseribed by Dr. Charles Girard in Proceedings of the Academy of Natural Seience of Philadelphia, 1856. Proc. U. S. Nat. Mus $1885(1886), 8,118-127$.

1886.]

A list of the fishes known from the Pacific coast of tropical America, from the tropice of Cancer to Panama. Proc. U. S. Nat. MLs. 1885) (1886), 8 , $361-394$.

1886.2

Note on Eipinephelus nigrilus. Proc. U. S. Nat. Mus. 1885 (1886), 8 $2018-209$.

$188(6 .:)$

Note on Mr. (iarman's paper on the American salmon and trout. Proc U. S. Vat. Mus. 18si) (1886), 8, 81-83. 1886.
- Note on some Linnarin names of American fishes. Proc. U. S. Nat. Mus. 1855 (1886), 8, 394-396.

1886.5

Note on the scientific name of the yellow perch, the striped bass and other North American fishes. Proc. U. S. Nat. Mus. 1885 (1886), 8, 72-73.

1886.6

- On the Etheostoma varintum of Kirtland. Proc. U. S. Nat. Mus. 188.) (1886), 8, 163-165.

1886.7

- Rafinesque. Pop. Sci. Monthly, $1886,29,212-221$.

1886.8

[Review of ] The freshwater fishes of Europe, by H. G. Seeley. The Dial, 1886, June, 34-35.

1886.9

A catalogue of the fishes known to inhabit the waters of North America north of the tropic of Cancer, with notes on the species discovered in 1883 and 1884. Rept. U. S. I'ish Comm. 1885 (1887), 13, 789-973.

1887.1

The fisheries of the Pacific coast (In 'The fisheries and fishery industries of the United States, edited by George Brown Gioode, 2. sect., D. 589-630. Washington, 1887) 1887.2

- - List of fishes collected at Havana, Cuba, in December, 1883, with notes and descriptions. Proc. U. S. Nat. Mis. $1886(1887), 9,31-55 . \quad 1887.3$

Note on Polynemus californiensis of 'Thominot. Proc. U. S. Nat. Mus. 1886 (1887), 9, 32.

1887.4

Notes on fishes collected at Beaufort, North Carolina, with a revised list of the species known from that locality. Proe. U. S. Nat. Mus. 1886 (1887), $9,25-30$.

1887.5

- Notes on some fishes collected at Pensacola by Mr. Silas Stearns, with descriptions of one new species (Chato(lon aya) Proc. U. S. Nat. Mus. 1886 $(1887), 9,225-229$.

1887.6

- Notes on typical specimens of fishes described by Cuvier and Valenciennes, and preserved in the Museum d'Histoire Naturelle in Paris. Proc. U.S. Nat. Mus. 1886 (1887), 9, 525-546.

1887.7

A preliminary list of the fishes of the West indies, Proc. U. S. Nat. Mus. $1886(1887), 9,554-608 . \quad 1887.8$

- Soricnce sketches. Chicago, 1887. 276 1). $8^{\circ}$

1887.9

The dispersion of freshwater fislles, p. 8:3-132 
Description of a new species of Callionymus (Callionymus bairdii) from the gulf of Mexico. Proc. U. S. Nat. Mus. 1887 (1888), 10, 501-502. 1888.1

Description of a new species of Xyrichthys ( $\boldsymbol{X}$. jessice) from the gulf of Mexico. Proc. U. S. Nat. MIus. 1887 (1888), 10, 698

1888.2

Description of two new species of fishes from South America (Mycteroperca xenarcha and Cristiceps eigenmanni) Proc. Acad. Nat. Sci. Philad. 1887 (1888), 387-388.

1888.3

A manual of the vertebrate animals of the northern United States, including the district north and east of the Ozark mountains, south of the Laurentian hills, north of the southern boundary of Virginia, and east of the Missouri river; inclusive of marine species. 5. ed. Chicago, 1888. 375 p. $8^{\circ}$. 1888.4

Fishes, p. 8-173.

Note on Achirus lorenlzi. Proc. Acad. Nat. Sci. Philad. 1857 (1888), $389-391$.

1888.5

- Note on the "Analyse de la nature" of Rafinesque. Proc. U.S. Nat. Mus. 1887 (1888), 10, 480-481.

1888.6

Deseription of a new species of Etheosloma (E. longimana) from James river, Virginia. Proc. Acad. Nat. Sci. Philad. 1888 (1889), 179.

1889.1

Descriptions of fourteen species of freshwater fishes collected by the U.S. Fish Commission in the summer of 1888 . Proc. U. S. Nat. Mus. 1888 (1889), 11, $351-363.3 \mathrm{pls}$

1889.2

List of fishes now in the United States National Museum, collected in Nicaragua by Dr. Louis I'. H. Birt. Proc. U. S. Nat. Mus. 1888 (1889), 11, $411-416$.

1889.3

List of fishes collected by $\mathrm{Al}$ phonse Forrer about Mazatlan, with descriptions of two new species. Proc. U. S. Nat. Mus. 1888 (1889), 11, 329334.

1889.4

- On the generic name of the tunny. Proc. Acad. Nat. Sci. Philad. 1888 (1889), 180. 1889.5

On the ocenirrence of the Great. Lake trout (Salvelinus namaycush) in the waters of British Columbia. Proc. U. S. Nat. Mus. 1888 (1889), 11, 58. 1889.6
A catalogue of fishes collected at Port Castries, Saint Lucia, by the steaner "Albatross." Proc. U. S. Nat. Mus. 1889 (1890), 12, 645-652。 1890.1

The fishes of the Yellowstome park. 'Loë, $1890,1,38-40$. 1890.2

List of fishes collected in the waters of southern Florida by Dr. James A. Henshall, under the direction of the U. S. Fish Commission. Bull. U. S. Fish Comm. 1888 (1890), 8, 371$: 379$

1890.3

Report of explorations made during the summer and autumn of 1888 , in the Alleghany region of Virginia, North Carolina and T'ennessee, and in western Indiana, with an account of the fishes found in each of the river basins of those regions. Bull. U.S. Iish Comm. 1888 (1890), 8, 97-192. 15 pls. 1890.4

- A list of fishes collected in the harbor of Bahia, Brazil, by the U. S Fish Commission steaner "Albatross." Proe. U. S. Nat, Mus. 1890 (1891), 13, $313-336$.

1891.1

Notes on fishes of the genera Agosia, Algansea and Zophendum. Proc. U. S. Nat. Mus. 1890 (1891), 13, $287-$ 288.

1891.2

On the fishes deseribed in Muiller's supplemental volume to the Systema Nature of Iinneus. Proc. Acad. Nat. Sci. Philad. 1890 (1891), 48-50.

1891.3

Report of an exploration of the waters of the Yellowstone park made under the direction of the U. S. Fish Commission. Bull. U. S. Fish Comm. 1889 (1891), 9, 41-63. $\quad 1891.4$

Report of explorations made by the U.S. Fish Commission during the summer of 1889 in Colorado and Utah, with an account of the fishes found in each river basin examined. Bull. U.S. Hish Comm. 1889 (1891), 9, 1-40.

1891.5

A review of the labroid fishes of America and Europe. Rept. U. S. I'ish Comm. 1887 (1891), 15, 559-699. 11 pls.

1891.6

- 'The fisheries of California. Overland Monthly, 1892, 20,469-478. 1892.1

Rolations of temperature to veriebre among fishes. Proc. U. S. Nat. Mus. 1891 (1892), 14, 107-120.

1892.2 
Jordan, $D . S$.

- A description of the golden trout of Kern river, California (Salmo mykiss aguabonita) Proc. U. S. Nat. Mus. 1892 (1893), 15, 481-483.

1893.1

-Temperature and vertebræ: a study in evolution, being a discussion of the relations of the numbers of vertebræ among fishes to the temperature of the water and to the character of the struggle for existence (In Wilder Quarter-century Book, p. 13-36. Ithaca, N. Y., 1893) 1893.2

Historical sketch with literature references, p. $32-36$.

Description of a new species of cyprinoid fish (Couesius greeni) from the headwaters of Frazer river in British Columbia. Proc. U. S. Nat. Mus. 1893 (1894), 16, 313-314.

1894.1

- Descriptions of new varieties of trout. 13. Bienn. Rept. California State Board Fish Comm., 1894, 142-143. 3 pls. 1894.2

Latitude and vertebræ; a study in the evolution of fishes. Pop. Sci. Monthly, 1894, 45, 346-350. 1894.3

- Salmon and trout of the Pacific coast. 13. Bienn. Rept. California State Board Fish Comm., 1894, 125-141. 7 pls.

1894.4

- Description of a new subspecies of trout from McCloud river, California. Proc. Acad. Nat. Sci. Philad. 1894 (1895), 60. 1895.1

Description of Evermannia, a new genus of gobioid fishes. Proc. California Acad. Sci., 1895, 2. ser. 4, 592.

1895.2

The fishes of Sinaloa. Proc. California Acad. Sci., 1895, 2. ser. 5, 377514. 29 pls. Reprint in Contrib. Biol. Hopkins Seaside Labor., 3, 1-71. 1895.3

Notes on the freshwater fishes of San Luis Obispo county, California. Bull. U. S. Fish Comm. 1894 (1895), 14, 141-142.

1895.4

_ Sketch of Charles A. Le Sueur. Pop. Sci. Monthly, 1895, 46, 547-550.

1895.5

Description of a new species of pipe-fish (Siphostoma sinaloæ) from Mazatlan. Proc. California Acad. Sci., 1896, 2. ser. 6, 268.

1896.1

Notes on fishes little known or new to science. Proc. California Acad.
Sci., 1896, 2. ser. 6, 201-244. Reprint in Contrib. Biol. Hopkins Seaside Labor., 5, 1-48. 1896.2

- Biographical sketch of George Brown Goode (In "The Smithsonian Institution, 1846-1896," p. 501-515. Washington, 1897) $\quad 1897.1$

- Agassiz on recent fishes. Amer. Naturalist, 1898, 32, 173-176. 1898.1

- Description of a species of fish (Mitsukurina owstoni) from Japan, the type of a distinct family of lamnoid sharks. Proc. California Acad. Sci., 1898, 3. ser. 1, 199-202. 2 pls. 1898.2

- In the little brook. Pop. Sci. Monthly, 1899, 55, 355-362. 1899.1

Popular account of lives of various freshwater fishes.

A manual of the vertebrate animals of the northern United States, including the district north and east of the Ozark mountains, south of the Laurentian hills, north of the southern boundary of Virginia, and east of the Missouri river. 8. ed. Chicago, 1899. 397 p. $8^{\circ}$.

1899.2

The first species named as the type of the genus. Science, 1900, 2. ser. 12, 785-787.

1900.1

The lateral line in the toad-fish. Amer. Naturalist, 1900, 34, 234. 1900.2

_ Notes on recent fish literature. Amer. Naturalist, 1900, 34, 897-899.

1900.3

The whitefish of lake Chapala. Amer. Naturalist, 1900, 34, 523. 1900.4

An error corrected. Amer. Naturalist, 1901, 35, 226.

1901.1

Interchange of descriptions of Collettia and Ethoprora and omission of Neoscopelus macrolepidotus in Jordan and Evermann "Fishes of North and Middle America."

The fish-fauna of Japan, with observations on the geographical distribution of fishes. Science, 1901, 2. ser. 14, 545-567.

1901.2

- The geographical distribution of fishes. Science, 1901, 2. ser. 14, 936. 1901.3

Identity of Xenichthys xenurus and Kuhlia malo. Amer. Naturalist, 1901, 35, 84 .

1901.4

Transplanting of California trout. Amer. Naturalist, 1901, 35, 225-226. 1901.5 
The colors of fishes. Amer. Naturalist, $1902,36,803-807 . \quad 1902.1$

The evolution of fishes. Pop. Sci. Monthly, 1902, 60, 556-564. 1902.2

- The fishes of Japan, with observations on the distribution of fishes. Pop. Sci. Monthly, 1902, 60, 76-79.

1902.3

Fishes of southern California, being a popular account of the fishes of this region. Illustrated by Mary Wellman and Kako Morita. Saturday Evening Post, Los Angeles, 1902. 1902.4

- The history of ichthyology: an address. Proc. Amer. Assoc. Adv. Sci., 51. meet., 1902, 427-456. - Science, n. s. 16, 241-258.

1902.5

- How to collect fishes. Pop. Sci Monthly, 1902, 62, 85-88. $\quad 1902.6$

Informal report on the investigation of the fishes of the Samoan islands [In a letter to Captain U. Sebree] Privately printed leaflet. Tutuila, Samoan Islands, 1902. 3 p. $\quad 1902.7$

- The oarfish, Regalecus, on the coast of southern California. Amer. Naturalist, 1902, 36, 65-66. $\quad 1902.8$

Origin of the fins of fishes. Pop. Sci. Monthly, 1902, 61, 536-547. 4 figs. 1902.9

- A point in nomenclature. Science, 1902 , 2. ser. 16, 870

1902.10

The salmon and trout of Japan. Annot. Zool. Japon., Tokyo, 1902, 4 69-75.

.1902 .11

The classification of fishes. Pop. Sci. Monthly, 1903, 63, 5-13. 1903.1

- The parent stream theory of the return of the salmon. Pop. Sci. Monthly, 1903, 64, 48-52. 1903.2 A review of the Cepolidx, or band-fishes, of Japan. Proc. U. S. Nat. Mus., 1903, 26, 699-702. 1903.3

The salmon and salmon streams of Alaska [Oncorhynchus] Pop. Sci. Monthly, 1903, 64, 165-172. 1903.4

Supplementary note on Bleekeria mitsukurii, and on certain Japanese fishes. Proc. U. S. Nat. Mus., 1903, 26, 693-696. 3 figs.

1903.5

Boulenger on the classification of bony fishes [A synopsis of the suborders and families of teleostean fishes, by $\mathrm{G}$. A. Boulenger] Amer. Naturalist, 1904, 38, $597-599$.

1904.1

Ichthyology in the "Encyclopredia Americana." Science, 1904, 2. ser. $19,675-676 ; 767$.

1904.2

A loach [Orthrias, n. sp.] from Nanaimo. Science, 1904, 2. ser. 19, 634635.

1904.3

Notes on fishes collected in the Tortugas archipelago. Bull. U. S. Fish Comm. 1902 (1904), 22, 539-544. 2 pls. 1904.4

The transplanting of trout in the streams of the Sierra Nevada. Amer. Naturalist, 1904, 38, 885-887. $\quad 1904.5$

A guide to the study of fishes. 2 vols. New York, 1905. 427 illust. Reviews in Nature, 72, 625-626. Amer. Naturalist, 40, 525-526. - Science, 2. ser. 22, 861-865.

1905.1

This work presents an excellent non-technical account of the entire subject of ichthyology. The chapter on the history of the science contains a résumé of the progress of our knowledge of fossil fishes, by Dr. Bashford Dean.

- The loch Leven trout in California. Science, 1905, n. s. 22, 714-715.

1905.2

- Note on the salmon and trout of Japan. Annot. Zool. Japon., Tokyo, 1905, 5, 161-162. - Proc. U. S. Nat. Mus., 1905, 28, 365-366. 1905.3

Notes on recent fish literature. Amer. Naturalist, 1905, 39, 91-94.

1905.4

- Ontogenetic species and other species. Science, 1905, 2. ser. 22, 872873.

1905.5

The origin of species through isolation. Science, 1905, n. s. 22, 545562 .

1905.6

A review of the sand lances or Ammodytidx of the waters of Japan. Proc. U. S. Nat. Mus., 1906, 30, 715719.

1906.1

- The yellow-fin albacore (Germo macropterus Schlegel) in California. Pop. Sci. Monthly, 1906, 68, 376. 1906.2

—- Fishes. New York, 1907. xv, 789 p. 18 pls. \& 673 figs. (American nature series)

1907.1

The flying-fish problem. Amer. Naturalist, $1907,41,347-348 . \quad 1907.2$ 
Jordan, D. S.

- The fossil fishes of California, with supplementary notes on other species of extinct fishes. Univ. California Publ., Bull. Dept. Geol., 1907, 5, 95-144. pl.

1907.3

A review of the fishes of the family Gerricle found in the waters of Japan. Proe. U. S. Nat. Mus., 1907, 32, 245-248. 2 figs.

1907.4

A review of the fishes of the family Histiopterida found in the waters of Japan; with a note on Tephritis Günther [renamed Velifracta] Proc. U. S. Nat. Mus., 1907, 32, 235-239.

1907.5

The fishes of the deep sea. Strange life forms near the ocean's bottom. Scient. Amer. Suppl., 1908, 65, 109-110. 5 figs.

1908.1

Note on a fossil stickleback fish from Nevada. Smithson. Miscell. Collect., 1908, 52, 117.

1908.2

Identity of Gasterosteus williamsoni leptosomus Hay with the earlier described Merriamella doryssa Jordan.

Descriptions of three new species of cisco, or lake herring (Argyrosomus) from the Great lakes of America; with a note on the species of whitefish. Proc. U. S. Nat. Mus., 1909, 36, 165-172. 3 figs.

1909.1

Ichthyology. Amer. Naturalist, $1909,43,560-567$. 1909.2

- Description of a collection of fossil fishes from the bituminous shales at Riacho Doce, state of Alagôas, Brazil. Ann. Carnegie Mus., Pittsburgh, 1910, 7, 23-34. 9 pls.

1910.1

- Notes on ichthyology [Review of recent literature] Amer. Naturalist, $1910,44,178-191 ; 634-639 . \quad 1910.2$

Note on the generic name Safole, replacing Boulengerina, for a genus of kuhliid fishes. Proc. U. S. Nat. Mus., $1912,42,655$.

1912.1

Description of Anguilla manabei, a new eel from Japan. Proc. U. S. Nat. Mus., 1913́, 44, 359-360. pl. 1913.1

_- Ellimma, a genius of fossil herrings. Proc. Biol. Soc. Washington, 1913, 26, 79.

1913.2

The nomenclature of American fishes as affected by the opinions of the international commission on zoological nomenclature. Copeia, 1916, no. 29, $25-28$

1916.1
On Hepsetia Bonaparte, a forgotten genus of atherinoid fishes Copeia, 1916, no. 32, 47-48. 1916.2

Jordan, David Starr, \& Beal, Carl Hugh. Supplementary notes on fossil sharks. Univ. California Publ., Bull. Dept. Geol., 1913, 7, 243-256. fig.

1913.1

Jordan, David Starr, \& Bollman, Charles Harvey. List of fishes collected at Green Turtle bay, in the Bahamas, by Charles L. Edwards, with descriptions of three new species. Proc. U.S. Nat. Mus. 1888 (1889), 11, 549-553.

1889.1

- Description of new species of fishes collected at the Galapagos islands and along the coast of the United States of Colombia, 1887-1888. Proc. U. S. Nat. Mus. 1889 (1890), 12, 149-183.

1890.1

Jordan, David Starr, \& Branner. John Casper. The Cretaceous fishes of Ceará, Brazil. Smithson. Misc. Coll., 1908, 52, 1-29. 8 pls. \& 22 figs. 1908.1

Jordan, David Starr, \& Brayton, Alembert Winthrop. On Lagochila, a new genus of catostomoid fishes. Proc. Acad. Nat. Sci. Philad., 1877, 280-283.

1877.1

Contributions to North American ichthyology. III. B. On the distribution of the fishes of the Alleghany region of South Carolina, Georgia and Tennessee, with descriptions of new or little known species. Bull. U. S. Nat. Mus., 1878, no. 12, 1-95. 1878.1

Jordan, David Starr, \& Clark, G. A. The Bogoslofs. Pop. Sci. Monthly, $1906,69,481-489$. 1906.1

Notices dredge-hauls of three deep-sea "grenadiers."

Jordan, David Starr, \& Copeland, Herbert Edson. The genus Pomoxys Rafinesque [Centrarchus] Proc. Acad. Nat. Sei. Philad., 1876, 68-71. 1876.1

Johnny darters [Etheostomoids]

Amer. Naturalist, $1876,10,335-341$. 3 figs.

1876.2

Check-list of the fishes of the fresh-waters of North America. Bull. Buffalo Soc. Nat. Hist. 1876 (1877), 2, $133-161$.

1877.1

-_- The sand-darter. Amer. Naturalist, $1877,11,86-88 . \quad 1877.2$

Jordan, David Starr, \& Davis, Bradley Woore. A preliminary review of 
the apodal fishes or ecls inhabiting the waters of America and Europe. Rept. U. S. Fish Comm. 1888 (1892), 16, 581677. $8 \mathrm{pls}$

1892.1

Jordan, Daül Slarr, \& Dickerson, Mary Cynthia. Description of a new species of half-beak (Hemiramphus mioprorus) from Nagasaki, Japan. Proc. U.S. Nat. Mus., 1908, 34, 111-112. fig.

1908.1

Notes on a collection of fishes from the gulf of Mexico at Vera Cruz and Tampico. Proc. U. S. Nat. Mus., 1908, 34, 11-22.

1908.2

- On a collection of fishes from Fiji, with notes on certain Hawailan fishes. Proc. U. S. Nat. Mus., 1908, 34. 603-617. 6 figs.

1908.3

Jordan, David Starr, \& Edwards, Charles $L$. A review of the Ameriean species of 'T'etraodontidx. Proc. U.S. Nat. Mus. 1886 (1887), 9, 230-247.

1887.1

Jordan, David Starr, \& Eigenmann, Carl H. Notes on skeletons of Etheostomatina. Proc. U. S. Nat. Mus. 1885 (1886), 8, 68-72.

1886.1

A review of the Gobiidxe of North America. Proc. U. S. Nat. Mus. 1886 (1887), 9, 477-518.

1887.1

- Notes on a collection of fishes sent by Mr. Charles C. Leslie from Charleston, S. C. Proc. U. S. Nat. Mus. 1887 (1888), 10, 269-270.

1888.1

A review of the Scirnida of America and Europe. Rept. U. S. Fish Comm. 1886 (1889), 14, 343-446. 4 pls.

1889.1

- A review of the genera and species of Serranidx found in the waters of America and Europe. Bull. U. S. Fish Comm. 1888 (1890), 8, 329-441. 10 pls.

1890.1

Jordan, David Starr, \& Evermann, Barton Warren. The food-fishes of Indiana. Rept. Indiana State Board Agric., 1886, 156-173.

1886.1

Description of six new spécies of fishes from the gulf of Mexico, with notes on other species. Proc. U. S. Nat. Mus, 1886 (1887), 9, 466-476. 1887.1

Description of the yellow-finned trout of Twin lakes, Colorado (Salmo mykiss macdonaldi) Proc. U. S. Nat. Mus. 1889 (1890), 12, 453-454. 1890.1
Description of a new darter (Etheostoma tipnecanoe) from the Tippecanoe river, Indiani. Proc. U. S. Nat. Mus. 1890 (1891), 13, 3-4. 1891.1

- A check-list of the fishes and fish-like vertebrates of North and Middle America. Rept. U. S. Fish Comm. 1895 (1896), 21, 207-584. 1896.1

The fishes of North and Middle America. A descriptive catalogue of the species of fish-like vertebrates found in the waters of North America, north of the isthmus of Panama. Bull. U.S. Nat. Mus., 1896, 47, pt. 1, v-lx; 1-1240. Ibid., 1898, pt. 2, iii-xxx; 1241-2183. Ibid., 1898, pt. 3, v-xxiv; 2183a-3136. Ibid., 1900, pt. 4, iii-ci; $3137-3313$. 392 pls.

1896.2

This is the most complete and authoritative systematic work of descriptive and distribu tional nature dealing with the fishes and fishlike vertebrates of North and Middle America with key to the identification of species.

Part i deals with Amphioxus, Marsipobranchii, Selachii, IIolocephali, and a portion of the Acanthopteri among teleostome fishes. Parts ii and iil complete the discussion of the Acanthopteri, and Part iv contains additional descriptions and an explanation of plates, 392 in number. An index of genera and species, and an artificial key to the families of teleostomes, are also found in Part iii.

American food and game fishes. A popular account of all the species found in America north of the equator, with kevs for ready identification, life historjes, and methods of capture. I ondon \& New York, 1902. 573 p. 74 pls. \& figs. $8^{\circ}$.

1902.1

The fishes and fisheries of the Hawaina islands. Rept. U. S. Fish Comm. 1901 (1902), 27, 353-499. 7 pls.

1902.2

Notes on a collection of fishes from the island of Formosi. Proc. U. S. Nat. Mus., 1903, 25, 315-368. 29 figs.

1903.1

- Descriptions of a new genus and two new species of fishes from the Hawaiian islands. Bull. U. S. Fish Comm. 1902 (1904), 22, 209-210.

1904.1

Descriptions of new genera and species of fishes from the Hawaiian islands, Bull. U. S. Fish Comm. 1902 (1904), 22, 161-208.

1904.2

- Preliminary report of the Alaska Salmon Commission. U. S. House Doc. no. 477, 1904, 58. Congr., 2. sess., 1-37.

1904.33 


\section{Jordan \& Evermann.}

The aquatic resources of the Hawaiian islands. I. The shore fishes of the Hawaiian islands, with a general account of the fish fauna. Bull. U. S. Fish Comm. 1903 (1905), 23, 1-574. 138 pls. \& 229 figs.

Abstract in Shield's Mag., 1, 426.

1905.1

- Descriptions of three new species of cisco, or lake herring (Argyrosomus) from the Great lakes of America; with a note on the species of whitefish. Proc. U. S. Nat. Mus., 1909, 36, 165-172. 3 figs.

1909.1

A review of the salmonoid fishes of the Great lakes, with notes on the whitefishes of other regions. Bull. Bureau Fisheries 1909 (1911), 29, 1-41. 7 pls. \& 23 figs.

1911.1

Jordan, David Starr, \& Fesler, Bert. A review of the sparoid fishes of America and Europe. Rept. U. S. Fish Comm. 1889-91 (1893), 27, 421-544. 55 pls.

1893.1

Jordan, David Starr, \& Fordice Morton W. A review of the American species of Belonidx. Proc. U. S. Nat. Mus. 1886 (1887), 9, 339-361. 1887.1

Jordan, David Starr, \& Fowler, Henry $W_{\text {[eed] Notes on little known }}$ Japanese fishes, with description of a new species of Aboma. Proc. U. S. Nat. Mus., 1902, 25, 573-576. pl.

1902.1

A review of the Chrtodontidx and related families of fishes found in the waters of Japan. Proc. U. S. Nat. Mus., 1902, 25, 513-563. 6 figs. 1902.2

A review of the cling-fishes (Gobiesocidx) of the waters of Japan. Proc. U. S. Nat. Mus., 1902, 25, 413415. pl.

1902.3

- A review of the dragonets (Callionymidx) and related fishes of the waters of Japan. Proc. U.S. Nat. Mus., 1902, 25, 939-959.

1902.4

- A review of the ophidioid fishes of Japan. Proc. U. S. Nat. Mus, 1902, 25, 743-766. 5 figs.

1902.5

A review of the oplegnathoid fishes of Japan. Proc. U. S. Nat. Mus. $1902,25,75-78$.

1902.6

A review of the trigger-fishes, file-fishes and trunk-fishes of Japan. Proc. U. S. Nat. Mus., 1902, 25, 251286. 6 figs.
- A review of the berycoid fishes of Japan. Proc. U. S. Nat. Mus., 1903, 26, 1-21. 4 figs.

1903.1

A review of the Cepolida or band-fishes of Japan. Proc. U. S. Nat. Mus., 1903, 26, 699-702. pl. 1903.2

A review of the Cobitidx, or loaches, of the rivers of Japan. Proc. U. S. Nat. Mus., 1903, 26, 765-774. 2 figs.

1903.3

A review of the cyprinoid fishes of Japan. Proc. U. S. Nat. Mus., 1903, 26, 811-862. 8 figs.

1903.4

- A review of the elasmobranchiate fishes of Japan. Proc. U. S. Nat. Mus., 1903, 26, 593-674. 2 pls. \& 10 figs.

1903.5

- A review of the siluroid fishes or catfishes of Japan. Proc. U. S. Nat. Mus., 1903, 26, 897-911. 2 figs. 1903.6

Jordan, David Starr, \& Gilbert, Charles Henry. List of fishes of Indiana. Indiana Farmer, Jan. 17, 1877. 1877.1

On the genera of North American freshwater fishes. Proc. Acad. Nat. Sci. Philad., 1877, 83-104.

1877.2

Notes on the fishes of Beaufort harbor, North Carolina. Proc. U. S. Nat. Mus., 1878, 1, 365-388. - Smithson. Misc. Coll., 1880, 19, art. 1. 1878.1

-Description of a new agonoid fish (Brachyopsis xyosternus) from Monterey bay, California. Proc. U. S. Nat. Mus., 1880, 3, 152-154. - Smithson. Misc. Coll., 1881, 22, art. 1. 1880.1

Description of a new agonoid (Agonus vulsus) from the coast of California. Proc. U. S. Nat. Mus., 1880, 3 , 330-332. - Smithson. Misc. Coll., 1881, 22, art. 1 .

1880.2

Description of a new embiotocoid (Abeona aurora) from Monterey, California, with notes on a related species. Proc. U. S. Nat. Mus., 1880, 3, 299-301. - Smithson. Misc. Coll., 1881, 22, art. 1 .

1880.3

Description of a new embiotocoid fish (Cymatogaster rosaceus) from the coast of California. Proc. U. S. Nat. Mus., 1880, 3, 303-305. - Smithson. Misc. Coll., 1881, 22, art. 1. 1880.4

Description of a new embiotocoid fish (Ditrema atripes) from the coast of California. Proc. U. S. Nat. Mus., 1880, 3, 320-322. - Smithson. Misc. Coll., 1881, 22, art. 1. 
- Description of a new flounder (Hippoglossoides exilis) from the coast of California. Proc. U. S. Nat. Mus., 1880, 3, 154-156. - Smithson. Misc. Coll., 1881, 22, art. $1 . \quad 1880.6$

Description of a new flounder (Platysomatichthys stomias) from the coast of California. Proc. U. S. Nat. Mus., 1880, 3, 301-303. - Smithson. Misc. Coll., 1881, 22, art. 1. 1880.7

Description of a new flounder (Pleuronichthys verticalis) from the coast of California, with notes on other species. Proc. U. S. Nat. Mus., 1880, 3, 4951. - Smithson. Misc. Coll., 1881, 22, art. 1.

1880.8

- Description of a new flounder (Xystreurys liolepis) from Santa Catalina island, California. Proc. U.S. Nat. Mus., 1880, 3, 34-36. - Smithson. Misc. Coll., 1881, 22, art. 1.

1880.9

Description of a new ray (Platyrhina triseriata) from the coast of California. Proc. U. S. Nat. Mus., 1880, 3, 36-38. - Smithson. Misc. Coll., 1881, 22 , art. 1.

1880.10

Description of a new scorprenoid fish (Sebastichthys maliger) from the coast of California. Proc. U. S. Nat Mus., 1880, 3, 322-324. - Smithson. Misc. Coll., 1881, 22, art. 1. 1880.11

Description of a new scorpænoid fish (Sebastichthys proriger) from Monterey bay, California. Proc. U. S. Nat. Mus., 1880, 3, 327-329. - Smithson. Misc. Coll., 1881, 22, art. 1. 1880.12

- Description of a new species of deep-water fish (Icichthys lockingtoni) from the coast of California. Proc. U.S. Nat. Mus., 1880, 3, 305-308. - Smithson. Misc. Coll., 1881, 22, art. 1. 1880.13

Description of a new species of Hemirhamphus (Hemirhamphus rose) from the coast of California. Proc. U. S. Nat. Mus., 1880, 3, 335-336.Smithson. Misc. Coll., 1881, 22, art. 1.

1880.14

Description of a new species of Nemichthys (Nemichthys avocetta) from Puget sound. Proc. U. S. Nat. Mus., 1880, 3, 409-110. - Smithson. Misc. Coll., 1881, 22, art. 1 .

1880.15

Description of a new species of notidanoid shark (Hexanchus corinus) from the Pacific coast of the United States. Proc. U. S. Nat. Mus., 1880, 3,
352-355. - Smithson. Misc. Coll., 1881, 22 , art. 1.

1880.16

Description of a new species of Paralepis (Paralepis coruscans) from the straits of Juan de Fuca. Proc. U. S. Nat. Mus., 1880, 3, 411-413. - Smithson. Misc. Coll., 1881, 22, art. 1. 1880.17

Description of a new species of ray (Raia rhina) from the coast of California. Proc. U. S. Nat. Mus., 1880, 3, 251-253. - Smithson. Misc. Coll., 1881, 22, art. 1.

1880.18

Description of a new species of ray (Raia stellulata) from Monterey, California. Proc. U. S. Nat. Mus., 1880, 3, 133-135. - Smithson. Misc. Coll., 1881, 22, art. 1.

1880.19

Description of a new species of rock cod (Sebastichthys serriceps) from the coast of California. Proc. U. S. Nat. Mus., 1880, 3, 38-40. - Smithson. Misc. Coll., 1881, 22, art. $1 . \quad 1880.20$

Description of a new species of "rock-fish" (Sebastichthys carnatus) from the coast of California. Proc. U.S. Nat. Mus, , 1880, 3, 73-75. - Smithson. Misc. Coll., 1881, 22, art. 1. 1880.21

Description of a new species of rock-fish (Sebastichthys chrysomelas) from the coast of California. Proc. U.S. Nat. Mus., 1880, 3, 465. - Smithson. Misc. Coll., 1881, 22, art. 1. $\quad 1880.22$

Description of a new species of Sebastichthys (Sebastichthys miniatus), from Monterey bay, California. Proc. U. S. Nat. Mus., 1880, 3, 70-73.Smithson. Misc. Coll., 1881, 22, art. 1. 1880.23

Description of seven new species of sebastoid fishes from the coast of California. Proc. U.S. Nat. Mus., 1880 , 3, 287-298. - Smithson Mise. Coll., 1881,22 , art. 1 . $\quad 1880.24$

Descriptions of new species of Xiphister ( $X$. chirus and $X$. rupestris) and Apodichthys (A. fucorum) from Monterey, California. Proc. U. S. Nat. Mus., 1880, 3, 135-140. - Smithson. Misc. Coll., 1881, 22, art. 1. $\quad 1880.25$

Descriptions of two new species of fishes (Ascelichthys rhodorus and Scytalina cerdale) from Neah bay, Washington territory. Proc. U. S. Nat. Mus., 1880, 3, 264-268. - Smithson. Misc. Coll., 1881, 22, art. 1. 1880.26 


\section{Jordan \& Gilbert.}

Descriptions of two new species of flounders (Parophrys ischyrus and Hippoglossoides elassodon) from Puget sound. Proc. U. S. Nat. Mus., 1880, 3, 276-280. - Smithson. Mise. Coll., 1881, 22, art. 1.

1880.27

Descriptions of two new species of scopeloid fishes (Sudis ringens and Myctophum crenulare) from Santa Barbara channel, California. Proc. U. S. Nat. Mus., 1880, 3, 273-276. - Smithson. Misc. Coll., 1881, 22, art. 1. 1880.28

Descriptions of two new species of Sebastichthys (Sebastichthys entomelas and Sebastichthys rhodochloris) from Monterey bay, California. Proc. U. S. Nat. Mus., 1880, 3, 142-146. - Smithson. Misc. Coll., 1881, 22, art. 1. 1880.29

List of the fishes of the Pacific coast of the United States, with a table showing the distribution of the species. Proc. U. S. Nat. Mus., 1880, 3, 452-458. — Smithson. Misc. Coll., 1881, 22, art. 1.

1880.30

Notes on a collection of fishes from San Diego, California. Proc. U.S. Nat. Mus., 1880, 3, 23-34. - Smithson. Misc. Coll., 1881, 22, art. 1. 1880.31

Notes on a collection of fishes from Utah lake. Proc. U.S. Nat. Mus., $1880,3,459-165$. - Smithson. Misc. Coll., 1881, 22, art. 1. 1880.32

Notes on sharks from the coast of California. Proc. U. S. Nat. Mus., 1880, 3, 51-52. - Smithson. Misc. Coll., 1881,22 , art. 1.

1880.33

On the generic relations of Belone exilis Grd. Proc. U. S. Nat. Mus., 1880 , 3, 459. - Smithson. Mise. Coll., 1881, 22 , art. 1.

1880.34

On the generic relations of Platyrhina exasperata. Proc. U. S. Nat. Mus., 1880, 3, 53. - Smithson. Misc. Coll., 1881, 22, art. 1.

1880.35

On the occurrence of Cephaloscyllium laticeps (Duméril) Gill, on the coast of California. Proc. U. S. Nat. Mus., 1880, 3, 40-42. - Smithson. Misc. Coll., 1881, 22, art. 1.

1880.36

On the oil shark of southern California (Galeorhinus galeus) Proc. U.S. Nat. Mus., 1880, 3, 42-13. - Smithson. Misc. Coll., 1881, 22, art. 1. 1880.37

Observations on the salmon of the Pacific. Amer. Naturalist, 1881, 15 . $177-186$. 1881.1
Description of a new species of goby (Gobiosoma ios) from Vancouver island. Proc. U. S. Nat. Mus. 1881 (1882), 5, 437-438.

1882.1

- Description of a new species of Pomadasys $[P$. cosius] from Mazatlan, with a key to the species known to inhabit the Pacific coasts of tropical America. Proc. U. S. Nat. Mus. 1881 (1882), 4, 383-388.

1882.2

- Description of a new species of Ptychochilus (Ptychochilus harfordi) from Sacramento river. Proc. U. S. Nat. Mus. 1881 (1882), 4, 72-73. 1882.3

Description of a new species of Xenichthys (X. xenumus) from the west coast of Central America. Proc. U. S. Nat. Mus. 1881 (1882), 4, 454. 1882.4

Description of five new species of fishes from Mazatlan, Mexico [Tylosurus sierrita, $T$. fodiator, Cynoscion xanthulum, Culius cequidens, Centropomus robalito] Proc. U.S. Nat. Mus. 1881 (1882), 4, 458-463.

1882.5

- Description of Sebastichthys mystinus. Proc. U. S. Nat, Mus, 1881 (1882), 4, 70-72.

1882.6

- Descriptions of nineteen new species of fishes from the bay of Panama. Bull. U. S. Fish Comm. 1881 (1882), 1, 306-335.

1882.7

- Descriptions of thirty-three new species of fishes from Mazatlan, Mexico. Proc. U. S. Nat. Mus. 1881 (1882), 4 , 338-365.

1882.8

List of fishes collected by Lieut. Henry E. Nichols, U. S. N., in the gulf of California and on the west coast of lower California, with descriptions of four new species [Cynoscion othonopterum, Stolephorus opercularis, Opisthognathus rhomaleus, Umbrina roncador Proc. U. S. Nat. Mus. 1881 (1882), 4, 273-279.

1882.9

Note on Raia inornata. Proc. U. S. Nat. Mus. 1881 (1882), 4, 73-74.

1882.10

Notes on a collection of fishes made by Lieut. Henry E. Nichols, U. S. $N$, on the west coast of Mexico, with descriptions of new species [Caranx orthogrammus, Balistes mento, Platyglossus nicholsi, Sciana alutal Proc. U. S. Nat. Mus. 1881 (1882), 4, 225-233. 1882.11

Notes on the fishes of the Pacific coast of the United States. Proc. U.S. Nat. Mus. 1881 (1882), 4, 29-70.

1882.12 
Catalogue of the fishes collected by Mr. John Xantus at cape San Lucas, which are now in the United States National Museum, with descriptions of eight new species. Proc. U.S. Nat. Mus. 1582 (1883), 5, 353-371.

1883.1

Description of a new cyprinodont (Xygonectes imurus) from southern Illinois. Proc. U.S. Nat. Mus. 1882 (1883), 5, $143-144$.

1853.2

-.. Description of a new eel (Sidera castanea) from Mazatlan, Mexico. Proc. U.s. Nat. Mus. 1882 (1853), 5, 647-648.

1883.3

Description of a new shark (Carcharias lamiella) from San Diego, California. Proc. U. S. Nat. Mus. 1882 (1883), 5, 110-111.

1883.4

Description of a new species of Artedius (Artedius fenestratis) from Puget sound. Proc. U. S. Nat. Mus. 188.2 (1883), 5, 577-579. 1883.5

Description of a new species of Conodon (Conodon serrifer) from Boca Soledad, lower California. Proc. U.S. Nat. Mus. 1882 (1883), 5, 351-352.

1883.6

Description of a new species of Uranidea (Uranidea pollicaris) from lake Michigan. Proc. U. S. Nat. Mus. 1882 (1883), 5, 222-223. 1883.7

Description of a new species of Urolophus (Urolophus asterias) from Mazatlan and Panama. Proc. U. S. Nat. Mus. 1882 (1883), 5, 579-580.

1883.8

- Description of four new species of sharks from Mazatlan, Mexico. Proc. U.S. Nat. Mus. 1882 (1883), 5, 102-110.

1883.9

- Descriptions of two new species of fishes (Myrophis vafer and Chloroscombrus orqueta) from Panama. Proc. U. S. Nat. Mus. 1882 (1883), 5, 645-647.

1883.10

Descriptions of two new species of fishes (Sebastichthys umbrosus and Citharichthys stigmaus) collected at Santa Barbara, California, by Andrea Larco. Proc. U. S. Nat. Nus. 1882 (1883), 5, 410-112. 1883.11

List of a collection of fishes made by Mr. L. Belding, near cape San L.ucas, lower California. Proc. L.S. Nat. Mus. 1882 (18S3), 5, 378-381.

1883.12
List of fishes collected at Mazatlan, Mexico, by Charles Henry Gilbert. Bull. U. S. Fish Comm. 1882 (1883), 2, 105-108.

1883.13

- List of fishes collected at Panama by Capt. John M. Dow, now in the United States National Museum. Proc. U.S. Nat. Mus. 1882 (1883), 5, 373-378. 1883.14

by List of fishes collected at Panama Tenry Gilbert. Bull. U. S Fish Comm. 1852 (1883), 2, 109-111.

1883.15

List of fishes collected at Panama by Rev. Mr. Rowell, now preserved in the United States National Museum. Proc. U. S. Nat. Mus. 1882 (1883), 5, 381-382.

1883.16

List of fishes collected by Mr. John Xantus at Colima, Mexico. Proc. U. S. Nat. Mus. 1882 (1883), 5, 371-372.

1883.17

List of fishes now in the museum of Yale College, collected by Prof. Frank H. Bradley at Panama, with descriptions of three new species. Proc. U.S. Nat. Mus. 1882 (1883), 5, 620-632.

1883.18

Notes on a collection of fishes from Charleston, South Carolina, with descriptions of three new species. Proc. U. S. Nat. Mus. 1882 (1883), 5, 580620 .

1883.19

-.. Notes on fishes observed about Pensacola, Florida, and Galveston, 'lexas, with descriptions of new species. Proc. U. S. Nat. Mus. 1882 (1883), 5, $211-307$.

1883.20

- On certain neglected generic names of Lacépède. Proc. U. S. Nat. Mus. 1882 (1883), 5, 570-576. 1883.21

On the nomenclature of the genus Ophichthys. Proc. U. S. Nat. Ius. 1882 (1883), 5, 648-651. 1883.22

On the synonymy of the genus Bothus Rafinesque. Proc. U. S. Nat. Mus. 1882 (1883), 5, 576-577. 1883.23

A review of the siluroid fishes found on the Pacific coast of tropical America, with descriptions of three new species (Arius insculptus, A. elatturus, 1. osculus) Bull. U. S. Fish Comm. 1882 (1883), 2, 34-54. 1883.24

A synopsis of the fishes of North America. Bull. U. S. Nat. Mus., 1883. $16,1-1018 . \quad 1883.25$ 


\section{Jordan \& Gilbert.}

Description of a new murænoid eel (Sidera chlevastes) from the Galapagos islands. Proc. U. S. Nat. Mus. 1883 (1884), 6, 208-210.

1884.1

Description of a new species of Rhinobatus (Rhinobatus glaucostigma) from Mazatlan, Mexico. Proc. U. S. Nat. Mus. 1883 (1884), 6, 210-211.

1884.2

Description of two new species of fishes (Aprion ariommus and Ophidium beani) from Pensacola, Florida. Proc. U. S. Nat. Mus. 1883 (1884), 6, 142-144.

1884.3

Note on the genera of Petromyzontidx. Proc. U. S. Nat. Mus. 1883 (1884), 6, 208.

1884.4

- Notes on the nomenclature of certain North American fishes. Proc. U. S. Nat. Mus. 1883 (1884), 6, 110-111.

1884.5

- A review of the American Caranginæ. Proc. U. S. Nat. Mus. 1883 (1884), 6, 188-207.

1884.6

Description of Sciona sciera, a new species of Sciæna from Mazatlan and Panama. Proc. U. S. Nat. Mus. 1884 (1885), 7, 480.

1885.1

Descriptions of ten new species of fishes from Key West, Florida. Proc. U. S. Nat. Mus. 1884 (1885), 6, 24-32.

1885.2

Note on Calamus proridens, a new species of Calamus. Proc. U. S. Nat. Mus. 1884 (1885), 7, 150. 1885.3

Note on Caranx ruber and Caranx bartholomai. Proc. U. S. Nat. Mus. 1884 (1885), 7, 32-33.

1885.4

A review of the species of the genus Calamus. Proc. U. S. Nat. Mus. 1884 (1885), 7, 14-24.

1885.5

List of fishes collected in Arkansas, Indian Territory and Texas, in September, 1884, with notes and descriptions. Proc. U. S. Nat. Mus. 1886 (1887), 9, 1-25.

1887.1

- Description of a new species of Thalassophryne (Thalassophryne dowi) from Punta Arenas and Panama. Proc. U. S. Nat. Mus. 1887 (1888), 10, 388.

1888.1

The fisheries and fishery interests of the United States, by George Brown Goode and a staff of associates.
Section II. A. A geographical review of the fishery industries and fishing communities for the year 1880 . Washington, $1888.8^{\circ}$.

1888.2

Part on fisheries of California, Oregon and Washington, by Jordan and Gilbert, p. 589-629.

Description of a new species of ribbon-fish (Trachypterus rex-salmonorum) from San Francisco. Proc. California Acad. Sci., 1894, 2. ser. 4, 144146. pl.

1894.1

- Note on the wall-eyed pollack (Pollachius chalcogrammus fucensis) of Puget sound. Proc. U. S. Nat. Mus. 1893 (1894), 16, 315-316. 1894.2

List of the fishes inhabiting Clear lake, California. Bull. U. S. Fish Comm. 1894 (1895), 14, 139-140. 1895.1

The fishes of Bering sea (In Jordan, D. S. Fur-seals and fur-seal islands of the north Pacific ocean, pt. 3, 433-492. 43 pls. Washington, 1899) 1899.1

Macrouridx (In Jordan, D. S. and Starks, E. C. List of fishes dredged by the steamer "Albatross" off the coast of Japan. . . Bull. U. S. Fish Comm. 1902 (1904), 22, 602-621. pl. \& 10 illust.)

1904.1

Jordan, David Starr, \& Goss, David Kopp. A review of the flounders and soles (Pleuronectidæ) of America and Europe. Rept. U. S. Fish Comm. 1886 (1889), 14, 225-342. 9 pls.

1889.1

Jordan, David Starr, \& Grinnell, Joseph. Description of a new species of trout (Salmo evermanni) from the upper Santa Ana river, Mount San Gorgonio, southern California. Proc. Biol Soc. Washington, 1908, 21, 31-32. pl.

1908.1

Jordan, David Starr, \& Gunn, James Alexander. List of fishes collected at the Canary islands by O. F. Cook, with descriptions of four new species. Proc. Acad. Nat. Sci. Philad. 1898 (1899), 339-347.

1899.1

Jordan, David Stam, \& Henshaw, Henry $W$. Report on the fishes collected during the years 1875, 1876 and 1877, in California and Nevada. Ann. Rept. U.S. Geogr. Surv. West 100th Meridian, 1878, 187-200. 3 pls. - Ann. Rept. Chief Engin., 1878, pt. 3, 1609-1622. 4 pls.

1878.1

Jordan, David Starr, \& Herre, Albert Christian. A review of the her- 
ring-like fishes of Japan. Proc. U. S. Nat. Mus., 1906, 31, 613-645. 5 figs. 1906.1

- A review of the cirrhitoid fishes of Japan. Proc. U. S. Nat. Mus., 1907, $33,157-167.2$ figs.

1907.1

A review of the lizard-fishes or Synodontidx of the waters of Japan. Proc. U. S. Nat. Mus., 1907, 32, 513-524. 12 figs.

1907.2

Jordan, David Starr, \& Hofiman, Horace Addison. See Hofiman \& Jordan.

Jordan, David Starr, \& Holder, Charles Frederick. See Holder \& Jordan.

Jordan, David Starr, \& Hughes, Elizabeth $G$. A review of the American species of the genus Prionotus. Proc. U. S. Nat. Mus. 1886 (1887), 9, 327-338.

1887.1

- A review of the genera and species of Julidinæ found in American waters. Proc. U. S. Nat. Mus. 1886 (1887), 9, 56-70.

1887.2

Jordan, David Starr, \& Jouy, Pierre Louis. Checklist of duplicates of fishes from the Pacific coast of North America, distributed by the Smithsonian Institution in behalf of the United States National Museum. Proc. U. S. Nat. Mus. 1881 (1882), 4, 1-18.

1882.1

Jordan, David Starr, \& McGregor, Richard Crittenden. List of fishes collected at the Revillagigedo archipelago and neighboring islands. Rept. U. S. Fish Comm. 1898 (1899), 24, 271-284. 2 pls.

1899.1

Description of a new species of threadfin (family Polynemida) from Japan. Proc. U. S. Nat. NIus., 1906, 30, $813-815$

1906.1

Jordan, David Starr, \& Meek, Seth Eugene. Description of four new species of Cyprinida in the United States National Museum. Proc. U. S. Nat. Mus. 1884 (1885), 7, 474-477.

1885.1

Description of Zygonectes zonifer, a new species of Zygonectes from Nashville, Georgia. Proc. U. S. Nat. Mus. 1884 (1885), 7, 482.

1885.2

- List of fishes observed in the St. John river at Jacksonville, Florida. Proc U. S. Nat. Mus. 1884 (1885), 7. 235-237.
List of fishes collected in Iowa and Missouri in August, 1884, with descriptions of three new species. Proc. U. S. Nat. Mus. 1885 (1886), 8, 1-17.

1886.1

A review of the American species of flying fishes (Exococtus) Proc. U.S. Nat. Mus. 1885 (1886), 8, 44-67. 1886.2

Jordan, David Starr, \& Metz, Charles William. Descriptions of two new species of fishes from Honolulu, Hawaii. Proc. U. S. Nat. Mus, 1912, 42, 525-527. pl.

1912.1

A catalogue of the fishes known from the waters of Korea. Mem. Carnegie Mus., 1913, 6, 1-65. 10 pls. \& 67 figs.

1913.1

Jordan, David Starr, \& Richardson, Robert Earl. Description of a new species of killifish, Lucania browni, from a hot spring in lower California. Proc. U. S. Nat. Mus., 1907, 33, 319-321. fig. 1907.1

On a collection of fishes from Echigo, Japan. Proc. U. S. Nat. Mus., $1907,33,263-266.3$ figs. $\quad 1907.2$

Fishes from islands of the Philippine archipelago. Bull. Bureau Fisheries, 1908, 27, 233-287.

1908.1

A review of the flat-heads, gurnards and other mail-cheeked fishes of the waters of Japan. Proc. U. S. Nat. Mus., 1908, 33, 629-670. 9 figs. 1908.2

A catalogue of the fishes of the island of Formosa, or Triwan, based on the collections of Dr. Hans Sauter. Mem. Carnegie Mus., 1909, 4, 159-204. 11 pls. \& 29 figs.

1909.1

Check-list of the species of fishes known from the Philippine archipelago. Manila, 1910.78 p.

1910.1

A review of the Serranidæ or seabass of Japan. Proc. U. S. Nat. Mus, 1910, 37, 421-474. 16 figs. $\quad 1910.2$

Jordan, David Starr, \& Rutter, Cloudslcy. A collection of fishes made by Joseph Seed Roberts in Kingston, Jamaica. Proc. Acad. Nat. Sci. Philad. 1897 (1898), 91-133. 1898.1

Jordan, David Starr, \& Seale, Alvin. Description of a new trout (Salmo gairdneri beardsleei) from Crescent lake, Washington. Contrib. Biol. Hopkins Seaside Labor., 1896, 6, $209 . \quad 1896.1$ 


\section{Jordan \& Seale.}

List of fishes collected by Dr. Bashford Dean on the island of Negros, Philippines. Proc. U. S. Nat. Mus., $1905,28,769-803$. figs.

1905.1

List of fishes collected in 1882-83 by Pierre Louis Jouy at Shanghai and Hongkong, China. Proc. U. S. Nat. Mus., 1905, 29, 517-529. 6 figs. 1905.2

Descriptions of six new species of fishes from Japan. Proc. U. S. Nat. Mus, 1906, 30, 143-148. 6 figs. 1906.1

'The fishes of Samoa, description of the species found in the archipelago, with a provisional check-list of the fishes of Oceania. Bull. Bureau Fisheries 1905 (1906), 25, 175-455. 20 pls \& 111 figs.

1906.2

Fishes of the islands of Luzon and Panay. Bull. Bureau Fisheries 1906 (1907), 26, 1-48. 20 figs. 1907.1

List of fishes collected at Hong Kong by Captain William Finch, with description of five new species. Proc. Davenport Acad. Sci., 1907, 10, 1-17 13 pls.

1907.2

Iist of fishes collected in the river at Buytenzorg, Java, by Dr. Douglas Houghton Campbell. Proc. U. S. Nat. Mus., 1907, 33, 535-543. 2 figs.

1907.3

Jordan, Drwid Starr, \& Sindo, Michilaro. A review of the Japanese species of surf fishes or Embiotocidx. Proc. U. S. Nat. Mus., 1902, 24, $353-$ 359. 2 figs.

1902.1

- A review of the pediculate fishes or anglers of Japan. Proc. U. S. Nat. Mus., 1902, 24, 361-381. 7 figs. 1902.2

Jordan, Drvid Starr, \& Snyder, John Otterbein. Description of nine new species of fishes contained in museum. of Japan. Journ. Coll. Sei., Imper. Univ. Tokyo, 1901, 15, 301-311. 2 pls.

1901.1

Descriptions of two new genera of fishes (Ereminis and Draciscus) from Japan. Proc. California Acad. Sci. 1901, 3. ser. 2, 377-380. 2 pls. 1901.2

List of fishes collected in 1883 and 1885 by Pierre Louis Jouy and preserved in the United States National Museum, with deseriptions of six new species. Proc. U. S. Nat. Mus, 1901, 23, 739-769. $6 \mathrm{pls}$.
A list of fishes collected in Japan by Keinosuke Otaki, and by the United States Fish Commission steamer " Albatross." with descriptions of fourteen new species. Proc. U. S. Nat. Mus., 1901, 23, 335-380. 11 pls.

1901.4

- Notes on a collection of fishes from the rivers of Mexico, with descriptions of twenty new species. Bull. U.S. Fish Comm. 1899 (1901), 19, 115-147.

1901.5

A preliminary check-list of the fishes of Japan. Annot. Zool. Japon., $1901,3,1-159$.

1901.6

A review of the apodal fishes or cels of Japan, with descriptions of nineteen new species. Proc. U. S. Nat. Mus., 1901, 23, 837-890. 1901.7

A review of the cardinal fishes of Japan. Proc. U. S. Nat. Mus., 1901, 23, 391-913. 2 pls.

1901.8

A review of the gobioid fishes of Japan, with descriptions of twenty-one new species. Proc. U. S. Nat. Mus., 1901, 24, 33-132. 33 figs. 1901.9

A review of the gymnodont fishes of Japan. Proc. U. S. Nat. Mus. 1901, 24, 229-264. 8 figs. $\quad 1901.10$

A review of the hypostomide and lophobranchiate fishes of Japan. Proc. U. S. Nat. Mus., 1901, 24, 1-20, 12 pls.

1901.11

A review of the lancelets, hagfishes and lampreys of Japan, with a description of two new species. Proc. U. S. Yat. Mus., 1901, 23, 725-734. pl.

1901.12

Deseriptions of two new species of squaloid sharks from Japan. Proc. U.S. Nat. IL 1902.1

On certain species of fishes confused with Bryostemma polyactocephalum, Proc. U. S. Nat. Mus., 1902, 25, 613-618. 3 figs.

1902.2

A review of the blennioid fishes of Japan. Proc. U. S. Nat. Mus., 1902, 25, 441-504. 28 figs.

1902.3

A review of the discobolous fishes of Japan. Proc. U. S. Nat. Mus., 1902, 24, 343-351. 2 figs. 1902.4

A review of the labroid fishes and related forms found in the waters of Japan. Proc. U. S. Nat. Mus., 1902, 24, 595-662. 10 figs. 
- A A review of the salmonoid fishes of Japan. Proc. U. S. Nat. Mus., 1902, $24,567-593$. figs.

1902.6

A review of the trachinoid fishes and their supposed allies found in the waters of Japan. Proc. U. S. Nat. Mus., 1902, 24, 461-497. 7 figs.

1902.7

On a collection of fishes made by Mr. Alan Owston in the deep waters of Japan. Smithson. Misc. Coll., 1903, 45, 230-240. 11 pls.

1903.1

Notes on collections of fishes from Oahu island and Laysan island, Hawaii, with descriptions of four new species. Proc. U. S. Nat. Mus., 1904, 27, 939-948.

1904.1

On the species of white Chimwra from Japan. Proc. U. S. Nat. Mus., $1904,27,223 \div 226$. figs. 1904.2

Description of a new species of fish (A pogon evermanni) from the Hawaiian islands, with notes on other species. Proc. U. S. Nat. Mus., 1905, 28, 123-126.

1905.1

- A list of fishes collected in Tahiti by Mr. Henry P. Bowie. Proc. U.S. Nat. MIus., 1905, 29, 353-357. 3 figs.

1905.2

- The giant bass of Japan Wtereolypis ischinagi and Érilepis zonifer Proc. U. S. Nat. Mus., 1906, 30, 841$8+5$.

1908.1

___ On a species of loach, Misgurnus decemcirrosus (Basilewsky) from northern China. Proc. U.S. Nat. NIus., 1906. $30,833-834$.

1906.2

- - A review of the Poceiliide or killifishes of Japan. Proc. U. S. Nat. IIus., 1906, 31, 287-290.

1906.3

A synopsis of the sturgeons (Acipenserida) of Japan. Proc. U. S. Nat. Mus., 1906, 30, 397-398. 1906.4

Notes on fishes of Hawaii, with descriptions of new species. Bull. Bureau Fisheries 1906 (1907), 26, 205218. 2 pls. \& 4 figs.

1907.1

Description of three new species of carangoid fishes from Formosa. Mem. Carnegie Mus., 1908, 2, 37-40. 3 pls.

1908.1

Description of a trout from lake Kootenay in British Columbia. Proc. Biol. Soc. Washington, 1908, 21, 33-34. pl.
- Description of a new whitefish (Coregonus oregonius) from Mclienzic river, Oregon Proc. U. S. Nat, Mus., 1909, 36, 425-430. fig. 1909.1

Description of the Iachats "smelt," a new species of atherinoid fish from Oregon. Proc. U. S. Nat. Mus., 1913, 45, 575-576. pl.

1913.1

Jordan, David Starr, \& Starks, Edwin Chapin. The fishes of Puget sound. Proc. California Acad. Sci. 1895, 2. ser. 5, 785-855. 38 pls. Reprint in Contrib. Biol. Hopkins Seaside Labor., 3, 1-71.

1895.1

-- Description of a new species of pipefish (Siphostoma sinalow) from Mazatlan. Proc. California Acad. Sci. 1896, 2. ser. 6, 266-267. 1896.1

Deseriptions of three new species of fishes from Japan. Proc. California lead. Sci., 1901, 3. ser. 2, 381-386. 1901.1

On the relationships of the lutianoid fish (Aphareus furcatus) Proc. U. S. Nat. MI S., 1901, 23, 719-723.

1901.2

A review of the atherine fishes of Japan. Proc. U. S. Nat. Mus,, 1901, 24,199-206. 4 figs. 1901.

Description of a new eyprinoid fish, Hemibarbus joiteni, from the Pei Ho, Tientsin, China. Smithson. Mise. Coll. 1903, 45, 241-242. pl. 1903.1

Description of a new species of sculpin [Coltunculus brephocephalus] from Japan. Proc. U. S. Nat. Mus., 1903, 26, 689-690. fig.

1903.2

A review of the fishes of Japan belonging to the family of Hexagrammidae. Proc. U. S. Nat. Mus., 1903, 26, 1003-1013. 3 figs. 1903.3

A review of the hemibranchiate fishes of Japan. Proc. U.S. Nat. Mus. 1903, 26, 57-73. 3 figs. 1903.4

A review of the synentognathous fishes (Scombresocida) of Japan. Proc. U. S. Nat. Mus., 1903, 26, 525-544.

1903.5

List of fishes dredged by the steamer "Albutross" off the coast of Japan in the summer of 1900. Bull. U.S. Fish Comm. 1902 (1904), 22, 577630. 8 pls. \& figs.

1904.1

A review of the Cottidxe or sculpins found in the waters of Japan. Proc. U.S. Nat. Mus., 1904, 27, 231-335. 43 figs. 
Jordan \& Starks.

A review of the Japanese fishes of the family of Agonidr. Proc. U. S. Nat. Mus., 1904, 27, 575-599. figs.

1904.3

A review of the scorpænoid fishes of Japan. Proc. U. S. Nat. Mus., 1904, 27, 91-175. 2 pls. \& 21 figs.

1904.4

Schmidtina, a genus of Japanese sculpins. Proc. U. S. Nat. Mus., 1904, 27, 961 .

1904.5

On a collection of fishes made in Korea by Pierre Louis Jouy, with descriptions of new species. Proc. U.S. Nat. Mus., 1905, 28, 193-211. fig.

1905.1

List of fishes collected on Tanega and Yaku, offshore islands of southern Japan, by Robert Van Vleck Anderson, with descriptions of seven new species. Proc. U. S. Nat. Mus., 1906, 30, 695706.

1906.1

Notes on a collection of fishes from Port Arthur, Manchuria, obtained by James Francis Abbott. Proc. U. S. Nat. Mus., 1906, 31, 515-526. 5 figs.

1906.2

A review of the flounders and soles of Japan. Proc. U. S. Nat. Mus. 1906, 31, 161-246. 27 figs.

1906.3

List of fishes recorded from Okinawa or the Riu Kiu islands of Japan. Proc. U.S. Nat. Mus., 1907, 32, 491-504.

1907.1

Note on Otohime, a new genus of gurnards. Proc. U. S. Nat. Mus., 1907, 32, 131-133. fig.

1907.2

Notes on fishes from the island of Santa Catalina, southern California. Proc. U. S. Nat. Mus., 1907, 32, 67-77. 8 figs.

1907.3

Jordan, David Starr, \& Swain, Joseph. List of fishes collected in the Clear Fork of the Cumberland, Whitley county, Kentucky, with descriptions of three new species. Proc. U. S. Nat. Mus. 1883 (1884), 6, 248-251. 1884.1

Description of three new species of fishes (Prionotus stearnsi, Prionotus ophryas, and Anthias vivanus) collected at Pensacola by Mr. Silas Stearns. Proc. U. S. Nat. Mus. 1884 (1885), 7, 541-545.

1885.1

Descriptions of scaroid fishes from Havana and Key West, including five new species. Proc. U. S. Nat. Mus. 1884 (1885), 7, 81-102.

1885.2

Notes on fishes collected by David S. Jordan at Cedar keys, Florida. Proc. U. S. Nat. Mus. 1884 (1885), 7, 230-234.

1885.3

A review of the American species of Epinephelus and related genera. Proc. U. S. Nat. Mus. 1884 (1885), 7, $358-410$

1885.4

A review of the American species of marine Mugilidæ. Proc. U. S. Nat. Mus. 1884 (1885), 7, 261-275. 1885.5

A review of the species Lutjaninæe and Hoplopagrinx found in American waters. Proc. U. S. Nat. Mus. 1884 (1885), 7, 427-474.

1885.6

A review of the species of the genus Hrmulon. Proc. U.S. Nat. Mus. 1884 (1885), 7, 281-317.

1885.7

Jordan, David Starr, Tanaka, Shigeho, \& Snyder, John Otterbein. A catalogue of the fishes of Japan. Journ. Coll. Sci., Imper. Univ. Tokyo, 1913, 33, 1-497. 396 figs.

1913.1

Jordan, David Starr, \& Thompson, $J . C$. The fish-fauna of the Tortugas archipelago. Bull. Bureau Fisheries, 1905, 24, 231-256. fig.

1905.1

Jordan, David Starr, \& Thompson, William Francis. Description of a new species of deep-water sculpin (Triglopsis ontariensis) from lake Ontario, with notes on related species. Proc. U. S. Nat. Mus., 1910, 38, 75-78. 3 figs.

1910.1

Note on the gold-eye, Amphiodon alesoides Rafinesque, or Elattonistius chrysopsis (Richardson) Proc. U.S. Nat. Mus., 1910, 38, 353-357. 2 figs. 1910.2

Notes on a collection of fishes made by James Francis Abbott at Irkutsk, Siberia. Ann. Carnegie Mus., $1910,7,81-88.4$ pls. 1910.3

A review of the fishes of the families Lobotidx and Lutianidre, found in the waters of Japan. Proc. U. S. Nat. Mus., 1911, 39, 435-471. 8 figs. 1911.1

- A review of the scixnoid fishes of Japan. Proc. U. S. Nat. Mus,, 1911, 39, 241-261. 4 figs.

1911.2

A review of the Sparida and related families of perch-like fishes found in the waters of Japan. Proc. U. S. Nat. Mus., 1912, 41, 521-601. 15 figs. 1912.1 
Notes on a collection of fishes from the island of Shikoku in Japan, with a description of a new species, Gnathypops iyonis. Proc. U. S. Nat. Mus., 1913, 46, 65-72. 5 figs. 1913.1

- Record of the fishes obtained in Japan in 1911. Mem. Carnegie Museum, 1914, 6, 205-313. 19 pls. \& 87 figs.

1914.1

Three new genera and twenty new species are described.

Jordan, David Starr, \& Van Vleck, Balfour $H$. A popular key to the birds, reptiles, batrachians and fishes of the northern United States, east of the Mississippi river. Appleton, Wisconsin, 1874. 100 p. $8^{\circ}$.

1874.1

Jordan, David Starr, \& others. The Wilder Quarter-century book; a collection of original papers dedicated to ... B. G. IVilder at the close of his twenty-fifth year of service in Cornell University (1868-1893) by some of his former students. Ithaca, N. Y., 1893. vi, 493 p. 28 pls. $8^{\circ} . \quad 1893.1$

Temperature and vertebræ, a study in evolution, etc., by D. S. Jordan, p. 13-36.

Jordana y Morera, José. Apuntes bibliográfico-forestales, ó sea breve resúmen de los libros, folletos, ... y demás trabajos originales, ó traducidos por autores españoles relativos á la cria, cultivo... legislación y economía de los montes, arbolados, plantíos, prados, caza y pesca. Madrid, 1873. 320 p. $8^{\circ}$.

1873.1

Joris, Hermann. Le lobe postérieur de la glande pituitaire. Mém. Cour. Acad. Méd. Belgique, 1908, 19, 1-29. 4 pls. 1908.1

Joseph, Heinrich. Beiträge zur Histologie des Amphioxus. Arb. Zool. Instit. IVien, $1900,12,99-132$. pl. \& figs. 1900.1

- Einige anatomische und histologische Notizen über Amphioxus. Arb. Zool. Instit. Wien, 1902, 13, 125-154. 2 pls.

1902.1

Ueber eigentümliche Zellstrukturen im Zentralnervensystem von Amphioxus. Verh. Anat. Ges., 1904, 18. Vers., 16-26. 6 figs.

1904.1

- Zur Beurteilung gewisser granulärer Einschlüsse des Protoplasmus. Verh. Anat. Ges., 1904, 18. Vers., 105112. 8 figs.

1904.2

Einiges über das Nierensystem von Myxine glutinosa. Centralbl. Physiol. Ges. Berlin, 1905, 18, 788-789.

1905.1
Ein Doppelei von Scyllium nebst Bemerkungen über die Eientwicklung. Anat. Anz., 1906, 29, 367-372. 2 figs.

1906.1

Die epidermoidalen Sinneszellen des Amphioxus. Anat. Anz., 1908, 32, 448-455. 7 figs.

1908.1

Josephson, Aksel Gustav Salomon (editor) Catalogue méthodique des Acta et nova acta Regix Societatis Scientarum Upsaliensis, 1774-1889. Upsala [1889] 1889.1

Joslyn, C. D. The policy of ceding the control of the Great lakes from state to national supervision. 'Trans. Amer. Fisheries Soc. 1905 (1906), 217 222.

1906.1

Jossifov, M. S. M. Sur les voies principales et les organes de propulsion de la lymphe chez certains poissons osseux. C. R. Mém. Soc. Biol. Paris, 1905, 58, 205-207.

1905.1

- Sur les voies principales et les organes de propulsion de la lymphe chez certains poissons. Arch. Anat. Micr., 1906, 8, 398-424. pl. \& fig. $\quad 1906.1$

Jouan, Henri. Note sur une petite lamproie [Petromyzon] provenant de Sauxmesnil. Mém. Soc. Imp. Sci. Nat. Cherbourg 1859 (1860), 7, 367-369.

1860.1

Poissons de mer observés à Cherbourg en 1858 et 1859. Mém. Soc. Imp. Sci. Nat. Cherbourg 1859 (1860), 7, 116-147. Ibid., 1864, 10, 313-314.

1860.2

- Note sur quelques espèces de poissons de la Nouvelle-Calédonie. Mém. Soc. Imp. Sci. Nat. Cherbourg 1860 (1861), 8, 241-308. Ibid., 1861 (1862), 9, 177-187.

1861.1

Notes sur quelques espèces de poissons de la Basse-Cochinchine. Mém. Soc. Imp. Sci. Nat. Cherbourg 1864 (1865), 11, 257-328. $\quad 1865.1$

Description de quelques poissons de lîlle de Poulo-Condor. Mém. Soc. Imp. Sci. Nat. Cherbourg 1865 (1866), $12,113-128$.

1866.1

- Description de quelques poissons et de quelques oiseaux du nord de la Chine. Mém. Soc. Imp. Sci. Nat. Cherbourg 1865 (1866), 12, 263-276.

1866.2

Notes sur quelques poissons de mer observés à Hong-Kong. Mém. Soc. Imp. Sci. Nat. Cherbourg 1866 (1867), 13 (2. sér. 3), 241-282.
1867.1 
Jouan, $H$.

- Note sur quelques poissons nuisibles du Japon. Mém. Soc. Imp. Sci. Nat. Cherbourg 1866 (1867), 13 (2. sér. 3), 142-144.

1867.2

Coup d'œil sur l'histoire naturelle du Japon. Mém. Soc. Imp. Sci Nat. Cherbourg, 1869, 2. sér. 4, 49-96.

1869.1

Notes sur l'archipel Hawaiien (Iles Sandwich) Mém. Soc. Nat. Sci. Nat. Cherbourg, 1873, 17, 5-104.

Liste des poissons, p. 89-92.

1873.1

Sur la présence de requins dans l'Adriatique et sur les côtes d'Italic. Act. Soc. Linn. Bordeaux, 1573, 29 (3. sér. 9), 28.

1873.2

Additions aux poissons de mer observés à Cherbourg. Mén. Soc. Nat. Sci. Nat. Cherbourg, 1874, 18 (2. sér. 8), 353-368.

1874.1

Sur quelques espèces rares de poissons de mer de Cherbourg. Bull. Soc. Linn. Normandie 1873-74 (1874), 2. sér. 8, 412-421.

1874.2

Mélanges zoologiques [Poissons. Mortalité sur les poissons à la côte do Malabar Mém. Soc. Nat. Sci. Nat. Cherbourg, 1875, 19, 233-245. 1875.1

Quelques mots sur la faune ichthyologique de la côte nord-est d'Australie et du détroit de Torres comparée à celle de la Nouvelle-Calédonie. Mém. Soc. Nat. Sci. Nat. Cherbourg, 1878, 3. sér. 21, 328-335.

1878.1

Les poissons et les oiseaux de haute mer. Caen, 1881. $8^{\circ}$. 1881.1

Notes ichthyologiques. Nouvelles espèces de poissons de mer observés ì Cherbourg. Mém. Soc. Nat. Sci. Nat. Cherbourg, 1884, 24, 313-316. 1884.1

_- Un poisson rare ì Cherbourg, le "cernier" [Polyprion cernium] Bull. Soc. Linn. Normandie, 1895, 4. sér.9, $46-48$.

1895.1

- Trois poissons rares it Cherbourg. Mém. Soc. Nat. Sci. Nat. CherDourg, 1900, 31, 219-224.

1900.1

Joubin, Louis. Note sur les ravages wausés chez les sardines par un crustacé parasite. C. R. Acad. Sei. Paris, 1888, 107, $842-844$.

1888.1

- Sur un copépode parasite des sardince. C. R. Acad. Sci. Paris, 1885, 107. $1177-1178$
- La vie dans les océans. Paris, 1912.1

Jouffroy, (Comte) Joseph de. Isit pêche et les lois économiques de la production. Bésançon, 1865. $8^{\circ}$. 1865.1

Joukowsky, $E$. Sur quelques affleurements nouveaux de roches tertiaires dans l'isthme de Panama. Mém. Soc. Phys. Hist. Nat. Genève, 1906, 35 . 155-178. 2 pls. \& 5 figs.

1906.1

Jourdain, Sylvain. Recherches sur la veine porte-rénale (chez les oiseaux, les reptiles, les batraciens et les poissons) Ann. Sci. Nat. (Zool.), 1859, 4. sér. 12, 134-188; 321-368. Also separate; Paris, 1860.103 p. 5 pls. $4^{\circ}$.

1859.1

Note sur l'appareil post-rénal hépatique de la baudroie (Lophius piscatorius I.) C. R. Mém. Soc. Biol. Paris 1860 (1861), 3. sér. 2, 149-150. L'Institut, 1861, 29, 228-229. 1861.1

Sur les filets pêcheurs de la baudroie (Lophius piscatorius L.) L'Institut, 1861, 29, 238-239. $\quad 1861.2$

Note sur un corps d'apparence glanduleuse observé dans la baudroie. C. R. Acad. Sci. Paris, $1863,56,598-599$.

1863.1

Note sur le système lymphatioue du Gadus morrhua. Ann. Sci. Nat. (Zool.), 1867, 5. sér. 8, 141-144.-Bull. Hebd. Assoc. Sci. France, 1867, 2, 350352 .

1867.1

- Sur la structure du coeur des poissons du genre Gadus. C. R. Acad. Sci. Paris, 1867, 64, 192-194. - Ann. Mag. Nat. Hist., 3. ser. 19, 225-226.

1867.2

Coup d'oil sur le système veineux et lymphatique de la raie bouclée [Raja clavata] Ann. Acad. La Rochelle 1866-67 (1868), no. 8, 21-34. pl. 1868.1

Recherches sur le système lymphatique du congre (Murana conger L. ) C. R. Acad. Sci. Paris, 1868, 67, 12641266. - Ann. Sci. Nat. (Zoot.), 1868, 5. sér. 10, 372-374. - Journ. Anat., 1869 , $3333-335$.

1868.2

Sur les appendices digitiformes des poissons du genre Trigla. Ann. Sci. Nat. Charente-Inférieure 1868-69 (1870), 9, 121-126. $\quad 1870.1$

Matériaux pour servir à l'histoire anatomique du poisson lune $(O r-$ thagoriscus mola) C. R. Acad. Sci. Paris; 1S71, 73, 1225-1229. 1871.1 
Matériaux pour servir à l'histoire du gymnètre épée (Gymnetrus gladius C. et V.) C. R. Acad. Sci. Paris, $1872,74,58-62$.

1872.1

- Recherches sur la trompe buecale de l'esturgeon. Paris, 1877. pl. $\mathrm{S}^{\circ}$

1877.1

L'appareil maxillo-mandibulaire de quelques poissons osseux. Rev. Sei. Nat., 1878, 7, 36-41. pl.

1878.1

De l'action de la eyclamine sur les poissons. Bull. Hebd. Assoc. Sci. Irance, 1878, 23, 157-158. 1878.2

- Sur les ammodytes des côtes de Ia Manche. Rev. Sci. Nat., 1879, 8 (2. sér. 1), 203-210.

1879.1

Sur les poissons du genre Lepadogaster des côtes de la Manche. Bull. Hebd. Assoc. Sci. France, 1879, 24, 2527.

1879.2

Sur le développement tardif des écailles chez les anguilles. Rev. Sci Nat., 1880, 2. sér. 2.

1880.1

-. Sur l'existence d'une circulation lymphatique chez les pleuronectes. C. R. Acad. Sci. Paris, 1880, 90, 14301432.

1880.2

- Sur l'anguille. C. R. Acad. Sci.

Paris, 1889, 109, 200-202.

1889.1

Jourdain, Sylvain, \& Friaut, $A$. Recherches anatomiques sur la trompe buccale de l'esturgeon. Bull. Soc. Sci. Nancy, 1877, 2. sér. 3, 116-121. 1877.1

Jourdan, Antoine Jacques Louis [1788-1848] Dictionnaire raisonné, étymologique, synonymique et polyglotte des termes usités dans les sciences naturelles. 2 vols. Paris, 1834. 8 1834.1

Jourdan, Claude. Des cestracions. Mém. Acad. Imp. Sci. Lyon, 1869-70, 17, 303-307.

1869.1

Jourdan, Etienne. Sur les organes du gout des poissons osseux. C. R. Acad. Sci. Paris, 1881, 92, 743-745.Ann. Mag. Nat. Hist., 5. ser. 7, 423425.

1881.1

Structure histologique des barbillons et des rayons libres du Peristedion cataphractum. Arch. Zool. Expér. Gén., 1890, 2. sér. 8, 603-616. pl. 1890.1

Jourdeuil, $E$. La truite, son histoire, ses habitudes, ses différentes modes de pêche. Dijon, 1872. 144 p. $8^{\circ}$.

1872.1
Jourdier, August. La pisciculture et la production des sangsues; avec une introduction par M. Coste. Paris, 1856. 30 figs. $16^{\circ}$. 1856.1

Jousset de Bellesme, Georges Louis Marie Félicien [1839 - ] De l'alimentation des poissons cultivés en étang. Pisciculture Pratique, 1897, 3, 33-37.

1897.1

New method of pond culture [translated by Dr. Tarleton H. Bean] 'Trans. Amer. Fisheries Soc. 1896 (1897). $69-87$.

1897.2

- De l'emploi des filtres en pisciculture, Pisciculture Pratique, 1899, 5. 1899.1

Culture du saumon (Salmo salar) C. R. Acad. Sci. Paris, 1901, 132, 272274.

1901.1

- La pisciculture en France de 1881 à 1900. Paris, 1909. 532 p. $8^{\circ} .1909 .1$

Jouy, Pierre Lowis. Description of a new species of Squalius (Squalius alicice) from Utah lake. Proc. U.S. Nat. Mus. $1881(1882), 4,19.1882 .1$

On cormorant fishing in Japan. Amer. Naturalist, 1888, 22, 1-3. 1888.1

Jouy, Pierre Louis, \& Jordan, David Starr. See Jordan \& Jouy.

Joynt, Ald. William L. Upon the salmon fishery and fishery laws of Ireland. Journ. Roy. Dublin Soc. 186062 (1862), 3, 181-183. 1862.1

Juday, Chancey. Fishes of Boulder county, Colorado. Univ. Colorado Stud., 1904, 2, 113-114. 1904.1

L I ist of fishes collected in Boulder county, Colorado, with description of a new species of Leuciscus [L. evermanni] Bull. Bureau Fisheries, 1905, 24, 223227. fig.

1905.1

_- The food of the trout of the Kern river region (In Evermann, B. WV. The golden trout of the southern high Sierras. Bull. Bureau Fisheries, 1906, 25, 43-49)

1906.1

Notes on lake T'ahoe, its trout and trout-fishing. Bull. Bureau Fisheries, $1907,26,133-146$.

1907.1

- A study of 'Twin lakes, Colorado, with especial consideration of the food of the trouts. Bull. Bureau Hisheries, $1907,26,147-178$. pl. . 1907.2 
Juday, Chancey, \& Birge, Edward A. See Birge \& Juday.

Juday, Chancey, \& Wagner, George. Dissolved oxygen as a factor in the distribution of fishes. Trans. Wisconsin Acad. Sci., 1908, 16, pt. 1, 17-22. 1908.1

Juel, (Lieut.) Niels. Fra Opsynschefen ved Lofotfiskeriet. Lofotfiskereit, Kristiana, 1880.

1880.1

The Loffoden fishery in 1880 . Rept. U. S. Fish Comm. 1881 (1884), 9, 533-610.

1884.1

Jüngling, Reinhold. Einiges über den Diamantbarsch und seine Zucht. Wochenschr. Aquar.-Terrar. Kunde, 1909, 6. Jahrg., 693-694. fig. 1909.1

Jürgens, W. Zur Fortpflanzung von Callichthys punctatus. Blätt. Aquar.Terrar. Freunde, 1900, 11. Jahrg., $217-$ 219.

1900.1

- Der Kalikobarsch (Pomoxis saproides) im Aquarium. Blätt. Aquar.Terrar. Freunde, 1901, 12. Jahrg., 287 289.

1901.1

- Der Pfeilschnabel (Mastacembelus) Blätt. Aquar.-Terrar. Kunde, 1904, 15. Jahrg., 248-250.

1904.1

- Ueber die Fortpflanzung des Callichthys punctatus. Wochenschr. Aquar.-'Terrar. Kunde, 1906, 3. Jahrg., 368-371. fig.

1906.1

- Zur Fortpflanzung von Callichthys punctatus. Blätt. Aquar-Terrar. Kunde, 1909, 20. Jahrg., 265-266.

1909.1

_Phractoloemus ansorgii Boulenger. Blätt. Aquar.-Terrar. Kunde, 1910, 21. Jahrg., 129-131. 4 figs.

1910.1

Neigt das Bachneunauge zum Parasitismus? Blätt. Aquar--Terrar. Kunde, 1911, 22. Jahrg., 624-625; 695696. fig.

1911.1

Jürgens, $W ., \&$ Köhler, Walther. Drei merkwürdige fische von der $\mathrm{Ni}$ germündung. Blatt. Aquar.-Terrar. Kunde, 1906, 17. Jahrg., 395-398; 403404; 415-418.

1906.1

Jürss, Heinrich. Die Kampffische. Wochenschr. Aquar.-Terrar. Kunde, 1911, 8. Jahrg., 489-490. 2 figs. 1911.1

Ostindische Cypriniden. Wochenschr. Aquar--Terrar. Kunde, 1911, 8. Jahrg, 417-420. 6 figs. 1911.2
Parosphromenus deissneri Blkr. Wochenschr. Aquar-Terrar. Kunde, 1912, 9. Jahrg., 1-2. fig. 1912.1

-_ Ueber Haltung und Pflege von Petersius spilopterus Boulenger. Wochenschr. Aquar.-Terrar. Kunde, 1913, 10. Jahrg., 229-230. fig.

1913.1

- Zur Metamorphose der Jungfische. Wochenschr. Aquar.-Terrar. Kunde, 1913, 10. Jahrg., 682-683. 5 figs.

1913.2

Juge, M. Recherches sur les nerfs cérébraux et la musculature céphalique de Silurus glanis. Rev. Suisse Kool. Genève, 1899, 6, 1-171. 3 pls. 1899.1

Juillerat, Eugène. Note sur un lophobranche du genre Colonotus $[C$. vaillantii] Bull. Soc. Philom. Paris 1879-80 (1880), 7. sér. 4, 176. 1880.1

- Etude sur la saumon de Californie en eau close et apercu sur son élevage. Bull. Soc. Acclim. Paris, 1905, 52, 305-309.

1905.1

Jukes, Joseph Beete [1811-1869] Excursions in Newfoundland, with an account of the cod fishery, fog-banks, sealing expeditions and a geological survey of the island. London, 1853. $8^{\circ}$. 1853.1

Jukes-Browne, Alfred Joseph [18511914] On the zones of the Upper Chalk in Suffolk. Proc. Geol. Assoc., London, 1903, 18, 85-94. map.

1903.1

The Cretaceous rocks of Great Britain. III. The Upper Chalk of England. Mem. Geol. Surv. United Kingdom, London, $1904 . \quad \mathrm{x}, 566$ p. 1904.1

Contains references to fossil fishes.

Julin, Charles. Le système nerveux grand-sympathique de l'Ammocoetes (Petromyzon planeri) Arch. Zool. Expér. Gén., 1886, 6, no. 3, 46-47. - Anat. Anz., 1887, 2. Jahrg., 501. 1886.1

De la signification morphologique de l'epiphyse (glande pinéale) des vertébrés. I. L'epiphysse des poissons. Structure et développement. Bull. Sci. France \& Belge, 1887, 2. sér. 10, 55-65.

1887.1

De la valeur morphologique du nerf latéral du Petromyzon. Bull. Acad. Sci. Belgique, 1887, 3. sér. 13, 300-309.

1887.2

Des origines de l'aorte et des carotides chez les poissons cyclostomes. Anat. Anz., 1887, 2. Jahrg., 228-238. 4 figs. 
Les deux premières fentes branchiales des poissons cyclostomes, sontelles homologues respectivement à l' évent et à la fente hyobranchiale des sélaciens? Communication préliminaire. Bull. Acad. Sci. Belgique, 1887 , 3. sér. 13, 275-291. pl.

1887.4

Quelle est la valeur morphologique du corps thyroide des vertébrés? Communication préliminaire. Bull. Acad. Sci. Belgique, 1887, 3. sér. 13, 293-300.

1887.5

- Recherches sur l'anatomie de l'Ammocoetes. Bull. Sci. France it Belgique, 1887, 18 (2. sér. 10), 265-295. pl.

1887.6

Le système nerveux grandsympathique de l'Ammocoetes (Petromyzon planeri) Communication préliminaire. Anat. Anz., 1887, 2. Jahrg., 192201.

1887.7

Sur l'appareil vasculaire et le système nerveux périphérique de l'Ammocoetes; réponse à M. le Dr. Dohrn. Zool. Anz., 1888, 11, 567-568. 1888.1

Recherches sur la morphologie de l'Ammocoetes. Bull. Sci. France \& Belgique, 1889, 19 (3. sér. 1), 281-282.

1889.1

Julin, Johan. Bref till Hr. Prof. Bergius. Laik. Naturf., 1787, 8, 378381.

1787.1

Fortsättning af väderleks journalen som blifvit hållen uti Uleåborg, ifrån och med år 1776 till och med år 1787. K. Vet. Akad. Handl., Stockholm, 1789, 10, 179-195.

1789.1

Bref till $\mathrm{Hr}$. Intendenten $\mathrm{Fi}-$ scherström om de uti Oesterbotten, särdeles omkring Uleåborg samlade naturalier. Ny Journ. Hushålln., 1792, 15, $28-34 ; 55-73 ; 105-134$.

1792.1

Förteckning på några uti Oesterbotten, särdeles omkring Uleåborg samlade naturalier med anmärkningar. Ny Journ. Hushålln., 1800, 19, 103-118.

1800.1

Jullien, Jules [-1897] Remarques sur le vol des poissons appartenant au genre Exocète. Bull. Soc. Zool. France, 1878, 3, 109-112.

1878.1

Jungersen, Hector Frederik Estrup. Eine Berichtigung ru W. Haacke: Ueber eine neue Art uterinaler Brutpflege bei Wirbelthieren] Zool. Anz. $1885,8,560-561$.
Beiträge zur Kenntniss der Entwickelung der Geschlechtsorgane bei den Knochenfischen. Arb. Instit. Würzburg, 1889, 9, 89-219. 2 pls. - Vidensk. Meddel. Naturh. Foren. 1889 (1890), 101-237. Also separate; Kjobenhavn, 1889. $144 \mathrm{p}$.

1889.1

- Die Embryonalniere von Amia calva. 'Lool. Anz., 1894, 17, 246-252. figs.

1894.1

Om embryonalnyren hos storen (Acipenser sturio) Vidensk. Meddel. Naturh. Foren. 1893 (1894), 188-203. - Lool. Anz, 1893, 16. Jahrg. 464467 ; 469-472. Also separate; Kjobenhavn, $1894.8^{\circ}$. 1894.2

[Critique of] "Ueber die Embryonalniere von Calamoichthys calabaricus (Smith)" von J. Lebedinsky. Zool. Centralbl., 1895, 2, 54-59. 1895.1

—_ Fra "Ingolf-expeditionen." Bemærkninger om dybhavsfaunaen og dens fordeling i de nordlige Have. Efter et foredrag holdt 5te Jan. 1897 i det kgl. danske geogr. Selskab. Geogr. Tidsskr., Kjobenhavn, 1898, 14, 36-44.

1898.1

- Om appendices genitales hos havkalen, Somniosus microcephalus Bl. Schn., og andre selachier. Danske Ingolf-Exped. Kjobenhavn, 1898, 2, no. 2, 1-84. pls. \& figs.

1898.2

Ueber die Bauchflossenanhänge (Copulationsorgane) der Selachiermännchen. Anat. Anz., 1898, 14, 498-513. 16 figs. 1898.3

Fra den danske Ingolf-expedition: bemærkninger om Udbredelsen af Dybets Dyreverden i de nordlige Have. Frohandl. 15 Skand. Naturfor. Stockholm 1898 (1899), 271-274. 1899.1

Ueber die Urogenitalorgane von Polypterus und Amia. Zool. Anz., 1900, 23, 328-334.

1900.1

Ved forelæggelsen af to Hefter af Værket om Ingolf-expeditionen. Overs. Danske Vidensk. Selsk. Forh., $1905,127-135$.

1905.1

Ichthyolotomical contributions. Danske Vidensk. Skrift. Naturv., 19081910.

1908.1

i. The structure of the genera Amphisile and Centriscus, Danske Vidensk. Skrift. Naturv., 1908,7 . ser. 6, 41-109. 2 pls. \& 33 figs.

ii. The structure of the Aulostomidx, Syngnathidre and Solenostomidx. Ibid., 1910, 7. ser. 8, 268-364. 7 pls. \& fig. 
Jungersen, $H, F, E$.

On the osteology of the Lophobranchii. Rept. Brit. Assoc. Adv. Sci. 79. meet., 1909, 503-504. 1909.1

Some noteworthy points concerning Pegasus and Solenostomus 'Text in Japanese] Dōbuts. Zasshi, Tokyo, 1910, 22, 471-476. 1910.1

Translation into Japanese of a letter to $\mathrm{S}$. Tanaka.

Junod, De la pisciculture naturelle et artificielle, ou de la reproduction et propagation du poisson dans les affluents des lacs et des rivières de la Suisse, spécialement dans l'Arnon. Lauzanne, 1854.15 p. $8^{\circ}$. 1854.1

Jurinac, A.E. [List of the fishes of Croatia] Rad Jugoslav Akad., 1887, $83,114-121$.

1887.1

Jurine, Louis [1751-1819] Mémoire sur quelques particularités de l'œil du thon (Scomber thynnus Linn.), et d'autres poissons. Mém. Soc. Phys. Hist. Nat. Genève, 1821, 1, 1-18. fig. 1821.1

Note sur les dents et la mastication des poissons appelés cyprins. Mém. Soc. Phys. Hist. Nat. Genève, 1821, 1 , 19-24. fig.
Histoire abrégée des poissons du lac Léman. Mém. Soc. Phys. Hist. Nat. Genève, 1825, 3, pt. 1, 133-235. - Bull. Sci. Nat. (Férussac), 13, 245-250. Also separate; Genève, 1825 . 102 p. 15 pls. $4^{\circ}$.

1825.1

Jurinskiǐ, $T$. Uebersicht der phänologischen Frïhjahrserscheinungen in Ostsibirien in den Jahren 1905 und 1906. [Text in Russian] Izv. Vost. Sib. Otd. Russ. Geogr. Obšč., Irkutsk, 1909, 38, $32-63$.

1909.1

Juselius, — Fiskevägen genom saarikoski fors i Kiurwesi socken. Teckniska Föreningens i Finland Forh. Helsingfors, 1905, 25. Jahrg., 219-22'2.

1905.1

Jussieu, Adrien de, Beudant, $F$.S., \& Edwards, $H$. Milne. See Beudant, Edwards \& Jussieu.

Justander, Johan Gustaf. Specimen calendarii floræ et faunæ Aboensis. Inaug. Dissert., Abo, 1786, 20 p. $4^{\circ}$.

Carl Niclas Hellenius, proses.

1786.1

Juvelius, $E r$. Om Nejnögons fisket i Oesterbotten. Tidn. Sällsk, Abo, 1772, no. $20,158-160 ;$ no. $21,160-165$. Also separate; Stockholm, 1772. 8 p. $8^{\circ}$.

1772.1 
K., - Fish devoured by snails. Longevity of the stickleback. Zoologist, $1861,19,7400$.

1861.1

K., (Baron) von. Fish-culture as a means of improving the race of fish. Bull. U. S. Fish Comm. 1S85, 5, 289-291.

1885.1

K., C.A. Concerning eels, Forest \& Stream, 1879, 12, 463 .

1879.1

K., $J . N$. Fish planting in Massachusetts. Forest \& Stream, 1878, 11. 399.

1878.1

K. (junior), S. Alligator gar-fish. Forest \& Stream, 1877, 8, 82. 1877.1

K., W. Fish-culture in Mississippi. Forest \& Stream, 1878, 10, 318. 1878.1

-.-.-Moonstruck fish. Forest \& Stream, 1879, 11, 512. 1879.1

Kade, $G$. Ueber die devonischen Fischreste eines Diluvialblockes. Meseritz, 1858. pl. $4^{\circ}$. 1858.1

Kaensche, C.C. Beiträge zur Kenntniss der Metamorphose des Ammocotes branchialis in Petromyzon. Zool. Beitr. Breslau, 1890, 2, 219-250. 4 pls.

1890.1

Kässbohrer, Matthäus. Abnahme des Fischbestandes in der Donau. Cir. cul. Deutsch. Fischerei Ver., 1880, no. 6, 185-186.

1880.1

Kaestner, S. Doppelbildungen bei Wirbelthieren; ein Beitrag zur Casuistik. Arch. Anat. Physiol. (Anat. Abth.), 1898, 81-94. pl. \& 2 figs.

1898.1

Kahilainen, Wäinö. Amerikkalainen järvisampi eli-saita (Acipenser rubicundus) Suomen Urheilu Lehti, 1899, 2, 322-323. pl.

1899.1

- Rullavapa lannistaa jättiläiskalatkin. Suomen Urheilu Lehti, 1899, 2 , 182-186. 2 figs.

1899.2

Valtameren piru, jonka mr. Is. Diguet oli tuonut mukanaan Kalifornian lahdesta. Suomen Urheilu Lehti, 1899, 2, 187-189. fig
Kahlenberg, $I_{\text {s., }}$ \& Mehl, II ugo $l$. Giftwirkung von Electrolyten auf Fische. Chem. Centralbl., 1901, 1.

1901.1

Kaika, I., \& Fritsch, Anton. See Fritsch \& Kaika.

Kaiser, Emanuel. Clavias robecchi Vincig. Blätt. Aquar-Terrar. Kunde, 1910, 21. Jahrs., 245-246. fig. 1910.1

Etwas über die Familie der Loricaridx. Blätt. Aquar-Terrar. Kunde, 1910, 21. Jahrg., 161-163; 186187. 2 figs.

1910.2

- Pimelodus spec. und Pimelodus sapo Val. Blätt. Aquar.-Terrar. Kunde, 1910, 21. Jahrg., 213-214. 2 figs. 1910.3

Tetrodon cutcutia Hamb. Buch. Blätt. Aquar.-'Terrar. Kunde, 1911, 22. Jahrg., 497-499; 511-512. 2 figs. 1911.1

Kaiser, Paul. Die naturwissenschaftlichen Schriften der Hildegard von Bingen (In Programm des Konigstädlischen Gymnasiums zu Berlin, Ostern, 1901) 1901.1

Kalberlah, $F$. Ueber das Rückenmark der Plagiostomen. Ein Beitrag zur vergleichenden Anatomie des Centralnervensystems. Zeitschr. Naturw., Stuttgart, 1900, 73, 1-40. pl. \& fig.

1900.1

Kallius, E. Endigungen motorischen Nerven in der Muskulatur der Wirbeltiere. Ergebnisse Anat. Entw. Gesch., $1897,6,26-43$.

1897.1

Kalm, Pehr (proses) [1715-1779] Tankar om sättet att rätt traktera historia naturalis. Inaug. Dissert., Abo, 1760. 23 p. $4^{\circ}$. 1760.1

Henrik Aulin, respond.

En resa til Norra America ... af Pehr Ḱalm...3 vols. Stockholm, 1753-1761.

1761.1

This is the editio princeps. There are various other editions, i.e. German; 1754-61; English, 1770-1771, 1772 \& 1812; Belgic, 2 vols. Utrecht, $17 \% 2$

Contains notes on the sturgeon fisheries of the Hudson, of the fisheries of Quebec and of the fishculture in olden time; also observations on poisonous fishes. 
Kalm, $P$.

- (proses) Enfaldiga tankar om nyttan som England kan hafva af sina nybyggen i Norra America. Inaug. Dissert., Abo, 1763. 22 p. $4^{\circ}$. 1763.1

Sven Gonovinius, respond.

Kaltenegger, $F$. Ueber die biologischen und technischen Bedingungen des Lebendtransportes von Fischen und anderen Wassertieren. Verh. Ges. Deutsch. Nat. Aerzte, 1906, 77, pt. 2, $111-115$.

1906.1

Kaluza, A ugust [1776-1836] Systematische Beschreibung der schlesischen Amphibien und Fische. Breslau, 1815. $8^{\circ}$.

1815.1

Kamada, Takezo. Experiments on herring fishery [Text in Japanese] Suisan Koshujo Shiken Hokoku, Tokyo, 1909, 5, 1-15.

1909.1

Kamenskil, Serghyei Nikolaevich. On a new species of Squalius (S. pinnomaculatus) [Text in Russian] Trudui Obshch. Kharkov. Univ., 1896, 30, 131 143. pl.

1896.1

On the presence of Gobius marmoratus Pall. in the government of Kharkov [Text in Russian] Trudui Obshch. Kharkov. Univ., 1896, 29, 139-147. pl.

1896.2

- On Caucasian ichthyology [Text in Russian] Trudui Obshch. Kharkov. Univ., 1897, 31, 77-99. 2 pls. 1897.1

- Die Cypriniden der Kaukasusländer und ihrer angrenzenden Meere [Text in Russian, with German résumé] 4 pts. Tiflit, $1899.8^{\circ}$.

1899.1

Lief. 1 contains 349 p. \& 12 pls. Lief, 2 contains 124 p. \& 6 pls. $8^{\circ}$.

Kammerer, Paul. Hängende Glaskugeln für Goldfische. Tierfreund, 1900 , 54 , no. 6 .

1900.1

- Die künstliche Fischzucht in Torbole. Blätt. Aquar.-Terrar. Kunde, 1900, 11. Jahrg., no. 24.

1900.2

Der Allensteiger See. Oesterr. Tiermarkt, Suppl. (Lotus-Mitteil.), 1901, 1 (Sept. 15)

1901.1

- Faunistische und biologische Skizzen von Pommerns Ostseeküste. Nerthus, Altona, 1901, 3, nos. 3-5.

1901.2

Ichthyologische Beobachtungen. Oesterr. Tiermarkt, Suppl. (LotusMitteil.), 1901, 1 (Oct. 15) 1901.3
Blennius vulgaris. Blätt. Aquar.Terrar. Kunde, 1903, 13. Jahrg., no. 17. 1903.1

- Das Bachneunauge, Petromyzon planeri Bloch. Wochenschr. Aquar.'Terrar. Kunde, 1905, 2. Jahrg., 263-265.

1905.1

Donaubarsche. Blätt. Aquar.Terrar. Kunde, 1905, 16, 321-324; 333334 ; 344-346; 353-355; 368-369. Ibid., $1908,19,97-100 ; \quad 111-115 ; \quad 122-126$; $133-135 ; 145-148 ; 159-163 ; 173-176$; $185-188 ; 197-200 ; 211-214 ; 261-266$; $284-286 ; 297-301 ; 315-317 . \quad p l$.

1905.2

Beiträge zur Oekologie, Anatomie und Phylogenie der elektrischen Fische. I. Oekologische Beobachtungen am Zitterwels (Malapterurus electricus (Gmel.) Lacép.) II. Die Zitterrochen (Torpedinix) nebst allgemeinen Bemerkungen über die Lebensweise elektrischer Fische. III. Die Schnabelfische (Mormyridx) . . Blätt. Aquar-Terrar. Kunde, 1906, 17. Jahrg., 41-44; 53-55; $61-63 ; 73-76 ; 144-147 ; 156-159 ; 166-$ 167.

1906.1

- Das Gefangenleben der Aalquappe (Lota lota Linné) Blätt. Aquar.Terrar. Kunde, 1906, 17. Jahrg., 443$445 ; 455$.

1906.2

Eine Naturforscherfahrt durch Aegypten und den Sudan. Wochenschr. Aquar.-Terrar. Kunde, 1906, 3. Jahrg. Also separate; Braunschweig, 1906.

1906.3

Auffütterung von Barschbrut aus dem Ei. Fischerei Zeitg., 1907, 10, no. 20 . 1907.1

- Bastardierung von Flussbarsch (Perca fluviatilis L.) und Kaulbarsch (Acerina cernua L.) Arch. Entw.Mech., Leipzig, 1907, 23, 511-551. 2 pls. \& fig. 1907.2

Der Donauwels (Waller, Schaiden; Silurus glanis L.) Blätt. Aquar.Terrar. Kunde, 1907, 18. Jahrg., no. 50. 1907.3

Die Flussgroppe (Kaulkopf, Koppen, Kotzen; Cottus gobio L.) Blätt. Aquar.-Terrar. Kunde, 1907, 18. Jahrg., no. 49 .

1907.4

Regulationserscheinungen bei Reptilien, Amphibien und Fischen. Blätt. Aquar.-Terrar. Kunde, 1907, 18. Jahrg., no. 16. 1907.5 - Sieben Tage an den Versuchsteichen bei Frauenberg. Oesterr. Fi- 
scherei Zeitg., 1907, 4, nos. 6-10.-Mitth. Teichwirtsch. Versuchsstat. Frauenberg, Böhmen, 1.

1907.6

Der Sterlett (Acipenser ruthemus L.) Blätt. Aquar-T'errar. Kunde, 1907, 18. Jahrg., no. 18.

1907.7

- Süsswasserfische in Salzwasser und anderen abnormalen Wasserzusammensetzungen. Blätt. Aquar-Terrar. Kunde, 1907, 18. Jahrg., no. 36. 1907.8

- Zweiter Aufenthalt in Frauenberg. Oesterr. Fischerei Zeitg., 1907, 4, nos. 17-19.

1907.9

Fische aus dem Gardasee. Wochenschr. Aquar-'Terrar. Kunde, 1908, 5. Jahrg., 107-108; 130-132; 157-159. 3 figs.

1908.1

Iische im Seewasseraquarium und ihre Gewöhnung an Süsswasser. Blätt. Aquar.-Terrar. Kunde, 1909, 20. Jahrg., 123; 166-168; 179-182. 1909.1

_- Unsere einheimischen Süsswasserfische. Einzelne Beobachtungen an Schleihe, Karausche, Orfe, Plötze, Moderlieschen und Gründling. Blätt. Aquar.-Terrar. Kunde, 1909, 20. Jahrg. 513-517. 6 figs.

1909.2

_- Zucht des Gardasee-Weissfisches (Leuciscus alburnellus Poll.) im Aquarium. Blätt. Aquar.-Terrar. Kunde, 1909, 20. Jahrg., 525-531. fig. 1909.3

Vererbungsversuche bei Fischen. Oesterr. Fischerei Zeitg., 1910, 7, no. 23.

1910.1

Was kann das Fischereiwesen von den Einrichtungen eines wissenschaftlichbiologischen Institutes lernen? Deutsch. Fischerei Korresp., 1910, 14 (Nov.) - Mitth. Mähr. Land. Fischerei Ver., 1911, 20, nos. 2-3.

1910.2

Das Riechen der Fische. Wochenschr. Aquar--Terrar. Kunde, 1911, 8. Jahrg., $45-47$.

1911.1

Kamon, $K$. Ueber die "Geruchsknospen" [der Fische] Arch. Mikr. Anat., 1904, 64, 653-664. 1904.1

Kampen, $P . N$. van. Galeocerdo fasciatus, n. sp., aus dem indischen Archipel. Bull. Dépt. Agric. IndesNéerl., 1907, 8, 9-12.

1907.1

Ueber zwei Scomber-Arten des indischen Archipels. Bull. Dépt. Agric. Indes-Néerl., 1907, 8, 1-8. pl. 1907.2
IIurze Notizen über Fische des Java-Meeres. I. Histiophorida von Batavia. II. Die Nahrung von Rhinodon typicus Smith. Natuurk. 'Tijdschr. Néerl.-Indie 1907 (1908), 67, 120-124. 1908.1

Overzicht der hulpmiddelen bij de zeevisscherij van Java en Madoera in gebruik. Batavia Meded. Visscherijstation, 1908, 1, 1-32.

1908.2

Aanteckeningen omtrent de visscherij van Sumatra en Riouw [Bermerkungen über die Fischerei von Sumatra und Riouw] Meded. Dept. Landbourd, 1909, 3, 1-29.

1909.1

- De hulpmiddelen der seevisscherij, op Java en Madoera in gebruik. Meded. Dept. Landbourd, 1909, no. 9, 1-116. 19 pls.

1909.2

Kurze Notizen über Fische des Java-Meeres. III. Die Larve von Megalops cyprinoides Brouss. Bull. Dépt. Agric. Indes-Néerl. 1908 (1909), 20, $10-12$.

1909.3

— Kurze Notizen über Fische des Java-Meeres. IV. Mobulidx aus der Java-See. V. Brutpflege von Arius sagor [etc.] Bull. Dépt. Agric. IndesNéerl., 1910, 35, 9-13.

1910.1

Kampen, $P . N$. van, \& Roosendaal, A. M. van. See Roosendaal \& Kampen.

Kane, $D . P$. Statement concerning the menhaden fishery. Rept. U. S. Fish Comm. 1877 (1879), 5, 483. $\quad 1879.1$

Kantorowicz, $R$. Ueber Bau und Entwicklung des Spiraldarms der Selachier. Zeitschr. Naturw., 1897, 70, 337-364. 4 pls. \& 3 figs. 1897.1

Kapelikin, $V$. Der histologische Bau der Haut von Petromyzon. Bull. Soc. Nat. Moscou 1896 (1897), 481-514. 2 pls. Abstract in Journ. Roy. Micr. Soc., 1897 , pt. 1, 64-65.

1897.1

- Zur Frage über die Färbung der Fische [Text in Russian] Psov. Ružejn. Ochota, Moskva, 1904, pt. 11, 66-69.

1904.1

Die biologische Bedeutung der Silberglanzes der Fischschuppen I'Text in Russian] Jestestv. Geogr., Moskva, 1905, pt. 1, 61-65. - Biol. Centralbl., $1907,27,252-256$.

1905.1

Kappers, Cornelius Ubbo Ariëns. Die Bahnen und Zentren im Gehirn der Teleostier und Selachier [Text in Dutch] Amsterdam, 1904. 194 p. 7 pls. $8^{\circ}$. 
Kappers, $C \cdot U \cdot A$.

The structure of the teleostean and selachian brain. Journ. Comp. Veurol., 1906, 16, 1-112. 16 pls. 1906.1

Untersuchungen über das Gehirn der Ganoiden Amia calva und Lepidosteus osseus. Abh. Senckenb. Naturf. Ges. Frankfurt-a.-M., 1907, 30, 447-500. pl. \& 6 figs.

1907.1

Eversion and inversion of the dorso-lateral wall in different parts of the brain. Journ. Comp. Neurol., 1908, 18, 433-436. 5 figs.

1908.1

Deals with brain-structure of teleosts.

Weitere Mitteilungen über die Phylogenese des Corpus striatum und des Thalamus. Anat. Anz., 1908, 33, 321-336. 6 figs.

1908.2

Weitere Mitteilungen über Neurobiotaxis. II. Die phylogenetische Entwicklung des horizontalen Schenkels des Facialiswurzelknies. Folia NeuroBiol., 1908, 2, 255-261. 2 figs. 1908.3

- Inurze Skizze der phylogenetischen Entwicklung der Oktavus- und Lateralisbahnen mit Berücksichtigung der neuesten Ergebnisse. Zentralbl. Physiol., 1909, 23, 545-55t. 1909.1

Die Furchen am Vorderhirn einiger 'leleostier, nebst Diskussion ủber den allgemeinen Bauplan des Vertebratenhirns und dessen Kommissursysteme. Anat. Anz., 1911, 40, 1-18. 7 figs.

1911.1

De rangschikking van de motorische kernen in de oblongata en middenhersenen van Chimera monstrosa vergeleken bij die van andere visschen The arrangement of the motor nuclei in Chimcera monstrosa compared with other fishes] Versl. Akad. Wet. Amsterdam, Wis. Nat. Afd., 1912, 20, 1141-1148. Proc. Akad. Wet. Amsterdam, 14, 11761180. 3 figs. 1912.1

- De oculomotorius- en trochleariskernen bij lagere vertebraten. Werk. Gen. Nat. Geneesk. Heelkunde Amsterdam, 1913, 2. ser. 7, 135-138. 1913.1

Kappers, Cornelius Ubbo Ariëns, \& Carpentier, F. W. Das Gehirn von Chimara monstrosa. Folia Nuero-Biol., $1911,5,127-160$.

1911.1

Kappers, Cornelius Ubbo Ariëns, \& Theunissen, $W . F$. Zur vergleichenden Anatomie des Vorderhirnes der Vertebraten. Anat. Anz., 1907, 30, 496-509. 1907.1
Kappler, August [1815-1887] Some semi-popular notes on the fishes of Dutch Guiana [Text in German] Ausland, 1885, 879-880; 896-899; 918-920; 936-938.

1885.1

Karakash, Nikolai Ivanovich. Le Crétacé inférieur de la Crimée et sa faune [Text in Russian] Trav. Soc. Nat. St. Pétersb. (Geol.), 1907, 32, pt. 5 , 1-482. $28 \mathrm{pls}$.

1907.1

Karl, Johann. See Käroli, János, formerly Karl.

Karny, G. Einiges über Hechtenfang. Oesterr.-ungar. Fischerei Zeitg., 1880 . $321-322$.

1880.1

Károli, János [-1882] A Duna halóriásai. 'Természet. Füzetek, 1. Fuizet, $1877,12-16 ; 2$. Füzet, 1877, 77-81. [Résumé in German] Die Fischriesen der Donau. Ibid., 1877, p. 51; 119-126. 1877.1

- A magyar halfauna egy új faja. 'Természet. Füzetek, 1. Füizet, 1877 , p. 16 .

1877.2

Catalogus piscium Hungaria. Budae, 1879. $8^{\circ}$ 1879.1

Prodromus piscium Asix orientalis a Domino Joanne Xantus annis 1868-70 collectorum. 'Természet. Füzetek, 5. Fiizet, 1882, 147-187. Also separate; Budapest, 1882. $8^{\circ}$. 1882.1

Karpinskii, Aleksandr Petrovich [1846 - ] Osztucznem rozmnazaniu ryb. Varszava, 1874. 35 p. $8^{\circ}$ 1874.1

Ueber die Reste von Edestiden und die neue Gattung Helicoprion [Text in Russian] Mém. Acad. Sci. St. Pétersb. 1899, 8. sér. 8, no. 7. - Verh. Russ. Mineral. Ges. St. Petersb., 2. ser. 36, $361-475$.

1899.1

Ueber das Auftreten der Gattung Campodus de Koninck in den artinskischen Ablagerungen Russlands [Text in Russian] Verh. Russ. Mineral. Ges. St. Petersb., 1904, 2. ser.41, 32-37. 5 figs.

1904.1

Notes sur l'Helicoprion et les autres édestides [Text in Russian] Bull. Acad. Sci. St. Pétersb. 1911, 1105-1122. 1911.1

- On Helicoprion and other Edestide. Verh. Russ. Mineral. Ges. St. Petersb., 1912, 2. ser. 49, 69-94. 6 figs. 1912.1 
- Notice sur la nature de l'organe hélicoidal du Helicoprion. Bull. Soc. Oural. Sci. Nat. Ekatérinebourg, 1915, 35, 117-145. pl. \& figs.

1915.1

Preliminary communication on a new species of Helicoprion, $H$. clerci] [ Text in Russian] Bull. Acad. Imp. Sci. St. Pétersb., 1916, 10, 701-708. figs.

1916.1

Karpinsky, Aleksandr Petrovich. See Karpinskil, A. P.

Karr, Alphonse. Dictionnaire du pêcheur. 'Traité complet de la pêche en eau douce et en eau saléc. Paris, 1855. iv, $336 \mathrm{p} .12^{\circ}$.

1855.1

… J Ja pêche en eau douce et en eau salée; histoire, moeurs, habitudes des poissons, crustacés, testacés, etc.; lois, usages, procédés, ruses et secrets des pêcheurs, suivi du dictionnaire du pêcheur. Paris, 1560. 12 ${ }^{\circ}$ 1860.1

\section{Karsten, __, Weber, _ \& Nuss- baum, - Sce Nussbaum, Karsten \& Weber.}

Karsten, Gustav [1820-1900] On the scientific investigation of the Baltic and the German ocean. Rept. U. S. Fish Comm. 1878 (1880), 6, 283-294. 1880.1

'The physical condition of the Baltic and the North sea, from investigations of the commission for the scientific examination of the German seas. Rept. U. S. Fish Comm. 1879 (1882), 7, 525-533.

1882.1

Kasanzeff, W. Ueber die Entstehung des Hautpanzers bei Syngnathus acus. Lool. Anz., 1906, 30, 8.54-861. 6 figs.

1906.1

Kaschejev, S. S. Die Iischereigewerbliche Bedeutung des Kaspischen Meeres ['Text in Russian] Dnevn. Otd. Icht. Imp. R. Obsch. Acclimat., Moskva, 1901，3，96-102. Ibid., 4, 120-133. Ibid., 5, 172-177. Ibid., 6, 198-205.

1901.1

Kaschkaroff, D. Ueber die Epidermis bei Trachyptorus tania. Anat. Anz., $1913,44,214-218.3$ figs.

1913.1

Kasem-Beck,__ e Dogiel, Johann. Beitrag zur Kenntmiss der Struktur und der Funktion des Herzens der Kinochenfische. Zeitschr. Wiss. Zool., 1882, 37, $247-262.2 \mathrm{pls}$.

1882.1

Kaskarov, D. N. Das Skelet der siluroidei [Text in Russian] Trd.
Sravnit-Anatom. Instit. Univ. Moskva, 1907, 1-91. pl. 1907.1

Kasteliz, Raimund. Eine Abnormalität der Fluss-Barbe [Barbus fluviatilis] Oesterr-ungar. Fischerei Zeitg., 1880, $107-108$.

1880.1

- Der Forellenbach Wessnitz in Krain. Oesterr.-ungar. Fischerei Zeitg. $1880,288$. 1880.2

Kastschenko, $N$. Zur Entwicklungsgeschichte des Selachierembryos. Anat. Anz., 1888, 3. Jahrg., 445-467.

1888.1

Zur Frage über die Herkunft der Dotterkerne im Selachierei. Anat. Anz., 1888, 3. Jahrg., 253-257. pl.

1888.2

Ueber den Reifungsprocess des Selachiereies, Zeitschr. Wiss. Zool., $1890,50,428-442$. pl. $\quad 1890.1$

'Lur frühesten Entwickelung besonders der Muskeln der Elasmobranchier. Zool. Beiträge, 1890, 2, 251-266. pl.

1890.2

Kathariner, L. Die Gattung Gyrodactylus v. Nordmann. Arb. Zool. Instit. Würzburg, 1895, 10, 125-164. 2 pls.

1895.1

In Kiemenschleime von Cyprinus brama und C. carpio gefunden, p. 152-155.

- Findet sich cine "Trägerfunction" der parigen Flossen nur bei den Dipnoern? Zool. Anz., 1S99, 22, 345346.

1899.1

Kató, $H$. Ueber die peripherischen Endigungen des Nervus acusticus beim Leucopsarion petersi Hilgendorf. Folia Neurobiol., 1911, 5, 425-435. 1911.1

Kattendijke, J.L. Huyssen van. See Huyssen van Kattendijke, $J . L$.

Katuric, $M$. Cenni ittiologici-erpetologici. Zagreb, 1887. S $^{\circ}$ 1887.1 1891. Ranzania truncata Nardo. Zagreb,
1891.1

Ichtijološke-erpetološke bilješke. Glasnik Naravosl. Druzt., 1896, 8, 115 116.

1896.1

- Sull' Anquilla fluviatitis della Dalmazia. Zagreb, 1899. 1899.1

Lampris luna Linn. Rad Jugoslav. Akad., Zagreb, 1902, 149, 89-92.

1902.1

Novo nalazište jesetre atlantske, Acipenser sturio L. Rad Jugoslav. Akad., Zagreb, 1903, 154, 1-6. 1903.1 
Katuric, $M$.

Elenco dei corpi naturali finora raccolti. Museo Civico Storia Naturale Zara, 1907.

1907.1

Katzer, Friedrich [1861-] A fauna devonica do rio Maecurú e as suas relacões com a fauna de outros terrenos devonicos do globo. Bol. Mus. Paraense, 1897, 2, 204-246. map.

1897.1

Kaufmann, Ernst. Die künstliche Fischzucht. Zeitschr. Acclim., Berlin, $1859,2,162-220 ; 247-256$.

1859.1

Kaumann, - Zur Aalfrage. Circul. Deutsch. Fischerei Zeitg., 1878, 1. Jahrg., 214-215.

1878.1

Kaup, Johann Jacob [1803-1873] Beiträge zur Amphibiologie und Ichthyologie. Isis (Oken), 1826, 87-90. 1826.1

- Genus Narke. Arch. Anat. Physiol., 1826, 365. 1826.2

- Fall of fish [Clupea cultrata\} Journ. Asiat. Soc. Bengal, 1834, 3, 367.

1834.1

- Das Thierreich in seinen Hauptformen systematisch beschrieben. 3 vols. Darmstadt, 1835-37. 535 figs. $8^{\circ}$.

1835.1

Bd. iii, Teil 1. Naturgeschichte der Fische.

Uebersicht der Lophobranchier. Arch. Naturgesch., 1853,19 , pt. 1, 226234.

1853.1

Enchelynassa, neue Gattung aus der Familie der Aale. Arch. Naturgesch., 1855, 21, pt. 1, 213-214. pl. \& fig.

1855.1

Ueber die Synonymie von Symbranchus immaculatus Bl. Arch. Naturgesch., 1855, 21, pt. 1, 59-61. 1855.2

- Uebersicht über die Species ciniger Familien der Sclerodermen. Arch. Naturgesch., 1855, 21, pt. 1, 215233.

1855.3

Catalogue of the apodal fish in the collection of the British Museum. London, 1856. $19 \mathrm{pls} .8^{\circ}$. 1856.1

Catalogue of the lophobranchiate fish in the collection of the British Museum. London, $1856.4 \mathrm{pls} .12^{\circ}$.

1856.2

Einiges über die Unterfamilie Ophidinæ. Arch. Naturgesch., 1856, 22, pt. 1, 93-100.

1856.3

Ueber die Gattung Echiodon.

Verh. Phys.-Med. Ges. Würzburg, 1856

7, pt. 2, 233-234.
- Ueber die Schwimmblasen von Carapus incequilabiatus Val. Arch. Naturgesch., 1856, 22, pt. 1, 88-92. pl. \& 2 figs.

1856.5

- Uebersicht der Aale. Arch. Naturgesch., 1856, 22, pt. 1, 41-77.

1856.6

Uebersicht der Gymnotidæ. Arch. Naturgesch., 1856, 22, pt. 1, 78 87. pl. \& 10 figs.

1856.7

- Einiges über die Acanthopterygiens à joue cuirassée Cuv. Arch. Naturgesch., 1858, 24, pt. 1, 329-343.

1858.1

On Nemiphos, a new genus of riband-shaped fishes. Proc. Zool. Soc. London, 1858, pt. 26, 168-169. - Ann. Mag. Nat. Hist., 3. ser. 2, 301-303.

1858.2

Uebersicht der Familie Gadidx. Arch. Naturgesch., 1858, 24, pt. 1, 8593.

1858.3

Uebersicht der Plagusinæ, der fünften Subfamilie der Pleuronectidæ. Arch. Naturgesch., 1858, 24, pt. 1, 105110.

1858.4

- Uebersicht der Soleina, der vierten Subfamilie der Pleuronectidæ. Arch. Naturgesch., 1858, 24, pt. 1, 94104.

1858.5

- Description of a new species of fish, Peristethus rieffeli. Proc. Zool. Soc. London, 1859, pt. 27, 103-107. pl. Ann. Mag. Nat. Hist., 1859, 3. ser. 5, 64-68.

1859.1

- Anabas trifoliatus n. sp. Arch. Naturgesch., 1860, 26, pt. 1, 124-128. pl. \& fig.

1860.1

Hoplarchus, neues Genus der Familie Labridx. Arch. Naturgesch., 1860, 26, pt. 1, 128-133.

1860.2

Neue aalähnliche Fische des Hamburger Museums. Abh. Naturr. Verein Hamburg 1859 (1860), 4, Abth. 2. $35 \mathrm{p}$.

1860.3

On some new genera and species of fishes collected by Drs. Keferstein and Heckel at Messina. Ann. Mag. Nat. Hist., 1860, 3. ser. 6, 270-273. pl. 1860.4

Ueber die Chxtodontidæ. Arch. Naturgesch., 1860, 26, pt. 1, 133-156. 1860.5

Ueber eine neue art Trigla $\boldsymbol{T}$. armata ${ }_{1}$ aus China. Arch. Naturgesch. 1860,26 , pt. 1, 17-23. 1860.6 
Eine neue Art des Genus Pegasus Linn. [P. lancifer] Arch. Naturgesch., 1861, 27, pt. 1, 116-117.

1861.1

Eine neue Art von Spatularia [S. (Polyodon) angustifolium] Arch. Naturgesch., 1862, 28, pt. 1, 278-281.

1862.1

- Bemerkungen über Caprodon, Serranus octocinctus, etc. Nederl. Tijdschr. Dierk., 1863, 1, 19-23. 1863.1

Ueber cinige Arten der Gattung Chrtodon. Nederl. Tijdschr. Dierk., $1863,1,125-129$.

1863.2

Ueber einige Japanische Fische. Nederl. Tijdschr. Dierk, 1863, 1, 161162.

1863.3

- Ueber die Familie Triglidæ nebst einigen Worten über die Classification. Arch. Naturgesch., 1873, 39, pt. 1, $71-94$.

1873.1

Kavraiskil, Theodor Theodorovich [1866 - ] Lists and descriptions of the specimens preserved in the zoological museum of the Imperial University of Moscow. Section 1, no. 2. Lists and descriptions of the collection of fishes in the museum [Text in Russian] Nachr. k. Ges. Liebhaber Naturk. Moskau, 1893, 56. $50 \mathrm{p}$.

1893.1

- Die Lachse der Kaukasusländer und ihrer angrenzenden Meere. 2 pts. Tiflis, 1896-97. 170 p. 14 pls. $8^{\circ}$.

1896.1

- Bemerkungen über kaukasische Fische. II. Die kaukasischen UckleiArten. Genus Alburnus [Text in Russian] Mitt. Kaukas. Mus. Tiflis, 1897. 1. $20 \mathrm{p}$.

1897.1

- Schlussresultat über die Untersuchungen von Salmo trutta caspius Kessl., S. trutta L., S. lacustris und $S$. trutta fario L. Radde's "Sammlungen des Kaukasischen Museums" (Zool.), 1899, 1, 327-328.

1899.1

- Rechenschaftbericht über die Abcommandirung zur Untersuchung des Kura-Flusses und der Seen in den Gouvernements Tiflis und Kars [Text in Russian] Věst. Rybopromyšl., St. Pétersb., 1901, pts. 8, 9, \& 10. 1901.1

__. Die Störarten der Kaukasusländer und ihrer angrenzenden Meere [Text in Russian and German] Tiflis, 1907. xii, 78 p. 14 pls. $8^{\circ}$. 1907.1

The final portion of this work is thus indicated: "Lieferung 5 und Schluss des Werkes: Die Fische des Kaukasus."
- Beiträge zur Kenntniss der Laichverhältnisse der lische in den Jahren 1910-11 nach den Beobachtungen des Ichthyologischen Laboratoriums [Russian text with German résumé] Arb. Ichth. Laboriums Astrachan 1912 (1913), 2. ser. 4, 39-54.

1913.1

Kavraiskii, Theodor Theodorovich, \& Zoghraff, $N . Y$. See Zoghraff \& Kavraiski.

Kawrajskij, $F . F$. See Kavraiskil, T.T.

Kaye, C.T., \& Egerton, (Sir) Philip de Malpas Grey. See Egerton \& Kaye.

Kayser, Friedrich Heinrich Emanuel [1845 - ] [Ueber Ctenacanthus aus den unterdevonischen Nereitenschichten Thüringens] Zeitschr. Deutsch. Geol. Ges., 1877, 29, 423-424. 1877.1

Ueber Dinichthys? eifelensis von Gerolstein. Zeitschr. Deutsch. Geol. Ges., 1880, 32, 817-818. $\quad 1880.1$

—_ [Ueber Macropetalichthys prümiensis] Zeitschr. Deutsch. Geol. Ges., $1880,32,677-678$.

1880.2

- Lehrbuch der geologischen Formationskunde. 5. ed. Stuttgart, 1913. 852 p. 97 pls. \& 190 figs. $\quad 1913.1$

This also bears the title: Lehrbuch der Geologie in zwei Teilen.

Contains frequent mention of fossil fishes.

Keene, John Harrington. The enemies of trout. Fishing Gazette, 1877 , n. s. 1,4 .

1877.1

- A chat about the grayling [Thymallus vulgaris! Fishing Gazette, 1878 , n. s. 2, 109-110. $\quad 1878.1$

___ Fish-culture and farming. Fishing Gazette, 1878, n. s. 2, 147. 1878.2 Gill fever in young fish. Fishing Gazette, 1878, n. s. 2, 171; 185.

1878.3

Methods of grayling fishing. Fishing Gazette, 1878, n. s. 2, 26. 1878.4

- Fish-fancying. Trout. Fishing Gazette, 1879, n. s. 3, 231. $\quad 1879.1$

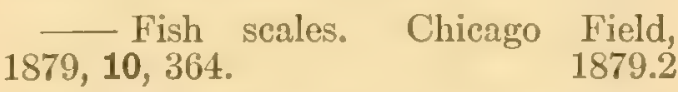

Food of salmon in sea and freshwater. Fishing Gazette, 1879, n. s. 3, 468.

1879.3

- The loves of the fishes. Sci. Gossip, 1879, 15, 125-127. 1879.4 
Keene, J. $H$.

Notes on the natural history of freshwater fishes. No. I. Pike. Fishing Gazette, 1879, n. s. 3, 561-562; 597598. - No. II. 'The Perch. Ibid., 1880, n. s. 4, 9-11. - No. III. The chub [Lenciscus cephalus] Ibid., 16-17. No. IV. The roach [Leuciscus mutilus] Ibid., 28-29; 79-80. - No. V. Rudd or red eye [Leuciscus erythrophthalmus] Ibid., p. 87. - No. VI. The dace [Leuciscus vulgaris] Ibid., p. 98. - No. VII. The dobule and blue roaches, the ide and graining [Leuciscus dobula, $L$. coruleus, idus, lancastriensis] Ibid., 287-288. - No. VIII. Bleak [Leuciscus alburnus] Ibid., 299-300. - No. IX. Bream IAbramis brama, blicca, briggenhagii] Ibid., 312. - No. X. The gudgeon [Gobio fluviatilis] Ibid., 432. No. XI. The carps. Ibid., 589; 600-601.

1879.5

-. Parasites on fish. Fishing Gazette, 1879, n. s. 3, 272. 1879.6

Curiosities of salmon history Fishing Gazette, 1880, n. s. 4, 470-471.

1880.1

The emotions of fishes. Fishing Gazette, 1880, n. s. 4, $110 . \quad 1880.2$

-... American fish culture. Fishing Gazette, 1881, 11. s. 5, 521-522. 1881.1

Miscellaneous notes. Fishing Gazette, 1881, n. s. 5, 288. $\quad 1881.2$

- The natural history of the eel. Fishing Gazette, 1881, n. s. 5, 137; 186187.

1881.3

Perch and perch fishing. Fishing Gazette, 1881, n. s. 5, 550-551.

1881.4

- The practical fisherman; dealing with the natural history, the legendary lore, the capture of British freshwater fish, and tackle and tackle making. London, 1881. iv, 481 p. illust. $8^{\circ}$.

1881.5

Osmund Lambert in his "Angling literature in England "says that this work" "cannot be too highly spoken of. It contains some of the most beautiful drawings of fish ever published."

- Some notes on coarse fishculture. Fishing Gazette, 1881, n. s. 5, $586-587 ; 637-638$.

1881.6

Keferstein, Wilhelm Moritz [18331570] Beitrag zur Geschichte der Physik der electrischen Fische. Nachrichten, Göttingen, 1859, 17-34.Untersuch. (Moleschott), 1859, 6, 158172.

1859.1
Ueber den feineren Bau der quergestreiften Muskeln von Petromyzon marinus. Arch. Anat. Physiol., 1859, $548-549$.

1859.2

Keferstein, Wilhelm Moritz, \& Bronn, Heinrich Georg. Die Klassen und Ordnungen des Thierreichs. See Bronn, $H . G_{.,}$\& Keferstein, W.

Keferstein, Wilhelm Moritz, \& Kupffer, Carl. Ueber den feineren Bau des electrischen Organs beim Zitter-Aal (Gymnotus electricus) Nachrichten, Göttingen, 1857, 253-268.

1857.1

Untersuchung über die electrischen Organe von Gymnotus electricus und Mormyrus oxyrhynchus. Zeitschr. Ration. Medicin (Henle \& Pfeufer), 1858, 2, 344-356.

1858.1

Kegel, - Besprechung der Fischerei-Austellung. Jahrb. Deutsch. Landwirthschaft. Ges., 1902, 17, 297-303.

1902.1

Kehrer, $F$. A. Zur Phylogenie des Beckens. Verh. Nat.-Med. Ver., Heidelberg, 1896, n. s. 5, 346-359. 2 pls.

Contains references to fishes.

1896.1

Keibel, Franz. Normentafeln zur Entwickelungsgeschichte der Wirbeltiere. Anat. Anz., 1896, 11, 225-234.

1896.1

Das biogenetische Grundgesetz und die Cenogenese. Ergebnisse Anat. Entw.-Ges., 1898, 7, 722-792. 1898.]

Zu Mehnert's Bemerkungen über meine Kritiken und Referate. Anat. Hefte, 1898, 12, 567-573. 1898.2 See also Mehnert, $E$.

(editor) Normentafeln zur Entwicklungsgeschichte der Wirbelticre. 3 vols. Jena, 1909.

1909.1

Bd. iii no. $x$. Normal plates of the development of Lepidosiren paradoxa and Protopterus annectans, by J. G. Kerr. Jena, 1909 31 p. 3 pls.

Keilhack, Friedrich Ludwig Heinrich Konrad [1858-] Thiere und Pflanzen als Gesteinsbilder in Gegenwart und Vorzeit. Prometheus, Berlin, 1896, 7, 577-583; 595-598; 611-615. 7 figs. 1896.1

Contains some references to fishes.

Contribution ì la connaissance de la faune des eaux dans les Alpes du Dauphiné. Ann. Univ. Grenoble, 1907. 1907.1 
- Bemerkungen zur Fischfauna des nördlichen Njassa-Gebietes: einige neue Arten aus den Gattungen Barbus und Synodontis und Beiträge zur Systematik der Gattung Clarias. Sitzber. Ges. Naturf. Freunde Berlin, 1908, 164169.

1908.1

- Njassa-Fische gesammelt von Professor Dr. Fülleborn. Mitth. Zool. Mus. Berlin, 1910, 5, 89-115. 2 pls. \& 3 figs.

1910.1

Ueber einige von Herrn Dr. H. Monke in Duala (Kamerun) gesammelte Fische. Mitth. Zool. Mus. Berlin, $1910,5,117-124$. fig.

1910.2

Rassen-Untersuchungen an Nordsee-Schollen. Wiss. Meeresuntersuch. Kiel ( $A b t$. Helgoland), 1913, n. s. $10,168-186$.

1913.1

Keim, De B. Randolph. Washington and its environs: a descriptive and historical handbook to the capital of the United States of America. Washington [1861]

1861.1

Section 1, Ichthyology.

Keith, Arthur. Three demonstrations on congenital malformations of palate, face, and neck. Brit. Med. Journ., 1909, 2, 310-313; 363-367; 438141. 30 figs.

1909.1

Contains references to fishes.

Keith, Arthur, \& Flack, Martin. 'The form and nature of the muscular connections between the primary divisions of the vertebrate heart. Journ. Anat. Physiol., London, 1907, 41, 172-189. 8 figs.

1907.1

Fish material consists of eel, dogfish and salmon.

Kelaart, Edward Frederich [1818?1860] Prodromus fauna Zeylanice Ceylon, 1852. $8^{\circ}$.

1852.1

Keller, Conrad [1848-] Notiz über Ceratodus. Vierteljahrsschr. Naturf. Ges. Zürich, 1880, 25. Jahrg., 415-416.

1880.1

Keller, Gustav. Thiere der Vorwelt. Reconstructionen vorweltliche Thiere, mit Erläuterung von Prof. Dr. Andreaes. Wandtafeln für den Anschauungsunterricht mit Textheft. Cassel, 1901. 34 p. $\mathrm{S}^{\circ}$.

1901.1

Keller, $H$. Anlage der Fischwege. Berlin, 1885. figs. $8^{\circ}$.

1885.1

- Freedom of migration for fish in Germany. Bull. U. S. Fish Comm. 1886 (1887), 6, 113-116.
Keller, Oszkiir. A csontos halak clöés közbülsõ agyanak alaktana (Ueber die Morphologie des Vorder- und Zwischenhirns der Teleostier] Allatt. Közlem., 1906, 5, 48-86; 105. pl. \& 12 figs. Abstract in Math.-Nat. Ber. Ungarn, $1909,24,370$.

1906.1

- A halak gerinczoszlopínak elferdülése [Die Verkrümmung der Wirbelsäule der Fische] Természet. Közl., Budapest, 1911, 43, 818-819. 1911.1

Keller, Otto [1838 - ] Dic antike Tierwelt. 2 vols. Leipzig, 1909-13. illust. $8^{\circ}$.

1909.1

Bd. i. Säugetiere

Bd. ij. Vögel, Reptilien, Fische, etc.

Keller, Robert. Das Schweizerbild, eine Niederlassung aus paläolithischer und neolithischer Zeit. N. Denkschr. Allgem. Schweiz. Gesell. Nat., 1896, 35. - Biol. Centralbl., 1897, 17, 545-559.

1896.1

Kellicott, William Erskine [1878-] The development of the vascular system of Ceratodus. Biol. Bull. Wood's Hole, 1904, 6, 320-321. - Anat. Anz., 26, 200 $208 ; 400$.

1904.1

- The development of the vascular and respiratory systems of Ceratodus. Mem. N. Y. Acad. Sci., 1905, 2, 135-249. 5 pls.

1905.1

- The growth of the brain and viscera in the smooth dogfish (Mustelus canis Mitchill) Amer. Journ. Anat., 1905, 8, 319-353. 7 pls. \& 3 tables.

1908.1

The growth of parts in the dogfish. Science, 1909, n. S. 29, 437. 1909.1

- $A$ contribution to the theory of growth. Verh. 8, Intern. Zool. Congr. Graz, 1912, 597-601.

1912.1

Contains reference to Mustelus.

- Outlines of chordate development. New York, 1913. 471 p. illust. $8^{\circ}$.

1913.1

- A textbook of general embryology. New York, 1913. 376 p. $8^{\circ}$.

1913.2

Kellogg, Albert $J$. Salmon of Long lake. Chicago Field, 1878, 10, 260.

1878.1

Kemna, Ad. Les caractères généraux des vertébrés. Bull. Soc. Roy. Malac. Belgique, 1903, 38, xevii-cvii. 1903.1

- Les récentes découvertes de poissons fossiles primitifs. Bull. Soc. Belge Géol., 1903, 17, 339-382. 17 figs. 1903.2 
Kemna, $A$.

_- L'origine de la corde dorsale. Bull. Soc. Roy. Malac. Belgique, 1904, $39, \mathrm{xxxy}-\mathrm{clvii}$.

1904.1

- Les récentes découvertes de poissons fossiles primitifs. Deuxième notice. Bull. Soc. Belge Géol., 1901, 18, 3-78. 14 figs.

1904.2

Les structures cérébrales dorsales chez les vertébrés inférieurs. Bull. Soc. Roy. Malac. Belgique, 1904, 39, clxvi-cei.

1904.3

La biologie des eaux potables. Ann. Soc. Roy. Malac. Belgique, 1905, 39 (mém.), 9-132.

1905.1

Notices bibliographiques. G.A. Boulenger sur la distribution des poissons d'eau douce africains. Ann. Soc. Roy. Malac. Belgique, 1905, 40, 35-41. 1905.2

L'Amphioxus comestible. Ann. Soc. Roy. Malac. Belgique, 1906, 41, 127-128.

1906.1

Analyse du mémoire de $\mathrm{O}$. Jaekel: Ueber die Beurteilung der paarigen Extremitäten. Ann, Soc. Roy. Vialac. Belgique, $1910,45,36-41$.

1910.1

Kemps, David. Statement concerning the menhaden fishery. Rept. U. S. Fish Comm. 1877 (1879), 5, 481.

1879.1

Kemp-welch, E.B. Tenacity of life in sharks. Zoologist, 1875, 2. ser. 10, 4460 .

1875.1

Boar-fish (Capros aper Lacép.) on the British coast. Sci. Gossip, 1879, 15,137 .

1879.1

Kendall, William Converse [1861-] Notes on the freshwater fishes of Washington county, Maine. Bull. U. S. Fish Comm. 1894 (1895), 14, 43-54. 1895.1

Description of a new stickleback, Gasterosteus gladiunculus, from the coast of Maine. Proc. U. S. Nat. Mus. 1895 (1896), 18, 623-624.

1896.1

- Notes on the food of four species of the cod family. Rept. U. S. Fish Comm. 1896 (1898), 22, 177-186. 1898.1

Notes on the silversides of the genus Menidia, of the east coast of the United States, with descriptions of two new subspecies. Rept. U.S. Fish Comm. 1901 (1902), 27, 241-267. 6 figs. 1902.1
Habits of some of the commercial catfishes (Siluridx) Bull. U. S. Fish Comm. 1902 (1904), 22, 399-415.

1904.1

- Identifying the catch (In The Maine woods, Bangor and Aroostook R. R. vacation guide book, p. 34-66. 26 figs. Bangor, 1904)

1904.2

Notes on some freshwater fishes from Maine, with descriptions of three new species. Bull. U.S. Fish Comm. 1902 (1904), 22, 353-368. 5 figs. 1904.3

Descriptions are given of Leuciscus carletoni, Pimephales anuli and Coregonus stanleyi Kendall

History of Pierce pond "quinnat." Maine Central R. R. publication, June and July 1905.

1905.1

The trouts of the Rangely lakes. Maine Sportsman, Bangor, 1905, 12 , no. $138,103-105$.

1905.2

The whitefish as a game fish. Maine Central R. R. publication, 1905 , 140-144. fig.

1905.3

- Perch would do harm (In The Maine woods, Bangor and Aroostook R. R. vacation guide book, p. 3. Bangor, 1906)

1906.1

The white perch; other fish (In The Maine woods, Bangor and Aroostook R. R. vacation guide book. Bangor, 1906)

1906.2

Fauna of New England. List of the Pisces. Occ. Papers Boston Soc. Nat. Hist., 1908, no. 7, 1-152. 1908.1

Identity of a supposed whitefish, Coregonus angusticeps Cuvier \& Valenciennes, with a northern cyprinid, Platygobio gracilis (Richardson) Smithson. Misc. Coll., 1908, 52, 95-99. 1908.2

The Maine chub. Maine Woods, 1908, 30, no. 47, 5-7. 4 figs. $\quad 1908.3$

The fishes of Labrador. Proc. Portland Soc. Nat. Hist., 1909, 2, $207-$ 243.

1909.1

American catfishes: habits, culture and commercial importance. Rept. U. S. Comm. Fisheries 1908 (1910), 3-39. 10 pls.

1910.1

Effects of the menhaden and mackerel fisheries upon the fish supply (In Proc. 4. Intern. Fish. Congr., Washington, 1908) Bull. U. S. Fish Comm. 1908 (1910), 28, pt. 1, 279-293. 1910.2 
Report on the fishes collected by Mr. Owen Bryant on a trip to Labrador in the summer of 1908. Proc. U. S. Nat. Mus., 1910, 38, 503-510. pl. 1910.3

An account of Tisbury Great pond, Martha's Vineyard, with a part of fishes collected in October and November, 1906. Rept. Comm. Fisheries, Game, Mass. 1910 (1911), Public Doc. no. 25.

1911.1

- Notes on Percopsis guttatus Agassiz and Salmo omiscomaycus WValbaum. Proc. Biol. Soc. Washington, 1911, 24, 45-52.

1911.2

- Notes upon two rare flatfishes (Gymnachirus fasciatus Günther and $G$. nudus Kaup) Proc. U. S. Nat. Mus., 1911, 40, 201-203. 2 figs.

1911.3

- Notes on a new species of flatfish from off the coast of New England. Bull. Bureau Fisheries, 1912, 30, 389394. pl.

1912.1

Fishes and fishing in Sunapee lake. Bull. Bureau Fisheries, 1913, Doc. no. $783,5-96.9$ pls. \& 4 figs.

1913.1

The Chinook vs, other salmonoids as a game fish with which to stock lakes. Forest \& Stream, 1914, 82, 209-211.

1914.1

The fisheries of New England. The salmon family. Part i. The trout or chars. Mem. Boston Soc. Nat. Hist., 1914, 8, no. 1.7 pls. \& 13 figs. 1914.2

A new record for the lumpfish in Chesapeake bay. Copeia, 1914, no. 13. $\mathrm{pl}$.

1914.3

A new record for the prowfish. Copeia, 1914, no. 12, 1-2.

1914.4

Kendall, William Converse, \& Adams, A.C. See Adams \& Kendall.

Kendall, William Converse, \& Evermann, Barton Warren. See Evermann \& Kendall.

Kendall, William Converse, \& Goldsborough, $E . L$. The fishes of the Connecticut lakes and neighboring waters, with notes on the plankton environment. Rept. Comm. Fisheries, 1907, Doc. no. 633. 77 p. 12 pls. \& 5 figs.

1907.1

The shore fishes (In Reports on the scientific results of the expedition to the tropical Pacific, in charge of
Alexander Agassiz, by the U. S. Fish Commission steamer "Albatross," from August, 1899 , to March, 1900) Mem. Mus. Comp. Zool. Harv. Coll., 1911, 26, 239-343. 7 pls.

1911.1

Kendall, William Converse, \& Radcliffe, Lewis. The shore fishes of the "Albatross" Expedition, 1904-1905] Mem. MIus. Comp. Zool. Harv. Coll., 1912, 25, 75-171. 8 pls. 1912.1

Kendall, William Converse, \& Smith, Hugh McCormick. Extension of the recorded range of certain marine and freshwater fishes of the Atlantic coast of the United States. Bull. U. S. Fish Comm. 1894 (1895), 14, 15-21. 1895.1

Notes on the extension of the recorded range of certain fishes of the United States coast. Rept. U. S. Fish Comm. 1896 (1897), 22, 169-176. 1897.1

Kennard, A. S., \& Hinton, Martin A. C. See Hinton \& Kennard.

Kennedy, Clarence Hamilton, \& Eigenmann, Carl $H$. See Eigenmann \& Kennedy.

Kenney, R. C. Statement concerning the menhaden fishery. Rept. U. S. Fish Comm. 1877 (1879), 5, 414. 1879.1

Kennicott, Robert [1835-1866] Catalogue of animals observed in Cook county, Illinois. Trans. Ill. State Agric. Soc. 1853-54 (1855), 1, 577-595. 1855.1

Kenniston, G. B. Statement concerning the menhaden fishery. Rept. U. S. Fish Comm. 1877 (1879), 5, 382.

1879.1

Kensington, $E . T$. Composition of some of the food-fishes. Bull. U. S. Fish Comm. 1884, 4, 74-75. 1884.1

Kent, Alexander. Diseases of fish. Forest \& Stream, 1874, 3, 100.1874 .1

Journal kept of shad-hatching camp on Chester river. Rept. Comm. Fisheries Maryland, 1876, 71-79. 1876.1

Kent, William Saville. Fish distinguished by their action. Nature, $1873,8,263-264 . \quad 1873.1$

Notes from the Brighton aquarium. Zoologist, 1873, 2. ser. 8, 36343639 .

1873.2

Permanent and temporary variation of colour in fish. Nature, 1873,8 , 25. 
Kent, $1 W . S$.

Phosphorescence in fish. $\mathrm{Na}-$ ture, $1873,7,47-48$.

1873.4

An angler or fishing frog $[\mathrm{LO}$ phius piscatorius! at the Manchester aquarium. '/soologist, 1874,2 . ser. 9 , $4264-4266$.

1874.1

Fiskenes bevaegelser. Nord. Tidssk. Fiskeri, 1874, n. s. 1. Jahrg., 105- 112 .

1874.2

Motions of fishes. Zoologist, 1874, 2. ser. 9, 3872.

1874.3

Marine and freshwater fishes of the British islands. Intern. Fisheries Exhib. Lit., London, 1883. Hindbooks, 1, pt. 2. 129 p. figs.

1883. 1

New or rare fish taken in Tasmanian waters. Rept. Fisheries Tasmania, 1886, 13-14.

1886.1

Observations on the acclimatisation of the true salmon (Salmo salar) in 'Tasmanian waters and upon the reported salmon disease at the breeding establishment on the river Plenty. Proc. Roy. Soc. Tasmania, 1887, 5t-66.

1887.1

Description of a new species of true barrimundi, Osteoglossum jardinit, from north Queensland. Proc. Soc. Queensland, 1892, 8, 105-108. 1892.1

'The great barrier reef of Australia; its products and potentialities. London, 1893.

1893.1

Description of P'olyacanthus quecnslandia, p. 30 s.

- The naturalist in Australia. London, 1897. 302 p. 50 pls. \& figs. $4^{\circ}$.

Contains observations on fishes.

1897.1

Kerb, Heinz. Betrachtungen zur Ernährungsphysiologie des Fisches. Arch. Hydrobiol. Planktonkunde, 1910. 5, 283-286.

1910.1

Kerbert, Coenraad. Beiträge zur Kenntniss die niederlïndischen Fauna. Tijdschr. Nederl. Dierk. Ver., 1884, 5 , pt. 1, 1-20. 2 pls.

1884.1

Chromatophagus parasiticus, a contribution to the natural history of parasites. Rept. U. S. Fish Comm. 1884 (1886), 12, 1127-1136. 1886.1

On the fishes of the Kira sea. Amsterdam, 1s87. fol.
- Het aquarium en zijne bewoners. Bijdr. Dierk. Zool. Genootsch. Nat. Art. Mag. Amsterdam, Feest-nummer, 1888, 5-98. 2 pls.

1888.1

Kermode, Philip M. C. Phycis blennoides (Günther) off the Manx coast 'loologist, 1882, 3. ser. 6, 353-354.

1882.1

Contributions to a vertebrate fauna of the Isle of Man. Fishes Zoologist, 1893, 3. ser. 17, 65-70. 1893.1

Large halibut at Isle of Man (Hippoglossus vulgaris) Zoologist, 1897, 4. ser, 1, 235.

1897.1

- The porbeagle in Manx waters. Zoologist, 1897, 4. ser. 1, 579. 1897.2

Sharks in Manx waters. Lioar Mannin, Isle of Man, 1898, 3, 339-341.

1898.1

- List of the fishes. 5. Rept. Fauna Liverpool Bay, 1900, 32-33.

1900.1

Kerr, John Graham [Account of his recent expedition to the Gran Chaco of Paraguay with the object of investigating the development of Lepidosiren. Proc. '/sool. Soc. London, 1897, 921-922.

1897.1

[Exhibition of specimens of Lepidosiren and other fishes collected in the Gran Chaco of Paraguay] Proc. 'zool. Soc. London, 1898, 492. 1898.1

Notes on the dry-season habits of Lepidosiren, communicated to him in a letter by Mr. R. J. Hunt, of Paraguay. Proc. Zool. Soc. London, 1898, $41-44$.

1898.2

- A fishing expedition in the Gran Chaco. Christ's College Mag., Cambridge, 1899, 118-132.

1899.1

'The development of Lepidosiren paradoxa Fitz., 1900-1902.

1900.1

i. The extcrnal feitures in the development of Lepidosiren paradoxa Fitz. Phil. Trans. Roy soc. London 1899 (1900), 192, 229-230. 5 pls. d 82 figs. Review in Proc. Roy, Soc. London, 1899 65, 160-161. - Zool. Anz., 1899, 22, 292-294.

ji. The development of Lepidosiren paradoxa. with a note upon the corresponding stages in the development of Protopterus annectens. Quart. Journ. Mier. Sci., 1901, 2. ser. 45, $1-10$. 4 pls.

iii. Develomment of the skin and its derivatives. Lbil., 1902, 2. ser. 46, 417-159, 5 pls. of 3 figs.

Note on hypotheses as to the origin of the paired limbs of vertebrates. Proc. Phil. Soc., Cambridge, 1900, 10, $227-235$

1900.2 
'The zoological position of Palaospondylus Traquair. Proc. Phil. Soc. Cambridge, 1900, 10, 298-299. $\quad 1900.3$

On the male genito-urinary organs of the Lepidosiren and Protopterus. Proc. Zool. Soc. London, 1901, pt. 2, 484-498. 2 pls. \& 11 figs. 1901.1

The origin of the paired limbs of vertebrates. Rept. Brit. Assoc. Adv. Sci., 71. meet., 1901, 693-695. 1901.2

- The early development of muscles and motor nerves in Lepidosiren. Rept. Brit. Assoc. Adv. Sci., 72. meet. $1902,655-657$.

1902.1

The genito-urinary organs of dipnoan fishes. Proc. Phil. Soc., Cambridge, 1902, 11, 329-333. 1902.2

Note on the developmental material of Polypterus obtained by the late Mr. J. S. Budgett. Rept. Brit. Assoc: Adv. Sci., 74. meet., 1904, 604-605.

1904.1

- On some points in the early development of motor nerve trunks and myotomes in Lepidosiren paradoxe (Fitz.) Trans Roy. Soc. Edinb., 1904, 41, 119-128. 6 pls.

1904.2

The embryology of certain of the lower fishes and its bearing upon vertebrate morphology. Proc. Roy. Phys. Soc. Edinb., 1906, 16, 191-215. 1906.1

The development of Polypterus. Proc. Roy. Phys. Soc. Edinb., 1907, 17 73-75.

1907.1.

The development of Polypterus senegalus Cuv. (In Budgett Memorial volume, p. 195-284. 3 pls. \& 67 figs. Cambridge, 1907) Review in Science, n. s. 18, 477-478.

1907.2

(editor) The work of John Samuel Budgett, Balfour student of the University of Cambridge: being a collection of his zoological papers, together with a biographical sketch by A. E. S. Shipley, F. R. S., and contributions by Richard Assheton, Edward J. Bles, Edward T. Browne, J. Herbert Budget and J. Graham Kerr. Cambridge, 1907. 494 p. 29 pls. $4^{\circ}$.

1907.3

For contents of this work, see Budgett, $J$. S.

Note on swim-bladder and lungs. Proc. Roy. Phys. Soc. Edinb., 1908, 17, 170-174. 2 figs.

1908.1

Note on the autostylic skull of vertebrates. Proc. Roy. Phys. Soc. Edinb., 1908, 17, 169 .
Note on the cause of disappearance of the fifth aortic arch in airbreathing vertebrates. Proc. Roy. Phys. Soc. Edinb., 1908, 17, 167-16s. 5 figs. 1908.3

- - Normal plates of the development of Lepidosiren paradoxa and Protopterus annectens (In Normentafeln zur Entwicklungsgeschichte der Wirbeltiere, herausgegeben von F. Keibel, Bd. iii, 1-31. 3 pls. Jena, 1909) 1909.1

- Ichthyology; anatomy [of fishes] Encycl. Britannica, 11. ed., 1910, 14, $250-26 \%$

1910.1

Morphological method and the ancestry of vertebrates. Nature, 1910 , $85,203-205$.

1910.2

Note on the posterior vena cava in Polypterus. Proc. Roy. Phys. Soc. Edinb., 1910, 18, 102-104. fig. 1910.3

- On certain features in the development of the alimentary canal in Lepidosiren and Protopterus. Quart. Journ. Micr. Sci., 1910, 54, 483-518. 13 figs.

1910.4

- Presidential address. I. Remarks upon certain points connected with evolutionary theory. II. The development of the peripheral nerves of vertebrates [Lepidosiren] Proc. Roy. Phys. Soc. Edinb., 1910, 18, 1-20. 6 figs.

1910.5

Selachians. Encycl. Britannica, 11. ed., 1911, 24, 594-597.

1911.1

- Note on the morphology of the heart of vertebrates. Proc. Roy. Phys. Soc. Edinb., 1913, 19, 37-43. 2 figs.

1913.1

Kerr, John Graham, \& Günther, Albert [Carl Luduig Gotthilf] See Guinther \& Kerr.

Kerr, John W. Letter relating to the whitefish of lakes Erie and Ontario. Rept. U. S. Fish Comm. 1872-73 (1874), 2. $80-81$.

1874.1

Kerry, Mortimer, pseudonym for Murphy, J. Mortimer.

Kershaw, $H^{\top}$. W. La industria pesquera en los Estados Unidos. Boletin de Bosques, Pesca i Caza, Santiago, $1912,1,624-628$.

1912.1

Kershaw, James $A$. Swordfish in Port Phillip. Victorian Naturalist, 1901, $18,100$.
1901.1 
Kershaw, $J . A$.

Notes on a rare Victorian shark (Cetorhinus maximus) Victorian Naturalist, $1902,19,62-66.2$ pls. $\quad 1902.1$

- A colour variety of the common eel, Anguilla australis Rich. Victorian Naturalist, $1904,20,140 . \quad 1904.1$

General zoology, Wilson's promontory. Victorian Naturalist, 1906, 22, 197-207.

Fishes, p. 202-203.

- On some additions to the fishfauna of Victoria. Victorian Naturalist, 1906, 23, 121-127. Ibid., 1909, 26, 78-79. Ibid., 1911, 28, 93-95. 1906.2

- Migration of eels in Victoria. Victorian Naturalist, 1911, 27, 196-201. 2 pls.

1911.1

- Pseudaphrilis bassii Cuv. \& Val. Victorian Naturalist, 1911, 28, 92.

1911.2

- Additions to the fish-fauna of Victoria [Family Lamprididæ] Victorian Naturalist, $1913,30,95-96$. pl.

1913.1

Kerville, Henri Gadeau de. See Gadeau de Kerville, $H$.

Kessler, Karl Theodorovich [18151881] Zur Ichthyologie des südwestlichen Russlands. Bull. Soc. Nat. Moscou, 1856, 29, pt. 1, 335-393. Ibid., 1857, 30, pt. 2, 453-481. Also separate; Moscou \& Riga, 1856-57. $8^{\circ}$. 1856.1

- Beiträge zur Kenntniss der den Unterordnungen Anacanthini Müll., Pharyngognathi Müll., Physostomi Müll. und Lophobranchii Cuv. angehörenden Knochenfische des Schwarzen Meeres. Bull. Soc. Nat. MIoscou, 1859, 32 , no. $4,437-478$.

1859.1

- Systematische Uebersicht der Stachelflosser (Acanthopteri Müller), welche im nordwestlichen Theile des Schwarzen Meeres und in den Mündungen der in derselben sich ergiessenden südrussischen Flüsse vorkommen (In his Auszüge aus dem Berichte über eine an die nordwestlichen Küsten des Schwarzen Meeres und durch die westliche Krym unternommene Reise. II) Bull. Soc. Nat. Moscou, 1859, 32, no. 3, 186-268.

1859.2

- Ueber die Süsswasserfische der Krym (In his Auszüge aus dem Berichte über eine an die nordwestlichen Küsten des Schwarzen Meeres und durch die westliche Irym unternommene Reise. I) Bull. Soc. Nat. Moscou, 1859,32 , no. 2, 520-546. 1859.3

- Ueber einige Fische des Schwarzen Meeres. Amtl. Ber. 35. Vers. Deutsch. Naturf. 1860 (1861), p. 85 .

1861.1

- Ichthyological fauna of Turkestan [Text in Russian] Bull. Soc. Sci. Moscou, $1872,10,47-76 .-\mathrm{N}$. Mém. Soc. Nat. Moscou, 1872, 10. 32 p. 7 pls.

1872.1

- Letter relating to fishes of Turkestan [Text in German] Bull. Soc. Nat. Moscou, 1873, 47, pt. 1, 183-184.

1873.1

- On a remarkable fish of the family of sturgeons discovered by M. A. P. Fedtschenko in the river Suirdar (Scaphirhynchus fedtschenkoi) Ann. Mag. Nat. Hist., 1873, 4. ser. 12, 269 276.

1873.2

A new ganoid-fish Wcaphirhynchus fedtschenkoi from Turkestan. Pop. Sci. Rev., 1874, 13, $109 . \quad 1874.1$

- Pisces (In Fedtschenko's expedition to Turkestan. Zoogeographical researches) Bull. Soc. Sci. Moscou, $1874,11,1-63$.

1874.2

Descriptions of the fishes collected by Col. Prejevalsky in Mongolia [Text in Russian] (In Prejevalsky, N. Mongolia i Strana Tangutov, ii, pt. 4, 1-36. 3 pls. St. Petersburg, 1876)

1876.1

Fishes of the Aralo-CaspioPontine region (In his The Aralo-Caspian expedition. St. Petersburg, 1877. 360 p. 26 figs.) 1877.1

- Reisebriefe aus der Kírym. Bull. Soc. Nat. Moscou, 1878, 53, pt. 2, 212216.

1878.1

Beiträge zur Ichthyologie von Central-Asien. Bull. Acad. Sci. St. Pétersb., 1879, 25, 282-310. - Mél. Biol. Bull. Acad. Sci. St. Pétersb., 1879, 10, 233-272.

1879.1

Notiz über die Fische des Flusses Tuapse. Bull. Soc. Nat. Moscou, 1879 , 54, pt. 1, 424-428.

1879.2

Kesteloot, Toxicographie de quelques poissons et crustacés de la Mer du Nord. Bull. Acad. Sci. Bruxelles, 1841, 8, pt. 2, 502-511. 1841.1 
Kesteven, Leighton. The venom of the fish Notesthes robusta. Proc. Linn. Soc. N. South Wales, 1914, 39, pt. 1, 9192.

1914.1

Ketel, $H$. Ueber das Gehörorgan der Cyclostomen. Anat. Studien 1872 (1873), 3, 489-541. Also separate; Leipzig, 1872. $8^{\circ}$.

1873.1

Kettler, - Girardinus decemmaculatus. Blätt. Aquar.-Terrar. Freunde, 1901, 12. Jahrg., 64-65.

1901.1

Key, Axel, \& Retzius, Gustaf. Studien in der Anatomie des Nervensystems und des Bindegewebes. 2 vols. Stockholm, 1875-76. 75 pls. fol. 1875.1

Keyes, $C . M$. The fishing industry' of lake Erie, past and present. Bull. U. S. Fish Comm. 1893 (1894), 13, 349353.

1894.1

Keyes, Charles Rollin [1864-] On some fossils from the lower Coal Measures at Des Moines, Iowa. Amer. Geologist, 1888, 2, 23-28. 1888.1

Pisces. Petrodus occidentalis and Diplodus (sp.?)

- Fossil faunas in central Iowa. Proc. Acad. Nat. Sci. Philad., 1891, 242-265.

1891.1

Palæontology of Missouri, part ii. Rept. Missouri Geol. Surv., 1894, 5 , 1-266. 24 pls.

1894.1

Vertebrates [fossil fishes] p. 227-238,

Keyserling, (Count) Alexander Friedrich Michael Leberecht Arthur von, \& Blasius, $J . H$. Die Wirbelthiere Europa's. Erstes Buch: Die unterscheidenden Charactere. Braunschweig, 1840. 248 p. $8^{\circ}$.

1840.1

Keyserling, (Count) Eugen von [18331889] Neue Cypriniden aus Persien Zeitschr. Ges. Naturw., 1861, 17, 1-24. Also separate; Berlin, 1861. 8 . Extract in Rev. Mag. Zool., 1863, 2. ser. 15, $419-422$.

1861.1

Keysselitz, — Ueber flagellate Blutparasiten bei Süsswasserfischen. Sitzber. Ges. Naturf. Freunde Berlin, 1904, 285-296.

1904.1

Khvorostansky, $C$. Sur la lumination des animaux de la mer Blanche. Congr. Intern. Zool., Moscou, 1892, 2. sess., pt. 4, no. 24, 184-186. 1892.1

Kiær, Anders Nicolai. Bericht über Norwegens Fischerei im Jahre 1868. Circul. Deutsch. Fischerei Ver., 1871, no. 1, 3-9.
Notes on the Norwegian fisheries of 1885. Rept. U. S. Fish Comm. 1886 (1889), 14, 1055-1064.

1889.1

Kiær, Hans. Om Tromsosundets fiske; en oversigt over deres udbredelse og biologi. Tromsø Mus. Aarsbog, 1905, 27, 127-169. 4 figs.

1905.1

Kiær, Johan [1870-] Om jordens ældste fiske. Nyt Mag. Nat., 1910, 48, 373-374.

1910.1

A new Downtonian fauna in the sandstone series of the Kristiania area. A preliminary report. Skrift. Vidensk. Selsk. Kristiania, 1911, no. 7, 5-22.

1911.1

Describes five new genera of Silurian fishes.

Kidd, Waring. On the occurrence of the boar-fish at Brighton. Zoologist, $1843,1,191-192$.

1843.1

Kidder, J. A. Blood temperature of fishes. Chicago Field, 1880, 13, 156157.

1880.1

Effect of cold and heat on fishes. Forest \& Stream, 1880, 15, 425. 1880.2

Kidder, Jerome $H$. Contributions to the natural history of Kerguelen island made in connection with the United States Transit of Venus expedition, 1874-75. Washington, 1876. 122 p. $8^{\circ}$.

1876.1 42.

Fishes, identified by Theodore N. Gill, p. 41-

Report of experiments upon the animal heat of fishes, made at Provincetown, Mass., during the summer of 1879 , in connection with operations of the U. S. Fish Commission. Proc. U. S. Nat. Mus., 1880, 2, 306-326. Abstract in Nature, $1880,21,156 . \quad 1880.1$

Kiel, Peter. Letters relating to the whitefish of lake Erie and lake Ontario. Rept. U. S. Fish Comm. 1872-73 (1874), 2, 80-84.

1874.1

Kielmann, Friedrich. Fassung für Fischnetze. D. R. Pat. Kl. 45 h., 1906, no. 171391. 1 p. pl. 1906.1

Kielsen, Frederik Christian [17741850] Icones piscium. Hafnix, 1835. $8^{\circ}$. Notice in Arch. Naturges. (WViegmann), 1836, 2. Jahrg., pt. 2, 164.

1836.1

Kiesow, $J$. Ueber silurische und devonische Geschiebe Westpreussens [Pisces] Schrift. Naturf. Ges. Danzig, 1885, 6, 289-290. pl. \& fig. 1885.1 
Kikkert, $H$. Holländischer oder schottischer Häring? Circul. Deutsch. Fischerei /teitg., 1879, 2. Jahrg., 385386.

1879.1

Kilbourn, J.K. Kish preservation and refrigeration. Intern. Fisheries Exhib. Lit., London, 1883. Conferences, 7, pt. 8 .

1883.1

Killermann, Sebastien. Das Tierbuch des Petrus Candidus, geschrieben 1460, gemalt im 16. Jahrhundert (Codex Vaticanus Urb. lat. 276) Zool. Annalen, 1914, 6, 113-221. 8 pls.

Fische, p. 182-197. pl.

1914.1

Killian, Gustav. Zux Metanerie des Selachierkopfes. Anat. Anz., 1891, 7 (Verh. Anat. Ges.), 85-107. figs.

1891.1

Kinahan, John Robert [1828-1863] On the nidus and ova of Gasterosteus leinrus. Nat. Hist. Rev., 1854, 1, 235-236.

1854.1

- On the spawning of the smoothtailed stickleback [Gasterosteus leiurus] with a list of the fishes inhabiting the Dodder. Proc. Nat. Hist. Soc. Dublin, 1854, 1, 129-134. - Nat. Hist. Rev., $1854,81-83 ; 235-236$.

1854.2

Notes on the marine fauna of the coast of Clare. Proc. Nat. Hist. Soc. Dublin, 1859, 3, 99-103.

1859.1

On the genus Raniceps, and the occurrence of the tadpole-fish $R$. trifurcatus in Dublin bay. Nat. Hist. Rev., 1859, 6, 459-460.- Proc. Nat. Hist. Soc. Dublin 1856-59 (1860), 2, 197-198.

1859.2

Kincaid, Walter $S$. New methods of transporting eggs and fish (In Proc. 4. Intern. Fish. Congr., Washington) Bull. Bureau Fisheries 1908 (1910), 28, pt. 2, $1037-1039$.

1910.1

Kinder, - Recollections of early days of American fish-culture revived. Chicago Field, 1879, 11, 340. 1879.1

Kindle, Edward Martin [1869-] The South American catfishes belonging to Cornell University. Ann. N. Y. Acad. Ści., 1895, 8, 249-256. 1895.1

The relation of the fauna of the Ithaca group to the faunas of the Portage and Chemung. Bull. Amer. Pal., 1896, 2, 1-56. pl.

1896.1

- A catalogue of the fossils of Indiana, accompanicd by a bibliography of the literature relating to them. 22. Ann. Rept. Dep. Geol. and Natural Resources of Indianaj 1897 (1898), 407514. 1898.1

The list of fossil vertebrates is found at 481485.

King, Obed. 'Testimony in regard to the present condition of the fisheries, taken in 1871. Rept. U. S. Fish Comm. 1871-72 (1873), 1, 12-13.

1873.1

King, Richard [1811? -1876] Temperature of quadrupeds, birds, fishes, plants and earths, as ascertained at different times and places in aretic America during Capt. Back's expedition. Edinb. New Phil. Journ., 1836, 21, 150-151. Journ. Pharm., 1836, 22, 515-516.

1836.1

King, William. A monograph of the Permian fossils of England. Monogr. Palpontogr. Soc. 1849 (1850), 1-285. 28 pls. 1850.1

Fossil fishes, p. 221-236.

King, William Ross [1822-] The sportsman and naturalist in Canada; with notes on the fish of that country. London, 1866. $\mathrm{xV}, 334$ p. $8^{\circ} .1866 .1$ Fishes, p. 245-330.

Kingfisher (pseudon.) Raising white fish in confinement. Chicago Field, 1878, 9, 243.

1878.1

Gameness of the pickerel (Esox) Chicago Field, 1880, 13, 35. $\quad 1880.1$

Kingsbury, Benjamin Freeman [1872 - ] The lateral line system and sense-organs in some American amphibia, and comparison with the dipnoans. Trans. Amer. Micr. Soc., 1896, 17, 115154. 5 pls.

1896.1

The encephalic evaginations in ganoids. Journ. Comp. Neurol., 1897, $7,37-44$.

1897.1

The structure and morphology of the oblongata in fishes. Journ. Comp. Neurol., 1897, 7, 1-36. 5 pls. 1897.2

Kingsbury, $C$. A. The blue-back trout. Forest \& Stream, 1874, 3, 277.

1874.1

Kingsbury, $W . H$. Alphabetical list of Victorian edible salt and freshwater fish. Geelong Natural., 1896, 5, no. 3, 18-19.

1896.1

Kingsley, Ainsworth, W. $F$. i Tristram, H. B. See Ainsworth, Tristram \& Kingsley. 
Kingsley, John Sterling [1859-] Discovery of male eels. Forest \& Stream. $1879,12,386$.

1879.1

The naturalist's assistant, with a bibliography of 1500 works necessary for the systematic zoologist. Boston, 1882. 228 p. $8^{\circ}$.

1882.1

The bibliography contains referenees to about 100 ichthyological papers.

- (editor) 'The standard natural history. 6 yols. Boston, 1885. 1885.1 Vol. iii. Vertebrata. Introduction, by R. R. Wright.

Cyclostomi and Elasmobranchii, by J. S. Tingsley.

Ganoidea, by J. S. Ǩ̈ingsley.

Symbranchia, Apodes and Lyomeri, by T.N. (iill.

Nematognathi, Scyptophori and Teleocephali (Gymnonoti to Xenomi), by D. S. Jordan.

Teleocephali (Synentognathi to Heterosomata) Hemibranchii, Lophobranchii, Plectonathi and Pediculati, by T. N. Gill.

Dipnoi, by J. S. Kingsley.

-... The origin of the vertebrate skeleton. Amer. Naturalist, 189t, 28 , $635-640$.

1894.1

Edward Drinker Cope ra memorial notice] Amer. Naturalist, 1897. 31, 414-419.

1897.1

Textbook of vertebrate zoology London, 1900.439 p. 378 figs. $S^{\circ}$.

1900.1

The dogfish (Acanthias); an elasmobranch (Guides for vertebrate dissection) New York, 1907. v, $32 \mathrm{p}$. $8^{\circ}$

1907.1

- Comparative anatomy of rertebrates. Philadelphia, 1912. $401 \mathrm{p}$ illust.

1912.1

Kingsley, John Sterling, \& Conn, Herbert William. Some observations on the embryology of the teleosts. Mem. Boston Soc. Nat. Hist., 1883, 3, 183210. 2 pls.

1883.1

Kingsley, John Sterling, \& Packard (junior), A.S. Sce Packard \& Kingsley.

Kingsley, $R$. I. On a specimen of the great ribbon-fish (Regalecus argenteus) taken in Nelson harbor. 'Trans. Proc. New Zealand Inst., 1889, 15, 333338. pl.

1889.1

Kinnear, $N . B$. Large mahseer. Journ. Bombay Nat. Hist. Soc., 1910. $20,234-235$

1910.1

Kinnear, $\boldsymbol{W}$. Tait. Homacanthus borealis Traq., a new selachian from the Lower Old Red of Caithness; with plate and description by Dr. R. H. Traquair.
'Trans, Geol. Soc. Edinb., 1892, 6, 205208. pl.

1892.1

Kinnear, $W$. T'ait, \& Anderson, $W$. Notes on the fossils of the first Gilmerton limestone. Trans. Geol. Soc. Edinb. 1883, 299-306.

1883.1

Carboniferous sharks' tecth are noted.

Kinoshita, T., \& Kreidl, 1 . See Kreidl \& Kinoshita.

Kinsey, J. II. [Boz, pseudon.] Bluefish versus weakfish. Chicago Field $1879,12,36$.

1879.1

1879,12, Menhaden. Chicago Field,

$1879,12,100$.

Purse nets and the menhaden. Chicago Field, 1880, 14, $43 . \quad 1880.1$

Kiprijanov, Valerian Aleksandrovich [1818 - ] Ueberreste von Fischen im Kurskschen eisenhaltigen Sandsteine. Bull. Soc. Nat. Moscou, 1852, 25, 221 226; 483-495. Ibid., 1853, 26, 331-336: 286-294. 2 pls. Ibid., 1851, 27, 373397. 2 pls. Ibid. $1857,30,151-162$. 2 pls. Ibid., $1860,33,40-56 ; 601-670$ 3 pls.

1852.1

Coprolntes, sharks' teeth and Saurocephalus are described.

- Erster Zusatz zur Beschreibung des Koprolithes mantellii Ag. Bull. Soc. Nat. Moscou, 1854, 27, 251-254. 4 figs. 1854.1

\section{'Wweiter Beitrag zu Hybodus} eichraldi. Bull. Soc. Nat. Moscou, $1855,28,392-400$. pl. 1855.1

Erster Beitrag is the same as Part 3 of FischUeberreste im Kurskschen eisenhaltigen Sandstein. See supra.

Kirchmeister, Friedrich. Freie Uebersetzung und Bearbeitung des Aufsatzes von Jules Haime "La Pisciculture" in der Revue des Deux Mondes vom Juni 1854. Allgem. Deutsch. Naturhist. Zeitg., 1855, 1, 1. 1855.1

Kirk, H.B. Some features of the circulatory system of Heptatrema cirrata Forster. Trans. Proc. New Zealand Inst., 1912, 44, 241-244. 2 pls. 1912.1

Kirk, Henry C. [Dexter, pseudon.] Black bass of New York. Horest d Stream, 1876, 7, 300. 1876.1

- Freshwater fishes in salt water. Forest \& Stream, 1877, 8, 340. 1877.1 Death of salmon by osmosis.

10,265 . 
Kirk, $H . C$.

- "Piscators" herring. Forest \& Stream, 1878, 11, $114 . \quad 1878.2$

Kirk, Thomas IV. [1828-1898] Additions to the list of New Zealand fishes. 'I'rans. Proc. New Zealand Inst., 1880. 12,308 .

1880.1

Kirkaldy, J.W. On the head kidney of Myxine. Quart. Journ. Micr. Sci., London, 1894, n. s. 35, 353-359. pl.

1894.1

A revision of the genera and species of the Branchiostomidxe. Quart. Journ. Micr. Sci., 1895, 37, 303-323. 2 pls.

1895.1

Kirkby, James Walker [1834-1901] On the remains of fish and plants from the Upper limestone of the Permian series of Durham. Ann. Mag. Nat. Hist., 1862, 3. ser. 9, 267-269. - Quart. Journ. Geol. Soc. London, 1862, 20, 345-358. pl. \& 2 figs. - Trans. Nat. Hist. Soc. Northumb., 1, 64-83. pl.

1862.1

Palæoniscid remains are mentioned.

Fossil fish in Magnesian limestone at Fulwell hill. Trans. Tyneside Nat. Field Club, 1863, 5, 248. 1863.1

Palæoniscus and Acrolepis.

On the occurrence of fossils in the highest beds of the Durham Coal Measures. Trans. Tyneside Nat. Field Club, 1864, 6, 220-225.

Ganoid scales.

1864.1

- On the fossils of the Marl-slate and Lower Magnesian limestone (Durham, no. II) Trans. Nat. Hist. Soc. Northumb., 1867, 1, 184-200. 1867.1

Contains notes on Pygopterus mandibularis and Platysomus striatus among ganoid fishes.

- On the occurrence of marine fossils in the Coal Measures of Fife. Quart. Jour. Geol. Soc., 1888, 44, 747754.

1888.1

Stybodus teeth are mentioned.

On Lower Carboniferous strata and fossils at Randerstone, near Crail, Fife. Trans. Edinb. Geol. Soc., 1905, 8, 61-75. pl.

List of ganoid fishes.

1905.1

Kirkby, James Walker, \& Atthey,

Thomas. On some fish-remains from the Durham and Northumberland Coal Measures. Trans. Tyneside Nat. Field Club, 1864, 6, 231-235. pl. 1864.1 Sharks' teeth and ganoids.

Kirkby, James Walker, \& Binney, Eduard W. See Binney \& Kirkby.
Kirkpatrick, C.A. Salmon fishery on the Sacramento river. California Mag., 1860, 4, 529-534.

1860.1

Kirsch, A. Ueber internationale Massregeln zum Schutze und zur Vermehrung des Lachses in der Ostsce. Congr. Intern. Pêche Piscicult. St. Pétersbourg, 1903, pt. 1, 116-119.

1903.1

Kirsch, $D . W$. Ueber Zucht der Goldorfen. Circul. Deutsch. FischereiVer., 1872, 1. Jahrg., no. 4, 102-104.

1872.1

On the raising of the "gold orfe" (Cyprinus orfus) Rept. U. S. Fish Comm. 1873-75 (1876), 3, 559-561.

1876.1

Rothe Orfen [Leuciscus idus] und deren Zucht. Deutsch. Fischerei Zeitg., 1880, 3. Jahrg., 124-125; 132-134. Oesterr.-ungar. Fischerei Zeitg., 1880. 1. Jahrg., 58-59; 68-70. 1880.1

Kirsch, Philip Henry [-1900] Notes on a collection of fishes from the Rio Gila at Fort Thomas, Arizona, obtained by Lieut. W. L. Carpenter, U. S. Army. Proc. U. S. Nat. Mus. 1888 (1889), 11, 555-558.

1889.1

A review of the American species of thread-fins (Polynemidx) Ann. N.Y. Acad. Sci., 1889-91, 5, 231-236. 1890.1

Notes on the streams and fishes of Clinton county, Kentucky, with a description of a new darter. Bull. U.S. Fish Comm. 1890 (1892), 10, 289-292. fig.

1892.1

Notes on a collection of fishes from the southern tributaries of the Cumberland river in Kentucky and Tennessee. Bull. U. S. Fish Comm. 1891 (1893), 11, 259-268. 1893.1

- A report upon explorations made in Eel river basin in the northeastern part of Indiana in the summer of 1892. Bull. U. S. Fish Comm. 1894 (1895), 14. $31-40$.

1895.1

- Report upon investigations in the Maumee river basin during the summer of 1893. Bull. U. S. Fish Comm. 1894 (1895), 14, 315-337.

1895.2

Kirsch, Philip Henry, \& Fordice, Morton IV. A review of the sturgeons (Acipenseridx) of North America. Proc. Acad. Nat. Sci. Philad. 1889 (1890), 245257. 
Kirschbaum, C.I. Die Reptilien und Fische des Herzogthums Nassau; Verzeichniss und Bestimamungstabelle. Jahrb. Ver. Naturk. Nassau, 1863, 1718, 77-122. - Zeitsch. Naturw. Halle, $1863,27,94$.

1863.1

Kirtland, Frederick. Shad spawning in October. Forest \& Stream, 1879, 12, 5.

1879.1

Kirtland, Jared Poller [1793-1877] Report on the zoology of Ohio. Columbus, $1838.8^{\circ}$.

1838.1

Contains some account of fishes.

- Description of fifteen new species of fishes. Amer. Journ. Sci., 1840, 38, 392.

1840.1

- Descriptions of eleven species of fishes from western rivers. Amer. Journ. Sci., 1840-41, 40, 388. 1840.2

- Notice of the completion of the descriptions and figures of the fishes of western waters. Amer. Journ. Sci., 1840 , 39,375 .

1840.3

Descriptions of four new species of fishes. Boston Journ. Nat. Hist. 1840 (1841), 3, 273-279.

1841.1

New species are described of Gasterosteus, Etheostoma and Hydrargira.

Descriptions of the fishes of the Ohio river and its tributaries. Boston Journ. Nat. Hist., 1841, 3, 338-352; 469-482. Ibid., 4, 16-26; 303-308. Ibid., 5, 21-32.

1841.2

66 species are enumerated, 8 of which are new.

Descriptions of Acipenser rubicundus, A. platyrhynchus and Rutilus storerianus. Proc. Boston Soc. Nat. Hist. 1841-44 (1844), 1, $71 . \quad 1844.1$

[Descriptions of several new species of fishes] Proc. Boston Soc. Nat. Hist. 1841-44 (1844), 1, 1. 1844.2

- Description of Leuciscus storerianus, sp. nov., from Ohio. Proc. Boston Soc. Nat. Hist. $1841-44$ (1844), 1, 199 200.

1844.3

Descriptions of the fishes of lake Erie, the Ohio river and their tributaries. Boston Journ. Nat. Hist., 1844, 4, 231240. Ibid., $1846,5,265-276 ; 330$ 344. pls.

1844.4

Remarks on Acipenser rubicundus and Rutilus plagiurus. Proc. Boston Soc. Nat. Hist. 1841-44 (1844), 1, 71.
- Description of a new species of fish from Ohio [Exoglossum dubium] Proc. Boston Nat. Hist. Soc. 1845-48 (1848), 2, 49-50.

1848.1

- On the resuscitation of frozen fish, in a letter to Prof. O. P. Hubbard. Amer. Journ. Sci., 1851, 12, 291-292.

1851.1

Describes experiments with eels at Middletown, Conn.

Fish-culture. Amer. Sportsman, $1874,3,347$.

1874.1

Kiselevich, $K$. Beiträge zur Ichthyofauna der Bucht von Odessa [Text in Russian] Sborn. Stud. Biol. Kruž, Odessa, 1908, 3, 116-140. $\quad 1908.1$

Kishinouye, Kamakichi. The Japanese mackerel and mackerels from Europe and America [Text in Japanese] Journ. Imp. Fish. Bureau, Tokyo, 1893, 2, 1-6. 3 pls.

1893.1

- A large bonito I'Text in Japanese! Zool. Mag., 1894, 6, 342. 1894.1

- Food of fishes of the mackerel family ['Text in Japanese] Journ. Imp. Fish. Bureau, Tokyo, 1895, 4, no. 2, 1732. pl. - Zool. Mag., 1895, 7, 111.

1895.1

Injury of Ayu (Plecoglossus altivelis) to other fishes [Text in Jap. anese! Zool. Mag., 1895, 7, 255. 1895.2

The fishing industry in Japan. Bergen, 1898. 13 p. $8^{\circ}$. 1898.1 Faunal lists; Pisces, p. 5.

The goldfish and other ornamental fish of Japan. Nat. Sci., 1898, 13, 39-42. 4 figs.

1898.2

The grey mullet fishery in Japan. Nat. Sci., 1898, 13, 253-258. 6 fixs.

1898.3

The Japanese species of the genus Pagrus. Journ. Imp. Fish. Bureau, Tokyo, 1901, 10, 31-42. 6 pls. \& figs.

1901.1

- On a new [unnamed] species of Salanx from the Ariake sea, Japan ['I'ext in Japanese] Dobuts. Zasshi., Tokyo, 1901, 13, 359-360.

1901.2

A rare shark, Rhinodon pentalineatus, n. sp. Zool. Anz., 1901, 24, 694695. 2 figs.

1901.3

- About Ingandarumi (Ruvettes pretiosus) ['T'ext in Japanese! Zool. Mag., 1902, 14, 418-419. 1902.1 
Kishinouye, $K$.

Investigations regarding the $\mathrm{Pa}$ grus fishery [Text in Japanese] Suisan Chosa Hokuku, Tokyo, 1902, 10, 57-68. pls.

1902.2

Nomenclature of Iidai (Pagrus tumifrons Schlegel $=$ Dentex hypselosoma Bleeker) [Text in Japanese] Zool. Mag., $1902,14,439$.

1902.3

- Nomenclature of Katsuwo (nec Gymnosarda affinis Cantor) l'Text in Japanese] Zool. Mag., 1903, 15, 415416 .

1903.1

On Yasurizame (Rhinodon pentalineatus) and Torafuzame (Stegostoma tigrinum) (Text in Japanese] Dobuts. Zasshi, Tokyo, 1903, 16, 41-44. figs.

1903.2

- Inawashiroko no Nijimasu [Salmo irideus in the lake Inawashiros Dobuts. Zasshi, Tokyo, 1904, 16, 387-388.

1904.1

The Nigisu again (Argentina semifasciata Kish.) ['Text in Japanese] Dobuts. Zasshi, Tokyo, 1904, 16, 26 ; $197-198$.

1904.2

Gyorui zakki [Miscellaneous notes on fishes] Dobuts. Zasshi, Tokyo, $1905,17,176-179$.

1905.1

Hompo ni sansuru 3 shu no Amadai The three species of Latilus in Japan] Dobuts. Zasshi, Tokyo, 1907, $19,56-60$.

1907.1

___ Homposan kurodai zoku no uwo 4 shu lOn the four Japanese species of the genus Sparus] Dobuts. Zasshi, Tokyo, 1907, 19, 326-329.

1907.2

Notes on the natural history of the sardine. Journ. Imp. Fish. Bur., Tokyo, 1907, 14, 71-105. 6 pls. 1907.3

Iwashi gyogyo chosa [Investigations regarding the fishery of clupeids] Suisan Chosa Hokoku, Tokyo, 1908, 14, 72-111. pls.

1908.1

This is the Japanese edition of "Notes on the natural history of the sardine" in Journ. Imp. Fish. Bur., Tokyo, 1907, 14, 71-105.

Ushisawara oyobi Kamarusawara Scomberomorus chinensis (Schl.) and Acanthocybium solandri (Cuv. \& Val.)] Dobuts. Zasshi, 'Tokyo, 1908, 20, 1-3. pl.

1908.2

Description of the clupeoid fishes from Ogasawara or Bonin islands. Journ. College Agriculture 'Tokyo, 1911, 2, no. $7.383-386 . \mathrm{pl}$.

1911.1
Prehistoric fishing in Japan. Journ. College Agriculture Tokyo, 1911, 2, no. 7, 327-382. 11 pls. \& 10 figs.

1911.2

Kiss, Elek. A hal mint tápszer [Fish as food] Vasárnapi Ujág., 1871, 41, 515.

1871.1

Kissling, Ernst. Die Tauna des Mittel-Oligocäns im Berner Jura. Abh. Schweiz. Paläont. Ges., 1896, 22, no. 3. 74 p. 9 pls. 1896.1

Tertiary fish-remains are referred to

Meeresmolasse im Emmenthal. Mitth. Nat. Ges. Bern 1901 (1902), 98101. 1902.1

Teeth of Lamna are mentioned.

Stachel eines Rochen aus der Meeresmolasse des Belpberges. Mitth. Nat. Ges. Bern 1901 (1902), 101-102.

Spines of Myliobatis.

1902.2

Kistler, Herbert D. The primitive pores of Polyodon spathula. Journ. Comp. Neurol., 1906, 16, 294-298. pl.

1906.1

Kitahara, Tasaku. Scombridæ of Japan. Journ. Imp. Fish. Bureau, Tokyo, 1897, 6, 1-3. 4 pls. $\quad 1897.1$

Note on the Leucopsarion petersi Hilg. Annot. Zool. Japon., Tokyo, 1904, 5, pt. 3, 113-115. pl.

1904.1

Preliminary note on the salmon and trout of Japan. Annot. Zool. Japon. Tokyo, 1904, 5, pt. 3, 117-120. 1904.2

Homposan sakerui |The Salmonidxe of Japan] Dobuts. Zasshi, 'Tokyo, 1905, 17, 175-176.

1905.1

The fisheries of Japan considered from a geographical standpoint (In Proc. 4. Intern. Fish. Congr., Washington, D. C.) Bull. Bureau Fisheries 1908 (1910), 28, pt. 1, 375-379. 1910.1

On the hydrographical observations made on board the "Kinkasan Maru," 1910. Rept. Imp. Fish. Bur., Tokyo, Scient. Invest., 1912, 1, 1-3. 3 maps.

1912.1

Kittary, Modeste. Recherches anatomiques sur les poissons du genre Acipenser. Bull. Soc. Nat. Moscou, 1850, 23, pt. 2, 389-445. 2 pls.

1850.1

Kittler, O. Ueber die Zucht von Pyrrhulina filamentosa Cuv. et Val. Wochenschr. Aquar.-Terrar. Kunde, 1907, 4. Jahrg., 545-546. 
Die Zucht von Pyrrhutina nattereri. Wochenschr. Aquar-Terrar. Kunde, 1909, 6. Jahrg., 548-519. 1909.1

Kittlitz, Albert Freiherr von. Zur Entwickelung der Gefässe im Auge der Forelle. Anat. Hefte, Wiesbaden, 1906. 32, 1. Abt., 279-305. 3 figs. Also separate; Wiesbaden, 1906. Inaug. Dissert.

1906.1

Kittlitz, Friedrich Heinrich von [1799-1874] Beschreibung mehrerer neuer oder wenig gekannter Arten des Geschlechtes Acanthurus, im stillen Ocean. Museum Senckenb., Frankfurta.-M., 1834, 1, 189-194.

1834.1

Denkwirdigkeiten einer Reise nach dem russischen Amerika, nach Mikronesien und durch Kamschatka. 2 vols. Gotha, 1858. pls. 8 1858.1

Description of different species of fish, $\mathrm{Bd}$. i, p. 57-66; 223-227; 299-303. Bd, ii, p. 65-66; $101-102 ; 123-126$.

Klaatsch, Hermann. Zur Morphologie Fischschuppen und zur Geschichte der Hartsubstanzgewebe. I. Die Schuppen der Selachier. II. Die Rhombenschuppen der Ganoiden. III. Die Schuppen der Teleostier. IV. Die Cycloidschuppen der Dipnoer und fossiler Ganoiden. Die Phylogenese der "Cycloidschuppen." V. Die Schuppen von Ichthyophis. VI. Die Ableitung der Schuppen. VII. Die Geschichte der Hartsubstanzgewebe. Morphol. Jahrb., 1890, 16, 97-203; 209-258. 2 pls.

1890.1

Appended are references to the works of 48 authors who have treated the subject.

Beiträge zur vergleichenden Anatomie der Wirbelsäule. Morphol. Jahrb., 1892-95. 1892.1

i. Ueber den Urzustand der Fischwirbelsäule. Mlorphol. Jahrb., 1892, 19, 649-680. pl. \& fig.

ii. Ueber die Bildung knorpeliger Wirbelkörper bei Fischen. Ibid., 1893, 20, 143-186. pl.

iii. Zur Phylogenese und zur Geschichte der Umwandlungen der Chordastruktur. Ibid., 1895, 22, 514-560. 2 pls.

- Ueber die Wirbelsäule der Dipnoer. Anat. Anz., 1893, 9 (Verh. Anat. Ges.), 130-132.

1893.1

- Ueber die Herkunft der Ścleroblasten. Ein Beitrag zur Lehre von der Osteogenese. Morphol. Jahrb., 1894, 21, 153-240. 5 pls. \& figs. 1894.1 _- Die Brustflosse der Crossopterygier. Ein Beitrag zur Anwendung der Archipterygium-Theorie auf die Gliedmassen der Landwirbelthiere (In Festschrift zum siebenzigsten Geburtstage von Carl Gegenbaur, Bd. i, p. 261-391. 4 pls. \& 42 figs. Leipzig, 1896) 1896.1

Appended is a list of 75 papers pertaining to the subject discussed.
- Bemerkungen ïber die Gastrula des Amphioxus. Morphol. Jahrb., 1897, 25, 224-243. pl. \& 4 figs. Abstracts in Zool. Centralbl., 4. Jahrg., 712-714. Journ. Roy. Micr. Soc. London, 1897, 357.

1897.1

- 'Lur Frage nach der morphologischen Bedeutung der Hypochorda. Morphol. Jahrb., 1897, 25, 156-169. pl. 1897.2

Die Intercellularstructuren an der Keimblase des Amphioxus. Sitzber. Mkad. Wiss. Berlin, 1898, 800-806. 4 figs.

1898.1

Ueber den Bau und die Entwickelung des Tentakelapparates des Amphioxus. Anat. Anz, 1898, 14, (Verh. Anat. Ges.), 184-195. 1898.2

- Zur Deutung von Helicoprion Karp. Centralbl. Mineral., Stuttgart, 1901, 429-436. 2 figs.

1901.1

Klaatsch, Hermann Martin August [1827-1885] De cerebris piscium Ostacanthorum aquas nostras incolentium. Dissertatio inauguralis zootomica. Pars commentationis a gratioso medicorum ordine præmio ornata. Halis Saxonix, 1850. 40 p. 4 pls. $4^{\circ}$. 1850.1

Klapproth, Adolf. Der Maulbrüter, seine Pflege und Zucht im Aquarium. Wochenschr. Aquar.-Terrar. IKunde, 1909, 6. Jahrg., pp. 445-447. fig. 1909.1

Klaptocz, A. Reptilien, Amphibien und Fische aus Französisch Guinea. Zool. Jahrb. (Syst. Abt.), 1913, 279-290.

1913.1

Klaussner, $F$. Mehrfachbildungen bei Wirbeltieren. München, 1890.

1890.1

Kleberg, O. Ofversigt af Plagiostomernas anatomi. Lund, 1868. $8^{\circ}$.

1868.1

Klein, A. von. Beiträge zur Bildung des Schädels der Knochenfische. I-III. Jahr. Ver. Vaterl. Naturk. Württemberg, 1884, 40, 129-251. Ibid., 1885, 41, 107256. Ibid., 1886, 42, 205-300. pls.

1884.1

Klein, Edward Emanuel. Beiträge zur Anatomie der Lepidosiren [Protopte*us] annectens. Jahresh. Ver. Vaterl. Naturk. Württemberg, 1864, 20, 134144.

1864.1

Der Kiopf der Pleuronectidx. Jahresh. Ver. Vaterl. Naturk. Württemberg, 1868, 24, 271-30s. pl. 1868.1 
Klein, $E, E$. Vergleichende Beschreibung des Schädels der Wirbelthiere. Versuch einer auf anatomische Gründe sich stützenden, gleichartig durchgeführten Benennung der Schädelknochen. Jahresh. Ver. Vaterl. Naturk. Württemberg, 1868, 24, 71-171.

1868.2

- Beitråge zur Osteologie des Genus Balistes Cuv. (Sclerodermi) Jahresh. Ver. Vaterl. Naturk. Württemberg, 1872, 28, 262-300.

1872.1

Researches on the first stages of the development of the common trout, Salmo fario. Monthly Micr. Journ., 1872, 7, 193-200. 2 pls.

1872.2

Observations on the early development of the common trout (Salmo fario) Quart. Journ. Micr. Sci., 1876, n. s. $16,113-131$. pl.

1876.1

Beiträge zur Osteologie des Schädels der Knochenfische. Jahresh. Ver. Vaterl. Naturk. Württemberg, 1879, 35, 66-126. pl.

1879.1

- Beiträge zur Osteologie der Fische. Jahresh. Ver. Vaterl. Naturk. Württemberg, 1881, 37, 325-360. pl.

1881.1

Beiträge zur Bildung des Schädels der Knochenfische. Jahresh. Ver. Vaterl. Naturk. Württemberg, 1884, 40, 129-257. Ibid., 1855, 41, 107-261. Ibid., 1886, 42, 205-300.

1884.1

Klein, Jacob Theodor [1685-1759] Specimen descriptionis petrefactorum Gedanensium cum syllabo tabularum. - Probe einer Beschreibung und Abbildung der in der Dantziger und umliegenden Gegend befindlichen Versteinerungen. Nürnberg, 1770.16 p. 24 pls.

1770.1

Latin and German in parallel columns.

J. T. Kleinii Ichthyologia enodata, sive Index rerum ad historiam piscium naturalem, synonymis recentissimorum systematicorum explicatus ab J. J. Walbaum. Lipsix, 1793. 114 p. $4^{\circ}$. See Walbaum, $J . J$.

1793.1

- Ichthyologia; seu, Historix piscium naturalis quinque missus. Cui accedit Ichthyologia Kleiniana enodata, sive Index rerum ad historiam piscium naturalem, cum synonymis recentissimorum systematicorum Artedi, Linnxi, Gmelini, Blochii, etc., explicatam. Lipsiæ, 1802. 53 pls. $4^{\circ}$.

1802.1

This is a later edition of Klein's pre-Linnæan Historia Piscium, appended to which are Walbaum's emendations, first published in 1793. See Walbaum, $J . J$.
Kleine, Max. Die Zucht des Gründlings (Gobio fluviatilis Flem.) im Aquarium. Blätt. Aquar-Terrar. Kunde, 1912, 23, 466-468. fig.

1912.1

Kleinert, - Extrait du rapport sur les essais de pisciculture faits à Herrenalb. Bull. Soc. Acclim. Paris, 1861 , 8, 38-44. fig. 1861.1

Klencke, P.F.Hermann. Alexander von Humboldt, ein biographisches Denkmal. Leipzig, 1851 . xii, 252 p. $8^{\circ}$. 1851.1

- The same. 2. Auflage. Leipzig, 1852. xvi, $224 \mathrm{p}$. 1852.1

An English translation, by Juliette Bauer, was published at London in 1852.

Klinckowström, Axel. Beiträge zur Kenntniss des Verlaufes der Darm- und Lebervenen bei Myxine glutinosa. Biol. Fören. Förh., Stockholm, 1890, 2, 62-67. 1890.1

Ueber die blutführenden Lymph. räume bei Myxine glutinosa. Biol. Fören. Förh., Stockholm, 1891, 4. 1891.1

Beitråge zur Kenntniss der Augen von Anableps tetrophthalmus. Skand. Arch. Physiol., Leipzig, 1893, 5. 1893.1

Die Zirbel und das Foramen parietale bei Callichthys ( $C$. asper und tittoralis) Anat. Anz., 1893, 8, 561-564. figs.

1893.2

Om ett nyligen funnet moget ägg of piraten (Myxine glutinosa) Vet. Akad. Förh., Stockholm, 1895, 52. Jahrg., 55-56. Abstract in Zool. Centralbl., 4. Jahrg., no. 1, 37.

1895.1

Klingelho̊ffer, $W$. Das Auge der Wirbeltiere. Wochenschr. Aquar.-Terrar. Kunde, 1911, 8. Jahrg.

1911.1

- Der Brechungszustand und die Einstellungsvorrichtung des Schlammspringerauges. Wochenschr. Aquar.Terrar. Kunde, 1912, 9. Jahrg., 196-197. 2 figs.

1912.1

Klingspor, $D . M$. Södra sveriges fiskeriförenings insjöfiske år 1910. Skrift. Södra Sveriges Fiskerifören., 1911, 1, no. $8,23-27$.

1911.1

Klinkhardt, Werner. Beiträge zur Entwickelungsgeschichte der Kopfganglien und Sinneslinien der Selachier. Jena Zeitschr. Naturw., 1905, 40, 423-486. 3 pls. \& 6 figs.

1905.1

Klippart, John H. [-1878] On fish guano. Rept. Ohio Agric., 1861, $180-220$ 
- An essay on fish-culture. Columbus, Ohio, 1873. 20 p. $8^{\circ}$. 1873.1 Do inland fish migrate? Forest \& Stream, 1876, 6, 132.

1876.1

History of the fisheries of Toledo and Sandusky. 1. Ann. Rept. Ohio State Fish Comm. 1875 (1876), 30-41.

1876.2

Kliss von Zilah, $A$. Ueber den schädlichen Einfluss von Mikroorganismen auf die künstliche Forellenzucht Oesterr. Monatschr. Tierheilk., 1897. $433-435$.

1897.1

Klose, C. Der Uckelei [Alburnus lucidus] Wochenschr. Aquar.-Terrar. Kunde, 1910, 7. Jahrg., 101-103.

1910.1

Klug, C. Die Wasserinsektenzucht als Nahrung für Fische Deutsch. Fischerei Zeitg., 1878, 1. Jahrg., 182 183.

1878.1

Klug, Johann Christoph Friedrich [1775-1856] Die Arten der Gattung Megalopus. Jahrbücher Insectenkunde, $1834,1,208-223$.

1834.1

Contains incidental mention of fishes.

Note sur le genre Thynnus. I'Institut, $1840,8,310$. - Rev. Zool. $1840,285$.

1840.1

Klunzinger, Carl Benjamin [1834 - ] Synopsis der Fische des Rothen Meeres. I. Theil. Percoiden-Mugiloiden. Verh. Zool.-Bot. Ges. Wien, 1870, 20, 669-834.

1870.1

- Synopsis der Fische des Rothen Meeres. II. 'Theil. Verh. Zool.-Bot. Ges. Wien, 1871, 21, 441-668. 1871.1

The two parts were also published separately in one volume, with an appendix entitled Systematische Uebersicht der Fische des Rothen Meeres, als Anhang und Register zur Synopsis Wien, 1871. $8^{\circ}$.

Systematische Uebersicht der Fische des Rothen Meeres, als Anhang und Register zur Synopsis. Verh. Zool.-Bot. Ges. Wien, 1871, 21, 13531368.

1871.2

Ueber den Fang und die Anwendung der Fische und anderer Meeresgeschöpfe im Rothen Meere. Zeitschr. Erdkunde Berlin, 1871, 6, 58-72. 1871.3

Eine zoologische Exkursion auf ein Korallriff des Roten Meeres, bei Koseir. Zeitschr. Ges. Erdkunde, Berlin, 1872, 20-56. Abstract in Verh. Zool.-Bot. Ges. Wien, 1870, 389-394.

Observations on fishes, p. 50-56.
- Zur Fischfauna von Süd-Australien. Arch. Naturgesch., 1872, 38. Jahrg., pt. 1, 17-47. 1872.2

-- Bilder aus Oberägypten, der Wüste, und dem Roten Meere. Stuttgart, 1877. 400 p. illust. $\quad 1877.1$

Fische vom Nil, p. 148. - Die Fischer, p. $297-$ 300. - Zubereitung der Fische, p. 300-301. Dei Naturschätze des Roten Meeres (Fische), p. $365-373$.

Upper Egypt, its people and its products. With sketches of the natural history and geology ... and with prefatory notice by G. Schweinfurth. London, etc., 1878.408 p. illust. $8^{\circ}$.

1878.1

Die von Müller'sche Sammlung australischer Fische in Stuttgart. Sitzber. Akad. Wiss. Wien, 1880, 80, 1. Abth., 325-430. 8 pls.

1880.1

Die Fische in Württemberg, faunistisch-biologisch betrachtet, und die Fischereiverhaltnisse daselbst. Jahresh. Ver. Vaterl. Naturk. Württemberg, 1881, 37, 172-304.

1881.1

Die Fische des Roten Meeres. Eine kritische Revision mit Bestimmungs-Tabellen. Teil I. Acanthopteri veri Owen. Stuttgart, 1884. 133 p. pls. \& figs. fol. 1884.1

Ueber die Felchenarten des Bodensees. Jahresh. Ver. Vaterl. Naturk. Württemburg, 1884, 40, 105-128. 1884.2

Ueber Bach- und Seeforellen. Jahresh. Ver. Vaterl. Naturk. Württemberg, 1885, 41, 266-288. 1885.1

_ Die Fischfauna der Schweiz nach Fabio. Naturw. Wochenschr., 1891,6 , no. 51, 513-515. 1891.1

Bodenseefische, deren Pflege und Fang. Stuttgart, 1892. 232 p. 88 figs. $8^{\circ}$.

1892.1

Die Fischerei Ausstellung in Friedrichshafen (am Bodensee) am vierten deutschen Fischereitag. Circul. Deutsch. Fischerei Ver., 1892, 1-15.

1892.2

Ueber die prähistorischen Fischereigerätschaften, insbesondere der Pfahlbauten des Bodensee's. Circul. Deutsch. Fischerei Ver., 1892. 6 p.

1892.3

Ueber Zwergrassen bei Fischen und bei Felchen insbesondere. Jahresh. Ver. Vaterl. Naturk. Württemberg, 1900, 56, 519-532. 1900.1 
Klunzinger, $C . B$.

Die zoologischen und anatomisch-physiologischen lienntnisse und Anschauungen des Aristotles. Jahresh. Ver. Vaterl. Naturk. Württemberg, 1901, 57, Ixxi-lxxiii.

1901.1

Gangfisch und Blaufelchen $[\mathrm{Co}$ regonus exigutes und C. macrophthalmus] Jahresh. Ver. Vaterl. Naturk. Württemberg, 1903, 59, 255-266. 2 pls. 1903.1

Ueber Melanismus bei Tieren im allgemeinen und bei unseren einheimischen insbesondere. Jahresh. Ver. Vaterl. Naturk. Würt temberg, 1903, 59, 267-297.

1903.2

- Entgegnung auf Nüsslin's Ausführungen in der Gangfisch-BlaufelchenFrage vom September 1903. Jahresh. Ver. Vaterl. Naturk. Württemberg, $1904,60,335-343$.

1904.1

-Dchlusswort auf obenstehende "Letzte Eirwiderung" Professor Niisslin's, in dieser Zeitschrift die GangfischBlaufelchen-Frage betreffend. Jahresh. Ver. Vaterl. Naturk. Württemberg. $1905,61,307-309$.

1905.1

- Ucher neue Finde von schwarzen Fröschen und Forellen im Murgtal. Jahresh. Ver. Vaterl. Naturk. Würtemberg, 1907, 63, Ixxv-lxxvi.

1907.1

- Die 'Trommelsucht der Kropffelchen oder Kilchen. (Coregomus acronius Rapp.) Verh. Deutsch. Zool. Ges., $1908,18,241-243$.

1908.1

Futtertiere für Aquarien-Fische Vochenschr. Aquar-Terrar. IIunde, $1911,378-379$

1911.1

Ueber die Goldfischabinten und ihre künstliche Erzeugung nach Tornier. Jahresh. Ver. Vaterl. Naturk. Wiirtemberg, 1912, 68, xevi-cii.

1912.1

Knapp, $r, I I,[-1863]$ Ueber die medicinische Wirkung des Leberthrans und deren Ursachen. Annal. Pharm. (Lichig), 1S46, 58, 81-89

1846.1

Knauer, fiviedrich Kurl. Abenteuerliche Fischgestalten. Eine Wanderung durch die Formenwelt der Fische. Oesterr.-ungar. IHischerei '/eitg., 1880 , 286-287; 29-1-295; 302-303. 1880.1

Handwörterbuch der 'toologie. Unter Mitwirkung von Prof, von Dalla 'l'orre bearbeitet. Stuttgar, 1887. xiv, $\$ 28$ p. 9 pls. $8^{\circ}$. 1857.1
- Neue Beobachtungen an Fischen. Wochensehr. Aquar.-Terrar. Kunde, $1908,5,455-456$.

1908.1

Die Bauchmuskulatur der Fische. Arb. Zool. Inst. Wien, 1910, 18 207-226. 3 pls. \& 6 figs.

1910.1

Knauthe, Karl [Remarks on the endurance of fish in pools, the water of which has been completely frozen up Zool. Garten, 1887, 29, 71-73; 142-148.

1887.1

- [Remarks on the breeding habits of Phoxinus lavis, Leucaspius delineatus and Cobitis barbatula in Silesias Zool. Garten, 1890, 31, 56-57.

1890.1

Ueber Barbus petenyi Heck. in s'chlesien. Zool. Anz., 1890, 13, 720 721.

1890.2

-... Bastarde von Gobio fluviatilis und Lenciscus phoximus, etc. Zool. Anz., 1891, 14, 258. 1891.1

- Further biological notes on German freshwater fishes! Zool. Garten, 1891, 32, 17-23.

1891.2

lchthyologische Mittheilungen. Zool. Anz., 1891, 14, 259-264. 5 figs.

1891.3

- Meine Erfahrungen über das Verhalten von Amphibien und Fischen gegenüber der Kïlte. Zool. Anz., 1891 14, $104-106 ; 109-115 . \quad 1891.4$

- Ueber Entwicklungsformen von Gobio fluviatitis. Zool. Anz., 1891, 14, 59-61. 1891.5

_ ' Zur Biologie der Fische. 'Zool. Anz, 1891, 14, 73-76. 1891.6

'Zur Bressen und Zanderzucht. Berichte Fischerei Ver. Ost- U. Westpreuss.; 1891-92.

1891.7

- Ueber Melanismus bei Fischen. Zool. Anz., 1892, 15, 25. 1892.1

Ichthyologische Notiz. Zool. Anz, 1893, 16, 109-110; 355-356.

1893.1

Ueber einen neuen Fortpflanzungsfuhigen Cypriniden aus Mittelschlesien, Albumus leydigii mihi, sp. nov. (1. lucidus $\times$ Leucaspius delineatus) Zool. Anz., 1893, 16, 448-450. 1893.2

Zwei Falle von latenter Vererbung der Mlopsköpfigkeit bei Cyprinoiden. Biol. Centralbl., 1893, 13, 766767.

1893.3 
Zwei Fortpflanzungsfähige CYprinidenbastarde. Zool. Anz., 1893, 16. +16-418.

1893.4

- Einfluss der Nahrung auf Farbung. Zeitschr. Naturw., 1894, 67.

1894.1

Cypriniden-Bastarde.

Zool. 1895.1

Anz., 1895, 18, 407.

Einige Notizen über Bliccopsis erythrophthalmoides Jäck. Zool. Anz., $1895,18,490-491$.

1895.2

Maximaltemperaturen, bei denen Fische am Leben bleiben. Biol. Centralbl., 1895, 15, 752 .

1895.3

'Two fertile cyprinoid hybrids. Bull. U. S. Fish Comm. 1894 (1895), 14, $29-30$.

1895.4

- Blendlinge zwischen Bitterling und Rapfenlaube (Rhodeus amarus und Leucaspius delineatus) Zool. Garten, 1896, 37. Jahrg., 220.

1896.1

- Die deutschen Süsswasserfische, ihre Lebensverhältnisse, Zucht und Pflege. Die Natur, 1896, 45. Jahrg., $569-571 ; 577-580$. 5 figs. 1896.2

Fortpflanzung des Aales. Biol. Centralbl., 1896, 16, 847 -84S. 1896.3

- Nahrung des Karpfens. Zool. Garten, 1896, 37. Jahrg., 345-346.

1896.4

Ueber die Erbrïtung der Forelleneier und Aufzucht der Jungbrut. Correspbl. Fischzucht., 1896, 3. Jahrg., 110. 4, 59-62.

1896.5

Ueber Weissfischbastarde aus den Gewässern in der Nähe von Berlin. Forschungsber. Biol. Station Plon, 1896 , 4, 262-272.

1896.6

- Zur Biologie der Süsswasserfische. Biol. Centralbl., 1896, 16, 410 $\$ 16$.

1896.7

- Dic Verdaungsorgane des Karpfens. Deutsch. Fischerei Zeitg., 1897.

1897.1

- Untersuchungen über die $\mathrm{Ver}$ daung der Fische. Fischerei Zeitg. 1S98, 1 .

1898.1

Zur Kenntniss des Stoffwechsels der Fische. Arch. Gesammt. Anat. 1898,73, 490-500.

1898.2

Beobachtungen ïber den Gasgehalt der Gewässer im Winter. Biol. Centralbl., 1899, 19, 783-799. 1899.1
- Ueber neuere Fut terausnut zangsversuche an Karpfen. Fischerei 'Leitg., $\begin{array}{lll}1899,2 . & 1899.2\end{array}$

- Newere Erfahrungen in der lischfüterung. Fischerei Zeitg., 1900 , 8.

1900.1

- Fischsterben bei Gewittern. Fischerei Zeitg., 1901, 4, 71-72. 1901.1

Gewitter und Fischsterben; eine Umfrage. Allgem. Fischerei 'Leitg., 1901, 26, 74-76. - Natur, Halle, 50, 100-101. -Deutsch. Landw. Presse, Berlin, 28, 101-102. - Zool. Garten, 42. Jahrg., 153-1.56. - Natur u. Haus, 9, 32.5-327. 1901.2

_- Die Käarpfenzucht. Neudamm, 1901. 3 . figs. $S^{\circ}$. 1901.3 Nahrung der Rotfeder. Zool. Garten, 1902, 43. Jahrg., 40t-405.

1902.1

Cariotaten des Hechtes: Tool. Garten, 1902, 43. Jahrg., 405. 1902.2

Zur Frage der Degeneration und Bastardbildung bei Fischen. Fischerei Zeitg., 1902, 5, 629. 1902.3

- Zusammenhang zwischen Degeneration und Bastardbildung bei Weissfischen. Zool. Garten, 1903, 44. Jahrg., $57-58$.

1903.1

Ueber rationelle ISarpfenzucht unter hesonderer Berïksichtigung von Düngung und Füitterung. Oester,-ungar. Fischerei Zeitg., 1905.

1905.1 194 figs. $\mathrm{S}^{\circ}$. 1007.1

- Ueber Säurebildung in Gewässern und deren Bezichung zum Auftreten von Fischkrankheiten. Areh. Hydrobiol. Planktonkunde, Stuttgart, 1905, 3, 290-308. $\quad 1908.1$

Knauthe, Karl, Apstein, C., Berthelmann, — Borcherding, Fr. Cronheim, - , \& Debschitz, $H$. von. Die Kirpfenzucht. Anleitung zum praktischen Betriebe unter Berïcksichtigung der neuesten wissenschaftlichen Erfahrungen. Neudamm, 1901. 389 p. 53 figs. $8^{\circ}$. 1901.1

Knauthe, Karl, \& Zuntz, Nathan. See Zuntz \& Knauthe.

Kneeland, Samuel [1821-1888] Dissection of a female fox shark (Alopias vulpes) Boston Journ. Nat. Hist., 1847, 5. $485-486$. 
Kneeland, $S$.

- Dissection of Scymnus brevipinna (Lesueur) Boston Journ. Nat. Hist., $1847,5,479-485$. fig.

1847.2

- - [How to avoid having fish enter the water-pipes of reservoirs] Proc. Boston Soc. Nat. Hist., 1856, 5, 206-207.

1856.1

- Some crustacean parasites from the skin of a sunfish, Orthagoriscus mola, obtained at Cohasset. Proc. Boston Soc. Nat. Hist., 1858, 6, 396.

1858.1

[Respiration of fishes of the blenny family, and genus Pholis, called shanny in Europe] Proc. Boston Soc. Nat. Hist. 1861 (1862), 8, 103.1862 .1

-... Fish from Cochituate waterpipe. Proc. Boston Soc. Nat. Hist. 1866, 5, 206-207.

1866.1

- A zoologist on the Pacific coast. Amer. Naturalist, 1871, 5, 312. 1871.1

Describes movements of flying-fish in the Pacific.

Account of a trip in 1870, from San Francisco to Panama. Proc. Boston Soc. Nat. Hist., 1872, 14, $137-$ 139.

1872.1

Remarks upon flying-fish, etc

Remarks on the abundance of the hair-finned dory (Argyriosus capillaris Mitch.) near Cohasset. Proc. Boston Soc. Nat. Hist., 1877, 19, 4 .

Kner, Rudolf [1810-1869] Ueber die beiden Arten Cephalaspis lloydii und C. lewisii Agassiz, und einige diesen zunächst stehenden Schalenreste. Naturwiss. Abhandl. (Haidinger), 1847, 1. 159-168. pl.

1847.1

Lehrbuch der Zoologie. Wien, 1849. $8^{\circ}$.

1849.1

A third edition of this work entitled "Compendium der Zoologie," was published at Vienna in 1862 .

Ueber die Verschiedenheiten der Blinddärme bei den Salmonen. Sitzber. Akad. Wiss. Wien, 1851, 6, 240-248. pl.

1851.1

Ueber die Mägen und Blinddärme der Salmoniden. Sitzber. Akad. Wiss. Wien, 1852, 7, 201-232. 1852.1

Die Hypostomiden. Zweite Hauptgruppe der Familie der Panzerfische (Loricata vel Goniodontes) Denkschr. Akad. Wiss. Wien, 1854, 7, 251-286. pls. - Abstract in Sitzber. Akad. Wiss. Wien, 1853, 10, 279-282.

1854.1
Die Panzerwelse des $k . k$. HofNaturalien-Cabinetes zu Wien. I. Abtheilung. Loricarinæ. Denkschr. Akad. Wiss. Wien, 1854, 6, 65-98. 8 pls. Abstract in Sitzber. Akad. Wiss. Wien, $1853,10,113-116$.

1854.2

- Ueber einige Sexual-Unterschiede bei der Gattung Callichthys und die Schwimmblase bei Doras C. Val. Sitzber. Akad. Wiss. Wien 1853 (1854), 11, 138-146. pl.-Also separate; Wien, 1854. 10 p. $8^{\circ}$.

1854.3

Ichthyologische Beiträge. Sitzber. Akad. Wiss. Wien, 1855, 17, 92162. 9 pls.

1855.1

Under this title various of the author's contributions appearing in the Sitzungsberichte and Denkschriften of the Vienna Academy were also published separately, 1855-58.

Ueber ein neues Genus aus der Familie der Welse, Siluroidei IClarotes heuglini 1 Sitzber. Akad. Wiss. Wien, $1855,17,313-316.2$ pls. $\quad 1855.2$

Ichthyologische Beiträge. II. Abtheilung. Sitzber. Akad. Wiss. Wien, 1858, 26, 373-448. 9 pls.

1858.1 Siluridæ from Brazil.

Kritische Bemerkungen über Castelnau's Siluroiden. Arch. Naturgesch., 1858, 24, pt. 1, 344-350. 1858.2

Ueber Trachypterus altivelis und Chactodon truncatus, n. sp. Sitzber. Akad. Wiss. Wien, 1859, 34, 437-445. 2 pls.

1859.1

Zur Familie der Characinen. III. Folge der Ichthyologischen Beiträge. Denkschr. Akad. Wiss. Wien, 1859, 17, 137-182. 9 pls. Tbid., 1860, 18, 9-62. 8 pls. Abstract in Sitzber. Akad. Wiss. Wien, 30, 75-80. Ibid., 32, $163-169$.

1859.2

Ueber Belonesox belizanus, nov. gen. et spec., aus der Familie der Cyprinodonten. Sitzber. Akad. Wiss. Wien, 1860, 40, 419-422. pl. 1860.1

Ueber den Flossenbau der Fische Sitzber. Akad. Wiss. Wien, 1860, 41, 807-824. Ibid., 1861, 42, 1. Abth., 232260, 759-786. Ibid., 1862, 43, 1. Abth., 123-152. Ibid., 1863, 44, 1. Abth., 4980. 72 figs.

1860.2

- Ueber einige noch unbeschriebene Fische. Sitzber. Akad. Wiss. Wien, 1860, 39, 531-547. pl. 1860.3 Centropus, Amphisile, Hemirhamphus, Astronesthes. 
Uebersicht der ichthyologischen Ausbeute während der Reise Sr. kais. Maj. Fregatte "Novara." Sitzber. Akad. Wiss. Wien, 1860, 40, 423-428.

1860.4

Preliminary note with remarks on geographical distribution.

Zur Charakteristik und Systematik der Labroiden. Sitzber. Akad. Wiss. Wien, 1860, 40, 41-57. 2 pls.

1860.5

Ichthyologische Berichtigungen. Arch. Naturgesch., 1861, 27, pt. 1,5759.

1861.1

- Ueber Kiemen-Anhänge bei Characinen. Verh. Zool.-Bot. Ver. Wien, 1861, 11, 189-192. pl. 1861.2

Kleinere Beiträge zur Kenntniss der fossilen Fische Oesterreichs. Sitzber. Akad. Wiss. Wien, 1862, 45, 1. Abth., 485-498. 2 pls.

1862.1

New species are described of Julis, Palimphemus and Pagrus from the Eocene of the Leithagebirge.

Ueber die drei Fischgattungen Pterophyllum, Symphysodon und Monocirrhus Heck. Sitzber. Akad. Wiss. Wien, 1863, 45, 1. Abth., 294-303. 2 pls.

1863.1

Ueber die sogenannten Spornschuppen der Fische und ihre Bedeutung für die Systematik. Sitzber. Akad. Wiss. Wien, 1863, 46, 1. Abth., 477-481. 1863.2

Ueber einige fossile Fische aus den Kreide- und Tertiärschichten von Comen und Podsused. Sitzber. Akad. Wiss. Wien, 1863, 48, 1. Abth., 126-148. 3 pls. 1863.3

New species are described of Amionsis (= Amiurus), Scombroclupea, Elopopsis, Coelodus and Clupea from the Cretaceous, and of Clupea and Brasmius from the Tertiary of Croatia. Note on Palimphemus, p. 148.

Einige für die Fauna der Oesterreichischen Suisswasserfische neue Arten. Verh. Zool.-Bot. Ver. Wien, 1864, 14, 75-84. Notice in Zeitschr. Gesam. Naturwiss. Berlin, 26, 225-226. 1864.1 Acerina, Gobius, Cyprinus, Carpio, etc.

Einige neue Fische: Thysanocheilus ornatus, Leius ferox, Cottus gigas, Osmerus oligodon. Anzeiger Akad. Wiss. Wien, 1864, 1, 185-187. Notice in Ann. Mag. Nat. Hist., 3. ser. 15, $77-78$.

1864.2

Einiges über die Thymusdrüse bei Fischen und die Schwimmblase der Stachelflosser. Sitzber. Akad. Wiss.
IVien, 1864, 49, 1. Abth., 455-459.-

Anzeiger Akad. Wiss. Wien, 1, 63-64.

1864.3

Specielles Verzeichniss der Während der Reise der kaiserlichen Fregatte "Novara" gesammelten Fische. Sitzber. Akad. Wiss. Wien, 1864, 49, 1. Abth., 481-486. Ibid., 51, 1. Abth., 499-504. Ibid., 53, 1. Abth., 543-550.

List of teleosts.

1864.4

Fische aus dem naturhistorischen Museum der Herren J. C. Godeffroy \& Sohn in Hamburg. Denkschr. Akad. Wiss. Wien, 1865, 24, 1. Abth. 1-12. 4 pls. 1865.1

Psalidostoma, eine neue Characinen-Gattung aus dem weissen Nil. Sitzber. Akad. Wiss. Wien, 1865, 50, 1. Abth., 99-102. pl. Notice in Ann. Mag. Nat. Hist., 3. ser. 14, 399. 1865.2

Reise der österreichischen Fregatte "Novara" um die Erde in den Jahren 1857-1859, unter den Befehlen des Commodore B. von WüllerstorfUrbain. Wien, 1865-67. $4^{\circ}$. 1865.3 Zoologischer Theil, Fische。1-3 Abth. 433 p. 16 pls.

Ueber Salmoniden-Bastarde. Verh. Zool.-Bot. Ver. Wien, 1865, 15, 199-202. Abstract in Zeitschr. Gesam. Naturw. Berlin, 27, 453-454. 1865.4

- Vergleichung eines jungen Zeus faber mit Argyropelecus hemigymnus. Verh. Zool.-Bot. Ver. Wien, 1865, 15, $287-290$.

1865.5

Betrachtungen über die Ganoiden, als natürliche Ordnung. Sitzber. Akad. Wiss. Wien, 1866, 54, 1. Abth., 519-536. Abstract in Geol. Mag., 5, 429-432.

1866.1

Die Fische der bituminösen Schiefer von Raibl in Kärnthen. Sitzber. Akad. Wiss. Wien, 1866, 53, 1. Abth., 152-197. 6 pls. 1866.2

Fossile Fische aus Ungarn. Verh. Geol. Reichsanst., Wien, 1866, 16, 143145 .

1866.3

- Die fossilen Fische der Asphaltschiefer von Seefeld in Tirol. Sitzber. Akad. Wiss. Wien, 1866, 54, 1. Abth., 303-341. 6 pls.

1866.4

Supplementary notes to this paper, entitled "Nachtrag I" and "Nachtrag II," are contained in Sitzber. Akad. Wiss, Wien, 56, 1. Abth., 898-909, and 909-913, with pls. i-iii.

The following genera are discussed: Eugnathus, Lepidotus, Semionotus, Pholidophorus. 
Kner, $R$.

- Neue Fische aus dem Museum der Herren J. Cas. Godeffroy \& Sohn in Hamburg. Sitzber. Akad. Wiss. Wien, 1866, 54, 356-395.5 pls. Also separate; Hamburg, 1867.1866 .5

Berycida, Trachinida, Trichiuridæ, Carangidæ, Scombride, Gobiidx; Blenniida, Centriscidæe, Labridæ and Ophidiidæ.

Veber das Vorkommen dex Schimmblase und die Anordnung der Sesualorgane bei Aalähnlichen Fischen. Sitaber. Akad. Wiss. Wien, 1866, 52 , 648-653. Notice in Aun. Mag., Nat. Hist.., 3. xer. 17, 385.

1566.6

Nichtrag zu den fossilen Fischen von Raihl. Sitzber. Akad. Wiss. Wien, $1867,55,1$. Abth. 718-722. pl.

1867.1

Thoracopterus, Pteryopterus, etc., from the Trias.

- Neuer Beitrag zur Kenntniss der fossilen Fische von Comen bei Görz. Sitzber. Akad. Wiss. Wien., 1867, 56. $171-200$.

1867.2

Hemisaurida, saurocephalus, Hemirhvnchus, lalæobalistes, saurorhamphus, Scombroclupea, Chirocentrites, Ellopopsis.

Ueber Orthacanthus decheni Goldf. oder Xenacanthus dechenii Beyr. Sitzber. Akad. Wiss. Wien, 1867, 55, 1. Abth., 540-58t. 10 pls. Notices in Ann. Mag. Nat. Hist, 3. ser. 19, 152. Geol. Mag., 5, 376-380.

1867.3

- Ueber Conchopoma gadiforme nov. gen. et spec., und Acanthodes aus dem Rothliegenden (der untern Dyas) von Lebach bei Saarbrücken in Rheinpreussen. Sitzber. Akad. Wiss. Wien, 57, 1868, 1. Abth., 278-305. \& pls. Abstract in Geol. Mag., 7, 29-30. 1S68.1

Ceber die fossilen Fische in der Ireide von Sendenhorst. Zeitschr. Gesam. Naturw, Halle, 1868, 31, 374 $: 37$.

1868.2

- Ueber neue lische aus dem Museum der Herren Johann Cäsar Godeffroy \& Sohn in Hamburg. IV. Folge. Sitzber. Akad. Wiss. Wien, 1868, 58, 26-31. Ibid., 293-356. 9 pls. 1868.3

Berveillx, Percidæ, Mullidx, Squamipennes, Trachinidx, Carangidx and other Acanthopteri.

Kner, Ruelolf, \& Heckel, Johann Jakoh. See Heckel \& Kner.

Kner, Rudolf, \& Steindachner, Franz. Neue Beitrïge zur Kenntniss der fossilen Fische Ocsterreichs. Denk- schr. Akad. Wiss. Wien, 1863, 21, 17-

36. 7 pls.

1863.1

Fishes are described of the following groups: clupeoids, scombroids, lophobranchiates, gadoids and Raida (Urolophus).

Beiträge zur Kenntniss der Chromiden Mexico's und Central-Amerika's. Denkschr. Akad. Wiss. Wien, 1864, 23: 5 pls.

1864.1

- Veue Gattungen und Arten von Fischen aus Central-Amerika, gesammelt von Prof. Moritz Wagner. Abhandl. Bayer. Akad. Wiss.; München, $1870,10,1-61.6$ pls.

1870.1

sciænoidæ, Chromidæ, Elcotrini, Clupcoidei Cyprinodontidi, Erythrini, Characini, siluroidei. Trichomycterini, Loricati.

\section{- See also Steindachner of Kner.}

Knies, Jan. Stopy diluviálního člověka a fossilní zviřena jeskyñ Ludmirovskych [Spuren des Diluvialmenschen und fossile Tiere der IudmirovHöhlen] Casop. moravsk. Mus. 'Lemsk. Ročn., 1905, 5, 213-254.

1905.1

Incidental mention of fossil fish-remains.

Knight, A. P. The action of certain chemical salts on the heart-beat of the embryo of Fundulus magellus. Brit Med. Journ., London, 1897, 2, 1484.

1897.1

The effects of polluted waters on fish life. 32. Ann. Rept. Dept. Mar. Fish. Canada, 1902, no. 22a, 9-18

1902.1

Sawdust and fish life. 'T'rans. Canadian Instit., 1903, 7, 1-12; 425466. 6 figs. Also separate; Toronto, 1903.

1903.1

- The effects of dynamite explosions upon fish life. Ann. Rept. Dept. Mar. Fish. Canada, Ottawa, 1907, 39, 21-30.

1907.1

- A further report upon the effects of sawdust on fish life. Ann. Rept. Dept. Mar. Fish. Canada, Ottawa, $190 \overline{7}, 39,37-54$.

1907.2

- Sawdust and fish life. Final report. Ann. Rept. Dept. Mar. Fish. Canada, Ottawa, 1907, 39, 111-120.

1907.3

Knight, John T'. Presence of shad in the rivers tributary to the gulf of Mexico. Rept. U. S. Fish Comm. 1872-73 (1874), 2, 391.

1874.1

Knight, $J$. W. On the fin of the Balista. Trans. Med. Phys. Soc. Calcutta, $1836,8,134-136$. 1836.1 
Knight, Thomas $F$ '. Descriptive catalogue of the fishes of Nova Scotia. Halifax, N.S., 1866. 54 p. S०. 1866.1

51 nominal species are enumerated, of which 41 are salt or brackish-water forms, and 7 freshwater.

-.- Shore and deep-sea fisheries of Nova Scotia. Halifax, 1867. vi, 113 p. $\mathrm{S}^{\circ}$.

1867.1

'This and the preceding publication, in paper covers, are respectively entitled, at middle half $[1,2]$ Pamphlets on the fishes and fisheries of Nova Scotia. No. I. Fishes of Nora scotia. No. II. Shore and deep-sea fisheries.

Knight, Wilbur C. [-1903] Some new Jurassic vertebrates from Wyoming. Amer. Journ. Ści., 4. ser. 5, 1898, 186; 375-380. pl. \& 2 figs.

1898.1

Dental plates of Ceratodus are referred to two new species, $C$. rubustus and $C$. americanus.

- The Nebraska Permian. Journ. Geol., 1899, 7, 357-374.

1899.1

The occurrence of Styptobasis and Diplodus n. sp. is reported. Some of the forms were subsequently described by C. R. Eastman.

Knight, William. A bill proposed to the Maryland legislature at the session of 1876 , and entitled "An act to regulate the catching and to provide for the preservation of fish in the waters of the state and of the Potomac river." Bull. U. S. Fish Comm. 1882 (1883), 2, 265272.

1883.1

Knipovich, Nicolai Michailovich. Report of voyage in the Arctic ocean on cruiser of 2d rank "Najezdnik" (Rider) in the summer of 1893 . 'Trav. Soc. Imp. Nat. St. Pétersb., 1894, 25.

1894.1

- Status of marine fish and animal industries of Archangel province, 1895. St. Petersburg, 1897.

1897.1

- Verzeichniss der Fische des Weissen und Murmanschen Meeres. Ann. Mus. St. Pétersb., 1897, 2, 144 158.

1897.2

Nachtrag zu demselben. Ibide, 1898, 3, 1-11.

- Einige Worte über das Vorkommen von Lampris pelagicus (Gunn.) an den nördlichen Küusten Russlands. Ann. Mus. Acad. Imp. St. Pétersb., 1900, 5, 244-245.

1900.1

Short review of the works of expedition for scientific and industrial investigations of the Murman coast [Text in Russian] Mém. Acad. Imp. Sci. St. Pétersb., 1900, 12, no. 5. 1900.2

Einige Resultate der wissenschaftlich praktischen Untersuchungen an der Murman-Küste im Jahre 1900.
Rev. Intern. Pêche Piscicult., St. Pétersbourg, 1901, 3, 11-12.

1901.1

- Zoologische Ergebnisse der russischen Expeditionen nach Spitzbergen. Ann. Mus. Zool. Acad. Sci. St. Pétersb., 1901, 6, 56-83. Ibid., 1903, 8, 144-156.

$$
\text { Nachtrag: Fische. }
$$

1901.2

Expedition für wissenschaftlichpraktische Untersuchungen an der Murmanküste. I. Edition des comités fiir Unterstützung der Küsten-Bevölkerung des russischen Nordens Text in Russian ] St. P'étersbourg, 1902. viii, 544 p. 11 pls. \& 73 figs. map. $8^{\circ}$ 1902.1

Deutsches Résumé, p. 545-650.

Zoölogical investigations on the icebreaker "Ermak" in the summer of 1901. [n. p.] 1902 .

1902.2

- Scientific results of the expedition for investigation of the Murman coast. [n. p.] 1903.

1903.1

pisces, vol. ii, pt. 1.

Ueber die geographische Verbreitung einiger' Fische. 'Trav. Soc. Imp. Nat. St. Pétersb., 1903, 34, 1. livr. 258.

1903.2

Description is given of Lycodes maris-albi, sp. nov.

Zoologische Ergebnisse der russischen Expeditionen nach Spitzbergen (Nachtrag) Ann. Zool. Mus. St. Pétersb., 1903, 2.

Fische, p. 144-156.

1903.3

Hydrobiologische Untersuchungen des Kaspischen Meeres. Schluss. Petermanns Geogr. Mittheil., 1904, 50, 291-294.

1904.1

- Mitheilungen aus der Biologie des Kaspischen Meeres l'lext in Russian] Trav. Soc. Imp. Nat. St. Pétersb., 1904, 35, C. R. 318-320. 1904.2

-_ Hydrologische Untersuchungen im europäischen Eismeer. Annal. Hydrol. Marit. Meteorol., Berlin, 1905.

Remarks on fishes are included.

1905.1

Summary of the works of the Caspian expedition of 1904 l'l'ext in Russian] Bull. Russ. Imp. Geogr. Soc. St. Pétersb., 1905.

1905.2

Ueber die neuesten Lrforschungen des Kaspischen Meeres ['T'ext in Russian] Jestestv. Geogr., Moskva, 1905 , pt. $5,39-46 . \quad 1905.3$ 
Knipovich, N.M.

Arbeiten der Kaspischen Expedition im Jahre 1904. Bd. 1. Allgemeine Uebersicht der Arbeiten der IIaspischen Expedition im Jahre 1904. St. Petersburg, 1906. i, 104 p. $8^{\circ}$.

1906.1

Deutsche Zusammenfassung, p. 105-113.

Grundzüge der Hydrologie des europäischen Eismeeres "l'ext in Russian with German résumé] Mém. Soc. Russe Géogr. St. Pétersb., 1906, 40.

1906.2

Ichthyologische Untersuchungen im Eismeer, St. Petersburg, 1906-08.

1906.3

i. Lycodes und Lycenchelys, Mém. Acad. Sci. St. Pétersb., 1906, 8. sér. 19, pt. 1, 1-130. pl. \& map.

ii. Gymnelis und Enchelyopus sive Zoarces. Ibid., 1908, 22, pt. 4, 40 .

Zoologische Ergebnisse der russischen Expeditionen nach Spitzbergen. Ueber die in Jahren 1899-1900 im Gebiete von Spitzbergen gesammelten Fische. Ann. Mus. Zool. Acad. St. Pétersb., 1907, 6.

1907.1

Zur Ichthyologie des Eismeeres. Die von der Russischen Polar-Expedition im Eismeer gesammelten Fische. Mém. Acad. Sci. St. Pétersb., 1907, 8. sér. 18, pt. 5, 53. 2 pls.

1907.2

Rapport sur les collections zoologiques, faites pour le Musée Zoologique de l'Académie Impériale des Sciences par N. M. Knipovich et S. A. Pavlovich dans la mer Baltique durant l'été de 1890. Ann. Mus. Zool. Acad. Sci. St. Pétersb., 1909, 14, 0131-0245. map.

1909.1

Neue Exemplare von Lycodes maris-albi Knipovich. Ann. Mus. Zool. Acad. Sci. St. Pétersb., 1911, 16, 155157.

1911.1

Ueber das Vorkommen von Chirolophis galerita (1.) sive Carelophus ascanii (Walb.), an der Murmanküste. Ann. Mus. Zool. Acad. Sci. St. Pétersb., $1911,16,152-154$.

1911.2

Knoch, Julius [1828-1893] Ueber die Anstalten zur kiunstlichen Fisch7ucht in Russland. St. Petersb. Med. Zeitschr., 1869, 15, 347-350. 1869.1

- Die Beschreibung der Reise zur Wolga, bchufs der Sterlettbefruchtung. Bull. Soc. Nat. Moscou, 1871, 44, pt. 1, 254-289. pl. Ibid., 1872, 45, pt. 1,351355.

1871.1
Ueber Missbildungen betreffend die Embryonen des Salmonen- und Coregonus-Geschlechts. Bull. Soc. Nat. Moscou, 1873, 46, pt. 1, 173-228. 2 pls.

1873.1

Knocker, $H . H$. Stickleback in salt water. Sci. Gossip, 1868, 87. 1868.1

Knöptler, Franz. Ein Beitrag zur Ienntnis der Lebensweise des Kletterfisches (Anabas scandens C. V.) in der gefangenschaft. Blätt. Aquar-Terrar. Kunde, 1909, 20. Jahrg., 667-668; 684685.

1909.1

Knörrich, $F$. W. Studien über die Ernährungsbedingungen einiger für die Fischproduction wichtiger Mikroorganismen des Süsswassers. Stuttgart, 1900. 54 p. $8^{\circ}$.

1900.1

Knoll, $P$. Ueber die Blutkörperchen bei wechselwarmen Wirbelthieren. Sitzber. Akad. Wiss. Wien, 1896, 105, 3. Abth., 35-66. 3 pls. \& figs. $\quad 1896.1$

Contains incidental reference to teleosts.

Knorr, Georg Wolfgang [1705-1761] Delicixe natura selectx; oder, Auserlezenes Naturalien-IKabinet aus den drey Reichen der Natur. Fortgesetzt von Ph. L. Statius Müller. 2 vols. Nürnberg, 1766. 90 col. pls. fol. 1766.1

Text in German and French.

Fische, Bd. ii, p. 42-65. 8 pls. 34 figs.

Sammlung von Merckwürdigkeiten der Natur und Alterthümern des Erdbodens, welche petrificirte Körper enthält, ausgewiesen und beschrieben, etc. Nüraberg, 1775. pls.

1775.1

Knorr, Georg Wolfgang, \& Walch, $J$.E. E. Recueil des monumens des catastrophes que le globe terrestre a essuiés, contenant des pétrifactions dessinées, gravées et enluminées d'après les originaux. 3 vols. in 4. Nüirnberg, 1768-77. 273 col. pls. fol. 1768.1

This work is a translation of the German edition of 1755. It contains plates of fossil fishes.

Knorring, Frans $P$. von. Gamla Finland eller det fordna Wiborgska guvernementet. Abo, 1833. 269 p. $8^{\circ}$. 1833.1

Knowles, Herbert $M$. Dead fish on the coast of Rhode Island. Bull. U. S. Fish Comm. 1886 (1887), 6, 194-195.

1887.1

Knox, Arthur Edward [1808?-1886] Autumns on the Spey. London, 1872. illust. $8^{\circ}$.

1872.1

Five of the chapters are on salmon fishing, and one on "Tynet burn and its ichthyolites." 
Knox, Frederick John. On the New Zealand swordfish. Trans. Proc. New Zealand Inst. 1869 (1870), 2, 13-16. pl. 1870.1

- Observations on an albino eel Trans. Proc. New Zealand Inst., 1871. 4,378 .

1871.1

- Observations on Coridodax pullus. Trans. Proc. New Zealand Inst. 1871, 3, 130-132. fig.

1871.2

- Notes on the anatomy of the Kanae (Mugil sp.) Trans. Proc. New Zealand Inst. 1871 (1872), 4, 189-191.

1872.1

Note on Ctenolabrus knoxi. Trans. Proc. New Zealand Inst. 1872, (1873), 5, 308

1873.1

Knox, Robert [1791-1862] Observations relative to the action of the heart in fishes. Edinb. Med. Surg. Journ. $1822,18,564-567$.

1822.1

Observations on the general anatomy of the Gymnotus electricus, the electric eel of America; and on the microscopical anatomy of the electric organs. Edinb. Journ. Sci., 1824, 1, 9699.

1824.1

Observations on the structure and functions of the canal of Petit and of the marsupium nigrum, or peculiar vascular tissue traversing the vitreous humour, in the eyes of birds, fishes and reptiles. Edinb. New Phil. Journ., 1824, 10, 323-325. - Trans. Roy. Soc. Edinb., 10, 231-252.

1824.2

On the theory of the existence of a sixth sense in fishes, supposed to reside in certain peculiar tubular organs, found immediately under the integuments of the head in sharks and rays. Edinb. Journ. Sci., 1825, 2, 12-16.

1825.1

_- Der sechste Sinn bei den Fischen. Notizen (Froriep), 1825, 9, 164-165.

1825.2

Observations on the size of the teeth in sharks compared with the fossil teeth of an animal analogous to the present shark, and described by MM. Lacépède and Faujas St. Fond in the Annales du Muséum. Edinb. Journ. Sci., 1826, 5, 16-18. - Bull. Sci. Nat. (Férussac), 11, 387.

1826.1

Sur l'existence d'un sixième sens chez les poissons. Bull. Sci. Nat. (Férussac), 1827, 12, 135-137. 1827.1
Notice of a swordfish recently caught in the river Tay. Edinb. Journ. Sei., $1830,2,427-430$.

1830.1

Notice regarding the nature of a peculiar structure observed in the second stomach of certain Cetacea, generally considered as simply glandular, but seemingly analogous to the electric organs of the Torpedo and Gymnotus. Edinb. Journ. Sci., 1830, 3, 319-324. Isis (Oken), 1830, 302.

1830.2

Observations on the natural history of the salmon. Rept. Brit. Assoc. Adv. Sci., 1831-32, 587-589. - Notizen (Froriep), 1832, 37, 33-35. 1832.1

- Observations on the natural history of the salmon, herring and vendace. Trans. Roy. Soc. Edinb., $1834,12,462-518 . \quad 1834.1$

- On the anatomy of the charr (Salmo umbla) Proc. Roy. Soc. Edinb. $1845,1,90-91$.

1845.1

On the natural history of the salmon. Proc. Roy. Soc. Edinb., 1845, $1,7-10$.

1845.2

Recollections of researches into the natural and economic history of certain species of the Clupeidx, Coregoni and Salmonidx. Rept. Brit. Assoc. Adv. Sci., 16. meet., 1846, pt. 2, 79-80.

1846.1

Fish and fishing in the lone glens of Scotland, with a history of the propagation, growth and metamorphoses of the salmon. London, 1854. $8^{\circ}$.

1854.1

Inquiries into the philosophy of zoology. I. On the dentition of the Salmonidx. II. Coloration of the Salmonidx. III. The proportions of the Salmonidx, as compared with each other and with the generic animal. Zoologist, 1855, 13, 4777-4792. 1855.1

- On the food of certain gregarious fishes. Proc. Linn. Soc. London (Zool.), 1855, 2, 354-359. - Zoologist, 1855, 13, 4709-4724. - Ann. Mag. Nat. Hist., 1855, 2. ser. 16, 57-60.

1855.2

On the growth of the salmon from the egr to the adult. Koologist, $1855,13,4792-4798$.

1855.3

Some observations on the Salmo estuarius or estuary trout. Zoologist, $1855,13,4662-4673$. 1855.4 
Knox, $R$

The present position of the salmon question, considered physiologically. Zoologist, 1856, 14, 4985-4992.

1856.1

Kobert, Eduard Rudolf [1854-] Ueber Giftfische und Fischgifte. Med. Voche, Berlin, 1902, 199-201; 209$212 ; 221-225 ; 236-241$. Also separate; Stuttgart, 1905. 36 p. 11 figs. $8^{\circ}$.

1902.1

Fischgifte, i. $\varepsilon_{*}$, Gifte für den Fischfang.

Koch, Antal $[=$ Anton $][1843-]$ Die Tertiärbildungen des Beckens der siebenbürgischen Landestheile. II. Neogene Abtheilung. Budapest, 1900. 369 p. 3 pls. \& 50 figs.

1900.1

- T'arnócz in Komitat Nógrád, als neuer reicher Fundort fossiler Haifischzähne. Földtani Közlöny (Geol. Mittheil.), Budlapest, 1903, 33, 139-164. 2 pls.

1903.1

Apró palaeontologiai közlemények [Kleine paläontologische Mitteilungen] Földtani Közlöny (Geol. Mittheil.) Budapest, 1904, 34, 332-335; 365-368.

Fossil fishes are noticed.

1904.1

Ergänzungen zur Haifischfauna des untermediterrainen Sandsteines von Tornocz ['Text in Hungarian? Földtan Közlöny, Budapest, 1904, 37, 202-203; 274

1904.2

Fossile Haifischzähne und Säugetierreste von Felsöesztergály, im Komitate Nógrúd. Földtani Közlöny (Geol. Mittheil.), Budapest, 1904, 34, 190-203; 260-27t. pl. \& 3 figs.

1904.3

- Die fossilen Fische des Beocsiner Cernentmergels. Ann. Mus. Nat. Hungarici, 1904, 2, 1-72. 7 pls. \& 2 figs

1904.4

_- Geologisches aus Siebenbürgen [Text in Hungarian] Sitzber. Siebenburg. Mus.-Ver., 1905, 27, 90-149.

Notices of fossil fishes.

1905.1

Die fossilen Fische des Beocsiner Kementmergels. Math.-Nat, Ber. Ungarn, 1906, 23, 274-275.

1906.1

Koch, Carl Ludwig [1778-1857] Fauna ratisbonensis. Regensburg, $1840.8^{\circ}$

liaunal list of fishes.

$18+10.1$

Koch, Charles. Statement concerning the menhaden fishery. Rept. U.S. lish Comm. 1877 (1879), 5, 482.

1879.1
Koch, Max. Bemerkungen zu E. Schmidt: Die Flunder als Aquarienfisch. Blätt. Aquar-Terrar. Kunde, 1912, 23, 387-389. fig. 1912.1

Ueber ein gehäuftes Vorkommen von Wirbelsäulenverkrümmungen bei Fischen. Berlin. Klin. Wochenschr. $1912,49,323-324$.

1912.2

Kochetov, N.A. Untersuchungen ïber das Pigment-Epithel der Retina im Zusammenhange mit der Frage über die Teilung der Zellen. Vorläufige Mitteilung [Text in Russian] Trav. Soc. Nat. St. Pétersb., 1908, 39 (C. R. livr. 1), 166-167. pl. \& fig.

1908.1

Kochmann, $M$. Beiträge zur Pharmakologie der Mischnarkose. I. Wixkung von Narcoticagemischen auf poikilotherme Wasserthiere. Zeitschr. Exper. Path. Berlin, 1913, 12, 328-340

1913.1

Kochs, W. Ueber die Ursachen der Schädigung ler Fischbestände im strengen Winter. Biol. Centralbl., 1891, 11 , $498-508$.

1891.1

Ueber die Vorgänge beim Einfrieren von Tieren und Pflanzensamen. Biol. Centralbl., 1892, 12.

1892.1

Versuche ïber die kiinstliche Vermehrung kleiner Crustaceen. Biol. Centralbl., 1892, 12.

1892.2

Koefoed, Einar. Brislingen (The sprat) Rept. Norwegian Fishery \& Marine Investigations, 1909,2 , pt. 1 , $128-132$.

1909.1

Les poissons de la croisière océanographique de la "Belgica" dans la mer du Grönland, 1905. Bruxelles, 1909. pl.

1909.2

Koehler, Johann Jakob. Die altenglischen Fischnamen. Anglistische Forschungen, 1906, Heft 21, 1-87. Also separate; Heidelberg, 1906. 87 p. $\mathrm{S}^{\circ}$.

1906.1

Köhler, Kuarl Ernst [1765-183S] Der Fischfang der Alten und die Bereitung des "T'arichos."

Not seen; title from $r$. Carus, in his Geschichte der Zoologie, 1872, p. 718

Kœhler, René. Résultats scientifiques de la campagne du "Caudan" dans le golfe de Gascogne, aout-septembre, 1895. Poissons. Ann. Univ. Lyon. $1896,26,475-526.2$ pls. 1896.1

Kœhler, René, \& Bataillion, $E$ Observations sur les phénomènes kirro- 
kinétiques dans les cellules du blastoderme des téléostéens. C. R. Acad. Sci. Paris, 1893, 117, 521-524. 1893.1 - Recherches sur l'extension du blastoderme et l'orientation de l'embryon dans l'oeuf des téléostéens. C. R . Acad. Sci. Paris, 1893, 117, 490-493.

1893.2

Köhler, Walther. Chromis multicolor Schoeller, ein Fisch, der seine Eier im Maule ausbrütet. Nerthus, 1903, 5. Jahrg., 821-823; 835-837. fig. 1903.1

- Blitzlichtaufnahmen lebender Fische. Photogr. Rundschau, Halle, 1904, 31-36. - Photogr. Centralbl., Halle, 1904, 10, 31-36. 1904.1

- Neotroplus carpintis Jordan und Snyder. Blätt. Aquar.-Terrar. Kunde, 1905, 16. Jahrg., 393-395.

1905.1

-..- Nomenklaturfragen ibetreffend Barbus pyrrhopterus, $B$. viltatus, und Lepidocephatichthys gunteri] Blätt. Aquar-'Terrar. Kunde, 1905, 16. Jahrg. $402-406 ; 415-416$.

1905.2

Osphromenus trichopterus (Pall.) var. cantoris Giinther. Blätt. Aquar.'Terrar'. Kunde, 1905, 16. Jahrg., 501505.

1905.3

Zur Nomenklatur von Pacilia reticulata Peters. Blätt. Aquar-Terrar, Kunde, 1906, 17. Jahrg., 497-498.

1906.1

Beiträge zur Biologie der Ophiocephalidx (Schlangenkopffische) Blätt. Aquar-Terrar. Kunde, 1907, 18. Jahrg. $13-16 ; 21-25$.

1907.1

Untersuchungen ïber das Schaumnest und den Schaumnestbau der Osphromeniden. Blätt. Aquar--Terrar. Kunde, 1908, 19. Jahrg., 382-384; 392$396 . \mathrm{pl}$.

1908.1

Etwas vom Steinbeisser (Cobitis tania L.) Blätt. Aquar-Terrar. Kunde, 1909, 20. Jahrg., 517-521. 2 figs. 1909.1

- Weitere Mitteilungen über den Formenkreis des Girardinus reticulatus Pet. Blätt. Aquar-Terrar. Kunde, 1910, 21. Jahrg., 657-658. 1910.1

Nordseefische, die sich zu Zuchtversuchen im Aquarium eignen. Blätt. Aquar-Terrar. Kunde, 1913, 24. Jahrg., $214-216 ; 231-234.2$ figs. 1913.1

Koelbel, Carl [-1897] Ueber die Identität des Gobius semilunaris Heck. und $G$. rubromaculatus Iriesch mit $G$. marmoratus Pallas. Verh. Zool.-Bot. Ges. Wien, 1874, 24, 569-57t. 1874.1

Kölliker, Rudolf Albert von [1817-] Ueber das Geruchsorgan von Amphioxus. Arch. Anat. (Müller), 1843, 3235. figs

1843.1

Ueber die elektrischen Organe des Mormyrus longipinnis Rüpp. Ber. Zool. Anst. Würzburg, 1849. 1849.1

Zur Entwickelungsgeschichte der Fische. Zeitschr. Wiss. Zool., 1850, 2 $267-270$

1850.1

- Bau von Leptocephalus und Helmichthys, Zeitschr. Wiss. Zool. $1853,4,360-366 . \quad 1853.1$

Weitere Bemerkungen über die Helmichthyiden. Verh. Phys. Med. Ges. Würzburg, 1853, 4, Heft 1, 100-102. 1853.2

Notiz über die electrischen Nerven des Malapterurus. Verh. Phys. Med. Ges. Würzburg, 1854, 4, 102-103. 1854.1

Sur la terminaison des nerfs dans l'organe électrique de la torpille. C. R Acad. Sci. Paris, 1856, 43, 792-794. Verh. Phys. Med. Ges. Wuirzburg, 1857 , 8, Heft 1, 2-12.

1856.1

Allgemeine Bemerkungen über Porenkanäle in Zellmembranen; Nachschrift zu Leuckart's Nachweis von Porenkanälchen in den Epidermiszellen von Ammocoetes. Verh. Phys. Med. Ges. Würzburg, 1857, 7, 195-198. 1857.1

Nervenkörperchen in der Haut von Stomias barbatus. Verh. Phys. Med. Ges. Würzburg, 1857, 8, Heft 1, 28-31. fig.

1857.2

On the different types in the microscopic structure of the skeleton of osseous fishes. Proc. Roy. Soc. London, 1857, 9, 656-668. - Ann. Mag. Nat. Hist., 1859, 3. ser. 4, 67-77. $1557 . ?$

Sur l'appareil folliculaire nerveux de Savi. Verh. Phys. Med. Ges. Würzburg, 1857, 8, Heft 1, 26-28. $185 \overline{7} .4$

- - Ueber die Ausbreitung der Nerven in der Geruchsschleimhaut von Plagiostomen. Verh. Phys. Med. Ges. IVürzburg, 1857, 8, Heft 1, 31-37.

1857.5

Ueber das Schwanzorgan der gewöhnlichen Rochen. Verh. Phys. Med. Ges. Wirzburg, 1857, 8, Heft 1, 12-25. fig. 
Kölliker, R. A.

Ueber das Schwanzorgan der Zitterrochen. Verh. Phys, Med. Ges. Würzburg, 1857, 8, Heft 1, 25-26.

1857.7

Vorlïufige Mittheilung über den Bau des Rückenmarks bei niederen Wirbelthieren. Zeitschr. Wiss. Zool., $1858,9,1-11$.

Fische, p. 9-11.

On the different types in the microscopic structure of the skeleton of osseous fishes. Proc. Roy. Soc. London, 1859, 9, 656-668.

1859.1

Ueber verschiedene Typen in der mikroskopischen Structur des Skelettes der Knnochenfische. Verh. Phys. Med. Ges. Würzburg, 1859, 9, 257-271; Ann. Mag. Nat. Hist., 1859, 3. ser. 4, 67-77.

1859.2

- Histologisches über Rhinocryptis (Lepidosiren) anneclens Pet. Würzburg. Naturw. Zeitschr., 1860, 1, 11-19.

1860.1

On the structure of the Chorda dorsalis of the Plagiostomes and some other fishes, and on the relation of its proper sheath to the development of the vertebræ. Ann. Mag. Nat. Hist., 1860, 3. ser. 5, 323-329. - Proc. Roy. Soc. London, 1860, 10, 214-222.

1860.2

Ueber das Ende der Wirbelsâule der Ganoiden und einiger Teleostier. Leipzig, 1860.27 p. 4 pls. $8^{\circ}$.

1860.3

Ueber den Antheil der Chordascheide an der Bildung des Schädelgrundes der Squalidæ. Würzburg. Naturw. Zeitschr., 1860, 1, 97-105. Notizen (Froriep), 1861, 3, 15. 1860.4

Ueber den Bau der Säge des Sägefisches [Pristis] Würzburg. Naturw. Zeitschr., 1860, 1, 144-149.

1860.5

-...- Ueber den Inhalt der Schleimsïcke der Myxinoiden und die Epidermis der Neunaugen. Würzburg. Naturw. Zeitschr., 1860, 1, 1-10. 1860.6

Ueber die Beziehungen der Chorda dorsalis zur Bildung der Wirbel der Selachier und einiger andern Fische. Verh. Phys. Med. Ges. Würzburg, 1860 , 10, 193-243.

1860.7

Ueber die Knochen von Orthagoriscus, Verh. Phys. Med. Ges. Würzburg, 1860, 10, xxxviii.
Weitere Beobachtungen über die Wirbel der Selachier, insbesondere über die Wirbel der Lamnoidei, nebst allgemeinen Bemerkungen über die Bildung der Wirbel der Plagiostomen. Abhl. Senckenberg. Naturf. Ges., 1864-65, 5, 51-99. Also separate; Frankfurt a. M., 1864. 51 p. $4^{\circ}$.

1864.1

Festschrift. A. von Kölliker zur Feier seines siebenzigsten Geburtstages gewidmet von seinen Schülern. Leipzig, 1887. See Gegenbaur, C., \& others.

1887.1

Koelpin, Alexander Bernhard [17391801] Anmarkningar vid svard-fiskens [Xiphias] anatomie och naturalhistoria. K. Svensk. Vetensk. Akadem. Handling., 1770, 32, 7-18. Ibid., 1771, 33, 115-121. 1770.1

Koelreuter, Joseph Gottlieb [17331866] Piscium variorum e Museo Petropolitano excerptorum descriptiones. Nov. Comment. Acad. Petropol., 1761, 8, 404-430. 1761.1

13 species of fishes are described.

-Descriptio piscis e Gadorum genere, Russi Nawaga dicti, historicoanatomica. Nov. Comment. Acad. Petropol., 1769, 14, 484-497. pl. 1769.1

Descriptio Cyprini rutili, quem Halawel Russi vocant, historico-anatomica. Nov. Comment. Acad. Petropol., $1770,15,494-503$. pl. 1770.1

Descriptio piscis, e Coregonorum genere, russice Sig vocati, historicoanatomico [Coregonus lavaretus] Nov. Comment. Acad. Petropol., 1770, 15, $504-516$.

1770.2

Observationes splanchnologicæ ad Acipenseri rutheni L., anatomi spectantes. Nov. Comment. Acad. Petropol., 1771, 16, 511-524. pl. 1771.1

Continuatio ad auditus organum spectantem. Nov. Comment. Acad. Petropol., 1772, 17, 522-541. 2 pl. 1772.1

- Descriptio piscis e Coregonorum genere, russice Riapache dicti, historicoanatomico [Salmo albula] Nov. Comment. Acad. Petropol., 1773, 18, Hist., 47; Mem., 503-511. Ibid., 19, Hist., 40; Mem., 304. 1773.1

Descriptio Pleuronecti flesi et passeris L. historico-anatomica. Nova Acta Acad. Petropol., 1791, 9, 327-350. 1791.1

Koelreuter, Joseph Theophilus. See Koelreuter, Joseph Gottlieb. 
Koelsch, Adolf. Ichthyologische Umschau. Kosmos, Stuttgart, 1908, 5, 129132. fig.

1908.1

Koenen, Adolf von [1837-1915] Ueber Coccosteus (Brachydirus) birkensis. Zeitschr. Deutsch. Geol. Ges., 1876, 28, $667-668$.

1876.1

- Ueber Coccosteus-Arten aus dem Devon von Birken. Zeitschr. Deutsch. Geol. Ges., 1880, 32, 673-675. 1880.1

Beitrag zur Kenntniss der Placodermen des norddeutschen Oberdevon's. Abh. Ges. Wiss. Göttingen, 1883, 30, 1-41. 4 pls.

1883.1

Ueber eine paleocäne Fauna von Kopenhagen [Pisces] Abh. Ges. Wiss. Göttingen, 1885, 32, 111-116. pl. \& 8 figs.

1885.1

Coccosteus decipiens. Geol. Mag. 1890, 3. dec. 7, 191.

1890.1

Discusses the supposed presence of a pectoral spine in this form.

Hat Coccosteus vordere Ruderorgane? Neues Jahrb. Mineral., 1890 , 2, pt. 2, 198 .

1890.2

Ueber einige Fischreste des norddeutschen und böhmischen Devons. Abhl. Ges. Wiss. Göttingen, 1895, 40 no. $2,1-37.5$ pls.

1895.1

Koenig, Alexander Ferdinand [1858 -] Die Entwicklung des Aales. Mitth. Sect. Naturk. Oesterr. Touristen-Club. 1898, 10. Jahrg., 53-56. fig. 1898.1

König, Clemens. Der Dorschfang auf die Lofoten. Dresden, 1895. $8^{\circ}$.

1895.1

Die geographische Verbreitung des australischen Lungenfisches. Nat. Wochenschr., Jena, 1911, 26, 104-107. fig.

1911.1

König, Joseph, \& Hünnemeier, $B$. Ueber den niedrigsten für das Leben der Fische nothwendigen Sauerstoffgehalt des Wassers. Zeitschr. Untersuch Nahrungs-Genussmit., Berlin, 1901, 4 385-391.

1901.1

König, Joseph, Thienemann, $A u$ gust, \& Limprich, - Der Einfluss des Futterfettes auf das Körperfett der Karpfen. Zeitschr. Untersuch. Nahrungs-Genussmit., Berlin, 1912, 23, 177197.

1912.1

Koenig-Warthausen,

(Freiherr) Richard von. Naturwissenschaftlicher Jahresbericht für 1893. Jahreshefte Ver.
Vaterl. Naturk. Württemberg, 1896, 41, 163-164.

1896.1

Teleosts, p. 163-164.

Körner, Otto. Zur Fischkrankheit. Isis (Russ), 1877, 2. Jahrg., 175. 1877.1

Können die Fische hören? (In Beiträge zur Ohrenheilkunde, Festschrift für A. Lucas, p. 93-127. Berlin, 1905) 1905.1

Abstracts in Ber. Senckenberg. Nat. Ges. Frankfurt a. M., 1908, 110-111.- Arch. Hydrobiol., Stuttgart, 2, 9-20.

Koerting, Berthold. Ornamental fishes. Suggestions for the aquarium. Scient. Amer. Suppl., 1909, 68, 92-93. 11 figs.

1909.1

Ueber Zierfische. Prometheus, 1909, 20, 497-502. 11 figs. $\quad 1909.2$

Köstler, Max. Ueber Knochenverdickungen am Skelette von Knochenfischen. Zeitschr. Wiss. Zool., 1882, 37, 429-456. pl. 1882.1

Köstlin, Otto [1818-1884] Der Bau des knöchernen Kopfes in den vier Klassen der Wirbelthiere. Stuttgart, 1844. $\mathrm{x}, 506$ p. pls. $8^{\circ}$.

1844.1

- Fischzucht im grossen. Jahresh. Ver. Vaterl. Naturk. Württemberg, $1854,10,176-193$.

1854.1

Köttgen, Else, \& Abelsdorff, Georg. Die Arten des Sehpurpurs in der Wirbelthierreihe. Sitzber. Akad. Wiss. Berlin, 1895, 921-926.

1895.1

Visual purple in teleosts

Köttl, Johann. Transportirung der edleren Speisefische. Deutsch. Fischerei Zeitg., 1878, 1. Jahrg., 390-391.

1878.1

Zur Entwicklung der Aesche Thymallus vulgaris] Deutsch. Fischerei Zeitg., 1878, 1. Jahrg., $241 . \quad 1878.2$

- Die Bewirthschaftung der Fischwasser. Oestter.-ungar. Fischerei Zeitg., $1880,13$.

1880.1

Kofoid, Charles Atwood [1865-] Notes on the natural history of Polyodon. Science, 1900 , n. s. 11, 250-252.

1900.1

Life history of the eel. Amer. Naturalist, 1908, 42, 491-496. 13 figs. 1908.1

Kohaut, Rezsó. A pisztráng falánkságáról [Ueber die Fressgier der Forelle] Természet. Közl., Budapest, 1906, 38, 637. 1906.1 
Kohl, Carl. Einige Bemerkungen ïber Sinnesorgane des 1 mphioxus lanceolatus. Zool. Anz., 1890, 13, 182-185.

1890.1

Das Auge von Petromyzon planeri und von Muxine glutinosa. Leipzig, 1892. $8^{\circ}$. 1892.1

- Rudimentäre Wirbeltieraugen. 'Teil I. Bibliot. Zool., Cassel, 1892, Ileft 13. Teil II. Ibid., 1895, Heft 14 'Teil III. Zusammenfassung, Ibid., 181274

1895.1

Kohl, Johann Georg [1808-1878] Der schellfischfang von Norderney (In his Nordwestdeutsche Skizzen, 1864, Bd. ii, p. 371-391)

1864.1

Kohl-Jakimova, Nina, \& Jakimov, Vraimir D. See Jakimov \& KohlJakimova.

Kohn, Alfred. Die Nebenniere der selachier nebst Beitrïgen zur Kenntniss der Norphologie der Wirbelthiernebenniere im Allgemeinen. Arch. Mikr. Anat. Bonn, 1898, 53, 281-312. pl.

1898.1

Dic chromaftinen Zellen des sympathicus. Anat. Anz., 1899, 15 $393-400$

1899.1

Cells of supravenal bodics of selachians

Koike, Izuo. Ueber die Schlagfolge dos elektrischen Organes des Zitterwolses. Zeitschr. Biol., 1910, 54, 431454. pl. \& 12 figs

1910.1

Koken, Ernst [Friedrich Rudolf Karl] [1860-1912] For biographical notice see Pompecki, J. F. Ernst Koken, mit einem Portrït. Palæontogr., 1913, 59, $i-i v$.

- Ueber Fisch-Otolithen, insbesondere über diejenigen der norddeutschen Oligocïn-Ablagerungen. Zeitschr. Deutsch. Geol. Ges., 1884, 36, 50056.5. 4 pls.

1884.1

Neue Untersuchungen an tertiaren lisch-Otolithen. 'Zeitschr. Deutsch. Geol. Ges., 1888, 40, 274-305. 3 pls.

1888.1

liossile lisch-Otolithen. Sitzber. Ges. Naturf. Freunde Berlin, 1889, 117 121.

1889.1

Pleuracanthus Ag. oder Xenacanthus Beyr. Sitzber. Ges. Naturf Freunde Berlin, 1859, 77-94. 5) figs.

1859.2
- - Referat über von Ihering's "Bemerkungen über die zoologischsystematische Bedeutung der FischOtolithen] Sitzber.Ges. Naturf. Freunde Berlin, 1891, 26-28.

1891.1

Helicoprion im Productus-Kalk der Saltrange. Centralbl. Mineral. Stuttgart, 1901, 225-227. fig. 1901.1

Ueber Hybodus. Geol. Palæontol. Abh., 1907, n. s. 5, pt. 4, 261-276. 4 pls. 1907.1

- (editor) Pisces (In Zittel, IK. A. von. Grundzůge der Paläiontologie. Zweite Abteilung. Vertebrata. 2. ed. p. 3-142. München \& Berlin, 1911. $8^{\circ}$ ) 1911.1

Kolb, Max. Die Fische in Bezug auf ihren Nutzen und Handel. Zeitschr. Landw. Ver. Bayern., 1868, 58. Jahrg., 177-183.

1868.1

Kolessnikow, $N$. Ueber die Eientwickelung bei Batrachiern und Innochenfischen. Arch. Mikr. Anat., 1878, 15 382-414. pl.

1878.1

Kolff, Wilhemina M. Sulla fisiologia del cuore dei pesci teleostei. Rend. Accad. Lincei, Roma, 1907, 5. ser. 16 pt. 2, $479-499.5$ figs. 1907.1

Sur la physiologie du coeur des poissons téléostéens. Arch. Ital. Biol. $1907,48,337-351.5$ figs. $\quad 1907.2$

Untersuchungen über die Herztätigkeit bei Teleostiern. Arch. Ges. Physiol., 1908, 122, 37-97. 28 figs.

1908.1

Kolikov, $N . K$. Die Entwicklung des Veunaugenkopfes (Petromyzon planeri) Beitrag zur Lehre von der Metamerie des Vertebratenkopfes Text in Russian Zap. Univ. (Otd. Jest. 1stor.), Moskva, 1901, 16, 395-400. 7 pls. 1901.1

Kollbrunner, $E$. Erhebungen über die Fischfauna und die hierauf bezüglichen Verhältnisse der Gewiisser des Kantons Thurgau. Mith. Thurgauischen Naturf. Ges., 1879, Heft 4, 3-104. 1879.1

Die Thurgauische Fischfauna und bezügliche Gewässerverhältnisse Frauenfeld, 1879. 102 p. $S^{\circ}$. 1879.2

Koller, Die heurige Dïre und die Forellengewäisser [n. p.] 1905.

1905.1

Kollmann, Eugène. Sur quelques résultats des recherches entreprises par l'Association Internationale pour l'exploration de la mer du Nord. Rev. Ścient. 1909, õ. sér. 10, 141-145. 1909.1 
Kollmann, $J$. Der Mesoblast und die Entwicklung der Gewebe bei den Wirbelthieren. Biol. Centralbl., 1883, 3, no. 24 .

1883.1

Der Bandwulst und der Ursprung der Stützsubstanz. Arch. Anat. Physiol. (Abth. Anat.), 1854, 341-434; $461-465.3 \mathrm{pls}$

1884.1

- Gemeinsame EntwicklungsBahnen der Wirbelthiere. Arch. Anat Physiol. (Abth. Anat.), 1885, 279-306. pl.

1885.1

Die Geschichte des Primitivstreifens bei den Meroblastiern. Verh. Naturf. Gesell. Basel, 1886, Theil 8, Heft 1.

1886.1

- Ueber Furchung an dem Selachier-Ei. Verh. Naturf. Ges. Basel, $1886,8,103-105$.

1886.2

Kolmer, Walther. Ueber das Verhalten der Neurofibrillen an der Peripherie [Die Riechzellen der Fische auf das Verhalten der Neurofibrillen hin untersucht] Anat. Anz., 1905, 26, 560 569. 8 figs.

1905.1

Zur Iienntniss des Rückenmarks von Ammocoetes. Anat. Hefte, 1905, 29, 16:3-213. 9 pls.

1905.2

- Zur Kenntnis der Riechepithelien. Anat. Anz., 1907, 30, 513-517. fig. 1907.1

Ueber einen sekretartigen Bestandteil der Stäbchenzapfenschicht der Wirbeltierretina. Vorläufige Mitteilung. Arch. Gesam. Physiol., Bonn, 1909, 129, 35-45. pl.

1909.1

- - Ueber Strukturen im Epithel der Sinnesorgane. Anat. Anz, 1910, 36, 281-299. pl. \& 3 figs.

1910.1

- - Ueber das Ligamentum annulare in der vorderen Kammer des Auges von Anabas scandens. Anat. Anz., 1913, 44, $183-186$.

1913.1

Kolombatovič, Juro [=George $]$ Osservazioni sul lavoro di M. Stossich dal titolo: "Prospetto della fauna dei vertebrati dell' Adriatico." Spalato, 1880. 1880.1

- Pesci delle acque di Spalato e catalogo degli anfibi e dei rettili dei con. torni di Spalato. Spalato, 1881. 1881.1

- Fische welche in den Gewässern von Spalato beobachtet und iiberhaupt. im Adriatischen Meere registrirt wurden. Spalato, 1882.

1852.1
- Mammiferi, anfibi e rettili della Dalmazia, e pesci rari e nuovi per l'Adriatico che furono catturati nelle acque de Spalato. Spalato, 1882.35 p. $8^{\circ}$.

1882.2

Agriunte ai "Vertebrati" pubblicati nei programmi degli anni scolastici 1879-82. Spalato, 1884. 28 p. $8^{\circ}$.

1884.1

- Secunda aggiunta ai "Vertebrati" della Dalmazia. Splitu, 1885. $8^{\circ}$.

1885. 1

-... Innenik kralješnka Dalmacije On the reptiles, batrachians, and fishes of Dalmatia] Spalato, 1886.12 p. $8^{\circ}$.

1886.1

- Su Sleuronectes hoscii Risso e $P$. megastoma (Donov.) Godišnje izoješce C. K. Telike Realke u Splitu, 1887, 2733. Also separate; Spalato, 1887.

1887.1

- Catalogus vertebratorum Dalmaticorum. Spalati, $1888 . \quad 1888.1$

1891. Gobii della Dalmazia. Spalato,
1891.1

- Notizie sui pesci del circondario marittimo di Spalato (Dalmazia) Glasnik Narav. Druztva, Zagreb, 1891, 6, $172-186$.

1891.2

- Vertebrati della Dalmazia. Spalato, 1891.

1891.3

- Blennius zvonimiri, n. sp., nova vrsta babice dalmatinskoga nora. Glasnik Narav. Druztva, Zagreb, 1892, 7, 107-112. pl.

1892.1

- Novi nadodatci liralješnjacima Dalmacije. Spalato, 1893.27 p. $8^{\circ}$.

1893.1

- O navodima vrsti meci (Cephalopoda) i kralješnjakâ (Vertebrata) jadranškoga mora. Spalato, 1894.

1894.1

_ Druge zoologiske vijesti iz Dalmaciji. Spalato, 1900. $34 \mathrm{p} . \mathrm{S}^{\circ}$.

1900.1

Contribuzioni alla fauna dei vertebrati della Dalmatia. Glasnik Naray. Druztva, Zagreb, 1902, 13, 22-37. pl. Ibid., 1904, 15, 182-200. Ibid., 1907, 19, 1-24.

1902.1

Kolombatovič, Georg, \& Steindachner, Franz. See Steindachner it Kolombatovič. 
Kolster, [Karl Fredrik] Rudolf. Studien über das centrale Nervensystem, 1898-1902.

1898.1

I. Ueber das Rückenmark einiger Teleostier. Acta Soc. Sci. Fenn. Helsingfors, 1898, 24, 1-88. $9 \mathrm{pls}$

II. Zur Kenntniss der Nervenzellen von Petromyzon fuviatilis. Ibid., 1902, 29, no. 2, 1-93. $6 \mathrm{pls}$.

Ueber bemerkenswerte Ganglienzellen im Rückenmark von Perca fluviatilis. Anat. Anz., 1898, 14, 250-253. figs.

1898.2

Ueber die Mauthner'schen Fasern einiger Teleostier. Verh. Anat. Ges., Anat. Anz., 1898, 14, 145-148.

1898.3

Beiträge zur Kenntniss der Histogenese der peripheralen Nerven, nebst Bemerkungen über die Regeneration derselben nach Verletzungen. Beitr. Anat. Allgem. Pathol., 1899, 26, 190 201. pl.

1899.1

- Studier öfver protoplasmastrukturer i spinalganglieceller. Finska Läkaresällsk. Handl., 1899, 41, 552-598.

French résumé, p. xlii-xlvi

1899.2

Ueber das Vorkommen von Zentralkörpern in den Nervenzellen von Cottus scorpius. Anat. Anz., 1900, 17, 172-173. figs.

1900.1

Ueber die Embryotrophe, speziell bei Zoarces viviparus Cuv. (In Festschrift Palmén, 1905, no. 4, p. 1-46. 5 pls.)

1905.1

Ueber die Magenschleimhaut von Centrophorus granulosus. Anat. Hefte, 1907, 33, 1. Abth., 491-511. 2 pls.

1907.1

Weitere Beiträge zur Kenntnis der Embryotrophe. I. Die Embryotrophe bei den Lophobranchiern. Anat. Hefte, Wiesbaden, 1907, 34, 1. Abth., 401-428. 2 pls.

1907.2

Koltz, Jean Pierre Joseph [1827-] Traité de pisciculture: multiplication artificielle des poissons. 2e éd. Bruxelles, 1858. illust. 160 p. $12^{\circ}$. (Bibl. rurale, vol. xxxix)

1858.1

The same. 3, ed. Paris, 1866. $12^{\circ}$.

The artificial propagation of fish. Rept. U. S. Fish Comm. 1880 (1883) 8, 491-519. 27 figs.

1883.1

- Traité de pisciculture pratique, ou Les procédés de multiplication et d'incubation naturelle et artificielle des poissons d'eau douce. 4. ed. Paris, 1883. $8^{\circ}$.
Koltzoff, $N . K$. Das primäre Skelet der Bauchflossen der Teleostier. Bull. Soc. Imp. Nat. Moscou, 1896, 514-521. 12 figs.

1896.1

- Metamerie des Kopfes von Petromyzon planeri. Vorläufige Mitteilung. Anat. Anz., 1899, 16, 510-523. 3 figs.

1899.1

Entwickelungsgeschichte des Kopfes von Petromyzon planeri. Bull. Soc. Imp. Nat. Moscou, 1901 (1902) 259-589. 7 pls. \& 3 figs. Also separate Moscow, 1901. 395 p. $8^{\circ}$. 1902.1

Literature references are found at p. 259.

Koninck, Laurent [Guillaume] de [1809-1887] Description des animaux fossiles qui se trouvent dans le terrain carbonifère de Belgique. Liège, 184244. iv, 716 p. \& atlas of 60 pls. $4^{\circ}$.

1842.1

Poissons, p. 608-618. pl. liv lerroneously marked pl. liii]

_- Mémoires de paléontologie Nos. i-viii. Bruxelles, $1857-58$ [-71] 82 p. 5 pls. $8^{\circ}$.

1857.1

Under the above collective title are included the following ichthyological papers, reprinted from Bull. Acad. Roy. Belg., 1864-70:

iv. Notice sur le Paladaphus insignis, par P. J. van Beneden et L. de Koninck. Bull. 1864 , 17.

vii. Notice sur un nouveau genre de poissons fossiles [Ankistrodus] de la craie supérieure. Bull. 1870, 30, 27-28 (See following title)

Notice sur un nouveau genre de poissons fossiles de la craie supérieure [Ankistrodus] Bull. Acad. Sci. Roy. Bruxelles, 1870, 2. ser. 29, 75-79. Ibid., 1870, 30, 27-28. - Journ. Zool. (Gervais), $1872,1,394$-396. figs. 1870.1

Faune du calcaire carbonifère de la Belgique; première partie. Ann. Mus. Roy. Hist. Nat. Belgique, 1878, 2 , 1-152. 31 pls. 1878.1

Pt. 1. Poissons et genre Nautile, p. 9-76. 8 pls.

Koninck, Laurent [Guillaume] de, \& Beneden, P.J.van. See Beneden \& Koninck.

Koningsberger, $J . C$. Verslag over visscherij in Nederlandsch Indie. Jaarb. Dept. Landbouw Nederl. Indie, Batavia, $1907,51-62$.

1907.1

Konnertz, A. Entwickelung der Jungfische bei Hemichromis bimaculatus. Wochenschr. Aquar-Terrar. Kunde, 1913, 10. Jahrg., 941-942. 3 figs. 1913.1

Kopal, Gustav. Kieler Bücklinge. Gartenlaube, Leipzig, 1878, no. 6, 94-98. 1878.1 
Koppen, Hermam. Ueber Epithelien mit netzförmig angeordneten Zellen und über die Flossenstacheln von Spinax niger. Zool. Jahrb. (Anat. Abth.), 1901, 14, 477-522. 3 pls. \& figs.

1901.1

Kopsch, Friedrich. Oberflächenbilder des sich entwickelnden Forellenkeimes. Verh. Anat. Ges., Anat. Anz., $1894,10,60-66$. fig.

1894.1

- Ueber Bildung und Bedeutung des Canalis neurentericus. Sitzber. Ges. Naturf. Freunde Berlin, 1896, 165-175. Ibid., 1897, 5-13. figs.

1896.1

i. Amphibien, Selachier, Iñohenfische.

ii. Amphioxus, Tunicaten.

Experimentelle Untersuchungen ïber den Keimhautrand der Salmoniden. Verh. Anat. Ges., Anat. Anz., 1896, 12. 113-121. 10 figs.

1896.2

Ueber die Ei-Ablage von Scyllium conicula in dem Aquarium der zoologischen Station zu Rovigno. Biol. Centralbl., 1897, 17, 885-893. 3 figs.

1897.1

- Die Entwicklung der äusseren Form des Forellen-Embryos. Arch. Mikr. Anat, 1898, 51, 181-213. 2 pls.

1898.1

Experimentelle Untersuchungen am Primitivstreifen des Hühnchens und an Scyllium-Embryonen. Verh. Anat. Ges., Anat. Anz., 1898, 14, 49-67. 10 figs. - Discussion, 79-80. 1898.2

Gemeinsame Entwickelungsformen bei Wirbeltieren und Wirbellosen. Verh. Anat. Ges., Anat. Anz., 1898, 14. 67-80. 13 figs. 1898.3

Die Organisation der Hemididymi und Anadidymi der Knochenfische und ihre Bedeutung für die Theorien über Bildung und Wachstum des Knochenfischembryos. Zugleich ein Beitrag zur Differenzierungsfähigkeit embryonaler Zellen. Intern. Monatsschr. Anat. Physiol., 1899, 16, 221-267. 2 pls. \& 4 figs.

1899.1

Homologie und phylogenetische Bedeutung der Kupffer'schen Blase. Anat. Anz., 1900, 17, 497-509. 1900.1

—Die Entstehung des Dottersackentoblasts und die Furchung bei Belone acus. Intern. Monatssehr. Anat. Physiol., 1901, 18, 43-127. 34 figs.

1901.1

Art, Ort und 'Zeit der Entstehung des Dottersackentoblasts bei ver- schiedenen Kinochenfischarten. Intern. Monatsschr. Anat. Physiol., 1902, 20 , 101-124. 15 figs.

1902.1

Ueber die kiunstliche Befruchtung der Eier von Cristiceps urgentatus. Sitzber. Ges. Naturf. Freunde Berlin. $1902,33-36$.

1902.2

Untersuchungen üiber Gistrulation und Embryobildung bei den Chordaten. Morphologische Bedeutung des Keimhautrandes und dic Embryobildung bei der Forelle. I eipzig, 1904. iv, 166 p. 10 pls. \& 18 figs. 4\% 1904.1

- Die Entstehung des Dottersuckentoblast und die Furchung bei der Forelle (Salmo fario) Arch. Mikr. Anat. 1911, 78, Abth. 1, 618-659. 16 figs.

1911.1

Kopsch, Friedrich, \& Hilgendorf, Fronz Martin. See Hilgendorf is Kopsch.

Kopsch, II. Fish-culture in China. Forest (t Stream, 1875), 5, 259. 1875.1

Notes on pisciculture in Kiangsi. Rept. U.S. Fish Comm. 1873-75 (1876), $3,543-547$.

1876.1

Koraes or Corais or Coray] Adlemantios [1748-1833] Griecs bibliothece appendix. 9 vols. in 6. Paris, 1809-27. $8^{\circ}$. 1809.1

Vol. iii. Xenocrates:

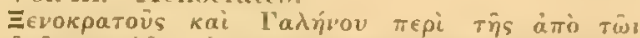

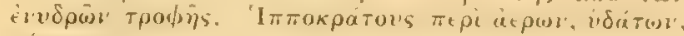
$u \pi(n) l^{\prime}$

An important commentary on the writings of Xenocrates and Galen, in which the names of fishes mentioned by these authors and by Hippocrates are considered.

Koranyi, A. Beitrïge zur Entwickelung der Iirystallinse bei den Virbelthieren. Intern. Journ. Inat. Histol., $1886,3,229-2: 38$.

1886.1

Fishes, p. 235-237.

Koren, Johan, \& Düben, M. von. See Düben \& Koren.

Korff, K. von. Zur Histogenese der bindegewebigen stuitzsubstanzen niederer Wirbeltiere. Anat. Anz., 1910, 37. 128-136. pl.

1910.1

Kornhuber, G. Andris. Beitrag zur Kenntniss der Fische im Waag-Gebiet. Verh. Ver. Naturk. Presburg, 1860. 40-4t. Ibid., 1861, lv-lvi. 1860.1

Bemerkungen über das Vorkommen der Fische um Presburg und an cinigen anderen Orten Ungarns. Correspbl. Ver. Naturk. Presburg, 1863, 2. Jatirg., 205-213. 
Kornhuber, $G . A$.

- Der Thebener Kabel. Ein Beitrag zu seiner Naturgeschichte. Verh. Ver. Nat.-Heilk. Presburg, 1599, n. s. $10,57-97$.

1899.1

-...- Hochzeitskleid bei einheimischen Fischen. Verh. Ver. Nat.-Heilk. Presburg, 1900, 20, 81-85.

1900.1

_Erstaunliche Gefrüssigkeit bei Vischen, Verh. Ver. Nat.-Heilk. Presburg, 1901, 21, 36-39.

1901.1

Vom Scherg oder Sternhausen, Acipenser stellatus Pallas. Verh. Ver. Nat-Heilk. Presburg, 1901, 21, 32-31.

1901.2

- Vom Stein-Schnee und vom Stör Gmelin's [Lucioperca volgensis und Acipenser gmelini] Verh. Ver. Nat.Heilk. Presburg, 1901, 21, 39-41. 1901.3

- Vom Waxdick, Acipenser gludenstädli Brandt. Verh. Ver. Nat.-Heilk. Presburg, 1901, 21, 30-32.

1901.4

Korotnev, Alexis. Bericht an das Ministerium der Landwirthschaft und der Staatsdomänen über die 'Thätigkeit der zoologischen Expedition auf dem Baikalsee im Sommer des Jahres 1902 [Text in Russian] Moskva, 1902. 27 p. 9 figs.

1902.1

- Rapport sur les résultats d'une expédition au lac Baĩkal pendant l'été de 1902. Aperçu faunistique et spécialement ichthyologique. Congr. Intern. Pêche Piscicult. St. Pétersb., 1903, pt. 1, 244-248. - Arch. Zool. Expér. Gén., 4. sćr. 2, 1-26. figs. - Rev. Intern. Pêche Piscicult., 5, 4-9.

1903.1

_- Ueber einen Baikalfisch (Comephorus) Biol. Centralbl., 1904, 24, 641644. 5 figs.

1904.1

_- Die Comephoriden des BaikalSees. Wiss. Ergebn. Zool. Exped. Baikal See, 1905, 2. Lief. 39 p. 3 pls. it 19 figs.

1905.1

Korpela, Johan Em. Erån Mäntyharju. Fiskeritidskr. Finl., 1893, 2, 80.

1893.1

Korschelt, Eugen [1858-] Zoologie (In Handwörterbuch der Naturwissenschaften. 7 vols. Jena, 1912-14. illust. $8^{\circ}$ )

1912.1

Koschkarov, D. N. Beitrïge zur Morphologie des Skelets der Teleostier. Das Skelet der Siluroidei. Bull. Soc. Tat. Uloscou, 1905, 209-307. pl. \& 72 figs.
Koshida, T'okujiro. Report on the salmonid fishes of Kamtschatka [Text in Japanese] Rept. Fish. Instit., Tokyo, 1910, 6, no. 2, 1-39. 9 pls.

1910.1

Kosić, N.B. Nova grada za dubrovačku nomenclatura i fauna riba. Glasnik Naravosl. Družtva, Zagreb, $1898,10,77-88$.

1898.1

Koskinen, Yrjö. Kertomus hämeenkyrön pitäjästä. Suomi, 1852,11 , 17-116. map.

$15.0^{\circ} 2.1$

Kosmak, George William. Dermal armor of the sturgeon. Journ. N. Y. Mier. Soc., 1895, 11, 1-21. 3 pls. 1895.1

Koss, R. A. Trout and trout culture. Bull. U. S. Fish Comm., 1883, 3, $473-476$.

1883.1

Kossel, Albrecht. Ueber den einfachsten Eiweisskörper [Preparation of a histon from Centrophorus] Biochem. Centralbl., 1907, 5, 35 .

1907.1

Ueber eine neue Base aus dem Tierkörper. Sitzber. Heidelberg. Akad. Wiss., math.-nat. Kl., 1910, Abh. 11, $1-5$.

1910.1

Agmatin aus Heringshoden.

Weitere Mittheilung über den Proteine der Fischspermien. [n. p.] 1913.

1913.1

Kossel, Albrecht, \& Kutscher, $F$. Beiträge zur Kenntniss der Eiweisskörper. Zeitschr. Physiol. Chem., 1900, 31,165 .

1900.1

Contains account of preparation of Gadus histon.

Kossmann, Robby August [1849-] Ueber die sogenannte Chorda des Amphioxus. Würzburg, 1873. pl. 1873.1

Bericht über eine im Auftrage der königlichen Akademie der Wissenschaften zu Berlin ausgeführte Reise in die Küstengebiete des rothen Meeres zur Erforschung der dortigen Fauna der Wirbellosen. Verh. Nat.-Med. Ver. Heidelberg, 1877, n. s. 1, 140-151.

1877.1

Wissenschaftliche Ergebnisse einer Reise in die Küstengebiete des Rothen Meers im Auftrage der königlichen Akademie der Wissenschaften zu Berlin ausgeführt von Robby Kossmann. Erste Abtheilung. Verh. Nat.Med. Ver. Heidelberg, 1877, 1, 378-420.

1877.2

Fische, von R. A. Kóssmann und H. Räuber. 
- List of fishes mostly from the Red sea which are offered for exchange [Text in German] Zool. Anz., 1879, 2, 21-22.

1879.1

Kossmann, Robby August, \& Råuber, $H$. Pisces (In Zoologische Ergebnisse einer im Auftrage der königlichen Akademie der Wissenschaften zu Berlin ausgeführten Reise in die Küstengebiete des Rothen Mecres. Leipzig, $1877-80.4^{\circ}$ )

1877.1

Kostanecki, $K$. 'Zur vergleichenden Morphologie des Blind-Darmes unter Berücksichtigung seines Verhältnisses zum Bauchfell. Anat. Hefte, 1913, 48, 1. Abth., 307-38s. pls.

1913.1

Kotarbinksi, Euzebjusz. Manuel pour servir ì la détermination des poissons de la Pologne ['ext in Polish] Warszawa, 1909. 29 p. $\mathrm{S}^{\circ}$.

1909.1

Kotschetow, $\lambda .1$, See Kochetov, i. A.

Kouliabko, A. Notice biologique sur la lamproie (Petromyzon fluviatilis) 'Tert in Russian] Bull. Acad. Sci. St. Pétersb., 1897, 5. sér. 7, 27-28. 1897.1

Kouznetzoff, Innokintic Dmitrierich. See Kuznetzov, $I . D$.

Kovalevski, Mieczuslav. Die Gastrulation und die sogenannte Allantois bei den 'Telcostiern. Sitzber. Soc. Physik.-Med. Erlangen, 1886, Heft 18, 31-36. pl.

1856.1

Ueber die ersten Entwickelungsprocesse der Knochenfische. Zeitschr. IViss. Zool., 1886, 43, 434-480. pls.

1886.2

Kovalevskiĭ, Alelisundr Onufricvich [1840-1901] For biographical notice see that by E. Ray Lankester in Nature, $1902,66,395$.

Le développement de l'Amphioxus lanceolatus. Abstracts in Arch. Phys. Nat. Genève, 1866, n. s. 27, 193195. - Ann. Mag. Nat. Hist., 1867, 3. ser. 19, 69-70.

1866.1

Entwickelungsgeschichte von Amphioxus lanceolatus. Mém. Acad. Imp. Sci. St. Pétersb., 1867, 7. sér. 11, no. $4,1-17.3$ pls.

1867.1

Development of Acanthias vulnaris and Mustelus lovis I'Text in Russian Mém. Soc. Nat. Kiev, 1870, 1, 163-187. 2 pls.
- Weitere Studien iiber dis Intwicklungsgeschichte des 1 mphioxus lanceolatus, nebst einem Beilrage zur Homologie des Nervensystems der Würmer und Wirbelthiere. Arch. Mikr. Anat., 1877, 13, 181-204. 2 pls. 1877.1

Kovalevskiǔ, Aleksandr Onufrievitch, Ovsjannikov, Phillipp, \& Wagner, Rudolf. Die Lintwickelungsgeschichte der Störe. Bull. Acad. Sci. St. Pétersh. $1870,14,317-325.7$ figs. 1870.1

Kozhevnikov, Ghrighorii dleksandrovich [1866-] Fischfang und Fischzucht auf der Weltausstellung 1900 in Paris [Text in Russian] Dnevn. Otd. Icht. Imp. R. Obšč. Acelim., Moskva, $1901,4,109-120$.

1901.1

Die internationale Ausstellung für Fischerei und Fischzucht in Wien im Jahre 1902 ['T'ext in Russian] Dnevn. Otd. Icht. Imp. R. Obšč. Aeclim., Moskva, 1904, 2, pt. 3, 1-8. 1904.1

Kozlov, D. Ueber die Pflege und Aufzucht von Danio rerio in Aquarium ['l'ext in Russian] Akvarium, Moskva, $1905,1,215-222$.

1905.1

Kozubov, $Y$. Ueber die Fischzucht im Gouvernement Mogilev [Text in Russian] Dnevn. Otd. Icht. Imp. R. Obšě. Acclim., Moskva, 1902, 7, 207213.

1902.1

Kracheninnikov, Stefan Petrovich [1713-1755] 'The history of Kamtschatka and the Kurilski islands, with the countries adjacent. Translated into English by J. Grieve. Gloucester, 1764. viii, 280 p. 5 pls. \& 2 maps. $4^{\circ} .1764 .1$

Lal description du Kamtchatka traduit du russe ... (In Chappe d'Auteroche, J. Voyage en Sibérie, etc. vol. ii. Paris, 1768. illust. $4^{\circ}$ ) 1768.1

Poissons, p. $455-485$.

Kraemer, Adolph. Beitrïge zur Anatomie und Histologie der Cestoden der Suisswasserfische. Zeitschr. Wiss. Zool. 1892, 53, 647-722. 2 pls. 1892.1

Ueber den inneren Bau der T'menien der' Süsswasserfische. '/sool. Anz., 1892, 15, 14-18. 1892.2

Krämer, Augustin. Der Purgierfisch der Gilbertinseln. Globus, Braunschweig, 1901, 79, 181-183. 1901.1

Kraepelin, Karl Mathias Friedrich [1848 - ] Die Fauna der Umgegend Hamburgs (In Das Naturhistorische Museum, 1). 32-149. Hamburg, 1901. $\left.8^{\circ}\right)$

1901.1 
Krafft, Carl. Die neuesten Erhebungen über die Zustände der Fischerei in dem im Reichsrathe vertretenen Königreichen und Iändern und an den österreichisch-ungarischen Meereskïsten. Wien, 1874. $145 \mathrm{p} .8^{\circ}$.

1874.1

Die Seefischerei der im Reichsrathe vertretenen Königreiche und Lander im Jahre 187:3-74. Statistische Monatsschr., Wien, 1875, 1, 160-171.

1875.1

Krall, Albert. Die männliche Beckenflosse von Hexanchus griseus M. u. H. Ein Beitrag zur Kenntnis der Copulationsorgane der Selachier und deren Herkunft. Morphol. Jahrb., 1908, 37. 529-585. 2 pls. \& 17 figs.

1908.1

Kramberger, Karl Gorjanović. See Gorjanović-Kramberger, Dragutin $\llbracket=$ Karl]

Kramp, E. Haplochilus sp. und seine Zucht. Blätt. Aquar-'Terrar. Kunde, 1913, 24. Jarhg., 565-666. fig.

1913.1

Meine Erfahrungen bei der Zucht von Fundulus sjöstedti. Wochenschr. Aquar.-Terrar. Kunde, 1913, 10. Jahrg., 247-248. fig.

1913.2

Kramp, $P$. L. Report on the fish eggs and larva collected by the Danish research steamer "Thor" in the Langelandsbelt in 1909. Medd. Havunders. Kjobenhavn, 1913, 4 (Ser. Fiskeri), no. 5, $1-38$.

1913.1

Krasheninnikov, Slefan Petrovich See Kracheninnikov, S. $P$.

Krause, - Cod and halibut fisheries near the Shumagin islands. Bull. U.S. Fish Comm. 1881 (1882), 1, 259 260.

1882.1

Krause, Ennst [1839-1903] Chemische Bedenken gegen die WirbelthierVerwandtschaft des Lanzetthieres Kosmos, $1877,1,170-171 . \quad 1877.1$

- Die elektrisehen Fische. Kiosmos, $1877,1,255-260 . \quad 1877.2$

- Dic Entwickolung des Aales, Prometheus, 1897, S. Jahrg., 485-491. fig.

1897.1

Der sonnenfisch. P'romethens 1897,8 . Jalurg., $756-758$. 3 figs. 1897.2

- Neu entstandene Fischaten [. Hherina riqueti Roule] Prometheus, 1902, 14. Jahrg., $27-29$.
Krause, Ernst, \& Sterne, Carus. Dic Brutpflege der Fische. Prometheus, 1902, 13. Jahrg., 121-125. 5 figs.

1902.1

Krause, Lrnst II. I. Fliegende Fische (Exococtus sp.) und Fischzüge. Abh. Nat. Ver. Bremen, 1888, 10. 1888.1

Krause, $K$. Experimentelle Untersuchungen über die Sehbahnen des Goldkarpfens (Cyprinus auratus) Areh. Mikrosk. Anat., 1898, 51, 820-839. pl.

1898.1

Krause, K. L. II. A hybrid plaice, Plalessa vulgaris with Rhombus maximus. Bull. U. S. Fish Comm. 1882 (1883), 2, 341-342.

1883.1

Krause, Richard. Der Aal. Wochenschr. Aquar.-l'errar. Kunde, 1911, 8. Jahrg., 198-199.

1911.1

Krause, Rudolf. Die Endigungsweise des Nervus acusticus im Gehörorgan. Verh. Anat. Ges., 1896, 10. Vers., 165-170. :3 figs.

1896.1

- Die Entwickelung des Aquaductus vestibuli sive Ductus endolymphaticus. Anat. An\%., 1901, 19, 49-59. figs.

1901.1

Die Endigung des Nervus acusticus im Gehörorgan des Flussneunauges. Sitzber. Akad. IViss. Berlin, 1905, 10151032. 5 figs.

1905.1

- Entwickelungsgeschichte des Gehörorgans (In Hertwig, Oscar. Handbuch der vergleichenden und experimentelle Entwickelung der Wirbeltiere, vol. ii, pt. 2, p. 83-138; 76-145. Jena, 1906. 3 vols.

1906.1

- Das Gehörorgan der Petromyzonten. Anat. Anz., 1906, 29 (Suppl.), 257-265. 4 figs. 1906.2

Krause, Wilhelm [1833-] Die Nerven-Endigung in der Retina. Arch. Mikr. Anat., 1876, 12, 742-790. 1876.1

Die Retina. II. Die Retina der Fische. Monat. Anat. Histol., 1885, 3 $41-73$.

1885.1

Die Nervenendigung im electrischen Organ [Torpedo ocellala] Monat. Anat. Histol., 1886, 3, 285-308. pl. Ibid., 4,371-392. 2 pls. 1886.1

Ueber die Folgen der Resection der elektrischen Nerven des Zitterrochen. Sitzber. Akad. Wiss. Berlin, 1856, 675-680. fig. - Arch. Anat. Physiol. (Physiol. Abth.), 1887, 148-153. fig.

1887.1 
Die Nervenendigung im electrischen Organ. Dritter Artikel. Monat. Anat. Histol., 1891, 8, 250-26.5. pl.

1891.1

-Die Retina der Fische. Monat. Anat. Histol., 1892, 9.

1892.1

- Die Farbenempfindung des Amphioxus. Zool. An\%., 1897, 20, 513-515.

1897.1

- Historische Bemerkungen über Amphioxus. Zool. Anz., 1898, 21, 48148.3.

1898.1

Die Lichtempfindung des Amphioxus. Anat. Anz., 1898, 14, 470-471.

1898.2

Krauss, lierdinand von. Ueber den Bitterling (Rhodeus amarus Ag.) Jahresh. Ver. Vaterl. Naturk. Württemberg, 1858, 14, 115-123.

1858.1

[Beobachtungen über das 'Zahlenverhältniss der im Neckar vorkommenden verschiedenen Fischarten] Jahresh. Ver. Vaterl. Naturk. Württemberg, $1863,19,56-57$.

1863.1

Ueber eine fur das Neckargebiet neue Brachsen-art (Abamis leuckartii Heckel), und über eine bei Heilbronn gefangene Meeruricke (Petromyzon marinus L.) Jahresh. Ver. Vaterl. Naturk. Württemberg, 1863, 19, 5t-56. 1863.2

-_ Ueber einen lebendigen Lungenfisch (Lepidosiren annectens Owen) Jahresh. Ver. Vaterl. Naturk. Wirttemberg, 1864, 20, 126-133.

1864.1

- Ein Lachs (Trutta salar. L.) aus dem Neckar bei Heilbronn. Jahresh. Ver. Vaterl. Naturk. Wiirttemberg, $1865,21,276-277$

1865.1

- Das Zahlenverhältniss der in Neckar vorkommenden Fischarten. Jahresh. Ver. Vaterl. Naturk. Wiurttemberg, 1865, 21, 165-167. 1865.2

Kopfmissbildung einer Bachforelle. Jahresh. Ver. Vaterl. Naturk. Württemberg, 1886, 42, 345-346. 1886.1

Kravetz, L. Hntwickelung des Knorpelschädels von Ceratodus. Bull. Soc. Nat. Moscou 1910 (1911), 332-365. 22 pls. \& 5 figs.

1911.1

Krebs, Wilhelm. Die Helchenfauna der deutschen Seen. Globus, 1904, 86, 3.5.

1904.1

Geophysikalische, besonders klimatische Beziehungen des Auftretens der Heringsschwärme in der süclöstlichen Nordsce. Fischerbote, 1911, 3, 150-152.

1911.1

Geophysikalische Verhältnisse auf den Fundstellen der Aallarven im Atlantik und im Mittelmeer. Fischerbote, $1911,3,180-184 . \quad 1911.2$

Vulkanische 'liefseeheizung und Aalbrut. Mitth. Deutsch. Seefischerei Ver., 1912, 28, 258-263. 2 figs. 1912.1

Krefft, Johann Ludwig Gerhard [18.501881] Notes on Australian freshwater fishes, and descriptions of four new species [Eleotris coxii, E. australis, E. grandiceps, E. compressus] Proc. '/ool. Soc. London, 1864, 182-184. - Ann. Mag. Nat. Hist., 3. ser. 15, 68-71.

$186+1$

Descriptions of some new Australian freshwater fishes. Proc. $1 /$ ool. Soc. London, 1867, 942-941. 1867.1

Description of a gigantic amphibian allied to the genus Lepidosiren, from the Wide-Bay district, Queensland [Ceratodus forsteri] Proc. Zool. Soc. London, 1870, 221-224. 1870.1

- Lin neuer Ganoidfisch aus Australien (East-Queensland) Das Ausland, 1870,792 . 1870.2

Beschreibung cines giguntischen Amphibiums aus der Verwandtschaft der Gattung Lepidosiren, aus dem WideBay district in Queensland. Arch. Naturgesch., 1871, 37. Jahrg., 1, 321324.

1871.1

- The Ceratodus forsteri. Nature, $1871,3,107-108$.

1571.2

Kreidl, Alois. Ueber die Perception der Schallwellen bei den Fischen. Arch. Physiol., 1895, 61, 450-464. Abstract in Centralbl. Physiol., 1896, 10, 56-57.

1895. 1

Ueber den Ursprung der Hemmungsnerven des Herzens bei Fischen. Arch. Gesim. Physiol., 1899, 77, 196 201. '2 figs.

1899.1

Kreidl, llois, \& Kinoshita, 'T'. Ueber die Entladung des elektrischen Organes von 'Torpedo marmorata im Süisswasser. Zentralbl. Physiol., 1910, 24, 831. - Med. Klinik, 6. Jahrg., 2034. - Arch. Intern. Physiol., 10, p. $63 . \quad 1910.1$

Kressner, $M . G$., \& Dietzell, B. E. She Dietzell \& Kressner. 
Kreuter, Erwin. Ueber den soliden Oesophagus der Selachier. Inaug. Dissert. Erlangen, 1903. 40 p. 2 pls.

1903.1

Kreyenberg, $M$. Win Beitrag zur Iienntniss der Fische der Yangtze und seiner Zuflüsse. Abh. Mus. NaturHeimatk. Magdeburg, 1910, 2, 1-24.

1910.1

- Briefe aus Chinal. V. Ueber die 'Zucht der Goldfischrassen in China. Blätt. Aquar.-Terrar. Kunde, 1911, 22. Jahrg., 265-267. fig.

1911.1

Eine neue Cobitinen-Gattung [Gobiobotia pappenheimi, n. g., n. sp.] aus China. Zool. Anz., 1911, 38, 417-419. 4 figs.

1911.2

Ueber die Zucht der Goldfischrassen in China. Blätt. Aquar-Terrar. Funde, 1911, 22. Jahrg., 265-267.

1911.3

Kreyenberg, $M_{\text {., \& }}$ Pappenheim, $P$. Ein Beitrag zur Kenntnis der Fische des Jangtze und seiner Zufliusse. Sitzber. Ges. Naturf. Freunde Berlin, 1908, 95109. - Abh. Ber. Mus. Nat. Heimatkunde Nat. Ver. Magdeburg, 1909, 2, $1-24$.

1908.1

Kriesch, János [1834-1888] A mesterséges haltenyésztésröl. Term. 'Tud. Közl., 1869, 1, 409-421.

1869.1

Ein neuer Gobius ( $G$. maculatus) Verh. Zool.-Bot. Ges. Wien, 1873, 23, 369-376. fig.

1873.1

Egy új hal-faj [Gobius mubromaculatus] Math. Természett. Közlemények, 1872 (1875), 10, 221-232. fig. 1875.1

Krisch, A. Die Fischerei im Adriatischen Meere. Wien \& Pola, 1900. 280 p. 89 figs. $S^{\circ}$.

1900.1

- Der Wiener Fischmarkt. Volkswirthschaftliche den Hausfrauen der öesterreichischen Haupt- und Residenzstadt gewidmete Studie. Wien, 1900. 50 p. $8^{\circ}$.

1900.2

Kroeff,,$. M . T$. On herring fisheries. Edinb. New Phil. Journ., 1858 , $8,450-470$.

18.58 .1

Krohn, August David [180t?-1891] Ueber das Brutorgan der Gattung Hippocampus. Arch. Naturgesch. (Wiegmann), 1840, 6. Jahrg., 1, 16-17. 1840.1

Kronecker, $I I .$, \& Nicolaides, $R$. Ueber dic Erregung der Gefissmerven- centren durch Summation elektrischer Reize. Arch. Anat. Physiol., 1883, 2742. 2 pls.

1883.1

Krotov, $B$. Fische der permischen Ablagerungen Russlands TText in Russian] Arb. Nat. Ges. Kasan, 1904, 38, no. 3. 40 p. 2 pls.

1904.1

Kroyer, IIenriti Nicolaj [1799-1870] De Danske ostersbanker et bidrag ti kundskab om Danmarks fiskerier. Kijobenhavn, 1837. $8^{\circ}$.

1837.1

Notice in Arch. Naturgesch. (Wiegmann), 1839 , pt. 1, 358 .

Ichthyologiske bidrag. Naturhist. 'Tidssk. (Kroyer), 1837, 1, 25-38 213-282; 639-649. Ibid., 1846, 2, 225288. 1837.2

i. Chirus procisus, en ny gronlandsk fisk.

ii. Blennius lampetraformis Walb.

-.- Ichthyologiske noticer, den nordiske fauna vedrorende. Naturhist. Tidssk. (Krøyer), 1837, 1, 371-387.

1837.0

Notice om den norske Lumpenus. Naturh. 'Tidsskr. (Kroyer), 1837. $1,519-520$.

1837.4

Notice om den stromske Blennius lumpenus af Udg. Naturhist. Tidssk. (Írøyer), 1837, 1; 519-549.

1837.5

Om Pleuronectes-arterne. Naturh. 'Tidsskr. (Kroyer), 1837, 1, 378384.

1837.6

- Zur Verbreitung von Cyprinus farenus. Arch. Naturgesch. (Wiegmann), 1837, 3. Jahrg., 393. 1837.7

- Danmarks Fiske. 4 vols. in 3. Kjobenhavn, 1838-53. illust. $8^{\circ}$.

1838.1

Vol. iv contains a bibliography which gives full references to the older writers on Scandinavian ichthyology. A second edition of this work was published in 1853 .

Ichthyologische, die nordische Fauna betreffende Notizen. Isis (Oken), 1841, 24-32.

1841.1

- Om slaegten 'Tricaster Ag. Naturhist. 'Tidsskr. (Kroyer), 1841, 3, 544545.

1841.2

Aqriomus albogutlatus. Naturhist. 'Tidsskr. (K'royer), 1845, n. s. 1, $224-227$.

1845.1

Aspidophorus decagonus. Naturhist. Tidsskr. (Kroyer), 1845, n. s. 1 , $243-250$.

1845.2

Ispidophorus niger. Naturhist. l'idsskr. (Kroyer), 1845, n. s. 1, 23824.3. 
Aspidophorus spinosissimus. Naturhist. Tidsskr. (Kroyer), 1845, n. s. 1, 250-253.

1845.4

Caracanthus typicus. Naturhist. Tidsskr. (Kroyer), 1845, n. s. 1, 264-268.

1845.5

Carelophus strömii. Naturhist. Tidsskr. (Krøyer), 1845, 1, 227-238.

1845.6

- Ceratias hollbölli. Naturhist. Tidsskr. (Kroyer), 1845, n. s. 1, 639649.

1845.7

Icelus hamatus. Naturhist. Tidsskr. (Kroyer), 1845, n. s. 1, 253264.

1845.8

Meddeler forögelser til kundskab om de Gröndlandske fiske-arter. Oversigt Danske Vid. Selsk. Forh. 1844 (1845), no. 8, 139-141.

1845.9

- Om de nordiske arter af slaegten Sebastes. Naturhist. Tidsskr. (Krøyer), 1845, n. s. 1, 268-282.

1845.10

- Oplegnathus fasciatus. Naturhist.' Tidsskr. (Kroyer), 1845, n. s. 1, 213223.

1845.11

- Poissons de la mer du Nord, reçus pendant le voyage scientifique en Scandinavie, en Laponie, etc., exécuté sous la direction de P. Gaimard. Paris, 1847.

1847.1

Atlas of 20 colored plates, unaccompanied by explanatory text.

Cyclopterus spinosus Fabr. Naturhist. Tidsskr. (Krøyer), 1849, n. s. 2. $262-274$

1849.1

Liparis fabrici Irr. et $L$. lineatus Kr. Naturhist. Tidsskr. (Kroyer), 1849, n. s. 2, 274-290. 1849.2

Paralepis borealis Rhdt. Naturhist. 'Tidsskr. (Krøyer), 1849, n. s. 2, $241-252$.

1849.3

- Scopelus glacialis Rhdt. Naturhist. Tidsskr. (Krøyer), 1849, n. s. 2, 225-240.

1849.4

Stomias ferox Rhdt. Naturhist. Tidsskr. (Kroyer), 1849, n. s. 2, 252261.

1849.5

Danmarks Fiske. 2. ed. 4 vols. in 3. Kjøbenhavn, 1853. illust. $8^{\circ}$.

1853.1

The vernacular names of fishes are given in connection with the species treated.

Nogle bidrag til Nordisk ichthyologi. Naturhist. Tidsskr. (Krøyer), 1861, 3. ser. 1, 233-310.
- Nogle yderligere bemaerkninger i anledning af Liparis lineata [vulgaris] Naturhist. 'Iidsskr. (Kroyer), 1861, 3. ser. 1, 539-553.

1861.2

To nye fiske for den danske fauna. 'Tidsskr. Fiskeri, 1868, 2. Jahrg., $70-71$. 1868.1

Krüger, Albert. Ueber die Verbreitung junger Schollen an der deutschen Ostseekiiste im Sommer und Herbst 1903. Mitth. Deutsch. Seefischerei Ver., $1903,19,449-456$.

1903.1

- Berieht über die . . Untersuchung zur Feststellung des Vorkommens junger Schollen an der deutschen Ostreekiiste. Mitth. Deutsch. Seefischerei Ver., 1904, 20, 330-335. "1904.1

-C Untersuchungen über das Pankreas der Knochenfische. Wiss. Meeresuntersuch. Kiel (Abt. Kiel), 1905, n. s. 8, 57-81. 2 pls. 1905.1

Krüger, Alfred. Bella rubra (Perugia) Wochenschr. Aquar.-Terrar. Kunde, 1912, 9. Jahrg., 668-669. 1912.1

Krüger, Berthold. Der Argusfisch, Scatophagus argus. Prakt. Zierfischzüchter, 1910, 10-12. $\quad 1910.1$

- Etwas vom Belonesox belizanus Kner. Prakt. Zierfischzüchter, 1910, 35-36. 1910.2

- Der neue Tetragonopterus spec. Prakt. Zierfischzïchter, 1910, 17-19. fig.

1910.3

- Barbus ticto (Hamm. Buch.) inre Pflege und Zucht. Blätt. Aquar.-'Terrar. Kunde, 1912, 23. Jahrg., 839-840. fig. 1912.1

- Ein neuer Cichlide der Gattung Cichlasoma. Blït. Aquar.'Terrar. Kunde, 1912, 23. Jahrg., 821-822. fig. 1912.2

Ueber das Vorkommen von Aquarienfischen in und bei BuenosAires. Blätt. Aquar--Terrar. Kunde, 1912, 23. Jahrg., 465-466. 1912.3

- Beobachtungen an Barbus caltipterus vom Kongo. Wochenschr. Aquar.-'Terrar. Kunde, 1913, 10. Jahrg., 797-798. fig.

1913.1.

Gasteropelecus strigatus Günther (Carnegiella strigata Günther) und seine Pflege im Aquarium. Blätt. Aquar.Terrar. Kunde, 1913, 24. Jahrg., 342343.
1913.2 
Krüger, $B$.

- Leporinus melanopleura Günther. Wochenschr. Aquar.-Terrar. Kunde, 1913, 10. Jahrg., 601-603. fig. 1913.3

Monocimus polyacanthus Heckel. IVochenschr. Aquar.-Terrar. Kunde, 1913, 10. Jahrg., 777-778. fig. 1913.4

Win newer bunter Hemichromis von West-Afrila. Blätt. Aquar-Terrar. Siunde, 1913, 24. Jahrg., 747-749. fig.

1913.5

_... Ein neuer "stahlblauer" Fundulus von ITest-Afrika. Wochenschr. Aquar.-'Terrar. Kunde, 1913, 10. Jahrg. $753-754$. fig.

1913.6

Ueber die Pflege des 'T'etragonopterus mexicanus Filippi. Wochenschr. Aquar.-'Terrar. Kunde, 1913, 10. Jahrg., $835-838$.

1913.7

Weitere Mitteilungen zur Kenntnis der Schlafstellungen bei Suisswasserfischen. Biol. Centralbl., 1913, 33, 1417.

1913.8

Krüger, Berthold, \& Wolterstorff, $W$. 'Zur Nomenklatur von Girardinus guppyi, etc. Blätt, Aquar-'Terrar. Kunde, 1910, 21. Jahrg., 396-397.

1910.1

Krueger, Johann Friedrich $[1770$ 1836] (editor) Die versteinerten Fische von de Blainville, aus dem Französischen übersetzt. Herausgegeben, mit Anmerkungen und mit einer Vorrede versehen von .J. F. Krueger. Quedlinburg \& Leipzig, 1823. 232 p. 8. 1823.1

Krüger, J.G. Die ersten Gründe der Naturlehre auf eine leichte und angenchme Art zum Gebrauch der Jugend und Anfänger. Halle, 1759. 370 p. with portrait. $12^{\circ}$

Capitel 9. Von dem IVasser. 10. Von der Erde.

1.t. Von den l'flanzen und Thieren.

Krukenberg, Carl Friedrich Wilhelm [1852-1889] Versuche zur vergleichende Physiologie der Verdauung mit besonder Beruicksichtigung der Verhältnisse bei den Fischen. Untersuch. Physiol. Instit. Heidelberg, 1877, 1.

1877.1

'Zur Verdauung bei den Fischen. Untersuch. Physiol. Instit. Heidelberg, 1879,2 , Heft 4, 385-401.

1879.1

Untersuchung der lileischextracte verschiedener Fische und Wirbellosen. Untersuch. Physiol. Inst. Heidelherg, 1881, 4, Heft 1.

1881.1
Zur Kenntnis des chemischen Baues von Amphioxus lanceolatus und der Cephalopoden. 'Lool. Anz., 1881, 4, 64-66.

1881.2

Die Pigmente der Fischhaut. Vergl. Physiol. Stud. Adria, 1882, 2, 5558 ; 138-143. 2 pls.

1882.1

-- Ueber die chemische Beschaffenheit der sogenannten Hornfäden bei Mustelus und iiber die Zusammensetzung der keratinösen Hüllen und der Eiern von Scyllium stellare. Mitth. Zool. Stat. Neapel, 1885, 6, 286-296.

1885.1

Neue Tatsachen für cine vergleichende Physiologie der Phosphorescenzerscheinungen bei Tieren und Pflanzen. Vergl. Physiol. Stud. Heidelberg, 1887,2 . ser.

1887.1

La rétention de l'urée chez les sélaciens, avec quelques remarques sur l'accumulation d'autres substances cristaloïdes dans les tissus contractiles de certains espèces animales. Ann. Mus. Hist. Nat. Marseille, 1888, 3, pt. 3.

1888.1

Krukenberg, Carl Friedrich Wilhelm, \& Ewald, August. See Ewald \& Krukenberg.

Krumbacher, Karl. Das mittelgriechisches Fischbuch (Opsaralogos) Sitzber. Bayer. Akad. Wiss., phil.-nat. C1. $1903,345-386$.

1903.1

Bibliography of glossaries of classical names, etc., p. 365. Review in Zool. Annalen, 1905, 1 . 396 , and noticed with other writings on ancient Greek names of fishes by C. R. Eastman in science, $1905, \mathrm{n}$. s. 22, 23 .

Krumbholz, Johannes. Anatomie des Darmtraktus einiger Macruriden und des Zoareiden Lamprogammus niger. Inaug. Dissert., Borna-Leipzig, 1910. 52 p. $8^{\circ}$.

1910.1

Kruuse, $I I . G$. Nogle meddelelser om fiskeriet paa vestkysten af Sydamerika. Nord. Tidsskx. Fiskeri, 1879, n. s. 5. Jahrg., 286-299.

1879.1

- The fisheries on the west coast of South America. Rept. U. S. Fish Comm. 1879 (1882), 7, 515-522. 18s2.1

Krynicki, J. Schilus pallasii descriptus et icone illustratus. Nouv. Mém. Soc. Nat. Moscou, 1832, 2, 441446. pl.

1832.1

Kschischkowsky, $K$. Beitrige zur Physiologie des Nervus terminalis bei den Selachiern. Arch. Gesam. Physiol., $1912,148,585-607$. 
Kucera, Albin. Der Wandertrieb der Forellen. Oesterr. Fischerei Zeitg., 1908, 5, 175-176. 1908.1

Kuchin, I. B. Erforschung der Fischerei auf dem Beloozero See. Naturhistorische Beschreibung des Sees [Text in Russian] Vèst. Rybopromyšl., St. Petersb., 1902, 17, 331-359. 1902.1

- Beobachtungen über das Leben des Stintes im Ilmensee Text in Russian] Fischzuchtanst. Nikolsk St. Petersb., 1903, no. 7, 42-49.

1903.1

Die Fischaucht im Ural-Gebiet r'lext in Russian] Trd. Jub. Akklim. Sjězda, Moskva, 1908 (1909) (pt.2. sec. ichtiol.), 169-187.

1909.1

- Matériaux sur la pisciculture et la pêche dans la contrée de l'Oural. I. Partie transouralienne du gouvernement de Perm. [Text in Russian] Bull. Soc. Oural. Nat., Ekaterinburg, 1909, 28, 47-121.

1909.2

Essai de fécondation artificielle du frai de Stenodus leucichthys et de sterlet, et plan des travaux subséquents en vue de développer la pisciculture dans la région des monts Ouraliens ['Text in Russian] Bull. Soc. Oural. Amat. Sci. Nat. Ekaterinburg, 1910, 30, 29-47.

1910.1

- Die Fischzucht und das Fischereigewebe in den Seen des Urals. Ausgabe des Department der Landwirtschaft [Text in Russian] St. Petersburg, 1910. ix, 80 p. 6 pls. map.

1910.2

Kuchin, $N^{\top}$. Die Fischerei auf dem Ilmen-See l'lext in Russian] V'ést. Rybopromyšl., St. Petersb., 1904, 19, pt. 1,1-35. Ibid., pt. 2, 93-150. 1904.1

Küchenmeister, Goltlob Friedrich Heinnich [1821-1890] Freie Uebersetzung und Bearbeitung des Aufsatzes von Jules Haime: "La pisciculture," in der Revue des Deux Mondes vom Juni 1854 nebst Zusätzen. Allgem. Deutsch. Nat. Hist. Zeitg., 1855, 1, 129-152. 1855.1

- Schonung der Lachse und Forellen. Annal. Landw. Wochenbl., 1861, 1. Jahrg., 30 .

1861.1

Zur kiinstlichen Fischzucht. Mitth. Central-Instit. Akklim., 1861, 3. Jảhrg., 51-53.

1861.2

- Ueber den Befruchtungsmodus bei den Fischen und über die Parthenogenesis bei den niederen Thieren. Sitzber. Naturw. Ges. Isis, Dresden, 1866, S7-8s.

1866.1
Ueber künstlichen Fischzucht. Jahresber. Ges. Natur- u. Heilk. Dresden, 1879, 103-10t. $\quad 1879.1$

Kuechler, Anton. Fischerci. Sarnen, 1895. $16^{\circ}$. 1895.1

Kühne, Willy, \& Sewall, H. Zur Physiologie des Sehepithels [Abramis brama] Verh. Nat. Med. Ver. Heidelberg, 1850, n. s. 2, 324-328. - Journ. Physiol., Cambridge, 1880, 3, 88-92.

1880.1

Kuinstler, $J$. Recherches sur la reproduction du saumon de la Dordogne. C. R. Congr. Intern. Zool. Paris, 1889 , S3-96.

1889.1

Observations sur le saumon de Norvège. C. R. Acad. Sci. Paris, 1890. $111,695-696$.

1890.1

_ Sur la fécondation artificielle du Cantharus griseus. Act. Soc. Linn. Bordeaux, 1893, 5. ser. 5, 241-243. 1893.1

- Congrès de la fédération des sociétés de pisciculture et de pêche du sud-ouest de la France. litangs \& Rivières, $1897,10,123-125 ; 136-139$.

1897.1

La question surdinière et la crise aquicole en général. 'Trav. Labor. Soc. Sci. Arcachon, 1903, 7. année, 33-86.

$190: 3.1$

Note sur les mours du muge de l'étang de Mimizan. C. R. Mém. Soc. Biol. Paris, 1904, 56, 427-42S. 1904.1

- La mission de pêche du bane d'Anguin. Rev. Gén. Marine March., Paris, 1905, 1-6s. fig. 1905.1

Observations sur l'Amiurus nebulosus. C. R. Mém. Soc. Biol. Paris, 1907, 62, 922-924. - Réun. Biol., Bordeaux, 1907, 61-63.

1907.1

Amiurus nebulosus et Eupomotis gibbosus. Bull. Soc. Nat. Acclim. France, 1908, 55. année, 238-244. 1908.1

L'ide mólanote dans les caux du sud-ouest. C. R. Mém. Soc. Biol. Paris, $1908,64,838-810$.

1908.?

La reproduction du goujon. ( . R. Mém. Soc. Biol. Paris, 1908, 64, $545-546$.

1908.8

Le rouvet précieux dans le golfe de Gascogne. C. R. Mém. Soc. Biol. Paris, 1908, 64, 500-501. 1908.4

Bassins à carpes (petite culture) C. R. Mém. Soc. Biol. Paris, 1910, 69, $595-596$. 
Künstler, $J$.

- Sur la plasticité évolutive des salmonides sous l'influence des conditions ambiantes. Bull. Soc. Acclim. Paris, 1913, 1-3.

1913.1

Kuinstler, J., \& Chaine, Joseph. Notice ichthyologique (le Beryx decarlactylus Cuv, et Val.) Proc. Verb. Soe. Sei. Phys. Nat., 1904, 27-29;50. 1904.1

- Le Centriscus scolopax L. dans l'océan Atlantique. 'Trav. Labbor. Soc. Ści. Arcachon 1905 (1906), S. imnée, 126.

1906.1

- Note sur la centrine humantin (Centrina vulpecula Bel.) "l'rav. Labor. Soc. Sei. dreachon 1905 (1906), S. année, 120-125. ¿2 figs.

1906.2

Note sur la castagnole [Brama] Le Naturaliste, 1906, 2. sér. 2S. année, $138-139$

1906.3

Künstler, J., \& Gruvel, \&. Sur certaines déformations particulières des hématies des poissons. C. R. Acad. Sci. Paris, 1899, 128, 618-620.

1899.1

Küster, IIeinrich Carl [1807-1876] Verzeichniss der Iische in Umgegend Nürnbergs (In Lochner, - Nïnbergs Vorzeit, p.364. Nünberg, [n.d.])

Not seen; reference from Bosgoed.

- Systematisches Verzeichniss der in ter Ümgegend Erlangens beobachteten 'Thieren. Erlangen, 1810. $8^{\circ}$.

1840.1

Namenverzcichniss der Fische der Regnitzund Regnitz-Gewässer.

Kuffer, Johannes Baplist. Bericht des landwirthschaftliche Vereins-Fischers ... in München über die Resultate der künstlichen Fischzucht während der Vinterlaichperiode 1860-61. Zeitschr. Landw. Ver. Bayern, 1861, 51. Jahrg. $526-528$.

1861.1

Kuhl, Heinrich [1797-1821] Bcitrige zur Zoologie und vergleichenden Anatomie. 2 pts. Frankfurt-a.-M. 1820. $4^{\circ}$

1820.1

Lettre à M. Boie, sur l'anatomic de quelques poissons. Nllgem. Kunst u. Litterb., 1822, 20. - Bull. Sci. Nat. (Férussac), 1822, 2, 206-207. 1822.1

Kuhl, Heinrich, \& Hasselt, $J . K$. van. Anatomische Beschreibung vieler rische, vorzitiglich der Nordsee, in splanchnologischer und myologischerHinsicht (In Kuhl, H. Beitrige zur Zoologic und vergleichenden Anatomie,
Abt. 2, p. 127-150. Frankfurt-a.-M. 1820)

1820.1

- Notice anatomique sur quelques poissons. Bull. Sci. Nat. (Férussac) $1824,2,206-207$.

1524.1

Kuhlmann, Waller. Beobachtungen am Bachneuhauge. Blitt. Aquar.'lerrur. Kunde, 1912, 23. Jahrg., p. 521.

1912.1

Kuhn, Abraham. Untersuchungen über das häutige Labyrinth der Innochenfische. Arch. Mikr. Anat., Bonn, 1877, 14, 264-308. 4 pls. 1877.1

Kuhnert, $R$. Ueber die Düngung von 'Teichen und deren Wirkung auf den Fischerei-Ertrag. Arch. Hydrobiol. Planktonkde., 1909, 4, 383-392. 1909.1

Kuhnt, B. Weitere Mitteilungen ïber den Formenkreis des Girardinus reticulatus Pet. Blätt. Aquar-'Terrar. Kunde, 1910, 21. Jahrg., 658. 1910.1

Kuiper, T'aco. Sul meccanismo respiratorio dei pesei ossei. Rendic. Accad. Lincei, Roma, 1906, 5. ser. 16, pt. 1, 355-394. 9 figs. - Arch. Ital. Biol., 'lorino, 45, 393-405. 1906.1

-Untersuchungen über die Atmung der 'Teleostier. Arch. Gesam. Physiol., 1907, 117, 1-107. 1907.1

Kukula, Wilhelm. Dic Fischfauna Oberösterreichs. 5. Jahresber. Ver. Naturk. Oesterreich, Enns zu Linz, 1874, 17-25.

1874.1

Kulchitzkiř, $N$. Beiträge zur Kenntniss des Darmkanals der Fische [Text in Russian] Mem. New Russ. Soc. Nat., Odessa, 1888, 12, pt. 2. 1888.1

Biologische Notizen. I. Glandula lacrimalis preparotidea bei Nagetieren. II. Das Adenoide Organ in der Speiseröhre der Selachier. Arch. Mikr. Anat., 1911, 78, Abt. 1, 234-244. 2 pls.

1911.1

Kulczycki, Wlodzimierz, \& Nusbaum, Jozef. See Nusbaum \& Kulczycki.

Kuliabko, Al. 1. Notice biologique sur la lamproie, Petromyzon fluviatalis. Bull. Acad. Imp. Sci. St. Pétersb., 1897, 7, no. 1, 27-28.

1897.1

- Linige Beobachtungen über dic Leber des. Hussneunauges (Petromyzon fluviatilis) Centralbl. Physiol., 1898, 12, $380-381$.
1898.1 
Anwendung der künstlichen Circulation am abgeschnittenen Fischkopf [Text in Russian] Mém. Acad. Sci. St. Pétersb., 1907, S. sćr. 20, pt. 7, 22 p. 2 pls.

1907.1

Application de la circulation artificielle aux têtes de poisson coupées. Bull. Acad. Imp. Sci. St. Pétersb., 1907, 6. sér. 1, pt. 1, 103-104.

1907.2

Kuliabko, 1., \& Diamare, Vincenzo. See Diamare \& Kuliabko.

Kumlien, Thure Ludwig Theodor [1819-1888] Contributions to the natural history of arctic America, made in ... 1877-78. Bull. U. S. Nat. Muselum, 1879 , no. $15,1-179$.

1879.1

Fishes collecterl in Cumberland gulf and Disco bay, by 'T'. H. Bean, p. 131-138.

Fisheries of the Great Irakes (In The fisheries and fishery industries of the United States, edited by George Brown Goode, sect. 5, vol. i, p. 755769. 12 pls. Washington, 1887) 1887.1

Kumlien, 'Thure Ludwig Theodor, \& True, Frederick William. 'The fishinggrounds of the Great Lakes (In The fisheries and fishery industries of the United States, edited by George Brown Goode, sect. 3, 117-131. Washington, 1887)

1887.1

Kummer, Hans. Clenops viltalus Cuv, et Val. Blätt. Aquar.'-' 'errar. Kunde, 1904, 15. Jahrg., 273-274.

1904.1

Kums, A. Les choses naturelles dans Homère [Poissons] Antwerp \& Paris, 1897. $194 \mathrm{p}, 8^{\circ}$. Review in Nature, $57,146-148$.

1897.1

Kunisch, Hermann [1850-1893] Sactylolepis gogolinensis, gen. et sp. nov. Zeitschr. Deutsch. Geol. Ges., 1885, 37, 588-594. pl.

1885.1

Kunkel, - On the conditions under which trout exist in the German waters. Bull. U. S. F ish Comm., 1884, $4,393-395$.

1884.1

Kunth, A. Ueber Pteraspis. Zeitschr. Deutsch. Geol. Ges., 1872, 24, 1-8. pl. - Verh. Geol. Reichsanst. Wien, 1872, 336. - Neues Jahrb. Mineral., 1872,892 .

1872.1

Kuntz, A. The development of the sympathetic nervous system in certain fishes. Journ. Comp. Jeurol., 1911, 21 , 177-214. 15 figs.

1911.1
The evolution of the sympathetic nervous system in vertebrates. Journ. Comp. Neurol., 1911, 21, 215-236. 6 figs.

1911.2

Kuntzmann, Johann IIeinrich Lebrecht. Bemerkungen über die S'chupjen der Fische. Verh. Ges. Naturf. Freunde Berlin, 1829, 1, 269-284; 369-374. 4 pls. Abstracts in Bull. Sci. Nat. (IĆrussac), 7, 118. Ibid., 18, 289. Isis (Oken), 5, 4t4. 1829.1

Kupfier, Carl Wilhclm von [18291902] For biographical notice, see Life and work with bibliography, by Bashford Dean. Scicnee, n.s. 1900, 11, $364-369 \%$.

Ueber den feineren Batu des elektrischen Organs beim /itteraal (Gymnotus electricus), mit Rücksicht auf den Bau bei andren elchtrischen, inbesondre bei Mormyrus oxyrhynchus. "keitschr. Rat. Medicin., 18.57, 3. ser. 2, 1. 1857.1

- Untersuchungen über die Entwickelung des Harn und Geschlechtssystems. Arch. Nikr. Anat., 1865, 1, 23:3298. Itrid., 1866, 2, 473-488. p)1. 1865.1

Review by Pieter Harting in Album Natuur, $186 s$ (Wetensch, bijblad), 19.

Die Bildung des Embryo im Li der Knochenfische. Nachr. Univ. Ges. Wiss. Göttingen, 1867, 317-324. 1867.1

- Beobachtungen über die Entwicklung der Iinochenfische. Arch. Mikr. Anat., 1868, 4, 209-272. yls. - Abstract in Monthly Micr. Journ., $1869,1,47-48$. 1868.1

- Die Entwicklung der Retina des Fischauges. Med. Centralbl., 1868, 6. Jahrg., 641-64:3.

1868.2

Die Stammverwandtschaft zwischen Ascidien und Wirbelthieren. Arch. Mikr. Anat. 1869, 5, 459-463. Ibid. 1870, 6, pp. 11.5-172. 1869.1

- Ucber die Hairingsfischerei in der Schlei. Schrift. Naturw. Ver. Schlesw.Holst., 1876, 2, Heft 1, 209-210. 1876.1

- Ucher das Laichen und die Entwicklung des Hairings (Strömlings) bei Pillau und über einen ersten Versuch, den Entwicklungsgang eines Fisches durch kontinuirliche photographische Aufnahme zur Darstellung zu bringen. 1. Ber. Sitzung. Fischerei Ver. Prov. Preussen, 1876.

1876.2

Ueber den Keim und die Befruchtung der Fischeier. 2. Ber. Sitzung Fischerei Ver. Prov. Preussen, 1877, 1-5. 1877.1 
Kupffer, $C .11$.

Die Entwickelung des Herings im Ei. 4. 6 . Jahresber. Komm. Deutsch. Meere Kiel, 1878, 175-226. 3 pls.

1878.1

Ueber Laichen und Entwickelung des Herings im westlichen Ostsee. 4.-6. Jahresber. Komm. Deutsch. Mecre liel, 1878, 23-35. 1878.2

Die Entstehung der Allantois und die Gastrula der Wirbelthiere. Zool. Anz., 1879, 2, 520-522; 593-597; 612-617.

1879.1

Die Gastrulation an den meroblastischen Eiern der Wirbelthiere und die Bedentung des Primitivstreifs. Arch Anat. Physiol., 1884, 1-38. 2 pls.

1884.1

- Die Befruchtung des Forelleneies. Bayer. Fischerei Zeitg., 1886.

1886.1

Leber den Camalis neurentericus der Wirbeltiere. Sitzber. Ges. Morphol. Physiol. München, 1887, 3, 1-8, 1887.1

Leber die Entwicklung von Petromyzon planeri. Arch. Mikr. Anat, 1889, 35, 469-558. pls, - Sitzber. Bayer. Akad. Wiss., München, 1888, 18, 71-79. Abstract in Journ. Roy. Mier S'ci., 1885, 5, 708-709.

1888.1

Die Entwickelung der Kópfnerven der Vertebraten. Verh. Anat. Ges., Anat. Anz., 1S91, 7. Jahrg., 22-55. figs.

1891

Mitteilungen der Entwicklungsgeschichte des Kopfes bei Acipenser sturio. Sitzber. Ges. Morphol. Physiol. IIümchen, 1891, 8, 107-123. 1891.2

- Ueber die Entwicklung von Milz und Pankreas. Sitzber. Ges. Morphol. Physiol. Niunchen, 1892, 8 $27-41$.

1892.1

Studien zur vergleichenden Entwicklungsgeschichte des Kopfes der Kranioten. j) Hefte. 1893-1900.

1893.1

i. Jie Entwicklung des Liopfes von Acipenser sturio. MIunchen at Leipzig, 1893. $95 \mathrm{p} .9 \mathrm{pls}$. $\mathrm{S}^{\circ}$.

ii. Die Entwicklung des Kíopfes von 1 mmocotes planeri. München \& Leipzig, 1894. 79 p. $12 \mathrm{pls}$

iii. Die Entwicklung des Kópfes von Ammocates planeri. Münelen, $1895,50 \mathrm{p} .4 \mathrm{~s}$ figs.

Ueber das Pankreas bei Ammocates. Sitzber. Ges. Morph. Physiol. München, 189:3, 9, 37-58. figs. 1893.2
- - Ergebnisse der Entwicklungsgeschichte des Kopfes. Ergebnisse Anat. Entwick., Wiesbaden, 1893, 2, 501-564.

1893.3

- Ueber Monorhinie und Amphirhinie. Sitzber. Bayer. Akad. Wiss., math.-phys. Cl., 1894, 24, 1. Heft, 5160.

1894.1

Ueber die Entwickelung des Kiemenskelets von Ammocotes und die Organogene Bestimmung des Exoderms. Verh. Anat. Ges., Anat. Anz., 1895, 11 105-122. figs. Abstract in Journ. Roy. Micr. Soc. London, 1895, 6, 610. 1895.1

Ergebnisse der Entwicklungsgeschichte des Kopfes. Ergebnisse Anat. Entwick., Wiesbaden, 1896, 5, 562-618.

1896.1

Festschrift zum siebenzigsten Geburtstag von Carl von Kupffer. Jena, 1899.

1899.1

Verlauf und Schichtenbau des Darmkanals von Myxine glutinosa L., von Otto Maas, p. 197 220. $3 \mathrm{pls}$

Zur Kopfentwicklung von Bdellostoma. Sitzber. Ges. Morphol. Physiol. München, 1899, 15, 21-35. 7 figs.

1899.2

- Die Morphogenie des Centralnervensystems [Bdellostoma, Petromyzon, Elasmobranchier, Ganoiden, Teleostier] (In Hertwig, O. Handbuch der vergleichenden und experimentellen Entwickelungslehre der Wirbeltiere, vol. ii, pt. 3, 1-166. figs. Jena, 1906)

1906.1

Kupffer, Carl Withelm von, \& Benecke, Berthold. Der Vorgang der Befruchtung am Ei der Neunaugen $[\mathrm{Pe}-$ tromyzon] beobachtet (In Festschrift Theodore Schwann. Königsberg, 1878. $24 \mathrm{p}$. pl. $4^{\circ}$ )

1878.1

Kupffer, Carl Withelm von, \& Keferstein, Wilhelm. Ueber den feineren Bau des electrischen Organs beim Zitter-Aal (Gymnotus electricus) mit Rücksicht auf den Bau bei anderen electrischen Fischen insbesondere bei Mormyrus oxyrhynchus, mit nachtrüglichen Bemerkungen der Nerven im Allgemeinen, von Rudolph Vagner. Nachr. Univ. Ges. WViss. Göttingen, 1857, no. 19, 253-268. 1857.1

Untersuchung über die elektrischen Organe von Gymnotus electricus und Mormyrus oxyrhynchus. Zeitschr. Rat. Medicin., 1858, 2, pt. 3, 344-356. 2 pls. 
Kupzis, $J$. Ueber den niedrigsten für das Leben der Fische nothwendigen Sauerstoffgehalt des Wassers und über die für dieselben giftigen Mengen im Wasser gelöster Kohlensäure. Zeitschr. Untersuch. Nahr. Genussmit., Berlin, 1901, 4, 631-638.

1901.1

Die Naphthafischgifte und ihr Einfluss auf Fische, andere Tiere und Bakterien. Zeitschr. Fischerei, Berlin, 1902, 9, 134-167.

1902.1

Kurajeff, $D$. Ueber das Protamin aus den Spermatozoen der Makrele. Zeitschr. Physiol. Chem., 1899, 26.

1899.1

Ueber das Protamin aus den Spermatozoen des Acipenser stellatus. Zeitschr. Physiol. Chem., 1901, 32, 197200.

1901.1

Kurze, Robert. Altes und Neues iiber Acara-Zucht. Wochenschr. Aquar.Terrar. Kunde, 1909, 6. Jahrg., 389-390.

1909.1

Kusnetzow, Innekentii Dmitrievich. See Kuznetzov, I. D.

Kutchin, Harriet Lehmann. Studies on the peripheral nervous system of Amphioxus. Proc. Amer. Acad. Arts Sci., 1913, 49, 571-624. 8 pls. 1913.1

Kutchin, Howard $M$. Report on the salmon fisheries of Alaska, 1897-98. Washington, 1898-99. $8^{\circ}$. 1899.1

Report on inspection of the salmon fisheries (In Cobb, J. N. Report on the fisheries of Alaska. Rept. U. S. Bureau Fisheries, 1906 (1907), 25-44)

1907.1

Kutorga, Stepan Semenovich [18121861] Beitrag zur Geognosie und Paläontologie Dorpats und seiner nächsten Umgebungen. St. Pétersbourg, 1835. iv, 25 p. 3 pls. $8^{\circ}$.

1835.1

Zweiter Beitrag. St. Pétersbourg, 1837.51 p. $8^{\circ}$.

Contains descriptions of Devonian fishes.

Kutscher, $F$. \& Kossel, Albrecht. See Kossel \& Kutscher.

Kutzner, A. Noch etwas über den Geschlechtsunterschied des Hemichromis bimaculata. Wochenschr. Aquar.'Terrar. Kunde, 1909, 6. Jahrg., 450.

1909.1

Kuznetzov, Innokentiv Dmitrievich. On the spring migration of Clupea caspice ['Text in Russian] Journ. Fish Industr. St. Petersb., 1894, 9, 147-165.

1894.1
Fischerei und Tiererbentung in den Gewässern Russlands. Minist. fui Landw. Reichsdomänen, St. Petersb. 1898. 120 p. $8^{\circ}$.

1898.1

The fisheries of the Terek river and the neighboring sea Text in Russian] St. Petersburg, 1898.120 p. $8^{\circ}$.

1898.2

Zur Biologie der Wolgahäringe ['lext in Russian] Věst. Rybopromyšl., St. Petersb., 1904, 19, 629-640. 1904.1

Un exemplaire de Barbus brachycephalus Iiessl. trouvé dans la Volga en amont de Tsaritsyn. Ann. Mus. Zool. Acad. Sci. St. Pétersb., 1908, 13, p. xlvxlvi. fig.

1908.1

Le scombre macquereau dans la mer Blanche. Ann. Mus. Zool. Acad. Sci. St. Pétersb., 1908, 13, p. xlv. 1908.2

- Der gegenwärtige Zustand der Fischerei im Baikal-See [Text in Russianl Trd. Jud. Akhlim. Sjězda, Moskva, 1908 (1909) (pt. 2, sec. ichtiol.), 112-124.

1909.1

A continuation of this paper was published by N. P. Sokolinikov in 1911 .

Kuznetzov, I. D., \& Berg, Lev Semenovich. See Berg \& Kuznetzov.

Kwietniewski, C. Ricerche intorno alla struttura istologica dell' integumento dei selachi. Padova, 1905. 156 p. 6 pls.

1905.1

Kwitka, S. $K$. Ueber einige Fossilien von Saray und Massasyr auf der Halbinsel Apsch eron. Verh. Russ. Mineral. Ges., 1901, 2. ser. 38, 359-385. 3 figs.

1901.1

Kybitz, $C$. $\boldsymbol{H}^{r}$. Bibliography of forestry, hunting and fishing of Brunswick. Jahresber. Ver. Naturw. Braunschweig, 1893 , no. 7 .

1893.1

Kyle, Harry $M$. Note on the reproductive organs of a hermaphrodite ling. 15. Ann. Rept. Fish. Board Scotland, 1897, pt. 3, 396-398. pl. 1897.1

- Report on the pelagic ova, larvx, and young fishes procured by the s. S. "Garland" during the greater part of 1896. 15. Ann. Rept. Fish. Board Scotland, 1897, pt. 3, 246-261. 1897.2

The post-larval stages of the plaice, dab, flounder, long rough dab, and lemon dab. 16. Anm. Rept. Fish. Board Scotland, 189s, pt. 3, 225-247. 2 pls. 
Kyle, $/ 1 . M$.

- - The natural history of the herring (abstract of "Naturgeschichte des Herings" von F. Heincke) 17. Ann. Rept. Fish. Board Scotland, 1899, pt. 3, $274-287$.

1899.1

'The classification of the flatfishes (Heterosomata) 18. Inn. Rept. Fish. Board Scotland, 1900, 335-369. 2 pls.

1900.1

Contributions towards the natural history of the plaice ( $P$. platessa L.) 17. Ann. Rept. Fish. Board Scotland, $1900,189-241.2 \mathrm{pls}$.

1900.2

Fishing nets, with special reference to the otter-trawl. Journ. Mar. Biol. Issoc., 1900-03, n. s. 6, 562-586. 2 pls.

1900.3

- - Notes and memoranda. Journ. MIar. Biol. Assoc., 1900-03, n. s. 6, 617625. pl.

1900.4

- Occupation of a table at the Zoological Station at Naples. Appendix 1. The anatomy of the flatfishes (Heterosomata) Rept. Brit. Assoc. Adv. Sci., 70. meet., 1900, 380-383. 1900.5

On the presence of nasal secretory sacs and a naso-pharyngeal communication in Teleostei, with especial reference to Cynoglossus semilavis Gthr. Journ. Linn. Soc. London (Zool.), 1900 , 27, 5+1-556. pl.

1900.6

-... 'The reproduction of the flatfishes. Journ. Mar. Biol. Assoc, 190003 , n. s. 6, 490-198. 1900.7

- On a new genus of flat-fishes from New Zealand. Proc. Zool. Soc. London, 1901, 986-992. 3 figs. 1901.1

...- On the action of the spurge (Euphorbia hiberna L.) on salmonoid fishes. Proc. Roy. Soc. London, 1901, $70,48-66$.

1901.2

Rapport sommaire sur les expériments avec filets. Conseil Perm. Intern. Explor. de la Mer, Rapp., 1905, 4. 8t-101. tables.

1905.1
Rapport sur les statistiques concernant les petites plies envoyées au bureau. Conseil Perm. Intern. Explor. de la Mer, Rapp., 1905, 4, 46-74. tables.

1905.2

- Statisties of the North Sea fisheries. II. Summary of the available fisheries statistics and their value for the solution of the problems of overfishing. Conseil Perm. Intern. Explor. de la Mer, Rapp., 1905, 3 (Append. K), 3-58. figs.

1905.3

Bulletin statistique des pêches maritimes des pays du nord de l'Europe. Conseil Perm. Intern. Explor. de la Mer, Rapp., 1906, 1, 1-262, 12 charts.

1906.1

- Memorandum ïber die internationalen Schollenmessungen mit besonderer Berücksichtigung der Methoden, welche statistische Angaben behandeln. Conseil Perm. Intern. Explor. de la Mer, Proc. Verb., 1907, 7, 83-103. 1907.1

Bulletin statistique des pêches maritimes des pays du nord de l'Europe. Conseil Perm. Intern. Explor. de la Mer, Bull., 1908, 2, 1-157. Ibid., 1909, 3, 1-83. Ibid., 1910, 4, 1-83. Ibid., 1911, $5,1-87$.

1908.1

- Flat-fishes (Heterosomata) (In Report Danish Oceanographical Expeditions 1908-10 to the Mediterranean and adjacent seas, 1913, vol. ii, p. 1-150 pls.)

1913.1

Kyle, Harry $M_{\text {.. \& Hoek, Paulus }}$ l'eronius Cato. See Hoek \& Kyle.

Kyle, Harry M., Johansen, Anders Cornelius Jacob, \& Petersen, C.G.J. Sce Petersen, Kyle \& Johansen.

Kyle, Hary $M$. . Petersen, C.G.J., \& Garstang, Walter. See Petersen, Garstang \& Kyle.

Kynaston, Augustus $F$. Report on the fisheries in the bay of Fundy - (In Perley, M. H. Rept. Fish New Brunswick, p. 252-260. 2. ed. St. John, N. B., 1852)

1852.1

Relates chiefly to the herring fishery of Grand Manan and its protection. 


